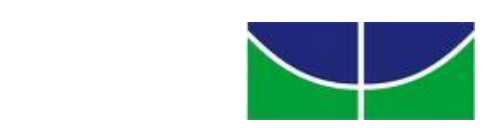

UNIVERSIDADE DE BRASÍLIA - UnB

INSTITUTO DE LETRAS - IL

DEPARTAMENTO DE LINGUÍSTICA, PORTUGUÊS E LíNGUAS CLÁSSICAS LIP

PROGRAMA DE PÓS-GRADUAÇÃO EM LINGUÍSTICA - PPGL

\title{
ARTE E DISCURSO MULTIMODAL: \\ ANÁLISE DA LINGUAGEM VISUAL EM SUA RELAÇÃO \\ COM O RELATO DA HISTÓRIA DE VIDA E DA PRODUÇÃO ARTÍSTICA DE VAN GOGH
}

CRISTINA AZRA BARRENECHEA 
UNIVERSIDADE DE BRASÍLIA - UnB

INSTITUTO DE LETRAS - IL

DEPARTAMENTO DE LINGUÍSTICA, PORTUGUÊS E LÍNGUAS CLÁSSICAS LIP

PROGRAMA DE PÓS-GRADUAÇÃO EM LINGUÍSTICA - PPGL

CRISTINA AZRA BARRENECHEA

\title{
ARTE E DISCURSO MULTIMODAL: \\ ANÁLISE DA LINGUAGEM VISUAL EM SUA RELAÇÃO \\ COM O RELATO DA HISTÓRIA DE VIDA E DA PRODUÇÃO ARTÍSTICA DE VAN GOGH
}

\author{
Tese apresentada como requisito parcial para \\ obtenção do título de Doutora em Linguística à \\ Banca Examinadora do Programa de Pós- \\ Graduação em Linguística da Universidade de \\ Brasília. \\ Orientadora: Profa. Dra. Josenia Antunes Vieira \\ Brasília, 04 de Março de 2016
}


B271a Barrenechea, Cristina Azra.

Arte e Discurso Multimodal - análise da linguagem visual em sua relação com o relato da história de vida e da produção artística de van Gogh. / Cristina Azra Barrenechea - 2016.

$600 \mathrm{f.}:$ il.; $30 \mathrm{~cm}$

Tese (Doutorado) - Universidade de Brasília, 2016.

Orientação: Profa. Dra. Josenia Antunes Vieira

1. Semiótica social. 2. Linguística Sistêmico-Funcional. 3. Multimodalidade. 4. Análise de Discurso Crítica. 5. Van Gogh. I. Vieira, Josenia Antunes, orient. II. Título. 


\section{Cristina Azra Barrenechea}

\section{Arte e Discurso Multimodal - análise da linguagem visual em sua relação com o relato da história de vida e da produção artística de van Gogh}

Tese apresentada ao Programa de Pós-Graduação em Linguística (PPGL-IL) da Universidade de Brasília (UnB), na área de Concentração: Linguagem e Sociedade, na linha de pesquisa: Discurso, Representações Sociais e Textos, como pré-requisito parcial para a obtenção do título de Doutora em Linguística.

Aprovada em:

BANCA EXAMINADORA

Profa. Dra. Josenia Antunes Vieira Orientadora/ Presidente (UnB/LIP/PPGL/BSB)

Profa. Dra. Sara Regina Scotta Cabral - Membro efetivo externo (UFSM/PPGL/RS)

Profa. Dra. Flaviane Faria Carvalho - Membro efetivo externo- (Senac/MG)

Profa. Dra. Edna Cristina Muniz da Silva - Membro efetivo interno (UnB/LIP/ PPGL/BSB)

Profa. Dra. Elda Alves Oliveira Ivo - Membro efetivo (CEUB/BSB) 
Dedido a tese aos meus pais, Felix Alejandro Barrenechea Aviléz e Lola Azra Barrenechea, às minhas avós, Rosa Mio Malab e Felipa Barrenechea Aviléz, ao meu amigo Odair Moraes Barbosa, à minha companheira Simone Aparecida Lisniowski, aos meus queridos filhos, sobrinhos, irmãos e familiares e à memória do meu sobrinho Gustavo Cunha Barrenechea. 


\section{AGRADECIMENTOS}

Agradeço,

a Deus por tudo,

à Simone Aparecida Lisniowski, pelo apoio incondicional, aos filhos, pela paciência com a minha ausência,

à minha família, irmãos e primos por todo o apoio, aos sobrinhos pela compreensão com a minha escassez, ao Odair Moraes Barbosa pela amizade e apoio, ao meu pai Felix Azra Barrenechea pela inspiração, à minha mãe Lola Azra Barrenechea, pela sensibilidade, aos meus alunos, pelo incentivo e entusiasmo, à Josenia Antunes Vieira, pela orientação e confiança, à professora Edna Cristina pelo feedback sistêmico-funcional, aos professores, funcionários do PPGL e alunos, pela identidade Linguística a todos os autores que, direta ou indiretamente, contribuíram para a investigação. 


\section{RESUMO}

A presente tese consiste de uma pesquisa qualitativa e interpretativa realizada na área de Linguagem e Sociedade, na linha de Discursos, Representações Sociais e Textos, no Programa de Pós-Graduação em Linguística da Universidade de Brasília, Brasil. A pesquisa propôs a Tese de que o discurso artístico de Vincent van Gogh é integrado tanto por seu discurso pictórico quanto por seu discurso epistolar. A fim de compreender o discurso artístico de van Gogh no contexto de sua produção discursiva nas duas modalidades, foram analisados os elementos discursivos presentes na produção pictórica e nas cartas que o pintor escreveu acerca de sua produção artística, bem como na análise de sua história de vida. A investigação contou com o aporte de três bases teóricas da Linguística para analisar os corpora pictórico e epistolar: a Teoria Semiótica Social Multimodal (TSSM), que foi empregada para analisar a produção de sentidos nas telas; a Teoria da Linguística SistêmicoFuncional (LSF), que auxiliou a análise da produção de sentidos nas cartas referentes às telas; e a Análise de Discurso Crítica (ADC) que subsidiou a análise de uma carta na íntegra para a compreensão de aspectos contextuais do discurso artístico. Com o emprego de categorias da TSSM, LSF e ADC e de categorias novas, propostas por esta pesquisa, foram triangulados os dados dos corpora pictórico e epistolar, para descrever as ocorrências e as recorrências de elementos ou estratégias discursivas nos dois gêneros textuais analisados. Na triangulação foram aplicadas novas categorias de análise tais como Gesto Pictórico, Transparência, Inacabamento, Incompletude e Limiar Artístico que constituem uma contribuição desta pesquisa para a área da multimodalidade, em especial para a análise do discurso artístico. A triangulação buscou investigar a colaboração entre elementos discursivos nos dois gêneros pesquisados, observando para isso, se os elementos discursivos encontrados nas telas correspondiam com alguma função desempenhada por elementos encontrados nas cartas. Dessa forma, foi analisado se e como os modos e estratégias discursivas presentes nas cartas ocorreram nas telas; e se e como os modos e estratégias discursivas nas telas ocorreram nas cartas a fim de descrever qual a natureza e função dessas ocorrências. Com a ajuda da triangulação, foi possível descrever a ocorrência dos elementos discursivos visuais que se relacionam com a ocorrência de elementos correspondentes, presentes na análise do Sistema de Transitividade das cartas. As ocorrências observadas na triangulação foram categorizadas como ocorrências de natureza semântica e léxico-gramatical. Na triangulação, foi verificada a ocorrência simultânea de mais de uma categoria na mesma oração e/ou no mesmo construto visual devido à natureza interdependente dos elementos discursivos para construir o sentido e a observação dos padrões de agrupamentos pode indicar as estratégias discursivas presentes tanto nas telas quanto nas cartas. Para sondar as conexões de nexo entre os achados da análise visual com os achados da análise textual, propus alguns caminhos possíveis de comparação: por sentido, por forma e por função. Essas possibilidades foram transpostas para as funções e metafunções visuais e da linguagem, propostas por O'Toole (1994) e por Halliday (2014) e puderam se desdobrar em diferentes combinações de acordo com sua ocorrência e intercorrência. A triangulação trouxe à tona a recorrência da combinação de usos semióticos, o que proporcionou para esta pesquisa construir, preliminarmente, uma visão panorâmica das recorrências do uso conjugado dos recursos semióticos que pode indicar a organização interna da urdidura do discurso artístico de van Gogh.

Palavras-chave: Van Gogh, arte, discurso multimodal, semiótica social, linguística sistêmico-funcional. 


\begin{abstract}
This thesis is a qualitative and interpretative research conducted at the University of Brasilia's Graduate Program in Linguistics, on the area of Language and Society in Discourses, Social Representations and texts, in Brazil. This research proposed the thesis that the artistic discourse of Vincent van Gogh is integrated by both his pictorial and his epistolary discourse. In order to understand van Gogh's art discourse in the context of its production, the research analyzed the discourse's elements of four paintings and the discourse's elements of the letters the painter wrote about these paintings, and also, his history of life. The investigation included the input of three Linguistics' theoretical bases to analyze the pictorial and epistolary data: Multimodal Social Semiotics Theory, (TSSM) which was used to analyze the paintings' meanings production; Systemic Functional Linguistic Theory (LSF), which helped the analysis of the letters referring to the paintings; and Critical Discourse Analysis (ADC) which supported the understanding of contextual aspects of the artistic discourse by the analysing a full letter. With the employment of TSSM, LSF and ADC categories and the new categories proposed by this research, the pictorial and epistolary data were triangulated to describe the elements or discursive strategies occurrences and recurrences in both modalities. At the triangulation phase, there were applied new analysis categories such as Painterly Gesture, Transparency, Incompleteness and Artistic Threshold that constitute a contribution of this research to the field of multimodality, especially for the study of the artistic discourse. The triangulation sought to investigate the collaboration between discursive elements in both modalities surveyed, watching for this, if the discursive elements found on the paintings corresponded to any function performed by elements found in the letters. In order to describe the nature and function of such occurrences, it was examined whether and how the modes and discursive strategies in the letters occurred on the paintings; and whether and how the modes and discursive strategies on the paintings occurred in the letters. With the aid of triangulation it was possible to describe the occurrence of visual discourse elements that relate to the occurrence of corresponding elements found by the analysis of Transitivity in the letters. The events observed at the triangulation were categorized as instances of semantic and lexicalgrammatical nature. Due to the discursive elements that build meaning's interdependent nature, simultaneous occurrences were verified in the triangulation, in more than one category on the same sentence and /or in the same visual construct. The observation of patterns has shown the discursive strategies both in the paintings and the letters. To probe the connections of the nexus between the visual analysis' findings with the textual analysis' findings, the research proposed some possible ways of comparison. These possibilities were based on visual functions proposed by O'Toole (1994) and metafunctions proposed by Halliday (2014) and unfolded in different combinations according to their occurrences. The triangulation has shown the uses' recurrence of the semiotic combinations, which provided for this research to preliminarily build a panoramic view of the combined semiotic uses that may indicate the warp's internal organization of van Gogh's artistic discourse.
\end{abstract}

Key-words: Van Gogh, art, multimodal discourse, social semiotics, Systemic Functional Linguistic. 


\section{LISTA DE FIGURAS}

Figura 1: Por de Sol: Campo de trigo perto de Arles (1888)................................................ 21

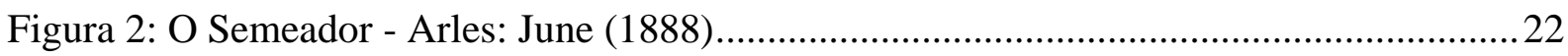

Figura 3: The Cafe Terrace on the Place Du Forum, Arles, at Night. September (1888)...... 22

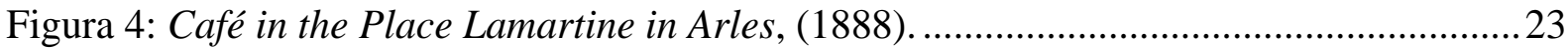

Figura 5: Configuração e constituição das metafunções de Halliday......................................52

Figura 6: Tela Wheat Field with Reaper and Sun de Vincent van Gogh ...............................63

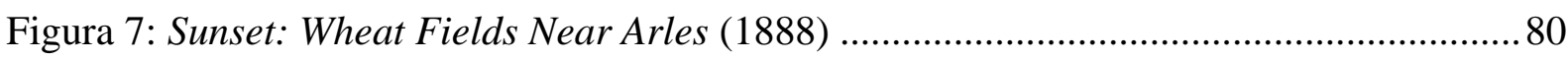

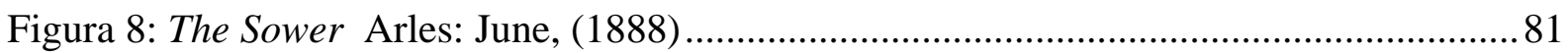

Figura 9: The Café Terrace on the Place Du Forum, Arles, at Night (1888) ......................... 81

Figura 10: The Night Café in the Place Lamartine in Arles (1888) ....................................... 82

Figura 11: Por de Sol: Campo de trigo perto de Arles (1888) ............................................. 128

Figura 12: O Semeador - Arles: Junho, 1888 ................................................................... 129

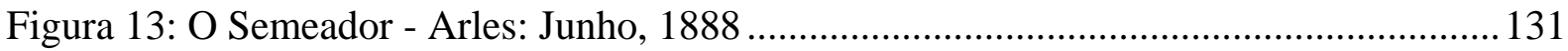

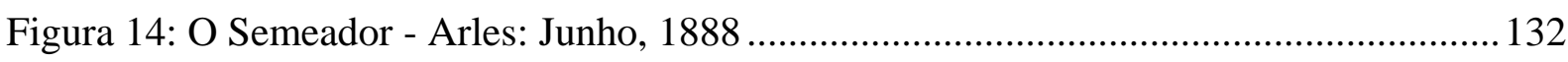

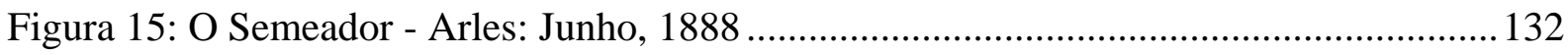

Figura 16: A Esplanada do Café na Place du Forum, Arles, à Noite de van Gogh................ 192

Figura 17: The Night Café in the Place Lamartine in Arles................................................. 193

Figura 18: The Night Café in the Place Lamartine in Arles................................................ 195

Figura 19: The Night Café in the Place Lamartine in Arles................................................. 197

Figura 20: The Night Café in the Place Lamartine in Arles................................................. 199

Figura 22: Le Café de Nuit - Gauguin, Arles: 4-12 de Novembro, 1888 .............................. 218 


\section{LISTA DE QUADROS}

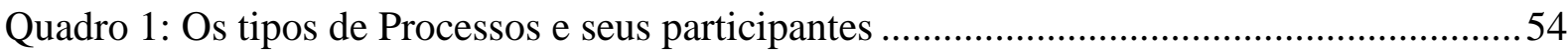

Quadro 2: Exemplo de uma oração material e seus constituintes funcionais...........................55

Quadro 3: Uma oração mental e seus constituintes funcionais ...............................................56

Quadro 4: Uma oração mental e seus constituintes funcionais .............................................57

Quadro 5: Uma oração relacional e seus constituintes funcionais .........................................57

Quadro 6: Uma oração relacional e seus constituintes funcionais. .........................................58

Quadro 7: Uma oração Comportamental e seus constituintes funcionais ................................59

Quadro 8: Uma oração Verbal e seus constituintes funcionais. ..............................................59

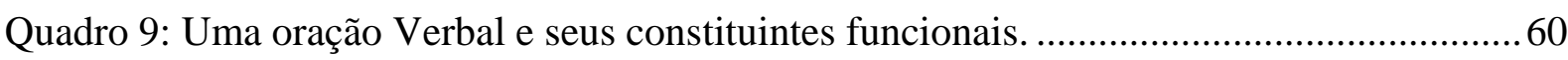

Quadro 10: Uma oração Existencial e seus constituintes funcionais ......................................60

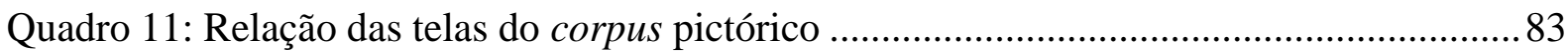

Quadro 12: Relação das telas com as cartas do corpus textual. ............................................... 86

Quadro 13: Lista de cartas, excertos e telas a que se referem ................................................ 88

Quadro 14: Tipos de processos e participantes ................................................................... 100

Quadro 15: Modelo de análise da transitividade por oração ................................................ 101

Quadro 16: Mapa de categorias analíticas em Analysing discourse. .................................... 117

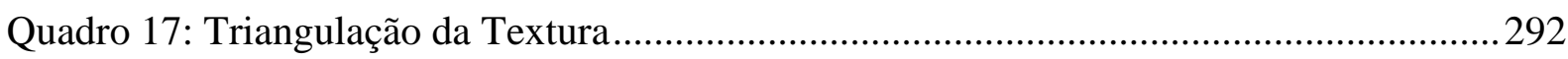

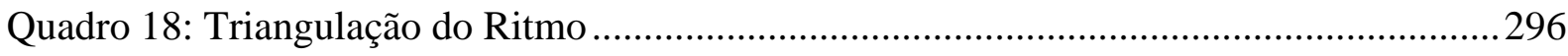

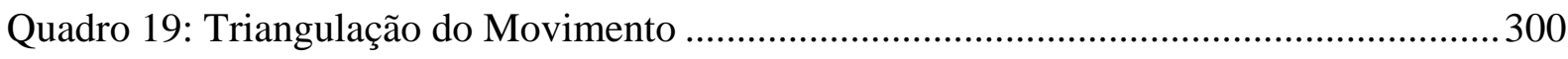

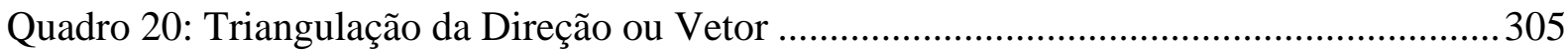

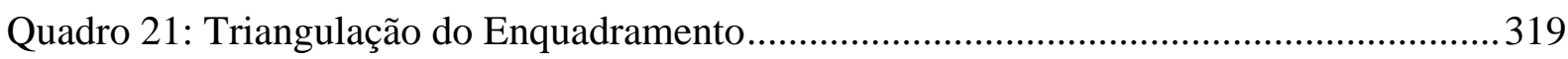

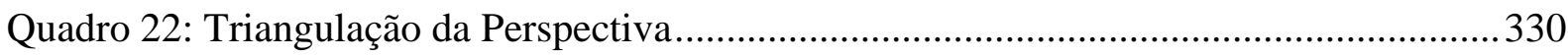

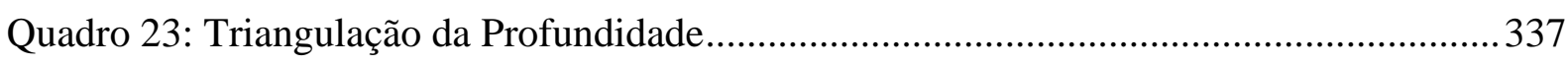

Quadro 24: Triangulação da Distorção do ponto de vista ...................................................... 342

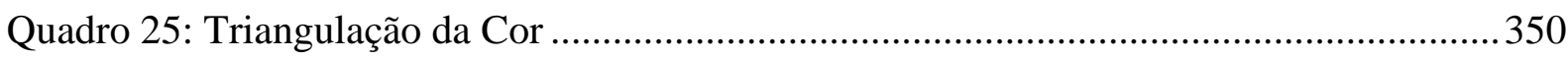

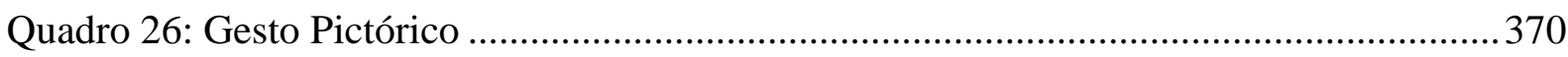

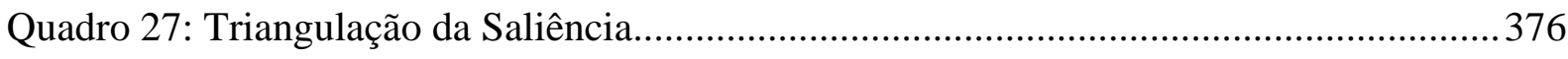

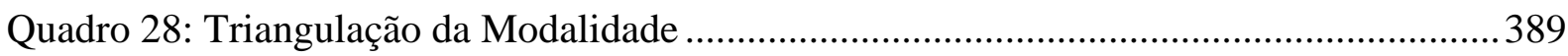

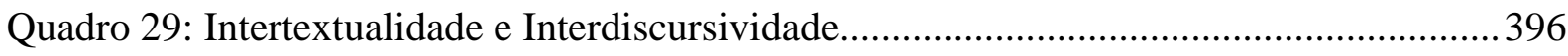

Quadro 30: Triangulação do uso de Associações metafóricas e simbolismo.......................... 405

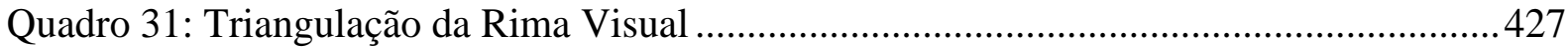

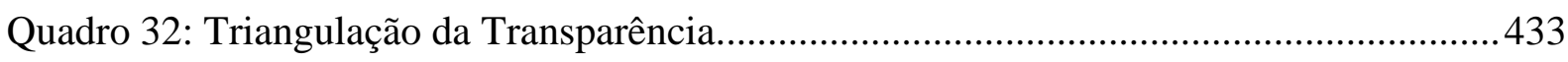

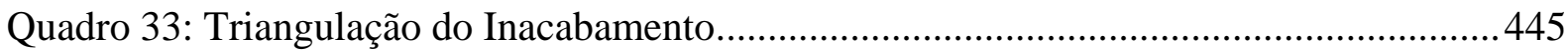

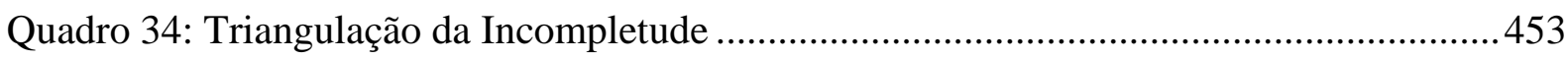

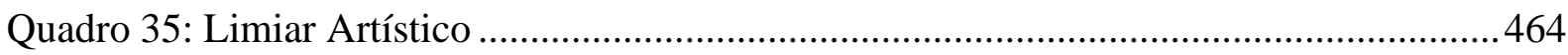

Quadro 36: Porcentagem de repetição da categoria ............................................................ 479

Quadro 37: Porcentagem entre as categorias considerando a frequência total....................... 480 


\section{LISTA DE ABREVIATURAS E SIGLAS}

ADC - Análise de Discurso Crítica

GSF - Gramática Sistêmico Funcional

LSF - Linguística Sistêmico-funcional

TSSM - Teoria Semiótica Social da Multimodalidade 


\section{SUMÁRIO}

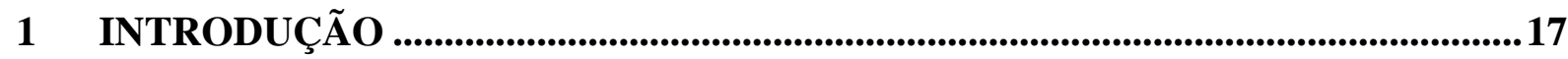

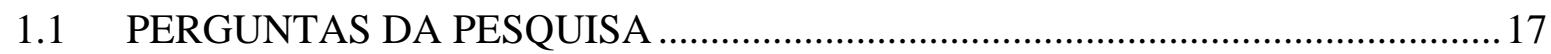

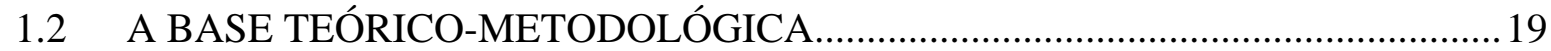

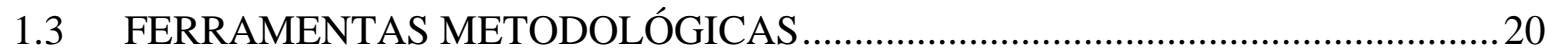

1.3.1 Os Corpora....................................................................................................................21

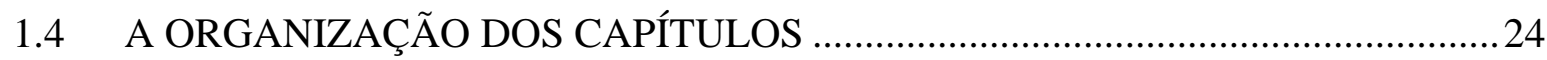

CAPÍTULO 2: O CONTEXTO DA VIDA E OBRA DE VINCENT VAN GOGH ..........27

2 INTRODUÇÃO: UMA VISITA À SEGUNDA METADE DO SÉCULO XIX.........27

2.1 CONTEXTO SÓCIO-HISTÓRICO-CULTURAL ..................................................29

2.1.1 A construção cultural do discurso artístico de cada época...............................37

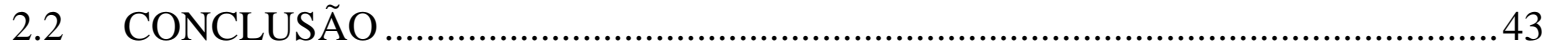

CAPÍTULO 3: FUNDAMENTAÇÃO TEÓRICA ................................................................44

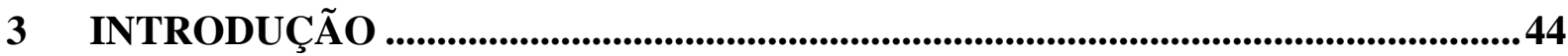

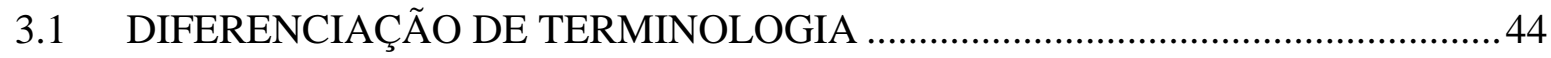

3.2 A LINGUÍSTICA SISTÊMICO-FUNCIONAL - LSF ............................................ 45

3.2.1 A Linguagem para Halliday ...............................................................................45

3.2.2 O contexto..........................................................................................................4 48

3.2.3 Pressupostos da Linguística Sistêmico-funcional ..............................................49

3.2.4 O sistema de Transitividade ................................................................................53

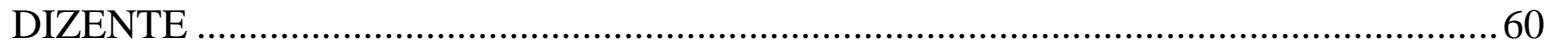

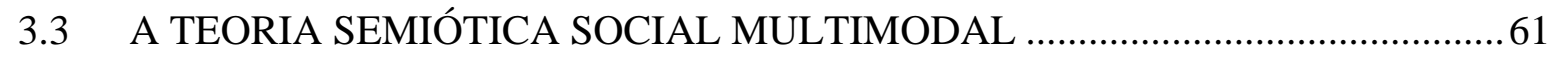

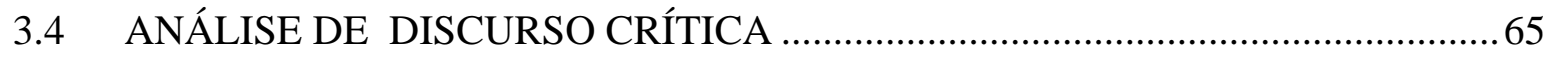

3.4.1 Conceito de Discurso ............................................................................................65

3.4.2 Funções da ADC: identitária, Relacional e Ideacional ...................................69

3.5 PONTOS DE CONTATO ENTRE A COMUNICAÇÃO VISUAL E A

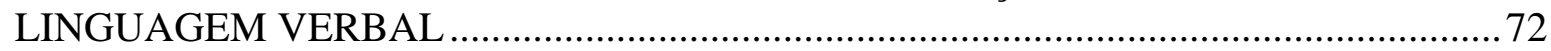

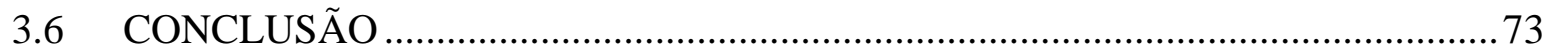

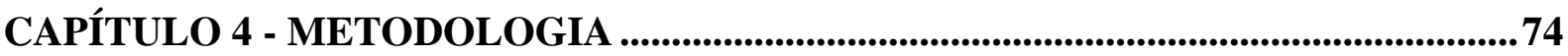

4 INTRODUÇÃO .............................................................................................................74

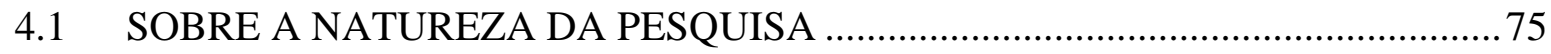

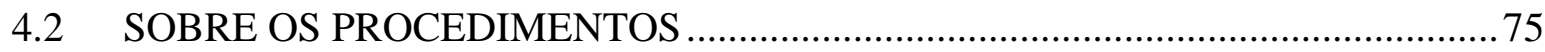


4.2.1 Análise pictórica ………………...............................................................................76

4.2.2 Análise epistolar..........................................................................................................77

4.2.3 Triangulação dos corpora .....................................................................................79

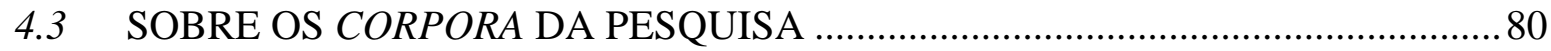

4.3.1 Corpus visual ...............................................................................................................8

4.3.2 Corpus Epistolar ...................................................................................................82

4.4 JUSTIFICATIVA E CARACTERIZAÇÃO DOS CORPORA DA PESQUISA …... 83

4.5 APRESENTAÇÃO DO CORPUS PICTÓRICO .................................................... 83

4.6 JUSTIFICATIVA PARA A ESCOLHA DO CORPUS EPISTOLAR ……………....... 84

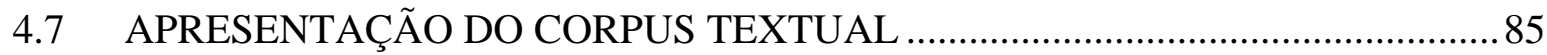

4.7.1 Apresentação do Corpus Textual Primário ..........................................................86

4.7.2 Apresentação do Corpus Textual Contextual....................................................92

4.8 CONDIÇÕES DE PRODUÇÃO, DISTRIBUIÇÃO E CONSUMO DOS GÊNEROS

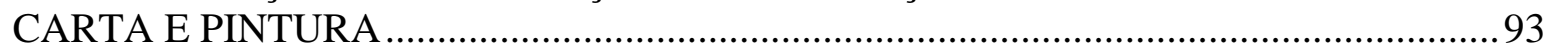

4.9 PROCEDIMENTOS DE COLETA, TRATAMENTO E ANÁLISE DOS DADOS 94

4.10 PROCEDIMENTOS DE ANÁLISE DOS CORPORA ………………………........94

4.10.1 Procedimentos de Análise do Corpus pictórico ..................................................94

4.10.2 Procedimentos de análise do Corpus epistolar ...................................................99

4.10.3 Procedimentos de análise da triangulação dos corpora...................................119

CAPÍTULO 5: ANÁLISE DOS DADOS......................................................................122

5 INTRODUÇÃO: ANÁLISE DOS CORPORA VISUAL E TEXTUAL.....................122

5.1 ANÁLISE DO CORPUS TEXTUAL CONTEXTUAL ........................................... 122

5.1.1 Carta de van Gogh-Junho 1880- Carta 155 (VAN GOGH, 2009k) .............122

5.1.2 Intertextualidade ................................................................................................123

5.1.3 Interdiscursividade ....................................................................................124

5.1.4 Pressuposição ...........................................................................................126

5.1.5 Modalidade e de Avaliação ........................................................................127

5.2 ANÁLISE DA TELA POR DE SOL: CAMPO DE TRIGO PERTO DE ARLES . 128

5.3 ANÁLISE TEXTUAL DOS EXTRATOS DE CARTAS RELATIVOS À TELA POR DE SOL: CAMPO DE TRIGO PERTO DE ARLES ................................................ 129

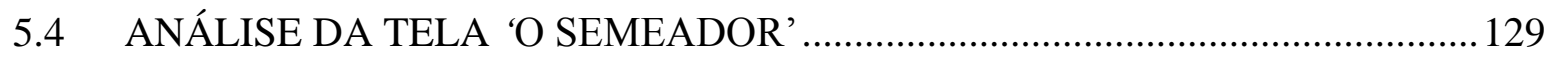

5.4.1 Análise da Função Composicional da tela O Semeador..................................130

5.4.2 Análise da Função Modal da tela O Semeador.................................................131

5.4.3 Análise da Função Representacional da tela O Semeador ............................142

5.4.4 Conclusão da análise visual da tela 'O Semeador'..........................................152 
5.5 ANÁLISE TEXTUAL DOS EXTRATOS RELATIVOS À TELA O SEMEADOR 155

5.5.1 Extrato $\mathrm{n}^{\circ} \mathbf{2 a}$ 155

5.5.2 Extrato $\mathrm{n}^{0} \mathbf{2 b}$ 181

629 - TO THEO VAN GOGH. ARLES, THURSDAY, 21 JUNE 1888. (VAN GOGH, 2009E).

5.6 ANÁLISE DA TELA A ESPLANADA DO CAFÉ NA PLACE DU FORUM, ARLES, À NOITE.

5.7 ANÁLISE TEXTUAL DOS EXTRATOS DE CARTA RELATIVOS À TELA 'A ESPLANADA DO CAFÉ NA PLACE DU FORUM, ARLES, À NOITE'

5.8 ANÁLLISE DA TELA O CAFÉ NOTURNO NA PLACE LAMARTINE, EM ARLES.

5.8.1 Análise da Função Composicional da tela The Night Café in the Place Lamartine in Arles.

5.8.2 Análise da Função Modal da tela The Night Café in the Place Lamartine in Arles 201

5.8.3 Análise da Função Representacional da tela The Night Café in the Place Lamartine in Arles.

5.8.4 Conclusão da análise visual da tela O Café Noturno na Place Lamartine, em Arles.

5.9 ANÁLISE TEXTUAL DOS EXTRATOS DE CARTA RELATIVOS À TELA O CAFÉ NOTURNO NA PLACE LAMARTINE, EM ARLES....

5.9.1 Extrato $\mathrm{n}^{0} \mathbf{4 a}$ .247

5.9.2 Extrato $n^{0} 4 b$ .256

5.9.3 Extrato $n^{\circ} 4 c$ 259

5.9.4 Extrato $n^{\circ} 4 d$ .273

CARTA 680 - TO THEO VAN GOGH. ARLES, ON OR ABOUT TUESDAY, 11 SEPTEMBER 1888.

5.9.5 Extrato $n^{0} 4 \mathrm{e}$.

5.9.6 Conclusão da análise textual da tela O Café Noturno na Place Lamartine, em Arles.

VI. CAPÍTULO 6 - DISCUSSÃO DOS RESULTADOS. .290

6 CATEGORIAS GERAIS DA POÉTICA NA OBRA DE VAN GOGH. 290

6.1 TEXTURA. 290

6.2 RITMO. 296

6.2.1 Triangulação do Ritmo ...........................................................................296

6.3 MOVIMENTO.

6.3.1 Triangulação do Movimento 


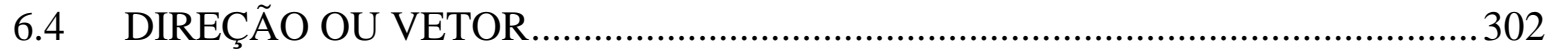

6.4.1 Triangulação da Direção ou Vetor ................................................................303

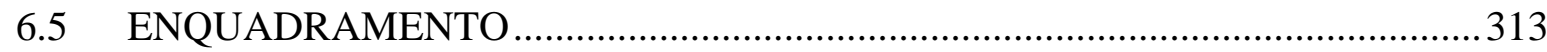

6.5.1 Triangulação do Enquadramento .............................................................317

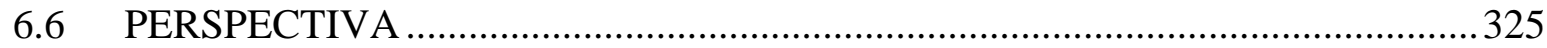

6.6.1 Abandono da perspectiva e da técnica do Chiaroescuro ..............................326

6.6.2 Triangulação da Perspectiva .................................................................329

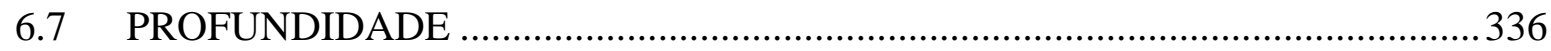

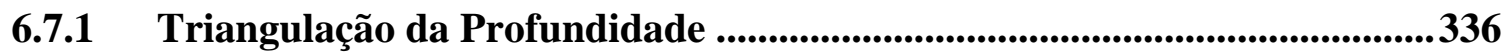

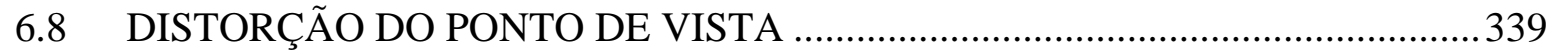

6.8.1 Inversão do ponto de vista ........................................................................340

6.8.2 Triangulação da Distorção do ponto de vista.................................................3 341

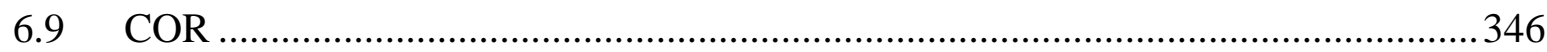

6.9.1 O uso da cor no Impressionismo .......................................................................346

6.9.2 Uso Simbólico da Cor .................................................................................................... 348

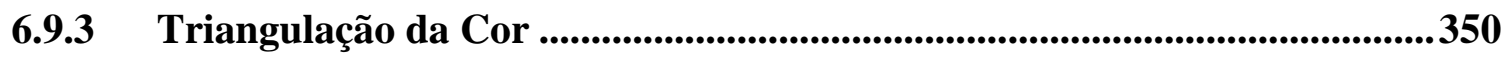

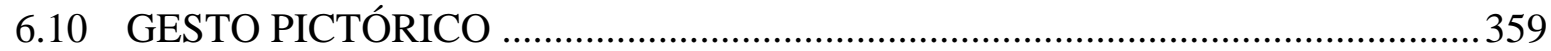

6.10.1 Divisionismo ou Pontilhismo nas pinceladas......................................................362

6.10.2 Pinceladas Contidas...........................................................................................363

6.10.3 Caligrafia pictórica .................................................................................. 364

6.10.4 Pinceladas - caligrafia pictórica..................................................................365

6.10.5 Escrita-desenho: Desenhar como se escreve ...................................................365

6.10.6 Automatismo na Pincelada ........................................................................................3366

6.10.7 Triangulação do Gesto Pictórico .......................................................................368

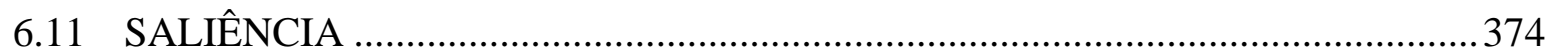

6.11.1 Triangulação da Saliência......................................................................335

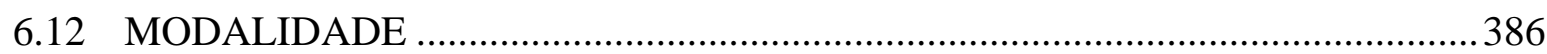

6.12.1 Triangulação da Modalidade.......................................................................387

6.13 INTERDISCURSIVIDADE E INTERTEXTUALIDADE ...................................... 392

6.13.1 Interdiscursividade na recepção da obra .................................................392

6.13.2 Interdiscursividade e Intertextualidade na concepção da obra ...................393

6.13.3 Triangulação da Intertextualidade e Interdiscursividade na Recepção da Obra 395

6.14 ASSOCIAÇÕES METAFÓRICAS E SIMBOLISMO ….................................... 402

6.14.1 Triangulação do Uso de associações metafóricas e simbolismo ....................404 


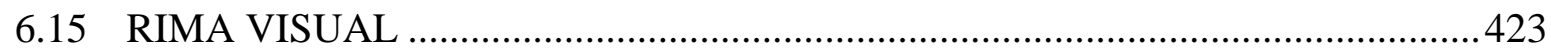

6.15.1 Triangulação da Rima Visual .......................................................................426

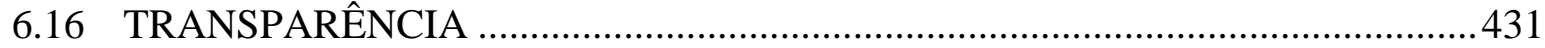

6.16.1 Triangulação da transparência ..................................................................433

6.17 INACABAMENTO - PROCESSO DE REALIZAÇÃO ..................................... 442

6.17.1 Triangulação do Inacabamento....................................................................445

6.18 INCOMPLETUDE - CONDIÇÃO EXISTENCIAL .............................................. 451

6.18.1 Triangulação da Incompletude ..............................................................452

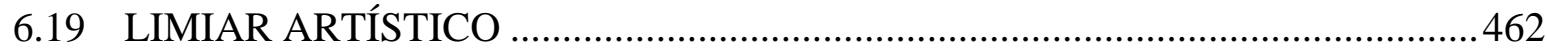

6.19.1 Triangulação do Limiar Artístico ............................................................462

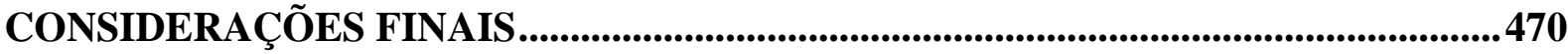

7 CONSIDERAÇÕES FINAIS DA TRIANGULAÇÃ̃.............................................470

7.1 PERGUNTAS DA PESQUISA E ACHADOS CONCLUSIVOS DA TESE .........470

7.1.1 Contribuições da pesquisa ........................................................................................... 475

7.1.2 Intercorrências entre as categorias ..................................................................477

7.1.3 Porcentagem de Repetição da categoria ..................................................................478

7.1.4 Recorrência entre as categorias considerando a frequência total...............480

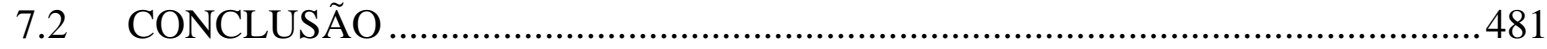

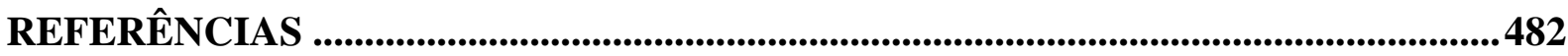

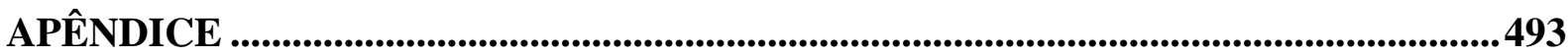




\section{INTRODUÇÃO}

Vincent van Gogh deixou uma produção pictórica que compreende 864 telas e uma produção de textos epistolares em torno de 902 cartas igualmente importantes para a compreensão de sua obra. Essa relevante produção em dois gêneros textuais pede pela investigação sobre a constituição do discurso artístico na intersecção e na interação dessas duas modalidades textuais.

Nesta pesquisa investigo pela perspectiva da Linguística, mais especificamente da Semiótica Social, a tese de que o discurso artístico de Vincent van Gogh é integrado tanto por seu discurso pictórico quanto por seu discurso epistolar.

Para compreender o discurso artístico do pintor Vincent van Gogh no contexto de sua produção nestas duas modalidades, pesquiso seu discurso pictórico e escrito, com base na análise dos elementos discursivos presentes em sua produção pictórica e na análise dos elementos discursivos presentes nas cartas que o pintor escreveu acerca de sua produção artística.

Utilizo para esta pesquisa três bases teóricas da Linguística para investigar os corpora pictórico e epistolar: a Teoria Semiótica Social Multimodal (TSSM), a Linguística SistêmicoFuncional (LSF) e a Análise de Discurso Crítica (ADC). Com a ajuda da Teoria Semiótica Social Multimodal, analiso a produção de sentidos nas telas; com o auxílio da Linguística Sistêmico-funcional analiso a produção de sentidos nas cartas; com o subsídio da ADC analiso uma carta na íntegra para a compreensão de aspectos contextuais do discurso artístico. Com o emprego de categorias da ADC, da LSF e da TSSM e de categorias propostas por esta pesquisa, busco a triangulação dos dados analisados para compreender como diferentes estratégias e elementos discursivos presentes nestes dois gêneros integram a construção do discurso artístico de Vincent van Gogh.

Esta pesquisa está situada na linha de pesquisa Discursos, Representações Sociais e Textos, na área de concentração Linguagem e Sociedade do Programa de Pós-graduação em Linguística da Universidade de Brasília.

\subsection{PERGUNTAS DA PESQUISA}

Para defender a tese acima enunciada, apoio-me nas seguintes questões de pesquisa para nortear a investigação: 
1. Como se dá a ocorrência dos elementos e das estratégias discursivas que se encontram presentes nas telas? São esses elementos presentes nas telas recorrentes, correspondentes, similares, complementares, antagônicos, contraditórios aos elementos e estratégias discursivas que se encontram nas cartas?

2. Como se dá a ocorrência dos elementos e das estratégias discursivas que se encontram presentes nas cartas? São esses elementos presentes nas cartas recorrentes, correspondentes, similares, complementares, antagônicos, contraditórios aos elementos e estratégias discursivas que se encontram nas telas?

3. A análise das telas e das cartas que relatam a produção pictórica pode ajudar a revelar como se deu o processo de produção de sentidos nos discursos pictórico e textual? Existe uma interação discursiva entre esses elementos na construção de sentidos nas telas e nas cartas? Como ela ocorre?

A fim de responder às perguntas da pesquisa, analiso quatro telas de Vincent van Gogh, que serão apresentadas a seguir no item 1.3.1. Essas telas foram criadas em Arles no período mais produtivo de sua carreira, que antecede a chegada de Gauguin, pintor contemporâneo a quem van Gogh convida para compartilhar seu ateliê e acomodações e que o instiga a questionar e mudar muitos aspectos de seu discurso visual. A fase anterior à chegada de Gauguin apresenta uma unidade estilística que possibilita a identificação do uso mais recorrente de estratégias pictóricas nas obras produzidas neste período. À análise de cada tela seguiu a análise de extratos de cartas escritas para seu irmão Theo, para sua irmã Wilhelmine e para seu amigo Bernard no mesmo período em que foi pintada a referida tela. Os excertos coletados referem-se diretamente às telas analisadas ou às concepções pictóricas presentes em mais de uma tela.

Com apoio nos registros linguísticos que participaram na construção do texto visual e do texto escrito, procuro investigar a interrelação entre estes dois gêneros a fim de compreender a construção do discurso artístico de Vincent van Gogh no contexto do universo discursivo do autor. A compreensão do processo de construção discursiva, com a ajuda dos aportes da Semiótica Social pode ser muito importante para ampliar as nossas possibilidades de recepção e leitura do texto de arte. Procuro compreender o texto artístico no contexto do universo linguístico que o produziu a fim de identificar as semioses que interligam o discurso verbal com o discurso pictórico do autor por meio da análise do texto visual e do texto escrito, por ele produzidos. 


\subsection{A BASE TEÓRICO-METODOLÓGICA}

A fim de examinar como a ocorrência dos elementos discursivos nas cartas e nas telas revela sua contribuição para a construção do discurso artístico de van Gogh propus explorar as possibilidades descritivas, analíticas e interpretativas, oferecidas pelas: Teoria Semiótica Social Multimodal (TSSM) e Linguística Sistêmico-Funcional (GSF) e pela Análise de Discurso Crítica (ADC).

A pesquisa se apoia na triangulação teórica e metodológica da Teoria Semiótica Social Multimodal (TSSM) para analisar as telas e da Linguística Sistêmico-Funcional (LSF), para analisar as cartas, e da Análise de Discurso Crítica (ADC). A triangulação dos enfoques teóricos da TSSM, da LSF, e da ADC justifica-se pela necessidade de investigar a constituição do discurso artístico de van Gogh em diferentes gêneros textuais.

O emprego dos pressupostos, conceitos e categorias destas duas bases teóricas fundamenta a triangulação dos corpora, a fim de analisar como os textos visuais e escritos colaboraram para a construção do discurso artístico de van Gogh:

1. A Teoria Semiótica Social Multimodal (TSSM) apoia a análise do corpus pictórico (O’TOOLE, 1994; KRESS e VAN LEEUWEN, 1996; VAN LEEUWEN, 2001 apud MACHIN, 2007; MACHIN, 2007; VAN LEEUWEN, 2008; VAN LEEUWEN, 1996. KRESS, 2010; JEWITT, 2011; VAN LEEUWEN, 2011).

2. A Linguística Sistêmico-Funcional (LSF) apoia a análise do corpus epistolar das cartas diretamente relacionadas com o corpus pictórico e das cartas que relatam concepções artísticas presentes em mais de uma tela (HALLIDAY; HASAN, 1985; HALLIDAY; MATHIESSEN, 2004, 2014; EGGINS, 2012; THOMPSON, 2004, BUTT et al, 2000).

3. A Análise de Discurso Crítica subsidia categorias para a análise de uma carta na íntegra para evidenciar aspectos contextuais do pensamento artístico e de representação identitária constantes no discurso de van Gogh (FAIRCLOUGH, 2001, FAIRCLOUGH, 2003; FAIRCLOUGH, 2010). 


\subsection{FERRAMENTAS METODOLÓGICAS}

A metodologia está desenvolvida em três etapas: na primeira, são analisadas quatro telas com base na Teoria Semiótica Social Multimodal (TSSM); na segunda, são analisados os extratos de cartas que se referem às telas analisadas e às concepções artísticas presentes em mais de uma tela. A etapa de análise das cartas foi realizada com o apoio da teoria da LSF. Na terceira etapa, foi desenvolvida uma triangulação entre a análise visual e a análise escrita, para observar e para descrever as ocorrências e as recorrências de elementos ou estratégias retóricas nos dois gêneros textuais analisados.

Com a análise Multimodal das telas selecionadas, pretendi examinar a natureza das funções que os elementos discursivos visuais desempenham na constituição do texto visual e com a análise Sistêmico-Funcional dos excertos pretendi examinar a natureza das funções que os elementos discursivos nas cartas desempenham no texto escrito usando como enfoque o sistema de transitividade.

$\mathrm{Na}$ triangulação da análise das telas e da análise dos extratos das cartas, procuro investigar como a ocorrência dos elementos discursivos visuais nas funções Modal, Representacional e Composicional relacionam-se com a ocorrência de elementos correspondentes, presentes na análise do sistema de transitividade das cartas.

$\mathrm{Na}$ triangulação das análises das telas e das cartas, são examinadas as correspondências, similaridades ou incongruências nas ocorrências em ambas as análises, visual e textual. A triangulação busca investigar a colaboração entre elementos discursivos nos dois gêneros pesquisados observando para isso se os elementos discursivos encontrados em um gênero correspondiam com alguma função desempenhada nos elementos encontrados no outro e vice-versa. Mais especificamente com a triangulação, busco analisar se e como os modos e estratégias discursivas presentes nas cartas ocorrem nas telas; se e como os modos e estratégias discursivas nas telas ocorrem nas cartas a fim de descrever qual a natureza e função dessas ocorrências. 


\subsubsection{Os Corpora}

\subsubsection{O Corpus pictórico}

Para a análise das telas, foram selecionadas quatro telas de Vincent van Gogh da produção pictórica de 864 telas, de acordo com o levantamento do Museu van Gogh.

a) Por de Sol: Campo de trigo perto de Arles ${ }^{1}$ (1888).

b) O Semeador ${ }^{2}$ (1888).

c) A Esplanada do Café na Place du Forum, Arles, à Noite ${ }^{3}$ (1888).

d) O Café Noturno na Place Lamartine, em Arles ${ }^{4}$ (1888).

Figura 1: Por de Sol: Campo de trigo perto de Arles (1888)

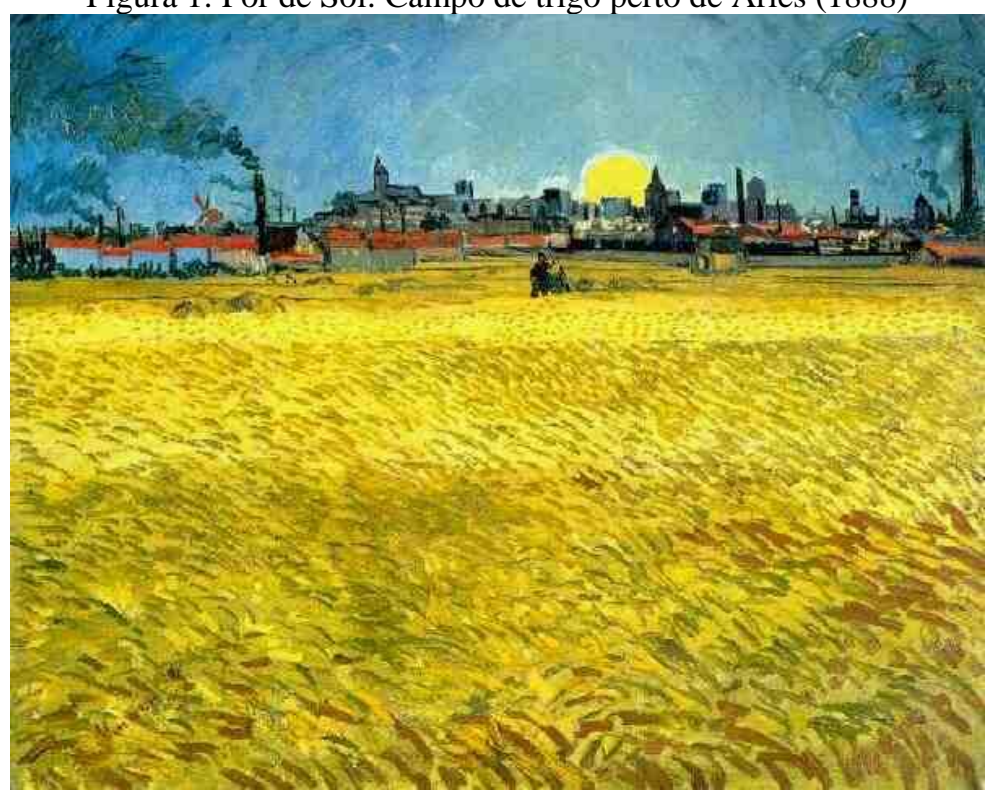

Fonte: van Gogh (1888a).

Oil on canvas, $73.5 \times 92.0 \mathrm{~cm}$.

Arles: June, 1888

F 465, JH 1473

Localização: Winterthur: Kunstmuseum Winterthur, PAÍS??

\footnotetext{
${ }^{1}$ Sunset: Wheat Fields Near Arles

2 The Sower

${ }^{3}$ The Cafe Terrace on the Place Du Forum, Arles, at Night

${ }^{4}$ Café in the Place Lamartine in Arles
} 
Figura 2: O Semeador - Arles: June (1888)

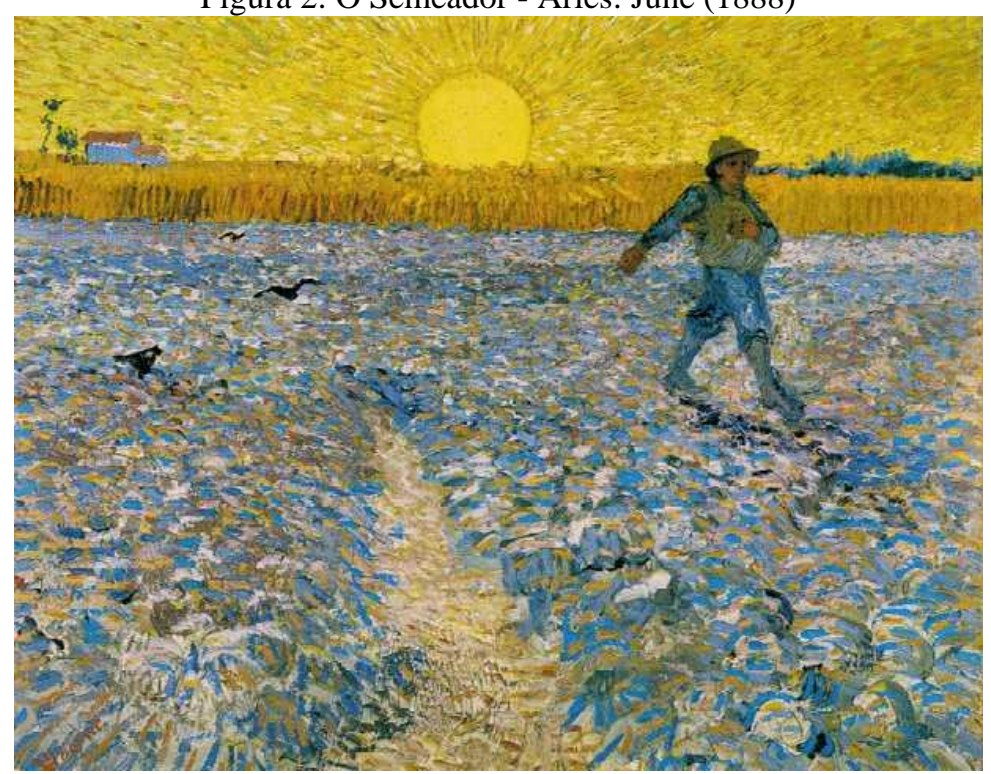

Fonte: van Gogh (1888b).

Oil on canvas, 64.0 x $80.5 \mathrm{~cm}$.

Arles: June, 1888

F 422, JH 1470

Localização: Otterlo, Rijksmuseum Kröller-Müller Museum, Holanda.

Figura 3: The Cafe Terrace on the Place Du Forum, Arles, at Night. September (1888).

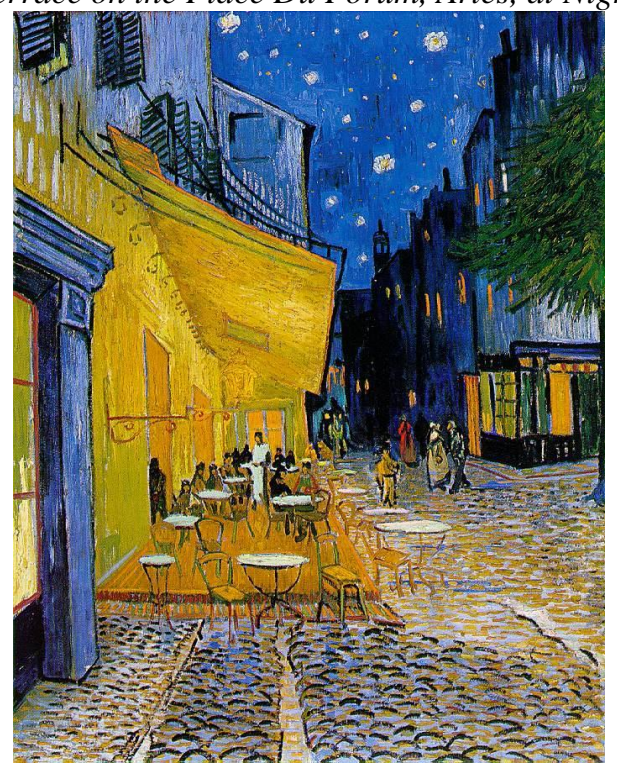

Fonte: van Gogh (1888c).

Oil on canvas,

$81.0 \times 65.5 \mathrm{~cm}$

Arles: September, 1888

F 467, JH 1580

Localização: Otterlo: Kröller-Müller Museum 
Figura 4: Café in the Place Lamartine in Arles, (1888).

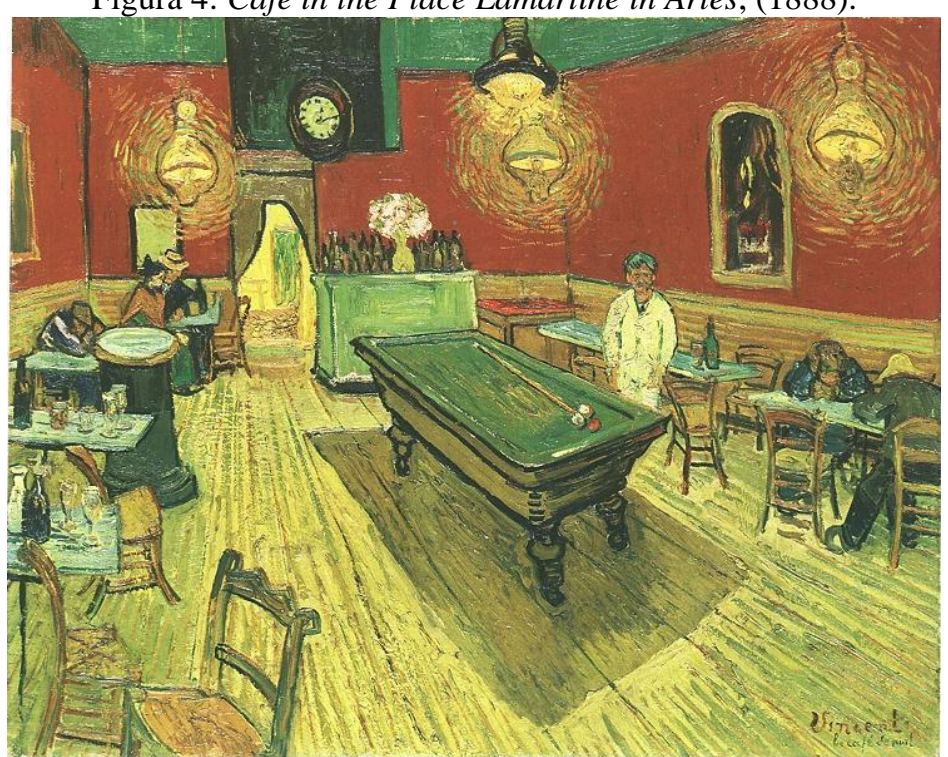

Fonte: van Gogh (1888d).

Óleo sobre tela, 70.0 x $89.0 \mathrm{~cm}$.

Arles: 5-8 Septembro de 1888.

F 463, JH 1575

Localização: New Haven, Connecticut: Yale University Art Gallery

\subsubsection{O Corpus epistolar}

O corpus analisado foi dividido em dois grupos para ajudar na sistematização da análise.

a) No primeiro grupo, encontram-se os extratos de 12 cartas que se referem diretamente às telas analisadas, selecionados de uma correspondência de 902 cartas que van Gogh manteve com seus familiares e amigos;

b) No segundo grupo, encontram-se excertos de uma carta escrita para Theo quando van Gogh decidiu se tornar pintor em Julho de 1880. A análise desta carta tem a finalidade de descrever registros e padrões do contexto semântico e léxicogramatical da produção discursiva de van Gogh bem como aspectos do contexto de situação e do contexto de cultura para subsidiar a triangulação. Estes aspectos discursivos mais amplos explicitam as escolhas linguísticas do pintor, e explicitam elementos de intertextualidade e interdiscursividade que podem estar na base tanto da produção das telas quanto da produção das cartas;

$\mathrm{Na}$ fase descritiva da análise das cartas, os excertos foram segmentados em orações que foram analisadas em relação às categorias da Transitividade da LSF. Na fase interpretativa das cartas e na triangulação, além das categorias da Transitividade, a análise 
apoia-se em algumas categorias da Análise de Discurso Crítica, tais como intertextualidade, interdiscursividade, bem como no Contexto de Situação e no Contexto de Cultura da LSF, no qual foram produzidas tanto as telas quanto as cartas. Estes aspectos são coletados dos relatos dos biógrafos Naifeh e Smith (2012), Haziot (2010), Cabanne (1971), Forrester (1983), Edwards (2009), Pereira (1990), Coli (2006) e pelos historiadores de arte Petrie (1974), McQuillan (1989), Schapiro (2010), Walther (1990) e Walther e Metzger (2012, 2015).

\subsection{A ORGANIZAÇÃO DOS CAPÍTULOS}

Esta pesquisa organiza-se em seis capítulos, além do apêndice e dos anexos que sistematizam os documentos que constituíram a investigação dos corpora.

O capítulo 1 apresenta a tese, as indagações investigativas e o problema da pesquisa e o justifica.

O capítulo 2 apresenta o contexto de cultura no qual os textos analisados foram produzidos, enfocando as questões mais relevantes do contexto histórico, social, cultural, artístico e familiar da formação de Vincent van Gogh.

O capítulo 3 desenvolve a discussão das noções, das questões e das perspectivas teóricas que fundamentaram a análise dos corpora. Da TSSM, eu focalizo principalmente as funções Modal, Representacional e Composicional e da LSF, o Sistema de Transitividade da metafunção Ideacional e as noções de Texto, Contexto de Cultura, Contexto de Situação e Registro. Da ADC, focalizo o significado Acional, Representacional e Identificacional e o emprego dos conceitos de discurso e as categorias da intertextualidade, interdiscursividade, cadeias textuais e a categoria sociológica da Identidade. Na triangulação dessas perspectivas teóricas, busco estabelecer os pontos de contato entre a TSSM, a LSF e a ADC. O restante do capítulo discute os Elementos da Linguagem Visual e as Estratégias de Composição, apropriados das áreas da Arte e da Percepção Visual (KANDINSKY, 1926 apud VAN LEEUWEN, 2011; ITTEN, 1973; ARNHEIM, 1974; DONDIS, 2007). Esses conceitos oferecem contribuições para a análise do gênero pictórico que materializa o discurso artístico de van Gogh.

O capítulo 4 organiza a metodologia com os objetivos e as perguntas da pesquisa, os critérios para a seleção do corpus e as condições de sua produção, os procedimentos para a sistematização e para a categorização dos corpora e os procedimentos de análise. Este capítulo: a) apresenta a abordagem metodológica; b) justifica e caracteriza os corpora da 
pesquisa, bem como os gêneros analisados; c) apresenta o corpus pictórico, justifica sua escolha; d) apresenta o corpus das cartas, dividido em dois segmentos: o corpus textual primário (composto por extratos de cartas que se referem diretamente às telas analisadas, comentando algum de seus aspectos) e o corpus textual contextual (contendo excertos de uma carta como amostragem de um texto para contextualizar e demonstrar amplamente o discurso do autor); e) descreve as condições de produção, distribuição e consumo dos corpora, para o gênero pintura e para o gênero epistolar; f) explicita as categorias da Multimodalidade usadas na análise do corpus visual; as categorias da Gramática Sistêmico-funcional, usadas na análise do corpus textual primário, as categorias da ADC usadas na análise do corpus textual contextual e as categorias da Multimodalidade, LSF e ADC usadas na triangulação dos corpora. À descrição das categorias de cada perspectiva teórica usada para a análise, segue-se a descrição dos procedimentos de análise do corpus pictórico; dos procedimentos de análise do corpus epistolar e dos procedimentos de análise da triangulação dos corpora.

O capítulo 5 apresenta e desenvolve a análise dos dados. Está dividido em sessões para melhor organizar os resultados em consonância com os objetivos e com as perguntas do Capítulo 3. São esses os resultados para os textos visuais, os resultados para os textos epistolares, cada um desses subdivididos de acordo com as etapas de análise. A análise dos dados está organizada em dois momentos: a) a análise visual das Funções Modal, Representacional e Composicional de cada uma das telas analisadas; b) a análise de Transitividade do corpus epistolar.

O Capítulo 6 apresenta os resultados em dois momentos e descreve: a) a análise Multimodal, Sistêmico-funcional e de Discurso Crítica da triangulação dos corpora que investiga a natureza das ocorrências e examina como os elementos discursivos presentes nas cartas ocorrem nas telas bem como os elementos discursivos nas telas ocorrem nas cartas a fim de descrever qual a natureza dessas ocorrências; b) discute os resultados encontrados e expõe uma visão geral das possibilidades para pesquisas futuras enquanto faz considerações acerca do processo de construção do discurso artístico de van Gogh desde a interconexão de seu discurso pictórico e epistolar. Ao final, apresenta-se uma sessão de Referências, Apêndice que contém as análises na íntegra e os Anexos contendo os corpora na íntegra.

A organização da tese em capítulos busca contemplar a necessidade desta pesquisa de se subsidiar com uma perspectiva histórica, por serem os dados documentais imprescindíveis para ancorar a análise linguística que se segue.

Considero uma tarefa desafiante e talvez inexequível tentar falar da importância da obra de Vincent van Gogh para a arte e para a cultura. Quem de nós não se sentiu extasiado 
ou talvez desconcertado ao ver pela primeira vez a tela ou a reprodução de Starry Night, entre outras tantas, igualmente impactantes? Quem não se sentiu intrigado pela visão de estranha força e lirismo, liberdade, voluptuosidade, instanciados e magistralmente integrados em sistemas linguísticos cujos usos van Gogh promoveu para limiares inimaginados por seus contemporâneos. Por considerar inesgotável o tema em suas possibilidades investigativas, limito-me a construir uma visão da sua biografia com base no que falam estudiosos que se debruçaram para apreciar e compreender seu legado cultural e por que não dizer, linguístico.

O capítulo que se segue contextualiza a vida do pintor Vincent van Gogh, autor dos textos analisados na presente pesquisa, que viveu na segunda metade do século XIX entre a Holanda, Inglaterra e a França. A discussão da literatura histórica que circunda a biografia de Vincent van Gogh é de grande relevância para contextualizar e subsidiar a análise das cartas e das telas proposta nesta pesquisa. São inúmeros os estudos a respeito da vida e da obra de Vincent van Gogh e para esta pesquisa foram consultados os biógrafos Naifeh e Smith (2012), Haziot (2010), Cabanne (1971), Forrester (1983), Coli (2006) e os historiadores de arte Petrie (1974), McQuillan (1989), Walther (1990), Walther e Metzger (2012, 2015), Schapiro (2010), Edwards (2009) e Pereira (1990). 


\section{CAPÍTULO 2: O CONTEXTO DA VIDA E OBRA DE VINCENT VAN GOGH}

\section{INTRODUÇÃO: UMA VISITA À SEGUNDA METADE DO SÉCULO XIX}

As transformações ocorridas desde o aniversário de nascimento de van Gogh nos distanciaram do mundo que ele encontrou ao nascer, impondo um desafio tangível para realizar essa pesquisa: o de compreender não apenas o contexto de situação em que foram produzidas as telas e as cartas analisadas, mas também o contexto de cultura no qual o discurso artístico de van Gogh se constituiu. Este capítulo se dedica ao exercício de reconstruir a cultura do século XIX, a fim de situar a produção das obras de van Gogh no mundo em que ele viveu.

Quando Vincent van Gogh nasceu, já há 31 anos, o primeiro imperador do Brasil era Dom Pedro I. O presidente dos Estados Unidos era Franklin Pierce e estava apenas a sete anos da guerra de secessão. Vitória era rainha da Inglaterra há 16 anos, o imperador da França era Napoleão III e só faltavam 17 anos para o fim do Segundo Império Francês. O papa era Beato Pio IX e a Rússia vivia sob o regime do czar Nicolau I, da família Romanov.

Estávamos a 64 anos da revolução Russa que derrubou a autocracia e inaugurou o socialismo; a 61 da Primeira Guerra Mundial, que elevou para o nível global os conflitos na Europa; e a 86 da Segunda Guerra Mundial que transformou o mapa geopolítico das superpotências mundiais.

Van Gogh nasceu em um século mais dinâmico e conturbado do que o século que o sucedeu. Nasceu e viveu em um século que engendrou e manifestou grandes revoluções, no pensamento, na organização social, nos sistemas políticos, que só foram assimiladas e consolidadas no século seguinte.

No advento de sua chegada ao mundo, a fotografia havia sido inventada há 27 anos e impactaria grandemente na estética com que os artistas de sua geração conceberiam a arte e na experiência da visualidade de seu tempo. Ele 'veria' nascer o telefone em 1854, mas não o cinemascópio (projetor cinematográfico), em 1894. O fonógrafo só nasceria em 1878 e para se ler em uma sala iluminada por uma lâmpada elétrica haveria ainda trinta anos de espera. Em 37 anos, Vincent van Gogh veria passar o reinado de William III do reino dos Países Baixos, dez presidentes dos Estados Unidos e um papa. A Redução da Escravidão ao redor do mundo havia sido iniciada há 59 anos com uma revolta de escravos no Haiti e com o império 
Português sendo o primeiro a abolir a escravidão, seguido da Inglaterra só em 1834 e da América em 1865.

No ano de seu nascimento, ainda viviam Carlyle com 58 anos, Corot com 57, Eugene Delacroix com 55, Balzac com 54, Victor Hugo com 51 anos. Charles Dickens era um escritor aclamado, eram passados quatro anos da publicação de um de seus mais famosos romances: David Copperfield. Charlotte Bronte tinha 37 anos e já havia publicado o romance Jane Eyre sob o pseudônimo Currer Bell.

Karl Marx, aos 35 anos, sentia a realização de, nove anos antes, ter publicado os manuscritos econômico-filosóficos de 1844, que 14 anos depois seriam incorporados no conjunto mais importante de sua obra: "O Capital". Freud ainda publicaria a Teoria Psicanalítica dali a 43 anos. Aos 44 anos, Darwin recebia a medalha real da Royal Society com o estudo sobre cracas (Cirripedia) e estabelecia definitivamente a sua reputação como cientista. Já maduro, só no ano seguinte divulgaria a Teoria da Evolução, quando ele completaria esta pesquisa e voltaria a sua atenção para a sua teoria de transmutação das espécies, estando ainda a sete anos de distância de publicar 'A Origem das Espécies' que sacudiria o cenário científico da época.

Baudelaire aos 32 anos, ainda estava a quatro de publicar 'As Flores do Mal'. Dostoiévski, aos 32, a 13 para publicar 'Crime e Castigo' e a 28 para publicar 'Os Irmãos Karamazov', considerado posteriormente por Freud como o melhor romance já escrito e que impactou a leitura de van Gogh sobre o mundo e a vida. Charles Sanders Peirce, precursor da Semiótica tinha 14 anos e estava a 14 anos de escrever seu artigo "Sobre uma nova lista de categorias" (Qualidade, Relação e Representação) para a experiência e pensamento. Ferdinand de Saussure nasceria dali a quatro anos para desenvolver os conceitos que serviriam de base para o estruturalismo no século seguinte. Claude Monet, aos 13 anos, pintaria somente dali a 19 anos a tela Impressão - nascer do sol, o quadro inaugural do impressionismo que ampliaria para sempre as fronteiras da visualidade.

De sua geração de artistas, Paul Gauguin tinha cinco anos e Cézanne estava com oito. Renoir era um garoto de 12 anos, e Claude Monet tinha 13, mesma idade de Odilon Redon. Edgar Degas tinha 19 anos e Edouard Manet e Alfred Sisley tinham ambos 21. Pissarro, aos 23 anos, tomava a decisão de se tornar pintor.

Émile Zola, que viria a ser um dos precursores do naturalismo, tinha 13 e escreveria sua obra-prima “Germinal” em 32 anos. Pintores do Realismo Social, como Daumier com 45, Daubigny com 36 e Millet com 29 estavam em plena atividade. John Everett Millais, com 24 já tinha fundado há cinco anos a 'Irmandade Pré-Rafaelita'. Josef Israels, aos 29 anos, e 
George Henry Boughton também estavam no auge, e enquanto Mauve, aos 15, Lucke Fields aos 10, Frank Holl aos 8, Hubert Herkomer aos 4, viriam a ser grandes referências para van Gogh com o realismo europeu.

Seus futuros amigos Geoges-Pierre Seurat (1859) e Émile Bernard (1868) ainda não haviam nascido. Muito menos eram Freud (1856), Debussy (1862), Wild (1854) e Mahler (1860), eleito o compositor da Bele Epòque. Também não tinham nascido George Elliot (1862) e Arthur Rimbaud (1854). Van Gogh nasceu antes até de James Joyce (de 1882) e de Ravel (de 1875).

Estes e muitos outros atores habitaram e juntamene com van Gogh transformaram o século XIX, ajudaram a construir com suas práticas discursivas os movimentos que engendraram o cenário no século em que van Gogh viveu. Com seus textos eles testemunham e manifestam a aventura que consistiu viver no século XIX.

\subsection{CONTEXTO SÓCIO-HISTÓRICO-CULTURAL}

Ponto culminante de profundas transformações econômicas, sociais, políticas, filosóficas, científicas e artísticas, o século XIX desenvolve-se a bojo da justaposição de revoluções e movimentos culturais de amplo espectro que tiveram início no século XVIII: a Revolução Francesa (no período entre 1789-1799); a Consolidação da Revolução Industrial (no período entre 1760 a algum momento entre 1820 e 1840); a Ascensão da Burguesia (surgiu na Europa na Idade Média nos séculos XI e XII com o renascimento comercial e urbano e a partir do século XIX passou a ser vista como a classe dominante); o Romantismo (surgido nas últimas décadas do século XVIII na Europa e perdurou por grande parte do século XIX); a Era Vitoriana (iniciada em meados do século XIX, de junho de 1837 a janeiro de 1901); o Liberalismo, que começou a se fortalecer em meados do século XIX, após as décadas de 1830-1840 e teve sua maior representação na França. Se juntou mais tarde à ideia do Nacionalismo, e foi usado como pilar da Unificação da Alemanha (1864-1870 - Otto von Bismarck) e a Unificação da Itália (1848 - Mazzini e Garibaldi); a Belle Époque (começou no fim do século XIX (1871) e durou até a eclosão da Primeira Guerra Mundial em 1914). O século XIX é analisado por Hobsbawm (2014, p. 24-25):

\footnotetext{
A história do nosso período [século XIX] é, portanto, desigual. Ela é basicamente a do maciço avanço da economia do capitalismo industrial em escala mundial, da ordem social que ele representou, das ideias e credos que pareciam legitimá-lo e ratificá-lo: na razão, na ciência, no progresso e no liberalismo. É a era da burguesia triunfante, embora a burguesia europeia ainda hesitasse em assumir uma ordem
} 
política pública. Para isso - e talvez apenas para isso - a era das revoluções ainda não havia terminado. As classes médias da Europa estavam assustadas e permaneceram assustadas com o povo: a "democracia" ainda era vista como o prelúdio rápido e certeiro para o "socialismo". Os homens que oficialmente presidiam os interesses da vitoriosa ordem burguesa no seu momento de triunfo eram os profundamente reacionários nobres do campo da Prússia, um falso imperador na França e uma sucessão de aristocratas proprietários de terra na Inglaterra. $\mathrm{O}$ medo da revolução era real, a insegurança básica que ele indica estava arraigada.

Como explica Hobsbawm (2014, p. 24-25), o século XIX constituiu um tempo no qual foram alicerçadas as ideias e práticas que consolidaram a organização social, a concentração do poder e da renda no mundo contemporâneo:

Ao fim do nosso período, o único exemplo de revolução num país avançado, uma
insurreição em Paris quase local e de vida curta, produziu um banho de sangue
maior do que o fizera qualquer fato de 1848 e uma enxurrada de nervosas trocas
diplomáticas. Já nesse tempo, os dirigentes dos Estados avançados da Europa, com
maior ou menor relutância, começavam a reconhecer não apenas que a
"democracia", isto é, uma Constituição Parlamentar fundamentada no sufrágio
universal, era inevitável, como também provavelmente viria a ser um aborrecimento,
mas politicamente inofensivo. Essa descoberta já havia sido feita muito antes pelos
dirigentes dos Estados Unidos. [...] O drama mais óbvio desse período foi
econômico e tecnológico: o ferro derramando-se em milhões de toneladas pelo
mundo, serpenteando em estradas de ferro que cortavam continentes, cabos
submarinos atravessando o Atlântico, a construção do Canal da Suez, as grandes
cidades, como Chicago, surgidas do solo virgem do meio-oeste americano, os
imensos fluxos migratórios. Era o drama do poder europeu e norte-americano, com o
mundo a seus pés. Mas aqueles que exploraram esse mundo conquistado eram, se
excluirmos o pequeno número de aventureiros e pioneiros, homens sóbrios em
roupas sóbrias, espalhando respeitabilidade e um sentimento de superioridade racial
juntamente com gasômetros, estradas de ferro e empréstimos.

Em termos de movimentos culturais e artísticos, os dois séculos anteriores colocaram em curso importantes rupturas que foram consolidadas no século XIX como expõem Naifeh e Smith (2012, p. 588):

Em 1885, quando Hugo foi sepultado num Panteão dessacralizado, com uma salva de 21 tiros de artilharia, o mundo tinha se transformado. Se sua condição de pária heroico sobrevivia como exemplo para artistas de todas as espécies, inclusive Vincent van Gogh, sua confiança no triunfo derradeiro do espírito humano não resistiu. A chacina insensata da Guerra Franco-Prussiana, o caos da Comuna, o deslocamento gerado pelas mudanças tecnológicas, os reveses dos ciclos econômicos e o assombro trazido pelos avanços científicos, tudo se somava para que qualquer aspiração a uma verdade superior viesse a parecer mera vaidade burguesa. Quem conseguiria manter o idealismo de Hugo diante das provas de Poincaré de que o tempo e o espaço não eram constantes (subvertendo o universo estável de Newton); diante da descoberta de Pasteur de agentes invisíveis letais; do mapeamento de Flammarion de mundos invisíveis no firmamento norturno - para nem mencionar a incalculável barbárie do capitalismo?.

Para compreender o tempo em que van Gogh viveu e as condições de produção que ele encontrou para realizar suas obras, é preciso retroceder à Revolução Francesa e à Revolução Industrial para analisar as rupturas que esses movimentos trouxeram para o campo da arte. 
Abaixo, descrevo as transformações que a Revolução Francesa colocou em curso para a forma como os artistas viviam e produziam sua arte:

a) A relação do artista com o público, desde a Revolução Francesa, o trabalho dos artistas, antes comissionados pela nobreza, passou a ser exposto em salões e comprado pela nova elite burguesa em ascenção, como explica Gombrich (1999, p. 481):

Em lugar de trabalharem para mecenas individuais cujos desejos entendiam, ou para o grande público, cujo gosto podiam aferir, os artistas tinham que trabalhar agora para o êxito numa exposição onde havia sempre o perigo do espetacular e pretensioso superar o simples e sincero. De fato, a tentação era grande, para os artistas, de atraírem as atenções mediante a seleção de temas que impressionassem o público. Assim, não causa surpresa que alguns artistas desprezassem a "arte oficial" das academias e que o choque de opiniões, entre aqueles cujos dotes lhes permitiam atrair o gosto do público e aqueles que se viam excluídos, ameaçasse destruir o espaço comum em que toda a arte se desenvolvera.

b) As práticas de produção - antes as obras eram feitas em oficinas e depois passaram a ser feitas em ateliês e academias. A diferença na forma de aprender, ensinar e produzir a arte mudou drasticamente, pois as academias privilegiavam uma abordagem teórica e a observação dos antigos mestres enquanto nas oficinas se aprendia no próprio ofício de pintar as telas. Gombrich (1999, p. 480) discorre sobre essa mudança:

(...) a pintura deixara de ser um ofício ordinário cujos conhecimentos eram transmitidos de mestre para aprendiz. Convertera-se, em vez disso, numa disciplina, como a filosofia, a ser ensinada em academias. A própria palavra "academia" sugere essa nova abordagem. Deriva do nome do bosque onde o filósofo grego Platão ensinava seus discípulos e foi gradualmente aplicada a reuniões de eruditos em busca da sabedoria. Os artistas italianos do século XVI chamaram inicialmente aos seus locais de reunião "academias" para destacar essa igualdade com os humanistas que eles tinham em tão alto preço; mas só no século XVIII essas academias assumiram gradualmente a função de ensinar arte a estudantes. Assim, os antigos métodos, pelos quais os grandes mestres do passado tinham aprendido o seu ofício, triturando cores e ajudando os mais velhos, entraram em declínio. Não admira que os professores acadêmicos como Reynolds se sentissem compelidos a conclamar seus jovens alunos a estudarem diligentemente as obras-primas do passado e a assimilarem sua eficiência técnica. As academias do século XVIII estavam sob o patrocínio régio, para manifestar o interesse que o rei tomava pelo florescimento das artes em seu reino. Mas, para que as artes floresçam, menos importante é que sejam ensinadas em Instituições Reais e mais importante é que haja bastante gente disposta a comprar pinturas e esculturas de artistas vivos.

c) As práticas de circulação da obra de arte - antes era reservada aos compradores, depois passaram a ser expostas em salões onde eram avaliadas por críticos e pelo público, gerando uma ruptura entre os artistas que agradavam o gosto das autoridades dos salões e os que estavam excluídos desse circuito. Gombrich (1999, p. 480) explica o impacto dos salões na circulação da produção artística: 
Foi ai que surgiram as principais dificuldades, porque a própria ênfase sobre a grandeza dos mestres do passado, que era favorecida pelas academias, fazia com que a clientela se inclinasse mais a comprar velhos mestres em vez de encomendar pinturas aos novos. Para remediar tal situação, as academias, primeiro em Paris e depois em Londres, começaram a organizar exposições anuais das obras de seus membros.

d) As práticas de comercialização da arte - A arte, que antes era patrocinada pelos mecenas que mantinham o mercado de arte da época, passou a ser comprada pela nova classe burguesa que desejava ter um quadro em sua sala de jantar para se identificar com a nobreza.

e) A autonomia do artista na escolha dos temas de suas obras - Antes as obras eram comissionadas pelos nobres que determinavam os temas a serem representados. Depois da Revolução Francesa ocorreu uma ruptura na homogeneidade temática. Alguns artistas, tal como John Singleton Copley (17371815) com a obra Carlos I exigindo a entrega dos cinco membros da Câmara dos Comuns atingidos por impeachment, 1641, em 1785, experimentou pela primeira vez uma maior liberdade na escolha de um tema sobre a história recente da Inglaterra, ao invés de temas convencionais da antiguidade clássica (GOMBRICH, 1999). No estilo neo-clássico, Jacques-Louis David (1748-1825) com a obra Marat Assassinado, em 1793 impulsionou o interesse pela pintura de temas históricos, enquanto Francisco Goya (1746-1828) com a obra $O$ gigante, 1818 e William Blake (1757-1827) com a obra $O$ ancião dos Dias, 1794, pintaram temas voltados para um mundo fantástico. Gombrich (1999, p. 481) comenta sobre essa nova autonomia do artista na escolha do tema:

A maioria das obras mais antigas, é claro, representa episódios religiosos extraídos da Bíblia e lendas de santos. Entretanto, mesmo as pinturas de caráter secular estão limitadas, sobretudo, a um punhado de assuntos selecionados. Temos a mitologia da Grécia antiga, com suas histórias de amores e brigas entre os deuses; temos os relatos heroicos de Roma, com seus exemplos de coragem e abnegação; e temos, finalmente, os motivos alegóricos que ilustram alguma verdade geral por meio de personificações. É curioso verificar até que ponto, antes de meados do século XVIII, era raro os artistas se desviarem dos estreitos limites da ilustração, pintarem uma cena de romance ou um episódio da história medieval ou de seu próprio tempo. Tudo isso mudou muito rapidamente durante o evoluir da Revolução Francesa. De repente, os artistas sentiram-se livres para escolher qualquer coisa como tema, desde uma cena de Shakespeare a um acontecimento do dia, o que quer que, de fato, apelasse para a imaginação e despertasse interesse. Esse descaso pelos temas objetos tradicionais da arte pode ter sido a única característica que os artistas bemsucedidos do período e os rebeldes solitários tinham em comum.

f) a própria arte, que com os ateliês e a arte das academias, ganhou a distinção entre arte maior e arte menor. Com os esforços dos acadêmicos, o estilo passou a seguir cânones mais rigorosos, acompanhou a racionalidade da Revolução 
Francesa, promovendo o retorno do estilo clássico, marcado pelo rigor, privilegiando a razão, a simplicidade sobre o excesso da arte do período anterior (rococó). A tendência do neoclassicismo identificou esse novo estilo com os valores da nova ordem política e filosófica da Revolução Francesa. Em termos do que era considerado arte maior, houve uma ruptura: com a liberdade temática, a pintura de paisagens que era considerada secundária e menor ganhou força com a ajuda de artistas como J.M.W.Turner (1775-1851) e John Constable (1776-1837), como explica Gombrich (1999, p. 490-492):

Os artistas, em particular os que ganhavam a vida pintando "cenários" de casas de campo, jardins ou panoramas pitorescos, não eram considerados verdadeiros artistas. Tal atitude mudou um pouco graças ao espírito romântico do final do século XVIII, e excelentes pintores dispuseram-se seriamente a elevar esse tipo de pintura a uma nova dignidade.

No entanto, Gombrich (1999) ressalta que, enquanto ambos se dedicaram a elevar a paisagem ao status de arte maior, eles seguiram tendências distintas:

A ruptura com a tradição deixara aos artistas duas possibilidades que estavam consubstanciadas em Turner e Constable. Eles podiam tornar-se poetas na pintura e buscar efeitos comoventes e dramáticos, ou podiam manter-se fiéis ao motivo diante deles, explorando-o com toda a insistência e honestidade de que eram capazes. (GOMBRICH, 1999, p. 496).

Com a liberdade temática, duas tendências se sobressaíram nesse período. Enquanto alguns pintores românticos realizaram uma arte lírica, dramática e comovente, outros, como Constable, buscaram representar fielmente a realidade a sua volta. Para Gombrich (1999), os pintores que 'tentaram explorar o mundo visível, em vez de evocarem estados de ânimo poéticos, realizaram algo de importância mais duradoura'.

A Revolução Industrial também trouxe muitas transformações para a arte, descritas a seguir:

a) o lugar social do artista, sofreu transformações na forma de produzir, divulgar, comercializar e avaliar o trabalho de arte, relatado por Gombrich (1999, p. 501):

A vida do artista nunca estivera isenta de dificuldades e angústias, mas uma coisa pode ser dita em favor dos "bons tempos antigos": nenhum artista precisava perguntar-se por que viera a este mundo. Em alguns aspectos, seu trabalho estava tão bem definido quanto o de qualquer outra profissão. Havia sempre retábulos a fazer, retratos a pintar; as pessoas queriam comprar quadros para seus salões, ou encomendavam, para suas residências de verão, decorações murais. $\mathrm{O}$ artista podia trabalhar em todas essas linhas de acordo com normas mais ou menos preestabelecidas: ele fornecia os artigos que o freguês esperava. É verdade que poderia produzir tanto uma obra anódina como realizá-la tão superlativamente bem que o trabalho seria um ponto de partida para uma transcendente obra-prima. Sua posição na vida, porém, estava mais ou menos assegurada. E foi justamente esse sentimento de segurança que os artistas perderam no século XIX. 
Com a Revolução Industrial a destituição do lugar social do artista é aprofundada, no novo modelo econômico e produtivo, pontuado por Coli (2006, p. 29-30):

\begin{abstract}
Creio que, sem muito abuso generalizador, pode-se dizer que até os fins do século XVIII havia uma coerência cultural, solidamente estruturada, que dava ao artista seu lugar, sua função, que o colocava ao serviço do poder, da ordem, e que, por isso mesmo, impossibilitava toda revolta profunda. Os conflitos, por mais ásperos que fossem (pensemos no comportamento de Michelangelo) eram episódios individuais que não comprometiam a situação efetiva do artista. [...] Mas nas relações de produção, no contato do artista com o mecenas, com o público, com o poder, neste nível primeiro que determina as condições de possibilidade do objeto artístico e de seu próprio criador, tudo se passava com clareza: cada um conhecia seu lugar, o que devia fazer, o que devia esperar, até onde podia ir. O ultimo grande artista desse tipo dos integrados na sua época, foi David, que se harmonizou perfeitamente com o poder napoleônico.
\end{abstract}

Dentro da nova ordem produtiva o artista se encontra ulteriormente isolado em si mesmo, e esta limitação se torna seu salvo conduto para o início de um novo caminho: representar sua subjetividade na arte. Coli (2006, p. 31-33) descreve essa transformação:

Lembremos apenas que Courbet é o primeiro artista a romper conscientemente com o poder, a desdenhar o público, a assumir o papel contestador, de crítico, a reivindicar uma situação diametralmente oposta à de David. [...] A ruptura de Courbet é proposta de modo programado e claro, em nome de uma nova dignidade da arte, a dignidade do não conformismo, criando o personagem do artista independente, orgulhoso, do demiurgo senhor de si, confiante na sua arte, contra tudo e contra todos. [...] Esta atitude se encontra com certeza na base da nova consciência de si de artistas como Cézanne, van Gogh ou Gauguin. [...] Desta forma o terreno da marginalidade que van Gogh pode ocupar já havia sido preparado por Courbet. Mas não é tudo. Courbet trouxera também a ideia de um combate artístico que não se dava apenas no campo das questões formais ou estilísticas, mas que estava associado à ideia de uma reforma profunda das artes, à criação de um universo artístico moderno, próprio e específico. É ai que vai surgir, embora a palavra não fosse ainda aplicada, a ideia de vanguarda. Para Courbet, seu realismo era uma denúncia contra a pintura literária, de imaginação, que desviava o homem dos problemas de seu tempo e o dirigia para um mundo de artifícios. Courbet tinha consciência de instaurar a modernidade da arte, contradizendo a produção artística convencional da época.

A destituição do antigo lugar social do artista dentro da nova ordem produtiva o impeliu a buscar novas aspirações e a reinventar um novo lugar social, manifestando na arte as transformações a sua volta, usando sua arte como campo para contestação política ao confrontar o status quo acadêmico e burguês. Levaram adiante as rupturas iniciadas pelos artistas do romantismo assumindo o lugar do artista como o do transformador social.

b) a situação em que viviam e trabalhavam os artistas - De acordo com Gombrich (1999, p. 499) “A Revolução Industrial começou a destruir as próprias tradições do sólido artesanato; o trabalho manual cedia lugar à produção mecânica, a oficina cedia passo à fábrica.” Essa situação é analisada por Gombrich (1999, p. 501-502) a seguir: 
A ruptura na tradição abria-lhes um campo ilimitado de opções. Cabia ao artista plástico decidir se queria pintar paisagens ou cenas dramáticas do passado, se preferia temas inspirados em Milton ou nos clássicos, se adotava a maneira comedida da ressurreição clássica de David ou a maneira fantástica dos mestres românticos. Mas quanto mais ampla se tornava a gama de opções, menos provável era que o gosto do artista coincidisse com o do público. [...] O gosto do comprador fixava-se em uma direção; mas o artista não se sentia obrigado a satisfazer suas imposições. Quando se via forçado a isso por falta de dinheiro, sentia estar fazendo "concessões", perdendo seu amor-próprio e o respeito dos outros. Se decidia ouvir apenas sua voz interior e rejeitar uma encomenda que não se harmonizava com a sua ideia de arte, corria o perigo de passar fome. Assim desenvolveu-se uma profunda brecha no século XIX entre os artistas cujo temperamento lhes permitia obedecer às convenções e satisfazer à demanda do público e os que se orgulhavam de seu isolamento auto-imposto. O que tornava as coisas ainda piores era que a Revolução Industrial, com o declínio do artesanato, a ascenção de uma nova classe média que frequentemente carecia de tradição e a produção de bens vulgares e pretensiosos, quase sempre mascarados de "arte", tinham acarretado a deterioração do gosto popular.

c) a concepção de arte - Gombrich (1999, p. 499) afirma que "As academias e exposições, os críticos e connoisseurs, tinham-se esforçado por introduzir uma distinção entre Arte com 'A' maiúsculo e o mero exercício de um ofício, fosse o de pintor ou de construtor.". Gombrich (1999, p. 504) homenageia o empenho dos artistas do século XIX em ressignificar a arte:

E, no entanto, é provável que continue sendo sempre verdadeiro que, desde a Grande Revolução, a palavra Arte adquiriu para nós um significado diferente e que a história da arte no século XIX nunca venha a ser a história dos mestres de maior êxito e mais bem-pagos desse período. Vemo-la antes como a história de um punhado de homens solitários que tiveram a coragem e a persistência de pensar por si mesmos, de examinar convenções sem temor e em termos críticos, criando assim novas possibilidades e perspectivas para a arte.

Os artistas tinham questionado os temas comissionados e passaram a comercializar sua produção para a classe burguesa em ascenção. No entanto, a busca de autonomia viu-se restringida pelas preferências do gosto burguês que seguia a forte tendência do academicismo, como descreve Gombrich (1999, p. 502):

(...) embora a carreira de um artista estivesse eivada de armadilhas sumamente perigosas, as novas condições também tinham suas compensações. As armadilhas são óbvias. $\mathrm{O}$ artista que vendia sua alma e se mostrava complacente com o gosto dos que careciam de educação estética estava perdido. O mesmo acontecia do artista que dramatizava a situação, considerando-se um gênio pelo simples fato de não encontrar compradores. Mas a situação só era desesperada para os débeis de caráter. Pois a vasta gama de opções, e a independência dos caprichos do cliente, conquistada por tão alto preço, também tinham suas vantagens. Pela primeira vez tornou-se verdade que a arte era um veículo perfeito para expressar a individualidade - desde que houvesse mesmo uma individualidade a expressar.

Insatisfeitos com as normas dos ateliês e salões de pintura que ditava o gosto burguês, alguns artistas começaram a questionar a autoridade das academias de arte e assumirão uma 
maior autonomia em relação à expressão na arte. Gombrich (1999, p. 503) examina essa transformação:

A ideia de que a verdadeira finalidade da arte era expressar a personalidade só poderia ganhar terreno quando a arte tivesse perdido todas as demais finalidades. Não obstante, com a evolução das coisas, isso era um enunciado verdadeiro e valioso. Pois o que as pessoas interessadas em arte passaram a procurar em exposições e estúdios já não era uma exibição de habilidade vulgar - que se tornara comum demais para justificar qualquer atenção; o que elas queriam era que a arte as aproximasse de homens com quem valeria a pena ter relações, homens cujo trabalho era testemunho de uma sinceridade incorruptível, artistas que não se contentavam em copiar efeitos criados por outros e não dariam uma única pincelada sem perguntar a si mesmos se ela satisfazia a sua consciência artística.

d) a relação entre artista e o público - Gombrich (1999) explica que essa busca se pautou pela reação aos sistemas estabelecidos pelas academias de belas artes e desencadeou uma quebra da antiga unidade entre artista e público que havia predominado até o classicismo:

A desconfiança era geralmente recíproca entre os artistas e o público. Para o homem de negócios bem-sucedido, um artista era apenas pouco melhor do que um impostor que exigia preços absurdos por algo a que dificilmente se poderia chamar trabalho honesto. Entre os artistas, por outro lado, tornou-se um reconhecido passatempo "chocar o burguês", obrigá-lo a sair da sua complacência e deixá-lo boquiaberto e bestificado. Os artistas começaram a ver-se como uma raça à parte, deixaram crescer cabeleiras e longas barbas, vestiam-se de veludo, usavam chapéus de abas largas e, em vez de gravata, um largo nó esvoaçante à lavallière; de um modo geral, enfatizavam seu desdém pelas convenções do "cidadão respeitável". (GOMBRICH, 1999, p. 502).

A partir do Romantismo, os artistas buscaram romper com as normas neoclássicas da pintura que ditavam os cânones de como deveriam ser a pintura consagrada da época. A amplitude da ruptura entre os artistas e o público é analisada por Coli (2006, p. 29):

Nunca antes, na história, houve uma ruptura tão radical entre os artistas e o público. Nem a solidão da velhice de Rembrandt, nem o comportamento de enfant terrible de Caravaggio, nem as malandragens de Cellini têm um ponto qualquer de comparação com esse isolamento - e ao mesmo tempo essa certeza do bom caminho - que encontramos nos mestres do fim do século XIX.

Em meio aos impactos avassaladores da Revolução Industrial, não foi por acaso que Vincent se deparou com uma equação que desafiou todos os seus contemporâneos: a de viver da própria arte. Ele viveu em uma época de desestruturação na forma como a arte era exposta, comercializada e consumida. Esse desafio é examinado por Coli (2006, p. 137):

Num momento de descompasso entre o gosto do público e a criação artística que se renova, num momento de transformações profundas das infra-estruturas comerciais da produção artística, em que os marchands, as galerias de arte se afirmam como um motor capital no interior da dinâmica das artes, nesse período de mudanças, casos críticos como o da relação van Gogh/público são perfeitamente compreensíveis como sintomas. O contrário é que seria de espantar: o público de ontem não é culpado de seus critérios, nem o público de hoje tem mérito pelos seus. O que houve foi uma conjunção de fatores que determinaram esses critérios coletivos, e uma evolução cultural permitiu depois a recuperação de Vincent van Gogh. 


\subsubsection{A construção cultural do discurso artístico de cada época}

Para falar de discurso artístico, é preciso pensá-lo como uma produção cultural, história, política, subjetiva e, sobretudo, coletiva. O discurso artístico de Vincent van Gogh não se constituiu isolada ou fortuitamente. Ele é produto das ordens discursivas, da circulação das ideias e de discursos que povoaram os espaços, as práticas e o século em que ele viveu e forneceram insumo para que ele os materializasse em seu discurso artístico. Para compreender o processo de construção discursiva que ocorria no campo da arte, será necessário uma breve exposição dos movimentos artísticos que antecederam ou que conviveram justapostos no tempo em que van Gogh desenvolveu seu discurso artístico. Essa retrospectiva engloba o período que remonta à Revolução Francesa seguida da Revolução Industrial, duas grandes revoluções que incidem em um tempo pleno de transformações, e podem revelar os discursos e os sentidos que, ao longo daquele período, estavam sendo negociados na cultura e materializados na arte, por atores como van Gogh e outros artistas já citados na introdução deste capítulo.

\subsubsection{Neoclassicismo}

O século XIX começa já sob a tendência do Neoclassicismo em amplo desenvolvimento. Essa escola postulava os valores centrais de uma arte de austeridade moral e de propósito político a serviço dos ideais da Revolução Francesa que se espalhavam pelo continente, como descreve Gombrich (1999, p. 485):

O principal artista desse estilo neoclássico foi o pintor Jacques-Louis David (17481825), que foi o "artista oficial" do Governo Revolucionário e desenhou os trajes e cenários para eventos de propaganda como o "Festival do Ser Supremo", no qual Robespierre oficiava como sumo sacerdote autonomeado. Essas pessoas achavam estar vivendo tempos heróicos, e consideravam os acontecimentos de seus próprios dias tão dignos da atenção do pintor quanto os episódios da história grega e romana. Quando um dos líderes da Revolução Francesa, Marat, foi assassinado na banheira por uma jovem fanática, David pintou-o como um mártir que morrera por sua causa (Fig.316). [...] A situação não parece prestar-se a um quadro de dignidade e grandeza, mas David conseguiu fazê-lo parecer heróico, [...]. Ele aprendera, do estudo da escultura grega e romana, como modelar os músculos e tendões do corpo e dar a este uma aparência de nobre beleza; também aprendera com a arte clássica a desprezar todos os detalhes que não são essenciais ao efeito principal, e a almejar a simplicidade. 


\subsubsection{Romantismo}

Essa tendência foi questionada em seguida pelos artistas Românticos, tais como o alemão, contemporâneo de Turner (1775-1881), Caspar David Friedrich (1774-1840), “cujas paisagens refletem o estado de espírito da poesia lírica romântica do seu tempo" (GOMBRICH, 1999, p. 496). No Romantismo, prevaleceu a crença no indivíduo como força motriz da história e do progresso e o emocional, o irracional, o místico, o intuitivo e o simbólico foram valorizados como centralidade do pensamento artístico em contraposição à racionalidade e às regras limitadoras. O Romantismo deu impulso para os artistas romperem com a opressão das acadêmicas de arte, com o utilitarismo social da arte imposto pelas instituições sociais e políticas, com a opinião pública e com o senso comum sobre o bom gosto, a tradição, as convenções da ordem estabelecida.

\subsubsection{Realismo}

Outros movimentos também impulsionaram essa ruptura. Um deles foi o Realismo, que foi tanto uma escola de pensamento quanto uma corrente artística, e seus pintores se rebeleram contra a arte acadêmica e a representação de aristrocatas e mitos. Os pintores do Realismo, tais como, Jean-François Millet (1814-75), Gustave Courbet (1819-77) e Daumier (1808-79) pensavam que todo o conhecimento significativo advinha do que eles podiam ver e experienciar diretamente e os temas do academicismo não representavam o mundo repleto pelos recentes avanços científicos e tecnológicos da época. Gombrich (1999) enfatiza que eles preferiam representar cenas banais da vida cotidiana, da pobreza, dos trabalhadores em sua lida:

\footnotetext{
Por mais que a calma maestria de Corot fosse amada e admirada também por seus colegas mais jovens, eles não queriam acompanhá-lo nesse caminho. De fato, a revolução seguinte envolveu principalmente as convenções que regem a temática. Nas academias, ainda era preponderante a ideia de que pinturas dignas devem representar personagens dignos, e de que trabalhadores e camponeses fornecem temas adequados somente para as cenas de genre, na tradição dos mestres holandeses (p. 381, 428). Durante a Revolução de 1848, um grupo de artistas reuniuse na aldeia francesa de Barbizon para seguir o programa de Constable e observar a natureza com novos olhos. Um deles, Jean-François Millet (1814-75), decidiu estender o programa das paisagens às figuras. Quis pintar cenas de vida camponesa tal como realmente era, pintar homens e mulheres trabalhando no campo. É curioso refletir por que, afinal, isso deveria ser considerado revolucionário; mas ocorre que, na arte do passado, os camponeses eram geralmente vistos como labregos ridículos, conforme Bruegel os pintara. (GOMBRICH, 1999, p. 508-509)
}

Este movimento influenciou profundamente a formação do discurso artístico de Vincent van Gogh. Ao estudá-lo, observa-se a identificação de Vincent por meio de um 
diálogo intermitente com esse movimento ao longo de sua obra. Na tela As respigadeiras, por exemplo, Millet representa três mulheres trabalhando em uma colheita. A cena não mostra nenhum acontecimento além do trabalho, não há graciosidade nas figuras ou uma sugestão de idílio na natureza. Ao contrário, as camponesas não são graciosas, duas estão curvadas e voltadas para o chão, e parecem absorvidas por um trabalho árduo. Millet representa mulheres robustas com uma simplicidade nos contornos bem definidos que lhes empresta uma dignidade natural e despretensiosa. A composição inteira por ser uma cena banal, parece casual, mas a deliberada distribuição das figuras dá uma estabilidade ao espaço e constrói um sentido de equilíbrio e tranquilidade como pontua Gombrich (1999, p. 511):

\begin{abstract}
A ideia de um pintor se representar em mangas de camisa e como uma espécie de andarilho deve ter parecido um ultraje aos artistas "respeitáveis" e seus admiradores. De qualquer modo, era essa a impressão que Coubert queria causar. Pretendia que seus quadros fossem um protesto contra as convenções aceitas do seu tempo, "chocassem a burguesia" para obrigá-la a sair de sua complacência, e proclamassem o valor da intransigente sinceridade artística contra a manipulação hábil de clichês tradicionais. As telas de Courbet são, fora de qualquer dúvida, sinceras. Escreveu ele numa carta característica em 1854: "Espero sempre ganhar a vida com minha arte, sem me desviar um milímetro dos meus princípios, sem ter mentido à minha consciência nem por um único momento, sem pintar sequer o que pode ser coberto pela palma da mão só para agradar a alguém ou para vender mais facilmente.” A deliberada renúncia de Courbet a feitos fáceis, e sua determinação de representar o mundo tal como o via, estimularam outros a rejeitar o convencionalismo e a seguir apenas sua própria consciência artística.
\end{abstract}

Muito lentamente, o gosto burguês inicialmente voltado para as escolas mais tradicionais e conservadoras terminou por ceder para uma maior liberdade que os artistas buscavam para explorar novos temas e explorar novos estilos. Dessa forma eles passaram a buscar novas formas de representar o mundo real, trabalhando ao ar livre, em contato direto com a luz e com a luminosidade do ambiente externo, como argumentam Naifeh e Smith (2012, p. 584-585):

Em 1885, escritores e poetas haviam, em sua maioria, abandonado o campo que Hugo defendera com tanto vigor - assustados, como todos os demais, pelo espectro da falta de sentido. Alguns, como Zola, firmaram uma paz em separado com as forças sombrias do modernismo. Abraçando o credo positivista da salvação por meio da ciência, dispunham os "fatos" do cotidiano em ordem de combate para atacar a complacência burguesa - o mesmo inimigo que Hugo combatera longamente com criações de impacto e uma retórica elevada. Mas outra geração mais nova de escritores pouco conforto encontrava no mundo limitado dos fenômenos observáveis apresentado pelos naturalistas. Como o registro de dados, mesmo o brilhante registro de dados de Zola, seria capaz de captar a inquietante fermentação das emoções humanas ou o mistério da existência? A realidade absoluta não seria a realidade sentida, em vez de observável? Não o mundo "real", mas a percepção do mundo real? Se havia significado a encontrar na vida - e esse "se" era crucial -, então só poderia ser encontrado no tortuoso labirinto da psique. O imperativo supremo da arte era, sem dúvida, mapear esse labirinto: expressar diretamente, sem ornamentos nem atenuantes a realidade elementar da consciência humana. 
Esse tempo de maior experimentação ocorreu principalmente na França e deu lugar a novos métodos de trabalhar e com eles, a novas tendências e estilos que privilegiaram as impressões, a estrutura, a objetividade, a emoção subjetiva, os instintos, a política de classe, a visão social, os símbolos, o império.

\title{
2.1.1.4 Impressionismo
}

O outro movimento que impactou tanto o século XIX quanto o seguinte foi o Impressionismo. Os pintores impressionistas, tais como Édouard Manet (1832-83), Claude Monet (1840-1926), Sisley (1839-99), Camille Pissarro (1830-1903), Auguste Renoir (18411919), Signac (1863-1935), Henri de Toulouse-Lautrec (1864-1901), Edgar Degas (18341917) entre outros deram passos importantes para romper com a prática das academias de se pintar em lugares fechados com base em esboços preparatórios e previlegiaram pintar como experienciavam as sensações da luz capturadas no momento fugaz da percepção direta da cena, ao ar livre. O programa impressionista é descrito por Gombrich (1999, p. 512-513):

\begin{abstract}
A terceira onda de revolução na França (após a primeira onda de Delacroix e a segunda de Courbet) foi iniciada por Édouard Manet (1832-83) e seus amigos. Esses artistas tomaram muito a sério o programa de Courbet. Procuraram convenções na pintura que se tinham tornado corriqueiras e destituídas de significado. Concluíram que a pretensão da arte tradicional, de que descobrira o modo de representar a natureza tal como a vemos, se baseava numa concepção errônea. No máximo, admitiram que a arte tradicional encontrara um meio de representar homens e objetos sob condições muito artificiais. Os pintores fazem seus modelos posarem em estúdios onde a luz jorra através da janela, e utilizam a lenta transição da luz para a sombra visando a causar a impressão de volume e solidez. Os estudantes de arte nas academias eram treinados desde o começo para basear seus quadros na interação entre luz e sombra. No início, desenhavam usualmente a partir de moldes em gesso de estátuas antigas, sombreando cuidadosamente os desenhos para obter diferentes densidades. Uma vez adquirido esse hábito, aplicavam-no a todos os objetos. $\mathrm{O}$ público acostumara-se de tal modo a ver as coisas representadas dessa maneira que acabara esquecendo que, ao ar livre, em geral não percebemos tais gradações partindo do escuro para a luz. Existem contrastes violentos na luz solar. Os objetos retirados das condições artificiais do estúdio do artista não parecem tão redondos nem tão modelados quanto os moldes em gesso de uma escultura antiga. As partes que estão iluminadas parecem muito mais brilhantes do que no estúdio, e até as sombras não são tão uniformemente cinzentas ou negras, porque os reflexos de luz dos objetos circundantes afetam a cor dessas partes não-iluminadas. Se confiarmos em nossos olhos e não em nossas ideias preconcebidas sobre como as coisas devem parecer, de acordo com as regras acadêmicas, faremos as mais excitantes descobertas.
\end{abstract}

Ao romper com a convenção de pintar com a aparência naturalista das formas, o Impressionismo explorou a impressão da aparência das formas sob a luminosidade cambiante da incidência da luz e não a sua solidez permanente e priorizou a cor e a luz em lugar das linhas e dos contornos das formas. 


\subsubsection{Pós-impressionismo}

O Pós-impressionismo é o próximo movimento de arte que dará o grande salto para engendrar a arte do século XX. Vincent van Gogh (1853-1890), Paul Cézanne (1839-1906), Paul Gauguin (1848-1903), Georges Seurat (1859-91) e Odilon Redon (1840-1916) são considerados por críticos e historiadores como pós-impressionistas. Embora eles não compartilhassem o mesmo estilo, temas e concepções de arte e fossem muito diferentes uns dos outros. Esta denominação foi aplicada restrospectivamente, ou seja, o pós-impressionismo foi definido pelo crítico inglês Roger Frey, e deve-se ao título dado à exposição "Manet e os pós-impressionistas", realizada em Londres (1910-1911). O pós-impressionismo passou a ser usado por críticos e historiadores em um esforço de abranger a produção artística que ocorreu entre 1880 e o início do século XX e também como uma forma de identificar entre esses artistas, elementos linguísticos comuns tais como o foco na estrutura, na composição, no significado simbólico, na forma significativa, na visão social, como centralidade para comunicar emoção.

Em vida, eles nunca integraram um movimento e nem sequer tinham objetivos artísticos em comum. No entanto, a exposição "Manet e os pós-impressionistas", realizada em Londres (1910-1911), tornou-se emblemática de um novo movimento que deixava para trás o impressionismo, uma vez que as obras destes artistas foram colocadas ao lado das obras de Manet como que indicando de onde os quadros de Manet vinham e o que estavam deixando para trás. Enquanto Manet rompia com a tradição em busca de seu próprio olhar, os pósimpressionistas buscaram ir além desse objetivo. Manet buscou uma visão própria com seu Dejeuner sur l'herbe, afirmando a liberdade de romper com a tradição e esse objetivo foi reconhecido como um denominador comum para os Pós-Impressionistas que o levaram mais adiante rompendo completamente com os padrões do gosto burguês.

Eles também estavam insatisfeitos, assim como Manet, com as preocupações artísticas dos impressionistas com a luz, as impressões momentâneas, a natureza. O PósImpressionismo se caracterizou como um movimento artístico amplo, anti-burguês com um foco maior na estrutura e composição, e que recusou a imitação da natureza ou a moralização por meio de temas narrativos. Para isso priorizaram o foco na composição, na estrutura e na forma, restabelecendo a ênfase no sentido emocional, espiritual e simbólico da arte e são por isso considerados os precursores da arte moderna.

As contribuições do trabalho de Cézanne foram centrais para o Pós-Impressionismo marcado por uma pintura que precisava ser planejada e estruturada. Gauguin também rompeu 
com os padrões tradicionais e naturalistas, tais como: a profundidade espacial, a modelagem dos volumes, os efeitos de luz e sombra e priorizou o significado emocional e simbólico, buscando dar forma para a composição, enfatizando áreas que eram pintadas em cores chapadas, estruturando suas pinturas a fim de transmitir o que ele sentia ser a verdade espiritual da sua temática. Com sua arte, van Gogh avançou na direção do rompimento com os padrões naturalistas e com o gosto burguês, tanto na técnica quanto nas temáticas. Seus trabalhos concentraram-se na intensidade cromática, na textura e no ritmo das pinceladas que declaram uma preferência pós-impressionista pelas formas simplificadas e cor intensa.

Para dar a medida da importância da sua contribuição para os sistemas semióticos da arte que se seguirão, é preciso dimensionar o impacto de van Gogh, Cézanne e Gauguin na história da arte, considerados os precursores da quase totalidade dos movimentos modernos do século XX por sua visão sobre o que pode vir a ser a arte. Eles causaram uma profunda transformação na forma como os artistas concebiam sua prática e pensavam acerca de si mesmos, instaurando um pensar filosófico e uma visão de mundo associada à prática pictórica e esse pensamento está presente no discurso epistolar de van Gogh, em sua correspondência com seus pares. A partir deles, os artistas apropriaram-se de novas práticas discursivas e passaram cada vez mais a se perceber como protagonistas de uma visão social transformadora, para a qual se comprometiam até o ponto de rejeitar, se fosse preciso, as recompensas financeiras ou as benesses do reconhecimento social.

De acordo com Gombrich (1999), esse empoderamento simbólico do lugar artista pela reengenharia do seu papel social foi talvez tão importante quanto os inestimáveis avanços em relação aos métodos e ao uso original dos sistemas pictóricos. Estes não foram conquistados sem um grande investimento humano, moral, psíquico e físico pelos artistas que experienciavam o deslocamento de seu lugar social que acompanhou as grandes revoluções iniciadas no século XVIII (GOMBRICH, 1999). Entre os quais, é preciso que se diga, encontra-se Vincent van Gogh, que deixou um legado para arte e para os artistas redimensionando usos para o grande manancial linguístico e enorme potencial transformador que a linguagem artística detém. Até o final daquele século XIX, os artistas vanguardistas identificariam a arte com a sua capacidade de autenticidade enquanto indivíduos e enquanto propositores das transformações sociais que sua arte deflagaria. 


\subsection{CONCLUSÃO}

Espero que este capítulo tenha reunido elementos do contexto histórico e cultural, senão suficientes, pelo menos preliminares, para subsidiar a investigação sobre o discurso artístico de van Gogh que está linguisticamente materializado nas telas que ele produziu e na correspondência que ele trocou com seus irmãos Theo e Wilhelmine e seu amigo Bernard no período mais profícuo de sua obra pictórica. Os biógrafos Naifeh e Smith (2012), Haziot, (2010), Cabanne (1971), Forrester (1983) e historiadores de arte Gombrich (1999), Petrie (1974), McQuillan (1989), Walther e Metzger (2012, 2015), Schapiro (2010), Coli (2006), Edwards (2009) e Pereira (1990), contribuíram com relevantes informações em uma perspectiva histórica que contribui para revelar aspectos do contexto social, religioso e familiar e que se contrapõem ao mito de um artista alheio ao seu tempo, que circunda a figura de van Gogh.

Neste capítulo, eu procurei concentrar informações históricas e biográficas de Vincent van Gogh do contexto sócio-histórico-cultural, reunindo principalmente as dimensões da arte, da religião, das práticas da família parental. Para isso, focalizei um pouco mais na cultura familiar para destacar algumas práticas adotadas por van Gogh em sua vida adulta, tais como o desenho, a pintura e o hábito da correspondência que estiveram na base da sua formação familiar e do registro da produção de seu discurso artístico. Dessa forma, considero seguro afirmar, a análise linguística desta pesquisa observa os pressupostos da Semiótica Social e examina os aspectos históricos e sociais nos quais o discurso artístico de Vincent van Gogh se ancora, entre eles a sua bagagem familiar e sua história de leituras, sem os quais, suas concepções de mundo e seu discurso artístico não podem ser amplamente compreendidos. A seguir introduzo o capítulo da Fundamentação Teórica, que expõe os pressupostos e ferramentas conceituais da Linguística Sistêmico-funcional e da Teoria Semiótica Social Multimodal e da Análise de Discurso Crítica que baseiam esta pesquisa. 


\section{CAPÍTULO 3: FUNDAMENTAÇÃO TEÓRICA}

\section{INTRODUÇÃO}

Com a finalidade de subsidiar a análise das telas e cartas produzidas por van Gogh, a presente pesquisa apoiou-se nas bases teóricas da Gramática Sistêmico Funcional (HALLIDAY; HASAN, 1985; EGGINS, 2012; HALLIDAY; MATTHIESSEN, 1985, 2004, 2014; BUTT et al., 2000; THOMPSON, 2004) e da Teoria Semiótica Social Multimodal, associada ao conceito da Multimodalidade (O'TOOLE, 1994; KRESS; VAN LEEUWEN, 1996, 2008, 2011; VAN LEEUWEN, 2001 apud MACHIN, 2007; MACHIN, 2007; KRESS, 2010; JEWITT, 2011) e a Teoria da Análise de Discurso Crítica (FAIRCLOUGH, 2001, 2003, 2010).

A pesquisa beneficiou-se das perspectivas teóricas da Multimodalidade O’Toole (1994), Kress e van Leeuwen (1996), van Leeuwen (2011), para analisar respectivamente o corpus das telas, e da Linguística Sistêmico-Funcional postulados em Halliday (1978, 1994), Halliday e de Mathiessen (1985, 1994, 2004, 2014), Halliday e Hasan (1989), Eggins (2012), Butt et al. (2000), Martin e Rose (2003) Thompson (2004) para analisar o corpus das cartas produzidas por van Gogh e da combinação dessas duas teorias com a Análise de Discurso Crítica para a etapa da triangulação das análises dos corpora e da discussão dos achados.

\subsection{DIFERENCIAÇÃO DE TERMINOLOGIA}

Encontrei uma diferença na terminologia utilizada por O’Toole (1994) e por Kress e van Leeuwen (1996) que considerei relevante fazer a diferenciação a seguir. O termo 'função Modal' é empregado por O’Toole (1994) e diferencia-se do termo 'função Interativa', que é usado por Kress e van Leeuwen (1996) para a mesma função. O termo 'função Modal' de O’Toole foi adotado nesta pesquisa para a análise das telas selecionadas uma vez que o modelo proposto por esse autor descreve com maior acuidade as especificidades da linguagem pictórica.

Além de embasar os eventos pesquisados com as considerações de teóricos da Semiótica Social, tais como Halliday e Mathiessen (2004), Kress e van Leeuwen (1996) e O’Toole (1994), dediquei uma sessão dentro do tópico da Multimodalidade para descrever algumas características da linguagem pictórica que não foram descritas até o presente 
momento pela Gramática do Design Visual. Para isso, busquei subsídios nas áreas da Arte e da Percepção Visual, com as noções dos elementos da linguagem e das estratégias de composição desde o ponto de vista de Kandinsky (1926 apud VAN LEEUWEN, 2011), Itten (1973), Arnheim (1974), Dondis (2007), a fim de complementar as concepções da TSSM e da Gramática do Design Visual de Kress e van Leeuwen (1996), van Leeuwen (2011) e O’Toole (1994), para promover um diálogo transdisciplinar.

\subsection{A LINGUÍSTICA SISTÊMICO-FUNCIONAL - LSF}

Na seção que segue, desenvolvo os pressupostos teóricos e as ferramentas conceituais disponíveis na Linguística Sistêmico-funcional que concebe a linguagem como sistema semiótico. A Gramática Sistêmico-funcional é parte da Linguística Sistêmico-funcional, é uma forma de descrição gramatical em uma rede de sistemas para construir os significados. Os subsídios teóricos da LSF foram usados na análise do discurso epistolar de van Gogh.

\subsubsection{A Linguagem para Halliday}

A concepção de linguagem desenvolvida pela Linguística Sistêmico-funcional busca investigar de que forma a línguagem, vista como processo social, se organiza para produzir sentido. A linguagem é um sistema de recursos que permite a troca e a produção de significados utilizados no meio social para o falante desempenhar papéis sociais. A linguagem possibilita a materialização de uma ampla gama de significados potenciais que, pelo uso, viabilizam a construção de sentidos e estabelecem as relações sociais.

Eggins (2012, p. 3) pontua que o interesse na linguagem, na perspectiva da Semiótica Social (HALLIDAY, 1978), tem capturado as preocupações dos principais linguístas sistêmicos e essas organizam-se basicamente em quatro pressupostos que norteiam as questões teóricas sobre o uso da linguagem:

1) A linguagem é usada funcionalmente;

2) A função da linguagem é a de produzir sentidos;

3) O contexto social e cultural exerce influência para a construção dos sentidos;

4) $\mathrm{O}$ processo de usar a linguagem é um processo de construir sentidos por meio de escolhas léxico-gramaticais e é, portanto, um processo semiótico. 
Esses quatro pressupostos indicam que o uso da linguagem é funcional, semântico, contextual e semiótico. A perspectiva sistêmica é uma abordagem funcional-semântica da linguagem em dois aspectos principais:

1) Como as pessoas usam a linguagem?

2) Como a linguagem está estruturada para o uso?

Os sistemicistas sugerem que a função geral da linguagem é semântica, uma vez que ao analisar os textos produzidos na interação social cotidiana, eles observaram que as pessoas negociam textos a fim de produzirem sentidos entre si. Dessa forma, eles reformularam as questões funcionais de forma semântica.

1) É possível diferenciar os tipos de significados usados na linguagem? Quantos tipos de significados nós usamos na linguagem para produzir sentido?

2) Como os textos são estruturados para produzir os significados? Como a linguagem se organiza para produzir significados?

Halliday (1985, 1994) defende que a linguagem está estruturada para produzir simultaneamente três tipos de metafunções que permitem significados ideacionais, interpessoais e textuais, que se integram em unidades linguísticas em uma complexidade semântica.

O texto é uma instanciação da linguagem, pois a linguagem se materializa por meio de textos. Halliday e Matthiessen (2004, p. 4-5) definem texto como "qualquer instância da linguagem, em qualquer meio que faz sentido para alguém que conhece a linguagem." O texto organiza significados semânticos em um contexto de situação no qual falante e ouvinte trocam significados.

Como um sistema semiótico baseado na gramática, a linguagem se organiza por estratos ou níveis e pela sua variedade funcional. No estrato semântico, está o sistema de significados que se materializa no estrato seguinte pelo uso da léxico-gramática, que é um sistema de estruturas gramaticais e itens lexicais. A léxico-gramática materializa-se pelo uso da fonologia e da grafologia, no estrato seguinte, que respondem pelos sistemas de sonoridade e de grafia da linguagem. Todos esses sistemas são interdependentes uma vez que eles integram na prática o texto que é a manifestação do estrato semântico, que está envolvido pelo contexto.

Para Halliday e Mathiessen (1999), é fundamental diferenciar a estrutura do sistema sendo que:

- a estrutura é uma organização sintagmática na linguagem que opera por meio de padrões ou regularidades de uso e ordena o que vai junto com o que. 
- o sistema é uma organização paradigmática na linguagem que funciona por meio de padrões ou regularidades de uso e ordena o que pode figurar em lugar do que. Sempre que há um conjunto de alternativas, temos um sistema.

Cada sistema da rede realiza os significados por meio das escolhas feitas pelo falante nos diferentes níveis de sua comunicação. Nessa visão, o sistema linguístico vai se formando por meio dos usos, ou seja, das escolhas feitas pelo falante, de acordo com o contexto do uso. Isso se torna possível porque a linguagem é um sistema que pode ser codificado por meio de convenções e essas convenções são possibilitadas por um conjunto de escolhas. Este conjunto de escolhas é que faz da linguagem um sistema semiótico no qual cada escolha adquire seu significado em contraste com um conjunto de escolhas que poderiam ter sido feitas e não foram. As escolhas revelam uma rede de outros significados disponíveis no sistema.

Na concepção de Halliday, a gramática da linguagem é vista como um sistema de redes e não como um inventário de estruturas prontas. Os significados inter-relacionados formam uma rede semântica que serve de recurso para outros sistemas e subsistemas que disponibilizam escolhas nas quais o significado é produzido. Essa capacidade associativa permite que os sistemas semióticos se distingam de outros tipos de sistema. Esta compreensão da linguagem como um sistema semiótico nos permite pensar a pertinência ou a não pertinência de diferentes escolhas linguísticas de acordo com os contextos de seu uso e nos permite ver a linguagem como um recurso que é usado para produzir sentidos em seu contexto de uso. E na arte, como são feitas estas escolhas?

Uma análise integrada do discurso artístico preocupa-se em abordar a obra de arte no contexto do universo discursivo do autor que é produzido em modalidades diversas, encontrando nesta relação, elementos basilares que participaram na construção do texto visual e do texto escrito. A compreensão desses sentidos é muito importante para compreender o texto artístico no contexto do universo linguístico que o produziu e articular a análise do texto visual e do texto escrito no contexto das semioses que interligam o discurso verbal com o discurso pictórico do autor.

No processo de produção de sentidos, manifestam-se diferentes estratégias de expressão que podem apresentar correspondência tanto no discurso pictórico quanto no discurso escrito. A relação entre as estratégias discursivas usadas nos diferentes gêneros revelam a elaboração de um potencial de expressão inexplorado com o qual o artista produz sua linguagem e que revelam um registro comum e compartilhado nas cartas e nas telas com base em concepções artísticas que fornecem um denominador comum na construção de textos diversos. 
Quando o artista articula os recursos semióticos em uma tela, ele pode usar alguns desses elementos como indexadores de uma camada de sentidos que ele deseja comunicar. Dessa forma, o autor constrói uma camada de sentidos por meio de associação a um sistema de escolhas potenciais dos recursos pictóricos que ficam referenciados, em seu discurso, à um sentido implícito que condensa sentidos. $\mathrm{O}$ espectador da tela pode observar que o artista construiu um texto visual no qual não se vê apenas um sentido, mas camadas de outros sentidos indexados pela conjugação de elementos compositivos. Esses, por sua vez, criam associações metafóricas e sistemas de escolhas potenciais e integram a experiência do artista ao texto visual, resultando em um texto polissêmico, que pode ter qualquer um de seus elementos evidenciados pela condensação de sentidos.

Diferente do discurso científico que define, delimita e formaliza os sentidos na tentativa de reduzir a ambivalência e a ambiguidade, o discurso artístico expande e transpõe as fronteiras dos usos linguísticos; ao fazê-lo constrói semioses imponderáveis, e que vão muito além do uso comum, propondo novos modos, usos e práticas de fazer sentido, mesmo que, para realizar essa proeza, faça um uso farto de ambiguidade, de deslocamentos e transposições de construtos que circulam e transitam nas diferentes modalidades nas quais van Gogh se expressou.

\subsubsection{O contexto}

A LSF apoia-se em dois conceitos, considerados fundamentais por Halliday (1999) para entender a linguagem na perspectiva de seu uso. São eles os conceitos de 'Contexto de Situação' e 'Contexto de Cultura', fundamentais para compreender os usos e escolhas que ajudaram na construção de sistemas semióticos no pensamento e na obra de Van Gogh, quando vistos desde o contexto cultural e social no qual foram produzidos.

Eles fornecem duas perspectivas diferentes para observar a mesma coisa: o potencial para qualquer situação que pode acontecer, e a situação que de fato acontece, como uma manifestação da cultura. A diferenciação entre os dois conceitos foi ilustrada por Halliday e Mathiessen (1999, p. 9, tradução nossa) por meio da metáfora: 
quando nós estamos olhando de perto, e clima quando estamos olhando para ela de uma distância. ${ }^{5}$

O conceito de contexto de situação transposto por Halliday, McIntosh e Stevens (2007) foi concebido pelo antropólogo inglês Malinowski (1923 apud VAN LEEUWEN, 2011), professor de Halliday, para explicar os usos lexicais da lingua Kiriwinian, das Ilhas Trobriand do Pacífico Sul. Para Halliday e Mathiessen (1999), o conceito de contexto de situação é um dos pilares da LSF e abrange "três componentes significativos: a atividade social subjacente, as pessoas ou 'vozes' envolvidas naquela atividade e as funções particulares de acordo com o texto." (HALLIDAY; MATHIESSEN, 1999, p. 10). Ele rotula esses componentes tecnicamente como: campo, relação e modo de discurso.

Já o conceito de contexto de cultura, que significa "os estilos de vida tradicionais, crenças, e sistema de valores de uma linguagem de comunidade" (HALLIDAY; MATHIESSEN, 1999, p.17), foi emprestado por Halliday e Mathiessen (1999) de Sapir e Whorf (apud HALLIDAY; MATHIESSEN, 1999). Halliday (1999) considera que o contexto de cultura abrange quatro estágios: no primeiro, os aprendizes produzem texto; no segundo, eles relacionam esse texto com o contexto da situação na qual ele foi criado; no terceiro, eles constroem os sentidos potenciais contra os quais os sentidos do texto se manifestam e, por último, eles relacionam esse texto com o contexto compreensivo de cultura.

\subsubsection{Pressupostos da Linguística Sistêmico-funcional}

A LSF expõe, segundo Eggins (2012, p. 5), algumas concepções da linguagem que servem como pilar para sua base teórica, conceitual e metodológica. Nesse sentido a LSF pressupõe que:

1) a linguagem evoluiu devido ao uso. Essa visão suscita o interesse pelo estudo das manifestações que resultam do uso da linguagem.

2) a linguagem é compreendida como um sistema semiótico, que opera pela disponibilização de sentidos potenciais a serem escolhidos ao invés de um sistema de regras que estruturam seu uso.

\footnotetext{
5 Tradução livre da autora. "The difference between "culture" and "situation" is rather like that between the "climate" and "weather". Climate and weather are not two different things; they are the same thing, which we call weather, when we are looking at it close up, and climate when we are looking at it from a distance." (HALLIDAY; MATHIESSEN, 1999, p. 9)
} 
3) a forma que organiza o sistema semiótico é paradigmática, em outras palavras, o sistema semiótico é organizado por recursos sistemáticos para produzir sentido por meio de escolhas que os usuários, quando usam a linguagem, fazem, ao invés de outras escolhas disponíveis no sistema que deixam de ser usadas. O sentido é construido não apenas pela escolha feita, mas por todas as outras possibilidades de sentidos que não foram escolhidas. Nessa concepção paradigmática, o princípio organizador é o paradigma com que se usa o sistema e não o sintagma que estrutura o uso da linguagem. O princípio organizador está no sistema e seu funcionamento e não em sua estrutura. A visão de um princípio paradigmático organizador do sistema fundamenta a perspectiva sistêmica da LSF. (HALLIDAY; HASAN, 1989);

4) as estruturas da linguagem são formadas e direcionadas por um sistema de escolhas, ou seja, a linguagem é vista como um sistema de escolhas no qual as estruturas semânticas e léxico-gramaticais resultam das escolhas feitas enquanto as materializam na forma de funções estruturais que fundamentam a perspectiva funcional da LSF.

5) elementos extralinguísticos do contexto influenciam as escolhas de itens em um dado sistema intralinguístico que é por eles determinadas e/ou ativadas.

Os pressupostos da LSF possibilitaram o surgimento de outras teorias, duas das quais: a Gramática do Design Visual e a Análise de Discurso Crítica fornecem seus princípios e ferramentas investigativas para a presente pesquisa.

a) Potencial de Estrutura Genérica (EPG ou PEG) - Hasan (1989);

b) Análise de Discurso Crítica- Fairclough (2003);

c) Gramática do Design Visual - Kress e Van Leeuwen (1996);

d) Teoria da Avaliatividade - Martin e White (2005).

A Gramática Sistêmico-funcional preocupa-se em descrever os padrões de uso da linguagem que contribuem para a construção do significado no texto por meio de duas perspectivas.

a) A perspectiva sistêmica da LSF vê a linguagem como sistemas linguísticos interligados por redes e que disponibilizam escolhas das quais fazemos uso para construir os sentidos. Os sistemas oferecem um conjunto de escolhas que são semânticas, léxico-gramaticais ou fonológico-grafológicas.

b) A perspectiva funcional descreve os padrões de uso gramatical em relação às suas funções no texto. Para Halliday $(1985,1994)$ a linguagem é um sistema de 
significados que implica a competência comunicativa do indivíduo e a forma como são interacionalmente articuladas as expressões e enunciados.

A Linguística Sistêmico-funcional (LSF) aborda o estudo da linguagem no contexto de suas funções sociais e compreende que os significados são construídos por meio de escolhas que o falante faz no contexto das funções e relações possíveis e disponíveis nos sistemas da linguagem.

Halliday $(1985,1994)$ parte do pressuposto que os usos que fazemos do sistema da linguagem são em função das nossas necessidades de convívio em sociedade. Dessa forma, a LSF busca relacionar o texto ao contexto social, e relaciona as variáveis contextuais com as metafunções que se realizam por meio dos sistemas léxico-gramaticais. Esses são conhecidos como o sistema de transitividade, de modo e de estrutura temática. Nesta pesquisa será enfocado o sistema de transitividade, que será melhor explicado adiante.

Halliday $(1985,1994)$ concebe três metafunções da linguagem de acordo com as finalidades da comunicação. Estas três metafunções acontecem de forma simultânea na linguaguem estando associadas umas às outras em uma estrutura linguística, seja ela um texto, seja uma oração ou uma sentença. Essas metafunções são: a) ideacional - metafunção de representar as experiências do mundo exterior e interior; b) interpessoal - expressão das interações sociais e c) textual - expressão da forma estrutural do texto.

Halliday $(1985,1994)$ descreve três metafunções para a linguagem, mostrando suas finalidades e seus propósitos:

a) ideacional - função de representação das experiências do mundo exterior e interior. "A função ideacional se realiza no sistema da transitividade, especificando os papéis dos elementos, denominados participantes, na oração e codificando a representação do mundo" (NOVELLINO, 2007). Esta é a metafunção de representação da experiência por meio da representação simbólica de eventos, ações, estados e práticas sociais.

b) interpessoal - expressão das interações sociais. Esta metafunção especifica as funções entre as trocas dos falantes que expressam relações sociais e pessoais.

c) textual - expressão da estrutura e formato do texto, que correspondem a aspectos voltados para a estrutura lexical, gramatical e semântica no texto. 
Figura 5: Configuração e constituição das metafunções de Halliday

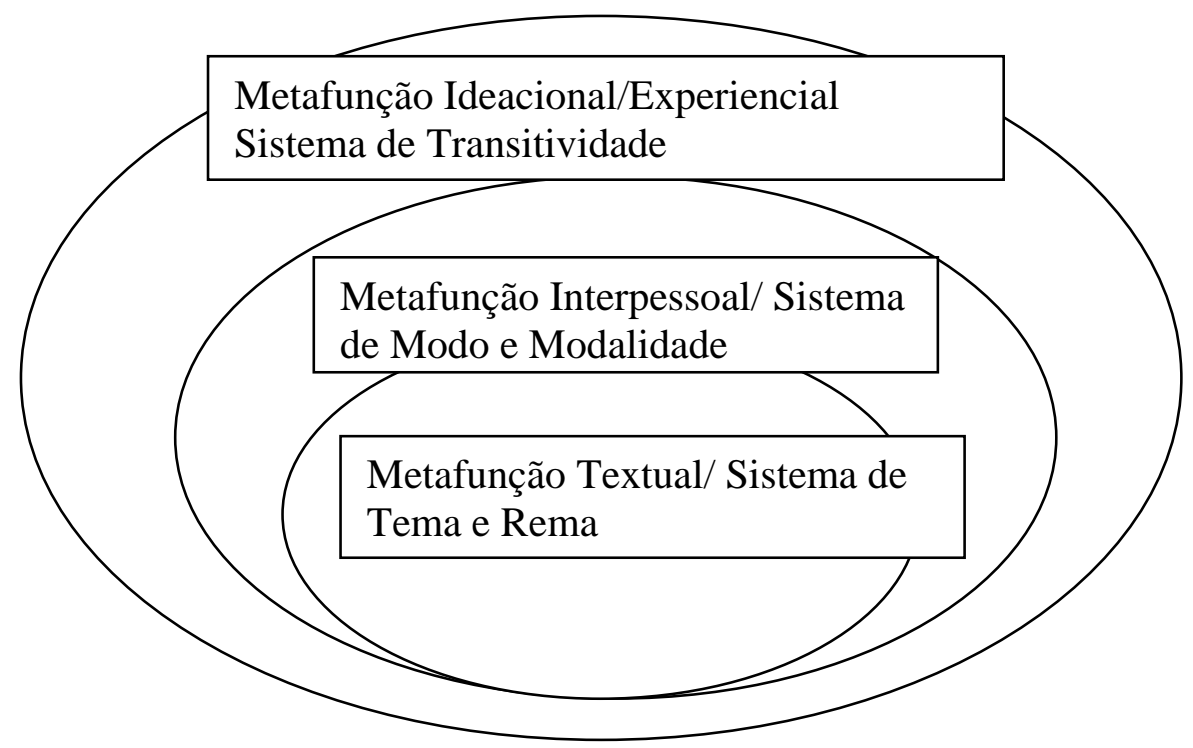

Fonte: Adaptado de Halliday (1994).

Cada uma destas metafunções se realiza em um sistema no qual os diferentes significados são relacionados com as diferentes funções da linguagem. No processo de construção dos sentidos pelo sistema metafuncional da linguagem, são ativados elementos extralinguísticos e intralinguísticos interligados por essas redes semânticas. As três metafunções da linguagem coexistem dentro do estrato semântico intralinguístico. A metafunção ideacional ou reflexiva se refere aos significados experienciais ou lógicos no uso da linguagem; a metafunção interpessoal ou ativa envolve os significados interpessoais e a metafunção textual ou capacitadora, organiza os dispositivos de coesão e coerência nos textos.

No estrato semântico intralinguístico, essas categorias semânticas se alinham com essas três variáveis do contexto da situação (Campo, Relações e Modo de discurso). Além disso, elas alinham-se com o estrato abaixo da léxico-gramatica, no qual o potencial da linguagem é atualizado nos textos. Este estrato da léxico-gramatica é considerado por Halliday e Matthiessen (2004) a "caixa de força da linguagem" e opera por três áreas sistêmicas: o sistema de transitividade, o sistema de modo e modalidade e os sistemas de tema e informação. Estes sistemas é que dão atualidade, ou materialidade, para o estrato semântico e potencial, por meio de sistemas que se organizam por áreas de funcionamento. $\mathrm{O}$ uso da Linguística Sistêmico-funcional para analisar as cartas escritas por van Gogh vai possibilitar compreender as escolhas significativas que foram realizadas.

Nas relações hierárquicas dos estratos, temos o contexto de cultura, seguido do contexto de situação, seguido pela semântica, seguido pela léxico-gramática, seguido pela 
fonologia e grafologia. Estes estratos são intercomunicantes e bidirecionais. $\mathrm{O}$ estrato superior ativa e é realizado no estrato inferior que ativa e é realizado pelo estrato inferior. Por exemplo, o estrato do contexto de cultura ativa e é realizado no estrato do contexto de situação; que ativa e é realizado no estrato semântico; que por sua vez, ativa e é realizado no estrato léxico-gramatical; que finalmente ativa e é realizado no estrato fonológico e grafológico. Como isso é feito? Como o campo variável do contexto de situação é realizado pelo estrato léxico-gramatical? Ele ativa no estrato da léxico-gramática os sistemas de transitividade e as relações táticas e lógico-semânticas. As ativações de escolhas no estrato da fonologia e da grafologia são essas realizações.

Como a variável Relações do contexto de situação é realizada? Por meio de escolhas de sentidos interpessoais que, no nível léxico-gramatical são realizados por meio dos sistemas de modo e modalidade, em textos escritos ou falados. Como a variável modo do contexto de situação é realizada? Por meio dos sentidos textuais que, no estrato léxico-gramatical, são realizados pelos sistemas de tema e informação.

Considerando que a produção pictórica e de cartas de van Gogh expressa uma concepção particular de percepções, valores, ideias, e de si mesmo como um artista em um esforço de simbolização de sua experiência de estar no mundo, escolhemos o sistema de transitividade para analisar os elementos textuais presentes no discurso escrito e visual de van Gogh.

\subsubsection{O sistema de Transitividade}

Esta pesquisa focalizou no significado experiencial, na forma como eles estão materializados pelo Sistema de Transitividade no estrato léxico-gramatical dos excertos de cartas analisados.

O sistema de transitividade pertence à metafunção ideacional descrita por Halliday (2004) como a função com a qual representamos experiências exteriores e interiores. Essa função se materializa por meio do sistema da transitividade, que na oração se instancia por meio dos participantes da oração. O sistema de transitividade tem a função de representar simbolicamente eventos, ações, estados e práticas sociais que constituem a nossa experiência no mundo. 
Dessa forma, seis processos são identificados por Halliday e Matthiessen (2004): material, mental e relacional, verbal, comportamental e existencial. No quadro a seguir, estão descritos os tipos de processos e seus participantes centrais e adicionais.

Quadro 1: Os tipos de Processos e seus participantes

\begin{tabular}{|c|c|c|c|c|}
\hline \multicolumn{2}{|l|}{ Tipo de Processo } & Aspecto Semântico & Participante Central & $\begin{array}{l}\text { Participante } \\
\text { Adicional }\end{array}$ \\
\hline \multirow{2}{*}{\multicolumn{2}{|c|}{ Material }} & Fazer & Ator, Meta & \multirow{2}{*}{$\begin{array}{l}\text { Escopo/Extensão, } \\
\text { Atributo, } \\
\text { Beneficiário } \\
\text { (Recipiente e Cliente) }\end{array}$} \\
\hline & & Acontecer & Ator & \\
\hline \multirow{4}{*}{\multicolumn{2}{|c|}{ Mental }} & Perceber & \multirow{4}{*}{$\begin{array}{l}\text { Experienciador, } \\
\text { Fenômeno }\end{array}$} & \multirow[t]{4}{*}{ ( } \\
\hline & & Pensar/Saber & & \\
\hline & & Querer & & \\
\hline & & Sentir & & \\
\hline \multirow{2}{*}{ Relacional } & Atributivo & \multirow{2}{*}{$\begin{array}{l}\text { Ter } \\
\text { Ser }\end{array}$} & \multirow{2}{*}{$\begin{array}{l}\text { Portador, Atributo, } \\
\text { Identificador, } \\
\text { Identificado }\end{array}$} & \multirow{2}{*}{-} \\
\hline & Identificador & & & \\
\hline \multirow{2}{*}{ Comportamental } & Fisiológico & \multirow{2}{*}{ Comportar } & \multirow{2}{*}{ Comportante } & \multirow{2}{*}{ Comportamento } \\
\hline & Psicológico & & & \\
\hline \multicolumn{2}{|l|}{ Verbal } & Dizer & Dizente, Verbiagem & Recipiente, Alvo \\
\hline \multicolumn{2}{|l|}{ Existencial } & Existir & Existente & - \\
\hline
\end{tabular}

Fonte: Adaptado de Humphrey e Droga (2002, p.16, SOUZA, 2011).

\subsubsection{Processos Materiais}

Os Processos Materiais, conforme descritos no quadro acima, são aqueles relacionados ao 'fazer e acontecer', ou seja, estão relacionados às ações; elas podem estender ou não para alguma entidade. As ações de 'fazer', podem ser transformativas ou criativas. Em uma oração de processo material do tipo 'fazer', os principais participantes são o Ator e a Meta. Nas orações materiais ativas, o Ator é considerado por Halliday (2004) uma entidade responsável pela ação, enquanto a Meta é considerada a entidade que é afetada pela ação ativada pelo ator. No caso de uma oração material causativa, encontramos um participante a mais, o Iniciador, que é uma entidade que desencadeia uma ação que coloca o Ator em movimento. A seguir, ilustro com um exemplo de uma oração retirada dos excertos de cartas de Van Gogh que serão analisados por seus constituintes funcionais: 
Quadro 2: Exemplo de uma oração material e seus constituintes funcionais.

\begin{tabular}{|l|l|l|}
\hline Ator & Proc.: Material & Meta \\
\hline $\mathrm{Eu}$ & acabei de terminar & $\begin{array}{l}\text { uma tela que representa um interior } \\
\text { de café à noite }\end{array}$ \\
\hline
\end{tabular}

Eu acabei de terminar uma tela que representa um interior de café à noite, iluminado por lâmpadas.

Fonte: Van Gogh (2009g).

Adicionalmente a esses participantes principais, existem outros tipos de constituintes estruturais Escopo, Beneficiário (Recipiente ou Cliente), Atributo, e Escopo (HALLIDAY; MATHIESSEN, 2004) e podem assumir outros papéis de participantes em orações materiais. Em um processo de 'acontecimento', o constituinte 'Escopo' é responsável pela extensão da ação, como em 'correr dez kilometros' ou pela expressão da ação quando o verbo é lexicalmente vazio como em 'matar tempo'. O constituinte 'Beneficiário' pode caracterizar-se tanto como Recipiente, constituinte que recebe os resultados do processo em forma de bens, ou com constiuinte 'Cliente', que os recebe em forma de serviços. O constituinte 'Atributo' qualifica o Ator ou a Meta quando há resultado ou conclusão no processo de 'fazer'. O constituinte 'Escopo' dimensiona o domínio no qual o processo acontece sem afetar, no entanto, a ação diretamente da mesma forma como o Ator o faz.

\subsubsection{Processos Mentais}

Enquanto os processos materiais constroem significados experienciais de nosso mundo externo, os processos mentais de pensamento constroem "um quantum de mudança no fluxo de eventos acontecendo em nossa consciência." (HALLIDAY; MATTHIESSEN, 2004, p. 197) Os processos mentais expressam as dinâmicas relacionadas com a consciência e com o sentir e perceber, pois se referem a representação das experiências internas do Experienciador tais como pensamento, compreensão, cognição, emoção, conhecimento. Segue abaixo um exemplo dos excertos de cartas de Van Gogh que servem para ilustrar uma oração mental analisada por sua configuração funcional: 
Quadro 3: Uma oração mental e seus constituintes funcionais

\begin{tabular}{|l|l|l|l|}
\hline Experienciador & $\begin{array}{l}\text { Proc.: Mental } \\
\text { Afetivo }\end{array}$ & $\begin{array}{l}\text { Adjunto de modo./Tem função na } \\
\text { metafunção interpessoal }\end{array}$ & Oração Projetada \\
\hline $\mathrm{Eu}$ & gosto & enormemente & de pintar no local à noite. \\
\hline
\end{tabular}

Eu gosto enormemente de pintar no local à noite.

Fonte: Van Gogh (2009g).

O Experienciador é um componente da oração que, de acordo com Praxedes Filho (2007, p. 36), pode ser considerado "um humano ou qualquer outra entidade - animada ou inanimada - para a qual a característica humana da consciência é atribuída". O Experienciador é um participante que atua em processos mentais que podem ser de quatro tipos: emotivos perceptivos, cognitivos ou desiderativos. (HALLIDAY; MATHIESSEN, 2014, p. 245-250).

Os processos mentais perceptivos referem-se aos fenômenos percebidos pelos 5 sentidos: visão, olfato, gustação, audição e tato. As orações mentais cognitivas referem-se à consciência, ao conhecimento, imaginação e pensamento, por exemplo. As orações mentais afetivas ou emotivas revelam os diferentes graus e qualidades da afeição. E as orações mentais desiderativas exprimem "desejo, vontade, interesse em algo" (HALLIDAY; MATHIESSEN, 2014, p. 245-250).

Nos processos mentais há ainda a gradabilidade lexical e gramatical, por exemplo, adorar tem uma graduação maior do que gostar. A gradabilidade também pode se manifestar com o uso de elementos lexicais como 'mais que' e 'menos que'. Outro aspecto é a bidirecionalidade semântica quando os processos equivalem semanticamente mas não no léxico.

O complemento nas orações de processos mentais é o Fenômeno, cujos processos expressos pelo Experienciador são a ele atribuídos, realizados geralmente por grupos nominais.

Quando o Fenômeno assume a forma léxico-gramatical de uma oração não finita no particípio, no infinitivo ou no gerúndio. Ocorre quando uma oração pode projetar outras orações de processos mentais tanto perceptivos quanto emotivos, ele pode assumir a função de um Macrofenômeno.

Quando ele assume a forma de um 'fato' Metafenômeno, em uma oração finita ele pode ser realizado em orações mentais perceptivas e emotivas e assim a oração pode assumir a forma de uma 'ideia' Metafenômeno. Quando assume a forma de ato é a configuração de 
um processo, com participantes e eventuais cirscunstâncias. Quando ele assume a forma de uma 'ideia' Metafenômeno, pode ser realizado em orações mentais cognitivas e desiderativas.

Quadro 4: Uma oração mental e seus constituintes funcionais

\begin{tabular}{|l|l|l|l|}
\hline A ideia do semeador & ainda continua & a me & assombrar. \\
Fenômeno & $\begin{array}{l}\text { Finito da metafunção interpessoal, } \\
\text { não participa da metafunção } \\
\text { relacional. }\end{array}$ & Experienciador & Processo mental emotivo. \\
\hline
\end{tabular}

A ideia do semeador ainda continua a me assombrar.

Fonte: Van Gogh (2009b).

\subsubsection{Processos Relacionais}

O terceiro tipo de processos são os relacionais que são relativos ao 'ser' e 'possuir' e são atributivos ou identificadores. Quando são atributivos em orações relacionais, ao expressarem o processo de ter ou ser, eles estabelecem uma relação de caracterização ou de atribuição que pode ser intensiva (caracterizam uma entidade - ser e estar), possessiva (caracterizam posse, como os verbos ter, possuir, envolver, pertencer) ou circunstancial (a relação entre os termos é de tempo, lugar, modo, causa, acompanhamento, papel, assunto ou ângulo). Elas também se apresentam de dois modos: atributivas e identificadoras.

Os participantes nas orações relacionais atributivas são o Portador, uma entidade que detém a coisa atribuída pelo falante ou escritor, e o Atributo, que expressa o que está sendo atribuído para o Portador. As orações relacionais atributivas possuem quatro características: 1) o atributo constrói uma classe e é indefinido; 2) possui dois participantes, o Portador e o Atributo; 3) utiliza-se geralmente o verbo ser, mas também verbos atributivos; 4) é possível interrogar a oração fazendo as perguntas 'o que?' e 'como?'; 5) não são reversíveis semanticamente, ao inverter altera-se o sentido (HALLIDAY; MATHIESSEN, 2014, p. 245250).

Quadro 5: Uma oração relacional e seus constituintes funcionais

\begin{tabular}{|l|l|l|}
\hline Portador & $\begin{array}{l}\text { Proc. Rel. } \\
\text { Atributivo }\end{array}$ & Atributo \\
\hline $\begin{array}{l}\text { Cidade violeta, estrela } \\
\begin{array}{l}\text { amarela, céu azul-esverdeado; } \\
\text { os campos de trigo }\end{array}\end{array}$ & têm & $\begin{array}{l}\text { todos os tons: ouro velho, cobre, ouro verde, ouro } \\
\text { vermelho, ouro amarelo, verde, vermelho e amarelo } \\
\text { bronze. }\end{array}$ \\
\hline
\end{tabular}

Cidade violeta, estrela amarela, céu azul-esverdeado; os campos de trigo têm todos os tons: ouro velho, cobre, ouro verde, ouro vermelho, ouro amarelo, verde, vermelho e amarelo bronze.

Fonte: Van Gogh (2009c). 
Quando são identificadores, os processos relacionais estabelecem uma relação de identidade entre um participante e outro, ou de um participante por outro. Ao contrário das atributivas, as orações do modo identificador são reversíveis e possuem algumas características como: 1) na oração a entidade representa uma identidade única do ser; 2) a oração possui dois participantes, o Identificado (recebe a representação) e o Identificador; 3) a oração utiliza verbos ser e relacionais identificadores do tipo 'equativo'; 4) coloca-se à prova a oração interrogando 'quem?'; 5) as orações são reversíveis.

Em outras palavras, os constituintes nessas orações são: o Identificador, que dá uma identidade para outro participante, chamado de Identificado, para quem a identidade foi dada pelo Identificador. Os participantes Identificador e Identificado nos processos relacionais atributivos têm o mesmo referente e suas posições são reversíveis na sequência dos constituintes na oração. Abaixo, ilustro com meus dados uma oração atributiva relacional e sua análise de transitividade.

Quadro 6: Uma oração relacional e seus constituintes funcionais.

\begin{tabular}{|l|l|l|}
\hline Identificado & Proc.: Relacional & Identificador / Circunstância \\
\hline Essa & é & a primeira pintura esta semana. \\
\hline
\end{tabular}

Essa é a primeira pintura esta semana.

Fonte: Van Gogh (2009f).

\subsubsection{Processos Comportamentais}

Os processos materiais, mentais e relacionais pertencem ao grupo maior dos processos e eles não são fáceis de identificar e analisar, mas são os três mais básicos. Entretanto, isso não ocorre com os processos comportamentais, devido à imensa quantidade de aspectos que compartilham com os processos material e mental. Adicionalmente, Halliday e Matthiessen (2004) estimam que os processos comportamentais sejam os mais nebulosos na análise da transitividade devido a outros aspectos associados a processos verbais. Sua característica principal é definir comportamentos psicológicos ou fisiológicos que podem estar próximos ao material (postura corporal ou atividades de lazer), ao mental (processos de consciência) ou ao verbal (processos verbais como forma de comportamento) ou processos fisiológicos.

Um dos componentes nas orações de processos comportamentais é o Comportante que é uma entidade capaz de ações conscientes e detentora de atributos psicológicos e 
fisiológicos. O outro componente nas orações comportamentais é o Escopo (no caso de estar próximo ao processo material). O Comportante desencadeia o processo e pode ter associada uma circunstância quando próxima a processos mentais ou verbais.

Abaixo segue um exemplo retirado dos meus dados de pesquisa.

Quadro 7: Uma oração Comportamental e seus constituintes funcionais

\begin{tabular}{|l|l|l|}
\hline Alguns pobres vagabundos da noite & estão dormindo & em um canto. \\
\hline Comportante & Proc. Comportamental & Circunstância de Localização: Lugar \\
\hline
\end{tabular}

Fonte: Van Gogh (2009g).

\subsubsection{Processos Verbais}

Os Processos Verbais expressam aqueles significados que são simbólicos. Linguisticamente, esses processos simbólicos são construídos como processos de ‘dizer’ e são divididos em dois tipos: atividade (alvo, fala) e semiose (neutro, indicação e comando). Nas orações com processos verbais, um dos participantes é o Dizente que é uma entidade responsável pela ação de dizer. O Dizente não precisa ter consciência, como ocorre com o Ator nas orações materiais com o Experienciador nas orações mentais e o Comportante nas orações comportamentais. O outro participante das orações com processos verbais é a Verbiagem, que é o conteúdo que resulta da negociação de sentido do Dizente. A Verbiagem pode ser uma oração completa, que expressa uma locução ou reporta uma fala indiretamente. Nesse caso, a Verbiagem pode ocorrer na forma de uma oração hierárquica projetada que está paratática ou hipotaticamente situada. A Verbiagem pode vir na forma de citação ou relato. Há ainda outros participantes em uma oração de processo verbal. São eles: o Receptor, que se trata de uma entidade a quem o ato de dizer ou reportar é direcionado; Alvo (Target), no qual o conteúdo da Verbiagem recai. Abaixo, ilustro duas instâncias de um processo verbal, o primeiro projetando um relato e o segundo uma citação, uma oração de locução.

Quadro 8: Uma oração Verbal e seus constituintes funcionais.

\begin{tabular}{|l|l|l|l|l|}
\hline Dizente & Receptor & $\begin{array}{l}\text { Proc.: Verbal } \\
\text { (semiose, neutro) }\end{array}$ & $\begin{array}{l}\text { Verbiage } \\
\text { (locução) }\end{array}$ & Alvo \\
\hline Você & (nunca) me & disse & se você tinha lido & $\begin{array}{l}\text { Bel-ami de Guy de } \\
\text { Maupassant, e o que você } \\
\text { pensa agora do talento dele em } \\
\text { geral. }\end{array}$ \\
\hline
\end{tabular}

Você nunca me disse se você tinha lido Bel-ami de Guy de Maupassant, e o que você pensa agora do talento dele em geral.

Fonte: Van Gogh (2009g). 
Quadro 9: Uma oração Verbal e seus constituintes funcionais.

\begin{tabular}{|l|l|l|l|l|}
\hline & Dizente & $\begin{array}{l}\text { Processo } \\
\text { verbal }\end{array}$ & circunstância & Verbiagem \\
\hline $\begin{array}{l}\text { Ai, ai, é } \\
\text { como }\end{array}$ & $\begin{array}{l}\text { nosso excelente } \\
\text { amigo Cyprien }\end{array}$ & diz, & $\begin{array}{l}\text { em 'En ménage' a JK } \\
\text { Huysmans: }\end{array}$ & $\begin{array}{l}\text { as mais belas pinturas são aquelas que alguem } \\
\text { sonha enquanto fuma um cachimbo em sua } \\
\text { cama, mas a qual ele não pinta. }\end{array}$ \\
\hline
\end{tabular}

Ai, ai, é como nosso excelente amigo Cyprien diz, em 'En ménage' por JK Huysmans: as mais belas pinturas são aquelas que alguém sonha enquanto fuma um cachimbo em sua cama, mas a qual ele não pinta.

Fonte: Van Gogh (2009c).

\subsubsection{Processos Existenciais}

O processo existencial representa nossos mundos tanto interior quanto exterior como “existentes”. Nas orações com processo Existencial, há um participante único, o Existente, que expressa diferentes fenômenos ou eventos, tais como ações, abstrações, pessoas, instituições etc. Em português, as orações com o processo Existencial são realizadas pelo verbo "haver" na terceira pessoa do singular e, em Inglês, são realizadas pelo posicionamento de um 'there' vazio, que ocupa o lugar de um agente, no caso, um participante Experienciador, seguido pelo verbo 'to be', verbo principal padrão nessas construções [there to be]. O objeto da existência pode estar tanto na forma plural quanto na forma singular. Os processos existenciais podem ser de três tipos: neutros (com sentido de existir, acontecer); com traços circunstanciais (de tempo e de lugar) e abstratos Abaixo segue um exemplo de processo existencial retirado dos meus dados de análise:

Quadro 10: Uma oração Existencial e seus constituintes funcionais

\begin{tabular}{|l|l|l|}
\hline Circunstância de lugar & Processo existencial & Existente (a oração encaixada faz parte da existente). \\
\hline No terraço & há & pequenas figuras de pessoas que bebem. \\
\hline
\end{tabular}

No terraço, há pequenas figuras de pessoas que bebem.

Fonte: Van Gogh (2009g).

A transitividade nuclear inclui as circunstâncias que são outros participantes além dos processos e seus participantes tratados até agora. As circunstâncias se referem a elementos que podem ser realizados livremente por meio de diferentes conjuntos de processos. Por exemplo, um elemento circunstancial pode responder às perguntas quando, onde, como e por quê. Nessa função, o evento do processo em questão é circunscrito nas dimensões semânticas de espaço, tempo, maneira e causa pelos elementos circunstanciais. A diferença entre as circunstâncias e os outros participantes é que estes pertencem à gramática de MODO, 
funcionando como Agente, equivalente ao Sujeito ou Complemento, e as circunstâncias funcionam como Adjuntos e são realizados por um grupo Adverbial ou por uma frase preposicional.

Ao modelo de transitividade, de processo-participante-circunstância, segue-se a discussão acerca do conceito de templates que, para Thompson (2009), são "representações esquemáticas de estruturas de transitividade nas quais existem padrões recorrentes de uma ou mais das entidades que aparecem em distribuição complementar em papéis particulares de participantes ou circunstâncias" (THOMPSON, 2009, p.3).

A análise das cartas está mais preocupada em responder como o sistema de transitividade poderá auxiliar a evidenciar as instanciações linguísticas nas cartas que podem também estar presentes nas telas.

\subsection{A TEORIA SEMIÓTICA SOCIAL MULTIMODAL}

Kress e van Leeuwen (1996, p. 30) constatam uma crescente mudança ao longo das últimas décadas na forma como são usados os modos linguísticos e os modos visuais. Eles argumentam que a comunicação está assumindo uma característica multimodal mais preponderante na cultura ocidental. Eles se apoiaram no modelo teórico da Gramática Funcional de Halliday e Mathiessen (1999, 2004), para sugerir três funções comunicativas em uma linguagem ou sistema semiótico. No entanto, eles fazem uma importante diferenciação na forma como os sistemas semióticos são pensados pela Teoria Semiótica Social Multimodal (TSSM). Eles pontuam que muitos estudos semióticos visuais ainda olham para o uso dos recursos linguísticos desde o ponto de vista do léxico e não do ponto de vista da gramática. Essa distinção faz toda a diferença para o emprego de sistemas semióticos multimodais. A perspectiva de cunho lexical focaliza nos recursos linguísticos separadamente e não na forma como, quando combinados, eles são capazes de construir declarações cheias de sentido.

A perspectiva semiótica de enfoque lexical se preocupa em entender como cada recurso linguístico, individualmente, constrói sentidos denotativos, conotativos ou simbólicos. Dessa forma os recursos linguísticos são compreendidos como recursos semióticos para construir sentidos associados com essa significação individual. Essa perspectiva teórica é exemplificada por Machin (2007, p.2), com o uso dos signos de animais em brasões empregados como itens lexicais para produzir um sistema semiótico lexical que associa as características desses signos ao sentido que se intenciona conotar. Assim como signos, 
recursos semióticos tais como cores e fontes tipográficas, por exemplo, também podem ser usados de forma lexical para conotar algum significado que se quer associar. Essa perspectiva semiótica lexical tende a ver os signos como produzindo um sentido fixo, enquanto que a perspectiva gramatical compreende os signos como produtores de sentidos que acontecem por meio de escolhas de combinações potenciais.

A multimodalidade pauta-se pelo enfoque gramatical que está preocupado em compreender como os recursos semióticos, quando combinados com outros recursos, produzem sentidos. Quando um recurso semiótico está associado a outro recurso, ele pode conotar um sentido, e estando associado a outro, outro sentido é produzido. Os sentidos, portanto, podem variar de acordo com a léxico-gramática que se produz por meio de diferentes combinações entre os recursos semióticos. O enfoque gramatical preocupa-se em ver as imagens como um sistema semiótico complexo no qual o sentido é produzido por meio da léxico-gramática dos participantes e não por sentidos fixos ligados a signos individuais como postula a perspectiva estruturalista.

O modelo léxico-gramatical de Halliday (1985), usado para a análise de imagens por Kress e van Leeuwen (1996) destaca-se por essa perspectiva distinta. Esse enfoque léxicogramatical é essencial para a linguagem visual e permite fazer avanços sobre os usos dos recursos nos sistemas semióticos que se dividem em simples e complexos. No sistema simples, o recurso equivale, de forma direta, ao significado, ou seja, são itens lexicais que tem significados fixados a eles. Os sistemas semióticos simples são adequados para um enfoque léxico-gramatical semiótico das imagens. No sistema complexo, o sentido atribuído ao recurso é mediado pela léxico-gramática, ou seja, para Halliday (1996), esse sistema complexo da léxico-gramática é algo abstrato que se apóia no sistema de escolhas dos sentidos potenciais. Diferentemente do sentido fixo que a semiótica lexical procura no recurso, a semiótica léxico-gramatical procura no recurso semiótico o seu sentido potencial. Esse sentido potencial do recurso semiótico só é realizado ou manifestado graças ao uso sintático da gramática.

Os semioticistas que usam o enfoque léxico-gramatical de Halliday e de Matthiessen $(1985,2004)$ voltam-se para estudar o sistema de escolhas que atribui os sentidos potenciais para os recursos semióticos. O sentido potencial de um recurso semiótico não descansa no signo em si mesmo, mas pelo seu lugar e pertencimento dentro do sistema semiótico complexo. Como ilustra Machin (2007), no sistema visual semiótico, o significado do vermelho não está no vermelho, mas na sua articulação a outras cores e recursos com ele associados dentro da composição, e que articulados produzem um sistema de sentidos 
potenciais. Ao olhar para o vermelho, é possível construir um sentido no contexto das escolhas potencialmente presentes e disponíveis pelo sistema complexo que possibilita essas escolhas. Da mesma forma, o uso da cor por Van Gogh assume toda uma nova ordem de sentidos denotativos, conotativos e metafóricos por sua articulação sintática na composição. Esse uso está ilustrado na figura abaixo.

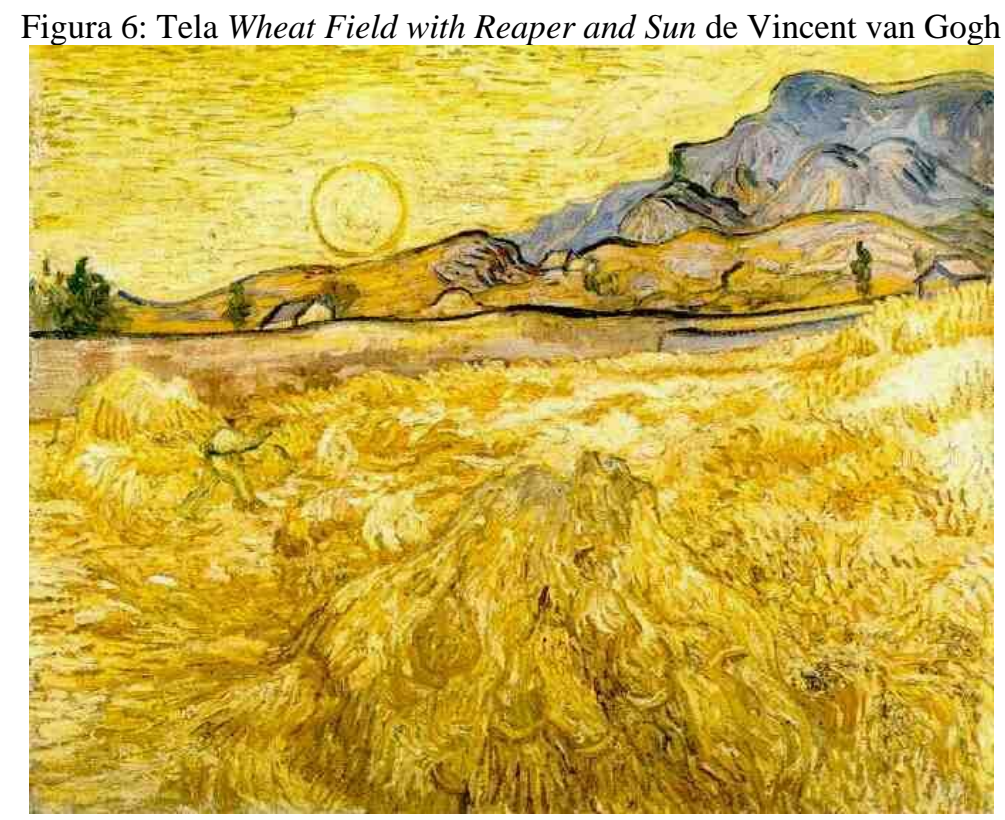

Fonte: Van Gogh (1888a).

Nesta tela, van Gogh o uso do amarelo tem efeitos de uma nova ordem de sentidos denotativos, conotativos e metafóricos por sua articulação sintática na composição, ao observarmos o uso do amarelo como uma superposição e uma saliência que conferem à composição a comunicação da intensificação de uma experiência por meio de uma condensação de sentidos.

Para Halliday (1999, 2004), não são os recursos lexicais simples sozinhos que asseguram o sentido, mas a léxico-gramática permite a produção de um sentido que é pelo uso das palavras em contexto de cultura e contexto de situação e não pelo valor do item lexical em si mesmo. Nos sistemas semióticos complexos, há uma arbitrariedade nas relações entre os itens lexicais, a gramática e o sentido, que pode ser revelada por meio da descrição do sistema de escolhas e das combinações possíveis. Em sua teoria da léxico-gramática, Halliday (1999, 2004) argumenta que os tipos de combinações entre itens lexicais são previsíveis e demonstra que as combinações detêm um sentido próprio, ou seja, combinações léxico-gramaticais assumem em si mesmas características de recurso semiótico e adquirem um sentido potencial. Esse fenômeno afeta a forma como os linguístas podem descrever os recursos semióticos e os 
seus sentidos e é de especial importância para o estudo da semiótica visual, uma vez que as composições em si mesmas e os tipos de composição são centrais na produção de sentidos. Nas composições de Van Gogh, poderemos observar como as combinações que ele faz dos recursos pictóricos assumem um significado próprio e distinto do significado que os próprios recursos têm em si mesmos e que se somam aos outros sentidos que estão construindo o texto visual. Esses exemplos serão expostos com maior detalhe na sessão da análise pictórica.

\begin{abstract}
Não é a emoção, a sinceridade do sentimento da natureza que nos impele? E se essas emoções são às vezes tão fortes que trabalhamos sem sentir que trabalhamos, quando as pinceladas vêm às vezes com uma sequencia e relações entre si como as palavras num discurso ou numa carta, cabe então lembrar que nem sempre foi assim e que no futuro também haverá dias pesados sem inspiração.” (HAZIOT, 2010, p. 199).
\end{abstract}

Para Halliday e Mathiessen (2004), mesmo quando as orações têm itens lexicais diferentes e sentidos diferentes, muitas delas têm similaridades por causa dos seus grupos nominais, que se organizam em torno de um nome que descreve algum evento. Os grupos nominais estão separados, mas relacionam-se entre si por verbos e eles podem assumir o papel de 'ator' ou de 'meta' dentro da oração. São essas estruturas previsíveis que permitem que os participantes individuais sejam combinados em padrões identificáveis, por meio dos quais eles conseguem produzir sentido uma vez que eles trazem nomes para se relacionarem entre si. As combinações previsíveis também tendem a ser recursos semióticos em seu próprio direito.

Dessa forma, se o 'sentido não reside nem no item individual lexical, nem na gramática', seria um equívoco buscar o sentido em um ou em outro' (MACHIN, 2007, p. 4). Halliday e Mathiessen (2004) argumenta que o sistema semiótico se encontra entre um e outro, entre o recurso semiótico e o sentido, cunhando para definir esse evento o termo 'lexicogramática'. Quando criamos declarações linguísticas ou visuais, estamos cientes de um sistema de escolhas com o qual podemos representar o nosso sistema de recurso semiótico complexo no qual o recurso semiótico mais a lexicogramática produzem o sentido.

A lexicogramática é constituída por duas partes que ocorrem ao mesmo tempo, uma que caracteriza os aspectos dos sistemas fechados e outra que descreve os aspectos abertos e potencialmente ilimitados. Esse modelo da gramática da linguagem de Halliday (2004) foi aplicado por Kress e van Leeuwen (1996) na comunicação visual ampliando-o para uma “abordagem Multimodal que envolve a criação de inventários das escolhas disponíveis e os padrões que governam essas escolhas" (MACHIN, 2007, p.5). 
A iniciativa de aplicar a gramática de Halliday (2004) à linguagem visual levou à pergunta se, assim como na linguagem verbal e escrita, também existiria uma léxicogramática visual. No entanto, existem objeções contra a prática de usar esse modelo de linguagem para olhar as imagens. As diferenças entre o sistema semiótico simples e o complexo são instrumentais para compreender a perspectiva Multimodal da linguagem.

O enfoque lexical volta-se para estudar o sistema semiótico simples, no qual o sentido está diretamente ligado ao item lexical. No sistema simples, pode ser estudada a ocorrência de um número infinito de itens lexicais. Os itens lexicais são tratados individualmente e o foco está em sentidos diretos e fixos para os recursos semióticos ou signos. A perspectiva Multimodal focaliza o estudo do sistema semiótico complexo, no qual o sentido está ligado ao iten lexical por meio de uma instância chamada lexicogramática. O enfoque voltado para o sistema complexo coloca uma ênfase no sentido que é produzido por meio de combinações nas quais os itens lexicais são articulados como participantes de um sistema de escolhas. No sistema semiótico complexo, só se observa um número finito de escolhas.

\subsection{ANÁLISE DE DISCURSO CRÍTICA}

Nesta sessão desenvolvo o conceito de discurso, por sua importância central para a tese aqui investigada. A seguir, irei desenvolver acerca do conceito de identidade por ser principal para a compreensão da representação de van Gogh de sua prática e de sua inserção em um coletivo de artistas radicados em Paris e que se empenhavam com práticas colaborativas para levar adiante um movimento vanguardista na arte do fim do século XIX. Em seguida descrevo as ferramentas conceituais e metodológicas da ADC que serão instrumentais tanto para fundamentar a triangulação dos corpora analisados como para embasar a discussão dos achados na triangulação.

\subsubsection{Conceito de Discurso}

A seguir busco desenvolver o conceito de Discurso com base na discussão ensejada por Halliday (1996) e Kress (2001), contextualizando em seguida seu denominador comum para os objetivos desta pesquisa.

$\mathrm{Na}$ fundamentação teórica, foi dada atenção para o conceito de discurso e seus aspectos constitutivos. $\mathrm{Na}$ análise, procuramos compreender como os recursos pictóricos 
operaram para transportar, individualmente ou combinados a fim de "conotar as idéias e modelos complexos do mundo". (MACHIN, 2007, p.1).

Os pressupostos da Análise de Discurso Crítica também foram usados para fundamentar alguns aspectos da análise das telas e das cartas em especial no que tange o exame dos tipos de participantes, atividades e valores representados.

Para a perspectiva mais tradicional da semiótica os signos podem conotar ideias diretamente ligadas a eles, tais como as ideias de nacionalismo que uma bandeira transporta. Mas a mesma bandeira que poderia conotar nacionalismo e patriotismo pode significar novos sentidos quando associada com grupos neonazistas, ou com visões conservadoras da sociedade. Dessa forma, ocorre um transporte de sentido com o uso de uma bandeira nacional, que transporta os sentidos de um domínio do nacionalismo, para o domínio do racismo e do conservadorismo dando a esses signos individuais a capacidade de conotar idéias complexas. A forma como pensamos as ideias complexas são compreendidas como 'discursos' para Foucault (1977, 1980 apud MACHIN, 2007). O termo discurso na perspectiva multimodal se refere ao conhecimento socialmente construído sobre a forma como o mundo funciona e sobre a realidade. Ao mesmo tempo que um item lexical pode conotar um sentido simples, as combinações de itens lexicais mais complexas são feitas para incluir novos sentidos e associações, e também para ligar discursos.

A construção de um discurso que oculta certos aspectos ao revelar outros é ilustrativa após a Primeira Guerra Mundial quando o Governo Britânico investiu na confecção de estátuas de heróis da guerra ao redor do País, para que as classes trabalhadoras acreditassem que uma guerra em nome da nação estaria acima das lutas de classes empreendidas para diminuir as desigualdades sociais que eles experienciavam. Dessa forma os monumentos nacionais de guerra são usados como ilustração dessa questão por Hobsbawm e Ranger (1992 apud MACHIN, 2007), na forma como eles foram usados para promover idéias de nacionalismo em um momento em que as classes trabalhadoras lutavam contra a opressão das classes dominantes na Inglaterra, que esteve muito mais próxima de uma revolução do que é narrado pela história (MILIBAND, 1973 apud MACHIN, 2007). O uso desses monumentos visou organizar um discurso sobre a sociedade Inglesa, que procurou transformar a morte de milhões de jovens em valores cristãos e humanos. Para fazê-lo um conjunto de recursos semióticos tais como o bronze, as fontes tipográficas, e o tom bíblico das inscrições, foram empregados em combinação na confecção das estátuas, de forma a transportar sentidos para a noção de nacionalismo. Os sentidos potenciais de cada uma dessas combinações foram usados para conotar um discurso particular sobre a guerra e sobre a união das nações ser algo mais 
importante do que as desigualdades sociais internas. Essa associação contínua de recursos semióticos para denotar o nacionalismo levou a uma naturalização de noções que foram adotadas como senso comum e depois como um fato, aponta Billig (1995 apud MACHIN, 2007). Para van Leeuwen e Wodak (1999 apud VAN LEEUWEN, 2011) o uso do discurso legitima certas práticas, assim como o acenar de uma bandeira, não seria apenas o agitar de um signo que designa uma área geográfica, mas um amálgama de discursos sobre nação, disseminado em varias práticas educativas, esportivas, cívicas e de entretenimento nas quais somos familiarizados com a idéia de nos unirmos por um interesse comum maior e que legitimam que lutemos contra um 'outro'. Nessas práticas são enfatizados discursos acerca da vitória dos 'nossos atletas', dos 'nossos garotos', que lutam contra o mal em outras terras. Recursos semióticos são combinados para conotar os discursos que ajudam a construir uma visão particular da realidade.

Uma variedade de recursos semióticos visuais tais como cor, tipografia, postura, vestimenta, local, acessórios, é empregada para conotar discursos multimodalmente por meio de linguagem e imagens afirmam Machin e Thornborrow (2003, 2006 apud MACHIN, 2007) em seu estudo sobre os conteúdos visuais na revista feminina Cosmopolitan que foram usados deliberadamente para conotar discursos de mulher e poder. A análise revelou que as mulheres eram representadas de forma a afirmar seu valor com assuntos pessoais ou sexuais e sugerem que esse discurso "tem um interesse investido nas mulheres verem-se a si mesmas como poderosas não por meio de agirem ação para mudar a sociedade, mas por meio da comprarem produtos que são carregados com sentido de poder”. (MACHIN; THORNBORROW, 2003, 2006 apud MACHIN, 2007, p. 13).

No mundo real, não há um modelo pronto sobre como a mulher exerce o poder, mas a composição visual na revista Cosmopolitan parece empregar os recursos semióticos visuais para combinar representações de modernidade com certas representações de mulher e sedução que conseguem ocultar uma real passividade nesse discurso, porque transportam para essa passividade as conotações de discursos feministas, que representam a mulher como agente de mudanças, como capaz de ter agência, igualdade de direitos com os homens, e capaz de experienciar o sexo e sua sexualidade independe dos sentidos dados pelos homens.

O termo 'scripts' é usado por van Leeuwen e Wodak (apud VAN LEEUWEN, 2011), para descrever como um discurso particular está associado e uma sequência de comportamento. Eles explicam que as idéias que são veiculadas nos discursos não são simples idéias que se encontram representadas por textos e imagens, mas concepções, modelos e formas de agir no mundo que são legitimados e naturalizados. Eles explicam que o script em 
um discurso de guerra como um bem maior para a nação envolve jovens dispostos a lutar na guerra e pessoas não sendo críticas com o governo em tempo de crise. Esse discurso foi atualizado após o ataque às torres gêmeas em 2001, por meio de signos visuais associados à bandeira dos EUA sendo agitada, quando se tornou uma postura antipatriótica às críticas aos Estados Unidos e suas políticas governamentais.

Quando os discursos são legitimados nas práticas e se tornam dominantes seus sentidos são transportados como um valor de verdade para um amplo conjunto de realizações em diferentes modos de comunicação. A concepção de 'terrorismo mundial' construída por meio de uma ampla prática discursiva impactou na organização da força policial em torno do mundo, dos sistemas de transporte, comunicação e dos tipos de pessoas que passam a 'ser legitimamente bombardeadas em defesa da 'liberdade', como aponta Iedema (2003 apud MACHIN, 2007). No caso da concepção da 'sociedade como uma meritocracia' amplamente legitimada pelo discurso, as desigualdades sociais passam a ser uma falha de cada indivíduo em obter riqueza, casa própria, bem estar social. Esse discurso não busca resolver a pobreza e a exclusão que causam os problemas sociais, mas legitima a necessidade de mais prisões e endurecimento do policiamento e das sentenças. A consolidação dessas noções lhes dá a força de senso comum e institucionaliza certos discursos e certas práticas como valores neutros para se pensar os eventos sociais. Machin (2007) ilustra como os discursos são compostos por participantes, ações, maneira de agir, circunstâncias, tempos, materiais, que são comunicados por meio de recursos semióticos que transportam associações e sentidos. Ele aponta para a seleção dos recursos semióticos adequados para as estátuas dos soldados da Primeira grande guerra a fim de transportam tipos de pessoas, circunstâncias e valores aos espectadores. Muitas noções foram transportadas por meio da postura da estátua, tamanho e ângulo pelo qual ela seria vista com respeito, de baixo para cima, com associações metafóricas de alto e baixo, a aparência cuidadosa e determinada do soldado representado, expressando gravidade, a fonte tipográfica associando formalidade, o material em bronze ao invés de pedra, conotando a guerra.

Os discursos usam recursos semióticos para conotar diferentes associações, por meio do tipo certo de cores, fontes, poses, posições de visão articulados para criar um conjunto diferente de associações, e relacioná-las a um conjunto diferente de pessoas e ações.

O tipo de recursos mais efetivos para se endereçar para um segmento específico da audiência não é explicitado nos manuais de design e composição visual, simplesmente porque todos os recursos semióticos podem ser usados para conotar diferentes associações metafóricas para discursos na forma de valores, noções e comportamentos particulares. Os 
recursos semióticos transportam qualidades por meio de associação metafórica que podem conotar um discurso com certos atores, ações e lugares. Os sistemas semióticos podem ser escolhidos e combinados, pois eles têm um sentido potencial que lhes permitem transportar valores e lógicas associadas a um domínio para realizá-las em um novo domínio. Os recursos semióticos são utilizados para transportar discursos ou sentidos a fim de comunicar modelos mais complexos de como o mundo funciona. Os discursos são compostos por valores, tipos de participantes, ações, formas de agir no mundo, circunstâncias, tempos, materiais, legitimação.

\subsubsection{Funções da ADC: identitária, Relacional e Ideacional}

A consideração de Fairclough (2001, p. 91) acerca do discurso como prática social implica considerá-lo como uma forma de ação sobre o mundo e as pessoas, em relação dialética com a estrutura, pois o "discurso é uma prática, não apenas de representação do mundo, mas de significação do mundo, constituindo e construindo o mundo em significado". Constroem identidade e posições de sujeito, relações sociais e sistemas de conhecimento e de crenças. São funções da linguagem que o autor denominou "identitária", "relacional", "ideacional".

O método analítico de Fairclough (2001) oferece uma reflexão importante para a pesquisa da relação entre contexto, história de vida, criação e transformação dos sentidos pelo sujeito na constituição de sua identidade. $\mathrm{O}$ autor considera na sua análise de discurso não apenas as reproduções sociais presentes no discurso, mas também a relação entre as mudanças discursivas e as mudanças sociais e culturais como um processo dialético no qual o sujeito cria e ressignifica os sentidos, organizando-os de forma a representar sua organização imaginária e simbólica do mundo e da sociedade.

$\mathrm{Na}$ análise deste corpus foram utilizadas as categorias sintetizadas por Resende e Ramalho (2006) e se dividem em: acional, representacional e identificacional.

- Acional - Na análise textual, Fairclough (2001) enfatiza: a gramática, analisando como as orações se combinam para construir identidades, relações sociais, conhecimentos e crenças e também como o vocabulário possui significação específica para cada grupo de pessoas diferentes; coesão, que compreende a arquitetura do texto e os modos de racionalidades, assim como suas modificações; e a estrutura textual, analisando a maneira e a ordem como são combinados os 
episódios, convenções e sistemas compartilhados. Além disso, na análise da prática discursiva são considerados aspectos formais como a 'força' dos enunciados, isto é, os tipos de atos de fala (ideais, crenças, princípios, etc.) constituídos pelo artista; a 'coerência' dos textos (unidade da produção artística e da reflexibilidade do artista); e a 'intertextualidade' dos textos (verbal e visual). Em 2003, Fairclough (2003) define três principais modos de interação: acional, representacional e identificacional. O acional corresponde à análise textual por considerar no texto o foco da análise das interrelações entre eventos sociais, considerando a perspectiva multifuncional na análise do discurso para compreensão da "linguagem como prática social dialeticamente interconectada aos demais momentos dessas práticas" (RESENDE; RAMALHO, 2006, p. 61), incluímos aqui a produção artística como prática social relevante para ser compreendida na articulação com outras linguagens.

- Representacional - O discurso é um espaço de transformação, de criação e expressão da reflexibilidade, que ao incorporar diferentes ordens discursivas, cria espaços de inovação e produção de sentidos que impactam no outro. O método de análise de discurso, com ênfase na mudança e na reprodução discursiva, proposto por Fairclough (2001), oferece tanto a análise textual quanto a análise da prática discursiva verbal e não-verbal para estudar as possibilidades de mudança social e cultural e as resistências e repetições produzidas pela ideologia e pelas formações discursivas impostas ao sujeito pelo discurso do grupo.

- Identificacional - O estudo da prática discursiva envolve a análise dos: a) processos de produção: quem é o autor do discurso e como ele o produz, que papel exerce, quais as relações que estabelece, significado interpessoal, o efeito do contexto no qual ele fala, sua força e coerência, assim como seu status no grupo e posição de sujeito; b) processos de distribuição: é simples quando é produzido no mesmo momento que é distribuído, pertence ao contexto no qual é produzido, como uma conversa, mas pode ser complexa quando envolve recursos diversos e se o sujeito tem recursos para a distribuição; c) processos de consumo textual: o processo de produção e de interpretação compreendem a força e a coerência, a força pode ser direta ou indireta e a coerência é produzida por quem interpreta, por quem dá sentido à fala do outro.

Segundo o autor, a coerência depende mais da interpretação do que do processo de produção da linguagem. Muitas vezes a fala faz sentido porque ao relatar ele constrói 
metadiscursos, inferindo relações de sentidos e explicitando sentidos que antes estavam latentes (FAIRCLOUGH, 2001). Essas inferências podem estar apoiadas em novas articulações entre pressupostos ideológicos, filosóficos e sociais como podem fazer diferentes leituras de diferentes textos. Este aspecto diz respeito à 'intertextualidade', pois os textos visuais possuem fragmentos de relatos e pensamentos, explicitamente ou implicitamente, de forma complementar ou contraditória. E a interdiscursividade se produz nesta heterogeneidade de elementos das ordens de discurso, que pode ser articulada na análise do discurso dos elementos visuais na linguagem plástica e dos elementos semânticos no relato verbal. E é nesta interdiscursividade que aparece a relação entre os elementos da linguagem visual e verbal na ordem discursiva de cada formação discursiva e dos elementos do discurso.

Assim, a linguagem visual e verbal pode ser analisada como práticas sociais que se complementam e se conflitam, explicitando as lacunas e também potenciais de criação artística. Assim, a produção artística pode ser analisada tanto no seu aspecto de reprodução das relações de poder e de ideologias quanto no processo de transformação das relações sociais a partir da construção de novos sentidos e elementos que compõem a estrutura da linguagem organizada pelo sujeito para expressar esta tensão.

A partir da análise de Fairclough (2001) nos perguntamos qual é o papel da linguagem na transformação das relações de poder? Como os elementos estruturais da linguagem plástica podem estar mobilizando novos sentidos para a experiência social?

Esta é uma questão colocada por Fairclough (2001, p. 22): "como diferentes discursos se combinam em condições sociais particulares para produzir um novo e complexo discurso?" A relação entre discurso verbal e visual parece se apresentar como algo ainda indefinido, mas uma relação que, ao ser analisada, pode trazer a tona os diferentes elementos que pertencem a estas duas modalidades discursivas, possibilitando a discriminação dos elementos estruturais das diferentes modalidades de linguagem e a explicitação de sentidos e processo social latente ou implícito no discurso visual e verbal.

Acredita-se que a análise de um discurso pode facilitar a compreensão de elementos implícitos presentes em outro discurso, assim as linguagens verbal e visual se complementam e possibilitam a explicitação de sentidos a partir de uma forma de estruturação dos elementos linguísticos de cada modo de expressão: o relato da história de vida e a produção da obra artística.

A heterogeneidade de sentidos presentes no discurso é um elemento importante para analisar as diferentes identidades e representações assumidas no relato e na produção artística, que compõe o processo de produção do artista. As diferentes molduras identitárias e a busca 
de integração em uma identidade coesa geram na prática discursiva, tanto verbal quanto visual, uma heterogeneidade do discurso que Fairclough (2001) discutirá como sendo a 'intertextualidade' e a 'interdiscursividade'. Compreender as formas de organização discursivas na linguagem visual que mantém ou que transformam os sentidos pode auxiliar na compreensão desses processos em outras linguagens e relações sociais.

\subsection{PONTOS DE CONTATO ENTRE A COMUNICAÇÃO VISUAL E A LINGUAGEM VERBAL}

A Gramática do Design Visual ou GDV (KRESS; VAN LEEUWEN, 1996, 2001) foi pensada a partir dos pressupostos teóricos da Gramática Sistêmico-Funcional (HALLIDAY; MATHIESSEN, 1985, 1994, 2004) e relacionou mais especificamente a noção de metafunções da linguagem de Halliday e de Mathiessen para a análise dos textos visuais e multimodais criando uma correspondência dessas com as funções da linguagem multimodal. Kress e van Leeuwen (1996) argumentam que a coerência entre imagens e contexto social se dá de muitas formas e realiza uma realidade semiótica.

Existe uma diferença estrutural intrínseca entre a linguagem verbal e a comunicação visual. Na linguagem verbal, o sentido é construído por meio da escolha entre diferentes classes de palavras e de estruturas sintático-semânticas, já na comunicação visual o sentido é construído por meio da combinação de diferentes estruturas compositivas.

A proposta de Kress e van Leeuwen (2001) com a Gramática do Design Visual não foi a de verificar se as estruturas da linguagem encontram seus correspondentes nas estruturas visuais, uma vez que essas duas modalidades não são formas correspondentes para representar a mesma coisa. Cada uma dessas modalidades tem seus códigos e regras próprias. (KRESS; VAN LEEUWEN, 2001).

Gramática vai além de regras formais de correção. Ela é um meio de representar padrões da experiência. Ela possibilita aos seres humanos construir uma imagem mental da realidade, a fim de dar sentido às experiências que acontecem ao seu redor e dentro deles. (HALLIDAY, 1985, p.101).

Ao conceber a Gramática do Design Visual, Kress e van Leeuwen (1996) partiram da mesma concepção de linguagem de Halliday e Hasan (1985) e orientaram-se pelos pressupostos das metafunções para propor funções correspondentes para analisar a linguagem visual. Mas como a linguagem verbal possui regras distintas da linguagem visual, Kress e van Leeuwen (1996) propõem outros termos para essas funções nomeadas como: composicional, 
representacional e interativa.

Kress e van Leeuwen (2001) propõem uma teoria Semiótica Funcional da imagem que utiliza uma organização metafuncional para a linguagem visual que realiza seus sentidos por meio das mesmas funções propostas por Halliday (2004). No entanto, ao propor essa correspondência entre as metafunções e as funções, eles propõem termos mais próprios para a comunicação visual já que cada uma dessas modalidades tem suas especificidades. Segue a exposição da correlação entre as metafunções de Halliday e as funções de Kress e van Leeuwen (1996).

Essa discussão é tratada com maior detimento no apêndice para diminuir o volume da tese.

\subsection{CONCLUSÃO}

Neste capítulo, procurei desenvolver subsídios para apoiar teoricamente a pesquisa da constituição do discurso artístico de Vincent van Gogh por meio da investigação sobre a colaboração entre o seu discurso pictórico e seu discurso epistolar. Para isso, fundamentei com as bases teóricas da Linguística, usando a Multimodalidade, a LSF e a ADC, apoiadas também pelas constribuições dos aportes conceituais das Artes Visuais e da Percepção Visual para complementar a análise dos corpora e subsidiar a discussão dos achados da investigação que serão desenvolvidos no capítulo seguinte, Metodologia. 


\section{CAPÍTULO 4 - METODOLOGIA}

\section{INTRODUÇÃO}

A presente investigação é constituída de uma pesquisa documental qualitativa para analisar as relações discursivas existentes entre as cartas e as telas produzidas pelo pintor Vincent van Gogh. A pesquisa se baseou nos aportes teóricos e metodológicos da: Teoria Semiótica Social Multimodal (TSSM); a Gramática do Design Visual (GDV) de O’Toole (1994), Kress e van Leeuwen (1996), van Leeuwen (1996, 2011) e Machin (2007) para a análise do corpus pictórico e sua articulação com o corpus das cartas. Para a análise dos elementos discursivos textuais encontrados no corpus das cartas, utilizei os subsídios teóricometodológicos da Linguística Sistêmico-funcional (LSF) de Halliday e de Matthiessen (1985, 1994, 2004, 2014) Butt et al (2000) e Eggins (2004), e para a triangulação dos dados, contei com os aportes teóricos da TSSM, da LSF e da Análise de Discurso Crítica (ADC) de Fairclough (2003).

Como metodologia de pesquisa aplicarei a triangulação entre três bases teóricas: a TSSM, a LSF e a ADC para analisar a produção escrita de Vincent van Gogh a respeito a sua produção pictórica. A investigação possibilitou a triangulação da análise dos relatos do artista acerca de sua produção pictórica com a análise dos elementos que compõem o seu discurso visual.

$\mathrm{Na}$ análise do corpus visual, aplicarei o modelo proposto por O’Toole (1994) que propõe as funções Modal, Representacional e Composicional do texto pictórico. As funções propostas por O’Toole (1994) têm ponto de contato respectivamente com as metafunções Interpessoal, Ideacional e Textual de Halliday e de Mathiessen (1985, 2004). A metafunção Ideacional de Halliday (1994) tem ponto de contato com o Significado Representacional de Fairclough (2003); a metafunção Interpessoal de Halliday (1994) se conecta com o Significado Identificacional de Fairclough (2003); a metafunção Textual de Halliday (1994) é compatível com o Significado Acional de Fairclough (2003);

Como enfoque para a análise do corpus textual epistolar, será investigado mais especificamente o Sistema de Transitividade e as relações lógico-semânticas presentes nos complexos oracionais. A compatibilidade entre a TSSM e a LSF permite a triangulação teórica e metodológica das perspectivas da Multimodalidade e da Linguística Sistêmicofuncional para explorar as intersecções entre o sistema visual e o sistema escrito na constituição do discurso artístico de Vincent van Gogh. 
A triangulação da análise da produção pictórica com a análise da produção epistolar tem a finalidade de compreender a interação de sistemas linguísticos em ambas as modalidades. Essa metodologia permite observar como se dão as ocorrências de elementos correspondentes em ambos os gêneros e verificar como a ocorrência dos elementos discursivos visuais nas funções Modal, Representacional e Composicional se relacionam com a ocorrência de elementos correspondentes nas cartas, nas metafunções Interpessoal, Ideacional e Textual. Com a ajuda da TSSM, da LSF e da ADC, a triagulação explicita os elementos dos textos pictóricos que dialogam com os elementos dos textos epistolares, em articulação com o contexto discursivo das práticas, do cotidiano de trabalho, da história de leituras, das referências e das identificações, expressos no registro documental de suas cartas.

\subsection{SOBRE A NATUREZA DA PESQUISA}

Esta pesquisa é de natureza:

a) Exploratória, pois busca identificar os elementos no corpus pictórico e epistolar que colaboram para o discurso artístico de Van Gogh e com base nisso, triangular os dados encontrados na análise dessas duas modalidades;

b) Bibliográfica, uma vez que busca compreender mais detidamente o contexto histórico, social e cultural no qual os textos foram produzidos;

c) Documental, porque se volta para a análise da produção epistolar de van Gogh no que se refere às telas analisadas;

d) Dedutiva-indutiva, uma vez que descreve os sistemas de crenças e a ideologia e os elementos extralinguísticos, por exemplo: a visão de mundo de van Gogh, mas que estão latentes e implícitos nos textos por ele produzidos;

e) Qualitativa, no que se refere aos corpora, pois concentra-se na interpretação e na reflexão das ocorrências linguísticas tanto nas cartas quanto nas telas analisadas.

\subsection{SOBRE OS PROCEDIMENTOS}

A metodologia foi desenvolvida em três etapas, na primeira, foram analisadas quatro telas com base na TSSM; na segunda, foram analisados, com o apoio da teoria da Linguística Sistêmico-funcional doze excertos de cartas que se referem às telas estudadas e um excerto de 
uma carta que se refere a aspectos mais gerais do pensamento pictórico do autor; na terceira etapa, foi feita uma triangulação entre as análises - visual e escrita. A análise dos corpora segue um momento descritivo e outro interpretativo.

Com a análise multimodal das telas selecionadas, examinarei a natureza e as funções que os elementos discursivos visuais desempenham na constituição do discurso visual e com a análise Sistêmico-funcional dos extratos de cartas que se referem às telas analisadas, examinei a natureza e as funções que os elementos discursivos nas cartas desempenham no texto escrito. Com a triangulação, comparei os achados em ambas as análises para localizar ocorrências compatíveis ou contraditória desses elementos no discurso artístico de van Gogh.

\subsubsection{Análise pictórica}

Esta pesquisa propõe a análise multimodal dos elementos de linguagem visual em quatro quadros de Vincent van Gogh a fim de investigar aspectos e elementos deflagradores dos efeitos de sentidos que estão sendo negociados na experiência da criação e da fruição dessas composições pictóricas.

A análise da modalidade visual se apoiou no referencial teórico da TSSM e da Gramática do Design Visual de Kress e van Leeuwen (1996), van Leeuwen (2011) e nas obras de O’Toole (1994) e Machin (2007) em razão de sua compatibilidade teórica e metodológica com a Gramática Sistêmico-funcional, de Halliday e Mathiessen (1985, 1994, 2004, 2014), Butt et al. (2000), que fundamentou a análise da modalidade escrita.

A investigação buscou compreender o processo no qual Vincent van Gogh se apropriou de signos linguísticos visuais para significar conteúdos diversos de seus sentidos compartilhados pelo senso comum, atribuindo-lhes outros significados que não estavam inicialmente evidentes, mas que instauraram uma nova rede de significados dentro do sistema pictórico.

No corpus pictórico, investiguei, com base na fundamentação teórica da Multimodalidade, quatro pinturas de Vincent van Gogh: Sunset Wheat fields near Arles 1888 (VAN GOGH, 1888a); The Night Café in the Place Lamartine in Arles, 1888 (VAN GOGH, 1888d) e The Cafe Terrace, 1888 (VAN GOGH, 1888c), The Sower, 1888 (VAN GOGH, 1888b) no contexto do percurso histórico e cultural do sujeito que as produziu. 


\subsubsection{Objetivos da análise pictórica}

- Examinar as funções que os elementos discursivos visuais desempenham na constituição do texto visual;

- Desenvolver considerações acerca de elementos presentes na tela que são recorrentes em outras telas, analisando como estes dialogam na representação pictórica de suas concepções éticas e estéticas de van Gogh.

\subsubsection{Análise epistolar}

$\mathrm{Na}$ análise das cartas foi investigado como o discurso artístico está linguisticamente materializado nas cartas que Vincent van Gogh escreveu.

A análise buscou evidenciar:

a) a ocorrência de padrões semântico e léxico-gramaticais na construção da enunciação;

b) a ocorrência de padrões lógico-semânticos na construção das orações complexas;

c) a oração como representação da visão de mundo e da experiência artística de van Gogh;

d) como as escolhas de transitividade feitas por van Gogh em suas cartas podem revelar ou ocultar sua forma de representar sua obra, seu fazer artístico e seu pensamento acerca da arte;

e) que tipo de relação van Gogh constrói com sua obra por meio da análise das orações complexas e das relações lógico-semânticas;

f) como os conceitos 'Contexto de Situação' e 'Contexto de Cultura' descritos na subseção 4.4.1 'Justificativa para a escolha do corpus pictórico' podem ser instrumentais para revelar os conteúdos nas cartas de van Gogh que são relevantes para compreender seu discurso artístico;

g) a representação escrita que o artista fez de sua obra;

h) aspectos de seu fazer artístico;

i) aspectos de sua produção de sentidos em torno de sua prática;

j) aspectos de sua reflexão acerca de sua prática.

Mais especificamente, a análise parte das referências que o pintor faz às telas analisadas na pesquisa, com base na coleta de um significativo registro documental composto 
pela correspondência que o artista manteve com familiares e amigos, sua biografia e sua produção pictórica.

Além da correspondência produzida por van Gogh, a análise documental também se apoiou em uma ampla historiografia possibilitada por crônicas e relatos dos acontecimentos da família disponível na literatura de diversos biógrafos do artista, como Cabanne (1971), Forrester (1983), Haziot (2010), Naifeh e Smith (2011), Edwards (2009).

Os relatos dos acontecimentos familiares foram produzidos periodicamente como uma tradição familiar de registrar os acontecimentos, uma vez que em 1697 a família esteve à beira da extinção. Devido às guerras e inundações, teve seu clã reduzido à apenas um indivíduo de nome Gerrit Carbentus, avô materno de van Gogh (NAIFEH; SMITH, 2011, p.13). Além das crônicas da família, uma extensa correspondência entre seus membros foi produzida, possivelmente impulsionada pelo contexto da cultura protestante que incentivava todas as práticas de letramento. Entre elas, o hábito da correspondência como uma de suas estratégias para fortalecer o vínculo identitário e os valores protestantes; para cultivar a unidade familiar em meio às dificuldades sociais do momento político de segregação religiosa em sua cidade e no país e, por fim, como resposta às tragédias coletivas que ocorreram com avós e bisavós dos pais de van Gogh, na época da guerra dos oitenta anos. A prática da troca de correspondência entre familiares, ao longo da vida de van Gogh, veio a se tornar uma das ferramentas basilares para a produção do seu pensamento artístico, crítico, criativo e auto-reflexivo e propiciou o ordenamento de sua inquietude intelectual, emocional e artística em um discurso e uma obra, coesos.

\subsubsection{Objetivos da análise epistolar}

- Examinar as funções que os elementos discursivos desempenham no texto escrito das cartas;

- Desenvolver considerações sobre os elementos presentes na carta que são recorrentes em outras cartas, analisando como estes dialogam na representação escrita de suas concepções éticas e estéticas. 


\subsubsection{Triangulação dos corpora}

A investigação possibilitou a triangulação da análise dos relatos do artista acerca de sua produção pictórica com a análise dos elementos que compõem o seu discurso visual a fim de observar como se dão as ocorrências de correspondências, similaridades ou incongruências nas ocorrências em ambas as análises, visual e textual.

A triangulação buscou investigar a colaboração entre elementos discursivos nos dois gêneros estudados e para verificar se os elementos discursivos encontrados em um gênero desempenham alguma função na construção de estruturas linguísticas no outro e vice-versa.

$\mathrm{Na}$ triangulação da análise das telas e da análise dos extratos das cartas, investiguei como a ocorrência dos elementos discursivos visuais nas funções Modal, Representacional e Composicional relacionam-se com a ocorrência de elementos correspondentes, presentes no Sistema de Transitividade da Metafunção Ideacional, que foram identificados na análise Sistêmico-funcional das cartas. Além disso, verifiquei as relações entre os elementos lógicosemânticos das orações complexas e os elementos conectivos nas telas.

Com a triangulação, busquei analisar se e como alguns modos e estratégias discursivas presentes nas cartas foram usados nas telas; e se e como alguns modos e estratégias discursivas nas telas foram usados nas cartas a fim de descrever qual a natureza e função dessas ocorrências.

\subsubsection{Objetivos da triangulação da análise pictórica com a análise epistolar}

- Analisar quais modos de produção textual do autor encontram correspondência na produção visual;

- Investigar de que forma elementos discursivos visuais que ocorrem nas funções modal, representacional e composicional correspondem a elementos discursivos escritos que ocorrem no sistema de transitividade da metafunção ideacional;

- Verificar se as relações lógico-semânticas, encontradas nas orações complexas, encontram correspondência nos elementos conectivos que colaboram para a coesão da narrativa visual;

- Examinar a natureza da correspondência dos elementos discursivos que são similares ou desempenham funções correspondentes na constituição do discurso pictórico e do discurso epistolar, cuja ocorrência é identificada na tela e na carta, 
verificando se eles são recorrentes, complementares, similares, antagônicos ou contraditórios;

- Identificar se há uma transposição entre as funções nas telas e o sistema de transitividade da metafunção ideacional nas cartas quando se verifica uma ocorrência de elementos correspondentes ou compartilhados nos dois gêneros textuais.

\subsection{SOBRE OS CORPORA DA PESQUISA}

\subsubsection{Corpus visual}

A produção pictórica de van Gogh, de acordo com o levantamento do Museu van Gogh é de 864 telas (VAN GOGH MUSEUM, 2014). Das 864 telas, foram selecionadas as pinturas de van Gogh abaixo relacionadas. As informações acerca do local e data de sua produção e localização atual, além da fonte da imagem, estão disponíveis também no item: 4.5, 'Apresentação do corpus pictórico', na metodologia.

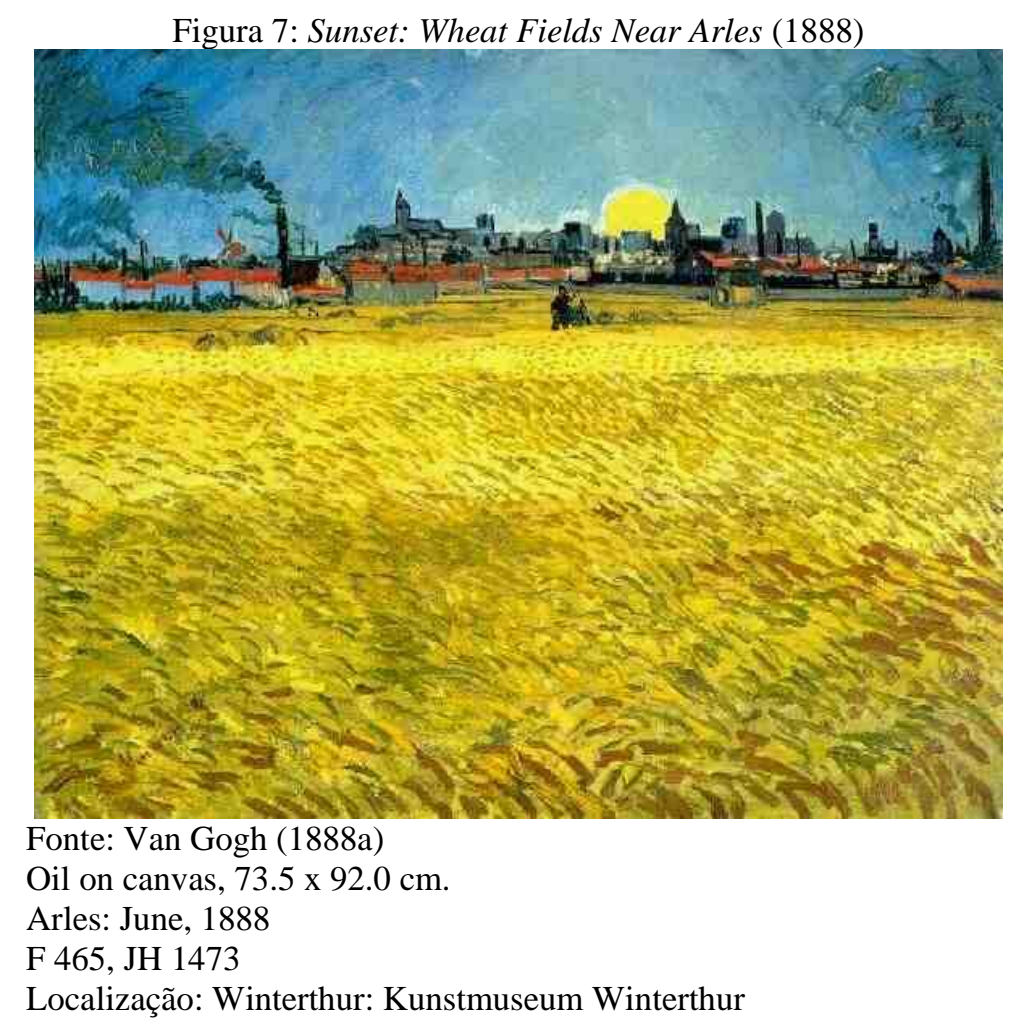


Figura 8: The Sower Arles: June, (1888)

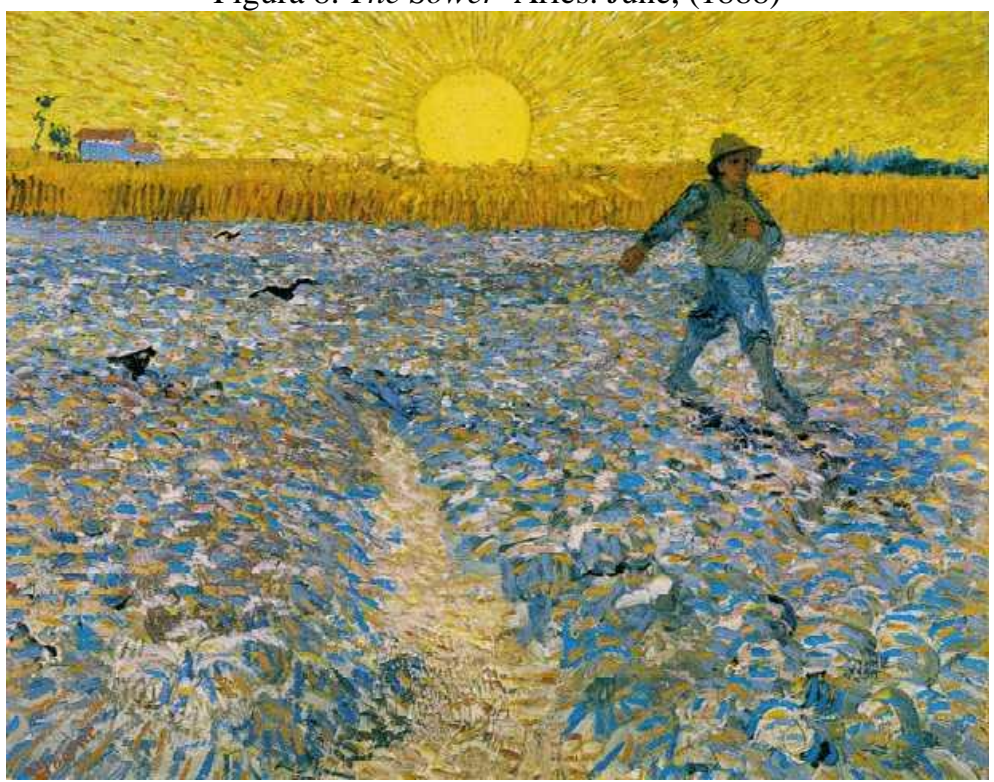

Fonte: Van Gogh (1888d)

Oil on canvas, $64.0 \times 80.5 \mathrm{~cm}$.

Arles: June, 1888

F 422, JH 1470

Localização: Otterlo, Rijksmuseum Kroller-Muller.

Figura 9: The Café Terrace on the Place Du Forum, Arles, at Night (1888)

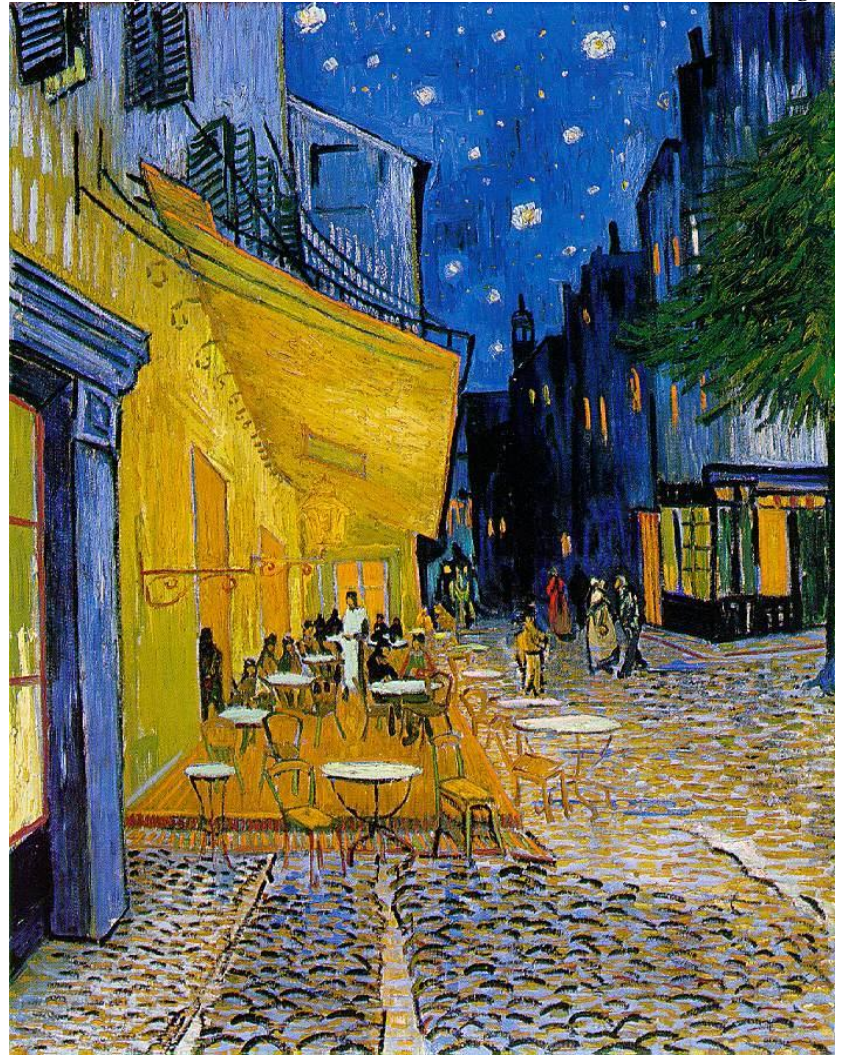

Fonte: Van Gogh (1888c)

Oleo sobre tela, $1.0 \times 65.5 \mathrm{~cm}$.

Arles: September, 1888

F 467, JH 1580

Localização: Otterlo, Rijksmuseum Kroller-Muller. 


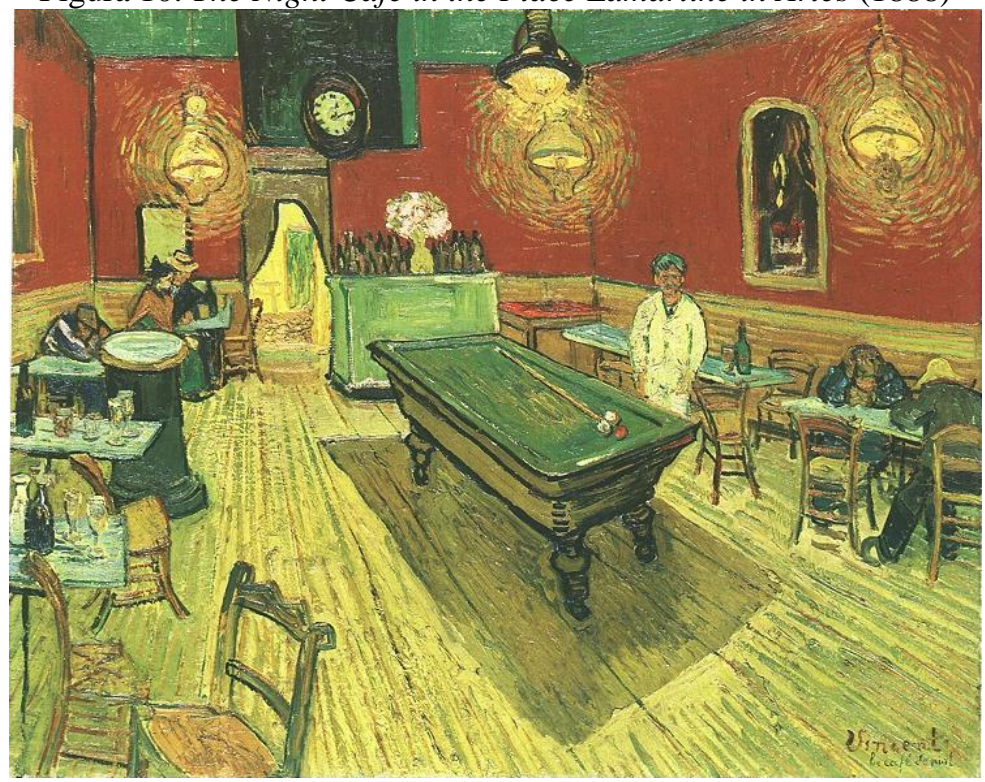

Fonte: Van Gogh (1888d)

Óleo sobre tela, $70.0 \times 89.0 \mathrm{~cm}$.

Arles: 5-8 Septembro de 1888.

F 463, JH 1575

Localização: New Haven, Connecticut: Yale University Art Gallery

\subsubsection{Corpus Epistolar}

O corpus das cartas está constituído dos excertos de cartas que se referem diretamente às telas analisadas. O corpus textual primário consiste dos extratos de 12 cartas que se relacionam com as obras citadas, selecionadas em uma correspondência de 902 cartas que van Gogh manteve com seus familiares e amigos;

$\mathrm{Na}$ análise das cartas, os excertos do corpus primário foram segmentados em orações, analisadas com a ajuda das ferramentas metodológicas da Linguística Sistêmico Funcional (LSF), com enfoque nas categorias da Transitividade e das orações complexas para buscar as relações lógico-semânticas.

A interpretação da descrição na análise desses corpora apoiou-se também nos relatos dos biógrafos do artista (WALTHER; METZGER, 2012; NAIFEH; SMITH, 2011; HAZIOT, 2010; WALTHER, 1990; PEREIRA, 1990; CABANNE, 1971; FORRESTER, 1983) e no estudo do contexto sócio-histórico no qual foram produzidas tanto as telas quanto as cartas para compreender os sistemas semânticos e semióticos à sua luz. 


\subsection{JUSTIFICATIVA E CARACTERIZAÇÃO DOS CORPORA DA PESQUISA}

A justificativa e caracterização dos corpora da pesquisa foram relocadas no apêndice para reduzir o volume da tese.

\subsection{APRESENTAÇÃO DO CORPUS PICTÓRICO}

O corpus pictórico desta pesquisa segue abaixo descrito:

Quadro 11: Relação das telas do corpus pictórico

\begin{tabular}{|c|c|c|c|}
\hline $\begin{array}{l}\text { Título e } \\
\text { informaçõe } \\
\text { s sobre a } \\
\text { tela }\end{array}$ & Imagem & $\begin{array}{l}\text { Data e } \\
\text { local da } \\
\text { produção }\end{array}$ & Fonte \\
\hline $\begin{array}{l}\text { Por de Sol: } \\
\text { Campo de } \\
\text { trigo perto } \\
\text { de Arles de } \\
\text { van Gogh } \\
\\
\text { Óleo sobre } \\
\text { tela, } 73.5 \text { x } \\
92.0 \text { cm., F } \\
465, \text { JH } \\
1473 \text {, } \\
\text { Localização } \\
: \\
\text { Winterthur: } \\
\text { Kunstmuseu } \\
\text { m } \\
\text { Winterthur }\end{array}$ & 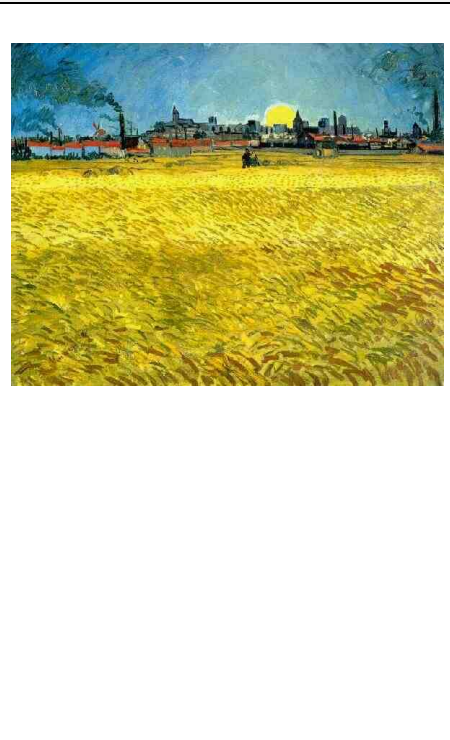 & $\begin{array}{l}\text { Arles: } \\
\text { June, } 1888 .\end{array}$ & $\begin{array}{l}\text { Fonte: Van Gogh Gallery, disponível em } \\
\text { 24.7.2014, } \\
\text { http://www.vggallery.com/painting/p_0465.htm }\end{array}$ \\
\hline $\begin{array}{l}\text { O Semeador } \\
\text { de van } \\
\text { Gogh } \\
\text { Óleo sobre } \\
\text { tela, } 64.0 \mathrm{x} \\
80.5 \mathrm{~cm} . \\
\text { Arles: June, } \\
1888 \\
\text { F } 422 \text {, JH } \\
\text { 14701 } \\
\text { Localização } \\
\text { : Otterlo, } \\
\text { Rijksmuseu } \\
\text { m Kroller- } \\
\text { Muller. }\end{array}$ & $3 x+5 \cdot$ & $\begin{array}{l}\text { Arles: } \\
\text { June, } 1888 .\end{array}$ & (1) \\
\hline
\end{tabular}




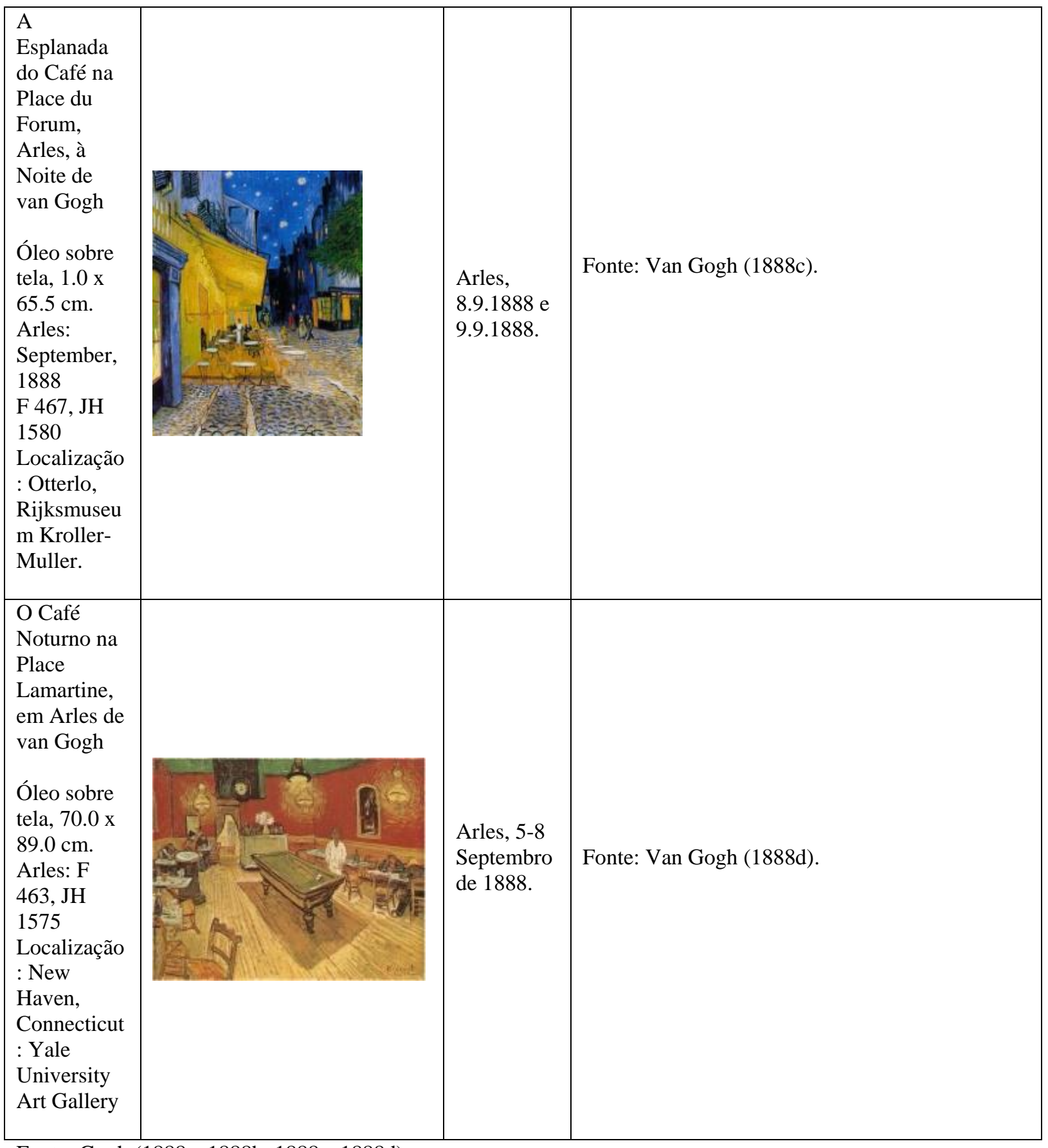

Fonte: Gogh (1888a, 1888b, 1888c, 1888d).

\subsection{JUSTIFICATIVA PARA A ESCOLHA DO CORPUS EPISTOLAR}

A justificativa da escolha do corpus epistolar da pesquisa foi alocada no apêndice para reduzir o volume da tese. 


\subsection{APRESENTAÇÃO DO CORPUS TEXTUAL}

A correspondência produzida por Van Gogh constitui um conjunto de 902 cartas que compõem as cartas sobreviventes que ele escreveu e recebeu de seus correspondentes entre 1853-1890. Recentemente o conjunto das cartas que constitui a correspondência de Van Gogh foi catalogado e reeditado em um empreendimento que recebeu o nome de Van Gogh Letters Project, fruto do trabalho colaborativo entre o Museu Van Gogh e o Instituto Huygens da Academia Real Holandesa de Artes e Ciências cujo forte é a publicação acadêmica de textos literários e históricos. Este ambicioso empreendimento foi levado ao cabo em quinze anos e em 2009 foi lançada uma nova coletânea da correspondência de Van Gogh que contemplou várias necessidades de tratamento, tais como a transcrição, a disponibilização do original digitalizado, a tradução em três idiomas e a disponibilização em um banco de dados online. (JANSEN; LUIJTEN; BAKKER, 2009).

A leitura do conjunto de cartas permitiu perceber uma série de características e funções da correspondência para Vincent, por exemplo, suas cartas escritas ao seu irmão mostram uma transformação ao longo dos anos na qual ele passa de um correspondente que segue as convenções sociais para um escritor que depende da correspondência como um meio de reflexão e de desenvolvimento pessoal e de vínculo com seu correspondente Theo, como confirmam os editores das cartas de Vincent, Jansen, Luijten e Bakker (2009, p. 1):

\footnotetext{
[...] desde a primeira carta que ele assumiu o papel do irmão mais velho e mais sábio para Theo. Ele usou a correspondência para aconselhar-lhe o que devia e não devia fazer para sair adiante na vida. Ele moralizava e confortava Theo se ele tinha dificuldades no trabalho ou lamentava a perda de um amigo. E dava-lhe conselhos sobre a arte e a literatura. Estes foram seus principais interesses, como resulta da maioria de suas cartas.
}

Quando morou em Dordrecht e Amsterdam, Vincent passa por muitas transformações e elas estão refletidas na forma como ele passa a escrever para Theo. Suas cartas descrevem com detalhes vivos o que ele observa em suas caminhadas, as condições nas minas e a vida dos mineiros no trabalho debaixo do chão. Ele começou a relatar sua impressão do que se passa a sua volta, e o seu estado de espírito diante de uma paisagem do campo ou da cidade, tornando-se menos reservado para confidenciar a Theo, algo impensável em suas primeiras cartas, seu desejo de se tornar pintor e as grandes dificuldades que encontra para levar este projeto adiante. No início da correspondência, Vincent seguia o comportamento social adequado para as convenções da época em suas cartas, mas no final da década de 1870 e daí em diante, sua escrita assumiu as funções de: canal para sua expressão pessoal, registro de suas impressões, organizar suas ideias e questões e, por meio dela, definir-se, tanto para si e 
para Theo, seu interlocutor e confidente. As cartas foram um meio autoreflexivo de desenvolver um pensamento e um discurso acerca da sua experiência e da sua visão da vida e da arte. A leitura das cartas oferece tanto uma noção de aspectos particulares quanto uma visão de conjunto de seu processo de amadurecimento acerca de suas escolhas artistas, desde as mais simples soluções representativas de uma tela até as concepções mais totalizantes na sua obra. A seguir apresento o corpus textual da pesquisa.

\subsubsection{Apresentação do Corpus Textual Primário}

Nesta sessão serão apresentados os extratos de cartas diretamente relacionadas com as telas do corpus visual (coletados de JANSEN; LUIJTEN; BAKKER, 2009).

Quadro 12: Relação das telas com as cartas do corpus textual.

\begin{tabular}{|c|c|c|}
\hline Telas - Data & Imagem - Fonte & Cartas \\
\hline $\begin{array}{l}\text { 1) Por de Sol: } \\
\text { Campo de } \\
\text { trigo perto de } \\
\text { Arles de van } \\
\text { Gogh } \\
\\
\text { Arles - Arles: } \\
\text { June, 1888: }\end{array}$ & 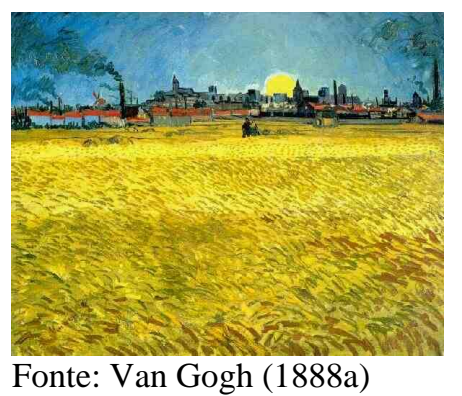 & $\begin{array}{l}\text { Extrato 1a - Carta } 680 \text { - To Theo van Gogh. Arles, on or } \\
\text { about Tuesday, } 11 \text { September } 1888 \text {. (VAN GOGH, } \\
\text { 2009b). } \\
\text { Extrato } 1 \text { b - Carta } 628 \text { - To: Emile Bernard. Arles, on or } \\
\text { about Tuesday, } 19 \text { June 1888. (VAN GOGH, 2009c). }{ }^{7} \\
\text { Extrato 1c - Carta } 633 \text { - To: Emile Bernard. Arles, } \\
\text { Wednesday, } 27 \text { June } 1888 \text {. (VAN GOGH, 2009d). }\end{array}$ \\
\hline $\begin{array}{l}\text { 2) O } \\
\text { Semeador de } \\
\text { van Gogh } \\
\text { Arles: June, } \\
\text { 1888 }\end{array}$ & 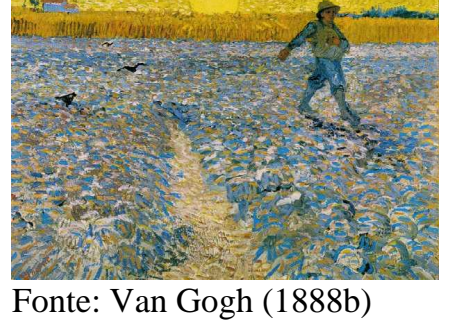 & $\begin{array}{l}\text { Extrato } 2 \mathrm{a} \text { - Carta } 628 \text { - To: Emile Bernard. Arles, on or } \\
\text { about Tuesday, } 19 \text { June } 1888 \text {. (VAN GOGH, 2009c). } \\
\text { Extrato } 2 \mathrm{~b} \text { - Carta } 629 \text { - To: Theo van Gogh. Arles, } \\
\text { Thursday, } 21 \text { June } 1888 \text {. (VAN GOGH, 2009e). }{ }^{10}\end{array}$ \\
\hline
\end{tabular}

\footnotetext{
${ }^{6}$ Disponível em: 〈http://vangoghletters.org/vg/letters/let680/letter.html $>$.

${ }^{7}$ Disponível em: $\langle$ http://vangoghletters.org/vg/letters/let628/letter.html $>$.

${ }^{8}$ Disponível em: $\langle$ http://vangoghletters.org/vg/letters/let633/letter.html $>$.

${ }^{9}$ Disponível em: 〈http://vangoghletters.org/vg/letters/let628/letter.html $>$.

${ }^{10}$ Disponível em: 〈http://vangoghletters.org/vg/letters/let629/letter.html $>$.
} 


\begin{tabular}{|l|l|l|}
\hline $\begin{array}{l}\text { 3) A } \\
\text { Esplanada do } \\
\text { Café na Place } \\
\text { du Forum, } \\
\text { Arles, à Noite } \\
\text { de Van Gogh }\end{array}$ & $\begin{array}{l}\text { Extrato 3a - Carta 681 - Br. 1990: 685 | CL: 537 - From: } \\
\text { Vincent van Gogh To: Theo van Gogh - Date: Arles, } \\
\text { Sunday, 16 September 1888. (VAN GOGH, 2009f). }\end{array}$ \\
$\begin{array}{l}\text { Arles - } \\
\text { 8.9.1888 e } \\
\text { 9.9.1888: } \\
\text { Vincent To: Willemien van Gogh - Date: Arles, Sunday, } 9 \\
\text { and about Friday, 14 September 1888. (VAN GOGH, } \\
\text { 2009f). }{ }^{12}\end{array}$ \\
\hline
\end{tabular}

Os excertos do corpus textual primário, apresentados a seguir, foram selecionados na base de dados eletrônica da edição Inglesa das cartas de Van Gogh entitulada: "Vincent van Gogh - The Letters, the Complete Illustrated and Annotated Edition" (JANSEN; LUIJTEN; BAKKER, 2009) por meio de palavras-chave relacionadas com os temas representados nas telas, e também por aproximação das datas e períodos em que as telas foram produzidas. Os excertos na língua original em que foram escritos e a sua tradução para o Inglês se encontram nos anexos.

\footnotetext{
${ }^{11}$ Disponível em: <http://vangoghletters.org/vg/letters/let681/letter.html>.

${ }^{12}$ Disponível em: $\langle$ http://vangoghletters.org/vg/letters/let678/letter.html $>$.

${ }^{13}$ Disponível em: $\langle$ http://vangoghletters.org/vg/letters/let676/letter.html $>$.

${ }^{14}$ Disponível em: $\langle$ http://vangoghletters.org/vg/letters/let676/letter.html $>$.

${ }^{15}$ Disponível em: $\langle$ http://vangoghletters.org/vg/letters/let677/letter.html $>$.

${ }^{16}$ Disponível em: 〈http://vangoghletters.org/vg/letters/let680/letter.html $>$.

${ }^{17}$ Disponível em: 〈http://vangoghletters.org/vg/letters/let678/letter.html 〉.
} 
Quadro 13: Lista de cartas, excertos e telas a que se referem

\begin{tabular}{|c|c|c|}
\hline $\begin{array}{l}\text { Id. Tela } \\
\text { Imagem tela }\end{array}$ & $\begin{array}{l}\text { Id. da Carta } \\
\text { Id. do Extrato }\end{array}$ & Extrato da Carta \\
\hline $\begin{array}{l}\text { Por de Sol: Campo } \\
\text { de trigo perto de } \\
\text { Arles } \\
\text { Arles: June, } 1888 \\
\text { Fonte: Van Gogh } \\
\text { (1888a) }\end{array}$ & $\begin{array}{l}\text { Carta } 680 \\
{\text { Extrato }{ }^{\circ} 1 \mathrm{a}} \\
\text { To Theo van Gogh. } \\
\text { Arles, on or about } \\
\text { Tuesday, } 11 \\
\text { September } 1888 . \\
\text { Linhas } 97 \text { a } 100\end{array}$ & $\begin{array}{l}\text { "Eu tenho um terceiro estudo, agora, de uma paisagem com fábrica, } \\
\text { e um enorme sol em um céu vermelho, acima de telhados } \\
\text { vermelhos, em que a natureza parece estar em um acesso de raiva, } \\
\text { em um dia de mistral desagradável." (VAN GOGH, 2009b, p. 1). }\end{array}$ \\
\hline $\begin{array}{l}\text { Por de Sol: Campo } \\
\text { de trigo perto de } \\
\text { Arles } \\
\text { Arles: June, } 1888 \\
\text { Fonte: Van Gogh } \\
\text { (1888a) }\end{array}$ & $\begin{array}{l}\text { Carta } 628 \\
\text { Extrato } \mathrm{n}^{\circ} 1 \mathrm{~b} \\
\text { To Emile Bernard. } \\
\text { Arles, on or about } \\
\text { Tuesday, } 19 \\
\text { September } 1888 \text {. }\end{array}$ & $\begin{array}{l}\text { Aqui está outra paisagem. Sol poente? Lua nascendo? Noite de } \\
\text { verão, de qualquer modo. Cidade violeta, estrela amarela, céu azul- } \\
\text { esverdeado; os campos de trigo tem todos os tons: ouro velho, } \\
\text { cobre, ouro verde, ouro vermelho, ouro amarelo, verde, vermelho e } \\
\text { amarelo bronze. Tela quadrada número } 30 \text {. } \\
\text { Eu pintei-a ao ar livre no mistral. Meu cavalete foi fixado no chão } \\
\text { com estacas de ferro, um método que eu recomendo a você. } \\
\text { [esboço C] } \\
\text { Você enterra os pés do cavalete e, em seguida, você empurra a } 50 \\
\text { centímetros de comprimento um peso de ferro ao lado deles. Você } \\
\text { amarra tudo com cordas; dessa forma, você pode trabalhar com o } \\
\text { vento. (VAN GOGH, 2009c, p. } 1 \text { ). }\end{array}$ \\
\hline $\begin{array}{l}\text { Por de Sol: Campo } \\
\text { de trigo perto de } \\
\text { Arles } \\
\text { Arles: June, } 1888 \\
\text { Fonte: Van Gogh } \\
\text { (1888a) }\end{array}$ & $\begin{array}{l}\text { Carta } 633 \\
\text { Extrato } \mathrm{n}^{\circ} 1 \mathrm{c} \\
\text { To: Emile Bernard } \\
\text { Date: Arles, } \\
\text { Wednesday, } 27 \\
\text { June } 1888\end{array}$ & $\begin{array}{l}\text { Eu também sou totalmente incapaz de julgar o meu próprio } \\
\text { trabalho. Eu não posso ver se os estudos são bons ou ruins. Tenho } \\
\text { sete estudos de trigais, infelizmente todos eles nada além de } \\
\text { paisagens, muito contra a minha vontade. Paisagens amarelo ouro } \\
\text { velho - feito rápido rápido rápido e com pressa, como o ceifeiro que } \\
\text { está em silêncio sob o sol escaldante, concentrando-se em ter o } \\
\text { trabalho terminado. (VAN GOGH, 2009d, p. 1). }{ }^{20}\end{array}$ \\
\hline $\begin{array}{l}\text { O Semeador } \\
\text { Arles: June, } 1888 \\
\text { Fonte: Van Gogh } \\
\text { (1888b) }\end{array}$ & $\begin{array}{l}\text { Carta } 628 \\
\text { Extrato } \mathrm{n}^{\circ} 2 \mathrm{a} \\
\text { To Emile Bernard. } \\
\text { Arles, on or about } \\
\text { Tuesday, } 19 \\
\text { September } 1888 \text {. }\end{array}$ & $\begin{array}{l}\text { Aqui está um esboço de um semeador> um grande campo lavrado } \\
\text { com torrões de terra, na sua maioria fracamente cor de violeta. } \\
\text { Um campo de trigo maduro, de tom amarelo-ocre com um pouco de } \\
\text { carmim. } \\
\text { O céu, amarelo-crómio, quase tão luminoso quanto o próprio Sol, } \\
\text { que é amarelo-crómio no } 1 \text {, misturado com um pouco de branco, } \\
\text { enquanto o resto do céu é uma mistura dos amarelos-crómios } 1 \text { e } 2 \text {. } \\
\text { Tão amarelo! A camisa do semeador é azul e as calças brancas. } \\
\text { Tamanho da tela - } 25 \text {, quadrada. } \\
\text { Há várias sugestões de amarelo no solo, tons neutros resultantes da }\end{array}$ \\
\hline
\end{tabular}

\footnotetext{
${ }^{18}$ Disponível em: 〈http://vangoghletters.org/vg/letters/let680/letter.html $>$.

${ }^{19}$ Disponível em: 〈http://vangoghletters.org/vg/letters/let628/letter.html >

${ }^{20}$ Disponível em: 〈http://vangoghletters.org/vg/letters/let633/letter.html $>$.
} 


\begin{tabular}{|c|c|c|}
\hline & & $\begin{array}{l}\text { mistura de violeta e amarelo; mas tenho travado uma luta diabólica } \\
\text { para atingir a verdade das cores. Preferia muito mais fazer quadros } \\
\text { naifs tirados de velhos almanaques, aqueles velhos "almanaques dos } \\
\text { lavradores" nos quais o granizo, a neve, a chuva e o bom tempo são } \\
\text { retratados de modo primitivo, como o Anquetin atingiu tão bem no } \\
\text { seu A Colheita. } \\
\text { Não te vou ocultar que não desgosto da região, pois fui criado lá- } \\
\text { ainda me encanta a magia das recordações do passado, de um desejo } \\
\text { do infinito, do qual o semeador e o enfeixador são símbolos -, tanto } \\
\text { quanto antes gostava. } \\
\text { Mas quando eu farei o céu estrelado, então, essa pintura que está } \\
\text { sempre na minha mente? Ai, ai, é como nosso excelente amigo } \\
\text { Cyprien diz, em 'En ménage' por JK Huysmans: as mais belas } \\
\text { pinturas são aquelas que um sonha enquanto fuma um cachimbo em } \\
\text { sua cama, mas a qual ele não pinta. Mas é uma questão de atacá-las, } \\
\text { no entanto, não importa o quão incompetente um pode sentir-se vis- } \\
\text { à-vis as perfeições inefáveis do glorioso esplendor da natureza. } \\
\text { [...] } \\
\text { Aqui está o que eu queria dizer sobre o branco e o preto. Vamos } \\
\text { tomar o Semeador. A pintura é dividida em dois; metade é amarelo, } \\
\text { o topo; a base é violeta. Bem, as calças brancas descansam os olhos } \\
\text { e os distraem exatamente quando o contraste simultâneo excessivo } \\
\text { de amarelo e violeta iriam irritá-lo. Isso é o que eu queria dizer. } \\
\text { (VAN GOGH, 2009c, p. 1). }{ }^{21}\end{array}$ \\
\hline $\begin{array}{l}\text { O Semeador } \\
\text { Arles: June, } 1888 \\
\text { Fonte: Van Gogh } \\
\text { (1888b) }\end{array}$ & $\begin{array}{l}\text { Carta } 629 \\
\text { Extrato } \mathrm{n}^{\circ} 2 \mathrm{~b} \\
\text { To Theo Van } \\
\text { Gogh. Arles, } \\
\text { Thursday, } 21 \text { June } \\
1888 \text {. }\end{array}$ & $\begin{array}{l}\text { Eu tive uma semana de concentrado trabalho duro nos campos de } \\
\text { trigo debaixo do sol, o resultado foi de alguns estudos de campos de } \\
\text { trigo, paisagens e - um esboço de um semeador. Em um campo } \\
\text { arado, um grande campo de torrões de terra roxa - levantados em } \\
\text { direção ao horizonte - um semeador em azul e branco. No horizonte } \\
\text { um campo de trigo curto, maduro. 1v: } 2 \\
\text { Acima de tudo isso um céu amarelo com um sol amarelo. } \\
\text { Você pode sentir a partir da mera nomenclatura das tonalidades - } \\
\text { que a cor desempenha um papel muito importante nesta } \\
\text { composição. } \\
\text { E o esboço como tal - uma tela número } 25 \text { - também me preocupa } \\
\text { muito, no sentido de que eu me pergunto se eu não deveria levar a } \\
\text { sério e fazer uma pintura tremenda disso. Meu Deus, como eu } \\
\text { adoraria fazer isso. Mas eu só me pergunto se eu vou ter o poder } \\
\text { necessário de execução. } \\
\text { Eu estou colocando o esboço de lado assim como é, mal ousando } \\
\text { pensar nisso. } \\
\text { Por um longo tempo ele foi meu grande desejo de fazer um } \\
\text { semeador, } 5 \text {, mas os desejos que tive por um longo tempo nem } \\
\text { sempre são alcançados. Então, eu estou quase com medo deles. E, } \\
\text { no entanto, depois de Millet e Lhermitte o que resta a ser feito é... o } \\
\text { semeador, com cor e em um grande formato. (VAN GOGH, 2009e, } \\
\text { p. 1). }{ }^{22}\end{array}$ \\
\hline
\end{tabular}

\footnotetext{
${ }^{21}$ Disponível em: $\langle$ http://vangoghletters.org/vg/letters/let628/letter.html $>$.

${ }^{22}$ Disponível em: <http://vangoghletters.org/vg/letters/let629/letter.html $>$.
} 


\begin{tabular}{|c|c|c|}
\hline $\begin{array}{l}\text { A Esplanada do } \\
\text { Café na Place du } \\
\text { Forum, Arles, à } \\
\text { Noite } \\
\text { Arles: September, } \\
1888 \\
\text { F } 467, \text { JH } 1580 \\
\text { Fonte: Van Gogh } \\
(1888 \text { c) }\end{array}$ & $\begin{array}{l}\text { Carta } 681 \\
\text { Extrato }{ }^{\circ} 3 \mathrm{a} \\
\text { Br. 1990: } 685 \text { | CL: } \\
537 \\
\text { From: Vincent van } \\
\text { Gogh } \\
\text { To: Theo van Gogh } \\
\text { Date: Arles, } \\
\text { Sunday, } 16 \\
\text { September } 1888 . \\
\text { Linhas } 46 \text { a } 50\end{array}$ & $\begin{array}{l}\text { "Essa é a primeira pintura esta semana. A segunda mostra o exterior } \\
\text { de um café, iluminado no terraço externo por uma grande lâmpada } \\
\text { de gás dentro da noite azul, com um retalho de céu azul estrelado. } \\
\text { 3". (VAN GOGH, 2009f, p. 1). }{ }^{23}\end{array}$ \\
\hline $\begin{array}{l}\text { A Esplanada do } \\
\text { Café na Place du } \\
\text { Forum, Arles, à } \\
\text { Noite } \\
\text { Arles: September, } \\
1888 \\
\text { F } 467 \text {, JH } 1580 \\
\text { Fonte: Van Gogh } \\
\text { (1888c) }\end{array}$ & $\begin{array}{l}\text { Carta } 678 \\
\underline{\text { Extrato } n^{\circ} 3 \mathrm{~b}} \\
\text { Br. 1990: } 681 \mid \mathrm{CL} \text { : } \\
\text { W7 } \\
\text { From: Vincent } \\
\text { To: Willemien van } \\
\text { Gogh } \\
\text { Date: Arles, } \\
\text { Sunday, } 9 \text { and } \\
\text { about Friday, } 14 \\
\text { September } 1888 . \\
\text { Linhas } 100-136 \\
\text { Café Terrace }\end{array}$ & $\begin{array}{l}\text { "Fui interrompido precisamente pelo trabalho que uma nova pintura } \\
\text { da parte externa de um café à noite tem me dado nos últimos dias. } \\
\text { No terraço, há pequenas figuras de pessoas que bebem. Uma } \\
\text { enorme lanterna amarela ilumina o terraço, a fachada, a calçada, e } \\
\text { até mesmo projeta luz sobre os paralelepípedos da rua, que } \\
\text { adquirem uma coloração violeta-rosa. As frentes das casas em uma } \\
\text { rua que segue sob o céu azul salpicado de estrelas são azul escuro } \\
\text { ou violeta, com uma árvore verde. Agora há uma pintura de noite } \\
\text { sem preto. Com nada mais do que um belo azul e violeta e verde e } \\
\text { nestes arredores da praça iluminada é colorido por enxofre pálido, } \\
\text { amarelo limão. Eu gosto enormemente de pintar no local à noite. No } \\
\text { passado, eles costumavam desenhar e pintar a tela do desenho } \\
\text { durante o dia. Mas acho que me convém pintar a coisa no momento. } \\
\text { É bem verdade que eu possa tomar um azul por um verde no escuro, } \\
\text { um azul lilás por um rosa lilás, uma vez que você não pode perceber } \\
\text { a natureza do tom claramente. Mas é a única maneira de se livrar da } \\
\text { noite negra convencional com uma luz pobre, pálida e } \\
\text { esbranquiçada, quando na verdade uma mera vela por si só nos dá } \\
\text { os mais ricos amarelos e laranjas. Eu também fiz um novo retrato de } \\
\text { mim mesmo, como um estudo, no qual eu pareço um Japonês. Você } \\
\text { nunca me disse se você tinha lido Bel-ami de Guy de Maupassant, e } \\
\text { o que você pensa agora do talento dele em geral. Digo isto porque o } \\
\text { início de Bel- Ami é precisamente a descrição de uma noite } \\
\text { estrelada em Paris, com os cafés iluminados da avenida, e isso é } \\
\text { algo como o mesmo tema que eu pintei bem agora." (VAN GOGH, } \\
2009 \text { g, p. 1). }{ }^{24}\end{array}$ \\
\hline $\begin{array}{l}\text { O Café Noturno na } \\
\text { Place Lamartine, }\end{array}$ & $\begin{array}{l}\text { Carta } 676 \\
\text { Extrato } n^{\circ} 4 \mathrm{a} \\
\text { Br. 1990: } 679 \mid \mathrm{CL}: \\
\text { 533 - From: } \\
\text { Vincent To: Theo } \\
\text { van Gogh - Date: }\end{array}$ & $\begin{array}{l}\text { "Muitas vezes parece-me que a noite é muito mais viva e ricamente } \\
\text { colorida do que o dia. Agora como para recuperar o dinheiro pago } \\
\text { ao senhorio através da minha pintura, eu não estou fazendo questão } \\
\text { disto, porque a pintura é uma das mais feias que eu já fiz. É o } \\
\text { equivalente, embora diferente, dos comedores de batata. } 4 \text { 1v: } 2 \\
\text { Eu tentei expressar as terríveis paixões humanas com o vermelho e } \\
\text { o verde. } \\
\text { A sala é vermelho-sangue e amarelo sem graça, uma mesa de bilhar }\end{array}$ \\
\hline
\end{tabular}

\footnotetext{
${ }^{23}$ Disponível em: 〈http://vangoghletters.org/vg/letters/let681/letter.html $>$.

${ }^{24}$ Disponível em: 〈http://vangoghletters.org/vg/letters/let678/letter.html $>$.
} 


\begin{tabular}{|c|c|c|}
\hline $\begin{array}{l}\text { em Arles } \\
\text { Arles: } 5-8 \\
\text { September } 1888 \\
\text { Fonte: Van Gogh } \\
\text { (1888d) }\end{array}$ & $\begin{array}{l}\text { Arles, } 8 \text { September } \\
1888 .\end{array}$ & $\begin{array}{l}\text { verde no centro, } 4 \text { lâmpadas de amarelo limão com um brilho } \\
\text { laranja e verde. } \\
\text { Em todos os lugares é uma batalha e uma antítese dos mais } \\
\text { diferentes verdes e vermelhos; nas personagens dos rufiões } \\
\text { adormecidos, pequenos na alta sala vazia, algum roxo e azul. O } \\
\text { vermelho-sangue e o amarelo-verde da mesa de bilhar, por exemplo, } \\
\text { contrasta com o pouco de verde delicado Louis XV do balcão, onde } \\
\text { há um buquê rosa. } \\
\text { A roupa branca do proprietário, vigiando as coisas a partir de um } \\
\text { canto deste forno, torna-se amarelo-limão, verde luminoso pálido. } \\
\text { Eu estou fazendo um desenho dele em tons aquarela para enviar-lhe } \\
\text { amanhã, para dar a voce uma idéia dele." (VAN GOGH, } 2009 \mathrm{j}, \text { p. } \\
\text { 1). }\end{array}$ \\
\hline $\begin{array}{l}\text { O Café Noturno na } \\
\text { Place Lamartine, } \\
\text { em Arles } \\
\text { Arles: } 5-8 \\
\text { September } 1888 \\
\text { Fonte: Van Gogh } \\
\text { (1888d) }\end{array}$ & $\begin{array}{l}\text { Carta } 676 \\
\text { Extrato }{ }^{\circ} 4 \mathrm{~b} \\
\text { Br. 1990: 679 | CL: } \\
\text { 533 - From: } \\
\text { Vincent To: Theo } \\
\text { van Gogh - Date: } \\
\text { Arles, 8 September } \\
\text { 1888. }\end{array}$ & $\begin{array}{l}\text { "Mais tarde, quando eu tiver levado esses experimentos mais longe, } \\
\text { o semeador ainda vai ser a primeira tentativa nesse gênero. } \\
\text { O café noturno é uma continuação do semeador, como é a cabeça do } \\
\text { velho camponês e do poeta, se eu conseguir fazer essa ultima tela. } \\
\text { É uma cor, então, que não é localmente verdadeira do ponto de vista } \\
\text { realista do trompe l'oeil, mas uma cor que sugere alguma emoção, } \\
\text { um temperamento ardente." (VAN GOGH, 2009j, p. 1). }{ }^{26}\end{array}$ \\
\hline $\begin{array}{l}\text { O Café Noturno na } \\
\text { Place Lamartine, } \\
\text { em Arles } \\
\text { Arles: } 5-8 \\
\text { September } 1888 \\
\text { Fonte: Van Gogh } \\
\text { (1888d) }\end{array}$ & $\begin{array}{l}\text { Carta } 677- \\
\text { Extrato n }{ }^{\circ} 4 \mathrm{c} \\
\text { Br. 1990: } 680 \text { | CL: } \\
\text { 534 - From: } \\
\text { Vincent van Gogh } \\
\text { To: Theo van Gogh } \\
\text { - Date: Arles, } 9 \\
\text { September } 1888 \text {. }\end{array}$ & $\begin{array}{l}\text { "Na minha pintura do café à noite eu procurei exprimir que o café é } \\
\text { um lugar onde você pode arruinar-se, enlouquecer, cometer crimes. } \\
\text { De qualquer forma, eu tentei com contrastes de rosa delicado e } \\
\text { vermelho-sangue e vinho tinto. Verde doce Luís XV e Veronese } \\
\text { contrastando com os verdes amarelos e os verdes azuis duros. } \\
\text { Tudo isso em uma atmosfera de fornalha infernal, de enxofre } \\
\text { pálido. } \\
\text { Exprimir como a potência dos cantos escuros de uma taberna. } \\
\text { Contudo sob uma aparência da alegria japonesa e da boa natureza } \\
\text { de Tartarin. } \\
\text { Que diria portanto desse quadro o Sr. Tersteeg? Diante de um } \\
\text { Sisley, Sisley, o mais discreto e delicado dos Impressionistas - já } \\
\text { disse: "Não posso me impedir de pensar que o artista que pintou } \\
\text { isso estava um pouco tonto". Diante do meu quadro, então a mim } \\
\text { ele diria que ele é um caso de delirium tremens". (VAN GOGH, } \\
2009 \mathrm{~h}, \text { p. 1). }{ }^{27}\end{array}$ \\
\hline & $\begin{array}{l}\text { Carta } 680 \\
\text { Extrato } n^{\circ} 4 d \\
\end{array}$ & $\begin{array}{l}\text { "A idéia do semeador ainda continua a me assombrar. Estudos } \\
\text { exagerados, como o semeador, como o café noturno agora, } \\
\text { geralmente parecem-me atrozmente feios e ruins, mas quando eu } \\
\text { estou movido por alguma coisa, como aqui por este pequeno artigo }\end{array}$ \\
\hline
\end{tabular}

\footnotetext{
${ }^{25}$ Disponível em: <http://vangoghletters.org/vg/letters/let676/letter.html $>$.

${ }^{26}$ Disponível em: 〈http://vangoghletters.org/vg/letters/let676/letter.html $>$.

${ }^{27}$ Disponível em: 〈http://vangoghletters.org/vg/letters/let677/letter.html $>$.
} 


\begin{tabular}{|c|c|c|}
\hline $\begin{array}{l}\text { O Café Noturno na } \\
\text { Place Lamartine, } \\
\text { em Arles } \\
\text { Arles: } 5-8 \\
\text { September } 1888 \\
\text { Fonte: Van Gogh } \\
\text { (1888d) }\end{array}$ & $\begin{array}{l}\text { To Theo van Gogh. } \\
\text { Arles, on or about } \\
\text { Tuesday, } 11 \\
\text { September } 1888 \text {. } \\
\text { Linhas } 90 \text { a } 96\end{array}$ & $\begin{array}{l}\text { sobre Dostoievski, em seguida, eles são os únicos que me parecem } \\
\text { ter um significado mais importante." (VAN GOGH, 2009b, p. 1). }{ }^{28}\end{array}$ \\
\hline $\begin{array}{l}\text { O Café Noturno na } \\
\text { Place Lamartine, } \\
\text { em Arles } \\
\text { Arles: } 5-8 \\
\text { September } 1888 \\
\text { Fonte: Van Gogh } \\
\text { (1888d) }\end{array}$ & $\begin{array}{l}\text { Carta } 678 \\
\text { Extrato } n^{\circ} 4 \mathrm{e} \\
\text { Br. 1990: } 681 \text { | CL: } \\
\text { W7 - From: } \\
\text { Vincent To: } \\
\text { Willemien } \\
\text { Date: Arles, } \\
\text { Sunday, } 9 \text { and } \\
\text { about Friday, } 14 \\
\text { September } 1888 \text {. } \\
\text { Linhas } 39-47\end{array}$ & $\begin{array}{l}\text { "Eu acabei de terminar uma tela que representa um interior de café à } \\
\text { noite iluminado por lâmpadas. Alguns pobres vagabundos noturnos } \\
\text { estão dormindo em um canto. A sala está pintada de vermelho, e no } \\
\text { interior, na luz a gás, a mesa de bilhar verde, a qual lança uma } \\
\text { imensa sombra sobre o chão. Nesta tela, há } 6 \text { ou } 7 \text { vermelhos } \\
\text { diferentes, desde vermelho-sangue até rosa delicado, fazendo } \\
\text { oposição com o mesmo número de verdes pálidos ou escuros." } \\
\text { (VAN GOGH, 2009g, p. 1). }{ }^{29}\end{array}$ \\
\hline
\end{tabular}

Fonte: Jansen, Luijten e Bakker (2009).

\subsubsection{Apresentação do Corpus Textual Contextual}

A correspondência completa entre Vincent e Theo, guardada e organizada por GoghBonger (2008), viúva de Theo, compreende 652 cartas organizadas cronologicamente e foi lançada em 1914 em um volume de mais de 1.000 páginas publicado pela editora holandesa Maatschappif Voor Goede.

A carta analisada nesta pesquisa foi inicialmente coletada em uma publicação editada em Paris na década de 30, obedecendo à clássica antologia de Van Gogh (2010). No entanto, esta edição teve uma tradução interpretativa e levou à necessidade de buscar uma fonte mais acurada que disponibilizasse a transcrição da carta sem supressão de suas características originais. A versão da carta usada no corpus contextual foi coletada do Site Van Gogh The Letters Project que disponibiliza em uma website as transcrições digitalizadas das cartas, bem

\footnotetext{
${ }^{28}$ Disponível em: 〈http://vangoghletters.org/vg/letters/let680/letter.html〉.

${ }^{29}$ Disponível em: 〈http://vangoghletters.org/vg/letters/let678/letter.html $>$.
} 
como o seu fac-símile (JANSEN; LUIJTEN; BAKKER, 2009). Segue abaixo a carta de 22-24 de Junho de 1880 que constitui em sua íntegra o corpus textual contextual.

\section{Corpus Textual Contextual - a carta de 22-24 de Junho de 1880}

Esta carta foi coletada no site ${ }^{30}:$ http://vangoghletters.org/vg/letters/let155/letter.html

\section{5}

Br. 1990: 154 | CL: 133

From: Vincent van Gogh

To: Theo van Gogh

Date: Cuesmes, between about Tuesday, 22 and Thursday, 24 June 1880

Source status: Original manuscript

Location: Amsterdam, Van Gogh Museum, inv. nos. b153 a-b V/1962

A apresentação do corpus textual contextual foi alocada no apêndice para reduzir o volume da tese.

\subsection{CONDIÇÕES DE PRODUÇÃO, DISTRIBUIÇÃO E CONSUMO DOS GÊNEROS CARTA E PINTURA}

As condições de produção, distribuição e consumo dos gêneros carta e pintura estão alocados no apêndice para reduzir o volume da tese.

\footnotetext{
${ }^{30}$ Tradução livre da autora. "Data: Em de Junho de 1880, Theo escreveu aos seus pais dizendo que ele havia recebido uma carta de Vincent. A reação deles para o que Theo disse a eles revela que a carta em questão deve ser a presente, a qual deve portanto ter sido escrita muitos dias antes. (FR b2494 and b2495, Mr and Mrs van Gogh to Theo, 5 July 1880). Date: On 25 June 1880, Theo wrote to his parents, saying that he had received a letter from Vincent. Their reaction to what Theo told them reveals that the letter in question must be the present one, which must therefore have been written several days previously (FR b2494 and b2495, Mr and Mrs van Gogh to Theo, 5 July 1880).

Adicional: Esta é a primeira carta que van Gogh escreveu em Francês. Ela é seguida por outras sete cartas em Francês, datando do seu período Belga. Vincent escreve mais e mais frequentemene em Francês da carta $567 \mathrm{em}$ diante. Uma análise da estrutura de sua carta aparece em Pollock 1980, pp. 624-630; cf. também Pollock e Orton 1978, pp. 7-10, e exibição catalográfica em Amsterdã 1980, pp. 21-27. / Additional: This is the first letter that Van Gogh wrote in French. It is followed by seven more letters in French, dating from his Belgian period. Vincent writes more and more frequently in French from letter 567 onwards. An analysis of the structure of this letter appears in Pollock 1980, pp. 624-630; cf. also Pollock and Orton 1978, pp. 7-10, and exhib. cat. Amsterdam 1980, pp. 21-27.

(VAN GOGH, 2009k, p. 1, tradução nossa).
} 


\subsection{PROCEDIMENTOS DE COLETA, TRATAMENTO E ANÁLISE DOS DADOS}

Os procedimentos de coleta e tratamento dos dados estão no apêndice para reduzir o volume da tese.

\subsection{PROCEDIMENTOS DE ANÁLISE DOS CORPORA}

\subsubsection{Procedimentos de Análise do Corpus pictórico}

No presente corpus, procurei analisar as obras escolhidas de acordo com o modelo multimodal proposto por O’Toole (1994). Dessa forma, a análise está organizada em três etapas que contemplam três perspectivas:

A função Modal na qual observo como a combinação dos recursos semióticos captura a atenção e constrói o envolvimento com o espectador criando uma relação com a tela ou levando-o a interagir com a ambiência da cena na tela.

A função Representacional na qual procuro examinar os elementos que constroem a narrativa visual e que sentidos se destacam como mais evidentes nos sistemas de escolhas de sentidos potenciais;

A função Composicional na qual procuro descrever como a composição se organiza na sintaxe dos elementos da linguagem pictórica e das estratégias de composição. Nesse estágio, procuro descrever o uso dos elementos de linguagem visual e sua articulação entre si para formar efeitos de sentidos e procurei descrever que efeitos de sentidos são construídos nas relações entre as categorias episódio, figura e membro e sua relação com o conjunto da imagem. Também procurei observar e descrever o uso de estratégias de composição de forma a evidenciar aspectos na composição que o autor buscou criar. A seguir, busco analisar os efeitos de sentidos que são produzidos como resultados dessas estratégias compositivas. Nesse estágio procuro encontrar as evidências para responder com que finalidade o autor constituiu tais efeitos pictóricos partindo das estratégias usadas e evidenciar as análises feitas nas funções: modal e representacional.

Isso irá se intercalando e enquanto analisar é um trabalho profundo de prospecção das possibilidades de análise contidas em cada tela, o trabalho de desenvolvimento do texto oferecerá um momento de pausa e pequeno distanciamento para ir amarrando e relacionando 
partes de um todo. Esse processo permite explicitar aspectos que não se fazem muito faiscantes quando se apresentam, mas desde sua tímida aparição oferecem potencial de desenvolvimento na articulação com outros aspectos já mais explicitados em outra modalidade.

Além de me basear nos conceitos da GDV, procurei me apropriar de alguns conceitos do campo da Percepção Visual, tais como os elementos de linguagem visual e as estratégias composicionais. Esses conceitos, usados por Kandinsky (1996), Arnheim (1974) Dondis (2007) complementaram as categorias da GDV empregadas para fazer uma descrição dos elementos presentes nas telas analisadas para depois analisá-los em sua função em cada categoria da TSSM de O’Toole (1994) (obra, episódio, figura, membro). Depois da descrição dos elementos presentes na composição, analisei a sua relação entre as categorias, a sua relação entre as funções, e sua relação com o conjunto, a gestalt, da obra. As categorias serão descritas no item 4.10.1.1 Categorias de Análise do Corpus Pictórico.

Dessa forma, ficarão evidenciados todos os elementos da tela e como eles trabalham em conjunto para criar as funções modal, representacional e composicional. Além de ficar evidenciado, ficará sistematizado, permitindo verificar como eles afetam a categoria em que se encontram como eles dialogam com outros elementos e que tipo de relações eles criam: de contraste ou de harmonia, de ligação ou de ruptura, de recorrência ou de imprevisibilidade. Essas relações poderão explicitar como é construída a retórica visual.

A análise buscará explicitar

a) Os elementos;

b) Como eles se relacionam entre os da mesma categoria;

c) Como eles se relacionam com os elementos de outra categoria;

d) Como eles se relacionam com o todo da obra;

e) Que tipos de relações ele fazem com outros elementos e quais os efeitos produzidos;

f) Que estratégias composicionais eles concorrem para contribuir e construir; quantas estratégias são evidenciáveis;

g) Fazer uma pequena quantificação da ocorrência dos elementos, dos tipos de relação que eles estabelecem, das estratégias que eles corroboram para construir. 


\subsubsection{Categorias usadas na análise do corpus visual}

Nesta sessão desenvolverei preliminarmente as categorias usadas para analisar as telas de Van Gogh que integram o corpus pictórico desta pesquisa. No entanto, novas categorias podem se revelar essenciais à medida que a análise revelar sua importância para a compreensão do discurso pictórico de van Gogh.

a) Ritmo - O uso do ritmo está muito evidenciado no movimento direcional e constante de padrões visuais que sugerem repetição. $\mathrm{O}$ ritmo pode ser usado para sugerir direção, movimento e textura, por exemplo.

b) Movimento - É percebido com o uso articulado de diferentes recursos semióticos como o ritmo, a direção, que juntos podem criar um ou vários efeitos de sentidos perceptíveis como um efeito visual de 'movimento'.

c) Direção ou Vetor - A articulação de diferentes recursos de linguagem ajudam a conduzir o olhar por caminhos visuais e dar ênfase para alguns aspectos da composição.

d) Textura - A textura pode ser evidenciada de forma tátil ou ocular. Ela se conecta com uma dimensão mais sensorial e usa as qualidades da materialidade do texto visual para comunicar uma função modal de envolvimento com o espectador com a cena representada.

e) Enquadramento - De acordo com Kress e Van Leeuwen (1996, p. 124, tradução nossa) o enquadramento comunica a distância social do espectador com a imagem:

Existe uma segunda dimensão para os sentidos interativos das imagens, relacionados com o enquadramento, com a escolha entre o close-up, meia distância ou longa distância, e assim por diante. Assim como os produtores de imagem, ao representar os participantes humanos ou quase-humanos, devem escolher representa-los tão próximos ou distantes do espectador - e isso se aplica com a representação de objetos também. E, como a escolha entre a 'oferta' e a 'demanda', a escolha da distância pode sugerir diferentes relações entre os participantes representados e os espectadores. ${ }^{31}$

f) Perspectiva - É um recurso semiótico muito central na obra de van Gogh. Kress e Van Leeuwen (1996, p. 129, tradução nossa) descrevem o enquadramento:

Produzir uma imagem envolve não apenas a escolha entre a 'oferta' e 'demanda' e a seleção de um certo tamanho do enquadramento, mas também, e ao mesmo tempo, a seleção do ângulo, um 'ponto de vista', e isso implica na possibilidade de expressar atitudes subjetivas em direção aos participantes representados, humanos e outros. Ao dizer 'atitudes subjetivas', nós não queremos dizer que essas atitudes são sempre

\footnotetext{
31 Tradução livre da autora. "There is a second dimension to the interative meanings of images, related to the 1size of frame', to the choice between close-up, médium shot and long shot, and so on. Just as image-producers, in depicting human or quasi-human participants, must choose to depict them as close to or far away from the viewer - and this applies to the depiction of objects also. And, like the choice between the 'offer' and the 'demand', the choice of distance can suggest different relations between represented participants and viewers." (KRESS; VAN LEEUWEN, 1996, p.124).
} 
individuais e únicas. Nós vamos ver que elas são frequentemente atitudes socialmente determinadas. Mas elas são sempre codificadas como se elas fossem subjetivas, individuais e únicas. O sistema da perspectiva que realiza 'atitude' foi desenvolvido na Renascença, um período no qual a individualidade e a subjetividade se tornaram valores sociais importantes e isso se desenvolveu precisamente para permitir que as imagens se tornassem informadas pelos pontos de vista subjetivos. ${ }^{32}$

g) Profundidade - o uso do plano da frente e o plano de fundo para representar a percepção de profundidade em uma cena.

h) Distorção do Ponto de Vista - Van Gogh distorcia a perspectiva e criava um efeito de distorção do ponto de vista do espectador, levando à um efeito de sentido de estranhamento, de aguçamento com a obra e ao mesmo tempo de distanciamento pela dificuldade de se indentificar com a distorção, que remetia à associação a quem pintou a tela.

i) Cor - A cor é um dos aspectos mais centrais no sistema semiótico construído por van Gogh, e atende desde a função Modal de envolvimento até a função Representacional na medida em que van Gogh instituiu um código próprio de significados particulares que as cores simbolizavam. A escala de modulação de cores pode ser construída por meio de cores ricamente texturizadas que podem ser percebidas como fiéis aos detalhes e à textura da cor real.

j) Transparência - Refere-se à forma de ser transparente na execução de sua pintura deixando transparecer suas experiências e emoções subjetivas.

k) Inacabamento - Está relacionado com um tipo de abordagem pictórica que privilegia a imprecisão, a dissipação dos contornos, a despreocupação com o refinamento e os retoques.

l) Incompletude - A incompletude traduz-se pelo reconhecimento da impossibilidade de manifestação da perfeição da natureza por meio da arte e pela busca em direção a um ideal de perfeição que ele chama de desejo de infinito. Esta busca estética está presente em seu discurso artístico, tanto nas telas quanto em suas cartas.

\footnotetext{
${ }^{32}$ Tradução livre da autora. "Producing an image involves not only the choice between 'offer' and 'demand' and the selection of a certain size of frame, but also, and at the same time, the selection of an angle, a 'point of view', and this implies the possibility of expressing subjective attitudes towards represented participants, human or otherwise. By saying 'subjective attitudes', we do not mean that these attitudes are always individual and unique. We will see that they are often socially determined attitudes. But they are always encoded as though they were subjective, individual and unique. The system of perspective which realizes 'attitude' was developed in the Renaissance, a period in which individuality and subjectivity became important social values, and it developed precisely to allow images to become informed by subjective points of view." (KRESS; VAN LEEUWEN, 1996, p.129).
} 
m) Intertextualidade e Interdiscursividade - Para Fairclough (2003), por meio da intertextualidade são atualizados no texto, os elementos de outros textos de forma direta como a citação ou indireta como a paráfrase por exemplo. Para Fairclough (2001), o discurso é permeado pela interdiscursividade e estabelece uma relação multiforme com outros discursos. A interdiscursividade e a intertextualidade são possibilidades de transformação por meio de ressignificações e mudanças na prática discursiva. Com base na observação das ocorrências, inferimos que a obra de van Gogh está fortemente construída na interdiscursividade e na intertextualidade que ele fazia com autores com quem ele compartilhava um universo de sentidos e visões.

n) Associações Metafóricas - Na perspectiva da semiótica social, os elementos da linguagem visual carregam significados potenciais que se manifestam por meio de metáforas potenciais ou associações metafóricas. Esses significados potenciais se tornam mais específicos quando manifestados nos contextos culturais e nos contextos de situação. Van Gogh foi um dos pioneiros do uso semiótico da cor para representar sua experiência subjetiva. Para conseguir que a cor comunicasse diretamente ideias e sentimentos ele recorreu à metáfora experiencial e aos processos relacionais atributivos como veículo.

o) Saliência - Cria ênfase pelo uso conjugado de vários modos construindo um discurso visual coeso e dinâmico que conduz o olhar pelos campos da composição sem perder o sentido de unidade.

p) Rima Visual - Contribui para evidenciar a forma como a unidade e a coesão são construídas entre os elementos da composição tais como as semelhanças de tonalidades, formas ou, inclusive, temas. O sentido da rima visual que está fortemente amarrado pela conversa entre os modos que se reforçam mutuamente na construção da narrativa visual.

q) Gesto Pictórico - é o uso que van Gogh dá para o pincel, a forma como ele toca a tela com o pincel guarda uma série de caracteríscas que são muito particulares da poética de van Gogh. Com ela ele construiu um sistema semiótico muito central na sua obra.

r) Limiar Artístico - é um conceito produzido por esta pesquisa para designar uma instância de produção discursiva que se situa entre o potencial e o manifesto no processo de produção de sentidos. 
s) Modalidade - Para Kress e Van Leeuwen (2006) a modalidade é definida como o uso de recursos semióticos que atribuem o grau de fidedignidade, ou seja, expressam quão verdadeiro ou real é uma representação e podem assumir um valor de verdade com base nas associações disponibilizadas pelo contexto de cultura.

A partir da análise da tela, procurei analisar a composição no contexto de uma cadeia de textos, apoiando-me para tanto nas noções de interdiscursividade e intertextualidade da ADC. Embora não seja este o foco específico deste estudo, esse estágio da análise pode complementar como uma abordagem secundária e sistemática na análise semiótica do texto visual uma vez que este texto constitui a materialização de um discurso que se manifesta em outras instâncias discursivas. Dessa forma, foi considerada neste estudo a possibilidade de investigar textos que se articulam com as obras analisadas na busca de evidenciar aspectos que não estão tão explícitos nos próprios textos visuais analisados, mas se revelam na articulação de uma análise de elementos de intertextualidade em uma cadeia de textos. Esse estágio de análise só pode ser feito depois de finalizadas as análises das telas individualmente em coerência formal e de terem sido esgotadas as análises dos recursos pictóricos na sua articulação com a construção de um discurso visual.

\subsubsection{Procedimentos de análise do Corpus epistolar}

Como já foi exposto, o corpus textual está agrupado em dois conjuntos: a) o corpus textual primário e b) o corpus textual contextual. Esta sessão sobre os procedimentos de análise está organizada em dois momentos.

Inicialmente foi considerado, como procedimento, apenas a análise das orações principais para examinar o sistema de Transitividade. No entanto, uma leitura mais detida dos extratos revelou estruturas como o apagamento do participante principal, orações sem processos, e complexos oracionais nos quais a construção do sentido foi deslocada para dentro da oração hipotática, revelando uma estratégia retórica incomum. Dessa forma, foi decidido proceder à análise das orações complexas para descrever as relações lógico-semânticas nelas contidas a fim de evidenciar padrões não só de transitividade, como de elementos conectivos nas orações. 


\subsubsection{Procedimentos de análise dos Corpora: textual primário}

A perspectiva da Gramática Sistêmico-Funcional foi usada na análise dos extratos de carta do corpus textual primário. Cada oração foi analisada pela perspectiva da gramática do significado experiencial da metafunção Ideacional e nela, o Sistema de Transitividade. A análise Sistêmico-funcional do Sistema de Transitividade para os extratos de cartas do corpus primário seguiu, em linhas gerais, o modelo abaixo:

Quadro 14: Tipos de processos e participantes

\begin{tabular}{|l|l|l|l|}
\hline Agente & Processo & Participantes & Circunstância \\
\hline \multirow{2}{*}{ Ator } & Material & Meta & As circunstâncias \\
Experienciador & Mental & Fenômeno & ocorrem em qualquer \\
Portador & Relacional & Atributo/identificado & dessas categorias são \\
Comportante & Comportamental & Comportamento & Extensão, Localização, \\
Dizente & Verbal & Verbiage/ Receptor & Modo, \\
Existente & Existencial & Existente & Causa, Contingência e \\
& & & Acompanhamento. \\
& & & \\
\hline
\end{tabular}

Alguns procedimentos foram levados em consideração para fazer análise das cartas:

- Fiz uma análise preliminar de dois excertos de cartas para identificar o que esses excertos tinham a oferecer em termos de processos e outras ocorrências do uso léxico-gramatical.

- Procurei ler nos extratos o que havia em comum em todas as sentenças. Esta busca preliminar ajudou a revelar como os significados são expressos. Os dados explicitaram as categorias, por exemplo, se houve muita modalização, se havia uma categoria sociológica e neste caso foi preciso verificar como a estrutura lexicogramatical manifestou esse conteúdo para apreender o sentido construído pelo uso da modalização e qual o propósito deste uso. Por exemplo, observei que a ausência / falta de participantes na oração é muito presente nas cartas de Van Gogh e podia ser vista como uma categoria.

- Fiz um levantamento quantitativo para ver quais os processos eram mais recorrentes. Por exemplo, se ocorria muito processo mental, relacional ou comportamental - esses poderiam ser comentários avaliativos.

- A interpretação qualitativa analisa a ocorrência das estruturas léxicogramaticais nas cartas para depois triangular estes resultados com os resultados da análise das telas. Nesta fase da triangulação, a análise se preocupou com os processos que formavam algum tipo de relação de correspondência ou não com os processos e 
representações identificados nas telas. Após a análise de cada oração, foram verificados os dados categorizados para tentar induzir hipóteses a partir do que as estruturas evidenciaram. Tentei deduzir padrões que se relacionavam ou explicitavam sentidos condensados nas telas a partir das recorrências de escolhas que Van Gogh fez, ou da explicitação das escolhas que ele deixou de fazer, disponíveis na gama de alternativas potenciais em detrimento de outras escolhas.

- Partí de categorias sociológicas e artísticas tais como identidade, incompletude e transparência para chegar às categorias linguísticas.

- Identifiquei em cada oração como está representado o ator social. Para isso, procurei nos dados o que eles têm a dizer sobre o agente.

- Analisei como estão estruturados nas orações os Participantes, Processos e Circunstâncias.

Quadro 15: Modelo de análise da transitividade por oração

\begin{tabular}{|l|l|l|l|l|}
\hline Oração & \multicolumn{4}{|l|}{} \\
\hline Ideacional & Participante & Processo & Participante & Circunstância \\
\hline
\end{tabular}

- Verifiquei na transitividade quais são os processos e de que forma eles constroem os significados.

- A análise e descrição dos Processos se fundamentaram em Halliday e Matthiessen (2004). A classificação foi feita no contexto da análise das orações isoladamente, deixando as discussões sobre a análise das imagens ou fac-símile dos originais das cartas para uma pesquisa futura.

- A análise restringiu-se aos extratos que se referem às telas analisadas e não abrange cada carta na sua íntegra nem as imagens que pertencem ao texto epistolar. Não se trata de ignorar a importância das imagens que foram produzidas nas cartas cujos extratos são analisados nesta pesquisa, mas focalizar os procedimentos de análise para atender o objetivo aqui proposto.

\subsection{Descrição e Interpretação dos dados}


Os procedimentos de análise das cartas têm duas etapas: descrição e interpretação.

\section{a) Procedimentos de descrição:}

Para Butt et al. (2000), a escolha de diferentes constituintes nos permite a representação da experiência de diferentes formas e a descrição da oração nos ajuda a revelar o potencial de significação que a oração tem para representar a experiência humana.

Butt et al. (2000) argumentam que o valor em descrever a língua em termos da gramática experiencial está na possibilidade de explicitar de forma sistemática "a matriz de opções disponíveis para a tomada de significados sobre a experiência humana em uma oração" (BUTT et al., 2000, p. 77).

$\mathrm{Na}$ primeira etapa dos procedimentos de análise, descrevi estas escolhas a fim de compreender como o significado, a função e a estrutura estão articuladas. Com essa finalidade, foram observados os seguintes constituintes da oração:

- os tipos de processos que podem constituir o núcleo verbal de uma oração.

- os papéis desempenhados pelos participantes, que se relacionam com cada tipo de processo.

- os tipos de circunstâncias que podem descrever os processos.

$\mathrm{Na}$ etapa de descrição, foram exploradas as funções que cada uma das escolhas gramaticais analisadas desempenha para representar o significado experiencial na oração e as estruturas nas quais o significado experiencial foi expresso.

Butt et al. (2000) destacam que a distinção entre os diferentes tipos de processos revela os padrões estruturais na oração de forma que "se considerarmos que existem diferentes tipos de orações constroem diferentes tipos de significado as diferenças na estrutura serão reveladas como funcionais" (BUTT et al, 2000, p.77-78).

\section{b) Procedimentos de interpretação:}

De acordo com Butt et al (2000), a estrutura da oração pode ser descrita por meio de seus campos potenciais disponíveis para construir o sentido experiencial. O campo do Processo tem o potencial de alcançar uma função material ou relacional. Os grupos verbais são as estruturas que realizam essa função.

Ele argumenta que as escolhas ao preencher estes campos são motivadas por:

- a finalidade que desejamos alcançar com o texto;

- o campo do contexto imediato da situação. 
Com base na descrição das orações analisadas estas duas categorias foram empregadas para basear a interpretação do discurso epistolar de Van Gogh:

- a finalidade que ele desejava alcançar com o texto;

- o contexto imediato da situação em que ele se encontrava ao produzir a carta.

Estas informações foram pesquisadas em fontes documentais e relatos de biógrafos e historiadores a fim de sondar sua relação com os elementos explicitados na etapa da descrição.

A interpretação se baseou também em perguntas de sondagem propostas por Butt et al. (2000) para explorar o significado experiencial nas estruturas das orações nos textos.

A análise em torno das categorias de Processo, Participante e Circunstância e suas subcategorias diferentes serão o foco para interpretar a descrição do Sistema de Transitividade nas orações analisadas. $\mathrm{O}$ uso dessas categorias oferece um caminho para fazer perguntas a fim de sondar a estrutura de uma oração sobre o seu significado experiencial.

Algumas destas perguntas são exemplificadas em Butt et al. (2000):

- Qual é o processo ou o grupo verbal em questão? Que função ele desempenha na oração? Ele envolve alguma ação física ou material; ou identifica e descreve e relaciona; ou diz ou percebe algo?

- A ação é feita por quem ou o que, que a está relacionando, percebendo ou dizendo?

- Para quem ou para o que a ação está sendo feita, relacionada, dita ou sentida?

- A oração que diz ou percebe algo projeta outra oração? É uma fala citada ou direta, ou é uma fala indireta ou relatada? $\mathrm{Na}$ oração o pensamento é direto ou citado, indireto ou relatado?

A ação acontece quando, onde, como, porque, com quem ou o que, por quanto tempo?

As respostas para estas perguntas de sondagem do sentido experiencial revelam os padrões estruturais da linguagem ao explicitar:

a) a forma como um grupo nominal extremamente longo e complexo pode permanecer como uma unidade funcional dentro de uma oração;

b) uma oração (mais conhecida como oração substantiva) pode assumir o significado potencial de um campo de participante dentro de outra oração, tornando-se um constituinte dessa oração.

Foram observadas as ocorrências de nominalização, metáfora gramatical (um processo no qual ocorre uma alteração no alinhamento entre um significado e sua expressão 
gramatical). Quando ocorre nominalização, a metáfora gramatical ocorre porque um evento que é experienciado na vida real e pode ser representado na linguagem como um processo, é representado como um participante em uma forma substantivada. A ocorrência de nominalizações no discurso epistolar de Van Gogh pode ser uma chave importante para compreender como ela impacta na estrutura da oração bem como, como as escolhas gramaticais para a construção dos sentidos são expressas nas orações.

De acordo com Butt et al (2000) as escolhas que são feitas na gramática experiencial para produzir textos têm duas motivações:

a) O propósito que queremos alcançar com o texto

b) O contexto da situação imediata em que o texto é produzido

A estrutura de um texto está diretamente ligada ao seu propósito geral e emerge a partir da forma que as palavras e estruturas gramaticais são usadas na construção do texto e na forma como ele se desenvolve.

A etapa da interpretação direciona a atenção para como esses dois aspectos contextuais encontram seu caminho dentro das orações analisadas. Para ajudar a iluminar as escolhas na representação experiencial que Van Gogh fez nos excertos analisados, estes dois aspectos mais amplos sugeridos por Butt et al. (2000) foram levados em consideração, mas para aprofundar a compreensão da dimensão artística do discurso epistolar de Van Gogh, levei em consideração um terceiro critério:

c) O contexto de cultura no qual o texto foi produzido.

Estes três aspectos foram investigados com a ajuda de fontes documentais, relatos biográficos e historiográficos já citados no capítulo 1 .

Para isso, foi observada a forma como as palavras e estruturas que expressam significados experienciais estão colaborando com a estrutura das orações e com o seu propósito final.

Butt et al. (2000) ressaltam alguns critérios que ajudam a explicitar nas narrativas a forma como as palavras e estruturas estão construindo o significado experiencial na oração:

1) $\mathrm{Na}$ Orientação para:

- como as pessoas, lugares e coisas são introduzidos por processos existenciais na narrativa;

- as circunstâncias que definem um lugar e um tempo para a narrativa;

- como os processos relacionais são empregados para identificar e descrever as personagens; 
- quais são os processos materiais usados para introduzir a ação realizada pelas personagens;

2) $\mathrm{Na}$ Complicação para:

- qual é a sequência de processos materiais usados para manter a ação em andamento;

- quais são os processos verbais usados para retardar a ação, projetando enquanto isso o que as personagens estão verbalizando;

- como os processos relacionais e mentais são empregados para congelar a ação, criar suspense, revelar pensamentos e sentimentos das personagens e avaliar o que está acontecendo;

3) na resolução e /ou retomada para:

- quais processos relacionais revelam mensagem da narrativa?

A análise se baseou neste tipo de exploração a fim de revelar os padrões gramaticais que estruturaram diferentes orações. Por exemplo, van Gogh usava muitos processos relacionais para identificar, descrever e atribuir identidade para suas telas e ainda que a maior parte dos processos sejam materiais, as orações semanticamente mais significativas para analisar o discurso artístico foram construídas em sua maior parte com o uso de processos relacionais. Dessa forma, os processos relacionais, ainda que não representem a maior parte dos processos encontrados no corpus, estavam nas orações com maior carga de sentido e relevância para a o foco da investigação: o discurso artístico. Essas orações com processos relacionais serão descritas e interpretadas na análise do corpus textual no capítulo 5.

Os construtos léxicogramaticais codificam experiências de mundo em contextos de situações cotidianas. Para analisar as narrativas de van Gogh, levando em consideração o contexto de sua prática artística foi preciso explorar a escolha de palavras e expressões técnicas ou relacionadas com o universo da sua prática artística e discursiva. Por exemplo, quando ele diz: "Agora há uma noite sem preto", ele ressalta a circunstância de tempo, e do ineditismo que significa, a existência de algo apenas a partir de agora. Esta escolha também implica a construção de que antes não havia. Dessa forma, para identificar as estruturas que revelam um pensamento sobre arte e sobre pintura que é mais abrangente e geral, foram observadas: 
a) a escolha das palavras e como Van Gogh colocou essas palavras em grupos, frases, orações e complexos oracionais que codificam as relações especializadas com o assunto que ele está representando;

b) a escolha dos participantes que representam categorias, conceitos e processos mais gerais ao invés de representar pessoas ou eventos cotidianos mais específicos;

c) o uso de nominalizações, de forma que seja possível:

- codificar como substantivos os eventos e série de eventos;

- em um grupo nominal estes substantivos podem se tornar Coisa, de forma que o evento ou processo possa ser quantificado, classificado, descrito e/ou avaliado;

- na oração, o grupo nominal que ocorre por meio de uma nominalização passa a ter um papel de Participante;

d) identificar, descrever, classificar e definir pelo uso de processos relacionais;

e) nas cláusulas em que os eventos reais são codificados como Participantes e não podem ser representados como Processos, usar processos relacionais;

f) para aumentar a precisão e identificar as condições ou restrições, o uso de Circunstâncias;

Outro aspecto apontado por Butt et al. (2000) como importante para a interpretação dos dados é a forma como a gramática experiencial representa Campo. Será observado como Van Gogh usou a gramática experiencial para construir um ambiente no qual seu leitor ficaria imerso e no qual ele desenvolve as personagens de suas narrativas. Para compreender como Van Gogh constrói seu mundo narrativo, devo aplicar os critérios sugeridos por Butt et al (2000), observando o uso de:

- circunstâncias para localizar a história narrada em um tempo e lugar;

- processos existenciais para introduzir o seu leitor para os lugares, pessoas, e objetos do seu universo na narrativa;

- processos relacionais para identificar e descrever as personagens em sua narrativa;

- grupos nominais que expressam os papéis dos participantes para revelar as qualidades das personagens;

- processos materiais para revelar o que está acontecendo no universo da sua narrativa;

- processos de projeção para revelar o universo interior das personagens na narrativa; 
- gramática experiencial para combinar dois campos de experiência na mesma história: por exemplo, um mundo de lembranças e um mundo cotidiano; um mundo imaginário e um mundo real. No caso de van Gogh, encontramos uma grande ocorrência do uso da gramática experiecial para misturar dois campos, o do mundo real e o do mundo que acontece em suas telas. Por isso, a noção de gramática experiencial e o campo são muito importantes na interpretação do corpus das cartas, pois ora está falando desde o mundo real onde há uma tela com coisas nela, ora a tela deixa de existir na narrativa pois passamos para dentro dela.

A exploração do campo poderá auxiliar a revelar o vocabulário e as estruturas que são relevantes nas passagens entre estes dois mundos representados por van Gogh: o mundo real e o mundo de suas telas.

Butt et al. (2000, p. 81) afirmam que a "exploração da gramática experiencial, portanto, revela muito sobre a visão de mundo expressa em um texto". Dessa forma, procurei encontrar inscrita nas escolhas das palavras e na forma como as estruturas foram sequenciadas para construir as orações, a visão de mundo de Van Gogh e nela suas concepções pictóricas e artísticas.

Para descrever e interpretar as orações analisadas pela perspectiva da gramática experiencial, as palavras e as estruturas escolhidas por Van Gogh foram observadas a fim de evidenciar como ele percebe e experimenta o que está acontecendo no mundo.

Com o intuito de explorar a visão de mundo expressa na gramática experiencial dos extratos das cartas a serem analisados irei aplicar as diretrizes propostas por Butt et al (2000).

1) Considerar os eventos em que a narrativa se baseia. Pensar acerca de todos os eventos que poderiam ter ajudado a constituir ou contribuir com o incidente ou que aconteceram como resultado deste incidente. Depois observar como esses eventos estão representados como Processos na narrativa, analisando:

- a existência de acontecimentos que não estão representados na história. Por que isso ocorre desta forma? Que impacto isso pode ter sobre a percepção do leitor acerca do acontecimento?

- como Van Gogh representou os eventos em termos de processos. Se o processo é material, relacional ou por meio dos processos de projeção:

- se a narrativa representa principalmente ações, relacionando identidades e descrições ou se projeta as palavras e os pensamentos das pessoas. Neste caso, as 
palavras e os pensamentos das pessoas representadas são citados diretamente ou relatados indiretamente?

- que efeito a representação dos eventos tem na percepção do leitor acerca do incidente, na forma como eles foram representados nas estruturas gramaticais?

2) Ao levantar todas as pessoas que têm uma participação nos eventos da narrativa, observar quais são aquelas que são representadas nos papéis dos participantes na narrativa quais são aquelas que não são.

- Procurar responder por que algumas pessoas foram representadas como participantes e outras não?

- Que efeito estas escolhas têm sobre a forma como o leitor percebe o incidente narrado?

3) Identificar como os tipos de papéis dos participantes usados para diferentes categorias de pessoas revelam:

- quais pessoas são representadas como ator que faz a ação e que ação elas fazem;

- quais pessoas são representadas como dizentes cujas palavras são ouvidas e o que essas pessoas chegam a dizer;

- quais pessoas são representadas como Experienciador, cujos pensamentos e sentimentos são revelados e quais dos seus pensamentos e sentimentos são revelados;

- quais pessoas são representadas como a Meta, ou seja, pessoas que recebem a ação e que ações foram feitas para elas;

- quais pessoas são representadas como Receptor (pessoas para quem as coisas são ditas) e o que é dito para elas;

- quais pessoas são representadas como Fenômeno (as pessoas que estão projetadas na narrativa pelos pensamentos de outra pessoa) e como essas pessoas são projetadas;

- como os processos relacionais são utilizados para identificar e descrever pessoas diferentes. Como a forma como as pessoas são representadas nas estruturas gramaticais afeta a percepção que o leitor tem do incidente e das pessoas envolvidas nele?

4) Anotar as palavras usadas no interior dos grupos nominais que expressam os papeis dos Participantes. Esta investigação revela em um nível mais delicado 
como diferentes pessoas são representadas no texto. Para isso foi preciso observar como certos tipos de pessoas estão representados:

- com palavras que têm uma sensação positiva ou negativa (por exemplo, vagabundos, senhorio);

• em termos de relações familiares (por exemplo, esposa, irmão) e em termos do papel na comunidade (prefeito, artista).

- Como a seleção das palavras pode afetar a percepção do leitor sobre o incidente e as pessoas envolvidas nele?

5) Observar se as Circunstâncias esclarecem os processos, em termos de tempo, lugar, maneira ou causa e o efeito que isso tem sobre a percepção que os leitores têm dos eventos narrados;

6) Procurar padrões da gramática experiencial que:

- contribuem para a estrutura e finalidade de todo o texto; procurar a finalidade e estrutura do texto na forma como ele se manifesta e é revelado na gramática experiencial;

- constroem o campo da situação imediata; descrever a natureza do campo. Como o campo é representado no vocabulário e nas estruturas gramaticais do texto? Por exemplo, é um campo do cotidiano ou um campo representado nas telas? É um campo literário ou uma combinação de campos?

- como a visão de mundo está representada na gramática experiencial manifesta no texto?

- relacionar os achados sobre a ocorrência da gramática experiencial no corpus às necessidades do problema e dos objetivos de pesquisa;

\subsection{Categorias da LSF usadas na análise do corpus textual primário}

O contexto de cultura e o contexto de situação são duas categorias basilares para interpretar os dados.

Inicialmente a leitura da biografia de Vincent van Gogh, escrita pelos autores Haziot (2010) e Naifeh e Smith (2012), possibilitou compreender o contexto histórico, social, cultural, das práticas familiares e das referências linguísticas na história de leituras que contribuíram para a formação da identidade e da visão de mundo de Van Gogh. Estes conhecimentos de diferentes aspectos de seu contexto de vida ofereceram subsídios para o 
método indutivo-dedutivo e permitiram subsidiar algumas relações entre as cartas e suas escolhas linguísticas na produção dos sentidos.

Dessa forma, as categorias fundamentais para a análise das cartas se apoiaram nas noções de contexto de situação e contexto de cultura, e de registro, pois a análise das cartas foi feita à luz de informações acerca do contexto no qual elas foram escritas. Com base nestes conceitos, as informações de contexto serão usadas para subsidiar a análise e para a construção de hipóteses pelo método dedutivo indutivo.

O estudo do Sistema de Transitividade ofereceu uma base teórica e metodológica para analisar e descrever a construção da representação que Van Gogh faz acerca de sua produção artística e identificar as dinâmicas que possam ter ocorrências também nos textos pictóricos. O Sistema de Transitividade oferece ferramentas metodológicas para essa evidenciação por meio da observação das posições que os Participantes têm nos complexos oracionais. Foi feito um breve levantamento quantitativo dos extratos das cartas do corpus textual primário e secundário com o foco na observação:

a) da quantidade de Participantes e Processos: ainda que sido uma contagem manual dos participantes e dos processos, ela forneceu critérios de análise para determinar as ações em relação às obras de arte e entre si;

b) das Circunstâncias nas quais os processos aconteciam, que pode evidenciar informações acerca do contexto de situação e do contexto de cultura dos eventos representados nas cartas, ajudando a interpretá-los;

c) da existência ou inexistência de fatores externos que agem sobre os Participantes. Os fatores externos podem mostrar a responsabilidade dos Participantes sobre as ações ou a falta de responsabilidade quando for o caso da existência de um Agente, que inicia o Processo.

d) da existência de complexos oracionais, e da simplicidade/complexidade estrutural das sentenças, vistas como fenômenos que facilitam ou dificultam a representação. A observação da presença de várias orações hipotáticas para compreender o nível de conhecimento do que está sendo representado, por exemplo, em especial quando Van Gogh está falando de algum fenômeno sem conseguir fazer de forma clara e direta se apoiando em comparações, metáforas, exemplos.

e) As orações hipotáticas foram abordadas com a mesma prioridade porque foram consideradas como representativas de uma diferença significativa uma vez que seus sentidos afetavam o sentido geral da oração complexa. Por isso a 
identificação dessas estruturas e suas ocorrências foram contabilizadas, e foram descritas detalhadamente e interpretadas porque interferiram nos resultados qualitativos.

A categorização dos extratos de cartas referentes às telas, pela perspectiva do Sistema de Transitividade, possibilitou evidenciar as ocorrências de padrões de uso que revelam aspectos do discurso artístico de Vincent van Gogh levando em consideração as escolhas que ele fez para representar o seu processo de concepção e produção das telas. Essas escolhas foram feitas dentro do potencial de significados da língua Francesa, sem deixar de considerar o contexto de situação e o contexto de cultura na produção tanto das cartas quanto das telas.

As ocorrências encontradas no corpus das cartas destacaram:
a) descrições (físicas e de atividades) atribuídas ao processo de pintar;
b) desejos latentes de representar e principalmente de ser ouvido.
c) ações que reforçam os valores artísticos por ele professados;
d) ações que mostram uma direção de superação dessa equiparação.

\subsubsection{Procedimentos de análise do corpus textual contextual}

Os procedimentos de análise do corpus textual contextual são distintos dos procedimentos de análise do corpus textual primário uma vez que no primeiro foi utilizada a perspectiva da ADC para fazer a análise de alguns excertos da carta de junho de 1880;

Dessa forma, foi desenvolvido para o corpus textual contextual uma abordagem metodológica que descrevo a seguir em três fases metodológicas. A primeira trata-se de uma etapa quantitativa que não foi implementada devido à limitação de tempo para o término da pesquisa. No entanto, considerei importante deixar a primeira etapa como parte integrante dos procedimentos de analise do corpus textual contextual como uma contribuição metodológica deste trabalho. Esta primeira fase compreendeu uma proposta de abordagem quantitativa que poderia ajudar a mapear padrões e ver "de cima", quantitativamente organizando os dados obtidos com a abordagem da Linguística Sistêmica Funcional para explicitar como o Van Gogh organizava seu pensamento pictórico, a partir das metafunções gramaticais e construções gramaticais nos relatos que escreveu com relação ao seu trabalho artístico.

A seguir descrevo as fases metodológicas dos procedimentos de análise do corpus textual contextual composto por um excerto da carta de junho de 1880: 


\section{$1^{\text {a }}$ Fase - qualitativa}

a) apresentar a análise respeitando a sequência original da carta. Nessa etapa busquei analisar os processos no contexto da ocorrência, relacionando elementos do próprio contexto da carta e buscando desenvolver uma interpretação dos sentidos presentes nas estruturas linguísticas e confrontando-os com a minha hipótese e os meus objetivos;

b) problematizar os usos de cada um desses elementos oferecendo exemplos de uso, estudos sobre os usos baseados em literatura da arte;

c) Usar esses conceitos e problematizações para articular a análise com a fundamentação teórica;

d) construir novos questionamentos no contexto do que falam os autores;

e) localizar os processos presentes na carta pela recorrência;

f) identificar a ocorrência isolada de um processo;

g) identificar a influência de um processo em outro processo e qual o efeito de sentidos que isso produz;

h) identificar a mudança de processos ao longo da carta;

i) conceituar cada processo e problematizar a construção dos processos ao longo da carta de van Gogh;

j) localizar ocorrência e recorrência e construção dos processos na carta;

k) mapear estruturas linguísticas e gramaticais próprias, metáforas e símbolos, em sua ocorrência, recorrência, similaridade, complementaridade, disparidade para comunicar e organizar suas concepções de arte, mundo e de estar no mundo;

1) identificar essas concepções pela recorrência dessas estruturas;

\section{$2^{\mathrm{a}}$ Fase - Mapear as ocorrências}

\section{O procedimento da análise}

O procedimento de análise foi concebido em 9 etapas:

- Etapa 1 - a primeira etapa compreendeu o estudo da produção da carta no contexto biográfico dos atores nela representados; 
- Etapa 2 - foram lidos os parágrafos para entender o sentido semântico das orações. A segunda etapa se restringiu a uma leitura do sentido direto e mais evidente dos enunciados na carta para observar somente o que estava sendo dito;

- Etapa 3 - na terceira etapa, a leitura foi feita com atenção, buscando camadas mais sugestivas de sentidos, que estariam 'ao redor' do sentido direto, que estariam 'por ali', presentes, mas não tão explícitas. Nessa etapa, foram procurados indícios de camadas mais profundas em cada colocação, lendo com o "ouvido" para tentar ouvir a "voz" do autor, por exemplo, se ele estava exaltado, esse humor pode ter ficado subjacente na construção da oração, ou no encadeamento de orações. Essa entonação pode ficar evidente de forma explícita ou implícita. Algumas considerações basearam a análise, por exemplo: se essa camada mais profunda de sentidos implícitos parece se colocar nos interstícios e não exatamente nas colocações, mas nas injunções, entre uma colocação e outra. Como esse sentido aparece? No encadeamento entre uma colocação e outra. Foram levadas em conta as perguntas: porque ele falou uma ideia em seguida de outra? Porque uma coisa se associa outra imediatamente? Seria um encadeamento acidental de ideias? Verifiquei algumas possibilidades: se a princípio o encadeamento das orações pode parecer seguir um raciocínio lógico, mas na realidade está seguindo um caminho de escolhas para essa construção, pois van Gogh poderia ter seguido " $n$ " cursos diferentes. Porque ele escolhe concatenar e ter seguido a ideia que se apresenta em seguida de uma oração? Ela é aleatória, é 'automática' ou está no curso de uma associação que pertence a uma 'estrutura' maior de sentidos? Se for este o caso, faz sentido que um termo se apresente em seguida ao que antecede porque eles estão de fato associados e representam estruturas de significados que para o sujeito estão articulados na sua representação dos temas e questões de que fala. A descrição desses encadeamentos de significados foi de especial interesse para a análise, porque eles mostraram a aparição de certas expressões (que podem ser apontadas como categorias de análise na discussão dos achados) um pouco antes do conteúdo mais revelador do sentido se apresentar. Por exemplo, logo antes de van Gogh fazer um encadeamento de sentidos, foi possível observar a aparição de uma suposição, não muito complexa, mas uma expressão do tipo suposição, que é seguida de uma representação de atores sociais. Essa constatação levantou o interesse para entender porque esse encadeamento se estrutura de forma a uma a suposição 
preceder uma representação. Os casos são diferentes e são muitos, por exemplo, algumas relações entre categorias na construção de um parágrafo são recorrentes e dá para começar a se perguntar se é possível observar a presença de um padrão de construção semântica.

- Etapa 4 - Na quarta etapa busquei voltar e tentar reconhecer categorias na construção desses sentidos descritos na terceira etapa de análise, pois notei uma dificuldade: há colocações que podem ser uma, duas ou três categorias simultaneamente. Para evitar começar a procurar cabelo em ovo procurei me distanciar de muita informação, pois quanto menos 'recepção' melhor se fica para 'ouvir' o sujeito da pesquisa. Levei em consideração analisar um pouco todo dia, mas não por muitas horas, é preciso estar com a cabeça bem limpinha e bem cedo foi o melhor horário para ter esse 'ouvido'. Nesta etapa levei em consideração uma explicação para a ocorrência de muitas categorias superpostas ou concomitantes: quando um texto é denso e compactado com muitas camadas de sentidos. Talvez esse seja o caso do corpus textual contextual, por ser uma cartamanifesto de uma pessoa olhando para o precipício entre o seu existir e ser para o mundo. Entre as incomensuráveis limitações que encontra e as possibilidades que deseja realizar. Um precipício vivido em silêncio e que se esforça para se manifestar pela via tênue das palavras. Acho que por esse motivo a multiplicidade de sentidos, de categorias justapostas, interconectadas em um espaço tão pequeno de fala, amontoadas por metro cúbico de linhas bem articuladas no esforço de se representar, de ser para alguém. Nessa quarta etapa, procurei entender porque essas categorias estarem onde estão e porque a aparição delas no lugar e na ordem onde elas aparecem. Haveria funções que elas assumem na estruturação de seu pensamento?

- Etapa 5 - Busquei analisar como o texto foi organizado, se há uma estratégia retórica, ou se ele tem uma estrutura genérica (FAIRCLOUGH, 2003) ou mais espontânea e fluida. Se o texto está organizado em partes e como estas partes são articuladas e conectadas. Procurei encontrar os elementos que fazem essa função articuladora para localizar as estratégias discursivas;

- Etapa 6 - Na sexta etapa, pensei em fazer um mapa da ocorrência das categorias e verificar se ocorre muitas categorias ocupando um mesmo espaço e cada uma delas deve estar dando sustentação para uma camada diferente de sentidos que também estão acontecendo em polifonia, como em um acorde musical. Então a 
partir de cada categoria desse acorde, busquei rastrear 'linhas melódicas' que estariam acontecendo como em uma estrutura de 'contraponto e fuga' ou seja, com cada uma delas indicando o encadeamento de uma camada de sentido, posta a vista pela ocorrência de uma justaposição de categorias. Como baleias, elas emergem e submergem e foi preciso perseguir seus rastros ao conseguir mapear quantas ocorrências há daquela categoria na tessitura do texto e em que momento elas apareceram. Foi observada sua posição de ocorrência relativa a outras ocorrências. Usei como metáfora o trabalho em um sítio arqueológico, no qual a posição dos artefatos em relação aos outros artefatos também fornece dados sobre a sua função de uso. Considerei a estrutura maior do texto, a posição de ocorrência que as categorias se encontravam em relação aos outros 'artefatos' linguísticos do texto identificados em conexão ou isolados, pode revelar muito sobre a construção discursiva de van Gogh.

- Etapa 7 - Na sétima etapa, busquei olhar para esse mapa de aparições e ocorrências para tentar perceber se há um padrão de uma categoria preceder a aparição de uma estrutura, ou aparecer como uma função articuladora ou com uma outra função na construção dessa estrutura de sentidos estruturados, fluidos, fundidos, difusos, confusos, fragmentados, ou integrados por movimentos de repetição e criação de novos sentidos;

- Etapa 8 - Procurei fazer um mapeamento da aparição dos significados acional, representacional e identificacional e observar se a ocorrência e lugar onde aparecem revela um padrão de uso de significados. Indagar se o encadeamento de significados tem um significado em si, ou seja, se a relação entre significados pode indicar um diálogo (continuação, reforço, complementação, oscilação, ambivalência, interrupção, fragmentação, contraposição, etc.) entre 'modos de agir, de representar e de ser.' Indagar se esse padrão de ocorrência entre os significados indica níveis discursivos que revelam uma relação dos processos de organização discursiva no texto com estruturas discursivas mais amplas. Indagar como a análise da relação entre os significados no texto pode auxiliar a entender a relação entre o texto, os eventos, as práticas e o discurso do agente desse texto;

- Etapa 9 - Procurei articular a base teórica com a constatação das categorias. Considero importante deixar na organização, essa trajetória feita na análise para que o leitor possa acompanhar e entender o processo que foi possibilitando a explicitação dos sentidos. Ao analisar, levei em consideração a necessidade de 
começar a analisar pelo sentido mais imediato, e depois pelo sentido oculto, para só depois proceder ao reconhecimento da presença de categorias e analisar sua ocorrência, lugar e função na estrutura mais ampla do texto ou documento. Esse trajeto permitiu que certos sentidos se evidenciassem porque existiam em forma de vestígio, ou às vezes de 'ausência' entre uma expressão e outra, uma voz que não está, mas que ecoa, ou entre uma camada de significado e outra que não mostra, mas evoca um sentido subjacente ao sentido expresso.

\subsection{Categorias da ADC usadas na análise do corpus textual contextual}

- Intertextualidade - O conceito de intertextualidade para Fairclough (2003) articula a voz de quem escreve o texto com outras vozes. Para Fairclough (2003), por meio da intertextualidade são atualizados no texto, os elementos de outros textos de forma direta como a citação ou indireta como a paráfrase por exemplo. Os trabalhos de Van Gogh são inspirados algumas vezes pelos trabalhos de outros artistas, tais como a sua versão de uma obra de Jean-François Millet ou por referências à literatura. Por exemplo, a tela 'O Semeador' foi inspirada em tela semelhante de Millet, e a tela 'A Esplanada do Café na Place du Forum, Arles, à Noite' dialoga com outra tela, "Avenue de Clichy in the Evening" de Anquetin e ainda que não se saiba se Van Gogh foi diretamente inspirado pelo trabalho Anquetin, pode-se afirmar que "Café Terrace" é um trabalho singular entre os demais produzidos por Van Gogh.

- Interdiscursividade - O discurso é permeado pela interdiscursividade e estabelece uma relação multiforme com outros discursos. A interdiscursividade e a intertextualidade são possibilidades de transformação por meio de ressignificações e mudanças na prática discursiva. "A mudança envolve formas de transgressão, o cruzamento de fronteiras, tais como a reunião de convenções existentes em novas combinações, ou sua exploração em situações que geralmente as proíbem" (FAIRCLOUGH, 2001, p.127).

- Pressuposição - Fairclough (2003, p. 40) explica a pressuposição como "o que não é dito, mas tomado como dado". A pressuposição parece ter uma função semelhante a da intertextualidade uma vez que o ela associa que é enunciado em outros textos, deixando vago o lugar dessa enunciação em outros textos. 
- Modalidade - Para Fairclough (2001), com relação ao que os autores se comprometem como um estatuto de verdade, a modalidade é vista em termos do que é necessário, e a avaliação é vista em termos do que é desejável ou indesejável, bom ou mal. Fairclough (2001) acredita que as coisas com as quais as pessoas se comprometem no texto "é uma parte importante de como elas se identificam a si mesmas, a tecitura das identidades.

- Representação de eventos/atores sociais - Fairclough (2001, p. 43) enfatiza a heterogeneidade na "investigação da mudança discursiva dentro da mudança social e cultural mais ampla". Neste processo de construção de posições e sentidos implícitos é importante analisar o caráter ideológico associado às convenções sociais compartilhadas pelo sujeito que compõe sua identidade, assim como o caráter transformador e criativo da produção de novos sentidos e combinação de novos elementos estruturais da linguagem.

As categorias usadas na análise do corpus textual contextual foram baseadas em Fairclough (2003) como descritas abaixo. Utilizei cores para cada categoria para diferencialas, uma vez que elas apareciam superpostas ao longo dos excertos analisados.

Quadro 16: Mapa de categorias analíticas em Analysing discourse.

\begin{tabular}{|c|c|c|}
\hline Significado do discurso & Categoria & Questões \\
\hline \multirow{4}{*}{ Significado acional } & Intertextualidade & $\begin{array}{l}\text { De outros textos/ vozes relevantes, quais são } \\
\text { incluídos? Quais são significativamente } \\
\text { excluídos? } \\
\text { Como outras vozes são incluídas? São atribuídas? } \\
\text { Se sim, especificamente ou não especificamente? } \\
\text { As vozes atribuídas são relatadas diretamente } \\
\text { (citação) ou indiretamente? } \\
\text { Como outras vozes são tecidas em relação à voz } \\
\text { do/a autor/a e em relação umas com as outras? }\end{array}$ \\
\hline & Pressuposição & $\begin{array}{l}\text { Que pressuposições existenciais (sobre o que } \\
\text { existe), proposicionais (sobre como as coisas são } \\
\text { ou serão) ou valorativas (sobre o que é bom ou } \\
\text { ruim) são feitas? } \\
\text { É o caso de se ver algumas pressuposições como } \\
\text { ideológicas? }\end{array}$ \\
\hline & Gênero/ Estrutura genérica & $\begin{array}{l}\text { O texto se situa em uma cadeia de gêneros? } \\
\text { O texto é caracterizado por uma mistura de } \\
\text { gêneros? } \\
\text { Que gêneros o texto articula (em termos de } \\
\text { atividade, relações sociais, tecnologias de } \\
\text { comunicação)? } \\
\text { Como o texto se organiza em termos de pré- } \\
\text { gêneros e subgêneros? }\end{array}$ \\
\hline & $\begin{array}{l}\text { Relações semânticas/ } \\
\text { gramaticais entre períodos } \\
\text { e orações }\end{array}$ & $\begin{array}{l}\text { Quais são as relações semânticas predominantes } \\
\text { entre períodos e orações (causa - razão, } \\
\text { consequência, propósito; condicional; temporal; }\end{array}$ \\
\hline
\end{tabular}




\begin{tabular}{|c|c|c|}
\hline & & $\begin{array}{l}\text { aditiva; elaborativa; contrastiva/concessiva)? } \\
\text { Há relações semânticas em nível mais alto entre } \\
\text { partes maiores do texto (por exemplo, problema- } \\
\text { solução)? } \\
\text { Há relações particularmente significativas de } \\
\text { equivalência e diferença construídas no texto? }\end{array}$ \\
\hline & $\begin{array}{l}\text { Trocas, funções da fala, } \\
\text { modo gramatical }\end{array}$ & $\begin{array}{l}\text { Quais são os tipos predominantes de troca (troca } \\
\text { de atividade ou de conhecimento) e funções da } \\
\text { fala (afirmação, pergunta, demanda, oferta)? } \\
\text { Que tipos de afirmação há (afirmações de fato, } \\
\text { previsões hipotéticas, avaliações)? } \\
\text { Há relações 'metafóricas' entre trocas, funções da } \\
\text { fala ou tipos de afirmação (por exemplo, } \\
\text { demandas que aparecem como afirmações, } \\
\text { avaliações que aparecem como afirmações } \\
\text { factuais)? } \\
\text { Qual é o modo gramatical predominante } \\
\text { (declarativo, interrogativo, imperativo)? }\end{array}$ \\
\hline \multirow[b]{3}{*}{$\begin{array}{l}\text { Significado } \\
\text { representacional }\end{array}$} & Interdiscursividade & $\begin{array}{l}\text { Que discursos são articulados no texto e como são } \\
\text { articulados? Há uma mistura significativa de } \\
\text { discursos? } \\
\text { Quais são os traços que caracterizam os discursos } \\
\text { articulados (relações semânticas entre palavras, } \\
\text { colocações, metáforas, presunções, traços } \\
\text { gramaticais)? }\end{array}$ \\
\hline & Significado de palavra & $\begin{array}{l}\text { É relevante para a análise investigar a construção } \\
\text { do sentido de alguma palavra ou termo em } \\
\text { especial? Se sim, quais são os padrões de } \\
\text { colocação envolvendo essa palavra ou termo? Há } \\
\text { padrões de co-ocorrência? }\end{array}$ \\
\hline & $\begin{array}{l}\text { Representação de } \\
\text { eventos/atores sociais }\end{array}$ & $\begin{array}{l}\text { Que elementos dos eventos sociais representados } \\
\text { são incluídos ou excluídos? Que elementos } \\
\text { incluídos são mais salientes? } \\
\text { Quão abstrata ou concretamente os eventos são } \\
\text { representados? } \\
\text { Como os processos são representados? Quais são } \\
\text { os tipos de processo predominantes (material, } \\
\text { mental, verbal, relacional, existencial, } \\
\text { comportamental)? } \\
\text { Há instâncias de metáfora gramatical na } \\
\text { representação de processos? } \\
\text { Como atores sociais são representados } \\
\text { (ativado/passivado, pessoal/impessoal, } \\
\text { nomeado/classificado, específico/ genérico)? } \\
\text { Como tempo, espaço e a relação entre ‘tempos- } \\
\text { espaços’ são representados? }\end{array}$ \\
\hline \multirow[t]{2}{*}{ Significado identificacional } & Estilos & $\begin{array}{l}\text { Que estilos são articulados no texto? Como são } \\
\text { articulados? } \\
\text { Há mistura significativa de estilos? } \\
\text { Quais são os traços que caracterizam os estilos } \\
\text { articulados ('linguagem corporal', pronúncia e } \\
\text { outros traços fonológicos, vocabulário, metáfora, } \\
\text { modalidade, avaliação)? }\end{array}$ \\
\hline & & Como os autores se comprometem em termos de \\
\hline
\end{tabular}




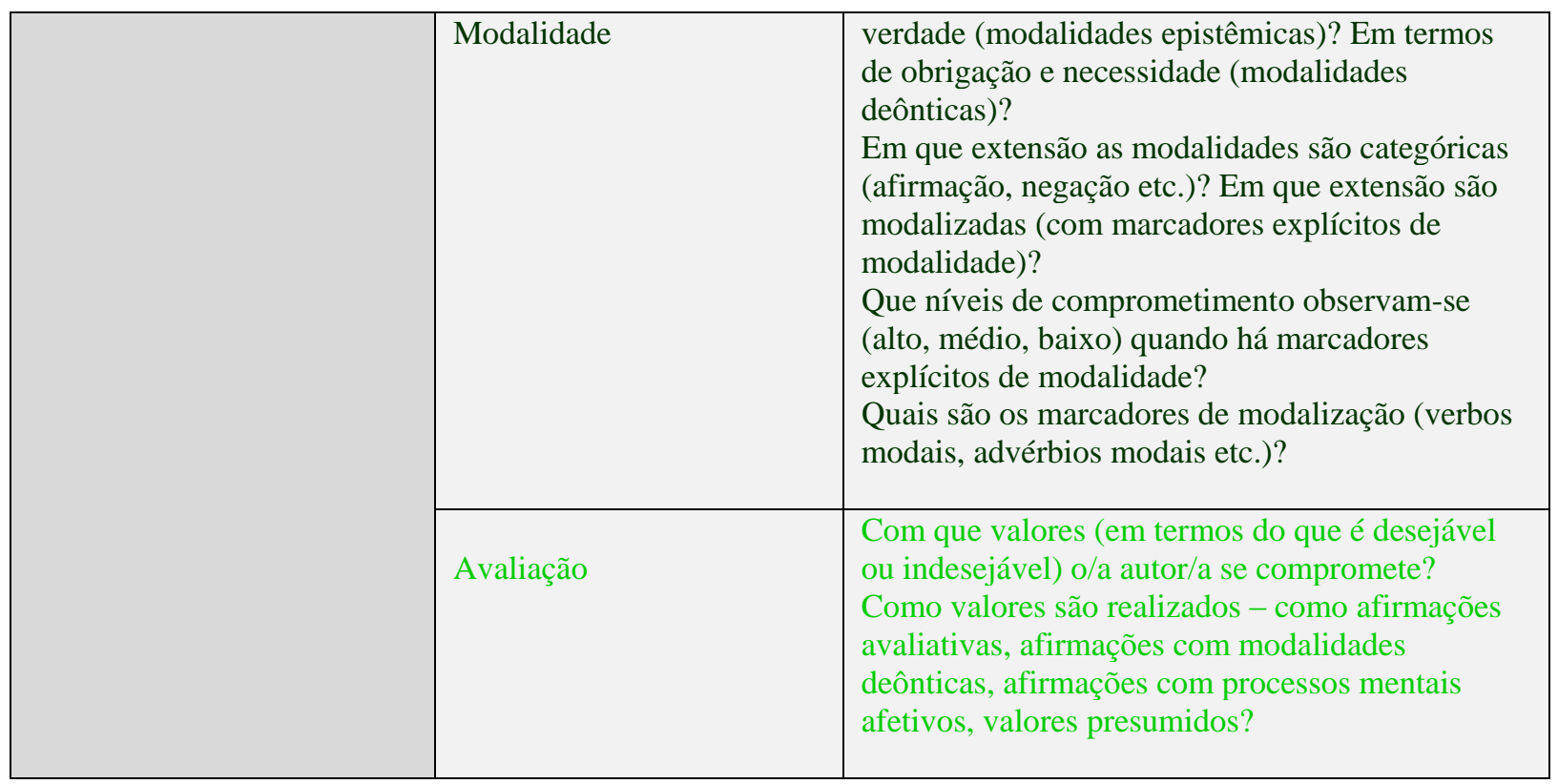

Fonte: Adaptado de Fairclough (2003, p. 191-194).

\subsubsection{Procedimentos de análise da triangulação dos corpora}

Os procedimentos de triangulação para realizar a análise da relação discursiva entre o Corpus TELAS e o Corpus CARTAS exigiram um maior cuidado com a sistematização.

Esta seção foi pensada de uma forma mais flexível e aberta a modificações uma vez que a sua organização seria uma consequência do que foi encontrado nas duas sessões anteriores. Foram pensadas as seguintes diretrizes para contemplar as preocupações que pautaram essa fase da análise. Preliminarmente, proponho os seguintes procedimentos de triangulação:

1) fazer uma relação entre os dados textuais e visuais analisados da pesquisa para perceber recorrências, similaridades, correlações, disparidades, complementaridades, contradições, conflitos de opiniões.

2) à medida que forem sendo encontrados elementos que os dados estão trazendo, agrupar em categorias que revelam aspectos ou dimensões do discurso imagético ou textual que está sendo investigando. Essas categorias foram apresentadas como subtópicos na apresentação da análise dos dados.

a) Intertextualidade Visual entre telas;

b) Intertextualidade Textual entre cartas;

c) Intertextualidade entre tela e cartas diretas, gerais, contextuais. 
3) fazer uma contagem manual dos dados para subsidiar a interpretação dos resultados no intuito de verificar as correlações entre ocorrências visuais e textuais.

4) fazer uma interpretação qualitativa sobre a ocorrência de sentidos no discurso textual que são reiterados no discurso visual. Ou que embasam a construção dos sentidos visuais.

Os pontos de contato entre o discurso verbal e o discurso visual foram descritos na fundamentação teórica com base na discussão de Machin (2007) acerca das contribuições de Kress e Van Leeuwen (1996) para estabelecer essa conexão. Porém, essa comparação sobre as correlações observadas entre o discurso verbal e o discurso visual aborda apenas pontualmente alguns aspectos que encontram conexões, mas falha em seguir um sistema de comparação entre as duas modalidades que verifique todos os níveis do estrato da linguagem.

Para analisar a relação entre as telas e as cartas de Van Gogh, procurei fazer uma interpretação das ocorrências de categorias da multimodalidade nas telas analisadas, de ocorrências de categorias de LSF e de ADC nas cartas analisadas para observar se há algum tipo de relação entre essas ocorrências.

Para os procedimentos de triangulação, algumas considerações foram levantadas, uma vez que se trata de contrastar os pontos de contato entre a o discurso verbal e o discurso visual:

a) a linguagem verbal e a comunicação visual têm naturezas, estruturas e funções diferentes;

b) a comunicação visual não parte de uma base de comparação direta com a linguagem verbal porque em vários níveis elas não encontram base de comparação, como nos níveis lexical, fonológico, morfológico, por exemplo;

c) na comparação com outros estratos da linguagem verbal, a comunicação visual pode apresentar correspondência tais como no nível do contexto de situação, no nível semântico, no nível grafológico além de em alguns aspectos no nível gramatical como evidenciados por Kress e Van Leeuwen (1996) e já discutidos na fundamentação teórica desta pesquisa.

O nível do contexto de situação é comum para a comunicação visual e para a linguagem verbal e isso é facilmente demonstrável por meio da noção de Registro. Os conceitos Contexto de Cultura, Contexto de Situação e Registro serão categorias fundamentais para os procedimentos de análise da triangulação. 
O conceito de Registro irá fundamentar a triangulação entre as telas e as cartas que compartilham o mesmo contexto de situação e permitirá a busca de ocorrências de uso comuns entre os dados pictóricos e textuais.

Porque os textos que pertencem ao mesmo registro têm sentidos em comum, eles
também compartilham padrões na léxico-gramática. Esse conhecimento é muito útil
para criar nossos próprios textos; é mais fácil produzir um texto de um certo tipo
quando você conhece os padrões gramaticais de uso. (BUTT et al., 2000, p.7).

O conceito de registro se dá quando dois textos compartilham a mesma experiência. Quando esses dois textos compartilham o mesmo contexto de situação isso é um registro porque o mesmo contexto de situação gerou dois textos, então provavelmente eles compartilham os mesmos significados textual, experiencial e interpessoal.

Penso em usar o conceito de registro para fazer a triangulação, em especial para o corpus textual primário e para o corpus textual secundário. Estou usando o arcabouço dos estratos da linguagem para buscar o que há em comum e o que não há, entre as cartas e as telas.

O nível semântico também pode ter muitas compatibilidades, mas foi preciso descrever e identificar as estruturas semânticas que ocorrem em uma relação de comparação.

O nível léxico-gramatical já foi em grande parte descrito por Kress e Van Leeuwen (1996) e algumas conexões foram estabelecidas entre os dois sistemas linguísticos, enquanto outras não, devido às naturezas diferentes dos dois sistemas.

Dessa forma, trouxe para os procedimentos de análise da triangulação a proposta de, a partir dos dados analisados tanto no corpus pictórico quanto no corpus textual, analisar os pontos de contato entre a comunicação visual e a linguagem verbal, na perspectiva de sua transitividade. Quando existiam correspondências, foi preciso fazer a descrição das ocorrências e a interpretação dessas materializações em relação ao_propósito do texto, ao contexto de situação e de cultura e ao registro ou experiência comum e subjacente à produção dos textos.

Nesta triangulação, propus comparar aspectos estruturais que estão no nível léxicogramatical da linguagem como o sistema de transitividade nas cartas com as funções representacional, modal e composicional nas telas. Os elementos que surgiram na análise do sistema de transitividade nos excertos das cartas foram comparados com os achados da análise multimodal das telas, também feitas a partir da perspectiva das três funções Modal, Representacional e Composicional, na etapa da triangulação. O conceito de Vetores de Kress e Van Leeuwen (1996) foi de especial importância nessa prospecção. 


\section{CAPÍTULO 5: ANÁLISE DOS DADOS}

\section{INTRODUÇÃO: ANÁLISE DOS CORPORA VISUAL E TEXTUAL}

Neste capítulo, desenvolvi a análise de quatro telas usando a base teórica da multimodalidade; a análise de doze extratos de carta do corpus textual primário a que se referem às telas analisadas com a ajuda da Linguística Sistêmico-funcional e um extrato de carta do corpus textual contextual com apoio da Análise de Discurso Crítica.

O extrato de carta do corpus textual contextual será analisado a seguir pela perspectiva da ADC. As categorias empregadas na análise da carta de julho de 1880 foram descritas no item 4.10.2.2.1 nomeado "Categorias da ADC usadas na análise do curpus textual contextual". Como as categorias utilizadas na análise ocorreram de forma justaposta ao longo do texto, elas foram diferenciadas por cores diversas que estão descritas no Quadro "Mapa de categorias analíticas em Analysing discourse" (FAIRCLOUGH, 2003) no item acima referenciado que está ao final do capítulo 4.

\subsection{ANÁLISE DO CORPUS TEXTUAL CONTEXTUAL}

\subsubsection{Carta de van Gogh-Junho 1880- Carta 155 (VAN GOGH, 2009k)}

155

Br. 1990: 154 | CL: 133

From: Vincent van Gogh

To: Theo van Gogh

Date: Cuesmes, between about Tuesday, 22 and Thursday, 24 June 1880

Source status: Original manuscript

Location: Amsterdam, Van Gogh Museum, inv. nos. b153 a-b V/1962

A análise do corpus textual contextual foi alocada no apêndice para reduzir o volume da tese. 


\subsubsection{Conclusão da Análise do corpus textual contextual}

Por ser muito extensa e ter impactado no volume geral da tese, a análise do corpus textual contextual foi realocada no apêndice da mesma. Nesta seção, limitei a apresentação das categorias que foram encontradas na análise do corpus textual contextual.

\subsubsection{Intertextualidade}

O conceito de intertextualidade foi instrumental para a análise, e as vezes confundido com o conceito de interdiscursividade. A categoria da intertextualidade foi frequente na análise, compreensivelmente por se tratar de uma carta que, enquanto um gênero mais potencial do que situado (Resende, 2006) articula muitos pré-gêneros e subgêneros na busca de corporificar o interlocutor que está distante e apartado do agente. Este busca estabelecer um ambiente de diálogo dentro da carta, seja ao pressupor uma pergunta e ecoá-la "voce me perguntara se isso ocorre" ou por antecipar uma resposta ao propor um tema em forma de pergunta e em seguida responde-lo em forma de afirmação. Esses são dois pequenos exemplos dessa busca de recriação de um ambiente de conversação sem que haja um diálogo de fato e abre o campo para a categoria não só da intertextualidade, mas da interdiscursividade. Ele também convida novos participantes desse diálogo intertextual agora na forma de citações de autores conhecidos, e em seguida trás seu pai para dentro do mesmo ambiente conversacional parafraseando uma conversa entre ambos. Essas citações e paráfrases sugerem que novos níveis de intertextualidade direta e indireta estão em suspensão no texto, bem como os vestígios da presença de um interlocutor silencioso, a quem van Gogh não ousa interpelar, este seria seu irmão mais velho e falecido.

Para Fairclough, por meio da intertextualidade são atualizados no texto, os elementos de outros textos de forma direta como a citação ou indireta como a paráfrase por exemplo. Acredito que ainda há outras formas de atualizar outros textos, de forma mais implícita, como pela ausência, pelo eco, e pela associação entre ideias na qual o ‘outro texto’ se coloca não em uma ideia ou em outra, mas 'entre' essas, na forma como elas são associadas, não estando visível, mas se fazendo presente. O conceito de intertextualidade para Fairclough (2003) articula a voz de quem escreve o texto com outras vozes. No caso da carta, observei que van Gogh articula diferentes formas às outras vozes, dando a impressão que existem várias possibilidades de intertextualidade. Não apenas por meio da citação e da paráfrase, mas da 
associação de ideias que evocam outras camadas de discurso e de sentido oriundos de outras vozes que estão sendo negociadas, contrapostas ou usadas para conferir legitimidade à sua própria voz na sua escrita. Essa dinâmica de 'conversação' entre as vozes pode gerar o desdobramento dos pré-gêneros e subgêneros, assim como a justaposição de diversas categorias tais como a pressuposição, o estilo, a representação de atores sociais, por exemplo, conferindo diferentes subcategorias para a intertextualidade, restando saber que tipos seriam.

\subsubsection{Interdiscursividade}

Há uma interrelação entre o conceito de interdiscursividade e intertextualidade, na qual se explica que a interdiscursividade está para o discurso assim como a intertextualidade está para o texto. Essa colocação me ajudou a fazer a diferenciação mais essencial para a minha compreensão das duas categorias. Ela se situa no nível da estrutura linguística. A interdiscursividade e a intertextualidade têm uma função similar, operam o mesmo tipo de trabalho, só que em estratos diferentes.

A interdiscursividade se situa no nível do modo de representar e a intertextualidade se situa no modo de agir. Entender dessa forma me ajuda a visualizar o nível onde elas operam no sistema da língua. Se é que há alguma relação hierárquica entre os significados acional, representacional e identificacional, ou de que um precede o outro. De acordo com Maingueneau (1998), a intertextualidade "é uma variante da Interdiscursividade" e pode ser porque o conceito de interdiscursividade apareceu primeiro e se refere a um domínio mais amplo do discurso, enquanto que a intertextualidade se refere a uma categoria equivalente, mas no domínio do texto.

No entanto, para Fairclough, texto engloba tudo de concreto que o discurso gera. Então passo a compreender que a interdiscursividade explica o entrelaçamento e a dança entre os diferentes discursos que se entrecruzam na dimensão potencial da língua, aquela zona onde não é tão abstrata nem é tão concreta, que não é tão palpável como o texto, mas é organizada

o suficiente para organizar um sistema de crenças e de valores, e um sistema ideológico. É nesse nível que a interdiscursividade acontece e se apresenta como um diálogo entre diferentes representações de mundo, e que precede a construção do texto. Nessa faixa potencial de discurso, se encontra o nível representacional, e por isso é que ele está muito mais embutido no texto porque o precede. Ele está no âmbito da concepção das ideias, da construção dos sentidos que serão representados no texto, e na articulação entre os sistemas de 
valores que também estarão disputando um lugar na negociação de sentidos que se dá no decurso da articulação acional do discurso no texto. Por isso a interdiscursividade pode ser identificada (em contraposição com a intertextualidade) como uma negociação entre discursos que competem lugar dentro do texto, seja para se complementarem, seja para darem sustentação e legitimidade ou para se contraporem, quando o texto revela que há um conflito entre valores e crenças que é internalizado na representação do agente do discurso.

A interdiscursividade aparece de forma mais implícita no texto, porque estaria nesse nível mais potencial do discurso, mas pode ter uma relação direta com a intertextualidade que a denuncia. No entanto, não podemos contar com isso como uma regra, porque a intertextualidade tem outras funções além de 'entregar' a presença de uma interdiscursividade e a interdiscursividade pode ser denunciada na aparição de outras categorias. Para a minha análise a compreensão da interdiscursividade será de muita importância, até agora eu não estava tendo o domínio dessa diferença e estava me deparando com uma dificuldade em diferenciar a ocorrência de ambas e de saber quando elas estavam justapostas, uma reforçando a ocorrência da outra.

O conceito da interdiscursividade me ajudou a compreender e a apontar as evidências dos conflitos com os quais van Gogh lida ao longo dessa carta. Observei conflitos entre as vozes e os discursos externos que se contrapõe com a sua voz, e os conflitos de representação que ele próprio está a negociar em um processo de transformação lento e solitário. Esse processo que o levará a afirmar a sua identidade de artista sobre as demais representações identitárias com as quais ele dialoga em um processo metamórfico no qual ele ora negocia ora rompe com as representações anteriores.

Intertextualidade e Interdiscursividade > Assim como o entendem mal na sua subjetividade, ele teme que o irmão também compreenda mal suas associações entre artistas com estilos diferentes. Inferi que ele teme que venha a ser excluído pelo irmão, não só pela forma como se veste, mas pela forma como pensa ao associar autores tão diversos. Van Gogh (1853-1890) cria uma argumentação que busca relatar eventos e reflexões acerca de suas experiências artísticas com a pintura e a literatura, com a religião e a estética. Espera que cada autor citado por ele remeta também a Theo uma cadeia de textos e de sentidos que o ajude a compreender o que se passa na sua experiência artística. Relata as associações entre os artistas, o quanto um está 'dentro' do outro, o quanto um está 'presente no outro', o quanto personalidades aparentemente muito diferentes sob um determinado olhar tornam-se a interconectadas. Por meio da interdiscursividade, ele descreve para Theo uma rede de sentidos que revela seu processo de amadurecimento como artista, seu caminho, seu estilo, seu olhar. 
Como outras vozes são tecidas em relação à voz do autor e em relação umas com as outras? A pintura é uma produção que revela um modo de significação do mundo. Ela é constituída a partir de um processo de interação deste ator social nas suas relações mais significativas. As vozes de todos estes artistas são intensas em sua experiência, ele as absorve, vive dentro das telas, sua única salvação para a solidão e a exclusão à qual é submetido incessantemente, em diferentes grupos. Com as ideias, com as imagens, ele cria relações, sentidos, conexões, as vozes das telas se tornam sua própria voz, se tornam seu próprio olhar, dificilmente compreendido pelos outros que vêem 'o mau sentido' das comparações que faz. Mas ele está ocupado em construir um diálogo identitário com os outros artistas, apropriandose de suas vozes, olhares, sentidos. Ele é a continuação das falas de um outro representado nas telas, e se apropria desta vida como sendo ele próprio, Vincent é a pintura. Uma identificação que o leva a amar a arte e ao mesmo tempo denuncia sua solidão, sua exclusão, seu abandono. Dualidades e contrastes que estarão presentes em seus quadros, que associam diferentes vozes em uma síntese tensa, impossível, sempre se modulando, se associando com outros sentimentos, pensamentos, desejos.

\subsubsection{Pressuposição}

A pressuposição foi um conceito muito útil na medida em que revelava a presença de um discurso implícito no nível representacional. Apesar de ela se encontrar no nível acional, sendo a manifestação concreta de crenças e valores ela aponta para representações e discursos que estão acontecendo no nível representacional do texto. Estou entendendo o nível representacional como um nível mais potencial e menos concreto do texto, como um prétexto, um lugar onde se encontra o substrato com o qual se faz o texto. A pressuposição aparece em diversos momentos na minha análise e encadeada com as mais diferentes categorias, e às vezes justaposta. Ela antecede ou se segue a representações, e muitas vezes apenas denuncia uma representação que está subsumida no discurso. Será preciso investigar a aparição e ocorrência da pressuposição como sinal de uma dinâmica entre categorias na articulação do discurso de Vincent. Aqui, segue um exemplo: "É por isto que antes de mais nada, sou levado a crer, seja vantajoso, e melhor resolução a tomar, e o mais razoável, que eu vá embora e me mantenha a uma distância conveniente, que eu faça como se não existisse.." 


\subsubsection{Modalidade e de Avaliação}

Modalidade e Avaliação pareceram como duas categorias muito importantes. No entanto, ao considerar que esta carta poderia ser vista como um manifesto de Vincent a Theo, pois ele parece selar, de acordo com historiadores, um acordo tácito entre os parceiros de um empreendimento ambicioso e ousado. Nesse sentido, o texto parece apresentar duas camadas de construção: uma identificatória interna para van Gogh, na qual ele negocia uma nova identidade na contraposição com identidades anteriores e para isso, ele usa em sua organização discursiva, largas doses de modalidade e avaliação; e a segunda representacional de van Gogh para Theo, na qual ele questiona suas identidades anteriores, os valores nelas envolvidos e coisas como a necessidade, verdade, e desejabilidade de se viver subordinado a valores com os quais ele não se identifica e não deseja se comprometer. Olhando por essa perspectiva, essas duas categorias foram instrumentais para identificar e reconhecer os momentos de 'virada' e transformação nas camadas de representação e identificação com as quais van Gogh está construindo uma nova existência para si, para o irmão e para o mundo.

\subsubsection{Conclusão da análise textual contextual}

O discurso artístico de van Gogh está infundido com sua vida, seu discurso visual, artístico e experiencial, como coloca Walther (1990, p. 88-89)

\footnotetext{
Van Gogh desenvolveu os três princípios básicos de toda a pintura - cor, linha e composição - não só como elementos de estilo artístico, mas também os compreendeu e utilizou como novos meios de expressão: a cor como o espírito, que só então empresta vida a todas as coisas; a linha como princípio de acção, como dinâmica da vida, como energia indestrutível; a composição como lugar para sentimentos, para a sua mundividência. Realização e solidão, anseio e desespero, amor e desalento, devotamento e renúncia, harmonia e desassossego, proximidade e lonjura, permanência e efemeridade, foi o que o homem e os artista pintou nos seus quadros. Ele que queria sempre com a sua arte dar consolo - o consolo de que ele mesmo necessitaria, ele que dava ao mundo e à vida o seu amor - e do amor sempre ficou vazio. Sofreu neste mundo e nele se dilacerou - e criou com a sua arte um mundo próprio e novo, colorido e movimentado que contém tudo o que ele sabia da existência. (WALTHER, 1990, p.88-89)
}

Os modos de produção da vida humana, nossa subsistência e as significações que dão sentido à vida são constituídos para atender interesses e ideais e tem como fundamento as relações sociais que sustentam estas significações, sendo a prática discursiva a manifestação concreta de uma totalidade acerca das relações sociais que sustentam este modo de produção. Assim, van Gogh ao escrever a carta ao irmão constrói seu discurso a partir de uma relação 
que dá condições para a sua produção artística. Nessa representação de van Gogh como artista mais do que como membro da família, que função essas características identitárias, essas qualidade atribuídas a ele ganham nesse momento de ressignificação do seu lugar no mundo? Na carta de julho de 1880, van Gogh manifesta sua dificuldade de existir no mundo, e a construção de um novo caminho de representação identitária para existir em suas telas. Em seu relato representa sua dificuldade para se inserir socialmente na família, nas instituições por onde passou, mesmo em relação ao próprio Theo que pareceu reconhecer com base em seu processo de produção artística. A análise dos elementos discursivos sugere que van Gogh encontrou dentro das telas, não fora delas, o espaço para ser no mundo, para se fundar, se encontrar, se expressar, se conhecer, viver. Um mundo livre criado por ele, e assim integrar seu mundo com o mundo que ele tanto desejou participar e pertencer.

A seguir dá-se início à análise do corpus pictórico e do corpus textual primário.

\subsection{ANÁLISE DA TELA POR DE SOL: CAMPO DE TRIGO PERTO DE ARLES}

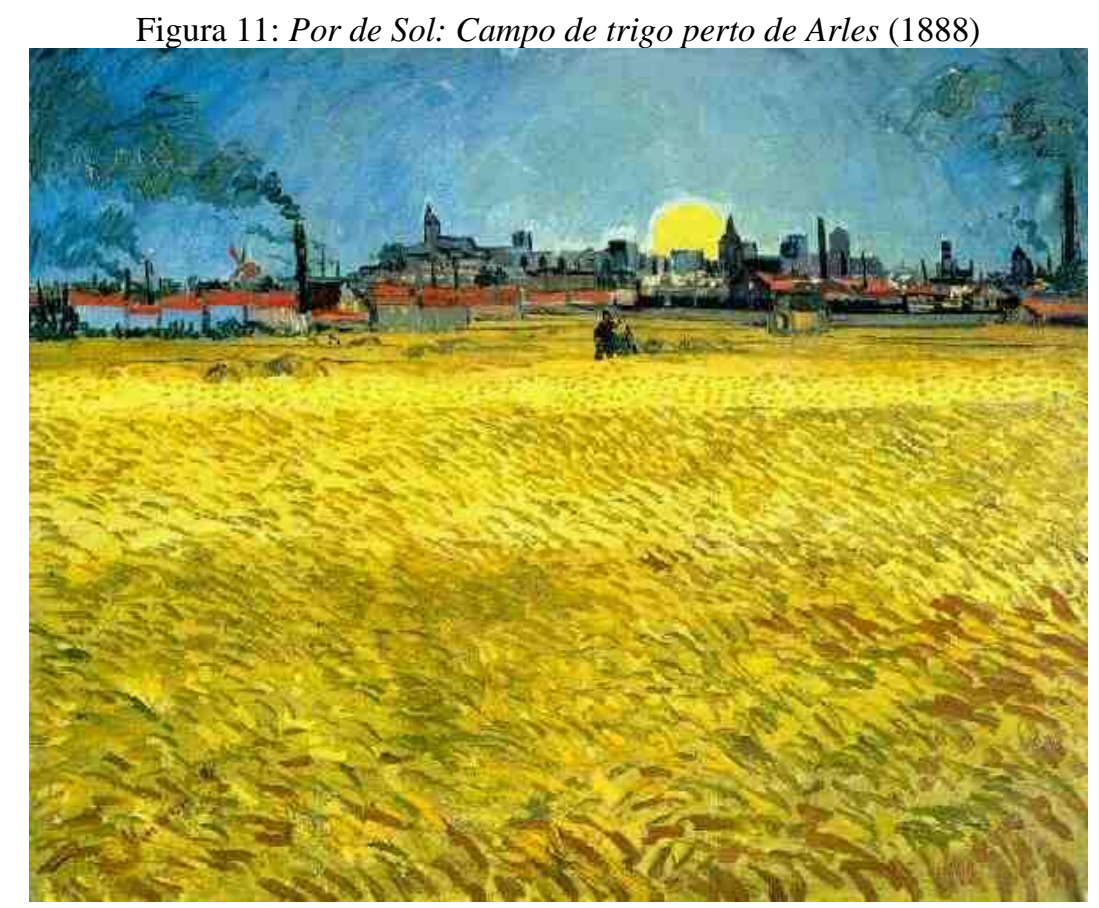

Fonte: Van Gogh (1888a).

Oil on canvas, $73.5 \times 92.0 \mathrm{~cm}$.

Arles: June, 1888

F 465, JH 1473

Localização: Winterthur: Kunstmuseum Winterthur

A análise da tela Por de sol: campo de trigo perto de Arles foi alocada no apêndice para reduzir o volume da tese. 


\subsection{ANÁLISE TEXTUAL DOS EXTRATOS DE CARTAS RELATIVOS À TELA POR DE SOL: CAMPO DE TRIGO PERTO DE ARLES}

A análise dos extratos de carta que se referem à tela Por de sol: campo de trigo perto de Arles foi alocada no apêndice para reduzir o volume da tese.

\subsection{ANÁLISE DA TELA 'O SEMEADOR'}

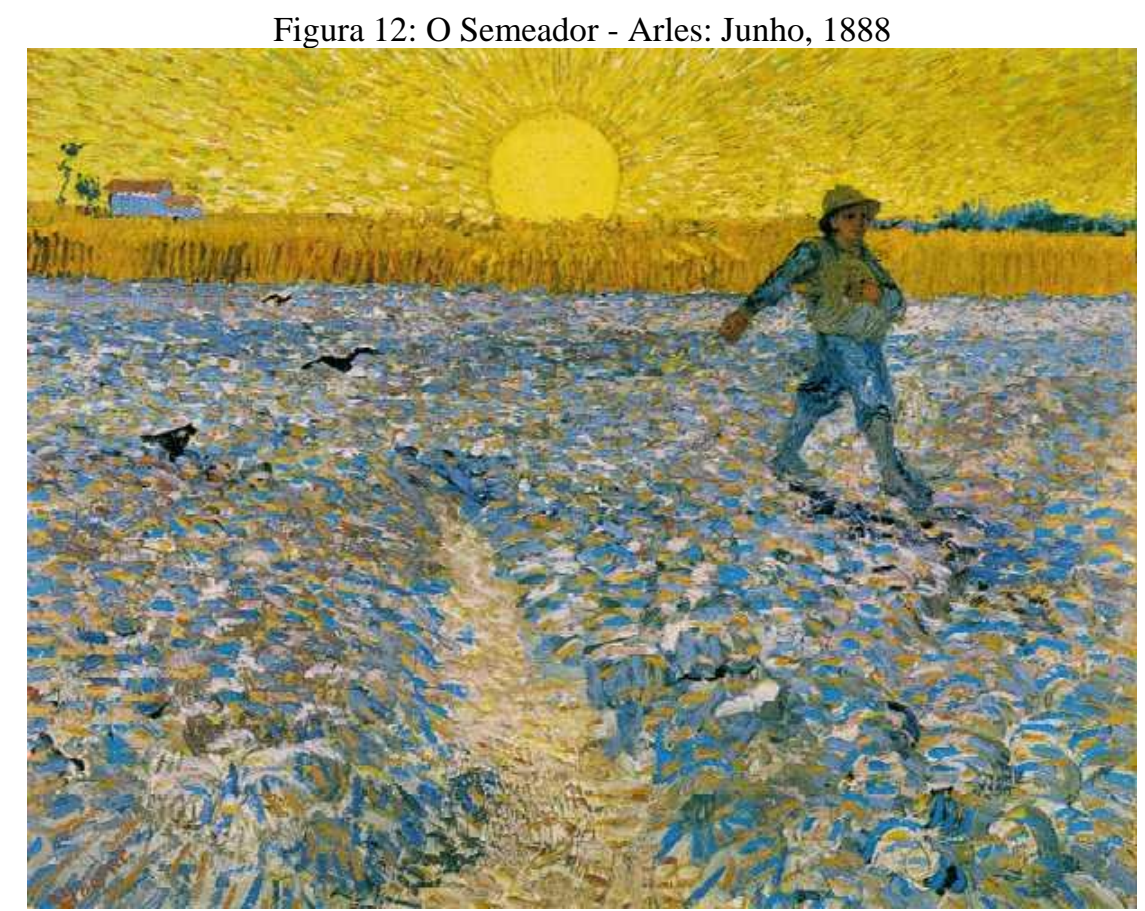

Fonte: Van Gogh (1888b).

Oil on canvas, $64.0 \times 80.5 \mathrm{~cm}$.

Arles: June, 1888

F 422, JH 1470

Localização: Otterlo, Rijksmuseum Kroller-Muller.

A tela O Semeador será analisada considerando a abordagem da Teoria Social Semiótica Multimodal e nos aportes teóricos da Gramática do Design Visual. Walther e Metzger (2015) relatam as palavras de van Gogh para narrar para o irmão a composição do Semeador e explicam que a tela do Semeador surgiu após uma série de trabalhos com a temática dos campos de trigo e das colheitas:

Terminei mesmo agora uma semana cheia de trabalho passada lá fora, nos campos, debaixo de um Sol escaldante", relatou Vincent (carta 501). "O resultado foram estudos de campos de milho, paisagens e um esboço de um semeador. Num campo lavrado, com uma vasta área de torrões de terra violeta estendendo-se até ao horizonte está um semeador vestido de azul e branco. No horizonte, um campo humilde de milho maduro. Por cima, está um céu amarelo com um Sol da mesma cor. Perceberão a partir do registro simples dos valores da cor que esta tem um papel muito importante nesta composição." Este semeador (p.344) surge no final da série de colheitas, tal como, na realidade, ele só semeia depois de terminada a ceifa e dos campos estarem desocupados. (WALTHER; METZGER, 2015, p. 354). 


\title{
5.4.1 Análise da Função Composicional da tela O Semeador
}

\subsubsection{Espaço Composicional}

Horizontalmente, a tela se divide em três espaços principais nos quais o campo arado ocupa dois terços da tela enquanto o campo maduro e o céu ocupam um terço da tela. Embora sendo da categoria semântica 'campo de trigo' e possam guardar um sentido similar, o campo de trigo maduro se agrupa com o céu, pois divide com o céu um terço do espaço horizontal da tela, sugerindo uma associação interessante entre os sentidos do trigo maduro e os sentidos do céu e do sol que nele se encontra: o calor, a vida, a força, o crescimento, a plenitude. Essa associação metafórica é confirmada pela divisão cromática da tela, na qual o campo de trigo maduro se alinha com os tons quentes do céu e do sol, que se contrapõem aos tons frios do campo arado sugerindo dois domínios cromáticos com sentidos semióticos distintos. O campo arado tem tons frios que sugerem o repouso, o silêncio, o vazio. $\mathrm{O}$ campo de trigo maduro com o céu e o sol têm tons quentes que sugerem atividade, exuberância, crescimento. ${ }^{33}$

A tela está dividida em três planos: no primeiro plano temos um campo plano, com torrões de terra e pronto para a semeadura, no segundo plano, o semeador e alguns corvos, e no terceiro plano, na linha do horizonte, há um campo de milho maduro, duas árvores e uma casa à esquerda da tela, e um bosque à direita da tela. ${ }^{34}$ Acima do horizonte há o céu, narrado por van Gogh em sua carta ao irmão:

\begin{abstract}
Acabo de terminar uma semana repleta de trabalho duro nos campos sob um sol escaldante", informou Vincent (carta 501). "O que resultou foram estudos das roças de milho, paisagens e - um esboço de um semeador. Em um campo arado, uma vasta área de torrões de terra violeta chegando ao horizonte - um semeador em azul e branco. Um baixo campo de milho maduro no horizonte. Sobre ele um céu amarelo com um sol amarelo. Você vai reunir a partir de minha conta simples dos valores de cor que a cor desempenha um papel muito importante nesta composição. (WALTHER; METZGER, 2012, p. 360).
\end{abstract}

Com ajuda dos planos, a profundidade ${ }^{35}$ é construída pela modulação cromática dos tons azuis e lilases do campo arado que vão gradativamente perdendo a sua intensidade cromática nas faixas de terra que estão demarcadas na figura abaixo:

\footnotetext{
${ }^{33}$ Ocorrência de Associação Metafórica é construída pela associação dos sentidos do trigo maduro e os sentidos do céu e do sol: calor, vida, força e crescimento, confirmada pela divisão do espaço composicional e pela divisão cromática da tela na qual o campo maduro tem tons quentes e o campo arado tem tons frios.

${ }^{34}$ Ocorrência de Enquadramento, pelo uso do plano aberto para representar a cena.

35 A profundidade visual é construída pela divisão do espaço em planos, e pela gradação cromática das tonalidades de azuis do campo. Ela também é construída com a ajuda da perspectiva, dada pelos caminhos visuais no campo arado.
} 
Figura 13: O Semeador - Arles: Junho, 1888

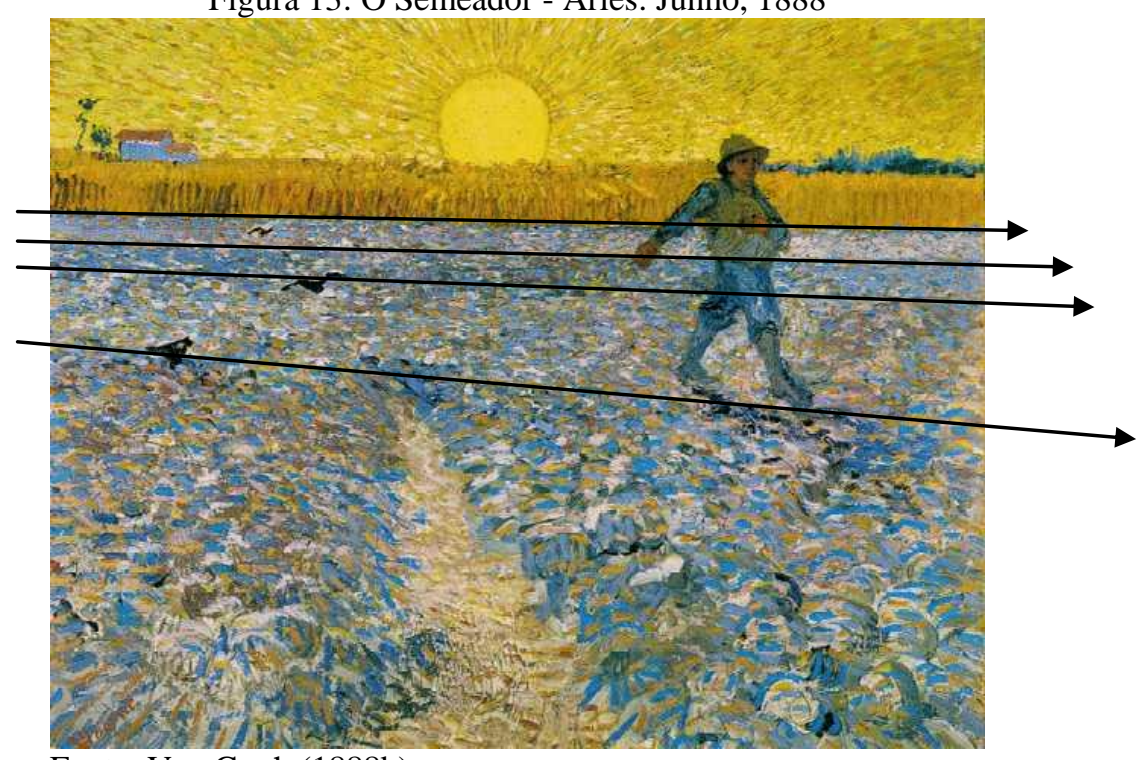

Fonte: Van Gogh (1888b).

\subsubsection{Análise da Função Modal da tela O Semeador}

\subsubsection{Perspectiva}

Vários recursos ajudam na articulação da perspectiva: assim como na composição da tela 'Por de Sol: Campo de trigo perto de Arles', ela também é construída por meio de planos com ângulos de enquadramento diferenciados, sugeridos por áreas em forma de cunhas no campo arado. Estas cunhas estão dispostas em diferentes enquadramentos, o primeiro mais plongee, e o segundo mais frontal. As cunhas são sugeridas por meio da modulação dos tons dos torrões de terra que aqui estão representados por tons de azuis, lilazes, e brancos justapostos. $^{36}$

\footnotetext{
${ }^{36}$ Ocorrência de Perspectiva pelo uso de vários recursos tais como planos com ângulos de enquadramento diferenciados, em forma de cunhas que são sugeridas pela modulação cromática dos torrões de terra.
} 
Figura 14: O Semeador - Arles: Junho, 1888

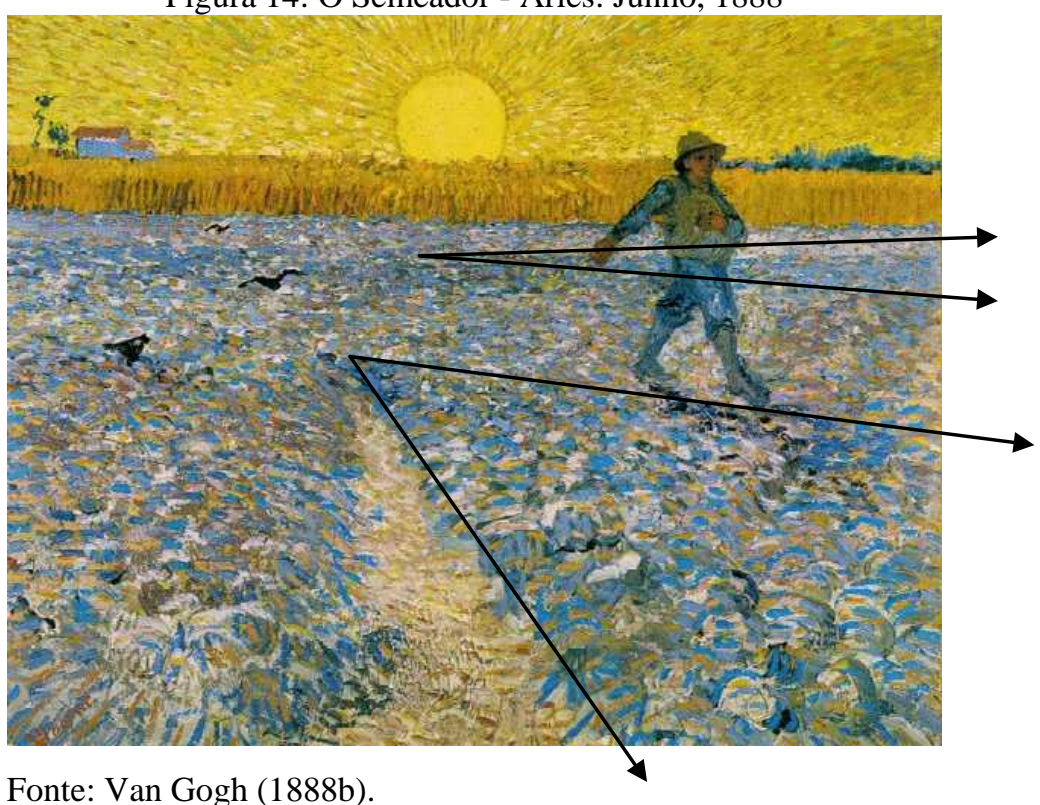

Fonte: Van Gogh (1888b).

\subsubsection{Caminhos visuais}

Na composição observei três tipos de direção: no primeiro plano há o sulco na terra, que junto com os corvos e a casa no horizonte agrupam um caminho visual que ajuda a construir a perspectiva; esse caminho de terra aberto no meio do campo arado constrói uma percepção de profundidade e conduz o nosso olhar para dentro da cena. ${ }^{37}$

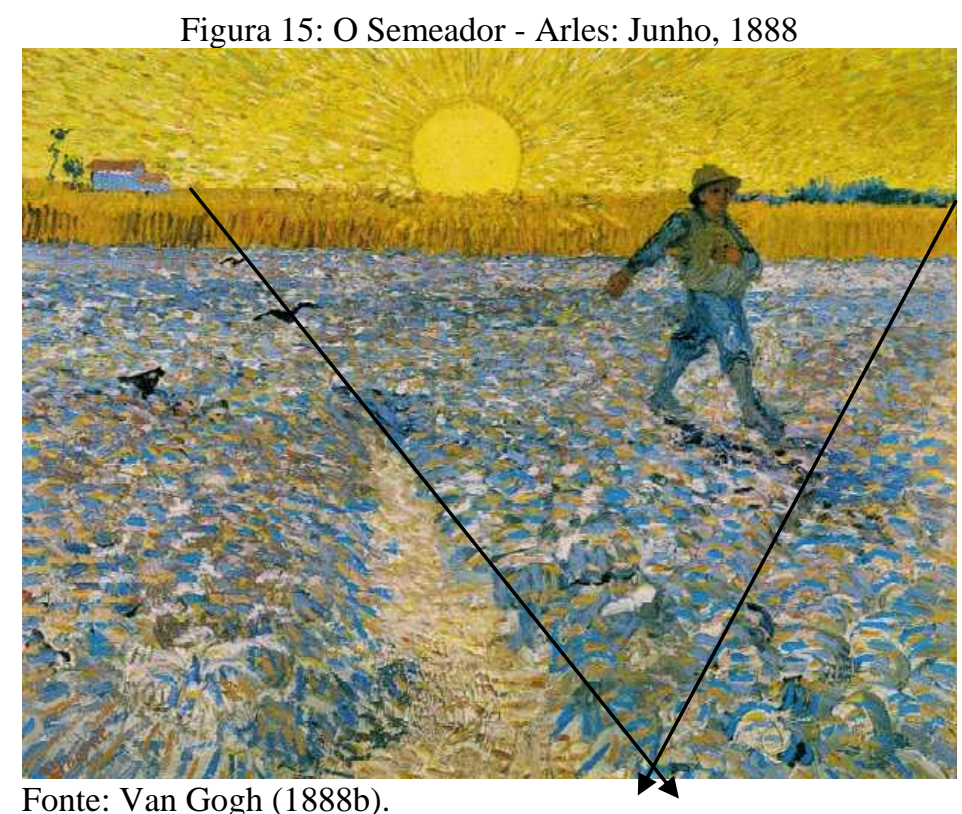

\footnotetext{
${ }^{37}$ Ocorrência de Perspectiva e Profundidade construídas por caminhos visuais conferidos pelo agrupamento de membros como o caminho de terra, os corvos e a casa.
} 
O sulco tem a forma de uma seta que parece apontar para o campo de milho maduro no horizonte como que sugerindo que esta é a meta do semeador, chegar a possuir um campo maduro para colher e uma casa para sustentar. Com os planos temos uma narrativa em episódios, no primeiro plano a terra nua, aberta, pronta para receber a semeadura. No segundo plano um semeador que percorre todo o campo e o semeia. No terceiro plano, um campo maduro, como uma sequência temporal de um ciclo de trabalho e natureza associados. O sulco de terra representa uma estrada que segue até o campo de trigo maduro, sugerindo uma transição entre o campo arado e o campo maduro, ou mais: uma narrativa cíclica entre o antes (campo arado) e o depois (campo maduro). ${ }^{38}$

\subsubsection{Direção}

No segundo plano temos o caminhar e olhar do Semeador que anda para a direita da tela. Apesar de semear o campo inteiro, ele se move e olha para a direita, indicando uma ação vetorial que nos leva a ler a tela da esquerda para a direita. De acordo com Kress e Van Leeuwen (1996), na informação de valor, os objetos posicionados à esquerda da composição podem ser associados com o velho, enquanto que os objetos posicionados à direita da tela, com o novo. Com base nessa noção, o semeador pode estar agindo hoje, mas ele se move em direção ao futuro. Ou seja, ele planta hoje para colher amanhã. Ele busca o sustento de amanhã. Ele também parece se mover para longe dos corvos, conotando que os corvos são elementos que conflitam com a sua tarefa de semear. Essa relação entre o semeador e os corvos pode assumir uma conotação simbólica conflitante entre os corvos e os significados metafóricos que semear assume. ${ }^{39}$

No terceiro plano, acima da linha do horizonte, temos o sol representado por seus raios que se dispersam radialmente pelo céu. Seus raios estão se movendo por meio de pinceladas contidas e diagonais, criando uma direção radial que nos comunica um significado expansivo e abrangente. Esse movimento é mais suave do que o movimento do gesto pictórico frenético que constrói os torrões do campo de trigo. ${ }^{40}$

\footnotetext{
${ }^{38}$ Ocorrência de Vetor 1 e Associação metafórica por meio de um caminho visual do primeiro plano para o último plano que constrói um movimento direcional e as metáforas de uma narrativa visual.

${ }^{39}$ Ocorrência de Vetor 2 construída pelo Semeador que anda e olha para a direita da tela. O Vetor constrói a Associação metafórica que o Semeador se desloca do passado para o futuro. Há também uma metáfora de conflito entre o significado simbólico dos corvos e o do semear.

${ }^{40}$ Ocorrência de Movimento, construida pela representação dos raios do sol que comunicam um movimento expansivo e abrangente.
} 


\subsubsection{Enquadramento}

De acordo com Kress e Van Leewen (1996, p. 124) o ângulo com que se representa o objeto intencionado comunica o distanciamento com o espectador:

$\mathrm{O}$ ângulo longo médio mostra a figura completa. No longo ângulo a figura humana ocupa cerca de metade da altura da estrutura, e o ângulo muito longo é qualquer coisa 'mais ampla' do que isso. Variantes estilísticas são possíveis, mas elas estão sempre vistas e faladas em termos desse sistema, como quando as peessoas de cinema e televisão falam de 'ângulos perto apertados' ou 'enquadramento apertado', ou sobre a quantidade de 'espaço de cabeça' em uma foto ( isto é, o espaço entre o topo da cabeça e a linha de armação superior). ${ }^{41}$

O enquadramento da composição mostra o semeador no segundo plano, de corpo inteiro e distanciado do espectador. Kress e van Leeuwen (1996) argumentam que a escolha desse ângulo de enquadramento denota uma certa impessoalidade entre o espectador e o semeador:

Distância pessoal Próxima' é a distância em que 'se pode segurar ou agarrar a outra pessoa' e, portanto, também a distância entre as pessoas que têm uma relação íntima com a outra. Não-íntimos não podem chegar tão perto e, se o fizerem, vai ser experimentado como um ato de agressão. 'Distância pessoal longe' é a distância que 'se estende a partir de um ponto que está fora da distância de contato por uma pessoa de um ponto onde duas pessoas podem tocar os dedos se ambos estender seus braços', a distância em que 'temas de interesses pessoais e envolvimentos são discutidos' $^{42}$ (KRESS; VAN LEEUWEN, 1996, p. 124).

No enquadramento do semeador, a distância não parece assumir esse sentido de impessoalidade, até porque o semeador está andando em direção ao espectador, em uma linha diagonal. Na cena, parece que o espectador é quem toma distância, e poderia se aproximar se realmente quisesse. Há uma tranquilidade e um aspecto relaxado no corpo do semeador que o torna afável aos olhos do espectador, familiar e convidativo. A distância se dá por uma condição de sua ação na cena, não por uma intencionalidade de representar o distanciamento do semeador com o espectador, já que ele semeia e está inteiramente tomado por esta tarefa,

\footnotetext{
${ }^{41}$ Tradução livre da autora. The medium long shot shows the full figure. In the long shot the human figure occupies about half the height of the frame, and the very long shot is anything 'wider' than that. Stylistic variants are possible, but they are always seen and talked about in terms of this system, as when film and television people talk of 'tight close shots' or 'tight framing', or about the amount of 'headroom' in a picture (i.e. space between the top of the head and the upper frame line). (KRESS; VAN LEEUWEN, 1996, p. 124).

42 Tradução livre da autora. 'Close personal distance' is the distance at which 'one can hold or grasp the other person' and therefore also the distance between people who have an intimate relation with each other. Nonintimates cannot come this close and, if they do so, it will be experienced as an act of aggression. 'Far personal distance' is the distance that 'extends from a point that is just outside easy touching distance by one person to a point where two people can touch fingers if they both extend their arms', the distance at which 'subjects of personal interests and involvements are discussed'. (KRESS; VAN LEEUWEN, 1996, p.124).
} 
sua condição o coloca a meia distância, entre o mundo dos homens e o mundo da natureza, entre a concretude da terra e a espiritualidade. ${ }^{43}$

Esse sentido se sobrepõe. No caso do semeador, podemos levar em consideração a intencionalidade de fazer uma pintura que representasse uma experiência espiritual, e que é descrita nas cartas como um desafio quase impossível, podemos inferir que a distância do semeador do espectador representa essa relação entre possibilidade/impossibilidade de vivenciar a profundidade do seu significado na experiência humana e ao mesmo tempo a sua concretude e onipresença nas coisas mais simples, como o ato de semear. ${ }^{44}$

Eles defendem que a proximidade ou distanciamento entre as figuras e o espectador depende apenas de uma relação imaginária que será construída pelos sentidos que o autor quis representar:

\begin{abstract}
A relação entre os participantes humanos representados em imagens e o espectador é mais uma vez uma relação imaginária. As pessoas são retratadas como se fossem amigos, ou como se eles são estranhos. Imagens nos permitem imaginariamente nos aproximar de figuras públicas como se fossem nossos amigos e vizinhos - ou olhar para pessoas como nós como estranhos, "outros". ${ }^{45}$ (KRESS; VAN LEEUWEN, 1996, p.126).
\end{abstract}

Talvez a distância do semeador mostra uma ambiguidade, ao mesmo tempo próximo, ao mesmo tempo distante, mas não impossível de estabelecer contato.

Observei o uso do ângulo plongee para representar o enquadramento da cena e que deixa em suspenso o ponto de vista com que se olha o campo. Inferi que o uso desse ângulo vertical pode ter tido a função de criar um estranhamento do espectador e levá-lo à um distanciamento da cena. ${ }^{46}$

\title{
5.4.2.5 Ritmo
}

O ritmo nessa composição desempenha uma função predominante, pois se encarrega de dar ao campo movimento, textura e direção, criando padrões nos torrões de terra que constroem a textura e a sensação ótica de terra revolvida. O ritmo tem uma função muito

\footnotetext{
${ }^{43}$ Ocorrência de Enquadramento na representação do Semeador no segundo plano, em pé, denota um certo distanciamento entre o espectador e a tela.

44 Ocorrência de Associação Metafórica e de Incompletude na contradição entre distanciamento do enquadramento e os outros recursos que convidam à aproximação e envolvimento.

45 The relation between the human participants represented in images and the viewer is once again an imaginary relation. People are portrayed as though they are friends, or as though they are strangers. Images allow us to imaginarily come as close to public figures as if they were our friends and neighbors - or to look at people like ourselves as strangers, 'others'. (KRESS; VAN LEEUWEN, 1996, p. 126).

${ }^{46}$ Uso do plongee para representar a cena, causa um certo distanciamento do espectador e estabelece a perspectiva com a qual van Gogh quis que o espectador olhasse a cena.
} 
básica na composição, construindo com seus padrões uma percepção visual de pulsação. ${ }^{47}$

Kress e Van Leeuwen (1996, p. 203) comentam a função do ritmo nos textos visuais:

Ritmo e equilíbrio também formam a maioria dos aspectos corporais dos textos, a interface entre nossos eus físicos e semióticos. Sem ritmo e equilíbrio, a coordenação física no tempo e no espaço é impossível. Eles formam uma matriz indispensável para a produção e recepção de mensagens e são vitais na interação humana. Além disso, é em algum forte grau do sentido de ritmo e do sentido de equilíbrio composicional que nosso prazer estético nos textos e nossas relações afetivas para os textos são derivadas. ${ }^{48}$

Van Gogh imprimiu ritmo para os torrões do campo arado e para os raios do sol por meio de pinceladas direcionais. Essa técnica que se tornou um sistema semiótico em si mesmo, van Gogh incorporou de vários outros artistas como explica Gombrich (1995, p. 541542):

A paisagem com o Monte Sainte-Victoire, no sul da França (Fig. 350), está banhada em luz e, no entanto, é firme e sólida. Apresenta um padrão lúcido e, ao mesmo tempo, dá-nos a impressão de grande profundidade e distância. Há uma sensação de ordem e repouso no modo como Cézanne marcou a horizontal do viaduto, a estrada no centro e as verticais da casa em primeiro plano, mas em nenhuma parte sentimos tratar-se de uma ordem imposta por Cézanne à natureza. Suas pinceladas estão dispostas de modo a coinciderem com as principais linhas do desenho e a reforçarem a sensação de harmonia natural. O modo como Cézanne alterou a direção das suas pinceladas sem recorrer nunca ao desenho de contornos pode ser também apreciado na Fig. 351, a qual mostra como o artista neutralizou deliberadamente o efeito do padrão plano que poderia ter resultado na metade superior, enfatizando as sólidas formas tangíveis das rochas no primeiro plano. Seu maravilhoso retrato da esposa (Fig. 352) revela-nos até que ponto a concentração de Cézanne em formas simples e bem-delineadas contribui para a impressão de equilíbrio e tranquilidade.

Van Gogh também incorporou a técnica de Cèzanne de usar as pinceladas, levando mais adiante porém, como explica Gombrich (1995, p. 543-544):

Cézanne deixara de aceitar como axiomáticos quaisquer dos métodos tradicionais da pintura. Decidira partir da estaca zero, como se nenhuma pintura existisse antes dele. O mestre holandês pintara sua natureza-morta para exibir um estupendo virtuosismo. Cézanne escolhera os seus motivos para estudar alguns problemas específicos que queria resolver. Sabemos que ele estava fascinado pela relação da cor com a modelação. Um sólido redondo, brilhante e colorido, como uma maçã, era um motivo ideal para explorar essa questão. Sabemos que ele estava interessado na realização de um desenho equilibrado. Pois por isso ele esticou para a esquerda o prato da fruteira, de modo a encher um vazio. Como queria estudar em suas relações todas as formas espalhadas sobre a mesa, esta foi simplesmente inclinada para frente, de modo a ficarem todas bem à vista. Talvez o exemplo seja sugestivo de como Cézanne se tornou o pai da "arte moderna". Em seu tremendo esforço para realizar uma sensação de profundidade sem sacrificar o brilho das cores, e para

\footnotetext{
${ }^{47}$ Ocorrência de Ritmo, Textura, Direção e Movimento pelo Gesto Pictórico de van Gogh para representar o campo arado.

${ }^{48}$ Tradução livre da autora. "Rhythm and balance also form the most bodily aspects of texts, the interface between our physical and semiotic selves. Without rhythm and balance, physical coordination in time and space is impossible. They form an indispensable matrix for the production and reception of messages and are vital in human interaction. Moreover, it is to quite some degree from the sense of rhythm and the sense of compositional balance that our aesthetic pleasure in texts and our affective relations to texts are derived." (KRESS; VAN LEEUWEN, 1996, p. 203).
} 
construir um arranjo ordenado sem sacrificar a sensação de profundidade - em todas as lutas e experiências havia uma única coisa que Cézanne estava preparado para sacrificar, sempre que fosse necessário: a "correção" convencional do lineamento. Não tinha o propósito deliberado de distorcer a natureza; mas não the importava muito se ela tivesse que ser distorcida em alguns detalhes de menor importância, desde que isso o ajudasse a obter o efeito desejado (...).

Essa característica de usar a pincelada para construir a sugestão de linhas e de caminhos visuais, bem como a distorção do ponto de vista foram recursos primeiro incorporados por van Gogh e depois desenvolvidos em sistemas semióticos mais complexos, como expõe Coli (2006, p. 46) ao imaginar como seria a narrativa de van Gogh de um autoretrato:

Nela, há um princípio constitutivo elementar: as minhas pinceladas direcionais se organizam de uma forma chamejante, como labaredas sinuosas que se resolvem em turbilhão. É um princípio que empreguei para pintar alguns ciprestes, alguns céus estrelados; no fundo do meu quadro, estas unidades-labaredas poderiam evocar os desenhos decorativos da moda art-noveau, se não fosse o prazer que eu tive em inventar o caminho próprio de cada uma dessas chamas, recusando a repetição sistemática. Assim, nesses motivos, há uma vida interna turbilhonante, essencial e não decorativa. Meu paletó e meu rosto participam também desse incêndio, incêndio particular, pois quis fazê-lo frio, com verdes, azuis e cremes, entremeados de violetas, rosas, e sobretudo desse amarelo-limão, uma das minhas cores preferidas. Em tudo isso, o poder das minhas pinceladas, sempre tão visíveis, tão materializadas, ao mesmo tempo criam o movimento e o cristalizam. Nessa fogueira vibrante, mas imóvel e fria, o colorido de meu rosto, de minha pilosidade avermelhada, se destaca: os cabelos vão para trás, as sobrancelhas e a barba são minúsculas chamas paralelas e ativas. Sublinhei a boca com um pouco de vermelho, como se nela um traço de sangue corresse. Acentuei bastante minhas pálpebras para que meus olhos sobressaíssem, franzi os sobrolhos numa interrogação.

\subsubsection{Pinceladas Direcionais}

Van Gogh usou as pinceladas direcionais para criar, por meio de pontos e traços curtos, a sugestão de linhas e de caminhos visuais, de aguçamento, de saliência. Mesmo quando as pinceladas são da mesma cor, ele as distingue pelo uso do empasto, criando uma sinergia entre a textura, o ritmo, o movimento e a direção de suas pinceladas. A essa sinergia chamei na pesquisa de gesto pictórico. Coli (2006, p. 82), comenta sobre a articulação entre a textura, ritmo e direção por meio de pinceladas:

Como sempre, sua composição é perfeita, estruturada, organizada, pensada. Mas a natureza que nela é vazada nunca é estática, porque os elementos coloridos que a constituem são feitos de toques direcionais do pincel que guardam uma textura rítmica intrínseca. E a concepção do quadro desenvolve um prodígio de associações de ritmos diferentes - circulares, oblíquos, verticais - que possuem força tão intensa porque são determinados em registros claros, num conjunto seguro. 


\subsubsection{Textura}

A textura aqui é alcançada por meio da técnica do empasto e por meio do gesto pictórico. Van Gogh articulou diferentes recursos como textura, ritmo, movimento e direção em um sistema semiótico que aqui chamei de gesto pictórico para construir movimento direcional e caminhos visuais, por exemplo. A textura também foi usado na composição para criar uma saliência para o campo, que dificilmente passa desapercebido pelo espectador. $\mathrm{Na}$ escolha dos recursos semióticos, van Gogh deu maior centralidade para o uso da textura na representação do campo arado, ele concentra o maior tratamento de textura dado para a composição, dando a ele uma grande saliência em relação aos outros elementos e indicando que o campo arado concentra maior significação na narrativa. ${ }^{49}$ A saliência que van Gogh quis dar ao campo arado é confirmada pelo uso dos contrastes simultâneos de azuis, amarelos, lilazes e roxos em partes proporcionais, criando uma atmosfera pulsante na grande área que representa o campo. Essa pulsação é ultimamente aguçada pelo contraste do campo com o céu. Essa rica trama cromática e de textura do constrói uma relação sensorial do espectador com o campo arado. Essa relação sensorial construída pela materialidade da tinta nos remete a materialidade da terra, pela relação sensorial e tátil com a plasticidade da textura. $\mathrm{O}$ efeito tátil da textura desperta sentidos sensoriais, sinestésicos e as nossas memórias da nossa relação com a terra, condensando associações metafóricas e efeitos de sentidos relacionados com as nossas primeiras experiências corporais com a terra e com a luz solar que a inunda. Dessa forma, a textura foi usada por van Gogh para construir um sentido próximo e até mesmo íntimo com as qualidades da terra, do toque, do tato, das sensações. A combinação da textura com as cores construída pelas cores de contrastes simultâneos justapostas lado a lado nas pinceladas conduz a uma atmosfera sobrenatural e efusiva que acumula efeitos de sentidos simbólicos para todas as experiências que o campo vazio a espera de sementes nos suscitam. ${ }^{50}$

Há um segundo uso de textura como efeito de saliência e esse uso foi dado para o sol e os raios do sol, construindo um efeito de iridescência salientados pelo uso duplicado da cor amarelo no sol, nos raios e no céu. O detalhamento e ênfase foi dada para o sol como o segundo elemento mais importante na tela, observado tanto em seu posicionamento quanto na textura e na cor não natural dada para o sol e o céu, "um sol amarelo sobre um céu amarelo".

\footnotetext{
49 Ocorrência do uso conjugado de Textura, ritmo, movimento, direção, gesto pictórico e saliência na representação dos torrões de terra revolvida no campo arado.

50 Ocorrência de Textura, Contrastes Simultâneos, Saliência, Sinestesia e Associações Metafóricas da materialidade da tinta com a nossa memória sensorial e tátil da plasticidade da terra.
} 
Os sentidos dados para o campo arado, o sol e o céu na composição serão discutidos na função representacional. ${ }^{51}$

\subsubsection{Movimento}

A percepção de movimento na composição pode ser alcançada pela articulação de diversos recursos tais como as linhas, formas, planos, textura, direção, gestos e direção do olhar das figuras representadas, e pela direção das pinceladas na construção de caminhos visuais. Assim como o ritmo, a direção e a textura, o movimento também é construído pelas pinceladas, ou seja, pelo gesto pictórico. Na composição, o movimento mais evidente é o do semeador, que caminha pelo campo distribuindo as sementes fazendo uma ação vetorial equivalente, no modo textual, ao processo material semear. ${ }^{52}$

Mas há um outro movimento, que parece mais central e por isso mais importante: o dos raios do sol que estão visíveis por meio do gesto pictórico e da textura. Essa ação vetorial dos raios do sol pode ser considerada equivalente ao processo existencial. Materialmente, os raios brilham no céu, mas semanticamente, é sugerido que eles se prolongam no espaço do campo arado, sendo esse vetor muito central na construção de um recurso unificador de rima visual e na construção de um sentido integrador para os sentidos que de outro modo estariam divididos em dois domínios: o do céu e o da terra. ${ }^{53}$

\subsubsection{Cor}

Van Gogh se apropriou da técnica impressionista da mistura das cores no olho do espectador. Os impressionistas inovaram na noção de produzir cores a partir da técnica de misturar as tintas direto na tela, ao invés de misturá-las na paleta, pela sobreposição de pinceladas de cores diferentes, deixando que o olho ou o cérebro faça a mistura na hora de apreender a imagem. Gombrich (1995, p. 544) explica as implicações dessa inovação técnica e semiótica na pintura:

Enquanto Cézanne se batia por uma conciliação dos métodos do impressionismo com a necessidade de ordem, um artista bem mais jovem, Georges Seurat (1859-91),

\footnotetext{
${ }^{51}$ Ocorrência de Contrastes de Saturação, Saliência, Associação Metafórica e Incompletude na representação do céu e do sol, em amarelo sobre amarelo.

${ }^{52}$ Ocorrência de Movimento, Gesto Pictórico e Vetor 1, sugerido pelo andar do Semeador.

${ }^{53}$ Ocorrência de Movimento, Gesto Pictórico, Vetor 2, Rima Visual e Incompletude, sugerido pelos raios do sol em toda a pintura.
} 
dispôs-se a enfrentar essa questão como se fosse uma equação matemática. Usando como ponto de partida o método impressionista da pintura, estudou a teoria científica da visão cromática e decidiu construir seus quadros por meio de pequenas e regulares pinceladas de cor ininterrupta como um mosaico. Esperava ele que isso levasse à mistura das cores no olho (ou, melhor dizendo, no cérebro), sem que perdessem sua consistência e luminosidade. Mas essa técnica extrema, que se tornou conhecida como pontilhismo, pôs naturalmente em perigo a clareza de suas pinturas ao evitar todos os contornos e decompor cada forma em áreas de pontos multicores. Seurat foi assim impelido a compensar a complexidade da sua técnica pictórica por uma simplificação de formas ainda mais radical do que Cézanne jamais cogitara (Fig. 354). Existe algo quase egípcio na ênfase de Seurat sobre as verticais e horizontais, que o levou a distanciar-se cada vez mais da reprodução fiel das aparências naturais e no sentido de uma exploração de padrões interessantes e expressivos.

Van Gogh incorporou muitas das novas técnicas dos impressionistas e dos pontilhistas, no entanto, ao aplicá-las, deu um passo adiante no sentido de usar as pinceladas soltas e inacabadas, ${ }^{54}$ e de usar a disposição das cores puras na própria tela para construir uma estrutura formal para a composição por meio de caminhos visuais, direção e movimento, como expõe Gombrich (1995, p. 554):

Van Gogh acreditara que, rendendo-se às impressões visuais e explorando somente as qualidade ópticas da luz e da cor, a arte corria o perigo de perder a intensidade e a paixão através das quais - e só através das quais - o artista pode expressar seus sentimentos e transmiti-los aos seus semelhantes.

\subsubsection{Sinestesia}

Com o uso dos contrastes complementares entre azuis e alaranjados e lilazes e amarelos van Gogh criou um efeito visual de contraste simultâneo no qual cada cor potencializam o efeito da sua complementar. Walther e Metzger (2015, p. 421) encontram uma forma de explicar o mecanismo e a função semiótica da sinestesia:

Intensidade e tranquilidade, uma sensibilidade subtil e um gosto pelo vulgar e inacabado, tudo isso contribuía para este processo - Huysmans, ao escrever um encómio a Stéphane Mallarmé, o poeta simbolista por excelência, definia a sinestesia nos seguintes termos: "Ele repara na correspondência mais remota e, frequentemente, através de uma única palavra que transmite a forma, o aroma, a cor, as características e o esplendor por analogia, apresenta-nos um objeto ou um ser para o qual seriam necessários muitos e vários epítetos, se quizéssemos descrever tecnicamente os seus traços distintivos e nuances." Não foi só na literatura que a sinestesia se valeu das analogias. A alusão é utilizada como forma de evocar recordações de vários géneros de percepção; ao introduzirem um vasto repertório de informação cultural, as coisas simples levam a associações com coisas complexas, é aqui que entra Van Gogh: a sua é uma arte de analogia - analogia de significado e de forma.

\footnotetext{
${ }^{54}$ Ocorrência de Inacabamento na representação do campo arado. Devido à técnica de pintar aprendida com os pontilhistas e aperfeiçoada para um sistema semiótico próprio, o Inacabamento pode ser observado como uma parte integrante do Gesto Pictórico.
} 
Esse efeito, operado pelo contraste simultâneo, acontece na retina do espectador, pois cria um jogo de sinergia e alternância cromática dessas cores que intensifica toda a área do campo arado e que, junto com a textura, o ritmo e o movimento criam um efeito de sinestesia entre a textura tátil do empasto e a textura ocular da trama cromática. ${ }^{55}$ Walther e Metzger (2015, p.418-421) explicam a sinestesia quando ela se torna o efeito oposto do resultado que se produziu, em termos semióticos:

"Temos de copiar dos povos de origem não-européia", escreveu Gottfried Semper,
arquiteto e gênio dirigente do movimento das artes, "a arte de capturar aquelas
melodias simples e compreensíveis da forma e da cor que o instinto introduz nas
obras do Homem quando estas estão no seu estado mais simples, mas que são cada
vez mais difíceis de localizar e registrar se os meios disponíveis forem mais
sofisticados." Semper fala em "melodias", dando o típico salto intelectual que
reaplica o princípio sofisticado da sinestesia ao que é primitivo. Van Gogh seguiu o
mesmo raciocínio sofístico ao prestar homenagem a Wagner: "Se intensificamos
todas as cores, recuperamos a paz e a harmonia. É semelhante ao que acontece com
a música de Wagner - não é por ser tocada por uma grande orquestra que deixa de
ser menos íntima. Mas preferimos atmosferas coloridas e cheias de Sol e penso
frequentemente que, no futuro, muitos pintores hão de ir pintar para os trópicos."
(Carta W3) Também ele pensava de forma dialética, vendo o sentimentalismo de
Wagner como tranquila simplicidade. Para os simbolistas, este foi o_grande mistério
da sinestesia: uma vez que o artifício está em seu pico, de repente, reverte em seu
oposto, tornando-se a base de uma nova simplicidade. Intensidade e calma, uma
sensibilidade sutil e um gosto para o grosso e inacabado, tudo desempenha um papel
neste processo.

Para ilustrar, Walther e Metzger (2015, p. 433) discutem uma comparação feita por van Gogh sobre a sinestesia em Wagner:

\begin{abstract}
"Ah, meu querido amigo", escreveu Van Gogh a Gauguin (Carta 573a), em jeito de desabafo, "para fazer da pintura o que a música de Berlioz e Wagner já conseguiu ser uma arte reconfortante para os corações despedaçados! Há poucos que tenham já sentido isto como tu e eu sentimos." Segundo o ponto de vista de Van Gogh, Wagner não era o romântico que ressuscitara o sentimentalismo na ópera e fundira todas as artes - a arte de Wagner era reconfortante e só por isso é que era notável. O facto de estar a criar uma Gesamtkunstwerk era simplesmene secundário para a comunicação e solidariedade humanas. A arte de Van Gogh aproxima-se da de Wagner: "A minha única preocupação", disse Vincent a Theo na Carta 576, "é realmente poder um dia oferecer-te cerca de trinta estudos de alguma importância, capazes de ter dar uma impressão genuinamente reconfortante do trabalho do artista." A arte significava solidariedade humana, conforto e compaixão. Comparadas com a devoção pessoal de Van Gogh pela compaixão, as subtilezas estéticas dos simbolistas pareciam jogos triviais. Van Gogh não mostrava relutância em participar nesses jogos; mas tudo o que fazia tornava-se rapidamente muito sério.
\end{abstract}

Em outras palavras, a ambiência criada pelas pinceladas, ritmo, movimento, textura, produzem um efeito de sinestesia e que nos remetem para a experiência tátil do contato sensorial com a terra. Essa experiência com a materialidade da tela nos remete também para a nossa experiência física e corporal de se estar no mundo, do tocar a terra, sentir seus grãos,

\footnotetext{
${ }^{55}$ Ocorrência de Sinestesia produzida pelo contraste simultâneo que potencializa o efeito da textura tátil e da textura visual.
} 
sua porosidade, sua textura, sua aspereza, sua maleabilidade, sua plasticidade assim como sentimos a plasticidade da tela. ${ }^{56}$

\subsubsection{Saliência}

A saliência se refere ao uso de recursos visuais utilizados para conferir ênfase aos elementos representados e atrair a atenção dos expectadores, por exemplo: o tamanho, as cores intensas ou com alta temperatura, uma proporção distorcida, como explicam Kress e van Leeuwen (1996, p. 201):

Mas a composição de uma imagem ou de uma página também envolve diferentes graus de saliência nos seus elementos. Não importa onde eles estão posicionados, a saliência pode criar uma hierarquia de importância entre os elementos, selecionando alguns como mais importantes, mais valiosos de atenção do que outros. O Dado pode ser mais saliente do que o Novo, por exemplo, ou o Novo mais saliente do que o Dado, ou ambos podem ser igualmente salientes. E o mesmo se aplica ao Ideal e Real, e ao Centro e Margem. ${ }^{57}$

Van Gogh construiu uma ênfase para o campo arado, o semeador e o sol. Essa ênfase ele alcança pelo uso conjugado de vários modos tais como ritmo, textura, movimento, direção, perspectiva, enquadramento e outros, construindo um discurso visual coeso e dinâmico que conduz o nosso olhar pelos campos da composição sem perder o sentido de unidade fortemente amarrado pela conversa entre os modos que se reforçam na construção da narrativa visual. Essa coesão entre os modos também corrobora na construção da rima visual. ${ }^{58}$

\subsubsection{Análise da Função Representacional da tela O Semeador}

\footnotetext{
${ }^{56}$ Ocorrência de Associação Metafórica da materialidade pictórica com a nossa experiência física e corporal de tocar a terra e sua plasticidade.

57 Tradução livre da autora. "But the composition of a picture or a page also involves different degrees of salience to its elements. Regardless of where they are placed, salience can create a hierarchy of importance among the elements, selecting some as more important, more worthy of attention than others. The Given may be more salient than the New, for instance, or the New more salient than the Given, or both may be equally salient. And the same applies to Ideal and Real and to Centre and Margin.” (KRESS; VAN LEEUWEN, 1996, p. 201).

${ }^{58}$ Ocorrência de Saliência, Rima Visual, construída pelo uso conjugado de vários recursos.
} 


\subsubsection{Escolha do tema}

Para falarmos do que se passa na função representacional nessa tela, será preciso antes, compreendermos o que estava se passando na vida de van Gogh e no seu contexto de situação. A tela $O$ Semeador foi pintada após a morte de seu tio Cor. Este evento parece ter suscitado em Van Gogh uma ligação mais profunda com suas raízes da Holanda, com sua infância próxima de um ambiente eminentemente rural, sua familiaridade com os trabalhadores das lavouras, seu amor inefável pela natureza, seu imaginário repleto de figuras de linguagem proferidas nos sermões do pastor e pai Theodorus Van Gogh. Inferi que, na realização desta tela, Vincent parece adotar um ponto de vista ainda mais atemporal e misterioso do que seus estudos dos campos de trigo e das colheitas em Arles, que é construído pela atmosfera sobrenatural da coloração do ocaso sobre o campo arado. Com ela, ele parece comunicar questões transcendentes que o tomaram nesse momento: o sentido da vida, o sentido da morte, os ciclos que se sucedem e como é preciso morrer para nascer, assim como o trigo.

A tela em seu caráter metafórico parece um manifesto de suas crenças, de sua visão de mundo, de sua filosofia de vida: adensados ao longo de seus anos de formação familiar, de definição de sua identidade, de afirmação de suas escolhas; condensada em uma composição que acumula elaboradas camadas de sentidos, longamente urdidos na incessante maquinaria de van Gogh e enunciados de forma sintética e brilhante. Como atestam as cartas de van Gogh, $O$ Semeador não foi uma tela temporã, mas antes longamente amadurecida, secretamente ansiada e negociada nos interstícios de seu desejo:

\footnotetext{
E o esboço como tal - uma tela número 25 - também me preocupa muito, no sentido de que eu me pergunto se eu não deveria levar a sério e fazer uma pintura tremenda disso. Meu Deus, como eu adoraria fazer isso. Mas eu só me pergunto se eu vou ter o poder necessário de execução. (...) Eu estou colocando o esboço de lado assim como é, mal ousando pensar nisso. (...) Por um longo tempo ele foi meu grande desejo de fazer um semeador, mas os desejos que tive por um longo tempo nem sempre são alcançados. Então, eu estou quase com medo deles. E, no entanto, depois de Millet e Lhermitte o que resta a ser feito é ... o semeador, com cor e em um grande formato. (VAN GOGH, 2009e, p. 1).
}

\subsubsection{Simbolismo no tema}


Petrie analisa a diferenciação entre o discurso impressionista e o discurso simbólico de van Gogh, comprometido com um sentido filosófico, com uma mensagem ao mesmo tempo ética e estética:

\begin{abstract}
No meio das suas próprias paisagens, teve sempre tendência para valorizar mais as que apresentavam um forte impulso lírico para além de uma mera caracterização expressiva, em quadros como o Semeador dotados de um sol simbólico (ilut. 35) ou a Noite Estrelada (ilust. 48). Essas obras não são "literárias", no sentido narrativo da The Pilgrim's Progress de Boughton, mas também não permanecem bem dentro dos limites do mundo fenomenal, como as paisagens impressionistas. Os sentimentos associados a certas obras narrativas foram por vezes preservados, mesmo que a própria narração o não tenha sido. "O Impressionismo - salientou ele relevantemente - não vos compromete com coisa alguma." (PETRIE,1984, p.8).
\end{abstract}

Van Gogh compartilhou com os pintores Gauguin e Bernard as ideias do simbolismo como evidenciam Walther e Metzger (2015, p.427-428):

\begin{abstract}
"A poesia simbolista", escreveu Jean Moréas, "procura vestir a Idéia de uma forma sensível, o que não constitui um fim em si mesmo mas está subordinado à Ideia que se quer expressar. Por outro lado, quando a Ideia surge, ela não devia despojar dos elaborados adornos das analogias alusivas, pois é próprio da essência da arte simbolista nunca exprimir diretamente uma ideia." Tantos simbolistas e tantos manifestos! A qualidade literária do movimento pode ser apreciada na enorme quantidade de publicações, periódicos, afirmações e teorias existentes. Os simbolistas serviram-se frequentemente da forma escrita - livros, poemas e assim por diante - para lançar uma "ideia". Este método foi tacitamente adotado por todos, casando bem com a prática artística de van Gogh, já que ele também era um artista conceptual. Quando escolhia o seu motivo, há muito que tinha em mente uma ideia ou tema. As pinturas de Van Gogh estão verdadeiramente recheadas de significado. Também ele seguiu o princípio de "nunca exprimir diretamente uma idea". E nós só conseguimos descodificar o seu simbolismo oculto se estivermos familiarizados com as fontes literárias de que se valeu para envolver o seu trabalho de significado. Todos os seus motivos - os girassóis e o semeador, da mesma maneira que os escavadores e barcos - são mais do que simples objetos ou pessoas. Só ficam completos com determinadas associações literárias.
\end{abstract}

De acordo com Kress e van Leeuwen (1996, p. 106), nos processos simbólicos sugestivos, nos quais só há um participante que é o portador, o significado e a identidade são representados como um valor que está vindo de dentro do portador que tem essas qualidades em sua essência. Nos processos atributivos simbólicos, nos quais há dois participantes, o Portador e o Atributo, o significado e identidade são representados como valores que estão sendo conferidos ao Portador. Nos processos nos quais há apenas um participante, chamados de processos sugestivos simbólicos, a ênfase que é dada ao Portador busca favorecer uma 'ambiência' que é construída com o uso de alguns recursos semióticos tais como as cores: o brilho, a transparência, a intensidade cromática, os contrastes; a suavidade dos contornos, a iluminação intensificada. O sentido sugestivo do Portador é construído por essa atmosfera, e dá a ele uma qualidade de essência geral na qual os detalhes emprestam um valor simbólico 
pela associação com as características da ambiência, por exemplo, uma atmosfera de brilho dourado constrói valores associados com qualidade da suavidade e luminosidade.

Observei na tela $O$ Semeador, a ocorrência de um processo sugestivo simbólico, no qual a atmosfera de luz difusa do ocaso constrói um sentido imanente para o Semeador, com atributos e identidade que são inerentes a ele. Esse processo simbólico se confirma pelo tratamento dado a luz que está difusa por toda a tela e deixa o semeador como uma silhueta, porque está sendo visto contra o sol. Toda a luz que irradia do céu envolve o semeador e o campo arado, dando ênfase para a ambiência da luz e das cores do dia que começa ou que termina. Para isso, van Gogh diminuiu o detalhe da representação e favoreceu os efeitos gerais produzidos pelos contrastes de cor simultâneos que empresta um estado de espírito intenso que infundiam o Portador significados simbólicos. ${ }^{59}$ Kress e Van Leeuwen (1996, p. 105) comentam sobre essa dinâmica:

Processos simbólicos se tratam do que o participante significa ou é. Ou existem dois participantes - o participante cujo sentido ou identidade é estabelecido na relação, o Portador, e o participante que representa o significado ou identidade em si mesmo, o Atributo Simbólico - ou existe apenas um participante, o Portador, e nesse caso o significado simbólico é estabelecido de outra forma, a ser descrita abaixo. O primeiro tipo de processo nós chamaremos de Atributivo Simbólico; o último, Sugestivo Simbólico. ${ }^{60}$

\subsubsection{Interdiscursividade}

A inferência de que van Gogh instância uma superposição de outros discursos na tela O Semeador foi possível com base na análise de Edwards a respeito da interdiscursividade encontrada em outra tela, a Natureza morta com Bíblia aberta e novela de Zola:

Inesperadamente, seu pai morreu quando voltava para casa de uma visita paróquia
em 1885, e Vincent procurou homenagear a vida do pai, organizando em uma mesa
uma natureza morta com a Bíblia do pai, uma vela apagada, e um muito desgastado
livro de bolso amarelo. Ele descreveu a pintura que ele estava prestes a enviar para
Theo: Eu envio-lhe uma natureza morta de uma Bíblia aberta - assim um branco
gasto - encadernada em couro contra um fundo preto com um primeiro plano
marrom amarelo com um toque de amarelo-limão. (Carta 429) (...) A descrição
discreta de Vincent possui várias camadas de significados que emergem quando se
estuda essa pintura. Certamente a ponderosa Bíblia do pai e a vela extinta indicam a
profissão do pai e a sua morte. O "toque de amarelo citron" parece uma intrusão,

\footnotetext{
${ }^{59}$ Ocorrência de Associação Metafórica e Incompletude construídos pela luz difusa que constrói um sentido de ambiência que envolve toda a cena e constrói significados simbólicos.

${ }^{60}$ Tradução livre da autora. Symbolic processes are about what a participant means or is. Either there are two participants - the participant whose meaning or identity is established in the relation, the Carrier, and the participant which represents the meaning or identity itself, the Symbolic Attribute - or there is only one participant, the Carrier, and in that case the symbolic meaning is established in another way, to be described below. The former type of process we will call Symbolic Attributive; the latter, Symbolic Suggestive. (KRESS; VAN LEEUWEN, 1996, p.105).
} 
uma novela de Paris barata e desgastada com a sua autoria e título claramente à vista. ${ }^{61}$ (EDWARDS, 2009, p.19-20).

Edwards (2009, p.22-23) prossegue analisando a interdiscursividade presente na tela Natureza morta com Bíblia aberta e novela de Zola:

Intérpretes desta pintura em geral perdem seu significado intencionado. Jan Hulsker, no The New complet Van Gogh, encontra forte contraste entre a Bíblia aberta com Isaías e o título da novela, 'La Joie de vivre' (208). HR Graetz, em 'A linguagem simbólica de Vincent Van Gogh,' similarmente coloca toda a ênfase em cima do contraste: $\mathrm{O}$ pequeno romance em frente à Bíblia pesada simboliza a oposição entre o modo de vida moderno e a forte tradição religiosa com a condenação em Isaías da alegria de viver - de joie de vivre. (40-42) (...) Graetz, de fato, é culpado de um duplo erro. Primeiro, ele interpreta mal Isaías. Longe de ser um profeta sisudo de condenação, Isaías é um profeta de canto, celebração e regozijo. Porque Deus provê um servo que carrega o sofrimento dos outros, a humanidade é convidada a "romper cantando" (Isaías 54: 1), para "vir comprar vinho e leite sem dinheiro e sem preço" (Isaías 55: 1). Anunciando que a humanidade está curada pelo agente, Isaías chama a sua mensagem de "boas novas" ou "evangelho" (Isaías 61: 1). (...) Mas o erro mais grave, compartilhado pela maioria dos intérpretes, é a ênfase sobre a pintura como uma intenção simples de contraste entre o romance de Zola e a Bíblia: a Bíblia virtuosa e resistente defronte a um livro de bolso berrante e frágil. Isso, de fato, é o nível superficial de interpretação que Vincent lutou contra. É a visão defeituosa exibida por seu pai e outros intérpretes "acadêmicos", a própria visão que levou seu pai a mandá-lo para fora da casa paroquial. Aqueles que se concentram sobre o contraste entre a Bíblia e o romance de Zola são culpados da omissão perpetrada pelo Pastor van Gogh. Eles não estão dispostos a ler o romance de Zola e ponderar a sua mensagem: "Muitas vezes eu disse para o pai, em seguida, basta lê-lo, até mesmo algumas páginas desse livro, e você vai ficar impressionado mesmo; mas o pai se recusa obstinadamente" 62 (Carta 159).

\footnotetext{
${ }^{61}$ Tradução livre da autora. "Unexpectedly, his father died when returning home from a parish visit in 1885 , and Vincent sought to honor his father's life by arranging on a table a still life with his father's Bible, a snuffed-out candle, and a much worn yellow paperback novel. He described the painting he was about to send to Theo: (p.19) I send to you a still life of an open - so a broken white - Bible, bound in leather against a black background with a yellow brown foreground with a touch of citron yellow. (Letter 429) (...) Vincent's understated description holds several layers of meaning that emerge as one studies that painting. Certainly his father's ponderous Bible and the extinguished candle indicate his father's profession and death. The "touch of citron yellow" seems an intrusion, a cheap and worn Parisian novel with its authorship and title clearly in view." (EDWARDS, 2009, p.19-20).

${ }^{62}$ Tradução livre da autora. "Interpreters of this painting have generally missed its intended meaning. Jan Hulsker, in The New Complete Van Gogh, finds stark contrast between the Bible opened to Isaiah and the novel's title, La Joie de vivre (208). H.R. Graetz, in The Symbolic Language of Vincent Van Gogh, similarly places all the emphasis upon contrast: The little novel in front of the weighty Bible symbolizes the opposition between the modern way of life and the strong religious tradition with the condemnation in Isaiah of joy in living - of joie de vivre. (40-42) (...) Graetz, in fact, is guilty of a double error. First, he misinterprets Isaiah. Far from being a dour prophet of condemnation, Isaiah is a prophet of singing, celebration, and rejoicing. Because God provides a servant who carries the suffering of others, humanity is invited to "break forth into singing" (Isaiah 54:1), to "come buy wine and milk without money and without price" (Isaiah 55:1). Announcing that humanity is healed by the servant, Isaiah calls his message "good tidings" or "gospel" (Isaiah 61:1). (...) But the more serious error, shared by most interpreters, is the emphasis upon the painting as intending a single-minded contrast between Zola's novel and the Bible: the virtuous and sturdy Bible over against a garish and flimsy paperback novel. That, in fact, is the shallow level of interpretation Vincent struggled against. It is the faulty view exhibited by his father and other "academic" interpreters, the very view that had led his father to order him out of the parsonage. Those who focus on the contrast between Bible and Zola novel are guilty of the omission perpetrated by Pastor van Gogh. They have not been willing to read the Zola novel and consider its message: "So often I have said to father, then just read it, even a few pages of such book, and you will be impressed yourself; but father obstinately refuses" (Letter 159). (EDWARDS, 2009, p.22-23).
} 
Assim como na tela Natureza morta com Bíblia aberta e novela de Zola, também na tela O Semeador observa-se uma sobreposição de discursos. Enquanto van Gogh faz uma associação metafórica inevitável com a parábola do novo testamento, ele também está falando de um semeador que é um lavrador, um trabalhador do campo, sugerindo a interposição de dois discursos um religioso e um social. Sabemos que a tela O Semeador começou como um desenho copiando uma pintura de Millet também sobre um semeador, e evoluiu para uma outra concepção de representação muito distinta daquela. A justaposição de dois discursos e de duas interdiscursividades tornam esta tela extremamente instigante. Enquanto ' $O$ Semeador' da parábola é uma metáfora que transcende nossa visão cotidiana e oferece uma reflexão sobre o nosso propósito na terra, na existência, 'O Semeador' de Millet é um sujeito histórico que trabalha na terra; ela nos fala de uma condição laboral, do trabalho no campo característico de uma classe social que sofre exploração. O semeador também se refere a uma condição social que van Gogh deseja enunciar, em toda a sua beleza e complexidade, e em todo o seu resplendor, indexando inevitavelmente em seu texto, o texto de pintores realistas como Millet, e romancistas realistas como Zola. ${ }^{63}$

Dessa forma, a história de leituras sugere que a escolha do tema na obra de van Gogh condensa diferentes camadas de sentidos caros para ele: a sua formação religiosa com forte apelo para as metáforas das parábolas bíblicas, a admiração pela corrente do realismo na pintura e na literatura, os valores humanistas e socialistas, a sua empatia e identificação com os trabalhadores do campo, a sua crítica à industrialização e ao desfavorecimento das classes trabalhadoras pela mais valia. Estes temas aparecem justapostos na tela O Semeador, que parece ser uma congregação de vozes e discursos que circularam em seu tempo e que van Gogh se apropriou, referendou e enunciou pictoricamente e que a seguir irei examinar.

\subsubsection{O Céu e a terra}

Em termos de valor de informação, o solo, ou o campo arado está mais centralizado e mais valorizado do que o céu, indicando que é nele que a ação principal se desenvolve. De acordo com Kress e Van Leeuwen (1996), o valor de informação do topo pode representar o ideal e o valor de informação da base, o real, como parece ocorrer nessa composição que sugere um forte apelo para os sentidos metafóricos sobre os assuntos da terra e do céu. Os sentidos da terra estão associados ao plano terreno da vida, aqui representados pela lida, pelo

\footnotetext{
${ }^{63}$ Ocorrência de Interdiscursividade e Intertextualidade. Foi identificada a superposição do discurso religioso e
} do discurso social e político da época, bem como elementos de outros textos visuais e escritos. 
lavrar a terra e obter-se o sustento. Os sentidos do céu estão associados ao plano espiritual; aqui representados pelo sol e pela luz, uma forte associação metafórica para a luz divina no imaginário de nossa cultura ocidental. ${ }^{64}$

Na composição observei que dois terços da tela estão ocupados pelo campo arado. No entanto, apesar de ocupar apenas um terço do espaço, o céu tem uma elaborada construção de recursos semióticos tais como o gesto pictórico de pinceladas ritmadas, que geram o efeito de ritmo, textura, movimento e direção, articuladas por pinceladas diagonais que divergem do ponto concêntrico que o sol ocupa. Cromaticamente, o céu se funde e é uma continuação do sol, criando um efeito de sentido de que o céu e o sol estão integrados em sua natureza mais essencial, a de propagar luz e calor para a terra e para os homens que nela trabalham. A semelhança de tons amarelos entre o céu e o sol exprime que o céu e o sol a outro domínio, diverso do domínio terreno e humano. O sol é uma estrela, um corpo celeste que transita o céu. Céu e sol, portanto, fazem parte desse domínio, que sugere associações de uma realidade eterna, divina, diversa da realidade humana e terrena. ${ }^{65}$

Céu e o sol têm uma vibração cromática intensa, e que constrói uma atmosfera de calor que pode ser associada com sentidos simbólicos, tais como a luz, o calor, a vibração, a vida. Céu e o sol estão cromaticamente em contraste simultâneo com o solo, que está representado por tons de azuis, lilazes, cinzas, marrons e brancos sugerindo uma contraposição metafórica entre os significados do domínio celeste e os significados do domínio terreno. ${ }^{66}$

\subsubsection{A Natureza e o homem}

O sol ocupa o lugar de centralidade na tela enquanto o Semeador está posicionado e se orienta mais em direção à periferia da tela, conotando no valor de informação que o sol, como uma metáfora da natureza ou como um símbolo do mundo espiritual é o mais importante enquanto o ser humano ocupa uma posição secundária nessa relação. A localização do sol no topo superior da tela confirma essa associação do sol como um significado de ideal, enquanto

\footnotetext{
${ }^{64}$ Ocorrência de Associação Metafórica de teor religioso, sugerida pelo valor de informação contido na divisão do espaço da composição.

${ }^{65}$ Ocorrência de Saliência e Associação Metafórica para o céu e o sol, construída pelo uso de ritmo, textura, movimento e direção articulados pelo gesto pictórico.

${ }^{66}$ Ocorrência de Associação Metafórica, construída pelo contrates simultâneo sugere contraposição metafórica de significados do céu e da terra.
} 
o homem, que está posicionado no solo, na parte da base da tela está associado com o valor de informação do domínio do real. ${ }^{67}$

No posicionamento dos demais componentes da composição vemos à extrema esquerda da tela uma casa e à extrema direita da tela um bosque. A casa, estando posicionada à esquerda, pode conotar um valor de informação conectado com o passado, enquanto o bosque, à direita pode significar o futuro. O posicionamento do bosque como o valor de Novo, mostra quão alto van Gogh valorizava a Natureza, ${ }^{68}$ como relata Walther (1990, p. 65):

O esforço principal de Vincent era aproximar-se tanto quanto possível da natureza. Através de toda a sua vida o acompanha esta relação directa, erótica para com a Natureza: "Não é tanto a linguagem do pintor, como é a da natureza que se tem de escutar." Captar esta força vital era a intenção primária da sua pintura que devia atingir a "raiz ou o princípio das coisas". Van Gogh queria penetrar na vida tão profundamente quanto possível e, por assim dizer, sentir-lhe a pulsação.

Outra questão surge na composição do espaço: enquanto o campo arado e o campo maduro são áreas construídas por meio da horizontalidade na composição, o Semeador se organiza na verticalidade. A linha horizontal conota um sentido de descanso, de acolhimento, o mesmo sentido da própria terra, um sentido de estabilidade, de aceitação, de durabilidade, de recepção. A linha vertical exprime um sentido de inquietação, de ação, de interação com a linha horizontal. É a linha vertical que interfere na linha horizontal, que delimita sua continuidade, que intervém em seu descanso, que a fecunda. A forma do sol é circular, cíclica, contínua, perene, perfeita. De seus raios saem linhas diagonais, em sentido radial, que conotam a expansão, a comunicação, a força unificadora, a integração do ambiente pelo alcance dos seus raios. Nessa organização da composição por meio das formas mais simples, observei três instâncias de enunciação: o céu, com seu estatuto do domínio do que é perene, espiritual; a terra com sua constância e continuidade, suporta, recebe, gesta, germina; e o humano, que atua, inicia, interfere. A relação dessas três instâncias se dá por meio dos processos vetoriais: o sol ilumina, aquece, dá a vida. A terra recebe e concebe, o homem semeia, labora, fecunda. Essas três instâncias podem sugerir uma associação metafórica com a divina trindade, ou com um triângulo entre o sol, a terra, e o ser humano ou a união entre o divino, o terreno e o humano. ${ }^{69}$

\footnotetext{
${ }^{67}$ Ocorrência de Saliência e Associação Metafórica pelo posicionamento relativo do Sol na composição, ocupando o centro e a parte superior da tela.

${ }^{68}$ Ocorrência de Associação Metafórica pela posição relativa dos membros casa e bosque na composição, dando maior ênfase para o bosque que simboliza os valores da Natureza.

${ }^{69}$ Ocorrência de Associação Metafórica e Vetor, construída pelas formas e movimentos direcionais de horizontalidade, verticalidade e radiais dos membros na composição que sugerem a união do divino, do terreno e do humano.
} 
A tela é rica em sentidos condensados e possibilidades de associações metafóricas. Apesar de aparentemente ser uma composição sintética, van Gogh construiu um sistema semiótico complexo, com muitas camadas de significação no qual ele dá para a Natureza um sentido mítico, religioso, como explica Walther (1990, p. 68)::

\begin{abstract}
Aqui abre-se caminho a uma nova concepção do mundo que o não entende mais como vale de lágrimas, mas a que também não nega simplesmente um princípio superior de vida a seu favor. Do encontro com os poderes originais da existência, que ele descobriu na Natureza, provém a sua mística da Natureza onde se vai fundir a sua pintura. Com isto se quer exprimir a sua disposição total de se abandornar à Natureza, de se identificar com ela.
\end{abstract}

\title{
5.4.3.6 Os ciclos da terra
}

O plantar e o colher são outro eixo de significação contido na narrativa. Enquanto vemos um campo arado e pronto para a semeadura, vemos no horizonte um campo maduro, pronto para colheita. O campo colhido é azul, e é frio. O campo maduro é laranja e é quente. Os dois campos estão contrapostos e se complementam. Essa contraposição nos fala da passagem do tempo, e dos ciclos. Este campo já foi como aquele, maduro e sua colheita já foi feita. Está limpo e vazio, pronto para um novo cultivo. Aquele campo está maduro, e em breve será colhido, depois arado e cultivado. Os significados dos dois campos está associado ao uso simbólico da cor. O campo maduro tem suas cores quentes, o campo colhido, frias. Há uma contraposição de estados, de condições, mas que também indica um rodízio dessas condições, que é cíclico. Esse movimento cíclico nos remete à própria existência na terra, enquanto algumas coisas estão em seu auge, e prontas para serem colhidas, outras já alcançaram o seu propósito e agora estão sendo esvaziadas para dar lugar a novos processos e acontecimentos. É como a passagem do tempo, é como própria vida. Cada campo pode significar uma etapa em nossas vidas que, se em um momento estão plenas, em outro podem estar vazias e cansadas. Cada campo pode significar que não somos eternos e que um dia, seremos como o campo arado. ${ }^{70}$

\footnotetext{
${ }^{70}$ Ocorrência de Associação Metafórica construída pelo uso simbólico da cor para construir o significado cíclico do plantar e do colher e outras associações de sentidos potenciais são sugeridas como vida e morte.
} 


\title{
5.4.3.7 Simbolismo na Cor
}

A representação sobrenatural das cores como van Gogh representa a luz e as cores na composição é confirmada por Walther e Metzger (2015, p. 446-447):

\begin{abstract}
Van Gogh descreveu à irmã (Carta W9) as suas intenções nesta pintura: "Não sei se consegues entender que é possível fazer poesia através apenas de um bom arranjo de cores, tal como se pode transmitir uma sensação de conforto através da música. Além do mais, as linhas bizarras, quase artificiais e repetitivas que se cruzam ao longo de todo o quadro não pretendem representar o jardim tal como ele é normalmente, mas como nós o veríamos num sonho, no seu verdadeiro aspecto, ainda que, simultaneamente, parecesse mais estranho do que na realidade." Como ele próprio diz (com palavras que podiam ser de Gauguin, e provavelmente até eram), Van Gogh estava interessado nas linhas "bizarras, quase artificiais", que afastavam a sua cena da realidade cotidiana. A pintura constitui um exercício deliberado de analogia das formas. Havia um preço muito alto a pagar: para pintar desta forma, Van Gogh tinha de abandonar os motivos originais e mergulhar na sua própria imaginação. Estava, até certo ponto, a criar imagens vindas de dentro de si, que, de outro modo, teriam sido fornecidas diretamente pelas coisas do mundo. Tal como o próprio título indica, o quadro é um exercício de memória, de evocação do passado, característica que permite ligá-lo a outros quadros da mesma altura, tais como O Semeador (pp. 446 e 447), O Salão de Baile de Arles (pp. 464-465) e Espectadores na Arena, em Arles (p.466). "A arte é abstração", segundo a definição de Paul Gauguin, "deve-se deduzir a abstração da natureza a partir dos sonhos e pensar mais no nosso trabalho criativo e nos seus resultados do que na realidade." Van Gogh manteve-se fiel a esta máxima com forte determinação.
\end{abstract}

A experiência com a luz da Provença marcou o cromatismo de van Gogh, ele deixou de representar naturalisticamente as cores, e experimentou com o cromatismo arbitrário e simbólico.Walther e Metzger (2015, p. 354) também descrevem a representação fantasiosa da luz do sol que não ilumina o semeador nem o campo:

Este quadro põe em evidência todo o significado do trabalho de Van Gogh durante aqueles primeiros meses no Sul. Em primeiro lugar, inclui o reconhecimento da área circundante, o seu afeto por tudo o que era característico da Provença: o seu semeador está igualmente na vasta planície de La Crau. Em segundo lugar, a pintura traz-lhe recordações da sua terra natal, que levam o artista a optar por motivos que lhe são familiares. A figura do semeador é retirada de um desenho da fase inicial (p.20), em que ele estava a copiar Millet. Em seguida, temos a procura da luz inerente às coisas e a sua tendência para excluir todas as fontes de luz das suas imagens. Nem mesmo o Sol gigantesco que se ergue por cima do horizonte consegue espalhar o seu amarelo poderoso por todo o lado: e nem o semeador nem a quinta do último plano parecem estar iluminados por ele. Finalmente, temos ainda a autonomia da cor, que ele agora levou um pouco mais longe: na pintura do semeador, o céu azul e os sulcos lavrados de um bege terra mudaram de cor. ${ }^{71}$

\footnotetext{
${ }^{71}$ Tradução livre da autora. This picture focuses the entire significance of van Gogh's work during those first few months in the south. First, it includes his reconnaissances of the surrounding area, his affectionate interest in all that was characteristic of Provence: his sower, too, is on the broad plain of La Crau. Second, the painting offers memories of his homeland, memories that prompt the artists to choose motifs that are of a familiar nature. The figure of the sower is even quoted from an early drawing (p.20) in which he was copying Millet. Then there is van Gogh's quest for the light within things, and his tendency to banish light sources from his pictures. Even the giant sun rising over the horizon fails to spread its powerful yellow everywhere: neither the sower nor the farmstead in the background seems lit by it. And finally there is the colour autonomy, which he has now taken a striking step further: in the sower painting, the blue sky and earthy beige ploughed furrows have exchanged colours. (WALTHER; METZGER, 2012, p. 360).
} 
Ele passou a usar cores puras, intensificando-as por meio do contraste simultâneo entre as cores complementares. Nessa tela, o contraste simultâneo opera em dois eixos principais pelo uso do contraste entre azuis e alaranjados e do contraste entre lilazes e amarelos. Essas cores trabalham no sentido de intensificar a sua cor complementar e viceversa, produzindo uma pulsação por meio de pequenos choques cromáticos nas pinceladas com cores opostas que estão posicionadas lado a lado. Oticamente, elas produzem um efeito ocular rebatimento, competindo pela atenção, se chocando, e produzindo uma vibração que empresta à composição uma ambiência de cor fugidia e sobrenatural, de difícil apreensão. Esse esquema de cores trouxe para a tela uma intensidade exuberante com a qual ele construiu a atmosfera de luz fugidia da aurora. ${ }^{72}$ Ribeiro $(2000$, p. 83 ) relata como van Gogh narrou esta tela para seu irmão:

(...) um grande campo arado, cheio de torrões de terra, na sua maior parte francamente roxos. Um campo de trigo maduro, em uma tonalidade ocre-amarelada, com um toque de carmim. O céu é de um amarelo-cromo, quase tão brilhante quanto o próprio sol, que é cromo-amarelado 1, com um pouco de branco enquanto o resto do céu é amarelo-cromo $\mathrm{n}^{\circ} 1$ e 2 misturados. Tudo muito amarelo. A camisa do semeador é azul e suas calças, brancas" (...).

Enquanto formalmente a composição nos apresenta uma narrativa simples, cromaticamente ela oferece um uso elaborado de sistemas semióticos que condensam diferentes camadas de associações metafóricas. O sentido simbólico dado ao campo arado é confirmado pelo tratamento com que van Gogh o representa, construindo uma atmosfera cromática fantástica, sobrenatural que, de acordo com Kress e Van Leeuwen (1996) são indicadores de uma conotação de sentidos simbólicos. O uso da cor funciona para atribuir significados para os episódios e participantes. Dessa forma, o uso da cor é arbitrário apenas no sentido em que não acompanha uma representação naturalista da natureza. No entanto, a finalidade do uso da cor não é arbitrária: segue ao propósito de representar uma narrativa simbólica. ${ }^{73}$

\subsubsection{Conclusão da análise visual da tela 'O Semeador'.}

Nesta tela van Gogh representou basicamente dois campos de trigo, um no primeiro plano, arado, pronto para ser semeado e outro no terceiro plano, maduro e pronto para ser

\footnotetext{
${ }^{72}$ Ocorrência de Contrastes Cromáticos Complementares de azuis e lilazes em contraposição com laranjas e amarelos, causa uma ambiência de vibração e intensidade para representar a luz do ocaso, e são compatíveis com a ocorrência de uma Distorção do Ponto de vista.

${ }_{73}$ Ocorrência de Uso Simbólico da Cor para conferir Associação Metafórica para os episódios, participantes e membros da pintura.
} 
colhido. No terceiro plano, observei uma contraposição do campo maduro com o campo arado no primeiro plano, que também adquire contornos simbólicos: o campo maduro tem cores quentes. Estas se contrapõem às cores frias do campo arado. Além disso, o campo maduro está alinhado com o céu e o sol pelo seu cromatismo, por isso, seus sentidos estão associados aos sentidos que possam ser atribuídos ao sol e ao céu: calor, vida, força, nascimento, crescimento, auge, plenitude, colheita, fatura, generosidade, alegria, abundância, dons e dádivas. Se formos pela metáfora religiosa da parábola do Semeador, também esse campo de trigo maduro pode significar o alcance da missão na terra, o semear e o colher, no domínio espiritual, tendo laborado ao longo da existência. ${ }^{74} \mathrm{~A}$ cor amarela também assume um estatuto semiótico no período em que ele pintou os campos e as colheitas, como defende Haziot (2010, p. 203):

O amarelo havia feito sua aparição no livro de A alegria de viver pousado junto à bíblia paterna; também o vimos como um grito de amor no fundo do retrato de Agostina Segatori. Alguns quiseram descobrir na predileção por essa cor uma doença da visão em Vincent, que o faria ver tudo em amarelo. Mas essa doença, chamada xantopsia também enfraquece os azuis, e assim a hipótese de uma tal afecção não se aplica a um pintor cuja força dos amarelos irá crescer com a dos azuis. Além disso, o exame da obra mostra que o amarelo só se inflama no período arlesiano depois dos pomares; está menos presente em Saint-Rémy, e o período de Auvers-sur-Oise é marcado por uma tonalidade fria, de dominante azul.

O simbolismo da cor sugere o sentido potencial para os dois campos de trigo. O campo arado tem cores frias significando a morte, a ausência, o recolhimento, a interiorização, o término, o recomeço, a lacuna, o recesso, o interstício, a passagem entre o fim e o começo. Esse sentido está reforçado com a ambiguidade do horário que a cena está acontecendo: o ocaso, a passagem entre o dia e a noite, ou entre a noite e o dia, o horário quando não é nem noite fechada, nem pleno dia. É o horário de transição no céu que está espelhado no campo arado, um período de transição no qual nada ainda aconteceu, está em estado de repouso e de espera para o que virá. Esse estado de latência inunda a tela toda, está ricamente representado pela atmosférica feérica com que van Gogh representou o céu e seu primeiro (ou último) raio tocar no solo do campo de trigo arado. É um toque leve, suave, indireto, difuso, que deixa grandes sombras nos torrões de terra, e confunde a percepção das cores que já não refletem sua cor característica na luz cheia e abundante do dia. Os montões de terra revolvidos agora adquirem uma coloração fugidia, um tom furta-cor no qual a decomposição de cores pode ser observada: azuis, lilazes, cinzas, brancos, e marrons. Apesar de ter tons frios e representar a morte, a ausência, ou a espera, este é o campo que foi privilegiado pelo enquadramento. $\mathrm{O}$

\footnotetext{
${ }^{74}$ Ocorrência de Uso Simbólico da Cor para conferir Associação Metafórica para os sentidos simbólicos do campo maduro e do campo arado e da parábola do Semeador.
} 
campo, vazio, revirado, e de tons azuis e frios é o campo que não apenas está em primeiro plano, como também ocupa dois terços da tela. Esse fato não pode ser ignorado simplesmente. Este campo é a estrela da tela. ${ }^{75} 76$

Van Gogh quis representar o campo arado como sendo o participante principal, ou como o recipiente principal da ação do participante principal. No entanto, esse participante principal, o semeador, não está no primeiro plano, está no segundo plano e o enquadramento mostra uma distância social da figura do semeador. Dessa forma, o enquadramento revela que, apesar de, vetorialmente ser o semeador o participante principal, a saliência maior foi dada para o campo arado, trazendo este para o lugar de destaque, não para quem está comandando a ação principal, mas para quem está recebendo a ação principal. Observei que aqui ocorre uma inversão enunciativa. Se transpusesse essa enunciação para duas orações, nelas, o sentido principal sofreria um deslocamento da oração paratática: ' $O$ semeador semeia' para a oração hipotática: 'o campo arado recebe a ação de semear do Semeador'. Essa estratégia de deslocamento do sentido principal para a oração hipotática foi também observada em muitos complexos oracionais construídos nas cartas de van Gogh. Por causa do enquadramento escolhido por van Gogh, depreendi um outro sentido dessa relação: talvez a ação principal nessa narrativa não seja a de semear, mas a de receber a semeadura. A posição do campo no primeiro plano, pelo detalhamento dos contornos da terra revolvida por meio de textura e gesto das pinceladas, sugere que o campo é mais importante do que o Semeador, que se encontra no segundo plano e não está representado com tanto detalhamento. Esta observação levou a aventar a hipótese que o campo arado ocupa a posição paratática nesta imagem, e, portanto, carrega o vetor principal que compreende as ações realizadas pelo campo: a inação, a inatividade, a espera, a aceitação, o recebimento, o existir, e ser o recipiente de uma ação humana. O destaque é dado a terra, ao solo, a natureza, e as suas qualidades intrínsecas: a quietude, a estabilidade, a constância, a renovação, o tudo acolher, transformar, germinar, enquanto que o elemento humano ocupa o segundo plano e suas ações são, portanto, secundárias nesta narrativa. ${ }^{77}$

Este quadro abriga uma grande narrativa fundadora: a Natureza, que semioticamente van Gogh representou com a terra, a natureza que abriga, gera, germina, dá a vida, o sustento

\footnotetext{
${ }^{75}$ Ocorrência de Uso Simbólico da Cor para conferir Saliência e Associação Metafórica para os sentidos simbólicos do campo arado.

${ }^{76}$ Esta valorização do que aparentemente está destituído de valor é observada na tela 'O Café Noturno na Place Lamartine, em Arles', com um trabalho de contraposição e antítese de sentidos.

${ }^{77}$ Ocorrência de Enquadramento, Saliência, Vetor para construir a centralidade do campo na narrativa, e o sentido principal do enunciado que é o de receber a semeadura do semeador. Observei um deslocamento da agência da ação que é compatível com as ocorrências de deslocamento da agência da ação nas orações escritas por van Gogh.
} 
para a vida e todos os demais ciclos que por ela passam. Ele representou a natureza em processo, desde a abundância até o fenecimento e a promessa de renascimento. Para dar unidade a narrativa desse grande campo de experiência ele articulou micro-estruturas alcançadas pelas pinceladas de cores complementares justapostas e contrastadas, e uma macro-estrutura que constrói um espelhamento das cores do céu no solo, interligando essas duas áreas pelos raios solares e pela profusão de cores equivalentes distribuídas em todos os planos transformando a coesão textual em uma metáfora do que ele quis representar: a amálgama entre ser humano e natureza, o mito fundador do nosso vínculo primordial com a mãe terra. ${ }^{78}$

\subsection{ANÁLISE TEXTUAL DOS EXTRATOS RELATIVOS À TELA O SEMEADOR}

\subsubsection{Extrato $n^{\circ}$ 2a}

628 - To Emile Bernard. Arles, on or about Tuesday, 19 September 1888. (VAN GOGH, 2009c).

(Narrativa)

"Aqui está um esboço de um semeador: um grande campo lavrado com torrões de terra, na sua maioria fracamente cor de violeta.

Um campo de trigo maduro, de tom amarelo-ocre com um pouco de carmim.

O céu, amarelo-crómio, quase tão luminoso quanto o próprio Sol, que é amarelo-crómio $n^{o} 1$, misturado com um pouco de branco, enquanto o resto do céu é uma mistura dos amareloscrómios 1 e 2. Tão amarelo! A camisa do semeador é azul e as calças brancas. Tamanho da tela-25, quadrada.

(Comentário)

Há várias sugestões de amarelo no solo, tons neutros resultantes da mistura de violeta e amarelo; mas tenho travado uma luta diabólica para atingir a verdade das cores. Preferia muito mais fazer quadros naifs tirados de velhos almanaques, aqueles velhos "almanaques dos lavradores" nos quais o granizo, a neve, a chuva e o bom tempo são retratados de modo primitivo, como o Anquetin atingiu tão bem no seu A Colheita.

Não te vou ocultar que não desgosto da região, pois fui criado lá - ainda me encanta a magia das recordações do passado, de um desejo do infinito, do qual o semeador e o enfeixador são símbolos -, tanto quanto antes gostava.

(Comentário)

Mas quando eu farei o céu estrelado, então, essa pintura que está sempre na minha mente? $A i$, ai, é como nosso excelente amigo Cyprien diz, em 'En ménage' por JK Huysmans: as mais belas pinturas são aquelas que alguem sonha enquanto fuma um cachimbo em sua cama, mas

\footnotetext{
${ }^{78}$ Ocorrência de Associação Metafórica e Incompletude construída pela Rima Visual e pelo Gesto pictórico para representar a unidade entre o Homem e a Natureza.
} 
a qual ele não pinta. Mas é uma questão de atacá-las, no entanto, não importa o quão incompetente alguem pode sentir-se vis-à-vis as perfeições inefáveis do glorioso esplendor da natureza.

[...]

(Comentário)

Aqui está o que eu queria dizer sobre o branco e o preto. Vamos tomar o Semeador. A pintura é dividida em dois; metade é amarelo, o topo; a base é violeta. Bem, as calças brancas descansam os olhos e os distraem exatamente quando o contraste simultâneo excessivo de amarelo e violeta iriam irritá-lo. Isso é o que eu queria dizer. (VAN GOGH, 2009c, p. 1).

\section{Análise:}

Aqui está um esboço de um semeador: um grande campo lavrado com torrões de terra, na sua maioria fracamente cor de violeta.

\begin{tabular}{|l|l|l|}
\hline Aqui (tela) & está & $\begin{array}{l}\text { um esboço de um semeador: [um grande campo lavrado com torrões de terra, na } \\
\text { sua maioria fracamente cor de violeta.] }\end{array}$ \\
\hline Portador & $\begin{array}{l}\text { Processo } \\
\text { Relacional } \\
\text { Circunstancial }\end{array}$ & $\begin{array}{l}\text { Atributo } \\
\text { [elaboração dentro do grupo nominal] }\end{array}$ \\
\hline
\end{tabular}

Um campo de trigo maduro, de tom amarelo-ocre com um pouco de carmim.

\begin{tabular}{|l|l|l|}
\hline Um campo de trigo maduro, & de tom amarelo-ocre com um pouco de carmim. \\
\hline Grupo Nominal & $\begin{array}{l}\text { Atributo } \\
\text { [elaboração dentro do grupo nominal] }\end{array}$ \\
\hline
\end{tabular}

\section{Interpretação:}

A carta é um gênero narrativo. No primeiro momento ele narra o quadro: 'Aqui está um esboço..' por meio de processo relacional circunstancial. $\mathrm{O}$ atributo está em relação ao que está na tela.

No segundo momento ele está comentando sobre a tela: 'Há sugestões...', ele começa a explicar a tela, o que ele fez, o que ele sente em relação a tela. Ele passa a falar de si mesmo. Observei pela mudança na estrutura léxico-gramatical, já com complexos oracionais. Quando ele usa o processo relacional atributivo, ele está falando da tela. Que processos ele usa quando fala de si mesmo?

"Aqui está um esboço de um semeador: um grande campo lavrado com torrões de terra, na sua maioria fracamente cor de violeta. Um campo de trigo maduro, de tom amarelo-ocre com um pouco de carmim." (VAN GOGH, 2009c, p. 1).

Esta é uma oração complexa que, no entanto, está separada por um ponto onde deveria ser uma vírgula. Aparentemente Van Gogh usou o ponto para destacar um grupo nominal e 
com isso dar destaque para o atributo. ${ }^{79}$ Porque? Na primeira oração a tela é o Portador, que possui vários atributos dentro de um grupo nominal: "um esboço de um semeador: um grande campo lavrado com torrões de terra, na sua maioria fracamente cor de violeta" Ou seja, ele inicia o trecho da carta referindo-se à uma tela, cujo esboço tem como atributo um campo, e dentro deste campo, outros atributos. ${ }^{80} \mathrm{Na}$ segunda oração, que poderia integrar a primeira por meio de uma vírgula, o campo tornou-se o portador, e os atributos passam a ser as suas cores; "de tom amarelo-ocre com um pouco de carmim". Iniciando uma nova oração ele parece dar destaque para o campo e suas cores, como se já adentrando no mundo da tela. Ele já abandonou o lugar de distanciamento fora da tela para se referir às coisas representadas nela, e, tornando o próprio campo representado o participante principal que desencadeia os processos.

"Aqui está um esboço de um semeador: um grande campo lavrado com torrões de terra, Ina sua maioria fracamente cor de violetal. Um campo de trigo maduro, de tom amarelo-ocre com um pouco de carmim." (VAN GOGH, 2009c, p. 1).

Depois dos dois pontos, 'um grande campo' se constitui um aposto (um termo que explica outro termo) que explica a tela. 'Um grande campo' dá destaque para o atributo que tem uma oração hipotática de elaboração dentro do grupo nominal. Nesta oração, 'campo' é o principal item lexical e suas cores, são os seus principais atributos na construção da oração. ${ }^{81}$

Na segunda oração, 'Um campo de trigo maduro, de tom amarelo-ocre com um pouco de carmim', a forma como ele construiu o protagonismo das cores para narrar o campo de trigo maduro sugere que a oração é uma metáfora na qual o campo e a cor se tornam a mesma coisa, não são duas coisas separadas, indicando uma ocorrência de Associação Metafórica. Parece que ele tenta representar essa unidade e o protagonismo entre o trigo e a cor com a linguagem escrita, ao deixar ocultos os processos: "Um campo de trigo maduro, (tem) de tom amarelo-ocre com um pouco de carmim". ${ }^{82}$

1([[++]]2+) 2 O céu, amarelo-crómio, quase tão luminoso quanto o próprio Sol,// que é amarelo-crómio $\mathrm{n}^{\circ} 1, / / \mathbf{1}(\mathbf{1 + 2})+2$ (está) misturado com um pouco de branco, /enquanto o

\footnotetext{
${ }^{79}$ Ocorrência de Saliência por meio do uso de um ponto onde deveria haver uma vírgula para conferir destaque para um grupo nominal.

${ }^{80}$ Ocorrência de Enquadramento estabelecido pela escolha léxico-gramatical da agência da primeira oração, que coloca um esboço seguido de um grupo nominal que constrói o universo representado por van Gogh na tela.

${ }^{81}$ Ocorrência de Saliência na escolha léxico-gramatical de 'grande campo' que é acompanhado de um grupo nominal que atribui suas cores.

82 Ocorrência de Associação metafórica construída pela Saliência do grupo nominal que dá o atributo de cores para o campo de trigo, por meio de um apagamento do processo tornando o atributo e o portador uma só coisa. A Rima Visual é construída pelo apagamento do processo e por um sentido de superposição do sentido do campo ao sentido das cores que lhe são atribuídas.
} 
resto do céu é uma mistura dos amarelos-crómios 1 e 2 . Tão amarelo! /// ^ A camisa do semeador é azul // +2 e as calças brancas. Tamanho da tela - 25, quadrada.

\begin{tabular}{|l|l|l|l|l|l|}
\hline O céu, & $\begin{array}{l}\text { amarelo- } \\
\text { crómio, }\end{array}$ & $\begin{array}{l}\text { quase tão luminoso } \\
\text { quanto o próprio Sol, } \\
\text { (Portador) }\end{array}$ & que & é & $\begin{array}{l}\text { amarelo-crómio } \mathrm{n}^{\circ} 1, \\
\text { misturado com um } \\
\text { pouco de branco, }\end{array}$ \\
\hline Portador & Atributo & Atributo & Item lexical & $\begin{array}{l}\text { Proc. Rel. } \\
\text { Atributivo } \\
\text { intensivo }\end{array}$ & Atributo \\
\hline
\end{tabular}

enquanto o resto do céu é uma mistura dos amarelos-crómios 1 e 2. Tão amarelo!

\begin{tabular}{|l|l|l|l|}
\hline $\begin{array}{l}\text { enquanto o resto } \\
\text { do céu }\end{array}$ & é & uma mistura dos amarelos-crómios 1 e 2. & Tão amarelo! \\
\hline Portador & Proc. Rel. Atributivo & Atributo & \\
\hline
\end{tabular}

\section{$1(1+2)+2$}

O céu, amarelo-crómio, quase tão luminoso quanto o próprio Sol, //que é amarelo-crómio $\mathrm{n}^{\circ} 1, / /$ (está) misturado com um pouco de branco, / (Narrativa)

enquanto o resto do céu é uma mistura dos amarelos-crómios 1 e 2. Tão amarelo! (Oração hipotática temporal)

\section{Interpretação:}

Nesta oração o que está mais enfatizado é o esforço de van Gogh em explicar e descrever as suas escolhas no processo de produção da tela e também de explicitar a concepção do resultado que ele esperava antes da produção da tela e o que ele iria fazer para alcançar o resultado. O que fica mais evidente é como esse ideal que ele imagina e representa na tela vai ganhando uma autonomia existencial tanto que quando ele descreve, ele próprio se surpreende: “Tão amarelo!”. Após a narração da tela, ela passa a ser o Portador e o autor passa a ser o narrador da existência desse Portador, indicando uma ocorrência de Incompletude.

Como isso aparece no discurso textual? Esse distanciamento entre o autor e a obra aparece com a ausência de um sujeito que tenha intensionado a representação do quadro, que tenha produzido, e que tenha percebido a tela. ${ }^{83}$

Há um predomínio da atribuição, que se refere ao contexto do momento que é a busca de representar um céu que seja tão luminoso quanto o sol, e o resto do céu seja igualmente

83 Ocorrência de de Transparência, Incompletude, Enquadramento e Perspectiva na organização léxicogramatical na qual ele coloca tela como o agente Portador dos atributos das cores idealizadas no esboço. 
luminoso. Em resumo: “O céu que é amarelo, quase tão luminoso quanto o sol (que é amarelo), enquanto o resto do céu é amarelo. Tão amarelo!” (VAN GOGH, 2009c, p. 1).

Ou seja, ao criar uma correspondência entre amarelo e luminoso, van Gogh constrói uma metáfora para o atributo luminoso por meio do atributo da cor amarela na construção da representação do sol e do céu, em especial ao terminar a oração com a exclamação: "Tudo é tão amarelo", que muito bem poderia ser substituída por: "Tudo é tão luminoso" (VAN GOGH, 2009c, p. 1). E sua ênfase está na descrição da cor e no uso da cor na produção desta luminosidade. A descrição do atributo da cor "amarelo-crómio", "amarelo-crómio nº1, misturado com um pouco de branco", "uma mistura dos amarelos-crómios 1 e 2" é a narração do processo de representação da tela. ${ }^{84}$ Essa representação constrói uma sequência que é análoga à ocorrência de Ritmo e de Gesto Pictórico. O circuito criado pela recorrente escolha do item lexical céu é compatível com a ocorrência de Rima Visual.

A predominância do atributo 'amarelo', que aparece quatro vezes neste complexo oracional, deixa claro que o participante principal não é o portador: 'céu' e 'sol', mas seus atributos, as cores. A segunda parte do complexo oracional é uma oração hipotática intensificadora temporal, que identifica só um aspecto externo que é a cor. Esta oração retoma o item 'céu' que abre e fecha a oração, criando um circuito léxico-gramatical, ou seja, 'o céu é tão amarelo quanto o sol, enquanto o resto do céu é amarelo'. ${ }^{85}$

O processo para relatar a execução de uma tela poderia ter sido o processo material, então van Gogh poderia ter relatado esse processo usando os processos materiais, como por exemplo: "eu usei o amarelo cromo", "eu misturei amarelo com branco", "eu criei um céu amarelo", "eu pintei um céu tão luminoso quanto o sol”. O fato de ele não usar o processo material evidencia o seu modo peculiar de se representar como artista, que é o de viver o seu trabalho como o do ceifador que lida diretamente com a natureza das coisas. Ele está falando da natureza desse céu, muito embora esse céu não existisse antes dele criar, é dessa maneira que ele se relaciona com as coisas, na inteireza de como as coisas se apresentam para ele. Ele experiencia a sua produção como ela sendo a coisa e não a representação da coisa. Por isso ele se coloca como um relator, um observador, ao invés de se colocar como um autor. ${ }^{86}$

\footnotetext{
${ }^{84}$ Ocorrência de Saliência e Associação Metafórica pela equiparação do sentido de 'luminoso' para o 'sentido de amarelo'.

${ }^{85}$ Ocorrência de Rima Visual, Gesto Pictórico e Ritmo, construída por uma sequência de escolhas lexicais que é análoga a ocorrência de ritmo e de gesto pictórico. O circuito criado pela recorrente escolha do item lexical 'céu' é compatível com a ocorrência de Rima Visual.

${ }^{86}$ Ocorrência de Enquadramento, Perspectiva, Transparência, Incompletude e Limiar Artístico na escolha léxicogramatical de como ele organiza a oração de modo a deslocar a agência da ação de si para a natureza que está sendo representada, como um ente em seu próprio direito.
} 
$1+2$ - A camisa do semeador é azul e as calças brancas.

\begin{tabular}{|l|l|l|l|}
\hline A camisa do semeador & é & azul & e as calças brancas. \\
\hline Portador & Proc. Rel. Atributivo & $\begin{array}{l}\text { Atributo [elaboração dentro do } \\
\text { grupo nominal] }\end{array}$ & \\
\hline
\end{tabular}

Tamanho da tela - 25, quadrada.

\begin{tabular}{|l|l|l|}
\hline Tamanho da tela -25, & (é) & quadrada. \\
\hline Portador & Processo Relacional Atributivo & Atributo - identificada \\
\hline
\end{tabular}

Há várias sugestões de amarelo no solo, tons neutros resultantes da mistura de violeta e amarelo; mas tenho travado uma luta diabólica // para atingir a verdade das cores.

\begin{tabular}{|l|l|}
\hline Há & várias sugestões de amarelo no solo, tons neutros resultantes da mistura de violeta e amarelo; \\
\hline Processo & Existente \\
Existencial & \\
\hline
\end{tabular}

\begin{tabular}{|l|l|l|l|}
\hline mas (eu) & tenho travado & uma luta diabólica & $\begin{array}{l}\text { para atingir a verdade das } \\
\text { cores. }\end{array}$ \\
\hline Experienciador & $\begin{array}{l}\text { Processo Mental } \\
\text { Desiderativo (estabelecido) }\end{array}$ & Fenômeno & Outra ação \\
\hline
\end{tabular}

$1^{\wedge}+2(\alpha \times \beta)$

ALFA - Há várias sugestões de amarelo no solo, tons neutros resultantes da mistura de violeta e amarelo;

BETA Oração hipotática por extensão - mas tenho travado uma luta diabólica para atingir a verdade das cores.

\section{Interpretação:}

Há várias sugestões de amarelo no solo, tons neutros resultantes da mistura de violeta e amarelo; mas tenho travado uma luta diabólica para atingir a verdade das cores.

$\mathrm{Na}$ oração Alfa, encontram-se as ocorrências da narrativa da cor e do processo de representação da tela. Quando ele utiliza o processo existencial para descrever as cores do solo ele modaliza com o item lexical "sugestões" de amarelos e de tons neutros. Essa modalização é bem diferente da intensificação que ele usa para descrever a presença do amarelo no céu, na oração anterior: "O céu, amarelo-crómio, quase tão luminoso quanto o próprio Sol, que é amarelo-crómio $\mathrm{n}^{\circ} 1$, misturado com um pouco de branco, /enquanto o resto do céu é uma mistura dos amarelos-crómios 1 e 2 . Tão amarelo!”. O processo relacional atributivo que ele usa para narrar o céu é diferente do processo existencial que ele usa para 
narrar a terra. Por que, ao narrar o céu ele usa o processo relacional atributivo e para narrar a terra, ele usa o processo existencial? Porque o céu se altera, se modifica, está em movimento, o vento se move, as cores do sol mudam, enquanto a terra está representando algo mais estável, que não é volúvel, que não é mutável. ${ }^{87}$ Embora o trigo esteja sendo semeado, embora haja uma mudança acontecendo, essa mudança só acontece pela presença do Semeador. Por si mesma a terra não se altera. Talvez por isso ele tenha escolhido, ao descrever a terra, o processo existencial.

Já na oração hipotática por extensão 'mas tenho travado uma luta diabólica para atingir a verdade das cores', van Gogh passa para o processo mental desiderativo, com o termo 'tenho travado' no sentido de 'estabelecido', mas dessa vez ele se coloca como o experienciador, ainda que de forma oclusiva 'mas (eu) tenho travado'. Por que ao falar de um processo mental como uma luta interna ele oculta o sujeito experienciador? ${ }^{88}$

A escolha lexical indica uma intensificação do processo que ele representa por meio dos itens 'travado' e 'luta diabólica' e que sugere um processo extremado para chegar ao conhecimento das cores. O sentido principal deste complexo oracional está na oração hipotática, sugerindo um deslocamento de 'planos' causando um efeito de 'profundidade' no enunciado. $^{89}$

Essa representação de luta na oração se assemelha, é compatível com a representação da tela do semeador que, tendo atravessado uma noite escura, se encontra em um campo para receber os primeiros raios do sol e fazer a sua semeadura. Semanticamente esta representação de luta se assemelha, no nível gramatical da tela, com o contraste simultâneo que produz um tipo de embate entre as cores. Esse embate visual também produz, visualmente, um sentido no nível semântico que é compatível com o sentido da oração. Ou seja, o sentido produzido no nível semântico da oração é compatível com um sentido que é produzido no nível gramatical da tela (contraste cromático) e com um sentido que é produzido em seu nível semântico (conflito, embate, oposição).

No nível semântico da oração, o sentido de uma luta que ele trava para atingir a verdade das cores é compatível com a representação visual do contraste cromático que é sentido de embate cromático. Metaforicamente, essa construção da luta que ele trava para

\footnotetext{
${ }^{87}$ Ocorrência de Associação metafórica no nível léxico-gramatical sugerida pela mudança de processo na oração alfa para a oração beta que simbolizam as qualidades que ele associa ao céu e a terra.

${ }^{88}$ Ocorrência de Transparência pela escolha do processo mental para expressar sua experiência subjetiva ao combinar as cores.

${ }^{89}$ Ocorrência de Profundidade, Enquadramento e Perspectiva no nível gramatical, já que o sentido principal foi deslocado para a oração hipotática.
} 
chegar a verdade das cores, parece com o próprio processo da existência em busca da verdade, não das cores, mas da vida, na qual se trava uma luta diabólica antes que se encontre a luz. ${ }^{90}$

No momento de conceber a tela van Gogh se coloca como participante principal, ainda que oclusivo, na busca 'espiritual' da verdade das cores. Simbolicamente, a essencialidade de uma verdade na natureza coloca como possível a expressão da verdade divina. E nesta busca van Gogh representa o processo como uma batalha contra o mal, a falsidade, a inverdade, a superficialidade. Ele exige do resultado do seu trabalho a inteireza da concepção espiritual da verdade. No momento de falar do processo não poupa adjetivos para explicar seu compromentimento com a verdade das cores. Para ele as cores representam a própria Vida, a Natureza, a Espiritualidade, a Divindade, que ele representa e experiencia na pintura, havendo compatibilidade da escrita tanto no nível léxico-gramatical quanto no nível semântico. ${ }^{91}$

"Há várias sugestões de amarelo no solo, tons neutros resultantes da mistura de violeta e amarelo; mas tenho travado uma luta diabólica para atingir a verdade das cores." (VAN GOGH, 2009c, p. 1).

O conectivo 'mas' liga a ação que produziu o solo ao ideal de representação do uso das cores para van Gogh e o 'mas' também sugere uma limitação na existência do amarelo quando ele se mistura ao violeta e aos tons neutros. Na oração anterior, a descrição de van Gogh não tinha nenhuma possibilidade do uso de 'mas' porque as cores eram os participantes principais. Nesse momento em que ele descreve o solo, há uma hesitação que presentifica a representação do solo, como um processo construído pelo autor, como por exemplo, as palavras que denotam imprecisão. A escolha lexical 'Várias' denota imprecisão na oração, e a escolha 'tons neutros' que são resultado de uma mistura, imprecisão em relação ao amarelo no solo, resultando que o amarelo se torne apenas uma 'sugestão' de cor e não a cor em si. Esse sentido de imprecisão de cores no solo constrói uma área de ambiguidade que representa uma imprecisão que as cores adquirem na luz do ocaso e sugere que van Gogh estava empenhado em representar como ele experienciava a verdade das cores de acordo com a iluminação do momento. Por isso, ele vai atrás da verdade das cores de acordo com a iluminação do momento. ${ }^{92}$

\footnotetext{
${ }^{90}$ Associação metafórica no nível semântico da oração, é compatível a associação metafórica contida nos contrastes complementares na tela, no nível semântico com a metáfora de conflito e embate, e no nível gramatical com a contraposição cromática que resulta do contraste entre cores opostas.

${ }^{91}$ Observei a ocorrência da Transparência, Incompletude e Limiar Artístico na escolha do construto 'a verdade das cores'.

${ }^{92}$ Ocorrência de Inacabamento e Incompletude, por meio da escolha léxico-gramatical 'mas', 'várias' e 'tons neutros' que sugere imprecisão na oração.
} 
Preferia muito mais // fazer quadros naifs [[tirados de velhos almanaques, aqueles velhos "almanaques dos lavradores" ((nos quais o granizo, a neve, a chuva e o bom tempo são retratados de modo primitivo,))]] como o Anquetin atingiu tão bem no seu A Colheita.

\begin{tabular}{|l|l|l|l|}
\hline (Eu) & Preferia & $\begin{array}{l}\text { muito mais //fazer quadros naifs } \\
\text { [[tirados de velhos almanaques, } \\
\text { aqueles velhos "almanaques dos } \\
\text { lavradores" [[nos quais o granizo, a } \\
\text { neve, a chuva e o bom tempo são } \\
\text { retratados de modo primitivo,]]] } \\
\text { Fenômeno }\end{array}$ & $\begin{array}{l}\text { como o Anquetin atingiu tão bem } \\
\text { no seu A Colheita. }\end{array}$ \\
$\begin{array}{l}\text { Experienciador } \\
\text { Processo } \\
\text { Mental } \\
\text { Emotivo }\end{array}$ & $\begin{array}{l}\text { Circunstância de Modo } \\
\text { Comparação }\end{array}$ \\
\hline \\
$\boldsymbol{\alpha}^{\prime} \boldsymbol{\beta}[[\boldsymbol{\alpha} \neq \boldsymbol{\beta}]] \boldsymbol{\alpha}\left(\boldsymbol{\alpha}^{\prime} \boldsymbol{\beta}[[\boldsymbol{\alpha}=\boldsymbol{\beta}]]\right) \mathbf{x} \boldsymbol{\beta}$ \\
$\boldsymbol{\alpha}^{\wedge} \mathbf{x} \boldsymbol{\beta}$
\end{tabular}

ALFA - Preferia muito mais fazer quadros naifs tirados de velhos almanaques, aqueles velhos "almanaques dos lavradores" nos quais o granizo, a neve, a chuva e o bom tempo são retratados de modo primitivo,

BETA - como o Anquetin atingiu tão bem no seu A Colheita.

\section{Interpretação:}

O quadro que van Gogh idealiza está apenas como esboço. Neste trecho van Gogh não faz críticas ao modo de representação ingênua, nem tão pouco minimiza sua relevância. Ao reconhecer que Anquetin 'atingiu' a representação da região onde van Gogh viveu e ao dizer que 'preferia muito mais fazer quadros naifs' ele dá indícios de que o que o motiva a fazer os quadros não é a sua preferência em relação à técnica e nem a possibilidade de 'atingir' uma representação da natureza, já que ele poderia e preferiria atingir a representação da natureza pelo modo naif também. Porém, seu modo de pintar, diferente do modo naif, implica em uma luta diabólica explicitada na oração anterior.

Van Gogh usa o processo mental emotivo para se referir a um tipo de representação pelo qual ele tem afeto, uma representação ingênua (naif) dos almanaques que retratam a natureza de modo primitivo. No entanto, este não é o tipo de representação que ele faz atualmente, e essa oposição fica implícita quando ele diz 'preferia muito mais fazer quadros naifs". Se ele pudesse, ele preferiria fazer representações ingênuas da natureza. Por que ele não pode? Porque van Gogh não é Anquetin. Anquetin 'atingiu' e representou, já está feito. A escolha lexical 'preferia' sugere que este seria um caminho mais confortável para van Gogh, que ele gostaria de estar, se ele não estivesse 'travando uma luta diabólica com a verdade das cores'. Ou seja, entrando em contato direto com a verdade, ainda que por meio de uma luta 
diabólica, não há mais caminho de volta para a ingenuidade de uma estética Naif que ele até preferiria, mas não consegue mais, porque agora ele enxerga 'a verdade das cores'. Os quadros Naifs constroem em uma representação que se baseia em um tipo de conhecimento quase esquemático da realidade enquanto que a estética Impressionista que van Gogh subscreve, se baseia na representação de um conhecimento experiencial da realidade, ou seja, em uma representação da experiência da realidade. Desse forma, por meio de intertextualidade e interdiscursividade, van Gogh constrói uma metáfora (associação metafórica) para tornar transparente para Theo sua experiência em pintar desde um ponto de vista que é naif, mas que precisa travar uma luta diabólica para representar o que ele experiencia como uma verdade (modalidade). ${ }^{93}$ Esta oração pode demonstrar um encadeamento de ocorrências de categorias de análise que constitui um exemplo de como elas interagem na construção do discurso artístico no texto escrito.

Ao sugerir que ele poderia pintar ao modo naif van Gogh pode estar antecipando um conselho que poderia ser dado por alguém que tentasse preservá-lo dessa luta diabólica, ao que ele responde utilizando o processo 'preferia', para indicar que não é uma questão de escolha.

$\mathrm{Na}$ narrativa, observei um deslizamento na agência, que antes colocava o protagonismo na própria tela ou no céu nela representado, e o coloca agora em van Gogh, indicando uma mudança no enfoque, no enquadramento com que a oração é concebida.

Pode-se perceber no início deste trecho da carta, nas orações iniciais, que van Gogh não utiliza o processo material 'eu pintei, eu misturei, eu criei' para relatar o processo de produção da tela, optando pelo processo relacional 'O céu que é amarelo, quase tão luminoso quanto o sol (que é amarelo), enquanto o resto do céu é amarelo. Tão amarelo!', indicando nessa escolha a ocorrência de Enquadramento e de Perspectiva. E nesta oração: 'Preferia muito mais fazer quadros naifs (...)', quando van Gogh se coloca como participante no processo, ele de fato não ocupa o lugar de criador ou autor, mas de envolvido em uma luta diabólica e que preferia não se envolver, se pudesse. Preferiria o modo naif de pintar, entretanto ele trava lutas para executar seu trabalho da forma como é, da forma como é seu trabalho e da forma como é a natureza, as cores e as coisas, e van Gogh deve representar o que é, nesta batalha em busca da verdade das cores, sugerindo a ocorrência de Modalidade.

\footnotetext{
${ }^{93}$ Ocorrência de Intertextualidade e Interdiscursividade , Associação metafórica, Transparência e Modalidade ao relacionar a obra de Anquetin e a estética Naif com sua própria experiência para representar 'a verdade das cores. Ocorrência de Associação Metafórica pela comparação que ele usa como metáfora para explicar qual é a ordem de sua experiência interna na escolha da combinação de cores.
} 
Essa era a forma de ver dos impressionistas que van Gogh havia adotado e sugere a ocorrência de Transparência pela ênfase vivencial como pressuposto para o processo artístico.

A luta diabólica que ele trava para atingir a verdade das cores é uma batalha que ele trava também na escrita da carta, ao organizar este extrato em duas partes, a primeira na qual ele narra o uso das cores na composição de seu esboço, e a segunda na qual ele comenta sua experiência em relação a essa composição, indicando a ocorrência de Transparência. Nessas duas partes observei que na primeira parte onde ele narra a tela, ele utiliza principalmente os processos relacionais atributivos, pois se preocupa em dar qualidades às entidades que participam de sua visão da obra, sugerindo a ocorrência de Enquadramento e Perspectiva. Na segunda parte, ele passa a comentar como o processo ocorre internamente, e passa a usar processos mentais, como é o exemplo da oração 'mas tenho travado uma luta diabólica para atingir a verdade das cores' conotando não apenas sua luta para estabelecer uma representação que ele considera compatível com a sua concepção da natureza, mas a condição imperiosa dessa tarefa. A escolha da expressão 'a verdade das cores' sugere que van Gogh está ocupado em acessar, por meio de sua experiência artística, a essência das cores e como elas se comportam na realidade, na Natureza sugerindo a ocorrência de Transparência em seu empenho em experiênciar as cores. A escolha da expressão 'luta diabólica' sugere que o processo para 'atingir a verdade das cores' não é fácil e nem está solucionado, indicando a ocorrência de Incompletude e Limiar artístico como duas categorias recorrentes em seu discurso. Nesses comentários, ele passa a construir seu discurso para explicar a natureza do seu conflito, a natureza do seu compromisso e do seu trabalho, pois ele ainda está "travando uma luta”, sugerindo Inacabamento e Limiar Artístico. ${ }^{94}$

Não te vou ocultar //que não desgosto da região,// pois fui criado lá // - ainda me encanta a magia das recordações do passado, de um desejo do infinito,// do qual o semeador e o enfeixador são símbolos / -, tanto quanto antes gostava.//

$1(\alpha ' \beta(1+2) \times Y)+2(1=2)$

ALFA - ( $\boldsymbol{\alpha}$ - Não te vou ocultar

BETA - " $\boldsymbol{\beta}(\mathbf{1}+\mathbf{2})$ - que não desgosto da região, pois fui criado lá- [...], tanto quanto antes gostava

\footnotetext{
${ }^{94}$ Ocorrência de Enquadramento, Perspectiva, Inversão do ponto de vista, Transparência, Inacabamento, Incompletude, e Limiar artístico com a mudança na representação do protagonismo nas orações e nas escolhas lexicais 'verdade das cores', 'luta diabólica' e 'atingir a verdade das cores' .
} 
BETA - ainda me encanta a magia das recordações do passado, de um desejo do infinito, // do qual o semeador e o enfeixador são símbolos.

\section{Alfa:}

\begin{tabular}{|l|l|l|l|l|l|}
\hline \multicolumn{3}{|c|}{$(\boldsymbol{\alpha}$} & \multicolumn{2}{c|}{$\boldsymbol{\text { ' } \boldsymbol { \beta } ( \mathbf { 1 + 2 } )}$} & X Y) \\
\hline$($ Eu) Não & te & vou ocultar // & que não desgosto & da região, & pois fui criado lá \\
\hline $\begin{array}{l}\text { Dizente } \\
\text { polaridade }\end{array}$ & receptor & Processo verbal & Relato & circunstância & relato \\
\hline
\end{tabular}

\begin{tabular}{|l|l|l|}
\hline- tanto quanto antes & $(\mathrm{eu})$ & gostava. \\
\hline Circunstância de modo e de tempo & Experienciador & Processo mental afetivo \\
\hline
\end{tabular}

\section{Beta:}

ainda me encanta a magia das recordações do passado, de um desejo do infinito

\begin{tabular}{|l|l|l|}
\hline ainda me & encanta & $\begin{array}{l}\text { a magia das recordações do passado, de um desejo do } \\
\text { infinito, }\end{array}$ \\
\hline Experienciador & Processo mental emotivo & Fenômeno \\
\hline
\end{tabular}

do qual o semeador e o enfeixador são símbolos -

\begin{tabular}{|l|l|l|}
\hline do qual o semeador e o enfeixador & são & símbolos - \\
\hline Portador & $\begin{array}{l}\text { Processo relacional } \\
\text { Atributivo }\end{array}$ & Atributo \\
\hline
\end{tabular}

\section{Interpretação:}

O uso de um processo verbal na oração alfa e de um processo mental afetivo na oração Beta denota uma construção léxico-gramatical para dialogar com o irmão sobre uma experiência comum acerca do passado.

Na oração alfa: 'Não te vou ocultar que não desgosto da região, pois fui criado lá- [...], tanto quanto antes gostava' vejo uma estrutura léxico-gramatical de contraposições que se referem à região onde são produzidas representações naif da natureza, relatadas na oração anterior a esta. Van Gogh utiliza o processo verbal para afirmar duas negações ' não te vou ocultar' e 'não desgosto'. Essas contraposições ${ }^{95}$ léxico gramaticais são compatíveis com inversões de sentido, com negativas e com indiretas para modalizar, para dizer sem dizer. Elas são explicadas na oração seguinte Beta, na qual ele comenta sobre a sua experiência subjetiva com relação à mesma região que é de encantamento pelas recordações e pelo desejo de

95 Ocorrência de contraposições léxico-gramaticais pelo uso de inversões de sentido, com negativas e com indiretas para modalizar e dizer sem falar que são compatíveis com Saliência e Distorção do ponto de vista. 
infinito, confirmando que a dupla negação da oração alfa é na verdade uma afirmação do contrário.

Ao relatar a lembrança das figuras naif van Gogh associa sua diferença com Anquetin como sendo também a diferença entre o modo simples e ingênuo de experienciar a região e o modo ambíguo e construído por meio de negações: 'não te vou ocultar', 'não desgosto', 'tanto quanto antes gostava'. Ele não deixa claro como e quanto gostava e não compara esta região com outras regiões, por exemplo. Na oração alfa há um processo verbal cujo relato não explicita o afeto do dizente em relação à região, mas na Beta ele explicita o afeto pelas recordações e o lugar ocupado pela 'região' na sua experiência afetiva demonstrando que ele deixa para expressar na oração secundária o sentido mais importante para ele, produzindo um descolar do enquadramento e da perspectiva ao se ler a oração. ${ }^{96}$ Este é um lugar de 'criação', um lugar de 'não desgosto' e um lugar de permanência afetiva na experiência de van Gogh: 'tanto quanto antes gostava'. A escolha léxico-gramatical nesta oração indica a ocorrência de Transparência.

$\mathrm{Na}$ oração hipotática Beta 'ainda me encanta a magia das recordações do passado, de um desejo do infinito, do qual o semeador e o enfeixador são símbolos', ocorre um processo mental emotivo que enfatiza a relação de van Gogh com o interlocutor de sua carta, seu irmão Theo. Com base na oração, inferi que o que motiva van Gogh a pintar é o encantamento experienciado a partir das recordações do passado que ganham para ele um aspecto mágico de um desejo do infinito, indicando a ocorrência de Incompletude e de Limiar Artístico. Ao compartilhar com o irmão, ele espera que este compreenda seu esforço em optar por uma pintura que retrate esta experiência, e não a experiência de quem produz uma tela naif. Mesmo que este esforço implique em uma 'luta diabólica para atingir a verdade das cores'. A escolha do processo mental nesta oração Beta, para dizer o que sente pela região, evidencia um esforço de diálogo com o irmão para que este compreenda sua produção artística desde este lugar, sugerindo a ocorrência de Interdiscursividade e Perspectiva. As escolhas léxicogramaticais deste conjunto oracional denotam a busca de explicitar a natureza da sua motivação na produção artística. A diferença entre as suas pinturas e as pinturas naifs estão nestas recordações do passado, compartilhadas com o irmão, que é talvez o único capaz de compreender ao que van Gogh se refere. Neste trecho da oração van Gogh exemplifica o processo simbólico pelo qual passa a produção de suas obras. Van Gogh não vê a pintura naif como possibilidade para representar o desejo de infinito. Esta é uma outra contraposição

\footnotetext{
${ }^{96}$ Ocorrência de Enquadramento e da Perspectiva pelo deslocamento do sentido principal para a oração secundária.
} 
léxico-semântica que indica a ocorrência de Incompletude, na medida em que ele contrapõe 'naif' com 'a verdade das cores' como uma forma de simbolizar o que não é tangível, como por exemplo 'o desejo de infinito'. 97

Este complexo oracional mostra claramente o processo de semiotização das cores para indexar novos sentidos que são à ele muito caros. Os portadores desta semiotização, deste ‘desejo de infinito', são o semeador e o enfeixador. Estes elementos da obra carregam um atributo que é uma condensação de sentidos, um valor simbólico que expressa o desejo que foi criado no passado e ainda permanece no presente e que impulsiona uma luta diabólica para se fazer representar na pintura por meio das cores. ${ }^{98}$

Van Gogh está se referindo a uma condição que não é escolhida como uma expressão da liberdade do indivíduo. Ele é um meio para que algo maior aconteça. Então é como se o Semeador e o Enfeixador não escolheram ser Semeador e Enfeixador. Van Gogh fez uma escolha que não foi a de ser o meio, ele rejeitou, não se adaptou para ser o evangelizador que o pai esperava. Então quando ele representa o Semeador é como se ele estivesse representando o desejo que o motivou a ser um meio dessa semeadura, mas sem ocupar esse lugar do Semeador. Ser o Semeador sem ser o Semeador, porque o que ele tenta apreender é uma essência talvez com um conteúdo espiritual que estava presente nele desde aquelas lembranças que o conectavam com o mundo das metáforas bíblicas do pai.

Há um processo de diferenciação entre a experiência do passado naquela região e o resultado dessa experiência na subjetividade de van Gogh. Observei que há uma escolha do processo verbal na oração Alfa para dizer que não desgosta da região, que indica a ocorrência de Perpectiva. Por meio de negações e contraposições parece criar um distanciamento, uma hesitação, uma lacuna que depois é preenchida com o uso do processo mental afetivo na oração Beta para afirmar o gostar. Essa sequência léxico-gramatical indica um movimento no qual a forma como van Gogh entra em contato com o ser capaz de produzir simbolicamente esses sentidos é entrando em contato com este ser que foi constituído naquele lugar, a partir daquelas experiências que atualmente são recordações. ${ }^{99}$ Ele não tem como entrar em contato com a força dessa natureza que a experiência do passado lhe deu e a força desse ser que ele

\footnotetext{
${ }^{97}$ Ocorrência de Transparência, Incompletude, Limiar Artístico, Interdiscursividade e Associação Metafórica no nível semântico da oração Beta ao explicitar a natureza da sua motivação na produção artística e ao usar a contraposição criada pela comparação entre 'Naif 'e 'a verdade das cores' como metáfora para explicar ao irmão o seu desejo de infinito.

98 Ocorrência de Contraste Cromático usado como Associação metafórica para expressar o Limiar Artístico representados no Semeador e no Enfeixador.

99 Ocorrência de Perspectiva e Profundidade no uso de construtos que são compatíveis com o Enquadramento Plongee, e que fazem uma diferenciação entre campos de experiência no passado e presente e criam planos e distanciamento para expressar um sentido muito particular.
} 
foi constituído nesse lugar, sem entrar em contato com o lugar em si, com a região na qual foi criado. Para van Gogh, quando ele faz um relato sobre essa região, ele não está se referindo à região desde o lugar do artista, que a representa do ponto de vista naif. Ele está se referindo a essa região do ponto de vista da experiência, simbolizada pelo semeador. Ele se refere a uma outra região, à região da recordação. ${ }^{100}$ Então ao escrever isso na carta quando ele se refere à existência física dessa região, ele se mantém diferenciado e distanciado dela. Mas quando ele explicita a sua recordação, ele se atenta para que Theo compreenda a profundidade que aquela experiência teve na produção dele como artista e o fato de que ela o mantém imbuído da tarefa de trazer a verdade sobre essa experiência à tona. Uma verdade que ele acredita que Theo compartilha com ele, e espera que ele possa expressar por meio da sua arte.

Mas quando eu farei o céu estrelado, então, essa pintura [[que está sempre na minha mente? ]]

\begin{tabular}{|l|l|l|l|}
\hline Mas quando & eu & farei & o céu estrelado, \\
\hline Circunstância & ator & Processo material & meta \\
\hline
\end{tabular}

então, essa pintura que está sempre na minha mente?

\begin{tabular}{|l|l|l|}
\hline então, essa pintura que & está & sempre na minha mente? \\
\hline Portador & $\begin{array}{l}\text { Processo } \\
\text { Relacional }\end{array}$ & Atributo \\
\hline
\end{tabular}

\section{$1 \times 2[[\ldots]]$}

Paratátixa - Mas quando eu farei o céu estrelado,

Hipotáxica - então, essa pintura que está sempre na minha mente?

\section{Interpretação:}

Nesta oração, van Gogh assume o lugar protagonista na produção da representação idealizada, planejada e que exigiu dele um investimento psíquico para compreender a melhor forma de representação dessa imagem que já estava previamente concebida em sua mente. ${ }^{101}$ Ele antecipa e anseia pelo momento em que materializará uma representação que em sua mente já existe: 'essa pintura que está sempre na minha mente?' Ele fala de um lugar no qual ele não está falando da cena dentro da pintura, mas da tela e da circunstância de tempo, que nesta oração, assume o papel de participante principal, pois ele a coloca em modo de pergunta: 'quando?' Outra escolha lexical de tempo é 'sempre' que se contrapõe a 'quando'.

\footnotetext{
${ }^{100}$ Ocorrência de Limiar Artistico na escolha lexical de uma região para significar uma experiência que é remota e basilar e está sendo mediada agora pela expressão artística.

${ }^{101}$ Ocorrência de Limiar Artístico no nível semântico da oração 'essa pintura que está sempre na minha mente'.
} 
Ele contrapõe uma tela que já existe e sempre existe em sua mente a uma tela que não se sabe quando materializará. Esta contraposição serve para marcar uma lacuna e talvez um lugar de expectância que são compatíveis com as categorias de Inacabamento e Incompletude pela contraposição de 'quando' (Inacabamento) e 'sempre' (Incompletude). ${ }^{102}$ Ao se referir à produção da tela enfatizando a circunstância 'quando' ele parece negar a impossibilidade de produzi-la. Ele só não sabe quando o fará. A pergunta dele é 'quando eu farei?', ao invés de ‘será que eu farei?' A escolha gramatical demonstra uma afirmação implícita em forma de pergunta, se retirarmos 'quando' temos a construção 'eu farei o céu estrelado'.

No complexo oracional, ocorre uma ênfase dada 'o céu estrelado' que é reiterado pelo construto 'então, essa pintura' e finalmente pela oração beta 'que está sempre na minha mente?'. Dessa forma a ênfase que ele coloca não é nele como o experienciador do processo. A ênfase é na manifestação dessa verdade. Em que momento que essa verdade se revelará, por meio do surgimento, do aparecimento, do desvelamento desse céu estrelado. É como ele estivesse esperando esse céu se manifestar. ${ }^{103}$

$\mathrm{Na}$ oração Beta ele constrói o sentido por meio de um processo relacional, ou seja ele relaciona a pintura com a mente, uma representação que existe em um espaço interior, consciente, em um espaço de representação. No entanto, ele manifesta sua ansiedade pelo momento de concretiza-la no espaço da tela. O céu estrelado já existe e ele está sempre na minha mente. Como uma pintura está dentro da mente? Ele não escolheu o item lexical 'ideia' para explicar que ela está sempre na mente. Ele se refere à coisa, que já está lá, na mente. Ele só precisa descobrir como trazer ela para fora, por que meios ele irá instancia-la. Isso mostra como van Gogh não pintava intuitivamente, ou impulsivamente. Ele tinha uma ideia muito clara da tela antes de produzi-la. ${ }^{104}$

Essa oração também revela uma transposição ainda por fazer, ele tem instanciada em sua mente uma narrativa mas que ainda não foi materializada enquanto texto pictórico gerando nele antecipação e ansiedade. Essa construção oracional revela dois campos de experiência, um material, do domínio do concreto, do fazer, (quando eu farei) e o outro mental, do domínio do pensamento, da imaginação (...está sempre na minha mente). Essa

\footnotetext{
102 Ocorrência de Inacabamento e Incompletude pelo uso dos itens lexicais 'quando' e 'sempre' em contraposição e que constroem uma camada de sentido.

${ }^{103}$ Ocorrência de Limiar Artístico e Incompletude por meio do uso da ênfase na Meta (ideia da tela) mesmo sendo ele o participante principal na oração alfa.

${ }^{104}$ Ocorrência de Transparência e Inacabamento por meio do uso de um processo relacional para expressar uma experiência que poderia ser expressa por um processo mental, e que está pronta 'em sua mente' mas precisa ser materializada enquanto texto pictórico.
} 
organização oracional constrói a contraposição entre dois planos de experiência, um que é interno, mental e presente, e outro que é externo, material e futuro. ${ }^{105}$

1 - Mas quando eu farei o céu estrelado,

2 - então, essa pintura que está sempre na minha mente?

Van Gogh se pergunta quando irá terminar essa luta diabólica e finalmente poderá conhecer a verdade sobre as cores para representar esse simbolismo do 'desejo infinito' na natureza. A pintura é portadora da mente de van Gogh mais do que van Gogh é portador desta pintura? A escolha do processo Relacional atributivo coloca van Gogh em um lugar no qual ele atribui uma existência para a tela, talvez como tentativa de se aproximar cada vez mais do processo criativo e antecipar sua existência como pintura. Esse processo de antecipação exige de van Gogh um nível de concepção e de planejamento que é característico do seu processo criativo. Quando ele vai pintar a tela já está pronta. Na oração, ele parece ocupado existencialmente como portador de uma idéia, como portavoz de uma experiência que Theo compartilha. E ele busca no seu interlocutor a empatia pelo seu sacrifício em uma 'luta diabólica', em nome deste 'desejo do infinito' capaz de ser expresso por meio da 'verdade das cores' na pintura. ${ }^{106}$ A realização deste 'desejo do infinito' é a realização da completude como artista, de materialização da sua existência, de atingir o cerne da natureza da experiência interna e externa pela integração, entre o que está na mente e o que está na região/natureza, na tela. ${ }^{107}$

O termo lexical 'então' conota uma urgência na manifestação e concretização desta pintura, e explicita sua impaciência neste processo de espera e sua promessa de finalização da 'luta diabólica' e o encontro com a luminosidade. O ontem da experiência, o amanhã da realização; entre eles, o hoje da angústia. ${ }^{108}$

1 - Mas quando eu farei o céu estrelado,

2 - então, essa pintura que está sempre na minha mente?

\footnotetext{
${ }^{105}$ Ocorrência de Contraposição entre uma instância mental e presente e uma instância material e futura gerando dois planos de experiência em contraposição.

106 Ocorrência de Interdiscursividade e de Limiar Artístico pelo uso do processo relacional atributivo que constrói um protagonismo para a ideia da tela e aproxima o interlocutor de van Gogh dessa experiência de Limiar Artístico que van Gogh tenta comunicar e compartilhar com o irmão.

${ }^{107}$ Ocorrência de Limiar artístico e Incompletude presente na organização da oração que constrói dois planos que representação: o esboço em potencial em sua mente e a materialização dele quando puder pintá-lo.

108 Ocorrência de Transparência e Inacabamento pelo uso do item lexical 'então' que constrói um sentido de temporalidade que não está definida, mas que paira em suspenso pela dúvida e pela incerteza expressa em sua pergunta.
} 
Na oração encontrei uma contraposição semântica. A oração paratática 'Mas quando eu farei o céu estrelado,' expressa incerteza, enquanto a oração hipotática 'essa pintura que está sempre na minha mente?' expressa a certeza da constância. No mundo real, ele não possui garantias de quando manifestará a tela. No mundo da mente, ela existe para sempre. As contraposições entre a incerteza da possibilidade de existência da tela no mundo de um lado, e a certeza de sua existência plena na mente servem para enfatizar sua urgência em concretizar essa idéia, indicando a ocorrência de Contraposição no nível semântico entre as orações paratática e hipotática. Ao mesmo tempo, ele direciona a pergunta ao seu interlocutor: 'Mas quando eu farei o céu estrelado, então, essa pintura que está sempre na minha mente?', enfatizando sua presença no diálogo da carta. ${ }^{109} \mathrm{O}$ uso da interlocução para enfatizar a presença do leitor é compatível com a ocorrência de Inversão do Ponto de vista que, na imagem, enfatiza a presença do pintor.

Ai, ai, é como nosso excelente amigo Cyprien diz, em 'En ménage' por JK Huysmans:

\begin{tabular}{|l|l|l|l|l|}
\hline Ai, ai, é como & $\begin{array}{l}\text { nosso excelente } \\
\text { amigo Cyprien }\end{array}$ & diz, & $\begin{array}{l}\text { em 'En ménage' } \\
\text { a JK Huysmans: }\end{array}$ & $\begin{array}{l}\text { as mais belas pinturas são aquelas que } \\
\text { alguem sonha enquanto fuma um } \\
\text { cachimbo em sua cama, mas a qual ele } \\
\text { não pinta. }\end{array}$ \\
\hline Interpessoalidade & Dizente & $\begin{array}{l}\text { Processo } \\
\text { verbal }\end{array}$ & circunstância & Verbiagem \\
\hline
\end{tabular}

as mais belas pinturas são aquelas que alguém sonha enquanto fuma um cachimbo em sua cama, mas a qual ele não pinta.

\begin{tabular}{|l|l|l|l|}
\hline $\begin{array}{l}\text { as mais belas } \\
\text { pinturas }\end{array}$ & $\begin{array}{l}\text { são } \\
\text { enquelas [[que alguém sonha // } \\
\text { cama,// }\end{array}$ & mas a qual ele não pinta. ]] \\
\hline Identificado & $\begin{array}{l}\text { Processo } \\
\text { Relacional } \\
\text { Identificativo }\end{array}$ & Circunstância de lugar e de modo & Identificador \\
\hline
\end{tabular}

$1+{ }^{\prime 2} 2(1[[\alpha \times x]]+2)$

Van Gogh (1888) afirma que a resposta para a pergunta no complexo oracional 'é como diz', ou seja, é parecida, é próxima ao que diz um amigo em comum, indicando o uso de uma metáfora na verbiagem. Além disso, ele busca na voz de outrem a afirmação de uma resposta que ele já tem, mas não enuncia como sujeito dizente, usando para isso o processo

\footnotetext{
${ }^{109}$ Ocorrência de Interdiscursividade pelo uso de Enquadramento, Perspectiva e Inversão do ponto de vista ao trazer o leitor para o lugar em que se encontra o artista ao expressar com Saliência, uma forte contraposição entre uma incerteza (de quando fará a tela) e uma certeza (ela está sempre em sua mente).
} 
verbal. ${ }^{110}$ A verbiagem na oração parece ser o principal participante. Mas dizer não é a mesma coisa que pintar. Dizer é uma possibilidade de expressar a impossibilidade da representação da pintura vivenciada neste momento. Revela a ocorrência de Incompletude, Inacabamento expressos na verbiagem da oração. No nível semântico, a verbiagem 'as mais belas pinturas são aquelas que alguém sonha enquanto fuma um cachimbo em sua cama, mas a qual ele não pinta' expressa que há algo que alguém sonha mas não pinta. No nível léxico-gramatical temos um construto similar, na medida em que é uma Verbiagem, mas não é uma tela. Nesse sentido, ele equipara a Verbiagem de seu amigo ao sonho, ao devaneio, ao desejo que alguém pode entreter acerca de uma tela imaginada, os quais não substituem uma tela pintada. Ou seja, a Verbiagem não substitui a tela, assim como o sonho não substitui a tela. Dessa forma, o sentido presente no nível léxico-gramatical da oração é paralelo ao seu sentido semântico. Esse sentido de um plano de experiência: sonho/Verbiagem que não substitui outro plano: pintar uma tela. Essa sobreposição e contraposição de diferentes planos ou instâncias tais como sonho/execução denota a ocorrência de Incompletude e Inacabamento, uma vez que expressa a diferença entre sonhar e realizar, além de denotar a ocorrência de Enquadramento, Perspectiva e Inversão de ponto de vista, na medida em que ele desliza entre dois domínios tanto no nível semântico (sonho-pintura real) quanto no nível léxico-gramatical (Verbiagempintura real). ${ }^{111}$

A Verbiagem 'as mais belas pinturas são aquelas que alguém sonha enquanto fuma um cachimbo em sua cama, mas a qual ele não pinta', reafirma a incerteza expressa na pergunta anterior, enfatizando ainda mais esta dúvida. Assim, van Gogh explicita aqui que a linguagem escrita serve como possibilidade de compartilhar a experiência artística quando esta o angustia, mas não realiza a experiência que pertence ao domínio de outra modalidade. A oração evidencia que há uma experiência de complementaridade entre o artista/pintor e o artista/reflexivo do seu processo de criação.

\footnotetext{
${ }^{110}$ Ocorrência de Interdiscursividade e Intertextualidade ao expressar uma ideia por meio da afirmação (processo Verbal) de seu amigo Cyprien. Essa afirmação (Verbiagem) é usada como uma metáfora para explicar o que ele experiencia ao desejar realizar a tela, indicando a ocorrência de Associação metafórica no construto da verbiagem, para dar Transparência ao que ele van Gogh pensa.

111 Ocorrência de Incompletude, Inacabamento expressos na Verbiagem da oração, uma vez que expressa a diferença entre sonhar e realizar. Além disso, foi observada a ocorrência de Enquadramento, Perspectiva e Inversão de ponto de vista, que no nível semântico expressa a mesma coisa que no nível léxico-gramatical na medida em que ele desliza entre dois domínios tanto no nível semântico (sonho-pintura real) quanto no nível léxico-gramatical (Verbiagem-pintura real).
} 
1 - Ai, ai, é como nosso excelente amigo Cyprien diz, em 'En ménage' por JK Huysmans:

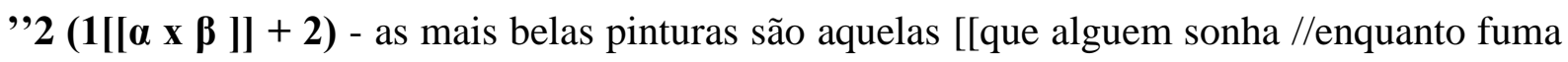
um cachimbo em sua cama,// mas a qual ele não pinta.]]

Também é possível perceber que van Gogh se refere à citação 'é como', de Cyprien, como uma metáfora que é uma aproximação, é algo parecido com o que ele diz. O uso da citação é uma forma de diminuir sobre si mesmo o peso da tarefa imperiosa de realizar a pintura. Dessa forma, a citação de Cyprien oferece uma possibilidade de explicação de que nem tudo que se idealiza pode ser concretizado, nem tudo pode ser expresso, nem tudo é passível de ser apreendido pelo autor e criado. ${ }^{112}$ Ela aparece como uma saída alternativa para angústia, mas é um ato de abnegação. É optar não ter certeza, nem resposta, nem solução. Mas van Gogh não tem a intenção de permanecer aprisionado entre a idéia idealizada da concepção do 'desejo de infinito' e a 'verdade das cores'. Então a citação de Cyprien serve como mote para, na próxima oração, van Gogh afirmar a decisão em continuar seu percurso no mundo das cores e não na explicação verbal da impossibilidade.

+2 Mas é uma questão [[de atacá-las]], // + 3 no entanto, não importa o quão incompetente // alguém pode sentir-se vis-à-vis as perfeições inefáveis do glorioso esplendor da natureza.

\begin{tabular}{|l|l|l|l|}
\hline Mas (isso) & é & uma questão [[de atacá-las,]] & $/ /$, no entanto, \\
\hline Portador & Processo relacional atributivo & Circunstância (modo) & \\
\hline
\end{tabular}

\begin{tabular}{|l|l|l|l|}
\hline $\begin{array}{l}\text { não importa o quão } \\
\text { incompetente// }\end{array}$ & alguém & pode sentir-se & $\begin{array}{l}\text { vis-à-vis as perfeições inefáveis do glorioso } \\
\text { esplendor da natureza. }\end{array}$ \\
\hline Fenômeno & Experienciador & $\begin{array}{l}\text { Processo mental } \\
\text { emotivo }\end{array}$ & Circunstância \\
\hline$+2[[\ldots]]+3[[\ldots]]$
\end{tabular}

\section{Interpretação:}

Na oração 2 'Mas é uma questão de atacá-las,'a questão que resta ao artista é atacar a pintura, não haverá resposta e nem explicações possíveis para diminuir a urgência e a necessidade de encontrar a forma ideal de representação para a ideia da pintura acerta da pintura da ideia de céu estrelado e suas cores que estão já presentificadas na mente do artista.

\footnotetext{
112 Ocorrência de Associação Metafórica pelo construto 'é como' que usa a verbiagem de seu amigo para expressar sua experiência subjetiva acerca do processo de criação de uma tela. Ocorrência de Incompletude e Limiar artístico no nível semântico da verbiagem.
} 
Ele é taxativo ao afirmar que a esta situação de limitação é uma questão de escolha, ou ele escolhe atacar ou fugir para o mundo dos sonhos.

Na oração 3 'no entanto, não importa o quão incompetente alguém pode sentir-se visà-vis as perfeições inefáveis do glorioso esplendor da natureza' van Gogh comenta, por meio do uso de um processo mental emotivo, o seu posicionamento. A escolha léxico-gramatical 'não importa o quão' parece explicitar uma condição na qual o artista se vê diante de uma tarefa que é maior do que sua fraqueza. O sentimento de incompetência, incompletude ou angústia parece ser reduzido nesta afirmação a uma condição inevitável: para o artista não importa o seu sentimento de incompetência, ou ele ataca a pintura ou ele deixa de ser artista. ${ }^{113}$ A escolha do complexo nominal 'as perfeições inefáveis do glorioso esplendor da natureza' indica uma hipérbole ao se referir à natureza. Ou seja, para van Gogh, ser artista é ser alguém imperfeito diante da natureza perfeita, esta é a condição do ser artista e é a condição da arte. Esta afirmação sugere que para ele, não importa o artista e seus sentimentos, o que importa é a natureza e seu esplendor e o que diferencia o artista de outros é atacar ou não a pintura. Essa visão da natureza é indica a ocorrência da Incompletude.

O encadeamento discursivo no qual ele 'trava uma luta diabólica para atingir a verdade das cores', e 'não importa o quão incompetente alguém pode sentir-se vis-à-vis as perfeições inefáveis do glorioso esplendor da natureza.' sugere que, para van Gogh, a verdade das cores só é difícil de alcançar por causa da perfeição da natureza. ${ }^{114}$

$\mathrm{Na}$ oração 'Mas é uma questão de atacá-las, no entanto, não importa o quão incompetente um pode sentir-se vis-à-vis as perfeições inefáveis do glorioso esplendor da natureza,' van Gogh está falando de si, ainda que use para isso a terceira pessoa 'não importa o quão incompetente um pode sentir-se'. ${ }^{115}$ Essa escolha léxico-gramátical da terceira pessoa para explicar uma experiência que é de foro pessoal, indica o uso de uma metáfora, talvez com a função de criar um distanciamento de si mesmo para obter visibilidade de sua própria experiência subjetiva.

Além do uso desse recurso metafórico para falar de si ocorre uma outra particularidade: ele poderia ter utilizado o processo mental cognitivo para julgar-se incompetente, mas ele usou o processo mental emocional 'sentir'-se incompetente. Na oração

\footnotetext{
${ }^{113}$ Ocorrência de Transparência e Incompletude pela escolha 'não importa o quão', que expressa que a tarefa de pintar é maior do que o sentimento de incompetência, incompletude ou angústia diante das 'perfeições da natureza'.

${ }^{114}$ Ocorrência de Incompletude na análise de discurso do encadeamento de duas orações e seu sentido semântico implícito.

${ }^{115}$ Ocorrência de Associação metafórica pela escolha léxico-gramátical da terceira pessoa para explicar uma experiência que é de foro pessoal, talvez com a função de criar um distanciamento de si mesmo para obter visibilidade de sua própria experiência subjetiva.
} 
anterior na qual ele afirma que 'não se sente capaz de julgar seu trabalho', van Gogh demonstra sua parcimônia para usar o processo mental cognitivo para julgar sua incompetência, mas se comunica pelo processo mental emocional para dizer como ele se sente. Inferi que van Gogh procura expressar com a maior precisão possível o que deseja comunicar ao seu interlocutor, para que sua experiência seja compreendida por Theo, seu interlocutor privilegiado. ${ }^{116}$ Também inferi que a mesma precisão que van Gogh busca nas pinturas é almejada nas cartas, embora sempre de maneira aproximada, com metáforas, citações, comparações, contraposições, e releituras de seu próprio discurso até que finalmente consegue instanciar na escrita o que antes era uma idéia, uma concepção do processo e da obra acabada. Esse processo de busca de precisão por aproximação pressupõe o uso de recursos semióticos ao longo da narrativa que é compatível com as ocorrências de categorias como Enquadramento, Perspectiva, Distorção do ponto de vista, Intertextualidade e Interdiscursividade, Saliência, Associação metafórica, Transparência, Inacabamento, Incompletude, Modalidade e Limiar artístico para citar algumas. Quando foi observada a ocorrência de estrutura análoga no nível léxico-gramátical, esta tendeu a coincidir em maior frequência com categorias como Ritmo, Textura, Movimento, Profundidade, Cor, Rima e Gesto Visual.

Aqui está o que eu queria dizer sobre o branco e o preto.

\begin{tabular}{|l|l|l|}
\hline Aqui & está & o que eu queria dizer sobre o branco e o preto. \\
\hline Circunstância & Processo relacional Circunstancial & Identificador \\
\hline
\end{tabular}

O uso do processo relacional circunstancial 'está' trás para a afirmação de van Gogh, um estatuto definidor de seu discurso. ${ }^{117}$ É uma enunciação que possui uma carga de descoberta sobre o que ele buscava dizer ao final, do que ele identifica como o cerne do que ele deseja comunicar ao irmão. Atacar a pintura, descobrir a verdade das cores, é disso que se trata 'ser ou não ser', os contrastes entre ser artista e não sê-lo. Não há meio termo, não é possível ser artista e fugir de sua tarefa de trazer o esplendor da natureza na tela. Sua função, sua existência está dependente deste processo de ser/estar na tela. E ele aponta no seu discurso: 'aqui está' o que é relevante, o que deve ser observado, 'o que eu queria dizer', sobre algo que é discernível, oposto e complementar, diferente e igual, 'sobre o branco e o

\footnotetext{
116 Ocorrência de Transparência na escolha léxico-gramatical do processo mental emotivo ao invés de um processo mental cognitivo para expressar sua experiência de incapacidade diante da tela demonstra uma preocupação do autor com a precisão na comunicação de seu estado interior.

${ }_{117}$ Ocorrência de Saliência na escolha do processo relacional circunstancial 'está' para salientar o que ele queria dizer.
} 
preto', sobre as cores e sua verdade. O Identificador 'sobre o branco e o preto' poderia ser interpretado como uma figura de linguagem para uma afirmação indubitável 'Aqui está o que eu queria dizer preto no branco', por exemplo, significando que ele fará uma afirmação sem margens para interpretações. Para compreender o contexto de cultura que circunda essa oração, busquei analisar o significado do preto e do uso da cor preta na prática da pintura. $\mathrm{O}$ estudo da estética Impressionista revela que o preto era uma cor usada com muita cautela e parcimônia pois eles preferiam representar a sombra por uma combinação de cores em contraste simultâneo com as cores próximas a ela. Isso indica que ele não está se referindo ao uso da cor branca e preta diretamente, mas usando a relação entre o branco e o preto como uma metáfora para enfatizar que o que ele quer dizer não deixa dúvidas, e como o preto sobre o branco.

Vamos tomar o Semeador.

\begin{tabular}{|l|l|l|}
\hline Vamos & tomar & o Semeador. \\
\hline Experienciador & Processo mental cognitivo & Fenômeno \\
\hline
\end{tabular}

'Vamos tomar o Semeador.' Nessa oração van Gogh usa o processo mental cognitivo para conduzir Theo por uma das soluções possíveis para este dilema que se apresenta ao artista, pegando concretamente o exemplo do 'semeador'. Nas orações anteriores ele falou da impossibilidade de produzir a pintura sonhada e idealizada, e do imperativo no qual o artista tem que atacá-la, para finalmente descrever uma solução possível, alcançada no estudo da tela O Semeador. Nesse momento ele está rompendo com a impossibilidade do mundo dos sonhos e lidando com o que é possível no mundo da tela ao expor para Theo como que nesses termos: 'bom talvez você acredite que ninguém seria capaz de produzir o esplendor da natureza em uma tela, mas vou te mostrar como ela se torna possível, e foi possível no Semeador, nessa tela que foi concebida, com uma escolha cuidadosa de cores, e foi ganhando forma até se tornar 'O Semeador'.' O processo mental cognitivo indica esse caminho para convencer Theo dessa possibilidade. Ele usa o Semeador como metáfora para explicar algo sobre sua tela idealizada do céu estrelado, indicando a ocorrência de Associação Metafórica.

A pintura é dividida em dois; metade é amarelo, o topo; a base é violeta.

\begin{tabular}{|l|l|l|}
\hline A pintura & é dividida & em dois; \\
\hline Portador & Processo Relacional Atributivo & Atributo \\
\hline
\end{tabular}

\begin{tabular}{|l|l|l|}
\hline Metade & é & amarelo, o topo; \\
\hline Portador & Processo Relacional Atributivo & Atributo \\
\hline
\end{tabular}




\begin{tabular}{|l|l|l|}
\hline a base & é & violeta. \\
\hline Portador & Processo Relacional Atributivo & Atributo \\
\hline
\end{tabular}

$\mathrm{O}$ atributo que corresponde à tela é de estar dividida. $\mathrm{O}$ topo tem o atributo amarelo e a base tem o atributo violeta. Juntos eles formam um todo de contraste e complementaridade, de diferença (amarelo, violeta) e semelhança (ambos são cores). É a luta pela verdade das cores que ganha uma representação na totalidade, a verdade das cores é realçada pelo contraste entre elas. Elas formam juntas, portanto, uma totalidade complementar, sugerindo a ocorrência de Rima Visual. Mas o que van Gogh buscava? A representação da totalidade da cor na representação da sua natureza inerentemente contrastante? Ou o contraste da natureza por meio do uso das cores? Quem é o portador de tantos atributos? A tela, a cor, ou a natureza? Quando problematiza a dificuldade em representar a natureza, o desejo de infinito, o atributo da tela parece ser simbólico. Não é a cor que ele busca representar, mas, por meio dela, o desejo de infinito, sugerindo a ocorrência de Incompletude. Entretanto, após a pintura estar pronta, o amarelo e o violeta passam a ter centralidade no discurso de van Gogh indicando a ocorrência de Contrastes Cromáticos e Associação Metafórica. Enquanto se referia ao ‘céu estrelado' problematizava sua luta diabólica pela representação do 'desejo de infinito' sugerindo a ocorrência de Limiar artístico, mas quando se refere ao 'semeador' descreve minuciosamente os elementos da tela e problematiza não o sentido simbólico, mas como os atributos se comportam em relação ao portador (tela), indicando a ocorrência de Modalidade.

(1) Bem, as calças brancas descansam os olhos e (2) os distraem exatamente / quando o contraste simultâneo excessivo de amarelo e violeta iriam irritá-lo.

\begin{tabular}{|l|l|l|l|}
\hline Bem, / as calças brancas & descansam & os olhos // & e os distraem \\
\hline Fenômeno & Processo mental perceptivo & experienciador & Processo mental perceptivo \\
\hline
\end{tabular}

Mas há um fenômeno novo, uma cor que quebra o forte contraste, que serve como ponto de ligação para que o homem possa descansar da luta diabólica, há o semeador, e suas calças brancas fazem a ponte entre os opostos. Os olhos, em outras palavras, o experienciador descansa e se distrai da luta. O uso do branco, sugere a ocorrência de Rima Visual pelo uso das cores.

\begin{tabular}{|l|l|l|l|}
\hline $\begin{array}{l}\text { exatamente / } \\
\text { quando }\end{array}$ & $\begin{array}{l}\text { o contraste simultâneo } \\
\text { excessivo de amarelo } \\
\text { e violeta }\end{array}$ & iriam irritá- & - lo. \\
\hline Circunstância & Fenômeno & Processo mental perceptivo (irritar os olhos) ou & Experienciador \\
\hline
\end{tabular}




\section{$1+2(\alpha \times \beta)$}

1 - Bem, as calças brancas descansam os olhos

2 (coordenada por extensão) - e os distraem exatamente // quando o contraste simultâneo excessivo de amarelo e violeta iriam irritá-lo.

Neste complexo oracional, observei uma predominância de processos mentais perceptivos, considerando a ênfase que van Gogh dá para o efeito da cor na percepção do observador. Ele se refere ao efeito de exacerbação oriundo do contraste complementar entre o amarelo e o violeta que pode efetivamente levar a uma irritação sensível, perceptiva ou emocional, mas que é interrompida pela presença do branco que ajuda a temperar a intensidade deste contraste. O uso do branco, de acordo com o comentário, parece ser um ponto de equilíbrio delicado, que o artista alcança por meio de contrastes e pontes de ligação. É possível trabalhar com as cores da natureza, seus contrastes e oposições, mas como elas podem ser representadas na pintura de forma que o artista faça os elos que na natureza são espontâneos? Se o uso do branco faz o elo entre o amarelo e o violeta e a calça do semeador é branca talvez quem faz esse elo para van Gogh é a figura mítica do semeador. Assim como quem faz o elo entre a verdade das cores e a natureza é o simbolismo.

Dessa forma ele cria uma correspondência entre a cor branca e o papel do elo de transição entre duas instâncias que ele articula em seu discurso: a verdade das cores e a natureza. Sabemos que van Gogh almeja representar o desejo de infinito que a natureza significa para ele. A fim de alcançar esse projeto, ele busca a verdade das cores que serão na tela a semiose para representar tanto o esplendor da natureza quanto o desejo de infinito que ele sente quando a experiencia. Dessa forma, com o uso das cores, ele cria uma correlação entre este equilíbrio delicado de constrastes e o desejo de infinito que, ao invés de nos irritar é capaz de comunicar o esplendor da natureza.

Este simbolismo torna possível a relação com as cores e suas verdades, fazendo a ponte entre o ideal concebido pelo artista e a concretude do quadro. Mas, e no 'céu estrelado' quem pode fazer a ponte? A solução ainda não está dada. O branco pode salvá-lo da luta diabólica ou o preto. Há algo entre as cores que o discurso escrito procura expressar, mas que somente a produção artística de van Gogh tornou possível dizer. E assim ele finaliza: 'isso é o que eu queria dizer'. E que por enquanto é suficiente dizer sobre um processo que está 
inacabado, um processo de 'luta diabólica' que só finaliza após a produção de uma pinura que retrate a idéia, o ideal, o simbólico 'desejo de infinito'.

Isso é

\begin{tabular}{|l|l|}
\hline Isso & É \\
\hline Verbiagem & \\
\hline
\end{tabular}

o que eu queria dizer.

\begin{tabular}{|l|l|l|}
\hline o que & eu & queria dizer. \\
\hline Verbiagem & Dizente & Processo Verbal \\
\hline
\end{tabular}

"Isso é o que" não precisa ser considerado como oração.

"O que eu queria dizer" forma uma sequência de orações clivadas. O sentido da oração pode ser entendido como: Eu queria dizer isso. Os participantes são: 'Eu' - Dizente; 'queria dizer' processo verbal; ‘isso' - Verbiagem.

\section{Interpretação:}

Essa oração desempenha o papel de salientar o que apenas foi dito: "Aqui está o que eu queria dizer sobre o branco e o preto. Vamos tomar o Semeador. A pintura é dividida em dois; metade é amarelo, o topo; a base é violeta. Bem, as calças brancas descansam os olhos e os distraem exatamente quando o contraste simultâneo excessivo de amarelo e violeta iriam irritá-lo." Ao retomar o oração que abre o parágrafo ‘Aqui está o que eu queria dizer sobre o branco e o preto' ele reforça e redireciona para o sentido inicial que ele estava preocupado em explicitar, o que ele tem a dizer sobre o branco e o preto, ou sobre o que ele tem a dizer 'preto no branco' que tem o sentido de 'colocar sem rodeios'. A função de saliência dessa oração está, dessa forma, relacionada com o sentido do parágrafo, claramente, ele trata sobre o poder visual do contraste complementar entre o amarelo e o violeta que dividem a tela em dois campos. Ele explica que o branco tem a função de amenizar a força contrastiva do encontro dessas duas cores, de tal modo que elas chegam a irritar o espectador. Ele quer enfatizar a importância do poder do contraste simultâneo entre violetas e amarelos e o poder do branco para corrigir esse embate visual. ${ }^{118}$

\footnotetext{
118 Ocorrência do uso de saliência na oração 'Isso é o que eu queria dizer' que retoma e reforça o sentido da oração 'Aqui está o que eu queria dizer sobre o branco e o preto.' que abre o parágrafo que fala sobre a função do branco para amenizar o conflito entre o violeta e o amarelo que preenchem os dois campos da tela.
} 


\subsubsection{Extrato $n^{\circ} 2 b$}

629 - To Theo Van Gogh. Arles, Thursday, 21 June 1888. (VAN GOGH, 2009e).

Eu tive uma semana de concentrado trabalho duro nos campos de trigo debaixo do sol, o resultado foi de alguns estudos de campos de trigo, paisagens e - um esboço de um semeador. Em um campo arado, um grande campo de torrões de terra roxa-levantados em direção ao horizonte - um semeador em azul e branco. No horizonte um campo de trigo curto, maduro. $1 v: 2$

Acima de tudo isso um céu amarelo com um sol amarelo.

Você pode sentir a partir da mera nomenclatura das tonalidades - que a cor desempenha um papel muito importante nesta composição.

E o esboço como tal - uma tela número 25 - também me preocupa muito, no sentido de que eu me pergunto se eu não deveria levar a sério e fazer uma pintura tremenda disso. Meu Deus, como eu adoraria fazer isso. Mas eu só me pergunto se eu vou ter o poder necessário de execução.

Eu estou colocando o esboço de lado assim como é, mal ousando pensar nisso.

Por um longo tempo ele foi meu grande desejo de fazer um semeador, mas os desejos que tive por um longo tempo nem sempre são alcançados. Então, eu estou quase com medo deles. E, no entanto, depois de Millet e Lhermitte o que resta a ser feito é ... o semeador, com cor e em um grande formato. (VAN GOGH, 2009e, p. 1).

\section{Análise:}

Eu tive uma semana de concentrado trabalho duro nos campos de trigo debaixo do sol, o resultado foi de alguns estudos de campos de trigo, paisagens e - um esboço de um semeador.

\begin{tabular}{|l|l|l|}
\hline $\mathrm{Eu}$ & tive & $\begin{array}{l}\text { uma semana de concentrado trabalho duro nos } \\
\text { campos de trigo debaixo do sol, }\end{array}$ \\
\hline Portador & Processo Relacional Atributivo possessivo & Atributo \\
\hline
\end{tabular}

\begin{tabular}{|l|l|l|}
\hline o resultado & foi & $\begin{array}{l}\text { de alguns estudos de campos de trigo, } \\
\text { paisagens e - um esboço de um semeador. }\end{array}$ \\
\hline Portador & Processo Relacional Atributivo & Atributo \\
\hline
\end{tabular}


ALFA: Eu tive uma semana de concentrado trabalho duro nos campos de trigo debaixo do sol,

BETA: o resultado foi de alguns estudos de campos de trigo, paisagens e - um esboço de um semeador.

Neste complexo oracional encontrei uma predominância dos processos relacionais atributivos nos quais os atributos são complexos nominais. Na oração Alfa, Van Gogh está descrevendo as condições de execução do seu trabalho. Van Gogh parece enfatizar nesta oração a execução do seu trabalho atribuindo a ele características e circunstâncias que possibilitam ao leitor imaginar como foi sua semana de 'concentrado trabalho duro nos campos de trigo debaixo do sol'. Na segunda oração, ele apresenta como resultado o que ele alcançou: 'estudos' e um 'esboço'. Van Gogh parece tentar mostrar ao seu interlocutor, a relação entre o ‘trabalho duro' e o resultado na dureza do sol, nas condições precárias que não o impediram de tentar diariamente criar uma forma de representar sua idéia, O Semeador que vinha idealizando há tanto tempo.

Em um campo arado, um grande campo de torrões de terra roxa - levantados em direção ao horizonte - um semeador em azul e branco.

\begin{tabular}{|l|l|l|l|}
\hline $\begin{array}{l}\text { Em um campo arado, um grande campo de torrões de } \\
\text { terra roxa - levantados em direção ao horizonte - }\end{array}$ & (há) & $\begin{array}{l}\text { um } \\
\text { semeador }\end{array}$ & em azul e branco. \\
\hline Circunstância & $\begin{array}{l}\text { Processo } \\
\text { Existencial }\end{array}$ & Existente & $\begin{array}{l}\text { Circunstância de } \\
\text { modo }\end{array}$ \\
\hline
\end{tabular}

Por meio de processo Existencial oculto (há), van Gogh narra o universo da tela e nele, um semeador. Ele narra a figura representada não como $o$ semeador, alguém que ele retratou, mas sim como um semeador, deslocando a figura representada para uma categoria conceitual. Essa escolha léxico-gramatical reforça a suposição de que van Gogh planejou construir por meio da figura de um semeador, um enunciado filosófico, ético e estético.

Nesta oração, ele se refere à representação dentro da tela, em contraposição com a oração anterior na qual ele se refere aos aspectos do trabalho de pintar, externos à tela. Após descrever a situação na qual ele tem trabalhado diariamente, ele descreve a pintura com a qual ele tem se ocupado. Na circunstância de lugar descrita 'Em um campo arado, um grande campo de torrões de terra roxa - levantados em direção ao horizonte' há um semeador, como o principal ser existente da narrativa. Ele está representado em duas cores, em uma tela representada em duas cores principais, sugerindo uma dualidade. 
No horizonte um campo de trigo curto, maduro. 1v: 2

\begin{tabular}{|l|l|l|}
\hline No horizonte & (há) & um campo de trigo curto, maduro \\
\hline Circunstância & Processo Existencial & Existente \\
\hline
\end{tabular}

Na oração, van Gogh não explicita o processo, está oculto, é existencial. Nesta oração observei o uso do processo existencial para descrever a linha do horizonte na representação. Van Gogh parece conduzir o leitor para dentro da tela como o conduziria à paisagem na natureza, explicando as características do trigo no horizonte. $\mathrm{O}$ artista trabalhador do campo apresenta o fruto do seu trabalho após um longo e árduo período sob o sol. E o que ele tem a apresentar é a existência, pura e simples de um campo de trigo. Van Gogh enfatiza na descrição a circunstância 'no horizonte' e o existente 'um campo de trigo curto, maduro'. Semioticamente, o que temos no horizonte é o amadurecimento desta tela tão almejada por um artista maduro, calejado pelo sol, após longo período de espera, produzindo uma tela que acima de tudo 'é'. Nesta tela algo existe; e sua existência, embora curta, sintetiza uma verdade.

Acima de tudo isso um céu amarelo com um sol amarelo.

\begin{tabular}{|l|l|l|}
\hline Acima de tudo isso & (há) & $\begin{array}{l}\text { um céu amarelo com um sol } \\
\text { amarelo. }\end{array}$ \\
\hline Circunstância de lugar & Processo Existencial & Existente \\
\hline
\end{tabular}

Acima de tudo isso um céu amarelo com um sol amarelo.

Aqui também, o processo está oculto, é existencial. Nesta oração van Gogh usa de novo o processo existencial para descrever a parte superior da tela. Ele cria uma ênfase com o item lexical 'amarelo', usado duas vezes como atributo de 'céu' e de 'sol', reforçando a qualidade de amarelo que há na parte superior da tela. 'Acima de tudo', daquilo que está representado na parte inferior da tela, o que temos é o amarelo. Porque o sol e o céu se fundem em uma mesma coisa, o amarelo, que é totalizante.

Ele dá também dá destaque à circunstância 'acima de tudo isso'. A escolha léxicogramatical de 'Tudo isso' sugere mais uma vez que ele não fala da tela como uma pintura sobre um pedaço de tecido, um pequeno espaço de representação, mas de um domínio no qual ele experiencia a vastidão do campo de trigo. O campo de trigo cria o horizonte, ele é o infinito. O céu e o sol amarelo não o limitam, mas dão a ele uma dimensão: acima, abaixo. O céu, também infinito, com um amarelo infinito. É como se van Gogh dissesse 'não veja o quadro, veja o infinito, o in-visível, veja além do quadro'. Veja o meu desejo de infinito. Van 
Gogh apresenta a tela sem explicitar o processo, deixando a ênfase na existência em si, do céu e do sol.

Você pode sentir a partir da mera nomenclatura das tonalidades - que a cor desempenha um papel muito importante nesta composição.

\begin{tabular}{|l|l|l|l|}
\hline Você & pode sentir & $\begin{array}{l}\text { a partir da mera } \\
\text { nomenclatura das } \\
\text { tonalidades - }\end{array}$ & $\begin{array}{l}\text { que a cor desempenha um papel muito importante } \\
\text { nesta composição. }\end{array}$ \\
\hline Sentidor & $\begin{array}{l}\text { Processo } \\
\text { mental } \\
\text { afetivo }\end{array}$ & Circunstância & Fenômeno \\
\hline
\end{tabular}

$\alpha, \boldsymbol{\beta}$

'Você pode sentir a partir da mera nomenclatura das tonalidades - que a cor desempenha um papel muito importante nesta composição.' Oração Complexa

\section{Interpretação:}

Neste complexo oracional, o que é mais importante 'a cor desempenha um papel muito importante nesta composição', está na oração hipotática. Porque van Gogh escolheu colocar o enunciado principal na oração hipotática? As escolhas léxico-gramaticais sugerem que ele não deseja declará-lo definitivamente, mas apelar ao irmão, por meio de uma argumentação, para que este também reconheça e concorde com sua percepção.

Theo não viu a tela ainda, e van Gogh está dependendo das palavras para materializar visualmente como imagem representacional para o irmão, o que ele fez em termos concretos de uma pintura real.

Tudo o que o irmão vai ter acesso, neste momento, é a descrição que van Gogh faz por meio das palavras. Por isso, ele não começa a oração declarando que o que predomina são as cores. Ele, nas orações anteriores descreveu-a, mas as palavras são poucas. Nesta oração, van Gogh parece buscar se certificar se ele descreveu bem a tela. É como se ele fizesse uma simulação com o irmão, na qual ele propõe que, pela nomenclatura das cores, o irmão perceba que as cores nesse quadro tem um papel extremamente relevante. Por isso ele enfatiza tanto a narrativa da tela por meio de diferentes recursos semióticos. Para mostrar através das palavras ao Theo o quanto a cor desempenhou um papel relevante na composição.

A mudança na narrativa da tela em si para um comentário sobre o que van Gogh pensa a respeito da tela sugere a relação que há entre o processo criativo na concepção e na produção da pintura e o processo de representação da pintura nas cartas. Esses processos têm 
muitos pontos em comum, e o discurso textual que van Gogh produz é capaz de evidenciar uma negociação de sentidos intensa que faz parte da constuição do seu próprio discurso artístico.

A descrição serve para van Gogh possibilitar para o irmão a produção da imagem antes deste ter acesso ao resultado final: a tela. De certa forma, neste momento, Theo está próximo ao lugar ocupado por van Gogh antes da produção da tela, quando van Gogh apenas concebia e imaginava como seria o uso das cores e a disposição dos elementos na tela.

Por isso ele descreve suas ideias em relação ao amarelo, ao sol, ao campo de trigo como sendo prévias da produção da tela em si. Então ele espera que com as palavras que ele enuncia, Theo seja capaz de imaginar a tela que ele, com estas ideias e palavras também foi capaz de conceber a produção da tela produzida.

$\mathrm{Na}$ oração principal deste complexo oracional, van Gogh usa o processo mental afetivo 'sentir' para convidar seu interlocutor a sentir o que ele sente, 'que a cor desempenha um papel muito importante nesta composição.' Ele poderia ter escolhido um outro processo, o verbal por exemplo, para simplesmente declarar o que ele acaba de enunciar como uma experiência afetiva. Por que ele não escolhe declarar diretamente ao irmão qual deve ser o papel da cor na composição? Porque, aparentemente, não se trata de uma decisão racional, mas sim uma experiencia afetiva da qual essa verdade, de que a cor tem um papel importante na obra, não pode se separar. Ele está compartilhando um conhecimento que é experiencial, que é da ordem do sensível, e precisa ser sentido pelo irmão. Mesmo quando ele está usando as próprias palavras para representar as ideias e não o quadro em si. Quando ele usa processos mentais, ele está expondo como ele percebe e convidando Theo a experienciar afetivamente a verdade das cores que ele próprio experiencia. É como se ele falasse: 'Você pode sentir (....) que a cor desempenha um papel muito importante nesta composição', como eu sinto.

E o esboço como tal - uma tela número 25 - também me preocupa muito, no sentido de que eu me pergunto se eu não deveria levar a sério e fazer uma pintura tremenda disso.

\begin{tabular}{|l|l|l|l|}
\hline $\begin{array}{l}\text { E o esboço como tal - } \\
\text { uma tela número 25 - }\end{array}$ & também me & preocupa & no sentido de que \\
\hline Fenômeno & Experienciador & Processo Mental Emotivo & \\
\hline
\end{tabular}

eu me pergunto se eu não deveria levar a sério e fazer uma pintura tremenda disso. (oração projetada)

\begin{tabular}{|l|l|l|l|}
\hline eu & me pergunto & $\begin{array}{l}\text { se eu não deveria levar a } \\
\text { sério }\end{array}$ & $\begin{array}{l}\text { // e fazer uma pintura } \\
\text { tremenda disso.// }\end{array}$ \\
\hline
\end{tabular}




\begin{tabular}{|l|l|l|l|}
\hline Dizente & Processo Verbal & Verbiagem & Verbiagem \\
\hline
\end{tabular}

$\alpha \times \beta(\alpha, \beta(1+2))$

Alfa - E o esboço como tal - uma tela número 25 - também me preocupa muito,

Beta explicativa - no sentido de que eu me pergunto

Beta - se eu não deveria levar a sério e fazer uma pintura tremenda disso.

(a) E o esboço como tal - uma tela número 25 - também me preocupa muito, (b) no sentido de que eu me pergunto (c) se eu não deveria levar a sério (d) e fazer uma pintura tremenda disso.

Neste complexo oracional observei quatro tipos de processos: 'preocupa', 'pergunto', 'deveria levar' e 'fazer' em um comentário que van Gogh faz em relação ao seu esboço O Semeador. Esta sequência de processos nos permite inferir uma negociação de sentidos na produção da tela $\mathrm{O}$ semeador. $\mathrm{O}$ complexo oracional sugere que ele percorreu quatro etapas em seu discurso: motivação, concepção, compromisso e execução. No primeiro momento algo chama a atenção dele, ele experiencia como emoção, algum elemento no esboço o preocupa. No segundo momento, ele passa para a concepção e se pergunta sobre qual é o grau de relevância do esboço. Se for algo que deve ser levado a sério, ele estabelecerá um compromisso, nessa terceira etapa para, no quarto momento, partir para a ação, e fazer do esboço uma tremenda pintura.

$\mathrm{Na}$ oração 'se eu não deveria levar a sério e fazer uma pintura tremenda disso' a escolha léxico-gramatical indica que a questão presente para van Gogh é levar a sério aquilo que realmente importa. Van Gogh não pode deixar passar nada importante, ele assume a tarefa de pintar seus ideais como uma missão. Ele se pergunta, como quem cobra de si mesmo um compromisso, julgando e questionando sua responsabilidade com sua tarefa: 'fazer uma pintura tremenda disso'.

Meu Deus, como eu adoraria fazer isso.

\begin{tabular}{|l|l|l|l|}
\hline Meu Deus, como & eu & adoraria & fazer isso. \\
\hline & Experienciador & Processo Mental desiderativo & Oração Projetada \\
\hline
\end{tabular}

$\alpha, \beta$

O processo mental desiderativo aparece como súplica a Deus, uma expressão cristã para o pedido de um milagre. De certa forma, van Gogh pede a Deus que conceda a ele o poder de executar tal obra, uma obra, portanto, divina. Esta locução 'Meu Deus' mostra a ênfase para a força de seu desejo. 
Ao mesmo tempo, van Gogh expressa na intensidade do seu pedido, a satisfação imensa que experienciaria na sua execução, a realização final de uma obra acabada.

A oração 'Meu Deus, como eu adoraria fazer isso' nos remete ao universo religioso não apenas pela expressão 'Meu Deus', mas pela escolha do processo desiderativo 'adoraria', porque semanticamente adoramos a Deus. Mas seu desejo é de tal ordem, que ele pede a Deus a permissão de seguir e ser capaz de realizar uma tal obra. Este seria um ato de adoração a Deus que o inspirou a fazê-lo. Nessa oração ele eleva a experiência artística à instância divina, vivenciando em sua fé enunciada na oração a articulação entre a experiência do divino na religião e a experiência do divino na arte como meio para realização do bom e do belo.

Mas eu só me pergunto se eu vou ter o poder necessário de execução.

\begin{tabular}{|l|l|l|}
\hline Mas / eu só & me pergunto & se eu vou ter o poder necessário de execução. \\
\hline Dizente & Processo Verbal & Verbiagem Oração Projetada \\
\hline
\end{tabular}

$\ldots+2(\alpha, \beta)$

\section{Interpretação:}

Nesta oração, observei a ocorrência de uma oração projetada 'se eu vou ter o poder necessário de execução' como verbiagem do processo verbal 'me pergunto' demonstra um processo de interlocução interna de van Gogh. Com o uso lexical de 'só', Van Gogh enfatiza a pergunta que não sai da sua cabeça, pois a pergunta é dirigida a si mesmo, como um circuito no qual ele pergunta e ele responde. Esta organização léxico-gramatical denota um processo produção discursiva intenso, porque esta oração aparece imediatamente após a oração anterior: 'Meu Deus, como eu adoraria fazer isso.'

Enquanto na oração anterior ele expressou o desejo, nesta oração e na mesma intensidade, ele experiencia a dúvida de realizar a pintura. Por isso o 'mas' aparece como uma contraposição, um senão. Novamente observa-se a enunciação de uma dúvida, a mesma dúvida que já ocorreu em outras orações acima.

Com relação à verbiagem que é o objeto de sua dúvida, observei a escolha lexical 'poder' que reforça a ideia não de técnica, habilidade, condições materiais ou vontade, mas algo além, expresso por ele como 'poder de execução' dando para a sua pergunta um sentido de dramaticidade que deve corresponder ao conflito que ele sustenta entre o desejo e a dúvida em seu 'poder'. 
Eu estou colocando o esboço de lado assim como é, mal ousando pensar nisso.

\begin{tabular}{|l|l|l|l|}
\hline $\mathrm{Eu}$ & estou colocando & $\begin{array}{l}\text { o esboço de lado assim } \\
\text { como é, }\end{array}$ & mal ousando pensar nisso. \\
\hline Comportante & $\begin{array}{l}\text { Processo Mental } \\
\text { Perceptivo emotivo na } \\
\text { fronteira entre material e } \\
\text { mental }\end{array}$ & $\begin{array}{l}\text { Oração não-finita (tem } \\
\text { função de circunstância de } \\
\text { tempo. }\end{array}$ \\
\hline
\end{tabular}

$\alpha(1=2) \times \beta\left(\alpha^{\prime} \beta\right)$

ALFA - Eu estou colocando o esboço de lado assim como é,

intensificadora de comparação - assim como é,

BETA não finita, modal - mal ousando pensar nisso.

Eu estou colocando o esboço de lado assim como é, mal ousando pensar nisso.

Van Gogh então se rende ao sentimento de impossibilidade diante da exigência do ideal em relação ao real e conclui 'Eu estou colocando o esboço de lado assim como é', ou seja, incompleto, imperfeito. Diante da impossibilidade de mudar o que está feito, o esboço, e de ir além, de concretizar seu ideal da tela.

A oração não finita aponta para uma escolha lexical que revela mais; a dramaticidade da sua relação com a obra é da ordem da vida e da morte, mal ousando pensar na mortífera impossibilidade. Só há vida na produção, só há vida na execução do belo. Mas com a escolha lexical, ele deixa vago quando afirma 'mal ousando pensar nisso'. Pensar em que? $\mathrm{Na}$ possibilidade de execução, no semeador idealizado ou na falta de poder para a execução? Ou ainda 'mal ousando pensar' em tudo isso, mal ousando estar vivo com esta ideia presente o tempo todo.

O processo comportamental próximo ao mental ' $\mathrm{Eu}$ estou colocando o esboço de lado assim como é' pode ser analisado também como processo material, pois ao mesmo tempo em que decide, ele executa, ele efetivamente faz uma ação, de abandono da ação, da possibilidade de execução.

Por um longo tempo ele foi meu grande desejo de fazer um semeador, mas os desejos que tenho tido por um longo tempo nem sempre são alcançados.

\begin{tabular}{|l|l|l|l|}
\hline Por um longo tempo & ele & foi & $\begin{array}{l}\text { meu grande desejo de } \\
\text { fazer um semeador, }\end{array}$ \\
\hline $\begin{array}{l}\text { Circunstância de } \\
\text { localização: tempo }\end{array}$ & Identificador & Processo Relacional Identificativo & Identificado \\
\hline
\end{tabular}




\begin{tabular}{|l|l|l|l|}
\hline Atributo & Portador & $\begin{array}{l}\text { Processo } \\
\text { Relacional } \\
\text { Atributivo }\end{array}$ & $\begin{array}{l}\text { Oração não-finita (tem função de circunstância } \\
\text { de tempo. }\end{array}$ \\
\hline
\end{tabular}

\section{$1+2\langle<[[. .]]>.>$}

- Por um longo tempo ele foi meu grande desejo de fazer um semeador,

- mas os desejos que tenho tido por um longo tempo nem sempre são alcançados.

\section{Interpretação:}

'Por um longo tempo ele foi meu grande desejo de fazer um semeador, mas os desejos que tenho tido por um longo tempo nem sempre são alcançados.'

$\mathrm{Na}$ oração anterior ocorre ao mesmo tempo uma idéia e uma execução 'Eu estou colocando o esboço de lado assim como é'; ao colocar o esboço de lado, ele está colocando de lado a concepção da tela e o esboço. Nesta oração, a escolha léxico-gramatical indica uma despedida do esboço, na medida em que ele se refere ao desejo de executá-lo no pretérito. Um desejo que ele há poucas orações atrás enunciou como algo presente para ele. Agora que, na oração anterior ele resolveu colocar de lado o esboço, ele se distancia do desejo, ao enfatizar a circunstancia de localização de tempo 'Por um longo tempo'.

No encadeamento da oração anterior e desta, 'Eu estou colocando o esboço de lado assim como é, mal ousando pensar nisso' e 'Por um longo tempo ele foi meu grande desejo de fazer um semeador', observei que ele fala e ao falar, age. Enquanto na primeira oração ele está falando em deixar de lado, na segunda oração ele já anuncia o abandono do desejo e do quadro. Ao enunciar, ele concretiza uma nova ação. A fala dele tem o poder de instanciar uma nova condição, e a partir do momento em que ele fala ele cria uma nova configuração da relação dele com a tela. Este encadeamento demonstra a função da fala em transformar a ação. Ele decide e deixa de lado ao mesmo tempo, e nesta oração já fala no passado: 'foi meu desejo', ou seja, não é mais. E por que? Só haveria um motivo para sustentar um grande desejo, o poder de executá-lo. Mas os desejos, mesmo aqueles que se mantém durante longo tempo, nem sempre são alcançados. Van Gogh assume o lugar não daquele que tem o poder de executar, mas daquele que está sob o poder do seu desejo. Estas oposições colocam o artista em um dilema recorrente, a idealização e a possibilidade de execução, a submissão a uma idéia de pintura e o poder de executá-la. A inspiração é algo que domina e sufoca o artista, a execução é algo que o empodera e liberta. 
Então, / eu estou quase com medo deles.

\begin{tabular}{|l|l|l|}
\hline Então,/ eu & estou & quase com medo deles. \\
\hline Portador & Processo Relacional Atributivo & Atributo \\
\hline
\end{tabular}

Nesta oração, o processo relacional atributivo se destaca como comentário de van Gogh. Ele não explicita se tem medo de que os desejos não se realizem. Sua escolha léxicogramatical deixa ambíguo o que ele teme: 'eu estou quase com medo deles'. Medo de que? Dos desejos, de continuar sentindo desejo; medo da impossibilidade, medo de ser essa pessoa que deseja muito alcançar a execução de uma tela ou medo do que esse desejo pode causar nele em termos de frustração, de perda de sentido, de não se ver como artista, de achar que ele não é um artista porque não consegue executar o que ele idealiza? O que o desejo de infinito não realizado pode fazer com Van Gogh? O que um desejo que não se realiza poderia levar a acontecer que deixaria Van Gogh com medo? O desejo do impossível é impossível de manter por longo tempo sem causar dano no sujeito. Mas van Gogh qualifica sua condição de estar na fronteira, 'quase com medo', que sentimento é este, entre a coragem de executar e o medo paralisante? Entre a fé cega e a imutabilidade da condição humana, sujeita ao próprio desejo, mesmo quando este é irrealizável. Van Gogh revela a seriedade com a qual ele encara seu desejo, suas ideias, seus ideais. E ele parece ter medo de si mesmo, teme seus limites, de não poder executar, ou a falta de limites, um desejo de infinito?

E, no entanto, / depois de Millet e Lhermitte o que resta a ser feito é ... o semeador, com cor e em um grande formato.

\begin{tabular}{|l|l|l|l|}
\hline $\begin{array}{l}\text { E, no entanto,/ depois de } \\
\text { Millet e Lhermitte }\end{array}$ & $\begin{array}{l}\text { o que resta a ser feito (por } \\
\text { mim, })\end{array}$ & é ... & $\begin{array}{l}\text { o semeador, com cor e em } \\
\text { um grande formato. }\end{array}$ \\
\hline Circunstância & $\begin{array}{l}\text { Identificador } \\
\text { (o ator está na voz } \\
\text { passiva) }\end{array}$ & $\begin{array}{l}\text { Processo Relacional } \\
\text { Identificativo }\end{array}$ & Identificado \\
\hline
\end{tabular}

$\ldots+2(\alpha \times \beta)$

E, no entanto, depois de Millet e Lhermitte o que resta a ser feito é ... o semeador, com cor e em um grande formato.

Observei uma mudança no padrão de ocorrência das escolhas do processo relacional atributivo para o processo relacional indentificativo na medida em que van Gogh antes se referia a tela como um semeador e agora se refere a ela como $o$ semeador. Depois de mostrar a profundidade do seu dilema, da sua angústia, do seu desejo e do seu medo, van Gogh nesta 
oração diz 'o que resta a ser feito é'. É o que sobra, considerando tudo, a impossibilidade de fazer $u m$ semeador, o que resta é fazer $O$ Semeador. Por que ao falar do ideal van Gogh faz a escolha lexical 'um semeador', e quando fala do exequível usa 'o semeador'? Não um semeador unico, um capaz de sintetizar todos, mas $o$ semeador, aquele entre tantos outros, plausível, palpável, exequível, um dentre outros em uma categoria.

Como ele próprio, um artista dentre outros, um van Gogh entre um Millet e um Lhermitte, um a mais e que aceita este lugar, de mais um. A escolha léxico-gramatical 'depois de Millet e Lhermitte o que resta a ser feito é ... o semeador,' sugere que ele não pode abandonar este projeto, já que este projeto é a próxima coisa a ser feita depois de tudo o que já foi feito por seus antecessores. Esta é mais uma evidência da gravidade com que van Gogh pesa na balança seriedade de sua tarefa e de seu compromisso com o avanço de uma linguagem que precisa superar o que já foi feito por outros. Quando ele enuncia, o que resta a ser feito, não é tanto em relação ao que ele consegue fazer em relação ao seu ideal inatingível, mas sim em relação ao que já foi feito por outros. Isto nos resta saber.

E que ele seja feito 'com cor e em um grande formato'. Então, ele se ateve à execução deste possível, se concentrou para que ele tenha características próximas do ideal e em grande formato para representar a grandiosidade de seus elementos, e sua própria possibilidade de grandiosidade. Esta oração sintetiza a negociação de sentidos pela qual van Gogh atravessa ao escrever para o irmão deixando clara como a escrita torna-se uma ferramenta de reflexão, de tomada de decisões, de contemporização de seus processos criativos. 
5.6 ANÁlise DA TELA A ESPLANADA DO CAFÉ NA PLACE DU FORUM, ARLES, À NOITE

Figura 16: A Esplanada do Café na Place du Forum, Arles, à Noite de van Gogh

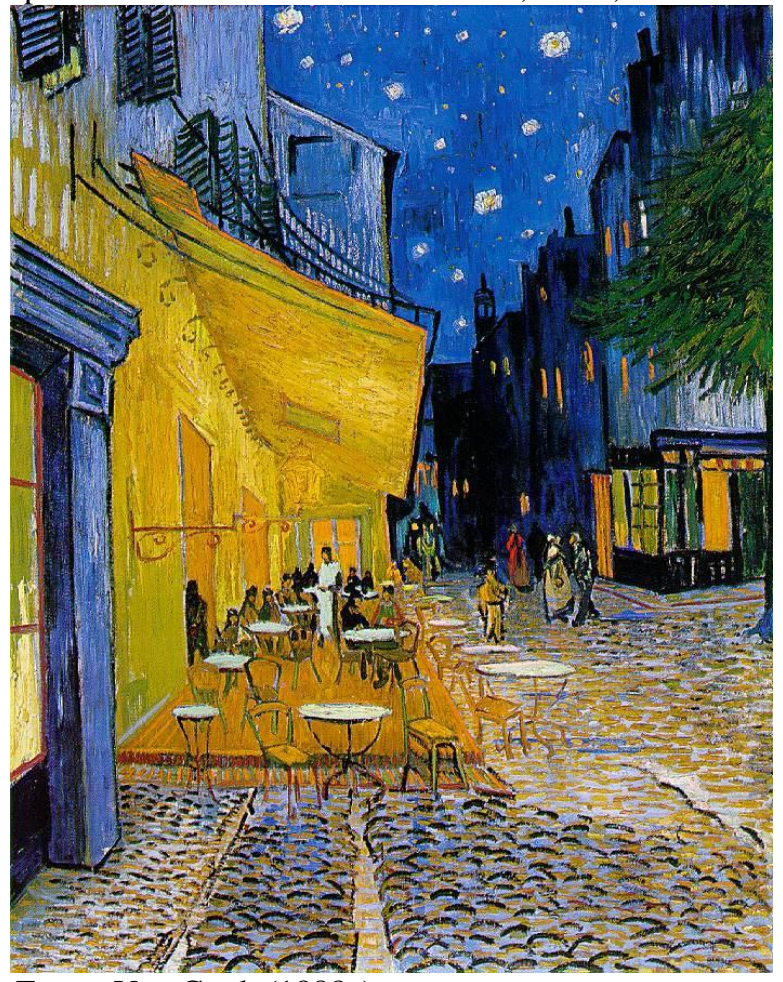

Fonte: Van Gogh (1888c).

Oil on canvas,

$81.0 \times 65.5 \mathrm{~cm}$

Arles: September, 1888

F 467, JH 1580

Localização: Otterlo: Kröller-Müller Museum

A análise da tela A Esplanada do Café na Place du Forum, Arles, à noite foi colocada no apêndice para reduzir o volume da tese.

5.7 ANÁLISE TEXTUAL DOS EXTRATOS DE CARTA RELATIVOS À TELA 'A ESPLANADA DO CAFÉ NA PLACE DU FORUM, ARLES, À NOITE'

A análise textual dos extratos de carta relativos à tela A Esplanada do Café na Place du Forum, Arles, à noite foi colocada no apêndice para reduzir o volume da tese. 
5.8 ANÁlLISE DA TELA O CAFÉ NOTURNO NA PLACE LAMARTINE, EM ARLES

Figura 17: The Night Café in the Place Lamartine in Arles

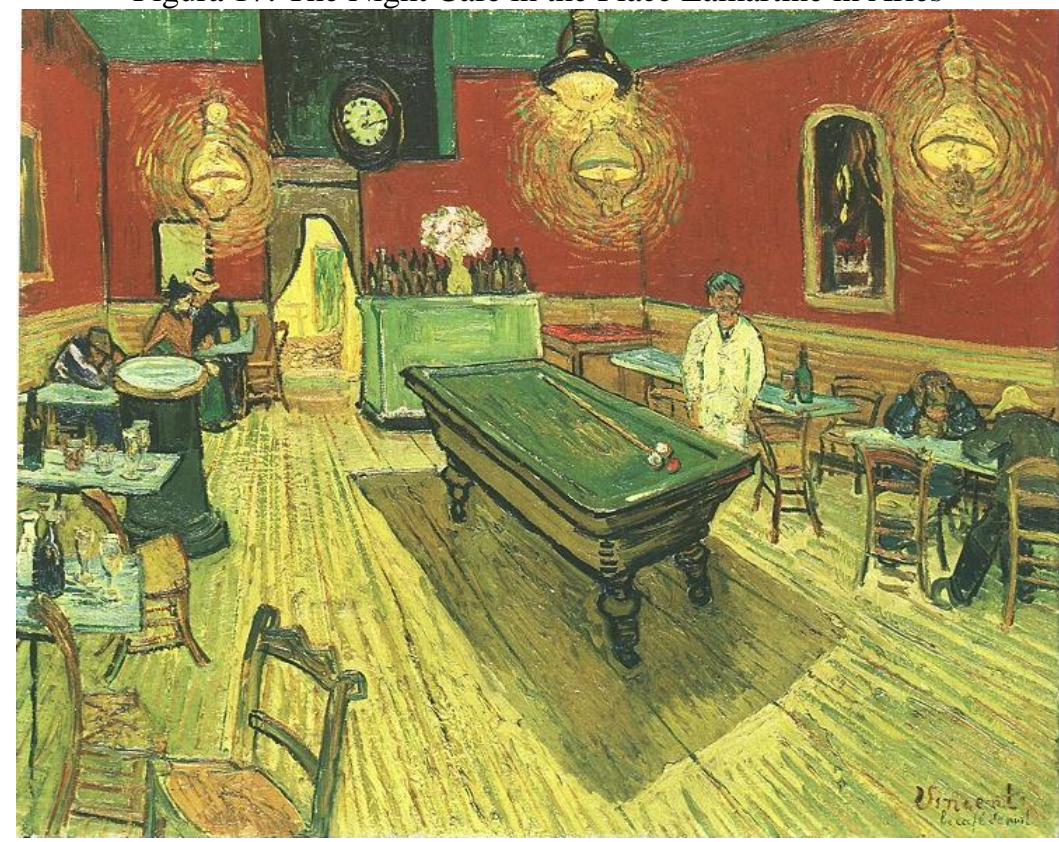

Fonte: Van Gogh Gallery. Disponível em 15 de julho de 2013:

http://www.vggallery.com/painting/p_0463.htm

Óleo sobre tela, $70.0 \times 89.0 \mathrm{~cm}$.

Arles: 5-8 Septembro de 1888.

F 463, JH 1575

Localização: New Haven, Connecticut: Yale University Art Gallery

\section{Descrição da tela}

Van Gogh representa nesta tela um café à noite. Nas duas paredes do salão do Café, vemos duas filas periféricas de mesas vazias e com poucos clientes que se debruçam nas mesas mostrando cansaço e apatia. No centro do café, há uma mesa de bilhar e um homem que está parado e olha diretamente para alguém que não vemos na tela. Dá a impressão que olha e espera essa pessoa para entrar em contato. O homem parado olha na sua direção com expectância, em contraposição com os clientes que estão imersos em seus mundos particulares e não estão interagindo. 


\subsubsection{Análise da Função Composicional da tela The Night Café in the Place Lamartine in Arles}

Espaço compositivo

\section{Planos}

Em termos de perspectiva, profundidade e de representação tridimensional do espaço, a representação da sala do café à noite está dividida em quatro planos. O primeiro plano vai até o pé da mesa de bilhar, o segundo plano vai até o fim da mesa de bilhar, o terceiro plano é representado pelo fundo da sala, onde estão um balcão com bebidas e um casal no canto esquerdo da porta que está ao fundo. O quarto plano parece mostrar o vestíbulo ou ante-sala de entrada para o bar ou para as outras dependências do prédio. ${ }^{119}$

\section{Espaço composicional - Planos sobrepostos}

A composição apresenta os planos por camadas e eles não mostram uma coerência com o real, devido à distorção criada deliberadamente na representação da perspectiva e que produz a percepção de estarmos olhando para o piso de diferentes pontos de vista e essa experiência produz diferentes ângulos para se ver o chão que avança para o fundo da sala. Essas diferentes camadas de pontos de vista se superpõem criando uma sensação indescritível de não sabermos ao certo de que ponto estamos olhando a cena, pois as linhas de contorno estão levemente distorcidas. ${ }^{120}$

\section{Espelhamento assimétrico das mesas}

Outro contraste com ênfase na função composicional está no fato de que as duas fileiras periféricas de mesas e cadeiras onde se encontram os frequentadores do Café estão invertidas em termos de ocupação humana. A fileira da direita está ocupada, logo em seu início, no segundo plano por dois homens que parecem muito cansados, seguida de mesas e cadeiras vazias. Já a fileira de mesas da esquerda está ocupada em seu início apenas com cadeiras e mesas vazias e só vai ter mesas ocupadas por figuras humanas ao final, no terceiro plano. Essa

\footnotetext{
119 Ocorrência de Enquadramento que interage com a Perspectiva e a Profundidade presentes na divisão dos planos no espaço composicional.

${ }^{120}$ Ocorrência de Distorção do Ponto de Vista nas linhas da perspectiva, criada com a interação do uso de Enquadramento, Perspectiva e Profundidade.
} 
inversão elimina a possibilidade de simetria que há por acompanharem uma mesma linha de perspectiva e empresta maior dinâmica ao posicionamento dos objetos e figuras na cena.

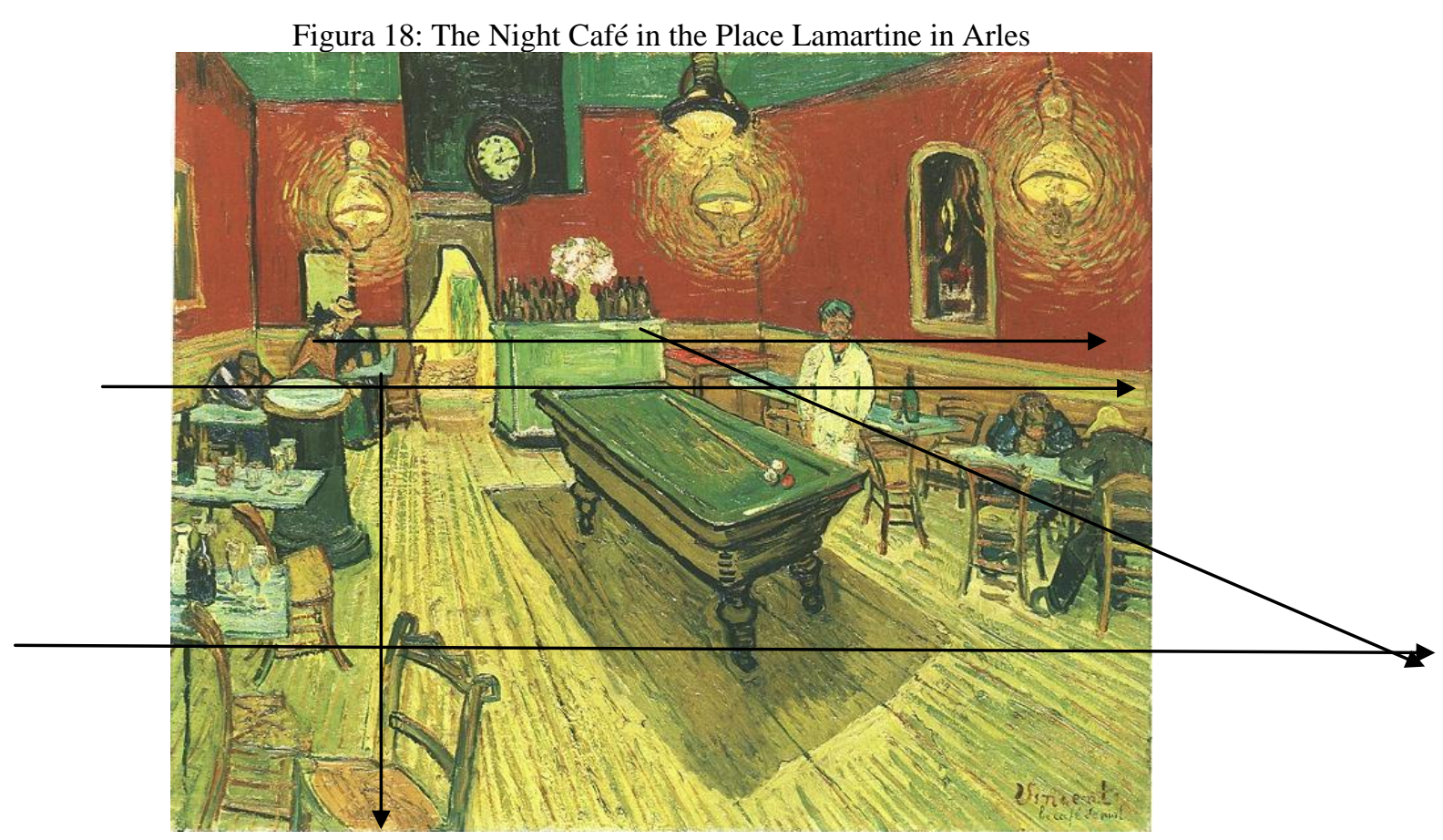

\section{Seções horizontais}

A tela parece estar dividida tanto da direita para a esquerda em três seções, quanto do primeiro plano, segundo e terceiro, quanto de baixo para cima em mais três seções perfazendo o total de nove episódios que organizam a divisão do espaço compositivo.

Na leitura horizontal, que segue a direção da direita para a esquerda:

a) a primeira seção começa na extremidade da direita e termina no final da parede da direita no fundo da sala;

b) a segunda seção começa desta esquina e vai até o fim da porta que está no fundo da sala. A linha esquerda do batente da porta é acompanhada pela linha de um acabamento na pintura da parede do fundo que parece emoldurar o relógio em um quadrado de cor verde escuro. O contorno esquerdo deste acompanha o contorno esquerdo da porta criando um caminho visual que finaliza a segunda seção e inicia:

c) a terceira seção à esquerda da composição e que acompanha a parede da esquerda de quem olha a tela. A terceira seção está ocupada por cadeiras vazias na frente e 
mesas vazias e mesas ocupadas por um homem e por um casal ao fundo. As cadeiras no primeiro plano foram representadas parcialmente e não tem uma proporção e um alinhamento compatível com as perspectiva das tábuas no chão. ${ }^{121}$

Na primeira seção horizontal, ao longo da parede a direita de quem olha para a cena, vemos cadeiras e mesas vazias, com exceção da primeira mesa na qual se encontram dois frequentadores com as cabeças abaixadas. Bem acima deles, uma lâmpada está ricamente representada por um detalhamento de pinceladas que expressam a luz que ela irradia. Perto da fila de cadeiras e mesas vazias avança do segundo plano da tela para o terceiro encontra-se um homem em pé que olha diretamente para o espectador. No terceiro plano há uma mesa de tampo vermelho está encostada na parede no fundo, nesta mesma direção.

No centro da tela, temos, no primeiro plano um espaço vazio, representando apenas as tábuas do chão fortemente iluminado pelas lâmpadas do recinto. Este episódio central no primeiro plano está ocupado também pela sombra que uma mesa de bilhar projeta. A mesa ocupa o segundo plano do espaço central da tela e está sem jogadores. Parado próximo a ela e também ocupando o centro da tela, está um homem que olha frontalmente. Acima da mesa de bilhar vemos duas lâmpadas superpostas, uma similar a da seção anterior, de brilho intenso e ricamente representado, e parece iluminar o espaço atrás da mesa; e outra mais a frente que tem um modelo de cúpula diferente e ilumina a mesa de bilhar. No centro da tela e ao fundo, e no terceiro plano, está um balcão com bebidas e um buquê de flores encostado na parede atrás da mesa de bilhar.

$\mathrm{Na}$ terceira seção, a esquerda de quem olha para a tela, vemos uma nova fila de cadeiras e mesas, dessa vez, inversamente ocupadas. Ou seja, as cadeiras no primeiro plano estão vazias, e são ricamente detalhadas. Vemos duas cadeiras uma voltada para outra, sugerindo como se estivessem sido ocupadas por dois interlocutores, pessoas que estavam uma diante da outra interagindo. No entanto não há uma mesa, entre elas, sugerindo reunião, e as cadeiras deixadas assim vazias e livres no espaço, sugerem contraposição. ${ }^{122}$

No segundo plano, nesta direção, vemos uma mesa com dois cálices vazios e duas garrafas, uma cheia e uma vazia, sugerindo que os seus ocupantes acabaram de deixar o recinto. Em seguida, ainda no segundo plano, uma cadeira vazia, voltada para a mesa de bilhar e para o homem sugere que alguém esteve ali observando ou participando de uma partida de bilhar. Essas cadeiras estão distorcidas em suas linhas de perspectiva criando a

121 Ocorrência de Enquadramento, Inacabamento, Perspectiva e Distorção do Ponto de vista. As cadeiras no primeiro plano foram representadas parcialmente e não tem uma proporção e um alinhamento compatível com as perspectiva das tábuas no chão.

${ }^{122}$ Ocorrência de Incompletude, pela associação de sentidos potenciais do vazio que a cadeiras sugererem. 
impressão de que têm 'personalidades' diferentes. Esta terceira cadeira é seguida de uma segunda mesa que tem em seu topo dois cálices vazios, dois copos, um cheio e um vazio e uma garrafa.

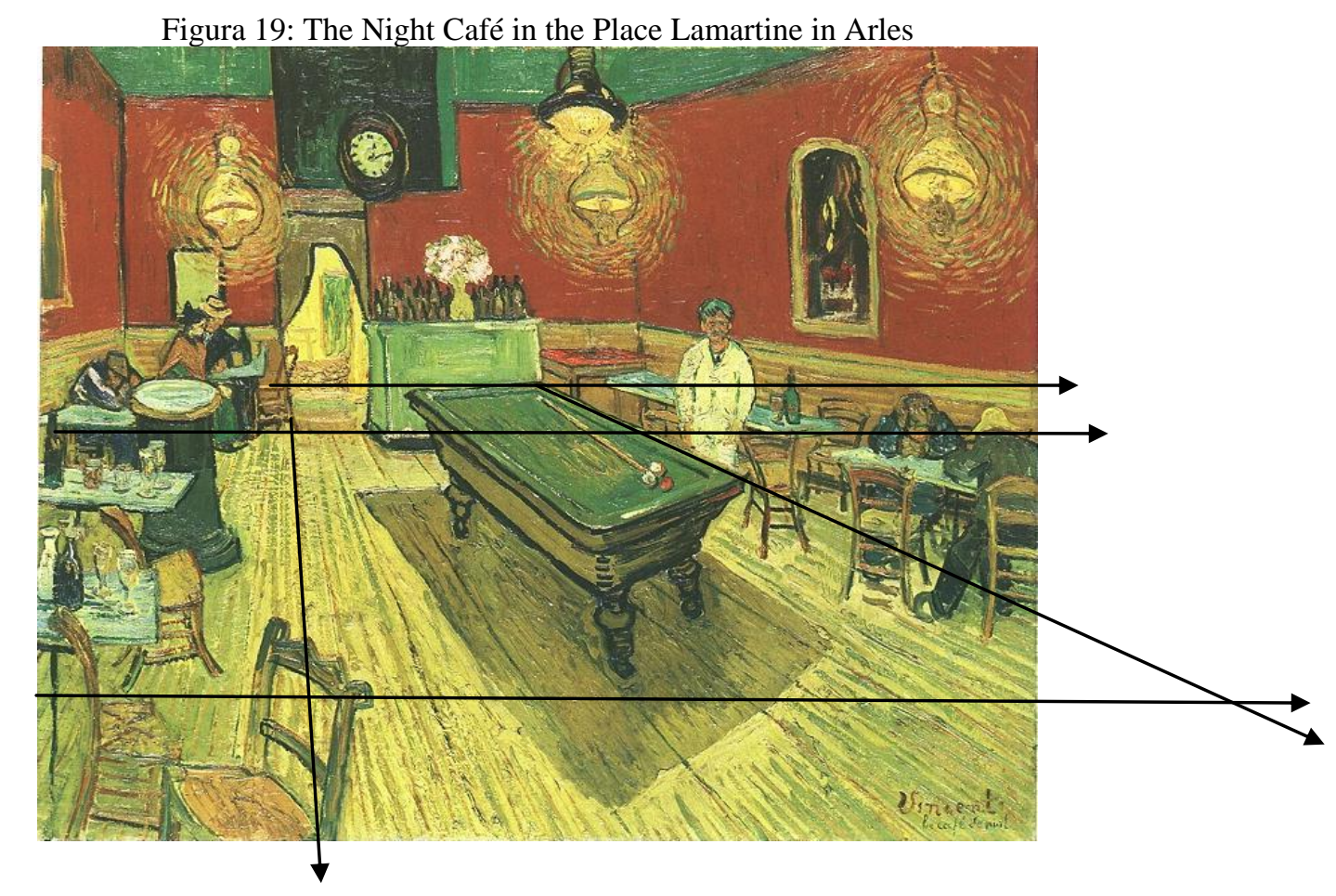

A seguir, ainda no segundo plano desta seção, vemos o que parece ser um aquecedor em formato cilindrico e atrás dele, já no terceiro plano, um homem está sentado na mesa e parece adormecido sobre ela. Ao fundo do salão, também no terceiro plano a esquerda há uma mesa encostada na parede e nela, um casal, sentados muito próximos no mesmo lado da mesa, parecem trocar carícias. Acima destas três figuras humanas no terceiro plano da esquerda está uma terceira lâmpada ricamente trabalhada de forma a enfatizar a luz que derrama sobre o lugar.

\section{Seções verticais}

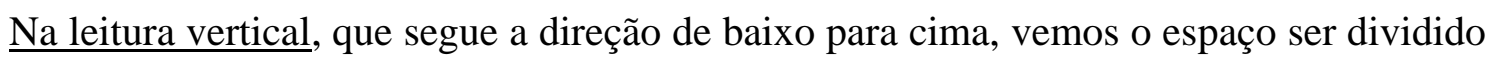
por cores em três seções.

De forma cromática, o espaço também está dividido em três planos de baixo para cima. $\mathrm{O}$ primeiro é em tons de amarelo e verde representa o chão e a parte inferior das paredes. $\mathrm{O}$ 
segundo é vermelho escuro e representa a metade superior das paredes. O terceiro é verde escuro e representa o teto. ${ }^{123}$

$\mathrm{Na}$ escolha da paleta de cores com as quais van Gogh representa este Café, vemos a combinação de três cores principalmente, o verde na parte superior da tela, o vermelho nas zonas médias da tela e o amarelo nas seções inferiores da tela. Essas áreas ajudam a dividir a tela e a organizar o espaço composicional da cena em nove diferentes episódios nos quais van Gogh representa coisas bastante distintas. ${ }^{124}$

Na seção amarela, encontram-se as figuras humanas, os móveis, as mesas e as cadeiras nos quais se sentam os frequentadores do bar, uma mesa de bilhar que ocupa a maior parte da sala, e um balcão no fundo, no qual se encontram as garrafas com bebidas.

Na seção vermelha, vemos as lâmpadas, bastante detalhadas com pinceladas que produzem textura e ritmo para a luz que delas depreendem em todas as direções, ${ }^{125}$ e nas paredes, estão aparentemente um espelho e uma tela que não está detalhada acerca do que representa. A lâmpada do centro parece estar superposta com outra lâmpada, que é diferente desta, uma que desce do teto verde e parece estar na frente da lâmpada que é semelhante às outras duas e com elas perfaz uma tríade que ocupa todo o espaço compositivo do episódio em vermelho.

Na seção verde, que é menor e está mais afastada dos objetos e figuras dos outros dois episódios, não há objetos, apenas um objeto de transição entre a seção vermelha e a seção verde que é um relógio na parede que nesta área tem a cor verde como a do teto e não a cor vermelha como o resto da parede.

\footnotetext{
${ }^{123}$ Ocorrência de Contrastes simultâneos entre o verde e o vermelho escuro no interior do café.

${ }^{124}$ Ocorrência do uso das cores para dividir verticalmente os episódios da composição.

${ }^{125}$ Ocorrência do uso de Saliência e Vetor interrelacionados com a ocorrência de Textura e Gesto Pictórico para construir a luz das lâmpadas a gás. O vetor ocorre em direção radial.
} 
Figura 20: The Night Café in the Place Lamartine in Arles

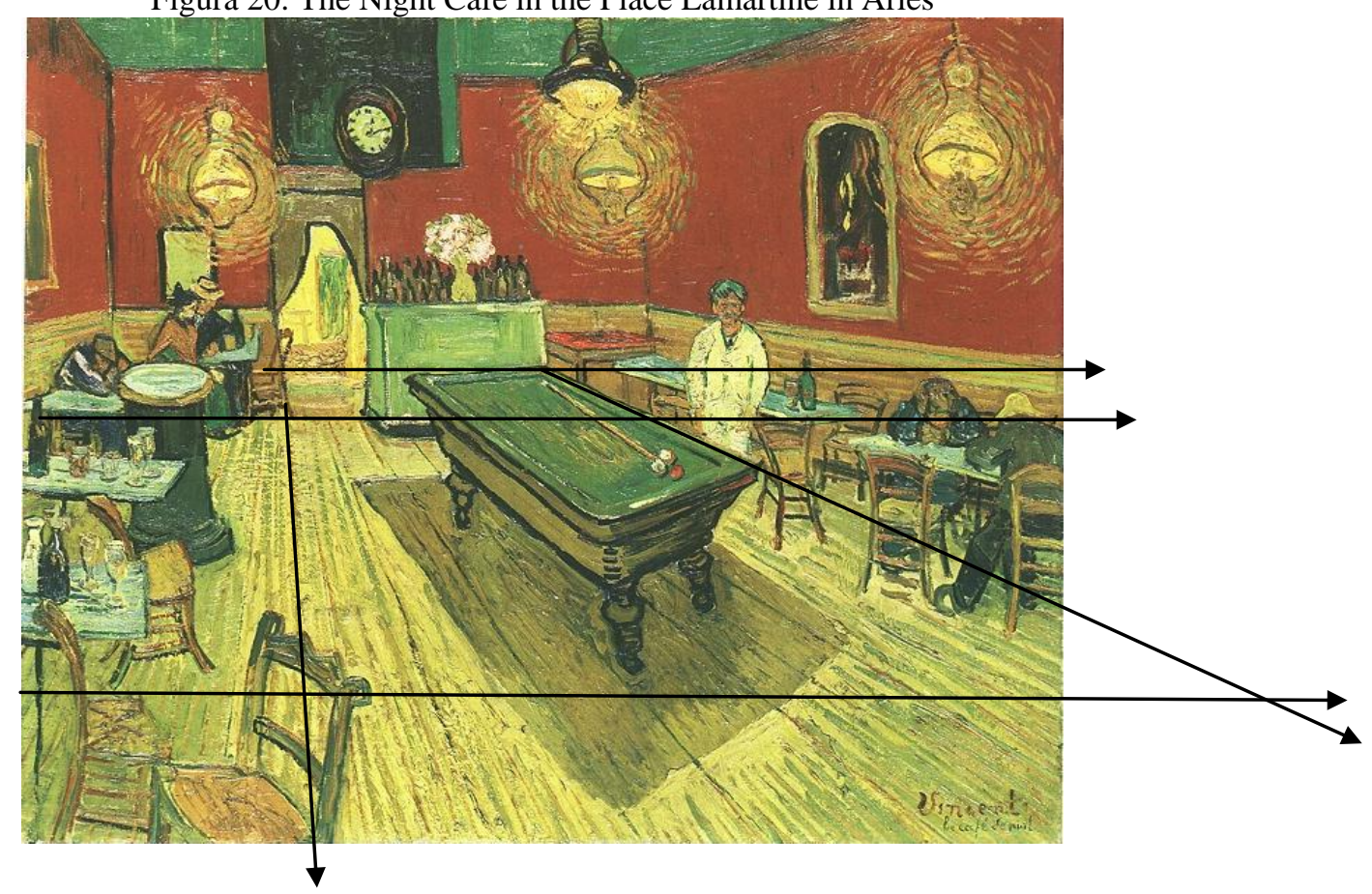

\section{Episódios}

Na leitura por Episódios, temos uma sequência que progride da direita para a esquerda e de baixo para cima.

No primeiro Episódio, na parte inferior e a direita da tela vemos um espaço vazio, que representa apenas as tábuas do assoalho e neste espaço temos a assinatura de Vincent. No segundo Episódio, na parte inferior central da tela, no primeiro plano, vemos também um espaço vazio, e nele a sombra da mesa de bilhar que está representada por um contraste de saturação cromática muito intensa entre a tonalidade esverdeada da sombra da mesa e o brilho intenso da luz refletida em todo o assoalho de madeira amarelo ocre. ${ }^{126}$

No terceiro Episódio, na parte inferior no primeiro plano a esquerda da tela há duas cadeiras voltadas uma para a outra, de forma assimétrica e que não correspondem à percepção de perspectiva clássica, causando uma sensação de distorção das suas formas e uma sensação de instabilidade por ser a terceira delas um pouco inclinada em seus apoios. ${ }^{127}$

No quarto Episódio, no segundo plano à direita de quem vê a tela, vemos encostada na parede uma mesa, na qual dois sujeitos sentados parecem cansados e se apoiam na mesa em

\footnotetext{
${ }^{126}$ Ocorrência de Saliência construída pelo Contraste de saturação entre o amarelo do chão no primeiro plano e a sombra da mesa de bilhar amarelo-esverdeado.

${ }^{127}$ Ocorrência de Distorção do Ponto de Vista, construída pela representação das cadeiras em desalinho com as linhas de perspectiva das tábuas do chão.
} 
busca de uma posição mais confortável. Nessa mesa vemos o encosto de duas cadeiras paralelas que conferem um ritmo ao Episódio. ${ }^{128}$

No quinto Episódio, no segundo plano, no centro da tela, vemos uma mesa de bilhar vazia e próximo à ela está parado um homem que olha frontalmente em atitude de expectativa. ${ }^{129}$ Apesar de não estar no primeiro plano e sim no segundo, os contornos da mesa são ricamente detalhados e enfatizados, como que para representar a sombra que ela produz em suas pernas. ${ }^{130} \mathrm{~A}$ mesa de bilhar está no segundo plano que deveria ser menos importante do que o primeiro. No entanto, a ênfase dada à mesa denota que ela é central na representação do café. ${ }^{131}$ As linhas da mesa são levemente distorcidas e não correspondem aos padrões de representação do mundo real. As pernas da mesa não são paralelas às linhas de perspectiva da mesa e por estarem desalinhadas, emprestam uma 'personalidade' como se fossem de um ser animado. Que metáfora visual o pintor associou a forma como ele representou esta mesa? Do ponto de vista simbólico a mesa de bilhar vazia, a sombra exagerada que ela projeta no chão e a atmosfera que a circunda oferecem uma narrativa sugestiva. ${ }^{132}$

No sexto Episódio no segundo plano na parede à esquerda, há apenas duas mesas e uma cadeira, vazias, em sua superfície, cálices vazios e garrafas. E um móvel escuro e redondo que parece ser um aquecedor com brasas.

No sétimo Episódio, no terceiro plano à direita de quem olha a tela, vemos três mesas vazias encostadas na parede, duas com tampo branco e uma com tampo vermelho. Na seção vermelha da tela a direita, vemos uma lâmpada ricamente trabalhada que irradia luz sobre os dois sujeitos que estão no quarto Episódio. ${ }^{133}$ Eles não projetam sombra sobre o chão.

No oitavo Episódio, no terceiro plano no centro da tela na seção vermelha da tela vemos um balcão com garrafas e um vaso de flores brancas e uma porta com cortina. Acima há uma lâmpada superposta com a lâmpada que está sobre a mesa de bilhar, e ao fundo um relógio na parede.

\footnotetext{
${ }^{128}$ Ocorrência de Ritmo construído pelos encostos das duas cadeiras à direta de quem olha a tela, conduzem o olhar para o homem de branco em pé.

${ }_{129}$ Ocorrência de Vetor construída pela figura do homem no centro da sala que olha diretamente para o espectador.

${ }^{130}$ Ocorrência de Saliência, construida pelo detalhamento da mesa de bilhar, feita pelo desenho-pintura.

${ }^{131}$ Ocorrência de Profundidade visual - apesar de estar no segundo plano que seria de menor importância do que o primeiro, a mesa de bilhar está ricamente detalhada, denotando que ela é o elemento principal da composição.

${ }_{132}$ Ocorrência de Associação Metafórica conferida pela Distorção do Ponto de Vista presente na representação da mesa de bilhar.

${ }_{133}$ Ocorrência de Saliência construída com o uso de Textura, Ritmo, Movimento e Gesto Pictórico para representar o brilho da lâmpada na representação das figuras no fundo da sala.
} 
No nono Episódio, no terceiro plano e a esquerda da tela, vemos um homem solitário em uma mesa e mais ao fundo um homem e uma mulher que estão em uma interação íntima. Acima deles uma lâmpada irradia uma luz ricamente representada. ${ }^{134}$

Esses nove Episódios parecem conter em cada um deles, pequenas narrativas distintas e que juntas constroem a unidade pictórica do texto, com significados simbólicos que começam a emergir da conjugação dos recursos usados na composição e começam a fazer sentido no contexto das semioses e das metáforas visuais que eles sugerem.

Essas narrativas em cada um dos nove episódios serão analisadas na função representacional a seguir, bem como serão analisadas as formas como elas se relacionam entre si para construir sistemas semióticos na tela.

\section{O contraste cromático}

Contraste de luz e sombra - Este contraste é acentuado pelo brilho excessivo da luz das lâmpadas no assoalho, que cria um contraste de saturação cromática que produz um clima de brilho excessivo e uma sensação rarefeita na sala. E essa mesma luz de cores saturadas que se espalha no assoalho enfatiza a única sombra da mesa de bilhar que assume,com isso, um estatuto metafórico. Tudo no café está acometido pela luz, exceto o espaço sob a mesa de bilhar. $^{135}$

\subsubsection{Análise da Função Modal da tela The Night Café in the Place Lamartine in Arles}

Perspectiva - levemente distorcida com pontos de fuga contraditórios

As linhas da parede e as linhas da mesa de bilhar e das tábuas do chão ajudam a construir as linhas da perspectiva, mas elas estão em desacordo. Elas não estão alinhadas de forma paralela como deve ser, para construir a perspectiva clássica, e produzem uma certa deformação na construção do espaço da sala. Van Gogh parece ter produzido uma distorção

\footnotetext{
${ }^{134}$ Ocorrência de Associação Metafórica construída com o uso de Profundidade e Perspectiva na representação das figuras no fundo.

${ }^{135}$ Ocorrência de Contraste de saturação cromática que produz um clima de excesso de luz das lâmpadas refletidas no assoalho.
} 
na perspectiva com que a mesa é representada. ${ }^{136}$ Walther $(1990$, p. 49-50) comenta a deformação da perspectiva em outra tela de van Gogh:

No quadro "A ponte perto de Trinquetaille" (fig.p.56), pintado em Outubro de 1888, van Gogh desiste quase inteiramente da cor, submete o efeito do quadro ao jogo contrastivo entre as texturas lineares do lado esquerdo e as zonas maiores, mais calmas do lado direito. Esta vista da ponte sobre o Ródano, que não mostra o rio, orienta-se, na economia da cor, pelas obras anteriores do período holandês, no motivo, pelos trabalhos do período pariesiense. Mas na extrema deformação do espaço, nas perspectivas confusas, o quadro é bem o produto dos anos posteriores. A escada em primeiro plano, irresistivelmente atraída pela abertura da passagem ao fundo, contrasta com o balanço vacilante da ponte de aço que ameaça ruir a qualquer momento. Expressividade do espaço poderia chamar-se a este periclitante equilíbrio, a este balanço sempre frágil. Foi van Gogh o primeiro expressionista? O seu tratamento do espaço deixa-nos responder afirmativamente a esta pergunta. (Walther, 1990, p.49-50)

Figura 21: A Ponte Langlois em Arles, maio, 1888.

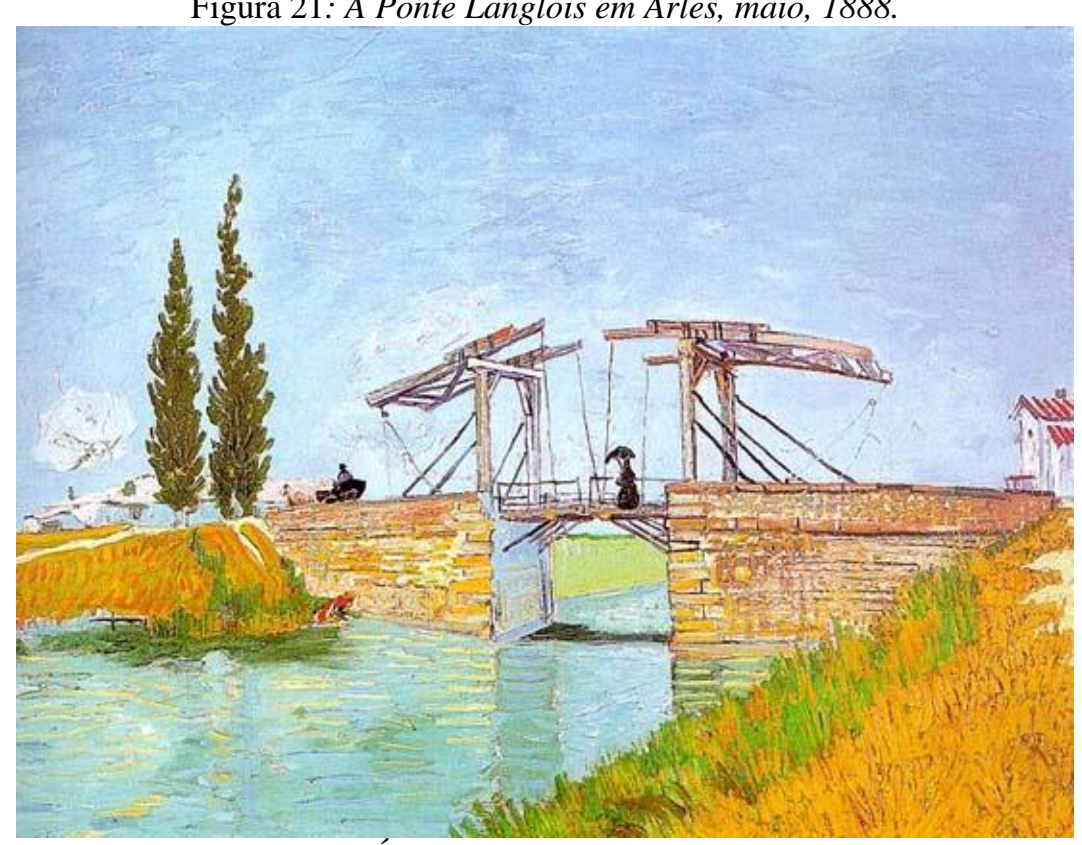

Fonte: Van Gogh (1888e) Óleo (49.5 cm x $64.0 \mathrm{~cm})$. Cologne: Wallraf-Richartz-Museum

\section{Elementos em contraposição e Expressividade Exacerbada}

Por meio do uso dos elementos pictóricos em 'O Café Noturno na Place Lamartine, em Arles', van Gogh parece ter feito escolhas nessa tela que enfatizam o desconforto, o estranhamento, a inquietação. O quadro constrói, por meio da conjugação de algumas estratégias de composição tais como os contrastes cromáticos, de luz e sombra, de volume, e a distorção da perspectiva, uma expressividade exacerbada para a representação de um café à

\footnotetext{
${ }^{136}$ Ocorrência de Distorção do Ponto de Vista, Inacabamento e Incompletude, construídas com ajuda da perspectiva, profundidade e enquadramento na representação das linhas de perspectiva distorcidas.
} 
noite. Esses contrastes parecem dar, por meio dos tensionamentos criados, uma sensação de mal-estar e perturbação para os olhos atentos à cena. ${ }^{137}$

Além disso, eles constroem um dinamismo para os elementos que estão em contraposição: figuras isoladas x figuras que conversam; figura que olha para nós x figuras que negam o olhar; figuras periféricas x figura centralizada; centralidade de objetos x periferia de figuras humanas; valorização de cadeiras vazias no primeiro plano x menor valorização de pessoas representadas nos planos mais distantes. A maior valorização que van Gogh parece construir ao posicionar ao centro e no primeiro plano objetos vazios instancia a noção de inversão e estranhamento na cena. ${ }^{138}$

\section{Modalidade}

Van Gogh usou a distorção para chamar a atenção do espectador para os sentidos metafóricos do ser humano.

A deformação e o exagero na representação do Café são construídos por meio das linhas da composição que criam a perspectiva e a espacialidade da cena. A distorção na perspectiva cria uma entonação de instabilidade para a tela e preenche um importante aspecto da função Modal. ${ }^{139}$ Essa deformação da perspectiva corresponde ao aspecto da "modalidade" em gramática, como explica O’Toole (1994, p. 9) “A modalidade se encarrega de colorir o conteúdo experiencial de um enunciado pelo uso de um verbo modal, ou advérbio, ou por um padrão de entonação diferente." 140

Podemos afirmar que nesta tela, van Gogh construiu uma entonação exacerbada que tem uma função de aguçar os sentidos para uma conotação metafórica sobre a condição humana limítrofe, moral ou social. ${ }^{141}$

O’Toole (1994, p.9) comenta sobre a relação entre a deformação da perspectiva e a da "modalidade" em gramática:

\footnotetext{
137 Ocorrência de Distorção do Ponto de Vista e Transparência, construídos com ajuda da Saliência e de Contrastes cromáticos simultâneos e de saturação exacerbados para representar uma sensação de desconforto.

138 Ocorrência de Contraposição entre elementos tais como isolamento/convergência, centro/periferia, vazio/ocupado e sua salientação pelo posicionamento relativo na composição produzem um sentido de inversão e estranhamento.

139 Ocorrência de Distorção do ponto de vista nas linhas da composição conferem instabilidade para a representação.

${ }^{140}$ Ocorrência de baixa Modalidade naturalistica, mas alta Modalidade Subjetiva e Transparência, conferida pela distorção do ponto de vista.

${ }^{141}$ Ocorrência da Associação metafórica com a condição humana extrema, construída pelo uso de Distorção do Ponto de vista.
} 
Outro aspecto da função Modal é o que nós chamados da "entonação" que o pintor dá para a realidade representada. Isso é equivalente ao que os linguistas chamam de "modalidade" em gramática, onde o conteúdo Experiencial de um enunciado é colorido por um verbo modal, ou advérbio, ou por um padrão distinto de entonação. ${ }^{142}$

Inferi isso pela forma como ele usa uma representação distorcida do real para introduzir um sentido, uma percepção de outra realidade, uma realidade talvez subjetiva ou moral que está sendo representada em sua narrativa do Café. Como o uso dos recursos visuais em uma sintaxe do exagero está comunicando processos e dinâmicas representados? De que processos ele fala? ${ }^{143}$

Talvez a deformidade de caráter é representada pela distorção da cor e da perspectiva que enfatizam ainda mais esse aspecto por meio de um tom de amarelo fatigante, e um contraste entre o verde escuro e um vermelho escuro que não é nada harmonioso e convidativo. ${ }^{144}$ Inferimos isso com base na análise feita por Whalter e Meztger sobre duas pinturas que representam o interior do Café Lamartine na mesma época, esta por van Gogh e outra por Gauguin. A distorção usada como recurso semiótico por van Gogh fica muito mais aparente quando observei a tela pintada por Gauguin.

Ao representar uma cena real com efeitos exagerados, por meio da força expressiva dos recursos e estratégias pictóricas, van Gogh teria usado a cena do ambiente soturno do Café à noite para fazer uma declaração que depois é explicitada também em suas cartas e que estão analisadas na seção da análise do corpus textual desta tela. A análise das escolhas semióticas nesta tela, busca reconhecer os recursos de modalização usados para compreender a linguagem visual e assim reconstruir essa declaração explicitada na tela e também explicitada nas cartas. ${ }^{145}$

Podemos dizer que essa tela tem uma 'entonação' exacerbada para representar o Café e esta foi uma escolha deliberada do pintor para construir uma narrativa visual e nela, um estatuto o qual, suponho, seja o uso da distorção para aguçar nossos sentidos para uma conotação simbólica de uma condição humana extrema, moral ou social. ${ }^{146}$

\footnotetext{
142 Tradução livre da autora. "Another aspect of the Modal function is what we might call the "slant" the painter gives to the reality being depicted. This is equivalent to what linguists call "modality" in grammar, whereby the Experiential content of an utterance is coloured by a modal verb, or adverb, or by a distinctive intonation pattern." (O’TOOLE, 1994, p. 9).

${ }^{143}$ Ocorrência de Distorção do ponto de vista e de Saliência, que ele constrói para representar uma realidade que é do domínio moral e subjetivo.

${ }^{144}$ Ocorrência de Associação metafórica construída pelo uso dos contrastes cromáticos que enfatizam um tom de amarelo fatigante para representar a deformidade de caráter.

145 Ocorrência de Associação metafórica construída pelo uso da Intertextualidade entre carta e tela.

146 Ocorrência de Distorção do ponto de vista pelo uso de cores e de linhas de perspectiva e como estratégia de modalização para construir Saliência e Associação metafórica.
} 
Luz, iluminação e o contraste de luz e sombra

Nesta tela não há muita ênfase por meio de grandes contrastes de luz porque a luminosidade excessiva parece homogenizar o ambiente todo por igual sem destacar nenhum objeto em particular, com exceção da mesa de bilhar no centro da tela que é o único objeto que possui sombra na sala. A falta de contrastes de luz e sombra dada pelo excesso de iluminância, retira a profundidade que, de outra forma, seria dada pela gradação cromática que aqui, se sustenta pelas linhas de perspectiva da composição. ${ }^{147}$

Luz

A luz parece muito intensa e desproporcional para o ambiente e produz um ofuscamento no chão no primeiro plano e um achatamento no volume das figuras. Pode ser que não seja noite, mas dá a impressão que são altas horas da noite. Isso dá uma ambiguidade muito grande, pois para que tanta luz se é de dia e como um lugar poderia ficar tão iluminado com apenas quatro lâmpadas se é de noite? Então, a representação da luz tem um efeito modalizador para dar para a cena uma 'entonação'. ${ }^{148}$

\section{Sombra}

Com exceção da sombra da mesa de bilhar, não existem outras sombras na tela. A negação de outras sombras parece enfatizar o fato de que esta é a única. Qual é a função da sombra? Parece ser a negação da luz. Esta negação atua como uma modalização também. Com qual finalidade? Qual seria a finalidade de ter uma saturação em tudo e não colocar sombra em nada? Que sentidos o pintor conjuga com o excesso de luz e da negação da luz, que é a sombra? É um efeito duplo que tem a função de reforçar a presença da luz, mesmo onde deveria haver sombra. O que ele alcança como resultado? Talvez essa ausência de sombra nas figuras e objetos periféricos tenha a função de dar ênfase no único objeto que tem sombra de fato e que está no centro, já tendo ênfase por seu posicionamento central no espaço

\footnotetext{
${ }^{147}$ Ocorrência de Distorção do ponto de vista pela baixa profundidade e Saliência pelos contrastes de saturação que geram uma iluminação excessiva.

${ }_{148}$ Ocorrência de Distorção do ponto de vista produzida pela baixa Modalidade na representação do ambiente do café. De acordo com Kress e van Leeuwen (1996), a ambiguidade é um traço de ocorrência de modalidade.
} 
composicional, junto com a figura do homem. Quer dizer, ele dá ênfase para um objeto que já tem ênfase. Por que o exagero? ${ }^{149}$

O’Toole (1994) destaca que há um leque de possibilidades de uso dos recursos pictóricos como sistemas modais para envolver o espectador. No entanto, eles não devem ser esgotados em uma pintura com o risco de criar uma redundância, com exceção de ser este excesso uma escolha deliberada do artista. Este parece ser o caso da tela 'Café da Noite',onde encontrei a sobreposição de recursos de modalização que criam uma hipérbole visual, por assim dizer. Resta-nos inferir o efeito de sentidos que esta conjugação de recursos semióticos de modalização produziu. É fatigante esse uso dos recursos em excesso e superpostos para exacerbar os efeitos visuais e seus sentidos e que pode ser associado à um sentido de fadiga nas figuras representadas. Observei em toda a tela o uso do Exagero como sistema modal, como Modalização, e como Saliência. Existe um exagero no uso de todos os elementos, que muitas vezes estão trabalhando na composição de forma redundante e esse uso não é por acaso ou por descuido, mas sim, um uso para construir uma percepção no leitor, e tem uma forte conotação Modal. ${ }^{150}$

A sala está tão iluminada e sem sombras nas figuras e nos objetos que nos parece queu as sombras são as próprias pessoas que estão pintadas de forma bem escura. A ausência de sombra pode ter uma função representacional, pois as figuras não têm sombra, mas elas estão tão escuras, não obstante a luz intensa que as atinge desde o teto, que é como se elas fossem a própria sombra e não pudessem ser iluminadas pelas lâmpadas. Essa representação das pessoas nesse modo cria um sistema semiótico ao se apoiar em escolhas do espectador de sentidos potenciais para a construção de uma metáfora visual que associa luz das lâmpadas representadas com as convenções socialmente compartilhadas sobre as possíveis conotações para a luz. ${ }^{151}$

\section{Caminhos visuais A sombra da mesa}

A sombra da mesa parece criar uma seta que aponta para algo que está fora da tela, ela direciona o olhar do leitor para o ponto de onde se viu a cena e implicitamente, para o pintor que desde lá, observa o cenário. Esta hipótese é reforçada pelo homem que, parado no meio

\footnotetext{
${ }^{149}$ Ocorrência de Saliência construída pela ausência de sombras e apenas uma sombra no centro da composição.

150 Ocorrência de Saliência construída pelo exagero no uso de todos os elementos, que muitas vezes estão trabalhando na composição de forma redundante para obter um efeito de sentido.

${ }^{151}$ Ocorrência de Associação metafórica para os sentidos potenciais da luz que ilumina as pessoas no café.
} 
da sala, olha diretamente para alguém que não aparece no quadro. ${ }^{152}$ A seta criada pela sombra da mesa de bilhar acentua a função Modal não para conduzir o espectador para dentro da tela, mas estando já dentro da cena por outros recursos modais, ela direciona sua curiosidade para perguntar sobre quem estaria posicionado na direção desta seta que a sombra da mesa de bilhar aponta e enfatiza. ${ }^{153}$

Observei aqui uma inversão do ponto de vista, construída pelo uso de um Vetor, dado pelo homem no centro da sala que olha para o espectador. Há o uso de Direção para construir um sentido na leitura do espectador. Outros recursos se encarregam de levar o espectador para dentro da cena. A seta, criada pela sombra da mesa se encarrega de levar a atenção do espectador para aquele ponto desde o qual se olha a cena. Esse sentido constrói uma inversão e um deslocamento no Enquadramento e na Perspectiva que vai desde o envolvimento até o distanciamento para se olhar a cena. ${ }^{154}$

\section{Corredores de luz em volta da mesa}

Por outro lado, a forma de seta criada pela sombra da mesa é contrastada pelos corredores de luz em torno da mesa de bilhar, construídos pelo uso da intensidade da luz que se espalha por todo chão da sala. ${ }^{155}$ Esses corredores carregam outra ambiguidade em si, ao mesmo tempo em que não são estreitos para uma pessoa passar, eles não são convidativos porque eles começam largos e terminam no fundo da sala com um aparente estreitamento. Essa aparência de estreitamento é criada pelo uso da perspectiva conflitante entre a sombra da mesa e as tábuas do chão que não se acompanham de forma simétrica. Enquanto as linhas das tábuas do chão fazem um ângulo de perspectiva em direção ao fundo da sala, as linhas do contorno da sombra que também são de perspectiva, não se alinham com aquelas de forma harmoniosa ou paralela, e criam uma instabilidade e um estreitamento nos caminhos visuais que os nossos olhos tenderiam a percorrer. Essa pequena distorção nos caminhos visuais que conduzem o olhar para o fundo da sala, produz um conflito visual entre luz e sombra que não

\footnotetext{
152 Ocorrência de Direção ou Vetor criada pela sombra da mesa que se assemelha a uma seta e pelo olhar do homem que parece nos fitar diretamente.

${ }^{153}$ Ocorrência de Inversão do ponto de vista, devolve o Enquadramento e Perspectiva para o lugar do espectador da cena.

${ }^{154}$ Ocorrência de Inversão do Ponto de vista, construída pelo Vetor, dado pelo homem no centro da sala que olha para o espectador. A seta, criada pela sombra da mesa se encarrega de levar a atenção do espectador para aquele ponto desde o qual se olha a cena. Esse sentido constrói uma inversão e um deslocamento no Enquadramento e na Perspectiva que vai desde o envolvimento até o distanciamento para se olhar a cena.

${ }^{155}$ Ocorrência de Vetor, construído pela relação com o Contraste Cromático da sombra e a sua Saliência produzida em oposição aos corredores de luz.
} 
é fácil de resolver e não é agradável de sentir na experiência sensorial, devido à falta de simetria. ${ }^{156}$

Assim, para o observador, o espaço existente entre as cadeiras e a mesa de bilhar é o mesmo tanto no primeiro quanto no terceiro plano, mas sensorialmente o uso da perspectiva cria uma percepção de estreitamento que confunde o olhar para o que é da ordem do real e o que é estranho para os olhos. Cria uma imprevisibilidade na relação espacial pelo uso da proporção, das medidas, da posição e da forma que alteram a percepção do espaço. ${ }^{157}$ Essa ambiguidade entre o que é previsível e o que é imprevisível cria uma imprevisibilidade da relação espacial do espectador com a cena. Este dilema entre os caminhos visuais, construídos para os olhos percorrerem, pode ser uma metáfora visual na qual uma pessoa pode ficar aprisionada na contradição entre as perspectivas que são ambíguas. Essa metáfora visual parece falar sobre como é difícil sair dessa sala uma vez que você entra nela porque você fica prisioneiro de uma contradição de perspectivas que são ambíguas, distorcidas, conflitadas e insolúveis. $^{158}$

Talvez esse recurso usado por van Gogh tenha sido capaz de reproduzir uma experiência subjetiva de perda da identidade, da consciência de certo e errado, de dúvida sobre o seu julgamento. E talvez de distorção de si mesmo e do seu próprio lugar naquele espaço. Talvez ele estivesse falando de uma experiência limítrofe onde ele, bem como qualquer pessoa, pode se ver, destituída de sentido, e sem perspectivas, sem esperanças. ${ }^{159}$

\section{Figuras}

\section{Centralidade de uma Figura na tela}

Um homem quase ao centro da tela nos fita e nos intriga em sua atitude ambígua e com isso nos engaja na cena, seja interagindo com o homem que nos olha com expectativa,

\footnotetext{
${ }^{156}$ Ocorrência de Metáfora Visual com o uso da Distorção na perspectiva para a construção de uma saliência de que o café é um ambiente de conflitos e de uma percepção distorcida da realidade.

${ }^{157}$ Ocorrência de Distorção do ponto de vista pela discordância entre as linhas de perspectiva da composição, deformam a perspectiva.

${ }^{158}$ Ocorrência de Associação metafórica com a ajuda da Distorção do ponto de vista constrói um sentido de ambiguidade e perspectivas conflitadas.

${ }^{159}$ Ocorrência de Transparência construída com o uso conjugado de Associação metafórica e da Distorção do ponto de vista, Contraste cromático.
} 
seja nos identificando com a solidão dos presentes e esse dilema nos prende dentro da tela. ${ }^{160}$ O’Toole (1984, p. 8), explica a função do olhar em uma composição:

Muitas vezes as pinturas nos abordam diretamente também. Um exemplo claro dessa função Modal é o Olhar direto de uma ou mais figuras diretamente para nós, os espectadores. Nós todos conhecemos aqueles retratos que parecem nos seguir com os olhos por toda a sala; eles são fortemente modais. ${ }^{161}$

Vetor - O Olhar

Ao olhar para a tela, podemos sentir um impulso e um conflito ao mesmo tempo e precisar decidir a qual deles atender. Podemos empatizar e querer ficar nesse estado introspectivo em que estão mergulhadas as pessoas na sala do café; ou podemos nos identificar com a figura desse homem que está parado no centro da tela ao lado da mesa de bilhar e olha diretamente para a nossa direção. No entanto, o olhar do homem, ao invés de convidar para a interação, cria na verdade um conflito, porque a tela inteira puxa para a solidão e isolamento e ele possui o único olhar está sendo direcionado para o espectador e buscando interação com o espectador. Este dilema proposto não oferece um alternativa. Ou se interage com essa espectativa posta pela personagem central ou se isola-se como os outros, sem espaço para interação que estão, mergulhados na inércia. ${ }^{162}$

Esse dilema, que é Modal, por não ser solúvel nos deixa presos e trata de prender a nossa atenção naquela ambiência saturada e mórbida. Van Gogh criou um recurso semiótico Modal por meio do conflito e não pela combinação harmoniosa de elementos. Ele construiu uma unidade visual com base em contrastes e conflitos semânticos, uma unidade conflitante e sem significados homogêneos. ${ }^{163}$ O’Toole (1994) ressalta que quando analisada, a função Modal revela como a totalidade da tela impacta e trabalha na nossa rercepção.

O todo desta tela nos captura não pelas sensações prazerosas de simetria, harmonia, caminhos visuais previsíveis, proporções compatíveis, formas proporcionais, contrastes de cores equilibrados, mas pelos opostos, pelos sentidos construídos com intenção de criar tensionamento, dilema, estranhamento e ausência. ${ }^{164}$ Os usos desses elementos contraditórios

\footnotetext{
${ }^{160}$ Ocorrência de Saliência construida pelo Vetor e pela posição relativa do homem no centro da sala e dos bêbados nas mesas periféricas.

161 Tradução livre da autora. "Quite often paintings address us directly too. A clear example of this Modal function is the direct Gaze of one or more of die figures straight at us, the viewers. We all know those portraits that seem to follow you round the room with their eyes; they ate strongly modal." (O'TOOLE, 1984, p. 8)

162 Ocorrência de Vetor e de Saliência sobre a atitude do homem que se contrapõe à apatia que toma as outras figuras na cena.

${ }_{163}$ Ocorrência de Contraposição com base em contrastes e conflitos semânticos e gramaticais visuais.

${ }^{164}$ Ocorrência de Associação metafórica pelo uso de Contraposições.
} 
podem ser analisados em sua colaboração nas funções Composicional, Modal e Representacional.

A postura nesse homem sugere uma atitude atípica, de alguém que está determinado a interagir não pelas convenções sociais dos gestos amistosos e claros, dos sorrisos e olhares familiares, mas com um olhar ávido, talvez impositivo sobre o qual, não sabemos o que pensar.

Essa representação parece falar desses tipos de figuras, que são passíveis de se encontrar em um ambiente como o que van Gogh representa, no qual estamos sujeitos a todo o tipo de pessoas e a todo o tipo de estados de humor. Talvez ele quis representar o limiar entre a civilidade que há nos costumes e regras sociais de convívio, e o lado mais selvagem e imprevisível que há nos seres humanos que frequentam a noite e que pode estar presente em qualquer pessoa que nos deparamos em um Café noturno como aquele. ${ }^{165}$

A escolha do pintor parece não ter sido pintar um olhar cordial ou de outro modo, um olhar agressivo, ele optou por representar no homem uma atitude tão ambigua e disforme que não dá para detectar a intenção da pessoa, ele tem muitas rugas de expressão, muitas marcas da experiência que não nos deixam ver qual é a intencionalidade desta pessoa a anos olhar diretamente. ${ }^{166}$

A postura desse homem que olha em nossa direção não deixa clara sua intenção, mas pode ganhar uma conotação hostil, se associada ao contexto da cena. Essa possível hostilidade não está clara, ela fica dúbia, porque seu olhar e atitude não revelam uma intenção ou sentimento, apenas a busca de um contato. Ao olhar fixamente, ele pode estar impondo sua presença. Ele tem uma mão no bolso e uma outra na frente, e a atitude do seu corpo mostra que ele está mobilizado e possui uma atitude mais ativa do que as demais figuras representadas na cena. Ele mostra a ação de ir em nossa direção ou na direção de alguém que ele estaria olhando dentro da narrativa. ${ }^{167}$ Ele olha para o que, e por que?

Há um sujeito, há uma ação, mas a intencionalidade não está explicita. Ao mesmo tempo em que ele olha, não fica clara na feição dele uma expressão cordial, e não há uma definição da intencionalidade dele na interação conosco. Podemos aqui pensar que este é um vetor no qual há um sujeito, uma ação, mas a meta dessa ação, equivalente ao complemento do verbo em uma sentença, está oculta. Por exemplo, poderia-se transpor esta cena para a linguagem com a oração: Um homem no centro da sala olha diretamente. Esta frase suscita a

\footnotetext{
165 Ocorrência de Transparência e Incompletude para representar a sua experiência com o ambiente de um café noturno.

${ }^{166}$ Ocorrência de Inacabamento na representação da expressão do homem que parece nos fitar.

${ }^{167}$ Ocorrência de Vetor construído na postura ativa do homem que parece nos fitar.
} 
busca pelo complemento, ou a meta da ação de olhar do ator da sentença, o homem. O homem parado no centro da sala do Café Lamartine, ao lado da mesa de bilhar está olhando diretamente para alguém que não se encontra representado na cena. Este olhar sugere uma ação vetorial, como em uma oração com sujeito, processo, mas sem uma meta. Encontrei a ocorrência da representação escrita dessa ação do homem parado próximo a mesa de bilhar do Café da Noite que olha diretamente para alguém ou para algo, elas são discutidas na triangulação. ${ }^{168}$

Que efeito de sentido o pintor desejou articular com o ocultamento da meta neste verbo visual? Talvez tenha sido uma escolha para acentuar a função Modal, nos deixando mais intrigados para compreender o que se passa nesta ação, uma vez que a 'frase' não está completa. Observei que o olhar está claramente atendendo a função modal como um recurso visual para capturar a nossa atenção e envolvimento com a cena, enquanto que a ambiguidade presente neste vetor visual, pode ter sido usada com uma função representacional, para construir um sentido que está relacionado com outros elementos da composição e que veremos mais adiante.

O uso de um olhar ambíguo enfatiza e nos faz lembrar do olhar do autor, como uma referência a uma intenção de quem produziu aquele olhar ambíguo dentro da tela. O sentido não está na personagem, mas no olhar de van Gogh sobre o Café. O que ele viu quando olhou para esse Café? O que ele quis dizer? Com essa ambiguidade, van Gogh produz um efeito de sua presença dentro da tela. É preciso saber o que o autor quis para entender a construção desse sistema semiótico visual do olhar e qual foi o significado que ele deu para aquele olhar. Se o olhar do homem na sala era direcionado para o pintor que o retratava, pode ser que este olhar aponte para o artista e o reconheça como um sujeito dentro da representação. ${ }^{169}$

Há um sujeito que produz esse quadro e esse sujeito pensa, sente e produz alguma coisa em relação àquilo que pinta. Ele quer que o vejamos, ele quer ver retratada a sua experiência subjetiva, a sua percepção. A ambiguidade desse olhar induz a um diálogo, não com a tela, ou com a cena representada, mas com a forma como ela foi representada, e com esse sujeito que pinta dessa forma e com essa subjetividade com a qual ele pinta. ${ }^{170}$

\footnotetext{
168 Ocorrência de Vetor e Inacabamento que é construído pela ausência de uma 'meta' para a ação de olhar do homem. Não sabemos para o que ele olha, a ação está inconclusa, conotando uma ocorrência de Inacabamento nessa representação.

${ }^{169}$ Ocorrência de Inversão do ponto de vista construído pelo Vetor do olhar do homem no centro da sala que olha para o pintor e com isso, inverte a perspectiva da tela, criando um jogo de espelhamento com o espectador.

${ }^{170}$ Ocorrência de Interdiscursividade e de Transparência com a inversão do ponto de vista que trás van Gogh para dentro da tela por meio do olhar do homem que parece nos fitar.
} 
Por exemplo, é diferente da ambiguidade da Monalisa. Nela, todos querem saber se ela está sorrindo ou se está séria mas não estão intrigados com a intencionalidade do pintor, como se a Monalisa fosse a representação de uma mulher real. $\mathrm{O}$ olhar do homem junto a mesa de bilhar suscita uma pergunta. O olhar da Monalisa, oferece uma resposta, pois é um olhar calmo e direto, dirigido para o espectador da tela. As pinturas antes do modernismo parecem enunciar verdades, enquanto as pinturas do pré-modernismo em diante parecem suscitar perguntas, sem o compromisso em respondê-las. Acerca da subjetividade e da ambiguidade, O’Toole (1994, p. 9) comenta:

A modalidade é "interpessoal", uma vez que o falante está expressando para o seu interlocutor a sua falta de certeza acerca de um acontecimento que tenta descrever. Assim como na linguagem escrita ou falada, é possível um pintor dar para a sua pintura essa falta de certeza, e construir um grau de ambigüidade seja nas posturas, ou no que suscitam as ações das figuras representadas na cena como é ilustrado por diversas pinturas que nos deixam intrigados com o grau de ambigüidade das imagens.

Será que a escolha de van Gogh está sendo usada para nos conduzir para dentro da cena? Ao enfatizar a centralidade desta figura na tela e acentuar a função Modal com o olhar que ela nos dirige diretamente, o pintor também usou a ambiguidade de intenção desse olhar como modalidade. Não podemos esquecer que os recursos usados pelo artistas são escolhidos com intencionalidade. ${ }^{171}$

Na carta 676, que van Gogh escreve a Theo em 8 de Setembro de 1888, ele explicita a natureza de sua relação com o proprietário do café da noite:

E assim como preocupações não vêm sozinhas, nem alegrias, tão pouco. Porque na
verdade, sempre curvado sob este problema de dinheiro com casa - com senhorios,
eu aturo isso alegremente. Eu tinha gritado o que penso para o referido senhorio, que
não é um homem ruim, afinal, e eu disse a ele, isso para obter a minha própria
desforra nele por tê-lo pago tanto dinheiro para nada, que eu pintaria toda a sua
imunda casa velha como uma forma de obter o meu dinheiro de volta. Bem, para a
grande alegria do guardador de bagagens do alojamento, o carteiro a quem eu já
havia pintado, os vagabundos visitantes da noite e eu, por noites eu fiquei acordado
a pintar, indo para a cama durante o dia. Muitas vezes parece-me que a noite é muito
mais viva e ricamente colorida do que o dia. Agora como para recuperar o dinheiro
pago ao senhorio através da minha pintura, eu não estou fazendo questão disto,
porque a pintura é uma das mais feias que eu já fiz. É o equivalente, embora
diferente, dos comedores de batata.

Este excerto deixa claro que van Gogh tem uma visão crítica sobre o café, e esse olhar, que transparece tanto no excerto quanto na narrativa da tela, deve ter transparecido também para o senhorio. Talvez o olhar enigmático do proprietário se deva à sua ciência acerca do olhar crítico de van Gogh para com o seu café, e ele esteja devolvendo para van Gogh um olhar que equivale ao olhar que ele recebe de van Gogh, demonstrando a existência de um

${ }^{171}$ Ocorrência de Modalidade construida por meio da ambiguidade da intenção do olhar do homem. 
olhar de estranhamento entre eles, que paira no limiar da quase-cordialidade e a quasehostilidade. Esta pode ser a expressão de hesitação ou de indagação que captamos sem definir no olhar do homem que fita van Gogh, em uma atitude que nos transmite um certo tensionamento, seja ele na contraposição com as outras figuras do café, seja por confirmar uma não identificação, um não acolhimento que é mútuo entre o proprietário e o pintor, não apenas pelos seus olhares, mas pela forma com que ele olham e veem o café da noite.

Em sua carta $677^{172}$, van Gogh declara que "Na minha pintura do café à noite eu procurei exprimir que o café é um lugar onde você pode arruinar-se, enlouquecer, cometer crimes." Ele quis representar a possibilidade de o café levar a pessoa a cometer um crime, então, a ambiguidade na figura desse homem pode ter sido um recurso para construir uma semiose de que qualquer ser humano é capaz de qualquer coisa, dadas as circunstâncias. ${ }^{173}$

Há um outro tipo de modalide produzida pela ambiguidade do olhar; é o olhar do espectador que procura entender o signficado daquela figura. $\mathrm{O}$ olhar ambíguo leva o espectador a procurar um sentido e uma intencionalidade na figura da tela e isso produz como resultado a imediata projeção de sentido que construimos socialmente e que revela conteúdos subjetivos e culturais de quem olha a tela e não da figura representada na tela. Assim o olhar ganha uma outra entonação que é a da subjetividade do espectador. $\mathrm{O}$ olhar pode ganhar uma entonação de assustador, ameaçador, irônico, sincero, convidativo, e esse sistema semiótico que se apoia nas nossas vivências culturais para construir um sentido de escolhas potenciais, abre um campo para a dialogicidade e interação dos espectadores com o texto. ${ }^{174}$

De acordo com Stuart Hall (1998, p. 102) que estuda os processos de construção da identidade, os indivíduos em sociedade privilegiam aspectos positivos para a constituição de uma identidade pessoal e aqueles aspectos que são considerados negativos são muitas vezes recolhidos e não estão disponíveis para a constituição da identidade do sujeito se tornando aspectos que geram estranhamento. Assim, quando um indivíduo em sociedade se depara com uma situação inusitada de estranhamento, tende a reconhecer alí aqueles aspectos negados em sua identidade. $\mathrm{O}$ espectador reconhece melhor o estranho e o estranhamento no outro e esse mecanismo de buscar por se relacionar com o outro e com aqueles aspectos que também são

172 Carta 677 - Br. 1990: 680 | CL: 534 - From: Vincent van Gogh To: Theo van Gogh. Date: Arles, 9 September 1888. Linhas 124 a 145 Disponível em 27 de Agosto de 2012 em: http://vangoghletters.org/vg/letters/let677/letter.html

173 Ocorrência de Associação metafórica e Intertextualidade, construida por meio da ambiguidade na intencionalidade do homem que parece nos fitar conotando que qualquer pessoa é capaz de qualquer ação.

${ }^{174}$ Ocorrência de Interdiscursividade e Modalidade no uso da ambiguidade no olhar do homem para o espectador criar analogias e Associações metafóricas. Observei na ambiguidade, a ocorrência de Inacabamento na representação e Incompletude no sentido construído. 
estranhos em nós e também não reconhecemos como familiares a nós, tornando o que é estranho em nós, o estranho no outro e, negando aspectos negativos como a nossa agressividade e a nossa animosidade, tendemos a ver no estranho, no ambíguo essas qualidades. $^{175}$

O olhar do homem é tão ambíguo que pode despertar reações dicotômicas em quem interage com ele, inclusive uma reação desproporcionalmente agressiva e de rejeição à intenção imaginada ou atribuida para a figura, mostrando que até quem olha de fora pode ser afetado pelo café de uma maneira violenta, agressiva, trazendo à tona aqueles aspectos que negamos e preferimos projetar no outro, nos dando conta sobre os nossos próprios pontos de vista ao fazê-lo.

Cor

Podemos pensar a princípio que o uso das cores não nos convida para dentro da cena, uma vez que os contrastes entre vermelhos, verdes e amarelos são excessivos, asfixiantes mesmo, e conferem uma sensação de desconforto e cansaço à cena. No entanto, ao olharmos para essa cena, automaticamente nos colocamos dentro dela, e fica difícil negar que, ainda que as escolhas de cores e tons não sejam as mais agradáveis, elas dão conta de comunicar um clima para o ambiente do café. Isso acontece porque o contraste complementar do vermelho e verde funciona de forma efetiva para ampliar a qualidade cromática de cada um, intensificando mutuamente sua força expressiva de forma dinâmica e vibrante. Este não é um contraste harmonioso entre uma cor primária e uma cor secundária, em especial no tom escuro com que foram escolhidas, mas um duelo de titãs no qual as duas cores reciprocamente intensificadas disputam pela atenção dos nossos olhos e a tensão produzida tem a capacidade de prender o nosso olhar em um dilema de foco entre o verde e o vermelho e nos arrastar para dentro da tela. O uso das cores enfatiza, portanto, o conflito entre as cores e não o poder ou a ênfase de uma cor sobre a outra. A escolha do contraste cromático complementar é o que melhor representa o conflito no ambiente do café e foi usada de forma magistral como função Modal para capturar a atenção do espectador e assegurar que esta seja mantida refém dos assuntos representados na cena. ${ }^{176}$

\footnotetext{
${ }^{175}$ Ocorrência de Interdiscursividade, Transparência, Inacabamento e Incompletude na ambiguidade do olhar do homem no café.

${ }^{176}$ Ocorrência de Contraste simultâneo para construir o sentido de tensão e contraposição.
} 


\subsubsection{Análise da Função Representacional da tela The Night Café in the Place Lamartine in Arles}

Van Gogh descreve para Theo, em uma carta, a sua motivação para pintar um bar que ele frequentava: "Na minha concepção do "Café da Noite" Eu tentei expressar a idéia de que o café é um lugar onde se pode arruinar-se, enlouquecer ou cometer um crime. Então, eu tentei expressar, por assim dizer, os poderes das trevas em uma casa de baixo público, por suaves verde Louis XV e malaquita, contrastando com o amarelo-verde e azul-verde duro, e tudo isso em uma atmosfera como a fornalha do diabo, de enxofre pálido". ${ }^{177}$

Das quatro telas analisadas, apenas esta possui uma referências nas cartas sobre o que ele quiz representar. Encontrei com essa dialogia entre a tela e a explicitação de seu sentido pelo autor em sua carta ao irmão, uma evidência de natureza semântica. ${ }^{178}$

Ele reconhece em outra carta a Theo, que ao tentar transmitir um ambiente pertubador ele foi bem sucedido: "A idéia do "Semeador" continua a assombrar-me o tempo todo. Estudos exagerados como o "Semeador" e como este "Café da Noite" geralmente parecem-me atrozmente feios e maus, mas quando eu sou movido por algo, como agora por este pequeno artigo sobre Dostoievsky, então esses são os únicos que parecem ter qualquer significado profundo." ${ }^{179}$ (11 de setembro de 1888 carta ${ }^{\circ}$ 680.)

\section{A escolha do tema}

Que experiência van Gogh buscou representar ao pintar o Café da Noite?

Aos olhos do público nos nossos dias, a escolha do tema não parece despertar uma grande comoção, mas imaginemos o choque que deve ter causado na época a cena de um café como esse representado. Para compreender esse contexto é preciso lembrar que a escolha do tema a ser pintado, nos períodos artísticos anteriores, seguia uma convenção, como explica Gombrich (1995, p.520):

Não era apenas a técnica pictórica que enfurecia tanto os críticos, mas também os motivos escolhidos por esses pintores. No passado, esperava-se que os pintores observassem um recanto da natureza que, por consenso geral, fosse "pitoresco".

177 Carta 677 - Br. 1990: 680 | CL: 534 - From: Vincent van Gogh To: Theo van Gogh. Data: Arles, 9 September 1888. Linhas 124 a 145 disponível em 27 de Agosto de 2012 em: http://vangoghletters.org/vg/letters/let677/letter.html

178 Ocorrência de Intertextualidade e Metáfora Visual construída com a explicitação textual acerca do sentido visual, foi possível encontrar, no nível semântico, o mesmo sentido, contruído visualmente, como está amplamente evidenciado pela análise visual dos sentidos encontrados na função representacional.

${ }_{179}$ Carta 680 - To Theo van Gogh. Arles, on or about Tuesday, 11 September 1888. Disponível em 27 de agosto de $2012 \mathrm{em}$ : <http://vangoghletters.org/vg/letters/let680/letter.html> 
Poucas pessoas se apercebem de que essa exigência era, de um certo modo, irracional. Consideramos "pitorescos" aqueles motivos que já vimos antes em pinturas. Se os artistas tivessem de ater-se apenas a eles, ficariam repetindo-se interminavelmente uns aos outros. Foi Claude Lorrain quem tornou as ruínas romanas "pitorescas" (p. 396, Fig. 255) e Jan van Goyen quem converteu os moinhos holandeses em "motivos" (p. 419, Fig. 272). Constable e Turner, na Inglaterra, cada um à sua maneira, tinham descoberto novos modelos para a arte. $\mathrm{O}$ "Vapor numa tempestade de neve", de Turner (p. 493, Fig. 323), era tão novo no tema quanto na apresentação.

Dessa forma, a escolha em si do tema da tela 'Café da Noite', fala muito sobre o que van Gogh queria comunicar, uma vez que ele não seguia as convenções como nos períodos artísticos anteriores. O que van Gogh escolheu representar? O interior de um café noturno, que fica aberto à noite toda e que serve de abrigo para os vagabundos que não tem onde dormir. Estes dormem sentados nas mesas, como única opção de pernoite. Não seria o próprio van Gogh um desses vagabundos que tantas vezes antes não teve outra opção para passar a noite ${ }^{180}$ Porque ele elegeu esse café para retratar? Inferi que sim com base em uma carta de van Gogh para Theo, relatada por Haziot (2010, p.217):

Vincent está instalado desde 16 de setembro na Casa Amarela, onde respira um
bem-estar cuja profundidade nem sempre foi bem percebida. De fato, era a primeira
vez, desde Haia e a experiência com Sien, que ele se sentia em casa. "Esta noite
dormi na casa e, embora ainda haja coisas por fazer, me sinto muito contente." C538
Depois confessará a Théo que se tornou insuportável "viver como viajante nos
cafés", pois não tinha mais idade para isso.

Não estaria ele mobilizado para denunciar o destino de homens e mulheres que se tornaram excluídos na nova ordem produtiva trazida pela Revolução Industrial e resolvido a representar de perto e com cores vivas o mundo dos destituídos de um lugar ao sol na nova ordem econômica? ${ }^{181}$ A exclusão social gerada pela revolução industrial não foi um evento pontual, como explica Hobsbawm (2014, p. 25-26):

O “drama do progresso" é uma metáfora. Mas para duas espécies de pessoas era uma realidade literal. Para milhões de pobres, transportados para um novo mundo frequentemente transpondo fronteiras e oceanos, ele significou uma mudança cataclísmica. Para os povos do mundo fora do capitalismo, que eram agora atingidos e sacudidos por ele, significou a escolha entre uma resistência passiva em nome de suas antigas tradições e modos de ser e um traumático processo de retomada das armas do Ocidente para voltá-las contra os conquistadores: de compreensão e manipulação do progresso por eles mesmos. O mundo dos últimos 25 anos de século XIX foi um mundo de vitoriosos e vítimas. Seu drama consistiu nas dificuldades não dos primeiros, mas primordialmente, dos últimos.

\footnotetext{
${ }^{180}$ Ocorrência de Transparência na escolha do tema e na forma de representar uma experiência que era muito subjetiva para van Gogh.

${ }^{181}$ Ocorrência de Associação Metafórica sobre a condição de exclusão em que estão mergulhados os bêbados no café.
} 
Van Gogh estava atento e sensível às vicissitudes de seu tempo, ao ler os principais críticos das transformações sociais, entre eles, Zola, como atesta Edwards (2009, p.27):

\begin{abstract}
Voltemos ao foco de Vincent em Zola como um autor que pintou a vida como ele a sentiu. Ao fazer isso ele satisfez "a necessidade que todos sentimos de ser dita a verdade." Sobre a sua descoberta de Zola em 1882 e sua promessa de "ler tudo de Zola", e sua comparação de suas próprias ações com personagens de Zola e sua justificação de algumas das suas pinturas por um apelo a Zola, nós agora adicionamos a sua justaposição de um romance de Zola e da Bíblia. Ele apresentou Zola como profeta de uma nova era. ${ }^{182}$
\end{abstract}

A tela 'Café Lamartine' parece ser uma expressão do compromisso de van Gogh com a arte do campo, com o trabalhador, como relata Mcquillan (1989, p. 144):

Em seus desenhos de figura dos anos de Haia van Gogh recorreu constantemente a modelos nas revistas ilustradas. Mais comumente ele representou os socialmente marginalizados: homens velhos da oficina, trabalhadores (operários, camponeses, pescadores) e mulheres da classe trabalhadora desgastadas de fadiga, realizando tarefas domésticas e mantendo a família.

Essa expressão é instanciada em forma de denúncia: este trabalhador do campo agora é um vagabundo das cidades nas quais não encontra acolhimento, lugar, ocupação a não ser nos cafés "noturnos" onde se refugia com os outros destituídos da nova ordem para passar a noite. Ele usou o contraste de cores carregadas e as expressões de desânimo e fadiga para representar a precariedade da condição humana, representada com o uso da distorção das linhas de perspectiva, da deformação da mesa de bilhar e da excessiva iluminação artificial das lâmpadas a gás. No entanto ele não representou a deformação nas pessoas, mas no ambiente que as circunda. ${ }^{183}$ Nessa e em outras telas van Gogh fala desde um lugar de empatia com esses sujeitos para denunciar as consequências da exploração do homem e para explicitar as perdas trazidas pelo sistema industrial que retira, não apenas o sustento, mas o sentido de dignidade e de humanidade. ${ }^{184}$

Van Gogh relata em sua carta que há uma relação com a tela 'Os Comedores de Batatas' e com a tela 'O Semeador'. Inferi que a conexão se faz pelo viés de uma ideologia realista social só que em uma arte de vanguarda. Essas telas sugerem uma denúncia sobre a desvalorização do ser humano a partir da lógica da exploração além dos limites da ética

\footnotetext{
${ }^{182}$ Tradução livre da autora. "Let us return to Vincent's focus on Zola as an author who painted life as he felt it. In doing so he satisfied "the need we all feel for being told the truth." To his discovery of Zola in 1882 and his pledge to "read everything by Zola," and his comparison of his own actions with characters in Zola and his justification of certain of his paintings by an appeal to Zola, we now have added his juxtaposition of a Zola novel and the Bible. He has presented Zola as prophet of a new age." (EDWARDS, 2009, p.27)

${ }^{183}$ Ocorrência de Associação metafórica para representar a precariedade da condição humana naquele contexto social e histórico por meio da Distorção do ponto de vista.

${ }^{184}$ Ocorrência de Intertextualidade no uso da Distorção para construir um sentido semântico na tela que ele representou semanticamente na carta: a precariedade da condição humana no interior de um café da noite. $\mathrm{O}$ sentido que, semanticamente, ele constrói na carta, é aqui representado por outros recursos pictóricos tais como os contrastes cromáticos, o excesso de iluminação e a distorção da perspectiva.
} 
imposta pela revolução industrial. As duas telas versam sobre o desespero de se viver na periferia e na exclusão, na condição de párias do sistema econômico. Segundo Sweetman (1993, p. 97), “foi sua identificação com a condição dos mineiros que o empurrou mais fortemente em direção à arte, e os poucos exemplos dessas primeiras tentativas de desenho que chegaram até nós seriam rotulados de realismo social numa época posterior”.

Figura 22: Le Café de Nuit - Gauguin, Arles: 4-12 de Novembro, 1888

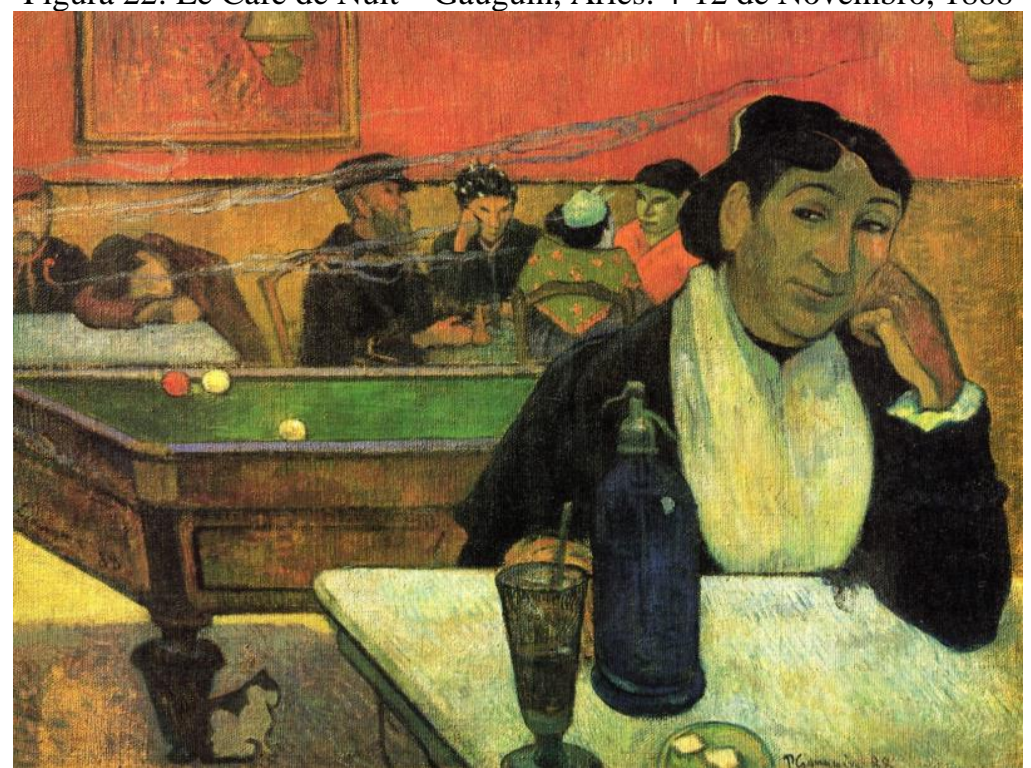

Fonte: Wikiart, disponível em 24 de maio de 2011em: <http://www.wikiart.org/en/paulgauguin/night-cafe-in-arles-madame-ginoux-1888

Gauguin, que morou com van Gogh pouco depois que este pintou o café, também pintou a mesma cena. No entanto a atmosfera dos dois quadros é bastante distinta. A tela de van Gogh constrói um sentido de desespero e isolamento, e a de Gauguin constrói um sentido de convívio e interação mais acolhedor e dinâmico no qual a Madame Ginoux tem destaque no primeiro plano. O quadro de Gauguin é comentado por Walther e Metzger (2015, p. 450):

O quadro do café noturno, de Gauguin, apresenta-nos dois quadros em um: o café, por si só, serve apenas de pano de fundo para o retrato da proprietária e constitui, ao mesmo tempo, uma espécie de atributo que indica a condição social da personagem principal.

Em sua tela, van Gogh compõe uma sintaxe visual articulando contrastes cromáticos improváveis para os códigos visuais mais convencionais da época, tais como a combinação de amarelos e vermelhos em uma grande área da tela. ${ }^{185}$ Talvez ele tenha sido fiel na representação das cores do café, como atesta outra tela do interior do Café pintada pelo pintor Gauguin.

\footnotetext{
185 Ocorrência de Contrastes cromáticos pouco convencionais como a combinação de amarelos e vermelhos em grandes áreas da composição para causar a sensação de desconforto.
} 
No entanto, o uso de recursos cromáticos na tela de van Gogh exacerbam o brilho feérico das lâmpadas, a ausência de sombras nas figuras, a distorção da perspectiva e o ângulo do enquadramento da cena levemente plongee, deixam claro o seu investimento semiótico arrojado para construir um sentido de fadiga e de destituição nas figuras e no ambiente que as envolve. Se compararmos a abordagem da composição em ambas as telas, fica evidente que van Gogh estava empenhado em articular uma narrativa muito mais precisa e contundente para os sentidos que ele escolheu conjugar em sua narrativa enquanto Gauguin escolheu um ponto de vista e uma conotação diversa ao representar a mesma cena, como comentam Walther e Metzger (2015, p. 448-449):

Desde a sua chegada, Gauguin selecionara os seus temas de entre os motivos já trabalhados por van Gogh. Foi assim que produziu interpretações alternativas das pinturas de colheitas, de $O$ Canal do "Roubine du Roi"com Lavadeiras (p. 372), do jardim do poeta, e A Vinha Vermelha (p. 444). A certa altura, pegou também na menina dos olhos de Vincent, $O$ Café Noturno, que, segundo Van Gogh, só era igualado por Os Comedores de Batatas. A versão de Gauguin (p. 434) prescinde completamente da triste atmosfera de isolamento que van Gogh registrara. As pessoas que estão nos cantos a beber deixam de ter importância perante a figura de Madame Ginoux, a proprietária do café, em primeiro plano. Ela olha fixamente para fora da pintura, tornando mais fácil o contato com o quadro e libertando a cena interior da carga opressiva de isolamento que van Gogh lhe conferira.

A comparação dessas duas telas deixa muito clara a motivação de van Gogh em fazer de sua pintura a representação de um "lugar onde pode-se arruinar-se, enlouquecer ou cometer um crime.”. A diferença entre o sentido construído nas duas telas é explicitada por Walther e Metzger (2015, p. 448-449):

A cena de Van Gogh era noturna, quanto mais não fosse pelo sombrio desalento da
sua atmosfera. Gauguin, pelo contrário, mostra-nos simplesmente um café - não
sabemos se costuma estar aberto à noite ou não. Pintou o quadro no estúdio, e não
logo no local, e consequentemente a obra não nos transmite a disposição do pintor.
No entanto, Gauguin trabalhava de forma demasiado controlada e racional para que
os seus quadros fossem meros registros descritivos de situações. Dito isto, o seu café
não deixa então de possuir aquela atmosfera de desolação que o lugar deveria ter na
realidade. E era por isso que van Gogh adorava o quadro, enquanto Gauguin o
desprezava: "Não faz nada o meu estilo", escreveu ele a Schuffenecker, "as cores
locais de um bar qualquer não me atraem". Teria inevitavelmente abandonado os
seus princípios se tivesse acompanhado Van Gogh na investigação do lado mais
desagradável da vida humana. Queria que as suas pinturas permanecessem puras; até
mesmo o fumo do cigarro que pairava ao longo da sala enevoada era demasiado
realista. O que nos chama a atenção não é tanto o que van Gogh retrata nesta tela, mas a forma como ele o faz. O destaque dado à mesa de bilhar no centro, sua colocação e posicionamento em relação à perspectiva apontada pelas linhas do assoalho, a ênfase dada às lâmpadas e à luz 
que elas emitem, ${ }^{186}$ são vários os sistemas semióticos que colaboram para construir sentidos associados às sensações produzidas pela combinação de elementos. O crítico de arte Brian Petrie (1974, p. 8) argumenta sobre a estreita relação que van Gogh tinha com as cenas que ele pintava:

Conforme sugerido pelo exemplo da obra Café Noturno, o tema pintado raramente
lhe era indiferente. Numa outra carta escrita em 1884 atacava o criticismo artístico
de Zola, pela reivindicação, em defesa de Manet, dos valores da "pura pintura" e da
igualdade essencial, em termos de grande arte, entre a natureza-morta e a pintura
figurativa. "Diga-me só - pergunta Vincent - se existe alguma diferença entre um
prato de louça encarnado com um bacalhau, por exemplo e a figura de um cavador
ou um semeador? Existe ou não existe alguma diferença entre Rembrandt e Van
Beyeren (tecnicamente de igual inteligência), entre Vollon e Millet?" Vincent pintou
efetivamente muitas naturezas-mortas. Mas na sua maioria foram concebidas como
exercícios primários: por elas nunca aspirou aos níveis mais elevados da sua arte,
nem mesmo naquelas em que figuram secretamente elementos autobiográficos.
Todas as grandes obras de Vincent partilham a premissa de uma tensão estimulante
entre o tema e a maneira como ele é tratado; daí resultando que os tipos da
paisagem, do retrato e da pintura figurativa revelam cada um deles um aspecto da
sua personalidade artística e também inevitavelmente humana.

O uso da combinação entre o vermelho da parede e os amarelos do assoalho, a luz que inunda a sala e a forma como ele os representa são uma escolha deliberada para produzir a percepção visual que pode ser associada à sensação de cansaço e desconforto. Estes recursos são a evidência visual para a metáfora escrita "fornalha do diabo."187

A seguir analiso as várias estratégias de composição usadas com a função Representacional na tela para expressar conflitos, contrastes, estranhamentos e ausências para falar de sentimentos e percepções que o pintor desejou articular na imagem, como por exemplo, pelo uso de contraposições e contrastes para representar processos dicotômicos tais como: centralidade $\mathrm{x}$ periferia; olhar $\mathrm{x}$ negação do olhar; presença $\mathrm{x}$ ausência; mundano $\mathrm{x}$ espiritual. $^{188}$

\section{Ritmo}

O fluxo da iluminação não é contínuo ou estático, ele tem ritmo e percorre caminhos de luz representados por contornos e formas. A intensidade luminosa é construída de uma forma mais global na tela, e é expressa na falta de contrastes de luz e sombra, e contrastes

\footnotetext{
${ }^{186}$ Ocorrência de Saliência dada a mesa de bilhar pelo uso da Distorção do ponto de vista articulado com outros recursos semióticos.

${ }_{187}$ Ocorrência de Intertextualidade e Associação metafórica por meio do uso de Contrastes cromáticos e Sinestesia. A excessiva luz que inunda a sala e a forma como ele representa os contrastes podem ser considerados semioses equivalentes à expressão escrita "fornalha do diabo."

${ }^{188}$ Ocorrência de Associações metafóricas por meio de Contraposições e contrastes para representar processos dicotômicos tais como: centralidade $\mathrm{x}$ periferia; olhar $\mathrm{x}$ negação do olhar; presença $\mathrm{x}$ ausência; mundano $\mathrm{x}$ espiritual.
} 
cromáticos, no excesso de saturação cromática nos amarelos, e na falta de volumes nas figuras e objetos representados na sala. Estes recursos colaboram para dar sustentação para o fluxo da iluminação na tela. ${ }^{189}$

Há uma grande ênfase na forma detalhada e com riqueza de texturas e movimento de pinceladas para representar a luz que irradia das lâmpadas. ${ }^{190}$ Essa ênfase constrói uma centralidade metafórica para esses objetos na cena, as lâmpadas. Essa centralidade não se coloca nas lâmpadas em si mesmas, mas na luz que delas emana e que inunda todos os cantos da sala. Dessa forma, inferi que a luz ocupa um lugar de destaque sendo tratada talvez como o elemento semiótico central que concentra e interliga os processos e dinâmicas na narrativa dando unidade à composição. ${ }^{191}$

De outro modo, ao criarem um ritmo tanto na sequência das lâmpadas ao longo da sala quanto na forma como a luz que delas depreende é representada, as lâmpadas podem estar construindo uma unidade temática ao longo de toda a cena; e uma unidade rítmica para toda a pintura, em especial nas seções verticais que vão do chão e parede inferior à parte superior da parede e do teto. Essa unidade pictórica é construída com a ajuda das lâmpadas, justamente porque há luz nas lâmpadas, mas não somente nelas. Há luz em todos os lugares da sala, e essa luz é um elemento de coesão na gramática pictórica que van Gogh construiu. ${ }^{192}$ Existe um elemento de coesão textual, qual?

Ela dá uma unidade para a divisão vertical do espaço da composição em três seções: a primeira, em tons amarelos, que vai do chão até a metade da parede. A segunda, em vermelho escuro que vai da parte superior da parede até o teto. E a terceira, em verde escuro, no teto. Esta divisão vertical deixaria a composição fraturada com espaços bem separados visualmente se não houvesse essa luz constante e ritmada a pulsar por toda a tela. As lâmpadas e sua luz funcionam como elementos de ligação e de transição entre as pequenas narrativas que ocorrem nos episódios na tela construindo uma unidade e funcionam modalmente na visão de conjunto com a ajuda do ritmo. ${ }^{193}$ De acordo com O’Toole $(1994$, p. 145) , “a análise da função Modal nos diz muito sobre como um todo de uma tela funciona em nós."

\footnotetext{
189 Ocorrência de Ritmo, Textura, Movimento e Rima Visual pelo Gesto Pictórico para expressar o fluxo e a intensidade da iluminação na sala.

${ }_{190}$ Ocorrência de Saliência, por meio do uso de Ritmo, Movimento, Textura, Vetor e Gesto Pictórico que são usados para representar o brilho intermitente das lâmpadas, pintado com riqueza de detalhes, textura e movimento direcional.

${ }^{191}$ Ocorrência de Associação metafórica por meio do uso de Ritmo, Movimento, Textura, Vetor, Gesto Pictórico e Rima Visual que juntos constroem uma metáfora visual para a luz que interliga todos os processos na narrativa. ${ }^{192}$ Ocorrência de Rima Visual e Gesto Pictórico na representação da luz como uma metáfora visual que interliga todos os elementos da tela; o Ritmo é o recurso que expressa essa metáfora e que constrói a coesão visual.

${ }^{193}$ Ocorrência e Rima Visual por meio do Ritmo, Movimento e Vetor na representação da Luz que funciona como elemento de ligação e de transição entre as pequenas narrativas.
} 
A centralidade dada para a luz pode ser interpretada de várias formas. As lâmpadas emanam uma luz que parece que está em movimento e vibrando e essa vibração tem um ritmo, mas não é um ritmo convidativo porque parece muito intenso e até desagradável de se olhar. Não é um ritmo que nos coloca dentro da cena, ao contrário, o ritmo das lâmpadas, que são objetos grandes e por emitirem luz, parecem se chocar com o resto dos objetos na cena, competindo pela atenção que dada à mesa de bilhar e ao homem parado próximo a ela. ${ }^{194}$

No entanto, observei mais um tipo de conflito: as lâmpadas parecem conflitar com a centralidade da mesa e constroem uma centralidade em si mesmas. Elas geram uma convulsão de estratégias destoantes que perturbam nossos sentidos ao invés de colaborarem em um único sentido, mais harmonioso e mais complementar. Há conflito entre as figuras que estão no piso e as lâmpadas acima e que parecem ter vida própria. Além disso, o conflito é expresso por dois contrastes simultâneos: pelo contraste entre ritmo e ausência de movimento e entre a centralidade das lâmpadas e a centralidade das figuras na sala. Esse outro é também um contraste de ritmos: as lâmpadas expressam movimento e as pessoas estão paradas, inativas, voltadas para si mesmas. Por que van Gogh deu tanta centralidade para o conflito? ${ }^{195}$

A ênfase no conflito, quando ele poderia ter trabalhado para amenizar diferenças e construir uma visão harmoniosa e agradável da tela evidencia sua intenção deliberada em 'escrever' com tinta um estatuto por meio de seu sistema semiótico original e do uso de associações metafóricas.

A luz

As lâmpadas emitem luz e as pessoas estão sombreadas, não obstante a luz que nelas derrama. Portanto, esse ritmo da luz que emana das lâmpadas comunica uma metáfora visual por meio da sintaxe com os outros elementos, que são as figuras humanas e os objetos na sala, se contrapõem na composição. Por que a luz não ilumina as pessoas? De que conflito a luz dessas lâmpadas em contraste com as figuras na sala fala? Que processos representados na tela estão em conflito? Que processos em conflito estão representados por meio de um uso conflitado dos recursos sintáticos e semânticos nos elementos da composição? Se o sentido da

\footnotetext{
${ }^{194}$ Ocorrência de Ritmo, Movimento, Textura e Vetor para construir a luz que parece que está em movimento e vibrando.

195 Ocorrência de Associação metafórica pelo uso de Contraposição entre a centralidade das lâmpadas e a centralidade da mesa de bilhar, para expressar a sensação de tensão e sentidos conflitantes como atividade/inatividade.
} 
luz for análogo à luz do Progresso, esta não ilumina as pessoas. Se o sentido da luz for o da luz espiritual, podemos procurar outras associações para esta não iluminação das pessoas.

Podemos verificar se há conflito ou a representação deles no corpus textual referente à tela. Inferi que van Gogh quis enunciar um conflito entre o mundo secular e o mundo espiritual, o primeiro instanciado como símbolo pela mesa de bilhar, o segundo, instanciado como símbolo pela luz emitida pelas lâmpadas. Os homens estão apáticos e passivos no meio deste conflito porque ele se encontram no limite deste conflito e o equilíbrio é muito delicado diante de sua precariedade circunstancial. Em que construtos textuais van Gogh também previlegia o conflito, o contraste?

Van Gogh fez um uso de recursos visuais em conflito para falar de um outro conflito na narrativa que ele quer representar. $O$ que ele quer representar ao colocar ritmo e movimento na luz enquanto expressa sombra e inatividade nas figuras humanas? Com esse contraste entre a luz da lâmpada e a ausência de luz nas pessoas ele parece ter construído uma semiose que se apoia nos nossos sentidos construídos socialmente para o significado da luz e da ausência dela e que podemos associar ao sistema semiótico dos conflitos representados na tela do 'Café da Noite'. 196

Outra possibilidade que inferi para a centralidade na representação das lâmpadas é a construção de uma metáfora visual para o que a luz simboliza, para nós espectadores e para o pintor.

Relatos dos biógrafos Haziot (2010) e Edwards (2009) sugerem que, para van Gogh, a luz era uma metáfora de conotação religiosa. A fonte de luz pode significar a presença de Deus entre nós, ou a luz do espírito em nossas vidas. Dessa forma, inferi nessa tela que ele representa os conflitos e contradições humanas por meio dos contrastes de luz e sombra, de cor, e de posicionamento das figuras e objetos representados na tela. ${ }^{197}$

\section{Iluminação exacerbada na sala}

A sala está tão iluminada e sem sombras nas figuras e nos objetos que nos parece que as sombras são as próprias pessoas que estão pintadas de forma bem escura. A ausência de sombra pode ter uma função representacional, pois as figuras não têm sombra, mas elas estão tão escuras, não obstante a luz intensa que as atinge desde o teto, que é como se elas fossem a

\footnotetext{
${ }^{196}$ Ocorrência de Associação metafórica pela representação da ausência de iluminação das figuras, estando o ambiente tão excessivamente iluminado.

${ }^{197}$ Ocorrência de Associação metafórica dos conflitos e contradições humanas por meio dos contrastes de luz e sombra, de cor, e de posicionamento das figuras e objetos.
} 
própria sombra e não pudessem ser iluminadas pelas lâmpadas. Essa representação das pessoas nesse modo cria um sistema semiótico ao se apoiar nos sistemas léxico-semânticos convencionados do espectador para a construção de uma metáfora visual que associa a luz das lâmpadas representadas com as convenções socialmente compartilhadas sobre as possíveis conotações para a luz. ${ }^{198}$

Se atribuirmos para as lâmpadas uma possibilidade de sentido metafórico, tal como a luz espiritual, a luz divina, ela representaria um conflito com as coisas humanas, mundanas, seculares que estariam representadas pelas figuras humanas e suas atividades no Café. De que conflito, van Gogh fala? Talvez ele se refira à própria existência humana, que estaria a seu ver, conflitada com a natureza divina da existência ${ }^{199}$ Walther (1990, p. 41) ressalta como os sentidos da tela se apoiam mais em associações do que na composição em si mesma:

\begin{abstract}
Assim a atmosfera nocturna neste quadro, resulta antes pelas associações da solidão, dor e desespero do que pela própria composição. Só as auréolas amareladas em volta das lâmpadas lembram aqui que o quadro foi feito durante a noite. Porém, o "Café de noite" é também só um passo intermediário, um estudo da pintura nocturna.
\end{abstract}

Ou seja, os efeitos de sentidos que depreendi da cena estão mais apoiados nas associações que fiz com o ambiente do 'Café Lamartine' que em si parece mergulhado em perplexidade.

Essa associação pode ser reforçada pelo fato de que as lâmpadas estão sempre acima da cabeça das figuras no Café, e nunca acima das mesas e cadeiras vazias, metaforizando que a luz está disponível para iluminar os sujeitos desse lugar, por mais desesperançado que seja o estado em que eles se encontrem. ${ }^{200}$

A forma detalhada e a riqueza de texturas e movimento de pinceladas com que ele representou a luz que irradia das lâmpadas dá uma grande ênfase. Esta ênfase constrói uma centralidade metafórica para essas lâmpadas na cena, não por elas mesmas, mas pela luz que delas emana e que inunda todos os cantos da sala. Dessa forma, inferi que a luz ocupa um lugar de destaque sendo tratada talvez como o elemento central que concentra os processos e dinâmicas na narrativa. Essa centralidade dada para a luz pode ser interpretada como uma metáfora visual para outras escolhas associativas e mais abstratas, como o que a luz simboliza e representa no léxico visual particular do pintor. Sabendo que para van Gogh a luz pode ser

\footnotetext{
198 Ocorrência de Associação metafórica de sentidos potenciais apoiada no discurso religioso que faz a analogia da luz com a luz espiritual e da sombra com a ausência de luz espiritual.

199 Ocorrência de Associação metafórica nas escolhas de sentidos potenciais para a relação entre a luz e a natureza humana.

${ }^{200}$ Ocorrência de Associação metafórica corrobora com o sentido da luz estar em relação ao ser humano, pela disposição das lâmpadas sempre acima das cabeças das figuras, nunca acima de cadeiras vazias.
} 
associada ao simbolismo divino, e a fonte de luz como a presença de Deus, a narrativa pode ser analisada à luz dessa metáfora visual para indagarmos de que luz ele fala. ${ }^{201}$

Na tela 'Café da Noite' a luz das Lâmpadas é muito clara e produz uma coloração amarelada na pele das pessoas representadas. Cada uma das figuras humanas representadas na cena tem uma lâmpada sobre sua cabeça e essa escolha semiótica pode ter uma função Representacional chave para a construção de uma associação. Para examinar as possibilidades de construção do sentido que a representação da luz nesta tela suscita, é preciso observar as associações metafóricas dadas por nossa cultura, e em especial pela cultura de onde van Gogh veio, na qual a luz tem uma conotação espiritual. ${ }^{202}$

Dessa forma inferi nesta cena que, por mais que as pessoas estejam mergulhadas em seus próprios dramas, conflitos, angústias, desesperos, elas têm uma luz sobre elas e essa luz, pode ser uma metáfora da luz divina, da espiritualidade, que está presente para todos os homens. Mesmo que essa luz não chegue neles, ou que eles não pareçam ser iluminados por elas, elas estão sobre eles e derramam seu brilho intenso por todo o lugar. ${ }^{203}$ Observo aqui uma interligação sobre a luz do ponto de vista Modal com a luz do ponto de vista Representacional. Também encontrei em Walther (1990, p. 40), referências para a associação da Luz ao sentido do progresso: "Sobretudo para se habituar ao trabalho à luz artificial, pintou ele, em Setembro de 1888, o 'Café de noite, na Place Lamartine'.”

De acordo com o relato de Whalter e Metzger (2015), van Gogh estava particularmente interessado em representar diferentes fontes de luz: a luz das estrelas e do sol, vistas por ele como símbolos da luz da Natureza, em contraposição com a luz artificial, da lâmpada a gás, do progresso tecnológico, vista por ele como uma luz estranha, dura e invasiva. Também inferi em uma segunda opção de leitura, se partirmos da associação metafórica da luz com o sentido do progresso tecnológico. Enquanto a luz do progresso chega, ocupa e modifica todo o ambiente, ela não retira as pessoas do seu isolamento e de sua precariedade social. Essa luz artificial simbolizando o progresso da revolução industrial, ele contrapõe com as pessoas na sombra, para representar os conflitos e contradições humanas por meio de semioses articuladas pelos contrastes de luz e sombra, de cor, e de posicionamento na tela.

\footnotetext{
201 Ocorrência de Associação metafórica por meio de Saliência, Ritmo, Movimento, Textura e Gesto Pictórico para dar centralidade para luz.

202 Ocorrência de Associação metafórica por meio de escolhas potenciais para construir um sentido de espiritualidade.

${ }_{203}$ Ocorrência de Associação metafórica de escolhas potenciais para construir um sentido de que a Luz espiritual brilha sobre todos.
} 


\section{Representação de membros}

\section{As lâmpadas}

Acima das cabeças dos frequentadores há quatro lâmpadas, sendo três delas muito similares e alinhadas. Elas atravessam o espaço da sala em diagonal. A luz que emana delas é representada de forma bastante elaborada, para enfatizar a presença da luz que se espalha no ambiente.

O brilho da luz está representado pela intensidade da cor do amarelo em contraste com as cores da parede vermelha e do teto verde escuro. A iluminância está expressa pela ausência de sombras nas figuras na sala, como se ela ocupasse todo o ambiente por igual, o que não é verdade porque as lâmpadas estão posicionadas em uma linha diagonal e iluminam de cima para baixo. ${ }^{204} \mathrm{O}$ que van Gogh quis dizer com a ênfase no brilho e na intensidade desse brilho? Em uma carta ele faz referência à auréola dos santos da idade média, mostrando que ele não está alheio à esta conotação.

Dessa posição em que se encontram, elas deveriam projetar uma sombra nos objetos e figuras na sala, desde onde elas refletem sua luz. Aqui observo uma contradição na representação e ela pode ter sido uma escolha para significar um excesso de iluminância em um nível tal, que não possa haver sombras. No entanto há um único objeto no centro da sala que não acompanha esse padrão representacional. É a mesa de bilhar, que projeta sua sombra de forma incontestável, pois é uma sombra exagerada, distorcida e desproporcional e que não é coerente com as fontes de luz que incidem sobre a mesa. Essa é uma segunda contradição que não pude deixar de perceber, a fim de examinar suas possíveis conotações. Por que todos os objetos e figuras na sala não possuem sombra? Por que apenas a mesa possui? É este contraste um sistema semiótico de caráter representacional? Que associações ele nos possibilita ao apoiar esta sentença visual nas nossas compreensões acerca das experiências e significação da sombra e da ausência dela? ${ }^{205}$

Neste caso, a metáfora para a luz da lâmpada pode bem ser de outra ordem, e não sobre a contraposição entre a luz espiritual e a existência mundana, como apontam Walther e Metzger (2012, p. 383): "O tema da iluminação artificial foi rapidamente resolvido em sua famosa obra-prima The Night Café in the Place Lamartine in Arles (pp.428-29)."

\footnotetext{
${ }^{204}$ Ocorrência de baixa Modalidade por meio de baixa Profundidade, Cor chapada e Saliência para representar o brilho da luz de forma gráfica.

${ }^{205}$ Ocorrência de Associação metafórica por meio de Saliência, Contradição e Distorção do Ponto de Vista para representar a sombra da mesa em contraste com a ausência de sombras nos outros objetos e figuras.
} 
Van Gogh parece dedicar-se a representar uma inovação tecnológica que estava chegando às casas e aos estabelecimentos naquele tempo: a luz a gás. Tudo no café está inundado por essa luz, desconfortável, excessiva, e que parece agredir os olhos e invadir a intimidade das pessoas. Essa luz a gás, com seu brilho duro, direto e que tirou da cena as fontes de iluminação mais tênues e mais intimistas como os candelabros e lampiões. Ele parece ter feito esta cena para expressar seu desagrado com esse tipo de luz de clareza exagerada para a sensibilidade dos olhos das pessoas que não conheciam a luz a gás e não eram acostumadas com o seu brilho. ${ }^{206}$ Whalter e Metzger (2015, p. 378-379) fazem um relato muito apropriado sobre o interesse de van Gogh por representar a luz a gás:

A clareza com que van Gogh interpreta sua própria pintura não está em conformidade com o amor que nutre pelo paradoxo. Declara que o seu trabalho trata de "terríveis paixões humanas" e na carta seguinte (534) caracteriza o bar como "um lugar onde uma pessoa se pode arruinar, onde pode enlouquecer ou cometer crimes." $\mathrm{E}$ as figuras amontoadas nas mesas têm realmente um ar perdido e copos vazios constituem uma prova dos excessos de alcoolismo. Mas junto à parede do fundo está um casal sentado e enlaçado; de facto, o último plano transmite-nos a ideia de maior conforto, com um ramo de flores esbranquiçadas e uma passagem tapada por uma cortina para uma sala luminosa e alegre. Porém, Van Gogh insiste em ver a composição em termos negativos. São os candeeiros que por si só realçam o desespero lúgubre e miserável da atmosfera. $\mathrm{O}$ seu brilho expõe implacavelmente o que a luz subsidiária das velas deixaria escondido. A luz fixa e impessoal torna tudo impiedosa e friamente anónimo. Resumindo, este é o comentário de Van Gogh aos elogios que se faziam à iluminação artificial: mesmo que isso significasse produzir uma arte não subtil e dogmática, ele queria demonstrar que um mundo que presta homenagem à nova forma de iluminação tinha perdido o contacto com toda a humanidade.

Para Walther e Metzger, van Gogh enuncia sua crítica à luz que todos comemoram, e ao brilho duro e invasivo que, assim como o progresso eu a trouxe, destitui as pessoas de sua pessoalidade, de sua subjetividade, de seu sentido próprio.

Para compreender o interesse representativo pelo tema é preciso vê-lo do ponto de vista das práticas sociais que interligam as pessoas naquele momento histórico ganhando um significado compartilhado, coletivamente, em uma cultura que está mudando, e se tornando moderna. A luz faz uma ligação entre a subjetividade das pessoas que estão ali naquele ambiente e a sociedade enquanto um sistema que está se reorganizando. E ai toda a conotação que essa transformação trás também pra aquele ambiente e que gera condições de exclusão, exploração, abandono. ${ }^{207}$

\footnotetext{
${ }^{206}$ Ocorrência de Associação metafórica relativa à introdução da lâmpada a gás e de sentidos potenciais a ela associados.

${ }^{207}$ Ocorrência de Associação metafórica por meio de Interdiscursividade para representar a luz produzida pela lâmpada a gás, e Modalidade, por se tratar de um tema que era muito atual para as questões da época.
} 
Inferi que a lâmpada a gás era uma invenção recente naquele momento e que seu brilho poderia representar uma experiência de desconforto e até de estranhamento com a mudança da iluminação nas salas e recintos de convívio social, com a qual as pessoas da época não estavam acostumadas. Que impacto esta nova luminosidade de brilho duro e iluminância mais intensa, ampla e intermitente deve ter tido para a percepção das pessoas? Que impacto ela tinha no estado psicológico delas? É sabido que a luminosidade exerce um efeito determinante na nossa disposição subjetiva. Como teria sido para aquelas pessoas, experienciar esta nova luminosidade com contornos mais definidos e mais duros, por causa de brilho mais direto e mais constante, tão diversa da luz das velas e lampiões com a qual estavam habituados e que tinham uma luminosidade mais tênue e com um brilho mais indireto e difuso, com um efeito mais sombrio no ambiente. Como teria sido recebida esta mudança na experiência perceptiva visual causada por essa nova fonte de iluminação artificial? Como ela foi vivenciada por esse observador implacável do comportamento da luz? Talvez Vincent representasse nessa tela a luz do ambiente do Café, iluminado por lâmpadas por toda a sala, como uma luz muito agressiva e cansativa, por ser este talvez o sentimento mais subjetivo causado pela sua experiência com as lâmpadas. Além disso, ele pode ter escolhido enfatizar a representação das lâmpadas e dar-lhes uma centralidade de personagem principal na narrativa, para fazer uma declaração crítica à modernidade que adentrava o século com suas transformações avassaladoras nos modos de viver e sentir daqueles que não estavam ocupando a centralidade nas transformações sociais, mas sendo excluídos por ela. Talvez por isso, nessa tela, as figuras humanas pareçam ocupar um lugar periférico na sala e não sejam valorizadas nas escolhas de articulação dos recursos visuais que Vincent conjugou em sua representação do Café. Quem são essas pessoas? ${ }^{208}$

Assim como nesse momento histórico o que estava sendo valorizado eram os avanços econômicos e da tecnologia e não a subjetividade e a humanidade desses homens que nesse sistema, são vistos apenas como mão de obra para serem explorados e descartados e, ao serem desumanizados pelo ethos da sua própria sociedade, eles perdem sua centralidade na vida social. Se o Café for uma metáfora para a sociedade, nele as lâmpadas, vistas como metáfora visual do progresso, estão no centro e as pessoas na periferia. A mesa de bilhar está vazia, eles não participam desse jogo. Se o café for uma metáfora para o reduto onde se refugiam os excluídos, esta é uma outra opção de sentido. Van Gogh parece representar o perigo de um lugar como o Café, que pode ser um lugar metafórico para onde vão as pessoas que vivem no

${ }^{208}$ Ocorrência de Transparência por meio de Associação metafórica dos sentidos potenciais da experiência subjetiva associados à introdução da luz da lâmpada a gás no cotidiano de van Gogh e de seus contemporâneos. 
limiar dessa sociedade. E é nesse lugar onde os dramas, conflitos, contradições e perdas são vividas e podem levar um sujeito a abandonar-se aos vícios e descaminhos da perda de sentido. ${ }^{209}$

O discurso artístico de van Gogh espelha sua participação nas ideias que circulavam no século XIX. Sua história de leituras construíram sua visão de mundo e sua visão da pintura. Sendo ele um leitor ávido da literatura e das telas dos realistas sociais, na pintura (Millet) e na literatura (Zola), e um pensador que buscou refletir o seu tempo, talvez ele quisesse fazer associações entre o brilho duro da nova luz, que nada deixava de fora naquele ambiente e o despontar desse novo tempo com seus adventos científicos e técnicos que invadiram a cena cotidiana ainda mais rapidamente com o avanço da revolução industrial, com suas mudanças na sociedade e no mundo do trabalho e que eram percebidas com agudez por Van Gogh. ${ }^{210}$

A composição propõe diferentes possibilidades de escolhas associativas que se apoiam em um sistema de escolhas potenciais de sentido culturalmente construído. Essas possibilidades de escolhas foram disponibilizadas nos sistemas semióticos na tela, para o espectador construir suas experiências visuais e associar sentidos. Petrie (1984, p. 9) discorre a respeito desses sistemas de escolhas:

Mas o que é o "simbolismo" de Vincent? Não é com certeza algo que se distinga
radicalmente da "caracterização". Parece ter dois pontos de partida, um dentro da
própria natureza, e o outro no conhecimento particular da sociedade cristã; mas
nunca em qualquer procedimento artístico predeterminado. Trata-se muito mais de
uma questão de imagem do que de estilo. "Eu sei que faz bem ao espírito de muita
gente reencontrar temas poéticos, O Céu Estrelado, As Videiras em Folha, Campos
Lavrados (Os Sulcos)".

Além disso, percebe-se o contraste entre centralidade e periferia, no qual o que ocupa o lugar do centro é uma mesa de bilhar vazia, e uma figura de um homem que olha frontalmente, em contraste com duas fileiras de mesas ao longo das paredes. Por que o que está no centro está vazio? Vazio de ação, vazio de interação, parece chamar a atenção para o que simboliza em si mesmo, tanto a mesa, quanto o homem. Essas mesas se encontram na periferia da cena, estão ocupadas por figuras que negam o olhar para o ponto de quem olha a tela. O contraste entre ocupar o lugar central e o lugar periférico sofre uma inversão, uma vez que o lugar central está ocupado por uma mesa de bilhar que está vazia e um homem que tem uma expressão ambígua e de expectância, enquanto que na periferia da cena é que se

\footnotetext{
${ }^{209}$ Ocorrência de Associação metafórica dos sentidos potenciais do Café como um lugar para onde vão os excluídos.

${ }^{210}$ Ocorrência de Interdiscursividade por meio da Associação metafórica da luz a gás como a chegada do Progresso e seus impactos sociais.
} 
encontram as pessoas que poderiam ser o motivo central do tema. E quem são essas pessoas? São tipos humanos comuns como os que encontramos todos os dias, absortos em seu universo particular. ${ }^{211}$

Essa contradição em que as figuras humanas estão na periferia e a mesa de bilhar, que está vazia, é que ocupa o centro, é reforçada pelas cadeiras vazias que ocupam o lugar de destaque do primeiro plano da tela e ainda por cima, estão trabalhadas em ricos detalhes para dar proeminência a sua importância na cena tal como estão: vazias. Por que van Gogh escolheu posicionar cadeiras vazias no primeiro plano, em um lugar que é de proeminência e valorização, e uma mesa, também vazia, no centro da tela? ${ }^{212}$ Forrester (1983, p. 11) discorre acerca do sentido do vazio, cheio de significados em van Gogh, e que nos escapam à elucidação:

Ninguém deveria atrever-se a chamar de "um Van Gogh" nenhuma dessas
superfícies pintadas em carne viva, abertas, orgásticas, onde, sem trégua, um homem
tenta nascer em vão, e cria ao preço de "esforços extraordinários com seu sangue e
sua inteligência" os lugares de um nascimento possível. O lugar onde isto se dá. O
lugar onde ele não está. Onde nós não estamos. Suas telas assinam uma ausência.

Considerei necessário investigar a ocorrência da centralidade e periferia nos construtos textuais, bem como se van Gogh constrói o vazio também em seu discurso escrito, e como o faz. Qual é a semiose que está articulada com essas metáforas da centralidade de objetos vazios, desocupados em contraposição com as figuras na periferia da cena, e que são tipos comuns, absortos em si mesmos? Seriam essas figuras, pessoas desocupadas, significando, sem emprego e, portanto, sem um valor diante daquela sociedade produtiva, pragmática, sem um lugar social, sem uma centralidade?

Será que o objeto no centro pode conotar que os objetos se tornaram mais importantes do que as pessoas? A mesa pode estar no centro para divertir as pessoas, mas não há pessoas ali que ela possa divertir. As pessoas no Café não têm ânimo e ao que parece, elas não estão indo no Café para se divertir. O Café se tornou um espaço de vivência da angústia, da exclusão, da falta de sentido, da perda do sentido de pertencimento que eles estão experienciando em grupo. ${ }^{213}$ Se tornou um lugar que elas podem passar a noite em segurança, assegurada pela forte iluminação (EDWARDS, 2009) já que van Gogh explica que este é um

\footnotetext{
211 Ocorrência de Associação metafórica, Enquadramento, Perspectiva e Incompletude por meio do sentido de Contraposição entre centro/periferia, olhar/não olhar, ativo/apático construído pela posição relativa das figuras.

${ }^{212}$ Ocorrência de Associação metafórica, Saliência e Incompletude pela ênfase dada à representação de cadeiras vazias e mesa de bilhar vazia.

213 Ocorrência de Associação metafórica, por meio da posição relativa das figuras, dos sentidos potenciais das cadeiras e mesa desocupadas como uma metáfora visual para o esvaziamento, a perda de lugar das pessoas desocupadas que ocupam o café.
} 
café que funciona a noite toda e é para dar abrigo aos viandantes. A influência do ambiente produzido pelos sujeitos, pela subjetividade desses sujeitos é mais forte do que a influência de um objeto que está ali disponível para diversão e essa influência infunde toda a tela.

\section{Mesa de bilhar}

Comparando a forma como Vincent representa pictoricamente a mesa de bilhar no centro da tela, ocupando o segundo plano e o armário ao fundo do bar ocupando o terceiro plano, há um contraste entre na forma como ele define estes dois objetos. Enquanto o armário não tem seus contornos definidos, os pés da mesa de bilhar são extremamente definidos e reforçados por uma linha negra e espessa que enfatiza seu contorno e sua forma. ${ }^{214}$ As linhas de contorno em van Gogh são usadas de forma distinta do movimento cloisonista de seus colegas. O uso de linhas de contorno nas figuras e membros do programa cloisonista é explicado por Walther e Metzger (2015, p.440):

No idílico retiro de verão em Pont-Aven, Gauguin e Bernard, juntamente com Anquetin e Charles Laval, tinham estado a trabalhar num projeto que criasse um tipo de arte independente da natureza e somente interessada na delicadeza do impacto visual. Apesar das poucas experiências que fizeram, ainda produziram um manifesto. Foi escrito por Edouard Dujardin, amigo dos tempos de escola de Anquetin, e ao surgir na Revue Indépendant (possivelmente o mais importante dos muitos periódicos simbolistas), introduziu o termo "Cloisonismo". Os ourives medievais desenvolveram a técnica cloisonné nos utensílios esmaltados de cozinha. A nova teoria ocupava-se dos contornos que conferem aos objetos de um quadro - os motivos que se podem ver na tela - uma presença sólida e, consequentemente, independência e autonomia. Muitos séculos antes, os artesãos costumavam usar elegantes tiras de metal para separar áreas de esmalte umas das outras; agora, por analogia, era o uso exato e autoritário da linha que pretendia fixar as coisas nos seus lugares de modo bastante inequívoco e implantá-las, permanentemente, na natureza bidimensional de uma pintura.

Esta ênfase pode ser decorrente do efeito da sombra que a mesa produz exigindo do pintor a garantia de que mesmo sem luz, os contornos dos pés da mesa sejam percebidos e este detalhamento tenha assegurado suas características particulares. Com que propósito? $\mathrm{Na}$ luz, esse detalhamento não parece ser necessário para definir e diferenciar os elementos em relação ao contexto. No Café da Noite, parece que a luz assombra mais do que a sombra. Mas o que Van Gogh queria simbolizar com uma mesa de bilhar vazia, no meio da noite, no centro de um Café decadente? Que associações metafóricas podem ser feitas sobre o lugar e a posição da mesa em relação aos outros objetos e às outras figuras na composição? Walther (1990, p.46-48) também expõe este aspecto do uso das linhas de contorno nos objetos representados:

O meio pictural do simbolismo era o enquadramento de todos os objectos, através de uma linha de contorno que os envolvia. Assim, podia dar-se expressão à particularidade daquilo que inflamara a força de imaginação do artista e ao

\footnotetext{
${ }^{214}$ Ocorrência de Saliência, por meio de Textura e Gesto Pictórico no uso do Desenho-Pintura para detalhar a representação dos contornos da mesa de bilhar.
} 
isolamento dos objectos, que afinal era necessário para fazer deles símbolos, para estilizá-los em referências a algo que os excedia. A esta forma de pintar, derivada, por um lado da ourivesaria medieval, por outro, como sempre na época, das xilogravuras japonesas, chamava Dujardin "cloisonnisme".

Por estar envolvida por linhas de contorno, parece que a mesa foi sublinhada por linhas grossas como que para destacá-la dos demais móveis dando a ela um estatuto simbólico. Embora tenha usado de modo diverso, van Gogh aderiu ao programa no uso do contorno para conferir aos objetos um estatuto simbólico, este parece ser o caso da mesa de bilhar. ${ }^{215}$ Os sentidos produzidos pelo uso das linhas de contorno são expostos por Walther (1990, p.48):

\begin{abstract}
"A Arlesiana" de van Gogh (fig.p.51), de Novembro de 1888, o retrato de Madame Ginoux, proprietária do café da estação de caminhos de ferro em Arles, é um exemplo-padrão deste "cloisonnisme". O encosto da cadeira, o tampo da mesa, a figura da mulher, são envolvidos por uma linha de contorno, acentuando assim a sua silhueta. Dentro deste plano gráfico, van Gogh pode então usar as suas grandes superfícies de cor que ganham efeito através do contraste. A composição é completamente plana, vivendo os pormenores puramente da linha colorida que os esboça. Van Gogh explica assim o seu "cloisonnisme": "As áreas que são envolvidas por linhas de contorno, existentes ou não, mas sempre sentidas, essas encho eu então com tons igualmente simplificados."
\end{abstract}

Van Gogh por sua vez não fazia contorno em tudo apenas nos objetos e figuras que queria ver ressaltados. Em muitas de suas obras, como por exemplo $O$ Quarto, ele não usou as sombras para dar volume ou solidez nos móveis como atesta Muhlberger (2002, p.27):

Van Gogh admitiu que não foi fácil "alcançar simplicidade com cores vistosas". Uma maneira foi usar grandes áreas de cores chapadas - azul, verde, amarelo, cor de alfazema e vermelho. Esses matizes chocantes faziam os objetos familiares destacarem-se. Mas também criou outra maneira para conseguir isso. Cada peça é contornada em preto ou marrom-escuro, para ganhar ênfase. Ao não usar sombras embaixo dos móveis, van Gogh fez que parecessem planos, como nas gravuras japonesas, e flutuassem acima do chão. Ele também inclinou o piso, deixando o lado direito mais alto do que o esquerdo, e a parede do fundo torna-se oblíqua em relação à cama. Tudo isso dá a impressão de um espaço um pouco desordenado; apenas os móveis parecem estáveis. Em contraste com o quarto, os móveis têm um "espírito familiar e tranquilizador", o que segundo van Gogh levava ao repouso.

Van Gogh começou a usar o delineamento, desenhando o contorno dos móveis ou formas para emprestar uma aparência de solidez, ao invés usar a técnica do chiaroscuro para dar volume, mas van Gogh usou este recurso de modo diversificado de seus contemporâneos, delineando alguns objetos apenas, ${ }^{216}$ como explica Walther (1990, p. 48-49):

\footnotetext{
${ }^{215}$ Ocorrência de Associação metafórica e Saliência, por meio da posição relativa da mesa de bilhar em relação às figuras, usada como uma metáfora visual.

${ }^{216}$ Ocorrência de Saliência, Inacabamento, Modalidade por meio dos Contrastes Cromáticos e do Gesto Pictórico no uso dos recursos semióticos do delineamento do contorno dos móveis e objetos, como as cadeiras e a mesa de bilhar.
} 
O "cloisonnisme" era a marca da "escola de Pont-Aven", cujo mentor era Gauguin. $\mathrm{O}$ enquadramento de todas as áreas com linhas de contorno, era para Gauguin quase dogmático. Elas eram para ele a garantia de recusa à imitação da realidade. Van Gogh, por outro lado, viu tudo isso com menos rigor. As suas linhas de contorno, na maior parte variadas na cor, apareciam segundo a necessidade, ou nem eram usadas, dependendo o seu uso do efeito da pintura, não de um conceito teórico. Daí, a crítica de Gauguin de trabalhar com demasiada imprecisão, o que viria a ser uma causa para a ruptura posterior entre eles.

Essa marca estilística de dispensar a representação de sombras pode chamar a atenção para uma modalização pela ausência, bem como para um construto simbólico apoiado na ausência de sombras nos móveis e pessoas representadas no 'Café da Noite'. E se a ausência de sombras pode apenas evidenciar uma iluminação excessiva, porque apenas a mesa de bilhar projeta sombra? Seria o significado simbólico da mesa de bilhar algo que está relacionado com a produção também simbólica de sombra? Ou seja, o que a presença de uma sombra na mesa de bilhar, em relação a sua ausência em todos os outros móveis e pessoas nos diz? E, atentem ainda, não apenas para a presença de uma sombra na mesa de bilhar, mas para a forma como ela é representada. A ênfase na sua forma, dada pela sua distorção parece querer nos comunicar algo a mais do que uma simples representação literal da cena. ${ }^{217}$ Como relatam Walther e Metzger (2015, p. 387):

\begin{abstract}
Analogias à parte, o retrato Boch e o autorretrato podem, contudo, ser atribuídos cada qual à sua esfera particular. Van Gogh (utilizando também praticamente o mesmo contraste entre o vermelho e o verde que usara no interior do café noturno) vê-se a si próprio como pertencendo ao mesmo mundo ameaçador do Café Nortuno na Place Lamartine, em Arles. Está demasiado consciente do caráter visionário dos seus rostos - que apelam às estrelas e tentam alcançar uma vida melhor - para esquecer a natureza precária da sua própria existência. E, de fato, as duas pinturas funcionam da mesma maneira que as duas naturezas-mortas com cadeiras: como um díptico que invoca amizade e harmonia. Vistas isoladamente, cada uma delas expressa a impossibilidade de reconciliação com a Vida; no fundo, definem a própria polaridade do dia e da noite.
\end{abstract}

A centralidade da mesa vazia, uma mesa de bilhar que está ali com a proposta de interação e diversão das pessoas enfatiza ainda mais o isolamento das figuras que estão na tela e consequentemente o nosso isolamento porque nós também não estamos lá na mesa de bilhar, porque nós também estamos sozinhos olhando para a tela. Na centralidade da mesa de bilhar há uma centralidade da solidão humana. ${ }^{218}$ Como Vincent faz isso? Com o uso da perspectiva ele coloca a mesa e sua sombra no centro, ele coloca movimento e ritmo em objetos inanimados nas luzes e não nas pessoas, e ele representa a paralisia com um homem com a mão na cabeça abaixada quase adormecido, e um casal no fundo que provavelmente está

\footnotetext{
${ }^{217}$ Ocorrência de Distorção do Ponto de Vista, Incompletude e Associação metafórica por meio da distorção da forma e do tamanho da sombra da mesa de bilhar que se impõe pela exclusão de outras sombras.

${ }^{218}$ Ocorrência de Associação metafórica pela Inversão de sentidos pela escolha de uma mesa de bilhar para simbolizar a solidão e o isolamento humano.
} 
introspectivo, cochichando um com o outro, e não querem ninguem ali para interagir com eles. $^{219}$

\section{Relógio}

Há um relógio da parede do fundo do recinto que marca meia noite e quinze minutos, e indica que o tempo da cena engloba a segunda parte da noite, a madrugada, com todos os sentidos metafóricos a ela associados. Ele é o único objeto que está associado com a cor verde do teto, embora ele esteja na parede, há na parede um quadrado verde como se fosse uma moldura ou um acabamento da pintura que deixou aquela seção da parede com a mesma cor do teto. Dessa forma, inferi que o relógio é um objeto de transição entre a seção em cor vermelha na parte superior da parede e o teto. Ele pode ter uma conotação simbólica, uma vez que não encontrei nenhum outro elemento semiótico na seção do teto, na forma de figura, objeto ou membro. O que o relógio representa, no contexto das pequenas narrativas agrupadas nos Episódios? Talvez um elemento unificador, um elemento que é igual para todos os que estão na sala, que o tempo assim como a língua, assim como a experiência de viver, assim como a luz, é um denominador comum e igual para todos que estão vivos e pertencem ao grupo humano. ${ }^{220}$

\section{Volume}

Apesar dos objetos e das figuras humanas estarem um pouco destituídos de volume, ou estejam representados com pouco naturalismo, isso se deve à representação de áreas de cores chapadas e à ausência de sombra que contribuiria para construir a percepção de volume na superfície bidimensional da tela. A falta de volume se deve a incidência de luz que retira os contornos e dá uma sensação de achatamento para as superfícies e uma homogeneidade entre os elementos participantes da cena. A incidência de luz em excesso, poderia produzir uma sombra igualmente intensa, mas não é isso o que se vê e sim uma ausência de sombras. Esse recurso pode ter sido usado como uma estratégia para criar uma indiferenciação entre as figuras humanas e o próprio ambiente do Café, como se não houvesse uma identidade própria

\footnotetext{
${ }^{219}$ Ocorrência de Enquadramento, Perspectiva, Ritmo, Movimento por meio de Contraposições e de Inversão de sentido ao colocar movimento em objetos inanimados e paralisia em figuras humanas. Observei também essa ocorrência no discurso escrito, por exemplo, procuramos por 'o que é vazio está no centro e tem destaque'.

${ }^{220}$ Ocorrência de Associação metafórica por meio da posição relativa do Relógio, para os sentidos potenciais associados ao tempo e à passagem do tempo.
} 
em cada figura. ${ }^{221}$ Ao mesmo tempo essa homogeneidade dá uma unidade de sentido na obra. $^{222}$

A sombra, que em uma tela bidimensional contribuiria para construir a percepção de volume e superfície nos objetos, aqui está ausente. Inferi que esta ausência de volume talvez possa ter uma função Modal, e também Representacional, pois parece suscitar a nossa sensação de uma indiferenciação entre as figuras humanas, os objetos e o ambiente do Café em si. E isso não aconteceria devido ao excesso de iluminação. Então, porque as figuras e objetos não projetam sua sombra pelo chão? Inferi que a escolha do pintor por representar as pessoas e objetos da sala destituídos de volume, pode ter tido uma finalidade: a de construir um efeito de sentido, por exemplo, que a luz está por toda a parte, ou um estranhamento, que nos mantém intrigados com esta narrativa, ou ainda um contraste com o único objeto que parece ter volume e sombra: a mesa de bilhar. Simbolicamente ele pode estar enunciando que os homens não projetam sombra por terem algo de divino em sua natureza, não projetam a ausência de luz. O homem é bom, a sociedade é que o corrompe. Já a mesa de bilhar projeta essa enorme e desproporcional sombra por ser um objeto associado ao jogo e ao vício. ${ }^{223}$

Também inferi que a falta de volume pode ser uma estratégia Modal para obter coesão visual para dar unidade na tela. Mas também há uma outra hipótese presente, para dar ênfase ao único objeto que possui sombra, pois a falta de volume nas demais figuras e objetos tornaas periféricas à mesa de bilhar. Esta sim tem uma enorme sombra e volume, que torna secundária a importância dessas figuras na tela, e confere destaque para o objeto que possui volume. Esse contraste entre volume e ausência dele pode ser intencional para enfatizar a centralidade da mesa de bilhar que, além de estar no centro da tela, tem mais volume do que os demais objetos, e está representada de forma muito definida e detalhada em seus contornos. A centralidade da mesa de bilhar chama a atenção para as metáforas visuais associadas com a mesa de bilhar. ${ }^{224}$

Além de ter volume, a mesa está um pouco exagerada em sua forma e proporção. Além disso, ela está deformada pela representação em perspectiva cuja representação não se

\footnotetext{
221 Ocorrência de Distorção do Ponto de Vista, Inacabamento, Associação metafórica por meio da distorção da baixa Modalidade com que o volume é representado, devido à ausência de sombras e a homogienização das superfícies.

${ }^{222}$ Ocorrência de Rima Visual pelo uso de Inacabamento e Distorção do Ponto de vista presentes na ausência de volume e homogienização da iluminação nas superfícies e áreas de cor.

${ }^{223}$ Ocorrência de Associação metafórica e baixa Modalidade por meio da diminuição da Profundidade e da Indiferenciação que produz um efeito de sentido simbólico sobre a ausência de sombra das figuras e presença de sombra da mesa de bilhar.

${ }^{224}$ Ocorrência de Associação metafórica por meio de Saliência, Rima Visual e Profundidade na construção de um sentido simbólico para a mesa de bilhar.
} 
preocupou muito com o realismo, e suas linhas de perspectiva estão em conflito com as linhas de perspectiva das tábuas do chão, criando uma sensação de conflito e de estranhamento. Esse desalinhamento de perspectiva entre a mesa e as tábuas do chão é decorrente do fato que a mesa não está posicionada de forma paralela com as tábuas. Os pés de trás da mesa estão apoiados em uma tábua e os pés da frente estão apoiados em outra tábua no chão, mostrando que não há um alinhamento entre a mesa e o piso do Café. Consequentemente a sombra dela também não segue a mesma perspectiva das tábuas. Isso gera uma sensação de desorganização do espaço. A mesa está desalinhada, o paletó do garçom não está alinhado, as pessoas não estão com uma postura alinhada; essas conotações de desalinho podem ser um sistema semiótico para significar, por associação, um estado de desordem e instabilidade. ${ }^{225}$

É intrigante que, uma sombra desse tamanho na mesa é tão enfatizada que de certa maneira é como se ela emprestasse volume para o Café inteiro. Concentrar o volume de todo o ambiente em um único objeto é um sentido construído para significar alguma coisa muito específica. É preciso prestar atenção para perceber que os outros objetos não têm volume e nem sombra e esse fato deve ter uma significância a parte. Isso também pode ser associado a outros sentidos mais abstratos e subjetivos, por exemplo, pode-se atribuir esse desalinho a um estado de leviandade, desequilíbrio, veleidade, doidice. ${ }^{226}$ Os estados de espírito humanos, e o medo do descontrole, representados no 'Café Lamartine' parecem falar de um ambiente muito familiar para van Gogh, relatado por Naifeh e Smith (2012, p.36-7):

Cercada de tais lições, Anna, a filha do meio de Willem, cresceu com a uma visão sombria e temerosa da vida. Por toda parte havia forças ameaçando devolver a família ao caos de onde conseguira sair tão pouco tempo antes, com o mesmo ímpeto repentino e destruidor do mar tragando uma aldeia. $\mathrm{O}$ resultado foi uma infância cercada pelo medo e pelo fatalismo: pela sensação de que a vida e a felicidade eram precárias, e assim não se podia confiar nelas. Segundo as palavras da própria Anna, o mundo era "um lugar cheio de problemas e preocupações [que] são inerentes a ele"; um lugar onde "as decepções nunca cessarão" e apenas os tolos "querem muito" da vida. Devíamos simplesmente "aprender a suportar", dizia ela, "entender que ninguém é perfeito", que "sempre existem falhas na realização de nossos desejos", e que as pessoas deviam ser amadas "apesar de seus defeitos". A natureza humana, em especial, era caótica demais para merecer confiança, sempre em risco de se descontrolar. E avisava aos filhos: "Se pudéssemos fazer tudo o que quiséssemos, sem sofrer as consequências, sem ser vistos, sem ser incomodados, não nos desviaríamos ainda mais do caminho certo?".

\footnotetext{
${ }^{225}$ Ocorrência de Associação metafórica por meio de Distorção do Ponto de Vista e Inacabamento presentes na representação da Perspectiva das tábuas do chão da sala que estão em desalinho com a representação da perspectiva da mesa de bilhar.

${ }_{226}$ Ocorrência de Associação metafórica por meio de Saliência, Transparência e Profundidade na escolha potencial de sentidos associados à exclusividade da sombra da mesa em relação à ausência de sombra dos outros objetos e figuras.
} 
A falta de volume pode servir como um recurso de representação da superfície, conotando a superficialidade, não no sentido de falta de conteúdo, mas no sentido de enfatizar a vida, a existência. Parece dizer que o conteúdo existencial daquelas pessoas que estão no café é prioritariamente solitário, doentio, perdido, sem esperança, então, é como se fosse uma mensagem no sentido: não adianta procurar algo além disso; o que está na superfície é o que é. 227

\title{
Contrastes cromáticos
}

Os contrastes complementares, nesta tela assumem um peso simbólico, eles têm uma conotação de conflito e antítese, como afirma van Gogh na carta C533 relatada por Haziot (2010, p. 215):

\begin{abstract}
No início de setembro, Vincent se fez notívago. "Durante três noites fiquei acordado a pintar, dormindo de dia." Fez então um quadro importante em sua obra, pelo simbolismo das cores que empregou: $O$ café noturno. Trata-se aqui do interior de um café situado perto da estação ferroviária de Arles. Sabemos da concordância do azul e do amarelo, símbolo da vida, da felicidade. Mas aqui Vincent coloca em cena a estridência do vermelho e do verde, essa marca da paixão ruim, negativa, criminosa, símbolo da morte. Ele mesmo disse que "o quadro é um dos mais feios que já fiz. É equivalente, embora distinto, ao Comedores de batatas.” (...) "Procurei", ele explcia, "exprimir com o vermelho e o verde as terríveis paixões humanas. (...) Por toda parte há um combate e uma antítese dos verdes e dos vermelhos mais diversos." C533
\end{abstract}

O clima do ambiente do Café é vicioso, e ele constrói essa impressão por meio da sensação que os contrastes cromáticos complementares de vermelhos e verdes e os contrastes de saturação cromática de amarelos e brancos transmitem. ${ }^{228}$ Van Gogh, em carta relatada por Haziot (2010, p. 215), explicita os sentidos associados a estes contrastes:

\begin{abstract}
O tema o ocupa de tal modo que ele volta ao assunto numa outra carta: "No meu quadro do Café noturno, busquei exprimir que o café é um lugar onde podemos nos arruinar, enlouquecer, cometer crimes, enfim, por contrastes do rosa-claro e do vermelho-sangue e borra de vinho, do verde suave Luis XV e Veronese com os verdes-amarelos e verdes azuis duros, tudo isso numa atmosfera de fornalha infernal, de enxofre pálido, busquei exprimir como que a força das trevas de uma taverna." C534
\end{abstract}

Os contrastes de saturação entre os tons de amarelos e brancos são usados para representar uma luz intensa, muito clara e direta. O uso da cor passa a sensação de desconforto, cansaço e irritação que deve ser o resultado da combinação das tonalidades

\footnotetext{
${ }^{227}$ Ocorrência de Associação metafórica por meio de por meio de Profundidade ou pela falta dela, conota um sentido de superficialidade.

${ }^{228}$ Ocorrência de Contrastes Cromáticos Simultâneos que constroem um sentido de excesso, de fadiga e decadência por meio de Intertextualidade e Associações metafóricas.
} 
muito claras de amarelos e das tonalidades muito escuras de vermelhos em uma proporção excessiva. ${ }^{229}$ A carta de van Gogh, relatada por Walther e Metzger, deixa inequívoca a intenção de contruir conflitos e antíteses na paleta extremamente variada de verdes, vermelhos e amarelos. ${ }^{230} \mathrm{O}$ uso desse tipo de contraste é comentado por Walther e Metzger (2015, p.377378)

O artista abordou o assunto na Carta 533. "Para grande prazer do proprietário do
café, do agente postal e de todos aqueles que gostam da noite, e para o meu próprio
prazer, estive a pé durante três noites, dormido durante o dia. Por vezes, a noite
parece-me ser muito mais viva e as suas cores mais intensas do que as do dia. É
claro que vai ser bastante difícil recuperar o dinheiro que paguei ao proprietário com
o meu quadro, pois é um dos mais dissonantes que já fiz. Equipara-se aos
Comedores de Batatas. Tentei expressar através dos vermelhos e verdes as terríveis
paixões humanas. A sala é de um vermelho cor de sangue e amarelo não muito
pronunciado, com uma mesa de bilhar verde no meio e quatro candeeiros amarelo-
limão que projetam uma luz cor de laranja e verde. Há, em toda a pintura, conflitos e
antíteses: nos verdes e vermelhos extremamente variados, nas pequenas figuras de
pessoas da noite, na sala vazia e triste, no violeta e no azul."

O amarelo intenso perpassa todo o ambiente desde as lâmpadas que brilham e ofuscam contra o vermelho escuro e fechado e refletem no chão contra tons de branco e amarelo claro que nos deixa cansados, pois o excesso de saturação retira a sensação de profundidade que o matiz cromático empresta as nossas percepções. A falta de tons mais frios e escuros produz um efeito de achatamento que a falta de sombras produz no ambiente que, por sua vez, produz um desconforto sensorial e visual, pois não vemos a profundidade que os objetos e seus volumes têm. ${ }^{231}$

Esse desconforto é causado pela sensação de não se estar em um ambiente similar à forma como a luz se comporta no mundo real, que nos é familiar e transmite uma sensação de segurança, de estabilidade e de identificação. No ambiente do Café da Noite, a saturação da cor é tamanha que mesmo a sombra da mesa está clara para as convenções tradicionais dos efeitos de sombreamento, que usam tons mais frios e escuros, e mais intenso por estar no primeiro plano. ${ }^{232}$ Walther $(1990$, p.36-37) ressalta o uso simbólico da cor também nos retratos:

O Retrato significa para van Gogh a ocupação artística com pessoas, com a amizade e simpatia que tanta vez lhe foram negadas na vida. O retrato "deixa-me desenvolver o que há de melhor e mais profundo em mim", diz ele mesmo. As cores tornam-se cada vez mais portadoras da descrição do caráter, cada vez mais independentes do

\footnotetext{
${ }^{229}$ Ocorrência de Contraste cromático de Saturação para representar a sensação de uma luz intensa que constrói a cena.

${ }^{230} \mathrm{O}$ uso simbólico da cor também foi observado nesta mesma ocorrência na tela e no extrato de carta que se refere à esse uso de contraste cromático.

${ }^{231}$ Ocorrência de Contraste cromático de Saturação e baixa Modalidade que retira a percepção de Profundidade e aumentam a sensação de desconforto e fadiga.

${ }_{232}$ Ocorrência de Contraste cromático de Saturação e Inacabamento na representação da sombra da mesa de bilhar.
} 
aspecto concreto do retratado. De certo modo, eram todos, como ele mesmo, marginalizados.

Há um contraste cromático complementar entre o vermelho e o verde que é suavizado pela tonalidade que vem da luz amarela das lâmpadas. Haziot (2010, p. 202) também comenta acerca do estatuto simbólico conferido por van Gogh para os contrastes de azul e amarelo, e vermelho e verde:

Está finalmente em sua casa e pinta uma natureza-morta, na qual reúne uma cafeteira, taças e jarras que acaba de adquirir, junto com laranjas e limões sobre uma toalha azul com um fundo amarelo esverdeado. Cada objeto tem um azul diferente. Esse trabalho acerca das cores complementares é conduzido com cuidado durante uma semana, e Vincent fala da tela, em suas cartas, como de um grande êxito. Pintar um objeto é sua maneira de apropriar-se dele. Essa natureza-morta revela uma felicidade, uma calma interior, e teremos a ocasião de ver que a combinação azulamarelo é para ele a da felicidade, da vida, enquanto vermelho-verde exprime a morte as paixões ruins, e preto-vermelho, a angústia.

Por que van Gogh escolheu esses tons de cores complementares para representar o ambiente do Café, e para organizar os Episódios da cena narrada? Teriam esses tons de cores um significado metafórico para ele, ou por meio delas ele queria criar um clima para o ambiente? O que elas significam em sua narrativa? Sim. Estas perguntas não são excludentes. $^{233}$ Ele queria criar um clima para o ambiente e esse clima tem um significado metafórico, como explica Walther (1990, p. 33-34):

Com isto van Gogh desenvolve uma nova forma de pintura tonal, deixando soberanamente atrás de si o seu mestre Delacroix. Aqui unificam-se autonomia de cor e pintura tonal como antes, o colorido do quadro desenvolve-se a partir de variações sobre uma cor, em tonalidades; só que esta cor básica usada não tem mais nenhuma correspondência na realidade. Um amarelo intenso, um vermelho vivo perdem a função de representar um aspecto externo. A cor é agora apenas portadora da expressão individual, e de uma imaginação da realidade na psique do pintor. Luz e sombra, refracções e reflexos da cor são sopeados, pois têm o seu princípio figurativo na percepção e não na imaginação. Uma determinada cor não é agora usada só porque representa adequadamente a realidade, mas sim porque reforça a veemência da mensagem. Esta cor já não pode ser examinada objectivamente, só sentida subjectivamente.

Uma das marcas na obra de van Gogh é o uso autônomo, ou arbitrário da cor. O 'Café da Noite' realmente tem as cores representadas por van Gogh e é possível conferir com a tela do 'Café da Noite' pintada por Gauguin meses depois. No entanto, van Gogh deu para as cores do café uma instância simbólica, expressa em suas cartas. Haziot (2010, p. 218) ressalta

\footnotetext{
${ }^{233}$ Ocorrência de Associação metafórica pelo uso do Contraste Simultâneo entre vermelhos e verdes para construir uma metáfora visual.
} 
que, para Van Gogh, as cores assumiam um estatuto simbólico, como que para simbolizar emoções. $^{234}$

Depois do exterior da Casa Amarela, era preciso pintar o interior. Vincent declara que, após suas jornadas fatigantes, dorme doze horas seguidas. $\mathrm{O}$ repouso nesse lugar providencial e a quietude que ali reina the dão a ideia de pintar o quarto. Faz uma tela, hoje no museu de Amsterdã, e uma segunda versão, as duas sendo geralmente confundidas. No entanto só uma terá essa gama dourada do período arlesiano: o leito e o soalho possuem aquele ouro comestível, diríamos, que caracteriza os tempos felizes de Arles. As réplicas feitas por Vincent são determinadas por seu estado psicológico e as cores se revelam bastante diferentes. Em particular, ele fará uma cópia em Saint-Rémy na qual o piso será de um castanho-verde que evoca a cor de um pântano. Esse mesmo castanho-verde aparece no autoretrato que ele pintou ao sair de uma crise. $\mathrm{O}$ estudo dessas três versões mostraria a que ponto a cor é determinada, num pintor, por seu sentimento íntimo. De fato, quando volta a pintar o quarto de Arles, ele não consegue reencontrar a mesma gama cromática. $\mathrm{O}$ desenho, ligado ao intelecto, é fielmente reproduzido, mas a cor não se submete à vontade ou ao pensamento racional.

Talvez, se olharmos para os objetos e figuras que estão em cada episódio, tenhamos uma pista dos significados associados a cada um desses tons de cores, na forma como elas foram escolhidas para serem usadas. Por exemplo, o uso do amarelo com altas quantidades de branco para representar o brilho duro da luz no chão, e o uso de amarelo sobre vermelho para representar o brilho das lâmpadas comunicam a sensação também comunicada na oração 'Tudo isso em uma atmosfera de fornalha infernal, de enxofre pálido.' do extrato de carta $4 \mathrm{c}^{235}$.

Petrie $\left(1974\right.$, p. 8) expõe a forma simbólica ${ }^{236}$ como van Gogh buscou usar a cor, para conferir a esse uso uma instância semiótica com sentidos próprios:

Uma visão mais amadurecida resultou especialmente da sua reflexão sobre a função da cor na pintura. Se Delacroix e Rubens podiam pintar quadros cuja cor, considerada fora do tema, era tida como expressiva, certamente que a cor era capaz de enaltecer a expressividade temática da pintura. Vincent não estava no fundo especialmente interessado nos aspectos científicos das teorias do complementarismo dicutido por neo-impressionistas como seu amigo Signac, mas antes obsessivamente interessado no poder expressivo dos contrastes complementares. Em Paris pintou alguns quadros em que os princípios do divisionismo foram utilizados com o que parece ter sido um intuito primariamente naturalista, tendo logo começado a desenvolver um colorismo que não significava simplesmente uma maneira de reconstruir opticamente as sensações derivadas da Natureza, mas sim destinado a elevar essa experiência de modo a conceder à pintura o equivalente perceptual de um sentimento. Esse tipo de pintura figura no famoso quadro Café Noturno, por exemplo. E é neste sentido que o significado da sua grande obra reside não "fora da pintura", mas "dentro dela".

\footnotetext{
${ }^{234}$ Ocorrência de Transparência por meio do uso simbólico da cor, para os contrastes entre vermelhos e verdes, explicitado por van Gogh em seu extrato de carta.

${ }^{235}$ Carta 677 - Extrato no 4c -_Br. 1990: 680 | CL: 534 - From: Vincent van Gogh To: Theo van Gogh - Date: Arles, 9 September 1888.

${ }^{236}$ Ocorrência de Associação metafórica pelo uso simbólico da Cor na distribuição dos contrastes na tela.
} 


\section{A figura do homem no centro da sala}

O homem parado ao lado da mesa de bilhar não deixa saber porque ele olha diretamente para o primeiro plano. Porque, por mais que seu olhar e atitude não sejam convidativos, a ambiguidade com que ele se apresenta nos captura a curiosidade e nos aprisiona dentro da cena, sem compreender e portanto sem nos libertarmos. A ambiguidade nos instiga a buscar compreender os dilemas apresentados pela modalização desta ambiguidade, que foram escolhas deliberadas de van Gogh. ${ }^{237}$

Em nosso isolamento, na nossa solidão humana, como que nos relacionamos com o outro estranho. Temos um olhar de compaixão, de medo, é o sentimento que teriamos com um estranho que nos deparamos na rua, vamos olhar para aquele humano com o sentimento que predomina em nós naquelas situações que nos deparamos com o estranhamento, com situações inusitadas, e que podem ser sentimentos de compaixão em relação ao outro, medo, curiosidade, repugnância, desejo, inúmeras coisas. Cada um olha e sente uma coisa. O que está em jogo aqui é a centralidade no vazio da existência, e como cada um se depara com a sua própria morte, inclusive negando-a. É possível projetar e ver o que quizermos no vazio da ambiguidade proposta por van Gogh, presentes no olhar enigmático do homem no centro da sala. $^{238}$

Vetor

Olhar..e ser olhado, ver... e ser visto

O olhar do homem próximo à mesa de bilhar cria um movimento direcional para o pintor que não aparece, mas se faz presente na cena por meio desse olhar delator. Dessa maneira, a figura pintada dialoga com o sujeito que a pinta, criando um fluxo que a inclui no texto visual, de forma indireta e implícita. Enquanto ele olha a cena, também é olhado por um de seus participantes. Esta relação entre o elemento que existe na tela e o elemento que está ausente da tela fica explicita. Que efeitos de sentidos isso provoca no leitor? Que o que olhamos também nos vê. 239

\footnotetext{
${ }^{237}$ Ocorrência de Modalidade pelo uso da ambiguidade para representar a expressão do homem parado junto à mesa de bilhar.

${ }^{238}$ Ocorrência de Incompletude pelo uso da ambiguidade para representar a expressão do homem parado junto à mesa de bilhar.

${ }^{239}$ Ocorrência de Distorção do Ponto de Vista e de Interdiscursividade pela Perspectiva Invertida que cria uma interação entre o que está dentro da tela e o que está fora dela.
} 
E se o sentido da ação que sobressai é ver, ele é reforçado pelas lâmpadas da sala. Elas parecem bastante elaboradas por van Gogh de modo a valorizar sua importância semântica, como que a dar ênfase à luz, ainda que uma luz direta que deixa a sala com um ar cansado. Ainda assim elas são uma fonte de luz, e isso pode ter um sentido muito especial para o sistema de possibilidades metafóricas de van Gogh.

Além disso, as lâmpadas parecem olhos, abertos, e com pupilas que reforçam a mensagem de o pintor ser olhado pelos objetos por ele representados na cena. Quem espreita van Gogh? E quando o espreita, o que vê? Por quem Vincent se sente observado? De quem são os olhos que o acompanham? ${ }^{240}$

\section{Ritmo}

As três lâmpadas mais aparentes, e que tem a semelhança de olhos, estão em três. Além de emprestar textura e volume para a cena por meio de um preciosismo na forma de representar a luz que delas emana. Elas criam um ritmo que pode construir uma metáfora visual para representar à Divina Trindade que, não obstante estar em um bar que representa a decadência humana, a angústia e o desespero que a cena suscita, não deixa de mostrar sua força para 'iluminar' todos os cantos da sala. ${ }^{241}$

\section{Perspectiva e Enquadramento - sutilmente distorcido, sutilmente plongée}

No café noturno as pessoas estão ao fundo, são 'pequenas figuras' e representam esse local do social, esse espaço que não é íntimo, que não nos permite nos aproximar com facilidade, pois o quadro as distancia de uma experiência íntima com o espectador. $\mathrm{Na}$ verdade, eles são tão pequenos que mal podemos distinguir suas características faciais. Esta descrição contempla bem o significado das pessoas no café noturno, elas são 'pequenas figuras', não há distinção entre elas, suas características, experiências e expressões não são importantes agora, mas o ambiente em que elas estão: a distância neste caso permite que outro elemento ganhe em simbolismo na cena: a noite e o café. No Café da Noite as faces também ficam disformes, borradas, os rostos e corpos estão tão distantes fisicamente quanto psicologicamente, estão virados, estão compenetrados em seus mundos internos e dramas pessoais.

\footnotetext{
${ }^{240}$ Ocorrência de Associação metafórica pela Saliência dada às lâmpadas que se assemelham com olhos.

241 Ocorrência de Associação metafórica construída pela Saliência, Ritmo, Textura e Movimento na representação das lâmpadas e da luz que delas emana.
} 
Kress e van Leeuwen nos mostram que não podemos ficar indiferentes em relação às personagens que aparecem no quadro, seja perto ou longe, este significa o seu lugar na composição, um lugar social que tem efeitos subjetivos no espectador. Portanto, é possível se sentir familiar com 'O Semeador', mas não com as pequenas figuras que, aliás, aparecem ao longe e têm pouca importância no 'Café Terrace' e no 'Por de Sol: Campo de Trigo em Arles', por outro lado, no 'Café da Noite' seu significado e importância é intermediário. O tema no 'Café da Noite' é o próprio ambiente do café, mas também suas consequências no espírito humano, o que o café, enquanto voz, discurso, sentido, causa nas pessoas. E a voz, sentido e discurso de autoridade do café aparece representado pela figura que 'recebe/rechaça' o espectador, que está em pé, no centro, cuidando do café, de quem entra e quem sai, como entra e como sai. ${ }^{242}$ Kress e van Leeuwen (1996, p. 126) discorrem a esse respeito:

Padrões de distância podem tornar-se convencionais em gêneros visuais. Na atual televisão assuntos, por exemplo, "vozes" de estatuto diferente são habitualmente enquadrado de forma diferente. A câmera 'se move em maiores para close-ups de sujeitos que estão revelando seus sentimentos, enquanto o set-up para o "expert" geralmente é o mesmo que para o entrevistador - o tiro bolso do peito'. ${ }^{243}$

No extrato de carta ${ }^{244}$ analisado mais adiante, van Gogh explicita que o homem parado no centro da sala ao lado da mesa de bilhar é o proprietário do café, com a oração: 'A roupa branca do proprietário, vigiando as coisas a partir de um canto deste forno, torna-se amarelolimão, verde luminoso pálido.' É preciso destacar a importância dessa informação que van Gogh explicita na carta, e que pode conferir uma nova camada de sentido metafórico acerca do lugar social do proprietário, que está ocupando uma posição central na composição, enquanto os 'vagabundos da noite', estão representados na periferia da cena. Ou seja, o lugar de 'proprietário' no Café da Noite é diferente do lugar dos 'vagabundos'. O proprietário está no centro, de frente para o espectador, ele tem uma 'voz' proeminente no quadro, é o seu discurso, os outros estão ocupando um espaço produzido por ele, poderiam ser outros, não há diferença entre eles, estão todos a meia distância, em posições análogas, reforçando sua homogeneidade simbólica. ${ }^{245}$

\footnotetext{
${ }^{242}$ Ocorrência de Enquadramento e Perspectiva para construir um distanciamento das figuras representadas, como que para diminuir sua importância na cena.

${ }^{243}$ Tradução livre da autora. "Patterns of distance can become conventional in visual genres. In current affairs television, for example, 'voices' of different status are habitually framed differently: the camera 'moves in for bigger close-ups of subjects who are revealing their feelings, whereas the set-up for the "expert" is usually the same as that for the interviewer - the breast pocket shot'." (KRESS E VAN LEEUWEN, 1996, p.126)

${ }^{244}$ Carta 676 - Extrato no 4a - Br. 1990: 679 | CL: 533 - From: Vincent To: Theo van Gogh - Date: Arles, 8 September 1888

${ }^{245}$ Ocorrência de Associação metafórica construída pelo Enquadramento e posição relativa das figuras no espaço compositivo. O proprietário tem a posição central, os vagabundos da noite têm uma posição periférica na tela.
} 
Kress e van Leeuwen (1996, p. 127) explicam a importância do posicionamento das figuras dentro da representação visual:

Gostaríamos, no entanto, de sugerir que pelo menos três distâncias significativas podem ser distinguidas, e que existem correspondências entre essas distâncias e nossa experiência cotidiana de objetos e do ambiente; em outras palavras, que o tamanho do enquadramento também pode sugerir as relações sociais entre o espectador e objectos, edifícios e paisagens. ${ }^{246}$

Não só a distância das personagens é importante, mas também dos objetos. Encontrei aqui uma recorrência importante, tanto no 'Cafe Terrace' quanto no 'Café da Noite' há a proeminência das cadeiras voltadas para o espectador, a proeminência da luz e das lâmpadas. A cadeira significa um objeto disponível para receber, para acomodar: só existe porque alguém irá sentar-se nela, seja para comer, conversar, beber ou descansar. Ela representa a possibilidade de relaxar e atender as necessidades de alguém, ou também a possibilidade de já ter atendido a várias pessoas, ela pode estar gasta, velha, muito usada. A impermanência dos homens pode estar representada simbolicamente na cadeira que acabou de ser usada e foi desocupada, ou da cadeira que aguarda o retorno de seu usuário. Foi observado um sentido de movimentação conferida aos objetos inanimados em contraposição à paralisia das figuras humanas na tela que endossa a disposição desorganizada e oblíqua das cadeiras, transmitindo a sensação de que a presença, o fulgor e a movimentação de pessoas ali naquele espaço ainda estivessem presentes, quentes, embora elas já tenham ido embora daquele local que é reforçado pela ocorrência de vetores projetados pelas cadeiras.

$\mathrm{O}$ ator está e não está na cena, e este é o tema que subjaz na cadeira colocada no primeiro plano. A cadeira vazia, presente em várias cenas representadas por van Gogh tem valor simbólico na tela e seu lugar na cena nos aproxima desse vazio presente. ${ }^{247}$

Há uma outra questão no enquadramento da cena. Na obra produzida por van Gogh, observei a construção de um discurso visual particular e distinto. Na representação do café, o ambiente da sala está representado em um ar cansado, uma luz sufocante, um ar decadente. Na construção da dimensão espacial do recinto, a perspectiva aparece distorcida, ela cria uma perspectiva forçada que produz a sensação de que o pintor que olha para cena está um pouco acima do ponto de vista natural, como se estivesse pairando um pouco acima do solo. A distorção da proporção natural e do sentido de perspectiva são aspectos que acompanham a

\footnotetext{
${ }^{246}$ Tradução livre da autora. "We would nevertheless suggest that at least three significant distances can be distinguished, and that there are correspondences between these distances and our everyday experience of objects and the environment; in other words, that size of frame can also suggest social relations between the viewer and objects, buildings and landscapes." (KRESS E VAN LEEUWEN, 1996, p.127)

${ }^{247}$ Ocorrência de Associações metafóricas, Saliência, Incompletude construída pelo Enquadramento das cadeiras vazias no primeiro plano que instanciam uma representação simbólica para a transitoriedade e a impermanência das pessoas no café.
} 
poética de van Gogh em vários trabalhos, mas o que ela significará em sua construção semiótica neste quadro? Quanto mais se olha para tela, mais claro fica esse efeito de sentido, de se estar pairando no ar, e não no nível do chão. O que isso quer dizer para van Gogh? Não estar sobre o chão, não estar pisando no chão, mas em um ponto acima do chão. Nesta tela, é possível observar os ângulos verticais tais como o plongée (mais poder do espectador) ao contrário do contre-plongée (menos poder do espectador). $\mathrm{O}$ efeito de sentido que o plongee, presente no enquadramento provoca no espectador é o de um estranhamento e um distanciamento, que nos leva a pensar de que lugar o pintor olhou para essa cena e por que ele escolheu representá-la desse ângulo vertical. ${ }^{248}$

Defendo que a semiose de estar acima do solo, que aparece em outras telas do pintor, pode estar associada com um conflito no qual ele não se põem em uma posição de pisar no chão, andar no solo, e desde ai, ocupar um lugar no mundo. Ele pode estar representando este conflito em ocupar um lugar na tela, e por uma metáfora visual, no mundo real. Se estendermos por associação a metáfora de 'lugar no mundo' para um lugar social podemos pensar que ele esteja falando de um lugar que ele não conseguiu ocupar no mundo; mas ocupou o seu lugar dentro de suas telas, vivendo dentro da cena por ele representada, a qual ele não apenas observa e pinta, mas se coloca vivamente no espaço que representa e desde lá, expressa e comunica seu estar no mundo de forma contundente. ${ }^{249}$

Dessa forma ele buscou integrar Vida e Arte, por meio de sentidos dinâmicos de unidade, coesão, totalidade e um ponto de vista diferenciado nas telas, que ele conseguiu pela conjugação dos recursos aqui descritos, tais como o gesto pictórico, a rima visual, o ritmo, o movimento, os caminhos direcionais, o arranjo cromático, por exemplo, como exposto por Walther (1990, p. 87): “Arte e vida tornaram-se para ele numa unidade inseparável - e assim deixou tornar-se realidade um velhíssimo sonho de artista. Criar arte queria dizer para ele não menos que pintar a vida; não a mera realidade, mas sim o princípio da força vital." A capacidade coesiva no discurso artístico de van Gogh é um reflexo da forma como ele integrava Vida e Arte, comentada por Walther e Metzger (2015, p. 306-7):

Uma educação cristã, uma intensidade romântica, esperanças socialistas no futuro e uma instrução indubitavelmente deficiente como um artista, tudo isso teve alguma influência. A pintura tornou-se um alter ego, meta de toda uma dedicação pessoal e centro das suas intenções. Arte e Vida constituíram uma unidade única. O próprio Van Gogh ainda longe de transformar esta unidade num programa. De certa forma, ele já se tinha colocado nessa posição contra a sua própria vontade. Mas a Arte

\footnotetext{
${ }^{248}$ Uso de Distorção do Ponto de Vista construída com Enquadramento e Perspectiva em um ângulo de enquadramento levemente plongee, como se van Gogh estivesse pairando acima do nível do chão.

249 Ocorrência de Associação metafórica, Transparência, Incompletude e Limiar Artístico, com o uso do Enquadramento, Perspectiva, Profundidade, Distorção do Ponto de Vista, levemente plongee para o sentido do lugar social com o qual van Gogh se identifica.
} 
nunca mais voltaria a ser a mesma; e teve em Van Gogh uma figura de proa que percorreu esse caminho de forma exemplar, coerente e firme até à sua morte.

Por que ele flutua? Porque sua presença se faz presente na tela a partir deste efeito de estranhamento da visão, da posição, do posicionamento, do olhar do artista que constrói toda a estrutura da imagem a partir de uma visão que não é compartilhada pelo senso comum, uma vez que comunica uma certa diferença entre a altura de onde o espectador olha a imagem e a altura de onde ela foi aparentemente representada, e que parece um pouco acima do chão. Haziot (2010) defende que o fato de van Gogh ter nascido no mesmo dia um ano após a morte de seu irmão primogênito natimorto e ter recebido seu nome de batismo teve um impacto em sua aventura humana. Inferi inúmeras questões relacionadas com sua dificuldade de estar no mundo, 'ocupando' o lugar de alguém que não está, não pode se fazer presente, vivo, real. Pode haver uma implicatura na qual ele estaria significando que não está entre os vivos, mas em um não lugar entre os vivos?

\subsubsection{Conclusão da análise visual da tela O Café Noturno na Place Lamartine, em Arles}

\subsubsection{A Gestalt da Composição}

\subsection{Convergência dos caminhos visuais divergentes em um ponto de fuga}

Observei que há linhas de perspectiva diferentes e contraditórias que se conflitam ao longo da cena. Van Gogh cria um sistema semiótico para a falha, a intermitência, para nos compelir a completar as linhas inacabadas e interrompidas por onde nos soltamos em infinitas lacunas e possibilidades. Haziot (2010, p. 117) comenta sobre a intenção semiótica de van Gogh ao desenhar com imprecisão.

\footnotetext{
Sua arte só podia ser febril, louca, de um "extraordinário impudor para os seus contemporâneos", como disse nosso amigo François Baranger, ele próprio pintor e desenhista, para quem o segredo da pintura de Van Gogh repousa, ele nos afirmava, sobre a linha. "A linha libera as forças obscuras, pois o olhar prossegue o traço para além do ponto onde ela se detém." Fazer uma paisagem com traços descontínuos arrasta o olhar para muito além de uma atitude de repouso em que se recebe tudo. $O$ olhar deve "trabalhar", e junto com ele o espirito; isso suscita o sonho, o alhures, a sugestão, que não se limitam ao tema pintado.
}

As tábuas no chão têm um ângulo de perspectiva e estão em conflito com o contorno da mesa que tem outro ângulo de perspectiva, enquanto a linha das lâmpadas segue ainda por um terceiro ângulo de perspectiva. Essas três linhas diagonais sugeridas pela composição 
criam caminhos visuais diversos que não nos deixam partir de um único ponto de vista para olhar a cena. Isso pode ser uma instanciação de que não podemos ou devemos olhar para a realidade de um único ponto de vista, mas de vários, ou que não há um ponto de vista certo para ver o mundo. Essa profusão de pontos de vista também pode ser uma metáfora visual que é compatível com a instabilidade e a precariedade que ele deseja comunicar como um sentido central na experiência do café da noite. Além disso, nos coloca em um estado de inconsistência e inconstância como deve ser o estado mais próximo de viver, sem certezas, sem seguranças sobre como ver as coisas, como olhar para elas. Este deve ser o estado que o pintor atesta como o mais autêntico com qual nos encontramos para experienciar a existência, sem certezas, ou pontos de vista definidos, definitivos. ${ }^{250}$

No entanto, esta diversidade de pontos de vista tem uma coisa em comum: as linhas de perspectiva de ângulos diferenciados convergem para o casal que está no fundo da sala. Esta sintaxe composicional parece simbolizar que todas essas formas diferenciadas com que olhar o mundo podem convergir para um denominador comum: o casal que de forma cúmplice compartilha o mesmo lado da mesa simboliza o amor. O amor é o ponto central estruturante da cena e dos caminhos visuais construídos para conduzirem para eles. Mesmo diante da asfixia do ambiente, produzida pela escolha dos tons das cores, esta dupla ao fundo da sala produz um contraste com as outras figuras da sala que ora parecem sucumbir ao cansaço, ora à solidão. A convergência dos caminhos visuais parece conferir a eles um destaque sutil, mas definidor como uma seta construída por diversos caminhos a apontar para a esperança que há no amor e na intimidade. ${ }^{251}$

\subsection{ANÁLISE TEXTUAL DOS EXTRATOS DE CARTA RELATIVOS À TELA O CAFÉ NOTURNO NA PLACE LAMARTINE, EM ARLES}

\subsubsection{Extrato $n^{\circ} 4 a$}

Carta 676 - Br. 1990: 679 |CL: 533 - From: Vincent van Gogh To: Theo van Gogh

Date: Arles, 8 September 1888

http://vangoghletters.org/vg/letters/let676/letter.html

\footnotetext{
250 Ocorrência de Transparência, Incompletude, Modalidade e Limiar Artístico pelo uso do Inacabamento, Enquadramento, Perspectiva, Distorção do Ponto de Vista, Direção, como marca estilística das linhas que organizam a perspectiva da sala.

${ }^{251}$ Ocorrência de Associação metafórica com a ajuda de Vetor, Perspectiva e Saliência na representação do casal no fundo da sala.
} 
Muitas vezes parece-me que a noite é muito mais viva e ricamente colorida do que o dia. Agora como para recuperar o dinheiro pago ao senhorio através da minha pintura, eu não estou fazendo questão disto, porque a pintura é uma das mais feias que eu já fiz. É o equivalente, embora diferente, dos comedores de batata. $41 v: 2$

Eu tentei expressar as terríveis paixões humanas com o vermelho e o verde. 5

A sala é vermelho-sangue e amarelo sem graça, uma mesa de bilhar verde no centro, 4 lâmpadas de amarelo limão com um brilho laranja e verde.

Em todos os lugares é uma batalha e uma antítese dos mais diferentes verdes e vermelhos; nas personagens dos rufiões adormecidos, pequenos na alta sala vazia, algum roxo e azul. O vermelho-sangue e o amarelo-verde da mesa de bilhar, por exemplo, contrasta com o pouco de verde delicado Louis XV do balcão, onde há um buquê rosa. A roupa branca do proprietário, vigiando as coisas a partir de um canto deste forno, torna-se amarelo-limão, verde luminoso pálido.7

Eu estou fazendo um desenho dele em tons aquarela para enviar-lhe amanhã, para dar a voce uma idéia dele."

Muitas vezes parece-me que a noite é muito mais viva e ricamente colorida do que o dia.

\begin{tabular}{|l|l|l|l|}
\hline Muitas vezes & parece & me & $\begin{array}{l}\text { que a noite é muito mais viva e ricamente colorida do que o } \\
\text { dia. }\end{array}$ \\
\hline $\begin{array}{l}\text { Circunstância } \\
\text { de Modo }\end{array}$ & $\begin{array}{l}\text { Processo } \\
\text { mental } \\
\text { perceptivo } \\
\text { Modalidade }\end{array}$ & experienciador & fenômeno \\
\hline
\end{tabular}

\section{Interpretação}

Van Gogh inicia a oração com a circunstância de modo, salientando a importância 'muitas vezes' do fenômeno a que ele se refere com o processo mental perceptivo 'pareceme'. Ele destaca para Theo nesta oração marcada que não são poucas as vezes que ele percebe 'que a noite é muito mais viva e ricamente colorida do que o dia'. Este fato está destacado porque tem uma importância central para a forma que ele optou representar o café: com um tipo de riqueza e intensidade cromática que expressa o que ele é capaz de experienciar em sua percepção das cores à noite. Este mesmo fato van Gogh (1888) também destacou nas cartas relativas ao Café Terrace:

No terraço, há pequenas figuras de pessoas que bebem. Uma enorme lanterna amarela ilumina o terraço, a fachada, a calçada, e até mesmo projeta luz sobre os paralelepípedos da rua, que adquirem uma coloração violeta-rosa. As frentes das casas em uma rua que segue sob o céu azul salpicado de estrelas são azul escuro ou violeta, com uma árvore verde. Agora há uma pintura de noite sem preto. Com nada 
mais do que um belo azul e violeta e verde e nestes arredores da praça iluminada é colorido por enxofre pálido, amarelo limão. ${ }^{252}$

Dessa forma não é casual este comentário, trata-se da coluna vertebral que sustenta o discurso visual que organizou o Café Lamartine: o fato que a noite é mais viva e ricamene colorida do que o dia. ${ }^{253}$

A comparação entre as cores da noite, que parecerem para ele, mais vivas e ricas do que as cores do dia, parece-nos uma incongruência e uma contradição. No entanto, para os olhos humanos, treinados para olhar, ver e enxergar, a excessiva claridade do dia pode esmaecer a tonalidade cromática das coisas devido a um aumento de sua saturação, enquanto que à noite, pela escassa iluminação ainda que menos saturada ou até escurecida, a natureza cromática se intensifica.

Agora como para recuperar o dinheiro pago ao senhorio através da minha pintura, eu não estou fazendo questão disto, porque a pintura é uma das mais feias [[que eu já fiz.]]

\begin{tabular}{|l|l|l|l|}
\hline Agora como para & recuperar & o dinheiro pago ao senhorio através da minha pintura, & eu \\
\hline & $\begin{array}{l}\text { Processo } \\
\text { Material }\end{array}$ & Meta & Experienciador \\
\hline
\end{tabular}

\begin{tabular}{|l|l|l|}
\hline não estou fazendo questão & disto, & porque a pintura é uma das mais feias [[que eu já fiz.]] \\
\hline Processo mental afetivo & & \\
\hline
\end{tabular}

$\boldsymbol{\alpha} \mathbf{x} \boldsymbol{\beta}$ (oração não-finita - intensificação de finalidade) - Agora como para recuperar o dinheiro pago ao senhorio através da minha pintura,

ALFA (dominante) - eu não estou fazendo questão disto,

= BETA (intensificação razão) - porque a pintura é uma das mais feias que eu já fiz.

\section{Interpretação}

No complexo oracional 'Agora como para recuperar o dinheiro pago ao senhorio através da minha pintura, eu não estou fazendo questão disto, porque a pintura é uma das mais feias que eu já fiz.', há uma intrincada construção que sugere uma intensa negociação de sentidos para van Gogh. Na primeira oração Beta, ele inicia o complexo explicando a finalidade da pintura do café da noite, ele pretende ao pintar a tela, 'recuperar o dinheiro pago ao senhorio'. Mas a construção não explicita se ele vai vender a tela e recuperar dessa forma

${ }^{252}$ Carta 678 - Br. 1990: 681 | CL: W7 - From: Vincent To: Willemien van Gogh. Date: Arles, Sunday, 9 and about Friday, 14 September 1888. Linhas 100-136. Acesso em: 24 de Maio 2012. Disponível em: http://vangoghletters.org/vg/letters/let678/letter.html

${ }^{253}$ Uso de cores, no quadro e na carta. Ele enfatiza a percepção de uma noite mais viva e ricamente colorida do que o dia que ele experiencia e representa tanto textualmente quanto visualmente ao representar o Café Terrace, explicitando a variedade de cores que ele consegue observar a noite. 
um dinheiro já gasto com a hospedagem, ou se, ao pintar o café em uma tela, que tem para ele um valor implícito muito elevado, ele recupera o investimento que considera ter gasto em vão com a hospedagem que é muito ruim.

A análise do contexto de situação em que van Gogh se encontra, sem conseguir vender nenhuma tela, nos sugere que ele se refere a uma troca simbólica: ele gasta seu dinheiro com a hospedagem no café da noite, e em troca e para recuperá-lo por outra via, ele o pinta com os sentidos e valores de sua genialidade. Como? Com uma inusitada equação. Ele gasta dinheiro com uma hospedagem que não vale o dinheiro, e 'recupera' o dinheiro gasto com um outro tipo de valor, um valor simbólico, o valor que a pintura do café pode ter em si. Esta oração Beta reafirma de certa forma, o mesmo sentido expresso na tela, a ordem econômica e monetária em contraposição com a ordem humana, subjetiva, sensível, criativa, simbólica. Com a oração, van Gogh simboliza essa contraposição, essa inversão, essa antítese que ele também representa com contrastes complementares na tela. ${ }^{254} \mathrm{O}$ que ele tenta inverter com uma troca simbólica, disfarçada de anedota mas que contém seu fundo de verdade: uma ação criadora que pode reverter e transformar os sentidos e os valores, e o fez. Com a tela, atualmene daria para pagar muitas hospedagens, comprá-las muitas vezes. Sim, ele 'recuperou' o dinheiro pago ao senhorio!

Em seguida, na oração Alfa ele declara com uma perífrase verbal funcionando como processo mental afetivo que não está fazendo questão de recuperar o dinheiro, e na próxima oração Beta ele explica: porque a pintura é uma das mais feias que eu já fiz.

Em algumas cartas, van Gogh mencionou para o irmão a sua relação com a beleza e a feiura, deixando claro que ele não segue os padrões estéticos convencionais da época. Então quando ele fala que a pintura é uma das mais feias que ele já fez, provavelmente, ele se refere ao fato de que ela parece feia para os compradores, e dessa forma ele não faz questão de recuperar o dinheiro, por sabe-la invendável em sua época. Mas ele deixa implícito que talvez ele não faça questão de recuparar o dinheiro porque talvez ele não faça questão de vendê-la, porque gosta dela. Neste complexo oracional ele constrói um argumento para sua relação com os valores com que ele negocia sua existência, os serviços ruins de hospedagem pelos quais ele paga o seu escasso dinheiro, e seu movimento em busca de repor essa perda ao produzir algo de valor, algo que preencha para ele um lugar e uma experiência que não estão submetidos à essa ordem das trocas simbólicas do mundo real, do mundo do capital.

\footnotetext{
${ }^{254}$ Ocorrência do uso de um construto de contraposição e antítese no nível semântico da oração 'Agora como para recuperar o dinheiro pago ao senhorio através da minha pintura, eu não estou fazendo questão disto, porque a pintura é uma das mais feias que eu já fiz', que é compatível com o uso de contrastes complementares de verdes e vermelhos e com a oração na qual ele explicita que a tela fala de 'conflitos e antíteses por toda parte'.
} 
É o equivalente, embora diferente, dos comedores de batata.

\begin{tabular}{|l|l|l|l|}
\hline É & o equivalente & embora diferente, & dos comedores de batata. \\
\hline $\begin{array}{l}\text { Processo Relacional } \\
\text { Identificativo }\end{array}$ & Identificado & $\begin{array}{l}\text { Circunstância de Modo: } \\
\text { comparação }\end{array}$ & Identificador \\
\hline
\end{tabular}

\section{Interpretação}

Por meio de um processo relacional identificativo, van Gogh cria uma metáfora para explicar ao irmão a importância da pintura 'O café da noite' ao compará-la com a tela 'Os Comedores de Batata'. Essa oração guarda dois níveis de significação, pois embora ele use a tela 'Os Comedores de Batata' para explicar a natureza da tela 'O Café da Noite' ele não o faz sem ressaltar que há uma diferença entre as duas. A semelhança e essa diferenciação entre estas duas telas ele não explicita no discurso textual, indicando a necessidade de um estudo mais profundo para compreender a relação entre estas duas obras. A priori, se observarmos o tema da tela 'Os Comedores de Batata', podemos inferir que para van Gogh, 'O Café da Noite' pode ser de forma mais avançada uma expressão da tendência e compromisso com a arte do campo, com o trabalhador, se tornando uma arte denúncia de que este trabalhador do campo agora é um vagabundo das cidades nas quais não encontra acolhimento, lugar, ocupação a não ser nos cafés "fím de linha" onde se refugiam com os outros destituídos da nova ordem para passar a noite. Esta é uma das possibilidades de construção de sentido da relação que van Gogh menciona, entre 'O café da Noite' e 'Os Comedores de Batatas', como também com 'O Semeador' se olharmos pela posição ideológica do realismo social na pintura, só que em uma arte de vanguarda. De Micheli (1991, p. 24) ${ }^{255}$, comenta como van Gogh subescreve à posição política do realismo social dentro de uma lacuna histórica porque nem os valores do realismo social nem os pintores que o propuseram existiam mais:

(...) sente que os artistas não estão mais integrados à sociedade, mas acham-se opostos a ela, são "refugos" da sociedade, como a prostituta, "nossa amiga e irmã" neste destino. (...) Agora, toda a vida terá esta única e desesperada finalidade: buscar aquilo que, historicamente, já não pode ser encontrado (...) Ele atira sobre a realidade sua exaltada fome de amor pelos homens, impregna a realidade do seu sentimento, que não encontrou os desabafos naturais num movimento concreto, numa história comum.

${ }^{255}$ De Micheli, M. As vanguardas artísticas do século XX. São Paulo: Martins Fontes, 1991. 
No entanto, apesar de tardiamente subscrever ao realismo histórico, van Gogh transformou essa ausência em uma oportunidade para dar o passo seguinte em direção a uma arte de vanguarda, rompendo com a unidade histórica e estética do século XIX.

Eu tentei expressar as terríveis paixões humanas com o vermelho e o verde.

\begin{tabular}{|l|l|l|l|l|}
\hline Eu & tentei & expressar & $\begin{array}{l}\text { as terríveis paixões } \\
\text { humanas }\end{array}$ & $\begin{array}{l}\text { com o vermelho e o } \\
\text { verde. }\end{array}$ \\
\hline Ator & $\begin{array}{l}\text { É da metafunçao Interpessoal. } \\
\text { Não tem função experiencial }\end{array}$ & $\begin{array}{l}\text { Processo Material } \\
\text { Criativo }\end{array}$ & $\begin{array}{l}\text { Meta } \\
\text { Modo: Meio }\end{array}$ \\
\hline
\end{tabular}

\title{
Interpretação
}

Com esta oração van Gogh em uma rara ocasião, explicita que ele usou o vermelho e o verde para representar as terríveis paixões humanas, deixando claro que a cor se tornou uma semiose, um modo de associação metafórica de sentidos muito específicos. ${ }^{256} \mathrm{O}$ uso simbólico da cor é discutido por Goethe (1970 [1810], p.350, apud, Van Leeuwen, 2011, p.23):

\begin{abstract}
Uma aplicação [de cor] coincidindo com a natureza pode ser chamada simbólica, uma vez que a cor seria empregada em conformidade com o seu efeito, e de uma só vez expressa o seu significado, por exemplo, o vermelho puro para designar majestade. Outra aplicação é quase aliada a essa, ela pode ser chamada alegórica. Nela, há mais de acidente e capricho, na medida em que o significado do sinal deve ser previamente comunicado a nós antes de sabermos o que é para significar, por exemplo, verde para esperança.
\end{abstract}

Observei na enuniciação, a preocupação de van Gogh de previamente comunicar o significado do sentido antes de Theo saber o que é para significarem o verde e o vermelho: as terríveis paixões humanas. Por que van Gogh se preocupa em comunicar previamente para Theo este sentido se ele não o fez antes em nenhuma outra tela? Isso nos fala da importância e da centralidade que esta semiose tinha para van Gogh nesta tela: falando para Theo, ele assegurou que este significado, muito específico para ele, o artista, chegasse até nós, o público, uma vez que Theo era o representante comercial de suas telas e as explicaria no mercado de arte. Van Gogh quis explicitar este sentido, que passa a estar semanticamente presente tanto na escrita quanto em sua pintura. Haziot (2010, p. 215-216) analisa o uso do vermelho e do verde por van Gogh como um recurso pictórico em outras telas além desta, para construir esse mesmo significante:

Esse acorde dissonante, para Vincent, do vermelho e do verde vai muito além desse quadro. Tais cores reunidas são para ele como o sinal da morte próxima, da morte que está no coração dos homens e que pode levá-los à loucura, ao crime suicídio...

\footnotetext{
256 Observei o uso de Associação Metafórica e o uso Simbólico da Cor sendo explicitado nesta oração. A ocorrência é compatível com a ocorrência do contraste complementar a que ela se refere na tela.
} 
Notemos que a poltrona de Gauguin pintada mais tarde tem as mesmas cores; os caminhos que não levam a nenhum lugar do seu último quadro, Campo de trigo com corvos, também estão nessa gama vemelho-verde, e não é necessário que Vincent fale disso nas cartas para compreender o que quis dizer, ao usar esse acorde rangente que se ouve ao abrir a porta das trevas.

A sala é vermelho-sangue e amarelo sem graça, uma mesa de bilhar verde no centro, quatro lâmpadas de amarelo limão com um brilho laranja e verde.

\begin{tabular}{|l|l|l|}
\hline A sala & é & $\begin{array}{l}\text { vermelho-sangue e amarelo sem graça, uma mesa de bilhar verde no centro, } \\
\text { quatro lâmpadas de amarelo limão com um brilho laranja e verde. }\end{array}$ \\
\hline Portador & $\begin{array}{l}\text { Processo } \\
\text { Relacional } \\
\text { Atributivo }\end{array}$ & Atributo \\
\hline
\end{tabular}

$\mathrm{Na}$ oração 'A sala é vermelho-sangue e amarelo sem graça, uma mesa de bilhar verde no centro, quatro lâmpadas de amarelo limão com um brilho laranja e verde’ van Gogh constrói, por meio de um processo relacional atributivo, o ambiente do 'Café da Noite'. Ele faz algumas escolhas léxico-gramaticais que, aos olhos dele, parecem representar os elementos principais da composição: o contraste entre vermelho escuro e amarelo sem-graça; a posição central da mesa de bilhar; as quatro lâmpadas e sua cor amarelo limão e a cor de seu brilho laranja e verde parecem ser importantes para ele. Estes elementos recebem uma atenção maior sobre os outros pela forma como ele escolheu estes e não outros para descrever para Theo o interior do café que ele pintou. Dessa forma, o discurso textual indexa elementos que assumem uma maior centralidade na construção do discurso visual pela forma como van Gogh os prioriza na representação escrita. Eles podem conotar sentidos entrelaçados com a concepção e o discurso que motivaram van Gogh a pintar a tela.

Em todos os lugares é uma batalha e uma antítese dos mais diferentes verdes e vermelhos; nas personagens dos rufiões adormecidos, pequenos na alta sala vazia, algum roxo e azul.

\begin{tabular}{|l|l|l|}
\hline Em todos os lugares & é & $\begin{array}{l}\text { uma batalha e uma antítese dos mais diferentes verdes e vermelhos; nas } \\
\text { personagens dos rufiões adormecidos, pequenos na alta sala vazia, } \\
\text { algum roxo e azul. }\end{array}$ \\
\hline $\begin{array}{l}\text { Circunstância de } \\
\text { localização: lugar }\end{array}$ & $\begin{array}{l}\text { Processo } \\
\text { Relacional } \\
\text { Atributivo }\end{array}$ & Atributo \\
\hline
\end{tabular}

\section{Interpretação}

$\mathrm{Na}$ oração: 'Em todos os lugares é uma batalha e uma antítese dos mais diferentes verdes e vermelhos; nas personagens dos rufiões adormecidos, pequenos na alta sala vazia, algum roxo e azul' há um processo relacional atributivo, porém não há o portador. Ao iniciar a oração dando destaque: 'Em todos os lugares' van Gogh constrói novamente uma oração 
marcada pela circunstância de localização. O atributo 'uma batalha e uma antítese dos mais diferentes verdes e vermelhos; nas personagens dos rufiões adormecidos, pequenos na alta sala vazia, algum roxo e azul' é um complexo nominal extenso que descreve a principal dinâmica que toma lugar na composição: 'uma batalha e uma antítese' que ele simboliza pelos 'mais diferentes verdes e vermelhos' e no contraste entre os roxos e azuis dos rufiões e os amarelos e laranjas no piso e nas lâmpadas. Com esta oração, van Gogh indexa o significado de batalha e antítese para os mais diferentes verdes e vermelhos. Mas de antítese ele fala? A que batalha ele se refere? À batalha que se trava dentro do outro sentido também por ele indexado para o contrate entre verdes e vermelhos: as terríveis paixões humanas. E neste território onde se travam as batalhas que van Gogh quis representar com o Café da Noite. ${ }^{257}$

Edwards $(2009$, p. 8) analisa a contribuição que a tela 'O Café da Noite' trás para a linguagem pictórica pelo seu uso de blocos de cores puras em direta contraposição:

Mas diretamente na minha frente, brilhante em uma galeria holofotes, estava "O
Café da Noite." Minha primeira impressão foi que eu estava na presença de um
ícone ortodoxo oriental. Os verdes e vermelhos da pintura foram cercados pelas
ondulações de lâmpadas de gás do café e as placas amarelas ásperas do piso do café.
Elas davam a impressão de um ambiente de ouro para jóias brilhantes. Os vermelhos
e os verdes das paredes e do teto na pintura entraram em confronto uns com os
outros e pareciam iluminar o café por dentro. Estas não eram "cores impressionistas"
silenciadas fundidas em uma atmosfera de luz nebulosa. As cores puras vibrantes
foram o passo gigante de Vincent para além do impressionismo, ou talvez um passo
para trás para alguma abordagem popular anterior à arte; ou ele estava
comemorando sua resposta à sua coleção de estampas japonesas? Em meio aos
brilhantes blocos de cor do café, cada cadeira, mesa, vidro, garrafa, e pessoa tinham
sido investidos de uma vida distinta por si própria. ${ }^{258}$

O uso simbólico de cores puras e opostas em grandes áreas, associada a outros recursos como a distorção, a pintura-desenho, o exagero da representação da luz e da iluminação formaram um novo sistema semiótico pictórico para expressar o programa político e ideológico do realismo social, porém sem o compromisso com a representação naturalista daquela corrente pictórica.

\footnotetext{
${ }^{257}$ Uso de Associações Metafóricas e uso simbólico da cor. Ao expressar o sentido simbólico dos verdes e vermelhos textualmente ele cola esse sentido no uso dessas cores na tela, construindo uma ponte entre a carta e a tela, criando uma cadeia de textos. Observei uma ocorrência do uso simbólico da cor em ambas modalidades não pela forma, mas pelo sentido associado a este uso.

${ }^{258}$ Tradução livre da autora. "But directly in front of me, glowing in a gallery spotlight, was "The Night Café."My first impression was that I was in the presence of an Eastern Orthodox icon. The greens and reds of the painting were bordered by the undulating ripples from the cafe's gaslights and the rough yellow boards of the café floor. They gave the impression of a golden setting for brilliant gems. The reds and greens of the walls and ceiling in the painting clashed with one another and appeared to illuminate the café from within. These were no "impressionist colors" muted and merged in an atmosphere of hazy light. The pure vibranting colors were Vincent's giant step beyond impressionism, or perhaps a step back to some earlier folk approach to art; or was he celebrating his response to his collection of Japanese prints? Among the café's bright blocks of color, each chair, table, glass, bottle, and person had been invested with a distinct life of its own." (EDWARDS, 2009, p.8)
} 
O vermelho-sangue e o amarelo-verde da mesa de bilhar, por exemplo, contrasta com o pouco de verde delicado Louis XV do balcão, onde há um buquê rosa.

\begin{tabular}{|l|l|l|}
\hline $\begin{array}{l}\text { O vermelho-sangue e o amarelo-verde da } \\
\text { mesa de bilhar, por exemplo, }\end{array}$ & $\begin{array}{l}\text { com o pouco de verde delicado Louis XV do } \\
\text { balcão, // onde há um buquê rosa. }\end{array}$ \\
\hline Identificado & $\begin{array}{l}\text { Processo } \\
\text { Relacional } \\
\text { Identificativo }\end{array}$ & $\begin{array}{l}\text { Identificador } \\
\end{array}$ \\
\hline
\end{tabular}

$\boldsymbol{\alpha}=\boldsymbol{\beta}$

\section{Interpretação}

$\mathrm{Na}$ oração 'O vermelho-sangue e o amarelo-verde da mesa de bilhar, por exemplo, contrasta com o pouco de verde delicado Louis XV do balcão, onde há um buquê rosa.', van Gogh passa a utilizar o processo relacional identificativo ao se referir ao verde delicado Louis XV do balcão. Esse verde deve exercer para van Gogh um papel muito preponderante na construção dos sentidos associados à representação cromática na tela. A escolha lexical 'contrasta' é a chave para a relação identificativa entre 'O vermelho-sangue e o amarelo-verde da mesa de bilhar' e 'o pouco de verde delicado Louis XV do balcão, onde há um buquê rosa' corroborando com o atributo 'uma batalha e uma antítese' usados na oração anterior. Nesta oração os sentidos em batalha são os das cores intensas e densas com os sentidos associados às cores pálidas e delicadas.

A roupa branca do proprietário, vigiando as coisas a partir de um canto deste forno, torna-se amarelo-limão, verde luminoso pálido.

\begin{tabular}{|l|l|l|l|}
\hline $\begin{array}{l}\text { A roupa branca do } \\
\text { proprietário, }\end{array}$ & $\begin{array}{l}\text { vigiando as coisas a partir de } \\
\text { um canto deste forno, }\end{array}$ & $\begin{array}{l}\text { torna-se } \\
\text { luminoso pálido. }\end{array}$ \\
\hline Portador & Oração BETA & $\begin{array}{l}\text { Processo } \\
\text { Relacional } \\
\text { Atributivo }\end{array}$ & Atributo \\
& & & \\
\hline
\end{tabular}

ALFA - A roupa branca do proprietário, torna-se amarelo-limão, verde luminoso pálido.

= BETA - , vigiando as coisas a partir de um canto deste forno,

\section{Interpretação}

$\mathrm{Na}$ oração 'A roupa branca do proprietário, vigiando as coisas a partir de um canto deste forno, torna-se amarelo-limão, verde luminoso pálido' o processo relacional atributivo tem a função de enfatizar um sentido simbólico da cor da roupa do proprietário, que de branca se torna amarelo-limão e verde luminoso pálido, dando uma saliência adicional à posição 
central dele junto à mesa de bilhar, e demonstrando que a cor da roupa, antes branca é suscetível a se tornar com a coloração do ambiente, conotando com isso que a essência 'pura', genuína, do branco, pode se transformar com a influência de outras cores.

É preciso explorar os significados da cor amarelo-limão e verde luminoso pálido, porque estes estão associados à figura do proprietário do café da noite. Além da oração dominante, há a oração Beta 'vigiando as coisas a partir de um canto deste forno,' sugerindo que o proprietário 'vigia as coisas' e que o lugar é um 'forno' e corrobora com a sensação visual de um lugar bastante desconfortável. ${ }^{259}$

Eu estou fazendo um desenho dele em tons aquarela para enviar-lhe amanhã, para dar a voce uma ideia dele.

\begin{tabular}{|l|l|l|l|}
\hline Eu & estou fazendo & $\begin{array}{l}\text { um desenho dele em tons } \\
\text { aquarela }\end{array}$ & $\begin{array}{l}\text { para enviar-lhe amanhã, //para dar a voce } \\
\text { uma idéia dele. }\end{array}$ \\
\hline Ator & $\begin{array}{l}\text { Processo material } \\
\text { Criativo }\end{array}$ & Meta & $\begin{array}{l}\text { Circunstância de Causa: Propósito } \\
\text { Orações hipotáticas }\end{array}$ \\
\hline
\end{tabular}

$\boldsymbol{\alpha} \times \boldsymbol{\beta} \times \mathbf{Y}$

\section{Interpretação}

Somente depois de ter descrito a tela por meio de processos relacionais atributivos e identificativos, van Gogh passa a falar da composição desde o ponto de vista de sua participação na feitura do desenho em tons de aquarela. Observei nessa estratégia um padrão de construção léxico-gramatical e retórica que se repetiu em mais de uma tela, na qual ele apaga a sua presença e privilegia o modo de representar a tela por meio dos processos relacionais, enquanto a descreve em uma tentativa de modalizar e recriar para o irmão o ambiente no qual ele, van Gogh, estava imerso ao concebê-la. A partir do momento em que ele termina de reconstruir esse ambiente 'interno' da tela, ele passa a usar processos materiais, passa a explicitar o ator do processo, ele, e passa a se referir à tela como um objeto, não como um ambiente, um mundo em si.

\subsubsection{Extrato $n^{\circ} 4 b$}

Carta 676 - Br. 1990: 679 |CL: 533 - From: Vincent To: Theo van Gogh Date: Arles, 8 September 1888.

http://vangoghletters.org/vg/letters/let676/letter.html

\footnotetext{
${ }^{259}$ Observei o uso de associações metafóricas e uso simbólico da cor com a escolha do item lexical "forno" no extrato de carta, que é correspondente à representação visual da luz excessiva no interior do café.
} 
"Mais tarde, quando eu tiver levado esses experimentos mais longe, o semeador ainda vai ser a primeira tentativa nesse gênero.

O café noturno é uma continuação do semeador, como é a cabeça do velho camponês e do poeta, se eu conseguir fazer essa ultima tela. É uma cor, então, que não é localmente verdadeira do ponto de vista realista do trompe l'oeil, mas uma cor que sugere alguma emoção, um temperamento ardente."

II Mais tarde, [quando eu tiver levado esses experimentos mais longe,] III o semeador ainda vai ser a primeira tentativa nesse gênero.

\begin{tabular}{|l|l|l|l|}
\hline Mais tarde, & quando eu & tiver levado & esses experimentos mais longe, \\
\hline Circunstância de tempo & Ator & Processo material & Meta \\
\hline
\end{tabular}

\begin{tabular}{|l|l|l|}
\hline o semeador ainda & vai ser & a primeira tentativa nesse gênero. \\
\hline Portador & Processo relacional Atributivo & Atributo \\
\hline
\end{tabular}

\section{$\mathbf{X} \boldsymbol{\beta}^{\wedge} \boldsymbol{\alpha}$}

xBETA - (oração hipotática de tempo) - [quando eu tiver levado esses experimentos mais longe,]

ALFA - o semeador ainda vai ser a primeira tentativa nesse gênero.

Novamente, ele dá ênfase iniciando a oração com uma circunstância de tempo 'Mais tarde, quando' ou seja, depois, no tempo em que ele tiver avançado com seus experimentos dos quais 'O Semeador' é uma parte. Então, 'O Semeador' será a primeira tentativa nesse gênero. Que gênero? O mesmo do qual o 'Café da Noite' é parte. Para compreender que tipo de experimento van Gogh empreendeu nas telas 'O Semeador' e 'O Café da Noite', e a cabeça do velho camponês e do poeta, será preciso fazer um estudo comparado dessas duas telas e estabelecer qual é a natureza da sua relação. Assim poderá ser evidenciado de que tipo de experimento van Gogh se refere. Não investiguei a natureza dessa relação por não ser o objeto desta pesquisa. ${ }^{260}$

III O café noturno é uma continuação do semeador, como é a cabeça do velho camponês e do poeta, II se eu conseguir fazer essa última tela.

\begin{tabular}{|l|l|l|l|}
\hline O café noturno & é & uma continuação do semeador, & como é \\
\hline Portador & $\begin{array}{l}\text { Processo relacional } \\
\text { Atributivo }\end{array}$ & Atributo & $\begin{array}{l}\text { Conjunção } \\
\text { Processo Relacional atributivo }\end{array}$ \\
\hline
\end{tabular}

\begin{tabular}{|l|l|l|l|l|}
\hline a cabeça do velho camponês e do poeta, & se & eu & conseguir fazer & essa última tela. \\
\hline Portador & & Ator & Processo material & Meta \\
\hline
\end{tabular}

\footnotetext{
${ }^{260}$ Por não ser o objeto da pesquisa da tese, deixamos como sugestão para estudos posteriores.
} 


\section{$\boldsymbol{\alpha} \times \boldsymbol{\beta} \times \mathbf{Y}$}

ALFA - O café noturno é uma continuação do semeador,

XBETA - (oração dominada por comparação) - como é a cabeça do velho camponês e do poeta,

x oração hipotática - (oração dominada condicional ) - se eu conseguir fazer essa última tela.

Ao falar de seus experimento neste gênero, van Gogh estabelece uma linha de trabalhos que são parte desse estudo no qual um trabalho é a continuação de outro: ' $O$ Semeador', depois 'O café da Noite', depois a 'A cabeça do velho camponês' e 'A cabeça do poeta', e acrescenta: 'se eu conseguir fazer essa última tela.' Ele refere-se à um sistema semiótico que ele está construindo e ao qual ele se refere como 'gênero' ao falar da tela ' $\mathrm{O}$ Semeador' na oração anterior. Estas quatro telas são capazes de revelar que semioses van Gogh estava pesquisando e colocando em prática.

É uma cor, então, [que não é localmente verdadeira do ponto de vista realista do trompe l'oeil,] mas uma cor que sugere alguma emoção, um temperamento ardente."

\begin{tabular}{|l|l|l|l|l|l|}
\hline$\vec{E}$ & $\begin{array}{l}\text { uma cor, } \\
\text { então, }\end{array}$ & $\begin{array}{l}\text { que não é localmente } \\
\text { verdadeira do ponto de vista } \\
\text { realista do trompe l'oeil, }\end{array}$ & $\begin{array}{l}\text { mas uma } \\
\text { cor }\end{array}$ & que sugere & $\begin{array}{l}\text { alguma emoção, } \\
\text { um } \\
\text { ardente. }\end{array}$ \\
\hline $\begin{array}{l}\text { Processo } \\
\text { Existencial }\end{array}$ & Existente & Oração encaixada & Portador & $\begin{array}{l}\text { Processo } \\
\text { Relacional } \\
\text { Atributivo }\end{array}$ & Atributo \\
\hline
\end{tabular}

1 - É uma cor, então, [que não é localmente verdadeira do ponto de vista realista do trompe l'oeil,]

2 - É uma cor, então, (...), mas uma cor que sugere alguma emoção, um temperamento ardente.

ALFA - É uma cor, então,

= BETA - que não é localmente verdadeira do ponto de vista realista do trompe l'oeil,

2. Oração Coordenada - mas uma cor que sugere alguma emoção, um temperamento ardente.

\section{Interpretação}

No sequenciamento da oração anterior, van Gogh revela nesta do que se tratam os experimentos pictóricos: tratam-se do uso simbólico da cor. Mas não é um uso qualquer, mas 
sim um uso que não busca a ilusão de realidade dada pela técnica trompe l'oeil ${ }^{261}$, mas um uso voltado para sugerir 'alguma emoção, um temperamento ardente'. Dessa forma ele enuncia que a cor para ele, deixa de representar a realidade e, nesses experimentos, passa a assumir intencionalmente e declaradamente um significante para as experiências do universo interior do artista que ele deseja comunicar com sua composição. ${ }^{262}$

\subsubsection{Extrato $n^{\circ} 4 c$}

Carta 677 - Br. 1990: 680|CL: 534 - From: Vincent van Gogh To: Theo van Gogh

Date: Arles, 9 September 1888.

http://vangoghletters.org/vg/letters/let677/letter.html

"Na minha pintura do café à noite eu procurei exprimir que o café é um lugar onde você pode arruinar-se, enlouquecer, cometer crimes. De qualquer forma, eu tentei com contrastes de rosa delicado e vermelho-sangue e vinho tinto. Verde doce Luís XV e Veronese contrastando com os verdes amarelos e os verdes azuis duros.

Tudo isso em uma atmosfera de fornalha infernal, de enxofre pálido. Exprimir como a potência dos cantos escuros de uma taberna.

Contudo sob uma aparência da alegria japonesa e da boa natureza de Tartarin.

Que diria portanto desse quadro o Sr. Tersteeg? Diante de um Sisley, Sisley, o mais discreto e delicado dos Impressionistas - já disse: "Não posso me impedir de pensar que o artista que pintou isso estava um pouco tonto". Diante do meu quadro, então a mim ele diria que ele é um caso de delirium tremens".

Na minha pintura do café à noite eu procurei exprimir que o café é um lugar [[onde você pode arruinar-se, //enlouquecer, //cometer crimes.]]

\begin{tabular}{|l|l|l|l|}
\hline $\begin{array}{l}\text { Na minha pintura do café } \\
\text { à noite }\end{array}$ & eu & procurei exprimir & $\begin{array}{l}\text { que o café é um lugar [[onde você pode } \\
\text { arruinar-se, //enlouquecer,// cometer crimes.]] }\end{array}$ \\
\hline $\begin{array}{l}\text { Circunstância } \\
\text { Localização: lugar }\end{array}$ & Dizente & $\begin{array}{l}\text { Processo Relacional } \\
\text { Identificativo }\end{array}$ & Oração projetada relacional \\
\hline
\end{tabular}

\footnotetext{
${ }^{261}$ trompe l'oeil é uma expressão francesa que designa o enganar dos olhos por meio de uma técnica pictórica cuja perspectiva e sombreamento à distância parecem reais. Disponível em: https://pt.wikipedia.org/wiki/Trompe-1\%27oeil e também em: http://www.colegiodearquitetos.com.br/dicionario/2009/02/o-que-e-trompe-1\%C2\%B4oeil/

${ }^{262}$ Observei a ocorrência textual do uso simbólico da cor indexada ao uso simbólico da cor na tela. Textualmente esta é uma ocorrência de cunho semântico porque na carta ele explicita o significado que o uso da cor tem na tela.
} 
$\alpha " \beta[[1+2+3]]$

$\alpha^{\wedge}$ ' $\beta$

Na minha pintura do café à noite eu procurei exprimir [que o café é um lugar onde você pode arruinar-se, enlouquecer, cometer crimes.]

ALFA - Na minha pintura do café à noite eu procurei exprimir 'BETA oração projetada relacional - [que o café é um lugar onde você pode arruinar-se, enlouquecer, cometer crimes.]

\section{Interpretação}

Neste complexo oracional van Gogh narra o que ele quis comunicar com a representação. Interpretei o verbo 'exprimir' como um processo relacional identificativo ao substituí-lo pelos verbos 'representar' e 'atribuir' que dão o sentido mais aproximado para a oração. Durante a análise ocorreu uma dúvida com relação ao processo usado por van Gogh na oração Alfa: 'Na minha pintura do café à noite eu procurei exprimir'. O uso do verbo 'expressar' pode ser compreendido como processo verbal, mas se analisarmos como um processo de atribuir características para uma composição pictórica, podemos também interpretar como um processo relacional. Para explorar as implicações dessas possibilidades interpretativas, foi proposto um teste para cada uma das opções:

Se for processo verbal: ele está explicitando o que está implícito na tela. Ao produzir a tela ele articulou os recursos pictóricos e simbólicos para dar unidade a uma condição humana. Esse processo criativo tem uma intencionalidade que o autor não consegue controlar absolutamente. Algo escapa desse processo que é da ordem do simbólico e do real da experiência que nem sempre conseguem ser expressos por meio da linguagem. Ao falar sobre o quadro e construir discurso sobre o sentido que está presente na tela, van Gogh usa a expressão 'procurei exprimir' que revela uma intencionalidade em dizer algo sem o uso das palavras. Após a produção da tela ele verbaliza sua intenção em relação a produção desses sentidos por meio do uso dos elementos pictóricos. Por isso que é verbal.

Se for processo relacional: na oração 'Na minha pintura do café à noite eu procurei exprimir que o café é um lugar onde você pode arruinar-se, enlouquecer, cometer crimes' podemos pensar que o processo 'exprimir' seja um processo verbal com uma oração projetada. No entanto, argumento que este seja um processo relacional identificativo porque ele não está apenas dizendo algo, ele está relacionando algo que não é evidente na tela, e que ele constrói 
na oração por meio de uma relação entre cena representada, e o que ela representa para ele, dando para a tela uma uma identidade 'que o café é um lugar onde você pode arruinar-se, enlouquecer, cometer crimes'. Van Gogh constrói na oração um sentido de algo que está oculto na representação da tela, ele está dando um valor simbólico para a tela que não é um discurso é um atributo de identidade. Mas nesta oração, van Gogh está usando a pintura para representar uma outra ideia ou noção por detrás do que ele pinta. Ele não está representando o café por si mesmo, mas usando a representação do café para expressar 'a noção de que o café é um lugar onde você pode arruinar-s, enlouquecer, cometer crimes' Esta noção só é construída por meio de um processo relacional entre o café representado e ela.

Observei nesse complexo a ocorrência de um uso léxico-gramatical frequente no estilo retórico de van Gogh. Ele desloca o sentido semântico central para a oração Beta que neste caso é uma oração projetada relacional. Como essa ocorrência tende a aparecer em vários momentos do corpus textual, examinei se ela se relaciona com as estratégias de composição visual. Visualmente é como se ele retirasse o enquadramento do primeiro plano da composição e o deslocasse para o segundo plano e essa ocorrência foi observada nas quatro telas. Textualmente é como se ele deslocasse o sentido principal para a oração secundária, e aparentemente esta pode ter sido uma estratégia de modalização. Outra possibilidade é que ele utiliza a oração Alfa na qual recai uma maior atenção do leitor para enfatizar a importância do que ele irá falar na oração Beta. Ele usa a oração Alfa como uma preparação do leitor para depois depositar a maior carga de sentido na oração Beta, criando com isso uma ênfase que é análoga ao aguçamento visual. Entendo que esse deslocar do sentido principal entre as orações Alfa e Beta pode funcionar como um deslocar do foco ou do enquadramento em uma composição visual. ${ }^{263}$ Será necessário um estudo posterior para investigar as outras ocorrências desse fenômeno para compreender sua dinâmica no discurso de van Gogh.

'Na minha pintura do café à noite eu procurei exprimir [que o café é um lugar onde você pode arruinar-se, enlouquecer, cometer crimes.]'

Van Gogh inicia a oração com algo inusitado em sua escrita que é o uso do pronome possessivo 'minha' demonstrando uma apropriação da pintura. Contraditoriamente essa é uma pintura ou prometida ao senhorio como forma de pagamento ou que van Gogh se refere ironicamente ao dizer que faria essa pintura como forma de recuperar o dinheiro pago ao senhorio ou como forma de compensação do dinheiro que o senhorio retirou dele. A produção

\footnotetext{
263 Observei a ocorrência do uso de Enquadramento ao deslocar o sentido principal para a oração Beta. Este exemplo de enquadramento na oração é compatível com o uso de ênfase no segundo plano na composição visual.
} 
de uma obra que não intenciona representar a beleza, a unidade, valores superiores, a espiritualidade, tem para van Gogh um sentido negativo de posse. É como se possuísse uma falta, uma perda, uma desapropriação, uma destituição, ao expressar 'na minha pintura do cafe a noite'. Van Gogh pode estar usando esse pronome possessivo porque as outras pinturas não são suas, elas são uma forma de pagamento para o irmão, elas são uma mensagem para o mundo, elas têm uma intencionalidade em si, elas carregam sentidos que são uma expressão de uma missão que van Gogh tem com valores espirituais. Essa tela parece não ser isso, mas uma expressão de valores opostos a isso e nesse momento ele usa dessa expressão de posse de ser dele a tela porque esse lugar de falta de desapropriação, de privação, é um lugar familiar para van Gogh no sentido existencial. E ele não parece esperar que esse quadro reflita uma expressão da sua arte naquilo que era simbolicamente importante para ele que é a espiritualidade.

Na oração Alfa ele declara para Theo o que ele tentou exprimir na pintura do café da noite. Em nenhum dos extratos das outras telas analisadas foi encontrado um tal tipo de explicitação do que ele quis expressar com a tela, nem mesmo na tela 'O Semeador' que tem uma forte condensação de sentidos e, como van Gogh coloca, está diretamente relacionada com esta em uma linha experimental. Talvez ele estava em processo de elaboração acerca do sentido da tela e fez uma declaração autoreflexiva do limiar artístico. ${ }^{264} \mathrm{Ou}$ simplesmente, ele tinha um sentido muito definitivo para a tela e quis torná-lo inequívoco para Theo, seu representante comercial das telas, seu interlocutor com o público. É é esse sentido, concentrado na oração Beta, que irei explorar a seguir.

Na oração projetada aparece o que ele quis exprimir com a tela. É na oração Beta: 'que o café é um lugar onde você pode arruinar-se, enlouquecer, cometer crimes' que concentra-se a análise interpretativa do sentido atribuído por van Gogh para a tela 'O Café da Noite'.

De todo modo, há uma característica nessa oração que não é comum encontrar no discurso escrito de van Gogh: a explicitação do sentido intrínseco da pintura. Aparentemente quando van Gogh relata sobre os quadros, ele procura não se referir ao sentido simbólico para que justamente o quadro não perca em termos de significação com a explicitação através da linguagem escrita; mas com uma tela que considera feia, não tem porque ele ter esse cuidado porque ela não está ali para expressar um valor superior, um valor de beleza, então ele utiliza o processo 'procurei exprimir'. O que ele procurou expresssar? O café como um lugar onde

264 'Limiar artístico' é uma contribuição desta pesquisa para designar uma instância do processo criativo que não foi apreendida pelo artista e por isso supõe um processo reflexivo que, pode envolver a produção de novos textos na busca de explicitar aqueles sentidos que se encontram implícitos para o próprio artista. Este conceito será melhor desenvolvido na discussão dos achados da tese, no capítulo 6. 
voce pode arruinar-se, enlouquecer, cometer crimes. Aparentemene há nessa descrição um processo de decadência, arruinar-se é um processo interno, arruinar a si mesmo, é uma ação do sujeito e do café no sentido de desapropriação dos valores, da dignidade, é tornar ruim, e tornar ruínas o que antes era algo uno, é fragmentar-se. Após esse processo de arruinar-se, há um mecanismo interno do sujeito que já não depende mais de uma ação externa sobre ele, e que é um enlouquecimento, então o café nesse momento não é um local de ação sobre o sujeito, mas é um local no qual o sujeito pode enlouquecer, é um local de enlouquecimento. O enlouquecimento não é estranho a esse lugar. No café um louco pode passar desapercebido. No terceiro processo, já é o momento de uma pessoa que se arruinou e enlouqueceu, é o auge do processo de desagregação e degradação que é o de cometer um crime. Ou seja, o café é um local onde um crime não seria algo absurdo. Ele é o fechamento de um processo de manifestação dos elementos que isoladamente compõem um estado psíquico, emocional, social e humano. O que há no café, capaz de promover tamanha destituição? Edwards (2009 p. 29) defende que a tela 'O Café da Noite' está em consonância com a leitura que van Gogh fez do romance ' $L$ 'Assomoir 'de Zola, porque nesta oração, van Gogh usa o mesmo termo incomum para designar café usado por Zola. Nesse romance, um café é o cenário do vício do álcool que leva os homens e mulheres a cometerem atos degradantes:

Vincent chama "O Café da Noite", um "assommoir", e essa designação liga sua pintura com o romance de Zola de mesmo nome. Quando eu pontuei para o Dr. Marty que Van Gogh usou o termo assommoir para "O Café da Noite", escreveume: "Isso reforça a ligação entre Zola e Van Gogh, e provavelmente demonstra que a leitura de Van Gogh do L'Assommoir de Zola criou em sua mente uma imagem próxima ao que ele vê e sente no café dos Ginoux. "Dr. Marty continuou,"

Eu acredito que é muito provável de haver uma profunda conexão entre a pintura de Van Gogh, sua carta para Theo, e algumas cenas específicas no romance ". ${ }^{265}$

$\mathrm{Na}$ oração Beta '[que o café é um lugar onde você pode arruinar-se, enlouquecer, cometer crimes.]' van Gogh fala de um lugar que não é um lugar qualquer. Ele se refere ao café como um lugar que tem o poder de transformar o caráter e a natureza humana de uma pessoa. Aparentemente ele não está falando de um café específico, mas usando o café como uma metáfora para um lugar social no qual as esperanças são perdidas, os valores aniquilados, o sentido de ser esvaziado. Porque ele se refere a esse lugar, e porque ele usa o café como um signo para representar esse lugar social de desapropriação da dignidade e da consciência

\footnotetext{
265 Tradução livre da autora. "Uncertain of the accuracy of my understanding of the use of the term assommoir, I contacted Fernand Marty, a retired professor of French language and culture and an expert on French lexicography. The term fascinated him. He traced it back to the name of the Belleville drinking place, its mention in a song by Colmance, and its appearance in Delvau's Dictionnaire de la langue verte in 1866. He noted that Zola did not use the term in any other of his many novels, and likely intended it as the proper name of a single drinking place. Dr. Marty's view is that during 1877-1888 "the word assommoir designating a cabaret was only very rarely used." (EDWARDS, 2009, p.29)
} 
moral? Para elucidar essa questão foi necessário compreender o contexto de cultura que envolveu os cafés no século XIX, e que papel eles desempenharam na sociedade francesa naquela época. Edwards (2009, p. 28) descreve uma lista de termos que designam café, entre eles 'assommoir', um termo adotado para o título de um romance de Zola:

\begin{abstract}
Vamos destacar nesta lista o termo "assommoir", e observe que ele era um termo bastante incomum quando escolhido por Zola, e tornou-se mais conhecido e entrou para a lista acima em grande parte através da popularidade do romance de Zola de mesmo nome. O substantivo é retirado do assommer verbo, que significa "quebrar", "a martelo", "para cacetear" ou "para atordoar". Lilian Furst, em seu livro L'Assommoir: a vida de uma mulher trabalhadora, observa que "assommoir" pode ter sido originalmente usado para o "machado usado para atordoar o gado antes do abate ..." (28). Aparentemente, um saloon dos Trabalhadores em Belleville, um subúrbio da classe trabalhadora de Paris, foi então dado esse nome, "L'Assommoir", e o termo fez o seu caminho no Dicionário da Língua não oficial: Uma comparação de expressões Parisienses (1866) de Alfred Delvau. Zola que atraiu centenas de palavras do dicionário que moldaram a linguagem dos trabalhadores em seu romance, decidiu usar esse mesmo nome para o local de beber Colombo, uma localização central para a sua história. Por meio do uso o termo em Zola tornou-se uma descrição bastante rara de um "lugar público de baixo convívio" frequentado principalmente por trabalhadores onde se pode ir para ficar "esmagado". Uma tradução precoce do romance de Zola para o Inglês apropriadamente intitulou o livro "O Bludgeon carregado", mas mais frequentemente o termo de baixo calão levou a títulos ingleses mais oblíquos, como "o Dram Shop","bebida","O Palácio Gin", ou mesmo simplesmente o nome da personagem principal, "Gervaise."266
\end{abstract}

Van Gogh cita com frequência este romance em suas cartas ao irmão. Edwards (2009,

p. 29) defende que 'O Café da Noite' de van Gogh tem uma interdiscursividade irrefutável com o romance de título 'L'Assommoir' de Zola no qual a personagem principal passa por um processo de degradação social e humana dentro de um café:

Então Zola tinha escolhido um nome de gíria bastante obscura, mas colorida de um café real para nomear seu romance e o café Paris, onde a heroína da novela, Gervaise, foi "martelada" em sujeição, degradação, e, finalmente, a morte. Foi no "Old Colombe's L'Assommoir", onde seu marido perdeu o dinheiro dela, arruinou o seu negócio e, finalmente, convenceu-a a ceder ao alcoolismo, que a arrastou para a pobreza, a fome, a tentativa de prostituição e a morte. ${ }^{267}$

266 Tradução livre da autora. "Let us single out from this list the term "assommoir," and note that it was a rather
unusual term when chosen by Zola, and became better known and joined the above list largely through the
popularity of Zola's novel by that name. The noun is taken from the verb assommer, meaning "to smash", "to
hammer," "to bludgeon," or "to stun." Lilian Furst, in her book L'Assommoir: A Working Woman's Life, notes
that "assommoir" may originally have been used of the "pole-ax used to stun cattle before slaughter..." (28).
Apparently, a worker's saloon in Belleville, a working-class suburb of Paris, was then given that name,
"L'Assommoir," and the term made its way into Alfred Delvau's Dictionary of Off Language: A Comparison of
Parisian Slangs (1866). Zola, who drew hundreds of words from that dictionary to shape the language of the
laborers in his novel, decided to use that very name for Colombe's drinking plae, a location central to his story.
Through Zola's use, the term became a rather rare description of a "low public drinking place" frequented
largely by laborers where one might go to get "smashed." An early translation of Zola's novel into English aptly
titled the book "The loaded Bludgeon," but more often the slang term led to such oblique English titles as "The
Dram Shop," "Drink," "The Gin Palace," or even simply the name of the chief character, "Gervaise."
(EDWARDS, 2009, p. 28)
267 Tradução livre da autora. "So Zola had chosen a rather obscure but colorful slang name of an actual café to
name his novel and the Paris café where the novel's heroine, Gervaise, was "hammered" into subjection,
degradation, and finally death. It was in "Old Colombe's L'Assommoir," where her husband wasted her money, 
Parece claro que a representação do Café da Noite se trata de um manifesto pictórico de van Gogh com base em sua interlocução com os pensadores do realismo social tanto na pintura e do naturalismo na literatura, ainda que ele tenha características estilísticas diversas dos artistas do realismo social e tenha rompido com a unidade e harmonia visual daquela corrente pictórica.

De qualquer forma, eu tentei com contrastes de rosa delicado e vermelho-sangue e vinho tinto.

\begin{tabular}{|l|l|l|l|}
\hline De qualquer forma, & eu & Tentei (expressar) & $\begin{array}{l}\text { com contrastes de rosa delicado e vermelho-sangue e } \\
\text { vinho tinto. }\end{array}$ \\
\hline Circunstância de Modo & Ator & $\begin{array}{l}\text { Proc. Relacional } \\
\text { Atributivo }\end{array}$ & Circunstância \\
\hline
\end{tabular}

Verde doce Luís XV e Veronese contrastando com os verdes amarelos e os verdes azuis duros.

\begin{tabular}{|l|l|l|l|}
\hline $\begin{array}{l}\text { Verde malaquita Luís XV e } \\
\text { Veronese }\end{array}$ & contrastando & com os amarelos verdes e os azuis verdes duros. \\
\hline Ator & Processo Material & Meta \\
\hline
\end{tabular}

Tudo isso em uma atmosfera de fornalha infernal, de enxofre pálido.

\begin{tabular}{|l|l|l|l|}
\hline $\begin{array}{l}\text { Tudo isso //em um ambiente de } \\
\text { uma fornalha infernal,// }\end{array}$ & em enxofre pálido. & \\
\hline $\begin{array}{l}\text { Circunstância de localização: } \\
\text { lugar }\end{array}$ & Circunstância de Modo & $\begin{array}{l}\text { O participante/agente está } \\
\text { oculto }\end{array}$ \\
\hline
\end{tabular}

Exprimir como a potência do poder das trevas de uma taberna.

\begin{tabular}{|c|c|c|c|}
\hline Para & & exprimir & $\begin{array}{l}\text { como a potência do poder das trevas de } \\
\text { uma taberna. Contudo sob uma aparência } \\
\text { da alegria japonesa e da boa natureza de } \\
\text { Tartarin. }\end{array}$ \\
\hline $\begin{array}{l}\text { Circunstância de } \\
\text { finalidade }\end{array}$ & $\begin{array}{lr}\text { O ator está } & \text { oculto. } \\
\text { Apagamento } & \text { do } \\
\text { agente da } & \text { ação } \\
\text { (Quem?) } & \end{array}$ & Processo Material & $\begin{array}{l}\text { Meta } \\
\text { Parece uma Oração projetada, separada por } \\
\text { um ponto, mas deveria ser por uma vírgula. }\end{array}$ \\
\hline
\end{tabular}

Contudo sob uma aparência da alegria japonesa e da boa natureza de Tartarin.

\begin{tabular}{|l|l|l|}
\hline E ainda & com a aparência & $\begin{array}{l}\text { da alegria japonesa e da } \\
\text { boa natureza de Tartarin. }\end{array}$ \\
\hline Circunstância & nominalização verbal & \\
\hline
\end{tabular}

'De qualquer forma, eu tentei com contrastes de rosa delicado e vermelho-sangue e vinho tinto. Verde doce Luís XV e Veronese contrastando com os verdes amarelos e os verdes azuis duros. Tudo isso em uma atmosfera de fornalha infernal, de enxofre pálido.

Exprimir como a potência do poder das trevas de uma taberna.

ruined her business, and finally convinced her to give in to alcoholism, which dragged her down to poverty, hunger, attempted prostitution, and death." (EDWARDS, 2009, p. 29) 
Contudo sob uma aparência da alegria japonesa e da boa natureza de Tartarin.'

\section{Interpretação}

Há aqui uma sequência de orações que tem um sentido concatenado: 'De qualquer forma, eu tentei com contrastes de rosa delicado e vermelho-sangue e vinho tinto. Verde doce Luís XV e Veronese contrastando com os verdes amarelos e os verdes azuis duros.' $\mathrm{Na}$ primeira oração, por exemplo, o ponto que a separa da segunda poderia ser uma vírgula. Talvez ele separou as orações por um ponto porque estava agrupando dois tipos de contrastes que tinham uma função muito distinta, tanto na articulação pictórica das cores quanto na significação que estes grupos de contrastes tinham para ele.

Tanto na primeira oração quanto na segunda, van Gogh atribui cores para a composição, para descrever para Theo o ambiente do interior do café: 'Tudo isso em uma atmosfera de fornalha infernal, de enxofre pálido.' $\mathrm{Na}$ primeria oração há o complexo nominal: 'com contrastes de rosa delicado e vermelho-sangue e vinho tinto' e na segunda, dois complexos nominais separados pelo processo material 'contrastando': 'Verde doce Luís $\mathrm{XV}$ e Veronese' e 'com os verdes amarelos e os verdes azuis duros.' Estes complexos nominais indicam que para van Gogh, a cor desempenha um papel central para a construção dos sentidos do ambiente que ele deseja representar. Ou seja, além do papel das formas e figuras distribuídas no espaço e que estão construindo um sentido em si, van Gogh quis construir uma segunda camada de sentidos que aprofundam aquele e adicionam novos sentidos para a narrativa visual. ${ }^{268}$

Nas duas primeiras orações ele usa a contraposição de cores aparentemente incompatíveis, por significados culturalmente a elas associados, para criar uma metáfora, por exemplo entre o que é suave e delicado e o que é passional e denso no caso da primeira oração e entre o que é doce e o que é duro, na segunda. ${ }^{269}$

Edwards (2009, p. 34-35) discorre a respeito da forma como van Gogh usa os contrastes para construir sentidos metafóricos:

Vincent sugere tais possibilidades destrutivas no Café da Noite em grande parte através da cor, o choque ameaçado entre vermelhos e verdes sob as vibrantes ondas verdes e amarelas das lâmpadas de gás. Este foi o momento em que Vincent estava buscando descobrir equivalentes simbólicos para as cores e sua justaposição. Ele descreveu essa busca para Theo em sua carta de segunda-feira, 3 de setembro, um

\footnotetext{
268 Observei o uso simbólico da cor não apenas com o uso de contraste complementar, mas com o uso de contraste de saturação dessas cores complementares. Há uma ênfase na descrição textual desses contrastes, e uma ocorrência semântica da cor nestas orações que é compatível com a ocorrência na tela.

${ }^{269}$ Uso de associações metafóricas para os sentidos indexados a estes contrastes que estão descritos nas duas orações, por exemplo entre o que é suave e delicado e o que é passional e denso no caso da primeira oração e entre o que é doce e o que é duro, na segunda.
} 
dia antes de ele começar "O Café da Noite": (...) Então, eu estou sempre entre duas correntes de pensamento, as primeiras dificuldades materiais, girando e girando para ganhar a vida; e em segundo lugar, o estudo da cor. Estou sempre na esperança de fazer uma descoberta lá, para expressar o amor de dois amantes por um casamento de duas cores complementares, sua mistura e sua oposição, as vibrações misteriosas de tons afins. Para expressar o pensamento de uma sobrancelha pelo brilho de um tom de luz contra um fundo sombrio. Para expressar a esperança por alguma estrela, a ânsia de uma alma por uma radiação do sol. Certamente não há realismo ilusório em que, mas não é algo que realmente existe? (Carta 531) ${ }^{270}$

A sequência das duas primeiras orações denota que van Gogh está construindo, pelo uso simbólico da cor, um ambiente de contraposição que possa representar 'uma atmosfera de fornalha infernal' com a qual ele possa exprimir 'a potência dos cantos escuros de uma taberna.' Na oração 'Exprimir como a potência do poder das trevas de uma taberna.' van Gogh usa no francês a palavra 'assommoir' para designar taberna ou bar de baixo convívio. Edwards (2009, p. 29-30) argumenta que a escolha deste termo por van Gogh o associa ao romance de Zola, uma vez que "durante 1877-1888 a palavra assommoir que designa um cabaret foi apenas muito raramente utilizada" mas se tornou popular com o romance de Zola:

Então descobrimos que Vincent levou para o seu ato de pintar a Cafeteria do Ginoux sua lembrança imaginativa do L'Assommoir de Zola, um trabalho que incorpora a celebração da terra da "alegria" e "bom caráter" do trabalhador de um lado e o "poder das trevas "," ruína" e "crime" do outro. Esta é a interseção de uma "grande riqueza e alegria" e "as coisas mais pungentes e trágicas" Vincent alegou estavam nos romances franceses que ele valorizava e foram "começando a ser a regra na arte da pintura" (Carta a Wilhelmina, W3). Olhando para a própria pintura "O Café da Noite", podemos imaginar Vincent pintando o rescaldo da celebração muito animada e colorida no Assommoir do Colombe. ${ }^{271}$

Edwards (2009, p.29) defende que o sentido que van Gogh busca expressar com a atmosfera do café da noite está associado com os sentidos experienciados por ele com a leitura deste romance de Zola:

Nesta passagem, a única palavra escolhida por Vincent, às vezes traduzida como acima, "uma casa pública baixa", é o termo incomum assommoir, escolhido por Zola

\footnotetext{
270 Livre tradução da autora. "Vincent suggests such destructive possibilities in the Night Café largely through color, the threatening clash of reds and greens under the undulating green and yellow ripples of the gaslights. This was the very time when Vincent was seeking to discover symbolic equivalents to colors and their juxtaposition. He described that quest to Theo in his letter of Monday, September 3, the day before he began "The Night Café": (...) So I am always between two currents of though, first the material difficulties, turning round and round to make a living; and second, the study of color. I am always in hope of making a discovery there, to express the love of two lovers by a wedding of two complementary colors, their mingling and their opposition, the mysterious vibrations of kindred tones. To express the thought of a brow by the radiance of a light tone against a somber background._To express hope by some star, the eagerness of a soul by a sunset radiance. Certainly there is no delusive realism in that, but isn't it something that actually exists? (Letter 531)" (EDWARDS, 2009, p. 29).

271 Tradução livre da autora. "So we discover Vincent carrying to his act of painting the Ginoux café his imaginative recollection of Zola's L'Assommoir, a work incorporating the earthy celebration of the laborer's "gaiety" and "good nature" on the one hand and the "power of darkness," "ruin," and "crime" on the other. This is The intersection of a "great richness and gaiety" and "the most poignantly tragic things" Vincent claimed were in the French novels he valued and were "beginning to be the rule in the art of painting" (Letter to Wilhelmina, W3). Looking at "The Night Café" painting itself, we may imagine Vincent painting the aftermath of the very sort of lively and colorful celebration in Colombe's Assommoir." (EDWARDS, 2009, p.29-30)
} 
para o título de seu romance. A carta de Vincent nessa passagem chave descrevendo seu "Café da Noite" lê, "la puissance des Tenebres d'un assommoir", o "poder das trevas de um assommoir."

Van Gogh associou o ambiente de decadência de uma taberna com a metáfora para um lugar no qual 'você pode arruinar-se, enlouquecer, cometer crimes' devido 'a potência do poder das trevas de uma taberna.'

Ao que ele se refere com a expressão 'a potência do poder das trevas'? Edwards (2009, p.32) defende que há uma forte interlocução entre os sentidos da sua tela 'O Café da Noite' e uma obra de Zola e outra de Tostoi:

\begin{abstract}
Pode ser também que, na mente de Vincent as palavras "la puissance des Ténèbres" (o poder das trevas), que ele vinculou com a palavra assommoir em sua carta a Theo, fundiu uma peça de Tolstoy na qual uma criança é assassinada com um cena terrível na novela de Zola, uma cena em que um pai bêbado espanca até a morte de sua jovem filha. A história assustadora de Tolstoy foi encenada em Paris durante a estada de Vincent no inverno passado na cidade, e o drama recebeu um bom bocado de publicidade. A versão francesa do trabalho escuro de Tolstoy foi intitulado "la puissance de Ténèbres".
\end{abstract}

$\mathrm{Na}$ oração 'Tudo isso em uma atmosfera de fornalha infernal, de enxofre pálido.' observei a ausência de processo, esse construto é compatível com a imprecisão e o inacabamento na maneira como ele pinta a tela. Com esta oração ele explica a sua escolha do item 'enxofre pálido' para significar um ambiente de 'fornalha infernal' e, novamente, indexa ao texto visual por meio do texto escrito (criando uma cadeia textual interdependente) um significado muito particular para o amarelo. ${ }^{272}$ Este significado está, por sua vez, enraizado em leituras de outros autores como evidenciados nos extratos a seguir, e como infere Edwards (2009) ao analisar os sentidos semânticos do Café no romance de Zola, que ele defende, tiveram um papel preponderante na concepção dos sentidos que van Gogh deseja materializar com o Café da Noite.

Observei novamente um encadeamento entre duas orações claramente interligadas semanticamente e que poderiam estar separadas por uma vírgula já que estão intimamente relacionadas: 'Exprimir como a potência do poder das trevas de uma taberna.' e 'Contudo sob uma aparência da alegria japonesa e da boa natureza de Tartarin.'. Apesar de não aparentar, encontrei nessas duas orações uma contraposição semântica, paradoxal e que expressa o coração do sentido construído visualmente, e agora verificado textualmente, que ele definiu como 'uma batalha e antítese', significada visualmente por contrastes entre os verdes e os vermelhos. Nestas duas orações ele explicita a dinâmica e o sentido deste conflito: Ele

\footnotetext{
${ }^{272}$ Uso de Inacabamento na organização de uma oração sem processo. Na mesma oração foi observado o uso de Associações Metafóricas pela associação da cor 'enxofre pálido' com 'uma atmosfera de fornalha infernal'.
} 
pretende expressar a potência dos cantos escuros, do lado negro de uma taberna usando para isso, a aparência da alegria japonesa e da boa natureza de Tartarin ${ }^{273}$. Van Gogh quer expressar um extremo usando o seu oposto, testando a latitude da capacidade semiótica de significação, criando com isso a possibilidade de expressar o lado negro com a 'alegria e a boa natureza'. Por que ele desejou construir a poética da contradição? Encontrei construtos léxico-gramaticais de inversão (gramatical e lexical) que envolvem expressar um sentido usando o sentido oposto? Esta foi uma preocupação conceptual, discursiva e certamente estilística com a qual van Gogh desenvolveu um sistema semiótico que deve ter sua trajetória em outras telas, tais como 'O Semeador', na qual ele coloca os valores cromáticos do céu no solo e os do solo no céu. Será preciso investigar em estudos futuros, o processo e a dinâmica do uso de elementos contraditórios na construção do sentido, ou do uso de um elemento para expressar o seu oposto, tanto visualmente quanto textualmente. ${ }^{274}$

Estas duas orações: 'Tudo isso em uma atmosfera de fornalha infernal, de enxofre pálido. Exprimir como a potência do poder das trevas de uma taberna', assim como as duas orações anteriores, poderiam ter sido separadas por uma vírgula, ao invés de um ponto já que estão concatenadas numa construção de sentido. Por que ele separou por pontuação? Porque os contrastes descritos e agrupados em duas orações anteriores são aqui reunidos em uma terceira camada de sentidos, que os unifica em 'uma atmosfera de fornalha infernal' por meio do uso da cor 'de enxofre pálido'. Por isso, essa terceira camada está destacada em uma única oração, em uma única unidade de sentido, para que Theo possa valorizar e compreender o mecanismo pelo qual van Gogh construiu a narrativa.

Na próxima oração ele explica a finalidade dessa intrincada articulação cromática: '(Para) Exprimir como a potência do poder das trevas de uma taberna'. O uso da palavra Exprimir foi considerado como um processo relacional, uma vez que ele está em realidade identificando uma característica da sua composição, por meio de uma comparação pelo uso do conectivo 'como'. Ele não está dizendo que a tela exprime o poder das trevas, mas sim que ela exprime 'como' o poder das trevas. Com 'Exprimir como a potência do poder das trevas de uma taberna.' van Gogh constrói uma oração sem agente. Aqui há a lacuna e a ausência na organização léxico-gramatical compatível com a ausência encontrada nas telas, tanto no nível gramatical visual como nas pinceladas e linhas interrompidas quanto no nível lexical e

\footnotetext{
273 Tartarin é uma personagem de um romance que expressa a boa índole.

${ }^{274}$ Uso de contraposição nas orações é compatível com os contrastes cromáticos na tela usados para representar 'batalha e antítese'. Nestas duas orações, verificamos a ocorrência de uma contraposição e de uma inversão que, no nível semântico, está compatível com a contraposição encontrada nos contrastes cromáticos usados para significar o mesmo sentido expresso nas orações. Ao representar um sentido com o seu sentido oposto, van Gogh usa o nível semântico para construir uma forma paradoxal em sua estratégia retórica textual.
} 
semântico como cadeiras vazias e expressões ambíguas do homem de branco no centro da cena. Observei nessa oração o uso de associação metafórica pela escolha do item do conectivo ‘como' que implica em um modo, e em uma comparação. Ou seja, o café é uma metáfora para exprimir 'a potência do poder das trevas de uma taberna'. ${ }^{275}$

Por que van Gogh associa o poder das trevas à atmosfera de uma taberna? Se levarmos em consideração o argumento de Edwards que 'O Café da Noite' guarda um intenso diálogo com os escritores naturalistas do século XIX como Zola, será necessário examinar as questões levantadas pelo romance "L'Assommoir" de Zola. Nele, que a intoxicação causada pelo consumo excessivo de álcool leva os trabalhadores a cometerem crimes, a se entregarem a uma onda de violência, a se corromperem e a se degradarem, como representado no romance de Zola, relatado por Edwards (2009, p. 30-31):

Este contraste de alegria e desejo, medo e pavor, então aponta fortemente na direção
de poderes destrutivos, tornando-se mais venenoso e violento no final de uma noite
em L'Assommoir: "Os pequenos cafés estavam fechados, e nos bares, a luz a gás
estava crescendo escura e vermelha e um podia ouvir o som de vozes engrossadas
pela bebida. Diversão foi dando lugar a disputas e lutas. Algum grande diabo
esfarrapado estava gritando: "Estou indo para tirá-lo à parte, portanto, conte seus
ossos". Uma garota estava batendo em seu amante na porta de um bar, chamando-o
de bastardo sujo e um porco sujo ... A bebida trazia para as ruas um desejo de
violência, algo selvagem ... Nome de Deus! Facas estavam saindo de bolsos e o
pequeno festival estava se desenrolando em derramamento de sangue. Mulheres
apressaram o passo, enquanto os homens perseguindo, de olhar penetrante, como
lobos, enquanto a noite engrossava, grande com atos terríveis. (ZOLA, Capítulo 12,
772-73)" (...) A visão do artista do Café da Noite como "um lugar onde se pode
estragar-se, ficar louco, ou cometer um crime" é bem adequado para descrição acima
de Zola dos trabalhadores do Assommoir e da rua na qual a sua violência bêbada
confluiu. A própria imaginação fértil de Vincent provavelmente intensificou o clima
de perigo e violência.

Ao consider-se essa cadeia de textos, as orações contidas nos extratos analisados se revelam como verdadeiros indexadores de outros discursos, outras vozes que circulam no discurso escrito e visual de van Gogh, e para os quais ele dá nova materialidade através de suas pinturas. 'O Café da Noite' dessa forma, condensa os discursos que van Gogh subscreveu e materializa um estatuto acerca do embrutecimento, da despessoalização, da perda de sentido, da corrupção, da degradação, do aniquilamento do ser humano diante da 'potência do poder das trevas de uma taberna'.

Que diria portanto desse quadro o Sr. Tersteeg?

\begin{tabular}{|l|l|l|l|}
\hline Que & diria & portanto desse quadro & o Sr. Tersteeg? \\
\hline Verbiagem & Processo Verbal & Circunstância & Dizente \\
\hline
\end{tabular}

\footnotetext{
${ }^{275}$ Uso de Inacabamento na organização de uma oração sem agente. Uso de associação metafórica observado com a escolha do item lexical 'como' que explicita que o café é uma metáfora para realizar o sentido 'a potência do poder das trevas de uma taberna'.
} 
Diante de um Sisley, Sisley, o mais discreto e delicado dos Impressionistas - já disse: / "Não posso me impedir de pensar que o artista que pintou isso estava um pouco tonto".

\begin{tabular}{|l|l|l|l|}
\hline $\begin{array}{l}\text { Diante de um Sisley, Sisley, o mais discreto } \\
\text { e delicado dos Impressionistas - já disse: }\end{array}$ & (eu) & $\begin{array}{l}\text { Não posso me } \\
\text { impedir de pensar }\end{array}$ & $\begin{array}{l}\text { que o artista que pintou isso } \\
\text { estava um pouco tonto". }\end{array}$ \\
\hline Oração projetante ou projetada & Dizente & Processo Verbal & Citação \\
\hline
\end{tabular}
$\alpha, \beta[[\alpha ' \beta]]$

$\alpha^{\wedge} \beta$

ALFA - Diante de um Sisley, Sisley, o mais discreto e delicado dos Impressionistas - já disse:

BETA oração projetada - "Não posso me impedir de pensar que o artista que pintou isso estava um pouco tonto".

Diante do meu quadro, então a mim ele diria que ele é um caso de delirium tremens".

\begin{tabular}{|l|l|l|l|l|}
\hline Diante do meu quadro, então & a mim & ele & Diria que & ele é um caso de delirium tremens. \\
\hline Circunstância & Recebedor & Dizente & $\begin{array}{l}\text { Processo } \\
\text { verbal }\end{array}$ & $\begin{array}{l}\text { Verbiagem } \\
\text { Comentário do dizente }\end{array}$ \\
\hline $\boldsymbol{\alpha}^{\wedge}{ }^{\mathbf{6}} \boldsymbol{\beta}$ &
\end{tabular}

ALFA -

“ BETA oração projetada verbal -

\section{Interpretação}

Nesta oração com processo verbal van Gogh demonstra preocupação sobre a opinião do Sr. Tersteeg acerca de sua pintura. Por que a opinião do Sr. Tersteeg é importante para ele? Por meio de um processo verbal, van Gogh invoca para dentro do diálogo postal com seu irmão um terceiro interlocutor, o Sr. Tersteeg, um conhecido mútuo que foi o treinador e mentor de van Gogh e Theo na atividade de comerciantes de quadros, como atestam Jansen et al:

Quando a correspondência entre os irmãos Van Gogh inaugurado em 29 de setembro de 1872 com as palavras 'Meu querido Theo', 10 a 19-year-old Vincent já havia trabalhado por três anos no ramo de Haia, de arte e de impressão comerciantes franceses Goupil \& Cie, sob a supervisão do jovem e enérgico HG Tersteeg. Pode-se supor que Tersteeg foi uma importante influência formativa sobre Vincent, bem como sobre Theo um par de anos mais tarde. 11 Ele os treinou, colocou-os em contato com artistas e ajudou a moldar os seus gostos na arte e na literatura. Desta forma, ele preparou-os para lidar com colecionadores de arte e revendedores "círculos superiores" a eles por causa de suas origens. (JANSEN et al, 2010, $\begin{array}{llll}\text { disponível em } & \text { 22.7.2014 no }\end{array}$ http://vangoghletters.org/vg/letter_writer_2.html\#intro.I.2.1)

Van Gogh pergunta a Theo o que o Sr. Tersteeg diria no sentido do que ele pensaria de seu quadro 'O Café da Noite'. Esse sentido do uso do verbo suscitou a dúvida sobre um 
processo mental ao invés de um processo verbal. Por que van Gogh levanta o interesse sobre o que o Sr. Tersteeg pensaria de sua tela? A oração seguinte explica: ele está confrontando dois tipos de discursos artísticos, um para o qual ele próprio subscreve e sob cuja perspectiva ele concebeu 'O Café da Noite'; e o outro, cujo representante seria o Sr. Tersteeg, e se contrapõe à sua própria concepção estética. Esse posicionamento com o qual o Sr. Tersteeg é representado fica muito evidente no sentido construído na oração, por meio de um processo verbal que projeta uma citação do que Tersteeg já disse sobre uma tela Impressionista das mais suaves: "Não posso me impedir de pensar que o artista que pintou isso estava um pouco tonto". 276

Nestas duas orações interligadas com a anterior, van Gogh faz uma simulação sobre uma situação imaginada: o que diria o Sr. Tersteeg sobre a sua tela. Por que a opinião do Sr. Tersteeg é importante para ele? Ele desenvolve seu argumento: se diante de outro pintor, Sisley, que está oposto em estilo ao estilo que van Gogh desenvolve, o Sr. Tersteeg considerou vertiginoso, então diante de van Gogh, Tersteeg o consideraria como um caso extremo de perda de equilíbrio. A metáfora usada para invocar no discurso o pensamento, a reação de Tersteeg ao trabalho de van Gogh, 'O Café da Noite' e dentro dela, a metáfora da comparação com o trabalho de Sisley, é como um teste proposto por van Gogh para auferir o impacto que sua tela terá diante dos críticos e dos compradores no mercado de arte. Van Gogh está convicto do valor intrínseco de sua tela, de seu valor semiótico, ele já mostrou sua consciência sobre o que acaba de realizar e está sensível e preocupado sobre como esse trabalho será recebido no circuito parisiense.

Mas afinal, em meio a sua retórica, qual é a função de van Gogh simular uma possível avaliação do Sr. Tersteeg sobre sua tela 'O Café da Noite'? Por que van Gogh precisa comparar e confrontar o discurso representado pelo Sr. Tersteeg com o seu próprio? A resposta parece condensada na última oração desse encadeamento: 'Diante do meu quadro, então a mim ele diria que ele é um caso de delirium tremens"'. Ou seja, para van Gogh, o discurso artístico ao qual o Sr. Tersteeg subscreve estaria diametralmente em contraposição com o seu próprio discurso artístico, chegando mesmo a considerar sua tela 'um caso de delirium tremens' e não uma obra de arte. Van Gogh sabe que sua tela confronta muito as convenções estéticas estabelecidas e deseja dar uma idéia para o irmão do quanto além ele

\footnotetext{
276 Observei aqui uma contraposição no nível semântico, entre o discurso que o Sr. Tersteeg representa e o discurso que van Gogh representa. Além disso, há também a ocorrência de uma metáfora que seria a comparação da reação de Tersteeg à uma tela de Sisley e à tela 'O Café da Noite' de van Gogh.
} 
ousou pintando 'O Café da Noite', por isso ele simula essa contraposição de discursos como parâmetro para o irmão compreender o tipo de transgressão estética que se trata este trabalho.

\subsubsection{Extrato $n^{\circ} 4 d$}

Carta 680 - To Theo van Gogh. Arles, on or about Tuesday, 11 September 1888.

http://vangoghletters.org/vg/letters/let680/letter.html

"A ideia do semeador ainda continua a me assombrar. Estudos exagerados, como o semeador, como o café noturno agora, geralmente parecem-me atrozmente feios e ruins, mas quando eu estou movido por alguma coisa, como aqui por este pequeno artigo sobre Dostoievski, em seguida, eles são os únicos que me parecem ter um significado mais importante."

A ideia do semeador ainda continua a me assombrar.

\begin{tabular}{|l|l|l|l|}
\hline A ideia do semeador & ainda continua & a me & assombrar. \\
\hline Fenômeno & $\begin{array}{l}\text { Finito da metafunção interpessoal, } \\
\text { não participa da metafunção } \\
\text { relacional. }\end{array}$ & Experienciador & Processo mental emotivo. \\
\hline
\end{tabular}

III Estudos exagerados, como o semeador, como o café noturno agora, geralmente parecemme atrozmente feios e ruins, II mas quando eu estou movido por alguma coisa, como aqui por este pequeno artigo sobre Dostoievski, em seguida, III eles são os únicos que me parecem ter um significado mais importante."

\begin{tabular}{|c|c|c|c|c|}
\hline $\begin{array}{l}\text { Estudos exagerados, como o } \\
\text { semeador, como o café } \\
\text { noturno agora, }\end{array}$ & geralmente & parecem & - me & $\begin{array}{l}\text { atrozmente } \\
\text { feios e ruins, }\end{array}$ \\
\hline Fenômeno & Circunstância & $\begin{array}{l}\text { Processo mental } \\
\text { perceptivo }\end{array}$ & Experienciador & Atributo \\
\hline
\end{tabular}

\begin{tabular}{|l|l|l|l|l|}
\hline mas quando & eu & estou movido & por alguma coisa, & $\begin{array}{l}\text { como aqui por este pequeno artigo } \\
\text { sobre Dostoievski, em seguida, }\end{array}$ \\
\hline $\begin{array}{l}\text { Circunstância de } \\
\text { localização: tempo }\end{array}$ & meta & $\begin{array}{l}\text { Processo Material } \\
\text { transformativo }\end{array}$ & Ator & Circunstância de comparação \\
\hline
\end{tabular}

\begin{tabular}{|l|l|l|l|}
\hline eles & são & os únicos & que me parecem ter \\
\hline Identificado & $\begin{array}{l}\text { Processo Relacional } \\
\text { Identificativo }\end{array}$ & Identificador & Oração encaixada. Faz parte do identificador \\
\hline
\end{tabular}

\begin{tabular}{|l|l|l|}
\hline um signficado mais importante. & & \\
\hline Atributo & & \\
\hline
\end{tabular}


ALFA - Estudos exagerados, como o semeador, como o café noturno agora, geralmente parecem-me atrozmente feios e ruins,

BETA - mas quando eu estou movido por alguma coisa, como aqui por este pequeno artigo sobre Dostoievski, em seguida,

BETA - eles são os únicos que me parecem ter um significado mais importante.

\title{
Interpretação
}

Com a oração 'A ideia do semeador ainda continua a me assombrar' van Gogh explicita o investimento psíquico que ele coloca na tela 'O Semeador'. Ele ainda não a realizou, por isso se refere a ela como uma ideia que está presentificada, porém em nível de idéia, não de texto. Em seguida há uma oração que tem o sentido concatenado com esta em um sequenciamento de ideias: 'Estudos exagerados, como o semeador, como o café noturno agora, geralmente parecem-me atrozmente feios e ruins, mas quando eu estou movido por alguma coisa, como aqui por este pequeno artigo sobre Dostoievski, em seguida, eles são os únicos que me parecem ter um significado mais importante.' Aqui há um complexo oracional no qual, na oração Alfa: 'Estudos exagerados, como o semeador, como o café noturno agora, geralmente parecem-me atrozmente feios e ruins,' van Gogh explicita o que pensa das telas. Na percepção dele, elas são 'Estudos exagerados' e 'atrozmente feios e ruins'. Em seguida na oração hipotáxica de expansão: 'mas quando eu estou movido por alguma coisa, como aqui por este pequeno artigo sobre Dostoievski, em seguida', ele esclarece para Theo que há uma interdiscursividade entre a tela 'O Café da Noite' e a leitura de um 'pequeno artigo sobre Dostoievski'. Esta é mais uma evidência de que 'O Café da Noite' condensa discursos, de $\underline{\text { Zola, de Tostoi e de Dostoievski em uma cadeia de textos que van Gogh apropriou em seu }}$ próprio discurso visual. ${ }^{277}$

Outro excerto de carta para sua irmã Wilhelmina, relatado por Edwards (2009, p. 17) atesta essa interlocução de van Gogh com os escritores:

\begin{abstract}
Apenas cinco meses antes de pintar 'O Café da Noite', Vincent escreveu para a irmã Wilhelmina de novo, comparando a riqueza de dois dos autores acima mencionados com a mesma abordagem que ele estava buscando na pintura das pessoas de Arles: "E então as pessoas aqui são pitorescas também, e enquanto no nosso país um mendigo parece mais como um horrendo fantasma, ele se torna uma caricatura aqui. Porque - como voce irá observar quando voce ler Zola e Guy de Maupassant - o que eles absolutamente insistem sobre é uma grande riqueza e uma grande alegria na arte - mesmo apesar de que esse mesmo Zola e Guy de Maupassant disseram talvez as
\end{abstract}

277 Ocorrência de Intertextualidade e Interdiscursividade, explicitada por van Gogh na oração: 'Estudos exagerados, como o semeador, como o café noturno agora, geralmente parecem-me atrozmente feios e ruins, mas quando eu estou movido por alguma coisa, como aqui por este pequeno artigo sobre Dostoievski, em seguida, eles são os únicos que me parecem ter um significado mais importante. 
coisas mais trágicas e pungentes que já foram ditas - essa mesma tendência está começando a ser a regra na arte de pintar também." (Carta para Wilhelmina, W3)

Na próxima oração hipotáxica: 'eles são os únicos que me parecem ter um significado mais importante' van Gogh finalmente deposita o significado central deste complexo oracional. Para ele, diante da leitura de Dostoievski, os estudos feios e ruins são os únicos que tem um significado mais importante.

Esta oração constrói um sentido que não está explicitado nela, mas é retomado e se trata de um complexo retórico. Na primeira oração 'A ideia do semeador ainda continua a me assombrar', van Gogh se refere à uma ideia que o assombra, que o persegue com um processo mental emotivo para explicar sua relação pessoal com este quadro. Na oração 'Estudos exagerados, como o semeador, como o café noturno agora, geralmente parecem-me atrozmente feios e ruins, mas quando eu estou movido por alguma coisa, como aqui por este pequeno artigo sobre Dostoievski, em seguida, eles são os únicos que me parecem ter um significado mais importante.', ele retoma a ideia do quadro 'O Semeador' referindo-se a ele como 'um estudo exagerado' e relacionando-o com o quadro 'O Café da Noite' e avaliandoos como 'atrozmente feios e ruins.' Estas duas telas parecem mecher muito com van Gogh, e ele explica a relação intrínseca delas com os sentidos que ele está mobilizado em construir ao ler um artigo de Dostoiewski e que adquirem uma importância única, assim como as telas. Essa é a importância das telas para van Gogh, elas tem uma importância de sentidos que parecem ser os únicos a ter um significado mais importante para ele, ainda que elas pareçam atrozmente feias e ruins. Ele não se liga nelas pela beleza externa, mas pela beleza de seu sentido. Ao relacionar os sentidos construídos na leitura de Dostoiewski com os sentidos das telas, van Gogh revela um importante aspecto de seu processo criativo, e que confirma o argumento de Edwards (2009, p. 17) que van Gogh possuía uma imaginação literária que infundia com sentidos a concepção do seu discurso visual:

Vincent agora tinha acrescentado à sua apreciação de certos "magníficos" autores
franceses que "pintavam a vida como eles a sentiam," uma nova apreciação da sua
capacidade para expressar o contraste da "riqueza e uma grande alegria" com "as
coisas mais pungentes e trágicas que foram ditas. "E esse contraste, afirmou, foi
uma" tendência ... começando a ser a regra na arte de pintar também."(...) A um
escritor cujo nome é apontado por Vincent como de importância proeminente na
"pintura" dos contrastes da alegria e do trágico, foi Emile Zola. Vincent revelou a

${ }^{278}$ Tradução livre da autora. Just five months before painting "The Night Café," Vincent wrote sister Wilhelmina again, comparing the richness of two of the above-mentioned authors with the very approach he was seeking in painting the people of Arles: "And then people here are picturesque too, and whereas in our country a beggar looks more like a hideous phantom, he becomes a caricature here. Because - as you will observe when you read Zola and Guy de Maupassant - what they absolutely insist on is a great richness and a great gaiety in art - even though this same Zola and Guy de Maupassant have said perhaps the most poignant tragic things that have ever been said - this same tendency is beginning to be the rule in the art of painting too. (Letter to Wil, W3) (EDWARDS, 2009, p. 17) 
Theo como ele descobriu o trabalho de Zola durante uma internação hospitalar em Haia, durante seus primeiros anos como um pintor. Em uma carta em 6 de Julho de 1882, cerca de seis anos antes da pintura "O Café da Noite", escreveu Vincent: "Mas por acaso, enquanto eu estava no hospital, eu estava muito impressionado por um artista que descreve este "tout Paris gris" com mão de mestre. Em uma página d'Amour por Emile Zola eu encontrei algumas vistas para a cidade tão soberbamente pintadas ou desenhadas, bem no clima da passagem simples em sua carta. E aquele pequeno livro leva-me a ler tudo por Zola." (VAN GOGH, Carta 212)

III Estudos exagerados, como o semeador, como o café noturno agora, geralmente parecemme atrozmente feios e ruins, II mas quando eu estou movido por alguma coisa, como aqui por este pequeno artigo sobre Dostoievski, em seguida, III eles são os únicos que me parecem ter um significado mais importante."

Observei aqui uma ocorrência de contraposição, pois enquanto que na oração alfa ele considera estes estudos 'atrozmente feios e ruins', na oração beta eles são 'os únicos que me parecem ter um significado mais importante.' Estes sentidos atribuidos para os quadros, em uma mesma oração, representam significados bastante divergentes, senão conflituosos, pois van Gogh está falando que são feios e ruins para ele, ou seja, para os padrões estéticos dele, não para os padrões convencionais. Enquanto ele considera esses quadros 'atrozmente feios e ruins' no seu critério, ele os considera 'os únicos a terem um significado mais importante' na sua avaliação. Por estar partindo de seu próprio julgamento, ele de fato está colocando juntos dois juízos valorativos senão opostos e paradoxais, pelo menos muito díspares. A forma como o complexo oracional foi organizado revela que mais um construto de conflito e antítese compatível com a narrativa visual da tela. ${ }^{279}$

Observei também a ocorrência de enquadramento, uma vez que o sentido principal está colocado na oração Beta. Esta ocorrência de deslocamento do sentido mais importante para a oração hipotáxica é compatível com o uso da ênfase no segundo plano da tela, e apresenta um uso recorrente nas telas e orações analisadas. O complexo oracional apresenta uma perspectiva com a qual van Gogh olha para os seus estudos, não pela beleza, já que para ele, são atrozmente feios e ruins, mas pela importância de seu significado. A oração indica que van Gogh descobriu a função discursiva desses estudos ao articular seu conflito na carta, ao explicitar sua divisão com a qual ele lidava em sua concepção das telas. Ele precisou partir de um ponto de vista no qual ele considera os estudos atrozmente feios e ruins e talvez por isso, inaceitáveis, e chegar a um outro ponto de vista no qual os estudos são os únicos a terem

\footnotetext{
${ }^{279}$ Uso de Contraposição e Conflito no nível semântico, nos sentidos expressos na oração, que é compatível com a ocorrência da representação visual de conflito por meio de constrastes cromáticos.
} 
um significado mais importante. Esse significado é infundido por seu diálogo com Dostoiewski. $^{280}$

Com a escolha do termo 'únicos' para a exclusão de todos os outros estudos, van Gogh não deixa dúvidas para o irmão sobre o nível de importância discursiva que estas telas têm para ele. Ele não está preocupado com a sua beleza, mas com o sentido que elas guardam.

Para compreender o discurso artístico de van Gogh foi necessário levar em conta a forma como ele via o mundo, a partir de seus ideais espirituais nos quais ora ele via a beleza da Natureza, e nela, seu Criador, ora ele via a degradação de um modo muito cru, de perda de sentidos, de perdição de si. É possível perceber essa postura muito presente na forma como ele representou o interior do Café na praça Lamartine. Enquanto as pessoas viam um café - e isso fica muito patente com a representação do interior do mesmo café feita por seu colega Gauguin - van Gogh via tudo no grau extremo em que ele experienciava o mundo, porque ele vivia a partir do seu ideal espiritual. Van Gogh se interessa pelo mundo, pelos sentidos do mundo para fazer um sentido da experiência, ele tinha uma necessidade de expresssar e de propagar um sentido da espiritualidade que ele experienciava internamente. Por isso ele menciona a leitura de Dostoievsky em conexão com a sua pintura do interior do café da praça Lamartine. Porque seu sentido espiritual era de uma profundidade tão intensa para experienciar a existência, que era dificil encontrar um equivalente nas interações cotidianas e casuais, mas era como uma explosão de identificação quando ele reconhecia a expressão desta experiência em outro artista.

Ele busca expressar essa espiritualidade e encontra, em alguns artistas os sentidos e as formas de expressão pelas quais ele reconhece esses valores e ideais. Parece que resgata em Dostoiweviski e em pessoas em que ele reconhece a expressão de seus valores. Isso o impulsiona para manifestar sua experiência de mundo na tela do interior do Café na praça Lamartine. Imediatamente, e movido por esta identificação, ele pinta o Café Lamartine.

\subsubsection{Extrato $n^{\circ} 4 e$}

Carta 678 - Br. 1990: 681 | CL: W7 - From: Vincent To: Willemien van Gogh Date: Arles, Sunday, 9 and about Friday, 14 September 1888.

http://vangoghletters.org/vg/letters/let678/letter.html

\section{Linhas 39-47 Café Lamartine}

\footnotetext{
${ }^{280}$ Observei o uso de Enquadramento no nível gramatical e no uso de Perspectiva no nível semântico da construção do complexo oracional que é compatível com a perspectiva visual com a qual ele representa $\mathrm{O}$ café da Noite.
} 
"Eu acabei de terminar uma tela que representa um interior de café à noite iluminado por lâmpadas. Alguns pobres vagabundos noturnos estão dormindo em um canto. A sala está pintada de vermelho, e no interior, na luz a gás, a mesa de bilhar verde, a qual lança uma imensa sombra sobre o chão. Nesta tela, há 6 ou 7 vermelhos diferentes, desde vermelho-sangue até rosa delicado, fazendo oposição com o mesmo número de verdes pálidos ou escuros."

Eu acabei de terminar uma tela que representa um interior de café à noite iluminado por lâmpadas.

\begin{tabular}{|l|l|l|}
\hline Eu & acabei de terminar & $\begin{array}{l}\text { uma tela [[que representa um interior de café à noite iluminado por } \\
\text { lâmpadas.]] }\end{array}$ \\
\hline Ator & Processo material criativo & Meta \\
\hline
\end{tabular}

\section{Interpretação}

Aqui, van Gogh não se refere ao universo representado na tela, mas talvez ao café que existe na realidade e que ele acabou de pintar. Isso pode explicar o posicionamento dele como o protagonista da oração, o uso do processo material 'acabei de terminar' e a forma como ele escreve que acabou de pintar 'uma tela que representa um interior de café à noite iluminado por lâmpadas.'

Nesta oração van Gogh inicia com o processo 'acabei de terminar' expressando seu posicionamento como ator da ação do processo material criativo que não tinha sido empregado por ele nos extratos anteriores. Ele acaba de terminar a tela e começa a escrita da carta. Inferi que o processo 'terminar' a tela está conectado com o processo de escrever a carta, ambos materiais, que reforçam o protagonismo de van Gogh na narrativa. Embora o segundo processo não esteja representado na oração eles parecem interligados. Estes processos podem revelar elementos de proximidade entre a produção pictórica e a produção da carta ao irmão com a continuação de uma produção discursiva alternada que constrói uma cadeia de textos interconectada. Os primeiros elementos que van Gogh enfatiza na descrição do quadro são o espaço 'interior de café' e a localização temporal 'noite', mas que não é escuro, e sim 'iluminado por lâmpadas'.

No texto original em francês não há vírgula, não há pausa, tudo está interligado e o que anteriormente está sendo descrito, o café, está completamente iluminado por lâmpadas. Nesta oração notei uma nova forma de construção: não há vírgulas, não há modalizadores, 
não há conectivos nem relações lógico-semânticas. Ele é o sujeito da ação, e a única ênfase que notei está no processo ‘acabei de terminar' que duplica o sentido de 'fim' com as escolhas 'acabei' e 'terminar'. ${ }^{281}$ Para van Gogh esta tela está pronta. Ele se refere ao trabalho com a escolha lexical 'tela', não estudo, não um mundo representado, que existe em sua idealização.

Talvez por isso, observei a mudança na construção da narrativa, na qual ele assume o protagonismo e não descreve mais a tela por meio de um processo relacional atributivo como aconteceu anteriormente. O processo de concepção está findo. Ele se refere a uma tela material, não mais ao universo representado no qual ele ainda se encontra elaborando uma experiência que ele vivencia enquanto cria.

Alguns pobres vagabundos da noite estão dormindo em um canto.

\begin{tabular}{|l|l|l|}
\hline Alguns pobres vagabundos da noite & estão dormindo & em um canto. \\
\hline Comportante & Proc. Comportamental & Circunstância de Localização: Lugar \\
\hline
\end{tabular}

\section{Interpretação}

Nesta oração van Gogh utiliza o processo comportamental para descrever a ação de 'alguns pobres vagabundos da noite', um complexo nominal que descreve as características do comportante. Ele escolhe o termo lexical 'alguns' cuja indefinição deixa implícito que a quantidade não importa, eles representam uma categoria que implica uma condição, e é esta condição que van Gogh procura representar no quadro, a de se estar dormindo em um café, a de se estar em um canto, a de se ser 'pobre vagabundo da noite' que dorme em um café que abre a noite toda. 'Pobre vagabundo' é uma síntese de uma condição, e ser 'pobre' ganha aqui uma gama de significações: pobre no sentido econômico, social, emocional e espiritual, ou ainda, no sentido de despertar pena e compaixão e 'vagabundo' porque não trabalha, seja porque não tem trabalho, seja porque não tem condições para trabalhar. ${ }^{282}$

$\mathrm{Na}$ oração, esses 'pobres vagabundos da noite' estão em um canto, acomodados, inertes, dormindo, mas também encostados, esquecidos, abandonados. O processo que os caracteriza 'dormindo' é um tipo de inação e é desde esse lugar de imobilidade que eles participam da ação, ou melhor, que eles protagonizam a ação. Este processo tem muito a dizer sobre a participação dos comportantes na representação do interior do café, e se esse café

\footnotetext{
${ }^{281}$ Uso de Aguçamento, Saliência e Vetor na construção 'Acabei de terminar uma tela.'

${ }^{282}$ Seria importante investigar o significado de vagabundo naquele tempo e para van Gogh, bem como observar se ele usa esse termo outras vezes nas cartas e em que contexto, essa investigação sobre o contexto do uso do item lexical 'vagabundo' deixamos para uma pesquisa adicional sobre o sentido, então vigente, usado para vagabundo, que pode ser diferente do sentido usado atualmente.
} 
simboliza uma dimensão humana e social, então temos um estatuto muito forte nesta oração e nesta tela, pois se refere a pessoas que protagonizam a ação da tela com a sua inação. ${ }^{283}$

A sala está pintada de vermelho, e no interior, na luz a gás, a mesa de bilhar verde, a qual lança uma imensa sombra sobre o chão.

\begin{tabular}{|l|l|l|l|}
\hline A sala & está pintada & $\begin{array}{l}\text { de vermelho } \\
\text { // }\end{array}$ & e no interior, na luz a gás, \\
\hline Portador & Proc. Relacional Atributivo & Atributo & Circunstância de Localização: lugar \\
\hline
\end{tabular}

\begin{tabular}{|l|l|l|l|}
\hline a mesa de bilhar verde, & $/ /$ a qual & lança & $\begin{array}{l}\text { uma imensa sombra sobre o } \\
\text { chão. }\end{array}$ \\
\hline Ator & Ator & $\begin{array}{l}\text { Proc. material } \\
\text { transformativo }\end{array}$ & Meta \\
\hline
\end{tabular}

$1+2(\alpha \times \beta)$

1 - A sala está pintada de vermelho,

2 - e no interior, na luz a gás, a mesa de bilhar verde, a qual lança uma imensa sombra sobre o chão.

\section{Interpretação}

$\mathrm{Na}$ oração iniciadora 'A sala está pintada de vermelho' a escolha léxico-gramatical enfatiza o vermelho, como o atributo da sala representada na tela. Por ser mencionado sozinho na oração iniciadora, este atributo recebe ênfase e sugere que 'vermelho' tem um significado muito importante para a representação de van Gogh da sala. Ou seja, o vermelho adquiriu uma nova camada metafórica de sentido além da camada descritiva. ${ }^{284}$

Neste complexo paratáxico van Gogh volta a escrever na voz passiva que sugere uma ambiguidade em seu posicionamento para descrever a tela e também na forma impessoal ou distanciada para narrar a representação do café. ${ }^{285}$

$\mathrm{O}$ posicionamento dele na oração anterior 'Eu acabei de terminar uma tela que representa um interior de café à noite iluminado por lâmpadas.' não se mantém nesta. Por exemplo, ele não escreve, pintei a sala de vermelho, mas 'a sala está pintada de vermelho'. Por que ao descrever a sala ele não se coloca como ator no processo material de tê-la pintado?

\footnotetext{
${ }^{283}$ Uso do significante oposto ao significado para construir o sentido. Aqui vemos mais um construto oracional e também na tela no qual o sentido ‘ação' e 'protagonismo' é construído pela 'inação' e pela não participação da ação.

${ }^{284}$ Uso da Saliência - na oração paratática, ele descreve a sala como pintada de vermelho, e ao não mencionar as outras cores que também estão na representação da sala que ele descreve no texto ele produz uma saliência para a cor vermelha da sala.

${ }^{285}$ Mudança na perspectiva e no foco com a qual van Gogh narra, textualmente, a cena do café. Ele volta a tornar a sala representada, o agente da ação na oração.
} 
Ela já existe. Já é um ente independente dele. É como se ele nos dissesse, não importa quem pintou, ela já está lá e agora ele nos remete para dentro da sala.

Ao contrário das lâmpadas que dominam o ambiente ou dos pobres vagabundos que estão isolados em um canto, o vermelho das paredes interage com outros elementos da tela, e interage no sentido de estar dentro do processo, talvez como o elemento que interliga e dá unidade a ele. Os pobres vagabundos e as lâmpadas ele descreve como elementos presentes na tela, mas no momento de descrever a sala, a sala é o ambiente da tela. É ela que dá esse contimento, é ela que delimita, e isso acontece tanto na tela quanto na escrita da descrição da tela. O vermelho das paredes serve como uma espécie de contimento do todo da tela e por isso, provavelmente, van Gogh dá um protagonismo para o vermelho da sala no momento de descrever o quadro na carta. ${ }^{286}$

$\mathrm{Na}$ oração continuadora 'e no interior, na luz a gás, a mesa de bilhar verde, a qual lança uma imensa sombra sobre o chão’ ele descreve a mesa de bilhar como sendo o participante protagonista do processo material 'lança'. A circunstância de localização ' e no interior, na luz a gás' confere ênfase para a mesa, porque é uma circunstância muito detalhada, a mesa está no interior e está na luz a gás. O complexo nominal 'uma imensa sombra sobre o chão' mostra uma 'saliência' pelo uso de 'imensa', sugerindo que tanto a mesa quanto a sombra que ela lança sobre o chão têm um significado importante para van Gogh nessa representação escrita do café. Esta organização gramatical confere destaque para a mesa e a sombra por ela projetada está compatível com a organização visual da tela que confere destaque para a mesa e sua sombra por meio de diferentes recursos tais como o posicionamento, a distorção e o contorno dado pelo desenho-pintura. ${ }^{287}$

Na sala há uma 'imensa sombra' sendo lançada pela mesa de bilhar como se esta fosse o protagonista de uma ação, mas também está assujeitada pela ação da lâmpada a gás. A ação sobre um objeto pode ter efeitos que são desproporcionais. Esse clima de desequilíbrio já havia começado a ser descrito na oração anterior, mas era um desequelíbrio controlado, no canto, agora a representação do desequilíbrio está no centro e representado em uma dimensão

\footnotetext{
${ }^{286}$ Uso de Rima Visual - Van Gogh descreve a sala como sendo vermelha porque o vermelho confere unidade para a narrativa. Ele atribui para o vermelho essa função de interligar os demais elementos da composição que ele narra na carta.

${ }^{287}$ Uso de saliência na oração 'e no interior, na luz a gás, a mesa de bilhar verde, a qual lança uma imensa sombra sobre o chão.' A saliência é construída pela circunstância 'e no interior, na luz a gás' e pelo complexo nominal 'imensa sombra'. A ocorrência de saliência textual está compatível com a ocorrência de saliência visual, ambas constroem o mesmo sentido de ênfase pela desproporção.
} 
'imensa'. Ou seja, alguns participantes na representação estão sob controle, outros reagem sob o efeito da luz das lâmpadas de maneira desproporcional. ${ }^{288}$

E como estes vagabundos ainda conseguem dormir com uma luz e uma sombra imensa no centro da sala? Por que uma luz tão intensa? O chão apaziguado recebe esta sombra e a sustenta. A ação começa no alto da tela, nas lâmpadas a gás, recaem sobre a mesa de bilhar que recebe a ação e produz um efeito que é lançado ao chão, que recebe esta imensa sombra e a sustenta. $^{289}$

Com esta oração, van Gogh já nos conduz para o 'interior' da sala, na qual a 'mesa de bilhar' ao mesmo tempo em que está sob a 'luz a gás', também 'lança uma imensa sombra sobre o chão'. A mesa de bilhar parece constituir um elemento mediador que recebe a luz a gás do alto e projeta uma sombra no chão sugerindo que a mesa de bilhar exerce uma função mediadora entre dualidades tais como a luz e a sombra, e o lugar passivo e o ativo no protagonismo da cena. Se há significados simbólicos para luz e sombra, o significado de mesa nesse sistema semiótico seria exatamente aquele de uma instância que transforma a luz em sombra, e uma sombra enorme. A transformação da luz em sombra pode ser metafóricamente falando a materialização no texto visual e aqui nesta oração, o sentido contido na oração anterior ' $\mathrm{Na}$ minha pintura do café a noite eu procurei exprimir que o café é um lugar onde voce pode arruinar-se, enlouquecer, cometer crimes.' Neste sistema semiótico 'luz a gás', 'mesa de bilhar', 'imensa sombra no chão' observei que van Gogh usou de associações metafóricas da luz, que pode ser construída como a luz do espírito, ou a luz do progresso industrial. Essa luz que emana de um advento tecnológico, novo para a época, que ao recair sobre um objeto que representa tanto a diversão quanto o vício, lança sobre o chão, que representaria uma dimensão estável, uma sombra imensa, desproporcional e que, ao ser enfatizada na oração, pode estar significando um desequilíbrio em relação a outros participantes na ação que ocorre na tela. Assim como as lâmpadas a gás, a mesa de bilhar em si não representa algo bom ou ruim, mas o efeito delas pode ser desequilibrante. Esse efeito é dado por qual participante efetivamente? Van Gogh escolhe um processo que enfatiza a projeção como uma ação entre participantes, e nesta frase os participantes estão conectados por relações de causa e efeito que resulta em um desequilíbrio, sugerindo, nesta oração, que é

\footnotetext{
${ }^{288}$ Uso de distorção tanto na escrita quanto na tela: com a escolha do item lexical 'imensa' na oração 'a qual lança uma imensa sombra sobre o chão.' observei a ocorrência de distorção que é compatível com a distorção da sombra representada no quadro.

${ }^{289}$ Uso de direção ou Vetor no construto: 'mesa de bilhar, a qual lança uma imensa sombra sobre o chão' que é compatível com a representação da imagem da mesa de bilhar e sua enorme sombra apontando para o primeiro plano. A sombra representa a consequência da ação da luz; a forma da sombra confirma o direcionamento dessa ação da luz sobre a mesa.
} 
a relação deles que é desequilibrada, pois os elementos 'mesa de bilhar' e 'lâmpada' não são desproporcionais e sim seu efeito, uma imensa sombra. ${ }^{290}$

Embora na oração van Gogh enfatize a desproporção da sombra, observei que na pintura, os participantes 'lâmpada a gás' e 'mesa de bilhar' carregam em si desproporções que não se referem à sua dimensão, como é o caso da sombra, que é desproporcional nas suas dimensões e a luz que delas emana que é excessiva. Na tela, o desequilíbrio próprio da mesa de bilhar é enfatizado por van Gogh pelas pernas instáveis. Esse desequilíbrio não aparece como causa do desequilíbrio representado pela sombra. Esta oração 'A sala está pintada de vermelho, e no interior, na luz a gás, a mesa de bilhar verde, a qual lança uma imensa sombra sobre o chão.' também demonstra que as pernas não são a causa do desequilíbrio representado pela sombra. Ou seja, a relação de desequilíbrio entre os objetos não é mecânica ou simplista. $\mathrm{Na}$ tela, há na mesa de bilhar um desequilíbrio de base, representado pela forma como foram pintadas as suas pernas, que não produzem a sombra, mas produzem instabilidade para a mesa, assim como a desproporção das lâmpadas a gás não se referem a sua dimensão espacial, mas a intensidade da sua luz que emanam delas, que é excessiva. Uma intensidade que em si não produziria uma sombra desproporcional em suas dimensões, apenas em sua tonalidade, mas que a explicita, dando a essa desproporção uma intensidade maior. Por isso, a oração e a tela parecem enfatizar a relação entre os participantes e não sua presença em si isoladamente. $^{291}$

T - A descrição tem um tom dramático: a 'imensa sombra' nos dá uma descrição clara do que efetivamente ocorre na tela. Há um espaço 'imenso' ocupado pela sombra da mesa de bilhar. Van Gogh descreve o efeito com o qual produziu a sombra e explicita sua intencionalidade em produzir um elemento desproporcional na pintura. Por isso essa desproporcionalidade, essa distorção deve ser observada como um item semiótico com um significado indexado associado a ele. Um dos significados possíveis poderia ser o de que a desproporção e o desequilíbrio representam a perda de controle, a perda de sentido, e o lado sombrio da natureza humana. ${ }^{292}$

\footnotetext{
${ }^{290}$ Uso de Simbolismo nas temáticas e narrativas - na oração 'e no interior, na luz a gás, a mesa de bilhar verde, a qual lança uma imensa sombra sobre o chão.', observei a ocorrência de simbolismo na escolha do item lexical 'mesa de bilhar verde' com base na ocorrência de aguçamento e ênfase para a forma como a sua ação está representada. Esta ocorrência é compatível com a representação visual da mesa de bilhar na tela, que também foi representada com ênfase por meio de distorção, textura e desenho-pintura para aguçar o seu sentido simbólico.

${ }^{291}$ Ocorrência de Relação entre os participantes tanto na oração escrita quanto na tela.

${ }^{292}$ Uso de distorção do ponto de vista e do enquadramento. A escolha do item lexical 'imensa' denota um uso desproporcional de um atributo 'imensa' para sombra, que não está compatível com os outros atributos usados para 'vermelha' ou 'luz' por exemplo, representados na mesma oração. Essa representação desproporcional da sombra na oração também ocorre na tela, cuja sombra da mesa ocupa uma grande área no primeiro plano da tela,
} 
T - A relação de causa e efeito e a simetria de ações entre as lâmpadas, a mesa e o chão está descrita na carta de forma direta e simples, mas também intensa, com itens lexicais tanto carregados de sentido concreto quanto de sentido simbólico pelo uso de 'interior', 'lança' e 'imensa'. Poderia-se sugerir que são itens que guardam um sentido emocional, cuja carga afetiva está presente tanto no quadro quanto no discurso da carta. Talvez o uso de ênfase na oração, possa indicar o uso de metáforas visuais na tela, como parece ser este o caso. Será preciso observar em outras orações quando o uso de ênfase na oração é um indicador do uso de associações metafóricas ou de itens deliberadamente simbólicos que van Gogh implicitava em sua linguagem escrita por meio de recursos de ênfase e comparações ou contraposições. Nas orações ele não explicitava os itens simbólicos em suas telas, nem mesmo para o irmão que era seu mais próximo e amiúde interlocutor porque sendo um signatário do movimento cloisonista ele valorizava manter o sentido latente e evitava obviedade em sua expressão. No entanto, mesmo cuidando para não entregar o sentido implícito em suas telas, inferi que ao escrever suas cartas ele deixava marcas de sua presença na forma como ele construía a oração e nas escolhas léxico-gramaticais e léxico-semânticas que nos possibilitam resgatar as escolhas que van Gogh fazia tanto para conceber a visualidade em tela, quanto para construir suas orações. Ou seja, as escolhas léxico-gramaticais e léxico-semânticas que van Gogh fazia ao construir as orações deixam à vista como ele via a tela, seus elementos constituintes, suas relações; como ele se via em relação à tela, e quais aspectos da representação eram mais importantes para ele. Cito como exemplo este complexo oracional ora analisado: 'A sala está pintada de vermelho, e no interior, na luz a gás, a mesa de bilhar verde, a qual lança uma imensa sombra sobre o chão', no qual a escolha da ênfase 'imensa' para a sombra que a mesa de bilhar lança produziu nesta análise a chave para compreender a função simbólica da mesa dentro de um sistema semiótico proposto por van Gogh nesta tela. Esta ênfase na oração se tornou um indexador para confirmar a intensionalidade na produção de um desequilíbrio na tela para construir uma associação metafórica para o sentido da sombra. ${ }^{293}$

Nesta tela, há 6 ou 7 vermelhos diferentes, desde vermelho-sangue até rosa delicado, fazendo oposição com o mesmo número de verdes pálidos ou escuros.

\begin{tabular}{|l|l|l|l|l|}
\hline Nesta tela, & há & $\begin{array}{l}6 \text { ou } 7 \text { vermelhos diferentes, } \\
\text { desde vermelho-sangue até rosa }\end{array}$ & $\begin{array}{l}\text { fazendo oposição com o mesmo } \\
\text { número de verdes pálidos ou escuros. }\end{array}$ \\
\hline
\end{tabular}

denotando sua centralidade e importância na narrativa. A distorção da representação da sombra na oração é análoga à distorção da sombra na narrativa visual.

${ }^{293}$ Uso de associações metafóricas para os itens lexicais 'interior', 'lança' e 'imensa' que sugerem uma condensação de sentidos que está presente como vetor tanto na tela quanto na carta. 


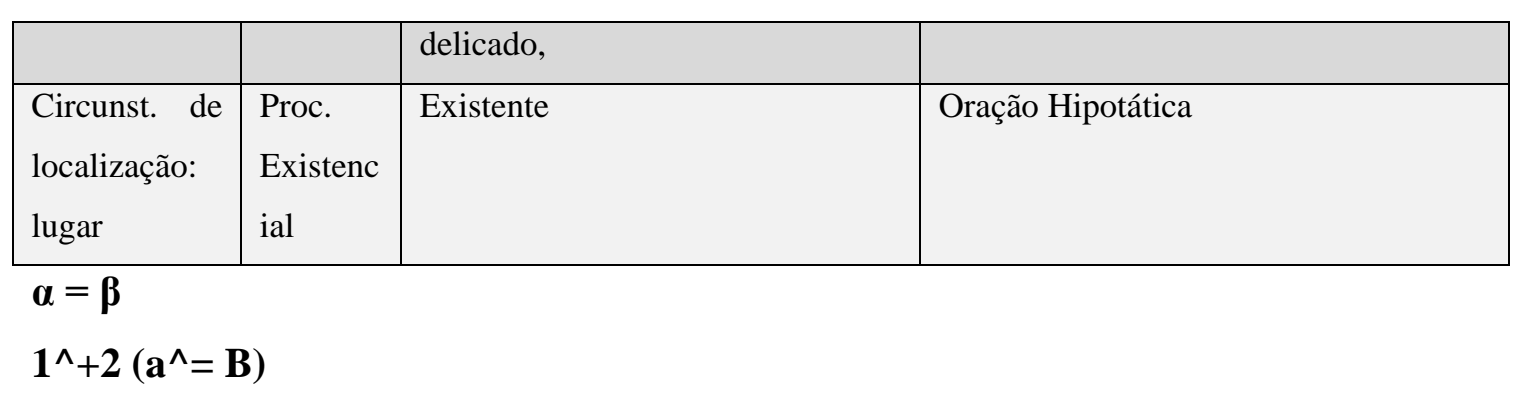

ALFA - Nesta tela, há 6 ou 7 vermelhos diferentes, desde vermelho-sangue até rosa delicado, = BETA (não finita) - II fazendo oposição com o mesmo número de verdes pálidos ou escuros. (oração hipotática por elaboração).

Nesta oração 'Nesta tela, há 6 ou 7 vermelhos diferentes, desde vermelho-sangue até rosa delicado, fazendo oposição com o mesmo número de verdes pálidos ou escuros.', van Gogh utiliza o processo existencial para descrever as cores e seus contrastes na tela. Nela, ele se concentra em fazer unicamente uma descrição geral do uso das cores o que indica a importância que as cores, e suas relações internas, têm para ele nessa tela.

Com a relação lexical, ele narra as cores na tela com uma alta concentração de diferentes tonalidades de vermelhos e verdes. $\mathrm{O}$ uso do contraste entre os vermelhos e os verdes em graus tão diversos seria um recurso não convencional de usar o contraste complementar, e que, portanto, propõem um novo sistema de escolhas para a produção de um efeito pictórico.

A escolha lexical ' 6 ou 7 vermelhos diferentes, desde vermelho-sangue até rosa delicado, fazendo oposição com o mesmo número de verdes pálidos ou escuros' caracteriza o interior do café, ao contrário da oração anterior na qual apenas o vermelho descrevia o interior do café, indicando que esta não é uma sala apenas vermelha, mas com outras tonalidades de cores. Talvez na oração anterior ele descreveu a sala como 'pintada de vermelho' para enfatizar a importância semiótica da cor vermelha para o sentido que ele intencionou construir na composição da tela. Nesta oração 'Nesta tela, há 6 ou 7 vermelhos diferentes, desde vermelho-sangue até rosa delicado, fazendo oposição com o mesmo número de verdes pálidos ou escuros' a ênfase recai na relação entre as cores, que é de oposição. Esta ênfase no uso de contrastes cromáticos está presente tanto na produção pictórica, dada pelos contrastes cromáticos da tela, quanto na oração escrita, construída pela escolha lexical de 'fazendo oposição'. Pela escrita ele constrói uma visualidade, com a ajuda da coesão lexical, que 
permite ao interlocutor ver as cores que na tela são representadas por vetores ou pelos contrastes complementares. $^{294}$

T - Na oração 'Nesta tela, há 6 ou 7 vermelhos diferentes, desde vermelho-sangue até rosa delicado, fazendo oposição com o mesmo número de verdes pálidos ou escuros’ van Gogh enfatiza o contraste entre as cores vermelho e verde; e explica mais detalhadamente a sala ao descrever a relação lexical entre diversos tons de vermelhos e verdes em uma escala que vai do mais claro ao mais escuro. Aqui a ênfase não são as cores, como na oração anterior, mas $a$ relação entre elas. Esta oposição é dada no discurso da carta pelo item lexical 'fazendo uma oposição' e sugere mais uma metáfora para a relação de oposição que há entre os vermelhos e os verdes, produzindo uma semiose para o contraste complementar vermelho/verde fortemente presente tanto na oração quanto na tela. Por meio de um processo 'fazendo oposição', van Gogh produz no texto da carta uma associação simbólica para o uso das cores contrastantes, construindo assim uma visualidade por meio da coesão lexical entre participantes presentes na oração. Com esta descrição, van Gogh permite ao interlocutor visualizar o efeito das cores na tela, valorizando aspectos que são representados na produção pictórica no sentido simbólico que resultam: oposições e conflitos. ${ }^{295}$

A escolha lexical 'fazendo uma oposição' também denota fortemente a presença de um vetor no qual a ênfase está na ação que ocorre entre as cores que fazem oposição umas às outras. Essa escolha mostra uma direção para a ação, que está focada, aprisionada no embate, e que direciona o movimento para a cor a qual ela faz oposição. O vetor desta oposição ocorre tanto na oração quanto na tela na qual, visualmente, presencia-se a força da oposição que há no contraste entre os verdes e os vermelhos. ${ }^{296}$

\subsubsection{Conclusão da análise textual da tela O Café Noturno na Place Lamartine, em Arles}

\footnotetext{
${ }^{294}$ Uso de contrastes cromáticos. Esta ênfase no uso de contrastes cromáticos está presente tanto na produção pictórica, dada pelos contrastes cromáticos da tela, quanto na oração escrita, construída pela escolha lexical de 'fazendo oposição'.

${ }^{295}$ Uso de associações metafóricas. Van Gogh usou a oposição entre as cores vermelho e verde para significar uma nova camada de sentido, o conflito que há nas 'terríveis paixões humanas'. Com a escolha lexical 'fazendo uma oposição’ que constrói na oração um sentido simbólico que ele deseja indexar ao sentido já existente que é o contraste entre essas cores. Esse sentido simbólico ele também indexa na narrativa visual por meio da escolha lexical 'batalhas e antíteses' presente em outra oração para se referir aos contrastes entre verdes e vermelhos. A associação metafórica de 'fazendo uma oposição' é uma ocorrência evidenciada tanto na oração quanto na tela.

${ }^{296}$ Uso de vetor com a escolha lexical 'fazendo oposição' na oração, na qual o movimento está aprisionado nesta ação, e na tela, na qual o movimento está no contraste entre o vermelho e o verde.
} 
No encadeamento das orações, observei que van Gogh ora se refere à tela, ora se refere ao universo representado dentro da tela. Por exemplo, ele escreve 'acabei de terminar uma tela com o interior de um café'; na próxima oração, escreve: 'a sala está pintada de vermelho'; e na seguinte: 'nesta tela há 6 ou 7 vermelhos diferentes'. Ou seja, na primeira oração ele usa o item 'tela', na segunda o item 'sala' e na terceira o item 'tela' de novo, indicando uma alternância entre uma instância que é a tela enquanto obra e outra, que é do domínio do universo que está representado dentro da tela. ${ }^{297}$

Para investigar esta dinâmica entre a instância na qual ocorre o protagonismo na oração será preciso verificar que elementos na tela situam o espectador dentro da cena e que elementos o situam fora da cena. Essas instâncias podem indicar diferentes níveis de experiência de van Gogh na relação com a obra, e que são revelados na forma como a oração foi construída. Ele está usando recursos discursivos de aproximação e entrada na tela e distanciamento e saída da tela. ${ }^{298}$

Inferi que há na produção desta tela uma dinâmica pautada por oposições, conflitos, vínculos e rupturas. Ao descrever a tela, van Gogh ressaltou alguns participantes, alguns elementos pictóricos e não outros. No entanto percebi que existem elementos na tela que levam o leitor para dentro da tela e outros elementos que levam o espectador para fora da tela. Estes elementos não foram descritos por van Gogh neste trecho da carta, mas podem estar tendo a mesma dinâmica e a mesma estrutura. Por exemplo, quando ele fala do vermelho ele não fala do vermelho sempre do ponto de vista de dentro da tela, ele também fala do vermelho de forma distanciada como parte da tela. Quando fala da mesa de bilhar desde o ponto de vista do interior do café, a sombra da mesa de bilhar, no entanto, se projeta para fora da tela em direção ao espectador, fazendo essa função de distanciamento.

Não há uma relação mecânica na função de oposição e distanciamento. A função existe tanto no discurso quanto na tela. Isso é uma manifestação do próprio temperamento de van Gogh, ele não via a vida, as pessoas, a natureza humana de uma maneira simplista ou dicotômica. Ele tentava ver essas características interrelacionadas. A pintura é tão dinâmica que ele não cria pontos de estagnação, não existem pontos de rigidez, está tudo interligado e dinâmico. Em outro extrato ele fala que o senhorio não é ruim,... sugerindo que há uma dificuldade de definir, ele não se sentia no lugar de alguém que está julgando, definindo, etc.

\footnotetext{
${ }^{297}$ Uso de Enquadramento e de Perspectiva. Ao mudar o agente em cada oração, ele faz um deslocamente no enquadramento com que ele enfoca o assunto que ele está descrevendo, a representação da tela.

${ }^{298}$ Uso de aproximação e distanciamento da tela ocorre tanto na escrita quanto na tela.
} 
O sentido que van Gogh constrói parece ser dado ora pelos participantes ora pelos elementos pictóricos, ora pela relação entre estes, e embora ele possa empregar esses mesmos recursos tanto nas telas quanto nas cartas ao descrever as telas, talvez ele não os use nas cartas com a mesma função que usou nas telas.

T - O sentido geral dessa tela é criar oposições e uma das oposições é dentro e fora. Isso tem um valor semântico muito grande, porque ora ele fala como um protagonista na oração, ora ele coloca a tela e ora ele coloca a sala como protagonista. Há uma dinâmica entre fora e dentro da tela que entendi como um limiar discursivo no qual ele transita e constrói diferentes significados para diferentes universos representados. Inferi que há uma diferença entre descrever a tela e descrever a cena representada na tela e ocorre em alternância no discurso escrito de van Gogh. Ao mesmo tempo em que as ideias estão separadas por sentenças, há um compartilhamento de sentidos pelos participantes nas orações, como por exemplo, as oposições entre cores e entre figuras. A sala estar pintada de vermelho, a tela pintada em vermelho e verde, a luz do café, o intenso vermelho guardam relações entre si nas orações e o elemento de ligação, de coesão entre as orações é semântico; é o sentido que está compartilhado entre elas. Assim ele, ao falar 'acabei de terminar uma tela' inicia a oração seguinte descrevendo 'pobres vagabundos estão dormindo' no segundo exemplo ele escreve 'a sala está pintada de vermelho' e em seguida 'nesta tela há 6 ou 7 vermelhos'. As ênfases recaem ora nas figuras: como a sala, os pobres vagabundos, a mesa, as lâmpadas representadas no café, ora nos elementos pictóricos, que dão conteúdo a estas figuras: como cor, sombra, contraste, intensidade. $\underline{O}$ encadeamento das orações sugere que há uma construção de significado por meio de associações metafóricas entre forma e conteúdo, que guardam simbolismos que são intencionalmente articulados pelo autor, tanto na carta quanto $\underline{\text { na tela. }}$

Desta forma, van Gogh fez algumas orações descrevendo participantes no interior do café e assim destacou alguns mais relevantes neste momento. Posso afirmar que no encadeamento de orações nesse trecho do extrato há, em termos de relevância, uma descrição gradual da tela, que inicia pelos elementos pictóricos 'sala pintada de vermelho' passa para os figurativos 'pobres vagabundos' e volta aos pictóricos: '6 ou 7 vermelhos diferentes, desde vermelho-sangue até rosa delicado, II fazendo oposição com o mesmo número de verdes pálidos ou escuros'. Esta sequência sugere um enquadramento que vai aproximando o enfoque e levando para dentro da cena. ${ }^{299}$

\footnotetext{
${ }^{299}$ Observei o uso de enquadramento na estratégia retórica presente no encadeamento das orações.
} 
A descrição dos elementos pictóricos é complementar à descrição figurativa. Ele inicia a oração enfatizando 'nesta tela', ou seja, especialmente nesta, ele utilizou ' 6 ou 7 vermelhos diferentes' e em oposição a eles há 'o mesmo número de verdes pálidos ou escuros'. Os verdes estão fazendo oposição aos vermelhos enfatizando o sentido de um ambiente conflitante na tela. Ênfase também é dada pela ação da luz sobre a mesa e da mesa que lança sobre no chão uma sombra que conflita com a luz e reforça o sentido de oposição entre os vermelhos e os verdes, com a oposição entre o claro e o escuro. 


\section{CAPÍTULO 6 - DISCUSSÃO DOS RESULTADOS}

\section{CATEGORIAS GERAIS DA POÉTICA NA OBRA DE VAN GOGH}

Neste tópico disponho os resultados da análise visual a partir de uma recategorização de aspectos que foram encontrados na análise de uma ou mais telas. Nem todas as categorias são oriundas da Gramática do Design Visual de Kress e van Leeuwen (1996). Senti a falta de categorias que contemplassem aspectos intrínsecos à natureza do texto artístico e do texto pictórico que ainda não foram desenvolvidas nos estudos multimodais. Dessa forma, apropriei também algumas categorias da área das Artes e da Percepção Visual da Psicologia, apoiadas nos estudos de Arnheim (1974) e Dondis (2007). Outras categorias ainda, tais como Gesto Pictórico, Transparência, Inacabamento, Incompletude e Limiar Artístico são contribuições desta pesquisa para a área dos estudos multimodais. Elas contemplam uma camada de sentido mais implícita, porém não menos importante, que se encontra na urdidura do texto artístico. As categorias que surgiram a partir da contemplação dos resultados da análise visual dessa pesquisa foram agrupadas de acordo com recortes das bases teóricas que subsidiaram a análise:

1) categorias da GDV;

2) categorias das Artes e da Percepção Visual;

3) categorias limiares, propostas por esta pesquisa para contemplar o sistema semiótico criado por Van Gogh e podem auxiliar novas pesquisas do texto de arte.

Abaixo, defini as categorias encontradas, sua ocorrência no corpus visual, e a sua triangulação com as ocorrências no corpus textual.

Triangulação com notas de rodapé

Triangulação com notas de rodapé

\subsection{TEXTURA}

Por meio do uso do empasto, uma técnica pictórica que consiste na aplicação de grossas camadas de tinta na superfície da tela, van Gogh compreendeu o poder semiótico da textura. Ele fez dela uma aliada para explorar as fronteiras da linguagem visual em seu tempo 
deixando uma nova marca nas possibilidades de comunicação por meio da experiência sensorial proporcionada pelo uso da textura. O Modo como van Gogh usa a textura para construir o texto visual constitui uma das marcas que mais caracterizam a construção de sua poética. O uso da textura como uma categoria de análise constitui um Modo que concentra sua comunicação no campo de experiência mais sensorial. Na medida em que associou os recursos semióticos da textura com outros recursos semióticos tais como o ritmo, o movimento e a direção para construir resultados tais como a saliência, as associações metafóricas e a rima visual, Van Gogh usou a textura como um sistema semiótico com grande poder de comunicação. A textura na obra de Van Gogh desempenha um papel central para o envolvimento do espectador com a narrativa visual, com base no apelo para a memória sensorial do espectador, de sua experiência direta com o mundo. No uso conjugado com outros recursos semióticos tais como a cor, o ritmo, o movimento, o gesto pictórico, as associações metafóricas, por exemplo, van Gogh conseguiu produzir um poder sinestésico para a textura que confere novas possibilidades de sentidos construídos pela dissolução entre o visual e o táctil. O uso da textura como recurso semiótico para a criação de um discurso puramente visual não encontra paralelo ou transposição em outras formas discursivas porque traduz mais completamente e com maior liberdade e totalidade uma experiência do artista que é subjetiva e intransferível.

\section{Triangulação da Textura}

Textura, no texto escrito e em relação à triangulação - Na modalidade visual, textura é compreendida como uma experiência táctil de rugosidade ou aspereza que nos coloca em contato direto com a materialidade na obra. A textura em uma obra visual pode ser real, ou percebida visualmente, como por exemplo, o brilho acetinado das vestes ou aveludado das uvas em telas do período clássico. Van Gogh não usou a textura para replicar a realidade, mas como um calor em seu próprio direito, em sua beleza plástica para construir novas semioses. A textura é um importante recurso semiótico para a função modal, pois convida o espectador para uma relação sensorial e afetiva com a materialidade da obra, seu brilho, cintilância, contornos, volumes, aspereza, sensações que desperta. Além disso, a textura adiciona ênfase e pode ajudar a construir caminhos visuais dentro da composição, acrescentando uma carga expressiva para o trabalho feito pelos outros recursos visuais como a cor, o ritmo, o movimento, por exemplo. Na linguagem musical, muitos compreendem a textura como a materialidade do som, ou seja, as características que cada instrumento empresta ao som, 
dando a ele um temperamento pessoal e intransferível: o seu timbre. Os compositores trabalham com timbres combinados, para conseguir certas sonoridades e efeitos musicais destinados a envolver o ouvinte e a comunicar determinados estados de espírito por eles intencionados. Este é o caso da Sinfonia 'O Bolero', de Ravel que, por repetir tantas vezes a mesma melodia poderia ser percebida como aborrecida, mas não é, porque a cada recomeço do tema melódico, são totalmente novos os timbres utilizados. No caso do texto escrito, a textura pode ser compreendida pelas características mais materiais e sonoras do texto, pelo uso de recursos morfológicos e léxico-gramaticais para incrementar a carga semântica em uma oração, por meio da relação perceptiva, sensorial e semiótica causada pela força expressiva desse uso. Não se trata exatamente de identificar que recursos léxico-gramaticais expressam a textura nas orações, mas sim, como eles são usados para construir essa relação tátil e sensorial, enfatizando a materialidade sonora, do acento, da carga enfática ou lacônica na forma como a oração é construída. O uso desses recursos para construir textura na oração pode ser identificado a partir de um uso não convencional dos recursos textuais e que acrescentaram força expressiva e sensorial para o discurso textual, como segue o exemplo:

Quadro 17: Triangulação da Textura

\begin{tabular}{|c|c|c|}
\hline Ocorrência nas telas & Orações & Comentário \\
\hline $\begin{array}{l}\text { Na tela 'Por de Sol: Campo de } \\
\text { trigo perto de Arles', observei } \\
\text { a ocorrência de textura visual } \\
\text { conferida pelo gesto das } \\
\text { pinceladas no campo de trigo, } \\
\text { registrada nas notas de rodapé } \\
61 \text { e } 81 \text { no apêndice, na qual } \\
\text { observei que o gesto pictórico } \\
\text { produz textura, ritmo, } \\
\text { movimento e vetor para dar } \\
\text { ênfase para o campo de trigo. }\end{array}$ & $\begin{array}{l}\text { Aqui está outra paisagem. Sol } \\
\text { poente? Lua nascendo? Noite de } \\
\text { verão, de qualquer modo. Cidade } \\
\text { violeta, estrela amarela, céu azul- } \\
\text { esverdeado; os campos de trigo têm } \\
\text { todos os tons: ouro velho, cobre, } \\
\text { ouro verde, ouro vermelho, ouro } \\
\text { amarelo, verde, vermelho e amarelo } \\
\text { bronze. }\end{array}$ & $\begin{array}{l}\text { Neste complexo oracional observei a } \\
\text { ausência de processos em algumas } \\
\text { orações, que poderiam ser } \\
\text { desconsideradas como material de } \\
\text { análise. No entanto, sua função modal } \\
\text { na construção do sentido levou a } \\
\text { compreender que elas constroem um } \\
\text { tipo de textura no discurso, destinada a } \\
\text { causar uma relação sensorial do leitor } \\
\text { com o texto. }\end{array}$ \\
\hline $\begin{array}{l}\text { Na tela 'Por de Sol: Campo de } \\
\text { trigo perto de Arles', observei } \\
\text { a ocorrência de textura visual } \\
\text { conferida pelo gesto das } \\
\text { pinceladas no campo de trigo, } \\
\text { registrada na nota de rodapé } \\
81 \text { no apêndice na qual } \\
\text { observei que o gesto pictórico } \\
\text { produz textura, ritmo, } \\
\text { movimento e vetor para dar } \\
\text { ênfase para o campo de trigo. }\end{array}$ & $\begin{array}{l}\text { Eu tenho um terceiro estudo, agora, } \\
\text { de uma paisagem com fábrica, e um } \\
\text { enorme sol em um céu vermelho, } \\
\text { acima de telhados vermelhos, em } \\
\text { que a natureza parece estar em um } \\
\text { acesso de raiva, em um dia de } \\
\text { Mistral desagradável. } \\
\text { Van Gogh parece se referir à } \\
\text { sensação que sentiu ao pintar a tela } \\
\text { em um dia tão ventoso que foi } \\
\text { necessário amarrar o cavalete ao } \\
\text { chão. }\end{array}$ & $\begin{array}{l}\text { Na tela, as pinceladas deixaram marcas } \\
\text { que parecem a reprodução do trigo } \\
\text { balançando no vento, conferidas pela } \\
\text { textura plástica das pinceladas que } \\
\text { representam o trigo. A textura aparece } \\
\text { na oração com uma conotação } \\
\text { emocional de raiva. Na oração a } \\
\text { textura é construída pela escolha } \\
\text { lexical 'acesso de raiva' que, } \\
\text { visualmente é comunicada pelo } \\
\text { movimento direcional da pincelada } \\
\text { que vai da direita para a esquerda, } \\
\text { contrariando o sentido da nossa leitura } \\
\text { visual da tela que é da esquerda para } \\
\text { direita. Essa direção contrária }\end{array}$ \\
\hline
\end{tabular}




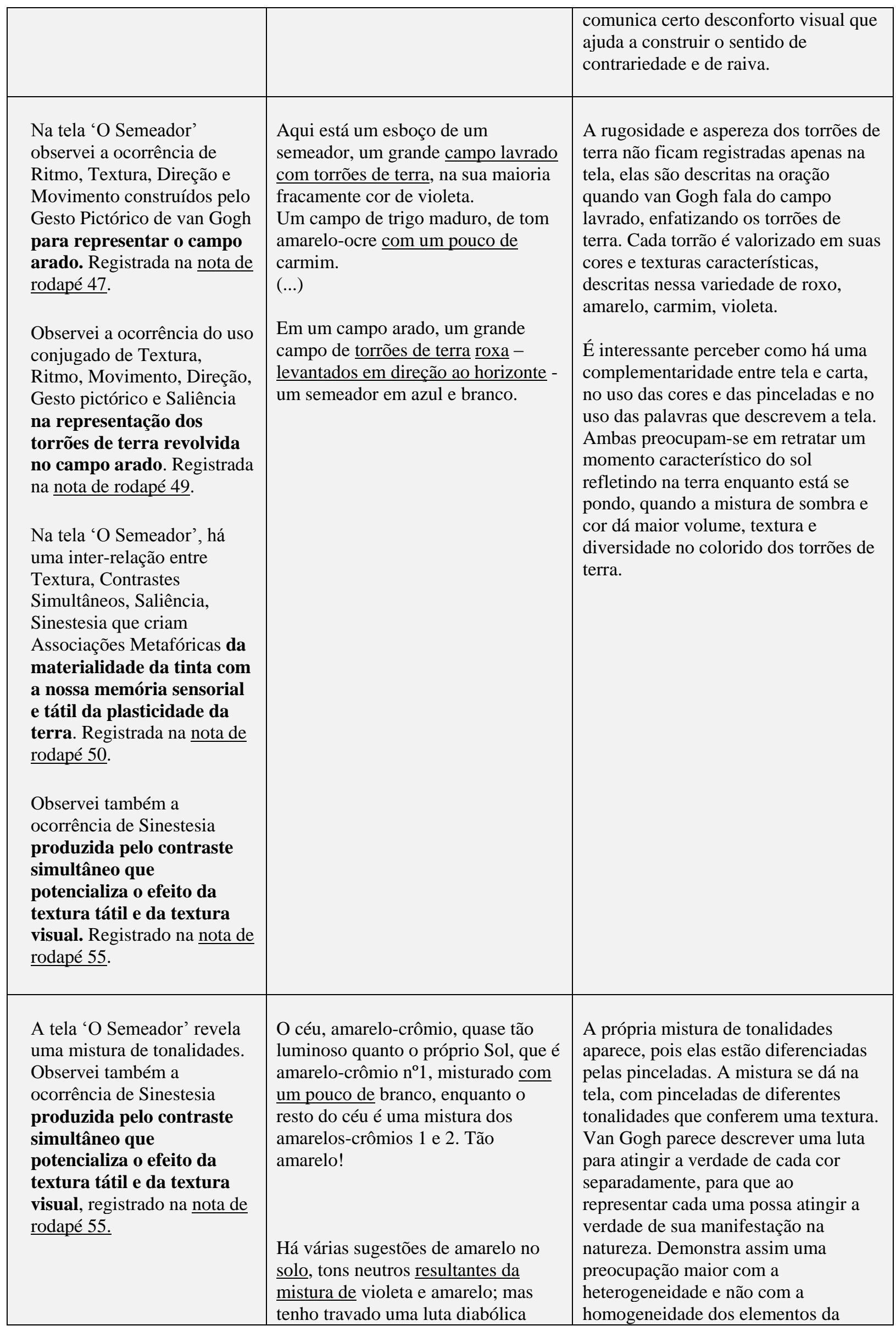




\begin{tabular}{|c|c|c|}
\hline & para atingir a verdade das cores. & $\begin{array}{l}\text { natureza. Ao contrário dos artistas do } \\
\text { passado, que tentavam construir a } \\
\text { unidade dos elementos por meio de } \\
\text { uma homogeneidade, ele constrói a } \\
\text { unidade pela heterogeneidade, nem } \\
\text { que para isso tenha que travar uma luta } \\
\text { diabólica com cores que a princípio } \\
\text { contrastam e não possibilitam essa } \\
\text { unidade facilmente. Nesta unidade } \\
\text { heterogênea vi representada a unidade } \\
\text { da natureza (interna e externa) da } \\
\text { experiência do artista com a natureza, } \\
\text { das cores da paleta com as cores da } \\
\text { natureza. }\end{array}$ \\
\hline $\begin{array}{l}\text { Na tela 'A Esplanada do } \\
\text { Café na Place du Forum, } \\
\text { Arles, à Noite', observei a } \\
\text { ocorrência e Inter-relação } \\
\text { entre Ritmo, Movimento, } \\
\text { Textura, Gesto Pictórico, } \\
\text { Desenho-Pintura para } \\
\text { construir a Perspectiva do } \\
\text { calçamento, registrados na } \\
\text { nota de rodapé } 126 \text { no } \\
\text { apêndice. }\end{array}$ & $\begin{array}{l}\text { A segunda mostra o exterior de um } \\
\text { café, iluminado no terraço externo } \\
\text { por uma grande lâmpada de gás } \\
\text { dentro da noite azul, com um retalho } \\
\text { de céu azul estrelado. } \\
\text { As frentes das casas em uma rua que } \\
\text { segue sob o céu azul salpicado de } \\
\text { estrelas são azul escuro ou violeta, } \\
\text { com uma árvore verde. }\end{array}$ & $\begin{array}{l}\text { A textura da calçada e do 'céu azul } \\
\text { SALPICADO de estrelas' mostra } \\
\text { como o uso da textura auxilia na } \\
\text { construção da profundidade. A } \\
\text { diversidade de textura cria tanto o } \\
\text { contraste quanto a profundidade. E as } \\
\text { diferentes texturas cria contraste entre } \\
\text { os ambientes que permite com que a } \\
\text { luz seja projetada no calçamento sem } \\
\text { que haja ambiguidade entre os } \\
\text { ambientes externo e interno. }\end{array}$ \\
\hline $\begin{array}{l}\text { Na tela 'O Café Noturno na } \\
\text { Place Lamartine, em Arles', } \\
\text { observei a ocorrência do uso } \\
\text { de Saliência e Vetor inter- } \\
\text { relacionados com a } \\
\text { ocorrência de Textura e } \\
\text { Gesto Pictórico para } \\
\text { construir a luz das } \\
\text { lâmpadas a gás. Registrada } \\
\text { nas notas de rodapé 125 e } \\
\text { 133. O vetor ocorre em } \\
\text { direção radial. } \\
\text { Na tela 'O Café Noturno na } \\
\text { Place Lamartine, em Arles', } \\
\text { observei a ocorrência de } \\
\text { Saliência construída com o } \\
\text { uso de Textura, Ritmo, } \\
\text { Movimento e Gesto } \\
\text { Pictórico para representar o } \\
\text { brilho da lâmpada. } \\
\text { Registrada na nota de rodapé } \\
\text { 135. } \\
\text { Ocorrência de Ritmo, } \\
\text { Textura, Movimento, Vetor e } \\
\text { Rima Visual pelo Gesto } \\
\text { Pictórico para expressar o } \\
\text { fluxo e a intensidade da } \\
\text { iluminação na sala. } \\
\text { Registrada nas notas de }\end{array}$ & $\begin{array}{l}\text { Tudo isso em uma atmosfera de } \\
\text { fornalha infernal, de enxofre pálido. } \\
\text { Exprimir como a potência dos cantos } \\
\text { escuros de uma taberna. } \\
\text { Observei o uso simbólico da cor não } \\
\text { apenas com o uso de contraste } \\
\text { complementar, mas com o uso de } \\
\text { contraste de saturação dessas cores } \\
\text { complementares. Há uma ênfase na } \\
\text { descrição textual desses contrastes, e } \\
\text { uma ocorrência semântica da cor } \\
\text { nestas orações que é compatível com } \\
\text { a ocorrência na tela. Registrada na } \\
\text { nota de rodapé } 268 .\end{array}$ & $\begin{array}{l}\text { A textura das lâmpadas chama a } \\
\text { atenção por este efeito de fornalha, } \\
\text { como se estivesse projetando seu calor } \\
\text { 'infernal' no ambiente. O uso da } \\
\text { textura da mais concretude a esta } \\
\text { ambiente de 'descontrole' das } \\
\text { emoções. O fluxo e a intensidade da } \\
\text { luz realçam os contrastes de cores e de } \\
\text { textura no ambiente. No caso da } \\
\text { textura vi realçada a marca nas tábuas } \\
\text { no chão do café, que ganha uma } \\
\text { riqueza de detalhes como se cada sulco } \\
\text { tivesse sido representado, dando um } \\
\text { efeito de textura ainda mais } \\
\text { proeminente. }\end{array}$ \\
\hline
\end{tabular}


rodapé 187 e 189.

Ocorrência de Saliência, por meio do uso de Ritmo,

Movimento, Textura, Vetor e Gesto Pictórico que são usados para representar $\mathbf{0}$ brilho intermitente das lâmpadas, pintado com riqueza de detalhes, textura e movimento direcional. Registrados na nota de rodapé 190 .

Ocorrência de Associação metafórica por meio do uso de Ritmo, Movimento, Textura, Vetor, Gesto Pictórico e Rima Visual que juntos constroem uma metáfora visual para a luz que interliga todos os processos na narrativa. Registrados na nota de rodapé 191.

Ocorrência de Ritmo, Movimento, Textura e Vetor para construir a luz, que parece que está em movimento e vibrando. Registrados na nota de rodapé 192, 193 e 194.

Uso de Associação metafórica por meio de Saliência, Ritmo, Movimento, Textura e Gesto Pictórico para dar centralidade para luz.

Registrada na nota de rodapé 201.

Na tela 'O Café Noturno na Place Lamartine, em Arles', observei a ocorrência de Associação metafórica construída pela Saliência, Ritmo, Textura e Movimento na representação das lâmpadas e da luz que delas emana. Registrada na nota de rodapé 240 e 241.

Fonte: Triangulação para Textura dos dados dos corpora visual e textual, com os extratos das cartas. 


\subsection{RITMO}

O uso do ritmo está muito evidenciado no movimento direcional e constante do Modo como van Gogh usa o pincel. A análise sugere o uso deste Modo para construir outros Modos tais como a direção, o movimento e a textura. Estes Modos estão entrelaçados e intimamente relacionados na construção da linguagem de van Gogh.

\subsubsection{Triangulação do Ritmo}

Ritmo, no texto escrito e em relação à triangulação - O ritmo é compreendido como a repetição de linhas, formas, planos, cores e outros elementos visuais que possibilita a leitura de padrões que ocorrem com certa regularidade na composição visual. Van Gogh usou o ritmo para construir direção, movimento, textura e com eles, os caminhos visuais. Em relação ao discurso textual, pensei no uso repetido de quaisquer elementos léxico-gramaticais a fim de construir um efeito de sentido de ritmo e movimento. Por exemplo, o uso de pontuação, vírgula ou travessão para criar pausa, e de palavras cuja concatenação cria um sentido cadenciado. Uma construção ritmada na oração pode produzir uma tensão, um crescendo, uma ênfase maior para o que se é dito, concentrando uma maior atenção nesse construto. A seguir examino algumas ocorrências de ritmo no discurso textual dos excertos analisados.

Quadro 18: Triangulação do Ritmo

\begin{tabular}{|c|c|c|}
\hline Ocorrência nas telas & Orações & Comentário \\
\hline $\begin{array}{l}\text { Na tela 'Por de Sol: Campo } \\
\text { de trigo perto de Arles', } \\
\text { Pinceladas ritmadas para } \\
\text { representar o vento } \\
\text { ventando no trigal, por } \\
\text { meio das pinceladas } \\
\text { ritmadas, conferida pelo } \\
\text { gesto pictórico, pela textura } \\
\text { e pelo movimento. As } \\
\text { ocorrências estão registradas } \\
\text { nas notas de rodapé } 62,71, \\
72,73 \text { e } 77 \text { no apêndice. }\end{array}$ & $\begin{array}{l}\text { Paisagens amarelo ouro velho - feito } \\
\text { rápido rápido rápido e com pressa, } \\
\text { como o ceifeiro que está em silêncio } \\
\text { sob o sol escaldante, concentrando- } \\
\text { se em ter o trabalho terminado. }\end{array}$ & $\begin{array}{l}\text { A repetição da palavra 'rápido' três } \\
\text { vezes e o uso do sinônimo ‘com } \\
\text { pressa' constroem o movimento } \\
\text { ritmado com que ele trabalhou nas } \\
\text { pinceladas para suplantar a força do } \\
\text { vento e para registrar essa experiência } \\
\text { visualmente. O ritmo do vento } \\
\text { soprando está presente tanto na } \\
\text { representação visual quanto na } \\
\text { representação textual, porque está } \\
\text { impregnado em sua própria } \\
\text { experiência de pintar ao ar livre em } \\
\text { meio a uma ventania muito forte e a } \\
\text { um sol escaldante. }\end{array}$ \\
\hline $\begin{array}{l}\text { Na tela 'Por de Sol: Campo } \\
\text { de trigo perto de Arles', } \\
\text { observei a ocorrência de } \\
\text { Gesto pictórico e ritmo, }\end{array}$ & $\begin{array}{l}\text { 'Sol poente? Lua nascendo? Noite de } \\
\text { verão, de qualquer modo.' } \\
\text { Estas orações criam uma marcação } \\
\text { rítmica muito forte e cadenciada }\end{array}$ & $\begin{array}{l}\text { A descrição do uso dos tons no campo } \\
\text { de trigo cria na linguagem um efeito } \\
\text { de poesia ritmada que foi } \\
\text { provavelmente o mesmo estado de }\end{array}$ \\
\hline
\end{tabular}




\begin{tabular}{|c|c|c|}
\hline $\begin{array}{l}\text { observada pelo modo como } \\
\text { ele distribui as pinceladas, } \\
\text { com repetições regulares e } \\
\text { irregulares para representar e } \\
\text { enfatizar o campo de trigo. } \\
\text { Registrada nas notas de } \\
\text { rodapé } 59,60,61,62,63 \text { no } \\
\text { apêndice. }\end{array}$ & $\begin{array}{l}\text { evidenciando a ocorrência do Gesto } \\
\text { pictórico na representação de uma } \\
\text { visualidade que também ocorre na } \\
\text { tela. Registrado na nota de rodapé } \\
\underline{113 \text { no apêndice. }} \\
\text { Noite de verão, de qualquer modo. } \\
\text { Cidade violeta, estrela amarela, céu } \\
\text { azul-esverdeado; os campos de trigo } \\
\text { têm todos os tons: ouro velho, cobre, } \\
\underline{\text { ouro verde, ouro vermelho, ouro }} \\
\underline{\text { amarelo, verde, vermelho e amarelo }} \\
\text { bronze. }\end{array}$ & $\begin{array}{l}\text { espírito do momento de produção da } \\
\text { tela, no qual van Gogh se vê absorto } \\
\text { pela multiplicidade de cores que ele } \\
\text { percebe visualmente e experiencia } \\
\text { espiritualmente. }\end{array}$ \\
\hline $\begin{array}{l}\text { Na tela 'O Semeador' } \\
\text { observei a ocorrência de } \\
\text { Ritmo, Textura, Direção e } \\
\text { Movimento construídos pelo } \\
\text { Gesto Pictórico de van Gogh } \\
\text { para representar o campo } \\
\text { arado. Registrados na nota } \\
\text { de rodapé } 47 .\end{array}$ & $\begin{array}{l}\text { Preferia muito mais fazer quadros } \\
\text { naifs tirados de velhos almanaques, } \\
\text { aqueles velhos "almanaques dos } \\
\text { lavradores" nos quais o granizo, a } \\
\text { neve, a chuva e o bom tempo são } \\
\text { retratados de modo primitivo, como } \\
\text { o Anquetin atingiu tão bem no seu } A \\
\text { Colheita. }\end{array}$ & $\begin{array}{l}\text { Aqui vi o ritmo nas pinceladas que } \\
\text { ajudam a criar uma integração entre os } \\
\text { elementos da natureza na tela: o } \\
\text { campo arado, o campo maduro, o céu, } \\
\text { o sol, a luz. Esse ritmo que integra os } \\
\text { elementos naturais está presente } \\
\text { também na oração em que expressa } \\
\text { sua preferência pela pintura da } \\
\text { natureza. }\end{array}$ \\
\hline $\begin{array}{l}\text { Observei o uso conjugado de } \\
\text { Textura, ritmo, movimento, } \\
\text { direção, gesto pictórico e } \\
\text { saliência na representação } \\
\text { dos torrões de terra } \\
\text { revolvida no campo arado. } \\
\text { Registrados na nota de } \\
\text { rodapé } 49 . \\
\text { Na tela 'O Semeador', há } \\
\text { uma inter-relação entre } \\
\text { Textura, Contrastes } \\
\text { Simultâneos, Saliência, } \\
\text { Sinestesia que criam } \\
\text { Associações Metafóricas da } \\
\text { materialidade da tinta com } \\
\text { a nossa memória sensorial } \\
\text { e tátil da plasticidade da } \\
\text { terra, registrado na nota de } \\
\text { rodapé } 50 .\end{array}$ & $\begin{array}{l}\text { O céu, amarelo-crômio, quase tão } \\
\text { luminoso quanto o próprio Sol,// que } \\
\text { é amarelo-crômio no } 1, / / \text { (está) } \\
\text { misturado com um pouco de branco, } \\
\text { /enquanto o resto do céu é uma } \\
\text { mistura dos amarelos-crômios } 1 \text { e } 2 \text {. } \\
\text { Tão amarelo! /// A camisa do } \\
\text { semeador é azul // e as calças } \\
\text { brancas. Tamanho da tela - } 25, \\
\text { quadrada. }\end{array}$ & $\begin{array}{l}\text { Nesse excerto, observei a ocorrência } \\
\text { de Rima Visual, Gesto Pictórico e } \\
\text { Ritmo, construída por uma sequência } \\
\text { de escolhas lexicais que é análoga à } \\
\text { ocorrência de ritmo e de gesto } \\
\text { pictórico. O circuito criado pela } \\
\text { recorrente escolha do item lexical } \\
\text { 'céu' é compatível com a ocorrência } \\
\text { de Rima Visual registrado na nota de } \\
\text { rodapé } 85 \text {. }\end{array}$ \\
\hline $\begin{array}{l}\text { Na tela 'O Café Noturno na } \\
\text { Place Lamartine, em Arles', } \\
\text { observei a ocorrência de } \\
\text { Ritmo construído pelos } \\
\text { encostos das duas cadeiras } \\
\text { à direta de quem olha a tela, } \\
\text { conduzem o olhar para o } \\
\text { homem de branco em pé, } \\
\text { registrado na nota de rodapé } \\
\underline{128} .\end{array}$ & $\begin{array}{l}\text { Ai, ai, é como nosso excelente amigo } \\
\text { Cyprien diz, em 'En ménage' por JK } \\
\text { Huysmans: as mais belas pinturas } \\
\text { são aquelas que um sonha enquanto } \\
\text { fuma um cachimbo em sua cama, } \\
\text { mas a qual ele não pinta. }\end{array}$ & $\begin{array}{l}\text { A interjeição 'Ai, ai,' cria um ritmo no } \\
\text { início da oração que tem duas funções, } \\
\text { criar uma saliência para o que ele dirá } \\
\text { a seguir, e estabelecer uma maior } \\
\text { proximidade com seu leitor, Theo, } \\
\text { para revelar um aspecto muito íntimo } \\
\text { de sua experiência, os devaneios } \\
\text { acerca de quadros que ele sonha em } \\
\text { pintar. Foi preciso procurar a } \\
\text { ocorrência de um recurso visual que } \\
\underline{\text { cria uma saliência para atentar para }} \\
\text { outro elemento visual, criando uma } \\
\text { sequência cadenciada de recursos }\end{array}$ \\
\hline
\end{tabular}




\begin{tabular}{|c|c|c|}
\hline & & visuais. \\
\hline $\begin{array}{l}\text { Na tela 'A Esplanada do } \\
\text { Café na Place du Forum, } \\
\text { Arles, à Noite', observei a } \\
\text { ocorrência e Inter-relação } \\
\text { entre Ritmo, Movimento, } \\
\text { Textura, Gesto Pictórico, } \\
\text { Desenho-Pintura para } \\
\text { construir a Perspectiva do } \\
\text { calçamento. Registrados na } \\
\text { nota de rodapé } 126 \text { no } \\
\text { apêndice. }\end{array}$ & $\begin{array}{l}\text { Uma enorme lanterna amarela } \\
\text { ilumina o terraço, a fachada, a } \\
\text { calçada, e até mesmo projeta luz } \\
\text { sobre os paralelepípedos da rua, que } \\
\text { adquirem uma coloração violeta- } \\
\text { rosa. }\end{array}$ & $\begin{array}{l}\text { Nesta oração, as vírgulas } \\
\text { interrompem,entrecortam o fluxo das } \\
\text { palavras criando um movimento } \\
\text { sincopado que termina em uma nota } \\
\text { mais longa com 'e até mesmo projeta } \\
\text { luz sobre os paralelepípedos da rua'. A } \\
\text { escolha de palavras paroxítonas: } \\
\text { terraço, fachada, calçada, constrói um } \\
\text { ritmo conduzido pela própria } \\
\text { sonoridade lexical. }\end{array}$ \\
\hline $\begin{array}{l}\text { Na tela 'O Café Noturno na } \\
\text { Place Lamartine, em Arles', } \\
\text { observei a ocorrência de } \\
\text { Saliência construída com o } \\
\text { uso de Textura, Ritmo, } \\
\text { Movimento e Gesto } \\
\text { Pictórico na representação } \\
\text { das figuras no fundo da } \\
\text { sala, registrada na nota de } \\
\text { rodapé 134. } \\
\\
\text { Ocorrência de Ritmo, } \\
\text { Textura, Movimento, Vetor e } \\
\text { Rima Visual pelo Gesto } \\
\text { Pictórico para expressar o } \\
\text { fluxo e a intensidade da } \\
\text { iluminação na sala. } \\
\text { Registrados na nota de } \\
\text { rodapé 189. } \\
\text { Ocorrência de Saliência, por } \\
\text { meio do uso de Ritmo, } \\
\text { Movimento, Textura, Vetor e } \\
\text { Gesto Pictórico que são } \\
\text { usados para representar o } \\
\text { brilho intermitente das } \\
\text { lâmpadas, pintado com } \\
\text { riqueza de detalhes, textura e } \\
\text { movimento direcional. } \\
\text { Registrados na nota de } \\
\text { rodapé 190. } \\
\text { Ocorrência de Associação } \\
\text { metafórica por meio do uso } \\
\text { de Ritmo, Movimento, } \\
\text { Textura, Vetor, Gesto } \\
\text { Pictórico e Rima Visual que } \\
\text { juntos constroem uma } \\
\text { metáfora visual para a luz } \\
\text { que interliga todos os } \\
\text { processos na narrativa. } \\
\text { Registrados na nota de } \\
\text { rodapé 191. }\end{array}$ & $\begin{array}{l}\text { O vermelho-sangue e o amarelo- } \\
\text { verde da mesa de bilhar, por } \\
\text { exemplo, contrasta com o pouco de } \\
\text { verde delicado Louis XV do balcão, } \\
\text { onde há um buquê rosa. } \\
\text { Verifiquei a ocorrência do uso de um } \\
\text { construto de contraposição e antítese } \\
\text { no nível semântico da oração Agora } \\
\text { como para recuperar o dinheiro pago } \\
\text { ao senhorio através da minha } \\
\text { pintura, eu não estou fazendo } \\
\text { questão disto, porque a pintura é uma } \\
\text { das mais feias que eu já fiz que é } \\
\text { compatível com o uso de contrastes } \\
\text { complementares de verdes e } \\
\text { vermelhos e com a oração na qual } \\
\text { ele explicita que a tela fala de } \\
\text { 'conflitos e antíteses por toda parte'. } \\
\text { Registrado na nota de rodapé } 254 .\end{array}$ & $\begin{array}{l}\text { Observei que na oração Beta, as } \\
\text { escolhas lexicais são feitas aos pares } \\
\text { que se agrupam entre vírgulas que } \\
\text { constroem um ritmo para a narrativa. } \\
\text { A sequência de cores e a relação entre } \\
\text { parece conferir uma vibração ao } \\
\text { ambiente, uma complementaridade } \\
\text { entre as cores que é descrita na oração } \\
\text { de forma ritmada. Segui a descrição na } \\
\text { tela e acompanhar o uso do ritmo que } \\
\text { contrasta entre estagnação e vibração, } \\
\text { dando uma tensão ao quadro na sua } \\
\text { totalidade. } \\
\text { Uso de Associaçães Metafóricas e do } \\
\text { Uso Simbólico da Cor. Ao expressar o } \\
\text { sentido simbólico dos verdes e } \\
\text { vermelhos textualmente ele cola esse } \\
\text { sentido no uso dessas cores na tela, } \\
\text { construindo uma ponte entre a carta e a } \\
\text { tela, criando uma cadeia de textos. } \\
\text { Observei uma ocorrência do uso } \\
\text { simbólico da cor em ambas as } \\
\text { modalidades não pela forma, mas pelo } \\
\text { sentido associado a este uso. } \\
\text { Registrado na nota de rodapé } 257 .\end{array}$ \\
\hline
\end{tabular}




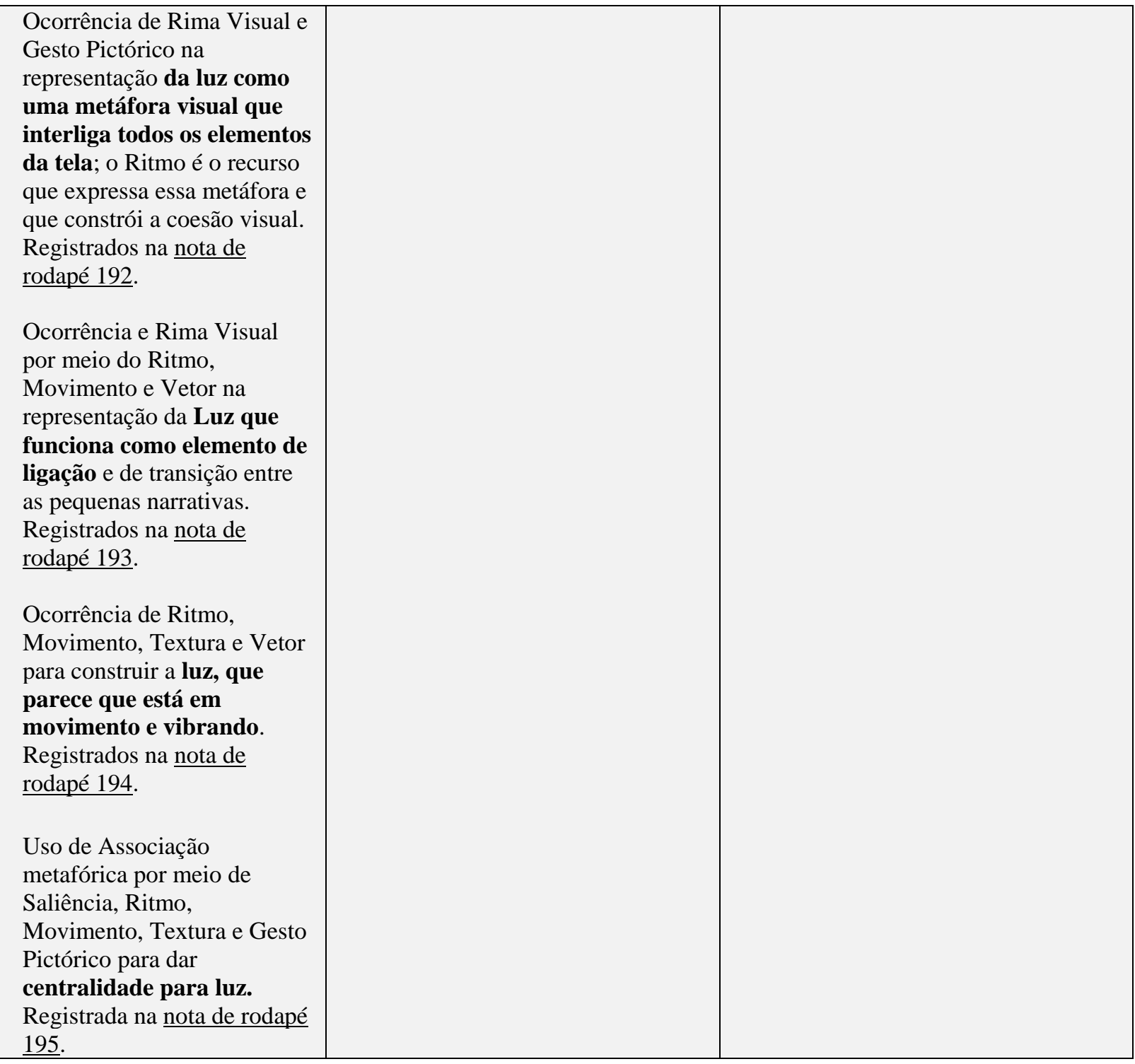

Fonte: Triangulação para Ritmo dos dados dos corpora visual e textual, com os extratos das cartas.

\subsection{MOVIMENTO}

É criado tanto mecanicamente pela energia com que van Gogh descarrega e trabalha o pincel a fim de construir efeitos de textura, direção e ritmo, quanto pelo resultado perceptivo destas características físicas e mecânicas das pinceladas que cria um ou vários efeitos de sentidos perceptíveis como um efeito visual de 'movimento'. Chamei isso de um Modo próprio com o qual van Gogh cria o movimento, pelo uso magistral de vários elementos visuais para compor sua narrativa pictórica. 


\subsubsection{Triangulação do Movimento}

\section{Movimento, no texto escrito e em relação à triangulação - $\mathrm{O}$ sentido do movimento} no texto escrito pode ser encontrado não nos elementos usados, mas na forma como eles são usados, que emprestem a característica particular de movimento: fluidez, sequenciamento, ritmo, cadência, por exemplo. O uso dos sinais de pontuação pode contribuir para a percepção de movimento, como no caso do travessão e das reticências que constroem um represamento, para depois dar vazão ao fluxo discursivo. A seguir examino algumas ocorrências:

Quadro 19: Triangulação do Movimento

\begin{tabular}{|c|c|c|}
\hline Ocorrência nas telas & Orações & Comentário \\
\hline $\begin{array}{l}\text { Na tela 'Por de Sol: Campo de } \\
\text { trigo perto de Arles', observei } \\
\text { a ocorrência de Movimento, } \\
\text { Ritmo e Textura e Vetor } \\
\text { conferidos pelo gesto } \\
\text { pictórico para representar o } \\
\text { campo de trigo, registrados na } \\
\text { nota de rodapé } 71 \text { no apêndice. } \\
\text { Ocorrência do Movimento, } \\
\text { construído pela diferença de } \\
\text { espaçamento que as pinceladas } \\
\text { ora criam um conjunto } \\
\text { homogêneo e indiferenciado, } \\
\text { ora ressaltam a individualidade } \\
\text { de cada ramo de trigo. Isso } \\
\text { produz uma contraposição } \\
\text { entre a homogeneidade e a } \\
\text { diferenciação das pinceladas } \\
\text { que constrói um sentido de } \\
\text { alternância e de movimento, a } \\
\text { estratégia de narrativa visual } \\
\text { de contraposição entre } \\
\text { homogeneidade e } \\
\text { diferenciação está registrada } \\
\text { na nota de rodapé } 73 \text { no } \\
\text { apêndice. }\end{array}$ & $\begin{array}{l}\text { Eu tenho um terceiro estudo, agora, } \\
\text { de uma paisagem com fábrica, e um } \\
\text { enorme sol em um céu vermelho, } \\
\text { acima de telhados vermelhos, em } \\
\text { que a natureza parece estar em um } \\
\text { acesso de raiva, em um dia de } \\
\text { Mistral desagradável. } \\
\text { (...) } \\
\text { Paisagens amarelo ouro velho - feito } \\
\text { rápido rápido rápido e com pressa, } \\
\text { como o ceifeiro que está em silêncio } \\
\text { sob o sol escaldante, concentrando- } \\
\text { se em ter o trabalho terminado. }\end{array}$ & $\begin{array}{l}\text { O movimento do vento, representado } \\
\text { no movimento do trigo representa para } \\
\text { van Gogh um 'dia de Mistral } \\
\text { desagradável'. Por um lado, a noite de } \\
\text { verão possibilita cores contrastantes, } \\
\text { mas que combinada à ventania faz } \\
\text { parecer que a natureza está em um } \\
\text { estado emocional de 'acesso de raiva'. } \\
\text { O movimento do sol, se pondo, e o } \\
\text { movimento do vento, balançando o } \\
\text { trigo são representados na tela de } \\
\text { forma estática, pois a tela não tem } \\
\text { movimento. Van Gogh precisa } \\
\text { conseguir este efeito de movimento } \\
\text { para representar este dia e para isto ele } \\
\text { pincela freneticamente a tela de forma } \\
\text { a apreender justamente este } \\
\text { movimento e estado emocional da } \\
\text { natureza. }\end{array}$ \\
\hline $\begin{array}{l}\text { A tela 'Por de Sol: Campo de } \\
\text { trigo perto de Arles', sugere } \\
\text { um conflito presente na } \\
\text { forma como os elementos } \\
\text { que deveriam se relacionar } \\
\text { de maneira harmônica estão } \\
\text { em todo momento se } \\
\text { contrastando. Seja pela } \\
\text { diferença de direções do } \\
\text { trigo no campo, pela } \\
\text { diferença de cores do trigo, } \\
\text { pela diferença de }\end{array}$ & $\begin{array}{l}\text { Aqui está outra paisagem. Sol } \\
\text { poente? Lua nascendo? Noite de } \\
\text { verão, de qualquer modo. Cidade } \\
\text { violeta, estrela amarela, céu azul- } \\
\text { esverdeado; os campos de trigo têm } \\
\text { todos os tons: ouro velho, cobre, } \\
\text { ouro verde, ouro vermelho, ouro } \\
\text { amarelo, verde, vermelho e amarelo } \\
\text { bronze. Tela quadrada número } 30 \text {. }\end{array}$ & $\begin{array}{l}\text { Essa produção de homogeneidade e } \\
\text { diferenciação na forma como ele } \\
\text { agrupa os elementos representados na } \\
\text { composição pode ser uma estratégia } \\
\text { de acentuação de sensações visuais } \\
\text { que produzem Textura, Movimento, } \\
\text { Vetor e Gesto Pictórico, e conduzem à } \\
\text { sinestesia e à Modalidade sensorial } \\
\text { está registrada nas notas de rodapé } 68 \text {, } \\
69,70 \text { e } 71 \text { no apêndice. }\end{array}$ \\
\hline
\end{tabular}




\begin{tabular}{|c|c|c|}
\hline $\begin{array}{l}\text { espaçamento que as } \\
\text { pinceladas ora criam um } \\
\text { conjunto homogêneo e } \\
\text { indiferenciado, ora ressaltam } \\
\text { a individualidade de cada } \\
\text { ramo de trigo. }\end{array}$ & & \\
\hline $\begin{array}{l}\text { Na tela 'Por de Sol: Campo } \\
\text { de trigo perto de Arles', } \\
\text { observei o uso de } \\
\text { Movimento para dar } \\
\text { ênfase para o sol, registrado } \\
\text { na nota de rodapé } 52 \text { no } \\
\text { apêndice. }\end{array}$ & $\begin{array}{l}\text {...e um enorme sol em um céu } \\
\text { vermelho, acima de telhados } \\
\text { vermelhos,... }\end{array}$ & $\begin{array}{l}\text { Tanto na tela quanto na oração } \\
\text { observei um gestual que sugere um } \\
\text { movimento direcional tanto no uso do } \\
\text { pincel para cobrir o céu, quanto no uso } \\
\text { das escolhas léxico-gramaticais para } \\
\text { construir a oração. }\end{array}$ \\
\hline $\begin{array}{l}\text { Na tela 'O Semeador' } \\
\text { observei a ocorrência de } \\
\text { Movimento, construída pela } \\
\text { representação dos raios do } \\
\text { sol que comunicam um } \\
\text { movimento expansivo e } \\
\text { abrangente. Esse } \\
\text { movimento é mais suave do } \\
\text { que o movimento do gesto } \\
\text { pictórico frenético que } \\
\text { constrói os torrões do campo } \\
\text { arado. Registrada na nota de } \\
\text { rodapé } 40 . \\
\text { Observei também a } \\
\text { ocorrência de Movimento, } \\
\text { Gesto Pictórico, Vetor } 2, \\
\text { Rima Visual e Incompletude, } \\
\text { sugerido pelos raios do sol } \\
\text { em toda a pintura. } \\
\text { Registrados na nota de } \\
\text { rodapé } 53 \text {. }\end{array}$ & $\begin{array}{l}\text { Não te vou ocultar que não desgosto } \\
\text { da região, pois fui criado lá - ainda } \\
\text { me encanta a magia das recordações } \\
\text { do passado, de um desejo do infinito, } \\
\text { do qual o semeador e o enfeixador } \\
\text { são símbolos -, tanto quanto antes } \\
\text { gostava. }\end{array}$ & $\begin{array}{l}\text { A oração principal 'Não te vou } \\
\text { ocultar' tem um movimento que sofre } \\
\text { uma mudança de velocidade, quando } \\
\text { ocorre uma segunda oração hipotática } \\
\text { entre os travessões. Observei na oração } \\
\text { paratática um sentido mais externo, } \\
\text { voltado para uma região na qual ele } \\
\text { compartilhava experiências com o } \\
\text { irmão. Na oração hipotática ele está } \\
\text { falando de uma experiência interna, } \\
\text { existencial. Nesse complexo oracional } \\
\text { há uma mudança de movimento, que } \\
\text { vai da experiência externa na região } \\
\text { para uma experiência interna e da } \\
\text { experiência do passado para uma } \\
\text { experiência que é presente. } \\
\text { O travessão aqui foi usado para } \\
\text { desacelerar o discurso, criar uma pausa } \\
\text { cheia de sentidos enfatizados; entre os } \\
\text { travessões está o sentido central dessa } \\
\text { oração que foi colocado na oração } \\
\text { hipotáxica. }\end{array}$ \\
\hline $\begin{array}{l}\text { Na tela 'O Semeador' vários } \\
\text { elementos visuais dão a } \\
\text { ideia de processo, desde o } \\
\text { nível semântico e } \\
\text { representacional como os } \\
\text { ciclos do plantar, colher e } \\
\text { fenecer, até o nível } \\
\text { composicional com a ajuda } \\
\text { dos caminhos visuais e dos } \\
\text { raios do sol que comunicam } \\
\text { uma continuidade. } \\
\text { Registrado nas notas de } \\
\text { rodapé } 37 \text { e } 40 .\end{array}$ & $\begin{array}{l}\text { A ideia do semeador ainda continua } \\
\text { a me assombrar. }\end{array}$ & $\begin{array}{l}\text { Além do movimento representado na } \\
\text { própria tela, van Gogh refere-se a ela } \\
\text { como um processo, um movimento em } \\
\text { direção a um objetivo que continua, } \\
\text { refere-se a uma ideia que o persegue, o } \\
\text { assombra. }\end{array}$ \\
\hline $\begin{array}{l}\text { Na tela 'A Esplanada do } \\
\text { Café na Place du Forum, } \\
\text { Arles, à Noite', observei a } \\
\text { ocorrência e Inter-relação } \\
\text { entre Ritmo, Movimento, } \\
\text { Textura, Gesto Pictórico, } \\
\text { Desenho-Pintura para } \\
\text { construir a Perspectiva do }\end{array}$ & $\begin{array}{l}\text { As frentes das casas em uma rua que } \\
\text { segue sob o céu azul salpicado de } \\
\text { estrelas são azul escuro ou violeta, } \\
\text { com uma árvore verde. }\end{array}$ & $\begin{array}{l}\text { O calçamento da rua em frente ao café } \\
\text { está em movimento ao horizonte, onde } \\
\text { encontra a carruagem ao fundo, o olha } \\
\text { segue este caminho, pois a textura, a } \\
\text { cor e a perspectiva possibilitam esse } \\
\text { efeito de movimento ao fundo. }\end{array}$ \\
\hline
\end{tabular}




\begin{tabular}{|l|l|l|}
\hline $\begin{array}{l}\text { calçamento, registrados na } \\
\text { nota de rodapé 126 no } \\
\text { apêndice. }\end{array}$ & \\
\hline $\begin{array}{l}\text { Na tela 'A Esplanada do } \\
\text { Café na Place du Forum, } \\
\text { Arles, à Noite', observei a } \\
\text { ocorrência de Vetor, } \\
\text { construído pelo Movimento } \\
\text { das pessoas que se acercam } \\
\text { do café. Registrados na nota } \\
\text { de rodapé 129 no apêndice. }\end{array}$ & $\begin{array}{l}\text { No terraço, há pequenas figuras de } \\
\text { pessoas que bebem. }\end{array}$ & $\begin{array}{l}\text { Outros movimentos presentes são as } \\
\text { pessoas que bebem no café. As } \\
\text { pessoas na tela conferem movimento à } \\
\text { cena. }\end{array}$ \\
\hline Fon Tre
\end{tabular}

Fonte: Triangulação para Movimento dos dados dos corpora visual e textual, com os extratos das cartas.

\subsection{DIREÇÃO OU VETOR}

Kress e van Leeuwen (1996) descrevem vetores como 'verbos visuais' com base na concepção de Halliday (1985) na qual em uma sentença os participantes se relacionam com o processo com o auxílio do verbo. O verbo representa uma transação que cria um relacionamento entre os participantes. Eles examinam a transação e a ação que transita nas imagens, levando em consideração quem é o ator, qual é o processo, qual é o objetivo e em qual circunstância ele ocorre.

Van Gogh apoia-se fortemente no uso da direção para construir uma via que conduza o olhar e construa por meio desta os sentidos. Ele utiliza não apenas a perspectiva para construir o efeito de direção, mas vários elementos pictóricos: contrastes cromáticos, as linhas e planos da composição, a textura, o ritmo das pinceladas, o ponto de vista e o ponto de fuga da perspectiva. A articulação de diferentes elementos pictóricos na composição corrobora para conduzir o olhar por caminhos visuais e privilegiar alguns aspectos da composição. Kress e van Leeuwen (1996, p. 50) discorrem a esse respeito:

Nosso uso desses termos não implica que as imagens e diagramas funcionam da mesma forma que a linguagem; apenas que elas podem 'dizer' (algumas das) mesmas coisas que a linguagem - de formas muito distintas: o que em linguagem é realizado por meios de configurações sintáticas de certas classes de nomes e certas classes de verbos é visualmente realizado, feito perceptível e comunicável, por relações vetoriais entre volumes. Nas palavras de Arnheim, 'Nós precisamos distinguir entre volumes e vetores, entre ser e agir' (ARNHEIM, 1982, p. 154 apud KRESS e VAN LEEUWEN, 1996, p. 50) ${ }^{300}$

\footnotetext{
${ }^{300}$ Tradução livre da autora. "Our use of these terms does not imply that images and diagrams work in the same way as language; only that they can 'say' (some of) the same things as language - in very different ways: what in language is realized by means of syntactic configurations of certain classes of nouns and certain classes of verbs is visually realized, made perceivable and communicable, by the vectorial relations between volumes. In Arnheim's words, 'We shall distinguish between volumes and vectors, between being and acting' (1982: 154)." (KRESS E VAN LEEUWEN, 1996, p. 50)
} 


\subsubsection{Triangulação da Direção ou Vetor}

Direção ou Vetor, no texto escrito e em relação à triangulação - Assim como no sistema de transitividade verbal, o ator exerce o papel de protagonista da ação e a meta recebe essa ação, na imagem, os participantes são os elementos que executam ou sofrem as ações, com os papéis de atores ou metas e alvos das ações. Nos processos de ação, a maior característica é a existência de vetores ou linhas de ação, que representam a interação entre dois participantes que são o ator e a meta e que indicam a direção da ação ou do processo acional. Eles podem ter uma só direção que vai do ator para a meta, ou duas quando os participantes são em um momento atores e em outro, metas. Também encontrei os processos de reação, além dos processos de ação. Neles, o elemento principal é o olhar dos participantes, que são nomeados de reatores. Nesses processos, os participantes devem ter características humanas ou semelhantes.

O Vetor é um aspecto muito central da triangulação. A categoria da direção, movimento direcional ou vetor pode ter muitas facetas. A direção no texto escrito implica uma ação, uma intencionalidade do agente que promove a ação. Pode-se entender direção no sentido semântico que é dado ao conteúdo da oração analisada, mas pode-se também investigar o direcionamento da ação que ocorre na representação da experiência dentro da oração. Além disso, outro sentido de direção pode estar mais profundamente imbricado na estratégia retórica e no encadeamento das ideias, bem como no uso de recursos discursivos que preparam um caminho lógico-semântico para conduzir o leitor para um sentido intencionado. No texto escrito o sentido da direção pode ser construída por diferentes semioses:

1) por meio de uma série de estratégias retóricas que conduzem o rumo do argumento e que organizam a estrutura na qual as ideias vão se encadeando e se desenvolvendo. Pensando que a estrutura do texto escrito é sequencial, ou seja, ela é organizada por meio de orações que vão encadeando significações nas quais o sentido posterior é resultado do sentido anterior e direciona o próximo sentido, pode-se compreender que a categoria de direção no texto escrito é construída não apenas dentro da oração, mas no sequenciamento das orações.

2) pode ser construída pelos conectivos lógico-semânticos das estruturas léxicogramaticais, por exemplo: contudo, no entanto, não obstante, tanto, quanto, mas, etc. 
3) pode-se também observar, no nível semântico, os advérbios de tempo e lugar que estruturam um senso de espacialidade e temporalidade;

4) entre os participantes da oração, as circunstâncias de tempo e lugar podem oferecer pistas do sentido de direcionamento.

5) em termos de transitividade; a direção da ação na oração é dada pelo agente, que define para que direção está sendo direcionado o olhar do leitor. Nesta categoria a transitividade tem um papel central: o agente dá a direção da ação, o processo mostra como a direção foi dada. Para descobrir a direção da ação, no discurso textual, precisamos responder as seguintes perguntas elaboradas por Butt et al (2000): a) Qual é o processo ou o grupo verbal em questão? Que função ele desempenha na oração? Ele envolve alguma ação física ou material; ou identifica e descreve e relaciona; ou diz ou percebe algo? b) A ação é feita por quem ou o que, que a está relacionando, percebendo ou dizendo? c) Para quem ou para o que a ação está sendo feita, relacionada, dita ou sentida? d) A oração que diz ou percebe algo que projeta outra oração? É uma fala citada ou direta, ou é uma fala indireta ou relatada? Na oração o pensamento é direto ou citado, indireto ou relatado? e) A ação acontece quando, onde, como, porque, com quem ou o que, por quanto tempo?

6) estas perguntas podem ser aplicadas ao discurso visual para encontrarmos a direção da Transitividade visual. No discurso textual, inferi que quando há uma grande ocorrência de voz passiva, há uma dispersão na direção dentro da oração. Quando há muita modalização e ou o apagamento do sujeito, a direção pode fica ambígua também.

7) a categoria da direção ou vetor pode estar conectada com a categoria da perspectiva e do enquadramento, porque há um tipo de direção relacionado com o lugar de onde o autor escreve a oração. No caso de van Gogh, observo que direção ele dá para a oração, a partir do lugar de onde ele a escreve, se ele está dentro do universo representado na tela narrando suas características, ou se ele está fora da tela descrevendo-a com outro tipo de direcionamento e enfoque que costuma ser mais direto e sintético. 
Quadro 20: Triangulação da Direção ou Vetor

\begin{tabular}{|c|c|c|}
\hline Ocorrência nas telas & Orações & Comentário \\
\hline $\begin{array}{l}\text { Na tela 'Por de Sol: Campo } \\
\text { de trigo perto de Arles', } \\
\text { observei a ocorrência de } \\
\text { Vetor ou Movimento } \\
\text { Direcional, por meio de } \\
\text { pinceladas direcionais que } \\
\text { produzem a sensação } \\
\text { visual de que está ventando } \\
\text { no trigo e criam a ação de } \\
\text { 'ventar'. Registrada nas } \\
\text { notas de rodapé } 65,66,68 \text { e } \\
81 \text { no apêndice. } \\
\\
\text { Ocorrência de movimento } \\
\text { direcional e rima visual são } \\
\text { conferidos pelo uso do gesto } \\
\text { pictórico, do ritmo, da } \\
\text { textura e do movimento no } \\
\text { trigal. }\end{array}$ & $\begin{array}{l}\text { Eu tenho um terceiro estudo, agora, } \\
\text { de uma paisagem com fábrica, e um } \\
\text { enorme sol em um céu vermelho, } \\
\text { acima de telhados vermelhos, em } \\
\text { que a natureza parece estar em um } \\
\text { acesso de raiva, em um dia de } \\
\text { Mistral desagradável. } \\
\text { Eu pintei-a ao ar livre no Mistral. } \\
\text { Meu cavalete foi fixado no chão com } \\
\text { estacas de ferro, um método que eu } \\
\text { recomendo a você. } \\
\text { Você enterra os pés do cavalete e, } \\
\text { em seguida, você empurra a } 50 \\
\text { centímetros de comprimento um } \\
\text { peso de ferro ao lado deles. Você } \\
\text { amarra tudo com cordas; dessa } \\
\text { forma, você pode trabalhar com o } \\
\text { vento. (VAN GOGH, 2009c, p. } \\
\text { 1). } 301\end{array}$ & $\begin{array}{l}\text { O movimento na tela produz uma ação } \\
\text { que define uma meta de comunicação } \\
\text { com o observador. A ação do vento ao } \\
\text { ar livre direciona o olhar para um } \\
\text { ambiente que é dinâmico e van Gogh } \\
\text { enfatiza esse movimento interno da } \\
\text { tela de uma forma muito singular e } \\
\text { logo em seguida ele associa a fixidez } \\
\text { do cavalete no chão. E em seguida } \\
\text { após descrever toda a dinâmica interna } \\
\text { do quadro ele descreve para o irmão } \\
\text { como que aquele movimento, aquela } \\
\text { dinâmica do vento precisa ser } \\
\text { controlada por ele no momento da } \\
\text { produção da obra. Então ele descreve } \\
\text { todas as suas ações para fincar o } \\
\text { cavalete no chão. }\end{array}$ \\
\hline $\begin{array}{l}\text { Na tela 'Por de Sol: Campo } \\
\text { de trigo perto de Arles', } \\
\text { observei a ocorrência de } \\
\text { Vetor ou Movimento } \\
\text { Direcional. A tela sugere um } \\
\text { conflito presente na forma } \\
\text { como os elementos que } \\
\text { deveriam se relacionar de } \\
\text { maneira harmônica estão em } \\
\text { todo momento se } \\
\text { contrastando. Seja pela } \\
\text { diferença de direções do } \\
\text { trigo no campo, pela } \\
\text { diferença de cores do trigo, } \\
\text { pela diferença de } \\
\text { espaçamento que as } \\
\text { pinceladas ora criam um } \\
\text { conjunto homogêneo e } \\
\text { indiferenciado, ora ressaltam } \\
\text { a individualidade de cada } \\
\text { ramo de trigo. Registradas } \\
\text { nas notas de rodapé } 68,69, \\
\underline{70,71,72 \text { e } 73 \text { no apêndice. }}\end{array}$ & $\begin{array}{l}\text { Aqui está outra paisagem. Sol } \\
\text { poente? Lua nascendo? Noite de } \\
\text { verão, de qualquer modo. Cidade } \\
\text { violeta, estrela amarela, céu azul- } \\
\text { esverdeado; os campos de trigo têm } \\
\text { todos os tons: ouro velho, cobre, } \\
\text { ouro verde, ouro vermelho, ouro } \\
\text { amarelo, verde, vermelho e amarelo } \\
\text { bronze. Tela quadrada número } 30 \text {. }\end{array}$ & $\begin{array}{l}\text { Essa produção de homogeneidade e } \\
\text { diferenciação na forma como ele } \\
\text { agrupa os elementos representados na } \\
\text { composição pode ser uma estratégia } \\
\text { de acentuação de sensações visuais } \\
\text { que produzem Textura, Movimento, } \\
\text { Vetor e Gesto Pictórico, e conduzem à } \\
\text { sinestesia e à Modalidade sensorial. } \\
\text { Registradas nas notas de rodapé } 68 \text {, } \\
69,70,71,72 \text { e } 73 \text { no apêndice. }\end{array}$ \\
\hline $\begin{array}{l}\text { Na tela 'Por de Sol: Campo } \\
\text { de trigo perto de Arles', } \\
\text { observei a ocorrência de } \\
\text { Vetor } 1 \text { - pinceladas } \\
\text { direcionais do gesto } \\
\text { pictórico sugerem que a }\end{array}$ & $\begin{array}{l}\text { Paisagens amarelo ouro velho - feito } \\
\text { rápido rápido rápido e com pressa, } \\
\text { como o ceifeiro que está em silêncio } \\
\text { sob o sol escaldante, concentrando- } \\
\text { se em ter o trabalho terminado. }\end{array}$ & $\begin{array}{l}\text { A forma como ele descreve a ação de } \\
\text { criação e de recriação e de } \\
\text { representação do campo de trigo } \\
\text { sugere uma colagem entre o } \\
\text { movimento do vento sobre o trigo e o } \\
\text { movimento do pincel sobre a tela. }\end{array}$ \\
\hline
\end{tabular}

${ }^{301}$ Disponível em: 〈http://vangoghletters.org/vg/letters/let628/letter.html〉. 


\begin{tabular}{|c|c|c|}
\hline $\begin{array}{l}\text { ação está no trigo. } \\
\text { Registrada na nota de rodapé } \\
90 \text { no apêndice. }\end{array}$ & & \\
\hline $\begin{array}{l}\text { Na tela 'Por de Sol: Campo } \\
\text { de trigo perto de Arles', } \\
\text { observei a ocorrência de } \\
\text { Vetor } 2 \text { - pinceladas } \\
\text { direcionais do gesto } \\
\text { pictórico sugerem que a } \\
\text { ação está no vento. } \\
\text { Registrada na nota de rodapé } \\
\text { 91 no apêndice. }\end{array}$ & $\begin{array}{l}\text { Eu tenho um terceiro estudo, agora, } \\
\text { de uma paisagem com fábrica, e um } \\
\text { enorme sol em um céu vermelho, } \\
\text { acima de telhados vermelhos, } \underline{\text { em }} \\
\text { que a natureza parece estar em um } \\
\text { acesso de raiva, em um dia de } \\
\underline{\text { Mistral desagradável. }}\end{array}$ & $\begin{array}{l}\text { Van Gogh descreve a tela como um } \\
\text { objeto que em parte está estático } \\
\text { (tenho) e em parte está em movimento } \\
\text { (estudo) e que internamente parte está } \\
\text { estática (telhado, céu) e parte está em } \\
\text { movimento (a natureza em um dia de } \\
\text { Mistral desagradável). A ação se } \\
\text { coloca na contraposição entre duas } \\
\text { condições, uma de ser e outra de estar. } \\
\text { Na oração a natureza aparece como } \\
\text { mutável na oração e na tela, o vento } \\
\text { aparece como agente da ação. }\end{array}$ \\
\hline $\begin{array}{l}\text { Na tela 'Por de Sol: Campo } \\
\text { de trigo perto de Arles', } \\
\text { observei a ocorrência de } \\
\text { Vetor } 3 \text { com pinceladas } \\
\text { direcionais do gesto } \\
\text { pictórico que sugerem que } \\
\text { a ação está no Sol. } \\
\text { Registrada na nota de rodapé } \\
92 \text { no apêndice. }\end{array}$ & $\begin{array}{l}\text { Eu tenho um terceiro estudo, agora, } \\
\text { de uma paisagem com fábrica, e um } \\
\text { enorme sol em um céu vermelho, } \\
\text { acima de telhados vermelhos, em } \\
\text { que a natureza parece estar em um } \\
\text { acesso de raiva, em um dia de } \\
\text { Mistral desagradável. } \\
\text { Aqui está outra paisagem. Sol } \\
\text { poente? Lua nascendo? Noite de } \\
\text { verão, de qualquer modo. Cidade } \\
\text { violeta, estrela amarela, céu azul- } \\
\text { esverdeado; os campos de trigo têm } \\
\text { todos os tons: ouro velho, cobre, } \\
\text { ouro verde, ouro vermelho, ouro } \\
\text { amarelo, verde, vermelho e amarelo } \\
\text { bronze. }\end{array}$ & $\begin{array}{l}\text { Nas construções dessas orações } \\
\text { observei uma ênfase dada ao sol, que } \\
\text { pode ser considerada compatível com } \\
\text { a ênfase dada para o sol na tela e } \\
\text { sugerem nessa ênfase um } \\
\text { protagonismo dado para o sol. }\end{array}$ \\
\hline $\begin{array}{l}\text { Na tela 'O Semeador, } \\
\text { Observei a ocorrência de } \\
\text { Vetor } 1 \text { e Associação } \\
\text { metafórica por meio de um } \\
\text { caminho visual do primeiro } \\
\text { plano até o último plano, } \\
\text { que constrói um movimento } \\
\text { direcional e as metáforas de } \\
\text { uma narrativa visual. } \\
\text { Registrada na nota de rodapé } \\
\underline{8} . \\
\text { Na tela 'O Semeador', } \\
\text { observei a ocorrência de } \\
\text { Enquadramento, Saliência, } \\
\text { Vetor } 1 \text { para construir uma } \\
\text { maior centralidade do } \\
\text { campo na narrativa, e um } \\
\text { sentido igualmente } \\
\text { importante do enunciado que } \\
\text { é o de receber a semeadura }\end{array}$ & $\begin{array}{l}\text { Em um campo arado, um grande } \\
\text { campo de torrões de terra roxa - } \\
\text { levantados em direção ao horizonte- } \\
\text { um semeador em azul e branco. No } \\
\text { horizonte um campo de trigo curto, } \\
\text { maduro. } \\
\text { Acima de tudo isso um céu amarelo } \\
\text { com um sol amarelo. }\end{array}$ & $\begin{array}{l}\text { A similaridade entre a descrição } \\
\text { escrita da tela e a representação } \\
\text { visual se dá pelo contimento da ação } \\
\text { da terra de baixo para cima e do sol } \\
\text { de cima para baixo sobre o plano } \\
\text { central, no qual o semeador está } \\
\text { trabalhando. No nível } \\
\text { representacional e no nível da } \\
\text { descrição escrita da tela as ações } \\
\text { centrais são do sol e do campo } \\
\text { arado, ficando o semeador, com base } \\
\text { nessas escolhas léxico-gramaticais, } \\
\text { como uma figura que não concentra } \\
\text { em si a centralidade da ação, mas } \\
\text { que a divide com o próprio campo } \\
\text { arado. }\end{array}$ \\
\hline
\end{tabular}




\begin{tabular}{|c|c|c|}
\hline $\begin{array}{l}\text { do semeador. } \\
\text { Observei um deslocamento } \\
\text { da agência da ação que é } \\
\text { compatível com as } \\
\text { ocorrências de deslocamento } \\
\text { da agência da ação nas } \\
\text { orações escritas por van } \\
\text { Gogh. }\end{array}$ & & \\
\hline $\begin{array}{l}\text { Na tela 'O Semeador, } \\
\text { observei a ocorrência de } \\
\text { Vetor } 2 \text { construída pelo } \\
\text { Semeador que anda e olha } \\
\text { para a direita da tela. O } \\
\text { Vetor constrói a Associação } \\
\text { metafórica que o Semeador } \\
\text { se desloca do passado para o } \\
\text { futuro. Há também uma } \\
\text { metáfora de conflito entre o } \\
\text { significado simbólico dos } \\
\text { corvos e o do semear, } \\
\text { registrada na nota de rodapé } \\
\text { 39. } \\
\text { Observei também a } \\
\text { ocorrência de Movimento, } \\
\text { Gesto Pictórico e Vetor } 1, \\
\text { sugerido pelo andar do } \\
\text { Semeador. Registrada na } \\
\text { nota de rodapé } 52 .\end{array}$ & $\begin{array}{l}\text { Em um campo arado, um grande } \\
\text { campo de torrões de terra roxa - } \\
\text { levantados em direção ao horizonte - } \\
\text { um semeador em azul e branco. No } \\
\text { horizonte um campo de trigo curto, } \\
\text { maduro. } \\
\text { Acima de tudo isso um céu amarelo } \\
\text { com um sol amarelo. }\end{array}$ & $\begin{array}{l}\text { O semeador segue em um movimento } \\
\text { direcional ao horizonte. O vetor é tanto } \\
\text { o semeador e seu movimento de } \\
\text { semear quanto do caminho entre a } \\
\text { terra arada em direção ao campo de } \\
\text { trigo maduro, ambos estão indo na } \\
\text { direção da colheita, futura e no } \\
\text { horizonte da ação. O uso metafórico } \\
\text { dos elementos pictóricos confere um } \\
\text { sentido unitário à tela. Assim, inferi } \\
\text { que a ação do semeador e a ação do } \\
\text { caminho no campo arado dão direção } \\
\text { metafórica ao quadro: semear, colher. } \\
\text { Por outro lado, a direção do artista, } \\
\text { que se vê em direção ao horizonte, mas } \\
\text { se pergunta se terá o poder necessário } \\
\text { para a futura colheita, para a produção } \\
\text { de sentidos que representem na tela } \\
\text { seu desejo. Mas é esta sua direção, é } \\
\text { este seu caminho. }\end{array}$ \\
\hline $\begin{array}{l}\text { Na tela 'O Semeador' } \\
\text { observei a ocorrência de } \\
\text { Ritmo, Textura, Direção e } \\
\text { Movimento construídos pelo } \\
\text { Gesto Pictórico para } \\
\text { representar o campo } \\
\text { arado. Registrados na nota } \\
\text { de rodapé } 47 . \\
\\
\text { Observei o uso conjugado de } \\
\text { Textura, ritmo, movimento, } \\
\text { direção, gesto pictórico e } \\
\text { saliência na representação } \\
\text { dos torrões de terra } \\
\text { revolvida no campo arado. } \\
\text { Registrado na nota de rodapé } \\
\text { 49. } \\
\\
\text { Na tela 'O Semeador', há } \\
\text { uma inter-relação entre } \\
\text { Textura, Contrastes } \\
\text { Simultâneos, Saliência, } \\
\text { Sinestesia que criam } \\
\text { Associações Metafóricas da } \\
\text { materialidade da tinta com } \\
\text { a nossa memória sensorial }\end{array}$ & $\begin{array}{l}\text { Aqui está um esboço de um } \\
\text { semeador, um grande campo lavrado } \\
\text { com torrões de terra, na sua maioria } \\
\text { fracamente cor de violeta. } \\
\text { Um campo de trigo maduro, de tom } \\
\text { amarelo-ocre com um pouco de } \\
\text { carmim. } \\
\text { (...) } \\
\text { Há várias sugestões de amarelo no } \\
\text { solo, tons neutros resultantes da } \\
\text { mistura de violeta e amarelo; mas } \\
\text { tenho travado uma luta diabólica } \\
\text { para atingir a verdade das cores. } \\
(\ldots) \\
\text { Em um campo arado, um grande } \\
\text { campo de torrões de terra roxa - } \\
\text { levantados em direção ao horizonte - } \\
\text { um semeador em azul e branco. No } \\
\text { horizonte um campo de trigo curto, } \\
\text { maduro. } \\
\text { Acima de tudo isso um céu amarelo } \\
\text { com um sol amarelo. } \\
\text { Você pode sentir a partir da mera } \\
\text { nomenclatura das tonalidades - que a } \\
\text { cor desempenha um papel muito }\end{array}$ & $\begin{array}{l}\text { A construção léxico-gramatical nessas } \\
\text { orações evidencia o uso de complexos } \\
\text { nominais na representação do campo } \\
\text { arado que são compativeis com o uso } \\
\text { de textura e contrastes cromáticos na } \\
\text { tela para salientar os significados da } \\
\text { terra revolvida e preparada para a } \\
\text { semeadura. }\end{array}$ \\
\hline
\end{tabular}




\begin{tabular}{|c|c|c|}
\hline $\begin{array}{l}\text { e tátil da plasticidade da } \\
\text { terra. Registrado na nota de } \\
\text { rodapé } 50 .\end{array}$ & importante nesta composição. & \\
\hline $\begin{array}{l}\text { Na tela 'A Esplanada do } \\
\text { Café na Place du Forum, } \\
\text { Arles, à Noite', observei a } \\
\text { ocorrência de Vetor e de } \\
\text { contraposição entre vetores. } \\
\text { O vetor mais importante é } \\
\text { o da lâmpada a gás que } \\
\text { irradia, os secundários são } \\
\text { as pessoas que convergem e } \\
\text { a noite que escurece. A } \\
\text { lâmpada ilumina, a noite } \\
\text { escurece. Esses vetores } \\
\text { secundários se contrapõem } \\
\text { com a ação do vetor central, } \\
\text { formando eixos de } \\
\text { contraposição. Registrados } \\
\text { na nota de rodapé } 131 \text { no } \\
\text { apêndice. } \\
\text { Observei também a } \\
\text { ocorrência de Vetor na } \\
\text { representação da luz que } \\
\text { congrega as pessoas } \\
\text { debaixo do toldo. Registrada } \\
\text { na nota de rodapé } 161 \text { no } \\
\text { apêndice. }\end{array}$ & $\begin{array}{l}\text { No terraço, há pequenas figuras de } \\
\text { pessoas que bebem. Uma enorme } \\
\text { lanterna amarela ilumina o terraço, a } \\
\text { fachada, a calçada, e até mesmo } \\
\text { projeta luz sobre os paralelepípedos } \\
\text { da rua, que adquirem uma coloração } \\
\underline{\text { violeta-rosa. As frentes das casas em }} \\
\text { uma rua que segue sob o céu azul } \\
\text { salpicado de estrelas são azul escuro } \\
\text { ou violeta, com uma árvore verde. }\end{array}$ & $\begin{array}{l}\text { No nível semântico, observei que a } \\
\text { segunda oração constrói uma ênfase } \\
\text { para o processo 'ilumina' vetorizado } \\
\text { pela lanterna, por meio da escolha } \\
\text { lexical de 'enorme' e 'amarela'. Essa } \\
\text { ação ganha uma nova ênfase dada pelo } \\
\text { complexo nominal o terraço, a } \\
\text { fachada, a calçada, e até mesmo } \\
\text { projeta luz sobre os paralelepípedos da } \\
\text { rua, que adquirem uma coloração } \\
\text { violeta-rosa. O Vetor da ação da } \\
\text { lâmpada se contrapõe com o Vetor da } \\
\text { ação da noite, construído na terceira } \\
\text { oração deste excerto: 'As frentes das } \\
\text { casas (...)' que coloca a ênfase na } \\
\text { coloração das casas que estão 'sob o } \\
\text { céu azul salpicado de estrelas'. A } \\
\text { sequência dessas duas orações mostra } \\
\text { não apenas esses dois Vetores, mas a } \\
\text { sua relação de contraposição na } \\
\text { construção de sentidos que ele quis } \\
\text { enunciar acerca da relação entre a } \\
\text { iluminação artificial da lâmpada a gás } \\
\text { e da iluminação natural da noite. }\end{array}$ \\
\hline $\begin{array}{l}\text { Na tela 'A Esplanada do } \\
\text { Café na Place du Forum, } \\
\text { Arles, à Noite', observei a } \\
\text { ocorrência de Vetor que } \\
\text { resulta em Distorção do } \\
\text { ponto de vista, na } \\
\text { representação das cadeiras } \\
\text { vazias no primeiro plano, } \\
\text { ambas voltadas para a o } \\
\text { pintor que as pinta sugerindo } \\
\text { um caminho visual inverso, } \\
\text { de ponto de fuga invertido, } \\
\text { como observado em outras } \\
\text { telas analisadas. Registrada } \\
\text { na nota de rodapé } 162 \text { e } 165 \\
\text { no apêndice. }\end{array}$ & & \\
\hline $\begin{array}{l}\text { Na tela 'O Café Noturno na } \\
\text { Place Lamartine, em Arles', } \\
\text { observei a ocorrência do uso } \\
\text { de Saliência e Vetor inter- } \\
\text { relacionados com a } \\
\text { ocorrência de Textura e } \\
\text { Gesto Pictórico para }\end{array}$ & $\begin{array}{l}\text { Uma enorme lanterna amarela } \\
\text { ilumina o terraço, a fachada, a } \\
\text { calçada, e até mesmo projeta luz } \\
\text { sobre os paralelepípedos da rua, que } \\
\text { adquirem uma coloração violeta- } \\
\text { rosa. }\end{array}$ & $\begin{array}{l}\text { O movimento de projeção da luz é } \\
\text { representado na tela pelo amarelo na } \\
\text { calçada. Há uma ação da luz em toda a } \\
\text { tela, seja pela luminosidade artificial } \\
\text { do café, seja pela luminosidade natural } \\
\text { do céu estrelado. Nesta tela a luz tem } \\
\text { um papel proeminente na direção do }\end{array}$ \\
\hline
\end{tabular}


construir a luz das

lâmpadas a gás. Registrada

na nota de rodapé 125 . O

vetor ocorre em direção

radial.

Ocorrência de Ritmo,

Textura, Movimento, Vetor e Rima Visual pelo Gesto

Pictórico para expressar o

fluxo e a intensidade da iluminação na sala.

Registrado na nota de rodapé 189.

Ocorrência de Saliência, por meio do uso de Ritmo,

Movimento, Textura, Vetor e Gesto Pictórico que são usados para representar o brilho intermitente das lâmpadas, pintado com riqueza de detalhes, textura e movimento direcional. Registrado na nota de rodapé $\underline{190 .}$.

Ocorrência de Associação metafórica por meio do uso de Ritmo, Movimento, Textura, Vetor, Gesto Pictórico e Rima Visual que juntos constroem uma metáfora visual para a luz que interliga todos os processos na narrativa, registrados na nota de rodapé 191.

Ocorrência e Rima Visual por meio do Ritmo,

Movimento e Vetor na representação da Luz que funciona como elemento de ligação e de transição entre as pequenas narrativas. Registrados na nota de rodapé 193.

Ocorrência de Ritmo, Movimento, Textura e Vetor para construir a luz, que parece que está em movimento e vibrando. Registrados na nota de rodapé 194.
A segunda mostra o exterior de um café, iluminado no terraço externo por uma grande lâmpada de gás dentro da noite azul, com um retalho de céu azul estrelado. olhar, ela age sobre a paisagem, e sua ação modifica os elementos da tela. A luz direciona o olhar sobre os elementos que compõe a tela, agrega sentido e valor àqueles elementos que de outra forma não apareceriam. 


\begin{tabular}{|c|c|c|}
\hline $\begin{array}{l}\text { Ocorrência e Rima Visual } \\
\text { por meio do Ritmo, } \\
\text { Movimento e Vetor na } \\
\text { representação da Luz que } \\
\text { funciona como elemento de } \\
\text { ligação e de transição entre } \\
\text { as pequenas narrativas. } \\
\text { Registrados na nota de } \\
\text { rodapé 193. } \\
\\
\text { Ocorrência de Associação } \\
\text { metafórica por meio do uso } \\
\text { de Ritmo, Movimento, } \\
\text { Textura, Vetor, Gesto } \\
\text { Pictórico e Rima Visual que } \\
\text { juntos constroem uma } \\
\text { metáfora visual para a luz } \\
\text { que interliga todos os } \\
\text { processos na narrativa. } \\
\text { Registrados na nota de } \\
\text { rodapé } 191 .\end{array}$ & $\begin{array}{l}\text { Agora há uma pintura de noite sem } \\
\text { preto. No passado, eles costumavam } \\
\text { desenhar e pintar a tela do desenho } \\
\text { durante o dia. Mas acho que me } \\
\text { convém pintar a coisa no momento. } \\
\text { Mas é a única maneira de se livrar da } \\
\text { noite negra convencional com uma } \\
\text { luz pobre, pálida e esbranquiçada, } \\
\text { quando na verdade uma mera vela } \\
\text { por si só nos dá os mais ricos } \\
\text { amarelos e laranjas. } \\
\text { As frentes das casas em uma rua que } \\
\text { segue sob o céu azul salpicado de } \\
\text { estrelas são azul escuro ou violeta, } \\
\text { com uma árvore verde. }\end{array}$ & $\begin{array}{l}\text { A luz dá unidade à tela, possibilitando } \\
\text { criar um elo de transiçãa entre seus } \\
\text { elementos. Na carta enviada a Theo, } \\
\text { van Gogh descreve este efeito de } \\
\text { transição da luz em toda a tela e afirma } \\
\text { que 'agora há uma pintura sem preto'. } \\
\text { A luz à noite pode oferecer as mais } \\
\text { ricas cores e inclusive a possibilidade } \\
\text { de pintar uma noite sem preto. }\end{array}$ \\
\hline $\begin{array}{l}\text { Na tela 'O Café Noturno na } \\
\text { Place Lamartine, em Arles', } \\
\text { observei a ocorrência de } \\
\text { Vetor construída pela figura } \\
\text { do homem no centro da } \\
\text { sala que olha diretamente } \\
\text { para o espectador. } \\
\text { Registrada na nota de rodapé } \\
129 \text {. } \\
\text { Observei também que o } \\
\text { homem parado no centro da } \\
\text { sala, ao lado da mesa de } \\
\text { bilhar está olhando } \\
\text { diretamente para alguém } \\
\text { que não se encontra } \\
\text { representado na cena. Este } \\
\text { olhar sugere uma ação } \\
\text { vetorial, como em uma } \\
\text { oração com sujeito, } \\
\text { processo, mas sem uma } \\
\text { meta. Encontrei a ocorrência } \\
\text { da representação escrita } \\
\text { dessa ação do homem } \\
\text { parado próximo à mesa de } \\
\text { bilhar do Café da Noite que } \\
\text { olha diretamente para } \\
\text { alguém ou para algo. } \\
\text { Registrado nas notas de } \\
\text { rodapé } 129,167 \text { e } 168 .\end{array}$ & $\begin{array}{l}\text { Agora como para recuperar o } \\
\text { dinheiro pago ao senhorio através da } \\
\text { minha pintura, eu não estou fazendo } \\
\text { questão disto, porque a pintura é uma } \\
\text { das mais feias que eu já fiz. } \\
\text { Eu também fiz um novo retrato de } \\
\text { mim mesmo, como um estudo, no } \\
\text { qual eu pareço um Japonês. Você } \\
\text { nunca me disse se você tinha lido } \\
\text { Bel-ami de Guy de Maupassant, e o } \\
\text { que você pensa agora do talento dele } \\
\text { em geral. Digo isto porque o início } \\
\text { de Bel- Ami é precisamente a } \\
\text { descrição de uma noite estrelada em } \\
\text { Paris, com os cafés iluminados da } \\
\text { avenida, e isso é algo como o mesmo } \\
\text { tema que eu pintei bem agora. } \\
\text { A ideia do semeador ainda continua } \\
\text { a me assombrar. Estudos exagerados, } \\
\text { como o semeador, como o café } \\
\text { noturno agora, geralmente parecem- } \\
\text { me atrozmente feios e ruins, mas } \\
\text { quando eu estou movido por alguma } \\
\text { coisa, como aqui por este pequeno } \\
\text { artigo sobre Dostoievski, em } \\
\text { seguida, eles são os únicos que me } \\
\text { parecem ter um significado mais } \\
\text { importante. }\end{array}$ & $\begin{array}{l}\text { O movimento de ambivalência } \\
\text { emocional está presente no discurso } \\
\text { escrito (recuperar o dinheiro perdido, a } \\
\text { pintura é uma das mais feias que já fiz) } \\
\text { e na representação dos elementos na } \\
\text { tela (o olhar de confrontação do } \\
\text { homem próximo à mesa de bilhar, a } \\
\text { indiferença dos demais, o abandono e } \\
\text { a feiura) }\end{array}$ \\
\hline $\begin{array}{l}\text { Na tela ‘O Café Noturno na } \\
\text { Place Lamartine, em Arles', } \\
\text { observei a ocorrência de } \\
\text { Associação metafórica com a }\end{array}$ & $\begin{array}{l}\text { Nesta tela, há } 6 \text { ou } 7 \text { vermelhos } \\
\text { diferentes, desde vermelho-sangue } \\
\text { até rosa delicado, fazendo oposição } \\
\text { com o mesmo número de verdes }\end{array}$ & $\begin{array}{l}\text { Van Gogh costuma usar a associação } \\
\text { metafórica da oposição entre cores } \\
\text { complementares com a simbologia de }\end{array}$ \\
\hline
\end{tabular}




\begin{tabular}{|c|c|c|}
\hline $\begin{array}{l}\text { ajuda de Vetor, Perspectiva, } \\
\text { Enquadramento e Saliência } \\
\text { na representação do casal } \\
\text { no fundo da sala. } \\
\text { Registrada na nota de rodapé } \\
\text { 251. }\end{array}$ & $\begin{array}{l}\text { pálidos ou escuros. } \\
\text { Verifiquei a ocorrência do uso de um } \\
\text { construto de contraposição e antítese } \\
\text { no nível semântico da oração ‘Agora } \\
\text { como para recuperar o dinheiro pago } \\
\text { ao senhorio através da minha } \\
\text { pintura, eu não estou fazendo } \\
\text { questão disto, porque a pintura é uma } \\
\text { das mais feias que eu já fiz'. Essa } \\
\text { contraposição é compatível com o } \\
\text { uso de contrastes complementares de } \\
\text { verdes e vermelhos e com a oração } \\
\text { na qual ele explicita que a tela fala } \\
\text { de 'conflitos e antíteses por toda } \\
\text { parte'. Registrado na nota de rodapé } \\
254 \text {. }\end{array}$ & $\begin{array}{l}\text { um casamento. Dessa forma a } \\
\text { representação do casal no fundo da } \\
\text { sala, no ponto para o qual convergem } \\
\text { os caminhos visuais vetorizados pelas } \\
\text { linhas de perspectiva construídas pelas } \\
\text { tábuas do chão, pode ser uma metáfora } \\
\text { para o mesmo sentido de } \\
\text { contraposição que está sendo afirmado } \\
\text { pelo uso de } 6 \text { ou } 7 \text { tipos de contrastes } \\
\text { entre vermelhos e verdes que estão a } \\
\text { fazer oposição. } \\
\text { 'Uso de vetor com a escolha lexical } \\
\text { 'fazendo oposição' na oração, na qual } \\
\text { o movimento está aprisionado nesta } \\
\text { ação, e na tela, na qual o movimento } \\
\text { está no contraste entre o vermelho e o } \\
\text { verde. Registrado na nota de rodapé } \\
296 .\end{array}$ \\
\hline $\begin{array}{l}\text { Na tela 'O Café Noturno na } \\
\text { Place Lamartine, em Arles', } \\
\text { observei a ocorrência de } \\
\text { Inversão do Ponto de vista, } \\
\text { construída pelo Vetor, dado } \\
\text { pelo homem no centro da } \\
\text { sala que olha para o } \\
\text { espectador. A seta, criada } \\
\text { pela sombra da mesa se } \\
\text { encarrega de levar a } \\
\text { atenção do espectador para } \\
\text { aquele ponto desde o qual } \\
\text { se olha a cena. Esse sentido } \\
\text { constrói uma inversão e um } \\
\text { deslocamento no } \\
\text { Enquadramento e na } \\
\text { Perspectiva que vai desde o } \\
\text { envolvimento até o } \\
\text { distanciamento para se } \\
\text { olhar a cena. Registrados na } \\
\text { nota de rodapé } 154 \text {. }\end{array}$ & $\begin{array}{l}\text { A sala está pintada de vermelho, e no } \\
\text { interior, na luz a gás, a mesa de } \\
\text { bilhar verde, a qual lança uma } \\
\text { imensa sombra sobre o chão. }\end{array}$ & $\begin{array}{l}\text { Um dos vetores principais em quase } \\
\text { todas as telas de van Gogh é o efeito } \\
\text { da luz no ambiente. A luz modifica, } \\
\text { age sobre o ambiente de forma } \\
\text { incisiva. Na descrição da tela van } \\
\text { Gogh afirma que a luz 'lança uma } \\
\text { imensa sombra sobre o chão'. } \\
\text { A luz tem papel proeminente na cena, } \\
\text { ela aparece lançando luz e sombra. } \\
\text { Parece haver nesta ação da luz um } \\
\text { sentido metafórico, de um objeto } \\
\text { aparentemente pequeno é possível } \\
\text { extrair um efeito imenso. O } \\
\text { descontrole da ação e seu efeito no } \\
\text { ambiente podem estar representando o } \\
\text { efeito das emoções (luz) sobre as ações } \\
\text { (sombrias). O movimento da luz sobre } \\
\text { o ambiente está presente tanto na tela } \\
\text { quanto na carta, mas a escolha das } \\
\text { palavras para descrever o efeito da luz } \\
\text { no ambiente sugere uma centralidade } \\
\text { de seu significado metafórico, } \\
\text { causando no leitor outro olhar sobre a } \\
\text { tela. }\end{array}$ \\
\hline $\begin{array}{l}\text { Na tela 'O Café Noturno na } \\
\text { Place Lamartine, em Arles', } \\
\text { observei a ocorrência de } \\
\text { Direção ou Vetor criada pela } \\
\text { sombra da mesa que se } \\
\text { assemelha a uma seta e } \\
\text { pelo olhar do homem que } \\
\text { parece nos fitar diretamente. } \\
\text { Registrada nas notas de } \\
\text { rodapé } 152 \text { e } 166 .\end{array}$ & $\begin{array}{l}\text { A sala está pintada de vermelho, e no } \\
\text { interior, na luz a gás, a mesa de } \\
\text { bilhar verde, a qual lança uma } \\
\text { imensa sombra sobre o chão. }\end{array}$ & $\begin{array}{l}\text { Uso de direção ou Vetor no construto: } \\
\text { ‘mesa de bilhar, a qual lança uma } \\
\text { imensa sombra sobre o chão' que é } \\
\text { compatível com a representação da } \\
\text { imagem da mesa de bilhar e sua } \\
\text { enorme sombra apontando para o } \\
\text { primeiro plano. A sombra representa a } \\
\text { consequência da ação da luz; a forma } \\
\text { da sombra confirma o direcionamento } \\
\text { dessa ação da luz sobre a mesa. } \\
\text { Registrado na nota de rodapé } 289 \text {. }\end{array}$ \\
\hline
\end{tabular}




\begin{tabular}{|c|c|c|}
\hline $\begin{array}{l}\text { observei a ocorrência de } \\
\text { Vetor, construído pela } \\
\text { relação com o Contraste } \\
\text { Cromático da sombra e a } \\
\text { sua Saliência produzida em } \\
\text { oposição aos corredores de } \\
\text { luz, registrados na nota de } \\
\text { rodapé 155. }\end{array}$ & & \\
\hline $\begin{array}{l}\text { Na tela 'O Café Noturno na } \\
\text { Place Lamartine, em Arles', } \\
\text { observei a ocorrência de } \\
\text { Saliência construída pelo } \\
\text { Vetor e pela posição } \\
\text { relativa do homem no } \\
\text { centro da sala e dos } \\
\text { bêbados nas mesas } \\
\text { periféricas. Registrada na } \\
\text { nota de rodapé } 160 .\end{array}$ & $\begin{array}{l}\text { Alguns pobres vagabundos noturnos } \\
\text { estão dormindo em um canto. } \\
\text { A roupa branca do proprietário, } \\
\text { vigiando as coisas a partir de um } \\
\text { canto deste forno, torna-se amarelo- } \\
\text { limão, verde luminoso pálido. }\end{array}$ & $\begin{array}{l}\text { Observei o uso de associações } \\
\text { metafóricas e uso simbólico da cor } \\
\text { com A escolha do item lexical "forno" } \\
\text { no extrato de carta, que é } \\
\text { correspondente à representação visual } \\
\text { da luz excessiva no interior do café } \\
\text { registrado na nota de rodapé } 259 \text {. }\end{array}$ \\
\hline $\begin{array}{l}\text { Na tela 'O Café Noturno na } \\
\text { Place Lamartine, em Arles', } \\
\text { observei a ocorrência de } \\
\text { Vetor e de Saliência sobre a } \\
\text { atitude do homem que se } \\
\text { contrapõe à apatia que } \\
\text { toma as outras figuras na } \\
\text { cena, registrado na nota de } \\
\text { rodapé 162. } \\
\text { Também observei a } \\
\text { ocorrência de Vetor } \\
\text { construído na postura ativa } \\
\text { do homem que parece nos } \\
\text { fitar. Registrada nas notas } \\
\text { de rodapé } 166 \text { e 167. } \\
\\
\text { Observei a ocorrência de } \\
\text { Vetor e Inacabamento que } \\
\text { é construído pela ausência } \\
\text { de uma 'meta' para a ação } \\
\text { de olhar do homem. Não } \\
\text { sabemos para o que ele } \\
\text { olha, a ação está } \\
\text { inconclusa, conotando uma } \\
\text { ocorrência de Inacabamento } \\
\text { nessa representação. } \\
\text { Registrada na nota de rodapé } \\
168 .\end{array}$ & $\begin{array}{l}\text { Em todos os lugares é uma batalha e } \\
\text { uma antítese dos mais diferentes } \\
\text { verdes e vermelhos; nas personagens } \\
\text { dos rufiões adormecidos, pequenos } \\
\text { na alta sala vazia, algum roxo e azul. } \\
\text { O vermelho-sangue e o amarelo- } \\
\text { verde da mesa de bilhar, por } \\
\text { exemplo, contrasta com o pouco de } \\
\text { verde delicado Louis XV do balcão, } \\
\text { onde há um buquê rosa. } \\
\text { A roupa branca do proprietário, } \\
\text { vigiando as coisas a partir de um } \\
\text { canto deste forno, torna-se amarelo- } \\
\text { limão, verde luminoso pálido. }\end{array}$ & $\begin{array}{l}\text { Uso de Associações Metafóricas e do } \\
\text { Uso Simbólico da Cor. Ao expressar } \\
\text { o sentido simbólico dos verdes e } \\
\text { vermelhos textualmente ele cola esse } \\
\text { sentido no uso dessas cores na tela, } \\
\text { construindo uma ponte entre a carta e } \\
\text { a tela, criando uma cadeia de textos. } \\
\text { Observei uma ocorrência do uso } \\
\text { simbólico da cor em ambas as } \\
\text { modalidades não pela forma, mas } \\
\text { pelo sentido associado a este uso. } \\
\text { Registrado na nota de rodapé } 257 . \\
\text { O homem parado no centro da sala } \\
\text { do Café Lamartine, ao lado da mesa } \\
\text { de bilhar está olhando diretamente } \\
\text { para alguém que não se encontra } \\
\text { representado na cena. Este olhar } \\
\text { sugere uma ção vetorial, como em } \\
\text { uma oração com sujeito, processo, } \\
\text { mas sem uma meta. Encontrei na } \\
\text { escrita a ocorrência no nível } \\
\text { semântico dessa ação do homem } \\
\text { parado próximo à mesa de bilhar do } \\
\text { Café da Noite que olha diretamente } \\
\text { para alguém ou para algo. Registrado } \\
\text { na análise visual com a nota de } \\
\text { rodapé } 129 .\end{array}$ \\
\hline $\begin{array}{l}\text { Ocorrência de Inversão do } \\
\text { ponto de vista construído } \\
\text { pelo Vetor do olhar do } \\
\text { homem no centro da sala } \\
\text { que olha para o pintor e } \\
\text { com isso inverte a } \\
\text { perspectiva da tela, criando } \\
\text { um jogo de espelhamento } \\
\text { com o espectador. Registrada }\end{array}$ & & \\
\hline
\end{tabular}




\begin{tabular}{|c|c|c|}
\hline $\begin{array}{l}\text { nas notas de rodapé } 169 \mathrm{e} \\
170 .\end{array}$ & & \\
\hline $\begin{array}{l}\text { Na tela 'O Café Noturno na } \\
\text { Place Lamartine, em Arles', } \\
\text { observei a ocorrência de } \\
\text { Transparência, } \\
\text { Incompletude, Modalidade e } \\
\text { Limiar Artístico pelo uso do } \\
\text { Inacabamento, } \\
\text { Enquadramento, Perspectiva, } \\
\text { Distorção do Ponto de Vista, } \\
\text { Direção, Profundidade, como } \\
\text { marca estilística das linhas } \\
\text { que organizam a } \\
\text { perspectiva da sala. } \\
\text { Registrada na nota de rodapé } \\
\text { 250. }\end{array}$ & $\begin{array}{l}\text { Que diria portanto desse quadro o Sr. } \\
\text { Tersteeg? Diante de um Sisley, } \\
\text { Sisley, o mais discreto e delicado dos } \\
\text { Impressionistas - já disse: "Não } \\
\text { posso me impedir de pensar que o } \\
\text { artista que pintou isso estava um } \\
\text { pouco tonto". Diante do meu quadro, } \\
\text { então a mim ele diria que ele é um } \\
\text { caso de delirium tremens". }\end{array}$ & $\begin{array}{l}\text { No excerto van Gogh faz uma } \\
\text { comparação para construir a } \\
\text { metáfora para se referir ao efeito da } \\
\text { distorção que ele criou com as linhas } \\
\text { que organizam a perspectiva. Com a } \\
\text { escrita desse trecho bem humorado, } \\
\text { van Gogh revela que a distorção foi } \\
\text { uma escolha intencional para } \\
\text { significar o desequilíbrio e o clima } \\
\text { de excesso relacionado à } \\
\text { representação que ele fez do } \\
\text { ambiente do café da noite. }\end{array}$ \\
\hline
\end{tabular}

Fonte: Triangulação para Direção ou Vetor dos dados dos corpora visual e textual, com os extratos das cartas.

\subsection{ENQUADRAMENTO}

Em algumas telas van Gogh inova o enquadramento tradicional da composição na pintura, como é o caso da tela 'Café da Noite'. Esta nova forma de enfoque da cena pode ter recebido influência da linguagem fotográfica sobre a linguagem pictórica, que introduz uma nova possibilidade de recorte da composição, pela escolha de um novo ângulo com que se observa a cena e de um enquadramento que disso resulta. Como explica Gombrich (1995, p.524-525), a Fotografia impactou na mudança da representação do enquadramento da cena:

A máquina fotográfica ajudou a descobrir o encanto das cenas fortuitas e do ângulo
inesperado. Além disso, o desenvolvimento da fotografia iria impelir ainda mais os
artistas em seu caminho de exploração e experimentos. Não havia necessidade de a
pintura executar a tarefa que um dispositivo mecânico podia realizar melhor e mais
barato. Não devemos esquecer que, no passado, a arte da pintura serviu a numerosos
fins utilitários. Era usada para registrar a imagem de uma pessoa notável ou de uma
residência campestre. O pintor era um homem que podia derrotar a natureza
transitória das coisas e preservar o aspecto de qualquer objeto para a prosperidade.
Ignoraríamos o aspecto do Dodô se um pintor holandês do século XVII não tivesse
usado sua habilidade para retratar um espécime pouco antes de essas aves estarem
extintas. A fotografia no século XIX estava prestes a assumir essa função da arte
pictórica. Foi um golpe na posição dos artistas, tão sério quanto a abolição das
imagens religiosas pelo protestantismo (p.374). Antes da máquina fotográfica, quase
toda pessoa que se prezava devia posar para o seu retrato, pelo menos uma vez na
vida. Agora, as pessoas raramente se sujeitam a esse incômodo, a menos que
quisessem obsequiar ou ajudar um pintor amigo. Por causa disso, os artistas viram-
se cada vez mais compelidos a explorar regiões onde a máquina não podia substituí-
los. De fato, a arte moderna dificilmente se converteria no que é sem o impacto da
invenção da fotografia.

Mas esta relação entre a pintura e o impacto da fotografia não foi evidenciada no trabalho de van Gogh, uma vez que ele afirmava não gostar da fotografia. As experimentações 
com enquadramento em suas composições pode estar mais relacionada com a sua vasta erudição pictórica e seu contato com dezenas de artistas, entre eles, os pintores Impressionistas que tiveram um peso inegável no amadurecimento do discurso visual de van Gogh. Por este viés se inscreve a influência que a fotografia possivelmente estava tendo no olhar dos pintores do final do século XIX com os quais ele conviveu como, por exemplo, Degas, que inovou com seus enquadramentos, como relata Gombrich (1995, p. 527):

Não há história nos quadros de Degas. Ele não se interessa pelas bailarinas por serem moças bonitas. Tampouco parece importar-se com o estado de espírito delas. Olha-as com a objetividade desapaixonada com que os impressionistas olham uma paisagem à sua volta. Importante era o jogo de movimento ou espaço. Degas provou ao mundo acadêmico que, longe de serem incompatíveis com o desenho perfeito, os novos princípios dos jovens artistas estavam equacionando problemas que só o mais consumado mestre do desenho poderia resolver.

Gombrich (1995, p. 522) explica o impacto que a liberdade de escolha dos temas e dos enquadramentos teve na construção de um novo paradigma pelo qual os artistas viam o mundo:

\begin{abstract}
A sensação de uma nova liberdade e de um novo poder adquirido por esses artistas deve ter sido algo muito inebriante; deve tê-los compensado por boa parte da zombaria e hostilidade que tinham enfrentado. Num repente, o mundo inteiro oferecia temas adequados para a paleta do pintor. Onde quer que ele descobrisse uma bela combinação de tons, uma configuração interessante de cores e formas, uma alegre e satisfatória mancha de sol e sombras coloridas, podia instalar seu cavalete e tentar transferir sua impressão para a tela. Os velhos chavões do "tema digno", da "composição equilibrada", do "desenho correto" foram sepultados. O artista só era responsável pelo que pintava e como pintava ante a sua própria sensibilidade. (GOMBRICH, 1995, p.522)
\end{abstract}

Van Gogh escolhe enquadramentos inusitados na representação da cena. O enquadramento nas composições de van Gogh teve como sua principal influência a gravura japonesa. As descobertas em Paris foram se sucedendo, de acordo com Haziot (2010 p.167168):

\footnotetext{
$\mathrm{Na}$ arte japonesa ele reencontrava a ideia - menos conscientemente buscada, talvez, ainda que isso seja discutível - do desenho no cruzamento da representação e da escrita ideográfica, uma espécie de "desenho-escritura". A arte japonesa, originada do zen, era obcecada pelo traço como gesto quase instintivo e altamente meditado ao mesmo tempo. Conhecemos as tigelas de chá modeladas em alguns gestos, ainda no ponto de formação-deformação, e decoradas com alguns traços fulgurantes como que expelidos por um pincel tão espontâneo quanto engenhoso. Estamos aqui a anos-luz da arte apolínea da maravilhosa cerâmica Song chinesa. Essa arte japonesa da cerâmica, dionisíaca, tem mais relação com a irrupção do que com elaboração.
}

$\mathrm{Na}$ loja Bing, ele encontrou e admirou centenas de gravuras japonesas que já conhecia desde a estada na Antuérpia, e comprou algumas. Gombrich (1995, p. 526) examina o impacto das gravuras japonesas na representação do enquadramento das cenas para os impressionistas: 
O segundo aliado que os impressionistas encontraram em sua busca afoita de novos motivos e novos esquemas de cor foi a cromotipia japonesa. A arte do Japão desenvolvera-se a partir da arte chinesa (p.155) e prosseguira nesse rumo durante quase mil anos. No século XVIII, entretanto, talvez sob a influência das estampas europeias, os artistas japoneses abandonaram os motivos tradicionais da arte no Extremo Oriente e escolheram cenas da vida humilde como temas para suas xilogravuras coloridas, que combinavam grande arrojo de invenção com uma perfeição técnica magistral. (...) Os artistas do círculo de Manet estiveram entre os primeiros a apreciar as estampas e a colecioná-las avidamente. Viram nelas uma tradição não-contaminada pelas regras e lugares-comuns acadêmicos que os pintores franceses lutavam por eliminar. As gravuras japonesas os ajudaram a observar até que ponto as convenções europeias ainda persistiam entre eles, sem que se dessem conta. Os japoneses compraziam-se em todos os aspectos inesperados e não-convencionais. Seu mestre, Hokusai (1760-1849), representaria o Monte Fuji como que por acaso atrás de um poço (Fig. 341); Utamaro (1753-1806) não hesitaria em mostrar algumas de suas figuras cortadas pela margem de uma gravura ou por uma cortina de bambu (Fig. 342). Esse arrojado desdém por uma regra elementar da pintura europeia exerceu grande efeito sobre os impressionistas. Descobriram eles nessa regra um último esconderijo da antiga dominação do conhecimento sobre a visão. Por que havia a pintura de mostrar sempre todo ou uma parte relevante de cada figura numa cena?

A forma como as gravuras japonesas influenciavam van Gogh era completamente diferente da forma como elas tinham influenciado os Impressionistas. A liberdade do desenho, da cor, pela simplicidade e evidência das composições dos "crepons" de Utamaro, Hokusai, Hiroshigue o fascinaram e ele se tornou um dos maiores propagandistas dessa arte. Sua carta atesta a influência das gravuras japonesas em seu trabalho:

(...) E é tudo. Neste quarto nada existe que sugira penumbra, cortinas corridas. As amplas linhas do mobiliário, repito, devem expressar absoluto repouso. Retratos nas paredes, um espelho, uma toalha e algumas roupas. A moldura - como não existe branco no quadro - será branca. Isso à maneira de vingança pelo repouso forçado que fui obrigado a fazer. Trabalhei nele o dia inteiro, mas voce pode ver como a concepção é simples. As gradações de cor e as sombras estão suprimidas, o quadro está pintado com camadas leves e planas, livremente jogadas na tela à maneira das gravuras japonesas... (Carta de Van Gogh a Theo, Arles)

Nas obras do corpus visual desta pesquisa, há uma predominância do plano geral que dá importância aos elementos circunstanciais da composição e acentua o grau de distanciamento estabelecido entre os elementos da composição e nós, os espectadores, como conta Haziot (2010, p. 138):

Kerssemakers relata como, em seus passeios, Vincent isolava um trecho de paisagem "enquadrando-o" com as mãos e fechando depois os olhos pela metade para ver apenas "manchas de cores". Paul Gachet contará que em Auvers, Vincent lançava a cabeça para trás com olhos semicerrados, a fim de captar o essencial de um motivo. Uma prática que sempre aconselhou. (..) Ele mandava seus alunos pintarem naturezas-mortas, insistindo que fizessem, para progredir, cerca de cinquenta!

Para Kress e van Leeuwen (1996, p. 124-125), o distanciamento das figuras em uma tela informa muito sobre o enquadramento. Eles usam o estudo de Stuart Hall sobre o que significa socialmente o distânciamento entre duas pessoas, e no caso, comparam com o 
distanciamento entre a figura representada e o espectador para transpor esse mesmo significado, no entanto, eles ressaltam que o significado para a distância estabelecida pode variar em cada cultura:

'Distância social próxima'começa apenas fora desta faixa e é a distância em que
'negócios impessoais ocorrem'. 'Distância social longe' é 'a distância em que as
pessoas se movimentam quando alguém diz "Fique longe para que eu possa olhar
para você" - 'negócios e interação social conduzidos a esta distância têm um caráter
mais formal e impessoal do que na fase perto'. "Distância Pública, finalmente, é
nada mais do que isso, " a distância entre as pessoas que são e devem permanecer
estranhos". Estes julgamentos se aplicam, naturalmente, dentro de uma cultura
particular, e Hall cita muitos exemplos de mal-entendidos que podem surgir de
diferenças interculturais na interpretação da distância. ${ }^{302}$

A distância com a qual a figura foi representada pode influenciar o envolvimento do espectador com a cena. Ao contemplar o quadro estamos envolvidos pelo objeto, como reforçam Kress e Van Leeuween (1996, p. 128) "Bem perto dali, gostaríamos de sugerir, o objeto é mostrado como se o espectador estivesse envolvido com ele.”.

De acordo com Kress e van Leeuwen (1996, p. 127-128), "Na meia distância, o objeto é mostrado na íntegra, mas sem muito espaço ao redor. Ele é representado como dentro do alcance do espectador, mas não como efectivamente utilizado.” Observei esse efeito na mesa de bilhar, a mesa ocupa muito espaço, está ao alcance, mas não é efetivamente usada. Kress e van Leeuwen (1996, p. 128) comentam:

Paisagens, também, pode ser vista a partir de dentro; a partir de uma espécie de meia distância, com um objeto em primeiro plano, sugerindo, talvez, que o espectador é imaginariamente localizado dentro da paisagem, mas parar por um momento, como se para fazer um balanço do que está à frente; ou a partir de uma longa distância, a partir do ar, talvez, ou a partir de uma posição "vigia", não é em si um lugar na paisagem, mas proporcionando uma visão geral da mesma, como, por exemplo, em muitas das ilustrações fotográficas em livros de geografia. ${ }^{303}$

Este é o efeito que ocorre na tela Por de Sol: Campo de Trigo em Arles, que representa a cidade no horizonte. Pode-se ver parte dela por inteiro, como um recorte que ilustra sua configuração, sua totalidade.

\footnotetext{
302 Tradução livre da autora. "'Close social distance' begins just outside this range and is the distance at which 'impersonal business occurs'. 'Far social distance' is 'the distance to which people move when somebody says "Stand away so I can look at you" - 'business and social interaction conducted at this distance has a more formal and impersonal character than in the close phase'. 'Public distance', finally, is anything further than that, 'the distance between people who are and are to remain strangers'. These judgments apply, of course, within a particular culture, and Hall cites many examples of the misunderstandings which can arise from intercultural differences in the interpretation of distance." (KRESS E VAN LEEUWEN, 1996, P.124-125)

303 Tradução livre da autora. "Landscapes, too, can be seen from within; from a kind of middle distance, with a foreground object suggesting, perhaps, that the viewer is imaginarily located within the landscape, but stopping for a moment, as if to take stock of what is ahead; or from a long distance, from the air, perhaps, or from a 'lookout' position, a place not itself in the landscape but affording an overview of it, as, for instance, in many of the photographic illustrations in geography textbooks." (KRESS E VAN LEEUWEN, 1996, p.128)
} 


\subsubsection{Triangulação do Enquadramento}

Enquadramento, no texto escrito e em relação à triangulação - $\mathrm{O}$ enquadramento supõe uma escolha do que se vai abordar na representação visual. Pode-se falar o mesmo da oração, ou seja, o enquadramento na oração é constituído pelo que van Gogh seleciona ao enunciar a oração, e o ângulo com que ele fala do assunto, ou seja, de que ângulo ele vai abordar a construção do sentido. Como recurso metafórico para compreender essa escolha de enfoque da representação enunciativa, pode-se pensar nos ângulos visuais convencionais de enquadramento, tais como o ângulo aberto, o plongee, ou o close-up, que aqui são usados como recursos metafóricos para comparar com o enquadramento dado para a oração. Por exemplo, se ele está descrevendo uma ampla gama de sentidos, enumerando e listando-os, pode-se considerar uma tomada de ângulo aberto. Se ele está esmiuçando um mesmo sentido, usando novos construtos para dar mais especificidade para o mesmo assunto, pode-se considerar um enquadramento fechado, de close-up. Se há movimento de níveis, podemos considerar como um zoom, ou como uma panorâmica, nos quais ele desliza de uma descrição para outra mudando de planos, e se detém mais na segunda para 'fechar' o foco nela, por exemplo.

Ilustro o uso do enquadramento na oração e na tela, encontrado na triangulação da tela 'O Café Noturno na Place Lamartine, em Arles', no qual observei que van Gogh usou no ângulo aberto para representar o interior do café. Essa ocorrência de Enquadramento interage também com as categorias de Perspectiva e Profundidade, presentes na divisão dos planos no espaço composicional. No excerto de carta que descreve essa tela, encontrei uma oração que a descreve com um ângulo aberto: "A sala é vermelho-sangue e amarelo sem graça, uma mesa de bilhar verde no centro, 4 lâmpadas de amarelo limão com um brilho laranja e verde. Em todos os lugares é uma batalha e uma antítese dos mais diferentes verdes e vermelhos; nas personagens dos rufiões adormecidos, pequenos na alta sala vazia, algum roxo e azul." A descrição escrita valoriza o ângulo aberto usado na produção da tela do interior de um 'Café Noturno'. A sala e a mesa de bilhar são contrastantes, o enquadramento é feito na antítese das cores em uma grande sala vazia. Vazia? Van Gogh pincela pequenos personagens, insignificantes diante da amplidão de uma sala cuja lâmpada projeta uma luz incapacitante, devastadora sobre as pequenas personagens paralisadas. O enquadramento é feito na antítese das cores. Ou seja, as cores e sua relação de contraposição e tensão delimitam o espaço do recinto e condicionam tudo nela à essa percepção de intensidade, de densidade não apenas de seu cromatismo individual que por si só já é intenso, mas também 
pela relação de tensão e de contraposição causada pelo seu contraste mútuo. O contraste cromático na tela Café da Noite cumpre com o papel de desconectar dois mundos ou sentimentos opostos, exprimindo esta dicotomia tensa e conflituosa dos sentidos que ele quis comunicar.

Em outro exemplo, ocorre um deslocamento de enquadramento, vejamos. Na oração dominante "Eu tenho um terceiro estudo, agora, de uma paisagem com fábrica, e um enorme sol em um céu vermelho", temos o pintor como o Portador do processo relacional atributivo (VAN GOGH, 2009b, p. 1). O Atributo (um terceiro estudo de uma paisagem com fábrica [e] um enorme sol em um céu vermelho,) é construído em um espaço representativo: a tela, ao qual ele se reporta e descreve pelo uso de um extenso grupo nominal (atributo). Na oração dominante, Van Gogh (2009b) descreve a tela e se coloca como Portador, ele é portador de algo que possui atributos. Observei que a oração inicia com o foco no agente da ação: 'Eu tenho um terceiro estudo'. No entanto, ocorre um deslocamento do nível real 'Eu tenho' para o nível da tela: 'uma paisagem com fábrica, e um enorme sol em um céu vermelho', na qual há outra dimensão representativa, o mundo representado pictoricamente. Enquanto que na oração, observei um deslocamento da instância do mundo real para o mundo pictórico, na tela ocorre o contrário: um deslocamento do mundo pictórico para o mundo real por meio de uma inversão de ponto de vista e por meio de uma assinatura de van Gogh no meio do trigal, que, de repente, nos tira do estado de identificação e envolvimento com a cena, e nos devolve a consciência de que estamos olhando para um quadro, assinado pelo pintor. Sua assinatura nos tira do mundo representado e nos devolve para o mundo real.

Abaixo, seguem alguns exemplos de enquadramento: 
Quadro 21: Triangulação do Enquadramento

\begin{tabular}{|c|c|c|}
\hline Ocorrência nas telas & Orações & Comentário \\
\hline $\begin{array}{l}\text { Na tela 'Por de Sol: Campo } \\
\text { de trigo perto de Arles', } \\
\text { observei o Enquadramento } \\
\text { aberto na construção da } \\
\text { composição, como registrado } \\
\text { nas notas de rodapé } 43 \text { e } 79 \\
\text { no apêndice na qual observei } \\
\text { que o Enquadramento } \\
\text { produz um sentido de } \\
\text { Associação Metafórica. A } \\
\text { escolha do enquadramento, } \\
\text { no qual o sol está se pondo } \\
\text { para o campo é uma } \\
\text { escolha que produz um } \\
\text { sentido metafórico } \\
\text { relacionado ao final de } \\
\text { uma era da qual van Gogh } \\
\text { foi uma testemunha ocular. } \\
\text { A escolha do } \\
\text { enquadramento, no qual o } \\
\text { sol está se pondo para o } \\
\text { campo é uma escolha que } \\
\text { produz um sentido } \\
\text { metafórico relacionado ao } \\
\text { final de uma era do qual van } \\
\text { Gogh foi uma testemunha } \\
\text { ocular. Apesar de narrar toda } \\
\text { a vida que há no campo, van } \\
\text { Gogh também está falando } \\
\text { da relação entre campo e } \\
\text { cidade, e nessa relação, } \\
\text { claramente, ele dá saliência } \\
\text { para a beleza, força e vida } \\
\text { que há no campo. Registrado } \\
\text { nas notas de rodapé } 79 \text { e } 104 \\
\text { no apêndice. } \\
\text { nationa }\end{array}$ & $\begin{array}{l}\text { "Eu tenho um terceiro estudo, agora, } \\
\text { de uma paisagem com fábrica, e um } \\
\text { enorme sol em um céu vermelho, } \\
\text { acima de telhados vermelhos, em } \\
\text { que a natureza parece estar em um } \\
\text { acesso de raiva, em um dia de } \\
\text { Mistral desagradável." } \\
\text { A mudança na Perspectiva e no } \\
\text { Enquadramento, feita por um } \\
\text { deslocamento na agência que na } \\
\text { oração paratática é 'eu tenho' uma e } \\
\text { na hipotática é 'a natureza parece } \\
\text { estar' está registrada e comentada } \\
\text { nas notas de rodapé } 108,109 \text { e } 110 \\
\text { no apêndice. } \\
\text { Em outro exemplo no excerto: “Tela } \\
\text { quadrada número } 30 . \text { Eu pintei-a ao } \\
\text { ar livre no Mistral. Meu cavalete foi } \\
\text { fixado no chão com estacas de ferro, } \\
\text { um método que eu recomendo a } \\
\text { voce. Voce enterra os pés do } \\
\text { cavalete e, em seguida, voce } \\
\text { empurra a } 50 \text { centímetros de } \\
\text { comprimento um peso de ferro ao } \\
\text { lado deles. Voce amarra tudo com } \\
\text { cordas; dessa forma, voce pode } \\
\text { trabalhar com o vento.”, observei a } \\
\text { ocorrência de uma mudança de } \\
\text { Enquadramento na escolha da } \\
\text { agência e dos processos das orações } \\
\text { que se sucedem nesse excerto. } \\
\text { Registrado na nota de rodapé } 115 \text { no } \\
\text { apêndice. }\end{array}$ & $\begin{array}{l}\text { O enquadramento aparece em } \\
\text { diferentes níveis. No nível da tela o } \\
\text { enquadramento se dá em relação à } \\
\text { paisagem. No do relato ele se dá na } \\
\text { relação do artista com a tela, que no } \\
\text { caso, van Gogh se refere a um estudo. } \\
\text { Em um exercício comparativo, } \\
\text { poderíamos imaginar o que o artista } \\
\text { tem quando ele olha para a paisagem? } \\
\text { E o que um olhar de fora um } \\
\text { observador tem ao ver o artista com a } \\
\text { obra. Van Gogh parece fazer um } \\
\text { esforço de se colocar no lugar do } \\
\text { irmão e descrever o que o irmão veria } \\
\text { se estivesse observando ele. Então van } \\
\text { Gogh descreve a paisagem na tela com } \\
\text { um duplo enquadramento: o } \\
\text { enquadramento do olhar do outro, no } \\
\text { caso Theo, em relação ao } \\
\text { enquadramento feito por ele, van } \\
\text { Gogh, sobre a paisagem. }\end{array}$ \\
\hline $\begin{array}{l}\text { Na tela 'Por de Sol: Campo } \\
\text { de trigo perto de Arles', } \\
\text { observei a ocorrência de } \\
\text { Enquadramento, pelo uso } \\
\text { do plano aberto para } \\
\text { representar a cena. }\end{array}$ & $\begin{array}{l}\text { Aqui está outra paisagem. Sol } \\
\text { poente? Lua nascendo? Noite de } \\
\text { verão, de qualquer modo. Cidade } \\
\text { violeta, estrela amarela, céu azul- } \\
\text { esverdeado; os campos de trigo têm } \\
\text { todos os tons: ouro velho,cobre, } \\
\text { ouro verde, ouro vermelho, ouro } \\
\text { amarelo, verde, vermelho e amarelo } \\
\text { bronze. Tela quadrada número } 30 .\end{array}$ & $\begin{array}{l}\text { Van Gogh escolhe um enquadramento } \\
\text { que valoriza o campo de trigo, o por } \\
\text { de sol, mas que apresenta em detalhes } \\
\text { outros elementos. Assim, percebo na } \\
\text { descrição a proeminência das cores. } \\
\text { Os elementos visuais (cidade, pessoas) } \\
\text { parecem pretextos para composição } \\
\text { das cores em contraste com o sol e o } \\
\text { campo de trigo. Não há dos elementos } \\
\text { em si, tanto que não importa se o astro } \\
\text { representado é o sol ou a lua, o que } \\
\text { importa é seu colorido na noite de } \\
\text { verão. Todos eles ganham um tom } \\
\text { característico. O enquadramento, tanto } \\
\text { na tela quanto na descrição da tela, } \\
\text { parece ser das cores e não de seus }\end{array}$ \\
\hline
\end{tabular}




\begin{tabular}{|c|c|c|}
\hline & & $\begin{array}{l}\text { elementos individuais. Tela e orações } \\
\text { se complementam na construção dos } \\
\text { contrastes enquadrados pelo artista. }\end{array}$ \\
\hline $\begin{array}{l}\text { Na tela 'Por de Sol: Campo } \\
\text { de trigo perto de Arles', o } \\
\text { homem representado na } \\
\text { composição se encontra no } \\
\text { fundo do campo e aparenta } \\
\text { ser um camponês próximo a } \\
\text { um monte de trigo. Ao } \\
\text { mesmo tempo, por estar } \\
\text { próximo a uma área } \\
\text { intermediária entre o campo } \\
\text { e a cidade, ele aparece como } \\
\text { um elemento de transição } \\
\text { entre essas duas áreas, } \\
\text { registrado na nota de rodapé } \\
\text { 80 no apêndice. }\end{array}$ & $\begin{array}{l}\text { Eu também sou totalmente incapaz } \\
\text { de julgar o meu próprio trabalho. Eu } \\
\text { não posso ver se os estudos são bons } \\
\text { ou ruins. Tenho sete estudos de } \\
\text { trigais, infelizmente todos eles nada } \\
\text { além de paisagens, muito contra a } \\
\text { minha vontade. Paisagens amarelo } \\
\text { ouro velho - feito rápido rápido } \\
\text { rápido e com pressa, como o ceifeiro } \\
\text { que está em silêncio sob o sol } \\
\text { escaldante, concentrando-se em ter o } \\
\text { trabalho terminado. }\end{array}$ & $\begin{array}{l}\text { O posicionamento do homem em um } \\
\text { enquadramento amplo e distante cria } \\
\text { um distanciamento. Isso nos leva a } \\
\text { observa-lo não de um ponto de vista } \\
\text { próximo e de envolvimento com os } \\
\text { detalhes de sua atividade, mas de um } \\
\text { ponto de vista quase abstraído de sua } \\
\text { dimensão individual e pessoal e que } \\
\text { pode nos remeter a uma instância mais } \\
\text { conceptual. Registrado na nota de } \\
\text { rodapé } 81 \text { no apêndice. }\end{array}$ \\
\hline $\begin{array}{l}\text { O enquadramento sugere a } \\
\text { metáfora visual de que este } \\
\text { homem se encontra em } \\
\text { transição entre dois mundos. } \\
\text { Ou, ainda que no campo, se } \\
\text { encontra nas imediações do } \\
\text { mundo industrial. Registrado } \\
\text { na nota de rodapé } 79 \text { no } \\
\text { apêndice. }\end{array}$ & & \\
\hline $\begin{array}{l}\text { Van Gogh quis representar o } \\
\text { campo arado como sendo o } \\
\text { participante principal, ou } \\
\text { como o recipiente principal } \\
\text { da ação do participante } \\
\text { principal. No entanto, esse } \\
\text { participante principal, o } \\
\text { semeador, não está no } \\
\text { primeiro plano, está no } \\
\text { segundo plano e o } \\
\text { enquadramento mostra uma } \\
\text { distância social da figura do } \\
\text { semeador. Dessa forma, o } \\
\text { enquadramento revela que, } \\
\text { apesar de, vetorialmente ser } \\
\text { o semeador o participante } \\
\text { principal, a saliência maior } \\
\text { foi dada para o campo arado, } \\
\text { trazendo este para o lugar de } \\
\text { destaque, não para quem está } \\
\text { comandando a ação } \\
\text { principal, mas para quem } \\
\text { está recebendo a ação } \\
\text { principal. } \\
\text { Inferi que aqui ocorre uma } \\
\text { inversão enunciativa. Se } \\
\text { transpuséssemos essa } \\
\text { enunciação para duas } \\
\text { orações, nelas, o sentido }\end{array}$ & $\begin{array}{l}\text { Há várias sugestões de amarelo no } \\
\text { solo, tons neutros resultantes da } \\
\text { mistura de violeta e amarelo; mas } \\
\text { tenho travado uma luta diabólica // } \\
\text { para atingir a verdade das cores. } \\
\\
\text { Observa-se, no nível léxico- } \\
\text { gramatical, um deslocamento do } \\
\text { Enquadramento na escolha do } \\
\text { processo Existencial 'há' que remete } \\
\text { o leitor para dentro da tela. Em } \\
\text { seguida a escolha do processo } \\
\text { 'tenho travado' constrói um sentido } \\
\text { de deslocamento no ponto de vista e } \\
\text { no enquadramento da oração, } \\
\text { levando o leitor para o plano do } \\
\text { pintor e de seu processo na escolha } \\
\text { das cores com que pintou a tela. } \\
\text { Ocorrência de deslocamento do } \\
\text { Enquadramento, Perspectiva, } \\
\text { Inversão do ponto de vista, } \\
\text { Transparência, Inacabamento, } \\
\text { Incompletude e Limiar artístico com } \\
\text { a mudança na representação do } \\
\text { protagonismo nas orações e nas } \\
\text { escolhas lexicais 'verdade das } \\
\text { cores', 'luta diabólica' e 'atingir a }\end{array}$ & $\begin{array}{l}\text { Ocorrência de Profundidade, } \\
\text { Enquadramento e Perspectiva no nível } \\
\text { gramatical, já que o sentido principal } \\
\text { foi deslocado para a oração hipotática. } \\
\text { Registrado na nota de rodapé } 89 . \\
\text { A escolha lexical indica uma } \\
\text { intensificação do processo que ele } \\
\text { representa por meio dos itens } \\
\text { 'travado' e 'luta diabólica' e que } \\
\text { sugere um processo extremado para } \\
\text { chegar ao conhecimento das cores. O } \\
\text { sentido principal deste complexo } \\
\text { oracional está na oração hipotática, } \\
\text { sugerindo um deslocamento de } \\
\text { 'planos' causando um efeito de } \\
\text { 'profundidade' no enunciado. }\end{array}$ \\
\hline
\end{tabular}




\begin{tabular}{|c|c|c|}
\hline $\begin{array}{l}\text { principal sofreria um } \\
\text { deslocamento da oração } \\
\text { paratática: 'O semeador } \\
\text { semeia' para a oração } \\
\text { hipotática: 'o campo arado } \\
\text { recebe a ação de semear do } \\
\text { Semeador'. Essa estratégia } \\
\text { de deslocamento do sentido } \\
\text { principal para a oração } \\
\text { hipotática foi também } \\
\text { observada em muitos } \\
\text { complexos oracionais } \\
\text { construídos nas cartas de van } \\
\text { Gogh. Registrado na nota de } \\
\text { rodapé } 77 .\end{array}$ & $\begin{array}{l}\text { verdade das cores'. Registradas na } \\
\text { nota de rodapé } 94 .\end{array}$ & \\
\hline $\begin{array}{l}\text { Ao falar do Semeador na } \\
\text { carta, referindo-se à tela que } \\
\text { ele está pintando, van Gogh } \\
\text { pergunta-se quando ele fará } \\
\text { o céu estrelado que está } \\
\text { sempre em sua mente, } \\
\text { revelando que o Semeador e } \\
\text { o céu estrelado estão de } \\
\text { alguma forma interligados. } \\
\text { Acredito que os sentidos } \\
\text { desenvolvidos por van Gogh } \\
\text { no Semeador estão também } \\
\text { presentes e se manifestam no } \\
\text { céu estrelado em categorias } \\
\text { tais como Incompletude, } \\
\text { Modalidade sensorial, } \\
\text { Inacabamento, Textura, } \\
\text { Rimo, Contrastes } \\
\text { Cromáticos, Rima Visual e } \\
\text { Gesto Pictórico. }\end{array}$ & $\begin{array}{l}\text { Mas quando eu farei o céu estrelado, } \\
\text { então, essa pintura [[que está sempre } \\
\text { na minha mente? ]] }\end{array}$ & $\begin{array}{l}\text { Ocorrência de Interdiscursividade pelo } \\
\text { uso de Enquadramento, Perspectiva e } \\
\text { Inversão do ponto de vista ao trazer o } \\
\text { leitor para o lugar em que se encontra } \\
\text { o artista ao expressar com Saliência, } \\
\text { uma forte contraposição entre uma } \\
\text { incerteza (de quando fará a tela) e uma } \\
\text { certeza (ela está sempre em sua } \\
\text { mente). Registrado na nota de rodapé } \\
\underline{109} \text {. }\end{array}$ \\
\hline $\begin{array}{l}\text { A atmosfera da luz difusa do } \\
\text { crepúsculo, construída pelos } \\
\text { efeitos dos contrastes } \\
\text { cromáticos, da diminuição } \\
\text { dos detalhes e do tratamento } \\
\text { geral desfocado e com baixa } \\
\text { definição e acabamento é } \\
\text { compatível com o sentido de } \\
\text { sonho expressado nesse } \\
\text { excerto de carta. A luz difusa } \\
\text { expressa Inacabamento e } \\
\text { Incompletude também } \\
\text { expressa na Verbiagem do } \\
\text { excerto. }\end{array}$ & $\begin{array}{l}\text { Ai, ai, é como nosso excelente amigo } \\
\text { Cyprien diz, em 'En ménage' por JK } \\
\text { Huysmans: as mais belas pinturas } \\
\text { são aquelas [[que alguém sonha } \\
\text { //enquanto fuma um cachimbo em } \\
\text { sua cama,// mas a qual ele não } \\
\text { pinta.]] } \\
\text { Van Gogh cita Cyprien que é citado } \\
\text { por Huymans criando uma } \\
\text { Verbiagem dentro de outra } \\
\text { Verbiagem, sugerindo um } \\
\text { deslizamento de planos dentro da } \\
\text { oração. }\end{array}$ & $\begin{array}{l}\text { No nível semântico, ocorrência de } \\
\text { Incompletude, Inacabamento } \\
\text { expressos na Verbiagem da oração, } \\
\text { uma vez que expressa a diferença } \\
\text { entre sonhar e realizar. Além disso, foi } \\
\text { observada a ocorrência de } \\
\text { Enquadramento, Perspectiva e } \\
\text { Inversão de ponto de vista, que no } \\
\text { nível semântico, expressa a mesma } \\
\text { coisa que no nível léxico-gramatical, } \\
\text { na medida em que van Gogh desliza } \\
\text { entre dois domínios tanto no nível } \\
\text { semântico (sonho-pintura real) quanto } \\
\text { no nível léxico-gramatical } \\
\text { (Verbiagem-pintura real). Registradas } \\
\text { na nota de rodapé 111. }\end{array}$ \\
\hline $\begin{array}{l}\text { Na tela 'O Semeador', } \\
\text { observei a ocorrência de } \\
\text { Perspectiva pelo uso de } \\
\text { vários recursos tais como o } \\
\text { uso do plano aberto para }\end{array}$ & $\begin{array}{l}\text { Na oração: “Aqui está um esboço de } \\
\text { um semeador: um grande campo } \\
\text { lavrado com torrões de terra, /na } \\
\text { sua maioria fracamente cor de } \\
\text { violeta/. Um campo de trigo }\end{array}$ & $\begin{array}{l}\text { E o esboço como tal - uma tela } \\
\text { número } 25 \text { - também me preocupa } \\
\text { muito, no sentido de que eu me } \\
\text { pergunto se eu não deveria levar a } \\
\text { sério e fazer uma pintura tremenda }\end{array}$ \\
\hline
\end{tabular}




\begin{tabular}{|c|c|c|}
\hline $\begin{array}{l}\text { representar a cena, registrado } \\
\text { na nota de rodapé } 34 \text { e do } \\
\text { uso de planos com ângulos } \\
\text { de Enquadramento } \\
\text { diferenciados, em forma de } \\
\text { cunhas que são sugeridas } \\
\text { pela Modulação Cromática } \\
\text { dos torrões de terra, } \\
\text { registrado na nota de rodapé } \\
\underline{36} \text {. }\end{array}$ & $\begin{array}{l}\text { maduro, de tom amarelo-ocre com } \\
\text { um pouco de carmim." observei a } \\
\text { ocorrência de Enquadramento } \\
\text { estabelecido pela escolha léxico- } \\
\text { gramatical da agência da primeira } \\
\text { oração, que coloca um esboço } \\
\text { seguido de um grupo nominal que } \\
\text { constrói o universo representado por } \\
\text { van Gogh na tela, registrado na nota } \\
\text { de rodapé } 80 \mathrm{e} 83 \text {. }\end{array}$ & $\begin{array}{l}\text { disso. Meu Deus, como eu adoraria } \\
\text { fazer isso. Mas eu só me pergunto se } \\
\text { eu vou ter o poder necessário de } \\
\text { execução. } \\
\text { O enquadramento da tela valoriza o } \\
\text { campo, o horizonte e o semeador. } \\
\text { Qual é o enquadramento feito por van } \\
\text { Gogh? Nesta tela van Gogh parece ter } \\
\text { enquadrado não o semeador, mas a } \\
\text { semeadura, a terra arada pronta para } \\
\text { ser semeada, o ato do semeador sobre } \\
\text { a terra e o resultado da semeadura no } \\
\text { campo maduro no horizonte. O } \\
\text { processo é enquadrado, a valorização } \\
\text { da luz do sol sobre o campo de trigo, } \\
\text { sobre a terra e o semeador, este como } \\
\text { mais um elemento no processo do que } \\
\text { tendo proeminência em relação aos } \\
\text { demais elementos. }\end{array}$ \\
\hline $\begin{array}{l}\text { Na tela, o protagonismo do sol } \\
\text { é representado pelo uso } \\
\text { excessivo e absoluto do } \\
\text { amarelo, como um valor } \\
\text { simbólico que é salientado } \\
\text { pela sobreposição de } \\
\text { diferentes tonalidades de } \\
\text { amarelo para representar o } \\
\text { céu, o sol e a luz que dele } \\
\text { emana, na forma de raios } \\
\text { solares que fluem em direção } \\
\text { radial. Este sentido simbólico, } \\
\text { construído por meio da } \\
\text { saliência conferida pela } \\
\text { sobreposição cromática de } \\
\text { diferentes amarelos é } \\
\text { compatível com a } \\
\text { representação da tela na carta, } \\
\text { na qual van Gogh descreve o } \\
\text { uso de uma sequência de } \\
\text { diferentes amarelos que } \\
\text { reconstroem na escrita a } \\
\text { luminosidade que ele desejou } \\
\text { comunicar na tela. }\end{array}$ & $\begin{array}{l}\text { O céu, amarelo-crômio, quase tão } \\
\text { luminoso quanto o próprio Sol,/// que } \\
\text { é amarelo-crômio no } 1, / / \text { (está) } \\
\text { misturado com um pouco de branco, } \\
\text { lenquanto o resto do céu é uma } \\
\text { mistura dos amarelos-crômios } 1 \text { e } 2 . \\
\text { Tão amarelo! }\end{array}$ & $\begin{array}{l}\text { No nível léxico-gramatical, há uma } \\
\text { ocorrência de Enquadramento, } \\
\text { Perspectiva, Transparência e } \\
\text { Incompletude na forma como ele } \\
\text { organiza a oração de modo a deslocar } \\
\text { a agência da ação de si para a natureza } \\
\text { que está sendo representada, como um } \\
\text { ente em seu próprio direito. } \\
\text { Registrado na nota de rodapé } 86 .\end{array}$ \\
\hline
\end{tabular}




\begin{tabular}{|c|c|c|}
\hline $\begin{array}{l}\text { Na tela 'A Esplanada do } \\
\text { Café na Place du Forum, } \\
\text { Arles, à Noite', observei a } \\
\text { ocorrência de } \\
\text { Enquadramento, Perspectiva } \\
\text { e Profundidade construída } \\
\text { por linhas diagonais que } \\
\text { convergem no centro e } \\
\text { dividem a tela em quatro } \\
\text { seções. As quatro linhas } \\
\text { diagonais que conduzem o } \\
\text { olhar para dentro da tela. } \\
\text { Registrado na nota de rodapé } \\
132 \text { no apêndice. }\end{array}$ & $\begin{array}{l}\text { Essa é a primeira pintura esta } \\
\text { semana. A segunda mostra o } \\
\text { exterior de um café, iluminado no } \\
\text { terraço externo por uma grande } \\
\text { lâmpada de gás dentro da noite azul, } \\
\text { com um retalho de céu azul } \\
\text { estrelado. }\end{array}$ & $\begin{array}{l}\text { O café, o terraço, a lâmpada e o céu } \\
\text { estão dentro da noite. Todos os } \\
\text { elementos convergem para representar } \\
\text { um sentido único, a noite sem preto. O } \\
\text { enquadramento valoriza a } \\
\text { luminosidade da lâmpada a gás e do } \\
\text { céu estrelado. Ambos trabalhando } \\
\text { para gerar os contrastes que darão } \\
\text { unidade entre luz e sombra. O } \\
\text { enquadramento cerca diferentes } \\
\text { elementos desta noite, valorizando } \\
\text { como cada um se comporta diante da } \\
\text { luz da lâmpada e do céu azul } \\
\text { estrelado. }\end{array}$ \\
\hline $\begin{array}{l}\text { Na tela 'A Esplanada do } \\
\text { Café na Place du Forum, } \\
\text { Arles, à Noite', observei a } \\
\text { ocorrência de Vetor que } \\
\text { resulta em Distorção do } \\
\text { ponto de vista, na } \\
\text { representação das cadeiras } \\
\text { vazias no primeiro plano, } \\
\text { ambas voltadas para a o } \\
\text { pintor que as pinta sugerindo } \\
\text { um caminho visual inverso, } \\
\text { de ponto de fuga invertido, } \\
\text { como observado em outras } \\
\text { telas analisadas. Registrada } \\
\text { na nota de rodapé } 162 \text { e } 165 \\
\text { no apêndice. }\end{array}$ & $\begin{array}{l}\text { (Alfa) A segunda mostra o exterior } \\
\text { de um café, (Beta) [[ iluminado no } \\
\text { terraço externo por uma grande } \\
\text { lâmpada de gás dentro da noite azul, } \\
\text { com um retalho de céu azul } \\
\text { estrelado.]] }\end{array}$ & $\begin{array}{l}\text { Ocorrência de Enquadramento e } \\
\text { Perspectiva: há uma mudança no ponto } \\
\text { de vista com que van Gogh representa } \\
\text { o assunto: a tela. Na oração Alfa, ele } \\
\text { está fora da tela, e na oração Beta ele } \\
\text { se encontra dentro da cena. Registrado } \\
\text { na nota de rodapé } 167 \text { no apêndice. }\end{array}$ \\
\hline $\begin{array}{l}\text { Na tela 'O Café Noturno na } \\
\text { Place Lamartine, em Arles', } \\
\text { observei que van Gogh usou } \\
\text { no ângulo aberto para } \\
\text { representar o interior do } \\
\text { café. } \\
\text { Ocorrência de } \\
\text { Enquadramento que interage } \\
\text { com a Perspectiva e a } \\
\text { Profundidade presentes na } \\
\text { divisão dos planos no espaço } \\
\text { composicional. Registrada } \\
\text { na nota de rodapé } 119 .\end{array}$ & $\begin{array}{l}\text { Ângulo aberto: } \\
\text { A sala é vermelho-sangue e amarelo } \\
\text { sem graça, uma mesa de bilhar verde } \\
\text { no centro, } 4 \text { lâmpadas de amarelo } \\
\text { limão com um brilho laranja e } \\
\text { verde. } \\
\text { Em todos os lugares é uma batalha e } \\
\text { uma antítese dos mais diferentes } \\
\text { verdes e vermelhos; nas personagens } \\
\text { dos rufiões adormecidos, pequenos } \\
\text { na alta sala vazia, algum roxo e azul. } \\
\text { Uso de Associações Metafóricas e do } \\
\text { Uso Simbólico da Cor. Ao expressar } \\
\text { o sentido simbólico dos verdes e } \\
\text { vermelhos textualmente ele cola esse } \\
\text { sentido no uso dessas cores na tela, } \\
\text { construindo uma ponte entre a carta } \\
\text { e a tela, criando uma cadeia de } \\
\text { textos. Observei uma ocorrência do } \\
\text { uso simbólico da cor em ambas as }\end{array}$ & $\begin{array}{l}\text { A descrição valoriza o ângulo aberto } \\
\text { usado na produção da tela do interior } \\
\text { de um 'Café Noturno'. A sala e a mesa } \\
\text { de bilhar são contrastantes, o } \\
\text { enquadramento é feito na antítese das } \\
\text { cores em uma grande sala vazia. } \\
\text { Vazia? Van Gogh pincela pequenos } \\
\text { personagens, insignificantes diante da } \\
\text { amplidão de uma sala cuja lâmpada } \\
\text { projeta uma luz incapacitante, } \\
\text { devastadora sobre as pequenas } \\
\text { personagens paralisadas. } \\
\text { Ou seja, as cores e sua relação de } \\
\text { contraposição e tensão delimitam o } \\
\text { espaço do recinto e condicionam tudo } \\
\text { nela a essa percepção de intensidade, } \\
\text { de densidade não apenas de seu } \\
\text { cromatismo individual que por si só já } \\
\text { é intenso, mas também pela relação de } \\
\text { tensão e de contraposição causada pelo } \\
\text { seu contraste mútuo. O contraste } \\
\text { cromático na tela Café da Noite } \\
\text { cumpre com o papel de desconectar }\end{array}$ \\
\hline
\end{tabular}




\begin{tabular}{|c|c|c|}
\hline & $\begin{array}{l}\text { modalidades não pela forma, mas } \\
\text { pelo sentido associado a este uso. } \\
\text { Registrado na nota de rodapé } 257 .\end{array}$ & $\begin{array}{l}\text { dois mundos ou sentimentos opostos, } \\
\text { exprimindo esta dicotomia tensa e } \\
\text { conflituosa dos sentidos que ele quis } \\
\text { comunicar. }\end{array}$ \\
\hline $\begin{array}{l}\text { Verifiquei a ocorrência do uso } \\
\text { de um construto de } \\
\text { contraposição e antítese no } \\
\text { nível semântico da oração } \\
\text { 'Agora como para recuperar o } \\
\text { dinheiro pago ao senhorio } \\
\text { através da minha pintura, eu } \\
\text { não estou fazendo questão } \\
\text { disto, porque a pintura é uma } \\
\text { das mais feias que eu já fiz'. } \\
\text { Essa contraposição é } \\
\text { compatível com o uso de } \\
\text { contrastes complementares de } \\
\text { verdes e vermelhos e com a } \\
\text { oração na qual ele explicita } \\
\text { que a tela fala de 'conflitos e } \\
\text { antíteses por toda parte'. } \\
\text { Registrado na nota de rodapé } \\
254 .\end{array}$ & $\begin{array}{l}\text { Ângulo fechado ou montagem } \\
\text { (edição): } \\
\text { Em todos os lugares é uma batalha e } \\
\text { uma antítese dos mais diferentes } \\
\text { verdes e vermelhos; nas personagens } \\
\text { dos rufiões adormecidos, pequenos } \\
\text { na alta sala vazia, algum roxo e azul. } \\
\text { O vermelho-sangue e o amarelo- } \\
\text { verde da mesa de bilhar, por } \\
\text { exemplo, contrasta com o pouco de } \\
\text { verde delicado Louis XV do balcão, } \\
\text { onde há um buquê rosa. }\end{array}$ & $\begin{array}{l}\text { Sequência de pequenos close-ups } \\
\text { compatível com a edição } \\
\text { cinematográfica, ou montagem } \\
\text { sequencial de imagens para construir a } \\
\text { narrativa visual por meio da descrição } \\
\text { seccionada de diferentes ângulos de } \\
\text { tomada da cena para apresentar os } \\
\text { detalhes da tela. }\end{array}$ \\
\hline $\begin{array}{l}\text { Na tela 'O Café Noturno na } \\
\text { Place Lamartine, em Arles', } \\
\text { observei a ocorrência de } \\
\text { Enquadramento, Perspectiva, } \\
\text { Ritmo, Movimento por meio } \\
\text { de Contraposições e de } \\
\text { Inversão de sentido ao } \\
\text { colocar movimento em } \\
\text { objetos inanimados e } \\
\text { paralisia em figuras } \\
\text { humanas. Registrada na } \\
\text { nota de rodapé } 219 .\end{array}$ & $\begin{array}{l}\text { Nesta tela, há } 6 \text { ou } 7 \text { vermelhos } \\
\text { diferentes, desde vermelho-sangue } \\
\text { até rosa delicado, fazendo oposição } \\
\text { com o mesmo número de verdes } \\
\text { pálidos ou escuros. } \\
\text { Uso de aproximação e } \\
\text { distanciamento da tela ocorre tanto } \\
\text { na escrita quanto na tela. Registrado } \\
\text { na nota de rodapé } 298 . \\
\text { Observei o uso de enquadramento na } \\
\text { estratégia retórica presente no } \\
\text { encadeamento das orações. } \\
\text { Registrado na nota de rodapé } 299 \text {. }\end{array}$ & $\begin{array}{l}\text { Observei também essa ocorrência no } \\
\text { discurso escrito, por exemplo, procurei } \\
\text { por 'o que é vazio está no centro e tem } \\
\text { destaque', e as pessoas estão na } \\
\text { periferia. } \\
\text { Uso de Enquadramento e de } \\
\text { Perspectiva. Ao mudar o agente em } \\
\text { cada oração, ele faz um deslocamento } \\
\text { no enquadramento com que ele enfoca } \\
\text { o assunto que ele está descrevendo, a } \\
\text { representação da tela. Registrado na } \\
\text { nota de rodapé } 297 .\end{array}$ \\
\hline $\begin{array}{l}\text { Na tela 'O Café Noturno na } \\
\text { Place Lamartine, em Arles', } \\
\text { observei a ocorrência de } \\
\text { Enquadramento e } \\
\text { Perspectiva para construir } \\
\text { um distanciamento das } \\
\text { figuras representadas, } \\
\text { como que para diminuir } \\
\text { sua importância na cena. } \\
\text { Registrada na nota de rodapé } \\
\underline{242} \text {. }\end{array}$ & $\begin{array}{l}\text { Na minha pintura do café à noite eu } \\
\text { procurei exprimir que o café é um } \\
\text { lugar onde você pode arruinar-se, } \\
\text { enlouquecer, cometer crimes. } \\
\text { Observei a ocorrência do uso de } \\
\text { Enquadramento ao deslocar o } \\
\text { sentido principal para a oração Beta. } \\
\text { Este exemplo de enquadramento na } \\
\text { oração é compatível com o uso de } \\
\text { ênfase no segundo plano na } \\
\text { composição visual. Registrado na } \\
\text { nota de rodapé } 263 \text {. }\end{array}$ & $\begin{array}{l}\text { O enquadramento é da força da sala, } \\
\text { da força da luz e da fraqueza dos } \\
\text { demais elementos diante dessa } \\
\text { condição inefável do café. O ângulo } \\
\text { aberto que valoriza a amplitude da sala } \\
\text { e a incidência da luz parece minimizar } \\
\text { a ação das personagens. Na oração fica } \\
\text { ainda mais evidente a construção do } \\
\text { café como um lugar opressivo, } \\
\text { sufocante, capaz de evidenciar } \\
\text { aspectos sombrios da natureza } \\
\text { humana. }\end{array}$ \\
\hline $\begin{array}{l}\text { Na tela 'O Café Noturno na } \\
\text { Place Lamartine, em Arles', } \\
\text { observei a ocorrência de } \\
\text { Associações metafóricas, } \\
\text { Saliência, Incompletude } \\
\text { construída pelo }\end{array}$ & $\begin{array}{l}\text { Alguns pobres vagabundos noturnos } \\
\text { estão dormindo em um canto. } \\
\text { Uso do significante oposto ao } \\
\text { significado para construir o sentido. } \\
\text { Aqui há mais um construto oracional } \\
\text { e também na tela no qual o sentido }\end{array}$ & $\begin{array}{l}\text { Foi observado um sentido de } \\
\text { movimentação conferida aos objetos } \\
\text { inanimados em contraposição à } \\
\text { paralisia das figuras humanas na tela } \\
\text { que endossa a disposição } \\
\text { desorganizada e oblíqua das cadeiras, }\end{array}$ \\
\hline
\end{tabular}




\begin{tabular}{|l|l|l|}
\hline $\begin{array}{l}\text { Enquadramento das } \\
\text { cadeiras vazias no primeiro } \\
\text { plano que instanciam uma } \\
\text { representação simbólica } \\
\text { para a transitoriedade e a } \\
\text { impermanência das pessoas }\end{array}$ & $\begin{array}{l}\text { 'ação’ e ‘protagonismo’ é construído } \\
\text { pela 'inação' e pela não participação } \\
\text { da ação. Registrado na nota de }\end{array}$ & $\begin{array}{l}\text { transmitindo a sensação de que a } \\
\text { presença, o fulgor e a movimentação } \\
\text { de pessoas ali naquele espaço ainda }\end{array}$ \\
$\begin{array}{l}\text { no café, registrada na nota } \\
\text { de rodapé } 247 .\end{array}$ & & $\begin{array}{l}\text { estivessem presentes, quentes, embora } \\
\text { elas já tenham ido embora daquele }\end{array}$ \\
& & $\begin{array}{l}\text { local que é reforçado pela ocorrência } \\
\text { de vetores projetados pelas cadeiras. }\end{array}$ \\
\hline
\end{tabular}

Fonte: Triangulação para Enquadramento dos dados dos corpora visual e textual, com os extratos das cartas.

\subsection{PERSPECTIVA}

Van Gogh faz uso da perspectiva como Modo para conduzir o percurso do olhar pela composição, criando o sentido de direção que ao mesmo tempo em que produz o efeito de um espaço tridimensional que é apenas percebido, também organiza a estratégia composicional que irá articular os elementos pictóricos em uma sintaxe visual. Schapiro (2010, p. 135) comenta sobre o uso da perspectiva para van Gogh:

Esse padrão de perspectiva era de suprema importância para Van Gogh, uma de suas principais preocupações como artista. Nos primeiros desenhos, como principiante que se debatia com as regras de perspectiva e utilizava um equipamento mecânico para traçar as linhas escorçadas que o intrigavam e deliciavam, ele já percebia tanto a concretude desse estratagema geométrico de representação quanto seu momento subjetivo e expressivo. Na prática, a perspectiva linear não era um mero conjunto impessoal de regras, mas algo tão real quanto os próprios objetos, uma qualidade da própria paisagem que ele estava vendo. Esse esquema paradoxal ao mesmo tempo deformava as coisas e as fazia parecer mais reais; tornava o olhar do artista mais escravo da aparência, mas também o fazia interagir com o mundo de maneira mais ativa. Enquanto nos quadros do Renascimento era um meio de construir um espaço objetivo completo em si mesmo e distinto do espectador, mesmo que organizado em relação ao seu olhar, como o espaço de um palco, nas primeiras paisagens de van Gogh o mundo parece emanar de seu olhar numa fantástica descarga, na ação contínua das linhas rapidamente convergentes.

A forma como van Gogh organiza a perspectiva em suas composições teve uma grande influência do programa impressionista. Essa influência estilística será descrita a seguir.

Van Leeuwen (2011, p. 405) aponta para uma dicotomia no pensamento ocidental desde os tempos clássicos, que nos levou, por um longo período da história da arte, a privilegiar a forma em detrimento da cor:

Por alguns 2,500 anos os filósofos ocidentais têm lutado com o assunto, muitas vezes vendo a cor como altamente subjetiva e como "excessiva", necessitando de contenção e submissão a uma ordem racional. A cor sempre foi, e ainda é, um tema que evoca sentimentos fortes. Plínio, que viveu no primeiro século dC, criticou a cor abundante e a 'pintura floreada'. O grande pintor grego Apeles, ele disse, usou apenas quatro cores austeras, comedidas, um negro chamado 'atramentum', um branco de Milos, amarelo Attic e um vermelho de Sinope, no Mar Negro. Esta ênfase nas virtudes morais de um número limitado de cores 'puras' ou 'primárias', ordenadas em termos de algum esquema racional, corre como um fio através da teoria da cor, desde os seus primeiros dias. O filósofo pré-socrático Demócrito 
(século $\mathrm{V}$ aC) já reconhecia apenas quatro cores (branco, preto, vermelho e 'chloron', um pálido amarelo-esverdeado), cada uma relacionada a uma forma básica, um 'átomo' (Demócrito foi o criador do termo 'átomo', que significa 'indivisível' em grego), e Aristóteles, como Newton faria mais tarde, reconheceu sete cores básicas (branco, preto, vermelho, amarelo, marrom, violeta, verde e azul), relacionadas por regularidades numéricas e análogas à oitava na música.

De acordo com van Leeuwen, estes textos clássicos foram redescobertos pelos artistas de Florença no Renascimento originando a discussão entre o disegno e colore, na qual o design passou a ter uma função central na obra por ser o meio pelo qual a mente concebe a obra. Para os renascentistas, a cor tinha a função secundária e estava relacionada com os sentidos disputando a atenção da mente. Mesmo o Chiaroscuro, uma técnica de sombreamento gradual de uma superfície para causar a impressão de volume, foi mais importante do que o uso da cor, como explica van Leeuwen (2011, p. 4-5):

Como Alberti escreveu em seu tratado sobre a pintura em 1435, branco e preto são 'as cores com as quais nós expressamos luz e sombra', enquanto outras cores são apenas 'uma questão de que variações de luz e sombra podem ser aplicadas" (citado em Gage, 1995: 118). Leonardo da Vinci, também, preferia luz e escuro, evitando a cor abundante, e concentrando-se em criar uma ilusão de realidade, ao invés de usar a cor para expressar significados simbólicos ou deleitar-se com as belezas de cores brilhantes, como havia sido comum na Idade Média, quando cores denotavam virtudes teológicas, personagens da Bíblia ou as fileiras dos nobres, e também foram altamente apreciados pela sua beleza intrínseca.

\subsubsection{Abandono da perspectiva e da técnica do Chiaroescuro}

Os impressionistas aboliram o uso da perspectiva, embora eles também quisessem uma representação realista da natureza, e usavam para isso meios diferentes das escolas anteriores, como explica Gombrich (1995, p. 543-544):

A invenção de Brunelleschi da "perspectiva linear" (p. 229) não o interessou muito [Cézanne]. Desprezou-a quando descobriu que ela dificultava o seu trabalho. No fim de contas, essa perspectiva científica fora inventada para ajudar os pintores a criarem a ilusão de espaço - como Masaccio fizera em seu afresco de Santa Maria Novella (p. 228, Fig. 149). Cézanne não se propunha criar qualquer ilusão. $O$ que ele queria era transmitir a sensação de solidez e profundidade, e descobriu que podia fazê-lo sem recorrer ao desenho convencional. Dificilmente se terá apercebido de que esse exemplo de indiferença pelo "desenho correto" iniciaria uma arrasadora e irrefreável avalancha no campo da arte.

Eles procuravam ser fiéis à representação do mundo real tal como eles o percebiam desde a experiência imediata, ao contrário dos acadêmicos e dos mestres antigos que construíram um conjunto de artifícios para construir o real, com base no conhecimento do mundo real e não da experiência do mundo real. Esta distinção é fundamental para apreciarmos a mudança na representação da perspectiva, que Gombrich (1995, p. 536) expõe: 
De fato, foi somente com o Impressionismo que a conquista da natureza se completou, que tudo o que se apresentava aos olhos do pintor pôde converter-se em motivo de um quadro e que o mundo real, em todos os seus aspectos, passou a ser um objeto digno de estudo do artista. Talvez tenha sido exatamente esse triunfo total dos métodos que fez alguns artistas hesitarem em aceitá-los. Por um momento, pareceu que todos os problemas de uma arte que visava a imitar a impressão visual tinham sido resolvidos e que nada haveria a ganhar se explorassem ainda mais a fundo esse objetivo.

Com o domínio dos métodos para representar o mundo com o realismo o uso da perspectiva caiu em desuso no impressionismo. Os impressionistas desejavam representar a natureza tal como eles a experienciavam e não a partir do conhecimento dela. E para representar o mundo a partir do que eles viam e não do que eles sabiam estar lá, eles precisaram abandonar os métodos pictóricos convencionais, tais como o uso da perspectiva, do sombreamento claro-escuro para construir o volume, da suavização gradativa dos contrastes cromáticos para construir a percepção de profundidade, por exemplo.Essa mudança é descrita por Gombrich (1995, p. 539-540):

O problema não era novo para a arte. Recordemos que a conquista da natureza e a invenção da perspectiva no Quattrocento italiano puseram em perigo os lúcidos arranjos da pintura medieval e criaram um problema que só a geração de Rafael estivera habilitada a resolver (p.262, 319). Agora, a mesma questão se repetia num plano diferente. A dissolução de contornos firmes na luz bruxuleante e a descoberta de sombras coloridas pelos impressionistas tinham, uma vez mais, criado um novo problema: como poderiam essas realizações ser preservadas sem acarretar uma perda de ordem e clareza? Numa linguagem mais simples: as telas impressionistas tendiam a ser mais brilhantes, mais confusas. Cézanne detestava a confusão. Entretanto, não queria retornar às convenções acadêmicas do desenho e do sombreado para criar a ilusão de solidez, assim como não pretendia voltar às paisagens "compostas" para obter construções harmoniosas.

Enquanto os impressionistas abandonaram a preocupação com a perspectiva tradicional, van Gogh, Cézanne e Gauguin resgataram o uso da perspectiva, sem abandonar as inovações do programa dos impressionistas; integraram a ele a estrutura na composição e a clareza nas formas. Eles trabalharam para integrar essa ruptura nos sistemas de representação do espaço como discorre Gombrich (1995, p. 551-553):

Cézanne, Van Gogh e Gauguin foram três homens desesperadamente solitários; eles trabalharam com escassa esperança de ser algum dia compreendidos. Mas os problemas de sua arte, dos quais tinham uma consciência tão aguda e dolorosa, foram sentidos por um número cada vez maior de artistas da geração mais jovem, que não encontravam a menor satisfação nas habilidades adquiridas nas escolas de belas-artes. Tinham aprendido como representar a natureza, como desenhar corretamente e como usar tinta e pincel; tinham até absorvido as lições da Revolução impressionista e tornaram-se hábeis na representação dos reflexos da luz do sol e das vibrações do ar. Na verdade, alguns grandes artistas ainda perseveraram nesse caminho e defenderam os novos métodos em países onde a resistência ao Impressionismo ainda era forte, mas muitos pintores das gerações mais jovens buscaram novos métodos para solucionar, ou pelo menos contornar, as dificuldades que Cézanne sentira. Basicamente, essas dificuldades surgiram do conflito (discutido anteriormente, p.495-5) entre a necessidade de uma gradação de tom para sugerir profundidade e o desejo de preservar a beleza das cores que vemos. A 
arte dos japoneses os convenceu de que uma pintura poderia causar impressão mais forte se a modelação e outros detalhes fossem sacrificados para reforçar a simplificação. Tanto Van Gogh quanto Gauguin enveredaram de certa forma por esse caminho, acentuando suas cores e desconsiderando a impressão de profundidade, e Seurat foi ainda mais adiante, com seus experimentos com o pontilhismo.

Os impressionistas aboliram a preocupação com a representação da profundidade por meio do uso da perspectiva e da gradação dos contrastes e a representação do volume por meio do esfumato e do quiaroescuro, a correção do lineamento do desenho, a definição dos contornos. Eles privilegiaram a dissipação dos contornos, a mistura de cores direto na tela e não na paleta, a explosão de contrastes 'duros' para representar como a luz realmente se comporta no mundo real, dando à cena uma fluidez e espontaneidade, mas uma imprecisão e uma perda de solidez. No entanto, van Gogh, junto com Cézanne e Gauguin, se preocuparam em resolver os problemas da forma, do desenho, da estrutura, da profundidade, sem abandonar os pressupostos e as inovações pictóricas dos impressionistas, porém indo mais além no uso dessas técnicas aprendidas com os impressionistas, explorando novos empregos, dando-lhes novos sentidos, criando novas semioses pictóricas. Coli (2006, p. 87) comenta a esse respeito:

Com efeito, os dois anos passados em Paris permitiram a Vincent fazer novos conhecimentos e amizades - Emile Bernard, Pissarro, Toulouse-Lautrec, Signac, Seurat... e nada menos que duzentos quadros. A rapidez de van Gogh, e ao mesmo tempo o seu perfeito domínio pictural mostram que, de agora em diante, ele está de posse de todos os elementos necessários à sua obra. $O$ grafismo vigoroso, o sentido do espaço, do volume, da composição - cuja estrutura é sempre nítida, clara, equilibrada, impecável -, a fantástica maestria no emprego das cores, a utilização da pincelada como elemento construtor, tudo isso estará sempre presente em cada quadro - seja ele atormentado ou sereno -, em cada paisagem, em cada retrato, em cada natureza-morta. Assim, ele adquiriu uma virtuosidade que lhe permite uma execução fulgurante das telas. Para sua irmã, numa carta datada de Arles, no verão de 1888 , compara-se precisamente a um violinista ou a um pianista e diz que "num par de horas, deve ser possível pintar o campo de trigo, com o céu por cima, ao longe".

Uma das grandes contribuições de van Gogh é sem dúvida resgatar a estrutura, o uso da perspectiva, do desenho, da forma, sem perder a fluidez, o movimento, o ritmo, privilegiando o uso dos contrastes, a explosão de luz, a representação do mundo pela ótica dos avanços feitos pelos impressionistas, mas indo mais além, como exposto por Gombrich (1995, p. 543-544):

A invenção de Brunelleschi da "perspectiva linear" (p. 229) não o interessou muito. Desprezou-a quando descobriu que ela dificultava o seu trabalho. No fim de contas, essa perspectiva científica fora inventada para ajudar os pintores a criarem a ilusão de espaço - como Masaccio fizera em seu afresco de Santa Maria Novella (p. 228, Fig. 149). Cézanne não se propunha criar qualquer ilusão. O que ele queria era transmitir a sensação de solidez e profundidade, e descobriu que podia fazê-lo sem recorrer ao desenho convencional. Dificilmente se terá apercebido de que esse 
exemplo de indiferença pelo "desenho correto" iniciaria uma arrasadora e irrefreável avalancha no campo da arte.

\subsubsection{Triangulação da Perspectiva}

Perspectiva, no texto escrito e em relação à triangulação - A perspectiva na oração pode ser compreendida como o ponto de vista com que ele constrói o sentido intencionado, ou seja, o lugar de onde ele fala, onde ele se coloca ou não se coloca para instanciar a construção oracional. Em muitas orações observou-se uma característica na forma como van Gogh desenvolve a narrativa sobre a tela: ele não se coloca como o sujeito que produziu a tela. Há um apagamento de seu papel no processo de confecção da tela, como demonstra o extrato $2^{\mathrm{a}}$, da carta 628 do corpus textual:

Aqui está um esboço de um semeador: um grande campo lavrado com torrões de
terra, na sua maioria fracamente cor de violeta. Um campo de trigo maduro, de tom
amarelo-ocre com um pouco de carmim.O céu, amarelo-crômio, quase tão luminoso
quanto o próprio Sol, que é amarelo-crômio n ${ }^{\circ}$, misturado com um pouco de
branco, enquanto o resto do céu é uma mistura dos amarelos-crômios 1 e 2 . Tão
amarelo! A camisa do semeador é azul e as calças brancas. Tamanho da tela - 25 ,
quadrada. Há várias sugestões de amarelo no solo, tons neutros resultantes da
mistura de violeta e amarelo; mas tenho travado uma luta diabólica para atingir a
verdade das cores. 304

Ele poderia ter dito 'eu pintei a tela dessa e dessa forma', mas ele diz 'a tela tem essa e essa forma', colocando a tela no 'primeiro plano' dessa cena que ele está criando para o leitor da oração. Quando escreve para Theo, ele não está dizendo: eu pintei, eu fiz, ele privilegia a tela como um espaço no qual deseja que seu irmão adentre e reconstrua em sua imaginação. Ele usa o recurso do apagamento de sua presença na oração para enfatizar a tela enquanto um ambiente criado, e para envolver e conduzir Theo para dentro da cena. Esta é uma função Modal no texto escrito assim como no visual, usada para envolver e conduzir a atenção para dentro do discurso. Na tela ele consegue essa tarefa por meio da perspectiva, e na escrita, o ponto de vista com que ele fala da tela, é responsável por construir uma 'perspectiva' com que o leitor de sua carta irá 'enxergar' a tela que ele está descrevendo, sem tê-la diante de si. A perspectiva nas orações se dá pela construção do lugar do leitor, com base na centralidade do sujeito da oração. Como van Gogh utiliza com frequência a voz passiva, ele se retira e trás para o primeiro plano a tela. Ao fazê-lo, ele não se coloca como ponto de vista/perspectiva na produção de sentido, o foco é o irmão, ele deixa ambíguo ou esvaziado o lugar do

${ }^{304}$ Extrato no $^{\circ} \mathrm{a}$ - Carta 628 - To Emile Bernard. Arles, on or about Tuesday, 19 September 1888. (VAN GOGH, 2009c). 
protagonismo para o irmão, ao ler ocupá-lo, conduzindo por meio de uma descrição que valoriza o percurso para se aproximar dos elementos da tela e não sua posição pessoal diante dela. As orações que constroem perspectiva estão descritas abaixo:

Quadro 22: Triangulação da Perspectiva

\begin{tabular}{|c|c|c|}
\hline Ocorrência nas telas & Orações & Comentário \\
\hline $\begin{array}{l}\text { Na tela 'Por de Sol: Campo de } \\
\text { trigo perto de Arles', observei } \\
\text { o uso de perspectiva registrado } \\
\text { nas notas de rodapé } 44,45 \text { e } \\
47 \text { no apêndice. } \\
\text { A perspectiva é construída } \\
\text { com a ajuda da modulação } \\
\text { cromática no campo de trigo. }\end{array}$ & $\begin{array}{l}\text { "Aqui está outra paisagem. Sol } \\
\text { poente? Lua nascendo? Noite de } \\
\text { verão, de qualquer modo. Cidade } \\
\text { violeta, estrela amarela, céu azul- } \\
\text { esverdeado; os campos de trigo têm } \\
\text { todos os tons: ouro velho, cobre, } \\
\text { ouro verde, ouro vermelho, ouro } \\
\text { amarelo, verde, vermelho e amarelo } \\
\text { bronze. Tela quadrada número } 30 .\end{array}$ & $\begin{array}{l}\text { A perspectiva no texto é criada por } \\
\text { meio de um processo existencial que } \\
\text { abre a sequência e coloca a certa } \\
\text { distância da cena. Em seguida, há um } \\
\text { grupo de orações sem o agente da } \\
\text { ação, seguidos por um novo processo } \\
\text { relacional atributivo que é empregado } \\
\text { para descrever, qualificar e envolver o } \\
\text { leitor na cena descrita. O leitor, agora, } \\
\text { está "dentro da cena". Inferi que o uso } \\
\text { da perspectiva está fortemente } \\
\text { relacionado com a função Modal. }\end{array}$ \\
\hline $\begin{array}{l}\text { Na tela 'Por de Sol: Campo } \\
\text { de trigo perto de Arles', } \\
\text { observei a ocorrência do uso } \\
\text { do plongee, com outra } \\
\text { função, a de criar o } \\
\text { distanciamento do } \\
\text { espectador. Explicada nas } \\
\text { notas de rodapé } 50,101 \text { e } \\
103 \text { no apêndice. } \\
\text { A perspectiva nesta tela é } \\
\text { construída por uma } \\
\text { combinação de recursos } \\
\text { semióticos tais como: as } \\
\text { cunhas, a gradação nas } \\
\text { tonalidades de amarelo, a } \\
\text { profundidade obtida pela } \\
\text { gradação de contrastes de } \\
\text { claro e escuro no céu, os } \\
\text { pontos de fuga na distância, } \\
\text { o enquadramento } \\
\text { levemente plongee que } \\
\text { além de contribuir para a } \\
\text { construção da } \\
\text { profundidade e da } \\
\text { perspectiva, também } \\
\text { contribui para a distorção } \\
\text { do ponto de vista. }\end{array}$ & $\begin{array}{l}\text { Eu tenho um terceiro estudo, } \\
\text { agora, de uma paisagem com } \\
\text { fábrica, e um enorme sol em um } \\
\text { céu vermelho, acima de telhados } \\
\text { vermelhos, em que a natureza } \\
\text { parece estar em um acesso de } \\
\text { raiva, em um dia de Mistral } \\
\text { desagradável. } \\
\text { A mudança na Perspectiva e no } \\
\text { Enquadramento, feita por um } \\
\text { deslocamento na agência que na } \\
\text { oração paratática é 'eu tenho' uma } \\
\text { e na hipotática é 'a natureza parece } \\
\text { estar'. Está registrada e comentada } \\
\text { nas notas de rodapé 108, 109 e } 110 \\
\text { no apêndice. } \\
\text { Na oração, a partir do momento } \\
\text { em que van Gogh dá um atributo } \\
\text { para a tela, ele faz um } \\
\text { deslocamento que torna autônomo } \\
\text { este participante "paisagem". Ao } \\
\text { fazê-lo, van Gogh como } \\
\text { participante portador, deixa de ser } \\
\text { o produtor e passa a ser o } \\
\text { possuidor e esse processo de } \\
\text { atribuição é um momento } \\
\text { reflexivo no qual ele como pintor } \\
\text { se distancia do seu lugar como } \\
\text { participante neste processo. }\end{array}$ & $\begin{array}{l}\text { Inferi que o uso do ângulo vertical } \\
\text { plongee tem a função de criar um } \\
\text { distanciamento do espectador. } \\
\text { Na nota de rodapé } 50 \text { no apêndice, } \\
\text { observei que há um deslocamento na } \\
\text { construção do ponto de vista da } \\
\text { oração, que causa um } \\
\text { distanciamento do ponto de vista do } \\
\text { leitor, pode ser compatível com o } \\
\text { uso do ângulo plongee no texto } \\
\text { visual, também usado com a função } \\
\text { de causar um distanciamento no } \\
\text { espectador. Aqui vemos um tipo de } \\
\text { compatibilidade de função, não de } \\
\text { forma ou de sentido. } \\
\text { Outro exemplo de deslocamento da } \\
\text { perspectiva está no excerto: “Tela } \\
\text { quadrada número } 30 . \text { Eu pintei-a ao } \\
\text { ar livre no Mistral. Meu cavalete foi } \\
\text { fixado no chão com estacas de } \\
\text { ferro, um método que eu recomendo } \\
\text { a você. Voce enterra os pés do } \\
\text { cavalete e, em seguida, voce } \\
\text { empurra a } 50 \text { centímetros de } \\
\text { comprimento um peso de ferro ao } \\
\text { lado deles. Voce amarra tudo com } \\
\text { cordas; dessa forma, voce pode } \\
\text { trabalhar com o vento.”, observei a } \\
\text { ocorrência de uma mudança de } \\
\text { Enquadramento na escolha da } \\
\text { agência e dos processos das orações } \\
\text { que se sucedem nesse excerto. } \\
\text { Registrado na nota de rodapé } 115 \text { no } \\
\text { apêndice. }\end{array}$ \\
\hline
\end{tabular}




\begin{tabular}{|c|c|c|}
\hline $\begin{array}{l}\text { Na tela 'Por de Sol: Campo } \\
\text { de trigo perto de Arles', } \\
\text { observei a ocorrência de um } \\
\text { uso original semiótico: a } \\
\text { inversão do ponto de fuga, } \\
\text { trazendo para o plano do } \\
\text { espectador o foco com que } \\
\text { olhar a perspectiva e } \\
\text { levando-o a se identificar } \\
\text { inevitavelmente com o } \\
\text { lugar do experienciador da } \\
\text { tela, o artista. Este é um uso } \\
\text { original de perspectiva para } \\
\text { construir a distorção do } \\
\text { ponto de vista que } \\
\text { caracteriza o sistema } \\
\text { semiótico de van Gogh. Esta } \\
\text { ocorrência está registrada } \\
\text { nas notas de rodapé } 48 \text { e } 49 \\
\text { no apêndice. }\end{array}$ & $\begin{array}{l}\text { Aqui está outra paisagem. Sol } \\
\text { poente? Lua nascendo? Noite de } \\
\text { verão, de qualquer modo. Cidade } \\
\text { violeta, estrela amarela, céu azul- } \\
\text { esverdeado; os campos de trigo têm } \\
\text { todos os tons: ouro velho, cobre, } \\
\text { ouro verde, ouro vermelho, ouro } \\
\text { amarelo, verde, vermelho e amarelo } \\
\text { bronze. Tela quadrada número } 30 . \\
\text { Eu pintei-a ao ar livre no Mistral. } \\
\underline{\text { Meu cavalete foi fixado no chão }} \\
\underline{\text { com estacas de ferro, um método }} \\
\text { que eu recomendo a você. } \\
\text { Você enterra os pés do cavalete e, } \\
\underline{\text { em seguida, você empurra a } 50} \\
\text { centímetros de comprimento um } \\
\text { peso de ferro ao lado deles. Você } \\
\text { amarra tudo com cordas; dessa } \\
\underline{\text { forma, você pode trabalhar com o }} \\
\underline{\text { vento. }}\end{array}$ & $\begin{array}{l}\text { Observei também na análise dos } \\
\text { excertos das cartas uma alternância } \\
\text { na representação de si próprio dentro } \\
\text { da oração. Assim como na tela, ele } \\
\text { se faz presente indiretamente por } \\
\text { meio de recursos semióticos } \\
\text { indexadores de sua presença, nas } \\
\text { orações ele procurou muitas vezes } \\
\text { o apagamento de sua presença } \\
\text { para representar na oração } \\
\text { apenas os assuntos da tela, dando } \\
\text { a voz ativa para a tela e seus } \\
\text { elementos representados, } \\
\text { enquanto em outras orações ele se } \\
\text { representou como o agente da } \\
\text { ação. Esta ocorrência de distorção } \\
\text { da perspectiva pela alternância do } \\
\text { apagamento do agente ou } \\
\text { participante principal dentro da } \\
\text { oração está documentada na nota de } \\
\text { rodapé } 49 \text { no apêndice e também } \\
\text { documentada na análise do corpus } \\
\text { textual. }\end{array}$ \\
\hline $\begin{array}{l}\text { Na tela 'O Semeador', } \\
\text { observei a ocorrência de } \\
\text { Enquadramento, Saliência, } \\
\text { Vetor para construir a } \\
\text { centralidade do campo na } \\
\text { narrativa, e o sentido } \\
\text { principal do enunciado que é } \\
\text { o de receber a semeadura } \\
\text { do semeador. Observei um } \\
\text { deslocamento da agência da } \\
\text { ação que é compatível com } \\
\text { as ocorrências de } \\
\text { deslocamento da agência } \\
\text { da ação nas orações escritas } \\
\text { por van Gogh. Registrado na } \\
\text { nota de rodapé } 77 .\end{array}$ & $\begin{array}{l}\text { Em um campo arado, um grande } \\
\text { campo de torrões de terra roxa - } \\
\text { levantados em direção ao horizonte - } \\
\text { um semeador em azul e branco. No } \\
\text { horizonte um campo de trigo curto, } \\
\text { maduro. } \\
\text { Acima de tudo isso um céu amarelo } \\
\text { com um sol amarelo. } \\
\text { Na primeira oração, observei que } \\
\text { uma grande ênfase é dada para o } \\
\text { campo arado, por meio de uma } \\
\text { cadeia de complexos nominais que } \\
\text { dão atributos para o campo e } \\
\text { constroem uma narrativa visual, em } \\
\text { comparação com uma descrição } \\
\text { muito sintética e pontual da figura } \\
\text { do semeador. A oração não deixa } \\
\text { dúvidas sobre o protagonismo } \\
\text { relativo entre o campo arado e o } \\
\text { semeador, para van Gogh. }\end{array}$ & $\begin{array}{l}\text { Van Gogh parece antecipar que o } \\
\text { observador ficará surpreendido com } \\
\text { o fato de que dois terços da tela são } \\
\text { ocupados pelo campo arado assim } \\
\text { como a evidente direção do olhar } \\
\text { para o horizonte. Nessa perspectiva } \\
\text { há um distanciamento em relação ao } \\
\text { campo de trigo maduro. Como se } \\
\text { não bastasse, no espaço ocupado } \\
\text { pelo campo, acima e distante deles } \\
\text { talvez em um sentido concreto } \\
\text { material da tela, mas também num } \\
\text { sentido metafórico, estão o sol e o } \\
\text { céu. }\end{array}$ \\
\hline $\begin{array}{l}\text { Na tela ‘O Semeador', a } \\
\text { profundidade visual é } \\
\text { construída pela divisão do } \\
\text { espaço em planos, e pela } \\
\text { gradação cromática das } \\
\text { tonalidades de azuis do } \\
\text { campo. Ela também é } \\
\text { construída com a ajuda da } \\
\text { perspectiva, dada pelos } \\
\text { caminhos visuais no campo } \\
\text { arado. Observei a ocorrência } \\
\text { de Perspectiva pelo uso de } \\
\text { vários recursos tais como }\end{array}$ & 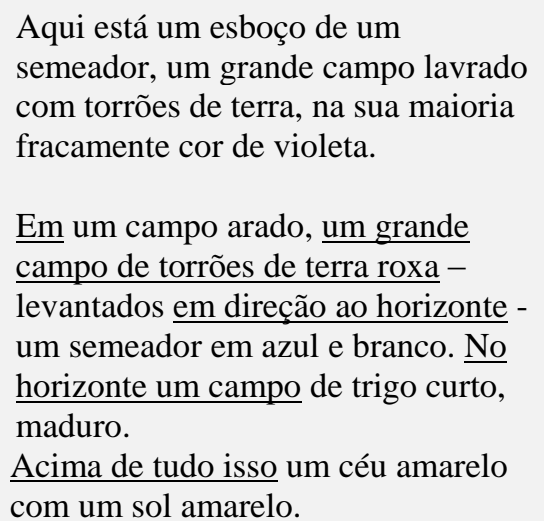 & $\begin{array}{l}\text { No nível semântico, as orações } \\
\text { constroem uma “tomada" que } \\
\text { aproxima o leitor da cena e o coloca } \\
\text { "dentro" da tela. } \\
\text { A primeira oração inicia dando ênfase } \\
\text { na tela em sua materialidade enquanto } \\
\text { um texto 'Aqui está um esboço', para } \\
\text { depois adentrar no espaço 'interno' da } \\
\text { tela: ‘um grande campo'. A divisão do } \\
\text { espaço em planos se dá, na oração, } \\
\text { pela construção 'com torrões de terra' } \\
\text { e depois no detalhamento de sua } \\
\text { gradacão cromática: ' na sua maioria }\end{array}$ \\
\hline
\end{tabular}




\begin{tabular}{|c|c|c|}
\hline $\begin{array}{l}\text { planos com ângulos de } \\
\text { enquadramento } \\
\text { diferenciados, em forma de } \\
\text { cunhas que são sugeridas } \\
\text { pela modulação cromática } \\
\text { dos torrões de terra. } \\
\text { Registrado nas notas de } \\
\text { rodapé 35 e 36. } \\
\text { A Perspectiva e } \\
\text { Profundidade também são } \\
\text { construídas por caminhos } \\
\text { visuais conferidos pelo } \\
\text { agrupamento de membros } \\
\text { como o caminho de terra, } \\
\text { os corvos e a casa. } \\
\text { Registradas na nota de } \\
\text { rodapé } 37 .\end{array}$ & $\begin{array}{l}\text { Com a escolha léxico-gramatical da } \\
\text { primeira oração, van Gogh constrói } \\
\text { que um grande campo de torrões de } \\
\text { terra roxa está em um campo arado e } \\
\text { nele, há um semeador, denotando } \\
\text { uma relação de pertencimento, de } \\
\text { conteúdo e continente. A } \\
\text { espacialidade é a principal categoria } \\
\text { organizadora das orações, como se } \\
\text { observa nas orações seguintes. }\end{array}$ & $\begin{array}{l}\text { fracamente cor de violeta', indicando } \\
\text { uma compatibilidade com a ocorrência } \\
\text { visual de profundidade na tela. } \\
\text { O mesmo é observado no segundo } \\
\text { excerto, que igualmente constrói uma } \\
\text { representação do espaço compositivo } \\
\text { por meio de enquadramentos e de } \\
\text { planos pela escolha dos itens lexicais } \\
\text { 'Em', 'em direção', 'No horizonte', e } \\
\text { 'Acima de tudo isso'. }\end{array}$ \\
\hline $\begin{array}{l}\text { Na tela 'O semeador' a } \\
\text { perspectiva faz com que } \\
\text { nos desloquemos para a } \\
\text { distância da tela, deste um } \\
\text { ponto muito próximo onde } \\
\text { se encontram os torrões } \\
\text { arados até o campo } \\
\text { maduro e a casa, bem ao } \\
\text { longe. } \\
\text { O uso do plongee, registrado } \\
\text { na nota de rodapé } 46, \text { faz a } \\
\text { função contrária de } \\
\text { distanciamento do } \\
\text { espectador, enquanto } \\
\text { outros recursos de } \\
\text { profundidade, } \\
\text { enquadramento e } \\
\text { perspectiva, trabalham } \\
\text { para colocá-lo dentro da } \\
\text { cena representada. }\end{array}$ & $\begin{array}{l}\text { A pintura é dividida em dois; metade } \\
\text { é amarelo, o topo; a base é violeta. } \\
\text { Bem, as calças brancas descansam os } \\
\text { olhos e os distraem exatamente } \\
\text { quando o contraste simultâneo } \\
\text { excessivo de amarelo e violeta iriam } \\
\text { irritá-lo. Isso é o que eu queria dizer. }\end{array}$ & $\begin{array}{l}\text { Deslocamento da perspectiva: dentro e } \\
\text { fora da tela. Nessa sequência de } \\
\text { orações evidenciei novamente um } \\
\text { deslocamento na perspectiva que } \\
\text { inicia 'dentro' da tela por meio de } \\
\text { processos relacionais para construir a } \\
\text { descrição das cores. Em seguida, ele } \\
\text { descreve a relação do branco da calça } \\
\text { que distrai os olhos e da irritação } \\
\text { causada pelo efeito do contraste } \\
\text { complementar violeta amarelo. Na } \\
\text { próxima oração, ele 'tira' o leitor de } \\
\text { dentro do universo representado } \\
\text { iniciando uma oração na qual ele traz } \\
\text { a atenção para si e para a sua intenção } \\
\text { ao narrar a cena. }\end{array}$ \\
\hline $\begin{array}{l}\text { Na tela 'O Semeador', } \\
\text { observei a ocorrência de } \\
\text { Perspectiva pelo uso de } \\
\text { vários recursos tais como } \\
\text { planos com ângulos de } \\
\text { enquadramento } \\
\text { diferenciados, em forma de } \\
\text { cunhas que são sugeridas } \\
\text { pela modulação cromática } \\
\text { dos torrões de terra. } \\
\text { Registrado na nota de rodapé } \\
\text { 36. }\end{array}$ & $\begin{array}{l}\text { "Aqui está um esboço de um } \\
\text { semeador: um grande campo lavrado } \\
\text { com torrões de terra, na sua maioria } \\
\text { fracamente cor de violeta. } \\
\text { Um campo de trigo maduro, de tom } \\
\text { amarelo-ocre com um pouco de } \\
\text { carmim. } \\
\underline{\text { O céu, amarelo-crômio, quase tão }} \\
\text { luminoso quanto o próprio Sol, que } \\
\text { é amarelo-crômio no } 1 \text {, misturado } \\
\text { com um pouco de branco, enquanto } \\
\text { o resto do céu é uma mistura dos } \\
\text { amarelos-crômios } 1 \text { e } 2 \text {. Tão } \\
\text { amarelo! A camisa do semeador é } \\
\text { azul e as calças brancas. Tamanho } \\
\text { da tela }-25 \text {, quadrada. }\end{array}$ & $\begin{array}{l}\text { Deslocamento da perspectiva: dentro e } \\
\text { fora da tela. A carta é um gênero } \\
\text { narrativo. No primeiro momento ele } \\
\text { narra o quadro: 'Aqui está um } \\
\text { esboço..' por meio de processos } \\
\text { relacionais atributivos. O atributo está } \\
\text { em relação ao que está na tela. } \\
\text { No segundo momento ele está } \\
\text { comentando sobre a tela: 'Há } \\
\text { sugestões (...) Preferia muito mais } \\
\text { fazer', ele começa a explicar a tela, o } \\
\text { que ele fez, o que ele sente em relação } \\
\text { a tela. Ele passa a falar de si mesmo. } \\
\text { Observei pela mudança na estrutura } \\
\text { léxico-gramatical, já com complexos } \\
\text { oracionais. Quando ele usa o processo } \\
\text { relacional atributivo, ele está falando } \\
\text { da tela que são diferentes dos } \\
\text { processos usados quando fala de si } \\
\text { mesmo. A perspectiva com que ele }\end{array}$ \\
\hline
\end{tabular}




\begin{tabular}{|c|c|c|}
\hline $\begin{array}{l}\text { cena por meio de uma } \\
\text { combinação de caminhos } \\
\text { visuais que constroem a } \\
\text { aproximação do } \\
\text { espectador. Outros recursos } \\
\text { usados são descritos na nota } \\
\text { de rodapé } 38 .\end{array}$ & & $\begin{array}{l}\text { narra a tela no primeiro parágrafo, } \\
\text { muda no segundo parágrafo. No } \\
\text { primeiro só existe a tela para se } \\
\text { adentrar em uma narrativa. No } \\
\text { segundo parágrafo ele se coloca, } \\
\text { explicita e comenta sobre a sua } \\
\text { posição em relação à tela. Há uma } \\
\text { mudança de perspectiva na narrativa. }\end{array}$ \\
\hline $\begin{array}{l}\text { Van Gogh quis representar o } \\
\text { campo arado como sendo o } \\
\text { participante principal, ou } \\
\text { como o recipiente principal } \\
\text { da ação do participante } \\
\text { principal. No entanto, esse } \\
\text { participante principal, o } \\
\text { semeador, não está no } \\
\text { primeiro plano, está no } \\
\text { segundo plano e o } \\
\text { enquadramento mostra uma } \\
\text { distância social da figura do } \\
\text { semeador. Dessa forma, o } \\
\text { enquadramento revela que, } \\
\text { apesar de, vetorialmente ser } \\
\text { o semeador o participante } \\
\text { principal, a saliência maior } \\
\text { foi dada para o campo arado, } \\
\text { trazendo este para o lugar de } \\
\text { destaque, não para quem está } \\
\text { comandando a ação } \\
\text { principal, mas para quem } \\
\text { está recebendo a ação } \\
\text { principal. } \\
\text { Inferi que aqui ocorre uma } \\
\text { inversão enunciativa. Se } \\
\text { transpuséssemos essa } \\
\text { enunciação para duas } \\
\text { oraç̃̃es, nelas, o sentido } \\
\text { principal sofreria um } \\
\text { deslocamento da oração } \\
\text { paratática: 'O semeador } \\
\text { semeia' para a oração } \\
\text { hipotática: 'o campo arado } \\
\text { recebe a ação de semear do } \\
\text { Semeador'. Essa estratégia } \\
\text { de deslocamento do sentido } \\
\text { principal para a oração } \\
\text { hipotática foi também } \\
\text { observada em muitos } \\
\text { complexos oracionais } \\
\text { construídos nas cartas de van } \\
\text { Gogh. Registrado na nota de } \\
\text { rodapé } 77 . \\
\end{array}$ & $\begin{array}{l}\text { Há várias sugestões de amarelo no } \\
\text { solo, tons neutros resultantes da } \\
\text { mistura de violeta e amarelo; mas } \\
\text { tenho travado uma luta diabólica // } \\
\text { para atingir a verdade das cores. }\end{array}$ & $\begin{array}{l}\text { Ocorrência de Profundidade, } \\
\text { Enquadramento e Perspectiva no nível } \\
\text { gramatical, já que o sentido principal } \\
\text { foi deslocado para a oração hipotática } \\
\text { registrado na nota de rodapé 89. } \\
\\
\text { A escolha lexical indica uma } \\
\text { intensificação do processo que ele } \\
\text { representa por meio dos itens } \\
\text { 'travado' e 'luta diabólica' e que } \\
\text { sugere um processo extremado para } \\
\text { chegar ao conhecimento das cores. O } \\
\text { sentido principal deste complexo } \\
\text { oracional está na oração hipotática, } \\
\text { sugerindo um deslocamento de } \\
\text { 'planos' causando um efeito de } \\
\text { 'profundidade' no enunciado. }\end{array}$ \\
\hline $\begin{array}{l}\text { Na tela 'O Semeador' o } \\
\text { deslocamento da perspectiva } \\
\text { ocorre com o uso do } \\
\text { plongee, registrado na nota } \\
\text { de rodapé } 46, \text { que deixa o } \\
\text { ponto de vista do }\end{array}$ & $\begin{array}{l}\text { Não te vou ocultar //que não } \\
\text { desgosto da região,// pois fui criado } \\
\text { lá // - ainda me encanta a magia das } \\
\text { recordações do passado, de um } \\
\text { desejo do infinito,// do qual o } \\
\text { semeador e o enfeixador são }\end{array}$ & $\begin{array}{l}\text { Na oração alfa há um processo verbal } \\
\text { cujo relato não explicita o afeto do } \\
\text { dizente em relação à região, mas na } \\
\text { Beta ele explicita o afeto pelas } \\
\text { recordações e o lugar ocupado pela } \\
\text { 'região' na sua experiência afetiva }\end{array}$ \\
\hline
\end{tabular}




\begin{tabular}{|c|c|c|}
\hline $\begin{array}{l}\text { espectador um pouco } \\
\text { suspenso do chão e causa } \\
\text { um distanciamento ao } \\
\text { mesmo tempo em que os } \\
\text { outros recursos o levam a } \\
\text { se aproximar da cena. } \\
\text { Uso do plongee para } \\
\text { representar a cena, causa um } \\
\text { distanciamento do } \\
\text { espectador e estabelece a } \\
\text { perspectiva com a qual van } \\
\text { Gogh quis que o espectador } \\
\text { olhasse a cena, registrado na } \\
\text { nota de rodapé } 46 .\end{array}$ & $\begin{array}{l}\text { símbolos / -, tanto quanto antes } \\
\text { gostava. // } \\
\text { Ocorrência de Perspectiva e } \\
\text { Profundidade no uso de construtos } \\
\text { que fazem uma diferenciação entre } \\
\text { campos de experiência no passado e } \\
\text { presente e criam planos e } \\
\text { distanciamento para expressar um } \\
\text { sentido muito particular registrados } \\
\text { na nota de rodapé } 99 .\end{array}$ & $\begin{array}{l}\text { demonstrando que ele deixa para } \\
\text { expressar na oração secundária o } \\
\text { sentido mais importante para ele, } \\
\text { produzindo um descolar do } \\
\text { enquadramento e da perspectiva ao se } \\
\text { ler a oração. Ocorrência de } \\
\text { Enquadramento e da Perspectiva pelo } \\
\text { deslocamento do sentido principal } \\
\text { para a oração secundária registrado na } \\
\text { nota de rodapé } 96 .\end{array}$ \\
\hline $\begin{array}{l}\text { Na tela 'A Esplanada do } \\
\text { Café na Place du Forum, } \\
\text { Arles, à Noite', observei a } \\
\text { ocorrência de } \\
\text { Enquadramento, Perspectiva } \\
\text { e Profundidade construída } \\
\text { por linhas diagonais que } \\
\text { convergem no centro e } \\
\text { dividem a tela em quatro } \\
\text { seções. As quatro linhas } \\
\text { diagonais que conduzem o } \\
\text { olhar para dentro da tela. } \\
\text { Registrado na nota de rodapé } \\
132 \text { no apêndice. }\end{array}$ & $\begin{array}{l}\text { No terraço, há pequenas figuras de } \\
\text { pessoas que bebem. Uma enorme } \\
\text { lanterna amarela ilumina o terraço, a } \\
\text { fachada, a calçada, e até mesmo } \\
\text { projeta luz sobre os paralelepípedos } \\
\text { da rua, que adquirem uma coloração } \\
\text { violeta-rosa. As frentes das casas em } \\
\text { uma rua que segue sob o céu azul } \\
\text { salpicado de estrelas são azul escuro } \\
\text { ou violeta, com uma árvore verde. }\end{array}$ & $\begin{array}{l}\text { Na tela o Enquadramento, Perspectiva } \\
\text { e Profundidade são construídas por } \\
\text { linhas diagonais que convergem no } \\
\text { centro. Na oração ele constrói a } \\
\text { centralidade por meio da ênfase dada } \\
\text { pelas escolhas léxico-gramaticais } \\
\text { como 'No terraço', 'enorme' e pela } \\
\text { vetorização do processo 'ilumina', } \\
\text { enfatizado pela ocorrência de Ritmo } \\
\text { com 'o terraço, a fachada, a calçada e } \\
\text { até mesmo projeta luz'. Com os } \\
\text { recursos de Ritmo, Saliência e Vetor } \\
\text { para a lanterna amarela, ele constrói a } \\
\text { convergência da ação na tela. }\end{array}$ \\
\hline $\begin{array}{l}\text { Na tela 'A Esplanada do } \\
\text { Café na Place du Forum, } \\
\text { Arles, à Noite', observei um } \\
\text { ângulo plongee com o qual } \\
\text { van Gogh representou a } \\
\text { cena, um pouco acima do } \\
\text { nível do chão e que produz } \\
\text { um efeito de } \\
\text { distanciamento provoca } \\
\text { um distanciamento do } \\
\text { espectador, enquanto outros } \\
\text { recursos semióticos (cores, } \\
\text { perspectiva, ponto de fuga) } \\
\text { trabalham para conduzir o } \\
\text { espectador para dentro da } \\
\text { cena. Esta ocorrência está } \\
\text { registrada na nota de rodapé } \\
124 \text { no apêndice. }\end{array}$ & $\begin{array}{l}\text { A segunda mostra o exterior de um } \\
\text { café, iluminado no terraço externo } \\
\text { por uma grande lâmpada de gás } \\
\text { dentro da noite azul, com um retalho } \\
\text { de céu azul estrelado. }\end{array}$ & $\begin{array}{l}\text { Neste complexo oracional, observei } \\
\text { um deslocamento não apenas de } \\
\text { planos, mas de pontos de vista. Na } \\
\text { oração alfa, van Gogh se refere à tela } \\
\text { enquanto que na oração beta, ele está } \\
\text { se referindo à cena que está } \\
\text { representada na tela. Dessa forma ele } \\
\text { desliza de um ponto de vista externo à } \\
\text { cena, para um ponto de vista que está } \\
\text { dentro da cena. }\end{array}$ \\
\hline $\begin{array}{l}\text { Observei também a } \\
\text { ocorrência de } \\
\text { Enquadramento que interage } \\
\text { com a Perspectiva e a } \\
\text { Profundidade, presentes na } \\
\text { divisão dos planos no } \\
\text { espaço composicional. } \\
\text { Registrada na nota de rodapé } \\
\underline{119} .\end{array}$ & $\begin{array}{l}\text { Fui interrompido precisamente pelo } \\
\text { trabalho que uma nova pintura da } \\
\text { parte externa de um café à noite tem } \\
\text { me dado nos últimos dias. } \\
\text { As frentes das casas em uma rua que } \\
\underline{\text { segue sob o céu azul salpicado de }} \\
\underline{\text { estrelas são azul escuro ou violeta, }} \\
\text { com uma árvore verde. }\end{array}$ & $\begin{array}{l}\text { Na oração: A segunda mostra o } \\
\text { exterior de um café, [[ iluminado no } \\
\text { terraço externo por uma grande } \\
\text { lâmpada de gás dentro da noite azul, } \\
\text { com um retalho de céu azul } \\
\text { estrelado.]] constatei a ocorrência de } \\
\text { profundidade, com destaque para o } \\
\text { segundo plano, ou seja, para a oração } \\
\text { Beta. Registrado na nota de rodapé }\end{array}$ \\
\hline
\end{tabular}




\begin{tabular}{|c|c|c|}
\hline & & 166 no apêndice. \\
\hline $\begin{array}{l}\text { A noite e as estrelas foi um } \\
\text { tema iniciado possivelmente } \\
\text { por van Gogh. Walther e } \\
\text { Metzger (2012, p. 383) } \\
\text { argumentam que "ele criou } \\
\text { um novo gênero artístico: a } \\
\text { cena noturna ao ar livre". } \\
\text { Seu interesse pela luz } \\
\text { noturna o levou a representar } \\
\text { uma série de noites } \\
\text { estreladas. }\end{array}$ & $\begin{array}{l}\text { Agora há uma pintura de noite sem } \\
\text { preto. Com nada mais do que um } \\
\text { belo azul e violeta e verde e nestes } \\
\text { arredores da praça iluminada é } \\
\text { colorido por enxofre pálido, amarelo } \\
\text { limão. }\end{array}$ & $\begin{array}{l}\text { Van Gogh inovou não apenas no tema, } \\
\text { mas na proeza de registrar as cores } \\
\text { noturnas, como são as cores dos } \\
\text { objetos quando iluminados pelo } \\
\text { lampião a gás e a luz das estrelas e } \\
\text { quando iluminados apenas pela noite. }\end{array}$ \\
\hline $\begin{array}{l}\text { Na tela 'O Café Noturno na } \\
\text { Place Lamartine, em Arles', } \\
\text { observei a ocorrência de } \\
\text { Enquadramento, } \\
\text { Inacabamento, Perspectiva e } \\
\text { Distorção do Ponto de vista. } \\
\text { As cadeiras no primeiro } \\
\text { plano foram representadas } \\
\text { parcialmente e não tem } \\
\text { uma proporção e um } \\
\text { alinhamento compatível } \\
\text { com as perspectiva das } \\
\text { tábuas no chão. Registrada } \\
\text { na nota de rodapé } 127 \text { e } 225 .\end{array}$ & $\begin{array}{l}\text { A sala está pintada de vermelho, e no } \\
\text { interior, na luz a gás, a mesa de } \\
\text { bilhar verde, a qual lança uma } \\
\text { imensa sombra sobre o chão. } \\
\text { Mudança na perspectiva e no foco } \\
\text { com a qual van Gogh narra, } \\
\text { textualmente, a cena do café. Ele } \\
\text { volta a tornar a sala representada, o } \\
\text { agente da ação na oração. Registrado } \\
\text { na nota de rodapé } 285 \text {. }\end{array}$ & $\begin{array}{l}\text { Foi observado um sentido de } \\
\text { movimentação conferida aos objetos } \\
\text { inanimados em contraposição à } \\
\text { paralisia das figuras humanas na tela } \\
\text { que endossa a disposição } \\
\text { desorganizada e oblíqua das cadeiras, } \\
\text { transmitindo a sensação de que a } \\
\text { presença, o fulgor e a movimentação } \\
\text { de pessoas ali naquele espaço ainda } \\
\text { estivessem presentes, quentes, embora } \\
\text { elas já tenham ido embora daquele } \\
\text { local que é reforçado pela ocorrência } \\
\text { de vetores projetados pelas cadeiras. }\end{array}$ \\
\hline $\begin{array}{l}\text { Na tela 'O Café da Noite', } \\
\text { além do ângulo aberto para } \\
\text { representar o interior do } \\
\text { café, van Gogh usou um } \\
\text { segundo ângulo, o plongee. } \\
\text { Registrado na nota de rodapé } \\
103 \text { no apêndice. } \\
\\
\text { Uso de Distorção do Ponto } \\
\text { de Vista construída com } \\
\text { Enquadramento e } \\
\text { Perspectiva em um ângulo de } \\
\text { enquadramento levemente } \\
\text { plongee, como se van Gogh } \\
\text { estivesse pairando acima do } \\
\text { nível do chão. Registrado na } \\
\text { nota de rodapé } 248 .\end{array}$ & $\begin{array}{l}\text { Mudança de enfoque: } \\
\text { Ele desliza da narração das telas } \\
\text { para a narração do artigo e volta } \\
\text { para as telas. } \\
\text { "Estudos exagerados, como o } \\
\text { semeador, como o café noturno } \\
\text { agora, geralmente parecem-me } \\
\text { atrozmente feios e ruins, mas } \\
\text { quando eu estou movido por alguma } \\
\text { coisa, como aqui por este pequeno } \\
\text { artigo sobre Dostoievski, em } \\
\text { seguida, eles são os únicos que me } \\
\text { parecem ter um significado mais } \\
\text { importante." }\end{array}$ & $\begin{array}{l}\text { O ângulo plongee, dentro da semiose } \\
\text { construída por van Gogh, tem a } \\
\text { função de causar um estranhamento e } \\
\text { um distanciamento no espectador. } \\
\text { Esse estranhamento ocorre ao mesmo } \\
\text { tempo em que a perspectiva o leva } \\
\text { para dentro da cena o ângulo plongee } \\
\text { o leva a pensar no pintor, de onde ele } \\
\text { teria pintado esta cena, pois pelo } \\
\text { ponto de vista de quem olha não } \\
\text { parece que ele estava no nível do } \\
\text { chão. Com isso, há uma mudança de } \\
\text { enfoque, um deslizamento do ponto de } \\
\text { vista de quem faz a narração, e que } \\
\text { leva o espectador a deslizar também, } \\
\text { entre se aproximar e se distanciar da } \\
\text { cena. }\end{array}$ \\
\hline
\end{tabular}

Fonte: Triangulação para Perspectiva dos dados dos corpora visual e textual, com os extratos das cartas. 


\title{
6.7 PROFUNDIDADE
}

A profundidade no texto visual normalmente é compreendida como uma modulação progressiva da intensidade do plano mais próximo do espectador até os planos mais distantes. Ou seja, o primeiro plano tem tons mais intensos, traços mais definidos, contornos mais demarcados, detalhes mais elaborados, textura mais profusa, enquanto o segundo plano perde um pouco nesses itens.

O terceiro plano perde mais ainda, causando uma percepção de distância espacial. Além dessa graduação cromática das tonalidades, outros recursos pictóricos ajudam a construir a percepção de profundidade, como a perspectiva, o ponto de fuga, os caminhos visuais, e o enquadramento.

Em muitas de suas telas, van Gogh recorreu ao uso de segundo plano chapado com tons intensos (influência de Gauguin e da gravura Japonesa) ou com textura muito trabalhada (influência de Monticelli) que se confunde e compete com o primeiro plano causando um efeito de sentido. Walther e Metzger (2015, p. 451) discorrem sobre a influência de Gauguin:

\begin{abstract}
Ambos os artistas representaram a madame Ginoux na mesma pose, apoiada no cotovelo esquerdo e com a cabeça pousada na mão esquerda. Gauguin pintou-a de frente, apropriando-se dos princípios de Van Gogh, que sempre valorizara muito o contacto visual com os seus modelos. Aliás, a prontidão com que Van Gogh se deixou manobrar mostra bem o profundo respeito que tinha pelo colega. Porém, logo que começou a pintar voltou às características de antigamente: áreas monocromáticas monumentais, contrastes impressionantes e camadas espessas de tinta espremida diretamente das bisnagas.
\end{abstract}

\subsubsection{Triangulação da Profundidade}

Profundidade, no texto escrito e em relação à triangulação - A profundidade na pintura é construída por vários recursos pictóricos tais como a gradação cromática, a perspectiva, o ponto de fuga, e as linhas que conduzem o olhar para ele. Na oração, a profundidade pode ser encontrada em um complexo oracional, no qual a oração paratáxica exerceria a mesma função que o primeiro plano, e as orações hipotáxicas, exerceriam as funções de segundo e terceiro plano. No entanto, van Gogh estava explorando e experimentando novas possibilidades de representação, com a influência das gravuras japonesas que tinham um plano de fundo chapado e de igual valor cromático ao do primeiro plano, com detalhes e linhas de valor similar. O mesmo acontecia pela influência de seus amigos Cloisonistas como Gauguin, Bernard e Anquetin que estavam igualmente explorando a ruptura com a profundidade, trazendo o segundo plano no mesmo grau de detalhamento e de 
intensidade cromática do que o primeiro. Evidenciei na análise dos corpora, que o mesmo padrão semiótico que van Gogh usou nas telas ao igualar a intensidade, definição e detalhamento do segundo plano com o primeiro plano, ele também o fez nas orações, levando o sentido mais importante para a oração hipotáxica. Esse padrão ocorreu em um sem número de exemplos, e levou a um sem número de hipóteses e inferências devido à frequência de ocorrências das quais alguns exemplos estão a seguir:

Quadro 23: Triangulação da Profundidade

\begin{tabular}{|c|c|c|}
\hline Ocorrência nas telas & Orações & Comentário \\
\hline $\begin{array}{l}\text { Na tela 'Por de Sol: Campo } \\
\text { de trigo perto de Arles', } \\
\text { observei o uso de } \\
\text { profundidade nas colunas de } \\
\text { fumaça também contribuem } \\
\text { com outro movimento: } \\
\text { linhas direcionais que } \\
\text { reforçam o sentido do vento } \\
\text { que sopra no trigo. Estas } \\
\text { linhas são também } \\
\text { descritivas do espaço celeste, } \\
\text { e como nuvens, estão } \\
\text { paralelas às linhas do chão e } \\
\text { vão se diminuindo com a } \\
\text { distância, construindo uma } \\
\text { maior profundidade e } \\
\text { perspectiva espacial na cena. } \\
\text { Registrada na nota de rodapé } \\
57 \text { no apêndice. }\end{array}$ & $\begin{array}{l}\text { Aqui está outra paisagem. Sol } \\
\text { poente? Lua nascendo? Noite de } \\
\text { verão, de qualquer modo. Cidade } \\
\text { violeta, estrela amarela, céu azul- } \\
\text { esverdeado; os campos de trigo têm } \\
\text { todos os tons: ouro velho, cobre, } \\
\text { ouro verde, ouro vermelho, ouro } \\
\text { amarelo, verde, vermelho e amarelo } \\
\text { bronze. Tela quadrada número } 30 \text {. }\end{array}$ & $\begin{array}{l}\text { Na oração é possível observar um } \\
\text { paralelismo nas escolhas léxico- } \\
\text { gramaticais para construir o período } \\
\text { que denota que as orações foram } \\
\text { organizadas de forma compatível } \\
\text { como a composição da tela foi } \\
\text { pensada, separada em duas grandes } \\
\text { áreas que representam o céu e a terra } \\
\text { nas quais suas linhas descritivas do } \\
\text { espaço se espelham e se acompanham } \\
\text { construindo a percepção de } \\
\text { profundidade. }\end{array}$ \\
\hline $\begin{array}{l}\text { Na tela 'O Semeador', a } \\
\text { profundidade visual é } \\
\text { construída pela divisão do } \\
\text { espaço em planos, e pela } \\
\text { gradação cromática das } \\
\text { tonalidades de azuis do } \\
\text { campo. Registrada na nota } \\
\text { de rodapé } 33 \text { e } 34 . \\
\text { Ela também é construída } \\
\text { com a ajuda da perspectiva, } \\
\text { dada pelos caminhos } \\
\text { visuais no campo arado. } \\
\text { Registrado na nota de rodapé } \\
\underline{35} .\end{array}$ & $\begin{array}{l}\text { Há várias sugestões de amarelo no } \\
\text { solo, tons neutros resultantes da } \\
\text { mistura de violeta e amarelo; mas } \\
\text { tenho travado uma luta diabólica } \\
\text { para atingir a verdade das cores. }\end{array}$ & $\begin{array}{l}\text { O sentido principal deste complexo } \\
\text { está na oração hipotática, sugerindo } \\
\text { um deslocamento de 'planos' } \\
\text { causando um efeito de 'profundidade' } \\
\text { no enunciado. } \\
\text { A escolha lexical indica uma } \\
\text { intensificação do processo que ele } \\
\text { representa por meio dos itens } \\
\text { 'travado' e 'luta diabólica' e que } \\
\text { sugere um processo extremado para } \\
\text { chegar ao conhecimento das cores. O } \\
\text { sentido principal deste complexo } \\
\text { oracional está na oração hipotática, } \\
\text { sugerindo um deslocamento de } \\
\text { 'planos' causando um efeito de } \\
\text { 'profundidade' no enunciado. } \\
\text { Ocorrência de Profundidade, } \\
\text { Enquadramento e Perspectiva no nível }\end{array}$ \\
\hline
\end{tabular}




\begin{tabular}{|c|c|c|}
\hline $\begin{array}{l}\text { conferidos pelo } \\
\text { agrupamento de membros } \\
\text { como o caminho de terra, } \\
\text { os corvos e a casa. } \\
\text { Registradas na nota de } \\
\text { rodapé } 37 .\end{array}$ & & $\begin{array}{l}\text { gramatical, já que o sentido principal } \\
\text { foi deslocado para a oração hipotática. } \\
\text { Registrado na nota de rodapé } 89 .\end{array}$ \\
\hline $\begin{array}{l}\text { Na tela 'O Semeador' o } \\
\text { deslocamento da perspectiva } \\
\text { ocorre com o uso do } \\
\text { plongee, registrado na nota } \\
\text { de rodapé 46, que deixa o } \\
\text { ponto de vista do } \\
\text { espectador um pouco } \\
\text { suspenso do chão e causa } \\
\text { um distanciamento ao } \\
\text { mesmo tempo em que os } \\
\text { outros recursos o levam a } \\
\text { se aproximar da cena. } \\
\text { Uso do plongee para } \\
\text { representar a cena, causa um } \\
\text { distanciamento do } \\
\text { espectador e estabelece a } \\
\text { perspectiva com a qual van } \\
\text { Gogh quis que o espectador } \\
\text { olhasse a cena, registrado na } \\
\text { nota de rodapé } 46 \text {. }\end{array}$ & $\begin{array}{l}\text { Não te vou ocultar //que não } \\
\text { desgosto da região,// pois fui criado } \\
\text { lá // - ainda me encanta a magia das } \\
\text { recordações do passado, de um } \\
\text { desejo do infinito,// do qual o } \\
\text { semeador e o enfeixador são } \\
\text { símbolos / -, tanto quanto antes } \\
\text { gostava.//. } \\
\text { Ocorrência de Perspectiva e } \\
\text { Profundidade no uso de construtos } \\
\text { que fazem uma diferenciação entre } \\
\text { campos de experiência no passado e } \\
\text { presente e criam planos e } \\
\text { distanciamento para expressar um } \\
\text { sentido muito particular registrados } \\
\text { na nota de rodapé } 99 \text {. }\end{array}$ & $\begin{array}{l}\text { Na oração alfa há um processo verbal } \\
\text { cujo relato não explicita o afeto do } \\
\text { dizente em relação à região, mas na } \\
\text { Beta ele explicita o afeto pelas } \\
\text { recordações e o lugar ocupado pela } \\
\text { 'região' na sua experiência afetiva } \\
\text { demonstrando que ele deixa para } \\
\text { expressar na oração secundária o } \\
\text { sentido mais importante para ele, } \\
\text { produzindo um descolar do } \\
\text { enquadramento e da perspectiva ao se } \\
\text { ler a oração. Ocorrência de } \\
\text { Enquadramento e da Perspectiva pelo } \\
\text { deslocamento do sentido principal } \\
\text { para a oração secundária registrado na } \\
\text { nota de rodapé } 96 .\end{array}$ \\
\hline $\begin{array}{l}\text { Na tela 'A Esplanada do Café } \\
\text { na Place du Forum, Arles, à } \\
\text { Noite', o segundo plano está } \\
\text { representado tão ricamente } \\
\text { ou mais do que o primeiro } \\
\text { plano, registrado na nota de } \\
\text { rodapé } 123 \text { no apêndice. }\end{array}$ & $\begin{array}{l}\text { A segunda mostra o exterior de um } \\
\text { café, iluminado no terraço externo } \\
\text { por uma grande lâmpada de gás } \\
\text { dentro da noite azul, com um retalho } \\
\text { de céu azul estrelado. } \\
\text { Nessa oração: (Alfa) A segunda } \\
\text { mostra o exterior de um café, (Beta) } \\
\text { [[ iluminado no terraço externo por } \\
\text { uma grande lâmpada de gás dentro } \\
\text { da noite azul, com um retalho de céu } \\
\text { azul estrelado.]] constatei a } \\
\text { ocorrência de profundidade, com } \\
\text { destaque para o segundo plano, ou } \\
\text { seja, para a oração Beta. Registrado } \\
\text { na nota de rodapé } 166 \text { no apêndice. }\end{array}$ & $\begin{array}{l}\text { Neste complexo oracional, observei } \\
\text { um deslocamento não apenas de } \\
\text { planos, mas de pontos de vista. A } \\
\text { oração Alfa é um preâmbulo para o } \\
\text { sentido principal que está na oração } \\
\text { Beta, que está ricamente detalhado, } \\
\text { muito mais do que na oração Alfa. } \\
\text { Esta ocorrência de 'planos' na oração } \\
\text { é compatível com a ênfase que é dada } \\
\text { no segundo plano da tela. }\end{array}$ \\
\hline $\begin{array}{l}\text { Na tela ‘O Café Noturno na } \\
\text { Place Lamartine, em Arles', } \\
\text { observei uma ocorrência } \\
\text { visual na qual há } \\
\text { Associação metafórica por } \\
\text { meio de por meio de }\end{array}$ & $\begin{array}{l}\text { Agora como para recuperar o } \\
\text { dinheiro pago ao senhorio através da } \\
\text { minha pintura, eu não estou fazendo } \\
\text { questão disto, porque a pintura é } \\
\text { uma das mais feias que eu já fiz. } \\
\text { x BETA (oração não-finita - }\end{array}$ & $\begin{array}{l}\text { No complexo oracional, observei que } \\
\text { o sentido secundário está na primeira } \\
\text { oração xBeta 'Agora como para } \\
\text { recuperar o dinheiro pago ao senhorio } \\
\text { através da minha pintura', e também } \\
\text { na oração alfa, 'eu não estou fazendo }\end{array}$ \\
\hline
\end{tabular}




\begin{tabular}{|c|c|c|}
\hline $\begin{array}{l}\text { Profundidade ou pela falta } \\
\text { dela, conota um sentido de } \\
\text { superficialidade e que é } \\
\text { compatível com a ocorrência } \\
\text { textual. Registrado na nota } \\
\text { de rodapé } 227 . \\
\text { Ocorrência de Contraste } \\
\text { cromático de Saturação e } \\
\text { baixa Modalidade que retira } \\
\text { a percepção de Profundidade } \\
\text { e aumenta a sensação de } \\
\text { desconforto e fadiga. } \\
\text { Registrado na nota de rodapé } \\
231 .\end{array}$ & $\begin{array}{l}\text { intensificação de finalidade) - Agora } \\
\text { como para recuperar o dinheiro pago } \\
\text { ao senhorio através da minha } \\
\text { pintura, } \\
\text { ALFA (dominante) - eu não estou } \\
\text { fazendo questão disto, } \\
\text { = BETA (intensificação razão) - } \\
\text { porque a pintura é uma das mais } \\
\text { feias que eu já fiz. }\end{array}$ & $\begin{array}{l}\text { questão disto', enquanto que o sentido } \\
\text { principal foi colocado na segunda } \\
\text { oração =Beta ' porque a pintura é uma } \\
\text { das mais feias que eu já fiz.'. Isso } \\
\text { sugere um deslocamento do } \\
\text { enquadramento, bem como uma } \\
\text { distorção do ponto de vista. }\end{array}$ \\
\hline $\begin{array}{l}\text { Na tela 'O Café Noturno na } \\
\text { Place Lamartine, em Arles', } \\
\text { observei uma ocorrência } \\
\text { visual que é compatível com } \\
\text { a ocorrência textual, na qual } \\
\text { o elemento central está no } \\
\text { segundo plano e não no } \\
\text { primeiro. Apesar de estar } \\
\text { no segundo plano, que } \\
\text { seria de menos importância } \\
\text { do que o primeiro, a mesa } \\
\text { de bilhar está ricamente } \\
\text { detalhada, denotando que } \\
\text { ela é o elemento principal } \\
\text { da composição. Registrada } \\
\text { na nota de rodapé } 131 \text {. }\end{array}$ & $\begin{array}{l}\text { Observei a ocorrência do uso de } \\
\text { Enquadramento ao deslocar o } \\
\text { sentido principal para a oração Beta. } \\
\text { Este exemplo de enquadramento na } \\
\text { oração é compatível com o uso de } \\
\text { ênfase no segundo plano na } \\
\text { composição visual. Registrado na } \\
\text { nota de rodapé } 263 \text {. }\end{array}$ & $\begin{array}{l}\text { O assunto principal está na oração } \\
\text { beta, deixando a oração alfa apenas } \\
\text { com um preâmbulo para introduzir o } \\
\text { assunto mais importante. Essa } \\
\text { ocorrência é compatível com o } \\
\text { deslocamento do maior ênfase no } \\
\text { segundo plano, como é o caso da mesa } \\
\text { de bilhar que está representada no } \\
\text { segundo plano da pintura. Observei } \\
\text { que tanto a ocorrência visual quanto a } \\
\text { textual é de caráter formal, não na } \\
\text { função ou no sentido. }\end{array}$ \\
\hline
\end{tabular}

Fonte: Triangulação para Profundidade dos dados dos corpora visual e textual, com os extratos das cartas.

\subsection{DISTORÇÃO DO PONTO DE VISTA}

A ligeira distorção da perspectiva leva a um efeito de estranhamento que remete para o campo implícito do ponto de vista de quem olha a cena e por associação de quem pintou a tela. Esse estranhamento trás de volta a presença de alguém que está ausente na tela, o pintor, que se faz presente de forma indireta e subentendida por meio de um efeito de sentido construído pela distorção do ponto de vista.

Van Gogh teve o propósito de distorcer a natureza, para comunicar um estado subjetivo, e isso foi muito, muito original naquele ponto da história da arte. Ele criou uma semiose para comunicar uma coisa diversa daquilo que estava pintando, ou seja, para comunicar uma realidade interior, além da realidade exterior que era o tema da composição, 
conferindo para a imagem representada uma nova camada de sentido, colada no sentido original que a imagem comunicava. Gombrich (1995, p. 548) expõe sobre a distorção:

\begin{abstract}
É evidente que Van Gogh não estava principalmente interessado na representação correta. Usou cores e formas para transmitir o que sentia em relação às coisas que pintava e o que desejava que outros sentissem. Não se importava muito com o que chamava de "realidade estereoscópica", ou seja, a reprodução fotograficamente exata da natureza. Exagerava e até mudava a aparência das coisas, se isso se adequasse ao seu propósito. Assim, chegara por um caminho diferente a uma conjuntura semelhante àquela em que Cézanne se encontrou durante esses mesmos anos. Ambos deram o passo importante de abandonar deliberadamente a finalidade da pintura como "imitação da natureza". As suas razões, é claro, foram diferentes. Quando Cézanne pintava uma natureza-morta, queria explorar as relações de formas e cores, e só aproveitava da "perspectiva correta" aquela parcela de que porventura necessitasse para uma determinada experiência. Van Gogh, por sua parte, queria que a sua pintura expressasse o que ele sentia, e, se a distorção o ajudasse a realizar esse objetivo, utilizaria a distorção sem hesitar. Ambos tinham chegado a esse ponto sem querer derrubar os antigos padrões de arte. Não se arvoravam em "revolucionários"; não queriam chocar os críticos complacentes. De fato, ambos tinham quase abandonado a esperança de que alguém prestasse atenção às suas obras; trabalhavam porque tinham de fazê-lo.
\end{abstract}

\title{
6.8.1 Inversão do ponto de vista
}

Observei a inversão do ponto de vista, que é um efeito de sentido conseguido, visualmente, com a ajuda de uma articulação entre caminhos direcionais e vetores que apontam para o lugar onde o espectador se encontra e levam o ponto de fuga para o primeiro plano, ao invés de para o último plano, como é convencional. A inversão do ponto de vista é um recurso semiótico criado por van Gogh e que foi observado nesta pesquisa nas telas 'Por de Sol: Campo de trigo perto de Arles'(1888), 'O Semeador' (1888), 'O Café Noturno na Place Lamartine, em Arles' (1888), e por Schapiro (2010, p.133), ao analisar a tela 'Corvos sobre Campo de Trigo' (1890):

A tela já é singular por suas proporções, comprida e estreita, como se fosse destinada a dois espectadores, uma imagem maior do que a vista pode abarcar. E esse formato extraordinário é acompanhado pela própria paisagem, que não é apenas panorâmica, mas um campo que se estende a partir do primeiro plano por meio de três caminhos divergentes. Uma situação perturbadora para o espectador, que fica indeciso diante do grande horizonte e que, além disso, não pode atingi-lo por nenhuma das estradas à sua frente; estas terminam cegamente no campo de trigo ou saem do quadro. A incerteza de van Gogh projeta-se aqui através da incerteza de movimentos e direções. A rede de perspectiva do campo aberto, que ele havia pintado antes diversas vezes, agora é invertida; como corredeiras, as linhas convergem do horizonte para o primeiro plano, como se subitamente o espaço houvesse perdido o seu foco e todas as coisas se voltassem agressivamente para o espectador. 


\subsubsection{Triangulação da Distorção do ponto de vista}

Distorção do ponto de vista, no texto escrito e em relação à triangulação - $\mathrm{O}$ ponto de vista na oração foi associado com a categoria da perspectiva, criada pelo lugar onde van Gogh se coloca ao construir a oração. A distorção do ponto de vista ocorre quando ele já está nesse lugar, nessa perspectiva e sofre um deslocamento, um estranhamento. Ou seja, a distorção ocorre na forma como ele instância a oração tendo ele já feito a escolha do seu ponto de vista para instanciá-la. A distorção do ponto de vista, na oração pode ser entendida como uma distorção na enunciação que, no entanto, não prejudica a compreensão do sentido, apenas cria um estranhamento nesse processo. Com esse efeito, van Gogh constrói um sentido agregado que não chega a ser exatamente uma ênfase apenas, mas um aguçamento de sentidos condensados sobre o lugar de onde ele fala e sobre o que ele experiencia desde esse lugar, mais do que sobre o objeto em si do qual ele está falando.

Por exemplo, na oração 'A sala está pintada de vermelho, e no interior, na luz a gás, a mesa de bilhar verde, a qual lança uma imensa sombra sobre o chão', a escolha léxicogramatical 'imensa sombra' explicita a abordagem para o uso do espaço 'imenso' ocupado pela sombra da mesa de bilhar. Ele descreve o efeito da sombra e ao fazê-lo, explicita sua escolha em dar centralidade para este sentido, não apenas na descrição verbal sobre a tela, mas na centralidade que a sombra ocupa visualmente na composição. A importância da distorção da sombra, como um efeito de sentido para van Gogh, está clara tanto na construção da oração quando na construção da composição visual. A desproporcionalidade da sombra propõe uma distorção como um item léxico-gramatical tanto na carta quanto na tela, com um sentido associado a ele. Inferi, na relação com outros significados, que a desproporção e o desequilíbrio representam a perda de controle, a perda de sentido, e o lado sombrio da natureza humana.

A oração descreve de forma direta e simples a relação de causa e efeito e a simetria de ações entre as lâmpadas, a mesa e o chão. A escolha dos itens lexicais indica tanto um sentido concreto quanto de sentido simbólico pelo uso de 'interior', 'lança' e 'imensa', sugerindo um sentido emocional, cuja carga afetiva está presente tanto no quadro quanto no discurso da carta. Inferi que a ocorrência de ênfase na oração seja um indicador do uso de metáforas visuais na tela que pode se configurar com um padrão em outras orações se o uso de ênfase indicar o uso de associações metafóricas na linguagem escrita por meio de recursos de ênfase e comparações ou contraposições. Van Gogh não costumava explicitar o sentido simbólico intencional de certos itens em suas telas, nem mesmo para Theo porque ele valorizava manter 
o sentido latente e evitava obviedade nesse uso. No entanto, inferi que ele entregava 'deixas' ao escrever suas cartas na forma como ele construía a oração e nas escolhas léxicogramaticais e semânticas que nos possibilitam resgatar as escolhas que van Gogh fazia tanto para conceber a visualidade em tela, quanto ao reconstruí-las em suas orações. As escolhas léxico-gramaticais revelam como ele via a composição e que elementos constituintes e suas relações ele priorizava. Como exemplo a oração: 'A sala está pintada de vermelho, e no interior, na luz a gás, a mesa de bilhar verde, a qual lança uma imensa sombra sobre o chão'. Esta oração demonstra a escolha da ênfase 'imensa' para a sombra que a mesa de bilhar lança revela uma chave para compreender a função simbólica da mesa dentro do sistema semiótico proposto por van Gogh nesta tela. Esta ênfase na oração se tornou um indexador para confirmar a intencionalidade na produção de um desequilíbrio na tela para construir uma associação metafórica para o sentido da sombra.

Quadro 24: Triangulação da Distorção do ponto de vista

\begin{tabular}{|c|c|c|}
\hline Ocorrência nas telas & Orações & Comentário \\
\hline $\begin{array}{l}\text { Na tela 'Por de Sol: Campo } \\
\text { de trigo perto de Arles', } \\
\text { observei a ocorrência de } \\
\text { um uso original semiótico: } \\
\text { a inversão do ponto de } \\
\text { fuga, trazendo para o } \\
\text { plano do espectador, o } \\
\text { foco com que olhar a } \\
\text { perspectiva e levando-o a } \\
\text { se identificar } \\
\text { inevitavelmente com o } \\
\text { lugar do experienciador } \\
\text { da tela, o artista. Este é } \\
\text { um uso original de } \\
\text { perspectiva para construir a } \\
\text { distorção do ponto de vista } \\
\text { que caracteriza o sistema } \\
\text { semiótico de van Gogh. } \\
\text { Esta ocorrência está } \\
\text { registrada nas notas de } \\
\text { rodapé } 48 \text { e } 49 \text { no apêndice. }\end{array}$ & $\begin{array}{l}\text { Aqui está outra paisagem. Sol } \\
\text { poente? Lua nascendo? Noite de } \\
\text { verão, de qualquer modo. Cidade } \\
\text { violeta, estrela amarela, céu azul- } \\
\text { esverdeado; os campos de trigo têm } \\
\text { todos os tons: ouro velho, cobre, } \\
\text { ouro verde, ouro vermelho, ouro } \\
\text { amarelo, verde, vermelho e amarelo } \\
\text { bronze. Tela quadrada número } 30 . \\
\text { Eu pintei-a ao ar livre no Mistral. } \\
\text { Meu cavalete foi fixado no chão com } \\
\text { estacas de ferro, um método que eu } \\
\text { recomendo a você. } \\
\text { Você enterra os pés do cavalete e, em } \\
\underline{\text { seguida, você empurra a } 50} \\
\underline{\text { centímetros de comprimento um peso }} \\
\text { de ferro ao lado deles. Você amarra } \\
\underline{\text { tudo com cordas; dessa forma, você }} \\
\text { pode trabalhar com o vento. }\end{array}$ & $\begin{array}{l}\text { Inversão de ponto de vista na tela e na } \\
\text { oração: } \\
\text { Van Gogh descreve a paisagem com } \\
\text { orações sem o participante principal, } \\
\text { ou sem processo, ocultando ou } \\
\text { modalizando o protagonismo da ação. } \\
\text { Logo em seguida desloca o ponto de } \\
\text { vista de dentro da tela para fora da tela } \\
\text { e coloca o foco nele, o protagonista da } \\
\text { ação: 'Eu pintei-a ao ar livre no } \\
\text { Mistral.' Irá dedicar às próximas } 3 \\
\text { orações nesse enfoque no qual há uma } \\
\text { inversão do ponto de vista da paisagem } \\
\text { para o trabalho, a ação realizada por } \\
\text { ele, fora da tela. Ele leva a atenção de } \\
\text { Theo para dentro da paisagem para } \\
\text { logo voltá-la para fora da tela que } \\
\text { passa a ser o principal ponto de vista. }\end{array}$ \\
\hline
\end{tabular}




\begin{tabular}{|c|c|c|}
\hline $\begin{array}{l}\text { Na tela 'Por de Sol: Campo } \\
\text { de trigo perto de Arles', } \\
\text { observei a ocorrência da } \\
\text { distorção do ponto de vista, } \\
\text { criada pelo uso do plongee } \\
\text { para causar um efeito de } \\
\text { sentido de estranhamento } \\
\text { no espectador. Registrada } \\
\text { nas notas de rodapé } 50,101 \\
\text { e } 103 \text { no apêndice. } \\
\\
\text { Na tela 'Por de Sol: Campo } \\
\text { de trigo perto de Arles', } \\
\text { observei a ocorrência do } \\
\text { uso do ângulo plongee no } \\
\text { enquadramento que além } \\
\text { de contribuir para a } \\
\text { construção da } \\
\text { profundidade e da } \\
\text { perspectiva, também } \\
\text { contribui para a distorção } \\
\text { do ponto de vista. Esta } \\
\text { ocorrência está registrada } \\
\text { nas notas de rodapé } 50,101 \\
\text { e } 103 \text { no apêndice. } \\
\text { Observei com esse uso o } \\
\text { efeito de distorção do ponto } \\
\text { de vista. Esta escolha } \\
\text { mostra a intenção de } \\
\text { construir um efeito de } \\
\text { sentido no espectador e } \\
\text { uma interação deste com } \\
\text { o posicionamento adotado } \\
\text { pelo pintor para retratar } \\
\text { a cena. }\end{array}$ & $\begin{array}{l}\text { 'Eu tenho um terceiro estudo, agora, } \\
\text { de uma paisagem com fábrica, e um } \\
\text { enorme sol em um céu vermelho, } \\
\text { acima de telhados vermelhos, em que } \\
\text { a natureza parece estar em um acesso } \\
\text { de raiva, em um dia de Mistral } \\
\text { desagradável.' } \\
\text { Na oração hipotáxica 'em que a } \\
\text { natureza parece estar em um acesso } \\
\text { de raiva, em um dia de Mistral } \\
\text { desagradável' van Gogh parece ter } \\
\text { uma relação panteísta com a } \\
\text { natureza, na qual ela assume não } \\
\text { apenas o lugar de participante } \\
\text { principal, mas também de Portador } \\
\text { de um atributo, o acesso de raiva. } \\
\text { Observei que o deslocamento do } \\
\text { agente 'Eu' da oração alfa, para 'a } \\
\text { natureza' na oração Beta, que causa } \\
\text { um distanciamento do ponto de vista } \\
\text { do leitor, pode ser compatível com o } \\
\text { uso do ângulo plongee no texto } \\
\text { visual, também usado com a função } \\
\text { de causar um distanciamento no } \\
\text { espectador. Aqui há um tipo de } \\
\text { compatibilidade de função, não de } \\
\text { forma ou de sentido. Registrado na } \\
\text { nota de rodapé } 110 \text { no apêndice. }\end{array}$ & $\begin{array}{l}\text { Em outro exemplo, na oração: 'Eu } \\
\text { pintei-a ao ar livre no Mistral. Meu } \\
\text { cavalete foi fixado no chão com } \\
\text { estacas de ferro, um método que eu } \\
\text { recomendo a você. } \\
\text { Você enterra os pés do cavalete e, em } \\
\underline{\text { seguida, você empurra a } 50} \\
\text { centímetros de comprimento um peso } \\
\text { de ferro ao lado deles. Você amarra } \\
\text { tudo com cordas; dessa forma, você } \\
\text { pode trabalhar com o vento. } \\
\text { O plongee sugere que van Gogh estaria } \\
\text { sendo levantado e sendo levado pelo } \\
\text { vento, assim como os diversos objetos } \\
\text { que viu alçar certa altura e trajetória } \\
\text { devido à força da ventania. Ele } \\
\text { representou vivamente esta experiência } \\
\text { de sua relação física com a força da } \\
\text { ventania, não apenas pelo ritmo, } \\
\text { textura, movimento e gesto pictórico, } \\
\text { mas também pelo ângulo plongee } \\
\text { usado no enquadramento da paisagem. }\end{array}$ \\
\hline $\begin{array}{l}\text { Na tela 'O Semeador' toda } \\
\text { a luz que irradia do céu } \\
\text { envolve o semeador e o } \\
\text { campo arado, dando ênfase } \\
\text { para a ambiência da luz e } \\
\text { das cores do dia que } \\
\text { começa ou que termina. } \\
\text { Para isso, van Gogh } \\
\text { diminuiu o detalhe da } \\
\text { representação e favoreceu } \\
\text { os efeitos gerais produzidos } \\
\text { pelos contrastes de cor } \\
\text { simultâneos que empresta } \\
\text { um estado de espírito } \\
\text { intenso que infundiam o } \\
\text { Portador com significados } \\
\text { simbólicos. }\end{array}$ & $\begin{array}{l}\text { Há várias sugestões de amarelo no } \\
\text { solo, tons neutros resultantes da } \\
\text { mistura de violeta e amarelo; mas } \\
\text { tenho travado uma luta diabólica para } \\
\text { atingir a verdade das cores. } \\
\text { Aqui está o que eu queria dizer sobre } \\
\text { o branco e o preto. Vamos tomar o } \\
\text { Semeador. A pintura é dividida em } \\
\text { dois; metade é amarelo, o topo; a } \\
\text { base é violeta. Bem, as calças } \\
\text { brancas descansam os olhos e os } \\
\text { distraem exatamente quando o } \\
\text { contraste simultâneo excessivo de } \\
\text { amarelo e violeta iriam irritá-lo. Isso } \\
\text { é o que eu queria dizer. }\end{array}$ & $\begin{array}{l}\text { Ocorrência de Enquadramento, } \\
\text { Perspectiva, Inversão do ponto de } \\
\text { vista, Transparência, Inacabamento, } \\
\text { Incompletude e Limiar artístico com a } \\
\text { mudança na representação do } \\
\text { protagonismo nas orações e nas } \\
\text { escolhas lexicais 'verdade das cores', } \\
\text { 'luta diabólica' e 'atingir a verdade das } \\
\text { cores'. Registradas na nota de rodapé } \\
\underline{94} \text {. }\end{array}$ \\
\hline $\begin{array}{l}\text { Na tela, a inversão de } \\
\text { sentido se dá pelo uso das } \\
\text { cores. Ele representa o céu } \\
\text { com amarelos e }\end{array}$ & $\begin{array}{l}\text { Não te vou ocultar que não desgosto } \\
\text { da região, pois fui criado lá - ainda } \\
\text { me encanta a magia das recordações } \\
\text { do passado, de um desejo do infinito, }\end{array}$ & $\begin{array}{l}\text { Não vou te ocultar = vou te revelar } \\
\text { Que não desgosto = que gosto } \\
\text { Para dizer 'vou te revelar que gosto', } \\
\text { ele utiliza quatro negativas, recurso }\end{array}$ \\
\hline
\end{tabular}




\begin{tabular}{|c|c|c|}
\hline $\begin{array}{l}\text { alaranjados, e a terra, com } \\
\text { azuis e lilases. Essa } \\
\text { concentração de cores frias } \\
\text { na terra, que } \\
\text { tradicionalmente são } \\
\text { associadas ao céu e de } \\
\text { cores quentes à terra, } \\
\text { sugere uma inversão } \\
\text { deliberada no uso } \\
\text { cromático que indexa } \\
\text { saliência e associação } \\
\text { metafórica. Essa ocorrência } \\
\text { de inversão no uso } \\
\text { cromático é compatível } \\
\text { com a escolha léxico- } \\
\text { gramatical na carta. } \\
\text { A distorção no ponto de } \\
\text { vista e o efeito de vibração } \\
\text { das cores causada pelo } \\
\text { contraste simultâneo e da } \\
\text { luz difusa criada pela } \\
\text { representação do } \\
\text { crepúsculo, bem como a } \\
\text { inversão da concentração } \\
\text { de cores frias para o solo e } \\
\text { de cores quentes para o céu } \\
\text { é compatível com a } \\
\text { ocorrência de distorção do } \\
\text { ponto de vista no excerto } \\
\text { da carta. }\end{array}$ & $\begin{array}{l}\text { do qual o semeador e o enfeixador } \\
\text { são símbolos -, tanto quanto antes } \\
\text { gostava. } \\
\text { Mas quando eu farei o céu estrelado, } \\
\text { então, essa pintura que está sempre } \\
\text { na minha mente? (...) } \\
\text { Por um longo tempo ele foi meu } \\
\text { grande desejo de fazer um semeador, } \\
\text { mas os desejos que tive por um longo } \\
\text { tempo nem sempre são alcançados. } \\
\text { (...) } \\
\text { Mas é uma questão de atacá-las, no } \\
\text { entanto, não importa o quão } \\
\text { incompetente um pode sentir-se vis- } \\
\text { à-vis as perfeições inefáveis do } \\
\text { glorioso esplendor da natureza. }\end{array}$ & $\begin{array}{l}\text { que deixa qualquer leitor com a vista } \\
\text { embaralhada. Este é um estranhamento } \\
\text { usado para construir não apenas ênfase, } \\
\text { mas um efeito de sentido maior do que } \\
\text { a ênfase é uma distorção na forma } \\
\text { como ele constrói a oração e que nos } \\
\text { leva a prestar uma maior atenção aos } \\
\text { sentidos ali contidos, causando um } \\
\text { aguçamento. Ocorrência de } \\
\text { contraposições léxico-gramaticais pelo } \\
\text { uso de inversões de sentido (Não te } \\
\text { vou ocultar que não desgosto) com } \\
\text { negativas e com indiretas para } \\
\text { modalizar e dizer sem falar que são } \\
\text { compatíveis com Saliência e Distorção } \\
\text { do ponto de vista. Registradas na nota } \\
\text { de rodapé } 95 \text {. } \\
\text { A escolha do conectivo 'mas' nos dois } \\
\text { complexos oracionais seguintes } \\
\text { também indica uma contraposição de } \\
\text { ideias e uma inversão no ponto de vista } \\
\text { com que ele representa seu desígnio de } \\
\text { pintar uma tela. }\end{array}$ \\
\hline $\begin{array}{l}\text { Na tela 'A Esplanada do } \\
\text { Café na Place du Forum, } \\
\text { Arles, à Noite', observei a } \\
\text { ocorrência de Distorção do } \\
\text { Ponto de Vista e } \\
\text { Inacabamento, construída } \\
\text { pela representação } \\
\text { distorcida das linhas de } \\
\text { perspectiva da edificação } \\
\text { do café, registrado na nota } \\
\text { de rodapé } 125 \text { no apêndice. }\end{array}$ & $\begin{array}{l}\text { Agora há uma pintura de noite sem } \\
\text { preto. Com nada mais do que um } \\
\text { belo azul e violeta e verde e nestes } \\
\text { arredores da praça iluminada é } \\
\text { colorido por enxofre pálido, amarelo } \\
\text { limão. } \\
\text { Nesta oração acima não se verifica } \\
\text { uma distorção do ponto de vista, em } \\
\text { termos de inversão da saliência dada } \\
\text { para os planos, ou de distorção das } \\
\text { linhas que formam a perspectiva, ou } \\
\text { de inversão de perspectiva que } \\
\text { aponta para o pintor. No entanto, } \\
\text { observei que há uma licença poética } \\
\text { para mudar as regras de pontuação } \\
\text { para dar destaque para o complexo } \\
\text { nominal que fica na segunda oração e } \\
\text { que pode ser compatível com a } \\
\text { produção de um efeito de distorção } \\
\text { por meio do uso de pontuação para } \\
\text { separar a oração e criar ênfase para o } \\
\text { segundo período. }\end{array}$ & $\begin{array}{l}\text { Não é uma distorção do ponto de vista, } \\
\text { mas há uma licença poética para mudar } \\
\text { as regras de pontuação. } \\
\text { Na oração: A segunda mostra o exterior } \\
\text { de um café, [[ iluminado no terraço } \\
\text { externo por uma grande lâmpada de gás } \\
\text { dentro da noite azul, com um retalho de } \\
\text { céu azul estrelado.]] constatei a } \\
\text { ocorrência de profundidade, com } \\
\text { destaque para o segundo plano, ou seja, } \\
\text { para a oração Beta. Registrado na nota } \\
\text { de rodapé } 166 \text { no apêndice. }\end{array}$ \\
\hline $\begin{array}{l}\text { Na tela 'O Café Noturno na } \\
\text { Place Lamartine, em } \\
\text { Arles', observei a } \\
\text { ocorrência de } \\
\text { Enquadramento, }\end{array}$ & $\begin{array}{l}\text { 'A sala está pintada de vermelho, e } \\
\text { no interior, na luz a gás, a mesa de } \\
\text { bilhar verde, a qual lança uma imensa } \\
\text { sombra sobre o chão.' }\end{array}$ & $\begin{array}{l}\text { Foi observado um sentido de } \\
\text { movimentação conferida aos objetos } \\
\text { inanimados em contraposição à } \\
\text { paralisia das figuras humanas na tela } \\
\text { que endossa a disposição }\end{array}$ \\
\hline
\end{tabular}




\begin{tabular}{|c|c|c|}
\hline $\begin{array}{l}\text { Inacabamento, Perspectiva } \\
\text { e Distorção do Ponto de } \\
\text { vista. As cadeiras no } \\
\text { primeiro plano foram } \\
\text { representadas } \\
\text { parcialmente e não tem } \\
\text { uma proporção e um } \\
\text { alinhamento compatível } \\
\text { com as perspectiva das } \\
\text { tábuas no chão, registrada } \\
\text { nas notas de rodapé } 127 \text { e } \\
\text { 225. } \\
\text { Observei também a } \\
\text { ocorrência de Distorção do } \\
\text { Ponto de Vista, construída } \\
\text { pela representação das } \\
\text { cadeiras em desalinho } \\
\text { com as linhas de } \\
\text { perspectiva das tábuas do } \\
\text { chão, registrada nas notas } \\
\text { de rodapé } 121 \text { e } 225 . \\
\text { Ocorrência de Distorção do } \\
\text { ponto de vista pelo uso de } \\
\text { cores e de linhas de } \\
\text { perspectiva e como } \\
\text { estratégia de modalização } \\
\text { para construir Saliência e } \\
\text { Associação metafórica, } \\
\text { registrada na nota de } \\
\text { rodapé } 146 . \\
\text { Ocorrência de Vetor que } \\
\text { resulta em Distorção do } \\
\text { ponto de vista, na } \\
\text { representação das cadeiras } \\
\text { vazias no primeiro plano, } \\
\text { ambas voltadas para a o } \\
\text { pintor que as pinta } \\
\text { sugerindo um caminho } \\
\text { visual inverso, de ponto de } \\
\text { fuga invertido, como } \\
\text { observado em outras telas } \\
\text { analisadas registrada nas } \\
\text { notas de rodapé } 162 \text { e } 165 \\
\text { no apêndice. } \\
\end{array}$ & $\begin{array}{l}\text { Uso do significante oposto ao } \\
\text { significado para construir o sentido. } \\
\text { Aqui há mais um construto oracional } \\
\text { e também na tela no qual o sentido } \\
\text { 'ação' e 'protagonismo' é construído } \\
\text { pela 'inação' e pela não participação } \\
\text { da ação, registrado na nota de rodapé } \\
283 . \\
\text { Uso de distorção tanto na escrita } \\
\text { quanto na tela: com a escolha do item } \\
\text { lexical 'imensa' na oração 'a qual } \\
\text { lança uma imensa sombra sobre o } \\
\text { chão. 'observei a ocorrência de } \\
\text { distorçãa que é compatível com a } \\
\text { distorção da sombra representada no } \\
\text { quadro, registrado na nota de rodapé } \\
288 .\end{array}$ & $\begin{array}{l}\text { desorganizada e oblíqua das cadeiras, } \\
\text { transmitindo a sensação de que a } \\
\text { presença, o fulgor e a movimentação } \\
\text { de pessoas ali naquele espaço ainda } \\
\text { estivessem presentes, quentes, embora } \\
\text { elas já tenham ido embora daquele } \\
\text { local que é reforçado pela ocorrência } \\
\text { de vetores projetados pelas cadeiras. }\end{array}$ \\
\hline $\begin{array}{l}\text { Ocorrência de Distorção do } \\
\text { ponto de vista pela baixa } \\
\text { profundidade e Saliência } \\
\text { pelos contrastes de } \\
\text { saturação que geram uma } \\
\text { iluminação excessiva } \\
\text { registrado na nota de } \\
\text { rodapé 147. }\end{array}$ & $\begin{array}{l}\text { 'A sala está pintada de vermelho, e } \\
\text { no interior, na luz a gás, a mesa de } \\
\text { bilhar verde, a qual lança uma imensa } \\
\text { sombra sobre o chão.' }\end{array}$ & $\begin{array}{l}\text { Uso de distorção tanto na escrita quanto } \\
\text { na tela: com a escolha do item lexical } \\
\text { 'imensa' na oração 'a qual lança uma } \\
\text { imensa sombra sobre o chão. ' observei } \\
\text { a ocorrência de distorção que é } \\
\text { compatível com a distorção da sombra } \\
\text { representada no quadro. } \\
\text { Uso de distorção do ponto de vista e do } \\
\text { enquadramento. A escolha do item } \\
\text { lexical 'imensa' denota um uso } \\
\text { desproporcional de um atributo } \\
\text { 'imensa' para sombra, que não está } \\
\text { compatível com os outros atributos }\end{array}$ \\
\hline
\end{tabular}




\begin{tabular}{|l|l|}
\hline $\begin{array}{l}\text { do café. De acordo com } \\
\text { Kress e van Leeuwen } \\
\text { (1996), a ambiguidade é } \\
\text { um traço de ocorrência de } \\
\text { modalidade, registrado na } \\
\text { nota de rodapé 148. }\end{array}$ & $\begin{array}{l}\text { usados para 'vermelha' ou 'luz' por } \\
\text { exemplo, representados na mesma } \\
\text { oração. Essa representação } \\
\text { desproporcional da sombra na oração } \\
\text { também ocorre na tela, cuja sombra da } \\
\text { mesa ocupa uma grande área no } \\
\text { primeiro plano da tela, denotando sua } \\
\text { centralidade e importância na narrativa. } \\
\text { A distorção da representação da sombra } \\
\text { na oração é análoga à distorção da } \\
\text { sombra na narrativa visual. Registrado } \\
\text { na nota de rodapé 292. }\end{array}$ \\
\hline
\end{tabular}

Fonte: Triangulação para Distorção do ponto de vista dos dados dos corpora visual e textual, com os extratos das cartas.

\subsection{COR}

Os contrastes foram usados por van Gogh com uma função modal, para construir o envolvimento com o espectador por meio de caminhos visuais e de saliência visual. Van Gogh fez uso dos contrastes complementares, de quente e frio, de claro e escuro e dos contrastes de saturação. $\mathrm{O}$ uso de contrastes consegue capturar e conduzir o olhar pela tela para os pontos que o autor deseja enfatizar. Ele se aprofundou na técnica do uso dos contrastes para intensificar o efeito da cor por meio de sua articulação com outras cores na tela e por meio da justaposição de pinceladas de cores complementares próximas umas das outras para causar um efeito ótico ao olharmos a composição. A forma como van Gogh usa a cor nas telas recebeu a influência de Delacroix, Monticelli e dos Impressionistas que será detalhada a seguir.

\subsubsection{O uso da cor no Impressionismo}

Enquanto o impressionismo rompeu com uma representação modalizada da cor, feita pelos mestres do passado, não rompeu com a busca de uma representação naturalista ao experimentar cores mais arrojadas, como relata Gombrich (1995, p. 536):

\footnotetext{
Algumas pessoas podem considerar os impressionistas os primeiros dos modernos, porque desafiaram regras da pintura ensinadas nas academias. Mas convém lembrar que os impressionistas não divergiam, em seus propósitos, das tradições da arte que se desenvolviam desde a descoberta da natureza na Renascença. Eles também queriam pintar a natureza tal como a viam, e sua controvérsia com os mestres conservadores era menos em torno desse objetivo do que dos meios para alcançálo. A exploração impressionista dos reflexos das cores, suas experiências com o efeito do trabalho mantendo solto o pincel, visavam à criação de uma réplica ainda mais perfeita da impressão visual.
} 
O uso do reflexo das cores umas nas outras e do aguçamento recíproco em cores envolvidas em uma relação de contrastes complementares foi muito explorado pelos pintores impressionistas, que Gombrich (1995, p. 539-540) descreve:

Ele enfrentava uma questão ainda mais urgente ao ponderar sobre o uso correto da cor. Cézanne era sedento de cores fortes e intensas, tanto quanto de padrões lúcidos. Lembremo-nos de que os artistas medievais (p.181-3) eram capazes de satisfazer livremente esse mesmo desejo porque não se sentiam obrigados a respeitar o aspecto real das coisas. Entretanto, quando a arte retornou à observação da natureza, as cores puras e brilhantes dos vitrais ou das iluminuras de livros medievais cederam lugar àquelas suaves misturas de tons com que os maiores pintores entre os venezianos (p.326) e os holandeses (p.424) lograram sugerir luz e atmosfera. Os impressionistas tinham renunciado à mistura de pigmentos na paleta e passaram a aplicá-los separadamente na tela em pequenas pinceladas que reproduziam os reflexos oscilantes de uma cena ao "ar livre". Faziam pinturas muito mais brilhantes nos tons do que qualquer um dos seus predecessores, mas Cézanne ainda não se satisfazia com o resultado. Ele queria transmitir os tons ricos e uniformes que pertencem à natureza sob os céus meridionais, mas concluiu que um simples regresso à pintura de áreas inteiras em puras cores primárias punha em perigo a ilusão de realidade. Os quadros pintados dessa maneira assemelham-se a padrões planos e não conseguem dar a impressão de profundidade. Assim Cézanne parecia estar cercado de contradições por todos os lados. Seu desejo de ser inteiramente fiel às suas impressões sensoriais em face da natureza parecia colidir com o desejo de converter - como ele próprio disse - "o impressionismo em algo mais sólido e duradouro, como a arte dos museus". (...) Não admira que, frequentemente, ficasse à beira do desespero, trabalhasse como um escravo em sua tela e jamais deixasse de realizar experimentos. O verdadeiro motivo de espanto é que Cézanne conseguiu realizar em suas obras o que era aparentemente impossível. Se a arte fosse uma questão de cálculo, isso não poderia ser feito; mas certamente não é. Esse equilíbrio e harmonia, a cujo respeito os artistas se preocupam tanto, nada têm a ver com o equilíbrio mecânico. "Acontece" de súbito, e ninguém sabe exatamente como ou por quê.

Van Gogh também fez muitos experimentos com o uso da cor, e veio a romper com a representação naturalista da cor como relata Haziot (2010, p. 147):

[Vincent] Faz esta observação capital após o estudo das leis da cor e da visita a Amsterdã: "Minha paleta está começando a degelar, a esterilidade do início desapareceu". Diz poder assim trabalhar mais depressa. Compreendeu também que o tom local, a cor exata que temos sob os olhos, levava ao impasse estéril, o que não compreendem tantos pintores que ainda hoje seguem as práticas da escola de PontAven. "Essa beleza dos tons que jogam um com o outro na natureza se perde por uma imitação penosa, literal; ela se conserva quando recriada por uma gama de cores paralelas, mas não fatalmente exatas e mesmo muito longe de serem conformes ao modelo." (HAZIOT, 2010, p.147)

David Haziot (2010, p. 147) explica como van Gogh privilegia cores que não seguem uma representação literal da cena:

A cor do pintor só pode ser recriação - se necessário, numa quase alucinação -, como acontecerá em Arles. Ele volta a dizer isso de um modo ainda mais bonito: "Começa-se querendo em vão seguir a natureza e tudo sai errado. Acaba-se por criar tranquilamente partindo da própria paleta, então a natureza acompanha e acerta o passo." (HAZIOT, 2010, p.147) 
Como um sistema semiótico complexo e central na poética de van Gogh, o uso da cor é descrito a seguir em suas características mais marcantes nos Modos como van Gogh o empregou, como explica van Leeuwen (2011, p. 74):

Quais são as características essenciais do esquema de cores de van Gogh? Primeiro de tudo, a crescente força da pureza e saturação de suas cores. Isso, mais do que qualquer outra coisa, expressa a intensidade de sua visão a qual, depois de mais de um século, ainda nos movem. Segundo, a modulação criada pelas pinceladas invisíveis que entretecem valores mais claros e mais escuros da mesma cor, ou cores adjacentes tais como amarelo e verde. Terceiro, a luminosidade de suas cores, acima de todos os amarelos e alaranjados que são tão característicos de seu trabalho, frequentemente colocados contra o azul. E finalmente, uma forma particular de diferenciação - o choque de cores complementares com o qual Van Gogh, inúmeras vezes buscou comunicar suas ideias, expressando, por exemplo, 'o amor de dois amantes pelo casamento de duas cores complementares, sua conexão e sua oposição, as vibrações misteriosas de tons bondosos' (ibid.: 26). ${ }^{305}$

\subsubsection{Uso Simbólico da Cor}

Ao invés de focalizar em criar uma ilusão de realidade ele usou as cores como signos de emoções subjetivas, como evidenciado pelos excertos de carta referentes à tela ' $\mathrm{O}$ Café Noturno na Place Lamartine, em Arles'. Walther e Metzger (2015, p.354-5) explicam o uso simbólico da cor para van Gogh:

De facto, as coisas têm uma vida estética própria, um poder que transcende o mero registro representativo de um tema. E Van Gogh tem confiança no seu motivo, tenta captá-lo de uma forma descritiva e vê nele uma pluralidade de sentidos que advém de sua vida própria ou da iconografia universalmente válida da Arte. No entanto, este conjunto tradicional de experiências surge cada vez mais acompanhado ou até obscurecido pelo desejo intenso de criar um mundo só seu e de o captar na sua obra. A ideia do Japão tornou este desejo mais definido; e o poder transformador da cor conferiu-lhe um conteúdo manifesto. A cor constituiu a forma de Van Gogh articular aquela dimensão extra que transcendia a presença real e diária do tema. Foi a cor que tornou o futuro palpável. Esta acepção era fundamentalmente utópica, uma vez que não podia existir fora das pinturas de Van Gogh. E a ideia que tinha do futuro ficou sempre no vácuo da estética pura. Todavia, continuou a encarnar a unidade da Vida e da Arte de forma tão viva que acreditava realmente na possibilidade de tornar real, no aqui e agora, aquele mundo melhor utópico.

Para van Gogh, a cor passou a ser determinada pelo seu estado emocional. Quando chegou a Arles, a luminosidade impactou em sua experiência das cores, ele aprofundou o seu

\footnotetext{
${ }^{305}$ Tradução livre da autora. "What are the essential characteristics of Van Gogh's colour scheme? First of all, the increasingly strong saturation and purity of his colours. This, more than anything else, expresses the intensity of his vision which, after more than a century, still speaks to us. Second, the modulation created by the invisible brush strokes which intermingle lighter and darker values of the same colour, or adjacent colours such as yellow and green. Third, the luminosity of his colours, above all the yellows and oranges which are so characteristic of his work, often offset against blue. And finally, a particular form of differentiation - the clash of complementary colours with which Van Gogh, time and again, sought to express his ideas, expressing, for instance, 'the love of two lovers by a wedding of two complementary colours, their mingling and their opposition, the mysterious vibrations of kindred tones' (ibid.: 26). ( VAN LEEUWEN, 2011, p. 74)
} 
rompimento com a representação naturalista das cores e declarou-se como um colorista arbitrário e usava cores puras, direto da bisnaga, para representar emoções intensas. Haziot (2010, p. 199) relata um excerto de carta no qual van Gogh fala sobre a relação da pintura com as emoções:

Não é a emoção, a sinceridade do sentimento da natureza que nos impele? E se essas emoções são às vezes tão fortes que trabalhamos sem sentir que trabalhamos, quando as pinceladas vêm às vezes com uma sequência e relações entre si como as palavras num discurso ou numa carta, cabe então lembrar que nem sempre foi assim e que no futuro também haverá dias pesados sem inspiração.

Van Gogh criou um novo sistema semiótico na pintura pela sua forma de usar as cores para expressar significados simbólicos. Van Gogh usou a cor de muitos modos: para causar aguçamento e ênfase, para construir a profundidade e a ambiência, e para simbolizar sentidos diversos de uma representação naturalista. Na cor encontrei o índice mais fiel de seu estado de espírito, como explica Haziot (2010, p. 218):

Depois do exterior da Casa Amarela, era preciso pintar o interior. Vincent declara que, após suas jornadas fatigantes, forme doze horas seguidas. O repouso nesse lugar providencial e a quietude que ali reina lhe dão a ideia de pintar o quarto. Faz uma tela, hoje no museu de Amsterdã, e uma segunda versão, as duas sendo geralmente confundidas. No entanto só uma terá essa gama dourada do período arlesiano: o leito e o soalho possuem aquele ouro comestível, diríamos, que caracteriza os tempos felizes de Arles. As réplicas feitas por Vincent são determinadas por seu estado psicológico e as cores se revelam bastante diferentes. Em particular, ele fará uma cópia em Saint-Rémy na qual o piso será de um castanho-verde que evoca a cor de um pântano. Esse mesmo castanho-verde aparece no autorretrato que ele pintou ao sair de uma crise. $\mathrm{O}$ estudo dessas três versões mostraria a que ponto a cor é determinada, num pintor, por seu sentimento íntimo. De fato, quando volta a pintar o quarto de Arles, ele não consegue reencontrar a mesma gama cromática. O desenho, ligado ao intelecto, é fielmente reproduzido, mas a cor não se submete à vontade ou ao pensamento racional.

O uso de contrastes simultâneos lado a lado nas pinceladas confere uma vibração na experiência da apreensão visual da cor.

A escala de modulação também é importante para compreender o uso da cor por van Gogh. Ela se relaciona intimamente com a textura. Essa escala de modulação pode ser construída pelo uso de cores totalmente moduladas, ricamente texturizadas. As cores moduladas podem ser percebidas, em geral, como fiéis aos detalhes e à rica textura da cor real, sendo mais exuberantes nas obras de van Gogh e parecem representar não apenas as cores do mesmo modo em que aparentam no mundo real, mas como recursos semióticos para mostrar como o mundo é percebido pelo autor. 


\subsubsection{Triangulação da Cor}

Cor, no texto escrito e em relação à triangulação - $\mathrm{O}$ uso da cor no texto escrito pode ser encontrado tanto no nível semântico quanto na produção de contrastes, contraposições e no uso arbitrário das conotações, que emprestam o colorido e a tonalidade para o sentido que ele está construindo. Abaixo seguem alguns exemplos da ocorrência do emprego da cor nas orações. Na modulação da cor, podemos entender a modulação como uma transição da maior intensidade cromática para menor intensidade cromática, ou seja, como o uso de modalizações na forma como ele constrói o sentido nas orações. Encontrei ocorrências análogas na linguagem textual.

\begin{tabular}{|c|c|c|}
\hline \multicolumn{3}{|c|}{ Quadro 25: Triangulação da Cor } \\
\hline Ocorrência nas telas & Orações & Comentário \\
\hline $\begin{array}{l}\text { Na tela 'Por de Sol: Campo de } \\
\text { trigo perto de Arles', observei } \\
\text { o uso de modulação cromática } \\
\text { no campo de trigo para } \\
\text { produzir o efeito de } \\
\text { profundidade, registrado nas } \\
\text { notas de rodapé } 42,84 \text { e } 75 \text { do } \\
\text { apêndice observei a ocorrência } \\
\text { de modulação e do uso } \\
\text { simbólico da cor, para } \\
\text { organizar os espaços } \\
\text { composicionais, a perspectiva } \\
\text { e para criar caminhos visuais. } \\
\text { Observei a ocorrência de cor e } \\
\text { saliência conferida pelos } \\
\text { contrastes de quente-frio e } \\
\text { entre azuis e amarelos. } \\
\text { Registrado nas notas de rodapé } \\
74 \text { e } 76 \text { no apêndice. }\end{array}$ & $\begin{array}{l}\text { Noite de verão, de qualquer modo. } \\
\text { Cidade violeta, estrela amarela, céu } \\
\text { azul-esverdeado; os campos de } \\
\text { trigo têm todos os tons: ouro velho, } \\
\text { cobre, ouro verde, ouro vermelho, } \\
\text { ouro amarelo, verde, vermelho e } \\
\underline{\text { amarelo bronze. }}\end{array}$ & $\begin{array}{l}\text { A modulação da cor do trigal é } \\
\text { detalhadamente descrito nesse trecho } \\
\text { da carta revelando que a } \\
\text { intencionalidade dessa variedade de } \\
\text { cores tem relevância significativa na } \\
\text { forma como van Gogh busca } \\
\text { representar a riqueza natural e } \\
\text { simbólica do campo de trigo. } \\
\text { Existe uma similaridade poética e } \\
\text { afetiva entre a descrição da variedade } \\
\text { de cores e a apresentação dessa } \\
\text { variedade de cores na tela mostrando } \\
\text { que há um componente afetivo e até } \\
\text { mesmo lúdico no uso que van Gogh } \\
\text { faz de pequenas diferenças cromáticas, } \\
\text { como quem está se permitindo } \\
\text { experimentar os efeitos que um tom } \\
\text { causa no outro. A descrição dele revela } \\
\text { essa liberdade poética no uso dos } \\
\text { efeitos das cores na tela. }\end{array}$ \\
\hline $\begin{array}{l}\text { Na tela 'O Semeador', } \\
\text { observei também a } \\
\text { ocorrência de Associação } \\
\text { Metafórica, construída pelo } \\
\text { contrates simultâneo sugere } \\
\text { contraposição metafórica de } \\
\text { significados do céu e da } \\
\text { terra. Registrado na nota de } \\
\text { rodapé } 66 .\end{array}$ & $\begin{array}{l}\text { Noite de verão, de qualquer modo. } \\
\text { Cidade violeta, estrela amarela, céu } \\
\text { azul-esverdeado; os campos de } \\
\text { trigo têm todos os tons: ouro velho, } \\
\text { cobre, ouro verde, ouro vermelho, } \\
\text { ouro amarelo, verde, vermelho e } \\
\text { amarelo bronze. }\end{array}$ & $\begin{array}{l}\text { Na tela e nas cartas o contraste entre o } \\
\text { violeta, o amarelo e o azul aparece } \\
\text { evidenciado e as cores se } \\
\text { complementam para construir um todo } \\
\text { que é a noite de verão. }\end{array}$ \\
\hline
\end{tabular}




\begin{tabular}{|c|c|c|}
\hline $\begin{array}{l}\text { Na tela 'O Semeador', } \\
\text { observei a ocorrência } \\
\text { conjugada de Contrastes de } \\
\text { Saturação, Saliência, } \\
\text { Associação Metafórica e } \\
\text { Incompletude na } \\
\text { representação do céu e do } \\
\text { sol, em amarelo sobre } \\
\text { amarelo. Registrado na nota } \\
\text { de rodapé } 51 .\end{array}$ & $\begin{array}{l}\text { Um campo de trigo maduro, de tom } \\
\text { amarelo-ocre com um pouco de } \\
\text { carmim. } \\
\text { O céu, amarelo-crômio, quase tão } \\
\text { luminoso quanto o próprio Sol, que } \\
\text { é amarelo-crômio no } 1 \text {, misturado } \\
\text { com um pouco de branco, enquanto } \\
\text { o resto do céu é uma mistura dos } \\
\text { amarelos-crômios } 1 \text { e } 2 \text {. Tão } \\
\text { amarelo! A camisa do semeador é } \\
\text { azul e as calças brancas. Tamanho } \\
\text { da tela - } 25 \text {, quadrada. }\end{array}$ & $\begin{array}{l}\text { Observei a ocorrência de modulação } \\
\text { textual no construto. No uso lexical } \\
\text { ele vai intensificando a ênfase no } \\
\text { amarelo, pela repetição e pela } \\
\text { exclamação, a fim de descrever o } \\
\text { amarelo. }\end{array}$ \\
\hline $\begin{array}{l}\text { Na tela 'O Semeador', a } \\
\text { profundidade visual é } \\
\text { construída pela divisão do } \\
\text { espaço em planos, e pela } \\
\text { gradação cromática das } \\
\text { tonalidades de azuis do } \\
\text { campo. Ela também é } \\
\text { construída com a ajuda da } \\
\text { perspectiva, dada pelos } \\
\text { caminhos visuais no campo } \\
\text { arado, como registrado nas } \\
\text { notas de rodapé } 35 \text { e } 37 .\end{array}$ & $\begin{array}{l}\text { Há várias sugestões de amarelo no } \\
\text { solo, tons neutros resultantes da } \\
\underline{\text { mistura de violeta e amarelo; mas }} \\
\text { tenho travado uma luta diabólica } \\
\text { para atingir a verdade das cores. }\end{array}$ & $\begin{array}{l}\text { Tanto a gradação cromática } \\
\text { perceptível na tela quanto a descrição } \\
\text { da oração dos diferentes tons sugerem } \\
\text { que van Gogh construiu } \\
\text { intencionalmente a diferenciação entre } \\
\text { tons na terra e no horizonte com } \\
\text { intuito de ser fiel à percepção de cada } \\
\text { detalhe. Assim ele revela que a } \\
\text { natureza proporciona uma diversidade } \\
\text { de cores que os olhos menos atentos } \\
\text { homogeneízam a fim de apreender } \\
\text { somente o todo. E neste esforço ele } \\
\text { relata que tem "travado uma luta } \\
\text { diabólica para atingir a verdade das } \\
\text { cores". }\end{array}$ \\
\hline $\begin{array}{l}\text { Na tela 'O Semeador', } \\
\text { observei a ocorrência de } \\
\text { Perspectiva pelo uso de } \\
\text { vários recursos tais como } \\
\text { planos com ângulos de } \\
\text { enquadramento } \\
\text { diferenciados, em forma de } \\
\text { cunhas que são sugeridas } \\
\text { pela modulação cromática } \\
\text { dos torrões de terra. } \\
\text { Registrado na nota de rodapé } \\
\underline{36} .\end{array}$ & $\begin{array}{l}\text { Há várias sugestões de amarelo no } \\
\text { solo, tons neutros resultantes da } \\
\text { mistura de violeta e amarelo; mas } \\
\text { tenho travado uma luta diabólica } \\
\text { para atingir a verdade das cores. }\end{array}$ & $\begin{array}{l}\text { Aqui, observa-se o uso da modulação } \\
\text { cromática: 'tons neutros resultantes da } \\
\text { mistura de violeta e amarelo'. O uso } \\
\text { da modulação é observado na } \\
\text { construção léxico-gramatical pela } \\
\text { escolha da sequência lexical e pelo } \\
\text { uso de 'sugestão de amarelo', 'tons } \\
\text { neutros', 'mistura de violeta e } \\
\text { amarelo' que constroem uma gradação } \\
\text { de cores. }\end{array}$ \\
\hline $\begin{array}{l}\text { Na tela 'O Semeador', há } \\
\text { uma inter-relação entre } \\
\text { Textura, Contrastes } \\
\text { Simultâneos, Saliência, } \\
\text { Sinestesia que criam } \\
\text { Associações Metafóricas da } \\
\text { materialidade da tinta com a } \\
\text { nossa memória sensorial e } \\
\text { tátil da plasticidade da terra. }\end{array}$ & $\begin{array}{l}\text { Não te vou ocultar que não desgosto } \\
\text { da região, pois fui criado lá - ainda } \\
\text { me encanta a magia das recordações } \\
\text { do passado, de um desejo do infinito, } \\
\text { do qual o semeador e o enfeixador } \\
\text { são símbolos -, tanto quanto antes } \\
\text { gostava. } \\
\text { Ocorrência de Contraste Cromático }\end{array}$ & $\begin{array}{l}\text { Modulação na linguagem = } \\
\text { Modalização. Neste complexo } \\
\text { oracional foi construído um intrincado } \\
\text { construto léxico-gramatical que } \\
\text { empresta colorido à oração pelas } \\
\text { oposições e contrastes, de sentidos } \\
\text { empregados. A escolha do construto } \\
\text { 'não vou te ocultar que não desgosto' } \\
\text { contém } 4 \text { negativas para construir } 2\end{array}$ \\
\hline
\end{tabular}




\begin{tabular}{|c|c|c|}
\hline $\begin{array}{l}\text { Registrado na nota de rodapé } \\
\text { 50. } \\
\text { Observei também a } \\
\text { ocorrência de Sinestesia } \\
\text { produzida pelo contraste } \\
\text { simultâneo que potencializa } \\
\text { o efeito da textura tátil e da } \\
\text { textura visual. } \text { Registrado na } \\
\text { nota de rodapé 55. }\end{array}$ & $\begin{array}{l}\text { usado como Associação metafórica } \\
\text { para expressar o Limiar Artístico } \\
\text { representados no Semeador e no } \\
\text { Enfeixador. Registrados na nota de } \\
\text { rodapé } 98 .\end{array}$ & $\begin{array}{l}\text { afirmações (como já demonstrado } \\
\text { antes) e cria com isso uma trama de } \\
\text { oposições e contrastes que dá um } \\
\text { efeito de sentido colorido para a } \\
\text { linguagem. O segundo contraste se } \\
\text { encontra no deslocamento dentro do } \\
\text { tempo da ação. Ele inicia o período no } \\
\text { presente e esclarece que gosta da } \\
\text { região, abre um travessão e se desloca } \\
\text { para o passado, descrevendo, } \\
\text { detalhando, esmiuçando a natureza } \\
\text { desse gostar; é como se ele estivesse a } \\
\text { viver lá. Em seguida ele fecha o } \\
\text { travessão retornando para o presente, } \\
\text { fazendo a comparação com o tempo } \\
\text { atual e integrando estes dois tempos. }\end{array}$ \\
\hline $\begin{array}{l}\text { Na tela 'O Semeador', } \\
\text { observei o uso de modulação } \\
\text { cromática de tons de } \\
\text { amarelos que estão } \\
\text { superpostos e que } \\
\text { conjugados, atingem um } \\
\text { aguçamento dos sentidos } \\
\text { compatíveis com experiência } \\
\text { extática que van Gogh } \\
\text { parece querer comunicar. }\end{array}$ & $\begin{array}{l}\text { O céu, amarelo-crômio, quase tão } \\
\text { luminoso quanto o próprio Sol, que é } \\
\text { amarelo-crômio no } 1, \text { misturado com } \\
\underline{\text { um pouco de branco, enquanto o }} \\
\text { resto do céu é uma mistura dos } \\
\text { amarelos-crômios } 1 \text { e } 2 . \text { Tão } \\
\text { amarelo! }\end{array}$ & $\begin{array}{l}\text { Obsermos no discurso textual a } \\
\text { ocorrência semântica de modulação na } \\
\text { oração que descreve diferentes } \\
\text { tonalidades de amarelos, e a } \\
\text { ocorrência gramatical com a oração: } \\
\text { 'Tão amarelo!' que culmina o } \\
\text { crescendo das tonalidades de amarelos } \\
\text { descritos na oração que a antecede. É } \\
\text { como um clímax de um crescendo que } \\
\text { explode com o construto: 'Tão } \\
\text { amarelo!'. }\end{array}$ \\
\hline $\begin{array}{l}\text { Na tela 'O Semeador' } \\
\text { observei a ocorrência de } \\
\text { Associação Metafórica } \\
\text { construída pelo uso } \\
\text { simbólico da cor para } \\
\text { construir o significado } \\
\text { cíclico do plantar e do } \\
\text { colher, e outras associações } \\
\text { de sentidos potenciais são } \\
\text { sugeridas como vida e morte. } \\
\text { Registrada na nota de rodapé } \\
\underline{70} . \\
\text { Observei também a } \\
\text { ocorrência de Uso Simbólico } \\
\text { da Cor para conferir } \\
\text { Associação Metafórica para } \\
\text { os sentidos simbólicos do } \\
\text { campo maduro e do campo } \\
\text { arado e da parábola do } \\
\text { Semeador. Registrada na } \\
\text { nota de rodapé } 74 .\end{array}$ & $\begin{array}{l}\text { Aqui está um esboço de um } \\
\text { semeador, um grande campo lavrado } \\
\text { com torrões de terra, na sua maioria } \\
\text { fracamente cor de violeta. } \\
\text { Um campo de trigo maduro, de tom } \\
\text { amarelo-ocre com um pouco de } \\
\text { carmim. } \\
\text { Ocorrência de Associação } \\
\text { metafórica construída pela Saliência } \\
\text { do grupo nominal que dá o atributo } \\
\text { de cores para o campo de trigo, por } \\
\text { meio de um apagamento do } \\
\text { processo tornando o atributo e o } \\
\text { portador uma só coisa. Registrado } \\
\text { na nota de rodapé } 82 .\end{array}$ & $\begin{array}{l}\text { O campo amarelo que tem um pouco } \\
\text { de carmim, o campo arado de terra } \\
\text { roxa que tem um pouco de amarelo. } \\
\text { Vida e morte se entrelaçam, uma } \\
\text { dentro da outra, parecer construir } \\
\text { metaforicamente nas orações e na tela } \\
\text { um movimento cíclico com as cores } \\
\text { fazendo a transição entre os diferentes } \\
\text { momentos da semeadura. O valor } \\
\text { simbólico da cor potencializado pelo } \\
\text { valor simbólico da semeadura. Van } \\
\text { Gogh valoriza a transição das cores, a } \\
\text { sua heterogeneidade e seu sentido } \\
\text { simbólico na produção da tela } \\
\text { denominada "o Semeador", na qual a } \\
\text { cor ganha grande proeminência, mais } \\
\text { do que a figura em si do semeador. }\end{array}$ \\
\hline
\end{tabular}




\begin{tabular}{|c|c|c|}
\hline $\begin{array}{l}\text { Observei também a } \\
\text { ocorrência de uso Simbólico } \\
\text { da Cor para conferir } \\
\text { Saliência e Associação } \\
\text { Metafórica para os sentidos } \\
\text { simbólicos do campo arado. } \\
\text { Registrada na nota de rodapé } \\
\text { } \underline{75} .\end{array}$ & & \\
\hline $\begin{array}{l}\text { Na tela 'O Semeador' } \\
\text { observei a ocorrência de } \\
\text { Sinestesia pelo contraste } \\
\text { simultâneo entre o violeta e } \\
\text { o amarelo que potencializam } \\
\text { mutuamente o seu efeito e } \\
\text { que é aguçado o efeito da } \\
\text { textura tátil e da textura } \\
\text { visual. } \text { Registrado na nota de } \\
\text { rodapé } 55 .\end{array}$ & $\begin{array}{l}\text { Aqui está o que eu queria dizer } \\
\text { sobre o branco e o preto. A pintura é } \\
\text { dividida em dois; metade é amarelo, } \\
\text { o topo; a base é violeta. Bem, as } \\
\text { calças brancas descansam os olhos e } \\
\text { os distraem exatamente quando o } \\
\text { contraste simultâneo excessivo de } \\
\text { amarelo e violeta iriam irritá-lo. Isso } \\
\text { é o que eu queria dizer. }\end{array}$ & $\begin{array}{l}\text { Ocorrência do uso de saliência na } \\
\text { oração 'Isso é o que eu queria dizer' } \\
\text { que retoma e reforça o sentido da } \\
\text { oração 'Aqui está o que eu queria } \\
\text { dizer sobre o branco e o preto. ' que } \\
\text { abre o parágrafo que fala sobre a } \\
\text { função do branco para amenizar o } \\
\text { conflito entre o violeta e o amarelo } \\
\text { que preenchem os dois campos da } \\
\text { tela. }\end{array}$ \\
\hline $\begin{array}{l}\text { Na tela 'O Semeador', } \\
\text { observei a ocorrência de } \\
\text { Contrastes Cromáticos } \\
\text { Complementares de azuis e } \\
\text { lilases em contraposição com } \\
\text { laranjas e amarelos, causa } \\
\text { uma ambiência de vibração e } \\
\text { intensidade para representar } \\
\text { a luz do ocaso, e são } \\
\text { compatíveis com a } \\
\text { ocorrência de uma Distorção } \\
\text { do Ponto de vista. Registrado } \\
\text { na nota de rodapé } 72 .\end{array}$ & $\begin{array}{l}\text { Há várias sugestões de amarelo no } \\
\text { solo, tons neutros resultantes da } \\
\text { mistura de violeta e amarelo; mas } \\
\text { tenho travado uma luta diabólica } \\
\text { para atingir a verdade das cores. }\end{array}$ & $\begin{array}{l}\text { A oração constrói, no nível semântico, } \\
\text { um sentido similar ao sentido criado } \\
\text { pela contraposição entre azuis e } \\
\text { laranjas e lilases e amarelos, uma } \\
\text { terceira cor que é o resultado desses } \\
\text { contrastes. Van Gogh se refere a esse } \\
\text { efeito como 'tons neutros resultantes } \\
\text { da mistura', e que, por representarem a } \\
\text { mistura de tons opostos, representam } \\
\text { essa indiferenciação das cores que é } \\
\text { característica do crepúsculo. }\end{array}$ \\
\hline $\begin{array}{l}\text { Na tela 'O Semeador', } \\
\text { observei a ocorrência de Uso } \\
\text { Simbólico da Cor para } \\
\text { conferir Associação } \\
\text { Metafórica para os episódios, } \\
\text { participantes e membros da } \\
\text { pintura. Registrado na nota } \\
\text { de rodapé } 73 \text {. }\end{array}$ & $\begin{array}{l}\text { Mas é uma questão de atacá-las, no } \\
\text { entanto, não importa o quão } \\
\text { incompetente um pode sentir-se vis- } \\
\text { à-vis as perfeições inefáveis do } \\
\text { glorioso esplendor da natureza. }\end{array}$ & $\begin{array}{l}\text { No nível semântico, a oração revela } \\
\text { que van Gogh está buscando uma } \\
\text { forma de representar 'as perfeições } \\
\text { inefáveis do glorioso esplendor da } \\
\text { natureza'. Ele demonstra na tela que } \\
\text { essa forma é encontrada e } \\
\text { materializada. Por meio do uso das } \\
\text { cores, da construção de efeitos de } \\
\text { sentidos causados pelos contrastes } \\
\text { simultâneos, da associação metafórica } \\
\text { resultante do uso simbólico das cores } \\
\text { ele representa 'as perfeições inefáveis } \\
\text { do glorioso esplendor da natureza'. }\end{array}$ \\
\hline $\begin{array}{l}\text { Na tela 'A Esplanada do } \\
\text { Café na Place du Forum, } \\
\text { Arles, à Noite', observei a } \\
\text { ocorrência de Modulação }\end{array}$ & $\begin{array}{l}\text { Agora há uma pintura de noite sem } \\
\text { preto. Com nada mais do que um } \\
\text { belo azul e violeta e verde e nestes } \\
\text { arredores da praça iluminada é }\end{array}$ & $\begin{array}{l}\text { Nesta oração observei uma modulação } \\
\text { de intensidade. Ele inicia descrevendo } \\
\text { a tela com apenas uma cor 'sem } \\
\text { preto'. Depois há uma ênfase 'nada }\end{array}$ \\
\hline
\end{tabular}




\begin{tabular}{|c|c|c|}
\hline $\begin{array}{l}\text { Cromática e Inacabamento } \\
\text { para construir uma gradação } \\
\text { de tons de azuis que são mais } \\
\text { escuros e profundos no fim } \\
\text { da rua e ficam gradualmente } \\
\text { mais claros quando se } \\
\text { aproximam do café criando } \\
\text { uma zona de transição } \\
\text { cromática, registrado na nota } \\
\text { de rodapé } 128 \text { no apêndice. }\end{array}$ & $\begin{array}{l}\text { colorido por enxofre pálido, amarelo } \\
\text { limão. }\end{array}$ & $\begin{array}{l}\text { mais’ e utiliza três cores. Depois há } \\
\text { uma ênfase mais intensa ‘é colorido e } \\
\text { utiliza cores que à noite não são tão } \\
\text { intensas, mas na oração elas são } \\
\text { representadas como intensas porque } \\
\text { são os agentes da ação de colorir a } \\
\text { praça iluminada. }\end{array}$ \\
\hline $\begin{array}{l}\text { Na tela 'A Esplanada do } \\
\text { Café na Place du Forum, } \\
\text { Arles, à Noite', observei a } \\
\text { ocorrência de Saliência dada } \\
\text { pelos Contrastes Cromáticos } \\
\text { do tipo Simultâneo, } \\
\text { Quente/Frio, e de Saturação } \\
\text { para construir caminhos } \\
\text { visuais e saliência na área } \\
\text { do café e conduzir o olhar } \\
\text { para dentro da tela. } \\
\text { Registrados na nota de } \\
\text { rodapé } 133 \text { no apêndice. } \\
\text { Observei também a } \\
\text { ocorrência de contrastes } \\
\text { simultâneos para construir } \\
\text { uma ênfase mútua entre as } \\
\text { áreas que ele quis representar } \\
\text { com maior destaque: o café e } \\
o \text { céu estrelado. Registrado } \\
\text { na nota de rodapé } 133 \text { no } \\
\text { apêndice. }\end{array}$ & $\begin{array}{l}\text { Uma enorme lanterna amarela } \\
\text { ilumina o terraço, a fachada, a } \\
\text { calçada, e até mesmo projeta luz } \\
\text { sobre os paralelepípedos da rua, que } \\
\text { adquirem uma coloração violeta- } \\
\text { rosa. As frentes das casas em uma } \\
\text { rua que segue sob o céu azul } \\
\text { salpicado de estrelas são azul escuro } \\
\text { ou violeta, com uma árvore verde. } \\
\text { Agora há uma pintura de noite sem } \\
\text { preto. Com nada mais do que um } \\
\text { belo azul e violeta e verde e nestes } \\
\text { arredores da praça iluminada é } \\
\underline{\text { colorido por enxofre pálido, amarelo }} \\
\underline{\text { limão. }}\end{array}$ & $\begin{array}{l}\text { A cor da lanterna é projetada para } \\
\text { além dela mesma, incidindo sobre } \\
\text { todos os elementos da tela. A } \\
\text { incidência pode ser direta ou indireta, } \\
\text { proporcionando a produção de uma } \\
\text { noite sem preto. Nesta tela fica ainda } \\
\text { mais evidente o papel das cores na } \\
\text { composição do sentido da obra, ela } \\
\text { aqui ganha não só um sentido } \\
\text { metafórico, mas também histórico. } \\
\text { Até então só havia uma forma de } \\
\text { representar a noite, utilizando a cor } \\
\text { preta na composição. Graças à } \\
\text { combinação dos diferentes matizes em } \\
\text { uma noite iluminada é possível utilizar } \\
\text { a luz para construir a ideia de uma } \\
\text { noite iluminada. O uso combinado das } \\
\text { cores aqui é fundamental nessa } \\
\text { construção intencional de van Gogh, } \\
\text { de produzir uma noite sem utilizar a } \\
\text { cor preta para representá-la. }\end{array}$ \\
\hline $\begin{array}{l}\text { Na tela 'A Esplanada do } \\
\text { Café na Place du Forum, } \\
\text { Arles, à Noite', observei a } \\
\text { ocorrência de Inovação } \\
\text { Pictórica com a } \\
\text { representação das cores à } \\
\text { noite, à luz do lampião a } \\
\text { gás. Registrada na nota de } \\
\text { rodapé } 135 \text { no apêndice. }\end{array}$ & $\begin{array}{l}\text { Muitas vezes parece-me que a noite } \\
\text { é muito mais viva e ricamente } \\
\text { colorida do que o dia. } \\
\text { Uso de cores, no quadro e na carta. } \\
\text { Ele enfatiza a percepção de uma } \\
\text { noite mais viva e ricamente colorida } \\
\text { do que o dia que ele experiencia e } \\
\text { representa tanto textualmente quanto } \\
\text { visualmente ao representar o Café } \\
\text { Terrace, explicitando a variedade de } \\
\text { cores que ele consegue observar a } \\
\text { noite. Registrado na nota de rodapé } \\
253 \text {. }\end{array}$ & $\begin{array}{l}\text { Com essa asserção, tanto na carta } \\
\text { quanto na tela, ele está explicitando } \\
\text { um tipo de experiência que é ousada e } \\
\text { inovadora, ao explorar as } \\
\text { possibilidades de representar as cores } \\
\text { com a luminosidade noturna, como } \\
\text { também o fez tanto na tela do Café } \\
\text { Terrace quanto nas cartas a ela } \\
\text { referidas. }\end{array}$ \\
\hline $\begin{array}{l}\text { Na tela 'A Esplanada do } \\
\text { Café na Place du Forum, } \\
\text { Arles, à Noite', observei }\end{array}$ & $\begin{array}{l}\text { É bem verdade que eu possa tomar } \\
\text { um azul por um verde no escuro, um } \\
\text { azul lilás por um rosa lilás, uma vez }\end{array}$ & $\begin{array}{l}\text { Nesta oração van Gogh procura } \\
\text { explicar que o objetivo na composição } \\
\text { não foi representar a cor que os }\end{array}$ \\
\hline
\end{tabular}




\begin{tabular}{|c|c|c|}
\hline $\begin{array}{l}\text { também a ocorrência de } \\
\text { Modulação Cromática na } \\
\text { representação da cor à noite, } \\
\text { iluminada pela lâmpada a } \\
\text { gás. Registrada na nota de } \\
\text { rodapé } 136 \text { no apêndice. }\end{array}$ & $\begin{array}{l}\text { que você não pode perceber a } \\
\text { natureza do tom claramente. Mas é a } \\
\text { única maneira de se livrar da noite } \\
\text { negra convencional com uma luz } \\
\text { pobre, pálida e esbranquiçada, } \\
\text { quando na verdade uma mera vela } \\
\text { por si só nos dá os mais ricos } \\
\text { amarelos e laranjas. }\end{array}$ & $\begin{array}{l}\text { objetos assumiriam durante o dia, mas } \\
\text { tomar a cor pela forma como ela se } \\
\text { manifesta à noite. Uma luz que incide } \\
\text { sobre um objeto à noite proporciona } \\
\text { cores que não seria possível visualizar } \\
\text { durante o dia. O que importa na } \\
\text { composição é ser fiel à interação entre } \\
\text { a luz e os outros elementos para } \\
\text { valorizar cada matiz e valorizar cada } \\
\text { aspecto da cor em uma noite } \\
\text { iluminada pela lâmpada a gás e pelo } \\
\text { céu estrelado. Duas luzes diferentes, } \\
\text { uma amarelada e outra esbranquiçada. } \\
\text { Cada uma interagindo e produzindo } \\
\text { matizes diferentes na calçada, na } \\
\text { frente nos prédios e sobre as pessoas. }\end{array}$ \\
\hline $\begin{array}{l}\text { Na tela A Esplanada do Café } \\
\text { na Place du Forum, Arles, à } \\
\text { Noite observei a ocorrência } \\
\text { de Modalidade pela } \\
\text { construção da Modulação de } \\
\text { cores como van Gogh as } \\
\text { percebia. A sua } \\
\text { fidedignidade para captar e } \\
\text { representar as cores noite } \\
\text { confere modalidade para a } \\
\text { noite representada na tela. } \\
\text { Registrada na nota de rodapé } \\
159 \text { no apêndice. }\end{array}$ & $\begin{array}{l}\text { Agora há uma pintura de noite sem } \\
\text { preto. Com nada mais do que um } \\
\text { belo azul e violeta e verde e nestes } \\
\text { arredores da praça iluminada é } \\
\text { colorido por enxofre pálido, amarelo } \\
\text { limão. }\end{array}$ & $\begin{array}{l}\text { Observei a ocorrência de contraste na } \\
\text { escolha lexical 'noite' cujo sentido } \\
\text { está implicitamente relacionado com a } \\
\text { não escolha de 'dia'. O tema da noite, } \\
\text { em contraposição com o dia, seus } \\
\text { desafios e mistérios em contraposição } \\
\text { com as certezas e facilidades da } \\
\text { experiência de representar as cores do } \\
\text { dia, estão de certa forma imbricados } \\
\text { na representação textual da tela Café } \\
\text { da Noite e da tela do Café Terrace na } \\
\text { experiência de pintá-las. }\end{array}$ \\
\hline $\begin{array}{l}\text { Uso de cores, no quadro e na } \\
\text { carta. Ele enfatiza a } \\
\text { percepção de uma noite mais } \\
\text { viva e ricamente colorida do } \\
\text { que o dia que ele experiencia } \\
\text { e representa tanto } \\
\text { textualmente quanto } \\
\text { visualmente ao representar o } \\
\text { Café Terrace, explicitando a } \\
\text { variedade de cores que ele } \\
\text { consegue observar a noite. } \\
\text { Registrada na nota de rodapé } \\
253 \text {. }\end{array}$ & $\begin{array}{l}\text { É bem verdade que eu possa tomar } \\
\text { um azul por um verde no escuro, um } \\
\text { azul lilás por um rosa lilás, desde } \\
\text { que você não pode perceber a } \\
\text { natureza do tom claramente. }\end{array}$ & $\begin{array}{l}\text { Observei quando ele modula na } \\
\text { linguagem, quando ele modula as } \\
\text { cores da rua iluminada pelo lampião } \\
\text { há uma ambiguidade, pois ele } \\
\text { descreve uma cor que está entre uma } \\
\text { cor e outra, porque há uma transição. } \\
\text { Quando ele escreve 'pareço um } \\
\text { japonês' há um tipo de transição. } \\
\text { 'tomar um azul por um verde', 'um } \\
\text { azul-lilás por um rosa lilás. ' Além da } \\
\text { modulação este trecho constrói } \\
\text { semanticamente uma paleta, a mesma } \\
\text { que encontrei ocorrência na tela. Há } \\
\text { uma ocorrência de ordem semântica. }\end{array}$ \\
\hline $\begin{array}{l}\text { Na tela 'O Café Noturno na } \\
\text { Place Lamartine, em Arles', } \\
\text { observei a ocorrência dos } \\
\text { Contrastes simultâneos entre } \\
\text { o verde e o vermelho escuro } \\
\text { no interior do café. }\end{array}$ & $\begin{array}{l}\text { 'Procuro com o verde e o vermelho } \\
\text { pintar as terríveis paixões humanas. } \\
\text { Verifiquei a ocorrência do uso de } \\
\text { um construto de contraposição e }\end{array}$ & $\begin{array}{l}\text { O uso dos contrastes cromáticos está } \\
\text { presente, semanticamente, tanto na } \\
\text { tela quanto nas cartas, e tornou-se um } \\
\text { indicador para verificar construtos } \\
\text { dentro das orações que explicitassem } \\
\text { contrastes e contraposições. }\end{array}$ \\
\hline
\end{tabular}




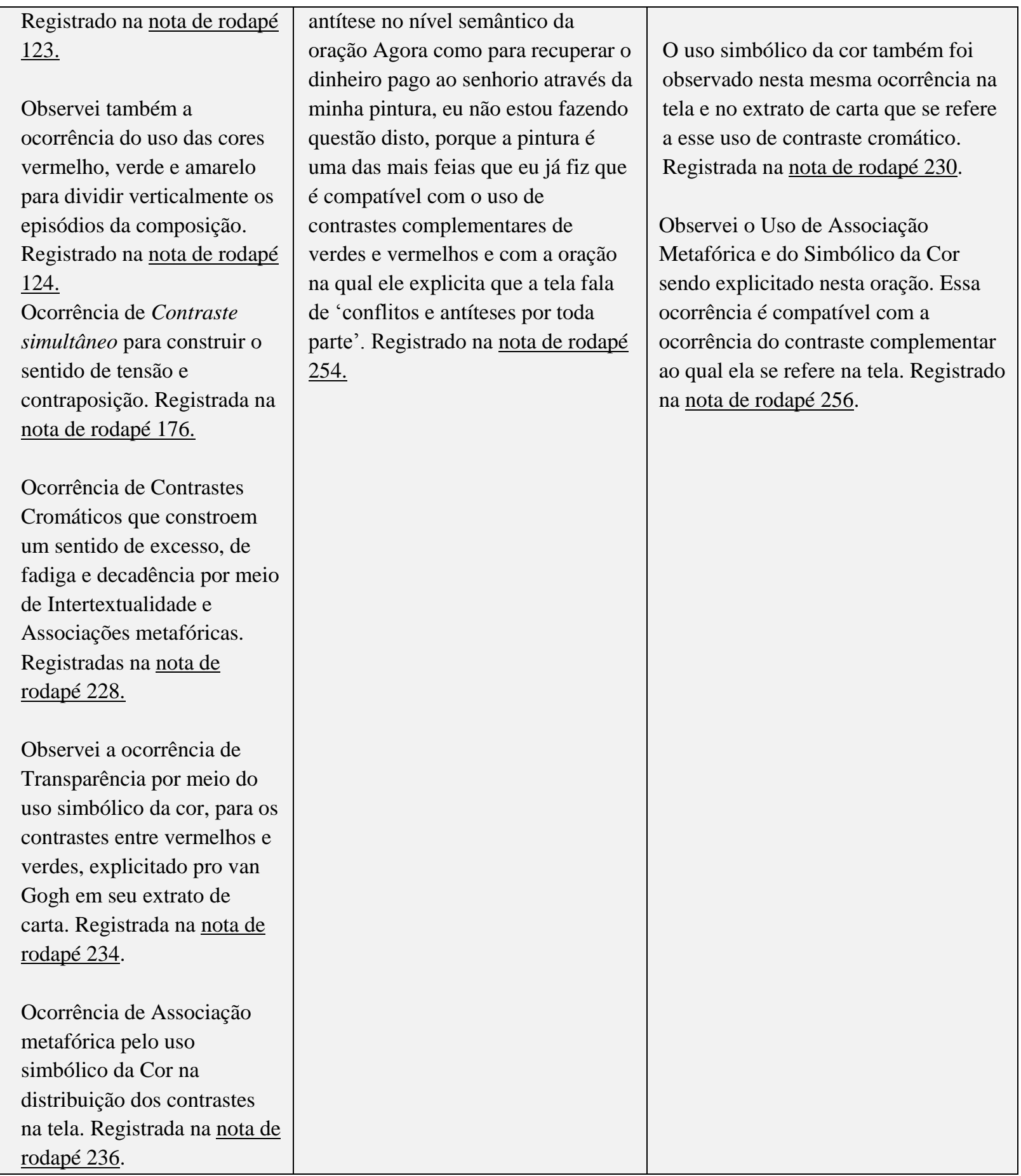




\begin{tabular}{|c|c|c|}
\hline 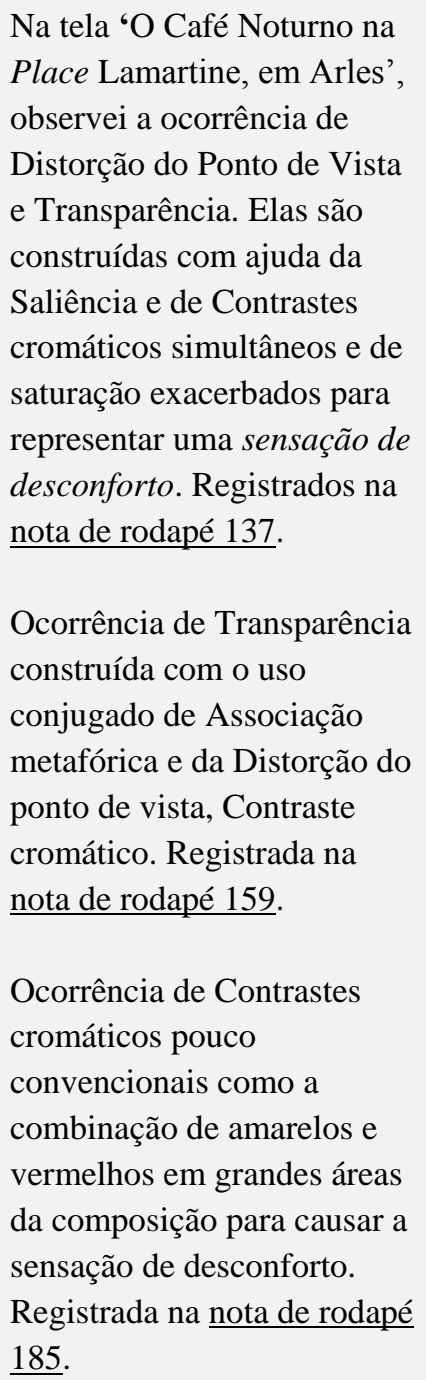 & $\begin{array}{l}\text { Na minha pintura do café à noite eu } \\
\text { procurei exprimir que o café é um } \\
\text { lugar onde você pode arruinar-se, } \\
\text { enlouquecer, cometer crimes. De } \\
\text { qualquer forma, eu tentei com } \\
\text { contrastes de rosa delicado e } \\
\text { vermelho-sangue e vinho tinto. } \\
\text { Verde doce Luís XV e Veronese } \\
\text { contrastando com os verdes } \\
\text { amarelos e os verdes azuis duros. } \\
\text { Tudo isso em uma atmosfera de } \\
\text { fornalha infernal, de enxofre pálido. } \\
\text { Exprimir como a potência dos } \\
\text { cantos escuros de uma taberna. } \\
\text { Contudo sob uma aparência da } \\
\text { alegria japonesa e da boa natureza } \\
\text { de Tartarin. } \\
\text { Observei o uso simbólico da cor não } \\
\text { apenas com o uso de contraste } \\
\text { complementar, mas com o uso de } \\
\text { contraste de saturação dessas cores } \\
\text { complementares. Há uma ênfase na } \\
\text { descrição textual desses contrastes, e } \\
\text { uma ocorrência semântica da cor } \\
\text { nestas orações que é compatível com } \\
\text { a ocorrência na tela. Registrado na } \\
\text { nota de rodapé } 268 \text {. }\end{array}$ & $\begin{array}{l}\text { Uso de associações metafóricas, pois } \\
\text { na tela observei esse uso excessivo de } \\
\text { amarelo, e no extrato de carta } \\
\text { encontrei a expressão "fornalha" que } \\
\text { indexa o sentido do amarelo na tela, } \\
\text { registrado na nota de rodapé } 187 . \\
\text { Na minha pintura do café à noite eu } \\
\text { procurei exprimir que o café é um } \\
\text { lugar onde você pode arruinar-se, } \\
\text { enlouquecer, cometer crimes. } \\
\text { Observei a ocorrência do uso de } \\
\text { Enquadramento ao deslocar o sentido } \\
\text { principal para a oração Beta. Este } \\
\text { exemplo de enquadramento na oração } \\
\text { é compatível com o uso de ênfase no } \\
\text { segundo plano na composição visual. } \\
\text { Registrado na nota de rodapé } 263 .\end{array}$ \\
\hline $\begin{array}{l}\text { Na tela ‘O Café Noturno na } \\
\text { Place Lamartine, em Arles', } \\
\text { observei a ocorrência de } \\
\text { Contraste cromático de } \\
\text { Saturação e Inacabamento } \\
\text { na representação da } \\
\text { sombra da mesa de bilhar. } \\
\text { Registrada na nota de rodapé } \\
232 .\end{array}$ & $\begin{array}{l}\text { A sala está pintada de vermelho, e no } \\
\text { interior, na luz a gás, a mesa de } \\
\text { bilhar verde, a qual lança uma } \\
\text { imensa sombra sobre o chão. Nesta } \\
\text { tela, há } 6 \text { ou } 7 \text { vermelhos diferentes, } \\
\text { desde vermelho-sangue até rosa } \\
\text { delicado, fazendo oposição com o } \\
\text { mesmo número de verdes pálidos ou } \\
\text { escuros. }\end{array}$ & $\begin{array}{l}\text { Uso de contrastes cromáticos. Esta } \\
\text { ênfase no uso de contrastes cromáticos } \\
\text { está presente tanto na produção } \\
\text { pictórica, dada pelos contrastes } \\
\text { cromáticos da tela, quanto na oração } \\
\text { escrita, construída pela escolha lexical } \\
\text { de 'fazendo oposição'. Registrado na } \\
\text { nota de rodapé } 294 . \\
\text { Uso de Enquadramento e de } \\
\text { Perspectiva. Ao mudar o agente em } \\
\text { cada oração, ele faz um deslocamento } \\
\text { no enquadramento com que ele enfoca } \\
\text { o assunto que ele está descrevendo, a } \\
\text { representação da tela. Registrado na } \\
\text { nota de rodapé } 297 .\end{array}$ \\
\hline
\end{tabular}




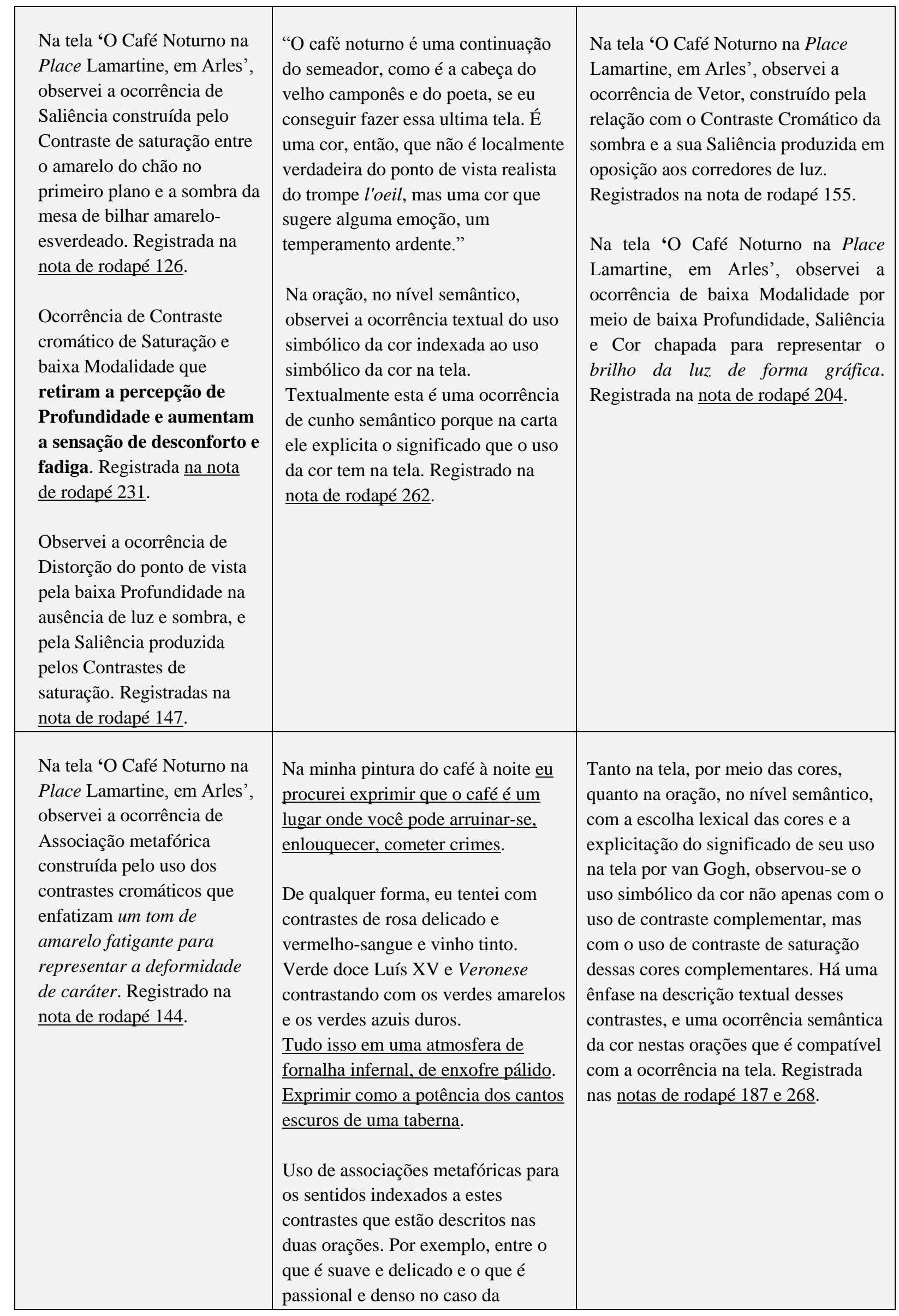




\begin{tabular}{|c|c|c|}
\hline & $\begin{array}{l}\text { primeira oração e entre o que é doce } \\
\text { e o que é duro, na segunda. } \\
\text { Registrada na nota de rodapé } 269 .\end{array}$ & \\
\hline $\begin{array}{l}\text { Na tela 'O Café Noturno na } \\
\text { Place Lamartine, em Arles', } \\
\text { observei a ocorrência de } \\
\text { Associação metafórica pelo } \\
\text { uso do Contraste Simultâneo } \\
\text { entre vermelhos e verdes } \\
\text { para construir uma metáfora } \\
\text { visual. Registrada na nota de } \\
\text { rodapé } 233 \text {. }\end{array}$ & $\begin{array}{l}\text { A ideia do semeador ainda continua } \\
\text { a me assombrar. Estudos exagerados, } \\
\text { como o semeador, como o café } \\
\text { noturno agora, geralmente parecem- } \\
\text { me atrozmente feios e ruins, mas } \\
\text { quando eu estou movido por alguma } \\
\text { coisa, como aqui por este pequeno } \\
\text { artigo sobre Dostoievski, em } \\
\text { seguida, eles são os únicos que me } \\
\text { parecem ter um significado mais } \\
\text { importante. }\end{array}$ & $\begin{array}{l}\text { Ao comparar o 'Café da Noite' com a } \\
\text { tela 'O Semeador', inferi que ele está } \\
\text { se referindo ao uso do contraste } \\
\text { simultâneo em ambas. A oração } \\
\text { 'quando eu estou movido por alguma } \\
\text { coisa, como aqui por este pequeno } \\
\text { artigo sobre Dostoievski,' denota que } \\
\text { ambas as telas possuem uma camada } \\
\text { de significação que não se encontra na } \\
\text { própria cena em si, mas em uma ideia, } \\
\text { externa à cena representada e que o } \\
\text { move a comunicá-la por meio de uma } \\
\text { metáfora cromática. }\end{array}$ \\
\hline
\end{tabular}

Fonte: Triangulação para Contrastes Cromáticos dos dados dos corpora visual e textual, com os extratos das cartas.

\subsection{GESTO PICTÓRICO}

Enquanto Cézanne e Gauguin procuraram dar unidade visual à tela pela estrutura das formas principalmente, van Gogh criou um sistema semiótico pictórico que gerou nesta pesquisa a necessidade de propor uma nova categoria de análise que vou chamar de gesto pictórico. No gesto pictórico ele articulou a estrutura, o sistema cromático e o pintar, ou seja, o modo como distribuiu as pinceladas na superfície da tela, imprimindo por meio de seu gesto pictórico, elementos como movimento, direção, ritmo, textura, grafia e cor, articulados para construir a unidade visual na composição da tela. Esta unidade era de tal modo amarrada que fazia todos os elementos se comunicarem na construção de uma harmonia, de uma coesão que é conhecida como marcante na obra de van Gogh. Por exemplo, foi observado o efeito de equilíbrio conferido pelo movimento e ritmo suaves das pinceladas nas telas "O semeador" e a "Esplanada do Café", enquanto na tela "Pôr do Sol" as pinceladas têm uma orientação angular e oblíqua, configurando sensação de abrasividade, tensão e desconforto visual. Nas telas "O semeador" e "Esplanada do Café" as orientações das pinceladas são retilíneas ou de curvatura arredondada, transmitindo assim maior conforto visual.

O gesto pictórico é uma categoria diferenciada da Rima Visual, ainda que ambas colaboram para criar a unidade e a harmonia visual, a gestalt da obra. O gesto pictórico se diferencia da Rima Visual porque, enquanto na Rima Visual qualquer elemento pode contribuir para construir a unidade e a harmonia, o gesto pictórico constitui uma marca 
estilística muito central no sistema semiótico de van Gogh e é construído pelo uso consistente de determinados recursos visuais. O gesto pictórico é proposto por essa pesquisa como uma categoria mais abrangente que reúne todas as características da pincelada de van Gogh.

De acordo com van Leeuwen (2011, p.4-8), sempre existiu uma dicotomia entre cor e forma, onde alguns artistas privilegiavam forma em detrimento da cor, e outros privilegiavam cor em detrimento da forma. O primeiro caso aconteceu com as escolas do Renascimento até o Neoclassicismo, com exceção de Delacroix e alguns pintores românticos; e o segundo caso ficou muito patente com o movimento impressionista que quebrou uma tradição das escolas que vinham mantendo a hegemonia da forma sobre a cor. Cèzanne e Gauguin apartaram-se dos impressionistas, privilegiando a forma e as estruturas. Diferente dos seus contemporâneos impressionistas, van Gogh buscou integrar a cor e a forma, usando ambas para alcançar um efeito de totalidade do texto visual, chamada também de gestalt. Esse efeito é descrito por Haziot (2010, p. 219) ao comentar a série Jardins do Poeta:

Outras obras-primas se sucedem nesse final de ano. Evocamos apenas as que
mostram uma etapa no desenvolvimento do artista. Todas respiram o silêncio, a
plenitude, uma intensa poesia, como a série dos "jardins do poeta", motivos
pintados na Place Lamartine. Esses quadros traduzem com certeza um equilíbrio
mental, pela estrutura poderosa do desenho, pelo equilíbrio das massas, pela
variedade e o domínio da pincelada, pelo fato de Vincent conter seus movimentos
para dar uma impressão de calma, não de movimento turbilhonante ou torrencial
partindo num único sentido. A pincelada é pouco exaltada ou interpretativa, mas
ligada à representação equilibrada do tema. (HAZIOT, 2010, p. 219)

Van Gogh conseguiu integrar a cor e a forma por meio de uma nova semiose que ele criou. Esta semiose não estava no que ele pintava, mas na forma como ele usava o pincel e como ele pintava. A forma como ele vivenciava o ato de pintar ele imprimia nas pinceladas, no gesto com que carregava e soltava o pincel que sugere uma analogia com o ato da fala.

Dessa forma, foi preciso nomear uma nova categoria pictórica para definir um conjunto de traços linguísticos que constituem uma semiose muito particular: o gesto pictórico. O gesto pictórico em Vincent van Gogh é uma das semioses mais importantes e consistentes em sua obra, porque ele se encarrega de:

a) imprimir uma constância rítmica que garante a unidade da imagem;

b) confirmar e fortalecer a direção das linhas e das formas que constituem o arcabouço da composição, e constituir as formas;

c) interligar as zonas de transição entre sombras e luz;

d) contrapor as zonas de contrastes, aguçando contrastes de cor enquanto confirmando continuidade nas formas, ou o contrário; 
e) construir o movimento direcional com o qual ele conduz o olhar e a atenção para as áreas que deseja enfatizar na composição;

f) produzir modulações e contrastes de tonalidade ou de saturação;

g) justapor cores puras para obter o efeito de mistura dessas cores na retina do espectador, produzindo uma profusão de efeitos colorísticos insuspeitos;

h) construir um arcabouço de falhas, lacunas e desvãos que produzem um efeito visual para o público de incompletude; i) deixar a sua caligrafia pictórica, a marca de sua presença na tela.

O gesto pictórico em van Gogh é uma semiose que se transformou em sua marca estilística, sua assinatura, sua poética, mas além de tudo isso, é uma inovação linguística e estética de alta genialidade ao resolver o dilema da contraposição entre forma versus cor, que acompanhava as gerações anteriores de artistas. O gesto pictórico de van Gogh dissolveu os limites entre estes dois domínios: cor e forma, integrando-os por meio da pincelada. Como? Integrando em uma única pincelada que carrega a cor e define a forma, em micro unidades que somadas definem a forma mais ampla e a cor mais ampla. Diferente dos pontilhistas, van Gogh ousa dar novos atributos para a técnica divisionista: outros usos à semiose da construção da cor por meio de pequenos pontos, estáticos e bem equilibrados em termos de contrastes cromáticos, que justapunham tons complementares exatos próximos uns aos outros. Van Gogh pega os pontos, que juntos constroem a leitura de cores, e os usa para descarregar pinceladas que não são estáticas; são linhas curtas, contidas, que, juntas, constroem a leitura de cores, direção, ritmo, textura, movimento e forma. Neste gesto pictórico ele dá conta não apenas de construir, confirmar, enfatizar as linhas das formas e seus contornos, mas também os volumes e a percepção de profundidade, de perspectiva, de densidade, de estrutura. Com o gesto pictórico ele faz a amarração da forma, construindo linhas direcionais das formas, ele também faz a amarração da composição, construindo caminhos visuais por onde transita o olhar pela obra, conduzindo o espectador pela sua narrativa visual. Com o gesto pictórico, ele colore a cena com as emoções, empurra o uso da cor para o seu limite e extrapola, explora o limite das possibilidades do uso dos contrastes complementares. Com o gesto pictórico, ele os potencializa desde a sua microestrutura de pinceladas curtas, ritmadas, contidas, densas, compactas, descarregadas com decisão, ele arma microbombas de contrastes cromáticos que explodem nos olhos do olhar desavisado. Essas pinceladas de contrastes complementares reciprocamente agudizados, construídas uma a uma, na rapidez de um gesto ininterrupto que marca o movimento, a energia, o afã, o entusiasmo, a emoção com que possivelmente esse pintor os realizou. Essas pinceladas são o gesto que o inscrevem na obra e testemunham sua 
passagem indelével na execução da imagem, revelando a sua presença, a sua existência, e compartilham a sua experiência mais íntima e confidencial impressa na visualidade produzida pela intensidade das suas pinceladas. Ao seu modo ele solucionou uma dualidade que até os impressionistas dividia fortemente a nossa civilização ocidental, na dicotomia entre cor e forma, sentimento e razão na forma da representação. Van Leeuwen (2011, p. 4-5) relata as bases dessa dicotomia no pensamento ocidental:

Por alguns 2,500 anos os filósofos ocidentais têm lutado com o assunto, muitas vezes vendo a cor como altamente subjetiva e como "excessiva", necessitando de contenção e submissão a uma ordem racional. A cor sempre foi, e ainda é, um tema que evoca sentimentos fortes. Plínio, que viveu no primeiro século $\mathrm{dC}$, criticou a cor abundante e a 'pintura floreada'. O grande pintor grego Apeles, ele disse, usou apenas quatro cores austeras, comedidas, um negro chamado 'atramentum', um branco de Milos, amarelo Attic e um vermelho de Sinope, no Mar Negro. Esta ênfase nas virtudes morais de um número limitado de cores 'puras' ou 'primárias', ordenadas em termos de algum esquema racional, corre como um fio através da teoria da cor, desde os seus primeiros dias.

A relação entre a cor e a forma marca a história da pintura como uma equação que determina o estilo de cada pintor e de cada época, como explica van Leeuwen ( 2011, p. 4-5):

\begin{abstract}
Artistas e pensadores renascentistas redescobriram e traduziram estes escritos antigos, e iniciaram o longo debate entre disegno e colore. Pintores florentinos, como da Vinci e Michelangelo viram o design como o aspecto essencial da obra de arte, o meio em que obras de arte são concebidas, portanto, uma criação da mente. A cor, eles viam como secundária, na melhor das hipóteses avivando o trabalho, e apelando aos sentidos, ao invés da mente. Chiaroscuro, o jogo sutil de luz e sombra, ganhou precedência sobre a cor. Como Alberti escreveu em seu tratado sobre a pintura em 1435, branco e preto são 'as cores com as quais nós expressamos luz e sombra', enquanto outras cores são apenas 'uma questão de que variações de luz e sombra podem ser aplicadas' (citado em Gage, 1995: 118). Leonardo da Vinci, também, preferia luz e sombra, evitando a cor abundante, e concentrando-se em criar uma ilusão de realidade, ao invés de usar a cor para expressar significados simbólicos ou deleitar-se com as belezas de cores brilhantes, como havia sido comum na Idade Média, quando cores denotavam virtudes teológicas, personagens da Bíblia ou as fileiras dos nobres, e também foram altamente apreciados pela sua beleza intrínseca.
\end{abstract}

Enquanto algumas escolas privilegiaram a forma na composição valorizando o intelecto e outras, a cor enfatizando a emocionalidade, van Gogh integrou a cor e a forma valorizando ambas na mesma medida. Essa integração que chamei de gesto pictórico constrói a coesão e a gestalt nas telas de van Gogh.

\title{
6.10.1 Divisionismo ou Pontilhismo nas pinceladas
}

Van Gogh incorporou a técnica e as semioses inventadas por Seurat, que aplicava os pontos na tela com tinta pura para produzirem colorações pelos efeitos de sua proximidade 
entre si, mas dando um movimento para os pontos que em Seurat eram mais estáticos e comedidos, como registra uma carta de van Gogh relatada por Coli (2006, p. 41-42):

Servi-me do divisionismo, que meu amigo Seurat inventara e praticava, mas de um divisionismo meu. As pinceladas separadas me seduziam muito, porque elas acentuavam a materialidade das cores, que podem ser modeladas, por assim dizer, na matéria de que são feitas. Seurat quer que as pinceladas, isoladas, vibrem num conjunto, e que se irmanem nessa vibração. Eu gosto de senti-las individualmente, bem marcadas no seu trajeto. E gosto de dirigir esse trajeto. Nos quadros de Seurat as pinceladas são imóveis. Vejam, ao contrário, como as minhas partem das arestas do nariz, cobrindo o rosto, escorrendo pela barba; como o meu olho direito é o centro de curvas que substituem as sombras; como sobem paralelas, as pinceladas claras pelo chapéu, como descem as azuis pelo paletó. E como, para assinalar a eternidade do meu espírito, substituí a auréola dos santos por esse fundo feito de traços azuis concêntricos, cravejados de pontos vermelhos - pontos que empreguei também para colorir minha barba. Nada ficou ao acaso e eu quis que todos esses ritmos tivessem um centro: meus olhos - não mais carvões extintos.

Com base nas técnicas de seus amigos Pissaro, Signac e Seurat, van Gogh deu vários usos pictóricos para as pincelas tornando-as um recurso central na criação de um sistema semiótico. Os usos que van Gogh deu para suas pinceladas são descritos a seguir:

\subsubsection{Pinceladas Contidas}

As pinceladas curtas, contidas, como uma bomba de energia prestes a explodir são uma das marcas do gesto pictórico de van Gogh. Essa característica é comentada por Haziot (2010, p. 217-218):

O quadro de Vincent utiliza o mesmo efeito que o do retrato de Boch. A casa é iluminada como em pleno meio-dia, num amarelo intenso, mas o céu é de um azul cobalto tão profundo que faz pensar mais num céu noturno. Observa-se, sobretudo, que o céu é pintado com grossas pinceladas cruzadas, como na parede branca atrás do retrado do zuavo. Nessas obras, Vincent não deixa o pincel correr para nos arrastar num turbilhão; temos a impressão de que ele quer impedir esse movimento, interrompendo cada pincelada por sua perpendicular. É como se quisesse parar o tempo, o da felicidade de viver, na pequena casa que arrumou e que sonha ser o ateliê onde se reunirão os pintores do futuro. (HAZIOT, 2010, p. 217-218)

Como destaca Haziot (2010, p. 218), as pinceladas são curtas, estancadas, não criam uma superfície homogênea, fluida, mas são mais como o estacato na música, sincopadas e intensas. São caracterizadas pelo 'ataque' na forma e tocar o pincel a tela com o pincel equilibrava energia, intensidade e contimento e essa energia nos transmite uma percepção visual tátil que é também sinestésica:

Pinta então o famoso quadro A Casa Amarela no Place Lamartine. Pinta-a como para se apropriar dela. (...) O quadro de Vincent utiliza o mesmo efeito que o do retrato de Boch. A casa é iluminada como em pleno meio-dia, num amarelo intenso, mas o céu é de um azul cobalto tão profundo que faz pensar mais num céu noturno. Observa-se, sobretudo que o céu é pintado com grossas pinceladas cruzadas, como 
na parede branca atrás do retrado do zuavo. Nessas obras, Vincent não deixa o pincel correr para nos arrastar num turbilhão; temos a impressão de que ele quer impedir esse movimento, interrompendo cada pincelada por sua perpendicular. É como se quisesse para o tempo, o da felicidade de viver, na pequena casa que arrumou e que sonha ser o ateliê onde se reunirão os pintores do futuro.

\subsubsection{Caligrafia pictórica}

Van Gogh constrói uma caligrafia pessoal percebida como modo de sua linguagem visual, a partir do sentido, ritmo, direção, constância, movimento e energia com que descarrega a tinta na tela. $\mathrm{O}$ efeito produzido pelo modo como usa o pincel para pintar, constrói uma marca caligráfica inconfundível de sua autoria e que compõe um dos elementos mais centrais na constituição de sua poética visual. Que usos van Gogh deu para os recursos disponíveis na linguagem pictórica que podem ser compreendidos como modos linguísticos característicos de sua 'caligrafia pictórica'?

O leitor se lembra de suas preocupações quando o desenho em Haia, essa busca quase primitiva do traço como gesto, dirigindo-se a técnicas sempre mais arcaicas e que chegam a utilizar os dedos para espalhar a tinta na tela. Mauve reprovava-lhe isso vivamente, e Vincent, claro, rebelava-se: se o efeito buscado era obtido, que importância tinha usar os dedos ou um instrumento qualquer? Posteriormente, ele pesquisou com mais consciência para dar a seu desenho o automatismo da escrita, o que começou a transpor para o pincel em algumas das ultimas obras em Nuenen. Essa pesquisa é o nervo da arte de Vincent: fundir escrita, grafismo, pincelada de cor. (HAZIOT, 2010, p 168)

Muitos já se depararam com um quadro de Van Gogh e se perguntaram se a força expressiva de suas pinceladas foi resultado de uma ação intuitiva ou a produção calculada a partir do domínio de técnicas de pintura associadas à capacidade de expressão de um pensamento pictórico. O modo de van Gogh de usar o pincel tornou-se um estilo inconfundível, sua própria caligrafia pictórica, mas, sobretudo, tornou-se o modo como van Gogh organizou um sistema semiótico para comunicar o incomunicável. Haziot (2010, p. 197) comenta acerca de sua pincelada:

Quando as árvores frutíferas se puseram a florir por ondas sucessivas conforme as espécies, Vincent, animado pelas telas de pontes levadiças tão bem-vindas, lançouse ao trabalho. Amendoeiras, ameixeiras, pessegueiros, abricoteiros foram pintados sob um céu azul e um vento forte, numa exaltação crescente. Desde o início ele encontrou o estilo próprio e almejado havia tanto tempo, o desenho feito a golpes de pincel nervosos, precisos e sobretudo descontínuos. Não cessará de aperfeiçoar esse estilo que pertence somente a ele, mas que já está presente nos "estudos" de pomares. 


\subsubsection{Pinceladas - caligrafia pictórica}

Para construir um sistema semiótico no modo de usar o pincel, van Gogh associou o movimento e o ritmo do ataque do pincel com a técnica de colocação de cores justapostas que aprendeu com os impressionistas e com Seurat, adaptando-a para uma finalidade semiótica diversa, como discorre Gombrich (1995, p. 547):

De fato, Van Gogh também absorvera as lições do impressionismo e do pontilhismo de Seurat. Gostava da técnica de pintar em pontos e pinceladas de cor pura, mas nas suas mãos tal técnica tornou-se algo diferente em relação ao que os artistas de Paris pretendiam realizar com ela. Van Gogh usou cada pincelada não só para dispersar a cor, mas também para externar a sua própria excitação. Em uma das cartas de Arles, descreve o seu estado de inspiração, quando_as emoções são, às vezes, tão fortes que trabalho sem ter consciência de estar trabalhando... e as pinceladas acodem com uma sequência e coerência idênticas às de palavras numa fala ou numa carta". A comparação não podia ser mais clara. Em tais momentos, Van Gogh pintava como outros homens escrevem. Assim como o aspecto de uma página manuscrita, os traços deixados pela pena sobre a folha de papel revela algo dos gestos de quem escreve, de modo que sentimos instintivamente quando uma carta foi escrita sob grande tensão emocional - também as pinceladas de Van Gogh nos dizem algo a respeito do seu estado mental. Antes dele, nunca um artista usara esse meio com tanta consciência e efeito. Recordemos que existe um trabalho solto e audacioso de pincel em obras anteriores, nas pinturas de Tintoretto (p.370, Fig. 237), Hals (p.417, Fig. 270) e Manet (p.518, Fig. 337); mas, em todos estes, isso reflete a mestria soberana do artista, sua rápida percepção e capacidade mágica para evocar uma visão. Em Van Gogh, porém, ajuda a comunicar a exaltação mental do artista. Ele gostava de pintar objetos e cenas que propiciassem plena amplitude a esse novo meio - motivos que tanto podia desenhar como pintar com o seu pincel, usando a cor espessa, tal como um escritor que sublinha suas palavras. Por isso ele foi o primeiro pintor a descobrir a beleza do restolho, das cercas vivas e dos trigais, dos galhos descarnados das oliveiras e das formas escuras dos ciprestes, esguios e pontiagudos como labaredas (Fig. 355).

\subsubsection{Escrita-desenho: Desenhar como se escreve}

O desenho tem sua presença junto às pinceladas, lá se inscrevem os traços e as pinceladas são também usadas como linhas direcionais, de contorno, como linhas de desenho, e o modo de usar o pincel se assemelha ao modo de desenhar um esboço para registrar uma ideia. Haziot (2010, p. 200-201) discorre acerca desse uso:

Vincent fez então uma pausa em pintura para se dedicar ao desenho. Livre da necessidade de calcular a todo momento as relações de tons enquanto pinta, Vincent buscará aperfeiçoar o meio de captar a verdade do motivo por traços descontínuos, cerrados ou soltos, conforme os valores. Quer progredir ainda mais na direção daquela escrita-desenho que busca há muito tempo e cujas descobertas aplicará a seguir nos seus quadros que serão no final uma escrita-pintura, como se pode ver no detalhe de um quadro célebre como $O$ campo de trigo com corvos. Nas margens do Ródano, ele encontra caniços bem melhores do que em Haia, onde havia experimentado essa técnica: corta-os e trabalha com esse instrumento primitivo. Os resultados são impressionantes. Vincent consegue agora expressar por esse meio a circulação das forças ou das ondas plásticas irradiadas por uma paisagem. Seu olho percebe as vertigens do lugar e as exprime a uma velocidade louca, com traços de 
caniço nervosos, de uma precisão instintiva e absoluta. É talvez aí que ele mais se aproxima da arte japonesa. (...) "Busco agora exagerar o essencial e deixar propositalmente vago o banal" escreve. (C490) E acrescenta: "As coisas daqui têm tanto estilo. E quero chegar a um desenho mais voluntário, mais exagerado." (C495) percebe-se por aí de que modo as conquistas do desenho serão a seguir transpostas na pintura, que continuará a crescer em simplicidade selvagem e em vibração da pincelada.

Haziot (2010, p. 168) elucida o papel do desenho nesse novo modo semiótico da pincelada que van Gogh estava desenvolvendo:

Na arte japonesa ele reencontrava a ideia - menos conscientemente buscada, talvez,
ainda que isso seja discutível - do desenho no cruzamento da representação e da
escrita ideográfica, uma espécie de "desenho-escritura". A arte japonesa, originada
do zen, era obcecada pelo traço como gesto quase instintivo e altamente meditado ao
mesmo tempo. Conhecemos as tigelas de chá modeladas em alguns gestos, ainda no
ponto de formação-deformação, e decoradas com alguns traços fulgurantes como
que expelidos por um pincel ta espontâneo quanto engenhoso. Estamos aqui a anos-
luz da arte apolínea da maravilhosa cerâmica Song chinesa. Essa arte japonesa da
cerâmica, dionisíaca, tem mais relação com a irrupção do que com elaboração.
Vincent chegou a vê-la num museu? Não é impossível. O museu Guimet das artes
asiáticas só abriu suas portas em 1889 em Paris, mas existia um departamento
China-Japão no Louvre, falava-se muito das artes asiáticas, e um museu indochinês
fora inaugurado, em 1882, no Trocadéro.

A caligrafia pictórica com que van Gogh se incrivia na tela são o resultado não apenas e uma técnica adaptada mas de um pensamento discursivo que o instava a precipitar sua energia criadora em gesto e livre como um automatismo caligráfico.

\subsubsection{Automatismo na Pincelada}

A escrita automática é um conceito da psicologia no qual o sujeito escreve sem opor a essa ação o crivo racional de seu julgamento e escolhas. Dessa ação, de livre escrita, resulta uma fluidez de pensamentos escritos que servem para acessar uma ordem discursiva mais livre, mais espontânea, menos regulada ou normatizada. O movimento Dadaísta viria a usar a escrita automática como ferramenta de trabalho no processo criativo e nas pesquisas de linguagem. Essa tese defende que van Gogh criou em sua pincelada um tipo de 'escrita automática' por características que argumento a seguir:

A escrita automática é uma instância enunciativa implícita, e ela muda ao longo da obra à medida que os sentidos que ela comunica também mudam. Por exemplo: as pincelas da Holanda são diferentes das de Arles, que são diferentes de Auvers-sur-Oise e a cada processo que van Gogh vive, elas vão se transformando. As pinceladas são o elemento que mais confere unidade para a tela, e comunicam sentidos implícitos aos sentidos que estão 
explicitados. Ali estão comunicados aspectos mais latentes de sua experiência. Van Gogh cria um estilo retórico em seu discurso visual, a escrita automática. O automatismo na pintura com suas pinceladas comandadas por um trabalho ritmado, fluido e arrebatado que produz a percepção de movimento, revela sentidos que estão subjacentes aos temas representados. Como uma marca estilística de sua poética empresta à tela, em articulação com outros elementos linguísticos, uma percepção de pulsação e vibração que pode ser associada com sentidos de energia, liberdade e fusão com a natureza. Estes sentidos mais subjetivos evidenciados por nossa análise sugerem uma construção de sentidos ocultos não explicitados pelos elementos linguísticos mais evidentes, mas pelo jogo de um efeito de sentidos. A "escrita automática com o pincel" confere unidade e organicidade ao texto, por meio do ritmo, da textura, do movimento. A imprevisibilidade do movimento com que se produz esse grafismo pictórico parece abrir um canal direto de comunicação de sentidos mais imprecisos e latentes que se alojam logo abaixo dos sentidos mais evidentes que o texto visual produz. Defendo que possa haver uma similaridade de finalidade entre o automatismo nas pinceladas de van Gogh com a escrita automática de Sigmund Freud, uma vez que o automatismo plástico na linguagem criada por van Gogh sugere uma via para se expressar livremente os conteúdos subjetivos que não estão manifestados e que se encontram no limiar criativo. Assim como a "escrita automática", o automatismo das pinceladas de van Gogh, funcionam como uma maquinaria que liberta sentidos implícitos através de um empapamento de sensações, um empastamento de texturas, um adensamento de significados que permitem a manifestação de conteúdos dissolvidos e velados no discurso verbal. Acredito que a linguagem visual foi apropriada e aprimorada como um território de língua franca, um território potencialmente rico para a expressão integradora dos conflitos, fantasmas, questões, impasses, impossibilidades vivenciadas e silenciadas por van Gogh. Esse automatismo em suas pinceladas, cruas, bruscas, inacabadas, guiadas por um movimento indômito, pode ser compreendido como sua caligrafia pessoal, sua assinatura indubitável. A escrita automática em pintura criada por van Gogh marca sua relação com a vida, com a expressão, com a aventura da linguagem em sua natureza mais faiscante e revoluciona a linguagem pictórica.

A fluidez com que van Gogh pinta suas telas é comentada por Haziot (2010, p. 116117):

Vincent teria gostado de ser o Wagner da pintura. Wagner situou-se no cruzamento entre o falado e o cantado (Sprechgesang). Vincent abre o caminho, no interior de uma estética aparentemente muito tradicional, que se situava entre o grafismo e a pintura. Seu gesto é o do traço primitivo e quase instintivo sobre uma parede. Podese mesmo dizer que ele "escrevia" seus quadros a partir de 1888 , e sempre mais rápido com o passar do tempo. Isso dá à sua pintura aquela vibração única que faz 
de uma paisagem uma espécie de bacanal do traço, e também explica a rapidez de criação dessas telas geniais, feitas em poucas horas. Vincent foi aos poucos se tornando capaz de soltar as rédeas a todos os automatismos da escrita gráfica, mas em cores, fazendo como que a síntese dos três homens que existiam nele: o escritor epistolar, o desenhista, o pintor.

Nos interstícios das falhas e lacunas deixadas pelo trajeto desse automatismo pictórico se alojam sentidos apenas sugeridos e que nos convidam a construir seu significado, muitos deles fugidios, do domínio do sentimento. Haziot (2010, p. 199) discorre a esse respeito:

\footnotetext{
"Não é a emoção, a sinceridade do sentimento da natureza que nos impele? E se essas emoções são às vezes tão fortes que trabalhamos sem sentir que trabalhamos, quando as pinceladas vêm às vezes com uma sequencia e relações entre si como as palavras num discurso ou numa carta, cabe então lembrar que nem sempre foi assim e que no futuro também haverá dias pesados sem inspiração." C504 (HAZIOT, 2010, p.199) (...) "As pinceladas vêm como as palavras...”, obsessão de pintar ou desenhar como se escreve, com o mesmo automatismo tão buscado pelos surrealistas. Aí está o formidável avanço de Vincent na história da arte. Mas ele nunca viu nisso senão um meio, um desejo, não uma revolução que liberava a mão do pintor para exprimir a emoção, a sensação, no instante mesmo em que surgiam no corpo em efervescência.
}

\subsubsection{Triangulação do Gesto Pictórico}

\section{Gesto Pictórico, no texto escrito e em relação à triangulação - O gesto pictórico} nos remete ao ritmo, movimento, direção, textura, uso da cor e rima visual que são resultantes dele. Nas orações, é possível observarmos algumas dessas ocorrências, que descrevo a seguir:

a) observei as características de ritmo, movimento, direção, textura na esperança de identificar um gesto pictórico também na experiência da produção do discurso textual. Agrupo várias subcategorias referentes às pinceladas que estão diretamente relacionadas com o gesto pictórico;

b) busquei também a ocorrência do gesto pictórico no texto pela tentativa de integrar aspectos de conteúdo e forma a fim de criar uma coesão interna entre a estrutura semântica e a estrutura léxico-gramatical.

c) talvez essa relação do gesto pictórico esteja na intensidade com que ele escrevia diariamente, como um influxo de energia vital, de palavras que brotavam, borbulhavam, emergiam nesse movimento contínuo de produção textual do qual ele necessitava e que fazia parte de sua produção cotidiana.

d) nas associações livres e na acuidade no momento de construir a significação por sua preocupação em transmitir para Theo exatamente como ele está experienciando, mas ao mesmo tempo a carta é construída com fluidez em uma associação livre, é muito íntima e também deixa à vista suas marcas mais íntimas. 
e) as marcas que deixa na carta, como grifos, palavras riscadas, rabiscos, escorregar da tinta, e marcas de pontuação. São observados os movimentos da escrita que resultam em uma relação física e mecânica do encontro da pena com o papel. Esses movimentos incluem a inclinação da letra, o ritmo da grafia, a intensidade das marcas da escrita no papel, a grossura das linhas e o tamanho das letras, a forma como ocupa o espaço da página, e a fluência com que discorre, construindo movimento, ritmo, velocidade e direção de ideias por meio das associações que ele faz ao longo do texto.

O processo de produção das cartas e de construção das orações revela uma busca de van Gogh para integrar experiências e sentimentos opostos. Ele sempre buscou viver aquilo que ele acreditava; para ele não fazia sentido acreditar em uma coisa e viver outra. Então o ideal humanitário dele de fraternidade estava presente no processo do fazer da obra de arte dele. A honestidade que ele tinha durante esse processo de produção aparece por meio das cartas no momento em que van Gogh explicita seus valores, suas motivações, suas intencionalidades sem esconder ou negar características humanas que ele sempre carregou de sentimentos muito fortes e muito intensos. Essa disponibilidade e esta honestidade para revelar suas emoções e experiências são uma importante circunstância para que a sua escrita seja, assim como a sua pintura, uma instância de expressão plena e genuína.

A carta revela um esforço de integração, nas orações muitas vezes ele coloca elementos opostos em um esforço dessa integração, por exemplo, quando ele diz que ele gritou com o dono do quarto que ele estava alugando. Ele revela, de forma muito real na escrita, a frustração, a exclusão, a injustiça. Ele fala que por causa desse sentimento ele gritou com o dono. Em seguida ele então escreve que o dono não é especialmente ruim e com esse construto van Gogh mostra que não suporta a expressão dicotomizada em um discurso. Ele sempre busca expressar uma totalidade, ele procura expressar nas orações uma complexidade inerente à experiência humana. Por isso essa escrita, que parece uma escrita rudimentar, mais livre, que vai associando partes, ao mesmo tempo em que parece que são pedaços, eles revelam um todo complexo. O que ela consegue revelar nessas partes concatenadas é um todo muito complexo e muito real. Cada vez mais se percebe que as cartas de van Gogh tem um valor de obra literária porque elas têm uma riqueza de forma e de conteúdo, elas têm uma profundidade que só foi possível expressar porque ele criou recursos de linguagem que são tão criativos e intensos quanto foi a vida e a produção artística dele. 
Quadro 26: Gesto Pictórico

\begin{tabular}{|c|c|c|}
\hline Ocorrência nas telas & Orações & Comentário \\
\hline $\begin{array}{l}\text { Na tela 'Por de Sol: Campo } \\
\text { de trigo perto de Arles', } \\
\text { observei a ocorrência de } \\
\text { pinceladas direcionais, } \\
\text { ritmadas para representar o } \\
\text { vento ventando no trigal por } \\
\text { meio da combinação do uso } \\
\text { do ritmo, contraste cromático } \\
\text { de saturação, movimento } \\
\text { direcional, para construir a } \\
\text { rima visual. Registradas nas } \\
\text { notas de rodapé } 71,72 \text { e } 73 \\
\text { no apêndice. } \\
\text { Ocorrência de Gesto } \\
\text { pictórico e ritmo, observada } \\
\text { pelo modo como ele distribui } \\
\text { as pinceladas, com repetições } \\
\text { regulares e irregulares para } \\
\text { representar o campo de trigo, } \\
\text { também observada nas notas } \\
\text { de rodapé } 78 \text { e } 81 \text { no } \\
\text { apêndice. }\end{array}$ & $\begin{array}{l}\text { Paisagens amarelo ouro velho - feito } \\
\text { rápido rápido rápido e com pressa, } \\
\text { como o ceifeiro que está em silêncio } \\
\text { sob o sol escaldante, concentrando-se } \\
\text { em ter o trabalho terminado. } \\
\text { Observei que van Gogh escreve do } \\
\text { mesmo modo como pinta, ou para, } \\
\text { desse modo, expressar como é a } \\
\text { pintura, ou porque ao escrever sobre } \\
\text { como pintou, ele está de fato } \\
\text { vivenciando a experiência dessa ação } \\
\text { e a escrita reflete isso. }\end{array}$ & $\begin{array}{l}\text { O autor associou os elementos de } \\
\text { textura, cor, tom, para dar ritmo em } \\
\text { sua composição, ao usar pinceladas } \\
\text { para produzir diferentes contrastes de } \\
\text { cores e formas dando a impressão } \\
\text { que, apesar de todo movimento, há } \\
\text { uma constância garantida pela cor do } \\
\text { sol. Ele está lá constantemente } \\
\text { iluminando tudo, sendo que o } \\
\text { elemento de inconstância é o vento } \\
\text { que muda a tonalidade da cor no } \\
\text { campo de trigo. Existem alguns } \\
\text { elementos de constância e alguns } \\
\text { elementos de inconstância. Alguns } \\
\text { de homogeniedade e alguns de } \\
\text { diferenciação. Essas estratégias de } \\
\text { composição é que dão uma dinâmica } \\
\text { particular à essa tela. Essa rica } \\
\text { tessitura de homogeniedade e } \\
\text { diferenciação ele cria por meio do } \\
\text { movimento que ele imprime as } \\
\text { pinceladas que nesta pesquisa vou } \\
\text { chamar de gesto pictórico registrada } \\
\text { na nota de rodapé } 70 \text { no apêndice. }\end{array}$ \\
\hline $\begin{array}{l}\text { A tela 'Por de Sol: Campo de } \\
\text { trigo perto de Arles' parece } \\
\text { sugerir um conflito presente } \\
\text { na forma como os elementos } \\
\text { que deveriam se relacionar de } \\
\text { maneira harmônica estão em } \\
\text { todo momento se } \\
\text { contrastando. Seja pela } \\
\text { diferença de direções do trigo } \\
\text { no campo, pela diferença de } \\
\text { cores do trigo, pela diferença } \\
\text { de espaçamento que as } \\
\text { pinceladas ora criam um } \\
\text { conjunto homogêneo e } \\
\text { indiferenciado, ora ressaltam } \\
\text { a individualidade de cada } \\
\text { ramo de trigo. }\end{array}$ & $\begin{array}{l}\text { Aqui está outra paisagem. Sol } \\
\text { poente? Lua nascendo? Noite de } \\
\text { verão, de qualquer modo. Cidade } \\
\text { violeta, estrela amarela, céu azul- } \\
\text { esverdeado; os campos de trigo têm } \\
\text { todos os tons: ouro velho, cobre, } \\
\text { ouro verde, ouro vermelho, ouro } \\
\text { amarelo, verde, vermelho e amarelo } \\
\text { bronze. Tela quadrada número } 30 . \\
\text { Ocorrência de Saliência, que ajudam } \\
\text { a construir uma materialidade } \\
\text { compatível com a ocorrência de } \\
\text { Gesto Pictórico e de Rima Visual na } \\
\text { sequência das três orações, } \\
\text { registrados na nota de rodapé } 114 \text { no } \\
\text { apêndice. }\end{array}$ & $\begin{array}{l}\text { Essa produção de homogeneidade e } \\
\text { diferenciação na forma como ele } \\
\text { agrupa os elementos representados } \\
\text { na composição pode ser uma } \\
\text { estratégia de acentuação de } \\
\text { sensações visuais que produzem } \\
\text { Textura, Movimento, Vetor e Gesto } \\
\text { Pictórico, e conduzem à sinestesia e } \\
\text { à Modalidade sensorial está } \\
\text { registrada nas notas de rodapé } 68,69, \\
\underline{70 \text { e } 71 \text { no apêndice. }}\end{array}$ \\
\hline $\begin{array}{l}\text { Na tela 'Por de Sol: Campo } \\
\text { de trigo perto de Arles', } \\
\text { observei a ocorrência do } \\
\text { Gesto Pictórico na forma da } \\
\text { integração de recursos } \\
\text { gráficos com a plasticidade } \\
\text { do pincel para construir o } \\
\text { campo de trigo, registrado na } \\
\underline{\text { nota de rodapé } 61 \text { no }} \\
\underline{\text { apêndice. }}\end{array}$ & $\begin{array}{l}\text { Cidade violeta, estrela amarela, céu } \\
\text { azul-esverdeado; os campos de trigo } \\
\text { têm todos os tons: ouro velho, cobre, } \\
\text { ouro verde, ouro vermelho, ouro } \\
\text { amarelo, verde, vermelho e amarelo } \\
\underline{\text { bronze. }}\end{array}$ & $\begin{array}{l}\text { Em sua fisicalidade, o Gesto } \\
\text { pictórico integra, visualmente, vários } \\
\text { recursos semióticos como ritmo, } \\
\text { textura, movimento, vetor. Na escrita } \\
\text { observei uma fisicalidade também } \\
\text { nas vírgulas, no ritmo e no } \\
\text { encadeamento da escolha lexical das } \\
\text { cores. Cada palavra é como se fosse } \\
\text { uma pincelada de uma dessas cores } \\
\text { sobre o papel, reproduzindo a ação } \\
\text { do pincel para aproximar o leitor da }\end{array}$ \\
\hline
\end{tabular}




\begin{tabular}{|c|c|c|}
\hline $\begin{array}{l}\text { Observei que ele misturava as } \\
\text { cores direto na tela, aplicando } \\
\text { cores puras sobrepostas ao } \\
\text { modo dos pontilhistas, mas } \\
\text { com um movimento de } \\
\text { pinceladas ritmado e } \\
\text { dinâmico. Ele também estava } \\
\text { usando o pincel graficamente, } \\
\text { como se estivesse } \\
\text { desenhando e criando efeitos } \\
\text { como esfuminho no céu e } \\
\text { rachuras no trigal, registrado } \\
\text { na nota de rodapé } 58 \text { no } \\
\text { apêndice. }\end{array}$ & & $\begin{array}{l}\text { carta ao lugar de observador da tela } \\
\text { sem que esse tenha acesso à pintura. }\end{array}$ \\
\hline $\begin{array}{l}\text { Na tela 'O Semeador' } \\
\text { observei a ocorrência de } \\
\text { Ritmo, Textura, Direção e } \\
\text { Movimento construídos pelo } \\
\text { Gesto Pictórico de van Gogh } \\
\text { para representar } \text { o campo } \\
\text { arado, registrados na nota de } \\
\text { rodapé } 47 . \\
\\
\text { Observei a ocorrência do uso } \\
\text { conjugado de Textura, ritmo, } \\
\text { movimento, direção, gesto } \\
\text { pictórico e saliência na } \\
\text { representação dos torrões de } \\
\text { terra revolvida no campo } \\
\text { arado. Registrado na nota de } \\
\text { rodapé } 49 . \\
\\
\text { Na tela 'O Semeador', há } \\
\text { uma inter-relação entre } \\
\text { Textura, Contrastes } \\
\text { Simultâneos, Saliência, } \\
\text { Sinestesia que criam } \\
\text { Associações Metafóricas da } \\
\text { materialidade da tinta com a } \\
\text { nossa memória sensorial e } \\
\text { tátil da plasticidade da terra, } \\
\text { registrado na nota de rodapé } \\
\text { 50. }\end{array}$ & $\begin{array}{l}\text { Há várias sugestões de amarelo no } \\
\text { solo, tons neutros resultantes da } \\
\text { mistura de violeta e amarelo; mas } \\
\text { tenho travado uma luta diabólica para } \\
\text { atingir a verdade das cores. }\end{array}$ & $\begin{array}{l}\text { O momento da produção da tela } \\
\text { criou uma tensão para reprodução } \\
\text { das cores, em sua textura e na } \\
\text { materialidade dos torrões de terra. } \\
\text { Essa tensão que ele relata como uma } \\
\text { luta diabólica fica marcada no } \\
\text { movimento da produção da tela. A } \\
\text { luta é dele com a cor, mas o } \\
\text { resultado da tela parece que a luta se } \\
\text { dá na terra. Ela está pulsando, ela } \\
\text { está em movimento. Há uma tensão } \\
\text { dentro dele, um movimento que ele } \\
\text { buscava e que ficou representado na } \\
\text { tela. O gesto nasce nesse movimento } \\
\text { interno, que vai para o ato de pintar, } \\
\text { que vai para a tela, e que vai para a } \\
\text { oração. }\end{array}$ \\
\hline $\begin{array}{l}\text { Na tela 'O Semeador', } \\
\text { observei a ocorrência de } \\
\text { Movimento, Gesto Pictórico } \\
\text { e Vetor 1, sugerido pelo } \\
\text { andar do Semeador, } \\
\text { registrado na nota de rodapé } \\
\text { 52. }\end{array}$ & $\begin{array}{l}\text { Em um campo arado, um grande } \\
\text { campo de torrões de terra roxa - } \\
\text { levantados em direção ao horizonte - } \\
\text { um semeador em azul e branco. }\end{array}$ & $\begin{array}{l}\text { Nessa oração, a ênfase é dada ao } \\
\text { campo arado, pelo uso de complexos } \\
\text { nominais, e atributos usados com a } \\
\text { mão farta, enquanto o semeador } \\
\text { aparece nesse cenário amplamente } \\
\text { narrado. }\end{array}$ \\
\hline $\begin{array}{l}\text { Na tela 'O Semeador', } \\
\text { observei a ocorrência de } \\
\text { Movimento, Gesto Pictórico, } \\
\text { Vetor 2, Rima Visual e }\end{array}$ & $\begin{array}{l}\text { O céu, amarelo-crômio, quase tão } \\
\text { luminoso quanto o próprio Sol, que é } \\
\text { amarelo-crômio } n^{\circ} 1, \text { misturado com } \\
\text { um pouco de branco, enquanto o }\end{array}$ & $\begin{array}{l}\text { A textura na oração não é construída } \\
\text { pela escolha lexical da palavra } \\
\text { 'amarelo' em si, mas pelo } \\
\text { encadeamento de amarelos no uso da }\end{array}$ \\
\hline
\end{tabular}




\begin{tabular}{|c|c|c|}
\hline $\begin{array}{l}\text { Incompletude, sugerido pelos } \\
\text { raios do sol em toda a } \\
\text { pintura, registrado na nota de } \\
\text { rodapé } 53 . \\
\text { Observei também a } \\
\text { ocorrência de Saliência e } \\
\text { Associação Metafórica para } \\
\text { o céu e o sol, construída pelo } \\
\text { uso de ritmo, textura, } \\
\text { movimento e direção } \\
\text { articulados pelo gesto } \\
\text { pictórico, registrado na nota } \\
\text { de rodapé } 65 .\end{array}$ & 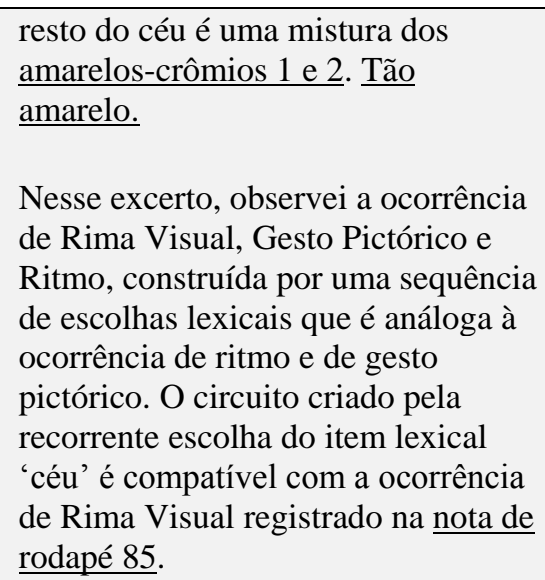 & $\begin{array}{l}\text { cor na linguagem, que reproduz a } \\
\text { simultaneidade e sobreposição de } \\
\text { amarelos que são usados em } \\
\text { sequência e de forma saturada. Na } \\
\text { escolha lexical que van Gogh faz } \\
\text { parece estar presente a mesma } \\
\text { intensidade luminosa que foi } \\
\text { intencionalmente representada no } \\
\text { quadro. Há uma preocupação nele } \\
\text { não só de descrever o quadro, mas de } \\
\text { reproduzir de forma quase táctil, } \\
\text { vivencial, experiencial, o que o } \\
\text { observador sente quando observa o } \\
\text { quadro. }\end{array}$ \\
\hline $\begin{array}{l}\text { Na tela 'O Semeador', } \\
\text { observei a ocorrência de } \\
\text { Associação Metafórica e } \\
\text { Incompletude, construídas } \\
\text { pela Rima Visual e pelo } \\
\text { Gesto pictórico, para } \\
\text { representar a unidade entre o } \\
\text { Homem e a Natureza, } \\
\text { registrados na nota de rodapé } \\
\underline{78} .\end{array}$ & $\begin{array}{l}\text { Em um campo arado, um grande } \\
\text { campo de torrões de terra roxa - } \\
\text { levantados em direção ao horizonte - } \\
\text { um semeador em azul e branco. } \\
\text { Neste complexo oracional observei } \\
\text { um encadeamento de complexos } \\
\text { nominais que sugerem em seus } \\
\text { agrupamentos, uma cadência que é } \\
\text { compatível com o gesto pictórico e } \\
\text { com a busca de construir uma } \\
\text { unidade formal para a oração, ao } \\
\text { ocultar os processos, e substituí-los } \\
\text { por vírgulas e travessões como para } \\
\text { organizar os grupos nominais. }\end{array}$ & $\begin{array}{l}\text { A Rima visual e o Gesto pictórico na } \\
\text { tela têm uma qualidade de } \\
\text { inacabamento e de incompletude que } \\
\text { expressam uma dissolução de limites, } \\
\text { contornos e definições, confirmados } \\
\text { pela indefinição das cores ocasionada } \\
\text { por misturas de cores opostas que } \\
\text { gera uma cor indefinida e pulsante e } \\
\text { que representam essa fusão entre o } \\
\text { homem e a natureza. A oração } \\
\text { apresenta aspectos de inacabamento e } \\
\text { indefinição, pela ocultação dos } \\
\text { processos: 'Em um campo arado, (há) } \\
\text { um grande campo de torrões de terra } \\
\text { roxa - (que estão) levantados em } \\
\text { direção ao horizonte - (onde está) um } \\
\text { semeador em azul e branco.' que são } \\
\text { compatíveis com a ocorrência de } \\
\text { gesto pictórico e de rima visual na } \\
\text { tela. }\end{array}$ \\
\hline $\begin{array}{l}\text { Na tela 'A Esplanada do Café } \\
\text { na Place du Forum, Arles, à } \\
\text { Noite', observei a ocorrência } \\
\text { e Inter-relação entre Ritmo, } \\
\text { Movimento, Textura, Gesto } \\
\text { Pictórico, Desenho-Pintura } \\
\text { para construir a Perspectiva } \\
\text { do calçamento, registrados na } \\
\text { nota de rodapé } 126 \text { no } \\
\text { apêndice. }\end{array}$ & $\begin{array}{l}\text { No terraço, há pequenas figuras de } \\
\text { pessoas que bebem. Uma enorme } \\
\text { lanterna amarela ilumina o terraço, a } \\
\underline{\text { fachada, a calçada, e até mesmo }} \\
\underline{\text { projeta luz sobre os paralelepípedos }} \\
\underline{\text { da rua, que adquirem uma coloração }} \\
\underline{\text { violeta-rosa. }} . \text { As frentes das casas em } \\
\underline{\text { uma rua que segue sob o céu azul }} \\
\text { salpicado de estrelas são azul escuro } \\
\text { ou violeta, com uma árvore verde. } \\
\text { Agora há uma pintura de noite sem } \\
\text { preto. Com nada mais do que um } \\
\text { belo azul e violeta e verde e nestes } \\
\text { arredores da praça iluminada é } \\
\text { colorido por enxofre pálido, amarelo } \\
\text { limão. }\end{array}$ & $\begin{array}{l}\text { Na oração van Gogh utiliza } \\
\text { processos materiais que explicitam o } \\
\text { gesto pictórico utilizado na produção } \\
\text { da tela: 'projeta luz', 'rua que segue', } \\
\text { 'céu azul salpicado'. } \\
\text { A ação dada por diferentes } \\
\text { pinceladas conferem ao resultado um } \\
\text { sentido também diferenciado. Por } \\
\text { exemplo, a descrição do céu como } \\
\text { salpicado de estrela dá à ação do } \\
\text { artista um movimento diferente. Há } \\
\text { uma complementaridade entre o } \\
\text { efeito das estrelas que saltitam no } \\
\text { céu e a descrição de que elas } \\
\text { realmente foram salpicadas pelas } \\
\text { pinceladas. }\end{array}$ \\
\hline $\begin{array}{l}\text { Na tela 'O Café Noturno na } \\
\text { Place Lamartine, em Arles', } \\
\text { observei a ocorrência do uso } \\
\text { de Saliência e Vetor inter- }\end{array}$ & $\begin{array}{l}\text { Agora há uma pintura de noite sem } \\
\text { preto. Com nada mais do que um } \\
\text { belo azul e violeta e verde e nestes } \\
\text { arredores da praça iluminada é }\end{array}$ & $\begin{array}{l}\text { Van Gogh enfatiza que a ele convém } \\
\text { pintar a tela no momento, sem } \\
\text { esboço prévio. A descrição na oração } \\
\text { valoriza os diferentes usos das cores }\end{array}$ \\
\hline
\end{tabular}


relacionados com a

ocorrência de Textura e

Gesto Pictórico para construir

a luz das lâmpadas a gás, registrado na nota de rodapé 125. O vetor ocorre em direção radial.

Observei a ocorrência de Saliência construída com o uso de Textura, Ritmo, Movimento e Gesto Pictórico para representar o brilho da lâmpada, registrado na nota de rodapé 135.

Ocorrência de Ritmo,

Textura, Movimento, Vetor e Rima Visual pelo Gesto Pictórico para expressar o fluxo e a intensidade da iluminação na sala, registrados na nota de rodapé 189.

Ocorrência de Saliência, por meio do uso de Ritmo,

Movimento, Textura, Vetor e Gesto Pictórico que são usados para representar o brilho intermitente das lâmpadas, pintado com riqueza de detalhes, textura e movimento direcional, registrados na nota de rodapé $\underline{190 .}$.

Ocorrência de Associação metafórica por meio do uso de Ritmo, Movimento, Textura, Vetor, Gesto Pictórico e Rima Visual que juntos constroem uma metáfora visual para a luz que interliga todos os processos na narrativa, registrados na nota de rodapé $\underline{191 .}$

Ocorrência de Rima Visual e Gesto Pictórico na representação da luz como uma metáfora visual que interliga todos os elementos da tela; o Ritmo é o recurso que expressa essa metáfora e que constrói a coesão visual, registrados na nota de rodapé 192. colorido por enxofre pálido, amarelo limão. Eu gosto enormemente de pintar no local à noite. No passado, eles costumavam desenhar e pintar a tela do desenho durante o dia. Mas acho que me convém pintar a coisa no momento. É bem verdade que eu possa tomar um azul por um verde no escuro, um azul lilás por um rosa lilás, uma vez que você não pode perceber a natureza do tom claramente. Mas é a única maneira de se livrar da noite negra convencional com uma luz pobre, pálida e esbranquiçada, quando na verdade uma mera vela por si só nos dá os mais ricos amarelos e laranjas. com intuito de apresentar a interação entre cor e sombra, este movimento de interação aparece quando em uma pincelada temos a sombra e ao seu lado uma pincelada que representa a projeção da luz no objeto que se encontra entre a noite e a luz do café. Ele sofre a ação da noite e da luz, esta interação exige de van Gogh uma pincelada que possibilite transmutar o jogo de sombra e luz para a tela. 


\begin{tabular}{|c|c|c|}
\hline $\begin{array}{l}\text { Uso de Associação } \\
\text { metafórica por meio de } \\
\text { Saliência, Ritmo, } \\
\text { Movimento, Textura e Gesto } \\
\text { Pictórico para dar } \\
\text { centralidade para luz, } \\
\text { registrada na nota de rodapé } \\
\text { 201. }\end{array}$ & & \\
\hline $\begin{array}{l}\text { Na tela 'O Café Noturno na } \\
\text { Place Lamartine, em Arles', } \\
\text { observei a ocorrência de } \\
\text { Saliência construída com o } \\
\text { uso de Textura, Ritmo, } \\
\text { Movimento e Gesto Pictórico } \\
\text { para representar o brilho da } \\
\text { lâmpada em contraste com os } \\
\text { tons de vermelho e verde } \\
\text { escuro registrada na nota de } \\
\text { rodapé } 126 .\end{array}$ & $\begin{array}{l}\text { A sala é vermelho-sangue e amarelo } \\
\text { sem graça, uma mesa de bilhar verde } \\
\text { no centro, } 4 \text { lâmpadas de amarelo } \\
\text { limão com um brilho laranja e verde. } \\
\text { Em todos os lugares é uma batalha e } \\
\text { uma antítese dos mais diferentes } \\
\text { verdes e vermelhos; nas personagens } \\
\text { dos rufiões adormecidos, pequenos } \\
\text { na alta sala vazia, algum roxo e azul. } \\
\text { O vermelho-sangue e o amarelo- } \\
\text { verde da mesa de bilhar, por } \\
\text { exemplo, contrasta com o pouco de } \\
\text { verde delicado Louis XV do balcão, } \\
\text { onde há um buquê rosa. }\end{array}$ & $\begin{array}{l}\text { O brilho laranja e verde não é dado } \\
\text { somente pela cor, mas pelo formato } \\
\text { arredondado que o gesto pictórico } \\
\text { confere à luz que emana da lâmpada. } \\
\text { O gesto é crucial para conferir } \\
\text { movimento e ritmo à luz que incide } \\
\text { sobre a sala vazia, para que ela } \\
\text { ganhasse movimento foi necessário } \\
\text { imprimir na tela este movimento, um } \\
\text { gesto contínuo, porém desigual, ora } \\
\text { mais forte, ora mais fraco, mas } \\
\text { incessante. }\end{array}$ \\
\hline $\begin{array}{l}\text { Na tela 'O Café Noturno na } \\
\text { Place Lamartine, em Arles', } \\
\text { observei a ocorrência de } \\
\text { Saliência, por meio de } \\
\text { Textura e Gesto Pictórico no } \\
\text { uso do Desenho-Pintura para } \\
\text { detalhar a representação dos } \\
\text { contornos da mesa de bilhar, } \\
\text { registrado na nota de rodapé } \\
\text { 214. } \\
\text { Ocorrência de Saliência, } \\
\text { Inacabamento, Modalidade } \\
\text { por meio dos Contrastes } \\
\text { Cromáticos e do Gesto } \\
\text { Pictórico no uso dos recursos } \\
\text { semióticos do delineamento } \\
\text { do contorno dos móveis e } \\
\text { objetos, como as cadeiras e a } \\
\text { mesa de bilhar, registrados } \\
\text { na nota de rodapé } 216 .\end{array}$ & $\begin{array}{l}\text { A sala está pintada de vermelho, e no } \\
\text { interior, na luz a gás, a mesa de } \\
\text { bilhar verde, a qual lança uma } \\
\text { imensa sombra sobre o chão. Nesta } \\
\text { tela, há } 6 \text { ou } 7 \text { vermelhos diferentes, } \\
\text { desde vermelho-sangue até rosa } \\
\text { delicado, fazendo oposição com o } \\
\text { mesmo número de verdes pálidos ou } \\
\text { escuros. }\end{array}$ & $\begin{array}{l}\text { O gesto pictórico que produz a } \\
\text { imensa sombra confere especial } \\
\text { destaque ao contorno da sombra da } \\
\text { mesa de bilhar no chão do café. O } \\
\text { gesto fica registrado no contorno da } \\
\text { mesa, marcado, acentuado, com } \\
\text { objetivo claro de destacar a diferença } \\
\text { de luz e sombra. Na oração van Gogh } \\
\text { enfatiza os contrastes de luz e } \\
\text { sombra, de claro e escuro, } \\
\text { descrevendo a multiplicidade de } \\
\text { tonalidades usadas para construir } \\
\text { essa batalha entre as cores. }\end{array}$ \\
\hline
\end{tabular}

Fonte: Triangulação para Gesto Pictórico dos dados dos corpora visual e textual, com os extratos das cartas.

\subsection{SALIÊNCIA}

A saliência confere um destaque para alguns elementos na imagem pelo uso conjugado de vários modos que colaboram para a coesão do discurso visual. Ela constrói o sentido de unidade concatenado pela interação entre os modos que se complementam na composição. 
Kress e Van Leeuwen (1996, p.202) explicam como essa ênfase é construída na narrativa visual:

\begin{abstract}
Quando a composição é o modo de integração, a saliência é julgada pelas pistas visuais. Os espectadores das composições espaciais são capazes de intuitivamente julgar o 'peso' de vários elementos de uma composição, e quanto maior é o peso de um elemento, maior a sua saliência. Essa saliência, de novo, não é mensurável objetivamente, mas resulta de uma interação complexa, uma complexa negociação entre um número de fatores: tamanho, definição do foco, contraste tonal (áreas de alto contraste tonal - por exemplo, bordas entre o branco e o preto - tem alta saliência), contraste de cor (por exemplo, o contraste entre cores fortemente saturadas e cores brandas, ou o contraste entre vermelho e azul), a localização no campo visual (elementos não apenas se tornam 'mais pesados' como eles se movem em direção ao topo, mas também aparem mais 'pesados' quanto mais longe eles se movem em direção a esquerda, devido a assimetria no campo visual), perspectiva (objetos no primeiro plano são mais salientes do que os elementos que estão por trás), e também fatores especificamente culturais, tais como a aparência de uma figura humana ou um símbolo cultural potente. E, assim como o ritmo cria uma hierarquia de importância entre os elementos de textos integrados temporariamente, o peso visual cria uma hierarquia de importância entre os elementos de textos integrados espacialmente, causando alguns de atraírem maior atenção para si mesmos do que outros. ${ }^{306}$
\end{abstract}

\title{
6.11.1 Triangulação da Saliência
}

Saliência, no texto escrito e em relação à triangulação - A saliência no texto escrito pode ser dada pelo 'peso' que algum participante na oração adquire com a ajuda da relação entre os elementos.

\footnotetext{
306 Tradução livre da autora. "When composition is the integration mode, salience is judged on the basis of visual clues. The viewers of spatial compositions are intuitively able to judge the 'weight' of the various elements of a composition, and the greater the weight of an element, the greater its salience. This salience, again, is not objectively measurable, but results from complex interaction, a complex trading-off relationship between a number of factors: size, sharpness of focus, tonal contrast (areas of high tonal contrast - for instance, borders between black and white - have high salience), colour contrasts (for instance, the contrast between strongly saturated and 'soft' colours, or the contrast between red and blue), placement in the visual field (elements not only become 'heavier' as they are moved towards the top, but also appear 'heavier' the further they are moved towards the left, due to an asymmetry in the visual field), perspective (foreground objects are more salient than background objects, and elements that overlap other elements are more salient than the elements they overlap), and also quite specific cultural factors, such as the appearance of a human figure or a potent cultural symbol. And, just as rhythm creates a hierarchy of importance among the elements of temporally integrated texts, so visual weight creates a hierarchy of importance among the elements of spatially integrated texts, causing some to draw more attention to themselves than others." (KRESS E VAN LEEUWEN, 1996, p. 202)
} 
Quadro 27: Triangulação da Saliência

\begin{tabular}{|c|c|c|}
\hline Ocorrência nas telas & Orações & Comentário \\
\hline $\begin{array}{l}\text { Na tela 'Por de Sol: Campo } \\
\text { de trigo perto de Arles', } \\
\text { observei a ocorrência de } \\
\text { Saliência e Sinestesia, } \\
\text { construída pelo uso } \\
\text { combinado de Textura, } \\
\text { Ritmo, Movimento, Direção } \\
\text { e Volume para representar o } \\
\text { trigal, registradas nas notas } \\
\text { de rodapé } 71,75 \text { e } 77 \text { no } \\
\text { apêndice. Observei também } \\
\text { a ocorrência de Cor e } \\
\text { Saliência conferida pelos } \\
\text { contrastes quente/frio entre } \\
\text { azuis e amarelos registrada } \\
\text { na nota de rodapé } 74 \text { no } \\
\text { apêndice. }\end{array}$ & $\begin{array}{l}\text { Eu tenho um terceiro estudo, agora, } \\
\text { de uma paisagem com fábrica, e um } \\
\text { enorme sol em um céu vermelho, } \\
\text { acima de telhados vermelhos, em que } \\
\text { a natureza parece estar em um acesso } \\
\text { de raiva, em um dia de Mistral } \\
\text { desagradável. }\end{array}$ & $\begin{array}{l}\text { Em ambos, tanto no quadro quanto } \\
\text { na oração, ele está salientando um } \\
\text { momento que é no quadro um por do } \\
\text { sol com vento no trigo. Desse } \\
\text { momento resulta uma experiência na } \\
\text { qual agora possui um estudo. Inferi } \\
\text { que, tanto na tela quanto na carta ele } \\
\text { expressa o momento da experiência. } \\
\text { Isso sugere que ele percebe a vida } \\
\text { dele como momentos que são } \\
\text { relatados e expressados para Theo: } \\
\text { em um deles o momento de } \\
\text { experiência dele com a natureza (no } \\
\text { quadro) e em outro o momento dele } \\
\text { em relação à tela (na carta). }\end{array}$ \\
\hline $\begin{array}{l}\text { Na tela 'Por de Sol: Campo } \\
\text { de trigo perto de Arles', } \\
\text { observei a ocorrência de } \\
\text { Saliência no fino halo branco } \\
\text { em torno do sol que pode } \\
\text { enfatizar seu brilho e } \\
\text { também produzir uma } \\
\text { associação com o sentido de } \\
\text { espiritualidade e de } \\
\text { santidade, registrada nas } \\
\text { notas de rodapé } 51 \text { e } 59 \text { no } \\
\text { apêndice. }\end{array}$ & $\begin{array}{l}\text { Ocorrência de Saliência, que ajudam } \\
\text { a construir uma materialidade } \\
\text { compatível com a ocorrência de Gesto } \\
\text { Pictórico e de Rima Visual na } \\
\text { sequência das três orações, registrado } \\
\text { na nota de rodapé } 114 \text { no apêndice. }\end{array}$ & $\begin{array}{l}\text { A saliência que van Gogh está dando } \\
\text { com a escolha lexical 'Aqui' para a } \\
\text { paisagem deixa ambígua a definição } \\
\text { de que corpo celeste ele representa no } \\
\text { céu. É como se ele dissesse: 'estamos } \\
\text { em uma noite de verão e nesse } \\
\text { espetáculo da natureza, pouco } \\
\text { importa se é a lua ou se é o sol, o que } \\
\text { importa é que nós estamos em uma } \\
\text { noite de verão na qual é possível } \\
\text { contemplar a natureza'. É como se } \\
\text { ele dissesse assim, 'não vamos nos } \\
\text { apegar às coisas em si, mas àquilo } \\
\text { que elas nos proporcionam. }\end{array}$ \\
\hline $\begin{array}{l}\text { Na tela 'Por de Sol: Campo } \\
\text { de trigo perto de Arles', } \\
\text { observei a ocorrência de } \\
\text { Saliência nos tons de verde } \\
\text { que aparecem no céu para } \\
\text { dar ênfase para as colunas } \\
\text { de fumaça. Registrado na } \\
\text { nota de rodapé } 55 \text { no } \\
\text { apêndice. }\end{array}$ & $\begin{array}{l}\text { Cidade violeta, estrela amarela, céu } \\
\text { azul-esverdeado; os campos de trigo } \\
\text { têm todos os tons: ouro velho, cobre, } \\
\text { ouro verde, ouro vermelho, ouro } \\
\text { amarelo, verde, vermelho e amarelo } \\
\text { bronze. } \\
\text { A escolha léxico-gramatical 'todos os } \\
\text { tons' surge aqui como um exagero, } \\
\text { usado para salientar a importância da } \\
\text { variedade com que ele construiu sua } \\
\text { escolha de cores para significar a } \\
\text { riqueza latente do trigal. }\end{array}$ & $\begin{array}{l}\text { A saliência está nos detalhes, no uso } \\
\text { de recursos pictóricos para enfatizar } \\
\text { cada aspecto. O azul do céu se } \\
\text { mistura à fumaça esverdeada. São } \\
\text { muitas colunas, cerca de } 8 \text { no total, } \\
\text { todas com fumaça que contrasta com } \\
\text { o amarelo do astro e que está } \\
\text { separado do restante por um halo } \\
\text { branco. Toda a composição serve } \\
\text { para enfatizar o contraste, } \\
\text { provavelmente metafórico, entre a } \\
\text { natureza e a indústria nascente no } \\
\text { século XIX. } \\
\text { Observei, dessa forma, um exagero } \\
\text { no tom verde da fumaça das fábricas, } \\
\text { e um exagero na escolha léxico- } \\
\text { gramatical 'todos os tons' na oração, } \\
\text { indicando a ocorrência de uma } \\
\text { saliência implícita que torna essas } \\
\text { escolhas compatíveis com a } \\
\text { existência de um discurso artístico } \\
\text { que esta na sua origem. }\end{array}$ \\
\hline
\end{tabular}




\begin{tabular}{|c|c|c|}
\hline $\begin{array}{l}\text { Na tela 'Por de Sol: Campo } \\
\text { de trigo perto de Arles', } \\
\text { observei também a } \\
\text { ocorrência de Saliência pelo } \\
\text { uso cromático de um tom de } \\
\text { amarelo mais claro na área } \\
\text { onde o homem se encontra } \\
\text { registrado nas notas de } \\
\text { rodapé } 44,80 \text { e } 96 \text { no } \\
\text { apêndice. }\end{array}$ & $\begin{array}{l}\text { Paisagens amarelo ouro velho - feito } \\
\text { rápido rápido rápido e com pressa, } \\
\text { como o ceifeiro que está em silêncio } \\
\text { sob o sol escaldante, concentrando-se } \\
\text { em ter o trabalho terminado. }\end{array}$ & $\begin{array}{l}\text { É interessante que ele se refere ao } \\
\text { ceifeiro concentrado a ter o trabalho } \\
\text { terminado que é semelhante ao sol } \\
\text { que está se pondo tendo o seu } \\
\text { trabalho terminado. Nesse momento } \\
\text { de auge quando ele está se pondo, ele } \\
\text { tem um halo de luz diferente e o } \\
\text { ceifeiro no momento em que está } \\
\text { terminando o trabalho dele, também } \\
\text { tem uma luminosidade diferente, } \\
\text { mais intensa, naquele espaço. }\end{array}$ \\
\hline $\begin{array}{l}\text { Na tela 'Por de Sol: Campo } \\
\text { de trigo perto de Arles', } \\
\text { observei a ocorrência de } \\
\text { Saliência muito sutil e de } \\
\text { Associação Metafórica. O } \\
\text { uso da saliência, pelo } \\
\text { posicionamento do moinho } \\
\text { junto à chaminé da fábrica, } \\
\text { ambos em um dos pontos de } \\
\text { fuga da composição, sugere } \\
\text { uma metáfora de que o } \\
\text { moinho está em } \\
\text { contraposição com a } \\
\text { fábrica e todos os } \\
\text { significados que isso } \\
\text { implica, registrados na nota } \\
\text { de rodapé } 85 \text { e } 87 \text { no } \\
\text { apêndice. }\end{array}$ & $\begin{array}{l}\text { Eu tenho um terceiro estudo, agora, } \\
\text { de uma paisagem com fábrica, e um } \\
\text { enorme sol em um céu vermelho, } \\
\text { acima de telhados vermelhos, }\end{array}$ & $\begin{array}{l}\text { É interessante que van Gogh } \\
\text { representa a fábrica de uma maneira } \\
\text { pouco evidente no quadro, mas ao } \\
\text { descrevê-la na oração, ele se refere à } \\
\text { tela como uma paisagem com } \\
\text { fábrica. Quer dizer a fábrica é } \\
\text { salientada na oração como um } \\
\text { diferencial desta tela em relação a } \\
\text { muitas outras nas quais ele não } \\
\text { pintou a fábrica, justamente porque } \\
\text { não é um tema recorrente nas telas } \\
\text { dele pintar o espaço urbano e sim a } \\
\text { Natureza. Mesmo quando ele pinta } \\
\text { como um detalhe longínquo difícil de } \\
\text { id ao descrever ele fala um aspecto } \\
\text { que a diferencia das demais, o fato de } \\
\text { que ali tem uma fábrica. }\end{array}$ \\
\hline $\begin{array}{l}\text { Na tela 'Por de Sol: Campo } \\
\text { de trigo perto de Arles', } \\
\text { observei a ocorrência de } \\
\text { Enquadramento, pela } \\
\text { escolha do ponto de vista } \\
\text { que privilegia a } \\
\text { representação do campo } \\
\text { sobre a cidade e com isso, } \\
\text { constrói uma relação que } \\
\text { realça o valor do campo. } \\
\text { Observei também a } \\
\text { ocorrência de Saliência e } \\
\text { Associação metafórica por } \\
\text { meio do enquadramento que } \\
\text { aproxima o campo e } \\
\text { distancia a cidade, } \\
\text { registrado nas notas de } \\
\text { rodapé } 63 \text { e } 99 \text { no apêndice. }\end{array}$ & $\begin{array}{l}\text { Aqui está outra paisagem. Sol } \\
\text { poente? Lua nascendo? Noite de } \\
\text { verão, de qualquer modo. Cidade } \\
\text { violeta, estrela amarela, céu azul- } \\
\text { esverdeado; os campos de trigo têm } \\
\text { todos os tons: ouro velho, cobre, ouro } \\
\text { verde, ouro vermelho, ouro amarelo, } \\
\text { verde, vermelho e amarelo bronze. } \\
\text { Tela quadrada número } 30 . \\
\text { Eu pintei-a ao ar livre no Mistral. } \\
\text { Meu cavalete foi fixado no chão com } \\
\text { estacas de ferro, um método que eu } \\
\text { recomendo a você. }\end{array}$ & $\begin{array}{l}\text { Os telhados laranja salientam ainda } \\
\text { mais a separação entre cidade e } \\
\text { campo de trigo. Há um esverdeado } \\
\text { no campo, assim como há amarelo no } \\
\text { por de sol. Mas essa comunicação } \\
\text { parece salientar ainda mais a } \\
\text { diferença e a distância entre o campo } \\
\text { e a cidade, a horizontalidade do trigo } \\
\text { e a verticalidade da cidade, o amarelo } \\
\text { e o violeta, o movimento do vento no } \\
\text { trigo e o movimento da fumaça. São } \\
\text { ênfases que trabalham na construção } \\
\text { metafórica sobre a relação entre a } \\
\text { vida do campo e da natureza e a vida } \\
\text { urbana e da indústria. }\end{array}$ \\
\hline
\end{tabular}




\begin{tabular}{|c|c|c|}
\hline $\begin{array}{l}\text { Na tela 'O Semeador', } \\
\text { observei a ocorrência do uso } \\
\text { conjugado de Textura, ritmo, } \\
\text { movimento, direção, gesto } \\
\text { pictórico e saliência na } \\
\text { representação dos torrões de } \\
\text { terra revolvida no campo } \\
\text { arado. Registrados na nota } \\
\text { de rodapé } 49 . \\
\\
\text { Há uma inter-relação entre } \\
\text { Textura, Contrastes } \\
\text { Simultâneos, Sinestesia que } \\
\text { criam Associações } \\
\text { Metafóricas da } \\
\text { materialidade da tinta com } \\
\text { a nossa memória sensorial } \\
\text { e tátil da plasticidade da } \\
\text { terra, registrado na nota de } \\
\text { rodapé } 50 .\end{array}$ & $\begin{array}{l}\text { Aqui está um esboço de um } \\
\text { semeador, um grande campo lavrado } \\
\text { com torrões de terra, na sua maioria } \\
\text { fracamente cor de violeta. Um campo } \\
\text { de trigo maduro, de tom amarelo- } \\
\text { ocre com um pouco de carmim. } \\
\text { Um grande campo' dá destaque para } \\
\text { o atributo que tem uma oração } \\
\text { hipotática de elaboração dentro do } \\
\text { grupo nominal. Ocorrência de } \\
\text { Saliência na escolha léxico- } \\
\text { gramatical de 'grande campo' que é } \\
\text { acompanhado de um grupo nominal } \\
\text { que atribui suas cores, registrado na } \\
\text { nota de rodapé } 81 .\end{array}$ & $\begin{array}{l}\text { Observei a ocorrência de Saliência na } \\
\text { oração por meio do uso de um ponto } \\
\text { onde deveria haver uma vírgula, } \\
\text { usada para conferir destaque para um } \\
\text { grupo nominal. Registrado na nota de } \\
\text { rodapé } 79,81 \text { e } 82 \text {. } \\
\text { Na oração 'Um campo de trigo } \\
\text { maduro, de tom amarelo-ocre com } \\
\text { um pouco de carmim', a forma como } \\
\text { ele construiu o protagonismo das } \\
\text { cores para narrar o campo de trigo } \\
\text { maduro sugere que a oração é uma } \\
\text { metáfora na qual o campo e a cor se } \\
\text { tornam a mesma coisa, ao deixar } \\
\text { ocultos os processos. }\end{array}$ \\
\hline $\begin{array}{l}\text { Observei também a } \\
\text { ocorrência de Saliência e } \\
\text { Rima Visual construída } \\
\text { pelo uso conjugado de } \\
\text { vários recursos, tais como } \\
\text { ritmo, textura, movimento, } \\
\text { direção, perspectiva, } \\
\text { enquadramento registrado na } \\
\text { nota de rodapé } 58 .\end{array}$ & $\begin{array}{l}\text { O céu, amarelo-crômio, quase tão } \\
\text { luminoso quanto o próprio Sol, que é } \\
\text { amarelo-crômio n'1, misturado com } \\
\text { um pouco de branco, enquanto o } \\
\text { resto do céu é uma mistura dos } \\
\text { amarelos-crômios } 1 \text { e } 2 \text {. Tão } \\
\text { amarelo! A camisa do semeador é } \\
\text { azul e as calças brancas. Tamanho da } \\
\text { tela - 25, quadrada. } \\
\text { Ocorrência de Saliência e Associação } \\
\text { Metafórica pela equiparação do } \\
\text { sentido de 'luminoso' para o 'sentido } \\
\text { de amarelo', registrado na nota de } \\
\text { rodapé 84. } \\
\underline{\text { Há várias sugestões de amarelo no }} \\
\underline{\text { solo, tons neutros resultantes da }} \\
\underline{\text { tentura de violeta e amarelo; } \text { mas }} \\
\underline{\text { tenho travado uma luta diabólica para }} \\
\underline{\text { atingir a verdade das cores. }}\end{array}$ & $\begin{array}{l}\text { Para dar a ideia de um campo } \\
\text { lavrado, na qual os torrões de terra } \\
\text { estão revolvidos para o plantio, van } \\
\text { Gogh preciso salientar o movimento } \\
\text { usado para cavar a terra e neste } \\
\text { movimento salientou o gesto } \\
\text { pictórico que daria movimento aos } \\
\text { torrões. Para isto utilizou uma } \\
\text { variedade de cores e contrastes que } \\
\text { ajudaram a salientar a conformação } \\
\text { dos torrões de terra sobre o solo. Em } \\
\text { contraste com este movimento no } \\
\text { solo está o céu amarelo com o sol } \\
\text { amarelo que ganha destaque pela } \\
\text { homogeneidade do sol pintado com } \\
\text { um tom de amarelo e o restante do } \\
\text { céu pintado com misturas de } \\
\text { tonalidades. }\end{array}$ \\
\hline
\end{tabular}




\begin{tabular}{|c|c|c|}
\hline $\begin{array}{l}\text { Na tela 'O Semeador', } \\
\text { observei a ocorrência } \\
\text { conjugada de Contrastes de } \\
\text { Saturação, Saliência, } \\
\text { Associação Metafórica e } \\
\text { Incompletude na } \\
\text { representação do céu e do } \\
\text { sol, em amarelo sobre } \\
\text { amarelo, registrado na nota } \\
\text { de rodapé } 51 .\end{array}$ & $\begin{array}{l}\text { O céu, amarelo-crômio, quase tão } \\
\text { luminoso quanto o próprio Sol, que é } \\
\text { amarelo-crômio no } 1 \text {, misturado com } \\
\text { um pouco de branco, enquanto o } \\
\text { resto do céu é uma mistura dos } \\
\text { amarelos-crômios } 1 \text { e } 2 \text {. Tão } \\
\text { amarelo! A camisa do semeador é } \\
\text { azul e as calças brancas. Tamanho da } \\
\text { tela - } 25 \text {, quadrada. }\end{array}$ & $\begin{array}{l}\text { O uso de superlativos enfatiza } \\
\text { qualidades na oração equivalentes ao } \\
\text { uso das cores sobrepostas com intuito } \\
\text { salientar seu papel na composição. } \\
\text { Ao descrever o quadro van Gogh } \\
\text { salienta o uso cromático do amarelo } \\
\text { com construtos que parecem saturar } \\
\text { na linguagem o que foi anteriormente } \\
\text { saturado na tela. }\end{array}$ \\
\hline $\begin{array}{l}\text { Observei também a } \\
\text { ocorrência de Saliência e } \\
\text { Associação Metafórica } \\
\text { para o céu e o sol, } \\
\text { construída pelo uso de ritmo, } \\
\text { textura, movimento e direção } \\
\text { articulados pelo gesto } \\
\text { pictórico, registrado na nota } \\
\text { de rodapé } 65 .\end{array}$ & & \\
\hline $\begin{array}{l}\text { Observei também a } \\
\text { ocorrência de Saliência e } \\
\text { Associação Metafórica pelo } \\
\text { posicionamento relativo do } \\
\text { Sol na composição, } \\
\text { ocupando o centro e a parte } \\
\text { superior da tela, registrado } \\
\text { na nota de rodapé } 67 .\end{array}$ & & \\
\hline \multirow[t]{2}{*}{$\begin{array}{l}\text { A Saliência na tela é } \\
\text { construída pelo uso } \\
\text { combinado de diferentes } \\
\text { recursos semióticos como, } \\
\text { por exemplo, pelo uso de } \\
\text { diferentes tons de amarelos e } \\
\text { laranjas no sol e no céu para } \\
\text { salientar a centralidade da } \\
\text { luz e da iluminação que } \\
\text { adquirem uma característica } \\
\text { de excesso e de distorção. }\end{array}$} & $\begin{array}{l}\text { Não te vou ocultar que não desgosto } \\
\text { da região, pois fui criado lá - ainda } \\
\text { me encanta a magia das recordações } \\
\text { do passado, de um desejo do infinito, } \\
\text { do qual o semeador e o enfeixador } \\
\text { são símbolos -, tanto quanto antes } \\
\text { gostava. }\end{array}$ & $\begin{array}{l}\text { Ocorrência de contraposições léxico- } \\
\text { gramaticais pelo uso de inversões de } \\
\text { sentido (Não te vou ocultar que não } \\
\text { desgosto) com negativas e com } \\
\text { indiretas para modalizar e dizer sem } \\
\text { falar que são compatíveis com } \\
\text { Saliência e Distorção do ponto de } \\
\text { vista, registradas na nota de rodapé } \\
\text { 95. } \\
\text { Observei como saliência a escolha } \\
\text { lexical 'ainda' e 'tanto quanto antes' } \\
\text { reforçam a continuidade de uma } \\
\text { condição que mobiliza van Gogh a } \\
\text { criar (ou recriar) um desejo de } \\
\text { infinito que só se aproximou de ser } \\
\text { revelado no uso metafórico da luz, } \\
\text { seja no céu estrelado, no campo de } \\
\text { trigo ou na figura do Semeador. }\end{array}$ \\
\hline & $\begin{array}{l}\text { Mas quando eu farei o céu estrelado, } \\
\text { então, essa pintura que está sempre } \\
\text { na minha mente? (...) } \\
\text { Por um longo tempo ele foi meu } \\
\text { grande desejo de fazer um semeador, } \\
\text { mas os desejos que tive por um longo } \\
\text { tempo nem sempre são alcançados. }\end{array}$ & $\begin{array}{l}\text { Ocorrência de Interdiscursividade } \\
\text { pelo uso de Enquadramento, } \\
\text { Perspectiva e Inversão do ponto de } \\
\text { vista ao trazer o leitor para o lugar } \\
\text { em que se encontra o artista ao } \\
\text { expressar com Saliência, uma forte } \\
\text { contraposição entre uma incerteza (de }\end{array}$ \\
\hline
\end{tabular}




\begin{tabular}{|c|c|c|}
\hline & $\begin{array}{l}\text { (...) } \\
\text { Mas é uma questão de atacá-las, no } \\
\text { entanto, não importa o quão } \\
\text { incompetente um pode sentir-se vis- } \\
\text { à-vis as perfeições inefáveis do } \\
\text { glorioso esplendor da natureza. }\end{array}$ & $\begin{array}{l}\text { quando fará a tela) e uma certeza (ela } \\
\text { está sempre em sua mente). } \\
\text { Registrado na nota de rodapé } 109 .\end{array}$ \\
\hline $\begin{array}{l}\text { Na tela 'O Semeador' } \\
\text { observei a ocorrência de } \\
\text { Sinestesia pelo contraste } \\
\text { simultâneo entre o violeta e } \\
\text { o amarelo que potencializam } \\
\text { mutuamente o seu efeito e } \\
\text { que é aguçado o efeito da } \\
\text { textura tátil e da textura } \\
\text { visual, registrado na nota de } \\
\text { rodapé 55. }\end{array}$ & $\begin{array}{l}\text { Aqui está o que eu queria dizer sobre } \\
\text { o branco e o preto. Vamos tomar o } \\
\text { Semeador. A pintura é dividida em } \\
\text { dois; metade é amarelo, o topo; a } \\
\text { base é violeta. Bem, as calças brancas } \\
\text { descansam os olhos e os distraem } \\
\text { exatamente quando o contraste } \\
\text { simultâneo excessivo de amarelo e } \\
\text { violeta iriam irritá-lo. Isso é o que eu } \\
\text { queria dizer. }\end{array}$ & $\begin{array}{l}\text { Ocorrência do uso de saliência na } \\
\text { oração 'Isso é o que eu queria dizer' } \\
\text { que retoma e reforça o sentido da } \\
\text { oração 'Aqui está o que eu queria } \\
\text { dizer sobre o branco e o preto.' que } \\
\text { abre o parágrafo que fala sobre a } \\
\text { função do branco para amenizar o } \\
\text { conflito entre o violeta e o amarelo } \\
\text { que preenchem os dois campos da } \\
\text { tela. }\end{array}$ \\
\hline $\begin{array}{l}\text { Na tela 'O Semeador', } \\
\text { observei a ocorrência de } \\
\text { Enquadramento, Saliência, } \\
\text { Vetor para construir a } \\
\text { centralidade do campo na } \\
\text { narrativa, e o sentido } \\
\text { principal do enunciado que é } \\
\text { o de receber a semeadura do } \\
\text { semeador. Observei na tela } \\
\text { um deslocamento da } \\
\text { agência da ação que é } \\
\text { compatível com as } \\
\text { ocorrências de } \\
\text { deslocamento da agência } \\
\text { da ação nas orações escritas } \\
\text { por van Gogh, registrado na } \\
\text { nota de rodapé } 77 .\end{array}$ & $\begin{array}{l}\text { Eu tive uma semana de concentrado } \\
\text { trabalho duro nos campos de trigo } \\
\text { debaixo do sol, o resultado foi de } \\
\text { alguns estudos de campos de trigo, } \\
\text { paisagens e - um esboço de um } \\
\text { semeador. (...) } \\
\text { Em um campo arado, um grande } \\
\text { campo de torrões de terra roxa - } \\
\text { levantados em direção ao horizonte - } \\
\text { um semeador em azul e branco. } \\
\text { Na segunda oração, observei que uma } \\
\text { grande ênfase é dada para o campo } \\
\text { arado, por meio de uma cadeia de } \\
\text { complexos nominais que dão } \\
\text { atributos para o campo e constroem } \\
\text { uma narrativa visual, em comparação } \\
\text { com uma descrição muito sintética e } \\
\text { pontual da figura do semeador. A } \\
\text { oração não deixa dúvidas sobre o } \\
\text { protagonismo relativo entre o campo } \\
\text { arado e o semeador, para van Gogh. }\end{array}$ & $\begin{array}{l}\text { A saliência é dada no campo de trigo } \\
\text { e no horizonte, a ação da semeadura } \\
\text { perde centralidade diante da imensa } \\
\text { porção ocupada pelo campo arado e o } \\
\text { campo de trigo maduro. As saliências } \\
\text { estão no campo arado e no campo de } \\
\text { trigo que compõe uma paisagem na } \\
\text { qual o semeador é apenas mais um } \\
\text { elemento. }\end{array}$ \\
\hline $\begin{array}{l}\text { Na tela 'A Esplanada do } \\
\text { Café na Place du Forum, } \\
\text { Arles, à Noite, observei a } \\
\text { ocorrência de Saliência, } \\
\text { dada para a lâmpada a gás } \\
\text { que concentra a atenção na } \\
\text { cena, registrada na nota de } \\
\text { rodapé } 130 \text { no apêndice. }\end{array}$ & $\begin{array}{l}\text { Essa é a primeira pintura esta } \\
\text { semana. A segunda mostra o exterior } \\
\text { de um café, iluminado no terraço } \\
\text { externo por uma grande lâmpada de } \\
\text { gás dentro da noite azul, com um } \\
\text { retalho de céu azul estrelado, }\end{array}$ & $\begin{array}{l}\text { A saliência é dada na tela pela } \\
\text { proeminência da lâmpada a gás e na } \\
\text { oração pela ênfase 'grande' ao } \\
\text { qualificar a lâmpada. A cena está } \\
\text { concentrada na luz que emana dela, } \\
\text { cuja luz é projetada nos outros } \\
\text { elementos da tela. }\end{array}$ \\
\hline $\begin{array}{l}\text { Na tela 'A Esplanada do } \\
\text { Café na Place du Forum, } \\
\text { Arles, à Noite', observei a } \\
\text { ocorrência de Saliência dada } \\
\text { pelos Contrastes Cromáticos } \\
\text { do tipo Simultâneo, } \\
\text { Quente/Frio, e de Saturação } \\
\text { para construir caminhos } \\
\text { visuais e saliência na área } \\
\text { do café e conduzir o olhar }\end{array}$ & $\begin{array}{l}\text { Fui interrompido precisamente pelo } \\
\text { trabalho que uma nova pintura da } \\
\text { parte externa de um café à noite tem } \\
\text { me dado nos últimos dias. No terraço, } \\
\text { há pequenas figuras de pessoas que } \\
\text { bebem. Uma enorme lanterna } \\
\text { amarela ilumina o terraço, a fachada, } \\
\text { a calçada, e até mesmo projeta luz } \\
\text { sobre os paralelepípedos da rua, que } \\
\text { adquirem uma coloração violeta-rosa. }\end{array}$ & $\begin{array}{l}\text { Os caminhos visuais são construídos } \\
\text { para mostrar que a luz que é } \\
\text { projetada na calçada é proveniente da } \\
\text { lâmpada a gás, na oração este } \\
\text { caminho á facilmente construído } \\
\text { quando van Gogh explicita a lâmpada } \\
\text { a gás como agente na ação de } \\
\text { projetar a luz nos paralelepípedos. }\end{array}$ \\
\hline
\end{tabular}




\begin{tabular}{|c|c|c|}
\hline $\begin{array}{l}\text { para dentro da tela, } \\
\text { registrados na nota de rodapé } \\
133 \text { no apêndice. }\end{array}$ & & \\
\hline $\begin{array}{l}\text { Na tela 'A Esplanada do } \\
\text { Café na Place du Forum, } \\
\text { Arles, à Noite', observei a } \\
\text { ocorrência de Saliência na } \\
\text { representação detalhada das } \\
\text { estrelas que, apesar de não } \\
\text { estarem no primeiro plano } \\
\text { ganham destaque e } \\
\text { evidenciam seu grau de } \\
\text { importância semiótica na } \\
\text { narrativa, registrada na nota } \\
\text { de rodapé } 141 \text { no apêndice. }\end{array}$ & $\begin{array}{l}\text { Agora há uma pintura de noite sem } \\
\text { preto. Com nada mais do que um } \\
\text { belo azul e violeta e verde e nestes } \\
\text { arredores da praça iluminada é } \\
\text { colorido por enxofre pálido, amarelo } \\
\text { limão. Eu gosto enormemente de } \\
\text { pintar no local à noite. No passado, } \\
\text { eles costumavam desenhar e pintar a } \\
\text { tela do desenho durante o dia. Mas } \\
\text { acho que me convém pintar a coisa } \\
\text { no momento. É bem verdade que eu } \\
\text { possa tomar um azul por um verde no } \\
\text { escuro, um azul lilás por um rosa } \\
\text { lilás, uma vez que você não pode } \\
\text { perceber a natureza do tom } \\
\text { claramente. Mas é a única maneira de } \\
\text { se livrar da noite negra convencional } \\
\underline{\text { com uma luz pobre, pálida e }} \\
\text { esbranquiçada, quando na verdade } \\
\text { uma mera vela por si só nos dá os } \\
\text { mais ricos amarelos e laranjas. }\end{array}$ & $\begin{array}{l}\text { Embora não estejam ocupando um } \\
\text { grande espaço na tela, este retalho do } \\
\text { céu ganha destaque por estar no alto } \\
\text { da composição. Assim, o céu } \\
\text { salpicado de estrelas adquire } \\
\text { importância semiótica por seu } \\
\text { sentido metafórico, mas também por } \\
\text { seu sentido histórico no modo de } \\
\text { pintar a noite, que van Gogh inovou, } \\
\text { ao representá-la sem o uso da cor } \\
\text { preta. }\end{array}$ \\
\hline $\begin{array}{l}\text { Na tela 'A Esplanada do } \\
\text { Café na Place du Forum, } \\
\text { Arles, à Noite', observei a } \\
\text { ocorrência de Saliência e } \\
\text { Cor, construída pelo } \\
\text { detalhamento e pela } \\
\text { intensidade cromática com } \\
\text { que a árvore, mesmo estando } \\
\text { no segundo plano, é } \\
\text { representada, registrada na } \\
\text { nota de rodapé } 154 \text { no } \\
\text { apêndice. }\end{array}$ & $\begin{array}{l}\text { As frentes das casas em uma rua que } \\
\text { segue sob o céu azul salpicado de } \\
\text { estrelas são azul escuro ou violeta, } \\
\text { com uma árvore verde. }\end{array}$ & $\begin{array}{l}\text { Cada elemento na tela é enfatizado } \\
\text { por van Gogh, dependendo do ângulo } \\
\text { e da atenção que se dá em cada } \\
\text { detalhe. É como se ele tivesse } \\
\text { representado cada elemento em toda } \\
\text { sua profundidade e inteireza. Assim, } \\
\text { ao descrever ele enfatiza que toda a } \\
\text { cena é composta 'com uma arvore } \\
\text { verde'. Mesmo à noite, a árvore não } \\
\text { perde seu colorido, e ganha } \\
\text { proeminência na descrição. }\end{array}$ \\
\hline $\begin{array}{l}\text { Na tela 'O Café Noturno na } \\
\text { Place Lamartine, em Arles', } \\
\text { observei a ocorrência de } \\
\text { Distorção do ponto de vista e } \\
\text { de Saliência, que ele } \\
\text { constrói para representar } \\
\text { uma realidade que é do } \\
\text { domínio moral e subjetivo, } \\
\text { registrados na nota de rodapé } \\
143 .\end{array}$ & $\begin{array}{l}\text { Eu tentei expressar as terríveis } \\
\text { paixões humanas com o vermelho e o } \\
\text { verde. }\end{array}$ & $\begin{array}{l}\text { Observei o Uso de Associação } \\
\text { Metafórica e do Simbólico da Cor } \\
\text { sendo explicitado nesta oração. A } \\
\text { ocorrência é compatível com a } \\
\text { ocorrência do contraste complementar } \\
\text { a que ela se refere na tela, registrado } \\
\text { na nota de rodapé } 256 .\end{array}$ \\
\hline $\begin{array}{l}\text { Na tela 'O Café Noturno na } \\
\text { Place Lamartine, em Arles', } \\
\text { observei a ocorrência de } \\
\text { Vetor e de Saliência sobre a } \\
\text { atitude do homem que se } \\
\text { contrapõe à apatia que } \\
\text { toma as outras figuras na } \\
\text { cena, registrado na nota de } \\
\text { rodapé } 162 .\end{array}$ & $\begin{array}{l}\text { A roupa branca do proprietário, } \\
\text { vigiando as coisas a partir de um } \\
\text { canto deste forno, torna-se amarelo- } \\
\text { limão, verde luminoso pálido. }\end{array}$ & $\begin{array}{l}\text { Observei o uso de associações } \\
\text { metafóricas e uso simbólico da cor } \\
\text { com A escolha do item lexical } \\
\text { "forno" no extrato de carta, que é } \\
\text { correspondente à representação } \\
\text { visual da luz excessiva no interior do } \\
\text { café, registrado na nota de rodapé } \\
\underline{259} \text {. }\end{array}$ \\
\hline
\end{tabular}


Na tela 'O Café Noturno na Place Lamartine, em Arles', observei a ocorrência do uso de Saliência e Vetor interrelacionados com a ocorrência de Textura e Gesto Pictórico para construir a luz das lâmpadas a gás, registrado na nota de rodapé 125 . O vetor ocorre em direção radial.

Ocorrência de Saliência, por meio do uso de Ritmo, Movimento, Textura, Vetor e Gesto Pictórico que são usados para representar o brilho intermitente das lâmpadas, pintado com riqueza de detalhes, textura e movimento direcional, registrados na nota de rodapé $\underline{190 .}$.

Uso de associação metafórica por meio de Saliência, Ritmo, Movimento, Textura e Gesto Pictórico para dar centralidade para luz, registrada na nota de rodapé $\underline{201}$.

Ocorrência de baixa Modalidade por meio de baixa Profundidade, Saliência e Cor chapada para representar o brilho da luz de forma gráfica, registrada na nota de rodapé 204.

Na tela 'O Café Noturno na Place Lamartine, em Arles', observei a ocorrência de Saliência construída pelo Contraste de saturação entre o amarelo do chão no primeiro plano e a sombra da mesa de bilhar amareloesverdeado, registrada na nota de rodapé 126.
Eu acabei de terminar uma tela que representa um interior de café à noite iluminado por lâmpadas. Alguns pobres vagabundos noturnos estão dormindo em um canto. A sala está pintada de vermelho, e no interior, na luz a gás, a mesa de bilhar verde, a qual lança uma imensa sombra sobre o chão. Nesta tela, há 6 ou 7 vermelhos diferentes, desde vermelho-sangue até rosa delicado, fazendo oposição com o mesmo número de verdes pálidos ou escuros.

'A sala está pintada de vermelho, e no interior, na luz a gás, a mesa de bilhar verde, a qual lança uma imensa sombra sobre o chão.'

Uso da Saliência - na oração paratáxica, ele descreve a sala como pintada de vermelho, e ao não mencionar as outras cores que também estão na representação da sala que ele descreve no texto ele produz uma saliência para a cor vermelha da sala, registrado na nota de rodapé 284.

Uso de saliência na oração 'e no interior, na luz a gás, a mesa de bilhar verde, a qual lança uma imensa sombra sobre o chão. ' A saliência é construída pela circunstância 'e no interior, na luz a gás' e pelo complexo nominal 'imensa sombra'. A ocorrência de saliência textual está compatível com a ocorrência de saliência visual, ambas constroem o mesmo sentido de ênfase pela desproporção, registrado na nota de rodapé 287.

Muitas vezes parece-me que a noite é muito mais viva e ricamente colorida do que o dia. Agora como para recuperar o dinheiro pago ao senhorio através da minha pintura, eu não estou fazendo questão disto, porque a pintura é uma das mais feias que eu já fiz. É o equivalente, embora diferente, dos comedores de batata.
Uso de Aguçamento, Saliência e Vetor na construção 'Acabei de terminar uma tela.' registrado na nota de rodapé 281.

Uso de distorção tanto na escrita quanto na tela: com a escolha do item lexical 'imensa' na oração 'a qual lança uma imensa sombra sobre o chão. 'observei a ocorrência de distorção que é compatível com a distorção da sombra representada no quadro, registrado na nota de rodapé 288.

Uso do significante oposto ao significado para construir o sentido. Aqui há mais um construto oracional e também na tela no qual o sentido ‘ação' e 'protagonismo' é construído pela 'inação' e pela não participação da ação, registrado na nota de rodapé $\underline{283}$.

A intensidade da luz é salientada no café e, portanto, todas as tonalidades ganham um detalhamento que fica registrado nas orações. Van Gogh salienta no início da oração 'acabei de terminar', ele escreve a carta assim que termina de pintar a tela. Ela parece estar presente em toda sua intensidade ao descrever para o irmão as cores e os sentidos metafóricos presente na pintura. Ele enfatiza na descrição da tela sua relação passional com os significados metafóricos presentes nos elementos visuais e avalia afirmando que 'é uma das mais feias', embora posteriormente afirme que talvez seja uma das mais significativas.

Assim como ele enfatiza os sentidos metafóricos presentes da composição, ele também enfatiza o sentido metafórico da tela em si mesma em relação às demais telas, comparando-a aos comedores de batata, e aos artigos de Dostoievski. Ou seja, há uma semiose na tela em relação à sua obra em geral. E van Gogh enfatiza essa analogia entre telas aparentemente distintas, mas que contém uma similaridade na construção do próprio discurso artístico. 


\begin{tabular}{|c|c|c|}
\hline $\begin{array}{l}\text { Na tela 'O Café Noturno na } \\
\text { Place Lamartine, em Arles', } \\
\text { observei a ocorrência de } \\
\text { Saliência, construída pelo } \\
\text { detalhamento da mesa de } \\
\text { bilhar, feita pelo desenho- } \\
\text { pintura, registrada na nota de } \\
\text { rodapé } 130 \text { e } 131 .\end{array}$ & $\begin{array}{l}\text { Eu acabei de terminar uma tela que } \\
\text { representa um interior de café à noite } \\
\text { iluminado por lâmpadas. Alguns } \\
\text { pobres vagabundos noturnos estão } \\
\text { dormindo em um canto. A sala está } \\
\text { pintada de vermelho, e no interior, na } \\
\text { luz a gás, a mesa de bilhar verde, a } \\
\text { qual lança uma imensa sombra sobre } \\
\text { o chão. Nesta tela, há } 6 \text { ou } 7 \\
\text { vermelhos diferentes, desde } \\
\text { vermelho-sangue até rosa delicado, } \\
\text { fazendo oposição com o mesmo } \\
\text { número de verdes pálidos ou escuros. }\end{array}$ & $\begin{array}{l}\text { A mesa de bilhar ganha uma saliência } \\
\text { na tela do café, porém na descrição } \\
\text { van Gogh enfatiza sua sombra, ou } \\
\text { seja, revela que seu sentido na } \\
\text { composição se deve mais pela enorme } \\
\text { sombra que projeta do que pelo seu } \\
\text { significado em si mesma. A saliência } \\
\text { em relação à mesa de bilhar é sua } \\
\text { sombra, que inclusive aparece } \\
\text { detalhadamente representada na } \\
\text { composição, com ênfases de luz a sua } \\
\text { volta e traços enegrecidos que a } \\
\text { diferenciam do ambiente, dando um } \\
\text { aspecto monstruoso na composição } \\
\text { geral da tela, como se fosse muito } \\
\text { mais do que originalmente seria. }\end{array}$ \\
\hline $\begin{array}{l}\text { Na tela ‘O Café Noturno na } \\
\text { Place Lamartine, em Arles', } \\
\text { observei a ocorrência de } \\
\text { Saliência construída com o } \\
\text { uso de Textura, Ritmo, } \\
\text { Movimento e Gesto } \\
\text { Pictórico para representar o } \\
\text { brilho da lâmpada na } \\
\text { representação das figuras no } \\
\text { fundo da sala, registrada na } \\
\text { nota de rodapé 134. }\end{array}$ & $\begin{array}{l}\text { Alguns pobres vagabundos noturnos } \\
\text { estão dormindo em um canto. }\end{array}$ & $\begin{array}{l}\text { Van Gogh utiliza três adjetivos para } \\
\text { descrever as personagens que se } \\
\text { encontram no café. A ênfase que ele } \\
\text { dá a estas personagens justifica } \\
\text { estarem dormindo em um café a } \\
\text { noite. São pobres, estão vagando a } \\
\text { noite, portanto são vagabundos e } \\
\text { noturnos. Há uma crítica social à esta } \\
\text { condição de vida. Enquanto os } \\
\text { comedores de batatas comem no } \\
\text { escuro, estes vagabundos dormem } \\
\text { embaixo de uma luz insidiosa. }\end{array}$ \\
\hline $\begin{array}{l}\text { Na tela 'O Café Noturno na } \\
\text { Place Lamartine, em Arles', } \\
\text { observei a ocorrência de } \\
\text { Distorção do ponto de vista } \\
\text { pela baixa Profundidade na } \\
\text { ausência de luz e sombra, e } \\
\text { pela Saliência produzida } \\
\text { pelos Contrastes de } \\
\text { saturação, registradas na nota } \\
\text { de rodapé } 147 . \\
\\
\text { Observei a ocorrência de } \\
\text { Saliência construída pela } \\
\text { ausência de sombras e } \\
\text { apenas uma sombra no } \\
\text { centro da composição, } \\
\text { registrada na nota de rodapé } \\
149 \text {. }\end{array}$ & $\begin{array}{l}\text { As sombras e sombras projetadas } \\
\text { estão removidas; foi colorido em tons } \\
\text { chapados como as gravuras japonesas } \\
\text { Isso vai contrastar, com a diligência } \\
\text { Tarascon e o café à noite. } \\
\text { A ideia do semeador ainda continua a } \\
\text { me assombrar. Estudos exagerados, } \\
\text { como o semeador, como o café } \\
\text { noturno agora, geralmente parecem- } \\
\text { me atrozmente feios e ruins, mas } \\
\underline{\text { quando eu estou movido por alguma }} \\
\text { coisa, como aqui por este pequeno } \\
\text { artigo sobre Dostoievski, em seguida, } \\
\text { eles são os únicos que me parecem } \\
\text { ter um significado mais importante. }\end{array}$ & $\begin{array}{l}\text { A ausência de sombra nos outros } \\
\text { elementos da cena enfatiza ainda mais } \\
\text { a sombra da mesa de bilhar. A } \\
\text { ausência de sombra chama a atenção } \\
\text { para o efeito chapado das imagens. } \\
\text { Como em uma crítica pela } \\
\text { passividade das personagens, uma } \\
\text { passividade inclusive diante da luz } \\
\text { intensa. Não reagem, não respondem } \\
\text { a nada. Van Gogh parece enfatizar } \\
\text { este aspecto anulando a sombra como } \\
\text { forma de dar ênfase à ausência de } \\
\text { ação das personagens. Que, ao } \\
\text { contrário, estão sujeitas à luz doentia } \\
\text { do café. }\end{array}$ \\
\hline $\begin{array}{l}\text { Observei a ocorrência de } \\
\text { Associação metafórica por } \\
\text { meio de Saliência, } \\
\text { Contradição e Distorção do } \\
\text { Ponto de Vista para } \\
\text { representar a sombra da } \\
\text { mesa em contraste com a } \\
\text { ausência de sombras nos } \\
\text { outros objetos e figuras. } \\
\text { Registrada na nota de rodapé }\end{array}$ & & \\
\hline
\end{tabular}




\begin{tabular}{|c|c|c|}
\hline $\begin{array}{l}149 \text { e } 205 . \\
\text { Observei a ocorrência de } \\
\text { Associação metafórica por } \\
\text { meio de Saliência, } \\
\text { Transparência e } \\
\text { Profundidade na escolha } \\
\text { potencial de sentidos } \\
\text { associados à exclusividade } \\
\text { da sombra da mesa em } \\
\text { relação à ausência de } \\
\text { sombra dos outros objetos } \\
\text { e figuras, registrada na nota } \\
\text { de rodapé } 226 .\end{array}$ & & \\
\hline $\begin{array}{l}\text { Na tela 'O Café Noturno na } \\
\text { Place Lamartine, em Arles', } \\
\text { observei a ocorrência de } \\
\text { Saliência construída pela } \\
\text { distorção do ponto de vista } \\
\text { e pelo exagero no uso de } \\
\text { todos os elementos, que } \\
\text { muitas vezes estão } \\
\text { trabalhando na composição } \\
\text { de forma redundante para } \\
\text { obter um efeito de sentido, } \\
\text { registrada na nota de rodapé } \\
\underline{150 .}\end{array}$ & $\begin{array}{l}\text { Tudo isso em uma atmosfera de } \\
\text { fornalha infernal, de enxofre pálido. } \\
\text { Exprimir como a potência dos cantos } \\
\text { escuros de uma taberna. } \\
\underline{\text { Contudo sob uma aparência da alegria }} \\
\text { japonesa e da boa natureza de } \\
\text { Tartarin. } \\
\text { Que diria, portanto desse quadro o Sr. } \\
\text { Tersteeg? Diante de um Sisley, } \\
\text { Sisley, o mais discreto e delicado dos } \\
\underline{\text { Impressionistas - já disse: "Não posso }} \\
\text { me impedir de pensar que o artista } \\
\text { que pintou isso estava um pouco } \\
\text { tonto". Diante do meu quadro, então } \\
\text { a mim ele diria que ele é um caso de } \\
\text { delirium tremens. }\end{array}$ & $\begin{array}{l}\text { Observei aqui uma contraposição no } \\
\text { nível semântico, entre o discurso que } \\
\text { o Sr. Tersteeg representa e o discurso } \\
\text { que van Gogh representa. Além disso, } \\
\text { há também a ocorrência de uma } \\
\text { metáfora que seria a comparação da } \\
\text { reação de Tersteeg diante de uma tela } \\
\text { de Sisley e à tela 'O Café da Noite' } \\
\text { de van Gogh, registrado na nota de } \\
\text { rodapé } 276 .\end{array}$ \\
\hline $\begin{array}{l}\text { Na tela 'O Café Noturno na } \\
\text { Place Lamartine, em Arles', } \\
\text { observei a ocorrência de } \\
\text { Saliência construída pelo } \\
\text { Vetor e pela posição } \\
\text { relativa do homem no } \\
\text { centro da sala e dos } \\
\text { bêbados nas mesas } \\
\text { periféricas, registrada na } \\
\text { nota de rodapé } 160 .\end{array}$ & $\begin{array}{l}\text { Primeiro excerto: 'Alguns pobres } \\
\text { vagabundos noturnos estão dormindo } \\
\text { em um canto. A sala está pintada de } \\
\text { vermelho, e no interior, na luz a gás, a } \\
\text { mesa de bilhar verde, a qual lança } \\
\text { uma imensa sombra sobre o chão. } \\
\text { Nesta tela, há } 6 \text { ou } 7 \text { vermelhos } \\
\text { diferentes, desde vermelho-sangue até } \\
\text { rosa delicado, fazendo oposição com } \\
\text { o mesmo número de verdes pálidos } \\
\text { ou escuros.' } \\
\text { Segundo excerto: 'Muitas vezes } \\
\text { parece-me que a noite é muito mais } \\
\text { viva e ricamente colorida do que o } \\
\text { dia. Agora como para recuperar o } \\
\text { dinheiro pago ao senhorio através da } \\
\text { minha pintura, eu não estou fazendo } \\
\text { questão disto, porque a pintura é uma } \\
\text { das mais feias que eu já fiz. É o } \\
\text { equivalente, embora diferente, dos } \\
\text { comedores de batata. } \\
\text { Eu tentei expressar as terríveis } \\
\text { paixões humanas com o vermelho e o } \\
\text { verde. } \\
\text { A sala é vermelho-sangue e amarelo } \\
\text { sem graça, uma mesa de bilhar verde } \\
\text { no centro, } 4 \text { lâmpadas de amarelo }\end{array}$ & $\begin{array}{l}\text { No primeiro excerto van Gogh inicia } \\
\text { a narração da tela pela descrição dos } \\
\text { bêbados: 'Alguns pobres vagabundos } \\
\text { noturnos estão dormindo em um } \\
\text { canto', revelando a importância } \\
\text { dessas figuras na concepção de sua } \\
\text { composição. Ainda que eles ocupem } \\
\text { uma posição periférica na tela e no } \\
\text { nível semântico da oração pela } \\
\text { escolha 'em um canto', van Gogh } \\
\text { revela sua centralidade iniciando por } \\
\text { eles a descrição escrita da } \\
\text { composição da tela. A escolha de } \\
\text { iniciar a descrição pela figura dos } \\
\text { vagabundos demonstra que a posição } \\
\text { relativa dessas figuras exerce uma } \\
\text { chave semiótica para o sentido que } \\
\text { van Gogh deseja construir. Ao } \\
\text { mesmo tempo, ele não menciona a } \\
\text { figura do proprietário não obstante o } \\
\text { fato que ele ocupa o centro da tela, } \\
\text { denotando uma inversão na } \\
\text { valorização da posição relativa das } \\
\text { figuras tanto na composição quanto } \\
\text { na carta. Essa inversão de importância } \\
\text { para quem está na periferia e falta de } \\
\text { importância para quem está no centro } \\
\text { pode revelar um construto semiótico }\end{array}$ \\
\hline
\end{tabular}




\begin{tabular}{|c|c|c|}
\hline & $\begin{array}{l}\text { limão com um brilho laranja e verde. } \\
\text { Em todos os lugares é uma batalha e } \\
\text { uma antítese dos mais diferentes } \\
\text { verdes e vermelhos; nas personagens } \\
\text { dos rufiões adormecidos, pequenos na } \\
\text { alta sala vazia, algum roxo e azul. O } \\
\text { vermelho-sangue e o amarelo-verde } \\
\text { da mesa de bilhar, por exemplo, } \\
\text { contrasta com o pouco de verde } \\
\text { delicado Louis XV do balcão, onde há } \\
\text { um buquê rosa. } \\
\text { A roupa branca do proprietário, } \\
\text { vigiando as coisas a partir de um } \\
\text { canto deste forno, torna-se amarelo- } \\
\text { limão, verde luminoso pálido.' }\end{array}$ & $\begin{array}{l}\text { para os sentidos indexados a esta } \\
\text { escolha, tanto léxico-gramatical } \\
\text { quanto compositiva. A posição } \\
\text { relativa das figuras e a relação entre } \\
\text { centro e periferia assumem na } \\
\text { composição um valor metafórico } \\
\text { determinante na construção do } \\
\text { sentido. } \\
\text { No segundo excerto van Gogh } \\
\text { menciona o homem que está no } \\
\text { centro da tela apenas no final da } \\
\text { narrativa sobre como é visualmente a } \\
\text { composição do café. No entanto, ao } \\
\text { falar do homem, o foco está mais na } \\
\text { sua roupa branca (oração alfa) e nos } \\
\text { tons de amarelo e verde que ela } \\
\text { adquire no ambiente do café do que } \\
\text { na atitude de vigilância do homem } \\
\text { (oração beta). }\end{array}$ \\
\hline $\begin{array}{l}\text { Na tela 'O Café Noturno na } \\
\text { Place Lamartine, em Arles', } \\
\text { observei a ocorrência de } \\
\text { Vetor, construído pela } \\
\text { relação com o Contraste } \\
\text { Cromático da sombra e a } \\
\text { sua Saliência produzida em } \\
\text { oposição aos corredores de } \\
\text { luz, registrados na nota de } \\
\text { rodapé 155. } \\
\text { Na tela 'O Café Noturno na } \\
\text { Place Lamartine, em Arles', } \\
\text { observei a ocorrência de } \\
\text { Saliência dada à mesa de } \\
\text { bilhar pelo uso da } \\
\text { Distorção do ponto de vista } \\
\text { articulado com outros } \\
\text { recursos semióticos, } \\
\text { registrada na nota de rodapé } \\
186 .\end{array}$ & $\begin{array}{l}\text { A sala está pintada de vermelho, e no } \\
\text { interior, na luz a gás, a mesa de bilhar } \\
\text { verde, a qual lança uma imensa } \\
\text { sombra sobre o chão. }\end{array}$ & $\begin{array}{l}\text { Uso de saliência na oração ‘e no } \\
\text { interior, na luz a gás, a mesa de bilhar } \\
\text { verde, a qual lança uma imensa } \\
\text { sombra sobre o chão.' A saliência é } \\
\text { construída pela circunstância ‘e no } \\
\text { interior, na luz a gás' e pelo complexo } \\
\text { nominal 'imensa sombra'. A } \\
\text { ocorrência de saliência textual está } \\
\text { compatível com a ocorrência de } \\
\text { saliência visual, ambas constroem o } \\
\text { mesmo sentido de ênfase pela } \\
\text { desproporção, registrado na nota de } \\
\text { rodapé } 287 .\end{array}$ \\
\hline $\begin{array}{l}\text { Na tela 'O Café Noturno na } \\
\text { Place Lamartine, em Arles', } \\
\text { observei a ocorrência de } \\
\text { Associação metafórica e } \\
\text { Saliência, por meio da } \\
\text { posição relativa da mesa de } \\
\text { bilhar em relação às } \\
\text { figuras, usada como uma } \\
\text { metáfora visual, registrada } \\
\text { na nota de rodapé } 215 .\end{array}$ & & \\
\hline $\begin{array}{l}\text { Na tela ‘O Café Noturno na } \\
\text { Place Lamartine, em Arles', } \\
\text { observei a ocorrência de } \\
\text { Associação metafórica pela } \\
\text { Saliência dada às lâmpadas }\end{array}$ & $\begin{array}{l}\text { Tudo isso em uma atmosfera de } \\
\text { fornalha infernal, de enxofre pálido. } \\
\text { Exprimir como a potência dos cantos } \\
\text { escuros de uma taberna. } \\
\text { Contudo sob uma aparência da alegria }\end{array}$ & $\begin{array}{l}\text { No nível semântico, este excerto o } \\
\text { construto ‘uma atmosfera de fornalha } \\
\text { infernal, de enxofre pálido' é usado } \\
\text { para explicitar o significado 'potência } \\
\text { dos cantos escuros de uma taberna'. }\end{array}$ \\
\hline
\end{tabular}




\begin{tabular}{|l|l|l|}
\hline $\begin{array}{l}\text { que se assemelham com } \\
\text { olhos, registrada na nota de } \\
\text { rodapé } 240 \text { e 241. }\end{array}$ & $\begin{array}{l}\text { japonesa e da boa natureza de } \\
\text { Tartarin. }\end{array}$ & $\begin{array}{l}\text { Além disso, van Gogh também } \\
\text { salienta o uso de uma contraposição } \\
\text { que está presente tanto na oração, no } \\
\text { nível semântico, quanto na tela: o } \\
\text { significado sombrio da taberna é } \\
\text { construído por meio de 'uma } \\
\text { aparência da alegria japonesa e da boa } \\
\text { natureza de Tartarin. 'Registrado na } \\
\text { nota de rodapé 187. }\end{array}$ \\
$\begin{array}{l}\text { Asservei a ocorrência de } \\
\text { construída metafórica }\end{array}$ & \\
$\begin{array}{l}\text { Ritmo, Textura e Movincia, } \\
\text { na representação das } \\
\text { lâmpadas e da luz que } \\
\text { delas emana. Registrado nas } \\
\text { notas de rodapé 187, 240 e }\end{array}$ & & \\
\hline$\underline{241 .}$ & & \\
\hline
\end{tabular}

Fonte: Triangulação para Saliência dos dados dos corpora visual e textual, com os extratos das cartas.

\title{
6.12 MODALIDADE
}

Na perspectiva da semiótica social, o naturalismo é definido como modalidade, que é definida como o uso de recursos semióticos que atribuem o grau de fidedignidade, ou seja, expressam quão verdadeiro ou real é uma representação. (VAN LEEUWEN, 2005, p.160; KRESS e VAN LEEUWEN, 2006, p.154ff, apud, VAN LEEUWEN, 2011, p.21).

De acordo com Van Leeuwen (2011, p. 72), o uso da cor pelos Impressionistas está na base de uma revolução na representação da modalidade, não com base na verdade da objetividade científica, mas com base na verdade da percepção subjetiva:

\begin{abstract}
Os Impressionistas trouxeram de volta a cor na arte Ocidental, usando a cor em vez do desenho como o ponto de partida da composição visual. Eles estavam ainda interessados na veracidade da representação, mas eles usaram um novo critério para a verdade da pintura. A verdade que eles estavam interessados não era a objetividade científica, mas a verdade subjetiva da percepção. Nisso eles foram influenciados pelo físico von Helmholtz, que, in 1855, tinha afirmado que 'nós nunca percebemos os objetos do mundo externo diretamente'. 'Ao contrario', ele disse, 'nós apenas percebemos os efeitos desses objetos nos nossos próprios aparatos nervosos, e isso tem sido sempre dessa forma, desde o primeiro momento de nossas vidas (quoted in Gage, 1993: 206). Esse 'efeito no aparato nervoso' é o que os Impressionistas queriam capturar. Eles queriam 'registrar a sensação', como Cézanne expressara mais tarde (ibid.: 210). Isso levou para a agora bem conhecida, mas então inovadora técnica da pintura de taches, pequenas formas coloridas que, por si próprias, não representavam nada, mas lentamente construíam uma representação reconhecível, assim como pedaços coloridos de um grande quebra-cabeça no começo não parecem representar nada, mas lentamente começam a revelar uma casa, uma árvore, ou o céu, quando vão sendo montados. ${ }^{307}$ (VAN LEEUWEN, 2011, p. 72)
\end{abstract}

\footnotetext{
307 Tradução livre da autora. "The Impressionists brought back colour in Western art, using colour rather than drawing as the starting point of visual composition. They were still interested in truthful representation, but they used a new criterion for the truth of painting. The truth they were interested in was not the objective truth of science, but the subjective truth of perception. In this they were influenced by the physicist von Helmholtz, who, in 1855 , had said that 'we never perceive the objects of the external world directly'. 'On the contrary', he had said, 'we only perceive the effects of these objects on our own nervous apparatuses, and it has always been like that, from the first moment of our lives (quoted in Gage, 1993: 206). This 'effect on the nervous apparatus' is that the Impressionists wanted to capture. They wanted to 'record sensation', as Cézanne would later put it (ibid.: 210). This led to the now well-known but then innovative technique of painting taches, small coloured shapes
} 
A modalidade na comunicação visual pode empregar critérios de verdade sensoriais, naturalistas ou abstratos. O critério de verdade é perceptivo, no uso de modalidade naturalista, e se apoia no princípio de verossimilhança. Quanto mais a representação visual se assemelha a realidade, ao que nós veríamos se víssemos na realidade, maior valor de verdade elas atribuiriam. Esse tipo de representação iniciada com o Renascimento culminou na fotografia, que possibilitou esses mesmos recursos de modalidade como critérios de verdade: perspectiva, representação detalhada do jogo de luz e sombra, modulação detalhada da cor, definição dos contornos.

Há, no entanto, outros critérios visuais de verdade, um deles é a modalidade abstrata, no qual o critério de verdade é cognitivo e se baseia na representação, ou sua ausência, de um padrão geral superficialmente subjacente a diferentes instâncias, ou a uma "essência" mais profunda do que é representado. A representação naturalista é reduzida. Nesse caso, as ilustrações em livros de ciência não se apoiam na similaridade, mas em desenhos simples, de duas dimensões de linha, sendo assim mesmo tomados como representações de verdades científicas.

Na cultura ocidental, desde o Renascimento a modalidade naturalista tem sido o critério dominante de verdade na representação visual. Isso pode ser observado até mesmo nos usos dos recursos de modalidade nas novas mídias, tal como nos jogos de computador. (VAN LEEUWEN, 2011, p.22)

Por meio de seu sistema semiótico original, van Gogh experimentou e demonstrou novas possibilidades de verdade que não dependem dos padrões de verossimilhança tradicionais. A modalidade nos termos de van Gogh, foi encontrada tanto no discurso visual quanto no escrito.

\subsubsection{Triangulação da Modalidade}

Modalidade, no texto escrito e em relação à triangulação - Para expressar graus de probabilidade, a linguagem lança mão de outros recursos modais, por exemplo, "pode", "irá" e "deve". "Poderá chover" é usado como um significado menos provável do que "vai chover". $\mathrm{Na}$ linguagem existem outros tipos de modalidade e outros recursos de modalidade. Há a possibilidade de realizar a 'modalidade objetiva', com o uso de frases como 'é provável que',

which, on their own, represented nothing, but slowly built up a recognizable representation, just as the coloured pieces of a large jigsaw puzzle at first do not seem to represent anything, but slowly begin to reveal a house, a tree, or the sky, as they are assembled." (VAN LEEUWEN, 2011, p. 72) 
ou 'é mais do que provável que'. A 'modalidade subjetiva' é obtida por meio dos "verbos de processo mental", por exemplo, "adivinhar", "acreditar", e "saber”. O emprego de recursos de modalidade não é em si uma expressão direta da verdade ou ausência dela, eles apenas são usados para construir uma expressão mais verdadeira ou mais real. Por exemplo, o uso de alta modalidade não é uma garantia de um alto valor de verdade, pois a alta modalidade pode ser empregada para emprestar credibilidade para algo que não é verdade ou não é real, como um conto de fadas que é contado com grande realismo. O emprego de baixa modalidade com a finalidade de lançar dúvidas sobre algo que de fato existe ou existiu, pode ser uma estratégia de negação de um crime, por exemplo, tal como a negação da existência do holocausto.

$\underline{\mathrm{O} \text { outro critério de verdade é emotivo e se expressa pela modalidade sensorial, que se }}$ baseia no efeito de prazer ou desagrado criado por representações visuais. Ao compreender as concepções estéticas e filosóficas às quais van Gogh subscrevia, é possível inferir que sua busca por modalidade se diferia da busca por modalidade empreendida por exemplo, pelos artistas renascentistas e pelos artistas das correntes artísticas subsequentes cuja preocupação foi a de representar a realidade com base no nosso conhecimento dela, e não com base na forma como nós a experienciamos. Essa diferença paradigmática está na base de uma mudança muito marcante no que os artistas Impressionistas e pós Impressionistas consideravam ser uma expressão de autenticidade.

Ao ir além das limitações da representação naturalista, a modalidade sensorial é representada pelo "excesso", pelo uso da perspectiva muito profunda, de cores muito vivas ao invés das cores suaves e harmoniosas da representação naturalista, do uso de contrastes complementares que se intensificam mutuamente, o uso de textura e de distorção dos planos e do ponto de vista. Este é o caso na obra de van Gogh: a ocorrência da modalidade sensorial, que privilegia o valor de verdade construído com base na saliência dos aspectos da materialidade pictórica que corroboram para a comunicação da transparência emocional. A autenticidade com que van Gogh construiu suas composições confere um caráter de valor de verdade que é muito central no seu sistema semiótico.

A modalidade está associada à categoria das associações metafóricas. Machin (2007) explica que, para atribuir um valor de verdade, por exemplo, os recursos semióticos podem ser escolhidos e combinados, pois eles têm um sentido potencial que os permitem transportar valores e lógicas associadas a um domínio para realizá-las em um novo domínio. Nessa transposição, são também transportados os valores de fidedignidade e verossimilhança de um domínio para o outro. Dessa forma na modalidade, os sentidos podem assumir um valor de verdade com base nas associações disponibilizadas pelo contexto de cultura. 
A modalidade também está associada às categorias da transparência e, indiretamente, da incompletude. Van Gogh buscou dar modalidade para o universo subjetivo, para a instância mais incomunicável que ele experienciava internamente e para isso ele inaugurou um novo tipo de sistema semiótico para atualizar e alçar a novos níveis a modalidade sensorial.

A modalidade sensorial na obra de van Gogh é um dos achados da pesquisa ao analisar as obras sob o viés da modalidade sensorial, que se baseia no efeito de prazer ou desagrado criado por representações visuais. Por exemplo, a busca pela representação da verdade da cor, verbalizada inclusive nas cartas escritas por van Gogh, foi interpretada como a busca do artista em recorrer à modalidade. Ele o fez para tentar ser fiel à representação do seu universo subjetivo, da instância mais incomunicável que ele experienciava internamente e para isso ele inaugurou um novo tipo de sistema semiótico e alçou novos níveis a modalidade sensorial.

Quadro 28: Triangulação da Modalidade

\begin{tabular}{|c|c|c|}
\hline Ocorrência nas telas & Orações & Comentário \\
\hline $\begin{array}{l}\text { Na tela 'Por de Sol: Campo } \\
\text { de trigo perto de Arles', } \\
\text { observei a ocorrência de } \\
\text { Modalidade na forma como } \\
\text { ele representou o campo de } \\
\text { trigo em um dia de ventania, } \\
\text { por meio dos recursos } \\
\text { semióticos como Textura, } \\
\text { Ritmo, Movimento, Cor, e } \\
\text { Direção ou Vetor. Registrado } \\
\text { nas notas de rodapé } 65,66, \\
67,68,69 \text { e } 70 \text { no apêndice. }\end{array}$ & $\begin{array}{l}\text { Tela quadrada número } 30 . \text { Eu } \\
\text { pintei-a ao ar livre no Mistral. Meu } \\
\text { cavalete foi fixado no chão com } \\
\text { estacas de ferro, um método que eu } \\
\text { recomendo a voce. Voce enterra os } \\
\text { pés do cavalete e, em seguida, voce } \\
\text { empurra a } 50 \text { centímetros de } \\
\text { comprimento um peso de ferro ao } \\
\text { lado deles. Voce amarra tudo com } \\
\text { cordas; dessa forma, voce pode } \\
\text { trabalhar com o vento. }\end{array}$ & $\begin{array}{l}\text { Ocorrência de Modalidade tanto na } \\
\text { prática de pintar ao ar livre e em } \\
\text { contato com as mudanças } \\
\text { atmosféricas, quanto na necessidade } \\
\text { que van Gogh demonstra de relatar as } \\
\text { condições em que a tela foi pintada } \\
\text { como se essas condições fossem } \\
\text { fundamentais para a compreensão do } \\
\text { que ele buscou comunicar com a tela, } \\
\text { registrada na nota de rodapé } 117 \text { no } \\
\text { apêndice. }\end{array}$ \\
\hline $\begin{array}{l}\text { A tela 'O Semeador' sugere } \\
\text { um conflito presente na } \\
\text { forma como os elementos } \\
\text { que deveriam se relacionar } \\
\text { de maneira harmônica estão } \\
\text { em todo momento se } \\
\text { contrastando. Seja pela } \\
\text { diferença de direções do } \\
\text { trigo no campo, pela } \\
\text { diferença de cores do trigo, } \\
\text { pela diferença de } \\
\text { espaçamento que as } \\
\text { pinceladas ora criam um } \\
\text { conjunto homogêneo e } \\
\text { indiferenciado, ora ressaltam } \\
\text { a individualidade de cada } \\
\text { ramo de trigo. }\end{array}$ & $\begin{array}{l}\text { Aqui está outra paisagem. Sol } \\
\text { poente? Lua nascendo? Noite de } \\
\text { verão, de qualquer modo. Cidade } \\
\text { violeta, estrela amarela, céu azul- } \\
\text { esverdeado; os campos de trigo têm } \\
\text { todos os tons: ouro velho, cobre, } \\
\text { ouro verde, ouro vermelho, ouro } \\
\text { amarelo, verde, vermelho e amarelo } \\
\text { bronze. Tela quadrada número } 30 \text {. }\end{array}$ & $\begin{array}{l}\text { Essa produção de homogeneidade e } \\
\text { diferenciação na forma como ele } \\
\text { agrupa os elementos representados na } \\
\text { composição pode ser uma estratégia } \\
\text { de acentuação de sensações visuais } \\
\text { que produzem Textura, Movimento, } \\
\text { Vetor e Gesto Pictórico, e conduzem à } \\
\text { sinestesia e à Modalidade sensorial } \\
\text { está registrada na nota de rodapé } 68, \\
\underline{69,70 \text { e } 71 \text { no apêndice. }}\end{array}$ \\
\hline
\end{tabular}




\begin{tabular}{|c|c|c|}
\hline $\begin{array}{l}\text { A Modalidade sensorial é } \\
\text { construída na tela pelo } \\
\text { contraste simultâneo e pelo } \\
\text { contraste de saturação que } \\
\text { produz uma luminosidade } \\
\text { exacerbada e uma } \\
\text { indiferenciação na tonalidade } \\
\text { de cada cor empregada que é } \\
\text { compativel com a } \\
\text { experiência real da } \\
\text { percepção das cores na luz } \\
\text { do ocaso. Esta ocorrência na } \\
\text { tela é compatível no nível } \\
\text { semântico com a descrição } \\
\text { do contraste simultâneo } \\
\text { excessivo e que criam, além } \\
\text { da modalidade sensorial, } \\
\text { ênfase e associação } \\
\text { metafórica. }\end{array}$ & $\begin{array}{l}\text { Preferia muito mais // fazer quadros } \\
\text { naifs [[tirados de velhos } \\
\text { almanaques, aqueles velhos } \\
\text { "almanaques dos lavradores" [[nos } \\
\text { quais o granizo, a neve, a chuva e o } \\
\text { bom tempo são retratados de modo } \\
\text { primitivo,]]]] como o Anquetin } \\
\text { atingiu tão bem no seu A Colheita. }\end{array}$ & $\begin{array}{l}\text { Ocorrência de Intertextualidade e } \\
\text { Interdiscursividade, Associação } \\
\text { metafórica, Transparência e } \\
\text { Modalidade ao relacionar a obra de } \\
\text { Anquetin e a estética Naif com sua } \\
\text { própria experiência para representar 'a } \\
\text { verdade das cores. Ocorrência de } \\
\text { Associação Metafórica pela } \\
\text { comparação que ele usa como } \\
\text { metáfora para explicar qual é a ordem } \\
\text { de sua experiência interna na escolha } \\
\text { da combinação de cores registrada na } \\
\text { nota de rodapé } 93 \text {. }\end{array}$ \\
\hline $\begin{array}{l}\text { Na tela A Esplanada do Café } \\
\text { na Place du Forum, Arles, à } \\
\text { Noite observei a ocorrência } \\
\text { de Modalidade pois van } \\
\text { Gogh quis retratar a sutileza } \\
\text { da cor sob a iluminação } \\
\text { natural das estrelas e a } \\
\text { diferença entre esta e a cor e } \\
\text { sob a iluminação artificial } \\
\text { da lâmpada a gás, registrada } \\
\text { na nota de rodapé } 138 \text { no } \\
\text { apêndice. }\end{array}$ & $\begin{array}{l}\text { Muitas vezes parece-me que a noite } \\
\text { é muito mais viva e ricamente } \\
\text { colorida do que o dia. } \\
\text { Agora há uma pintura de noite sem } \\
\text { preto. Com nada mais do que um } \\
\text { belo azul e violeta e verde e nestes } \\
\text { arredores da praça iluminada é } \\
\text { colorido por enxofre pálido, amarelo } \\
\text { limão. Eu gosto enormemente de } \\
\text { pintar no local à noite. No passado, } \\
\text { eles costumavam desenhar e pintar a } \\
\text { tela do desenho durante o dia. Mas } \\
\text { acho que me convém pintar a coisa } \\
\text { no momento. É bem verdade que eu } \\
\text { possa tomar um azul por um verde } \\
\text { no escuro, um azul lilás por um rosa } \\
\text { lilás, uma vez que você não pode } \\
\text { perceber a natureza do tom } \\
\text { claramente. Mas é a única maneira } \\
\text { de se livrar da noite negra } \\
\text { convencional com uma luz pobre, } \\
\text { pálida e esbranquiçada, quando na } \\
\text { verdade uma mera vela por si só nos } \\
\text { dá os mais ricos amarelos e laranjas. }\end{array}$ & $\begin{array}{l}\text { Observei também a ocorrência de } \\
\text { Modalidade, ou de baixa modalidade e } \\
\text { Inacabamento, Van Gogh representou } \\
\text { o azul da noite mais claro do que ele é } \\
\text { na realidade, para dessa forma, poder } \\
\text { representar os tons de lilases e verdes } \\
\text { que ele identificava ocularmente, mas } \\
\text { que não seriam aparentes na pintura. } \\
\text { No entanto, a busca de representar a } \\
\text { variada coloração que ele via é uma } \\
\text { forma de dar modalidade para a } \\
\text { representação, registrada na nota de } \\
\text { rodapé } 138 \text { e } 146 \text { no apêndice. }\end{array}$ \\
\hline $\begin{array}{l}\text { Na tela A Esplanada do Café } \\
\text { na Place du Forum, Arles, à } \\
\text { Noite observei a ocorrência } \\
\text { de Modalidade na forma de } \\
\text { representar a irradiação da } \\
\text { luz das estrelas, porque essa } \\
\text { irradiação está em } \\
\text { movimento. Van Gogh quis } \\
\text { representar a luz das estrelas } \\
\text { com o dinamismo com que } \\
\text { elas pareciam para ele, } \\
\text { registrada na nota de rodapé }\end{array}$ & $\begin{array}{l}\text { Uma enorme lanterna amarela } \\
\text { ilumina o terraço, a fachada, a } \\
\text { calçada, e até mesmo projeta luz } \\
\text { sobre os paralelepípedos da rua, que } \\
\text { adquirem uma coloração violeta- } \\
\text { rosa. As frentes das casas em uma } \\
\text { rua que segue sob o céu azul } \\
\text { salpicado de estrelas são azul escuro } \\
\text { ou violeta, com uma árvore verde. } \\
\text { Agora há uma pintura de noite sem } \\
\text { preto. Com nada mais do que um } \\
\text { belo azul e violeta e verde e nestes }\end{array}$ & \\
\hline
\end{tabular}




\begin{tabular}{|c|c|c|}
\hline 141 e 142 no apêndice. & $\begin{array}{l}\text { arredores da praça iluminada é } \\
\text { colorido por enxofre pálido, amarelo } \\
\text { limão. }\end{array}$ & \\
\hline $\begin{array}{l}\text { Na tela A Esplanada do Café } \\
\text { na Place du Forum, Arles, à } \\
\text { Noite observei a ocorrência } \\
\text { de Modalidade pela } \\
\text { construção da Modulação de } \\
\text { cores como van Gogh as } \\
\text { percebia. A sua } \\
\text { fidedignidade para captar e } \\
\text { representar as cores noite } \\
\text { confere modalidade para a } \\
\text { noite representada na tela, } \\
\text { registrada na nota de rodapé } \\
159 \text { no apêndice. }\end{array}$ & $\begin{array}{l}\text { Agora há uma pintura de noite sem } \\
\text { preto. Com nada mais do que um } \\
\text { belo azul e violeta e verde e nestes } \\
\text { arredores da praça iluminada é } \\
\text { colorido por enxofre pálido, amarelo } \\
\text { limão. Eu gosto enormemente de } \\
\text { pintar no local à noite. No passado, } \\
\text { eles costumavam desenhar e pintar a } \\
\text { tela do desenho durante o dia. Mas } \\
\text { acho que me convém pintar a coisa } \\
\underline{\text { no momento. É bem verdade que eu }} \\
\text { possa tomar um azul por um verde } \\
\text { no escuro, um azul lilás por um rosa } \\
\text { lilás, uma vez que você não pode } \\
\text { perceber a natureza do tom } \\
\text { claramente. Mas é a única maneira } \\
\text { de se livrar da noite negra } \\
\text { convencional com uma luz pobre, } \\
\text { pálida e esbranquiçada, quando na } \\
\text { verdade uma mera vela por si só nos } \\
\text { dá os mais ricos amarelos e laranjas. }\end{array}$ & $\begin{array}{l}\text { Na tela, van Gogh procurou registrar a } \\
\text { nuance da tonalidade das cores como } \\
\text { ele as percebia sob a luz da lâmpada a } \\
\text { gás e sob a luz do céu estrelado, } \\
\text { construindo uma gradação de matizes } \\
\text { mais saturados e menos saturados para } \\
\text { representar a noite sem usar a cor } \\
\text { preta. No excerto da carta no qual ele } \\
\text { enfatiza esse feito de pintar uma noite } \\
\text { sem preto, ele descreve como ele } \\
\text { representou as cores da noite. Além } \\
\text { disso, ele explica e pormenoriza tanto } \\
\text { a prática convencional e sua inovação } \\
\text { de pintar no momento, e no local para } \\
\text { experienciar os tons das cores na luz } \\
\text { noturna. No nível semântico este } \\
\text { excerto é compatível com a ocorrência } \\
\text { de Modalidade na tela. }\end{array}$ \\
\hline $\begin{array}{l}\text { Na tela 'O Café Noturno na } \\
\text { Place Lamartine, em Arles', } \\
\text { observei a ocorrência de } \\
\text { Distorção do ponto de vista } \\
\text { produzida pela baixa } \\
\text { Modalidade na representação } \\
\text { do ambiente do café. De } \\
\text { acordo com Kress e van } \\
\text { Leeuwen (1996), a } \\
\text { ambiguidade é um traço de } \\
\text { ocorrência de modalidade, } \\
\text { registradas na nota de rodapé } \\
\text { 148. }\end{array}$ & $\begin{array}{l}\text { Exprimir como a potência dos } \\
\text { cantos escuros de uma taberna. } \\
\text { Contudo sob uma aparência da } \\
\text { alegria japonesa e da boa natureza } \\
\text { de Tartarin. } \\
\text { Que diria portanto desse quadro o } \\
\text { Sr. Tersteeg? Diante de um Sisley, } \\
\text { Sisley, o mais discreto e delicado } \\
\text { dos Impressionistas - já disse: "Não } \\
\text { posso me impedir de pensar que o } \\
\text { artista que pintou isso estava um } \\
\text { pouco tonto". Diante do meu } \\
\text { quadro, então a mim ele diria que } \\
\text { ele é um caso de delirium tremens. }\end{array}$ & $\begin{array}{l}\text { Ocorrência de Contraste cromático de } \\
\text { Saturação e baixa Modalidade que } \\
\text { retira a percepção de Profundidade e } \\
\text { aumenta a sensação de desconforto e } \\
\text { fadiga, registrado na nota de rodapé } \\
\underline{231} \text {. }\end{array}$ \\
\hline $\begin{array}{l}\text { Na tela 'O Café Noturno na } \\
\text { Place Lamartine, em Arles', } \\
\text { observei a ocorrência de } \\
\text { Modalidade construída por } \\
\text { meio da ambiguidade da } \\
\text { intenção do olhar do homem, } \\
\text { registrada na nota de rodapé } \\
\text { 171. }\end{array}$ & $\begin{array}{l}\text { A roupa branca do proprietário, } \\
\text { vigiando as coisas a partir de um } \\
\text { canto deste forno, torna-se amarelo- } \\
\text { limão, verde luminoso pálido. }\end{array}$ & $\begin{array}{l}\text { Observei o uso de associações } \\
\text { metafóricas e uso simbólico da cor } \\
\text { com A escolha do item lexical "forno" } \\
\text { no extrato de carta, que é } \\
\text { correspondente à representação visual } \\
\text { da luz excessiva no interior do café, } \\
\text { registrado na nota de rodapé } 259 .\end{array}$ \\
\hline $\begin{array}{l}\text { Na tela 'O Café Noturno na } \\
\text { Place Lamartine, em Arles', } \\
\text { observei a ocorrência de } \\
\text { Associação metafórica por } \\
\text { meio de Interdiscursividade } \\
\text { para representar a luz } \\
\text { produzida pela lâmpada a }\end{array}$ & $\begin{array}{l}\text { É uma cor, então, que não é } \\
\text { localmente verdadeira do ponto de } \\
\text { vista realista do trompe l'oeil, mas } \\
\text { uma cor que sugere alguma emoção, } \\
\text { um temperamento ardente. }\end{array}$ & $\begin{array}{l}\text { Observei a ocorrência textual do uso } \\
\text { simbólico da cor indexada ao uso } \\
\text { simbólico da cor na tela. Textualmente } \\
\text { esta é uma ocorrência de cunho } \\
\text { semântico porque na carta ele explicita } \\
\text { o significado que o uso da cor tem na } \\
\text { tela, registrado na nota de rodapé } 262 \text {. }\end{array}$ \\
\hline
\end{tabular}




\begin{tabular}{|c|c|c|}
\hline $\begin{array}{l}\text { gás, e Modalidade, por se } \\
\text { tratar de um tema que era } \\
\text { muito atual para as questões } \\
\text { da época, registrada na nota } \\
\text { de rodapé } 206 \text { e } 207 \text {. }\end{array}$ & & \\
\hline $\begin{array}{l}\text { Na tela 'O Café Noturno na } \\
\text { Place Lamartine, em Arles', } \\
\text { observei a ocorrência de } \\
\text { Associação metafórica e } \\
\text { baixa Modalidade por meio } \\
\text { da diminuição da } \\
\text { Profundidade e da } \\
\text { Indiferenciação que produz } \\
\text { um efeito de sentido } \\
\text { simbólico sobre a ausência } \\
\text { de sombra das figuras e } \\
\text { presença de sombra da } \\
\text { mesa de bilhar, registrada } \\
\text { na nota de rodapé } 204,217, \\
221,222 \text { e } 223 . \\
\text { Ocorrência de Distorção do } \\
\text { ponto de vista produzida pela } \\
\text { baixa Modalidade na } \\
\text { representação do ambiente } \\
\text { do café. De acordo com } \\
\text { Kress e van Leeuwen (1996), } \\
\text { a ambiguidade é um traço de } \\
\text { ocorrência de modalidade, } \\
\text { registrado na nota de rodapé } \\
148 .\end{array}$ & $\begin{array}{l}\text { Mais tarde, quando eu tiver levado } \\
\text { esses experimentos mais longe, o } \\
\text { semeador ainda vai ser a primeira } \\
\text { tentativa nesse gênero. } \\
\text { O café noturno é uma continuação } \\
\text { do semeador, como é a cabeça do } \\
\text { velho camponês e do poeta, se eu } \\
\text { conseguir fazer essa ultima tela. É } \\
\underline{\text { uma cor, então, que não é }} \\
\underline{\text { localmente verdadeira do ponto de }} \\
\underline{\text { vista realista do trompe l'oeil, mas }} \\
\text { uma cor que sugere alguma emoção, } \\
\text { um temperamento ardente. }\end{array}$ & $\begin{array}{l}\text { Ocorrência de Contraste cromático de } \\
\text { Saturação e baixa Modalidade que } \\
\text { retira a percepção de Profundidade e } \\
\text { aumenta a sensação de desconforto e } \\
\text { fadiga, registrado na nota de rodapé } \\
\underline{231} .\end{array}$ \\
\hline
\end{tabular}

Fonte: Triangulação para Modalidade dos dados dos corpora visual e textual, com os extratos das cartas.

\subsection{INTERDISCURSIVIDADE E INTERTEXTUALIDADE}

\subsubsection{Interdiscursividade na recepção da obra}

A incompletude na imagem foi uma inovação semiótica com muitos desdobramentos inclusive na relação entre o espectador, a obra e o autor, pois, além de contar com o espectador para 'completar' a obra, ainda faz com que o público se coloque no lugar do artista para apreender a imagem que não está dada, mas depende dessa interação imaginária entre espectador e artista. Ao apreender a imagem, o espectador precisa apreender o todo pelo olhar do artista que representou 'suas' impressões sobre a cena, no momento em que pintou, e isso é altamente subjetivo e pessoal. O público passa a depender de reconstituir o olhar subjetivo do autor para construir o sentido total da imagem e nesse processo uma intimidade, uma proximidade entre autor e espectador se forma na constituição do texto artístico. O autor 
estabelece um processo de interdiscursividade e de intertextualidade para a construção dos sentidos, pois depende do público para completar a imagem que ele quis representar.

\subsubsection{Interdiscursividade e Intertextualidade na concepção da obra}

A interdiscursividade e a intertextualidade são possibilidades de transformação por meio de ressignificações e mudanças na prática discursiva. "A mudança envolve formas de transgressão, o cruzamento de fronteiras, tais como a reunião de convenções existentes em novas combinações, ou sua exploração em situações que geralmente as proíbem" (FAIRCLOUGH, 2001, p. 127).

Nesse processo intersubjetivo o espectador interage com o artista e com os sentidos compartilhados para compreender a concepção que pautou a obra. Devido a essa condensação de sentidos em suas telas, presenciamos em seu discurso artístico o que Fairclough (2003) define como um processo no qual o autor articula sua voz com outros textos e atualiza em seu texto, elementos de outros textos.

Os pressupostos da Semiótica Social nos ajudam a inferir que o artista parece criar seu próprio sistema semiótico no qual articula elementos que tanto para ele quanto para os demais produz um efeito de sentidos em um jogo de explicitação e de ocultamento. O leitor pode perceber a ocorrência de uma condensação de sentidos que sugerem sentidos diversos, para além dos que são mais evidentes na tela. Esse processo parece estar relacionado com a interdiscursividade que integra no texto visual a experiência do artista, sua visão de mundo, a sua história de leituras aos sentidos que ele produz. Esta dialogia entre a dinâmica de criação do autor e a experiência de fruição do leitor pode resultar em um texto aberto e em uma leitura polissêmica da obra de arte que parece propor diferentes vozes e leituras devido aos efeitos de sentidos produzidos pelo autor e pelo leitor.

A apreciação do público se dá de forma intuitiva e a análise da crítica valoriza aspectos formais, técnicos, históricos e sociais, apoiada em pressuposições acerca das concepções do artista que basearam a sua linguagem visual. Forrester (1983, p. 10) comenta acerca da interação do público com a transparência que há nas obras de van Gogh: "Hoje, o olhar das multidões varre os vestígios de seu abandono: essas telas que põem sua solidão à mercê da multidão que nelas se sacia sem a reconhecer. E sem o reconhecer”. No entanto, van Gogh deixou uma ampla documentação na forma de sua correspondência, que está hoje acessível a todos, e que nos permite acessar a interdiscursividade e a intertextualidade 
presente em suas telas, com base na sua prática de produção discursiva, suas leituras, e seu universo de referências citado nas cartas. Nessa prática dialógica, pode-se acessar as marcas interdiscursivas e intertextuais que infundem sentidos à sua obra.

A relação de van Gogh com a Literatura se dava como prática discursiva que alimentava a concepção de seu discurso artístico. Suas cartas evidenciam essa relação intensa com a literatura, como relata Edwards (2009, p.17): "Não apenas ele citava autores e títulos específicos que ele considerava 'magníficos', ele descrevia esses autores como 'pintores da vida' e os recomendava como leitura necessária para aqueles que desejam entender a verdade sobre seu tempo". ${ }^{308}$ A relação de van Gogh com a literatura é, no argumento do próprio van Gogh em sua carta de julho de 1880 para Theo, tão importante quanto à pintura, como relatado por Edwards (2009 p. 15-16):

\begin{abstract}
Antes de tornar sua atenção para criar arte, Vincent tinha sido convencido de sua vocação para ser um pastor Cristão como seu pai e o pai de seu pai. Depois de uma tentativa fracassada para se preparar para os estudos superiores que o levaram em direção ao diploma Teológico, ele tinha entrado em uma escola de treinamento missionário em Brussels em 1879, na idade de 26 anos. No ano seguinte, ele teve permissão de ir como um evangelizador em probatório para um distrito mineiro na Bélgica chamado Borinage, mas muito em breve foi demitido pelo Conselho de Evangelização como inapropriado para o trabalho. Profundamente deprimido e confuso sobre sua missão na vida, ele se escondeu de sua família em uma vila de mineração, lendo cada livro que ele podia por as mãos. O irmão Theo aparentemente escreveu para admoestá-lo sobre desistir de sua anterior apreciação pela grande arte para simplesmente permanecer na obscuridade e ler livros. Vincent respondeu em uma carta pungente de Julho de 1980, defendendo seu amor pela literatura. Seu gosto pela grande literatura e grande arte naquela carta para Theo pode nos preparar para a descoberta de uma imaginação literária que estava em funcionamento quando ele mais tarde postou o seu cavalete no café Ginoux. Aqui está como Vincent defendeu seu amor aos livros que Theo, que agora estava trabalhando em uma galeria de arte: "Existem muitas coisas que uma pessoa precisa crer e amar. Existe algo de Rembrandt em Shakespeare, e de Correggio em Michelet, e de Delacroix em Victor Hugo; e depois existe algo de Rembrandt no Evangelho, ou algo do Evangelho em Rembrandt - qual seja que se torne o mesmo se apenas a pessoa compreender apropriadamente, sem interpretar mal e considerar a equivalência das comparações, as quais não pretendem diminuir os méritos das personalidades originais. E em Bunyan existe algo de Maris ou de Millet, e em Beecher Stowe existe algo de Ary Scheffer. (...) Se agora voce pode perdoar um homem por fazer um estudo completo das pinturas, admita também que o amor aos livros é tão sagrado quanto o amor de Rembrandt - eu até penso que os dois complementam-se mutuamente. (Carta 133 de Van Gogh) ${ }^{309}$
\end{abstract}

\footnotetext{
308 Tradução livre da autora. "Not only did he name specific authors and titles that he viewed as "magnificent," he described those authors as "painting life," and recommended them as necessary reading for those who wish to understand the truth about their times." (EDWARDS, 2009, p. 17)

309 Before he turned his attention to creating art, Vincent had been convinced of his calling to be a Christian pastor like his father and his father's father before him. After a failed attempt to prepare for university studies that might lead him toward a theological degree, he had entered a missionary training school at Brussels in 1879, at age twenty-six. The following year he was allowed to go as a probationary evangelist to the Belgian mining district called the Borinage, but was soon dismissed by the Synodal Board of Evangelization as unfit for the work. Deeply depressed and confused as to his mission in life, he hid himself from his family in a mining village, reading every book he could get his hands on. Brother Theo apparently wrote to chide him for giving up his earlier appreciation for great art to simply remain in obscurity and read books. Vincent replied in a poignant
} 
Alguns aspectos da interdiscursividade na obra de van Gogh estão na raiz da transposição entre elementos discursivos textuais para o discurso visual. Entre os aspectos que unem o discurso textual e o discurso visual pode-se enumerar a imaginação literária, dada pelo seu amor aos livros; e a imaginação semântica, rica em figuras de linguagem, dada pela sua formação religiosa, nos primeiros anos pela família e posteriormente pela sua formação como evangelizador.

\subsubsection{Triangulação da Intertextualidade e Interdiscursividade na Recepção da Obra}

\section{Intertextualidade e Interdiscursividade na Recepção da Obra, no texto escrito e} em relação à triangulação - No discurso textual das cartas encontrei muitas citações e referências a outros artistas e pensadores. No discurso visual, observei que os trabalhos de Van Gogh são inspirados algumas vezes pelos trabalhos de outros artistas e escritores, tais como a sua versão de uma obra de Jean-François Millet ou por referências à literatura. Por exemplo, a tela 'O Semeador' foi inspirada em tela semelhante de Millet, e a tela 'A Esplanada do Café na Place du Forum, Arles, à Noite' dialoga com outra tela, "Avenue de Clichy in the Evening" de Anquetin e ainda que não se saiba se Van Gogh foi diretamente inspirado pelo trabalho Anquetin, pode-se afirmar que "Café Terrace" é um trabalho singular entre os demais produzidos por Van Gogh. No extrato ${ }^{310} \mathrm{n}^{\mathrm{o}} 3 \mathrm{~b}$ da carta 678 van Gogh faz uma referência ao romance Bel-ami de Maupassant, como uma descrição de uma noite estrelada em Paris que nas palavras dele: "é algo como o mesmo tema que eu pintei bem agora".

Edwards argumenta que a concepção de seus trabalhos estava fortemente investida por uma imaginação literária com a qual van Gogh interpelava os autores com quem subscrevia seus ideais, como é o caso da tela 'O Café Noturno na Place Lamartine, em Arles', na qual Edwards evidencia uma interdiscursividade e uma intertextualidade com o romance de Zola:

letter of July 1880, defending his love of literature. His linking of great literature and great art in that letter to Theo may prepare us for the discovery of a literary imagination that was at work when he later set up his easel in the Ginoux café. Here is how Vincent defended his love of books to Theo, who was now working in an art gallery: [T] here are many things one must believe and love. There is something of Rembrandt in Shakespeare, and of Correggio in Michelet, and of Delacroix in Victor Hugo; and then there is something of Rembrandt in the Gospel, or something of the Gospel in Rembrandt - whichever it comes to the same if only one understands it properly, without misinterpreting it and considering the equivalence of the comparisons, which do not pretend to lessen the merits of the original personalities. And in Bunyan there is something of Maris or of Millet, and in Beecher Stowe there is something of Ary Scheffer.(...) If now you can forgive a man for making a thorough study of pictures, admit also that the love of books is as sacred as the love of Rembrandt - I even think the two complement each other. (Van Gogh, letter 133) (Edwards, 2009, p.15-16)

310 Carta 678, Extrato no 3b -_Br. 1990: 681 | CL: W7, From: Vincent To: Willemien van Gogh,

Date: Arles, Sunday, 9 and about Friday, 14 September 1888 . Disponível em: <http://vangoghletters.org/vg/letters/let678/letter.html > . 
L'assomoir. No extrato ${ }^{311} \mathrm{n}^{\mathrm{o}} 4 \mathrm{~d}$ da carta 680, van Gogh cita uma interdiscursividade desta tela com um artigo de Dostoievski. Dessa forma, pautados em ampla discussão e observação das ocorrências, inferi que a obra de van Gogh está fortemente construída na interdiscursividade e na intertextualidade de autores com quem ele compartilhava um universo de sentidos e visões.

Quadro 29: Intertextualidade e Interdiscursividade

\begin{tabular}{|c|c|c|}
\hline Ocorrência nas telas & Orações & Comentário \\
\hline $\begin{array}{l}\text { Na tela 'Por de Sol: } \\
\text { Campo de trigo perto de } \\
\text { Arles', observei a } \\
\text { ocorrência de } \\
\text { interdiscursividade e } \\
\text { Associação metafórica, } \\
\text { registrado na nota de } \\
\text { rodapé } 106 \text { e } 107 \text { no } \\
\text { apêndice. } \\
\text { O uso da } \\
\text { interdiscursividade } \\
\text { influenciou na escolha do } \\
\text { Enquadramento que por } \\
\text { sua vez ajudou na } \\
\text { construção das } \\
\text { Associações metafóricas. }\end{array}$ & $\begin{array}{l}\text { Paisagens amarelo ouro velho - feito } \\
\text { rápido rápido rápido e com pressa, } \\
\text { como o ceifeiro que está em silêncio } \\
\text { sob o sol escaldante, concentrando-se } \\
\text { em ter o trabalho terminado. } \\
\text { Van Gogh se compara com o ceifeiro } \\
\text { porque deseja se colocar no lugar do } \\
\text { trabalhador do campo, e se identificar } \\
\text { com o seu lugar social, o de um } \\
\text { trabalhador que precisa se concentrar } \\
\text { em ter o trabalho terminado. } \\
\text { Em excerto relativo à outra tela, O } \\
\text { Semeador, ele explicita o diálogo que } \\
\text { ele trava com obras de outros pintores } \\
\text { que estão construindo sentidos } \\
\text { análogos aos que van Gogh endossa } \\
\text { nessa tela: } \\
\text { Preferia muito mais fazer quadros } \\
\text { naifs tirados de velhos almanaques, } \\
\text { aqueles velhos "almanaques dos } \\
\text { lavradores" nos quais o granizo, a } \\
\text { neve, a chuva e o bom tempo são } \\
\text { retratados de modo primitivo, como o } \\
\text { Anquetin atingiu tão bem no seu } A \\
\text { Colheita. }\end{array}$ & $\begin{array}{l}\text { A análise de uma cadeia de produção } \\
\text { textual, bem como da sua história de } \\
\text { leituras e a interdiscursividade que daí } \\
\text { decorre em sua obra pode nos ajudar a } \\
\text { compreender os pressupostos } \\
\text { filosóficos e ideológicos que parecem } \\
\text { basear algumas escolhas compositivas } \\
\text { na tela 'Por de Sol: Campo de trigo } \\
\text { perto de Arles'. }\end{array}$ \\
\hline $\begin{array}{l}\text { Na tela 'Por de Sol: } \\
\text { Campo de trigo perto de } \\
\text { Arles', observei a } \\
\text { ocorrência de um uso } \\
\text { original semiótico: a } \\
\text { inversão do ponto de fuga, } \\
\text { trazendo para o plano do } \\
\text { espectador o foco da } \\
\text { perspectiva e levando-o a } \\
\text { se identificar } \\
\text { inevitavelmente com o } \\
\text { lugar do experienciador da } \\
\text { tela, o artista. Este é um } \\
\text { uso original de perspectiva } \\
\text { para construir a distorção } \\
\text { do ponto de vista que } \\
\text { caracteriza uma busca }\end{array}$ & $\begin{array}{l}\text { Eu também sou totalmente incapaz de } \\
\text { julgar o meu próprio trabalho. Eu não } \\
\text { posso ver se os estudos são bons ou } \\
\text { ruins. Tenho sete estudos de trigais, } \\
\text { infelizmente todos eles nada além de } \\
\text { paisagens, muito contra a minha } \\
\text { vontade. Paisagens amarelo ouro } \\
\text { velho - feito rápido rápido rápido e } \\
\text { com pressa, como o ceifeiro que está } \\
\text { em silêncio sob o sol escaldante, } \\
\text { concentrando-se em ter o trabalho } \\
\text { terminado. }\end{array}$ & $\begin{array}{l}\text { Na oração: 'Eu também sou } \\
\text { totalmente incapaz de julgar o meu } \\
\text { próprio trabalho. Eu não posso ver se } \\
\text { os estudos são bons ou ruins.' } \\
\text { observei a ocorrência de } \\
\text { Transparência, Incompletude e de } \\
\text { Limiar Artístico - observei a } \\
\text { ocorrência da categoria limiar artístico } \\
\text { no complexo oracional, no nível } \\
\text { semântico, registrada na nota de } \\
\text { rodapé } 119 \text { no apêndice. Observei } \\
\text { também nesta oração a ocorrência de } \\
\text { Interdiscursividade, uma vez que ele } \\
\text { explica que ele próprio é incapaz de } \\
\text { julgar o próprio trabalho, deixando } \\
\text { implícito que ele depende de um outro } \\
\text { que faça isso para ele. }\end{array}$ \\
\hline
\end{tabular}

${ }^{311}$ Carta 680, Extrato no 4d - To Theo van Gogh. Arles, on or about Tuesday, 11 September 1888. Disponível em: 〈http://vangoghletters.org/vg/letters/let680/letter.html >. 


\begin{tabular}{|c|c|c|}
\hline $\begin{array}{l}\text { estética de van Gogh, } \\
\text { registrado na nota de } \\
\text { rodapé } 48 \text { no apêndice. }\end{array}$ & & \\
\hline $\begin{array}{l}\text { Observei a ocorrência de } \\
\text { Intertextualidade e de } \\
\text { Interdiscursividade na tela } \\
\text { 'O Semeador' com a } \\
\text { parábola da Bíblia e com a } \\
\text { tela 'O Semeador' de } \\
\text { Millet. }\end{array}$ & $\begin{array}{l}\text { Preferia muito mais // fazer quadros } \\
\text { naifs [[tirados de velhos almanaques, } \\
\text { aqueles velhos "almanaques dos } \\
\text { lavradores" [[nos quais o granizo, a } \\
\text { neve, a chuva e o bom tempo são } \\
\text { retratados de modo primitivo,]]]] } \\
\text { como o Anquetin atingiu tão bem no } \\
\text { seu A Colheita. }\end{array}$ & $\begin{array}{l}\text { Ocorrência de Intertextualidade e } \\
\text { Interdiscursividade, Associação } \\
\text { metafórica, Transparência e } \\
\text { Modalidade ao relacionar a obra de } \\
\text { Anquetin e a estética Naif com sua } \\
\text { própria experiência para representar 'a } \\
\text { verdade das cores. Ocorrência de } \\
\text { Associação Metafórica pela } \\
\text { compaçãa que ele usa como } \\
\text { metáfora para explicar qual é a ordem } \\
\text { de sua experiência interna na escolha } \\
\text { da combinação de cores registrada na } \\
\text { nota de rodapé } 93 \text {. }\end{array}$ \\
\hline $\begin{array}{l}\text { Na tela 'O Semeador', } \\
\text { observei a ocorrência de } \\
\text { Interdiscursividade e } \\
\text { Intertextualidade. Foi } \\
\text { identificada a superposição } \\
\text { do discurso religioso e do } \\
\text { discurso social e político } \\
\text { da época, bem como } \\
\text { elementos de outros textos } \\
\text { visuais e escritos, } \\
\text { registrado na nota de } \\
\text { rodapé } 63 .\end{array}$ & $\begin{array}{l}\text { Por um longo tempo ele foi meu } \\
\text { grande desejo de fazer um semeador, } \\
\text { mas os desejos que tive por um longo } \\
\text { tempo nem sempre são alcançados. } \\
\text { Então, eu estou quase com medo } \\
\text { deles. E, no entanto, depois de Millet e } \\
\text { Lhermitte o que resta a ser feito é... o } \\
\text { semeador, com cor e em um grande } \\
\text { formato. }\end{array}$ & $\begin{array}{l}\text { Van Gogh parece querer dizer que o } \\
\text { desejo dele não é o mesmo de Millet e } \\
\text { Lhermittee que a representação do } \\
\text { Semeador não foi alcançada segundo } \\
\text { o seu desejo pelos artistas que } \\
\text { representaram o trabalhador do } \\
\text { campo. Para van Gogh não resta outra } \\
\text { coisa além de ir atrás desse ideal de } \\
\text { representação, até porque algo } \\
\text { parecido já foi feito, mas o Semeador, } \\
\text { tal como ele o idealiza ainda é um } \\
\text { desejo e um estudo. Ele quer alcançar } \\
\text { um sentido espiritual que está presente } \\
\text { junto com esses outros sentidos que } \\
\text { foram retratados por esses artistas } \\
\text { anteriores. }\end{array}$ \\
\hline $\begin{array}{l}\text { No excerto de carta, van } \\
\text { Gogh explicita que o } \\
\text { semeador e o enfeixador } \\
\text { são símbolos de seu desejo } \\
\text { de infinito. Este é um } \\
\text { importante indexador para } \\
\text { os sentidos construídos na } \\
\text { tela 'O Semeador.' } \\
\text { Ele também explicita, no } \\
\text { excerto, o uso de } \\
\text { intertextualidade, ao } \\
\text { comparar sua 'luta } \\
\text { diabólica para atingir a } \\
\text { verdade das cores' com o } \\
\text { estilo naif dos 'velhos } \\
\text { almanaques dos lavradores } \\
\text { nos quais o granizo, a } \\
\text { neve, a chuva e o bom } \\
\text { tempo são retratados de } \\
\text { modo primitivo, com } \\
\text { Anquetin atingiu tão bem } \\
\text { no seu A Colheita.' } \\
\text { Observei que van Gogh } \\
\text { usou a intertextualidade }\end{array}$ & $\begin{array}{l}\text { Não te vou ocultar //que não desgosto } \\
\text { da região,// pois fui criado lá // - ainda } \\
\text { me encanta a magia das recordações } \\
\text { do passado, de um desejo do infinito,// } \\
\text { do qual o semeador e o enfeixador são } \\
\text { símbolos / -, tanto quanto antes } \\
\text { gostava.// } \\
\text { Há várias sugestões de amarelo no } \\
\text { solo, tons neutros resultantes da } \\
\text { mistura de violeta e amarelo; mas } \\
\text { tenho travado uma luta diabólica para } \\
\text { atingir a verdade das cores. Preferia } \\
\text { muito mais fazer quadros naifs tirados } \\
\text { de velhos almanaques, aqueles velhos } \\
\text { "almanaques dos lavradores" nos quais } \\
\text { o granizo, a neve, a chuva e o bom } \\
\text { tempo são retratados de modo } \\
\text { primitivo, como o Anquetin atingiu tão } \\
\text { bem no seu A Colheita. }\end{array}$ & $\begin{array}{l}\text { Ocorrência de Transparência, } \\
\text { Incompletude, Limiar Artístico, } \\
\text { Interdiscursividade e Associação } \\
\text { Metafórica no nível semântico da } \\
\text { oração Beta ao explicitar a natureza da } \\
\text { sua motivação na produção artística e } \\
\text { ao usar a contraposição criada pela } \\
\text { comparação entre Naif e 'a verdade } \\
\text { das cores' como metáfora para } \\
\text { explicar ao irmão o seu desejo de } \\
\text { infinito, registrados na nota de rodapé } \\
\text { 97. }\end{array}$ \\
\hline
\end{tabular}




\begin{tabular}{|c|c|c|}
\hline $\begin{array}{l}\text { como uma metáfora para } \\
\text { explicitar o caminho que } \\
\text { ele percorre para atingir a } \\
\text { verdade das cores. Este } \\
\text { não é o caminho da } \\
\text { representação naif, mas } \\
\text { que revela 'tons neutros } \\
\text { resultantes da mistura de } \\
\text { violeta e amarelo' que } \\
\text { nada têm de naif. }\end{array}$ & & \\
\hline & $\begin{array}{l}\text { Mas quando eu farei o céu estrelado, } \\
\text { então, essa pintura [[que está sempre } \\
\text { na minha mente? ]] } \\
\text { Ocorrência de Interdiscursividade pelo } \\
\text { uso de Enquadramento, Perspectiva e } \\
\text { Inversão do ponto de vista ao trazer o } \\
\text { leitor para o lugar em que se encontra } \\
\text { o artista ao expressar com Saliência, } \\
\text { uma forte contraposição entre uma } \\
\text { incerteza (de quando fará a tela) e uma } \\
\text { certeza (ela está sempre em sua } \\
\text { mente). Registrado na nota de rodapé } \\
\underline{109} .\end{array}$ & $\begin{array}{l}\text { Ocorrência de Interdiscursividade e de } \\
\text { Limiar Artístico pelo uso do processo } \\
\text { relacional atributivo 'está' que } \\
\text { constrói um protagonismo para a ideia } \\
\text { da tela e aproxima o interlocutor de } \\
\text { van Gogh dessa experiência de Limiar } \\
\text { Artístico que van Gogh tenta } \\
\text { comunicar e compartilhar com o } \\
\text { irmão. Registrado na nota de rodapé } \\
\underline{107} \text {. }\end{array}$ \\
\hline $\begin{array}{l}\text { Ao se referir à tela no } \\
\text { excerto de carta, van Gogh } \\
\text { usa a intertextualidade, da } \\
\text { fala de um personagem de } \\
\text { um romance de Huysmans, } \\
\text { para construir uma } \\
\text { metáfora. Ele compara a } \\
\text { sua tela 'O Semeador' com } \\
\text { o desejo de alguém, que } \\
\text { está no plano do sonho, } \\
\text { mas que não pinta. Dessa } \\
\text { forma, quando ele a pinta, } \\
\text { ele a representa em uma } \\
\text { atmosfera de sonho, na luz } \\
\text { difusa do crepúsculo, } \\
\text { construída pelos efeitos } \\
\text { dos contrastes cromáticos, } \\
\text { da diminuição dos detalhes } \\
\text { e do tratamento geral } \\
\text { desfocado. Essa baixa } \\
\text { definição inacabamento } \\
\text { são compatíveis com o } \\
\text { sentido de sonho } \\
\text { expressado nesse excerto } \\
\text { de carta. A luz difusa } \\
\text { expressa Inacabamento e } \\
\text { Incompletude também } \\
\text { expressada na Verbiagem } \\
\text { do excerto. }\end{array}$ & $\begin{array}{l}\text { Ai, ai, é como nosso excelente amigo } \\
\text { Cyprien diz, em 'En ménage' por JK } \\
\text { Huysmans: } \\
\text { as mais belas pinturas são aquelas que } \\
\text { alguém sonha enquanto fuma um } \\
\text { cachimbo em sua cama, mas a qual ele } \\
\text { não pinta. }\end{array}$ & $\begin{array}{l}\text { Ocorrência de Interdiscursividade e } \\
\text { Intertextualidade ao expressar uma } \\
\text { ideia por meio da afirmação (processo } \\
\text { Verbal) de seu amigo Cyprien. Essa } \\
\text { afirmação (Verbiagem) é usada como } \\
\text { uma metáfora para explicar o que ele } \\
\text { experiencia ao desejar realizar a tela, } \\
\text { indicando a ocorrência de Associação } \\
\text { metafórica no construto da } \\
\text { Verbiagem, para dar Transparência ao } \\
\text { que ele van Gogh pensa. Registrado } \\
\text { na nota de rodapé } 110 .\end{array}$ \\
\hline $\begin{array}{l}\text { A noite e as estrelas foi um } \\
\text { tema iniciado por van } \\
\text { Gogh. Walther e Metzger }\end{array}$ & $\begin{array}{l}\text { Você nunca me disse se você tinha } \\
\text { lido Bel-ami de Guy de Maupassant, e } \\
\text { o que você pensa agora do talento dele }\end{array}$ & $\begin{array}{l}\text { A ocorrência de Intertextualidade é } \\
\text { evidenciada no excerto pela 'descrição } \\
\text { de uma noite estrelada em Paris, } \underline{\underline{\text { com }}}\end{array}$ \\
\hline
\end{tabular}




\begin{tabular}{|c|c|c|}
\hline $\begin{array}{l}\text { (2012, p. } 383) \text { argumentam } \\
\text { que "ele criou um novo } \\
\text { gênero artístico: a cena } \\
\text { noturna ao ar livre". }\end{array}$ & $\begin{array}{l}\text { em geral. Digo isto porque o início de } \\
\text { Bel- Ami é precisamente a descrição } \\
\text { de uma noite estrelada em Paris, com } \\
\text { os cafés iluminados da avenida, e e } \underline{\text { isso }} \\
\text { é algo como o mesmo tema que eu } \\
\text { pintei bem agora. }\end{array}$ & $\begin{array}{l}\text { os cafés iluminados da avenida' que } \\
\text { van Gogh usou como metáfora para o } \\
\text { sentido que ele compartilhou tanto na } \\
\text { leitura de Bel-Ami quanto na produção } \\
\text { de seu texto pictórico na forma da tela } \\
\text { 'A Esplanada do Café na Place du } \\
\text { Forum, Arles, à Noite'. }\end{array}$ \\
\hline $\begin{array}{l}\text { Van Gogh inovou não } \\
\text { apenas no tema, mas na } \\
\text { proeza de registrar as cores } \\
\text { noturnas, como são as } \\
\text { cores dos objetos quando } \\
\text { iluminados pelo lampião a } \\
\text { gás e a luz das estrelas e } \\
\text { quando iluminados apenas } \\
\text { pela noite, registrado nas } \\
\text { notas de rodapé } 145 \text { e } 146 \\
\text { no apêndice. }\end{array}$ & $\begin{array}{l}\text { Agora há uma pintura de noite sem } \\
\text { preto. Com nada mais do que um belo } \\
\text { azul e violeta e verde e nestes } \\
\text { arredores da praça iluminada é } \\
\text { colorido por enxofre pálido, amarelo } \\
\text { limão. Eu gosto enormemente de } \\
\text { pintar no local à noite. No passado, } \\
\text { eles costumavam desenhar e pintar a } \\
\text { tela do desenho durante o dia. Mas } \\
\text { acho que me convém pintar a coisa no } \\
\text { momento. }\end{array}$ & $\begin{array}{l}\text { Observei a ocorrência da } \\
\text { intertextualidade no excerto de carta } \\
\text { pela comparação que van Gogh faz de } \\
\text { sua forma de pintar no local à noite, } \\
\text { com os outros artistas do passado que } \\
\text { costumavam desenhar e pintar a tela } \\
\text { do desenho durante o dia. Essa } \\
\text { afirmação tem o sentido implícito de } \\
\text { que os pintores do passado pintavam a } \\
\text { representação da noite, durante o dia, } \\
\text { com base em sua ideia das cores da } \\
\text { noite, enquanto van Gogh pinta a noite } \\
\text { 'no momento', ou seja, com base em } \\
\text { sua percepção e experiência com a } \\
\text { noite real. Na tela observei a } \\
\text { ocorrência de intertextualidade na } \\
\text { medida em que sua tela incita uma } \\
\text { comparação inevitável com outras } \\
\text { representações pictóricas de cenas } \\
\text { noturnas feitas à época ou no passado. } \\
\text { Sua tela é um estatuto de que é } \\
\text { possível pintar as cores da noite como } \\
\text { elas são percebidas in loco pelo artista. }\end{array}$ \\
\hline $\begin{array}{l}\text { Na tela ‘O Café Noturno } \\
\text { na Place Lamartine, em } \\
\text { Arles', observei a } \\
\text { ocorrência de } \\
\text { Intertextualidade e } \\
\text { Associação metafórica por } \\
\text { meio do uso de Contrastes } \\
\text { cromáticos e Sinestesia. A } \\
\text { excessiva luz que inunda } \\
\text { a sala e a forma como ele } \\
\text { representa os contrastes } \\
\text { podem ser considerados } \\
\text { semioses equivalentes à } \\
\text { expressão escrita “fornalha } \\
\text { do diabo”, registrada nas } \\
\text { notas de rodapé } 146,147, \\
187,189,190,191,192, \\
193 \text { e } 194 .\end{array}$ & $\begin{array}{l}\text { Na minha pintura do café à noite eu } \\
\text { procurei exprimir que o café é um } \\
\text { lugar onde você pode arruinar-se, } \\
\text { enlouquecer, cometer crimes. De } \\
\text { qualquer forma, eu tentei com } \\
\text { contrastes de rosa delicado e } \\
\text { vermelho-sangue e vinho tinto. Verde } \\
\text { doce Luís XV e Veronese } \\
\text { contrastando com os verdes amarelos } \\
\text { e os verdes azuis duros. } \\
\text { Tudo isso em uma atmosfera de } \\
\text { fornalha infernal, de enxofre pálido. } \\
\text { Exprimir como a potência dos cantos } \\
\text { escuros de uma taberna. } \\
\text { Contudo sob uma aparência da alegria } \\
\text { japonesa e da boa natureza de } \\
\text { Tartarin. }\end{array}$ & $\begin{array}{l}\text { Uso de associações metafóricas para } \\
\text { os sentidos indexados a estes } \\
\text { contrastes que estão descritos nas duas } \\
\text { orações. Por exemplo, entre o que é } \\
\text { suave e delicado e o que é passional e } \\
\text { denso no caso da primeira oração e } \\
\text { entre o que é doce e o que é duro, na } \\
\text { segunda. Registrado na nota de rodapé } \\
269 \text {. Esses mesmos sentidos estão } \\
\text { representados visualmente por meio do } \\
\text { contraste entre cores suaves como rosa } \\
\text { e verde-malaquita e cores fechadas } \\
\text { como o vermelho sangue e o verde- } \\
\text { esmeralda. }\end{array}$ \\
\hline $\begin{array}{l}\text { Na tela 'O Café Noturno } \\
\text { na Place Lamartine, em } \\
\text { Arles', observei a } \\
\text { ocorrência de Distorção do } \\
\text { Ponto de Vista e } \\
\text { Transparência, construídos } \\
\text { com ajuda da Saliência e } \\
\text { de Contrastes cromáticos } \\
\text { simultâneos e de saturação }\end{array}$ & & \\
\hline
\end{tabular}




\begin{tabular}{|c|c|c|}
\hline $\begin{array}{l}\text { exacerbados para } \\
\text { representar uma sensação } \\
\text { de desconforto, } \\
\text { registrados na nota de } \\
\text { rodapé 137. } \\
\text { Ocorrência de } \\
\text { Transparência construída } \\
\text { com o uso conjugado de } \\
\text { Associação metafórica e da } \\
\text { Distorção do ponto de } \\
\text { vista, Contraste cromático, } \\
\text { registrada nas notas de } \\
\text { rodapé } 159,195,197 \text { e } \\
\underline{208 .}\end{array}$ & & \\
\hline $\begin{array}{l}\text { Na tela 'O Café Noturno } \\
\text { na Place Lamartine, em } \\
\text { Arles', observei a } \\
\text { ocorrência de Contrastes } \\
\text { Cromáticos Simultâneos } \\
\text { que constroem um } \\
\text { sentido de excesso, de } \\
\text { fadiga e decadência por } \\
\text { meio de Intertextualidade } \\
\text { e Associações metafóricas, } \\
\text { registrada na nota de } \\
\text { rodapé 146, 228. } \\
\\
\text { Na tela 'O Café Noturno } \\
\text { na Place Lamartine, em } \\
\text { Arles', observei a } \\
\text { ocorrência de Associação } \\
\text { metafórica construída pelo } \\
\text { uso da Intertextualidade } \\
\text { entre carta e tela, } \\
\text { registrada na nota de } \\
\text { rodapé } 145 . \\
\text { Ocorrência de } \\
\text { Intertextualidade } \\
\text { construída com a } \\
\text { explicitação textual acerca } \\
\text { do sentido visual foi } \\
\text { possível encontrar, no } \\
\text { nível semântico, o mesmo } \\
\text { sentido, construído } \\
\text { visualmente, como está } \\
\text { amplamente evidenciado } \\
\text { pela análise visual dos } \\
\text { sentidos encontrados na } \\
\text { função representacional, } \\
\text { registrada nas notas de } \\
\text { rodapé 171, 173, 174 e } \\
175 .\end{array}$ & $\begin{array}{l}\text { Eu tentei expressar as terríveis paixões } \\
\text { humanas com o vermelho e o verde. } \\
\text { A sala é vermelho-sangue e amarelo } \\
\text { sem graça, uma mesa de bilhar verde } \\
\text { no centro, } 4 \text { lâmpadas de amarelo } \\
\text { limão com um brilho laranja e verde. } \\
\text { Em todos os lugares é uma batalha e } \\
\text { uma antítese dos mais diferentes } \\
\text { verdes e vermelhos; nas personagens } \\
\text { dos rufiões adormecidos, pequenos na } \\
\text { alta sala vazia, algum roxo e azul. O } \\
\text { vermelho-sangue e o amarelo-verde da } \\
\text { mesa de bilhar, por exemplo, contrasta } \\
\text { com o pouco de verde delicado Louis } \\
\text { XV do balcão, onde há um buquê } \\
\text { rosa. } \\
\text { Uso de contraposição nas orações é } \\
\text { compatível com os contrastes } \\
\text { cromáticos na tela usados para } \\
\text { representar 'batalha e antítese'. Nestas } \\
\text { duas orações, verifiquei a ocorrência } \\
\text { de uma contraposição e de uma } \\
\text { inversão que, no nível semântico, está } \\
\text { compatível com a contraposição } \\
\text { encontrada nos contrastes cromáticos } \\
\text { usados para significar o mesmo } \\
\text { sentido expresso nas orações. Ao } \\
\text { representar um sentido com o seu } \\
\text { sentido oposto, van Gogh usa o nível } \\
\text { semântico para construir uma forma } \\
\text { paradoxal em sua estratégia retórica } \\
\text { textual, registrado na nota de rodapé } \\
274 .\end{array}$ & $\begin{array}{l}\text { Verifiquei a ocorrência do uso de um } \\
\text { construto de contraposição e antítese } \\
\text { no nível semântico da oração Agora } \\
\text { como para recuperar o dinheiro pago } \\
\text { ao senhorio através da minha pintura, } \\
\text { eu não estou fazendo questão disto, } \\
\text { porque a pintura é uma das mais feias } \\
\text { que eu já fiz que é compatível com o } \\
\text { uso de contrastes complementares de } \\
\text { verdes e vermelhos e com a oração na } \\
\text { qual ele explicita que a tela fala de } \\
\text { 'conflitos e antíteses por toda parte'. } \\
\text { Registrado na nota de rodapé } 254 \text {. } \\
\text { Uso de Associações Metafóricas e do } \\
\text { Uso Simbólico da Cor. Ao expressar o } \\
\text { sentido simbólico dos verdes e } \\
\text { vermelhos textualmente ele cola esse } \\
\text { sentido no uso dessas cores na tela, } \\
\text { construindo uma ponte entre a carta e } \\
\text { a tela, criando uma cadeia de textos. } \\
\text { Observei uma ocorrência do uso } \\
\text { simbólico da cor em ambas as } \\
\text { modalidades não pela forma, mas pelo } \\
\text { sentido associado a este uso, } \\
\text { registrado na nota de rodapé } 257 .\end{array}$ \\
\hline $\begin{array}{l}\text { Na tela 'O Café Noturno } \\
\text { na Place Lamartine, em }\end{array}$ & $\begin{array}{l}\text { A ideia do semeador ainda continua a } \\
\text { me assombrar. Estudos exagerados, }\end{array}$ & $\begin{array}{l}\text { Embora não tenha tido acesso ao } \\
\text { artigo sobre Dostoievski inferi que }\end{array}$ \\
\hline
\end{tabular}




\begin{tabular}{|c|c|c|}
\hline $\begin{array}{l}\text { Arles', observei a } \\
\text { ocorrência de } \\
\text { Intertextualidade no uso da } \\
\text { Distorção para construir } \\
\text { um sentido semântico na } \\
\text { tela que ele representou } \\
\text { semanticamente na carta: } \\
\text { a precariedade da } \\
\text { condição humana no } \\
\text { interior de um café da } \\
\text { noite. O sentido que, } \\
\text { semanticamente, ele } \\
\text { constrói na carta, é aqui } \\
\text { representado por outros } \\
\text { recursos pictóricos tais } \\
\text { como os contrastes } \\
\text { cromáticos, o excesso de } \\
\text { iluminação e a distorção da } \\
\text { perspectiva, registrada nas } \\
\text { notas de rodapé } 183 \text { e } 184 .\end{array}$ & $\begin{array}{l}\text { como o semeador, como o café } \\
\text { noturno agora, geralmente parecem- } \\
\text { me atrozmente feios e ruins, mas } \\
\text { quando eu estou movido por alguma } \\
\text { coisa, como aqui por este pequeno } \\
\text { artigo sobre Dostoievski, em seguida, } \\
\text { eles são os únicos que me parecem ter } \\
\text { um significado mais importante. } \\
\text { Ocorrência de Intertextualidade e } \\
\text { Interdiscursividade, explicitada por } \\
\text { van Gogh na oração: ‘Estudos } \\
\text { exagerados, como o semeador, como o } \\
\text { café noturno agora, geralmente } \\
\text { parecem-me atrozmente feios e ruins, } \\
\text { mas quando eu estou movido por } \\
\text { alguma coisa, como aqui por este } \\
\text { pequeno artigo sobre Dostoievski, em } \\
\text { seguida, eles são os únicos que me } \\
\text { parecem ter um significado mais } \\
\text { importante, registrado na nota de } \\
\text { rodapé } 277 \text {. }\end{array}$ & $\begin{array}{l}\text { van Gogh identificou um sentido } \\
\text { comum na produção artística e que ao } \\
\text { comparar a sua tela com produções } \\
\text { artísticas comuns na sua época ela seja } \\
\text { julgada como feia e como ruim. Mas } \\
\text { se for avaliada a partir de um sentido } \\
\text { mais profundo, vai ser possível } \\
\text { reconhecer o seu valor. Para dar } \\
\text { legitimidade para a sua insistência } \\
\text { nesse objetivo van Gogh se apoia em } \\
\text { autores, entre os quais Dostoievski, } \\
\text { que o inspiram e com os quais se } \\
\text { identifica. } \\
\text { Observei o uso de Enquadramento no } \\
\text { nível gramatical e no uso de } \\
\text { Perspectiva no nível semântico da } \\
\text { construção do complexo oracional que } \\
\text { é compatível com a perspectiva visual } \\
\text { com a qual ele representa O café da } \\
\text { Noite registrado na nota de rodapé } \\
\text { 280. }\end{array}$ \\
\hline $\begin{array}{l}\text { Na tela 'O Café Noturno } \\
\text { na Place Lamartine, em } \\
\text { Arles', observei a } \\
\text { ocorrência de Distorção do } \\
\text { Ponto de Vista e de } \\
\text { Interdiscursividade pela } \\
\text { Perspectiva Invertida que } \\
\text { cria uma interação entre } \\
\text { o que está dentro da tela } \\
\text { e o que está fora dela, } \\
\text { registrada na nota de } \\
\text { rodapé } 239 .\end{array}$ & $\begin{array}{l}\text { Mais tarde, quando eu tiver levado } \\
\text { esses experimentos mais longe, o } \\
\text { semeador ainda vai ser a primeira } \\
\text { tentativa nesse gênero. } \\
\text { O café noturno é uma continuação do } \\
\text { semeador, como é a cabeça do velho } \\
\text { camponês e do poeta, se eu conseguir } \\
\text { fazer essa última tela. É uma cor, } \\
\text { então, que não é localmente verdadeira } \\
\text { do ponto de vista realista do trompe } \\
\text { l'oeil, mas uma cor que sugere alguma } \\
\text { emoção, um temperamento ardente. } \\
\text { A ideia do semeador ainda continua a } \\
\text { me assombrar. Estudos exagerados, } \\
\text { como o semeador, como o café } \\
\text { noturno agora, geralmente parecem-me } \\
\text { atrozmente feios e ruins, mas quando } \\
\text { eu estou movido por alguma coisa, } \\
\text { como aqui por este pequeno artigo } \\
\text { sobre Dostoievski, em seguida, eles } \\
\text { são os únicos que me parecem ter um } \\
\text { significado mais importante. }\end{array}$ & $\begin{array}{l}\text { Na tela, a ocorrência da } \\
\text { interdiscursividade está presente por } \\
\text { meio do recurso da inversão do ponto } \\
\text { de vista no qual van Gogh conduz a } \\
\text { atenção do espectador para a posição } \\
\text { em que se encontra o artista, que olha } \\
\text { para a cena. Ele o faz por meio de um } \\
\text { caminho visual por meio da sombra da } \\
\text { mesa de bilhar e do uso do ângulo de } \\
\text { enquadramento plongee. Estes } \\
\text { recursos semióticos remetem o } \\
\text { espectador para o lugar do artista que } \\
\text { está fora da cena, criando um dialogo } \\
\text { entre a posição do espectador e a tela } \\
\text { que relativiza o universo representado } \\
\text { com um espaço 'dentro' e outro 'fora' } \\
\text { da tela que produz uma dialogia na } \\
\text { leitura. } \\
\text { Na escrita também verifiquei a } \\
\text { ocorrência de interdiscursividade. } \\
\text { Nela, van Gogh descreve uma série de } \\
\text { trabalhos, que ele reputa como } \\
\text { 'experimentos' e que estão interligados } \\
\text { por meio de uma concepção artística } \\
\text { na qual ele não usa uma cor } \\
\text { 'localmente verdadeira', mas 'uma cor } \\
\text { que sugere uma emoção, um } \\
\text { temperamento ardente'. Ele está } \\
\text { explicitando o uso simbólico da cor, } \\
\text { como um recurso semiótico que está } \\
\text { presente nas obras relatadas, revelando } \\
\text { a interdiscursividade artística entre } \\
\text { elas. } \\
\text { No segundo excerto, van Gogh } \\
\text { explicita que em seus experimentos } \\
\text { parecem a ele 'atrozmente feios e } \\
\text { ruins' mas que eles estão em forte }\end{array}$ \\
\hline
\end{tabular}




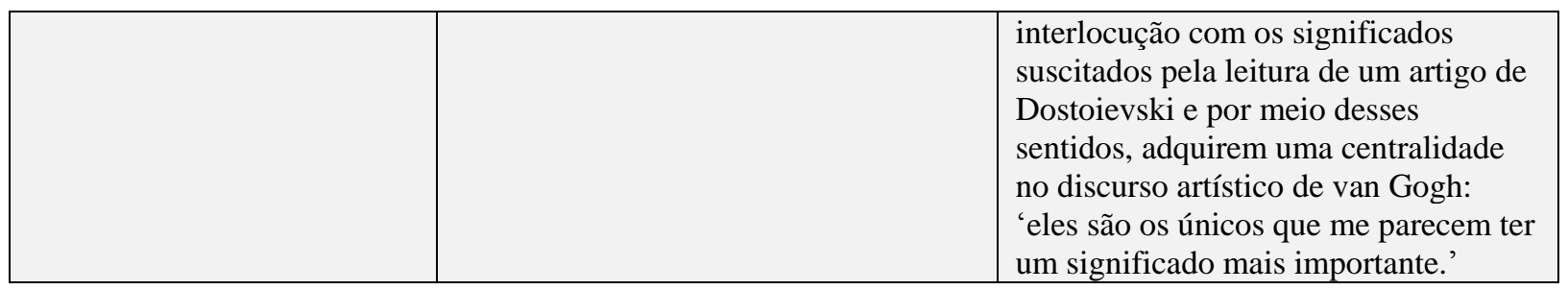

Fonte: Triangulação para Intertextualidade e Interdiscursividade dos dados dos corpora visual e textual, com os extratos das cartas.

\subsection{ASSOCIAÇÕES METAFÓRICAS E SIMBOLISMO}

Para Kress e van Leeuwen (1996, p.105), os processos simbólicos nas imagens têm correspondência com os processos relacionais atributivos ou identificativos. Na imagem, os processos simbólicos dizem respeito ao que um participante significa ou é. Quando na imagem há dois participantes, há um processo atributivo simbólico, no qual aquele participante cuja identidade ou significado é dado pela relação que é o Portador, e aquele participante que representa o atributo simbólico, que é o significado ou a identidade. Quando na imagem só há um participante, há um processo atributivo sugestivo, no qual o único participante que é o Portador, o significado simbólico é obtido de outras maneiras.

Os atributos simbólicos são objetos cujas características pictóricas realizam a relação de Atribuição. Kress e van Leeuwen buscaram em Hermeren (1969) e descrevem como segue:

1) os atributos possuem saliência quando representados por meio de diferentes estratégias compositivas, por exemplo, eles são posicionados no primeiro plano, ou recebem um detalhamento maior do que os outros objetos ou figuras, possuem um tamanho exagerado ou desproporcional na relação compositiva, estão com uma iluminação especial que atrai a atenção para eles, têm um alto grau de detalhamento ou de definição, tem uma cor intensa, ou fazem contraste acentuado com outros objetos e áreas de cor. Van Gogh também usou o traço do desenho para criar essa saliência, bem como a distorção do próprio objeto.

2) os atributos são apontados para. Ou seja, na composição ocorre a articulação de recursos que apontam para o atributo que se quer dar destaque. Seja por meio de um gesto que não se pode interpretar como ação, que seja diferente da ação de apontar para o espectador o atributo simbólico. O gesto de apontar pode ser construído na composição por meio de recursos como a perspectiva, o uso de enquadramento, ritmo, movimento, textura e direção que articulados colaboram na construção de caminhos direcionais para conduzir o olhar para o objeto do 
atributo. São como "flechas" que apontam para os atributos ou estabelecem uma relação de identidade.

3) os atributos parecem receber uma carga de sentido maior do que os demais participantes e figuras, e por isso, parecem de algum modo fora de lugar na rima visual, ou no todo da composição.

4) os atributos possuem associações metafóricas, estão associados convencionalmente com valores simbólicos.

Nos processos atributivos, os participantes humanos estão posando para o espectador ao invés de estarem desempenhando uma ação. Em alguns casos, eles são representados frontalmente, no nível dos olhos e estão estabelecendo um contato visual com o espectador em uma pose que não é narrativa, pois neles não há outro propósito do que se apresentar para o espectador.

De acordo com Kress e van Leeuwen (1996, p. 106), os processos sugestivos simbólicos, nos quais há apenas um participante, o Portador, não podem ser chamados de analíticos. Isso porque a ênfase que se obtém pelo detalhamento da imagem tem a função de favorecer um 'estado de espírito' ou 'atmosfera' que pode ser materializado pelo uso das cores, pelo contraste ou pelo brilho dourado, pela suavidade dos contornos, por uma iluminação exacerbada, intensificando a silhueta dos participantes. É a ambiência que constrói um sentido sugestivo nas imagens simbólicas, e dá a elas uma qualidade de generalidade que não descreve caracteríscas específicas, mas uma essência geral. Em articulação com essa ambiência generalizada, a identificação de detalhes empresta um valor simbólico para o Portador. Por exemplo, um brilho dourado suave pode dar para o Portador valores associados: com a qualidade da suavidade, com o tom quente do amarelo, com o brilho dourado. O significado e a identidade nos processos simbólicos sugestivos são representados como um valor que está vindo de dentro, no qual o portador deriva em si mesmo essas qualidades. Já nos processos atributivos simbólicos o significado e identidade são representados como valores que estão sendo conferidos ao Portador. Kress e van Leeuwen (1996, p. 109) discorrem acerca esses processos:

Existem alguns pontos de contato entre a forma como as estruturas conceituais são realizadas na linguagem e nas imagens. A comparação teria de ser feita com os tipos de estruturas linguísticas que Halliday chama de processos "relacionais" e "existenciais" (Halliday, 1985, p. 112). Estes têm pelo menos isso em comum com imagens conceituais nas quais eles representam o mundo em termos de estados mais ou menos permanentes de coisas ou de verdades gerais, em vez de em termos de ações ou processos mentais. Halliday reconhece duas categorias principais de processo relacional, o Atributivo e o processo de identificação. O significado de uma 
oração de processo atributivo pode ser esquematicamente descrito como 'a é um atributo de $\mathrm{x}$ '. $\mathrm{O}$ atributo 'a' é então chamado simplesmente de Atributo, e o participante de quem o atributo é, é o Portador - temos emprestado esses termos em nossa análise de imagens. 312

\subsubsection{Triangulação do Uso de associações metafóricas e simbolismo}

\section{Uso de associações metafóricas e simbolismo, no texto escrito e em relação à} triangulação - Walther e Metzger (2015) e Petrie (1974), citam o uso de elementos simbólicos e metáforas como uma forte característica na construção da linguagem visual de Van Gogh. Em seu discurso visual, van Gogh cria recursos semióticos e constrói significados com o apoio de sentidos que são culturalmente compartilhados, por meio de associações metafóricas. Ele combina elementos visuais pictóricos para representar experiências, formas de ver, sentir, pensar suas questões e experiências. Ao fazê-lo ele se apoia em sistemas semióticos simples e complexos, nos quais alguns elementos podem fazer o papel lexical e comunicar valores mais específicos, enquanto outros assumem a função léxico-gramatical em um sistema de escolhas potenciais e associativas para construir os discursos que van Gogh desejou comunicar. Petrie (1984, p. 8) comenta a respeito do uso de associações metafóricas feito por van Gogh:

No meio das suas próprias paisagens, teve sempre tendência para valorizar mais as
que apresentavam um forte impulso lírico para além de uma mera caracterização
expressiva, em quadros como o Semeador dotados de um sol simbólico (ilust. 35) ou
a Noite Estrelada (ilust. 48). Essas obras não são "literárias", no sentido narrativo da
The Pilgrim's Progress de Boughton, mas também não permanecem bem dentro dos
limites do mundo fenomenal, como as paisagens impressionistas. Os sentimentos
associados a certas obras narrativas foram por vezes preservados, mesmo que a
própria narração o não tenha sido. "O Impressionismo - salientou ele relevantemente
- não vos compromete com coisa alguma."

Pictoricamente, van Gogh diminuiu o detalhe da representação e favoreceu os efeitos gerais produzidos pelos contrastes de cor simultâneos que intensificavam mutuamente construindo uma coesão cromática. Além disso, os contrastes simultâneos construíam uma ambientação que emprestava um estado de espírito intenso que infundiam significados

\footnotetext{
312 Tradução livre da autora. "There are some points of contact between the way conceptual structures are realized in language and in images. The comparison would have to be made with the kinds of linguistic structures Halliday calls 'relational' and 'existential' processes (see Halliday, 1985: 112ff.). These have at least this in common with conceptual images that they represent the world in terms of more or less permanent states of affairs or general truths, rather than in terms of actions or mental processes. Halliday recognizes two main categories of relational process, the Attributive and the Identifying process. The meaning of an Attributive process clause can be schematically described as ' $a$ is an attribute of $x$ '. The attribute ' $a$ ' is then simply called Attribute, and the participant whose attribute it is, is the Carrier - we have borrowed these terms in our analysis of images." (KRESS; VAN LEEUWEN, 1996, p. 109)
} 
simbólicos como a ocorrência de associação metafórica do amarelo com os sentidos associados à força da natureza e da vida.

Para ilustrar o uso de associações metafóricas, há um exemplo na tela 'O Café Noturno na Place Lamartine, em Arles', no qual van Gogh representou uma sombra saliente da mesa de bilhar em contraste com a ausência de sombras nos outros objetos e figuras. A mesa, por estar sem ocupantes, foi interpretada na análise como a representação da solidão e do isolamento humano. No entanto, com a sombra distorcida, desproporcional e saliente que a mesa projeta, em contraste com a ausência de outras sombras na sala, uma nova camada de significado simbólico foi acrescentada; ela estaria associada ao aspecto sombrio do jogo, como uma representação simbólica do vício - uma vez que o jogo, praticado em excesso, pode arruinar a vida do jogador.

Outro exemplo visual de associação metafórica foi encontrado na tela 'O Semeador', na qual observei a divisão entre dois mundos conferida pela relação de antítese entre os laranjas e azuis e os violetas e amarelos. No entanto, o participante representado com saliência pela figura do semeador, ativamente em movimento, parece funcionar como um elemento mediador, integrando de certo modo dois mundos diferentes, dada a sua sobreposição em ambos sugerindo uma significação simbólica do elemento humano como um elemento de ligação entre o mundo espiritual e a natureza.

Quadro 30: Triangulação do uso de Associações metafóricas e simbolismo

\begin{tabular}{|c|c|c|}
\hline Ocorrência nas telas & Orações & Comentário \\
\hline $\begin{array}{l}\text { Na tela 'Por de Sol: Campo } \\
\text { de trigo perto de Arles', } \\
\text { observei a ocorrência de } \\
\text { associação metafórica do } \\
\text { amarelo com os sentidos } \\
\text { associados à força da } \\
\text { natureza e da vida, } \\
\text { registrado na nota de rodapé } \\
77 \text { no apêndice. } \\
\text { Na tela 'Por de Sol: Campo } \\
\text { de trigo perto de Arles', } \\
\text { observei a ocorrência de } \\
\text { ritmo e textura para conferir } \\
\text { saliência para o campo de } \\
\text { trigo. Observei que a } \\
\text { Saliência é usada para } \\
\text { produzir o efeito de } \\
\text { associação metafórica do } \\
\text { valor do campo sobre a } \\
\text { cidade, registrado nas notas } \\
\text { de rodapé } 104 \text { e } 105 \text { no } \\
\text { apêndice. }\end{array}$ & $\begin{array}{l}\text { Cidade violeta, estrela amarela, céu } \\
\text { azul-esverdeado; os campos de trigo } \\
\text { têm todos os tons: ouro velho, cobre, } \\
\text { ouro verde, ouro vermelho, ouro } \\
\text { amarelo, verde, vermelho e amarelo } \\
\text { bronze. }\end{array}$ & $\begin{array}{l}\text { Van Gogh enfatiza o campo sobre a } \\
\text { cidade tanto na tela quanto neste } \\
\text { excerto de carta em que descreve a } \\
\text { tela, indicando que há um sentido } \\
\text { metafórico associado a essa ênfase. } \\
\text { Na tela, ele representa um campo } \\
\text { de trigo ocupando uma área de } 2 / 3 \\
\text { da composição e nela, ele constrói } \\
\text { uma representação de um trigal ao } \\
\text { sabor do vento, em pinceladas } \\
\text { vigorosas e uma profusão de } \\
\text { amarelos e ocres que produzem } \\
\text { com o volume, movimento, textura, } \\
\text { ritmo e profundidade, a modalidade } \\
\text { sensorial de um trigal em sua força } \\
\text { e beleza expressiva. Na carta, ele } \\
\text { também representa o campo de } \\
\text { trigo com uma maior ênfase do que } \\
\text { a cidade. Apesar de iniciar a oração } \\
\text { com um complexo nominal para } \\
\text { descrever a cidade ele o faz de } \\
\text { forma genérica e com o recurso do } \\
\text { ritmo, quase como para situar o }\end{array}$ \\
\hline
\end{tabular}




\begin{tabular}{|c|c|c|}
\hline & & $\begin{array}{l}\text { leitor no cenário mas também para } \\
\text { construir um contraste com a } \\
\text { oração alfa que se seguirá e que se } \\
\text { dedica exclusivamente a descrever } \\
\text { em detalhe as cores com as quais } \\
\text { ele construiu a massa pictórica que } \\
\text { representa o trigal. Essa ênfase } \\
\text { dada ao trigal, em contraste com a } \\
\text { cidade, construída no nível léxico- } \\
\text { gramatical, é um indicativo da } \\
\text { ocorrência de associação } \\
\text { metafórica para o trigal. }\end{array}$ \\
\hline $\begin{array}{l}\text { Na tela 'Por de Sol: Campo } \\
\text { de trigo perto de Arles', } \\
\text { observei que a ocorrência de } \\
\text { Enquadramento produz um } \\
\text { sentido de associação } \\
\text { metafórica. A escolha do } \\
\text { enquadramento, no qual o } \\
\text { sol está se pondo para o } \\
\text { campo é uma escolha que } \\
\text { produz um sentido } \\
\text { metafórico relacionado ao } \\
\text { final de uma era ou o } \\
\text { começo de outra, registrado } \\
\text { nas notas de rodapé } 87,98 \mathrm{e} \\
99 \text { no apêndice. }\end{array}$ & $\begin{array}{l}\text { Aqui está outra paisagem. Sol } \\
\text { poente? Lua nascendo? } \\
\text { O Sol sugere sentidos simbólicos } \\
\text { para a luz como elemento do } \\
\text { domínio do intangível e do } \\
\text { espiritual, registrados nas notas de } \\
\text { rodapé } 94 \text { e } 95 \text { no apêndice. }\end{array}$ & $\begin{array}{l}\text { Há uma ambiguidade em relação } \\
\text { ao elemento da tela, Sol ou Lua, } \\
\text { começo ou fim, essa ambiguidade } \\
\text { simbólica revela uma metáfora da } \\
\text { experiência de van Gogh em } \\
\text { relação às mudanças que ocorrem } \\
\text { em sua época. }\end{array}$ \\
\hline $\begin{array}{l}\text { Na tela 'Por de Sol: Campo } \\
\text { de trigo perto de Arles', } \\
\text { observei que a ocorrência de } \\
\text { Associação Metafórica } \\
\text { conferida pelo } \\
\text { enquadramento em plano } \\
\text { aberto do homem que } \\
\text { sugerem que van Gogh fala } \\
\text { de uma categoria humana e } \\
\text { não de um homem } \\
\text { específico, registrado nas } \\
\text { notas de rodapé } 80,82,83 \mathrm{e} \\
97 \text { no apêndice. }\end{array}$ & $\begin{array}{l}\text { Paisagens amarelo ouro velho - feito } \\
\text { rápido rápido rápido e com pressa, } \\
\text { como o ceifeiro que está em silêncio } \\
\text { sob o sol escaldante, concentrando- } \\
\text { se em ter o trabalho terminado. } \\
\text { A figura de linguagem 'ceifeiro' } \\
\text { ajuda van Gogh a se abstrair de sua } \\
\text { experiência e enxergar-se com } \\
\text { distanciamento ao explicar a } \\
\text { experiência de sua produção. }\end{array}$ & $\begin{array}{l}\text { Observei a ocorrência de } \\
\text { associação metafórica no nível } \\
\text { semântico da oração, com o } \\
\text { construto: 'como o ceifeiro que } \\
\text { está em silêncio sob o sol } \\
\text { escaldante, concentrando-se em } \\
\text { ter o trabalho terminado. ' Ele } \\
\text { está comparando a forma como } \\
\text { ele trabalha pintando, com a } \\
\text { forma como o ceifeiro trabalha } \\
\text { ceifando, 'feito rápido rápido } \\
\text { rápido e com pressa', e 'em } \\
\text { silêncio sob o sol escaldante, } \\
\text { concentrando-se em ter o } \\
\text { trabalho terminado.' Apesar de } \\
\text { ser uma comparação, ela une } \\
\text { duas coisas aparentemente } \\
\text { díspares, pois uma se caracteriza } \\
\text { pela rapidez e a outra, pelo } \\
\text { silêncio. } \\
\text { Ao mesmo tempo ele faz uma } \\
\text { metáfora em que ele iguala o } \\
\text { movimento do ceifeiro sobre o } \\
\text { trigo e o movimento da pincelada } \\
\text { sobre a tela. Então em um nível } \\
\text { talvez metafórico o vento sobre o } \\
\text { trigo tenha um efeito sobre ele } \\
\text { como que de corte e por isso, ele } \\
\text { é representado na tela como o } \\
\text { resultado do trabalho do ceifeiro }\end{array}$ \\
\hline
\end{tabular}




\begin{tabular}{|c|c|c|}
\hline & & $\begin{array}{l}\text { no trigo. A metáfora também } \\
\text { sugere que o trabalho do artista } \\
\text { também é uma colheita. }\end{array}$ \\
\hline $\begin{array}{l}\text { Na tela 'Por de Sol: Campo } \\
\text { de trigo perto de Arles', } \\
\text { observei a ocorrência de } \\
\text { Associação metafórica do } \\
\text { tom da fumaça das fábricas } \\
\text { em contraposição com o tom } \\
\text { da luminosidade do céu para } \\
\text { conotar um conflito entre o } \\
\text { progresso econômico e a } \\
\text { natureza, registrada na nota } \\
\text { de rodapé } 56 \text { no apêndice. }\end{array}$ & $\begin{array}{l}\text { Eu tenho um terceiro estudo, agora, } \\
\text { de uma paisagem com fábrica, e um } \\
\text { enorme sol em um céu vermelho, } \\
\text { acima de telhados vermelhos, em } \\
\text { que a natureza parece estar em um } \\
\text { acesso de raiva, em um dia de } \\
\text { Mistral desagradável. } \\
\text { Obsevei aqui uma interação da } \\
\text { ocorrência da Associação metafórica } \\
\text { com a Transparência, a } \\
\text { Incompletude e o Limiar Artístico. }\end{array}$ & $\begin{array}{l}\text { Van Gogh intui que existe nesse } \\
\text { movimento de pincelada sobre a } \\
\text { tela uma energia transformadora e } \\
\text { criadora, mas que também tem uma } \\
\text { nuance descontrolada que carrega } \\
\text { uma emoção semelhante à da raiva. } \\
\text { Ele compara esse movimento que } \\
\text { representa o vento na tela ao } \\
\text { movimento da natureza na qual o } \\
\text { vento age sobre o trigo de maneira } \\
\text { desordenada, incontrolável e } \\
\text { incisiva. O ímpeto do artista no } \\
\text { momento de representação do } \\
\text { vento da tela o aproxima da } \\
\text { natureza e o aproxima de sua } \\
\text { natureza e da natureza daquilo que } \\
\text { faz a tela ser o que ela é. A } \\
\text { representação de um limiar entre } \\
\text { aquilo que o artista vê e aquilo que } \\
\text { ele não vê quando ele representa o } \\
\text { que ele vê. }\end{array}$ \\
\hline $\begin{array}{l}\text { Na tela 'Por de Sol: Campo } \\
\text { de trigo perto de Arles', } \\
\text { observei a ocorrência de } \\
\text { enquadramento e associação } \\
\text { metafórica no } \\
\text { posicionamento do homem, } \\
\text { que constrói um elemento de } \\
\text { transição e sugere a metáfora } \\
\text { de que este homem está } \\
\text { vivendo em um mundo em } \\
\text { transição, registrado nas } \\
\text { notas de rodapé } 79,80 \text { e } 83 \\
\text { no apêndice. }\end{array}$ & $\begin{array}{l}\text { Paisagens amarelo ouro velho - feito } \\
\text { rápido rápido rápido e com pressa, } \\
\text { como o ceifeiro que está em silêncio } \\
\text { sob o sol escaldante, concentrando- } \\
\text { se em ter o trabalho terminado. }\end{array}$ & $\begin{array}{l}\text { Observei a ocorrência de } \\
\text { Associação metafórica tanto na tela } \\
\text { quanto na carta. Na tela o lugar do } \\
\text { homem, à meia distância da cidade } \\
\text { e do campo, envolto por um } \\
\text { contraste de saturação que constrói } \\
\text { ênfase para o seu posicionamento, } \\
\text { sugere a ocorrência de uma } \\
\text { metáfora sobre a posição do } \\
\text { homem em relação com o campo e } \\
\text { a cidade, e na sua relação com } \\
\text { ambos. Na oração, van Gogh usa o } \\
\text { figura do ceifeiro como uma } \\
\text { metáfora. Ele compara as paisagens } \\
\text { de amarelo ouro velho que aqui } \\
\text { simbolizam o campo, com a } \\
\text { imagem do ceifeiro, 'que está em } \\
\text { silêncio sob o sol escaldante, } \\
\text { concentrando-se em ter o trabalho } \\
\text { terminado.' que simboliza um tipo } \\
\text { de homem que pertence a esse } \\
\text { universo. }\end{array}$ \\
\hline $\begin{array}{l}\text { Na tela 'Por de Sol: Campo } \\
\text { de trigo perto de Arles', } \\
\text { observei a ocorrência de } \\
\text { Enquadramento, pela } \\
\text { escolha do ponto de vista } \\
\text { que privilegia a } \\
\text { representação do campo } \\
\text { sobre a cidade e com isso, } \\
\text { constrói uma relação que } \\
\text { realça o valor do campo. } \\
\text { Observei também a }\end{array}$ & $\begin{array}{l}\text { Aqui está outra paisagem. Sol } \\
\text { poente? Lua nascendo? Noite de } \\
\text { verão, de qualquer modo. Cidade } \\
\text { violeta, estrela amarela, céu azul- } \\
\text { esverdeado; os campos de trigo têm } \\
\text { todos os tons: ouro velho, cobre, } \\
\text { ouro verde, ouro vermelho, ouro } \\
\text { amarelo, verde, vermelho e amarelo } \\
\text { bronze. Tela quadrada número } 30 \text {. }\end{array}$ & $\begin{array}{l}\text { No excerto, ele privilegia a } \\
\text { representação do campo sobre a } \\
\text { cidade, pois ao descrever a tela que } \\
\text { retrata uma cidade ao fundo, ele } \\
\text { nem sequer menciona a existência } \\
\text { da cidade, mas descreve o campo } \\
\text { detalhadamente por meio de uma } \\
\text { sequência de tonalidades. }\end{array}$ \\
\hline
\end{tabular}




\begin{tabular}{|c|c|c|}
\hline $\begin{array}{l}\text { ocorrência de Saliência e } \\
\text { Associação metafórica por } \\
\text { meio do enquadramento que } \\
\text { aproxima o campo e } \\
\text { distancia a cidade, registrado } \\
\text { nas notas de rodapé } 79,104 \\
\text { e } 105 \text { no apêndice. }\end{array}$ & & \\
\hline $\begin{array}{l}\text { Na tela 'O Semeador', } \\
\text { observei que a ocorrência de } \\
\text { Associação Metafórica é } \\
\text { construída pela associação } \\
\text { dos sentidos do trigo maduro } \\
\text { e os sentidos do céu e do sol: } \\
\text { calor, vida, força e } \\
\text { crescimento confirmados } \\
\text { pela divisão do espaço } \\
\text { composicional e pela divisão } \\
\text { cromática da tela na qual o } \\
\text { campo maduro tem tons } \\
\text { quentes e o campo arado tem } \\
\text { tons frios, registrada na nota } \\
\text { de rodapé 33. } \\
\text { Observei também a } \\
\text { ocorrência de Associação } \\
\text { Metafórica construída pelo } \\
\text { uso simbólico da cor para } \\
\text { construir } \text { o significado } \\
\text { cíclico do plantar e do } \\
\text { colher, e outras associações } \\
\text { de sentidos potenciais são } \\
\text { sugeridas como vida e morte, } \\
\text { registrada na nota de rodapé } \\
\underline{38 .} \\
\text { Observei também a } \\
\text { ocorrência de Uso Simbólico } \\
\text { da Cor para conferir } \\
\text { Associação Metafórica para } \\
\text { os sentidos simbólicos do } \\
\text { campo maduro e do campo } \\
\text { arado e da parábola do } \\
\text { Semeador, registrada na nota } \\
\text { de rodapé } 96 \text { no apêndice e } \\
\underline{74 .} \text {. }\end{array}$ & $\begin{array}{l}\text { Há várias sugestões de amarelo no } \\
\text { solo, tons neutros resultantes da } \\
\text { mistura de violeta e amarelo; mas } \\
\text { tenho travado uma luta diabólica } \\
\text { para atingir a verdade das cores. } \\
\text { 'Um campo de trigo maduro, de tom } \\
\text { amarelo-ocre com um pouco de } \\
\text { carmim. } \\
\text { O céu, amarelo-crômio, quase tão } \\
\text { luminoso quanto o próprio Sol, que é } \\
\text { amarelo-crômio n'1, misturado com } \\
\text { um pouco de branco, enquanto o } \\
\text { resto do céu é uma mistura dos } \\
\text { amarelos-crômios } 1 \text { e } 2 \text {. Tão } \\
\text { amarelo! } \\
\text { Na oração acima, há a ocorrência de } \\
\text { Associação metafórica no nível } \\
\text { léxico-gramatical sugerida pela } \\
\text { mudança de processo na oração alfa } \\
\text { para a oração beta que simbolizam as } \\
\text { qualidades que ele associa ao céu e a } \\
\text { terra. Registrado na nota de rodapé } \\
\text { 87. } \\
\text { Ocorrência de Saliência e } \\
\text { Associação Metafórica pela } \\
\text { equiparação do sentido de } \\
\text { 'luminoso' para o 'sentido de } \\
\text { amarelo', registrado na nota de } \\
\text { rodapé } 84 \text {. }\end{array}$ & $\begin{array}{l}\text { Em 'Um campo de trigo maduro, } \\
\text { de tom amarelo-ocre com um } \\
\text { pouco de carmim. 'há a ocorrência } \\
\text { de Associação metafórica. A forma } \\
\text { como ele construiu o protagonismo } \\
\text { das cores para narrar o campo de } \\
\text { trigo maduro sugere que a oração é } \\
\text { uma metáfora na qual o campo e a } \\
\text { cor se tornam a mesma coisa, ao } \\
\text { deixar ocultos os processos. Está } \\
\text { registrado na nota de rodapé } 82 . \\
\\
\text { MODALIDADE } \\
\text { Van Gogh expressa uma espécie de } \\
\text { lealdade com a natureza que exige } \\
\text { uma entrega no momento de } \\
\text { percepção das cores porque tende- } \\
\text { se a homogeneizar e ver no campo } \\
\text { de trigo só o amarelo e ver na terra } \\
\text { só o roxo, ou o marrom, ou o cinza } \\
\text { indiferenciado. Observo que ele vê } \\
\text { na produção do Semeador no } \\
\text { campo, o desafio de identificar a } \\
\text { heterogeneidade cromática nos } \\
\text { seus mínimos detalhes e por outro } \\
\text { lado, o movimento das pinceladas } \\
\text { exige um ritmo para ser fiel à } \\
\text { textura e à composição como um } \\
\text { todo. } \\
\text { Observei também a ocorrência de } \\
\text { Uso Simbólico da Cor para } \\
\text { conferir Saliência e Associação } \\
\text { Metafórica para os sentidos } \\
\text { simbólicos do campo arado } \\
\text { registrada na nota de rodapé } 75 \text {. }\end{array}$ \\
\hline
\end{tabular}




\begin{tabular}{|c|c|c|}
\hline $\begin{array}{l}\text { Ele também explicita, no } \\
\text { excerto, o uso de } \\
\text { intertextualidade, ao } \\
\text { comparar sua 'luta diabólica } \\
\text { para atingir a verdade das } \\
\text { cores' com o estilo naif dos } \\
\text { 'velhos almanaques dos } \\
\text { lavradores nos quais o } \\
\text { granizo, a neve, a chuva e o } \\
\text { bom tempo são retratados de } \\
\text { modo primitivo, com } \\
\text { Anquetin atingiu tão bem no } \\
\text { seu A Colheita.' Observei } \\
\text { que van Gogh usou a } \\
\text { intertextualidade como uma } \\
\text { metáfora para explicitar o } \\
\text { caminho que ele percorre } \\
\text { para atingir a verdade das } \\
\text { cores. Este não é o caminho } \\
\text { da representação naif, mas } \\
\text { que revela 'tons neutros } \\
\text { resultantes da mistura de } \\
\text { violeta e amarelo' que nada } \\
\text { têm de naif. }\end{array}$ & $\begin{array}{l}\text { Preferia muito mais // fazer quadros } \\
\text { naifs [[tirados de velhos } \\
\text { almanaques, aqueles velhos } \\
\text { "almanaques dos lavradores" [[nos } \\
\text { quais o granizo, a neve, a chuva e o } \\
\text { bom tempo são retratados de modo } \\
\text { primitivo,]]]] como o Anquetin } \\
\text { atingiu tão bem no seu A Colheita. }\end{array}$ & $\begin{array}{l}\text { Ocorrência de Intertextualidade e } \\
\text { Interdiscursividade, Associação } \\
\text { metafórica, Transparência e } \\
\text { Modalidade ao relacionar a obra de } \\
\text { Anquetin e a estética Naif com sua } \\
\text { própria experiência para } \\
\text { representar 'a verdade das cores. } \\
\text { Ocorrência de Associação } \\
\text { Metafórica pela comparação que } \\
\text { ele usa como metáfora para } \\
\text { explicar qual é a natureza de sua } \\
\text { experiência interna na escolha da } \\
\text { combinação de cores. Registrado } \\
\text { na nota de rodapé } 93 .\end{array}$ \\
\hline $\begin{array}{l}\text { Na tela ‘O Semeador’ } \\
\text { observei a ocorrência de } \\
\text { Contraste Cromático usado } \\
\text { como Associação metafórica } \\
\text { para expressar o Limiar } \\
\text { Artístico representados no } \\
\text { Semeador e no Enfeixador } \\
\text { registrados na nota de rodapé } \\
\text { 98. }\end{array}$ & $\begin{array}{l}\text { Não te vou ocultar //que não } \\
\text { desgosto da região,// pois fui criado } \\
\text { lá // - ainda me encanta a magia das } \\
\text { recordações do passado, de um } \\
\text { desejo do infinito,// do qual o } \\
\text { semeador e o enfeixador são } \\
\text { símbolos / -, tanto quanto antes } \\
\text { gostava.//. }\end{array}$ & $\begin{array}{l}\text { Ocorrência de Transparência, } \\
\text { Incompletude, Limiar Artístico, } \\
\text { Interdiscursividade e Associação } \\
\text { Metafórica no nível semântico da } \\
\text { oração Beta ao explicitar a } \\
\text { natureza da sua motivação na } \\
\text { produção artística e ao usar a } \\
\text { contraposição criada pela } \\
\text { comparação entre Naif e 'a verdade } \\
\text { das cores' como metáfora para } \\
\text { explicar ao irmão o seu desejo de } \\
\text { infinito, registrados na nota de } \\
\text { rodapé 97. }\end{array}$ \\
\hline $\begin{array}{l}\text { Ao se referir à tela no } \\
\text { excerto de carta, van Gogh } \\
\text { usa a intertextualidade, da } \\
\text { fala de um personagem de } \\
\text { um romance de Huysmans, } \\
\text { para construir uma metáfora. } \\
\text { Ele compara a sua tela 'O } \\
\text { Semeador' com o desejo de } \\
\text { alguém, que está no plano do } \\
\text { sonho, mas que não pinta. } \\
\text { Dessa forma, quando ele a } \\
\text { pinta, ele a representa em } \\
\text { uma atmosfera de sonho, na } \\
\text { luz difusa do crepúsculo, } \\
\text { construída pelos efeitos dos } \\
\text { contrastes cromáticos, da } \\
\text { diminuição dos detalhes e do } \\
\text { tratamento geral desfocado. } \\
\text { Essa baixa definição } \\
\text { inacabamento são }\end{array}$ & $\begin{array}{l}\text { Ai, ai, é como nosso excelente } \\
\text { amigo Cyprien diz, em 'En ménage' } \\
\text { por JK Huysmans: as mais belas } \\
\text { pinturas são aquelas [[que alguem } \\
\text { sonha //enquanto fuma um cachimbo } \\
\text { em sua cama,// mas a qual ele não } \\
\text { pinta.]] }\end{array}$ & $\begin{array}{l}\text { Ocorrência de Associação } \\
\text { Metafórica pelo construto 'é como' } \\
\text { que usa a Verbiagem de seu amigo } \\
\text { para expressar sua experiência } \\
\text { subjetiva acerca do processo de } \\
\text { criação de uma tela. Ocorrência de } \\
\text { Incompletude e Limiar artístico no } \\
\text { nível semântico da Verbiagem, } \\
\text { registradas na nota de rodapé } 112 .\end{array}$ \\
\hline
\end{tabular}




\begin{tabular}{|c|c|c|}
\hline $\begin{array}{l}\text { compatíveis com o sentido } \\
\text { de sonho expressado nesse } \\
\text { excerto de carta. A luz difusa } \\
\text { expressa Inacabamento e } \\
\text { Incompletude também } \\
\text { expressada na Verbiagem do } \\
\text { excerto. }\end{array}$ & & \\
\hline $\begin{array}{l}\text { Visualmente, observei a } \\
\text { ocorrência de associação } \\
\text { metafórica com o construto } \\
\text { da figura do semeador para } \\
\text { responder ao seu sentimento } \\
\text { de incompetência para } \\
\text { representar sua experiência } \\
\text { com a Natureza. } \\
\text { A oração ao lado expressa a } \\
\text { dificuldade de van Gogh } \\
\text { para representar 'as } \\
\text { perfeições inefáveis do } \\
\text { glorioso esplendor da } \\
\text { natureza', descrita com um } \\
\text { grupo nominal com muitos } \\
\text { atributos e cuja magnitude, } \\
\text { Van Gogh se sente } \\
\text { incompetente para expressar } \\
\text { à altura. } \\
\text { Dessa forma, uma tela que é } \\
\text { em si uma metáfora do seu } \\
\text { desejo de união com 'as } \\
\text { perfeições inefáveis do } \\
\text { glorioso esplendor da } \\
\text { natureza': 'O Semeador', } \\
\text { essa metáfora está } \\
\text { explicitada no excerto: '- } \\
\text { ainda me encanta a magia } \\
\text { das recordações do passado, } \\
\text { de um desejo do infinito, do } \\
\text { qual o semeador e o } \\
\text { enfeixador são símbolos-'. }\end{array}$ & $\begin{array}{l}\text { +2 Mas é uma questão [[de atacá- } \\
\text { las]], // + } \mathbf{3} \text { no entanto, não importa } \\
\text { o quão incompetente // alguém pode } \\
\text { sentir-se vis-à-vis as perfeições } \\
\text { inefáveis do glorioso esplendor da } \\
\text { natureza. }\end{array}$ & $\begin{array}{l}\text { Ocorrência de Associação } \\
\text { metafórica pela escolha léxico- } \\
\text { gramatical da terceira pessoa para } \\
\text { explicar uma experiência que é de } \\
\text { foro pessoal, talvez com a função } \\
\text { de criar um distanciamento de si } \\
\text { mesmo para obter visibilidade de } \\
\text { sua própria experiência subjetiva. } \\
\text { Registrada na nota de rodapé } 115 .\end{array}$ \\
\hline $\begin{array}{l}\text { Na tela 'O Semeador', } \\
\text { observei a ocorrência de } \\
\text { Associação Metafórica, } \\
\text { construída pelo contrates } \\
\text { simultâneo sugere } \\
\text { contraposição metafórica } \\
\text { de significados do céu e da } \\
\text { terra, registrada na nota de } \\
\text { rodapé } 66 .\end{array}$ & $\begin{array}{l}\text { Aqui está o que eu queria dizer } \\
\text { sobre o branco e o preto. Vamos } \\
\text { tomar o Semeador. A pintura é } \\
\text { dividida em dois; metade é amarelo, } \\
\text { o topo; a base é violeta. Bem, as } \\
\text { calças brancas descansam os olhos e } \\
\text { os distraem exatamente quando o } \\
\text { contraste simultâneo excessivo de } \\
\text { amarelo e violeta iriam irritá-lo. Isso } \\
\text { é o que eu queria dizer. }\end{array}$ & $\begin{array}{l}\text { Ele usa a pintura do Semeador } \\
\text { como metáfora para explicar o que } \\
\text { ele pensa sobre o branco e o preto, } \\
\text { que são tão opostos, tão } \\
\text { contrastantes que 'o contraste } \\
\text { excessivo iria irritá-lo', então ele } \\
\text { usa um elemento de transição para } \\
\text { distrair os olhos do impasse } \\
\text { causado pelo contraste excessivo. } \\
\text { Ao mesmo tempo ele usa o } \\
\text { contraste excessivo para simbolizar } \\
\text { sentidos opostos entre o céu e a } \\
\text { terra. }\end{array}$ \\
\hline $\begin{array}{l}\text { Na tela 'O Semeador', } \\
\text { observei a ocorrência } \\
\text { conjugada de Contrastes de } \\
\text { Saturação, Saliência, } \\
\text { Associação Metafórica e }\end{array}$ & $\begin{array}{l}\text { O céu, amarelo-crômio, quase tão } \\
\text { luminoso quanto o próprio Sol, que } \\
\text { é amarelo-crômio } n^{\circ} 1, \text { misturado } \\
\text { com um pouco de branco, enquanto } \\
\text { o resto do céu é uma mistura dos }\end{array}$ & $\begin{array}{l}\text { Visualmente são usados vários } \\
\text { recursos para construir saliência e } \\
\text { ênfase para o céu e o sol, } \\
\text { evidenciando um sentido } \\
\text { metafórico na tela. Esse construto é }\end{array}$ \\
\hline
\end{tabular}




\begin{tabular}{|c|c|c|}
\hline $\begin{array}{l}\text { Incompletude na } \\
\text { representação do céu e do } \\
\text { sol, em amarelo sobre } \\
\text { amarelo, registrado na nota } \\
\text { de rodapé 51. } \\
\text { Observei também a } \\
\text { ocorrência de Saliência e } \\
\text { Associação Metafórica para } \\
\text { o céu e o sol, construída pelo } \\
\text { uso de ritmo, textura, } \\
\text { movimento e direção } \\
\text { articulados pelo gesto } \\
\text { pictórico, registrado na nota } \\
\text { de rodapé 65. } \\
\text { Observei também a } \\
\text { ocorrência de Saliência e } \\
\text { Associação Metafórica pelo } \\
\text { posicionamento relativo do } \\
\text { Sol na composição, } \\
\text { ocupando o centro e a parte } \\
\text { superior da tela, registrado } \\
\text { na nota de rodapé 67. }\end{array}$ & $\begin{array}{l}\text { amarelos-crômios } 1 \text { e 2. Tão } \\
\text { amarelo! }\end{array}$ & $\begin{array}{l}\text { compatível, com a saliência dada } \\
\text { na representação da tela pela } \\
\text { oração, na qual há um minucioso } \\
\text { relato do emprego de diferentes } \\
\text { amarelos, associados a uma } \\
\text { metáfora cromática para o céu e } \\
\text { para o sol, construída com o uso da } \\
\text { ênfase que van Gogh construiu } \\
\text { tanto na tela quanto na oração. }\end{array}$ \\
\hline $\begin{array}{l}\text { Na tela 'O Semeador', } \\
\text { observei a ocorrência de } \\
\text { Vetor 2, construída pelo } \\
\text { Semeador que anda e olha } \\
\text { para a direita da tela. O } \\
\text { Vetor } 2 \text { constrói a } \\
\text { Associação metafórica que o } \\
\text { Semeador se desloca do } \\
\text { passado para o futuro. Há } \\
\text { também uma metáfora de } \\
\text { conflito entre o significado } \\
\text { simbólico dos corvos e o do } \\
\text { semear, registrada na nota de } \\
\text { rodapé } 39 \text {. }\end{array}$ & $\begin{array}{l}\text { Preferia muito mais fazer quadros } \\
\text { naifs tirados de velhos almanaques, } \\
\text { aqueles velhos "almanaques dos } \\
\text { lavradores" nos quais o granizo, a } \\
\text { neve, a chuva e o bom tempo são } \\
\text { retratados de modo primitivo, como } \\
\text { o Anquetin atingiu tão bem no seu } A \\
\text { Colheita. } \\
\text { Não te vou ocultar que não desgosto } \\
\text { da região, pois fui criado lá - } \underline{\text { ainda }} \\
\text { me encanta a magia das recordações } \\
\underline{\text { do passado, de um desejo do }} \\
\text { infinito, do qual o semeador e o } \\
\text { enfeixador são símbolos -, tanto } \\
\text { quanto antes gostava. } \\
\text { Mas quando eu farei o céu estrelado, } \\
\text { então, essa pintura que está sempre } \\
\text { na minha mente? }\end{array}$ & $\begin{array}{l}\text { A tela constrói algumas associações } \\
\text { metafóricas com a passagem do } \\
\text { tempo, tanto pelo vetor do } \\
\text { semeador que se desloca da } \\
\text { esquerda para a direita, sugerindo } \\
\text { uma transição do passado para o } \\
\text { futuro, quanto a metáfora do campo } \\
\text { arado e do campo maduro, que } \\
\text { também constroem um sentido de } \\
\text { passado e futuro e de um ciclo que } \\
\text { termina e um que inicia. } \\
\text { No excerto da carta, observei o uso } \\
\text { de algumas associações metafóricas } \\
\text { para a passagem do tempo, } \\
\text { evidenciadas por escolhas léxico- } \\
\text { gramaticais tais como: 'velhos } \\
\text { almanaques, aqueles velhos } \\
\text { "almanaques dos lavradores', 'o } \\
\text { granizo, a neve, a chuva e o bom } \\
\text { tempo são retratados de modo } \\
\text { primitiavo',-'ainda me encanta a } \\
\text { magia das recordações do passado', } \\
\text { 'tanto quanto antes gostava'”. }\end{array}$ \\
\hline $\begin{array}{l}\text { Ao se referir à tela no excerto } \\
\text { de carta, van Gogh usa a } \\
\text { intertextualidade, da fala de } \\
\text { um personagem de um } \\
\text { romance de Huysmans, para } \\
\text { construir uma metáfora. Ele } \\
\text { compara a sua tela 'O } \\
\text { Semeador' com o desejo de } \\
\text { alguém, que está no plano do } \\
\text { sonho, mas que não pinta. } \\
\text { Dessa forma, quando ele a }\end{array}$ & $\begin{array}{l}\text { Ai, ai, é como nosso excelente } \\
\text { amigo Cyprien diz, em 'En ménage' } \\
\text { por JK Huysmans: } \\
\text { as mais belas pinturas são aquelas } \\
\text { que alguém sonha enquanto fuma } \\
\text { um cachimbo em sua cama, mas a } \\
\text { qual ele não pinta. }\end{array}$ & $\begin{array}{l}\text { Ocorrência de Interdiscursividade } \\
\text { e Intertextualidade ao expressar } \\
\text { uma ideia por meio da afirmação } \\
\text { (processo Verbal) de seu amigo } \\
\text { Cyprien. Essa afirmação } \\
\text { (Verbiagem) é usada como uma } \\
\text { metáfora para explicar o que ele } \\
\text { experiencia ao desejar realizar a } \\
\text { tela, indicando a ocorrência de } \\
\text { Associação metafórica no } \\
\text { construto da Verbiagem, para dar }\end{array}$ \\
\hline
\end{tabular}




\begin{tabular}{|c|c|c|}
\hline $\begin{array}{l}\text { pinta, ele a representa em uma } \\
\text { atmosfera de sonho, na luz } \\
\text { difusa do crepúsculo, } \\
\text { construída pelos efeitos dos } \\
\text { contrastes cromáticos, da } \\
\text { diminuição dos detalhes e do } \\
\text { tratamento geral desfocado. } \\
\text { Essa baixa definição } \\
\text { inacabamento são compatíveis } \\
\text { com o sentido de sonho } \\
\text { expressado nesse excerto de } \\
\text { carta. A luz difusa expressa } \\
\text { Inacabamento e Incompletude } \\
\text { também expressada na } \\
\text { Verbiagem do excerto. }\end{array}$ & & $\begin{array}{l}\text { Transparência ao que ele van Gogh } \\
\text { pensa. Registrado na nota de } \\
\text { rodapé } 110 .\end{array}$ \\
\hline $\begin{array}{l}\text { Na tela 'O Semeador', há } \\
\text { uma inter-relação entre } \\
\text { Textura, Contrastes } \\
\text { Simultâneos, Saliência, } \\
\text { Sinestesia que criam } \\
\text { Associações Metafóricas da } \\
\text { materialidade da tinta com a } \\
\text { nossa memória sensorial e } \\
\text { tátil da plasticidade da terra, } \\
\text { registrado na nota de rodapé } \\
\underline{50 .} \\
\text { Observei também a } \\
\text { ocorrência de Associação } \\
\text { Metafórica da materialidade } \\
\text { pictórica com a nossa } \\
\text { experiência física e corporal } \\
\text { de tocar a terra e sua } \\
\text { plasticidade, registrado na } \\
\text { nota de rodapé 55 e 56. }\end{array}$ & $\begin{array}{l}\text { Há várias sugestões de amarelo no } \\
\text { solo, tons neutros resultantes da } \\
\text { mistura de violeta e amarelo; mas } \\
\text { tenho travado uma luta diabólica } \\
\text { para atingir a verdade das cores. }\end{array}$ & $\begin{array}{l}\text { Van Gogh constrói uma } \\
\text { experiência visual táctil do } \\
\text { espectador, por meio de textura, } \\
\text { ritmo, movimento, gesto pictórico, } \\
\text { rima visual e contrastes cromáticos. } \\
\text { O uso dos contrastes cromáticos na } \\
\text { tela, é compatível com a ocorrência } \\
\text { de sua descrição da tela nesse } \\
\text { excerto, no qual ele enfatiza a } \\
\text { importância 'tons neutros } \\
\text { resultantes da mistura de violeta e } \\
\text { amarelo' que formam um contraste } \\
\text { simultâneo, para produzir essa } \\
\text { experiência visual a qual ele chama } \\
\text { de ‘verdade das cores'. }\end{array}$ \\
\hline $\begin{array}{l}\text { Na tela 'O Semeador', } \\
\text { observei a ocorrência de } \\
\text { Associação Metafórica e } \\
\text { Incompletude, construídos } \\
\text { pela luz difusa do ocaso. A } \\
\text { luz constrói um sentido de } \\
\text { ambiência e que envolve } \\
\text { toda a cena e constrói } \\
\text { significados simbólicos, } \\
\text { registrado na nota de rodapé } \\
\underline{59} \text {. }\end{array}$ & $\begin{array}{l}\text { Há várias sugestões de amarelo no } \\
\text { solo, tons neutros resultantes da } \\
\text { mistura de violeta e amarelo; mas } \\
\text { tenho travado uma luta diabólica } \\
\text { para atingir a verdade das cores. }\end{array}$ & $\begin{array}{l}\text { Os atributos simbólicos realizam a } \\
\text { relação de Atribuição, como por } \\
\text { exemplo, por meio de } \\
\text { Saliência. Aqui, ela é conseguida } \\
\text { por meio de uma iluminação } \\
\text { especial que atrai a atenção o } \\
\text { campo arado, por meio da } \\
\text { ambiência incomum da luz do } \\
\text { ocaso. }\end{array}$ \\
\hline $\begin{array}{l}\text { Na tela 'O Semeador', } \\
\text { observei a ocorrência de } \\
\text { Associação Metafórica de } \\
\text { teor religioso, sugerida pelo } \\
\text { valor de informação contido } \\
\text { na divisão do espaço da } \\
\text { composição, registrado na }\end{array}$ & $\begin{array}{l}\text { Em um campo arado, um grande } \\
\text { campo de torrões de terra roxa - } \\
\text { levantados em direção ao horizonte - } \\
\text { um semeador em azul e branco. No } \\
\text { horizonte um campo de trigo curto, } \\
\text { maduro. } \\
\text { Acima de tudo isso um céu amarelo } \\
\text { com um sol amarelo. Você pode }\end{array}$ & $\begin{array}{l}\text { A divisão do espaço compositivo } \\
\text { por meio planos, mas também de } \\
\text { cores constrói uma camada de } \\
\text { significados simbólicos. }\end{array}$ \\
\hline
\end{tabular}




\begin{tabular}{|c|c|c|}
\hline nota de rodapé 64. & $\begin{array}{l}\text { sentir a partir da mera nomenclatura } \\
\text { das tonalidades - que a cor } \\
\text { desempenha um papel muito } \\
\text { importante nesta composição. }\end{array}$ & \\
\hline $\begin{array}{l}\text { Na tela 'O Semeador', } \\
\text { observei a ocorrência de } \\
\text { Associação Metafórica e } \\
\text { Incompletude construída } \\
\text { pela Rima Visual e pelo } \\
\text { Gesto pictórico para } \\
\text { representar a unidade entre o } \\
\text { Homem e a Natureza, } \\
\text { registrados na nota de rodapé } \\
\text { 78. }\end{array}$ & $\begin{array}{l}\text { Preferia muito mais fazer quadros } \\
\text { naifs tirados de velhos almanaques, } \\
\text { aqueles velhos "almanaques dos } \\
\text { lavradores" nos quais o granizo, a } \\
\text { neve, a chuva e o bom tempo são } \\
\text { retratados de modo primitivo, como } \\
\text { o Anquetin atingiu tão bem no seu } A \\
\text { Colheita. } \\
\text { Não te vou ocultar que não desgosto } \\
\text { da região, pois fui criado lá - ainda } \\
\text { me encanta a magia das recordações } \\
\text { do passado, de um desejo do } \\
\text { infinito, do qual o semeador e o } \\
\text { enfeixador são símbolos -, tanto } \\
\text { quanto antes gostava. }\end{array}$ & $\begin{array}{l}\text { O ritmo nas pinceladas ajuda a } \\
\text { criar uma integração entre os } \\
\text { elementos da natureza na tela: o } \\
\text { campo arado, o campo maduro, o } \\
\text { céu, o sol, a luz. Esse ritmo que } \\
\text { integra os elementos naturais está } \\
\text { presente também na oração em que } \\
\text { expressa sua preferência pela } \\
\text { pintura da natureza. } \\
\text { Nesse excerto, observei a } \\
\text { ocorrência de Rima Visual, Gesto } \\
\text { Pictórico e Ritmo, construída por } \\
\text { uma sequência de escolhas lexicais } \\
\text { que é análoga à ocorrência de } \\
\text { ritmo e de gesto pictórico. O } \\
\text { circuito criado pela recorrente } \\
\text { escolha do item lexical 'céu' é } \\
\text { compatível com a ocorrência de } \\
\text { Rima Visual registrado na nota de } \\
\text { rodapé } 85 \text {. }\end{array}$ \\
\hline $\begin{array}{l}\text { Na tela 'O Semeador', } \\
\text { observei a ocorrência de Uso } \\
\text { Simbólico da Cor para } \\
\text { conferir Associação } \\
\text { Metafórica para os episódios, } \\
\text { participantes e membros da } \\
\text { pintura, registrado na nota de } \\
\text { rodapé } 73 \text {. }\end{array}$ & $\begin{array}{l}\text { O café noturno é uma continuação } \\
\text { do semeador, como é a cabeça do } \\
\text { velho camponês e do poeta, se eu } \\
\text { conseguir fazer essa última tela. É } \\
\text { uma cor, então, que não é } \\
\text { localmente verdadeira do ponto de } \\
\text { vista realista do trompe l'oeil, mas } \\
\text { uma cor que sugere alguma emoção, } \\
\text { um temperamento ardente. }\end{array}$ & $\begin{array}{l}\text { No nível semântico, tanto na tela } \\
\text { quanto no excerto de carta, } \\
\text { observei o uso simbólico da cor, } \\
\text { como um recurso semiótico ao qual } \\
\text { ele indexa novos significados. Por } \\
\text { exemplo, no excerto, van Gogh } \\
\text { descreve uma série de trabalhos, } \\
\text { que ele reputa como 'experimentos' } \\
\text { e que estão interligados por meio } \\
\text { de uma concepção artística na qual } \\
\text { ele não usa uma cor 'localmente } \\
\text { verdadeira', mas 'uma cor que } \\
\text { sugere uma emoção, um } \\
\text { temperamento ardente'. Ele está } \\
\text { explicitando o uso simbólico da } \\
\text { cor, como um recurso semiótico } \\
\text { que está presente nas obras } \\
\text { relatadas, revelando a } \\
\text { interdiscursividade artística entre } \\
\text { elas. } \\
\text { No segundo excerto, van Gogh } \\
\text { explicita que em seus experimentos } \\
\text { parecem a ele 'atrozmente feios e } \\
\text { ruins' mas que eles estão em forte } \\
\text { interlocução com os significados } \\
\text { suscitados pela leitura de um artigo } \\
\text { de Dostoievski e por meio desses } \\
\text { sentidos, adquirem uma } \\
\text { centralidade no discurso artístico de } \\
\text { van Gogh: 'eles são os únicos que } \\
\text { me parecem ter um significado } \\
\text { mais importante.' }\end{array}$ \\
\hline
\end{tabular}




\begin{tabular}{|c|c|c|}
\hline $\begin{array}{l}\text { Na tela 'A Esplanada do } \\
\text { Café na Place du Forum, } \\
\text { Arles, à Noite', observei a } \\
\text { ocorrência de contraposição } \\
\text { entre a luz natural e a luz } \\
\text { artificial, sugerem uma } \\
\text { associação metafórica, } \\
\text { registrada na nota de rodapé } \\
134 \text { no apêndice. } \\
\\
\text { Observei também a } \\
\text { ocorrência de Associação } \\
\text { Metafórica pela } \\
\text { contraposição entre a cor } \\
\text { sob a luz natural e a cor sob } \\
\text { a luz artificial, que sugere } \\
\text { sentidos potenciais acerca da } \\
\text { contraposição Progresso x } \\
\text { Natureza, registrada na nota } \\
\text { de rodapé } 137 \text { no apêndice. }\end{array}$ & $\begin{array}{l}\text { A segunda mostra o exterior de um } \\
\text { café, iluminado no terraço externo } \\
\text { por uma grande lâmpada de gás } \\
\text { dentro da noite azul, com um retalho } \\
\text { de céu azul estrelado. } \\
\underline{\text { Uma enorme lanterna amarela }} \\
\text { ilumina o terraço, a fachada, a } \\
\text { calçada, e até mesmo projeta luz } \\
\text { sobre os paralelepípedos da rua, que } \\
\text { adquirem uma coloração violeta- } \\
\text { rosa. As frentes das casas em uma } \\
\text { rua que segue sob o céu azul } \\
\text { salpicado de estrelas são azul escuro } \\
\text { ou violeta, com uma árvore verde. } \\
\text { Agora há uma pintura de noite sem } \\
\text { preto. Com nada mais do que um } \\
\text { belo azul e violeta e verde e nestes } \\
\text { arredores da praça iluminada é } \\
\underline{\text { colorido por enxofre pálido, amarelo }} \\
\text { limão. Eu gosto enormemente de } \\
\text { pintar no local à noite. No passado, } \\
\text { eles costumavam desenhar e pintar a } \\
\text { tela do desenho durante o dia. Mas } \\
\text { acho que me convém pintar a coisa } \\
\text { no momento. É bem verdade que eu } \\
\text { possa tomar um azul por um verde } \\
\text { no escuro, um azul lilás por um rosa } \\
\text { lilás, uma vez que você não pode } \\
\text { perceber a natureza do tom } \\
\text { claramente. Mas é a única maneira } \\
\text { de se livrar da noite negra } \\
\text { convencional com uma luz pobre, } \\
\text { pálida e esbranquiçada, quando na } \\
\text { verdade uma mera vela por si só nos } \\
\text { dá os mais ricos amarelos e laranjas. }\end{array}$ & $\begin{array}{l}\text { No nível semântico, observei a } \\
\text { ocorrência Associação metafórica } \\
\text { para os significados da } \\
\text { contraposição entre a luz artificial e } \\
\text { a natureza. Essa metáfora é } \\
\text { construída, na tela, pela } \\
\text { contraposição entre a cor sob a luz } \\
\text { natural e a cor sob a luz artificial. } \\
\text { Na carta ela o é pela construção } \\
\text { léxico-gramatical 'iluminado no } \\
\text { terraço externo por uma grande } \\
\text { lâmpada de gás dentro da noite } \\
\text { azul' e 'com nada mais do que um } \\
\text { belo azul e violeta e verde e nestes } \\
\text { arredores da praça iluminada é } \\
\text { colorido por enxofre pálido, } \\
\text { amarelo limão'. que reunem na } \\
\text { mesma oração os sentidos da luz da } \\
\text { lâmpada em contraposição com os } \\
\text { sentidos da noite azul. }\end{array}$ \\
\hline $\begin{array}{l}\text { Na tela 'A Esplanada do } \\
\text { Café na Place du Forum, } \\
\text { Arles, à Noite', ocorrência } \\
\text { de Associações Metafóricas } \\
\text { e Intertextualidade para as } \\
\text { escolhas de sentidos que } \\
\text { van Gogh empresta à noite, } \\
\text { à luz noturna, evidenciado } \\
\text { no excerto da carta } 543 \\
\text { citada na análise, registrada } \\
\text { na nota de rodapé } 149 \text { no } \\
\text { apêndice. }\end{array}$ & $\begin{array}{l}\text { Você nunca me disse se você tinha } \\
\text { lido Bel-ami de Guy de Maupassant, } \\
\text { e o que você pensa agora do talento } \\
\text { dele em geral. Digo isto porque o } \\
\text { início de Bel- Ami é precisamente a } \\
\text { descrição de uma noite estrelada em } \\
\text { Paris, com os cafés iluminados da } \\
\text { avenida, e isso é algo como o } \\
\text { mesmo tema que eu pintei bem } \\
\text { agora. }\end{array}$ & $\begin{array}{l}\text { A ocorrência de associação } \\
\text { metafórica na oração, } \\
\text { é evidenciada pela escolha léxico- } \\
\text { gramatical 'e isso é algo como' que } \\
\text { compara sua tela com a 'descrição } \\
\text { de uma noite estrelada em Paris, } \\
\underline{\text { com os cafés iluminados da }} \\
\underline{\text { avenida'. Van Gogh usou esta }} \\
\text { descrição como metáfora para o } \\
\text { sentido que ele compartilhou tanto } \\
\text { na leitura de Bel-Ami quanto na } \\
\text { produção de seu texto pictórico na } \\
\text { forma da tela 'A Esplanada do Café } \\
\text { na Place du Forum, Arles, à Noite'. }\end{array}$ \\
\hline $\begin{array}{l}\text { Na tela 'A Esplanada do } \\
\text { Café na Place du Forum, } \\
\text { Arles, à Noite', ocorrência } \\
\text { de Incompletude e } \\
\text { Associação Metafórica } \\
\text { construída pela } \\
\text { representação das estrelas, }\end{array}$ & $\begin{array}{l}\text { Mas quando eu farei o céu estrelado, } \\
\text { então, essa pintura que está sempre } \\
\text { na minha mente? Ai, ai, é como } \\
\text { nosso excelente amigo Cyprien diz, } \\
\underline{\text { em 'En ménage' por JK Huysmans: }} \\
\underline{\text { as mais belas pinturas são aquelas }} \\
\text { que um sonha enquanto fuma um }\end{array}$ & $\begin{array}{l}\text { Assim como o semeador, van Gogh } \\
\text { usa a representação das estrelas } \\
\text { como uma metáfora para o seu } \\
\text { desejo de infinito, explicitados na } \\
\text { nota de rodapé } 144 \text {. Na oração, ele } \\
\text { usa a Verbiagem de Cyprien, uma } \\
\text { personagem de Huysmans como }\end{array}$ \\
\hline
\end{tabular}




\begin{tabular}{|c|c|c|}
\hline $\begin{array}{l}\text { seu brilho e seu halo, que } \\
\text { suscita escolhas de sentidos } \\
\text { potenciais metafóricos, como } \\
\text { o halo de santidade, } \\
\text { registradas na nota de rodapé } \\
144 \text { no apêndice. }\end{array}$ & $\begin{array}{l}\text { cachimbo em sua cama, mas a qual } \\
\text { ele não pinta. Mas é uma questão de } \\
\text { atacá-las, no entanto, não importa o } \\
\text { quão incompetente um pode sentir- } \\
\text { se vis-à-vis as perfeições inefáveis } \\
\text { do glorioso esplendor da natureza. }\end{array}$ & $\begin{array}{l}\text { metáfora para esse desejo } \\
\text { intangível, categorizado na } \\
\text { pesquisa como Incompletude. A } \\
\text { metáfora parece atender a uma } \\
\text { função tanto na tela quanto na carta } \\
\text { de representar esse desejo de } \\
\text { infinito. }\end{array}$ \\
\hline $\begin{array}{l}\text { Na tela 'A Esplanada do } \\
\text { Café na Place du Forum, } \\
\text { Arles, à Noite', ocorrência } \\
\text { de Interdiscursividade, } \\
\text { Associação Metafórica e } \\
\text { Transparência construídos } \\
\text { pelos sentidos potenciais que } \\
\text { sugerem a solidão, o } \\
\text { isolamento e a ausência } \\
\text { experienciada por van Gogh, } \\
\text { registrada na nota de rodapé } \\
163 \text { e } 164 \text { no apêndice. } \\
\\
\text { Na tela A Esplanada do } \\
\text { Café na Place du Forum, } \\
\text { observei a ocorrência de } \\
\text { Incompletude e de Limiar } \\
\text { Artístico, sugeridas pelo } \\
\text { sentido do vazio das } \\
\text { cadeiras salientadas no } \\
\text { primeiro plano e que estão } \\
\text { relacionadas com a } \\
\text { posição do pintor fora da } \\
\text { cena, construído uma } \\
\text { poderosa metáfora para a } \\
\text { ausência que, no entanto, } \\
\text { fica incógnita. Registrado } \\
\text { na nota de rodapé } 163 \text { no } \\
\text { apêndice. }\end{array}$ & $\begin{array}{l}\text { Mas quando eu farei o céu estrelado, } \\
\text { então, essa pintura que está sempre } \\
\text { na minha mente? Ai, ai, é como } \\
\text { nosso excelente amigo Cyprien diz, } \\
\text { em 'En ménage' por JK Huysmans: } \\
\text { as mais belas pinturas são aquelas } \\
\text { que um sonha enquanto fuma um } \\
\text { cachimbo em sua cama, mas a qual } \\
\text { ele não pinta. }\end{array}$ & $\begin{array}{l}\text { No nível semântico, observei tanto } \\
\text { na tela quanto na oração a } \\
\text { construção do sentido de } \\
\text { isolamento. Na tela, pelo } \\
\text { posicionamento relativo de cadeiras } \\
\text { vazias no primeiro plano, voltadas } \\
\text { para o pintor, e na carta pela } \\
\text { escolha léxico-gramatical de uma } \\
\text { Verbiagem na qual uma pessoa } \\
\text { solitária está a sonhar com uma } \\
\text { pintura a qual ela não pinta, ou } \\
\text { seja, ele se refere a uma experiência } \\
\text { de criação a qual ele não comunica. }\end{array}$ \\
\hline $\begin{array}{l}\text { Na tela ‘O Café Noturno na } \\
\text { Place Lamartine, em Arles', } \\
\text { ocorrência de Associação } \\
\text { Metafórica conferida pela } \\
\text { Distorção do Ponto de Vista } \\
\text { presente na representação da } \\
\text { mesa de bilhar, registrada } \\
\text { na nota de rodapé } 132 .\end{array}$ & $\begin{array}{l}\text { A sala está pintada de vermelho, e no } \\
\text { interior, na luz a gás, a mesa de } \\
\text { bilhar verde, a qual lança uma } \\
\text { imensa sombra sobre o chão. }\end{array}$ & $\begin{array}{l}\text { Tanto na tela quanto na oração, } \\
\text { observei o uso de saliência que } \\
\text { sugere a construção deliberada de } \\
\text { um significado metafórico para a } \\
\text { mesa de bilhar. Na oração, a } \\
\text { saliência é construída pela } \\
\text { circunstância 'e no interior, na luz a } \\
\text { gás' e pelo complexo nominal } \\
\text { 'imensa sombra'. A ocorrência de } \\
\text { saliência textual está compatível } \\
\text { com a ocorrência de saliência } \\
\text { visual, ambas constroem o mesmo } \\
\text { sentido de ênfase pela } \\
\text { desproporção, registrado na nota de } \\
\text { rodapé } 287 .\end{array}$ \\
\hline
\end{tabular}




\begin{tabular}{|c|c|c|}
\hline $\begin{array}{l}\text { Na tela 'O Café Noturno na } \\
\text { Place Lamartine, em Arles', } \\
\text { observei a ocorrência de } \\
\text { Distorção do Ponto de Vista } \\
\text { e Transparência, construídas } \\
\text { com ajuda de Saliência e de } \\
\text { Contrastes cromáticos } \\
\text { simultâneos e de saturação, } \\
\text { exacerbados para representar } \\
\text { uma sensação de } \\
\text { desconforto, registrados na } \\
\text { nota de rodapé 137. } \\
\text { Observei também a } \\
\text { ocorrência de Associação } \\
\text { metafórica com a ajuda da } \\
\text { Distorção do ponto de vista } \\
\text { constrói um sentido de } \\
\text { ambiguidade e perspectivas } \\
\text { conflitadas, registrada nas } \\
\text { notas de rodapé } 156,157 \text { e } \\
\underline{158 .}\end{array}$ & $\begin{array}{l}\text { "Que diria portanto desse quadro o } \\
\text { Sr. Tersteeg? Diante de um Sisley, } \\
\text { Sisley, o mais discreto e delicado } \\
\text { dos Impressionistas - já disse: "Não } \\
\text { posso me impedir de pensar que o } \\
\text { artista que pintou isso estava um } \\
\text { pouco tonto". Diante do meu } \\
\text { quadro, então a mim ele diria que } \\
\text { ele é um caso de delirium tremens". }\end{array}$ & $\begin{array}{l}\text { Nesse excerto, van Gogh está } \\
\text { usando uma comparação para } \\
\text { explicitar para o irmão o impacto } \\
\text { que a sua tela causará no meio } \\
\text { artístico, em especial na crítica de } \\
\text { arte da época. Na oração, ele usa a } \\
\text { Verbiagem, de um crítico de arte } \\
\text { acerca do trabalho do pintor Sisley, } \\
\text { como metáfora para avaliar como o } \\
\text { seu próprio quadro pareceria para o } \\
\text { Sr. Tersteeg, em comparação com o } \\
\text { que ele disse do trabalho de Sisley. } \\
\text { Esse uso indica uma Associação } \\
\text { metafórica que é compatível no } \\
\text { nível léxico-gramatical com o uso } \\
\text { de Associação metafórica na tela, } \\
\text { amplamente documentado ao longo } \\
\text { da análise e da triangulação. }\end{array}$ \\
\hline $\begin{array}{l}\text { Na tela 'O Café Noturno na } \\
\text { Place Lamartine, em Arles', } \\
\text { observei a ocorrência de } \\
\text { Metáfora Visual com o uso } \\
\text { da Distorção na perspectiva } \\
\text { para a construção de uma } \\
\text { saliência de que o café é um } \\
\text { ambiente de conflitos e de } \\
\text { uma percepção distorcida } \\
\text { da realidade. Registrado nas } \\
\text { notas de rodapé } 156 \text { e 157. } \\
\\
\text { Ocorrência de Associação } \\
\text { Metafórica pelo uso de } \\
\text { Contraposição entre a } \\
\text { centralidade das lâmpadas e } \\
\text { a centralidade da mesa de } \\
\text { bilhar, para expressar a } \\
\text { sensação de tensão e } \\
\text { sentidos conflitantes como } \\
\text { atividade/inatividade. } \\
\text { Registrado na nota de rodapé } \\
\text { 195. }\end{array}$ & $\begin{array}{l}\text { Eu acabei de terminar uma tela que } \\
\text { representa um interior de café à } \\
\text { noite iluminado por lâmpadas. } \\
\text { Alguns pobres vagabundos noturnos } \\
\text { estão dormindo em um canto. A sala } \\
\text { está pintada de vermelho, e no } \\
\text { interior, na luz a gás, a mesa de } \\
\text { bilhar verde, a qual lança uma } \\
\text { imensa sombra sobre o chão. Nesta } \\
\text { tela, há } 6 \text { ou } 7 \text { vermelhos diferentes, } \\
\text { desde vermelho-sangue até rosa } \\
\text { delicado, fazendo oposição com o } \\
\text { mesmo número de verdes pálidos ou } \\
\text { escuros. }\end{array}$ & $\begin{array}{l}\text { Uso de associações metafóricas. } \\
\text { Van Gogh usou a oposição entre as } \\
\text { cores vermelho e verde para } \\
\text { significar uma nova camada de } \\
\text { sentido, o conflito que há nas } \\
\text { 'terríveis paixões humanas'. Com a } \\
\text { escolha lexical 'fazendo uma } \\
\text { oposição' que constrói na oração } \\
\text { um sentido simbólico que ele } \\
\text { deseja indexar ao sentido já } \\
\text { existente que é o contraste entre } \\
\text { essas cores. Esse sentido simbólico } \\
\text { ele também indexa na narrativa } \\
\text { visual por meio da escolha lexical } \\
\text { 'batalhas e antíteses' presente em } \\
\text { outra oração para se referir aos } \\
\text { contrastes entre verdes e } \\
\text { vermelhos. A associação } \\
\text { metafórica de 'fazendo uma } \\
\text { oposição' é uma ocorrência } \\
\text { evidenciada tanto na oração quanto } \\
\text { na tela. Registrado na nota de } \\
\text { rodapé } 295 .\end{array}$ \\
\hline $\begin{array}{l}\text { Na tela ‘O Café Noturno na } \\
\text { Place Lamartine, em Arles', } \\
\text { observei a ocorrência de } \\
\text { Associação Metafórica } \\
\text { construída com o uso de } \\
\text { Profundidade e Perspectiva } \\
\text { na representação das figuras } \\
\text { no fundo, registrada nas } \\
\text { notas de rodapé } 133 \text { e } 134 .\end{array}$ & & \\
\hline
\end{tabular}




\begin{tabular}{|c|c|c|}
\hline $\begin{array}{l}\text { Na tela 'O Café Noturno na } \\
\text { Place Lamartine, em Arles', } \\
\text { observei a ocorrência de } \\
\text { Associação metafórica } \\
\text { construída pelo uso dos } \\
\text { contrastes cromáticos que } \\
\text { enfatizam um tom de } \\
\text { amarelo fatigante para } \\
\text { representar a deformidade } \\
\text { de caráter, registrado na } \\
\text { nota de rodapé 144. }\end{array}$ & $\begin{array}{l}\text { Na minha pintura do café à noite eu } \\
\text { procurei exprimir que o café é um } \\
\text { lugar onde você pode arruinar-se, } \\
\text { enlouquecer, cometer crimes. De } \\
\text { qualquer forma, eu tentei com } \\
\text { contrastes de rosa delicado e } \\
\text { vermelho-sangue e vinho tinto. } \\
\text { Verde doce Luís XV e Veronese } \\
\text { contrastando com os verdes } \\
\text { amarelos e os verdes azuis duros. } \\
\text { Tudo isso em uma atmosfera de } \\
\text { fornalha infernal, de enxofre pálido. } \\
\text { Exprimir como a potência dos } \\
\text { cantos escuros de uma taberna. } \\
\text { Contudo sob uma aparência da } \\
\text { alegria japonesa e da boa natureza } \\
\text { de Tartarin. }\end{array}$ & $\begin{array}{l}\text { Observei a ocorrência do uso de } \\
\text { Enquadramento ao deslocar o } \\
\text { sentido principal para a oração } \\
\text { Beta. Este exemplo de } \\
\text { enquadramento na oração é } \\
\text { compatível com o uso de ênfase no } \\
\text { segundo plano na composição } \\
\text { visual, registrado na nota de rodapé } \\
263 . \\
\text { Uso de associações metafóricas } \\
\text { para os sentidos indexados a estes } \\
\text { contrastes que estão descritos nas } \\
\text { duas orações. Por exemplo, entre o } \\
\text { que é suave e delicado e o que é } \\
\text { passional e denso no caso da } \\
\text { primeira oração e entre o que é } \\
\text { doce e o que é duro, na segunda, } \\
\text { registrado na nota de rodapé } 269 .\end{array}$ \\
\hline $\begin{array}{l}\text { Na tela 'O Café Noturno na } \\
\text { Place Lamartine, em Arles', } \\
\text { observei a ocorrência de } \\
\text { Associação metafórica } \\
\text { construída pelo uso da } \\
\text { Intertextualidade entre } \\
\text { carta e tela, registrada na } \\
\text { nota de rodapé } 145 .\end{array}$ & $\begin{array}{l}\text { Eu tentei expressar as terríveis } \\
\text { paixões humanas com o vermelho e } \\
\text { o verde. } \\
\text { A sala é vermelho-sangue e amarelo } \\
\text { sem graça, uma mesa de bilhar verde } \\
\text { no centro, } 4 \text { lâmpadas de amarelo } \\
\text { limão com um brilho laranja e } \\
\text { verde. } \\
\text { Em todos os lugares é uma batalha e } \\
\text { uma antítese dos mais diferentes } \\
\text { verdes e vermelhos; nas personagens } \\
\text { dos rufiões adormecidos, pequenos } \\
\text { na alta sala vazia, algum roxo e azul. } \\
\text { O vermelho-sangue e o amarelo- } \\
\text { verde da mesa de bilhar, por } \\
\text { exemplo, contrasta com o pouco de } \\
\text { verde delicado Louis XV do balcão, } \\
\text { onde há um buquê rosa. }\end{array}$ & $\begin{array}{l}\text { Observei o Uso de Associação } \\
\text { Metafórica e do Simbólico da Cor } \\
\text { sendo explicitado nesta oração. A } \\
\text { ocorrência é compatível com a } \\
\text { ocorrência do contraste } \\
\text { complementar a que ela se refere na } \\
\text { tela, registrado na nota de rodapé } \\
\underline{256} \text {. } \\
\text { Uso de contraposição nas orações é } \\
\text { compatível com os contrastes } \\
\text { cromáticos na tela usados para } \\
\text { representar 'batalha e antítese'. } \\
\text { Nestas duas orações, verifiquei a } \\
\text { ocorrência de uma contraposição e } \\
\text { de uma inversão que, no nível } \\
\text { semântico, está compatível com a } \\
\text { contraposição encontrada nos } \\
\text { contrastes cromáticos usados para } \\
\text { significar o mesmo sentido } \\
\text { expresso nas orações. Ao } \\
\text { representar um sentido com o seu } \\
\text { sentido oposto, van Gogh usa o } \\
\text { nível semântico para construir uma } \\
\text { forma paradoxal em sua estratégia } \\
\text { retórica textual, registrado na nota } \\
\text { de rodapé } 274 \text {. }\end{array}$ \\
\hline $\begin{array}{l}\text { Na tela 'O Café Noturno na } \\
\text { Place Lamartine, em Arles', } \\
\text { observei a ocorrência de } \\
\text { Associação metafórica para } \\
\text { os sentidos potenciais da } \\
\text { luz que ilumina as pessoas } \\
\text { no café, registrada na nota } \\
\text { de rodapé } 151 . \\
\\
\text { Ocorrência de Associação } \\
\text { metafórica por meio do uso }\end{array}$ & $\begin{array}{l}\text { Tudo isso em uma atmosfera de } \\
\text { fornalha infernal, de enxofre pálido. } \\
\text { Exprimir como a potência dos } \\
\text { cantos escuros de uma taberna. } \\
\text { Contudo sob uma aparência da } \\
\text { alegria japonesa e da boa natureza } \\
\text { de Tartarin. } \\
\text { É uma cor, então, que não é } \\
\text { localmente verdadeira do ponto de } \\
\text { vista realista do trompe l'oeil, mas }\end{array}$ & $\begin{array}{l}\text { Observei na tela a construção de } \\
\text { um sentido metafórico para a luz, } \\
\text { representada com recursos tais } \\
\text { como textura, ritmo, movimento, } \\
\text { gesto pictórico, rima visual para } \\
\text { conferir saliência e centralidade na } \\
\text { composição. Registrado na nota de } \\
\text { rodapé } 187 . \\
\text { O sentido da luz, construído como } \\
\text { uma iluminação intensa, excessiva } \\
\text { e fatigante é compatível com o }\end{array}$ \\
\hline
\end{tabular}




\begin{tabular}{|c|c|c|}
\hline $\begin{array}{l}\text { de Ritmo, Movimento, } \\
\text { Textura, Vetor, Gesto } \\
\text { Pictórico e Rima Visual que } \\
\text { juntos constroem uma } \\
\text { metáfora visual para a luz } \\
\text { que interliga todos os } \\
\text { processos na narrativa, } \\
\text { registrados na nota de rodapé } \\
\underline{191} .\end{array}$ & $\begin{array}{l}\text { uma cor que sugere alguma emoção, } \\
\text { um temperamento ardente. }\end{array}$ & $\begin{array}{l}\text { sentido construído para a luz na } \\
\text { oração, no qual ele a representa } \\
\text { com a figura de uma 'fornalha } \\
\text { infernal' indicando o uso de uma } \\
\text { metáfora. Em seguida ele explicita } \\
\text { a função semântica dessa luz } \\
\text { excessiva; para 'exprimir como a } \\
\text { potência dos cantos escuros de } \\
\text { uma taberna. } \\
\text { Contudo sob uma aparência da } \\
\text { alegria japonesa e da boa natureza } \\
\text { de Tartarin'. O uso do item lexical } \\
\text { 'como' é outro indicador de uma } \\
\text { associação metafórica na qual a luz } \\
\text { excessiva é como a potência dos } \\
\text { cantos escuros de uma taberna. } \\
\text { Observei aqui mais uma ocorrência } \\
\text { de um paradoxo, ele quer construir } \\
\text { um sentido de escuridão usando } \\
\text { para isso a representação da luz em } \\
\text { excesso, e indexando para ela um } \\
\text { novo e oposto significado de } \\
\text { sombra. }\end{array}$ \\
\hline $\begin{array}{l}\text { Na tela 'O Café Noturno na } \\
\text { Place Lamartine, em Arles', } \\
\text { observei a ocorrência de } \\
\text { Associação Metafórica sobre } \\
\text { a condição de exclusão em } \\
\text { que estão mergulhados os } \\
\text { bêbados no café, registrada } \\
\text { na nota de rodapé } 181 . \\
\text { Ocorrência de Associação } \\
\text { Metafórica para representar } \\
\text { a precariedade da condição } \\
\text { humana naquele contexto } \\
\text { social e histórico, por meio } \\
\text { da Distorção do ponto de } \\
\text { vista, registrada na nota de } \\
\text { rodapé } 183 .\end{array}$ & $\begin{array}{l}\text { Agora como para recuperar o } \\
\text { dinheiro pago ao senhorio através da } \\
\text { minha pintura, eu não estou fazendo } \\
\text { questão disto, porque a pintura é } \\
\text { uma das mais feias que eu já fiz. É o } \\
\text { equivalente, embora diferente, dos } \\
\text { comedores de batata. } \\
\text { No excerto observei a ocorrência de } \\
\text { uma Associação metafórica por meio } \\
\text { do uso lexical 'como' que indica que } \\
\text { van Gogh não deseja recuperar o } \\
\text { dinheiro pago ao senhorio, mas algo } \\
\text { que represente esse dinheiro gasto. A } \\
\text { oração não explicita de que forma } \\
\text { ele pretende 'recuperar' o dinheiro } \\
\text { pago 'através' da pintura, se é pelo } \\
\text { valor intrínseco que ela representa } \\
\text { para van Gogh. Ou seja, ao pintar o } \\
\text { café, ele extrairia 'algo de valor' em } \\
\text { troca do dinheiro gasto com o } \\
\text { senhorio. O uso da metáfora da troca } \\
\text { simbólica da pintura da tela pelo } \\
\text { dinheiro gasto no café se torna ainda } \\
\text { mais intrigante quando ele revela que } \\
\text { esta é 'uma das mais feias' que ele já } \\
\text { fez e a relaciona com os comedores } \\
\text { de batata pelo item lexical } \\
\text { 'equivalente'. }\end{array}$ & $\begin{array}{l}\text { Na tela, observei o uso de } \\
\text { associação metafórica do lugar } \\
\text { social de exclusão dos bêbados } \\
\text { representados no café, por meio de } \\
\text { sua posição relativa na composição, } \\
\text { e por meio de recursos cromáticos } \\
\text { que constroem um ambiente } \\
\text { decadente, de cansaço e desânimo. } \\
\text { O uso metafórico para construir } \\
\text { que o café é um lugar sem valor } \\
\text { também está presente no excerto no } \\
\text { qual van Gogh explicita que deseja } \\
\text { recuperar o dinheiro pago ao } \\
\text { senhorio pintando a tela, como se o } \\
\text { café não valesse o dinheiro que ele } \\
\text { gastou. }\end{array}$ \\
\hline $\begin{array}{l}\text { Na tela ‘O Café Noturno na } \\
\text { Place Lamartine, em Arles', } \\
\text { observei a ocorrência de } \\
\text { Intertextualidade e } \\
\text { Associacão metafórica por }\end{array}$ & $\begin{array}{l}\text { Na minha pintura do café à noite eu } \\
\text { procurei exprimir que o café é um } \\
\text { lugar onde você pode arruinar-se, } \\
\text { enlouquecer, cometer crimes. De } \\
\text { qualquer forma, eu tentei com } \\
\text { contrastes de rosa delicado e }\end{array}$ & $\begin{array}{l}\text { Uso de associações metafóricas } \\
\text { para os sentidos indexados a estes } \\
\text { contrastes que estão descritos nas } \\
\text { duas orações. Por exemplo, entre o } \\
\text { que é suave e delicado e o que é } \\
\text { passional e denso no caso da }\end{array}$ \\
\hline
\end{tabular}




\begin{tabular}{|c|c|c|}
\hline $\begin{array}{l}\text { meio do uso de Contrastes } \\
\text { cromáticos e Sinestesia. A } \\
\text { excessiva luz que inunda a } \\
\text { sala e a forma como ele } \\
\text { representa os contrastes } \\
\text { podem ser considerados } \\
\text { semioses equivalentes à } \\
\text { expressão escrita "fornalha } \\
\text { do diabo", registrada nas } \\
\text { notas de rodapé } 187,188, \\
189,190,191,192,193 \mathrm{e} \\
194 .\end{array}$ & $\begin{array}{l}\text { vermelho-sangue e vinho tinto. } \\
\text { Verde doce Luís XV e Veronese } \\
\text { contrastando com os verdes } \\
\text { amarelos e os verdes azuis duros. } \\
\text { Tudo isso em uma atmosfera de } \\
\text { fornalha infernal, de enxofre pálido. } \\
\text { Exprimir como a potência dos } \\
\text { cantos escuros de uma taberna. } \\
\text { Contudo sob uma aparência da } \\
\text { alegria japonesa e da boa natureza } \\
\text { de Tartarin. }\end{array}$ & $\begin{array}{l}\text { primeira oração e entre o que é } \\
\text { doce e o que é duro, na segunda, } \\
\text { registrado na nota de rodapé } 269 \text {. }\end{array}$ \\
\hline $\begin{array}{l}\text { Na tela 'O Café Noturno na } \\
\text { Place Lamartine, em Arles', } \\
\text { observei a ocorrência de } \\
\text { Associações metafóricas por } \\
\text { meio de Contraposições e } \\
\text { contrastes para representar } \\
\text { processos dicotômicos tais } \\
\text { como: centralidade } x \\
\text { periferia; olhar x negação } \\
\text { do olhar; presença x } \\
\text { ausência; mundano x } \\
\text { espiritual, registrada nas } \\
\text { notas de rodapé } 188 \text { e } 195 .\end{array}$ & $\begin{array}{l}\text { A ideia do semeador ainda continua } \\
\text { a me assombrar. Estudos } \\
\text { exagerados, como o semeador, como } \\
\text { o café noturno agora, geralmente } \\
\text { parecem-me atrozmente feios e } \\
\text { ruins, mas quando eu estou movido } \\
\text { por alguma coisa, como aqui por } \\
\text { este pequeno artigo sobre } \\
\text { Dostoievski, em seguida, eles são os } \\
\text { únicos que me parecem ter um } \\
\text { significado mais importante. }\end{array}$ & $\begin{array}{l}\text { Inversão de valores } \\
\text { Uso de Contraposição e Conflito no } \\
\text { nível semântico, nos sentidos } \\
\text { expressos na oração, que é } \\
\text { compatível com a ocorrência da } \\
\text { representação visual de conflito por } \\
\text { meio de contrastes cromáticos, } \\
\text { registrado na nota de rodapé } 279 \text {. } \\
\\
\text { Observei o uso de Enquadramento } \\
\text { no nível gramatical e no uso de } \\
\text { Perspectiva no nível semântico da } \\
\text { construção do complexo oracional } \\
\text { que é compatível com a perspectiva } \\
\text { visual com a qual ele representa } O \\
\text { café da Noite, registrado na nota de } \\
\text { rodapé } 280 .\end{array}$ \\
\hline $\begin{array}{l}\text { Ocorrência de Associação } \\
\text { metafórica dos conflitos e } \\
\text { contradições humanas por } \\
\text { meio dos contrastes de luz e } \\
\text { sombra, de cor, e de } \\
\text { posicionamento das figuras e } \\
\text { objetos. Registrado na nota } \\
\text { de rodapé 197. } \\
\\
\text { Ocorrência de Associação } \\
\text { metafórica de sentidos } \\
\text { potenciais apoiada no } \\
\text { discurso religioso que faz a } \\
\text { analogia da luz com a luz } \\
\text { espiritual e da sombra com a } \\
\text { ausência de luz espiritual, } \\
\end{array}$ & $\begin{array}{l}\text { Eu acabei de terminar uma tela que } \\
\text { representa um interior de café à } \\
\text { noite iluminado por lâmpadas. } \\
\text { Alguns pobres vagabundos noturnos } \\
\text { estão dormindo em um canto. A sala } \\
\text { está pintada de vermelho, e no } \\
\text { interior, na luz a gás, a mesa de } \\
\text { bilhar verde, a qual lança uma } \\
\text { imensa sombra sobre o chão. Nesta } \\
\text { tela, há } 6 \text { ou } 7 \text { vermelhos diferentes, } \\
\text { desde vermelho-sangue até rosa } \\
\text { delicado, fazendo oposição com o } \\
\text { mesmo número de verdes pálidos ou } \\
\text { escuros. } \\
\text { A ideia do semeador ainda continua } \\
\text { a me assombrar. Estudos } \\
\text { exagerados, como o semeador, como } \\
\text { o café noturno agora, geralmente } \\
\text { parecem-me atrozmente feios e } \\
\text { ruins, mas quando eu estou movido } \\
\text { por alguma coisa, como aqui por } \\
\text { este pequeno artigo sobre } \\
\text { Dostoievski, em seguida, eles são os } \\
\text { únicos que me parecem ter um } \\
\text { significado mais importante. }\end{array}$ & $\begin{array}{l}\text { Uso de Contraposição e Conflito no } \\
\text { nível semântico, nos sentidos } \\
\text { expressos na oração, que é } \\
\text { compatível com a ocorrência da } \\
\text { representação visual de conflito por } \\
\text { meio de contrastes cromáticos, } \\
\text { registrado na nota de rodapé } 279 \text {. } \\
\\
\text { Observei o uso de Enquadramento } \\
\text { no nível gramatical e no uso de } \\
\text { Perspectiva no nível semântico da } \\
\text { construção do complexo oracional } \\
\text { que é compatível com a perspectiva } \\
\text { visual com a qual ele representa 'O } \\
\text { café da Noite', registrado na nota } \\
\text { de rodapé } 280 .\end{array}$ \\
\hline
\end{tabular}




\begin{tabular}{|c|c|c|}
\hline \multicolumn{3}{|l|}{$\begin{array}{l}\text { registrada na nota de rodapé } \\
\underline{198} .\end{array}$} \\
\hline $\begin{array}{l}\text { Ocorrência de Associação } \\
\text { metafórica nas escolhas de } \\
\text { sentidos potenciais para a } \\
\text { relação entre a luz e a } \\
\text { natureza humana, registrada } \\
\text { na nota de rodapé } 199 .\end{array}$ & & \\
\hline $\begin{array}{l}\text { Ocorrência de Associação } \\
\text { metafórica corrobora com o } \\
\text { sentido de a luz estar } \text { em } \\
\text { relação ao ser humano, pela } \\
\text { disposição das lâmpadas } \\
\text { sempre acima das cabeças } \\
\text { das figuras, nunca acima de } \\
\text { cadeiras vazias, registrada na } \\
\text { nota de rodapé } 200 \text {. }\end{array}$ & & \\
\hline $\begin{array}{l}\text { Uso de associação } \\
\text { metafórica por meio de } \\
\text { Saliência, Ritmo, } \\
\text { Movimento, Textura e Gesto } \\
\text { Pictórico para dar } \\
\text { centralidade para luz, } \\
\text { registrada na nota de rodapé } \\
\text { 201. }\end{array}$ & & \\
\hline $\begin{array}{l}\text { Ocorrência de Associação } \\
\text { metafórica por meio de } \\
\text { escolhas potenciais para } \\
\text { construir um sentido de } \\
\text { espiritualidade, registrada na } \\
\text { nota de rodapé } 202 \text {. }\end{array}$ & & \\
\hline $\begin{array}{l}\text { Ocorrência de Associação } \\
\text { metafórica de escolhas } \\
\text { potenciais para construir um } \\
\text { sentido de que a Luz } \\
\text { espiritual brilha sobre todos, } \\
\text { registrada na nota de rodapé } \\
\text { 203. }\end{array}$ & & \\
\hline $\begin{array}{l}\text { Na tela 'O Café Noturno na } \\
\text { Place Lamartine, em Arles', } \\
\text { observei a ocorrência de } \\
\text { Associação metafórica dos } \\
\text { sentidos potenciais do Café } \\
\text { como um lugar para onde } \\
\text { vão os excluídos, registrada } \\
\text { na nota de rodapé } 209 .\end{array}$ & & \\
\hline $\begin{array}{l}\text { Na tela 'O Café Noturno na } \\
\text { Place Lamartine, em Arles', } \\
\text { observei a ocorrência de } \\
\text { Associação metafórica por } \\
\text { meio de Saliência, } \\
\text { Contradição e Distorção do }\end{array}$ & $\begin{array}{l}\text { A sala está pintada de vermelho, e } \\
\text { no interior, na luz a gás, a mesa de } \\
\text { bilhar verde, a qual lança uma } \\
\text { imensa sombra sobre o chão. }\end{array}$ & $\begin{array}{l}\text { Uso de associações metafóricas } \\
\text { para os itens lexicais 'interior', } \\
\text { 'lança' e 'imensa' que sugerem } \\
\text { uma condensação de sentidos que } \\
\text { está presente como vetor tanto na } \\
\text { tela quanto na carta, registrada na }\end{array}$ \\
\hline
\end{tabular}




\begin{tabular}{|c|c|c|}
\hline $\begin{array}{l}\text { Ponto de Vista para } \\
\text { representar a sombra da } \\
\text { mesa em contraste com a } \\
\text { ausência de sombras nos } \\
\text { outros objetos e figuras, } \\
\text { registrada na nota de rodapé } \\
205 .\end{array}$ & & nota de rodapé 293. \\
\hline $\begin{array}{l}\text { Na tela ‘O Café Noturno na } \\
\text { Place Lamartine, em Arles’, } \\
\text { observei a ocorrência de } \\
\text { Associação metafórica, } \\
\text { Enquadramento, Perspectiva } \\
\text { e Incompletude por meio do } \\
\text { sentido de Contraposição } \\
\text { entre centro/periferia, } \\
\text { olhar/não olhar, ativo/apático } \\
\text { construído pela posição } \\
\text { relativa das figuras, } \\
\text { registrada na nota de rodapé } \\
\underline{138} . \\
\text { Ocorrência de Associação } \\
\text { metafórica dos sentidos } \\
\text { potenciais das cadeiras e } \\
\text { mesa desocupadas como } \\
\text { uma metáfora visual para o } \\
\text { esvaziamento, a perda de } \\
\text { lugar das pessoas } \\
\text { desocupadas que ocupam o } \\
\text { café, registrada na nota de } \\
\text { rodapé } 213 .\end{array}$ & $\begin{array}{l}\text { A sala é vermelho-sangue e amarelo } \\
\text { sem graça, uma mesa de bilhar verde } \\
\text { no centro, } 4 \text { lâmpadas de amarelo } \\
\text { limão com um brilho laranja e } \\
\text { verde. } \\
\text { A roupa branca do proprietário, } \\
\text { vigiando as coisas a partir de um } \\
\frac{\text { canto deste forno, torna-se amarelo- }}{\text { limão, verde luminoso pálido. }} \\
\text { Eu acabei de terminar uma tela que } \\
\text { representa um interior de café à } \\
\text { noite iluminado por lâmpadas. } \\
\text { Alguns pobres vagabundos noturnos } \\
\text { estão dormindo em um canto. }\end{array}$ & $\begin{array}{l}\text { Observei o uso de associações } \\
\text { metafóricas e uso simbólico da cor } \\
\text { com A escolha do item lexical } \\
\text { "forno" no extrato de carta, que é } \\
\text { correspondente à representação } \\
\text { visual da luz excessiva no interior } \\
\text { do café, registrado na nota de } \\
\text { rodapé } 259 .\end{array}$ \\
\hline $\begin{array}{l}\text { Na tela ‘O Café Noturno na } \\
\text { Place Lamartine, em Arles', } \\
\text { observei a ocorrência de } \\
\text { Distorção do Ponto de Vista, } \\
\text { Incompletude e Associação } \\
\text { metafórica por meio da } \\
\text { distorção da forma e do } \\
\text { tamanho da sombra da mesa } \\
\text { de bilhar que se impõe pela } \\
\text { exclusão de outras sombras, } \\
\text { registrada na nota de rodapé } \\
\underline{217} \text {. } \\
\text { Na tela 'O Café Noturno na } \\
\text { Place Lamartine, em Arles', } \\
\text { observei a ocorrência de } \\
\text { Associação metafórica pela } \\
\text { Inversão de sentidos pela } \\
\text { escolha de uma mesa de } \\
\text { bilhar para simbolizar a } \\
\text { solidão e o isolamento } \\
\text { humano, registrada na nota } \\
\text { de rodapé } 218 .\end{array}$ & $\begin{array}{l}\text { A sala está pintada de vermelho, e } \\
\text { no interior, na luz a gás, a mesa de } \\
\text { bilhar verde, a qual lança uma } \\
\text { imensa sombra sobre o chão. }\end{array}$ & $\begin{array}{l}\text { Uso de Simbolismo nas temáticas e } \\
\text { narrativas - na oração 'e no } \\
\text { interior, na luz a gás, a mesa de } \\
\text { bilhar verde, a qual lança uma } \\
\text { imensa sombra sobre o chão. ', } \\
\text { observei a ocorrência de } \\
\text { simbolismo na escolha do item } \\
\text { lexical 'mesa de bilhar verde' com } \\
\text { base na ocorrência de aguçamento e } \\
\text { ênfase para a forma como a sua } \\
\text { ação está representada. Esta } \\
\text { ocorrência é compatível com a } \\
\text { representação visual da mesa de } \\
\text { bilhar na tela, que também foi } \\
\text { representada com ênfase por meio } \\
\text { de distorção, textura e desenho- } \\
\text { pintura para aguçar o seu sentido } \\
\text { simbólico. Registrado na nota de } \\
\text { rodapé } 290 .\end{array}$ \\
\hline
\end{tabular}




\begin{tabular}{|c|c|c|}
\hline $\begin{array}{l}\text { Ocorrência de Associação } \\
\text { metafórica por meio de } \\
\text { Saliência, Rima Visual e } \\
\text { Profundidade na construção } \\
\text { de um sentido simbólico para } \\
\text { a mesa de bilhar, registrada } \\
\text { na nota de rodapé 224. }\end{array}$ & & \\
\hline $\begin{array}{l}\text { Na tela 'O Café Noturno na } \\
\text { Place Lamartine, em Arles', } \\
\text { observei a ocorrência de } \\
\text { Contrastes Cromáticos que } \\
\text { constroem um sentido de } \\
\text { excesso, de fadiga e } \\
\text { decadência por meio de } \\
\text { Intertextualidade e } \\
\text { Associaçóes metafóricas, } \\
\text { registrada na nota de rodapé } \\
\underline{228 .}\end{array}$ & $\begin{array}{l}\text { Tudo isso em uma atmosfera de } \\
\text { fornalha infernal, de enxofre pálido. } \\
\text { Exprimir como a potência dos } \\
\text { cantos escuros de uma taberna. } \\
\text { Contudo sob uma aparência da } \\
\text { alegria japonesa e da boa natureza } \\
\text { de Tartarin. } \\
\text { É uma cor, então, que não é } \\
\text { localmente verdadeira do ponto de } \\
\text { vista realista do trompe l'oeil, mas } \\
\text { uma cor que sugere alguma emoção, } \\
\text { um temperamento ardente. } \\
\text { Estudos exagerados, como o } \\
\text { semeador, como o café noturno } \\
\text { agora, geralmente parecem-me } \\
\text { atrozmente feios e ruins, mas } \\
\text { quando eu estou movido por alguma } \\
\text { coisa, como aqui por este pequeno } \\
\text { artigo sobre Dostoievski, em } \\
\text { seguida, eles são os únicos que me } \\
\text { parecem ter um significado mais } \\
\text { importante. }\end{array}$ & $\begin{array}{l}\text { Uso de Contraposição e Conflito no } \\
\text { nível semântico, nos sentidos } \\
\text { expressos na oração, que é } \\
\text { compatível com a ocorrência da } \\
\text { representação visual de conflito por } \\
\text { meio de contrastes cromáticos, } \\
\text { registrado na nota de rodapé } 279 \text {. } \\
\text { Observei o uso de Enquadramento } \\
\text { no nível gramatical e no uso de } \\
\text { Perspectiva no nível semântico da } \\
\text { construção do complexo oracional } \\
\text { que é compatível com a perspectiva } \\
\text { visual com a qual ele representa O } \\
\text { café da Noite, registrado na nota de } \\
\text { rodapé } 280 .\end{array}$ \\
\hline $\begin{array}{l}\text { Na tela ‘O Café Noturno na } \\
\text { Place Lamartine, em Arles', } \\
\text { observei a ocorrência de } \\
\text { Associação metafórica pelo } \\
\text { uso do Contraste Simultâneo } \\
\text { entre vermelhos e verdes } \\
\text { para construir uma metáfora } \\
\text { visual, registrada nas notas } \\
\text { de rodapé } 233 \text { e } 234 \text {. }\end{array}$ & $\begin{array}{l}\text { Eu tentei expressar as terríveis } \\
\text { paixões humanas com o vermelho e } \\
\text { o verde. } \\
\text { Na minha pintura do café à noite eu } \\
\text { procurei exprimir que o café é um } \\
\text { lugar onde você pode arruinar-se, } \\
\text { enlouquecer, cometer crimes. De } \\
\text { qualquer forma, eu tentei com } \\
\text { contrastes de rosa delicado e } \\
\text { vermelho-sangue e vinho tinto. } \\
\text { Verde doce Luís XV e Veronese } \\
\text { contrastando com os verdes } \\
\text { amarelos e os verdes azuis duros. } \\
\text { Em todos os lugares é uma batalha e } \\
\text { uma antítese dos mais diferentes } \\
\text { verdes e vermelhos; nas personagens } \\
\text { dos rufiões adormecidos, pequenos } \\
\text { na alta sala vazia, algum roxo e azul. } \\
\text { O vermelho-sangue e o amarelo- } \\
\text { verde da mesa de bilhar, por } \\
\text { exemplo, contrasta com o pouco de } \\
\text { verde delicado Louis XV do balcão, } \\
\text { onde há um buquê rosa. }\end{array}$ & $\begin{array}{l}\text { Observei o Uso de Associação } \\
\text { Metafórica e do Simbólico da Cor } \\
\text { sendo explicitado nesta oração. A } \\
\text { ocorrência é compatível com a } \\
\text { ocorrência do contraste } \\
\text { complementar a que ela se refere na } \\
\text { tela, registrado na nota de rodapé } \\
256 . \\
\text { Uso de Associações Metafóricas e } \\
\text { do Uso Simbólico da Cor. Ao } \\
\text { expressar o sentido simbólico dos } \\
\text { verdes e vermelhos textualmente } \\
\text { ele cola esse sentido no uso dessas } \\
\text { cores na tela, construindo uma } \\
\text { ponte entre a carta e a tela, criando } \\
\text { uma cadeia de textos. Observei } \\
\text { uma ocorrência do uso simbólico } \\
\text { da cor em ambas as modalidades } \\
\text { não pela forma, mas pelo sentido } \\
\text { associado a este uso, registrado na } \\
\text { nota de rodapé } 257 . \\
\text { Uso de associações metafóricas } \\
\text { para os sentidos indexados a estes } \\
\text { contrastes, que estão descritos nas } \\
\text { duas orações. Por exemplo, entre o }\end{array}$ \\
\hline
\end{tabular}




\begin{tabular}{|c|c|c|}
\hline & & $\begin{array}{l}\text { que é suave e delicado e o que é } \\
\text { passional e denso no caso da } \\
\text { primeira oração e entre o que é } \\
\text { doce e o que é duro, na segunda, } \\
\text { registrado na nota de rodapé } 269 \text {. }\end{array}$ \\
\hline $\begin{array}{l}\text { Na tela 'O Café Noturno na } \\
\text { Place Lamartine, em Arles', } \\
\text { observei a ocorrência de } \\
\text { Associação metafórica } \\
\text { construída pela Saliência, } \\
\text { Ritmo, Textura e Movimento } \\
\text { na representação das } \\
\text { lâmpadas e da luz que } \\
\text { delas emana. Registrado nas } \\
\text { notas de rodapé } 240 \text { e } 241 \text {. }\end{array}$ & $\begin{array}{l}\text { A sala é vermelho-sangue e amarelo } \\
\text { sem graça, uma mesa de bilhar verde } \\
\text { no centro, } 4 \text { lâmpadas de amarelo } \\
\text { limão com um brilho laranja e } \\
\text { verde. } \\
\text { Tudo isso em uma atmosfera de } \\
\text { fornalha infernal, de enxofre pálido. } \\
\text { Exprimir como a potência dos } \\
\text { cantos escuros de uma taberna. } \\
\text { Contudo sob uma aparência da } \\
\text { alegria japonesa e da boa natureza } \\
\text { de Tartarin. }\end{array}$ & $\begin{array}{l}\text { O brilho laranja e verde não é dado } \\
\text { somente pela cor, mas pelo formato } \\
\text { arredondado que o gesto pictórico } \\
\text { confere à luz que emana da } \\
\text { lâmpada. O gesto é crucial para } \\
\text { conferir movimento e ritmo à luz } \\
\text { que incide sobre a sala vazia, para } \\
\text { que ela ganhasse movimento foi } \\
\text { necessário imprimir na tela este } \\
\text { movimento, um gesto contínuo, } \\
\text { porém desigual, ora mais forte, ora } \\
\text { mais fraco, mas incessante que } \\
\text { confere saliência para as lâmpadas } \\
\text { e reforça seus significados } \\
\text { metafóricos. } \\
\text { Observei o uso de associações } \\
\text { metafóricas e uso simbólico da cor } \\
\text { com A escolha do item lexical } \\
\text { "fornalha" no excerto de carta, que } \\
\text { é correspondente à representação } \\
\text { visual da luz excessiva no interior } \\
\text { do café, registrado na nota de } \\
\text { rodapé } 259 .\end{array}$ \\
\hline
\end{tabular}

Fonte: Triangulação para Associações Metafóricas e Simbolismo dos dados dos corpora visual e textual, com os extratos das cartas.

\subsection{RIMA VISUAL}

É um recurso referente à categoria enquadramento. Serve para estabelecer conexão visual e semântica entre dois ou mais elementos, como por exemplo, os elementos com cores e as formas ou tamanhos semelhantes.

A rima visual contribui para evidenciar a forma como a gestalt da obra, ou seja, a unidade e a coesão são construídas entre os elementos da composição. A coesão pode ser dada, por exemplo, pelas semelhanças de tonalidade, formas ou, inclusive, temas. As obras de van Gogh exibem uma coesão textual muito proeminente construída por meio da rima visual, articulada com o uso do ritmo, da textura, do movimento, do gesto pictórico das pinceladas, da perspectiva e dos contrastes cromáticos. Ele inovou no uso dos recursos pictóricos instanciando novas semioses capazes de articular poderosas rimas visuais em suas telas.

A seguir exponho como a rima visual era construída em cada corrente pictórica na história da arte. Os impressionistas abriram uma dimensão de significação para os sentidos de 
unidade e harmonia na obra pictórica que ajudaram van Gogh a alçar um novo patamar nessa busca.

A coesão textual na tela era criada de diversas formas, antes os pintores do classicismo e realismo procuravam dar unidade visual por meio da tonalidade. As telas tem uma tonalidade unificadora para as cores empregadas. Mas isso não corresponde às cores do mundo real. De acordo com Gombrich (1995, p. 508), os pintores românticos e realistas começaram a questionar essa unidade em detrimento da representação do real:

Podemos lembrar o conselho que Constable recebeu e rejeitou (p.495) para pintar o primeiro plano em marrom suave, como Claude e outros pintores fizeram. Essa sabedoria convencional repousava na observação de que verdes fortes tendem a conflitar com outras cores. Por mais fiel que uma fotografia (como a da p.461, Fig. 302) nos pareça, suas cores intensas certamente teriam um efeito destruidor nessa suave gradação de tons que também serviu para que Caspar David Friedrich (p.496, Fig. 326) alcançasse a impressão de distância. De fato, se olharmos a "Carroça de feno" (p. 495, Fig. 325) de Constable, veremos que ele também abafou a cor do primeiro plano e da folhagem para se manter dentro de uma faixa tom unificada. Corot parece ter capturado a luz radiante e a névoa luminosa da cena com sua paleta usando meios singulares. Trabalhou dentro de um tom de cinza prateado que não engole as cores, mas as mantém em harmonia sem afastar-se da verdade visual. Como Claude e como Turner, claro que ele nunca hesitou em povoar seu palco com figuras do passado clássico ou bíblico, e na verdade foi sua propensão poética que finalmente lhe assegurou fama internacional.

Os artistas românticos também passaram a questionar a construção da unidade visual por meio de uma tonalidade unificadora que ocorria em detrimento do uso das cores para expressar as emoções e a sensibilidade do pintor ao contemplar a paisagem. A unidade continuou a ser buscada pela luminosidade, como na tela de Corot Tivoli, Os jardins da Vila d'Este, 1843, como explica Gombrich (1995, p. 508):

Ocorre que cerca de cem anos antes Fragonard também escolheu um motivo do parque da Villa d'Este perto de Roma (p.473, Fig.310), e pode valer a pena uma pausa por um momento para comparar essas e outras imagens, principalmente porque a pintura de paisagens estava cada vez mais se tornando a mais importante vertente da arte do século XIX. Fragonard obviamente buscou a variedade, enquanto Corot buscou a claridade e o equilíbrio que nos lembram remotamente Poussin (p.395, Fig. 254) e Claude Lorrain (p.396, Fig. 255), mas a luz radiante e a atmosfera que preenchem a pintura de Corot são alcançadas de vários diferentes meios. Aqui a comparação com Fragonard pode nos ajudar de novo, porque o meio de Fragonard o compeliu na cuidadosa gradação de tom. Como desenhista, tudo de que dispunha era o branco do papel e várias intensidades de marrom; mas olhe, por exemplo, a parede no primeiro plano para ver como é suficiente para transmitir o contraste entre sombra e luz do sol. Corot alcançou efeitos semelhantes com o uso de sua paleta, e os pintores sabem que não existe realização menor. A razão é que a cor quase sempre entra em conflito com as gradações de tom em que Fragonard podia confiar.

Os impressionistas romperam com essas regras de unidade por meio da harmonia, buscando a coesão na composição pela representação da luz na cena, a partir do registro da impressão que esta causava no momento em que pintavam. Ou seja, não a luminosidade 
constante, harmoniosa, com gradações de tons criando transições controladas e amenas como no estilo neoclássico e realista, mas a luminosidade real, como ela lhes parecia no momento da apreensão da cena, a qual eles tentavam registrar fielmente as impressões, como relata Gombrich (1995, p. 517):

Mas o fato é que, ao ar livre e sob a plena luz do dia, as formas redondas parecem às
vezes planas, quais meras manchas coloridas. Era esse efeito que Manet queria
explorar. Daí resulta que, quando nos colocamos diante de um de seus quadros, ele
parece mais imediatamente real do que qualquer mestre antigo. (Temos a ilusão de
estar mesmo face a face com esse grupo no balcão. A impressão geral propiciada
pelo todo não é plana, mas, ao contrário, de real profundidade. Uma das razões para
esse impressionante efeito é a cor vigorosa no parapeito do balcão....) As novas
teorias não diziam respeito somente ao tratamento de cores ao ar livre (plein air),
mas também ao das formas em movimento. A Fig. 335 mostra uma das litografias de
Manet - (...) À primeira vista, podemos enxergar apenas algumas garatujas confusas.
É a ilustração de uma corrida de cavalos. Manet quer que tenhamos a impressão de
luz, velocidade e movimento, dando-nos nada mais do que uma escassa sugestão de
formas que emergem da confusão. Os cavalos correm na nossa direção a toda
velocidade, e nas bancadas vemos uma multidão excitada. O exemplo mostra, mais
claramente do que qualquer outro, como Manet se recusava a ser influenciado por
seus conhecimentos ao realizar uma representação de formas. Nenhum dos seus
cavalos tem as quatro patas. Acontece, porém, que simplesmente não vemos as
quatro patas num momentâneo relance quando presenciamos tais cenas. Gombrich (1995, p. 517) explica que, com esse novo enfoque na representação pictórica, eles priorizaram registrar a luz como ela realmente se comporta no mundo real, ou como nós realmente a percebemos se comportar: na exposição direta da luz do sol, vemos explosões de luz sobre os objetos, causando um achatamento em sua superfície, ao contrário da representação dos volumes por meio das gradações do chiaroescuro, vemos antes a distorção de suas formas, a perda dos seus contornos, a fusão entre planos diferentes:

Mas, na vida real, nunca seremos capazes, é claro, de registrar todas as imagens.
Num momento qualquer, só conseguimos focalizar em um ponto com os nossos
olhos, e tudo o mais nos parece um amálgama de formas desconexas. Podemos saber
o que são, mas não as vemos. Nesse sentido, a litografia de Manet de uma corrida de
cavalos é realmente muito mais "verdadeira" do que a do humorista vitoriano.
Transporta-nos por um instante para o alvoroço e a excitação da cena que o artista
presenciou e da qual registrou somente o que poderia garantir ter visto naquele
instante.

Com o enfoque na incidência da luz sobre os planos, a unidade na obra passou a ser buscada pela impressão que essa mesma luz causava a todos os objetos e figuras da cena. A impressão de profundidade antes era dada pela maior definição dos contornos no primeiro plano e pela menor, nos planos ao fundo. Era dada também pelos tons mais acentuados no primeiro plano, e mais esmaecidos e saturados nos planos de fundo. Os impressionistas romperam com essa técnica de representar a profundidade, uma vez que em sua abordagem os contornos no primeiro plano passaram a se desmanchar e perder suas bordas, assemelhando-se com uma perda geral da definição. Gombrich (1995, p. 514) avalia o impacto dessa mudança: 
Pode-se dizer que Manet e seus seguidores provocaram na reprodução das cores uma revolução quase comparável à revolução grega na representação de formas. Eles descobriram que, se olharmos a natureza ao ar livre, não vemos objetos individuais, cada um com sua cor própria, mas uma brilhante mistura de matizes que se combinam em nossos olhos ou, melhor dizendo, em nossa mente.

Essa perda dos contornos pode ter contribuído para dar uma sensação de unidade para a tela, bem como a proximidade da luz e da sombra em um jogo desordenado, fluido e fugaz que desafiou o olhar do público e a apreensão da cena na proporção em que eles estavam habituados a contemplar as telas do período anterior como descreve Gombrich (1995, p. 514):

Essas descobertas não foram efetuadas de uma vez, e nem todas por um só homem. Mas até as primeiras pinturas de Manet, em que ele abandonou o método tradicional de sombras suaves em favor de contrastes fortes e duros, causaram um clamor de protestos entre os artistas conservadores.

Diferente dos impressionistas, que dissolviam as formas e os planos, van Gogh, Cézanne e Gauguin se preocupavam com a estrutura da composição. Eles buscaram a rima visual por meio de uma articulação cromática, como por exemplo, pelo uso dos contrastes simultâneos para potencializar mutuamente a intensidade cromática de cada cor, gerando uma conversa intermitente entre as áreas de cor na tela. Outra forma de construir a rima visual foi pelo resgate do uso de recursos como a perspectiva que haviam sido banidos pelos Impressionistas, construindo caminhos visuais e com eles a profundidade, e o diálogo entre diferentes planos e áreas compositivas. Outro exemplo de rima visual foi encontrado na análise da tela $\mathrm{O}$ Semeador. Enquanto ocorre uma forte divisão espacial e cromática entre o campo arado e o céu, representando dois mundos apartados, van Gogh sobrepõe sobre esses dois campos uma figura de semeador, que funciona como um elemento de mediação, que integra simbolicamente esses dois mundos diferentes, sugerindo a instância humana como um elemento de ligação entre o mundo espiritual e a natureza. Dessa forma, observei que a rima visual nas telas analisadas e talvez ao longo da obra de van Gogh resulta de uma ampla e complexa orquestração de recursos semióticos tais como ritmo, movimento, direção, textura, gesto pictórico e arranjo cromático por exemplo.

\subsubsection{Triangulação da Rima Visual}

Rima Visual, no texto escrito e em relação à triangulação - Nessa categoria procurei elementos discursivos na escrita das orações que sejam compatíveis com os elementos pictóricos usados por van Gogh para construir a unidade e a harmonia na tela: ritmo, textura, movimento, direção e uso de contrastes de cor. A unidade na construção da 
oração pode ser conferida por diferentes recursos e estratégias usadas com a finalidade de construir coesão entre os participantes. Observei algumas ocorrências tais como o uso de ritmo, movimento e direção nas orações, bem como o uso dos processos relacionais atributivos em uma sequência concatenada para recriar para o irmão a atmosfera cromática das telas que ele estava concebendo em sua imaginação ou em esboços. Nesses momentos em que ele narra com detalhes a sequência do uso de cores para compor a cena, van Gogh está imerso em um movimento subjetivo de criação que se manifesta com ritmo, cadência, movimento, uma gestualidade com palavras. Existe na produção de van Gogh uma intencionalidade que se repete tanto na tela quanto nas orações da carta, no uso ritmado das cores narradas, que nas telas aparece por meio das pinceladas e na oração aparece por meio da descrição sequencial e unificada no uso das cores. O objetivo na produção da tela e na produção da carta é similar e embora o resultado possa não ser o mesmo, os recursos semióticos para expressar essa intencionalidade podem ser comparados, o seu uso, a sua finalidade e função. Nesse sentido pode haver uma amálgama, uma coesão construída por meio de semioses nas telas e nas orações.

Quadro 31: Triangulação da Rima Visual

\begin{tabular}{|c|c|c|}
\hline Ocorrência nas telas & Orações & Comentário \\
\hline $\begin{array}{l}\text { Na tela 'Por de Sol: Campo de } \\
\text { trigo perto de Arles', a } \\
\text { ocorrência de Rima Visual } \\
\text { conferida pelo uso } \\
\text { concomitante de Textura, } \\
\text { Ritmo, Movimento, Vetor, } \\
\text { Volume e Gesto Pictórico para } \\
\text { representar o trigal, registrada } \\
\text { nas notas de rodapé } 72 \text { e } 73 \text { no } \\
\text { apêndice. } \\
\text { Observei também que a } \\
\text { ocorrência de movimento } \\
\text { direcional e rima visual são } \\
\text { conferidos pelo uso do Gesto } \\
\text { Pictórico, do Ritmo, da } \\
\text { Textura e do Movimento no } \\
\text { trigal. }\end{array}$ & $\begin{array}{l}\text { Aqui está outra paisagem. Sol } \\
\text { poente? Lua nascendo? Noite de } \\
\text { verão, de qualquer modo. Cidade } \\
\text { violeta, estrela amarela, céu azul- } \\
\text { esverdeado; os campos de trigo têm } \\
\text { todos os tons: ouro velho, cobre, } \\
\text { ouro verde, ouro vermelho, ouro } \\
\text { amarelo, verde, vermelho e amarelo } \\
\text { bronze. Tela quadrada número } 30 \text {. }\end{array}$ & $\begin{array}{l}\text { Ritmo, cadência, movimento uso de } \\
\text { contrastes cromáticos. } \\
\text { As orações 'Sol poente? Lua } \\
\text { nascendo? Noite de verão, de } \\
\text { qualquer modo' mostram o uso não } \\
\text { convencional da linguagem em um } \\
\text { texto descritivo na carta. Mostram } \\
\text { também um recurso discursivo que } \\
\text { pode condensar outras semioses tais } \\
\text { como uma ênfase, um tom, um } \\
\text { colorido para o discurso, e além do } \\
\text { que, é um tom que é poético e } \\
\text { empresta para esse período ritmo, } \\
\text { movimento, cadência e colorido, pois } \\
\text { matiza o discurso com o seu } \\
\text { temperamento livre e que nos deixa } \\
\text { liberdade de interpretação. Essas três } \\
\text { orações, carregam uma camada } \\
\text { semiótica que deu ao período o que na } \\
\text { análise das telas chamo de Rima } \\
\text { Visual, ou seja, emprestou harmonia e } \\
\text { unidade para o período por meio de } \\
\text { um 'gesto textual' comparável com } \\
\text { suas pinceladas. }\end{array}$ \\
\hline $\begin{array}{l}\text { Na tela 'Por de Sol: Campo } \\
\text { de trigo perto de Arles', } \\
\text { observei a ocorrência de }\end{array}$ & $\begin{array}{l}\text { Cidade violeta, estrela amarela, céu } \\
\text { azul-esverdeado; os campos de trigo } \\
\text { têm todos os tons: ouro velho, cobre, }\end{array}$ & $\begin{array}{l}\text { As escolhas léxico-gramaticais da } \\
\text { oração descrevem como ele estrutura a } \\
\text { composição por meio de escolhas }\end{array}$ \\
\hline
\end{tabular}




\begin{tabular}{|c|c|c|}
\hline $\begin{array}{l}\text { Rima visual, construída por } \\
\text { meio das gradações } \\
\text { cromáticas no céu e que se } \\
\text { espelham no campo de } \\
\text { trigo integrando os dois } \\
\text { campos da tela, registrada } \\
\text { na nota de rodapé } 54 \text { no } \\
\text { apêndice. }\end{array}$ & $\begin{array}{l}\text { ouro verde, ouro vermelho, ouro } \\
\text { amarelo, verde, vermelho e amarelo } \\
\text { bronze. } \\
\text { Aqui ele separa a área do céu da área } \\
\text { da terra por meio de um ponto e } \\
\text { vírgula na oração, como se estivesse } \\
\text { organizando no espaço da oração, a } \\
\text { composição espacial da tela. Ao } \\
\text { mesmo tempo em que ele separa o } \\
\text { céu da terra na oração, ele não } \\
\text { interrompe esses dois campo por um } \\
\text { ponto final. Ele os separa por ponto e } \\
\text { vírgula para indicar uma } \\
\text { interdependência, uma } \\
\text { complementação ou uma sucessão } \\
\text { que indica o movimento e a rima } \\
\text { visual acontecendo também na } \\
\text { oração. }\end{array}$ & $\begin{array}{l}\text { cromáticas sucessivas que constroem } \\
\text { tanto na oração quanto na tela quanto } \\
\text { na tela. } \\
\text { A rima visual é obtida por meio de } \\
\text { uma modulação cromática de amarelos } \\
\text { que atuam como um elemento } \\
\text { unificador na composição, mas } \\
\text { também por meio de uma metáfora } \\
\text { visual da luz, que está em toda parte e } \\
\text { tudo interliga. }\end{array}$ \\
\hline $\begin{array}{l}\text { Na tela 'Por de Sol: Campo } \\
\text { de trigo perto de Arles', } \\
\text { observei a ocorrência de } \\
\text { Rima visual que, por meio do } \\
\text { uso da cor para representar a } \\
\text { luz do sol sobre a cidade e } \\
\text { o campo, constroem uma } \\
\text { associação metafórica da luz } \\
\text { divina que tudo interliga, } \\
\text { registrada nas notas de } \\
\text { rodapé } 94 \text { e } 95 \text { no apêndice. } \\
\text { Na oração ele também } \\
\text { recorre ao uso da metáfora } \\
\text { 'como como o ceifeiro que } \\
\text { está em silêncio sob o sol } \\
\text { escaldante, concentrando-se } \\
\text { em ter o trabalho terminado.' } \\
\text { que age como elemento } \\
\text { unificador do sentido que ele } \\
\text { deseja comunicar na oração } \\
\text { dominante 'Paisagens } \\
\text { amarelo ouro velho - feito } \\
\text { rápido rápido rápido e com } \\
\text { pressa'. }\end{array}$ & $\begin{array}{l}\text { Paisagens amarelo ouro velho - feito } \\
\text { rápido rápido rápido e com pressa, } \\
\text { como o ceifeiro que está em silêncio } \\
\text { sob o sol escaldante, concentrando- } \\
\text { se em ter o trabalho terminado. } \\
\text { Ocorrência de Associações } \\
\text { metafóricas da estrutura léxico- } \\
\text { gramatical, Enquadramento e } \\
\text { Perspectiva por meio do uso de } \\
\text { Ritmo, Gesto pictórico e Rima } \\
\text { visual, registrado na nota de rodapé } \\
\text { 122 no apêndice. } \\
\text { Observei tanto na tela quanto na } \\
\text { oração a ocorrência de Rima visual } \\
\text { por meio do uso da associação } \\
\text { metafórica, sendo a associação } \\
\text { metafórica uma semiose que não } \\
\text { apenas comunica um sentido } \\
\text { semântico, mas desempenha uma } \\
\text { função léxico-gramatical unificadora } \\
\text { da oração que é compatível com essa } \\
\text { mesma função unificadora da } \\
\text { composição. }\end{array}$ & $\begin{array}{l}\text { Além de semanticamente comparar } \\
\text { seu trabalho em pintar a tela com o } \\
\text { trabalho do ceifeiro trabalha em } \\
\text { silêncio e concentrado em terminar o } \\
\text { trabalho, ele constrói um outro tipo de } \\
\text { comparação que é léxico-gramatical: } \\
\text { ele compara o ritmo do ceifeiro em } \\
\text { cortar as espigas de trigo ou de milho } \\
\text { com a estrutura da oração que } \\
\text { descreve seu próprio trabalho em } \\
\text { pintar a tela por meio da analogia: } \\
\text { 'feito rápido rápido rápido e com } \\
\text { pressa'. Aqui há um tipo de uso que } \\
\text { também ocorre nas telas. Van Gogh } \\
\text { cria estruturas léxico-gramaticais que } \\
\underline{\text { são compatíveis com a natureza do }} \\
\underline{\text { sentido que ele quer narrar ou }} \\
\underline{\text { representar, de forma a produzir uma }} \\
\underline{\text { sensação sinestésica e quase física do }} \\
\underline{\text { sentido que ele deseja que o }} \\
\underline{\text { espectador, ou o leitor experiencie ao }} \\
\underline{\text { reconstruir e apreender os significados }} \\
\text { por ele intencionados. Ele não deseja } \\
\text { apenas comunicar, mas fisicamente, } \\
\text { materialmente, e esteticamente, } \\
\text { transportar o leitor para dentro da } \\
\text { experiência que promoveu o sentido } \\
\text { para ele, e que ele reconstrói com o } \\
\text { uso de estruturas léxico-gramaticais. }\end{array}$ \\
\hline $\begin{array}{l}\text { Na tela 'O Semeador', a } \\
\text { Rima Visual é conferida } \\
\text { pelas pinceladas criando } \\
\text { ritmo, textura, direção, } \\
\text { movimento, e cor: contraste } \\
\text { complementar, registrada na } \\
\text { nota de rodapé } 47 .\end{array}$ & $\begin{array}{l}\text { Aqui está um esboço de um } \\
\text { semeador: um grande campo lavrado } \\
\text { com torrões de terra, /na sua maioria } \\
\text { fracamente cor de violeta/. Um } \\
\text { campo de trigo maduro, de tom } \\
\text { amarelo-ocre com um pouco de } \\
\text { carmim. }\end{array}$ & $\begin{array}{l}\text { Ocorrência de Associação metafórica } \\
\text { construída pela Saliência do grupo } \\
\text { nominal que dá o atributo de cores } \\
\text { para o campo de trigo, por meio de um } \\
\text { apagamento do processo tornando o } \\
\text { atributo e o portador uma só coisa. A } \\
\text { Rima Visual é construída pelo } \\
\text { apagamento do processo e por um } \\
\text { sentido de superposição do sentido do } \\
\text { campo ao sentido das cores que lhe são }\end{array}$ \\
\hline
\end{tabular}




\begin{tabular}{|c|c|c|}
\hline & & $\begin{array}{l}\text { atribuídas, registrado na nota de } \\
\text { rodapé 82. } \\
\text { Os grupos nominais que dão atributo } \\
\text { para tanto para o campo lavrado } \\
\text { quanto para o campo de trigo maduro } \\
\text { são análogos com o uso de Rima } \\
\text { Visual na tela. }\end{array}$ \\
\hline $\begin{array}{l}\text { Na tela 'O Semeador', a } \\
\text { Rima Visual é conferida } \\
\text { pelas pinceladas criando } \\
\text { ritmo, textura, direção, } \\
\text { movimento, e cor: contraste } \\
\text { complementar, registrada nas } \\
\text { notas de rodapé } 49,50 .\end{array}$ & $\begin{array}{l}\text { O céu, amarelo-crômio, quase tão } \\
\text { luminoso quanto o próprio Sol, que } \\
\text { é amarelo-crômio no } 1 \text {, misturado } \\
\text { com um pouco de branco, enquanto } \\
\text { o resto do céu é uma mistura dos } \\
\text { amarelos-crômios } 1 \text { e } 2 \text {. Tão } \\
\text { amarelo! A camisa do semeador é } \\
\text { azul e as calças brancas. Tamanho } \\
\text { da tela - } 25 \text {, quadrada. }\end{array}$ & $\begin{array}{l}\text { Nesse excerto, observei a ocorrência } \\
\text { de Rima Visual, Gesto Pictórico e } \\
\text { Ritmo, construída por uma sequência } \\
\text { de escolhas lexicais que é análoga à } \\
\text { ocorrência de ritmo e de gesto } \\
\text { pictórico. O circuito criado pela } \\
\text { recorrente escolha do item lexical } \\
\text { 'céu' é compatível com a ocorrência } \\
\text { de Rima Visual registrado na nota de } \\
\text { rodapé } 85 .\end{array}$ \\
\hline $\begin{array}{l}\text { Na tela 'O Semeador', } \\
\text { observei que a Rima Visual é } \\
\text { construída pelo uso } \\
\text { conjugado e articulado de } \\
\text { vários recursos, tais como } \\
\text { ritmo, textura, movimento, } \\
\text { direção, perspectiva, } \\
\text { enquadramento e outros, } \\
\text { registrado na nota de rodapé } \\
\underline{58} .\end{array}$ & $\begin{array}{l}\text { Em um campo arado, um grande } \\
\text { campo de torrões de terra roxa - } \\
\text { levantados em direção ao horizonte - } \\
\text { um semeador em azul e branco. No } \\
\text { horizonte um campo de trigo curto, } \\
\text { maduro. Acima de tudo isso um céu } \\
\text { amarelo com um sol amarelo. } \\
\text { Você pode sentir a partir da mera } \\
\text { nomenclatura das tonalidades - que a } \\
\text { cor desempenha um papel muito } \\
\text { importante nesta composição. }\end{array}$ & $\begin{array}{l}\text { Observei que a Rima Visual é } \\
\text { construída na oração por meio do uso } \\
\text { do ritmo conferido pela escolha léxico- } \\
\text { gramatical ‘Em um campo arado, um } \\
\text { grande campo de torrões de terra roxa } \\
\text { - levantados em direção ao horizonte- } \\
\text { um semeador em azul e branco' que } \\
\text { constroem ênfase para o Portador. } \\
\text { Semanticamente, a Rima Visual é } \\
\text { construída na tela com os mesmos } \\
\text { sentidos expressos na oração, por meio } \\
\text { de recursos como ritmo, textura, } \\
\text { movimento, direção e contrastes } \\
\text { cromáticos. }\end{array}$ \\
\hline $\begin{array}{l}\text { Na tela 'O Semeador', } \\
\text { observei a ocorrência de } \\
\text { Associação Metafórica e } \\
\text { Incompletude construída } \\
\text { pela Rima Visual e pelo } \\
\text { Gesto pictórico para } \\
\text { representar a unidade entre } \\
\text { o Homem e a Natureza, } \\
\text { registrados na nota de rodapé } \\
\text { 78. }\end{array}$ & $\begin{array}{l}\text { Mas é uma questão de atacá-las, no } \\
\text { entanto, não importa o quão } \\
\text { incompetente um pode sentir-se vis- } \\
\text { à-vis as perfeições inefáveis do } \\
\text { glorioso esplendor da natureza. }\end{array}$ & $\begin{array}{l}\text { A Rima visual na tela é o resultado da } \\
\text { articulação de diferentes recursos para } \\
\text { construir o sentido de união do homem } \\
\text { com a Natureza. Na oração, ele } \\
\text { expressa semanticamente essa união } \\
\text { por meio da transparência a respeito de } \\
\text { seu sentimento de incompetência e de } \\
\text { busca de expressar o que ele chama de } \\
\text { 'perfeições inefáveis do glorioso } \\
\text { esplendor da natureza', conotando que } \\
\text { ele busca expressar essa integração } \\
\text { com a Natureza por meio de sua arte. }\end{array}$ \\
\hline $\begin{array}{l}\text { Na tela 'A Esplanada do } \\
\text { Café na Place du Forum, } \\
\text { Arles, à Noite', observei a } \\
\text { ocorrência de Rima Visual, } \\
\text { construída pelo } \\
\text { espelhamento do ritmo das } \\
\text { estrelas com o ritmo do } \\
\text { calçamento, registrada na } \\
\text { nota de rodapé } 127 \text { no } \\
\text { apêndice. }\end{array}$ & $\begin{array}{l}\text { Uma enorme lanterna amarela } \\
\text { ilumina o terraço, a fachada, a } \\
\text { calçada, e até mesmo projeta luz } \\
\text { sobre os paralelepípedos da rua, que } \\
\text { adquirem uma coloração violeta- } \\
\text { rosa. }\end{array}$ & $\begin{array}{l}\text { Observei a ocorrência de Rima Visual } \\
\text { tanto na tela quanto na oração por } \\
\text { meio do uso de Ritmo, conferido na } \\
\text { tela pelo espelhamento do padrão das } \\
\text { estrelas com o padrão do calçamento, e } \\
\text { na oração pelo uso do ritmo na escolha } \\
\text { léxico-gramatical 'ilumina o terraço, a } \\
\text { fachada, a calçada, e até mesmo } \\
\text { projeta luz' que confere unidade para o } \\
\text { período. }\end{array}$ \\
\hline
\end{tabular}




\begin{tabular}{|c|c|c|}
\hline $\begin{array}{l}\text { Na tela 'A Esplanada do } \\
\text { Café na Place du Forum, } \\
\text { Arles, à Noite', observei a } \\
\text { ocorrência de Rima Visual } \\
\text { construída pelo } \\
\text { espelhamento de cores nas } \\
\text { áreas correspondentes. Há } \\
\text { o cruzamento do azul da } \\
\text { porta que integra o fundo ao } \\
\text { primeiro plano e o alto à } \\
\text { base da composição, } \\
\text { enquanto o alaranjado da } \\
\text { janela integra a esquerda da } \\
\text { composição com a direita, } \\
\text { criando unidade e harmonia } \\
\text { para a tela, registrada nas } \\
\text { notas de rodapé } 145 \text { e } 147 \text { no } \\
\text { apêndice. }\end{array}$ & $\begin{array}{l}\text { Uma enorme lanterna amarela } \\
\text { ilumina o terraço, a fachada, a } \\
\text { calçada, e até mesmo projeta luz } \\
\text { sobre os paralelepípedos da rua, que } \\
\text { adquirem uma coloração violeta- } \\
\text { rosa. As frentes das casas em uma } \\
\text { rua que segue sob o céu azul } \\
\text { salpicado de estrelas são azul escuro } \\
\text { ou violeta, com uma árvore verde. } \\
\text { Agora há uma pintura de noite sem } \\
\text { preto. Com nada mais do que um } \\
\text { belo azul e violeta e verde e nestes } \\
\text { arredores da praça iluminada é } \\
\text { colorido por enxofre pálido, amarelo } \\
\text { limão. }\end{array}$ & $\begin{array}{l}\text { Observei a ocorrência de Rima Visual } \\
\text { tanto na tela quanto no excerto de carta } \\
\text { construída pelo uso de cores. Na tela, } \\
\text { no nível gramatical, em áreas } \\
\text { correspondentes que se espelham e } \\
\text { esse espelhamento confere unidade à } \\
\text { composição. Na oração, no nível } \\
\text { léxico-gramatical, pela disposição das } \\
\text { cores que se repetem em uma } \\
\text { sequência construindo rima: 'são azul } \\
\text { escuro ou violeta, com uma árvore } \\
\text { verde', ' 'um belo azul e violeta e } \\
\text { verde'. }\end{array}$ \\
\hline $\begin{array}{l}\text { Ocorrência de Ritmo, } \\
\text { Textura, Movimento, Vetor e } \\
\text { Rima Visual pelo Gesto } \\
\text { Pictórico para expressar o } \\
\text { fluxo e a intensidade da } \\
\text { iluminação na sala, } \\
\text { registrados nas notas de } \\
\text { rodapé } 189,190, \text { e 193. } \\
\text { Ocorrência de Associação } \\
\text { metafórica por meio do uso } \\
\text { de Ritmo, Movimento, } \\
\text { Textura, Vetor, Gesto } \\
\text { Pictórico e Rima Visual que } \\
\text { juntos constroem uma } \\
\text { metáfora visual para a luz } \\
\text { que interliga todos os } \\
\text { processos na narrativa, } \\
\text { registrados na nota de rodapé } \\
\text { 191. }\end{array}$ & $\begin{array}{l}\text { Eu acabei de terminar uma tela que } \\
\text { representa um interior de café à noite } \\
\text { iluminado por lâmpadas. Alguns } \\
\text { pobres vagabundos noturnos estão } \\
\text { dormindo em um canto. A sala está } \\
\text { pintada de vermelho, e no interior, } \\
\text { na luz a gás, a mesa de bilhar verde, } \\
\text { a qual lança uma imensa sombra } \\
\text { sobre o chão. Nesta tela, há } 6 \text { ou } 7 \\
\text { vermelhos diferentes, desde } \\
\text { vermelho-sangue até rosa delicado, } \\
\text { fazendo oposição com o mesmo } \\
\text { número de verdes pálidos ou } \\
\text { escuros. }\end{array}$ & $\begin{array}{l}\text { 'A sala está pintada de vermelho, e no } \\
\text { interior, na luz a gás, a mesa de bilhar } \\
\text { verde, a qual lança uma imensa } \\
\text { sombra sobre o chão.' } \\
\text { Uso de Rima Visual - Van Gogh } \\
\text { descreve a sala como sendo vermelha } \\
\text { porque o vermelho confere unidade } \\
\text { para a narrativa. Ele atribui para o } \\
\text { vermelho essa função de interligar os } \\
\text { demais elementos da composição que } \\
\text { ele narra na carta. Registrado na nota } \\
\text { de rodapé } 286 .\end{array}$ \\
\hline $\begin{array}{l}\text { Ocorrência de Rima Visual e } \\
\text { Gesto Pictórico na } \\
\text { representação da luz como } \\
\text { uma metáfora visual que } \\
\text { interliga todos os elementos } \\
\text { da tela; o Ritmo é o recurso } \\
\text { que expressa essa metáfora e } \\
\text { que constrói a coesão visual, } \\
\text { registrados na nota de rodapé } \\
192 .\end{array}$ & & \\
\hline $\begin{array}{l}\text { Ocorrência e Rima Visual } \\
\text { por meio do Ritmo, } \\
\text { Movimento e Vetor na } \\
\text { representação da Luz que } \\
\text { funciona como elemento de } \\
\text { ligação e de transição entre } \\
\text { as pequenas narrativas, } \\
\text { registrados na nota de rodapé } \\
193 .\end{array}$ & & \\
\hline
\end{tabular}


Na tela 'O Café Noturno na Place Lamartine, em Arles', observei a ocorrência de Rima Visual pelo uso de Inacabamento e Distorção do Ponto de vista presentes ausência de volume e homogeneização da iluminação nas superfícies e áreas de cor, registrada na nota de rodapé 187.
Em todos os lugares é uma batalha e uma antítese dos mais diferentes verdes e vermelhos; nas personagens dos rufiões adormecidos, pequenos na alta sala vazia, algum roxo e azul. O vermelho-sangue e o amareloverde da mesa de bilhar, por exemplo, contrasta com o pouco de verde delicado Louis XV do balcão, onde há um buquê rosa.
Uso de Associações Metafóricas e do Uso Simbólico da Cor. Ao expressar o sentido simbólico dos verdes e vermelhos textualmente ele cola esse sentido no uso dessas cores na tela, construindo uma ponte entre a carta e a tela, criando uma cadeia de textos.

Observei uma ocorrência do uso simbólico da cor em ambas modalidades não pela forma, mas pelo sentido associado a este uso, registrado na nota de rodapé 257.

Fonte: Triangulação para Rima Visual dos dados dos corpora visual e textual, com os extratos das cartas.

\subsection{TRANSPARÊNCIA}

A transparência, enquanto categoria de análise, não se refere às características da transparência na materialidade pictórica, tais como brilho, translucidez, opacidade, mas sim às características da transparência emotiva. A transparência emotiva está manifesta tanto no texto visual quanto no texto escrito. Refere-se ao esforço de van Gogh em ser o mais transparente possível. A transparência está relacionada com uma possibilidade muito nova que os artistas estavam experienciando em relação ao seu lugar social. Pela primeira vez, eles rompiam com a necessidade de atender as demandas do gosto burguês, e se sentiram livres para escolher a temática e a forma de representá-la. Essa liberdade possibilitou ao artista expressar sua individualidade e a sua subjetividade, como expõe Gombrich (1995, p. 503):

A ideia de que a verdadeira finalidade da arte era expressar a personalidade só
poderia ganhar terreno quando a arte tivesse perdido todas as demais finalidades.
Não obstante, com a evolução das coisas, isso era um enunciado verdadeiro e
valioso. Pois o que as pessoas interessadas em arte passaram a procurar em
exposições e estúdios já não era uma exibição de habilidade vulgar - que se tornara
comum demais para justificar qualquer atenção; o que elas queriam era que a arte as
aproximasse de homens com quem valeria a pena ter relações, homens cujo trabalho
era testemunho de uma sinceridade incorruptível, artistas que não se contentavam
em copiar efeitos criados por outros e não dariam uma única pincelada sem
perguntar a si mesmos se ela satisfazia a sua consciência artística.

Van Gogh vive essa liberdade em sua máxima capacidade. Essa busca coletiva pelo genuíno e autêntico na prática e no discurso artístico constitui um valor cultural para o qual van Gogh estava talhado para corporificar. A transparência em seu discurso compreende o esforço de van Gogh em tentar ser o que ele é. Essa qualidade de transparência na obra de van Gogh é comentada por Haziot (2010, p. 169):

Mas todos esses meios, tomados aqui e ali, servem a apenas um objetivo em Vincent: a transparência - a vontade de traduzir ao máximo o que ele sente, a emoção que lhe causa uma paisagem. Toda a sua vida de artista não foi senão uma 
luta para exprimir e dar aos outros, contra tantos obstáculos, esse momento de comunhão entre o objeto a ser pintado e ele mesmo.

Van Gogh buscou a união de Vida e Arte em seu discurso visual, construindo para isso seu próprio vocabulário semiótico. Como explicam Walther e Metzger (2015, p. 353): “O pintor do plein air era tão fiel ao seu programa quanto o peintre ouvrier. Era tudo uma questão de autenticidade. A nova intensidade da cor constituía mais uma prova de que o que mais interessava era o verdadeiro, o genuíno, e tudo aquilo que provocasse um impacto direto".

Van Gogh defendeu, viveu e praticou a transparência. A busca de van Gogh de fusão com a natureza expressa sua busca de integrar as diferentes experiências e dar transparência para elas, como comenta Haziot (2010. p. 169):

\begin{abstract}
Jean Starobinski escreveu um livro admirável sobre Jean Jacques Rousseau intitulado A transparência e o obstáculo. Vincent é animado pela mesma obsessão; busca a transparência, a fusão mística com o objeto a pintar, a eliminação de todas as mediações entre ele e esse ser amado que é a natureza que ele não cessa de invocar, seja ela paisagem ou figura humana. O quadro é o lugar dessa fusão-efusão; a paisagem torna-se uma "paisagem segundo o eu que a ama", e esse eu é paisagem, eles devem ser uma coisa só. De uma definição naturalista da arte lida em Zola ("um aspecto da natureza visto através de um temperamento"), Vincent fez uma estética mística, no sentido leigo da palavra - estética que exige, se não o impossível, ao menos uma tensão vertiginosa do indivíduo.
\end{abstract}

Ao referir-se ao "lugar dessa fusão-efusão; a paisagem torna-se uma 'paisagem segundo o eu que a ama' e esse eu é paisagem, eles devem ser uma coisa só.”, Haziot está falando de uma busca de van Gogh de fundir-se com a pintura e tornar-se uma coisa só. Essa busca também poderia ser chamada de "desejo de infinito" que van Gogh menciona em várias cartas ao seu irmão Theo. O desejo de infinito, de fusão, de completude, poderia ser identificado como uma categoria por si só, e ele será trabalhado nas próximas categorias que são: o Inacabamento e a Incompletude. A transparência em van Gogh torna possível para o espectador de suas obras e para o leitor de suas cartas, perceber diferentes experiências que ele vivência, uma vez que em sua transparência, ele não filtra nem modula, sejam elas de conflito, dúvida ou de "desejo do infinito". Dessa forma, a transparência nos permite perceber e nos dá a conhecer algumas das motivações e dos conflitos que impulsionaram a obra e o discurso artístico de van Gogh. 


\subsubsection{Triangulação da transparência}

Transparência, no texto escrito e em relação à triangulação - A transparência na pintura é o resultado da articulação de diversos recursos pictóricos para integrar suas experiências internas com as experiências artísticas, sejam elas conflitos, desejos, gosto, sentimento, ideais, dúvidas e incertezas. É por isso que a obra de van Gogh não poderia ser pintada com o formalismo artificial do academicismo. Essas vivências motivam e estão impressas e impregnadas na forma como ele concebe a tela, escolhe o tema, escolhe o ponto de vista, os recursos e como ele o executa. Essa transparência também está presente nas cartas, quando encontrei instanciações inusitadas, espontâneas, argumentativas, em tom de declaração, de confissão, de afirmação ou de dúvida, ele está sendo transparente com seu irmão acerca de como se sente, de que conflitos e dúvidas ele está lidando no momento de conceber ou de pintar a tela. Todas essas interjeições e interpelações têm a ver com transparência dos estados internos de Vincent. Observo a transparência como esse esforço de integração do interno e do externo. Ele é a mensagem do que ele acredita, do que ele defende. Como van Gogh tem isso como foco, ele revela e assume as suas contradições de uma forma muito direta e espontânea tanto nas telas quanto nas cartas. Esta é uma camada muito íntima da experiência que ele desvela em seu discurso sem maiores preocupações. Sempre que encontrei um momento confessional, ele tem essa mesma transparência que também sentimos ao experienciar a pintura porque van Gogh procurou ser transparente e inteiro em sua vida e em sua arte.

Quadro 32: Triangulação da Transparência

\begin{tabular}{|c|c|c|}
\hline Ocorrência nas telas & Orações & Comentário \\
\hline $\begin{array}{l}\text { Na tela 'Por de Sol: Campo } \\
\text { de trigo perto de Arles', } \\
\text { observei a ocorrência de } \\
\text { transparência na forma como } \\
\text { ele representou o campo de } \\
\text { trigo, integrando ao gesto de } \\
\text { pintar, a sua experiência de } \\
\text { lutar contra a ventania e nas } \\
\text { pinceladas rápidas e } \\
\text { ritmadas, transportar essa } \\
\text { experiência física e } \\
\text { subjetiva do contato com a } \\
\text { força do vento, registrada } \\
\text { nas notas de rodapé } 66,67 \text { e } \\
69 \text { no apêndice. }\end{array}$ & $\begin{array}{l}\text { Eu tenho um terceiro estudo, agora, } \\
\text { de uma paisagem com fábrica, e um } \\
\text { enorme sol em um céu vermelho, } \\
\text { acima de telhados vermelhos, em } \\
\text { que a natureza parece estar em um } \\
\text { acesso de raiva, em um dia de } \\
\text { Mistral desagradável. } \\
\text { Ocorrência de Transparência na } \\
\text { atribuição de uma experiência } \\
\text { 'raiva' para o Portador da oração } \\
\text { 'natureza', registrado na nota de } \\
\text { rodapé } 111 \text { no apêndice. } \\
\text { Eu pintei-a ao ar livre no Mistral. } \\
\text { Meu cavalete foi fixado no chão } \\
\text { com estacas de ferro, um método } \\
\text { que eu recomendo a você. }\end{array}$ & $\begin{array}{l}\text { É preciso ressaltar a transparência, a } \\
\text { autenticidade com que van Gogh } \\
\text { representou os elementos climáticos } \\
\text { como o sol escaldante do verão da } \\
\text { Provença e o Mistral, vento incessante } \\
\text { com o qual ele lidou ao pintar nos } \\
\text { campos, registrada nas notas de } \\
\underline{\text { rodapé } 65,66 \text { e } 67 \text { no apêndice. }}\end{array}$ \\
\hline
\end{tabular}




\begin{tabular}{|c|c|c|}
\hline & $\begin{array}{l}\text { Você enterra os pés do cavalete e, } \\
\text { em seguida, você empurra a } 50 \\
\text { centímetros de comprimento um } \\
\text { peso de ferro ao lado deles. Você } \\
\text { amarra tudo com cordas; dessa } \\
\text { forma, você pode trabalhar com o } \\
\text { vento. } \\
\text { Paisagens amarelo ouro velho - feito } \\
\text { rápido rápido rápido e com pressa, } \\
\text { como o ceifeiro que está em silêncio } \\
\text { sob o sol escaldante, concentrando- } \\
\text { se em ter o trabalho terminado. }\end{array}$ & $\begin{array}{l}\text { nota de rodapé } 116 \text { no apêndice. } \\
\text { Na oração: 'Eu também sou } \\
\text { totalmente incapaz de julgar o meu } \\
\text { próprio trabalho. Eu não posso ver se } \\
\text { os estudos são bons ou ruins.' } \\
\text { observei a ocorrência de } \\
\text { Transparência, Incompletude e de } \\
\text { Limiar Artístico - observei a } \\
\text { ocorrência da categoria limiar artístico } \\
\text { no complexo oracional, no nível } \\
\text { semântico, registrada na nota de } \\
\text { rodapé } 119 \text { no apêndice. }\end{array}$ \\
\hline $\begin{array}{l}\text { Na tela 'Por de Sol: Campo } \\
\text { de trigo perto de Arles', } \\
\text { observei a ocorrência de } \\
\text { Associação metafórica do } \\
\text { tom da fumaça das fábricas } \\
\text { em contraposição com o tom } \\
\text { da luminosidade do céu para } \\
\text { conotar um conflito entre o } \\
\text { progresso econômico e a } \\
\text { natureza, registrada na nota } \\
\text { de rodapé } 56 \text { no apêndice. }\end{array}$ & $\begin{array}{l}\text { Eu tenho um terceiro estudo, agora, } \\
\text { de uma paisagem com fábrica, e um } \\
\text { enorme sol em um céu vermelho, } \\
\text { acima de telhados vermelhos, em } \\
\text { que a natureza parece estar em um } \\
\text { acesso de raiva, em um dia de } \\
\text { Mistral desagradável. } \\
\text { Obsevei aqui uma interação da } \\
\text { ocorrência da Associação metafórica } \\
\text { com a Transparência, a } \\
\text { Incompletude e o Limiar Artístico. }\end{array}$ & $\begin{array}{l}\text { Van Gogh intui que existe nesse } \\
\text { movimento de pincelada sobre a tela } \\
\text { uma energia transformadora e } \\
\text { criadora, mas que também tem uma } \\
\text { nuance descontrolada que carrega uma } \\
\text { emoção semelhante à da raiva. Ele } \\
\text { compara esse movimento que } \\
\text { representa o vento na tela ao } \\
\text { movimento da natureza na qual o } \\
\text { vento age sobre o trigo de maneira } \\
\text { desordenada, incontrolável e incisiva. } \\
\text { O ímpeto do artista no momento de } \\
\text { representação do vento da tela o } \\
\text { aproxima da natureza e o aproxima de } \\
\text { sua natureza e da natureza daquilo que } \\
\text { faz a tela ser o que ela é. A } \\
\text { representação de um limiar entre } \\
\text { aquilo que o artista vê e aquilo que ele } \\
\text { não vê quando ele representa o que ele } \\
\text { vê. }\end{array}$ \\
\hline $\begin{array}{l}\text { Na tela 'Por de Sol: Campo } \\
\text { de trigo perto de Arles', com } \\
\text { a metáfora do sol que se põe } \\
\text { para o campo, van Gogh está } \\
\text { falando de uma era que } \\
\text { finda, e de uma perda que o } \\
\text { homem do campo vivencia. } \\
\text { Ele expressa com } \\
\text { transparência a nostalgia } \\
\text { dessa perda, registrada na } \\
\text { nota de rodapé } 87 \text { no } \\
\text { apêndice. }\end{array}$ & $\begin{array}{l}\text { Não te vou ocultar que não desgosto } \\
\text { da região, pois fui criado lá - ainda } \\
\text { me encanta a magia das recordações } \\
\text { do passado, de um desejo do } \\
\text { infinito, do qual o semeador e o } \\
\text { enfeixador são símbolos -, tanto } \\
\text { quanto antes gostava. } \\
\text { Mas quando eu farei o céu estrelado, } \\
\text { então, essa pintura que está sempre } \\
\text { na minha mente? Ai, ai, é como } \\
\text { nosso excelente amigo Cyprien diz, } \\
\text { em 'En ménage' por JK Huysmans: } \\
\text { as mais belas pinturas são aquelas } \\
\text { que um sonha enquanto fuma um } \\
\text { cachimbo em sua cama, mas a qual } \\
\text { ele não pinta. Mas é uma questão de } \\
\text { atacá-las, no entanto, não importa o } \\
\text { quão incompetente um pode sentir- } \\
\underline{\text { se vis-à-vis as perfeições inefáveis }} \\
\underline{\text { do glorioso esplendor da natureza. }}\end{array}$ & $\begin{array}{l}\text { Obsevei aqui uma interação da } \\
\text { ocorrência da Associação metafórica } \\
\text { com a Transparência, a Incompletude e } \\
\text { o Limiar Artístico. }\end{array}$ \\
\hline
\end{tabular}




\begin{tabular}{|c|c|c|}
\hline $\begin{array}{l}\text { Na tela 'Por de Sol: Campo } \\
\text { de trigo perto de Arles', há a } \\
\text { ocorrência de Transparência } \\
\text { na forma como ele } \\
\text { representou o campo de } \\
\text { trigo, integrando ao gesto de } \\
\text { pintar, a sua experiência de } \\
\text { lutar contra a ventania e nas } \\
\text { pinceladas rápidas e } \\
\text { ritmadas, transportar essa } \\
\text { experiência física e subjetiva } \\
\text { do contato com a força do } \\
\text { vento registrado na nota de } \\
\text { rodapé } 67 \text { no apêndice. }\end{array}$ & $\begin{array}{l}\text { Eu também sou totalmente incapaz } \\
\text { de julgar o meu próprio trabalho. Eu } \\
\text { não posso ver se os estudos são bons } \\
\text { ou ruins. Tenho sete estudos de } \\
\text { trigais, infelizmente todos eles nada } \\
\text { além de paisagens, muito contra a } \\
\text { minha vontade. Paisagens amarelo } \\
\text { ouro velho - feito rápido rápido } \\
\text { rápido e com pressa, como o ceifeiro } \\
\text { que está em silêncio sob o sol } \\
\text { escaldante, concentrando-se em ter o } \\
\text { trabalho terminado. }\end{array}$ & $\begin{array}{l}\text { Ocorrência de Saliência e de } \\
\text { Transparência pelas escolhas léxico- } \\
\text { gramaticais 'nada além' e 'muito } \\
\text { contra a minha vontade' usadas na } \\
\text { oração, registrado na nota de rodapé } \\
121 \text { no apêndice. }\end{array}$ \\
\hline $\begin{array}{l}\text { A tela } O \text { Semeador foi } \\
\text { pintada após a morte de seu } \\
\text { tio Cor. Este evento parece } \\
\text { ter suscitado em Van Gogh } \\
\text { uma ligação mais profunda } \\
\text { com suas raízes da Holanda, } \\
\text { com sua infância próxima de } \\
\text { um ambiente eminentemente } \\
\text { rural, sua familiaridade com } \\
\text { os trabalhadores das } \\
\text { lavouras, seu amor inefável } \\
\text { pela natureza, seu imaginário } \\
\text { repleto de figuras de } \\
\text { linguagem proferidas nos } \\
\text { sermões do pastor e pai } \\
\text { Theodorus Van Gogh. }\end{array}$ & $\begin{array}{l}\text { Não te vou ocultar que não desgosto } \\
\underline{\text { da região, pois fui criado lá - ainda }} \\
\text { me encanta a magia das recordações } \\
\text { do passado, de um desejo do } \\
\text { infinito, do qual o semeador e o } \\
\text { enfeixador são símbolos -, tanto } \\
\text { quanto antes gostava. } \\
\text { Ocorrência de Transparência, } \\
\text { Incompletude, Limiar Artístico, } \\
\text { Interdiscursividade e Associação } \\
\text { Metafórica no nível semântico da } \\
\text { oração Beta ao explicitar a natureza } \\
\text { da sua motivação na produção } \\
\text { artística e ao usar a contraposição } \\
\text { criada pela comparação entre Naif e } \\
\text { 'a verdade das cores' como metáfora } \\
\text { para explicar ao irmão o seu desejo } \\
\text { de infinito, registrado na nota de } \\
\text { rodapé } 97 .\end{array}$ & $\begin{array}{l}\text { Inferi que, na realização desta tela, } \\
\text { Vincent parece adotar um ponto de } \\
\text { vista ainda mais atemporal e } \\
\text { misterioso do que seus estudos dos } \\
\text { campos de trigo e das colheitas em } \\
\text { Arles, que é construído pela } \\
\text { atmosfera sobrenatural da coloração } \\
\text { do ocaso sobre o campo arado. Com } \\
\text { ela, ele parece comunicar questões } \\
\text { transcendentes que o tomaram nesse } \\
\text { momento: o sentido da vida, o } \\
\text { sentido da morte, os ciclos que se } \\
\text { sucedem e como é preciso morrer } \\
\text { para nascer, assim como o trigo. }\end{array}$ \\
\hline $\begin{array}{l}\text { A transparência na tela é } \\
\text { expressa pelo uso simbólico } \\
\text { das cores, na qual van Gogh } \\
\text { sobrepõe diferentes amarelos } \\
\text { para construir um efeito de } \\
\text { concentração e intensidade } \\
\text { cromática de modo a indexar } \\
\text { um sentido subjetivo, } \\
\text { transferindo para a } \\
\text { representação do céu, um } \\
\text { humor, um sentido } \\
\text { personificado. }\end{array}$ & $\begin{array}{l}\text { O céu, amarelo-crômio, quase tão } \\
\text { luminoso quanto o próprio Sol,// que } \\
\text { é amarelo-crômio no } 1, / / \text { (está) } \\
\text { misturado com um pouco de branco, } \\
\text { /enquanto o resto do céu é uma } \\
\text { mistura dos amarelos-crômios } 1 \text { e } 2 \text {. } \\
\text { Tão amarelo! }\end{array}$ & $\begin{array}{l}\text { Ocorrência de Enquadramento, } \\
\text { Perspectiva, Transparência e } \\
\text { Incompletude na escolha léxico- } \\
\text { gramatical que organiza a oração de } \\
\text { modo a deslocar a agência da ação de } \\
\text { si para a natureza que está sendo } \\
\text { representada, como um ente em seu } \\
\text { próprio direito registrado na nota de } \\
\text { rodapé } 86 .\end{array}$ \\
\hline $\begin{array}{l}\text { Na tela 'O Semeador' toda a } \\
\text { luz que irradia do céu } \\
\text { envolve o semeador e o } \\
\text { campo arado, dando ênfase } \\
\text { para a ambiência da luz e das } \\
\text { cores do dia que começa ou } \\
\text { que termina. Para isso, van } \\
\text { Gogh diminuiu o detalhe da }\end{array}$ & $\begin{array}{l}\text { Há várias sugestões de amarelo no } \\
\text { solo, tons neutros resultantes da } \\
\text { mistura de violeta e amarelo; mas } \\
\text { tenho travado uma luta diabólica } \\
\text { para atingir a verdade das cores. } \\
\text { No excerto de carta, van Gogh } \\
\text { explicita que o semeador e o } \\
\text { enfeixador são símbolos de seu }\end{array}$ & $\begin{array}{l}\text { Ocorrência de Transparência pela } \\
\text { escolha do processo mental para } \\
\text { expressar sua experiência subjetiva ao } \\
\text { combinar as cores, registrado na nota } \\
\text { de rodapé } 88 \text { e } 91 \text {, no qual observei a } \\
\text { ocorrência da Transparência, } \\
\text { Incompletude e Limiar Artístico na } \\
\text { escolha do construto 'a verdade das }\end{array}$ \\
\hline
\end{tabular}




\begin{tabular}{|c|c|c|}
\hline $\begin{array}{l}\text { representação e favoreceu os } \\
\text { efeitos gerais produzidos } \\
\text { pelos contrastes de cor } \\
\text { simultâneos que empresta } \\
\text { um estado de espírito intenso } \\
\text { que infundiam o Portador } \\
\text { com significados simbólicos. } \\
\text { Observei também a } \\
\text { ocorrência de Uso Simbólico } \\
\text { da Cor para conferir } \\
\text { Saliência e Associação } \\
\text { Metafórica para os } \\
\text { sentidos simbólicos do } \\
\text { campo arado registrada na } \\
\text { nota de rodapé } 75 \text {. }\end{array}$ & $\begin{array}{l}\text { desejo de infinito. Este é um } \\
\text { importante indexador para os } \\
\text { sentidos construídos na tela 'O } \\
\text { Semeador.' } \\
\text { Ele também explicita, no excerto, o } \\
\text { uso de intertextualidade, ao } \\
\text { comparar sua 'luta diabólica para } \\
\text { atingir a verdade das cores' com o } \\
\text { estilo naif dos 'velhos almanaques } \\
\text { dos lavradores nos quais o granizo, a } \\
\text { neve, a chuva e o bom tempo são } \\
\text { retratados de modo primitivo, com } \\
\text { Anquetin atingiu tão bem no seu A } \\
\text { Colheita.' Observei que van Gogh } \\
\text { usou a intertextualidade como uma } \\
\text { metáfora para explicitar o caminho } \\
\text { que ele percorre para atingir a } \\
\text { verdade das cores. Este não é o } \\
\text { caminho da representação naif, mas } \\
\text { que revela 'tons neutros resultantes } \\
\text { da mistura de violeta e amarelo' que } \\
\text { nada têm de naif. }\end{array}$ & cores'. \\
\hline $\begin{array}{l}\text { No excerto de carta, van } \\
\text { Gogh explicita que o } \\
\text { semeador e o enfeixador são } \\
\text { símbolos de seu desejo de } \\
\text { infinito. Este é um } \\
\text { importante indexador para os } \\
\text { sentidos construídos na tela } \\
\text { 'O Semeador.' } \\
\text { Ele também explicita, no } \\
\text { excerto, o uso de } \\
\text { intertextualidade, ao } \\
\text { comparar sua 'luta diabólica } \\
\text { para atingir a verdade das } \\
\text { cores' com o estilo naif dos } \\
\text { 'velhos almanaques dos } \\
\text { lavradores nos quais o } \\
\text { granizo, a neve, a chuva e o } \\
\text { bom tempo são retratados de } \\
\text { modo primitivo, com } \\
\text { Anquetin atingiu tão bem no } \\
\text { seu A Colheita.' Observei } \\
\text { que van Gogh usou a } \\
\text { intertextualidade como uma } \\
\underline{\text { metáfora para explicitar o }} \\
\text { caminho que ele percorre } \\
\text { para atingir a verdade das } \\
\text { cores, que para ele } \\
\text { representam a transparência } \\
\text { necessária para atingir o seu } \\
\text { desejo de infinito. Este não é } \\
\text { o caminho da representação } \\
\text { naif, mas que revela 'tons } \\
\text { neutros resultantes da } \\
\text { mistura de violeta e amarelo' } \\
\text { que nada têm de naif. }\end{array}$ & $\begin{array}{l}\text { Preferia muito mais // fazer quadros } \\
\text { naifs [[tirados de velhos } \\
\text { almanaques, aqueles velhos } \\
\text { "almanaques dos lavradores" [[nos } \\
\text { quais o granizo, a neve, a chuva e o } \\
\text { bom tempo são retratados de modo } \\
\text { primitivo,]]]] como o Anquetin } \\
\text { atingiu tão bem no seu A Colheita. } \\
\text { Não te vou ocultar //que não } \\
\text { desgosto da região,// pois fui criado } \\
\text { lá // - ainda me encanta a magia das } \\
\text { recordações do passado, de um } \\
\text { desejo do infinito,// do qual o } \\
\text { semeador e o enfeixador são } \\
\text { símbolos / -, tanto quanto antes } \\
\text { gostava.// } \\
\text { Ocorrência de Transparência, } \\
\text { Incompletude, Limiar Artístico, } \\
\text { Interdiscursividade e Associação } \\
\text { Metafórica no nível semântico da } \\
\text { oração Beta ao explicitar a natureza } \\
\text { da sua motivação na produção } \\
\text { artística e ao usar a contraposição } \\
\text { criada pela comparação entre Naif e } \\
\text { 'a verdade das cores' como metáfora } \\
\text { para explicar ao irmão o seu desejo } \\
\text { de infinito, registrados na nota de } \\
\text { rodapé } 97 .\end{array}$ & $\begin{array}{l}\text { Ocorrência de Intertextualidade e } \\
\text { Interdiscursividade, Associação } \\
\text { metafórica, Transparência e } \\
\text { Modalidade ao relacionar a obra de } \\
\text { Anquetin e a estética Naif com sua } \\
\text { própria experiência para representar 'a } \\
\text { verdade das cores. Ocorrência de } \\
\text { Associação Metafórica pela } \\
\text { comparação que ele usa como } \\
\text { metáfora para explicar qual é a ordem } \\
\text { de sua experiência interna na escolha } \\
\text { da combinação de cores registrada na } \\
\text { nota de rodapé 93. } \\
\text { Ocorrência de Enquadramento, } \\
\text { Perspectiva, Inversão do ponto de } \\
\text { vista, Transparência, Inacabamento, } \\
\text { Incompletude e Limiar artístico com a } \\
\text { mudança na representação do } \\
\text { protagonismo nas orações e nas } \\
\text { escolhas lexicais 'verdade das cores', } \\
\text { 'luta diabólica' e 'atingir a 'verdade } \\
\text { das cores', registradas na nota de } \\
\text { rodapé 94. }\end{array}$ \\
\hline Ao se referir à tela no excerto & Ai, ai, é como nosso excelente & Ocorrência de Interdiscursividade e \\
\hline
\end{tabular}




\begin{tabular}{|c|c|c|}
\hline $\begin{array}{l}\text { de carta, van Gogh usa a } \\
\text { intertextualidade, da fala de } \\
\text { um personagem de um } \\
\text { romance de Huysmans, para } \\
\text { construir uma metáfora. Ele } \\
\text { compara a sua tela 'O } \\
\text { Semeador' com o desejo de } \\
\text { alguém, que está no plano do } \\
\text { sonho, mas que não pinta. } \\
\text { Dessa forma, quando ele a } \\
\text { pinta, ele a representa em uma } \\
\text { atmosfera de sonho, na luz } \\
\text { difusa do crepúsculo, } \\
\text { construída pelos efeitos dos } \\
\text { contrastes cromáticos, da } \\
\text { diminuição dos detalhes e do } \\
\text { tratamento geral desfocado. } \\
\text { Essa baixa definição } \\
\text { inacabamento são compatíveis } \\
\text { com o sentido de sonho } \\
\text { expressado nesse excerto de } \\
\text { carta. A luz difusa expressa } \\
\text { Inacabamento e Incompletude } \\
\text { também expressada na } \\
\text { Verbiagem do excerto. }\end{array}$ & $\begin{array}{l}\text { amigo Cyprien diz, em 'En ménage' } \\
\text { por JK Huysmans: } \\
\text { as mais belas pinturas são aquelas } \\
\text { que alguém sonha enquanto fuma } \\
\text { um cachimbo em sua cama, mas a } \\
\text { qual ele não pinta. }\end{array}$ & $\begin{array}{l}\text { Intertextualidade ao expressar uma } \\
\text { ideia por meio da afirmação (processo } \\
\text { Verbal) de seu amigo Cyprien. Essa } \\
\text { afirmação (Verbiagem) é usada como } \\
\text { uma metáfora para explicar o que ele } \\
\text { experiencia ao desejar realizar a tela, } \\
\text { indicando a ocorrência de Associação } \\
\text { metafórica no construto da } \\
\text { Verbiagem, para dar Transparência ao } \\
\text { que ele van Gogh pensa. Registrado } \\
\text { na nota de rodapé 110. }\end{array}$ \\
\hline $\begin{array}{l}\text { Na tela 'O Semeador', } \\
\text { observei a ocorrência de Uso } \\
\text { Simbólico da Cor para } \\
\text { expressar seu desejo de } \\
\text { infinito. A tela é em si uma } \\
\text { metáfora do seu desejo de } \\
\text { união com 'as perfeições } \\
\text { inefáveis do glorioso } \\
\text { esplendor da natureza': 'O } \\
\text { Semeador', essa metáfora está } \\
\text { explicitada no excerto: '-ainda } \\
\text { me encanta a magia das } \\
\text { recordações do passado, de um } \\
\text { desejo do infinito, do qual o } \\
\text { semeador e o enfeixador são } \\
\text { símbolos-'. }\end{array}$ & $\begin{array}{l}\text { Mas é uma questão [[de atacá-las]], } \\
\text { // no entanto, não importa o quão } \\
\text { incompetente // alguém pode sentir- } \\
\text { se vis-à-vis as perfeições inefáveis } \\
\text { do glorioso esplendor da natureza. }\end{array}$ & $\begin{array}{l}\text { Na oração, verifiquei a ocorrência de } \\
\text { Transparência e Incompletude pela } \\
\text { escolha 'não importa o quão', que } \\
\text { expressa que a tarefa de pintar é maior } \\
\text { do que o sentimento de incompetência, } \\
\text { incompletude ou angústia diante das } \\
\text { 'perfeições da natureza'. Registrado na } \\
\text { nota de rodapé } 113 . \\
\text { Ocorrência de Transparência na } \\
\text { escolha léxico-gramatical do processo } \\
\text { mental emotivo ao invés de um } \\
\text { processo mental cognitivo para } \\
\text { expressar sua experiência de } \\
\text { incapacidade diante da tela demonstra } \\
\text { uma preocupação do autor com a } \\
\text { precisão na comunicação de seu } \\
\text { estado interior. Registrado na nota de } \\
\text { rodapé } 116 .\end{array}$ \\
\hline $\begin{array}{l}\text { Na tela 'O Semeador' céu e } \\
\text { o sol têm uma vibração } \\
\text { cromática intensa, e que } \\
\text { constrói uma atmosfera de } \\
\text { calor que pode ser associada } \\
\text { com sentidos simbólicos, tais } \\
\text { como a luz, o calor, a } \\
\text { vibração, a vida. Céu e o sol } \\
\text { estão cromaticamente em } \\
\text { contraste simultâneo com o } \\
\text { solo, que está representado } \\
\text { por tons de azuis, lilases, } \\
\text { cinzas, marrons e brancos }\end{array}$ & $\begin{array}{l}\text { Aqui está o que eu queria dizer } \\
\text { sobre o branco e o preto. Vamos } \\
\text { tomar o Semeador. A pintura é } \\
\text { dividida em dois; metade é amarelo, } \\
\text { o topo; a base é violeta. Bem, as } \\
\text { calças brancas descansam os olhos e } \\
\text { os distraem exatamente quando o } \\
\text { contraste simultâneo excessivo de } \\
\text { amarelo e violeta iriam irritá-lo. Isso } \\
\text { é o que eu queria dizer. }\end{array}$ & $\begin{array}{l}\text { O uso do contraste simultâneo entre os } \\
\text { alaranjados e os azuis, e entre os } \\
\text { amarelos e os violetas tem um } \\
\text { significado muito central para van } \\
\text { Gogh na concepção dessa tela na } \\
\text { medida em que ele enfatiza, tanto no } \\
\text { início e quanto no final do trecho } \\
\text { escrito que há um sentido que ele } \\
\text { deseja comunicar a respeito do uso do } \\
\text { contraste simultâneo. }\end{array}$ \\
\hline
\end{tabular}




\begin{tabular}{|c|c|c|}
\hline $\begin{array}{l}\text { sugerindo uma contraposição } \\
\text { metafórica entre os } \\
\text { significados do domínio } \\
\text { celeste e os significados do } \\
\text { domínio terreno. }\end{array}$ & & \\
\hline $\begin{array}{l}\text { Na tela 'A Esplanada do Café } \\
\text { na Place du Forum, Arles, à } \\
\text { Noite', observei a ocorrência } \\
\text { de Incompletude, } \\
\text { Transparência e Limiar } \\
\text { Artístico, construídos pela } \\
\text { forma de representar as } \\
\text { estrelas e a luz noturna que } \\
\text { para van Gogh simbolizavam } \\
\text { o infinito, registrada nas notas } \\
\text { de rodapé } 139 \text { e } 140 \text { no } \\
\text { apêndice. } \\
\text { Ocorrência de transparência na } \\
\text { forma como ele representa o } \\
\text { ambiente noturno e a luz das } \\
\text { estrelas, registrada na nota de } \\
\text { rodapé } 150 \text { no apêndice. }\end{array}$ & $\begin{array}{l}\text { Mas quando eu farei o céu estrelado, } \\
\text { então, essa pintura que está sempre } \\
\text { na minha mente? } \\
\text { Ocorrência de Transparência e } \\
\text { Inacabamento pelo uso do item } \\
\text { lexical 'então' que constrói um } \\
\text { sentido de temporalidade que não } \\
\text { está definida, mas que paira em } \\
\text { suspenso pela dúvida e pela } \\
\text { incerteza expressa em sua pergunta, } \\
\text { registrado na nota de rodapé } 108 .\end{array}$ & $\begin{array}{l}\text { Embora escrevendo par o irmão van } \\
\text { Gogh pergunta a si próprio, como se } \\
\text { estivesse falando consigo ou } \\
\text { pensando em voz alta. } \\
\text { Ocorrência de Transparência e } \\
\text { Inacabamento por meio do uso de um } \\
\text { processo relacional para expressar } \\
\text { uma experiência que poderia ser } \\
\text { expressa por um processo mental, e } \\
\text { que está pronta 'em sua mente', mas } \\
\text { precisa ser materializada enquanto } \\
\text { texto pictórico. Registrado na nota de } \\
\text { rodapé } 104 .\end{array}$ \\
\hline $\begin{array}{l}\text { Na tela 'A Esplanada do } \\
\text { Café na Place du Forum, } \\
\text { Arles, à Noite', observei a } \\
\text { ocorrência de Associação } \\
\text { Metafórica e Transparência } \\
\text { construídos pelos sentidos } \\
\text { potenciais que sugerem a } \\
\text { solidão, o isolamento e a } \\
\text { ausência experienciada por } \\
\text { van Gogh, registrada nas } \\
\text { notas de rodapé } 163 \text { e } 164 \text { no } \\
\text { apêndice. }\end{array}$ & $\begin{array}{l}\text { Eu também sou totalmente incapaz } \\
\text { de julgar o meu próprio trabalho. Eu } \\
\text { não posso ver se os estudos são bons } \\
\text { ou ruins. } \\
\text { Por um longo tempo ele foi meu } \\
\text { grande desejo de fazer um semeador, } \\
5 \text {, mas os desejos que tive por um } \\
\text { longo tempo nem sempre são } \\
\text { alcançados. Então, eu estou quase } \\
\text { com medo deles. } \\
\text { Esta segunda oração enfatiza não o } \\
\text { desejo, mas o tempo no qual o desejo } \\
\text { se encapsula sem ser realizado. Ele } \\
\text { enfatiza essa demora por meio da } \\
\text { repetição invertida do construto ‘Por } \\
\text { um longo tempo ele foi meu grande } \\
\text { desejo' 'mas os desejos que tive por } \\
\text { um longo tempo nem sempre são } \\
\text { alcançados' dando ênfase no } \\
\text { primeiro construto para 'longo } \\
\text { tempo' e no segundo construto para } \\
\text { 'desejo' no sentido que estes 'nem } \\
\text { sempre são alcançados'. Esta oração } \\
\text { é um importante exemplo do } \\
\text { deslocamento no enquadramento e } \\
\text { na perspectiva no processo de } \\
\text { construção discursiva de van Gogh. } \\
\text { Observei tanto no nível semântico, } \\
\text { quanto no nível léxico-gramatical } \\
\text { como aqui, que van Gogh usa } \\
\text { contraposições, estruturas invertidas, } \\
\text { e até sentidos paradoxais que ele }\end{array}$ & $\begin{array}{l}\text { Semanticamente, tanto na tela quanto } \\
\text { na carta, van Gogh constrói um sentido } \\
\text { de solidão. Na tela por meio das } \\
\text { cadeiras vazias no primeiro plano, e da } \\
\text { noite silenciosa em contraposição com } \\
\text { um café iluminado, cheio de pessoas } \\
\text { que convivem. Na oração ele expressa } \\
\text { o sentido da solidão por meio da } \\
\text { afirmação que é uma negação quando } \\
\text { se refere a sua percepção de si próprio: } \\
\text { "Eu também sou totalmente incapaz de } \\
\text { julgar o meu próprio trabalho. Eu não } \\
\text { posso ver se os estudos são bons ou } \\
\text { ruins." Sua declaração implica em um } \\
\text { pedido ao irmão, já que ele não tem a } \\
\text { capacidade de julgar seu próprio } \\
\text { trabalho. }\end{array}$ \\
\hline
\end{tabular}




\begin{tabular}{|c|c|c|}
\hline & $\begin{array}{l}\text { indexa tanto nas telas quanto nas } \\
\text { orações. }\end{array}$ & \\
\hline $\begin{array}{l}\text { Observei também a } \\
\text { ocorrência de Transparência } \\
\text { e Enquadramento, por meio } \\
\text { de Vetor e Perspectiva } \\
\text { invertida, que é observada na } \\
\text { composição de outras telas, } \\
\text { registradas na notas de } \\
\text { rodapé } 162 \text { e } 165 \text { no } \\
\text { apêndice. } \\
\text { Ocorrência de } \\
\text { Interdiscursividade e de } \\
\text { Transparência com a } \\
\text { inversão do ponto de vista } \\
\text { que trás van Gogh para } \\
\text { dentro da tela por meio do } \\
\text { olhar do homem que parece } \\
\text { nos fitar, registradas nas } \\
\text { notas de rodapé } 169 \text { e } 170 .\end{array}$ & $\begin{array}{l}\text { Fui interrompido precisamente pelo } \\
\text { trabalho que uma nova pintura da } \\
\text { parte externa de um café à noite tem } \\
\text { me dado nos últimos dias. No } \\
\text { terraço, há pequenas figuras de } \\
\text { pessoas que bebem. Uma enorme } \\
\text { lanterna amarela ilumina o terraço, a } \\
\text { fachada, a calçada, e até mesmo } \\
\text { projeta luz sobre os paralelepípedos } \\
\text { da rua, que adquirem uma coloração } \\
\text { violeta-rosa. As frentes das casas em } \\
\text { uma rua que segue sob o céu azul } \\
\text { salpicado de estrelas são azul escuro } \\
\text { ou violeta, com uma árvore verde. } \\
\text { Agora há uma pintura de noite sem } \\
\text { preto. Com nada mais do que um } \\
\text { belo azul e violeta e verde e nestes } \\
\text { arredores da praça iluminada é } \\
\text { colorido por enxofre pálido, amarelo } \\
\text { limão. Eu gosto enormemente de } \\
\text { pintar no local à noite. No passado, } \\
\text { eles costumavam desenhar e pintar a } \\
\text { tela do desenho durante o dia. Mas } \\
\text { acho que me convém pintar a coisa } \\
\text { no momento. É bem verdade que eu } \\
\text { possa tomar um azul por um verde } \\
\text { no escuro, um azul lilás por um rosa } \\
\text { lilás, uma vez que você não pode } \\
\text { perceber a natureza do tom } \\
\text { claramente. Mas é a única maneira } \\
\text { de se livrar da noite negra } \\
\text { convencional com uma luz pobre, } \\
\text { pálida e esbranquiçada, quando na } \\
\text { verdade uma mera vela por si só nos } \\
\text { dá os mais ricos amarelos e laranjas. }\end{array}$ & $\begin{array}{l}\text { Transparência na Inversão de Ponto de } \\
\text { Vista na oração. } \\
\text { Van Gogh inicia o excerto dando voz } \\
\text { ativa para o trabalho que a nova } \\
\text { pintura lhe dá. Depois ele desliza para } \\
\text { 'dentro' da paisagem e a descreve em } \\
\text { detalhes. Depois ele inverte o ponto de } \\
\text { vista e volta para o 'lado de fora' da } \\
\text { tela e começa a falar da experiência } \\
\text { subjetiva dele em pintar a noite. } \\
\text { Observei que a ocorrência de Inversão } \\
\text { do ponto de vista está conectada com } \\
\text { a necessidade que ele mostra em dar } \\
\text { visibilidade a sua experiência } \\
\text { subjetiva em pintar a tela, que ele quer } \\
\text { ver incluída no texto, seja visualmente } \\
\text { por sistema semiótico de Inversão de } \\
\text { Ponto de vista, seja na escrita, como } \\
\text { acabo de observar na estratégia } \\
\text { retórica do excerto. }\end{array}$ \\
\hline $\begin{array}{l}\text { Na tela ‘O Café Noturno na } \\
\text { Place Lamartine, em Arles', } \\
\text { observei a ocorrência de } \\
\text { Distorção do Ponto de Vista } \\
\text { e Transparência, construídos } \\
\text { com ajuda de Saliência, de } \\
\text { Contrastes cromáticos } \\
\text { simultâneos e de saturação, } \\
\text { exacerbados para representar } \\
\text { uma sensação de } \\
\text { desconforto. Registrados na } \\
\text { nota de rodapé 137. }\end{array}$ & $\begin{array}{l}\text { A ideia do semeador ainda continua } \\
\text { a me assombrar. Estudos } \\
\text { exagerados, como o semeador, como } \\
\text { o café noturno agora, geralmente } \\
\text { parecem-me atrozmente feios e } \\
\text { ruins, mas quando eu estou movido } \\
\text { por alguma coisa, como aqui por } \\
\text { este pequeno artigo sobre } \\
\text { Dostoievski, em seguida, eles são os } \\
\text { únicos que me parecem ter um } \\
\text { significado mais importante. }\end{array}$ & $\begin{array}{l}\text { Uso de Contraposição e Conflito no } \\
\text { nível semântico, nos sentidos } \\
\text { expressos na oração, que é compatível } \\
\text { com a ocorrência da representação } \\
\text { visual de conflito por meio de } \\
\text { contrastes cromáticos, registrado na } \\
\text { nota de rodapé } 279 . \\
\text { Observei o uso de Enquadramento no } \\
\text { nível gramatical e no uso de } \\
\text { Perspectiva no nível semântico da } \\
\text { construção do complexo oracional que } \\
\text { é compatível com a perspectiva visual } \\
\text { com a qual ele representa O café da } \\
\text { Noite, registrado na nota de rodapé } \\
\underline{280} \text {. }\end{array}$ \\
\hline
\end{tabular}




\begin{tabular}{|c|c|c|}
\hline $\begin{array}{l}\text { Na tela 'O Café Noturno na } \\
\text { Place Lamartine, em Arles', } \\
\text { observei a ocorrência de } \\
\text { baixa Modalidade } \\
\text { naturalística, mas alta } \\
\text { Modalidade Subjetiva e } \\
\text { Transparência, conferida } \\
\text { pela distorção do ponto de } \\
\text { vista, registrada na nota de } \\
\text { rodapé 140, } 141 \text { e } 143 . . \\
\text { Na tela 'O Café Noturno na } \\
\text { Place Lamartine, em Arles', } \\
\text { observei a ocorrência de } \\
\text { ocorrência de Transparência } \\
\text { por meio de Associação } \\
\text { metafórica dos sentidos } \\
\text { potenciais da experiência } \\
\text { subjetiva associados à } \\
\text { introdução da luz da } \\
\text { lâmpada a gás no cotidiano } \\
\text { de van Gogh e de seus } \\
\text { contemporâneos, registrada } \\
\text { na nota de rodapé } 208 .\end{array}$ & $\begin{array}{l}\text { Muitas vezes parece-me que a noite } \\
\text { é muito mais viva e ricamente } \\
\text { colorida do que o dia. } \\
\text { (...) } \\
\text { O café noturno é uma continuação } \\
\text { do semeador, como é a cabeça do } \\
\text { velho camponês e do poeta, se eu } \\
\text { conseguir fazer essa última tela. É } \\
\text { uma cor, então, que não é } \\
\text { localmente verdadeira do ponto de } \\
\text { vista realista do trompe l'oeil, mas } \\
\text { uma cor que sugere alguma emoção, } \\
\text { um temperamento ardente. }\end{array}$ & $\begin{array}{l}\text { Tanto na tela quanto na carta, observei } \\
\text { que o uso simbólico da cor confere } \\
\text { transparência para sentidos que são de } \\
\text { ordem subjetiva e que van Gogh deseja } \\
\text { indexar em sua representação da tela, } \\
\text { seja visualmente, seja em seus relatos } \\
\text { da tela ao irmão. A baixa modalidade } \\
\text { da iluminação real do café e o exagero } \\
\text { construído na representação da } \\
\text { iluminação do café, do brilho } \\
\text { ofuscante das lâmpadas no piso é um } \\
\text { claro exemplo visual da transparência } \\
\text { construída por uma modalidade } \\
\text { emocional, se assim posso chamar. Na } \\
\text { carta ele explicita esse uso da cor, não } \\
\text { 'do ponto de vista realista do trompe } \\
\text { l'oeil, mas uma cor que sugere alguma } \\
\text { emoção, um temperamento ardente' } \\
\text { indicando sua opção em usar a cor } \\
\text { como uma semiose para sentidos que } \\
\text { são de ordem subjetiva. }\end{array}$ \\
\hline $\begin{array}{l}\text { Na tela 'O Café Noturno na } \\
\text { Place Lamartine, em Arles', } \\
\text { observei a ocorrência de } \\
\text { Transparência e } \\
\text { Incompletude para } \\
\text { representar a sua } \\
\text { experiência com o } \\
\text { ambiente de um café } \\
\text { noturno, registrada na nota } \\
\text { de rodapé } 165 . \\
\text { Ocorrência de Transparência } \\
\text { na escolha do tema e na } \\
\text { forma de representar uma } \\
\text { experiência que era muito } \\
\text { subjetiva para van Gogh, } \\
\text { registrada na nota de rodapé } \\
\underline{180 .}\end{array}$ & $\begin{array}{l}\text { Na minha pintura do café à noite eu } \\
\text { procurei exprimir que o café é um } \\
\text { lugar onde você pode arruinar-se, } \\
\text { enlouquecer, cometer crimes. De } \\
\text { qualquer forma, eu tentei com } \\
\text { contrastes de rosa delicado e } \\
\text { vermelho-sangue e vinho tinto. } \\
\text { Verde doce Luís XV e Veronese } \\
\text { contrastando com os verdes } \\
\text { amarelos e os verdes azuis duros. } \\
\text { Tudo isso em uma atmosfera de } \\
\text { fornalha infernal, de enxofre pálido. } \\
\text { Exprimir como a potência dos } \\
\text { cantos escuros de uma taberna. } \\
\text { Contudo sob uma aparência da } \\
\text { alegria japonesa e da boa natureza } \\
\text { de Tartarin. }\end{array}$ & $\begin{array}{l}\text { Nesta oração van Gogh explicita a } \\
\text { busca de fazer transparecer nas cores e } \\
\text { na forma do café o sentimento interno } \\
\text { que era experienciado por ele neste } \\
\text { lugar. } \\
\text { O exagero, a intensidade colocada } \\
\text { para trazer à tona esse sentimento } \\
\text { coloca-o perto da loucura, da ruína } \\
\text { (parecem-me atrozmente feios e ruis) } \\
\text { e perto do seu objetivo em representar } \\
\text { a ideia que o assombra e que para ele } \\
\text { tem o significado mais importante. } \\
\text { Talvez por isso ele cite Dostoievski, } \\
\text { pela necessidade de encontrar a } \\
\text { beleza, que ele deva se aproximar do } \\
\text { crime. Ou seja, pela necessidade de } \\
\text { fazer representar a ideia que o } \\
\text { assombra, justifica produzir uma tela } \\
\text { que possa parecer aos olhos de um } \\
\text { observador, feia e ruim. Para observar } \\
\text { essa tela é preciso estar em busca } \\
\text { desse mesmo sentido oculto que está } \\
\text { presente no artigo de Dostoievski, que } \\
\text { é espiritual. }\end{array}$ \\
\hline $\begin{array}{l}\text { Na tela 'O Café Noturno na } \\
\text { Place Lamartine, em Arles', } \\
\text { observei a ocorrência de } \\
\text { Associação metafórica por }\end{array}$ & $\begin{array}{l}\text { A sala está pintada de vermelho, e } \\
\text { no interior, na luz a gás, a mesa de } \\
\text { bilhar verde, a qual lança uma } \\
\text { imensa sombra sobre o chão. Nesta }\end{array}$ & $\begin{array}{l}\text { No encadeamento das orações van } \\
\text { Gogh revela que o sentido da 'imensa } \\
\text { sombra' que a mesa projeta sobre o } \\
\text { chão é corroborado pelos } 6 \text { ou } 7\end{array}$ \\
\hline
\end{tabular}




\begin{tabular}{|c|c|c|}
\hline $\begin{array}{l}\text { meio de Saliência, } \\
\text { Transparência e } \\
\text { Profundidade na escolha } \\
\text { potencial de sentidos } \\
\text { associados à exclusividade } \\
\text { da sombra da mesa em } \\
\text { relação à ausência de } \\
\text { sombra dos outros objetos } \\
\text { e figuras, registrada na nota } \\
\text { de rodapé } 226 .\end{array}$ & $\begin{array}{l}\text { tela, há } 6 \text { ou } 7 \text { vermelhos diferentes, } \\
\text { desde vermelho-sangue até rosa } \\
\text { delicado, fazendo oposição com o } \\
\text { mesmo número de verdes pálidos ou } \\
\text { escuros. }\end{array}$ & $\begin{array}{l}\text { vermelhos diferentes fazendo oposição } \\
\text { com o mesmo número de verdes. O } \\
\text { sentido desses contrastes entre os } \\
\text { verdes e os vermelhos foi explicitado } \\
\text { em outra oração 'Eu tentei expressar as } \\
\text { terríveis paixões humanas com o } \\
\text { vermelho e o verde.' Outra oração } \\
\text { explicita o sentido simbólico e } \\
\text { subjetivo que van Gogh dá para o } \\
\text { contraste entre os verdes e os } \\
\text { vermelhos: 'Na minha pintura do café } \\
\text { à noite eu procurei exprimir que o café } \\
\text { é um lugar onde você pode arruinar-se, } \\
\text { enlouquecer, cometer crimes. De } \\
\text { qualquer forma, eu tentei com } \\
\text { contrastes de rosa delicado e } \\
\text { vermelho-sangue e vinho tinto. }\end{array}$ \\
\hline $\begin{array}{l}\text { Na tela 'O Café Noturno na } \\
\text { Place Lamartine, em Arles', } \\
\text { observei a ocorrência de } \\
\text { Transparência por meio do } \\
\text { uso simbólico da cor, para } \\
\text { os contrastes entre } \\
\text { vermelhos e verdes, } \\
\text { explicitado pro van Gogh em } \\
\text { seu extrato de carta, } \\
\text { registrada na nota de rodapé } \\
234 \text {. }\end{array}$ & $\begin{array}{l}\text { Na minha pintura do café à noite eu } \\
\text { procurei exprimir que o café é um } \\
\text { lugar onde você pode arruinar-se, } \\
\text { enlouquecer, cometer crimes. De } \\
\text { qualquer forma, eu tentei com } \\
\text { contrastes de rosa delicado e } \\
\text { vermelho-sangue e vinho tinto. } \\
\text { Verde doce Luís XV e Veronese } \\
\text { contrastando com os verdes } \\
\text { amarelos e os verdes azuis duros. }\end{array}$ & $\begin{array}{l}\text { Van Gogh criou um sistema semiótico } \\
\text { para indexar um sentido subjetivo das } \\
\text { 'paixões humanas' no uso que deu aos } \\
\text { contrastes entre vermelhos e verdes. } \\
\text { Ele usou diferentes tonalidades de } \\
\text { vermelho e verde, para criar uma } \\
\text { atmosfera de náusea, fadiga, excesso. } \\
\text { Embora van Gogh busque uma } \\
\text { experiência espiritual profunda ele se } \\
\text { percebe envolvido por sentimentos e } \\
\text { paixões que não são uma escolha para } \\
\text { ele e esses sentimentos e essas paixões } \\
\text { transparecem em ambientes mais } \\
\text { propícios à sua manifestação, como é } \\
\text { o caso do café. Assim o ambiente } \\
\text { ideal para representar esse estado de } \\
\text { espírito é o mesmo ambiente no qual } \\
\text { van Gogh pode acessa-los de uma } \\
\text { maneira mais crua e talvez até } \\
\text { descontrolada. Isso mostra como além } \\
\text { de ver na sua obra a busca de uma } \\
\text { beleza e de um simbolismo } \\
\text { espiritualmente elevado, ele procurou } \\
\text { ser fiel àqueles sentimentos que nos } \\
\text { tornam mais humanos e que nos } \\
\text { aproximam uns dos outros, mesmo nas } \\
\text { condições mais desumanas. }\end{array}$ \\
\hline $\begin{array}{l}\text { Na tela 'O Café Noturno na } \\
\text { Place Lamartine, em Arles', } \\
\text { observei a ocorrência de } \\
\text { Associação metafórica, } \\
\text { Transparência, Incompletude } \\
\text { e Limiar Artístico, com o uso } \\
\text { do Enquadramento, } \\
\text { Perspectiva, Profundidade, } \\
\text { Distorção do Ponto de Vista, } \\
\text { levemente plongee para o } \\
\text { sentido do lugar social com o } \\
\text { qual van Gogh se identifica. } \\
\text { Registradas nas notas de } \\
\text { rodapé } 103 \text { no apêndice, } 248 \\
\end{array}$ & $\begin{array}{l}\text { Mais tarde, quando eu tiver levado } \\
\text { esses experimentos mais longe, } \underline{o} \\
\text { semeador ainda vai ser a primeira } \\
\underline{\text { tentativa nesse gênero. }} \\
\underline{\text { O café noturno é uma continuação }} \\
\text { do semeador, como é a cabeça do } \\
\underline{\text { velho camponês e do poeta, se eu }} \\
\text { conseguir fazer essa última tela. É } \\
\text { uma cor, então, que não é localmente } \\
\text { verdadeira do ponto de vista realista } \\
\text { do trompe l'oeil, mas uma cor que } \\
\text { sugere alguma emoção, um } \\
\text { temperamento ardente. }\end{array}$ & $\begin{array}{l}\text { Observei a ocorrência de } \\
\text { Transparência na tela, por meio do uso } \\
\text { conjugado de vários recursos } \\
\text { semióticos. Esses recursos são: o } \\
\text { enquadramento com o ângulo plongee, } \\
\text { a construção das linhas de perspectiva } \\
\text { distorcidas, a saturação excessiva do } \\
\text { amarelo do piso, em contraposição } \\
\text { com a sombra que é desproporcional e } \\
\text { também contrasta com a ausência de } \\
\text { sombras nas demais figuras e o uso } \\
\text { simbólico das cores para expressar } \\
\text { sentimentos e estados internos. } \\
\text { A transparência no excerto está na }\end{array}$ \\
\hline
\end{tabular}




\begin{tabular}{|c|c|c|}
\hline e 249. & & $\begin{array}{l}\text { explicitação de seu uso simbólico da } \\
\text { cor para expressar 'alguma emoção, } \\
\text { um temperamento ardente' e é } \\
\text { compatível, no nível semântico, com a } \\
\text { ocorrência de transparência na tela } \\
\text { pelo uso gramatical das cores para } \\
\text { indexar significados emocionais. }\end{array}$ \\
\hline $\begin{array}{l}\text { Na tela 'O Café Noturno na } \\
\text { Place Lamartine, em Arles', } \\
\text { observei a ocorrência de } \\
\text { Transparência, } \\
\text { Incompletude, Modalidade e } \\
\text { Limiar Artístico pelo uso do } \\
\text { Inacabamento, } \\
\text { Enquadramento, Perspectiva, } \\
\text { Distorção do Ponto de Vista, } \\
\text { Direção, Profundidade, como } \\
\text { marca estilística das linhas } \\
\text { que organizam a perspectiva } \\
\text { da sala, registrada na nota de } \\
\text { rodapé } 250 .\end{array}$ & $\begin{array}{l}\text { Que diria portanto desse quadro o } \\
\text { Sr. Tersteeg? Diante de um Sisley, } \\
\text { Sisley, o mais discreto e delicado } \\
\text { dos Impressionistas - já disse: "Não } \\
\text { posso me impedir de pensar que o } \\
\text { artista que pintou isso estava um } \\
\text { pouco tonto". Diante do meu } \\
\text { quadro, então a mim ele diria que } \\
\text { ele é um caso de delirium tremens. }\end{array}$ & $\begin{array}{l}\text { A ocorrência de Transparência na tela } \\
\text { se verifica na distorção das linhas que } \\
\text { organizam a perspectiva e que } \\
\text { constroem uma aparência de } \\
\text { instabilidade e de ambiguidade para o } \\
\text { ambiente do Café que é compatível } \\
\text { com um sentido de cansaço e } \\
\text { desequilíbrio que van Gogh construiu } \\
\text { para representar o café. Ele associa } \\
\text { esse sentido de desequilíbrio com o } \\
\text { uso da Verbiagem do Sr. Tersteeg para } \\
\text { comparar sua tela com a tela de Sisley, } \\
\text { se naquela o artista estava um pouco } \\
\text { tonto, nesta o artista estava com } \\
\text { delirium tremens. Tanto na tela quanto } \\
\text { na oração van Gogh está explicitando } \\
\text { um estado de espírito ou de } \\
\text { consciência que é da ordem da } \\
\text { experiência pessoal sobre o ambiente } \\
\text { do Café noturno e seus sentidos. }\end{array}$ \\
\hline
\end{tabular}

Fonte: Triangulação para Transparência dos dados dos corpora visual e textual, com os extratos das cartas.

\subsection{INACABAMENTO - PROCESSO DE REALIZAÇÃO}

Assim como a presença e as repetições de elementos puderam revelar sistemas semióticos autorais, as lacunas, que nos inquietam diante da obra de arte, também ocorreram no discurso do artista. Essa abertura na estrutura do texto de arte, cujo sentido não se fecha e possibilita uma fascinação nossa em relação à obra mostrou pontos de convergência com o discurso escrito de van Gogh; tanto pela ausência de fechamento de sentido em ambos os discursos - oral e visual - quanto pela recorrência e condensação de sentidos em alguns desses elementos e estratégias discursivas.

O inacabamento é uma categoria que expressa a imprecisão como uma marca estilística na pintura de van Gogh e que busquei também triangular com os dados textuais. $\mathrm{O}$ inacabamento está imbricado em um sistema de crenças, compartilhado com seus contemporâneos pintores e que se relaciona com o compromisso de expressar a vida como ela é, ou seja, como cada um a experiencia, sem certezas ou respostas prontas e definidas. Van Gogh busca dar transparência a todas as experiências, sejam elas de dúvida ou de vulnerabilidade. $\mathrm{O}$ inacabamento é a forma como ele expressa essa transparência. É na falha, 
no vazio, que se revela a não existência, a não significação, a incerteza, a incompletude que ele expressa por meio do inacabamento. A incompletude é um estado que ele sente; o inacabamento é como ele expressa esse estado. Ele expressa essa dimensão de sua experiência subjetiva, interna por meio de um estilo impreciso e inacabado, comentado por Gombrich (1995, p. 530):

Para o público em geral, perfeição artística ainda significava que tudo devia ser bem-feito, bem-arrematado e polido. Ao desprezar essas convenções mesquinhas para expressar a sua visão do ato divino da Criação (Fig.346), Rodin ajudou a afirmar o que Rembrandt proclamara ser seu direito (p.422): considerar a obra terminada assim que atingisse sua finalidade artística. Como ninguém podia dizer que o seu procedimento resultava de ignorância, a influência de Rodin contribuiu muito para facilitar a aceitação do impressionismo fora do exíguo círculo de seus admiradores na França.

O inacabamento foi um estilo para o qual seus autores signatários precisaram abrir caminho a braço partido nos círculos artísticos da época. A noção de inacabamento não está apenas no estilo com que van Gogh pinta, mas na forma como ele vê as suas telas; ele as encara como estudos, trabalhos em progresso, como expõe Haziot (2010, p. 199):

O emprego que ele faz da palavra "estudo" para designar seus quadros é revelador. Um estudo, no seu espírito, é uma preparação para o "verdadeiro" quadro, mais elaborado, por vir. Mas ele nunca ou quase nunca fez senão "estudos". O emprego da palavra mostra que ele não ousava ir até o fim da descoberta e chamar de quadros o que por timidez chamava de estudos, para se defender da crítica de trabalhar rápido demais, de deixá-los "inacabados", até mesmo com a tela aparecendo ainda aqui ou ali. Pois essa autenticidade, que terá tanto valor no século $\mathrm{XX}$ não era prezada no seu tempo, mesmo por seus companheiros mais avançados.

O inacabamento, dessa forma, está ancorado em uma atitude, uma visão de mundo que implicou em um modo de vida para van Gogh, como Gombrich (1995, p. 530) relata: "Artistas de todo mundo entraram em contato com o impressionismo em Paris e levaram consigo, na volta, as novas descobertas, assim como a nova atitude do artista como um rebelde contra os preconceitos e convenções do mundo burguês."

Essa visão da arte que privilegiava a dissipação dos contornos e a imprecisão não era exclusiva de van Gogh, e se aproximou mais a um paradigma compartilhado pelos artistas do impressionismo, como argumenta Gombrich (1995, p. 522):

Se Renoir tivesse pintado todos os detalhes [da tela Baile no Moulin de la Galette, 1876], o quadro teria um aspecto enfadonho e sem vida. Recordemos que um conflito semelhante já fora enfrentado pelos artistas do século XV, quando pela primeira vez descobriram como refletir a natureza. Lembremos ainda que os próprios triunfos do naturalismo e da perspectiva tinham levado suas figuras a parecer um tanto rígidas, como se fossem de madeira, e que somente o gênio de Leonardo logrou superar essa dificuldade, fazendo com que as formas se fundissem intencionalmente em sombras - o recurso que foi então denominado sfumato (pp. 301-2, Figs. 193-4). A descoberta pelos impressionistas de que as sombras escuras do gênero usado por Leonardo para modelar não ocorrem ao ar livre e à luz do sol impediu para eles o recurso a essa saída tradicional. Por conseguinte tiveram que ir 
ainda mais longe do que qualquer geração anterior, realizando a dissipação intencional de contornos claros e definidos. (GOMBRICH, 1995, p.522)

O inacabamento, dessa forma, caracteriza um sistema semiótico que circulou em um coletivo de artistas preocupado em solucionar questões de linguagem para representar o ambiente ao ar livre, à luz do dia, a partir de suas impressões e experiências subjetivas do mundo real. Impulsionado por essa nova atitude diante da arte, van Gogh passa a apreciar pintores que privilegiam a imprecisão dos contornos, comentado por Haziot (2010, p.145):

E ele, a quem acabavam de reprovar o aspecto inacabado de seu Os comedores de batatas, que talvez duvidasse desse caminho escolhido, fica impressionado com as mãos e tantos outros detalhes que os grandes mestres tratavam com liberdade para lhes dar vida. "Admirei, sobretudo as mãos de Rembrandt e de Hals, mãos que viviam mas que não estavam 'terminadas', no sentido que querem dar agora à palavra 'terminar'; algumas mãos, em particular nos Síndicos dos têxteis e mesmo na Noiva judia, e em Frans Hals. E as cabeças também, os olhos, o nariz, a boca, feitos com as primeiras pinceladas, sem quaisquer retoques." (carta de Vincent a Theo, C 427, in HAZIOT, 2010, p. 145).

A questão do inacabamento dos contornos das formas parece ter percorrido a história da arte através de mestres como Da Vinci, Rembrandt e Hals, que inovaram estética e estilisticamente com suas obras ousando fazê-las imprecisas. Esse recurso passou a ser fortemente defendido pelo programa dos impressionistas e que instituíram a imprecisão como uma marca de sua linguagem, como explica Gombrich (1995, p. 522):

Sabiam que o olho humano é um instrumento maravilhoso. Basta fornecer-lhe a
sugestão certa e ele se encarrega de construir para nós a imagem total que sabe estar
ali. Contudo, é preciso saber como olhar para tais pinturas. As pessoas que visitaram
a primeira exposição impressionista obviamente enfiaram o nariz nas telas e nada
viram senão um conjunto de pinceladas ao acaso; por isso pensaram que os pintores
deviam ser loucos varridos. Levou algum tempo até o público descobrir que, para
apreciar um quadro impressionista, deve recuar alguns metros e desfrutar o milagre
de ver essas manchas intrigantes súbito se organizarem e ganharem vida diante dos
olhos. Realizar esse milagre e transferir a experiência visual do pintor para o
espectador constitui a verdadeira finalidade dos impressionistas.

Van Gogh aprendeu também das gravuras japonesas a influência sobre a imprecisão como um recurso para acrescentar força expressiva para suas composições, como relatada em sua carta 676:

Hokusai te faz chorar do mesmo modo - mas no caso dele com suas linhas, seu desenho, desde que na sua carta voce diz a si mesmo: essas ondas são mandíbulas, o barco está preso nelas, voce pode sentir isso. Ah bem, se nós fizéssemos a cor muito correta ou o desenho muito correto, nós não criaríamos aquelas emoções. (Carta 676 Br. 1990: 679 | CL: 533 - From: Vincent van Gogh To: Theo van Gogh , Date: Arles, 8 September 1888. Disponível em 30.3.2014 em: http://vangoghletters.org/vg/letters/let676/letter.html) 
É o modo pelo qual o artista busca tornar transparente sua experiência, seja ela de dúvida ou de vulnerabilidade. É justamente na falha, no vazio, que se revelam a experiência, a existência, a significação, a incompletude que Van Gogh expressa por meio do inacabamento.

\subsubsection{Triangulação do Inacabamento}

Inacabamento, no texto escrito e em relação à triangulação - $\mathrm{O}$ inacabamento na pintura se refere a uma marca estilística de imprecisão para privilegiar uma abordagem da experiência visual de movimento e fluidez em detrimento da definição do traço, do contorno das formas, da pincelada, do preenchimento das cores, do polimento da pintura. Em face da possível crítica que ele receberia por essa escolha estilística ele se refere as suas telas como estudos e esboços. O inacabamento que resulta em uma característica estilística está ancorado em uma atitude filosófica na forma como ele encarava sua produção discursiva, fosse ela pictórica ou textual, revelada por uma forma de se expressar visualmente ou descrever esse processo que não privilegia o acabamento.

Quadro 33: Triangulação do Inacabamento

\begin{tabular}{|c|c|c|}
\hline Ocorrência nas telas & Orações & Comentário \\
\hline $\begin{array}{l}\text { Na tela 'Por de Sol: Campo de } \\
\text { trigo perto de Arles' observei a } \\
\text { ocorrência de Inacabamento } \\
\text { na forma como ele mistura } \\
\text { as cores direto na tela, } \\
\text { registrado nas notas de rodapé } \\
53 \text { e } 58 \text { no apêndice. } \\
\text { Também observei } \\
\text { inacabamento na forma como } \\
\text { ele deixa aparecer o branco } \\
\text { da tela para criar um fino halo } \\
\text { branco em torno do sol e } \\
\text { enfatizar seu brilho. No } \\
\text { contorno do sol e no contorno } \\
\text { no topo das edificações à } \\
\text { esquerda van Gogh não cobre } \\
\text { a tela com os tons de azul, mas } \\
\text { deixa a tela nua, para esta } \\
\text { funcionar como uma cor e dar } \\
\text { ênfase na luminosidade do sol } \\
\text { e da luz que dele emana em } \\
\text { meio às cores do céu. } \\
\text { Registrado nas notas de rodapé } \\
51 \text { e } 59 \text { no apêndice. }\end{array}$ & $\begin{array}{l}\text { Aqui está outra paisagem. Sol } \\
\text { poente? Lua nascendo? Noite de } \\
\text { verão, de qualquer modo. Cidade } \\
\text { violeta, estrela amarela, céu azul- } \\
\text { esverdeado; os campos de trigo têm } \\
\text { todos os tons: ouro velho, cobre, } \\
\text { ouro verde, ouro vermelho, ouro } \\
\text { amarelo, verde, vermelho e amarelo } \\
\text { bronze. Tela quadrada número } 30 \text {. }\end{array}$ & $\begin{array}{l}\text { Ocorrência observada no uso da voz } \\
\text { passiva, que também dá uma } \\
\text { impressão de processualidade e } \\
\text { imprecisão que combina com a } \\
\text { mensagem pictórica que van Gogh } \\
\text { busca descrever ao irmão, que não é } \\
\text { direta, assertiva, objetiva, mas que é } \\
\text { sensorial, intuitiva e interpretativa. } \\
\text { Essa intenção de inacabamento na } \\
\text { significação fica evidenciada na } \\
\text { oração: 'sol poente? Lua nascendo? } \\
\text { Noite de verão...' possibilitando ao } \\
\text { espectador uma liberdade } \\
\text { interpretativa. Essa atitude de } \\
\text { inacabamento é como uma declaração: } \\
\text { não queira vir aqui encontrar uma } \\
\text { certeza para si; nem eu tenho uma } \\
\text { certeza. Se nem o artista tem o } \\
\text { controle do alcance de significação } \\
\text { que a obra tem, isso oferece uma } \\
\text { liberdade enorme para o espectador } \\
\text { interpretar o significado que ele quiser } \\
\text { com a obra. O inacabamento é livre e } \\
\text { liberta. }\end{array}$ \\
\hline Na tela, 'Por de Sol: Campo de & Paisagens amarelo ouro velho - & O inacabamento aparece nas orações \\
\hline
\end{tabular}




\begin{tabular}{|c|c|c|}
\hline $\begin{array}{l}\text { trigo perto de Arles' observei a } \\
\text { ocorrência de Inacabamento } \\
\text { construída por meio do ritmo, } \\
\text { da textura e do movimento que } \\
\text { articulam o gesto pictórico nas } \\
\text { pinceladas que representam o } \\
\text { campo de trigo. Registrado nas } \\
\text { notas de rodapé } 58 \text { e } 59 \text { no } \\
\text { apêndice. }\end{array}$ & $\begin{array}{l}\text { feito rápido rápido rápido e com } \\
\text { pressa, como o ceifeiro que está em } \\
\text { silêncio sob o sol escaldante, } \\
\text { concentrando-se em ter o trabalho } \\
\text { terminado. }\end{array}$ & $\begin{array}{l}\text { em forma de imprecisões na } \\
\text { construção gramatical que privilegiam } \\
\text { o movimento, o ritmo, o gesto } \\
\text { semântico, por exemplo, o construto } \\
\text { 'rápido rápido rápido e com pressa.' } \\
\text { que expressa e é análoga semântica e } \\
\text { formalmente, ao o gesto pictórico } \\
\text { desse movimento na tela. }\end{array}$ \\
\hline $\begin{array}{l}\text { Na tela, 'Por de Sol: Campo de } \\
\text { trigo perto de Arles' observei a } \\
\text { ocorrência de transparência na } \\
\text { forma como ele representou o } \\
\text { campo de trigo, integrando ao } \\
\text { gesto de pintar, a sua } \\
\text { experiência de lutar contra a } \\
\text { ventania e nas pinceladas } \\
\text { rápidas e ritmadas, transportar } \\
\text { essa experiência física e } \\
\text { subjetiva do contato com a } \\
\text { força do vento, registrado na } \\
\text { nota de rodapé } 67 \text { no apêndice. }\end{array}$ & $\begin{array}{l}\text { Tela quadrada número } 30 . \text { Eu } \\
\text { pintei-a ao ar livre no Mistral. Meu } \\
\text { cavalete foi fixado no chão com } \\
\text { estacas de ferro, um método que eu } \\
\text { recomendo a voce. Voce enterra os } \\
\text { pés do cavalete e, em seguida, voce } \\
\text { empurra a } 50 \text { centímetros de } \\
\text { comprimento um peso de ferro ao } \\
\text { lado deles. Voce amarra tudo com } \\
\text { cordas; dessa forma, voce pode } \\
\text { trabalhar com o vento. }\end{array}$ & $\begin{array}{l}\text { Ocorrência de Saliência, } \\
\text { Transparência, Inacabamento e } \\
\text { Incompletude na construção que } \\
\text { revela as condições de ter pintado a } \\
\text { tela ao vento como uma experiência } \\
\text { que é relevante na representação } \\
\text { escrita da tela que van Gogh faz para } \\
\text { Theo, registrada na nota de rodapé } \\
116 \text { no apêndice. }\end{array}$ \\
\hline $\begin{array}{l}\text { Observei na tela } O \\
\text { Semeador, a ocorrência de } \\
\text { um processo sugestivo } \\
\text { simbólico, no qual a } \\
\text { atmosfera de luz difusa do } \\
\text { ocaso constrói um sentido } \\
\text { imanente para o Semeador, } \\
\text { com atributos e identidade } \\
\text { que são inerentes a ele. }\end{array}$ & $\begin{array}{l}\text { Há várias sugestões de amarelo no } \\
\text { solo, tons neutros resultantes da } \\
\text { mistura de violeta e amarelo; mas } \\
\text { tenho travado uma luta diabólica } \\
\text { para atingir a verdade das cores. } \\
\text { Ocorrência de Inacabamento e } \\
\text { Incompletude por meio da escolha } \\
\text { léxico-gramatical 'mas', 'várias' e } \\
\text { 'tons neutros' que sugere imprecisão } \\
\text { na oração, registrada na nota de } \\
\text { rodapé } 92 .\end{array}$ & $\begin{array}{l}\text { Ocorrência de Transparência pela } \\
\text { escolha do processo mental para } \\
\text { expressar sua experiência subjetiva ao } \\
\text { combinar as cores, registrado nas } \\
\text { notas de rodapé } 88 \text { e } 91 \text {, no qual } \\
\text { observei a ocorrência da } \\
\text { Transparência, Incompletude e Limiar } \\
\text { Artístico na escolha do construto 'a } \\
\text { verdade das cores'. }\end{array}$ \\
\hline $\begin{array}{l}\text { Representar o halo de luz das } \\
\text { estrelas é diferente de } \\
\text { representar as estrelas, ele } \\
\text { privilegiou representar seu } \\
\text { brilho como o elemento que } \\
\text { dá vida a elas, pulsa, e se } \\
\text { comunica no espaço da } \\
\text { noite. A metáfora de estrelas } \\
\text { como fogos de artifício } \\
\text { ultrapassa, dessa forma, a } \\
\text { mera figura retórica e se } \\
\text { torna nas mãos de van Gogh, } \\
\text { uma associação metafórica } \\
\text { para sua 'necessidade de } \\
\text { infinito'. }\end{array}$ & $\begin{array}{l}\text { Mas quando eu farei o céu estrelado, } \\
\text { então, essa pintura que está sempre } \\
\text { na minha mente? }\end{array}$ & $\begin{array}{l}\text { A pintura que representa o céu } \\
\text { estrelado está sempre na mente de van } \\
\text { Gogh por que ela constitui uma busca } \\
\text { estética de expressão de uma } \\
\text { experiência de incompletude que } \\
\text { dificilmente van Gogh conseguiria } \\
\text { comunicar de outra forma e por isso, } \\
\text { produz uma percepção de } \\
\text { inacabamento. } \\
\text { Ocorrência de Inacabamento e } \\
\text { Incompletude pelo uso dos itens } \\
\text { lexicais 'quando' e 'sempre' em } \\
\text { contraposição e que constroem uma } \\
\text { camada de sentido. Registrada na nota } \\
\text { de rodapé 102. }\end{array}$ \\
\hline $\begin{array}{l}\text { Na tela 'O Semeador', } \\
\text { observei a ocorrência de } \\
\text { Inacabamento na } \\
\text { representação do campo } \\
\text { arado. Observei também } \\
\text { que, devido à técnica de }\end{array}$ & $\begin{array}{l}\text { Eu tive uma semana de concentrado } \\
\text { trabalho duro nos campos de trigo } \\
\text { debaixo do sol, o resultado foi de } \\
\text { alguns estudos de campos de trigo, } \\
\text { paisagens e - um esboço de um } \\
\text { semeador. }\end{array}$ & $\begin{array}{l}\text { A escolha lexical de ‘estudos’ para se } \\
\text { referir às suas telas sugere que van } \\
\text { Gogh se relacionava com o seu } \\
\text { processo de produção artística como } \\
\text { uma pesquisa. Esta concepção de } \\
\text { ‘estudo' fica evidenciada no excerto }\end{array}$ \\
\hline
\end{tabular}




\begin{tabular}{|c|c|c|}
\hline $\begin{array}{l}\text { pintar aprendida com os } \\
\text { pontilhistas e aperfeiçoada } \\
\text { para um sistema semiótico } \\
\text { próprio, o Inacabamento } \\
\text { pode ser observado como } \\
\text { uma parte integrante do } \\
\text { Gesto Pictórico, registrado } \\
\text { na nota de rodapé 54. }\end{array}$ & $\begin{array}{l}\text { (...) } \\
\text { Mais tarde, quando eu tiver levado } \\
\text { esses experimentos mais longe, o } \\
\text { semeador ainda vai ser a primeira } \\
\text { tentativa nesse gênero. } \\
\text { O café noturno é uma continuação } \\
\text { do semeador, como é a cabeça do } \\
\text { velho camponês e do poeta, se eu } \\
\text { conseguir fazer essa ultima tela. É } \\
\text { uma cor, então, que não é } \\
\text { localmente verdadeira do ponto de } \\
\text { vista realista do trompe l'oeil, mas } \\
\text { uma cor que sugere alguma emoção, } \\
\text { um temperamento ardente. }\end{array}$ & $\begin{array}{l}\text { no qual ele se refere ao semeador } \\
\text { como uma 'tentativa' que será a } \\
\text { primeira nesse gênero o qual é um } \\
\text { estudo que inicia no Semeador e } \\
\text { continua no Café da Noite e na } \\
\text { Cabeça do poeta. }\end{array}$ \\
\hline $\begin{array}{l}\text { A tela 'O Semeador', em seu } \\
\text { caráter metafórico parece um } \\
\text { manifesto de suas crenças, } \\
\text { de sua visão de mundo, de } \\
\text { sua filosofia de vida: } \\
\text { adensados ao longo de seus } \\
\text { anos de formação familiar, } \\
\text { de definição de sua } \\
\text { identidade, de afirmação de } \\
\text { suas escolhas; condensada } \\
\text { em uma composição que } \\
\text { acumula elaboradas camadas } \\
\text { de sentidos, longamente } \\
\text { urdidos na incessante } \\
\text { maquinaria de van Gogh. } \\
\text { Como atestam as cartas de } \\
\text { van Gogh, } O \text { Semeador não } \\
\text { foi uma tela temporã, mas } \\
\text { antes longamente } \\
\text { amadurecida, secretamente } \\
\text { ansiada e negociada nos } \\
\text { interstícios de seu desejo. O } \\
\text { Inacabamento também se } \\
\text { evidencia pela forma como } \\
\text { van Gogh se refere ao } \\
\text { trabalho, visto por ele como } \\
\text { um esboço. }\end{array}$ & $\begin{array}{l}\text { E o esboço como tal - uma tela } \\
\text { número } 25 \text { - também me preocupa } \\
\text { muito, no sentido de que eu me } \\
\text { pergunto se eu não deveria levar a } \\
\text { sério e fazer uma pintura tremenda } \\
\text { disso. Meu Deus, como eu adoraria } \\
\text { fazer isso. Mas eu só me pergunto se } \\
\text { eu vou ter o poder necessário de } \\
\text { execução. } \\
\text { Eu estou colocando o esboço de lado } \\
\text { assim como é, mal ousando pensar } \\
\text { nisso. } \\
\text { Por um longo tempo ele foi meu } \\
\text { grande desejo de fazer um semeador, } \\
\text { mas os desejos que tive por um } \\
\text { longo tempo nem sempre são } \\
\text { alcançados. Então, eu estou quase } \\
\text { com medo deles. E, no entanto, } \\
\text { depois de Millet e Lhermitte o que } \\
\text { resta a ser feito é... o semeador, com } \\
\text { cor e em um grande formato. }\end{array}$ & $\begin{array}{l}\text { No excerto, o Inacabamento assim } \\
\text { como a Transparência estão fortemente } \\
\text { evidenciados por escolhas léxico- } \\
\text { gramaticais tais como 'esboço', eu me } \\
\text { pergunto', 'se eu não deveria levar a } \\
\text { sério', 'como eu adoraria fazer isso', } \\
\text { 'eu só me pergunto', 'se eu vou ter o } \\
\text { poder necessário de execução', } \\
\text { 'colocando o esboço de lado', 'assim } \\
\text { como é', 'mal ousando', 'por um longo } \\
\text { tempo', 'nem sempre são alcançados', } \\
\text { 'estou quase com medo deles'. Esses } \\
\text { construtos demonstram uma intensa } \\
\text { negociação de sentidos na qual van } \\
\text { Gogh expressa sua dúvida, seu desejo, } \\
\text { sua impossibilidade, seu medo. Na tela } \\
\text { a manifestação do Inacabamento se dá } \\
\text { por meio de construtos visuais. São } \\
\text { eles: a luminosidade crepuscular, a } \\
\text { representação do semeador contra a } \\
\text { luz do sol e com baixa definição e } \\
\text { baixo acabamento, a ênfase na massa } \\
\text { pictórica por meio de textura, ritmo, } \\
\text { movimento e gesto pictórico em } \\
\text { detrimento de um refinamento no } \\
\text { tratamento do campo arado, por } \\
\text { exemplo, evidenciando o } \\
\text { Inacabamento tanto na tela quanto na } \\
\text { oração. }\end{array}$ \\
\hline $\begin{array}{l}\text { Na tela 'O Semeador', a } \\
\text { atmosfera da luz difusa do } \\
\text { crepúsculo, construída pelos } \\
\text { efeitos dos contrastes } \\
\text { cromáticos, da diminuição } \\
\text { dos detalhes e do tratamento } \\
\text { geral desfocado e com baixa } \\
\text { definição e acabamento é } \\
\text { compatível com o sentido } \\
\text { de sonho expressado nesse } \\
\text { excerto de carta. A luz } \\
\text { difusa expressa } \\
\text { Inacabamento e } \\
\text { Incompletude também } \\
\text { expressa na metáfora dos }\end{array}$ & $\begin{array}{l}\text { Preferia muito mais // fazer quadros } \\
\text { naifs [[tirados de velhos } \\
\text { almanaques, aqueles velhos } \\
\text { "almanaques dos lavradores" [[nos } \\
\text { quais o granizo, a neve, a chuva e o } \\
\text { bom tempo são retratados de modo } \\
\text { primitivo,]]]] como o Anquetin } \\
\text { atingiu tão bem no seu A Colheita. }\end{array}$ & $\begin{array}{l}\text { Ocorrência de Enquadramento, } \\
\text { Perspectiva, Inversão do ponto de } \\
\text { vista, Transparência, Inacabamento, } \\
\text { Incompletude e Limiar artístico com a } \\
\text { mudança na representação do } \\
\text { protagonismo nas orações e nas } \\
\text { escolhas lexicais 'verdade das cores', } \\
\text { 'luta diabólica' e 'atingir a verdade } \\
\text { das cores'. Registradas na nota de } \\
\text { rodapé 94. }\end{array}$ \\
\hline
\end{tabular}




\begin{tabular}{|c|c|c|}
\hline $\begin{array}{l}\text { quadros naifs do excerto } \\
\text { que ele tanto admira. }\end{array}$ & & \\
\hline $\begin{array}{l}\text { A tela 'O Semeador' constrói } \\
\text { algumas associações } \\
\text { metafóricas com a passagem } \\
\text { do tempo. Tanto pelo vetor } \\
\text { do semeador que se desloca } \\
\text { da esquerda para a direita, } \\
\text { sugerindo uma transição do } \\
\text { passado para o futuro, } \\
\text { quanto pela metáfora do } \\
\text { campo arado e do campo } \\
\text { maduro, que também } \\
\text { constroem um sentido de } \\
\text { passado e futuro e de um } \\
\text { ciclo que termina e um que } \\
\text { inicia. }\end{array}$ & $\begin{array}{l}\text { Mas quando eu farei o céu estrelado, } \\
\text { então, essa pintura [[que está sempre } \\
\text { na minha mente? ]] } \\
\text { Ocorrência de Transparência e } \\
\text { Inacabamento pelo uso do item } \\
\text { lexical 'então' que constrói um } \\
\text { sentido de temporalidade que não } \\
\text { está definida, mas que paira em } \\
\text { suspenso pela dúvida e pela } \\
\text { incerteza expressa em sua pergunta. } \\
\text { Registrado na nota de rodapé 108. } \\
\text { Ocorrência de Transparência e } \\
\text { Inacabamento por meio do uso de } \\
\text { um processo relacional para } \\
\text { expressar uma experiência que } \\
\text { poderia ser expressa por um } \\
\text { processo mental, e que está pronta } \\
\text { 'em sua mente', mas precisa ser } \\
\text { materializada enquanto texto } \\
\text { pictórico. Registrada na nota de } \\
\text { rodapé 104. }\end{array}$ & $\begin{array}{l}\text { O caminhar do semeador e o sentido } \\
\text { do campo arado e pronto para receber } \\
\text { o grão constrói um sentido de } \\
\text { inacabamento associado à passagem } \\
\text { do tempo que é compatível com as } \\
\text { escolhas lexicais 'quando' 'então' e } \\
\text { 'sempre' na oração. }\end{array}$ \\
\hline $\begin{array}{l}\text { Ao se referir à tela no excerto } \\
\text { de carta, van Gogh usa a } \\
\text { intertextualidade, da fala de } \\
\text { um personagem de um } \\
\text { romance de Huysmans, para } \\
\text { construir uma metáfora. Ele } \\
\text { compara a sua tela 'O } \\
\text { Semeador' com o desejo de } \\
\text { alguém, que está no plano do } \\
\text { sonho, mas que não pinta. } \\
\text { Dessa forma, quando ele a } \\
\text { pinta, ele a representa em uma } \\
\text { atmosfera de sonho, na luz } \\
\text { difusa do crepúsculo, } \\
\text { construída pelos efeitos dos } \\
\text { contrastes cromáticos, da } \\
\text { diminuição dos detalhes e do } \\
\text { tratamento geral desfocado. } \\
\text { Essa baixa definição } \\
\text { inacabamento são compatíveis } \\
\text { com o sentido de sonho } \\
\text { expressado nesse excerto de } \\
\text { carta. A luz difusa expressa } \\
\text { Inacabamento e Incompletude } \\
\text { também expressada na } \\
\text { Verbiagem do excerto. }\end{array}$ & $\begin{array}{l}\text { Ai, ai, é como nosso excelente } \\
\text { amigo Cyprien diz, em 'En ménage' } \\
\text { por JK Huysmans: as mais belas } \\
\text { pinturas são aquelas [[que alguém } \\
\text { sonha //enquanto fuma um cachimbo } \\
\text { em sua cama,// mas a qual ele não } \\
\text { pinta.]] }\end{array}$ & $\begin{array}{l}\text { Ocorrência de Incompletude, } \\
\text { Inacabamento expressos na } \\
\text { Verbiagem da oração, uma vez que } \\
\text { expressa a diferença entre sonhar e } \\
\text { realizar. Além disso, observei } \\
\text { ocorrências de Enquadramento, } \\
\text { Perspectiva e Inversão de ponto de } \\
\text { vista, que no nível semântico, } \\
\text { expressa a mesma coisa que no nível } \\
\text { léxico-gramatical, na medida em que } \\
\text { ele desliza entre dois domínios tanto } \\
\text { no nível semântico (sonho-pintura } \\
\text { real) quanto no nível léxico-gramatical } \\
\text { (Verbiagem -pintura real). Registradas } \\
\text { na nota de rodapé 111. }\end{array}$ \\
\hline $\begin{array}{l}\text { Na tela 'A Esplanada do } \\
\text { Café na Place du Forum, } \\
\text { Arles, à Noite', observei a } \\
\text { ocorrência de Inacabamento }\end{array}$ & $\begin{array}{l}\text { Fui interrompido precisamente pelo } \\
\text { trabalho que uma nova pintura da } \\
\text { parte externa de um café à noite tem } \\
\text { me dado nos últimos dias. }\end{array}$ & $\begin{array}{l}\text { A representação da árvore pela metade } \\
\text { indica uma interrupção abrupta que } \\
\text { revela uma escolha intencional do } \\
\text { pintor. O sentido de interrupção é } \\
\text { retomado na oração como uma escolha }\end{array}$ \\
\hline
\end{tabular}




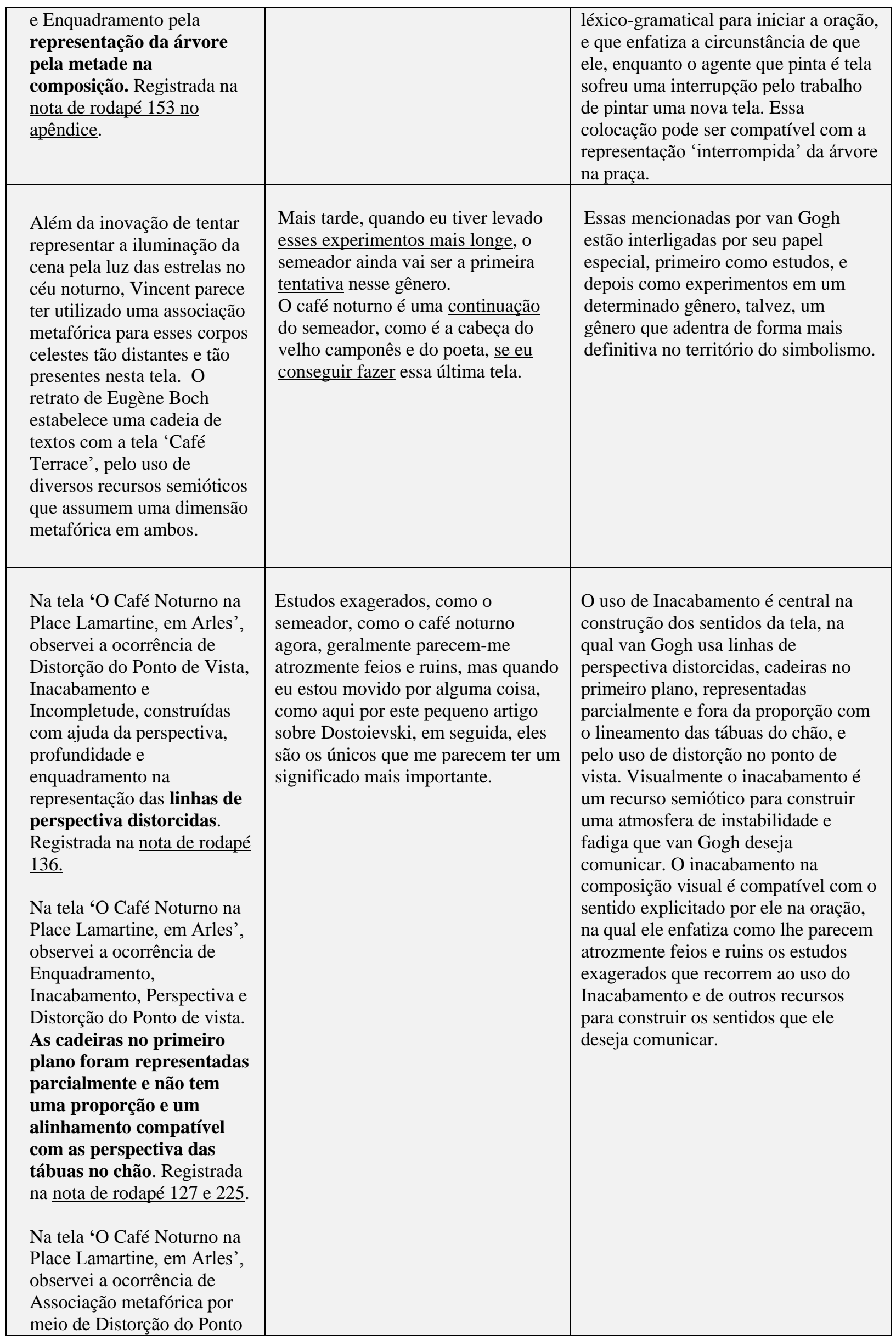




\begin{tabular}{|c|c|c|}
\hline $\begin{array}{l}\text { de Vista e Inacabamento } \\
\text { presentes na representação } \\
\text { da Perspectiva das tábuas } \\
\text { do chão da sala que estão } \\
\text { em desalinho com a } \\
\text { representação da } \\
\text { perspectiva da mesa de } \\
\text { bilhar. Registrada na nota de } \\
\text { rodapé } 120 \text { e } 225 . \\
\\
\text { Na tela 'O Café Noturno na } \\
\text { Place Lamartine, em Arles', } \\
\text { observei a ocorrência de } \\
\text { Transparência, } \\
\text { Incompletude, Modalidade e } \\
\text { Limiar Artístico pelo uso do } \\
\text { Inacabamento, } \\
\text { Enquadramento, Perspectiva, } \\
\text { Distorção do Ponto de Vista, } \\
\text { Direção, Profundidade, } \\
\text { como marca estilística das } \\
\text { linhas que organizam a } \\
\text { perspectiva da sala. } \\
\text { Registrada na nota de rodapé } \\
\text { 250 e } 225 .\end{array}$ & & \\
\hline $\begin{array}{l}\text { Na tela 'O Café Noturno na } \\
\text { Place Lamartine, em Arles', } \\
\text { observei a ocorrência de } \\
\text { Contraste cromático de } \\
\text { Saturação e Inacabamento na } \\
\text { representação da sombra } \\
\text { da mesa de bilhar, } \\
\text { registrada na nota de rodapé } \\
232 . \\
\text { Na tela 'O Café Noturno na } \\
\text { Place Lamartine, em Arles', } \\
\text { observei a ocorrência de } \\
\text { Distorção do Ponto de Vista, } \\
\text { Inacabamento, Associação } \\
\text { metafórica por meio da } \\
\text { distorção da baixa } \\
\text { Modalidade com que o } \\
\text { volume é representado, } \\
\text { devido à ausência de } \\
\text { sombras e a } \\
\text { homogeneização das } \\
\text { superfícies. Registrada nas } \\
\text { notas de rodapé } 221,222, \\
223 .\end{array}$ & $\begin{array}{l}\text { Estudos exagerados, como o } \\
\text { semeador, como o café noturno } \\
\text { agora, geralmente parecem-me } \\
\text { atrozmente feios e ruins, mas quando } \\
\text { eu estou movido por alguma coisa, } \\
\text { como aqui por este pequeno artigo } \\
\text { sobre Dostoievski, em seguida, eles } \\
\text { são os únicos que me parecem ter um } \\
\text { significado mais importante. }\end{array}$ & $\begin{array}{l}\text { No Excerto: 'De qualquer forma, eu } \\
\text { tentei com contrastes de rosa delicado } \\
\text { e vermelho-sangue e vinho tinto. } \\
\text { Verde doce Luís XV e Veronese } \\
\text { contrastando com os verdes amarelos e } \\
\text { os verdes azuis duros. Tudo isso em } \\
\text { uma atmosfera de fornalha infernal, de } \\
\text { enxofre pálido', foi observado o uso de } \\
\text { Inacabamento na organização de uma } \\
\text { oração sem processo. Na mesma } \\
\text { oração foi observado o uso de } \\
\text { Associações Metafóricas pela } \\
\text { associação da cor 'enxofre pálido' com } \\
\text { 'uma atmosfera de fornalha infernal'. } \\
\text { Registrada na nota de rodapé } 272 .\end{array}$ \\
\hline $\begin{array}{l}\text { Na tela 'O Café Noturno na } \\
\text { Place Lamartine, em Arles', } \\
\text { o Inacabamento está } \\
\text { evidenciado na Distorção do } \\
\text { ponto de vista produzida pela } \\
\text { baixa Modalidade na }\end{array}$ & $\begin{array}{l}\text { 'De qualquer forma, eu tentei com } \\
\text { contrastes de rosa delicado e } \\
\text { vermelho-sangue e vinho tinto. } \\
\text { Verde doce Luís XV e Veronese } \\
\text { contrastando com os verdes amarelos } \\
\text { e os verdes azuis duros. Tudo isso } \\
\text { em uma atmosfera de fornalha }\end{array}$ & $\begin{array}{l}\text { Observei o uso de Inacabamento na } \\
\text { organização de uma oração sem } \\
\text { agente. Nela, observei também o uso } \\
\text { de associação metafórica na escolha do } \\
\text { item lexical 'como' que explicita que o } \\
\text { café é uma metáfora para realizar o } \\
\text { sentido 'a potência do poder das trevas }\end{array}$ \\
\hline
\end{tabular}


representação do ambiente do café, usados para construir uma metáfora para os sentidos explicitados no excerto discutido ao lado. De acordo com Kress e van Leeuwen (1996), a ambiguidade é um traço de ocorrência de modalidade, registradas na nota de rodapé 148.

Fonte: Triangulação para Inacabamento dos dados dos corpora visual e textual, com os extratos das cartas. infernal, de enxofre pálido. $\quad$ de uma taberna'.

Exprimir como a potência do poder $\quad$ Registrado na nota de rodapé 275. das trevas de uma taberna.

Contudo sob uma aparência da alegria japonesa e da boa natureza de Tartarin.'

\subsection{INCOMPLETUDE - CONDIÇÃO EXISTENCIAL}

Os impressionistas partiram do pressuposto que não é necessário pintar as imagens com total definição de todos os elementos da cena, pois não é assim que o olho humano captura a totalidade de uma cena. Eles privilegiaram representar a cena com base na imprecisão com que o olho é capaz de capturar ao olhar uma cena e baseados no conhecimento de que a incompletude é suficiente para registrar as impressões, pois o cérebro completa a imagem. Van Gogh explorou as possibilidades semióticas da incompletude, dando para ela um uso original e inovador, que Haziot (2010, p.119) explica:

\footnotetext{
Nessa frase, única em toda a correspondência Vincent apresenta seu objetivo: fazer sonhar, fazer sonhar o olhar, através do inacabamento, da sugestão, do traço livre, em hachuras, descontinuidades, deixando vazios onde o olhar se aprofunda para sonhar. Toda a sua arte está aí, necessariamente incompreensível para os contemporâneos. Raros serão, mesmo entre os pintores modernos do seu tempo, os que verão o alcance revolucionário dessa inovação. Eles apenas a pressentiram, como Pissarro, que tinha o olhar generoso, sem poder colocá-lo em palavras. (HAZIOT, 2010, p.119).
}

A categoria da incompletude se refere a uma condição existencial com a qual van Gogh está lidando e negociando o tempo inteiro. É no momento de dúvida que vemos emergir a incompletude. Na transparência do momento de vulnerabilidade que ele mostra quem ele realmente é: alguém que não se esconde atrás de uma persona, de um ego, cheio de certezas. A incompletude se refere à experiência de um estado de falta, de incerteza, de imperfeição e o inacabamento é uma das formas como esse estado é materializado em seu discurso.

A incompletude refere-se ao reconhecimento da impossibilidade de manifestação da perfeição da natureza por meio da arte. É quando, por exemplo, ele reconhece que não é possível produzir essa completude enquanto o inacabamento é uma tentativa de alcançar a completude, ou seja, é o não reconhecimento da incompletude. É como se ele falasse que a tela é um esboço, um estudo, que é parcial e que poderia ser completo e que esse estudo pode 
se tornar uma tremenda tela, a incompletude é o reconhecimento dessa impossibilidade. Já na incompletude, é quando ele fala que não importa o quão incompetente ele se sinta diante da perfeição da natureza, ele tem que fazer mesmo que ele 'não tenha o poder de execução'. É como se ele falasse: Eu vou fazer, mesmo que incompleto. Depois de produzida a tela mesmo que incompleta, então ele se refere a ela como um estudo, uma tela em processo para chegar à tela ideal.

É como se houvessem duas etapas. Na primeira etapa ele reconhece o inacabamento e busca a completude. O inacabamento é o reconhecimento da incompletude, e se traduz por uma busca, por uma energia que o impulsiona em direção a um ideal, a esse desejo de infinito. É esse inacabamento que impulsiona van Gogh. Antes de existir qualquer tela, ele aceita a incompletude. Depois da tela produzida ele quer superar a incompletude.

Na segunda etapa ele reconhece a incompletude e produz mesmo assim. Ele não se sente competente para produzir a tela na sua completude. A incompetência não entra como

questão. É quando a manifestação do sentido escapa a sua intencionalidade e se manifesta de forma completa na representação da tela, portanto esse acabamento é o acabamento do simbólico, é o acabamento da significação que é possível ser traduzida na tela, mas não está à mercê da intencionalidade do artista. Ela acontece. Nem sempre talvez, nem mesmo ele tem todos os elementos para julgar que ela aconteceu. Essa experiência se dá no limiar criativo e suscita a produção discursiva do artista como forma de apreender essa incompletude. $\mathrm{O}$ acabamento escapa do julgamento inacabado e incompleto do artista. A tela está acima do artista e para além da sua compreensão, portanto o acabamento é possível apesar da incompletude do artista e é possível que se manifeste onde menos se espera. Vemos a ocorrência da incompletude no discurso textual, por exemplo, quando van Gogh fala do artigo de Dostoievski 'se não é essa a tela mais feia' que traz o sentido mais completo.

\subsubsection{Triangulação da Incompletude}

Incompletude, no texto escrito e em relação à triangulação - Em algumas cartas, van Gogh fala para Theo sobre o que o motiva a pintar o céu estrelado: é o seu desejo de infinito. $\mathrm{O}$ que podemos entender ser esse desejo de infinito que o motiva? $\mathrm{O}$ desejo do infinito é um esforço dele de simbolizar um conflito interno de precisar dessa completude para não vivenciar os conflitos que são intensos. Ele fica no processo de idealização de uma completude que revela mais incompletude do que outra coisa. 
Quadro 34: Triangulação da Incompletude

\begin{tabular}{|c|c|c|}
\hline Ocorrência nas telas & Orações & Comentário \\
\hline $\begin{array}{l}\text { Na tela 'Por de Sol: Campo } \\
\text { de trigo perto de Arles', o } \\
\text { ponto de vista de onde van } \\
\text { Gogh pinta parece estar } \\
\text { acima do chão, como se } \\
\text { olhasse de um nível de quem } \\
\text { está alçado no ar e vê } \\
\text { ligeiramente do alto a cena. } \\
\text { Ele consegue isso com o } \\
\text { enquadramento plongee e } \\
\text { tem a função de conferir uma } \\
\text { sensação de infinidade. } \\
\text { Registrada nas notas de } \\
\text { rodapé } 51,101 \text { e } 102 \text { no } \\
\text { apêndice. }\end{array}$ & $\begin{array}{l}\text { Inferi que o uso do ângulo } \\
\text { vertical plongee tem a função de } \\
\text { criar um distanciamento do } \\
\text { espectador. } \\
\text { Na nota de rodapé } 50 \text { no } \\
\text { apêndice, observei que há um } \\
\text { deslocamento na construção do } \\
\text { ponto de vista da oração, que } \\
\text { causa um distanciamento do } \\
\text { ponto de vista do leitor, pode ser } \\
\text { compatível com o uso do ângulo } \\
\text { plongee no texto visual, também } \\
\text { usado com a função de causar } \\
\text { um distanciamento no } \\
\text { espectador. Aqui há um tipo de } \\
\text { compatibilidade de função, não } \\
\text { de forma ou de sentido. } \\
\text { Outro exemplo de deslocamento } \\
\text { da perspectiva está no excerto: } \\
\text { "Tela quadrada número } 30 \text {. Eu } \\
\text { pintei-a ao ar livre no Mistral. } \\
\text { Meu cavalete foi fixado no chão } \\
\text { com estacas de ferro, um método } \\
\text { que eu recomendo a você. Voce } \\
\text { enterra os pés do cavalete e, em } \\
\text { seguida, voce empurra a } 50 \\
\text { centímetros de comprimento um } \\
\text { peso de ferro ao lado deles. Voce } \\
\text { amarra tudo com cordas; dessa } \\
\text { forma, voce pode trabalhar com } \\
\text { o vento.", observei a ocorrência } \\
\text { de uma mudança de } \\
\text { Enquadramento na escolha da } \\
\text { agência e dos processos das } \\
\text { orações que se sucedem nesse } \\
\text { excerto. Registrado na nota de } \\
\text { rodapé } 115 \text { no apêndice. }\end{array}$ & $\begin{array}{l}\text { Para Muhlberger (2002, p. 22), o uso do } \\
\text { plongee é em van Gogh a tentativa de } \\
\text { estender o alcance da vista e dar ao } \\
\text { espectador uma sensação de infinidade } \\
\text { para o campo de trigo. Esta semiose é } \\
\text { compatível com a sua busca de } \\
\text { representar o sentimento de } \\
\text { incompletude também presente em } \\
\text { semioses como o movimento do vento } \\
\text { no campo, a luz das estrelas, a coloração } \\
\text { da noite. }\end{array}$ \\
\hline $\begin{array}{l}\text { Na tela 'Por de Sol: Campo } \\
\text { de trigo perto de Arles', a } \\
\text { ocorrência de Incompletude } \\
\text { e Rima visual que, por meio } \\
\text { do uso da cor para } \\
\text { representar a luz do sol } \\
\text { sobre a cidade e o campo, } \\
\text { constroem uma associaçãoo } \\
\text { metafórica da luz divina que } \\
\text { tudo interliga. O significado } \\
\text { da luz do sol que a tudo } \\
\text { envolve, pode ser associado } \\
\text { às conotações como força, } \\
\text { vida, espírito e as dimensões } \\
\text { intangíveis da existência, } \\
\text { mais difíceis de explicitar na } \\
\text { narrativa visual, senão com a } \\
\text { ajuda de metáforas visuais. }\end{array}$ & $\begin{array}{l}\text { Eu também sou totalmente incapaz } \\
\text { de julgar o meu próprio trabalho. } \\
\text { Eu não posso ver se os estudos são } \\
\text { bons ou ruins. Tenho sete estudos } \\
\text { de trigais, infelizmente todos eles } \\
\text { nada além de paisagens, muito } \\
\text { contra a minha vontade. Paisagens } \\
\text { amarelo ouro velho - feito rápido } \\
\text { rápido rápido e com pressa, como } \\
\text { o ceifeiro que está em silêncio sob } \\
\text { o sol escaldante, concentrando-se } \\
\text { em ter o trabalho terminado. } \\
\text { Preferia muito mais fazer quadros } \\
\text { naifs tirados de velhos } \\
\text { almanaques, aqueles velhos } \\
\text { "almanaques dos lavradores" nos } \\
\text { quais o granizo, a neve, a chuva e }\end{array}$ & $\begin{array}{l}\text { Na oração: 'Eu também sou totalmente } \\
\text { incapaz de julgar o meu próprio } \\
\text { trabalho. Eu não posso ver se os estudos } \\
\text { são bons ou ruins.' observei a } \\
\text { ocorrência de Transparência, } \\
\text { Incompletude e de Limiar Artístico - } \\
\text { observei a ocorrência da categoria limiar } \\
\text { artístico no complexo oracional, no } \\
\text { nível semântico. Registrada na nota de } \\
\text { rodapé } 119 \text { no apêndice. }\end{array}$ \\
\hline
\end{tabular}




\begin{tabular}{|c|c|c|}
\hline $\begin{array}{l}\text { Registrada nas notas de } \\
\text { rodapé } 94 \text { e } 95 \text { no apêndice. }\end{array}$ & $\begin{array}{l}\text { o bom tempo são retratados de } \\
\text { modo primitivo, como o Anquetin } \\
\text { atingiu tão bem no seu A Colheita. } \\
\text { Não te vou ocultar que não } \\
\text { desgosto da região, pois fui criado } \\
\text { lá - ainda me encanta a magia das } \\
\text { recordações do passado, de um } \\
\text { desejo do infinito, do qual o } \\
\text { semeador e o enfeixador são } \\
\text { símbolos -, tanto quanto antes } \\
\text { gostava. }\end{array}$ & \\
\hline $\begin{array}{l}\text { Na tela 'Por de Sol: Campo } \\
\text { de trigo perto de Arles', } \\
\text { observei a ocorrência de } \\
\text { associação metafórica do } \\
\text { tom da fumaça das fábricas } \\
\text { em contraposição com o tom } \\
\text { da luminosidade do céu para } \\
\text { conotar um conflito entre o } \\
\text { progresso econômico e a } \\
\text { natureza. Registrada na nota } \\
\text { de rodapé } 56 \text { no apêndice. }\end{array}$ & $\begin{array}{l}\text { Eu tenho um terceiro estudo, } \\
\text { agora, de uma paisagem com } \\
\text { fábrica, e um enorme sol em um } \\
\text { céu vermelho, acima de telhados } \\
\text { vermelhos, em que a natureza } \\
\text { parece estar em um acesso de } \\
\text { raiva, em um dia de Mistral } \\
\text { desagradável. } \\
\text { Obsevei aqui uma interação da } \\
\text { ocorrência da Associação } \\
\text { metafórica com a Transparência, a } \\
\text { Incompletude e o Limiar Artístico. }\end{array}$ & $\begin{array}{l}\text { Van Gogh intui que existe nesse } \\
\text { movimento de pincelada sobre a tela } \\
\text { uma energia transformadora e criadora, } \\
\text { mas que também tem uma nuance } \\
\text { descontrolada que carrega uma emoção } \\
\text { semelhante à da raiva. Ele compara esse } \\
\text { movimento que representa o vento na } \\
\text { tela ao movimento da natureza na qual o } \\
\text { vento age sobre o trigo de maneira } \\
\text { desordenada, incontrolável e incisiva. O } \\
\text { ímpeto do artista no momento de } \\
\text { representação do vento da tela o } \\
\text { aproxima da natureza e o aproxima de } \\
\text { sua natureza e da natureza daquilo que } \\
\text { faz a tela ser o que ela é. A } \\
\text { representação de um limiar entre aquilo } \\
\text { que o artista vê e aquilo que ele não vê } \\
\text { quando ele representa o que ele vê. }\end{array}$ \\
\hline $\begin{array}{l}\text { A ocorrência de Incompletude } \\
\text { na tela está evidenciada pela } \\
\text { superposição de diferentes } \\
\text { amarelos para produzir, com a } \\
\text { intensidade cromática, um } \\
\text { efeito de sentido que é ao } \\
\text { mesmo tempo simbólico e } \\
\text { sinestésico. A intensidade } \\
\text { cromática materializada na tela } \\
\text { tão está materializada no } \\
\text { excerto pela descrição dos } \\
\text { amarelos e pela escolha lexical } \\
\text { 'Tão amarelo!'. }\end{array}$ & $\begin{array}{l}\text { O céu, amarelo-crômio, quase tão } \\
\text { luminoso quanto o próprio Sol,// } \\
\text { que é amarelo-crômio no } 1, / / \text { (está) } \\
\text { misturado com um pouco de } \\
\text { branco, /enquanto o resto do céu é } \\
\text { uma mistura dos amarelos-crômios } \\
1 \text { e } 2 \text {. Tão amarelo! } \\
\text { Ocorrência de Enquadramento, } \\
\text { Perspectiva, Transparência e } \\
\text { Incompletude na escolha léxico- } \\
\text { gramatical que organiza a oração } \\
\text { de modo a deslocar a agência da } \\
\text { ação de si para a natureza que está } \\
\text { sendo representada, como um ente } \\
\text { em seu próprio direito. Registrada } \\
\text { na nota de rodapé } 86 .\end{array}$ & $\begin{array}{l}\text { O fato de ele não usar o processo } \\
\text { material evidencia o seu modo peculiar } \\
\text { de se representar como artista, que é o de } \\
\text { viver o seu trabalho como o do ceifador } \\
\text { que lida diretamente com a natureza das } \\
\text { coisas. Ele está falando da natureza } \\
\text { desse céu, muito embora esse céu não } \\
\text { existisse antes dele criar, é dessa } \\
\text { maneira que ele se relaciona com as } \\
\text { coisas, na inteireza de como as coisas se } \\
\text { apresentam para ele. Ele experiencia a } \\
\text { sua produção como ela sendo a coisa e } \\
\text { não a representação da coisa por isso ele } \\
\underline{\text { se coloca como um relator, um }} \\
\text { observador, ao invés de se colocar como } \\
\text { um autor. }\end{array}$ \\
\hline $\begin{array}{l}\text { Na tela 'O Semeador' } \\
\text { observei a ocorrência de } \\
\text { Incompletude pela atmosfera } \\
\text { de luz difusa do crepúsculo. } \\
\text { Ela é construída pelos efeitos } \\
\text { dos contrastes cromáticos, da } \\
\text { diminuição dos detalhes e do } \\
\text { tratamento geral desfocado e } \\
\text { com baixa definição e } \\
\text { acabamento é compatível } \\
\text { com o desejo de infinito } \\
\text { expressado nesse excerto de }\end{array}$ & $\begin{array}{l}\text { Não te vou ocultar //que não } \\
\text { desgosto da região,// pois fui } \\
\text { criado lá // - ainda me encanta a } \\
\text { magia das recordações do passado, } \\
\text { de um desejo do infinito,// do qual } \\
\text { o semeador e o enfeixador são } \\
\text { símbolos / -, tanto quanto antes } \\
\text { gostava.// } \\
\text { Há várias sugestões de amarelo no } \\
\text { solo, tons neutros resultantes da } \\
\text { mistura de violeta e amarelo; mas }\end{array}$ & $\begin{array}{l}\text { Ocorrência de Intertextualidade e } \\
\text { Interdiscursividade, Associação } \\
\text { metafórica, Transparência, } \\
\text { Incompletude e Modalidade ao } \\
\text { relacionar a obra de Anquetin e a } \\
\text { estética Naif com sua própria } \\
\text { experiência para representar 'a verdade } \\
\text { das cores. Ocorrência de Associação } \\
\text { Metafórica pela comparação que ele usa } \\
\text { como metáfora para explicar qual é a } \\
\text { ordem de sua experiência interna na } \\
\text { escolha da combinação de cores. } \\
\text { Registrada na nota de rodapé } 93 \text {. }\end{array}$ \\
\hline
\end{tabular}




\begin{tabular}{|c|c|c|}
\hline $\begin{array}{l}\text { carta, no qual ele compara A } \\
\text { luz difusa expressa } \\
\text { Inacabamento e } \\
\text { Incompletude também } \\
\text { expressa na Verbiagem do } \\
\text { excerto. }\end{array}$ & $\begin{array}{l}\text { tenho travado uma luta diabólica } \\
\text { para atingir a verdade das cores. } \\
\text { Preferia muito mais fazer quadros } \\
\text { naifs tirados de velhos } \\
\text { almanaques, aqueles velhos } \\
\text { "almanaques dos lavradores" nos } \\
\text { quais o granizo, a neve, a chuva e } \\
\text { o bom tempo são retratados de } \\
\text { modo primitivo, como o Anquetin } \\
\text { atingiu tão bem no seu } A \text { Colheita. }\end{array}$ & \\
\hline $\begin{array}{l}\text { No excerto de carta, van } \\
\text { Gogh explicita que o } \\
\text { semeador e o enfeixador são } \\
\text { símbolos de seu desejo de } \\
\text { infinito. Este é um } \\
\text { importante indexador para os } \\
\text { sentidos construídos na tela } \\
\text { 'O Semeador.' } \\
\text { Ele também explicita, no } \\
\text { excerto, o uso de } \\
\text { intertextualidade, ao } \\
\text { comparar sua 'luta diabólica } \\
\text { para atingir a verdade das } \\
\text { cores' com o estilo naif dos } \\
\text { 'velhos almanaques dos } \\
\text { lavradores nos quais o } \\
\text { granizo, a neve, a chuva e o } \\
\text { bom tempo são retratados de } \\
\text { modo primitivo, com } \\
\text { Anquetin atingiu tão bem no } \\
\text { seu A Colheita.' Observei } \\
\text { que van Gogh usou a } \\
\text { intertextualidade como uma } \\
\text { metáfora para explicitar o } \\
\text { caminho que ele percorre } \\
\text { para atingir a verdade das } \\
\text { cores. Este não é o caminho } \\
\text { da representação naif, mas } \\
\text { que revela 'tons neutros } \\
\text { resultantes da mistura de } \\
\text { violeta e amarelo' que nada } \\
\text { têm de naif. }\end{array}$ & $\begin{array}{l}\text { Há várias sugestões de amarelo no } \\
\text { solo, tons neutros resultantes da } \\
\text { mistura de violeta e amarelo; mas } \\
\text { tenho travado uma luta diabólica } \\
\text { para atingir a verdade das cores. }\end{array}$ & $\begin{array}{l}\text { Ocorrência de Enquadramento, } \\
\text { Perspectiva, Inversão do ponto de vista, } \\
\text { Transparência, Inacabamento, } \\
\text { Incompletude e Limiar artístico com a } \\
\text { mudança na representação do } \\
\text { protagonismo nas orações e nas escolhas } \\
\text { lexicais 'verdade das cores', 'luta } \\
\text { diabólica' e 'atingir a verdade das } \\
\underline{\text { cores' . Registradas na nota de rodapé }} \\
\underline{94 .} \\
\text { Ocorrência de Transparência, } \\
\text { Incompletude, Limiar Artístico, } \\
\text { Interdiscursividade e Associação } \\
\text { Metafórica, no nível semântico da } \\
\text { oração Beta, ao explicitar a natureza da } \\
\text { sua motivação na produção artística e ao } \\
\text { usar a contraposição criada pela } \\
\text { comparação entre Naif e 'a verdade das } \\
\text { cores' como metáfora para explicar ao } \\
\text { irmão o seu desejo de infinito, } \\
\text { registrados na nota de rodapé } 97 .\end{array}$ \\
\hline $\begin{array}{l}\text { A tela 'O Semeador' constrói } \\
\text { algumas associações } \\
\text { metafóricas com a passagem } \\
\text { do tempo que expressam } \\
\text { Incompletude. Tanto pelo } \\
\text { vetor do semeador que se } \\
\text { desloca da esquerda para a } \\
\text { direita, sugerindo uma } \\
\text { transição do passado para o } \\
\text { futuro, quanto pela metáfora } \\
\text { do campo arado e do campo } \\
\text { maduro, que também } \\
\text { constroem um sentido de } \\
\text { passado e futuro e de um } \\
\text { ciclo que termina e um que } \\
\text { inicia. }\end{array}$ & $\begin{array}{l}\text { Mas quando eu farei o céu } \\
\text { estrelado, então, essa pintura que } \\
\text { está sempre na minha mente? } \\
\text { Na oração: 'Mas quando eu } \\
\text { farei o céu estrelado, então, } \\
\text { essa pintura que está sempre na } \\
\text { minha mente?' observei a } \\
\text { ocorrência de Limiar Artístico e } \\
\text { Incompletude por meio do uso } \\
\text { da ênfase na Meta (ideia da tela) } \\
\text { mesmo sendo ele o participante } \\
\text { principal na oração alfa. } \\
\text { Registrado na nota de rodapé } \\
\underline{103 .}\end{array}$ & $\begin{array}{l}\text { Ocorrência de Inacabamento e } \\
\text { Incompletude pelo uso dos itens lexicais } \\
\text { 'quando' e 'sempre' em contraposição e } \\
\text { que constroem uma camada de sentido. } \\
\text { Registrados na nota de rodapé } 102 . \\
\text { Ocorrencia de Limiar artístico e } \\
\text { Incompletude presente na organização } \\
\text { da oração que constrói dois planos que } \\
\text { representação: o esboço em potencial } \\
\text { em sua mente e a materialização dele } \\
\text { quando puder pintá-lo. Registrado na } \\
\text { nota de rodapé } 107 .\end{array}$ \\
\hline
\end{tabular}




\begin{tabular}{|c|c|c|}
\hline $\begin{array}{l}\text { A atmosfera da luz difusa do } \\
\text { crepúsculo, construída pelos } \\
\text { efeitos dos contrastes } \\
\text { cromáticos, da diminuição dos } \\
\text { detalhes e do tratamento geral } \\
\text { desfocado e com baixa } \\
\text { definição e acabamento é } \\
\text { compatível com o sentido de } \\
\text { sonho expressado nesse } \\
\text { excerto de carta. A luz difusa } \\
\text { expressa Inacabamento e } \\
\text { Incompletude também } \\
\text { expressa na Verbiagem do } \\
\text { excerto. } \\
\text { Ao se referir à tela no excerto } \\
\text { de carta, van Gogh usa a } \\
\text { intertextualidade, da fala de } \\
\text { um personagem de um } \\
\text { romance de Huysmans, para } \\
\text { construir uma metáfora. Ele } \\
\text { compara a sua tela 'O } \\
\text { Semeador' com o desejo de } \\
\text { alguém, que está no plano do } \\
\text { sonho, mas que não pinta. } \\
\text { Dessa forma, quando ele a } \\
\text { pinta, ele a representa em uma } \\
\text { atmosfera de sonho, na luz } \\
\text { difusa do crepúsculo, } \\
\text { construída pelos efeitos dos } \\
\text { contrastes cromáticos, da } \\
\text { diminuição dos detalhes e do } \\
\text { tratamento geral desfocado. } \\
\text { Essa baixa definição } \\
\text { inacabamento são compatíveis } \\
\text { com o sentido de sonho } \\
\text { expressado nesse excerto de } \\
\text { carta. A luz difusa expressa } \\
\text { Inacabamento e Incompletude } \\
\text { também expressada na } \\
\text { Verbiagem do excerto. } \\
\text { Vemala }\end{array}$ & $\begin{array}{l}\text { Ai, ai, é como nosso excelente } \\
\text { amigo Cyprien diz, em 'En } \\
\text { ménage' por JK Huysmans: as } \\
\text { mais belas pinturas são aquelas } \\
\text { [[que alguém sonha //enquanto } \\
\text { fuma um cachimbo em sua } \\
\text { cama,// mas a qual ele não pinta.]] }\end{array}$ & $\begin{array}{l}\text { Ocorrência de Incompletude, } \\
\text { Inacabamento expressos na Verbiagem } \\
\text { da oração, uma vez que expressa a } \\
\text { diferença entre sonhar e realizar. Além } \\
\text { disso, observei ocorrências de } \\
\text { Enquadramento, Perspectiva e Inversão } \\
\text { de ponto de vista, que no nível } \\
\text { semântico, expressa a mesma coisa que } \\
\text { no nível léxico-gramatical na medida } \\
\text { em que ele desliza entre dois domínios } \\
\text { tanto no nível semântico (sonho-pintura } \\
\text { real) quanto no nível léxico-gramatical } \\
\text { (Verbiagem-pintura real). Registradas } \\
\text { na nota de rodapé } 111 \text { e 112. }\end{array}$ \\
\hline $\begin{array}{l}\text { Na tela 'O semeador } \\
\text { observei a ocorrência de } \\
\text { associação metafórica com o } \\
\text { construto da figura do } \\
\text { semeador para responder ao } \\
\text { seu sentimento de } \\
\text { incompetência para } \\
\text { representar sua experiência } \\
\text { com a Natureza, esse } \\
\text { sentimento de incompetência } \\
\text { é compatível com a } \\
\text { ocorrência de Incompletude. } \\
\text { Em outra oração van Gogh } \\
\text { expressa sua incompetência } \\
\text { para representar 'as } \\
\text { perfeições inefáveis do } \\
\text { glorioso esplendor da } \\
\text { natureza', que indica a }\end{array}$ & $\begin{array}{l}\text { Mas é uma questão [[de atacá- } \\
\text { las]], // no entanto, não importa o } \\
\text { quão incompetente // alguém pode } \\
\text { sentir-se vis-à-vis as perfeições } \\
\text { inefáveis do glorioso esplendor da } \\
\text { natureza. }\end{array}$ & $\begin{array}{l}\text { Ocorrência de Transparência e } \\
\text { Incompletude pela escolha 'não importa } \\
\text { o quão', que expressa que a tarefa de } \\
\text { pintar é maior do que o sentimento de } \\
\text { incompetência, incompletude ou } \\
\text { angústia diante das 'perfeições da } \\
\text { natureza'. Registrado na nota de rodapé } \\
\underline{113} \text {. } \\
\text { Ocorrência de Incompletude na análise } \\
\text { de discurso do encadeamento de duas } \\
\text { orações e seu sentido semântico } \\
\text { implícito. Registrado na nota de rodapé } \\
\underline{114 .}\end{array}$ \\
\hline
\end{tabular}




\begin{tabular}{|c|c|c|}
\hline $\begin{array}{l}\text { experiência da } \\
\text { Incompletude. A tela é uma } \\
\text { resposta para essa } \\
\text { Incompletude. Ela é em si } \\
\text { uma metáfora do seu desejo } \\
\text { de união com 'as perfeições } \\
\text { inefáveis do glorioso } \\
\text { esplendor da natureza': 'O } \\
\text { Semeador', essa metáfora } \\
\text { está explicitada no excerto: } \\
\text { '-ainda me encanta a magia } \\
\text { das recordações do passado, } \\
\text { de um desejo do infinito, do } \\
\text { qual o semeador e o } \\
\text { enfeixador são símbolos-'. } \\
\text { Observei nessa metáfora que, } \\
\text { por meio do semeador, van } \\
\text { Gogh experiência sua busca } \\
\text { de união com a Natureza. }\end{array}$ & & \\
\hline $\begin{array}{l}\text { Com a metáfora do sol que } \\
\text { se põe para o campo, van } \\
\text { Gogh está falando de uma } \\
\text { era que finda, e de uma } \\
\text { perda que o homem do } \\
\text { campo vivencia. Ele } \\
\text { expressa com transparência a } \\
\text { nostalgia dessa perda, } \\
\text { registrada na nota de rodapé } \\
87 \text { no apêndice. } \\
\text { Com a metáfora do sol que } \\
\text { se põe para o campo, van } \\
\text { Gogh está falando de uma } \\
\text { era que finda, e de uma } \\
\text { perda que o homem do } \\
\text { campo vivencia. Ele } \\
\text { expressa com transparência a } \\
\text { nostalgia dessa perda, } \\
\text { registrada na nota de rodapé } \\
87 \text { no apêndice. }\end{array}$ & $\begin{array}{l}\text { Não te vou ocultar que não } \\
\text { desgosto da região, pois fui criado } \\
\text { lá - ainda me encanta a magia das } \\
\underline{\text { recordações do passado, de um }} \\
\frac{\text { desejo do infinito, do qual o }}{\text { semeador e o enfeixador são }} \\
\underline{\underline{\text { símbolos }-, \text { tanto quanto antes }}} \\
\text { gostava. } \\
\text { Obsevei aqui uma interação da } \\
\text { ocorrência da Associação } \\
\text { metafórica com a Transparência, a } \\
\text { Incompletude e o Limiar Artístico } \\
\underline{\text { registrada na nota de rodapé } 100 .} .\end{array}$ & $\begin{array}{l}\text { Talvez este sentido reforce o tom de } \\
\text { nostalgia da cena, na qual van Gogh } \\
\text { representa um campo de trigo de um } \\
\text { passado mítico. Aquele homem sentiu a } \\
\text { perda, nós só sabemos sentir uma falta } \\
\text { de algo que se perdeu: um sentido, um } \\
\text { sentimento, um modo de viver, de ver, } \\
\text { de sentir, de ser no mundo. Nós só } \\
\text { sentimos a falta de alguma coisa que } \\
\text { não sabemos mais sentir, porque já não } \\
\text { sentimos a perda, nem o que foi perdido. } \\
\text { Sentimos apenas a falta da perda, a falta } \\
\text { do que não está mais, registrada na nota } \\
\text { de rodapé } 87 \text { no apêndice. }\end{array}$ \\
\hline \multirow[t]{2}{*}{$\begin{array}{l}\text { Na tela 'O Semeador', } \\
\text { observei a ocorrência de } \\
\text { Associação Metafórica e } \\
\text { Incompletude, construídos } \\
\text { pela luz difusa do ocaso. A } \\
\text { luz constrói um sentido de } \\
\text { ambiência e que envolve } \\
\text { toda a cena e constrói } \\
\text { significados simbólicos. } \\
\text { Registrada na nota de } \\
\text { rodapé } 59 .\end{array}$} & $\begin{array}{l}\text { Em um campo arado, um grande } \\
\text { campo de torrões de terra roxa - } \\
\text { levantados em direção ao } \\
\text { horizonte - um semeador em azul } \\
\text { e branco. No horizonte um campo } \\
\text { de trigo curto, maduro. } \\
\text { Acima de tudo isso um céu } \\
\text { amarelo com um sol amarelo. } \\
\text { Você pode sentir a partir da mera } \\
\text { nomenclatura das tonalidades - } \\
\text { que a cor desempenha um papel } \\
\text { muito importante nesta } \\
\text { composição. }\end{array}$ & $\begin{array}{l}\text { Toda a luz que irradia do céu envolve o } \\
\text { semeador e o campo arado, dando ênfase } \\
\text { para a ambiência da luz e das cores do } \\
\text { dia que começa ou que termina. Para } \\
\text { isso, van Gogh diminuiu o detalhe da } \\
\text { representação e favoreceu os efeitos } \\
\text { gerais produzidos pelos contrastes de cor } \\
\text { simultâneos que empresta um estado de } \\
\text { espírito intenso que infundiam o } \\
\text { Portador significados simbólicos, como } \\
\text { registrados na nota de rodapé } 141 \text {. }\end{array}$ \\
\hline & $\begin{array}{l}\text { 'Eu também sou totalmente } \\
\text { incapaz de julgar o meu próprio } \\
\text { trabalho. Eu não posso ver se os } \\
\text { estudos são bons ou ruins. }\end{array}$ & $\begin{array}{l}\text { O acabamento escapa do julgamento } \\
\text { incompleto do artista. A tela está acima } \\
\text { do artista e para além da sua } \\
\text { compreensão. }\end{array}$ \\
\hline
\end{tabular}




\begin{tabular}{|c|c|c|}
\hline $\begin{array}{l}\text { Na tela 'O Semeador', } \\
\text { observei a ocorrência de } \\
\text { Associação Metafórica e } \\
\text { Incompletude, construídos } \\
\text { pela luz difusa do ocaso. A } \\
\text { luz constrói um sentido de } \\
\text { ambiência e que envolve } \\
\text { toda a cena e constrói } \\
\text { significados simbólicos. } \\
\text { Registrada na nota de rodapé } \\
\text { 59. }\end{array}$ & $\begin{array}{l}\text { Em um campo arado, um grande } \\
\text { campo de torrões de terra roxa - } \\
\text { levantados em direção ao } \\
\text { horizonte - um semeador em azul } \\
\text { e branco. No horizonte um campo } \\
\text { de trigo curto, maduro. } \\
\text { Acima de tudo isso um céu } \\
\text { amarelo com um sol amarelo. } \\
\text { Você pode sentir a partir da mera } \\
\text { nomenclatura das tonalidades - } \\
\text { que a cor desempenha um papel } \\
\text { muito importante nesta } \\
\text { composição. }\end{array}$ & $\begin{array}{l}\text { Toda a luz que irradia do céu envolve o } \\
\text { semeador e o campo arado, dando ênfase } \\
\text { para a ambiência da luz e das cores do } \\
\text { dia que começa ou que termina. Para } \\
\text { isso, van Gogh diminuiu o detalhe da } \\
\text { representação e favoreceu os efeitos } \\
\text { gerais produzidos pelos contrastes de cor } \\
\text { simultâneos que empresta um estado de } \\
\text { espírito intenso que infundiam o } \\
\text { Portador significados simbólicos, como } \\
\text { registrados na nota de rodapé } 141 \text {. }\end{array}$ \\
\hline $\begin{array}{l}\text { Na tela 'O Semeador', } \\
\text { observei a ocorrência de } \\
\text { Associação Metafórica e de } \\
\text { Incompletude na contradiçãoo } \\
\text { entre distanciamento do } \\
\text { enquadramento e os outros } \\
\text { recursos que convidam à } \\
\text { aproximação e } \\
\text { envolvimento. Registrada na } \\
\text { nota de rodapé } 44 .\end{array}$ & $\begin{array}{l}\text { 'Tenho sete estudos de trigais, } \\
\text { infelizmente todos eles nada além } \\
\text { de paisagens, muito contra a minha } \\
\text { vontade.' } \\
\text { Aqui está um esboço de um } \\
\text { semeador, um grande campo } \\
\text { lavrado com torrões de terra, na } \\
\text { sua maioria fracamente cor de } \\
\text { violeta. }\end{array}$ & $\begin{array}{l}\text { Não são em todas as telas que van } \\
\text { Gogh avança no sentido de se } \\
\text { aproximar da ideia que ele persegue } \\
\text { através da pintura, mas ele intui que } \\
\text { essa possibilidade compreende alguns } \\
\text { elementos pictóricos, embora ele } \\
\text { considere que esses elementos em si } \\
\text { não completam a ideia. Embora nos } \\
\text { estudos haja paisagem, a terra, o } \\
\text { semeador, há algo que está faltando, } \\
\text { que tornaria essas telas completas. Isso } \\
\text { dá uma ideia do quanto o processo de } \\
\text { criação artística de van Gogh era } \\
\text { penoso para ele, e a constância de lidar } \\
\text { com a incompletude possibilitou a } \\
\text { reprodução dessa experiência que } \\
\text { persegue todos nós na tela e que } \\
\text { identifiquei porque a incompletude } \\
\text { está lá. Ele se preocupava tanto com } \\
\text { ela que ela estava lá presente na tela. }\end{array}$ \\
\hline $\begin{array}{l}\text { Na tela 'O Semeador', } \\
\text { observei a ocorrência de } \\
\text { Associação Metafórica e } \\
\text { Incompletude construída } \\
\text { pela Rima Visual e pelo } \\
\text { Gesto pictórico para } \\
\text { representar a unidade entre } \\
\text { o Homem e a Natureza. } \\
\text { Registrados na nota de } \\
\text { rodapé } 78 .\end{array}$ & $\begin{array}{l}\text { E o esboço como tal - uma tela } \\
\text { número } 25 \text { - também me preocupa } \\
\text { muito, no sentido de que eu me } \\
\text { pergunto se eu não deveria levar a } \\
\text { sério e fazer uma pintura } \\
\text { tremenda disso. Meu Deus, como } \\
\text { eu adoraria fazer isso. Mas eu só } \\
\text { me pergunto se eu vou ter o poder } \\
\text { necessário de execução. } \\
\text { Eu estou colocando o esboço de } \\
\text { lado assim como é, mal ousando } \\
\text { pensar nisso. } \\
\text { Por um longo tempo ele foi meu } \\
\text { grande desejo de fazer um } \\
\text { semeador, mas os desejos que tive } \\
\text { por um longo tempo nem sempre } \\
\text { são alcançados. Então, eu estou } \\
\text { quase com medo deles. E, no } \\
\text { entanto, depois de Millet e } \\
\text { Lhermitte o que resta a ser feito } \\
\text { é... o semeador, com cor e em um } \\
\text { grande formato. } \\
\text { (...) } \\
\text { Mas é uma questão de atacá-las, no } \\
\text { entanto, não importa o quão }\end{array}$ & $\begin{array}{l}\text { A incompletude refere-se ao } \\
\text { reconhecimento da impossibilidade de } \\
\text { manifestação da perfeição da natureza } \\
\text { por meio da arte. É quando ele fala } \\
\text { que não importa o quão incompetente } \\
\text { ele se sinta diante da perfeição da } \\
\text { natureza, ele tem que fazer mesmo que } \\
\text { ele 'não tenha o poder de execução'. É } \\
\text { como se ele falasse: Eu vou fazer, } \\
\text { mesmo que incompleto. Depois de } \\
\text { produzida a tela mesmo que } \\
\text { incompleta, então ele se refere a ela } \\
\text { como uma tela em processo para } \\
\text { chegar à tela ideal. }\end{array}$ \\
\hline
\end{tabular}




\begin{tabular}{|c|c|c|}
\hline & $\begin{array}{l}\text { incompetente um pode sentir-se } \\
\text { vis-à-vis as perfeições inefáveis do } \\
\text { glorioso esplendor da natureza. }\end{array}$ & \\
\hline $\begin{array}{l}\text { Observar na tela } O \\
\text { Semeador, a ocorrência de } \\
\text { um processo sugestivo } \\
\text { simbólico, no qual a } \\
\text { atmosfera de luz difusa do } \\
\text { ocaso constrói um sentido } \\
\text { imanente para o Semeador, } \\
\text { com atributos e identidade } \\
\text { que são inerentes a ele. }\end{array}$ & $\begin{array}{l}\text { Há várias sugestões de amarelo no } \\
\text { solo, tons neutros resultantes da } \\
\text { mistura de violeta e amarelo; mas } \\
\text { tenho travado uma luta diabólica } \\
\text { para atingir a verdade das cores. } \\
\text { Ocorrência de Inacabamento e } \\
\text { Incompletude, por meio das } \\
\text { escolhas léxico-gramaticais: 'mas', } \\
\text { 'várias' e 'tons neutros' que } \\
\text { sugerem imprecisão na oração, } \\
\text { registrado na nota de rodapé } 92 .\end{array}$ & $\begin{array}{l}\text { Ocorrência de Transparência pela } \\
\text { escolha do processo mental para } \\
\text { expressar sua experiência subjetiva ao } \\
\text { combinar as cores, registrado na nota de } \\
\text { rodapé } 88 \text { e 91, no qual observei a } \\
\text { ocorrência da Transparência, } \\
\text { Incompletude e Limiar Artístico na } \\
\text { escolha do construto 'a verdade das } \\
\text { cores'. }\end{array}$ \\
\hline
\end{tabular}




\begin{tabular}{|c|c|c|}
\hline $\begin{array}{l}\text { Na tela A Esplanada do Café } \\
\text { na Place du Forum, Arles, à } \\
\text { Noite observei a ocorrência } \\
\text { de Incompletude, } \\
\text { Transparência e Limiar } \\
\text { Artístico, construídos pela } \\
\text { forma de representar as } \\
\text { estrelas e a luz noturna que } \\
\text { para van Gogh simbolizavam } \\
\text { o infinito. Registradas na } \\
\text { nota de rodapé 139 no } \\
\text { apêndice. } \\
\text { Observei também a } \\
\text { ocorrência de Incompletude, } \\
\text { Transparência e Limiar } \\
\text { Artístico, construídos pela } \\
\text { forma de representar as } \\
\text { estrelas e a luz noturna que } \\
\text { para van Gogh simbolizavam } \\
\text { o infinito e constituíram uma } \\
\text { semiose muito central em } \\
\text { seu discurso. Registrada na } \\
\text { nota de rodapé } 140 \text { no } \\
\text { apêndice. } \\
\text { Observei também a } \\
\text { ocorrência de Incompletude, } \\
\text { com a representação do } \\
\text { brilho das estrelas, van Gogh } \\
\text { construiu uma semiose para } \\
\text { seu desejo de infinito. } \\
\text { Registrada na nota de rodapé } \\
\text { 143 no apêndice. } \\
\text { Observei também a } \\
\text { ocorrência de Incompletude } \\
\text { e Associação Metafórica } \\
\text { construída pela } \\
\text { representação das estrelas, } \\
\text { seu brilho e seu halo, que } \\
\text { suscita escolhas de sentidos } \\
\text { potenciais metafóricos, como } \\
\text { o halo de santidade. } \\
\text { Registradas na nota de } \\
\text { rodapêndice. } \\
\text { ond }\end{array}$ & $\begin{array}{l}\text { Mas quando eu farei o céu } \\
\text { estrelado, então, essa pintura que } \\
\text { está sempre na minha mente? Ai, } \\
\text { ai, é como nosso excelente amigo } \\
\text { Cyprien diz, em 'En ménage' por } \\
\text { JK Huysmans: as mais belas } \\
\text { pinturas são aquelas que alguém } \\
\text { sonha enquanto fuma um } \\
\text { cachimbo em sua cama, mas a } \\
\text { qual ele não pinta. Mas é uma } \\
\text { questão de atacá-las, no entanto, } \\
\text { não importa o quão incompetente } \\
\text { alguém pode sentir-se vis-à-vis as } \\
\text { perfeições inefáveis do glorioso } \\
\text { esplendor da natureza. }\end{array}$ & $\begin{array}{l}\text { É quando, por exemplo, ele reconhece } \\
\text { que não é possível produzir essa } \\
\text { completude. Enquanto o inacabamento é } \\
\text { uma tentativa de alcançar a } \\
\text { completude, a incompletude é o } \\
\text { reconhecimento dessa impossibilidade. } \\
\text { É o não reconhecimento da } \\
\text { incompletude, é como se ele falasse que } \\
\text { a tela é um esboço, um estudo, que é } \\
\text { parcial e que poderia ser completo, que } \\
\text { esse estudo pode se tornar uma } \\
\text { tremenda tela. }\end{array}$ \\
\hline $\begin{array}{l}\text { Observei que, por meio do } \\
\text { semeador e do café noturno, } \\
\text { van Gogh experiência sua } \\
\text { busca de união com a } \\
\text { Natureza, explicitada no } \\
\text { excerto. '-ainda me encanta a } \\
\text { magia das recordações do } \\
\text { passado, de um desejo do } \\
\text { infinito, do qual o semeador } \\
\text { e o enfeixador são símbolos- } \\
\text { '. Dessa forma, ainda que } \\
\text { possam parecer 'atrozmente }\end{array}$ & $\begin{array}{l}\text { A ideia do semeador ainda } \\
\text { continua a me assombrar. Estudos } \\
\text { exagerados, como o semeador, } \\
\text { como o café noturno agora, } \\
\text { geralmente parecem-me } \\
\text { atrozmente feios e ruins, mas } \\
\text { quando eu estou movido por } \\
\text { alguma coisa, como aqui por este } \\
\text { pequeno artigo sobre Dostoievski, } \\
\text { em seguida, eles são os únicos que } \\
\underline{\text { me parecem ter um significado }} \\
\text { mais importante. }\end{array}$ & $\begin{array}{l}\text { O acabamento escapa do julgamento } \\
\text { inacabado e incompleto do artista. A } \\
\text { tela está acima do artista e para além da } \\
\text { sua compreensão, portanto o } \\
\text { acabamento é possível apesar da } \\
\text { incompletude do artista e é possível que } \\
\text { se manifeste onde menos se espera. } \\
\text { Quando van Gogh fala do artigo do } \\
\text { Dostoievsky 'se não é essa a tela mais } \\
\text { feia' que traz o sentido mais completo. }\end{array}$ \\
\hline
\end{tabular}




\begin{tabular}{|c|c|c|}
\hline $\begin{array}{l}\text { feios e ruins,' é por meio } \\
\text { deles que van Gogh } \\
\text { experiencia sua busca por } \\
\text { completude, ou sua } \\
\text { realização de Incompletude. }\end{array}$ & & \\
\hline $\begin{array}{l}\text { Na tela 'O Café Noturno na } \\
\text { Place Lamartine, em Arles', } \\
\text { observei a ocorrência de } \\
\text { Associação metafórica, } \\
\text { Enquadramento, Perspectiva } \\
\text { e Incompletude por meio do } \\
\text { sentido de Contraposição } \\
\text { entre centro/periferia, } \\
\text { olhar/não olhar, } \\
\text { ativo/apático construído } \\
\text { pela posição relativa das } \\
\text { figuras. Registrada na nota } \\
\text { de rodapé 138. }\end{array}$ & $\begin{array}{l}\text { Em todos os lugares é uma batalha } \\
\text { e uma antítese dos mais diferentes } \\
\text { verdes e vermelhos; nas } \\
\text { personagens dos rufiões } \\
\text { adormecidos, pequenos na alta sala } \\
\text { vazia, algum roxo e azul. } \\
\\
\text { Alguns pobres vagabundos } \\
\text { noturnos estão dormindo em um } \\
\text { canto. A sala está pintada de } \\
\text { vermelho, e no interior, na luz a } \\
\text { gás, a mesa de bilhar verde, a qual } \\
\text { lança uma imensa sombra sobre o } \\
\text { chão. Nesta tela, há } 6 \text { ou } 7 \\
\text { vermelhos diferentes, desde } \\
\text { vermelho-sangue até rosa delicado, } \\
\text { fazendo oposição com o mesmo } \\
\text { número de verdes pálidos ou } \\
\text { escuros. }\end{array}$ & $\begin{array}{l}\text { Uso de Associações Metafóricas e do } \\
\text { Uso Simbólico da Cor. Ao expressar o } \\
\text { sentido simbólico dos verdes e } \\
\text { vermelhos textualmente ele cola esse } \\
\text { sentido no uso dessas cores na tela, } \\
\text { construindo uma ponte entre a carta e a } \\
\text { tela, criando uma cadeia de textos. } \\
\text { Observei uma ocorrência do uso } \\
\text { simbólico da cor em ambas as } \\
\text { modalidades não pela forma, mas pelo } \\
\text { sentido associado a este uso, registrado } \\
\text { na nota de rodapé } 257 \text {. }\end{array}$ \\
\hline $\begin{array}{l}\text { Na tela 'O Café Noturno na } \\
\text { Place Lamartine, em Arles', } \\
\text { observei a ocorrência de } \\
\text { Associação metafórica, } \\
\text { Saliência e Incompletude } \\
\text { pela ênfase dada à } \\
\text { representação de cadeiras } \\
\text { vazias e mesa de bilhar } \\
\text { vazia. Registrada na nota de } \\
\text { rodapé } 211 .\end{array}$ & $\begin{array}{l}\text { A sala é vermelho-sangue e } \\
\text { amarelo sem graça, uma mesa de } \\
\text { bilhar verde no centro, } 4 \text { lâmpadas } \\
\text { de amarelo limão com um brilho } \\
\text { laranja e verde. }\end{array}$ & $\begin{array}{l}\text { Na tela ‘O Café Noturno na Place } \\
\text { Lamartine, em Arles’, observei a } \\
\text { ocorrência de Associação metafórica, } \\
\text { Enquadramento, Perspectiva e } \\
\text { Incompletude por meio do sentido de } \\
\text { contraposição entre cheio/vazio, } \\
\text { ocupado/desocupado, útil/inútill, bem } \\
\text { como centro/periferia, olhar/não olhar, } \\
\text { ativo/apático construído pela posição } \\
\text { relativa das figuras, registrada na nota de } \\
\text { rodapé } 138 \text {. Esse sentido é } \\
\text { interessantemente construído em } \\
\text { contraposição de sentido na qual mesa } \\
\text { de bilhar vazia e cadeiras vazias são } \\
\text { colocadas no centro e no primeiro plano } \\
\text { do espaço composicional enquanto as } \\
\text { mesas e cadeiras ocupadas estão } \\
\text { dispostas nos cantos do mesmo espaço, } \\
\text { indicando uma construção metafórica } \\
\text { para a posição relativa delas. }\end{array}$ \\
\hline $\begin{array}{l}\text { Na tela 'O Café Noturno na } \\
\text { Place Lamartine, em Arles', } \\
\text { observei a ocorrência de } \\
\text { Distorção do Ponto de Vista, } \\
\text { Incompletude e Associação } \\
\text { metafórica por meio da } \\
\text { distorção da forma e do } \\
\text { tamanho da sombra da mesa } \\
\text { de bilhar que se impõe pela } \\
\text { exclusão de outras sombras. } \\
\text { Registrada na nota de rodapé } \\
\text { 217. }\end{array}$ & $\begin{array}{l}\text { A sala está pintada de vermelho, e } \\
\text { no interior, na luz a gás, a mesa de } \\
\text { bilhar verde, a qual lança uma } \\
\text { imensa sombra sobre o chão. }\end{array}$ & $\begin{array}{l}\text { No centro da tela e no primeiro plano, } \\
\text { van Gogh representa uma imensa } \\
\text { sombra e confere especial destaque ao } \\
\text { contorno da sombra da mesa de bilhar no } \\
\text { chão do café em contraste com o chão } \\
\text { intensamente iluminado pelas lâmpadas } \\
\text { a gás. Na oração van Gogh enfatiza a } \\
\text { sombra está representada por uma } \\
\text { descrição detalhada em contraste com } \\
\text { uma descrição genérica da sala sugerem } \\
\text { que a contraposição se dá pelo uso de } \\
\text { Incompletude na descrição da sala. }\end{array}$ \\
\hline
\end{tabular}

Fonte: Triangulação para Incompletude dos dados dos corpora visual e textual, com os extratos das cartas. 


\subsection{LIMIAR ARTÍSTICO}

O conceito de limiar artístico é uma contribuição dessa pesquisa e designa uma instância discursiva que se situa entre o potencial e a sua manifestação. O processo de criação artística pode ser comparado ao processo de construção do sentido no sistema da linguagem, no qual é possível acessar, em uma instância abstrata, sentidos que estão potencialmente à disposição para serem usados no processo de construção do texto. Por sua natureza não normativa por excelência, o processo de criação artística pode melhor explicitar a busca de novos usos para os sentidos e para as escolhas potenciais que se encontram inexplorados e latentes nos sistemas da linguagem, disponíveis para serem articulados em novas materialidades textuais. A esse trabalho de prospecção e inovação dos usos linguísticos que o artista realiza na busca de dar concretude a textos novos, originais e inusitados, chamo de 'limiar artístico'.

\subsubsection{Triangulação do Limiar Artístico}

Limiar Artístico, no texto escrito e em relação à triangulação - A análise das cartas de van Gogh evidenciou sua dificuldade para produzir sozinho, os sentidos de seu discurso. Ele necessitava de uma prática discursiva dialógica na qual ele produzia e refletia acerca de seus sentidos. Essa categoria nos ajudou a evidenciar a natureza de parceria discursiva na constituição do discurso artístico de van Gogh possibilitada pela relação entre os dois irmãos como uma instância para essa prática acontecer.

1) Esta pesquisa partiu do pressuposto que, na aventura da linguagem, o artista busca experimentar e realizar um potencial expressivo latente. Para isso, ele adentra um limiar artístico inédito no qual experiencia os potenciais manifestos imanentes da expressão artística na busca de articular novos sistemas de sentido. Esses sistemas não estão claros e fechados para o artista. Ele os experimenta em primeira mão em um processo no qual se apropria de elementos linguísticos para significar conteúdos diversos de seus sentidos compartilhados pelo senso comum, atribuindo-lhes outros significados que não estavam inicialmente evidentes, propondo novos sistemas de escolhas potenciais e associações metafóricas, que são reconstruídas tanto em seus relatos sobre o processo quanto nos trabalhos de 
arte. O'Toole (1994, p. 4) comenta sobre a dificuldade de se explicitar esses sentidos novos que fazem parte de um novo domínio:

O envolvimento que cada um de nós tem com uma obra de arte é, de certa forma, privado; cada um de nós vê coisas de acordo com a nossa própria visão e estado de espírito e humor, fazendo os nossos próprios conjuntos de associações e em grande medida, os nossos olhos fazem a interpretação. Na verdade, muitas vezes nós descobrimos que transformar nossas percepções visuais em palavras perde o contato com a realidade perceptiva e congela nossas respostas complexas em uma espécie de falsa coerência ditada pelas estruturas da nossa língua.

2) Partí do pressuposto que o trabalho de criação na arte coloca o artista em um limiar artístico de produção de sentidos no qual ele busca conjugar experiências não manifestas e de difícil explicitação em um sistema de escolhas potenciais e associações metafóricas. Esses elementos que ele conjuga podem permanecer indiferenciados, mesmo depois de expressos, tanto para o próprio artista quanto para o público sem, contudo, diminuir seu potencial expressivo e seu valor cultural. Ao contrário, justamente por sua qualidade indiferenciada, os sistemas de sentidos novos, abertos às associações metafóricas, contribuem para a multiplicidade de sentidos que torna a arte, Arte.

3) A análise evidenciou que, sem prejuízo para a condensação de sentidos inerente ao texto artístico os elementos discursivos mais indiferenciados podem ser diferenciados e explicitados por meio da triangulação dos enfoques Multimodal, Sistêmico-Funcional e da Análise de Discurso Crítica. Esses sentidos, que estavam latentes tanto na obra quanto no discurso verbal, sua distinção localizou a sua presença difusa na obra e no discurso verbal, e identificou lacunas nas quais se encontram um adensamento de sentidos materializadores e estruturantes de uma poética discursiva.

4) Mesmo após a expressão de seus conteúdos por meio da linguagem pictórica, o artista pode experienciar a inesgotabilidade desse processo expressivo e ao fazêlo, pode buscar descrever o que ele pensa sobre o processo criativo de modo a apreender, elaborar sua experiência ou simplesmente condensar novos sentidos. Essa necessidade pode levar o artista a entrar em um novo movimento de criação que pode ser alternado por momentos reflexivos nos quais descreve seu processo criativo a fim de resgatar e organizar esses significados acerca da sua obra e da experiência de criação, ou por ser essa negociação de sentidos o objeto do processo de criação em si mesmo. Esse processo no qual ele continua a negociar sentidos pode ser recorrente na medida em que o artista não fecha e não totaliza 
um sentido final para os significados e conteúdos experienciados e expressos no limiar artístico. À medida que ele tenta organizar e negociar esses sentidos em seu discurso oral ou escrito, ele constrói uma condensação. Na análise dos corpora foi possível evidenciar, com a ajuda da LSF e TSSM, sentidos mais latentes e de difícil distinção que estavam condensados tanto nas cartas quanto nas telas.

5) A categoria do limiar criativo se relaciona com a categoria do enquadramento na medida em que observei um deslocar contínuo de van Gogh na posição que ele ocupa como o agente dos processos nas orações que constrói. Em alguns momentos ele situa a ação dentro da cena e presenciamos um apagamento de sua agência, e em outros momentos ele está fora da cena, falando da tela e se coloca como o agente da ação de pintar a tela. Inferi que esse ir e vir, esse entrar e sair, esse aproximar e distanciar está intimamente relacionado com a função de voltar a experienciar o limiar artístico em busca de articular e explicitar os sentidos que para ele, ainda estão latentes e ainda são fugidios.

6) Inferimos que essas duas categorias se relacionam pela sua função linguística. Essa relação pede por estudos posteriores para situar a natureza de sua correspondência.

\begin{tabular}{|c|c|c|}
\hline \multicolumn{3}{|c|}{ Quadro 35: Limiar Artístico } \\
\hline Ocorrência nas telas & Orações & Comentário \\
\hline $\begin{array}{l}\text { Na tela 'Por de Sol: Campo } \\
\text { de trigo perto de Arles', } \\
\text { observei a ocorrência de } \\
\text { associação metafórica do } \\
\text { tom da fumaça das fábricas } \\
\text { em contraposição com o tom } \\
\text { da luminosidade do céu para } \\
\text { conotar um conflito entre o } \\
\text { progresso econômico e a } \\
\text { natureza. Registrada na nota } \\
\text { de rodapé } 56 \text { no apêndice. }\end{array}$ & $\begin{array}{l}\text { Eu tenho um terceiro estudo, agora, } \\
\text { de uma paisagem com fábrica, e um } \\
\text { enorme sol em um céu vermelho, } \\
\text { acima de telhados vermelhos, em } \\
\text { que a natureza parece estar em um } \\
\text { acesso de raiva, em um dia de } \\
\text { Mistral desagradável. } \\
\text { Obsevei aqui uma interação da } \\
\text { ocorrência da Associação metafórica } \\
\text { com a Transparência, a } \\
\text { Incompletude e o Limiar Artístico. }\end{array}$ & $\begin{array}{l}\text { Van Gogh intui que existe nesse } \\
\text { movimento de pincelada sobre a tela } \\
\text { uma energia transformadora e } \\
\text { criadora, mas que também tem uma } \\
\text { nuance descontrolada que carrega uma } \\
\text { emoção semelhante à da raiva. Ele } \\
\text { compara esse movimento que } \\
\text { representa o vento na tela ao } \\
\text { movimento da natureza na qual o } \\
\text { vento age sobre o trigo de maneira } \\
\text { desordenada, incontrolável e incisiva. } \\
\text { O ímpeto do artista no momento de } \\
\text { representação do vento da tela o } \\
\text { aproxima da natureza e o aproxima de } \\
\text { sua natureza e da natureza daquilo que } \\
\text { faz a tela ser o que ela é. A } \\
\text { representação de um limiar entre } \\
\text { aquilo que o artista vê e aquilo que ele } \\
\text { não vê quando ele representa o que ele } \\
\text { vê. }\end{array}$ \\
\hline $\begin{array}{l}\text { Na tela 'Por de Sol: Campo } \\
\text { de trigo perto de Arles', } \\
\text { observei a ocorrência de um }\end{array}$ & $\begin{array}{l}\text { Eu também sou totalmente incapaz } \\
\text { de julgar o meu próprio trabalho. Eu } \\
\text { não posso ver se os estudos são bons }\end{array}$ & $\begin{array}{l}\text { Na oração: 'Eu também sou } \\
\text { totalmente incapaz de julgar o meu } \\
\text { próprio trabalho. Eu não posso ver se }\end{array}$ \\
\hline
\end{tabular}




\begin{tabular}{|c|c|c|}
\hline $\begin{array}{l}\text { uso original semiótico: a } \\
\text { inversão do ponto de fuga, } \\
\text { trazendo para o plano do } \\
\text { espectador o foco da } \\
\text { perspectiva e levando-o a se } \\
\text { identificar inevitavelmente } \\
\text { com o lugar do } \\
\text { experienciador da tela, o } \\
\text { artista. Este é um uso } \\
\text { original de perspectiva para } \\
\text { construir a distorção do } \\
\text { ponto de vista que } \\
\text { caracteriza uma busca } \\
\text { estética de van Gogh, } \\
\text { registrado na nota de rodapé } \\
48 \text { no apêndice. }\end{array}$ & $\begin{array}{l}\text { ou ruins. Tenho sete estudos de } \\
\text { trigais, infelizmente todos eles nada } \\
\text { além de paisagens, muito contra a } \\
\text { minha vontade. Paisagens amarelo } \\
\text { ouro velho - feito rápido rápido } \\
\text { rápido e com pressa, como o ceifeiro } \\
\text { que está em silêncio sob o sol } \\
\text { escaldante, concentrando-se em ter o } \\
\text { trabalho terminado. }\end{array}$ & $\begin{array}{l}\text { os estudos são bons ou ruins.' } \\
\text { observei a ocorrência de } \\
\text { Transparência, Incompletude e de } \\
\text { Limiar Artístico - observei a } \\
\text { ocorrência da categoria limiar artístico } \\
\text { no complexo oracional, no nível } \\
\text { semântico, registrada na nota de } \\
\text { rodapé } 119 \text { no apêndice. Observei } \\
\text { também nesta oração a ocorrência de } \\
\text { Interdiscursividade, uma vez que ele } \\
\text { explica que ele próprio é incapaz de } \\
\text { julgar o próprio trabalho, deixando } \\
\text { implícito que ele depende de outro que } \\
\text { faça isso para ele. }\end{array}$ \\
\hline $\begin{array}{l}\text { No excerto de carta, van } \\
\text { Gogh explicita que o } \\
\text { semeador e o enfeixador são } \\
\text { símbolos de seu desejo de } \\
\text { infinito. Este é um } \\
\text { importante indexador para os } \\
\text { sentidos construídos na tela } \\
\text { 'O Semeador.' } \\
\text { Ele também explicita, no } \\
\text { excerto, o uso de } \\
\text { intertextualidade, ao } \\
\text { comparar sua 'luta diabólica } \\
\text { para atingir a verdade das } \\
\text { cores' com o estilo naif dos } \\
\text { 'velhos almanaques dos } \\
\text { lavradores nos quais o } \\
\text { granizo, a neve, a chuva e o } \\
\text { bom tempo são retratados de } \\
\text { modo primitivo, com } \\
\text { Anquetin atingiu tão bem no } \\
\text { seu A Colheita.' Observei } \\
\text { que van Gogh usou a } \\
\text { intertextualidade como uma } \\
\text { metáfora para explicitar o } \\
\text { caminho que ele percorre } \\
\text { para atingir a verdade das } \\
\text { cores. Este não é o caminho } \\
\text { da representação naif, mas } \\
\text { que revela 'tons neutros } \\
\text { resultantes da mistura de } \\
\text { violeta e amarelo' que nada } \\
\text { têm de naif. }\end{array}$ & $\begin{array}{l}\text { Preferia muito mais // fazer quadros } \\
\text { naifs [[tirados de velhos } \\
\text { almanaques, aqueles velhos } \\
\text { "almanaques dos lavradores" [[nos } \\
\text { quais o granizo, a neve, a chuva e o } \\
\text { bom tempo são retratados de modo } \\
\text { primitivo,]]] como o Anquetin } \\
\text { atingiu tão bem no seu A Colheita. }\end{array}$ & $\begin{array}{l}\text { Ocorrência de Intertextualidade e } \\
\text { Interdiscursividade, Associação } \\
\text { metafórica, Transparência e } \\
\text { Modalidade ao relacionar a obra de } \\
\text { Anquetin e a estética Naif com sua } \\
\text { própria experiência para representar 'a } \\
\text { verdade das cores. Ocorrência de } \\
\text { Associação Metafórica pela } \\
\text { comparação que ele usa como } \\
\text { metáfora para explicar qual é a ordem } \\
\text { de sua experiência interna na escolha } \\
\text { da combinação de cores registrada na } \\
\text { nota de rodapé 93. } \\
\text { Ocorrência de Enquadramento, } \\
\text { Perspectiva, Inversão do ponto de } \\
\text { vista, Transparência, Inacabamento, } \\
\text { Incompletude e Limiar artístico com a } \\
\text { mudança na representação do } \\
\text { protagonismo nas oraçôes e nas } \\
\text { escolhas lexicais 'verdade das cores', } \\
\text { 'luta diabólica' e 'atingir a verdade } \\
\text { das cores', registrada na nota de } \\
\text { rodapé 94. }\end{array}$ \\
\hline $\begin{array}{l}\text { Com a metáfora do sol que } \\
\text { se põe para o campo, van } \\
\text { Gogh está falando de uma } \\
\text { era que finda, e de uma } \\
\text { perda que o homem do } \\
\text { campo vivencia. Ele } \\
\text { expressa com transparência a } \\
\text { nostalgia dessa perda. }\end{array}$ & $\begin{array}{l}\text { Não te vou ocultar que não desgosto } \\
\text { da região, pois fui criado lá - ainda } \\
\text { me encanta a magia das recordações } \\
\text { do passado, de um desejo do } \\
\text { infinito, do qual o semeador e o } \\
\text { enfeixador são símbolos -, tanto } \\
\text { quanto antes gostava. }\end{array}$ & $\begin{array}{l}\text { Talvez este sentido reforce o tom de } \\
\text { nostalgia da cena, na qual van Gogh } \\
\text { representa um campo de trigo de um } \\
\text { passado mítico. Aquele homem sentiu } \\
\text { a perda, nós só sabemos sentir uma } \\
\text { falta de algo que se perdeu: um } \\
\text { sentido, um sentimento, um modo de } \\
\text { viver, de ver, de sentir, de ser no }\end{array}$ \\
\hline
\end{tabular}




\begin{tabular}{|c|c|c|}
\hline $\begin{array}{l}\text { Registrada na nota de rodapé } \\
87 \text { no apêndice. }\end{array}$ & $\begin{array}{l}\text { Ocorrência de Transparência, } \\
\text { Incompletude, Limiar Artístico, } \\
\text { Interdiscursividade e Associação } \\
\text { Metafórica no nível semântico da } \\
\text { oração Beta ao explicitar a natureza } \\
\text { da sua motivação na produção } \\
\text { artística e ao usar a contraposição } \\
\text { criada pela comparação entre Naif e } \\
\text { 'a verdade das cores' como metáfora } \\
\text { para explicar ao irmão o seu desejo } \\
\text { de infinito. Registrada na nota de } \\
\text { rodapé } 97 .\end{array}$ & $\begin{array}{l}\text { mundo. Nós só sentimos a falta de } \\
\text { alguma coisa que não sabemos mais } \\
\text { sentir, porque já não sentimos a perda, } \\
\text { nem o que foi perdido. Sentimos } \\
\text { apenas a falta da perda, a falta do que } \\
\text { não está mais. Registrada na nota de } \\
\text { rodapé } 87 \text { no apêndice. } \\
\text { Ocorrência de Contraste Cromático } \\
\text { usado como Associação metafórica } \\
\text { para expressar o Limiar Artístico } \\
\text { representados no Semeador e no } \\
\text { Enfeixador. Registrada na nota de } \\
\text { rodapé } 98 .\end{array}$ \\
\hline $\begin{array}{l}\text { A atmosfera da luz difusa do } \\
\text { crepúsculo, construída pelos } \\
\text { efeitos dos contrastes } \\
\text { cromáticos, da diminuição dos } \\
\text { detalhes e do tratamento geral } \\
\text { desfocado e com baixa } \\
\text { definição e acabamento é } \\
\text { compatível com o sentido de } \\
\text { sonho expressado nesse } \\
\text { excerto de carta. A luz difusa } \\
\text { expressa Inacabamento e } \\
\text { Incompletude também } \\
\text { expressa na Verbiagem do } \\
\text { excerto. } \\
\text { Ao se referir à tela no excerto } \\
\text { de carta, van Gogh usa a } \\
\text { intertextualidade, da fala de } \\
\text { um personagem de um } \\
\text { romance de Huysmans, para } \\
\text { construir uma metáfora. Ele } \\
\text { compara a sua tela 'O } \\
\text { Semeador' com o desejo de } \\
\text { alguém, que está no plano do } \\
\text { sonho, mas que não pinta. } \\
\text { Dessa forma, quando ele a } \\
\text { pinta, ele a representa em uma } \\
\text { atmosfera de sonho, na luz } \\
\text { difusa do crepúsculo, } \\
\text { construída pelos efeitos dos } \\
\text { contrastes cromáticos, da } \\
\text { diminuição dos detalhes e do } \\
\text { tratamento geral desfocado. } \\
\text { Essa baixa definição } \\
\text { inacabamento são compatíveis } \\
\text { com o sentido de sonho } \\
\text { expressado nesse excerto de } \\
\text { carta. A luz difusa expressa } \\
\text { Inacabamento e Incompletude } \\
\text { também expressada na } \\
\text { Verbiagem do excerto. }\end{array}$ & $\begin{array}{l}\text { Mas quando eu farei o céu estrelado, } \\
\text { então, essa pintura que está sempre } \\
\text { na minha mente? } \\
\text { Ai, ai, é como nosso excelente amigo } \\
\text { Cyprien diz, em 'En ménage' por JK } \\
\text { Huysmans: as mais belas pinturas } \\
\text { são aquelas [[que alguém sonha } \\
\text { //enquanto fuma um cachimbo em } \\
\text { sua cama,// mas a qual ele não } \\
\text { pinta.]] } \\
\text { Ocorrência de Incompletude, } \\
\text { Inacabamento expressos na } \\
\text { Verbiagem da oração, uma vez que } \\
\text { expressa a diferença entre sonhar e } \\
\text { realizar. Além disso, observei } \\
\text { ocorrências de Enquadramento, } \\
\text { Perspectiva e Inversão de ponto de } \\
\text { vista, que no nível semântico, } \\
\text { expressa a mesma coisa que no nível } \\
\text { léxico-gramatical na medida em que } \\
\text { ele desliza entre dois domínios tanto } \\
\text { no nível semântico (sonho-pintura } \\
\text { real) quanto no nível léxico- } \\
\text { gramatical (Verbiagem-pintura real). } \\
\text { Registradas nas notas de rodapé } 111 \\
\text { e } 112 .\end{array}$ & $\begin{array}{l}\text { Ai, ai, é como nosso excelente amigo } \\
\text { Cyprien diz, em 'En ménage' por JK } \\
\text { Huysmans: as mais belas pinturas são } \\
\text { aquelas que um sonha enquanto fuma } \\
\text { um cachimbo em sua cama, mas a } \\
\text { qual ele não pinta. Mas é uma questão } \\
\text { de atacá-las, no entanto, não importa o } \\
\text { quão incompetente um pode sentir-se } \\
\text { vis-à-vis as perfeições inefáveis do } \\
\text { glorioso esplendor da natureza. } \\
\text { Ocorrência de Interdiscursividade e de } \\
\text { Limiar Artístico pelo uso do processo } \\
\text { relacional atributivo 'está' que } \\
\text { constrói um protagonismo para a ideia } \\
\text { da tela e aproxima o interlocutor de } \\
\text { van Gogh dessa experiência de Limiar } \\
\text { Artístico que van Gogh tenta } \\
\text { comunicar e compartilhar com o } \\
\text { irmão. Registrado na nota de rodapé } \\
\text { 106. } \\
\text { Ocorrência de Limiar artístico e } \\
\text { Incompletude presente na organização } \\
\text { da oração que constrói dois planos que } \\
\text { representação: um que é o esboço em } \\
\text { potencial e está em sua mente e o } \\
\text { outro é a materialização dele quando } \\
\text { puder pintá-lo. Essas duas instâncias } \\
\text { pressupõem uma transição entre o que } \\
\text { é da ordem do imanente e do tangível } \\
\text { que ele busca apreender pelo desejo de } \\
\text { realização da tela. Registrado na nota } \\
\text { de rodapé 107. }\end{array}$ \\
\hline $\begin{array}{l}\text { Na tela 'O Semeador', há } \\
\text { uma inter-relação entre } \\
\text { Textura, Contrastes } \\
\text { Simultâneos, Saliência, }\end{array}$ & $\begin{array}{l}\text { Há várias sugestões de amarelo no } \\
\text { solo, tons neutros resultantes da } \\
\text { mistura de violeta e amarelo; mas } \\
\text { tenho travado uma luta diabólica }\end{array}$ & $\begin{array}{l}\text { Ocorrência de Transparência pela } \\
\text { escolha do processo mental para } \\
\text { expressar sua experiência subjetiva ao } \\
\text { combinar as cores. Registrada nas }\end{array}$ \\
\hline
\end{tabular}




\begin{tabular}{|c|c|c|}
\hline $\begin{array}{l}\text { Sinestesia que criam } \\
\text { Associações Metafóricas da } \\
\text { materialidade da tinta com a } \\
\text { nossa memória sensorial e } \\
\text { tátil da plasticidade da terra, } \\
\text { registrado na nota de rodapé } \\
5 \underline{5} . \\
\\
\text { Observei também a } \\
\text { ocorrência de Associação } \\
\text { Metafórica da materialidade } \\
\text { pictórica com a nossa } \\
\text { experiência física e corporal } \\
\text { de tocar a terra e sua } \\
\text { plasticidade, registrado na } \\
\text { nota de rodapé } 55 \text { e } 56 .\end{array}$ & para atingir a verdade das cores. & $\begin{array}{l}\text { notas de rodapé } 88 \text { e } 91 \text {, nas quais } \\
\text { observei a ocorrência da } \\
\text { Transparência, Incompletude e Limiar } \\
\text { Artístico na escolha do construto 'a } \\
\text { verdade das cores'. }\end{array}$ \\
\hline $\begin{array}{l}\text { Por meio do uso dos } \\
\text { elementos pictóricos em ‘O } \\
\text { Café Noturno na Place } \\
\text { Lamartine, em Arles', van } \\
\text { Gogh fez escolhas nessa tela } \\
\text { que enfatizam o desconforto, } \\
\text { o estranhamento, a } \\
\text { inquietação. O quadro } \\
\text { constrói, por meio da } \\
\text { conjugação de algumas } \\
\text { estratégias de composição } \\
\text { tais como os contrastes } \\
\text { cromáticos, de luz e sombra, } \\
\text { de volume, e a distorção da } \\
\text { perspectiva, uma } \\
\text { expressividade exacerbada } \\
\text { para a representação de um } \\
\text { café à noite. Esses contrastes } \\
\text { parecem dar, por meio dos } \\
\text { tensionamentos criados, uma } \\
\text { sensação de mal-estar e } \\
\text { perturbação para os olhos } \\
\text { atentos à cena. }\end{array}$ & $\begin{array}{l}\text { "Eu também sou totalmente incapaz } \\
\text { de julgar o meu próprio trabalho. Eu } \\
\text { não posso ver se os estudos são bons } \\
\text { ou ruins." } \\
\text { Estudos exagerados, como o } \\
\text { semeador, como o café noturno } \\
\text { agora, geralmente parecem-me } \\
\text { atrozmente feios e ruins, mas } \\
\text { quando eu estou movido por alguma } \\
\text { coisa, como aqui por este pequeno } \\
\text { artigo sobre Dostoievski, em } \\
\text { seguida, eles são os únicos que me } \\
\text { parecem ter um significado mais } \\
\text { importante. }\end{array}$ & $\begin{array}{l}\text { Van Gogh ( } 2009 \text { d) declara para o } \\
\text { irmão sua incapacidade de avaliar seu } \\
\text { próprio trabalho. O sentido dessa } \\
\text { oração endossa completamente a } \\
\text { hipótese de que o artista cria seu } \\
\text { discurso artístico a partir de um limiar } \\
\text { artístico no qual ele não tem total } \\
\text { apreensão de seus sentidos e precisa } \\
\text { continuar a elaborar sua compreensão } \\
\text { desse processo por meio de uma } \\
\text { cadeia de textos que ele produz para } \\
\text { explorar os sentidos relacionados com } \\
\text { a sua produção artística. }\end{array}$ \\
\hline $\begin{array}{l}\text { Na tela 'O Semeador', } \\
\text { observei a ocorrência de } \\
\text { Enquadramento na } \\
\text { representação do Semeador } \\
\text { no segundo plano, em pé, o } \\
\text { que denota um certo } \\
\text { distanciamento entre o } \\
\text { espectador e a tela. } \\
\text { Registrada na nota de rodapé } \\
\text { 43. }\end{array}$ & $\begin{array}{l}\text { Não te vou ocultar que não desgosto } \\
\text { da região, pois fui criado lá - ainda } \\
\text { me encanta a magia das recordações } \\
\text { do passado, de um desejo do } \\
\text { infinito, do qual o semeador e o } \\
\text { enfeixador são símbolos -, tanto } \\
\text { quanto antes gostava. } \\
\text { Ocorrência de Limiar Artístico na } \\
\text { escolha lexical de uma região para } \\
\text { significar uma experiência que é } \\
\text { remota e basilar e está sendo } \\
\text { mediada agora pela expressão } \\
\text { artística. Registrada na nota de } \\
\text { rodapé 100. } \\
\text { Van Gogh está se referindo a uma } \\
\text { condição que não é escolhida como } \\
\text { uma expressão da liberdade do }\end{array}$ & $\begin{array}{l}\text { Van Gogh estava em busca de uma } \\
\text { essência, uma verdade primeira e se } \\
\text { esmerava em romper com ideias } \\
\text { preconcebidas, com qualquer valor } \\
\text { social, formal, que corrompesse com o } \\
\text { sentido existencial da ética mais } \\
\text { próxima da espiritualidade, de Deus e } \\
\text { do qual o Semeador é um símbolo. Ele } \\
\text { entra em contato com esse sentimento, } \\
\text { essa necessidade, essa condição no } \\
\text { momento em que ele se coloca no } \\
\text { lugar do Semeador. Ao construir uma } \\
\text { metáfora do Semeador para expressar } \\
\text { essa condição, ele não se identifica } \\
\text { com a centralidade que é dada para } \\
\text { essa ação, mas busca um sentido mais } \\
\text { profundo da ação do Semeador que é } \\
\text { o de ser um agente passivo. Por isso } \\
\text { van Gogh assume o lugar de artista }\end{array}$ \\
\hline
\end{tabular}




\begin{tabular}{|c|c|c|}
\hline & $\begin{array}{l}\text { indivíduo. Ele é um meio para que } \\
\text { algo maior aconteça. Então é como } \\
\text { se o Semeador e o Enfeixador não } \\
\text { escolheram ser Semeador e } \\
\text { Enfeixador. Van Gogh fez uma } \\
\text { escolha que não foi a de ser o meio. } \\
\text { Ele rejeitou e não se adaptou para } \\
\text { ser o evangelizador que o pai } \\
\text { esperava. Então quando ele } \\
\text { representa o Semeador é como se ele } \\
\text { estivesse representando o desejo que } \\
\text { o motivou a ser um meio dessa } \\
\text { semeadura, mas sem ocupar esse } \\
\text { lugar do Semeador. Ser o Semeador } \\
\text { sem ser o Semeador, porque ele } \\
\text { tenta apreender é uma essência } \\
\text { talvez com um conteúdo espiritual } \\
\text { que estava presente nele desde } \\
\text { aquelas lembranças que o } \\
\text { conectavam com o mundo das } \\
\text { metáforas bíblicas do pai. }\end{array}$ & $\begin{array}{l}\text { como uma condição imposta por uma } \\
\text { missão que é dada a ele e nesse lugar } \\
\text { ele se vê como meio e para ele se ver } \\
\text { como meio ele precisa transcender a } \\
\text { obra dele. Para ele é muito difícil } \\
\text { transcender a obra justamente porque } \\
\text { ele está preso a ela. Ele precisa dela } \\
\text { para sobreviver, assim como o } \\
\text { Semeador precisa do resultado da } \\
\text { semeadura e se vê preso na ação, se vê } \\
\text { preso à terra, mas com o desejo do } \\
\text { infinito. Van Gogh se vê preso à tela, } \\
\text { mas com desejo de infinito. No final } \\
\text { van Gogh repete o lugar que o pai o } \\
\text { destinou, de ser um Semeador preso à } \\
\text { sua palavra. }\end{array}$ \\
\hline $\begin{array}{l}\text { Observei também a } \\
\text { ocorrência de Incompletude, } \\
\text { Transparência e Limiar } \\
\text { Artístico, construídos pela } \\
\text { forma de representar as } \\
\text { estrelas e a luz noturna que } \\
\text { para van Gogh simbolizavam } \\
\text { o infinito e constituíram uma } \\
\text { semiose muito central em } \\
\text { seu discurso. Registrada na } \\
\text { nota de rodapé } 140 \text { no } \\
\text { apêndice. }\end{array}$ & $\begin{array}{l}\text { Mas quando eu farei o céu estrelado, } \\
\text { então, essa pintura que está sempre } \\
\text { na minha mente? Ai, ai, é como } \\
\text { nosso excelente amigo Cyprien diz, } \\
\text { em 'En ménage' por JK Huysmans: } \\
\text { as mais belas pinturas são aquelas } \\
\text { que um sonha enquanto fuma um } \\
\text { cachimbo em sua cama, mas a qual } \\
\text { ele não pinta. Mas é uma questão de } \\
\text { atacá-las, no entanto, não importa o } \\
\text { quão incompetente um pode sentir-se } \\
\text { vis-à-vis as perfeições inefáveis do } \\
\text { glorioso esplendor da natureza. }\end{array}$ & $\begin{array}{l}\text { Ocorrência de Limiar Artístico no } \\
\text { nível semântico da oração 'essa } \\
\text { pintura que está sempre na minha } \\
\text { mente'. Registrada na nota de rodapé } \\
\text { 101. } \\
\text { Ocorrência de Limiar Artístico e } \\
\text { Incompletude por meio do uso da } \\
\text { ênfase na Meta (ideia da tela) mesmo } \\
\text { sendo ele o participante principal na } \\
\text { oração alfa. Registrados na nota de } \\
\text { rodapé } 103 .\end{array}$ \\
\hline $\begin{array}{l}\text { Na tela 'O Café Noturno na } \\
\text { Place Lamartine, em Arles', } \\
\text { observei a ocorrência de } \\
\text { Associação metafórica, } \\
\text { Transparência, Incompletude } \\
\text { e Limiar Artístico, com o uso } \\
\text { do Enquadramento, } \\
\text { Perspectiva, Profundidade, } \\
\text { Distorção do Ponto de Vista, } \\
\text { levemente plongee para o } \\
\text { sentido do lugar social com o } \\
\text { qual van Gogh se identifica. }\end{array}$ & $\begin{array}{l}\text { "Eu também sou totalmente incapaz } \\
\text { de julgar o meu próprio trabalho. Eu } \\
\text { não posso ver se os estudos são bons } \\
\text { ou ruins." }\end{array}$ & $\begin{array}{l}\text { Na primeira oração, ele usa o processo } \\
\text { relacional atributivo: "Eu também sou } \\
\text { totalmente incapaz de julgar o meu } \\
\text { próprio trabalho" e na segunda o } \\
\text { processo mental cognitivo: "Eu não } \\
\text { posso ver se os estudos são bons ou } \\
\text { ruins" (VAN GOGH, } 2009 \mathrm{~d}, \mathrm{p} .1 \text { ), } \\
\text { sinalizando que ele fala de um lugar } \\
\text { no qual ele está dentro do processo e } \\
\text { relaciona a qualidade de se ver } \\
\text { incapaz de julgar seu próprio trabalho. }\end{array}$ \\
\hline
\end{tabular}


Registrada na nota de rodapé

103 no apêndice, 248 e 249.

Fonte: Triangulação para Limiar Artístico dos dados dos corpora visual e textual, com os extratos das cartas. 


\section{CONSIDERAÇÕES FINAIS}

\section{CONSIDERAÇÕES FINAIS DA TRIANGULAÇÃO}

A análise do discurso artístico de van Gogh levou em conta o contexto discursivo no qual van Gogh produziu as telas e as cartas, e encontrou nessa relação, recursos semióticos que colaboraram na construção do texto visual e do texto escrito. A observação da ocorrência desses elementos foi importante para compreender o discurso artístico no contexto do universo discursivo que o produziu e triangular a relação entre as ocorrências no texto visual e no texto escrito para desvelar as semioses que interligam o discurso verbal com o discurso pictórico do autor.

A triangulação teve como objetivo compreender como diferentes estratégias discursivas presentes nessas duas modalidades integram a construção do discurso artístico de Vincent van Gogh. A tese de que o discurso artístico de Vincent van Gogh é integrado tanto por seu discurso pictórico quanto por seu discurso epistolar ficou amplamente comprovada pela triangulação das interpretações das orações e das imagens analisadas. As ocorrências encontradas indicaram que alguns elementos presentes na obra visual e epistorar de van Gogh estão intrinsecamente conectados com os sentidos existenciais e identitários por ele construídos e negociados em seu discurso, como evidenciado na análise e na triangulação.

A seguir respondo às perguntas iniciais da pesquisa, exponho alguns dos achados conclusivos para a tese de que o discurso artístico de Vincent van Gogh é integrado tanto por seu discurso pictórico quanto por seu discurso epistolar, e discuto as contribuições dessa pesquisa.

\subsection{PERGUNTAS DA PESQUISA E ACHADOS CONCLUSIVOS DA TESE}

Nessa sessão, respondo as perguntas de pesquisa e exponho os achados referentes a elas.

1) A primeira pergunta da tese: 'Como se dá a ocorrência dos elementos e das estratégias discursivas que se encontram presentes nas telas? São esses elementos presentes nas telas recorrentes, correspondentes, similares, complementares, antagônicos, contraditórios aos elementos e estratégias discursivas que se 
encontram nas cartas?' foi respondida com a ajuda da análise multimodal do corpus visual e com a triangulação dos dados analisados.

a) Os elementos e estratégias discursivas descritos na análise das telas, tais como textura/ritmo/movimento/direção/rima visual/gesto pictórico ou como enquadramento/profundidade/perspectiva/distorção do ponto de vista, por exemplo, ocorrem de forma colaborativa. A sua ocorrência é, na maior parte das vezes agrupada com elementos que estão corroborando para a mesma função semiótica e a sua aparição em grupos ou em pares, pode indicar não apenas uma inter-relação linguística léxico-gramatical ou semântica, mas também uma compatibilidade funcional na construção do sentido. Por exemplo, nas telas, é frequente a incidência de diferentes recursos semióticos sendo conjugados em um mesmo construto, para a construção de um mesmo sentido, como é o caso da ocorrência de textura, ritmo, movimento, direção e gesto pictórico na construção do trigal na tela 'Por de Sol: Campo de trigo perto de Arles'. A ocorrência desses recursos semióticos em um mesmo construto visual é frequente em outras telas, sugerindo que seu uso conjugado faz parte de um repertório linguístico do pintor, ou que sua aparição agrupada se deva à natureza funcional da linguagem pictórica.

b) A triangulação dos elementos presentes nas telas com os elementos presentes nas orações, também sugeriu que as ocorrências compatíveis entre tela e carta, isoladas ou combinadas, podem ser do tipo: semântico, formal ou funcional.

c) Com a ajuda da análise multimodal, foi possível sondar as funções que os elementos discursivos visuais desempenham no texto visual. Essas funções já foram descritas como categorias de análises referentes à triangulação dos dados.

2) Para responder a segunda pergunta da tese: 'Como se dá a ocorrência dos elementos e das estratégias discursivas que se encontram presentes nas cartas? São esses elementos presentes nas cartas recorrentes, correspondentes, similares, complementares, antagônicos, contraditórios aos elementos e estratégias discursivas que se encontram nas telas?'

Com a ajuda da análise Sistêmico-Funcional dos excertos das cartas foi possível sondar a natureza das funções que os elementos discursivos nas cartas desempenham no texto escrito, descritas a seguir. 
a) Há uma predominância de recursos descritivos acerca das telas nas orações que são compatíveis com a produção da tela em si mesma. Na oração, van Gogh tentava reconstruir a tela por meio dos recursos semânticos e léxicogramaticais da escrita. Seus efeitos como representação escrita da imagem aparecem na construção das orações e revelam uma intercomunicabilidade com os diferentes recursos semióticos presentes nas telas que pode ser de natureza semântica, léxico-gramatical ou funcional, ilustrados na triangulação.

b) Os recursos que ocorrem nas orações e nas telas podem ser semanticamente compatíveis, ou seja, o sentido construído visualmente é compatível com o sentido construído na oração. Por exemplo, um construto de contrastes entre vermelhos e verdes na tela 'O Café da Noite', e uma oração na qual ele descreve os contrastes entre vermelhos e verdes ilustra uma ocorrência de conexão semântica entre tela e carta.

c) As ocorrências podem ter uma organização formal semelhante, como por exemplo, uma oração que tem uma forma de contraposição e um construto visual que também se organiza pela contraposição de elementos discursivos. Ou ainda, podem ter funções semelhantes, como o uso da inversão da perspectiva na tela e o uso da oração hipotática para expressar sentido principal que van Gogh queria comunicar. Observei em alguns complexos oracionais a recorrência de um uso léxico-gramatical frequente no estilo retórico de van Gogh. Ele desloca o sentido semântico central para a oração hipotática. Essa ocorrência apareceu em vários momentos do corpus textual e demonstrou uma relação com as estratégias de composição visual que apresentaram uma função semelhante, nas quais maior ênfase era dada para as figuras e membros no segundo plano, em vez do primeiro. Visualmente é como se ele retirasse o enquadramento do primeiro plano da composição e o deslocasse para o segundo plano e essa ocorrência foi observada nas quatro telas. Textualmente é como se ele deslocasse o sentido principal para a oração secundária e, aparentemente, esta pode ter sido uma estratégia de modalização. Outra possibilidade é que ele utiliza a oração Paratática, na qual recai uma maior atenção do leitor, para enfatizar a importância do que ele irá falar na oração hipotática. Entendo que esse deslocamento do sentido principal entre as orações paratática e hipotática pode funcionar como um deslocamento do foco do enquadramento em uma composição visual ou até mesmo uma inversão da 
perspectiva, dependendo da relação entre os participantes dentro da oração. Por exemplo na oração "Na minha pintura do café à noite eu procurei exprimir [que o café é um lugar onde você pode arruinar-se, enlouquecer, cometer crimes.]" observei a ocorrência de um uso léxico-gramatical frequente no estilo retórico de van Gogh. Ele desloca o sentido semântico central para a oração Beta que neste caso é uma oração projetada relacional. Como essa ocorrência tende a aparecer em vários momentos do corpus textual, examinei se ela se relaciona com as estratégias de composição visual. Visualmente é como se ele retirasse o enquadramento do primeiro plano da composição e o deslocasse para o segundo plano e essa ocorrência foi observada nas quatro telas. Textualmente é como se ele deslocasse o sentido principal para a oração secundária, e aparentemente esta pode ter sido uma estratégia de modalização. Outra possibilidade é que ele utiliza a oração Alfa na qual recai uma maior atenção do leitor para enfatizar a importância do que ele irá falar na oração Beta. Ele usa a oração Alfa como uma preparação do leitor para depois depositar a maior carga de sentido na oração Beta, criando com isso uma ênfase que é análoga ao aguçamento visual. Entendo que esse deslocar do sentido principal entre as orações Alfa e Beta pode funcionar como um deslocar do foco ou do enquadramento em uma composição visual.

d) Foi possível identificar ocorrências compatíveis na função que os elementos e estratégias visuais desempenham na composição e na oração, por exemplo, o uso de ênfase seguido de associação metafórica.

e) Há uma diferença na produção do sentido nas cartas e nas telas que impacta na organização interna do texto escrito e do texto visual. Esta diferença está na motivação e na finalidade com que van Gogh constrói o texto visual e o texto escrito. Ao construir o texto visual, van Gogh está dentro de uma experiência vivencial em si mesma. Ao construir o texto escrito ele está fora dessa experiência e retorna para ela por meio de diferentes estratégias discursivas, tais como o uso de deslocamentos, de construtos que possibilitam um 'ir e vir' de aproximação e distanciamento para reconstruir a experiência estando, ao mesmo tempo, fora dela. Ele consegue esse deslocamento por meio de estratégias tais como: a) pela mudança, dentro da oração, do enfoque de seu objeto representado, que chamei de 'enquadramento'. Essa mudança de ‘ângulo’ pode ser conseguida pela mudança na relação estabelecida entre os 
participantes, por meio das escolhas da agência, dos processos, das circunstâncias; b) pelo apagamento da agência, que chamei de 'perspectiva', na qual ora ele se coloca como ator, ora ele apaga essa 'voz'; c) pela inversão da função paratática e hipotática, que chamei de 'distorção do ponto de vista', colocando na oração hipotática o sentido principal que ele quer comunicar.

3) Será respondida a seguir a terceira pergunta da tese: 'A análise das telas e das cartas que relatam a produção pictórica pode ajudar a revelar como se deu o processo de produção de sentidos nos discursos pictórico e textual? Existe uma interação discursiva entre esses elementos na construção de sentidos? Como ela ocorre?'.

A triangulação entre os dados visuais e os dados textuais permitiu identificar como as semioses interligam o discurso verbal com o discurso pictórico do autor. Ela permitiu identificar e descrever as ocorrências, as recorrências e a interação entre os elementos ou estratégias discursivas nos dois gêneros textuais analisados. A seguir exponho alguns dos achados da triangulação.

a) Com a ajuda da triangulação foi possível descrever a ocorrência dos elementos discursivos visuais que se relacionam com a ocorrência de elementos correspondentes, presentes na análise do sistema de transitividade das cartas.

b) Foram encontrados sentidos que são compartilhados em textos pictóricos e escritos produzidos por van Gogh, indicando uma interação multimodal no nível semântico.

c) Foram encontrados sentidos cuja produção é compartilhada em textos pictóricos e escritos por van Gogh, indicando uma interação multimodal no nível léxicogramatical.

d) Na triangulação foi verificada a ocorrência simultânea de mais de uma categoria na mesma oração e/ou no mesmo construto visual. Por exemplo, a categoria de transparência faz a função da modalidade. Apesar das telas de van Gogh não seguirem o estilo naturalista, elas expressam um alto grau de modalidade porque ele faz uso da modalidade sensorial para dar um critério de verdade que é emotivo. Esse tipo de modalidade sensorial tem a função de expressar com transparência o sentido experiencial que ele deseja comunicar. À ocorrência da transparência, encontrei a ocorrência simultânea das categorias da incompletude, do gesto pictórico, da associação metafórica e do limiar artístico, que colaboraram para a função semiótica expressiva e de modalidade de sua mensagem. À esse 
exemplo somam-se outros tantos, de intercorrências e ocorrências simultâneas de categorias, caracterizadas como um uso conjugado de recursos semióticos que demonstram a organização interna do discurso artístico e seu funcionamento e que serão discutidos a seguir. Esse agrupamento de ocorrências de categorias em um mesmo construto se deve, provavelmente, à natureza interdependente dos elementos discursivos para construir o sentido.

\subsubsection{Contribuições da pesquisa}

\subsubsection{Novas Categorias de análise}

As categorias usadas na triangulação são resultado de uma combinação entre categorias da Gramática do Design Visual, categorias das Artes e da Percepção Visual e de novas categorias propostas por esta pesquisa, tais como Gesto Pictórico, Transparência, Inacabamento, Incompletude e Limiar Artístico. Estas novas categorias constituem uma contribuição desta pesquisa para os estudos multimodais em especial para a análise de textos do discurso artístico. A proposta dessas novas categorias se deveu à necessidade de definir e incluir aspectos que são intrínsecos à natureza do texto artístico e do texto pictórico que dessem conta de contemplar uma camada de sentido mais implícita, e mais latente, que se encontra nos interstícios da produção do sentido no texto artístico e podem ajudar nos estudos multimodais de diferentes discursos artísticos.

Entre as categorias observei níveis de funcionalidade dentro do discurso artístico, sendo o primeiro deles, de nível gramatical (telas) léxico-gramatical (cartas) e funcional, o segundo deles de nível semântico, e o terceiro deles de nível intermediário que tende a articular os níveis. Elas foram agrupadas como segue:

a) categorias que tendem a colaborar no nível gramatical (telas) léxico-gramatical (cartas) e funcional: Textura, Ritmo, Movimento, Direção ou Vetor, Enquadramento, Perspectiva, Profundidade, Cor;

b) categorias que tendem a colaborar no nível semântico: Interdiscursividade e Intertextualidade, Associação Metafórica e Simbolismo, Transparência, Incompletude, Limiar Artístico; 
c) categorias intermediárias, que tendem a se articular com as ocorrências nas outras duas categorias: Distorção do Ponto de Vista, Saliência, Gesto Pictórico, Rima Visual, Modalidade, Inacabamento.

\subsubsection{Caminhos possíveis de encontro entre o visual e o textual}

A triangulação ajudou a explicitar diferentes níveis em que se davam as compatibilidades das ocorrências, revelando uma interação nos níveis semânticos, gramaticais (telas) e léxico-gramaticais (cartas) e funcionais. Com base nessa observação, a pesquisa conclui que as conexões de nexo entre os achados visuais e os achados textuais podem ocorrer em diferentes níveis ou caminhos de comparação: por sentido, por forma e por função. Esses níveis que podem ser compatíveis com as funções e metafunções visuais e da linguagem, propostas por O'Toole e por Halliday.

Além desses níveis nos quais se dão as ocorrências, foram observadas ocorrências diretas e cruzadas. Ocorrências diretas são correspondentes na tela e nos extratos de cartas relativas à tela na qual se deu a ocorrência. Ocorrências cruzadas não aparecem nos extratos de carta referentes às telas nas quais se deu a ocorrência. Em outras palavras, a ocorrência na tela era compatível com uma ocorrência em extrato de carta que não se referia à mesma tela, ou seja, as ocorrências de determinados construtos não estão necessariamente nos extratos correspondentes às telas. A esse tipo de ocorrência, chamei de ocorrência cruzada. Com isso inferi que existe uma ideia recorrente acerca do construto e que permeia o discurso artístico. Estas ocorrências podem parecer aleatórias, no entanto, elas guardavam o mesmo padrão semântico, gramatical (telas) e léxico-gramatical (cartas) ou funcional e podem ser indicadores de padrões discursivos consistentes que permeiam o texto visual e escrito do pintor. Talvez essa ocorrência cruzada possa demonstrar alguns aspectos e padrões no discurso artístico que se revelam por meio da observação das recorrências mais constantes ao longo de um corpus maior. O mapeamento das ocorrências cruzadas no corpus dessa pesquisa não foi implementado devido à limitação de tempo para atingir os objetivos propostos. Dessa forma acredito que este achado pede por estudos posteriores para serem observados em que circunstâncias e com que finalidade as ocorrências cruzadas fazem a sua aparição em ambas modalidades.

As ocorrências observadas na triangulação foram categorizadas da forma descrita a seguir: 
a) ocorrência de natureza semântica - são ocorrências nas quais os sentidos são compatíveis.

b) ocorrência de natureza gramatical (tela) e léxico-gramatical (carta) - são ocorrências nas quais a organização formal dos construtos é compatível.

c) ocorrência de natureza funcional - são ocorrências nas quais há uma compatibilidade na sua função semiótica.

d) ocorrência semântico-gramatical - o sentido em uma modalidade é compatível com a forma na outra modalidade.

e) ocorrência semântico-funcional - o sentido em uma modalidade é compatível com a função na outra modalidade.

f) ocorrência gramatical-funcional - a forma em uma modalidade é compatível com a função na outra modalidade.

\subsubsection{Organização interna dos sistemas semióticos de van Gogh}

A triangulação dos achados visuais com os textuais revelou uma ampla interação entre os nexos produzidos visual e textualmente, e fornecem dados para a compreensão da forma como van Gogh conjugava os recursos semióticos. Ele os articulava para ampliar seu poder sinergético e potencializar seu poder comunicativo. Dessa forma, a observação não apenas da ocorrência do uso de um recurso semiótico, mas de sua interação com outros recursos semióticos para potencializar sua função dentro do texto proporciona uma forma tangível para mapear o uso conjugado dos recursos semióticos e compreender a organização interna do discurso artístico de van Gogh. Por exemplo, na tela 'Por de Sol: Campo de trigo perto de Arles' a conjugação de recursos semióticos para comunicar experiências, tais como o uso de saliência, cores, ritmo, textura e gesto pictórico colaboraram para transparecer a rapidez, o movimento, e a efervescência das experiências que van Gogh buscou comunicar, em seu estado de espírito. A seguir, são apresentados alguns dos resultados dessas recorrências.

\subsubsection{Intercorrências entre as categorias}


Apresento a seguir uma triangulação entre categorias da análise visual e da análise textual com o objetivo de compreender a relação entre os elementos presentes nas telas e nas orações. Desta forma, analisei em cada oração a presença de categorias da análise das telas. As categorias utilizadas foram: Saliência, Enquadramento, Direção ou vetor, Contraste, Perspectiva, Simbolismo, Incompletude, Transparência, Distorção, Inacabamento, Intertextualidade, Profundidade, Textura, Movimento, Ritmo, Rima visual, Gesto Pictórico.

O objetivo foi explicitar a função que a oração teve ao descrever as telas e os sentidos que estão presentes nas cartas e são similares nas telas. Por exemplo, quando van Gogh escreve que está fazendo "um estudo", compreendo que o sentido de ter optado por se referir à tela como estudo e não como produto final guarda relação com o sentido de Inacabamento, de uma produção em progresso, que não está finalizada. Em várias orações ele se utiliza de expressões metafóricas e simbólicas como "parece ser" ou "uma natureza... como em um acesso de raiva" que também sugerem a ocorrência de Inacabamento.

Algumas categorias da análise visual foram mais recorrentes na análise nas 139 orações analisadas. Percebo que algumas categorias se destacaram pela alta ocorrência no momento da análise. No apêndice, apresento o quadro 'Intercorrências entre as categorias' com uma síntese considerando a frequência das categorias nas orações.

\subsubsection{Porcentagem de Repetição da categoria}

Nesse item, busquei descrever a recorrência e relação entre categorias e processos, considerando as 139 orações analisadas. Algumas categorias aparecem com frequências ligadas a outras categorias, indicando que há uma recorrência de simultaneidade entre categorias. A categoria Saliência aparece com Enquadramento e Vetor em $41 \%$ de simultaneidade. Assim como Perspectiva, Contraste de Cor e Vetor aparecem cerca de 31\% das vezes simultaneamente. Outras categorias que apareceram simultaneamente com frequência foram Transparência, Incompletude e Associação Metafórica, assim como Profundidade, Transparência e Distorção. Em outra recorrência percebi a simultaneidade entre Ritmo e Movimento. Isto nos leva a inferir que efeitos usados nas telas para produzir sentido são também utilizados nas cartas, e que as funcionalidades no uso de recursos linguísticos textuais e visuais encontram relação entre si para produzir sentidos similares. A seguir, apresento o quadro 'Porcentagem de repetição da categoria, com a recorrência entre as categorias analisadas. 


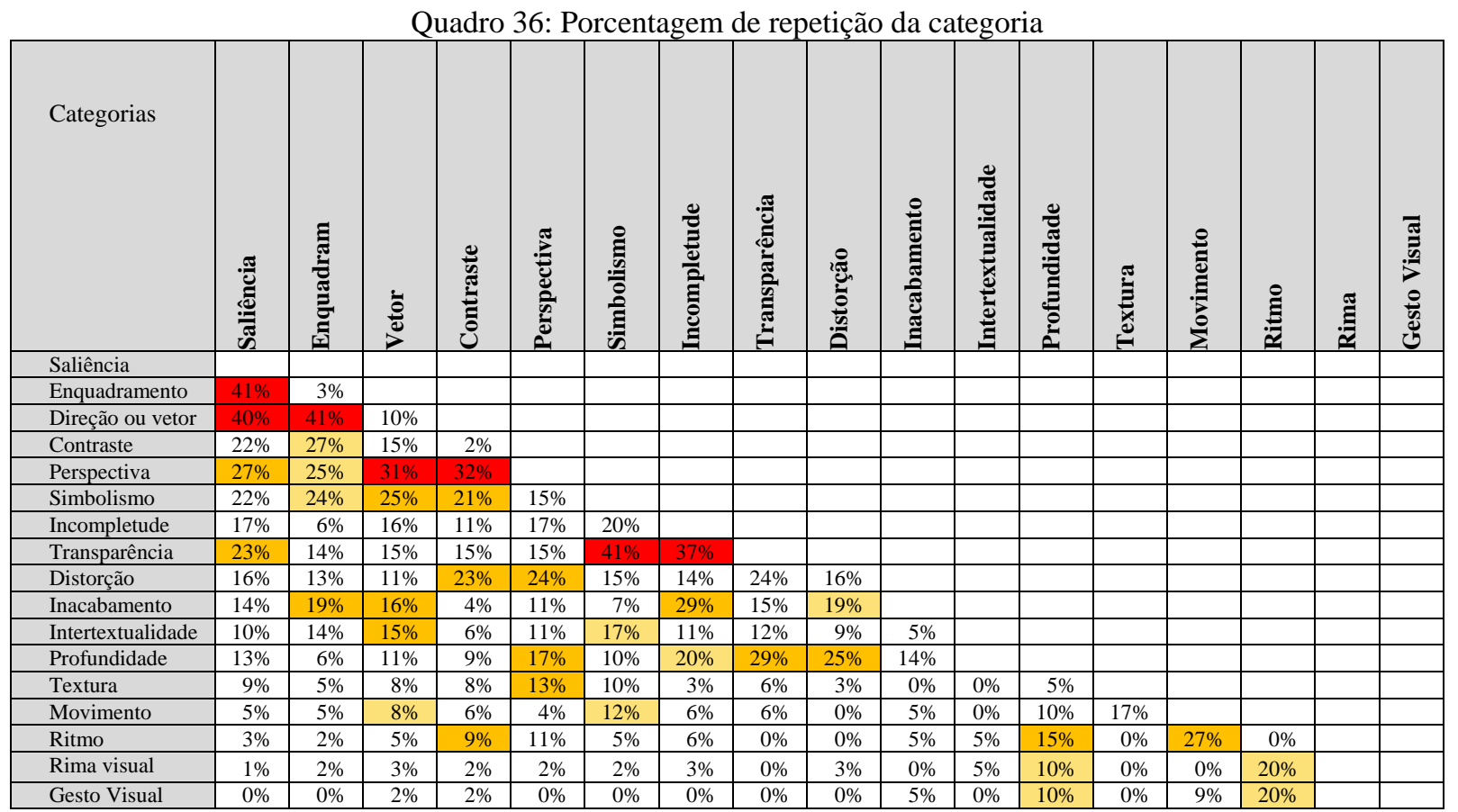

O quadro acima mostra a ocorrência de entrecruzamentos das categorias. Assim, embora saliência esteja presente em 86 orações (das 139 no total), ela aparece associada com até 5 outras categorias na mesma oração. Estas categorias guardam uma relação mais próxima umas com as outras quando analisei sua ocorrência entre si.

Associação Metafórica tem maior relação de ocorrência simultânea, proporcionalmente às ocorrências, com Transparência (41\%), Incompletude (20\%), Intertextualidade (17\%), Distorção (15\%) e Movimento (12\%).

A categoria Saliência apareceu com maior frequência associada às categorias Enquadramento (41\%), Vetor (40\%), Perspectiva (27\%) e Transparência (23\%).

A categoria Enquadramento apareceu com maior frequência com Saliência (41\%), Vetor (41\%), Contraste de Cor (27\%), Perspectiva (25\%), Associação Metafórica (24\%) e Inacabamento (19\%), considerando as 63 orações analisadas, nas quais ocorre enquadramento.

Além de Saliência (40\%) e Enquadramento (41\%), Vetor apareceu 6 vezes sozinho, em $10 \%$ das orações na qual aparece, e tem forte relação com Perspectiva (19), Associação Metafórica (15), Inacabamento (10) e Intertextualidade (9).

Contraste cromático apareceu mais vezes com Perspectiva (17), Associação metafórica (11), uma forte relação com Distorção do Ponto de Vista (12) e com Ritmo (5, considerando a 
pouca ocorrência desta categoria, ela apareceu junto com Contraste de cor em $50 \%$ das ocorrências).

Perspectiva também apareceu várias vezes com Distorção do Ponto de Vista (11), com Vetor (19), Profundidade e Textura. Talvez porque van Gogh construa a perspectiva utilizando a Textura da tinta na tela, articulada com o Contraste de cor. É interessante perceber que não somente nas telas, mas também nas orações aparece a relação entre Perspectiva e Distorção do Ponto de Vista, sendo frequente a distorção da perspectiva na tela como recurso semiótico.

Há uma relação entre a predominância de recursos descritivos acerca das telas nas orações que acompanha a produção da tela em si mesma, seus efeitos como imagem aparecem na construção das orações e revelam uma intercomunicabilidade nos diferentes recursos semióticos.

\subsubsection{Recorrência entre as categorias considerando a frequência total}

Nesta seção listo alguns achados da triangulação como uma consideração mais conclusiva da pesquisa. Das 139 orações analisadas, percebi que algumas categorias se destacaram pela alta ocorrência no momento da análise. Abaixo apresento um quadro síntese considerando a frequência das categorias nas orações:

\begin{tabular}{|c|c|c|c|c|c|c|c|c|c|c|c|c|c|c|}
\hline & 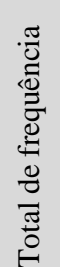 & 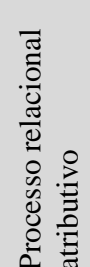 & $\begin{array}{l}\stackrel{\circ}{\Xi} \\
\text { 苞 } \\
\end{array}$ & 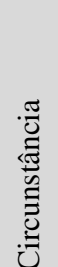 & 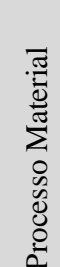 & $\frac{\grave{c}}{2}$ & 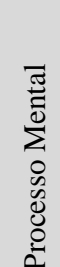 & 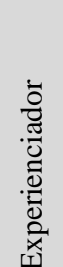 & 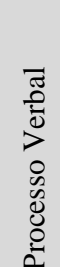 & 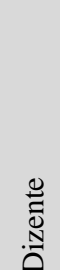 & 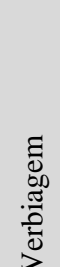 & $\begin{array}{l}\bar{\pi} \\
\frac{\pi}{0} \\
\frac{\pi}{0} \\
\frac{0}{\pi} \\
\text { II } \\
0 \\
0 \\
0 \\
0 \\
0 \\
0 \\
0\end{array}$ & 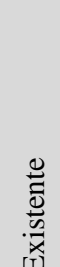 & 泀 \\
\hline Total - frequência & & 41 & 42 & 71 & 35 & 35 & 33 & 20 & 14 & 13 & 11 & 11 & 12 & \\
\hline Saliência & 86 & 1 & 4 & 26 & 0 & 6 & 2 & 2 & 3 & 3 & 0 & 0 & 2 & 37 \\
\hline Enquadramento & 63 & 10 & 5 & 9 & 0 & 3 & 0 & 0 & 0 & 1 & 2 & 1 & 3 & 29 \\
\hline Direção ou vetor & 61 & 9 & 1 & 0 & 26 & & 1 & 1 & 7 & 0 & 0 & 11 & 0 & 5 \\
\hline Contraste & 53 & 1 & 11 & 10 & 2 & 3 & & 1 & & 1 & & & 2 & 22 \\
\hline Perspectiva & 46 & 7 & 1 & 9 & & 1 & & 1 & 2 & & 3 & 2 & 3 & 17 \\
\hline Associação Metaf. & 41 & 2 & 11 & 5 & & & 4 & & 1 & 1 & 1 & 1 & 1 & 14 \\
\hline Incompletude & 35 & 1 & 2 & 4 & & 2 & 5 & 1 & 1 & & 1 & & & 18 \\
\hline Transparência & 34 & 3 & 2 & 1 & 3 & 1 & 11 & & 4 & 1 & & & & 8 \\
\hline Distorção & 32 & 3 & 3 & 6 & 3 & 1 & & & 1 & 1 & 4 & & & 10 \\
\hline Inacabamento & 22 & & 5 & 4 & 2 & 1 & & 1 & & & & & & 9 \\
\hline Intertextualidade & 22 & & 1 & 5 & & & & & 2 & 3 & 1 & & & 10 \\
\hline Profundidade & 20 & & 2 & 2 & & 2 & 2 & & & & 1 & & & 11 \\
\hline Textura & 12 & & & 1 & & & & & & & & & 1 & 10 \\
\hline Movimento & 11 & 1 & 1 & 1 & & & & & 1 & & & 1 & 1 & 5 \\
\hline Ritmo & 10 & 1 & 3 & 1 & & & & & & & & 1 & 1 & 3 \\
\hline
\end{tabular}




\begin{tabular}{l|l}
5 \\
2
\end{tabular}

$\mid$\begin{tabular}{l|l} 
& 1 \\
& 1 \\
\hline
\end{tabular}

\begin{tabular}{l|l|l}
\hline 1 & 2 \\
\hline & 1 & 1
\end{tabular}

\subsection{CONCLUSÃO}

Nesta pesquisa, me propus a investigar a tese de que o discurso artístico de Vincent van Gogh é integrado tanto por seu discurso pictórico quanto por seu discurso epistolar. Para isso, triangulei a análise do corpus visual, composto de quatro telas com a análise do corpus textual, composto de excertos de cartas relativas às telas, e de uma carta na íntegra, usando como subsídio teórico as bases teóricas da TSSM, da LSF e da ADC. Na triangulação usei categorias da GDV, das Artes e da Percepção Visual, e propus novas categorias tais como Gesto Pictórico, Transparência, Inacabamento, Incompletude e Limiar Artístico que constituem uma contribuição desta pesquisa para a área da multimodalidade, em especial para a análise do discurso artístico. Para sondar as conexões de nexo entre os achados da análise visual com os achados da análise textual, propus alguns caminhos possíveis de comparação: por sentido, por forma e por função. Essas possibilidades foram transpostas para as funções e metafunções visuais e da linguagem, propostas por O'Toole (1994) e por Halliday (2014) e puderam se desdobrar em diferentes combinações de acordo com sua ocorrência e intercorrência. O trabalho de prospecção por sondagem e aproximação na triangulação dos achados visuais com os textuais revelou um vasto cenário não só das ocorrências de nexos entre o visual e o textual, mas também apontou indícios da forma como van Gogh articulava recursos semióticos a fim de construir efeitos de sentidos e sistemas semióticos para potencializar a comunicação de sua experiência. Além de comprovar a tese, a triangulação trouxe à tona a recorrência da combinação de usos semióticos o que proporcionou para esta pesquisa construir, preliminarmente, um mapa que fornece a visão panorâmica das recorrências do uso conjugado dos recursos semióticos que pode indicar a organização interna da urdidura do discurso artístico de van Gogh. 


\section{REFERENCIAS}

ARNHEIM, Rudolf. Arte \& percepção visual: uma Psicologia da Visão Criadora. 3.ed. São Paulo: Livraria Pioneira Editora, 1974.

BOTTICELLI, Sandro. A primavera. 1482c. 1 fotografia. Fotografia publicada pelo site Estórias da história em 04 jun. 2013. Disponível em:

<http://estoriasdahistoria12.blogspot.com.br/2013/06/a-primavera-de-sandro botticelli.html $>$. Acesso em: nov. 2015.

BUTT, David et al. Using functional grammar: an explorer's guide. 2. ed. Sydney: Macquarie University, 2000.

CABANNE, Pierre. Van Gogh. Cacém: Editorial Verbo, 1971.

CHOULIARAKI, L.; FAIRCLOUGH, N. Discourse in late modernity: rethinking critical discourse analysis. Cambridge: Edinburgh University Press, 1999.

COLI, Jorge. Vincent Van Gogh: a noite estrelada. São Paulo: Perspectiva, 2006.

DE MICHELI, M. As vanguardas artísticas do século XX. São Paulo: Martins Fontes, 1991.

DONDIS, Donis A. Sintaxe da linguagem visual. São Paulo: Martins Fontes, 2007.

EDWARDS, Cliffs. Mystery of the night café: hidden key to the spirituality of Vincent van Gogh. Albany: State University of New York Press, 2009.

EGGINS, Suzanne. An introduction to systemic functional linguistics. 2. ed. New York: Continuum International Publishing Group, 2012.

FAIRCLOUGH, N. Analysing discourse: Textual analysis for social research. New York: Routledge, 2003.

FAIRCLOUGH, N. Critical discourse analysis: The critical study of language. London: Pearson Education Limited, 2010.

FAIRCLOUGH, N. Discurso e mudança social. Brasília: Universidade de Brasília, 2001. 
FORRESTER, Viviane. Van Gogh ou o enterro no campo de trigo. Porto Alegre: L\&PM, 1983.

FUZER, C.; CABRAL, S. R. S. Introdução à gramática sistêmico-funcional em língua portuguesa. Campinas, SP: Mercado das Letras, 2014.

GOMBRICH, E. H. A História da arte. 16. ed. Rio de Janeiro: LTC Editora, 1999.

HALLIDAY, M. A. K. Grammar and daily life: concurrence and complementarity. In: LOCKWOOD, David; FRIES, Peter H.; COPELAND, James E.(Eds.). Functional approaches to language, culture and cognition. Amsterdam: John Benjamins Publishing Company, 2000. p. 221-237.

HALLIDAY, M. A. K. Language as social semiotic: the social interpretation of language and meaning. London: Edward Arnold, 1978.

HALLIDAY, M. A. K. Language, text and context: aspects of language in a social semiotic perspective. Australia: Deakin University Press, 1985.

HALLIDAY, M. A. K.; MATTHIESSEN, C. M. I. M. An introduction to functional grammar. London: Edward Arnold, 1985. 387p.

HALLIDAY, M. A. K.; MATTHIESSEN, C. M. I. M. An introduction to functional grammar. 2. ed. London: Edward Arnold, 1994. 434p.

HALLIDAY, M. A. K.; MATTHIESSEN, C. M. I. M. An introduction to functional grammar. 3. ed. London: Oxford, 2004.

HALLIDAY, M. A. K.; MATTHIESSEN, C. M. I. M. An introduction to functional grammar. 4. ed. London: Oxford, 2014

HALLIDAY, M. A. K.; MCINTOSH, A.; STEVENS, P. The users and uses of language. In: WEBSTER, J. J. (Ed.). Language and society. London: Continuum, 2007. p. 5-37.

(Collected Works of M.A.K. Halliday, 10).

HALLIDAY, M.A.K. An introduction to functional grammar. London: Edward Arnold, 1994.

HALLIDAY, M.A.K. Categories of the theory of grammar. Word, v. 17, n. 3, p. 241-92, 1961. 
HALLIDAY, M.A.K.; HASAN, Ruqaia. An introduction to functional grammar. London: Edward Arnold, 1985.

HALLIDAY, M.A.K.; HASAN, Ruqaia. Language, context, and text: aspects of language in a social-semiotic perspective. Oxford: Oxford University Press, 1989.

HALLIDAY, M.A.K.; MATHIESSEN, Christian M.I.M. Construing experience through meaning: a language based approach to cognition. New York: Continuum, 1999.

HASAN, R. The structure of a text. In: Halliday, M.A.K.; Hasan, R. Language, context, and text: aspects of language in a social-semiotic perspective. 2. ed. Oxford: Oxford, 1989. University Press.

HAZIOT, David. Van Gogh. Porto Alegre: L\&PM, 2010.

HOBSBAWM, Eric. A era do capital, 1848-1875. 21. ed. São Paulo: Paz e Terra, 2014.

ITTEN, Johannes. The art of color: the subjective experience and objective rationale of color. New York: Van Nostrand Reinhold, 1973.

JAKOBSON, R.; HALLE, M. Fundamentals of language. Haia: Mouton \& CO., 1956.

JANSEN, Leo; LUIJTEN, Hans; BAKKER, Nienke (Eds.). Vincent van Gogh the letters: The Complete Illustrated and Annotated Edition. 2009. Disponível em:

$<$ http://vangoghletters.org/vg/>. Acesso em: nov. 2015.

JEWITT, Carey. The routledge handbook of multimodal analysis. Routledge: London, 2011.

JUNQUEIRA, Rafael. CMYK e RGB. 11 jul. 2014. Disponível em: $<$ https://mundopauta.wordpress.com/2014/07/11/cmyk-e-rgb/ $>$. Acesso em: nov. 2015.

KANDINSKY, Wassily. Do espiritual na arte. São Paulo: Martins Fontes, 1996.

KANDINSKY, Wassily. Ponto, linha, plano. Lisboa: Edições 70, 1970.

KRESS, G.; VAN LEEUWEN, T. J. Multimodal discourse: The Modes and Media of Contemporary Communication. London: Arnold, 2001. 
KRESS, G.; VAN LEEUWEN, T. J. Reading images: The Grammar of Visual Design. London: Routledge. 1996.

KRESS, G.; VAN LEEUWEN, T. Reading images: the grammar of visual design. 2. ed. London: Routledge, 2006.

KRESS, Gunther. Multimodality, a social semiotic approach to contemporary communication. Routledge: London, 2010.

LISCHTENSTEIN, Jacqueline (Org.) A pintura: O mito da pintura. São Paulo: Ed. 34, 2004.

LITTLE, Stephen. ...ismos para entender a arte. Portugal: Editora Globo, 2010.

MACHIN, D. Introduction to multimodal analysis. London: Routledge, 2007.

MARTIN, J. R.; ROSE, D. Working with discourse: meaning beyond the clause. London: Continuum, 2003.

MARTIN, J. R.; WHITE, P. R. R. The language of evaluation: appraisal in English. London: Palgrave, 2005.

MCLUHAN, H. M. Comunicação, mídia e consumo. ESPM, São Paulo, v. 5, n. 14, p. 123$148,2008$.

MCQUILLAN, Melissa. Van Gogh, world of art. London: Thames and Hudson, 1989.

MUHLBERGER, Richard, O que faz de um van Gogh um van Gogh?. São Paulo: Cosac Naify, 2002.

NAIFEH, S.; SMITH. G.W. Van Gogh: the life. São Paulo: Companhia das Letras, 2012.

NEVES, Maria Helena de Moura. A gramática funcional. São Paulo: Martins Fontes, 2004.

NORRIS, Sigrid. Multimodality in practice: Investigating theory-in-practice-through methodology. New York: Routledge Studies in Multimodality, 2012. 
NOVELLINO, Marcia Olivé. Fotografias em livro didático de inglês como língua estrangeira: análise de suas funções e significados. Dissertação (Mestrado em Letras)- PUC, Departamento de Letras, Rio de Janeiro, 2007.

O’HALLORAN, Kay (ed.). Multimodal discourse analysis: Systemic-Functional Perspectives. New York: Continuum International Publishing Group, 2004.

O’HALLORAN, Kay; SMITH, Bradley. Multimodal Studies: Exploring Issues and Domains, Routledge Studies in Multimodality. New York: Routledge Studies in Multimodality, 2011.

O'TOOLE, Michel. The language of displayed art. Cranbury: Fairleigh Dickinson University Press, 1994.

OLIVEIRA, Ana Claudia de (Org.) Semiótica plástica. São Paulo: Ed. Hacker, 2004.

ONG, Walter. Orality and literacy. London: Methuen, 1982.

PAGE, Ruth. New perspectives on narrative and multimodality. New York: Routledge Studies in Multimodality, 2011.

PAINTER, C. The role of colour in children's picture books: Choices in AMBIENCE. In: UNSWORTH, L. (Ed.). New Literacies and the English Curriculum. London: Continuum, 2008. p.89-111.

PALMEIRA, Nazare. As cores. 17 mar. 2014. Disponível em: <https://arteemlibras.wordpress.com/category/cores/>. Acesso em: nov. 2015.

PEREIRA, Orlindo G. Vincent Van Gogh palavra e imagem. Lisboa: Edições INAPA, 1990.

PETRIE, Brian. Obras-primas de Van Gogh. Lisboa: Editorial Verbo, 1974. CHOFAKIAN, Sarah. Style Tip: Combinando Cores Análogas. 29 nov. 2013. Disponível em:

<http://www.sarahchofakian.com.br/tag/circulo-cromatico/>. Acesso em: nov. 2015.

PRAXEDES FILHO, Pedro Henrique Lima. A corpora-based study of the development of EFL brazilian learners' interlanguage: from simplification to complexification in the light of systemic-functional grammar. 2007. 406 f. Tese (Doutorado em Letras) Universidade Federal de Santa Catarina, Programa de Pós-graduação em Letras/Inglês e Literatura Correspondente, Florianópolis-SC, 2007. 
RESENDE, Viviane de Melo; RAMALHO, Viviane. Análise de discurso crítica. São Paulo: Contexto, 2006, 158 p.

SCHAPIRO, Meyer. A arte moderna: séculos XIX e XX: ensaios escolhidos. São Paulo: Editora da Universidade de São Paulo, 2010.

SEURAT, Georges. A sunday on la grande jatte. 1884-1886. 1 fotografia. Fotografia publicada pelo site Art Institute Chicago. Disponível em:

<http://www.artic.edu/aic/collections/artwork/27992>. Acesso em: nov. 2015.

SOUZA, Anderson Alves de. 'Do the right, be firm, be fair': A systemic Functional Investigation of National Anthems written in English. 2008. Tese (Doutorado em Letras) Universidade Federal de Santa Catarina, Florianópolis, 2008.

THOMPSON, G. Introducing functional grammar. 2. ed. London: Edward Arnold, 2004.

THOMPSON, J. B. Ideologia e cultura moderna: teoria social crítica na era dos meios de comunicação de massa. 8. ed. Petrópolis, RJ: Vozes, 2009.

UNSWORTH, L. Comparing school science explanations in books and computer-based formats: The role of images, image/text relations and hyperlinks. International journal of instructional media, v. 31, n. 3, p. 283-301, 2004.

VAN GOGH MUSEUM. Vincent. 1 fotografia. [1872]. Disponível em: $<$ http://www.vangoghmuseum.nl/vgm/index.jsp?page=12259\&lang=en >. Acesso em: nov. 2015.

VAN GOGH, Vincent. 567 To Theo van Gogh. Paris, on or about Sunday, 28 February 1886. In: JANSEN, Leo; LUIJTEN, Hans; BAKKER, Nienke (Eds.). Vincent van Gogh the letters: the complete illustrated and annotated edition. 2009m. Disponível em: <http://vangoghletters.org/vg/letters/let567/letter.html >. Acesso em: nov. 2015.

VAN GOGH, Vincent. 628 To Emile Bernard. Arles, on or about Tuesday, 19 June 1888. In: JANSEN, Leo; LUIJTEN, Hans; BAKKER, Nienke (Eds.). Vincent van Gogh the letters: the complete illustrated and annotated edition. 2009c. Disponível em: <http://vangoghletters.org/vg/letters/let628/letter.html>. Acesso em: nov. 2015.

VAN GOGH, Vincent. 629 To Theo van Gogh. Arles, Thursday, 21 June 1888. In: JANSEN, Leo; LUIJTEN, Hans; BAKKER, Nienke (Eds.). Vincent van Gogh the letters: the complete illustrated and annotated edition. 2009e. Disponível em:

<http://vangoghletters.org/vg/letters/let629/letter.html>. Acesso em: nov. 2015. 
VAN GOGH, Vincent. 639 To Theo van Gogh. Arles, on or about Friday, 13 July 1888. In: JANSEN, Leo; LUIJTEN, Hans; BAKKER, Nienke (Eds.). Vincent van Gogh the letters: the complete illustrated and annotated edition. 2009n. Disponível em:

< http://vangoghletters.org/vg/letters/let639/letter.html\#translation>. Acesso em: nov. 2015.

VAN GOGH, Vincent. 656 To Theo van Gogh. Arles, Monday, 6 August 1888. In: JANSEN, Leo; LUIJTEN, Hans; BAKKER, Nienke (Eds.). Vincent van Gogh the letters: the complete illustrated and annotated edition. 20091. Disponível em:

<http://www.vangoghletters.org/vg/letters/let656/letter.html> . Acesso em: nov. 2015.

VAN GOGH, Vincent. 673 To Theo van Gogh. Arles, Monday, 3 September 1888. In: JANSEN, Leo; LUIJTEN, Hans; BAKKER, Nienke (Eds.). Vincent van Gogh the letters: the complete illustrated and annotated edition. 2009q. Disponível em:

<http://vangoghletters.org/vg/letters/let673/letter.html>. Acesso em: nov. 2015.

VAN GOGH, Vincent. 676 To Theo van Gogh. Arles, Saturday, 8 September 1888. In: JANSEN, Leo; LUIJTEN, Hans; BAKKER, Nienke (Eds.). Vincent van Gogh the letters: the complete illustrated and annotated edition. 2009j. Disponível em:

<http://vangoghletters.org/vg/letters/let676/letter.html>. Acesso em: nov. 2015.

VAN GOGH, Vincent. 677 To Theo van Gogh. Arles, Sunday, 9 September 1888. In: JANSEN, Leo; LUIJTEN, Hans; BAKKER, Nienke (Eds.). Vincent van Gogh the letters: the complete illustrated and annotated edition. 2009h. Disponível em:

< http://vangoghletters.org/vg/letters/let677/letter.html>. Acesso em: nov. 2015.

VAN GOGH, Vincent. 678 To Willemien van Gogh. Arles, Sunday, 9 and about Friday, 14 September 1888. In: JANSEN, Leo; LUIJTEN, Hans; BAKKER, Nienke (Eds.). Vincent van Gogh the letters: the complete illustrated and annotated edition. 2009g. Disponível em: <http://vangoghletters.org/vg/letters/let678/letter.html>. Acesso em: nov. 2015.

VAN GOGH, Vincent. 680 To Theo van Gogh. Arles, on or about Tuesday, 11 September 1888. In: JANSEN, Leo; LUIJTEN, Hans; BAKKER, Nienke (Eds.). Vincent van Gogh the letters: the complete illustrated and annotated edition. 2009b. Disponível em: <http://vangoghletters.org/vg/letters/let626/letter.html>. Acesso em: nov. 2015.

VAN GOGH, Vincent. 681 To Theo van Gogh. Arles, Sunday, 16 September 1888. In: JANSEN, Leo; LUIJTEN, Hans; BAKKER, Nienke (Eds.). Vincent van Gogh the letters: the complete illustrated and annotated edition. 2009f. Disponível em: <http://vangoghletters.org/vg/letters/let681/letter.html>. Acesso em: nov. 2015. 
VAN GOGH, Vincent. 705 To Theo van Gogh. Arles, Tuesday, 16 October 1888. In: JANSEN, Leo; LUIJTEN, Hans; BAKKER, Nienke (Eds.). Vincent van Gogh the letters: the complete illustrated and annotated edition. 2009i. Disponível em: <http://vangoghletters.org/vg/letters/let705/letter.html>. Acesso em: nov. 2015.

VAN GOGH, Vincent. 721 To Theo van Gogh. Arles, on or about Monday, 19 November 1888. In: JANSEN, Leo; LUIJTEN, Hans; BAKKER, Nienke (Eds.). Vincent van Gogh the letters: the complete illustrated and annotated edition. 2009o. Disponível em:

< http://vangoghletters.org/vg/letters/let721/letter.html\#translation>. Acesso em: nov. 2015.

VAN GOGH, Vincent. 879 To Willemien van Gogh. Auvers-sur-Oise, Thursday, 5 June 1890. In: JANSEN, Leo; LUIJTEN, Hans; BAKKER, Nienke (Eds.). Vincent van Gogh the letters: the complete illustrated and annotated edition. 2009p. Disponível em: <http://vangoghletters.org/vg/letters/let879/letter.html>. Acesso em: nov. 2015.

VAN GOGH, Vincent. Carta de Van Gogh: julho 1880: Carta 133. In: A ilha dos amores - I [site]. 2007. Disponível em: <https://ailhadosamores.wordpress.com/textos-linkados-nos postais/carta-de-van-gogh-julho-1880-carta-133/> . Acesso em: nov. 2015.

VAN GOGH, Vincent. Cartas a Théo. Tradução Pierre Ruprecht. Porto Alegre: L\&PM, 2010.

VAN GOGH, Vincent. Letter to Theo van Gogh. Publisher: Bulfinch, 1991.

VAN GOGH, Vincent. Park at asnieres in spring. 1887a. 1 fotografia. Fotografia publicada pelo site Van Gogh Gallery. Disponível em:

<http://www.artic.edu/aic/collections/artwork/27992>. Acesso em: nov. 2015.

VAN GOGH, Vincent. Self-portrait. 1887b. 1 fotografia. Fotografia publicada pelo site Van Gogh Gallery. Disponível em: 〈http://www.vggallery.com/painting/p_0320.htm>. Acesso em: nov. 2015.

VAN GOGH, Vincent. Sheaf-binder, the (after Millet). 1889a. 1 fotografia. Fotografia publicada pelo site Van Gogh Gallery. Disponível em:

<http://www.vggallery.com/painting/p_0693.htm>. Acesso em: nov. 2015.

VAN GOGH, Vincent. Starry night. 1889b. 1 fotografia. Fotografia publicada pelo site Van Gogh Gallery. Disponível em: <http://www.vggallery.com/painting/p_0612.htm>. Acesso em: nov. 2015. 
VAN GOGH, Vincent. Sunset: Wheat Fields Near Arles. 1888a. 1 fotografia. Fotografia publicada pelo site The Vincent van Gogh Gallery em 24 jul. 2014. Disponível em: <http://www.vggallery.com/painting/p_0465.htm>. Acesso em: nov. 2015.

VAN GOGH, Vincent. The café terrace on the place du forum. 1888c. 1 fotografia. Fotografia publicada pelo site The Vincent van Gogh Gallery em 24 jul. 2014. Disponível em: <http://www.vggallery.com/painting/p_0467.htm>. Acesso em: nov. 2015.

VAN GOGH, Vincent. The night café in the place Lamartine. 1888b. 1 fotografia. Fotografia publicada pelo site The Vincent van Gogh Gallery em 24 jul. 2014. Disponível em: <http://www.vggallery.com/painting/p_0463.htm>. Acesso em: nov. 2015.

VAN GOGH, Vincent. The sower. 1888d. 1 fotografia. Fotografia publicada pelo site The Vincent van Gogh Gallery em 07 jul. 2014. Disponível em: <http://www.vggallery.com/painting/p_0422.htm>. Acesso em: nov. 2015.

VAN GOGH, Vincent. The Langlois Bridge at Arles. 1888e. 1 fotografia. Fotografia publicada pelo site The Vincent van Gogh Gallery em 07 jul. 2014. Disponível em: <http://www.vggallery.com/painting/p_0570.htm>. Acesso em: nov. 2015.

VAN GOGH, Vincent. Trees in the garden of Saint-Paul hospital. 1889c. 1 fotografia. Fotografia publicada pelo site Van Gogh Gallery. Disponível em:

<http://www.vggallery.com/painting/p_0642.htm>. Acesso em: nov. 2015.

VAN GOGH, Vincent. Undergrowth with two figures. 1890b. 1 fotografia. Fotografia publicada pelo site Van Gogh Gallery. Disponível em:

<http://www.vggallery.com/painting/p_0773.htm>. Acesso em: nov. 2015.

VAN GOGH, Vincent. Village street and steps in Auvers with figures. 1890a. 1 fotografia. Fotografia publicada pelo site Van Gogh Gallery. Disponível em:

<http://www.vggallery.com/painting/p_0795.htm>. Acesso em: nov. 2015.

VAN GOGH, Vincent. Wheat field with crows. 1890c. 1 fotografia. Fotografia publicada pelo site Van Gogh Gallery. Disponível em:

<www.vggallery.com/painting/p_0779.htm>. Acesso em: nov.2015.

VAN GOGH, Vincent. Wheat field with reaper and sun. 1889d. 1 fotografia. Fotografia publicada pelo site the Vincent van Gogh Gallery. Disponível em:

<http://www.vggallery.com/painting/p_0617.htm>. Acesso em: nov. 2015. 
VAN GOGH, Vincent.155 To Theo van Gogh. Cuesmes, between about Tuesday, 22 and Thursday, 24 June 1880. In: JANSEN, Leo; LUIJTEN, Hans; BAKKER, Nienke (Eds.). Vincent van Gogh the letters: the complete illustrated and annotated edition. 2009k. Disponível em: <http://vangoghletters.org/vg/letters/let155/letter.html>. Acesso em: nov. 2015.

VAN GOGH, Vincent.626 To Willemien van Gogh. Arles, between Saturday, 16 and Wednesday, 20 June 1888. In: JANSEN, Leo; LUIJTEN, Hans; BAKKER, Nienke (Eds.). Vincent van Gogh the letters: the complete illustrated and annotated edition. 2009a. Disponível em: 〈http://vangoghletters.org/vg/letters/let626/letter.html>. Acesso em: nov. 2015.

VAN GOGH, Vincent.633 To Emile Bernard. Arles, Wednesday, 27 June 1888. In: JANSEN, Leo; LUIJTEN, Hans; BAKKER, Nienke (Eds.). Vincent van Gogh the letters: the complete illustrated and annotated edition. 2009d. Disponível em:

<http://vangoghletters.org/vg/letters/let633/letter.html>. Acesso em: nov. 2015.

VAN LEEUWEN, Theo. Discourse and practice: new tools for critical discourse analysis. New York: Oxford University Press, 2008.

VAN LEEUWEN, Theo. Narrative representations: designing social action. In: KRESS, Gunther; VAN LEEUWEN, Theo. Reading images: the grammar of visual design. Routledge: London, New York, 1996.

VAN LEEUWEN, Theo. The language of colour: an introduction, Routledge: New York, 2011.

VIEIRA. Afinal, existem metáforas visuais? IN: VIEIRA, BENTO \& ORMUNDO (orgs.). Discursos nas práticas sociais: perspectivas em multimodalidade e em gramática sistêmico-funcional. São Paulo: Annablume, 2010, p. 51- 66.

VIEIRA. Multimodalidade nos eventos de letramento. IN Vieira e Silvestre. Introdução à multimodalidade: contribuições da gramática sistêmico-funcional, análise de discurso crítica, semiótica social. Brasília, DF: Antunes Vieira, 2015, p. 43-74.

VIEIRA, Josenia Antunes. A identidade da mulher na modernidade. DELTA, São Paulo, v. 21, n. spe, p. 207-238, 2005. Available from http://www.scielo.br/scielo.php?script+sci_arttext\&pid=S010244502005000300012\&Ing=en\&nrm=iso. access on 11 Feb. $2016 . \quad<\mathrm{http}: / /$ dx.doi.org/100.1590/S0102-44502005000300012>. 
WALTHER, Ingo. Van Gogh. Koln: Taschen, 1990.

WALTHER, Ingo; METZGER, Rainer. Vincent van Gogh the complete paitings. California: Taschen, 2012.

WALTHER, Ingo; METZGER, Rainer.Van Gogh obra completa de pintura. Köln: Taschen, 2015.

WODAK, R.; MEYER, M. (Ed). Methods of critical discourse analysis. London: Sage, 2001.

WÖFFLIN, H. Conceitos fundamentais da história da arte. São Paulo: Martins Fontes, 1989. 


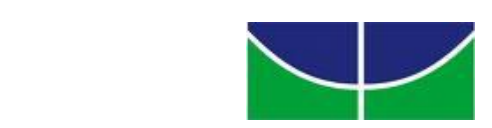

UNIVERSIDADE DE BRASÍLIA - UnB

INSTITUTO DE LETRAS - IL

DEPARTAMENTO DE LINGUÍSTICA, PORTUGUÊS E LíNGUAS CLÁSSICAS LIP

PROGRAMA DE PÓS-GRADUAÇÃO EM LINGUÍSTICA - PPGL

\section{ARTE E DISCURSO MULTIMODAL: \\ ANÁLISE DA LINGUAGEM VISUAL EM SUA RELAÇÃO COM O RELATO DA HISTÓRIA DE VIDA E DA PRODUÇÃO ARTÍSTICA DE VAN GOGH}

\section{APÊNDICE}

CRISTINA AZRA BARRENECHEA 


\section{LISTA DE FIGURAS}

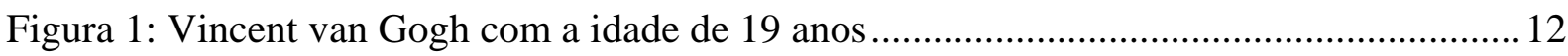

Figura 2: Theodorus van Gogh, pai de Vincent van Gogh ................................................. 28

Figura 3: Anna Cornelia van Gogh-Carbentus, mãe de Vincent van Gogh ............................28

Figura 4: Lar onde Vincent viveu sua infância em Groot-Zundert ........................................29

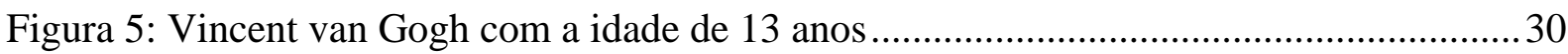

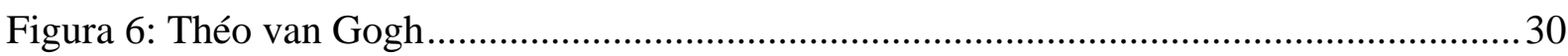

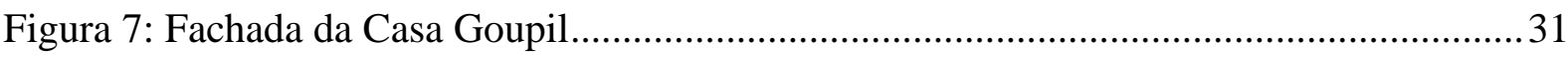

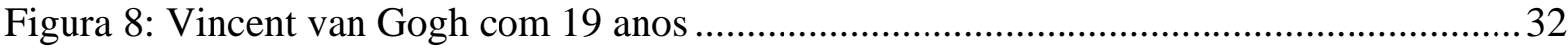

Figura 9: Fachada da Casa Goupil em Paris, na Rua Lepic ................................................ 32

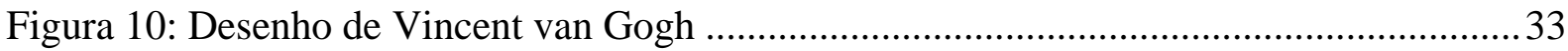

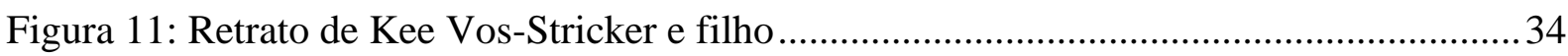

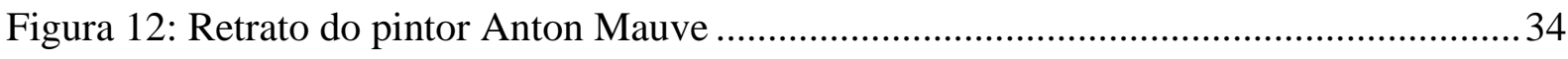

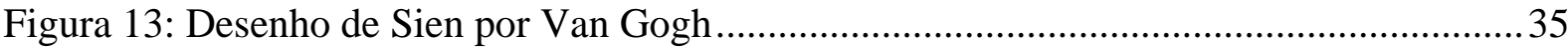

Figura 14: "Sorrow" desenho de Sien por Vincent van Gogh............................................... 36

Figura 15: Os comedores de batatas de Vincent van Gogh .................................................... 37

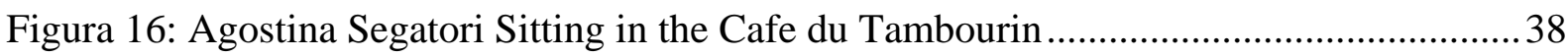

Figura 17: Tela de Vincent van Gogh: Self-Portrait with Bandaged Ear and Pipe .................. 39

Figura 18: Tela de Vincent van Gogh: Ward in the Hospital in Arles ................................... 40

Figura 19: Tela de Vincent van Gogh: Wheat Field with a Partridge .................................... 41

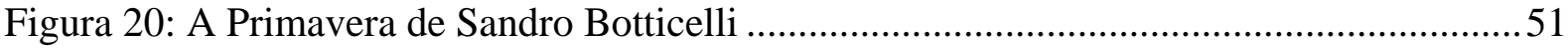

Figura 21: Tela A Sunday on La Grande Jatte de Georges Seurat.......................................... 80

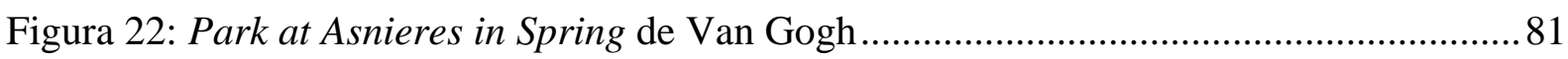

Figura 23: Village Street and Steps in Auvers with Figures de Van Gogh ............................ 83

Figura 24: Sheaf-Binder, The (after Millet) de Van Gogh .................................................... 86

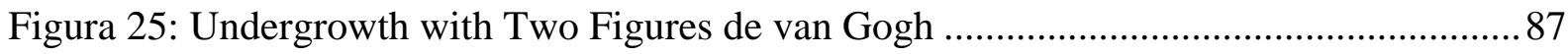

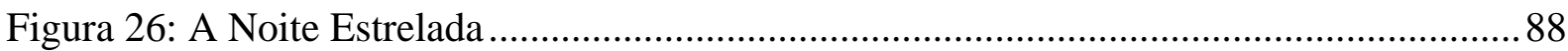

Figura 27: Trees in the Garden of Saint-Paul Hospital ....................................................... 91

Figura 28: Cores primárias, secundárias e terciárias .......................................................... 105

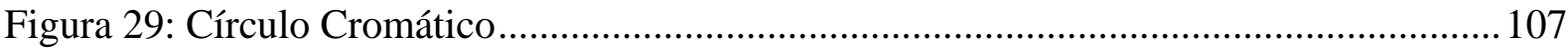

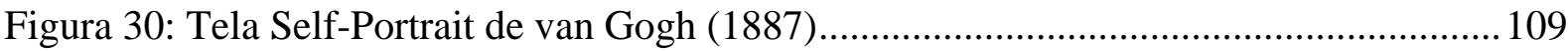

Figura 31: Tela de Van Gogh - Por de Sol: Campo de trigo perto de Arles (1888)............... 113 
Figura 32: Círculo Cromático.

Figura 33: Harmonia entre as cores no círculo cromático

Figura 34: Café in the Place Lamartine in Arles, (1888).................................................... 118

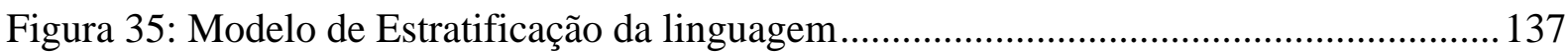

Figura 36: Tela Campo de trigo com Ceifeiro e Sol de Vincent van Gogh ............................ 148

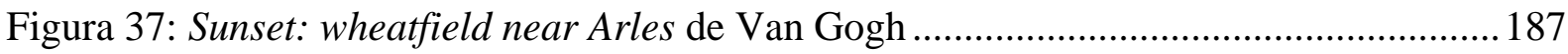

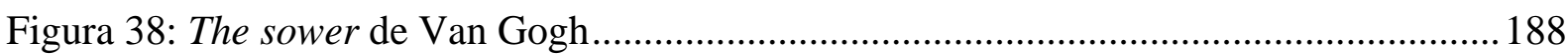

Figura 39: The Café Terrace on the Place Du Forum, Arles, at Night de Van Gogh............ 189

Figura 40: The Night Café in the Place Lamartine in Arles - Arles: 5-8 September 1888 .... 192

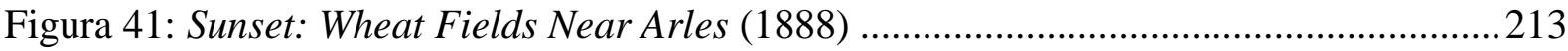

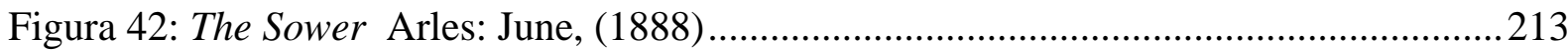

Figura 43: The Café Terrace on the Place Du Forum, Arles, at Night (1888) ......................2 214

Figura 44: The Night Café in the Place Lamartine in Arles (1888) ......................................214

Figura 45: Por de Sol: Campo de trigo perto de Arles (1888).............................................260

Figura 46: Por de Sol: Campo de trigo perto de Arles (1888).............................................261

Figura 47: Por de Sol: Campo de trigo perto de Arles (1888).............................................262

Figura 48: Por de Sol: Campo de trigo perto de Arles (1888)..............................................262

Figura 49 Por de Sol: Campo de trigo perto de Arles (1888) ...............................................263

Figura 50: Por de Sol: Campo de trigo perto de Arles (1888)...............................................264

Figura 51: Por de Sol: Campo de trigo perto de Arles (1888)............................................265

Figura 52: Corvos sobre Campo de Trigo (1890). Óleo (c. $50 \mathrm{~cm} \mathrm{x} 103 \mathrm{~cm}$ ). Auvers-sur-Oise, Julho, 1890. Museu Nacional Van Gogh, Amsterdam. .....................................................266

Figura 53: Por de Sol: Campo de trigo perto de Arles (1888) ...............................................267

Figura 54: Por de Sol: Campo de trigo perto de Arles (1888)................................................267

Figura 55: Por de Sol: Campo de trigo perto de Arles (1888)..............................................268

Figura 56: Por de Sol: Campo de trigo perto de Arles (1888)............................................. 290

Figura 57: Por de Sol: Campo de trigo perto de Arles (1888)................................................ 294

Figura 58: A Esplanada do Café na Place du Forum, Arles, à Noite de van Gogh .................309

Figura 59: The Café Terrace on the Place Du Forum, Arles, at Night de van Gogh ............. 310

Figura 60: The Café Terrace on the Place Du Forum, Arles, at Night de van Gogh ............. 311

Figura 61: The Café Terrace on the Place Du Forum, Arles, at Night de van Gogh .............312 


\section{LISTA DE QUADROS}

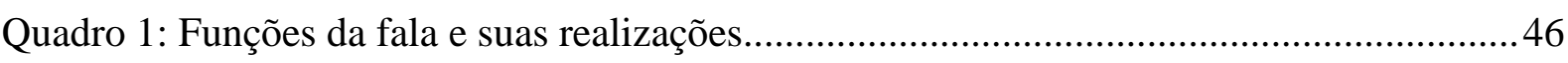

Quadro 2: Um aspecto do sistema de Modo com suas possibilidades realizacionais ..............47

Quadro 3: Funções do sistema de MODO com suas possibilidades transacionais ...................47

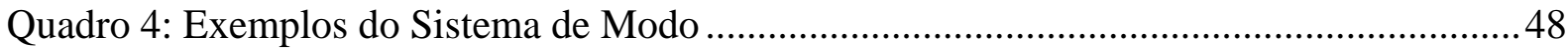

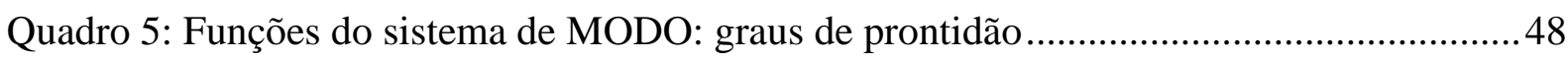

Quadro 6: Funções do sistema de MODO: graus de obrigação .............................................. 48

Quadro 7: Modalidade e suas realizações configuracionais .................................................. 49

Quadro 8: Aspectos e subaspectos da Modalidade: Definições e realizações lexicais - Valor,

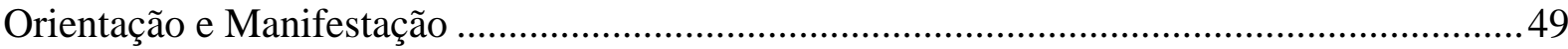

Quadro 9: As três funções da linguagem pictórica..................................................................54

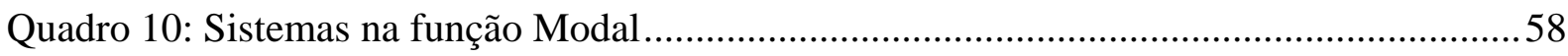

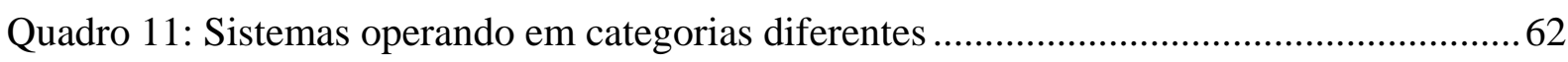

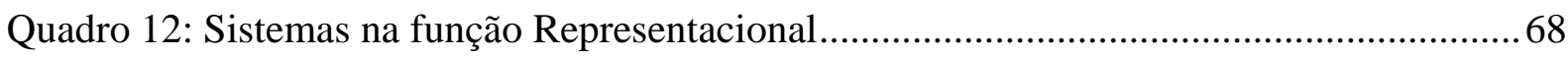

Quadro 13: Funções e Sistemas na Pintura ....................................................................... 71

Quadro 14: Quadro que esquematiza as diferenças entre linguagem e imagens.................... 166

Quadro 15: Relação das telas do corpus pictórico ..............................................................216

Quadro 16: Relação das telas com as cartas do corpus textual. ...........................................219

Quadro 17: Lista de cartas, excertos e telas a que se referem ............................................221

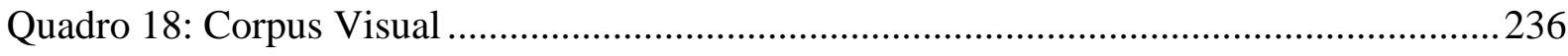

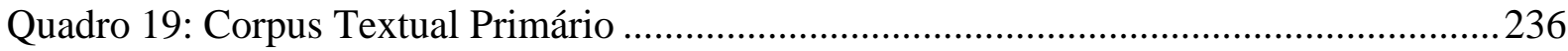

Quadro 20: Para organizar a triangulação entre telas e cartas ..............................................227

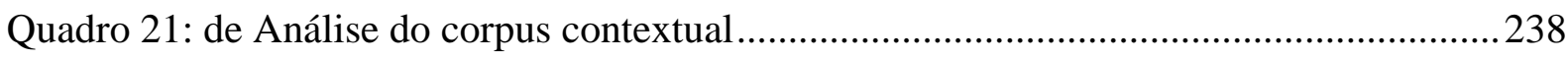

Quadro 22: Funções e Sistemas na Pintura com elementos levantados na análise da tela Por de

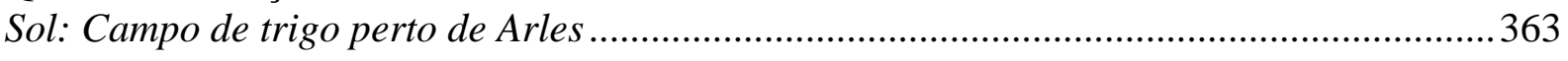

Quadro 23: Processos encontrados na análise textual relativa à tela 'Por de Sol: Campo de

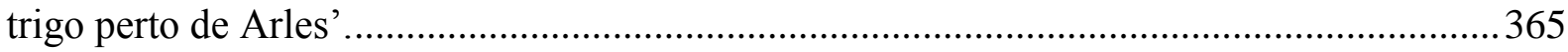

Quadro 24: Funções e Sistemas na Pintura - elementos levantados na análise da tela $\mathrm{O}$ Semeador.

Quadro 25: Processos encontrados na análise textual relativa à tela 'O Semeador'

Quadro 26: Funções e Sistemas com elementos da análise da tela 'A Esplanada do Café na Place du Forum, Arles, à Noite'

Quadro 27: Funções e Sistemas com elementos da análise da tela O Café Noturno na Place Lamartine, em Arles. 
Quadro 28: Processos encontrados na análise textual relativa à tela 'A Esplanada do Café na

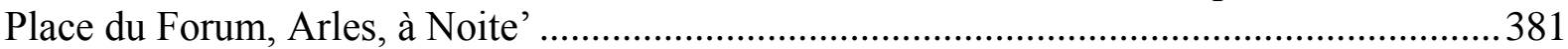

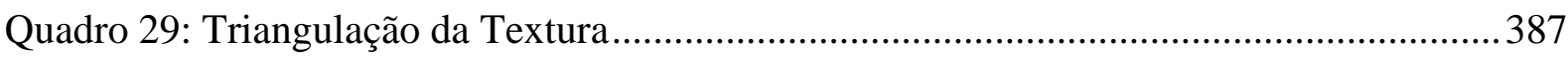

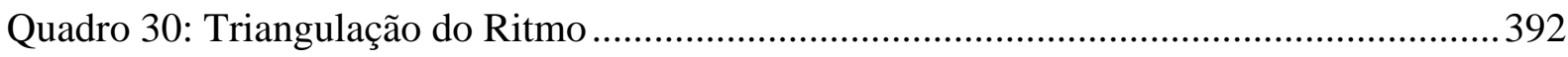

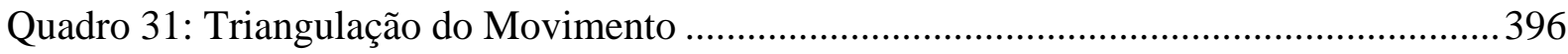

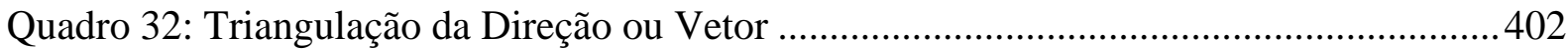

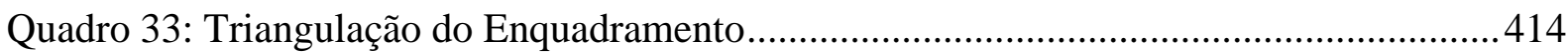

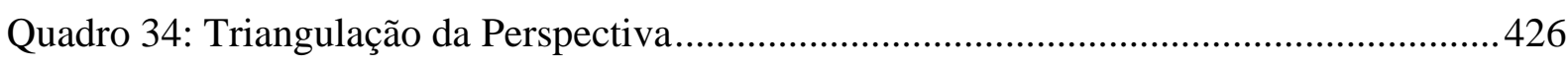

Quadro 35: Triangulação da Profundidade....................................................................... 435

Quadro 36: Triangulação da Distorção do ponto de vista .................................................... 441

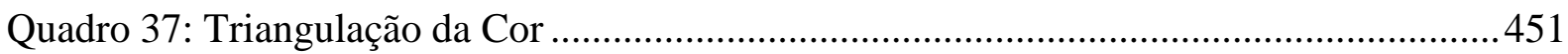

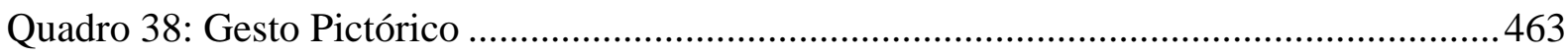

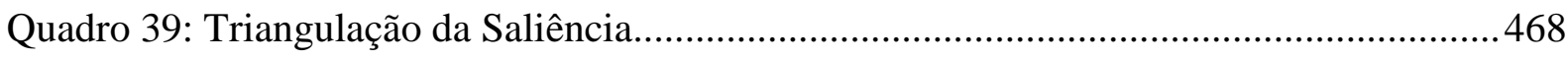

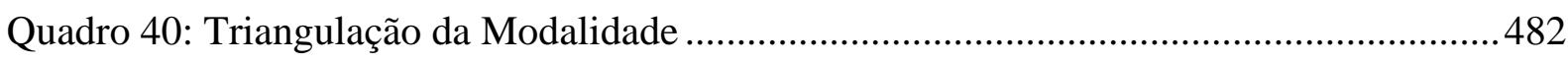

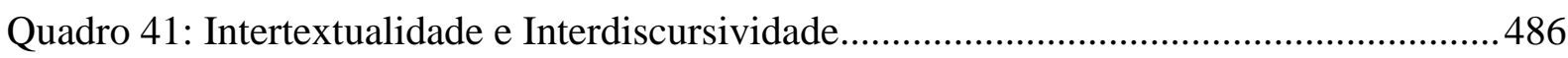

Quadro 42: Triangulação do uso de Associações metafóricas e simbolismo......................... 492

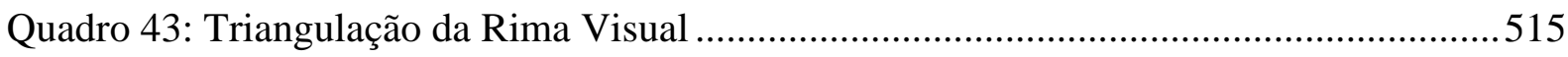

Quadro 44: Triangulação da Transparência......................................................................519

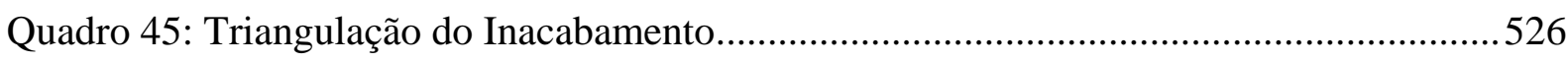

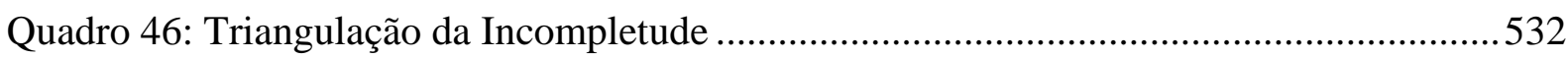

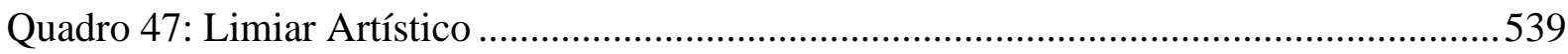

Quadro 48: Processo Relacional Atributivo (41 ocorrências) ...............................................543

Quadro 49: Em relação ao Atributo (42 ocorrências)..........................................................543

Quadro 50: Em relação à Circunstância (de todos os processos - 71 ocorrências).................543

Quadro 51: Em relação ao Processo Mental (33 ocorrências)...............................................544

Quadro 52: Em relação ao Experienciador (20 ocorrências)...............................................544

Quadro 53: Em relação ao Processo Verbal (14 ocorrências) .................................................544

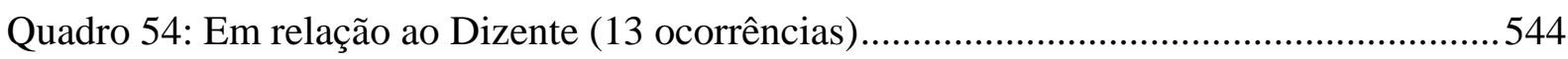

Quadro 55: Em relação à Verbiagem (11 ocorrências) .......................................................545

Quadro 56: Em relação ao Processo Existencial (11 ocorrências) ........................................545

Quadro 57: Em relação ao Existente (12 ocorrências) …….................................................545

Quadro 58: Em relação ao Processo Material (35 ocorrências) .............................................545

Quadro 59: Em relação ao Ator (35 ocorrências) ..............................................................545

Quadro 60: Intercorrências entre as categorias.................................................................546 
Quadro 61: Porcentagem entre as categorias considerando a frequência total......................547 


\section{SUMÁRIO}

1 CAPÍTULO 1 O CONTEXTO DA VIDA E OBRA DE VINCENT VAN GOGH...11

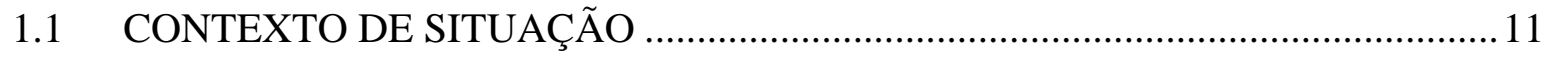

1.1.1 Dados biográficos de Vincent van Gogh.......................................................11

1.1.2 História de leituras de van Gogh ......................................................................14

1.1.3 História de leituras em linguagem de van Gogh...........................................15

1.1.4 História de leituras de imagens de van Gogh...............................................17

1.1.5 Anos de formação na Holanda ..................................................................... 18

1.1.6 Impressionado com os impressionistas ........................................................20

1.1.6.1 A aprendizagem de van Gogh com os Impressionistas ............................................20

1.1.7 Van Gogh como um pensador de seu tempo .............................................21

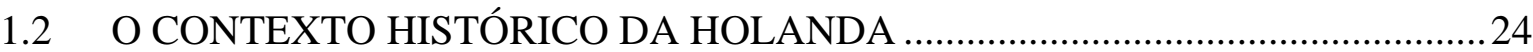

1.2.1 Contexto Histórico, Social e Biográfico de Vincent van Gogh ......................27

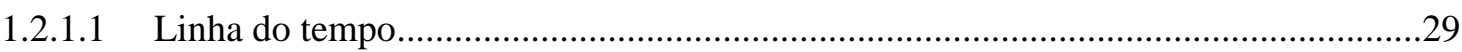

1.2.2 Valores, atitudes e visão de mundo em família ............................................41

2 CAPÍTULO 2 FUNDAMENTAÇÃO TEÓRICA.......................................................44

2.1 METAFUNÇÃO INTERPESSOAL: FUNÇÃO DA FALA E SISTEMAS DE

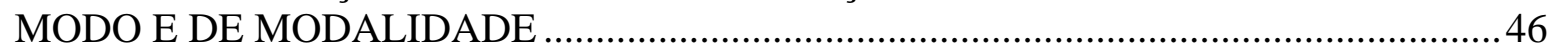

2.1.1 Multimodalidade na Pintura ...................................................................................551

2.1.1.1 A função Modal e seu trabalho de envolver o espectador ............................................54

2.1.1.2 A função Representacional em seu trabalho de informar o leitor ...............................61

2.1.1.3 A função composicional: em busca das proporções mágicas.......................................71

2.1.2 Elementos de Linguagem Visual vistos como unidades grafológicas da

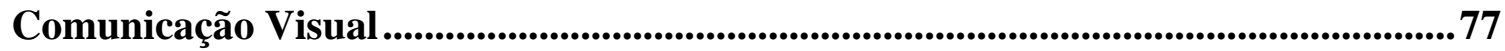

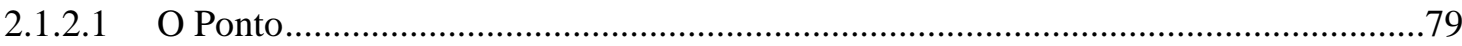

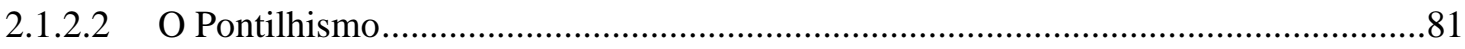

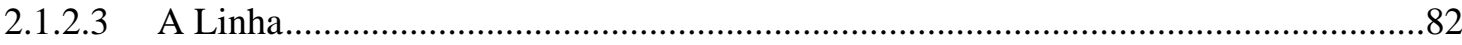

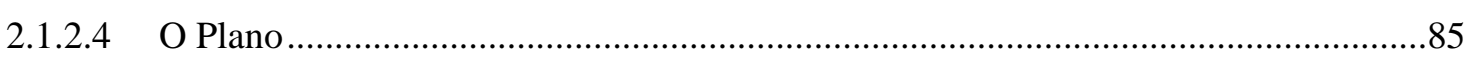

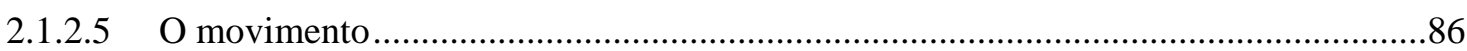

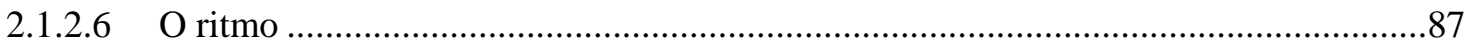

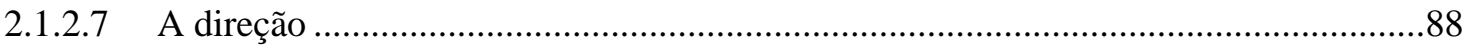

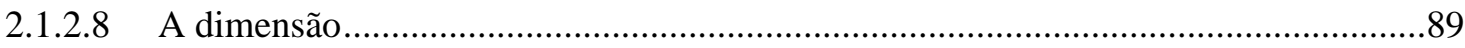

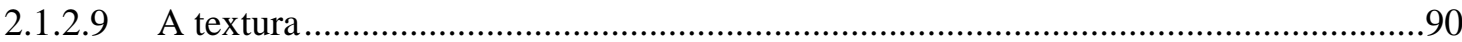

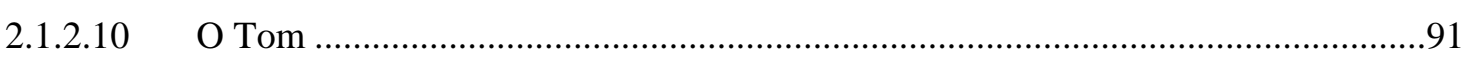

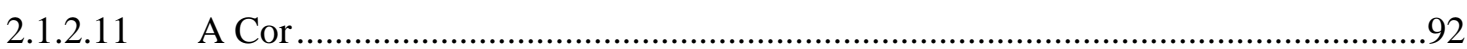




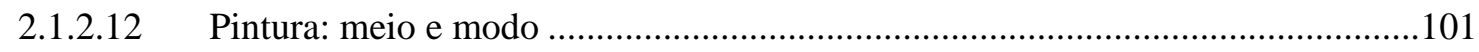

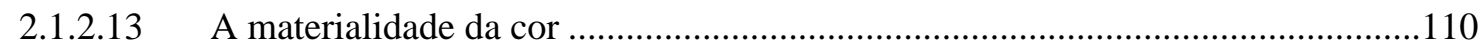

2.1.2.14 Composição e Expressividade Linguística..............................................................134

2.1.2.15 Um argumento sobre a importância das unidades de sentido................................135

2.2 PONTOS DE CONTATO ENTRE A LSF E A GDV ....................................... 141

2.2.1 Pontos de contato entre a Comunicação Visual e a linguagem verbal ...... 143 2.3 AS TRÊS METAFUNÇÕES DA LSF VISTAS PELA PERSPECTIVA DA ANÁLISE DE DISCURSO CRÍTICA …..................................................................... 167

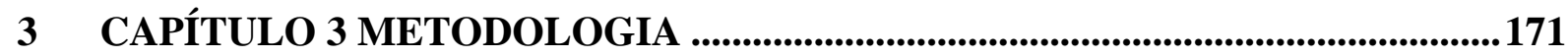

3.1 JUSTIFICATIVA E CARACTERIZAÇÃO DOS CORPORA DA PESQUISA.... 171

3.1.1 Justificativa para a escolha do corpus pictórico .......................................171

3.1.2 Pré-seleção do Corpus pictórico.................................................................178

3.1.3 Seleção do corpus pictórico...................................................................179

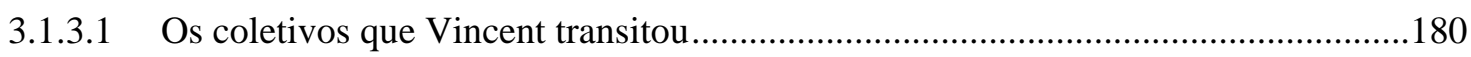

3.2 JUSTIFICATIVA PARA A ESCOLHA DO CORPUS EPISTOLAR ................... 182

3.2.1 Justificativa do Corpus Textual Primário: extratos de cartas que falam sobre as telas analisadas.................................................................................................. 185

3.2.2 Justificativa do Corpus Textual Contextual: carta para contextualizar a decisão de Van Gogh de se tornar artista...............................................................185

3.2.3 Condições de produção, distribuição e consumo da modalidade pintura.186

3.2.3.1 Circunstâncias históricas da produção das telas analisadas ......................................187

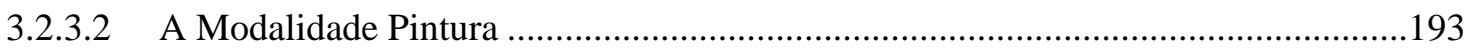

3.2.3.2.1 A modalidade pintura na articulação com a minha análise ...............................199

3.2.4 Condições de produção, distribuição e consumo da modalidade carta ..... 201

3.2.4.1 Condições de produção da modalidade carta: contexto de cultura da produção e

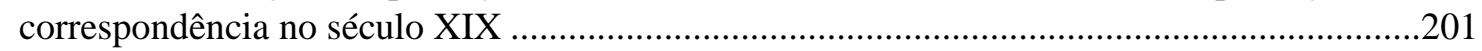

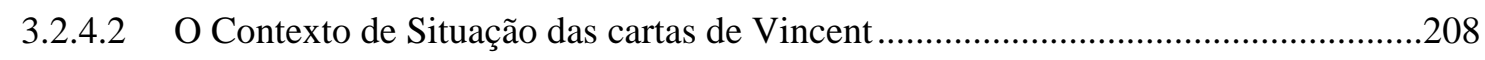

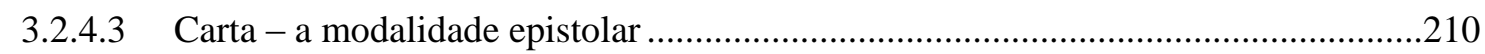

3.2.4.4 A modalidade Carta na articulação com a minha análise .........................................210

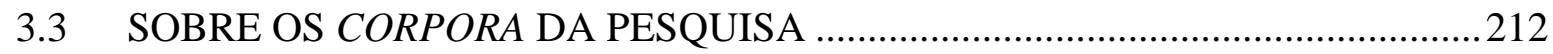

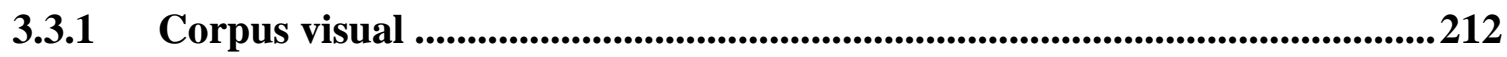

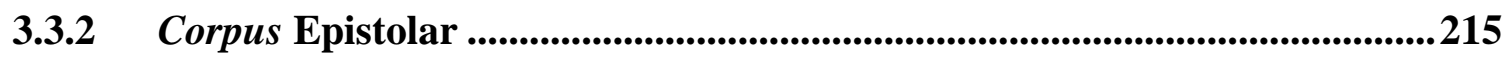

3.4 JUSTIFICATIVA E CARACTERIZAÇÃO DOS CORPORA DA PESQUISA....215

3.4.1 Justificativa para a escolha do corpus pictórico.........................................215

3.5 APRESENTAÇÃO DO CORPUS PICTÓRICO .................................................216

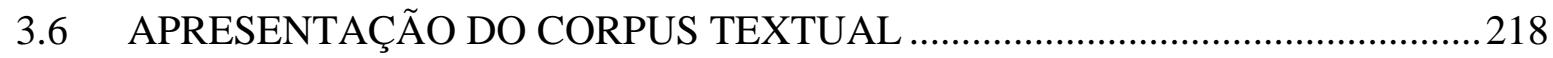

3.6.1 Apresentação do Corpus Textual Primário .....................................................219 
3.6.2 Apresentação do Corpus Textual Contextual

3.7 PROCEDIMENTOS DE COLETA, TRATAMENTO E ANÁLISE DOS DADOS 233

3.7.1 Procedimentos de coleta .233

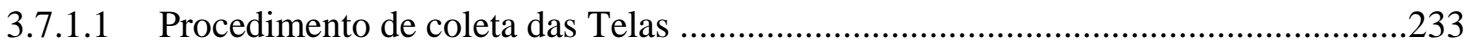

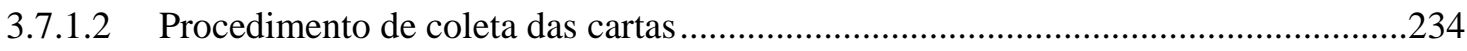

3.7.1.2.1 Sobre a questão de trabalhar com um corpus que passou por uma tradução .....235

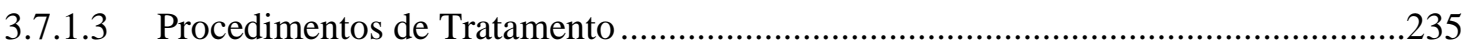

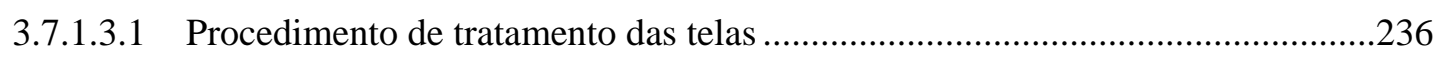

3.7.1.3.2 Procedimento de tratamento das cartas .............................................................236

3.7.1.3.3 Procedimento de tratamento da triangulação dos Corpora..................................237

4 CAPÍTULO 4: ANÁLISE DOS DADOS.................................................................238

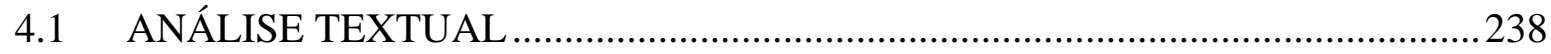

4.1.1 Análise do Corpus Textual Contextual...........................................................238

4.2 ANÁLISE DA TELA POR DE SOL: CAMPO DE TRIGO PERTO DE ARLES .260

4.2.1 Análise da Função Composicional da tela Por de Sol: Campo de trigo perto

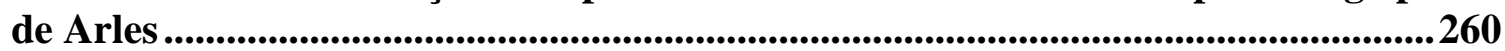

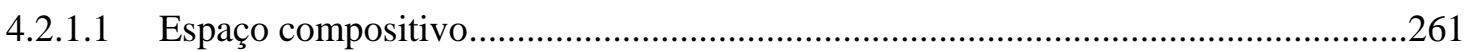

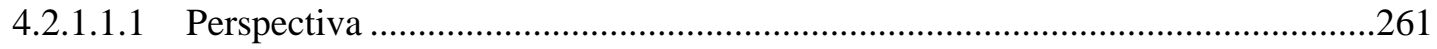

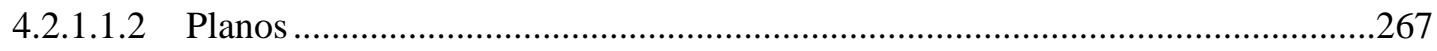

4.2.1.1.3 Halo de luz em torno do sol e dos edifícios .......................................................268

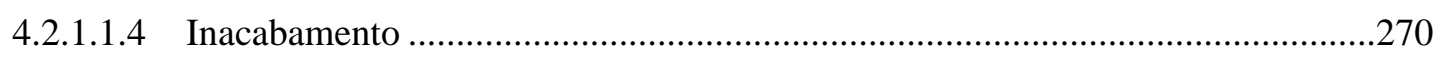

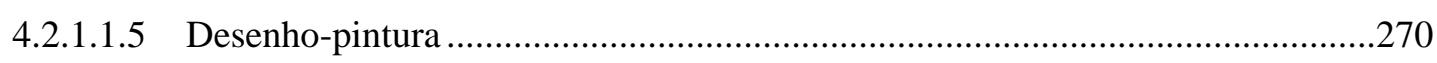

4.2.2 Análise da Função Modal da tela Sunset Wheat fields near Arles ............ 271

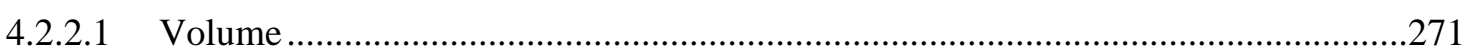

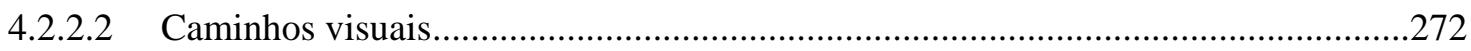

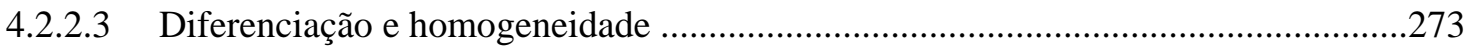

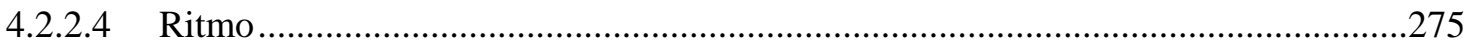

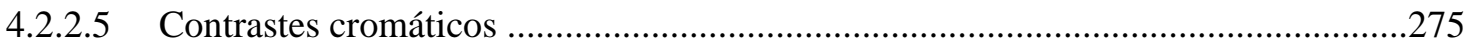

4.2.3 Análise da Função Representacional da tela Wheat fields near Arles ...... 277

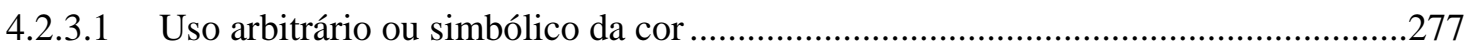

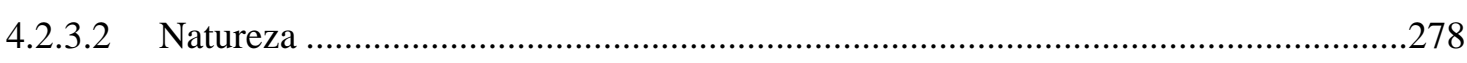

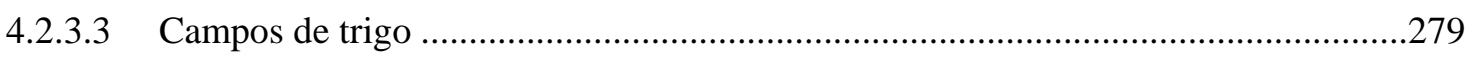

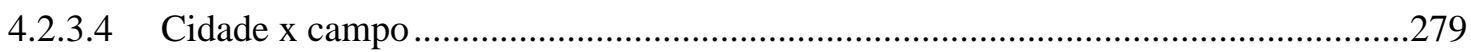

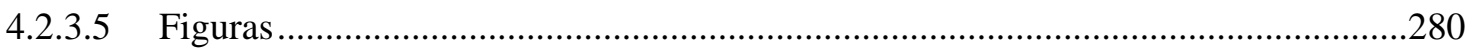

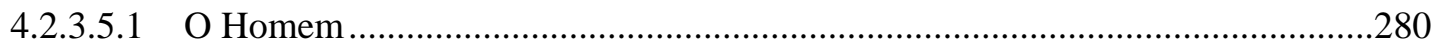

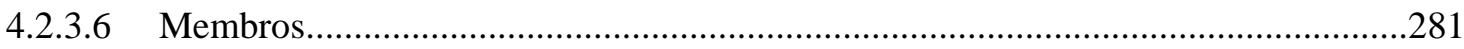




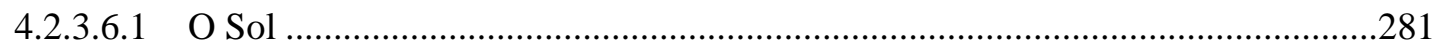

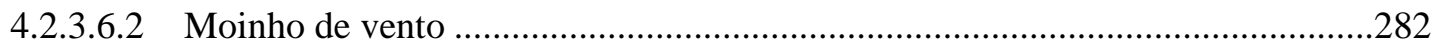

4.2.4 Nostalgia de uma era que se acaba com a revolução industrial ................... 283

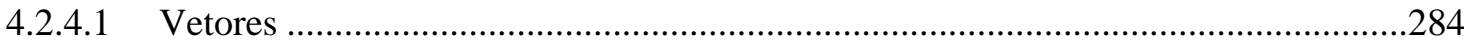

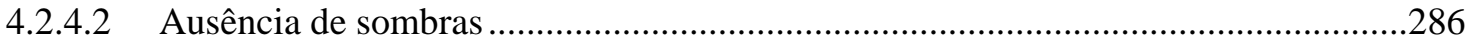

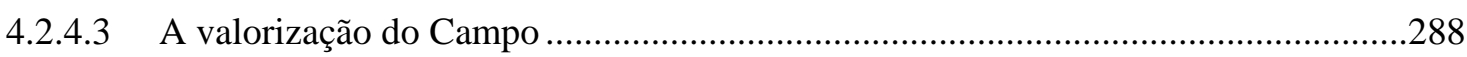

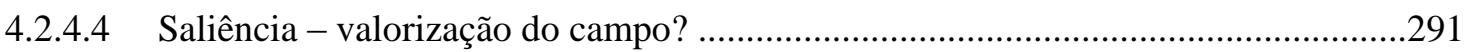

4.2.5 Conclusão da análise visual da tela Por de Sol: Campo de trigo perto de Arles 293

4.3 ANÁLISE TEXTUAL DOS EXTRATOS DE CARTAS RELATIVOS À TELA POR DE SOL: CAMPO DE TRIGO PERTO DE ARLES ...........................................294

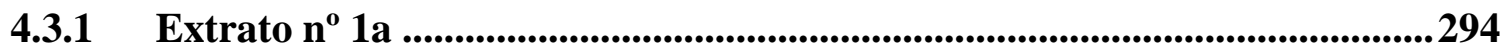

4.3.2 Extrato $\mathrm{n}^{\mathrm{0}} 1 \mathrm{~b}$................................................................................................... 298

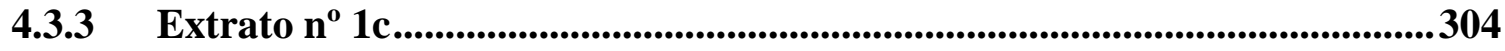

4.4 ANÁLISE DA TELA A ESPLANADA DO CAFÉ NA PLACE DU FORUM,

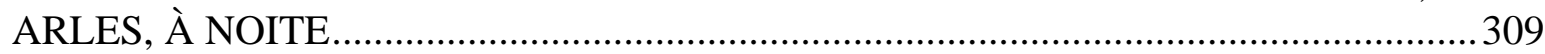

4.4.1 Análise da Função Composicional da tela The Café Terrace on the Place

Du Forum, Arles, at Night .................................................................................. 310

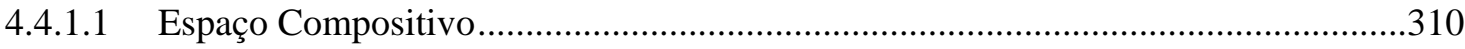

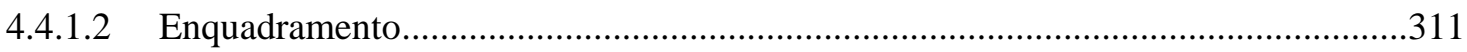

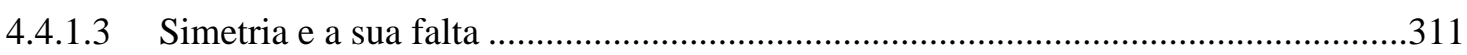

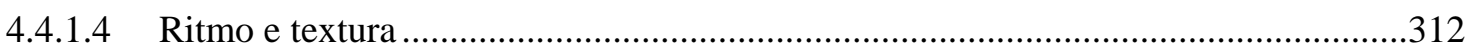

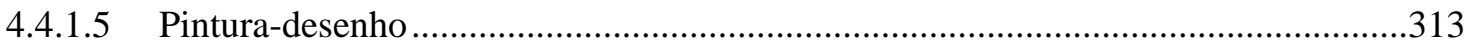

4.4.1.6 Transição cromática entre as zonas iluminadas e as zonas escuras da tela ..............314

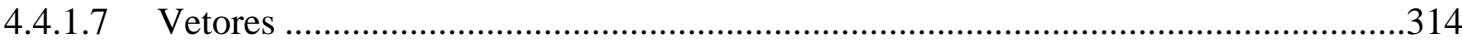

4.4.2 Análise da Função Modal da tela The Café Terrace on the Place Du Forum,

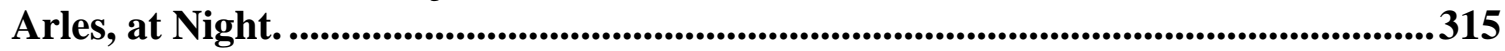

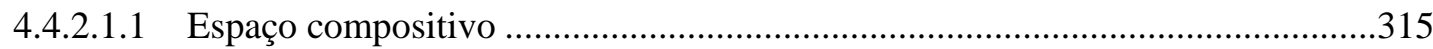

4.4.2.1.2 O uso da Perspectiva para criar Caminhos visuais ................................................316

4.4.2.2 O uso do cavalo como uma figura Intermediária ...........................................................

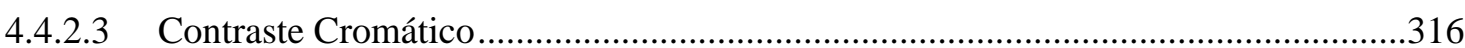

4.4.3 Análise da Função Representacional da tela The Café Terrace on the Place Du Forum, Arles, at Night ..................................................................................317

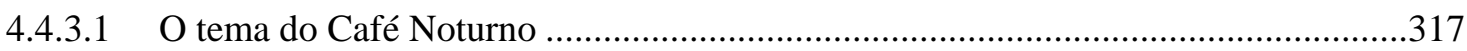

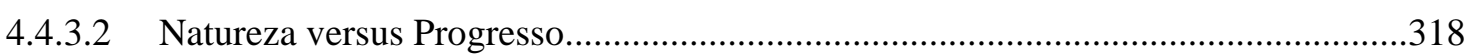

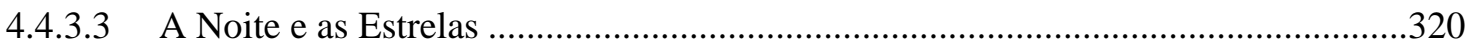

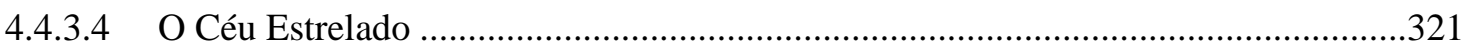

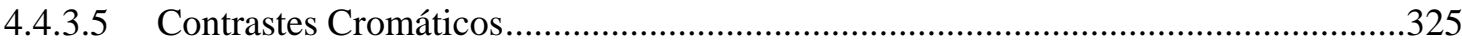




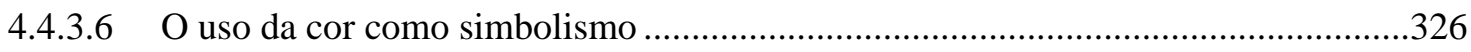

4.4.3.7 Uso de Simbolismo ou de Associações Metafóricas ....................................................327

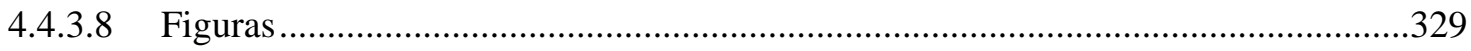

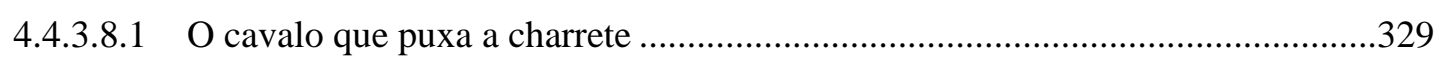

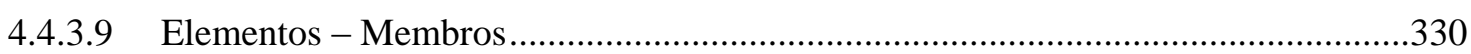

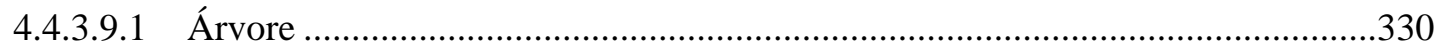

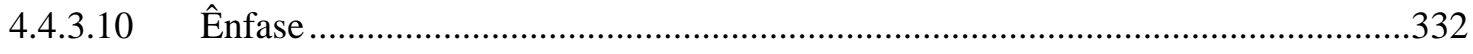

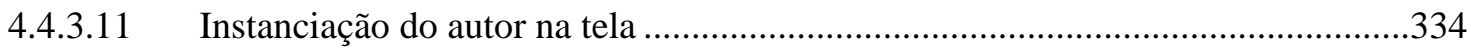

4.5 ANÁLISE TEXTUAL DOS EXTRATOS DE CARTA RELATIVOS À TELA 'A ESPLANADA DO CAFÉ NA PLACE DU FORUM, ARLES, À NOITE' ...................... 335

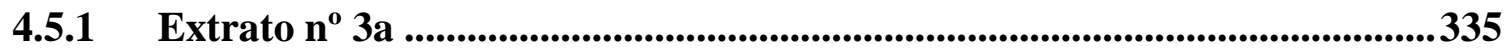

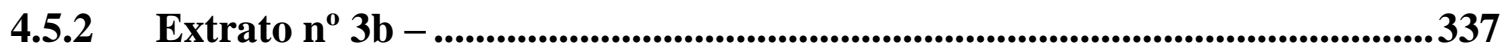

4.5.3 Conclusão da análise visual da tela Por de Sol: Campo de trigo perto de Arles 363

4.5.4 Quadro da análise visual da tela Por de Sol: Campo de trigo perto de Arles 363

4.6 ANÁLISE TEXTUAL DOS EXTRATOS DE CARTAS RELATIVOS À TELA POR DE SOL: CAMPO DE TRIGO PERTO DE ARLES ....

4.6.1 Quadro da análise textual da tela 'Por de Sol: Campo de trigo perto de Arles'. 365

4.6.2 Quadro da análise visual da tela 'O Semeador'. ..............................................367

4.6.3 Quadro da análise textual da tela O Semeador ............................................368

4.6.4 Quadro da análise visual da tela A Esplanada do Café na Place du Forum, Arles, à Noite 373

4.6.5 Quadro da análise textual da tela A Esplanada do Café na Place du Forum, Arles, à Noite 376

4.6.6 Quadro da análise visual da tela O Café Noturno na Place Lamartine, em Arles. 379

4.6.7 Conclusão da análise textual da tela O Café Noturno na Place Lamartine, em Arles. 381

5 CAPÍTULO 5: DISCUSSÃO DOS RESULTADOS 387

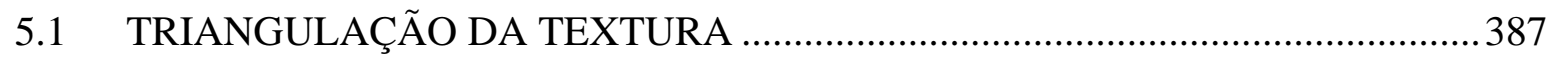

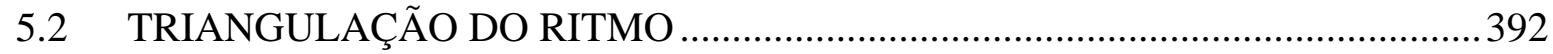

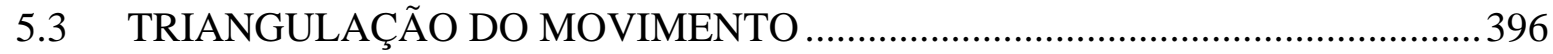

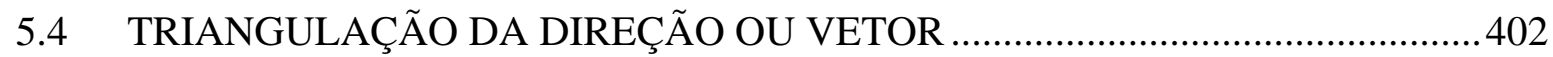

5.5 TRIANGULAÇÃO DO ENQUADRAMENTO ................................................. 414

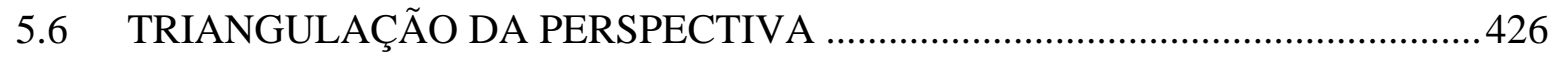

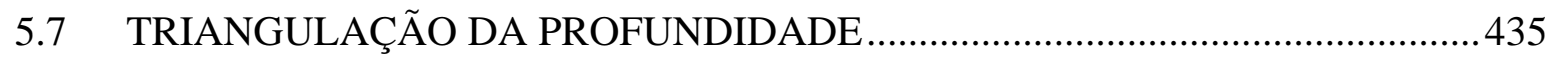


5.8 TRIANGULAÇÃO DA DISTORÇÃO DO PONTO DE VISTA ............................ 441

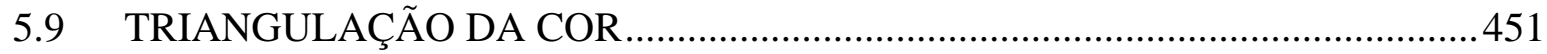

5.10 TRIANGULAÇÃO DO GESTO PICTÓRICO .................................................. 463

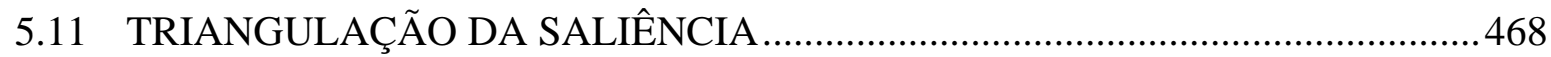

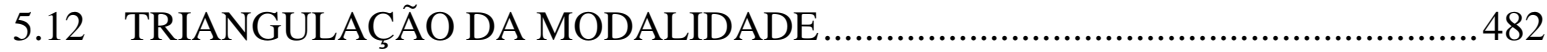

5.13 TRIANGULAÇÃO DA INTERTEXTUALIDADE E INTERDISCURSIVIDADE

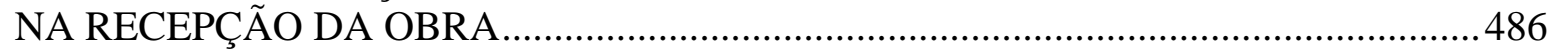

5.14 TRIANGULAÇÃO DO USO DE ASSOCIAÇÕES METAFÓRICAS E

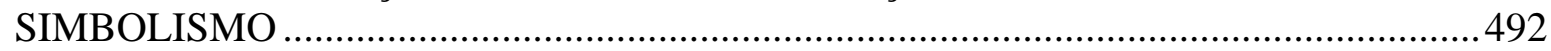

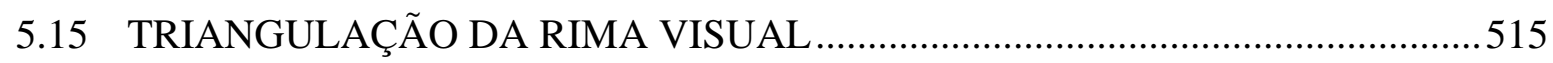

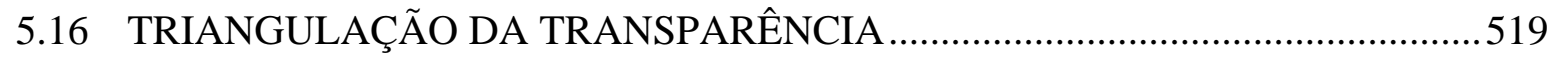

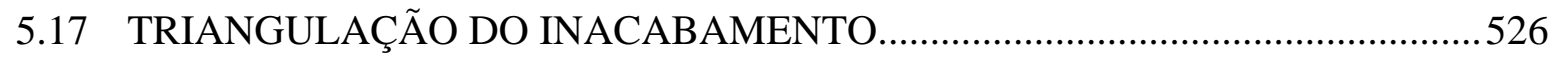

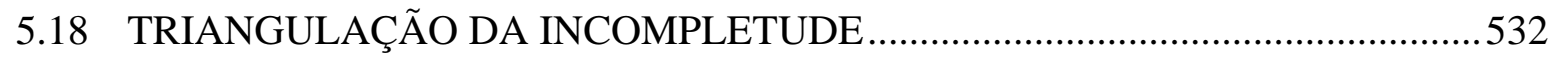

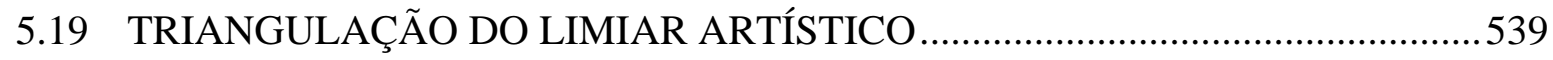

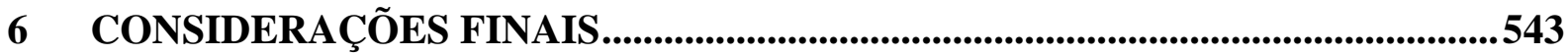

6.1 RECORRÊNCIA ENTRE AS CATEGORIAS CONSIDERANDO A

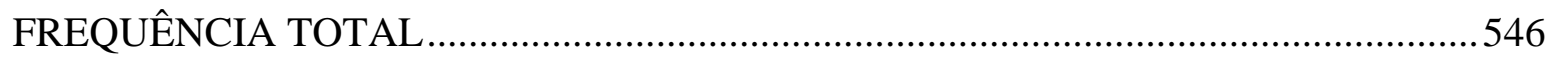




\section{CAPÍTULO 1 O CONTEXTO DA VIDA E OBRA DE VINCENT VAN GOGH}

\subsection{CONTEXTO DE SITUAÇÃO}

Vincent van Gogh nasceu e viveu durante a segunda metade do século XIX, em meio às grandes transformações sociais e filosóficas. A seguir, apresento um resumo biográfico que tomou como base o relato cronológico do crítico de arte Brian Petrie (1974, p.12-13) e do historiador de arte Coli (2006, p.13-18). No Apêndice, encontra-se uma Linha do Tempo com informações mais detalhadas da vida de Vincent van Gogh para servir como referência para os eventos que serão mencionados nas análises dos corpora de telas e de cartas.

\subsubsection{Dados biográficos de Vincent van Gogh}

Vincent Wilhelm van Gogh, filho da união de Theodorus van Gogh, pastor da Igreja Holandesa Reformada, e Anna Cornelia Carbentus, filha de um encadernador de livros, nasceu em 30 de Março de 1853, em Groot-Zundert, uma aldeia na região do Brabante no sul da Holanda. Ele é o segundo filho de seis crianças, sendo que o filho primogênito que o precedeu, chegou ao mundo natimorto e compartilha com Vincent, a mesma alcunha e o mesmo dia e mês de nascimento, só que um ano antes. Este fato foi enfocado na biografia "Van Gogh", escrita por Haziot (2010), e representado como um deflagrador de muitos conflitos na vida de van Gogh.

Vincent iniciou seus estudos na escola da vila em 1861 e em duas escolas de ensino médio posteriormente, interrompido possivelmente por dificuldades financeiras da família. Em sua infância, ele teve uma criação cercada de livros e de práticas familiares que favoreceram seu amor ao conhecimento e à arte. Foi um aprendiz excepcional de línguas, tendo estudado francês, inglês e alemão. Em março de 1868, com 15 anos, ele não suportou a solidão de estudar interno em uma escola em outra cidade, interrompendo abruptamente seus estudos e retornando a pé para a casa de seus pais. Dessa forma, ele não completou sua educação formal. 
Figura 23: Vincent van Gogh com a idade de 19 anos

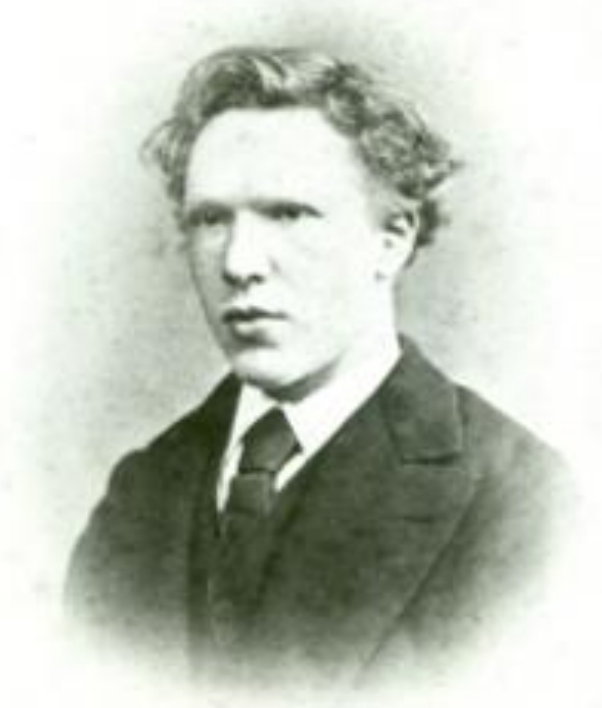

Fonte: Amsterdam, Van Gogh Museum ([1872]).

Em 1869, começa a trabalhar na galeria Goupil em Haia e depois em Bruxelas. Seu irmão Théo passa as férias do verão de 1872 com ele, dando início a uma correspondência amiúde entre os dois que duraria toda a vida.

Em 1873, é transferido para Londres onde sofre sua primeira decepção amorosa e se desinteressa pelo trabalho como marchand. É transferido para a sucursal em Paris, aí visita muitos museus e interessa-se pelo estudo da Bíblia negligenciando seu trabalho.

Em 1876, é despedido e emprega-se como como professor primário em Londres onde também auxilia o pastor Jones fazendo sermões.

Em 1877, trabalha por 4 meses em uma livraria em Dordrecht e vai para Amsterdã para estudar para o concurso para a Faculdade de Teologia.

Em 1878, não passa no concurso, mas é admitido em uma escola evangelista em Bruxelas e parte para trabalhar como evangelizador leigo no Borinage, região das minas de carvão. Em seu trabalho, passa a viver em total renúncia, doando suas roupas e comidas e vivendo na indigência e por isso é demitido do cargo.

Em 1979, vende dois desenhos para o pastor Pietersen que o aconselha. Nessa época, ele começa a se desligar da religião.

Em 1880, vive como um andarilho nos primeiros meses até se estabelecer em Bruxelas, e com ajuda financeira de Theo inicia o estudo de anatomia e perspectiva com estudos das obras de Jules Breton e Millet. Inicia uma amizade e correspondência com o pintor Ridder van Rappard. 
Em 1881, passa a morar com os pais em Etten e frequenta a cidade de Haia para se aconselhar com o pintor Anton Mauve seu parente. Começa a pintar a óleo e em aquarela. Os conflitos com a família aumentam e ele rompe com o pai após uma discussão acirrada, em dezembro, indo para Haia.

Em 1882, vive com ajuda financeira de Théo e de empréstimos de Mauve, mas rompe com este também. Encontra Sien, grávida, que ganha a vida se prostituindo e passa a viver com ela. Faz desenhos de encomenda de vistas da cidade para seu tio Cornelius, lê Zola e outros romancistas, desenha Sien, e dedica-se à pequena família com os filhos de Sién.

Em 1883, após conflitos com Sien e com seus pais, rompe com Sien e vai para Drenthe. Dedica-se a desenhar e a pintar a vida dos camponeses e dos operários. No final deste ano, volta para a casa dos pais em Nuenen e começa a estudar Delacroix.

Em 1884, trabalha na série dos tecelões e pinta uma encomenda para a sala de jantar de um ourives em Eindhoven.

Em 1885, morre o pastor Theodorus, seu pai. Termina a tela Os comedores de batatas que rende o rompimento com van Rappard devido às suas críticas à tela. Mora em um apartamento alugado na casa do sacristão de Nuenen, mas é despejado devido aos falsos boatos de que engravidara uma modelo.

Em 1886, vai para a Antuérpia e inica estudos na escola de Belas Artes na qual não se adapta. Estuda os trabalhos do pintor Rubens por quem se interessa. Adoece e parte ao encontro de Theo em Paris sem avisar, para ficar em seu apartamento. Lá toma aulas no ateliê de Cormon e conhece Emile Bernard e Toulouse-Lautrec. Théo lhe apresenta Monet, Sisley, Pisarro, Renoir, Seurat, Signac. Faz séries com auto-retratos, naturezas mortas, vistas da cidade. Conhece Gauguin.

Em 1887, descobre o pontilhismo e as gravuras japonesas, frequenta a loja de tintas de Tanguy e expõe no restaurante Tambourin lugar em que transitam outros pintores do impressionismo. O conflito com seu irmão aumenta e ele decide mudar-se para Arles.

Em 1888, muda-se para Arles e estabelece-se como pintor colorista. Recebe em outubro a visita do pintor Gauguin, mas no Natal do mesmo ano, devido a um desentendimento entre ambos, corta o lóbulo de sua orelha.

Em 1889, sofre seguidas crises nervosas e é internado no hospício de St.-Paul-deMausole, em Saint-Rémy-de-Provence, perto de Arles. Segue pintando vistas das janelas do hospício.

Em 1890, é publicada uma crítica de arte entusiasmada de Aubert Aurier a seu respeito e ele vende a tela $A$ Vinha Vermelha na exposição em Bruxelas. Em Maio de 1889, deixa 
Saint Remy e muda-se para Auvers-sur-Oise, a duas horas de Paris onde pinta vistas da cidade. Em Julho desse ano se despede da vida com um tiro no peito. Vem a falecer dois dias depois com 37 anos. Cabanne (1971, p. 177-179) expõe em síntese a trajetória de Vincent van Gogh:

\begin{abstract}
A instabilidade é uma das características mais surpreendentes do carácter de Vincent. Os doutores Doiteau e Leroy, no interessante e pertinente estudo consagrado à La Folie de Vincent van Gogh, fazem uma análise convincente destas singularidades, até ao tiro de pistola de Auvers: "Uma vez saído da casa paterna, permanece em Haia durante quatro anos, como empregado na Goupil; em Londres, nas mesmas condições, dois anos; em Paris, dez meses; de novo em Inglaterra, desta vez como pastor auxiliar, oito meses; em Dordrecht, como caixeiro de uma livraria, três meses; em Amsterdão, estudante eclesiástico, cartorze meses; na escola das missões de Bruxelas, quatro meses; pastor no Borinage, um ano e dez meses; depois disto, a sua vida evangélica pára brusca e definitivamente. Doravante será pintor. Regressa a Bruxelas, onde estuda desenho durante seis meses; vive em Haia um ano e dez meses; vagabundeia durante dois meses em Drenthe; regressa a casa do pai, nomeado recentemente para Nuenen, e aí vive dois anos e um mês; está três meses em Antuérpia; chega a Paris em Março de 1886 e aí fica dois anos e um mês; chega a Arles em Fevereiro de 1888; em Maio de 1889 é internado em Saint-Rémy; apesar do Dr. Peyron, obriga Théo a ceder, sai do asilo em Maio de 1890 e morre em Auvers-sur-Oise no mês de Julho do mesmo ano".
\end{abstract}

\title{
1.1.2 História de leituras de van Gogh
}

A compreensão da história de leituras de Vincent tornou-se uma tarefa relevante na pesquisa pelos seguintes motivos:

a) para subsidiar a interpretação das cartas que são repletas de referências a outros artistas, escritores, poetas e filósofos;

b) para compreender o papel da cultura do letramento em sua família e em seu grupo social;

c) porque evidencia o papel da interdiscursividade e da intertextualidade na construção do discurso artístico de van Gogh que é perpassado pela multiplicidade discursiva das ideias e ideais que constituiram a sua época.

d) para localizar evidências da transposição de elementos interdiscursivos e intergêneros nas suas telas. 


\subsubsection{História de leituras em linguagem de van Gogh}

Os biógrafos Naifeh e Smith (2012) descrevem não só as práticas de leitura na família de Vincent, mas as práticas de compartilhamento das experiências de leitura entre Vincent e seus irmãos que fomentaram sua incessante busca por conhecimento na idade adulta e nos falam de sua bagagem de leituras prévias:

Se a Bíblia sempre foi considerada "o melhor livro", mesmo assim as estantes do presbitério se curvavam sob o peso de inúmeros clássicos edificantes: os românticos alemães como Schiller, Goethe, Uhland e Heine; Shakespeare (em tradução holandesa); e até algumas obras francesas de autores como Moliére e Dumas. Estavam excluídos os livros considerados imoderados ou perturbadores, como Fausto, de Goethe, além de obras mais modernas e Balzac, Byron, Sand e, depois, Zola, que Anna descartava como "frutos de grandes intelectos, mas almas impuras". Lastimava-se que o maior livro holandês da época, Max Havelaar (de Eduard Dekker, com o pseudônimo de Multatuli), desferisse ataques virulentos à presença colonial holandesa na Indonésia e à "autoglorificação e benevolência hipócrita" da classe média holandesa. Outros entretenimentos infantis mais populares, em especial as histórias de índios e caubóis que vinham dos Estados Unidos, eram tidos como “estimulantes demais” para uma criação adequada (NAIFEH; SMITH, 2012, p. 51).

Em sua infância, Vincent teve acesso às leituras compartilhadas em família. De acordo com os biógrafos Naifeh e Smith (2012, p. 52), a literatura permitida para as crianças da família era a dos gêneros poesia e contos de fada. As poesias decoradas e declamadas eram uma forma de ensinar os valores e as virtudes enquanto foram permitidos os contos apenas de Andersen, como $O$ patinho feio, A princesa e a ervilha, A pequena sereia, A roupa nova do imperador. Na época em que Anna Carbentus iniciou sua família, os contos de Adersen já tinham grande aceitação e reconhecimento e foram adotados por não serem explicitamente cristãos ou excessivamente didáticos e por terem uma nova visão da infância, mais extravagante, refletindo o lazer vitoriano. Apesar de alguns retratarem as fraquezas humanas e não terem um final feliz, eles escaparam à censura dos pais. Naifeh e Smith (2012, p. 51) descrevem com preciosismo as preferências literárias dos van Gogh:

Como a maioria das famílias letradas na Europa vitoriana, os Van Gogh reservavam um lugar especial no coração para as histórias sentimentais. Todos ansiavam pelo último livro de Dickens ou de seu conterrâneo Edward Bulwer-Lytton (o primeiro a escrever "Era uma noite escura e tempestuosa..."). A tradução holandesa de A cabana do pai Tomás, de Harriet Beecher Stowe, chegou a Zundert mais ou menos na época do nascimento de Vincent, apenas um ano depois de sair o último capítulo nos Estados Unidos, e foi recebida no presbitério com a mesma aprovação entusiasmática que teve por toda parte.

Esse contato inicial com a literatura, deflagrou a trajetória literária de van Gogh, mas seu hábito de leitura terminou por se ampliar muito além dos livros indicados ou aprovados pelos pais, como atestam os editores de suas cartas Jansen, Luijten e Bakker (2009, p. 1):

Conhecer os clássicos e estar consciente das questões importantes do mundo das artes fazia parte do ideal burguês transmitida por seus pais, que era para ganhar-lhes 
o acesso aos círculos mais elevados através do autodesenvolvimento. Mas para o filho mais velho, arte e literatura gradualmente tornaram-se muito mais do que uma ajuda para a relação social. Eles tornaram-se absolutamente essenciais para ele. Ele precisava de arte e literatura, a fim de obter uma melhor compreensão de si mesmo, do comportamento humano e do mundo ao seu redor.

Lendo em uma velocidade assombrosa, ele devorou livros ao longo de toda a sua vida. Ao ler um autor, Vincent consumia toda a obra em poucas semanas. Cultivou o hábito de ler e de decorar poesias que inseria em suas cartas ou copiava em álbuns bem cuidados. $\mathrm{O}$ mundo fantástico que encontrou nos contos de Andersen o acompanhou com suas plantas antropomórficas, abstrações personificadas, sentimentos exagerados, imagens epigramáticas que deixaram uma marca vívida em sua imaginação. Muitos anos depois ainda dizia que os contos de Andersen eram "gloriosos...tão lindos e reais".

O biográfo de Vincent van Gogh, Haziot (2010) atesta que ele teve uma extensa exposição aos pensadores de sua época, pois era um ávido leitor de livros e de telas:

Observa-se, porém, uma constante durante esses anos de miséria: um convívio contínuo, obstinado, verdadeiro estudo no sentido amplo, com obras de escritores ou pintores antigos ou contemporâneos. Ele lê, na língua de origem, tudo o que encontra, de Shakespeare a Zola, passando por Charlotte Bronte, Hugo, Balzac, Dickens ou Carlyle; vê e cita obras de Durer, Rembrandt, Corot, Daumier, Millet, mas também Maris, Israels, Mauve...Como se, sob as tentativas de se tornar um homem da Igreja, ele se preparasse subterraneamente para outra coisa que ainda não ousa confessar ou confessar-se. Nestes e notáveis avanços intelectuais: vemos nascer ao longo da correspondência um julgamento de rara sutileza. Apesar das aparências, Vincent, onde quer que vá, nunca perde o seu tempo - não importa o que pense de si mesmo. (HAZIOT, 2010, p. 144).

Ao contrário da imagem mitificada de um pintor atormentado, voltado apenas para a sua arte e em descompasso com o pensamento de sua época, van Gogh nutriu-se não com uma, mas várias ordens discursivas que circulavam em seu tempo, e edificou sua obra no ideário de escritores contemporâneos e passados, como relembra Edwards (2009, p. 15):

O artista estava de fato proximamente conectado com a sociedade por meio da amplitude e profundidade de suas leituras. Ele estava atualizado com muitos dos movimentos literários e autores chave de sua época assim como com muitos dos textos importantes do passado que formaram a imaginação Ocidental. Sua ambição, amplamente realizada, era a de ler tudo da Bíblia, Shakespeare, Hugo, Dickens, Balzac, Flaubert, Daudet, de Maupassant, George Eliot, Os irmãos Goncourt, e muito mais. Mesmo os escritores Americanos tais como Edgar Alan Poe, Walt Whitman, e Harriet Beecher Stowe atrairam sua atenção.

As cartas de Vincent atestam sua erudição não apenas nos escritores clássicos e contemporâneos de sua época, como atestam os biógrafos Naifeh e Smith (2012, p. 589):

A desintegração da vanguarda artística horrorizava e repugnava Émile Zola. Via aí o malogro de seu grande projeto naturalista. Em A obra (L'oeuvre), que Vincent começou a ler em fascículos às vésperas de ir para Paris, Zola criticava todos os artistas, mesmo os impressionistas que antes defendera, por não terem conseguido encontrar uma arte unitária e emblemática para a nova época. Narrando a história do personagem Claude Lantier, um pintor à beira da loucura obcecado com a criação da 
obra perfeita, Zola rejeitava tanto a rendição dos simbolistas ao sobrenatural quanto a ciência impessoal de Seurat. Para criar uma verdadeira obra-prima moderna, dizia ele, um artista teria de dar mais de si ("o que era a Arte, afinal, se não simplesmente dar o que se tem dentro de si?") - mesmo que, como no caso de Lantier, isso significasse a insanidade e a morte certa. E Zola desafiou artistas de todos os naipes a aceitar seu desafio. O século inteiro tinha sido e continuaria a ser "um fracasso", trovejou ele, enquanto não se atendesse ao postulado da arte moderna - até que alguém, em algum lugar, encontrasse dentro de si uma arte ao mesmo tempo literal e poética, real e simbólica, pessoal e mítica.

As cartas de Vincent também evidenciam uma erudição pictórica inigualável e que certamente consolidaram um reservatório de recursos semióticos com os quais Vincent soube se valer para constituir seu próprio pensamento e discurso artístico. No próximo sub-ítem, desenvolvo a história de leituras visuais que compõem seu repertório pictórico.

\subsubsection{História de leituras de imagens de van Gogh}

A compreensão da história de leituras de imagens de Vincent suscitou um item à parte já que a relação que Vincent desenvolveu com as imagens é central para a sua formação discursiva e para a forma como ele materializou visualmente seu discurso. Uma atenção maior foi dada para os relatos biográficos a esse respeito, a fim de evidenciar suas identificações com pintores, desenhistas e gravuristas com quem ele entrou em contato e faz farta referência em suas cartas. Essas referências poderão ser úteis para compreender o contexto das escolhas semióticas que ele empreendeu na articulação de um sistema linguístico pictórico único e próprio. Algumas são descritas por Petrie (1974, p. 8):

Os seus primeiros gostos, que abarcaram obras de vários artistas desde então considerados de segunda classe (Boughton é um deles), embaraçaram muitos dos que escreveram sobre Vincent, embora não devam ser desprezados nem considerados como aberrações da juventude. Um outro que Vincent muito admirou foi Meissonier, um pintor francês de história e gênero, extraordinariamente bem sucedido e universalmente ignorado pelos vanguardistas. Mas Vincent defendeu-o, por vezes timidamente, outras vezes com petulância, até ao fim da vida, com a força da sua genuina reação emocional a uma das obras desse mestre. Por outro lado, onde não encontrava sensação, como no caso de um outro mestre acadêmico, Gérôme, dizia-o. Para Vincent, o desenvolvimento da linguagem expressiva e intrínseca da pintura, neste caso especialmente a linguagem da cor, não implicou, como aconteceu com alguns modernistas, uma rejeição dos fatores considerados alheios a uma estética redutivista.

O contato de Vincent com pintores de diferentes escolas ampliou seu reconhecimento de aspectos muito específicos daquelas obras com os quais ele se identificava, e isso foi possível porque ele se relacionava de forma despretensiosa e sem reservas com os trabalhos de outros pintores, sem se restringir a uma ou outra corrente artística. Coli (2006, p. 74-75) comenta acerca do autodidatismo nos anos de sua formação como pintor: 
A aquisição desses meios técnicos pessoais foi feita de uma maneira autodidata, indiscutivelmente. [...] Novamente, algo de prodigioso se manifesta: Vincent trabalha sozinho, mas como que guiado firmemente pela intuição de um método sem falha. Etapa por etapa, ele vence as dificuldades: primeiro o desenho da figura humana, dos objetos isolados; depois os conjuntos, e o espaço, a perspectiva; enfim as cores. Nenhum passo é dado sem que o terreno anterior esteja perfeitamente firme, sem que a dificuldade precedente esteja perfeitamente dominada.

O crítico de arte Petrie (1974) argumenta acerca da bagagem cultural que fomentou a formação do pensamento de Vincent van Gogh e que ultimamente impulsionou a organização de seu discurso artístico:

Pode parecer estranho dizer-se que Vincent é um "vitoriano", apesar de ter passado ao todo perto de três anos na Inglaterra aos vinte e poucos anos. Ele era, afinal, um holandês cujas obras mais importantes foram realizadas na França. Mas, para descrever o seu humanitarismo e fervor espiritual, que a princípio foram canalizados por uma vocação religiosa e mais tarde se exprimiram atraves da arte, o termo até nos parece bastante apropriado. E a verdade é que tanto os seus valores morais com as suas ideias sobre a arte foram em parte condicionados pela sua reação à arte e à literatura inglesas da era vitoriana - por Milais, G. H. Boughton, e "realistas sociais" como Frank Holl, Luke Fields, e Hubert Herkomer entre os pintores, por Carlyle, George Eliot e Dickens entre os escritores. Vincent continuou sempre a achar que possuia uma compreensão especial da arte inglesa e dos gostos do público inglês; os primeiros sentimentos e valores por ele experimentados através da arte inglesa permaneceram sempre como qualquer coisa em que poderia construir o seu empreendimento artístico. (PETRIE, 1974, p. 8).

A seguir serão descritas com maior detalhe as escolas de pensamento que o pintor subscreveu em seus anos de formação artística.

\subsubsection{Anos de formação na Holanda}

Em seu trabalho na galeria Goupil, van Gogh conheceu a obra dos antigos mestres da pintura, e os estudou incansavelmente.

[...] podemos nos perguntar se uma de suas sortes não foi ter sido um autodidata que só tomava lições com Rembrandt, Hals, Millet, Delacroix. Esse diálogo permanente com os criadores do passado o fecunda mais do que os cursos nos quais as lições dos mestres são cuidadosamente filtradas por professores obtusos como os do seu tempo. Assimilar as lições sozinho era mais demorado, mais doloroso, porém infinitamente mais enriquecedor. (HAZIOT, 2010, p. 145).

Por outro lado, a formação autodidata de van Gogh contribuiu para a sua erudição pictórica e teve um papel preponderante na construção de um modo peculiar de olhar a produção artística e na construção de um discurso pictórico seu como ilustra Haziot (2010, p. 180):

Théo era um homem organizado. Arrumara seu novo apartamento como um museu que reunia os quadros da sua coleção nas paredes. Apreciava os pintores novos, e as telas do seu apartamento teriam feito a alegria dos maiores museus da atualidade. [...] Mas Vincent transformava a casa num rebuliço, tirando as coisas de lugar e, 
quando os amigos de Théo apareciam, discutia com eles por isso ou por aquilo. Sua incrível erudição pictórica, sua cultura e sua inteligência excepcional lhe permitiam sempre encontrar argumentos definitivos, exemplos arrasadores. Com delicadeza, poderia ter feito aceitarem seu saber tão raro e também suas falhas, pois as tinha, uma vez que rejeitava tudo o que não era "real, como Baudelaire, Edgar Poe" e todos os escritores ou pintores que apelavam ao imaginário. Mas ele era muito abrupto na discussão, apaixonado demais pela verdade, pela sua verdade, para usar luvas. Acabava sendo desagradável e tornava a vida de Théo amarga.

Ele se apaixonou pelos ricos e opulentos contrastes cromáticos e a luminosidade produzida pela pincelada de Rembrandt, aqui ressaltado por Coli (2006, p. 78):

No início, é o domínio do corpo humano que lhe interessa: trabalha as formas do esqueleto, a partir de outro manual - Os Esboços Anatômicos para Uso dos Artistas, de John -, parte por parte. Em seguida, os músculos. Depois o corpo todo, de costas, de frente: ele quer formar, como diz a Théo, "um pequeno capital de conhecimentos anatômicos". Entra em contato com van Rappard, jovem pintor mundano: Visitei o Sr. van Rappard..."Isto" é o pedido de orientações feito por Vincent. Van Rappard se afeiçoara sinceramente a ele, e durante cinco anos essa amizade vai durar, tempestuosa. Até o momento em que van Rappard critica a primeira obra ambiciosa de Vincent, Os Comedores de Batatas - crítica, à qual Vincent responde com uma carta de ruptura violenta. É interessante notarmos que além das indicações picturais mais ou menos proveitosas de van Rappard, ele provocou em Vincent as primeiras reflexões sobre a necessidade de se radicalizar em arte.

Coli (2006) destaca que, na Escola de Haia, ele entrou em contato com o conhecimento dos contrastes cromáticos complementares e com o domínio dos contrastes em Delacroix:

Em 1881, ele entra em contato com Anton Mauve, um primo seu e também um dos principais pintores da escola de Haia (escola que produziu uma pintura muito rica e cuja descoberta internacional é recente), que lhe dá conselhos. Muitos dos personagens de van Gogh, desenhados por essa época, lembram os de Mauve. Mas, como sempre, seus sentimentos são desmedidos, e, alguns meses depois, rompe com o primo - por quem, no entanto, guarda funda afeição: em 1888, ao saber da morte dele, pinta o luminoso A árvore Florida, escrevendo no canto esquerdo: "Souvenir de Mauve/ Vincent" (hoje no museu de Kroler-Muller de Otterlo). (COLI, 2006, p. 76).

Fazer uma nota de rodapé explicando onde fica, cidade e país, esse museu.

Como Coli (2006) aponta, ele foi profundamente influenciado com o Realismo, em especial pela representação dos camponeses e trabalhadores e dos temas sociais:

Vincent inicia seu aprendizado solitariamente. Pede a Théo as séries de gravuras de Millet - pintor que é um de seus ídolos - , As Horas do Dia e O Trabalho dos Campos, para poder copiá-las. Entre elas, está o Semeador, figura que subsidiará como um tema constante durante toda sua vida. Pede também os Exercícios com Carvão e o Curso de Desenho, manuais de um certo Bargue. E assim, sem professor, com manuais modestos, que começa a formação de um dos maiores pintores de todos os tempos. (COLI, 2006, p. 77).

De acordo com Coli (2006), ele interessou-se também pela preocupação com a estrutura da composição nas obras de Millet, como equilíbrio que ajudavam a construir a percepção da tranquilidade do campo: 
Aos poucos, suas técnicas se enriquecem - aquarelas, litografias - e os assuntos também: marinhas, paisagens. Os personagens já não são mais isolados, mas articulam-se no espaço, em conjuntos. Em 1882 começam a aparecer as primeiras tentativas a óleo, de tom sombrio. E como o problema é então a figuração do espaço, van Gogh encomenda a seu irmão um aparelho inspirado num modelo de Dürer, que ele desenha cuidadosamente: um retângulo de madeira que serve de suporte para uma trama de fios, fornecendo "pontos de referência para traçar, com mão firme, um desenho acusando as grandes linhas e as proporções". Vem assim, aos poucos, o aprendizado da figuração do espaço, que só se afirma totalmente, em 1884, com a série dos Tecelões. (COLI, 2006, p. 79-80)

Outro pintor realista que o influenciou foi Courbet, como ressalta Coli (2006), com sua agenda contestadora e militante por uma revolução na arte para além das questões estéticas e na busca de uma nova ordem discursiva própria e moderna:

\begin{abstract}
Assim o domínio da técnica se acompanha de uma relação complexa com os objetos representados, aos quais é incorporada uma violenta carga emocional. É admirável como van Gogh sabe (saber que não implica consciência) dirigir os meios que possui para exprimir os problemas que lhe interessam. Neste período holandês, é a condição dura dos operários, a miséria dos trabalhadores - temas presentes no realismo de então, em Daumier, Millet e na escola de Haia - que ele explora de modo pessoal, muito além da imitação. Van Gogh não desenvolveu ainda suas capacidades de colorista, e é justamente essa ausência da maestria cromática, essas cores feias, sujas, escuras, que lhe permitem figurar, com violência, o mundo dos oprimidos. (COLI, 2006, p. 79-80).
\end{abstract}

\title{
1.1.6 Impressionado com os impressionistas
}

A seguir serão descritas as características das concepções programáticas dos impressionistas, como elas impactaram no pensamento artístico do século XIX e na formação do discurso artístico de van Gogh. Essas noções serão retomadas no capítulo 4 da metodologia, no item 4.8.1 das condições de produção pictórica, porque são fundamentais para compreender a interdiscursividade com a qual van Gogh dialogou com os seus pares na constituição de um novo olhar para a arte e um novo lugar para os artistas. Para entender a interdiscursividade de van Gogh com os impressionistas serão destacados os aspectos desse programa que ele se apropriou e incorporou ao seu próprio discurso artístico, produzindo novas semioses. Além dos impressionistas, van Gogh foi influenciado nesse período pela obra de Monticelli, pelo uso do impasto com cores vivas e pinceladas contidas; e pela simplificação das formas, contornos e planos de Gauguin. 
De acordo com o biógrafo Haziot (2010), no início da primavera de 1886, a chegada de Vincent a Paris foi uma oportunidade que Théo esperava para abrir os olhos do irmão para as novas correntes artísticas que despontavam naquela cidade. Para alguém como van Gogh, que tinha Millet como a referência do pintor mais avançado de seu tempo, conhecer os impressionistas da primeira e da segunda geração foi impactante. Nunca Théo teve tanta influência na obra de Vincent. Primeiro Théo convidou-o para conhecer a galeria onde trabalhava como marchand, onde, no térreo ele expunha as pinturas acadêmicas mais comerciais, premiadas em salões e louvada pelos críticos. No andar de cima, com a anuência dos diretores Boussod e Valadon, ele havia organizado uma exposição de quadros impressionistas que ele comprava e comercializava. Van Gogh conheceu trabalhos de Monet, Renoir, Pissarro e Degas. Depois, eles seguiram para a galeria do marchand Durand-Ruel, que vendia os impressionistas desde quando eles eram ainda anônimos para o público. Haziot (2010, p. 166) descreve o que deve ter sido para van Gogh um verdadeiro choque:

\begin{abstract}
Théo conduziu enfim Vincent à um outro marchand, Delarbeyrette, que possuía uma coleção importante do pintor marselhês Adolphe Monticelli. Outra maneira de abordar a cor, por meio de empastamentos e explosões coloridas de uma violência nunca vista. Flores, retratos, animais, cenas diversas: Monticelli, um aficionado de música lírica, dizia que a luz numa pintura era "o tenor". Ele morreu nesse ano de 1886 em Marselha, aos 61 anos, desconhecido dos contemporâneos. Monticelli foi um mestre para Vincent.
\end{abstract}

Ele absorveu muitas técnicas dos impressionistas, para seguir porém, um trajeto na pintura muito distinto do caminho que os impressionistas percorreram. É fácil observar esta distinção ao comparar as telas de van Gogh com as de outros impressionistas.

\title{
1.1.7 Van Gogh como um pensador de seu tempo
}

Vincent van Gogh viveu em na segunda metade do século XIX e conviveu com a era Vitoriana, com o Neoclassicismo, com o Romantismo, com o Realismo, com a escola de Hague, com o Impressionismo, com a Art Nouveau, com a emergência da cultura burguesa do século XIX, com a Belle Époque, e ajudou a fundar o Pós-Impressionismo. Ele manifesta em sua obra as ordens de discursos que emergiam nos círculos em que transitou e que coletivamente estavam sendo gestadas nas franjas das últimas revoluções.

Van Gogh expressa seu pensamento artístico e materializa em sua obra a confluência de movimentos estéticos e culturais tais como o romatismo, o realismo, e o que viria a ser chamado de pós-impressionismo: os primeiros passos dados na direção do expressionismo, do simbolismo e do modernismo, como pontuam Walther e Metzger (2015, p. 306-7): 
Uma educação cristã, uma intensidade romântica, esperanças socialistas no futuro e uma instrução indubitavelmente deficiente como um artista, tudo isso teve alguma influência. A pintura tornou-se um alter ego, meta de toda uma dedicação pessoal e centro das suas intenções. Arte e Vida constituíram uma unidade única. O próprio Van Gogh ainda longe de transformar esta unidade num programa. De certa forma, ele já se tinha colocado nessa posição contra a sua própria vontade. Mas a Arte nunca mais voltaria a ser a mesma; e teve em Van Gogh uma figura de proa que percorreu esse caminho de forma exemplar, coerente e firme até à sua morte.

Alguns historiadores de arte como Petrie (1974) o categorizam como um vitoriano. No entanto, é preciso ressaltar que van Gogh transitou por diversas correntes de pensamento. Um leitor incansável de diferentes pensadores, ele se identificou com os ideais revolucionários de Hugo, com as idéias libertárias do Realismo social expressas na obra de Zola e de pintores que referenciou em suas cartas, como o próprio Petrie expõe:

Apelidar Vincent de "vitoriano" não equivale, portanto, a dizer que ele era um puritano, e ainda menos que se tratava de um artista didático. Significa, antes, uma outra maneira de dizer que a sua arte continha, no sentido mais lato, uma finalidade moral, o que não é a mesma coisa do que uma arte moralista. O humanitarismo que transparecia nas suas atividades, quando era um pregador leigo e trabalhador social evangélico em Londres e no distrito mineiro belga do Borinage, não estava, visto ele ter decidido transformar-se num artista, expresso sob a forma de pintura moralizante, onde costuma haver um tema edificante simplesmente apresentado como uma finalidade em si. O didatismo hipócrita da igreja do seu tempo enojou-o; mais uma razão para evitar semelhante erro nos seus temas artísticos. O que encontrou na obra de certos artistas ingleses - mas sobretudo na obra do artista francês Millet, o pintor mais digno do seu respeito e emulação - foi algo que o atingiu profundamente. Subjacente à própria arte de Vincent está a crença de que, para se experimentarem certos tipos de sensações, de ternura, de respeito pelo sofrimento e pela privação, assim como sentimentos de beleza na Natureza, é preciso ser-se uma pessoa potencialmente mais humana, sendo esta toda a moralidade da sua arte. (PETRIE, 1974, p. 8).

Van Gogh orientou suas pinturas por sua resposta emocional aos temas por ele representados, como ilustram Naifeh e Smith (2012, p. 27):

Para Vincent, sua arte era um registro mais verdadeiro, mais revelador ("tão profundo - tão infinitamente profundo") de sua vida, até mais do que a enxurrada de cartas que sempre vinham de acompanhamento. Ele acreditava que toda onda de "serenidade e felicidade", todo estremecimento de dor e desespero ingressavam na pintura; todo sofrimento se infundia em imagens que geravam sofrimento; todo retrato se fazia em autoretrato. E dizia: "Quero pintar o que sinto e sentir o que pinto" [...] "Essa conviç̧ão o guiou até a morte - poucas horas depois da chegada de Theo a Auvers. De fato, ninguém enxerga de fato suas pinturas sem conhecer sua história. "O que minha arte é, eu sou também".

De acordo com Petrie (1974), ele compartilhou a busca dos Pós-Impressionistas por comunicar a emoção de uma forma a subverter as convenções sociais e estéticas:

É evidente que todos estes sentimentos, só por si, não eram suficientes para o transformarem num grande artista. Em 1884 ainda escrevia: "Um Corot, um Daumier, um Dupré, um Millet ou um Israels, todos eles são grandes orientadores pois a sua obra está indubitavelmente fora da pintura." Um ano mais tarde deve terse apercebido de que existe um sofisma escondido na distinção entre conteúdo e o seu modo de expressão, induzido por essa afirmação. (PETRIE, 1974, p. 8). 
Com essa declaração, van Gogh mostra-se consciente que não se pinta com as mãos, mas com a mente. E sua busca por 'grandes orientadores' nos pintores que o precederam é contínua, como atesta Petrie (1974, p. 7):

\begin{abstract}
Mas a constante e principal preocupação de Vincent relativamente à base emocional da sua atividade artística permitiu-lhe pelo menos guardar a esperança de que a humanidade de que fazia parte acabaria por partilhar das suas experiências. Os seus objetivos como artista de vaguarda no fim da década de 1880 eram no fundo semelhantes aos do início da década, em que a sua ambição era tornar-se ilustrador de revistas populares. "É pena - dizia ele a seu irmão Théo em 1882 - que haja pouco ou mesmo nenhum entusiasmo por uma forma de arte que tão bem se coaduna com o grande público." Apesar de o estilo avançado dos últimos anos representar um afastamento temporário desse mesmo público (e talvez também o reconhecimento de que o público não gosta de ser paternalizado), continua a haver uma continuidade nas suas mais profundas convicções. "A mesma maçã, só que mais amadurecida", assim anteviu ele, em 1885, a futura fase de maturidade de sua arte, estando isso certamente muito ligado a um triunfo eventual, mas póstumo.
\end{abstract}

Teve como professor o pintor Mauve, com quem se desentendeu, e que o ensinou a usar os contrastes cromáticos e "a pintar telas com aquela cor levada a incandescência pela ciência e a arte dos contrastes simultâneos" (HAZIOT, 2010, p. 200). No entanto, ele rompe com as correntes artísticas em voga na época de sua formação, como ilustrado na forma de seu desentendimento com seu mestre, o pintor Mauve, narrado por David Haziot (2010, p. 200):

Mauve havia sido bastante duro com ele, mas Vincent quis lembrar apenas o homem que o estimulara quando ele estava arrasado após a rejeição do seu amor por Kate Vos-Stricker. Certamente a pintura dele parecia agora ultrapassada a Vincent, votada ao esquecimento, mas sem Mauve ele talvez não estivesse ali, a pintar telas com aquela cor levada a incandescência pela ciência e a arte dos contrastes simultâneos. E Mauve lhe adiantara dinheiro, dera-lhe um leito quando não tinha nenhum. "Penso todo dia nele, eis tudo. [...] O homem talvez fosse mais profundo que o artista, e foi o homem que eu amei." CW2.

Em sua formação, van Gogh transitou por muitas correntes e recebeu a influência do Romantismo, do Realismo, do Classicismo, em seu auge na época em que ele estava formando seu discurso visual e artístico. Van Gogh poderia ter sido muito bem-sucedido pintando de acordo com as tendências mais aceitas nos círculos de compradores de arte. Mas ele não parou aí, e seu trânsito por diferentes correntes estéticas e sua capacidade de valorizar e assimilar elementos discursivos diversificados é que possibilitaram a construção de um discurso tão próprio e tão impactante. Haziot (2010, p. 170) descreve com clareza o processo de amadurecimento artístico de van Gogh:

Em Paris, Vincent recolhe, de uns e de outros, os meios para seguir seu próprio caminho. Mas essa busca absoluta necessitava uma força de convicção extrema. [...] Os impressionistas lhe ensinaram a vibração máxima da cor, Monticelli lhe mostrou que se pode usar as cores cruas mais violentas em empastamentos e contrastes, como fogos de artifício. Os japoneses lhe confirmaram que uma arte do traço fulgurante e quase "escrito" lhe permitiria dar um movimento irresistível a suas telas. Ele aprendeu com Seurat o meio de fazer auréolas e halos para as suas noites estreladas. 
[...] Empréstimos submetidos a finalidades que lhe são próprias: a fusão total, mas em equilíbrio, respeitando o real, entre o objeto visto e o eu. Mesmo que Vincent tenha sido um libertador pouco comum da subjetividade em arte, ele permaneceu um realista. Sua fragilidade psicológica não lhe permitia por em questão o real.

\subsection{O CONTEXTO HISTÓRICO DA HOLANDA}

Um breve panorama da história da Holanda nos séculos anteriores ao nascimento de Van Gogh pode dar uma visão esclarecedora das vicissitudes enfrentadas pelo povo holandês na construção de sua identidade. Essas experiências vividas coletivamente fizeram uma marca profunda nas famílias, e foram compartilhadas através das gerações impactando fortemente na visão de mundo de seus pais, avós e bisavós e colorindo vividamente o universo subjetivo de sua família.

A Holanda foi um lugar repleto de inundações desde o final da última idade do gelo quando o lago na boca do Reno enriqueceu o solo com minérios e atraiu os primeiros ocupantes que construíram diques para conter o mar e canais para trazer a água dos diques até suas plantações. No entanto, nem mesmo os diques conseguiam impedir as inundações e quando estes sucumbiam às ondas, o mar penetrava por quilômetros até o interior do País.

Somente nos séculos dezesseis e dezessete a invenção do moinho de vento tornou possível a drenagem de grandes territórios deflagrou a luta pela posse das grandes propriedades. Entre 1590 e 1740 mais de trezentos mil acres de terra foram incorporados aos Países Baixos adicionando quase um terço a mais de seu território. Essa incorporação ocorria no mesmo período em que os mercadores holandeses conquistavam o mercado marítimo e colonizaram terras distantes, e enquanto artistas e cientistas holandeses promoviam uma era de ouro comparada ao Renascimento na Itália. (NAIFEH; SMITH, 2011, p. 14)

Em 1568, a Holanda atravessou a guerra dos oitenta anos, uma revolta feita por dezessete províncias dos países baixos contra os invasores Espanhóis que dominavam o país. A revolta levantada por cidadãos protestantes foi combatida pela inquisição espanhola que condenou à morte como hereges um total de três milhões de homens, mulheres e crianças. Durante oitenta anos a Holanda esteve coberta de sangue, "exército combateu exército, classe combateu classe, milícia combateu milícia, vizinho combateu vizinho, ideia combateu ideia." (NAIFEH \& SMITH, 2011, p.16). Quando as províncias holandesas declararam a sua independência do rei espanhol em 1648 e a guerra foi declarada finda, uma nova onda de violência se levantou em 1672. Chamada Rampjaar, o 'ano da catástrofe', um novo levante 
de fúria levou os cidadãos das províncias e cidades a caçarem e esquartejarem em praça pública os líderes do governo prévio.

No século XVII, a Holanda teve a maior marinha do mundo e produziu artistas e filósofos como Rembrandt e Spinoza. Esse século de ouro das Províncias Unidas já havia acabado nos séculos seguintes. No início do século XVIII, reivindicações por eleições livres e abolição dos impostos em toda a Europa refletiam as ideias Iluministas que produziam uma força revolucionária igualada ao ímpeto das guerras e enchentes que a precederam.

Em 1795, tropas da República Francesa adentraram o território holandês como libertadores, mas permaneceram ali como conquistadores e confiscaram os bens, as propriedades e os recursos das famílias, fecharam negócios e geraram inflação e pobreza. O país foi dividido em departamentos franceses por Napoleão, seguidos à Revolução Francesa. De acordo com Naifeh e Smith (2011, p.35), mesmo quando Napoleão sofreu derrota na batalha de Waterloo em 1815 e o território Belga foi anexado às províncias Holandesas formando o Reino Unido dos Países Baixos. Esta reconfiguração não ajudou a diminuir as rivalidades, ao contrário.

Juntos com a maior parte do norte da Bélgica, os feudos do sul da Holanda pertenciam ao Brabante, um ducado medieval que teve sua breve idade de ouro nos séculos XIII e XIV antes de seu poder diminuiu e seus limites submergiram nas mudanças de impérios de seus vizinhos. Em 1581, quando a Holanda declarou sua independência do rei Espanhol, o Brabante se viu separado de seu vizinho ao norte por um golfo econômico, político e especialmente religioso que nunca iria ser integrado. Sendo em sua maioria católica e monarquista, permaneceu no lado oposto do golfo através de todos os eventos sangrentos que formaram os séculos XVII e XVIII. Com a formação do Reino Unido dos Países Baixos, os Brabantes se ressentiram da hegemonia política e econômica do norte e resistiram sua dominação cultural, e mesmo sua língua; os do norte viam os Brabantes como estúpidos, supersticiosos e não confiáveis. Em 1830 quando os Belgas romperam com o Reino Unido dos Países Baixos e declararam a Bélgica um país independente, essas inimizades mútuas vieram à tona. Brabantinos no lado Holandês da fronteira se aliaram com aqueles do lado Belga, e por quase uma década, pareceu para muitos na Holanda que todo o terço inferior do país poderia entrar em rebelião. (NAIFEH; WHITE, 2011, p.21)

Em 1839, foi feito um tratado que terminou por dividir o a região do Brabante ao meio. Para as áreas que circundavam a aldeia de Zundert, onde Vincent van Gogh nasceria dali a quatorze anos, essa divisão trouxe consequências devastadoras. Muitas famílias foram separadas, fazendas divididas ao meio, estradas interditadas, igrejas apartadas de suas congregações e as cidades que ficaram próximas a essa nova fronteira, foram tratadas pelo Governo de Haia como um território de ocupação de nação inimiga: o escoamento da produção de toda a região foi controlado por um único ponto de passagem. Os moradores da região precisaram viajar por várias milhas para levar ou trazer produtos e pagar pesados pedágios. Essa política ensejou a resistência do povo Brabantino que, levado pela miséria, 
iniciou uma prática audaciosa de contrabando através das charnecas selvagens da região, seguida de retaliação do governo e que deflagrou uma guerra Religiosa com muitas consequências para o povo do Brabante.

A revolta Belga e a "ocupação" que seguiu apenas aprofundou uma maior separação
entre Católicos e Protestantes em um clima de retaliação e intolerância por parte da
maioria católica da cidade. Por dois séculos, exércitos tinham lutado nas dunas de
areia de Zundert, instalando uma religião e perseguindo a outra. Quando as forças
católicas se aproximavam pelo sul, ou os Protestantes pelo norte, congregações
inteiras fugiam. Igrejas eram vandalizadas e apropriadas. Então os ventos políticos
mudavam: novas autoridades chegavam, e igrejas velhas eram reclamadas, contas
acertadas, e novas medidas opressivas impostas nos incrédulos. Na última rodada,
durante a revolta Belga, depois dos Católicos quebrarem as janelas da pequena
igreja em Groot Zundert, os protestantes só retornaram aos poucos (NAIFEH;
WHITE, 2011, p. 21).

De acordo com o biógrafo David Haziot (2010, p.12), o Reino Unido dos Países Baixos foi criado por iniciativa dos ingleses vencedores para servir como uma barreira contra a França. Uniu a Holanda, Bélgica e Luxemburgo e resultou no reinado de William I, rei da Holanda, mas nunca chegou a se impor por ser um Estado artificial. A Bélgica, católica, recusava a política religiosa protestante de William I. Além disso, a Bélgica era uma nação que estava se industrializando, era mais povoada do que a Holanda e estava mais acostumada com o francês. Seus cidadãos, os valões, não aceitavam o holandês como língua nacional nem seus costumes.

O Governo adotado por William I era autoritário, embora fosse baseado em uma constituição e tivesse duas Câmaras nomeadas, uma pelo rei e outra pelos Estados das províncias. O poder dos ministros era limitado às decisões do rei e o orçamento, proveniente das colônias era decidido a cada dez anos e era controlado unicamente pelo rei. Esse Governo de viés autocrático despertou a oposição da Bélgica que se insurgiu depois da revolução de 1830 e criou um reino onde reinou Leopoldo I. Como William I não aceitou a separação estas duas nações entraram em um longo conflito que custou muito aos cofres da Holanda. Por meio de uma intervenção dos ingleses e franceses em seu favor, a Bélgica ficou independente e, em 1840, William I abdicou o trono em favor de seu filho, William II.

Neste período a Holanda saia da guerra vencida e mergulhada em uma crise econômica com a escassez de alimentos. Neste cenário, o pai de Vincent estava então com 18 anos de idade e sua mãe com 21.

Em 1848, William II se alinhou com uma corrente política liberal em um movimento reformista que permitiu um renascimento na Holanda adotando uma constituição democrática nos moldes dos novos paradigmas democráticos da época. Os liberais fizeram reformas na política, aliviando a dureza do regime nas colônias e os negócios floresceram, desenvolvendo 
o país por meio da restituição à nação dos rendimentos coloniais aplicados na construção de ferrovias e obras de drenagem. No ano seguinte, William II morreu, dando início a um longo reinado de William III que durou até 1890. (HAZIOT, 2010 p.12).

Durante os reinados de William I (1815-40) e de seus sucessores, William II (184049) e William III (1849-90), a cobrança de impostos para proteger a economia e novas rotas de navegação ajudaram a reerguer a economia Holandesa no comércio marítimo. Em 1848, com a revolução se espalhando pela Europa, a Holanda reformulou sua constituição, descentralizando o poder da monarquia, aumentando a liberdade de imprensa e do Estado laico. As reformas políticas e sociais como a eleição do corpo legislativo, que antes era indicado pelo rei contribuíram transformar a Holanda em um reino com uma democracia parlamentar.

\subsubsection{Contexto Histórico, Social e Biográfico de Vincent van Gogh}

Em meio a esse contexto histórico e coletivo enfocamos a vida de Vincent van Gogh, que nasceu e viveu durante a metade do século XIX. Aqui começa a história, objeto desta pesquisa.

Em sua juventude, Vincent trabalhou em diferentes atividades iniciando com o comércio de quadros, e depois como professor, pastor, missionário, tentou estudar na universidade de Amsterdã e a despeito de sua devoção tanto na arte quanto na religião, que eram requisitos dessas atividades, fracassou em todas as tentativas de ter um meio de vida. No ano de 1880, parece encontrar finalmente um novo caminho: a pintura. A partir deste ano ele dedica-se inteiramente para se profissionalizar como pintor com a ajuda de seu irmão Théo que se torna seu patrocinador e parceiro na venda de suas telas. Em 1887 muda-se para Paris e conhece os impressionistas, em 1888 muda-se para Arles onde torna-se um pintor colorista e consuma sua linguagem pictórica própria. Recebe a vista do pintor Gauguin e devido a um desentendimento entre ambos no natal daquele ano, corta o lóbulo de sua orelha. Em 1889 sofre seguidas crises nervosas e é internado no hospício de St.-Paul-de-Mausole, em SaintRémy-de-Provence, perto de Arles. Segue pintando vistas das janelas do hospício. Em 1890, é publicada uma crítica de arte entusiasmada de Aubert Aurier a seu respeito e ele vende a tela A Vinha Vermelha na exposição em Bruxelas. Em Maio deixa Saint Remy e muda-se para Auvers-sur-Oise a duas horas de Paris onde pinta vistas da cidade. Em Julho desse ano se despede da vida com um tiro no peito e vem a falecer dois dias depois com 37 anos. 
1853 - Vincent Willem van Gogh nasceu da união em 1851 de Theodorus van Gogh, pastor da Igreja Holandesa Reformada, e Anna Cornélia Carbentus, filha de um encadernador de livros em Groot-Zundert, Holanda.

Figura 24: Theodorus van Gogh, pai de Vincent van Gogh

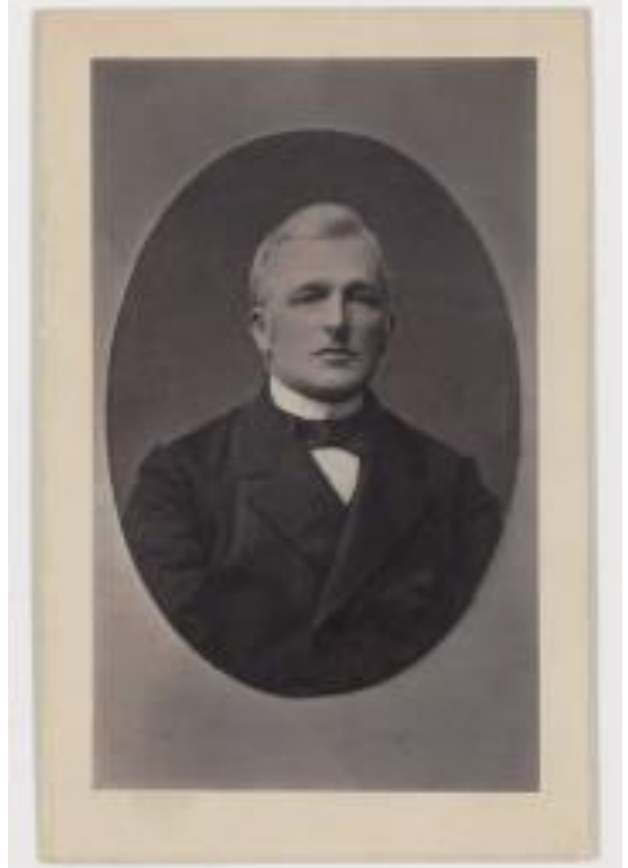

Fonte: The Van Gogh Letters Project (http://vangoghletters.org/vg/context 4.html)

Figura 25: Anna Cornelia van Gogh-Carbentus, mãe de Vincent van Gogh

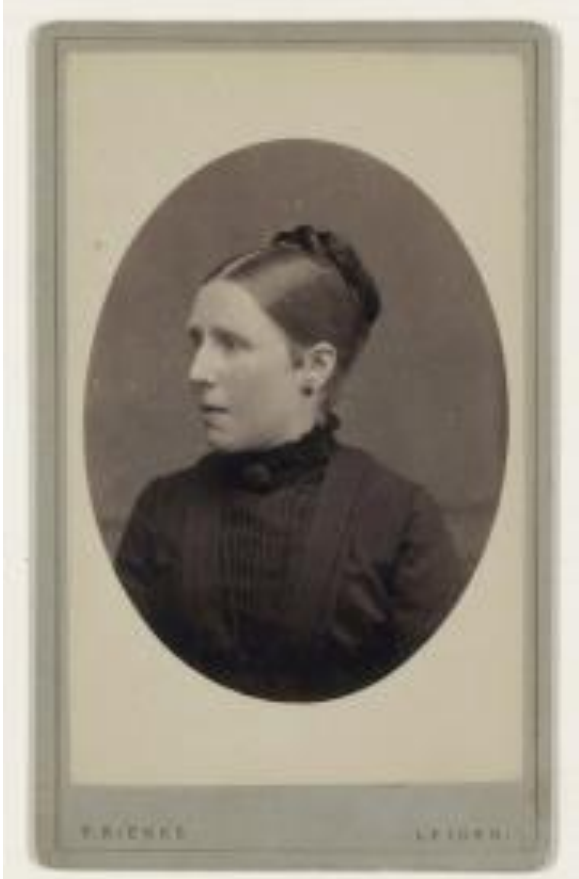

Fonte: The Van Gogh Letters Project (http://vangoghletters.org/vg/context_4.html)

Nascido em 30 de Março de 1853 em Groot-Zundert, uma aldeia na região do Brabante no sul da Holanda, ele é o segundo filho de seis crianças, sendo que o filho 
primogênito que o precedeu, chegou ao mundo natimorto e compartilha com Vincent, a mesma alcunha e o mesmo dia e mês de nascimento só que um ano antes.

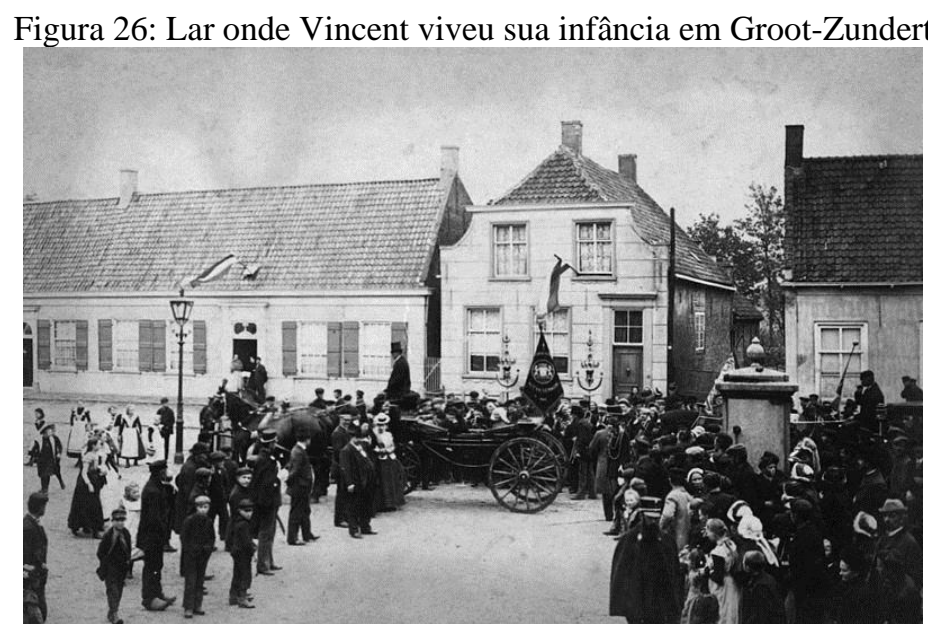

Fonte: http://pt.wikipedia.org/wiki/Theo_van_Gogh_(negociante_de_arte)

Vincent foi escolarizado na escola da vila em 1861 e em duas escolas de ensino médio posteriormente. Em sua infância, ele teve uma criação cercada de livros e de práticas familiares que favoreceram seu amor ao conhecimento e à arte. Foi um aprendiz excepcional de línguas, tendo estudado francês, inglês e alemão. Em março de 1868, ele não suportou a solidão de estudar interno em uma escola em outra cidade, retornando abruptamente a pé para a casa de seus pais e, dessa forma, ele não completou sua educação formal.

Em sua juventude, Vincent trabalhou em diferentes atividades iniciando com o comércio de quadros, e depois como professor, pastor, missionário, tentou estudar na universidade de Amsterdã e a despeito de sua devoção tanto na arte quanto na religião, que eram requisitos dessas atividades, fracassou em todas as tentativas de ter um meio de vida. No ano de 1880, parece encontrar finalmente um novo caminho: a pintura. A partir deste ano ele dedica-se inteiramente para se profissionalizar como pintor com a ajuda de seu irmão Théo que se torna seu patrocinador e parceiro na venda de suas telas.

\subsubsection{Linha do tempo}


Apresento abaixo uma linha do tempo resumida da vida de Vincent van Gogh para servir como referência para os eventos que serão mencionados nas análises dos corpora de telas e cartas. Este relato cronológico tomou como base o resumo biográfico do crítico de arte Brian Petrie (1984 p.12-13).

\section{3 - 0 anos}

No dia 30 de março nasce o pintor Vincent Willem van Gogh, na aldeia Groot-Zundert onde o pai Theodorus van Gogh trabalhava como pastor de uma congregação protestante.

Figura 27: Vincent van Gogh com a idade de 13 anos

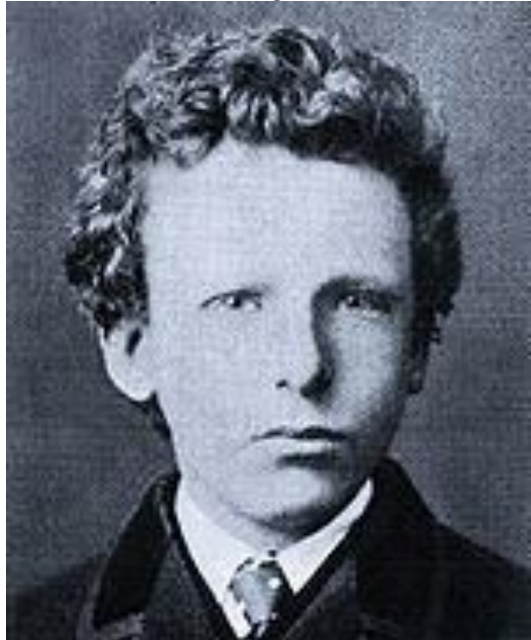

Fonte: Amsterdam, Van Gogh Museum / Vincent van Gogh Foundation disponível em 21.7.2014 http://vangoghletters.org/vg/context_4.html

\section{$1857-4$ anos}

Nasce, no dia $1^{\circ}$ de maio, o irmão mais novo Théo, companheiro e patrono da arte de Vincent. 


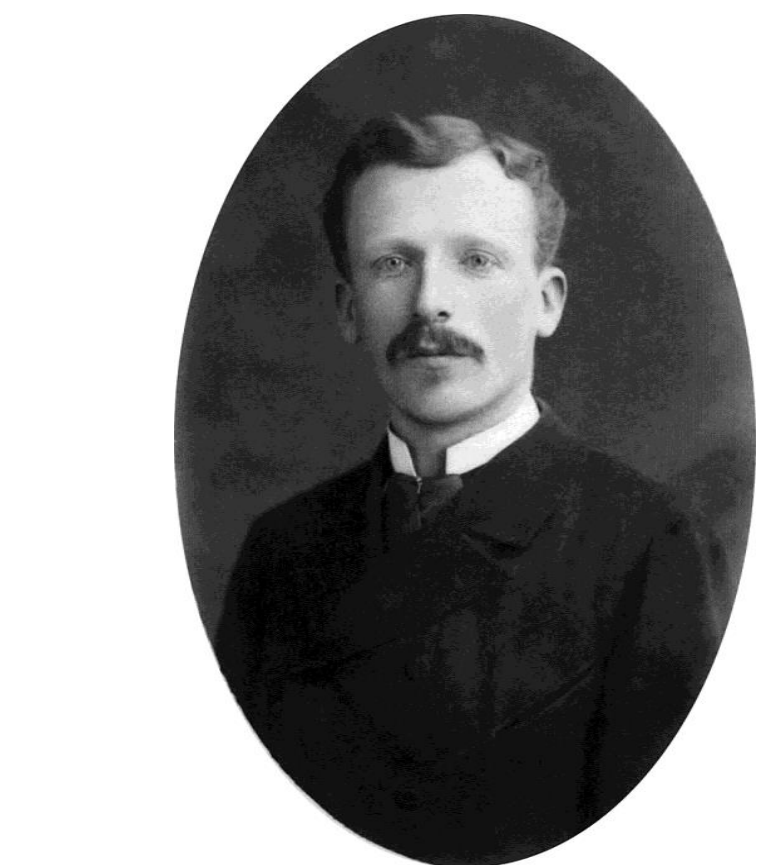

Fonte: http://pt.wikipedia.org/wiki/Theo_van_Gogh_(marchand)

\section{$1869-16$ anos}

Vincent deixa Zundert no final de julho para aprender o ofício de marchand na casa de Goupil em Haia.

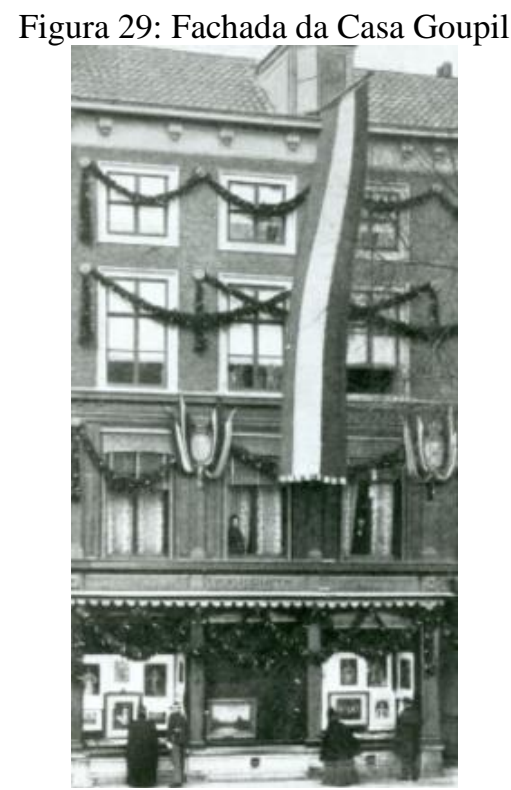

Fonte: Amsterdam, Van Gogh Museum / Vincent van Gogh Foundation. Disponível em 21.7.2014

\section{$1873-20$ anos}

Neste ano, Vincent é transferido duas vezes de estabelecimento e posição na casa Goupil. Em janeiro, para a sucursal em Bruxelas; em junho para a sucursal de Londres. Em 
Londres, apaixona-se por Úrsula Loyer, filha da senhoria onde se hospedava sem ser correspondido.

Figura 30: Vincent van Gogh com 19 anos

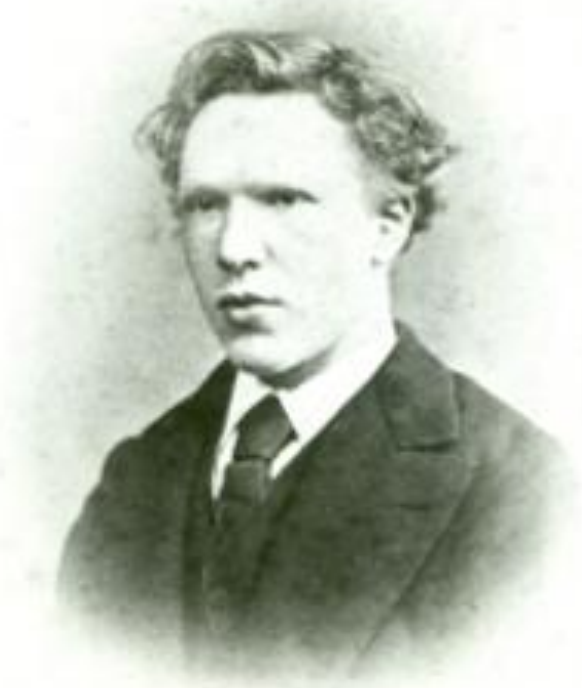

Fonte: Amsterdam, Van Gogh Museum / Vincent van Gogh Foundation. Disponível em 21.7.2014 http://www.vangoghmuseum.nl/vgm/index.jsp?page=12259\&lang=en

\section{4-1876 - entre 21 e 23 anos}

No ano de 1874, de outubro a dezembro, Vincent esteve à frente da sucursal em Paris da Goupil e, em Londres, de dezembro a maio do ano seguinte, 1875, após o que retornou a sucursal de Paris até o dia $1^{\circ}$ de abril do ano seguinte, em 1876, quando foi despedido.

Figura 31: Fachada da Casa Goupil em Paris, na Rua Lepic

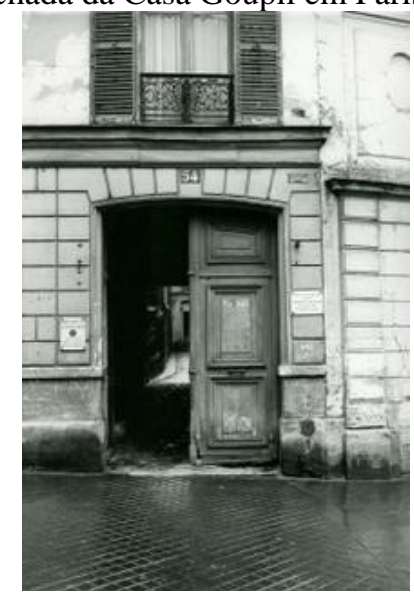

Fonte: Amsterdam, Van Gogh Museum / Vincent van Gogh Foundation. Disponível em 21.7.2014 http://www.vangoghmuseum.nl/vgm/index.jsp?page=12263\&lang=en 


\section{$1876-23$ anos}

Volta para a Inglaterra em meados de abril para lecionar em Ramsgate, e em julho Isleworth, perto de Londres. No final desse ano retorna para Etten, Holanda, lugar para onde seu pai tinha sido transferido.

\section{$1877-24$ anos}

Trabalha em uma livraria em Dordrecht, em janeiro de 1877, mas não se manteve no emprego. Vai para Amsterdam para se preparar para a admissão na Faculdade de Teologia da Universidade, em maio.

\section{$1878-25$ anos}

Abandona os estudos em julho. Ingressa em uma escola preparatória para evangelistas em Bruxelas, mas fracassa por comportamento difícil, relatado como "não é submisso". Viaja para o Sul da Bélgica, no distrito mineiro de Borinage em dezembro.

\section{$1879-26$ anos}

No Borinage assume o cargo de pregador leigo, onde vive com abnegação excessiva gerando o questionamento e o desligamento da ordem no final de julho. Foi para uma aldeia próxima e continuou esse trabalho, retomando a prática do desenho.

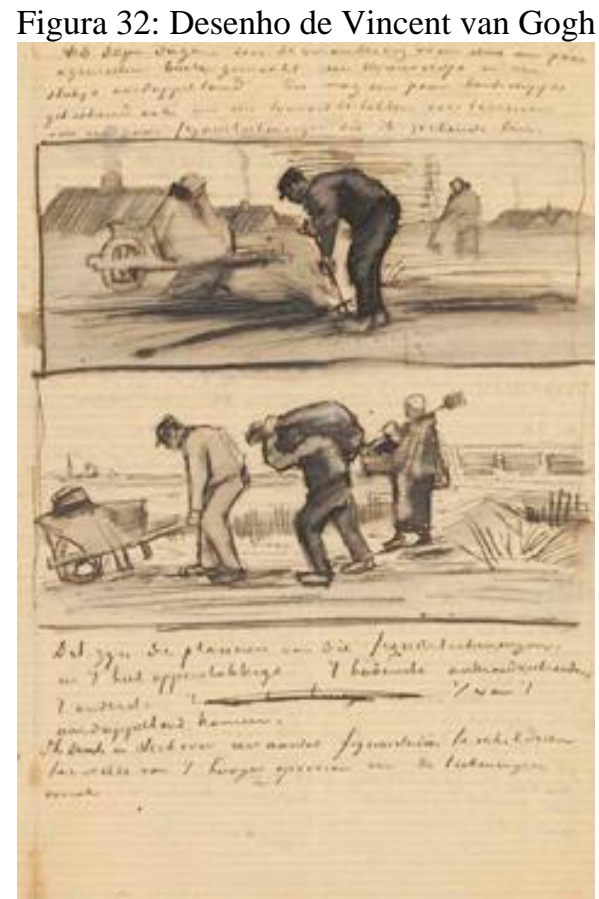

Fonte: Amsterdam, Van Gogh Museum / Vincent van Gogh Foundation. Disponível em 21.7.2014 http://www.vangoghletters.org/vg/ 


\section{$1880-27$ anos}

Neste ano, em julho, Vincent decide que será pintor e pede apoio a seu irmão Théo que passa a sustentá-lo em sua atividade até a sua morte. Em Bruxelas, ele conhece outro estudante de pintura, Anton Ridder Von Rappard, e os dois correspondem-se pelos próximos cinco anos.

\section{$1881-28$ anos}

Retorna para a casa dos pais em Etten, em abril, e no verão apaixona-se por sua prima Kee Vos-Stricker, viúva recente e morando com os pais. Os gestos impulsivos de Vincent criam uma situação tensa na família. Quase no final daquele ano, manifesta a sua decepção com a Igreja, mudando para Haia em dezembro onde teve aulas com Anton Mauve na escola de Haia.

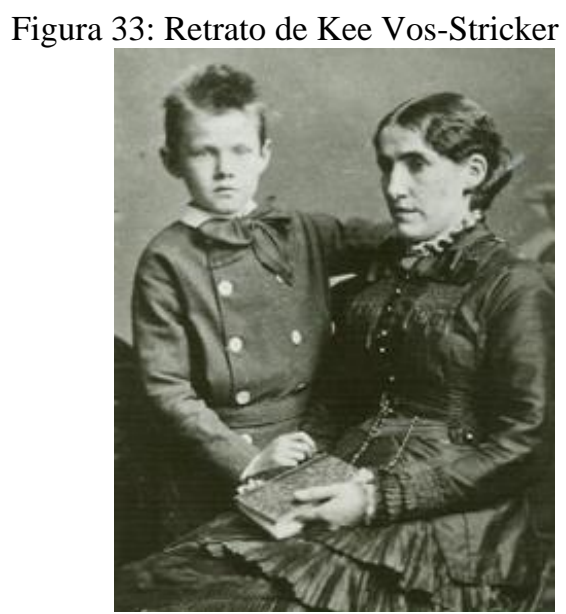

Fonte: Amsterdam, Van Gogh Museum / Vincent van Gogh Foundation.Disponível em 21.7.2014, http://www.vangoghmuseum.nl/vgm/index.jsp?page=12261\&lang=en

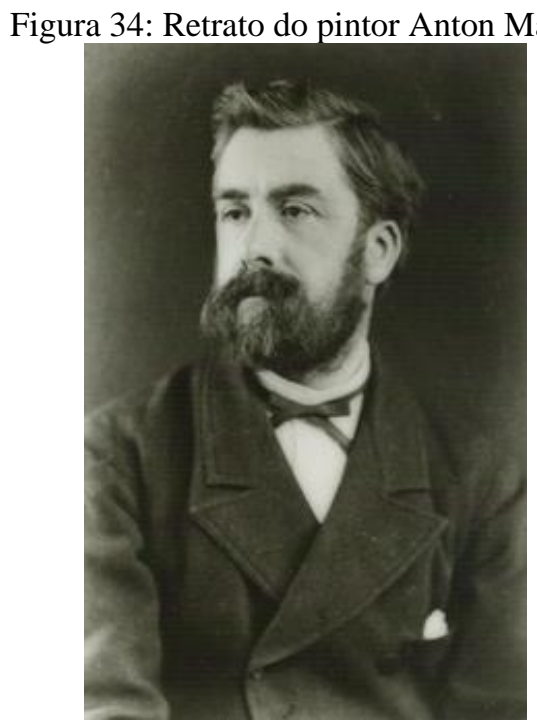

Disponível em 21.7.2014, http://en.wikipedia.org/wiki/Anton_Mauve 


\section{$1882-29$ anos}

Vincent conhece Sien (Clasina Hoornik) em janeiro de 1882, em Haia. Grávida e se prostituindo para viver até então, passa a morar com Vincent em março, dando à luz em julho. Vincent se envolve com Sien e a vê como sua mulher. Dedica-se ao domínio do desenho e da pintura.

Figura 35: Desenho de Sien por Van Gogh

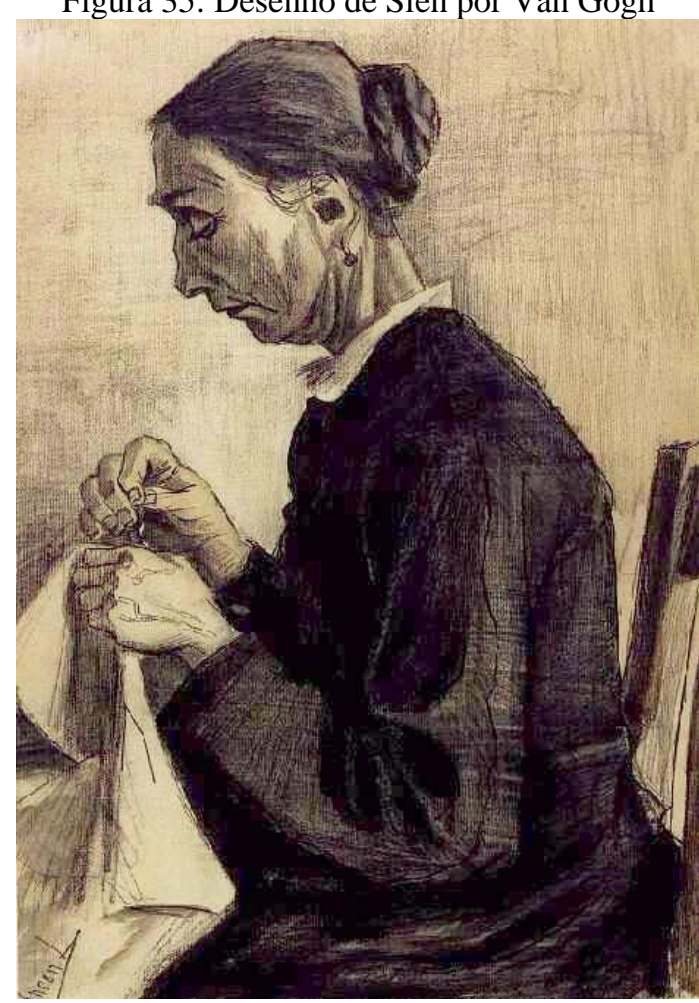

Fonte: Van Gogh Gallery, Sien, Sewing, Half-Figure, The Hague: 31 March 1883 (Rotterdam, Museum

Boijmans-van Beuningen, F 1025, JH 346, disponível em 21.7.2014, em http://www.vggallery.com/drawings/p_jh0554.htm

1883 - 30 anos

Devido à pressão de sua família, à intervenção de Théo para dissuadi-lo e aos desentendimentos com Sien, Vincent a deixa em setembro, mudando-se para uma região pobre e inexplorada do Norte na cidade de Drenthe. Retorna à casa dos pais em dezembro, já em Nuenen, por uma curta estadia. 
Figura 36: "Sorrow" desenho de Sien por Vincent van Gogh

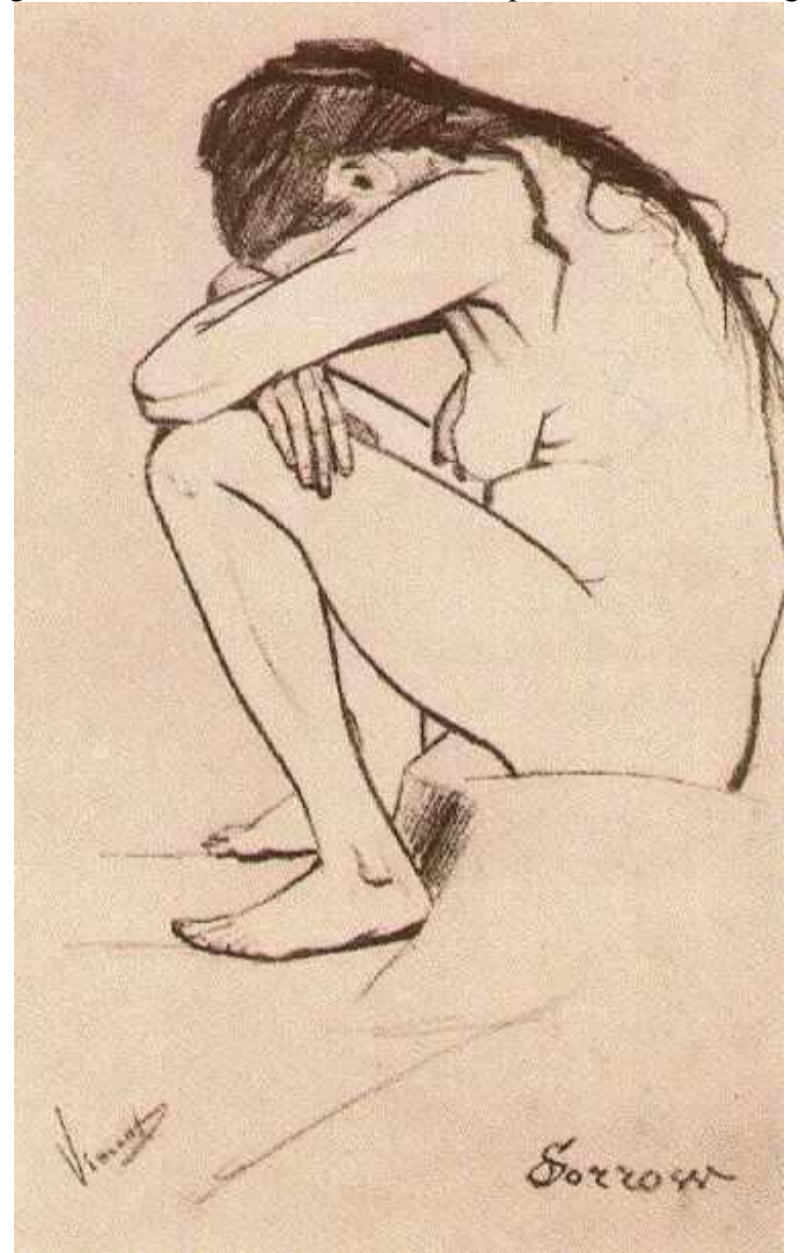

Fonte: Van Gogh Gallery, The Hague, c. 10 April 1882, (Private collection) F 929, JH 129. Disponível em 21.7.2014 em http://www.vggallery.com/drawings/p_0929.htm

\section{$1884-31$ anos}

Trabalha desde janeiro nos desenhos dos tecelões de Nuenen. Apaixona-se por Margot Begemann, e é correspondido, mas a família dela se opõe ao casamento e ela tenta o suicídio. Começa a trabalhar nas "cabeças do povo" e esses estudos culminam na tela "Os comedores de Batatas" no ano seguinte.

\section{5 - 32 anos}

Em 27 de março seu pai morre subitamente e ele segue dedicado a desenvolver-se como pintor. Durante o verão tem uma indisposição com seu amigo Rappard devido às críticas à tela "Os Comedores de Batatas" e termina esta amizade indo em novembro morar na Antuérpia. 
Figura 37: Os comedores de batatas de Vincent van Gogh

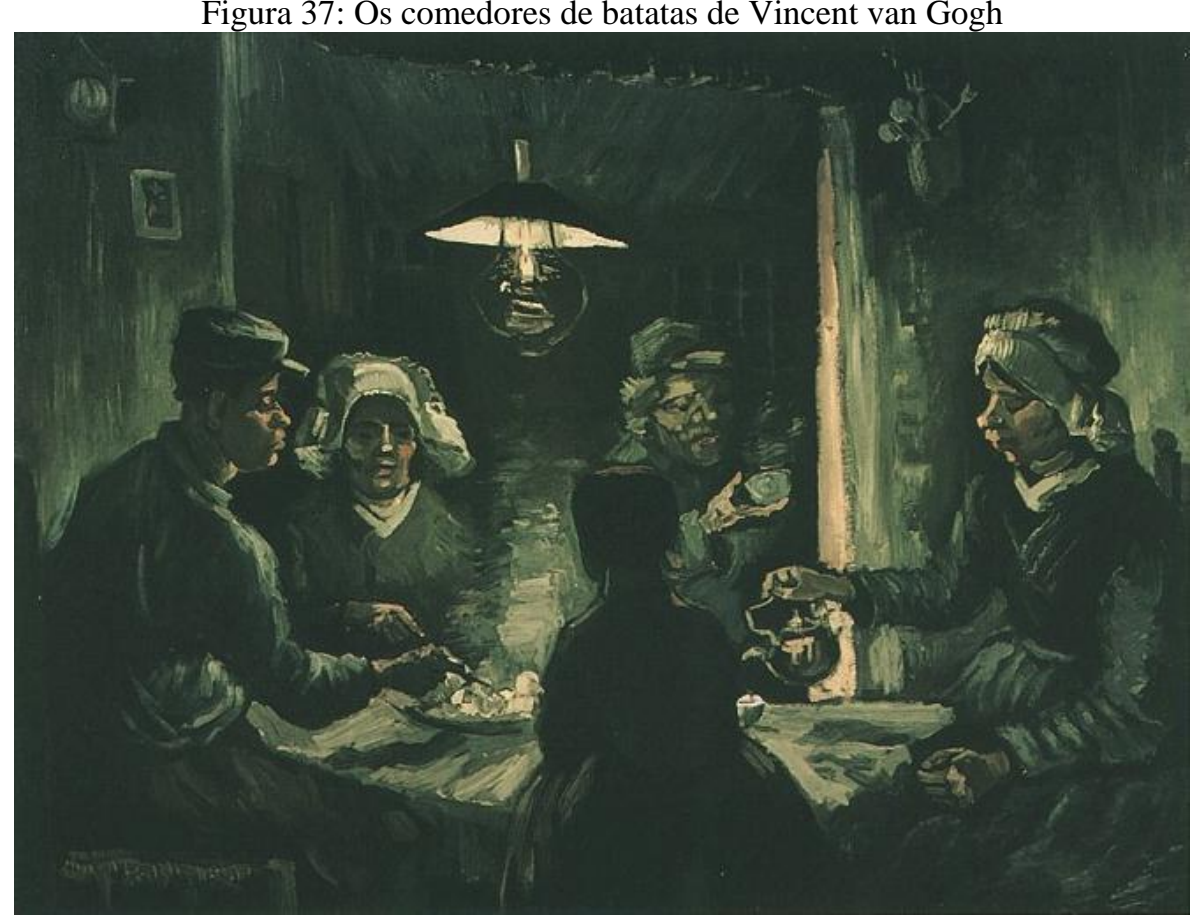

Fonte: Van Gogh Gallery, The Potato Eaters - oleo sobre tela, 72.0 x $93.0 \mathrm{~cm}$, Nuenen: Abril, 1885, F 78, JH 734, disponível em 21.7.2014 em http://www.vggallery.com/painting/p_0078.htm

\section{$1886-33$ anos}

Ingressa na Academia de Antuérpia. Aceita a técnica de trabalhar com modelos de esculturas antigas, mas rejeita a ênfase e mestria de contorno características daquela escola. Viaja para Paris em março e passa a viver com seu irmão Théo, frequentando o Atelier Cormon no qual conhece Toulouse-Lautrec e Émile Bernard.

\section{$1887-34$ anos}

Conhece os artistas de vanguarda de Paris, entre eles Pissarro, Gauguin, Seurat e Signac. Théo, no cargo de diretor da sucursal da casa Boussod et Valadon (sucessores de Goupil), buscou sem sucesso convencer seus superiores para apoiar essa vanguarda de artistas que influenciaram Vincent no vigor e nas propostas. Durante o ano de 1887, Vincent fez duas exposições no Café Tambourin, a primeira com as estampas japonesas e a segunda com trabalhos de Anquetin, Bernard, Lautrec e dele próprio. 
Figura 38: Agostina Segatori Sitting in the Cafe du Tambourin

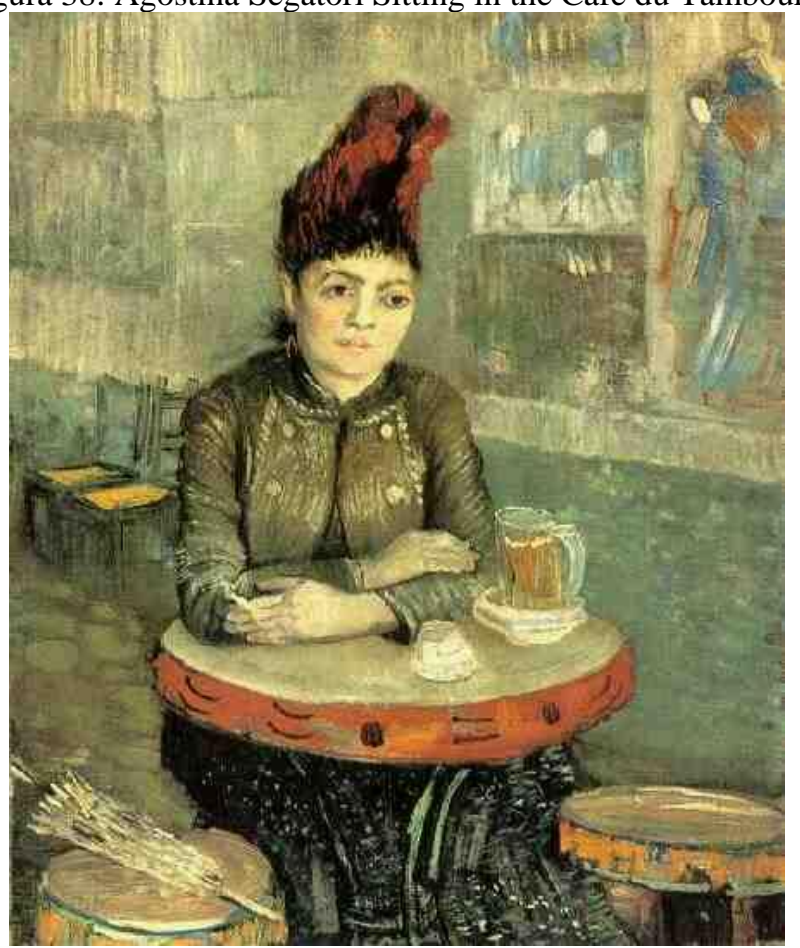

Fonte: Van Gogh Gallery, oleo sobre tela, 55.5 x 46.5 cm., Paris: February-March, 1887

F 370, JH 1208, Amsterdam: Van Gogh Museum, disponível em 21.7.14 em http://www.vggallery.com/painting/p_0370.htm

\section{8 - 35 anos}

Viaja para Arles em 20 de fevereiro em busca de uma luminosidade mais plena. Entre fevereiro e dezembro, vive a fase de produção mais intensa de sua carreira, registrando sua experiência em sua correspondência com Théo e com Bernard. Deu início à busca de concretizar um ideal, de organizar um "estúdio do Sul" para abrigar um coletivo de artistas com quem tinha afinidade e diálogo, entre eles Gauguin e Bernard, e talvez até Seurat. No dia 23 de Outubro, Théo realiza o desejo de Vincent e custeia a viagem de Gauguin à Arles para trabalhar em parceria com Vincent. Esse convívio terminou em um grande desentendimento, por ter Gauguin um temperamento, estilo e pensamento artístico muito diverso de Vincent, buscando como método o trabalho de memória. No dia 23 de dezembro, Vincent cortou a própria orelha esquerda, mergulhando em seguida em uma depressão nervosa que só melhoraria após a sua internação. O Natal daquele ano, Vincent passou com Théo no hospital. 
Figura 39: Tela de Vincent van Gogh: Self-Portrait with Bandaged Ear and Pipe

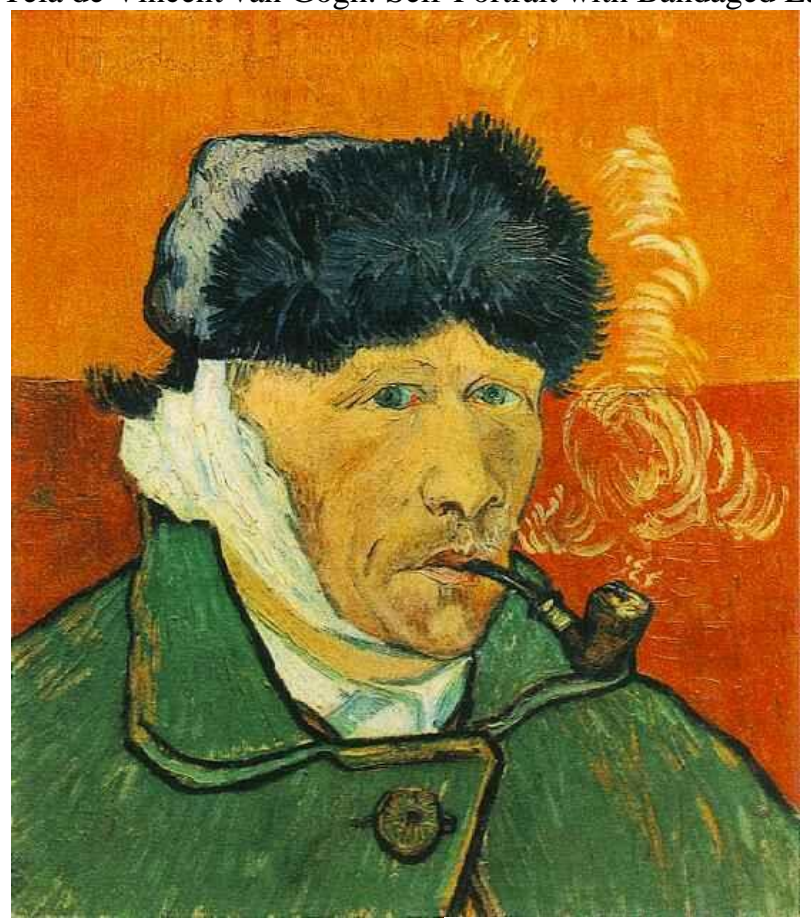

Fonte: Van Gogh Gallery, oleo sobre tela, 51.0 x $45.0 \mathrm{~cm}$. Arles: January, 1889 F 529, JH 1658, disponível em 21.7.14 em http://www.vggallery.com/painting/p 0529.htm

\section{9 - 36 anos}

Regressa para seu estúdio na Casa Amarela, no dia 7 de janeiro, mas sofre nova crise nervosa em fevereiro e volta a ser internado. Sua crise nunca foi esclarecida ou diagnosticada (os sintomas descritos por ele são de alucinações, desmaios e depressão). Em março foi internado a pedido dos moradores de Arles. No dia 8 de maio, Vincent deixa Arles e pede para ser internado no asilo Saint-Rémy, dando início a um período de depressões, em julho e dezembro e em janeiro e fevereiro de 1890, intercaladas por um trabalho febril e frenético. No final do ano, passou a identificar-se mais fortemente com Millet, o artista que sempre admirou e se espelhou. 
Figura 40: Tela de Vincent van Gogh: Ward in the Hospital in Arles

Fonte: Van Gogh Gallery, óleo sobre tela, 74.0 x 92.0 cm. Arles: April, 1889 F 646, JH 1686, disponível em 21.7.2014 em http://www.vggallery.com/painting/p_0646.htm

\section{0 - 37 anos}

$\mathrm{O}$ crítico de arte Albert Aurier publica em janeiro no Mercure de France o primeiro artigo sobre a obra de Vincent. Ele celebra o seu trabalho e o reputa como um "simbolista", no entanto, este escreve a Aurier, bastante incomodado com os elogios que não sente merecer. Uma de suas telas é vendida para a irmã de seu amigo Boch em Fevereiro por 400 francos na exposição de uma associação progressista de artistas em Bruxelas Les XX. Deixa Saint-Rémy, em 17 de maio para visitar seu irmão em Paris. Théo estava casado com Jo Bonger e com um filho de nome Vincent, nascido naquele janeiro. Deixa Paris e vai para Auvers-sur-Oise, para se tratar com o Dr. Gachet e ficar próximo de Pissaro. No dia 27 de julho, Vincent tenta se matar com um tiro e agoniza por dois dias, vindo a falecer no dia 29 de julho. Théo não resiste à morte do seu irmão e morre seis meses depois. 
Figura 41: Tela de Vincent van Gogh: Wheat Field with a Partridge

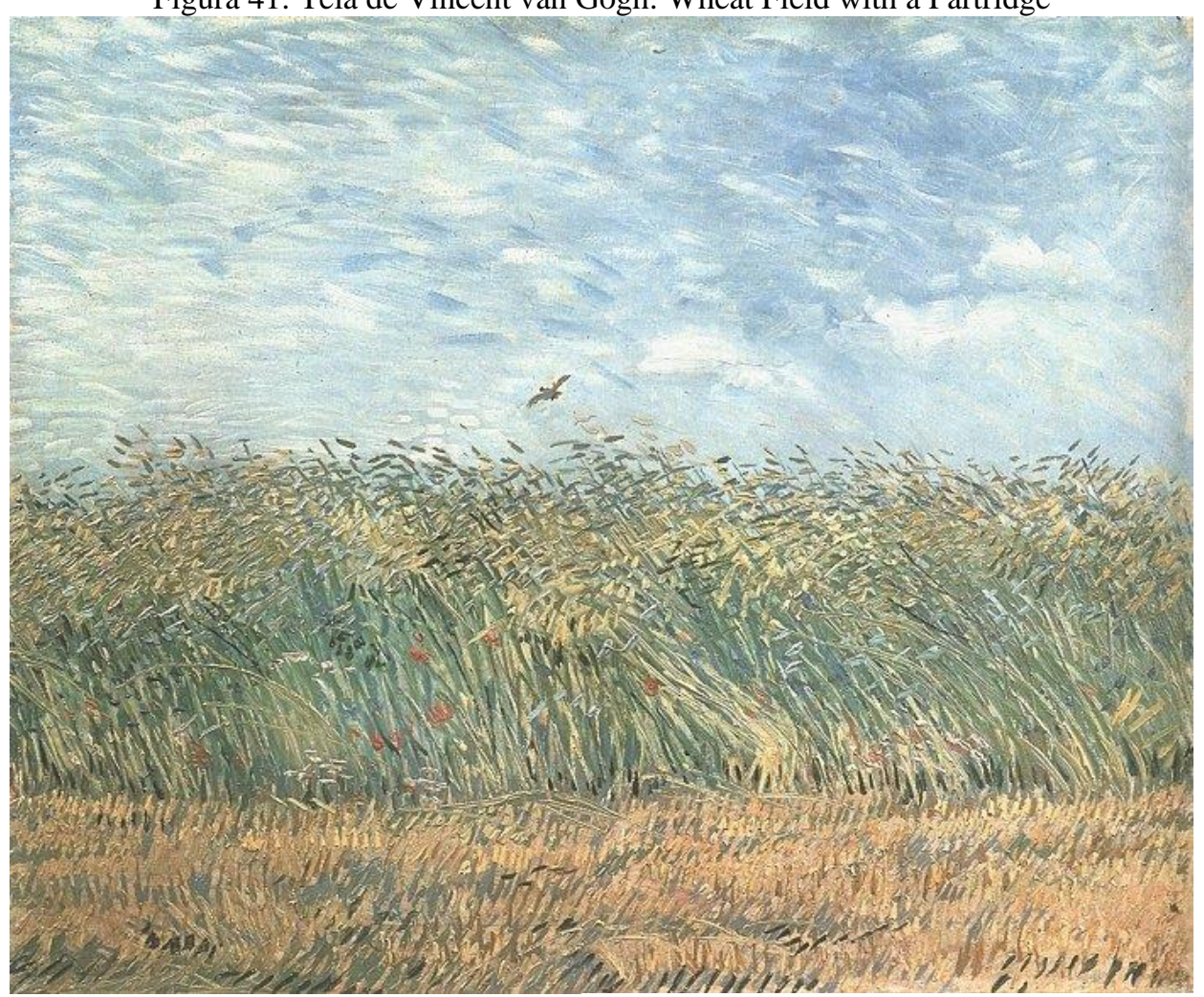

Fonte: Van Gogh Gallery, oleo sobre tela, 34.0 x 65.5 cm, Paris: Summer, 1887, F 310, JH 1274,

Amsterdam: Van Gogh Museum, disponível em 21.7.2014 em

http://www.vggallery.com/painting/p_0310.htm\#analysis

\subsubsection{Valores, atitudes e visão de mundo em família}

Enquanto Vincent transitou por diferentes escolas de pensamento e constituiu uma visão de mundo própria, não podemos deixar de falar sobre a visão de mundo que prevaleceu no ambiente familiar no qual ele cresceu, porque ela ocupou algum lugar no processo formativo de Vincent. Neste item são descritos pelos biógrafos Naifeh e Smith (2012), os valores vivenciados nos anos com a família, em especial a experiência de mundo que seu pai e sua mãe compartilharam com os filhos e que têm um papel basilar na formação da visão na experiência de mundo de Vincent. Naifeh e Smith dão conta de relatar experiências coletivas que influenciaram as expectativas e a visão de mundo dos pais de Vincent:

Nas primeiras décadas do século XIX, com o recuo da maré napoleônica, os holandeses voltaram a consertar os diques do Estado. Era tão generalizado o medo de cair de novo naquele violento redemoinho que a moderação se tornou a ordem do dia na política, na religião, na ciência e nas artes. "O medo da revolução deu origem ao crescimento de sentimentos reacionários", escreveu um cronista, e as características definidoras da época passaram a ser "a presunção e a vaidade nacional. (NAIFEH; SMITH, 2012, p. 35-36). 


\section{a) Visão de mundo em família}

Algumas crenças foram sedimentadas pelas tragédias vivenciadas tanto no âmbito familiar quanto coletivo nas gerações dos avós de Vincent van Gogh impactaram na formação da visão de mundo da geração de seus pais. Estes por sua vez, transmitiram para seus filhos e entre eles Vincent, sua experiência, expectativas, preocupações e conflitos fazendo uma marca incontestável na forma como Vincent organizou sua própria experiência, valores e ideais. Como exemplo da atmosfera familiar em que Vincent cresceu, Naifeh e Smith relatam a percepção fatalista que Anna, sua mãe, tinha da vida:

Cercada de tais lições, Anna, a filha do meio de Willem, cresceu com uma visão sombria e temerosa da vida. Por toda parte havia forças ameaçando devolver a família ao caos de onde conseguira sair tão pouco tempo antes, com o mesmo ímpeto repentino e destruidor do mar tragando uma aldeia. O resultado foi uma infância cercada pelo medo e pelo fatalismo: pela sensação de que a vida e a felicidade eram precárias, e assim não se podia confiar nelas. Segundo as palavras da própria Anna, o mundo era um lugar cheio de problemas e preocupações [que] são inerentes a ele"; um lugar onde "as decepções nunca cessarão" e apenas os tolos "querem muito" da vida. Devíamos simplesmente "aprender a suportar", dizia ela, "entender que ninguém é perfeito", que "sempre existem falhas na realização de nossos desejos", e que as pessoas deviam ser amadas "apesar de seus defeitos". A natureza humana, em especial, era caótica demais para merecer confiança, sempre em risco de se descontrolar. E avisava aos filhos: "Se pudéssemos fazer tudo o que quiséssemos, sem sofrer as consequências, sem ser vistos, sem ser incomodados, não nos desviaríamos ainda mais do caminho certo?" (NAIFEH; SMITH, 2012, p. 36$37)$.

Naifeh e Smith (2012) relatam a troca de cartas que Anna troca com os filhos e familiares mais distantes e que revela muito de sua experiência e percepção de mundo:

Em todos os aspectos da vida, e não apenas na religião, Anna procurava um terreno seguro. "Aprendam sempre a vida normal" - aconselhava aos filhos. "Sigam sempre pelo bom caminho." Numa sociedade pós-revolucionária, pós-traumática - uma sociedade que sempre valorizou e muitas vezes impôs a obediência -, era um ideal almejado praticamente por todos. A normalidade era o dever de toda moça holandesa, e não existia ninguém mais cumpridor de seus deveres do que Anna Carbentus. (NAIFEH; SMITH, 2012, p. 39).

Uma atitude amedrontada para experimentar a vida, somada com a sua sistematicidade para se comunicar, emerge nas cartas da mãe de Vincent e parece ter colorido sua interação com seus filhos:

Anna imprimiu essa visão receosa e fechada a todos os filhos. Não sendo de natureza afetuosa e pouco dada a contato físico, ela travava uma campanha verbal incessante: a afirmação dos laços de família, a invocação dos deveres filiais, a declaração de amor e a invocação dos sacrifícios dos pais, infinitamente entretecidas para formar o tecido da vida cotidiana. Não só a família deles era de uma felicidade única, como também uma "vida doméstica feliz" era indispensável para qualquer alegria. Sem ela, o futuro só podia ser "solitário e incerto". Sua campanha endossava a missão da unidade da família - o que um historiador chamou de "totalitarismo familiar" - que preenchia a literatura da época, na qual costumavam comparecer expressões de devoção familiar acompanhadas por soluços incontroláveis. "Não podemos viver uns sem os outros", escreveu Anna ao filho Theo, de dezessete anos. 
"Amamos demais uns aos outros para ficarmos separados ou não abrirmos mutuamente nossos corações.” (NAIFEH; SMITH, 2012, p. 47).

A prática de troca de cartas que Anna cultivou com os filhos parece ter sido um recurso para construir a lealdade ao grupo familiar, à qual Vincent se mantém fiel ao longo da vida adulta. Essa proximidade está evidenciada na correspondência com o irmão, não apenas na parceria, mas também nos conflitos expressos em alguns momentos.

Com respeito à visão de mundo no ambiente familiar é preciso ainda falar da religiosidade de seus pais. Naifeh e Smith dão conta de descrever a atmosfera de temeridade que Anna transmitia aos filhos:

\footnotetext{
Como criança medrosa, Anna foi naturalmente atraída para a religião. Exceto pelos casamentos e batismos, o aparecimento da religião no registro da família Carbentus é relativamente tardio: quando o exército francês chegou a Haia em 1795, o cronista culpou "a mão pesada de Deus" pelas depredações dos soldados aboletados e pelo confisco das moedas. Dois anos depois, quando a fúria que se desencadeara na terra encontrou Gerrit Carbentus sozinho na estrada de Rijswijk, a crônica irrompe de súbito num lamento de devoção: "Permita-nos Deus aceitar Suas decisões com coração obediente". Era esta a essência do sentimento religioso que nasceu dos anos de turbulência - tanto na família Carbentus quanto no país: o reconhecimento temeroso das consequências do caos. Sangrando e exaurido, o povo passou de uma religião que infundia vigor aos fiéis para outra que confortava os assustados. Anna sintetizou bem os objetivos mais amenos do novo credo: "preservar, apoiar e consolar". (NAIFEH; SMITH, 2012, p. 38).
}

O papel da religião na formação de Vincent e seus irmãos não parece muito valorizado pelos biógrafos em geral, talvez para não lançar uma sombra sobre a importância da sua arte. No entanto, é preciso lembrar que estes ideais espirituais, transmitidos muito cedo e ao longo de sua formação familiar certamente alicerçaram seus valores éticos e estéticos e estão sublimados dentro de sua expressão artística, no grau, intensidade e extremismo com o qual viveu e buscou expressar estes ideais, ao ponto de se tornar ele próprio e toda a sua existência, um meio para sua expressão.

\section{b) Práticas familiares que circundaram a infância de Van Gogh}

Como uma família protestante nos meados do século XIX, os pais de Vincent se preocupavam em promover práticas de lazer e cultura para manter os filhos em casa e longe da rua. No entanto, as práticas com que eles buscaram organizar a vida doméstica e o convívio, estavam associadas às percepções religiosas e morais, bem como à forma com que experienciavam a vida. Como descrevem Naifeh e Smith, Anna se encarregava de organizar as atividades em grupo que eram consideradas um lazer vitoriano: jardinagem, literatura, música e pintura: 
Tocava piano. Lia porque "mantém a gente ocupada [e] distrai a cabeça", dizia ela. Como mãe era obsecada com as vantagens da preocupação e insistia nisso com os filhos a cada oportunidade. "Obrigue a cabeça a se ocupar de outras coisas", foi o conselho que deu a um deles como tratamento para o "desânimo". (Foi uma lição que seu filho Vincent, talvez o artista mais deprimido e de produtividade mais incandescente da história, aprendeu até bem demais.) Quando nada mais funcionava, Anna se punha a limpar furiosamente. "Aquela queridíssima mamãe está ocupada com a limpeza", escreveu o marido, lançando algumas dúvidas sobre a eficácia de todas as estratégias da esposa, "mas pensa e se preocupa com tudo". (NAIFEH; SMITH, 2012, p.37).

Este trecho evidencia o impacto da sistematicidade da mãe de Vincent na 'produtividade incandescente' que foi uma marca de Van Gogh, não apenas na forma como devorava em poucas semanas obras inteiras de escritores por quem se interessava, mas por sua vigorosa produção pictórica dificilmente superada por outros artistas.

\section{c) O desenho e pintura na família}

Os biógrafos Naifeh e Smith relatam o contato de Vincent com o desenho e a pintura em sua primeira infância:

As mãos ativas de Anna também se dedicaram à arte. Junto com pelo menos uma irmã, Cornélia, ela aprendeu a desenhar e pintar aquarelas, passatempo adotado pela nova burguesia como símbolo e vantagem do ócio. Seu tema favorito era o usual dos artistas de salão da época: flores - buquês de violetas, ervilhas-de-cheiro, jacintos, miosótis. As irmãs Carbentus podem ter recebido algum incentivo nessa atividade convencional do excêntrico tio Hermanus, que pelo menos uma vez se apresentou como pintor. Também tinham o apoio e o exemplo de uma família nada convencional de artistas, os Bakhuyzen. As visitas de Anna à casa deles eram verdadeiras imersões no mundo da arte. O pai Hendrik, respeitado paisagista, dava aulas não só aos filhos (dois dos quais se tornaram artistas importantes) e talvez às irmãs Carbentus, mas também a um grupo variável de alunos que, mais tarde, criaram um novo movimento artístico enfaticamente holandês, a Escola de Haia. Trinta e cinco anos após as visitas de Anna, o mesmo movimento serviria de porto de onde seu filho deslancharia em sua breve carreira de artista, sujeita a tantas tempestades. (NAIFEH; SMITH, 2012, p. 37-38).

De acordo com Naifeh e Smith, esse contato familiar com a prática de desenhar e pintar, associados às aulas posteriores com o pintor Hendrik uma das figuras centrais da Escola de Haia pode ter feito uma marca em sua experiência e visão de mundo que possibilitou o seu posterior amadurecimento em um dos artistas mais explosivos e exuberantes do século XIX:

Nenhuma comemoração estava completa sem presentes. Desde a mais tenra idade, os filhos Van Goh iam encontrar ou criar seus presentes de aniversário e datas anuais. Todos sabiam montar arranjos de flores e cestas de alimentos. Por fim, todos os filhos de Anna desenvolveram um repertório de habilidades manuais que atendiam à demanda de lembrancinhas para as festas. As meninas aprendiam a bordar, a fazer crochê, tricô, macramê; os meninos, a fazer peças de argila e de madeira, [...] E todos aprendiam a desenhar. Sob a tutela da mãe, todos os filhos Van Gogh dominavam as artes sociais da colagem, do desenho e da pintura, para enfeitar e personalizar os presentes e bilhetes que trocavam incessantemente. Uma simples 
caixa podia ser enfeitada com um buquê de flores pintadas; a cópia de um poema, com um festão de papel recortado. Ilustravam as histórias favoritas, associando palavras e imagens como os livros de emblemas que eram tão usados para ensinar lições de moral às crianças. Com o tempo, as gravuras impressas e outros itens comprados em loja viriam a substituir as colagens e os bordados nas comemorações familiares, mas mesmo assim os presentes feitos à mão continuariam a ser considerados as oferendas mais autênticas no altar da família. (NAIFEH; SMITH, 2012, p.53-54). 


\section{CAPÍTULO 2 FUNDAMENTAÇÃO TEÓRICA}

\subsection{METAFUNÇÃO INTERPESSOAL: FUNÇÃO DA FALA E SISTEMAS DE MODO E DE MODALIDADE}

Halliday (2004) compreende a linguagem pela perspectiva de duas metafunções mais gerais: nós a usamos para representar experiências humanas internas e externas e para possibilitar a interação humana. Podemos investigar a primeira função da linguagem que se refere à representação das experiências humanas por meio da análise de funções configurativas nas orações tais como: processos, participantes e circunstâncias. No que se refere à segunda função da linguagem, que é tornar possível a interação humana, podemos analisar os sistemas de função da fala, de modo e modalidade para compreender como a linguagem se comporta na metafunção interpessoal. Na LSF há uma diferenciação para o uso do termo 'modo'. MODO - refere-se ao sistema que engloba toda a modalidade; Modo refere-se ao elemento interpessoal da oração e modo - refere-se ao modo verbal (indicativo, subjuntivo, imperativo)

Quanto às funções da fala, e aos sistemas de modo e de modalidade, ocorre que um bem é dado para, ou é demandado do interlocutor. Esse bem pode ser uma informação, ou bens e serviços. Para Halliday e Matthiessen (2004, p.107), “os tipos mais fundamentais do papel da fala, que estão por trás dos tipos mais específicos que nós podemos eventualmente ser capazes de reconhecer, são apenas dois: (i) dar e (ii) pedir/solicitar”. Para ilustrar esses participantes, veja o quadro abaixo:

Quadro 38: Funções da fala e suas realizações

\begin{tabular}{|c|c|c|}
\hline $\begin{array}{ll}\text { Papel na troca } & \text { Bem trocado } \\
\end{array}$ & Bens e Serviços & Informação \\
\hline Dando & $\begin{array}{l}\text { Oferta } \\
\text { Voce gostaria de mais chá? }\end{array}$ & $\begin{array}{l}\text { Declaração } \\
\text { Ele está dando a ela mais chá. }\end{array}$ \\
\hline Demandando & $\begin{array}{l}\text { Comando } \\
\text { Sirva-me mais chá. }\end{array}$ & $\begin{array}{l}\text { Pergunta } \\
\text { O que ele está dando a ela? }\end{array}$ \\
\hline
\end{tabular}

Fonte: Adaptado de Halliday e Matthiessen (2004, p. 107).

Uma análise dos significados interpessoais da linguagem que estão relacionados com interações construídas recairá em duas funções da fala. No processo de construção do sentido, a forma como essas funções estão organizadas dá margem aos movimentos interacionais de ofertas e demandas - propostas - tanto quanto às declarações e às questões - proposições. A 
iniciação da fala requer uma reação, que pode ser uma resposta esperada (apoio) ou uma resposta alternativa (confronto).

Estes processos de troca são realizadas por meio das escolhas no sistema de Modo. O sistema de MODO possibilita realizar movimentos interativos nas falas, oferecendo alternativas para a interação.

Quadro 39: Um aspecto do sistema de Modo com suas possibilidades realizacionais

\begin{tabular}{|c|c|c|c|}
\hline \multicolumn{4}{|c|}{ Um aspecto do sistema de modo } \\
\hline \multicolumn{2}{|c|}{ Indicativo } & \multicolumn{2}{|l|}{ Imperativo } \\
\hline Declarativo & Interrogativo & Inclusivo & Exclusivo \\
\hline $\begin{array}{l}\text { Aliás, ele precisava } \\
\text { rever Paris, e em } \\
\text { Paris talvez ele se } \\
\text { sinta mais em casa } \\
\text { do que aqui. }\end{array}$ & $\begin{array}{l}\text { Falemos agora de nosso } \\
\text { amigo Gaugin, eu o assustei? }\end{array}$ & $\begin{array}{l}\text { Diga a Gauguin que me } \\
\text { escreva }\end{array}$ & \\
\hline
\end{tabular}

Fonte: Adaptado de Halliday e Matthiessen (2004, p. 107) e Van Gogh (2009m).

Os componentes oracionais do sistema MODO são o Modo e o Resíduo. O Modo é composto por um agente (grupo nominal) e finito (grupo verbal ${ }^{313}$ ). O Resíduo pode ser de três tipos: predicador, complemento ou adjunto. A polaridade refere-se a uma informação positiva (Sim) ou negativa (Não).

Além dos significados interpessoais do sistema de MODO e de POLARIDADE relacionados à interação, há uma outra área de significados interpessoais mais indeterminados realizados na modalidade. Para Halliday e Mathiessen (2004, p.147). "o que o sistema de modalidade faz é construir a região de incerteza que está entre 'sim' e 'não'.” A modalidade realiza as nuances de significados que são mais fluidos.

$\mathrm{Na}$ área de incerteza na linguagem usada em trocas de informação que a modalidade realiza, são usados os pontos de polaridade 'sim' e 'não' como referências que ajudam a medir o grau de indeterminação no significado. Nas dimensões da modalidade chamadas de modalização, encontramos dois tipos de significados intermediários que existem entre as polaridades ‘é assim' e sua negação 'não é assim’ que são a probabilidade e a usualidade (HALLIDAY; MATTHIESSEN, 2004, p. 147).

Como exemplo, segue o excerto abaixo:

Quadro 40: Funções do sistema de MODO com suas possibilidades transacionais

\begin{tabular}{|l|l|c|}
\hline \multicolumn{1}{|c|}{ Agente } & \multicolumn{1}{c|}{ Finito } & Resíduo \\
\hline você & se tornou & um estranho para \\
\hline Até certo ponto você se tornou um estranho para mim, & Resíduo \\
\hline Agente & \multicolumn{1}{c|}{ Finito } & R \\
\hline
\end{tabular}

313 Que mostra o tempo de duração, a modalidade e sua validade, e a polaridade que pode ser positivia ou negativa (FUZER; CABRAL, 2014). 


\begin{tabular}{|l|l|l|}
\hline Eu & seja & \multicolumn{1}{c|}{ para você mais do } \\
\hline e eu talvez o seja para você mais do que você imagina; & \multicolumn{1}{c|}{ Resíduo } \\
\hline \multicolumn{1}{|c|}{ Agente } & \multicolumn{1}{c|}{ Finito } & Talvez fosse \\
\hline nós & não continuarmos \\
\hline talvez fosse melhor para nós dois não continuarmos assim”. & \\
\hline
\end{tabular}

Fonte: Van Gogh (2007).

Quadro 41: Exemplos do Sistema de Modo

\begin{tabular}{|l|l|}
\hline Obrigação & Bem, façam azul, e pronto! \\
\hline Prontidão & $\begin{array}{l}\text { O esboço assim com o está atormenta-me muito, pois pergunto a mim mesmo se não } \\
\text { será preciso tomá-lo a sério e fazer dele um quadro terrível e, Deus meu, como eu } \\
\text { gostaria de faze-lo! }\end{array}$ \\
\hline
\end{tabular}

Fonte: Van Gogh (2009e).

Quando há uma proposta em vez de uma proposição, temos a linguagem usada em trocas de bens e serviços na qual o parâmetro se situa entre o positivo 'faça isso' e sua negação 'não faça isso'. Entre estas duas polaridades, encontramos dois tipos de indeterminação de significado, que dependem da função da fala quando se trata de um comando ou uma oferta. O comando refere-se aos graus de obrigação, e a oferta refere-se aos graus de prontidão, divididos em subáreas de inclinação e de habilidade que são referidas como modulação.

Quadro 42: Funções do sistema de MODO: graus de prontidão

\begin{tabular}{|l|l|l|}
\hline \multicolumn{1}{|c|}{ Agente } & \multicolumn{1}{c|}{ Finito } & \multicolumn{1}{c|}{ Resíduo } \\
\hline eu & sentir & Na obrigação, na .. \\
\hline \multicolumn{2}{|c|}{ não fosse o fato de eu me sentir na obrigação, na necessidade de lhe escrever; } \\
\hline
\end{tabular}

Fonte: Van Gogh (2007).

Quadro 43: Funções do sistema de MODO: graus de obrigação
\begin{tabular}{|l|l|c|}
\hline \multicolumn{1}{|c|}{ Agente } & \multicolumn{1}{c|}{ Finito } & Resíduo \\
\hline Voce & fazer sentir & Esta necessidade \\
\hline não fosse o fato de você mesmo me fazer sentir esta necessidade." & \\
\hline
\end{tabular}

Fonte: Van Gogh (2007).

A probabilidade e a usualidade são duas dimensões da modalização e podem ser realizadas de três maneiras: 1) por um operador modal Finito no grupo verbal, 2) por um adjunto de Modalidade ou 3) por ambos juntos. Obrigação e prontidão são duas dimensões da modulação, e podem também ser realizadas (a) por um operador modal Finito ou b) por uma expansão de um Predicador. Na tabela abaixo são demonstrados as principais manifestações da Modalidade: 
Quadro 44: Modalidade e suas realizações configuracionais

\begin{tabular}{|l|l|l|}
\hline \multicolumn{2}{|c|}{ Modalidade } \\
\hline $\begin{array}{l}\text { Modalização } \\
\text { (Proposições) }\end{array}$ & $\begin{array}{l}\text { Modulação } \\
\text { (Propostas) }\end{array}$ \\
\hline Probabilidade & $\begin{array}{l}\text { 1) Operador Finito Modal } \\
\text { 2) Adjunto de Modalidade } \\
\text { 3) Ambos }\end{array}$ & $\begin{array}{l}\text { Obrigação } \\
\text { a) Operador Finito Modal }\end{array}$ \\
\hline Usualidade & $\begin{array}{l}\text { 1) Operador Finito Modal } \\
\text { 2) Adjunto de Modalidade } \\
\text { 3) Ambos }\end{array}$ & $\begin{array}{l}\text { Inclinação } \\
\text { a) Operador Finito Modal }\end{array}$ \\
\hline
\end{tabular}

Fonte: Adaptado de Halliday e Matthiessen (2004, p. 150).

O sistema de Tipo divide a modalidade em modulação (obrigação e inclinação) e modalização (probabilidade e usualidade). A rede de sistema da modalidade contém outros sistemas simultâneos. São eles: VALOR, ORIENTAÇÃO e MANIFESTAÇÃO. A força elocutória da modalidade em questão realiza o sistema de VALOR que estão divididos em três subaspectos: a) externo/baixo, se a modalidade é localizada no extremo inferior do continuum, b) médio, se a modalidade é localizada no meio do continuum e c) externo/ alto, se a modalidade está localizada no extremo superior do continuum. A função do sistema de ORIENTAÇÃO é selecionar entre 'objetivo' onde a fonte da modalidade não é o falante/escritor e pode ser localizada fora do evento comunicativo; e 'subjetivo' onde a fonte da modalidade é o falante/escritor ele mesmo. Já a função do sistema de MANIFESTAÇÃO é a de selecionar entre 'implícito', se a avaliação e opiniões são construídas sem declarar a fonte e 'explícito', se elas são construídas com uma declaração clara da fonte. Estes três sistemas de VALOR, ORIENTAÇÃO e MANIFESTAÇÃO estão demonstrados nas suas realizações no quadro abaixo:

Quadro 45: Aspectos e subaspectos da Modalidade: Definições e realizações lexicais - Valor, Orientação e Manifestação

\begin{tabular}{|l|l|l|l|}
\hline \multicolumn{1}{|l|}{ Aspectos e Subaspectos } & Definições & Realizações Lexicais \\
\hline \multirow{5}{*}{ valor } & Externo/ baixo & $\begin{array}{l}\text { Constrói o grau extremo } \\
\text { (externo) inferior (baixo) ou } \\
\text { grau mais fraco dos tipos de } \\
\text { modalidade. }\end{array}$ & $\begin{array}{l}\text { Pode, possivelmente, eu suponho, é } \\
\text { possível, às vezes, é raro, permitido } \\
\text { a, eu vou deixar, é permissível, irá, } \\
\text { querendo etc. }\end{array}$ \\
\cline { 2 - 4 } & Médio & $\begin{array}{l}\text { Constrói os graus } \\
\text { intermediários (entre os valores } \\
\text { externos) de modalidade. }\end{array}$ & $\begin{array}{l}\text { Seria, provavelmente, eu penso, é } \\
\text { parecido, usualmente, é usual, } \\
\text { deveria, era melhor, eu quero, é } \\
\text { desejável, gostaria de, ansioso para } \\
\text { etc. }\end{array}$ \\
\cline { 2 - 4 } & Externo/ alto & $\begin{array}{l}\text { Constrói o grau superior (alto) } \\
\text { extremo (externo) ou o grau } \\
\text { mais forte dos tipos de } \\
\text { modalidade. }\end{array}$ & $\begin{array}{l}\text { Precisa, certamente, eu sei, é certo, } \\
\text { sempre, nunca, tem que, requerido, } \\
\text { eu insisto, é necessário, determinado } \\
\text { a etc. }\end{array}$ \\
\hline Orientação & Objetivo & Constrói a fonte de valorizações & Provavelmente, é provável, \\
\hline
\end{tabular}




\begin{tabular}{|c|c|c|c|}
\hline & & $\begin{array}{l}\text { e de opiniões expressadas pelos } \\
\text { tipos de modalidade como se } \\
\text { eles não fossem o falante. }\end{array}$ & $\begin{array}{l}\text { usualmente, é comum, é desejável, } \\
\text { ansioso para, possivelmente, é } \\
\text { possível, às vezes, é raro, permitido } \\
\text { a, é permissível, disposto a, capaz de, } \\
\text { certamente, é certo, sempre. }\end{array}$ \\
\hline & Subjetivo & $\begin{array}{l}\text { Constrói o falante como a fonte } \\
\text { de avaliação e de opiniões } \\
\text { expressadas pelos tipos de } \\
\text { modalidade. }\end{array}$ & $\begin{array}{l}\text { Irá, eu penso, deveria, eu quero, } \\
\text { gostaria de, eu posso, suponho, eu } \\
\text { deixarei, precisa, eu sei, tem que, eu } \\
\text { insisto etc. }\end{array}$ \\
\hline Manifestação & Implícito & $\begin{array}{l}\text { Constrói a avaliação e opiniões } \\
\text { expressadas pelos tipos de } \\
\text { modalidade sem declarar sua } \\
\text { fonte. }\end{array}$ & $\begin{array}{l}\text { Irá, provavelmente, pode, } \\
\text { possivelmente, precisa, certamente, } \\
\text { usualmente, às vezes, tem que, } \\
\text { sempre, nunca, deveria, seria melhor, } \\
\text { suposto a, permitido a, tem que, } \\
\text { requerido a, gostaria de, etc. }\end{array}$ \\
\hline & \multirow[t]{2}{*}{ Explícito } & \multirow{2}{*}{$\begin{array}{l}\text { Constrói a avaliação e opiniões } \\
\text { expressadas pelos tipos de } \\
\text { modalidade declarando qual é a } \\
\text { fonte. Quando a manifestação é } \\
\text { explícita e a polaridade é } \\
\text { negativa, o último pode ser } \\
\text { localizado diretamente dentro } \\
\text { do segmento da modalidade da } \\
\text { sentença ou pode ser transferido } \\
\text { para o segmento no qual a fonte } \\
\text { da modalidade é declarada. }\end{array}$} & $\begin{array}{l}\text { Eu penso, é provável, eu suponho, é } \\
\text { possível, eu sei, é certo, é comum, é } \\
\text { raro, eu quero, é desejável } \\
\text { Direto Negativo: 'Eu penso/ é } \\
\text { provável, etc + sentença dependente } \\
\text { negativa' }\end{array}$ \\
\hline & & & $\begin{array}{l}\text { Negativo transferido: 'Eu não penso / } \\
\text { não é provável etc + sentença } \\
\text { dependente positiva' (VAN GOGH, } \\
\text { 2009b, 2009n, 2009o). }\end{array}$ \\
\hline
\end{tabular}

Fonte: Adaptado de Praxedes Filho (2007, p. 55).

Acima foram descritas as realizações congruentes da modalidade. No entanto, a modalidade pode também ser realizada não congruentemente e, quando isso ocorre, é denominada de metáfora interpessoal da modalidade que é observável no domínio de projeção de sentenças mentais citadas por Halliday e Mathiessen (2004, p. 614) no exemplo: Voce sabe o que está acontecendo amanhã às cinco da tarde, não sabe? A gama de domínio da expressão metafórica é bastante ampla. Está presente em todos os níveis da gramática e manifesta-se nas três metafunções.

Como as duas escolhas básicas de modo são indicativas e imperativas, sua realização pode variar desde uma simples função da fala de comando, a qual poderia ser congruentemente realizada por uma sentença imperativa como "Abra a porta" ou sua realização pode variar para a sentença modulada como Voce poderia abrir a porta, por favor?

Apesar de discorrer acerca do sistema de Modo e modalidade, procurei me concentrar no Sistema de Transitividade, como a área da LSF que usei na análise do meu corpus. Já para subsidiar a discussão dos achados, combinei a Linguística Sistêmico-funcional com a Teoria Semiótica Social Multimodal, enfocando as categorias que serão relevantes para os objetivos desta pesquisa. 


\subsubsection{Multimodalidade na Pintura}

O’Toole (1994) propõe em seu modelo teórico as funções Modal, Representacional e Composicional para analisar a modalidade pictórica. Ele propõe o termo 'função Modal' ao invés do termo 'função Interativa', utilizado por Kress e van Leeuwen (1996) para a mesma função. De acordo com O’Toole, (1994, p. 5), "Diferentes rótulos são apropriados para outros códigos semióticos, tais como pintura, escultura e música, mas os rótulos ainda servem para funções semelhantes, ou tipos de relação de significado."

Neste trabalho, adoto o termo 'função Modal' de O'Toole (1994) uma vez que este foi cunhado dois anos antes do uso do termo 'função interativa' por Kress e van Leeuwen (1996) e será usado como categoria para analisar o corpus pictórico ao lado de outras ferramentas conceituais que auxiliarão a descrever características da modalidade pictórica mais detalhadamente.

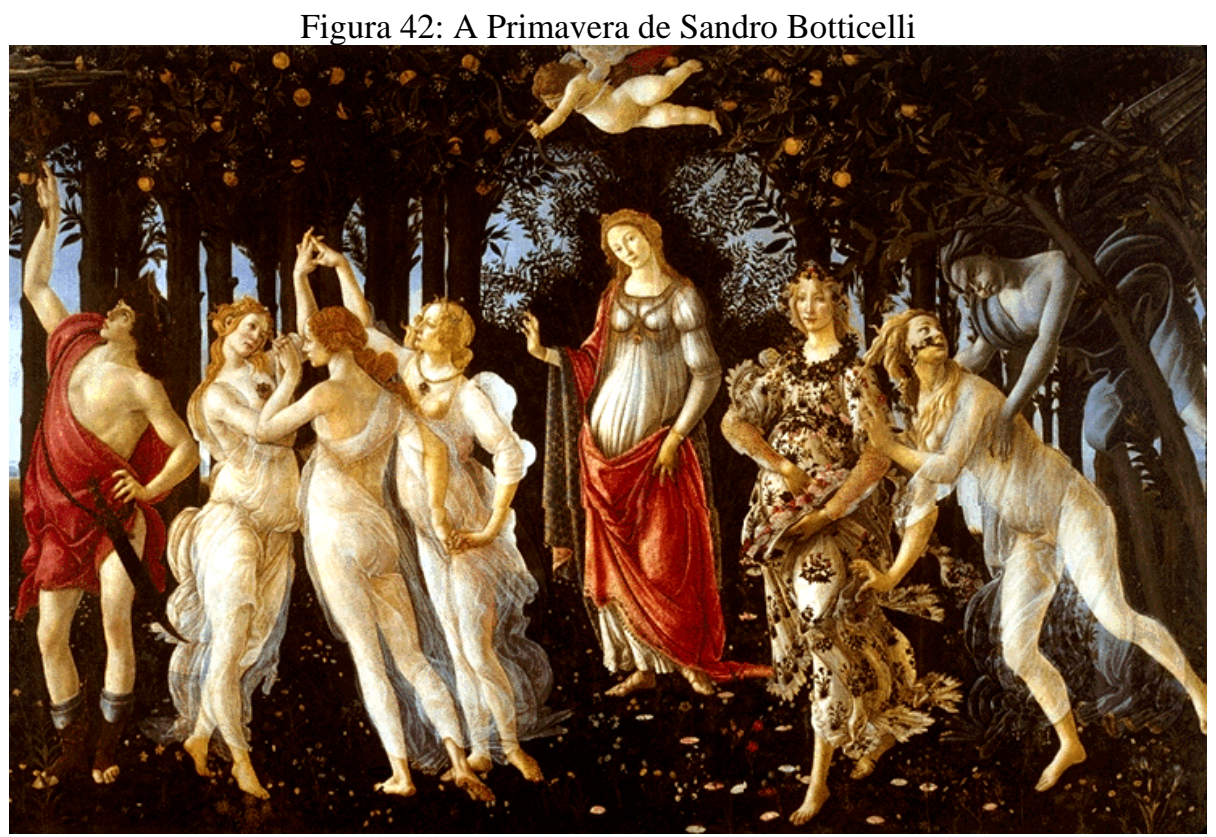

Fonte: Botticelli (1482c).

Em seu trabalho The Language of Displayed Art, O`Toole (1994) defende que a obra de arte seja discutida, não levando em consideração os eventos externos ao seu discurso visual, tais como aspectos históricos, biográficos ou técnicas empregadas na sua execução, mas tendo em vista os aspectos presentes no próprio texto pictórico. Ele ressalta que esses aspectos externos são estanques e não contribuem para relacionar entre si os diferentes aspectos presentes em uma pintura. Aparentemente, não se trata para O'Toole (1994) de contestar os pressupostos da Semiótica Social, que defende que o texto precisa ser 
compreendido no contexto no qual foi produzido, mas de ressaltar a importância de, quando discutindo um texto pictórico, buscar se ater aos aspectos pictóricos da composição pictórica que se observa e não se distrair com informações externas à obra para não perder a oportunidade que esta experiência de produção de sentidos oferece. O que ele ressalta é que, nesse enfoque de análise do texto pictórico, é necessário evitar partir de informações externas a obra, sob o risco de desperceber aspectos que se circunscrevem ao momento de construção dos sentidos que depreendem desta vivência e que só a experiência de interação entre observador e obra pode oferecer.

Em sua proposta de se ater à observação da obra pictórica em si, O’Toole (1994, p. 4) sustenta que há um desafio em atravessar a fronteira do mundo da experiência visual e transpô-lo em palavras, mesmo sob a custódia das 'estruturas da nossa língua'. Essa busca se põe na base de tantos esforços de nossa cultura elencados na forma de visitas guiadas em exposições, comitês editoriais, crítica de arte, manifestos, filmes, reuniões, encontros, palestras, livros, artigos e cursos para discutir e explicar o inexplicável, traduzir o intraduzível, na tentativa de explicitar as experiências estéticas visuais em narrativas verbais e escritas. E se esses esforços não cessam é porque as pessoas estão encontrando palavras para descrever e falar sobre a sua experiência com a arte.

O que O’Toole (1994) busca diferenciar, no entanto, justamente recai no mérito dessas narrativas. Enquanto esses esforços se voltam para os aspectos históricos, biográficos, econômicos ou técnicos, eles não nos ajudam em nada quando estamos diante de uma tela ou um trabalho de arte e nos percebemos sem palavras. Ainda que nesse momento, queiramos nos aquietar para entrar em contato com a nossa própria vivência da obra, há uma enorme possibilidade de, mais tarde, buscar articular essa vivência em palavras, quando estivermos em meio a uma conversa sobre arte. Nesse momento nos esforçaremos para identificar que aspectos da obra despertaram certas sensações e impressões.

A título de ilustração, ele descreve a dificuldade que um grupo de visitantes da Galeria Uffizi, encontra diante do quadro Primavera de Botticelli. A dificuldade está em fazer comentários sobre a tela que incluam a própria experiência perceptiva deles sobre o que estão vendo. Eles iniciam uma conversa sobre a tela descrevendo histórias periféricas e externas à cena do quadro em si mesma, tais como informações de fora da pintura, mitologia, história social e técnica que podem ser complementares em outro momento, pois apenas concorrem com a própria experiência de fruição da pintura. E porque esses relatos externos à tela não são capazes de articular os fatos visuais na tela e nem de relacionarem tudo o que poderiam comentar sobre a imagem que estão observando. Mais do que incapazes de articular as 
experiências pertinentes à pintura em si, essas informações externas à tela não são capazes de ajudar os visitantes a se relacionarem entre si porque não ajudam a incluir na conversa sobre a tela o que essas pessoas estão apreendendo na experiência e na forma como elas se relacionam com a imagem.

O exemplo usado por O’Toole (1994) ilustra a dificuldade que os espectadores de arte sentem para verbalizar experiências que são de outra ordem, uma ordem visual e não verbal. Ele ressalta que a experiência de envolvimento que cada pessoa tem com uma obra é de foro privado já que o que vemos o vemos de acordo com um estado de espírito particular e um ponto de vista privilegiado pelo nosso humor no momento que influencia nos conjuntos de associações e nas interpretações que podemos fazer. Essa experiência é, não apenas irreproduzível, como inenarrável e o sentimento que se segue à tentativa de transpor em palavras o que acabamos de sentir e perceber visualmente "congela nossas respostas complexas em uma espécie de falsa coerência ditada pelas estruturas da nossa língua" ( $\left(\mathrm{O}^{\prime}\right.$ TOOLE, 1994, p. 4).

Se nós pudéssemos encontrar os mesmos tipos de regularidades na comunicação visual, o mesmo tipo de poder sistemático de observação poderia ser transferido para esse modo. Convenientemente nós poderíamos simplesmente aplicar um conjunto pronto de conceitos_dos lingüistas. A ambigüidade do sentido visual poderia então ser domesticada. Mas nós precisamos estar conscientes de que só porque existem algumas formas paralelas de descrever as linguagens e imagens isso não necessariamente significa que elas são a mesma coisa. O desejo de impor tais estruturas no jeito visual pode nos levar a esconder o jeito que as imagens comunicam. Mitchell (1986:63) tem se referido para esse tipo de imposição como 'imperialismo lingüístico'. (MACHIN, 2007, p. 160)

Em outras palavras, para O'Toole (1994), as informações externas à pintura nos levam para fora dela e para fora dos sentidos que estão ali diante dos olhos para serem sentidos. Com isso, um precioso momento de troca é desperdiçado uma vez que os visitantes de uma galeria ou museu não conversam sobre como cada um percebe e reage ao quadro que é a Primavera em toda a sua exuberância.

É a tarefa da Semiótica buscar uma linguagem que nos ajude a compartilhar as nossas percepções e vivências com uma obra de arte e relacionar a natureza de nossa reação sobre uma dada obra com os aspectos históricos, intelectuais e econômicos que constituíram o mundo do autor e dos seus patronos, ou mesmo relacionar as nossas reações sobre a obra com o nosso próprio mundo. Para O`Toole (1994), a tarefa da Semiótica recai nessa busca por articular formas de falar sobre a composição em si com as técnicas e qualidades materiais da obra que não participam do texto pictórico em si.

Esta tarefa, proposta pela Semiótica "funcional", está organizada em três funções de linguagem que "governam a maneira que nós escolhemos nossas palavras e construímos 
nossas sentenças em linguagem falada ou escrita" (O'TOOLE, 1994, p. 5). Ele se apoia no pressuposto de que cada parte da comunicação tem três funções principais: 1) Função interpessoal - para envolver a nossa atenção e interesse, 2) Função Experiencial - para transmitir alguma informação sobre a realidade, e 3) Função Textual - para estruturar essas duas funções em uma forma textual coerente.

\begin{abstract}
Diferentes rótulos são apropriados para outros códigos semióticos, tais como pintura, escultura e música, mas os rótulos ainda servem para funções semelhantes, ou tipos de relação de significado. Para pintura adotei os termos "Função Modal", "Função Representacional", e "Função Composicional" para cobrir estes tipos de significado, e me proponho a construir uma espécie de mapa da linguagem da pintura ilustrada com exemplos de Primavera de Botticelli. (O'TOOLE, 1994, p. 5).
\end{abstract}

O’Toole (1994) argumenta que essas funções são capazes de nos ajudar a organizar a experiência com o texto pictórico e propõe os termos Função Modal, Função Representacional, e Função Composicional para tratar esses tipos de significados diversos na linguagem pictórica.

Para representar essas funções, ele propõe um mapa da linguagem que forneça uma visão geral e que seja capaz de mostrar uma série de rotas percorridas em cada função, de modo que esse ponto de vista mais amplo e a relação entre as rotas fiquem evidenciadas.

Quadro 46: As três funções da linguagem pictórica

\begin{tabular}{|l|l|l|l|}
\hline Unidade/ Função & REPRESENTACIONAL & MODAL & COMPOSICIONAL \\
\hline Trabalho & & & \\
\hline & & & \\
\hline
\end{tabular}

Fonte : Adaptado de O’Toole (1994, p. 6).

\title{
2.1.1.1 A função Modal e seu trabalho de envolver o espectador
}

A Função Modal encarrega-se de envolver o espectador com o trabalho de arte. Esse é o trajeto inicial para começar a falar sobre uma obra, ou seja, a forma como ela chama a atenção, emoções e pensamento do espectador e de que modo ele se relaciona com ela. Os aspectos na pintura que capturam a atenção podem ser diferentes para cada pessoa e pode não haver reações em comum para serem compartilhadas, mas o enfoque desta função Modal não trata apenas de como o espectador se relaciona com a pintura, mas também e principalmente como a pintura, da forma como ela foi pensada, se relaciona conosco. Quais estratégias foram empregadas para atrair a nossa atenção para dentro da tela? Os Recursos usados pelo autor para impactar a nossa visão com as visões que ele imprimiu na tela foram feitos, não para um, mas para todos os seus espectadores. Por mais diversa seja a nossa reação a uma mesma tela 
negociamos sentidos socialmente compartilhados nesse processo. Por mais diferentes que sejam os aspectos que chamam a nossa atenção e os motivos que comandam o nosso olhar em uma tela, é o argumento de O’Toole (1994) que as reações em nós elicitadas assim o são devido aos aspectos de estrutura da gramática pictórica que todos nós compartilhamos como uma linguagem socialmente convencionada; um sistema de representação praticamente universal que oferece um pano de fundo para nossas reações e cumpre a função Modal, que é a de envolver e de comandar o nosso olhar.

Para ilustrar a perspectiva da função Modal como o primeiro enfoque para uma obra de arte, ele descreve a tela "Primavera" do pintor renascentista Sandro Botticelli e, para isso, enfoca os aspectos e as preocupações que ocupam a função Modal em uma tela:

\begin{abstract}
As palavras que mais facilmente vêm à mente enquanto nós estamos na frente de "Primavera", penso eu, são "graça" e "charme". Mas essas são palavras subjetivas, notoriamente escorregadias. Que significado podem elas ter aqui? Em primeiro lugar, o ritmo: a pintura tem um ritmo gentil, ondulando que está em harmonia com os gestos graciosos e a postura das figuras, com o caimento de vestuário drapeado, com a colocação dos frutos, flores e folhagem e com a facilidade das cores misturadas. Quando nossos olhos tomam a tela inteira, temos a sensação de uma cortês dança, cujo ritmo é realizado por uma ligeira inclinação das figuras da direita para a para a esquerda, em particular no caso de Venus e a Graça central. Mesmo a vigorosa angularidade de Zephyr mergulhando para fora das árvores na extrema direita e o constrangimento desequilibrado que ele causa na figura da ninfa que ele está segurando parece ser resolvido à medida que avançamos para as figuras de Vênus e Mercúrio graciosamente posicionadas. Da mesma forma, o movimento para baixo dos gestos agressivos do Zephyr e os gestos assustados da ninfa são resolvidos em paralelo, com os gestos calmos do braço esquerdo de Vênus, a mão direita da Graça e Mercurio. Um ritmo triplo criado pelos dois conjuntos de três figuras parece ser ecoado na triplicação de frutas de cor laranja nas árvores acima de suas cabeças. (O`TOOLE, 1994, p. 7).
\end{abstract}

O exemplo é muito importante para explicitar o enfoque da função Modal no estudo semiótico de uma pintura, especialmente porque suscita perguntas cujas respostas nos ajudam a fazer a diferenciação entre as funções Modal e Composicional. Se padrões abstratos tais como ritmo e posição e forma descritos no exemplo acima são aspectos de composição, não deveriam ser abordados na função Composicional ao invés de na função Modal? A resposta é simples. Os elementos da linguagem visual e os aspectos da articulação usados em um dado texto pictórico podem ser abordados reiteradamente em todas as funções desde que ajudem a explicitar de que forma eles a atendem. Os mesmos padrões composicionais que trabalham na função Modal para um resultado podem trabalhar na função Composicional para outro resultado. Dependendo da finalidade com que eles foram empregados e de qual função eles desempenham no texto, esses mesmos padrões poderão voltar a ser descritos desde o enfoque da função Composicional quando eles ajudarem a explicar como a composição da tela foi concebida. No entanto, esses aspectos agora estão ajudando a evidenciar a função Modal na 
medida em que eles contribuem para capturar a atenção e envolver o espectador com o texto visual.

A função Interpessoal é percebida de forma mais óbvia na linguagem verbal, especialmente na forma direta que nos dirigimos a alguém: ou falamos diretamente ou usamos o pronome "você" - assim, o contato interpessoal é estabelecido. Esse é um exemplo da função Interpessoal na linguagem verbal. No caso das pinturas, na função modal, podemos dizer o mesmo. Elas também nos abordam de forma direta, como exemplo disso podemos notar como as pessoas representadas em uma tela podem olhar diretamente para nós, ao ponto de nos sentirmos 'seguidos' por seu olhar em qualquer ponto da sala. As telas que nos ‘abordam' diretamente são fortemente modais e para isso elas podem usar diversos recursos. No caso da tela 'Primavera' de Botticelli, usada como exemplo por O'Toole (1994), a função Modal está fortemente concentrada na figura central. É Vênus que nos olha diretamente e nos envolve, com seu olhar, seu gesto de saudação ou bênção, uma inclinação de cabeça e a forma como seu corpo se posta. Além da função Modal, essa sintaxe visual aqui descrita também serve à função Representacional, uma vez que existem motivos filosóficos e narrativos para a escolha de ser Vênus e não outra figura que nos envolve na cena. Além da função Modal e Representacional, esta mesma semiose visual aqui tratada irá igualmente atender à função Composicional, ao evidenciarmos muitas forças composicionais combinadas para dar a este olhar de Vênus uma absoluta e irrefutável centralidade para a obra e para a nossa relação com ela, como vemos na descrição a seguir:

\begin{abstract}
Modalmente, no entanto, o olhar é reforçado pelo fato de que ele está no centro de um sistema de irradiação de arcos: Vênus com adorno de cabeça, o arco das árvores atrás dela e até mesmo as figuras de Cupido acima dela e Flora a sua esquerda e a Graça à sua direita parecem destacar os limites de sua estrutura interna. Uma das funções dos halos em pinturas religiosas é intensificar o olhar da figura sagrada em nossa direção, mas um halo teria sido inadequado - mesmo sacrílego - neste contexto, por isso Botticelli explora o seu poder Modal, mas seculariza-o. Ele cria camadas de luz em torno da cabeça de Vênus, firmemente enquadrado como por uma janela de arco ou curva, e depois joga com elementos estáticos e dinâmicos em relação a esta luz. Assim, o material em torno do rosto brilhantemente iluminado de Vênus cria uma curva suave. Ele está rodeado com um caos animado de folhagem escura (o qual não obstante não deixa de ser cuidadosamente limitado: veja como as partes mais densas combinam com o formato de sua cabeça e ombros, quase como uma sombra projetada aproximadamente). Sua silhueta está, por sua vez, recortada contra uma das fontes de luz mais brilhantes na pintura, que é firmemente emoldurada pelo arco de árvores (regular o suficiente para ser uma porta ou janela de arco em outros lugares); mas, em seguida, a regularidade estática do arco que é suavizada e reintegrada nos ritmos da pintura como um todo pelas figuras fluidas e dinâmicas de Cupido, Flora, e da Graça mais próxima. (O`TOOLE, 1994, p. 8)
\end{abstract}

Assim como a perspectiva usada em outras pinturas, o jogo com enquadramentos concêntricos em torno do olhar de Vênus, nesta tela, é usado para acentuar a função Modal. A Arcádia parece ter sido construída em um conjunto de planos que se sobrepõem, ao invés do 
uso de uma perspectiva linear clássica que ajudaria a obter um resultado similar. No entanto, Botticelli posicionou as figuras mais ativas no primeiro plano para contrapor com o fundo, e logo depois, Vênus e Cupido, seguidos das árvores, frutas e folhas e no último plano, um céu iluminado de modo uniforme. O uso dos planos, bem como o uso da perspectiva, contribui fortemente para a função Modal, uma vez que eles conduzem o nosso olhar pelos espaços da tela.

De acordo com O’Toole (1994), esse uso é sistêmico, uma vez que se trata de uma escolha do pintor dentro de um sistema consolidado de signos. Aparentemente, Botticelli fez essa pintura em um período em que a teorização e os experimentos sobre o uso da perspectiva estavam mais proeminentes e escolheu entre a opção negativa de não ter nenhuma perspectiva contra a opção de usar a perspectiva linear, a reversa ou a múltipla. Esse tipo de escolha é uma função Modal na medida em que produz uma ausência de olhar, uma vez que temos o Cupido de olhos vendados, e a preocupação de Mercúrio com sua própria atividade. Kress e van Leeuwen (1996) também descrevem a função de Vetor que o olhar desempenha dentro da composição.

A "inclinação" que o pintor dá à realidade que está sendo representada é outro aspecto da função Modal. A inclinação na representação pictórica é equivalente ao aspecto da "modalidade" em gramática. A modalidade encarrega-se de colorir o conteúdo experiencial de um enunciado pelo uso de um verbo modal, ou advérbio, ou por um padrão de entonação diferente.

Por exemplo, a declaração "Cupido disparou uma flecha flamejante" poderia ser modalizada como "Cupido pode ter disparado uma flecha flamejante" ou "Possivelmente, Cupido disparou uma seta flamejante" ou, com uma entonação que cai e sobe: "Cupido disparou uma flecha flamejante, (mas...)". (O’TOOLE, 1994, p. 9).

A modalidade é "interpessoal", uma vez que o falante está expressando para o seu interlocutor a sua falta de certeza acerca de um acontecimento que tenta descrever. Assim como na linguagem verbal, é possível um pintor dar para a sua pintura essa falta de certeza e construir um grau de ambiguidade, seja nas posturas, seja no que suscitam as ações das figuras representadas na cena, tal como é ilustrado por diversas pinturas que nos deixam intrigados com o grau de ambiguidade das imagens. Usando a pintura 'Primavera' como exemplo, não seria esse próprio uso de um tema fictício para fazer algumas declarações? Não seria essa, uma forma de modalidade usada por Botticelli, que ao representar um mundo ficcional, usou da força expressiva de rapazes que voam e atiram flechas, a personificação do 
Vento, da Terra e das Flores, e uma deusa que nos olha e nos envolve desde onde estamos, aqui fora da tela, em um mundo que chamamos de real?

Para O’Toole (1994), comentar quais são as deidades mitológicas e as histórias que as acompanham desde os conhecimentos clássicos não basta, para se relacionar com tudo o que essa pintura nos propõe e convida a experienciar, mas sim nos perguntarmos como os visitantes da Galeria Uffizi, poderiam se relacionar com esses seres mitológicos e responder às premissas e exigências daquele mundo ficcional. Isto seria um tipo de diálogo infinitamente mais produtivo para participarmos do mundo que Vênus nos envolve e convida a adentrar.

Da mesma forma, as informações históricas e filosóficas externas ao quadro, de pouco serviriam para apoiar nossa conversa sobre a cena retratada a menos que nos ajudem a compreender o motivo da escolha desses mitos para a pessoa para a qual a tela foi encomendada originalmente, Lorenzo di Pierfrancesco.

No quadro abaixo, estão listadas as características principais que, de acordo com a análise até o momento, atendem a função Modal nesta obra de Botticelli. Nela podemos ver listados os principais sistemas em funcionamento na tela 'Primavera': Ritmo, Olhar, Enquadramento, Luz, Perspectiva e Modalidade.

Quadro 47: Sistemas na função Modal

\begin{tabular}{|l|l|l|l|}
\hline Unidade/ Função & Representacional & MODAL & Composicional \\
\hline Trabalho & $\begin{array}{l}\text { Ritmo } \\
\text { Modalidade }\end{array}$ & \\
\hline & & Olhar & \\
\hline & & Enquadramento & \\
\hline & Luz & \\
\hline
\end{tabular}

Fonte: Quadro adaptado de O’TOOLE (1994, p. 6).

$\mathrm{Na}$ análise multimodal proposta por O'Toole (1994), sabemos que existem mais alguns sistemas modais disponíveis para o pintor, e que foram usados na tela 'Primavera'. São eles: Cor, Volume, Caminhos e Intermediários.

Esses sistemas modais são amplamente utilizados, por exemplo, a Cor pode ser usada em sua intensidade ou nos contrates entre cores para criar ênfase visual; o Volume pode ser usado para dar mais imponência ou proeminência para as figuras representadas (como alguns Banhistas de Picasso); os Caminhos Visuais para conduzir o olhar e o envolvimento do espectador para dentro da tela (como frequentemente observamos nas paisagens) ou para dar uma maior centralidade às figuras que o pintor desejou destacar. Os caminhos visuais podem 
ser usados também como um dispositivo modal favorito de pintores europeus do século XVIII no qual são inseridas figuras menores, tais como as crianças, servos, animais ou pássaros, a fim de intermediar entre nós e as figuras e eventos que se quer dar maior centralidade na tela.

No entanto, nenhum desses recursos é usado por Botticelli na tela Primavera, a menos que o espaço desde a extremidade inferior da tela seja um caminho que conduz até Vênus.

Esses sistemas Modais oferecem um leque de possibilidades disponíveis para o artista "saudar" e envolver seus espectadores, mas eles não têm que ser usados em toda pintura, necessariamente, até porque seria uma redundância usar todos para a mesma finalidade e criaria um tipo de excesso que só é bem-vindo na pintura se fizer parte de uma escolha deliberada do próprio artista.

A análise da função Modal nos diz muito sobre como um todo de uma tela funciona em nós. Na tela Primavera, no entanto, não olhamos para o todo da tela e sim para o episódio central porque Vênus dirige seu olhar diretamente para nós, e sua elevação acima do nível das outras figuras, o seu isolamento e o enquadramento sugerido pelo arco acima de sua cabeça denotam essa função Modal. Os recursos usados nesse episódio podem também ser examinados em vista de sua contribuição para as funções Representacional e Composicional. O conceito de Vetores de Kress e van Leeuwen (1996) podem ser utilizados para analisar a função Modal na tela Primavera.

Quando falamos da tela, precisamos observar que na pintura existem quatro episódios distintos, nove figuras humanas que participam desses episódios e membros que se constituem por cada figura humana ou cada característica da paisagem. Dessa forma O’Toole (1994) categoriza os eventos na pintura em uma escala de unidades. Obra, Espisódio, Figura, Membro, que são listados no gráfico. Cada linha descreve uma unidade e essa unidade tem uma contribuição própria na tarefa de criar o envolvimento do leitor com o mundo representado na imagem.

À direita da tela, vemos um episódio no qual Flora, a deusa das flores da primavera, parece nos olhar quase diretamente enquanto dá um passo à frente em nossa direção, ao mesmo tempo em que as duas figuras nesse mesmo episódio se entreolham.

Entre os quatro episódios da tela, este episódio da direita parece ter os ritmos mais dinâmicos da pintura, que capturam a atenção que poderia de outro modo, ser dada para as figuras mais centrais na tela.

Uma das três Graças, no episódio a esquerda da tela, tem o rosto voltado para nós enquanto olha para a Graça a sua frente, que estando com seu rosto de perfil tem as costas voltadas para nós, mostrando com esta postura uma negação do Olhar. Enquanto à direita da 
tela vemos um ritmo forte e linear no episódio da Flora, encontramos um ritmo mais suave e circular neste episódio à esquerda da tela, na postura das três Graças. No último episódio à esquerda, vemos Mercúrio, como única figura neste episódio. Ainda que sua postura se volte para nós, o olhar direciona-se para as folhas no alto das árvores que ele parece acenar com sua varinha.

Outra figura que tem uma postura voltada para nós é Cupido, que apesar de ter a sua flecha flamejante apontada para a Graça do meio, tem o corpo torcido em nossa direção, ao mesmo tempo em que tem os olhos vendados - evidenciando outra negação do Olhar. Em termos de processo narrativo, cada uma dessas figuras desencadeia um vetor que é um processo de ação ou é recipiente da ação de uma outra figura da qual o vetor da ação emana.

Examinando cada episódio da pintura, podemos encontrar uma combinação de modalidades, de figura para figura, vemos ora diferentes graus de Olhar voltados em nossa direção e com a intenção de nos envolver na cena, ora o Olhar negado deixando uma lacuna e um distanciamento neste envolvimento que direciona para as figuras que de fato olham. Outra combinação de modalidades se evidencia pela mudança de ritmo nos episódios na medida em que olhamos a tela, da direita para esquerda, percorrendo a cena.

O'Toole (1994) atesta que, muitos argumentam que temos uma forma de olhar as pinturas de uma só vez, e não de episódio em episódio, mas no caso desta tela em particular, todos a leem episódio por episódio e é por isso que vemos tantas reproduções maiores do que a original e alguns desses episódios parece uma pintura em si mesma.

Mas poderíamos nos perguntar, questiona O'Toole (1994), porque esta pintura nos instiga a lê-la em episódios? De acordo com ele, se examinarmos com atenção, vemos que cada episódio tem uma cena mitológica distinta que parece justificar a divisão da tela em episódios. Uma questão importante é que os sistemas semióticos na categoria de Episódios devem ser examinados de forma diferenciada daqueles que estão operando no conjunto da tela como um todo. Nesse nível do todo, é a função Modal que estabelece a Escala que cada episódio tem a sua importância para o conjunto geral da cena. Essa escala é examinada em termos do foco da atenção e não em termos das proporções geométricas. Essa Escala de modalidade que direciona o foco entre os episódios, parece ser estabelecida pelas diferenças que tem os graus de Olhar, ou pelo vigor e a direção dos Ritmos das linhas em cada episódio.

Nesses episódios encontramos a categoria da Figura, e nessa categoria, diferentes relações de foco do espectador são construídas por meio do Olhar, Postura e Gestual, basta comparar a diferença entre as duas figuras Flora e Chloris dentro do episódio à direita da tela, ou a diferença entre Vênus e Cupido no episódio do centro da tela. Distintos graus de 
Caracterização nas figuras podem aumentar a função Modal, chamando mais a atenção para elas do que as outras. Outros sistemas semióticos podem ser usados para envolver nossa atenção em diferentes graus, com diferentes figuras em diferentes graus, pelo uso dos Contrastes e conflitos de Cor, Luz, Escala e Linha.

Na categoria Membro, os elementos que constroem a função Modal são mais abstratos e mais inconscientes, tais como grau de Estilização, por exemplo, entre a mão direita de Vênus e a sua mão esquerda. Ou ainda nas roupas de Flora e das Graças contra a de Vênus e Mercúrio. Esses elementos impactam tanto no nosso envolvimento com cada figura, quanto com a tela inteira.

A divisão da tela em sistemas semióticos, tais como Episódios, Figuras e Membros, vistos como categorias de leitura, não se faz relevante em todas as pinturas. Muitas pinturas são compostas em um único episódio tais como Les demoiselles d'Avignon de Picasso, ou com uma figura única como os retratos, ou com um Membro único como, por exemplo, a pintura Branco sobre Branco de Malevich ou um desenho anatômico de Leonardo.

Esses sistemas podem ser muito valiosos para distinguir categorias de unidade, uma vez que tendemos a percorrer a imagem em busca de aspectos familiares que podem ser categorizados como episódio, figura ou membro, que facilita o trajeto entre a nossa visão de cada unidade nesses sistemas e a pintura como um todo.

Para ajudar a visualização do que foi discutido, O’Toole (1994) apresenta uma versão do quadro com todos os constituintes da Função Modal enumerados em cada categoria. Ele ressalta que estes sistemas nem sempre estão operantes em todas as pinturas, pois a representação de um único episódio ou de muitos, de uma figura ou de muitas é uma escolha do pintor entre os recursos disponíveis em uma gramática pictórica em função de sua estratégia para capturar a atenção e envolver o espectador em sua obra.

\subsubsection{A função Representacional em seu trabalho de informar o leitor}

As funções modais nos ajudam a falarmos não sobre os aspectos externos a uma pintura, mas o que a pintura, aqui e agora, significa para nós ao olharmos para ela. Não precisa ser um relato subjetivo sobre o que ela desperta em termos de emoções e de imaginação, mas pode ser uma descrição dos recursos na pintura que são notados como aqueles que foram escolhidos para envolver os espectadores. Podemos até discordar sobre qual dos sistemas na pintura são os mais proeminentes, o importante é partirmos de uma 
linguagem comum, um sistema de convenções compartilhado que nos ajude a conversar sobre o que estamos vendo na tela.

Quadro 48: Sistemas operando em categorias diferentes

\begin{tabular}{|l|l|l|l|}
\hline $\begin{array}{l}\text { Unidade / } \\
\text { Função }\end{array}$ & REPRESENTACIONNAL & MODAL & COMPOSICIONAL \\
\hline Trabalho & & $\begin{array}{l}\text { Ritmo } \\
\text { Modalidade }\end{array}$ & \\
\hline & & Olhar & \\
\hline & & Enquadramento & \\
\hline & & Perspectiva & \\
\hline Episódio & & Proeminência Relativa & \\
\hline & & Escala & \\
\hline & & Centralidade & \\
\hline & & $\begin{array}{l}\text { Interrelação de } \\
\text { modalidades }\end{array}$ & \\
\hline Figura & & Olhar & \\
\hline & & Posição & \\
\hline & Caracterização & \\
\hline & Contraste: Escala, & \\
\hline & & Linha & \\
\hline & & Luz & \\
\hline & & Cor & \\
\hline Membro & & Estilização & \\
\hline
\end{tabular}

Fonte: Quadro adaptado de O’TOOLE (1994, p. 13).

Depois da identificação do que na tela está trabalhando para envolver o leitor, pode-se incluir o que a pintura trata. O’Toole (1994) ressalta a importância de não começarmos a ler a imagem pelo assunto que ela retrata por ser esta uma forma como as pessoas se relacionam a priori ao olharem para uma pintura. O hábito de relacionar com uma tela por meio do seu tema é tão forte que olhamos para a placa de identificação da tela, mesmo diante de telas com temas evidentes, como no Monte de feno de Monet, nos Jogadores de carta de Cezanne, ou nos Ciprestes de Van Gogh. De acordo com O’Toole (1994), a busca pela informação sobre o assunto que a tela retrata torna-se ainda mais forte quando estamos diante de telas desafiantes, com temas abstratos ou distorcidos ou que abordam cenas ou assuntos que não são familiares para nós. A dependência que sentimos das plaquetas de identificação das telas aumentam na medida em que não somos capazes de nos abandonar à experiência de olhar e deixar que os olhos mostrem o caminho da visão. O’Toole (1994) cita como exemplo o relato dos guias da galeria de arte em Perth sobre o fato de serem apenas as crianças pequenas que se arriscam a observar as pinturas mais abstratas e absorverem o que vêem. Os adultos e adolescentes 
passam reto por essas obras as quais eles não têm um elemento familiar de referência que possam reconhecer na sua própria experiência. Os visitantes de galerias sentem uma dependência inegável das informações contidas nas plaquetas com o título da obra e raramente se arriscam a deixar seus olhos dialogarem com a pintura diante de si, a menos que esta seja apontada como obra prima pela crítica ou tenha alguma história escandalosa que atraia os olhares curiosos.

Ao analisar a função Modal, podemos começar pela pintura como um todo e depois explorar progressivamente os detalhes. Mas, quando analisamos a função Representacional, fazemos o caminho inverso, do detalhe para o todo. Podemos começar pelas figuras individuais, depois explorar a categoria do Episódio e, por último, trabalhar o nível da pintura como um todo.

Ao examinar a função Representacional, podemos considerar o conceito de "Primavera" no contexto do pensamento renascentista e das circunstâncias da encomenda desta pintura, e as informações sobre a filosofia Neo-Platonista e sobre a família Medici podem ser muito úteis nesse momento. Ao analisar as figuras na perspectiva da função Representacional, por exemplo, é preciso não apenas nomear cada uma das figuras mitológicas separadamente, mas buscar compreender como, na cena total, as figuras se relacionam entre si.

$\mathrm{Na}$ função Representacional, ao iniciarmos pela categoria Figura observamos as ações e a posição de cada personagem na tela, e as informações básicas sobre seu status social. Na categoria Figura, analisamos também os detalhes dos objetos inanimados e das espécies vivas, seu tamanho e qualidades materiais, tais como as árvores nesta tela. Os detalhes como expressões faciais, postura, gestual, comportamento e vestimenta. Alguns desses aspectos se encontram no nível da categoria Membro e interagem com a categoria Figura na função Representacional.

O’Toole (1994) destaca que, ao observarmos as figuras, uma a uma da direita para a esquerda na tela Primavera, vemos um movimento rítmico que tem fortes implicações na construção da narrativa. À extrema direita, temos a figura de Zephyr, representando o vento quente que vem do Oeste no começo da primavera. Zephyr é a única figura que não toca o solo, ao contrário das outras, está inclinado para a esquerda e para baixo ao sair das árvores que também se inclinam diante de seu impulso. Em meio às árvores, vemos uma asa verdeazulada que sai de suas costas e se prolonga em diagonal até a extremidade superior da tela à direita. Parece importante para a representação que a metade inferior de seu corpo não toque o chão e, como sua asa e suas vestes, com contornos bastante dinâmicos apareçam do nada 
dando a impressão do ímpeto e da força do vento que sopra do Oeste na primavera e surpreende. Se observarmos algumas características dessa figura, vemos que suas bochechas infladas acentuam a ação de soprar que ele representa. E, em sua aparição, parece surpreender a inocente Chloris, ao agarrar o corpo levemente vestido da ninfa da terra de forma tão arrebatadora que parece que dificilmente ela consiga resistir ao seu movimento impetuoso. Em seu movimento de surpresa, essa figura representa toda a vulnerabilidade feminina diante de um ataque masculino fulminante. Suas vestes são tão delicadas que revelam suas formas femininas e seu olhar amedrontado em direção a Zephyr representa a dinâmica da situação, na qual seu corpo se desequilibrou e começa a cair e ela se sente sem condições de escapar dos avanços de Zephyr. Assim como a perna esquerda de Zephyr, a perna esquerda de Chloris também está cortada na extremidade direita da tela, enquanto todas as demais figuras se encontram totalmente representadas dentro da tela. Essas duas personagens, Zephyr e Chloris parecem fazer parte de um universo que precede o rito anual de primavera e por isso não estão completamente representados dentro do enquadramento, apenas parcialmente e com um ritmo dinâmico e arrebatador. A representação do corpo de Chloris é, no entanto pertubardora, em comparação com a postura das demais figuras, a figura de Chloris encontra-se em desalinho e, embora seus seios se ocultem atrás do braço esquerdo e do cabelo dourado, suas vestes diáfanas deixam à mostra seu púbis que parece ser o alvo principal da perseguição de Zephyr.

A posição e características dessas duas primeiras figuras à direita da tela destacam-se das demais por estarem envoltas em um movimento impetuoso, atraindo nosso olhar e interesse por entender porque elas se distinguem das demais. Isso nos dá uma boa oportunidade para procurar entender os elementos eróticos do imaginário que essa narrativa evoca, e que podemos encontrar nas circunstâncias com que a tela foi encomendada. Esse quadro não foi pintado originalmente para ser visto por milhões de visitantes como hoje acontece na Galeria Uffizi, mas para um único espectador, um jovem adolescente chamado Lorenzo di Pierfrancesco de Medici, primo do então Governador de Florença, Lorenzo Il Magnífico.

A tela Primavera foi encomendada para ser vista pelo jovem Lorenzo, seus familiares e um restrito grupo de artistas e intelectuais da época. Foi pendurada no quarto da nova Villa no Castello que foi construído para Lorenzo. Esse jovem de quinze anos pode ter encontrado um apelo erótico na tela que foi feita para ele desfrutar as formas sensuais femininas da mesma forma como os jovens de hoje apreciam em seus quartos as formas femininas das revistas eróticas. 
No entanto, se o elemento erótico está fortemente representado pelo encontro de Zephyr e Chloris ele é apenas o princípio do que a tela conta porque Flora, a deusa das flores da primavera é a próxima figura à esquerda dos dois. Ela está totalmente vestida e dá um passo a frente de forma independente para saudar o espectador. A narrativa nesse primeiro episódio da direita para a esquerda da tela é uma transcrição direta de um poema que narra como Chloris se esforça para escapar das mãos de Zephyr, e flores saem pela sua expiração assim que ele a toca se transformando, então, em Flora. A transformação narrada no poema o Fasti, de Ovídio, é, na verdade, um trocadilho com duplo sentido para uma transformação física e semântica, pois o nome grego Choloris para uma ninfa tímida e primitiva do campo é transformado no nome Romano de Flora, uma deusa confiante que trás consigo a primavera. A transformação lexical é feita por uma mudança nas consoantes e a transformação física acontece com o mecanismo das flores que caem da respiração da ninfa, assim que ela é tocada por Zephyr, o vento quente da primavera. Essas mesmas flores que caem de sua boca se misturam com as flores das vestes de Flora, bem como com as flores que se sobrepõem às mãos da deusa da primavera, mostrando um fluxo que pode denotar uma transformação em andamento, ao invés de um resultado apenas. Essa transformação em curso, também parece espalhar-se em volta, enquanto Flora distribui flores para sinalizar a sua chegada. De acordo com Edgar Wind, (WIND, 1967 apud O’TOOLE, 1994, p. 16) vemos uma metamorfose do Amor nessa metáfora Ovidiana, na qual a progressão da união entre Zephyr e Chloris se transforma em Flora, que é a fase inicial de outra progressão; a dialética entre a Beleza (Pulchritude), que emerge da discórdia entre a Castidade (Castitas) e o Amor (Love).

À esquerda da figura de Vênus que está no centro da tela, vemos um episódio com três figuras, as Graças, que representam Amor, Castidade e Beleza. Embora sejam semelhantes, elas têm muitas diferenças. Amor, ou Volúpia, está mais à esquerda e tem uma expressão voluntariosa, faces coradas e um olhar ousado. Seus cabelos em desalinho acompanham a roupa amassada que também realça suas formas e transmitem uma postura vigorosa de um corpo cheio de energia física. Nas pontas dos pés, ela tem uma postura ousada, um olhar confiante e inclina seu corpo cheio de paixão enquanto entrelaça sua mão direita com a mão de Castidade que não tem uma postura tão resoluta como a de Volúpia.

De costas, Castidade esconde suas formas e encantos de quem olha a tela. Sua postura está mais repousada e calma, suas vestes são mais simples do que as de Volúpia, seu cabelo está ordenado e preso, seu olhar é distante e a expressão vaga mostra incerteza e melancolia. À sua direita, vemos Beleza, que calmamente segura com a mão esquerda a mão de Castidade, e com a direita, entrelaça os dedos da mão de Volúpia em uma espécie de 
confrontação e luta de poder. Essa figura tem um corpo confiante e inclinado para frente, mas não da mesma forma que Volúpia, ela transmite equilíbrio e calma. Ela possui vestes mais elaboradas contidas por um pingente e seus cabelos estão alinhados e adornados por um véu de pérolas.

A composição neste episódio realiza a dialética expressa pelos passos, entrelaçar de mãos e posturas dessas três figuras contrapondo relações de concórdia, oposição e concórdia na oposição e representam mais uma transformação iniciada por Zephyr, Chloris e Flora. O episódio à direita da tela representa agora mais uma transformação manifesta na dança circular de Amor, Castidade e Beleza. Mas como a transformação ocorrida no primeiro episódio se relaciona com a transformação neste episódio? Por meio de Vênus que está harmoniosamente como figura que liga visualmente e simbolicamente esses dois episódios que se relacionam como imagens refletidas. Venus está colocada de forma equidistante entre os dois episódios e tem em ambos os lados como as figuras mais próximas, Flora e Beleza que criam uma simetria com Vênus por suas posturas, linhas gestuais e com os braços esquerdos paralelos ao braço esquerdo de Venus. Essas três figuras por sua simetria e similaridade reforçam uma sensação de fusão e de unidade entre os dois episódios à direita e à esquerda de Vênus.

Essa ligação introduzida por Vênus realiza o argumento para a narrativa nesta tela. Como na função Modal com seu olhar, postura e gestos, Vênus constrói um envolvimento direto com o espectador, conduzindo-o para dentro do seu jardim. Na perspectiva da função Representacional, ela constrói o nosso envolvimento com a narrativa visual, ao ligar e unir episódios que, de outro modo, estariam separados, por meio de um elo narrativo e argumentativo.

E ao nos envolver visualmente em seu mundo, e simbolicamente em sua narrativa, ela também nos envolve na dialética representada. Se pensarmos no espectador a quem a pintura foi encomendada, vemos o jovem adolescente Lorenzo dividido pelas forças dialéticas do amor e da castidade. Se pensarmos que a flecha de Cupido está direcionada para nós prestes a transformar a nossa castidade de criança na luxúria de adolescente, enquanto Vênus soluciona o conflito ao reconhecer a Beleza, pela beleza da natureza em seu jardim e pela dança artística do cortejo ou pelas ideias que essas contêm.

É sabido que o jovem a quem foi encomendada esta pintura era aluno de Ficino, um tutor da escola filosófico neo-platônica que escreveu uma carta para o aluno no ano de 1477 ou 1478, pouco tempo antes da execução dessa encomenda. A carta, que é aceita como a fonte das ideias que pautaram a pintura, expressa a conexão na filosofia neo-platônica do 
pensamento astrológico sobre o destino humano e do cultivo dos princípios de "Humanitas" que expressa aquilo do que há de mais humano na humanidade. Essa conexão de sistemas desses sistemas de pensamento está magistralmente sintetizada por Vênus nessa narrativa. Gombrich (1972, p. 42 apud O’TOOLE, 1994, p. 18) relata que em sua carta Ficino escreve:

\begin{abstract}
Sua Luna (lua) deveria fixar seus olhos em Vênus ela mesma, isto é, sobre a humanidade (Humanitas) (...) Porque a Humanidade a si mesma é uma ninfa de excelente beleza nascida do Céu e dos outros mais do que amados por Deus o altíssimo. Sua alma e mente são Amor e Caridade, seus olhos Dignidade e Magnanimidade, suas mãos Liberalidade e Magnificência, os pés Beleza e Modéstia. O conjunto é, então, Temperança e Honestidade, Charm e Esplendor. Oh, que rara beleza, como contemplar essa beleza. Meu querido Lorenzo, uma ninfa de tal nobreza foi inteiramente entregue em seu poder. Se você fosse para unir-se com ela em casamento e reclamá-la como sua, ela tornaria todos os seus anos doces e o faria pai de ótimas crianças.
\end{abstract}

A lógica do argumento de Ficino liga as qualidades de Vênus à realidade do casamento e da paternidade. Cupido, apesar de parecer ser contido pelo gesto de Vênus, na função representacional, ele é uma das forças dinâmicas na tela ao apontar uma flecha para o peito de Castidade mesmo estando com os olhos vendados.

Com base nessa observação, notamos que na tela as figuras dinâmicas são as masculinas que, não como as femininas, voltam-se para esquerda criando um ritmo e uma direção de leitura da narrativa na tela que flui da direita para a esquerda. A última figura desta sequência é Mercúrio conduzindo as Graças. Sua figura é tão masculina quanto as Graças são femininas. Enquanto metade de seu corpo volta-se para o alto e seu braço estende a varinha para agitar os ramos acima de sua cabeça, ele tem uma postura firme e bem plantada no chão. Assim como Zephyr e Cupido, Mercúrio tem asas em sua varinha e calcanhares. Ele é o mensageiro dos deuses e sendo também o guia das almas dos mortos em sua jornada para o Além, sua capa tem pequenas chamas invertidas que representam a morte. Enquanto Zephyr é o vento quente do Leste, Mercúrio é o que sopra as nuvens e revela os mistérios do céu. Ele é o deus do intelecto, da sondagem, do raciocínio e da eloquência. Em seu olhar absorto que contempla o céu, essa figura é uma continuação da dança, que completa o movimento da narrativa direcionado da direita para a esquerda, enfatizando o fluxo para a esquerda. $\mathrm{O}$ olhar de Castidade para Mercúrio mostra uma pista de ser ele a possível solução para o conflito em Castidade encontra-se, obrigada pela seta de Cupido e pela Volúpia. O papel de Mercúrio fica bem expresso na carta de Ficino, que explica sua visão humanista nesta atuação de Mercúrio:

Sua Luna também deveria direcionar seu olhar sobre Mercúrio, que está no bom conselho, razão e conhecimento, pois nada deve ser feito sem consultar o sábio, nem nada deve ser dito ou feito para o que nenhuma razão plausível pode ser apresentada. Um homem não versado em ciências e letras é considerado cego e surdo. (GOMBRICH, 1972, p. 42 apud O’TOOLE, 1994, p. 19). 
Esta carta manifesta de forma clara o papel de Ficino, que motiva seu jovem pupilo para cultivar o respeito com o conselho dos mais velhos e com a aprendizagem.

Para examinar a função Representacional, O’Toole (1994) aborda progressivamente os sistemas semióticos que constituem a tela, partindo da categoria das Figuras individualmente, após o que se move para a categoria dos Episódios da tela, abordando por fim a imagem total. Para analisar o que a tela representa, O’Toole (1994) leva em conta a complexidade da linha narrativa visual e sua ligação com a filosofia subjacente. Ele busca uma correspondência dessas com pequenos detalhes que são encontrados em membros individuais tais como braços, cabelo ou objetos como broches e varinha, examinando a reciprocidade entre esses membros e objetos e as figuras dos quais eles são parte, buscando a correspondência dessas figuras com os episódios maiores e a reciprocidade entre episódios e as relações entre episódios.

Dessa forma, O’Toole (1994) apresenta uma nova versão para o quadro abaixo, onde adiciona alguns títulos sob a função Representacional e que podem ser usados de forma sistemática na maioria das pinturas.

Quadro 49: Sistemas na função Representacional

\begin{tabular}{|l|l|l|l|}
\hline Unidade / Função & Representacional & MODAL & Composicional \\
\hline & Temas Narrativos & $\begin{array}{l}\text { Ritmo } \\
\text { Modalidade }\end{array}$ & \\
\hline Trabalho & Cenas & Olhar & \\
\hline & Retratos & Enquadramento & \\
\hline & Inter-relação de Episódios & Luz & \\
\hline & & Perspectiva & \\
\hline Episódio & Ações, eventos & Proeminência Relativa & \\
\hline & $\begin{array}{l}\text { Agentes - pacientes - } \\
\text { objetivos }\end{array}$ & Escala & \\
\hline & Focal / lado sequência & Centralidade & \\
\hline Figura & Inter-relação de ações & Interrelação de modalidades & \\
\hline & $\begin{array}{l}\text { Carater } \\
\text { Objeto }\end{array}$ & Olhar & \\
\hline & Ato / Posição / Gesto & Posição & \\
\hline & Componentes da Roupa & Caracterização & \\
\hline & & Contraste: Escala, & \\
\hline & & & Linha \\
\hline Membro & & Luz & \\
\hline & Parte do corpo / objeto & Estilização & \\
\hline & Forma Natural & Cor & \\
\hline
\end{tabular}

Fonte: Quadro adaptado de O’TOOLE (1994, p. 20).

O’Toole (1994) explica do topo para baixo, os títulos inseridos no quadro para a Função Representacional. 'Temas narrativos' é um rótulo que está no nível da pintura como 
um todo; é o nome para significar a história inteira ou os complexos de histórias quando a pintura foi feita para contar umas histórias. 'Cenas' é um nome para significar paisagem ou natureza-morta em telas que descrevem alguma história sem uma ação envolvida. Nesse significado, podem ser incluídos os 'Retratos', que representam uma pessoa ou muitas.

Algumas pinturas podem reunir esses rótulos quando elas constróem uma ação recíproca em torno de dois gêneros, tal como a Paisagem com a queda de Ícaro, de Bruegel, que reúne cena e história ou como a tela, Um Bar no Folies-Bergère, de Monet, que reúne um retrato e uma natureza morta. $\mathrm{O}$ enfoque usado para analisar pinturas deve ajudar a diferenciar as características específicas nas pinturas que constróem uma ação recíproca entre dois gêneros. Essa interação também deve ser distinguida quando uma tela é construída na interação de episódios narrativos como é o caso desta pintura A Primavera e tendo analisado os episódios separadamente é possível juntar as linhas narrativas.

No quadro vemos, na categoria do 'Episódio', a caixa rotulada 'Ações' que descreve o que as pessoas estão fazendo na pintura. Já a caixa rotulada 'Eventos' descreve as ocorrências naturais, relacionadas com as ações das pessoas retratadas. As caixas rotuladas 'Agentes', 'Pacientes' e 'Objetivos' descrevem os papeis dos participantes em cada ação. O 'Agente' da ação, que observamos no primeiro episódio da esquerda é Zephyr: que representa a força da primavera em ação que subjuga Chloris, a Paciente que se submete a essa ação que resulta em Flora, o Objetivo da ação de Zephyr. Ocorre uma variação na interpretação do que cada episódio representa. Por exemplo, um episódio pode ser considerado uma cena central ou uma cena lateral. Dependendo de quais episódios iremos considerar focais, iremos interpretar as pinturas de forma diferente. Essa diferença de interpretação faz parte da perspectiva da construção do quadro, contanto que se ofereça uma boa evidência, pois não se trata de buscar uma interpretação unívoca e consensual, mas de considerar a questão da polissemia no processo de leitura e de interpretação das imagens.

Quando observamos A Primavera, desde a função Representacional, os episódios começam a evidenciar-se como etapas progressivas de uma narrativa na qual a Interação das Ações que tomam lugar nas cenas é chave para a compreensão da história narrada. A Categoria da 'Figura' pode oferecer importantes pistas. É importante fazer a diferenciação entre Personagem (como apresentada na face), $\underline{\text { Ato }}$ (a ação empreendida pela personagem),

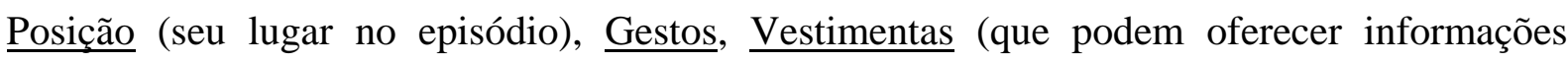
relevantes). Ainda na Categoria Figura, é importante observar a existência de Objetos, (próximos ou no lugar de personagens humanas) e suas partes Componentes (se elas ajudam a distinguir aspectos relevantes). Corpos e Objetos podem ser identificados e descritos na 
categoria de 'Membro' diferenciando suas Partes, mas, quando se trata de Formas Naturais, essas são essencialmente indivisíveis.

O’Toole (1994) ressalta que os rótulos que aparecem nas caixas do gráfico, não precisam necessariamente aparecer na análise de qualquer pintura, pois a maioria das pinturas dá pesos diferentes para objetos e corpos humanos, e alguns rótulos serão relevantes de acordo com cada caso.

Ao analisar a função Representacional, O’Toole (1994) resume os achados encontrados na narrativa: Zephyr se apresenta como uma força masculina jovem e poderosa, que adentra o episódio desde o alto da tela, entrando no enquadramento da cena desde "fora da direita do palco". Em sua ação de arrebatar a inocente ninfa da terra, Chloris germina flores e as transforma em Flora, uma confiante e madura deusa da primavera. A mediação de Vênus transforma esse processo linear em uma dança circular das Três Graças, que resolve, de forma dialética, o conflito entre Volúpia (Amor) e Castidade na terceira figura da Beleza. Uma outra força masculina adentra a cena desde o alto da tela, Cupido, que inicia o movimento da dança circular ao disparar uma de suas flechas em Castidade. O olhar de Castidade por sua vez, direciona-se para Mercúrio, a terceira força masculina que está no enquadramento da tela, mas tem sua ação e olhar voltados para o alto, mexendo com as nuvens acima do pomar com sua varinha mágica. Ele parece ser a chave para as ações e para os processos da narrativa; sendo um condutor personificado dos raios que canaliza as energias geradas na cena do assalto a Chloris e na dança das Graças para um domínio mais elevado e conduz as forças mágicas dos céus para o jardim terrestre transformando o desejo físico em humanidade e amor pela aprendizagem.

O’Toole (1994) faz menção a uma similaridade com uma série de narrativa alegóricas de autores, como Ovídio e outros com a narrativa central de A Primavera, na qual Vênus se encontra no centro das mudanças que ocorrem dentro do mundo daquela pintura. Ela transforma o conflito entre Desejo e Castidade em Beleza, já que as flechas de cupido que desencadeiam a transformação em Castidade estão sob o comando de Vênus que, como a deusa do amor e da beleza também transforma um drama terreno passional em uma dança etérea e graciosa. A pintura afirma a função das artes na humanização do sujeito e da sociedade, como Ficino pretendia. Ao mesmo tempo, como bem observado na função Modal, Vênus também é para os espectadores a dona do jardim e sua ação é a de envolver o espectador com as narrativas e suas moralidades. Essas narrativas vão conduzindo o espectador para um mundo mais elevado que Mercúrio representa no desfecho da narrativa, nos transformando em filósofos e admiradores das histórias narradas. 


\subsubsection{A função composicional: em busca das proporções mágicas}

Ao introduzir a função composicional, O’Toole (1994, p. 22) resgata o exemplo da visita de três amigos à galeria Ufizzi que, ao se depararem diante da Primavera pela primeira vez, falavam da tela de três pontos de vista diferentes e aparentemente desconectados. Ele relembra que o visitante da galeria, que tentava falar dos aspectos composicionais da Primavera estava pelo menos falando da própria pintura em si, enquanto os outros dois falavam de um ponto de vista extra-textual "histórico" e "mitológico", para falar da obra diante deles. As informações extra-textuais podem ser valiosas desde que sejam relevantes para evidenciar aspectos da própria pintura. Na Função Composicional, O’Toole (1994) reforça a necessidade de embasar com evidência as análises sobre a composição. Ele pontua que são feitas pelo pintor as escolhas do uso dos recursos tais como a distribuição das formas dentro da composição e o relacionamento entre as cores, a fim de comunicar o conteúdo representado ou produzir uma relação modal mais envolvente com o espectador. Nessa perspectiva, a escolha dos recursos pictóricos articula conjuntamente essas três funções que atuam de forma inseparável e que são trabalhadas separadamente por O’Toole (1994), para demonstrar por etapas os sistemas particulares que operam em cada função. Dessa forma, O’Toole (1994) enfatiza que a discussão sobre as três funções gira em torno da relação entre a composição com o que a pintura representa e como ela é comunicada para o espectador e faz referência a alguns dos sistemas presentes na função Composicional no quadro.

Quadro 50: Funções e Sistemas na Pintura

\begin{tabular}{|l|l|l|l|}
\hline Unidade / Função & Representacional & Modal & Composicional \\
\hline & Temas Narrativos & $\begin{array}{l}\text { Ritmo } \\
\text { Modalidade }\end{array}$ & Gestalt: Proporção \\
\hline Pintura & Cenas & Olhar & $\begin{array}{l}\text { Enquadramento } \\
\text { Geometria }\end{array}$ \\
\hline & Retratos & Enquadramento & Horizontais Linha \\
\hline & Inter-relação de Episódios & Luz & Verticais Ritmo \\
\hline Episódio & Ações, eventos & Proeminência Relativa & Piagonais Cor \\
\hline & $\begin{array}{l}\text { Agentes - pacientes - } \\
\text { objetivos }\end{array}$ & Escala & Alinhamento de formas \\
\hline & Focal / lado sequência & Centralidade & Inter-relação de formas \\
\hline & Inter-relação de ações & $\begin{array}{l}\text { Interrelação de } \\
\text { modalidades }\end{array}$ & Coerência de formas \\
\hline Figura & $\begin{array}{l}\text { Caráter } \\
\text { Objeto }\end{array}$ & Olhar & Posição Relativa no Episódio \\
\hline & Ato / Posição / Gesto & Posição & Paralelismo / Oposição \\
\hline & Componentes da Roupa & Caracterização & Sub-enquadramento \\
\hline & & Contraste: Escala, & \\
\hline & & & Linha \\
\hline
\end{tabular}




\begin{tabular}{|l|l|l|l|}
\hline & & Cor & \\
\hline Membro & Parte do corpo / objeto & Estilização & Coesão Referência \\
\hline & Forma Natural & & (paralelo / Contraste/ Ritmo) \\
\hline
\end{tabular}

Fonte: Quadro adaptado de O'TOOLE (1994, p. 24).

"Gestalt", como se vê no alto da coluna Composicional no quadro acima é uma ferramenta conceitual elaborada pela escola da Bauhaus. O termo Gestalt refere-se à nossa capacidade de percepção da imagem geral e de suas partes como unidade de significação, em um processo visual que apreende a imagem pelo seu todo e desde esse ponto de partida, quando olhamos para as partes, nós as percebemos em relação ao seu todo. A maioria das pinturas é retangular e alinhada com o horizonte, e no caso de A Primavera, um grupo de relacionamentos ocorre entre as formas.

De acordo Arnheim (1974), a experiência de apreensão de uma imagem pode se dar por diferentes caminhos. Podemos vê-la como um todo ou buscar olhar para as suas partes, ou fazer ambas as coisas simultaneamente. A imagem tem a qualidade de ser um texto que é recebido simultaneamente, ao contrário do texto escrito o qual precisamos nos ater primeiramente as partes para depois formarmos o sentido global. Oliveira (2004, p. 115-116) argumenta que:

Uma pintura, um conjunto de qualidades que são estruturadas num todo uno e
complexo, mostra-se por si mesma, por suas qualidades, àquele que a contempla. De
uma visão global do que é mostrado, o olho, órgão que opera inteiramente por
relaçães, por meio de contrastes entre os constituintes, traça percursos cujas
estratégias definem-se no e pelo perceber as partes do todo ou o todo e suas partes.
Essa duplicidade dos modos de ver - sendo que um pode se impor sobre o outro, ou
atuarem em combinatória, ora um, ora outro - só se define em função do que se vê e
não previamente; e como já esclareceram os gestaltistas o todo não é a soma das
partes: é algo mais...Entre esse ir e vir, a comparação entre os traços e o
estabelecimento das semelhanças e das diferenças tornam visível o percebido. Isso
faz com que o arranjo relacional da configuração do todo emirja dos perceptos das
partes ou, ao contrário, os constituintes ganham forma por meio dos perceptos
globais.

Dentro do espaço composicional, as formas que estão associadas aos eixos vertical e horizontal concorrem para a harmonia e estabilidade. Quando se alinham com os eixos diagonais, elas contribuem com dinamismo e energia. Os sistemas da Gestalt são como os elementos básicos da composição. Essas categorias podem ser aplicadas ao quadro $A$ Primavera e são funcionais para os sentidos que lemos nesta tela.

Na tela, é possível notar que as ações no quadro A Primavera, localizam-se entre Zephyr à direita da tela e Mercúrio à Esquerda. A figura de Zephyr abre a narrativa à direita e está, em parte, fora do enquadramento e alinha-se com o eixo diagonal. Isso cria tensão e energia no lado direito da tela e nos impulsiona a iniciar a leitura por essa extremidade. Já a 
figura de Mercúrio está alinhada com o eixo vertical e ocupa toda a extremidade esquerda, dando a impressão de finalizar o movimento que foi iniciado com Zephyr.

O’Toole (1994) ressalta que o enquadramento tem relevância nas três funções e não apenas na função composicional, pois o grau de inserção nesse espaço e o impulso dado por Zephyr também funciona modalmente para envolver o leitor na ação que toma lugar na cena: enquanto esse mesmo enquadramento constrói uma linha narrativa impulsionada por Zephyr que abre e inicia ao adentrar a tela de forma dinâmica e enérgica e é finalizada por Mercúrio que estanca a ação narrada.

A relação entre as partes e o todo da imagem é relevante nas três funções e o efeito psicológico do quadro diferencia-se em cada uma das funções em sua implicação para a forma como a história é representada, como ela trabalha para envolver o espectador e na forma como organiza as relações na composição.

Na composição, os membros reforçam essa relação uma vez que quase todos os pés das figuras estão paralelos com a linha inferior do enquadramento, menos os pés esquerdos de Chloris e Flora na extremidade direita do quadro e perturbam a harmonia dos pés da metade esquerda da composição. Essa relação entre os membros também denota e confirma com as formas o que está sendo comunicado na função representacional. A função composicional pode oferecer pistas e evidências para confirmar o que se observou no nível da função representacional e modal.

Da mesma forma que os pés, as cabeças das figuras, menos a de Vênus e de Cupido alinham-se com a linha que separa o céu e o topo das árvores. Essa diferenciação ajuda a destacar a importância distinta de Vênus das demais que, enquanto se encontra com os pés e a cabeça paralela com as linhas horizontais da tela, está mais elevada do que as outras figuras e se apresenta em um plano distinto do plano que os demais figuram.

Como observado na função modal, o excesso de vegetação em torno da cabeça de Vênus parece como uma sombra contra a luz de fundo que aparece delineada em forma de um arco, sugerindo a forma de uma aureola que ajuda a ressaltar ainda mais o olhar de Vênus que se volta para o espectador. Dessa forma, O’Toole (1994) ressalta que os aspectos composicionais não estão desvinculados da construção modal e das relações representacionais. Ele pontua que as características referidas como puramente estéticas em uma obra podem ser compreendidas no contexto do impacto que têm sobre o leitor da tela e as relações puramente formais entre os elementos da linguagem visual; suas relações entre si e com o todo da imagem. 
A forma pura em si mesma pode ter tido um significado maior para Botticelli, Ficino e seus patronos, como demonstrado por Fred Gettings, que argumenta que Vênus ocupa um espaço que foi magicamente definido, como na figura abaixo. Enquanto compartilha seu próprio plano apenas com Cupido, encontraremos à esquerda de Vênus, três, e à direita quatro figuras. As proporções das figuras distribuídas nos três episódios que organizam a pintura são de 4 para 2 para 3 e têm uma correspondência precisa com a divisão geométrica da tela.

A extremidade esquerda do episódio de Vênus tem uma linha vertical sugerida pela mão de Cupido, que se alinha com a mão direita de Vênus e o pé esquerdo da Graça mais próxima a Vênus; enquanto a extremidade direita do episódio surge de uma linha vertical sugerida por uma fruta alinhada com um tronco de uma árvore, o contorno da face de Flora, suas mãos e o seu pé direito que está visível. De acordo com Gettings (1978 apud O’TOOLE, 1994, p. 27), a harmonia na composição dessa tela acompanha uma teoria estética que dominou o final do século XV. Essa teoria se baseava na regra de ouro, na qual as proporções musicais estabelecidas por Pitágoras foram transportadas para a pintura por Alberti, um gênio do Renascimento. Entre todas as pinturas que incorporaram a proporção áurea A Primavera de Botticelli é uma obra que ilustra magistralmente esse pensamento estético e é considerada uma aula visual sobre a teoria que influenciou a produção artística daquela época. De acordo com Gettings (apud O’TOOLE, 1994) as ideias provenientes da matemática grega antiga, combinadas com a mitologia, Astrologia e com os códigos simbólicos "herméticos" de Alexandria, permearam o pensamento dos Neo-platonista do Renascimento, entre eles o de Ficino.

A influência dessas ideias fica mais evidente na carta de Ficino a seu aluno Lorenzo, para quem a tela foi encomendada. Nessa carta os conselhos astrológicos fazem referência à sua lua em aspecto com os planetas Vênus e Mercúrio. Sugerem a combinação de astrologia e mitologia para embasar um conselho moral que insta Lorenzo a atender à influência humanizadora do princípio regido pela deusa de amor e que o ajudará a transcender as paixões físicas por meio da aprendizagem e da arte regidos pela deusa. Com Mercúrio como o veículo, para formalizar a harmonia divina baseada nas relações matemáticas puras as quais Lorenzo deveria aspirar. As diagonais ligam os cantos da pintura até o canto oposto do episódio de Vênus sugerindo um polígono irregular de seis lados criado por uma estrutura subjacente.

Essas diagonais formam eixos para desenhar caminhos de movimento para outros episódios. Uma delas parte do canto superior direito e perpassa as linhas da mandíbula vigorosa de Zephyr e vulnerável de Chloris e continua até a região pubiana de Flora. Outra diagonal sai do canto superior esquerdo e perpassa entre os olhares de Luxuria e de Castidade, 
passando pela mão na região pubiana de Beleza que forma uma simetria com a posição da mão de Flora. A articulação dos elementos composicionais entre as categorias do Trabalho, Episódio, Figura e Membro produz uma Gestalt entre as microestruturas e as estruturas maiores resultando em uma unidade narrativa visual. Na categoria do Trabalho, temos as proporções dos episódios e as diagonais criando caminhos de energia, movimento e transição entre os episódios. Na categoria da Figura, vemos o enquadramento de Vênus e na categoria de Membro, os pontos focais dos olhares, mãos e região pubiana como ligação desses caminhos de articulação composicional que, em um movimento conjunto, criam o conjunto da tela.

O pensamento que baseou a composição permitiu uma quase infinita gama de padrões geométricos no arcabouço composicional, uma vez que a obra se coloca como um tratado visual dos conhecimentos de Matemática, Astrologia, Mitologia, e Ética. A função composicional pode ser instrumental para evidenciar como esses sistemas semióticos se articulam na função modal e representacional. O’Toole (1994) faz referência a gama e harmonia das cores da Primavera em sua análise da função composicional e que impacta nas funções modal e representacional. Na extremidade direita da tela, no ponto inicial para a narrativa da Primavera como já discutido na função representacional, encontram-se os tons mais frios de azuis e verdes nas vestes e asa de Zephyr, enquanto os tons mais quentes são encontrados no vermelho das vestes de Mercúrio e de Vênus. Essas duas figuras são as que apresentam as soluções modais e narrativas para a narrativa. Nas duas extremidades da direita e da esquerda da tela, encontram-se tonalidades opostas para a carne de Zephyr e Mercúrio, sendo a carne das figuras femininas de um tom harmoniosamente homogêneo, destacando um rubor no rosto de Flora e Luxúria, na garganta de Chloris, e nas costas da Castidade. A onda de transformação que inicia à direita da tela e segue para a esquerda, representada na metaformose no episódio à direita da tela e na dança à esquerda da tela parece ser reforçada pelas cores que confirmam uma 'onda em formação'. Essas ondas em formação contrapõemse com um sistema que O'Toole (1994) chama de 'formação-de-partícula' nas frutas em forma de um alaranjado que contrasta com as flores no chão. Esses dois sistemas de partículas produzem micro-ritmos que servem de ligação com as figuras centrais. Vários elementos produzem contraste tanto ritmicamente quanto representacionalmente, por exemplo, o ritmo de acenar de Vênus, os ritmos produzidos pelas dobras esvoaçantes das roupagens em torno dos quadris das Graças e de Chloris produzem um diálogo em movimento.

O’Toole (1994) reivindica que seu modelo semiótico nos permite nos relacionarmos com as três perspectivas de acordo com três funções e com quatro categorias que podem ser 
sistematizadas em um quadro que ajuda a organizar um grande número de sistemas de funcionamento diferentes.

O conceito de Escala de Delicadeza é uma ferramenta metodológica construída por O’Toole (1994) como uma "cláusula de fuga". Em sua visão, a análise de uma obra de arte precisa ser conduzida com delicadeza, refinamento e detalhe. Ele considera ser de alta prioridade iniciar pelo sistema de Ritmo, ou do Olhar, que se encontra no alto da caixa da função Modal e, por esse início, seríamos capazes de demonstrar como a pintura nos envolve e, partindo do olhar, relacionar com o ritmo que, da esquerda para a direita, evolui em uma linha narrativa mitológica. O olhar de Vênus, que se volta para o espectador, é de grande relevância para as razões que envolveram a encomenda, a concepção e a apresentação da tela para o jovem Lorenzo. Assim como os ritmos da pintura e o olhar de Vênus articulam-se com a composição das formas e com o uso das cores, relacionando diferentes níveis e perspectivas que circulam dentro da tela e materializam os sistemas funcionais que produzem o envolvimento Modal da tela, os elementos Representacionais da narrativa e as estratégias e estruturas da Composição. Esses elementos trabalham interligados para adicionar visualidade a um pensamento filosófico com o qual a tela argumenta para o jovem Lorenzo.

Em um segundo momento de análise, é possível transpor o momento de delicadeza e fazer o tratamento completo de todos os sistemas em todas as três funções. O’Toole (1994) argumenta que o seu modelo muldimensional é necessário para integrar as diferenciações polissêmicas na análise da obra. A espada de Mercúrio, por exemplo, pode não parecer relevante, mas isso não deveria nos impedir de buscar nela uma linha ou eixo de continuação com o braço erguido de Mercúrio ou uma simetria com o ângulo formado por Zephyr e Chloris na extremidade oposta da tela; ainda que não pareça ter uma função modal, esse elemento aparentemente secundário para a narrativa pode oferecer uma recorrência do ângulo formado pelas figuras que iniciam e que finalizam a narrativa, reforçando a harmonia da tela.

Por serem sistemas semióticos passíveis de interpretações distintas por indivíduos, gerações e culturas diferentes, eles são considerados sistemas abertos. Com isso, O’Toole (1994) ressalta que a análise dos sistemas semióticos e das dimensões funcionais nas obras de arte suscita um diálogo sem fim e são os textos de maior valor produzidos pela cultura, mas pontua que esta abertura não é, contudo, infinita. As interpretações, descrições e as análises são consideravelmente controladas pelo que se encontra no texto em si mesmo e a nossa análise e avaliação está condicionada ao conhecimento prévio que dispomos seja ele histórico, psicológico, filosófico, técnico e à prática de análise da linguagem pictórica. Nossa formação estética e a nossa prática para relacionar as obras a certas normas e convenções estabelecidas, 
irão desempenhar um papel na interpretação e na análise da obra. Mas, ele ressalta que esses conhecimentos requerem o nosso envolvimento a priori com a obra em si mesmo e que a análise das três camadas de significados funcionais nos ajuda a aprofundar o nosso conhecimento sobre ela à luz das normas pelas quais a obra foi produzida e foi convencionalmente avaliada.

\subsubsection{Elementos de Linguagem Visual vistos como unidades grafológicas da Comunicação Visual}

Por se tratar de um estudo da modalidade pintura, procurei emprestar alguns critérios e elementos das artes plásticas (KANDISKY, 1970; ARNHEIM, 1974; DONDIS, 2007) para descrever aspectos e relações mais específicas da linguagem pictórica. Essas transposições não comprometem o modelo de O'Toole (1994) e os pressupostos da GDV de Kress e van Leeuwen (1996) nos quais apoiei minha análise. Ao contrário, elas são compatíveis com a gramática do design visual de Kress e van Leeuwen (1996) e foram utilizadas neste estudo como ferramentas de análise quando as existentes no modelo proposto por O’Toole (1994) e na Gramática do Design Visual de Kress e van Leeuwen (1996) não foram suficientes para atender especificidades do corpus e não permitiram uma descrição mais precisa e sistemática. Espero com essas transposições do campo das Artes Visuais possam contribuir para propor novas categorias que iluminem como essas duas áreas epistemológicas, Linguística e Arte, possam se unir a fim de ampliar a compreensão das especificidades da linguagem pictórica e suas relações com a linguagem escrita.

No âmbito das Artes Visuais, a escolha dos elementos visuais que se articulam na composição visual está nas mãos do artista, a fim de constituir na imagem, um discurso visual rico de possibilidades de sentidos. Tendo em vista um resultado, as estratégias usadas na composição visual são decorrentes do uso combinado dos elementos mais básicos da linguagem visual. Discutiremos a seguir, a base teórica para a compreensão dos elementos de linguagem visual que nos servirá de suporte para a análise do corpus no contexto da produção discursiva multimodal do artista.

Com base nos pressupostos do enfoque da TSSM, O’Toole (1994) e Kress e van Leeuwen (1996), levei em consideração os elementos de linguagem visual descritos nos trabalhos de teóricos das Artes Visuais: Kandisky (1970), Arnheim (1974), Wöfflin (1989) e Dondis (2007) para argumentar que os elementos básicos da linguagem visual: ponto, linha, 
plano, ritmo, movimento, direção, proporção, textura, tom e cor deveriam ser considerados como unidades fundamentais e basilares para se analisar a comunicação visual, ao lado das categorias da TSSM e da GDV desenvolvidas por O’Toole (1994) e por Kress e van Leeuwen (1996).

Os trabalhos de Kandisky (1970), Arnheim (1974), Wolffin (1989) e Dondis (2007) oferecem subsídios para complementar as noções possibilitadas pela Gramática do Design Visual de Kress e van Leeuwen (1996). Arnheim (1974), em especial, tem sido uma importante referência para o pensamento em que baseou a multimodalidade, constituindo uma ponte interessante entre alguns pressupostos da Psicologia da Percepção Visual e a Linguística. Kress e van Leeween (1996) estimam como uma importante referência no desenvolvimento de sua gramática visual a obra de Arnheim (1974).

A comunicação visual é constituída por unidades linguísticas chamadas por Dondis (2007) de elementos de linguagem visual. Ponto, linha, plano, ritmo, movimento, direção, dimensão, tom, cor, textura são descritos em seu estudo como as menores unidades estruturantes da comunicação visual, com as quais são articuladas as imagens. Estes elementos básicos da comunicação visual são considerados nessa pesquisa como recursos semióticos nucleares que concorrem para construir as estruturas linguísticas visuais capazes de expressar os sentidos pretendidos pelo autor. O estudo dos elementos de linguagem visual e de sua articulação na materialidade do texto visual é fundamental para investigarmos os sentidos que depreendem das imagem analisadas. Como pontua van Leeuwen $(2011$, p. 1) é preciso enfatizar que a compreensão dos elementos de linguagem visual como unidades mais básicas de sentido precisa ocorrer dentro do enfoque da Semiótica Social, no qual os elementos de linguagem visual são vistos como recursos semióticos no contexto de três dimensões:

a) do estudo da história do surgimento dos recursos semióticos e o contexto dos seus usos e aplicações comunicativas e expressivas;

b) do estudo dos seus usos sociais e culturais no contexto das práticas semióticas;

c) do estudo dos processos de transformação dos sistemas semióticos, as mudanças na concepção, nos usos e na produção de sentidos.

O uso que o artista faz desses elementos organiza, na materialidade da imagem um texto rico de sentidos e possibilidades de leituras, ou seja, está nas mãos do artista, do autor da obra; ele é o orquestrador dos elementos visuais que colaboram para propor usar ou transformar semioses e construir as estruturas visuais de sentido. Considerar esses elementos nucleares e sua articulação na materialidade do texto pode ajudar a investigar novas camadas 
de sentidos que depreendem da imagem analisada e compreender como unidades mais basilares colaboram na construção de blocos de sentidos. A seguir, os elementos de linguagem visual conceituados por teóricos como Kandinsky (1926), Itten (1973), Arnheim (1974), Wöfflin (1989) e Dondis (2007) são descritos.

\subsubsection{O Ponto}

O ponto é considerado a menor unidade de comunicação visual e sem dimensão aparente, a mais simples e irredutivelmente mínima. A sua forma mais comum é a redonda, mais do que o quadrado e a reta, pois na natureza é comum a rotundidade. Ele funciona como indicador e demarcador de espaço. Qualquer dado ponto tem uma atração visual instantânea, pois desempenha um grande poder de atração visual sobre o olhar, exista ele naturalmente ou tenha sido colocado pelo homem em resposta a um objetivo qualquer. Os pontos, quanto mais próximos entre si estiverem, tanto maior será o efeito de fusão visual entre eles. Dessa forma, dois pontos podem ser usados como instrumento para a medição de um espaço ou para o desenvolvimento de um projeto visual. Desde os primórdios, a humanidade tem usado os pontos, fazendo marcas, com um bastão ou com tinta, para conotar um ponto de referência ou indicar um espaço. Desde então, temos utilizado o ponto como sistema de representação ideal, usando-o ao lado de outros instrumentos de medição, como a régua e o compasso. Na medida em que a complexidade de seu uso e as medidas necessárias à execução de um projeto aumenta, aumentam os pontos.

Quando em série, os pontos parecem ligar-se e essa fusão pode dirigir o olhar. Por exemplo, quando olhamos para o céu estrelado e enxergamos formas, é graças à nossa capacidade de 'ligar' os pontos mais próximos. Este fenômeno chamado por Dondis (2007) de agrupamento. A capacidade única que uma sequência de pontos tem de conduzir o olhar em uma direção é intensificada pela maior proximidade dos pontos e quanto mais próximos entre si, maior o efeito de fusão visual entre eles. Quando estão em grande número e justapostos, os pontos criam a ilusão de tom ou de cor e esta capacidade visual foi muito empregada pelos pontilhistas e mesmo por Van Gogh. Este fenômeno também baseia os meios mecânicos de reprodução de qualquer tom contínuo, bem como o sistema de cor na televisão. Esse fenômeno perceptivo da fusão visual foi genialmente explorado por Seurat em seus quadros pontilhistas, nos quais imprimiu cor e tom extraordinariamente variados, apenas com o uso de quatro cores - amarelo, vermelho, azul e preto - aplicados com pincéis muito pequenos e 
pontiagudos. Como exemplo dessa técnica, um trabalho de óleo sobre tela de 207.5 x 308.1, intitulado A Sunday on La Grande Jatte de Seurat (1884/6) foi executada apenas com o uso de amarelo, o vermelho, o azul e o preto.

Figura 43: Tela A Sunday on La Grande Jatte de Georges Seurat

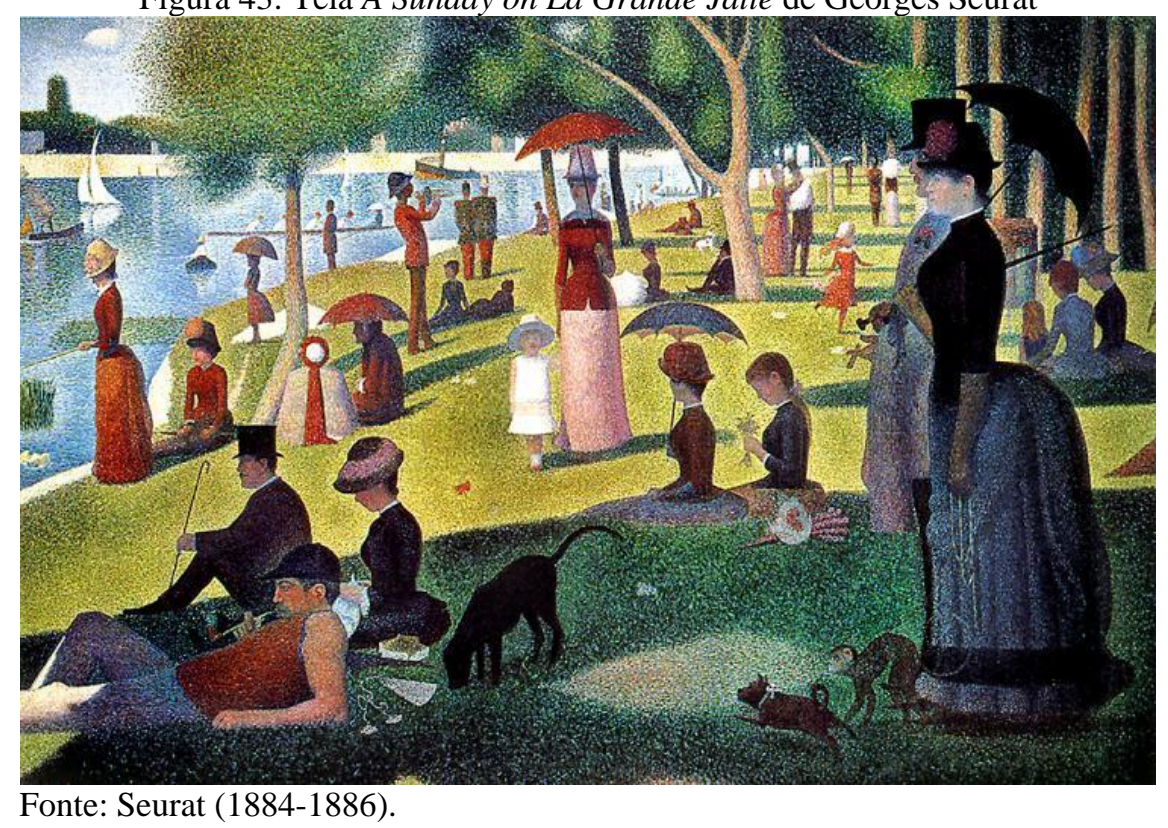

Os impressionistas fizeram muitos experimentos com os processos de fusão, contraste e organização, fenômenos que se sucedem com a percepção visual do espectador. Eles inovaram na dimensão da apreensão, fruição, recepção e construção do sentido do texto de arte como uma interação envolvente e estimulante entre o espectador e a obra. Este processo dialoga com algumas das mais recentes teorias de McLuhan (2008), para quem o envolvimento visual e a participação no ato de ver sejam partes do significado construído.

Ninguém, no entanto, pesquisou os limites do uso dessas possibilidades tão completamente quanto Seurat, que, em seus esforços, parece ter antecipado o processo de quadricromia a meio-tom, pelo qual são atualmente reproduzidos, na impressão em grande escala, quase todas as fotos e os desenhos em cores, de tom contínuo. Esse princípio se expressa na capacidade única que uma série de pontos tem de conduzir o olhar sendo intensificado pela maior proximidade dos pontos. Com essas inovações na arte, a ciência se beneficiou e muito. 


\title{
2.1.2.2 O Pontilhismo
}

\author{
Não menos importante foi o contato de van Gogh com Seurat e sua técnica do \\ pontilhismo ou divisionismo relatadas por Haziot (2010, p. 178-179):
}

Mas o movimento que agitava a Paris da pintura nesses anos era o divisionismo de Georges Seurat e de seu amigo Paul Signac. Seurat queria fazer uma pintura que se baseasse numa técnica cientificamente elaborada, aplicando ao pé da letra as leis de Chevreul. $\mathrm{O}$ que os impressionistas haviam compreendido de forma intuitiva, ele queria realizar com ciência. Sua ideia era a mistura óptica Se a luz refletida por um objeto fosse decomposta em pontos de cores cientificamente escolhidos, o olho, à distância, podia recompô-los pela mistura assim obtida na retina. De perto viam-se na tela apenas pontos de cores complementares em frequências calculadas para obter os efeitos desejados, mas de longe o objeto se recompunha com toda a sua vibração. Por exemplo, para representar um aspecto da relva passando da sombra à luz, ele pontuava os pontos verdes da relva com pontos laranja ou violeta, complementares do verde, em tonalidades precisas, segundo frequências crescentes ou decrescentes para mostrar a relva escurecida pela sombra (mais pontos violeta) ou iluminada pelo sol (mais pontos laranja). Examinada de perto, essa técnica inverossímil dava uma representação do objeto como se ele estivesse atrás de um véu que detivesse o instante pictórico pela eternidade. Tal técnica poderia ter um resultado absurdo, mas Seurat era um verdadeiro pintor, e sua grande tela Um domingo à tarde na ilha da Grande-Jatte é quase hierática. Esse instante, do qual Monet e seus amigos haviam mostrado o caráter efêmero e evanescente numa pintura de uma leveza e de uma delicadeza infinitas, tornava-se petrificado em Seurat, como que preso num verniz irremovível. Do instante fugaz se passava ao instante eterno. [...] Vincent teve a ocasião de vê-la e ficou vivamente impressionado. Seurat é o mestre, ele disse.

Essa técnica e estilo pictórico teve um enorme impacto no desenvolvimento da pincelada de Van Gogh que com os anos e muita prática veio a se tornar a sua assinatura artística, como explica Haziot (2010, p. 179):

Através de Pissarro e de Signac, que passou a ser seu amigo, Vincent foi iniciado no divisionismo ou pontilhismo e, digamos que influenciado por suas explicações, por algum tempo pôs alguns pontos na sua pintura. Mas, além de nunca aplicar a rigor a teoria, dificilmente essa paralisia do gesto pictórico, tão essencial para ele, podia durar muito tempo. A concepção minuciosa e aplicada de Seurat, que exigia semanas de trabalho paciente em ateliê, era diametralmente oposta à sua maneira de viver a pintura. Vincent viu nela, sobretudo, e desde o início, uma técnica a ser utilizada em certos casos, sem nunca generalizá-la: "Para o pontilhado, para aureolar ou outras coisas, acho isso uma verdadeira descoberta", ele escreverá mais tarde em Arles. 


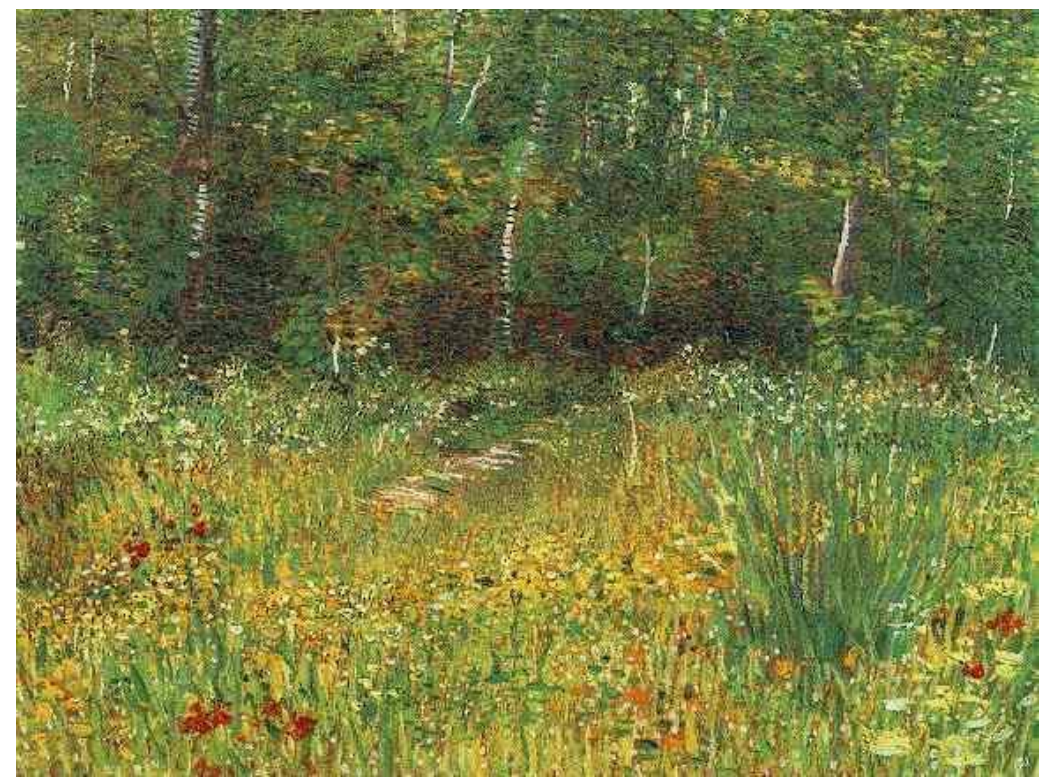

Fonte: Van Gogh (1887).

Para Van Gogh, o uso do ponto é constatável, devido à sua proximidade com Seurat e os divisionistas, e à influência que esses exerceram nos rumos de seu discurso artístico, como pontua Haziot (2010, p. 184):

Contudo, se ele mostrava com que domínio havia assimilado a lição dos impressionistas, seus quadros se distinguiam dos deles pela força realista. A teoria dos contrastes de cores ou os pequenos pontos de Seurat e Signac lhe serviam para uma forte captura do objeto. O grande Van Gogh já está aí, embora ainda não se arrisque a usar cores intensas, cores que não vê nesses arredores de Paris. Seus amarelos são ainda moderados. Mas já estão presentes, como na sua natureza-morta com livros amarelos sobre fundo amarelo.

\subsubsection{A Linha}

A linha é um elemento fluido e constituidor da forma, seja por meio da espontaneidade vacilante de um esboço, seja pela rigidez de um projeto técnico. Quando os pontos estão tão próximos entre si a ponto de não ser possível reconhecê-los unitariamente, aumenta a percepção de direção e juntos eles se convertem em um outro elemento visual: a linha. Resultado de uma cadeia de pontos, a linha pode adicionar personalidade à composição. Também poderíamos definir a linha como uma cadeia de pontos que dá a sensação de se mover em uma direção e avançar para algum propósito. Quando fazemos uma marca contínua, por meio de uma linha, nosso procedimento resume-se a colocar um marcador de pontos sobre uma superfície e movê-lo, segundo uma determinada trajetória, de tal forma que as marcas assim formadas se convertem em registro gráfico. Ela pode ser rigorosa quando empregada para áreas como arquitetura e design que exigem precisão técnica. Nas Artes 
Visuais, a linha tem, por sua própria natureza, uma enorme energia. Em sua força expressiva, pode ser indisciplinada, espontânea, expressiva, delicada, ondulada, vacilante, indecisa, interrogante. Ela nunca é estática; é o elemento visual inquieto e inquiridor do esboço. É o elemento essencial no desenho. Mas onde quer que seja utilizada, é o instrumento fundamental para a pré-visualização, o meio de apresentar, em forma palpável, aquilo que ainda não existe, a não ser na imaginação. Dessa maneira, contribui enormemente para o processo de instanciação do texto visual. As características principais da linha são as seguintes:

a) largura - grossa, fina, decrescente, cambiante, desigual, variável;

b) comprimento - longa, curta, contínua, quebrada, alternante;

c) direção- horizontal, vertical, diagonal, curva, perpendicular, oblíqua, paralela, radial, zigzag: sua trajetória tem uma direção e um propósito, ela vai a algum lugar;

d) foco - aguda, borrada, difusa, variável, entrecortada, ondulada, obscura, indistinta, velada, indefinida, mal acabada, confusa, imprecisa, incoerente, sem limites claros, torta: elas podem ter nuances de clareza, sombreamento, direção, curvatura, ou espessura.

e) sentimento - aguçada, irregular, contorcida, graciosa, suave, sutil, ambígua profusa, instável, reticente, ágil, fluida, interrompida, intercalada, impulsiva, desordenada, hesitante, plena, balbuciante etc.: pode ser espontânea, experimental, flexível. Pode ser usada para representação simbólica por meio da associação metafórica. 


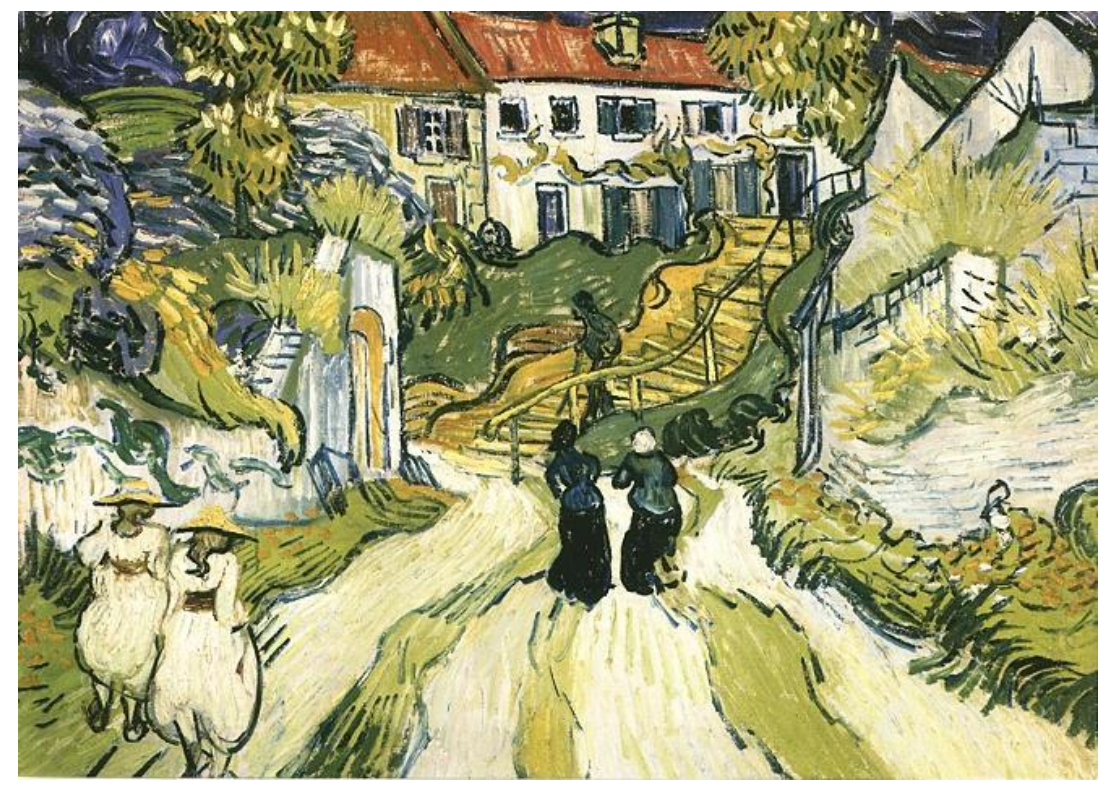

Fonte: Van Gogh (1890).

Van Gogh deixava o desenho aparente na tela, explicitando o processo do feitio do quadro e valorizando a linha de contorno como um recurso semiótico que rompia com a representação naturalista. Ele se apropriou do estilo de seus contemporâneos Cloisonistas: Gauguin e Bernard, e assim, deixar o desenho aparente na tela tornou-se uma das marcas do seu estilo pessoal, como explicam Walther e Metzger (2015, p. 440):

No idílico retiro de verão em Pont-Aven, Gauguin e Bernard, juntamente com Anquetin e Charles Laval, tinham estado a trabalhar num projeto que criasse um tipo de arte independente da natureza e somente interessada na delicadeza do impacto visual. Apesar das poucas experiências que fizeram, ainda produziram um manifesto. |Foi escrito por Edouard Dujardin, amigo dos tempos de escola de Anquetin, e ao surgir na Revue indépendant (possivelmente o mais importante dos muitos periódicos simbolistas), introduziu o termo "Cloisonismo". Os ourives medievais desenvolveram a técnica cloisonné nos utensílios esmaltados de cozinha. A nova teoria ocupava-se dos contornos que conferem aos objetos de um quadro - os motivos que se podem ver na tela - uma presença sólida e, consequentemente, independência e autonomia. Muitos séculos antes, os artesãos costumavam usar elegantes tiras de metal para separar áreas de esmalte umas das outras; agora, por analogia, era o uso exato e autoritário da linha que pretendia fixar as coisas nos seus lugares de modo bastante inequívoco e implantá-las, permanentemente, na natureza bidimensional de uma pintura.

As linhas podem ser usadas das mais variadas formas, podem variar na espessura, comprimento, curvatura, cor ou direção conforme descrito.

a) Silhuetas - Linhas feitas pelo limite de um objeto ou sua silhueta.

b) Linhas Gestuais - Linha que é energética e captura o movimento e os gestos de uma figura ativa. Desenho Gestual: o desenho de linhas dinâmicas e soltas para mostrar movimento em um tema.

c) Linhas Esboçadas - Linhas que capturam a aparência de um objeto ou a impressão de um lugar. 
d) Linhas Sugeridas - Linhas que não são desenhadas, mas criadas por um grupo de objetos vistos a uma distância. A direção para onde um objeto está apontando, ou a direção para onde uma pessoa está olhando que são compatíveis com a noção de vetores de Kress e van Leeuwen (1996) na qual diferentes elementos na composição ajudam a construir uma direção ou um caminho visual.

e) Linhas de Contorno - Linhas que descrevem a forma de um objeto e o detalhe interior. Desenho de contorno: o desenho de um objeto como se o desenho acompanhasse todos os limites da forma. O contorno é descrito pela linha. A linha materializa a complexidade do contorno. Os contornos básicos são figuras planas e simples que podem ser feitas e descritas por procedimentos visuais e verbais. O círculo, o quadrado e o triângulo são os três contornos básicos dos quais derivam todas as outras formas por meio de combinações e variações, a representação de formas concretas e abstratas.

Por meio da associação metafórica, culturalmente, sentidos distintos podem estar associados a eles tais como:

a) quadrado - figura geométrica com quatro ângulos e quatro lados iguais e com a mesma longitude. Honestidade, retidão, esmero.

b) círculo - figura curva contínua cujo perímetro é equidistante de todos os pontos ao centro. Infinidade, calidez, proteção.

c) triângulo equilátero - figura geométrica com três lados e três ângulos iguais. Ação, conflito, tensão.

\subsubsection{O Plano}

Um Plano é uma área visualmente perceptível. O plano é quando uma linha atravessa a si mesma ou faz uma interseção com outras linhas para fechar um espaço e criar um plano. É a configuração de uma superfície que pode formar a figura de um objeto. O seu contorno distingue-se de seu entorno.

Quando ele é bidirecional, o plano é um espaço que tem altura e largura, mas não tem profundidade. Uma área ou forma bidimensional pode ser aberta ou fechada, orgânica ou geométrica. Ela pode ser encontrada na natureza ou nas coisas fabricadas por nós. Os quatro planos básicos são o círculo, triângulo, quadrado e oval. Com base neles existem todas as suas infinitas variações, combinações, permutações de planos e dimensões. 
a) Planos Geométricos - círculos, quadrados, retângulos, e triângulos. Nós os vemos na arquitetura e nos itens manufaturados. Os contornos regulares, lineares, ou superfícies ou objetos descrevem as formas geométrica encontradas também na natureza.

b) Planos Orgânicos - folhas, conchas, flores. Nós os vemos na natureza e com características que são fluidas, informais e irregulares. Os planos ou formas que têm contornos irregulares se assemelham com formas orgânicas encontradas na natureza.

c) Planos Positivos - em um desenho ou pintura os planos positivos são formas sólidas em uma composição tais como um vaso ou fruta. Em uma escultura é a forma sólida da escultura.

d) Planos Negativos - em um desenho é o espaço em torno da forma positiva ou a forma em torno de um vaso ou fruta. Na escultura, é a forma vazia em torno dela e entre duas esculturas.

e) Plano Estático - planos que parecem estáveis e em repouso.

f) Plano Dinâmico - planos que parecem em movimento e ativos.

Um volume tridimensional ou a ilusão de três dimensões (relativas ao plano, que é bidimensional) pode ser construído pelas técnicas de sombreamento e pelas características particulares dos elementos visuais de um trabalho de arte, que são distintas de um tema ou conteúdo. A forma pode estar em um objeto tridimensional que tem volume e consistência. As quatro formas básicas são a esfera, o cone, o cilindro e o cubo. As formas adicionam significado e noção de estabilidade à composição.

\subsubsection{O movimento}

O movimento é um elemento que tem maior força expressiva e uma das forças visuais mais dominantes no modo visual. Está presente mais de forma implícita do que explícita na comunicação visual e pode ser sugerido pelo fluxo visual por meio da composição, dando a sugestão de movimento quando o olhar se move de um objeto a outro pela forma como eles estão localizados e posicionados. 


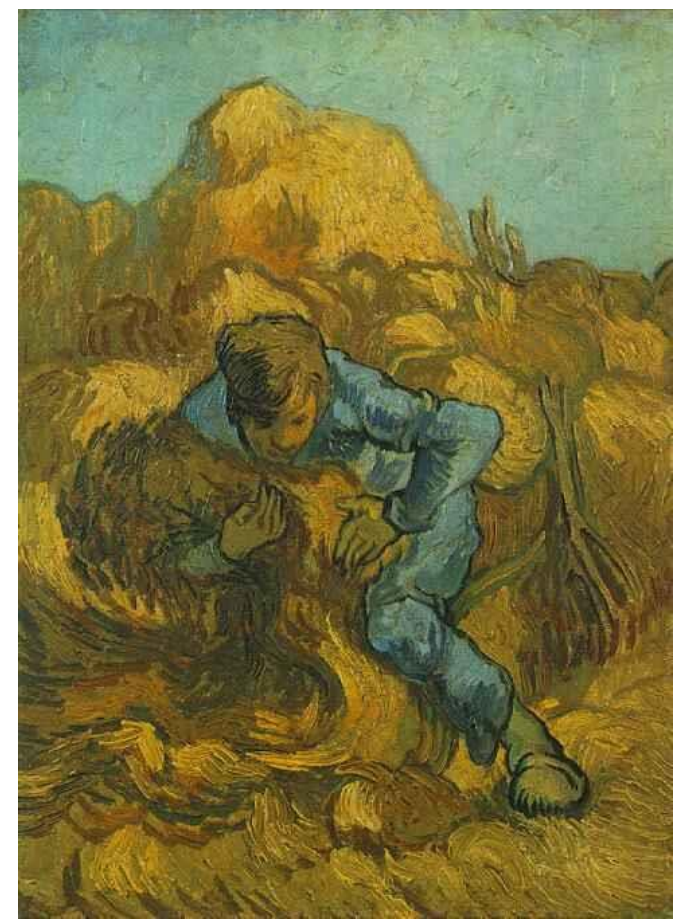

Fonte: Van Gogh Gallery (1889).

\subsubsection{O ritmo}

O ritmo é um movimento no qual alguns os elementos se repetem regularmente construindo um padrão. A repetição de elementos tais como linhas, formas e cores pode construir a percepção de movimento visual em uma composição que parecem como a batida de uma música. 


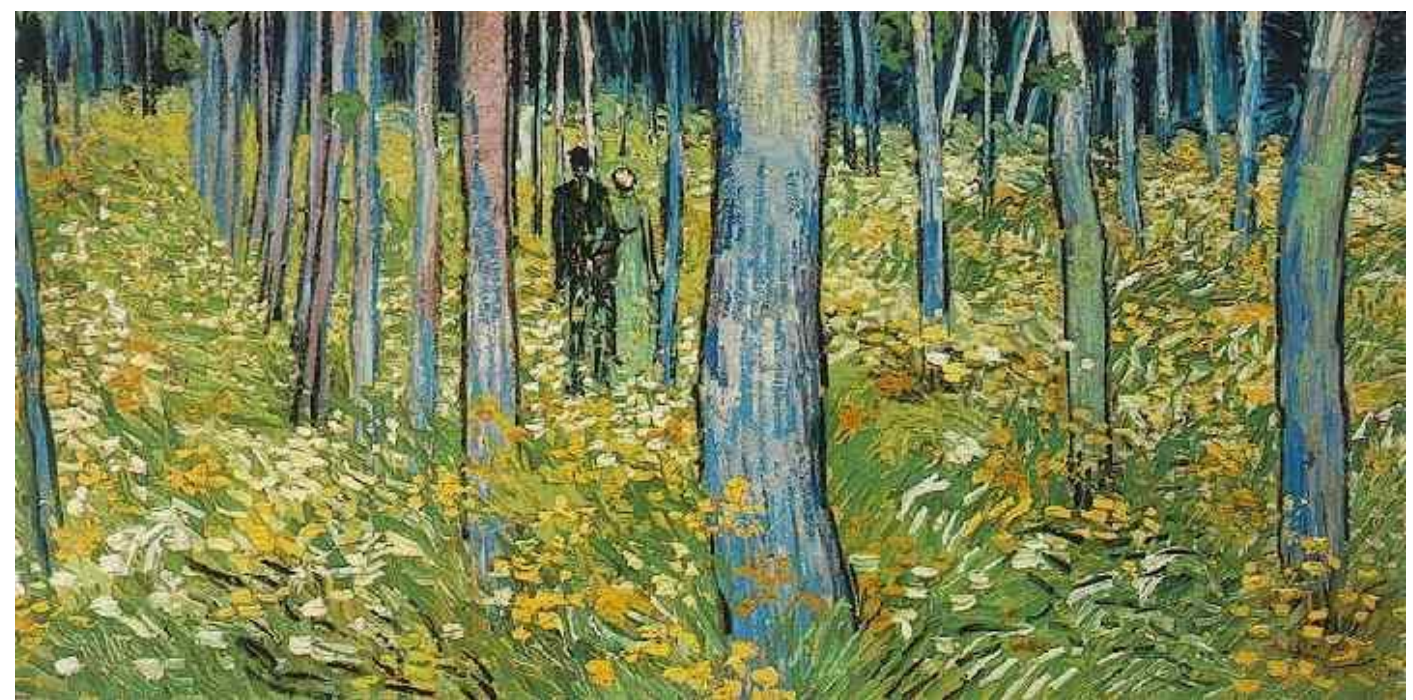

Fonte: Van Gogh (1890b).

\subsubsection{A direção}

A direção se refere à presença de elementos que sugerem um fluxo que direciona o olhar, ou ao impulso de movimento expresso pelas propriedades das formas básicas circulares, diagonais, perpendiculares. A direção é um valioso instrumento para a construção de sentidos com ajuda das forças direcionais construídas por meio da combinação de outros elementos como pontos, linhas e planos, por exemplo. A direção é importante para focalizar a intenção compositiva e dirigir a atenção do espectador para um efeito e um significado que se deseja enfatizar. A direção pode ser vertical, horizontal, diagonal, circular. Os contornos das formas expressam três direções visuais básicas e seus significados associados:

a) Quadrado: direção vertical e direção horizontal; diversidade, estabilidade; A direção horizontal - vertical, se refere à experiência fundamental de estabilidade, e de orientação na experiência do mundo físico.

b) Triângulo: direção diagonal; ruptura, força em expansão. A direção diagonal pode ser associada à experiência de instabilidade, movimento, ação.

c) Círculo: direção curva; sabedoria, igualdade, fraternidade; A direção curva pode ser associada ao significado de constância, repetição e calor. 


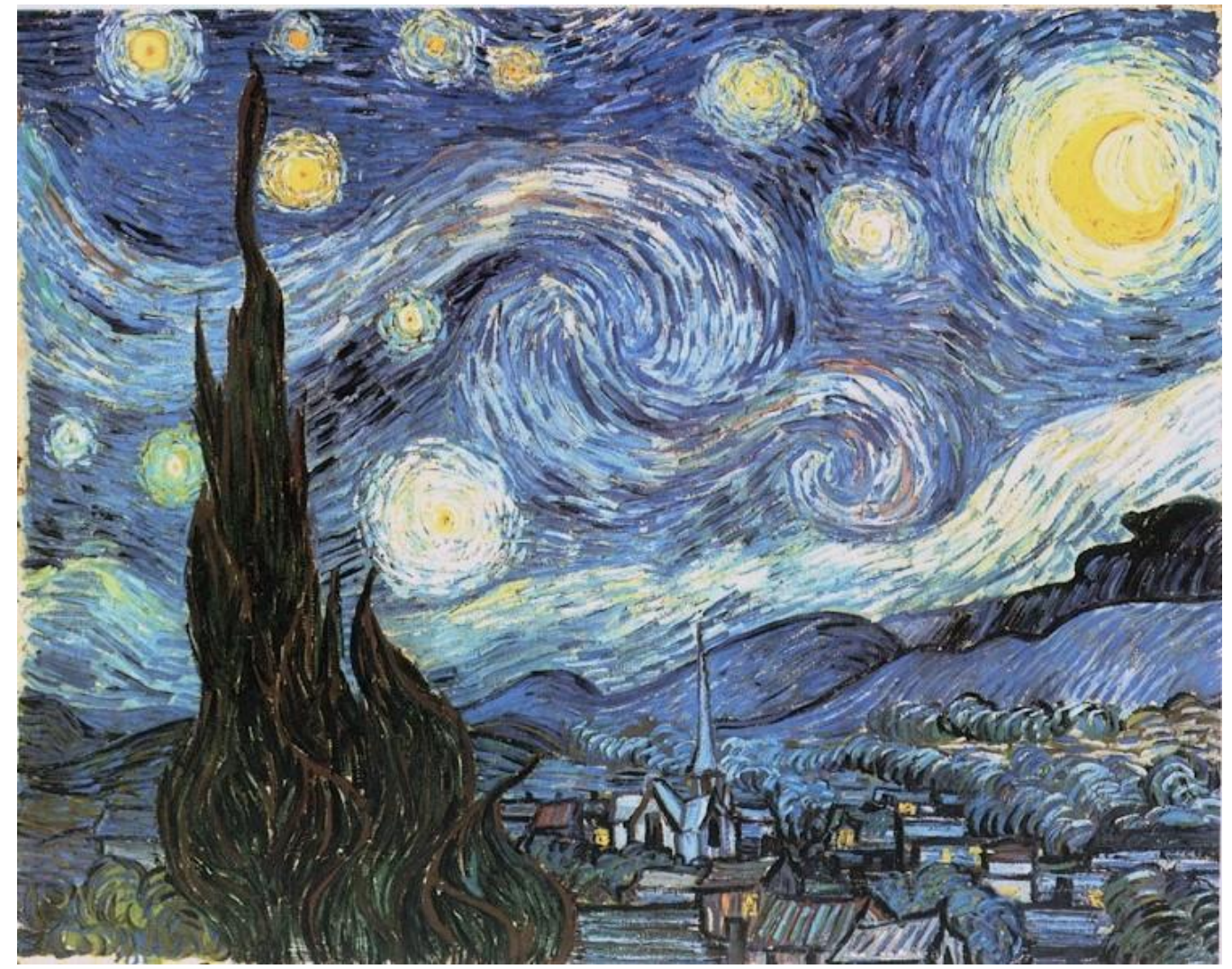

Fonte: Van Gogh (1889b).

\subsubsection{A dimensão}

A dimensão está relacionada com a representação proporcional de um volume real. É um elemento muito predominante na aplicação científica e industrial, no artesanato, na escultura, na arquitetura, e em qualquer aplicação que envolva o volume real. Para representar a dimensão, recorre-se à técnica da perspectiva e da volumetria. A dimensão pode ser representada por meio de pistas visuais que explicitam o tamanho relativo, pelas relações com o espaço e com o ambiente e com a ajuda de uma escala. A escala é uma ferramenta conceitual de medida visual relativa que usa o apoio de relações tais como: brilhante $\mathrm{x}$ apagado, grande x pequeno, claro x escuro, perto x longe. Outras ferramentas conceituais que ajudam a representar a dimensão são os sistemas convencionados para representar uma medição proporcional real como os planos e mapas. A arquitetura clássica produzida entre os anos 500 e 300 a.C. se orientou pela noção de organicidade e equilíbrio, apoiando suas proporções aos princípios matemáticos. 


\subsubsection{A textura}

A textura é um elemento visual usado para proporcionar uma experiência visual associada de outro sentido, o tato. No entanto, é possível sentir a textura tanto pelo tato quanto pela visão, ou combinando estes dois sentidos. A textura nas artes se refere à representação da qualidade da superfície dos materiais, tanto real e sentida pelo tato quanto sugerida e percebida visualmente e se preocupa como uma imagem pode ser feita para parecer rugosa ou lisa, macia ou áspera.

A textura real é a textura material de um objeto ou superfície e pode ser usada para criar o interesse visual no espectador. O artista pode criar uma textura real para evocar uma experiência ou sentimento associado, por exemplo, se for áspero, que este objeto veio da natureza, e se for liso, que foi feito por uma máquina. Uma textura implicada é sugerida visualmente em representação bidimensional feita para parecer como uma textura real. Como os desenhos de van Gogh, nos quais o tronco de uma árvore pareceria rugoso por meio de variações diminutas. A textura sugerida pode ser reconhecida pelos significados associados que temos do tato e da visão. A textura é um elemento visual que envolve as experiências sensórias de dois sentidos: a visual e a tátil e se apóia no fato de que a grande maioria das nossas experiências são ópticas e não táteis e por essa conexão, é possível representar visualmente a textura e enriquecer o condensamento de sentidos em uma composição visual. Van Gogh soube explorar a força expressiva da textura para aprofundar a nossa experiência sensorial com a tela. 


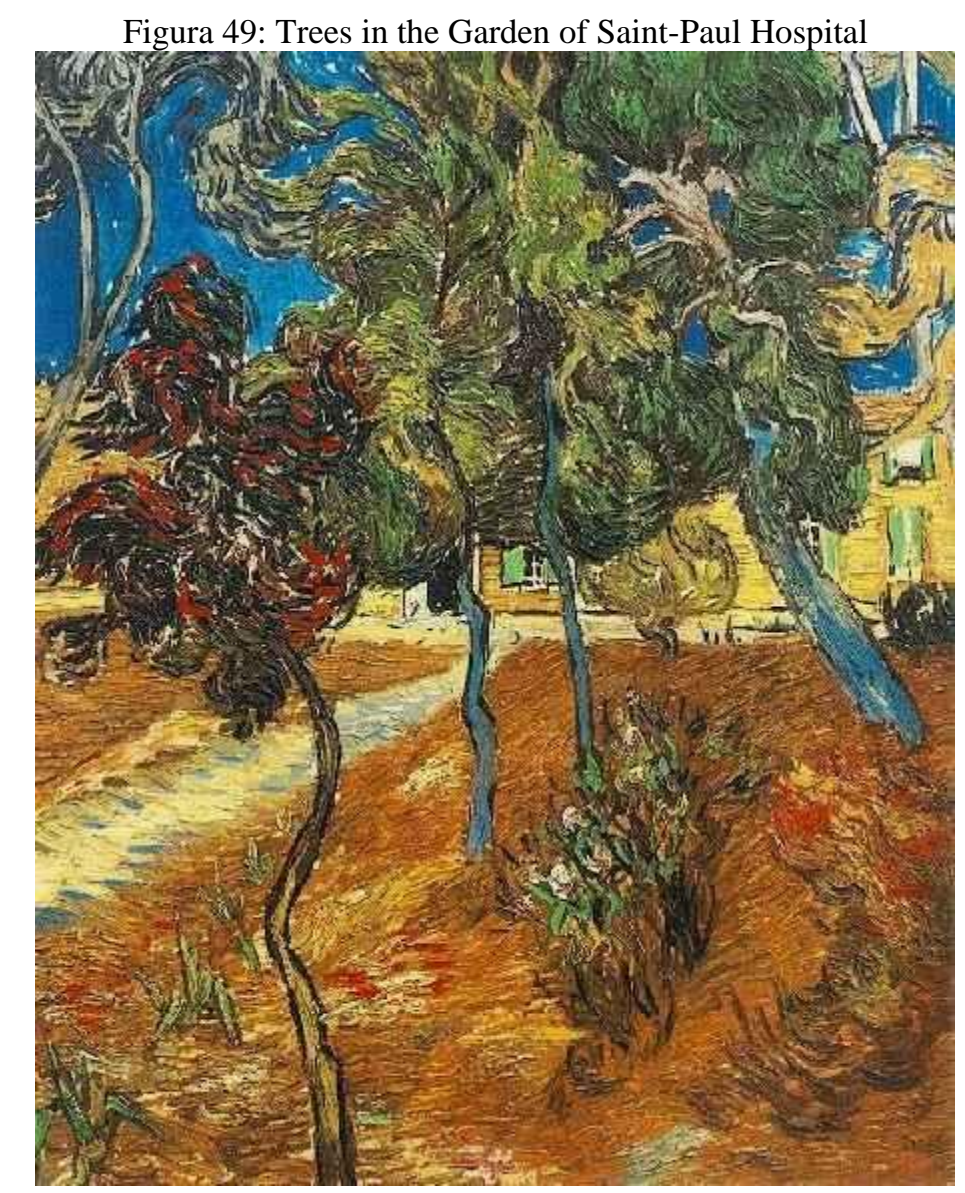

Fonte: Van Gogh (1889c).

\subsubsection{O Tom}

O tom indica a presença ou a ausência de luz no ambiente e é por meio dela que enxergamos uma superfície. Entre o escuro e a iluminação existem múltiplas graduações que nos permitem acessar a informação visual sobre o ambiente que se complementa pela perspectiva. A tonalidade é um dos maiores instrumentos para expressar o plano tridimensional em que vivemos. A tonalidade é muito importante para a arte são e com habilidade, consegue-se expressar até 33 tonalidades de cinza.

O excesso de iluminação e o escurecimento são tão essenciais para dimensionarmos o espaço a nossa volta que percebemos como 'naturais' as representações monocromáticas tais como a fotografia, o cinema, a televisão, a gravura, e o desenho. 


\subsubsection{A Cor}

A cor é discutida com base no trabalho The Language of Colour de van Leeuwen (2011), que contextua os usos históricos, sociais e culturais da cor com base nos pressupostos da Semiótica Social. A cor pode ser discutida a partir de diferentes ângulos, seja pela perspectiva das teorias científicas de Newton, sobre o comportamento físico da luz ou das teorias da psicologia sobre a percepção visual da cor, mas essas teorias pouco oferecem para compreender os usos, práticas e inovações da cor como um recurso semiótico. Nessa pesquisa, baseada na semiótica social, a cor será discutida pela perspectiva da ciência social da cor, como explica van Leeuwen (2011, p. 1, tradução nossa):

Trata-se da ciência social da cor. Trata-se da criação e uso deliberado de corantes, pigmentos, colorações, etc., e dos dispositivos para projetar e refletir a luz, e sobre a forma como eles são usados para manipular a cor para a expressão de sentimentos, para a comunicação de ideias, e para a interação social. ${ }^{314}$

A Semiótica Social oferece o suporte necessário para a compreensão do objeto da pesquisa como expõe van Leeuwen (2011, p. 2, tradução nossa):

Mas olhando para a cor como um recurso semiótico não só significa olhar para as tecnologias da cor, isso também significa olhar para as formas como os significados da cor foram desenvolvidos, olhar para o que as pessoas têm 'dito'e feito com a cor. A história da cor tem gradualmente construído um amplo repertório de possíveis significados de cores que continuam a estar disponíveis para nós como um recurso para a comunicação e expressão, e que é continuamente acrescido. ${ }^{315}$

O estudo da cor enquanto semiose pictórica é um dos elementos centrais na obra de Vincent van Gogh como explica Haziot (2010, p. 147):

[Vincent] Faz esta observação capital após o estudo das leis da cor e da visita a Amsterdã: "Minha paleta está começando a degelar, a esterilidade do início desapareceu". Diz poder assim trabalhar mais depressa. Compreendeu também que o tom local, a cor exata que temos sob os olhos, levava ao impasse estéril, o que não compreendem tantos pintores que ainda hoje seguem as práticas da escola de PontAven. "Essa beleza dos tons que jogam um com o outro na natureza se perde por uma imitação penosa, literal; ela se conserva quando recriada por uma gama de cores paralelas, mas não fatalmente exatas e mesmo muito longe de serem conformes ao modelo."

Nesse sentido, discutiremos a cor enquanto recurso semiótico, priorizando seus usos comunicativos e expressivos no contexto do desenvolvimento histórico, tecnológico e cultural

\footnotetext{
${ }^{314}$ Tradução livre da autora. "It is about the social science of colour. It is about the deliberate creation and use of dyes, pigments, stains, etc. and of devices for projecting and reflecting light, and about the way they are used to manipulate colour for the expression of feelings, for the communication of ideas, and for social interaction." (VAN LEEUWEN, 2011, p. 1).

${ }^{315}$ Tradução livre da autora. "But looking at colour as a semiotic resource not only means looking at colour technologies, it also means looking at the way colour meanings developed, looking at what people have 'said' and done with colour. The history of colour has gradually built up a large repertoire of possible colour meanings that continues to be available to us as a resource for communication and expression, and that is continually added to." (VAN LEEUWEN, 2011, p. 2).
} 
que os possibilitaram. A cor será discutida nessa sessão a partir das três dimensões propostas pela Semiótica Social:

a) no contexto histórico de seu desenvolvimento como recurso semiótico - estuda como as cores são criadas e como esses usos de cor acontecem, são apropriados e justificados como relata van Leeuwen (2011, p. 4-5):

Por alguns 2,500 anos os filósofos ocidentais têm lutado com o assunto, muitas vezes vendo a cor como altamente subjetiva e como "excessiva", necessitando de contenção e submissão a uma ordem racional. A cor sempre foi, e ainda é, um tema que evoca sentimentos fortes. Plínio, que viveu no primeiro século $\mathrm{dC}$, criticou a cor abundante e a 'pintura floreada'. O grande pintor grego Apeles, ele disse, usou apenas quatro cores austeras, comedidas, um negro chamado 'atramentum', um branco de Milos, amarelo Attic e um vermelho de Sinope, no Mar Negro. Esta ênfase nas virtudes morais de um número limitado de cores 'puras' ou 'primárias', ordenadas em termos de algum esquema racional, corre como um fio através da teoria da cor, desde os seus primeiros dias. O filósofo pré-socrático Demócrito (século $\mathrm{V}$ aC) já reconhecia apenas quatro cores (branco, preto, vermelho e 'chloron', um pálido amarelo-esverdeado), cada uma relacionada a uma forma básica, um ‘átomo' (Demócrito foi o criador do termo 'átomo', que significa 'indivisível' em grego), e Aristóteles, como Newton faria mais tarde, reconheceu sete cores básicas (branco, preto, vermelho, amarelo, marrom, violeta, verde e azul), relacionadas por regularidades numéricas e análogas à oitava na música.

b) no contexto social e cultural das práticas discursivas que fomentaram seus usos estuda como as pessoas usam a cor em contextos sociais específicos, como são esses usos, e como foram construídos e ordenados discursivamente como explica van Leeuwen (2011, p. 2, tradução nossa):

A semiótica social, portanto, precisa levar em conta tanto o que Pastoureau se refere como os "códigos", por exemplo, a gama de cores utilizadas em um determinado domínio, quanto os significados e associações ligados a eles nesse domínio, e dos contextos históricos e culturais dos códigos, a forma como eles foram criados, introduzidos na sociedade, e impostos ou justificados. ${ }^{316}$

c) no contexto das transformações de práticas e recursos semióticos - estuda como são as mudanças nas formas de pensar a cor e seus usos, e como essas formas transformaram as práticas e usos semióticos da cor.

[...] Esta inovação necessitou um reforço verbal. Como já dito, os significados da cor não são necessariamente entendidos naturalmente, sem o auxílio de explicações autorizadas. Há uma necessidade de discursos normativos, sejam eles formais ou informais, autorizados e prescritivo ou que trabalham com sugestões e conselhos da 'melhor prática'. ${ }^{317}$ (VAN LEEUWEN, 2011, p. 2, tradução nossa).

\footnotetext{
316 Tradução livre da autora. "Social semiotics, therefore, needs to take account both of what Pastoureau refers to as the 'codes', for instance the range of colours used in a given domain, and the meanings and associations attached to them in that domain, and of the cultural and historical contexts of the codes, the way they were created, introduced in society, and enforced or defended." (VAN LEEUWEN, 2011, p. 2).

317 Tradução livre da autora "This innovation needed verbal reinforcement. As said, colour meanings are not necessarily understood naturally, without the aid of authoritative explanations. There is a need for normative discourses, whether they are informal or formal, authoritative and prescriptive or working with suggestion and 'best practice' advice.” (VAN LEEUWEN, 2011, p.2)
} 
Na perspectiva da TSSM, a cor não produz a priori um sentido por si mesma ou possui um significado universal. Ela adquire sentido a partir dos usos comunicativos e expressivos que cada cultura faz para produzir suas representações de mundo, para produzir interação social ou para realizar ações comunicativas materializadas em textos que manifestam as práticas sociais discursivas.

Os autores Kress e van Leeuwen (2001) e Painter (2008) compartilham a visão de que a cor é vista em geral como "expressão" ou "produção" e não como "conteúdo" ou "design". De acordo com van Leeuwen (2011, p. 8), mesmo reconhecendo a cor como expressiva e significativa, os semióticos sociais percebem "seus significados como diferentes daqueles que são expressos por sistemas de linguagem". A cor possui um significado mais "múltiplo" e "cross-functional" do que aqueles expressos pelos sistemas linguísticos, levantando a necessidade de um enfoque diferenciado no método de análise desses significados. Kress e van Leeuwen (2001) sustentam que os significados das cores são construídos por meio da conotação e metáfora, e não por meio de sistemas gramaticais. Painter (2008) reconhece, assim como O'Halloran (2004), Kress e van Leeuwen (2002 apud MACHIN, 2007), a cor como multifuncional, no entanto, descreve a cor com base nos estados de espírito e humores que ela evoca, comuns a abordagem da psicologia da percepção visual, vendo o significado da cor como diferente do significado linguístico. Essa perspectiva é desafiante para a abordagem linguística apoiada na semiótica social. Van Leeuwen (2011) reconhece que ocorre pouco diálogo com as dimensões afetivas, estéticas e subversivas da cor, que foram resgatadas para o debate pelos filósofos pós-estruturalistas. Van Leeuwen (2011, p.8) comenta que esse momento representou a retomada do significado social da cor, após um período em que a "cor foi contida e reprimida em favor de um ambiente de cor mais suave e monocromático, e uma abordagem mais naturalista para o uso da cor na arte, a cor está agora fazendo um retorno como um meio de comunicação, desdobrando gradualmente as suas asas, tanto na prática como na teoria".

Gage (1999, p. 208 apud VAN LEEUWEN, 2011, p. 9) explica esse desenvolvimento:

Simultaneamente, a psicologia da cor tinha emergido, a partir do final do século XIX em diante. Tal como os filósofos pós-estruturalistas posteriores, esses primeiros psicólogos viram a cor como um sentimento altamente imediato, individual e esta ideia influenciou muitos dos artistas que, neste período, procuraram desenvolver uma arte não-representacional, abstrata na qual a cor teria um efeito direto, não mediada pela representação. Estudos experimentais, tais como aqueles de Stefanescu-Goanga estabeleceram a cor como uma 'matéria dos nervos', com efeitos psicológicos diretos (ver Gage, 1999: 192). O azul pode acalmar, por exemplo, e o vermelho pode excitar. Tais achados foram logo aplicados a 'cromoterapia', cura pela cor, com aplicações comerciais como neste anúncio de 1918. 
Anteriormente ao advento do computador, os filósofos pós-estruturalistas franceses, reintroduziram uma visão afetiva da cor, e a reputaram como 'feliz', 'transgressora', subjetiva e individual, além do alcance dos regulamentos e convenções sociais. (VAN LEEUWEN, 2011).

Van Leeuwen (2011) descreve como a cor é usada com a finalidade da comunicação social nos diferentes segmentos sociais. Ele se apoia nas 'metafunções' da comunicação (HALLIDAY, 1978) e sua tese de que os usos dos recursos semióticos se desenvolvem para suprir às necessidades sociais. A cor como recurso semiótico é usada de formas específicas na comunicação social, como é o caso do tom escuro das roupas para significar elegância e distinção. O pressuposto de que os recursos semióticos e entre eles a cor são desenvolvidos para atender as necessidades sociais não exclui a dimensão afetiva, subjetiva e sensorial da cor que é usufruída individualmente como explica Van Leeuwen (2011, p. 10):

\begin{abstract}
O próprio fato de que a nossa sociedade reconhece preferências individuais de cor, e as dota com a autoridade de investigação com financiamento público, significa que, como um semiólogo social, não posso ignorá-las, e a atração sensual de cor tem sido reconhecida ao longo da história, por aqueles que a comemoram, bem como por aqueles que pregavam contra ela. Mas, ao contrário dos primeiros psicólogos do século vinte (e muito poucos contemporâneos), eu também sei que outras sociedades podem não reconhecer essa ideia. O antropólogo Malinowski (1935: 50), durante seu trabalho de campo nas Ilhas Trobriand, viu crianças pegarem flores atraentes ou folhas coloridas, apenas para serem informadas por adultos "Ela não tem nome. É apenas uma erva daninha "ou "jogue fora, uma vez que é uma erva daninha". Os ilhéus de Trobriand claramente não valorizam as preferências de cores individuais, e não podiam conceber algo ser bonito sem ter uma função social.
\end{abstract}

Isto se explica com base na teoria das metafunções de Halliday, nas quais diferentes funções da linguagem estão presentes simultaneamente nos diferentes atos da comunicação social. São elas, a função ideacional, que se encarrega de construir as representações do mundo; a função interpessoal, que se ocupa de aprovar (ou de ajudar a aprovar) interações comunicativas das relações sociais; e a função textual, que organiza atos comunicativos em totalidades maiores, caracterizados por eventos comunicativos ou textos que materializam práticas sociais específicas.

Para Kress e van Leeuwen (2002 apud MACHIN, 2007), a cor, cumpre as três funções: a) quando usada Ideacionalmente, ela denotar 'pessoas, lugares e coisas específicas bem como as classes de pessoas, lugares e coisas e ideias mais gerais'. As corporações utilizam cores particulares para serem associadas a elas; b) quando usada interpessoalmente, a cor é usada para realizar propósitos sociais ou relações sociais específicas. Podemos fazer uma analogia: enquanto a linguagem nos possibilita realizar atos da fala, o uso da cor possibilita realizar 'atos da cor'. A cor pode ser usada para intimidar ao "vestir com poder", ou 
para alertar dos perigos ao pintá-los de laranja. No entanto, a cor em si não é capaz de desempenhar essas funções, mas as pessoas que fazem analogias e atribuem significados para a cor, e as utilizam para interagir, até que de forma persuasiva, a fim de energizar ou acalmar - de expressar os valores que estão associados com certas atividades. c) quando usada textualmente, a cor pode produzir coesão entre elementos distintos e aparentemente desconexos em um todo maior e/ou diferenciar as suas diferentes partes. A função textual da cor é facilmente reconhecida nas aplicações da programação visual, na qual as cores tem um papel central para organizar os espaços de um edifício pelas cores das portas, dos pavimentos e outros elementos para diferenciar departamentos criando simultaneamente, unidade e coesão (VAN LEEUWEN, 2011).

O uso semiótico da cor na comunicação social atende simultaneamente às três metafunções, por exemplo, quando usadas em um mapa podem desempenhar a função ideacional, mantendo ao mesmo tempo sua missão interpessoal, com um tratamento envolvente ou embotado, e a sua missão textual ao ajudar a garantir a unidade textual e a coesão. As visualizações científicas atuais oferecem um bom exemplo da metafunção ideacional, tal como a tomografia cerebral que utiliza as cores para distinguir a visualização dos elementos em questão.

Após uma época predominante "monocromática" na cultura, a cor expandiu, no século XX, a sua extensão semiótica, passando a atender um papel central na realização de cotidiana de significados ideacionais, interpessoais e textuais, sem deixar de desempenhar sua dimensão afetiva e sensual, revestindo a comunicação social com seu potencial de prazer e sensualidade.

Para van Leeuwen (2011, p. 15) "a mesma cor pode expressar muitos significados diferentes e o mesmo significado pode ser expressado por muitas cores diferentes." Ele defende que sistemas semióticos diferentes e até contraditórios podem existir lado a lado em uma mesma sociedade ou período, cada qual funcionando e cobrindo um pequeno campo de sentido. Pastoureau (2001, p. 8 apud VAN LEEUWEN, 2011, p. 15) desenvolve sobre a evolução histórica dos significados de cores e teorias da cor, e a questão da nomeação das cores para explicar a transformação no papel social da cor a partir do século XIX, expondo que:

cor é uma construção cultural complexa que resiste a generalização, e, na verdade a própria análise [...] Muitos autores procuram por verdades universais ou arquetípicas que imaginam residir na cor, mas a cor é antes de tudo um fenômeno social. Não há nenhuma verdade transcultural a percepção das cores.

A compreensão do significado da cor na história ocidental, de acordo com van Leeuwen, (2011, p. 15) pode ser compreendido a partir de três abordagens principais que se 
originaram nessa sequência no contexto histórico do uso das cores nas artes: a) o simbolismo da cor; b) o naturalismo na cor; e c) cor como um afeto e um efeito. Atualmente essas três abordagens coexistem e desempenham um papel no uso contemporâneo da cor.

A cor tem sido estudada por diferentes áreas e escolas de pensamento, que enfocam diferentes aspectos, seja pelo seu comportamento físico no ambiente, ou pela forma como ela é percebida pelo cérebro; ou como diferentes culturas se relacionam com as cores para construir sentidos compartilhados. Alguns desses enfoques, como a psicologia da percepção visual, buscou encontrar uma universalidade para os significados psicológicos das cores, acreditando haver uma única "linguagem da cor". No entanto o que se demonstrou foi uma infinidade de convenções para o uso da cor, baseadas em associações e códigos, voltados para contextos de aplicação específicos e domínios de significação restritos. (VAN LEEUWEN, 2011).

O simbolismo é definido na semiótica social como a relação entre um veículo e um atributo simbólico. Nessa relação, o atributo simbólico dá significado ou identidade para o seu veículo. Kress e van Leeuwen (2006) usam como exemplo o cavaleiro medieval como veículo e o brasão das armas como o atributo que dá ao cavaleiro uma identidade e um significado simbólico. São características do atributo (HERMEREN, 1969 apud VAN LEEUWEN, 2011):

a) Chamar atenção, sendo colocado em primeiro plano, bem iluminado, representado com maior detalhamento e definição, por meio de cores vivas, e contrastes de tom, ou exagerado no tamanho;

b) Tende a ser irrealista ou não natural, (em caso de ser uma imagem) ou destituído de uma função prática (no seu todo ou em uma parte);

c) Está suspenso, ou é apontado, mas não possui função além de exibir o atributo para o espectador;

d) Está associado aos valores simbólicos convencionados.

Van Leeuwen (2011, p. 19) oferece como exemplo das características do atributo a pintura medieval Menino Jesus, de pé no colo da Virgem Maria, na qual o menino Jesus segura uma maçã exageradamente grande, e a sustenta de uma forma que não parece que ele está prestes a comê-la. A representação da maçã evidencia o objetivo de chamar a atenção do espectador para sua função simbólica do comer o "fruto proibido no Jardim do Éden" que Cristo expiou. Mesmo na época em que prevaleceu o naturalismo, esses símbolos não desapareceram, só deixaram de ser representados não naturalisticamente. Na tela de Jan van Eyck, 'St Jerome em seu quarto de estudo', vemos uma maçã nem muito grande, nem 
particularmente visível, na prateleira. Esse tipo de atributo foi chamado por Panofsky (1971 apud MACHIN, 2007) de "símbolos disfarçados", uma vez que podem ser interpretados como apenas estando casualmente na cena, e realisticamente representados, ou como um símbolo que empresta significado ao seu portador.

Nos meios modernos as imagens usam simbolismo aberto e simbolismo disfarçado, dependendo da mídia e das intenções em jogo. Em filmes, os símbolos aparecem disfarçados sem serem notados e sem chamarem a atenção para eles mesmos. Já as publicidades e imagens de moda fazem um amplo uso do simbolismo aberto, por exemplo, nas fotos de moda, objetos estilizados e não naturais segurados pelas modelos indicam que estão ali para serem percebidos como atributos simbólicos e não como objetos para uso: óculos nos dedos da modelo podem atribuir a ela um ar de intelectualidade e consideração, por exemplo.

O Renascimento passou a priorizar uma arte 'monocromática', na qual a cor assumiu um papel "secundário", e passou a ser vista como um aspecto decorativo da obra. Além disso, a cor perdeu o seu papel semiótico, sendo usada naturalisticamente para descrever o mundo como ele parecia para o olho e não por seu valor simbólico. A preocupação de como a cor poderia ajudar os artistas a criarem uma ilusão da realidade ocupou a pauta do dia, em detrimento do que a cor queria dizer. O debate sobre o simbolismo da cor foi simplesmente esquecido pela literatura teórica, e as questões meteorológicas, físicas e ópticas - o sol, nuvens, pingos de chuva, e, especialmente, os fenômenos de reflexão e refração da luz ocuparam a cena. A fim de melhor compreender a forma como as superfícies de 'recebem' luz, o Tratado Sobre a Pintura (1435) de Alberti que introduziu a teoria e prática da perspectiva recomendou que os pintores "aprendam da natureza e dos objetos em si mesmos" (GAGE, 1993, p. 118 apud VAN LEEUWEN, 2011, p. 19).

Com as lentes desse novo paradigma da ciência, Leonardo da Vinci passou a ver o mundo que emergia de seus experimentos e técnicas de pintura. Uma citação de 1506 (DA VINCI, 2005 apud VAN LEEUWEN, 2011, p. 97) registra suas observações da cor esmaecida das montanhas ao longe e de experimentos científicos nos quais raios solares passam por buracos em uma câmara escura, e experimentos em pintura como fazer uma camada de branco fina e transparente sobre um negro intenso para observar o efeito (VAN LEEUWEN, 2011). Da Vinci (2005, p. 97 apud VAN LEEUWEN, 2011, p. 20-21) explica:

A atmosfera assume esse tom azul celeste, por causa das partículas de umidade, que capturam os raios do sol. Mais uma vez, podemos notar a diferença nas partículas de poeira, ou partículas de fumaça, nos raios de sol admitidos através de buracos em uma câmara escura, quando o primeiro vai parecer cinza de cinzas e a fumaça fina parece um azul dos mais belos. Pode ser visto novamente nas sombras escuras das montanhas distantes, quando o ar entre o olho e essas sombras vai parecer muito 
azul, embora as partes mais claras dessas montanhas não irão diferir muito de suas verdadeiras cores. Mas, se alguém deseja para uma prova final deixe-o pintar um quadro com várias cores, entre elas um preto intenso; e sobre tudo isso deixe-o pintar um revestimento muito fino e transparente de branco. Ele, então, vai ver que este branco transparente não vai mostrar em nenhum um azul mais lindo do que sobre o preto, mas essa camada de tinta deve ser muito fina e finamente moída.

Da Vinci (2005, p. 76 apud VAN LEEUWEN, 2011, p. 20-21) defendeu o uso de uma extensa gama de tons de sombra ao invés dos tradicionais quatro tons, porque em sua visão, "a sombra é um agente mais poderoso do que a luz, pois ela pode destituir inteiramente os corpos de sua luz, enquanto a luz pode nunca expelir as sombras de um corpo". Antecipando o impressionismo, ele observou os efeitos da cor nos reflexos de luz e nas sombras. "Cada objeto é mais ou menos tingido com a cor da superfície na qual é lançado'; e 'A superfície de cada corpo opaco é afetada pela cor [refletida] dos objetos que o rodeiam" (DA VINCI, 1506/2005, p. 98 apud VAN LEEUWEN, 2011, p. 21).

Os primeiros cientistas a tentar estudar a cor a viam como subjetiva e imune ao método científico, no entanto, Newton demonstrou que ela poderia ser medida e controlada, e esse avanço científico foi fundamental para o desenvolvimento da impressão a cores e do filme colorido. Van Leeuwen (2011) faz uma analogia dessa abordagem científica da cor com a fonética, que trata os sons da fala como um fenômeno fisiológico e físico, sem fazer referência a linguagem como um sistema de tomada de significado. Da mesma forma como o estudo dos sons da fala foi dividido em duas disciplinas, a fonética e a fonologia, o estudo da cor também foi dividido em duas áreas epistemológicas: de um lado, a química e a física e posteriormente a fisiologia da percepção das cores. Estas duas áreas concebiam cor como um fenômeno objetivo, separado do mundo humano e subjetivo. Depois, surgiu a psicologia da cor, dando centralidade à subjetividade humana. (VAN LEEUWEN, 2011, p. 21).

Goethe (1970 apud VAN LEEUWEN, 2011), em seu livro Teoria das Cores, fez uma distinção importante semioticamente, a distinção entre o efeito da cor e o significado simbólico da cor. De acordo com Goethe (1970 apud VAN LEEUWEN, 2011), alguns significados são simbólicos, e podem ser entendidos diretamente porque eles 'coincidem com a natureza'; já outros significados são 'alegóricos' "e só podem ser compreendidos se forem comunicados primeiro em palavras" (GOETHE, 1970, p. 350 apud VAN LEEUWEN, 2011) como exposto por Van Leeuwen (2011, p. 22-23):

No decorrer do século XIX, uma nova abordagem para o significado da cor surgiu, em grande parte estimulada pelo livro notável Teoria das Cores de Johann Wolfgang von Goethe (1970 [1810]). Na maior parte deste livro Goethe discute com Newton e desenvolve sua própria teoria da cor, com base na oposição entre claro e escuro, reconhecendo apenas o amarelo e o azul como cores puras, verdadeiras, (amarelo no lado do brilho, azul no lado das sombras) e vendo o vermelho como produzido a partir de amarelo e azul pelo processo de Steigerung ('aumento'). Mas 
não é por causa desta agora ultrapassada teoria que o livro de Goethe é tão importante. É porque, ao contrário de Newton, Goethe falou sobre os aspectos subjetivos, humanos de cor, apresentando ideias sobre o significado da cor que iriam influenciar profundamente como falamos de cor hoje. Foi Goethe quem primeiro formulou a ideia de que cor é essencialmente afetiva (a cor, ele disse, 'é imediatamente associada com as emoções da mente', IBID, p. 304), a ideia de que a cor pode expressar 'caráter', a ideia que as pessoas têm preferências de cor inatas; e a ideia de que a cor pode ter efeitos diretos, não mediados, sobre as pessoas.

Goethe (1970 apud VAN LEEUWEN, 2011) advogou o efeito emotivo da cor, e a sua importância como recurso para os artistas. Sua ideia foi aproveitada pelos pintores românticos em seu programa. Alguns pintores como os alemães 'Lucasbund' Friedrich Overbeck e Franz Pforr chegaram a convencionar seus próprios códigos de cores para expressar caráter, ainda que apenas em mulheres. Eles achavam que no caso da representação dos homens, a profissão é que determinava a cor da roupa (GAGE, 1999, p. 188-90 apud VAN LEEUWEN, 2011). Para eles, o cabelo preto combina com preto e violeta, preto e azul, branco e violeta, convencionando que tais cores significam uma personalidade 'orgulhosa e calma', mas 'alegre e feliz', por exemplo. (VAN LEEUWEN, 2011).

Os expressionistas, também seguiram esse pensamento e reviveram os significados afetivos da cor, descartando a representação da cor de forma naturalistas, e a representando não realisticamente, usando-a como um 'estímulo', ou um 'efeito psicológico não associativo', expandindo esse uso para além dos temas de vestimenta e representando 'céus verdes ';'prados violeta'e 'rios amarelos', muito atacados pelos críticos da época. (GAGE, 1993, p. 207 apud VAN LEEUWEN, 2011, p. 24).

A ideia de que a cor é afetiva, comunica diretamente e sem mediação um sentimento; e a ideia de que a cor pode ter efeitos involuntários, vem, desde Goethe (1970 apud VAN LEEUWEN, 2011), desempenhando um papel fundamental no discurso Ocidental sobre a cor. Essa ideia está presente em livros de design, que continuam a tradição da Bauhaus da década de 1920 e 1930, e de teóricos como como Kandinsky (1926) e Itten (1973), cujos estudos sobre a cor foram influenciados pelo legado de Goethe (1970 apud VAN LEEUWEN, 2011). Hornung (2005, p. 129 apud VAN LEEUWEN, 2011, p. 25), assim como Goethe (1970 apud VAN LEEUWEN, 2011), distingue as 'associações de cor simbólicas', das 'experiências da cor':

A fixação da cor azul para a abstração 'lealdade' é nebulosa [e] requer um público com experiências culturais compartilhadas... Se substituirmos a palavra experiência por sentido, podemos chegar perto da forma na qual a cor pode dar significado a forma. A cor, quando ela desperta sentimento, tende a fazê-lo não como um símbolo, mas como um análogo. Pessoas em todos os lugares parecem igualar azul, verde e violeta com frieza, e vermelho, laranja e amarelo com o calor... Essa associação provavelmente tem raízes na nossa relação física de longa data com gelo, 
sombras e águas profundas (frieza) e ao fogo, sol e deserto (calor) [...] o significado da cor parece brotar de uma reação psicológica à experiência física.

As reações psicológicas, de acordo com van Leeuwen (2011), são reações emotivas legítimas à arte, sancionadas socialmente pelos discursos especialistas de psicólogos, consultores de cor e designers. Por meio destes discursos nos sentimos licenciados, mesmo esperados, a reagir emocionalmente à cor, e reagir racionalmente em outros contextos nos quais a cor é apenas um código funcional como no caso do semáforo no sistema de transporte.

A história do significado cultural da cor na Europa teve três momentos distintos e o ultimo perdura até os nossos dias. Estas três tendências perduram em nossa cultura e permanecem disponíveis como recursos semióticos. Atualmente elas se alternam ou se misturam reconfigurando novos usos da cor, com os quais, novas formas multimodais de escrita e novas identidades são comunicadas, como explica van Leeuwen (2011, p. 26):

\footnotetext{
Para resumir têm existido três tendências que se sobrepõem na história Europeia do significado da cor. Na Idade Média, a cor desempenhou um papel fundamental na identificação de pessoas, seja figuras bíblicas, santos, monges, cavaleiros ou párias, e, significando ideias e ideais teológicos e cavalheirescos como 'humildade' e 'penitência' ou 'lealdade' e 'cortesia ". A partir do Renascimento em diante, a paisagem semiótica se tornou monocromática, e novas práticas e discursos científicos e naturalistas da cor já não se ocupavam com a questão do significado da cor. $\mathrm{Na}$ era romântica, finalmente, a obra de Goethe ligou a cor ao afeto, ao subjetivo,às emoções individuais e traços de personalidade, e para os efeitos diretos, não-mediados, no comportamento. As ideias de Goethe foram aproveitadas primeiro por pintores, e depois por psicólogos que, por sua vez, influenciaram importantes artistas do século XX e designers e, mais tarde, a área do marketing, com o seu interesse em apelar para as emoções e as 'desejos' dos consumidores.
}

Posterior ao desenvolvimento destas três tendências, a linguagem da cor se desenvolveu a partir do sistema de cor objetivo desenvolvido pelos cientistas e artistas baseados nas descobertas de Newton, e a partir da linguagem que usamos para falar sobre a cor. Tanto o sistema de cor científico quanto a linguagem com a qual falamos sobre cor são importantes para compreender como a cor funciona como sistema de comunicação em nosso mundo contemporâneo.

\subsubsection{Pintura: meio e modo}

Van Leeuwen (2011) explica que no passado as pinturas não eram consideradas objetos preciosos por serem criadas por artistas famosos, mas por usarem materiais difíceis de obter e considerados preciosos. As tintas eram produzidas a partir de diversas fontes minerais (conchas), vegetais e animais (insetos), que dão nome às tintas até os nossos dias, referindo-se 
ao lugar de origem (Índia, Afeganistão) ou ao processo de fabricação de seu pigmento. (VAN LEEUWEN, 2011).

Novas tintas foram criadas em torno de 1600, as partículas do pigmento ficavam revestidas por uma fina camada de óleo que as isolava e protegia contra as reações químicas que ocorriam na mistura com outros pigmentos presentes no meio no qual estavam suspensos. Essa nova tecnologia permitiu que as partículas de cada pigmento mantivessem a sua cor original proporcionando mais eficácia para o processo de mistura de cores.

Nesse período os pintores, entre eles Leonardo da Vinci deixaram de utilizar a tinta não modulada. Leonardo simplificou a sua paleta a um mínimo de cores primárias (branco, preto, azul, amarelo, vermelho e verde) e passou a mistura-las para privilegiar a transição da luz para a sombra e a refração sutil das cores na sombra, a fim de obter uma representação naturalista. Essa nova prática fez diminuir o status de preciosidade das tintas, bem como a busca estética pela pureza da cor não modulada. (VAN LEEUWEN, 2011).

A partir disso, a prática de trabalhar com a paleta mudou; os aprendizes do pintor sistematizavam para cada cor primária, as cores necessárias para os destaques e para as sombras. Essa prática deu lugar a ideia filosófica que baseou as teorias modernas da cor. A de que há um grupo limitado de cores primárias, e que a mistura delas produz todas as outras cores. As ideias que fundamentam a atual teoria das cores foram experimentada antes pelos artistas. Da Vinci (2005 apud VAN LEEUWEN, 2011) deixou escritos que possibilitaram que prática artística fosse assimilada nas teorias posteriores sobre a natureza da cor e que possibilitaram invenções, como a impressão a cores e fotografia colorida.

Essa mudança é usada por van Leeuwen (2011, p. 30) como exemplo para explicar a diferença entre modo e meio:

Um meio semiótico é um tipo de substância material (por exemplo, pintura ou
madeira) ou um tipo de ação física (por exemplo, vocalização), que passou a ser
usada para fins de expressão cultural e de comunicação social, mas de tal forma que
a materialidade do meio continua a desempenhar um papel importante na
comunicação do sentido, quer na base da "origem" (como no caso do azul
ultramarino) ou na base das suas qualidades físicas (o brilho de um negro particular;
etc.). Trabalhar com um meio, ou entender o que a cor, usada como um meio,
transmite, significa ser sensível às qualidades únicas e histórias culturais únicas de
cada pigmento, cada cor particular. Como um meio, a cor é, portanto, uma coleção
de substâncias materiais, tintas, corantes, pigmentos e assim por diante, cada um
com suas histórias e qualidades únicas, uma "linguagem", você poderia dizer, que só
tem vocabulário, e nenhuma gramática.

Já no modo semiótico, a produção do significado se apoia em regras de sistemas semióticos ou gramaticais. Essas regras possibilitam que a combinação de um número restrito de elementos produza uma vasta quantidade de significados, como acontece com diversos 
sistemas de representação tais como as 12 notas musicais que geram inúmeros acordes, ou as letras do alfabeto que geram inúmeras palavras. Quando as regras que permitem essa produção, se desenvolvem o modo deixa de depender de uma materialidade específica para assegurar o seu sentido, e os sentidos que ele gera podem ser materializados em outros meios, com diferentes materiais, assim como uma música pode ser executada em diferentes meios ou instrumentos e uma frase pode ser escrita ou falada. Com a cor ocorre o mesmo, já que ela é produzida em um sistema de cores primárias que, quando combinadas com base em um conjunto de regras geram inúmeras cores, essas regras permitem que elas não dependam da materialidade de um meio específico.

As regras que operam em um sistema abstrato podem ser aplicadas em diferentes meios. No caso das cores, é o argumento de van Leeuwen (2011), que ocorre um fator de diferenciação importante na mudança entre o meio físico e o meio eletrônico: as cores primárias no meio de luz projetada tais como as telas de computadores e televisão não produzem o mesmo significado das cores primárias refletidas na superfície dos meios físicos tais como corantes, tintas e pigmentos. Quando pensada como um modo, a cor pode perder alguns sentidos que estão relacionados com materialidade presente no meio em que ela é produzida. Ele pontua que:

\begin{abstract}
A desvantagem é que a cor, uma vez entendida como um modo,, pode deixar de ser apreciada pelos significados que a materialidade pode transmitir, e que, como veremos, é de fato o que aconteceu. Ainda hoje, quando a cor, como se vê nas telas dos computadores, perdeu muito de sua materialidade e tato, há um novo desejo ardente de materialidade e das nuances e ressonâncias que ela pode transmitir. (VANLEEUWEN, 2011, p. 30)
\end{abstract}

Para compreender a cor pela perspectiva da Semiótica Social, van Leeuwen (2011) ressalta a importância de se levar em consideração não apenas o matiz, a saturação, e o valor vistos como modo, mas vistos também como meios e seus materiais e tecnologias. No âmbito de sua materialidade, a cor deve ser compreendida em termos de suas características: o matiz, o valor, a intensidade.

a) Matiz ou tonalidade - se refere ao nome da cor, por exemplo, vermelho, azul e rosa.

b) Valor ou saturação - se refere à quão claro ou escuro é o matiz ou a cor natural. Um valor de luz vai parecer mais claro e um valor escuro vai parecer mais sombrio. $\mathrm{O}$ branco e o preto podem ser adicionados às cores para produzir o valor de luz. Algumas palavras são associadas com o valor: saturar quer dizer adicionar o branco no pigmento da cor para obter um valor mais claro tal como azul claro ou rosa. A sombra se consegue adicionando o preto na no pigmento da cor para 
obter valores escuros tal como um azul escuro ou um vermelho escuro. O conceito de High-Key se refere à predominância em uma tela de tons claros ou brilhantes. O conceito de Low-Key refere-se à ênfase de valores escuros em uma pintura. Pode ser usado para conotar restrição, discrição, despretensão, sutileza, modéstia. $\mathrm{O}$ valor de contraste se refere ao posicionamento de valores claros próximos aos valores escuros para aumentar a intensidade do contraste de luminosidade e enfatizar essa oposição. Geralmente, essa estratégia é usada para criar um caminho visual que direciona o olhar para a área de maior contraste na tela. Já a mudança gradual no valor ou na luminosidade desde o valor mais claro do matiz até o seu valor mais escuro é mostrada pela escala de valor. A escala de valor mostra a ampla gama de valores que progride do preto até o branco.

c) Intensidade ou brilho - a sensação visual da intensidade está na sua capacidade de refletir ou absorver a luz em uma superfície. Existem quatro tipos de escolhas de cores usadas em uma tela: a monocromática, a análoga, a complementar, ou mistas.

As teorias modernas da cor se apoiam principalmente nas áreas da ótica na física, e da psicologia da percepção visual, que se apoia na ideia da cor na perspectiva do modo. Ele resgata um pouco da história desse entendimento que está profundamente enraizado na ciência e nas artes atualmente, mas argumenta que essa perspectiva deixa de fora a construção história e cultural da cor a partir de sua materialidade e tecnologia. Essa perspectiva priva o entendimento da cor da sua dimensão semiótica que inclui o social e o cultural como ambitos que participam da produção dos sentidos atribuídos às cores, nos diferentes contextos em que são produzidas e usadas. Para se desenvolver uma perspectiva semiótica será necessário incluir a ideia como um meio, levando em consideração outros aspectos da cor, que também colaboram para os seus sentidos.

A teoria da cor se apoia principalmente na ideia de que todas as cores derivam das cores primárias. Estas são um conjunto restrito de três cores, azul, vermelho e amarelo que não podem ser alcançadas por mistura de outras cores e são consideradas fundamentais e irredutíveis na categorização das cores que daí decorre. Essa visão remonta aos filósofos gregos, os quais postulavam quatro cores primárias, relacionadas aos quatro elementos. Leonardo relacionava o azul ao ar, o verde à água, o amarelo-terra, o vermelho ao fogo.

O preto, o branco e o vermelho eram as cores primárias na Idade Média, não por serem irredutíveis, mas por serem simbolicamente consideradas mais importantes, sendo mais discutidas e terem mais regras para o seu uso. A hierarquia das cores foi muito discutida na 
heráldica, no século XV, sendo para alguns o ouro a cor mais nobre por brilhar como a luz, a seguir o vermelho, por ser a cor do fogo; depois o azul por ser a cor do ar, o branco porque é a luz, e preto como menos por se opor ao branco.

A apreciação da prática de misturar as cores primárias para obter as demais cores desencadeou a teoria moderna das cores. Da Vinci (2005 apud VAN LEEUWEN, 2011) considerava como primárias em sua prática as cores vermelho, amarelo, azul e verde, bem como preto e branco.

Da mistura dessas cores podem derivar as cores chamadas secundárias:

a) Vermelho + azul $=$ roxo

b) Vermelho + Amarelo = Laranja

c) Azul + Amarelo $=$ Verde

$\mathrm{Na}$ teoria moderna da cor, a mistura é subtrativa na qual a mistura de tintas e corantes é vista como oposta à mistura de feixes de luz colorida em meios eletrônicos.

Nesse sistema, as cores terciárias são decorrentes da mistura entre uma cor primária e uma cor secundária. A mistura das três primárias resulta em um preto opaco.

Figura 50: Cores primárias, secundárias e terciárias

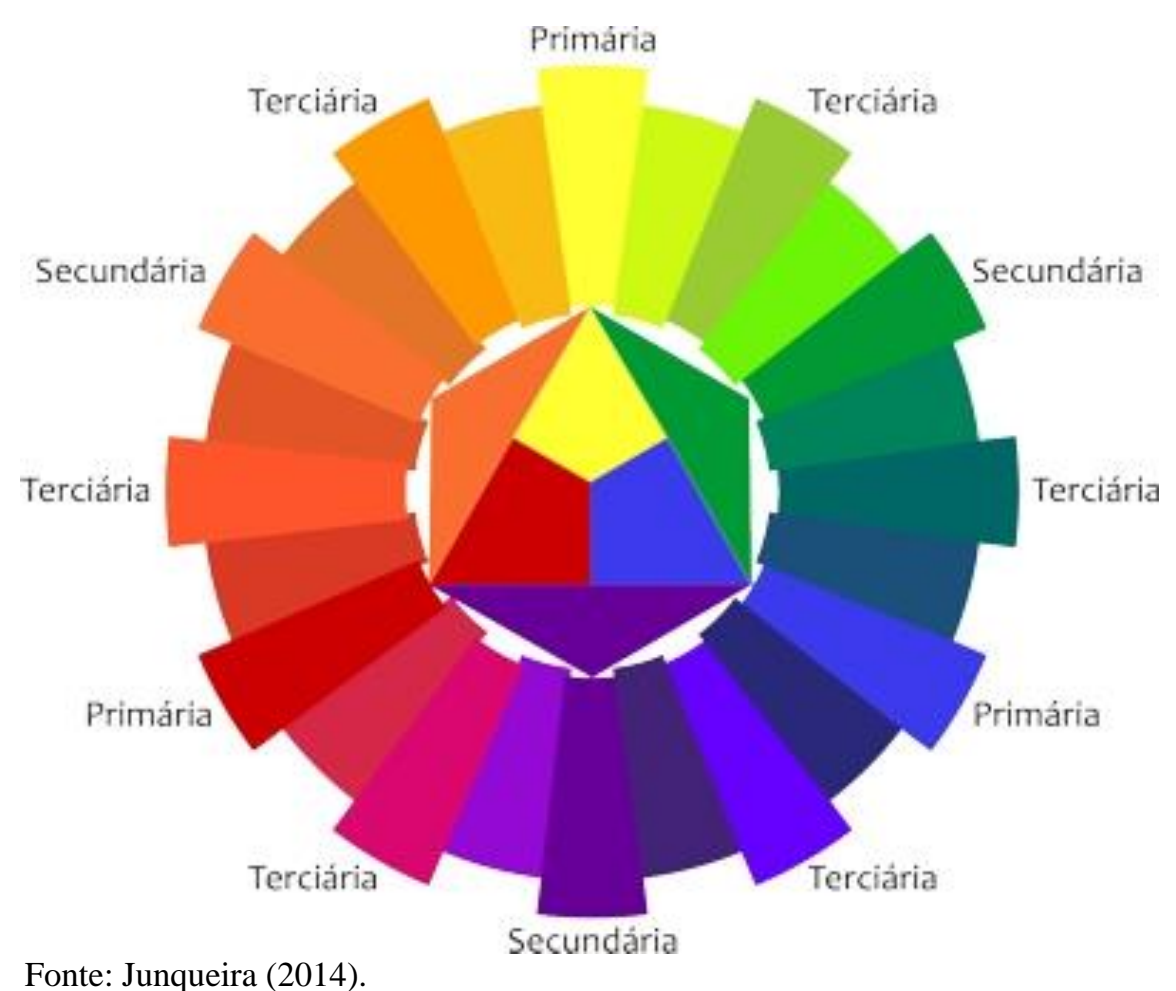

Na figura acima cada cor secundária está oposta à sua cor complementar e contígua às cores que a produziram por meio de mistura. Complementares são cores feitas a partir de 
mistura de uma cor primária e outra cor. Por exemplo, o verde é a cor complementar da cor primária vermelha. Ele é obtido pela mistura das outras duas primárias (amarelo e azul). $\mathrm{O}$ amarelo é a cor complementar do roxo, que é a mistura das primárias: azul e vermelho. As cores complementares podem também ser vistas como imagens residuais, quando olhamos fixamente para uma cor, por exemplo, vermelho e fechamos os olhos em seguida, se fechamos os olhos ou olhamos para uma parede ao lado da cor, "veremos" uma "imagem residual" da cor verde.

Com a descoberta de Newton das cores prismáticas, preto e branco passaram a ser compreendidos como modificações da cor e não como cores, mas como graus distintos de luminosidade ou escuridão de uma determinada cor e como uma dimensão separada, o valor da cor (ou,'brilho'). A partir disso, a teoria moderna das cores encontrou sua forma atual com as ideias do pintor Inglês Moses Harris (1731-1785), que propôs dois outros aspectos da cor: valor (que ele chamou de "intensidade") e saturação. A Figura abaixo mostra nove valores de 12 cores primárias, secundárias e terciárias, com as cores "puras", conectadas no meio do círculo.

A saturação ou o grau de pureza de uma cor foi o segundo aspecto adicionado ao círculo cromático. Podemos obter os diferentes graus de saturação misturando diferentes graus de cinza (ou da cor complementar) com a cor, para mantê-la igualmente clara ou escura, suavizando-a gradualmente, até um grau de "cinza cromático", que possui um toque leve da cor, e depois até um "cinza acromático", que é um cinza incolor. Moses Harris (apud VAN LEEUWEN, 2011) propôs um círculo cromático com 660 cores diferentes geradas por 18 tons, 20 níveis de valor e 20 níveis de saturação, tendo usado apenas 33 nomes de cores.

Diferentes níveis de saturação podem ser vistos na Figura abaixo: 


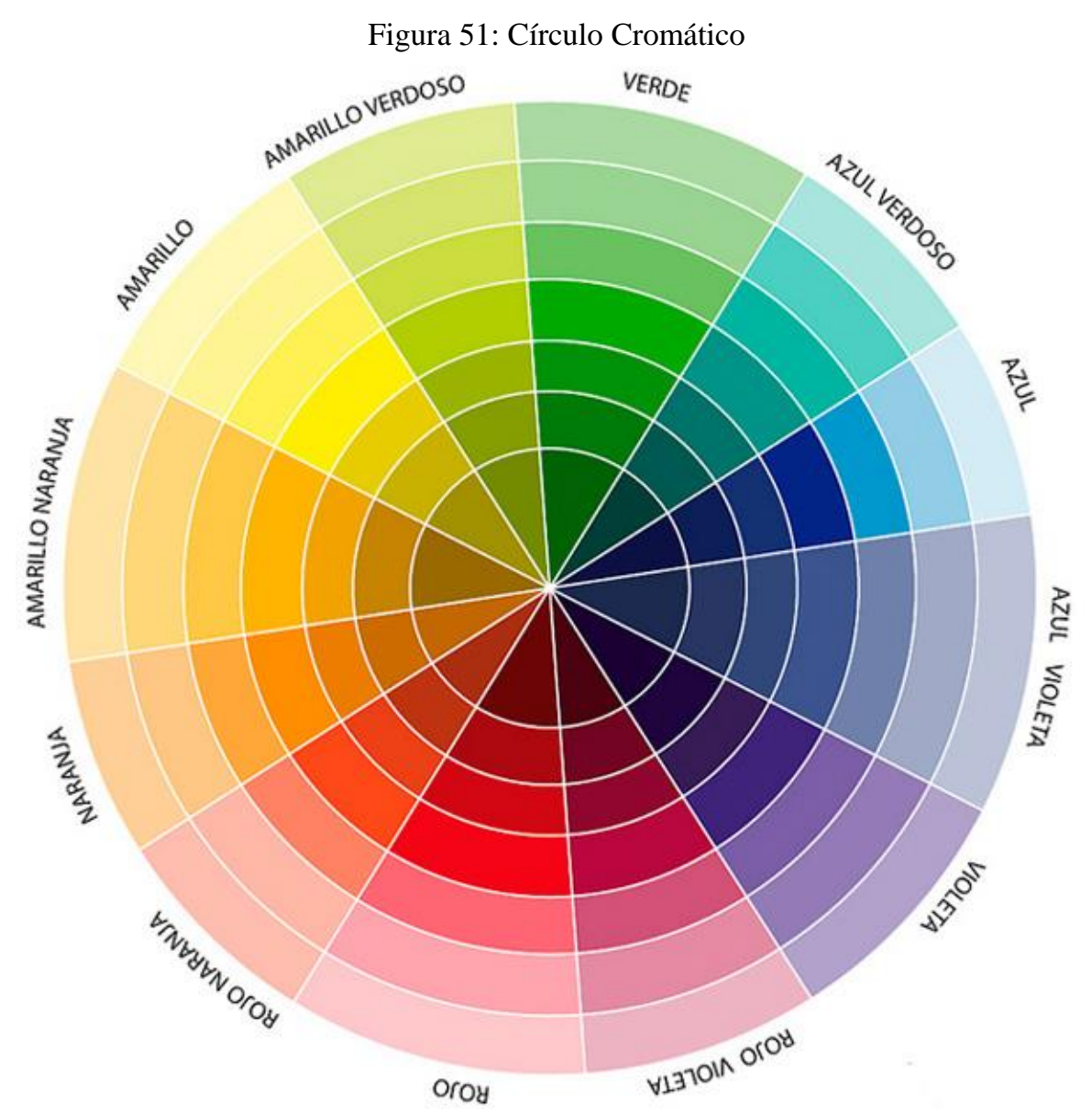

O pintor alemão Philip Runge (1777-1810) propôs um círculo cromático em três dimensões, em forma de esfera na qual as cores puras ficavam na linha do equador, e os valores acompanhavam a linha do eixo vertical com gradações de claro a escuro: até o branco no pólo norte ou o negro no polo sul negro. No centro da esfera a cor era cinza, assim a linha que acompanha um tom puro para o centro vai se suavizando gradativamente, em direção a um cinza acromático para o qual todas as cores são drenadas. A disposição das cores no equador da esfera faz com que cada cor fique oposta à sua complementar. Runge acreditava que este sistema não apenas classificava as cores, mas também expressava uma ordem divina.

O pintor e teórico da cor americano, Albert Munsell (1858-1918), adaptou o sistema de cor proposto por Philip Runge para um sistema que se encontra em uso hoje. Ele usou a mesma concepção tridimensional, mas distinguiu como cores principais somente cinco cores primárias, amarelo, vermelho, verde, azul e roxo, e para cada uma delas as seguintes complementares: 
Amarelo - Azul-roxo

Vermelho - Azul-verde

Green - Vermelho-roxo

Azul - Orange

Roxo - Amarelo- verde

Munsell (1969 apud VAN LEEUWEN, 2011) inovou o sistema acrescentando um sistema numérico. Do claro ao escuro em uma escala de dez etapas as cores puras eram 5 na linha do equador, e recebiam mais uma letra para indicar a cor, como no caso do amarelo puro, que seria 5Y. Números intermediários eram dados para as cores intermediárias, por exemplo, seria 10R uma intermediária entre o vermelho e o alaranjado. Um número adicional em uma escala de dez era dado para o valor, por exemplo, um rosa muito claro seria 5R9. Um número a mais expressava a saturação, num sistema de frações iguais que ia do cinza neutro até a maior saturação. Nessa escala de saturação cada cor poderia ter um valor específico 5R5 / 14 expressa um valor médio do vermelho puro. Esse sistema Cromático foi publicado em 1915, e em 1929, tendo sido adotado pela Associação Americana de Normas e tornou-se uma referência para especificar a cor na confecção de tintas, corantes, na produção de cosméticos, software de computador e no design de interiores.

A questão de que as cores podem produzir todas as outras pela mistura não é o
mesmo que a questão de quais as cores que são percebidas como simples e
irredutíveis, e grande parte das diferenças entre os vários sistemas se relacionam
com essas diferentes questões e as diferentes finalidades por trás deles. (ARNHEIM,
1974, p.340).

Para ilustrar essa afirmação de Arnheim (1974), van Leeuwen (2011) argumenta que os pintores modernos, determinam as suas próprias paletas e nelas suas próprias cores 'primárias' e 'irredutíveis'. Essas nada têm a ver com as paletas bem ordenadas dos pintores da Renascença. Como eram as paletas usadas por Van Gogh? Que cores eram para van Gogh primárias e irredutíveis? Seu auto-retrato de 1888 mostra-o com uma paleta contendo principalmente laranja, vermelho, azul e verde, ainda perto das primárias tradicionais. 


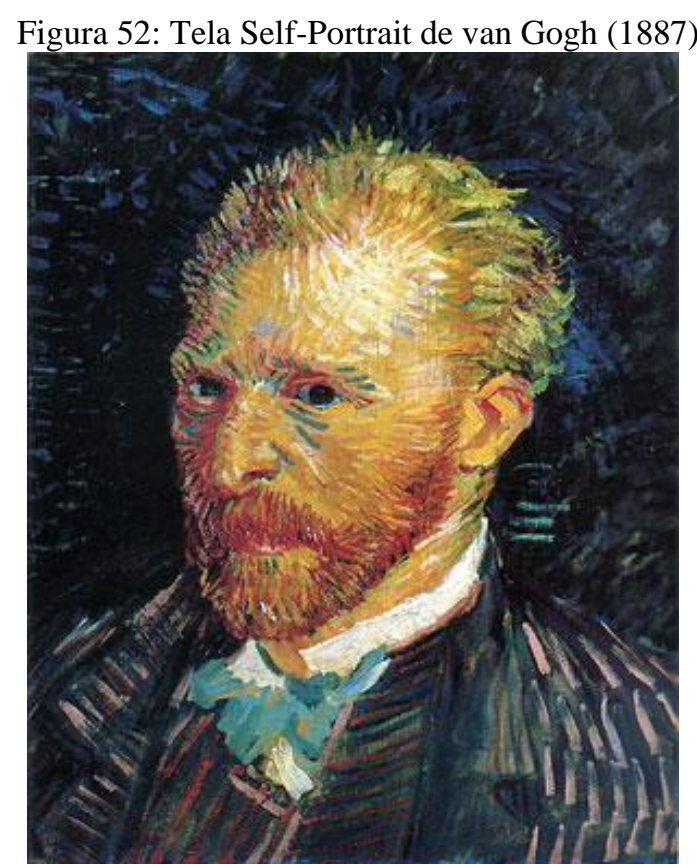

Fonte: Van Gogh (1887b).

Matisse (1973 apud VAN LEEUWEN, 2011) não seguia o sistema tradicional da composição das paletas. Contendo 17 cores em uma composição aparentemente arbitrária, guiava-se pelas características materiais das cores, pela sua sensação na retina, e pela sua vitalidade tátil. (MATISSE, 1973 apud VAN LEEUWEN, 2011).

Da mesma forma, Van Gogh explorou e experimentou as qualidades materiais das cores em suas telas, e pelas sensações visuais e táteis que essa materialidade, articulados com os demais recursos semióticos produzia.

Se por um lado a prática dos pintores fundamentou o desenvolvimento da teoria moderna da cor, já a prática da impressão gráfica a cores e da fotografia a cores necessitavam de cores primárias diferentes daquelas que fundamentaram a teoria das misturas cromáticas de tintas e pigmentos. O inventor da impressão gráfica em cores, Jacques Christophe Leblon (1667-1742), descobriu que a ideia de que o vermelho, amarelo e azul seriam capazes de gerar todas as outras cores não funcionava na prática quando se tratava de impressão gráfica colorida. Ele observou que as cores menos puras misturavam melhor e propôs o sistema de cores para a impressão contemporânea chamado CMYK que são as iniciais das 'primárias' por ele propostas: Ciano, Magenta e Amarelo, sendo que o K representa 'chave' ou preto.

As cores secundárias podem ser geradas a partir dessas cores da forma seguinte:

Amarelo + Ciano $=$ Verde

Ciano + Magenta $=$ Roxo 
Magenta + Amarelo = Laranja

Essas misturas podem gerar as seguintes cores terciárias - porém nelas o vermelho e o azul, paradoxalmente, se tornam cores terciárias aqui:

Amarelo + Verde $=$ amarelo- verde

Verde + Ciano $=$ Verde-azul-verde

Ciano + Violeta $=$ Azul

Violeta + Magenta $=$ Vermelho-violeta-vermelho

Magenta + Laranja $=$ vermelho

Laranja + Amarelo = amarelo-laranja

Os sistemas cromáticos foram se complexificando com o advento da impressão a cores e dos meios eletrônicos nos quais a cor era projetada por uma fonte luminosa. Quando se trata de imagens projetadas, a mistura de cores funciona de forma diferente, por meio da mistura aditiva, em vez de mistura subtrativa. No século XIX, o físico Hermann von Helmholtz (1821-1894) observou e sistematizou a diferença entre a mistura subtrativa e a mistura aditiva de cor, e demonstrou que as cores projetadas são mais intensas e possuem maior saturação do que as cores refletidas. As cores projetadas vão ficando mais saturadas na medida em que vão sendo misturadas, vão adicionando sua luz ao resultado final da mistura. Nas cores do mundo real, que são refletidas, cada cor que participa da mistura retira a luz, tornando a mistura subtrativa, e levando o resultado final da mistura um passo mais perto do preto.

\subsubsection{A materialidade da cor}

Van Leeuwen (2011) argumenta que a teoria moderna da cor a concebe como um "modo", um sistema abstrato, que gera os tons que são modificados pelo valor e pela saturação. Essa perspectiva relega para o segundo plano as qualidades materiais específicas das substâncias da cor, ainda que na idade média essas mesmas qualidades tenham tido uma importância central, mais central até do que o matiz. Essas qualidades materiais da cor, no entanto, sempre estiveram lá e mesmo quando elas foram relegadas para o segundo plano, elas continuaram a ser notadas e apreciadas. Mas no ultimo século, isso começou a mudar. Há quase um século, Tarabukin, crítico de arte russa argumentou que "os materiais das cores tem em si mesmos um valor estético autônomo, que não se esgota com o matiz" (GAGE, 1993, p. 
225 apud VAN LEEUWEN, 2011), fazendo um paralelo entre estes e os timbres dos instrumentos musicais, que resultam dos materiais usados para fazê-los. Ele ressaltou que no passado os materiais eram considerados um aspecto inferior.

As qualidades materiais da cor são descritas por van Leeuwen (2011):

\section{a) Luminosidade e luminescência}

A luminosidade é uma qualidade da cor quando ela consegue brilhar desde o seu interior. Quando as cores são mais claras e mais saturadas, elas adquirem essa qualidade mais luminosa. No entanto a luminosidade de uma cor pode advir também da refração das cores vizinhas. Na prática os pintores aumentam a capacidade luminosa de uma cor intensa cercando-a com cores menos saturadas, menos intensas, mais escuras, e "talvez em tons complementares, por exemplo, a luz alaranjada do sol refletida na água, cercada por água azul escura, como em Le Soleil dans le Brouillard (1904) de Monet".

A qualidade da luminosidade, ou brilho da cor, tem sido muitas vezes altamente valorizada, como o louvor ao roxo de Plínio explica Gage (1993, p. 25 apud VAN LEEUWEN, 2011, p. 36):

Essa cor preciosa que brilha com matiz de uma rosa escura... Este é o roxo para o qual os machados romanos abrem um caminho. É o emblema da nobre juventude; que distingue o senador do cavaleiro; ele é chamado para apaziguar os deuses. Ele ilumina cada peça de roupa e compartilha com Deus a glória do triunfo.

A cor quando é luminescente, brilha ou irradia porque é iluminada por trás, por exemplo, o vitral, ou a luz néon. Ou por ser uma fonte de luz, como as chamas de gás ou o brilho de radiadores.

\section{b) Lustro e iridescência}

O lustro ('brilho', 'fulgor') de uma cor é o resultado da reflexividade de superfícies coloridas ao invés da transmissão ou emissão de luz colorida. Superfícies reflexivas são obtidas por meio de sugestão pelos pintores ao usarem destaques e sombreando-as nas cores dos objetos que as cercam cujas cores as superfícies refletem. O uso de cores para sugerir brilho não é igual ao uso de cores brilhantes. Assim como a luminosidade, o brilho tem sido um aspecto fundamental das cores mais altamente valorizadas, como o ouro e o roxo. "Foi provavelmente o brilho, não o matiz, que proclamou o seu verdadeiro Púrpura Imperial" na veste da imperatriz Theodora em Ravena (c.540) (GAGE, 1993, p. 55 apud VAN LEEUWEN, 2011, p. 36). 
A iridescência pode ser um efeito do movimento que dá a impressão de que as superfícies e objetos brilham quando em movimento, ou quando o espectador se move e muda o ponto de vista, como por exemplo, nos mosaicos nas igrejas bizantinas, nos quais o movimento do espectador ajudava a criar brilho e fulgor. A iridescência adquiriu uma importância central nos mosaicos que representavam santos, nos quais a as auréolas eram feitas com cubos ligeiramente inclinados em forma de tabuleiro de damas para obter um brilho extra por meio de um sombreamento que aumentava a percepção de brilho dos objetos macios ou brilhantes. (GAGE, 1993 apud VAN LEEUWEN, 2011). Esse efeito de brilho simbolizava a luz da fé e da santidade. O brilho e cintilância tiveram importância central ainda no século $\mathrm{XV}$, de tal forma que as algumas pinturas eram cravejadas com joias reais e ouro para obter como efeito o fulgor. (GAGE, 1993 apud VAN LEEUWEN, 2011).

\section{c) Transparência e translucidez}

A transparência é uma qualidade da cor quando ela é transpassada pela luz deixando visíveis os objetos que estão por trás do primeiro plano. A aquarela ou o tingimento colorido na madeira são um exemplo da transparência na cor, fundindo a cor com o seu suporte, ela se sobrepõe a ele como fina camada transparente que lhe empresta uma qualidade menos material, mais etérea.

As superfícies translúcidas bloqueiam a luz que as atravessa de forma parcial, e dá aos objetos que estão por trás do primeiro plano uma característica macia e imprecisa, como se estivessem por detrás de um véu ou gaze. Leonardo da Vinci observou que os objetos a distância adquirem uma qualidade de translucidez: parecem mais claros em seu matiz e também mais similares em tom e valor, seus contornos e as cores de seus fundos parecem mais suavizados. (VAN LEEUWEN, 2011).

\section{d) Temperatura}

A qualidade da temperatura na cor é expressa pela ideia de que as cores da extremidade vermelha do espectro são quentes e as cores na extremidade azul do espectro são frias. Essa percepção de que a cor tem uma 'temperatura' é empregada para criar a ilusão de distância, fazendo os objetos do fundo da imagem parecerem mais distantes ao construir uma gradação de azuis claros enquanto faz-se os objetos próximos do primeiro plano parecerem avançar, aplicando mais vermelhos. 
Van Gogh usava essa técnica criando contrastes entre quentes e frios, e usando cores quentes para fazer as formas no primeiro plano avançarem e cores frias para aumentar a sensação de profundidade nas formas do fundo. Como, por exemplo, a tela Por de Sol: Campo de trigo perto de Arles (1888) que é analisada nesta pesquisa.

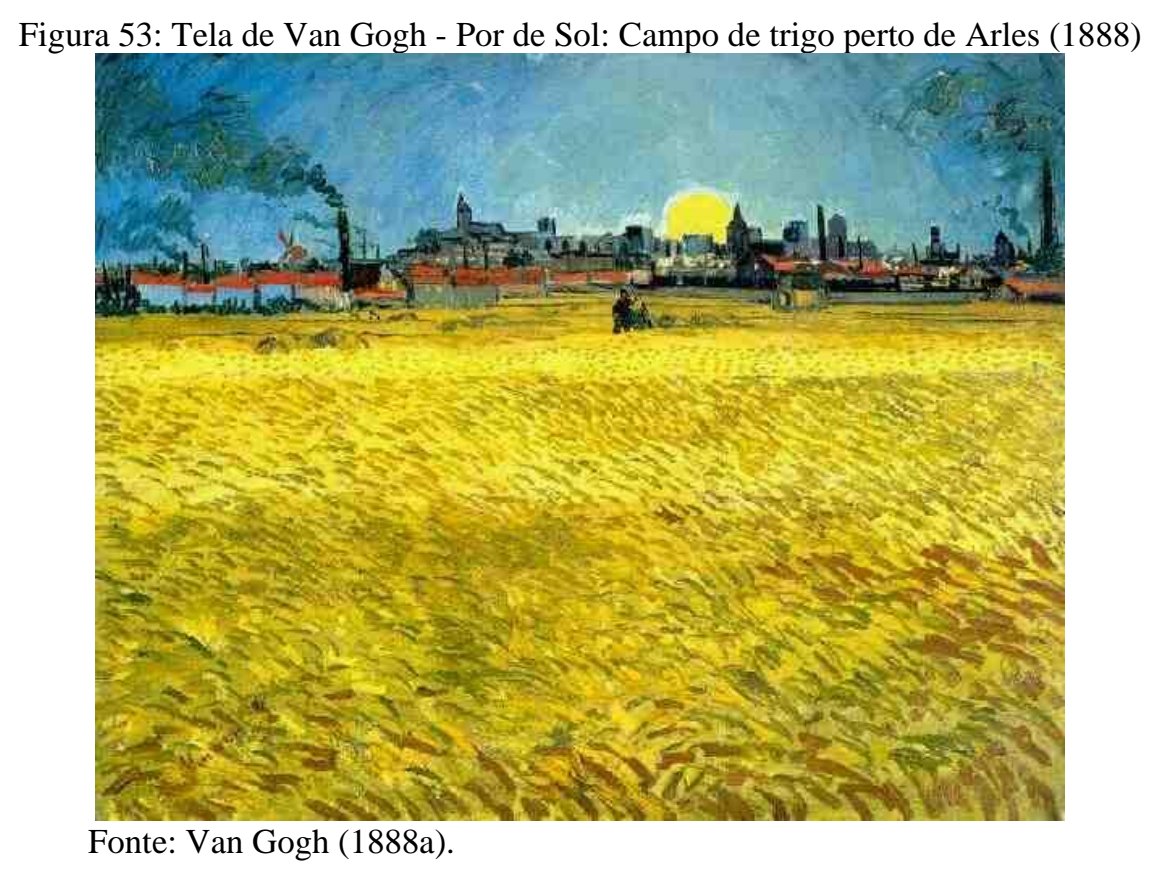

Para Albers (1975 apud VAN LEEUWEN, 2011), a percepção de temperatura de uma cor depende das cores próximas a ela, sendo que uma cor é 'influenciada' por outra cor 'influente'. Já Arnheim (1974) argumenta que a temperatura de uma cor não é percebida apenas pelo seu matiz, mas é influenciada por seu valor e saturação. Para ele, a qualidade de uma cor de ser quente ou ser fria não está na cor em si mesma, mas em um efeito no qual "é somente quando uma cor produz um efeito de tensão dinâmica, inclinando-se em direção a uma outra cor que revela suas características expressivas" (ARNHEIM, 1974, p. 36-37).

\section{e) Textura}

Um conjunto de qualidades da cor é descrito como textura, tanto a transparência e brilho, quanto qualidades texturais materiais que influenciam a cor, como a aspereza e suavidade. De acordo com Feisner (2006 apud VAN LEEUWEN, 2011) as texturas mais ásperas fazem as cores parecem mais escuras e mais quentes; as mais lisas e brilhantes parecem ter uma temperatura 'fresca'. Com impressionismo, a textura adquiriu proeminência na composição uma vez que os impressionistas se preocupavam com a materialidade da 
pintura, usando para isso telas ásperas e tintas rígidas para criar um efeito visual tátil por meio de pinceladas visíveis. A partir daí a materialidade dos recursos usados tais como tintas e telas tem tido um papel importante para os artistas. (VAN LEEUWEN, 2011).

Van Leeuwen (2011) argumenta que essas qualidades da cor têm sido marginalizadas pela teoria moderna da cor uma vez que eles não se encontram representados nos esquemas visuais da teoria da cor (rodas de cores e esferas de cores). Para ele, a teoria da cor está centrada em uma perspectiva na qual os recursos semióticos são vistos como "modos" e abstraídos de sua qualidade material e de seu potencial expressivo. Essa perspectiva está baseada em uma longa tradição filosófica e tem sido uma tendência de pensamento que abrange outros campos científicos. Como exemplo, ele cita a teoria musical que está centrada na e abstrai os timbres específicos das vozes e instrumentos musicais e algumas vertentes da linguística que favorecem as gramáticas que abstraem suas teorias dos aspectos físicos da fala, da escrita e da tipografia.

\section{f) Harmonia da Cor}

Van Leeuwen (2011), Arnheim (1974) e Itten (1973) defendem a necessidade de levar em consideração não apenas as qualidades das cores individualmente ou como elas se misturam para obter outras cores, mas como elas interagem, se combinam e exercem influencia umas com as outras. As cores são o resultado do reflexo da luz nas superfícies e por isso, elas refletem de volta a luz de seu matiz nos objetos e superfícies em volta. Ou seja, as cores não estão apenas nos objetos individualmente, elas estão ricocheteando, vindo e voltando, criando uma trama refratária invisível que tinge, acrescenta, modifica com novos matizes tudo a sua volta. Se fossemos representar em uma tela com esse fenômeno do comportamento refratário da luz no ambiente - que é imperceptível aos nossos olhos - esta seria a de uma trama dinâmica de raios coloridos circulando, ricocheteando, saracoteando no espaço, desenhando linhas de suas trajetórias em uma trama vibrante e incessante. Nessa cena, a cor de cada objeto sólido ou superfície receberia esse bombardeio de luzes refletidas de outros objetos e outras superfícies e seriam por elas alterados em seus matizes originais. No mundo real, a cor de uma superfície é alterada pelas cores das superfícies que a cercam. $\mathrm{Na}$ pintura, por exemplo, os matizes de cada superfície são alterados por cada novo acréscimo de um matiz em outro lugar da composição, por estarem inter-relacionados nesta trama integrada e esta interdependência atua de modo a tornar fria uma tonalidade que parecia quente antes de ser adicionada uma cor mais quente em outro lugar da composição. Essa constante 
interferência recíproca das cores torna a busca de harmonização das cores um trabalho de atenção, percepção e foco contínuo na inter-relação das cores e na dinâmica que resulta que daí resulta.

A observação sistemática da interação entre as cores foi iniciada no Renascimento, pela busca dos artistas para aperfeiçoar as técnicas para produzir a ilusão de profundidade nas telas. A forma como as cores complementares interagem para se realçarem mutuamente foi uma descoberta de Leonardo da Vinci. Ele observou que a tonalidade do sombreamento usado para modelar o volume e a profundidade não depende apenas da gradação menos saturada da mesma cor, mas que a sombra adquire um pouco do matiz das superfícies que a rodeiam, como chão, paredes, janelas e objetos próximos. Esta descoberta transformou-se em uma prática pictórica que dura até hoje de adicionar na tonalidade dos sombreamentos, a cor do próprio objeto da sombra e a cor dos objetos em volta.

As áreas iluminadas de uma forma chamadas aqui de destaque são mais coloridas, não apenas com a cor mais saturada do que a cor do objeto, mas com a cor mais saturada da cor primária que está próxima dele. As sombras que o objeto projeta tem a cor do objeto e a cor das superfícies em volta. No caso de uma laranja sobre uma toalha verde, a área iluminada da laranja tem um valor de laranja mais saturado, e o seu sombreamento, um valor de laranja mais escuro. A área sombreada da laranja será mais escura e menos saturada, com um pouco de verde. A sombra projetada vai ter um pouco mais de verde, menos saturado, e a sombra será verde escuro opaco com uma mistura de laranja, suavizando a tonalidade em direção as bordas.

O uso da cor também ajuda na ilusão de profundidade porque no primeiro plano as cores são mais quentes e mais saturadas. As cores do fundo são mais homogêneas em tonalidade e valor, mais frias e menos saturadas. As cores também são usadas como recursos semióticos para criar efeitos de textura, de destaque, de transparência, de refletividade. Estes são aspectos da interação da cor que podem ser usados para aumentar a ilusão de textura, volume e profundidade em imagens representadas em superfícies bidimensionais.

Michel Chevreul (1786-1889) teorizou essas descobertas. Como fabricante de tapeçaria, Chevreul descobriu que suas cores não funcionavam por causa da influência das outras cores próximas. Ele observou a 'lei do contraste simultâneo' que Da Vinci (2005 apud VAN LEEUWEN, 2011) e Goethe já haviam descoberto acerca das cores complementares. As cores complementares se intensificavam mutuamente e as não complementares "contaminavam" umas as outras. Goethe (1970 apud VAN LEEUWEN, 2011) argumentou que se olhamos o mesmo vermelho, antes sobre o amarelo e depois sobre o violeta, veremos 
dois vermelhos distintos: o primeiro será um vermelho escuro, o segundo terá um matiz alaranjado. Um amarelo poderá adquirir um tom de violeta se estiver próximo a um verde. Esta descoberta mudou a prática pictórica: os pintores sugeriam formas por meio do desenho de linha e passaram a sugerir formas por meio dessa ressonância do contraste da cor.

\section{g) Contraste Complementar ou Simultâneo}

Este contraste ocorre quando uma cor está contígua à sua complementar produzindo um efeito de intensificação mútua por meio de seu contraste. Os contrastes simultâneos são, por exemplo, verde vermelho; laranja e azul; violeta e amarelo.

Apesar da busca dos impressionistas de 'registrar impressões' e de representar o mundo como eles o viam subjetivamente, o estudo da interação entre as cores esteve a serviço da representação do mundo real pelo viés da percepção subjetiva do artista, ainda que se distinguisse do naturalismo da Renascença no qual os artistas buscavam pintar o mundo objetivamente. Tanto na arte abstrata, quanto na teoria moderna da cor, a preocupação não está no uso da interação das cores para a representação, mas nas ideias mais formais e estéticas sobre como, porque e quais cores se combinam.

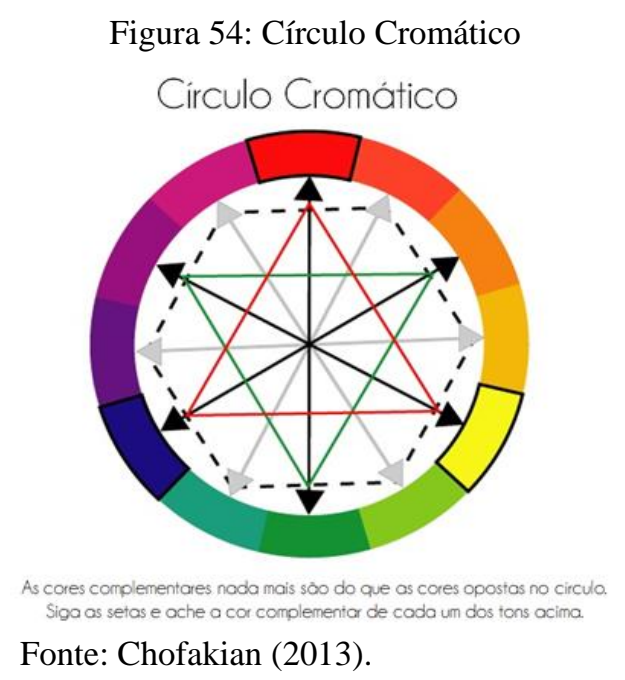

Van Leeuwen (2011) argumenta que as teorias sobre a harmonia das cores se baseavam na roda de cores que só representava o matiz e a complementaridade entre as cores excluindo dessa representação outros aspectos da cor como a sua materialidade, por exemplo.

Algumas variações o círculo cromático representam dois conjuntos de cores complementares, chamado 'Esquema Complementar Duplo de Cores'. No primeiro conjunto, os complementares opostos tais como azul/ laranja e verde/vermelho. No segundo conjunto, 
chamado de 'Esquema Complementar Dividido', qualquer cor pode ser combinada com duas cores adjacentes da sua cor complementar, tais como vermelho/ amarelo-esverdeado/ azulesverdeado. Também há um conjunto chamado de 'Harmonia de adjacentes' que combina três ou mais cores que são adjacentes entre si em uma roda de cor tais como amarelo-alaranjado/ laranja/ vermelho. Há o 'Esquema triplo de cores' que combina três cores equidistantes entre si na roda, tais como amarelo/ laranja/ vermelho, ou amarelo/ vermelho/ azul.

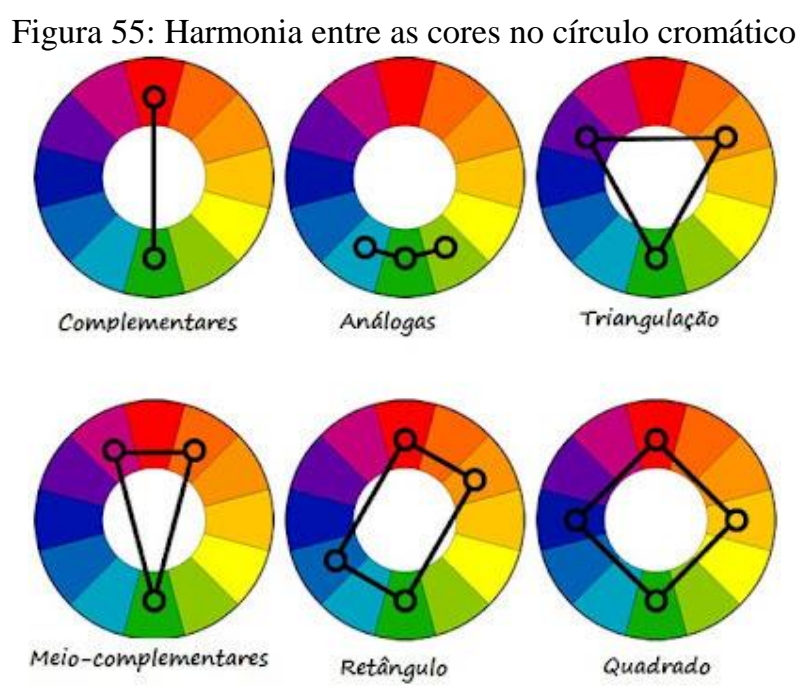

Fonte: Palmeira (2014).

\section{h) Modulação para a harmonia dos núcleos}

A cor pode ser harmonizada com base no valor e na saturação, dimensões que não são levadas nas teorias modernas da cor. Scott-taylor (1935 apud VAN LEEUWEN, 2011) chamou de 'harmonias monocromáticas' aquelas combinações entre valores diferentes da mesma cor. Ele experimentou com combinações entre quatro valores de duas cores complementares, tais como verde/ vermelho. Também desenvolveu esquemas de tríades equidistantes, pois elas também são complementares. Segundo Itten (1970 apud VAN LEEUWEN, 2011), importante teórico da cor que participou da Bauhaus, foi influenciado por Ostwald e desenvolveu o conceito de "modulação" da cor na qual se combinam muitos matizes e tons variantes de uma única cor principal. De acordo com Itten, na modulação, três dimensões são combinadas: a) a temperatura, que combina os tons frios e quentes; b) o valor, que combina o claro e o escuro; c) a saturação, que combina o opaco e o brilhante. Para Itten, qualquer contraste pode ser o ponto de partida para a criação de esquemas harmônicos de cores desde que se busque harmonizar elementos em comum, sendo eles a temperatura, o valor e a saturação. Munsell (1969 apud VAN LEEUWEN, 2011) corroborou com essa visão 
e desenvolveu um círculo cromático no qual o centro funcionava como "o ponto de equilíbrio para todas as cores, de modo que qualquer linha reta através desse centro iria ligar automaticamente as cores de harmonização" (VAN LEEUWEN, 2011, p. 39).

\section{i) Dissonância}

A noção de consonância e dissonância na teoria musical foi transportada para a teoria das cores por teóricos que defendem que em música a noção de harmonia implica em dissonância, porque a narrativa musical, seu interesse e drama se baseia no 'ir e vir' entre dissonância e consonância. Van Gogh (2009h, p. 1) trabalhava a dissonância nos contrastes das cores, até nas cartas como a seguir:

Na minha pintura do café à noite eu procurei exprimir que o café é um lugar onde você pode arruinar-se, enlouquecer, cometer crimes. De qualquer forma, eu tentei com contrastes de rosa delicado e vermelho-sangue e vinho tinto. Verde doce Luís $\mathrm{XV}$ e Veronese contrastando com os verdes amarelos e os verdes azuis duros. Tudo isso em uma atmosfera de fornalha infernal, de enxofre pálido. Exprimir como a potência dos cantos escuros de uma taberna. Contudo sob uma aparência da alegria japonesa e da boa natureza de Tartarin.

Van Gogh procurou essas combinações dissonantes, bem como as consonantes para construir as semioses nas funções modal, representacional e composicional, como vemos na tela abaixo:

Figura 56: Café in the Place Lamartine in Arles, (1888).

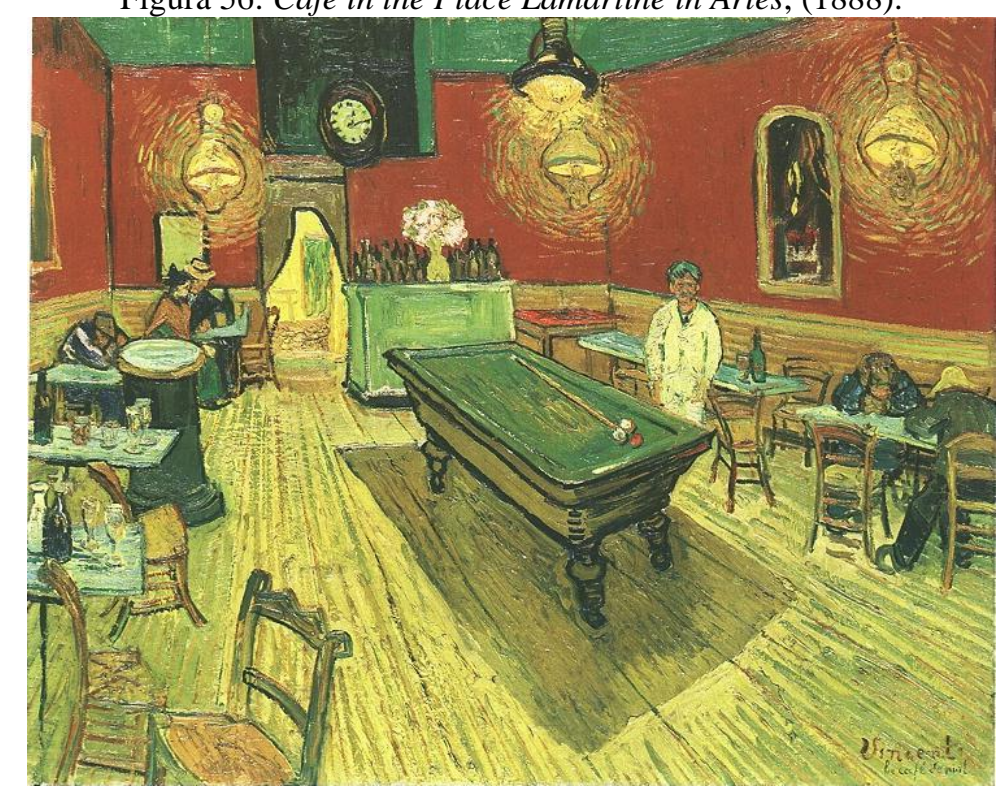

Fonte: Van Gogh (1888d).

A busca da harmonia 'consonante' das cores parece ter sido uma noção muito útil para as semioses das estéticas que abrangem o período do renascimento até o classicismo, mas 
levanta muitos questionamentos para os usos semióticos da cor atualmente tais como: se a pode ser considerado um tipo de harmonia das cores uma combinação na qual as cores se harmonizam com uma única cor dissonante que se destaca e dinamiza o todo? Para Arnheim (1974), perturbar o equilíbrio com conflito e discórdia não são necessariamente ruins se eles têm um papel e se encaixam na estrutura geral do trabalho. A noção de harmonia de cores com base no critério de semelhança e concordância é questionada por Arnheim como:

O tipo mais primitivo de harmonia, adequado na melhor das hipóteses para os esquemas de cores de creches e roupas de bebê... A composição de cores com base em nada além de um denominador comum poderia descrever apenas um mundo de paz absoluta, desprovido de ação, estático em humor. Representaria um estado de serenidade mortal em que, para usar a linguagem da física, a entropia se aproxima de um mínimo absoluto. (ARNHEIM,1974, p. 348)

Albers (1975, p. 42 apud VAN LEEUWEN, 2011, p. 159), outro teórico da cor também questionou a limitação do enfoque tradicional da harmonia das cores para a expressão artística:

Podemos esquecer por um tempo essas regras de ouro de complementaridades, sejam completas ou 'divididas', de tríades bem como de tétrades. Elas estão desgastadas... Nenhum sistema de cor mecânica é suficientemente flexível para précalcular os múltiplos e mutáveis fatores, como nomeados antes, em uma única receita. A boa pintura, a boa coloração é comparável à boa culinária. Mesmo uma boa receita culinária exige degustação e repetidas degustações enquanto ela está sendo preparada. E a melhor degustação ainda depende de um cozinheiro com bom paladar. Ao abrir mão da preferência pela harmonia, aceitamos que a dissonância seja tão desejável quanto à consonância.

A noção de harmonia das cores busca criar ordem e ser agradável ao invés de ser perturbadora. Esse enfoque tradicional de harmonia ainda é preponderante no ensino da teoria da cor e recomenda uma combinação de cores coerentes, ritmicamente distribuídas para obter unidade. Recomenda também a busca do equilíbrio entre claridade e sombra de forma que uma combinação de poucas cores é mais agradável do que uma com muitas, mas uma com poucos tons, porém que se diversificam em muitos valores tende a ser mais agradável.

Feisner (2006 apud VAN LEEUWEN, 2011) pontua que a harmonia somente pode ser perturbada em algum grau quando houver a necessidade de dar ênfase, criando uma área de importância para onde o olhar do espectador deve focar. Ele recomenda o uso de cores dominantes (altamente saturadas) para contrastar com cores próximas menos dominantes (menos saturadas).

Outros autores encorajam a exploração de combinações tanto consonantes quanto dissonantes. Alguns exercícios são recomendados por Hornung (2005 apud VAN LEEUWEN, 2011) para explorar princípios mais flexíveis para a criação de esquemas de cores tais como 'cores com muito em comum', 'quaisquer duas cores', 'duas cores completamente diferentes (juntamente com um conjunto de cores que ajude a transição entre 
elas)', e 'anomalia da cor (introduzindo uma cor que vai contra a coerência do todo'), ou por meio de inventariar as cores de um objeto, seja ele natural ou feito pelo homem.

No enfoque moderno, a teoria da cor reconhece três dimensões da cor: matiz, valor e saturação, enfatizando o matiz em detrimento do valor e da saturação. Ela se concentra principalmente em classificá-las e hierarquizá-las em cores 'puras' e cores 'mistas', e em abstrair esquemas de harmonia de cores com base nessas classificações. Alguns teóricos da cor argumentam que nesse enfoque a materialidade da cor, enquanto uma dimensão da cor foi colocada de lado em favor dos aspectos mais facilmente abstraíveis e teorizáveis da cor. A materialidade da cor compreende aspectos igualmente importantes no uso semiótico da cor, tais como luminosidade e brilho e que foram posteriormente ainda mais esquecidos com o avanço das imagens digitais e da desmaterialização da cor nas telas luminosas das novas mídias. No entanto, a materialidade da cor está abrindo espaço a partir da discussão de filósofos pós-modernos, teóricos culturais e artistas do século XX e XXI.

Van Leeuwen argumenta que há uma fragmentação entre a teoria moderna da cor que estuda a forma da cor e a psicologia das cores que estuda o significado da cor. Ele explica que a teoria moderna da cor se limita a classificar a cor e seus aspectos com base em um enfoque puramente formal e estético sem levar em consideração com o que e como a cor comunica. Essa desintegração entre estas duas dimensões forma e significado é insustentável para o estudo semiótico da cor que busca compreender como "a forma como os recursos da cor e os seus usos são socialmente estruturados para permitir que o tipo de expressão cultural e comunicação social que a sociedade necessita” (VAN LEEUWEN, 2011, p.40).

\section{j) Significado da Cor}

A área da psicologia tem estudado os significados da cor, no entanto, em sua perspectiva a cor tem significados universais, ainda que ela leve em consideração as diferenças nas culturas locais e em segmentos sociais diversificados. Esse olhar sobre a cor vê os significados das cores como quase instintivos, como afetivos, como expressão da personalidade, e como 'conotativos'. Para Jakobson (1960 apud VAN LEEUWEN, 2011), a cor tem um efeito direto no comportamento, seja ele calmante ou estimulante.

Van Leeuwen (2011) argumenta que essa visão instintiva não se adéqua ao perfil da vida atual, na qual as pessoas são ensinadas a associar significados para as cores, tais como as cores da moda, por exemplo, que são compartilhados nas mídias de comunicação e interação. No entanto, a área da semiótica pode contribuir com essa discussão sobre os significados da 
cor com base nas referências históricas e culturais, ao invés dos adjetivos da psicologia mais focados no afeto e no humor.

Atualmente as duas abordagens coexistem sem se excluírem mutuamente, mas também sem se integrarem. Os designers de moda, às vezes, falam em termos de preferências de cor e psicologia da cor, outras vezes em termos de esquemas de cores que são inspirados por referências histórico-culturais. Outra inconsistência entre a abordagem psicológica e a abordagem cultural é que quando a preferência de cores se baseia nos traços de personalidade estes sentidos são mais enraizados e difíceis de mudar; quando a preferência de cores se apoia nas referências culturais e históricas das cores, são mais mutáveis porque elas podem ser associadas a qualquer cor, facilitando a reinterpretação das cores, reconectando-as àqueles temas com ressonância cultural atual, para se afinar com as mudanças constantes. Nesse enfoque, as preferências baseadas no 'caráter' podem ser tornar 'identidade de estilo de vida', que pode ser alterada e na qual as crenças e os valores são expressos pelas preferências e escolhas dos consumidores, ao invés em vez de sê-lo pelos traços de personalidade. Van Leeuwen (2011) propõe um sistema para integrar a discussão da cor matiz, da roda de cores, do espectro de cores, da psicologia da cor. Van Leeuwen (2011) propõe um sistema que reintegra as características materiais da cor em seu papel na expressão cultural contemporânea uma vez que a o enfoque que busca associar matizes individuais com significados específicos não funciona e dá margem a muitas contradições, como exemplifica:

\footnotetext{
Para Goethe, o azul 'traz um princípio de escuridão com ele'(1970: 310) e 'dá-nos uma sensação de frio'. Para Kandinsky (1977: 38), ele é "a cor típica celeste ', criando uma sensação de descanso, embora 'quando ele afunda para quase preto, ecoa uma dor que é quase humana' e 'quando ele se eleva ao branco ... seu apelo fica mais fraco e mais distante'. Birren (1961: 43) vê o azul como 'subjugado, melancólico, contemplativo, sombrio', e relaciona-o com 'tristeza, medo, furtividade', enquanto Lacy (1996: 22-3) descreve-o como 'uma cor muito curativa, calmante , tranquilizante e refrescante ',' associado com lealdade, integridade e respeito, responsabilidade e autoridade', embora, por si só, não balanceado com algo mais quente, 'ele pode criar uma sensação de frieza e introspecção'. Verde, finalmente, é 'estático' e 'sem movimento', de acordo com Goethe: 'O espectador não tem nem a vontade nem o poder de imaginar um estado além dele' (1970: 316), enquanto que para Kandinsky (1977: 37) ele é 'doente e irreal'. (VAN LEEUWEN, 2011, p. 56).
}

Van Leeuwen aponta que nas citações de teóricos sobre o significado da cor, embora sejam encontradas semelhanças, as contradições são mais numerosas, sugerindo uma certa arbitrariedade na forma como o significado da cor é percebido. Enquanto o amarelo pode ser sereno, pode ser expansivo, agressivo, caloroso e alegre. Enquanto o azul pode ser escuro e sombrio, pode ser repousante, cicatrizante e calmante. Enquanto o verde pode ser refrescante, pode dar uma sensação de força, pode ser complacente, acomodado e estreito. Esses 
significados são relativos. Se o dia for ensolarado, o azul pode ser "calmo" e "saudável". Se for um dia escuro e nebuloso o azul pode ser "frio" e "sombrio". Ou seja, esses significados adquirem o seu sentido dentro de um contexto. Seus significados não podem ser vistos fora do contexto que os produziu, ou como um significado definitivo da cor. O significado da cor varia com as necessidades e interesses dos diferentes contextos culturais e situacionais.

Van Leeuwen pontua que uma abordagem para o significado da cor precisa: a) incluir todos os aspectos da cor, não apenas o matiz, e não apenas até tonalidade, saturação e valor; b) interpretar as características materiais da cor pelos seus significados possíveis, e não os seus significados reais, uma vez que este só pode ser determinado em contexto; c) considerar não somente o significado potencial das cores, mas também o significado potencial dos esquemas de cores, uma vez que não experienciamos as cores de forma isolada.

\section{k) Uma abordagem paramétrica para a análise da cor}

Van Leeuwen propõe uma abordagem baseada em seu trabalho com Gunter Kress (KRESS; VAN LEEUWEN, 2002 apud MACHIN, 2007), inspirado na "teoria do traço distintivo" dos linguistas Jakobson e Halle (1956). Os sons da fala, antes de Jakobson e Halle, eram vistos como as unidades mínimas da linguagem. Uma linguagem tem em torno de 30 a 70 fonemas. Os fonemas não têm significado próprio, sua função é permitir que as palavras sejam distinguidas entre si. O uso do [p] e do [b] vai distinguir palavras diferentes, por exemplo [pata] de [bata]. Nem sempre que pronunciamos o [b] os sons soarão iguais, ele pode ser como uma explosão ('BANG !!') ou como um suave murmúrio ('burburburbur'). Para a linguística, não importa quão explosivo ou não explosivo o [b] é pronunciado: [banho] continua a ser [banho]. Jakobson e Halle (1956) dividiram os fonemas em conjuntos de traços distintivos. Para Jakobson e Halle, o fonema [b] é frontal (pronunciado na parte da frente da boca), bilabial (pronunciado por um movimento dos lábios), plosivo (caracterizado por uma liberação repentina de ar) e vozeado. $\mathrm{O}$ [p] tem características semelhantes, só que é desvozeado. Jakobson e Halle inovaram ao diferenciar os sons da fala em Inglês com 12 traços ou características distintivas.

Kress e van Leeuwen (1996) propuseram analisar as cores como um conjunto de traços ou um "pacote de recursos" e não de uma forma unitária como "vermelho", "amarelo" etc. "Vermelho" como uma unidade de sentido, existe como um conceito teórico, não como uma realidade, porque "vermelho" é sempre um certo vermelho, escuro, claro, transparente, 
quente, etc. O enfoque de Kress e van Leeuwen (1996) para a cor difere do de Jackobson e Halle (1956) para os sons da fala de duas formas:

a) as características distintivas de Jakobson e Halle (1956) foram pensadas como opções binárias: um fonema ou é vozeado ou desvozeado; ou é frontal ou traseiro; ou tenso ou relaxado, etc. As consoantes são ou vozeadas, como o [b] ou o [g], ou desvozeadas, como o [p] ou o [k]. A 'plosividade' é uma questão de grau, ela é diferenciada em uma escala que vai de um grande "bang" a um suave 'pop'. A frontalidade é diferenciada pelo seu grau, se ao dizer 'bid' toca-se na ponta da língua e depois tira-se para dizer 'part', a língua se move para trás e o som muda gradualmente de [i] para [a]. Não importa se o [p] é plosivo, e se o [i] é relativamente frontal ou relativamente 'traseiro', as diferenças são ouvidas e fazem sentido. $\mathrm{O}[\mathrm{b}]$ só serve para diferenciar palavras, mas fonéticamente, em conjunto com os fonemas circundantes, ele pode expressar "explosão". Van Leeuwen (2011) compara este processo com o funcionamento da cor, uma vez que dentro de um espectro a cor flui para a próxima, do claro ao escuro em uma escala de cinza, da cor pura para o cinza em um continuum, e assim por diante. Os sistemas de cor tais como as rodas de cores e as esferas de cores representam unidades discretas, tais como 24 matizes distintos, 10 valores distintos e 10 níveis de saturação distintas.

b) Kress e van Leeuwen (1996) não veem as características distintivas como meramente distintivas e esse é o segundo ponto de diferença com a teoria de Jakobson e Halle (1956), chamando-as de parâmetros em vez de características distintivas. Os sons da fala contribuem para o significado.

Em um ensaio chamado "Quando as palavras cantam" (1986, p.180-1 apud VAN LEEUWEN, 2011, p. 58), o compositor Murray Schafer, defende que os significados dos sons da fala decorrem diretamente das características materiais dos sons, e/ou da forma como eles se articulam. Por exemplo, no [b] 'os lábios batem sobre ele', por isso é agressivo. O [i] escorre em torno da língua'e por isso é 'melado' e 'aguado'.

Para van Leeuwen (2011), há uma o significado da cor opera de forma similar. O significado potencial das cores e esquemas de cores se pauta por suas características materiais. A natureza sem mistura das cores pode expressar 'pureza' e a natureza mista, 'impureza', sendo a ela associadas uma série de metáforas. À 'impureza' cromática real, podem ser associadas noções abstratas tais como "contaminação", "hibridismo", "fusão", etc. Van Leeuwen (2011, p. 58) defende que: 
A metáfora experiencial não é apenas fundamental para a forma como o significado é feito na 'mídia', nas formas de expressão que funcionam diretamente e com as materialidades do assunto da expressão, é também fundamental para a semiose, para a criação de novos significados [...].

$\mathrm{Na}$ perspectiva da semiótica social, as cores não carregam em si significados específicos, mas sim significados potenciais que se manifestam por meio de metáforas potenciais ou associações metafóricas. Esses significados potenciais se tornam mais específicos quando manifestados nos contextos culturais e nos contextos de situação. Van Leeuwen (2011) ilustra essa noção com o uso semiótico de "luminosidade" como significado potencial de leveza e que é tornado específico nas pinturas religiosas quando assume o significado potencial de "luz divina","tranquilidade" e "paz" na decoração de interiores de igrejas.

Van Leeuwen (2011) também discorre sobre a distinção entre o significado potencial e o significado potencial de propiciamento, cujo termo vem da obra de Gibson (1979 apud VAN LEEUWEN, 2011) sobre a percepção visual (1979). Para Gibson (1979 apud VAN LEEUWEN, 2011), propiciamente é o uso de um determinado objeto como um significado potencial em virtude das propriedades perceptíveis do objeto. No entanto, diferentes espectadores vão notar diferentes propiciamentos, porque a sua percepção varia com as necessidades e interesses do observador. As propriedades no objeto que permanecem despercebidas continuam latentes, esperando para serem percebidas. Com o significado ocorre um processo similar. Os espectadores percebem significados nas qualidades materiais de um objeto. No entanto, de suas necessidades e interesses, individuais ou culturalmente compartilhados, vai depender quais qualidades materiais eles percebem no objeto e qual a significação eles darão a elas.

Halliday (1978) cunhou o termo significado potencial e distingue-se do termo significado potencial de propiciamento de Gibson (1979 apud VAN LEEUWEN, 2011). Significado potencial de Halliday refere-se aos propiciamentos que foram incorporados aos recursos semióticos que já passaram a ser reconhecidos em uma cultura ou em um segmento ou contexto mais específico. Todas as utilizações anteriores dos recursos semióticos tem um significado potencial teórico. Já os usos passados e presentes que são reconhecidos pelos usuários desse recurso em um contexto específico têm um significado potencial atual. A noção de metáfora se assemelha com a noção de propiciamento; por exemplo, é necessário perceber a periodicidade das ondas de água para conceber a noção de 'ondas de luz'. No entanto, a periodicidade é um dos muitos aspectos que podem ser percebidos nas ondas de 
água. Existem outras propiciamentos potenciais, ainda por serem descobertos e podem vir a ser percebidos, dependendo das necessidades e interesses que venham a surgir.

Além disso, van Leeuwen (2011) ressalta que o princípio de metáfora experiencial não é o único princípio para a criação de significado, mas ele é importante pelo seu poder de criar novos significados em especial atualmente quando a cor vem assumindo novos papéis na cultura e na comunicação. Os significados da cor têm sido muitas vezes criados a partir de sua proveniência ou pela sua função tais como verde militar, azul marinho, roxo real, cujos significados estão associados com o exército, a marinha e realeza. Outros significados de cores são dados arbitrariamente, tal como o código de cores usadas nos mapas do metrô de Londres.

Os artistas do final do século XIX, sendo van Gogh um dos precursores desse uso semiótico da cor, começando a usar a cor não apenas para representar a realidade, mas para representar sua experiência subjetiva. Para conseguir que a cor comunicasse_diretamente ideias e sentimentos eles recorreram à metáfora experiencial como veículo. Ele descreveu ao seu irmão Theo em uma carta, como ele usou o potencial significado da cor azul e pureza para expressar a ideia de "infinito":

Eu pinto o infinito, um fundo liso dos mais ricos, mais intenso azul que eu posso inventar, e por esta simples combinação da cabeça brilhante contra o fundo azul rico, eu recebo um efeito misterioso, como uma estrela no fundo de um céu azul. (VAN GOGH apud VAN LEEUWEN, 2011, p.59)

Com o passar do tempo e com uma lenta e gradual a assimilação do público para reconhecer as inovações artísticas realizadas pelos pintores impressionistas, pósimpressionistas e modernistas, os azuis e amarelos Van Goghianos foram incorporados ao léxico de referências históricas e culturais. Os azuis e amarelos de van Gogh adquirem um significado especial com base na sua origem e o seu reconhecimento público como 'cores de Van Gogh'. A forma como van Gogh fez uso das cores, sabendo extrair uma ampla gama de significados potenciais ao explorar a ampla variedade das suas características materiais tais como brilho, luminosidade, textura, ritmo, e intensidade.

Mas é sempre possível fazer o que van Gogh ele próprio fez, para voltar à fonte, para se reconectar com a materialidade da cor, e explorar as muitas propiciamentos que ainda não entraram para a corrente da produção cultural. (VAN LEEUWEN, 2011, p. 59)

Van Leeuwen (2011) ainda pontua a necessidade de diferenciar 'media' de 'modo'. Ele ressalta que 'media' são sistemas paramétricos e 'modos' são sistemas binários e essa diferença impacta na forma como estudamos e entendemos a cor. Pela perspectiva de 'modo, a cor e seus aspectos passam a ser teorizados como 'uma coisa ou outra'. Nesse caso, 
observamos que as contraposições e contrastes são preponderantes na discussão sobre o funcionamento da cor. Cada afirmação tende a excluir as demais possibilidades, como uma escolha entre duas opções, que determina e delimita a escolha feita e, o significado que daí resulta.

A perspectiva da 'media' está apoiada no princípio de sistema paramétrico que tende a organizar a discussão em termos de "tanto um quanto o outro" por meio de recursos graduáveis. Nesse caso a cor é teorizada enquanto um "meio" e nessa ótica, cada cor tem valor em uma escala de claro a escuro, valor em uma escala de completamente saturado até os cinzentos; e valor em uma escala de opaco a transparente, sem que uma valoração exclua outra. Todas estas características específicas e suas proporções resultam no significado potencial, assim como a combinação dos ingredientes resulta no sabor de um prato.

Uma abstração das materialidades que poderiam realizar as escolhas dos seus sistemas é uma das limitações do enfoque em Modo para teorizar a cor que não leva em conta o meio em que a cor é realizada, tal como tinta a óleo, aquarela, película de $35 \mathrm{~mm}$, slides de PowerPoint, etc. Por outro lado, no enfoque em media, a materialidade do meio usado, e suas qualidades específicas são relevantes e impactam no significado. Outra distinção nessas duas abordagens para a cor são que: a) o enfoque no modo tende a realizar o conteúdo das representações, ou, no caso de objetos e espaços, as funções desses objetos e espaços; b) o enfoque na mídia tende a realizar a coesão composicional, a identidade e a interpretação emotiva das representações, e as ressonâncias simbólicas e emotivas dos objetos e espaços. No caso de códigos de cores, a cor é melhor teorizada como um modo; no caso da arte moderna, e nos usos orientados para a identidade da cor no design de produto, design de moda e arquitetura contemporâneas, ela é melhor teorizada como um meio.

A seguir, são descritos os principais parâmetros da cor e uma descrição da forma como eles evocam um possível significado potencial no contexto de seu uso. Esses significados não devem ser olhados fora do contexto, pois a cor não tem um significado em si, nem os seus parâmetros têm um significado em si mesmos, pois os parâmetros interagem entre si. No mundo real, quando vemos a cor, está é a cor de algo, “e a natureza desse 'algo' influencia e canaliza a sua interpretação". (VAN LEEUWEN, 2011, p. 60).

\section{l) Valor}

O valor é um grau de cinza dentro de uma escala que vai desde a máxima luz (branco) ao máximo escuro (preto). A escala de valor assumiu uma importância central no 
Renascimento para expressar as experiências estéticas, bem como na pintura holandesa do século XVII. Para Wierzbicka (1996 apud VAN LEEUWEN, 2011, 60), todas as pessoas têm uma experiência que diferencia a luz e a escuridão, e provavelmente todas as culturas fizeram o uso do claro e do escuro na cor para expressar significados simbólicos e valores, mesmo que os significados e a forma como o fazem seja diversa. Pastoureau (2008, p. 125 apud VAN LEEUWEN, 2011, p. 60-1) descreve o seu significado:

Para muitos pintores calvinistas, podemos mesmo falar de um verdadeiro
puritanismo da cor [...] Esse é o caso com Rembrandt, por exemplo, que muitas
vezes pratica um tipo de ascetismo da cor, apoiando em tons escuros, contidos e
limitados em número (a tal ponto que ele às vezes é acusado de "monocromia ', para
dar prioridade aos poderosos efeitos de luz e ressonância. A partir desta paleta
particular emerge [...] uma intensidade espiritual inegável.

Nesse caso, a ausência de cor passa a ser uma das qualidades materiais da pintura, um parâmetro que impacta no seu significado. A abstenção do uso da cor, de acordo com Pastoureau, pode desbloquear sentidos metafóricos como "ascetismo" e "austeridade". O contraste com o valor de clareza, diretamente associado ao significado de leveza, pode adquirir um significado potencial que cria "uma intensidade espiritual inegável".

\section{m) Saturação}

Saturação é a gradação que varia entre o grau mais puro e intenso de uma cor até o seu grau de "cinza cromático" no qual vemos apenas um traço da cor, e no extremo da escala, temos um cinza acromático. A saturação é a plenitude da cor, e da emoção que ela comunica. A escala de saturação vai da máxima intensidade emotiva até o máximo da emoção contida, rebaixada. Quando aplicada em contextos específicos, seu uso pode evocar significados potenciais mais precisos, por exemplo, um alto grau de saturação sugerem exuberância e aventura, ou vulgaridade e excesso quando esta qualidade não é apreciada no contexto. $\mathrm{O}$ baixo grau de saturação pode evocar a sutileza e suavidade ou frieza, repressão, mal humor.

A saturação foi um recurso semiótico bem explorado por Van Gogh (2009p, p. 1)como lente de aumento da intensidade expressiva, apaixonada:

Gostaria de pintar retratos que pareceriam depois de um século para as pessoas que vivem então, como aparições. Com isso quero dizer que eu não me esforço para conseguir isso através da semelhança fotográfica, mas por meio de expressões apaixonadas, ou seja, usando o nosso ... gosto moderno para a cor como um meio de se chegar à expressão e à intensificação do personagem.

O movimento Futurista criticou o uso da cor dessaturada, vista como 'desbotada, fantasiosa, de penumbra e tons humilhantes' e adotou o uso de 'cores excitantes' (KOOLHAAS et al., 2001, p. 308 apud VAN LEEUWEN, 2011). Na mesma época, Paul 
Poiret introduziu cores primárias brilhantes na moda, assim, "perturbando a retina ultraconservadora da burguesia" (MORA, 2009, p. 13 apud VAN LEEUWEN, 2011, p. 61).

\title{
n) Pureza
}

Pureza é um parâmetro que vai do grau máximo de pureza de uma cor não diluída até o grau máximo de "hibridismo" ou "mistura". Na Antiguidade clássica, a pureza das cores foi um assunto muito discutido, pois as cores cores não misturadas eram consideradas superiores às cores mistas, com mácula. Esse questionamento pautou as discussões sobre quais seriam os critérios que determinariam quais cores podem ser consideradas primárias. Critérios físicos, psicológicos, e linguísticos foram usados. Nomes simples de cores tais como "marrom" e "verde" seriam critério de pureza na cor; nomes compostos como "azul-esverdeado" seriam mistas. Os critérios para determinar as cores primárias não foram amplamente aceitos e segundo Gage (1993 apud VAN LEEUWEN, 2011, p. 36)

\begin{abstract}
mostrou-se notavelmente inconsequente e [...] sobrecarregada com o pesado fardo da ideologia. No entanto, o significado potencial de uma cor, resulta da nossa experiência ao perceber as cores, e suas características visíveis. A pureza ou o hibridismo, é uma questão de preferência, a pureza é um parâmetro da cor que tem sido explorado como recurso semiótico para sugerir significados potenciais.
\end{abstract}

\section{o) Transparência}

Transparência é o grau que vai de transparente a opaco. No extremo da escala, a transparência na cor ocorre quando as coisas no fundo podem ser vistas atrás do primeiro plano colorido porque a luz pode atravessar a cor, como no caso dos vitrais. No outro extremo da escala temos a opacidade que torna a cor translúcida. Uma cor é translúcida quando a cor é atravessada pela luz parcialmente, porque é parcialmente bloqueada pela cor, criando uma característica de nebulosidade ou ambiguidade nas coisas que estão no fundo. As cores feitas com aquarelas são transparentes e mostram o papel por trás da cor. Cores de esmaltes sobre vidros mostram outras cores atrás do esmalte, a fibra da madeira aparece por trás da mancha colorida. Esses meios que possuem qualidades que dão transparência à cor, sugerem uma característica mais leve e etérea, envolvendo com uma película o suporte material que ela recobre, e deixando à vista a materialidade do papel ou da tela, ou a parede de um mural, como parte da obra, emprestando suas qualidades materiais agora transformadas pela cor. A transparência na cor, como no vidro colorido, por exemplo, tanto revela e transforma o que está por trás dela. 


\section{p) Luminosidade}

A luminosidade na cor é uma qualidade que se define pela sua capacidade de brilhar desde o seu interior. O designer Alessandro Mendini as define como: "cores de autoiluminação que colocam uma aura em torno das coisas", (KOOLHAAS et al., 2001, p. 243 apud VAN LEEUWEN, 2011, p. 62). As cores mais escuras e menos saturadas são menos luminosas do que as mais claras e mais fortemente saturadas. A cor no meio eletrônico como em telas e projetores é muitas vezes mais luminosa do que a cor que é o reflexo da luz na superfície. A luminosidade tem sido um dos parâmetros mais valorizados na cor, ao longo do tempo. Na idade média, os pintores queriam que a luz irradiasse diretamente das cores e contrastavam tão fortemente quanto possível a pintura do ouro com azuis ou verdes para trazer para fora a sua luminosidade. Já os pintores da Renascença e os pintores holandeses do século XVII representavam a luz que incide nas pessoas e objetos e não a luz que irradia de dentro da cor com a ajuda de contrastes provocados pela proximidade de outras cores. A característica de irradiar luz de dentro da cor pode ser usada como significado potencial da luminosidade - tanto o esplendor e o glamur, como o divino, a fé. Van Gogh (2009q, p. 1) descreve o uso de cores luminosas para significar o "eterno": "Eu tento pintar homens e mulheres com que aquele algo do eterno que o halo usado para simbolizar e o qual nós procuramos invejar pela radiancia e vibração da nossa coloração."

Atualmente a cor luminosa no meio eletrônico está paulatinamente se tornando o parâmetro da nossa experiência consciente com a cor e essa luminosidade deixa as cores reais que incidem nas superfícies do mundo real parecerem cores opacas e apagadas.

\section{q) Luminescência}

A luminescência é uma característica da cor que é emitida diretamente por uma fonte de luz, tal como uma tela de computador ou a luz neon. A luminescência é a qualidade de emitir luz e tem sido importante para ser associada aos seus significados potenciais tais como a sobrenaturalidade. Dionísio, o Areopagita, descreveu Deus como "light", "fogo" e "fonte de luz" como relata van Leeuwen:

A luz deriva do Bem e é a imagem da Bondade, daí Bom é comemorado com o nome de Luz ... [Bondade] ilumina todas as coisas capazes de participar dela, e sua luz é difundida sobre todas as coisas enquanto ela espalha o esplendor de seus raios sobre todo o mundo visível. (ECO, 2002, p. 102 apud VAN LEEUWEN, 2011, p. 63) 
Em 1144, o abade Suger (apud VAN LEEUWEN, 2011, p. 63) escreveu na ocasião da consagração da Igreja de St. Denis que "a igreja toda iria brilhar com a luz maravilhosa e ininterrupta da maioria das janelas luminosas". Atualmente vemos nas fotos de satélites o brilho luminoso das cidades que irradiam sua luz, soma de objetos eletrônicos, luzes acesas e cartazes luminosos.

\section{r) Lustro}

Lustro é um parâmetro que expressa a luz que é refletida ao invés da luz que é transmitida, e a capacidade reflexiva de superfícies coloridas. A sua capacidade de acender pode sugerir uma chave para o seu significado potencial. Na Idade Média, essa qualidade material da cor brilhar era muito apreciada e carregava um significado potencial da divindade no brilho das vestes dos santos, das superfícies brilhantes dos mosaicos, e das camadas de ouro em pinturas e esculturas. O brilho não perdeu sua importância, atualmente o brilho está na superfície perolada dos carros, no brilho acetinado do mármore, nas impressões em revistas e livros caros.

\section{s) Temperatura}

A temperatura é um parâmetro que segue as sequencia das cores do prisma e vai do azul ao vermelho. A escala de temperatura em uma abordagem paramétrica da cor é um dos fatores para os significados da cor. Enquanto não podemos estabelecer um significado universal para as cores, há a experiência com a escala de temperatura, onde no extremo da cor vermelha existe uma associação com o calor, energia, saliência, prontidão, e a extremidade azul com o frio, calma, distância, recolhimento. Uma sequencia de frio-quente adquire um significado potencial amplo para Itten (1970 apud VAN LEEUWEN, 2011) que listou alguns significados potenciais: transparente /opaco, sedativo / estimulante, raso /denso, arejado /terreno, longe /perto, leve /pesado e úmido /seco. O significado potencial não emana apenas da temperatura, mas de vários parâmetros de uma cor em questão, por exemplo, o vermelho real, que pode ser muito quente, escuro médio, altamente saturado, puro e modulado. Seu significado potencial resultará da combinação desses parâmetros e seu papel em contextos específicos. 


\section{t) Modulação}

Uma cor modulada é uma cor que combina diferentes parâmetros nela, como por exemplo, um azul texturizado com diferentes matizes e tonalidades. Uma escala de modulação vai de uma cor altamente modulada até a cor lisa. Na Teoria da Cor de Goethe (1970 apud VAN LEEUWEN, 2011), a modulação já foi reconhecida como uma característica da cor. Itten (1970, p.19 apud VAN LEEUWEN, 2011) observa essa caracteristica descrita por Ticiano como "uma tonalidade principal e muitos matizes e tons variantes". As variações na saturação da cor tem um papel importante na na modulação. Tanto na representação naturalista, quanto como uma fonte de significado em si mesma, a cor modulada cria qualidade materiais e sugere significados potenciais com seus nuances, sutilezas e variações. Matisse (1972, p. 143 apud VAN LEEUWEN, 2011) preferia superfícies lisas e desprovidas do "vibrato perturbador" dos efeitos texturizados e modulados de outros artistas. A ausência de modulação pode ser usada para realçar a cor essencial das coisas, ou como a ênfase de um significado em si mesmo por sua "coragem "e "simplicidade". Matisse (1972 apud VAN LEEUWEN, 2011) usou cores planas para escapar da representação naturalista e afirmar a expressividade da cor em si. A modulação pode ser a qualidade de uma única cor, ou de um tipo de esquema de cores. Rothko, por exemplo, usa um esquema de cores que torna os vermelhos e marrons sutilmente sombreados pela sua interação. As variações na textura também têm um papel importante na modulação. $\mathrm{O}$ uso da textura pode atender necessidades de representação naturalistas, tais como a forma dos volumes e a profundidade da composição. As modulações podem atender necessidades de representação abstrata - como padrões de estrias, manchas, veios, etc. que sugerem seus significados com base em suas qualidades materiais tais como sua retidão ou redondeza, sua orientação horizontal, vertical ou circular, sua regularidade ou irregularidade, características distintivas que sugerem associações metafóricas.

\section{u) Diferenciação}

A diferenciação é um parâmetro do esquema de cores e se refere ao grau em uma escala que vai do monocromático ao uso de uma paleta altamente diversificada. O signficado potencial é desencadeado a partir de suas qualidades materiais. A grande diferenciação pode ser associada ao sentido de 'diversidade', 'exuberância' ou espírito de aventura. A pequena diferenciação pode significar 'moderação' ou 'timidez'. Mas esses significados dependem do contexto, e em outro contexto 'moderação' pode ter um valor mais positivo. 
Modulação e diferenciação podem ser confundidas, mas em uma imagem, é possível levantar quantas cores participam da paleta, e depois, observar quais dessas cores são moduladas, variando em valor, grau de transparência, e padrões de estrias.

\section{v) Esquemas de cores}

As cores interagem entre si, influenciam e são influenciadas pelas cores vizinhas, avivando ou apagando o brilho das cores próximas, harmonizando-se ou distoando entre si.

Em uma carta ao seu irmão Theo, Van Gogh (1978, p. 28 apud VAN GOGH, 2010), explicou como ele havia expressado "as paixões terríveis da humanidade" por meio de "um choque de contrastes mais díspares dos vermelhos e verdes'. Na tela Café Lamartine, ele faz o uso semiótico da cor para causar um desconforto para o espectador, ao combinar o vermelho das paredes com um amarelo intenso da iluminação e do seu reflexo no chão.

Antes iniciar uma pintura Matisse (1972 apud VAN LEEUWEN, 2011) advogava a seleção de um sistema de entre 3 e 6 cores para articular as equações que dão vida à imagem. Alguns esquemas de cores marcaram uma época ou uma cultura, ou ainda uma instituição como é o caso do esquema de cores dos índios que tradicionalmente centrado nas combinações de vermelho-alaranjado, amarelo-laranja, cor de ferrugem, bem como azulvioleta, azul-verde e amarelo-verde. Tradicionalmente, o esquema de cores japonês combina mais azuis, roxos, cinzas, marrons e tons vermelho-alaranjados. A camuflagem dos exércitos pode ir do verde-oliva ao cáqui, passando pelas cores de terra. Vermelho, amarelo e azul, puros, além do preto e branco compõem o esquema de cores de Mondrian, caracterizando as cores da modernidade. Cianos e malvas pálidas em um esquema de cores significou por um tempo as cores da pós-modernidade. Há os esquemas de cores que utilizam cores fortes de forma arbitrária para sinalizar a sua função, tal como vermelho para os dispositivos de proteção contra incêndios, azul para caixas de controle interruptor, verde para equipamentos de primeiros socorros e medicamentos. Em geral os esquemas de cores foram debatidos e experimentados com base na roda de cores. Os esquemas de cores podem ser inspirados por referências culturais ou naturais e podem derivar significados potenciais a partir de sua origem ou função. Por exemplo, Le Corbusier usou a cor para simbolizar as virtudes funcionais dos transatlânticos na construção do Centre Le Corbusier em Zurique. Ele usou a cor do aço cinza de navios de guerra e o vermelho, amarelo e azul das bandeiras de semáforo para dar ao edifício o visual de um transatlântico. (RILEY, 1995 apud VAN LEEUWEN, 2011). 
É uma prática dos designers contemporâneos usarem referências de significados culturais e históricos na escolha do esquema de cores inteiro, ou de vários esquemas, combinando-os em uma paleta de conotações como, por exemplo, Bora Aksu cujos trabalhos usam 'uma pitada de punk, um pitada de Edwardian e uma pitada de sonho "e, ao mesmo tempo, inspirando-se nos guerreiros nômades". (MORA, 2009, p. 93 apud VAN LEEUWEN, 2011, p. 61).

Na prática do uso de cores, esses Designers contemporâneos pensam semioticamente sobre a cor, não com base nas harmonias e contrastes da roda de cores. Não só a harmonia entre as cores em um esquema de cores desempenha um papel importante no significado potencial de um esquema, mas os contrastes entre elas também. Ao cercar o brilho alaranjado do sol refletido na água com cores mais opacas e mais escuras Monet aumentou o significado desse brilho por meio do seu contraste com as outras cores de sua paleta.

O contraste de complementares entre vermelhos e verdes foi usado por van Gogh como significado potencial para expressar "as paixões terríveis da humanidade". Os designers usam os confrontos entre cores para criar significados potenciais. Allegra Hicks "combina cores saturadas com cores silenciosas e orgânicas", combinando "estas cores intensas com os chiques tons de terra para trazer uma sensação sofisticada, moderna para a minha coleção de impressão". (MORA, 2009, p. 127 apud VAN LEEUWEN, 2011, p. 65).

A relação de proporcionalidade das cores que participam de um esquema é outro aspecto muito importante, uma vez que uma cor pode ser tão discordante das demais que é preciso dosar a sua quantidade e basta um pequeno toque para criar um forte contraste com as outras. O artista pode dar ao contraste um uso semiótico para enfatizar alguma área na composição, para salientar algo, seja ele um contraste complementar, de saturação, ou de claro/escuro, por exemplo.

Nos projetos para aeroportos e estações de metrô, o arquiteto Norman Foster usa cores neutras para que transmitem calma, tranquilidade e confiança e dosa o uso de cores fortes como vermelhos apenas para sinais de direção e comunicados. Estes 'acentos' podem transmitir emoção que se contrasta com o ambiente neutro e oferece um contraponto importante para quebrar com placidez.

Hornung (2005 apud VAN LEEUWEN, 2011) argumenta sobre a necessidade de analisar os esquemas de cores prontos tais como as tabelas de cores de fabricantes de tintas, e os esquemas de cores de imagens. Isso é possível ao parear suas cores com as de um conjunto de tiras de papel colorido e em seguida cotejar essas tiras reconstruindo um "inventário proporcional de cor" na proporção em que elas foram usadas. A reconstrução de um 
inventário das cores usadas ajuda não só a reconhecer as cores do esquema, como a forma como elas foram combinadas.

Ao analisar esquemas de cores é preciso levar em conta que os parâmetros não terão a mesma importância, então será necessário distinguir os parâmetros que definem o esquema de cores, ao descrever os aspectos gerais e os contrastes.

Van Leeuwen ressalta que nas análises de esquemas de cores é preciso começar pelos parâmetros individuais para depois interpretar a dinâmica dos contrastes levando em consideração o contexto. Mesmo sendo uma análise sistemática não há uma fórmula nem para medir o papel de cada parâmetro no todo e qual a contribuição no resultado final nem para estabelecer como a cor é usada para uma interpretação. A descrição detalhada contribui para uma análise forma como a cor é usada de fato na prática e no seu contexto de uso, ao invés de uma análise baseada em uma descrição mais limitadas de algumas características que se encaixam em uma ideia teórica de como as cores funcionam.

\subsubsection{Composição e Expressividade Linguística}

A composição e a expressividade linguística são formadas pelas menores unidades de composição da linguagem pictórica e são analisadas considerando os fenômenos básicos da expressividade temática e abstrata do pensamento humano.

No âmbito das Artes Visuais, a escolha dos elementos visuais que se articulam na composição está nas mãos do artista, criador e visualizador a fim de instanciar, na imagem, um discurso visual rico de sentidos e possibilidades de leituras. Tendo em vista um resultado, as estratégias usadas na composição visual são decorrentes do uso combinado dos elementos visuais, articulados nos níveis grafológicos, morfológicos, sintáticos e semânticos da comunicação visual. Discutiremos a seguir a contribuição das Artes Visuais e da Percepção Visual para complementar a base teórica para a compreensão das unidades basilares da comunicação visual. Essa discussão comporá com o suporte teórico da Multimodalidade para a análise do corpus no contexto da produção discursiva pictórica do artista. 


\subsubsection{Um argumento sobre a importância das unidades de sentido}

Kress e van Leeuwen (2001, p.181) argumentam que a posição que os elementos ocupam no visual lhes confere "valores informativos específicos" que possibilitam a análise dos elementos da linguagem visual. Estes valores são: valores de informação, saliência e enquadramento.

O primeiro valor refere-se ao posicionamento dos elementos e a relação entre eles na construção da imagem, analisando como cada um dos elementos afetam outros e como juntos eles constroem um novo sentido. O segundo valor refere-se à ênfase que é dada para um dos elementos na estruturação da linguagem visual. E o terceiro valor se refere a conectores, recortes e enquadres que refletem o ponto de vista do artista.

$\mathrm{Na}$ análise dos elementos que compõem o objeto de arte, podem ser acrescentados não só outros 'valores' baseados na fundamentação específica da área, como também elementos considerados relevantes pelo próprio artista em sua representação do objeto de arte. Segundo D’Avilla (2004) é preciso iniciar a análise da produção artística pela desconstrução dos sentidos presentes nos textos viso-plásticos, buscando a apreensão das unidades mínimas de significação para encontrar os sentidos que designam a essência do não verbal (o seu nível profundo) que demonstra a existência de um caráter simbólico, puro e denotativo. Este processo de descrição das unidades mínimas de significação do objeto de arte pode ser realizado pelo próprio artista, auxiliando o analista do discurso a discriminar os elementos da linguagem visual e sua relação com a produção de sentidos que originaram a composição.

Os pontos de contato entre a linguagem verbal e a comunicação visual foram descritos na fundamentação teórica com base na discussão encetada por Machin (2007) acerca das contribuições de Kress e van Leeuwen (1996) para estabelecer essa conexão. Porém, essa comparação sobre as correlações observadas tanto na linguagem verbal quanto na comunicação visual se dá de maneira pontual porque, enquanto ela aborda alguns aspectos que encontram conexões, falha em comparar as duas linguagens pelo viés de conferir pontos de contato em todos os níveis da escala de estratos da linguagem.

A linguagem verbal foi amplamente descrita por Halliday e Mathiessen (1985; 2004; 2014), Halliday e Hassan (1985), dentro da pespectiva da Semiótica Social enquanto a comunicação visual tem sido estudada por O’Toole (1994), Kress e van Leeuwen (1996), van Leeuwen (2011) há relativamente pouco tempo.

No item 3.4 'Pontos de Contato entre a linguagem verbal e a Comunicação Visual', Machin (2007) discute se podemos tomar as evidências apresentadas por Kress e van 
Leeuwen (1996) para afirmar que existe de fato uma gramática visual. Machin (2007) examina as evidências de Kress e van Leeuwen (1996), tais como a correlação entre os vetores visuais com os verbos, por exemplo, para estabelecer uma conexão entre a comunicação visual e a linguagem verbal. Ele argumenta que, embora as evidências apresentadas demonstrem correlação entre a comunicação visual e a linguagem verbal elas são, no entanto, insuficientes para afirmar que a comunicação visual tenha uma gramática visual nos padrões da linguagem verbal.

A linguagem tem vários estratos, desde o estrato do contexto cultural e de situação até o seu estrato mais básico e material: o estrato grafológico-morfológico e fonológico. No entanto, argumento que, a fim de verificar a ocorrência dos pontos de contato entre o visual e o verbal e verificar se há correspondência entre elementos linguísticos e suas funções nesses dois sistemas linguísticos em cada um dos níveis da linguagem, é preciso usar o modelo da escala dos estratos da linguagem de Halliday e de Mathiessen (2004). Ainda que para Halliday o enfoque de análise da linguagem seja léxico-gramatical e não considere o nível morfológico, para investigarmos os pontos de contato entre a comunicação visual e a linguagem verbal, será preciso contrastar a comunicação visual com cada um dos níveis da escala dos estratos da linguagem verbal descritos por Halliday e Mathiessen (2004).

Para explorar os pontos de contato entre a linguagem verbal e a comunicação visual, tomo como ponto de partida os estratos da linguagem descritos por Halliday e Mathiessen (2004, 2014), Halliday (1985) e Butt et al. (2000, p. 6):

Linguistas frequentemente pensam a linguagem como uma série de níveis ou estratos utilizam o termo REALIZAÇÃO para descrever o relacionamento entre os níveis. [...] os contextos extralinguísticos estão realizados no nível do conteúdo da nossa linguagem, e ao conteúdo é dado forma na expressão.

De acordo com Butt et al. (2000), a linguagem funciona com base em dois estratos mais gerais, o nível extralinguístico, composto do contexto de cultura e do contexto de situação, e o nível linguístico, composto do nível do conteúdo e do nível da expressão. O nível do conteúdo consiste no estrato semântico e no estrato da léxico-gramática. O nível da expressão engloba os estratos da fonologia, da grafologia. Cada um desses estratos é realizado pelo estrato subsequente nessa escala de estratos que vai dos mais básicos até os estratos mais abrangentes.

Dessa forma, argumento que é necessário verificar estrato por estrato na escala dos estratos da linguagem para analisar os pontos de contato entre a comunicação visual e a linguagem verbal. Quando existirem correspondências, é preciso fazer a descrição das ocorrências e a interpretação dessas materializações em relação ao propósito de um texto a ser 
analisado, ao contexto de situação, ao contexto de cultura e ao registro ou experiência comum e subjacente à produção dos textos.

Figura 57: Modelo de Estratificação da linguagem

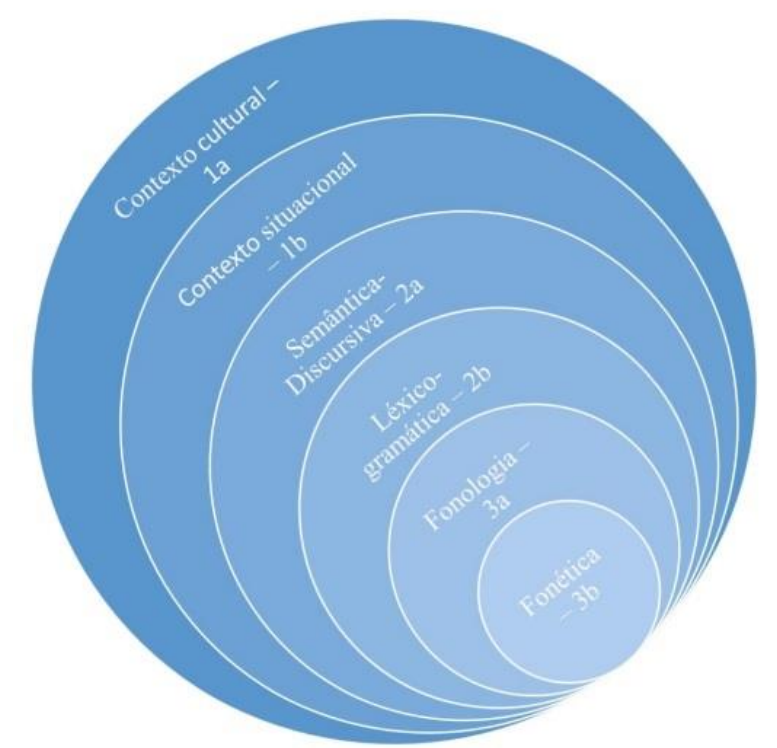

Fonte: Halliday e Mathiessen (2004, p. 25).

Na escala dos estratos da linguagem, o nível extralinguístico encontra-se na base de todos os textos produzidos no nível linguístico sejam eles de natureza verbal, sejam de natureza visual. Esse nível pode ser comum aos textos em linguagem e aos textos visuais, quando eles "compartilham o mesmo contexto de situação em maior ou menor grau, eles irão compartilhar os mesmos sentidos experiencial, interpessoal e textual e, dessa forma eles pertencem ao mesmo registro" (BUTT et al., 2000, p. 7). Os mesmos sentidos estão realizados em textos produzidos no mesmo contexto, apesar de terem conteúdos diferentes, os textos irão realizar as mesmas finalidades e relacionamentos.

O modelo da escala de estratos, que descreve a linguagem, é um arcabouço que possibilita comparar o visual e o verbal em cada um dos níveis da linguagem, explorando a ocorrência de correspondências nas duas linguagens, estrato a estrato. Seguindo os níveis da escala dos estratos da linguagem, é possível visualizar onde a comunicação visual encontra base de comparação com a linguagem verbal e onde não há nenhuma correlação.

Acredito ser fundamental explorar, no estrato grafológico, e compreender qual é a natureza da correspondência entre os blocos básicos na linguagem verbal e os elementos básicos da comunicação visual, conhecidos como os elementos da linguagem visual (ARNHEIM, 1974; DONDIS, 2007; KANDINSKY, 1926 apud VAN LEEUWEN, 2011). 
Embora o nível fonológico inexista na comunicação visual, e o nível morfológico talvez não exista, não na forma como ele se constitui na linguagem verbal, uma vez que a comunicação visual não se estrutura por meio de um encadeamento de palavras, mas, a apreensão dos blocos de sentido se dá de forma simultânea e não sequencial como é o caso das orações da linguagem verbal. Questiono se haveria outro tipo de morfologia, não para palavras, mas uma morfologia visual. Indago para isso se haveria o equivalente à oração, não como na estrutura linear e sequencial de uma oração escrita ou verbal, que seja um tipo de unidade linguística visual ordenadora e capaz de combinar e articular blocos de significação em uma ordem de leitura que seja simultânea e sintética como é a natureza da comunicação visual.

Ou seja, indago se, na comunicação visual, haveria correspondente para o nível lexical, para o nível morfológico e grafológico; guardadas as diferenças da natureza da estrutura e da forma de funcionamento da comunicação visual. Pergunto se haveriam núcleos de significado assim como os radicais e seus prefixos e sufixos, estes formados com base nos elementos grafológicos mais fundamentais, os elementos da linguagem visual, como são compreendidos por Kandinsky (1926 apud VAN LEEUWEN, 2011), Arnheim (1974) e Dondis (2007). Por último, pergunto se Kress e Van Leeuwen (1996) examinaram se há pontos de contato para os níveis lexical, morfológico, e grafológico entre a linguagem verbal e a comunicação visual, como eles o fizeram para o nível gramatical. Uma comparação no nível semântico será igualmente importante para compreender de que natureza são as correspondências entre estes dois sistemas linguísticos, a linguagem verbal e a comunicação visual.

Argumento que a verificação de todos estes estratos, começando pelo estrato do contexto de situação e do nível semântico e seguindo pelo nível léxico-gramatical e o morfológico e grafológico pode revelar uma correspondência mais ampla e consistente entre a comunicação visual e a linguagem verbal.

Talvez não se possa estabelecer que, juntando um elemento visual com outro, teríamos uma palavra visual porque a comunicação visual não funciona com palavras concatenadas linearmente em uma oração. Mas se entendermos que a comunicação visual funciona de forma diversa, e descrevermos de forma acurada como é essa forma, talvez possamos encontrar o nível morfológico visual, que funciona a partir de uma outra ordem de formação de sentido: a visual.

Talvez não seja possível entender a função dos elementos de linguagem visual como a função dos morfemas, porque os morfemas já têm sentido em si mesmos, enquanto os 
elementos de linguagem visual não têm um sentido prévio, nós é que damos um sentido quando os usamos para construir sentidos, como unidades básicas para a formação de blocos de sentido. Então eles podem ser comparados com o estrato grafológico mais básico, o alfabeto, por exemplo. Talvez não seja possível considerar os elementos da linguagem visual como morfemas porque eles são de fato os elementos nucleares e mais básicos na comunicação visual. Enquanto os morfemas já têm um significado vinculado a eles, os elementos de linguagem visual não o têm, eles são de fato os blocos, os tijolos, os núcleos mais básicos desse sistema linguístico que é o visual. Combinados, eles formam novos sentidos e poderiam ser comparados, em termos de função, com o alfabeto que não tem um sentido em si, mas são unidades formadoras de morfemas, de palavras e de orações na linguagem verbal. Dessa forma, os elementos de linguagem visual poderiam ser comparados com um alfabeto visual, que pode ser usado em inúmeras unidades de sentido que podemos chamar aqui de 'blocos'. Os elementos de linguagem visual funcionam como uma vogal ou consoante, que são articulados em mil morfemas. Guardada a distância de que a estrutura visual não é sequencial e linear como a linguagem, não é organizada por complexos oracionais, orações e palavras, mas funciona com base em outro paradigma, podemos pressupor que os elementos visuais funcionam como o alfabeto para aglutinar blocos básicos de sentido visual, mas não são equivalentes a morfemas porque não têm um sentido que está posto, como no caso do morfema. Por exemplo, a linha em si não tem sentido nenhum, mas quando usada para construir uma significação, ela passa a ter 'n' significados. Ela só tem sentido se um sentido é dado quando ela é usada para formar um sentido.

Os estudos de van Leeuwen (1996) contribuem para a análise da imagem, mais especificamente voltados para os textos de mídia, sendo que os estudos da análise da imagem na área das Artes Visuais levam em consideração elementos e categorias de análise específicos das Artes Plásticas. Dessa forma, recorrerei às contribuições de Kandinsky (1970), Arnheim (1974), Wöfflin (1989), Dondis (2007), da área das Artes Visuais para buscar subsídios relevantes para atender as necessidades mais específicas da linguagem pictórica.

Quatro teóricos das Artes Visuais contribuem para o diálogo com as Artes Visuais: Wöfflin (1989), Kandinsky (1970), Arnheim (1974) e Dondis (2007) para a construção de referências teóricas para balizar os conceitos usados na análise dos elementos de linguagem visual. Arnheim (1974), em especial tem sido uma importante referência para os teóricos da multimodalidade, constituindo uma ponte interessante entre a Psicologia da Percepção Visual e a Linguística. 
Kress e van Leween (2006, tradução nossa) citam a obra de Arnheim (1974) como uma importante referência no desenvolvimento de sua gramática visual:

Três escritores influenciaram nossas ideias de formas diferentes e fundamentais (...) Depois há Rudolg Arnheim. Quando mais nós lemos seu trabalho, mais nos conscientizamos que a maior parte do que nos temos a dizer já foi dita por ele, frequentemente melhor do que nós o fizemos, apesar de que normalmente em comentários de trabalhos de arte individuais ao invés de na forma de uma teoria mais geral. Ele é comumente associado com a psicologia da Gestalt: nós gostaríamos de reconhece-lo como um grande semoticista social. ${ }^{318}$

A linguagem visual é constituída por unidades linguísticas chamadas por Dondis (2007) de elementos de linguagem visual. Ponto, linha, forma, tom, cor, textura, direção, dimensão, movimento são descritos em seu estudo como as menores unidades semânticas estruturantes da linguagem visual, com as quais são articuladas as imagens. Serão usados para complemetar a base teórica de O'Toole (1994) e de Kress e van Leeuwen (1996) que são a espinha dorsal desta pesquisa por se tratar de uma análise discursiva na perspectiva da Linguistica. No entanto, por ser o objeto da análise um trabalho de Arte, será empreendida uma discussão teórica transdisciplinar entre a Linguistica, Artes Visuais e Percepção Visual a fim de construir uma ponte necessária entre as contrinuições destas áreas.

Os elementos básicos da linguagem visual: ponto, linha, forma, direção, cor, tonalidade, textura, proporção, escala, dimensão e movimento são descritos no apêndice, e são considerados na análise das telas, como elementos linguísticos nucleares que concorrem para construir os sentidos intencionados pelo autor. O estudo dos elementos de linguagem visual e de sua articulação na materialidade do texto visual podem auxiliar a compreender Kress e van Leeuwen (2001, p.181) argumentam que a posição que os elementos ocupam no visual lhes confere "valores informativos específicos" que possibilitam a análise dos elementos da linguagem visual. Estes valores são: valores de informação, saliência e enquadramento.

O primeiro valor refere-se ao posicionamento dos elementos e a relação entre eles na construção da imagem, analisando como cada um dos elementos afetam outros a função dos valores visuais descritos por Kress e van Leeuwen, tais como, por exemplo, a construção da ênfase e a construção de conectores, recortes e enquadres que refletem o ponto de vista do artista.

\footnotetext{
${ }^{318}$ Tradução livre da autora. Three writers influenced our ideas in different and fundamental ways.(...)Then there is Rudolf Arnheim. The more we read his work, the more we realize that most of what we have to say has already been said by him, often better than we have done it, albeit it usually in commentaries on individual works of art rather than in the form of a more general theory. He is commonly associated with Gestalt psychology: we would like to claim him as a great social semiotician. (KRESS; VAN LEEUWEN, 2006).
} 


\subsection{PONTOS DE CONTATO ENTRE A LSF E A GDV}

Como contribuição teórico-metodológica da tese, este item examina subsídios que se complementam para atender aos objetivos propostos pela pesquisa e explorar as interseções entre a Linguística Sistêmico-Funcional e a Gramática do Design Visual. Este tópico explora os pontos de contato que possibilitam a correspondência entre as metafunções de Halliday e as funções de O’Toole (1994), Kress e van Leeuwen (1996):

1) Composicional (KRESS; VAN LEEUWEN, 1996; O’TOOLE, 1994), Textual (HALLIDAY; MATHIESSEN, 2004), Acional (FAIRCLOUGH, 2003) - A poética visual do artista constitui o objeto da pesquisa acerca dos usos dos recursos semióticos e estratégias narrativas usadas na construção do texto pictórico;

2) Representacional (KRESS; VAN LEEUWEN, 1996; O'TOOLE, 1994), Ideacional (HALLIDAY; MATHIESSEN, 2004), Ideacional e Identitária (FAIRCLOUGH, 2001), Representacional e Identificacional (FAIRCLOUGH, 2003) - Essas ferramentas conceituais forneceram subsídios para analisar os assuntos que mobilizaram o interesse e a representação artística, os aspectos discursivos, ideológicos, identitários e que articulam as telas analisadas com o contexto nas quais foram produzidas. Nessa função, foram tratadas as questões da Interdiscursividade e das metáforas interdiscursivas que são usadas na construção de sistemas semióticos pelo pintor.

3) Modal (O’TOOLE, 1994), Interativa (KRESS; VAN LEEUWEN, 1996), Interpessoal (HALLIDAY; MATHIESSEN, 2004), Relacional e Identitária (FAIRCLOUGH, 1991), Identificacional e Acional (FAIRCLOUGH, 2003). O’Toole (1994) propõe o termo Modal para esta função como veremos mais adiante.

A Gramática do Design Visual, como proposta por Kress e van Leeuwen (1996), ao utilizar a base teórica da Gramática Sistêmica-Funcional, também realiza seus significados por meio das mesmas funções como propostas por Halliday.

A metafunção Ideacional (HALLIDAY; MATHIESSEN, 1985) corresponde à função Representacional (KRESS; VAN LEEUWEN, 1996) - Nessa metafunção, as experiências são construídas pelos indivíduos por meio da linguagem. Na metafunção Ideacional as estruturas organizam a natureza dos eventos, os participantes e as circunstâncias em que ocorrem, mostrando o que está envolvido no acontecimento e quais são as relações 
que ocorrem entre os elementos que participam da ação. A metafunção ideacional na linguagem (HALLIDAY; MATHIESSEN, 1994; HALLIDAY, 2000), chamada por Kress e van Leeuwen (1996) de função representacional ocorre no sistema da transitividade em função de os participantes serem representados nas imagens ou da organização desses elementos no conjunto da imagem e nas relações entre eles na composição serem capazes de criar afinidades. Na função Representacional, as estruturas organizam, na imagem, a cena, e nela, os acontecimentos, suas figuras, participantes e circunstâncias que as cercam.

No sistema de transitividade o Ator exerce o papel de agente da ação e a Meta exerce o papel de recipiente da ação. Na imagem, os participantes são os elementos que irão executar ou sofrer as ações, ou ter os papéis de atores ou metas e alvos das ações. Nos processos de ação, a maior característica é a existência de vetores ou linhas de ação, que representam a interação entre dois objetos que são o Ator e a Meta e que indicam a direção da ação ou do processo acional. Eles podem ter uma só direção que vai do Ator para a Meta. Também encontramos os processos de reação, além dos processos de ação. Neles, o elemento principal é o olhar dos participantes, que são nomeados de reatores. Nesses processos, os participantes devem ter características humanas ou semelhantes.

A metafunção Interpessoal (HALLIDAY, 2004) corresponde à função Interativa (KRESS; VAN LEEUWEN, 1996) - Na linguagem, a metafunção interpessoal (HALLIDAY; MATHIESSEN, 1994, 2004) é responsável pela relação entre os participantes. A metafunção interpessoal, denominada de função interativa (KRESS; VAN LEEUWEN, 1996) para a comunicação visual, em que recursos visuais constroem a "natureza das relações de quem vê e o que é visto." (UNSWORTH, 2004, p.72).

A metafunção Textual (HALLIDAY, 2004) corresponde à função Composicional (KRESS; VAN LEEUWEN, 1996; O'TOOLE, 1994) - A terceira metafunção proposta por Halliday (2004) como metafunção textual da linguagem é responsável pela estrutura e organização do texto. É realizada na função composicional na proposição para análise de imagens de Kress e van Leeuwen (1996) e se refere aos significados obtidos através da "distribuição do valor da informação ou ênfase relativa entre os elementos da imagem" (UNSWORTH, 2004, p.72).

A análise usará como base teórica a Gramática do Design Visual de Kress e van Leeuwen (1996) a fim de identificar as relações que os elementos presentes na tela desenvolvem entre si, com o conjunto da composição e também na triangulação com os elementos textuais presentes nas cartas. A análise possibilitada pela GDV prioriza aspectos 
como o posicionamento de cada elemento na composição e a existência de associações que possibilitam a produção de uma coesão entre eles.

\subsubsection{Pontos de contato entre a Comunicação Visual e a linguagem verbal}

Não poderia analisar as telas de van Gogh e a relação delas com as cartas que as descrevem sem antes identificar as diferenças e similaridades entre linguagem visual e a linguagem textual observando o que a GDV e a GSF têm a dizer a esse respeito. Dessa forma, a fundamentação teórica tem como objetivo examinar as relações entre o sistema da linguagem, partindo da Gramática Sistêmico-Funcional de Halliday $(1985,1994)$ e o sistema de imagens com Gramática do Design Visual de Kress e van Leeuwen (1996).

O conceito de linguagem é caracterizado por Hasan como sendo um sistema de significações que faz a mediação entre a existência humana (HALLIDAY; HASAN, 1989). Já o conceito de imagem, é descrito por Kress e van Leeuwen (2001) como um sistema complexo voltado para o contexto em que a linguagem é produzida. Baseando-se no argumento que as imagens são constituídas de elementos que as estruturam, Kress e van Leeuwen (1996) analisaram a comunicação visual com base no modelo teórico da GSF para estudar a linguagem, na tentativa de aplicar a GSF para analisar a comunicação visual.

Com base nesse argumento, os elementos visuais articulam-se dentro de uma gramática visual, construindo os sentidos com base nas escolhas de sentidos potenciais e nos padrões de estruturas e inventários que compõem essa gramática visual. A conjugação dessas estruturas visuais para a construção dos sentidos preenche as funções comunicativas da linguagem visual ao serem capazes de "comunicar humores, forma de endereçamento, ideias e coerência textual da mesma forma como a gramática da linguagem faz" (MACHIN, 2007, p. 159).

No entanto, a gramática visual não está para a gramática da linguagem em uma relação de correspondência simétrica, devido às diferenças inerentes à forma como essas duas modalidades de comunicação se constituem. A forma como os elementos que compõem as imagens podem ser decompostos não acontece da mesma forma como os elementos nas sentenças podem ser decompostos porque os sistemas que organizam as imagens não funcionam da mesma forma como na gramática.

A sintaxe visual não opera de forma análoga à léxicogramática e a forma como ela se organiza para comunicar não acompanha a forma como a linguagem se organiza para 
comunicar os sentidos. A linguagem é um código que comunica suas partes de forma sequencial. Sua comunicação dos sentidos dá-se por meio de um sequenciamento de codificações que vamos decodificando na medida em que lemos as orações e textos. Não apreendemos o sentido final de uma oração sem chegarmos ao fim de sua leitura. Dessa forma, a leitura é linear, sequencial e temporal, pois depende de um processo muito previsível. Sua compreensão se dá por etapas e separadamente.

A comunicação visual é um código que comunica suas partes de forma simultânea. Sua comunicação ocorre de forma integrada e global, como os estudiosos da Gestalt e da Percepção Visual já explicaram. A apreensão das codificações do texto visual acontece simultaneamente do todo para a parte e da parte para o todo em uma via de mão dupla que produz múltiplos caminhos de leitura e uma multiplicação de sentidos pelos caminhos percorridos nessa decodificação. Dessa forma, a leitura da imagem é simultânea, instantânea e global.

É preciso considerar duas ordens de discurso que são intrinsecamente diferentes. Essas diferenças foram levadas em consideração no desenvolvimento das ferramentas conceituais e metodológicas para essa pesquisa. Uma ampla exploração a respeito das diferenças e similaridades foi empreendida na busca de estabelecer considerações teóricas e metodológicas que ajudem a compreender a tarefa de analisar essas diferentes modalidades.

Mesmo considerando que os sistemas de inventários e padrões da modalidade visual e da linguagem verbal não funcionam de forma análoga, é importante destacar que este fato não impossibilita ou desmerece a necessidade desta investigação; ao contrário, pode revelar diferenças de funcionamento e estrutura que serão instrumentais para o avanço da compreensão da comunicação visual, em contraste com a linguagem.

Machin (2007) pontua que Kress e van Leeuwen (1996) encontraram nos pressupostos que explicam o funcionamento da linguagem verbal um ponto de partida para investigar “quais são as qualidades precisas da gramática da linguagem que nós devemos encontrar na comunicação visual para dizer que existe uma gramática visual” (MACHIN, 2007, p. 163).

Apesar de os inventários e padrões da linguagem visual não terem as mesmas características que a linguagem verbal, isso não retira as suas possibilidades de análise. Ao examinar se há uma linguagem visual como a linguagem verbal, Kress e Van Leeuwen (1996) procuraram os mesmos tipos de regularidade na comunicação visual, que ocorrem na gramática da linguagem. A gramática da linguagem é de certo modo previsível e estruturada, com escolhas limitadas. Vários teóricos, como Kress e van Leeuwen (1996) e Machin (2007), examinaram se haveria um paralelo entre a estrutura da comunicação visual e a linguagem 
que permitisse uma transposição ou equivalência com a sistematicidade observada nos padrões e estruturas da gramática da linguagem. Não encontrando essa correspondência, ao invés de buscar as semelhanças, Machin (2007) acredita que levantar as objeções feitas à gramática do design visual bem como focalizar nas diferenças entre a linguagem e as imagens pode ser mais produtivo para perceber suas características e distinções.

Para Halliday (1985), a distinção entre as modalidades deve começar a ser procurada pela distinção entre os sistemas semióticos simples e os sistemas semióticos complexos. A mudança do sistema de representação do hieróglifo para o alfabeto pode ser um bom exemplo dessa mudança de um sistema semiótico simples para um sistema semiótico complexo ou quando há um distanciamento do signo do sistema semiótico simples que permite que o som do signo passe a representar também a imagem que representa o objeto real. Isso torna o conjunto de pictogramas não apenas um conjunto de imagens, mas uma linguagem. $\mathrm{O}$ conhecimento de convenções e da gramática permite que a compreensão não dependa da habilidade de identificar imagens, mas de identificar convenções para o uso delas.

De acordo com Halliday (1985), nos sistemas complexos, o sentido é criado por meio de combinações previsíveis. Essas combinações ou blocos de gramática têm significado em si mesmas, produzindo um sentido potencial.

Se na linguagem que é um sistema semiótico complexo os recursos semióticos articulam os sentidos por meio da léxicogramática que dá o sentido por meio de convenções, o modo visual deveria ter uma gramática própria na qual os sentidos são criados por meio da sintaxe. A combinação dos recursos semióticos produziria itens lexicais visuais que não teriam um significado a partir de sua semelhança com o mundo real, mas por meio de convenções.

Para encontrar nas combinações dos componentes visuais a qualidade de gramática do modo visual, seria preciso em primeiro lugar, identificar nelas um sistema complexo com base em um léxico de elementos visuais que possibilitasse a criação de sentidos pautados em convenções e escolhas de combinações e não baseados em sua semelhança direta com o mundo. Em segundo lugar seria necessário um sistema de regras que convencionasse a combinação dos elementos visuais em um sistema de gramática visual.

Kress e van Leeuwen (1996) começaram a buscar qualidades da gramática da linguagem que, se encontradas na comunicação visual, evidenciariam a existência de uma gramática visual. Para isso, Machin (2007) argumenta que os 'vetores' e a 'modalidade' são duas ferramentas da GDV que apresentam qualidades compatíveis com as qualidades da linguagem. Em vez de focalizar as diferenças entre as duas modalidades, eles buscaram 
examinar se duas estruturas da comunicação visual, os 'vetores' e a 'modalidade' têm as mesmas qualidades da gramática da linguagem verbal que permitem dizer que existe uma gramática visual.

\section{a) Vetores}

Com o conceito de 'vetores', Kress e van Leeuwen (1996) descrevem 'verbos visuais' baseando-se na gramática sistêmico-funcional de Halliday (1985). Em uma sentença os participantes se relacionam com o processo, com auxílio do verbo. $\mathrm{O}$ verbo é um processo que significa uma ação e cria um relacionamento entre os participantes. Eles tomaram como base esse modelo para examinar a transação e a ação que transita na linguagem na qual as sentenças são analisadas, levando em consideração quem é o Ator, qual é o processo, qual é o objetivo e em qual circunstância ele ocorre.

De acordo com o estudo de percepção visual em Arnheim (1974) no qual Kress e van Leeuwen (1996) se apoiaram, as setas e formas geométricas são carregadas de sentidos. Eles argumentam, por exemplo, que setas podem indicar movimento e direção, e que quadrados podem sugerir volumes sólidos e estabilidade. Essas figuras geométricas associadas a sentidos tais como direção ou movimento poderiam ser codificadas para substituir o verbo e indicar uma ação como ela ocorre entre dois participantes em uma sentença, como no exemplo dado por Machin (2007, p.163):

No exemplo da Figura de Arnheim (1974) sugere que também nós distinguimos volumes de vetores nas imagens e fazemos distinção entre 'ser' e 'agir'.

O esquema simplificado representa os soldados e os terroristas como volumes e, sua dinâmica de interação, o ataque, está representada por uma flecha. Kress e van Leeuwen (1996) afirmam que esse tipo de associação metafórica pode ser identificado em imagens tais como desenhos e fotografias e ilustram com uma fotografia na qual homens ingleses olham e apontam armas em direção aos aborígenes ao fundo. $\mathrm{O}$ apontar das armas pode ser associado metaforicamente com a flecha do diagrama. Sugere a ação na qual os Ingleses são os Atores e os Aborigenes, a Meta. Seria possível descrever a ação na imagem como o processo verbal de 'ameaçar'. Kress e van Leeuwen (1996) argumentam que é possível representar esta imagem em um diagrama assim como a imagem dos soldados atacando terroristas no Iraque, onde as circunstâncias estão criando uma relação entre os ingleses e os Aborígenes. Estando em um mesmo cenário, este tipo de relacionamento é chamado de 'locativo' por Kress e van Leeuwen (1996). O processo em andamento os relaciona por meio de uma transação 
significada pelo apontar das armas ou ameaçar que é o equivalente visual de um verbo e é chamado por Kess e van Leeuwen (1996) de um 'vetor'.

Em uma imagem os participantes podem ser identificados quando eles estão 'sendo' ou 'agindo'. Quando os participantes estão ao fundo, podem ser representados como volumes enquanto participantes que são a origem de um vetor podem ser identificados como atores.

Uma vez que as imagens são feitas de elementos que ganham sentido quando são agrupados, assim como na linguagem verbal, Kress e van Leeuwen (1996) argumentam que é possível segmentar em blocos e unidades para descrever os vetores. Para Kress e van Leeuwen (1996), assim como para Dondis (2007) e para Arnheim (1974), o sentido se dá pela combinação dos elementos visuais descrita como sintaxe visual por Dondis (2007), e como sistema semiótico complexo pelos semioticistas sociais da TSSM. A noção de sintaxe visual não se dá da mesma forma como a noção de léxico-gramática da linguagem verbal, mas ela tem algumas características parecidas. Para fazer sentido de uma imagem, um espectador o faz da mesma forma que ele faria sentido na linguagem. Ele usa o conhecimento das convenções da gramática visual que permitem a compreensão do sentido não apenas pelos signos individualmente (apesar de seu sentido individual ser reconhecível, este não é o unívoco no texto), mas por meio de sua articulação no texto.

Os dois pontos de teste apresentados por Kress e van Leeuwen (1996) foram preenchidos e isso indica haver um léxico de elementos linguísticos que obtém o sentido pela convenção e uma gramática que alcança o sentido pela combinação dos elementos e não por um conjunto de itens individuais. Nesse segundo, o sentido visual é apreendido a partir das combinações entre Ator, processo, Meta e circunstância, assim como na linguagem verbal. No exemplo abaixo, na tela Campo de trigo com Ceifeiro e Sol de Vincent van Gogh, encontramos a combinação entre o Ator que é o ceifeiro e o trigo, que é a Meta, no trigal que é a circunstância. 
Figura 58: Tela Campo de trigo com Ceifeiro e Sol de Vincent van Gogh

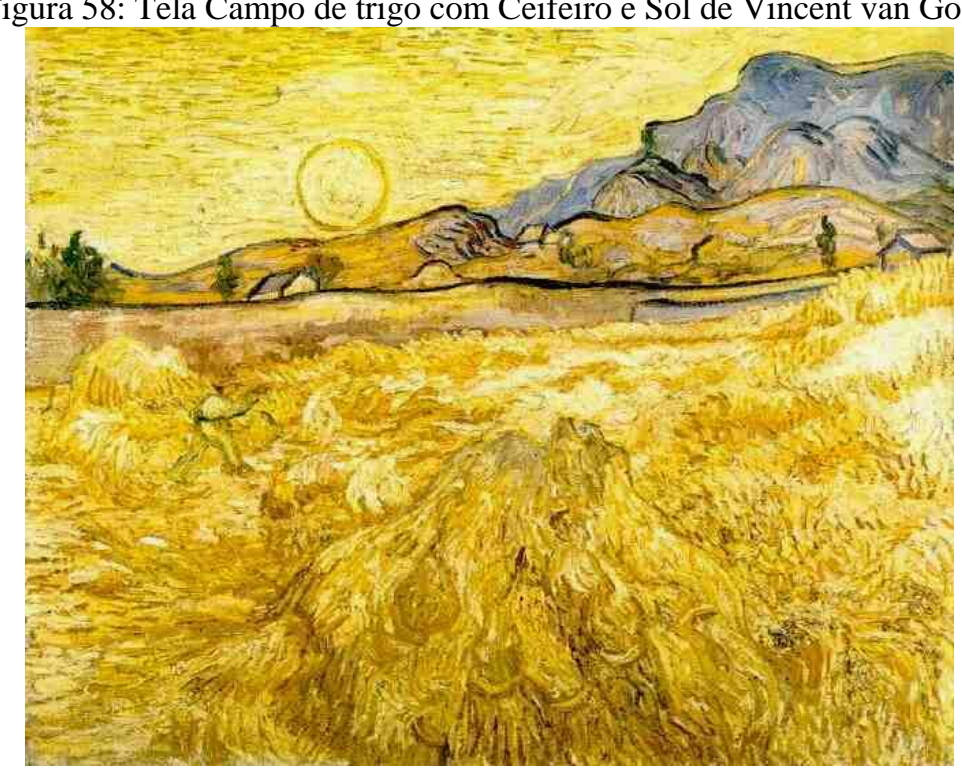

Fonte: Van Gogh (1889d).

Porém, os vetores não são uma constante em toda e qualquer imagem. Foram comparadas por Kress e Van Leeuwen (1996) imagens com vetores e imagens sem os mesmos. Eles chegaram a dois tipos de estruturas, as transacionais e as classificatórias. Em uma imagem com o vetor de uma modelo olhando sem qualquer expressão para o espectador, é considerada neste caso, uma imagem sem vetor, porque a modelo não atua como ator ou meta, mas como 'veículo'. Se transformarmos a imagem em uma sentença, como no caso da imagem dos ingleses apontando as armas para os aborígenes em 'Os Ingleses usam suas armas para ameaçar os Aborígenes' esta sentença seria algo como 'A vestimenta da modelo consiste de uma blusa vermelha, uma saia roxa, etc.

As imagens podem ser tanto do tipo classificatório quanto do tipo transacional e conter as duas estruturas. O caso de uma imagem conter os dois tipos de estruturas é bem ilustrado com a imagem de um soldado americano observando. Ao descrevê-la, podemos dizer que o soldado é um Ator, quando observa calmamente. O vetor do processo de 'observar' vai para fora do quadro para a direita, e seu uniforme limpo, maxilar forte e tecnologia são o veículo.

As representações narrativas são consideradas por Kress e Van Leeuwen (1996) como padrões vetoriais, uma vez que mostram ações acontecendo e mudanças ocorrendo. Imagens sem vetores que descrevem e classificam, são consideradas representações conceituais.

Podemos afirmar que os Vetores/verbos visuais são fundamentais para criar uma narrativa nas imagens assim como eles o são para a linguagem verbal? Esses verbos visuais podem ser considerados uma evidência da existência de uma gramática visual? Alguns 
problemas são essenciais para responder se 'os espectadores usam volumes e vetores como gramática visual para ler imagens, do mesmo modo que o fazem na linguagem verbal':

Para responder essa pergunta, Machin (2007, p. 166) propõe quatro testes:

1) Não é fácil decompor as imagens em unidades básicas. Tal como ocorre com as orações, é preciso observar se as imagens podem ser decompostas em unidades identificáveis e se elas podem ser decompostas pela descrição de vetores. A linguagem é antes de tudo um código arbitrário - um conjunto de semioses que adquirem o seu sentido por meio da escolha de sentidos potenciais que operam no contexto dos códigos. Se existem códigos visuais, resta saber se eles operam no mesmo nível de uma léxicogramática. Dessa forma, é preciso lembrar que os vetores ou verbos visuais evidenciam o conhecimento do espectador de uma gramática visual ou código convencionado que permite que as imagens façam sentido para ele.

2) Qualquer parte de uma imagem pode dar início a um número de regras semióticas. O fato de que Kress e Van Leeuwen (1996) se apóiam amplamente no contexto extralinguístico fora da gramática da imagem para interpretar uma imagem pode ser questionado como uma forma de buscar aqueles aspectos que fortalecem suas hipóteses, ao invés de buscar evidências na própria imagem em vez de no conhecimento contextual que a produziu.

3) É até possível verbalizar a cena em uma imagem, mas essa verbalização é um processo arbitrário, que pode acontecer de inúmeras formas. As imagens não são percepções estruturadas de forma gramatical do que elas representam visualmente. Ao buscar apoio no conhecimento contextual para entender a linguagem verbal, isso afeta o sentido da mesma forma e no mesmo nível?

4) Os códigos não operam na primeira camada de sentido na comunicação visual como eles operam na linguagem. No caso da existência de códigos e padrões de uso nas imagens, em que eles se diferem dos da léxicogramática da linguagem verbal?

Para que uma imagem tenha a mesma forma de funcionar de uma sentença, ela precisaria ter uma gramática e poder ser decomposta em partes ou unidades linguísticas definidas. Mas este não é o caso, de acordo com Dillon (2006 apud MACHIN, 2007). Kress e Van Leeuwen (1996) propõem um teste para responder se, como em uma sentença, uma imagem pode ser decomposta em volumes e Vetores/verbos visuais e descrevem uma fotografia de um pelotão de fuzilamento. Não se trata de um simples clicar de um homem 
levando tiros de uma fila de soldados. Imagine uma fotografia tirada pelo ângulo de um observador que está por detrás da fila de soldados e que mostra ao fundo um homem amarrado a uma estaca, vendado e caído. A partir da imagem não é possível estabelecer se ele caiu por medo ou pelos tiros. Atrás do homem caído, vê-se uma floresta e a cena está um tanto sem luz, porque foi tirada por detrás dos ombros de um soldado em uniforme militar. Este ângulo permite que vejamos a cena pela direita do ombro do soldado e pela esquerda dele, podemos ver outro soldado em uniforme olhando para fora do enquadramento e para a esquerda.

Nesta descrição de fotografia é possível imaginar uma cena na qual é possível para o espectador reconhecer claramente todos os elementos que compõem a imagem e poderia descrever o que está acontecendo na cena por meio de sentenças, mas isto não assegura que elas seriam estruturadas em torno de Vetores e volumes. O sentido que é dado ao homem amarrado na estaca, dos soldados atirando, e da floresta acontece por meio dos elementos isolados ou pela combinação deles na composição?

Os vetores na imagem poderiam ser identificados como o apontar das armas que vemos por cima do ombro do soldado, e o olhar do outro soldado para a esquerda. Mesmo se decompormos a imagem em volumes e Vetores e transpormos esses processos em sentenças o espectador não faria um sentido como o que está na imagem, como a narrativa de uma cena. Seriam sentenças como 'soldado aponta para o homem' ou 'soldado olha para algo' e esses sentidos dado pelas sentenças além de serem seccionados, não abrangem o que o espectador entende ao ver a cena, porque seu entendimento não vem dos verbos visuais, ou da combinação dos elementos entre si, mas de uma referência mais ampla.

Kress e van Leeuwen (1996) trabalham a noção de sentido potencial das posições de observar na qual eles falam sobre a sintaxe visual da forma como o espectador se alinha em relação aos participantes em uma imagem. Na imagem descrita acima, a foto é tirada por cima do ombro de um soldado no pelotão de fuzilamento, e isto sugere que o observador está alinhado com o homem de uniforme que aponta a arma e que ele vê a cena desta perspectiva. O espectador vê outro homem que olha para fora do enquadramento, que para Kress e Van Leeuwen (1996) é visto como um observador. No entanto, a Gramática é um conjunto de padrões para combinar elementos independentes em blocos ou unidades articuladas e cada elemento se relaciona com outros a partir dos padrões de uso ou pelas regras que tornam as sentenças possíveis. O problema com a decomposição de volumes e Vetores em uma imagem é que, ao serem descritos isoladamente, "cada um desses elementos visuais pode ativar qualquer regra semiótica independentemente” (MACHIN, 2007, p.167). 
Uma vez que as imagens não têm uma estrutura sequencial assim como ocorre nas sentenças, a ordem em que suas partes constroem o sentido não é definível e por isso, qualquer uma de suas partes pode iniciar a 'leitura' ou a construção do sentido. Qualquer parte pode detonar um número de regras semióticas e conjugá-las ao mesmo tempo ou não conjugar nenhuma.

Dessa forma, imagens podem ser decompostas aos seus elementos compositivos, mas não o seu sentido. Enquanto itens ou palavras lexicais são considerados os blocos ou unidades de construção na linguagem verbal, as imagens não se decompõem facilmente em blocos de construção. O trabalho de Davis (1992 apud MACHIN, 2007), a respeito da maneira que espectadores ocidentais contemporâneos tentam fazer sentido das imagens Egípcias antigas demonstrou a dificuldade dos especatadores em identificar os blocos ou elementos individuais nas imagens, porque não eram capazes de se apoiar no conhecimento contextual para construir os sentidos, ao invés dos sentidos que estão nas imagens, em si mesmos.

Arnheim (1974) e Stockl (2003 apud MACHIN, 2007) explicam que a percepção das imagens é simultânea ou gestáltica, enquanto a linguagem verbal é sequencial e linear e seu sentido é construido sequencialmente, já que os blocos e unidades de sentido são concatenados dentro das estruturas sequenciais e são apresentados em uma ordem para a compreensão.

No entanto, de acordo com Mitchell (1986 apud MACHIN, 2007) há o perigo de pensar que as pessoas veem qualquer imagem como um todo. $\mathrm{O}$ olhar do espectador pode ser conduzido a partir de qualquer uma das partes pela qual eles começam a fazer sentido uma vez que essa construção de sentido não depende de uma ordem estrutural pré-estabelecida como nas orações. Se não há componentes individuais de um todo para se falar do todo como se dá a compreensão das imagens? Nelson Goodman (1976 apud MACHIN, 2007) em "Linguagem da Arte" explica a diferença entre a imagem e a linguagem com a metáfora de dois termômetros, um com uma escala e o outro sem medidas. No primeiro termômetro observaríamos o mercúrio se ele está perto de um certo ponto da escala, e nesse caso, apenas esse ponto importa. Observamos quão longe o mercúrio se encontra deste ponto. No segundo termômetro sem a escala, a escala é infinita. Todos os pontos são observados porque são relativos e aproximados. Para Goodman (apud MACHIN, 2007), por serem organizadas de forma simultânea, as imagens são lidas de uma forma não sequencial, não gradativa, na qual qualquer ponto tem potencial semiótico uma vez que não se pode isolar nenhum de seus elementos como único a ter um caráter distinto. 
Essa característica da imagem é chamada por Goodman (apud MACHIN, 2007) de 'campo denso contínuo', que trabalha o sentido por um sistema de relações, e não como um caráter de distinção entre os elementos. Essa noção é exemplificada pela imagem da propaganda de um carro brilhante onde há a ênfase de um reflexo de luz. Enquanto que na imagem, a ênfase constrói seu sentido não pela diferenciação entre os elementos, mas pelo relacionamento entre eles, na linguagem verbal, os sentidos dos elementos precisam ser identificados unitariamente para se concatenar os sentidos de cada unidade. Como exemplo dessa característica, temos o alfabeto que está na base e funciona a partir do pressuposto que cada letra é diferente da outra. A linguagem, enquanto sistema funciona como um termômetro de escala no qual as lacunas e intervalos são importantes para distinguir os elementos entre si. Por isso a linguagem não trabalha com a noção de um continuum de 'a' até 'b' e depende da possibilidade de transferência para outros contextos onde cada letra mantém o mesmo valor. Nas imagens as qualidades podem ser transferidas sem manter o mesmo valor. No exemplo do carro, que qualidades poderiam ser transferidas para outros contextos?

Com base nessas considerações não podemos afirmar que as imagens são uma percepção visual de sentenças. Se as pessoas não constroem sentido de imagens apenas com base em uma decomposição de seus componentes mais básicos, não podemos conceber que as imagens são equivalentes visuais de sentenças como sugerido por Kress e van Leeuwen (1996). Não em sua totalidade, porque a comunição visual não é paralela, simétrica a linguagem verbal.

Enquanto algumas imagens podem se apresentar como equivalentes visuais simples de sentenças, como o exemplo de uma fotografia de uma mulher atirando em um homem poderia ser vista como o equivalente de uma sentença: 'A mulher atira no homem.' No entanto, nem todas as imagens podem se apresentar como equivalente visuais de sentenças, de forma que nem todos os exemplos podem ajudar a contornar a diferença fundamental entre linguagem verbal e imagem.

O exemplo do pelotão de fuzilamento mostra como essa imagem não é uma percepção visual da sentença 'o homem é acertado por um esquadrão de fuzilamento' e, com certeza não existe nenhum verbo visual para determinar com clareza que papel que os volumes têm na imagem. Não podemos afirmar que a imagem é a percepção verbal da sentença: o homem foi alvejado pelo pelotão de fuzilamento porque isto não está na imagem em si mesma (MACHIN, 2007). O uso de vetores e volumes só funciona quando podemos produzir verbalizações para imagens que são possíveis de serem feitas como no caso de "Os ingleses ameaçam os aborígenes". 
Existem inúmeras verbalizações que seriam possíveis de se fazer para uma única imagem. Em seu livro 'A Imagem e o Olho', Gombrich (1982 apud MACHIN, 2007), preocupou-se com a questão de que as imagens não são equivalentes de simples verbalizações e para ilustrar oferecia o exemplo da imagem de um gato sentado em um tapete:

Um momento de reflexão irá mostrar que a imagem não é o equivalente de uma
declaração. Nós não podemos expressar imageticamente se nós significamos 'o
gato' (um indivíduo) ou 'um gato' (um membro de uma classe); mais ainda, apesar
de a sentença poder ser uma descrição possível de uma imagem, existe um número
de outras declarações descritivas que pode poderia fazer tais como 'Existe um gato
visto por detrás', ou para um assunto 'Não existe nenhum elefante no tapete.'
(GOMBRINCH, 1982, p. 138 Apud MACHIN, 2007, p. 169).

Para responder a pergunta se é possível descrever uma imagem em termos verbais, Dillon (2006 apud MACHIN, 2007) ressalta que é preciso descrever formas nas quais as imagens são capazes de signficar e a linguagem verbal não é. Uma imagem de um círculo significa 'circularidade mais diretamente do que seria possível descrever com a linguagem verbal. A equivalência entre a imagem e a linguagem fica mais complexa quando perguntamos como é possível afirmar que um círculo é nele mesmo um equivalente da gramática que o descreve, que é um equivalente de uma verbalização? Dillon (2006 apud MACHIN, 2007) sustenta que as imagens capturam a essência das coisas de uma forma na qual inexiste equivalência na linguagem verbal.

Worth (1981 apud MACHIN, 2007) afirma que "Imagens não podem dizer nada" porque elas são similares ao verbo 'ser' no seu sentido existencial e descrevem ou retratam o que é. Ele argumenta que as imagens não descrevem "condicionais, negativos contrafatuais ou tempos de futuro do pretérito. Nem elas podem fazer transformações passivas, fazer perguntas, ou fazer uma série de coisas que uma linguagem verbal é capaz de fazer.”. (WORTH, 1981, p. 178 apud MACHIN, 2007, p. 171).

A diferença entre imagens e linguagem está no fato de que o nosso uso da fala está baseado em convenções que estabelecem um uso da sintaxe muito claramene definido que nos permite combinar proposições de verdadeiro ou falso. Nosso uso das imagens, em contraposição, se baseia em convenções que não dependem de uma sintaxe definida, nenhuma habilidade de articular proposições e de escrever. De acordo com Worth (1981 apud MACHIN, 2007), uma imagem não pode comentar sobre si mesma nem "fazer declarações 'meta' sobre declarações de baixo-nível do sistema da imagem.”. Por exemplo, uma imagem não pode descrever 'Essa imagem não é o caso', ou 'Essa imagem não é verdade'. (WORTH, 1981, p. 179 apud MACHIN, 2007, p. 171). 
De acordo com Worth (1981 apud MACHIN, 2007) a construção do significado pela gramática é uma característica muito clara na linguagem verbal e garante um retorno imediato. No caso das imagens, nota-se uma lentidão ou ausência de retorno e mostra que as imagens têm uma forma diversa de comunicar.

\section{b) O papel do conhecimento contextual na produção de verbalizações visuais}

Forceville (1999 apud MACHIN, 2007) acredita que as verbalizações de imagens que Kress e Van Leeuwen (1996) produzem está apoiada principalmente no conhecimento contextual e não na leitura da gramática visual e argumenta que a forma como eles lêem a imagem 'Os ingleses ameaçaram os Aborígenes' está muito mais apoiada nos conhecimentos que eles têm sobre a relação entre os Ingleses e os Aborígenes do que pelos códigos que estão dentro da imagem.

A análise de imagens de Kress e van Leeuwen (1996) recebeu de Bateman (2003 apud MACHIN, 2007, p. 172), o mesmo tipo de crítica sobre a capacidade das imagens de descreverem coisas novas e dadas e afirmam que: “Ainda não foi estabelecido se tal análise é na verdade mais do que uma racionalização post hoc de decisões de design que ocorrem em uma página por outras razões”. (BATEMAN, 2003, p. 67 apud MACHIN, 2007, p. 172).

A forma como as imagens comunicam parece mais apoiada em conhecimento extralinguístico de contexto do que em uma gramática intralinguística. Em vários exemplos nas artes, o sentido não está apoiado na imagem em si, mas nos enquadramentos. De acordo com Bal (2001 apud MACHIN, 2007), o contexto em que vemos uma imagem pode influenciar nossa leitura e influenciar quais sentidos vamos construir. Ele ilustra com a imagem de um homem que cai do World Trade Center no ataque de 11 de Setembro de 2001. A imagem serviu como evidência do que ocorreu, mas depois ela foi usada na produção de obras de arte, como pinturas e como estátuas, em diversas releituras. A imagem tem sido usada como um símbolo com respeito aos acontecimentos do dia 11 de Setembro e as lembranças que eles evocam. Se fossemos aplicar a análise de Vetor, o que poderia ser revelado? Poderiamos verbalizar o sentido desta imagem com o Vetor de cair para produzir todos os sentidos que a imagem evoca?

O mesmo questionamento é compartilhado por Sontag (1978 apud MARTIN, 2007) ao discutir que o sentido que há nas fotografias de guerra, fome e desastre que são veiculadas no noticiário não está tanto nos elementos na imagem, mas na forma como a sociedade está construindo sentidos para os eventos que estas imagens retratam. Por exemplo, em uma 
sociedade que enfatiza a negação das experiências de dor e onde o infortúnio e a doença são vistos como algo cruel, as imagens de miséria e privação chocam e despertam curiosidade. A circulação de imagens que são exploradas nas notícias mostra que há uma demanda para satisfazer a curiosidade sobre essa dimensão da experiência humana. O sentido dessas imagens não parece estar na gramática da imagem em si, mas no conhecimento contextual. Em outras palavras, as imagens possuem uma sintaxe visual que é explicitada por práticas culturais e contextuais. Para Halliday (2004), o sentido contextual também é fundamental para a linguagem verbal. Ele postulou que o sentido não está baseado exclusivamente na gramática, mas depende do contexto, das convenções e das circunstâncias. A forma linguística empregada realiza o significado potencial e a produção de sentido realiza esse amplo significado em uso. Halliday (1961) faz uma distinção entre o sentido formal e o sentido contextual, ao falar sobre o tipo de sentido que é codificado na linguagem. O sentido formal está na informação que usa uma certa forma linguística e não outra. O sentido contextual se realiza pelo seu uso no contexto. Na linguagem, a forma linguística de modais, como 'deve', por exemplo, é uma escolha linguística que pode indicar um compromisso maior do falante. Esse é o sentido formal dessa forma, mas está conectado com o seu sentido contextual na forma como nós usamos os modais nas situações de interação social e como eles são compreendidos.

Por exemplo, a sentença: 'Nós devemos ter uma família Real na Inglaterra', tem, além de seu sentido formal, um sentido contextual que indica sarcasmo com relação ao sentido formal. O sentido contextual de ironia é usado para mudar o sentido formal em 'deve' para um sentido completamente diverso. Em geral, a ironia não aparece de forma explícita no sentido formal, e seu sentido está fortemente apoiado no sentido contextual ao invés de se apoiar diretamente no sentido formal encontrado na gramática.

O sentido, para Halliday (2004), é construído por recursos que se encontram fora da gramática, e é assegurado pelo conhecimento dos códigos. No caso das imagens, a primeira camada de sentido não depende do conhecimento de um código. Se existem códigos e padrões para a construção de imagens, busco compreender em que eles diferem dos códigos da gramática da linguagem verbal.

Existem códigos para a comunicação visual, eles organizam padrões de uso para construir signficados. Nas fotografias, como no cinema, o enquadramento pode significar o ponto de vista, ou seja, de que ponto se vê a imagem. A forma como nos posicionamos para olhar um tema pode dar a ele uma posição de poder, por exemplo. Porém, esses sentidos só fazem sentido se temos conhecimento desses códigos. No universo da comunicação visual, os 
princípios semióticos são mais importantes do que nas regras de sintaxe da linguagem verbal na qual não existe significado sem a gramática e não se tem novas regras aparecendo sucessivamente. Já na comunicação visual, é preciso responder à pergunta sobre se os códigos visuais são arbitrários e precisam ser aprendidos para compreender as imagens ou se entender as imagens é como olhar simples e diretamente para o mundo a nossa volta.

Os enquadramentos fotográficos, por exemplo, que denotam um ponto de vista que olha para cima ou para baixo para construir um sentido de poder está apoiado na experiência cotidiana que os espectadores têm ao admirar ou desprezar as pessoas em suas vidas. A capacidade do espectador de construir sentido em uma fotografia que contém esses pontos de vista está apoiada na sua referência experiencial e não na sua habilidade de compreender um código arbitrário que é abstraído de experiências físicas. Já outros elementos que ajudam a construir o sentido formal, tais como enquadramento, ponto de vista, o potenical semiótico da tipografia e da cor são conhecimentos do mundo real, da nossa experiência física culturalmente mediada.

De acordo com Dillon (2006 apud MACHIN, 2007), no caso da linguagem não somos capazes de ler quando não compreendemos o código e isso porque os signos são arbitrários e não se assemelham com o que eles representam. Mas não é isso o que acontece no caso da imagem porque não precisamos decompor a imagem em componentes que oferecem sentidos por meio de suas combinações.

McCloud (1993 apud MACHIN, 2007) sustenta que a linguagem pede por conhecimento especializado para ser decodificada em seus símbolos abstratos e arbitrários, e que a imagem não requer conhecimento formal para se acessar a sua mensagem. Em seu exemplo, ele explica que mesmo em desenhos animados, nós não precisamos de conhecimento formal para decodificar símbolos mais abstratos, como o uso do círculo para representar o rosto, de pontos para os olhos e um traço para a boca. Já isso não se dá para decodificar a palavra 'face' que possui um nível de abstração muito maior e requer conhecimentos formais para decodicá-los, uma vez que esta palavra não tem nenhuma semelhança com a face real.

Por outro lado, há imagens que operam como o sistema da linguagem verbal, por meio de sistemas de códigos como ilustra McCloud (1993 apud MACHIN, 2007) no exemplo dos desenhos animados, onde cheiros não tem um equivalente visual, mas são representados por linhas sinuosas que sobem de algo como lixo e por este recurso, originou-se um código para simbolizar cheiro. 
Ainda comentando sobre o recurso de representar o cheiro com linhas sinuosas, podese dizer que há uma associação metafórica com as características físicas para a forma que os cheiros se expandem no mundo real, carregados pelo vento ou pela fumaça. Essas linhas onduladas são como códigos abstratos ou como uma metáfora visual e estão mais próximas de como a linguagem opera.

Além da distinção de 'sentido formal' e 'sentido contextual' feita por Halliday, temos a distinção feita por Harvey Sacks (SCHEGLOFF, 1987 apud MACHIN, 2007, p. 175) entre 'sentido construído' e 'sentido composto' na linguagem. Essas noções são muito importantes para compreendermos as camadas de sentido que compõem as imagens. Para Sacks (apud MACHIN, 2007), o 'sentido é construído’ é o que nós construímos ao combinar componentes na linguagem verbal, por meio do código da gramática. Já o 'sentido composto' é o que construímos por meio de um sentido mais abrangente que pode incluir uma experiência do mundo, ou a nossa história de leituras, ou uma resposta biológica que elicitamos para entender um texto. Como exemplo, Sacks (apud MACHIN, 2007) ilustra com a sentença "Aqui é uma aranha", que pode significar muitas coisas dependendo de fatores pessoais. No sentido construído, que todos vão obter pela decomposição dos signos, todos irão concordar com o sentido, mas isso já não ocorre no sentido composto.

Nas imagens, não há essa primeira camada de sentido construído por meio de uma combinação de signos codificados. Vamos direto para os sentidos que residem no 'sentido composto' que termina sendo onde se situa a primeira camada de sentido. Partindo dos argumentos apresentados acima, podemos afirmar que, ainda que seja possível descrever parcialmente uma imagem ao nomear alguns itens como volumes e outros como vetores, nós não podemos afirmar que isto seja uma gramática.

A princípio, seria preciso duas características presentes na comunicação visual para afirmar a existência de uma gramática visual que caberia no modelo de Halliday (2004) onde a léxico-gramática estava entre os signos e o sentido em um complexo sistema semiótico. Essa gramática visual deveria ter um léxico de itens que poderiam criar sentidos desde as combinações de escolhas. Essas combinações obtêm seu sentido por convenções e não pelas semelhanças com o conhecimento do contexto. Nessa gramática, deveria haver um sistema finito de códigos para as combinações e padrões de escolhas. No entanto, com a contribuição de vários teóricos, foi possível perceber que é difícil identificar elementos visuais em si mesmos. Alguns itens mais abstratos podem ser identificados, mas nas imagens mais complexas não encontramos itens facilmente reconhecíveis. No segundo caso não foi 
encontrado um código arbitrário para construir a primeira camada de sentido, como ocorre na linguagem verbal.

\section{c) Modalidade}

Até aqui foram examinados os vetores e se eles podem ser considerados uma evidência da existência de uma gramática visual. Nesse percurso, várias diferenças entre as duas modalidades foram elencadas com relação aos vetores. Agora, o mesmo exame será feito para a noção de modalidade e para as diferenças entre as imagens e a linguagem no que toca à noção de modalidade. Os vetores diferem da modalidade uma vez que os vetores são signos que podem ser identificados enquanto a modalidade é um conjunto de escalas e medidas.

O argumento de Kress e van Leeuwen (1996) para a noção de modalidade visual é a respeito da confiabilidade das mensagens como uma questão central na comunicação para estabelecer como nós sabemos se a comunicação é verdadeira ou inventada, a fim de tomarmos decisões sobre a confiabilidade da comunicação. Em termos de linguagem verbal, nós olhamos para aqueles signos que são criadores de modalidade porque eles nos mostram o que deve ser tratado como confiável e o que deve ser percebido como suspeito. Os criadores de modalidade na linguagem verbal são itens como 'poderia' e 'possível', como no exemplo:

- "Essa é uma fotografia de Adão tomando vodka."

- "Essa pode ser uma fotografia de Adão tomando vodka."

Na segunda sentença, o item 'pode' é o criador de modalidade e denota menor grau de certeza do que na primeira. Existem escalas de certeza, como por exemplo, uma sentença com menos certeza ainda:

- "Isso pode não ser uma fotografia de Adão tomando vodka."

$\mathrm{Na}$ linguagem, existem formas de indicar escalas de verdade e de certeza, escalas de quão real uma representação se diz. Mas nas imagens, encontramos criadores de modalidade onde o espectador é que julga como mais ou menos real. As escalas visuais podem ser consideradas como o equivalente das pistas na linguagem, chamadas de modais e outros meios de sinalizar modalidade, no contexto da escolha de palavras e estruturas.

Para Kress e van Leeuwen (1996), existem oito escalas ou criadores usados para decidir se uma imagem é mais ou menos real. Quando as marcas estão no nível mais baixo da escala, indicam baixa modalidade. Quando estão no nível mais alto da escala encontramos 'mais do que real' que pode criar um efeito sensorial. Se uma fotografia tem um detalhe no 
fundo, ela é menos do que real, mas se esse detalhe aumenta a iluminação, ele é mais do que real. Essas marcas nos permitem avaliar quão real uma imagem busca ser.

Estabelecidos por grupos sociais diversos entre si, existem quatro domínios de modalidade visual e Kress e van Leeuwen (1996) demonstram ao comparar descrições visuais de um processo de comunicação. A primeira descrição é a de um filme que mostra duas pessoas que dialogam em uma sala. A segunda é um diagrama esquemático que representa o fluxo de fala entre duas pessoas representadas por flechas e círculos que mostram a dinâmica de interação, da transmissão e da recepção. Estes dois tipos de descrição da comunicação são muito diferentes. A diferença é que o primeiro tipo representa o processo de comunicação como se nós estivéssemos na mesma sala com os falantes que dialogam e esta é uma instância muito específica de comunicação. O segundo tipo representa o processo de comunicação de forma fidedigna, por meio de uma abstração que pode ser generalizada para outros processos e apesar de muito diferentes, podemos afirmar que ambos os tipos de representação são verdadeiros. Para Kress e van Leeuwen (1996), essa diferença diz respeito não apenas a diferentes tipos de representação de uma mesma verdade, mas a diferentes tipos de verdade. Eles chamam o primeiro tipo de verdade representado no primeiro exemplo de 'modalidade naturalística' e o segundo tipo de verdade representado no segundo exemplo de 'modalidade científica'. Para este processo de distinção, eles buscaram apoio em Bernstein (1981) e chamam de 'orientações codificadas'.

Assim como a orientação naturalística e a orientaão científica, Kress e van Leeuwen (1996) apontam a existência de mais duas orientações codificadas que, de formas diversas, representam tipos diferentes de verdade. São a codificação sensorial e a modalidade abstrata. A modalidade sensorial representa a verdade dos sentidos e da percepção. Pinturas impressionistas ilustram isso, uma vez que elas não estão preocupadas em representar o nosso conhecimento da realidade, mas em representar a nossa experiência da realidade, da percepção da luz e das formas como o pintor as experieciou no momento em que pintou. É um tipo de orientação de verdade, que se pauta pela experiência sensorial e emocional da realidade. Van Gogh foi signatário desse paradigma com o qual pautou sua prática discursiva.

A orientação abstrata parece muito com a modalidade científica, e foi pouco descrita por Kress e van Leeuwen (1996). Essas quatro orientações produzem verdades visuais diversas entre si. As oito escalas de modalidade podem ser empregadas para avaliar a credibilidade visual em todas as quatro modalidades de orientações codificadas. Por serem de tipos diferentes, o emprego das oito escalas para verificar o grau de verdade poderia gerar configurações diferentes nas escalas como descrito abaixo. 
- Na modalidade naturalística encontraremos uma alta combinação de detalhes, a cor e iluminação deveriam aparecer como se estivéssemos presentes no local;

- Na modalidade científica vamos encontrar baixa combinação de detalhes (a iluminação, a cor e o brilho têm uma menor relevância neste caso);

- Na modalidade sensorial deveremos encontrar tanto alta e baixa articulação de detalhes, mas a falta de ordem poderá sinalizar essa orientação particular.

Ao reunir as escalas de modalidade e fazer um inventário, Kress e van Leeuwen (1996, p. 171) sugerem que podemos criar "configurações de modalidade" típicas. Com a ajuda dessas escalas torna-se possível julgar o grau no qual uma fotografia é de uma modalidade naturalística porque ela se encaixa na configuração ideal. Com a ajuda das "configurações de modalidade" é possível categorizar outros tipos de imagens até mesmo fluxogramas de arte.

Essas considerações levantam a seguinte pergunta para ajudar a entender os pontos de contato entre a linguagem verbal e a imagem: se as escalas de modalidade são utilizadas para julgar a verdade das imagens, elas podem ser consideradas como gramática?

Ao invés de idenficar signos visuais que funcionam como verbos visuais ou vetores, os criadores de modalidade identificam escalas e medidas que podem descrever padrões encontrados em representações visuais que são previsíveis até certo grau. Estes padrões podem ter semelhança com os grupos nominais que são padrões de uso gramatical na linguagem verbal, como por exemplo, a escolha do singular ou do plural. É possível criar um sistema de rede que permite descrever as escolhas viáveis ao construir estruturas do tipo das dos grupos nominais e as escalas de modalidade podem ser um sistema desse tipo. A amplitude de escalas que percorre do alto ao baixo grau de uso de certos marcadores visuais pode descrever os tipos de escolhas possíveis e são ilustradas por Kress e van Leeuwen (1996) em um mapa para representar esquematicamente as escalas.

No entanto, para que os marcadores de modalidade pudessem ser considerados como uma gramática, Machin (2007) encontra duas objeções.

1) A indefinição dos marcadores não oferece uma estrutura sistemática equivalente ao que encontramos na gramática. Essa objeção não é muito óbvia já que no diagrama esquemático proposto por Kress e van Leeuwen (1996), os marcadores parecem regras e passam a impressão de definição ou sistematicidade.

2) As quatro modalidades descritas por Kress e van Leeuwen (1996) não parecem contemplar a ampla diversidade de códigos que permitem aos espectadores identificarem tipos ou gêneros muito diversos de imagem. 


\section{d) Categorias indefinidas}

Muito sobre os marcadores de modalidade permanece vago, por exemplo, como eles deveriam ser aplicados em imagens individuais ou como eles poderiam ser empregados por meio de orientações de codificações diferentes. Porque no caso da gramática da linguagem verbal, isso seria de se esperar, que ela fosse capaz de explicitar em que condições suas regras são aplicáveis e que ela seja capaz de conservar sua estabilidade ao ser aplicada em uma diversidade de gêneros. Já no caso das escalas, não é explicitado sobre o que acontece onde os marcadores dessas escalas mudam para indicar baixa ou alta modalidade, e nem sobre os pontos destacados ou como eles se aplicam para gêneros diferentes. Para Forceville (1999, p. 168 apud MACHIN, 2007, p. 180), “o problema é que as categorias são raramente definidas; muitas categorias são indefinidas, e descrevem um continuum entre extremos ao invés de uma oposição binária com uma estrutura de alternância”.

Como teste Machin (2007) analisa o marcador de modalidade 'diferenciação de cor' que se aplica desde gama de diferenciação de cores maximizada até o mocromático. De acordo com essa escala, se olharmos para uma fotografia em preto e branco do Presidente dos Estados Unidos, nós olharíamos para uma imagem com baixa modalidade e de certa forma, vista como menos real, ou menos verdadeira. No entanto, é muito provável que um espectador encare essa imagem como um gênero de fotografia, e que é frequentemente usado para indicar credibilidade, seriedade, atemporalidade, neutralidade, distanciamento, por exemplo.

Se o marcador está se movendo em direção à modalidade mais baixa, que é a abstração, e nós avaliassemos como uma modalidade científica ou abstrata, não seria esta uma indicação de alta modalidade? O que não fica claro é em que ponto isso ocorre.

Se pegarmos a escala 'iluminação', que vai de uma representação completa de luz e sombra até a sua ausência podemos aplicar na fotografia do Presidente dos Estados Unidos. Nessa fotografia, a iluminação é mais forte do que em contextos do cotidiano, então o espectador pode assumir que essa imagem é mais do que real? Entraria em algum ponto a codificação sensorial? Como na diferenciação de cor, não é indicado na forma visual como e onde se coloca um ponto de destaque para a interpretação.

Não fica claro em que ponto o espectador mudaria sua avaliação de 'isso é real' para 'isso pode ser real' ou mesmo pensar que 'isso pode ser real em uma orientação de codificação diferente?'. Ainda que a distinção seja clara, existe uma grande probabilidade que o espectador veja essa imagem como determinado gênero de fotografia. 
Kress e van Leeuwen (1996) confirmam a ambiguidade no funcionamento das escalas e explicam que elas funcionam de forma independente e que o que é considerado da mais alta modalidade depende do tipo de imagem. No entanto, se a aplicação das escalas for depender do tipo de imagem, a informação de como aplicar as escalas não foi explicitada nesta gramática. A gramática da linguagem verbal, de acordo com Forceville (1999 apud MACHIN 2007) é estável ao longo dos gêneros que materializam a linguagem. Neles a modalidade funciona de forma muito dependente do gênero. Ao buscar uma equivalência entre a modalidade linguagem verbal e a comunicação visual, poderia se partir das características da modalidade na linguagem verbal que parece ser previsível. Uma gramática visual no que tange a modalidade precisa definir sob que condições as escalas operam.

Assim como com os vetores, os relatos de aplicação da modalidade na interpretação das imagens parecem para Forceville (1999 apud MACHIN, 2007) um pouco unilaterais. Ao buscar análises alternativas para as imagens, Forceville (1999 apud MACHIN, 2007) destaca que uma gramática, para ser operativa nas imagens precisa ter um compartilhamento intersubjetivo menor do que defendem Kress e van Leeuwen (1996).

De acordo com Machin, (2007), para além das orientações de codificação naturalista, nenhuma das escalas seria aplicável para a orientação de codificação sensorial. Em termos da codificação científica ou abstrata, qual a importância da escala das cores? Se um diagrama usasse cores, como isso afetaria a modalidade? Que importância teria a luz/iluminação e a aplicação da escala de luz em diagramas?

O fato é que não há uma escala real de modalidade para a codificação científica. Ao avaliar um diagrama científico o que importa é se ele representa como as coisas funcionam de forma acurada. A verdade não pode aumentar ou diminuir com níveis de abstração.

Mesmo quando estão abstraídos os desenhos científicos são uma expressão de culturas e tempos específicos, nos quais certos tipos de representações e padrões de diagramas são considerados mais verdadeiros não necessariamente por causa das escalas de modalidade, mas por fatores extralinguísticos de contexto, tais como convenções de estilo e de perspectiva, defende Elkins (1999 apud MACHIN, 2007).

É preciso fazer a seguinte diferenciação: uma coisa é dizer que os marcadores de modalidade nos ajudam a descrever graus variados de abstração nas imagens e, outra muito diferente, é afirmar que os marcadores de modalidade consistem em regras mais universais ou padrões mais estáveis para a gramática visual.

Para Machin (2007, p.182), as modalidades são úteis "para direcionar nossa atenção em direção a tipos de abstração em fotografias e diagramas que revelam formas importantes 
que as representações podem ocultar ou exagerar". No entanto, isso é muito diferente de afirmar haver nisto uma gramática visual, ou que será usado pelas pessoas para avaliar a credibilidade, a fidedignidade, a acuracidade ou o valor de verdade das imagens.

\section{e) Modalidade e Gênero}

Com relação à utilidade dos marcadores de modalidade, outra objeção poderia ser feita: se eles podem nos permitir saber que gênero de imagem que nós estamos olhando. Quando examinamos os vetores, nos perguntamos se eles funcionam na primeira camada de sentido como gramática da linguagem.

Para pensar essa questão, Machin (2007) oferece como exemplo, uma fotogradia de Adolf Hitler na qual foi adicionada cor a imagem, roupas, pele e cabelo. A cor está levemente saturada e a pergunta é, se as pessoas aceitam que esta seja uma imagem naturalística. De acordo com os marcadores de modalidade essas cores saturadas seriam mais do que real. $\mathrm{O}$ fundo está fora de foco, e neste caso, seria menos do que real. Seria uma imagem na qual Hitler é mais do que real em um fundo que é menos do que real, de acordo com os marcadores de modalidade. No entanto, o espectador a veria desse modo ou a veria como uma fotografia que é muito real, mas talvez um pouco estilizada?

Em um anúncio, se as cores são saturadas, o espectador acharia que a imagem é menos real ou que ela tinha se movido para uma codificação sensorial? Ele usaria essa saturação como um conjunto de pistas no texto e no contexto para saber que se tratava de um anúncio? E sabendo se tratar de um anúncio, qual a necessidade de perguntar se a imagem era verdadeira? As pessoas criticam anúncios por sua representação distorcida do mundo real, como ao representar todas as mães vestidas de branco. Mas essa distorção não pode ser detectada com as escalas de modalidade.

Um anúncio que tem a imagem de uma mulher pode ser visto pelo espectador como uma imagem de uma mulher real, mas que estava sendo usada como um anúncio e a pergunta sobre a verdade da imagem não passa pela iluminação, cor, foco e se estes marcadores foram manipulados digitalmente. Não há motivo por que o espectador aplicaria um conjunto de escalas para determinar o grau de verdade do texto se o que está determinando as escolhas é o uso de gêneros diferentes. Por exemplo, as revistas femininas usam cores altamente saturadas para comunicar riqueza de sentidos, sensualidade, mas não são usadas para estabelecer a verdade visual, mas a riqueza sensorial. Por exemplo, um alto grau de iluminação pode aumentar o nível de saturação e produzir um efeito macio e expansivo que comunica um 
otimismo sonhador. Esses são os tipos de códigos mais em experiência do que em uma gramática com um código arbitrário.

A questão central nesse caso, afirma Machin (2007), é a habilidade do espectador de reconhecer os gêneros nos quais as imagens foram produzidas. Em uma fotografia tirada na guerra, o espectador pensaria que ela era de baixa modalidade e, portanto menos real apenas porque tinha pouca definição, foco, ou um enquadramento muito atrapalhado? Apenas porque uma imagem de guerra está fora de contexto, isso significa que ela seja de baixa modalidade? Ela pareceria menos real?

Panofsky (1970 apud MACHIN, 2007, p. 183) propõe a noção de "significado representacional" que Machin (2007) resgata para pensar sobre o conhecimento prévio que o espectador tem acerca de estilos e gêneros. Panofsky (1970 apud MACHIN, 2007) defende que o espectador reconhece uma imagem a partir de sua própria experiência prática, de seu conhecimento dos estilos e convenções de representação. Todos sabem que uma fotografia é plana e bidimensional e que ela representa um mundo tridimensional. Também sabemos que iremos ver as fotografias do ponto de vista de quem tirou a foto, não como nós as vemos normalmente segurando nas mãos e olhando para baixo. Ao ver um anúncio no qual uma mulher tem um fundo branco atrás nós não pensamos que ela está flutuando no espaço, porque conhecemos as convenções de representação nos anúncios, eles não precisam ser naturalistas.

Devido ao nosso conhecimento de perspectiva e convenções de representação, Gombrich (1960 apud MACHIN, 2007) ressalta que o espectador ocidental contemporâneo não conseguiria entender a arte egípcia porque ela tem códigos de representação diferentes da cultura ocidental atual.

Para entender as pinturas e imagens produzidas em um tempo diferente do nosso, Panofsky (1970 apud MACHIN, 2007) defende que nós precisamos fazer uma imersão nas formas culturais de olhar as representações.

Os códigos visuais, no caso dos vetores, parecem estar em um nível diferente do que os códigos que estão na gramátia, mas esse não é o caso dos marcadores de modalidade que estão mais próximos desse tipo de código visual. Dessa forma, Machin (2007) contrapõe que, ao invés de tratar com quatro domínios de verdade visuais fixos, devemos tratar melhor esses que funcionam como códigos. Eles permitem que os espectadores reconheçam gêneros visuais distintos, sendo esses, muito mais do que quatro. Os marcadores de modalidade podem ajudar a descrever graus distintos de abstração e isso pode ser feito ao perguntar quanto, em uma cena representada, eles precisam ser mais reais ou naturalísticos, para que pareçam como se 
estivéssemos estado lá. Não fica claro se estes marcadores podem ser usados em qualquer situação para avaliar sobre o grau de verdade da imagem. Machin (2007) questiona com as seguintes questões se esses marcadores de modalidade são de fato utilizados pelos espectadores para ler imagens.

- Não está claro que as escalas de modalidade reduzem a modalidade ou ajudam a indicar uma mudança de uma codificação para outra orientação de codificação e parece que as escalas de modalidade são categorias indefinidas. Kress e van Leeuwen (1996) não explicitam esta limitação que as escalas de modalidade apresentam e representam os marcadores como um esquema para que eles pareçam mais definidos e objetivos. Devido ao fato que as pessoas têm critérios diversos para pensar sobre os diferentes tipos de imagens, as orientações de codificações da modalidade propostas por Kress e van Leeuwen (1996) parecem arbitrárias e limitadas para responderem ao aspecto polissêmico da leitura das imagens.

- Não está claro porque os marcadores de imagens devem ser considerados como gramática ainda que eles possam ser empregados para verificar os níveis de abstração. Assim como com o uso dos hieróglifos, talvez seja por meio de níveis de abstração que desenvolvemos a linguagem, mas esse aspecto não equivale a dizer que existe uma linguagem de abstração.

Machin (2007) levanta as seguines considerações para tentar responder a pergunta se de fato existe uma gramática visual. Ele argumenta que para determinar se há uma gramática visual precisaríamos encontrar os seguintes aspectos manifestos na comunicação visual:

- um léxico com elementos disponíveis para serem escolhidos e combinados a fim de produzir sentido, possível de ser compreendido por meio de convenções e não pela sua semelhança com o conhecimento e experiência de mundo;

- um sistema finito de regras e padrões de uso que possibilita a combinação dos itens lexicais, como é o caso da gramática da linguagem verbal. As imagens não são fáceis de decompor em itens lexicais, porque a semelhança e o sentido composto são muito importantes na forma como o espectador constrói o sentido das imagens, e por isso não foi possível estabelecer um léxico de itens disponíveis na linguagem visual.

- em vez de um sistema finito de regras para combinação que poderia ser chamado de gramática visual, foram encontrados "códigos e convenções que operavam por 
meio de associação e experiência física do que em um nível abstrato” (MACHIN, 2007, p. 185).

Ao invés de um sistema com padrões para leitura e produção do sentido, foi encontrado que o espectador poderia ativar qualquer regra semiótica em qualquer ponto dependendo do seu percurso de atenção e leitura da imagem, seja da parte para o todo ou do todo para a parte.

O quadro esquematiza as diferenças entre linguagem e imagem que foram levantadas por Machin (2007). As noções de sentido composto e sentido construído foram emprestados de Harvey Sacks (SCHEGLOFF, 1987 apud MACHIN, 2007). O sentido construído enfatiza a arbitrariedade dos signos e a função do código. O composto enfatiza a complexidade de fatores extralinguísticos, tais como a experiência de mundo, a biologia, e o contexto social e cultural que influenciam a produção de sentidos. O sentido composto e o sentido construído são características tanto da linguagem quanto da imagem, mas de formas diferentes e nesta diferença iniciam os problemas. Assim como a fotografia, a linguagem evoca imagens em nossas mentes que compreendemos emocionalmente e contextualmente e assim como a linguagem, as fotografias podem representar idéias abstratas e conceitos.

O quadro abaixo pode mostrar as diferenças mais amplas e os obstáculos que nos deparamos para definir uma gramática visual assim como a gramática da linguagem. Ela nos permite observar a diferença da natureza abstrata das palavras vistas como oposta à natureza dos signos visuais. O quadro descreve a forma como a linguagem ao ser comparada com a imagem tem itens identificáveis e um código previsível que nos revela que é o código a primeira camada de sentido na linguagem. Além disso, a linguagem tem dispositivos que a capacitam para uma descrição mais específica e para ser mais específica na intenção comunicativa.

Quadro 51: Quadro que esquematiza as diferenças entre linguagem e imagens

\begin{tabular}{|l|l|l|}
\hline Sentido Construído & Sentido Composto \\
\hline Linguagem & Icones/diagramas/ & Fotografias \\
\hline Componentes óbvios separados & $\leftarrow--------------\rightarrow$ & Sem componentes óbvios \\
\hline Códigos previsíveis & $\leftarrow-------------\rightarrow$ & $\begin{array}{l}\text { Qualquer regra semiótica ativada em qualquer } \\
\text { ponto }\end{array}$ \\
\hline
\end{tabular}




\begin{tabular}{|l|l|l|}
\hline Intenção Comunicativa mais clara & \multicolumn{1}{|c|}{ Intenção Comunicativa menos clara } \\
\hline $\begin{array}{l}\text { Código primeiro faz a camada de } \\
\text { sentido }\end{array}$ & $\leftarrow--------------\rightarrow$ & Contexto primeiro faz a camada de sentido \\
\hline $\begin{array}{l}\text { Representa ideias e conceitos } \\
\begin{array}{l}\text { Apresenta sentido denotatvo e } \\
\text { conotativo }\end{array}\end{array}$ & $\begin{array}{l}\text { Assemelha-se com o mundo real e representa } \\
\text { idéias e conceitos }\end{array}$ \\
\hline
\end{tabular}

Fonte: Aadaptado de Machin (2007, p. 186).

Machin (2007) ressalta a necessidade de mais pesquisas empíricas para definir na comunicação visual os tipos de padrões usados para articular uma sintaxe visual e a necessidade de caracterizarmos os tipos de códigos encontrados na comunicação visual. Para isso, ele aponta a necessidade de se levar em consideração as objeções e problemas que existem para se estabelecer uma gramática visual, pois as objeções não diminuem a importância de se pensar sistemicamente o uso dos recursos semióticos na comunicação visual.

\subsection{AS TRÊS METAFUNÇÕES DA LSF VISTAS PELA PERSPECTIVA DA ANÁLISE DE DISCURSO CRÍTICA}

Para articular a análise dos elementos visuais e verbais será preciso discriminar e categorizar estes elementos a partir de uma análise semântica do texto. Segundo Letart (1983), a semântica estuda o sentido das palavras, das frases e dos enunciados. O sujeito condensa diferentes sentidos nas palavras, complexifica seu significado e muda sua dinâmica no discurso. Os sentidos podem ser explícitos, mas ficam frequentemente implícitos no discurso.

Discriminar e definir esses elementos visuais e verbais no texto visual e no discurso verbal possibilita diferenciar e investigar sua manifestação no discurso. Podemos caracterizar esses sentidos, tais como lexicogramatical e semântico. $\mathrm{O}$ estrato lexical refere-se à produção do sentido de uma palavra no discurso, o estrato gramatical se refere à organização dos elementos visuais e verbais que compõe o enunciado, e finalmente o estrato semântico, se refere à relação entre a palavra e o mundo, sua significação. 
A categorização dos elementos visuais e verbais, possibilitada pela análise semântica, poderá evidenciar aqueles sentidos mais recorrentes no discurso visual e verbal. "A parte do procedimento que trata da análise textual pode ser denominada 'descrição', e as partes que tratam da análise da prática discursiva e da análise da prática social da qual o discurso faz parte podem ser denominadas 'interpretação'" (FAIRCLOUGH, 2001, p. 101). Ou seja, tanto os aspectos de forma quanto os aspectos de conteúdo são fundamentais para a análise discursiva e estão conectados, tantos nos aspectos textuais quanto nos sentidos/significados.

A perspectiva de Fairclough (2003) oferece uma reflexão importante para a pesquisa da relação entre contexto, história de vida, criação e transformação dos sentidos pelo sujeito na constituição de sua identidade. $\mathrm{O}$ autor considera na sua análise de discurso não apenas as reproduções sociais presentes no discurso, mas também a relação entre as mudanças discursivas e as mudanças sociais e culturais como um processo dialético no qual o sujeito cria e ressignifica os sentidos, organizando-os de forma a representar sua organização imaginária e simbólica do mundo e da sociedade.

Fairclough (2001, p. 22) propõe uma análise tridimensional:

A dimensão do 'texto' cuida da análise linguística de textos. A dimensão 'prática discursiva', como 'interação', na concepção 'texto e interação' de discurso, especifica a natureza dos processos de produção e interpretação textual [...] A dimensão de 'prática social' cuida de questões de interesse na análise social, tais como as circunstâncias institucionais e organizacionais do evento discursivo e como elas moldam a natureza da prática discursiva e os efeitos constitutivos/construtivos".

A análise do relato do artista acerca do seu processo de produção artístico e da forma de estruturação dos elementos visuais que compõe a obra de arte parece se situar tanto na 'prática discursiva' quando o autor focaliza a interpretação e a intenção do sujeito quando está criando e produzindo sentidos; como também a combinação de diferentes modos de discurso na sua fala, na combinação de elementos visuais, buscando compreender como estes diferentes modos discursivos se complementam e como conflituam, seja para buscar uma síntese identitária, seja visando uma transformação nos sentidos ou para fazer resistência a sentidos que se impõe em ambos os discursos.

Para Fairclough (2001, p. 128), "os processos sociocognitivos serão ou não inovadores e contribuirão ou não para a mudança discursiva, dependendo da natureza da prática social". Ao serem reconfiguradas no discurso ideológico, esses sentidos começam a fazer parte do discurso e ao se integrar, eles inserem novos sentidos e significados, mudando a prática discursiva e também as relações sociais, entre elas a relação do artista com sua produção artística. 


\section{1) Interativa - Interdiscursividade e negociação de sentidos}

Se considerarmos o conceito de discurso que enfatiza a interação, podemos analisar o discurso visual e verbal nesse processo interacional, no qual a interrelação entre as linguagens pode ser percebida como complementaridade entre diferentes modos de manifestação dos sentidos e formações discursivas, assim como evidenciar uma indiferenciação entre estes campos, ou um conflito entre modos de manifestação da experiência social.

A interdiscursividade e a intertextualidade são possibilidades de transformação por meio de ressignificações e mudanças na prática discursiva. "A mudança envolve formas de transgressão, o cruzamento de fronteiras, tais como a reunião de convenções existentes em novas combinações, ou sua exploração em situações que geralmente as proíbem" (FAIRCLOUGH, 2001, p. 27).

O estudo da prática discursiva envolve a análise dos: a) processos de produção: quem é o autor do discurso e como ele o produz; que papel exerce; quais as relações que estabelece; significado interpessoal; o efeito do contexto no qual ele fala, sua força e coerência, assim como seu status no grupo e posição de sujeito; b) processos de distribuição: é simples quando é produzido no mesmo momento que é distribuído, pertence ao contexto no qual é produzido, como uma conversa, mas pode ser complexa quando envolve recursos diversos e se o sujeito tem recursos para a distribuição; processos de consumo textual: o processo de produção e de interpretação compreendem a força e a coerência, a força pode ser direta ou indireta, e a coerência é produzida por quem interpreta, por quem dá sentido à fala do outro.

Segundo o autor, a coerência depende mais da interpretação do que do processo de produção da linguagem. Muitas vezes a fala faz sentido porque ao relatar ele constrói metadiscursos, inferindo relações de sentidos e explicitando sentidos que antes estavam latentes (FAIRCLOUGH, 2001). Essas inferências podem estar apoiadas em novas articulações entre pressupostos ideológicos, filosóficos e sociais como podem fazer diferentes leituras de diferentes textos. Esse aspecto diz respeito à 'intertextualidade', pois os textos visuais possuem fragmentos de relatos e de pensamentos, explicitamente ou implicitamente, de forma complementar ou contraditória. E a interdiscursividade produz-se nesta heterogeneidade de elementos das ordens de discurso, que pode ser articulada na análise do discurso dos elementos visuais na linguagem plástica e dos elementos semânticos no relato verbal. E é nesta interdiscursividade que aparece a relação entre os elementos da linguagem visual e verbal na ordem discursiva de cada formação discursiva e dos elementos do discurso. 
Assim, a linguagem visual e verbal pode ser analisada como práticas sociais que se complementam e se conflituam, explicitando as lacunas e também potenciais de criação artística. Assim, a produção artística pode ser analisada tanto no seu aspecto de reprodução das relações de poder e de ideologias quanto no processo de transformação das relações sociais com base na construção de novos sentidos e elementos que compõem a estrutura da linguagem organizada pelo sujeito para expressar esta tensão.

Com base na análise de Fairclough (2001) nos perguntamos qual é o papel da linguagem na transformação das relações de poder e como os recursos semióticos da linguagem plástica podem estar mobilizando novos sentidos para a experiência social.

Esta é uma questão colocada por Fairclough (2001, p. 22): "como diferentes discursos se combinam em condições sociais particulares para produzir um novo e complexo discurso?".

A relação entre discurso verbal e visual parece se apresentar como algo ainda indefinido, mas uma relação que ao ser analisada pode trazer à tona os diferentes elementos que pertencem a essas duas modalidades discursivas, possibilitando a discriminação desses elementos estruturais das diferentes modalidades de linguagem e a explicitação de sentidos e processos sociais, implícitos no discurso visual e no discurso verbal. Acredita-se que a análise de um discurso pode facilitar a compreensão de elementos latentes, presentes em outro discurso, assim as linguagens verbal e visual se complementam e possibilitam a explicitação de sentidos com base em uma forma de estruturação dos elementos linguísticos de cada modo de expressão: o relato da história de vida e a produção da obra artística.

A heterogeneidade de sentidos presentes no discurso é um elemento importante para analisar as diferentes identidades e representações assumidas no relato e na produção artística, que compõe o processo de produção do artista. As diferentes molduras identitárias e a busca de integração em uma identidade coesa geram na prática discursiva, tanto verbal quanto visual, uma heterogeneidade do discurso que Fairclough (2001) discutirá como sendo a 'intertextualidade' e a 'interdiscursividade'. Compreender as formas de organização discursivas na linguagem visual que mantém ou que transformam os sentidos pode auxiliar na compreensão destes processos em outras linguagens e relações sociais. 


\section{CAPÍTULO 3 METODOLOGIA}

\subsection{JUSTIFICATIVA E CARACTERIZAÇÃO DOS CORPORA DA PESQUISA}

\subsubsection{Justificativa para a escolha do corpus pictórico}

A seleção das telas seguiu os critérios descritos a seguir. Vincent van Gogh produziu, o levantamento do Museu van Gogh, em torno de 864 telas e essa produção extensa e intensa torna o trabalho de seleção do corpus bastante desafiante. Para fazer a seleção do corpus pictórico, foi preciso ler a literatura histórica e biográfica do artista para explorar critérios do 'Contexto de Situação' (MALINOWSKY, 1923 apud VAN LEEUWEN, 2011, p. 306) e do 'Contexto de Cultura' (SAPIR; WORF apud HALLIDAY; MATHIESSEN, 1999, p. 17). A escolha levou em consideração critérios que exerceram um papel significativo no desenvolvimento e amadurecimento de um pensamento artístico próprio de Van Gogh; que refletissem o percurso de escolhas linguísticas em seu trabalho pictórico e que fossem relevantes para o objeto e enfoque desta pesquisa.

Três foram os enfoques usados como ponto de partida para pensar os critérios de seleção das telas para esta pesquisa:

Primeiro, o contexto histórico social e cultural no qual estas telas foram produzidas para analisar o que este contexto fala sobre estas telas.

Segundo, o período em que elas foram pintadas e o que esse período fala sobre a trajetória desse protagonista e propositor de um sistema linguístico pictórico próprio. Ou seja, do ponto de vista linguístico, em que período ele produziu os textos visuais mais coesos, mais coerentes com seu discurso, mais consistentes com seu sistema de crenças, e com maior potencial semiótico?

Terceiro, perguntei como as telas se relacionam entre si, se elas podem ser agrupadas por algum aspecto semiótico e que, de alguma forma, reflita aspectos tais como: sua produção; os avanços na sua trajetória linguística; sua visão e experiência de mundo; as questões fulcrais em seu discurso artístico; seu lugar social como pintor e como alguém que produz um discurso.

Este último critério, assim como outras questões pertinentes, são discutidas no apêndice em virtude do volume da tese. 
Um último critério que não estava previsto nos três enfoques acima, surgiu durante a análise preliminar do corpus textual e vou me referir a ele como intertextualidade. Trata-se da indicação feita pelo próprio autor em suas cartas que aponta para uma relação direta entre duas telas, sendo que uma delas participa do corpus pictórico e a outra não tinha sido considerada. No extrato de $n^{\circ} 4$ b ele pontua que as duas telas têm uma relação direta: "O café noturno é uma continuação do semeador”. Abaixo ilustro com o excerto que sugeriu essa relação:

Mais tarde, quando eu tiver levado esses experimentos mais longe, o semeador ainda vai ser a primeira tentativa nesse gênero. [...] O café noturno é uma continuação do semeador, como é a cabeça do velho camponês e do poeta, se eu conseguir fazer essa ultima tela. É uma cor, então, que não é localmente verdadeira do ponto de vista realista do trompe l'oeil, mas uma cor que sugere alguma emoção, um temperamento ardente. (VAN GOGH, 2009j, p. 1).

Em outro extrato, $\mathrm{n}^{\circ}$ 4e de carta, ele também faz menção à tela do Semeador como sendo da mesma categoria da tela que ele está descrevendo no excerto analisado:

A idéia do semeador ainda continua a me assombrar. Estudos exagerados, como o
semeador, como o café noturno agora, geralmente parecem-me atrozmente feios e
ruins, mas quando eu estou movido por alguma coisa, como aqui por este pequeno
artigo sobre Dostoievski, em seguida, eles são os únicos que me parecem ter um
significado mais importante. (VAN GOGH, 2009b, p. 1).

A relação entre as duas como uma continuidade é um critério apontado pelo próprio van Gogh. Por esta razão, a tela $O$ Semeador passou a integrar o corpus pictórico para ser investigado se ocorrem semioses comuns às duas telas, visto que sua similaridade não é da temática em si, mas da forma como são representadas e explicadas por van Gogh como "a primeira tentativa nesse gênero":

Mais tarde, quando eu tiver levado esses experimentos mais longe, o semeador ainda vai ser a primeira tentativa nesse gênero.

A seguir desenvolvo os critérios que basearam a escolha das telas:

O contexto social e cultural no qual foram produzidas - Vincent van Gogh, é descendente por parte de pai de uma família que vem de uma aldeia chamada Cogh. Eles participaram da Revolução Luterana e das lutas religiosas para afirmar a nova ordem. Naifeh e Smith (2012) relatam que os membros da família tinham uma postura dogmática e extremista em relação à fé, em um país que participou da Reforma da Igreja e foi naquele momento histórico, dividido por lutas religiosas. ${ }^{319}$ Anos depois de seu desligamento da

\footnotetext{
${ }^{319}$ Nas próximas gerações os membros da família ascenderam a postos mais proeminentes dentro da igreja e nas gerações seguintes, deixaram o sacerdócio para ocupações liberais, mas ligadas à igreja. Um deles foi advogado de assuntos da igreja, e seus filhos voltaram-se para o comércio de fios de ouro para adornar as vestimentas dos luteranos e seus filhos, para o comércio de gravuras e de reproduções de telas famosas. Esse comércio, em um novo mercado que se abria, foi possível graças ao advento da prensa Gutemberg, que impulsionou a primeira
} 
atividade de marchand na galeria do tio Cent, ele retornou a Paris para viver com seu irmão Théo, agora marchand na mesma galeria. Theo o colocou em contato com vários pintores e artistas, chamados de segunda geração de impressionistas, e outros, Vincent tomou conhecimento em sua prática de pintura na cidade. Este coletivo de pintores consistia em um grupo de propositores engajados em experimentar, experienciar e articular novos sistemas semióticos na pintura, não necessariamente com concepções pictóricas consoantes. Eles enfrentavam uma enorme dificuldade para manterem-se com a venda de sua produção, uma vez que o mercado era dominado pelas tendências do academicismo, do romantismo e do realismo. Ao conhecer as vicissitudes dos artistas parisienses, Van Gogh buscou para si e para os pintores seus conhecidos, alternativas autossustentáveis. Ele pensou em um sistema de trabalho comunitário ou colaborativo no qual os artistas viveriam juntos no interior da França, dividiriam custos e conseguiriam sobreviver enquanto seu irmão Théo abriria um espaço no mercado de arte, divulgando as telas e conquistando novos clientes. Estes projetos são relatados na biografia de Van Gogh escrita por Haziot (2010, p. 196):

\begin{abstract}
Imediatamente voltou-lhe ao espírito a velha idéia de uma associação de pintores que ele não cessava de acalentar desde que se lançou no caminho da arte. Já que a sociedade leva tanto tempo para reconhecer o verdadeiro talento, por que os pintores não se associavam para se sustentar? Era o seu lado "Exército da salvação": servir, ajudar-se mutuamente. Uma vez mais, expôs seu grande sonho a Théo. "Por várias razões, eu gostaria de poder fundar uma pousada que, se não desse certo, serviria para fazer descansar no campo os pobres cavalos de Paris, que são voce mesmo e muitos de nossos amigos, os impressionistas pobres" C469.
\end{abstract}

onda de alfabetização na Europa (ONG, 1982) junto com a revolução luterana. A ascensão da classe burguesa trouxe a bojo a busca de sua distinção da classe camponesa por meio do consumo dos bens que conferiam o status da nobreza, entre eles a arte, que até então era comissionada pelos nobres e pela Igreja Católica. Essas obras encomendadas para representar temas religiosos, retratos e eventos históricos em telas grandes para os recintos dos palácios e das igrejas iriam agora diminuir de tamanho para ocupar as paredes da nova classe burguesa. Ter uma tela na sala de estar passou a simbolizar status e distinção. Nesse contexto, o tio de Van Gogh, chamado também de Vincent foi um visionário no comércio. Casou-se com uma mulher rica e abriu uma galeria em três capitais, Haia, Paris e Londres com o parceiro comercial Goupil, para vender gravuras e reproduções de telas com os motivos que caiam no gosto desta nova classe burguesa. Em sua galeria trabalharia primeiro o sobrinho Vincent van Gogh e depois, seu irmão mais novo, Theo van Gogh. Como marchand de tableau, Vincent foi um excelente pintor. Ele tentava ressaltar para os clientes, os aspectos singulares com valor pictórico inovador em telas que não caiam no gosto da classe burguesa, que preferia os motivos da moda a compreender a força expressiva e o potencial linguístico particular em uma tela. Vincent era um profundo conhecedor dos artistas que seu tio comercializava e dedicava-se a mergulhar nas telas que capturavam seu olhar aficcionado. No entanto, as tendências dos movimentos pictóricos que predominavam nas galerias na época compreendiam o Romantismo, o Realismo, o Medievalismo, o Orientalismo, o Classicismo, o Academicismo e o Neoclassicismo (LITTLE, 2010), todos de uma estética tradicional. Muitas dessas tendências pictóricas acompanhavam os movimentos culturais da época, como o Romantismo, por exemplo, que impactou na cultura e na política do século XIX inteiro. Van Gogh terminou por não se identificar com o trabalho de marchand e escolheu seguir o caminho mais íngreme para se dedicar por completo, primeiro para o ofício de evangelizador e, depois, para o ofício de pintor. É preciso destacar que há uma ligação inegável entre a natureza destas duas escolhas, especialmente na forma como ele as abordou, não como um meio de vida, um sustento, ou um lugar social a oferecer segurança e estabilidade; e, não como um meio para chegar a um fim de sucesso social, mas como uma missão visionária e acima de si mesmo, para a qual dedicou extremados esforços e pagou elevados preços. 
Essa proposta mostra o quanto Van Gogh não estava apenas preocupado em conquistar apenas o seu próprio espaço no mercado de arte, mas antes estava apaixonado pela ideia de trabalhar em prol de um ideal coletivo, de um meio de vida colaborativo, apoiado em valores solidários e em uma prática comunitária para a proposição dos novos rumos da arte. Seu empenho para tentar viabilizar o sustento dos novos artistas que, assim como ele eram desconhecidos, mostra a preocupação, não apenas com o desenvolvimento de uma linguagem própria, mas colaborar também com a proposição de um sistema semiótico amplo e de amplas abrangências. Embora não tenha conseguido um amplo reconhecimento e o pertencimento no grupo, como descrito por Haziot (2010), ele tentou com todos os seus recursos psíquicos e humanos fazer acontecer este ideal com ações e projetos que compartilhou com Théo:

[...] Mas essa ideia não podia encontrar nenhum sucesso entre homens tão
ferozmente individualistas como os pintores, ainda mais franceses. Vincent nunca
compreendeu que esse programa um tanto coletivista, que não era absurdo em si,
não poderia se realizar num país de mentalidade tão anarquista como a França. Teria
podido se realizar noutra parte? Nada é menos certo, pois a criação, com raras
exceções, continua sendo a expressão de uma grande solidão. Mas na França, onde
os criadores estavam prontos a criar movimentos, profissões de fé batalhadoras e
revistas provocadoras, a idéia não tinha futuro algum. Quem pode imaginar Seurat,
Van Gogh, Gauguin e Cézanne pintando lado a lado? E em paz! (HAZIOT, 2010,
p.196).

Dessa forma, acredito que as telas dos cafés simbolizam, sintetizam, condensam todos os sentidos compactados em ter sua vida comprometida com um empreendimento de alto risco e uma prática que não é isolada ou autorefenciada; ela se dinamizava em uma rede de relações de um coletivo muito particular, com quem ele convivia enquanto em Paris e mantinha contato amiúde, depois, por meio de correspondência. Gombrich (1999) descreve a efervescência que marcou essa época e impulsionou a formação de coletivos de artistas mobilizados em discutir os rumos da arte:

Os episódios mais espetaculares nesse desenvolvimento tiveram lugar em Paris. Com efeito, Paris tornara-se a capital artística da Europa no século XIX, tal como fora Florença no século XV e Roma no século XVII. Artistas do mundo inteiro afluíam a Paris para estudar com os grandes mestres e, sobretudo, para se juntar ao debate sobre a natureza da arte infindável nos cafés de Montmartre, onde a nova concepção de arte era laboriosamente preparada. (GOMBRICH, 1999, p. 504).

Por esse motivo, considerei as duas telas que representam cafés, como temas que falam, não apenas de um lugar físico, mas de um lugar de prática, onde os artistas se encontravam para compartilhar e contrapor ideias acerca de sua prática e significá-las no contexto de uma prática social e de um discurso emergentes e revolucionários. Naifeh e Smith (2012, p. 588) relatam o papel dos cafés parisienses na ebulição cultural que transbordava naquele momento: 
Numa cultura definida pelo consumismo e pelo desprezo de si mesma, a estética niilista dos fumistes logo virou moda. Círculos artísticos que tinham começado basicamente como meros conclaves em bares se transformaram em centros de entretenimento muito frequentados (os cabarets artistiques), onde empresários como Rodolphe Salis e Aristide Bruant propagandeavam a boemia extremada da arte vanguardista para o haut monde da sociedade parisiense e turistas boquiabertos. Adotavam nomes como Café dês Assassins, Cabaret dês Truands e Cabaret de l'Enfer. No mais famoso deles, Le Chat Noir (O Gato Preto, um trocadilho obsceno com uma gíria que designava órgãos genitais femininos), a clientela elegante e na moda se sentava em salas apertadas, decoradas com "a bagunça de um ateliê", servida por garçons usando os fardões verdes e dourados da Academia francesa. O proprietário Salis insultava os clientes com égalité republicana, oferecendo mesmo aos mais distintos um frisson da vida artística ao "tratá-los como cafetões e putas", segundo um relato.

Retomo estas considerações mais abaixo no terceiro critério para a escolha do corpus pictórico.

O período em que foram produzidas - Ao ler a biografia de Van Gogh escrita por Haziot (2010) pude compreender que o período de Arles, anterior à visita de seu colega e pintor contemporâneo Gauguin, destaca-se pela materialização de uma gramática e de uma sintaxe pictórica própria que manifesta com plenitude e exuberância as inovações discursivas em sua obra. Coli (2006, p.95) fala sobre a maturidade e a autonomia discursiva e estilística com que van Gogh adentra o período de Arles:

Chegando em Arles, ele possui portanto uma bagagem técnica e estilística que, em sua essência, não mudará até o final de sua produção. É certo que nesse percurso existem variações - mas não haverá mais mudanças radicais. É verdade que cada mudança, cada contato novo com uma nova paisagem determinará um diálogo entre a sua paleta e o mundo que descobre. Desse diálogo resultarão renovações picturais, mas que permanecerão sempre dentro dessa mesma técnica e desse mesmo estilo.

Esses recursos e estratégias semióticas, amealhadas até aquele ponto de sua trajetória em busca de desenvolver sua própria linguagem pictórica serão, após a chegada de Gauguin, questionadas, combatidas, desconstruídas; primeiro por Gauguin e depois pelo próprio Van Gogh por compreensões equivocadas de ambos acerca dos caminhos pictóricos que Van Gogh percorrera até ali e das suas escolhas linguísticas ao fazê-lo. Walther e Metzger (2015, p. 342343) descrevem o apogeu que compreendeu o período de Arles:

O artista saía para o trabalho dia após dia penetrando na florida paisagem montanhosa da Provença e produzindo obras-primas umas a seguir às outras. "É a excitação, a franqueza de responder à natureza que guia a nossa mão; e se esta excitação é muitas vezes tão forte que trabalhamos sem reparar que o estamos a fazer, se as pinceladas saem por vezes espessas e rápidas como as palavras numa conversa ou numa carta, não nos devemos esquecer de que nem sempre foi assim e de que muitos dias deprimentes e sem inspiração virão." Estas palavras (tiradas da Carta 540) assumem um tom profético se pensarmos na depressão por que Van Gogh passou antes de o ano chegar ao fim. Mas o enorme vigor que agora sentia apontava para um futuro melhor. E os produtos desta explosão criativa causam-nos uma sensação muito positiva, possuindo uma joie de vivre que nunca voltaríamos a encontrar em sua obra. A utopia em que vivia, com a sua atmosfera de otimismo, estimulou naturalmente a "excitação" de van Gogh. É possível que o otimismo fosse 
mais imaginário do que real; mas Van Gogh foi arrastado pelo "trabalhamos sem reparar que o estamos a fazer". Nos momentos de reflexão que fizeram aparecer a utopia em lugar da ficção foram raras as alterações no seu mundo visual. A precisão de O Pintor a Caminho do Trabalho enquanto descrição de um estado de espírito equipara-se à sua pungência enquanto exceção na sua obra de pintura. Por enquanto, Van Gogh estava a distinguir entre o presente e a promessa de felicidade futura registrada nos seus quadros. Ele dedicou-se ao futuro.

As transformações e rupturas que se sucederam ao encontro de van Gogh com Gauguin tanto no âmbito pessoal de Vincent quanto em sua obra, impactaram em sua paleta cromática nos períodos subsequentes já não veremos as explosões cromáticas quentes e deslumbrantes do período Arlesiano, ainda que ele siga nos surpreendendo com outras inovações em seu sistema semiótico pictórico. O período de Arles é considerado por Cabanne (1971, p. 198) como o sol pleno na produção artística de van Gogh:

Cerca de duzentos quadros foram executados por Vincent durante o período de Arles; cem paisagens, uns cinquenta retratos, quarenta naturezas-mortas ou interiores, sem falar das obras destruídas ou desaparecidas. Podemos igualmente enumerar uma centena de desenhos. É o período mais rico aquele em que o ritmo do traço e a força da cor atingem os seus mais altos cumes; o movimento da linha e o tom saído do tubo constituem outros tantos elementos-força que acompanham o seu impulso, a sua comunhão com a Natureza ou o objecto. Quando Vincent escreve: "Para alcançar o alto tom amarelo que atingi este Verão foi-me preciso preparar um pouco a coisa”, exprime esta espécie de tensão exacerbada à qual deve chegar para responder ao desafio da cor, para dar uma equivalência, de igual intensidade, à energia radiante do Sol. Todas as suas cores são nuas, puras, violentas. "A cor sugere a atmosfera inflamada da ceifa ao meio-dia, em plena canícula", nota Vincent. O campo de Arles está "florido de amarelo e violeta", é "uma variedade de azuis, animada por uma série de amarelos que vão até ao alaranjado", ou então procura, como escreve a Emile Bernard, "o efeito de um azul mais intenso no céu". As suas Vinhas, no Outono, são "verdes, púrpura, amarelas, de cachos violetas, de videiras negras ou alaranjadas". No retrato do seu amigo Boch quer pôr "alaranjados fulgurantes como ferro em brasa...tons de ouro-velho luminoso nas trevas" e qualifica algumas das suas telas, onde tentou dar à luz o seu máximo brilho irradiante, espécies de efeitos de vitrais de igrejas góticas". Vincent está tão seguro de se integrar, através do brilho deslumbrante dos girassóis, na fulgurância da explosão solar, que escreve a Théo: "Sabes que Jeannin 188 tem a peônia, que Quost 189 tem a malva-rosa, mas eu tenho um pouco o girassol.

Dessa forma, decidi delimitar a escolha de telas que comporão o corpus visual ao conjunto das obras realizadas durante o período que antecede a chegada de Gauguin em Arles. As telas desse período pertencem a uma fase de desenvolvimento linguístico notável, e têm a característica de não terem sido contestadas pelo próprio Vincent que ao realizá-las exerceu a culminância de sua concepção de uma pintura que ele acreditava e materializava com paixão, como afirmam suas cartas relatadas por Haziot (2010, p. 199):

Estudo ou quadro, ele está pelo menos contente com o que faz, e sua confiança aumenta com os dias: "Acho que posso te assegurar que o que faço aqui é superior ao campo de Asnières da última primavera". C473. De fato, por mais maravilhosas que tenham sido, as paisagens de Ansnières revelam ainda suas influências. Na Provença, Vincent encontrou finalmente seu caminho e não cessará de aprofundá-lo. Toda a sua vida não foi mais do que formação e preparação para esse instante. 
As telas desse período apresentam uma unidade linguística entre si, uma coesão interna e conjuntural que demonstram a maturidade e o apogeu de uma gramática própria pelo uso magistral dos recursos linguísticos e sistemas semióticos, relatado por Coli (2006, p. 9697):

\begin{abstract}
A centena de paisagens pintadas por Vincent nesse período arlesiano possui uma imensa serenidade. São segundo as estações, campos de flores, plantações de alfazema, jardins na primavera; pomares exuberantes, trigais amarelos no verão. Em sua grande maioria, esses quadros representam um vasto campo aberto no primeiro plano, animados por soluções cromáticas e ritmos diversos, limitado no horizonte por um perfil saliente: assim a cidade de Arles no fundo, entre as árvores, no quadro intitulado Vista de Arles com Íris no Primeiro Plano, do museu van Gogh de Amsterdã, ou a silhueta negra da mesma cidade diante de um campo de trigo, no Pôr do Sol no museu de Wintherthur, no o contorno das Alpilles no Chácaras do museu van Gogh de Amsterdã, ou ainda a calma, silenciosa e monumental Vista das Saintes-Maries, do museu Kroller-Muller de Otterlo, com a alternância das plantações verdes e violetas (a alfazema) que, convergentes, levam o nosso olhar para as casas, volumes geométricos cujas faces são suportes coloridos - de onde emerge, dominando, a estranha igreja fortificada.
\end{abstract}

Estes sistemas semióticos tinham sido incubados, gestados, manifestados no discurso de Van Gogh ao longo de suas diferentes incursões pictóricas nas cidades por que passou em busca de explorar e aprofundar sua compreensão e seu discurso artístico e corporificá-los em sua pintura. Considero o período de Arles anterior à chegada de Gauguin como o ponto alto da realização do discurso artístico de Van Gogh no que diz respeito não só à coesão conjuntural dos trabalhos como à outras categorias pictóricas presentes no seu sistema semiótico pictórico, como explica Coli (2006, p. 97):

E são os Semeadores, que ele continua a pintar, retomando o tema de Millet; as Colheitas de trigo, os Montes de Feno do tórrido verão provençal, que traduz em intensa gama de cores. É a época mais solar da arte de van Gogh, a apoteose de seus amarelos mais quentes - época dos vasos de girassóis, tão carregados de energia vital.

Dessa forma, o corpus pictórico foi escolhido das telas que materializam sistemas semióticos originais para a pintura naquele momento histórico, expressos em suas telas pela primeira vez. Eles estão descritos nas categorias de análise do corpus visual na seção 4.10.1.1.

A escolha do corpus pictórico levou em consideração alguns critérios, tais como a riqueza de sentidos potenciais dos sistemas semióticos, a inovação pictórica, e o potencial para a ocorrência de elementos de intertextualidade entre as telas e as cartas.

Essas foram as preocupações que pautaram a escolha do corpus visual a fim de contemplar as necessidades dessa pesquisa. 


\subsubsection{Pré-seleção do Corpus pictórico}

Na etapa preliminar da seleção, busquei reunir um grupo mais abrangente de telas para selecionar um corpo de três telas a serem analisadas. No momento inicial, esse conjunto mais amplo compreendeu telas das fases de Arles, Saint Remy e Auvers sur Oise, pois busquei ampliar o escopo da amostra das telas mais representativas do período da Provença e que apresentavam uma unidade linguística que contemplava os critérios pictóricos de seleção acima descritos.

Agrupei este corpo preliminar em conjuntos de telas que dialogam entre si pela temática. Inicialmente segui o critério para agrupar por temática a fim de observar a ocorrência de aspectos de intertextualidade entre elas:

\section{1) Os cafés}

- The Night Café in the Place Lamartine in Arles (VAN GOGH, 1988d) - data: 22.7.1888 e data: 6.8.1888;

- The Café Terrace on the Place Du fórum, Arles, at Night (VAN GOGH, 1888c) data: 8.9.1888 e data: 9.9.1888.

\section{2) Os campos}

- Sunset: wheatfield near Arles (VAN GOGH, 1888a) - Arles: June, 1888;

-Wheatfield - 22.6.1888 - sister w 4 - 8.8.1888;

-Wheatfield under thunderclouds - 10.7.1890;

- Wheatfield with crows - XX;

- Mountain Landscape seen across the walls 2.7.1889;

\section{3) Os semeadores e os ceifeiros}

- The Sower (VAN GOGH, 1988b) - O Semeador - Junho de 1888;

- The Sower (VAN GOGH, 1988b) - O Semeador - Outubro de 1888 -28.6.1888;

- A reaper at work in a wheatfield at Saint-Rémy;

-Wheatfield with a reaper - 3, 4, 5, 6 de Setembro de 1889;

4) Os ciprestes (período posterior a Arles)

- Starry Night - 17 ou 18.6.1889 (CABANNE, 1971, p. 236); 
-Wheatfield and Cypress - Julho de 1889;

- Road with Cypress and Star - (CABANNE, 1971, p. 249).

\section{5) As árvores}

- The Garden of Saint-Paul Hospital 20.11.1889.

\subsubsection{Seleção do corpus pictórico}

Dos conjuntos por temáticas, escolhi analisar duas telas:

a) The Night Café in the Place Lamartine in Arles (VAN GOGH, 1888d);

b) The Café Terrace on the Place Du fórum, Arles, at Night (VAN GOGH, $1888 c$ ).

Essas duas telas relacionadas à temática dos cafés noturnos foram escolhidas pelos motivos expostos a seguir:

De acordo com Halliday e Mathiessen (1999, p.10), o Contexto de Situação é um conceito muito central na LSF e abrange três componentes significativos: a Atividade Social Subjacente, as Pessoas ou 'Vozes' envolvidas nesta atividade, e as Funções particulares acordadas com o texto. De certa forma, a realização dessas duas telas nos leva a pensar nos elementos externos ao texto pictórico, mas a ele conectados: por exemplo, na atividade social subjacente a esse texto; nas 'vozes' envolvidas na composição desse texto e nas funções de seus significados, levantando as seguintes perguntas:

Porque Van Gogh escolheu representar dois cafés à noite? Que sentidos os cafés tinham para Van Gogh? Que vozes permeiam a atividade nos cafés? Para responder a essa pergunta será preciso compreender o papel dos cafés na segunda metade do século XIX, tido como um lugar de encontro para a comunidade de artistas e intelectuais engajados em construir, e para isso, em pensar juntos, as proposituras de uma nova direção para a arte. Nesse sentido, os cafés desempenharam uma função social, e constituíram um lugar essencial para que o convívio que possibilitou o desenvolvimento de uma prática semiótica para esse coletivo de artistas como atesta a carta 626 de Van Gogh (2009a, p. 1, tradução nossa):

E então aqueles vinte ou mais pintores que as pessoas chamam de Impressionistas, apesar de que poucos deles se tornaram bastante ricos e bastante grandes homens no mundo - tudo igual, a maioria deles são pobres almas que vivem em casas de café, dormem em abrigos baratos, vivem um dia após o outro. Mas - em um dia todos aqueles vinte de quem eu mencionei para voce que pintam tudo o que eles colocam 
os olhos em cima, e melhor do que muitos grandes homens que tem uma grande reputação no mundo da arte. Eu digo isso para fazê-lo entender que tipo de laços me liga aos pintores Franceses que as pessoas chamam os Impressionistas - que eu conheço muitos deles pessoalmente e gosto deles. E além disso que em minha própria técnica eu tenho as mesmas ideias com relação à cor, que até mesmo eu estava pensando a respeito quando eu estava ainda na Holanda. 320

O tema dos cafés, dessa forma, parece falar de um lugar de inserção social, de pertencimento a uma comunidade de prática, de reconhecimento de seus pares e parceiros de trabalho e de discurso, de produção de valores, de sentidos, de identidade grupal. Por serem os cafés um lugar de trânsito, de convívio e de compartilhamento, considero que a temática dos cafés expõe a forma como Van Gogh se vinculava, como se inseria, como se identificava e como ele vivenciava sua representação em relação ao social. Essa consideração é corroborada pelo relato de Haziot (2010, p. 179-180):

Todos esses encontros e conversas se passavam nos cafés ou nos restaurantes de Montmartre. Vincent se habituou a encontrar ali os amigos e começou a beber absinto, muito absinto, a ponto de provavelmente se intoxicar. Assaltado por tantas idéias novas e por tantos encontros com companheiros em busca como ele, seu espírito estava sempre esquecido. Ele precisava clarificar as idéias, assimilar o impressionismo e o divisionismo, examinar o caminho original de Cézanne, confrontar tudo isso com seu percurso anterior e encontrar o próprio caminho, uma vez que abandonara de certa forma o lado social na sua arte. Não falava mais em fazer uma arte pobre para os pobres e deve ter compreendido por que Théo não podia sequer mostrar suas obras enegrecidas a esses parisienses.

\subsubsection{Os coletivos que Vincent transitou}

No imaginário popular, existe uma percepção equivocada que van Gogh se isolou em sua arte, pois era incompreendido e que foi um pintor extemporâneo. Essa visão não poderia estar mais longe da realidade. É preciso lembrar que o encontro de van Gogh com os pintores Parisienses gerou nele uma explosão em seu pensamento artístico e em sua experiência de mundo e mudou o rumo da arte que ele vinha seguindo até então.

Van Gogh foi o ator de grandes transformações em seu tempo, não apenas por meio de sua pintura que era de vanguarda, mas também em seu meio intelectual e artístico no qual ele atuou com engajamento, procurando congregar um coletivo de artistas para facilitar a

\footnotetext{
${ }^{320}$ Tradução livre da autora. And so those 20 or so painters whom people call Impressionists, although a few of them have become fairly rich and fairly big men in the world - all the same, the majority of them are poor souls who live in coffee houses, lodge in cheap inns, live from one day to the next. But — in one day all those 20 whom I mentioned to you paint everything they set eyes on, and better than many a great man who has a big reputation in the art world. I say this to get you to understand what sort of tie binds me to the French painters whom people call the Impressionists - that I know many of them personally and like them. And furthermore that in my own technique I have the same ideas concerning colour, which even I was thinking about when I was still in Holland. (VAN GOGH, 1888e, p. 1).
} 
produção, divulgação e circulação das obras do grupo; para tentar quebrar as barreiras do monopólio naturalista das galerias e salões; para abrir caminho para os artistas da segunda geração do impressionismo, esses que depois lançaram as bases para a revolução artística e cultural que se seguiria no século seguinte.

De acordo com Haziot (2010) Van Gogh propôs a Theo que criasse sua própria galeria e lançasse os novos pintores. Van Gogh era um visionário e intuía acertadamente que os novos e jovens impressionistas da segunda geração, ainda desconhecidos, sucederiam os impressionistas da primeira geração, os do Grand Boulevard, o Boulevard Montmartre onde expunham. Em seu relato, Haziot (2010) atesta que ele conhecia e convivia com os do Petit Boulevard que expunham no Boulevard de Clichy e com lucidez propôs a Theo comprar a produção deles enquanto ainda eram praticamente anônimos e desdenhados pelos outros investidores de arte:

[...] Vincent procurava encaminhar para Théo todos os seus "cupinchas", fazendo dele o que Durand-Ruel havia sido para Monet, Renoir e outros. Assim, os dois irmãos logo passaram a ser vistos como um par - o par de sapatos das naturezasmortas de Vincent, talvez. Por sua ausência de preconceitos e sectarismo, Vincent podia se introduzir em toda parte e propor a Théo obras das diferentes tendências artísticas. [...] Ao menos, Théo reconheceu que Vincent o introduziu nas redes mais importantes da pintura de vanguarda, o que ele teria sido incapaz de fazer. Vincent estava em toda parte e era amigo de todos. Sua generosidade intelectual o fazia amar pintores dos mais diversos gêneros, enquanto estes às vezes se detestavam ou se recusavam a expor se fulano ou beltrano figurassem na exposição. Ele achava estranha e insuportável a prática tão francesa e parisiense dos grupelhos com suas estúpidas exclusões robespierristas. Não compreendia e ficava furioso quando via pintores que tinham dificuldade de ganhar seu pão promover o que ele chamava de "desatrosas guerras civis". (HAZIOT, 2010, p. 182).

Enquanto esse coletivo dos artistas parisienses da segunda metade do século XIX constituiu um rico ambiente para a formulação de ideias, práticas e identidades que circulava entre os propositores de um novo sistema semiótico pictórico, ele não foi nem de longe um grupo coeso e organizado em torno de um denominador comum, como descreve Haziot (2010, p. 182-183):

Os cloisonistas, depois sintetistas, como Bernard e Gauguin tinham horror dos
divisionistas, como Seurat e Signac. Gauguin recusava-se mesmo a falar com
Pissarro, que o ajudara, mas que seguia agora Seurat. Não poderiam eles se
respeitar, permanecer solidários diante da adversidade terrível que enfrentavam
mesmo pintando de modo diferente uns dos outros? Vincent, que sempre sonhou
com uma associação entre pintores que se ajudariam mutuamente, não compreendia.
Porém, acabou por ocupar uma espécie de posição central em Montmartre, que lhe
permitiu tomar iniciativas e organizar exposiçôes no final de sua temporada. (...)
Montmartre era, naqueles anos, novamente o caldeirão de onde sairiam discussões e
novas obras que dariam a volta ao mundo.

Foi talvez com o propósito de buscar fortalecer o vínculo com seus pares, um sentido de coesão identitário ou apenas de dar continuidade a essa troca de ideias que van Gogh, 
quando se mudou para Arles, manteve uma correspondência com seu irmão e amigos. Sua identidade estava mais profundamente imbricada nas práticas coletivas do que suspeitamos e esse aspecto da constituição do discurso artístico de Van Gogh fica patente em alguns excertos de cartas como o da carta 626 citado acima, e com os cafés que ele pintou. Esses cafés talvez falem de sua busca de pertencimento em um coletivo de artistas que lutou para sobreviver e para produzir um legado linguístico e semióticamente inovador de uma pintura sem precedentes. Com os cafés, ele pode ter falado de um lugar onde acontecia uma prática: a prática de um coletivo mobilizado em negociar os sentidos de suas práticas pictóricas.

No entanto, sua busca de inserção nos círculos parisiense não parece ter sido um processo de pertencimento e aceitação por parte dos pintores, mas de estranhamento e exclusão para com o 'estrangeiro', como atestado pelo biógrafo:

\begin{abstract}
Suzanne Valadon, modelo, depois pintora e mãe de Utrillo, contou uma história que mostra que Vincent, com exceção de alguns amigos que nem sempre o compreendiam, não se integrou no meio parisiense. Lautrec reunia toda semana o alegre bando de amigos no seu ateliê, e Vincent comparecia. "Ele chegava, com uma pesada tela debaixo do braço, punha-a num canto, mas bem visível, e esperava que alguém prestasse atenção. Ninguem notava. Ele se sentava de frente, observando os olhares, pouco se envolvia na conversa, depois, cansado, ia embora levando a tela. Mas na semana seguinte voltava, recomeçando o mesmo jogo. Suzanne Valadon se irritava de vê-lo ser ignorado pelos outros. Vincent deve ter sentido o que pode haver de duro na leviandade parisiense. Ele deixou Paris sem saudade. (HAZIOT, 2010, p. 190).
\end{abstract}

Dessa forma, os dois cafés pintados por Vincent van Gogh podem muito provavelmente estar textualizando um sentido mais amplo, e mais ideal. Essas telas de cafés podem estar se referindo não apenas um lugar geográfico, mas a um lugar social onde pertenciam os "sem-lugar", aqueles que se encontravam para reiventar seu lugar, seu pertencimento e ao fazê-lo reinstaurar uma nova ordem com novos sentidos e novos lugares onde existir o novo.

\title{
3.2 JUSTIFICATIVA PARA A ESCOLHA DO CORPUS EPISTOLAR
}

O corpus textual não está composto de cartas em sua integralidade, mas de excertos de cartas que se referem diretamente às telas analisadas, que chamarei de corpus textual. Das cartas que Van Gogh produziu ao longo de sua vida, está preservado um conjunto de novecentas e duas cartas. Este corpo documental tornou o trabalho de seleção do corpus um tanto desafiante. 
O corpus textual está composto de excertos de cartas que mencionam, descrevem telas ou explicam aspectos e circunstâncias relacionadas a telas que chamei de corpus textual primário. O critério para este agrupamento é semântico, ou seja, busquei palavras-chave que se relacionam diretamente com a temática representada nas telas analisadas. As cartas desse grupo foram pesquisadas por meio de uma busca de palavras-chave na base de dados de uma edição Inglesa das cartas de Van Gogh entitulada: "Vincent van Gogh - The Letters, the Complete Illustrated and Annotated Edition" (JANSEN; LUIJTEN; BAKKER, 2009). Maiores detalhes acerca das condições de produção e tratamento da edição completa das cartas de Van Gogh são descritos no item 4.8.2 que trata das "Condições de Produção, Distribuição e Consumo do gênero carta”.

Além de um conjunto de excertos que se refere diretamente às telas analisadas, escolhi um excerto de uma carta escrita ao seu irmão em Junho de 1880, que contextualiza aspectos da retórica de van Gogh bem como sua visão de mundo. O excerto desta carta que foi analisado a fim de contextualizar a relação de Van Gogh com a família, o trabalho, e suas expectativas em relação a estes, chamei de corpus textual contextual.

A seleção do corpus das cartas levou em consideração os seguintes critérios:

1) a finalidade da pesquisa: pesquisar a relação entre telas e cartas. Para isso fechei o foco na busca de:

a) cartas que se relacionavam semanticamente com as telas, por exemplo, que usavam palavras relacionadas com a temática das telas, tais como 'campo de trigo', 'campo arado', 'colheita', 'semeador', 'por de sol', 'café', 'céu estrelado'.

b) cartas que tivessem significados potencialmente semióticos e linguísticos que participassem da construção semiótica e linguística das telas. Por exemplo, cartas que falam de uma concepção pictórica, de uma forma de perceber, ou de uma forma de representar pictoricamente e que pode estar presente em mais de uma tela. Seria a busca de um pensamento artístico mais abrangente e que pode potencialmente se relacionar com as telas analisadas porque está na base da forma como ele pensa o que pinta. Estes extratos foram usados para subsidiar a compreensão das análises pictóricas, textuais e a triangulação.

c) cartas que possuíssem uma condensação de sentidos relacionados com o contexto de vida de Van Gogh. Busquei uma carta que tivesse a bojo, as questões de fundo que acompanharam Van Gogh ao longo de sua vida. Li várias cartas na íntegra que ajudassem a contextualizar os conflitos, necessidades e desejos mais presentes em sua existência em sua relação com a produção artística para 
compreender as questões presentes no seu contexto de vida. Estas cartas ajudaram a compreender o contexto de situação e de cultura nas análises pictóricas, textuais e a triangulação.

Esses três critérios atendem a finalidade da pesquisa e justificam a organização do corpus em dois conjuntos:

a) Corpus textual primário - cartas que possuem trechos que mencionam, descrevem telas ou explicam aspectos e circunstâncias relacionadas a telas. O critério para este agrupamento é semântico, ou seja, busquei palavras-chave que se relacionam diretamente com a temática representada nas telas analisadas. As cartas desse grupo foram pesquisadas por meio de uma busca de palavras-chave na base de dados de uma edição Inglesa das cartas de Van Gogh entitulada: "Vincent van Gogh - The Letters, the Complete Illustrated and Annotated Edition" (JANSEN; LUIJTEN; BAKKER, 2009). Maiores detalhes acerca das condições de produção e tratamento da edição completa das cartas de Van Gogh serão descritos no item 4.8.2 que trata das Condições de produção, distribuição e consumo do gênero carta.

b) Corpus textual contextual - Busquei uma carta que expressasse de forma mais abrangente o contexto de vida no qual Vincent se encontrava. Seus desafios, conflitos, necessidades, buscas e desejos expressos em sua própria experiência e visão de mundo. Essa carta foi analisada pelo enfoque da ADC, a fim de a perspectiva do discurso em sua construção retórica e narrativa.

Três critérios pautaram a seleção das cartas:

a) Por palavra-chave: palavras-chave para o mesmo tema - revelam trechos em que as telas foram diretamente mencionadas.

b) Por data: leitura de cartas escritas no mesmo período - revelam o pensamento que estava na base das composições realizadas então.

c) Pelo conteúdo: leitura de cartas que revelaram um adensamento das questões de fundo, e que pudessem ser relevantes para fornecer uma compreensão do contexto de vida de Van Gogh desde a sua própria representação de si mesmo, de sua experiência e visão de mundo. 


\subsubsection{Justificativa do Corpus Textual Primário: extratos de cartas que falam sobre as telas analisadas}

As cartas escritas por Vincent van Gogh versam sobre diferentes temas e se referem pontualmente a aspectos mais específicos de pinturas em particular, de forma eventual e fragmentada. São passagens e comentários breves que fazem referência a uma tela específica, apenas em um trecho da carta e tratam de assuntos diversos nos trechos sucessivos que não são relevantes para o objeto da análise.

Para constituir o corpus textual, foi feita uma varredura nas cartas que se referiam às telas selecionadas no corpus visual por meio da busca de palavras-chave como "Café", "Sunset", e "Wheatfield", por exemplo. Depois foi feita uma nova leitura das cartas préselecionadas em busca dos trechos relacionados com as pinturas. Esses extratos foram analisados com base na perspectiva de Linguística Sistêmico-funcional.

\subsubsection{Justificativa do Corpus Textual Contextual: carta para contextualizar a decisão de Van Gogh de se tornar artista}

O corpus textual contextual foi escolhido por meio da leitura de sua biografia e da produção de sua obra, escrita por diversos autores: Philippart (1930), Haziot (2010) e Naifeh e Smith (2012) que em preciosas edições, reuniram, editaram e indicaram trechos de cartas que trabalham como indexadores de sua linguagem pictórica. Outros extratos foram por mim selecionados pela leitura de algumas cartas que foram se comprovando de especial valor para compor o corpus textual.

Além do corpus constituído por extratos de cartas mais diretamente relacionados com a produção pictórica analisada, foi selecionada uma única carta para ser analisada parcialmente. Esta carta ofereceu uma perspectiva de análise, não como um indexador da produção visual, mas como um pano de fundo para contextuar as questões relativas à família, à profissão e aos questionamentos mais caros para o autor como o seu lugar no mundo e o seu sentido de ser.

Dessa forma, foi selecionada a carta de Junho de 1880, apontada por Haziot (2010, p. 12), como sendo de grande importância para a compreensão do processo da decisão de Van Gogh de se tornar pintor. Essa carta oferece uma fonte documental para examinar o contexto em que Van Gogh se inseria naquele momento de escolha de uma nova direção em sua vida. Até aquele momento, ele havia empreendido diversas formas de inserção no mundo do 
trabalho: como comerciante de quadros, professor, pastor, missionário, tentou estudar na universidade de Amsterdã, sem sucesso. Ao fracassar nessas tentativas, passou um período como andarilho e no ano de 1880 ele sugere em sua missiva ao irmão ter finalmente um novo caminho: a pintura, como Phillippart (apud VAN GOGH, 2010, p.12) pontua em sua narrativa:

\begin{abstract}
Apesar de todas as dificuldades e angústias ele, enfim, acredita ter descoberto o seu caminho: será pintor, nada mais que pintor! É julho de 1880 quando ele escreve a carta na qual abre-se profundamente a Théo, na qual descreve a horrível angústia em que se encontra, suas lutas, seus desesperos, e também sua esperança radiante. Teria alguém jamais escrito apelo tão comovente, tão dilacerante? Théo ficou profundamente emocionado. E ficou também completamente convencido. A partir de então, se dedicará inteiramente ao irmão. Esta ajuda, que até o momento lhe dedicara por pura afeição, agora compromete-se a continuá-la para sempre, porque confia. Acredita realmente em Vincent. E é graças a esta confiança que o gênio de Vincent aparecerá.
\end{abstract}

A carta de Julho de 1880, escrita por Van Gogh ao seu irmão, aponta para uma complexidade de conteúdos e associações que evidenciam a negociação de sentidos para a afirmação de uma identidade emergente que foi lentamente sendo formada na medida em que as portas iam se fechando para a inserção de Van Gogh no mundo do trabalho. O processo de escrita nessa carta parece quase um manifesto de seu desejo de assumir sua identidade de pintor, e denota um processo contínuo na construção de elementos que são recorrentes ao longo de toda correspondência posterior, mostrando uma cadeia de sentidos no discurso das cartas e nos quadros que produz. As cartas sugerem que Vincent elegeu este gênero, bem como suas telas, como um espaço de representação de uma identidade e como um espaço de relacionamento que vai sendo construída no decorrer na sua produção escrita e pictórica.

\title{
3.2.3 Condições de produção, distribuição e consumo da modalidade pintura
}

Van Gogh produziu intensamente ao longo de sua carreira como pintor, e entre dezenas de centenas de telas, desenhos e gravuras sobreviveram 864 pinturas e 1.200 desenhos e gravuras, como explica Coli (2006, p. 88):

O resultado dessa fúria criadora - mas perfeitamente dominada - é uma extraordinária densidade de produção: são 879 telas conhecidas de Vincent, num período que vai de dezembro de 1881 a julho de 1890 , ou seja, 110 telas em média por ano. Mas, na realidade, o ritmo de produção se acelera cada vez mais - em Auvers ele pinta praticamente um quadro por dia.

De acordo com o Museu van Gogh em Amsterdam, em seu acervo, está reunida a maior parte da obra de van Gogh contendo mais de 200 pinturas, 437 desenhos e 31 gravuras. Coleções de Van Gogh também se encontram nos Museus Kröller-Müller em Otterlo 
(Holanda) e d'Orsay em Paris. O restante de suas telas e desenhos encontra-se em Museus e em coleções particulares na Holanda, França, Alemanha, Estados Unidos e Japão. É possível visualizar todas as obras de Vincent no site Van Gogh Gallery (www.vggallery.com).

Para falar das condições de produção das obras, é preciso vê-las no contexto de cultura dos movimentos históricos, políticos, filosóficos e artísticos que incendiaram o século XIX e que compõe o cenário efervecente no qual Van Gogh constituiu-se como artista e como pensador de seu tempo. A conjuntura do contexto de cultura e de situação que fundou a base da formação de van Gogh, cujas ideias ele materializou em sua obra são discutidas ao longo do capítulo 2 e são cruciais para compreender como o discurso de Vincent van Gogh manifesta visual e textualmente atualizando as ordens de discurso que circularam em seu tempo.

\subsubsection{Circunstâncias históricas da produção das telas analisadas}

\section{1) Sunset: wheatfield near Arles - Arles: June, 1888}

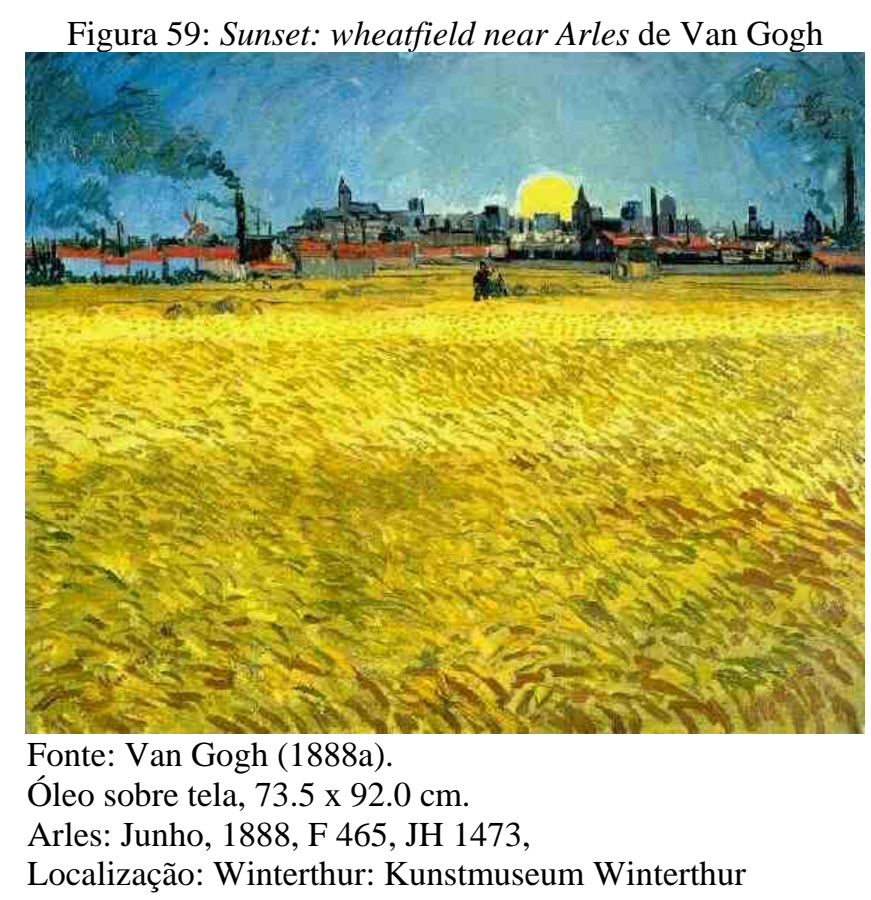

Os campos de trigo são um tema recorrente para Van Gogh e constituem uma referência em sua obra. Em Arles ele pintou uma série de trigais, como atestam Walther e Metzger (2015, p. 352-353):

Van Gogh recorreu igualmente ao material que já lhe era familiar nas séries mais extensas do verão desse ano. A exemplo do que fizera no passado, seguiu de perto as 
colheitas, registrando o trabalho dos agricultores e o estado dos campos. Em Arles, graças ao clima, o milho amadureceu mais depressa. E a tarefa do pintor tornou-se mais difícil, já que implicava estar debaixo de um Sol escaldante. Como acontecera já no norte, Van Gogh estava convencido de que tinha de aguentar qualquer clima: quer o mistral tempestuoso quer o calor seco e fatigante.

Em suas cartas ele se refere aos campos de trigo desde as memórias mais recônditas de sua infância na Holanda e em sua obra eles assumem uma carga metafórica visual condensada de sentidos que foram explorados na análise da função representacional da tela.

\section{2) The sower - Arles: June, 1888}

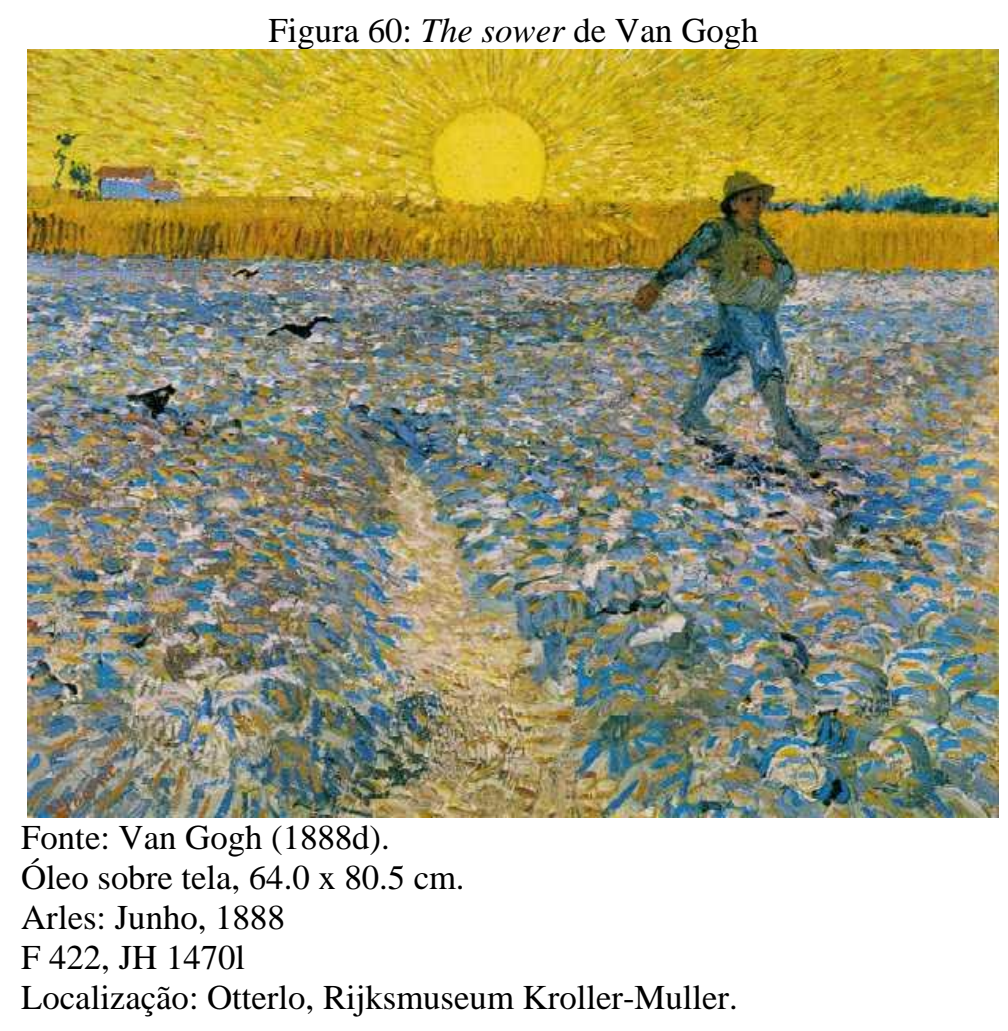

Por muitos críticos e historiadores de arte, ela é vista como uma expressão inequívoca do simbolismo na pintura de van Gogh devido às inevitáveis associações com a parábola do semeador da bíblia; o uso arbitrário da cor, e outros elementos na tela como o sol, a natureza, a luz, vistas como metáforas visuais que são exploradas mais detalhadamente na análise. Em suas cartas, van Gogh não menciona o sentido da tela, apenas descreve seus elementos constituintes e comenta algumas inovações pictóricas como, por exemplo, o uso do branco para impedir que o contraste entre o violeta e o amarelo fique muito excessivo e cansativo para o espectador:

Eu tive uma semana de concentrado trabalho duro nos campos de trigo debaixo do sol, o resultado foi de alguns estudos de campos de trigo, paisagens e - um esboço de um semeador. Em um campo arado, um grande campo de torrões de terra roxa levantados em direção ao horizonte - um semeador em azul e branco. No horizonte 
um campo de trigo curto, maduro. 1v: 2 Acima de tudo isso um céu amarelo com um sol amarelo. Você pode sentir a partir da mera nomenclatura das tonalidades - que a cor desempenha um papel muito importante nesta composição. E o esboço como tal - uma tela número 25 - também me preocupa muito, no sentido de que eu me pergunto se eu não deveria levar a sério e fazer uma pintura tremenda disso. Meu Deus, como eu adoraria fazer isso. Mas eu só me pergunto se eu vou ter o poder necessário de execução. Eu estou colocando o esboço de lado assim como é, mal ousando pensar nisso. Por um longo tempo ele foi meu grande desejo de fazer um semeador, 5, mas os desejos que tive por um longo tempo nem sempre são alcançados. Então, eu estou quase com medo deles. E, no entanto, depois de Millet e Lhermitte o que resta a ser feito é [...] o semeador, com cor e em um grande formato. (VAN GOGH, 2009e, p. 1)

No entanto nas linhas subsequentes a essas descrições ele deixa transparecer seu desejo adiado em executar esta obra longamente sonhada, pensada e planejada e expressa dúvida em sua capacidade de realizá-la. A julgar por essas considerações podemos inferir que esta tela ocupou um lugar central em suas preocupações e desejos de, por meio da obra $O$ Semeador dar um passo adiante no uso simbólico das cores e de outros elementos composicionais, estabelecendo novas semióses pictóricas.

\section{3) The Café Terrace on the Place Du Forum, Arles, at Night-8.9.1888 e 9.9.1888}

Figura 61: The Café Terrace on the Place Du Forum, Arles, at Night de Van Gogh

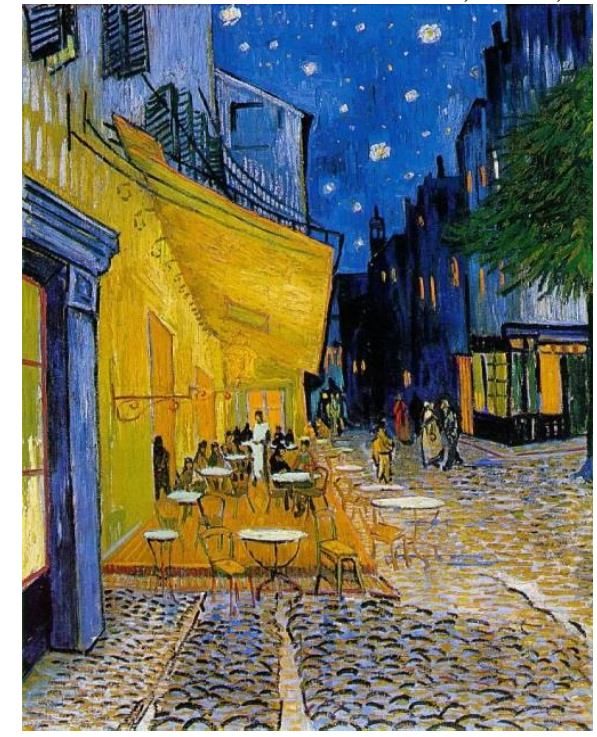

Fonte: Van Gogh (1888c).

Óleo sobre tela, $1.0 \times 65.5 \mathrm{~cm}$.

Arles: Setembro, 1888

F 467, JH 1580

Localização: Otterlo, Rijksmuseum Kroller-Muller.

Esta tela foi pintada sete meses depois que Van Gogh chegou a Arles e caracteriza uma importante mudança que aconteceu no uso das cores. Ele escreve à sua irmã Whilhemine e relata que, não obstante a tela ser uma cena noturna, ele a pinta com cores vivas. 
Alguns críticos encontram um diálogo desta tela com a tela Avenida Clichy: Cinco horas da tarde, de 1887, de Louis Anquetin. Os dois eram amigos e se influenciaram mutuamente na experimentação de muitas técnicas.

Com relação à representação do céu estrelado, esta tela é relacionada com outras duas que Vincent pintou: Noite Estrelada Sobre o Ródano, de 1888, e A Noite Estrelada, de 1889 como relata Coli (2006, p. 99):

Mas no outono ele passa da embriaguez cósmica do Sol à meditação noturna. Entre outras, as duas pinturas mais célebres são O café, à Noite (Museu Kroller-Muller de Otterlo) e A Noite Estrelada (primeira versão).(...) Num, aos amarelos da iluminação artificial do terraço do café, sobrepõe-se o azul noturno onde as estrelas como que explodem em pequenos halos brancos; noutro, a irradiação dos pontos luminosos celestres em cima dos reflexos dourados das luzes urbanas no azul profundo do Ródano.

Outra tela relacionada a esta por Haziot (2010, p 216-217) é o Retrato de Eugene Boch, de 1888:

Uma das grandes obras do período é o retrato de Eugène Bobh, pintor e poeta belga que morava nos arredores de Arles e que se tornou seu amigo. Boch era originário da região de Mons. Vincent o tomou como modelo para o seu Retrato do poeta: Boch, em amarelo dourado sobre um fundo de noite estrelada, vibra como um astro, um pedaço de ouro brilhante ou de sol caído do céu. Para pintá-lo, Vincent diz que se fez "colorista arbitrário. 'Exagero o loiro dos cabelos, chego aos tons alaranjados, aos cromos, ao limão pálido. Atrás da cabeça, em vez de pintar a parede banal do mesquinho apartamento, pinto o infinito, faço um fundo simples com o azul mais rico e mais intenso que posso preparar, e, por essa simples combinação da cabeça loira iluminada sobre o fundo azul, obtendo um efeito misterioso como a estrela no anil profundo'." ( colocar pé de página: V. Merlhès, Paul Gauguin et Vincent Van Gogh, op.cit.,p.256) [...] Vincent ainda não teve a ideia de mostrar por um halo de pontos a cintilação das estrelas, tomando de Seurat essa técnica. Sò recorrerá a ela em Saint-Remy. O fato é que a vibração do retrato de Eugène Boch, quando o vemos no museu, faz dele um dos maiores retratos de Vincent, se não o maior.

Muitas estórias circundam a execução desta tela. O historiador de arte, Brian Petrie (1974) cita a descrição do prório van Gogh a respeito desta tela e acrescenta um mito a respeito das práticas poucos ortodóxicas que van Gogh adotava para pintar a noite:

Este é um quadro noturno sem sombra de preto feito apenas com lindos azuis, roxos
e verdes, e a seu lado a praceta iluminada adquire uma cor de enxofre-pálido e
amarelo-limão-esverdeado. Gosto imenso de pintar a noite no próprio local. Eles
costumavam desenhar e pintar o quadro durante o dia depois do primeiro esboço.
Mas eu encontro uma certa satisfação na pintura das coisas.” [...] Conta-se, talvez
de maneira apócrifa, que para conseguir ver bem as cores da paleta Vincent
colocava velas a toda a volta da aba do chapéu, enquanto estava sentado a pintar o
quadro. (PETRIE, 1974, p.14). Ainda que a Casa Amarela na qual van Gogh fez seu Ateliê do Sul não exista mais, devido aos bombardeios da Segunda Guerra, este café permanece aberto sob o nome de Café Van Gogh. Walther e Metzger (2015, p. 375) explicam o interesse suscitado pelo café:

Ao contrário do que acontecera em Paris, em Arles Van Gogh raramente procurou companhia. Para pintar, preferia o espaço aberto do campo às vielas e traseiras da 
velha cidade. Aí, na melhor das hipóteses, talvez passeasse pelo parque perto da Place Lamartine, onde arrendara quartos. Só uma vez é que vencera a timidez e posicionara o cavalete mesmo no centro da cidade, na Place du Forum, não muito longe do famoso anfiteatro e Saint-Trophime. Foi lá que pintou A Esplanada do Café na Place du Forum, em Arles, à Noite (p.419). Só aí é que se conseguia ver o motivo de que andava à procura: a luz a gás que brilhava na escuridão desde a parede exterior do café até a praça.

O interesse de van Gogh por diferentes fontes de iluminação pode estar na base da decisão em representar esta cena noturna, talvez pelo desafio em registrar as cores noturnas à luz de um tipo de iluminação inteiramente nova, e talvez agressiva, grosseira e excessiva para a sensibilidade ótica das pessoas da época: a lâmpada a gás, como atestam Walter e Metzger (2015, p. 375):

A reunião, nesta pintura, de amarelos e azuis já antes utilizados possui uma vitalidade que nunca fora conseguida. A posição assumida pelas cores não é determinada tanto pelo princípio do contraste como pelo simples facto de ambas encarnarem valores luminosos. O amarelo berrante e o azul a ele subjugado representam áreas de um brilho impressionante e de uma delicada semiescuridão, exatamente como Van Gogh os deve ter visto. Os transeuntes estabelecem a ligação entre as duas zonas. Estas figuras são deixadas em total anonimato; as condições de iluminação tornam, por si só, impossível a sua identificação. A área brilhante à volta dos candeeiros a gás projeta uma encandeadora nas faces das figuras, enquanto a área não iluminada das ruas secundárias insiste na sombra. E, de facto, Van Gogh está menos preocupado com as cores das coisas do que com o modo como elas estão iluminadas. Existe apenas uma fonte de luz: os candeeiros. Nos anos 1880, o gás já chegara às províncias. A iluminação à gás apoderara-se das atmosferas. Faltava-lhe aquela brilho romântico e trémulo que fazia com que as estrelas no céu e as velas nas janelas parecessem envoltas em mistério. A iluminação a gás era artificial, representando o brilho direto de tudo o que era novo. Van Gogh mostra ter plena consciência desse facto ao pintar, no eixo central da obra, o encontro do velho e do novo. Há uma espécie de desolação na forma como o brilho uniforme da área coberta compete com os pontos brilhantes de luz que resplandecem na escuridão.

A tela estabelece uma importante inovação pictórica explicada pelo próprio Vincent em sua carta ao irmão Theo: “Agora há uma pintura de noite sem preto."321 . Esta inovação foi explorada na análise textual da declaração feita por van Gogh ao irmão.

321 Carta 678 - Br. 1990: 681 | CL: W7 - From: Vincent To: Willemien van Gogh Date: Arles, Sunday, 9 and about Friday, 14 September 1888. Disponível em 10.11.15 em 


\section{4) The Night Café in the Place Lamartine in Arles - Arles: 5-8 September 1888}

Figura 62: The Night Café in the Place Lamartine in Arles - Arles: 5-8 September 1888

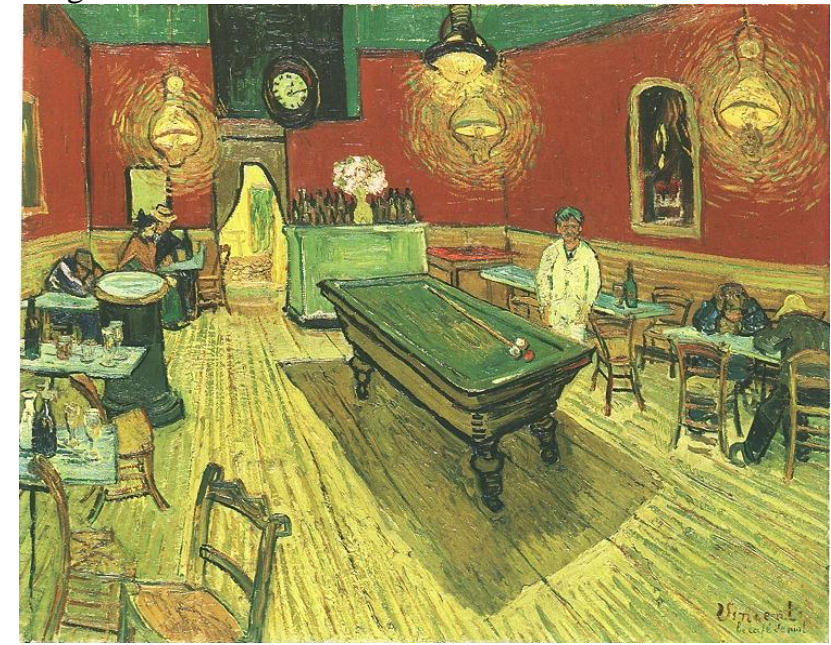

Fonte: Van Gogh (1888d).

Óleo sobre tela, 70.0 × $89.0 \mathrm{~cm}$.

Arles: 5-8 Septembro de 1888 .

F 463, JH 1575

Localização: New Haven, Connecticut: Yale University Art Gallery

A tela representa o interior do café de la Gare, na praça Lamartine. Walther (1990, p.

40-41) narra a atmosfera com que van Gogh representou o café:

Sobretudo para se habituar ao trabalho à luz artificial, pintou ele, em Setembro de 1888, o "Café de noite, na Place Lamartine". Durante meia semana só dormiu de dia, para à noite se recolher ao ambiente depressivo da taberna e pintá-la: bêbados solitários de bruços sobre a mesa, um jogador de bilhar, um par amoroso, furtivo, a um canto - personagens da desesperança. "Procurei", assim van Gogh interpreta o quadro, "com vermelho e verde expressar as terríveis paixões humanas. A sala é um encarnado e amarelo baço, um bilhar verde no meio, quatro lâmpadas amarelo-limão com círculos radiosos em laranja e verde. Por todo lado, há luta e antítese; nos vários verdes e vermelhos, nas pequenas figuras dos noctívagos adormecidos, na sala vazia, lúgubre, no violeta e azul." E num outro lugar: "Procurei expressar o pensamento de que o café é um lugar onde alguém se pode arruinar, enlouquecer ou cometer um crime", escreve van Gogh sobre a atmosfera neste quadro, um dos poucos em que o motivo da composição, por si só, é portador de um sentido de vida pessimista. O café como lugar "onde alguém se pode arruinar", embebedar-se e perder o seu último dinheiro viria, também, a acompanhar o próprio van Gogh, nos dois últimos anos de vida até o seu colapso.

Ela foi pintada em setembro de 1888, é também conhecida por "Le café de nuit" como está escrito por van Gogh no canto inferior da tela, abaixo da sua assinatura. Van Gogh referese a essa tela para Theo:

Hoje provavelmente eu irei começar o interior de um café onde possuo um cômodo, à noite, sob iluminação a gás. É o chamado "café de nuit" (muito freqüentes aqui), e que fica aberto toda a noite. Notívagos podem se refugiar quando não tem recursos para pagar pelo pernoite ou estão bêbados demais para serem aceitos. (VAN GOGH, 20091, p. 1). 
Seus proprietários Joseph-Michel Ginoux e Marie Ginoux eram amigos do pintor e, em novembro de 1888, a Sra. Ginoux posaria para a tela A Arlesiana de van Gogh e também para uma tela de Gauguin. O Sr. Ginoux também posou para telas dos dois artistas.

\subsubsection{A Modalidade Pintura}

Fairclough (2001) afirma que o texto é a manifestação de um discurso que se materializa em um tempo histórico e social. Kress e Van Leeuwen (1996, p. 220-221, tradução nossa) discorrem da perspectiva semiótica sobre essa questão:

A pintura permite ao espectador a escolha entre formas diferentes de se relacionar com o texto, ainda que esta escolha possa ser restringida na prática, como uma linha no chçao em frente a uma pintura proíbe a visitante da galeria de se aproximar muito da pintura. Eu posso desejar ver a pintura como 'uma representação', concentrando no que a pintura 'se trata', ou vê-la em termos de suas várias técnicas ('o uso efetivo da cor'), ou efeitos ('depressão'). Em cada caso eu irei me postarei na distância permitida. Eu posso desejar engajar com sua materialidade e com a forma na qual a mão do artista 'inscreveu' a tela - o assunto da aplicação da pintura; as pinceladas e nesse caso eu precisaria de me aproximar mais. A fotografia me permite a escolha da distância de observar, mas sem nenhum daqueles efeitos no sentido. Esse meio de 'registro' é representacional e pode apenas ser representacional. Ele abstrai da impressão da mão que o fez, mesmo quando ele reproduz arte. ${ }^{322}$

Não seria o contexto no qual o texto pictórico é produzido uma instância elucidadora para a análise, senão necessária para situar a produção do texto e suas relações com outras dimensões do discurso nele produzidos? Kress e Van Leeuwen (1996, p. 215-216, tradução nossa) discutem as diferenças semióticas entre os meios de representação:

Em nossa 'gramática' do design visual, nós quisemos nos distanciar de uma visão
totalizante dos recursos semióticos, uma visão na qual os recursos semióticos são
sistemas homogêneos nos quais pode haver diferenças no 'tamanho' das unidades,
mas nos quais todas as unidades são do mesmo tipo, todas 'pertencem' ao 'mesmo
sistema', de forma que todos os testos são, no final, construídos de um simples tipo
de 'unidade mínima', seja ela a pincelada, a 'figura icônica' (Eco, 1976a), o
'coloureme'(Saint-Martin, 1987), ou o fonema e morfema - em seus perspectivos
arrajos 'taticos'. Por contraste, nós queremos manter que uma dada forma de
semiose - por exemplo, 'pintura' - envolve uma gama de recursos de significação.
Alguns deles são como os sistemas de significação que nos discutimos nesse livro,
recursos que podem ser usados, não apenas na pintura, mas também na fotografia,
ou no desenho, para mencionar alguns exemplos. Qualquer dado tipo de meio de
produção pode, pelo menos em princípio, realizar a maioria das escolhas das redes

${ }^{322}$ Tradução livre da autora. "Painting allows the viewer a choice between different ways of relating to the text, even though this choice may be restricted in practice, as when a line on the floor in front of a painting prohibits the gallery visitor from coming too close to the painting. I may wish to view the painting as 'a representation', concentrating on what the painting 'is about', or view it in terms of its various techniques ('the effective use of colour'), or effects ('depression'). In each case I will stand at the requisite distance. I may wish to engage with its materiality and with the way in which the hand of the artist 'inscribed' the canvas - the matter of the application of the paint; the brushstrokes - and in that case I would need to move very close up. Photography allows me choice of distance of viewing, but without any of these effects in meaning. This 'recording' medium is representational and can only be representational. It abstracts away from the imprint of the hand that made it, even when it reproduces art." (KRESS; VAN LEEUWEN, 1996, p. 220-221). 
ideacionais, interpessoais e textuais que nós apresentamos nesse livro, apesar de há, na prática, historicamente e culturalmente restrições específicas na combinação das escolhas desses sistemas de significação; por exemplo, restrições no que pode ser pintado e como. Mas outros recursos semióticos são mais especificamente amarrados a formas específicas de produção material e podem ser realizados, por exemplo, apenas no meio da pintura ou apenas no meio da fotografia. ${ }^{323}$

O’Toole (1994) destaca como central para seu método de análise, a concepção de que

a análise dos sistemas semióticos construídos em uma imagem deve focalizar e se ater aos elementos contidos no espaço bidimensional da tela para que não sejam imputados sentidos interpretativos que não estão materializados na tela em questão. No entanto, nessa pesquisa, partimos do pressuposto que a representação artística é um processo de produção discursiva constituída dentro das condições culturais e históricas e interpenetrada pelos discursos que circulam na memória cultural. Dessa forma consideramos na análise o contexto de cultura e o contexto de situação como parte da produção da obra.

Kress e Van Leeuwen (1996, p. 221-222, tradução nossa) consideram algumas diferenças entre a pintura e fotografia quando discutem a questão da representação em diferentes meios:

Como um exemplo final, considere Cossacks de Kandinsky (figura 5). A representação está fortemente reduzida nessa pintura: se pode 'ver' Cossacks no lombo do cavalo e sabres puchados e faiscando, mas a figuração não está projetada; ou nós podemos dizer que o que está representado ideacionalmente é 'ação violenta'. A diferenciação da cor, por outro lado, está amplificada. E a cor é usada, não em uma função representacional/referencial (sombras de branco para representar as sombras 'reais' dos uniformes brancos, por exemplo), mas para permitir a substancia do meio de produção e os traços do ato de produção significarem em si mesmos. A cor é, nessa pintura, o recurso semiótico chave: blocos de branco jogados, piscadas de vermelho, curvas de amarelo e azul. Ação, energia, movimento e violência são representados pela forma como o meio de produção foi tratado. E isso nos leva de volta para a questão da individualidade com a qual nos terminamos a primeira seção desse capítulo, e talvez também para a distinção entre 'arte' e 'design'. O tratamento da pintura é próximo para a individualidade da escrita a mão, e foi precisamente essa marca de individualidade que veio a ser contada como a característica distintiva da arte pois ela marca a diferença da 'gravação'. Por outro lado, essa celebração da individualidade foi também algo de uma ultima tentativa da arte, em sua batalha perdida com a fotografia, e a mesma arte que veio a defender a expressão individual teve seus efeitos sociais principais na forma das reproduções fotográficas - ou seja,

\footnotetext{
${ }^{323}$ Tradução livre da autora. 'In our 'grammar' of visual design, we wanted to move away from a totalizing view of semiotic resources, a view in which semiotic resources are homogeneous systems in which there may be differences in the 'size' of units, but in which all the units are of the same kind, all 'belong' to 'the same system', so that all texts are, in the end, built up from a single kind of 'minimal unit', be it the brushstroke, the 'iconic figure' (Eco, 1976a), the 'coloureme' (Saint-Martin, 1987), or the phoneme and morpheme - in their respective 'tactic' arrangements. By contrast, we wanted to maintain that a given form of semiosis - for instance, 'painting' - involves a range of signifying resources. Some of these are like the signifying systems we have discussed in this book, resources which can be used, not just in painting, but also in photography, or in drawing, to mention just some examples. Any given type of production medium can, at least in principle, realize most of the choices from the ideational, interpersonal and textual networks we have presented in this book, though there are, in practice, historically and culturally specific restrictions on the combination of choices from these signifying systems; for example, restrictions on what can be painted and how. But other semiotic resources are more specifically tied to specific forms of material production and can be realized, for instance, only in the medium of paint or only in the medium of the photograph". (KRESS; VAN LEEUWEN, 1996, p. 215-216).
} 
sem as marcas da individualidade - enquanto os originais se tornaram relíquias sem preço de um ethos passado. ${ }^{324}$

Esta pesquisa apoia-se na concepção da materialidade textual no contexto de seu uso, a fim de ampliar as possibilidades de análise do corpus multimodal e analisar elementos de intertextualidade e de interdiscursividade presentes e evidentes no discurso visual presentificados nas obras pictóricas analisadas bem como no discurso escrito produzido nas cartas analisadas. Dessa o gênero Pintura é tratado aqui na perspectiva de sua origem e desenvolvimento para compreender sua práxis e sua função social na representação e transformação das idéias, concepções e mitos humanos.

Para Lichtenstein (2004), a pintura está, em sua origem, inextricavelmente ligada à religião e ao mito, tomando como exemplo as pinturas de cerimoniais em funerais egípcios e as representações da mitologia nas atividades pictóricas gregas. Lischtenstein (2004, p. 18) pontua que o próprio nascimento das artes como a música e a poesia está ligado a mitos de origem divina, enquanto não encontramos "registro de um nascimento tão prestigioso, nenhuma autoridade tão imemorial", ligados à origem da pintura:

Na falta de patrocínio dos deuses e heróis da Antiguidade, a pintura por muito tempo
teve que se contentar com biografias lendárias (Apeles, Zêuxis), relatos fabulosos
(Narciso) e lugares de aparição mais ou menos míticos. Acrescenta-se a essa origem
inglória a condição social do artista na Antiguidade: o pintor é antes de tudo um
homem que trabalha com as mãos, o que significa que sua atividade o afasta de
qualquer possibilidade de contemplar idéias, portanto, de qualquer teoria.
(LISCHTENSTEIN, 2004, p. 18).

A inferioridade social do pintor diante das outras artes foi por muito tempo um estatuto que novos mitos tentaram compensar ao enaltecer a habilidade e o virtuosismo como na história de Protógenes e Apeles, e que destaca a busca da perfeição na obra de arte capaz de aproximar o pintor dos deuses e heróis pelo brilho de suas obras. Lischtenstein (2004, p. 18) aponta que nesse lugar social destituído de nobreza, os relatos biográficos dos pintores adquirem a função de:

\footnotetext{
${ }^{324}$ As a final example, consider Kandinsky's Cossacks (plate 5). Representation is strongly reduced in this painting: one can 'see' Cossacks on horseback and drawn and flashing sabres, but figuration is not foregrounded; or, we might say that what is represented ideationally is 'violent action'. Colour differentiation, on the other hand, is amplified. And colour is used, not in a representational/referential function (shades of white to represent the 'real' shades of the white of uniforms, for instance), but to allow the substance of the production medium and the traces of the act of production themselves to signify. Colour is, in this painting, the key semiotic resource: jagged blocks of white, flashes of red, curves of yellow and blue. Action, energy, movement and violence are represented through the way the production medium has been handled. And this takes us back to the issue of individuality with which we ended the first section of this chapter, and perhaps also to the distinction between 'art' and 'design'. The handling of paint is close to the individuality of handwriting, and it was precisely this mark of individuality which came to be lauded as the distinguishing characteristic of art and as its mark of difference from 'recording'. On the other hand, this celebration of individuality was also somewhat of a lastditch stand for art, in its losing battle with photography, and the very same art which came to stand for individual expression had its principal social effects in the form of photographic reproductions - that is, without the marks of individuality - while the originals became the priceless relics of a past ethos. (KRESS; VAN LEEUWEN, 1996, p. 221-222).
} 
reativar, no interior da história da pintura, a idéia de um pintor perfeito. A biografia torna-se relato, o relato, paradigma, até atingir uma idealidade indiferente a qualquer determinação histórica. A grandeza de Apeles é proporcional à força do movimento retrospectivo que o transforma em pintor exemplar. A dimensão mítica de um artista é precisamente o que ela tem de positivo, isto é, produtivo para o fenômeno da imitação e emulação que suscita.

Ou seja, ao lado das grandes histórias fundadoras, os sofistas constroem topoi ou mitos teóricos constitutivos da ideia da pintura em seus discursos, tais como o ut pictura poesis, de Simônides, o Deus pictor, o Deus artifex, de Empédocles e Filóstrato. E mais tarde, um paradigma da Idade Média constrói a pintura como "Livro do Mundo" no qual se inscreve o dedo de Deus, transposto no período Barroco para o paradigma de "Teatro do Mundo". Essa cosmogonia das ideias e mitos fundadores da pintura constrói um ideário que possibilita sua existência como um campo específico da teoria da arte. Dessa forma, o aspecto histórico e o aspecto mítico estão muito imbricados na história da pintura. O aspecto histórico desenvolvese em torno das narrativas de fatos, circunstâncias da vida dos pintores que estão relacionados à criação de suas obras.

$\mathrm{O}$ aspecto mítico revolve na extensa formação de topoi, ou ideias fundadoras que remontam “às origens míticas, religiosas e sapienciais da atividade pictórica" (LISCHTENSTEIN, 2004, p. 19). Esses dois aspectos são tão basilares para a história da pintura que Vasari, o seu fundador, chega "às vezes, a confundí-los nas Vidas, sem, no entanto, prejudicar a precisão histórica" (LISCHTENSTEIN, 2004, p. 19). Topos para Lischtenstein (2004), no contexto da pintura, tem o sentido de um lugar-comum, pode ser compreendido como:

uma proposição, uma fonte de argumento, que pode ser uma idéia (por exemplo, a de Deus pictor), um relato mitológico (Narciso inventor da pintura) ou um lugar de origem (o Egito, onde a pintura teria se confundido com a escrita). Essa rede de topoi, que nunca deixou de ser reativada, reinterpretada e repetida pelos textos ou pelos protagonistas da história da pintura, não atua somente de maneira mítica sobre os espíritos e as práticas da arte ou da crítica. Ela própria é mítica já que costuma ser formada por relatos quase sempre inventados, por fábulas, (por exemplo, a de Pigmalião) constantemente reescritas. Há portanto, uma espécie de anterioridade do relato mítico em relação à história real, factual, da criação da obra, uma anterioridade ideativa do topos que estimula, faz nascer e alimenta uma vocação, enquanto o artista apenas atualiza as categorias míticas que lhe preexistem. É assim que Rubens e Poussin concentram em sua obra e na sua pessoa ao mesmo tempo os topoi do pintor erudito, do artista genial, da sabedoria criativa, e realizam, exemplicando-os, tudo que remete à "idéia do pintor perfeito". O pintor ideal é, nesse sentido, aquele que dá vida e forma a um conjunto de topoi e fecha o sistema de regras e princípios da teoria da arte. (LICHTENSTEIN, 2004, p. 19-20).

A argumentação de Lichtenstein (2004) acerca da dimensão mítica que está na base da práxis pictórica desde os primórdios nos ajuda a conceber o texto pictórico como um fenômeno linguístico que dá materialidade, pela força criadora, a um discurso que está culturalmente e civilizatoriamente condensado em um extrato potencial e imanente da 
linguagem e que se coloca em um limiar da experiência humana inextricavelmente unido às experiências simbólicas mais antigas e mágicas da humanidade. Forrester (1983, p. 35-36), biógrafa de van Gogh, discorre a esse respeito:

É falso pensar que pessoas como Baudelaire, Holderlin, Nerval, Artaud, por exemplo, ou como Van Gogh, eram marginais natos, personagens fantásticas que se deram ao luxo de suas orgiazinhas mentais às custas do outros, e dariam tudo por isso. Eles responderam, ao contrário, a uma demanda veemente, mas imperiosa da sociedade que tinha, para eles, um contrato já pronto. Um programa. (...)Esses pintores, esses escritores, esses músicos "malditos" são, na verdade, funcionários da sociedade, preenchendo um papel necessário e bem definido. O sistema sabe perfeitamente onde eles se encontram; como capturá-los. Sabe também, num primeiro tempo, lhes mostrar todos os estágios e sentidos do exílio a que os conduz. Sabe abatê-los num segundo tempo; a loucura, a morte precoce são suas armas favoritas. Num terceiro tempo, empenha-se em anulá-los, ficando apenas com os seus nomes, aquele nome sob o qual eles se deixaram perder e que, somente ele, vai simbolizá-los; aquele nome que vai expulsá-los do campo simbólico. E esse nome tem um preço. O preço está afixado. É o tempo das enciclopédias, das estátuas. É também o tempo do dinheiro que tanto lhes faltou em vida. O dinheiro é uma moeda, a pintura é uma outra, dizia Van Gogh. Mas no seu caso, uma vez morto, logo transformaram a moeda pintura na moeda dinheiro. Custa muito caro, caríssimo, suprimir, isto é, comprar um só Van Gogh, custa bilhões atualmente. O empenho foi muito grande em torno de suas telas para que se tenha a certeza de estar diante de "um" ou de "alguns" Van Gogh e que não se ouça mais o grito daquele que assinava - em nome de quem? - "Vincent".

Podemos encontrar a imagem social de Vincent Van Gogh, contemplada com múltiplos topoi do pintor genial, criador, visionário e teórico de ideias incandescentes. Esse van Gogh que condensa muitos topoi em sua pessoa e em sua práxis pictórica está em um limiar de uma importante transformação para a história da pintura e para a relação dessas duas facetas, mítica e histórica, da atividade pictórica. Lischtenstein (2004, p. 20-21) argumenta que:

A pintura precisou se apropriar de práticas discursivas desenvolvidas a seu respeito. É no Renascimento que os mais importantes textos fundadores, os de Alberti e Leonardo, têm a função de lembrar que a excelência da pintura não poderia ser reduzida unicamente à prática, ainda que magistral, mas que ela se afirma por meio da teoria. No século XV, observa-se um esforço no sentido de analisar e demonstrar que a arte é em si, na sua ainda relativa autonomia, um modo de conhecimento da realidade, uma expressão superior das idéias e até mesmo um modo de pensamento, como reivindica Leonardo.

Essa luta pelo reconhecimento intelectual e social da pintura empreendida por tratadistas e pintores do renascimento não podia se apoiar exclusivamente em exigências teóricas. Para encontrar um lugar correspondente à música e à poesia, buscou legitimar-se em uma origem mais antiga e mais nobre, produzindo narrativas, mitos e histórias dos pintores, atualizando o valor da arte e, na sua ausência, dos artistas da Antiguidade, para evocar ideias fundadoras e enobrecedoras da pintura. Nesse sentido, Lischtenstein (2004, p. 21-22) afirma que: 
o imaginário barroco e o pensamento medieval não se cansam de tecer reder de signos, correspondências e formas, as quais só podem ser entendidas por meio de suas representações. No século XVII, a corte de Urbano VIII assistirá a algumas tentativas radicais, como a muito ambiciosa de Sacchi, de representar, num movimento de extensão de todos os modos de visibilidade, a sabedoria divina. A pintura detém todos os poderes, metafóricos e miméticos, que lhe permitem transfigurar a natureza e a história. Com Lomazzo e Zuccaro, ela está prestes a revelar-se como pura atividade intelectual, expressão excepcionalmente adequada do concetto [conceito]. É dessa maneira que, no século XVII, a pintura acumulará os projetos mais ambiciosos e, às vezes, mais arriscados. Leonardo havia sonhado com uma arte capaz de abranger a totalidade dos fenômenos da natureza, mas eis que aparece, com Poussin, a figura do pintor erudito, sobretudo a do pintor filósofo, no qual vida e obra harmonizam-se no desígnio de resgatar o espírito do antigo. (...) À medida que se afirma a autonomia da arte, o espaço mítico se seculariza: todas as lendas e os temas são doravante integrados na pessoa do artista. A figura heroicizada do artista genial e solitário, permeada de biografias e lendas exemplares, pode ser considerada a derradeira forma de um topos reconhecido pela modernidade. $\mathrm{O}$ esgotamento da mitologia de maneira alguma ocasiona a morte do mito.

Para a compreensão atual, os significados de 'mito' e 'arte' tornam-se fora do alcance. A relação entre mito e arte torna-se mais inapreensível quando Hegel declara a morte da arte como capaz de nos revelar uma verdade, culminando um longo caminho já perceptível no advento da Reforma, radicalizado no século das Luzes, mas que começou bem antes, com o desaparecimento dos deuses. Esse movimento de secularização do mito e da própria arte tornou-se mais característico na modernidade traduziu a negação do imaginário mítico e no uso de estruturas mitológicas fundantes da arte. Podemos afirmar que Van Gogh, igualmente, personificou não um, mas muitos mitos do topos civilizatório sobre a arte e o artista que condensam e revivem o lugar social mítico da arte e do artista, e relacionamos esta, ao argumento de Lischtenstein (2004, p. 23):

na solidão do gênio, desafio a um conformismo sufocante, conflito com a ordem das instituições: o artista encontra justificação na sua fundamental ilegitimidade. Essa situação de ruptura e incompreensão, de fato real, torna-se o traço essencial de uma condição que a modernidade julga inerente à própria idéia de criação. A história se encarregará portanto de transfigurar a ausência de reconhecimento artístico e social, as vidas precárias de pintores que sacrificam muito a suas pesquisas plásticas, e ela o fará por meio de relatos hagiográficos que favorecerão a formação de novas lendas. A força dos velhos mitos, fontes de invenção da representação, é transferida para relatos mais ou menos heróicos da vida do artista. A oposição ao mundo da tradição constitui em si uma dinâmica própria na qual se cristalizam todas as esperanças da modernidade.

A ideia de revolução da linguagem pictórica saída das mãos de tantos artistas prémodernistas e modernistas não deixa de imprimir uma força primitiva e indubitavelmente mítica, assumindo talvez uma nova função social permitida pela sociedade pré-industrial um lugar para a existência do mito. As revoluções na linguagem pictórica vividas por inúmeros artistas impressionistas, pós-impressionistas e modernistas se materializaram não apenas nos textos imagéticos por eles produzidos, mas também por meio de narrativas e mitos contados e 
celebrados ao ponto de, no século XX, formar o horizonte e os paradigmas da arte sintetizando pelo exemplo o conceito de vanguarda. Um conceito que condensa e atualiza para a nossa compreensão pós-industrial, múltiplos sentidos e interpretações míticas e heróicas para as noções de estéticas e de filosofia da arte.

Como se situa van Gogh neste contexto de secularização crescente e da perda da relação mágica entre mito e arte? Muitos pintores encarnaram esses mitos, como Delacroix, que resumiu em sua pessoa e obra esse vácuo anterior a era moderna, criando novas “conversões e substituições simbólicas que determinaram a atividade criadora como fonte de novos mitos" (LICHTENSTEIN, 2004, p. 18-20). Quando perguntamos a qualquer pessoa um exemplo de pintor que concentra esse ideal de herói e martir, o nome de Van Gogh aparece como indubitável e não é a secularização da relação entre arte e mito que se verifica, mas a sua mais incognoscível ocorrência. Esse ideal está impreganado na representação cultural e com relação a Vincent, Forrester (1983, p. 37) discorre:

\begin{abstract}
Vincent foi esse pintor, apesar de si mesmo: "herói e mártir" contra a própria vontade. "Como sua cabeça deve ter trabalhado e como se arriscou até esse ponto extremo onde a vertigem é inevitável [...] Não precisa se arriscar nessas regiões misteriosas que parece poderem ser tocadas de leve mas não penetradas impunemente", lhe suplicará Théo. Vincent foi esse homem solto no mundo, um homem que viveu mortalmente só para "lucro" nosso. Para nos deleitarmos com seu inferno, com a "dor que vista daqui ocupa de tal forma todo o horizonte que adquire proporções de dilúvio desesperantes". Como se lhe tivesse sido imposto um papel dificílimo e a ele cabia representá-lo bem a fim de nos abarrotarmos de cultura. A fim de que os museus e os dicionários se enchessem de um resto; resto do sofrimento impensável, cotidiano, de um homem que se debatia, dotado de tanto poder, no seio de um tal saber, mas com muita inocência. E era bem nisso que estava seu sentimento de culpa.
\end{abstract}

\title{
3.2.3.2.1 A modalidade pintura na articulação com a minha análise
}

Ao analisar o corpus pictórico, foi levado em consideração o contexto de uma prática historicamente e culturalmente situada e o fato de que a pintura é uma modalidade eminentemente não normatizadora, e em muitas vezes, ela é transgressora de seus próprios códigos e parâmetros. Dessa forma a definição da modalidade pintura não nos ajuda tanto quanto considerar as questões mais intrínsecas da natureza da sua comunicação: o seu caráter de fluidez, plasticidade e mutabilidade enquanto suporte para a materialização de textos pictóricos. Essas e outras características e especificidades do texto pictórico conferem sua singularidade e apontam para a necessidade de novas categorias de análise que não estão contempladas pela GDV e que foram propostas nesta pesquisa para atender às especificidades do corpus analiso. 
A modalidade composição pictórica oferece uma riqueza de aspectos dialógicos, polifônicos, policrômicos que permitem analisar diferentes camadas de significação discursiva articuladas para representar a experiência estética e existencial de van Gogh no processo de construção da sua retórica visual.

O artista vive sua relação com a pintura pela forma como ele a organiza: em uma ação enunciativa, a qual ele busca reencontrar seu sentido imanente ao buscar reviver essa experiência por meio de novas narrativas que buscam refletir seu trabalho, como é o caso da produção discursiva epistolar que van Gogh empreende antes, durante e depois de suas produções pictóricas. A semiótica examina a pintura como um todo enunciativo, rico de significações que se articulam na composição na qual as diferentes camadas de sentidos desde as mais explícitas até as mais sutis se interprenetram e colaboram em uma sinergia semântica que percorre a composição das partes para o todo e do todo para as partes sem uma sequência pré-estabelecida. Esse processo de apreensão dos sentidos da obra é construído pela interação entre o olhar do artista que a organiza e o olhar do espectador em um dado contexto de situação, e um contexto cultural e histórico. A construção de sentido é, dessa maneira, um resultado da relação do pintor, sujeito enunciador, com suas escolhas: com o que ele vê e tudo o mais que ele deixa de ver, a fim de ver o que ele vê. E essa ação de ver está em relação com a sua posição no contexto físico e o seu lugar no mundo, ao seu ponto de vista físico e ao seu lugar histórico e cultural, a fim de que produza um texto que é essencialmente significativo nesse processo de descolamento do natural. É a sensibilidade de apreender e representar sua experiência no mundo e um desenvolvimento no modo de olhar que possibilita o reconhecimento dos seus efeitos de sentidos se para o que vemos podemos atribuir um conceito, uma identidade, ou ainda tentamos situar aquilo que vemos em esquemas classificatórios que permitem o seu reconhecimento.

Enquanto as bases da TSSM são inestimáveis para a realização dessa pesquisa, por suas especificidades, a modalidade pintura permitiu a investigação de diferentes categorias de análises que pareceram até o momento inexploradas pela GDV e pela multimodalidade, dada a atual necessidade de um maior adensamento de pesquisas nas modalidades das artes plásticas. Dessa forma a modalidade pintura na articulação com a minha análise possibilitou a exploração de diferentes camadas de sentidos, de diferentes ferramentas de análise e diferentes possibilidades de enfoque para a interseção entre a imagem e a palavra, permitidos pela riqueza e complexidade característicos de ambas as modalidades: pintura e carta. 


\subsubsection{Condições de produção, distribuição e consumo da modalidade carta}

Nas considerações sobre as condições de produção das cartas do corpus, foi levado em conta o papel que as cartas desempenhavam no contexto social e histórico em que foram produzidas. Busquei situar a produção das cartas no Contexto de Cultura e no Contexto de Situação para compreender a função social da troca de correspondência na vida das pessoas da segunda metade do século XIX que é distinta de sua função social em nosso século. Investigar esse contexto foi necessário para situar o papel social da prática epistolar na produção discursiva de Vincent van Gogh. A prática da escrita e da troca de cartas está interligada com uma prática de produção discursiva social e cultural, que não pode deixar de ser examinada em suas diferentes manifestações se quisermos compreender o contexto que impeliu e deu sentido a essa intensa produção e troca de correspondência.

3.2.4.1 Condições de produção da modalidade carta: contexto de cultura da produção e correspondência no século XIX

As cartas de Vincent foram produzidas no século XIX e a distância de nosso tempo atual, no qual escrevo esta pesquisa, exige certos cuidados para explicitar diferentes questões da coleta, tratamento e análise. Dessa forma, ao falar das condições de produção das cartas, não poderia deixar de levar em conta o levantamento do contexto histórico, cultural e social no qual estes textos foram produzidos, disseminados e consumidos. Não apenas do ponto de vista do contexto de situação imediata no qual os textos epistolares foram produzidos por van Gogh, mas do ponto de vista do contexto de cultura. Além de levar em consideração esses dois indicadores, foi considerado também o propósito a que estes textos foram destinados. Para tanto, desenvolvo a seguir diferentes aspectos do contexto de cultura no qual a prática da correspondência de cartas desempenhou um papel histórico, social e político.

Analisar um corpus que foi produzido em uma modalidade que caiu em desuso na atualidade é um desafio, porque requer do investigador um olhar mais cuidadoso para pensar a produção das cartas no contexto histórico em que elas foram produzidas, levando em consideração a função social que essa modalidade preenchia os sujeitos envolvidos nesta extensa correspondência e perguntando acerca do papel que a prática epistolar desempenhava naquela sociedade européia do século XIX. Ao pensar nessas considerações e desafios para a análise de um corpus textual produzido em outro século, é preciso destacar que o atual surgimento de novos meios de comunicação digitais tais como o computador e a internet, e 
que causou até certo ponto uma obsoletização da modaliadade epistolar tal como nós o conhecíamos, impõe um desafio para a pesquisa; o desafio de situar com maior precisão as condições em que foram produzidas as cartas que compõem o corpus da pesquisa. Foram levados em consideração os relatos dos biógrafos Naifeh e Smith (2012), Haziot (2010), Forrester (1983), que conduziram pesquisa sobre as práticas cultivadas na família de Vincent van Gogh, relevantes para situar as condições de produção das cartas que van Gogh escreveu ao longo de sua vida porque revelam os sentidos para essa produção em termos de uma prática social e culturalmente situada.

Alguns aspectos desse contexto foram levantados com base nos relatos biográficos a fim de reconstruir as questões contextuais que permearam o cultivo da prática da correspondência e que podem iluminar as condições em que se deu a produção de cartas entre van Gogh e seus pares.

Para falar sobre a condição de produção das cartas escritas por Vincent van Gogh, é preciso falar do contexto social, histórico e cultural em que ele as produziu e perguntar qual a razão de uma produção de cartas tão extensa e consistente. Para responder, é preciso entender as práticas sociais e familiares que deram sentido à troca de missivas tão constante e duradoura entre van Gogh e seus próximos. A produção e troca de cartas preencheu não só uma, mas diversas funções em um tempo em que muitas situações sociais, políticas e religiosas estavam em ebulição:

a) Letramento e práticas de leitura na Holanda no século XIX - De acordo com Ong (1982), uma onda de letramento e de disseminação de livros ocorreu com o advento da prensa de Gutemberg e a reforma da Igreja Protestante. A leitura de livros como prática social compartilhada, de acordo com os biógrafos Naifeh e White (2012), também foi impulsionada pela onda de afirmação da identidade nacional do povo holandês após o fim da ocupação dos franceses no território dos Países Baixos. O avô materno de van Gogh, chamado Willem, tinha uma oficina de encadernação de livros e prosperou com a onda de leitura que impulsionou as práticas sociais na Holanda em 1840, como relatam Naifeh e Smith (2012, p. 36):

Enquanto o país começava a sair das sombras da rebelião e das sublevações, Willem Carbentus reconstruía sua vida entre os destroços da tragédia pessoal. Casou-se aos 23 anos e teve nove filhos nos doze anos seguintes - sem nenhum natimorto, o que era de admirar. A estabilidade política e o "orgulho nacional" também trouxeram benefícios. Uma súbita onda de interesse por tudo o que era holandês criou uma explosão na demanda de livros. De Amsterdam ao menor dos vilarejos, formavamse grupos para promover a leitura de tudo, dos clássicos aos manuais de instruções. Aproveitando a oportunidade, Willem transferiu sua experiência no trabalho com o couro para a arte de encadernação de livros e abriu uma oficina na Spuistraat, principal zona comercial de Haia. Nas três décadas seguintes, transformou a oficina 
numa empresa próspera, criando a numerosa família nos aposentos de cima. Em 1840, quando o governo estava procurando um encadernador para a última versão da Constituição longamente discutida, recorreu a Willem Carbentus, que a partir daí passou a se apresentar como "encadernador real".

b) Como meio de comunicação - Em uma época em que não havia grande diversidade de meios de comunicação disponíveis, a correspondência de cartas foi um meio de comunicação das elites e, após a Reforma Protestante, da nova classe burguesa em ascenção. Sua prática foi impulsionada pela Reforma Lutherana da Igreja, quando a primeira onda de letramento (ONG, 1982) ampliou-se na Europa nos países que subscreveram à nova prática religiosa. A expansão do acesso da classe burguesa à cultura do livro e ao hábito da correspondência tornou-se uma forma de apropriação das práticas sociais de comunicação. A prática da correspondência assumiu o status de produção cultural e se popularizou após a Reforma Protestante com o advento da prensa de Guthemberg permitindo a ampliação do acesso aos livros. A nova classe burguesa em ascenção buscou diferenciar-se dos camponeses por meio do letramento, do consumo de livros, quadros e objetos de arte, e das práticas como os passeios no campo, o cultivo de jardins, o desenvolvimento de hobbies e de habilidades artísticas, a manutenção de crônicas para relatar a história familiar, a correspondência de cartas. Naifeh e Smith (2012, p. 47) descrevem com detalhe essas práticas:

Concentrando-se de forma tão exclusiva na vida do lar, Anna não só cumpria seus deveres de esposa e protestante, mas também mantinha as convenções de sua classe social. Tinha início o que os historiadores chamariam de "a era do triunfo da família". As crianças haviam deixado de ser pequenos adultos à espera de crescer. A infância se tornara um estado de ser próprio e precioso - "a sagrada juventude", como diziam - e a maternidade era uma vocação sagrada. "Deve-se garantir que [a juventude] partilhe o mínimo possível as mazelas da sociedade", advertia um dos mais populares manuais de educação da época. "Uma vida toda pela frente não consegue compensar uma juventude reprimida." Centenas de livros assim, e uma quantidade ainda maior de romances, aproveitavam e instruíam a nova obssessão da classe média. A mensagem desses livros era muito familiar a Anna: o mundo exterior era um lugar perigoso e turbulento; a família constituía o supremo refúgio.

c) Para romper o isolamento social e físico da família - É preciso contextualizar a prática da correspondência no tempo em que van Gogh produziu suas cartas. Aquele foi um tempo no qual havia uma prática social consolidada que atendia a diversas funções sociais. Esse contexto é ricamente relatado por Naifeh e Smith (2012, p. 43):

Durante dois séculos, as charnecas arenosas de Zundert tinham sido varridas pela ida e volta de exércitos, que estabeleciam uma religião e expulsavam outra. Quando se aproximavam tropas católicas vindas do Sul ou tropas protestantes vindas do Norte, congregações inteiras recolhiam seus pertences e fugiam. As igrejas eram vítimas de vandalismos e confiscos. Então mudavam os ventos políticos: chegavam novas 
autoridades, reinstituíam-se as velhas igrejas, vinha a desforra, novas medidas de opressão eram impostas aos infiéis. [...] Quando os Van Gogh chegaram vinte anos depois, a congregação protestante somava apenas 56 pessoas de um pequeno número de famílias, na proporção de uma para trinta em relação aos católicos, e constituíam um posto avançado da verdadeira fé nas charnecas papistas. Os protestantes suspeitavam profundamente das intenções católicas e tomavam o máximo cuidado para evitar conflitos com as autoridades católicas. Os católicos boicotavam os negócios protestantes e maldiziam o protestantismo, que chamavam de "a fé do invasor".

Eles atestam que morar em Zundert na época em que van Gogh nasceu constituiu um desafio para seus pais. Ali estava ocorrendo uma guerra religiosa entre católicos e protestantes e uma tensão política entre os moradores dessa região, que eram católicos, e o Governo de Haia que era protestante:

[...] Mas as amenidades não podia disfarçar a verdade: depois de sua vida de solteira no mundo distinto e requintado de Haia, ela tinha vindo parar num posto avançado religioso sob constante ameaça, num lugar inóspito e desconhecido, cercada por habitantes que, na maioria, não gostavam de sua presença, dos quais ela desconfiava e cujo dialeto mal conseguia entender. E tampouco era possível disfarçar a solidão. Sem poder andar desacompanhada pelas ruas da cidade, ela recebeu uma sucessão constante de visitas da família e, no final do verão, voltou a Haia, onde ficou por um bom período. (NAIFEH; SMITH, 2012, p. 44).

d) Como estratégia de ocupação populacional dos protestantes - O pai de Vincent, Theodorus van Gogh, pertencia à Igreja Reformada Holandesa que seguia o protestantismo iniciado no século XVI. Essa Igreja seguia a doutrina de Johannes Calvijn (1509-1564), mais conhecido como calvinismo. Como ministro de sua congregação, o pai de van Gogh cumpriu um papel moderado em meio às tensões de morarem em uma região dividida pelas lutas religiosas. A prática da correspondência era uma forma de manter a congregação coesa. Naifeh e Smith (2012, p. 44) explicam a esse respeito:

Conforme todas as outras características de sua vida anterior se desfaziam, uma se tornou cada vez mais importante: a respeitabilidade. Anna sempre vivera pelas regras das convenções. Mas agora, sob a férrea disciplina imposta pelo isolamento e pela hostilidade, essas regras adquiriram novo significado. Em primeiro lugar, e acima de tudo, as regras requeriam que mulheres de pastores, todas elas, tivessem filhos - montes de filhos.

e) Para afirmar os valores da família - Naifeh e Smith (2012) relatam que Anna morou vinte anos em Zundert, ao longo dos quais se manteve atávica ao temor e conformidade com que ensinou os filhos a enfrentar o mundo: "Somos moldados primeiro pela família e depois pelo mundo", escreveu ela (NAIFEH; SMITH, 2012, p. 45). Eles relatam que:

Para conter as forças obscuras Anna se mantinha em atividade frenética. Aprendeu a tricotar desde menina, e pelo resto da vida manejou as agulhas com uma "rapidez assustadora", segundo a crônica da família. Era missivista "incansável”, cujas 
cartas - cheias de múltiplas inserções e uma sintaxe atropelada - mostram o mesmo impeto apressado rumo a lugar nenhum. (NAIFEH; SMITH, 2012, p. 37).

f) Como registro da história pessoal e da família - Duas gerações antes de van Gogh nascer, a família de sua mãe quase desapareceu por completo quando as enchentes levaram todos os membros do clã dos Carbentus, menos um, o avô de van Gogh, Gerrit, como historiado por Naifeh e Smith (2012, p. 34-35):

Mas nada detinha o mar. Apesar de mil anos de um trabalho colossal - e, em alguns casos, justamente por causa disso -, as inundações continuavam tão inevitáveis como a morte. Com uma apavorante imprevisibilidade, as ondas transpunham os diques ou os diques desmoronavam sob as ondas, ou ambos, e a água se precipitava terra adentro, cobrindo as planícies rurais. Às vezes o mar simplesmente avançava e tragava a terra. Numa única noite de 1530, vinte vilarejos afundaram no abismo, deixando apenas a ponta dos pináculos das igrejas e as carcaças do gado acima da superfície da água.

Esse trágico episódio, seguido de muitas lutas e superações pode ter contribuído para o cultivo e para a manutenção de crônicas dos eventos familiares como forma de preservar a memória da existência daquela família. Este episódio é registrado com detalhes por Naifeh e Smith (2012, p. 35):

Gerrit Carbentus nascera ao final de uma sublevação cataclísmica; seu neto, que também se chamava Gerrit, chegou no início de outra. Desde os meados do século XVIII, em todo o continente europeu, as reivindicações revolucionárias de eleições livres, de ampliação do direito de voto e da abolição de impostos iníquos se fundiram com o espírito utópico do Iluminismo, criando uma força tão irresistível quanto a guerra ou o mar. Era apenas questão de tempo antes que o entusiasmo revolucionário alcançasse a família Carbentus. Quando as tropas da nova República francesa entraram na Holanda em 1795, vieram como libertadoras. Mas ficaram como conquistadoras. Os soldados se aboletaram em todas as residências do país (inclusive da família Carbentus); bens e capitais (como moedas de ouro e prata da família) foram confiscados; os lucros desapareceram; os negócios fecharam; os preços dispararam. Gerrit Carbentus, que trabalhava com couro e era pai de três filhos, perdeu seu ganha-pão. Mas o pior ainda estava por vir. No dia 23 de janeiro de 1797, Gerrit saiu cedo de casa, em Haia, para ir trabalhar numa cidade próxima. Às sete da noite, foi encontrado na beira da estrada de Rijswijk, roubado, espancado, agonizando. Quando foi levado para casa, já estava morto. A mãe, “ensandecida de dor, abraçou o corpo inerte e verteu uma torrente de lágrimas sobre ele", segundo a crônica da família Carbentus, um diário do clã mantido por gerações decronistas. "Este foi o fim de nosso querido filho, que era por si mesmo um pródigio. [...] Gerrit Carbentus deixou uma esposa grávida e três filhos pequenos. Um deles era Willem, de cinco anos de idade, avô do pintor Vincent Willem van Gogh.

A mãe de van Gogh cultivava a prática de escrever cartas aos familiares para contar as notícias de sua família, e deixar suas impressões e crônicas de seu tempo.

g) $\underline{O}$ perigo de desaparecimento da família Carbentus e suas consequências na visão de mundo da mãe de van Gogh - Como relatado pelos biógrafos Naifeh e Smith (2012, p. 33-34), eventos trágicos ocorreram com os antepassados de Anna: 
Em 1697, o destino da família Carbentus estava suspenso por um fio: Gerrit Carbentus, o único membro da família que sobrevivera às gerras, às enchentes, aos incêndios e às pestes dos 150 anos anteriores. Os antepassados de Gerrit haviam desaparecido na carnificina geral da Gerra dos Oitenta Anos, uma revolta das Dezessete Províncias dos Países Baixos contra seus brutais governantes espanhóis. Ela se iniciou em 1568, segundo um relato, quando os cidadãos protestantes em cidades como Haia se rebelaram "num cataclismo de fúria e destruição histérica". As vitímas eram amarradas juntas e atiradas do alto de janelas, afogadas, decapitadas e queimadas. A inquisição Espanhola reagiu condenando todos os habitantes dos Países Baixos, 3 milhões deles, homens, mulheres e crianças, à morte como hereges.

De acordo com os biógrafos Naifeh e Smith (2012, p. 37), ela "era missivista “incansável”, cujas cartas - cheias de múltiplas inserções e uma sintaxe atropelada - mostram o mesmo ímpeto apressado rumo a lugar nenhum”. Eles relatam que:

Depois do jantar, todos se reuniam em torno do fogão para outro ritual: o ensino da história da família. Dorus, o pai, que segundo a filha Lies era "bem informado sobre esses assuntos", contava histórias de ancestrais ilustres que tinham servido ao país durante suas múltiplas provações. Essas histórias sobre um passado tão distinto conolavam Anna em seu isolamento nas charnecas, voltando a ligá-la à cultura e à classe social que havia deixado para trás. Como praticamente todos de sua geração, Anna e Dorus van Gogh sentiam uma grande nostalgia pelo passado do país especialmente a "Idade de Ouro" seiscentista, quando as cidades-Estados do litoral dominavam os oceanos do planeta, alimentavam um império e eram os mentores da civilização ocidental nas ciências e nas artes. As aulas ao lado do fogão transmitiam à família um fascínio pela história e também uma vaga saudade desse Paraíso perdido. (NAIFEH; SMITH, 2012, p. 50).

h) Como Meio de afirmação ideológica dos valores religiosos dentro do grupo

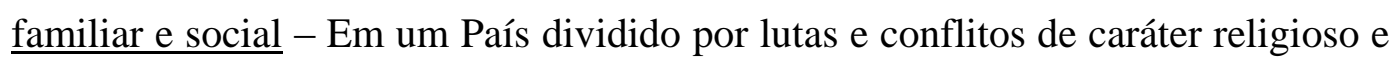
político os protestantes ao sul da Holanda estavam em menor número e de certo modo socialmente segregados. Como estratégia de resistência, de ocupação e de expansão de seus valores e modo de vida, era muito comum o casamento entre os indivíduos da comunidade protestante para fins de aumento da congregação. Junto com o crescimento da família, havia a necessidade não só da manutenção do vínculo familiar, mas do engajamento de cada um dos membros da família nos ideais religiosos do grupo. Além de desempenharem o papel de divulgar os valores religiosos que norteavam o estilo de vida e de relatar sua prática cotidiana, as cartas também exortavam a afiliação dos membros da família à doutrina protestante.

i) Como meio de fortalecimento dos vínculos familiares e grupais - Nesse contexto, onde as tensões sociais estavam afloradas e prestes a explodir, a família, socialmente isolada, estava mais voltada para o convívio com seus próprios membros. É preciso ressaltar que a troca de correspondência, entre outras práticas grupais, tais como as caminhadas, o cultivo dos jardins e a leitura de livros por 
todos os membros da família, eram incentivadas para fortalecer a coesão familiar e o senso de pertencimento dos membros do grupo. São relatados pelos biógrafos Naifeh e Smith (2012), várias práticas grupais da família de Vincent.

j) Visão de mundo de Anna e a unidade familiar que seria mantida por meio das correspondências entre os irmãos - São relatados pelos biógrafos Naifeh e Smith (2012, p. 47), várias práticas grupais da família de Vincent:

No ambiente claustrofóbico do presbitério (uma "atmosfera estranha, suscetível", segundo um relato), a campanha de Anna só podia sair vitoriosa. Os filhos cresceram presos à família como náufragos agarrados a uma jangada. "Oh! Não consigo imaginar como seria se um de nós tivesse de partir", escreveu a filha Elisabeth, que a família chamava de Lies, aos dezesseis anos "Sinto que somos todos juntos, que somos um só...Se agora faltasse alguem, era como se essa unidade tivesse deixado de existir." A separação, emocional ou física, de qualquer membro era dolorosa para todos. As reuniões eram celebradas com lágrimas de alegria e investidas do poder até de curar doenças.

As cartas evidenciam essa coesão familiar que se manteve mesmo quando os irmãos eram adultos e moravam distantes, eles continuavam a se corresponder, compartilhando, por exemplo, suas leituras mais recentes e sua interpretação dos autores. A prática de se corresponder com a família que van Gogh cultivou ao longo de sua vida é explicada por Naifeh e Smith (2012, p. 47-48):

\begin{abstract}
Anos depois, quando a separação se tornou inevitável todos os filhos de Anna sofreram a dor do afastamento. Sucediam-se as cartas (não somente de Vincent), de uns para os outros, num enorme empenho para manter os elos familiares. Acometidos de acessos de "inexprimível saudade" durante toda a vida adulta, segundo um dos parentes por afinidade, continuavam cautelosos em relação ao mundo exterior, preferindo a segura vida substituta que encontravam nos livros, em vez da realidade que os cercava. Para todos eles, uma das maiores alegrias da vida seria manter toda a família unida no presbitério, à semelhança de uma nau; um dos maiores medos da vida seria se ver excluído de tal alegria. "O sentimento de família e nosso amor recíproco é tão forte", escreveu Vincent anos depois, "que o coração se eleva e o olhar se volta para Deus e roga: 'Permite que eu não me afaste demais deles, não tempo demais, ó Senhor'.
\end{abstract}

k) Como Meio de produção identitária - A correspondência estava associada a um conjunto de práticas de produção de leituras compartilhadas de autores da época, e troca de ideias de um grupo que vivia a partir de um ideário filosófico, ético e religioso consoante com um estilo de vida que os definiam e os destacavam da comunidade predominantemente católica na cidade de Zundert. No relato de Naifeh e Smith (2012), a prática da leitura unia a família e era cultivada como estratégia para manter a unidade familiar:

Todos os serões na casa paroquial terminavam da mesma maneira: com um livro. Longe de ser uma atividade solitária e solipsista, a leitura em voz alta unia a família e a separava daquele oceano de analfabetismo católico rural que os cercava Anna e Dorus liam um para o outro e para os filhos; as crianças mais velhas liam para as mais novas; depois, anos mais tarde, os filhos liam para os pais. A leitura em voz 
alta, além de educar e entreter, servia para consolar os doentes e distrair os preocupados. Fosse à sombra do toldo no jardim ou à luz de um lampião, a leitura era (e continuaria a ser) a voz reconfortante da unidade familiar. Muito depois de terem cada qual seguido seu rumo, os filhos continuavam a trocar e recomendar livros com entusiasmo, como se nenhum livro fosse verdadeiramente lido enquanto não o fosse por todos. (NAIFEH; SMITH, 2012, p. 51).

\subsubsection{O Contexto de Situação das cartas de Vincent}

O estudo, sempre que possível, do contexto de situação no qual foram produzidas as cartas foi instrumental para desvelar a função dos recursos discursivos empreendidos na materialidade do texto das cartas. Nesta pesquisa, foram utilizadas as cartas em Francês cuja tradução para o Portugues respeitou uma transcrição do idioma em que foi escrito, e não uma tradução interpretativa. Nunca é demais enfatizar que a relação postal entre van Gogh e Theo teve um papel decisivo na articulação do pensamento pictórico de van Gogh, e alimentou o processo criativo como uma relação de parceria de prática discursiva entre ambos que fomentou a construção imagética e a produção pictórica em Vincent.

Van Gogh parece situar a produção de cartas como uma prática de construção discursiva da qual ele depende para articular seu pensamento sobre as questões importantes para. Essa interdependência é explicada por Haziot (2010, p. 180):

\footnotetext{
Mas ele não tinha mais a possibilidade de escrever aquelas longas cartas nas quais podia, após dez páginas e um pós-escrito igualmente longo, resolver as dificuldades mais complexas. Assim, logo que chegava em casa à noite, lançava-se sobre o pobre Théo para lhe falar, falar, falar sem parar. E quando Théo, já fatigado por uma jornada de trabalho, ia se deitar, Vincent pegava uma cadeira e sentava-se junto da cama para lhe continuar falando de Delacroix, de Monet, dos contrastes de cores, do valor das teorias de Seurat, etc.
}

As cartas que van Gogh escreveu a Theo se iniciaram em 29 de setembro de 1872, quando Vincent tinha dezenove anos e já morava há três em Haia para trabalhar na filial da galeria Goupil, na qual Théo seria empregado anos mais tarde. No começo dessa correspondência, eles falavam da profissão que ambos escolheram, trocavam breves relatos sobre eventos que aconteciam, seguindo as convenções sociais da época para a troca de cartas. Apenas com o passar dos anos, Vincent começa a escrever suas impressões sobre o seu entorno, e a articular questões de cunho pessoal, compartilhando com o irmão seu anseio por se tornar um pintor bem como as dificuldades que estava encontrando para deflagrar essa jornada rumo a sua profissionalização como artista. A partir desse momento Vincent parece encontrar uma voz e suas cartas assumem uma função mais reflexiva e organizadora de sua experiência no mundo, na qual Théo é convidado a compartilhar e a participar. 
Frequentemente, elas descrevem os conflitos e processos de identificação de Vincent com o trabalho e as ideias de autores e pintores de sua época, além disso, faz questionamentos existenciais. Ao mesmo tempo em que Vincent fala de aspectos de sua experiência que revelam o grau de intimidade e de confidência com que se relaciona com o irmão, nota-se o cuidado com as afirmações e os julgamentos. Muitos artistas morrem sem deixar vestígio de seu discurso e com eles se vai nossa chance de acessar e compartilhar seu pensamento, suas inquietações. A intensa correspondência entre van Gogh e seu irmão é dada por uma relação de complementaridade entre ambos que implicava num intenso compartilhar do processo de produção, pois Vincent estende ao irmão a autoria de sua própria produção, compartilhando o esforço, os gastos, os sentidos, os ideais, as esperanças, o sofrimento e a luta para construir um lugar de pertencimento. A correspondência entre ambos constituiu uma prática discursiva que está na base da produção pictórica e van Gogh.

Esse processo de correspondência, cumplicidade e identificação entre os irmãos permitiu o registro de um universo de significações que se articula com a obra e revela a gênese e o amadurecimento de um pensamento que se mostra em sua exuberância tanto nas telas quanto na escrita que eles trocaram. Van Gogh produziu uma via de comunicação robusta com Theo e parece encontrar nele, um interlocutor para seus anseios e uma testemunha de sua existência, em quem deposita suas expectativas de aceitação e reconhecimento que não encontra nas suas relações familiares e sociais. Sua identidade vai sendo construída na esteira dessa interlocução escrita e artística.

De acordo com os editores das cartas de Van Gogh, Jansen, Luijten, Bakker (2009) a correspondência de Vincent tornou-se amplamente conhecida desde que as suas cartas foram publicadas quase um século atrás. Jansen, Luijten e Bakker (2009, p. 1) argumenta que elas se tornaram:

[...] uma fonte de informaçoes sobre a história de vida emocionante de Van Gogh e um trabalho excepcional, e havia amplo reconhecimento das qualidades intrínsecas de sua escrita: o tom pessoal, estilo e linguagem evocativa animada. A combinação destes fatores levou algumas pessoas que estavam em posição de saber a conceder o status de literatura da correspondência. O poeta W.H. Auden, que publicou uma antologia com uma breve introdução, escreveu: "não há praticamente uma carta de Van Gogh que eu, que sou certamente nenhum perito, não acho fascinante '. Jan Hulsker, durante décadas, uma autoridade sobre a correspondência de Van Gogh, colocou sem reservas as cartas no nível da literatura mundial: "Vincent foi capaz de expressar-se esplendidamente, e é esta escrita de talento notável que tem garantido às cartas o seu lugar duradouro na literatura mundial, para muito além da sua importância para o estudo da sua vida e trabalho. ... Em muitas cartas suas emoções e crenças são expressas tão fortemente e de forma convincente que um escritor "real" dificilmente poderia ter melhorado em cima delas." Claro, qualificações como esta são, em parte, pessoais, mas se, de acordo com a essência da literatura, entende- 
se que ela expressa do geralmente válido até o específico a condição humana, então não pode ser negado que as cartas de Van Gogh são de fato altamente literárias.

\subsubsection{Carta - a modalidade epistolar}

As cartas são um gênero que inicialmente envolve um remetente e um destinatário, mas que podem ser organizadas e publicadas dependendo de seu interesse para o conhecimento sobre determinadas personalidades públicas. Ela frequentemente é escrita em primeira pessoa e tem como objetivo um determinado leitor, já conhecido e do qual se espera uma resposta. A linguagem é adequada ao tipo de destinatário para o qual está sendo escrita a carta, havendo em geral uma saudação, uma interlocução e uma despedida ao final. Jansen, Luijten e Bakker (2009, p. 1) cita a definição de carta de Mathijsen:

Editores de cartas precisam refletir sobre o que exatamente eles querem dizer com o termo. Em uma correspondência volumosa há sempre papéis que se diferem da forma padrão, que podem ser amplamente descritos como tendo uma saudação no início e uma assinatura no final; entre estes há o texto principal ocorrendo ao longo de uma ou mais folhas, e pode haver um ou mais escritos posteriores ao texto. A maioria das cartas na correspondência de Van Gogh está em conformidade com este padrão geral, mas há exceções, como cartas inacabadas, cartas copiadas por Theo e cartas em suportes inusitados. Apoiamos a definição de uma carta formulada por Marita Mathijsen em De brieven van De Schoolmeester e, ligeiramente alterada, em sua edição manual Naar de carta: "A carta é um texto que visa manter ou estabelecer contato entre o escritor e uma pessoa identificada ou o número de pessoas com quem ele ou ela tem uma conexão e que não se destina, em primeira instância, para publicação ou reprodução. O uso do tratamento de forma direta é típico, como é a presença de uma saudação e uma assinatura. O texto é feito para ser enviado ou entregue à pessoa a quem ela é dirigida.

A modalidade carta oferece uma riqueza de características dialógicas e interativas que permitem analisar diferentes camadas de significação discursiva articuladas para representar as buscas, preocupações, conflitos, dúvidas, convicções, visão de mundo e experiências de Vincent van Gogh em seu processo de construção de sua existência como artista. A análise do corpus epistolar focalizará o significado experiencial que se inscreve na análise da transitividade nas estruturas léxico-gramaticais das orações.

\subsubsection{A modalidade Carta na articulação com a minha análise}

As cartas escritas por Van Gogh ao seu irmão reúnem uma riqueza de conteúdos e associações que trazem, explícita e implicitamente, elementos que revelam uma identidade 
construída no decorrer do processo de criação artística e que tornou van Gogh o gênio que acabou sendo 'descoberto' após sua morte.

Durante a voluntária solidão em Arles, Vincent registrou para Theo todas as suas ideias e esperanças em cartas que se leem como diário contínuo. Estas cartas, escritas por um artista humilde e quase autodidata, que não fazia ideia nenhuma da fama que iria conquistar, estão entre as mais comoventes e excitantes de toda a literatura. Nelas podemos pressentir o sentimento de missão do artista, sua luta e seus triunfos, seu desesperado anseio por uma companhia, e ficamos conhecendo a imensa tensão sob a qual trabalhou com febril energia. (GOMBRICH, 1999, p. 545).

Este processo associativo denota um processo contínuo na construção de elementos que são recorrentes ao longo de toda correspondência, mostrando uma cadeia de sentidos no discurso das cartas e dos quadros que produz. Uma breve exposição do processo de correspondência de Vincent é descrito por Jansen, Luijten e Bakker (2009, p. 1)

As cartas dos três primeiros anos seguem mais ou menos o mesmo padrão. Elas começam com uma observação sobre o progresso da correspondência, como 'Obrigado por sua carta' ou 'É hora de você ouvir falar de mim de novo'. Se Van Gogh respondia a uma carta de um de seus correspondentes, ele lidava com isso em um par de frases curtas. Ele, então, voltava-se para notícias da família, tais como doenças, visitas que tiveram lugar e assim por diante. Isto era seguido por algo sobre sua própria situação ou experiências, e ele fechava com saudações a ser repassados para os outros e o pedido de rotina para que o correspondente escrevesse novamente. Ele era, ocasionalmente, um pouco mais informativo quando ele tinha se mudado para outro local porque os locais eram novos, como quando ele foi transferido para Londres, em junho de 1873. Em geral, porém, o padrão permaneceu praticamente o mesmo. O escritor de cartas em Van Gogh em ainda não tinha sido liberado. Isso não significa que nós não pudéssemos conhecê-lo um pouco. É claro, desde a primeira carta que ele assumiu o papel do irmão mais velho e mais sábio para Theo. Ele usou a correspondência para aconselhar-lhe sobre o que devia e não devia fazer para se sair adiante na vida. Ele moralizava e confortava Theo se ele tinha dificuldades no trabalho ou lamentava a perda de um amigo. E dava-lhe conselhos sobre a arte ea literatura. Estes foram seus principais interesses, como resultado da maioria de suas cartas.

Mais tarde, na ocasião de seu fracasso como ministro na região das minas de carvão, a correspondência entre os irmãos contribuiu para uma reinserção social de Van Gogh, e serviu como uma estratégia para reverter o processo de exclusão com o qual lidava ora de forma resignada ora de forma revoltada sem, contudo, encontrar meios de sair. A correspondência parece ter sido um modo acional de construir um discurso e uma prática interativa, dialógica que contribuiu diretamente para a representação de uma nova identidade, para a organização de uma nova prática de produção artística e para o desenvolvimento de um novo estar no mundo.

$\underline{\mathrm{O} \text { conceito de gênero, }}$ pela perspectiva da LSF, foi importante para a análise na medida em que o gênero carta é um gênero dialógico, que pressupõe a interlocução com um leitor e pode ter o caráter público ou privado. No caso do corpus textual constituir de cartas de van Gogh ao seu irmão Theo, o gênero tem qualidades de uma prática muito específica e 
muito situada. Trata-se de cartas de foro íntimo e pressupõe uma prática social confidencial na qual o autor despe suas dúvidas, incertezas e dialoga com o seu interlocutor que aparece no texto de forma indireta porque as colocações de Van Gogh têm um tom íntimo: de apelo, às vezes de queixa, às vezes de interpelação na medida em que tenta se representar para o irmão da forma como ele próprio se representa para si mesmo.

$\mathrm{Na}$ análise buscou-se aprofundar o conceito de gênero, em especial do conceito do gênero carta. Este gênero é dinâmico, uma vez que não é regido por uma 'faceta regulatória do discurso' muito pré-fixada, e oferece entre o espaço da saudação e da despedida, um campo fluido, flexível e dinâmico para diferentes construções discursivas na busca de estabelecer e corporificar o diálogo com o destinatário.

A carta dessa forma reúne e condensa sentidos e integra modos; de agir pela prática do diálogo, potencializada pelo tom íntimo e confessional de representar que ajuda Van Gogh a organizar sua representação não só para o irmão como para si mesmo; e de ser: na medida em que sua carta organiza o processo de identificação com seu irmão e com uma prática social que está a bojo de uma transformação lenta e dolorosa que irá revolucionar não somente a vida de Van Gogh, mas a história da pintura.

Seu processo de elaboração identitária pode ser reconhecido no sequenciamento de diferentes gêneros que aparecem intercalados na busca de construir um diálogo, uma aproximação, uma empatia, uma identificação de seu interlocutor com ele. Esses pré-gêneros estabelecem ritmos e abordagens que variam do distanciamento analítico para a aproximação emotiva, e escalam desde o distanciamento de quem nada espera até a exasperação de quem não encontra saída para ser no mundo.

\subsection{SOBRE OS CORPORA DA PESQUISA}

\subsubsection{Corpus visual}

A produção pictórica de van Gogh, de acordo com o levantamento do Museu van Gogh é de 864 telas (VAN GOGH MUSEUM, 2014). Das 864 telas, foram selecionadas as pinturas de van Gogh abaixo relacionadas. As informações acerca do local e data de sua produção e localização atual, além da fonte da imagem, estão disponíveis também no item: 4.5, 'Apresentação do corpus pictórico', na metodologia. 
Figura 63: Sunset: Wheat Fields Near Arles (1888)

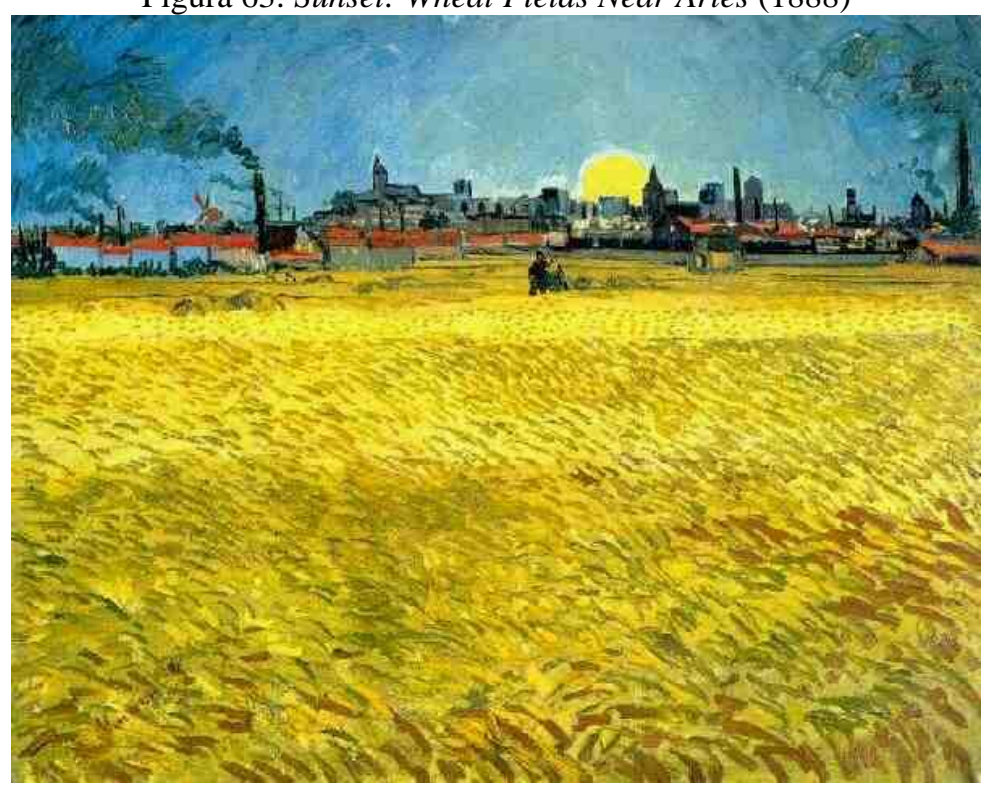

Fonte: Van Gogh (1888a)

Oil on canvas, $73.5 \times 92.0 \mathrm{~cm}$.

Arles: June, 1888

F 465, JH 1473

Localização: Winterthur: Kunstmuseum Winterthur

Figura 64: The Sower Arles: June, (1888)

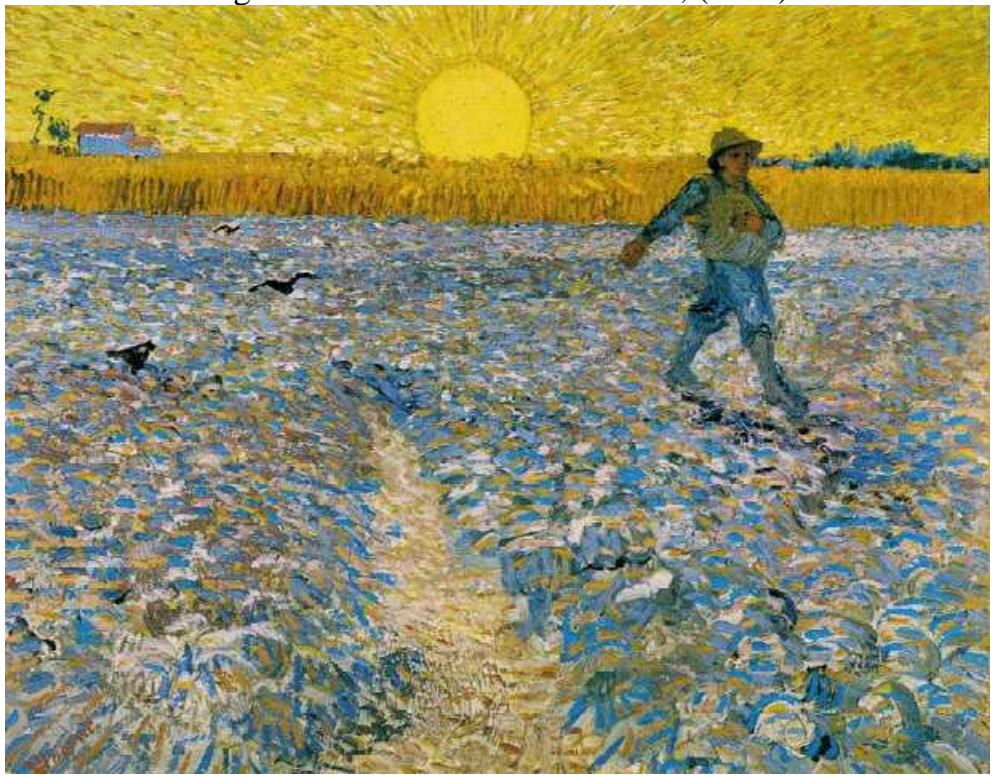

Fonte: Van Gogh (1888d)

Oil on canvas, $64.0 \times 80.5 \mathrm{~cm}$.

Arles: June, 1888

F 422, JH 1470

Localização: Otterlo, Rijksmuseum Kroller-Muller. 
Figura 65: The Café Terrace on the Place Du Forum, Arles, at Night (1888)

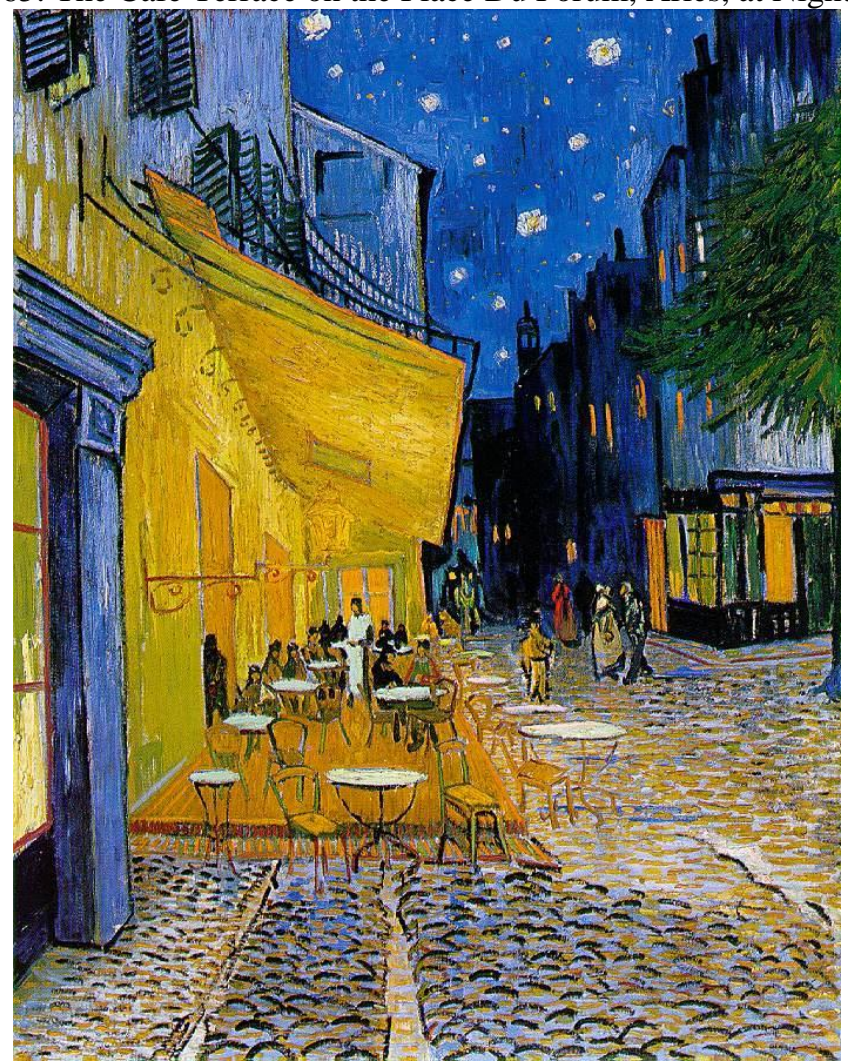

Fonte: Van Gogh (1888c)

Oleo sobre tela, $1.0 \times 65.5 \mathrm{~cm}$.

Arles: September, 1888

F 467, JH 1580

Localização: Otterlo, Rijksmuseum Kroller-Muller.

Figura 66: The Night Café in the Place Lamartine in Arles (1888)

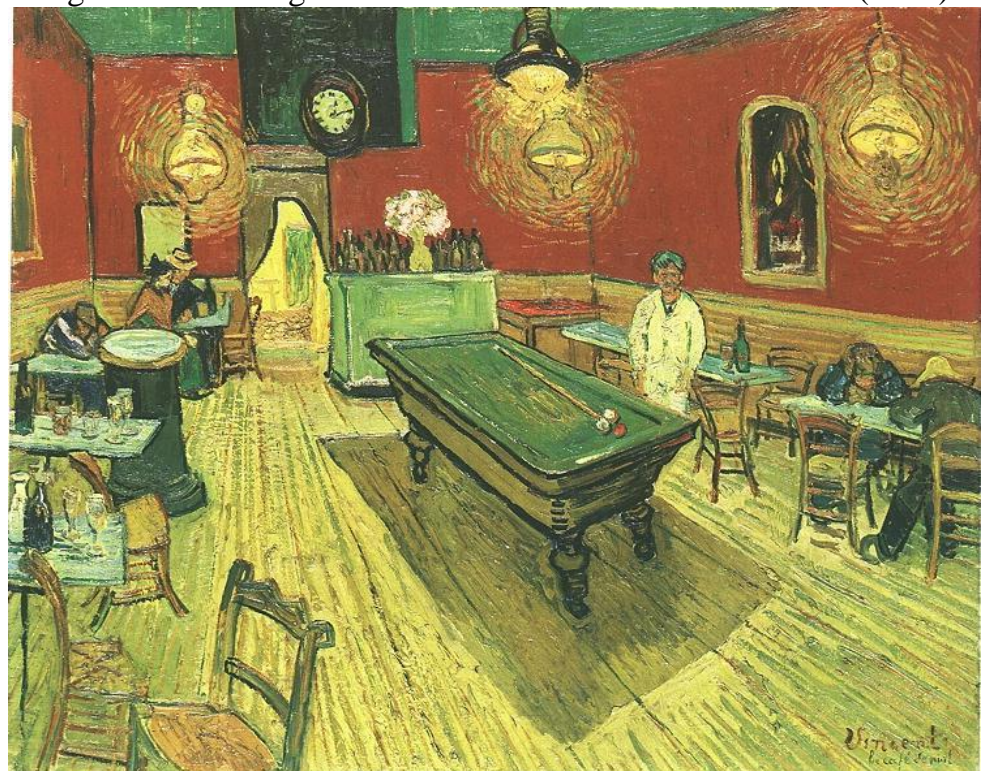

Fonte: Van Gogh (1888d)

Óleo sobre tela, $70.0 \times 89.0 \mathrm{~cm}$.

Arles: 5-8 Septembro de 1888.

F 463, JH 1575

Localização: New Haven, Connecticut: Yale University Art Gallery 


\subsubsection{Corpus Epistolar}

O corpus das cartas está constituído dos excertos de cartas que se referem diretamente às telas analisadas. O corpus textual primário consiste dos extratos de 12 cartas que se relacionam com as obras citadas, selecionadas em uma correspondência de 902 cartas que van Gogh manteve com seus familiares e amigos;

$\mathrm{Na}$ análise das cartas, os excertos do corpus primário foram segmentados em orações, analisadas com a ajuda das ferramentas metodológicas da Linguística Sistêmico Funcional (LSF), com enfoque nas categorias da Transitividade e das orações complexas para buscar as relações lógico-semânticas.

A interpretação da descrição na análise desses corpora apoiou-se também nos relatos dos biógrafos do artista (WALTHER; METZGER, 2012; NAIFEH; SMITH, 2011; HAZIOT, 2010; WALTHER, 1990; PEREIRA, 1990; CABANNE, 1971; FORRESTER, 1983) e no estudo do contexto sócio-histórico no qual foram produzidas tanto as telas quanto as cartas para compreender os sistemas semânticos e semióticos à sua luz.

\subsection{JUSTIFICATIVA E CARACTERIZAÇÃO DOS CORPORA DA PESQUISA}

\subsubsection{Justificativa para a escolha do corpus pictórico}

A seleção das telas seguiu os critérios descritos a seguir. Vincent van Gogh produziu, o levantamento do Museu van Gogh, em torno de 864 telas e essa produção extensa e intensa torna o trabalho de seleção do corpus bastante desafiante. Para fazer a seleção do corpus pictórico, foi preciso ler a literatura histórica e biográfica do artista para explorar critérios do 'Contexto de Situação' (MALINOWSKY, 1923 apud VAN LEEUWEN, 2011, p. 306) e do 'Contexto de Cultura' (SAPIR; WORF apud HALLIDAY; MATHIESSEN, 1999, p. 17). A escolha levou em consideração critérios que exerceram um papel significativo no desenvolvimento e amadurecimento de um pensamento artístico próprio de Van Gogh; que refletissem o percurso de escolhas linguísticas em seu trabalho pictórico e que fossem relevantes para o objeto e enfoque desta pesquisa.

Três foram os enfoques usados como ponto de partida para pensar os critérios de seleção das telas para esta pesquisa: 
Primeiro, o contexto histórico social e cultural no qual estas telas foram produzidas para analisar o que este contexto fala sobre estas telas.

Segundo, o período em que elas foram pintadas e o que esse período fala sobre a trajetória desse protagonista e propositor de um sistema linguístico pictórico próprio. Ou seja, do ponto de vista linguístico, em que período ele produziu os textos visuais mais coesos, mais coerentes com seu discurso, mais consistentes com seu sistema de crenças, e com maior potencial semiótico?

Terceiro, perguntei como as telas se relacionam entre si, se elas podem ser agrupadas por algum aspecto semiótico e que, de alguma forma, reflita aspectos tais como: sua produção; os avanços na sua trajetória linguística; sua visão e experiência de mundo; as questões fulcrais em seu discurso artístico; seu lugar social como pintor e como alguém que produz um discurso.

Este último critério, assim como outras questões pertinentes, são discutidas no apêndice em virtude do volume da tese.

\subsection{APRESENTAÇÃO DO CORPUS PICTÓRICO}

O corpus pictórico desta pesquisa segue abaixo descrito:

Quadro 52: Relação das telas do corpus pictórico

\begin{tabular}{|c|c|c|c|}
\hline $\begin{array}{l}\text { Título e informações } \\
\text { sobre a tela }\end{array}$ & Imagem & $\begin{array}{l}\text { Data e local } \\
\text { da produção }\end{array}$ & Fonte \\
\hline $\begin{array}{l}\text { Por de Sol: Campo de } \\
\text { trigo perto de Arles de } \\
\text { van Gogh } \\
\\
\text { Óleo sobre tela, } 73.5 \text { x } \\
92.0 \text { cm., F } 465, \text { JH } \\
\text { 1473, Localização: } \\
\text { Winterthur: } \\
\text { Kunstmuseum } \\
\text { Winterthur }\end{array}$ & 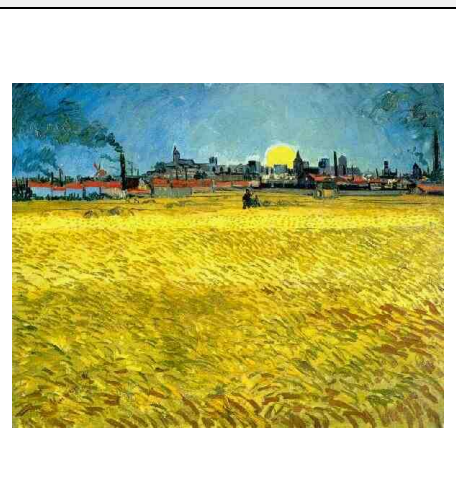 & $\begin{array}{l}\text { Arles: June, } \\
1888 .\end{array}$ & $\begin{array}{l}\text { Fonte: Van Gogh Gallery, } \\
\text { disponivel em 24.7.2014, } \\
\text { http://www.vggallery.com/painting/ } \\
\text { p_0465.htm }\end{array}$ \\
\hline
\end{tabular}




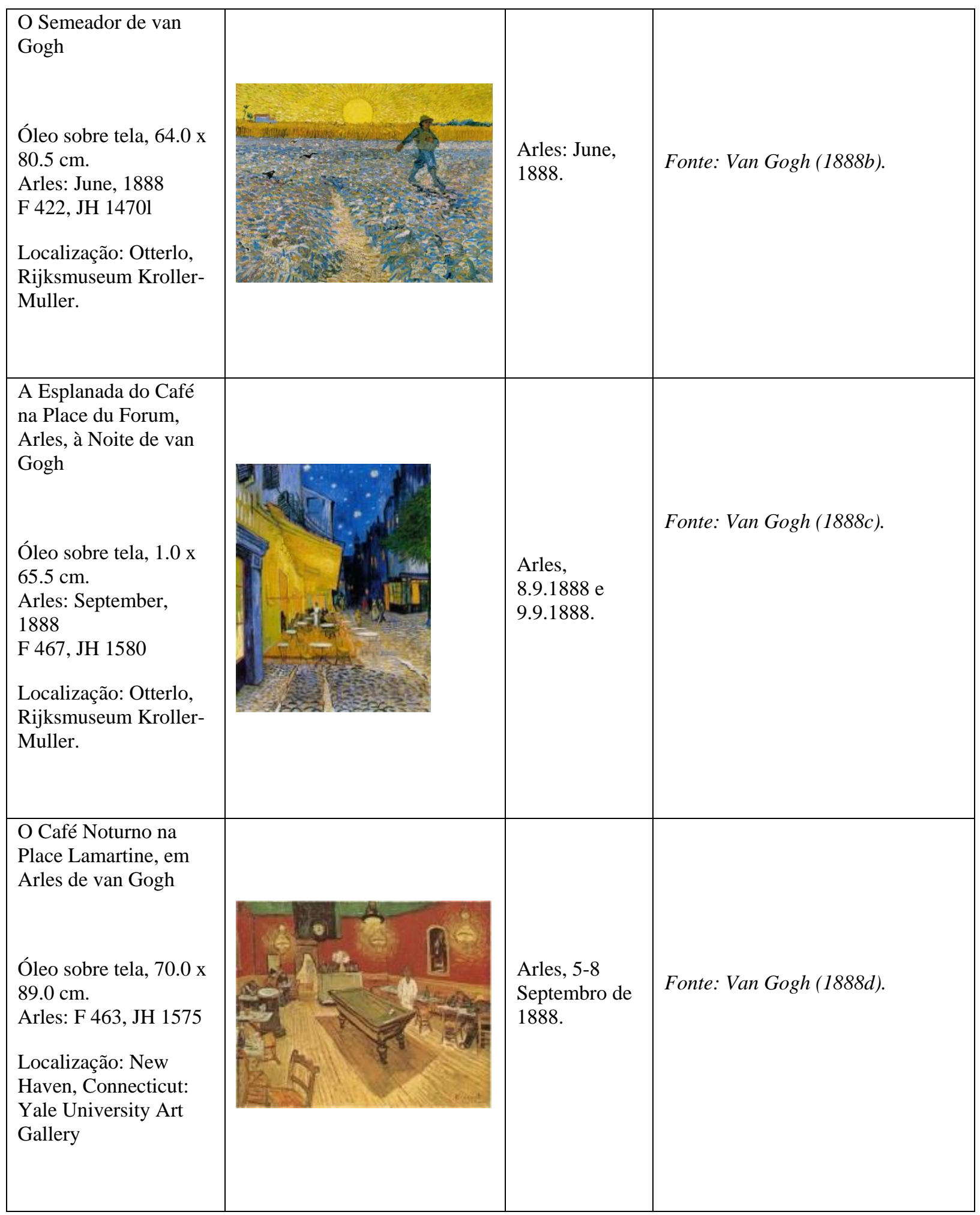

Fonte: Gogh (1888a, 1888b, 1888c, 1888d). 


\subsection{APRESENTAÇÃO DO CORPUS TEXTUAL}

A correspondência produzida por Van Gogh constitui um conjunto de 902 cartas que compõem as cartas sobreviventes que ele escreveu e recebeu de seus correspondentes entre 1853-1890. Recentemente o conjunto das cartas que constitui a correspondência de Van Gogh foi catalogado e reeditado em um empreendimento que recebeu o nome de Van Gogh Letters Project, fruto do trabalho colaborativo entre o Museu Van Gogh e o Instituto Huygens da Academia Real Holandesa de Artes e Ciências cujo forte é a publicação acadêmica de textos literários e históricos. Este ambicioso empreendimento foi levado ao cabo em quinze anos e em 2009 foi lançada uma nova coletânea da correspondência de Van Gogh que contemplou várias necessidades de tratamento, tais como a transcrição, a disponibilização do original digitalizado, a tradução em três idiomas e a disponibilização em um banco de dados online. (JANSEN; LUIJTEN; BAKKER, 2009).

A leitura do conjunto de cartas permitiu perceber uma série de características e funções da correspondência para Vincent, por exemplo, suas cartas escritas ao seu irmão mostram uma transformação ao longo dos anos na qual ele passa de um correspondente que segue as convenções sociais para um escritor que depende da correspondência como um meio de reflexão e de desenvolvimento pessoal e de vínculo com seu correspondente Theo, como confirmam os editores das cartas de Vincent, Jansen, Luijten e Bakker (2009, p. 1):

\footnotetext{
[...] desde a primeira carta que ele assumiu o papel do irmão mais velho e mais sábio para Theo. Ele usou a correspondência para aconselhar-lhe o que devia e não devia fazer para sair adiante na vida. Ele moralizava e confortava Theo se ele tinha dificuldades no trabalho ou lamentava a perda de um amigo. E dava-lhe conselhos sobre a arte e a literatura. Estes foram seus principais interesses, como resulta da maioria de suas cartas.
}

Quando morou em Dordrecht e Amsterdam, Vincent passa por muitas transformações e elas estão refletidas na forma como ele passa a escrever para Theo. Suas cartas descrevem com detalhes vivos o que ele observa em suas caminhadas, as condições nas minas e a vida dos mineiros no trabalho debaixo do chão. Ele começou a relatar sua impressão do que se passa a sua volta, e o seu estado de espírito diante de uma paisagem do campo ou da cidade, tornando-se menos reservado para confidenciar a Theo, algo impensável em suas primeiras cartas, seu desejo de se tornar pintor e as grandes dificuldades que encontra para levar este projeto adiante. No início da correspondência, Vincent seguia o comportamento social adequado para as convenções da época em suas cartas, mas no final da década de 1870 e daí em diante, sua escrita assumiu as funções de: canal para sua expressão pessoal, registro de suas impressões, organizar suas ideias e questões e, por meio dela, definir-se, tanto para si e 
para Theo, seu interlocutor e confidente. As cartas foram um meio autoreflexivo de desenvolver um pensamento e um discurso acerca da sua experiência e da sua visão da vida e da arte. A leitura das cartas oferece tanto uma noção de aspectos particulares quanto uma visão de conjunto de seu processo de amadurecimento acerca de suas escolhas artistas, desde as mais simples soluções representativas de uma tela até as concepções mais totalizantes na sua obra. A seguir apresento o corpus textual da pesquisa.

\subsubsection{Apresentação do Corpus Textual Primário}

Nesta sessão serão apresentados os extratos de cartas diretamente relacionadas com as telas do corpus visual (coletados de JANSEN; LUIJTEN; BAKKER, 2009).

Quadro 53: Relação das telas com as cartas do corpus textual.

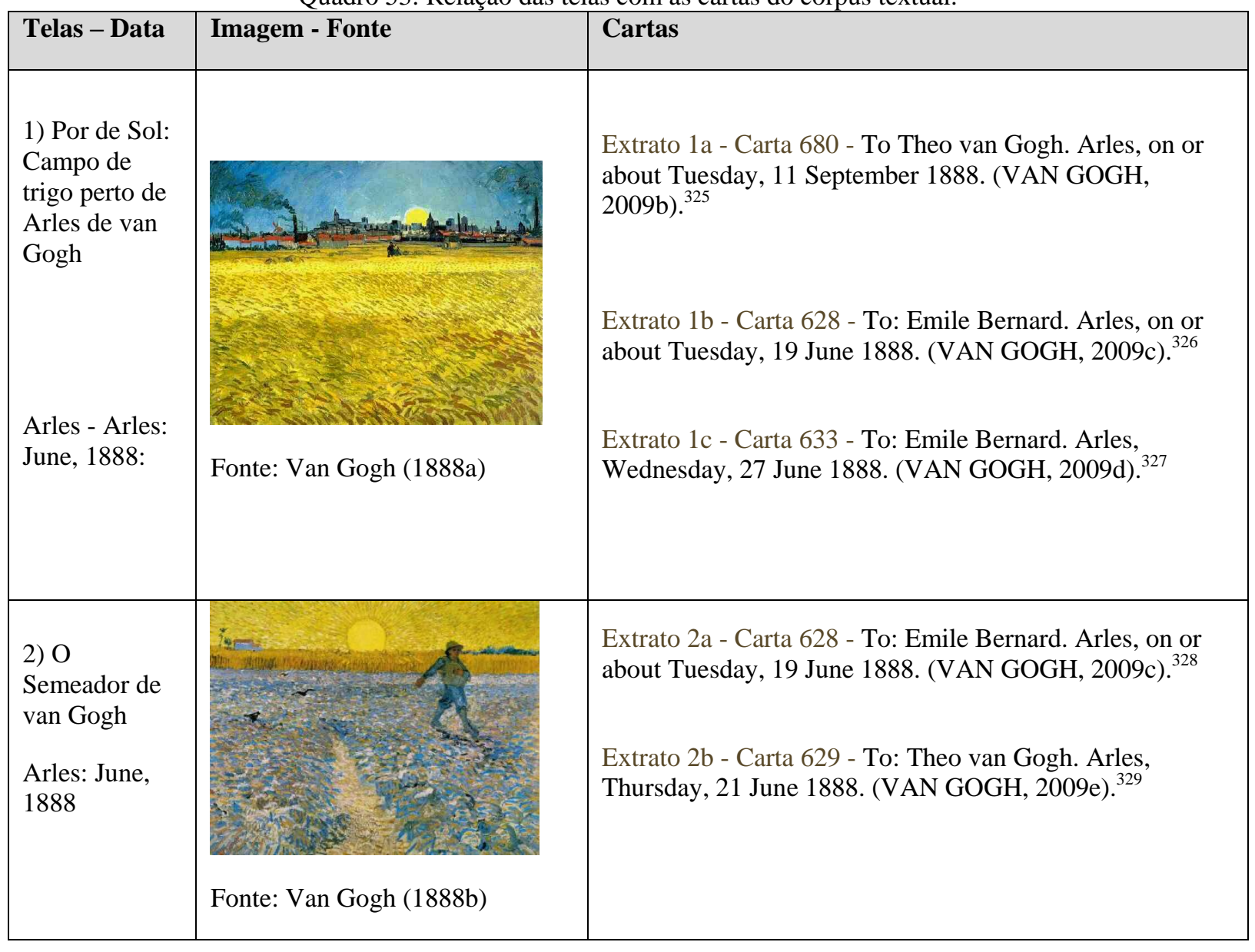

\footnotetext{
${ }^{325}$ Disponível em: <http://vangoghletters.org/vg/letters/let680/letter.html>.

${ }^{326}$ Disponível em: <http://vangoghletters.org/vg/letters/let628/letter.html>.

${ }^{327}$ Disponível em: <http://vangoghletters.org/vg/letters/let633/letter.html>.

${ }^{328}$ Disponível em: <http://vangoghletters.org/vg/letters/let628/letter.html >.

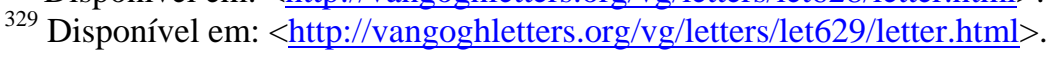




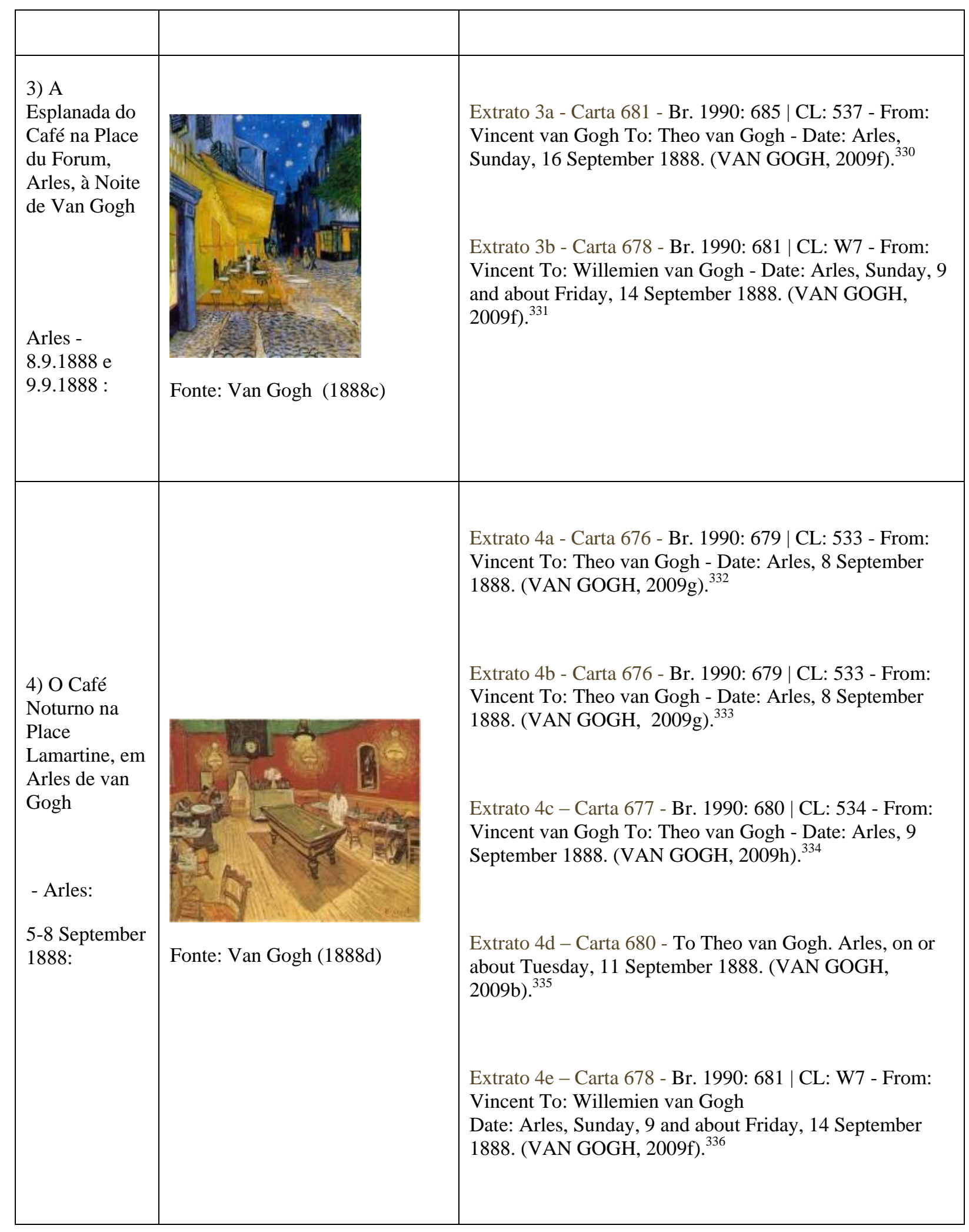

\footnotetext{
${ }^{330}$ Disponível em: 〈http://vangoghletters.org/vg/letters/let681/letter.html >.

${ }^{331}$ Disponível em: 〈http://vangoghletters.org/vg/letters/let678/letter.html〉.

${ }^{332}$ Disponível em: 〈http://vangoghletters.org/vg/letters/let676/letter.html $>$.

${ }^{333}$ Disponível em: 〈http://vangoghletters.org/vg/letters/let676/letter.html $>$.

${ }^{334}$ Disponível em: 〈http://vangoghletters.org/vg/letters/let677/letter.html $>$.

${ }^{335}$ Disponível em: <http://vangoghletters.org/vg/letters/let680/letter.html〉.

${ }^{336}$ Disponível em: <http://vangoghletters.org/vg/letters/let678/letter.html>.
} 
Os excertos do corpus textual primário, apresentados a seguir, foram selecionados na base de dados eletrônica da edição Inglesa das cartas de Van Gogh entitulada: "Vincent van Gogh - The Letters, the Complete Illustrated and Annotated Edition" (JANSEN; LUIJTEN; BAKKER, 2009) por meio de palavras-chave relacionadas com os temas representados nas telas, e também por aproximação das datas e períodos em que as telas foram produzidas. Os excertos na língua original em que foram escritos e a sua tradução para o Inglês se encontram nos anexos.

Quadro 54: Lista de cartas, excertos e telas a que se referem

\begin{tabular}{|c|c|c|}
\hline $\begin{array}{l}\text { Id. Tela } \\
\text { Imagem tela }\end{array}$ & $\begin{array}{l}\text { Id. da Carta } \\
\text { Id. do Extrato }\end{array}$ & Extrato da Carta \\
\hline $\begin{array}{l}\text { Por de Sol: Campo } \\
\text { de trigo perto de } \\
\text { Arles } \\
\text { Arles: June, } 1888 \\
\text { Fonte: Van Gogh } \\
\text { (1888a) }\end{array}$ & $\begin{array}{l}\text { Carta } 680 \\
\text { Extrato n } 1 \mathrm{a} \\
\\
\text { To Theo van Gogh. } \\
\text { Arles, on or about } \\
\text { Tuesday, } 11 \\
\text { September } 1888 . \\
\text { Linhas } 97 \text { a } 100\end{array}$ & $\begin{array}{l}\text { "Eu tenho um terceiro estudo, agora, de uma paisagem com fábrica, } \\
\text { e um enorme sol em um céu vermelho, acima de telhados } \\
\text { vermelhos, em que a natureza parece estar em um acesso de raiva, } \\
\text { em um dia de mistral desagradável." (VAN GOGH, 2009b, p. 1). }{ }^{337}\end{array}$ \\
\hline $\begin{array}{l}\text { Por de Sol: Campo } \\
\text { de trigo perto de } \\
\text { Arles } \\
\text { Arles: June, } 1888 \\
\text { Fonte: Van Gogh } \\
\text { (1888a) }\end{array}$ & $\begin{array}{l}\text { Carta } 628 \\
\text { Extrato } \mathrm{n}^{\mathrm{0}} 1 \mathrm{~b} \\
\\
\text { To Emile Bernard. } \\
\text { Arles, on or about } \\
\text { Tuesday, } 19 \\
\text { September } 1888 .\end{array}$ & $\begin{array}{l}\text { Aqui está outra paisagem. Sol poente? Lua nascendo? Noite de } \\
\text { verão, de qualquer modo. Cidade violeta, estrela amarela, céu azul- } \\
\text { esverdeado; os campos de trigo tem todos os tons: ouro velho, } \\
\text { cobre, ouro verde, ouro vermelho, ouro amarelo, verde, vermelho e } \\
\text { amarelo bronze. Tela quadrada número } 30 \text {. } \\
\text { Eu pintei-a ao ar livre no mistral. Meu cavalete foi fixado no chão } \\
\text { com estacas de ferro, um método que eu recomendo a você. }\end{array}$ \\
\hline
\end{tabular}

\footnotetext{
${ }^{337}$ Disponível em: <http://vangoghletters.org/vg/letters/let680/letter.html>.

${ }^{338}$ Disponível em: <http://vangoghletters.org/vg/letters/let628/letter.html>.
} 


\begin{tabular}{|c|c|c|}
\hline $\begin{array}{l}\text { Por de Sol: Campo } \\
\text { de trigo perto de } \\
\text { Arles } \\
\text { Arles: June, } 1888 \\
\text { Fonte: Van Gogh } \\
\text { (1888a) }\end{array}$ & $\begin{array}{l}\text { To: Emile Bernard } \\
\text { Date: Arles, } \\
\text { Wednesday, } 27 \\
\text { June } 1888\end{array}$ & $\begin{array}{l}\text { Eu também sou totalmente incapaz de julgar o meu próprio } \\
\text { trabalho. Eu não posso ver se os estudos são bons ou ruins. Tenho } \\
\text { sete estudos de trigais, infelizmente todos eles nada além de } \\
\text { paisagens, muito contra a minha vontade. Paisagens amarelo ouro } \\
\text { velho - feito rápido rápido rápido e com pressa, como o ceifeiro que } \\
\text { está em silêncio sob o sol escaldante, concentrando-se em ter o } \\
\text { trabalho terminado. (VAN GOGH, 2009d, p. } 1 \text { ). }{ }^{339}\end{array}$ \\
\hline O Semeador & $\begin{array}{l}\text { Carta } 628 \\
\text { Extrato }{ }^{\circ} 2 \mathrm{a} \\
\\
\text { To Emile Bernard. } \\
\text { Arles, on or about } \\
\text { Tuesday, } 19 \\
\text { September } 1888 .\end{array}$ & $\begin{array}{l}\text { Aqui esta um esboço de um semeador> um grande campo lavrado } \\
\text { com torrões de terra, na sua maioria fracamente cor de violeta. } \\
\text { Um campo de trigo maduro, de tom amarelo-ocre com um pouco de } \\
\text { carmim. } \\
\text { O céu, amarelo-crómio, quase tão luminoso quanto o próprio Sol, } \\
\text { que é amarelo-crómio no1, misturado com um pouco de branco, } \\
\text { enquanto o resto do céu é uma mistura dos amarelos-crómios } 1 \text { e } 2 \text {. } \\
\text { Tão amarelo! A camisa do semeador é azul e as calças brancas. } \\
\text { Tamanho da tela - 25, quadrada. } \\
\text { Há várias sugestões de amarelo no solo, tons neutros resultantes da } \\
\text { mistura de violeta e amarelo; mas tenho travado uma luta diabólica } \\
\text { para atingir a verdade das cores. Preferia muito mais fazer quadros } \\
\text { naifs tirados de velhos almanaques, aqueles velhos “almanaques dos } \\
\text { lavradores" nos quais o granizo, a neve, a chuva e o bom tempo são } \\
\text { retratados de modo primitivo, como o Anquetin atingiu tão bem no } \\
\text { seu A Colheita. } \\
\text { Não te vou ocultar que não desgosto da região, pois fui criado lá - } \\
\text { ainda me encanta a magia das recordações do passado, de um desejo } \\
\text { do infinito, do qual o semeador e o enfeixador são símbolos -, tanto } \\
\text { quanto antes gostava. } \\
\text { Mas quando eu farei o céu estrelado, então, essa pintura que está } \\
\text { sempre na minha mente? Ai, ai, é como nosso excelente amigo } \\
\text { Cyprien diz, em 'En ménage' por JK Huysmans: as mais belas } \\
\text { pinturas são aquelas que um sonha enquanto fuma um cachimbo em } \\
\text { sua cama, mas a qual ele não pinta. Mas é uma questão de atacá-las, } \\
\text { no entanto, não importa o quão incompetente um pode sentir-se vis- } \\
\text { à-vis as perfeições inefáveis do glorioso esplendor da natureza. } \\
\text { Aqui está o que eu queria dizer sobre o branco e o preto. Vamos } \\
\text { tomar o Semeador. A pintura é dividida em dois; metade é amarelo, } \\
\text { o topo; a base é violeta. Bem, as calças brancas descansam os olhos } \\
\text { e os distraem exatamente quando o contraste simultâneo excessivo }\end{array}$ \\
\hline
\end{tabular}

${ }^{339}$ Disponível em: <http://vangoghletters.org/vg/letters/let633/letter.html〉. 


\begin{tabular}{|c|c|c|}
\hline & & $\begin{array}{l}\text { de amarelo e violeta iriam irritá-lo. Isso é o que eu queria dizer. } \\
\text { (VAN GOGH, 2009c, p. 1). }{ }^{340}\end{array}$ \\
\hline $\begin{array}{l}\text { O Semeador } \\
\text { Arles: June, } 1888 \\
\text { Fonte: Van Gogh } \\
\text { (1888b) }\end{array}$ & $\begin{array}{l}\text { Carta } 629 \\
\text { Extrato } \mathrm{n}^{\circ} 2 \mathrm{~b} \\
\\
\text { To Theo Van } \\
\text { Gogh. Arles, } \\
\text { Thursday, } 21 \text { June } \\
1888 .\end{array}$ & $\begin{array}{l}\text { Eu tive uma semana de concentrado trabalho duro nos campos de } \\
\text { trigo debaixo do sol, o resultado foi de alguns estudos de campos de } \\
\text { trigo, paisagens e - um esboço de um semeador. Em um campo } \\
\text { arado, um grande campo de torrões de terra roxa - levantados em } \\
\text { direção ao horizonte - um semeador em azul e branco. No horizonte } \\
\text { um campo de trigo curto, maduro. 1v: } 2 \\
\text { Acima de tudo isso um céu amarelo com um sol amarelo. } \\
\text { Você pode sentir a partir da mera nomenclatura das tonalidades - } \\
\text { que a cor desempenha um papel muito importante nesta } \\
\text { composição. } \\
\text { E o esboço como tal - uma tela número } 25 \text { - também me preocupa } \\
\text { muito, no sentido de que eu me pergunto se eu não deveria levar a } \\
\text { sério e fazer uma pintura tremenda disso. Meu Deus, como eu } \\
\text { adoraria fazer isso. Mas eu só me pergunto se eu vou ter o poder } \\
\text { necessário de execução. } \\
\text { Eu estou colocando o esboço de lado assim como é, mal ousando } \\
\text { pensar nisso. } \\
\text { Por um longo tempo ele foi meu grande desejo de fazer um } \\
\text { semeador, } 5 \text {, mas os desejos que tive por um longo tempo nem } \\
\text { sempre são alcançados. Então, eu estou quase com medo deles. E, } \\
\text { no entanto, depois de Millet e Lhermitte o que resta a ser feito é ... o } \\
\text { semeador, com cor e em um grande formato. (VAN GOGH, 2009e, } \\
\text { p. 1). }{ }^{341}\end{array}$ \\
\hline $\begin{array}{l}\text { A Esplanada do } \\
\text { Café na Place du } \\
\text { Forum, Arles, à } \\
\text { Noite } \\
\text { Arles: September, } \\
1888\end{array}$ & $\begin{array}{l}\text { Carta } 681 \\
\text { Extrato n } 3 \mathrm{a} \\
\text { Br. 1990: } 685 \mid \mathrm{CL} \text { : } \\
\text { 537 } \\
\text { From: Vincent van } \\
\text { Gogh } \\
\text { To: Theo van Gogh } \\
\text { Date: Arles, } \\
\text { Sunday, } 16 \\
\text { September } 1888 . \\
\text { Linhas } 46 \text { a } 50\end{array}$ & $\begin{array}{l}\text { "Essa é a primeira pintura esta semana. A segunda mostra o exterior } \\
\text { de um café, iluminado no terraço externo por uma grande lâmpada } \\
\text { de gás dentro da noite azul, com um retalho de céu azul estrelado. } \\
\text { 3". (VAN GOGH, 2009f, p. 1). }{ }^{342}\end{array}$ \\
\hline
\end{tabular}

\footnotetext{
${ }^{340}$ Disponível em: <http://vangoghletters.org/vg/letters/let628/letter.html>.

${ }^{341}$ Disponível em: <http://vangoghletters.org/vg/letters/let629/letter.html>.

${ }^{342}$ Disponível em: <http://vangoghletters.org/vg/letters/let681/letter.html>.
} 


\begin{tabular}{|c|c|c|}
\hline $\begin{array}{l}\text { F 467, JH } 1580 \\
\text { Fonte: Van Gogh } \\
(1888 \mathrm{c})\end{array}$ & & \\
\hline $\begin{array}{l}\text { A Esplanada do } \\
\text { Café na Place du } \\
\text { Forum, Arles, à } \\
\text { Noite } \\
\text { Arles: September, } \\
1888 \\
\text { F 467, JH } 1580 \\
\text { Fonte: Van Gogh } \\
\text { (1888c) }\end{array}$ & $\begin{array}{l}\text { Br. 1990: } 681 \mid \text { CL: } \\
\text { W7 } \\
\text { From: Vincent } \\
\text { To: Willemien van } \\
\text { Gogh } \\
\text { Date: Arles, } \\
\text { Sunday, } 9 \text { and } \\
\text { about Friday, } 14 \\
\text { September } 1888 \text {. } \\
\text { Linhas } 100 \text { - } 136 \\
\text { Café Terrace }\end{array}$ & $\begin{array}{l}\text { "Fui interrompido precisamente pelo trabalho que uma nova pintura } \\
\text { da parte externa de um café à noite tem me dado nos últimos dias. } \\
\text { No terraço, há pequenas figuras de pessoas que bebem. Uma } \\
\text { enorme lanterna amarela ilumina o terraço, a fachada, a calçada, e } \\
\text { até mesmo projeta luz sobre os paralelepípedos da rua, que } \\
\text { adquirem uma coloração violeta-rosa. As frentes das casas em uma } \\
\text { rua que segue sob o céu azul salpicado de estrelas são azul escuro } \\
\text { ou violeta, com uma árvore verde. Agora há uma pintura de noite } \\
\text { sem preto. Com nada mais do que um belo azul e violeta e verde e } \\
\text { nestes arredores da praça iluminada é colorido por enxofre pálido, } \\
\text { amarelo limão. Eu gosto enormemente de pintar no local à noite. No } \\
\text { passado, eles costumavam desenhar e pintar a tela do desenho } \\
\text { durante o dia. Mas acho que me convém pintar a coisa no momento. } \\
\text { É bem verdade que eu possa tomar um azul por um verde no escuro, } \\
\text { um azul lilás por um rosa lilás, uma vez que você não pode perceber } \\
\text { a natureza do tom claramente. Mas é a única maneira de se livrar da } \\
\text { noite negra convencional com uma luz pobre, pálida e } \\
\text { esbranquiçada, quando na verdade uma mera vela por si só nos dá } \\
\text { os mais ricos amarelos e laranjas. Eu também fiz um novo retrato de } \\
\text { mim mesmo, como um estudo, no qual eu pareço um Japonês. Você } \\
\text { nunca me disse se você tinha lido Bel-ami de Guy de Maupassant, e } \\
\text { o que você pensa agora do talento dele em geral. Digo isto porque o } \\
\text { início de Bel- Ami é precisamente a descrição de uma noite } \\
\text { estrelada em Paris, com os cafés iluminados da avenida, e isso é } \\
\text { algo como o mesmo tema que eu pintei bem agora." (VAN GOGH, } \\
\text { 2009g, p. 1). }\end{array}$ \\
\hline 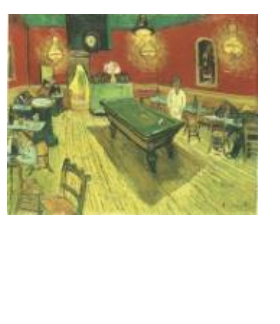 & $\begin{array}{l}\text { Carta } 676 \\
\text { Extrato }{ }^{\circ} 4 \mathrm{a} \\
\end{array}$ & $\begin{array}{l}\text { "Muitas vezes parece-me que a noite é muito mais viva e ricamente } \\
\text { colorida do que o dia . Agora como para recuperar o dinheiro pago } \\
\text { ao senhorio através da minha pintura, eu não estou fazendo questão } \\
\text { disto, porque a pintura é uma das mais feias que eu já fiz. É o } \\
\text { equivalente, embora diferente, dos comedores de batata. } 4 \text { 1v: } 2 \\
\text { Eu tentei expressar as terríveis paixões humanas com o vermelho e } \\
\text { o verde. }\end{array}$ \\
\hline $\begin{array}{l}\text { O Café Noturno na } \\
\text { Place Lamartine, } \\
\text { em Arles }\end{array}$ & $\begin{array}{l}\text { Br. 1990: } 679 \mid \mathrm{CL}: \\
\text { 533 - From: } \\
\text { Vincent To: Theo } \\
\text { van Gogh - Date: }\end{array}$ & $\begin{array}{l}\text { A sala é vermelho-sangue e amarelo sem graça, uma mesa de bilhar } \\
\text { verde no centro, } 4 \text { lâmpadas de amarelo limão com um brilho } \\
\text { laranja e verde. }\end{array}$ \\
\hline $\begin{array}{l}\text { Arles: 5-8 } \\
\text { September } 1888\end{array}$ & $\begin{array}{l}\text { Arles, } 8 \text { September } \\
1888 .\end{array}$ & $\begin{array}{l}\text { Em todos os lugares é uma batalha e uma antítese dos mais } \\
\text { diferentes verdes e vermelhos; nas personagens dos rufiões } \\
\text { adormecidos, pequenos na alta sala vazia, algum roxo e azul. O } \\
\text { vermelho-sangue e o amarelo-verde da mesa de bilhar, por exemplo, } \\
\text { contrasta com o pouco de verde delicado Louis XV do balcão, onde } \\
\text { há um buquê rosa. }\end{array}$ \\
\hline
\end{tabular}

${ }^{343}$ Disponível em: <http://vangoghletters.org/vg/letters/let678/letter.html>. 


\begin{tabular}{|c|c|c|}
\hline (1888d) & & $\begin{array}{l}\text { A roupa branca do proprietário, vigiando as coisas a partir de um } \\
\text { canto deste forno, torna-se amarelo-limão, verde luminoso pálido. } \\
\text { Eu estou fazendo um desenho dele em tons aquarela para enviar-lhe } \\
\text { amanhã, para dar a voce uma idéia dele." (VAN GOGH, 2009j, p. } \\
\text { 1).344 }\end{array}$ \\
\hline & Carta 676 & \\
\hline $\begin{array}{l}\text { Arles: } 5-8 \\
\text { September } 1888 \\
\text { Fonte: Van Gogh } \\
\text { (1888d) }\end{array}$ & $\begin{array}{l}\text { Br. 1990: } 679 \mid \text { CL: } \\
\text { 533 - From: } \\
\text { Vincent To: Theo } \\
\text { van Gogh - Date: } \\
\text { Arles, } 8 \text { September } \\
1888 .\end{array}$ & $\begin{array}{l}\text { "Mais tarde, quando eu tiver levado esses experimentos mais longe, } \\
\text { o semeador ainda vai ser a primeira tentativa nesse gênero. } \\
\text { O café noturno é uma continuação do semeador, como é a cabeça do } \\
\text { velho camponês e do poeta, se eu conseguir fazer essa ultima tela. } \\
\text { É uma cor, então, que não é localmente verdadeira do ponto de vista } \\
\text { realista do trompe l'oeil, mas uma cor que sugere alguma emoção, } \\
\text { um temperamento ardente." (VAN GOGH, 2009j, p. 1). }{ }^{345}\end{array}$ \\
\hline $\begin{array}{l}\text { Arles: 5-8 } \\
\text { September } 1888 \\
\text { Fonte: Van Gogh } \\
\text { (1888d) }\end{array}$ & $\begin{array}{l}\text { Br. } 1990: 680 \mid \text { CL: } \\
534 \text { - From: } \\
\text { Vincent van Gogh } \\
\text { To: Theo van Gogh } \\
\text { - Date: Arles, } 9 \\
\text { September } 1888 \text {. }\end{array}$ & $\begin{array}{l}\text { "Na minha pintura do café à noite eu procurei exprimir que o café é } \\
\text { um lugar onde você pode arruinar-se, enlouquecer, cometer crimes. } \\
\text { De qualquer forma, eu tentei com contrastes de rosa delicado e } \\
\text { vermelho-sangue e vinho tinto. Verde doce Luís XV e Veronese } \\
\text { contrastando com os verdes amarelos e os verdes azuis duros. } \\
\text { Tudo isso em uma atmosfera de fornalha infernal, de enxofre } \\
\text { pálido. } \\
\text { Exprimir como a potência dos cantos escuros de uma taberna. } \\
\text { Contudo sob uma aparência da alegria japonesa e da boa natureza } \\
\text { de Tartarin. } \\
\text { Que diria portanto desse quadro o Sr. Tersteeg? Diante de um } \\
\text { Sisley, Sisley, o mais discreto e delicado dos Impressionistas - já } \\
\text { disse: "Não posso me impedir de pensar que o artista que pintou } \\
\text { isso estava um pouco tonto". Diante do meu quadro, então a mim } \\
\text { ele diria que ele é um caso de delirium tremens". (VAN GOGH, } \\
\text { 2009h, p. 1). }{ }^{346}\end{array}$ \\
\hline
\end{tabular}

${ }^{344}$ Disponível em: <http://vangoghletters.org/vg/letters/let676/letter.html>.

${ }^{345}$ Disponível em: <http://vangoghletters.org/vg/letters/let676/letter.html〉.

${ }^{346}$ Disponível em: <http://vangoghletters.org/vg/letters/let677/letter.html>. 


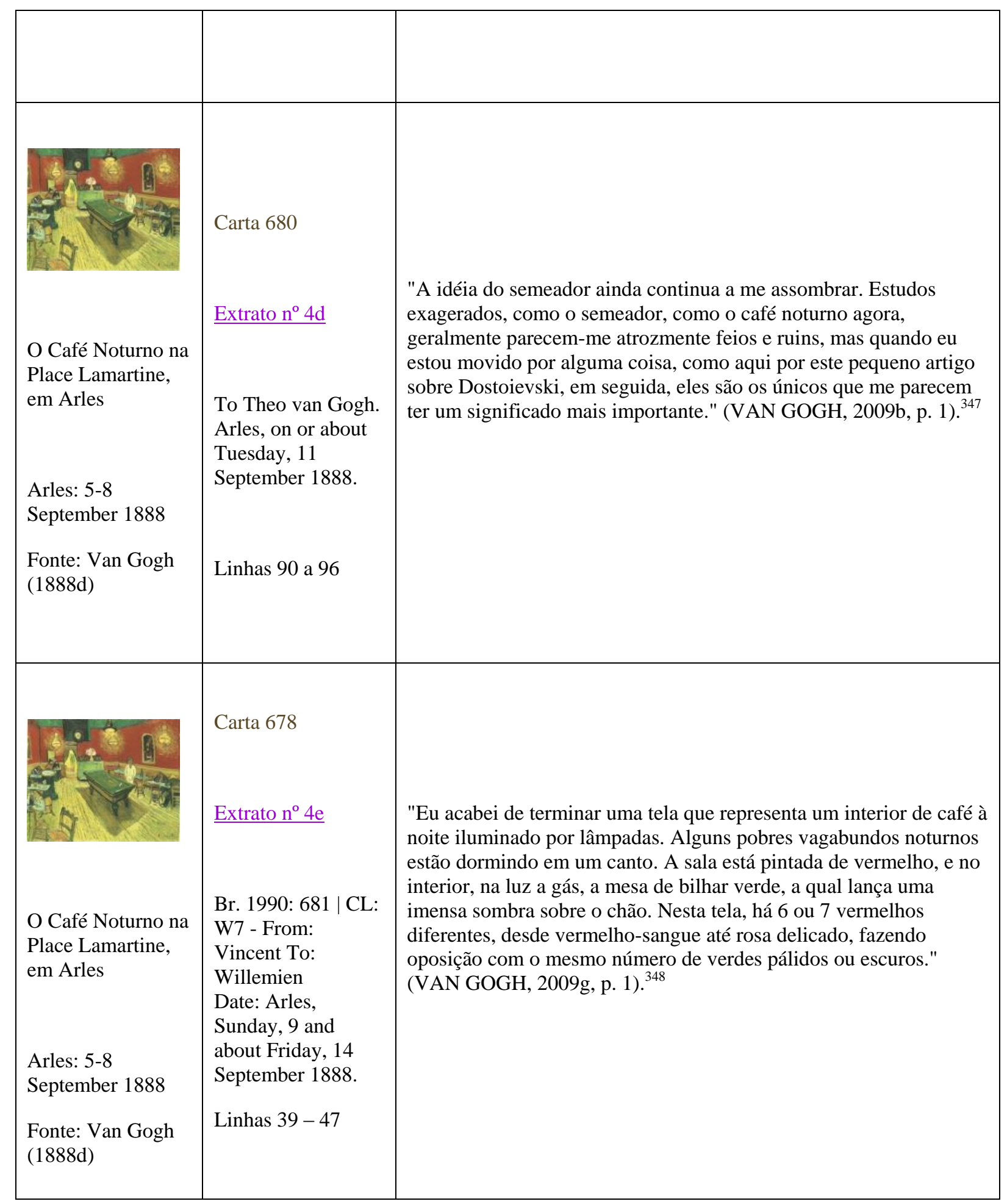

Fonte: Jansen, Luijten e Bakker (2009).

\footnotetext{
${ }^{347}$ Disponível em: <http://vangoghletters.org/vg/letters/let680/letter.html>.

${ }^{348}$ Disponível em: <http://vangoghletters.org/vg/letters/let678/letter.html>.
} 


\subsubsection{Apresentação do Corpus Textual Contextual}

A correspondência completa entre Vincent e Theo, guardada e organizada por GoghBonger (2008), viúva de Theo, compreende 652 cartas organizadas cronologicamente e foi lançada em 1914 em um volume de mais de 1.000 páginas publicado pela editora holandesa Maatschappif Voor Goede.

A carta analisada nesta pesquisa foi inicialmente coletada em uma publicação editada em Paris na década de 30, obedecendo à clássica antologia de Van Gogh (2010). No entanto, esta edição teve uma tradução interpretativa e levou à necessidade de buscar uma fonte mais acurada que disponibilizasse a transcrição da carta sem supressão de suas características originais. A versão da carta usada no corpus contextual foi coletada do Site Van Gogh The Letters Project que disponibiliza em uma website as transcrições digitalizadas das cartas, bem como o seu fac-símile (JANSEN; LUIJTEN; BAKKER, 2009). Segue abaixo a carta de 22-24 de Junho de 1880 que constitui em sua íntegra o corpus textual contextual.

\section{Corpus Textual Contextual - a carta de 22-24 de Junho de 1880}

Esta carta foi coletada no site ${ }^{349}:$ http://vangoghletters.org/vg/letters/let155/letter.html 155

Br. 1990: 154 | CL: 133

From: Vincent van Gogh

To: Theo van Gogh

Date: Cuesmes, between about Tuesday, 22 and Thursday, 24 June 1880

Source status: Original manuscript

Location: Amsterdam, Van Gogh Museum, inv. nos. b153 a-b V/1962

\footnotetext{
349 Tradução livre da autora. "Data: Em de Junho de 1880, Theo escreveu aos seus pais dizendo que ele havia recebido uma carta de Vincent. A reação deles para o que Theo disse a eles revela que a carta em questão deve ser a presente, a qual deve portanto ter sido escrita muitos dias antes. (FR b2494 and b2495, Mr and Mrs van Gogh to Theo, 5 July 1880). Date: On 25 June 1880, Theo wrote to his parents, saying that he had received a letter from Vincent. Their reaction to what Theo told them reveals that the letter in question must be the present one, which must therefore have been written several days previously (FR b2494 and b2495, Mr and Mrs van Gogh to Theo, 5 July 1880).

Adicional: Esta é a primeira carta que van Gogh escreveu em Francês. Ela é seguida por outras sete cartas em Francês, datando do seu período Belga. Vincent escreve mais e mais frequentemene em Francês da carta 567 em diante. Uma análise da estrutura de sua carta aparece em Pollock 1980, pp. 624-630; cf. também Pollock e Orton 1978, pp. 7-10, e exibição catalográfica em Amsterdã 1980, pp. 21-27. / Additional: This is the first letter that Van Gogh wrote in French. It is followed by seven more letters in French, dating from his Belgian period. Vincent writes more and more frequently in French from letter 567 onwards. An analysis of the structure of this letter appears in Pollock 1980, pp. 624-630; cf. also Pollock and Orton 1978, pp. 7-10, and exhib. cat. Amsterdam 1980, pp. 21-27.(VAN GOGH, 2009k, p. 1, tradução nossa).
} 


\section{a) Carta 155 de van Gogh a seu irmão Théo de 22-24 de Junho de 1880 traduzida para o português:}

\section{Corpus Textual Contextual}

"Meu caro Théo,

É um pouco a contragosto que lhe escrevo, não o tendo feito há tanto tempo, e isto por muitos motivos.

Até certo ponto você se tornou um estranho para mim, e eu talvez o seja para você mais do que você imagina; talvez fosse melhor para nós dois não continuarmos assim. É impossível que nem mesmo agora eu lhe tivesse escrito, não fosse o fato de eu me sentir na obrigação, na necessidade de lhe escrever; não fosse o fato de você mesmo me fazer sentir esta necessidade. Soube em Etten que você tinha me enviado cinquenta francos. Pois bem, eu os aceitei. Certamente a contragosto, certamente com um sentimento bem melancólico, mas estou numa espécie de beco sem saída ou de atoleiro, como fazer de outro modo?

E é portanto para agradecer que lhe escrevo.

Como talvez você já saiba, voltei ao Borinage (Região das minas de carvão onde Van Gogh desenvolveu sua relação com os mineiros), meu pai me disse que seria melhor ficar pelas vizinhanças de Etten: eu disse que não e acredito ter agido melhor assim. Involuntariamente, tornei-me na família uma espécie de personagem impossível e suspeito, seja como for, alguém que não merece confiança. A quem poderia eu ser útil de alguma maneira?

É por isto que antes de mais nada, sou levado a crer, seja vantajoso, e melhor resolução a tomar, e o mais razoável, que eu vá embora e me mantenha a uma distância conveniente, que eu faça como se não existisse.

O que para os pássaros é a muda, a época em que trocam de plumagem, a adversidade ou o infortúnio, os tempos difíceis, são para nós, seres humanos. Podemos permanecer neste tempo de muda, podemos também deixá-lo como que renovados, mas de qualquer forma isso não se faz em público, é pouco divertido, e por isto convém eclipsar-se. Pois seja.

Agora, por mais que reconquistar a confiança de toda uma família, talvez não totalmente desprovida de preconceitos e outras qualidades igualmente honoráveis e elegantes, seja de uma dificuldade mais ou menos desesperadora, eu ainda tenho algumas esperanças de que pouco a pouco, lenta e seguramente, a cordial compreensão seja restabelecida com uns e outros.

Assim é que em primeiro lugar eu gostaria muito de ver esta cordial compreensão, para não dizer mais, restabelecida entre mеи pai e eu, e desejaria muito que ela igualmente se restabelecesse entre nós dois.

Compreensão cordial vale infinitamente mais que mal entendido.

Preciso agora lhe aborrecer com algumas coisas abstratas, no entanto gostaria muito que você as escutasse com paciência. Sou um homem de paixões, capaz de, e sujeito a fazer coisas mais ou menos insensatas, das quais às vezes me arrependo mais ou menos.

Muitas vezes me ocorre falar ou agir um pouco depressa demais, quando seria melhor esperar com um pouco mais de paciência. Acredito que outras pessoas também possam às vezes cometer semelhantes imprudências.

Agora, sendo assim, o que se deve fazer, devo considerar-me como um homem perigoso e incapaz de qualquer coisa? Penso que não. Mas trata-se de por todos os meios tirar destas paixões o melhor partido. Por exemplo, para falar de uma paixão entre outras, tenho uma paixão mais ou menos irresistível pelos livros e preciso me instruir continuamente, estudar, se você quiser, assim como preciso comer meu pão. 
Você poderá entender isto. Quando eu estava num ambiente de quadros e de coisas de arte, você sabe
muito bem que fui tomado por uma paixão violenta, que chegava ao entusiasmo. E não me arrependo, $e$
ainda agora, longe dele, muitas vezes sinto saudade do mundo dos quadros.

Você talvez se lembre bem que eu sabia perfeitamente (e pode ser que ainda o saiba) o que era um Rembrandt, ou o que era um Millet, um Jules Dupré, um Delacroix, um Millais ou um Maris? Bomagora não estou mais neste ambiente, no entanto esta coisa que se chama alma pretende-se que não morre jamais, e que vive sempre e busca sempre mais e mais e ainda mais. Em vez de sucumbir de saudades, eu disse: "O país ou a pátria estão em todos os lugares". Em vez de me deixar levar pelo desespero, tomei o partido da melancolia ativa enquanto a tinha a potência de atividade, ou em outras palavras, preferi a melancolia que espera e que aspira e que busca, àquela que embota e, estagnada, desespera.

Portanto, estudei mais ou menos seriamente os livros ao meu alcance, como a Bíblia e a Revolução Francesa de Michelet, e, no último inverno, Shakespeare e um pouco de Victor Hugo e Dickens, $e$ Beecher Stowe e ultimamente Ésquilo e muitos outros, menos clássicos, vários grandes pequenos mestres. Você bem sabe que, entre os que se classificam como pequenos mestres encontram-se um Fabritius ou um Bida.

Agora quem é absorvido por tudo isto às vezes é chocante, shocking para os outros, e sem querer peca mais ou menos contra os usos e formas e conveniências sociais.

No entanto, é pena que se leve isto a mal. Por exemplo, você sabe que frequentemente eu negligenciei meu asseio, eu o admito, e admito que isto seja shocking. Mas veja bem, a penúria e a miséria contribuíram de algum modo para isto, e depois às vezes este é um bom método para garantir a solidão necessária, para poder aprofundar mais ou menos este ou aquele estudo que nos preocupa.

Um estudo muito necessário é o da medicina, não há um homem que não tenha desejado conhecê-la um mínimo que seja, que não tenha procurado saber pelo menos de que se trata e, veja, eu ainda não sei nada disto. Mas tudo isto me absorve, tudo isto me preocupa, tudo isto me faz sonhar, imaginar e pensar? Já fazem agora talvez cinco anos, não sei ao certo, que vivo mais ou menos sem lugar, errando aqui e ali. Agora vocês dizem desde tal ou qual época você caiu, você se apagou, você não fez mais nada. Será que isto é totalmente verdade?

É verdade que ora ganhei meu pedaço de pão, ora ele me foi dado por bondade de um amigo; vivi como pude, nem bem nem mal, como dava; é verdade que perdi a confiança de muitos; é verdade que minha situação pecuniária está num triste estado; é verdade que o futuro me é bem sombrio; é verdade que eu poderia ter feito melhor; é verdade que meus próprios estudos estão num estado lamentável e desesperador, e que me falta mais, infinitamente mais do que o que eu tenho. Mas vocês chamam isso de cair, de não fazer nada?

Talvez você diga: mas por que você não continuou como gostaríamos que continuasse, pelo caminho da universidade? Não responderei mais do que isso: é muito caro; e ademais este futuro não seria melhor do que o de agora, no caminho em que estou.

Mas no caminho em que estou devo continuar - se eu não fizer nada, se não estudar, se não procurar mais, então estarei perdido. Então, ai de mim.

Eis como eu vejo a coisa: continuar, continuar, isso é que é necessário.

Mas qual é o seu objetivo definitivo?, você perguntará. Este objetivo torna-se mais definido, desenharse-á lenta e seguramente como o croquis que se torna esboço e o esboço que se torna quadro, à medida que se trabalhe mais seriamente, que se aprofunde mais a idéia, no início e vaga, o primeiro pensamento fugidio e passageiro, a menos que o fixemos.

Você deve saber que entre os missionários acontece o mesmo que com os artistas. Há uma velha escola acadêmica muitas vezes execrável, tirânica, a abominação da desolação, enfim, homens que têm uma espécie de couraça, uma armadura de aço de preconceitos e convenções; estes, quando estão à testa dos negócios, dispõem dos cargos e, por meios indiretos, buscam manter seus protegidos e excluir os 
homens naturais.

Seu Deus é como o deus do beberrão Falstaff de Shakespeare, "o interior de uma igreja”, "the inside of a church"; na verdade certos senhores missionários (???) se acham por uma estranha coincidência (e talvez eles próprios, se fossem capazes de alguma emoção humana, ficariam um pouco surpresos de aí se acharem) plantados no mesmo ponto de vista que o beberrão típico tem das coisas espirituais. Mas há pouco a temer que algum dia sua cegueira a este respeito se transforme em clarividência.

Este estado de coisas tem seu lado ruim para quem não está de acordo com tudo isto, e que de toda sua alma, de todo coração, e com toda a indignação de que é capaz, protesta contra isto.

Quanto a mim, respeito os acadêmicos que não são como estes; mas os respeitáveis são mais raros do que acreditaríamos à primeira vista. Agora, uma das causas pelas quais eu estou agora deslocado-e por que durante tantos anos estive deslocado - é simplesmente porque tenho idéias diferentes das desses senhores que dão cargos àqueles que pensam como eles. Não se trata de uma simples questão de asseio, como hipocritamente me censuraram, é uma questão mais séria que isto, posso lhe garantir.

Por que lhe digo tudo isto? Não é para me queixar, não é para me desculpar naquilo em que eu possa ter mais ou menos errado, mas simplesmente para lhe dizer isto:

Quando de sua última visita no verão passado, quando nós dois passávamos perto da caverna abandonada. que chama de "A Feiticeira", você me lembrou que houve uma época em que também passeávamos os dois perto do velho canal e do moinho de Rijswick, "e então”, você me dizia, "nós estávamos de acordo sobre muitas coisas, mas", você acrescentou, "desde então mudou muito, você já não é mais o mesmo”. Pois bem, isto não é bem assim; o que mudou, é que minha vida era então menos difícil, e meu futuro aparentemente menos sombrio; mas quanto ao meu íntimo, quanto à minha maneira de ver e de pensar, nada disto mudou, e se de fato houvesse alguma mudança, é que agora eu penso e acredito e amo mais serenamente aquilo que na época eu também já pensava, acreditava e amava.

Seria portanto um mal entendido se você persistisse em acreditar que, por exemplo, agora eu seria menos caloroso por Rembrandt ou Millet ou Delacroix ou quem ou o que quer que fosse, pois acontece justo o contrário, apenas, veja você, há várias coisas em que acreditar e amar, e há algo de Rembrandt em Shakespeare, e de Corrège em Michelet, e de Delacroix em Victor Hugo e ainda há algo de Rembrandt no Evagelho e algo do Evangelho em Rembrandt, como queira, isto dá mais ou menos na mesma, desde que se entenda a coisa como bom entendedor, sem querer desviá-la para o mau sentido e se levarmos em conta os termos da comparação, que não tem a pretensão de diminuir os méritos das personalidades originais. E em Bunyan há algo de Maris ou de Millet e em Beecher Stowe há algo de Ary Scheffer.

Agora, se você pode perdoar um homem que se aprofunda nos quadros, admita também que o amor aos livros é sagrado quanto o amor a Rembrandt, e inclusive acredito que os dois se completam.

Gosto muito do retrato de homem de Fabritius que certo dia, ao passearmos também os dois, contemplamos longamente no museu do Harlem. Bom, mas eu gosto da mesma forma de Richard Cartone, de Dickens em sua Paris e sua Londres de 1793, e eu poderia ainda lhe mostrar outras figuras estranhamente comoventes em outros livros, com semelhanças mais ou menos impressionantes. E acredito que Kent, um personagem do Rei Lear de Shakespeare, é tão nobre e distinto quanto uma figura de Th. De Keyser, embora Kent e Rei Lear tenham supostamente vivido muito tempo antes. Isto para não dizer mais nada. Meu Deus, como é belo Shakespeare. Quem é misterioso como ele? Sua palavra e sua maneira de fazer equivalem a um pincel fremente de febre e emoção. Mas é preciso aprender a ler, como é preciso aprender a ver e aprender a viver.

Portanto, você não deve acreditar que eu renegue isto ou aquilo, sou uma espécie de fiel na minha infidelidade e, embora mudado, sou o mesmo e meu tormento não é mais do que este: no que eu poderia ser bom?

Não poderia eu servir e ser útil de alguma maneira? Como poderia saber mais e aprofundar este ou aquele tema? Como você vê, isto me atormenta continuamente. Além disto, sinto-me como um prisioneiro do meu tormento, excluído de participar nesta ou naquela obra, e tendo estas ou aquelas coisas necessárias fora de meu alcance. Por isto sentimo-nos melancólicos, e sentimos grandes vazios 
ali onde poderiam existir amizades e elevadas e sérias afeições, e sentimos um terrível desânimo corroendo nossa própria energia moral, e a fatalidade parece poder colocar obstáculos aos instintos de afeição, e uma maré de desgosto nos invade. E então dizemos: até quando, meu Deus?

O que você quer? O que se passa no intimo revela-se exteriormente? Fulano tem uma grande chama queimando em sua alma, e ninguém jamais vem nela se esquentar, e os transeuntes só percebem um pouquinho de fumaça no alto da chaminé e seguem então seu caminho. E agora, o que fazer? Sustentar esta chama interior, ter substância em si mesmo, esperar pacientemente, e no entanto com quanta impaciência, esperar, dizia, a hora que alguém desejará aproximar-se - e ficar? Que sei eu? Quem quer que acredite em Deus, que espere a hora que cedo ou tarde chegará.

Agora, no momento, ao que parece todos os meus negócios vão mal, e isto já está assim há um tempo bastante considerável, e assim pode ficar durante um futuro mais ou menos longo. Mas pode ser que, depois de tudo pareça ter dado errado, de repente tudo comece a melhorar. Não conto com isto, talvez isto nunca aconteça, mas no caso de acontecer alguma mudança para melhor, computaria isto como um ganho, ficaria contente, e diria: "Enfim, afinal havia alguma coisa".

Mas no entanto - você dirá - você é um ser execrável, já que tem ideias impossíveis sobre a religião, $e$ escrúpulos de consciência pueris. Se os tenho impossíveis ou pueris, possa eu me livrar disto, é tudo o que peço. Mas veja mais ou menos o ponto em que me encontro. Você encontrará em O filósofo sob os tetos, de Souvester, como um homem do povo, um simples operário muito miserável que seja, se imaginava a pátria. "Você talvez jamais pensou no que é a pátria", retomou ele pousando uma mão em meu ombro, "é tudo o que te envolve, tudo o que te criou e te alimentou, tudo que amaste, este campo que vês, estas casas, estas árvores, estas jovens que passam ali rindo, são a pátria. As leis que te protegem, o pão pago por teu trabalho, as palavras que tu trocas, a alegria e a tristeza provenientes das coisas ou dos homens entre os quais vives, são a pátria. O quartinho onde outrora viste tua mãe, as lembranças que ela te deixou, a terra em que ela repousa são a pátria. Tu a vês, tu a respiras em todos os lugares. Imagines os direitos e os deveres, as afeições e as necessidades, as lembranças e o reconhecimento, reúne tudo isso numa palavra será a pátria".

Ora, da mesma forma tudo o que é verdadeiramente bom e belo, de beleza interior moral, espiritual e sublime nos homens e em suas obras, acredito que vem de Deus, e tudo o que há de ruim e de mau nas obras dos homens e nos homens, não é de Deus, e Deus também não o acha bom.

Mas involuntariamente sou levado a crer que a melhor maneira de conhecer Deus é amar muito. Ame tal amigo, tal pessoa, tal coisa, o que quiser, e você estará no bom caminho para depois saber mais, eis o que eu digo a mim mesmo. Mas é preciso amar com uma grande e séria simpatia íntima, com vontade, com inteligência, e é preciso sempre procurar saber mais, melhor e mais. Isto conduz a Deus, isto conduz à fé inabalável.

Para citar um exemplo, alguém que ame Rembrandt, mas ame-o seriamente saberá que há um Deus, e Nele terá fé. Alguém que se aprofunde na história da Revolução Francesa - não será incrédulo, verá que também nas grandes coisas há uma potência soberana que se manifesta.

Alguém que tenha assistido, mesmo que por pouco tempo, ao curso gratuito da grande universidade da miséria e que tenha prestado às coisas que seus próprios olhos vêem e que seus ouvidos percebem, e que tenha refletido sobre isto, também acabará por crer e talvez aprenda mais do que imagina. Procure entender a fundo o que dizem os grandes artistas, os verdadeiros artistas, em suas obras-primas, $e$ encontrará Deus nelas. Um o terá dito ou escrito num livro, outro, num quadro.

Depois, leia simplesmente a Bíblia e o Evangelho: isso dá o que pensar, muito em que pensar, tudo em que pensar. Pois bem, pense este muito, pense este tudo, isto eleva seu pensamento acima do nível ordinário, independente de você. Já que sabemos ler, leiamos então.

Depois, às vezes pode-se até ficar um pouco abstraído, um pouco sonhador. Há quem fique abstraído demais, sonhador demais; talvez seja o que ocorre comigo, mas é minha culpa. Afinal, quem sabe, não havia motivo para isto. Estava abstraído, preocupado, inquieto por uma ou outra razão, mas a gente se 
refaz! O sonhador às vezes cai num poço, mas dizem que logo ele se reergue.

E o homem abstraído, em compensação, por vezes também tem sua presença de espírito. Às vezes é um personagem que tem sua razão de ser por um ou outro motivo que não distinguimos à primeira vista, ou que, na maioria das vezes, esquecemos involuntariamente. Fulano, que andou agitado como se estivesse num mar tempestuoso, chega enfim ao seu destino: um outro que parecia não valer nada e ser incapaz. de exercer qualquer função acaba por encontrar uma e, ativo e capaz de agir, mostra-se totalmente outro do que parecia à primeira vista. Escrevo-lhe um pouco ao acaso o que me vem à pena, ficaria muito contente se de alguma maneira você pudesse ver em mim mais que um vagabundo.

Acaso haverá vagabundos e vagabundos que sejam diferentes? Há quem seja vagabundo por preguiça e fraqueza de caráter, pela indignidade de sua própria natureza: você pode, se achar justo, me tomar por um destes.

Além deste, há um outro vagabundo, o vagabundo que é bom apesar de si, que intimamente é atormentado por um grande desejo de ação, que nada faz porque está impossibilitado de fazêe-lo, porque está como que preso por alguma coisa, porque não tem o que lhe é necessário para ser produtivo, porque a fatalidade das circunstâncias o reduz a este ponto, um vagabundo assim nem sempre sabe por si próprio o que poderia fazer, mas por instinto, sente: "No entanto, eu sirvo para algo, sinto em mim uma razão de ser, sei que poderia ser um homem completamente diferente. No que é que eu poderia ser útil, para o que poderia eu servir; existe algo dentro de mim, o que será então?’.

Este é um vagabundo completamente diferente; você pode, se achar justo, tomar-me por um destes.

Um pássaro na gaiola durante a primavera sabe muito bem que existe algo em que ele pode ser bom, sente muito bem que há algo a fazer, mas não pode fazê-lo. O que será? Ele não se lembra muito bem. Tem então vagas lembranças e diz para si mesmo: "Os outros fazem seus ninhos, têm seus filhotes e criam a ninhada”, e então bate com a cabeça nas grades da gaiola. E a gaiola continua ali, e o pássaro fica louco de dor.

“Vejam que vagabundo”, diz um outro pássaro que passa, "esse ai é um tipo de aposentado”. No entanto, o prisioneiro vive, e não morre, nada exteriormente revela o que se passa em seu íntimo, ele está bem, está mais ou menos feliz sob os raios de sol. Mas vem a época da migração. Acesso de melancolia - "mas" dizem as crianças que o criam na gaiola, "afinal ele tem tudo o que precisa". E ele olha lá fora o céu cheio, carregado de tempestade, e sente em si a revolta contra a fatalidade. "Estou preso, estou preso e não me falta nada, imbecis! Tenho tudo que preciso. Ah! Por bondade, liberdade! ser um pássaro como os outros."

Aquele homem vagabundo assemelha-se a este pássaro vagabundo...

E os homens ficam frequentemente impossibilitados de fazer algo, prisioneiros de não sei que prisão horrível, horrível, muito horrível.

Há também, eu sei, a libertação, a libertação tardia. Uma reputação arruinada com ou sem razão, a penúria, a fatalidade das circunstâncias, o infortúnio, fazem prisioneiros.

Nem sempre sabemos dizer o que é que nos encerra, o que é que nos cerca, o que é que parece nos enterrar, mas no entanto sentimos não sei que barras, que grades, que muros.

Será tudo isto imaginação, fantasia? Não creio; e então nos perguntamos: meu Deus, será por muito tempo, será para sempre, será para a eternidade?

Você sabe o que faz desaparecer a prisão. E toda afeição profunda, séria. Ser amigos, ser irmãos, amar isto abre a porta da prisão por poder soberano, como um encanto muito poderoso. Mas aquele que não tem isto permanece na morte.

Mas onde renasce a simpatia, renasce a vida.

Além disso, às vezes a prisão se chama preconceito, mal-entendido, ignorância, falta disto ou daquilo, desconfiança, falsa vergonha. 
Mas para falar de outra coisa, se eu caí, por outro lado você subiu. E se eu perdi simpatias, você por
seu lado as ganhou. Eis o que me deixa contente; falo sério e isto sempre me alegrará. Se você fosse
pouco sério e pouco profundo, eu poderia temer que isso não durasse muito, mas como acredito que
você seja muito sério e muito profundo, sou levado a crer que isto durará.
Só que se lhe fosse possível ver em mim algo mais que um vagabundo da pior espécie eu ficaria muito
contente. Então se eu puder alguma vez fazer algo por você, ser-lhe útil em alguma coisa, saiba que
estou à sua disposição.
Se aceitei o que você me deu, você também poderia, caso de alguma forma eu puder ajudá-lo, pedir-me:
eu ficaria contente e consideraria isso uma prova de confiança. Nós estamos muito distantes um do
outro e podemos ter pontos de vista diferentes; contudo, em dado momento, algum dia, poderíamos
ajudar-nos um ao outro.
Por hoje eu lhe aperto a mão, agradecendo novamente a bondade que você teve comigo.
Agora, se mais cedo ou mais tarde você quiser me escrever, meu endereço é chez Ch. Decrucq, rue du
Pavillon 8, em Cuesmes, perto de Mons.
E saiba que escrevendo-me você me fará bem.
Do seu,
Vincent

Fonte: Van Gogh (2009k, p. 1, tradução nossa)

São descritas com maior detalhamento as condições de produção, distribuição e consumo dos gêneros carta e pintura no apêndice.

\subsection{PROCEDIMENTOS DE COLETA, TRATAMENTO E ANÁLISE DOS DADOS}

\subsubsection{Procedimentos de coleta}

\subsubsection{Procedimento de coleta das Telas}

A coleta das telas foi feita do Site "The Vincent van Gogh Gallery", um projeto em parceria com o Van Gogh Letter Project do Museu Van Gogh. O catalogo raisonné 350 "The

\footnotetext{
${ }^{350}$ Tradução livre da autora. A melhor fonte de informação sobre a vida e os trabalhos de Vincent van Gogh teria que ser dois livros de catalogos raisonné que oferecem reproduces e insights em cada um e todos dos mais de 2.200 trabalhos de van Gogh. Cada um desses dois catálogos tem seus próprios méritos: the de la Faille is incredibly thorough and includes all provenance and exhibition information. The best source of information on the life and works of Vincent van Gogh would have to be the two catalogue raisonné books which offer reproductions and insights into each and every one of Van Gogh's more than 2,200 works. Each of these two
} 
Vincent van Gogh Gallery" é um projeto que levou dezoito anos para catalogar e disponibilizar em website um banco de imagens completo e abrangente das obras de Van Gogh. O site disponibiliza todas as obras e cartas conhecidas de Vincent van Gogh - um completo catálogo raisonné on-line da obra de Van Gogh em constante trabalho para exibir as obras ao lado de críticas e análises, comentários históricos, e uma rede mais ampla de hiperlinks para cruzamento de referências.

\subsubsection{Procedimento de coleta das cartas}

Compor o corpus com as cartas de Vincent van Gogh significou fazer uma pesquisa documental com manuscritos históricos, raros e de difícil acesso. Eles se encontram em sua maior parte no Museu Van Gogh e estão disponibilizados em um site graças a uma Edição comemorativa do centenário da morte de Van Gogh. Dessa forma, se tornou possível trabalhar diretamente com imagens desses manuscritos agora digitalizados e disponibilizados em facsímile do manuscrito original.

Além das imagens das cartas originais que contêm algumas dificuldades de legibilidade, utilizei uma versão de texto de leitura dessas cartas editada por esta publicação e que tomou o cuidado de se ater o quanto mais próximo possível do texto original, respeitando a forma do Francês de van Gogh do século XIX. Isso ajudou a esclarecer dúvidas quanto à grafia, deslizes de caneta e falhas de pontuação e otografia. As imagens das cartas que compõem o corpus desta pesquisa estão disponíveis nos anexos.

\footnotetext{
catalogues has its own merits: o de la Faille é incrivelmente complete e inclui todas as informações de circulação e exibições. O livro Hulsker não inclui isso, mas - não como o de la Faille—o Hulsker oferece comentários e análises atualizadas dos trabalhos. Além disso, o catalogo Hulsker tem a vantage de ser vinte seis anos mais atualizado. Um terceiro catalogo raisonné dos trabalhos de Van Gogh foi publicado em 2002: Vincent van Gogh: The Complete Works. Esse catalogo, lançado em CD-ROM, está mais atualizado do que o de la Faille ou o Hulsker e, diferente daqueles recursos, inclui imagens em cor da maioria dos trabalhos de van Gogh. Uma busca avançada, incluindo detalhes complestos das exibições e circulação de cada trabalho de arte. The best source of information on the life and works of Vincent van Gogh would have to be the two catalogue raisonné books which offer reproductions and insights into each and every one of Van Gogh's more than 2,200 works. Each of these two catalogues has its own merits: the de la Faille is incredibly thorough and includes all provenance and exhibition information. The Hulsker book doesn't include this, but--unlike the de la Faille--Hulsker provides ongoing commentary and analysis of the works. In addition, the Hulsker catalogue has the advantage of being twenty-six years more up to date. (...) A third catalogue raisonné of Van Gogh's works was published in 2002: Vincent van Gogh: The Complete Works. This catalogue, issued on CD-ROM, is more up-to-date than either the de la Faille or the Hulsker and, unlike these resources, includes colour images of the majority of Van Gogh's works. An advanced search feature, including full exhibition and provenance details for each art work, is included. (JANSEN; LUIJTEN; BAKKER, 2009, p. 1).
} 
Descrevo abaixo as condições de produção desta edição das cartas de van Gogh, na qual eu realizei a coleta dos documentos com os quais compus o corpus textual desta pesquisa.

Como exposto acima, as cartas que compõem o corpus textual desta pesquisa são documentos históricos e de difícil acesso. Essa edição distingue-se das edições de cartas anteriores por sua preocupação em produzir um corpo de documentos fidedignos e adequados para a comunidade acadêmica internacional que investiga Vincent van Gogh. ${ }^{351}$

\subsection{Sobre a questão de trabalhar com um corpus que passou por uma tradução}

A princípio tive o intuito no início de trabalhar com a versão das cartas traduzidas para o Inglês, uma vez que há uma versão de leitura cuja tradução procurou se manter o mais fiel possível ao Francês de van Gogh do século XIX. No entanto, uma questão de pesquisa me levou a desistir de tal intento. Para pesquisar a representação do significado experiencial de van Gogh, foi indispensável analisar na língua em que ele se expressa e articula suas experiências de mundo. Com base nessa consideração, decidi analisar os textos originais em Francês com o apoio dos textos de leitura em Francês para esclarecer dúvidas de grafia, pontuação e sentidos ambíguos. Isso foi possível por se tratar de um corpus textual relativamente pequeno e que em sua maior parte se refere a algumas telas. Para analisar o corpus estou me baseando nas imagens fac-símile do manuscrito original e fazendo a transcrição dos trechos que constituem o corpus, além de usar para consulta a versão de texto de leitura disponibilizada nesta edição on-line das cartas de van Gogh.

\subsubsection{Procedimentos de Tratamento}

Para ajudar no tratamento das telas e das cartas, e para organizar os achados das análises que serão trianguladas proponho três quadros:

a) Um quadro para tratar o corpus visual e organizar seus achados de acordo com o modelo proposto por O'Toole (1994);

b) Um quadro para tratar o corpus das cartas e organizar seus achados e;

\footnotetext{
${ }^{351}$ Uma descrição mais detalhada de como foram feitas as transcrições das cartas de Van Gogh na edição consultada está nos anexos e pode ser acessada em: http://vangoghletters.org/vg/about_2.html. (JANSEN; LUIJTEN; BAKKER, 2009).
} 
c) Um quadro para relacionar os achados visuais e textuais em uma análise multimodal. A seguir:

\subsection{Procedimento de tratamento das telas}

a) Quadro para organizar o corpus visual

Quadro 55: Corpus Visual

\begin{tabular}{|l|l|l|l|}
\hline Unidade / Função & Representacional & Modal & Composicional \\
\hline Pintura & & & \\
\hline Episódio & & & \\
\hline Figura & & & \\
\hline Membro & & & \\
\hline Vetores & & & \\
\hline
\end{tabular}

Fonte: Quadro adaptado de O'TOOLE (1994, p. 24).

\subsection{Procedimento de tratamento das cartas}

b) Quadro para organizar o corpus textual

Quadro 56: Corpus Textual Primário

\begin{tabular}{|l|l|l|l|l|l|}
\hline Oração & Participante 1 & Verbo & Processo & Participante 2 & Sigla \\
\hline EXTRATO 1a & & & & & \\
\hline & & & & & \\
\hline EXTRATO 2a & & & & & \\
\hline & & & & & \\
\hline & & & & & \\
\hline
\end{tabular}

Abaixo apresentamos os resultados da análise textual da tela The Café Terrace on the Place Du Forum, Arles, at Night. 
$\mathrm{M}=$ verbos que, provavelmente, realizam Processo Material

$\mathrm{Z}=$ verbos que, provavelmente, realizam Processo Mental

$\mathrm{V}=$ verbos que, provavelmente, realizam Processo Verbal

$\mathrm{R}=$ verbos que, provavelmente, realizam Processo Relacional

$\mathrm{E}=$ verbos que, provavelmente, realizam Processo Existencial

\subsection{Procedimento de tratamento da triangulação dos Corpora}

c) Quadro para relacionar os achados visuais e textuais em uma análise multimodal.

Quadro 57: Para organizar a triangulação entre telas e cartas

\begin{tabular}{|l|l|l|}
\hline Ocorrência nas telas & Ocorrência nas Orações & Comentário \\
\hline & & \\
\hline & & \\
\hline & & \\
\hline
\end{tabular}




\section{CAPÍTULO 4: ANÁLISE DOS DADOS}

\subsection{ANÁLISE TEXTUAL}

\subsubsection{Análise do Corpus Textual Contextual}

Carta de van Gogh-Junho 1880- Carta 155 (VAN GOGH, 2009k).

155

Br. 1990: 154 | CL: 133

From: Vincent van Gogh

To: Theo van Gogh

Date: Cuesmes, between about Tuesday, 22 and Thursday, 24 June 1880

Source status: Original manuscript

Location: Amsterdam, Van Gogh Museum, inv. nos. b153 a-b V/1962

Quadro 58: de Análise do corpus contextual

\begin{tabular}{|c|c|}
\hline Oração & Análise \\
\hline $\begin{array}{l}\text { Meu caro Théo, } \\
\text { É um pouco a contragosto } \\
\text { que lhe escrevo, não o } \\
\text { tendo feito há tanto tempo, } \\
\text { e isto por muitos motivos. } \\
\text { Até certo ponto você se } \\
\text { tornou um estranho para } \\
\text { mim, e eu talvez o seja para } \\
\text { você mais do que você } \\
\text { imagina; talvez fosse } \\
\text { melhor para nós dois não } \\
\text { continuarmos assim. }\end{array}$ & $\begin{array}{l}\text { Nesse exemplo ocorre a referência a si mesmo como estranho. O } \\
\text { estranhamento em relação aos outros é frequente nas cartas de van } \\
\text { Gogh, ele pressupõe que o sentimento de estranhamento dos outros } \\
\text { deve ser ainda maior do que ao estranhamento que ele sente com } \\
\text { relação ao outro, pois ele frequentemente foi julgado como excêntrico, } \\
\text { isolado e rechaçado socialmente pelo seu modo de vestir e de agir. O } \\
\text { que ele quer dizer quando escreve "talvez o seja (estranho) mais do que } \\
\text { você imagina" (VAN GOGH, 2009k, p. 1) }\end{array}$ \\
\hline & $\begin{array}{l}\text { Ele está supondo que há mais aspectos sobre ele que causariam } \\
\text { estranhamento que estão fora da percepção consciente do irmão ou fora } \\
\text { da lembrança que o irmão possa ter de van Gogh fruto quando ainda } \\
\text { conviviam. Van Gogh sugere que há um estranhamento maior do que o } \\
\text { irmão é capaz de imaginar. Ele parece também deixar implícito que ele } \\
\text { mudou muito, tanto a ponto de ter se tornado um estranho para a } \\
\text { família. Essa pressuposição pode ter sido resultado de um rompimento } \\
\text { com os valores, crenças e expectativas da família para buscar este outro } \\
\text { 'Vincent', ficando em um não-lugar para a família, sendo apontado } \\
\text { como alguém estranho aos outros ao seu redor, para os valores }\end{array}$ \\
\hline
\end{tabular}




\begin{tabular}{|c|c|}
\hline & $\begin{array}{l}\text { identitários do seu grupo. As suas tentativas anteriores de construir um } \\
\text { papel no grupo foram frustradas, seja como vendedor de arte, como } \\
\text { pastor e como missionário. Agora ele busca um caminho 'estranho' a } \\
\text { todos. }\end{array}$ \\
\hline $\begin{array}{l}\text { "É impossível que nem } \\
\text { mesmo agora eu lhe tivesse } \\
\text { escrito, não fosse o fato de } \\
\text { eu me sentir na obrigação, } \\
\text { na necessidade de lhe } \\
\text { escrever; não fosse o fato } \\
\text { de você mesmo me fazer } \\
\text { sentir esta necessidade" }\end{array}$ & $\begin{array}{l}\text { Pressuposição existencial, tenta explicar o fato de que é impossível que } \\
\text { nem em um momento de penúria como o que ele está experimentando } \\
\text { ele se dignou a escrever ao irmão contando como se encontra; e que só } \\
\text { o faz diante do evento social do envio de ajuda de Theo e de se sentir } \\
\text { obrigado a dar uma resposta ao irmão. Ele explica que se sente } \\
\text { constrangido a responder. }\end{array}$ \\
\hline $\begin{array}{l}\text { "Soube em Etten que você } \\
\text { tinha me enviado cinquenta } \\
\text { francos" }\end{array}$ & $\begin{array}{l}\text { Elementos dos eventos sociais representados são incluídos ou } \\
\text { excluídos? Ele fala sobre o envio dos cinquenta francos para iniciar } \\
\text { uma representação sobre 'evento social' de sua situação econômica, e } \\
\text { desemprego. }\end{array}$ \\
\hline $\begin{array}{l}\text { "Pois bem, eu os aceitei.' } \\
\text { (modo gramatical } \\
\text { predominante imperativo) } \\
\text { Certamente a contragosto, } \\
\text { certamente com um } \\
\text { sentimento bem } \\
\text { melancólico" }\end{array}$ & $\begin{array}{l}\text { Aqui van Gogh parece expressar sua contrariedade com a situação de } \\
\text { precisar de ajuda, de ser obrigado a aceitar ajuda, de se ver } \\
\text { constrangido a aceitar uma oferta, ainda que não tenha pedido ou } \\
\text { escrito, nem ao menos para contar como está sua vida. Isso também } \\
\text { pode ser entendido como uma Modalidade > modalidades deônticas, na } \\
\text { qual ele aceita, mas condiciona o aceite com dar a conhecer que se } \\
\text { sente contrariado em fazê-lo. } \\
\text { Quanto ao Significado de palavra, vemos duas ocorrências: a palavra } \\
\text { 'contragosto', que é recorrente no início do texto e a palavra } \\
\text { 'certamente' segue a declaração de aceitação e parece não apenas para } \\
\text { enfatizar a palavra 'contragosto' que significa 'mas não sem resistência } \\
\text { e melancolia', para enfatizar, 'eu aceitei, ainda que a contragosto, mas } \\
\text { também para ligar contragosto com melancolia, e aqui vemos uma } \\
\text { sequência, uma cadeia de termos que ajudam a dar ritmo, cadência, } \\
\text { traço fonológico, ou uma modalização, pode ser vista como Estilo. }\end{array}$ \\
\hline $\begin{array}{l}\text { mas (contraposição entre não } \\
\text { querer aceitar mas não tem } \\
\text { outra opção, por isso a palavra } \\
\text { contragosto) estou numa } \\
\text { espécie de beco sem saída ou } \\
\text { de atoleiro, (metáfora) como } \\
\text { fazer de outro modo? }\end{array}$ & $\begin{array}{l}\text { O conectivo 'mas' ocorre como uma contraposição entre não querer } \\
\text { aceitar, mas não tem outra opção, por isso a escolha 'contragosto'; e: } \\
\text { 'estou numa espécie de beco sem saída ou de atoleiro' (metáfora) } \\
\text { como fazer de outro modo? } \\
\text { Identifícacional - Estilos - metáfora, modalidade, avaliação; mas ao } \\
\text { mesmo tempo em que ele avalia a sua situação, parece ser a forma como } \\
\text { ele se representa - Representacional - Representação de eventos/atores } \\
\text { sociais; pois verificam-se instâncias de metáfora gramatical na } \\
\text { representação de processos, no caso ele se representa como passivo e, } \\
\text { diante dos eventos sociais, sem opções para declinar a oferta de ajuda do } \\
\text { irmão. }\end{array}$ \\
\hline
\end{tabular}




\begin{tabular}{|c|c|}
\hline $\begin{array}{l}\text { E é, portanto para agradecer } \\
\text { que lhe escrevo. }\end{array}$ & $\begin{array}{l}\text { Significado Acional - Modo gramatical - modo gramatical predominante } \\
\text { declarativo. }\end{array}$ \\
\hline $\begin{array}{l}\text { "Como talvez você já saiba, } \\
\text { voltei ao Borinage }\end{array}$ & $\begin{array}{l}\text { O que Borinage significa para van Gogh? O que esse movimento de } \\
\text { retorno representa para van Gogh, por que ele retornou para a região dos } \\
\text { mineiros quando não está mais no posto de missionários? seria porque } \\
\text { se indentifica com a situação de penúria dos mineiros? seria porque está } \\
\text { abdicando de seu vínculo com outras formas de participação e } \\
\text { pertencimento, estará ele fazendo isso para como um 'statement' uma } \\
\text { declaraçao de valores, intenções e identidade? Estaria ele se } \\
\text { contrapondo aos valores estabelecidos pela familia e pela sociedade e } \\
\text { aos quais não consegue se conformar, seguir e se adaptar? Estará ele } \\
\text { simplesmente se 'identificando' com os mineiros, em sua situação de } \\
\text { não pertencimento social, ou esta se sentindo acolhido por aqueles que } \\
\text { não o julgam, e não esperam que ele ocupe determinados papeis e } \\
\text { lugares sociais, aceitando-o como ele é para além das aparências de } \\
\text { aceio e produtividade e acolhendo-o como um 'homem natural'. Van } \\
\text { Gogh parece dar a esse evento um outro significante implícito de sua } \\
\text { busca de identidade: voltar a Borinage pode ter o sentido de 'where he } \\
\text { stands' onde ele se encontra na ordem das coisas (e dos discursos) e no } \\
\text { que ele acredita afinal, qual será o sentido de sua existencia e que coisas } \\
\text { ele valoriza. Na sequencia desse significador, ele menciona um diálogo } \\
\text { com o pai, dando a entender que está negociando um conflito entre } \\
\text { atender o desejo do pai que ele ocupe um lugar social ou procurar } \\
\text { afirmar sua individualidade, ser quem ele é, seja ele quem for. }\end{array}$ \\
\hline $\begin{array}{l}\text { "meu pai me disse que seria } \\
\text { melhor ficar pelas vizinhanças } \\
\text { de Etten": Aqui ele diz qual é } \\
\text { o desejo do pai: "eu disse que } \\
\text { não" é o desejo dele" }\end{array}$ & $\begin{array}{l}\text { Van Gogh declara para o pai sua posição contrária ao desejo do pai, e } \\
\text { declara para o irmão sua posição antagonica ao desejo do pai. } \\
\text { Observamos a ocorrência de Interdiscursividade: ele introduz a voz do } \\
\text { pai, a própria voz, e a interação dos dois, inserindo Theo nessa interação } \\
\text { por meio da reprodução de um diálogo. Também observamos a } \\
\text { representação de eventos e de atores sociais, descritos a seguir. }\end{array}$ \\
\hline $\begin{array}{l}\text { "e acredito ter agido melhor } \\
\text { assim". }\end{array}$ & $\begin{array}{l}\text { Além da interdiscursividade, tb observa-se a Representação de } \\
\text { eventos/atores sociais - o tipo de processo representado é relacional, e } \\
\text { não apenas para explicar a contraposição entre sua vontade e a vontade } \\
\text { do pai, que ele explica ao reproduzir um diálogo entre ele e o pai, mas } \\
\text { porque ao usar um diálogo para representar esse conflito, ele mostra que } \\
\text { onde o conflito ocorre, o conflito é de 'dialogo', de interação, de relação } \\
\text { entre ele e o pai. }\end{array}$ \\
\hline "Involuntariamente, torn & Observamos a Representação de eventos e de atores sociais / Avaliação \\
\hline
\end{tabular}

352 Borinage é uma região das minas de carvão onde van Gogh trabalhou como evangelizador e onde desenvolveu sua relação com os mineiros. 


\begin{tabular}{|c|c|}
\hline $\begin{array}{l}\text { me na família uma espécie } \\
\text { de personagem impossivel e } \\
\text { suspeito, seja como for, } \\
\text { alguém que não merece } \\
\text { confiança. A quem poderia } \\
\text { eu ser útil de alguma } \\
\text { maneira?" (VAN GOGH, } \\
\text { 2009k, p. 1). }\end{array}$ & $\begin{array}{l}\text { - afírmações avaliativas e valores presumidos/ Significado de palavra> } \\
\text { Há padrões de co-ocorrência. } \\
\text { Representação de eventos/atores sociais > Nesta oração observa-se que } \\
\text { van Gogh se representa como uma 'personagem impossível e suspeita' } \\
\text { como uma forma de explicitar o lugar de onde ele fala em relação ao seu } \\
\text { grupo familiar. } \\
\text { Aqui Van Gogh (2009k, p. 1) representa como os atores sociais da } \\
\text { família o veem: "uma espécie de personagem impossível, suspeito, que } \\
\text { não merece confiança". Ao usar o termo "involuntariamente tornei-me" } \\
\text { ele se representa como um ator passivo nesse processo, e alheio a este } \\
\text { processo de significação no grupo a qual ele pertence. Ao usar o termo } \\
\text { "uma espécie de personagem" ele declara um sentimento de } \\
\text { impessoalidade, de estranhamento e de horror a esse lugar no qual a } \\
\text { família o coloca. Ele não se identifica com a forma como a família o } \\
\text { representa. } \\
\text { Ao explicar: "seja como for, alguém que não merece confiança" ele está } \\
\text { enfatizando a imposição do discurso de sua família sobre que lugar ele } \\
\text { deve ocupar no grupo familiar e a gravidade como esse discurso impacta } \\
\text { na forma autodepreciativa como van Gogh se representa: (se sou) } \\
\text { "alguém que não merece confiança. A quem poderia eu ser útil de } \\
\text { alguma maneira?" (VAN GOGH, 2009k, p. 1). } \\
\text { Esta oração, se analisada no contexto das práticas discursivas da família } \\
\text { de van Gogh, pode revelar o caráter ideológico do discurso familiar } \\
\text { pautado pelas convenções sociais da época e pelos conflitos que van } \\
\text { Gogh experienciou para produzir um caráter transformador e criativo } \\
\text { em sua identidade e em sua prática artística. }\end{array}$ \\
\hline $\begin{array}{l}\text { "Involuntariamente, tornei-me } \\
\text { na família uma espécie de } \\
\text { personagem impossível e } \\
\text { suspeito, seja como for, } \\
\text { alguém que não merece } \\
\text { confiança. A quem poderia eu } \\
\text { ser útil de alguma maneira?" } \\
\text { (VAN GOGH, 2009k, p. 1). }\end{array}$ & $\begin{array}{l}\text { Significado de Palavra } \\
\text { Significado de palavra > construção do sentido de alguma palavra> } \\
\text { Os termos usados por van Gogh nessa oração são avassaladores e } \\
\text { denotam aqui todo o sofrimento do não pertencimento no seu grupo } \\
\text { familiar. Que sujeito aguentaria se tornar para a família uma 'espécie de } \\
\text { personagem', ou seja, uma despessoalização, uma ficção. Na sequência } \\
\text { encontram-se três expressões encadeadas, importantes para se entender } \\
\text { a natureza dessa personagem: 'impossível', 'suspeito', 'alguém que não } \\
\text { merece confiança'. No caso de 'impossível', o que ele quer dizer? } \\
\text { Impossível para ele ou para os outros? Se for impossível para os outros, } \\
\text { será uma personagem Impossível...de conviver, de se sustentar, de se } \\
\text { conduzir? Não sabemos. Se for para ele, será uma inversão: uma } \\
\text { personagem impossível de existir, pois para ser a personagem, ele } \\
\text { precisa deixar de ser, e isso aos seus olhos é impossível, por isso é uma } \\
\text { personagem impossível. Por que para ele é impossível ser essa } \\
\text { personagem que a família criou? Porque ao ocupar esse lugar da } \\
\text { personagem, para atender a representação que a família faz dele, ele terá } \\
\text { que se objetificar. Dessa forma, uma personagem impossível e } \\
\text { improvável, pois é impossível para ele ser uma personagem para quem } \\
\text { quer que seja. Além disso, ele introduz um elemento implícito em seu } \\
\text { discurso: a questão sobre o lugar que ocupa na família; sua busca por } \\
\text { uma afirmação de seu eu na existência em antagonismo com sua } \\
\text { necessidade de aceitação dos pais e pertencimento no grupo; aguçadas } \\
\text { pelo fato de estar substituindo o lugar de um irmão primogênito que }\end{array}$ \\
\hline
\end{tabular}




\begin{tabular}{|c|c|}
\hline & $\begin{array}{l}\text { morreu um ano antes e do qual ele herdou o nome, e a expectativa } \\
\text { contrariada dos pais de tê-lo perdido, e de ter tido Van Gogh um ano } \\
\text { depois (FORRESTER, 1983; HAZIOT, 2010). } \\
\text { A construção 'uma espécie de personagem impossível' pode fazer } \\
\text { referência a esse vazio e ou ao seu lugar na família, um lugar ficcional } \\
\text { que causa estranhamento e exclusão, o lugar de ser um personagem } \\
\text { impossível para ele ser, ou de ele ser uma criação, uma personagem } \\
\text { impossível que a família criou e que, portanto, nunca vai dar certo. A } \\
\text { 'desconfiança' que ele é uma tentativa malograda de dar vida ao outro } \\
\text { que morreu, de trazer de volta 'uma personagem impossível' que é o } \\
\text { irmão não vivo. Dessa maneira, ele se representa como uma } \\
\text { 'personagem 'no mínimo 'suspeita', aqui também ele levanta suspeitas } \\
\text { sobre essa fabricação da família, uma personagem, além de impossível, } \\
\text { suspeita. Uma personagem suspeita, seria um papel que ele sente } \\
\text { suspeito para ocupar, não está confiante para ocupar, porque caso o faça, } \\
\text { será uma personagem impossível e, portanto, suspeita para os olhos da } \\
\text { família. Com isso ele subdeclara: nunca será aceito, nem mesmo se } \\
\text { ocupar esse lugar pretenso, essa personagem impossível, nem mesmo } \\
\text { assim deixará de ser 'suspeito' aos olhos da família porque no fundo, } \\
\text { não é o primeiro Vincent Willem Van Gogh, o que morreu, o que não } \\
\text { está, o que ele não materializará. }\end{array}$ \\
\hline $\begin{array}{l}\text { Em consequência, ele se } \\
\text { representa ao sentenciar: } \\
\text { "tornei-me na família,(...) } \\
\text { alguém que não merece } \\
\text { confiança" (VAN GOGH, } \\
\text { 2009k, p. 1). }\end{array}$ & $\begin{array}{l}\text { Não é uma suposição, não é uma desconfiança: é uma certeza. Ele } \\
\text { declara em tom afirmativo, imperativo ser "alguém que não merece } \\
\text { confiança" (VAN GOGH, 2009k, p. 1). } \\
\text { Nessa oração Van Gogh emprega o termo 'tornei-me' indicando como } \\
\text { significados presentes no processo relacional identificacional a } \\
\text { ocorrência de uma construção identitária na interação com os membros } \\
\text { da família, não um processo de constituição identitária isolado. Trata-se } \\
\text { de um processo que foi construído dentro da relação com a família, que } \\
\text { molda o discurso e impõe o lugar disponível para ele em seu grupo } \\
\text { familiar. Ao falar de si, o mais interessante é que ele se representa como } \\
\text { um 'alguém' em contraposição com o que rejeita: ser uma 'espécie de } \\
\text { personagem'. Encontro aqui uma contraposição e uma afirmação, e uma } \\
\text { fundante de seu eu ao dizer-se um 'alguém' ao invés de 'uma espécie' } \\
\text { que conota qualquer coisa, um objeto, uma categoria, uma } \\
\text { generalização, uma abstração. Essa contraposição pode indicar conflito } \\
\text { que ele vive em forma de uma pressão esmagadora para ser aceito e } \\
\text { pertencer ao grupo familiar que ele parece sentir viver e carregar, mas } \\
\text { que desemboca com sua necessidade de se fundar como sujeito contra o } \\
\text { desígnio familiar em objetificá-lo numa 'espécie de personagem } \\
\text { impossível.' Diante disso, parece melhor 'não merecer confiança', mas } \\
\text { continuar sendo 'alguém' (VAN GOGH, 2009k, p. } 1 \text { ). }\end{array}$ \\
\hline $\begin{array}{l}\text { "A quem poderia eu ser útil de } \\
\text { alguma maneira?" (VAN } \\
\text { GOGH, 2009k, p. 1). }\end{array}$ & $\begin{array}{l}\text { Observou-se a ocorrência de Trocas, funções da fala, modo gramatical> } \\
\text { funções da fala> pergunta e também: } \\
\text { relações semânticas> Há relações semânticas em nível mais alto entre } \\
\text { partes maiores do texto--por exemplo, problema-solução. Aqui ele faz } \\
\text { uma pergunta que parece ter um significado acional mais do que }\end{array}$ \\
\hline
\end{tabular}




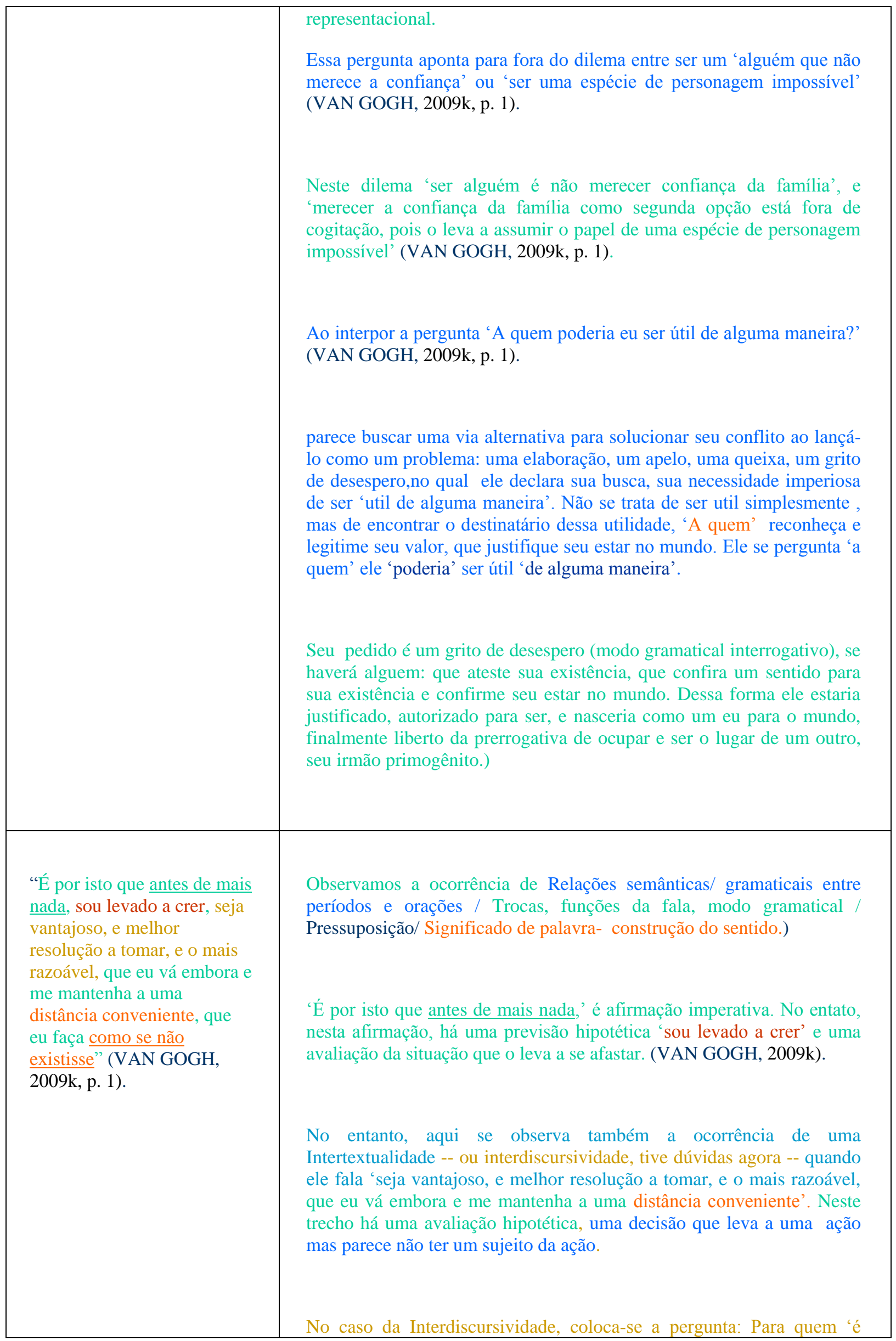




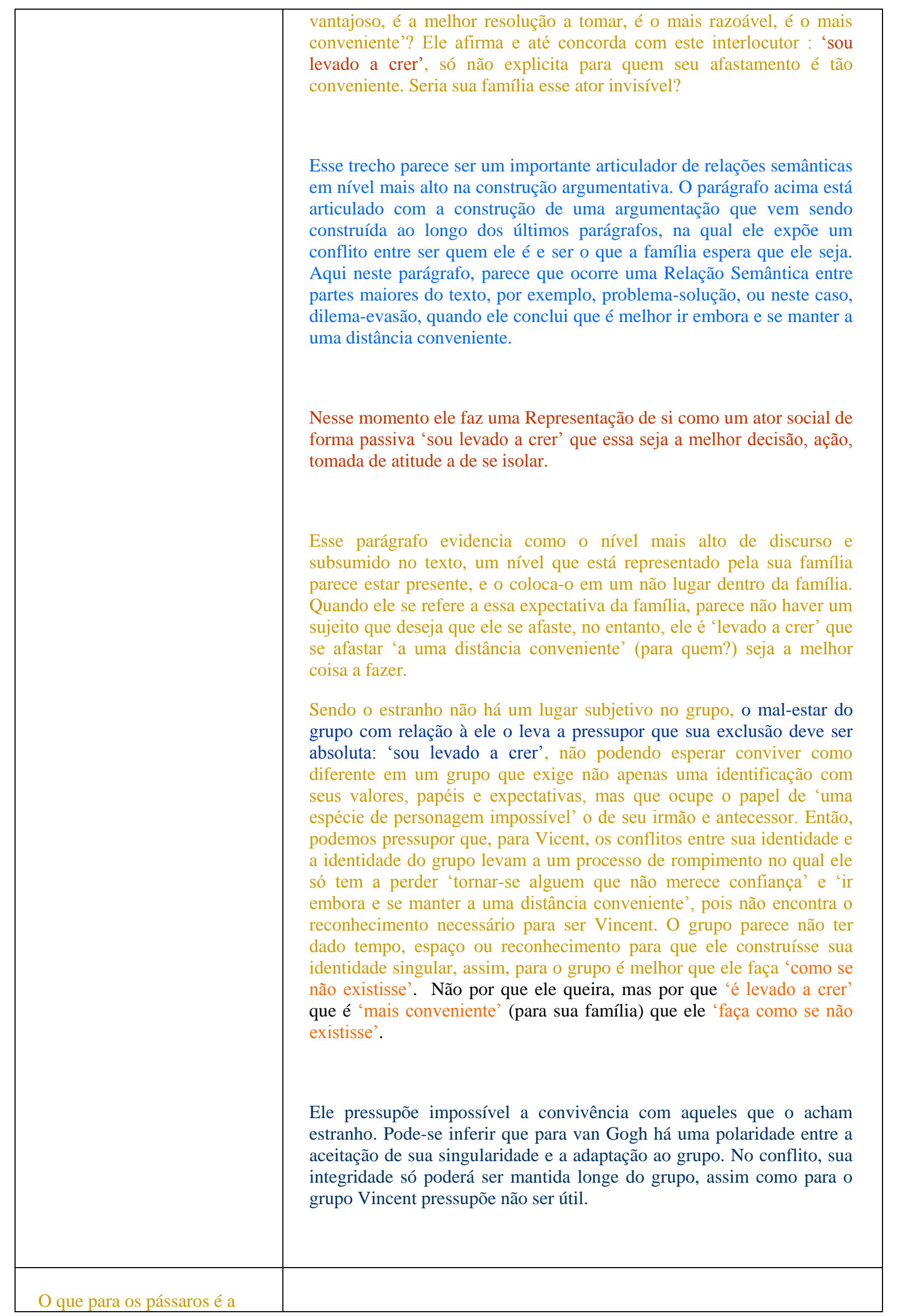




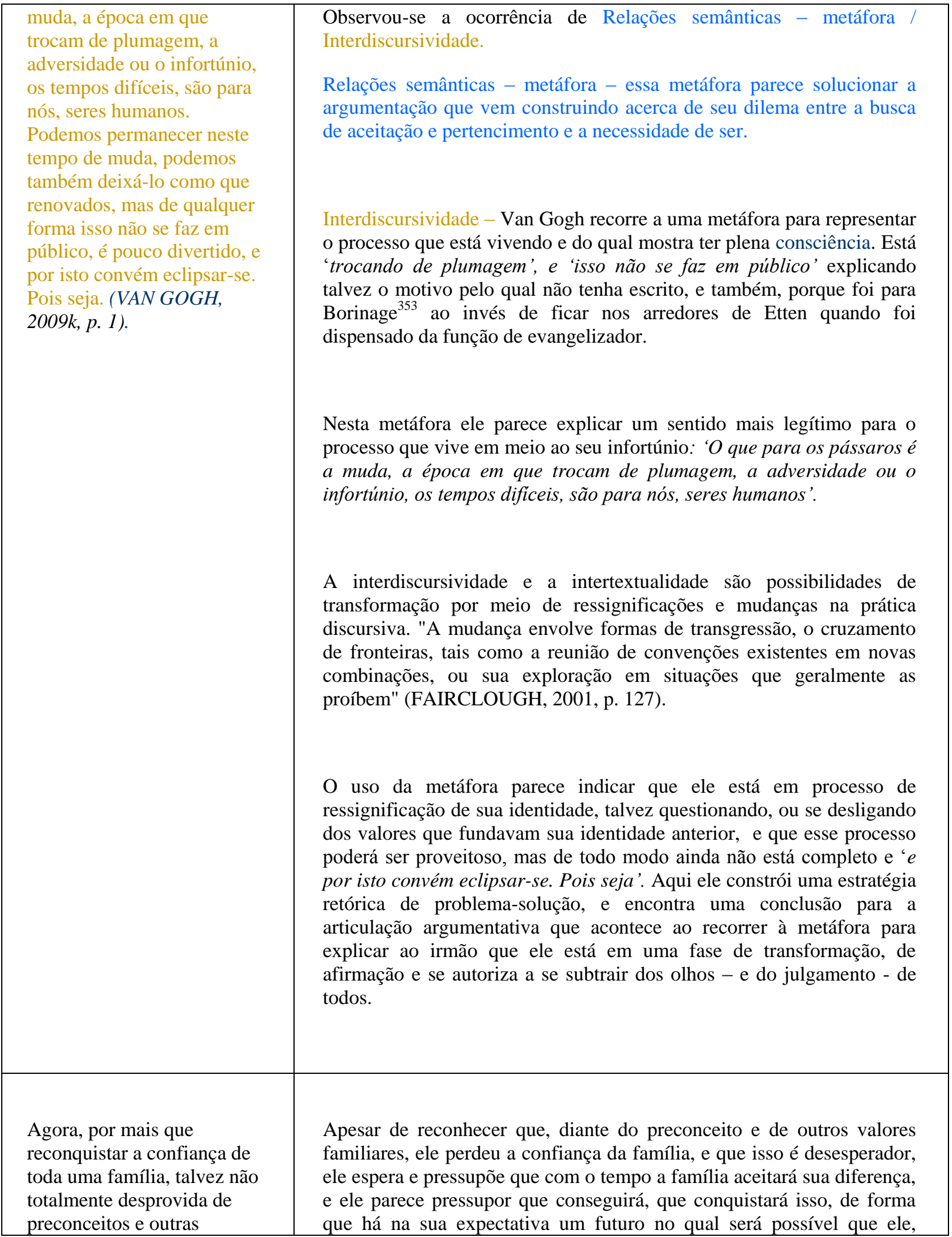

${ }^{353}$ No Borinage van Gogh assumiu em 1879 o cargo de pregador leigo, onde viveu com abnegação excessiva gerando o questionamento e o desligamento da ordem no final de Julho daquele ano com o pretexto de não possuir habilidade como orador. Mas ele não abandonou esta atividade, indo para uma aldeia próxima para continuar esse trabalho, retomando ao mesmo tempo sua relação com o desenho. Em Julho do ano seguinte, 1880, ele decide que será pintor e pede, por meio da carta aqui analisada, apoio a seu irmão Theo que passa a sustentá-lo em sua atividade até a sua morte. Permaneceu lá até Abril de 1881 quando finalmente retornou à casa dos pais em Etten. 


\begin{tabular}{|c|c|}
\hline $\begin{array}{l}\text { qualidades igualmente } \\
\text { honoráveis e elegantes, seja } \\
\text { de uma dificuldade mais ou } \\
\text { menos desesperadora, eu } \\
\text { ainda tenho algumas } \\
\text { esperanças de que pouco a } \\
\text { pouco, lenta e seguramente, } \\
\text { a cordial compreensão seja } \\
\text { restabelecida com uns e } \\
\text { outros. (VAN GOGH, } \\
\text { 2009k, p. 1) }\end{array}$ & $\begin{array}{l}\text { Vincent, possa existir no grupo familiar como o sujeito singular que foi } \\
\text { anteriormente rejeitado. Não pressupoe que ele mudará, mas que ele } \\
\text { provará que tem valor sendo quem ele é. Ele considera desesperador não } \\
\text { ser reconhecido pela família por se ver prisioneiro de um conflito no } \\
\text { qual ser um eu, assumir uma identidade é usurpar o lugar de um irmão } \\
\text { que não está entre os vivos. }\end{array}$ \\
\hline $\begin{array}{l}\text { "Assim é que em primeiro } \\
\text { lugar eu gostaria muito de } \\
\text { ver esta cordial } \\
\text { compreensão, para não dizer } \\
\text { mais, restabelecida entre } \\
\text { meu pai e eu, e desejaria } \\
\text { muito que ela igualmente se } \\
\text { restabelecesse entre nós } \\
\text { dois" (VAN GOGH, 2009k, } \\
\text { p. 1). }\end{array}$ & Observamos a ocorrência de função da fala, demanda. \\
\hline $\begin{array}{l}\text { "Compreensão cordial vale } \\
\text { infinitamente mais que mal- } \\
\text { entendido" (VAN GOGH, } \\
\text { 2009k, p. 1) }\end{array}$ & Ocorrência de avaliação. \\
\hline $\begin{array}{l}\text { Preciso agora lhe aborrecer } \\
\text { com algumas coisas } \\
\text { abstratas, no entanto gostaria } \\
\text { muito que você as escutasse } \\
\text { com paciência. (demanda) } \\
\text { Sou um homem de paixões, } \\
\text { capaz de, e sujeito a fazer } \\
\text { coisas mais ou menos } \\
\text { insensatas, das quais às } \\
\text { vezes me arrependo mais ou } \\
\text { menos. Muitas vezes me } \\
\text { ocorre falar ou agir um } \\
\text { pouco depressa demais, } \\
\text { quando seria melhor esperar } \\
\text { com um pouco mais de } \\
\text { paciência. Acredito que } \\
\text { outras pessoas também } \\
\text { possam às vezes cometer } \\
\text { semelhantes imprudências. } \\
\text { (VAN GOGH, 2009k, p. 1). }\end{array}$ & $\begin{array}{l}\text { Observamos a ocorrência de avaliação. } \\
\text { "Agora, sendo assim, o que se deve fazer, devo considerar-me como um } \\
\text { homem perigoso e incapaz de qualquer coisa?" (VAN GOGH, 2009k, p. } \\
\text { 1). Ocorrência de troca, funções da fala. }\end{array}$ \\
\hline
\end{tabular}




\begin{tabular}{|c|c|}
\hline $\begin{array}{l}\text { Agora, sendo assim, o que se } \\
\text { deve fazer, devo considerar- } \\
\text { me como um homem } \\
\text { perigoso e incapaz de } \\
\text { qualquer coisa? }\end{array}$ & (troca, funções da fala) \\
\hline $\begin{array}{l}\text { Penso que não. Mas trata-se } \\
\text { de por todos os meios tirar } \\
\text { destas paixões o melhor } \\
\text { partido. Por exemplo, para } \\
\text { falar de uma paixão entre } \\
\text { outras, tenho uma paixão } \\
\text { mais ou menos irresistível } \\
\text { pelos livros e preciso me } \\
\text { instruir continuamente, } \\
\text { estudar, se você quiser, } \\
\text { assim como preciso comer } \\
\text { meu pão. }\end{array}$ & Ocorrência de relações semânticas, relação com partes maiores do texto. \\
\hline $\begin{array}{l}\text { Você poderá entender isto. } \\
\text { Quando eu estava num } \\
\text { ambiente de quadros e de } \\
\text { coisas de arte, você sabe muito } \\
\text { bem que fui tomado por uma } \\
\text { paixão violenta, que chegava } \\
\text { ao entusiasmo. E não me } \\
\text { arrependo, e ainda agora, longe } \\
\text { dele, muitas vezes sinto } \\
\text { saudade do mundo dos } \\
\text { quadros. (VAN GOGH, } \\
\text { 2009k, p. 1). }\end{array}$ & $\begin{array}{l}\text { Anteriormente Van Gogh }(2009 \mathrm{k}) \text { revela no seu discurso a } \\
\text { impossibilidade de ter reconhecida sua singularidade pela família, mas } \\
\text { tem esperanças de ser compreendido. Logo em seguida, ele afirma 'você } \\
\text { poderá entender isto', pressupondo que o irmão compreenderá, apesar } \\
\text { do estranhamento decorrente das mudanças que Vincent sofreu, a paixão } \\
\text { que o arrebatou e o tornou o que ele atualmente é, um estranho. Ele } \\
\text { pressupõe que, por Theo compreender sua paixão pelos quadros não o } \\
\text { julgará a partir dos mesmos valores com os quais a família o julga. } \\
\text { Parece pressupor ainda que, em meio aos quadros, não se sentiria um } \\
\text { estranho, Vicent parece se identificar com os quadros. Assim como } \\
\text { Theo, que vive em meio aos quadros, e desta forma eles } \\
\text { compartilhariam a mesma paixão de formas diferentes, um como } \\
\text { vendedor e outro como pintor, e portanto supõe que Theo o } \\
\text { compreenderia. Este parece ser um dos argumentos fundadores para } \\
\text { contruir o pleito dele, de que o irmão o ajude, e de que se identifique } \\
\text { com sua necessidade. Ao mesmo tempo em que ele se representa como } \\
\text { alguém que ama a arte, assim como o irmão. }\end{array}$ \\
\hline $\begin{array}{l}\text { "Preciso agora lhe aborrecer } \\
\text { com algumas coisas abstratas, } \\
\text { no entanto gostaria muito que } \\
\text { você as escutasse com } \\
\text { paciência" (VAN GOGH, } \\
2009 k, p .1) \text {. }\end{array}$ & Ocorrência de demanda. \\
\hline $\begin{array}{l}\text { Sou um homem de paixões, } \\
\text { capaz de, e sujeito a fazer } \\
\text { coisas mais ou menos } \\
\text { insensatas, das quais às } \\
\text { vezes me arrependo mais ou }\end{array}$ & Ocorrência de avaliação. \\
\hline
\end{tabular}




\begin{tabular}{|c|c|}
\hline $\begin{array}{l}\text { menos. } \\
\text { Muitas vezes me ocorre falar } \\
\text { ou agir um pouco depressa } \\
\text { demais, quando seria melhor } \\
\text { esperar com um pouco mais } \\
\text { de paciência. Acredito que } \\
\text { outras pessoas também } \\
\text { possam às vezes cometer } \\
\text { semelhantes imprudências. } \\
\text { (VAN GOGH, 2009k, p. 1). }\end{array}$ & \\
\hline $\begin{array}{l}\text { "Agora, sendo assim, o que se } \\
\text { deve fazer, devo considerar- } \\
\text { me como um homem perigoso } \\
\text { e incapaz de qualquer } \\
\text { coisa?" (VAN GOGH, 2009k, } \\
\text { p. 1). }\end{array}$ & Ocorrência de troca, funções da fala. \\
\hline $\begin{array}{l}\text { Penso que não. Mas trata-se } \\
\text { de por todos os meios tirar } \\
\text { destas paixões o melhor } \\
\text { partido. Por exemplo, para } \\
\text { falar de uma paixão entre } \\
\text { outras, tenho uma paixão } \\
\text { mais ou menos irresistível } \\
\text { pelos livros e preciso me } \\
\text { instruir continuamente, } \\
\text { estudar, se você quiser, } \\
\text { assim como preciso comer } \\
\text { meu pão. (VAN GOGH, } \\
\text { 2009k, p. 1). }\end{array}$ & Ocorrência de relações semânticas, relação com partes maiores do texto. \\
\hline $\begin{array}{l}\text { "Você talvez se lembre bem } \\
\text { que eu sabia perfeitamente } \\
\text { (e pode ser que ainda o } \\
\text { saiba) o que era um } \\
\text { Rembrandt, ou o que era um } \\
\text { Millet, um Jules Dupré, um } \\
\text { Delacroix, um Millais ou um } \\
\text { Maris?" (VAN GOGH, } \\
\text { 2009k, p. 1). }\end{array}$ & $\begin{array}{l}\text { Ocorre uma demanda de que o irmão lembre a identidade anterior dele; } \\
\text { uma afirmação de que ele sabia distinguir telas de pintores e seus } \\
\text { estilos; e também pergunta para enfatizar sua expectativa de que o irmão } \\
\text { se lembre, e para isto oferece uma evidência que fundamenta sua } \\
\text { argumentação. }\end{array}$ \\
\hline $\begin{array}{l}\text { "Bom - agora não estou } \\
\text { mais neste ambiente, no } \\
\text { entanto esta coisa que se } \\
\text { chama alma pretende-se que } \\
\text { não morre jamais, e que vive } \\
\text { sempre e busca sempre mais } \\
\text { e mais e ainda mais" (VAN } \\
\text { GOGH, 2009k, p. } 1 \text { ). }\end{array}$ & $\begin{array}{l}\text { Ocorre uma afirmação para provar que, embora longe dos quadros, a } \\
\text { paixão continua tão intensa quanto foi na época em que estava neste } \\
\text { ambiente. Sua argumentação reforça que não é uma paixão passageira, } \\
\text { mas 'que não morre jamais'. Tem uma relação de tempo e espaço que } \\
\text { não delimitado pelo evento concreto, mas pelo seu efeito e impacto } \\
\text { 'para sempre' na formação de sua identidade e na definição de seus } \\
\text { projetos. }\end{array}$ \\
\hline $\begin{array}{l}\text { Em vez de sucumbir de } \\
\text { saudades, eu disse: "O país } \\
\text { ou a pátria estão em todos os } \\
\text { lugares". Em vez de me } \\
\text { deixar levar pelo desespero, }\end{array}$ & $\begin{array}{l}\text { Aqui observa-se um antagonismo entre vida e morte, entre paixão e } \\
\text { esquecimento, entre inclusão e exclusão, entre ser e não-ser, ele passa a } \\
\text { se representar como um ator social que luta por criar apesar do } \\
\text { sofrimento e que será fundamental para o argumento que se segue na } \\
\text { carta ao irmão, a de que ele ajude Vincent a permanecer pintando, que }\end{array}$ \\
\hline
\end{tabular}




\begin{tabular}{|c|c|}
\hline $\begin{array}{l}\text { tomei o partido da } \\
\text { melancolia ativa enquanto a } \\
\text { tinha a potência de } \\
\text { atividade, ou em outras } \\
\text { palavras, preferi a } \\
\text { melancolia que espera e que } \\
\text { aspira e que busca, àquela } \\
\text { que embota e, estagnada, } \\
\text { desespera. (VAN GOGH, } \\
\text { 2009k, p. 1). }\end{array}$ & $\begin{array}{l}\text { luta por transformar sua condição de melancolia/morte em } \\
\text { melancolia/vida. } \\
\text { Significado da Palavra - A palavra pátria é relevante e parece estar } \\
\text { sendo usada com a função de se referir a uma necessidade de inclusão, } \\
\text { de pertencimento e de contimento, que pode ser tanto com um sentido } \\
\text { direto - pertencimento social- ou com um sentido indireto - } \\
\text { pertencimento familiar. } \\
\text { O uso do sentido de pátria pode também estar sendo uma função da fala/ } \\
\text { uma relação metafórica para compreender como Vincent busca afirmar } \\
\text { sua identidade nas relações sociais embora tenha sido excluído por seu } \\
\text { núcleo familiar. }\end{array}$ \\
\hline $\begin{array}{l}\text { Portanto, estudei mais ou } \\
\text { menos seriamente os livros } \\
\text { ao meu alcance, como a } \\
\text { Bíblia e a Revolução } \\
\text { Francesa de Michelet, e, no } \\
\text { último inverno, Shakespeare } \\
\text { e um pouco de Victor Hugo } \\
\text { e Dickens, e Beecher Stowe } \\
\text { e ultimamente Ésquilo e } \\
\text { muitos outros, menos } \\
\text { clássicos, vários grandes } \\
\text { pequenos mestres. (VAN } \\
\text { GOGH, 2009k, p. 1). }\end{array}$ & $\begin{array}{l}\text { Podemos inferir que há aqui uma intertextualidade, pois ao citar autores, } \\
\text { Van Gogh ( } 2009 \mathrm{k}) \text { mostra a Theo que está fundado em idéias 'sérias', } \\
\text { incorporando à sua identidade sentidos de personalidades que são } \\
\text { reconhecidas socialmente, se poiando em outros autores para afirmar } \\
\text { sua própria personalidade, como alguém que estuda seriamente. } \\
\text { 'Portanto' denota o uso de uma relação semântica (propósito, } \\
\text { condicional) usada na construção de um argumento no qual Vincent } \\
\text { busca afirmar que de apesar das aparências ele está mentalmente ativo. }\end{array}$ \\
\hline $\begin{array}{l}\text { Você bem sabe que, entre os } \\
\text { que se classificam como } \\
\text { pequenos mestres } \\
\text { encontram-se um Fabritius } \\
\text { ou um Bida. Agora quem é } \\
\text { absorvido por tudo isto às } \\
\text { vezes é chocante, shocking } \\
\text { para os outros, e sem querer } \\
\text { peca mais ou menos contra } \\
\text { os usos e formas e } \\
\text { conveniências sociais. (VAN } \\
\text { GOGH, 2009k, p. 1). }\end{array}$ & $\begin{array}{l}\text { É como se van Gogh se representa para o irmão, é como justificasse que } \\
\text { aquilo que em seu discurso choca a família e a sociedade são } \\
\text { decorrentes de leituras legítimas, de grandes e pequenos 'mestres'. } \\
\text { Vincent afirma para o irmão que ele não simplemente lê ou estuda, mas } \\
\text { se deixa aborver pelo autores, e ele representa este processo como algo } \\
\text { estranho aos olhos dos outros. Implicitamente Vincent parece querer } \\
\text { argumentar que sua forma de agir é decorrente de uma seriedade no seus } \\
\text { estudos e na sua arte. Uma seriedade incomum, cujas consequencias } \\
\text { choca outras pessoas. Desta forma, Vincent se representa como ator de } \\
\text { sua própria construção subjetiva e artística. Ele parece argumentar que } \\
\text { ao ler, estudar e entrar em contato com outras obras de arte, ele se deixar } \\
\text { absorver para que elas ativem seu processo de construção de uma } \\
\text { estética e de uma ética. Se deixa aborver pelos diferentes discursos, } \\
\text { olhares e produções para que elas criem aquela ambiência que os } \\
\text { quadros anteriormente produziam e que o levaram a este } \\
\text { apaixonamento. }\end{array}$ \\
\hline $\begin{array}{l}\text { No entanto, é pena que se } \\
\text { leve isto a mal. Por exemplo, } \\
\text { você sabe que } \\
\text { frequentemente eu } \\
\text { negligenciei meu asseio, eu } \\
\text { o admito, e admito que isto } \\
\text { seja shocking. Mas veja } \\
\text { bem, a penúria e a miséria } \\
\text { contribuíram de algum modo } \\
\text { para isto, e depois às vezes } \\
\text { este é um bom método para } \\
\text { garantir a solidão necessária, }\end{array}$ & $\begin{array}{l}\text { Ocorrência de Representação de eventos/atores sociais / Significado da } \\
\text { palavra. } \\
\text { Representação atores sociais > Van Gogh ( } 2009 \mathrm{k}) \text { parece se representar } \\
\text { ao irmão como ator social que está excluído: 'é pena que se leve isto a } \\
\text { mal', ele também considera que esta pobreza o leva ao mesmo tempo a } \\
\text { uma aparência chocante e a uma solidão 'produtiva'. Por um lado, Van } \\
\text { Gogh ( } 2009 \mathrm{k}) \text { considera que a interpretação de seu discurso dada pelos } \\
\text { outros seja diferente daquela que ele intencionava. No entanto, tem } \\
\text { como consequencia que sejam intensificadas estas características em sua } \\
\text { personalidade, já que a solidão o levará a estudar mais e com maior } \\
\text { intensidade. Desta forma, no discurso: 'frequentemente eu negligenciei } \\
\text { meu asseio, eu o admito, e admito que isto seja shocking', Van Gogh }\end{array}$ \\
\hline
\end{tabular}




\begin{tabular}{|c|c|}
\hline $\begin{array}{l}\text { para poder aprofundar mais } \\
\text { ou menos este ou aquele } \\
\text { estudo que nos preocupa. } \\
\text { (VAN GOGH, 2009k, p. 1). }\end{array}$ & $\begin{array}{l}\text { (2009k) revela o quanto sua identidade de isolamento para se aprofundar } \\
\text { nos estudos é intensificada e passa a ser ressignificada como exclusão } \\
\text { pela forma como se configuram suas relações sociais. Ao invés de } \\
\text { recuar e se adaptar, ele insiste em se deixar tomar por sua paixão: 'Mas } \\
\text { veja bem...'. Há uma contradição, pois ao mesmo tempo em que o } \\
\text { isolamento o leva a ser cada vez mais exclúdo, ele o aproxima de sua } \\
\text { paixão, de uma identidade afirmadora de seu eu e de sua capacidade } \\
\text { criadora. }\end{array}$ \\
\hline $\begin{array}{l}\text { Um estudo muito necessário } \\
\text { é o da medicina, não há um } \\
\text { homem que não tenha } \\
\text { desejado conhecê-la um } \\
\text { mínimo que seja, que não } \\
\text { tenha procurado saber pelo } \\
\text { menos de que se trata e, } \\
\text { veja, eu ainda não sei nada } \\
\text { disto. Mas tudo isto me } \\
\text { absorve, tudo isto me } \\
\text { preocupa, tudo isto me faz } \\
\text { sonhar, imaginar e pensar? } \\
\text { (VAN GOGH, 2009k, p. 1). }\end{array}$ & 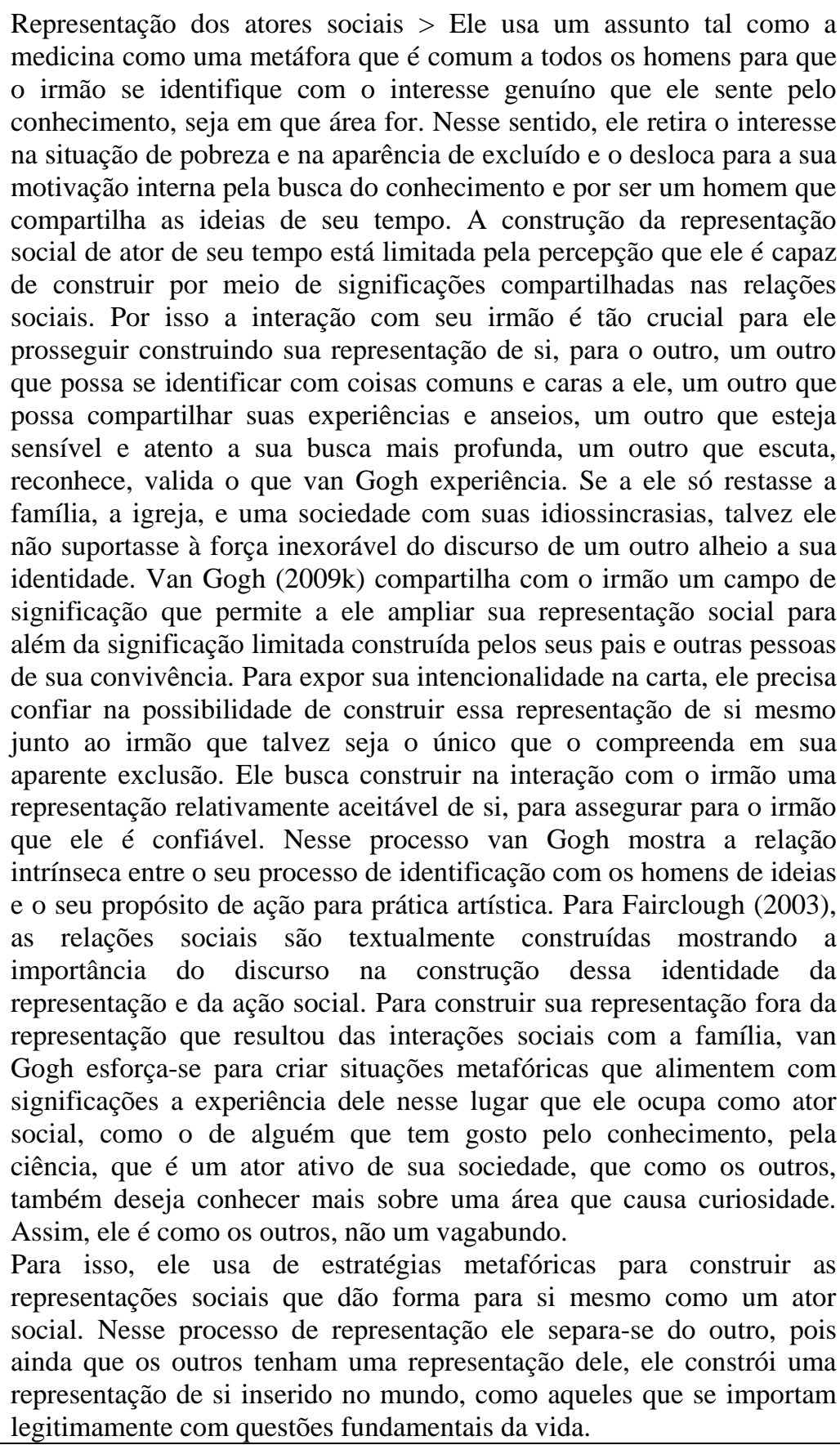 \\
\hline $\begin{array}{l}\text { "Já fazem agora talvez cinco } \\
\text { anos, não sei ao certo, que } \\
\text { vivo mais ou menos sem } \\
\text { lugar, errando aqui e ali. } \\
\text { Agora vocês dizem (...)". }\end{array}$ & $\begin{array}{l}\text { Ocorrência de interdiscursividade, intertextualidade> um discurso que é } \\
\text { tecido como um julgamento de quem Vincent se tornou, avaliando a } \\
\text { partir da forma como se veste. }\end{array}$ \\
\hline
\end{tabular}




\begin{tabular}{|c|c|}
\hline (VAN GOGH, 2009k, p. 1). & \\
\hline $\begin{array}{l}\text { "desde tal ou qual época } \\
\text { você caiu, você se apagou, } \\
\text { você não fez mais nada. Será } \\
\text { que isto é totalmente } \\
\text { verdade?" (VAN GOGH, } \\
\text { 2009k, p. 1). }\end{array}$ & $\begin{array}{l}\text { Uma pergunta hipotética, interrogativa do julgamento dos outros, mas } \\
\text { de modo a não negar definitivamente este julgamento, pois sua } \\
\text { aparência não corresponde a sua auto-percepção, às suas reflexões, à sua } \\
\text { auto-representação. Mas como fazer ver o que se passa nas suas } \\
\text { reflexões, como fazer com que os outros compreendam que, apesar de } \\
\text { sua aparência, existe um universo se construindo e formando um } \\
\text { autentico Vincent. }\end{array}$ \\
\hline $\begin{array}{l}\text { É verdade que ora ganhei } \\
\text { meu pedaço de pão, ora ele } \\
\text { me foi dado por bondade de } \\
\text { um amigo; vivi como pude, } \\
\text { nem bem nem mal, como } \\
\text { dava; é verdade que perdi a } \\
\text { confiança de muitos; é } \\
\text { verdade que minha situação } \\
\text { pecuniária está num triste } \\
\text { estado; é verdade que o } \\
\text { futuro me é bem sombrio; é } \\
\text { verdade que eu poderia ter } \\
\text { feito melhor; é verdade que } \\
\text { meus próprios estudos estão } \\
\text { num estado lamentável e } \\
\text { desesperador, e que me falta } \\
\text { mais, infinitamente mais do } \\
\text { que o que eu tenho. Mas, } \\
\text { vocês chamam isso de cair, } \\
\text { de não fazer nada? }\end{array}$ & $\begin{array}{l}\text { Ocorrência de Avaliação - afirmações avaliativas com a finalidade de } \\
\text { ponderar. Pode ser visto como Funções da fala na forma de avaliações } \\
\text { que aparecem como afirmações fatuais. }\end{array}$ \\
\hline $\begin{array}{l}\text { "Talvez você diga: mas por } \\
\text { que você não continuou } \\
\text { como gostaríamos que } \\
\text { continuasse, pelo caminho } \\
\text { da universidade?" (VAN } \\
\text { GOGH, 2009k, p. 1). }\end{array}$ & $\begin{array}{l}\text { Ocorrência de Pressuposição, Funções da fala, Intertextualidade, } \\
\text { Representação de Atores. } \\
\text { Uma suposição inicia uma processo de hibridização na estrutura } \\
\text { genérica; inicia uma suposição sobre como Theo vai responder às } \\
\text { afirmativas, justificativas e questionamentos de Vincent pode introduz o } \\
\text { agente de Theo como um ator social indireto dentro do discurso de } \\
\text { Vincent a hibridiza a retórica da carta introduzindo o subgenero de } \\
\text { interlocução no tipo de genero principal que é o de carta, e torna Theo } \\
\text { um agente indireto que presumidamente 'dialoga' com Vincent. Como } \\
\text { isso ajuda a Vincent se representar e representar Theo? } \\
\text { No trecho acima parecem se sobrepor quatro categorias: pressuposição, } \\
\text { Gênero/estrutura genérica, intertextualidade, representação de atores } \\
\text { sociais. }\end{array}$ \\
\hline $\begin{array}{l}\text { "Não responderei mais do } \\
\text { que isso: é muito caro; } \underline{\text { e }} \\
\text { ademais este futuro não seria } \\
\text { melhor do que o de agora, } \\
\text { no caminho em que estou" } \\
\text { (VAN GOGH, 2009k, p. 1). }\end{array}$ & $\begin{array}{l}\text { Ocorrência de Acional Trocas, funções da fala, modo gramatical - } \\
\text { previsões hipotéticas. } \\
\text { O uso do conectivo 'e ademais' sugere uma relação semântica aditiva - } \\
\text { relações semânticas/gramaticais entre períodos e orações. }\end{array}$ \\
\hline $\begin{array}{l}\text { "Não responderei mais do } \\
\text { que isso: é muito caro" } \\
\text { (VAN GOGH, 2009k, p. 1). }\end{array}$ & Ocorrência de Funções da fala. \\
\hline
\end{tabular}


"Mas no caminho em que estou devo continuar - se eu não fizer nada, se não estudar, se não procurar mais, então estarei perdido. Então, ai de mim" (VAN GOGH, 2009k, p. 1).
Ocorrência de acional - causa consequência - afirmação. As relações semânticas predominantes entre períodos. Há também afirmações de fato. Van Gogh parece tanto criar uma ambiência na qual ele afirma uma condição que independe da ajuda de Theo. É fato, ele irá estudar, portanto o que esperam dele não poderá acontecer, o de que ele volte seus interesses para os assuntos práticos da vida. Por outro lado, ao afirmar "ai de mim", Van Gogh (2009k) parece deixar implícito que poderá sofrer uma perda para além das perdas materiais que experienciou até o momento, e um sofrimento ainda maior do que o suportado até então.

Porque Vincent considera ser mandatório prosseguir estudando? Porque associa fazer alguma coisa útil com estudar, porque afirma que caso contrário algo terrível acontecerá? O que seria isso?O que o termo "ai de mim" significa ou oculta? Seria a perda de sua existência em si mesma? Seria a perda do sentido da sua existência? De acordo com sua biografia em especial para a pesquisadora Forrester (1983), essa falta de sentido ele já experiencia desde o seu nascimento e também experienciou em diversas buscas de inserção social em que fracassou aos olhos do pai e da família. Em sua busca de um sentido para sua existência, van Gogh procurou atuar em diferentes atividades: como comerciante de quadros, professor, pastor, missionário, e tentou estudar na universidade de Amsterdã, mas fracassou em todas essas iniciativas. Em torno do ano de 1880, mais precisamente nesta carta podemos ver que ele parece tentar explicar e convencer Theo sobre o que se passa com ele; parece estar confiante com uma determinação, estudar, seguir estudando, para que? No estudo, encontra uma via de expressão e atuação no mundo, pois estudando ele encontra seu caminho definitivo: uma linguagem com a qual ser no mundo.

Ocorrência de Significado de palavra e Estilo / Modalidade.

Ao repetir a palavra 'continuar' duas vezes, ele dá movimento e continuação a ela e a reforça para denotar sua convicção e intenção de seguir um curso de ação. A coocorrência da palavra 'continuar' pode estar indicando um contraste, pois ele supõe que os familiares não confiam mais nele no sentido de dar continuidade ao que inicia. Ele pode estar compensando uma representação que acredita fazerem dele, na qual ele seria uma pessoa que não segue em frente em seus empreendimentos como ocorreu quando foi marchand di tableau, vendedor de livros, professor, e evangelizador. Ao dizer: "continuar, continuar" ele parece afirmar que está determinado e ciente desta sua escolha de se tornar pintor (VAN GOGH, 2009k, p. 1).

Ele marca a oração iniciando com uma declaração 'Eis como eu vejo a coisa', na qual não deixa espaço para dúvidas ao anunciar. Além da ênfase na marcação "Eis como eu vejo a coisa" e da ênfase com o uso seguido da palavra 'continuar', observamos uma terceira ênfase na oração: 'isso é que é', que poderia ser enunciado como um simples 'isso é' para construir o sentido, mas que é marcado pelo 'que é' para reforçar, que continuar é uma necessidade imperiosa (VAN GOGH, 2009k, p. 1).

Com essa tripla ênfase, van Gogh busca convencer o irmão que somente ele, Vincent, sabe como deverá continuar esse processo em que ele se encontra imerso. Ao enfatizar que "continuar, continuar, isso é que é necessário" sem explicitar o que deve ser continuado, ele coloca toda a importância no processo e não na sua finalidade e se mostra inteiramente voltado para a experiência de prosseguir adiante não importa onde o caminho vai dar (VAN GOGH, 2009k, p. 1). 


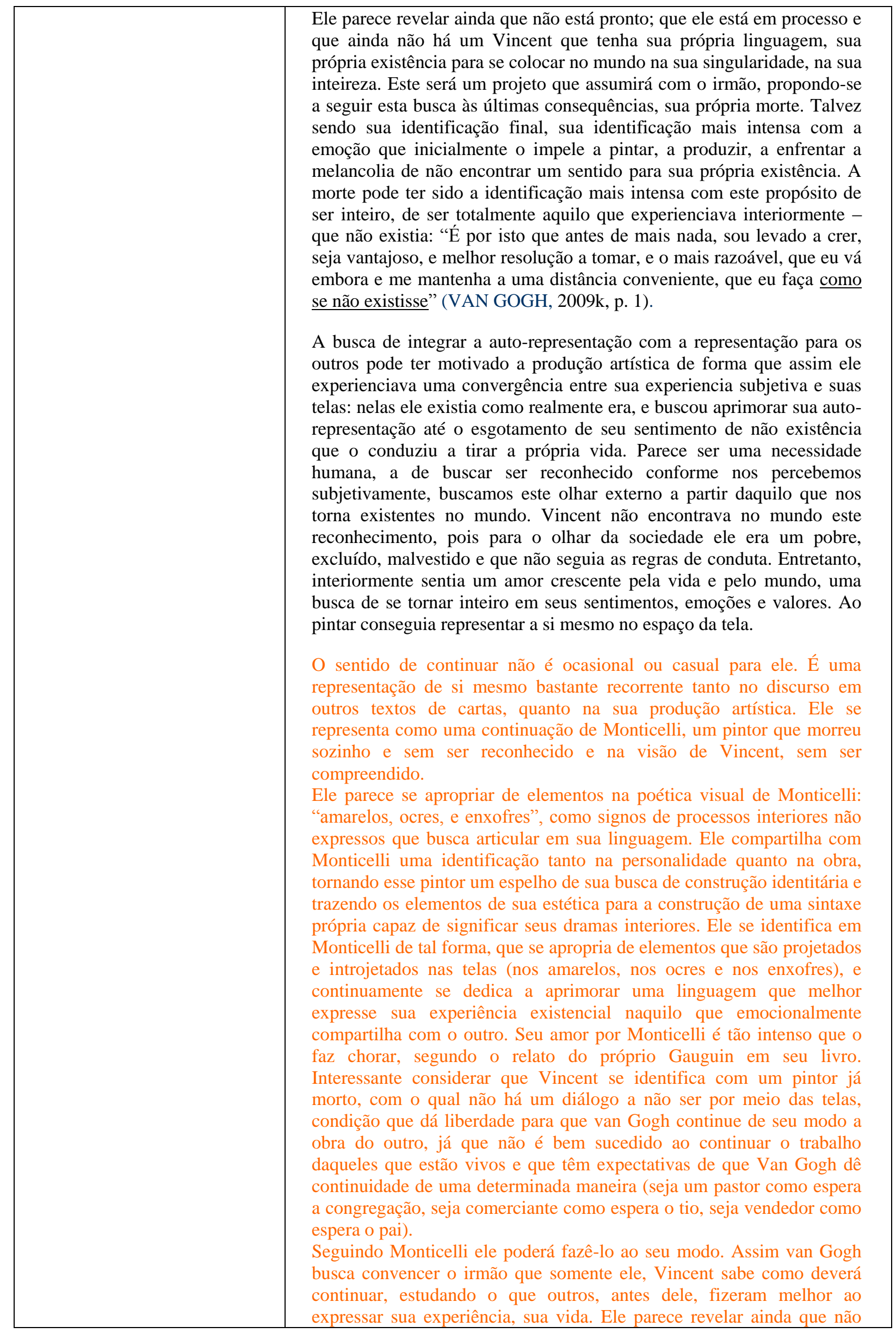




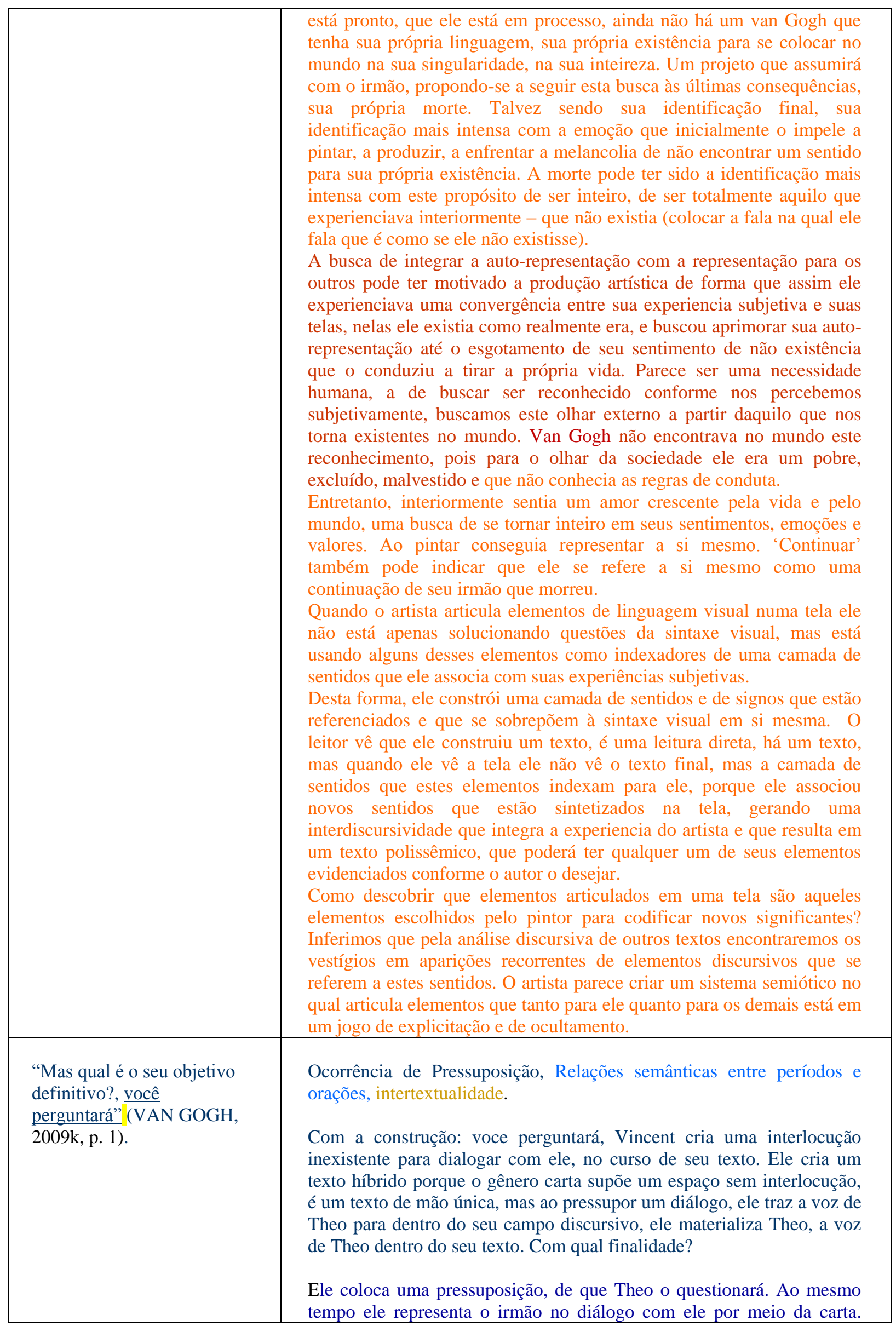




\begin{tabular}{|c|c|}
\hline & $\begin{array}{l}\text { Como outras vozes são tecidas em relação à voz do/a autor/a e em } \\
\text { relação umas com as outras? Este objetivo torna-se mais definido, } \\
\text { desenhar-se-á lenta e seguramente como o croquis que se torna esboço e } \\
\text { o esboço que se torna quadro. Ocorrência de metáfora, } \\
\text { Interdiscursividade, usando elementos da produção artística para } \\
\text { representar a si mesmo, à medida que se trabalhe mais seriamente, que } \\
\text { se aprofunde mais a idéia, no início e vaga, o primeiro pensamento } \\
\text { fugidio e passageiro, a menos que o fixemos. Vincent parece aqui } \\
\text { construir uma metáfora da própria afirmação de sua identidade, da } \\
\text { elaboração de seu sentido existencial. Há um quadro a ser feito, há uma } \\
\text { identidade a ser expressa, mas para que ela possa ser colocada na sua } \\
\text { inteireza é preciso elaborá-la, esboçá-la e finalmente pintá-la. a } \\
\text { representação de si mesmo está confundida com a representação da tela. } \\
\text { Nesta metáfora ele sugere que ele e a pintura passam pelo mesmo } \\
\text { processo de elaboração até se tornar real, até finalmente existir. Vincent } \\
\text { repetirá várias vezes em suas cartas o quanto sente como se ainda não } \\
\text { existisse. } \\
\text { A metáfora se torna real, pois à medida que Vincent pinta ele ocupa um } \\
\text { lugar no mundo, que é a tela, onde há espaço para ele existir. Este será o } \\
\text { lugar onde existirá na sua singularidade e onde encontra uma } \\
\text { possibilidade de existência que não foi possível nas relações com a } \\
\text { família e com a sociedade. De acordo com a análise de Forrester (ANO, } \\
\text { PAGINA), Vincent "não aprende a pintar, inventa a pintura", e esta } \\
\text { condição de "ter uma chama dentro de si que ninguém vem se aquecer" } \\
\text { torna-se uma melancolia que ele chama de produtiva e que o acompanha } \\
\text { em todos os momentos de sua experiência. }\end{array}$ \\
\hline $\begin{array}{l}\text { Você deve saber que entre } \\
\text { os missionários acontece o } \\
\text { mesmo que com os artistas. } \\
\text { Há uma velha escola } \\
\text { acadêmica muitas vezes } \\
\text { execrável, tirânica, a } \\
\text { abominação da desolação, } \\
\text { enfim, homens que têm uma } \\
\text { espécie de couraça, uma } \\
\text { armadura de aço de } \\
\text { preconceitos e convenções; } \\
\text { estes, quando estão à testa } \\
\text { dos negócios, dispõem dos } \\
\text { cargos e, por meios } \\
\text { indiretos, buscam manter } \\
\text { seus protegidos e excluir os } \\
\text { homens naturais. (VAN } \\
\text { GOGH, 2009k, p. 1). }\end{array}$ & $\begin{array}{l}\text { Aqui, é possível identificar duas categorias: a interdiscursividade e a } \\
\text { Representação de atores e eventos sociais. } \\
\text { Vincent parece recorrer à interdiscursividade para explicar a Theo a } \\
\text { dificuldade de se inserir no meio artístico e viver da pintura. Ele usa } \\
\text { como metáfora a instituição religiosa para explicar as instituições } \\
\text { acadêmias da arte, que segundo ele, são regidas por favoritismos, } \\
\text { 'preconceitos e convenções'. } \\
\text { Van Gogh aqui denuncia a luta de poder existente nas instituições para } \\
\text { que sejam mantidas as mesmas regras, os mesmos valores e se exclua } \\
\text { aqueles que buscarem a singularidade, a afirmação de sua diferença. A } \\
\text { forma como ele representa os eventos sociais da escola acadêmica está } \\
\text { cercado de uma luta de poder e de privilégios que excluem aqueles que } \\
\text { não se adaptam. Ao representar outros atores sociais que fizeram parte } \\
\text { de outros eventos sociais em sua experiência recente, malograda, ele } \\
\text { parece representar a causa de sua dificuldade em se inserir socialmente e } \\
\text { com isto justificar porque se encontra em situação de não- } \\
\text { pertencimento. Ele não denota auto-piedade, mas indignação com a } \\
\text { forma como o mundo está organizado, no qual o preconceito e as } \\
\text { práticas injustas e tendenciosas de protecionismo excluem e prejudicam } \\
\text { 'os homens naturais', que pode ser como ele se representa e que não } \\
\text { deixa de ser uma construção social do grupo em relação a ele, e que } \\
\text { impacta na representação que Van Gogh tem sobre como o veem, pois } \\
\text { deve ter sido frequentemente criticado por seu comportamento, sua falta } \\
\text { de postura, suas vestimentas, sendo visto como um selvagem. } \\
\text { Entretanto, não é assim que se percebe, pois ele nem ao menos se sente } \\
\text { como se estivesse existindo. }\end{array}$ \\
\hline $\begin{array}{l}\text { Seu Deus é como o deus do } \\
\text { beberrão Falstaff de } \\
\text { Shakespeare, "o interior de }\end{array}$ & $\begin{array}{l}\text { Mas há pouco a temer que algum dia sua cegueira a este respeito se } \\
\text { transforme em clarividência. } \\
\text { Ocorrência de Modalização. Van Gogh aqui parece modalizar, } \\
\text { utilizando de ironia para expressar seu desprezo, em forma de desdém }\end{array}$ \\
\hline
\end{tabular}




\begin{tabular}{|c|c|}
\hline $\begin{array}{l}\text { uma igreja", "the inside of a } \\
\text { church"; na verdade certos } \\
\text { senhores missionários (???) } \\
\text { se acham por uma estranha } \\
\text { coincidência "e talvez eles } \\
\text { próprios, se fossem capazes } \\
\text { de alguma emoção humana, } \\
\text { ficariam um pouco surpresos } \\
\text { de aí se acharem" plantados } \\
\text { no mesmo ponto de vista } \\
\text { que o beberrão típico tem } \\
\text { das coisas espirituais. }\end{array}$ & $\begin{array}{l}\text { em relação àqueles que não foram capazes de reconhecer o sua busca de } \\
\text { vínculo espiritual, praticando o desapego, a compaixão, a entrega ao } \\
\text { próximo sem nada pretender, e a identificação com aqueles que são os } \\
\text { desvalidos os pobres, os loucos, os doentes, as prostitutas, os bebados e } \\
\text { os feios. }\end{array}$ \\
\hline $\begin{array}{l}\text { "Este estado de coisas tem } \\
\text { seu lado ruim para quem não } \\
\text { está de acordo com tudo isto, } \\
\text { e que de toda sua alma, de } \\
\text { todo coração, e com toda a } \\
\text { indignação de que é capaz, } \\
\text { protesta contra isto". }\end{array}$ & $\begin{array}{l}\text { Ocorrência de Avaliação - Com que valores em termos do que é } \\
\text { desejável ou indesejável o/a autor/a se compromete? Como valores são } \\
\text { realizados como afirmações avaliativas aqui? } \\
\text { Aqui Van Gogh explicita com quais valores ele está comprometido: a } \\
\text { buscar com 'toda sua alma, seu coração' a protestar contra essa } \\
\text { exclusão. Forrester (1983) analisa que Van Gogh vive uma dupla } \\
\text { relação com esta exclusão ele não é aceito, mas gostaria de sê-lo, } \\
\text { entretanto sua conduta faz com que mais rapidamente seja excluído, } \\
\text { pois suas atitudes rudes e sua linguagem direta o levam a se excluir } \\
\text { quando todos já o querem distante. A forma como Van Gogh se } \\
\text { compromete na sua busca por afirmar seus valores é tranpassada pelo } \\
\text { seu desejo de ser incluído, de não ser abandonado, de ser amado, } \\
\text { inicialmente pelos pais e posteriormente por aqueles que cria vínculos e } \\
\text { expecativas. Todas as rejeições serão vividas como dores que nunca } \\
\text { cessam, como a rejeição por não ser o primeiro Vincent (que morreu } \\
\text { logo ao nascer), a rejeição do primeiro amor, a rejeição de Gauguin, e de } \\
\text { tantos outros, e finalmente a de Theo quando este se casa e tem o } \\
\text { primeiro filho e, ao batiza-lo de com o mesmo nome de Vincent, parece } \\
\text { substituí-lo pelo filho. Se foi inevitável para Van Gogh ter vindo ao } \\
\text { mundo para substituir um morto, sendo vivo, agora ele sucumbirá à } \\
\text { morte ao ser substituído por um outro Vincent vivo. }\end{array}$ \\
\hline $\begin{array}{l}\text { “Quanto a mim, respeito os } \\
\text { acadêmicos que não são } \\
\text { como estes; mas os } \\
\text { respeitáveis são mais raros } \\
\text { do que acreditaríamos à } \\
\text { primeira vista”. }\end{array}$ & $\begin{array}{l}\text { Van Gogh (ano) faz uma afirmação de fato, por meio de uma função } \\
\text { afirmativa da fala, cria um significado acional de julgamento a repeito } \\
\text { do grupo social da academia. Ele também representa a si mesmo como } \\
\text { um crítico desta forma de agir em relação aos atores destes eventos } \\
\text { sociais da acadêmia, da paróquia e da prática missionária. }\end{array}$ \\
\hline $\begin{array}{l}\text { Agora, uma das causas pelas } \\
\text { quais eu estou agora } \\
\text { deslocado - e por que } \\
\text { durante tantos anos estive } \\
\text { deslocado - é simplesmente } \\
\text { porque tenho idéias } \\
\text { diferentes das desses } \\
\text { senhores que dão cargos } \\
\text { àqueles que pensam como } \\
\text { eles. }\end{array}$ & $\begin{array}{l}\text { Ocorrência de Representação de eventos/atores sociais/ Relações } \\
\text { semânticas/ gramaticais entre períodos e orações/ Significado de } \\
\text { palavra. } \\
\text { Van Gogh relata os eventos sociais da academia novamente como uma } \\
\text { denúncia da causa de sua exclusão, colocando uma relação no seu } \\
\text { discurso entre a causa de estar deslocado, 'ter idéias diferentes das } \\
\text { desses senhores que dão cargo', e que tem como consequência estar } \\
\text { 'deslocado'. Ele enfatiza, repetindo duas vezes a palavra deslocado, mas } \\
\text { na segunda vez parece confirmar que se trata de uma condição do }\end{array}$ \\
\hline
\end{tabular}




\begin{tabular}{|c|c|}
\hline & $\begin{array}{l}\text { passado, embora no presente ainda esteja pobre e seja visto como um } \\
\text { vagabundo pelos pais e pela comunidade. }\end{array}$ \\
\hline $\begin{array}{l}\text { Não se trata de uma simples } \\
\text { questão de asseio, como } \\
\text { hipocritamente me } \\
\text { censuraram, é uma questão } \\
\text { mais séria que isto, posso lhe } \\
\text { garantir. } \\
\text { Por que lhe digo tudo isto? } \\
\text { Não é para me queixar, não } \\
\text { é para me desculpar naquilo } \\
\text { em que eu possa ter mais ou } \\
\text { menos errado, mas } \\
\text { simplesmente para lhe dizer } \\
\text { isto: } \\
\text { Quando de sua última visita } \\
\text { no verão passado, quando } \\
\text { nós dois passávamos perto } \\
\text { da caverna abandonada. que } \\
\text { chama de "A Feiticeira", } \\
\text { você me lembrou que houve } \\
\text { uma época em que também } \\
\text { passeávamos os dois perto } \\
\text { do velho canal e do moinho } \\
\text { de Rijswick, "e então", você } \\
\text { me dizia, "nós estávamos de } \\
\text { acordo sobre muitas coisas, } \\
\text { mas", você acrescentou, } \\
\text { "desde então mudou muito, } \\
\text { você já não é mais o } \\
\text { mesmo". Pois bem, isto não } \\
\text { é bem assim; o que mudou, é } \\
\text { que minha vida era então } \\
\text { menos difícil, e meu futuro } \\
\text { aparentemente menos } \\
\text { sombrio; mas quanto ao meu } \\
\text { intimo, quanto à minha } \\
\text { maneira de ver e de pensar, } \\
\text { nada disto mudou, e se de } \\
\text { fato houvesse alguma } \\
\text { mudança, é que agora eu } \\
\text { penso e acredito e amo mais } \\
\text { serenamente aquilo que na } \\
\text { época eu também já } \\
\text { pensava, acreditava e amava. }\end{array}$ & 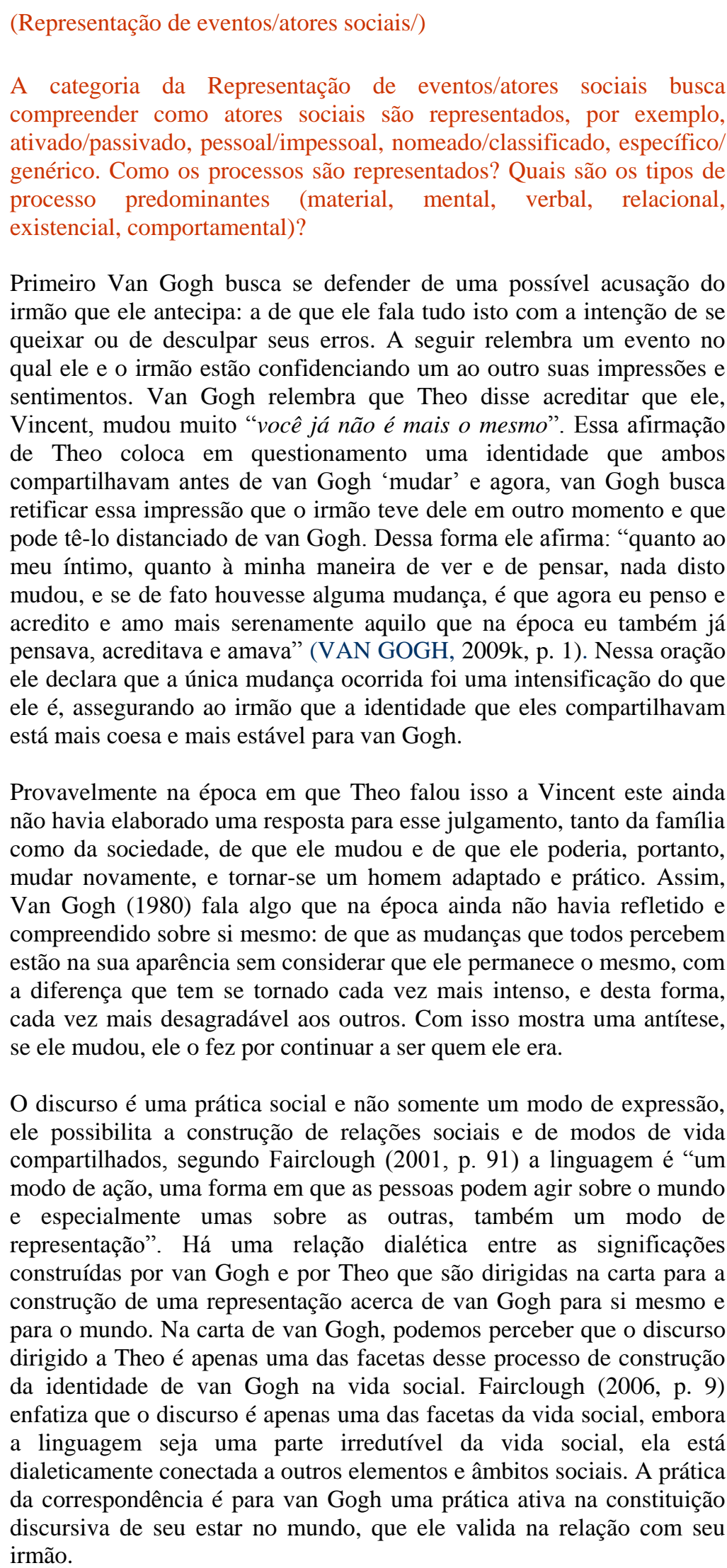 \\
\hline
\end{tabular}




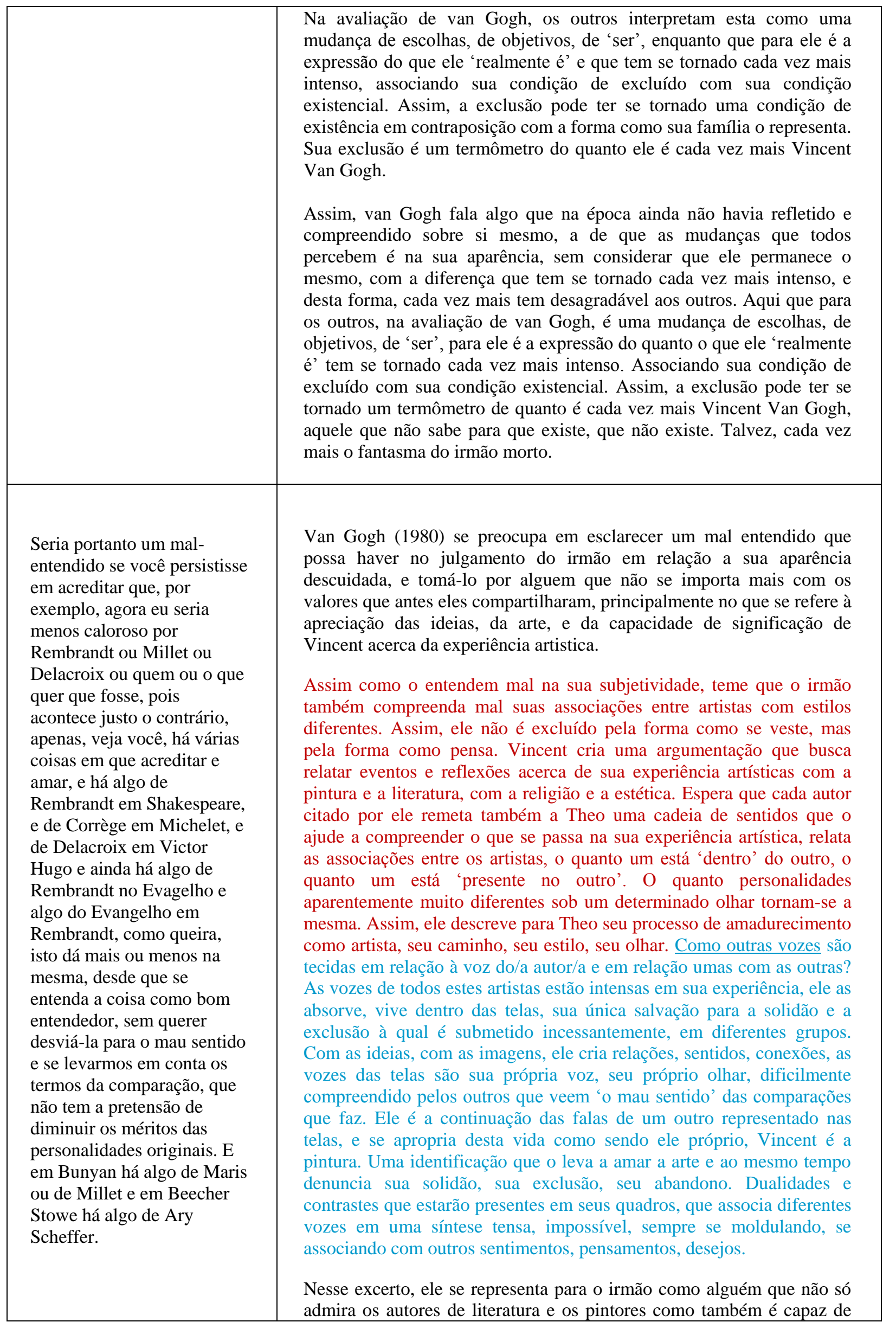




\begin{tabular}{|c|c|}
\hline & $\begin{array}{l}\text { rastrear uma genealogia de influências linguísticas que se fazem } \\
\text { presentes por meio da interdiscursividade. Dessa forma ele se auto- } \\
\text { representa como alguem que detém uma grande erudição não só na } \\
\text { literatura como na pintura, capaz de relacionar estas duas modalidades } \\
\text { pela presença sentida de um autor na obra de outro. Em um esforço para } \\
\text { construir seu lugar social no mundo van Gogh recorre àqueles com os } \\
\text { quais compartilha mais intensamente seus valores e sua identidade } \\
\text { existencial. Não social no sentido ocupado por esses autores no } \\
\text { imaginário social, mas social no sentido de reconstruir a partir deles } \\
\text { parte de sua experiência existencial de pertencimento em um grupo de } \\
\text { prática e de discurso. } \\
\text { Nesse trecho da carta, podemos inferir a materialização no discurso da } \\
\text { importância da vida social na constituição da representação do ator } \\
\text { social. A construção da identidade não se dá fora das interaçães } \\
\text { constituidas por van Gogh e para que o irmão reconheça aqueles } \\
\text { aspectos de sua identidade que não estão visíveis e passíveis de } \\
\text { interpretação pela sua aparência, van Gogh precisa explicitar para o } \\
\text { irmão o quanto o seu isolamento reflete uma rica experiência em outro } \\
\text { espaço social que é experienciado por ele a partir do mundo literário e } \\
\text { do mundo artístico. É a partir desse mundo que ele constituirá não só a } \\
\text { sua representação e a sua identidade, mas a sua prática social, fundada } \\
\text { em uma prática artística. Seu esforço será dali em diante em dar uma } \\
\text { unidade discursiva para este universo que se apresenta para ele em } \\
\text { fragmentos, de ideias e modos de expressão que ele encontra na } \\
\text { produção artística de outros atores sociais. }\end{array}$ \\
\hline $\begin{array}{l}\text { "Agora, se você pode } \\
\text { perdoar um homem que se } \\
\text { aprofunda nos quadros, } \\
\text { admita também que o amor } \\
\text { aos livros é sagrado quanto o } \\
\text { amor a Rembrandt, e } \\
\text { inclusive acredito que os } \\
\text { dois se completam" (VAN } \\
\text { GOGH, 1880, extrato da } \\
\text { carta de julho de 1880). }\end{array}$ & $\begin{array}{l}\text { Ocorrência de Avaliação - valores com os quais ele se compromete> } \\
\text { afirmações com processos mentais afetivos. }\end{array}$ \\
\hline
\end{tabular}

Fonte: VAN GOGH, 2009k, p. 1 


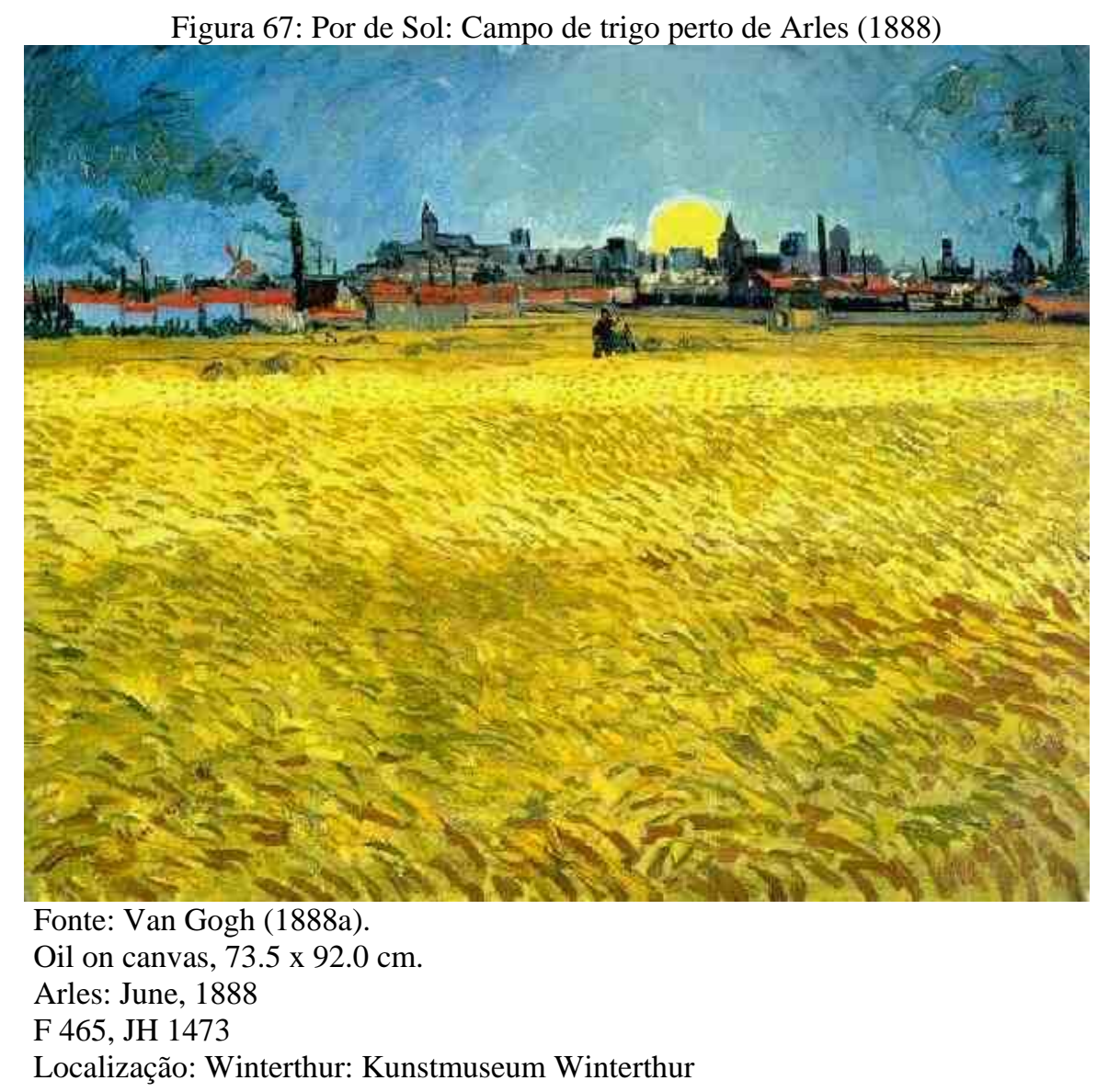

\subsubsection{Análise da Função Composicional da tela Por de Sol: Campo de trigo perto de Arles}

O campo é dividido em quatro planos dado por meio do contraste de saturação, que vai modulando as gradações de amarelos e ocres em áreas horizontais, criando no leitor a percepção de profundidade. ${ }^{354} \mathrm{Na}$ linha do horizonte vemos a silhueta dos prédios da periferia da cidade. Acima vemos o céu e o sol poente. A divisão do espaço da tela está feita em dois terços para o campo de trigo e um terço para a cidade e o céu. Essa divisão cria um efeito de sentido de que a tela, assim como seus significados, estão organizados em dois campos distintos: um que envolve o mundo do campo, do campo de trigo, o mundo rural; e o outro envolve a cidade, suas fábricas que transformam a paisagem e a atmosfera sugerindo que van

\footnotetext{
${ }^{354}$ Ocorrência de Modulação cromática no campo de trigo para construir a percepção de profundidade.
} 
Gogh quis representar a sociedade de então, e a ruptura entre a cidade e o campo que já estava em curso naquele momento da revolução industrial. ${ }^{355}$

\subsubsection{Espaço compositivo}

\subsection{Perspectiva}

Devido às modulações de cor no campo, especialmente aos contrastes de saturação dos amarelos, encontramos uma faixa de um amarelo mais intenso no meio do campo de trigo que quase separa a tela em duas, criando duas áreas pictóricas. Elas se integram por transições cromáticas dos tons de amarelo mais escuros que vão gradualmente se espalhando ao longo do campo de trigo. No entanto, essas duas áreas pictóricas são evidenciadas como distintas uma da outra pela faixa amarela mais clara e ininterrupta que divide a tela de lado a lado. Nela se encontra um homem provavelmente ocupado com a colheita do trigo. O amarelo mais intenso próximo ao homem foi, muito provavelmente, disposto aqui para dar maior saliência para a figura do homem, ou simplesmente para dar a percepção de profundidade por ser mais clara do que os amarelos no primeiro e segundo planos. ${ }^{356}$

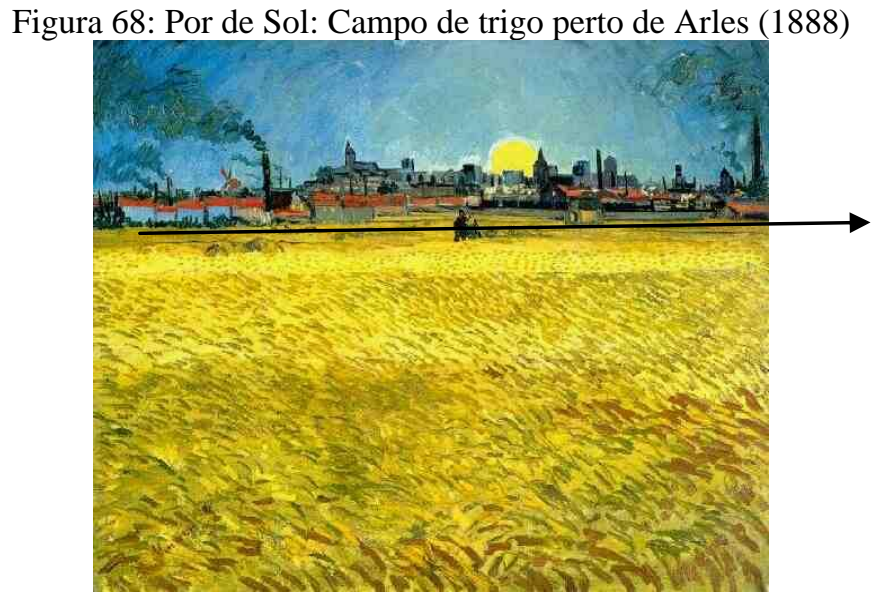

Fonte: Van Gogh (1888a).

\footnotetext{
${ }^{355}$ Ocorrência de Enquadramento, construída pela organização dos planos e pela divisão espacial da composição, com a ajuda de modulação cromática.

${ }^{356}$ Ocorrência da Perspectiva construída pela modulação, com o uso de gradação tonal de amarelos no campo de trigo, bem como com o uso de ponto de fuga. Essa ocorrência está compatível com a ocorrência de Perspectiva também encontrada no excerto de carta que descreve a cena pintada por van Gogh.
} 
A perspectiva é dada por dois pontos de fuga. O primeiro, pelo posicionamento de uma torre próxima ao sol um pouco à direita do centro da tela, e que forma com a figura humana uma linha imaginária diagonal que, a partir das sombras das espigas de trigo no campo, continua até o $1^{\circ}$ plano.

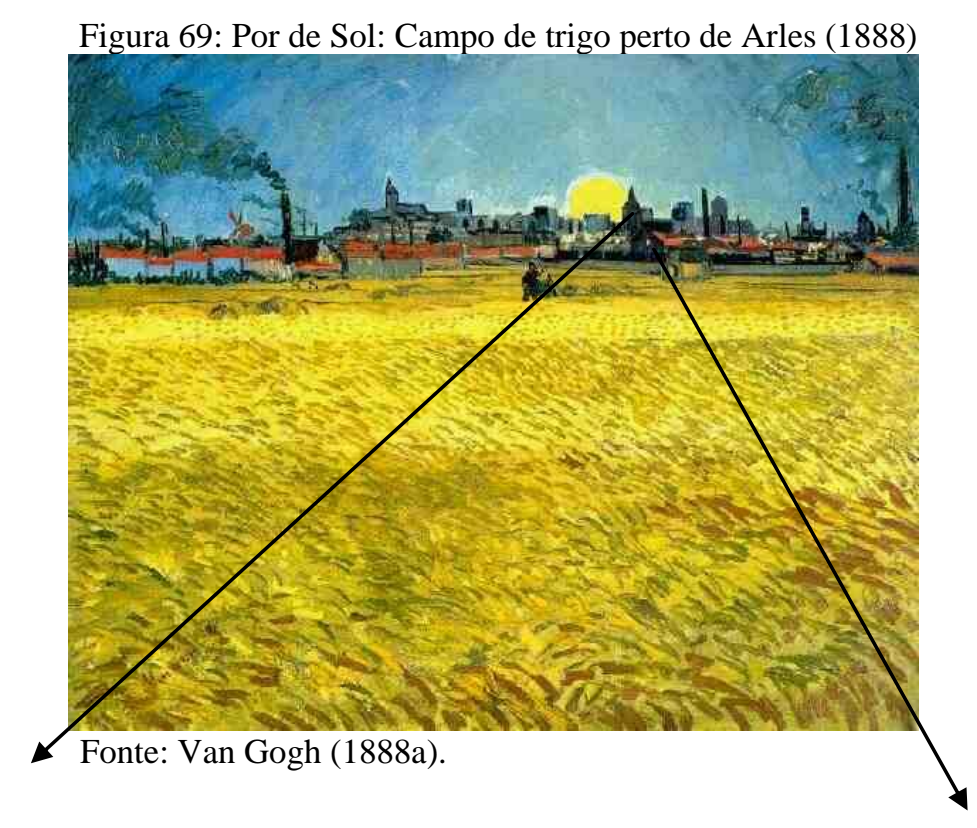

O segundo ponto de fuga é construído pelo alinhamento da chaminé mais alta à esquerda, próxima ao moinho de vento com um caminho visual feito por espigas de trigo mais escuras no trigal, que formam uma linha diagonal até esta chaminé. Saindo pelo canto inferior esquerdo vemos a faixa mais sombreada sugerir, por meio de contrastes de luz e sombra no trigal, linhas imaginárias que sugerem um ponto de fuga desde a chaminé mais ao centro, e constroem linhas de perspectiva que saem de um ponto muito próximo do espectador.

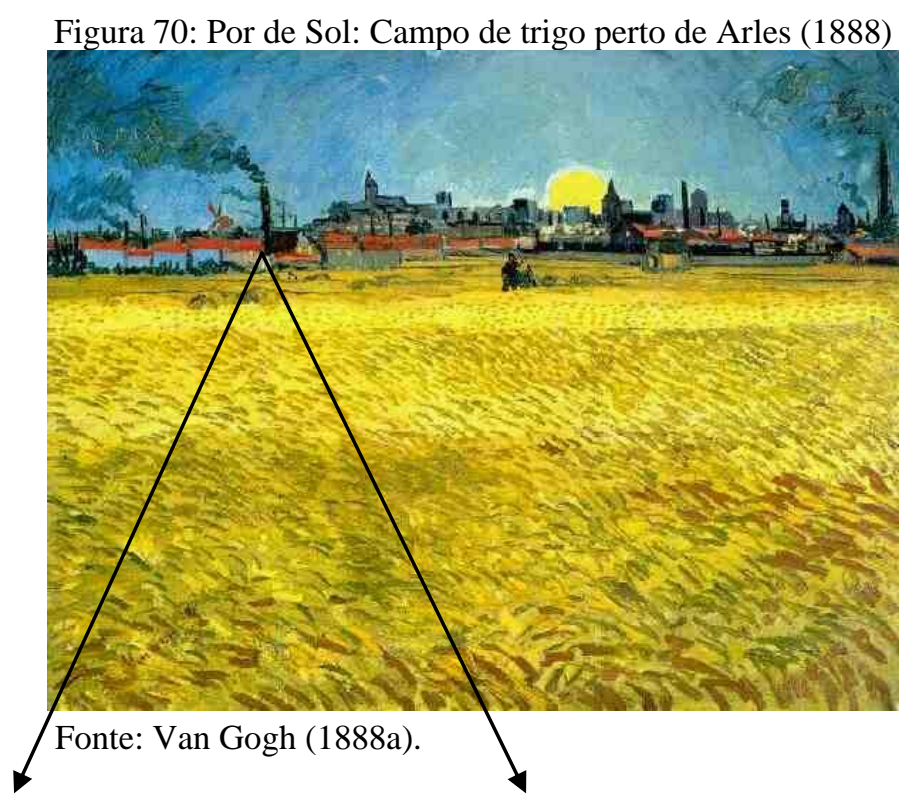


Esses caminhos visuais, resultado do jogo de sombra e luz cortando diagonalmente o trigal, criam linhas de perspectiva de dois pontos de fuga que desviam para mais longe o recuo da profundidade a partir do ponto focal óbvio no horizonte, o sol, em direção às margens da imagem e isolam um elemento mais afastado: uma segunda chaminé de fábrica à direita. $^{357}$

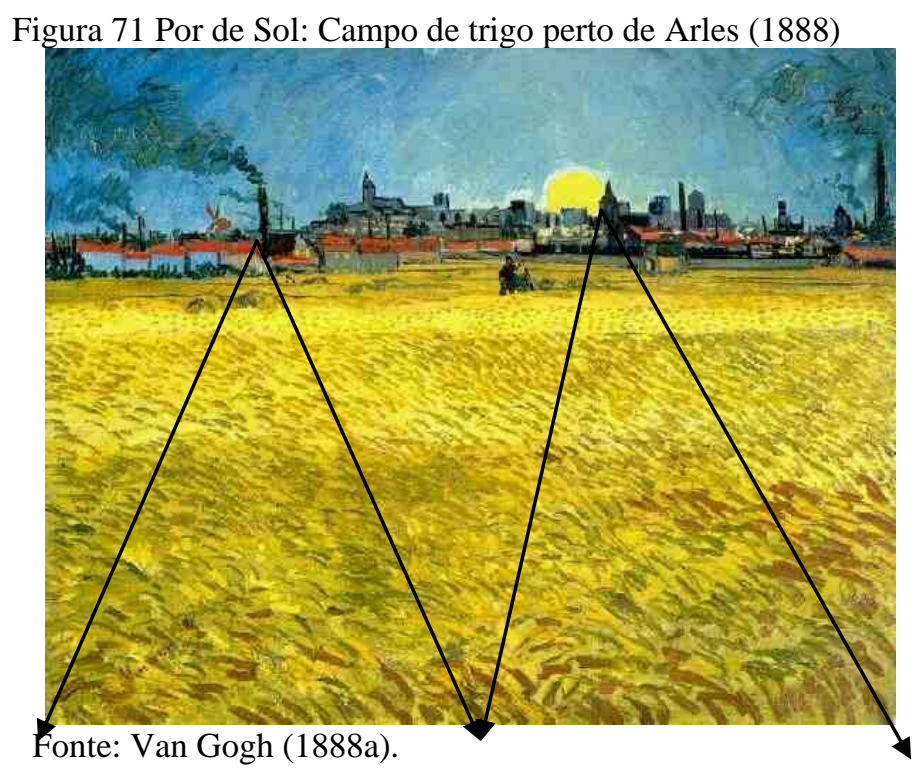

$\mathrm{Na}$ área central da tela, que fica isolada pelo desvio dos pontos de fuga, vemos o sol, a cidade e a figura pequena de um homem ao fundo, que está isolado em meio ao trigal. A estrutura espacial desta composição é similar à estrutura de um desenho chamado 'Tanques de Gás', realizado em Haia que é analisado por McQuillan ${ }^{358}$ (1989).

As linhas descritivas das espigas de trigo oferecem uma grade de perspectiva para a construção dos pontos de fugas. O campo central tem a forma de um triângulo que se inicia no plano perto do espectador e recua se inclinando no espaço central da composição produzindo o que McQuillan (1989, p. 142) descreve como uma "justaposição pictórica contraditória de convite e alienação". McQuillan (1989) analisa um desenho de composição espacial similar chamado "Gás Tanks in the Hague", feito como encomenda para o tio de Van Gogh. Ela explica que essa divisão do espaço compositivo é frequente em paisagens nos finais de 1890 e

\footnotetext{
357 Ocorrência de Perspectiva, construída por meio de dois pontos de fuga descritos acima.

${ }^{358}$ Tradução livre da autora. "In contrast with the centrally recessional space in Pawnshop, the foreground in Gas Tanks bifurcates into a heavily shaded ditch extending diagonally rightwards form the lower left corner and a much less emphatic furrow running along a wedge-like shadow, which inclines left and upwards from the middle foreground. The visual routes depart from a point very close to the spectator, but the two-point perspective deflects recession away from the obvious focal point on the horizon towards the margins of the picture, thus isolating the distant motif. Minute background figures skirt the empty lot and are themselves fenced off from the precincts of the tanks." (MCQUILLAN, 1989, p.142).
} 
constitui um dispositivo de composição que van Gogh iniciou possivelmente em seus estudos de perspectiva com o uso de um quadro de perspectiva na Hague School (MCQUILLAN, 1989). ${ }^{359}$

Schapiro (2010, p. 135) também relata o uso de dois pontos de fuga por van Gogh, em outra obra indicando que esse recurso semiótico fazia parte de seu discurso artístico:

Em sua obra posterior, esse voo para o objetivo raramente é desimpedido ou realizado; frequentemente há contra-objetivos, desvios. No desenho de um campo arado, os sulcos nos levam a um distante maciço de arbustos, informe e confuso; à direita está o vasto sol com suas linhas concêntricas irradiantes. Aqui há dois centros concorrentes ou formas centradas: uma subjetiva com o ponto de fuga, a projeção do artista não apenas como um olhar focalizador, mas também como criatura de desejo e paixão, pertencente a esse mundo; a outra mais externa, como um objeto, lateral, mas não menos carregada de sentimento. Elas se completam, como um grande desejo e sua realização; no entanto, não coincidem, e não o poderiam. Cada uma tem sua mobilidade característica: uma autocontida, mas expansiva, transbordante, irradiando suas qualidades inexauríveis; a outra, dirigida intencionalmente para um objetivo indefinido.

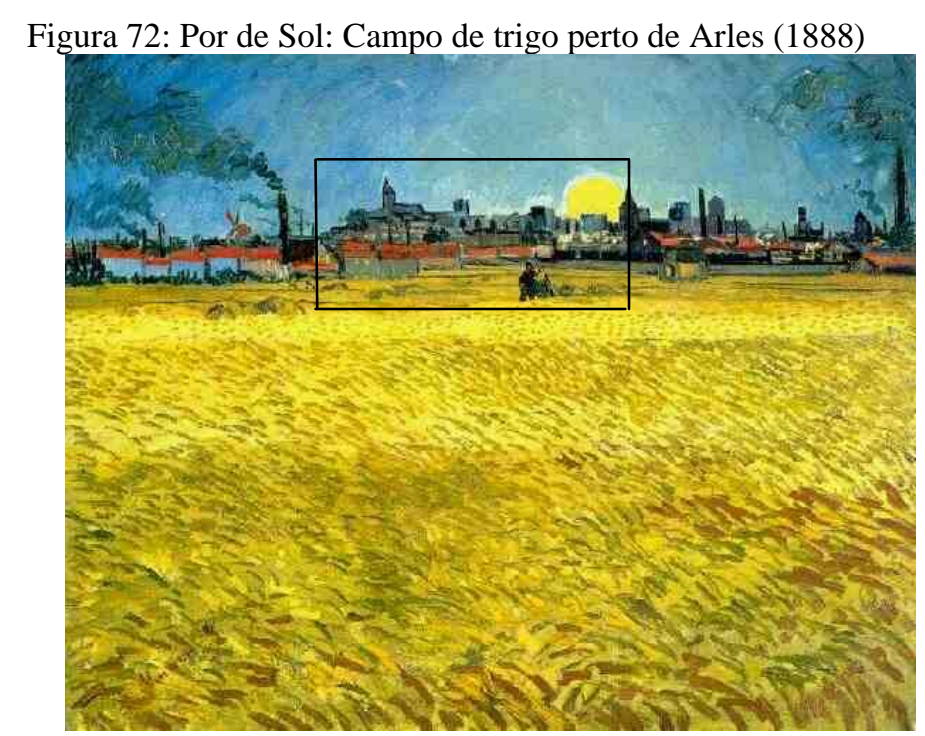

Fonte: Van Gogh (1888a).

A perspectiva se relaciona diretamente com os ângulos que o pintor selecionou para representar seu ponto de vista, e como recurso modal foi usado para construir relações de envolvimento a partir da atenção produzida no espectador e de sua identificação com o ponto de vista do pintor, como explica Schapiro (2010, p. 135):

Em outras obras, esse campo é marcado por inúmeras trilhas que levam à distância num movimento apressado. Essas linhas são os caminhos do impulso impetuoso de Van Gogh em direção ao objeto amado. Lembrem-se de como Cézanne reduziu a intensidade da perspectiva, atenuando a convergência em profundidade das linhas paralelas, fazendo os objetos sólidos retroceder do plano da pintura e trazendo para o mais perto os objetos distantes, para criar um efeito de contemplatividade no qual o

\footnotetext{
359 Aqui a Perspectiva é reforçada pelas 'linhas descritivas' construídas pelo gesto pictórico (pintura-desenho) que constroem as espigas de trigo.
} 
desejo fica suspenso. Van Gogh, num processo inverso, ativa a convergência, exagerando as extremidades no espaço, desde o enfático primeiro plano até o horizonte enormemente ampliado, com seus detalhes infinitesimais; desse modo ele confere à perspectiva sua qualidade de compulsão e pathos, como se movido pelo anseio de lograr contato com o mundo.

As duas linhas diagonais internas construídas por meio do jogo de sombra e luz que descrevem as espigas de trigo que partem destes dois pontos de fuga se encontram no primeiro plano no centro da tela e formam um triângulo invertido, cuja ponta indica o ponto desde o qual o pintor estaria observando a paisagem. Elas criam uma espécie de 'seta' de linhas imaginárias que apontam para o pintor e torna a sua presença implícita na paisagem. Elas também invertem o ponto de fuga para o ponto onde o pintor ou o espectador observa a cena.

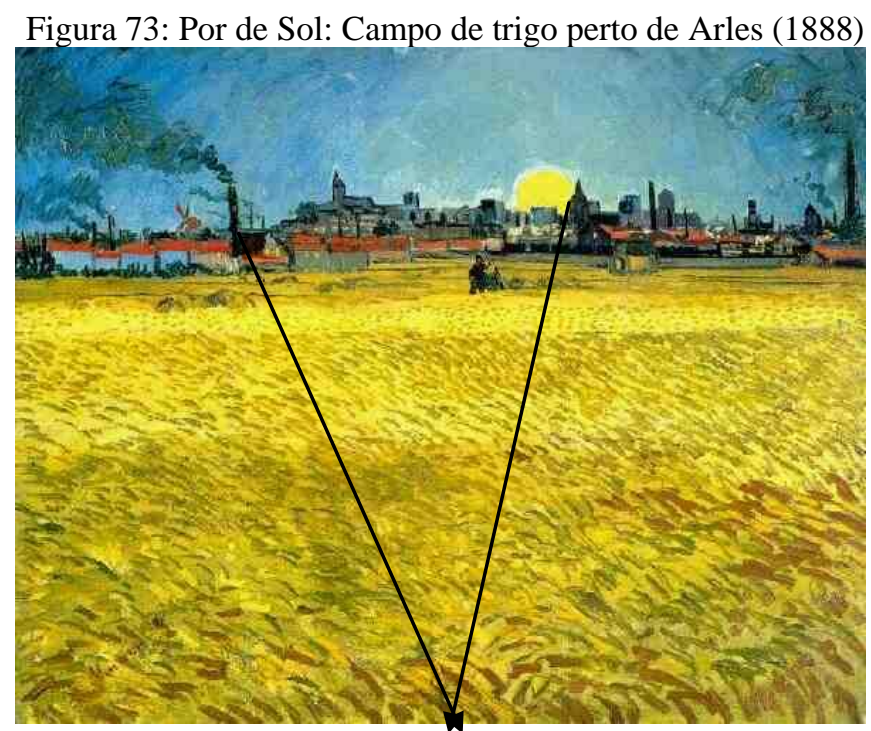

Fonte: Van Gogh (1888a).

Essa inversão que leva o ponto de fuga para o primeiro plano é um recurso semiótico que foi observado também nesta pesquisa na tela Café in the Place Lamartine in Arles (1888), no Semeador (1888) e por Schapiro (2010), ao analisar a tela Corvos sobre Campo de Trigo (1890) ilustrada abaixo: 
Figura 74: Corvos sobre Campo de Trigo (1890). Óleo (c. 50 cm x 103 cm). Auvers-sur-Oise, Julho, 1890.

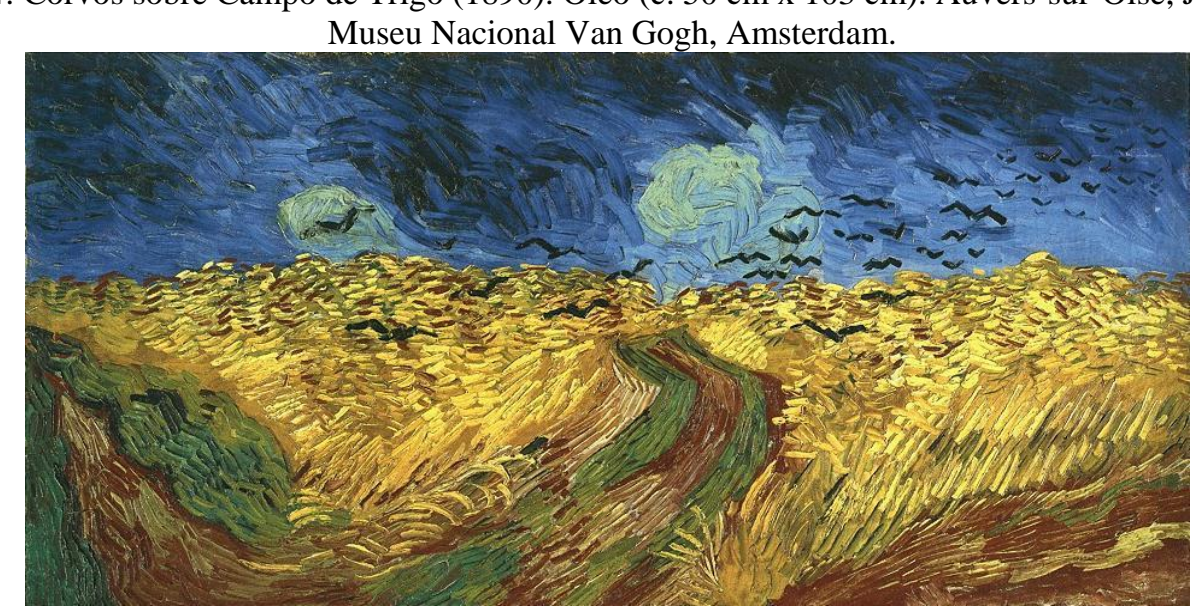

Fonte: Van Gogh (1890c)

Van Gogh também usou outro recurso visual, dando saliência para duas cadeiras no segundo plano da tela 'A Esplanada do Café na Place du Forum, Arles, à Noite' (1888) para obter o mesmo efeito que ele obteve com o uso da inversão do ponto de fuga nas telas citadas, criando uma espécie de 'seta' imaginária que aponta para o lugar do pintor para atualizar sua

presença na paisagem. $^{360}$

Observamos também na análise dos excertos das cartas uma alternância na representação de si próprio dentro da oração. Assim como na tela, ele se faz presente indiretamente por meio de recursos semióticos indexadores de sua presença, nas orações ele procurou muitas vezes o apagamento de sua presença para representar na oração apenas os assuntos da tela, dando a voz ativa para a tela e seus elementos representados, enquanto em outras orações ele se representou como o agente da ação. ${ }^{361}$

\footnotetext{
${ }^{360}$ Ocorrência de um uso original semiótico: a inversão do ponto de fuga, trazendo para o plano do espectador o foco da perspectiva e levando-o a se identificar inevitavelmente com o lugar do experienciador da tela, o artista. Este é um uso original de perspectiva para construir a distorção do ponto de vista que caracteriza uma busca estética de van Gogh.

${ }^{361}$ Ocorrência de Distorção da perspectiva pela alternância do apagamento do agente ou participante principal dentro da oração, como será documentado na análise do corpus textual.
} 
Figura 75: Por de Sol: Campo de trigo perto de Arles (1888)

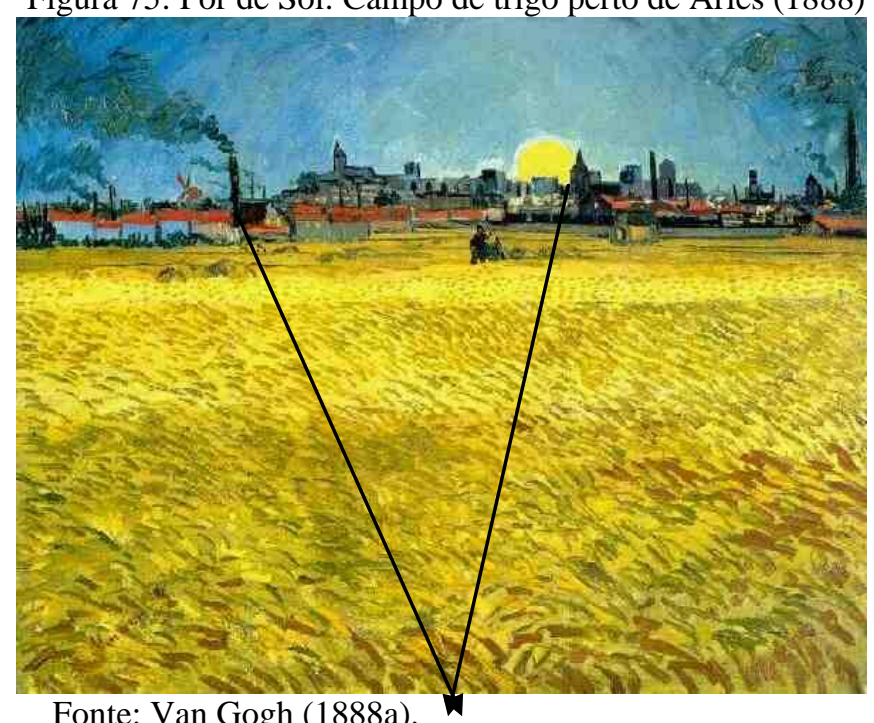

Os dois pontos de fuga formam uma grade de perspectiva de linhas diagonais que se espalham pela tela a partir destes dois pontos, na qual eles organizam a espacialidade. A estratégia de direcionamento do olhar pelo uso da perspectiva constitui um forte apelo modal para nos conduzir para dentro da tela. Portanto esta estratégia cria um envolvimento do espectador evidenciando na tela um importante papel da função Modal.

\subsection{Planos}

O campo de trigo está dividido em quatro planos com tonalidades distintas de amarelo.

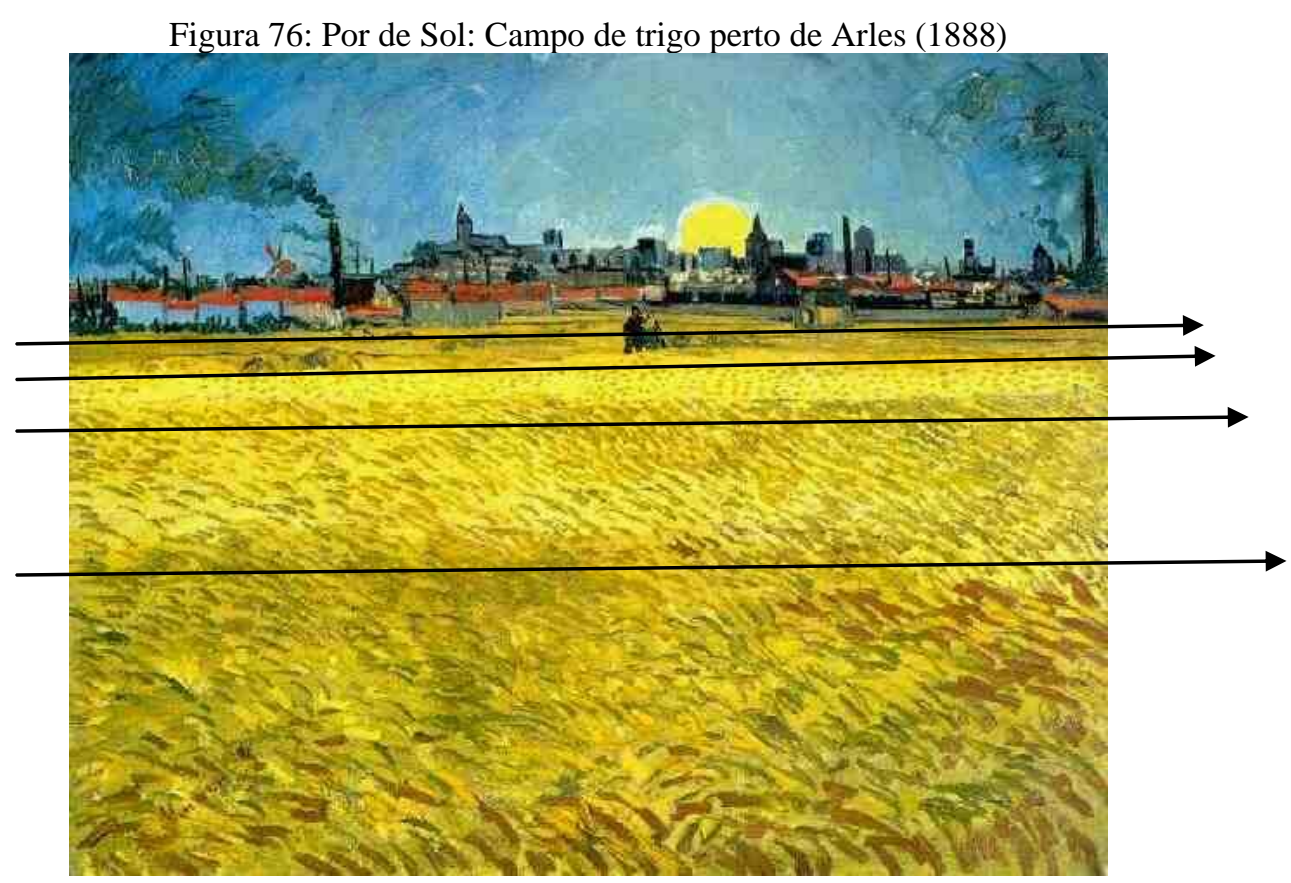

Fonte: Van Gogh (1888a). 
No espaço central da tela, as segunda e terceira faixa contendo uma tonalidade de amarelo mais claro fazem contraste com a faixa de trigo no primeiro plano que possui tonalidades mais escuras de amarelo, verde e marrons e constroem um caminho visual mais sombreado que continua diagonalmente para a direita, em tons de ocre. Tanto na faixa do primeiro plano do trigal, quanto na faixa do segundo plano, vemos duas áreas sombreadas em forma de cunha, inclinada para esquerda e para cima partindo do primeiro plano e do segundo plano médio. A forma como essas cunhas estão 'desenhadas' cria um ângulo de enquadramento plongee no qual a primeira cunha está mais vista de cima, a segunda menos, e a terceira é vista de frente. Esse recurso dá uma sensação de profundidade e de perspectiva para o espaço do campo. ${ }^{362}$

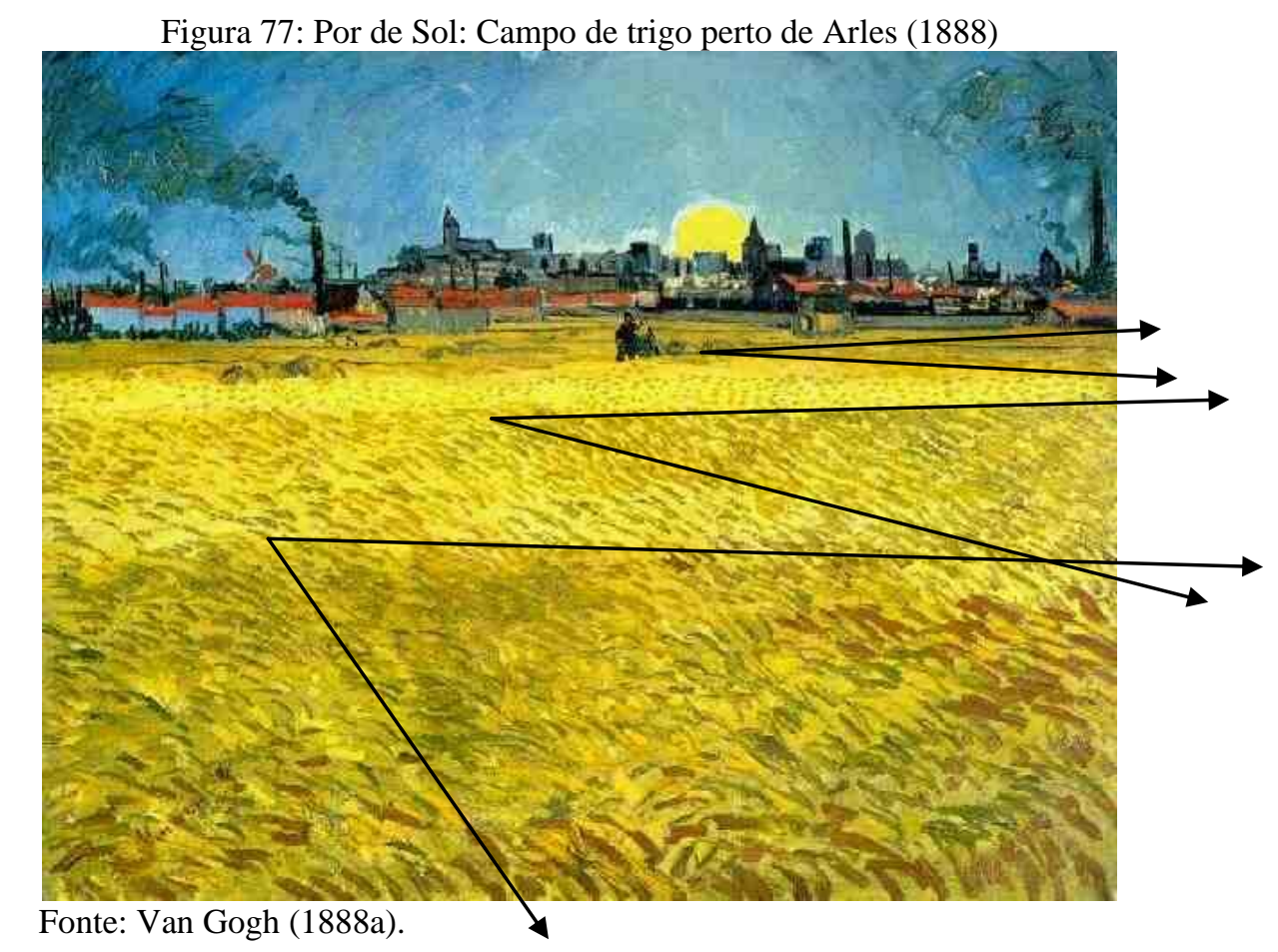

\subsection{Halo de luz em torno do sol e dos edifícios}

Como um recurso semiótico, van Gogh deixa aparecer o branco da tela para criar um fino halo branco em torno do sol e enfatizar seu brilho. No contorno do sol e no contorno no topo das edificações à esquerda, van Gogh não cobre a tela com os tons de azul, mas deixa a

\footnotetext{
362 A Perspectiva nesta tela é construída por uma combinação de recursos semióticos tais como: as cunhas, a gradação nas tonalidades de amarelo, a profundidade obtida pela gradação de contrastes de claro e escuro no céu, os pontos de fuga na distância, o enquadramento levemente plongee que além de contribuir para a construção da profundidade e da perspectiva, também contribui para a distorção do ponto de vista.
} 
tela nua, para esta funcionar como uma cor e dar ênfase na luminosidade do sol e da luz que de si emana em meio às cores do céu. ${ }^{363}$

O plano do céu é construído em um movimento direcional circular em torno do sol que cria uma ênfase para o sol como eixo desse movimento concêntrico do céu. Esse movimento concêntrico das pinceladas dá uma percepção espacial abobadada para o céu. ${ }^{364}$

O céu tem gradações de azul claro e manchas amarelas em torno do sol que produz tons de verde e vão se transformando em tons de azuis mais intensos. Estes tons de verde do céu são espelhados nos tons de verde da fumaça, fazendo uma transição interessante entre o azul do céu que se mistura ao amarelo do sol e cria um tom verde claro, e o negro da fumaça que, recebendo a luz amarela do sol, reflete um tom escuro de verde. ${ }^{365}$ Essas gradações de verdes-claro no céu e escuro na fumaça integram as cores da fumaça com as do céu, criando um maior dinamismo e uma rima visual e também os tons do céu com os da terra, onde os tons de verdes misturados aos ocres abundam causando um efeito de coesão visual no todo. ${ }^{366}$

No céu, no entanto, por sua aparição inusitada, esses tons de verde chamam atenção porque estão levemente 'exagerados' ${ }^{367}$ Por isso, eles sugerem uma metáfora de luz e sombra para o verde que ali se inscreve como mais luminoso no céu, e mais escuro e pesado na fumaça das fábricas, sugerindo uma qualidade de leveza e pureza para o que é da Natureza e de densidade e sujeira para o que é das Fábricas. O movimento circular concêntrico do céu é interrompido pelo negro das colunas de fumaça das fábricas, adicionando o sentido de intromissão que altera o equilíbrio luminoso do céu. ${ }^{368}$ Walther e Metzger (2015) comentam a interação entre a fumaça e o céu como um recurso semiótico de contraposição e sincretismo:

\begin{abstract}
A veemência com que van Gogh justapõe elementos heterogêneos equivale uma vez mais a uma nova forma de sincretismo; nuvens intermitentes de fumo saem pelas chaminés contrastando com a vasta extensão de amarelo, de forma realista mas não totalmente adequada, e as curvas irregulares conspiram para fazerem com que a superfície ofuscante de cor pareça ligeiramene ridícula. (WALTHER; METZGER, 2015, p. 352).
\end{abstract}

As colunas de fumaça também contribuem com outro movimento: linhas direcionais que reforçam o sentido do vento que sopra no trigo. Estas linhas são também descritivas do

\footnotetext{
363 Ocorrência de Saliência e de Associação metafórica, van Gogh deixa aparecer o branco da tela para criar um fino halo branco em torno do sol que pode enfatizar seu brilho e também produzir uma associação com o sentido de espiritualidade e de santidade.

${ }^{364}$ Observamos o uso de Movimento para dar ênfase para o sol.

365 Observamos o uso de Modulação cromática no céu para misturar a fumaça aos tons de azul do céu.

366 Ocorrência de Rima visual, construída por meio das gradações cromáticas no céu e que se espelham no campo de trigo integrando os dois campos da tela.

${ }^{367}$ Ocorrência de Saliência nos tons de verde que aparecem no céu para dar ênfase para as colunas de fumaça.

368 Ocorrência de Associação Metafórica do tom da fumaça das fábricas em contraposição com o tom da luminosidade do céu para conotar um conflito entre o progresso econômico e a natureza.
} 
espaço celeste, e como nuvens, estão paralelas às linhas do chão e vão se diminuindo com a distância, construindo uma maior profundidade e perspectiva espacial na cena. ${ }^{369}$

\subsection{Inacabamento}

A maior parte da tela é de cores quentes em contraste com as cores frias dos azuis usados no céu, com algumas exceções para os verdes que resultam de pinceladas de amarelo por cima das pinceladas de azuis ainda frescos na própria tela, recurso que van Gogh usava muito desde sua apropriação das técnicas pontilhistas que o liberaram de misturar as tintas na paleta para depois aplicar, pois aplicava-as puras e misturava-as direto na tela, sem se preocupar em finalizar a mistura, uma vez que o inacabamento das pinceladas seria completado na retina do espectador pela justaposição de cores. Isso demonstra que ele estava usando o pincél como se estivesse desenhando e criando efeitos como esfuminho no céu e rachuras no trigal. ${ }^{370}$

\subsection{Desenho-pintura}

A forma como van Gogh pintava constitui um sistema semiótico em si mesmo e deu novos usos para o desenho incorporando-o na forma como usava o pincel para pintar. Walther e Metzger (2015, p.357) descrevem a relação próxima entre duas modalidades distintas: o desenho e a pintura:

Os desenhos executados nesses meses podem ser estudados sob vários ângulos. Primeiro, podemos examiná-los como esboços para pinturas. Segundo, podemos observá-los à luz das obras de grande formato criadas em paralelo com os seus quadros. Terceiro, podemos refletir nas formas como Van Gogh tratou o mesmo tema tema nos quadros e nos desenhos, simultaneamente. E por último, há desenhos que constituem cópias de quadros.

Van Gogh experimentou vários recursos gráficos que ele transpôs para a pintura como novos recursos plásticos semióticos, como explicam Walther e Metzger (2015, p. 357):

A exemplo do que acontece com a maioria das obras dos artistas, a de Van Gogh
vive da influência mútua da pintura e das artes gráficas. Linha e cor são
completamente inseparáveis. A única diferença reside apenas no modo como Van
Gogh se dedicou exclusivamente aos desenhos durante semanas a fio. Desenhos
tinham constituído a forma de embarcar na vida artística; e do mesmo modo que as
pinturas tinham adaptado os motivos da sua Holanda a um ambiente tipicamente do

\footnotetext{
${ }^{369}$ Ocorrência de Profundidade construída pelo espelhamento das linhas descritivas do céu e da terra.
}

${ }^{370}$ Ocorrência de Inacabamento na forma como ele mistura as cores direto na tela. 
Sul, tentava agora aplicar a forma de representação preferida dos primeiros anos à nova situação. Até mesmo as linhas tiveram de ser ser traduzidas para o idioma oriental pelo qual se apaixonara: "Isto não parece Japonês, mas é realmente a coisa mais japonesa que já alguma vez fiz", escreveu ele a propósito da descrição de dois "grandes desenhos a pena e tinta". (Letter B10).

Nesta composição, van Gogh faz uso das pinceladas muito como se fossem linhas descritivas de desenho, rachuras, estrias, manchas grandes de claro-escuro, linhas incompletas para indicar o movimento do trigo ao sabor do vento, manchas de fumaça das chaminés bem ao modo do esfuminho a carvão ou crayon. Ele usa manchas de amarelo para a luminosidade que se depreende do sol, e a tela crua, como uma cor a mais, como já o fizera em Haia com o papel do desenho. ${ }^{371} \mathrm{O}$ uso dos recursos gráficos na pintura é pontuado por McQuillan (1989) e Walther e Metzger (2012). Haziot (2010, p.200-201) comenta:

\begin{abstract}
Vincent fez então uma pausa em pintura para se dedicar ao desenho. Livre da necessidade de calcular a todo momento as relações de tons enquanto pinta, Vincent buscará aperfeiçoar o meio de captar a verdade do motivo por traços descontínuos, cerrados ou soltos, conforme os valores. Quer progredir ainda mais na direção daquela escrita-desenho que busca há muito tempo e cujas descobertas aplicará a seguir nos seus quadros que serão no final uma escrita-pintura, como se pode ver no detalhe de um quadro célebre como $O$ campo de trigo com corvos. Nas margens do Ródano, ele encontra caniços bem melhores do que em Haia, onde havia experimentado essa técnica: corta-os e trabalha com esse instrumento primitivo. Os resultados são impressionantes. Vincent consegue agora expressar por esse meio a circulação das forças ou das ondas plásticas irradiadas por uma paisagem. Seu olho percebe as vertigens do lugar e as exprime a uma velocidade louca, com traços de caniço nervosos, de uma precisão instintiva e absoluta. É talvez aí que ele mais se aproxima da arte japonesa. (...) "Busco agora exagerar o essencial e deixar propositalmente vago o banal" escreve. (C490) E acrescenta: "As coisas daqui têm tanto estilo. E quero chegar a um desenho mais voluntário, mais exagerado." (C495) percebe-se por aí de que modo as conquistas do desenho serão a seguir transpostas na pintura, que continuará a crescer em simplicidade selvagem e em vibração da pincelada.
\end{abstract}

\title{
4.2.2 Análise da Função Modal da tela Sunset Wheat fields near Arles
}

\subsubsection{Volume}

Por meio de pinceladas rítmicas ${ }^{372}$, ele cria uma textura visual ${ }^{373}$ que dá volume e movimento ${ }^{374}$ para a plantação de trigo.

\footnotetext{
${ }^{371}$ Ocorrência do Gesto Pictórico na forma da integração de recursos gráficos com a plasticidade do pincel para construir o campo de trigo. Observamos também a ocorrência de Inacabamento construída por meio do ritmo, da textura e do movimento que articulam o gesto pictórico nas pinceladas que representam o campo de trigo.

372 Ocorrência de Ritmo na representação do campo de trigo, por meio das pinceladas ritmadas, conferida pelo gesto pictórico, pela textura e pelo movimento. O Ritmo é uma semiose presente nas quatro telas e foi considerada uma categoria de análise que é discutida no capítulo 6. Nesta tela 'Por de Sol: Campo de trigo perto de Arles', o ritmo foi usado de forma muito ampla para construir os sentidos do movimento direcional da
} 
Ele simplifica as linhas da cidade e faz um reforço seletivo dos $\operatorname{contornos}^{375}$ que permitem que a luz e a forma se integrem dando a percepção de volume e profundidade a partir de uma fonte de luz no último plano, sem precisar recorrer ao recurso do claro-escuro. A luz parece emanar a partir da imagem porque, além do campo de trigo estar infundido de luz, o tom dos prédios da cidade não é escuro como poderiam ser representados por estarem na contra-luz mas, tendo tonalidades de cinza-azulado claro e saturado indicam uma forte insolação em sua superfície, passando uma luz difusa, de contorno dissolvido das formas na distância que reforçam a percepção de profundidade na composição. ${ }^{376}$

\subsubsection{Caminhos visuais}

As pinceladas que sugerem a direção em que o vento penteia o trigal, interligadas por uma rica textura de pinceladas amarelas, ocres e verdes que infundem na paisagem ritmo e movimento, também ajudam a sugerir linhas imaginárias, caminhos visuais de uma grade de perspectiva na qual ele distribui alguns episódios e figuras e a própria cidade ao fundo.

As pinceladas criam um movimento direcional no sentido que vai do primeiro plano para o fundo, dando a sensação visual de que está ventando no trigo, não de maneira uniforme, mas com direções variáveis. Esse sentido, obtido também por meio de uma rica textura é produzido pelo efeito das pinceladas contínuas e ritmadas no mesmo sentido, porém indo em diferentes direções. Por outro lado, na fumaça produzida pelas indústrias parece haver uma constância na direção e na intensidade do vento que sopra. ${ }^{377}$

A direção das pinceladas para representar o vento no trigal é reforçada pela textura conferida pelo gesto pictórico na representação das espigas de trigo. Visualmente a textura é comunicada pelo movimento direcional da pincelada que vai da direita para a esquerda, contrariando o sentido da nossa leitura visual da tela que é da esquerda para direita. Essa

\footnotetext{
ventania, e para construir a unidade da tela pela Rima Visual.

${ }^{373}$ Ocorrência de Textura visual conferida pelo gesto das pinceladas no campo de trigo.

${ }^{374}$ Ocorrência de Movimento conferida pelo gesto pictórico no campo de trigo que, concomitantemente, produz ritmo e textura.

375 Ocorrência do Gesto pictórico, caracterizado pelo uso do grafismo para dar ênfase ao contorno das edificações no horizonte e contra a luz.

376 Ocorrência de Profundidade, obtida pelo uso da iluminação do céu que funciona como uma tonalidade saturada que confere a percepção de distância.

377 Ocorrência de Vetor ou Movimento direcional, por meio de pinceladas direcionais que produzem a sensação visual de que está ventando no trigo e criam a ação de 'ventar'.
} 
direção contrária comunica um certo desconforto visual que ajuda a construir o sentido de contrariedade e de raiva. ${ }^{378}$

É preciso ressaltar a transparência, a autenticidade com que van Gogh representou os elementos climáticos como o sol escaldante do verão da Provença e o mistral, vento incessante com o qual ele lidou ao pintar nos campos. ${ }^{379}$ Walther e Metzger (2015, p. 352353) comentam como van Gogh experienciou e representou na tela as condições da natureza:

\begin{abstract}
Van Gogh recorreu igualmente ao material que já lhe era familiar nas séries mais extensas do verão desse ano. A exemplo do que fizera no passado, seguiu de perto as colheitas, registrando o trabalho dos agricultores e o estado dos campos. Em Arles, graças ao clima, o milho amadureceu mais depressa. E a tarefa do pintor tornou-se mais difícil, já que implicava estar sob o debaixo e um Sol escaldante. Como acontecera já no norte, Van Gogh estava convencido de que tinha de aguentar qualquer clima: quer o mistral tempestuoso quer o calor seco e fatigante. $O$ pintor do plein air era tão fiel ao seu programa quanto o peintre ouvrier. Era tudo uma questão de autenticidade. A nova intensidade da cor constituía mais uma prova de que o que mais interessava era o verdadeiro, o genuíno, e tudo aquilo que provocasse um impacto direto.
\end{abstract}

A tela parece sugerir um conflito presente na forma como os elementos que deveriam se relacionar de maneira harmônica estão em todo momento se contrastando. Seja pela diferença de direções do trigo no campo, pela diferença de cores do trigo, pela diferença de espaçamento que as pinceladas ora criam um conjunto homogêneo e indiferenciado, ora ressaltam a individualidade de cada ramo de trigo. $\mathrm{Na}$ representação da cidade ocorre o mesmo, ora parece um conjunto homogêneo de casas e ora aparece um contraste entre uma casa e outra.

\title{
4.2.2.3 Diferenciação e homogeneidade
}

Essa produção de homogeneidade e diferenciação na forma como ele agrupa os elementos representados na composição pode ser uma estratégia de acentuação de sensações visuais. ${ }^{380}$ Elas são obtidas por meio da textura, ritmo, direção e volume, que fortalecem a função Modal e produzem um sentido que não é inicialmente percebido pelo leitor, mas que

\footnotetext{
${ }^{378}$ Ocorrência de Textura, movimento direcional e gesto pictórico que comunicam um sentido compatível com o sentido comunidacado na oração "em que a natureza parece estar em um acesso de raiva, em um dia de mistral desagradável."

379 Ocorrência de Transparência na forma como ele representou o campo de trigo, integrando ao gesto de pintar, a sua experiência de lutar contra a ventania e nas pinceladas rápidas e ritmadas, transportar essa experiência física e subjetiva do contato com a força do vento.

${ }^{380}$ Ocorrência de Saliência e Sinestesia, construída pelo uso combinado de textura, ritmo, movimento, direção e volume para representar o trigal.
} 
dá unidade ${ }^{381}$ para o conjunto da imagem e constrói um efeito subjetivo que torna a tela dinâmica, pulsante e com uma significação implícita do estado psicológico do autor. A contraposição entre a homogeneidade e a diferenciação das pinceladas constrói o movimento na composição. ${ }^{382}$

A estratégia de diferenciar certos elementos no campo e agrupá-los em conjuntos mais homogêneos pode ser observada em várias de suas telas de plantações, e emprestam um dinâmismo pela variação de contornos e texturas das pinceladas como explica Walther (1990, p. 68-69):

Este devotamento total à Natureza é legível também no quadro "Campo de trigo verde com ciprestes" (fig.p.66). Nele a vista é absorvida pelo verde-amarelo ondulante das espigas maduras que se espalham no centro do quadro, da esquerda para a direita, como um largo caudal. O mesmo amarelo encontra-se de novo nos telhados de colmo das casas em plano anterior, nas formações de nuvens e na configuração dos arbustos, em cima à direita. As palhinhas inclinadas e escuras em frente do campo vão apoiar o movimento fluido para a direita. A ele opõe-se um cipreste maciço, vertical, em verde-preto, apontando para o céu como uma lança uma acentuação forte de cor, meio em toda a movimentação do quadro. A seara amarela é enquadrada por áreas de cor verde a que, por outro lado, se opõe o azul claro do céu. Este contraste é suavizado pelo branco das espigas e das nuvens, de maneira a que, apesar de todo o movimento, resulte a impressão de harmonia e homogeneidade orgânica.

O autor associou os elementos de textura, cor, tom, para dar ritmo em sua composição, ao usar pinceladas que produziriam diferentes contrastes de cores e formas, dando a impressão que apesar de todo movimento há uma constância garantida pela cor do sol que está lá constantemente iluminando tudo, sendo que o elemento de inconstância é o vento que muda a tonalidade da cor no campo de trigo. Existem alguns elementos de constância e alguns elementos de inconstância. Alguns de homogeniedade e alguns de diferenciação. Essas estratégias de composição é que dão uma dinâmica particular à essa tela. Essa rica tessitura de homogeniedade e diferenciação ele cria por meio do movimento que ele imprime as pinceladas que nesta pesquisa vamos chamar de gesto pictórico. ${ }^{383}$

$\mathrm{Na}$ análise dos princípios de composição: equilíbrio, ênfase, ritmo, padrão, variedade, unidade, harmonia, contraste, movimento direcional, encontramos em evidência o uso do ritmo, da unidade, do contraste cromático de saturação, e do movimento direcional como estratégias compositivas para construir específicos efeitos de sentidos que são estruturantes da

\footnotetext{
${ }^{381}$ Ocorrência de Rima visual, conferida pelo uso concomitante de textura, ritmo, movimento, direção, volume e gesto pictórico para representar o trigal.

382 Ocorrência do Movimento, construído pela diferença de espaçamento que as pinceladas ora criam um conjunto homogêneo e indiferenciado, ora ressaltam a individualidade de cada ramo de trigo. Isso produz uma contraposição entre a homogeniedade e a diferenciação das pinceladas que constrói um sentido de alternância e de movimento.

383 Ocorrência de gesto pictórico, observado na combinação do uso do ritmo, contraste cromático de saturação, movimento direcional, para construir a rima visual.
} 
imagem e constroem a rima visual, os quais são descritos a seguir. Acredito que essa tela tem como principal estratégia a relação do ritmo entre os elementos de linguagem.

\subsubsection{Ritmo}

Esse ritmo é obtido por pinceladas que ora são regulares, ora irregulares e se repetem, ora com constância, ora com inconstância. E são produzidas em agrupamentos que são, ora homogêneos, ora diferenciados construindo um arcabouço por meio da forma, movimento, ritmo, textura e direção das pinceladas que chamamos nesta pesquisa de gesto pictórico. ${ }^{384} \mathrm{~A}$ estratégia com o uso de movimento direcional também é obtida por esses efeitos produzidos pelas pinceladas, enquanto que a unidade da tela é uma estratégia que está apoiada tanto na forma, no ritmo e na direção das pinceladas, quanto por meio de uma harmonia entre os tipos de contrastes presentes. ${ }^{385}$

\subsubsection{Contrastes cromáticos}

Identificamos contrastes de diferentes tipos: de cores (complementares; de quente-frio; de claro-escuro), de formas, de textura, de tonalidade. Porém estes contrastes estão equilibrados em sua ocorrência na tela. Nesta tela podemos falar sobre o uso da cor como recurso semiótico do pintor para nos levar para dentro da paisagem. Nesta função, falarei da cor do ponto de vista afetivo, como recurso modal, e na função representacional, mais adiante, falarei do uso da cor como recurso metafórico.

E esta nota, um pouco mais tarde: "Agora temos aqui um forte e glorioso calor, que muito me convém. Um sol, uma luz que, na falta de melhor, só posso chamar amarela, amarelo-enxofre pálido, limão pálido ouro. Como é bonito o amarelo!" C522. (HAZIOT, 2010, p. 210).

Observamos na composição o uso do contraste entre amarelos e azuis, na proporção de dois terços de amarelo para um terço de azuis, dando uma grande ênfase para o amarelo. Este é o contraste quente-frio, no qual maior saliência ${ }^{386}$ é dada para os tons quentes que ocupam a maior área da composição. Os tons quentes tem um forte apelo modal, em especial os tons de

\footnotetext{
${ }^{384}$ Ocorrência de Gesto pictórico e ritmo, observada pelo modo como ele distribui as pinceladas, com repetições regulares e irregulares para representar o campo de trigo.

${ }^{385}$ Ocorrência de movimento direcional e rima visual são conferidos pelo uso do gesto pictórico, do ritmo, da textura e do movimento no trigal.

${ }^{386}$ Ocorrência de Cor e Saliência conferida pelos contrastes quente-frio entre azuis e amarelos.
} 
amarelo que tem uma conotação expansiva e luminosa. Outras cores como branco, vermelhos, verdes e ocres são usados em quantidade bem reduzida, nos diferentes elementos da tela. Haziot (2010, p. 203-204) examina os sentidos do amarelo para van Gogh:

A paixão pelo amarelo lhe vinha dos anos de juventude e certamente da infância. Já falamos da carruagem amarela dos pais que o abandonam no internato de Provily. Quando lemos seus primeiros relatos de caminhadas, bem antes de ser pintor, notamos que ele tem um gosto intenso pelo fim do dia e pelos pores de sol que difundem os dourados, os amarelos, os alaranjados. A emoção transparece então em suas descrições, e o jovem Vincent fala de beleza. Mas tarde, em Dordrecht, viu no museu os quadros dourados de Cuyp e se maravilhou com pores de sol que despejavam um ouro líquido sobre os canais e as janelas. Sabemos que Vincent era muito friorento. Uma atração por essa cor quente e suave, assimilada à do amor, ao contrário do azul frio e do vermelho violento, atravessa toda a sua vida, ainda que fosse necessário o momento vivido e o lugar para colocá-la em cena.

O uso de contraste quente-frio, dando para a tela uma ampla extensão de tons quentes e convidativos do amarelo cria uma semióse expansiva e envolvente, e fala de um conhecimento emotivo da vida descrito Van Leeuwen (2011, p. 56):

E sobre amarelo, por exemplo? Para Goethe (1970: 307), o amarelo é 'brilhante, sereno, alegre, suavemente emocionante','quente' e 'agradável', mas passível de contaminação, por exemplo, com o verde, o que tornaria' sulfuroso ', ou em superfícies sem brilho o que tornariam 'apático' e 'ignominioso' (ibid.: 308). Para Kandinsky (1977: 37), 'amarelo, se olhado com constância... tem uma influência perturbadora, e revela na cor um caráter insistente, agressivo'. O conhecido teórico americano da cor Birren (1961: 143) diz que 'os americanos modernos' veem o amarelo como "motivador, inspirador, vital, celestial" e o relacionam com "espírito elevado" e "saúde", e a consultora de cor Lacy descreve o amarelo (1996: 20) como 'caloroso e expansivo', 'ativando a mente e abrindo-se a novas ideias', embora 'os amarelos mais escuros podem ter um efeito adverso e criar pessimismo e negativismo' e "um amarelo muito pálido pode sugar a energia'.

Do ponto de vista modal, van Gogh usou o amarelo para nos envolver emotivamente com o campo e depois, com a cena. Ele certamente usou a cor e a luminosidade dos tons mais claros de amarelo que emergem do fundo do trigal para emprestar para o campo uma vibração especial, uma atmosfera ensolarada. Com o uso magistral do amarelo, a tela nos arrasta para dentro dela, e não há recurso intelectual para isso, ele usa a linguagem da emoção. ${ }^{387}$

${ }^{387}$ Uso da cor com a função modal, para criar o envolvimento do espectador com a cena. 


\subsubsection{Análise da Função Representacional da tela Wheat fields near Arles}

\subsubsection{Uso arbitrário ou simbólico da cor}

No entanto, além do uso simbólico e subjetivo do amarelo, aqui vemos também o surgimento do uso "sugestivo da cor" que evoluirá mais tarde para o uso autônomo ou arbitrário da cor. Aqui vemos o uso simbólico da cor como explicam Walther e Metzger (2015, p. 395-396):

O amarelo é a cor do Sol: "O calor é agora glorioso e imenso, sem vento, o que me agrada. Um Sol, uma luz a que, à falta de um termo melhor, só posso chamar amarelo, um amarelo pálido sulfúreo, um amarelo limão pálido. Ah, como é belo aquele amarelo! E como vou ver agora muito melhor o Norte!" (Carta 522) O amarelo era também a cor preferida de um dos maiores modelos de Van Gogh: "Monticelli era um pintor que pintou o Sul todo em amarelo, cor de laranja e cores de enxofre. A maioria dos pintores não vê estas cores, pois não são peritos da cor." (Carta W8) Ficamos na dúvida sobre relativamente a quem considera serem os verdadeiros "peritos da cor": "Não sei se já alguém falou de cores sugestivas, mas mesmo que não tenham falado sobre elas, Delacroix e Monticelli pintaram-nas." (Carta 539) E acerca do maior deles todos tinha a dizer o seguinte: "Por que é que o maior colorista de sempre, Eugène Delacroix, considerava imperativo ir para o Sul, até África se fosse preciso? Obviamene porque lá - e não apenas em África, mas de Arles para baixo - esses contrastes encantadores do vermelho e do verde, do azul e do laranja, do amarelo sufúreo e do lilás enxofre ocorrem de forma natural" (Carta 538) Aqui Van Gogh descreve um círculo completo. A ânsia de ir para o Sul tinha a benção das autoridades supremas, Monticelli e Delacroix. Além disso, as obras dos dois artistas traziam-lhe à memória o seu próprio objetivo - "a cor sugestiva". O forte de Delacroix era o contraste e o de Monticelli o predomínio dos amarelos. Van Gogh prestou homenagem a Delacroix, ao apresentar uma perspectiva global da casa, e a Monticelli, ao registrar a sua cor. O Sol do Sul garantia as verdadeiras cores do artista. O Sul estava inundado de amarelo.

O uso do amarelo passa a comunicar uma camada de sentido pessoal e subjetivo para

van Gogh. A forma simbólica com que van Gogh usa o amarelo é comentada por Haziot (2010, p. 203):

É durante esses dias que ele pinta uma vista de Arles com uma linha de lírios em diagonal no primeiro plano e, no segundo, um campo de trigo quase maduro, "um mar amarelo", escreve a Émile Bernard. Faz um croqui na carta e observa: "Mas que motivo, hein? Esse mar amarelo com uma barra de lírios violetas e, ao fundo, a graciosa cidadezinha de belas mulheres! CB5 [...] Um mar amarelo [...] Nada diz melhor a euforia de Vincent. $\mathrm{O}$ amarelo faz sua aparição nesse quadro e na natureza morta com fundo amarelo esverdeado. Esse amarelo do trigo é também misturado de verde na Vista de Arles, cujo céu é ainda de um azul pálido, mais realista, incapaz de fazer vibrar o mar amarelo até as chamas, como ele fará mais tarde. Mas a cor do amor, segundo Vincent, está aí. Ela começará sua lenta ascenção até invadir o quadro inteiro, até se tornar tão ardente e carregada como o ouro em fusão".

As manchas de fumaça das chaminés tem um tom esverdeado, bem como as manchas de luz do sol, também tem um tom verde saturado. Esses tons de verde no céu contrapõem com os telhados das casas, e se harmonizam com os outros tons de verde no plano do trigal 
construindo coesão e rima visual por meio da distribuição das cores. O efeito de integração cromática entre o céu e o trigal que empresta uma harmonia para o todo da composição, pode ser vista como uma metáfora da integração entre céu e terra. No entanto, observamos aqui o uso arbitrário, e até mesmo simbólico da cor, e encontramos no céu as cores do trigo, que por sua vez são tingidas pelo sol que os ilumina em seus últimos reflexos, indicando uma significância de harmonia, totalidade, integração na Natureza. Cabanne (1971, p.143) comenta sobre o uso semiótico que van Gogh deu para a intensidade da cor:

\begin{abstract}
É verdade que o sol o arrancou brutalmente às suas hesitações, às suas incertezas, aos seus escrúpulos; em Arles, resplandecem a sua personalidade, o seu arrebatamento e a sua exaltação; sob o seu pincel tudo vibra, palpita, estremece; tudo flameja, até os próprios astros, e a sua alma eleva-se à medida que este fogo penetra nele. "Ainda é preciso carregar mais a cor", afirma, sempre insatisfeito, sempre pronto "a inovar", a ultrapassar-se e trabalha "mesmo ao meio-dia, à torradeira do sol, sem nenhuma sombra, nos campos de trigo".
\end{abstract}

O amarelo é usado muito mais tonalmente do que os trabalhos anteriores de Paris de van Gogh que estão limitados a uma escala de valor mais restrita. Na composição ele fez uso de uma gama mais alargada de manchas grandes de amarelo claro e amarelo escuro no trigal para organizar os espaços composicionais, a perspectiva e para criar caminhos visuais. Ainda nos trechos onde há amarelo mais escuro, ele deixa entrever um fundo de amarelo limão e muito luminoso que faz a luz emergir de dentro do trigo emprestando um efeito visual de luminescência e translucidez que sugerem que o trigo tem luz própria. ${ }^{388}$

O impacto dessa força cromática pode construir associações metafóricas sobre a força da vida, que impulsiona e que faz brotar e crescer e para o trigo como alimento e vida. Este é o trigo em seu auge e como em um mar, acariciado pelo vento, o trigo vive, em seu movimento fluido, em sua força anímica. ${ }^{389}$

\title{
4.2.3.2 Natureza
}

Nesta tela, van Gogh valoriza o campo com pinceladas que produzem uma profusão de formas irregulares, porém interconectadas por variações na inclinação e na incisão do pincel, 390 criando uma rica textura e ritmo que não deixam o campo de trigo parecer sem ação. Ao contrário, há um grande movimento de massas cromáticas que se contrapõem por contrastes,

\footnotetext{
${ }^{388}$ Ocorrência de modulação e do uso simbólico da cor, para organizar os espaços composicionais, a perspectiva e para criar caminhos visuais.

${ }^{389}$ Ocorrência de associação metafórica do amarelo com os sentidos associados à força da natureza e da vida e ao sentido de que há uma intensa vida no campo.

${ }^{390}$ Ocorrência de gesto pictórico, interconectado com a produção de textura, ritmo, movimento e vetor.
} 
ritmo e textura. Isto ajuda a construir um sentido de que há uma vida intensa no campo. Van Gogh construiu sistemas semióticos complexos para comunicar essa visão totalizante e panteísta da Natureza como uma grande categoria de sentido vivencial. Cabanne (1971, p. 144-145) descreve a forma mítica, com que van Gogh experienciava e representava a natureza:

\begin{abstract}
Em Julho anuncia a Bernard "sete estudos de campos de trigo, embora todos, contra a minha vontade, sejam apenas paisagens. Paisagens amarelo-ouro velho, feitas depressa, depressa e apressadamente como o ceifeiro que sob o sol ardente se cala, concentrando-se para cortar". Mas "trabalhar depressa não é trabalhar com menos seriedade; isso depende da firmeza e da experiência que se têm", acrescenta numa carta a Théo. E Vincent volta constantemente a isto para se explicar: "Não é a emoção, a sinceridade do sentimento perante a Natureza que nos transporta? E estas emoções são por vezes tão fortes que trabalhamos sem dar por isso, quando as pinceladas têm um seguimento e se relacionam como as palavras num discurso ou numa carta..." Perante o assunto que escolheu, esquece-se de si próprio, não é mais que uma espécie de sonâmbulo transcrevendo o choque emocional, guiado por esta tarefa; entre as suas sensações e a tela não há intermediários. Vincent não escolhe, não julga, e a sua obra é como um cadinho onde se projectam e expandem os seus estados de alma. Regressa destas sessões de trabalho fatigado, aniquilado, "absolutamente abstracto e incapaz das coisas vulgares".
\end{abstract}

\title{
4.2.3.3 Campos de trigo
}

Nesta tela $3 / 4$ do espaço composicional representam o campo de trigo que se encontra no $1^{\circ}$ plano e ao fundo a cidade e suas indústrias, no $2^{\circ}$ plano. A narrativa prioriza o campo no primeiro plano, sobre a cidade e suas indústrias representadas ao fundo. No entanto, não é só o campo que ele retrata e privilegia, tendo ao fundo uma cena urbana.

\subsubsection{Cidade x campo}

Van Gogh se dedicou a representar o imaginário do mundo rural, uma tradição que iniciou na Escola de Haia, mas 'Por de Sol: Campo de trigo perto de Arles' vai além. Ela oferece uma contraposição entre esse mesmo mundo rural e o mundo industrial. Para representar uma zona limítrofe entre o mundo rural e o mundo industrial nas bordas da cidade ele encontrou poucos trabalhos de outros artistas para basear seu estudo sobre a zona urbana vista desde o campo. Essas indústrias eram um novo assunto para suas temáticas.

Em Haia Van Gogh morou em uma área da cidade não categorizada, ou seja, não era nem cidade nem campo, nem subúrbio. Como explica McQuillan (1989, p.142-144),

Van Gogh viveu nessa zona não categorizada que não era nem cidade nem campo ou mesmo subúrbio. Como um artista que via o mundo através de uma série de 
imagens, ele aqui tentou entrar em acordo com o que ainda era visualmente não articulado. Isso ele tentou localizar nos interstícios da topografia, paisagem e confronto gráfico. A invasão da indústria desconfortavelmente se sobrepõe à natureza através de convenções visuais contraditórias e descontínuas.

Aqui, em um campo de trigo que termina onde começa a zona urbana com suas fábricas, van Gogh representa o campo e a cidade, o trabalho rural e o trabalho nas fábricas, o velho mundo, agrário, afeito à uma ordem natural, para o qual o sol está se ponto, e o novo mundo, industrial, comprometido com uma nova ordem lógica e tecnológica. A escolha do enquadramento, no qual o sol está se pondo para o campo é uma escolha que produz um sentido metafórico relacionado ao final de uma era do qual van Gogh foi uma testemunha ocular. Apesar de narrar toda a vida que há no campo, van Gogh também está falando da relação entre campo e cidade, e nessa relação, claramente, ele dá saliência para a beleza, força e vida que há no campo. ${ }^{391}$

\subsubsection{Figuras}

\subsection{O Homem}

O homem representado na composição se encontra no fundo do campo e aparenta ser um camponês próximo a um monte de trigo. Ao mesmo tempo, por estar próximo a uma área intermediária entre o campo e a cidade, ele aparece como um elemento de transição entre essas duas áreas e sugere a metáfora visual de que este homem se encontra em transição entre dois mundos, ou que, ainda que estando no campo, se encontra nas imediações do mundo industrial. ${ }^{392}$ Encontramos também essa posição em um elemento humano que faz a transição entre duas áreas também na tela 'A Esplanada do Café na Place du Forum, Arles, à Noite'.

A julgar pelos montes de trigo, ele parece estar realizando o trabalho da colheita. Pela distância, não há detalhamento, podemos vê-lo a boa distância. Kress e Van Leeuwen (1996, p. 125) argumentam que o enquadramento para a distância social denota um distanciamento entre a figura representada e o espectador:

\footnotetext{
391 Ocorrência de enquadramento que produz um sentido de associação metafórica. A escolha do enquadramento, no qual o sol está se pondo para o campo é uma escolha que produz um sentido metafórico relacionado ao final de uma era do qual van Gogh foi uma testemunha ocular.

392 Ocorrência de enquadramento e associação metafórica na posição do homem constrói um elemento de transição e sugere a metáfora de que este homem está vivendo em um mundo em transição. Observamos também a ocorrência de saliência pelo uso cromático de um tom de amarelo mais claro na área onde o homem se encontra.
} 
As distâncias que pessoas mantêm, portanto, dependem de sua relação social - não importa se este é o tipo mais permanente de relação social na qual Hall principalmente se concentra (a distinção entre íntimos, amigos, conhecidos, estranhos, etc.) ou o tipo de relação social que dura pela duração de uma interação social e é determinado pelo contexto (alguém na platéia de um discurso proferido por um conhecido ou parente estaria, no entanto, a uma distância do público, a distância do "desconhecido"). Mas essas distâncias, também, e, ao mesmo tempo, determinam o quanto da outra pessoa está em nosso campo de visão - tal como faz o enquadramento de uma pessoa em um retrato ou filme. ${ }^{393}$

O posicionamento do homem em um enquadramento amplo e distante cria um distanciamento para observa-lo não de um ponto de vista próximo e de envolvimento com os detalhes de sua atividade, mas de um ponto de vista quase abstraído de sua dimensão individual e pessoal e que pode nos remeter à uma instância mais conceptual. ${ }^{394}$

Esse distanciamento pode ajudar a colocar a figura do homem em um lugar generalizado e significá-lo como uma categoria conceitual: van Gogh não representa um camponês específico que estava na cena, ele representa uma categoria 'camponês'. Ele se refere a uma narrativa mais geral e simbólica, humana. ${ }^{395}$

\subsubsection{Membros}

\subsection{O Sol}

O sol é tão amarelo porque se está em um campo amarelo e a cor do campo intensifica na nossa retina a cor do sol, ou é o amarelo do sol que dá a cor do amarelo do campo? O uso intensificado do amarelo no campo sugere que este é uma continuação do sol e adquire as mesmas qualidades do sol. A representação da luz do sol sugere uma metáfora: o reflexo do sol mais forte está nessa faixa de amarelo mais intenso e claro porque está próximo ao homem. Isso pode conotar que a luz do Sol brilha mais para o homem que está no campo, que trabalha no campo. Se pensarmos em uma metáfora religiosa para a luz solar, análoga a luz

\footnotetext{
${ }^{393}$ Tradução livre da autora. "The distances people keep, then, depend on their social relation - whether this is the more permanent kind of social relation on which Hall mainly concentrates (the distinction between intimates, friends, acquaintances, strangers, etc.) or the kind of social relation that lasts for the duration of a social interaction and is determined by the context (someone in the audience of a speech given by an acquaintance or relative would nevertheless stay at public distance, the distance of the 'stranger'). But these distances also, and at the same time, determine how much of the other person is in our field of vision - just as does the framing of a person in a portrait or film shot." (KRESS; VAN LEEUWEN, 1996, p.125).

${ }_{394}^{394}$ Ocorrência do Enquadramento produz um distanciamento do espectador para observá-lo de forma abstraída.

${ }^{395}$ Ocorrência de Associação Metafórica conferida pelo enquadramento em plano aberto do homem que sugerem que van Gogh fala de uma categoria humana e não de um homem específico.
} 
divina, poderíamos construir um sentido de que a luz divina brilha para o homem que trabalha na terra. ${ }^{396}$

\title{
4.2.3.6.2 Moinho de vento
}

$\mathrm{Na}$ área do ponto de fuga à esquerda, próximo à torre da chaminé da fábrica há, bem mais ao longe, um minúsculo moinho de vento que discreta, mas insistentemente se contrapõem com a chaminé da fábrica, que por si representa a indústria moderna e a nova forma de energia. Por estarem ambos na área do ponto de fuga, tanto o moinho quanto a chaminé da fábrica, eles têm uma saliência e recebem a nossa atenção. Eles podem ter sido colocados justapostos para construir uma metáfora visual de contraposição; por causa da substituição dos moinhos de vento pelas chaminés de fábricas e suas novas fontes de energia que a modernidade trouxera àquele cenário urbano. ${ }^{397}$ Hobsbawm $(2014$, p. 25) comenta as mudanças irreversíveis trazidas pela revolução industrial:

Era o drama do progresso, a palavra-chave da época: maciço, iluminado, seguro de si, satisfeito, mas acima de tudo inevitável. Quase nenhum dos homens de poder e influência, em todos os acontecimentos no mundo ocidental, desejou pôr-lhe um freio. Apenas alguns pensadores e talvez um maior número de críticos intuitivos previram que esse avanço inevitável produziria um mundo bem diferente daquele para o qual aparentemente se caminhava: talvez exatamente o seu oposto. Nenhum deles - nem mesmo Marx, que havia imaginado uma revolução social em 1848 e para uma década depois - esperava um retrocesso imediato. Em meados de 1860, mesmo suas expectativas era para longo prazo.

Há um desenho que van Gogh fez em Haia para atender a uma encomenda de seu tio Cor, cuja organização do espaço compositivo dialoga imensamente com esta. Nele, van Gogh representa moinhos ao fundo, em contraposição com um cenário fabril, dos arredores de Haia.

\begin{abstract}
Apesar da prevalência do imaginário rural na pintura da Escola de Haia, van Gogh confrontou motivos urbanos em Haia. Para um desenho como Gas Tanks in The Hague, em março de 1882, ele não teve precursores na tradição de arte para seguir. Mesmo ilustrações ofereceram pouca ajuda para a construção de um imaginário da zona crua, desolada nas bordas de expansão urbana. Os tanques de gás eram um assunto novo. ${ }^{398}$ (MCQUILLAN, 1989, p. 141).
\end{abstract}

\footnotetext{
396 Ocorrência de Associação Metafórica conferida pelo uso da cor amarela que sugere que o campo de trigo é uma continuação do sol e assume as mesmas qualidades do sol. Essa associação sugere a metáfora que o sol brilha mais sobre o homem, e para o homem que está no campo. A esses sentidos são agregados sentidos religiosos.

397 Ocorrência de Saliência e de Associação Metafórica. O uso da saliência, pelo posicionamento do moinho junto à chaminé da fábrica, ambos em um dos pontos de fuga da composição, sugere uma metáfora de que o moinho está em contraposição com a fábrica e todos os significados que isso implica.

398 Tradução livre da autora. "Despite the prevalence of rural imagery in Hague School painting, van Gogh confronted urban motifs in The Hague. For a drawing like Gas Tanks in The Hague, March 1882, he had no precursors in the fine art tradition to follow. Even illustrations offered little help for constructing an imagery of the raw, desolate zone on the edges of urban expansion. The gas tanks were a new subject." (MCQUILLAN,
} 
Esta semiose compositiva foi empregada pela primeira vez por Van Gogh no desenho Gás Tanks in the Hague, em 1882, uma paisagem da periferia de Haia encomendada a ele por seu tio Cent, como aponta McQuillan (1989, p. 142): "Na grande distância, em um figurativo se não literal ponto de fuga, um moinho de vento diminuto, o elemento mais 'pitoresco', é ironicamente justaposto com os tanques de gás, elementos da moderna indústria e energia.”

Se em Haia van Gogh já havia empregado essa metáfora, na qual o moinho perde espaço simbólico para as fábricas, aqui nesta na composição, ela ganha destaque e pode confirmar o sentido do enunciado que van Gogh parece instanciar: assim como o moinho está cedendo lugar para as fábricas, o trabalho no campo está cedendo lugar para o trabalho nas fábricas. Vejamos: no aglomerado de edificações, vemos um moinho de vento vermelho, deslocado, perdido ao fundo, isolado em meio à proliferação das chaminés das fábricas e das novas fontes energéticas para mover a economia e a vida. Esta cena fala de uma perda, da perda de espaço dos moinhos para as fábricas e suas máquinas a vapor, e das perdas que se sucederam em ondas de choque num mundo em transição. O moinho se ergue solitário e diminuto, como uma testemunha das mudanças e como a presença de uma perda. Talvez este sentido reforce o tom de nostalgia da cena, na qual van Gogh representa um campo de trigo de um passado mítico. Aquele homem sentiu a perda, nós só sabemos sentir uma falta de algo que se perdeu: um sentido, um sentimento, um modo de viver, de ver, de sentir, de ser no mundo. Nós só sentimos a falta de alguma coisa que não sabemos mais sentir, porque já não sentimos a perda, nem o que foi perdido. Sentimos apenas a falta da perda, a falta do que não está mais. Por isso sentimos saudade de um tempo que não vivemos e essa saudade, essa falta é o mal do nosso tempo, e é dessa perda que van Gogh fala, é dessa saudade e dessa nostalgia que ele sente plenamente, reconhece, significa, pranteia...e se despede com o sol que se põe para esse campo, para esse homem. ${ }^{399}$

\subsubsection{Nostalgia de uma era que se acaba com a revolução industrial}

Naifeh e Smith (2012, p. 50) confirmam essa construção de sentido na narrativa:

Todos os filhos de Anna e Dorus herdaram suas nostalgias pelo passado, tanto do país quanto de suas famílias. Mas ninguém sentiu esse aguilhão agridoce com maior intensidade do que o primogênito Vincent, que depois se descreveu "enfeitiçado por fragmentos do passado". Quando adulto, devorava histórias e romances ambientados

1989, p. 141).

399 Ocorrência de Associação Metafórica pela construção de sentidos potenciais para a posição relativa do moinho junto aos outros membros na composição. 
em épocas passadas - que sempre imaginou mais puras, melhores do que a época em que vivia. Em tudo, da arquitetura à literatura, ele lamentava as virtudes perdidas de outros tempos ("os dias difíceis, mas nobres") e as insuficiências do presente insípido e "insensível”. Para Vincent, a civilização estaria sempre "em declínio" e a sociedade era invariavelmente "corrupta". "Sinto cada vez mais uma espécie de vazio", disse mais tarde, "que não consigo preencher com as coisas atuais".

Em sua obra pictórica e epistolar, van Gogh expressa os valores humanistas existencialistas, questiona os valores da Revolução Industrial, em sua dimensão social e ética, denuncia a lógica desumana do capitalismo e questiona o lugar social do artista e a massificação da arte como consequência das transformações trazidas pela Revolução Industrial. Ele testemunha o alvorecer da sociedade capitalista, na qual pessoas como ele permanecem à margem. Naifeh e Smith (2012, p. 50) falam sobre o espírito nostálgico de van Gogh:

$\mathrm{Na}$ arte, Vincent quase sempre se apresentaria como o paladino dos artistas esquecidos, dos temas arcaicos e movimentos extintos. Queixava-se da arte e dos artistas de sua época com lamúrias, explosões reacionárias e hinos melancólicos aos paraísos artísticos perdidos. Como a mãe, sentia agudamente que a felicidade era fugidia e evanescente - "a efemeridade das coisas na vida moderna" - e confiava que só a memória poderia capturá-la e conservá-la. Durante toda a vida, sempre pensava nos locais e fatos do seu próprio passado, e rememorava as alegrias perdidas com uma intensidade ilusória. Sofria de acessos de nostalgia que às vezes o paralisavam durante semanas, e revestia algumas lembranças com a força mágica de um mito. Mais tarde escreveu: "Há momentos na vida em que tudo, também dentro de nós é plena paz, e toda a nossa vida parece uma trilha pela charneca; mas nem sempre é assim".

\subsubsection{Vetores}

Os vetores em uma imagem designam o desdobramento de uma ação, realizada em geral por um ator para alguma meta ou alvo, Kress e Van Leeuwen (1996, p. 59) explicam os vetores:

De agora em diante nós iremos chamar tais padrões narrativos vetoriais - em Kress e van Leeuwen (1990) nós usamos o termo 'presentacional' - e contrastamos eles com padrões conceituais (veja a figura 2.12). Onde os padrões conceituais representam participantes em termos de sua classe, estrutura ou sentido, em outras palavras, em termos de sua essência generalizada e mais ou menos estável e atemporal, padrões narrativos servem para apresentar ações que estão se desdobrando e eventos, processos de mudança, arranjos espaciais transitórios. ${ }^{400}$

\footnotetext{
${ }^{400}$ Tradução livre da autora. "From here on we will call such vectorial patterns narrative - in Kress and van Leeuwen (1990) we used the term 'presentational' - and contrast them to conceptual patterns (see figure 2.12). Where conceptual patterns represent participants in terms of their class, structure or meaning, in other words, in terms of their generalized and more or less stable and timeless essence, narrative patterns serve to present unfolding actions and events, processes of change, transitory spatial arrangements." (KRESS; VAN LEEUWEN, 1996, p. 59).
} 
Os vetores são um conceito muito central para a triangulação das análises visuais e textuais nessa pesquisa. Kress e van Leeuwen (1996, p. 59) explicam um pouco mais sobre os vetores:

\begin{abstract}
A base de uma 'proposição' narrativa visual é a presença de um vetor: estruturas narrativas sempre tem um, estruturas conceituais nunca tem. Em imagens, esses vetores são formados por elementos representados que formam uma linha oblíqua, frequentemente uma linha diagonal, bem forte, como em "Os Britanicos usaram armas' (na figura 2.1), onde as armas e os braços esticados dos Britanicos formam uma tal linha. Os vetores podem ser formados por corpos ou ferramentas 'em ação', mas existem muitos outros jeitos de tornar elementos representados em linhas diagonais de ação. Uma estrada seguindo diagonalmente através do espaço da imagem, por exemplo, é também um vetor, e o carro dirigindo nele um 'Ator' no processo de dirigir. Em imagens abstratas tais como diagramas, processos narrativos são realizados por elementos gráficos abstratos - por exemplo, linhas com um indicador explicito de direcionalidade, usualmente a ponta de uma seta. ${ }^{401}$
\end{abstract}

A seguir descrevemos alguns vetores identificados na narrativa visual:

Pelas linhas direcionais do trigo, a ação parece estar no trigo em si mesmo, no trigo que vibra sua cor iridescente. O processo é existencial. O trigo é. Ele existe. Sua força vital é a grande ação que acontece, silenciosa, existe, vibra e está em harmonia com o todo, com a Natureza. ${ }^{402}$

A ação também está no vento que venta sobre o campo, sobre a fumaça das chaminés, sobre o mundo. As estrias descritivas do trigo fluem na mesma direção, em unissosono, e sugerem que venta, sendo este um elemento presente apesar de não ser visível. A ação do vento imprime movimento e ritmo para o trigo, e pode ser compreendida como um vetor na tela. Tanto quanto o sol ilumina; o trigo é; o vento venta..e sujeita o trigo a uma força maior, atmosférica, climática, cíclica, natural, integrando-o com a natureza, com o ambiente ao redor. Este movimento envolve todos os elementos da composição, criando uma sensação de unidade narrativa. ${ }^{403}$

A ação também está no sol que ilumina a plantação, que nutre, infunde com energia e vida. Além de iluminar, o sol se põe, lança seus últimos raios; põe fim a um ciclo. Nisso

\footnotetext{
${ }^{401}$ Tradução livre da autora. The hallmark of a narrative visual 'proposition' is the presence of a vector: narrative structures always have one, conceptual structures never do. In pictures, these vectors are formed by depicted elements that form an oblique line, often a quite strong, diagonal line, as in 'The British used guns' (in figure 2.1), where the guns and the outstretched arms of the British form such a line. The vectors may be formed by bodies or limbs or tools 'in action', but there are many other ways to turn represented elements into diagonal lines of action. A road running diagonally across the picture space, for instance, is also a vector, and the car driving on it an 'Actor' in the process of 'driving'. In abstract images such as diagrams, narrative processes are realized by abstract graphic elements - for instance, lines with an explicit indicator of directionality, usually an arrowhead. (KRESS; VAN LEEUWEN, 1996, p. 59).

${ }^{402}$ Ocorrência de Vetor 1 - pinceladas direcionais do gesto pictórico sugerem que a ação está no trigo.

${ }^{403}$ Ocorrência de Vetor 2 - pinceladas direcionais do gesto pictórico sugerem que a ação está no vento.
} 
temos a carga simbólica de uma despedida, seja de mais um dia de sua luz gloriosa sobre o campo, seja de uma era que finda. ${ }^{404}$

\begin{abstract}
Mas, ao mesmo tempo, chama a atenção para as qualidades da paisagem onde a cena se desenrola e é concebida, como um conjunto apropriadamente expressivo com o pormenor simbólico do sol-poente. Uma segunda obra muito admirada por Vincent era o quadro Chill October de Millais, paradoxalmente a primeira paisagem pura do artista. Representa a margem de um rio na Escócia, melancólica, desolada, coberta de canaviais; um crítico contemporâneo escreveu a respeito, "faz o que toda a boa paisagem deveria fazer - encarnar um sentimento e exprimir uma sensação". Foi isso que Vincent sempre procurou na arte - um sentimento, uma expressividade que fossem além do reflexivamente estético. (PETRIE, 1974, p. 8).'
\end{abstract}

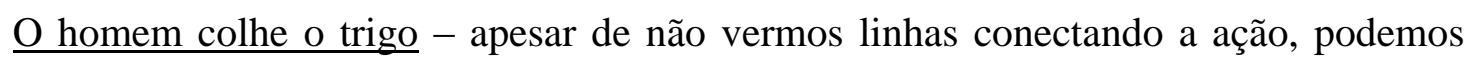
inferir esta ação, pela posição do homem e pelos montes de trigo cortado no chão, próximos a ele. A ação é do homem no campo, que colhe o trigo e van Gogh pode estar representando uma colheita literal ou figurada. Algumas linhas no fim do trigal sugerem que a colheita já foi iniciada ao fundo do campo e notamos isso por meio de um monte de trigo ao fundo, mais à esquerda. Van Gogh pode estar falando de um homem específico ou do conjunto dos homens, do campo: representados por aquele homem que colhe o trigo. Aqui vemos mais uma metáfora: a colheita. Quais são os sentidos para o trigo que é colhido? O que se colhe? O que se planta. Os sentidos podem ser construídos com a ajuda de todas as associações para colheita. Compartilhados em nossa cultura eles são aqui condensados pela associação metafórica. ${ }^{405}$

\title{
4.2.4.2 Ausência de sombras
}

Apesar de o sol estar se pondo, ele não projeta sombras sobre as edificações. No trigal ou nas edificações não há praticamente sombras, exceto no primeiro plano no trigal uma mancha esverdeada que parece ser a sombra de uma nuvem. A ausência de sombras pode ser uma metáfora visual que acompanha metáfora visual do sol, que possui um halo de luz, ao modo dos santos nas pinturas da idade média e sugere que van Gogh está simbolizando a luz divina usando o sol como metáfora, e por associação, podemos compreender a ausência de sombras diante da luz divina. ${ }^{406}$ Para construir a metáfora ele se apoia no contexto de cultura do espectador. Walther e Metzger (2015, p. 353-354) esclarecem algumas distinções entre van

\footnotetext{
${ }^{404}$ Ocorrência de Vetor 3 - pinceladas direcionais do gesto pictórico sugerem que a ação está no sol. 405 Ocorrência de Vetor 4 - pinceladas direcionais do gesto pictórico sugerem que a ação está no homem.

${ }^{406}$ Ocorrência de Associação Metafórica pela ausência de sombras na tela, que corrobora com a metáfora de luz divina para o sol, construída pelo halo de luz que remete ao sentido da divindade.
} 
Gogh e os Impressionistas sendo uma delas a luminescência que ele dava para a representação:

O pintor incluiu quase tudo o que seria de esperar numa cena de colheita: uma meda
de feno e uma quinta como enquadramento da composição, pessoas a desempenhar
tarefas específicas (a cavar, a amontoar e a transportar a colheita) e, em último
plano, um círculo de montanhas a rodear, de forma protetora, a atarefada cena. Nem
por razões topográficas Van Gogh apresentara uma visão tão alargada no seu
período holandês. Mas nessa altura talvez ainda não se tivesse apercebido dos seus
atrativos: só a visão distanciada do Impressionismo é que lhe tornou possível aceder
a esta perspectiva panorâmica. Van Gogh juntou a sua perspectiva à nova visão
panorâmica e deu os seus toques pessoais: as cores brilhantes, a sensação de que a
luz emana do interior dos motivos, a exclusão total das sombras (que só viriam
estragar a impressão geral causada).

Os contornos da cidade parecem estar enquadrados pelo halo de luz que emana do sol e são iluminados com o seu brilho. Dessa forma, significativamente, as formas arquitetônicas mais geométricas parecem envoltas e suavizadas pela forma natural da luz do sol. Apesar de estar no plano de fundo, o sol empresta leveza e ênfase para os edifícios com uma maior saturação da iluminação, dando-lhe um lugar de importância na cena. Enquanto se incluem dentro da natureza, os contornos da cidade se distinguem e se integram nela. A cidade também está envolta na luz que o sol irradia. Não há dicotomia entre o campo e a cidade, porque a luz do sol, ou seja, a luz divina a tudo envolve. O sol tem uma auréola que pode ser associada à representação da experiência espiritual dos santos na arte medieval. A luz pode ser associada às conotações como força, vida, espírito e as dimensões intangíveis da existência, mais difíceis de explicitar na narrativa visual, senão com a ajuda de metáforas visuais. $^{407}$

Apesar de terem pinceladas descritivas das espigas do trigo no primeiro plano, o valor mais intenso do amarelo, cromaticamente falando, está no segundo plano como que para levar a ênfase para aquela área no meio da tela. ${ }^{408}$ Isso ocorre, possivelmente por estar próxima da uma figura humana, que pela distância e por estar contra a luz do sol que se põe, não é possível identificar o rosto. O anonimato das figuras que compõem as paisagens nas telas de van Gogh é recorrente e empresta a elas uma instância universal. O anonimato da figura sugere que ele não está registrando uma cena específica com uma figura específica, mas representando por meio dela um conceito, um estatuto. Ao representar esse homem, ele fala de qualquer homem e de todos os homens do campo...ele fala de um conjunto humano representado nesse homem que dá as costas para a cidade e está de frente para o campo de

\footnotetext{
${ }^{407}$ Ocorrência de Rima visual que, por meio do uso da cor para representar a luz do sol sobre a cidade e o campo, constroem uma associação metafórica da luz divina que tudo interliga.

${ }^{408}$ Ocorrência de Saliência pelo uso da ênfase cromática de amarelo mais intenso junto à figura do homem.
} 
trigo e de frente para o pintor que o observa e o representa. ${ }^{409}$ Está implícito o reconhecimento mútuo entre ambos que trás para dentro da cena a presença do pintor.

\title{
4.2.4.3 A valorização do Campo
}

O ponto de vista com o qual o autor representa esta paisagem parece glorificar a vida no campo e criar um certo contraste deste com a vida na cidade, cercada por indústrias nascentes. A paisagem parece bucólica, se não fossem as fumaças enegrecidas das fábricas que se confundem com um céu escuro de uma noite que se inicia. Nesse contraste, parece ao observador da tela, que o pintor estaria situando o campo como o espaço mais importante na medida em que o representa no primeiro plano com articulação de diversos recursos pictóricos para dar a ele saliência e rima visual e na medida em que se coloca neste campo para olhar de longe e à distância o progresso urbano. ${ }^{410}$

O enquadramento distanciado do homem do campo, e da cidade, também revela uma escolha de van Gogh na construção do significado da cena: o distanciamento social com que o espectador irá observar o homem e a cidade, confirmando um ponto de vista mais reflexivo para se observar o homem e a cidade, enquanto está mais próximo do campo que foi representado de forma a criar o envolvimento emocional. ${ }^{411}$

Kress e Van Leeuwen (1996, p. 125) defendem o significado semiótico para a distância entre as figuras e o espectador:

\begin{abstract}
As distâncias que pessoas mantêm, portanto, dependem de sua relação social - se este é o tipo mais permanente de relação social na qual Hall principalmente se concentra (a distinção entre íntimos, amigos, conhecidos, estranhos, etc.) ou o tipo de relação social que dura para a duração de uma interação social e é determinado pelo contexto (alguém na platéia de um discurso proferido por um conhecido ou parente seria, no entanto, ficar a uma distância do público, a distância do "estrangeiro"). Mas essas distâncias, também, e, ao mesmo tempo, determinar o quanto da outra pessoa está em nosso campo de visão - tal como faz o enquadramento de uma pessoa em um retrato ou filme. ${ }^{412}$
\end{abstract}

\footnotetext{
${ }^{409}$ Ocorrência de Associação Metafórica pela caracterização anônima do homem, construída com a ausência de detalhamento, e por estar contra o sol, mostrando apenas sua silhueta.

${ }^{410}$ Ocorrência de Enquadramento, pela escolha do ponto de vista que privilegia a representação do campo sobre a cidade e com isso, constrói uma relação que realça o valor do campo. Observamos também a ocorrência de Saliência e Associação metafórica por meio do enquadramento que aproxima o campo e distancia a cidade.

${ }^{411}$ Ocorrência de Enquadramento que distancia o homem e a cidade tornando essa visão mais reflexiva, e aproxima o campo tornando essa relação de proximidade e envolvimento.

412 The distances people keep, then, depend on their social relation - whether this is the more permanent kind of social relation on which Hall mainly concentrates (the distinction between intimates, friends, acquaintances, strangers, etc.) or the kind of social relation that lasts for the duration of a social interaction and is determined by the context (someone in the audience of a speech given by an acquaintance or relative would nevertheless stay at public distance, the distance of the 'stranger'). But these distances also, and at the same time, determine how much of the other person is in our field of vision - just as does the framing of a person in a portrait or film shot.
} 
Sobre o enquadramento da cena, observamos ainda outra semiose. O lugar de onde van Gogh pinta parece estar alçado no ar, alguns metros acima do chão como se olhasse desde um ponto de vista de quem está no ar e vê ligeiramente do alto a paisagem, como no enquadramento plongee. Essa sensação é passada pelo ângulo com o qual ele representou o trigo, porque o vemos desde o alto e não desde quem está o vendo do solo. ${ }^{413}$ Que sentido haveria nessa forma de representar a paisagem? Talvez o sentido de criar um estranhamento em quem observa sua tela, e que aponta para o lugar desde onde o autor se encontra e que não é um lugar real, pisando no chão, mas um lugar imaginário. Esse lugar parece estar ressaltado de uma forma implícita e conduz o leitor a sentir sua presença dentro da paisagem, justamente pela dificuldade em se identificar e se envolver completamente com esse lugar que não é natural e nem real. Mesmo que a presença do autor não esteja explicitada, ou diretamente representada, o estranhamento causado pelo ponto de vista com o qual ele representa e ao representar, olha para o campo de trigo, nos leva a nos perguntar onde ele estaria? No alto de uma arvore? Em cima de um monte de feno? Em um declive? Esta informação não está evidente, mas o estranhamento nos leva a procurar sinais que mostrem o lugar de onde ele se posicionou para pintar e essas indagações nos levam a trazê-lo de forma indireta para dentro da nossa preocupação em compreender a tela e devolvem de forma indireta a sua presença dentro da cena. Muhlberger (2002, p. 22) oferece uma resposta para essas perguntas:

Van Gogh achava os campos de La Crau "tão belos e infinitos quanto o mar".
Queria memorizar o terreno, pois tinha em mente algo especial. Não queria pintá-lo
no nível do chão, pois isso o impediria de mostrar que os campos pareciam
estender-se sem limites. Queria a mesma sensação e infinidade captada nas vastas
paisagens pintadas por seu conterrâneo do século XVII Jacob van Ruisdael. Nos
quadros de van Ruisdael, as cenas eram vistas do alto. Depois de estudar o terreno
no nível do chão, van Gogh o imaginou a partir de um ponto de vista alto e o pintou
desta forma. A perspectiva elevada faz os campos se estenderem muito além do que
van Gogh realmente podia enxergar ao passear por eles.

A explicação de Muhlberger para a semiose de pintar o ponto de vista em um nível levemente acima do chão para estender a vista mais longe e dar uma 'sensação de infinidade' está compatível com a busca estética de van Gogh pela incompletude, evidenciada em sua representação dos campos a perder de vista, do vento em movimento, do brilho das estrelas, e da luminosidade misteriosa da noite. Para essa semiose que está presente em muitos momentos nas telas e nas cartas, criamos a categoria 'incompletude' ${ }^{414}$

(KRESS; VAN LEEUWEN, 1996, p. 125).

${ }^{413}$ Uso de Enquadramento e do ângulo vertical plongee para representar a cena. Observamos com esse uso o efeito de distorção do ponto de vista. Esta escolha mostra a intenção de construir um efeito de sentido no espectador e uma interação deste com o posicionamento adotado pelo pintor para retratar a cena.

${ }^{414}$ Uso da incompletude por meio do ângulo plongee para dar uma sensação de infinidade para o campo de trigo. 
Outra semiose que ficou evidenciada com o uso do ângulo plongee, e de outros recursos presentes nas telas e nas cartas, chamamos na pesquisa de distorção do ponto de vista porque ela também ocorre na tela Café Lamartine (1888). ${ }^{415}$ Se pelo ponto de vista distorcido, o pintor se coloca indiretamente dentro da cena, assim como pelo ponto de fuga invertido, comentado anteriormente na análise, ele também o faz com a sua assinatura, sutilmente colocada em meio ao trigal. Defendo que van Gogh usou o plongee para construir uma Distorção no Ponto de Vista para construir a Transparência de sua própria experência ao pintar a cena. Essa necessidade de se enunciar como parte da cena revela que a pintura não se trata apenas de uma cena, mas de uma enunciação que materializa a experiência pessoal e subjetiva dele.

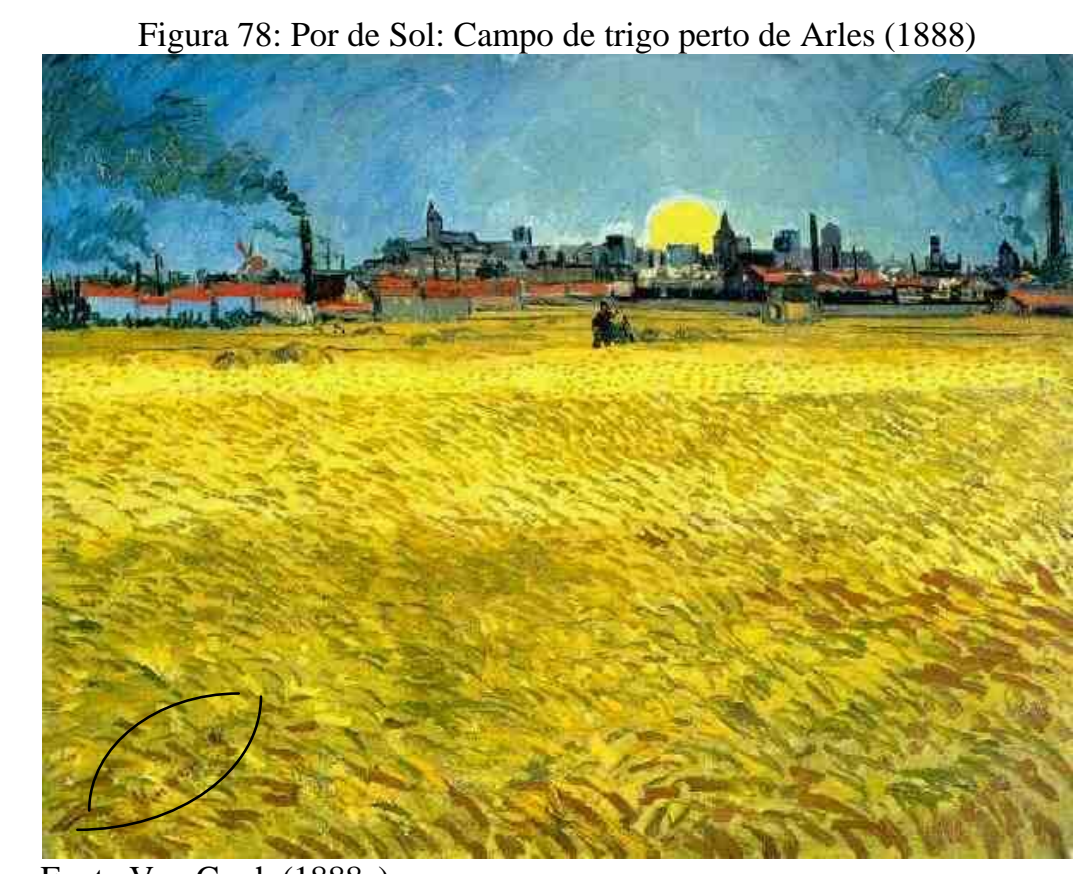

Fonte:Van Gogh (1888a).

Ao representar a cidade e principalmente a fábrica na distância, e de forma homogênea com o azul da noite o autor parece não valorizar o tema da cidade e da industrialização como sendo centrais em seu discurso visual, mas ao pintar um rico brocado texturizado para dar uma tal sensação de movimento e vida para o campo de trigo, parece enfatizar sua experiência subjetiva identificada com esse lugar que é agrário e natural em contraposição com o lugar dos progressos tecnológicos de seu tempo. ${ }^{416}$ Haveria aí uma crítica implícita e ideológica à

\footnotetext{
${ }^{415}$ Uso de distorção do Ponto de Vista por meio da escolha do ângulo levemente plongee para causar um efeito de sentido no envolvimento do espectador com a tela. Esta Distorção também foi observada na tela 'O café da noite', evidenciando mais um uso no sistema semiótico de van Gogh.

${ }^{416}$ Ocorrência de ritmo e textura para conferir saliência para o campo de trigo. Observamos que a Saliência é usada para produzir o efeito de associação metafórica do valor do campo sobre a cidade.
} 
industrialização? Não sabemos. Mas não resta dúvida que ele soube plantar essa dúvida em nosso olhar. No entanto, ao observarmos a forma como ele representou a cidade ao fundo, observamos uma certa ambivalência na atribuição de ênfase entre os planos do campo de trigo e da cidade, tanto pelo uso da cor quanto pelo detalhamento, explicado por McQuillan (1989, p. 142) em análise de composição similar: "Invertendo a suavização atmosférica convencional, as marcas mais amplas esboçam o primeiro plano, enquanto o melhor detalhamento gráfico descreve o plano de fundo. A observação atenta, delicadamente prestada compete com a diminuição da escala".

\subsubsection{Saliência - valorização do campo?}

Ao contrário do tratamento convencional de suavização dos tons para indicar a profundidade dos planos distantes e um maior detalhamento no primeiro plano para indicar proximidade, van Gogh constrói pinceladas mais amplas no primeiro plano (como que esboçando o trigo) e dá para o plano de fundo uma importância maior do que para o primeiro plano. Ele o faz trabalhando com um maior detalhamento gráfico para descrever o contorno das edificações da cidade no plano do fundo, com pinceladas mais precisas que observam a diminuição da escala. Esse tratamento nos fala de um efeito de contradição que é descrito por McQuillan (1989) como uma 'justaposição pictórica contraditória de convite e alienação'. Esse tratamento pode ser compreendido também como uma contradição implícita, ou um conflito, sobre o que deve ter mais importância, o campo de trigo que está no primeiro plano e tem uma carga cromática importante, ou a cidade que está ao fundo e na contra-luz, mas tem um detalhamento gráfico igualmente importante. Estaria ele falando sobre um conflito entre mundos, ou sobre o lugar de importância para esses mundos? Para responder essa pergunta, recorri ao contexto de cultura e ao contexto de situação do artista. ${ }^{417}$

$\mathrm{Na}$ época em que van Gogh era criança, a população da Holanda estava em torno de três milhões de habitantes tirando os principais rendimentos de uma duríssima política de exploração das riquezas de suas colônias, a qual foi criticada por políticos e pensadores da época. Sua economia interna era principalmente rural e mercantil, sem qualquer indústria e proletariado, como na Bélgica. Esse era o retrato da Holanda naquele momento: um país de cultura profundamente rural, mergulhado em um universo feudal e agrário.

\footnotetext{
417 Ocorrência de enquadramento, saliência e associação metafórica que constrói o sentido de valorização do campo.
} 
Em sua infância Vincent viveu, portanto, em um país considerado 'atrasado' em relação aos seus vizinhos, que se encontrava mergulhado em um mundo rural e imutável. Em suas telas ele representou os campos de trigo, os camponeses e esse universo rural sem ser, no entanto, de origem camponesa como o pintor Millet, ao qual muito tomou como referência estética. Haziot (2010, p. 13), autor da biografia de van Gogh afirma que "é o mínimo que se pode dizer: por mais longe que remontemos em sua genealogia, ninguém empunhou uma enxada ou uma foice para sobreviver".

Esta afirmação nos leva a seguinte questão, se a vida rural não estava presente na família dos Van Gogh há várias gerações, de que interesse estaria investida a representação do campo para Vincent? Esta pergunta ainda ganha novos contornos se investigarmos as mudanças econômicas e sociais que ocorreram a partir de 1848, cinco antes de seu nascimento, e que lançariam a Holanda na era da industrialização.

\footnotetext{
Quando Vincent começa a pintar, nos anos 1880, esse mundo rural não tem mais a mesma importância de trinta anos antes: a Holanda está em pleno desenvolvimento, mas Vincent olhará para os camponeses, virando as costas aos outros motivos e ao mundo mercantil que ele havia conhecido bem. Assim, a sua obstinação em pintar camponeses deve ser apreciada nesse contexto, e é daí que convém tirar sua significação. (HAZIOT, 2010, p.14)
}

Indago por que van Gogh parece se alinhar ao lado do homem do campo ou buscar se identificar como um, ao representar repetidas vezes os lavradores e os campos, sendo ele um homem que cresceu cercado por uma cultura familiar de tradição mercantil e religiosa, afeita às profissões liberais. Em sua obra, ele demonstra ter optado deliberadamente se posicionar no campo e ao lado do homem do campo.

Acredito que a pergunta não encontraria resposta na análise isolada desta tela, mas no conjunto de sua obra e na triangulação com suas cartas. A análise de suas cartas em combinação com a análise das composições pictóricas pode ajudar na busca de elementos que evidenciem os valores que van Gogh endossou a respeito do campo e das questões que eram caras a ele. A análise de uma cadeia de produção textual, bem como da sua história de leituras e a interdiscursividade que daí decorre em sua obra pode nos ajudar a compreender os pressupostos filosóficos e ideológicos que parecem basear algumas escolhas compositivas na tela 'Por de Sol: Campo de trigo perto de Arles'.

O que ele buscava representar? Não sabemos. O que sabemos vem de considerações acerca de sua época, marcada pela transição entre a agonia de uma sociedade rural e uma sociedade industrial nascente, e o embate entre esses dois mundos, um que recua e outro que avança em um cenário marcado por transformações na produção da existência e da subjetividade de seus sujeitos. 
Sua lealdade com o mundo que está ficando para trás na marcha do avanço social, tecnológico e econômico parece estar para além de um estatuto estético. Ele parece tomar para si a tarefa de expressar em seu discurso visual um estatuto político e ideológico, de crítica, talvez de denuncia em relação ao mundo industrial que avança sobre o campo, causando o surgimento de um novo tipo de trabalhador, valorizando um novo tipo de sujeito. ${ }^{418}$ Seu quadro parece nos perguntar: o que faremos com aqueles que não se inserem, aqueles que ficam para trás nessa marcha civilizatória irreversível? Descartamos, ignoramos, esquecemos? Não para van Gogh. Esta tela expressa suas reflexões, sensibilidade e profundo compromisso com o campo nessa luta campal, neste ocaso da uma nova era. Van Gogh toma para si o lado e a voz dos que perdem a vez ou que nunca a tiveram. Essas reflexões estão em sintonia com uma cadeia de textos que se produziam a respeito das questões sociais, políticas e filosóficas da época e que van Gogh explicita tanto nas telas quanto em suas cartas.

\subsubsection{Conclusão da análise visual da tela Por de Sol: Campo de trigo perto de Arles}

Na narrativa, o sol está se ponto, indicando mais um dia que acaba ou o término de um ciclo que pode ser associado com o término de uma era também. Ao se por, o sol está encarando o campo, e esse ponto de vista constrói a narrativa de que o sol está se pondo para o homem do campo, para esse lugar que esse homem ocupa um lugar social ao qual ele pertencia e que lhe dava um sentido. A narrativa pode estar significando que o sol se põe para o mundo rural, pois o sol poente e a fábrica estão diante do campo e do homem que nele trabalha dizendo sobre a perda de lugar, de emprego e de subjetividade do homem desse mundo rural, diante da revolução industrial. A escolha do enquadramento é uma confirmação da intenção desse enunciado, porque van Gogh não escolheu posicionar o seu cavalete no lado da cidade para olhar o campo. Ele escolheu estar no campo olhando para a cidade, mostrando claramente que o seu lugar é no campo, e seu olhar, sua experiência estão alinhados com o olhar e a experiência desse mundo rural do qual ele é parte. ${ }^{419}$

Nesta composição, o sol se põe para quem vê esta cena. E quem vê essa cena? O homem do campo e o esteta que a pinta. Ele se coloca no campo e desde o campo, ele observa o sol que se põe para o campo.

\footnotetext{
418 Ocorrência de Interdiscursividade e de Intertextualidade na forma como os sentidos comunicados pela composição dialogam com uma cadeia de textos visuais e escritos que ajudaram a construir o ideário do século XIX e que certamente permearam o processo de construção discursiva de van Gogh.

419 Ocorrência de interdiscursividade e Associação metafórica. O uso da interdiscursividade influenciou na escolha do Enquadramento que por sua vez ajudou na construção das Associações metafóricas.
} 
O sol se põe para quem observa a paisagem. Quem é esse observador? Onde ele está? Na cidade? Não. Ele está no campo e desde o campo observa a tudo: o campo onde este se encontra; a cidade e a indústria com sua atividade incessante, e o sol que se põe. $\mathrm{O}$ sol poente parece sugerir um efeito de sentido: ele está se pondo para aquele que está no campo. A este sujeito, que se encontra no campo, resta o olhar contemplativo, talvez melancólico de um tempo que termina. Que tempo é esse? Talvez o período que se encerra para um mundo rural que se completa em si mesmo e atônito, vê chegar o período de expansão industrial e urbana que van Gogh presenciou em sua juventude.

\subsection{ANÁLISE TEXTUAL DOS EXTRATOS DE CARTAS RELATIVOS À TELA POR DE SOL: CAMPO DE TRIGO PERTO DE ARLES}

Os extratos em Francês e em Inglês estão nos anexos. (COLOCAR LÀ)

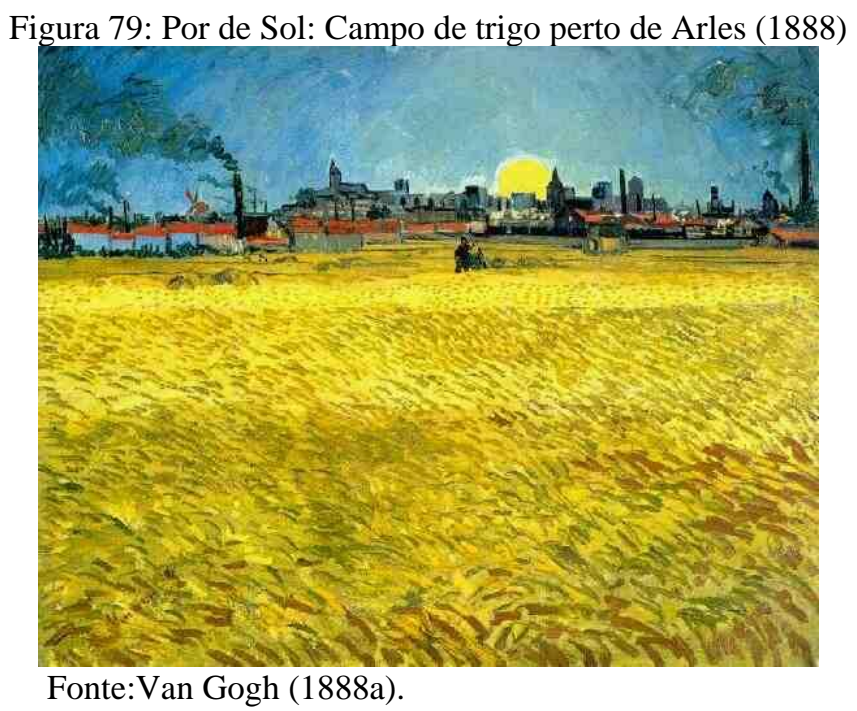

\subsubsection{Extrato $n^{0} 1 a$}

Carta 680 - To Theo van Gogh. Arles, on or about Tuesday, 11 September 1888. (VAN GOGH, 2009b)

"Eu tenho um terceiro estudo, agora, de uma paisagem com fábrica, e um enorme sol em um céu vermelho, acima de telhados vermelhos, em que a natureza parece estar em um acesso de raiva, em um dia de mistral desagradável". (VAN GOGH, 2009b, p. 1). 


\begin{tabular}{|l|l|l|l|l|}
\hline Eu & tenho & um terceiro estudo & agora & $\begin{array}{l}\text { de uma paisagem com fábrica [e] um } \\
\text { enorme sol }\end{array}$ \\
\hline Portador & $\begin{array}{l}\text { Proc. Rel. 1 } \\
\text { Atributivo } \\
\text { Intensivo }\end{array}$ & Atributo & Circunstância & $\begin{array}{l}\text { Atributo - pertencente ao grupo } \\
\text { nominal 'um terceiro estudo' }\end{array}$ \\
\hline
\end{tabular}

\begin{tabular}{|l|l|l|l|}
\hline $\begin{array}{l}\text { em um céu vermelho,acima de telhados } \\
\text { vermelhos em que (Beta) }\end{array}$ & a natureza & parece estar & $\begin{array}{l}\text { em um acesso de raiva, em um dia } \\
\text { de mistral desagradável. }\end{array}$ \\
\hline Circunstância de Localização: lugar & Portador & Proc. Relacional & Atributo \\
& & Atributivo \\
Circunstancial & \\
\hline
\end{tabular}

\section{Descrição: $\alpha=\boldsymbol{\beta}$}

$/ /\{$ Eu tenho [um terceiro estudo, ( $\alpha$ ) agora, de uma paisagem com fábrica [e] um enorme sol] em um céu vermelho, acima de telhados vermelhos $(\beta) / /$ em que a natureza parece estar em um acesso de raiva, em um dia de mistral desagradável.\}

ALFA - (oração dominante) Eu tenho um terceiro estudo, agora, de uma paisagem com fábrica (...) em que a natureza parece estar em um acesso de raiva, em um dia de mistral desagradável.

BETA - (oração dependente por elaboração) - / [e] um enorme sol em um céu vermelho, acima de telhados vermelhos/

Eu (portador) tenho (proc.rel.atrib.intensivo) um terceiro estudo (núcleo do grupo nominal), agora, de uma paisagem com fábrica [e] um enorme sol em um céu vermelho, acima de telhados vermelhos / em que a natureza parece estar em um acesso de raiva, em um dia de mistral desagradável.

Alfa $=$ Eu tenho um terceiro estudo, agora, de uma paisagem com fábrica, e um enorme sol em um céu vermelho, acima de telhados vermelhos,

Complexo nominal por extensão - um terceiro estudo (núcleo), agora, de uma paisagem com fábrica, e um enorme sol em um céu vermelho

Beta Oração dependente por elaboração porque está explicando (reelaborada) - em que a natureza parece estar em um acesso de raiva, em um dia de mistral desagradável 
(um terceiro estudo [de uma paisagem com fábrica e um enorme sol em um céu vermelho, acima de telhados vermelhos] complexo de grupo nominal por extensão

(e) é conectivo lógico-semântico que está ligando participantes e faz a função de extensão no grupo nominal.

\section{Interpretação}

"Eu tenho um terceiro estudo, agora, de uma paisagem com fábrica, e um enorme sol em um céu vermelho, acima de telhados vermelhos, em que a natureza parece estar em um acesso de raiva, em um dia de mistral desagradável". (VAN GOGH, 2009b, p. 1).

$\mathrm{Na}$ oração dominante "Eu tenho um terceiro estudo, agora, de uma paisagem com fábrica, e um enorme sol em um céu vermelho", temos o pintor como o Portador do processo relacional atributivo (VAN GOGH, 2009b, p. 1). O Atributo (um terceiro estudo de uma paisagem com fábrica [e] um enorme sol em um céu vermelho,) é construído em um espaço representativo: a tela, ao qual ele se reporta e descreve pelo uso de um extenso grupo nominal (atributo).

Na oração dominante, Van Gogh (2009b) descreve a tela e se coloca como Portador, ele é portador de algo que possui atributos. Mas na oração Beta ele desloca a ação (processo) para a natureza que está representada na tela, dando vida própria para a paisagem ser o Portador. Assim, ele passa a explicar as circunstâncias do atributo da oração dominante com uma nova oração de elaboração hipotática 'em que a natureza parece estar em um acesso de raiva, em um dia de mistral desagradável'. Nessa segunda oração, estes atributos se tornam independentes do processo iniciado por van Gogh, porque ele representa a natureza na tela como um participante que passa a ser o portador de um atributo. Como participante ela porta processos independentemente do seu autor. ${ }^{420}$

Na oração Beta o uso do processo "parece estar" muda o lugar de onde van Gogh fala sobre a tela e altera a intencionalidade com que ele fala da tela. $\mathrm{O}$ uso da expressão 'parece estar' é comumente utilizado por um observador que não produziu a tela e que faz uma interpretação a partir do que vê. Entretanto, Van Gogh (2009b) fala a partir do lugar de observador e não mais de Portador, suprimindo na explicação da tela, a sua presença como autor, não explicitando sua intencionalidade nesta oração. Afinal, o que queria van Gogh? O uso da expressão 'parece estar' atribui à natureza presente na tela autonomia em relação à

\footnotetext{
${ }^{420}$ A mudança de Portador da oração paratática para a oração hipotática sugere uma mudança de planos e de Enquadramento para a ação ou processo representado.
} 
intencionalidade do autor. De que lugar Van Gogh produziu a tela para que neste momento ele descreva seus atributos de modo a dar a ela uma existência independente de sua autoria ou do processo de produção? Este parece ser o lugar que ele se vê como sujeito mundo. No discurso van Gogh dá vida à tela como efetivamente deu vida à paisagem ao produzi-la. A natureza é superior ao homem, ela está acima de qualquer coisa. A natureza é. Quando ele pinta a natureza, a natureza é. Ele não retira da natureza a sua essencialidade, isso é imperativo, mesmo quando ele a representa. O fato de que ela é por si mesma, não obstante ao fato de que ele a possui, porque ela é. ${ }^{421}$

Quando van Gogh escolhe o processo "parece estar” ele possibilita a sua interpretação sobre a tela, mas não elimina outras interpretações e dá margem a outras experiências em relação à tela e à paisagem que, para ele, parece estar (algum atributo). A escolha léxicogramatical 'parece estar' é compatível com a ocorrência da categoria Inacabamento no texto visual.

A partir do momento em que van Gogh dá um atributo para a tela, ele faz um deslocamento que torna autônomo este participante "paisagem". Ao fazê-lo, van Gogh como participante portador, deixa de ser o produtor e passa a ser o possuidor e esse processo de atribuição é um momento reflexivo no qual ele como pintor se distancia do seu lugar como participante neste processo. ${ }^{422}$ Esse distanciamento é compatível com uma mudança de ponto de vista, ou com um enquadramento plongee, por exemplo, muito usado nas telas.

Esse deslocamento é construído com o uso da modalização 'parece', dando a impressão para o leitor de que não havia uma intencionalidade pelo efeito. $\mathrm{O}$ efeito não é produzido pelo van Gogh, é produzido pela tela.

Quando ele usa a expressão parece estar e cria essa existência da representação independente do autor, ele também usa da linguagem como possibilidade para se integrar à natureza representada e se fazer sujeito aí, nessa interpretação, nesse deslocamento o item lexical 'raiva' para uma cor e um movimento interno que encontra na natureza sua expressão mais genuína. ${ }^{423}$ Então observo um duplo deslocamento na linguagem, com o uso do processo 'parece estar' primeiro o deslocamento da intencionalidade, do portador/autor para o

\footnotetext{
${ }^{421}$ Mudança na Perspectiva e no Enquadramento, feita por um deslocamento na agência que na oração paratática é 'eu tenho' uma e na hipotática é 'a natureza parece estar'.

${ }_{422}$ Observei que esse deslocamento na construção da oração, que causa um distanciamento do ponto de vista do leitor, pode ser compatível com o uso do ângulo plongee no texto visual, também usado com a função de causar um distanciamento no espectador. Aqui vemos um tipo de compatibilidade de função, não de forma ou de sentido.

${ }^{423}$ Ocorrência de Transparência na atribuição de uma experiência 'raiva' para o Portador da oração 'natureza'.
} 
portador/tela), e o segundo deslocamento que é da experiência existencial que é do atributo/autor para o atributo/tela.

$\mathrm{Na}$ oração hipotática 'em que a natureza parece estar em um acesso de raiva, em um dia de mistral desagradável' van Gogh parece ter uma relação panteísta com a natureza, na qual ela assume não apenas o lugar de participante principal, mas também de Portador de um atributo, o acesso de raiva. Nessa oração ele constrói essa relação intensa com a natureza e os estados que ele experiênciava nessa relação, como relatam Naifeh e Smith (2012, p. 722):

Mas a verdadeira ventania que desequilibrava o cavalete de Vincent e lhe fazia tremer a mão era a que zunia dentro da sua cabeça. Com efeito, ele trabalhava melhor sob pressão, fosse uma tempestade na praia em Scheveningen, o mistral feroz do Crau ou as vozes acusadoras do passado. Apenas o atrito - entre ele e as forças da natureza, entre a esperança e a experiência, entre o planejamento cuidadoso e o ardor evangélico, entre o ditame cloisonista de simplificar e sua necessidade obsessiva de persuadir -, apenas o atrito podia induzir o "estado febril" de criatividade do qual, a seu ver, nasciam todos os seus melhores trabalhos. Como escreveu: "Dependo da exaltação que me vem em certos momentos, e então me entrego a extravagâncias". Descreveu a "lucidez terrível" que o acometia naqueles momentos, "quando a natureza é linda, não tenho mais consciência de mim e a pintura vem como num sonho". Invocava como modelo os artistas japoneses, com sua execução "feito um raio" e o toque absolutamente seguro ("tão simples como respirar"). Invocava também Monticelli, defendendo o pintor de Marselha tão malafamado - e a si mesmo - contra as acusações de pintar num frenesi de embriaguez ou de loucura. "Chamam um pintor de louco se vê as coisas com olhos diferentes dos deles", disse zombando e desafiando qualquer bêbado a realizar as proezas e acrobacias cromáticas que ambos executavam.

\subsubsection{Extrato $\mathrm{n}^{0} 1 \mathrm{~b}$}

628 - To Emile Bernard. Arles, on or about Tuesday, 19 September 1888. (VAN

GOGH, 2009c).

Aqui está outra paisagem. Sol poente? Lua nascendo? Noite de verão, de qualquer modo. Cidade violeta, estrela amarela, céu azul-esverdeado; os campos de trigo têm todos os tons: ouro velho, cobre, ouro verde, ouro vermelho, ouro amarelo, verde, vermelho e amarelo bronze. Tela quadrada número 30.

Eu pintei-a ao ar livre no mistral. Meu cavalete foi fixado no chão com estacas de ferro, um método que eu recomendo a você.

[esboço C]

Você enterra os pés do cavalete e, em seguida, você empurra a 50 centímetros de comprimento um peso de ferro ao lado deles. Você amarra tudo com cordas; dessa forma, você pode trabalhar com o vento. (VAN GOGH, 2009c, p. 1). 


\section{Análise}

Aqui está outra paisagem.

\begin{tabular}{|l|l|l|}
\hline Aqui & está & outra paisagem. \\
\hline Circunstância de Lugar & Processo Existencial & Existente \\
\hline
\end{tabular}

Sol poente? Lua nascendo?

\begin{tabular}{|l|l|l|l|l|}
\hline (o) sol & (está) & Poente? & (a) lua & Nascendo? \\
\hline & & & Existente & Processo Existencial \\
\hline
\end{tabular}

Noite de verão, de qualquer modo.

\begin{tabular}{|l|l|l|l|}
\hline (a) noite & (é) & de verão, & De qualquer modo \\
\hline Portador & Processo Relacional Atributivo & Atributo & Circunstância \\
\hline
\end{tabular}

Cidade violeta, estrela amarela, céu azul-esverdeado; os campos de trigo têm todos os tons: ouro velho, cobre, ouro verde, ouro vermelho, ouro amarelo, verde, vermelho e amarelo bronze.

\begin{tabular}{|l|l|l|l|}
\hline $\begin{array}{l}\text { cidade violeta, estrela } \\
\text { amarela, céu azul- } \\
\text { esverdeado; }\end{array}$ & $\begin{array}{l}\text { os campos } \\
\text { de trigo }\end{array}$ & têm & $\begin{array}{l}\text { todos os tons: ouro velho, cobre, ouro } \\
\text { verde, ouro vermelho, ouro amarelo, verde, } \\
\text { vermelho e amarelo bronze. }\end{array}$ \\
\hline $\begin{array}{l}\text { Grupo nominal } \\
\text { encaixado no portador }\end{array}$ & Portador & Proc. Rel. Atributivo & Atributo \\
\hline
\end{tabular}

\section{Interpretação}

Observamos no início do excerto: 'Sol poente? Lua nascendo? Noite de verão, de qualquer modo. Cidade violeta, estrela amarela, céu azul-esverdeado;' um conjunto de sintagmas nominais. Podemos apenas analisar no nível do grupo ou sintagma nominal;

Na oração: 'os campos de trigo têm todos os tons: ouro velho, cobre, ouro verde, ouro vermelho, ouro amarelo, verde, vermelho e amarelo bronze' encontramos um processo relacional atributivo no qual van Gogh narra os atributos dos campos.

No período: “Aqui está outra paisagem. Sol poente? Lua nascendo? Noite de verão, de qualquer modo. Cidade violeta, estrela amarela, céu azul-esverdeado; os campos de trigo têm todos os tons: ouro velho, cobre, ouro verde, ouro vermelho, ouro amarelo, verde, vermelho e amarelo bronze. Tela quadrada número 30" (VAN GOGH, 2009c, p. 1). Van Gogh (2009c) 
narra a cena como ele a concebe, por meio de processos relacionais atributivos. Ele não diz, 'eu pintei outra paisagem', mas, ‘Aqui está outra paisagem.' enfatizando a circunstância de lugar 'Aqui' para declarar a existência da tela. ${ }^{424}$

Em seguida ele descreve a cena por meio de três orações: 'Sol poente? Lua nascendo? Noite de verão, de qualquer modo.' Estas orações são seguidas de uma narrativa fortemente focalizada na construção de sentidos visuais por meio de processos relacionais destinados a construir uma visualidade dos tons empregados para pintar a cena do campo de trigo para o irmão que lê a carta. ${ }^{425}$ As orações criam uma marcação rítmica muito forte e cadenciada evidenciando a ocorrência do Gesto pictórico na representação de uma visualidade que também ocorre na tela.

$\mathrm{Na}$ oração 'Noite de verão, de qualquer modo.' indica um uso não convencional da linguagem em um texto descritivo na carta. Esse elemento não convencional de uma narrativa sem processo mostra um recurso discursivo que pode condensar outras semióses tais como uma ênfase, um tom, um colorido para o discurso. Além disso, é um tom que é poético e empresta para esse período ritmo, movimento, cadência e colorido, pois matiza o discurso com o seu temperamento livre e que nos deixa liberdade de interpretação. Essas três orações, carregam uma camada semiótica que confere ao texto o que na análise das telas chamamos de Rima Visual, ou seja, empresta harmonia e unidade para o período por meio de um 'gesto textual' comparável com suas pinceladas. ${ }^{426}$

Tela quadrada número 30.

Tela quadrada número 30.

Oração menor, não constitui uma oração.

Eu pintei-a ao ar livre no mistral.

\begin{tabular}{|l|l|l|l|}
\hline $\mathrm{Eu}$ & Pintei & -a & ao ar livre no mistral \\
\hline Ator & Processo Material criativo & Meta & Circunstância \\
\hline
\end{tabular}

Meu cavalete foi fixado no chão com estacas de ferro, um método que eu recomendo a você.

\footnotetext{
${ }^{424}$ Ocorrência de Enquadramento e Perspectiva construída pela escolha do Portador da oração para transportar o leitor direto para o universo representado na tela.

425 Ocorrência da representação de uma visualidade compatível com a categoria do Gesto pictórico, por meio do uso do Ritmo no sequenciamento das orações e nas escolhas léxico-gramaticais.

${ }^{426}$ Ocorrência de Saliência, que ajudam a construir uma materialidade compatível com a ocorrência de Gesto Pictórico e de Rima Visual na sequência das três orações.
} 


\begin{tabular}{|l|l|l|}
\hline Meu cavalete & foi fixado & no chão \\
\hline Meta & Proc. Material Transformativo & Circunstância de localização: lugar \\
\hline
\end{tabular}

\begin{tabular}{|l|l|}
\hline com estacas de ferro, & um método que eu recomendo a você. \\
\hline Circunstância de modo & \\
\hline
\end{tabular}

Você enterra os pés do cavalete e, em seguida, você empurra a 50 centímetros de comprimento um peso de ferro ao lado deles.

\begin{tabular}{|l|l|l|}
\hline Você & enterra & os pés do cavalete \\
\hline Ator & Proc. Material Transformativo & Meta \\
\hline
\end{tabular}

\begin{tabular}{|l|l|l|l|l|}
\hline e, em seguida, & voce & empurra & $\begin{array}{l}\text { a 50 centímetros de } \\
\text { comprimento }\end{array}$ & $\begin{array}{l}\text { um peso de ferro ao lado } \\
\text { deles }\end{array}$ \\
\hline $\begin{array}{l}\text { Circunstância de } \\
\text { localização: } \\
\text { tempo }\end{array}$ & Ator & $\begin{array}{l}\text { Proc. Material } \\
\text { Transformativo }\end{array}$ & Circunstância & Meta \\
\hline
\end{tabular}

Você amarra tudo com cordas; dessa forma, você pode trabalhar com o vento."

\begin{tabular}{|l|l|l|}
\hline Você & amarra & tudo com cordas; \\
\hline Ator & Proc. Material Transformativo & Meta \\
\hline
\end{tabular}

\begin{tabular}{|l|l|l|l|}
\hline dessa forma, & Você & pode trabalhar & com o vento. \\
\hline $\begin{array}{l}\text { Circunstância de } \\
\text { Modo }\end{array}$ & Ator & Proc. Material Transformativo & Circunstância de Modo \\
\hline
\end{tabular}

\section{Interpretação}

Van Gogh dedica um bom trecho de sua carta para descrever como ele faz para pintar ao ar livre, ao sabor de uma ventania que na região ganha o nome de mistral. No período:

Tela quadrada número 30. Eu pintei-a ao ar livre no mistral. Meu cavalete foi fixado no chão com estacas de ferro, um método que eu recomendo a voce. Voce enterra os pés do cavalete e, em seguida, voce empurra a 50 centímetros de comprimento um peso de ferro ao lado deles. Voce amarra tudo com cordas; dessa forma, voce pode trabalhar com o vento. (VAN GOGH, 2009c, p. 1).

Ele inicia com uma oração menor, sem processo, que se tivesse, apenas atribuiria o tamanho da tela. Na primeira oração o agente é a tela, na segunda é van Gogh, na terceira é o 
cavalete, e na quarta é o seu leitor, Theo. Observei um deslizamento na agência à medida que van Gogh foi construindo sua narrativa e que explicita suas escolhas de enfoque e de enquadramento para comunicar sua ideia.

Em seguida ele faz um deslocamento do estilo narrativo da primeira oração para uma sequência de seis orações todas elas usando processos materiais transformativos, com excessão da primeira desse conjunto que leva um processo material criativo: 'Eu pintei-a ao ar livre no mistral'. Essa diferenciação é importante para compreender a função do período na construção de novos sentidos. Van Gogh, claramente, introduziu o assunto da tela para o irmão usando dois processos existenciais e dois relacionais atributivos, ao invés de representar-se como ator da representação da tela. Talvez essa escolha se deva ao fato de ele estar narrando o universo representado na tela e nessa instância representativa, a tela passou a ser o agente principal e o leitor adentra em seu universo particular. Colocar-se como o agente da ação de pintar a tela, seria para van Gogh, uma quebra do que ele está tentando construir para o irmão: um caminho direto para dentro da tela, no qual não há um pintor que pinta uma tela, mas um universo que convida Theo para adentrar, participar e experiênciar por meio das palavras do irmão. Esta parece ser a grande magia que van Gogh opera ao narrar a composição omitindo sua condição de objeto pintado por ele, mas celebrando sua condição de mundo em seu próprio direito de existência. ${ }^{427}$

A partir do momento em que van Gogh termina o primeiro período onde narra a composição, ele finaliza com uma oração sem processo na qual declara o tamanho da tela. A partir dessa oração, ocorre um deslocamento na retórica: ele passa a falar das condições na qual pintou a tela. Ou seja, ele narra a tela e finaliza declarando o seu tamanho:'Tela quadrada número 30', e afirma: 'Eu pintei-a ao ar livre no mistral'. Essa oração não supre a necessidade de van Gogh de explicar o que ele quis dizer com o fato de que foi pintada ao ar livre no mistral. Dessa forma, ele sequencia com mais seis orações concatenadas em dois complexos oracionais, todas dedicadas a descrever o que ele quis dizer com 'pintar ao ar livre no mistral'. Apesar desse período não se referir diretamente a tela pintada, ele fala das condições em que a pintou e que indubitavelmente impactaram no seu resultado. Ele fala sobre a experiência com a natureza, com o vento, com o sol, com as dificuldades de observar o comportamento do trigal ao sabor do vento, com o desafio de representar o movimento do trigo ao vento: 'como um mar amarelo', com a inclemência do vento para fixar e estabilizar a tela. Com essa narrativa, passamos a imaginar que ele deve ter pintado em uma superfície vibrante, ondulada,

\footnotetext{
${ }^{427}$ Ocorrência de Enquadramento e Perspectiva que constrói um caminho para dentro da tela por meio de um delizamento na escolha dos agentes e dos processos das orações.
} 
sacolejante, e este movimento fez parte de sua experiência de pintar e sem dúvida ele transferiu para o movimento das pinceladas, que deviam ser feitas 'rapido, rápido, rápido e depressa'. ${ }^{428}$

Além disso, é preciso lembrar o programa estético que van Gogh seguia, no qual a experiência de se pintar ao ar livre, envolve muito mais do que a preocupação em se registrar fielmente o que conhecemos da realidade, mas está comprometida com registrar o que se experiencia da realidade quando se pinta. ${ }^{429}$

Essa perspectiva que os pintores Impressionistas estavam colocando em prática naquele momento, se aproxima da visão fenomenológica na filosofia, e é preciso investigar quais são as relações entre o programa dos impressionistas e os paradigmas da escola fenomenológica, uma vez que em muitos casos e por sua natureza de conhecimento experimental e intuitivo, a arte se antecede às outras ciências. As condições com as quais ele lidou para pintar a tela ensinaram a ele novas estratégias que ele transpôs em termos de semióses para dentro de seu sistema pictórico. Talvez por isso, van Gogh construiu as orações em sequência, porque não conseguiu sintetizar todos os sentidos desta experiência que ele quis comunicar ao irmão e compartilhar com ele a grande aventura que foi criar essa tela: 'Meu cavalete foi fixado no chão com estacas de ferro, um método que eu recomendo a voce. Voce enterra os pés do cavalete e, em seguida, voce empurra a 50 centímetros de comprimento um peso de ferro ao lado deles. Voce amarra tudo com cordas; dessa forma, voce pode trabalhar com o vento.' Haziot esclare os significados, talvez desconhecidos para nós, do mistral:

O mistral é um ator constante que sopra três dias a cada quatro, diz ele. "Tenho muita dificuldade de pintar por causa do vento, mas prendo meu cavalete com estacas no chão e trabalho assim mesmo, é bonito demais." C472 Dirá mais tarde que esse trabalho em condições tão difíceis lhe permitia captar o essencial, e que os retoques posteriores no ateliê lhe pareciam inúteis na maioria das vezes. Embora canse, o mistral também exalta e o faz saltar as barreiras como um álcool muito forte. Aumenta a febre de pintar, impele à rapidez, à fulgurância. Em certas ocasiões, sopra tão forte que as estacas não seguram: "Quando preciso pintar onde ele sopra, sou obrigado às vezes a pôr a tela diretamente no chão e trabalhar de joelhos, meu cavalete não podem ficar em pé”. CW5 (...) Imaginem esse artista sozinho no campo, pintando ajoelhado diante do vento! As pessoas da região por certo logo o tomaram por doido, pois a imagem está muito distante da de um pintor de domingo que medita longamente as pequenas pinceladas. O que elas viam era um louco num campo ventoso e se perguntavam que tesouro ele buscava. Como observou muito bem Meyer Schapiro, são paisagens arrancadas num instante fugaz,

\footnotetext{
${ }^{428}$ Ocorrência de Saliência, Transparência, Inacabamento e Incompletude na construção que revela as condições de ter pintado a tela ao vento como uma experiência que é relevante na representação escrita da tela que van Gogh faz para Theo.

429 Ocorrência de Modalidade tanto na prática de pintar ao ar livre e em contato com as mudanças atmosféricas, quanto na necessidade que van Gogh demonstra de relatar as condições em que a tela foi pintada como se essas condições fossem fundamentais para a compreensão do que ele buscou comunicar com a tela.
} 
e suas cores e a paixão da pincelada fazem delas uma visão do paraíso. (HAZIOT, 2010, p.198).

\subsubsection{Extrato $n^{0} 1 c$}

633 - To: Emile Bernard. Arles, Wednesday, 27 June 1888. (VAN GOGH, 2009d).

Eu também sou totalmente incapaz de julgar o meu próprio trabalho. Eu não posso ver se os estudos são bons ou ruins. Tenho sete estudos de trigais, infelizmente todos eles nada além de paisagens, muito contra a minha vontade. Paisagens amarelo ouro velho - feito rápido rápido rápido e com pressa, como o ceifeiro que está em silêncio sob o sol escaldante, concentrando-se em ter o trabalho terminado. (VAN GOGH, 2009d, p. 1).

\section{Análise}

Eu também sou totalmente incapaz de julgar o meu próprio trabalho.

\begin{tabular}{|l|l|l|l|}
\hline Eu também & sou & totalmente incapaz & $\begin{array}{l}\text { [[de julgar o meu próprio } \\
\text { trabalho.] }]\end{array}$ \\
\hline portador & $\begin{array}{l}\text { Processo Relacional } \\
\text { atributivo }\end{array}$ & Atributo & Oração encaixada \\
\hline
\end{tabular}

Eu não posso ver se os estudos são bons ou ruins.

\begin{tabular}{|l|l|l|}
\hline $\mathrm{Eu}$ & não posso ver & se os estudos são bons ou ruins. \\
\hline Experienciador & Processo Mental Cognitivo & Oração projetada \\
\hline
\end{tabular}

Tenho sete estudos de trigais,// infelizmente todos eles nada além de paisagens, muito contra a minha vontade.

\begin{tabular}{|l|l|l|}
\hline (eu) & Tenho & sete estudos de trigais, \\
\hline Portador & Processo Relacional atributivo & Atributo \\
\hline
\end{tabular}

\begin{tabular}{|l|l|l|l|}
\hline todos eles & (têm) & nada além de paisagens & $\begin{array}{l}\text { muito contra a minha } \\
\text { vontade. }\end{array}$ \\
\hline Portador & Processo Relac. Atributivo & Atributo & circunstância \\
\hline
\end{tabular}

Paisagens amarelo ouro velho - feito rápido rápido rápido e com pressa, como o ceifeiro que está em silêncio sob o sol escaldante, concentrando-se em ter o trabalho terminado. 


\begin{tabular}{|l|l|l|l|l|}
\hline $\begin{array}{l}\text { Paisagens amarelo } \\
\text { ouro velho }\end{array}$ & feito & $\begin{array}{l}\text { rápido rápido e com } \\
\text { pressa }\end{array}$ & $\begin{array}{l}\text { como o ceifeiro que } \\
\text { está em silêncio sob o } \\
\text { sol escaldante, }\end{array}$ & $\begin{array}{l}\text { concentrando-se em } \\
\text { ter o trabalho } \\
\text { terminado. }\end{array}$ \\
\hline Portador & $\begin{array}{l}\text { Processo } \\
\text { Relacional } \\
\text { atributivo }\end{array}$ & circunstância & & Oração não finita \\
\hline
\end{tabular}

Oração complexa: $\alpha+\beta$

\{Paisagens amarelo ouro velho - feito rápido rápido rápido e com pressa, $\alpha \alpha / / \beta$ [como o ceifeiro [[que está em silêncio sob o sol escaldante,]] / [concentrando-se [[em ter o trabalho terminado.]] (Beta)

ALFA - \{Paisagens amarelo ouro velho - feito rápido rápido rápido e com pressa, $\}$

BETA intensiva de comparação- [como o ceifeiro que está em silêncio sob o sol escaldante]

BETA - [concentrando-se em ter o trabalho terminado.]

\section{Interpretação:}

Nestas duas orações encadeadas pelo nível semântico: "Eu também sou totalmente incapaz de julgar o meu próprio trabalho. Eu não posso ver se os estudos são bons ou ruins" (VAN GOGH, 2009d, p. 1). Van Gogh (2009d) declara para o irmão sua incapacidade de avaliar seu próprio trabalho. O sentido dessa oração endossa completamente a hipótese de que o artista cria seu discurso artístico a partir de um limiar artístico ${ }^{430}$ no qual ele não tem total apreensão de seus sentidos e precisa continuar a elaborar sua compreensão desse processo por meio de uma cadeia de textos que ele produz para explorar os sentidos relacionados com a sua produção artística. Na primeira oração, ele usa o processo relacional atributivo: "Eu também sou totalmente incapaz de julgar o meu próprio trabalho" e na segunda o processo mental cognitivo: "Eu não posso ver se os estudos são bons ou ruins" (VAN GOGH, 2009d, p. 1), sinalizando que ele fala de um lugar no qual ele está dentro do processo e relaciona a qualidade de se ver incapaz de julgar seu próprio trabalho. Este grande sentido mostra o esforço que ele precisa fazer para se olhar de fora, desde o ponto distanciado de alguém que consegue apreender o todo que é o processo de criar. É como se ele estivesse dentro de um grande buraco de prospecção de diamantes só que sem a necessária iluminação para distinguir o que ele está manuseando dentro do buraco e precisasse recorrer a Theo, ao olhar distanciado desse interlocutor para que o ajudasse a identificar que tipo de pedras ele está explorando e

\footnotetext{
430 'Limiar artístico' é um conceito produzido nesta pesquisa para designar uma instância discursiva que se situa entre o imanente e o manifesto no processo de produção de sentido. O limiar artístico será discutido no capítulo 6 na discussão dos achados.
} 
retirando dentro do buraco. Estas duas orações mostram a dificuldade de van Gogh produzir sozinho os sentidos de seu discurso, sem a necessária prática discursiva na qual ele produzia e refletia acerca de seus sentidos. Evidencia também a natureza da relação entre os dois irmãos como uma instância para essa prática acontecer. ${ }^{431}$

Van Gogh tinha uma intensão de dialogar com as pessoas e de transmitir para elas a experiência e a forma de ver a vida e o mundo e para que isso acontecesse ele dependia de um olhar das pessoas. Como ele iria julgar o trabalho dele se a intencionalidade do trabalho dele é inerente ao resultado que é o de comunicar algo, de compartilhar algo da sua experiência com os outros. No entanto, ao ver os quadros ele se reconhecia por um lado, mas por outro os quadros não eram vendidos. Ele via que o que ele pensava e sentia estava no quadro, mas a resposta do outro não vinha, era um vazio. Por outro lado, ele não podia negar que as telas que ele pintava tinham uma expressividade artística que era almejada por ele. Ele sentia muito isso, mas em termos de julgamento, que depende de ter um reconhecimento social, de estar inserido em uma prática de discurso, ele não recebia esse retorno e ele ficava no meio do caminho. $^{432}$

Na oração: "Tenho sete estudos de trigais, infelizmente todos eles nada além de paisagens, muito contra a minha vontade" (VAN GOGH, 2009d, p. 1), Van Gogh (2009d) utiliza dois processo relacionais atributivos para explicar ao irmão que realizou sete estudos, mas que estes não são 'nada além de paisagens'. O uso da expressão 'nada além' instancia o sentido que para ele, as paisagens não são muito importantes. A circunstância 'muito contra a minha vontade, confirma este sentido. E mesmo contra a vontade dele, isso não significa que ele esteve menos envolvido e mesmo comprometido até o cerne com a produção das paisagens, como revelam os excertos das cartas aqui analisados. É preciso então recorrer ao contexto de situação para compreender do que fala van Gogh quando enuncia 'muito contra a minha vontade'. Talvez ele esteja dizendo que preferiria estar pintando outro gênero de pintura. Em várias cartas Van Gogh menciona e declara que para ele, os retratos de pessoas seriam os trabalhos que ele mais desejaria realizar, no entanto, ele tinha grandes limitações para encontrar pessoas que se disponibilizassem a posar para ele. Em primeiro lugar ele não tinha dinheiro para pagar por modelos, em segundo lugar, as pessoas de Arles, por exemplo, declinaram o convite porque achavam a pintura de Van Gogh feia e mal acabada para os padrões estéticos da época e receavam que elas seriam alvo de chacotas se fossem

\footnotetext{
431 Ocorrência de Transparência, Incompletude e de Limiar Artístico - observamos a ocorrência da categoria limiar artístico no complexo oracional, no nível semântico.

${ }^{432}$ Ocorrência de Interdiscursividade e de Inversão do Ponto de vista no nível semântico da oração.
} 
representadas por Van Gogh. Dessa forma, ele teve reduzidas oportunidades de praticar o gênero que ele mais desejou pintar. Os retratos que ele produziu podem oferecer novas pistas para compreender a distinção entre gêneros na produção do discurso visual de Van Gogh. ${ }^{433}$

\title{
Oração complexa: Alfa + Beta
}

\{Paisagens amarelo ouro velho - feito rápido rápido rápido e com pressa, \} (alfa)/ [como o ceifeiro que está em silêncio sob o sol escaldante,] (Beta) / [concentrando-se em ter o trabalho terminado.] (Beta)

\begin{abstract}
ALFA - \{Paisagens amarelo ouro velho - feito rápido rápido rápido e com pressa, \}
BETA intensiva de comparação- [como o ceifeiro que está em silêncio sob o sol escaldante,]
\end{abstract}

BETA - [concentrando-se em ter o trabalho terminado.]

Paisagens amarelo ouro velho - feito rápido rápido rápido e com pressa, como o ceifeiro que está em silêncio sob o sol escaldante, concentrando-se em ter o trabalho terminado."

No complexo oracional: "Paisagens amarelo ouro velho - feito rápido rápido rápido e com pressa, como o ceifeiro que está em silêncio sob o sol escaldante, concentrando-se em ter o trabalho terminado" (VAN GOGH, 2009d, p. 1). Van Gogh não está mais falando do universo representado dentro da tela, mas como ela é feita e para isso, ele cria uma metáfora por meio de duas orações hipotáticas, uma delas intensiva de comparação: 'como o ceifeiro que está em silêncio sob o sol escaldante, concentrando-se em ter o trabalho terminado' (VAN GOGH, 2009d, p. 1). Além de semânticamente comparar seu trabalho em pintar a tela com o trabalho do ceifeiro trabalha em silêncio e concentrado em terminar o trabalho, ele constrói um outro tipo de comparação que é léxico-gramatical: ele compara o ritmo do ceifeiro em cortar as espigas de trigo ou de milho com a estrutura da oração que descreve seu próprio trabalho em pintar a tela por meio da analogia: 'feito rápido rápido rápido e com pressa'. Aqui vemos um tipo de uso que também ocorre nas telas. Van Gogh cria estruturas léxicogramaticais que são compatíveis com a natureza do sentido que ele quer narrar ou representar, de forma a produzir uma sensação sinestésica e quase física do sentido que ele deseja que o espectador, ou o leitor experiencie ao reconstruir e apreender os significados por ele intendidos. Ele não deseja apenas comunicar, mas fisicamente, materialmente, e

\footnotetext{
${ }^{433}$ Ocorrência de Saliência e de Transparência pelas escolhas léxico-gramaticais 'nada além' e 'muito contra a minha vontade' usadas na oração.
} 
esteticamente, transportar o leitor para dentro da experiência que promoveu o sentido para ele, e que ele reconstrói com o uso de estruturas léxico-gramaticais. Ocorre por essa via, uma compatibilidade entre escrita e imagem que é da ordem formal no nível léxico-gramatical e da ordem do conteúdo no nível semântico. ${ }^{434}$

Por exemplo, observamos que esta forma enunciar o sentido por meio de uma estrutura análoga, no caso das pinturas, ocorre na tela 'Por de Sol: Campo de trigo perto de Arles', quando ele articula um gesto pictórico, ou seja, um ritmo para as pinceladas de modo a dar a experiência do vento ventando nas espigas de trigo, 'como um mar amarelo' porque este é o sentido que ele experiênciou de forma mais intensa ao pintar a tela, por meio do qual o trigal comunica sua vida. Na tela, 'O Semeador', que é analisada a seguir, van Gogh também tornou a estrutura sintática visual como uma metáfora do sentido que ele desejou representar: a integração entre natureza e ser humano. Essa integração, ele comunica na tela por meio de uma simbiose entre os contrastes de cores complementares que, ao mesmo tempo em que enunicam tensão e polaridade, trabalham para construir o equilíbrio cromático e a coesão textual da composição. A presença unificadora desses contrastes é de tal modo saliente que é impossível não percebê-la como uma metáfora para os significados fundadores da composição.

\footnotetext{
${ }^{434}$ Ocorrência de Associações metafóricas da estrutura léxico-gramatical, Enquadramento e Perspectiva por meio do uso de Ritmo, Gesto pictórico e Rima visual.
} 


\subsection{ANÁLISE DA TELA A ESPLANADA DO CAFÉ NA PLACE DU FORUM, ARLES, À}

\section{NOITE}

Figura 80: A Esplanada do Café na Place du Forum, Arles, à Noite de van Gogh

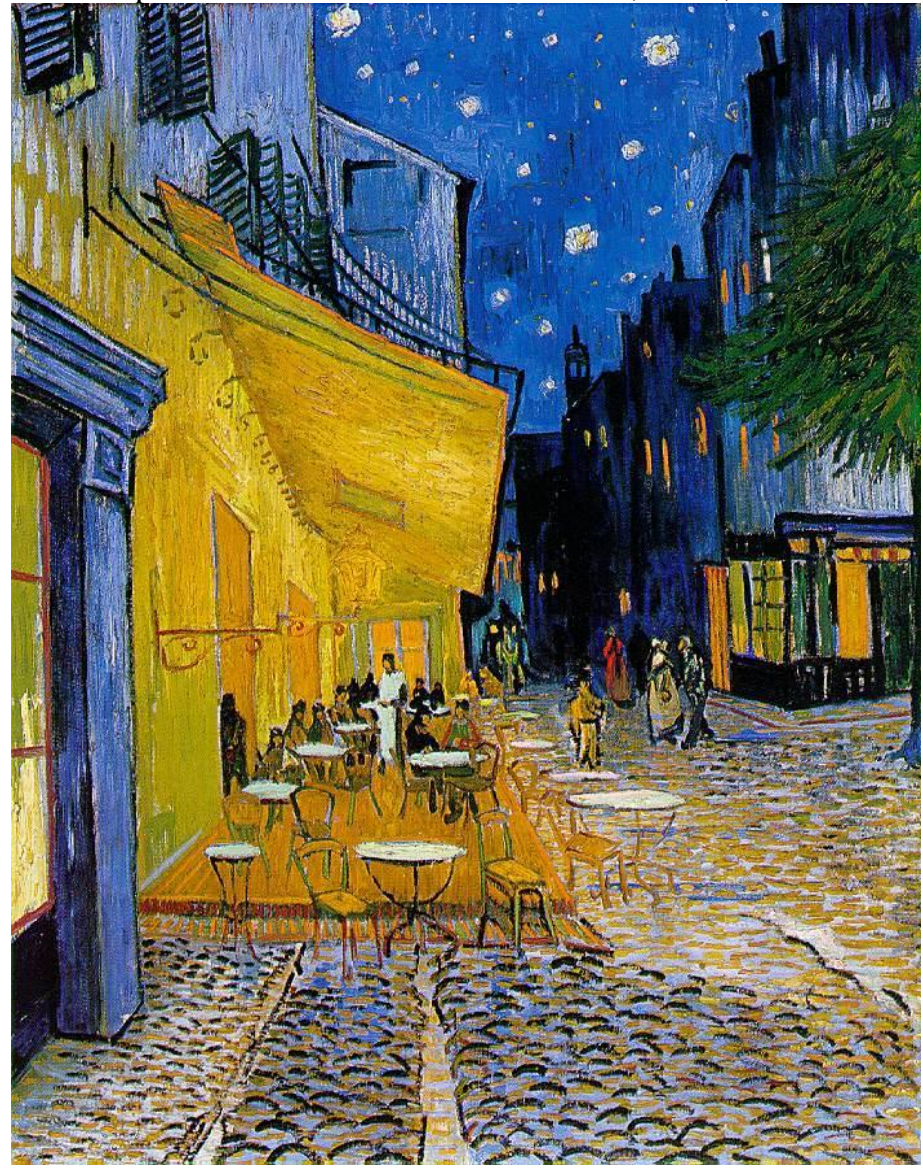

Fonte: Van Gogh (1888c).

Oil on canvas,

$81.0 \times 65.5 \mathrm{~cm}$

Arles: September, 1888

F 467, JH 1580

Localização: Otterlo: Kröller-Müller Museum

\section{O magnífico colorido da noite}

Pequenas figuras sob o toldo são representadas como silhuetas contra áreas de cores vivas. As linhas diagonais criadas pelos sulcos do calçamento da rua, as bordas do toldo, o terraço laranja e a posição oblíqua das portas e janelas do café, tudo conduz a ele. Um homem entra no café. O garçom atende um pedido. Os clientes sentam-se sob a deslumbrante luz do lampião, que faz brilhar as cores das paredes e da rua. Nas paredes, o amarelo se transforma em laranja e verde. As pedras do calçamento são cor de alfazema, púrpura, azul, amarela, laranja e até um pouco rosada. "A noite é mais animada e mais magnificamente colorida do que o dia", van Gogh escreveu a Theo. Ele estava orgulhoso por pintar uma noite "sem nenhum preto, nada além de belos azuis, violetas e verdes". Seu entusiasmo pelas cores revela-se na maneira generosa como as aplicava. Mesmo numa reprodução, suas grossas pinceladas podem ser percebidas em todo o lado inferior do toldo e nos galhos verde-escuros do pinheiro em frente. (MUHLBERGER, 2002, p. 20). 


\subsubsection{Análise da Função Composicional da tela The Café Terrace on the Place Du Forum, Arles, at Night}

\subsubsection{Espaço Compositivo}

Nesta tela, o pintor representa o exterior de um café e sua varanda iluminada e coberta por um toldo amarelo que se contrasta com a noite. Vemos cadeiras e mesas vazias no primeiro plano e as pessoas mais ao fundo, no segundo plano.

Figura 81: The Café Terrace on the Place Du Forum, Arles, at Night de van Gogh

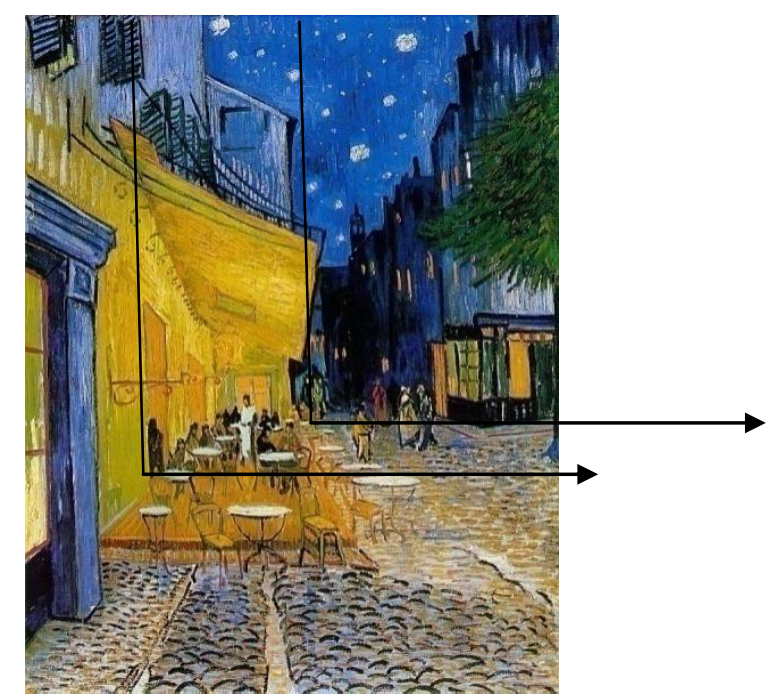

Fonte: Van Gogh (1888c).

No primeiro plano há, à esquerda, uma porta parcialmente representada. No início do segundo plano, à direita, vemos a copa de uma árvore, também parcialmente representada. Ainda no segundo plano, as pessoas transitam na rua em direção ao café. No café, também no segundo plano, temos o toldo amarelo e sob ele, a concentração dos clintes e garçom, mesas, cadeiras, e uma lâmpada a gás. ${ }^{435}$ No terceiro plano vemos os edifícios da rua contígua ao café que submerge na escuridão da noite e acima de todos há um céu estrelado.

\footnotetext{
${ }^{435}$ Na tela 'A Esplanada do Café na Place du Forum, Arles, à Noite', o segundo plano está representado tão ricamente ou mais do que o primeiro plano.
} 


\subsubsection{Enquadramento}

Observamos um ângulo plongee com o qual van Gogh representou a cena, um pouco acima do nível do chão e que produz um efeito de distanciamento provoca um distanciamento do espectador, enquanto outros recursos semióticos (cores, perspectiva, ponto de fuga) trabalham para conduzir o espectador para dentro da cena. ${ }^{436}$

Figura 82: The Café Terrace on the Place Du Forum, Arles, at Night de van Gogh

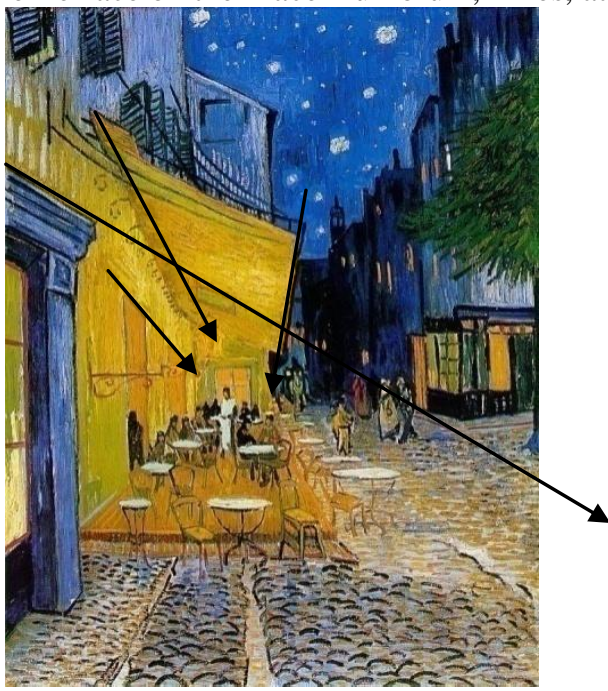

Fonte: Van Gogh (1888c).

\subsubsection{Simetria e a sua falta}

Vários são os elementos que constroem a simetria na tela, como as linhas do calçamento e o branco dos topos de mesa contra o branco das estrelas. No entanto, ele também usou elementos que se desconstroem a simetria onde ela é esperada, como explicam Walther e Metzger (2015, p. 421-424):

Voltemos novamente à pintura A Esplanada do Café na Place du Forum, Arles, à Noite (p.419). Neste caso, Van Gogh dá-nos um exemplo clássico da sua utilização de formas análogas. Há três linhas paralelas que vão da esquerda ao centro da composição: a que está mais abaixo é o lintel do caixilho da janela, à esquerda, depois vem a extremidade avermelhada do toldo da esplanada e, no ponto mais alto, está a empena de uma casa, que aponta para a imensidão azul do céu. $O$ facto de estas linhas serem paralelas desafia todas as leis regras de perspectiva, segundo as quais todas deveriam convergir para um ponto de fuga. Porém, Van Gogh zomba das regras de uma forma bastante deliberada - tudo para criar as suas próprias leis dentro do quadro. As linhas (parece ele dizer) desempenham outras funções, para além da mera descrição das extremidades, caixilhos e lintéis. Transmitem

\footnotetext{
${ }^{436}$ Ocorrência de enquadramento - observamos o uso do ângulo vertical levemente plongee para produzir um efeito de distanciamento que compete com o efeito de envolvimento gerado pela perspectiva e pelos contrastes cromáticos.
} 
igualmente uma mensagem a respeito delas próprias; tecem sobre a tela uma teia gráfica autorreferencial que confirma a existência de suas dimensões na pintura. Dois anos depois, Maurice Denis viria a resumir tudo isso na conhecida afirmação que se segue: "É preciso ter-se certeza absoluta de que um quadro, antes de ser um cavalo de batalha, um nu ou uma anedota, é uma superfície coberta por cores dispostas de determinado modo."

Observemos que a linha que demarca o limite do toldo em contato com a parede do Café parece curva como se acompanhasse uma parede curva ou que o toldo está velho e deformado pelo tempo. A moldura das duas portas debaixao do toldo não tem simetria com a moldura da porta no primeiro plano. Concordamos com o argumento de Walther e Metzger (2015), citado acima, de que não era uma preocupação para van Gogh a representação fiel da realidade a sua frente, mas que esta era um ponto de partida para representar o ambiente do café. $^{437}$

Figura 83: The Café Terrace on the Place Du Forum, Arles, at Night de van Gogh

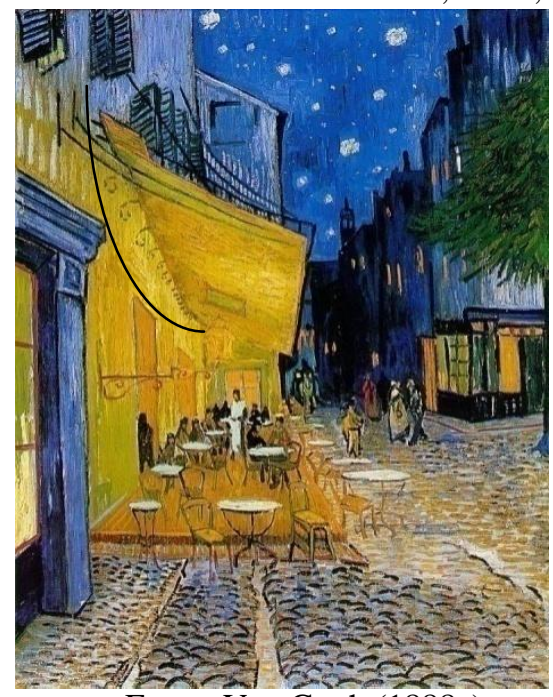

Fonte: Van Gogh (1888c).

\subsubsection{Ritmo e textura}

A profusão de linhas que desenham as pedras do calçamento forma um padrão de pequenas linhas curvas e criam um ritmo que colabora com a textura produzida pelas mesmas linhas. O ritmo e a textura das pedras do calçamento acompanham as linhas que constroem a perspectiva e ajudam a conduzir o olhar para dentro da cena. Estes dois elementos, ritmo e

\footnotetext{
${ }^{437}$ Ocorrência de Distorção do Ponto de Vista e Inacabamento, construída pela representação distorcida das linhas de perspectiva da edificação do café.
} 
textura, reforçam a perspectiva e os contrastes cromáticos que juntos exercem a função Modal de direcionar o olhar para o espaço da praça que circunda o café. ${ }^{438}$

O céu, em contraste com o calçamento do primeiro plano, também mostra um padrão de repetições com as estrelas, que de modo menos profuso e mais sutil, constroem um ritmo e uma textura, bastante diferenciada das representadas no chão, mas, que de certa forma 'espelham' o padrão das pedras do chão com seus padrões estelares. O padrão formado pelas estrelas também é lembrado pelo padrão formado pelos topos das mesas do bar que similarmente são de cor branca e parecem refletir as estrelas no céu. ${ }^{439}$ Este espelhamento ajuda a integrar o céu e a terra, e dar um senso de harmonia para o ambiente noturno que nos convida a nos colocarmos lá, nesta noite agradável como explicam Walther e Meztger (2012, p. 431-432):

\begin{abstract}
O fato de que o uso de linhas livres dos limites das leis de composição não ocorreu meramente por acaso ficou evidente em $O$ Zouave Assentado (p.367), que van Gogh pintou em junho de 1888. A vasta área do vermelho por si só é um reconhecimento da autonomia da forma. Esta autonomia está em desacordo com o princípio de um relato descritivo e pode ser visto como um passo intermediário no caminho para o objetivo real: o uso da analogia formal. O ombro direito, pescoço, boné e tassel enquadram uma área que lembra o formato do seu pé. Mais uma vez, a curvatura da sola da sua bota ecoa a forma da base das stool fezes (quase totalmente encoberta pela traje volumoso do homem). A área maciça de cor que representa a saia tradicional é atravessada por linhas amareladas que ecoam a cerâmica do chão. Ecos: há inúmeros exemplos desse uso da analogia formal na pintura. Foi o princípio da sinestesia que levou van Gogh usá-los. A pintura aspira à condição da música: um padrão rítmico de cores e formas, constantemente repetido, com variações sutis ou quebras sincopadas no padrão, está estabelecendo uma impressão. Van Gogh implantou os componentes de sua composição de uma forma abstrata, geométrica, em um nível que sugeriu comparação com o reino impalpável, indefinível de música. Seus motivos estavam lá como eles mesmos; ele não estava usando-os para representar uma dada realidade. Van Gogh continuou seu trabalho nesse problema durante o período com Gauguin. Ele se tornaria cada vez mais urgente, uma vez que implicava uma renúncia final necessária da realidade em favor da abstração.
\end{abstract}

\title{
4.4.1.5 Pintura-desenho
}

Algumas inovações no modo como van Gogh usa o pincel foram construídas a partir de uma estreita relação entre o desenho e a pintura; ele usa o pincel do mesmo modo como usa o caniço de nanquin e incorpora na pintura os recursos expressivos do desenho, como explica Haziot (2010, p. 169):

Tocamos aqui o ponto mais secreto da arte de Vincent. O que Bernard não pode ver, pois não dispunha do conjunto da obra é que Vincent buscou isso também e

\footnotetext{
${ }^{438}$ Ocorrência e Inter-relação entre Ritmo, Movimento,Textura, Gesto Pictórico, Desenho-Pintura para construir a Perspectiva do calçamento.

${ }^{439}$ Ocorrência de Rima Visual, construída pelo espelhamento do ritmo das estrelas com o ritmo do calçamento.
} 
sobretudo em pintura. Isso dá ao motivo um movimento prodigioso, pois toda a paisagem dança. A comparação entre desenho e pintura do mesmo motivo é impressionante. Só falta aos desenhos substituir os traços com caniço pela pincelada de cor com o pincel. E, logo que ele tiver suficiente habilidade técnica, poderá fazer três telas assim "escritas" num dia.

\subsubsection{Transição cromática entre as zonas iluminadas e as zonas escuras da tela}

Van Gogh utiliza como recurso de transição uma gradação tonal na qual ele aplica os azuis mais escuros no fundo rua e progressivamente adiciona tons de branco na medida em que a rua fica mais próxima ao café. Essa gradação pode ser considerada uma modalização dos tons frios de azuis que em contraste com os valores cromáticos quentes dos amarelos, laranjas e verde limão do café criam uma atmosfera envolvente. ${ }^{440}$

Observamos outro tipo de transição, feita com as linhas do calçamento que são mais finas em torno da praça e vão ficando mais grossas na medida em que avançam para o primeiro plano.

\subsubsection{Vetores}

A cena parece falar sobre a noite e o que acontece à noite, para onde as pessoas vão, e o que elas procuram. Aconchego, pertencimento, convívio com seus pares, a fuga da solidão e das ameaças inauditas da existência. Há um movimento de convergência, sugerido pela ação das pessoas representadas, que caminham em uma mesma direção, se acercam de um mesmo lugar, o café noturno, que concentra a ação da cena. ${ }^{441}$ Ainda que essa tela represente um movimento de convergência dos seres humanos, ela não o faz sem inserir os elementos que se contrapõe a essa convergência, criando um contraste entre a convergência dos seres humanos em um lugar convivial e ruas soturnas e solitárias da cidade, imersas em escuridão, o céu imenso e indevassável, e a natureza fugidia. Esses são os elementos que circundam o momento de encontro entre os seres humanos que convergem para as relações com seus semelhantes. A julgar pela enorme ênfase que é dada ao toldo amarelo, parece que o elemento de maior centralidade não são as pessoas, que têm seus rostos indefinidos, mas a lâmpada a

\footnotetext{
${ }^{440}$ Ocorrência de Modulação Cromática e Inacabamento para construir uma gradação de tons de azuis que são mais escuros e profundos no fim da rua e ficam gradualmente mais claros quando se aproximam do café criando uma zona de transição cromática.

${ }^{441}$ Ocorrência de Vetor, construído pelo Movimento das pessoas que se acercam do café.
} 
gás e a luz que dela se irradia. ${ }^{442}$ Apesar da diversidade dos vetores que participam da composição, observamos uma ordem na qual alguns vetores convergem para episódio do café terraço, enquanto outros são vetores relacionados com outras as figuras que simplesmente existem ao redor.

Enquanto algumas pessoas convergem para o café, ocorre um vetor que é o mais importante da cena: o vetor da lâmpada a gás que irradia sua luz no café e em volta dele na praça. Depois desse vetor, temos a ação das pessoas que se encaminham para o café, demonstrando a centralidade do café na cena. Temos aqui um contraste entre dois vetores: enquanto o vetor mais importante que é a lâmpada tem a ação de irradiar, o segundo vetor das pessoas, tem a ação de convergir. Temos um eixo de opostos nas ações 'convergir' e 'irradiar'. Outro eixo importante se dá pela ação da noite que escurece tudo a sua volta. Enquanto a lâmpada ilumina, a noite escurece. Temos outra relação de oposição entre as ações de iluminar e escurecer representadas na tela. ${ }^{443}$

A ação parece estar concentrada na lâmpada a gás que ilumina com sua luz feérica e compete com a outra fonte de luz, as estrelas que iluminam com sua luz suave.

\subsubsection{Análise da Função Modal da tela The Café Terrace on the Place Du Forum, Arles, at Night.}

O que nos leva para dentro da cena?

\subsection{Espaço compositivo}

O espaço compositivo da tela está dividido em quatro seções que se estruturam por linhas diagonais que se encontram no centro da tela. Essas linhas diagonais organizam o espaço representado na cena e constroem o ponto de fuga que comanda o olhar para dentro da cena.

\footnotetext{
${ }^{442}$ Ocorrência de Saliência, dada para a lâmpada a gás que concentra a atenção na cena.

443 Ocorrência de Vetor e de contraposição entre vetores. O vetor mais importante é o da lâmpada a gás que irradia, o secundário são as pessoas que convergem. A lâmpada ilumina, a noite escurece. Esses vetores scundários se contrapõem com a ação do vetor central, formando eixos de contraposição.
} 


\subsection{O uso da Perspectiva para criar Caminhos visuais}

O uso da perspectiva parece ser um recurso usado para conduzir o olhar para dentro da tela. A perspectiva linear clássica é usada nesta tela para reforçar a função Modal. A organização espacial da composição por meio da linha de fuga cria uma perspectiva que conduz o olhar diretamente para o centro da tela, onde vemos um cavalo que puxa uma charrete. Dele, partem quatro linhas de perspectiva que constroem a noção de espacialidade e de profundidade do ambiente que conduzem o olhar até o fundo da rua onde se encontra o cavalo e a charrete. ${ }^{444}$ Tudo parece ser trazido para este centro, como em um movimento centrípeto e com essa atração para o centro da tela, o conjunto empresta tranquilidade à noite, ao invés de turbulência. O clima da tela é escuro, mas sem uma ênfase nos aspectos sombrios da noite que não parecem se sobrepor ao impacto do toldo amarelo e das cores quentes que emanam do café.

\subsubsection{O uso do cavalo como uma figura Intermediária}

No século XVIII, os pintores europeus costumavam inserir figuras de menor destaque na cena, como crianças, criados e animais para contrastar com as figuras de maior centralidade na tela. As figuras menores eram um recurso modal, usados para criar a intermediação entre o espectador e as figuras e eventos que o artista quis dar maior destaque.

\subsubsection{Contraste Cromático}

O contraste cromático, em especial o contraste complementar é um recurso muito usado pelos artistas para capturar e conduzir o olhar do espectador pela narrativa visual. Nesta tela, vemos o uso de três tipos de contrastes pelo menos, o contraste de luz e sombra, de quente e frio, e o contraste complementar entre os azuis e laranjas que estão diluídos na rica paletta usada para representar o toldo amarelo e sua luz abundante.

O toldo amarelo, a primeira vista parece ter a ênfase principal da tela, e direciona a nossa atenção para os objetos representados em sua área de luz. No entanto, essa ênfase é

\footnotetext{
${ }^{444}$ Ocorrência de Enquadramento, Perspectiva e Profundidade construidas por linhas diagonais que convergem para o centro e dividem a tela em quatro seções. As quatro linhas diagonais que conduzem o olhar para dentro da tela.
} 
criada especialmente pelo contraste de sua luz com a sombra das cores frias do céu noturno e da escuridão das ruas. O contraste de luz e sombra dá-se entre a luz dos tons de amarelos e laranjas vibrantes contra os azuis sombrios e arroxeados dos prédios no lado oposto da rua. ${ }^{445}$

Esses elementos contrastados ajudam a criar um humor que nos envolve por meio de associação metafórica do contraste entre luz e sombra que nos remete à experiências muito familiares e à um imaginário que nos conduz para dentro do mundo retratado nesta tela.

\title{
4.4.3 Análise da Função Representacional da tela The Café Terrace on the Place Du Forum, Arles, at Night
}

\subsubsection{O tema do Café Noturno}

A noite e as estrelas foi um tema iniciado por van Gogh. Walther e Metzger (2012, p. 383) argumentam que "ele criou um novo gênero artístico: a cena noturna ao ar livre”. Seu interesse pela luz noturna o levou a representar uma série de noites estreladas como relata Cabanne:

\begin{abstract}
Nos primeiros dias de Setembro começa a série das "noites estreladas". Vincent pinta primeiro $O$ Café ao Anoitecer, um estabelecimento depois desaparecido, situado na Praça no Fórum; depois a Noite Estrelada sobre o Ródano e Café Nocturno, o café de Alcazar, onde dorme enquanto espera poder instalar-se na Casa Amarela. (CABANNE, 1971, p.154).
\end{abstract}

A composição tem como problema central a contraposição, entre a luz do café e a luz da noite e o ambiente acolhedor que essas duas luzes produzem, o ambiente da noite na praça. $\mathrm{Na}$ composição cromática da tela, o azul do céu passa a fazer contraste principalmente e diretamente com o amarelo do toldo, ${ }^{446}$ como expõe Haziot (2010, p. 216):

\begin{abstract}
Mais suave desta vez, e pensando certamente no seu colega do ateliê Cormon, Louis Anquetin, Vincent pinta o terraço de um outro café à noite, na Place Du Forum, um dos raros quadros do centro de Arles. Aqui não há mais contrastes de verde e vermelho; voltamos, ao contrário, ao amarelo vibrante do terraço iluminado e ao azul de um céu profundo e cheio de estrelas. Louis Anquetin havia representado um terraço de café no Boulevard de Clichy à noite, em amarelo e azul, que Vincent admirou em 1887, em Paris. Mas como pintar esse quadro, estando o cavalete na sombra? Vincent, que já descera à mina com um capacete munido de uma lâmpada, confeccionou um chapéu com velas para iluminar a tela enquanto pintava.
\end{abstract}

\footnotetext{
${ }^{445}$ Ocorrência Saliência dada pelos Contrastes Cromáticos do tipo Simultâneo, Quente/Frio, de Saturação para construir caminhos visuais e saliência na área do café e conduzir o olhar para dentro da tela.

${ }^{446}$ Ocorrência de contraposição entre a luz natural e a luz artificial, sugere uma associação metafórica.
} 
Na busca de representar as cores dos objetos na noite, iluminados pela luz a gás, ele fez parecer fácil uma tarefa muito árdua, como explica Walther (1990, p. 41) "o que, exactamente com escassa luz, é difícil de obter, deixam aqui a composição de um cenário nocturno parecer uma coisa natural". Walther relata como o uso de contrastes complementares entre azul e laranja contribuíram para van Gogh conseguir uma iluminação na tela difícil de se obter:

Com o quadro "Exterior de café à noite, na Place Du Forum em Arles", pintado pouco tempo mais tarde, van Gogh ousa um passo ao ar livre. Sob o céu estrelado, a esplanada do café parece muito iluminada, o amarelo avermelhado está em contraste complementar ao azul escuro da noite. Uma forte sucção para o centro negro do quadro, perceptível na perspectiva das linhas quase paralelas na verga da porta, em primeiro plano, na pérgula e empenas das casas, separa adicionalmente a convidativa claridade do café do seu ambiente escuro. Pontos destacados por luz clara, as estrelas no céu, além disso o contraste complementar, o que, exactamente com escassa luz, é difícil de obter, deixam aqui a composição de um cenário nocturno parecer uma coisa natural. (WALTHER, 1990, p.41).

Van Gogh inovou não apenas no tema, mas na proeza de registrar as cores noturnas, como são as cores dos objetos quando iluminados pelo lampião a gás e a luz das estrelas e quando iluminados apenas pela noite. ${ }^{447}$ De toda a forma, as cores da noite exerciam uma atração sobre van Gogh, como atesta sua carta, relatada por Haziot (2010, p. 208-209):

À noite, caminha à beira do mar na praia deserta. "Não foi alegre, mas tampouco triste: foi belo." Talvez tenha sido ali que teve a ideia de pintar a noite e o céu estrelado: "O céu de um azul profundo que o azul fundamental de um cobalto intenso, outras de um azul mais claro, como a brancura azulada de vias lácteas. No fundo azul as estrelas cintilavam claras, esverdeadas, amarelas, rosas mais claras, mais diamantinas que as pedras preciosas que conhecemos, mesmo em Paris...O mar de um ultramarino muito profundo - a praia me pareceu de um tom violáceo e castanho-claro, com moitas sobre as dunas...moitas azul da Prússia. C499.

\subsubsection{Natureza versus Progresso}

Nessa tela, podemos construir metaforicamente uma contraposição entre natureza $e$ sociedade; solidão e convívio; luz e sombra; luz das estrelas e luz do lampião; luz natural e luz artificial. A luz da lâmpada a gás, sinônimo do progresso tecnológico de seu tempo, van Gogh quis representar, em contraposição com a luz natural das estrelas, com sua luz sutil e perene, ${ }^{448}$ como explicam Walter e Metzger (2015, p.375):

A reunião, nesta pintura, de amarelos e azuis já antes utilizados possui uma vitalidade que nunca fora conseguida. A posição assumida pelas cores não é determinada tanto pelo princípio do contraste como pelo simples facto de ambas encarnarem valores luminosos. $\mathrm{O}$ amarelo berrante e o azul a ele subjugado representam áreas de um brilho impressionante e de uma delicada semiescuridão,

\footnotetext{
${ }^{447}$ Ocorrência de Inovação Pictórica com a representação das cores à noite, à luz do lampião a gás.

448 Ocorrência de Modulação Cromática na representação da cor à noite, iluminada pela lâmpada a gás.
} 
exatamente como Van Gogh os deve ter visto. Os transeuntes estabelecem a ligação entre as duas zonas. Estas figuras são deixadas em total anonimato; as condições de iluminação tornam, por si só, impossível a sua identificação. A área brilhante à volta dos candeeiros a gás projeta uma encandeadora nas faces das figuras, enquanto a área não iluminada das ruas secundárias insiste na sombra. E, de facto, Van Gogh está menos preocupado com as cores das coisas do que com o modo como elas estão iluminadas. Existe apenas uma fonte de luz: os candeeiros. Nos anos 1880, o gás já chegara às províncias. A iluminação à gás apoderara-se das atmosferas. Faltava-lhe aquela brilho romântico e trémulo que fazia com que as estrelas no céu e as velas nas janelas parecessem envoltas em mistério. A iluminação a gás era artificial, representando o brilho direto de tudo o que era novo. Van Gogh mostra ter plena consciência desse facto ao pintar, no eixo central da obra, o encontro do velho e do novo. Há uma espécie de desolação na forma como o brilho uniforme da área coberta compete com os pontos brilhantes de luz que resplandecem na escuridão.

Essa contraposição, entre a luz artificial e a luz natural pode servir de base para um uso metafórico do contraste e contraposição da fonte de luz natural (estrelas) e da fonte de luz artificial (progresso) que oblitera a atmosfera intimista das luzes mais fracas com sua iluminação direta e intensa. Van Gogh quis representar essa contraposição e principalmente o impacto da luz a gás no colorido da noite, sem esquecer de fazer a contraposição da luz natural, essa iluminação mais delicada que agora cedia espaço em nossa sensibilidade e em nossa subjetividade, para a luz incessante e dura trazida pelo progresso. ${ }^{449}$ Mas van Gogh homenageou as estrelas, mesmo em segundo plano, agora imperceptíveis, para sempre sobre as nossas cabeças. ${ }^{450}$ Essa contraposição é relatada por Walther e Metzger (2015, p.375-376):

Nesta pintura da esplanada do café na Place du Forum, à noite, Van Gogh estava a ilustrar duas ideias muito discutida na altura. Havia debates controversos sobre qual o monumento que iria coroar de glória a Exposição Mundial de Paris de 1889 e que faria parte, ao mesmo tempo, dos festejos do centenário Revolução Francesa. Haviam sido apresentadas duas hipóteses. Ambas eram torres, vistas como símbolos de um otimismo utópico, do espírito de progresso que inspirara o século XIX. A Torre do Sol (concebida por Jules Bourdais) "transformaria a noite em dia", segundo o slogan publicitário. Fora pensada de forma a iluminar a metrópole a partir de Pont Neuf, mesmo no coração de Paris e o seu brilho seria muito semelhante à luz do Sol. A luz vinda da torre seria projetada por espelhos até aos subúrbios mais remotos da cidade. Nada podia cantar mais elogios ao deus industrial do que o projeto pomposo de Bourdais - apesar de, na realidade, a outra hipótese, por que se acabou por optar, ser ligeiramente menos presunçosa. [...] O outro projeto tentava alcançar as estrelas. E foi essa a torre que se construiu - segundo os planos de Gustave Eiffel - que ainda hoje continua a ser o símbolo de Paris. Atualmente, já ninguém se lembra do seu simbolismo original. Pretendia-se que representasse o otimismo em relação ao futuro de uma sociedade que se abandonava aos sonhos das viagens pelo espaço. Os romances (os primeiros de ficção científica) que Júlio Verne andava na altura a escrever obedeciam ao mesmo objetivo. O limite (declarou a Torre Eiffel) era o universo. A plataforma mais alta parecia um observatório - era, de certa forma, uma rampa de lançamento para as idéias que já estavam lá no alto, entre as estrelas. Nesta época, todos sentiam que tudo era apenas uma questão de tempo. Como primeiro passo, construíram uma torre de trezentos metros de altura. O resto

\footnotetext{
449 Ocorrência de Associação Metafórica pela contraposição entre a cor sob a luz natural e a cor sob a luz artificial, que sugere sentidos potenciais acerca da contraposição Progresso x Natureza.

${ }^{450}$ Ocorrência de Modalidade, pois van Gogh quis retratar a sutileza da cor sob a iluminação natural das estrelas e a diferença entre esta e a cor e sob a iluminação artificial da lâmpada a gás.
} 
viria com o tempo. [...] Os quadros noturnos de Van Gogh podem ser interpretadas como comentários à irrealidade destes projetos. Ele via na sua arte o orgulho tecnológico da época com a tristeza disfarçada de um romântico, contrastando as pretensões do progresso com as da imaginação. O elemento irreal presente nas suas pinturas expunha a irrealidade desses projetos. E, pelo caminho, criou um novo género artístico: a cena noturna de plein air.

\subsubsection{A Noite e as Estrelas}

Os Impressionistas saíram da zona de conforto do estúdio e foram para a rua para pintar ao ar livre e capturar diretamente o comportamento da luz por meio de sua experiência ótica sensorial. Enquanto van Gogh subscreveu a essa nova forma de pensar a pintura ele foi adiante, buscando registrar a sua experiência sensorial ótica da luz noturna. No entanto, não é apenas essa busca que o move, conforme suas cartas para Theo atestam, mas a representação da experiência subjetiva que ele nomeou de 'desejo de infinito'. A noite e as estrelas constituíam para van Gogh uma metáfora dessa busca. O simbolismo da noite para Van Gogh é discutido por Walther e Metzger (2015, p.389):

Durante um mês (o de setembro de 1888), Van Gogh teve uma segunda mensagem para comunicar ao mundo e, acima de tudo, a si próprio. O Japão, por si só, já não era o símbolo da utopia; juntara-se-lhe agora o céu da noite estrelada. Mais uma vez, estava a utilizar uma série de alternativas para garantir que a Arte captasse um mundo melhor. O céu estrelado era, de certa forma, mais concreto e realista do que a obsessão de Van Gogh por uma viagem prolongada ao Extremo Oriente. Assim, as luzes lá longe no universo sugeriam a sua própria antítese num ambiente muito mais próximo: a iluminação a gás que, todas as noites, percorria as ruas de Arles. Não havia aí nada de utópico. E por isso as pinturas noturnas de Van Gogh não passariam de um episódio na sua obra - que detém, todavia, um significado pioneiro e inovador.

O que simbolizam as fontes de luz em face da ausência de iluminação trazida pela noite, e pela escuridão? O que são as pessoas em face da iluminação e do jogo de luz e escuridão? Van Gogh procurou experiênciar a luz pela sua ausência, e seus sentidos são debatidos por Walther e Metzger (2015, p.379-380):

Como é de hábito, Van Gogh não podia deixar de aliviar este pessimismo retomando o otimismo. O quadro que se seguiu à cena do café em ambiente noturno consistiu uma afirmação sincera, emocional e diametralmente oposta. As palavras de Immanuel Kant expressam bem essa diferença: "Há duas coisas que enchem o meu espírito de admiração crescente e renovada e de respeito, quanto mais vezes e mais constantemente dedico os meus pensamentos a elas: o céu estrelado que está acima de mim e os princípios morais existentes dentro de mim." Foi assim que Van Gogh pintou Noite Estrelada sobre o Ródano (p.425), um precursor pouco conhecido, mas concebido de forma muito mais consistente, da célebre obra-prima, realizada mais tarde (cf.pp.514-515). Aqui, tudo se estende sob a tranquilidade resplandescente das luzes naturais do céu. As estrelas cintilantes e os reflexos ondulantes na água não podiam ser mais do agrado dos gostos românticos. Com efeito, esta cena noturna baseou-se numa experiência genuinamente comovente da escuridão sem fim, que Van Gogh descreve na carta 499: "Uma vez, fui dar um passeio pela praia deserta, à 
noite. Não foi alegre, nem triste - foi belo." Esta é a única vez nas suas cartas em que ele fica de tal forma entusiasmado que invoca a Beleza tão enfaticamente - o que constitui razão suficiente para ver este entusiasmo como algo mais profundo do que uma mera indulgência momentânea à estética. Van Gogh andava a recorrer a todos os seus recursos românticos, contestando a tentativa positivista para ver as estrelas, científica e banalmente, como meros objetos do reino do conhecido. Temos um exemplo de profunda aversão a esse método no modo como os seus impulsos religiosos voltaram a vir à superfície: "Faz-me bem fazer qualquer coisa difícil. Mas isso não muda, de forma alguma, a minha imensa necessidade (será que devia usar a palavra) de religião; e então saio para o ar livre, à noite, e pinto as estrelas, sonhando sempre com a imagem de um grupo de figuras simpáticas e animadas." (Carta 543)

\subsubsection{O Céu Estrelado}

Pintar as estrelas, e mais do que isso, representar seu brilho, sua pulsação iridescente no céu noturno é outra inovação semiótica de Van Gogh; não apenas em termos de temática, mas sobretudo em termos de representação pictórica, uma vez que ele criou uma forma de representar as estrelas que é inegavelmente original. Ele se preocupou em pintar não as estrelas, mas seu brilho. Mas o que representa o brilho das estrelas? Para van Gogh, o infinito, ${ }^{451}$ como atesta sua carta relatada por Cabanne (1971, p.153-154):

Antes de terminar o retrado do seu amigo Boch, escreve a Théo: "Para o acabar, vou agora ser um colorista arbitrário. Exagero o loiro da cabeleira, chego aos tons alaranjados, aos crómios, ao limão pálido." Exalta-se até ao delírio e grita: "Por detrás da cabeça, em vez de pintar a parede banal do apartamento mesquinho, pinto o infinito..." 144 Está extenuado, come mal, vive num estado de tensão perpétua, mas isso não importa, pois pode "todavia sentir distintamente as estrelas $e o$ infinito, lá em cima". Este infinito para o qual tende a sua alma enfraquecida para aí se afundar e perder, finalmente vitorioso sobre o imperioso e trágico destino ao qual está ligado.

Além da inovação de tentar representar a iluminação da cena pela luz das estrelas no céu noturno, Vincent parece ter utilizado uma associação metafórica para esses corpos celestes tão distantes e tão presentes nesta tela. Essa associação simbólica que van Gogh constroi ao representar as estrelas é relatada por Cabanne (1971, p.156):

Vincent não procura encorajamentos, não solicita conselhos como outrora; aliás, desde que não vê a pintura dos outros é verdadeiramente ele mesmo; as suas hesitações, os seus subterfúgios, os seus temores, desapareceram e parece que também a angústia se desfez na alegria de pintar. Não há mais recriminações, mais remorsos, é feliz; já não se preocupa com comer pouco, com o estar privado - e para sempre - do calor de um lar, da perspectiva de conhecer essa "verdadeira vida" durante tanto tempo esperada, com o não ter amigos, viver no meio da indiferença ou dos sarcasmos. Atingiu essa plenitude de expressão em que seu ego se realizou finalmente e sua "terrível lucidez" se expande no delírio dionisíaco de que é possuído quando cria. Morreram o orador de outrora, o laborioso exegeta da Bíblia, o evangelista preocupado em penetrar a verdade dos homens e de Deus; perante a Natureza, Vincent aprendeu, no contacto com o "aspecto tranquilizante e familiar

${ }^{451}$ Ocorrência de Incompletude, Transparência e Limiar Artístico, construídos pela forma de representar as estrelas e a luz noturna que para van Gogh simbolizavam $o$ infinito. 
das coisas", que a sua alma ardente encontrava o único descanso nos sortilégios infinitos da realidade. E como é simples esta frase de uma carta para Théo: "Tenho uma necessidade enorme de - direi eu a palavra? - religião; então, à noite, vou para a rua pintar as estrelas".

Para van Gogh as estrelas tem um sentido religioso e de transcendência de nossas vidas cotidianas, ${ }^{452}$ como atesta sua carta relatada por Walther e Metzger (2015, p. 384-387):

[...] o mundo melhor que existia do outro lado da Terra e aquele das estrelas sobrepunham-se, tornando-se indistintos. Qualquer dúvida sobre esta interpretação poderá ser esclarecida por uma passagem, numa das cartas, que, com um negro e um tom de indiferença quase desesperantes, é certamente a mais expressiva que alguma vez escreveu: "A morte pode talvez não ser a coisa mais difícil na vida de um pintor. Devo dizer que nada sei nada sobre elas, mas quando olho para as estrelas, ponhome logo a sonhar, acontecendo-me exatamente a mesma coisa como quando observo os pontos negros que indicam as cidades e aldeias nos mapas. Pergunto-me eu, por que é que os pontos brilhantes do céu hão de ser menos acessíveis para nós do que os pontos negros de um mapa de França? Tal como apanhamos um comboio para ir até Tarascon ou Ruão, também nos servimos da morte para atingir uma estrela. De certo modo, isto não deixa de ser verdade: da mesma forma que não podemos viajar até uma estrela enquanto estamos vivos, também não podemos apanhar um comboio depois de mortos. Em todo o caso, não me parece impossível que a cólera, as pedras nos rins, o cancro ou a tuberculose possam ser meios de transporte celestiai, tal como as máquinas a vapor e os caminhos de ferro o são na terra. Morrer tranquilamente de velhice seria equivalente a ir a pé." Esta passagem da Carta 506 é crucial para se compreender o suicídio que pôs fim à vida de Van Gogh, mas por agora podemos analisá-la como elemento definidor de duas áreas: uma delas remota (desejada e inatingível), existente no universo; e outra existente neste mundo, localizada mais propriamente em Arles, que inclui todos os aborrecimentos da vida cotidiana.

Em sua carta 511, van Gogh constrói ainda outros sentidos para as estrelas, relatados por Walther e Metzger (2015, p. 384):

"É fascinante imaginar que as gloriosas escolas dos gregos, dos antigos holandeses, e dos mestres japoneses ainda existem algures entre as estrelas", refletia ele na Carta 511. "Onde estarão Newton, Copérnico, Galileu, Jesus, Buda, Confúcio e Sócrates?", perguntava o astrónomo Camille Flammarion nessa mesma altura e, como Van Gogh acabou por concluiu: "As estrelas deles ainda brilham, eles ainda existem, noutras esferas; estão a dar continuação, noutros mundos, ao trabalho interrompido na Terra." Inconscientemente, Van Gogh procurava parecer o mais oriental possível: o mundo melhor que existia do outro lado da Terra e aquele das estrelas sobrepuseram-se, tornando-se indistintos.

Podemos dizer que o detalhamento, em contraste com o não detalhamento dos elementos da cena parece indicar o grau de importância destes para o pintor. Ainda que elas não estejam no primeiro plano, como seria a forma convencional de indicar o maior grau de importância, o detalhamento das estrelas demonstra que na valoração de van Gogh, o céu adquire importância maior do que outros objetos representados na cena. ${ }^{453}$ Esse mesmo

\footnotetext{
452 Ocorrência de Incompletude, Transparência e Limiar Artístico, construídos pela forma de representar as estrelas e a luz noturna que para van Gogh simbolizavam o infinito e constituíram uma semiose muito central em seu discurso.

${ }^{453}$ Ocorrência de Saliência na representação detalhada das estrelas que, apesar de não estarem no primeiro plano ganham destaque e evidenciam seu grau de importância semiótica na narrativa.
} 
detalhamento com que ele observou e buscou representar as estrelas está declarado em sua carta de setembro de 1888:

Quero agora absolutamente pintar um céu estrelado. Frequentemente me parece que a noite é ainda mais ricamene colorida que o dia, colorida de violetas, de azuis e os mais intensos verdes...Quando voce prestar atenção, verá que certas estrelas são cor de limão, outras têm brilho cor-de-rosa, verdes, azuis, miosótis. (Carta de Van Gogh, Arles, setembro de 1888)

A representação de um céu estrelado foi uma inovação de van Gogh, mas ele se inspirou nas gravuras japonesas. Coli (2006, p. 98-100) comenta a influência de Hiroshige na forma de van Gogh representar as estrelas:

Vincent continua fascinado pela arte das estampas japonesas e refere-se constantemente a elas em suas cartas. Faz pouco tempo, pude ver uma estampa de Hiroshige intitulada Fogos de Artifício - Riogoku, da série 100 vistas de Edo (museu Britânico). É muito provável que Vincent a conhecesse - Théo possuía uma excelente coleção, e o próprio Vincent copiara algumas vistas de Edo de Hiroshige como A Ponte sob a Chuva, do museu de Amsterdã. No que toca os Fogos de Artifício, há uma relação possível com a Noite Estrelada de Arles. Evidentemente não se trata de cópia ou de pasticho - mas os pontos comuns entre a estampa e o quadro são numerosos e importantes.

Uma tela de Hiroshige que representa fogos de artifício explodindo em um céu escuro foi uma forte influência na forma como van Gogh representou as estrelas em suas telas noturnas, como explica Coli (2006, p.100):

[...] a representação dos pontos luminosos no céu. Em uma carta à sua irmã Wilhelmina, ele diz: "é evidente que para pintar um céu estrelado não é de forma alguma suficiente colocar pontos brancos sobre um fundo azul". Para evitar a representação banal, o que ele faz é colocar um núcleo central sobre uma espécie de irradiação cintilante: exatamente como Hiroshige faz para representar a explosão de seus fogos de artifício.

Acrescento a essa colocação de Coli (2006) que para Vincent não era de forma alguma suficiente colocar pontos brancos sobre um fundo azul, porque isso tornaria o céu estático. De certa forma, ele buscou representar a irradiação da luz das estrelas, porque essa irradiação está em movimento e chega até nós e, portanto, se comunica com os outros elementos da tela. ${ }^{454}$

Essa comunicação entre os episódios, figuras e membros da tela, ele construiu por meio do movimento das pinceladas, mas principalmente pela distruibuição cromática dos contrastes para alcançar unidade e dinamismo. Representar o halo de luz das estrelas é diferente de representar as estrelas, ele privilegiou representar seu brilho como o elemento que dá vida a elas, pulsa, e se comunica no espaço da noite. A metáfora de estrelas como

\footnotetext{
${ }^{454}$ Ocorrência de Modalidade na forma de representar a irradiação da luz das estrelas, porque essa irradiação está em movimento. Van Gogh quis representar a luz das estrelas com o dinamismo com que elas pareciam para ele.
} 
fogos de artifício ultrapassa, dessa forma, a mera figura retórica e se torna nas mãos de van Gogh, uma associação metafórica para sua 'necessidade de infinito'. ${ }^{455}$

Acima do café, vemos um céu ricamente representado pelas estrelas que não apenas são representadas por sua forma, mas por seu brilho e o halo de luz que produzem. O halo de luz tem em si uma significação simbólica para van Gogh. Como o halo que representa a santidade, o halo das estrelas comunica uma dimensão divina e comunica a sua 'necessidade de infinito'. O uso do halo como recurso de associação metafórica parece ter impulsionado uma cadeia de associações metafóricas para van Gogh que se materializaram em outras telas, ${ }^{456}$ como atestam Walther e Metzger (2015, p. 382):

$\mathrm{O}$ estilo noturno atingiu o auge no retrato do poeta e pintor belga Eugène Boch (p.414). Neste quadro reuniram-se todas as ideias de Van Gogh a respeito dos quadros da noite. "Sonho sempre com a imagem de um grupo de pessoas simpáticas e animadas": aqui não se tratava de um grupo, mas pelo menos era uma pessoa a quem Van Gogh se podia afeiçoar e em quem podia projetar aquele sentido de harmonia que atraía metáforas cósmicas. "Numa pintura quero sempre dizer algo de agradável, como a música", escreveu ele (Carta 531). "Gostaria de pintar homens e mulheres com aquela qualidade eterna que costumava ser simbolizada por uma auréola e que procuramos invocar por meio do brilho, da trémula vitalidade das nossas cores." E, de fato o crânio do amigo é delineado por um delicado traço dourado. De certo modo, constitui um resquício do nimbo que fora uma constante ao longo da história da arte. Com o céu estrelado em último plano a fazer o enquadramento, a aura religiosa parece quase surgir por iniciativa própria. Boch era um escritor - um "poeta", como Van Gogh lhe chamava. Ao escolher um homem das letras, um artista criativo, Van Gogh encontrara uma forma de projetar a sua concepção das estrelas como um mundo utópico oposto à imaginação, onde o artista se poderá sentir em casa. O mundo melhor que toda a sua energia criativa procurava nessa altura estava lá em cima, nas estrelas.

O retrato de Eugène Boch estabelece uma cadeia de textos com a tela Café Terrace, pelo uso de diversos recursos semióticos que assumem uma dimensão metafórica em ambos, como explica Haziot (2010, p. 216-217):

Uma das grandes obras do período é o retrato de Eugène Boch, pintor e poeta belga que morava nos arredores de Arles e que se tornou seu amigo. Boch era originário da região de Mons. Vincent o tomou como modelo para o seu Retrato do poeta: Boch, em amarelo dourado sobre um fundo de noite estrelada, vibra como um astro, um pedaço de ouro brilhante ou de sol caído do céu. Para pintá-lo, Vincent diz que se fez "colorista arbitrário. 'Exagero o loiro dos cabelos chego aos tons alaranjados, aos cromos, ao limão pálido. Atrás da cabeça, em vez de pintar a parede banal do mesquinho apartamento, pinto o infinito, faço um fundo simples com o azul mais rico e mais intenso que posso preparar, e, por essa simples combinação da cabeça loira iluminada sobre o fundo azul, obtenho um efeito misterioso como a estrela no anil profundo" C520 Esse efeito de um tema iluminado por um amarelo diurno sobre um fundo noturno será repetido em outras obras. Na verdade, temos aqui o equivalente, na cor moderna, dos claros-escuros de Rembrandt e de Caravaggio. Mas, como na Noite estrelada sobre o Ródano, Vincent ainda não teve a idéia de mostrar por um halo de pontos a cintilação das estrelas, tomando de Seurat essa

\footnotetext{
455 Ocorrência de Incompletude, com a representação do brilho das estrelas, van Gogh construiu uma semiose para seu desejo de infinito.

${ }^{456}$ Ocorrência de Incompletude e Associação Metafórica construída pela representação das estrelas, seu brilho e seu halo, que suscita escolhas de sentidos potenciais metafóricos, como o halo de santidade.
} 
técnica. Só recorrerá a ela em Saint-Rémy. O fato é que a vibração do retrato de Eugène Boch, quando o vemos no museu, faz dele um dos maiores retratos de Vincent, se não o maior.

Argumentamos que a representação do brilho das estrelas na tela Café Terrace cria um halo de luz, representado por uma massa desigual de branco que emula seu cintilar, ao contrário do que afirma Haziot (2010), que só será empregado por Van Gogh em Saint-Rémy. Enquanto Seurat pintava por pontos, van Gogh usando a mesma técnica de justaposição de cores para produzir o efeito de contrastes 'oculares' e empregava pinceladas mais dinâmicas e frenéticas para imprimir ritmo, movimento, textura e direção na representação. A representação do halo e da cintilância das estrelas constitui uma inovação semiótica muito importante, não apenas por sua carga expressiva, mas também por seu poder simbólico.

\subsubsection{Contrastes Cromáticos}

Provavelmente a cor é o recurso semiótico que van Gogh usou com maior domínio e conseguiu, em sua potência expressiva, construir uma rede de semioses, como explica Cabanne (1971, p.145):

A cor, sempre a cor. Vincent integra-se e funde-se nela, como se ele próprio fosse o elemento solar, e é em seu nome que o demiurgo chama o universo inteiro, numa espécie de abrasamento místico. Então, do muito "glorioso calor", "um sol, uma luz que, à falta de melhor, só posso chamar amarelo, um amarelo de enxofre pálido, limão claro, ouro", com uma "irradiação de enxofre pálido", brotam os girassóis, símbolos do culto solar, discos de fogo cujo flamejar é o do próprio astro. E as estrelas com que Vincent semeia o céu do Café ao Anoitecer e da Noite Estrelada são, como os candeeiros de petróleo do Café Nocturno, "outros tantos sóis giratórios ou coalhados..." 143.

Nesta tela van Gogh usou com muita ênfase o contraste complementar entre os azuis e os alaranjados, de forma que os azuis intensificam o efeito dos alaranjados e os alaranjados intensificam o efeito dos azuis produzindo uma ênfase mútua entre as áreas que ele quis representar com maior destaque: o café e o céu estrelado. ${ }^{457}$

Para enfatizar a intensidade do contraste entre o azul da noite e o alaranjado do café, ele usou tons claros, possibilitando a representação de uma noite tão clara, tão iluminada que tornou possível a representação de tons de violetas, lilazes e verdes de tons igualmente claros no chão da praça e nos arredores do café, onde deveria ser muito mais escuro. Esse valor de claridade e de iluminação no chão da praça é possível porque van Gogh usou para representar

\footnotetext{
${ }^{457}$ Ocorrência de contrastes simultâneos para construir uma ênfase mútua entre as áreas que ele quis representar com maior destaque: o café e o céu estrelado.
} 
o céu, um tom de azul muito mais claro do que seria a realidade. Van Gogh representou o azul da noite mais claro do que ele é na realidade, para dessa forma, poder representar os tons de lilazes e verdes que ele identificava ocularmente, mas que não seriam aparentes na pintura. No entanto, a busca de representar a variada coloração que ele via é uma forma de dar modalidade para a representação. O valor claro tanto dos azuis como dos alaranjados corroboram para atribuir brilho e leveza para as cores da noite que acontece tanto no café quanto na rua, ${ }^{458}$ como explicam Walther e Meztger (2012, p. 381):

A reunião de amarelos e azuis familiares nesta pintura tem uma vitalidade que ele nunca alcançou anteriormente. Seu lugar não é determinado tanto pelo princípio do contraste como pelo simples fato de que as duas cores incorporam valores claros. O amarelo alto e o azul suave representam áreas de brilho arrebatador e delicada semiescuridão exatamente como van Gogh deve ter visto eles.

$\mathrm{Na}$ figura abaixo vemos que o portal azul no primeiro plano funciona para integrar o azul do fundo da rua e do céu com o primeiro plano dando um sentido de unidade para a composição. Da mesma forma observamos que a janela alaranjada no prédio do outro lado da rua constrói um sentido de integração entre a área mais 'alaranjada' do café e a área mais 'azulada' da composição que fica na rua e no céu. O cruzamento do azul da porta, integra o fundo ao primeiro plano e o alto à base da composição, enquanto o alaranjado da janela integra a esquerda da composição com a direita, criando unidade e harmonia para a tela. ${ }^{459}$

\subsubsection{O uso da cor como simbolismo}

Van Gogh não estava comprometido em representar as cores de forma naturalista e em algumas cartas chegou a declarar-se um colorista arbitrário empregando cores sem uso de matizes e com o seu valor mais intens para representar suas emoções:

Os artistas e designers do final do século XIX e do século XX, começaram a usar a
cor, não para fins de representação naturalista, mas para representar diretamente
idéias e sentimentos. Nisso, a metáfora experiencial era seu veículo. (...) Van Gogh
foi um dos primeiros a fazê-lo. Em uma carta ao seu irmão Theo, ele descreve, por
exemplo, como ele usou o potencial significado da cor azul e pureza para expressar a
idéia de "infinito" (Van Gogh, 1978: 6): Eu pinto o infinito, um fundo liso dos mais
ricos, mais intenso azul que eu posso inventar, e por esta simples combinação da
cabeça brilhante contra o fundo azul rico, eu recebo um efeito misterioso, como uma
estrela no fundo de um céu azul. (VAN LEEUWEN, 2011, p. 59).

${ }^{458}$ Ocorrência de Modalidade, ou de baixa modalidade, e Inacabamento. Van Gogh representou o azul da noite mais claro do que ele é na realidade, para dessa forma, poder representar os tons de lilazes e verdes que ele identificava ocularmente, mas que não seriam aparentes na pintura. No entanto, a busca de representar a variada coloração que ele via é uma forma de dar modalidade para a representação.

${ }^{459}$ Ocorrência de Rima Visual construída pelo cruzamento de cores nas áreas correspondentes. Há o cruzamento do azul da porta que integra o fundo ao primeiro plano e o alto à base da composição, enquanto o alaranjado da janela integra a esquerda da composição com a direita, criando unidade e harmonia para a tela. 


\subsubsection{Uso de Simbolismo ou de Associações Metafóricas}

Tanto por sua associação com o programa da escola cloisonista que era simbolista, liderada por Bernard e Gauguin quanto por ter ele próprio desenvolvido uma cadeia de semioses que foram agregando novos sentidos e novas associações, tais como o céu estrelado no fundo do retrato de Eugène Boch. Van Gogh passou a produzir cada vez mais composições repletas de associações metafóricas como expõe McQuillan (1989, p. 63):

No retrato de Boch ele acrescentou estrelas no fundo. Não simplesmente um retrato, era um estudo para The Poet against a Starry Sky, cuja versão final ele destruiu juntamente com Christ with the Angel in Gethsemane, 'porque a forma não tinha sido estudada previamente a partir do modelo, que é necessário em tais casos', então ele explicou a Bernard (B19, outubro de 1888). Embora ele não estava pronto para pintar sem referência à realidade, ele investiu certas obras com significância simbólica intensificando cores e exagerando formas e construção espacial. Mesmo se o seu significado particular não pode ser lido a partir das pinturas sem a ajuda das cartas, a sua artificialidade implora associações extravisuais. The Night Café, em setembro de 1888, Café Terrace at Night e Starry Night over the Rhône, setembro, todos confirmam a associação de van Gogh com o simbolismo. ${ }^{460}$

É difícil não reparar que os temas noturnos, além da beleza da luz noturna que parece ser o ator principal da cena, introduzem o uso das associações metafóricas de grande apêlo e que nos convidam a indagar que construções de sentidos van Gogh empresta à noite, ou à luz, seja ela das lâmpadas ou das estrelas, a essa luz que banha e ilumina os seres e objetos no meio da escuridão. ${ }^{461} \mathrm{O}$ sentido metafórico da noite para van Gogh pode ser apreendido neste excerto em sua carta 534, relatada por Walther e Metzger (2015, p. 381): Van Gogh andava a recorrer todos os seus recursos românticos, contestando a
tentativa positivista de ver as estrelas, cientifica e banalmente, como meros objetos
do reino do conhecido. Temos um exemplo de profunda aversão a esse método no
modo como os seus impulsos religiosos voltaram a vir à superfície: "Faz-me bem
fazer qualquer coisa difícil. Mas isso não muda, de forma alguma, a minha imensa
necessidade (será que devia usar essa palavra) de religião; e então saio para o ar
livre, à noite, e pinto as estrelas, sonhando sempre com a imagem de um grupo de
figuras simpáticas e animadas." (Carta 543).

\footnotetext{
${ }^{460}$ Traduçao livre da autora. "Some of the portraits and the Sunflowers appear charged with an additional presence. Their flatness and the textured matière of the background likens them to icons. In the portrait of Boch he added stars to the background. Not simply a portrait, it was a study for The Poet against a Starry Sky, whose final version he destroyed along with Christ with the Angel in Gethsemane, 'because the form had not been studied beforehand from the model, which is necessary in such cases', so he explained to Bernard (B19, October 1888). Although he was not ready to paint without reference to reality, he invested certain works with symbolic significance, intensifying colours and exaggerating shapes and spatial construction. Even if his particular significance cannot be read from the paintings without the aid of the letters, their unnaturalness begs extravisual associations. The Night Café, September 1888, Café Terrace at Night and Starry Night over the Rhône, September, all support van Gogh's association with Symbolism." (McQUILLAN, 1989, p.63)

${ }_{461}$ Ocorrência de Associações Metafóricas e Intertextualidade para as escolhas de sentidos que van Gogh empresta à noite, à luz noturna, evidenciado no excerto da carta 543 citada na análise.
} 
Walther e Metzger (2012, p. 312) defendem que não podemos fazer inferências sem antes conhecer o que esses temas significam para o próprio Vincent. Walther e Metzger explicam a natureza do simbolismo nas obras de van Gogh (2015, p. 308):

A Bíblia foi banida de todas as naturezas-mortas que van Gogh pintou em Paris, em
1887; no entanto, nunca deixou de incluir os livros que informavam então a sua
maneira de pensar. A natureza-morta com os três livros (pp. 216) retrata La Fille
Elisa juntamente com Au Bonheur des Dames de Zola, e Braves gens de Jean
Richepin. Van Gogh estava, sem dúvida, igualmente a pensar em termos de
compatibilidade de cores quando os pintou. [...] Estes livros não são atributos. Não
são marcas de erudição ou de grande sabedoria tais como as que vemos várias vezes
em retratos. Representam o próprio Van Gogh - tal como as cadeiras ou os sapatos.
São símbolos e operam do mesmo modo que o idioma simbólico tradicional da
religião. No entanto, os símbolos de Van Gogh já não têm qualquer relevância
universal; é impossível compreendê-los de uma forma tão imediata quanto a Cruz ou
o Cordeiro do Cristianismo. Para podermos descodifica-los, teremos de conhecer a
vida do artista e o significado que ele lhes atribuiu; caso contrário, os livros não
passarão de simples objetos, com um interesse e uma importância iguais aos de
qualquer outro.

No entanto, podemos sondar esse significado com base na compreensão de que o discurso de van Gogh não está descolado de seu tempo, mas está imbricado e é produto da cultura e de suas produções simbólicas na qual ele se constitui, como relatam Walther e Metzger (2015, p. 308):

Essa intensa inter-relação entre signo e significado que sempre caracterizou os símbolos assenta num conhecimento prévio da parte do observador, conhecimento esse que é tido como certo pois começamos a adquiri-lo desde que nascemos. Ora, na obra de Van Gogh, esta imediata correspondência referencial faz apenas sentido em relação ao próprio artista. Só ele possui a chave para os significados mais profundos. Aqueles que tentarem desvendá-los necessitam da sua ajuda. Vemos instituir-se, em van Gogh, uma característica fundamental do Modernismo: o fenômeno do simbolismo individual.

Van Gogh e seus pares inauguraram a representação da subjetividade do sujeito na arte como uma característica que antecipou o modernismo. O papel ativo da subjetividade na constituição do discurso artístico está presente também na prática discursiva da correspondência com seu irmão Theo e com seus amigos pintores. Ao lermos as cartas é possível observar o papel da interação na construção de um discurso simbólico, individual, subjetivo que está intrinsecamente relacionado com a prática pictórica. ${ }^{462}$ A prática discursiva baseada na correspondência e no convívio social apoiou a forma como os artistas se representavam, construiam seus sistemas semióticos e concebiam sua prática pictórica na qual eles passaram a integrar sua dimensão subjetiva, ética, moral e espiritual na prática artística, empoderando o lugar simbólico do artista na reconfiguração de seu papel social.

\footnotetext{
462 Ocorrência de Transparência na forma como ele representa o ambiente noturno e a luz das estrelas.
} 


\subsubsection{Figuras}

\subsection{O cavalo que puxa a charrete}

No centro da tela o cavalo que puxa uma charrete marca o ponto de fuga que estrutura toda a composição. Apesar de que, no cromatismo, o café tem uma importância central, na estruturação espacial é o cavalo que ocupa a posição central na cena. $\mathrm{O}$ cavalo que puxa uma charrete é um elemento visual recorrente em sua obra e também nas cartas. Esta recorrência sugere a presença de uma associação metafórica que pode ser examinada com a ocorrência em suas cartas. ${ }^{463}$ Seus biografos Naifeh e Smith (2012, p. 69) também fazem menção a este episódio:

Num dia de chuva de outubro de 1864, Dorus e Anna van Gogh meteram o filho distante e emburrado dentro do coche amarelo da família e subiram 22 quilometros ao norte, até a cidade de Zevenbergen. Lá nos degraus de um internato, despediramse do menino de onze anos e foram embora.

A figura do cavalo e charrete possivelmente constitui um importante recurso semiótico para Van Gogh embora de um simbolismo muito pessoal e particular. Encontramos uma referência escrita que Vincent faz em uma carta enviada a Theo em que descreve quando seus pais o deixaram em um colégio interno pela primeira vez, e como foi ver a charrete, que sumiu na estrada, levando para longe seus pais, ${ }^{464}$ como relata Haziot (2010, p. 21):

Era um dia de outono", ele escreve a Théo. "Eu estava de pé na entrada da escola do sr. Provily, seguia com os olhos a carruagem na qual papai e mamãe iam embora de volta para casa. Avistava ao longe a pequena carruagem amarela na longa estrada molhada de chuva, margeada por árvores raquíticas, correndo através do campo. $\mathrm{O}$ céu cinza, por cima de tudo, se refletia nas poças d'agua. [...] Entre esses instantes e o dia de hoje se estendem os anos em que me senti alheio a tudo.

$\mathrm{Na}$ composição, o cavalo recebe a luz de alguma janela ou a luz que emana do próprio café que comanda a cena. Apesar de estar no plano do fundo, o fato de o cavalo encontrar-se no centro da tela parece dizer: é daqui que tudo começa, neste cavalo que puxa uma pequena charrete sugerindo que, para o autor, esta é uma semiose muito pessoal sobre o lugar que a figura do cavalo ocupa na tela em sua relação com os outros elementos compositivos.

\footnotetext{
463 Ocorrência de Associação Metafórica e Transparência para a posição relativa da charrete e o cavalo, construída pela Saliência dada pelo Enquadramento.

${ }^{464}$ Ocorrência de Intertextualidade evidenciada pela citação de van Gogh de um episódio no qual seus pais o deixaram na escola e foram embora em uma charrete amarela.
} 


\subsubsection{Elementos - Membros}

\subsubsection{1 Árvore}

Entrando pela extremidade direita da tela, aparece metade da copa e do caule de uma árvore, ${ }^{465}$ que apesar de estar no segundo plano na composição espacial, está muito bem definida e detalhada, ao contrário dos outros elementos humanos no segundo plano. A ela é dado um tratamento de contrastes cromáticos típico de primeiro plano, causando uma ênfase nesta figura não pela sua posição, mas pela sua intensidade cromática. ${ }^{466}$ Pelas convenções da época, ela deveria ter esta intensidade cromática se estivesse no primeiro plano e assim, causa uma ambiguidade pictórica que comanda a atenção do espectador para o segundo plano onde se encontram a árvore e também o café. Essa ênfase dada à árvore, junto com o céu azul, compete com a atenção que o toldo amarelo também atrai. Ela cria um jogo de forças e de contrastes no qual, apesar de a árvore estar representada por um verde intenso combinado com tons de cinza e preto, ela contrapõe com o toldo que é de um amarelo vibrante, causando um contraste entre esses dois objetos pictóricos. Ao mesmo tempo, estando bem em frente ao café, o intenso verde da árvore parece dialogar com o intenso amarelo do toldo, enquanto a forma da copa parece criar uma seta que aponta para o café. Além de estar pela metade, observamos que a copa em forma de seta aponta para o toldo, que seu verde intenso não é encontrado em nenhuma outra correspondência na tela, ressaltando o seu caráter cromático único, singular. ${ }^{467} \mathrm{O}$ que isto quer dizer?

E por fim, o tamanho da árvore é proporcionalmente, muito maior do que os outros elementos da cena, significando sua imponência e importância proporcional metafórica para o pintor. Que sentido há nessa ênfase? Podemos inferir pela forma como a árvore está representada que ela ocupa uma posição simbólica na tela, e faz uma indexação com a Natureza que é uma categoria em si mesma em grande parte das telas de van Gogh. ${ }^{468}$ Naifeh e Smith (2012, p.68) comentam sobre a experiência na natureza para van Gogh tão fartamente documentada em suas cartas:

\footnotetext{
${ }^{465}$ Ocorrência de Inacabamento e Enquadramento pela representação da árvore pela metade na composição.

${ }^{466}$ Ocorrência de Saliência e Cor, construída pelo detalhamento e pela intensidade cromática com que a árvore, mesmo estando no segundo plano, é representada.

${ }^{467}$ Ocorrência de Vetor pela representação da copa da árvore em forma de seta que aponta para o café.

468 Ocorrência de Associação Metafórica construida pelo tamanho desproporcional da árvore, em comparação com o tamanho dos outros membros representados na tela, sugerindo que van Gogh está atribuindo à árvore um estatuto simbólico mais amplo, ele se refere à categoria da Natureza.
} 
Como os românticos que admirava, porém, Vincent encontrava consolo, mas também perigo na imensa impassibilidade da natureza. $\mathrm{O}$ indivíduo podia se perder e sentir diminuído, sentir-se inspirado e esmagado pela imensidão, lembrava-o de seu afastamento do mundo - especialmente de um mundo onde a natureza e a família estavam entrelaçados de maneira tão íntima. Estava ali sozinho com a criação de Deus, ou estava ali apenas abandonado? De tempos em tempos, ao longo de toda a vida, ele iria procurar consolo para seus problemas enfronhando-se nos ermos agrestes, onde só encontraria ainda mais solidão e acabaria voltando ao mundo em busca da companhia humana que sempre lhe escapava, mesmo na infância, mesmo dentro da própria família.

O movimento de contraposição entre a tranquilidade na natureza e a busca do convívio humano parece central no tema do café, e a árvore em frente ao café parece reforçar esse sentido de dualidade. Apesar de ganhar uma valoração cromática de primeiro plano causando uma ênfase visual, a árvore está pintada pela metade, sugerindo que ela não faz parte da cena, mas se coloca na cena apesar disso. Ela se faz presente ainda que furtivamente. Dessa forma sua presença causa uma ambiguidade enunciativa, por um lado é valorizada cromaticamente pelo pintor de forma significativa, por outro lado ela se apresenta "pela lateral" da composição e "pela metade", é como uma "penetra" que não foi convidada. ${ }^{469}$

Inferimos que a árvore representada pela metade reforça o sentido da contraposição entre o progresso científico e a natureza, problematizado pela representação da luz artificial do lampião que sobrepuja e ofusca a iluminação natural do brilho das estrelas sobre os elementos da cena. O sentido de que a luz natural perde espaço para a luz artificial fica mais enfatizado pela presença parcial da árvore que representa o elemento natural. A posição que a árvore ocupa na cena sugere uma associação metafórica para a posição da natureza diante do progresso, seu lugar na nossa sociedade industrializada. Nesta tela van Gogh enuncia, uma vez mais, a perda de espaço, de sentido e de um tipo de subjetividade que nós desde o século XXI, não somos mais capazes de auferir. Ele sente a perda, nós apenas sentimos a falta do que foi perdido, a ausência que ficou no lugar do que não está mais ai para ser sentido, mas não sabemos do que sentimos falta. Uma falta é tudo o que sentimos. Van Gogh está se despedindo, de um mundo em que a luz de um lampião ainda é dura e agressiva para os olhos daqueles acostumados a enchergar com a luz suave das velas, da lua e das estrelas. Ela elimina toda a visualidade que é produzida a partir da ambiência suave e delicada que a luz natural produz. A sensibilidade com que as coisas são percebidas debaixo da iluminação natural está sendo perdida na medida em que uma luz mais forte ocupa todo o espaço e inibe nossos sentidos para se aguçarem na obscuridade de uma luz mais tênue. A subjetividade dessa relação também está se apagando, sendo substituída pela certeza de uma iluminação

\footnotetext{
${ }^{469}$ Ocorrência de Enquadramento construída pela representação da árvore pela metade está em contraposição com uma representação muito detalhada para um membro que está no segundo plano.
} 
homogênea e que deixa os contornos endurecidos e achatados. Essa é a possibilidade de experiência que chega com a revolução industrial e seu progresso e que desconfigura uma relação sensível e subjetiva mais natural com o mundo. Ele enuncia o sentimento de perda e recuo da natureza que está posicionada, não como mais um dos participantes da cena, mas como um elemento da natureza que adentra a cena, "pela lateral"; como uma força da natureza. Ao representar a árvore enigmática que se contrapõe à cena do café não estava van Gogh enunciando a nossa relação com a natureza, que ficou "pela metade" em sua natureza? 470

Se fossemos registrar com uma máquina fotográfica aquele mesmo café, iluminado com a mesma luz daquele lampião, as cores da foto seriam tão vivas quanto as da tela? Acredito que, até onde conheço as técnicas da fotografia, sem a ajuda de nenhuma luz adicional como flash, a julgar a distância que van Gogh estava pintando, a foto da cena sairia bastante escura na realidade, com cores bastante apagadas e desaturadas. No entanto sabemos que van Gogh não estava pintando apenas uma cena noturna, ele estava representando a acuracidade do olhar com que ele conseguia apreender e capturar as mais sutis variações de cores, justamente porque seus olhos estavam afeitos, educados, configurados para perceber o mundo com a iluminação natural, fosse ela de velas, do luar ou das estrelas. É dessa possibilidade e dessa perda que ele nos fala ao contar como tudo aconteceu. ${ }^{471}$

\subsubsection{0 Ênfase}

A textura do calçamento no primeiro plano parece conduzir o olhar, pelo uso do contraste de tons azuis e ocres das linhas do pavimento que cria um movimento direcional e conduz o olhar para uma mesa com duas cadeiras que estão vazias. Cadeiras vazias são um tema recorrente na obra de van Gogh, e podemos afirmar que se tornaram uma cadeia semiótica em duas telas posteriores a esta como relata Cabanne (1971, p.170):

O companheiro, por sua vez, começou duas telas cujo simbolismo aparecerá, alguns meses mais tarde, como premonitório. Uma representa uma cadeira, a sua, sobre o chão de ladrilhos encarnados, e a outra a de Gauguin. Sobre a primeira um cachimbo e um pacote de tabaco, sobre a segunda dois livros e uma candeia acesa. "Tentei pintar o seu lugar vazio", escreverá em Fevereiro de 1890 ao crítico Albert Aurier. Mas também o seu está vazio. Será uma imagem do futuro, esta dupla ausência do

\footnotetext{
${ }^{470}$ Ocorrência de Associação Metafórica construida pela representação da árvore pela metade que sugere um sentido potencial de contraposição entre o Progresso e a Natureza, ou que, diante do Progresso trazido pela luz a gás, a nossa Natureza ficou 'pela metade'.

471 Ocorrência de Modalidade pela construção da Modulação de cores como van Gogh as percebia. A sua fidedignidade para captar e representar as cores noite confere modalidade para a noite representada na tela.
} 
Atelier do Sul, nesta Casa dos Amigos, que agora não é mais que uma ilusão que se desvanece, mais uma? Amanhã, Vincent estará de novo só perante as duas cadeiras abandonadas, com o Inverno que chega, com o frio e a tristeza.

Elas têm uma significação simbólica de cunho pessoal para o pintor como atesta Muhlberger (2002, p.28-29) a respeito de duas telas pintadas meses depois:

Durante vários séculos, os artistas ocidentais utilizaram símbolos estabelecidos pelas tradições clássicas e cristãs. Os símbolos de van Gogh, no entanto, eram muito pessoais desenvolvendo-se a partir de seus pensamentos e desejos mais profundos. Como estudante longe de casa, ele chorou diante da cadeira vazia em que seu pai se sentara na visita. Para ele, cadeiras vazias simbolizavam ausência e morte. (...) Van Gogh não pintou retratos de Paul Gauguin, mas pintou a cadeira usada pelo amigo quando o visitou. Também pintou sua própria cadeira, como par com a de Gauguin. As cadeiras estão voltadas para lados opostos, e ambas são vistas de cima. Na cadeira de Gauguin, o verde e o amarelo unem as linhas curvas e espaçadas do acento listrado aos desenhos borrados do tapete. A cadeira de van Gogh tem as linhas retas como as bordas da porta atrás, e é rústica como o desenho do piso de cerâmica simples. Van Gogh disse que a cadeira de Gauguin continha dois romances e uma tocha acesa "no lugar do ausente". Talvez a "tocha", na verdade uma vela, estivesse iluminando o caminho para o retorno de Gauguin. Uma vela acesa é também um antigo símbolo de vida e ressurreição. A lamparina a gás acesa na parede, cria sombras púrpuras-azuladas no lado oposto da cadeira e deixa óbvio de que se trata uma cena noturna.

Este parece o enunciado de uma ausência. A quem ou ao que van Gogh se refere ao retratar duas cadeiras vazias? Estas cadeiras e mesa do primeiro plano parecem bem detalhadas enquanto as pessoas estão representadas sem muita definição, fundindo-se com os outros objetos representados no segundo plano. ${ }^{472}$

A intensidade dos amarelos e alaranjados conduz a atenção do olhar para o que se passa debaixo do toldo que concentra a iluminação e a ação da cena. No entanto as pessoas que participam dessa cena estão desfocadas e ao fundo, e sugere que a cena protagonizada não são as pessoas e seus negócios, mas sim a luz, ${ }^{473}$ o aconchego de se viver em sociedade, debaixo de um céu portentoso, e protegido da escuridão da rua. Para lá se dirigem os demais transeuntes, sugerindo que todos querem participar deste espaço de pertencimento.

No entanto algumas cadeiras estão vazias, sugerindo ou que serão ocupadas pelos que chegam, ou mais, um subtexto, sugerindo uma ausência. Quem não poderá sentar-se com os convivas? Quem não está? De que pessoa, cuja ausência Vincent parece enunciar? Que pessoa não participa desse grupo e suas experiências? As duas cadeiras estão ambas na mesma posição e ambas parecem olhar para o pintor. Dessa forma elas criam um caminho visual, um movimento direcional inverso que conduz o olhar do espectador, da tela para o pintor que as pinta e acabam incluindo este dentro da cena. No entanto são cadeiras vazias. De que ausência Vincent fala? Esta ausência está a 'vê-lo', desde sua posição incógnita na cena. Elas 'olham'

\footnotetext{
${ }^{472}$ Ocorrência de Saliência na representação das duas cadeiras no primeiro plano, pelo seu detalhamento.

${ }^{473}$ Ocorrência de Vetor na representação da luz que converge às pessoas debaixo do toldo.
} 
diretamente para o pintor e estabelecem uma relação vetorial bidirecional, que parece declarar uma falta, uma necessidade, talvez um desejo. As cadeiras parecem estar voltadas para o pintor da cena sugerindo um diálogo desde sua instanciação com o autor, o vazio sugere uma expectativa disso que não se sabe para com o próprio autor. ${ }^{474}$ Que presenças, a ausência representada pelas cadeiras vazias declara a falta? A que falta Vincent se refere? Como, para o autor, essa falta dialoga com ele? Ela o interpela, ela o interroga, ou ela o convida? Que relação se estabelece entre o objeto evidenciado pela ênfase linguística da tela e o autor, indiretamente presente, instanciado na cena? Como essa ausência dialoga com esse pintor, revelada pelo elemento linguístico da cadeira vazia que olha para o pintor e que assim indica sua também ausência na tela? ${ }^{475}$

Talvez esta semiose descreva a um só tempo, a sua ausência e a sua presença, ao sugerir uma ambiguidade tanto da ausência quanto da presença do artista na cena, produzindo uma poderosa metáfora desta existência conflituosa entre luz e sombra, claro e escuro, pertencimento e isolamento e de ausência e presença que podemos significar ou explorar seu sentido como enunciações de seus conflitos e questões existenciais. ${ }^{476}$

\subsubsection{Instanciação do autor na tela}

A pintura pressupõe uma prática social na qual o autor dialoga com o seu público, ainda que de forma indireta por meio de elementos de linguagem que enfatizam seu 'lugar' desde onde se expressa, e o seu 'lugar' de discurso dentro da cena representada. As composições pictóricas de van Gogh sugerem um tom pessoal também porque, por meio de uma vetorização inversa de elementos na cena, ele se reinsere na imagem representada de forma velada e implícita. ${ }^{477}$

\footnotetext{
${ }^{474}$ Ocorrência de Vetor que resulta em Distorção do ponto de vista, na representação das cadeiras vazias no primeiro plano, ambas voltadas para a o pintor que as pinta sugerindo um caminho visual inverso, de ponto de fuga invertido, como observado em outras telas analisadas.

${ }^{475}$ Ocorrência de Incompletude e de Limiar Artístico, sugeridas pelo sentido do vazio das cadeiras salientadas no primeiro plano e que estão relacionadas com a posição do pintor fora da cena, construído uma poderosa metáfora para a ausência que, no entanto, fica incógnita.

${ }^{476}$ Ocorrência de Associação Metafórica e Transparência, construídos pelos sentidos potenciais que sugerem a solidão, o isolamento e a ausência experienciada por van Gogh.

${ }^{477}$ Ocorrência de Transparência e Enquadramento, por meio de Vetor e Perspectiva invertida, que é observada na composição de outras telas.
} 
4.5 ANÁLISE TEXTUAL DOS EXTRATOS DE CARTA RELATIVOS À TELA 'A ESPLANADA DO CAFÉ NA PLACE DU FORUM, ARLES, À NOITE'

\subsubsection{Extrato $n^{\circ} 3 a$}

Carta 681 - Br. 1990: 685 | CL: 537 - From: Vincent van Gogh To: Theo van Gogh Date: Arles, Sunday, 16 September 1888. (VAN GOGH, 2009f).

Linhas 46 a 50

"Essa é a primeira pintura esta semana. A segunda mostra o exterior de um café, iluminado no terraço externo por uma grande lâmpada de gás dentro da noite azul, com um retalho de céu azul estrelado" (VAN GOGH, 2009f, p.1).

Essa é a primeira pintura esta semana.

\begin{tabular}{|l|l|l|l|}
\hline Essa & é & a primeira pintura & esta semana. \\
\hline Identificado & $\begin{array}{l}\text { Processo Relacional } \\
\text { identificador }\end{array}$ & Identificador & Circunstância \\
\hline
\end{tabular}

Essa é a primeira pintura esta semana. A segunda mostra o exterior de um café, iluminado no terraço externo por uma grande lâmpada de gás dentro da noite azul, com um retalho de céu azul estrelado.

$\boldsymbol{\alpha}=\boldsymbol{\beta}$

ALFA - A segunda mostra o exterior de um café,

= BETA não finita - iluminado no terraço externo por uma grande lâmpada de gás dentro da noite azul, com um retalho de céu azul estrelado.

\section{Interpretação}

$\mathrm{Na}$ oração 'Essa é a primeira pintura esta semana' O complexo nominal 'primeira pintura' está precedido de artigo determinante, tornando o participante como identificador e não como atributo. $\mathrm{O}$ uso do processo identificativo por van Gogh para se referir à tela indica a partir de padrões observados nos extratos anteriores, que a tela já está pronta para ele, ele já a identificou. 
A segunda mostra o exterior de um café, [[iluminado no terraço externo por uma grande lâmpada de gás dentro da noite azul, com um retalho de céu azul estrelado.]]

\begin{tabular}{|l|l|l|}
\hline $\begin{array}{l}\text { A segunda } \\
\text { (tela: } \text { ator) }\end{array}$ & mostra & o exterior de um café, \\
\hline Identificado & $\begin{array}{l}\text { Processo } \\
\text { Relacional }\end{array}$ & Identificativo \\
\hline
\end{tabular}

\begin{tabular}{|l|l|l|l|}
\hline [[ iluminado & no terraço externo & $\begin{array}{l}\text { por uma grande lâmpada } \\
\text { de gás }\end{array}$ & $\begin{array}{l}\text { dentro da noite azul com um retalho de } \\
\text { céu azul estrelado.]] }\end{array}$ \\
\hline $\begin{array}{l}\text { Processo } \\
\text { material } \\
\text { transformativo }\end{array}$ & Ator & Circunstância \\
\hline $\boldsymbol{\alpha}^{\wedge} \boldsymbol{\beta}$ & & \\
\hline
\end{tabular}

ALFA - A segunda mostra o exterior de um café,

BETA - [[ iluminado no terraço externo por uma grande lâmpada de gás dentro da noite azul, com um retalho de céu azul estrelado.]]

$\mathrm{Na}$ oração dominante, o participante principal é a tela, que mostra o exterior de um café. Van Gogh colocou a tela como o participante principal da ação; um dizente que mostra um café. Ele próprio não se coloca como o dizente da oração. Porque? Van Gogh poderia ter simplesmente enunciado, por exemplo, "eu pintei o exterior de um café." No entanto, em sua escolha, ele representa a tela como o dizente na oração, que por meio de um processo verbal, mostra algo, o exterior de um café. Nesta oração van Gogh enfatiza o que a tela mostra. A escolha do processo 'mostrar' enfatiza o que a tela revela e pela escolha do processo fica implícito que, enquanto ela mostra algumas partes de algumas coisas, ela não mostra tudo. A escolha do processo 'mostrar' está muito articulada com esse quadro especialmente, pois o uso do processo mostrar em outra tela não iria combinar, por exemplo, esta tela 'mostra' meu auto-retrato. Há uma relação entre a escolha lexical mostrar e características da tela, dessa relação entre parte e todo que a constitui.

A escolha do processo 'mostrar' implica em uma seleção, pois enquanto a tela mostra algo, ela também deixa de mostrar. Ela mostra o exterior, mas deixa de mostrar o interior. É uma escolha, que ele coloca para a tela assumir como dizente no processo. Dessa forma ele convida o espectador a observar o que a tela mostra e imaginar o que ela deixa de mostrar. e isso pode ser um recurso modal (de levar o espectador para dentro da cena...triangulação com a analise visual). 
Na oração beta 'iluminado no terraço externo por uma grande lâmpada de gás dentro da noite azul, com um retalho de céu azul estrelado' van Gogh detalha o exterior destacando, com um complexo nominal, o que acha mais importante: o 'terraço externo iluminado por uma grande lâmpada de gás' e ambos estão 'dentro da noite azul'. Na escolha lexical 'terraço' e 'lâmpada' não são enunciados como dentro da tela, mas como dentro da 'noite azul' colocando o leitor imediatamente em contato com o próprio ambiente representado na tela. Van Gogh deixa de se referir à pintura para se referir aos participantes e processos que se relacionam entre si. No discurso de van Gogh acerca deste quadro o que parece prevalecer é o que se mostra parcialmente. A noite principalmente está presente em sua totalidade por conter todos os outros elementos e em sua parcialidade, por aparecer somente em um retalho. Enquanto, van Gogh se refere à noite como um domínio vasto que contém todos os elementos da tela, ela é 'mostrada' parcialmente por um 'retalho de céu azul estrelado'. Essa construção cria uma espécie de ambiguidade entre o sentido que a noite ganha no discurso da carta e simbolicamente na tela, e sua parcialidade em termos de representação através do uso lexical 'retalho' e através do espaço que ela ocupa concretamente na tela. Ou seja, ela é simbolicamente muito maior do que efetivamente ela está representada.

Neste complexo oracional, observamos um deslocamento não apenas de planos, mas de pontos de vista. A oração Alfa é um preâmbulo para o sentido principal que está na oração Beta, que está ricamente detalhado, muito mais do que na oração Alfa. Esta ocorrência de 'planos' na oração é compatível com a ênfase que é dada no segundo plano da tela. ${ }^{478}$

Além disso, observamos que na oração alfa, van Gogh se refere à tela enquanto que na oração beta, ele está se referindo à cena que está representada na tela. Dessa forma ele desliza de um ponto de vista externo à cena, para um ponto de vista que está dentro da cena. ${ }^{479}$

\subsubsection{Extrato $n^{\circ} 3 b-$}

Carta 678 - Br. 1990: 681 | CL: W7 - From: Vincent To: Willemien van Gogh

Date: Arles, Sunday, 9 and about Friday, 14 September 1888. (VAN GOGH, 2009g).

Fui interrompido precisamente pelo trabalho que uma nova pintura da parte externa de um café à noite tem me dado nos últimos dias. No terraço, há pequenas figuras de pessoas que bebem. Uma enorme lanterna amarela ilumina o terraço, a fachada, a

\footnotetext{
${ }^{478}$ Ocorrência de profundidade, com destaque para o segundo plano, ou seja, para a oração Beta.

479 Ocorrência de Enquadramento e Perspectiva: há uma mudança no ponto de vista com que van Gogh representa o assunto: a tela. Na oração Alfa, ele está fora da tela, e na oração Beta ele se encontra dentro da cena.
} 
calçada, e até mesmo projeta luz sobre os paralelepípedos da rua, que adquirem uma coloração violeta-rosa. As frentes das casas em uma rua que segue sob o céu azul salpicado de estrelas são azul escuro ou violeta, com uma árvore verde. Agora há uma pintura de noite sem preto. Com nada mais do que um belo azul e violeta e verde e nestes arredores da praça iluminada é colorido por enxofre pálido, amarelo limão. Eu gosto enormemente de pintar no local à noite. No passado, eles costumavam desenhar e pintar a tela do desenho durante o dia. Mas acho que me convém pintar a coisa no momento. É bem verdade que eu possa tomar um azul por um verde no escuro, um azul lilás por um rosa lilás, uma vez que você não pode perceber a natureza do tom claramente. Mas é a única maneira de se livrar da noite negra convencional com uma luz pobre, pálida e esbranquiçada, quando na verdade uma mera vela por si só nos dá os mais ricos amarelos e laranjas. Eu também fiz um novo retrato de mim mesmo, como um estudo, no qual eu pareço um Japonês. Você nunca me disse se você tinha lido Bel-ami de Guy de Maupassant, e o que você pensa agora do talento dele em geral. Digo isto porque o início de Bel- Ami é precisamente a descrição de uma noite estrelada em Paris, com os cafés iluminados da avenida, e isso é algo como o mesmo tema que eu pintei bem agora. (VAN GOGH, 2009g, p. 1).

Na tela, a coesão lexical permitiu ver as cores na tela por vetores ou pelos contrastes. $\mathrm{Na}$ carta, a relação coesiva lexical entre as cores, cuja sequência forma uma escala cromática do mais claro para o mais escuro. (A relação entre as cores aparece na carta pela coesão lexical). O sem preto está qualificando a noite. Está estabelecendo uma coesão lexical entre as cores. Coteja a luz artificial como fonte de iluminação para compensar e comparar com a luz do dia, e dá novas cores - e é a maneira de pintar uma noite sem preto.

\section{Análise}

Fui interrompido precisamente pelo trabalho [[que uma nova pintura da parte externa de um café à noite tem me dado nos últimos dias.]]

\begin{tabular}{|l|l|l|l|}
\hline (eu) Fui interrompido & precisamente & pelo trabalho & $\begin{array}{l}\text { [[que uma nova pintura da parte } \\
\text { externa de um café à noite }\end{array}$ \\
\hline $\begin{array}{l}\text { Processo material } \\
\text { transformativo }\end{array}$ & Circunstância de modo & Ator & oração encaixada \\
\hline
\end{tabular}

\begin{tabular}{|l|l|l|l|}
\hline (uma nova pintura) & Tem dado & me & nos últimos dias.]] \\
\hline Ator & $\begin{array}{l}\text { Proc. } \\
\text { Trasnformativo }\end{array}$ & $\begin{array}{l}\text { Circunstância de localização: } \\
\text { tempo }\end{array}$ \\
\hline $\boldsymbol{\alpha}^{\wedge} \boldsymbol{\beta}$
\end{tabular}

ALFA - Fui interrompido precisamente pelo trabalho que uma nova pintura da parte externa de um café à noite

BETA - tem me dado nos últimos dias. 


\section{Interpretação}

Fui interrompido precisamente pelo trabalho que uma nova pintura da parte externa de um café à noite tem me dado nos últimos dias. $\mathrm{O}$ trabalho que o quadro está dando.

Nesta oração, van Gogh está falando do trabalho que o quadro está dando que é muito maior do que ele esperava. Mais uma vez, van Gogh coloca no trabalho na tela, o papel de participante central da oração. É o trabalho que interrompe van Gogh. Ele relata à irmã uma mudança na sua rotina de trabalho, causada por algo externo, uma pintura nova. Esta nova pintura tem ocupado ele nos últimos dias. Em outros momentos sabemos, por relatos, que van Gogh chegava a pintar dois quadros por dia, entretanto, este quadro especialmente tem ocupado ele nos 'últimos dias', sugerindo que sua rotina de trabalho foi interrompida.

O discurso e o quadro são complementares porque ele está criando sentidos que se referem à parte e ao todo. Uma parte do trabalho ficou interrompida porque ele está totalmente ocupado fazendo um quadro.

No discurso de van Gogh fica implícito que ao produzir este quadro ele tem lidado com sentimentos relacionados à parte e ao todo, a mostrar e não mostrar, a escolhas que independem dele: produzir o quadro ou fazer o trabalho que foi interrompido. Ele foi interrompido pelo quadro, ele não se coloca como um ator no processo, como um sujeito de escolha. O quadro se apresenta ocupando seus dias para que possa finalizá-lo. Van Gogh faz a escolha lexical 'precisamente' como forma de enfatizar que o seu trabalho anterior não foi interrompido por outra coisa senão por esta nova pintura. $\mathrm{O}$ uso de 'precisamente' indica uma modalização, uma oração marcada e dá um valor de definição de uma circunstância temporal. É uma referencia temporal que não da margem à interpretação ou à ambiguidade.

Ele não quer representar a posição dele diretamente na ação, com por exemplo: 'eu interrompi o trabalho' (VAN GOGH, 2009g). Nesta oração, A tela assume o lugar de participante principal da ação, a função de ator de um processo transformativo que é engendrado pelo artista, mas ao qual ele se coloca no discurso como submetido ao processo. Ao faze-lo, ele está assumindo um grau de comprometimento menor

Este apagamento de van Gogh como participante que desencadeia o processo é observado em outras orações.

No terraço, há pequenas figuras de pessoas que bebem.

\begin{tabular}{|l|l|l|}
\hline No terraço, & há & pequenas figuras de pessoas [[que bebem.]] \\
\hline Circunstância de lugar & Processo existencial & Existente (a oração encaixada faz parte da existente). \\
\hline
\end{tabular}




\section{Interpretação}

No terraço, há pequenas figuras de pessoas que bebem.

Van Gogh (2009g) enfatiza a circunstância de localização/espaço ao iniciar a oração 'No terraço' que ocupa um lugar de maior importância do que o lugar das figuras humanas na construção gramatical da oração. Após apresentar a centralidade da pintura no seu cotidiano 'Fui interrompido precisamente pelo trabalho' e no tempo que ela ocupa para ser executada: 'nos últimos dias' van Gogh apresenta os detalhes que compõem a pintura, ele fala da cena e da existência das pessoas. Enfatizando a circunstância de lugar, ele descreve o terraço ao dizer que há nele pequenas figuras. A forma como van Gogh descreve pode ter relação com a forma como vemos o quadro. No primeiro plano vemos o terraço e as figuras humanas ao fundo são pequenas em relação ao espaço ocupado pelo terraço na pintura. O mesmo ocorre na linguagem, o terraço inicia a oração e as figuras humanas existem em sua pequenez no final.

Uma enorme lanterna amarela ilumina o terraço, a fachada, a calçada, e até mesmo projeta luz sobre os paralelepípedos da rua,

\begin{tabular}{|l|l|l|}
\hline Uma enorme lanterna amarela & ilumina & o terraço, a fachada, a calçada, \\
\hline Ator & Processo Material transformativo & Meta \\
\hline
\end{tabular}

e até mesmo projeta luz sobre os paralelepípedos da rua,

\begin{tabular}{|l|l|l|l|l|}
\hline e, & até mesmo & projeta & luz & sobre os paralelepípedos da rua, \\
\hline Conjun-ção & $\begin{array}{l}\text { Adjunto modal } \\
\text { é da }\end{array}$ & $\begin{array}{l}\text { Processo } \\
\text { Material } \\
\text { transformativo }\end{array}$ & $\begin{array}{l}\text { Escopo / } \\
\text { domínio } \\
\text { do } \\
\text { processo }\end{array}$ & Circunstância de localização/ \\
textual & $\begin{array}{l}\text { Metafunção } \\
\text { interpessoal }\end{array}$ & & Portador da oração 3 \\
\hline
\end{tabular}

[[que adquirem uma coloração violeta-rosa.]]

\begin{tabular}{|l|l|l|}
\hline que & adquirem & uma coloração violeta-rosa. \\
\hline & Processo relacional atributivo & Atributo \\
\hline
\end{tabular}

III 1.Uma enorme lanterna amarela ilumina o terraço, a fachada, a calçada, / II 2+. e até mesmo projeta luz sobre os paralelepípedos da rua, II que adquirem uma coloração violetarosa. 
$\boldsymbol{\alpha}+\boldsymbol{\beta}[[\ldots]]$

1 oração iniciadora- Uma enorme lanterna amarela ilumina o terraço, a fachada, a calçada,

1. oração coordenada por extensão dentro da alfa - [e] até mesmo projeta luz sobre os paralelepípedos da rua,

BETA hipotática por elaboração - que adquirem uma coloração violeta-rosa.

\section{Interpretação}

"Uma enorme lanterna amarela ilumina o terraço, a fachada, a calçada, / II 2+ e até mesmo projeta luz sobre os paralelepípedos da rua, II que adquirem uma coloração violetarosa" (VAN GOGH, 2009g, p. 1).

Enquanto que na oração anterior a ênfase é dada para o terraço, aqui o participante principal é 'uma enorme lanterna amarela'. Ela ilumina o terraço, ela projeta luz até os paralelepípedos da rua. Assim, a principal qualidade do terraço, seu amarelo intenso, não pertence a ele, mas a uma 'enorme lantera amarela' o ator do processo. Na oração hipotática 'que adquirem uma coloração violeta-rosa' a luz emanada modifica o ambiente, alterando a cor dos paralelepípedos, que ganham um atributo, uma outra coloração. Ao enfatizar o participante 'lanterna' com 'enorme' e 'amarela', ele coteja a luz artificial como fonte de iluminação para comparar com a luz do dia, e suas novas cores. Essa é a maneira de pintar uma noite sem preto.

Na descrição o quadro ganha vida, movimento e dinâmica pela presença da luz. A cor do terraço está amarela, mas não sabemos que cor teria se não houvesse a luz. O terraço em seu lugar privilegiado na tela não é totalmente, independente, não existe por si só, ele depende dela. Novamente aqui percebemos a relação parte e todo, a luz o abarca, o contém, o transforma, e não o contrário. Van Gogh inverte o predomínio dos objetos, é a luz que predomina e não o terraço que tem uma lâmpada. Assim ele coloca no discurso a ambiguidade presente no quadro, o terraço é apenas um delimitador da luz emanada da lanterna que em si mesma foi tomada pela própria luz. Walther e Metzger (2012, p. 381) explicam como van Gogh escolheu o tema do Café Terrace:

Ao contrário do que acontecera em Paris, em Arles Van Gogh raramente procurou companhia. Para pintar, preferia o espaço aberto do campo às vielas e traseiras da velha cidade. Aí, na melhor das hipóteses. talvez passeasse pelo parque perto da Place Lamartine, onde arrendara quartos. Só uma vez é que vencera a timidez e posicionara o cavalete mesmo no centro da cidade, na Place du Forum, não muito longe do famoso anfiteatro e Saint-Trophime. Foi lá que pintou A Esplanada do Café na Place du Forum, em Arles, à Noite (p.419). Só aí é que se conseguia ver o motivo de que andava à procura: a luz a gás que brilhava na escuridão desde a parede exterior do café até a praça. 
As frentes das casas em uma rua [[ que segue sob o céu azul salpicado de estrelas ]] são azul escuro ou violeta, /com uma árvore verde.

As frentes das casas (...) são azul escuro ou violeta, com uma árvore verde. A

\begin{tabular}{|l|l|l|l|}
\hline $\begin{array}{l}\text { As frentes das casas em uma } \\
\text { rua que segue sob o céu azul } \\
\text { salpicado de estrelas }\end{array}$ & azul escuro ou violeta, & com uma árvore verde. \\
\hline Portador & $\begin{array}{l}\text { Processo Relacional } \\
\text { Atributivo }\end{array}$ & Atributo & Circunstância \\
\hline
\end{tabular}

BETA - em uma rua que segue sob o céu azul salpicado de estrelas

\begin{tabular}{|l|l|l|}
\hline em uma rua [[que & segue & sob o céu azul salpicado de estrelas.]] \\
\hline Existente & Processo existencial & Circunstância \\
\hline
\end{tabular}

Simplex - Na oração 'As frentes das casas (...) são azul escuro ou violeta, com uma árvore verde' temos um grupo nominal complexo.

Ela encapsula a oração 'em uma rua que segue sob o céu azul salpicado de estrelas'. Nesse complexo oracional ele descreve os atributos das casas na oração dominante; na oração hipotática, ele descreve a rua. Nessa descrição ele detalha: 'as frentes das casas'. Ou seja, não vemos a casa toda, apenas uma parte do todo: a sua frente. É interessante que ele seja tão específico com relação a isso, uma vez que ele poderia simplesmente enunciar a presença de casas. Mas ele detalha a frente das casas, cuja parte está na pintura e tem como atributo a cor azul escuro ou violeta.

Ele descreve junto a elas uma árvore verde, da qual aparece somente uma parte reforçando esse tipo de descrição semiótica parte/todo. Na oração acima, temos um grupo nominal complexo. O período "com uma árvore verde" faz parte do participante principal. Ele está narrando a cena representada e pelos padrões observados anteriormente, ele está atribuindo características para a cena, ao invés de identificar essas características como uma coisa pronta, ele ainda está no processo de conceber essas características ao escolher 'uma arvore'.

Por que razão van Gogh encapsulou dentro da oração 'As frentes das casas (...) são azul escuro ou violeta, com uma árvore verde.' a oração 'em uma rua que segue sob o céu azul salpicado de estrelas'? Nesta oração ele descreve a existência da rua sob o céu estrelado. 
A rua representa o espaço vazio, contido pelas paredes das casas e pela parede do café, tal como a frase que a descreve, que está contida dentro das partes da oração dominante. Assim como o céu que está delimitado pelas paredes das casas, ele também está delimitado pelos períodos da oração dominante.

Van Gogh procurou expressar na linguagem escrita o simbolismo e os elementos que estavam representados na pintura. As escolhas gramaticais revelam uma intencionalidade no discurso da carta que parece estar presente também na pintura. Dessa forma não consideramos que as escolhas de processos de participantes tenha sido casual, mas sim, carregadas de significado e que neste quadro especialmente parece estar vinculado com a relação parte e todo, e a relação conteúdo/contingente. As escolhas lexicais dão forma e volume assim como a luz e a sombra produzem efeito de forma e volume na pintura. A estrutura das orações guarda relação com a estrutura dos participantes e dos processos na representação pictórica. Ele procurou encontrar formas semióticas de conter as palavras e os sentidos, as cores e as coisas. Se eu fosse dar um tema para este quadro seria 'parte, todo', ele é completo e vazio, as coisas estão inteiras, mas representadas por suas partes, são vastas mas encontram limites que estabelecem formas. A linguagem escrita dá forma para as ideias que estão representadas no quadro. As descrições detalhadas, o cuidado na precisão da linguagem e o uso de recursos gramaticais que descrevem a preocupação que van Gogh teve na representação das relações entre luz e sombra.

Agora há uma pintura de noite sem preto.

\begin{tabular}{|l|l|l|}
\hline Agora & há & uma pintura de noite sem preto \\
\hline Circunstância de Localização: tempo & Processo Existencial & Existente \\
\hline
\end{tabular}

Oração anterior: As frentes das casas em uma rua [[ que segue sob o céu azul salpicado de estrelas ]] são azul escuro ou violeta, /com uma árvore verde.

\section{Interpretação}

Ao abrir a oração Van Gogh dá ênfase na circunstância de localização temporal: 'agora'. Ao que se refere com o uso do item 'Agora'? Ele se refere ao momento exato em que o enunciado foi escrito ou a outra categoria temporal? Ele subentende que essa pintura é algo que não havia antes. 'Agora', nesta oração, tem um sentido inaugural. Quer dizer, a partir de agora há uma pintura de noite sem preto. Semanticamente, o uso do agora está claramente marcado no sentido da oração: que a partir de agora, há uma nova forma de representar a noite 
em uma pintura sem o uso do preto. Então este agora não é momentâneo, ele transformou o agora que é indicativo de um instante, em um agora histórico, muito bem marcado na linha cronológica das inovações linguísticas no campo da arte.

É preciso falar do significado cultural da declaração 'agora há uma pintura de noite sem preto'. Semanticamente ele está dizendo: antes não havia uma pintura de noite sem preto, mas agora há. No entanto, as escolhas léxico-gramaticais exercem um papel em revelar as estratégias linguísticas usadas por van Gogh para fazer esta declaração. Além disso, elas revelam escolhas que constroem redes semióticas que podem ser ou não recorrentes em suas composições. Por exemplo: por que ele escolhe o item 'agora' para começar a frase? Iniciar a oração com este item lexical torna esta uma oração marcada. Ele dá ênfase ao 'Agora' trazendo este item lexical para o início da frase como ele faria em uma tela ao acentuar os contrastes de cor como uma estratégia para destacar a sua importância dentro da composição e assim criar uma ênfase.

Além disso, o uso de 'Agora há' na construção, abrindo a oração dá um sentido de uma certeza, de um manifesto, de uma declaração entusiasmada. Esta escolha léxicogramatical 'Agora há' indexa um outro sentido não dito: que antes não havia. A escolha pelo não uso lexical 'antes não havia' não causa seu apagamento, mas o embute no significado construído e atualiza sua ausência para dar um sentido mais amplo e contextual para a afirmação 'Agora há'... 'porque antes não havia'.

Podemos também afirmar que há uma metonímia uma vez que ele subentende que 'Agora há (na história da arte) uma pintura de noite sem preto'. Talvez o temperamento de van Gogh não permitisse uma tal declaração, e isso pode ter sido um recurso que ele usou por ser a irmã, a pessoa para quem ele endereça a carta. Van Gogh não se atém em explicar o sentido de sua afirmação 'agora há', no entanto, seu interlocutor tem intimidade com a produção e as preocupações de van Gogh e é capaz de reconhecer esse significado implícito e seu sentido oculto. O fato de van Gogh não explicitar parece mais uma característica discursiva sua do que um não reconhecimento desta tela que tráz algo novo no uso das cores.

Considerando como van Gogh vem construindo o discurso acerca da pintura, podemos dizer que esta tela tem um significado no todo da história da arte que inaugura uma nova categoria de representação pictórica da noite. A constatação de um fato novo é reconhecida por van Gogh no momento em que ele faz escolhas semânticas de uma construção inusitada do ponto de vista do discurso descritivo em relação à tela, colocando a tela em si como produtora de história. Ele sintetiza assim, por meio da construção discursiva o produtor e o produto. Este enunciado revela um sentido histórico para a produção desta noite; a primeira 
noite sem preto na pintura. O uso das cores na representação da noite ganha destaque na oração, pela ênfase, que não vascila diante de uma comprovação acerca da produção que van Gogh faz. É algo que chama a atenção pela diferença porque no decorrer da carta van Gogh privilegia a descrição das cores, dos elementos, dos participantes e dos processos.

No encadeamento da oração anterior e desta, observamos que ele consegue este efeito de noite, e não de entardecer, pela força presente da luz da lanterna. Só em uma noite escura é possível uma lanterna ter tanta proeminência na sua projeção. Dessa forma a lanterna e sua luz são usadas como semiose para o leitor construir associações metafóricas que apoiam a articulação das cores que constroem a representação da noite sem o uso da cor preta. Assim como as sombras estão representadas por azuis e violetas escuros, o retalho que representa o céu da noite é feito com um azul relativamente claro.

A relação lexical está narrando as cores em uma tela sem o preto. O uso do preto é convencional. $\mathrm{O}$ uso do preto seria um recurso linguístico semioticamente reconhecido até então pelo público e pelas convenções como representativo da noite, e agora ele declara que está inaugurando um novo sistema de escolhas, por meio do azul, violeta e verde, e até do enxofre e do amarelo limão, para representar a noite. Muhlberger (2002, p. 20) explica como van Gogh fez para representar as cores da noite:

Embora seja tarde da noite, van Gogh usou cores brilhantes para pintar o terraço do
café. As partes mais escuras são feitas de azul, verde e roxo profundos. Em nenhum
lugar encontramos preto puro. Seus amigos artistas de Paris lhe ensinaram que até as
sombras são compostas por uma mistura de cores.

A escolha lexical 'sem preto' está qualificando a noite. No entanto esta não é uma tela apenas sem preto, mas com muitas cores. Na próxima oração, van Gogh explica a noite por meio de uma relação lexical entre as cores. Essas cores constroem a noite, elas não são preto. Ao pintar uma noite sem preto e ele dá visibilidade para as cores que estavam lá, em uma escala que vai do mais claro ao mais escuro. É uma nova semiose para representar a noite. Pela escrita ele constrói uma visualidade, com a coesão lexical, permite ao interlocutor ver as cores que na tela são representadas por vetores ou pelos contrastes complementares.

Van Gogh faz esta afirmação como se por acaso, depois de uma oração com a descrição da fachada e do primeiro plano do quadro. A característica consisa da oração dá um tom de declaração conclusiva nas construções de van Gogh. Ele declara uma certeza, com um tom de verdade 'Voila un tableau de nuit sans noir' porque está anunciando um fato histórico. Entretanto, uma característica do discurso de van Gogh se mantém, ele não enfatiza sua própria participação nesse processo criativo para deixar a ênfase no papel da obra no contexto histórico. Assim como nas telas, ele deixa 'rastros' discretos da sua presença, pequenos 
indexadores da sua passagem por aquele cenário. Por exemplo, na tela Por de Sol: Campo de trigo perto de Arles, observamos um ponto de fuga invertido que indicava o lugar de onde van Gogh possivelmente pintou a tela; nesta tela do Café Terrace, observamos duas cadeiras no primeiro plano que estão voltadas para o lugar de onde ele observou a cena; na tela Café Lamartine observamos que a sombra da mesa de bilhar ao centro da tela, está distorcida criando um estranhamento e se parece com uma 'seta' que aponta para o lugar onde van Gogh deve ter se postado para pintar o interior do café, Estes elementos semióticos nas telas constroem uma relação similar ao tipo de narrativa que encontramos nas orações.

Tanto nas cartas quanto nas telas, van Gogh se representa de maneira implícita. Ele se coloca submetido a um ideal de pintura, ele se coloca como refém de um desejo de pintar uma determinada tela e ai ele se representa dessa maneira em relação ao processo criativo. A necessidade de pintar é tão imperiosa para ele que ele não tem uma escolha de não pintar. Escolher não pintar seria escolher não ser. Isso se faz presente na sua produção artística e escrita. Sua arte o contém. Essa similaridade disursiva que há nas escolhas lexicais na escrita das cartas e na produção pictórica revela um sentido comum: o fato de que a pintura em si, a produção artística de van Gogh o contém. A produção pictórica e a escrita das cartas tem um sentido comum: elas têm o protagonismo da ação e da existência. Podemos interpretar que tanto nas cartas quanto na tela van Gogh aparece como parte de um todo maior, como um participante por vezes secundário na sua produção artística que representa um todo que o engloba.

Há uma prevalência existencial da concepção da tela, da sua produção artística e da construção discursiva sobre a obra, que coloca van Gogh como um participante secundário, contido como parte desse processo. Então ele não aparece como um protagonista no discurso assim como ele não aparece como um protagonista nas telas. O que deixa marcado tanto na tela quanto no discurso não é a sua presença explicita, mas a sua ausência implícita.

Após a produção da obra ele não se coloca mais no texto como produtor, mas como um observador dos fenômenos que descreve, uma vez que ele não constrói a oração de modo a se colocar como a primeira pessoa da ação de ter produzido o quadro e de ter pintado seus elementos, e de ter planejado e concebido cada etapa. Dessa forma ele modaliza a importância do que está declarando, ao escolher o processo existencial e enfatiza a existência ao invés do feito. Aparentemente ele deixa o sujeito produtor oclusivo, no entanto é por meio da relevância da criação que a característica predominante do artista se revela.

No encadeamento discursivo da oração anterior 'As frentes das casas em uma rua que segue sob o céu azul salpicado de estrelas são azul escuro ou violeta, com uma árvore verde' e 
desta 'Agora há uma pintura de noite sem preto', um sentido ganha proeminência: a noite. Estas orações se referem a um diálogo que van Gogh está tendo com a irmã que é um conhecedor de obras de arte. Ao descrever a pintura ele explicita para a irmã uma reflexão que ele fez sobre o lugar dessa pintura no contexto da cultura de representação pictórica da noite. Ele se refere à forma de representar a noite.

O que a oração quer dizer? Seu significado vai além da pintura e se coloca em uma relação existencial na história da arte. A escolha de colocar a circunstância 'Agora' em destaque na oração indica uma forte presença do contexto de situação e do contexto de cultura. É preciso analisar esta oração em relação aos eventos históricos relacionados ao significado que ele marca ao colocar 'Agora' no início da oração. Do ponto de vista do contexto de situação, ele estava quebrando um limite pessoal, ao conseguir representar uma noite sem preto. Do ponto de vista do contexto de cultura, ele estava quebrando um limite na história da pintura, ao convencionar um novo sistema semiótico para representar a noite, sem o uso do preto.

Com nada mais do que um belo azul e violeta e verde e nestes arredores da praça iluminada se colore de enxofre pálido, amarelo limão.

\begin{tabular}{|l|l|l|l|l|}
\hline $\begin{array}{l}\text { Com nada mais do } \\
\text { que um belo azul e } \\
\text { violeta e verde }\end{array}$ & $\begin{array}{l}\text { e nestes arredores da } \\
\text { praça iluminada }\end{array}$ & se & colorem & $\begin{array}{l}\text { de enxofre pálido, } \\
\text { amarelo limão. }\end{array}$ \\
\hline $\begin{array}{l}\text { Circunstância de } \\
\text { Acompanhamento: } \\
\text { comitativo }\end{array}$ & Circunstância & Meta & $\begin{array}{l}\text { Processo Material } \\
\text { Criativo }\end{array}$ & Circunstância \\
\hline
\end{tabular}

Na oração, temos um processo relacional atributivo que, por meio de dois complexos nominais 'Com nada mais do que um belo azul e violeta e verde' e 'se colorem por enxofre pálido, amarelo limão' caracterizam os arredores da praça iluminada que van Gogh representa.

O uso lexico-gramátical 'com nada mais do que' enfatiza que a produção da tela se deu unicamente com uma combinação de cores, dessa forma por meio da descrição da tela, van Gogh reafirma o valor do uso das cores. Essa escolha indica que a cor não ganha prevalência apenas na produção pictórica, mas no discurso e nas construções semânticas que van Gogh escolhe para descrever seu processo criativo e o resultado na tela.

Na oração 'com nada mais do que um belo azul e violeta e verde e nestes arredores da praça iluminada se colorem de enxofre pálido, amarelo limão' observamos uma relação 
coesiva lexical entre as cores, cuja sequência forma uma escala cromática do mais escuro ao mais claro. A noite não é representada somente pelo retalho de céu azul, mas também pelas cores que compõem a praça que, compostas com a luz da lâmpada, ficam pálidas e com um colorido característico da noite como o verde, o violeta, o azul, o enxofre, o amarelo limão. As cores dos outros participantes da tela são as cores que produzem essa composição de uma noite sem preto.

Para pintar uma noite sem preto, van Gogh utilizou as cores da noite. Nesta oração ele explica o resultado desse uso: o belo azul, o violeta e o verde que ele observou na noite, se colorem de enxofre pálido e amarelo limão nos arredores. Esses participantes contribuem para a construção do sentido da oração anterior 'Agora há uma noite sem preto.' A relação entre as cores aparece na oração pela coesão lexical. Ele pintou uma noite sem preto e deu visibilidade das cores que estavam lá em uma escala que vai do mais claro ao mais escuro.

No encadeamento da oração anterior 'Agora há uma pintura de noite sem preto.' e esta 'com nada mais do que um belo azul e violeta e verde e nestes arredores da praça iluminada se colorem de enxofre pálido, amarelo limão' encontramos um sentido interligado. Mesmo sendo duas orações separadas por um ponto elas foram interpretadas como um complexo oracional por seu sentido semântico ser internamente conectado, como se elas estivessem intimamente ligadas pelo processo de construção do seu sentido: a noite sem preto, com nada mais do que um belo azul e violeta e verde e nestes arredores da praça iluminada se colorem de enxofre pálido, amarelo limão.

O ponto constrói um valor definitivo reforçado pelo processo existencial: declara uma certeza, comunica o entusiasmo, afirma um valor de verdade ou a certeza de uma coisa dada. A noite sem preto tem uma continuidade na oração seguinte que define suas características, descritas pelo uso das cores azul, violeta e verde, coloridas de enxofre pálido e amarelo limão. Dessa forma, apesar de estarem separadas por um ponto final, estas duas orações são do ponto de vista semântico, e até do ponto de vista léxico-gramatical, uma mesma oração, ou melhor, um complexo oracional no qual ele descreve o núcleo sintagmático da oração paratáxica 'uma noite sem preto' na próxima oração. O fato de haver um ponto final separando os dois períodos pode ser o indicativo de que ele procurou criar uma ênfase com este ponto ao construir uma oração simples, direta e compacta para narrar um fato novo que deseja declarar: ‘Agora há uma pintura de noite sem preto'.

O fato de a oração iniciar com letra minúscula pode ser um indício de que as duas orações estão interligadas por um processo interno de produção de sentido acerca deste fato, ou deste feito. Neste caso o ponto final antes de 'com nada mais do que' pode ser 
compreendido como uma pausa de ênfase, mas que não impede a conexão de sentido, uma vez que, nesta segunda oração van Gogh continua a descrever o núcleo semântico da primeira oração. Assim ele constata a existência da 'noite sem preto' e em seguida adiciona a ela uma nova descrição. Esta parece ser uma oração deslocada porque ele está tematizando e criando um complemento que descreve a noite sem preto. Esta hipotética 'oração hipotáxica' sugere um posicionamento qualificante para existência que ele declara e na oração seguinte 'com nada mais do que um belo azul...' ele descreve o existente da oração anterior e constrói um sentido existencial por meio de atributos que ele dá para a sua criação.

Observamos que quando ele quer dar um sentido existencial para outras pinturas, ele também qualifica características da obra descrevendo atributos da pintura que refletem um protagonismo.

Outra questão: ao que ele se refere quando enuncia que nos arredores da praça iluminada se colorem por enxofre pálido e amarelo limão? Ele se refere à noite e não à pintura, deixando claro que o núcleo sintagmático da oração principal é 'a noite sem preto', ao invés de 'A noite que acima no céu tem um 'belo azul e violeta e verde' (menos preto) mas que em torno da praça adquire um tom enxofre e amarelo (por causa da lâmpada do café). Ou seja, ao descrever a pintura, ele localiza o núcleo sintagmático da oração principal como sendo 'noite sem preto' ao invés de 'uma pintura', e isto pode ser verificado com o fato de que a descrição que ele desenvolve na oração hipotáxica não se refere à pintura em si, mas à noite sem preto que é representada na pintura. Ou seja, ele fala da representação e de suas escolhas para criar um novo sistema semiótico para descrever e assim representar a noite sem o uso do preto.

Para verificar esta hipótese, propus um teste de unir as duas orações como se elas estivessem conectadas por uma vírgula, como no exemplo a seguir: 'Agora há uma pintura de noite sem preto, com nada mais do que um belo azul e violeta e verde ' $e$ '_nestes arredores da praça iluminada se colorem por enxofre pálido, amarelo limão.’.

Neste caso o conectivo 'e' antes de 'nestes arredores' pode ser compreendido como o conectivo 'mas' uma vez que, nesta segunda oração ele continua a descrever o núcleo semântico da primeira oração que é 'noite sem preto' não apenas adicionando uma nova descrição às descrições anteriores, mas contrastando esta nova informação com as informações anteriores. Esta escolha de usar o item lexical 'e' naquele lugar da oração não apenas para adicionar, mas para contrastar a nova informação pode criar uma semiose na forma de um estranhamento sobre o sentido construído. Pode ser uma forma de criar ênfase ou marcar este novo sentido para a noite sem preto, que enquanto ela é azul, violeta e verde 
no céu, aos arredores da praça, ela se torna amarelo enxofre e amarelo limão. A mesma noite que tem tons escuros e frios como o azul, violeta e verde pode ter tons claros e quentes como o enxofre e o amarelo limão.

Este é um conectivo que marca a diferença entre dois coloridos da noite, e assim, por meio de um contraste semântico van Gogh emula o sistema semiótico pictórico de representar a mesma coisa 'noite', de duas formas diferentes, uma com cores escuras e outra com cores claras; e que pode perfeitamente estar a bojo da sua forma de construir o seu discurso escrito: usando os contrastes não só por meio de léxicos como os advérbios adversativos (mas, contudo, todavia) que sugerem contraposição, mas também com uso de conjunções conectivas que sugerem conexões, complementações, associações. Aqui ele usa o contraste mais no nível semântico do que nível léxico-gramatical, com a ajuda do conectivo 'e'. No entanto, o uso de contrastes semânticos ou léxico-gramaticais para construir significados é recorrente na construção dos enunciados de van Gogh e isto pode revelar um padrão semiótico apoiado em uma prática linguística e em um pensamento artístico igualmente presentes nas pinturas e nas cartas: a construção de contrastes complementares. Nas orações, com o uso de relações lógico-semânticas e nas telas com o uso de 'conectivos' que tem a função de 'construir orações visuais'. Para verificar esta ocorrência será preciso observar se ele está contrastando informações e se o mesmo contraste que ele faz nas orações ele faz nas composições pictóricas.

Eu gosto enormemente //de pintar no local à noite.

\begin{tabular}{|l|l|l|l|}
\hline Eu & gosto & Enormemente // & de pintar no local à noite \\
\hline Experienciador & $\begin{array}{l}\text { Processo Mental } \\
\text { Afetivo }\end{array}$ & $\begin{array}{l}\text { Adjunto de Modo } \\
\text { Tem função na metafunção } \\
\text { interpessoal }\end{array}$ & Oração Projetada \\
\hline $\boldsymbol{\alpha}$ ' $\beta$
\end{tabular}

Com o uso do processo mental afetivo, van Gogh declara sua experiência ao pintar ao ar livre à noite. De acordo com Walther (1990), ele foi o primeiro a pintar ao ar livre na luz noturna para representar uma cena à noite. Essa oração está semanticamente encadeada com a oração 'agora há uma pintura de noite sem preto'. Aqui observamos também uma declaração, que, mais do que expressar como é sua experiência afetiva ao pintar no local à noite, marca sua inovação na prática pictórica vivenciada por ele. No entanto, van Gogh não enfatiza sua escolha por pintar a noite como inovação metodológica, mas como a expressão de um gosto pessoal. Embora ele possa reconhecer que esse novo modo de pintar pode trazer novos elementos e novas formas de expressão pictórica ele é muito humilde, não afirma que está 
fazendo uma escolha por um motivo conceitual, mas sim por um gosto pessoal. Walther e Metzger (2015, p.381-382) relatam a inovação de Van Gogh na prática de pintar ao ar livre à noite:

\begin{abstract}
Pintar as estrelas ao ar livre - foi o que Van Gogh conseguiu nos quadros noturnos. A inovação foi sem dúvida o resultado da necessidade de se dedicar a qualquer coisa. Mas foi igualmente o produto da evolução da sua própria metodologia artística que fora desenvolvendo ao longo dos debates com Bernard. Tal como Gauguin, o seu jovem amigo era um devoto da "abstração" - pintar de memória que desprezava a aparência real das coisas por causa do efeito visual. "Vejamos, por exemplo, um céu estrelado," escrevera Van Gogh a Bernard já em abril de 1888 (Carta B3); "Gostava muito de tentar e de conseguir fazer qualquer coisa desse género... Mas como é que vou conseguir tratar esses assuntos se não me resolvo a trabalhar em casa, a partir da imaginação?" Nessa altura, ele ainda não tinha descoberto nenhuma maneira de pintar as suas cenas noturnas logo no local. Por outro lado, imitar os amigos e dizer adeus ao motivo real ia contra os procedimentos com que tanto se habituara a trabalhar. No verão desse ano, inventou mais um dos seus compromissos. Espetou velas acesas no chapéu de palha trabalhando nas telas com a pouca luz que lhe davam; é fácil imaginar a reação que deve ter suscitado nos transeuntes. Porém: "Estou terrivelmente fascinado pelo problema de pintar cenas ou efeitos noturnos no local, ou melhor, à noite." (Carta 537) Lançou-se então nesse novo entusiasmo, à verdadeira maneira de Van Gogh.
\end{abstract}

No passado, eles costumavam desenhar e pintar a tela do desenho durante o dia.

\begin{tabular}{|l|l|l|l|l|}
\hline No passado & eles & costumavam desenhar /e pintar & a tela do desenho & durante o dia. \\
\hline $\begin{array}{l}\text { Circunstância de } \\
\text { Localização: tempo }\end{array}$ & Ator & $\begin{array}{l}\text { Processo Material } \\
\text { criativo }\end{array}$ & Meta & $\begin{array}{l}\text { Circunstância de } \\
\text { Localização: lugar }\end{array}$ \\
\hline
\end{tabular}

\title{
$1+2$
}

'Eu gosto enormemente de pintar no local à noite.

No passado, eles costumavam desenhar e pintar a tela do desenho durante o dia.'

\section{Interpretação}

Novamente encontramos uma oração marcada, que inicia com o item 'no passado' uma circunstância de localização no tempo. Ele quis enfatizar o sentido construído de que o processo acontecia 'no passado'.

Essa escolha contrapõe com a oração 'agora há uma pintura de noite sem preto' que inicia com 'agora'. Observamos que, nesse encadeamento ele contrasta 'agora' no qual ele pinta uma noite sem preto com 'no passado' quando 'eles costumavam pintar a tela do desenho durante o dia'. Dessa forma ao se referir a um costume do passado, ele enfatiza o sentido da oração anterior 'agora'. Nesta oração, ele também explica uma prática anterior, como relata Walther (1990, p. 41): 
Pintar ao ar livre foi um progresso do séc. XIX. Pintar à luz artificial, já no Barroco, era um popular passatempo artístico. Pintar à noite, ao ar livre, à luz artificial, é invenção específica de van Gogh. Com isso, fica em flagrante contraste com a pintura luminosa do impressionismo, acentua a precisão do olhar sobre objectos ao crepúsculo, onde a pintura ao ar livre aprecia exactamente a sua absorção numa atmosfera brumosa. "A noite é mais viva e mais rica em cores do que o dia" entusiasmava-se van Gogh; os objectos pouco visíveis estimulam, então, precisão e fantasia artística. A pintura nocturna viria a acompanhar os poucos anos de van Gogh até à sua morte, com o seu ponto alto na "Noite estrelada".

Nas escolas que antecederam ao Impressionismo, o costume era desenhar a cena ao ar livre, na luz do dia e depois retornar para o estúdio para pintá-la a partir da anotação das cores observadas. Os impressionistas romperam com essa prática e passaram a pintar no local para capturar as alterações da luz com as variações climáticas ao longo do tempo. Mas essa prática até onde se sabe era feita durante o dia. Van Gogh, de acordo com Walther (1990) e Haziot (2010), foi o primeiro a pintar no local durante a noite. Nesta oração van Gogh opta por narrar a prática social dos pintores que o antecederam como que para explicar o fato de que ele rompeu com esse costume cultural, como explica Walther (1990, p. 38):

Durante o verão, van Gogh vai ocupar-se com um problema para o qual os pintores,
já desde há séculos, procuram encontrar solução: com a pintura da noite, a questão
de como se pode representar a escuridão por meio da cor. Como se pode trabalhar a
cor que vive da luz, de maneira a que represente exactamente o contrário, a
escuridão?A experiência-chave parece ter sido para Vincent um passeio à noite à
beira-mar: "Não estava sereno, não estava triste, estava - lindo", escreveu ele depois
a Theo, fortemente emocionado. Esta atmosfera de escassa luz, frente a um
horizonte escuro, queria ele captar para os seus quadros.

Em Arles, Van Gogh começa a pintar temas diferentes como Café Terrace at Night, setembro 1888; A casa amarela, setembro 1888; Railroad Bridge, em outubro de 1888, e A ponte em Trinquetaille, em outubro de 1888, e essa busca por novos temas infundem sua obra com grande entusiasmo, registrado em suas cartas à irmã. Os temas noturnos fazem a sua aparição na obra de Vincent, como descreve uma carta de Van Gogh (apud, CABANNE, 1971, p.142):

O céu, de um azul profundo, estava manchado por nuvens de um azul mais profundo que o azul fundamental de um cobalto intenso e por outras de um azul mais claro como a brancura azulada das vias lácteas. No fundo azul cintilavam estrelas claras, esverdeadas, amarelas, brancas, rosas guarnecidas de diamantes ou talvez mais como as nossas pedras preciosas, mesmo as de Paris, isto é, opalas, esmeraldas, lápislazúli, rubis e safiras. O mar de um ultramar muito profundo - a praia que me pareceu de um tom violáceo e arruivado pálido, com moitas nas dunas...moitas azulda-prússia.

A riqueza da descrição das cores da noite no trecho da carta acima mostra que van Gogh observa com detimento a profusão de cores que ele passou a representar nas pinturas da noite e a descrever nas cartas à irmã. Walther (1990) destaca que a prática de pintar ao ar livre para capturar a 
cena à luz natural ao modo dos impressionistas, ganha uma inovação de Van Gogh, que foi talvez o primeiro a pintar ao ar livre a noite para registrar a cena com a iluminação noturna.

Mas acho que me convém pintar a coisa no momento.

\begin{tabular}{|l|l|l|l|l|}
\hline Mas acho que & me & convém & pintar a coisa & no momento. \\
\hline $\begin{array}{l}\text { Metáfora interpessoal } \\
\text { (Modalidade) }\end{array}$ & Ator & Processo Material & Oração encaixada & $\begin{array}{l}\text { Circunstância de } \\
\text { Localização: tempo }\end{array}$ \\
\hline $\mathbf{1 + 2}$ & & & \\
\hline
\end{tabular}

'Eu gosto enormemente de pintar no local à noite.

No passado, eles costumavam desenhar e pintar a tela do desenho durante o dia.

Mas acho que me convém pintar a coisa no momento.'

\section{Interpretação}

Mas acho que me convém pintar a coisa no momento.

Neste complexo oracional, observamos em 'mas acho que' uma metáfora interpessoal que não será enfocada nesta análise. Em termos semânticos, van Gogh faz um percurso na oração que inicia com um processo mental cognitivo 'acho', em seguida usa um processo mental cognitivo 'convém' que se refere a uma avaliação da sua preferência e que está associado a um processo material 'pintar'. Assim ele coloca três processos acerca da produção de uma pintura que não é feita de modo convencional. A oração demonstra um processo reflexivo de quem está distanciado da ação. No sistema de transitividade, 'acho' constitui um processo mental cognitivo que expressa um comentário de van Gogh sobre sua decisão de pintar in loco ao invés de desenhar no local e depois pintar no estúdio como faziam os pintores acadêmicos. O item lexical ‘convém’ é um modalizador do processo 'pintar'. O item 'convém' funciona como um auxiliar de tempo do verbo 'pintar' que está no finito. Além disso 'convém' também indica uma preferência na ação e uma ênfase no processo material 'pintar'. O processo 'acho' está mais próximo dos fatores que ele leva em consideração para tomar a decisão sobre as condições de produção da pintura; o processo convém está próximo da reflexão acerca da decisão tomada; o processo 'pintar' se refere à ação em si que está voltado para alcançar a meta. Ele se vê distanciado do momento da produção da pintura. Para alcançar essa produção inovadora, ele passa por um processo metacognitivo que se revela no momento de construir o discurso em torno da escolha de pintar no local a noite. 
As escolhas lexicais na oração sugerem um percurso reflexivo em torno dessa nova prática como pintor. Van Gogh se preocupa em explicar para a irmã sua escolha por pintar a noite. Para explicar sua escolha, ele é chamado a se posicionar como sujeito, mas na oração ele revela que não pode dar garantias dos motivos que o levam a pintar a noite, então opta por processos que sugerem uma falta de certeza: 'acho' e 'convém'. Talvez ele escolha estes processos por não saber ao certo se pintar a noite vai levá-lo ao resultado que espera: para aquilo que ele quer expressar, produzir, experimentar, trazer a tona e para aquilo que ele quer realmente pintar. Estar no local à noite convém, para alcançar isso que ele está intencionando, mas ele não pode dar garantias disso nem à ele muito menos à irmã. É uma aposta que ele está fazendo, mas sem a garantia que, ao fazê-lo ele vai alcançar o resultado esperado na pintura, ainda mais se tratando das condições de uma pintura à noite. Assim, ele modaliza para não criar expectativas, e faz um efeito no discurso para minimizar a afirmação feita na oração anterior de que ele havia criado na pintura algo realmente novo 'Agora há uma noite sem preto'. Isso sugere a dificuldade com que van Gogh avaliava a si mesmo, pois ao mesmo tempo em que reconhecia um resultado na sua produção, também vacilava no momento de avaliá-la.

'Eu gosto enormemente de pintar no local à noite.

No passado, eles costumavam desenhar e pintar a tela do desenho durante o dia.

Mas acho que me convém pintar a coisa no momento.'

Observamos um encadeamento nas orações acima no qual van Gogh comenta sua preferência por pintar no local à noite, descreve como os artistas pintavam no passado, e explica porque ele pinta a tela 'no momento'. A escolha do item lexical 'no momento' parece sintetizar a importância desta circunstância de tempo na construção do sentido e tem uma correspondência semântica com a circunstância 'no local à noite'. Enquanto que 'no local a noite' é uma circunstância de lugar, e 'no momento' é uma circunstância de tempo, ambos os itens se referem à mesma inovação e comunicam diferentes qualidades e aspectos dessa nova prática de pintar ao ar livre à noite. A prática de pintar ao ar livre é descrita por Gombrich (1995, p. 518-519):

Pois a ideia de Monet de que toda pintura da natureza deve realmente ser terminada in loco não só exigia uma substancial mudança de hábitos e certa renúncia ao conforto, mas ia resultar forçosamente em novos métodos técnicos. A "natureza" ou o "motivo" muda de minuto a minuto, quando corre uma nuvem sob o sol ou o vento quebra o reflexo na água. O pintor que espera captar um aspecto característico não dispõe de tempo para misturar e combinar suas cores, muito menos para aplicá-las 
em camadas sobre uma base castanha, como tinham feito os velhos mestres. Ele tem que fixá-las imediatamente na sua tela, em pinceladas rápidas, cuidando menos dos detalhes e mais do efeito geral produzido pelo todo.

O encadeamento destes dois itens 'no local a noite' e 'no momento' sugerem uma experiência que é do domínio de uma nova prática. Outro item lexical reforça esse sentido de 'experiência' que está implícito nas orações. A escolha do ítem lexical 'coisa' na oração 'Mas acho que me convém pintar a coisa no momento.' também sugere algo mais do que a tela, a pintura ou o objeto representado. Ao usar 'coisa', ele parece se referir ao processo inteiro da pintura: ao objeto tela; ao ato de pintar; a idealização do que ele quer expressar pela pintura; e à experiência que resulta de pintar in loco, a experiência perceptiva que emerge da vivencia no próprio ambiente, no contato direto com o fluxo criador que resulta da imersão na prática de pintar no ambiente. Os pintores acadêmicos se contentavam em pintar a ideia de uma cena, que eles desenhavam pela manhã, anotavam as cores e continuavam a pintura dentro do ateliê. Para os impressinistas, a pintura só podia ser concebida ao ar livre, no contato direto com todas as qualidades da luz e dos elementos da natureza a sua volta. Van Gogh seguiu esse programa dos impressionistas, indo mais além ao se propor o desígnio de experiênciar essa prática à noite.

É bem verdade que eu possa tomar um azul por um verde no escuro, um azul lilás por um rosa lilás, uma vez que não se pode perceber a natureza do tom claramente.

\begin{tabular}{|l|l|l|l|l|}
\hline $\begin{array}{l}\text { É bem } \\
\text { verdade que }\end{array}$ & eu & $\begin{array}{l}\text { possa tomar (no } \\
\text { sentido de perceber) }\end{array}$ & $\begin{array}{l}\text { um azul por um verde no } \\
\text { escuro, um azul lilás por } \\
\text { um rosa lilás, }\end{array}$ & $\begin{array}{l}\text { uma vez que não se } \\
\text { pode } \\
\text { natureza } \\
\text { perceber aramente. }\end{array}$ \\
\hline $\begin{array}{l}\text { Metáfora } \\
\text { interpessoal } \\
\text { dom } \\
\text { Modalidade }\end{array}$ & Experienciador & $\begin{array}{l}\text { Processo mental } \\
\text { perceptivo }\end{array}$ & fenômeno & Circunstância de causa \\
\hline \begin{tabular}{l}
$\boldsymbol{\alpha} \mathbf{x}$ \\
\hline
\end{tabular}
\end{tabular}

ALFA - É bem verdade que eu possa tomar um azul por um verde no escuro, um azul lilás por um rosa lilás,

x BETA oração de causa - uma vez que não se pode perceber a natureza do tom claramente. (oração hipotática causal).

\section{Interpretação}

É bem verdade que eu possa tomar um azul por um verde no escuro, um azul lilás por um rosa lilás, uma vez que você não pode perceber a natureza do tom claramente.

Na oração alfa, 'É bem verdade que eu possa tomar um azul por um verde no escuro, um azul lilás por um rosa lilás,' o item 'possa' é um modalizador do processo 'tomar', no 
sentido de perceber que é um processo mental perceptivo. A oração dominante possui um processo mental perceptivo que explicita a problemática que van Gogh tinha para perceber com precisão as cores à noite.

Em relação à oração anterior, aqui van Gogh explica as especificidades desta nova prática. Esta oração reforça e confirma os processos usados 'acho' e 'convém' na oração anterior que vascilam diante de um julgamento acerca da escolha de pintar 'a coisa no momento' porque a percepção da cor na noite não é dada claramente. A escolha 'É bem verdade que' abre a oração alfa e constitui uma metáfora interpessoal e que sugere que Van Gogh receia não perceber a natureza dos matizes, e que é reforçada pelo uso da expressão 'não se pode perceber'. Durante o processo de produção criativa a definição precisa da natureza das cores é almejada como ideal e essa preocupação constante na produção artística de van Gogh se revela ao enfatizar a percepção da natureza da cor como o objetivo principal pela escolha de pintar in loco, mesmo à noite, na qual perceber a natureza das cores é uma tarefa desafiante.

A oração Beta de causa 'uma vez que não se pode perceber a natureza do tom claramente.' pode ser interpretada como uma oração concessiva pelo uso preposicional 'uma vez que'. Esse recurso está próximo de um processo investigativo no qual van Gogh não pode dar garantias de que o seu método e o seu objeto de percepção que está sob esse processo investigativo vão oferecer um caminho novo de produção artística e de mudança no percurso da história da produção artística. De certa maneira ele está experimentando uma nova prática cuja trajetória não só não oferece garantias como também não oferece um método de alcançar essas garantias. Então o artista fica com duas opções: permanece na prática da pintura como era feita antes ou inicia uma nova prática com todos os riscos envolvidos. Lidar com essas incertezas é um problema inerente à mudança na forma de pintar que se expressa no uso léxico-gramatical 'uma vez que não se pode perceber'. Para Halliday e Hasan (1976) as construções concessivas do tipo 'uma vez que' são mediadas por relações de contraste, seu significado principal é a contrariedade à expectativa inicial e está muito relacionada à adversidade. Ela dá um sentido de contrariedade, de impossibilidade de van Gogh alcançar o intento em pintar a noite por uma condição que está além de sua escolha, pois 'não se pode perceber a natureza do tom claramente'. Van Gogh constrói muitas orações concessivas porque esse recurso discursivo enfatiza uma relação de constraste entre o ideal e as condições possíveis dadas no momento da pintura, sejam elas de ordem pessoal ou da ordem das circunstâncias que estão dadas. 
Mas é a única maneira [[de sair da noite negra convencional com uma pobre luz, pálida e esbranquiçada,]] enquanto que ainda uma simples vela já nos fornece os amarelos e alaranjados mais ricos.

\begin{tabular}{|l|l|l|}
\hline Mas, & é & $\begin{array}{l}\text { a única maneira de sair da noite negra convencional com uma pobre luz, pálida } \\
\text { e esbranquiçada }\end{array}$ \\
\hline Conjunção & $\begin{array}{l}\text { Proc.Rel. } \\
\text { Identificativo }\end{array}$ & Identificador / Valor \\
\hline
\end{tabular}

\begin{tabular}{|l|l|l|l|l|}
\hline enquanto que ainda & uma simples vela já & nos & fornece & $\begin{array}{l}\text { os amarelos e alaranjados mais } \\
\text { ricos. }\end{array}$ \\
\hline $\begin{array}{l}\text { Oração } \\
\text { (temporal) } \\
\text { Intensificação }\end{array}$ & Ator & Beneficiário & $\begin{array}{l}\text { Proc. } \\
\text { Material } \\
\text { Criativo }\end{array}$ & Meta \\
\hline
\end{tabular}

$\ldots+2$ [[...] $] \times 3$

+ 2- Mas é a única maneira [[de sair da noite negra convencional com uma pobre luz, pálida e esbranquiçada,]]

x 3 hipotática temporal - enquanto que ainda uma uma simples vela já nos fornece os amarelos e alaranjados mais ricos.

Mas é a única maneira [[de sair da noite negra convencional com uma pobre luz, pálida e esbranquiçada,]] enquanto que ainda uma simples vela já nos fornece os amarelos e alaranjados mais ricos.

\section{Interpretação}

Neste complexo oracional, a oração dominante é concessiva 'Mas é a única maneira de sair da noite negra convencional com uma pobre luz, pálida e esbranquiçada' e enfatiza por meio do item lexical 'mas' o contraste com as limitações em se pintar a noite, expostas na oração anterior. O grupo nominal 'noite negra convencional com uma pobre luz, pálida e esbranquiçada,' na oração dominante está em contraposição com 'os mais ricos amarelos e laranjas.' na oração dependente por meio do grupo preposicional concessivo 'enquanto que ainda' que expressa uma estratégia discursiva de comparação e de contraposição. No complexo oracional a ênfase recai no contraste entre a 'pobre luz, pálida e esbranquiçada' e ‘os amarelos e alaranjados mais ricos' enfatizando o potencial da vela em revelar as cores que são dadas nas condições de pintura durante a noite.

A escolha do processo relacional identificativo 'é' marca a única opção possível para 'sair da noite negra convencional com uma pobre luz, pálida e esbranquiçada'. O processo 'é' não exprime uma existência, mas uma relação de identificação da opção abraçada por van 
Gogh, reforçada pelos itens lexicais 'a' e 'única' para qualificar o item 'maneira' e assim definir seu método de trabalho, identificando como única possibilidade de alcançar o resultado almejado.

Ao utilizar a expressão 'uma simples vela já' van Gogh explicita que para alcançar as cores mais intensas não é preciso ter condições extraordinárias. A 'saída da noite negra convencional'está nas coisas mais simples, como uma 'simples vela', que dá condições para perceber as cores como elas são. Ao usar o item lexical 'convencional', van Gogh se refere a uma forma de representação da noite que é o resultado de uma convenção criada a partir das condições históricas anteriores e não da observação da realidade como ela é, e da realidade das cores como elas são na noite. $\mathrm{O}$ uso da cor preta produz uma relação pobre e fria entre os matizes 'noite negra convencional com uma pobre luz, pálida e esbranquiçada', porque a cor preta apaga a vibração quente das cores na tela 'uma simples vela já nos fornece os amarelos e alaranjados mais ricos'. Ele está comparando o resultado da representação convencional da noite negra, com 'uma pobre luz, pálida e esbranquiçada' ou seja, com uma luz fria enquanto que, pintar a realidade de uma vela, permite van Gogh obter a percepção de cores quentes como 'os amarelos e alaranjados mais ricos'.

Por que van Gogh refere-se a uma simples vela se ele está descrevendo uma tela que foi pintada em uma cena iluminada por uma lâmpada a gás? A escolha lexical 'ainda', 'uma simples vela' e 'já' são modalizadores para enfatizar que até uma simples vela pode dar 'os amarelos e alaranjados mais ricos', o que dirá uma lâmpada a gás, ele subentende. Com essa comparação implícita, ele ressalta a importância de se observar as cores como elas são na noite.

A tela do Café Terraço que ele vem descrevendo não é produzida a partir de uma simples vela, mas de uma luz extraordinária, uma lâmpada a gás, e talvez por isso, van Gogh valorize tanto a luz da lanterna no terraço, que é uma luz que fornece as condições para pintar uma noite sem preto. Van Gogh parece revelar implicitamente que antes da lâmpada a gás não haviam as condições ambientais necessárias para se pintar uma noite sem preto. Uma simples vela revela cores que estão próximas a ela, mas no momento em que van Gogh vai para um ambiente cuja luz intensa de uma lâmpada a gás alcança a área da praça, ele pode perceber a noite sob outras cores, outros matizes. Nessa oração, van Gogh parece valorizar o mérito da vela ou da fonte de luz.

O seu mérito não está em criar a noite sem preto, mas em perceber a riqueza de cores daquele ambiente iluminado pela lâmpada a gás no momento da produção da tela. É a luz que fornece as cores e o quadro existe porque a luz cria a noite sem preto. Assim como não é van 
Gogh que produz esta noite não convencional, é a natureza da luz que a produz e ele é fiel à natureza das cores que emanam do ambiente. Nesta oração van Gogh coloca o protagonismo da luz no processo de produção da tela e seu papel histórico em produzir as condições para a pintura de uma noite sem preto.

Eu também fiz um novo retrato de mim mesmo, como um estudo, no qual eu pareço um Japonês.

\begin{tabular}{|l|l|l|l|l|}
\hline Eu & também & fiz & $\begin{array}{l}\text { um novo retrato de mim } \\
\text { mesmo, }\end{array}$ & como um estudo \\
\hline Ator & & $\begin{array}{l}\text { Processo material } \\
\text { criativo transitivo }\end{array}$ & Meta & Circunstância de Modo: Comparação \\
\hline
\end{tabular}

\begin{tabular}{|l|l|l|}
\hline no qual eu & pareço & um Japonês. \\
\hline Portador & Processo relacional atributivo & Atributo da pintura \\
\hline $\boldsymbol{\alpha}^{\wedge}=\boldsymbol{\beta}$ & & \\
\hline
\end{tabular}

ALFA - Eu também fiz um novo retrato de mim mesmo, como um estudo,

BETA hipotática por elaboração - no qual eu pareço um Japonês.

\section{Interpretação}

Esta oração não se refere à tela Café Terrace, por isso não é relevante para o objeto da análise. Van Gogh refere-se a um auto-retrato e ele usa usa o item lexical 'como um estudo' para referir-se a um trabalho que está em andamento.

Você nunca me disse [[ se você tinha lido Bel-ami de Guy de Maupassant, e o que você pensa agora do talento dele em geral.]]

\begin{tabular}{|l|l|l|l|}
\hline Você nunca & me & disse & se você tinha lido Bel-ami de Guy de Maupassant, \\
\hline Dizente & receptor & Processo verbal & Oração Projetada \\
\hline
\end{tabular}

\begin{tabular}{|l|l|l|l|l|}
\hline e o que & você & pensa & agora & do talento dele em geral. \\
\hline Fenômeno & Experienciador & $\begin{array}{l}\text { Processo Mental } \\
\text { Cognitivo }\end{array}$ & $\begin{array}{l}\text { Circunstância de } \\
\text { Localização: tempo }\end{array}$ & Fenômeno \\
\hline
\end{tabular}

Alfa - Você nunca me disse

Beta -

Oração Iniciadora 1 - se você tinha lido Bel-ami de Guy de Maupassant,

Oração continuadora $+\mathbf{2}$ - e o que você pensa agora do talento dele em geral. 
'Você nunca me disse se você tinha lido Bel-ami de Guy de Maupassant, e o que você pensa agora do talento dele em geral.'

\section{Interpretação}

Nesta oração paratáxica, van Gogh usa o processo verbal 'disse' para afirmar que a irmã Wilhelmina 'nunca disse' a ele a respeito da leitura do romance Bel-ami de Maupassant. É uma oração com forte ênfase na interlocução com a irmã, para interpelá-la sobre o que ela pensa deste romancista. Dessa forma vemos os processos 'disse' verbal, 'lido' material, e 'pensa' mental cognitivo encadeados em um complexo no qual van Gogh representa a irmã como dizente de um não dito. Ou seja, de algo que ela nunca disse, mas que ele deseja saber: se ela leu o romance de Maupassant. Afinal ele poderia ter enunciado esta oração na forma de pergunta. Porque ele a enuncia como uma afirmação, sugerindo que, se ela já havia lido, ela não tinha contado isso para ele? Além disso, van Gogh também modaliza com 'nunca' e 'agora' na mesma oração; são duas circunstâncias de tempo divergentes e que ele usa para enfatizar a interpelação para saber o que a irmã pensa deste escritor. Este não dito parece indexar uma questão cara para van Gogh, o romance Bel-ami.

Porque é tão urgente para van Gogh compartilhar com Wilhelmina a experiência de leitura do romance Bel-ami de Guy de Maupassant? Precisamente porque sua tela sobre o Café Terrace está profundamente conectada com algum elemento discursivo no romance de Maupassant, que van Gogh explica na próxima oração. De acordo com Edwards (2009) van Gogh constrói seu discurso pictórico a partir da experiência de leitura de romancistas e pensadores e por isso ele se refere com frequência a esses autores quando está descrevendo suas telas, como explica Edwards (2009, p.15-16):

Seu gosto pela grande literatura e grande arte naquela carta para Theo pode nos
preparar para a descoberta de uma imaginação literária que estava trabalhando
quando ele mais tarde arrumou seu cavalete no Café Ginoux. Aqui é como Vicent
defendeu seu amor aos livros para Theo, que estava agora trabalhando em uma
galeria de arte. "Existem muitas coisas que uma pessoa acredita e ama. Existe algo
de Rebrandt em Shakespeare, e de Correggio em Michelet, de Delacroix em Victor
Hugo; e depois há algo de Rembrandt na Bíblia ou algo da bíblia em Rembrandt -
seja o que for isso se torna o mesmo se apenas alguém compreende isso
propriamente, sem más interpretações, e considerando a equivalência das
comparações que não pretendem diminuir os méritos das personalidades originais. E
em Bunyan há algo de Mares ou de Millet, e em Beecher Stowe há algo de Ary
Scheffer. Se agora você pode perdoar um homem por fazer ume estudo completo das
pinturas, admita também que o amor aos livros é tão sagrado quanto o amor de
Rembrandt - eu até penso que os dois se complementam um ao outro. (carta 133)
480.

${ }^{480}$ Tradução livre da autora. "His liking of great literature e grande arte in that letter to Theo may prepare us for the discovery of a literary imagination that was at work when he later set up his easel in the Ginoux café. Here is how Vincent defended his love of books to Theo, who was now working in an art gallery: "[T] here are 
O excerto de carta de van Gogh citado por Edwards explicita a íntima conexão que os escritores e pintores tinham na visão de van Gogh, não somente intelectualmente, mas na construção de uma prática discursiva que era o seu trabalho diário.

(Eu) Digo isto [porque o início de Bel- Ami é precisamente a descrição de uma noite estrelada em Paris, com os cafés iluminados da avenida,] [ 2 - e isso é algo como o mesmo tema que eu pintei bem agora.]

\begin{tabular}{|l|l|l|}
\hline $\begin{array}{l}\text { Digo isto // porque o é } \\
\text { início de Bel- Ami }\end{array}$ & $\begin{array}{l}\text { precisamente a descrição de uma noite estrelada em Paris, } \\
\text { com os cafés iluminados da avenida, }\end{array}$ \\
\hline & Proc. Rel. Atributivo & Circunstância \\
\hline
\end{tabular}

\begin{tabular}{|l|l|l|l|}
\hline e isso & é & algo como o mesmo tema & que eu pintei bem agora. \\
\hline Portador & Processo Relacional Atributivo & Atributo & Oração encaixada \\
\hline
\end{tabular}

$\alpha \times \beta(1+2[[\ldots]])$

Alfa - (Eu) Digo isto

xBETA hipotática de causa - ( 1 oração iniciadora- porque o início de Bel- Ami é precisamente a descrição de uma noite estrelada em Paris, $+\mathbf{2}$ com os cafés iluminados da avenida, oração encaixada [[ e isso é algo como o mesmo tema que eu pintei bem agora.]])

1 oração iniciadora - (porque o início de Bel- Ami é precisamente a descrição de uma noite estrelada em Paris, 2 oração continuadora - com os cafés iluminados da avenida, oração encaixada - [[e isso é algo como o mesmo tema que eu pintei bem agora.]])

\section{Interpretação}

Nesse complexo oracional, van Gogh inicia com uma oração marcada pelo processo verbal 'digo' e pelo uso do item lexical 'isso' para se referir ao que ele acaba de dizer: 'Você

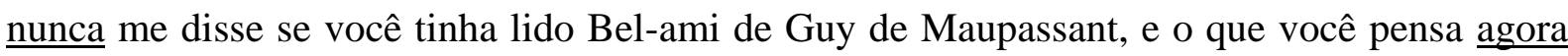
do talento dele em geral'. Este complexo mostra dois níveis semânticos, o primeiro, na oração paratáxica: 'Digo isto (...) e isso é algo como o mesmo tema que eu pintei bem agora.'; e na

many things one must believe and love. There is something of Rembrandt in Shakespeare, and of Correggio in Michelet, and of Delacroix in Victor Hugo; and then there is something of Rembrandt in the Gospel, or something of the Gospel in Rembrandt - whichever it comes to the same if only one understands it properly, without misinterpreting it and considering the equivalence of the comparisons, which do not pretend to lessen the merits of the original personalities. And in Bunyan there is something of Maris or of Millet, and in Beecher Stowe there is something of Ary Scheffer. If now you can forgive a man for making a thorough study of pictures, admit also that the love of books is as sacred as the love of Rembrandt - I even think the two complement each other. (letter 133)" (EDWARDS, 2009, p.15-16). 
hipotáxica: 'porque o início de Bel-Ami é precisamente a descrição de uma noite estrelada em Paris, com os cafés iluminados da avenida,'. Ambas constroem a relação entre a narrativa de Maupassant e a narrativa de van Gogh acerca de um café iluminado na avenida. Na oração 1, van Gogh cria um encadeamento com a oração anterior ao usar 'Digo isto (...) e isso é algo' e

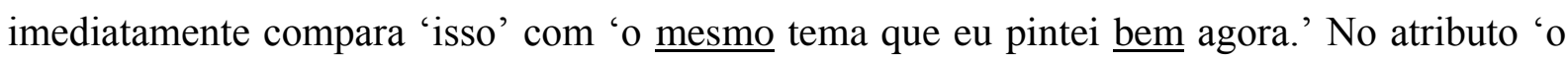
mesmo tema' e na oração encaixada 'que eu pintei bem agora', ele utiliza 'mesmo' e 'bem' para enfatizar a semelhança entre seu discurso visual e o discurso escrito de Maupassant.

\section{Interdiscursividade ADC}

Para van Gogh a experiência de leitura é tão importante quanto é a sua experiência na natureza, porque ele compartilha o pensamento de outros artistas ao ponto de articular seu próprio discurso nessa relação interdiscursiva. Se nos detivermos na leitura de Maupassant, poderemos encontrar não uma, mas algumas passagens que nos rementem às construções discursivas de van Gogh:

Ele se virou para a Madeleine e seguiu o fluxo de multidões oprimido pelo calor. Os grandes cafés, cheios de pessoas, transbordando para a calçada, exibindo seus bêbados públicos na luz brilhante e bem iluminada da sua fachada. Antes deles, em pequenas mesas, copos quadrados ou redondos, continham um líquido vermelho, amarelo, verde, marrom, todos as nuances; e nos interiores garrafões, jarros grandes, grandes cilindros de gelo transparentes brilhavam que resfriando a água clara e bonita. ${ }^{481}$

Encapsulado dentro da oração iniciadora, temos uma oração hipotáxica: 'porque o início de Bel-Ami é precisamente a descrição de uma noite estrelada em Paris, com os cafés iluminados da avenida' temos uma oração Alfa dominante: 'porque o início de Bel- Ami é precisamente a descrição de uma noite estrelada em Paris,' e uma oração Beta dependente: 'com os cafés iluminados da avenida'. Apesar de ser a oração hipotáxica, é nela que se aloja a resposta para o porque van Gogh está tão interessado que Wilhelmina leia Bel-ami; porque 'a descrição de uma noite estrelada em Paris, com os cafés iluminados da avenida' é, 'precisamente' uma descrição da tela que ele deseja narrar para sua irmã. Na forma como ele a concebeu e a executou. Observamos com frequência que o cerne do sentido que van constrói

\footnotetext{
${ }^{481}$ Trasução livre da autora. "Il tourna vers la Madeleine et suivit le flot de foule qui coulait accablé par la chaleur. Les grands cafés, pleins de monde, débordaient sur le trottoir, étalant leur public de buveurs sous la lumière éclatante et crue de leur devanture illuminée. Devant eux, sur de petites tables carrées ou rondes, les verres contenaient des liquides rouges, jaunes, verts, bruns, de toutes les nuances; et dans l'intérieur des carafes on voyait briller les gros cylindres transparents de glace qui refroidissaient la belle eau claire." (Maupassant, p. 02)
} 
nas orações se encontra em orações hipotáxicas, ou dependentes ou continuadoras. Seria esse um padrão discursivo de van Gogh? Porque que?

\subsubsection{Conclusão da análise visual da tela Por de Sol: Campo de trigo perto de Arles}

Abaixo descrevo os elementos levantados na análise visual da tela Sunset: wheatfield near Arles

\subsubsection{Quadro da análise visual da tela Por de Sol: Campo de trigo perto de Arles}

Abaixo descrevo os elementos levantados na análise visual da tela Por de Sol: Campo de trigo perto de Arles

Quadro 59: Funções e Sistemas na Pintura com elementos levantados na análise da tela Por de Sol: Campo de trigo perto de Arles

\begin{tabular}{|c|c|c|c|}
\hline Unidade / Função & Representacional & Modal & Composicional \\
\hline \multirow[t]{10}{*}{ Pintura } & $\begin{array}{l}\text { Temas Narrativos: cidade } \\
\text { e campo }\end{array}$ & Perspectiva & $\begin{array}{l}\text { Grade de perspectiva de linhas } \\
\text { diagonais no campo de trigo }\end{array}$ \\
\hline & $\begin{array}{l}\text { Duas Cenas: cidade e } \\
\text { campo- contraposição, } \\
\text { zona limítrofe, transição. }\end{array}$ & $\begin{array}{l}\text { Caminhos visuais para o } \\
\text { campo de trigo sugerem } \\
\text { movimento }\end{array}$ & $\begin{array}{l}\text { Contrastes de claro/escuro, } \\
\text { pintura desenho }\end{array}$ \\
\hline & & Dois pontos de fuga & \\
\hline & $\begin{array}{l}\text { Contraste de Episódios: } \\
\text { cidade e campo. } \\
\text { Uso simbólico do } \\
\text { amarelo. }\end{array}$ & $\begin{array}{l}\text { Ritmo /movimento } \\
\text { direcional/ textura/ } \\
\text { contrastes cromáticos no } \\
\text { campo de trigo: } \\
\text { Modalidade com uso do } \\
\text { amarelo. }\end{array}$ & $\begin{array}{l}\text { Contrastes cromáticos, dois } \\
\text { terço da tela são cores } \\
\text { quentes. }\end{array}$ \\
\hline & Luminosidade. ênfase. & Luz & Contraste de saturação \\
\hline & $\begin{array}{l}\text { Movimento, ritmo, } \\
\text { textura. }\end{array}$ & $\begin{array}{l}\text { Pincelada ritmada - gesto } \\
\text { pictórico }\end{array}$ & Desenho-pintura \\
\hline & Saliência & Cromaticamente no campo & Graficamente na cidade \\
\hline & $\begin{array}{l}\text { Homogeneidade/ } \\
\text { Diferenciação. }\end{array}$ & Dinamismo. & Agrupamento. \\
\hline & $\begin{array}{l}\text { Unidade visual, gestalt, } \\
\text { rima visual }\end{array}$ & Harmonização. cromática & $\begin{array}{l}\text { Espelhamento de tons } \\
\text { cromáticos nos diferentes } \\
\text { episódios. }\end{array}$ \\
\hline & Enquadramento & Distorção no ponto de vista & \\
\hline
\end{tabular}




\begin{tabular}{|c|c|c|c|}
\hline Episódio & Ações, eventos & $\begin{array}{l}\text { Proeminência Relativa do } \\
\text { campo }\end{array}$ & Posição Relativa na obra \\
\hline & Campo de trigo / ênfase & & Divisão em 4 planos \\
\hline & & $\begin{array}{l}\text { Contraste quente/frio } \\
\text { Cores quentes }\end{array}$ & Posição Relativa no Episódio \\
\hline & $\begin{array}{l}\text { Agentes - pacientes - } \\
\text { objetivos }\end{array}$ & & \\
\hline & $\begin{array}{l}\text { Céu } \\
\text { Uso arbitrário da cor }\end{array}$ & $\begin{array}{l}\text { Gradação de tons } \mathrm{de} \\
\text { azuis,verdes,amarelos }\end{array}$ & Movimento direcional circular \\
\hline & Focal & Centralidade & \\
\hline & Inter-relação de ações & $\begin{array}{ll}\text { Inter-relação } & \text { de } \\
\text { modalidades } & \end{array}$ & Coerência de formas \\
\hline Figura & $\begin{array}{l}\text { Caráter } \\
\text { Objeto }\end{array}$ & & Posição Relativa no Episódio \\
\hline & Ato / Posição / Gesto & Posição & Paralelismo / Oposição \\
\hline & $\begin{array}{l}\text { Elemento de transição, } \\
\text { intermediário. }\end{array}$ & & Homem. \\
\hline & & Caracterização & Sub-enquadramento. \\
\hline & & Contraste: Escala, & \\
\hline & & Linha & \\
\hline Membro & Sol & Luz & Halo de luz em volta do sol \\
\hline & Fumaça & Cor & $\begin{array}{l}\text { Linhas. direcionais paralelas } \\
\text { ao chão }\end{array}$ \\
\hline & Fábricas & & Posição Relativa no Episódio \\
\hline & $\begin{array}{l}\text { Moinho de vento - } \\
\text { contraposição com as } \\
\text { fábricas }\end{array}$ & & Posição Relativa no Episódio \\
\hline Vetores & $\begin{array}{l}\text { Trigal existe } \\
\text { Vento sopra } \\
\text { Sol brilha, se põe } \\
\text { Homem colhe }\end{array}$ & & \\
\hline
\end{tabular}

Fonte: Quadro adaptado de O’TOOLE (1994, p. 24). 


\subsection{ANÁLISE TEXTUAL DOS EXTRATOS DE CARTAS RELATIVOS À TELA POR DE SOL: CAMPO DE TRIGO PERTO DE ARLES}

\subsubsection{Quadro da análise textual da tela 'Por de Sol: Campo de trigo perto de Arles'.}

Abaixo apresentamos os resultados da análise textual da tela Por de Sol: Campo de trigo perto de Arles.

$$
\begin{aligned}
& M=\text { verbos que, provavelmente, realizam Processo Material } \\
& Z=\text { verbos que, provavelmente, realizam Processo Mental } \\
& \text { V = verbos que, provavelmente, realizam Processo Verbal } \\
& R=\text { verbos que, provavelmente, realizam Processo Relacional } \\
& \text { E = verbos que, provavelmente, realizam Processo Existencial }
\end{aligned}
$$

\begin{tabular}{|c|c|c|c|c|c|}
\hline Oração & Participante 1 & Verbo & Processo & Participante 2 & \\
\hline \multicolumn{6}{|l|}{ EXTRATO 1a } \\
\hline $\begin{array}{l}\text { Eu tenho um terceiro estudo, } \\
\text { agora, de uma paisagem com } \\
\text { fábrica, e um enorme sol em um } \\
\text { céu vermelho, acima de telhados } \\
\text { vermelhos, em que a natureza } \\
\text { parece estar em um acesso de } \\
\text { raiva, em um dia de mistral } \\
\text { desagradável. }\end{array}$ & $\begin{array}{l}\text { Eu } \\
\text { Portador }\end{array}$ & tenho & $\begin{array}{l}\text { Processo } \\
\text { Relacional } \\
\text { Atributivo }\end{array}$ & $\begin{array}{l}\text { um terceiro estudo } \\
\text { Atibuto }\end{array}$ & $\mathrm{R}$ \\
\hline $\begin{array}{l}\text { A natureza parece estar em um } \\
\text { acesso de raiva, em um dia de } \\
\text { mistral desagradável. }\end{array}$ & a natureza & $\begin{array}{l}\text { parece } \\
\text { estar }\end{array}$ & $\begin{array}{l}\text { Processo } \\
\text { Relacional } \\
\text { Atributivo }\end{array}$ & $\begin{array}{l}\text { em um acesso de } \\
\text { raiva, em um dia de } \\
\text { mistral desagradável. }\end{array}$ & $\mathbf{R}$ \\
\hline \multicolumn{6}{|l|}{ EXTRATO 1b } \\
\hline Aqui está outra paisagem. & $\begin{array}{l}\text { outra } \\
\text { paisagem. } \\
\text { existente }\end{array}$ & está & $\begin{array}{l}\text { Processo } \\
\text { Existencial }\end{array}$ & & $\mathbf{E}$ \\
\hline Sol poente? Lua nascendo? & $\begin{array}{l}\text { Lua } \\
\text { Existente }\end{array}$ & $\begin{array}{l}\text { Nascen- } \\
\text { do }\end{array}$ & $\begin{array}{l}\text { Processo } \\
\text { Existencial }\end{array}$ & & $\mathbf{E}$ \\
\hline $\begin{array}{l}\text { Noite de verão, de qualquer } \\
\text { modo. }\end{array}$ & $\begin{array}{l}\text { Noite } \\
\text { Portador }\end{array}$ & (é) & $\begin{array}{l}\text { Processo } \\
\text { Relacional } \\
\text { Atributivo }\end{array}$ & $\begin{array}{l}\text { De verão } \\
\text { Atributo }\end{array}$ & $\mathbf{R}$ \\
\hline $\begin{array}{l}\text { Cidade violeta, estrela amarela, } \\
\text { céu azul-esverdeado; os campos } \\
\text { de trigo têm todos os tons: ouro } \\
\text { velho, cobre, ouro verde, ouro } \\
\text { vermelho, ouro amarelo, verde, }\end{array}$ & $\begin{array}{l}\text { os campos de } \\
\text { trigo } \\
\text { Portador }\end{array}$ & têm & $\begin{array}{l}\text { Proc. } \\
\text { Relacional } \\
\text { Atributivo }\end{array}$ & $\begin{array}{l}\text { todos os tons: ouro } \\
\text { velho, cobre, ouro } \\
\text { verde, ouro vermelho, } \\
\text { ouro amarelo, verde, } \\
\text { vermelho e amarelo }\end{array}$ & $\mathbf{R}$ \\
\hline
\end{tabular}

Quadro 60: Processos encontrados na análise textual relativa à tela 'Por de Sol: Campo de trigo perto de Arles'. 


\begin{tabular}{|c|c|c|c|c|c|}
\hline vermelho e amarelo bronze. & & & & $\begin{array}{l}\text { bronze. } \\
\text { Atributo }\end{array}$ & \\
\hline Tela quadrada número 30. & $\begin{array}{l}\text { Tela } \\
\text { Portador }\end{array}$ & (é) & $\begin{array}{l}\text { Processo } \\
\text { Relacional } \\
\text { Atributivo }\end{array}$ & $\begin{array}{l}\text { quadrada número } 30 . \\
\text { Atributo }\end{array}$ & $\mathbf{R}$ \\
\hline Eu pintei-a ao ar livre no mistral. & $\begin{array}{l}\mathrm{Eu} \\
\text { Ator }\end{array}$ & Pintei & $\begin{array}{l}\text { Processo } \\
\text { Material } \\
\text { criativo }\end{array}$ & $\begin{array}{l}-\mathrm{a} \\
\text { Meta }\end{array}$ & M \\
\hline $\begin{array}{l}\text { Meu cavalete foi fixado no chão } \\
\text { com estacas de ferro, um método } \\
\text { que eu recomendo a voce. }\end{array}$ & & $\begin{array}{l}\text { foi } \\
\text { fixado }\end{array}$ & $\begin{array}{l}\text { Processo } \\
\text { Material } \\
\text { Transformati- } \\
\text { vo }\end{array}$ & $\begin{array}{l}\text { Meu cavalete } \\
\text { Meta }\end{array}$ & $\mathbf{M}$ \\
\hline $\begin{array}{l}\text { Voce enterra os pés do cavalete } \\
\text { e, em seguida, voce empurra a } 50 \\
\text { centímetros de comprimento um } \\
\text { peso de ferro ao lado deles. }\end{array}$ & $\begin{array}{l}\text { Voce } \\
\text { Ator }\end{array}$ & enterra & $\begin{array}{l}\text { Processo } \\
\text { Material } \\
\text { Transformati- } \\
\text { vo }\end{array}$ & $\begin{array}{l}\text { os pés do cavalete } \\
\text { Meta }\end{array}$ & $\mathbf{M}$ \\
\hline $\begin{array}{l}+\beta \text { voce empurra a } 50 \\
\text { centímetros de comprimento um } \\
\text { peso de ferro ao lado deles. }\end{array}$ & $\begin{array}{l}\text { Voce } \\
\text { Ator }\end{array}$ & $\begin{array}{l}\text { Empur- } \\
\text { ra }\end{array}$ & $\begin{array}{l}\text { Processo } \\
\text { Material } \\
\text { Transformati- } \\
\text { vo }\end{array}$ & $\begin{array}{l}\text { a } 50 \text { centímetros de } \\
\text { comprimento //um } \\
\text { peso de ferro ao lado } \\
\text { deles. } \\
\text { Meta }\end{array}$ & M \\
\hline $\begin{array}{l}\text { Voce amarra tudo com cordas; } \\
\text { dessa forma, voce pode trabalhar } \\
\text { com o vento. }\end{array}$ & $\begin{array}{l}\text { Voce } \\
\text { Ator }\end{array}$ & Amarra & $\begin{array}{l}\text { Processo } \\
\text { Material } \\
\text { Transformati- } \\
\text { vo }\end{array}$ & $\begin{array}{l}\text { tudo com cordas; } \\
\text { Meta }\end{array}$ & $\mathbf{M}$ \\
\hline $\begin{array}{l}\beta \text { voce pode trabalhar com o } \\
\text { vento. }\end{array}$ & voce & $\begin{array}{l}\text { pode } \\
\text { trabalhar }\end{array}$ & $\begin{array}{l}\text { Processo } \\
\text { Material } \\
\text { Transformati- } \\
\text { vo }\end{array}$ & & $\mathbf{M}$ \\
\hline \multicolumn{6}{|l|}{ EXTRATO 1c } \\
\hline $\begin{array}{l}\text { Eu também sou totalmente } \\
\text { incapaz [[de julgar o meu próprio } \\
\text { trabalho.]] }\end{array}$ & $\begin{array}{l}\text { Eu } \\
\text { portador }\end{array}$ & sou & $\begin{array}{l}\text { Processo } \\
\text { Relacional } \\
\text { Atributivo }\end{array}$ & $\begin{array}{l}\text { totalmente incapaz de } \\
\text { julgar o meu próprio } \\
\text { trabalho. } \\
\text { Atributo }\end{array}$ & $\mathbf{R}$ \\
\hline $\begin{array}{l}\text { Eu não posso ver se os estudos } \\
\text { são bons ou ruins. }\end{array}$ & $\begin{array}{l}\text { Eu } \\
\text { Experiencia- } \\
\text { dor }\end{array}$ & $\begin{array}{l}\text { não } \\
\text { posso } \\
\text { ver }\end{array}$ & $\begin{array}{l}\text { Processo } \\
\text { Mental } \\
\text { Cognitivo }\end{array}$ & $\begin{array}{l}\text { se os estudos são bons } \\
\text { ou ruins. } \\
\text { Fenômeno }\end{array}$ & $\mathbf{M}$ \\
\hline $\begin{array}{l}\text { Tenho sete estudos de trigais, } \\
\text { infelizmente todos eles nada } \\
\text { além de paisagens, muito contra } \\
\text { a minha vontade. }\end{array}$ & $\begin{array}{l}\text { (eu) } \\
\text { Portador }\end{array}$ & Tenho & $\begin{array}{l}\text { Processo } \\
\text { Relacional } \\
\text { Atributivo }\end{array}$ & $\begin{array}{l}\text { sete estudos de trigais, } \\
/ \\
\text { nada além de } \\
\text { paisagens } \\
\text { Atributo }\end{array}$ & $\mathbf{R}$ \\
\hline
\end{tabular}


Paisagens amarelo ouro velho feito rápido rápido rápido e com pressa, como o ceifeiro que está em silêncio sob o sol escaldante, concentrando-se em ter o trabalho terminado.

\begin{tabular}{|l|l|l|l|l|}
$\begin{array}{l}\text { Paisagens } \\
\text { amarelo ouro } \\
\text { velho }\end{array}$ & feito & $\begin{array}{l}\text { Processo } \\
\text { Relacional } \\
\text { Atributivo }\end{array}$ & $\begin{array}{l}\text { como o ceifeiro que } \\
\text { está em silêncio sob o } \\
\text { sol escaldante, } \\
\text { concentrando-se em } \\
\text { ter o trabalho } \\
\text { terminado. }\end{array}$ & $\mathbf{R}$ \\
& & & & \\
\hline
\end{tabular}

\subsubsection{Quadro da análise visual da tela 'O Semeador'.}

Abaixo descrevo os elementos levantados na análise visual da tela 'O Semeador'.

Quadro 61: Funções e Sistemas na Pintura - elementos levantados na análise da tela O Semeador

\begin{tabular}{|c|c|c|c|}
\hline $\begin{array}{l}\text { Unidade / } \\
\text { Função }\end{array}$ & Representacional & Modal & Composicional \\
\hline & $\begin{array}{l}\text { Temas Narrativos: } \\
\text { Um semeador semeia um } \\
\text { campo arado, ao fundo um } \\
\text { campo de trigo maduro. O sol } \\
\text { nasce ou se põe. }\end{array}$ & Perspectiva & $\begin{array}{l}\text { Grade de perspectiva de linhas } \\
\text { diagonais no campo arado,dão } \\
\text { a sensação de espacialidade do } \\
\text { campo. }\end{array}$ \\
\hline & $\begin{array}{l}\text { Unidade visual, gestalt, rima } \\
\text { visual }\end{array}$ & harmonização cromática & $\begin{array}{l}\text { Espelhamento de tons } \\
\text { cromáticos nos diferentes } \\
\text { episódios. }\end{array}$ \\
\hline & $\begin{array}{l}\text { Sinestesia, a ambiência } \\
\text { constrói um sentido simbólico. }\end{array}$ & $\begin{array}{l}\text { Contraste cromático, ritmo, } \\
\text { movimento, textura, direção; }\end{array}$ & Alternância cromática \\
\hline & $\begin{array}{l}\text { Simbolismo no tema: os ciclos } \\
\text { da vida }\end{array}$ & Simbolismo na cor & $\begin{array}{l}\text { Posição relativa, uso de } \\
\text { saliência, direção; } \\
\text { enquadramento; }\end{array}$ \\
\hline \multirow[t]{4}{*}{ Pintura } & $\begin{array}{l}\text { Duas Cenas: campo arado e } \\
\text { campo de trigo maduro - } \\
\text { contraposição, zona limítrofe. }\end{array}$ & $\begin{array}{l}\text { Caminhos visuais sugerem } \\
\text { transição do campo arado para } \\
\text { o campo de trigo maduro. }\end{array}$ & $\begin{array}{l}\text { Contrastes de claro/escuro, } \\
\text { quente e frio, cores } \\
\text { complementares de azuis e } \\
\text { alaranjados, e de lilases e } \\
\text { amarelos. }\end{array}$ \\
\hline & $\begin{array}{l}\text { Contraste de Episódios: campo } \\
\text { arado e campo maduro. }\end{array}$ & $\begin{array}{l}\text { Ritmo/movimento } \\
\text { direcional/textura/ }\end{array}$ & $\begin{array}{l}\text { Contrastes cromáticos, dois } \\
\text { terço da tela são cores frias, } \\
\text { um terço da tela são cores } \\
\text { quentes. }\end{array}$ \\
\hline & $\begin{array}{l}\text { Uso simbólico das cores } \\
\text { quentes e frias. }\end{array}$ & $\begin{array}{l}\text { contrastes cromáticos entre os } \\
\text { dois campos: } \\
\text { Modalidade com uso das } \\
\text { cores. }\end{array}$ & \\
\hline & $\begin{array}{l}\text { Luminosidade: } \\
\text { Saliência. }\end{array}$ & $\begin{array}{l}\text { Luz: } \\
\text { ênfase, }\end{array}$ & $\begin{array}{l}\text { Contraste de saturação, } \\
\text { complementar e quente/frio }\end{array}$ \\
\hline
\end{tabular}




\begin{tabular}{|c|c|c|c|}
\hline & $\begin{array}{l}\text { Pincelada ritmada } \\
\text { Gesto pictórico }\end{array}$ & Movimento, ritmo, textura & $\begin{array}{l}\text { Pintura-desenho } \\
\text { Grafismo nas pinceladas. }\end{array}$ \\
\hline \multirow[t]{5}{*}{ Episódio } & Ações, eventos & $\begin{array}{l}\text { Proeminência Relativa do } \\
\text { campo }\end{array}$ & Posição Relativa na obra \\
\hline & Campo arado: saliência. & $\begin{array}{l}\text { Contraste quente/frio } \\
\text { Cores frias }\end{array}$ & $\begin{array}{l}\text { Posição Relativa no Episódio; } \\
\text { ritmo, textura, movimento, } \\
\text { direção, cor. }\end{array}$ \\
\hline & $\begin{array}{l}\text { Céu } \\
\text { Uso arbitrário da cor }\end{array}$ & $\begin{array}{l}\text { Gradação de tons de } \\
\text { amarelos,alaranjados, } \\
\text { Ocres. }\end{array}$ & Movimento direcional radial \\
\hline & Inter-relação de ações & Inter-relação de modalidades & Coerência de formas \\
\hline & $\begin{array}{l}\text { Dualidades: } \\
\text { Céu e terra; } \\
\text { Campo arado/campo maduro; } \\
\text { Homem/natureza } \\
\text { Ciclos da terra }\end{array}$ & $\begin{array}{l}\text { Dualidades e contraposições } \\
\text { visuais }\end{array}$ & $\begin{array}{l}\text { Posição relativa, uso de } \\
\text { saliência, de rima visual, de } \\
\text { gesto pictórico }\end{array}$ \\
\hline \multirow[t]{3}{*}{ Figura } & $\begin{array}{l}\text { Caráter } \\
\text { Objeto }\end{array}$ & & Posição Relativa no Episódio \\
\hline & $\begin{array}{l}\text { Semeador: saliência. } \\
\text { Ato / Posição / Gesto }\end{array}$ & Posição & Direção, enquadramento \\
\hline & $\begin{array}{l}\text { Elementos de transição, } \\
\text { intermediários }\end{array}$ & & Corvos, casa, árvores, bosque \\
\hline Membro & $\begin{array}{l}\text { Sol: saliência. } \\
\text { Centralidade }\end{array}$ & $\begin{array}{l}\text { Luz } \\
\text { Focal }\end{array}$ & $\begin{array}{l}\text { Halo de luz em volta do sol, } \\
\text { direção radial }\end{array}$ \\
\hline Vetores & $\begin{array}{l}\text { Campo arado existe } \\
\text { Sol brilha, nasce ou se põe } \\
\text { Homem semeia }\end{array}$ & & \\
\hline
\end{tabular}

Fonte: Quadro adaptado de O’TOOLE (1994, p. 24).

\subsubsection{Quadro da análise textual da tela O Semeador}

Abaixo apresentamos os resultados da análise textual da tela O Semeador.

$\mathrm{M}=$ verbos que, provavelmente, realizam Processo Material

$\mathrm{Z}=$ verbos que, provavelmente, realizam Processo Mental 


$$
\begin{aligned}
& \mathrm{V}=\text { verbos que, provavelmente, realizam Processo Verbal } \\
& \mathrm{R}=\text { verbos que, provavelmente, realizam Processo Relacional } \\
& \mathrm{E}=\text { verbos que, provavelmente, realizam Processo Existencial } \\
& \mathrm{C}=\text { verbos que, provavelmente, realizam Processo Comportamental }
\end{aligned}
$$

\begin{tabular}{|c|c|c|c|c|c|}
\hline Oração & Participante 1 & Verbo & Processo & Participante 2 & \\
\hline \multicolumn{6}{|l|}{ EXTRATO 2a } \\
\hline $\begin{array}{l}\text { Aqui está um esboço de um } \\
\text { semeador: um grande campo } \\
\text { lavrado com torrões de terra, } \\
\text { na sua maioria fracamente } \\
\text { cor de violeta. }\end{array}$ & $\begin{array}{l}\text { Aqui (tela) } \\
\text { Circunstância } \\
\text { Identificado }\end{array}$ & está & $\begin{array}{l}\text { Processo } \\
\text { Relacional } \\
\text { Circunstancial } \\
\text { Identificativo }\end{array}$ & $\begin{array}{lr}\text { um esboço de um } \\
\text { semeador: } \\
\text { grande } & \text { campo } \\
\text { lavrado } & \text { com } \\
\text { torrões de } & \text { terra, na } \\
\text { sua } & \text { maioria } \\
\text { fracamente } & \text { cor de } \\
\text { violeta.] } & \\
\text { Atributo } & \end{array}$ & $\mathbf{R}$ \\
\hline $\begin{array}{l}\text { Um campo de trigo maduro, } \\
\text { de tom amarelo-ocre com um } \\
\text { pouco de carmim. }\end{array}$ & $\begin{array}{l}\text { Um campo de trigo } \\
\text { maduro, } \\
\text { Portador }\end{array}$ & (tem) & $\begin{array}{l}\text { Processo } \\
\text { Relacional } \\
\text { Atributivo }\end{array}$ & $\begin{array}{l}\text { de tom amarelo- } \\
\text { ocre com um pouco } \\
\text { de carmim. } \\
\text { Atributo }\end{array}$ & $\mathbf{R}$ \\
\hline $\begin{array}{l}\text { O céu, amarelo-crómio, } \\
\text { quase tão luminoso quanto o } \\
\text { próprio Sol, que é amarelo- } \\
\text { crómio }{ }^{\circ} 1 \text {, misturado com } \\
\text { um pouco de branco, / }\end{array}$ & $\begin{array}{l}\text { O céu, } \\
\text { Portador }\end{array}$ & é & $\begin{array}{l}\text { Processo } \\
\text { Relacional } \\
\text { Atributivo }\end{array}$ & & $\mathbf{R}$ \\
\hline $\begin{array}{l}\text { enquanto o resto do céu é } \\
\text { uma mistura dos amarelos- } \\
\text { crómios } 1 \text { e } 2 .\end{array}$ & $\begin{array}{l}\text { o resto do céu } \\
\text { Portador }\end{array}$ & é & $\begin{array}{l}\text { Processo } \\
\text { Relacional } \\
\text { Atributivo }\end{array}$ & $\begin{array}{l}\text { amarelo-crómio } \\
\mathrm{n}^{\circ} 1, \text { misturado com } \\
\text { um pouco de } \\
\text { branco, } \\
\text { Atributo }\end{array}$ & $\mathbf{R}$ \\
\hline $\begin{array}{l}\text { Tão amarelo! A camisa do } \\
\text { semeador é azul e as calças } \\
\text { brancas. Tamanho da tela - } \\
25 \text {, quadrada. }\end{array}$ & $\begin{array}{l}\text { A camisa do } \\
\text { semeador } \\
\text { Portador }\end{array}$ & é & $\begin{array}{l}\text { Processo } \\
\text { Relacional } \\
\text { Atributivo }\end{array}$ & $\begin{array}{l}\text { azul e as calças } \\
\text { brancas. } \\
\text { Atributo }\end{array}$ & $\mathbf{R}$ \\
\hline $\begin{array}{l}\text { Tamanho da tela }-25 \text {, } \\
\text { quadrada. }\end{array}$ & $\begin{array}{l}\text { Tamanho da tela - } \\
25, \\
\text { Portador }\end{array}$ & (é) & $\begin{array}{l}\text { Processo } \\
\text { Relacional } \\
\text { Atributivo }\end{array}$ & $\begin{array}{l}\text { quadrada. } \\
\text { Atributo- } \\
\text { identificada }\end{array}$ & $\mathbf{R}$ \\
\hline $\begin{array}{l}\text { Há várias sugestões de } \\
\text { amarelo no solo, tons neutros } \\
\text { resultantes da mistura de } \\
\text { violeta e amarelo; }\end{array}$ & $\begin{array}{l}\text { várias sugestões de } \\
\text { amarelo no solo, tons } \\
\text { neutros resultantes da } \\
\text { mistura de violeta e } \\
\text { amarelo; } \\
\text { existente }\end{array}$ & Há & $\begin{array}{l}\text { Processo } \\
\text { Existencial }\end{array}$ & & $\mathbf{E}$ \\
\hline
\end{tabular}

Quadro 62: Processos encontrados na análise textual relativa à tela 'O Semeador' 


\begin{tabular}{|c|c|c|c|c|c|}
\hline $\begin{array}{l}\text { mas tenho travado uma luta } \\
\text { diabólica para atingir a } \\
\text { verdade das cores. }\end{array}$ & $\begin{array}{l}\text { (eu) } \\
\text { experienciador }\end{array}$ & $\begin{array}{l}\text { tenho } \\
\text { travado }\end{array}$ & $\begin{array}{l}\text { Processo } \\
\text { Mental } \\
\text { Desiderativo }\end{array}$ & $\begin{array}{l}\text { uma luta diabólica } \\
\text { para atingir a } \\
\text { verdade das cores. } \\
\text { Fenomeno }\end{array}$ & $\mathbf{M}$ \\
\hline $\begin{array}{l}\text { Preferia muito mais fazer } \\
\text { quadros naifs tirados de } \\
\text { velhos almanaques, aqueles } \\
\text { velhos "almanaques dos } \\
\text { lavradores" nos quais o } \\
\text { granizo, a neve, a chuva e o } \\
\text { bom tempo são retratados de } \\
\text { modo primitivo, como o } \\
\text { Anquetin atingiu tão bem no } \\
\text { seu A Colheita. }\end{array}$ & $(\mathrm{Eu})$ & Preferia & $\begin{array}{l}\text { Processo } \\
\text { Mental } \\
\text { Emotivo }\end{array}$ & $\begin{array}{lr}\text { muito mais } & \text { fazer } \\
\text { quadros } & \text { naifs } \\
\text { tirados de velhos } \\
\text { almanaques, } \\
\text { aqueles velhos } \\
\text { "almanaques dos } \\
\text { lavradores" nos } \\
\text { quais o granizo, a } \\
\text { neve, a chuva e o } \\
\text { bom tempo são } \\
\text { retratados de modo } \\
\text { primitivo, } \\
\text { Fenômeno }\end{array}$ & $\mathbf{M}$ \\
\hline $\begin{array}{l}\text { Não te vou ocultar que não } \\
\text { desgosto da região, pois fui } \\
\text { criado lá - ainda me encanta } \\
\text { a magia das recordações do } \\
\text { passado, de um desejo do } \\
\text { infinito, do qual o semeador } \\
\text { e o enfeixador são símbolos }\end{array}$ & $\begin{array}{l}\text { (Eu) Não } \\
\text { Dizente }\end{array}$ & vou ocultar & $\begin{array}{l}\text { Processo } \\
\text { Verbal }\end{array}$ & $\begin{array}{l}\text { que não desgosto } \\
\text { relato }\end{array}$ & V \\
\hline -,tanto quanto antes gostava. & (Eu) & gostava. & $\begin{array}{l}\text { Processo } \\
\text { Mental } \\
\text { Emotivo }\end{array}$ & & $\mathbf{M}$ \\
\hline $\begin{array}{l}\text { ainda me encanta a magia } \\
\text { das recordações do passado, } \\
\text { de um desejo do infinito }\end{array}$ & $\begin{array}{l}\text { ainda me } \\
\text { Experienciador }\end{array}$ & encanta & $\begin{array}{l}\text { Processo } \\
\text { Mental } \\
\text { Emotivo }\end{array}$ & $\begin{array}{l}\text { a magia das } \\
\text { recordações do } \\
\text { passado, de um } \\
\text { desejo do infinito, } \\
\text { Fenomeno }\end{array}$ & $\mathbf{M}$ \\
\hline $\begin{array}{l}\text { do qual o semeador e o } \\
\text { enfeixador são símbolos - }\end{array}$ & $\begin{array}{l}\text { do qual o semeador e } \\
\text { o enfeixador } \\
\text { Portador }\end{array}$ & são & $\begin{array}{l}\text { Processo } \\
\text { Relacional } \\
\text { Atributivo }\end{array}$ & $\begin{array}{l}\text { símbolos - } \\
\text { Atributo }\end{array}$ & $\mathbf{R}$ \\
\hline $\begin{array}{l}\text { Mas quando eu farei o céu } \\
\text { estrelado, então, }\end{array}$ & $\begin{array}{l}\mathrm{Eu} \\
\text { Ator }\end{array}$ & farei & $\begin{array}{l}\text { Processo } \\
\text { material }\end{array}$ & o céu estrelado, & $\mathbf{M}$ \\
\hline $\begin{array}{l}\text { essa pintura que está sempre } \\
\text { na minha mente? }\end{array}$ & $\begin{array}{l}\text { então, essa pintura } \\
\text { que } \\
\text { Portador }\end{array}$ & está & $\begin{array}{l}\text { Processo } \\
\text { Relacional } \\
\text { Atributivo }\end{array}$ & $\begin{array}{l}\text { sempre na minha } \\
\text { mente? } \\
\text { Atributo }\end{array}$ & $\mathbf{R}$ \\
\hline $\begin{array}{l}\text { Ai, ai, é como nosso } \\
\text { excelente amigo Cyprien diz, } \\
\text { em 'En ménage' por JK } \\
\text { Huysmans: }\end{array}$ & $\begin{array}{l}\text { nosso excelente } \\
\text { amigo Cyprien } \\
\text { Dizente }\end{array}$ & diz, & $\begin{array}{l}\text { Processo } \\
\text { Verbal }\end{array}$ & $\begin{array}{l}\text { as mais belas } \\
\text { pinturas são } \\
\text { aquelas que alguem } \\
\text { sonha enquanto } \\
\text { fuma um cachimbo } \\
\text { em sua cama, mas a }\end{array}$ & $\mathrm{V}$ \\
\hline
\end{tabular}




\begin{tabular}{|c|c|c|c|c|c|}
\hline & & & & $\begin{array}{l}\text { qual ele não pinta. } \\
\text { verbiagem }\end{array}$ & \\
\hline $\begin{array}{l}\text { as mais belas pinturas são } \\
\text { aquelas que alguem sonha } \\
\text { enquanto fuma um cachimbo } \\
\text { em sua cama, mas a qual ele } \\
\text { não pinta. }\end{array}$ & $\begin{array}{l}\text { as mais belas } \\
\text { pinturas } \\
\text { Identificado }\end{array}$ & são & $\begin{array}{l}\text { Processo } \\
\text { Relacional } \\
\text { Identificativo }\end{array}$ & $\begin{array}{l}\text { mas a qual ele não } \\
\text { pinta. } \\
\text { Identificador }\end{array}$ & $\mathbf{R}$ \\
\hline $\begin{array}{l}\text { Mas é uma questão de atacá- } \\
\text { las, no entanto, }\end{array}$ & $\begin{array}{l}\text { Mas (isso) } \\
\text { Portador }\end{array}$ & é & $\begin{array}{l}\text { Processo } \\
\text { Relacional } \\
\text { Atributivo }\end{array}$ & & $\mathbf{R}$ \\
\hline $\begin{array}{l}\text { não importa o quão } \\
\text { incompetente alguém pode } \\
\text { sentir-se vis-à-vis as } \\
\text { perfeições inefáveis do } \\
\text { glorioso esplendor da } \\
\text { natureza. }\end{array}$ & $\begin{array}{l}\text { Alguém } \\
\text { Experienciador }\end{array}$ & $\begin{array}{l}\text { pode } \\
\text { sentir-se }\end{array}$ & $\begin{array}{l}\text { Processo } \\
\text { Mental } \\
\text { Emotivo }\end{array}$ & $\begin{array}{l}\text { vis-à-vis as } \\
\text { perfeições inefáveis } \\
\text { do glorioso } \\
\text { esplendor da } \\
\text { natureza. } \\
\text { Fenômeno }\end{array}$ & $\mathbf{M}$ \\
\hline $\begin{array}{l}\text { Aqui está o que eu queria } \\
\text { dizer sobre o branco e o } \\
\text { preto. }\end{array}$ & $\begin{array}{l}\text { o que eu queria dizer } \\
\text { Identificador }\end{array}$ & está & $\begin{array}{l}\text { Processo } \\
\text { Relacional } \\
\text { Identificativo }\end{array}$ & $\begin{array}{l}\text { sobre o branco e o } \\
\text { preto. } \\
\text { Identificado }\end{array}$ & $\mathbf{R}$ \\
\hline Vamos tomar o Semeador. & $\begin{array}{l}\text { Vamos } \\
\text { Experienciador }\end{array}$ & tomar & $\begin{array}{l}\text { Processo } \\
\text { Mental } \\
\text { Cognitivo }\end{array}$ & $\begin{array}{l}\text { o Semeador. } \\
\text { Fenômeno }\end{array}$ & $\mathbf{M}$ \\
\hline $\begin{array}{l}\text { A pintura é dividida em dois; } \\
\text { metade é amarelo, o topo; a } \\
\text { base é violeta. }\end{array}$ & $\begin{array}{l}\text { A pintura } \\
\text { Portador }\end{array}$ & é dividida & $\begin{array}{l}\text { Processo } \\
\text { Relacional } \\
\text { Atributivo }\end{array}$ & $\begin{array}{l}\text { em dois; } \\
\text { Atributo }\end{array}$ & $\mathbf{R}$ \\
\hline metade é amarelo, o topo; & $\begin{array}{l}\text { Metade } \\
\text { Portador }\end{array}$ & é & $\begin{array}{l}\text { Processo } \\
\text { Relacional } \\
\text { Atributivo }\end{array}$ & $\begin{array}{l}\text { amarelo, o topo; } \\
\text { Atributo }\end{array}$ & $\mathbf{R}$ \\
\hline a base é violeta. & $\begin{array}{l}\text { a base } \\
\text { Portador }\end{array}$ & é & $\begin{array}{l}\text { Processo } \\
\text { Relacional } \\
\text { Atributivo }\end{array}$ & $\begin{array}{l}\text { violeta. } \\
\text { Atributo }\end{array}$ & $\mathbf{R}$ \\
\hline $\begin{array}{l}\text { Bem, as calças brancas } \\
\text { descansam os olhos e }\end{array}$ & $\begin{array}{l}\text { os olhos e } \\
\text { Experienciador }\end{array}$ & descansam & $\begin{array}{l}\text { Processo } \\
\text { Mental } \\
\text { Perceptivo }\end{array}$ & $\begin{array}{l}\text { Bem, as calças } \\
\text { brancas } \\
\text { Fenômeno }\end{array}$ & $\mathbf{M}$ \\
\hline $\begin{array}{l}\text { os distraem exatamente / } \\
\text { quando o contraste } \\
\text { simultâneo excessivo de } \\
\text { amarelo e violeta iriam irritá- } \\
\text { lo. }\end{array}$ & $\begin{array}{l}\text {-lo. } \\
\text { Experienciador }\end{array}$ & $\begin{array}{l}\text { os distraem } \\
\text { e } \\
\text { iriam irritá- }\end{array}$ & $\begin{array}{l}\text { Processo } \\
\text { Mental } \\
\text { Perceptivo }\end{array}$ & $\begin{array}{l}\text { o contraste } \\
\text { simultâneo } \\
\text { excessivo de } \\
\text { amarelo e violeta } \\
\text { Fenômeno }\end{array}$ & $\mathbf{M}$ \\
\hline Isso é & $\begin{array}{l}\text { Isso } \\
\text { Existente }\end{array}$ & é & $\begin{array}{l}\text { Processo } \\
\text { Existencial }\end{array}$ & & $\mathbf{E}$ \\
\hline o que eu queria dizer. & eu & $\begin{array}{l}\text { queria } \\
\text { dizer. }\end{array}$ & $\begin{array}{l}\text { Processo } \\
\text { Mental }\end{array}$ & o que & $\mathbf{M}$ \\
\hline
\end{tabular}




\begin{tabular}{|c|c|c|c|c|c|}
\hline & & & Desiderativo & Fenômeno & \\
\hline \multicolumn{6}{|l|}{ EXTRATO 2b } \\
\hline $\begin{array}{l}\text { Eu tive uma semana de } \\
\text { concentrado trabalho duro } \\
\text { nos campos de trigo debaixo } \\
\text { do sol, }\end{array}$ & $\begin{array}{l}\mathrm{Eu} \\
\text { Portador }\end{array}$ & tive & $\begin{array}{l}\text { Processo } \\
\text { Relacional } \\
\text { Atributivo } \\
\text { Possessivo }\end{array}$ & $\begin{array}{l}\text { uma semana de } \\
\text { concentrado } \\
\text { trabalho duro nos } \\
\text { campos de trigo } \\
\text { debaixo do sol, } \\
\text { Atributo }\end{array}$ & $\mathbf{R}$ \\
\hline $\begin{array}{l}\text { o resultado foi de alguns } \\
\text { estudos de campos de trigo, } \\
\text { paisagens e - um esboço de } \\
\text { um semeador. }\end{array}$ & $\begin{array}{l}\text { o resultado } \\
\text { Portador }\end{array}$ & foi & $\begin{array}{l}\text { Processo } \\
\text { Relacional } \\
\text { Atributivo }\end{array}$ & $\begin{array}{l}\text { de alguns estudos } \\
\text { de campos de trigo, } \\
\text { paisagens e - um } \\
\text { esboço de um } \\
\text { semeador. } \\
\text { Atributo }\end{array}$ & $\mathbf{R}$ \\
\hline $\begin{array}{l}\text { Em um campo arado, um } \\
\text { grande campo de torrões de } \\
\text { terra roxa - levantados em } \\
\text { direção ao horizonte - um } \\
\text { semeador em azul e branco. }\end{array}$ & $\begin{array}{l}\text { Em um campo arado, } \\
\text { um grande campo de } \\
\text { torrões de terra roxa } \\
- \text { levantados em } \\
\text { direção ao horizonte } \\
- \\
\text { Portador }\end{array}$ & (tem) & $\begin{array}{l}\text { Processo } \\
\text { Relacional } \\
\text { Atributivo }\end{array}$ & $\begin{array}{l}\text { um semeador } \\
\text { Atributo }\end{array}$ & $\mathbf{R}$ \\
\hline $\begin{array}{l}\text { No horizonte um campo de } \\
\text { trigo curto, maduro. } 1 \mathrm{v}: 2\end{array}$ & & (há) & $\begin{array}{l}\text { Processo } \\
\text { Existencial }\end{array}$ & $\begin{array}{l}\text { um campo de trigo } \\
\text { curto, maduro } \\
\text { Existente }\end{array}$ & $\mathbf{E}$ \\
\hline $\begin{array}{l}\text { Acima de tudo isso um céu } \\
\text { amarelo com um sol } \\
\text { amarelo. }\end{array}$ & & (há) & $\begin{array}{l}\text { Processo } \\
\text { Existencial }\end{array}$ & $\begin{array}{l}\text { um céu amarelo } \\
\text { com um sol } \\
\text { amarelo. } \\
\text { Existente }\end{array}$ & $\mathbf{E}$ \\
\hline $\begin{array}{l}\text { Você pode sentir a partir da } \\
\text { mera nomenclatura das } \\
\text { tonalidades - que a cor } \\
\text { desempenha um papel muito } \\
\text { importante nesta } \\
\text { composição. }\end{array}$ & $\begin{array}{l}\text { Você } \\
\text { Sentidor }\end{array}$ & $\begin{array}{l}\text { pode } \\
\text { sentir }\end{array}$ & $\begin{array}{l}\text { Processo } \\
\text { Mental } \\
\text { Afetivo }\end{array}$ & $\begin{array}{l}\text { que a cor } \\
\text { desempenha um } \\
\text { papel muito } \\
\text { importante nesta } \\
\text { composição. } \\
\text { Fenômeno }\end{array}$ & $\mathbf{M}$ \\
\hline $\begin{array}{l}\text { E o esboço como tal - uma } \\
\text { tela número } 25 \text { - também me } \\
\text { preocupa muito, no sentido } \\
\text { de que }\end{array}$ & $\begin{array}{l}\text { me } \\
\text { Experienciador }\end{array}$ & preocupa & $\begin{array}{l}\text { Processo } \\
\text { Mental } \\
\text { Emotivo }\end{array}$ & $\begin{array}{l}\text { E o esboço como } \\
\text { tal - uma tela } \\
\text { número } 25- \\
\text { Fenômeno }\end{array}$ & $\mathbf{M}$ \\
\hline
\end{tabular}




\subsubsection{Quadro da análise visual da tela A Esplanada do Café na Place du Forum, Arles, à Noite}

Abaixo descrevo os elementos levantados na análise visual da tela 'A Esplanada do Café na Place du Forum, Arles, à Noite'

Quadro 63: Funções e Sistemas com elementos da análise da tela 'A Esplanada do Café na Place du Forum, Arles, à Noite'

\begin{tabular}{|c|c|c|c|}
\hline Unidade / Função & Representacional & Modal & Composicional \\
\hline & $\begin{array}{l}\text { Temas Narrativos: } \\
\text { Café, Noite }\end{array}$ & $\begin{array}{l}\text { Perspectiva - recurso usado } \\
\text { para conduzir o olhar para } \\
\text { dentro da tela. } \\
\text { Linhas diagonais organizam } \\
\text { o espaço e constroem o } \\
\text { ponto de fuga que conduz o } \\
\text { olhar para dentro da cena. }\end{array}$ & $\begin{array}{l}\text { Perspectiva } \\
\text { - Uso de linhas diagonais para } \\
\text { compor o ponto de fuga no } \\
\text { fim da rua } \\
\text { - Composição } \\
\text { focal/centralidade na divisão } \\
\text { diagonal do espaço. }\end{array}$ \\
\hline & $\begin{array}{l}\text { Café é o foco central da } \\
\text { narrativa, e concentra a } \\
\text { ação }\end{array}$ & $\begin{array}{l}\text { Cor do toldo e a } \\
\text { Posição obliqua das portas } \\
\text { e janelas conduzem ao café }\end{array}$ & $\begin{array}{l}\text { Linhas direcionais conduzem } \\
\text { ao café }\end{array}$ \\
\hline \multirow[t]{3}{*}{ Pintura } & $\begin{array}{l}\text { - Uso simbólico do } \\
\text { amarelo. } \\
\text { - Contraste entre dois } \\
\text { Episódios: luz da lâmpada } \\
\text { a gás/ luz das estrelas e da } \\
\text { noite }\end{array}$ & $\begin{array}{l}\text { - Uso intensificado da cor } \\
\text { amarela } \\
\text { - Contraste complementar } \\
\text { azul/amarelo } \\
\text { - Contrastes cromáticos, } \\
\text { dois terço da tela são cores } \\
\text { quentes. } \\
\text { Modalidade com uso do } \\
\text { amarelo. }\end{array}$ & $\begin{array}{l}\text { - Contraste complementar; de } \\
\text { claro/escuro, de quente/frio }\end{array}$ \\
\hline & Movimento, ritmo, textura & $\begin{array}{l}\text { Ritmo /movimento } \\
\text { direcional/ textura/ e } \\
\text { Pincelada ritmada } \\
\text { conduzem o olhar para } \\
\text { dentro da cena }\end{array}$ & $\begin{array}{l}\text { - uso do desenho-pintura nas } \\
\text { pedras do calçamento e nos } \\
\text { objetos do primeiro plano. } \\
\text { Padrões das pedras sugerem } \\
\text { ritmo, textura e movimento. }\end{array}$ \\
\hline & $\begin{array}{l}\text { - Uso simbólico da } \\
\text { Luminosidade. } \\
\text { - Ênfase no café por meio } \\
\text { da luminosidade. } \\
\text { Contraposição entre } \\
\text { natureza e sociedade, } \\
\text { solidão e convívio, luz e } \\
\text { sombra, luz das estrelas e } \\
\text { luz do lampião, luz natural }\end{array}$ & $\begin{array}{l}\text { Luz que emana do café e } \\
\text { ilumina a praça, faz brilhar } \\
\text { as cores do café e da rua. }\end{array}$ & Contraste de saturação \\
\hline
\end{tabular}




\begin{tabular}{|c|c|c|c|}
\hline & e luz artificial. & & \\
\hline & $\begin{array}{l}\text { Uso de associações } \\
\text { metafóricas }\end{array}$ & $\begin{array}{l}\text { Harmonização entre o café } \\
\text { e a noite. }\end{array}$ & $\begin{array}{l}\text { Uso de cores claras para } \\
\text { tornar o contraste } \\
\text { complementar harmonioso e } \\
\text { brilhante. } \\
\text { Uso de cores cruzadas para } \\
\text { criar comunicação entre as } \\
\text { áreas de cor. }\end{array}$ \\
\hline & $\begin{array}{l}\text { Homogeneidade/ } \\
\text { diferenciação }\end{array}$ & dinamismo & agrupamento \\
\hline & Unidade visual, gestalt & harmonização cromática & $\begin{array}{l}\text { Espelhamento de tons } \\
\text { cromáticos nos diferentes } \\
\text { episódios. }\end{array}$ \\
\hline \multirow[t]{5}{*}{ Episódio } & Ações, eventos & $\begin{array}{l}\text { Proeminência Relativa do } \\
\text { café }\end{array}$ & $\begin{array}{l}\text { Posição central do café na } \\
\text { composição }\end{array}$ \\
\hline & Café / ênfase & $\begin{array}{l}\text { Gradação de tons de } \\
\text { amarelos, laranjas, azuis, } \\
\text { lilases, verdes. Cores } \\
\text { quentes }\end{array}$ & Divisão em 4 planos \\
\hline & $\begin{array}{l}\text { Noite Estrelada / periférica } \\
\text { - padrão de repetições das } \\
\text { estrelas espelham padrões } \\
\text { dos tampos de mesas e } \\
\text { padrões no calçamento. }\end{array}$ & $\begin{array}{l}\text { Contraste quente/frio } \\
\text { Estrelas constroem ritmo e } \\
\text { textura que espelham as } \\
\text { pedras do chão }\end{array}$ & $\begin{array}{l}\text { Posição Relativa no Episódio } \\
\text { - uso da analogia formal }\end{array}$ \\
\hline & Uma noite clara. & Céu & $\begin{array}{l}\text { O uso de azul claro torna } \\
\text { brilhante o contraste com o } \\
\text { toldo alaranjado e amarelo. }\end{array}$ \\
\hline & Inter-relação de ações & $\begin{array}{l}\text { Inter-relação de } \\
\text { modalidades }\end{array}$ & Coerência de formas \\
\hline \multirow[t]{4}{*}{ Figura } & $\begin{array}{l}\text { Caráter } \\
\text { Objeto }\end{array}$ & & Posição Relativa no Episódio \\
\hline & $\begin{array}{l}\text { Posição relativa } \\
\text { Periferia/centro }\end{array}$ & Garçom & $\begin{array}{l}\text { Falta de detalhamento, } \\
\text { fisionomia anônima, } \\
\text { representado como silhueta } \\
\text { contra as cores vivas. }\end{array}$ \\
\hline & $\begin{array}{l}\text { Posição relativa } \\
\text { Periferia/centro }\end{array}$ & Pessoas que estão no café & $\begin{array}{l}\text { Falta de detalhamento, } \\
\text { fisionomias anônimas, } \\
\text { representadas como silhuetas } \\
\text { contra as cores vivas. }\end{array}$ \\
\hline & $\begin{array}{l}\text { Uso de associações } \\
\text { metafóricas }\end{array}$ & Cavalo e charrete & $\begin{array}{l}\text { Posição Relativa no Episódio } \\
\text { Falta de detalhamento. }\end{array}$ \\
\hline
\end{tabular}




\begin{tabular}{|c|c|c|c|}
\hline & $\begin{array}{l}\text { Pessoas como elemento de } \\
\text { transição, intermediário }\end{array}$ & $\begin{array}{l}\text { Três pessoas atravessam a } \\
\text { rua em direção ao café }\end{array}$ & $\begin{array}{l}\text { Fazem a ligação entre o café e } \\
\text { os seus arredores }\end{array}$ \\
\hline & $\begin{array}{l}\text { Uso de associações } \\
\text { metafóricas }\end{array}$ & Estrelas & Detalhamento \\
\hline & $\begin{array}{l}\text { Posição relativa } \\
\text { Periferia/centro }\end{array}$ & $\begin{array}{l}\text { Edifícios na rua ao lado do } \\
\text { café }\end{array}$ & $\begin{array}{l}\text { Uso de cores escuras para } \\
\text { ressaltar o contraste } \\
\text { claro/escuro com o toldo do } \\
\text { café. }\end{array}$ \\
\hline \multirow[t]{4}{*}{ Membro } & $\begin{array}{l}\text { Uso de associações } \\
\text { metafóricas }\end{array}$ & $\begin{array}{l}\text { Lâmpada a gás } \\
\text { Luz }\end{array}$ & $\begin{array}{l}\text { Detalhamento. Halo de luz em } \\
\text { volta da Lâmpada } \\
\text { Posição central no Episódio }\end{array}$ \\
\hline & $\begin{array}{l}\text { Uso de associações } \\
\text { metafóricas }\end{array}$ & $\begin{array}{l}\text { Cadeiras vazias no primeiro } \\
\text { plano fazem contraposição } \\
\text { com uma área ocupada por } \\
\text { pessoas no café }\end{array}$ & $\begin{array}{l}\text { Detalhamento. Desenho- } \\
\text { pintura que enfatiza as linhas } \\
\text { de contorno das cadeiras. } \\
\text { Posição Relativa no Episódio }\end{array}$ \\
\hline & & $\begin{array}{l}\text { Porta no primeiro plano } \\
\text { parcialmente representada }\end{array}$ & $\begin{array}{l}\text { Detalhamento. Desenho- } \\
\text { pintura que enfatiza as linhas } \\
\text { de contorno. } \\
\text { Posição Relativa no Episódio. }\end{array}$ \\
\hline & $\begin{array}{l}\text { Uso de associações } \\
\text { metafóricas }\end{array}$ & $\begin{array}{l}\text { Árvore no segundo plano } \\
\text { parcialmente representada }\end{array}$ & $\begin{array}{l}\text { Detalhamento. Desenho- } \\
\text { pintura que enfatiza as linhas } \\
\text { de contorno. } \\
\text { Posição Relativa no Episódio. }\end{array}$ \\
\hline Vetores & $\begin{array}{l}\text { Céu existe } \\
\text { Estrelas brilham } \\
\text { Café existe } \\
\text { Lâmpada ilumina as cores } \\
\text { da noite } \\
\text { Pessoas convivem no café } \\
\text { Pessoas caminham em } \\
\text { direção ao café }\end{array}$ & $\begin{array}{l}\text { A rua ao redor do café } \\
\text { recebe a luz da lâmpada a } \\
\text { gás }\end{array}$ & \\
\hline
\end{tabular}

Fonte: Quadro adaptado de O’TOOLE (1994, p. 24).

Encapsulado dentro da oração iniciadora, temos uma oração hipotáxica: 'porque o início de Bel-Ami é precisamente a descrição de uma noite estrelada em Paris, com os cafés iluminados da avenida' temos uma oração Alfa dominante: 'porque o início de Bel- Ami é precisamente a descrição de uma noite estrelada em Paris,' e uma oração Beta dependente: 'com os cafés iluminados da avenida'. Apesar de ser a oração hipotáxica, é nela que se aloja a resposta para o porque van Gogh está tão interessado que Wilhelmina leia Bel-ami; porque 'a 
descrição de uma noite estrelada em Paris, com os cafés iluminados da avenida' é, 'precisamente' uma descrição da tela que ele deseja narrar para sua irmã. Na forma como ele a concebeu e a executou. Observamos com frequência que o cerne do sentido que van constrói nas orações se encontra em orações hipotáxicas, ou dependentes ou continuadoras. Seria esse um padrão discursivo de van Gogh? Porque que?

\subsubsection{Quadro da análise textual da tela A Esplanada do Café na Place du Forum, Arles, à Noite}

Abaixo apresentamos os resultados da análise textual da tela A Esplanada do Café na Place du Forum, Arles, à Noite

$$
\begin{aligned}
& M=\text { verbos que, provavelmente, realizam Processo Material } \\
& Z \text { = verbos que, provavelmente, realizam Processo Mental } \\
& V=\text { verbos que, provavelmente, realizam Processo Verbal } \\
& R=\text { verbos que, provavelmente, realizam Processo Relacional } \\
& \text { E = verbos que, provavelmente, realizam Processo Existencial }
\end{aligned}
$$

\begin{tabular}{|c|c|c|c|c|c|}
\hline Oração & Participante 1 & Verbo & Processo & Participante 2 & \\
\hline \multicolumn{6}{|l|}{ EXTRATO 3a } \\
\hline $\begin{array}{l}\text { Essa é a primeira pintura esta } \\
\text { semana. }\end{array}$ & $\begin{array}{l}\text { Essa } \\
\text { Identificado }\end{array}$ & é & $\begin{array}{l}\text { Processo } \\
\text { Relacional } \\
\text { identificativo }\end{array}$ & $\begin{array}{l}\text { primeira pintura } \\
\text { Identificador }\end{array}$ & $\mathbf{R}$ \\
\hline $\begin{array}{l}\text { A segunda mostra o exterior de } \\
\text { um café, iluminado no terraço } \\
\text { externo por uma grande } \\
\text { lâmpada de gás dentro da noite } \\
\text { azul, com um retalho de céu } \\
\text { azul estrelado. }\end{array}$ & $\begin{array}{l}\text { A segunda } \\
\text { dizente }\end{array}$ & Mostra & $\begin{array}{l}\text { Processo } \\
\text { verbal }\end{array}$ & Verbiage & $\mathbf{V}$ \\
\hline \multicolumn{6}{|l|}{ EXTRATO 3b } \\
\hline $\begin{array}{l}\text { III Fui interrompido } \\
\text { precisamente pelo trabalho II } \\
\text { que uma nova pintura da parte } \\
\text { externa de um café à noite tem } \\
\text { me dado nos últimos dias. } \\
\text { (oração encaixada) }\end{array}$ & $\begin{array}{l}\text { [eu] } \\
\text { Meta oculta }\end{array}$ & $\begin{array}{l}\text { Fui } \\
\text { interrompido }\end{array}$ & $\begin{array}{l}\text { Processo } \\
\text { material } \\
\text { transformativo }\end{array}$ & $\begin{array}{l}\text { pelo trabalho } \\
\text { Ator }\end{array}$ & M \\
\hline $\begin{array}{l}\text { III No terraço, há pequenas } \\
\text { figuras de pessoas III que }\end{array}$ & & há & $\begin{array}{l}\text { Processo } \\
\text { existencial }\end{array}$ & $\begin{array}{l}\text { pequenas figuras } \\
\text { de pessoas }\end{array}$ & $\mathbf{E}$ \\
\hline
\end{tabular}

Quadro 39: Processos encontrados na análise textual relativa à tela 'A Esplanada do Café na Place du Forum,

$$
\text { Arles, à Noite' }
$$




\begin{tabular}{|c|c|c|c|c|c|}
\hline bebem. & & & & Existente & \\
\hline $\begin{array}{l}\text { III Uma enorme lanterna } \\
\text { amarela ilumina o terraço, a } \\
\text { fachada, a calçada III, que } \\
\text { adquirem uma coloração } \\
\text { violeta-rosa. (oração } \\
\text { encaixada) }\end{array}$ & $\begin{array}{l}\text { Uma enorme } \\
\text { lanterna amarela } \\
\text { Ator }\end{array}$ & ilumina & $\begin{array}{l}\text { Processo } \\
\text { Material } \\
\text { transformativo }\end{array}$ & $\begin{array}{l}\text { o terraço, a } \\
\text { fachada, a } \\
\text { calçada, } \\
\text { Meta }\end{array}$ & $\mathbf{M}$ \\
\hline $\begin{array}{l}\text { II e até mesmo projeta luz } \\
\text { sobre os paralelepípedos da } \\
\text { rua, }\end{array}$ & & projeta & $\begin{array}{l}\text { Processo } \\
\text { Material } \\
\text { transformativo }\end{array}$ & $\begin{array}{l}\text { Luz } \\
\text { Escopo / } \\
\text { domínio do } \\
\text { processo }\end{array}$ & $\mathbf{M}$ \\
\hline $\begin{array}{l}\text { que adquirem uma coloração } \\
\text { violeta-rosa. (oração } \\
\text { encaixada) }\end{array}$ & $\begin{array}{l}\text { [os } \\
\text { paralelepípedos } \\
\text { da rua,] }\end{array}$ & $\begin{array}{l}\text { que } \\
\text { adquirem }\end{array}$ & $\begin{array}{l}\text { Processo } \\
\text { relacional } \\
\text { atributivo }\end{array}$ & $\begin{array}{l}\text { uma coloração } \\
\text { violeta-rosa. } \\
\text { Atributo }\end{array}$ & $\mathbf{R}$ \\
\hline $\begin{array}{l}\text { III As frentes das casas em } \\
\text { uma rua II que segue sob o céu } \\
\text { azul salpicado de estrelas II são } \\
\text { azul escuro ou violeta, com } \\
\text { uma árvore verde III. }\end{array}$ & $\begin{array}{l}\text { As frentes das } \\
\text { casas } \\
\text { Portador }\end{array}$ & são & $\begin{array}{l}\text { Processo } \\
\text { Relacional } \\
\text { Atributivo }\end{array}$ & $\begin{array}{l}\text { azul escuro ou } \\
\text { violeta, } \\
\text { Atributo }\end{array}$ & $\mathbf{R}$ \\
\hline $\begin{array}{l}\text { III Agora há uma pintura de } \\
\text { noite sem preto III. }\end{array}$ & & há & $\begin{array}{l}\text { Processo } \\
\text { Existencial }\end{array}$ & $\begin{array}{l}\text { uma pintura de } \\
\text { noite } \\
\text { Existente }\end{array}$ & $\bar{E}$ \\
\hline $\begin{array}{l}\text { III Com nada mais do que um } \\
\text { belo azul e violeta e verde e } \\
\text { nestes arredores da praça } \\
\text { iluminada é colorido por } \\
\text { enxofre pálido, amarelo limão } \\
\text { III. }\end{array}$ & & é colorido & $\begin{array}{l}\text { Processo } \\
\text { material } \\
\text { criativo }\end{array}$ & & $\bar{M}$ \\
\hline $\begin{array}{l}\text { III Eu gosto enormemente de } \\
\text { pintar no local à noite III. }\end{array}$ & eu & gosto & $\begin{array}{l}\text { Processo } \\
\text { Mental Afetivo }\end{array}$ & & $\mathbf{Z}$ \\
\hline $\begin{array}{l}\text { III No passado, eles } \\
\text { costumavam desenhar e pintar } \\
\text { a tela do desenho durante o dia } \\
\text { III. }\end{array}$ & eles & $\begin{array}{l}\text { costuma } \\
\text { vam } \\
\text { desenhar e } \\
\text { pintar }\end{array}$ & $\begin{array}{l}\text { Processo } \\
\text { Material } \\
\text { Criativo }\end{array}$ & & $\mathbf{M}$ \\
\hline $\begin{array}{l}\text { II Mas acho que II III me } \\
\text { convém pintar a coisa no } \\
\text { momento III. }\end{array}$ & & pintar & $\begin{array}{l}\text { Processo } \\
\text { Material }\end{array}$ & & $\mathbf{M}$ \\
\hline $\begin{array}{l}\text { II É bem verdade que III eu } \\
\text { possa tomar um azul por um } \\
\text { verde no escuro, um azul lilás } \\
\text { por um rosa lilás, desde que } \\
\text { você não pode perceber a } \\
\text { natureza do tom claramente. }\end{array}$ & eu & possa tomar & $\begin{array}{l}\text { Processo mental } \\
\text { perceptivo }\end{array}$ & & $\mathbf{Z}$ \\
\hline $\begin{array}{l}\text { II Mas é a única maneira de se } \\
\text { livrar da noite negra }\end{array}$ & & é & Proc.Rel. & & $\mathbf{R}$ \\
\hline
\end{tabular}




\begin{tabular}{|c|c|c|c|}
\hline $\begin{array}{l}\text { convencional com uma luz } \\
\text { pobre, pálida e esbranquiçada, } \\
\text { quando na verdade III uma } \\
\text { mera vela por si só nos dá os } \\
\text { mais ricos amarelos e laranjas. }\end{array}$ & dá & $\begin{array}{l}\text { Identificativo } \\
\text { e } \\
\text { Proc. Material } \\
\text { Criativo }\end{array}$ & $\mathbf{M}$ \\
\hline $\begin{array}{l}\text { Eu também fiz um novo retrato } \\
\text { de mim mesmo, como um } \\
\text { estudo, no qual eu pareço um } \\
\text { Japonês. }\end{array}$ & $\begin{array}{l}\text { fiz } \\
\text { pareço }\end{array}$ & $\begin{array}{l}\text { Processo } \\
\text { material } \\
\text { criativo } \\
\text { transitivo }\end{array}$ & $\mathbf{M}$ \\
\hline $\begin{array}{l}\text { Você nunca me disse se você } \\
\text { tinha lido Bel-ami de Guy de } \\
\text { Maupassant, e o que você } \\
\text { pensa agora do talento dele em } \\
\text { geral. }\end{array}$ & $\begin{array}{l}\text { disse } \\
\text { pensa }\end{array}$ & $\begin{array}{l}\text { Processo Verbal } \\
\text { e } \\
\text { Processo } \\
\text { Mental } \\
\text { Cognitivo }\end{array}$ & $\mathbf{V}$ \\
\hline $\begin{array}{l}\text { Digo isto porque o início de } \\
\text { Bel- Ami é precisamente a } \\
\text { descrição de uma noite } \\
\text { estrelada em Paris, com os } \\
\text { cafés iluminados da avenida, e } \\
\text { isso é algo como o mesmo } \\
\text { tema que eu pintei bem agora. }\end{array}$ & 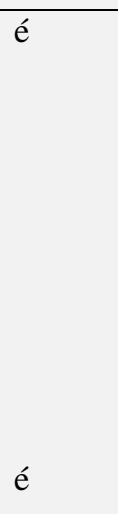 & $\begin{array}{l}\text { Processo } \\
\text { Relacional } \\
\text { Atributivo } \\
\text { e } \\
\text { Processo } \\
\text { Relacional } \\
\text { Atributivo }\end{array}$ & $\mathbf{R}$ \\
\hline
\end{tabular}


4.6.6 Quadro da análise visual da tela O Café Noturno na Place Lamartine, em Arles.

Abaixo segue-se um quadro demonstrativo com as ocorrências dos aspectos encontrados nas análises visuais. Este quadro funciona como um indexador na etapa da triangulação com os resultados da análise textual desta seção.

Quadro 64: Funções e Sistemas com elementos da análise da tela O Café Noturno na Place Lamartine, em Arles.

\begin{tabular}{|c|c|c|c|}
\hline Unidade / Função & Representacional & Modal & Composicional \\
\hline & $\begin{array}{l}\text { Temas Narrativos: } \\
\text { Interior de um Café a noite }\end{array}$ & $\begin{array}{l}\text { Perspectiva - recurso usado } \\
\text { para conduzir o olhar para } \\
\text { dentro da tela. } \\
\text { Linhas diagonais organizam } \\
\text { o espaço e constroem o } \\
\text { ponto de fuga para o qual o } \\
\text { olhar é conduzido para } \\
\text { dentro da cena. }\end{array}$ & $\begin{array}{l}\text { Perspectiva } \\
\text { - Uso de linhas diagonais para } \\
\text { compor o ponto de fuga no } \\
\text { fim do salão } \\
\text { - Composição focal na divisão } \\
\text { diagonal do espaço. }\end{array}$ \\
\hline & $\begin{array}{l}\text { O interior do café é o foco } \\
\text { central da narrativa, e } \\
\text { concentra a ação. }\end{array}$ & $\begin{array}{l}\text { A posição obliqua das } \\
\text { tábuas do chão conduzem o } \\
\text { olhar pelo interior do café }\end{array}$ & $\begin{array}{l}\text { Linhas direcionais conduzem } \\
\text { pelo interior do café }\end{array}$ \\
\hline \multirow[t]{3}{*}{ Pintura } & $\begin{array}{l}\text { - Uso simbólico do } \\
\text { contraste entre verde e } \\
\text { vermelho e do brilho } \\
\text { amarelo da lâmpada a gás. }\end{array}$ & $\begin{array}{l}\text { - Uso intensificado da cor } \\
\text { amarela. } \\
\text { - Contraste complementar } \\
\text { vermelho/verde. } \\
\text { - Contrastes cromáticos, a } \\
\text { quase totalidade da tela é de } \\
\text { cores quentes. } \\
\text { Modalidade com uso do } \\
\text { amarelo. }\end{array}$ & $\begin{array}{l}\text { - Contraste complementar; de } \\
\text { claro/escuro e de quente/frio. }\end{array}$ \\
\hline & Movimento, ritmo, textura & $\begin{array}{l}\text { Ritmo /movimento } \\
\text { direcional/ textura/ e } \\
\text { Pincelada ritmada } \\
\text { conduzem o olhar para } \\
\text { dentro da cena }\end{array}$ & $\begin{array}{l}\text { - uso do desenho-pintura nos } \\
\text { contornos da mesa de bilhar e } \\
\text { nas cadeiras no primeiro } \\
\text { plano. } \\
\text { Padrões do brilho das } \\
\text { lâmpadas sugerem ritmo, } \\
\text { textura e movimento. }\end{array}$ \\
\hline & $\begin{array}{l}\text { - Uso simbólico da } \\
\text { Luminosidade. } \\
\text { - Ênfase nas lâmpadas a } \\
\text { gás por meio da } \\
\text { luminosidade. } \\
\text { Contraposição entre } \\
\text { solidão e convívio, luz e }\end{array}$ & $\begin{array}{l}\text { Luz que emana das } \\
\text { lâmpadas a gás faz brilhar } \\
\text { as tábuas corridas do chão. }\end{array}$ & Contraste de saturação \\
\hline
\end{tabular}




\begin{tabular}{|c|c|c|c|}
\hline & sombra. & & \\
\hline & $\begin{array}{l}\text { Uso de associações } \\
\text { metafóricas }\end{array}$ & $\begin{array}{l}\text { Tensão visual pelo uso } \\
\text { excessivo do amarelo } \\
\text { contíguo ao vermelho. }\end{array}$ & $\begin{array}{l}\text { Uso de cores claras para } \\
\text { acentuar a impressão de } \\
\text { saturação de brilho e } \\
\text { luminescência. }\end{array}$ \\
\hline \multirow[t]{3}{*}{ Episódio } & Ações, eventos & $\begin{array}{l}\text { Proeminência Relativa das } \\
\text { lâmpadas a gás e da mesa } \\
\text { de bilhar }\end{array}$ & $\begin{array}{l}\text { Posição central da mesa de } \\
\text { bilhar na composição }\end{array}$ \\
\hline & Interior do Café / saliência & $\begin{array}{l}\text { Gradação de tons de } \\
\text { amarelos, vermelhos, } \\
\text { verdes. Cores quentes }\end{array}$ & Divisão em 4 planos \\
\hline & $\begin{array}{l}\text { Uma iluminação muito } \\
\text { clara. uso da analogia } \\
\text { formal }\end{array}$ & Lâmpadas a gás & $\begin{array}{l}\text { A tonalidade amarelo- } \\
\text { esbranquiçada do chão reforça } \\
\text { a percepção do brilho das } \\
\text { lâmpadas. }\end{array}$ \\
\hline \multirow[t]{3}{*}{ Figura } & $\begin{array}{l}\text { Caráter } \\
\text { Objeto }\end{array}$ & & $\begin{array}{l}\text { Posição Relativa no Episódio } \\
\text { - uso da analogia formal }\end{array}$ \\
\hline & $\begin{array}{l}\text { Posição central } \\
\text { Vetor }\end{array}$ & $\begin{array}{l}\text { Garçom olha diretamente } \\
\text { para o espectador }\end{array}$ & $\begin{array}{l}\text { Falta de detalhamento, } \\
\text { fisionomia anônima, } \\
\text { Enquadramento plano aberto, } \\
\text { distanciado. }\end{array}$ \\
\hline & $\begin{array}{l}\text { Posição relativa } \\
\text { Periferia/centro }\end{array}$ & Notívagos que estão no café & $\begin{array}{l}\text { Falta de detalhamento, } \\
\text { fisionomias anônimas, } \\
\text { Enquadramento plano aberto, } \\
\text { distanciado. }\end{array}$ \\
\hline \multirow[t]{4}{*}{ Membro } & $\begin{array}{l}\text { Uso de associações } \\
\text { metafóricas }\end{array}$ & $\begin{array}{l}\text { Lâmpada a gás } \\
\text { Luz }\end{array}$ & $\begin{array}{l}\text { Detalhamento. Ritmo, textura, } \\
\text { movimento, direção. } \\
\text { Halo de luz em volta da } \\
\text { Lâmpada } \\
\text { Posição central no Episódio }\end{array}$ \\
\hline & $\begin{array}{l}\text { Uso de associações } \\
\text { metafóricas }\end{array}$ & Mesa de Bilhar & $\begin{array}{l}\text { Detalhamento. Desenho- } \\
\text { pintura que enfatiza as linhas } \\
\text { de contorno. Posição Central } \\
\text { no Episódio }\end{array}$ \\
\hline & $\begin{array}{l}\text { Uso de associações } \\
\text { metafóricas }\end{array}$ & $\begin{array}{l}\text { Cadeiras vazias no primeiro } \\
\text { plano fazem contraposição } \\
\text { com uma área ocupada por } \\
\text { pessoas no café }\end{array}$ & $\begin{array}{l}\text { Detalhamento. Desenho- } \\
\text { pintura que enfatiza as linhas } \\
\text { de contorno das cadeiras. } \\
\text { Posição Relativa no Episódio }\end{array}$ \\
\hline & $\begin{array}{l}\text { Ante-sala ou vestíbulo que } \\
\text { dá acesso ao interior do } \\
\text { café. }\end{array}$ & $\begin{array}{l}\text { Porta no último plano dá } \\
\text { acesso para um espaço } \\
\text { parcialmente representado. }\end{array}$ & $\begin{array}{l}\text { Detalhamento. Desenho- } \\
\text { pintura que enfatiza as linhas } \\
\text { de contorno do cortinado da } \\
\text { porta. }\end{array}$ \\
\hline
\end{tabular}




\begin{tabular}{|l|l|l|l|}
\hline & $\begin{array}{l}\text { Uso de associações } \\
\text { metafóricas }\end{array}$ & $\begin{array}{l}\text { Posição Relativa no Episódio. } \\
\text { petalhamento. Desenho- } \\
\text { de contorno. } \\
\text { Posição Relativa no linhas }\end{array}$ \\
\hline Vetores & $\begin{array}{l}\text { Café existe } \\
\text { Lâmpadio. } \\
\text { Lâmpadas brilham iluminam as } \\
\text { pessoas e coisas dentro do } \\
\text { café }\end{array}$ & $\begin{array}{l}\text { Pessoas dormem e se } \\
\text { relacionam no interior do } \\
\text { café. }\end{array}$ & \\
\hline
\end{tabular}

Fonte: Quadro adaptado de O’TOOLE, 1994, p. 24.

\subsubsection{Conclusão da análise textual da tela O Café Noturno na Place Lamartine, em} Arles

Abaixo apresentamos os resultados da análise textual da tela O Café Noturno na Place Lamartine, em Arles.

$$
\begin{aligned}
& M=\text { verbos que, provavelmente, realizam Processo Material } \\
& Z \text { = verbos que, provavelmente, realizam Processo Mental } \\
& V=\text { verbos que, provavelmente, realizam Processo Verbal } \\
& R=\text { verbos que, provavelmente, realizam Processo Relacional } \\
& \text { E = verbos que, provavelmente, realizam Processo Existencial } \\
& C=\text { verbos que, provavelmente, realizam Processo Comportamental }
\end{aligned}
$$

Quadro 65: Processos encontrados na análise textual relativa à tela 'A Esplanada do Café na Place du Forum,

\begin{tabular}{|l|l|l|l|l|l|}
\hline Oração & Participante 1 & Verbo & Processo & Participante 2 & \\
\hline EXTRATO 4a & & & & & \\
\hline $\begin{array}{l}\text { Muitas vezes parece-me que a } \\
\text { noite é muito mais viva e } \\
\text { ricamente colorida do que o } \\
\text { dia. }\end{array}$ & me Experienciador & parece & $\begin{array}{l}\text { Processo Mental } \\
\text { perceptivo }\end{array}$ & $\begin{array}{l}\text { que a noite é } \\
\text { muito mais } \\
\text { viva } \\
\text { ricamente e } \\
\text { colorida do } \\
\text { que o dia. } \\
\text { Fenômeno }\end{array}$ \\
\hline
\end{tabular}




\begin{tabular}{|c|c|c|c|c|c|}
\hline $\begin{array}{l}\text { Agora como para recuperar o } \\
\text { dinheiro pago ao senhorio } \\
\text { através da minha pintura, }\end{array}$ & & recuperar & $\begin{array}{l}\text { Processo } \\
\text { Material }\end{array}$ & $\begin{array}{l}\text { o dinheiro } \\
\text { pago ao } \\
\text { senhorio } \\
\text { através da } \\
\text { minha pintura } \\
\text { Meta }\end{array}$ & $\bar{M}$ \\
\hline $\begin{array}{l}\text { eu não estou fazendo questão } \\
\text { disto, porque a pintura é uma } \\
\text { das mais feias que eu já fiz. }\end{array}$ & $\begin{array}{l}\text { eu } \\
\text { experienciador } \\
\text { a pintura }\end{array}$ & $\begin{array}{l}\text { não estou } \\
\text { fazendo } \\
\text { questão }\end{array}$ & $\begin{array}{l}\text { Processo Mental } \\
\text { Afetivo } \\
\text { Processo } \\
\text { relacional } \\
\text { atributivo }\end{array}$ & $\begin{array}{l}\text { uma das mais } \\
\text { feias que eu já } \\
\text { fiz. Atributo }\end{array}$ & 更 \\
\hline $\begin{array}{l}\text { É o equivalente, embora } \\
\text { diferente, dos comedores de } \\
\text { batata. }\end{array}$ & $\begin{array}{l}\text { dos comedores de } \\
\text { batata. } \\
\text { Identificador }\end{array}$ & É & $\begin{array}{l}\text { Processo } \\
\text { Relacional } \\
\text { Identificativo }\end{array}$ & $\begin{array}{l}\text { o equivalente } \\
\text { Identificado }\end{array}$ & $\mathbf{R}$ \\
\hline $\begin{array}{l}\text { Eu tentei expressar as terríveis } \\
\text { paixões humanas com o } \\
\text { vermelho e o verde. }\end{array}$ & $\begin{array}{l}\mathrm{Eu} \\
\text { Ator }\end{array}$ & expressar & $\begin{array}{l}\text { Processo } \\
\text { Material } \\
\text { Criativo }\end{array}$ & $\begin{array}{l}\text { as terríveis } \\
\text { paixões } \\
\text { humanas } \\
\text { Meta }\end{array}$ & $\mathbf{M}$ \\
\hline $\begin{array}{l}\text { A sala é vermelho-sangue e } \\
\text { amarelo sem graça, uma mesa } \\
\text { de bilhar verde no centro, } \\
\text { quatro lâmpadas de amarelo } \\
\text { limão com um brilho laranja e } \\
\text { verde. }\end{array}$ & $\begin{array}{l}\text { A sala } \\
\text { Portador }\end{array}$ & É & $\begin{array}{l}\text { Processo } \\
\text { relacional } \\
\text { atributivo }\end{array}$ & $\begin{array}{lr}\text { vermelho- } \\
\text { sangue r e } \\
\text { amarelo sem } \\
\text { graça, uma } \\
\text { mesa de bilhar } \\
\text { verder no } \\
\text { centro, quatro } \\
\text { lâmpada de } \\
\text { amarelo limão } \\
\text { com um brilho } \\
\text { laranja e } \\
\text { verde. } \\
\text { Atributo }\end{array}$ & $\mathbf{R}$ \\
\hline $\begin{array}{l}\text { Em todos os lugares é uma } \\
\text { batalha e uma antítese dos } \\
\text { mais diferentes verdes e } \\
\text { vermelhos; nas personagens } \\
\text { dos rufiões adormecidos, } \\
\text { pequenos na alta sala vazia, } \\
\text { algum roxo e azul. }\end{array}$ & & É & $\begin{array}{l}\text { Processo } \\
\text { relacional } \\
\text { atributivo }\end{array}$ & $\begin{array}{l}\text { uma batalha e } \\
\text { uma antítese } \\
\text { dos mais } \\
\text { diferentes } \\
\text { verdes e } \\
\text { vermelhos; nas } \\
\text { personagens } \\
\text { dos rufiões } \\
\text { adormecidos, } \\
\text { pequenos na } \\
\text { alta sala vazia, } \\
\text { algum roxo e } \\
\text { azul. } \\
\text { Atributo }\end{array}$ & $\mathbf{R}$ \\
\hline
\end{tabular}




\begin{tabular}{|c|c|c|c|c|c|}
\hline $\begin{array}{l}\text { O vermelho-sangue e o } \\
\text { amarelo-verde da mesa de } \\
\text { bilhar, por exemplo, contrasta } \\
\text { com o pouco de verde delicado } \\
\text { Louis XV do balcão, onde há } \\
\text { um buquê rosa }\end{array}$ & $\begin{array}{l}\text { com o pouco de } \\
\text { verde delicado } \\
\text { Louis XV do } \\
\text { balcão, onde há } \\
\text { um buquê rosa. } \\
\text { Identificador }\end{array}$ & contrasta & $\begin{array}{l}\text { Processo } \\
\text { relacional } \\
\text { Identificativo }\end{array}$ & $\begin{array}{l}\text { O vermelho- } \\
\text { sangue e o } \\
\text { amarelo-verde } \\
\text { da mesa de } \\
\text { bilhar, por } \\
\text { exemplo, } \\
\text { Identificado }\end{array}$ & $\mathbf{R}$ \\
\hline $\begin{array}{l}\text { A roupa branca do } \\
\text { proprietário, vigiando as coisas } \\
\text { a partir de um canto deste } \\
\text { forno, torna-se amarelo-limão, } \\
\text { verde luminoso pálido. }\end{array}$ & $\begin{array}{l}\text { A roupa branca do } \\
\text { proprietário, } \\
\text { Portador }\end{array}$ & torna-se & $\begin{array}{l}\text { Processo } \\
\text { relacional } \\
\text { atributivo }\end{array}$ & $\begin{array}{l}\text { amarelo- } \\
\text { limão, verde } \\
\text { luminoso } \\
\text { pálido. } \\
\text { Atributo }\end{array}$ & $\mathbf{R}$ \\
\hline $\begin{array}{l}\text { Eu estou fazendo um desenho } \\
\text { dele em tons aquarela para } \\
\text { enviar-lhe amanhã, para dar a } \\
\text { voce uma ideia dele. }\end{array}$ & $\begin{array}{l}\text { Eu } \\
\text { Ator }\end{array}$ & estou fazendo & $\begin{array}{l}\text { Processo } \\
\text { Material } \\
\text { Criativo }\end{array}$ & $\begin{array}{l}\text { um desenho } \\
\text { dele em tons } \\
\text { aquarela } \\
\text { Meta }\end{array}$ & $\bar{M}$ \\
\hline \multicolumn{6}{|l|}{ EXTRATO 4b } \\
\hline $\begin{array}{l}\text { Mais tarde, quando eu tiver } \\
\text { levado esses experimentos } \\
\text { mais longe, }\end{array}$ & $\begin{array}{l}\text { Eu } \\
\text { Ator }\end{array}$ & tiver levado & $\begin{array}{l}\text { Processo } \\
\text { Material }\end{array}$ & $\begin{array}{l}\text { esses } \\
\text { experimentos } \\
\text { mais longe, } \\
\text { Meta }\end{array}$ & $\bar{M}$ \\
\hline $\begin{array}{l}\text { o semeador ainda vai ser a } \\
\text { primeira tentativa nesse } \\
\text { gênero. }\end{array}$ & $\begin{array}{l}\text { o semeador ainda } \\
\text { Portador }\end{array}$ & vai ser & $\begin{array}{l}\text { Processo } \\
\text { relacional } \\
\text { atributivo }\end{array}$ & $\begin{array}{l}\text { a primeira } \\
\text { tentativa nesse } \\
\text { gênero. } \\
\text { Atributo }\end{array}$ & $\mathbf{R}$ \\
\hline $\begin{array}{l}\text { O café noturno é uma } \\
\text { continuação do semeador, } \\
\text { como é a cabeça do velho } \\
\text { camponês e do poeta, II }\end{array}$ & $\begin{array}{l}\text { O café noturno } \\
\text { Portador }\end{array}$ & é & $\begin{array}{l}\text { Processo } \\
\text { relacional } \\
\text { atributivo }\end{array}$ & $\begin{array}{l}\text { uma } \\
\text { continuação } \\
\text { do semeador, } \\
\text { Atributo }\end{array}$ & $\mathbf{R}$ \\
\hline $\begin{array}{l}\text { se eu conseguir fazer essa } \\
\text { última tela. }\end{array}$ & $\begin{array}{l}\text { se eu } \\
\text { Ator }\end{array}$ & $\begin{array}{l}\text { conseguir } \\
\text { fazer }\end{array}$ & $\begin{array}{l}\text { Processo } \\
\text { Material }\end{array}$ & $\begin{array}{l}\text { essa última } \\
\text { tela. } \\
\text { Meta }\end{array}$ & $\mathbf{M}$ \\
\hline $\begin{array}{l}\text { É uma cor, então, mas uma cor } \\
\text { que sugere alguma emoção, } \\
\text { um temperamento ardente }\end{array}$ & $\begin{array}{l}\text { uma cor, } \\
\text { Existente } \\
\text { mas uma cor } \\
\text { Portador }\end{array}$ & que sugere & $\begin{array}{l}\begin{array}{l}\text { Processo } \\
\text { existencial }\end{array} \\
\text { Processo } \\
\text { relacional } \\
\text { atributivo }\end{array}$ & $\begin{array}{l}\text { alguma } \\
\text { emoção, um } \\
\text { temperamento } \\
\text { ardente. } \\
\text { Atributo }\end{array}$ & $\mathbf{R}$ \\
\hline $\begin{array}{l}\text { [que não é localmente } \\
\text { verdadeira do ponto de vista } \\
\text { realista do trompe l'oeil,] }\end{array}$ & & não é & $\begin{array}{l}\text { Processo } \\
\text { relacional } \\
\text { atributivo }\end{array}$ & $\begin{array}{l}\text { localmente } \\
\text { verdadeira do } \\
\text { ponto de vista } \\
\text { realista do } \\
\text { trompe l'oeil. }\end{array}$ & $\mathbf{R}$ \\
\hline
\end{tabular}




\begin{tabular}{|c|c|c|c|c|c|}
\hline & & & & Atributo & \\
\hline \multicolumn{6}{|l|}{ EXTRATO 4c } \\
\hline $\begin{array}{l}\text { Na minha pintura do café à } \\
\text { noite eu procurei exprimir que } \\
\text { o café é um lugar onde você } \\
\text { pode arruinar-se, enlouquecer, } \\
\text { cometer crimes. }\end{array}$ & $\begin{array}{l}\mathrm{Eu} \\
\text { Dizente }\end{array}$ & $\begin{array}{l}\text { procurei } \\
\text { exprimir }\end{array}$ & $\begin{array}{l}\text { Processo } \\
\text { Verbal } \\
\text { Dúvida se não é } \\
\text { processo } \\
\text { relacional } \\
\text { atributivo }\end{array}$ & $\begin{array}{l}\text { que o café é } \\
\text { um lugar onde } \\
\text { você pode } \\
\text { arruinar-se, } \\
\text { enlouquecer, } \\
\text { cometer } \\
\text { crimes. } \\
\text { Verbiagem }\end{array}$ & $\mathrm{V}$ \\
\hline $\begin{array}{l}\text { De qualquer forma, eu tentei } \\
\text { com contrastes de rosa } \\
\text { delicado e vermelho-sangue e } \\
\text { vinho tinto. }\end{array}$ & $\begin{array}{l}\text { Eu } \\
\text { agente }\end{array}$ & $\begin{array}{l}\text { Tentei } \\
\text { (expressar) }\end{array}$ & Proc. Relacional & & \\
\hline $\begin{array}{l}\text { Verde doce Luís XV e } \\
\text { Veronese contrastando com os } \\
\text { verdes amarelos e os verdes } \\
\text { azuis duros. }\end{array}$ & $\begin{array}{l}\text { Verde malaquita } \\
\text { Luís XV e } \\
\text { Veronese } \\
\text { Ator }\end{array}$ & contrastando & $\begin{array}{l}\text { Processo } \\
\text { material }\end{array}$ & $\begin{array}{l}\text { com } \text { os } \\
\text { amarelos } \\
\text { verdes e os } \\
\text { azuis verdes } \\
\text { duros. } \\
\text { Meta. }\end{array}$ & $\bar{M}$ \\
\hline $\begin{array}{l}\text { Tudo isso em uma atmosfera } \\
\text { de fornalha infernal, de } \\
\text { enxofre pálido. }\end{array}$ & $\begin{array}{l}\text { O agente está } \\
\text { oculto }\end{array}$ & & $\begin{array}{l}\text { O Processo está } \\
\text { oculto }\end{array}$ & & \\
\hline $\begin{array}{l}\text { Exprimir como a potência dos } \\
\text { cantos escuros de uma taberna. }\end{array}$ & $\begin{array}{l}\mathrm{O} \text { ator está oculto. } \\
\text { Apagamento do } \\
\text { agente da ação. }\end{array}$ & Exprimir & $\begin{array}{l}\text { Processo } \\
\text { Verbal } \\
\text { Dúvida se não é } \\
\text { processo } \\
\text { relacional } \\
\text { atributivo }\end{array}$ & $\begin{array}{lr}\text { como } r & \text { a } \\
\text { potência } & \text { dos } \\
\text { cantos } & \text { escuros } \\
\text { de } & \text { uma } \\
\text { taberna. } & \end{array}$ & $\mathrm{V}$ \\
\hline \multicolumn{6}{|l|}{$\begin{array}{l}\text { Contudo sob uma aparência da } \\
\text { alegria japonesa e da boa } \\
\text { natureza de Tartarin. }\end{array}$} \\
\hline $\begin{array}{l}\text { Que diria portanto desse } \\
\text { quadro o Sr. Tersteeg? }\end{array}$ & $\begin{array}{l}\text { o Sr. Tersteeg? } \\
\text { Dizente }\end{array}$ & $\begin{array}{l}\text { diria } \\
\text { portanto }\end{array}$ & $\begin{array}{l}\text { Processo } \\
\text { Verbal }\end{array}$ & $\begin{array}{l}\text { desse quadro } \\
\text { Verbiagem }\end{array}$ & $\mathbf{V}$ \\
\hline $\begin{array}{l}\text { Diante de um Sisley, Sisley, o } \\
\text { mais discreto e delicado dos } \\
\text { Impressionistas - já disse: / } \\
\text { "Não posso me impedir de } \\
\text { pensar que o artista que pintou } \\
\text { isso estava um pouco tonto". }\end{array}$ & $\begin{array}{l}\text { (eu) } \\
\text { Dizente }\end{array}$ & $\begin{array}{l}\text { Não posso } \\
\text { me impedir } \\
\text { de pensar }\end{array}$ & $\begin{array}{l}\text { Processo } \\
\text { Verbal }\end{array}$ & $\begin{array}{l}\text { que o artista } \\
\text { que pintou } \\
\text { isso estava um } \\
\text { pouco tonto". } \\
\text { Citação }\end{array}$ & $\mathrm{V}$ \\
\hline $\begin{array}{l}\text { Diante do meu quadro, então a } \\
\text { mim ele diria que ele é um } \\
\text { caso de delirium tremens". }\end{array}$ & $\begin{array}{l}\text { Ele } \\
\text { Dizente }\end{array}$ & diria & $\begin{array}{l}\text { Processo } \\
\text { Verbal }\end{array}$ & $\begin{array}{l}\text { ele é um caso } \\
\text { de delirium } \\
\text { tremens. }\end{array}$ & $\mathrm{V}$ \\
\hline
\end{tabular}




\begin{tabular}{|c|c|c|c|c|c|}
\hline & & & & $\begin{array}{l}\text { Verbiagem } \\
\text { Comentário do } \\
\text { dizente. }\end{array}$ & \\
\hline \multicolumn{6}{|l|}{ EXTRATO 4d } \\
\hline $\begin{array}{l}\text { A ideia do semeador ainda } \\
\text { continua a me assombrar. }\end{array}$ & $\begin{array}{l}\text { a me } \\
\text { Experienciador }\end{array}$ & assombrar. & $\begin{array}{l}\text { Processo Mental } \\
\text { Afetivo }\end{array}$ & $\begin{array}{l}\text { A ideia do } \\
\text { semeador } \\
\text { Fenômeno }\end{array}$ & $\mathbf{Z}$ \\
\hline $\begin{array}{l}\text { Estudos exagerados, como o } \\
\text { semeador, como o café } \\
\text { noturno agora, geralmente } \\
\text { parecem-me atrozmente feios e } \\
\text { ruins, }\end{array}$ & $\begin{array}{l}\text {-me } \\
\text { Experienciador }\end{array}$ & parecem & $\begin{array}{l}\text { Processo Mental } \\
\text { Perceptivo }\end{array}$ & $\begin{array}{l}\text { Estudos } \\
\text { exagerados, } \\
\text { como o } \\
\text { semeador, } \\
\text { como o café } \\
\text { noturno agora, } \\
\text { Fenômeno }\end{array}$ & $\mathbf{Z}$ \\
\hline $\begin{array}{l}\text { mas quando eu estou movido } \\
\text { por alguma coisa, como aqui } \\
\text { por este pequeno artigo sobre } \\
\text { Dostoievski, em seguida, }\end{array}$ & $\begin{array}{l}\text { por alguma coisa, } \\
\text { Ator }\end{array}$ & $\begin{array}{l}\text { estou } \\
\text { movido }\end{array}$ & $\begin{array}{l}\text { Processo } \\
\text { Material } \\
\text { transformativo }\end{array}$ & $\begin{array}{l}\text { Eu } \\
\text { Meta }\end{array}$ & $\bar{M}$ \\
\hline $\begin{array}{l}\text { eles são os únicos que me } \\
\text { parecem ter um significado } \\
\text { mais importante. }\end{array}$ & $\begin{array}{l}\text { os únicos } \\
\text { Identificador }\end{array}$ & são & $\begin{array}{l}\text { Processo } \\
\text { Relacional } \\
\text { Identificativo }\end{array}$ & $\begin{array}{l}\text { Eles } \\
\text { Identificado }\end{array}$ & $\mathbf{R}$ \\
\hline \multicolumn{6}{|l|}{ EXTRATO 4e } \\
\hline $\begin{array}{l}\text { Eu acabei de terminar uma tela } \\
\text { que representa um interior de } \\
\text { café à noite iluminado por } \\
\text { lâmpadas. }\end{array}$ & $\begin{array}{l}\mathrm{Eu} \\
\text { Ator }\end{array}$ & $\begin{array}{l}\text { acabei de } \\
\text { terminar }\end{array}$ & $\begin{array}{l}\text { Processo } \\
\text { Material } \\
\text { Criativo }\end{array}$ & $\begin{array}{l}\text { uma tela que } \\
\text { representa um } \\
\text { interior de } \\
\text { café à noite } \\
\text { iluminado por } \\
\text { lâmpadas. } \\
\text { Meta }\end{array}$ & M \\
\hline $\begin{array}{l}\text { Alguns pobres vagabundos da } \\
\text { noite estão dormindo em um } \\
\text { canto. }\end{array}$ & $\begin{array}{l}\text { Alguns pobres } \\
\text { vagabundos da } \\
\text { noite } \\
\text { Comportante }\end{array}$ & $\begin{array}{l}\text { estão } \\
\text { dormindo }\end{array}$ & $\begin{array}{l}\text { Processo } \\
\text { Comportamental }\end{array}$ & & $\mathrm{C}$ \\
\hline $\begin{array}{l}\text { A sala está pintada de } \\
\text { vermelho, e no interior, na luz } \\
\text { a gás, }\end{array}$ & $\begin{array}{l}\text { A sala } \\
\text { Portador }\end{array}$ & está pintada & $\begin{array}{l}\text { Processo } \\
\text { relacional } \\
\text { atributivo }\end{array}$ & $\begin{array}{l}\text { de vermelho } \\
\text { Atributo }\end{array}$ & $\mathbf{R}$ \\
\hline $\begin{array}{l}\text { a mesa de bilhar verde, a qual } \\
\text { lança uma imensa sombra } \\
\text { sobre o chão. }\end{array}$ & $\begin{array}{l}\text { a mesa de bilhar } \\
\text { verde, a qual } \\
\text { Ator }\end{array}$ & lança & $\begin{array}{l}\text { Processo } \\
\text { Material } \\
\text { Transformativo }\end{array}$ & $\begin{array}{l}\text { uma imensa } \\
\text { sombra sobre } \\
\text { o chão. } \\
\text { Meta }\end{array}$ & $\bar{M}$ \\
\hline $\begin{array}{l}\text { Nesta tela, há } 6 \text { ou } 7 \\
\text { vermelhos diferentes, desde } \\
\text { vermelho-sangue até rosa } \\
\text { delicado, fazendo oposição } \\
\text { com o mesmo número de }\end{array}$ & $\begin{array}{l}6 \text { ou } 7 \text { vermelhos } \\
\text { diferentes, desde } \\
\text { vermelho-sangue } \\
\text { até rosa delicado, }\end{array}$ & há & $\begin{array}{l}\text { Processo } \\
\text { Existencial }\end{array}$ & & $\mathbf{E}$ \\
\hline
\end{tabular}




\begin{tabular}{|c|c|c|c|c|c|}
\hline verdes pálidos ou escuros. & Existente & & & & \\
\hline \multicolumn{6}{|l|}{ EXTRATO 4f } \\
\hline $\begin{array}{l}\text { Eu vou trabalhar nele de novo } \\
\text { durante todo o dia de amanhã, } \\
\text { mas você pode ver quão } \\
\text { simples a ideia é. }\end{array}$ & $\begin{array}{l}\text { Voce } \\
\text { Experienciador }\end{array}$ & Pode ver & $\begin{array}{l}\text { Processo Mental } \\
\text { Cognitivo }\end{array}$ & $\begin{array}{l}\text { quão simples a } \\
\text { idéia é. }\end{array}$ & $\mathbf{Z}$ \\
\hline $\begin{array}{l}\text { As sombras e sombras } \\
\text { projetadas estão removidas; }\end{array}$ & $\begin{array}{l}\text { As sombras e } \\
\text { sombras } \\
\text { projetadas } \\
\text { Portador }\end{array}$ & estão & $\begin{array}{l}\text { Processo } \\
\text { relacional } \\
\text { atributivo }\end{array}$ & $\begin{array}{l}\text { Removidas } \\
\text { Atributo }\end{array}$ & $\mathbf{R}$ \\
\hline $\begin{array}{l}\text { foi colorido em tons chapados } \\
\text { como as gravuras japonesas. }\end{array}$ & & foi colorido & $\begin{array}{l}\text { Processo } \\
\text { Material } \\
\text { Transformativo }\end{array}$ & $\begin{array}{l}\text { em tons } \\
\text { chapados } \\
\text { Meta }\end{array}$ & $\mathbf{M}$ \\
\hline $\begin{array}{l}\text { Isso vai contrastar, por } \\
\text { exemplo, com a diligência } \\
\text { Tarascon e o café à noite. }\end{array}$ & $\begin{array}{l}\text { Isso } \\
\text { Ator }\end{array}$ & $\begin{array}{l}\text { vai } \\
\text { contrastar }\end{array}$ & $\begin{array}{l}\text { Processo } \\
\text { Material }\end{array}$ & $\begin{array}{l}\text { com a } \\
\text { diligência } \\
\text { Tarascon e o } \\
\text { café à noite. } \\
\text { Meta }\end{array}$ & $\mathbf{M}$ \\
\hline
\end{tabular}




\title{
5 CAPÍTULO 5: DISCUSSÃO DOS RESULTADOS
}

\author{
Alguns dados das telas não obtiveram uma recorrência nos dados das cartas e vice- \\ versa, e não foram apresentados na discusssão dos achados na tese, eles estão expostos a \\ seguir.
}

\subsection{TRIANGULAÇÃO DA TEXTURA}

\begin{tabular}{|c|c|c|}
\hline \multicolumn{3}{|c|}{ Quadro 66: Triangulação da Textura } \\
\hline Ocorrência nas telas & Orações & Comentário \\
\hline $\begin{array}{l}\text { Na tela 'Por de Sol: Campo de } \\
\text { trigo perto de Arles', } \\
\text { observamos a ocorrência de } \\
\text { textura visual conferida pelo } \\
\text { gesto das pinceladas no campo } \\
\text { de trigo, registrada nas notas } \\
\text { de rodapé } 70,87 \text { e } 113 \text { na } \\
\text { qual observamos que o gesto } \\
\text { pictórico produz textura, } \\
\text { ritmo, movimento e vetor para } \\
\text { dar ênfase para o campo de } \\
\text { trigo. }\end{array}$ & $\begin{array}{l}\text { Aqui está outra paisagem. Sol } \\
\text { poente? Lua nascendo? Noite de } \\
\text { verão, de qualquer modo. Cidade } \\
\text { violeta, estrela amarela, céu azul- } \\
\text { esverdeado; os campos de trigo têm } \\
\text { todos os tons: ouro velho, cobre, } \\
\text { ouro verde, ouro vermelho, ouro } \\
\text { amarelo, verde, vermelho e amarelo } \\
\text { bronze. }\end{array}$ & $\begin{array}{l}\text { Neste complexo oracional observamos } \\
\text { a ausência de processos em algumas } \\
\text { orações, que poderiam ser } \\
\text { desconsideradas como material de } \\
\text { análise. No entanto, sua função modal } \\
\text { na construção do sentido levou a } \\
\text { compreender que elas constroem um } \\
\text { tipo de textura no discurso, destinada a } \\
\text { causar uma relação sensorial do leitor } \\
\text { com o texto. }\end{array}$ \\
\hline $\begin{array}{l}\text { Na tela 'Por de Sol: Campo de } \\
\text { trigo perto de Arles', } \\
\text { observamos a ocorrência de } \\
\text { textura visual conferida pelo } \\
\text { gesto das pinceladas no campo } \\
\text { de trigo, registrada nas notas } \\
\text { de rodapé } 70,87 \text { e } 113 \text { na } \\
\text { qual observamos que o gesto } \\
\text { pictórico produz textura, } \\
\text { ritmo, movimento e vetor para } \\
\text { dar ênfase para o campo de } \\
\text { trigo. }\end{array}$ & $\begin{array}{l}\text { Eu tenho um terceiro estudo, agora, } \\
\text { de uma paisagem com fábrica, e um } \\
\text { enorme sol em um céu vermelho, } \\
\text { acima de telhados vermelhos, em } \\
\text { que a natureza parece estar em um } \\
\text { acesso de raiva, em um dia de } \\
\underline{\text { mistral desagradável. }}\end{array}$ & $\begin{array}{l}\text { Na tela, as pinceladas deixaram marcas } \\
\text { que parecem a reprodução do trigo } \\
\text { balançando no vento, que ganha } \\
\text { corporidade conferida pela textura } \\
\text { plástica das pinceladas que } \\
\text { representam o trigo. A textura aparece } \\
\text { na oração com uma conotação } \\
\text { emocional de raiva. Na oração a } \\
\text { textura é construída pela escolha } \\
\text { lexical 'acesso de raiva' que, } \\
\text { visualmente é comunicada pelo } \\
\text { movimento direcional da pincelada } \\
\text { que vai da direita para a esquerda, } \\
\text { contrariando o sentido da nossa leitura } \\
\text { visual da tela que é da esquerda para } \\
\text { direita. Essa direção contrária } \\
\text { comunica um certo desconforto visual } \\
\text { que ajuda a construir o sentido de } \\
\text { contrariedade e de raiva. }\end{array}$ \\
\hline $\begin{array}{l}\text { Na tela 'O Semeador' } \\
\text { observamos a ocorrência de } \\
\text { Ritmo, Textura, Direção e }\end{array}$ & $\begin{array}{l}\text { Aqui está um esboço de um } \\
\text { semeador, um grande campo lavrado } \\
\text { com torrões de terra, na sua maioria }\end{array}$ & $\begin{array}{l}\text { A rugosidade e aspereza dos torrões de } \\
\text { terra não ficam registradas apenas na } \\
\text { tela, elas são descritas na oração }\end{array}$ \\
\hline
\end{tabular}




\begin{tabular}{|c|c|c|}
\hline $\begin{array}{l}\text { Movimento construídos pelo } \\
\text { Gesto Pictórico de van Gogh } \\
\text { para representar o campo } \\
\text { arado, registrados na nota de } \\
\text { rodapé } 133 \text {. } \\
\text { Observamos a ocorrência do } \\
\text { uso conjugado de Textura, } \\
\text { Ritmo, Movimento, Direção, } \\
\text { Gesto pictórico e Saliência } \\
\text { na representação dos } \\
\text { torrões de terra revolvida } \\
\text { no campo arado, registrado } \\
\text { na nota de rodapé } 135 \text {. } \\
\text { Na tela 'O Semeador', há } \\
\text { uma inter-relação entre } \\
\text { Textura, Contrastes } \\
\text { Simultâneos, Saliência, } \\
\text { Sinestesia que criam } \\
\text { Associações Metafóricas da } \\
\text { materialidade da tinta com } \\
\text { a nossa memória sensorial } \\
\text { e tátil da plasticidade da } \\
\text { terra, registrado na nota de } \\
\text { rodapé } 136 . \\
\text { Observamos também a } \\
\text { ocorrência de Sinestesia } \\
\text { produzida pelo contraste } \\
\text { simultâneo que } \\
\text { potencializa o efeito da } \\
\text { textura tátil e da textura } \\
\text { visual, registrado na nota de } \\
\text { rodapé } 141 .\end{array}$ & $\begin{array}{l}\text { fracamente cor de violeta. } \\
\text { Um campo de trigo maduro, de tom } \\
\text { amarelo-ocre com um pouco de } \\
\text { carmim. } \\
\text { (...) } \\
\text { Em um campo arado, um grande } \\
\text { campo de torrões de terra roxa - } \\
\text { levantados em direção ao horizonte - } \\
\text { um semeador em azul e branco. }\end{array}$ & $\begin{array}{l}\text { quando van Gogh fala do campo } \\
\text { lavrado, enfatizando os torrões de } \\
\text { terra. Cada torrão é valorizado em suas } \\
\text { cores e texturas características, } \\
\text { descritas nessa variedade de roxo, } \\
\text { amarelo, carmim, violeta. } \\
\text { É interessante perceber como há uma } \\
\text { complementaridade entre tela e carta, } \\
\text { no uso das cores e das pinceladas e no } \\
\text { uso das palavras que descrevem a tela, } \\
\text { ambas preocupam-se em retratar um } \\
\text { momento característico do sol } \\
\text { refletindo na terra enquanto está se } \\
\text { pondo, quando a mistura de sombra e } \\
\text { cor dão maior volume e diversidade no } \\
\text { colorido dos torrões de terra. }\end{array}$ \\
\hline $\begin{array}{l}\text { A tela revela uma mistura de } \\
\text { tonalidades. } \\
\text { Observamos também a } \\
\text { ocorrência de Sinestesia } \\
\text { produzida pelo contraste } \\
\text { simultâneo que } \\
\text { potencializa o efeito da } \\
\text { textura tátil e da textura } \\
\text { visual, registrado na nota de } \\
\text { rodapé } 141 \text {. }\end{array}$ & $\begin{array}{l}\text { O céu, amarelo-crómio, quase tão } \\
\text { luminoso quanto o próprio Sol, que é } \\
\text { amarelo-crómio no } 1 \text {, misturado com } \\
\text { um pouco de branco, enquanto o } \\
\text { resto do céu é uma mistura dos } \\
\text { amarelos-crómios } 1 \text { e } 2 \text {. Tão } \\
\text { amarelo! }\end{array}$ & $\begin{array}{l}\text { A própria mistura de tonalidades } \\
\text { aparece, pois elas estão diferenciadas } \\
\text { pelas pinceladas. A mistura se dá na } \\
\text { tela, com pinceladas de diferentes } \\
\text { tonalidades que conferem uma textura. } \\
\text { Van Gogh parece descrever uma luta } \\
\text { para atingir a verdade de cada cor } \\
\text { separadamente, para que ao } \\
\text { representar cada uma possa atingir a } \\
\text { verdade de sua manifestação na } \\
\text { natureza. Demonstra assim uma } \\
\text { preocupação maior com a } \\
\text { heterogeneidade e não com a } \\
\text { homogeneidade dos elementos da } \\
\text { natureza. Ao contrário dos artistas do } \\
\text { passado que tentavam construir a } \\
\text { unidade dos elementos por meio de } \\
\text { uma homogeneidade, ele constrói a } \\
\text { unidade pela heterogeneidade, nem } \\
\text { que para isso tenha que travar uma luta } \\
\text { diabólica com cores que a princípio } \\
\text { contrastam e não possibilitam essa }\end{array}$ \\
\hline
\end{tabular}




\begin{tabular}{|c|c|c|}
\hline & & $\begin{array}{l}\text { unidade facilmente. Nesta unidade } \\
\text { heterogênea vemos representada a } \\
\text { unidade da natureza (interna e externa) } \\
\text { da experiência do artista com a } \\
\text { natureza, das cores da paleta com as } \\
\text { cores da natureza. }\end{array}$ \\
\hline & Isso é o que eu queria dizer, & $\begin{array}{l}\text { Observamos um elemento de textura } \\
\text { nessa escolha lexical. Uma saliência } \\
\text { que se dá por um uso da linguagem, } \\
\text { que sobrepõe o dizente e um eu que } \\
\text { julga o que foi dito como algo } \\
\text { intencional e que revela uma ideia do } \\
\text { artista. }\end{array}$ \\
\hline $\begin{array}{l}\text { Na tela 'A Esplanada do } \\
\text { Café na Place du Forum, } \\
\text { Arles, à Noite', observamos } \\
\text { a ocorrência e Inter-relação } \\
\text { entre Ritmo, Movimento, } \\
\text { Textura, Gesto Pictórico, } \\
\text { Desenho-Pintura para } \\
\text { construir a Perspectiva do } \\
\text { calçamento, registrados na } \\
\text { nota de rodapé } 171 .\end{array}$ & $\begin{array}{l}\text { A segunda mostra o exterior de um } \\
\text { café, iluminado no terraço externo } \\
\text { por uma grande lâmpada de gás } \\
\text { dentro da noite azul, com um retalho } \\
\text { de céu azul estrelado. } \\
\\
\text { As frentes das casas em uma rua que } \\
\text { segue sob o céu azul salpicado de } \\
\text { estrelas são azul escuro ou violeta, } \\
\text { com uma árvore verde. }\end{array}$ & $\begin{array}{l}\text { A textura da calçada e do 'céu azul } \\
\text { SALPICADO de estrelas' mostra } \\
\text { como o uso da textura auxilia na } \\
\text { construção da profundidade. A } \\
\text { diversidade de textura cria tanto o } \\
\text { contraste quanto a profundidade. E as } \\
\text { diferentes texturas cria contraste entre } \\
\text { os ambientes que permite com que a } \\
\text { luz seja projetada no calçamento sem } \\
\text { que haja ambiguidade entre os } \\
\text { ambientes externo e interno. }\end{array}$ \\
\hline $\begin{array}{l}\text { Na tela 'O Café Noturno na } \\
\text { Place Lamartine, em Arles', } \\
\text { observamos a ocorrência do } \\
\text { uso de Saliência e Vetor } \\
\text { inter-relacionados com a } \\
\text { ocorrência de Textura e } \\
\text { Gesto Pictórico para } \\
\text { construir a luz das } \\
\text { lâmpadas a gás, registrado } \\
\text { na nota de rodapé } 216 . \text { O } \\
\text { vetor ocorre em direção } \\
\text { radial. }\end{array}$ & $\begin{array}{l}\text { Contudo sob uma aparência da } \\
\text { alegria japonesa e da boa natureza de } \\
\text { Tartarin. } \\
\text { Que diria portanto desse quadro o Sr. } \\
\text { Tersteeg? Diante de um Sisley, } \\
\text { Sisley, o mais discreto e delicado dos } \\
\text { Impressionistas - já disse: "Não } \\
\text { posso me impedir de pensar que o } \\
\text { artista que pintou isso estava um } \\
\text { pouco tonto". Diante do meu quadro, } \\
\text { então a mim ele diria que ele é um } \\
\text { caso de delirium tremens". }\end{array}$ & $\begin{array}{l}\text { A textura das lâmpadas chama a } \\
\text { atenção por este efeito de fornalha, } \\
\text { como se estivesse projetando seu calor } \\
\text { 'infernal' no ambiente. O uso da } \\
\text { textura da mais concretude a esta } \\
\text { ambiente de 'descontrole' das } \\
\text { emoções. O fluxo e a intensidade da } \\
\text { luz realça os contrastes de cores e de } \\
\text { textura no ambiente. No caso da } \\
\text { textura vemos realçada a marca nas } \\
\text { tábuas no chão do café, que ganha uma } \\
\text { riqueza de detalhes como se cada sulco } \\
\text { tivesse sido representado, dando um } \\
\text { efeito de textura ainda mais } \\
\text { proeminente. }\end{array}$ \\
\hline
\end{tabular}


Ocorrência de Ritmo,

Textura, Movimento, Vetor e

Rima Visual pelo Gesto

Pictórico para expressar o

fluxo e a intensidade da

iluminação na sala,

registrados na nota de rodapé 280.

Ocorrência de Saliência, por meio do uso de Ritmo,

Movimento, Textura, Vetor e

Gesto Pictórico que são

usados para representar $\mathbf{0}$

brilho intermitente das

lâmpadas, pintado com

riqueza de detalhes, textura e movimento direcional, registrados na nota de rodapé 281.

Ocorrência de Associação metafórica por meio do uso de Ritmo, Movimento, Textura, Vetor, Gesto Pictórico e Rima Visual que juntos constroem uma metáfora visual para a luz que interliga todos os processos na narrativa, registrados na nota de rodapé 282.

Ocorrência de Ritmo, Movimento, Textura e Vetor para construir a luz, que parece que está em movimento e vibrando, registrados na nota de rodapé 285.

Uso de Associação metafórica por meio de Saliência, Ritmo, Movimento, Textura e Gesto Pictórico para dar centralidade para luz, registrada na nota de rodapé 292.

Na tela 'O Café Noturno na Place Lamartine, em Arles', observamos a ocorrência de 


\begin{tabular}{|c|c|c|}
\hline $\begin{array}{l}\text { Associação metafórica } \\
\text { construída pela Saliência, } \\
\text { Ritmo, Textura e Movimento } \\
\text { na representação das } \\
\text { lâmpadas e da luz que } \\
\text { delas emana, registrada na } \\
\text { nota de rodapé } 332 .\end{array}$ & & \\
\hline $\begin{array}{l}\text { Na tela 'O Café Noturno na } \\
\text { Place Lamartine, em Arles', } \\
\text { observamos a ocorrência de } \\
\text { Saliência, por meio de } \\
\text { Textura e Gesto Pictórico no } \\
\text { uso do Desenho-Pintura para } \\
\text { detalhar a representação } \\
\text { dos contornos da mesa de } \\
\text { bilhar, registrada na nota de } \\
\text { rodapé } 305 \text {. }\end{array}$ & & \\
\hline & $\begin{array}{l}\text { A segunda mostra o exterior de um } \\
\text { café, iluminado no terraço externo } \\
\text { por uma grande lâmpada de gás } \\
\text { dentro da noite azul, com um retalho } \\
\text { de céu azul estrelado. } \\
\\
\text { As frentes das casas em uma rua que } \\
\text { segue sob o céu azul salpicado de } \\
\text { estrelas são azul escuro ou violeta, } \\
\text { com uma árvore verde. }\end{array}$ & \\
\hline & $\begin{array}{l}\text { Tudo isso em uma atmosfera de } \\
\text { fornalha infernal, de enxofre pálido. } \\
\text { Exprimir como a potência dos cantos } \\
\text { escuros de uma taberna. }\end{array}$ & \\
\hline
\end{tabular}

Fonte: Triangulação para Textura dos dados dos corpora visual e textual, com os extratos das cartas. 


\subsection{TRIANGULAÇÃO DO RITMO}

Quadro 67: Triangulação do Ritmo

\begin{tabular}{|c|c|c|}
\hline Ocorrência nas telas & Orações & Comentário \\
\hline \multirow[t]{2}{*}{$\begin{array}{l}\text { Na tela 'Por de Sol: Campo } \\
\text { de trigo perto de Arles', } \\
\text { Pinceladas ritmadas para } \\
\text { representar o vento } \\
\text { ventando no trigal, por } \\
\text { meio das pinceladas } \\
\text { ritmadas, conferida pelo } \\
\text { gesto pictórico, pela textura } \\
\text { e pelo movimento. A } \\
\text { ocorrência está registrada na } \\
\text { nota de rodapé } 69,81 \text {. }\end{array}$} & $\begin{array}{l}\text { Paisagens amarelo ouro velho - feito } \\
\text { rápido rápido rápido e com pressa, } \\
\text { como o ceifeiro que está em silêncio } \\
\text { sob o sol escaldante, concentrando- } \\
\text { se em ter o trabalho terminado. }\end{array}$ & $\begin{array}{l}\text { A repetição da palavra rápido três } \\
\text { vezes e o uso do sinônimo 'com } \\
\text { pressa' constroem o movimento } \\
\text { ritmado com que ele trabalhou nas } \\
\text { pinceladas para suplantar a força do } \\
\text { vento e para registrar essa experiência } \\
\text { visualmente. O ritmo do vento } \\
\text { soprando está presente tanto na } \\
\text { representação visual quanto na } \\
\text { representação textual, porque está } \\
\text { impregnado em sua própria } \\
\text { experiência de pintar ao ar livre em } \\
\text { meio a uma ventania muito forte e a } \\
\text { um sol escaldante. }\end{array}$ \\
\hline & $\begin{array}{l}\text { Aqui está outra paisagem. Sol } \\
\text { poente? Lua nascendo? Noite de } \\
\text { verão, de qualquer modo. }\end{array}$ & $\begin{array}{l}\text { Com a ausência de processos a } \\
\text { interpretação fica aberta para o leitor. }\end{array}$ \\
\hline $\begin{array}{l}\text { Na tela 'Por de Sol: Campo } \\
\text { de trigo perto de Arles', } \\
\text { observamos a ocorrência de } \\
\text { Gesto pictórico e ritmo, } \\
\text { observada pelo modo como } \\
\text { ele distribui as pinceladas, } \\
\text { com repetições regulares e } \\
\text { irregulares para representar e } \\
\text { enfatizar o campo de trigo, } \\
\text { registrada na nota de rodapé } \\
113 \text {. }\end{array}$ & $\begin{array}{l}\text { Noite de verão, de qualquer modo. } \\
\text { Cidade violeta, estrela amarela, céu } \\
\text { azul-esverdeado; os campos de trigo } \\
\text { têm todos os tons: ouro velho, cobre, } \\
\underline{\text { ouro verde, ouro vermelho, ouro }} \\
\underline{\text { amarelo, verde, vermelho e amarelo }} \\
\underline{\text { bronze. }}\end{array}$ & $\begin{array}{l}\text { A descrição do uso dos tons no } \\
\text { campo de trigo cria na linguagem } \\
\text { um efeito de poesia ritmada que foi } \\
\text { provavelmente o mesmo estado de } \\
\text { espírito do momento de produção da } \\
\text { tela, no qual van Gogh se vê absorto } \\
\text { pela multiplicidade de cores que ele } \\
\text { percebe visualmente e experiencia } \\
\text { espiritualmente. }\end{array}$ \\
\hline $\begin{array}{l}\text { Na tela 'O Semeador' } \\
\text { observamos a ocorrência de } \\
\text { Ritmo, Textura, Direção e } \\
\text { Movimento construídos pelo } \\
\text { Gesto Pictórico de van Gogh } \\
\text { para representar o campo } \\
\text { arado, registrados na nota de } \\
\text { rodapé } 133 \text {. }\end{array}$ & $\begin{array}{l}\text { Preferia muito mais fazer quadros } \\
\text { naifs tirados de velhos almanaques, } \\
\text { aqueles velhos "almanaques dos } \\
\text { lavradores" nos quais o granizo, a } \\
\text { neve, a chuva e o bom tempo são } \\
\text { retratados de modo primitivo, como } \\
\text { o Anquetin atingiu tão bem no seu } A \\
\text { Colheita. }\end{array}$ & $\begin{array}{l}\text { Aqui vemos o ritmo nas pinceladas } \\
\text { que ajudam a criar uma integração } \\
\text { entre os elementos da natureza na tela: } \\
\text { o campo arado, o campo maduro, o } \\
\text { céu, o sol, a luz. Esse ritmo que } \\
\text { integra os elementos naturais está } \\
\text { presente também na oração em que } \\
\text { expressa sua preferência pela pintura } \\
\text { da natureza. }\end{array}$ \\
\hline $\begin{array}{l}\text { Observamos a ocorrência do } \\
\text { uso conjugado de Textura, } \\
\text { ritmo, movimento, direção, }\end{array}$ & & \\
\hline
\end{tabular}




\begin{tabular}{|c|c|c|}
\hline 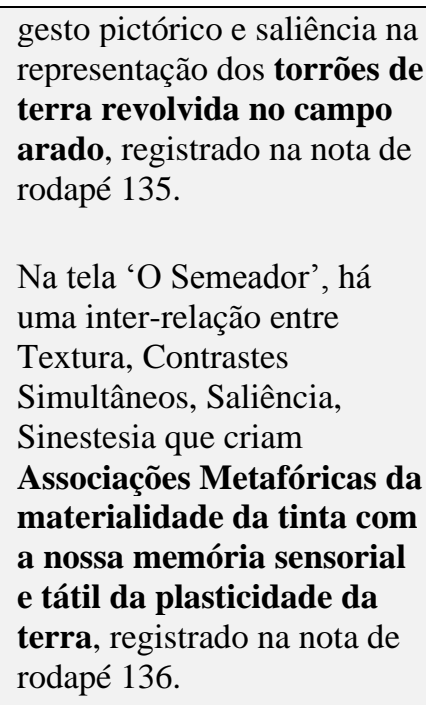 & & \\
\hline & $\begin{array}{l}\text { O céu, amarelo-crómio, quase tão } \\
\text { luminoso quanto o próprio Sol, que é } \\
\text { amarelo-crómio no } 1 \text {, misturado com } \\
\text { um pouco de branco, enquanto o } \\
\text { resto do céu é uma mistura dos } \\
\text { amarelos-crómios 1 e 2. Tão } \\
\text { amarelo! }\end{array}$ & $\begin{array}{l}\text { O Ritmo nesse complexo oracional é } \\
\text { construído com a ajuda das vírgulas } \\
\text { que estabelecem uma cadência de } \\
\text { construtos curtos que vão se } \\
\text { superpondo para construir uma } \\
\text { narrativa cromática do céu. Que } \\
\text { elementos na tela, poderia ser } \\
\text { compatível com a função das vírgulas? }\end{array}$ \\
\hline & $\begin{array}{l}\text { Eu tive uma semana de concentrado } \\
\text { trabalho duro nos campos de trigo } \\
\text { debaixo do sol, o resultado foi de } \\
\text { alguns estudos de campos de trigo, } \\
\text { paisagens e - um esboço de um } \\
\text { semeador. }\end{array}$ & $\begin{array}{l}\text { Van Gogh poderia ter dito } \\
\text { simplesmente 'eu tive uma semana } \\
\text { dura de trabalho'. A construção } \\
\text { 'concentrado trabalho duro' tem um } \\
\text { ritmo decrescente que inicia com uma } \\
\text { proparoxítona, depois uma paroxítona, } \\
\text { depois uma oxítona. Observamos que } \\
\text { o ritmo no discurso escrito emula o } \\
\text { ritmo do discurso verbal, com base na } \\
\text { sonoridade léxico-gramatical. }\end{array}$ \\
\hline $\begin{array}{l}\text { Na tela 'O Café Noturno na } \\
\text { Place Lamartine, em Arles', } \\
\text { observamos a ocorrência de } \\
\text { Ritmo construído pelos } \\
\text { encostos das duas cadeiras } \\
\text { à direta de quem olha a tela, } \\
\text { conduzem o olhar para o } \\
\text { homem de branco em pé, } \\
\text { registrado na nota de rodapé } \\
219 .\end{array}$ & $\begin{array}{l}\text { Ai, ai, é como nosso excelente amigo } \\
\text { Cyprien diz, em 'En ménage' por JK } \\
\text { Huysmans: as mais belas pinturas } \\
\text { são aquelas que um sonha enquanto } \\
\text { fuma um cachimbo em sua cama, } \\
\text { mas a qual ele não pinta. }\end{array}$ & $\begin{array}{l}\text { A interjeição 'Ai, ai,' cria um ritmo no } \\
\text { início da oração que tem duas funções, } \\
\text { criar uma saliência para o que ele dirá } \\
\text { a seguir, e estabelecer uma maior } \\
\text { proximidade com seu leitor, Theo, } \\
\text { para revelar um aspecto muito íntimo } \\
\text { de sua experiência, os devaneios } \\
\text { acerca de quadros que ele sonha em } \\
\text { pintar. Foi preciso procurar a } \\
\text { ocorrência de um recurso visual que } \\
\text { cria uma saliência para atentar para } \\
\text { outro elemento visual, criando uma } \\
\text { sequência cadenciada de recursos }\end{array}$ \\
\hline
\end{tabular}




\begin{tabular}{|c|c|c|}
\hline & & visuais. \\
\hline $\begin{array}{l}\text { Na tela 'A Esplanada do } \\
\text { Café na Place du Forum, } \\
\text { Arles, à Noite', observamos } \\
\text { a ocorrência e Inter-relação } \\
\text { entre Ritmo, Movimento, } \\
\text { Textura, Gesto Pictórico, } \\
\text { Desenho-Pintura para } \\
\text { construir a Perspectiva do } \\
\text { calçamento, registrados na } \\
\text { nota de rodapé } 171 .\end{array}$ & $\begin{array}{l}\text { Uma enorme lanterna amarela } \\
\text { ilumina o terraço, a fachada, a } \\
\text { calçada, e até mesmo projeta luz } \\
\text { sobre os paralelepípedos da rua, que } \\
\text { adquirem uma coloração violeta- } \\
\text { rosa. }\end{array}$ & $\begin{array}{l}\text { Nesta oração, as vírgulas } \\
\text { interrompem,entrecortam o fluxo das } \\
\text { palavras criando um movimento } \\
\text { sincopado que termina em uma nota } \\
\text { mais longa com 'e até mesmo projeta } \\
\text { luz sobre os paralelepípedos da rua'. A } \\
\text { escolha de palavras paroxítonas: } \\
\text { terraço, fachada, calçada, constrói um } \\
\text { ritmo conduzido pela própria } \\
\text { sonoridade lexical. }\end{array}$ \\
\hline $\begin{array}{l}\text { Na tela 'O Café Noturno na } \\
\text { Place Lamartine, em Arles', } \\
\text { observamos a ocorrência de } \\
\text { Saliência construída com o } \\
\text { uso de Textura, Ritmo, } \\
\text { Movimento e Gesto } \\
\text { Pictórico para representar o } \\
\text { brilho da lâmpada, } \\
\text { registrada na nota de rodapé } \\
224 \text {. }\end{array}$ & & \\
\hline & $\begin{array}{l}\text { O vermelho-sangue e o amarelo- } \\
\text { verde da mesa de bilhar, por } \\
\text { exemplo, contrasta com o pouco de } \\
\text { verde delicado Louis XV do balcão, } \\
\text { onde há um buquê rosa. }\end{array}$ & \\
\hline $\begin{array}{l}\text { Na tela 'O Café Noturno na } \\
\text { Place Lamartine, em Arles', } \\
\text { observamos a ocorrência de } \\
\text { Saliência construída com o } \\
\text { uso de Textura, Ritmo, } \\
\text { Movimento e Gesto } \\
\text { Pictórico na representação } \\
\text { das figuras no fundo da } \\
\text { sala, registrada na nota de } \\
\text { rodapé } 224 \text {. }\end{array}$ & $\begin{array}{l}\text { Em todos os lugares é uma batalha e } \\
\text { uma antítese dos mais diferentes } \\
\text { verdes e vermelhos; } \text { nas personagens } \\
\text { dos rufiões adormecidos, pequenos } \\
\text { na alta sala vazia, algum roxo e azul. }\end{array}$ & $\begin{array}{l}\text { Observamos que na oração Beta, as } \\
\text { escolhas lexicais são feitas aos pares } \\
\text { que se agrupam entre vírgulas que } \\
\text { constroem um ritmo para a narrativa. } \\
\text { A sequência de cores e a relação entre } \\
\text { parece conferir uma vibração ao } \\
\text { ambiente, uma complementaridade } \\
\text { entre as cores que é descrita na oração } \\
\text { de forma ritmada. Podemos seguir a } \\
\text { descrição na tela e acompanhar o uso } \\
\text { do ritmo que contrasta entre } \\
\text { estagnação e vibração, dando uma } \\
\text { tensão ao quadro na sua totalidade. }\end{array}$ \\
\hline
\end{tabular}


Ocorrência de Saliência, por meio do uso de Ritmo,

Movimento, Textura, Vetor e Gesto Pictórico que são usados para representar o brilho intermitente das lâmpadas, pintado com riqueza de detalhes, textura e movimento direcional, registrados na nota de rodapé 281.

Ocorrência de Associação metafórica por meio do uso de Ritmo, Movimento, Textura, Vetor, Gesto Pictórico e Rima Visual que juntos constroem uma metáfora visual para a luz que interliga todos os processos na narrativa, registrados na nota de rodapé 282.

Ocorrência de Rima Visual e Gesto Pictórico na representação da luz como uma metáfora visual que interliga todos os elementos da tela; o Ritmo é o recurso que expressa essa metáfora e que constrói a coesão visual, registrados na nota de rodapé 283.

Ocorrência e Rima Visual por meio do Ritmo, Movimento e Vetor na representação da Luz que funciona como elemento de ligação e de transição entre as pequenas narrativas, registrados na nota de rodapé 284.

Ocorrência de Ritmo, Movimento, Textura e Vetor para construir a luz, que parece que está em movimento e vibrando, registrados na nota de rodapé 


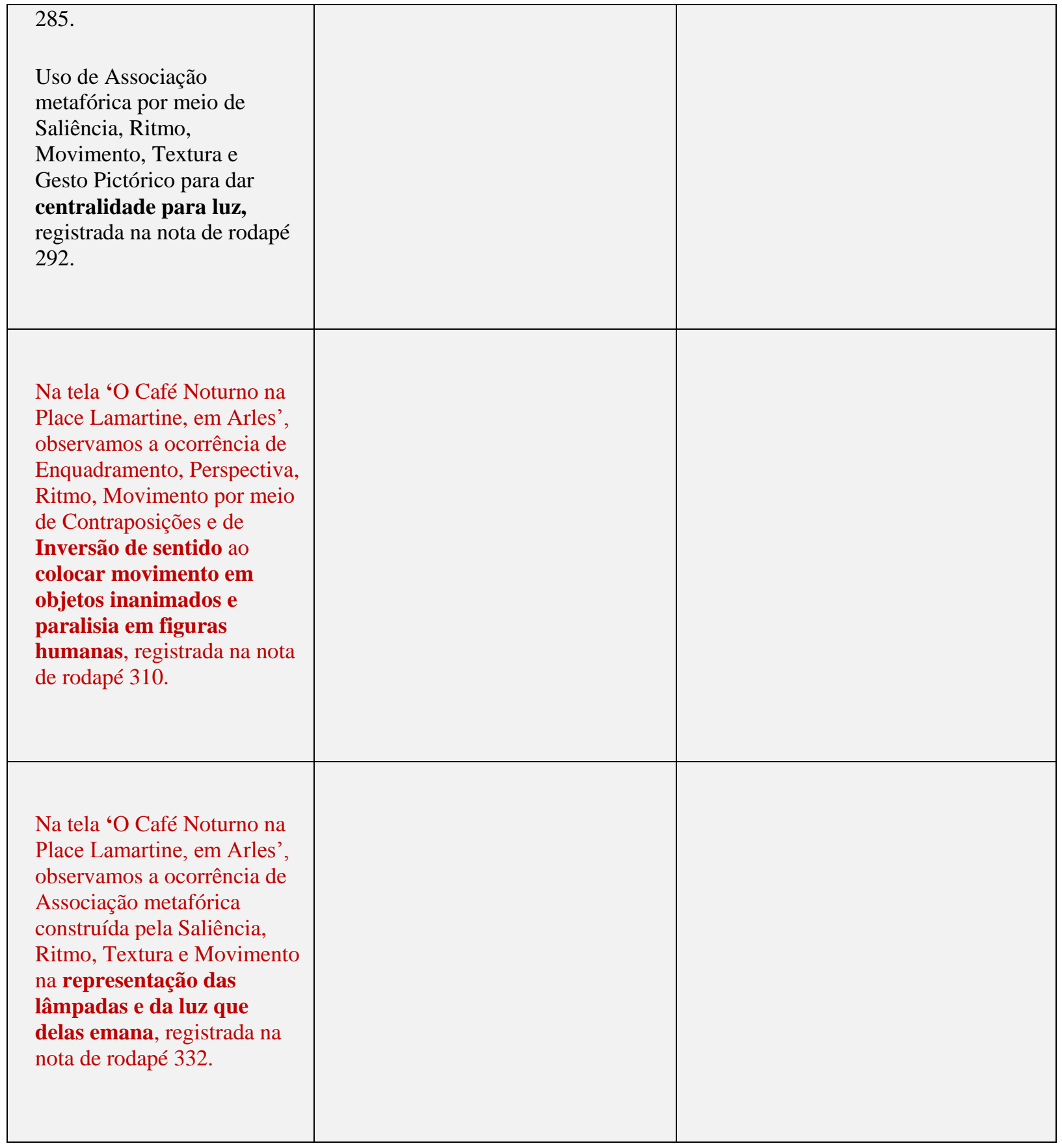

Fonte: Triangulação para Ritmo dos dados dos corpora visual e textual, com os extratos das cartas.

\subsection{TRIANGULAÇÃO DO MOVIMENTO}

Quadro 68: Triangulação do Movimento

\begin{tabular}{|l|l|l|}
\hline Ocorrência nas telas & Orações & Comentário \\
\hline $\begin{array}{l}\text { Na tela 'Por de Sol: Campo de } \\
\text { trigo perto de Arles', } \\
\text { observamos a ocorrência de } \\
\begin{array}{l}\text { Movimento, Ritmo e Textura } \\
\text { e Vetor conferidos pelo gesto }\end{array}\end{array}$ & $\begin{array}{l}\text { Eu tenho um terceiro estudo, agora, } \\
\text { de uma paisagem com fábrica, e um } \\
\text { enorme sol em um céu vermelho, } \\
\text { acima de telhados vermelhos, em }\end{array}$ & $\begin{array}{l}\text { O movimento do vento, representado } \\
\text { no movimento do trigo representa para } \\
\text { van Gogh um 'dia de mistral } \\
\text { desagradável'. Por um lado, a noite de }\end{array}$ \\
\hline
\end{tabular}




\begin{tabular}{|c|c|c|}
\hline $\begin{array}{l}\text { pictórico para representar o } \\
\text { campo de trigo, registrados na } \\
\text { nota de rodapé } 77 . \\
\\
\text { Ocorrência do Movimento, } \\
\text { construído pela diferença de } \\
\text { espaçamento que as pinceladas } \\
\text { ora criam um conjunto } \\
\text { homogêneo e indiferenciado, } \\
\text { ora ressaltam a individualidade } \\
\text { de cada ramo de trigo. Isso } \\
\text { produz uma contraposição } \\
\text { entre a homogeneidade e a } \\
\text { diferenciação das pinceladas } \\
\text { que constrói um sentido de } \\
\text { alternância e de movimento, a } \\
\text { estratégia de narrativa visual } \\
\text { de contraposição entre } \\
\text { homogeneidade e } \\
\text { diferenciação está registrada } \\
\text { na nota de rodapé } 79 \text {. }\end{array}$ & $\begin{array}{l}\text { que a natureza parece estar em um } \\
\text { acesso de raiva, em um dia de } \\
\text { mistral desagradável. } \\
\text { (...) } \\
\text { Paisagens amarelo ouro velho - feito } \\
\text { rápido rápido rápido e com pressa, } \\
\text { como o ceifeiro que está em silêncio } \\
\text { sob o sol escaldante, concentrando- } \\
\text { se em ter o trabalho terminado. }\end{array}$ & $\begin{array}{l}\text { verão possibilita cores contrastantes, } \\
\text { mas que combinada à ventania faz } \\
\text { parecer que a natureza está em um } \\
\text { estado emocional de 'acesso de raiva'. } \\
\text { O movimento do sol, se pondo, e o } \\
\text { movimento do vento, balançando o } \\
\text { trigo são representados na tela de } \\
\text { forma estática, pois a tela não tem } \\
\text { movimento. Van Gogh precisa } \\
\text { conseguir este efeito de movimento } \\
\text { para representar este dia e para isto ele } \\
\text { pincela freneticamente a tela de forma } \\
\text { a apreender justamente este } \\
\text { movimento e estado emocional da } \\
\text { natureza. }\end{array}$ \\
\hline $\begin{array}{l}\text { Na tela 'Por de Sol: Campo } \\
\text { de trigo perto de Arles', } \\
\text { observamos o uso de } \\
\text { Movimento para dar } \\
\text { ênfase para o sol, registrado } \\
\text { na nota de rodapé } 59 \text {. }\end{array}$ & $\begin{array}{l}\text {...e um enorme sol em um céu } \\
\text { vermelho, acima de telhados } \\
\text { vermelhos,... }\end{array}$ & \\
\hline $\begin{array}{l}\text { Na tela ‘O Semeador' } \\
\text { observamos a ocorrência de } \\
\text { Movimento, construída pela } \\
\text { representação dos raios do } \\
\text { sol que comunicam um } \\
\text { movimento expansivo e } \\
\text { abrangente. Esse } \\
\text { movimento é mais suave do } \\
\text { que o movimento do gesto } \\
\text { pictórico frenético que } \\
\text { constrói os torrões do campo } \\
\text { arado, registrado na nota de } \\
\text { rodapé } 126 .\end{array}$ & $\begin{array}{l}\text { Não te vou ocultar que não desgosto } \\
\text { da região, pois fui criado lá - ainda } \\
\text { me encanta a magia das recordações } \\
\text { do passado, de um desejo do infinito, } \\
\text { do qual o semeador e o enfeixador } \\
\text { são símbolos -, tanto quanto antes } \\
\text { gostava. }\end{array}$ & $\begin{array}{l}\text { A oração principal 'Não te vou } \\
\text { ocultar' tem um movimento que sofre } \\
\text { uma mudança de velocidade, quando } \\
\text { ocorre uma segunda oração hipotáxica } \\
\text { entre os travessões. Observamos na } \\
\text { oração paratáxica um sentido mais } \\
\text { externo, voltado para uma região na } \\
\text { qual ele compartilhava experiências } \\
\text { com o irmão. Na oração hipotáxica ele } \\
\text { está falando de uma experiência } \\
\text { interna, existencial. Nesse complexo } \\
\text { oracional há uma mudança de } \\
\text { movimento, que vai da experiência } \\
\text { externa na região para uma experiência } \\
\text { interna e da experiência do passado } \\
\text { para uma experiência que é presente. } \\
\text { O travessão aqui foi usado para } \\
\text { desacelerar o discurso, criar uma pausa } \\
\text { cheia de sentidos enfatizados; entre os } \\
\text { travessões está o sentido central dessa } \\
\text { oração que foi colocado na oração } \\
\text { hipotáxica. }\end{array}$ \\
\hline
\end{tabular}


Na tela 'O Semeador' observamos a ocorrência de Ritmo, Textura, Direção e Movimento construídos pelo Gesto Pictórico de van Gogh para representar o campo arado, registrados na nota de rodapé 133 .

Observamos a ocorrência do uso conjugado de Textura, ritmo, movimento, direção, gesto pictórico e saliência na representação dos torrões de terra revolvida no campo arado, registrado na nota de rodapé 135 .

Na tela 'O Semeador', há uma inter-relação entre Textura, Contrastes Simultâneos, Saliência, Sinestesia que criam Associações Metafóricas da materialidade da tinta com a nossa memória sensorial e tátil da plasticidade da terra, registrado na nota de rodapé 136.

Na tela 'O Semeador' observamos a ocorrência de Ritmo, Textura, Direção e Movimento construídos pelo Gesto Pictórico de van Gogh para representar o campo arado, registrados na nota de rodapé 133.

Vários elementos visuais dão a ideia de processo, desde o nível semântico e representacional como os ciclos do plantar, colher e fenecer, até o nível composicional com a ajuda dos caminhos visuais e dos raios do sol que comunicam uma continuidade.
A ideia do semeador ainda continua a me assombrar.
Além do movimento representado na própria tela, van Gogh refere-se a ela como um processo, um movimento em direção a um objetivo que continua, uma ideia que o persegue, o assombra.

Na tela 'O Semeador, observamos a ocorrência de Movimento, Gesto Pictórico e Vetor 1, sugerido pelo 


\begin{tabular}{|c|c|c|}
\hline $\begin{array}{l}\text { andar do Semeador, } \\
\text { registrado na nota de rodapé } \\
138 .\end{array}$ & & \\
\hline $\begin{array}{l}\text { Na tela 'A Esplanada do } \\
\text { Café na Place du Forum, } \\
\text { Arles, à Noite', observamos } \\
\text { a ocorrência e Inter-relação } \\
\text { entre Ritmo, Movimento, } \\
\text { Textura, Gesto Pictórico, } \\
\text { Desenho-Pintura para } \\
\text { construir a Perspectiva do } \\
\text { calçamento, registrados na } \\
\text { nota de rodapé } 171 .\end{array}$ & $\begin{array}{l}\text { As frentes das casas em uma rua que } \\
\text { segue sob o céu azul salpicado de } \\
\text { estrelas são azul escuro ou violeta, } \\
\text { com uma árvore verde. }\end{array}$ & $\begin{array}{l}\text { O calçamento da rua em frente ao café } \\
\text { está em movimento ao horizonte, onde } \\
\text { encontra a carruagem ao fundo, o olha } \\
\text { segue este caminho, pois a textura, a } \\
\text { cor e a perspectiva possibilitam esse } \\
\text { efeito de movimento ao fundo. }\end{array}$ \\
\hline $\begin{array}{l}\text { Na tela 'A Esplanada do } \\
\text { Café na Place du Forum, } \\
\text { Arles, à Noite', observamos } \\
\text { a ocorrência de Vetor, } \\
\text { construído pelo Movimento } \\
\text { das pessoas que se acercam } \\
\text { do café, registrados na nota } \\
\text { de rodapé } 174 .\end{array}$ & $\begin{array}{l}\text { No terraço, há pequenas figuras de } \\
\text { pessoas que bebem. }\end{array}$ & $\begin{array}{l}\text { Outros movimentos presentes são as } \\
\text { pessoas que bebem no café. As } \\
\text { pessoas na tela conferem movimento à } \\
\text { cena. }\end{array}$ \\
\hline & $\begin{array}{l}\text { Agora como para recuperar o } \\
\text { dinheiro pago ao senhorio através da } \\
\text { minha pintura, eu não estou fazendo } \\
\text { questão disto, porque a pintura é uma } \\
\text { das mais feias que eu já fiz. É o } \\
\text { equivalente, embora diferente, dos } \\
\text { comedores de batata. }\end{array}$ & \\
\hline & $\begin{array}{l}\text { O café noturno é uma continuação } \\
\text { do semeador, como é a cabeça do } \\
\text { velho camponês e do poeta, se eu } \\
\text { conseguir fazer essa última tela. }\end{array}$ & \\
\hline $\begin{array}{l}\text { Na tela 'O Café Noturno na } \\
\text { Place Lamartine, em Arles', } \\
\text { observamos a ocorrência de } \\
\text { Saliência construída com o } \\
\text { uso de Textura, Ritmo, } \\
\text { Movimento e Gesto } \\
\text { Pictórico para representar o }\end{array}$ & & \\
\hline
\end{tabular}




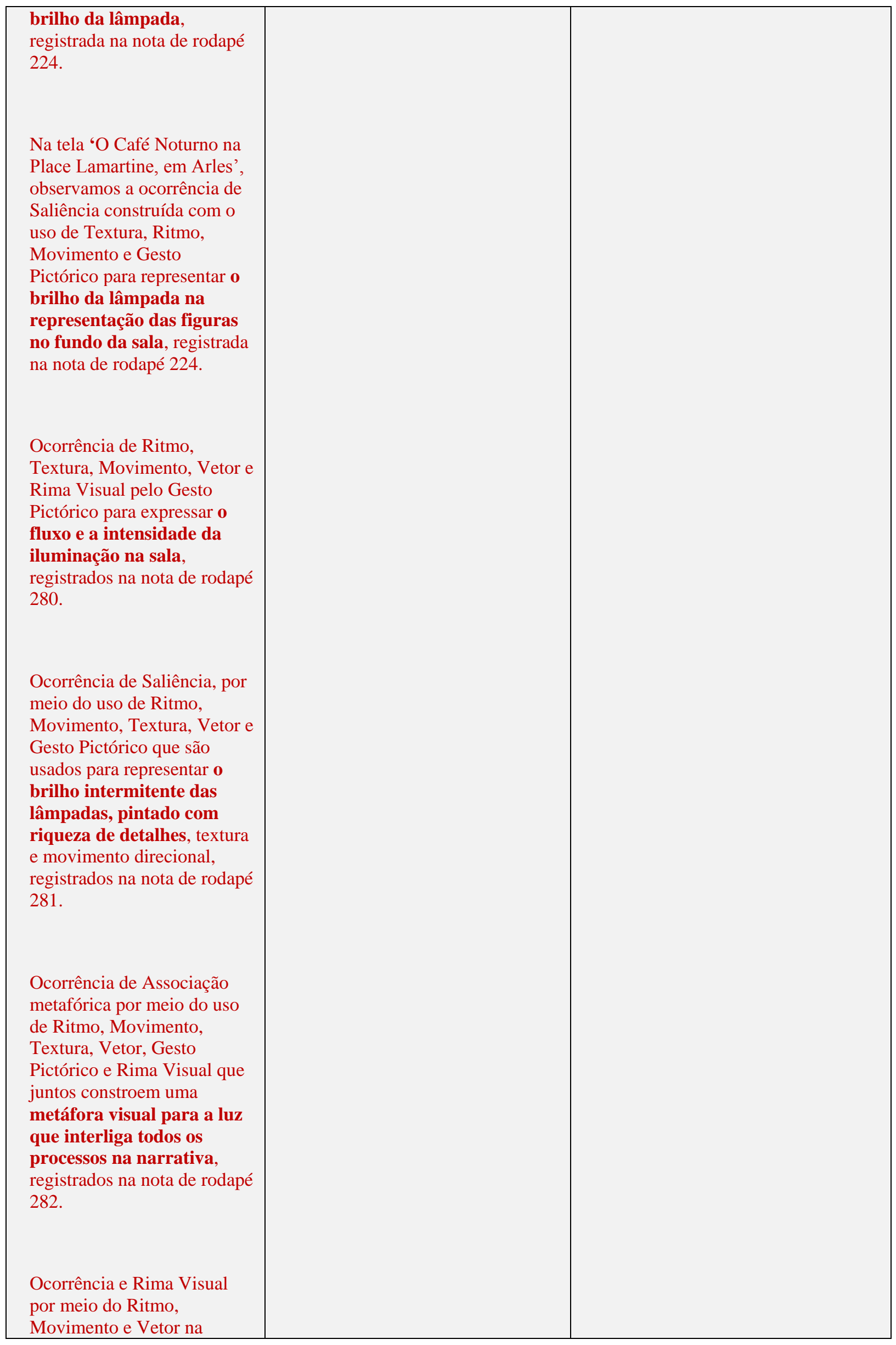




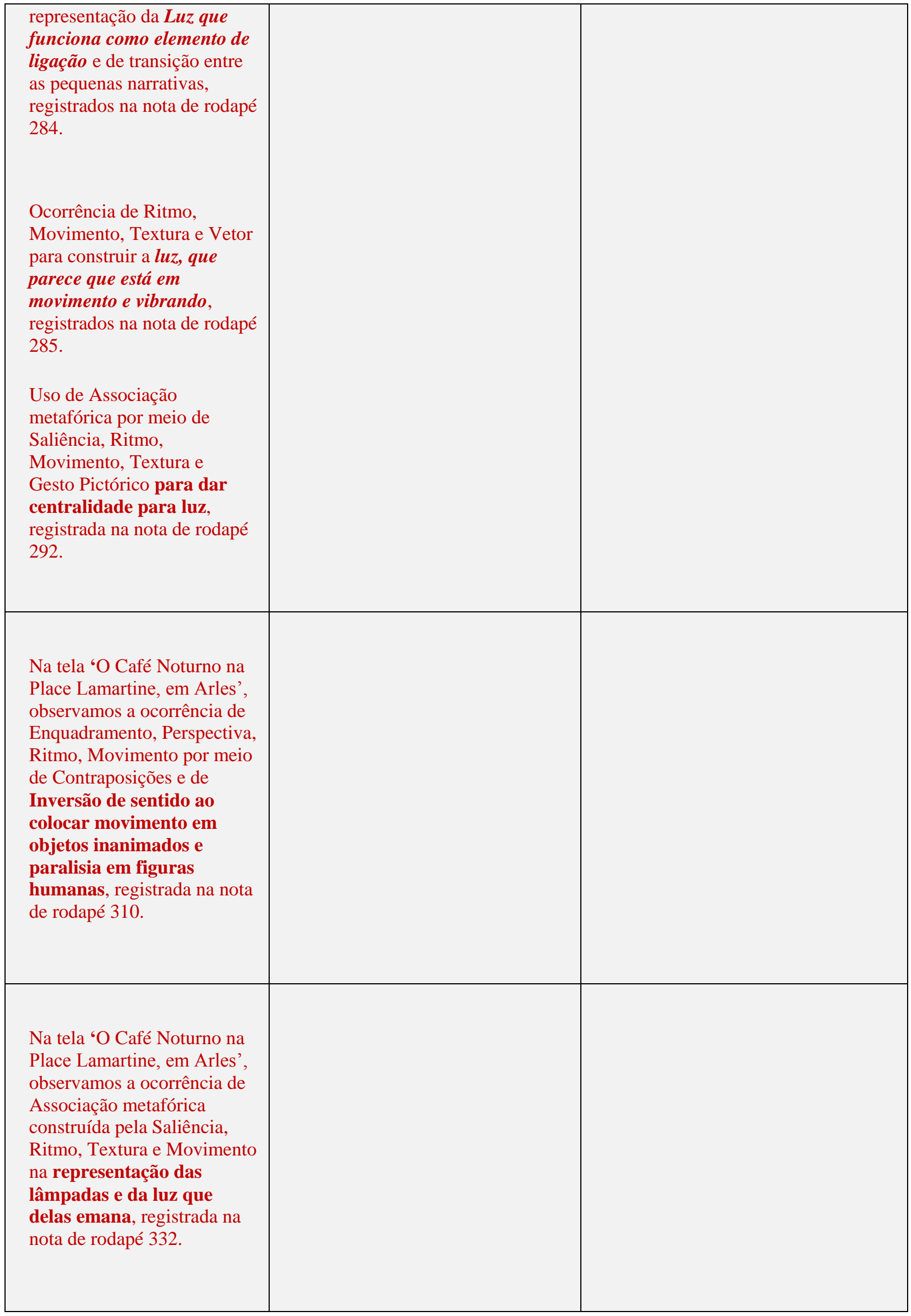

Fonte: Triangulação para Movimento dos dados dos corpora visual e textual, com os extratos das cartas. 


\subsection{TRIANGULAÇÃO DA DIREÇÃO OU VETOR}

\begin{tabular}{|c|c|c|}
\hline Ocorrência nas telas & Orações & Comentário \\
\hline $\begin{array}{l}\text { Na tela 'Por de Sol: Campo } \\
\text { de trigo perto de Arles', } \\
\text { observamos a ocorrência de } \\
\text { Vetor ou Movimento } \\
\text { Direcional, por meio de } \\
\text { pinceladas direcionais que } \\
\text { produzem a sensação } \\
\text { visual de que está ventando } \\
\text { no trigo e criam a ação de } \\
\text { 'ventar', registrada nas } \\
\text { notas de rodapé } 74,82 \text { e } 87 . \\
\text { Ocorrência de movimento } \\
\text { direcional e rima visual são } \\
\text { conferidos pelo uso do gesto } \\
\text { pictórico, do ritmo, da } \\
\text { textura e do movimento no } \\
\text { trigal. }\end{array}$ & $\begin{array}{l}\text { Eu pintei-a ao ar livre no mistral. } \\
\text { Meu cavalete foi fixado no chão com } \\
\text { estacas de ferro, um método que eu } \\
\text { recomendo a você. } \\
\text { Você enterra os pés do cavalete e, } \\
\text { em seguida, você empurra a } 50 \\
\text { centímetros de comprimento um } \\
\text { peso de ferro ao lado deles. Você } \\
\text { amarra tudo com cordas; dessa } \\
\text { forma, você pode trabalhar com o } \\
\text { vento. (VAN GOGH, } 2009 \text { c, p. } 1 \text { ). }\end{array}$ & $\begin{array}{l}\text { O movimento na tela produz uma ação } \\
\text { que define uma meta de comunicação } \\
\text { com o observador. A ação do vento ao } \\
\text { ar livre direciona o olhar para um } \\
\text { ambiente que é dinâmico e van Gogh } \\
\text { enfatiza esse movimento interno da } \\
\text { tela de uma forma muito singular e } \\
\text { logo em seguida ele associa a fixidez } \\
\text { do cavalete no chão. E em seguida } \\
\text { após descrever toda a dinâmica interna } \\
\text { do quadro ele descreve para o irmão } \\
\text { como que aquele movimento aquela } \\
\text { dinâmica do vento precisa ser } \\
\text { controlada por ele no momento da } \\
\text { produção da obra. Então ele descreve } \\
\text { todas as suas ações para fizar o } \\
\text { cavalete no chão. }\end{array}$ \\
\hline $\begin{array}{l}\text { Na tela 'Por de Sol: Campo } \\
\text { de trigo perto de Arles', } \\
\text { observamos a ocorrência de } \\
\text { Vetor } 1 \text { - pinceladas } \\
\text { direcionais do gesto } \\
\text { pictórico sugerem que a } \\
\text { ação está no trigo, } \\
\text { registrado na nota de rodapé } \\
99 .\end{array}$ & $\begin{array}{l}\text { Paisagens amarelo ouro velho - feito } \\
\text { rápido rápido rápido e com pressa, } \\
\text { como o ceifeiro que está em silêncio } \\
\text { sob o sol escaldante, concentrando- } \\
\text { se em ter o trabalho terminado. }\end{array}$ & $\begin{array}{l}\text { A forma como ele descreve a ação de } \\
\text { criação e de recriação e de } \\
\text { representação do campo de trigo } \\
\text { sugere uma colagem entre o } \\
\text { movimento do vento sobre o trigo e o } \\
\text { movimento do pincel sobre a tela. }\end{array}$ \\
\hline $\begin{array}{l}\text { Na tela 'Por de Sol: Campo } \\
\text { de trigo perto de Arles', } \\
\text { observamos a ocorrência de } \\
\text { Vetor } 2 \text { - pinceladas } \\
\text { direcionais do gesto } \\
\text { pictórico sugerem que a } \\
\text { ação está no vento, } \\
\text { registrado na nota de rodapé } \\
100 .\end{array}$ & $\begin{array}{l}\text { Eu tenho um terceiro estudo, agora, } \\
\text { de uma paisagem com fábrica, e um } \\
\text { enorme sol em um céu vermelho, } \\
\text { acima de telhados vermelhos, em } \\
\text { que a natureza parece estar em um } \\
\underline{\text { acesso de raiva, em um dia de }} \\
\underline{\text { mistral desagradável. }}\end{array}$ & $\begin{array}{l}\text { Van Gogh descreve a tela como um } \\
\text { objeto que em parte está estático } \\
\text { (tenho) e em parte está em movimento } \\
\text { (estudo) e que internamente parte está } \\
\text { estático (telhado, céu) e parte está em } \\
\text { movimento (a natureza em um dia de } \\
\text { mistral desagradável). A ação se } \\
\text { coloca na contraposição entre duas } \\
\text { condições, uma de ser e outra de estar. } \\
\text { Na oração a natureza aparece como } \\
\text { mutável na oração e na tela, o vento } \\
\text { aparece como agente da ação. }\end{array}$ \\
\hline $\begin{array}{l}\text { Na tela 'Por de Sol: Campo } \\
\text { de trigo perto de Arles', }\end{array}$ & & \\
\hline
\end{tabular}

${ }^{482}$ Disponível em: <http://vangoghletters.org/vg/letters/let628/letter.html>. 


\begin{tabular}{|c|c|c|}
\hline $\begin{array}{l}\text { observamos a ocorrência de } \\
\text { Vetor } 3 \text { - pinceladas } \\
\text { direcionais do gesto } \\
\text { pictórico sugerem que a } \\
\text { ação está no sol, registrado } \\
\text { na nota de rodapé } 101 .\end{array}$ & & \\
\hline $\begin{array}{l}\text { Na tela 'Por de Sol: Campo } \\
\text { de trigo perto de Arles', } \\
\text { observamos a ocorrência de } \\
\text { Vetor } 4 \text { - pinceladas } \\
\text { direcionais do gesto } \\
\text { pictórico sugerem que a } \\
\text { ação está no homem, } \\
\text { registrado na nota de rodapé } \\
102 .\end{array}$ & & \\
\hline $\begin{array}{l}\text { Na tela 'O Semeador, } \\
\text { Observamos a ocorrência de } \\
\text { Vetor } 1 \text { e Associação } \\
\text { metafórica por meio de um } \\
\text { caminho visual do primeiro } \\
\text { plano até o último plano, } \\
\text { que constrói um movimento } \\
\text { direcional e as metáforas de } \\
\text { uma narrativa visual, } \\
\text { registrado na nota de rodapé } \\
\text { 124. } \\
\text { Na tela 'O Semeador', } \\
\text { observamos a ocorrência de } \\
\text { Enquadramento, Saliência, } \\
\text { Vetor } 1 \text { para construir uma } \\
\text { maior centralidade do } \\
\text { campo na narrativa, e um } \\
\text { sentido igualmente } \\
\text { importante do enunciado que } \\
\text { é o de receber a semeadura } \\
\text { do semeador. } \\
\text { Observamos um } \\
\text { deslocamento da agência da } \\
\text { ação que é compatível com } \\
\text { as ocorrências de } \\
\text { deslocamento da agência } \\
\text { da ação nas orações } \\
\text { escritas por van Gogh, } \\
\text { registrado na nota de rodapé } \\
163 \text {. }\end{array}$ & $\begin{array}{l}\text { Em um campo arado, um grande } \\
\text { campo de torrões de terra roxa - } \\
\text { levantados em direção ao horizonte- } \\
\text { um semeador em azul e branco. No } \\
\text { horizonte um campo de trigo curto, } \\
\text { maduro. } \\
\text { Acima de tudo isso um céu amarelo } \\
\text { com um sol amarelo. }\end{array}$ & $\begin{array}{l}\text { A similaridade entre a descrição } \\
\text { escrita da tela e a representação } \\
\text { visual se dá pelo contimento da } \\
\text { ação da terra de baixo para cima e } \\
\text { do sol de cima para baixo sobre o } \\
\text { plano central na qual o semeador } \\
\text { está trabalhando. No nível } \\
\text { representacional e no nível da } \\
\text { descrição escrita da tela as ações } \\
\text { centrais são do sol e do campo } \\
\text { arado, ficando o semeador, com } \\
\text { base nessas escolhas léxico- } \\
\text { gramaticais, como uma figura que } \\
\text { não concentra em si a centralidade } \\
\text { da ação, mas que a divide com o } \\
\text { próprio campo arado. }\end{array}$ \\
\hline $\begin{array}{l}\text { Na tela 'O Semeador, } \\
\text { observamos a ocorrência de }\end{array}$ & $\begin{array}{l}\text { Em um campo arado, um grande } \\
\text { campo de torrões de terra roxa - }\end{array}$ & $\begin{array}{l}\text { O semeador segue em um movimento } \\
\text { direcional ao horizonte. } \mathrm{O} \text { vetor é tanto }\end{array}$ \\
\hline
\end{tabular}




\begin{tabular}{|c|c|c|}
\hline $\begin{array}{l}\text { Vetor } 2 \text { construída pelo } \\
\text { Semeador que anda e olha } \\
\text { para a direita da tela. O } \\
\text { Vetor constrói a Associação } \\
\text { metafórica que o Semeador } \\
\text { se desloca do passado para o } \\
\text { futuro. Há também uma } \\
\text { metáfora de conflito entre o } \\
\text { significado simbólico dos } \\
\text { corvos e o do semear, } \\
\text { registrada na nota de rodapé } \\
\text { 125. } \\
\text { Observamos também a } \\
\text { ocorrência de Movimento, } \\
\text { Gesto Pictórico e Vetor } 1 \text {, } \\
\text { sugerido pelo andar do } \\
\text { Semeador, registrado na } \\
\text { nota de rodapé } 138 .\end{array}$ & $\begin{array}{l}\text { levantados em direção ao horizonte - } \\
\text { um semeador em azul e branco. No } \\
\text { horizonte um campo de trigo curto, } \\
\text { maduro. } \\
\text { Acima de tudo isso um céu amarelo } \\
\text { com um sol amarelo. }\end{array}$ & $\begin{array}{l}\text { o semeador e seu movimento de } \\
\text { semear quanto do caminho entre a } \\
\text { terra arada em direção ao campo de } \\
\text { trigo maduro, ambos estão indo na } \\
\text { direção da colheita, futura e no } \\
\text { horizonte da ação. O uso metafórico } \\
\text { dos elementos pictóricos conferem um } \\
\text { sentido unitário à tela. Assim, } \\
\text { podemos inferir que a ação do } \\
\text { semeador e a ação do caminho no } \\
\text { campo arado dão direção metafórica } \\
\text { ao quadro: semear, colher. Por outro } \\
\text { lado, a direção do artista, que se vê em } \\
\text { direção ao horizonte, mas se pergunta } \\
\text { se terá o poder necessário para a futura } \\
\text { colheita, para a produção de sentidos } \\
\text { que representem na tela seu desejo. } \\
\text { Mas é esta sua direção, é este seu } \\
\text { caminho. }\end{array}$ \\
\hline & $\begin{array}{l}\text { E o esboço como tal - uma tela } \\
\text { número } 25 \text { - também me preocupa } \\
\text { muito, no sentido de que eu me } \\
\text { pergunto se eu não deveria levar a } \\
\text { sério e fazer uma pintura tremenda } \\
\text { disso. Meu Deus, como eu adoraria } \\
\text { fazer isso. Mas eu só me pergunto se } \\
\text { eu vou ter o poder necessário de } \\
\text { execução. }\end{array}$ & \\
\hline & $\begin{array}{l}\text { Não te vou ocultar que não desgosto } \\
\text { da região, pois fui criado lá - ainda } \\
\text { me encanta a magia das recordações } \\
\text { do passado, de um desejo do infinito, } \\
\text { do qual o semeador e o enfeixador } \\
\text { são símbolos -, tanto quanto antes } \\
\text { gostava. }\end{array}$ & \\
\hline & $\begin{array}{l}\text { Mas quando eu farei o céu estrelado, } \\
\text { então, essa pintura que está sempre } \\
\text { na minha mente? }\end{array}$ & \\
\hline & $\begin{array}{l}\text { Ai, ai, é como nosso excelente amigo } \\
\text { Cyprien diz, em 'En ménage' por JK } \\
\text { Huysmans: as mais belas pinturas } \\
\text { são aquelas que um sonha enquanto }\end{array}$ & \\
\hline
\end{tabular}




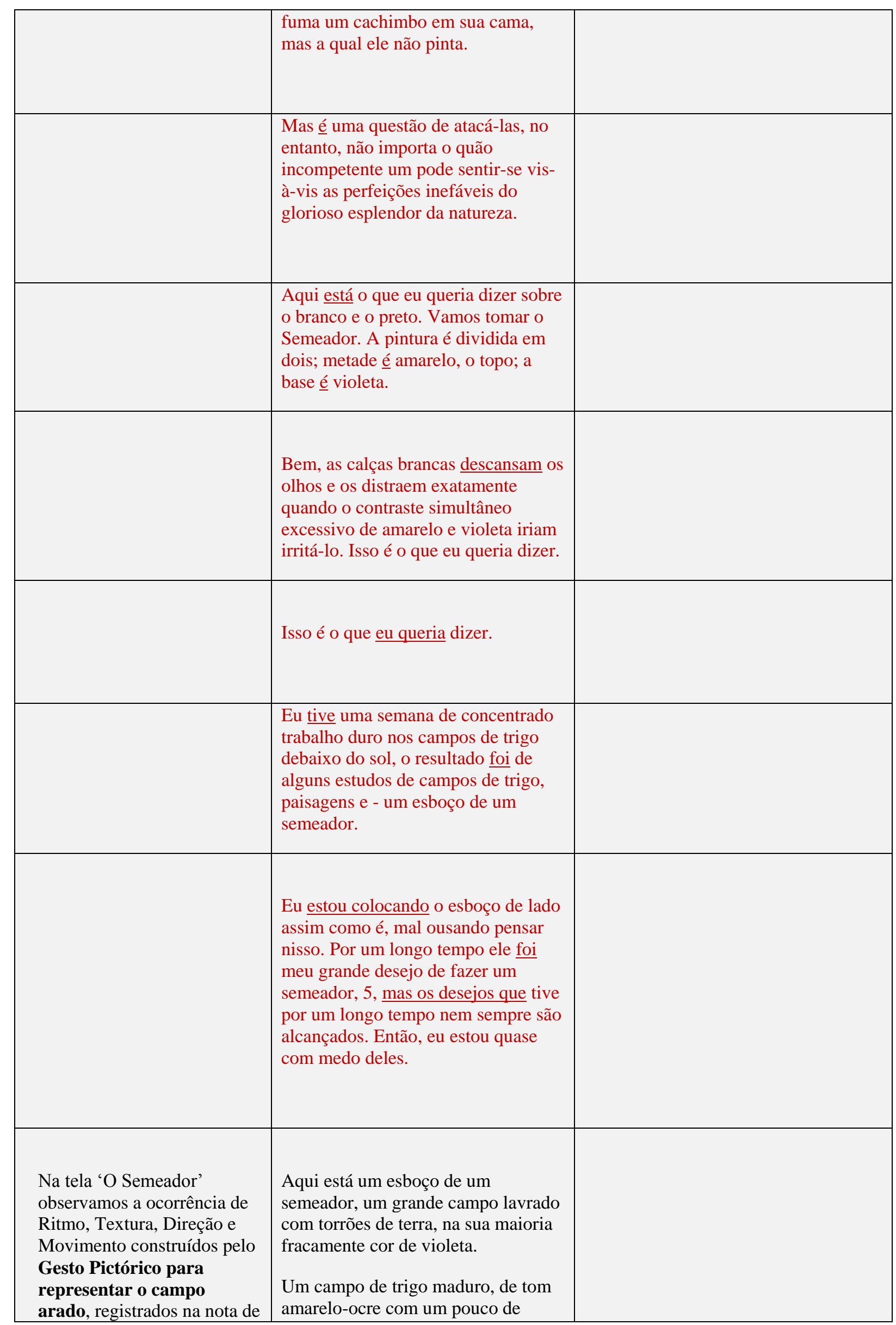




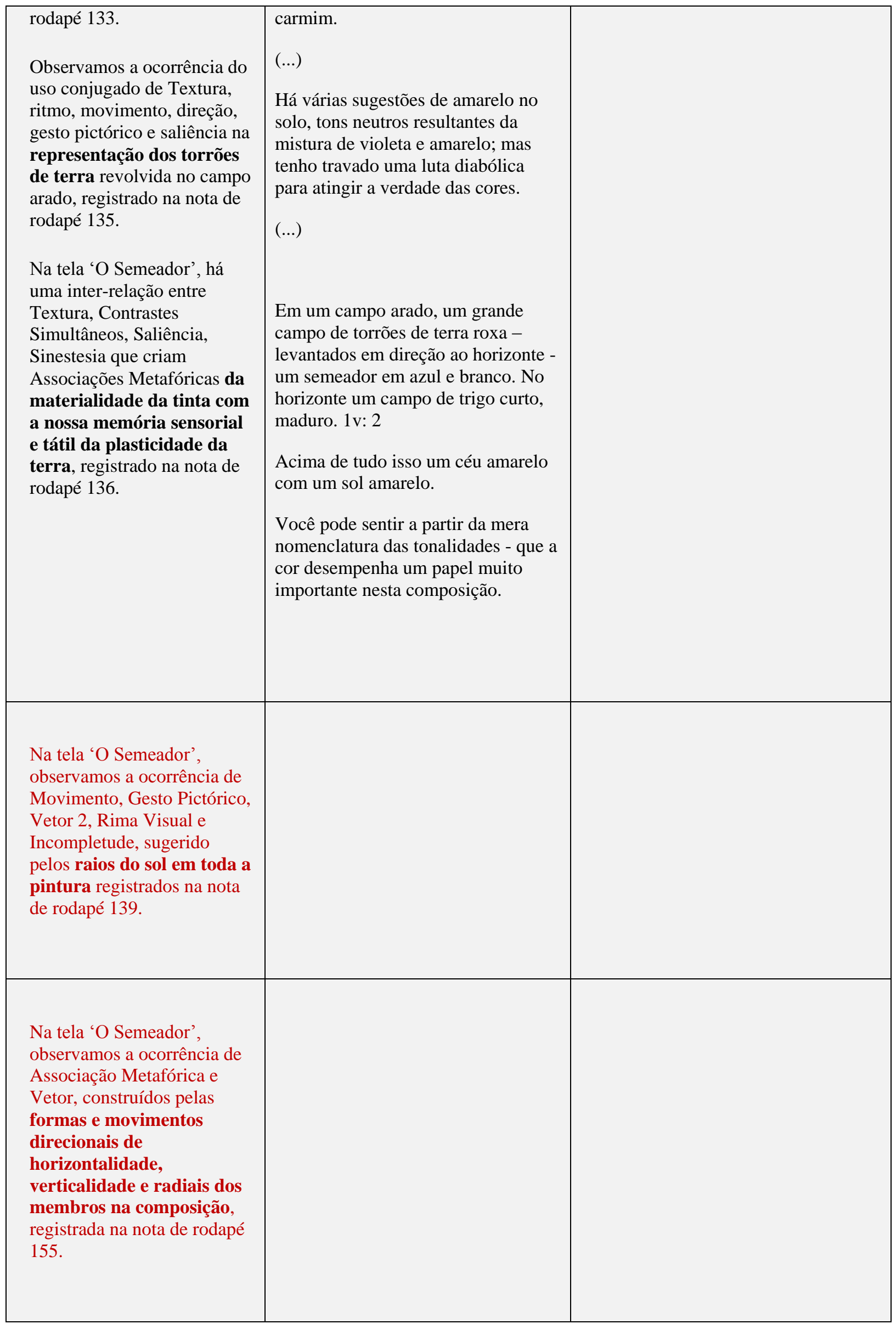




\begin{tabular}{|c|c|}
\hline $\begin{array}{l}\text { Na tela 'A Esplanada do } \\
\text { Café na Place du Forum, } \\
\text { Arles, à Noite', observamos } \\
\text { a ocorrência de Vetor, } \\
\text { construído pelo Movimento } \\
\text { das pessoas que se acercam } \\
\text { do café, registrados na nota } \\
\text { de rodapé } 174 .\end{array}$ & \\
\hline $\begin{array}{l}\text { Na tela 'A Esplanada do } \\
\text { Café na Place du Forum, } \\
\text { Arles, à Noite', observamos } \\
\text { a ocorrência de Vetor e de } \\
\text { contraposição entre vetores. } \\
\text { O vetor mais importante é } \\
\text { o da lâmpada a gás que } \\
\text { irradia, o secundário são as } \\
\text { pessoas que convergem. A } \\
\text { lâmpada ilumina, a noite } \\
\text { escurece. Esses vetores } \\
\text { secundários se contrapõem } \\
\text { com a çãa do vetor central, } \\
\text { formando eixos de } \\
\text { contraposição, registrados } \\
\text { na nota de rodapé } 176 .\end{array}$ & \\
\hline $\begin{array}{l}\text { Observamos também a } \\
\text { ocorrência de Vetor na } \\
\text { representação da luz que } \\
\text { congrega as pessoas } \\
\text { debaixo do toldo, registrada } \\
\text { na nota de rodapé } 206 .\end{array}$ & \\
\hline $\begin{array}{l}\text { Na tela 'A Esplanada do } \\
\text { Café na Place du Forum, } \\
\text { Arles, à Noite', observamos } \\
\text { a ocorrência de Vetor pela } \\
\text { representação da copa da } \\
\text { árvore em forma de seta } \\
\text { que aponta para o café, } \\
\text { registrada na nota de rodapé } \\
200 .\end{array}$ & \\
\hline $\begin{array}{l}\text { Na tela 'A Esplanada do } \\
\text { Café na Place du Forum, } \\
\text { Arles, à Noite', observamos }\end{array}$ & $\begin{array}{l}\text { Foi observado um sentido de } \\
\text { movimentação conferida aos objetos } \\
\text { inanimados em contraposição à }\end{array}$ \\
\hline
\end{tabular}




\begin{tabular}{|c|c|c|}
\hline $\begin{array}{l}\text { a ocorrência de Vetor na } \\
\text { representação das cadeiras } \\
\text { vazias no primeiro plano, } \\
\text { ambas voltadas para a o } \\
\text { pintor que as pinta } \\
\text { sugerindo um caminho } \\
\text { visual inverso, de ponto de } \\
\text { fuga invertido, como } \\
\text { observado em outras telas } \\
\text { analisadas, registrada na nota } \\
\text { de rodapé } 207 \text {. }\end{array}$ & & $\begin{array}{l}\text { paralisia das figuras humanas na tela } \\
\text { que endossa a disposição } \\
\text { desorganizada e oblíqua das cadeiras, } \\
\text { transmitindo a sensação de que a } \\
\text { presença, o fulgor e a movimentação } \\
\text { de pessoas ali naquele espaço ainda } \\
\text { estivessem presentes, quentes, embora } \\
\text { elas já tenham ido embora daquele } \\
\text { local que é reforçado pela ocorrência } \\
\text { de vetores projetados pelas cadeiras. }\end{array}$ \\
\hline $\begin{array}{l}\text { Observamos também a } \\
\text { ocorrência de Transparência } \\
\text { e Enquadramento, por meio } \\
\text { de Vetor e Perspectiva } \\
\text { invertida, que é observada } \\
\text { também na composição de } \\
\text { outras telas, registradas na } \\
\text { nota de rodapé } 210 \text {. }\end{array}$ & & \\
\hline $\begin{array}{l}\text { Na tela ‘O Café Noturno na } \\
\text { Place Lamartine, em Arles', } \\
\text { observamos a ocorrência do } \\
\text { uso de Saliência e Vetor } \\
\text { inter-relacionados com a } \\
\text { ocorrência de Textura e } \\
\text { Gesto Pictórico para } \\
\text { construir a luz das } \\
\text { lâmpadas a gás, registrado } \\
\text { na nota de rodapé } 216.0 \\
\text { vetor ocorre em direção } \\
\text { radial. }\end{array}$ & $\begin{array}{l}\text { Uma enorme lanterna amarela } \\
\text { ilumina o terraço, a fachada, a } \\
\text { calçada, e até mesmo projeta luz } \\
\text { sobre os paralelepípedos da rua, que } \\
\text { adquirem uma coloração violeta- } \\
\text { rosa. } \\
\text { A segunda mostra o exterior de um } \\
\text { café, iluminado no terraço externo } \\
\text { por uma grande lâmpada de gás } \\
\text { dentro da noite azul, com um retalho } \\
\text { de céu azul estrelado. }\end{array}$ & $\begin{array}{l}\text { O movimento de projeção da luz é } \\
\text { representado na tela pelo amarelo na } \\
\text { calçada. Há uma ação da luz em toda a } \\
\text { tela, seja pela luminosidade artificial } \\
\text { do café, seja pela luminosidade natural } \\
\text { do céu estrelado. Vemos que nesta tela } \\
\text { a luz tem um papel proeminente na } \\
\text { direção do olhar, ela age sobre a } \\
\text { paisagem, e sua ação modifica os } \\
\text { elementos da tela. A luz direciona o } \\
\text { olhar sobre os elementos que compõe a } \\
\text { tela, agrega sentido e valor àqueles } \\
\text { elementos que de outra forma não } \\
\text { apareceriam. }\end{array}$ \\
\hline $\begin{array}{l}\text { Ocorrência de Saliência, por } \\
\text { meio do uso de Ritmo, } \\
\text { Movimento, Textura, Vetor e } \\
\text { Gesto Pictórico que são } \\
\text { usados para representar o } \\
\text { brilho intermitente das } \\
\text { lâmpadas, pintado com } \\
\text { riqueza de detalhes, textura }\end{array}$ & & \\
\hline
\end{tabular}




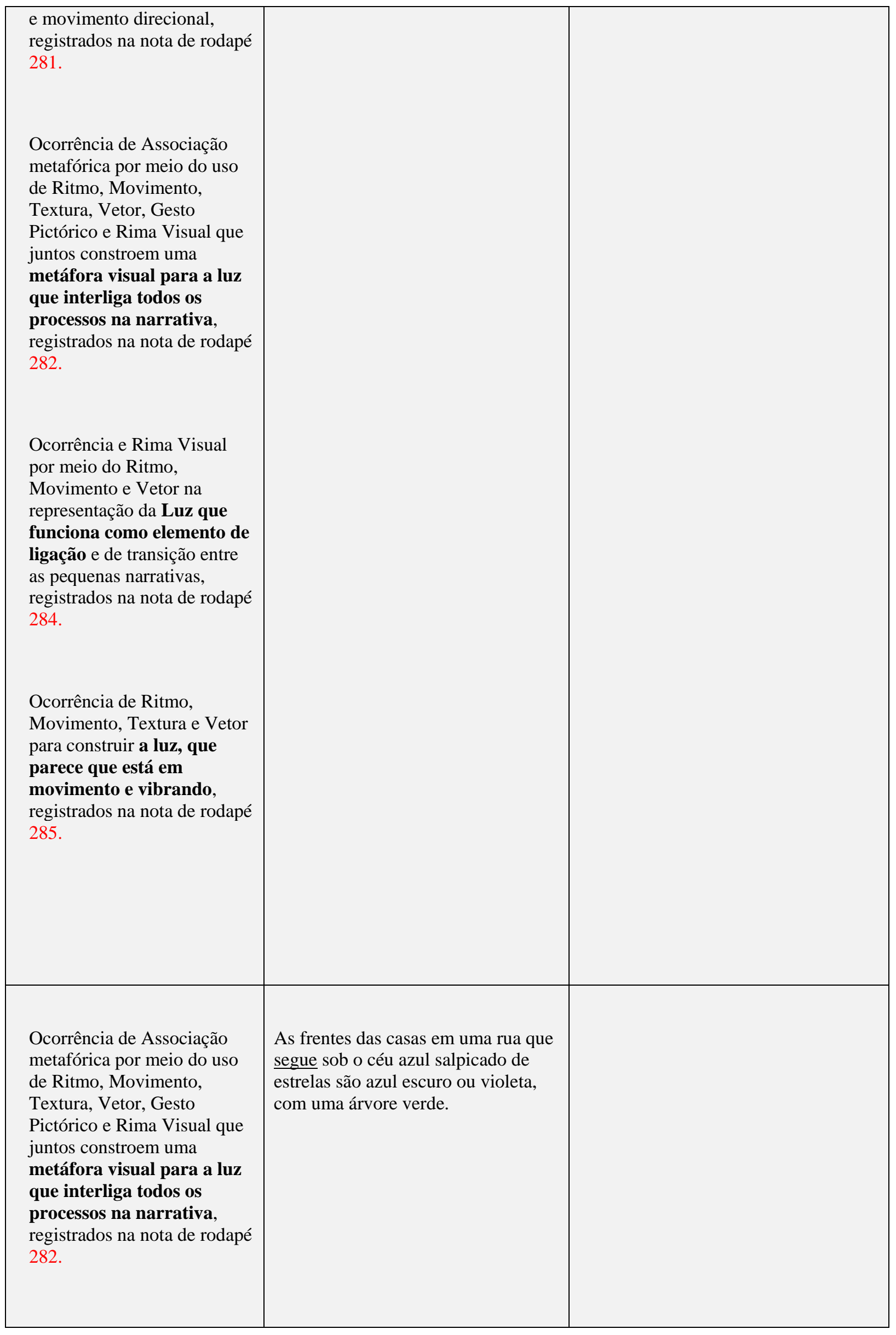




\begin{tabular}{|c|c|c|}
\hline & $\begin{array}{l}\text { Fui interrompido precisamente pelo } \\
\text { trabalho que uma nova pintura da } \\
\text { parte externa de um café à noite tem } \\
\text { me dado nos últimos dias. }\end{array}$ & \\
\hline $\begin{array}{l}\text { Ocorrência e Rima Visual } \\
\text { por meio do Ritmo, } \\
\text { Movimento e Vetor na } \\
\text { representação da Luz que } \\
\text { funciona como elemento de } \\
\text { ligação e de transição entre } \\
\text { as pequenas narrativas, } \\
\text { registrados na nota de rodapé } \\
284 \text {. }\end{array}$ & $\begin{array}{l}\text { Agora há uma pintura de noite sem } \\
\text { preto. No passado, eles costumavam } \\
\text { desenhar e pintar a tela do desenho } \\
\text { durante o dia. Mas acho que me } \\
\text { convém pintar a coisa no momento. } \\
\text { Mas é a única maneira de se livrar da } \\
\text { noite negra convencional com uma } \\
\text { luz pobre, pálida e esbranquiçada, } \\
\text { quando na verdade uma mera vela } \\
\text { por si só nos dá os mais ricos } \\
\text { amarelos e laranjas. }\end{array}$ & $\begin{array}{l}\text { A luz dá unidade à tela, possibilitando } \\
\text { criar um elo de transição entre seus } \\
\text { elementos. Na carta enviada a Theo, } \\
\text { van Gogh descreve este efeito de } \\
\text { transição da luz em toda a tela e afirma } \\
\text { que 'agora há uma pintura sem preto'. } \\
\text { A luz à noite pode oferecer as mais } \\
\text { ricas cores e inclusive a possibilidade } \\
\text { de pintar uma noite sem preto. }\end{array}$ \\
\hline $\begin{array}{l}\text { Na tela 'O Café Noturno na } \\
\text { Place Lamartine, em Arles', } \\
\text { observamos a ocorrência de } \\
\text { Vetor construída pela figura } \\
\text { do homem no centro da } \\
\text { sala que olha diretamente } \\
\text { para o espectador, } \\
\text { registrada na nota de rodapé } \\
220 .\end{array}$ & $\begin{array}{l}\text { Agora como para recuperar o } \\
\text { dinheiro pago ao senhorio através da } \\
\text { minha pintura, eu não estou fazendo } \\
\text { questão disto, porque a pintura é uma } \\
\text { das mais feias que eu já fiz. }\end{array}$ & $\begin{array}{l}\text { Na tela do Café Lamartine há uma } \\
\text { representação da cena no café sobre a } \\
\text { qual van Gogh tem uma relação } \\
\text { ambivalente, por um lado é uma das } \\
\text { mais feias que ele já fez, por outro, é a } \\
\text { que ganha maior significado. }\end{array}$ \\
\hline $\begin{array}{l}\text { Observamos também que o } \\
\text { homem parado no centro da } \\
\text { sala, ao lado da mesa de } \\
\text { bilhar está olhando } \\
\text { diretamente para alguém } \\
\text { que não se encontra } \\
\text { representado na cena. Este } \\
\text { olhar sugere uma ação } \\
\text { vetorial, como em uma } \\
\text { oração com sujeito, } \\
\text { processo, mas sem uma } \\
\text { meta. Encontramos a } \\
\text { ocorrência da representação } \\
\text { escrita dessa ação do } \\
\text { homem parado próximo à } \\
\text { mesa de bilhar do Café da } \\
\text { Noite que olha diretamente } \\
\text { para alguém ou para algo, } \\
\text { registrado na nota de rodapé } \\
\text { 256. }\end{array}$ & $\begin{array}{l}\text { Eu também fiz um novo retrato de } \\
\text { mim mesmo, como um estudo, no } \\
\text { qual eu pareço um Japonês. Você } \\
\text { nunca me disse se você tinha lido } \\
\text { Bel-ami de Guy de Maupassant, e o } \\
\text { que você pensa agora do talento dele } \\
\text { em geral. Digo isto porque o início } \\
\text { de Bel- Ami é precisamente a } \\
\text { descrição de uma noite estrelada em } \\
\text { Paris, com os cafés iluminados da } \\
\text { avenida, e isso é algo como o mesmo } \\
\text { tema que eu pintei bem agora. }\end{array}$ & $\begin{array}{l}\text { O café representa as paixões humanas, } \\
\text { embora as pessoas no café não estejam } \\
\text { assumindo uma ação explicitamente } \\
\text { emocional, a paralisia das personagens } \\
\text { contrasta com o movimento da luz } \\
\text { sobre elas. }\end{array}$ \\
\hline
\end{tabular}




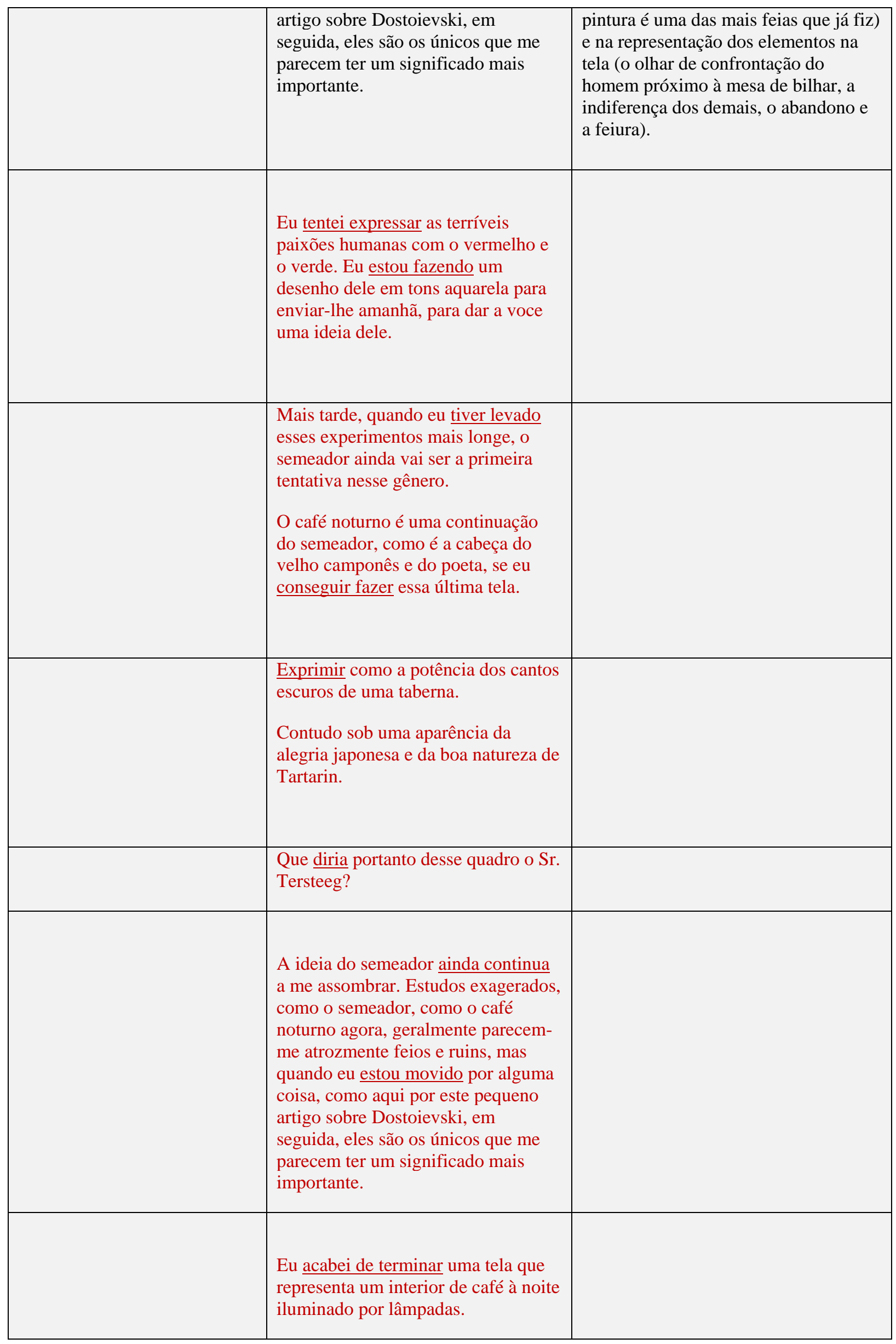




\begin{tabular}{|c|c|c|}
\hline $\begin{array}{l}\text { Na tela 'O Café Noturno na } \\
\text { Place Lamartine, em Arles', } \\
\text { observamos a ocorrência de } \\
\text { Associação metafórica com a } \\
\text { ajuda de Vetor, Perspectiva, } \\
\text { Enquadramento e Saliência } \\
\text { na representação do casal } \\
\text { no fundo da sala, registrada } \\
\text { na nota de rodapé } 342 \text {. }\end{array}$ & $\begin{array}{l}\text { Nesta tela, há } 6 \text { ou } 7 \text { vermelhos } \\
\text { diferentes, desde vermelho-sangue } \\
\text { até rosa delicado, fazendo oposição } \\
\text { com o mesmo número de verdes } \\
\text { pálidos ou escuros. }\end{array}$ & $\begin{array}{l}\text { Van Gogh costuma usar a associação } \\
\text { metafórica da oposição entre cores } \\
\text { complementares com a simbologia de } \\
\text { um casamento. Dessa forma a } \\
\text { representação do casal no fundo da } \\
\text { sala, no ponto para o qual convergem } \\
\text { os caminhos visuais vetorizados pelas } \\
\text { linhas de perspectiva construídas pelas } \\
\text { tábuas do chão, pode ser uma metáfora } \\
\text { para o mesmo sentido de } \\
\text { contraposição que está sendo afirmado } \\
\text { pelos } 6 \text { ou } 7 \text { tipos de contrastes entre } \\
\text { vermelhos e verdes que estão a fazer } \\
\text { oposição. }\end{array}$ \\
\hline $\begin{array}{l}\text { Na tela 'O Café Noturno na } \\
\text { Place Lamartine, em Arles', } \\
\text { observamos a ocorrência de } \\
\text { Inversão do Ponto de vista, } \\
\text { construída pelo Vetor, dado } \\
\text { pelo homem no centro da } \\
\text { sala que olha para o } \\
\text { espectador. A seta, criada } \\
\text { pela sombra da mesa se } \\
\text { encarrega de levar a } \\
\text { atenção do espectador para } \\
\text { aquele ponto desde o qual } \\
\text { se olha a cena. Esse sentido } \\
\text { constrói uma inversão e um } \\
\text { deslocamento no } \\
\text { Enquadramento e na } \\
\text { Perspectiva que vai desde o } \\
\text { envolvimento até o } \\
\text { distanciamento para se } \\
\text { olhar a cena, registrados na } \\
\text { nota de rodapé } 242 \text {. }\end{array}$ & $\begin{array}{l}\text { A sala está pintada de vermelho, e no } \\
\text { interior, na luz a gás, a mesa de } \\
\text { bilhar verde, a qual lança uma } \\
\text { imensa sombra sobre o chão. }\end{array}$ & $\begin{array}{l}\text { Um dos vetores principais em quase } \\
\text { todas as telas de van Gogh é o efeito } \\
\text { da luz no ambiente. A luz modifica, } \\
\text { age sobre o ambiente de forma } \\
\text { incisiva. Na descrição da tela van } \\
\text { Gogh afirma que a luz 'lança uma } \\
\text { imensa sombra sobre o chão'. } \\
\text { A luz tem papel proeminente na cena, } \\
\text { ela aparece lançando luz e sombra. } \\
\text { Parece haver nesta ação da luz um } \\
\text { sentido metafórico, de um objeto } \\
\text { aparentemente pequeno é possível } \\
\text { extrair um efeito imenso. O } \\
\text { descontrole da ação e seu efeito no } \\
\text { ambiente pode estar representando o } \\
\text { efeito das emoções (luz) sobre as ações } \\
\text { (sombrias). O movimento da luz sobre } \\
\text { o ambiente está presente tanto na tela } \\
\text { quanto na carta, mas a escolha das } \\
\text { palavras para descrever o efeito da luz } \\
\text { no ambiente sugere uma centralidade } \\
\text { de seu significado metafórico, } \\
\text { causando no leitor um outro olhar } \\
\text { sobre a tela. }\end{array}$ \\
\hline $\begin{array}{l}\text { Na tela 'O Café Noturno na } \\
\text { Place Lamartine, em Arles', } \\
\text { observamos a ocorrência de } \\
\text { Direção ou Vetor criada pela } \\
\text { sombra da mesa que se } \\
\text { assemelha a uma seta e } \\
\text { pelo olhar do homem que } \\
\text { parece nos fitar diretamente, } \\
\text { registrada na nota de rodapé } \\
243 .\end{array}$ & & \\
\hline
\end{tabular}




\begin{tabular}{|c|c|c|}
\hline $\begin{array}{l}\text { Na tela 'O Café Noturno na } \\
\text { Place Lamartine, em Arles', } \\
\text { observamos a ocorrência de } \\
\text { Vetor, construído pela } \\
\text { relação com o Contraste } \\
\text { Cromático da sombra e a } \\
\text { sua Saliência produzida em } \\
\text { oposição aos corredores de } \\
\text { luz, registrados na nota de } \\
\text { rodapé } 246 .\end{array}$ & & \\
\hline $\begin{array}{l}\text { Na tela 'O Café Noturno na } \\
\text { Place Lamartine, em Arles', } \\
\text { observamos a ocorrência de } \\
\text { Saliência construída pelo } \\
\text { Vetor e pela posição } \\
\text { relativa do homem no } \\
\text { centro da sala e dos } \\
\text { bêbados nas mesas } \\
\text { periféricas, registrada na } \\
\text { nota de rodapé } 251 .\end{array}$ & & \\
\hline $\begin{array}{l}\text { Na tela 'O Café Noturno na } \\
\text { Place Lamartine, em Arles', } \\
\text { observamos a ocorrência de } \\
\text { Vetor e de Saliência sobre a } \\
\text { atitude do homem que se } \\
\text { contrapõe à apatia que } \\
\text { toma as outras figuras na } \\
\text { cena, registrado na nota de } \\
\text { rodapé } 253 \text {. }\end{array}$ & $\begin{array}{l}\text { Em todos os lugares é uma batalha e } \\
\text { uma antítese dos mais diferentes } \\
\text { verdes e vermelhos; nas personagens } \\
\text { dos rufiões adormecidos, pequenos } \\
\text { na alta sala vazia, algum roxo e azul. } \\
\text { O vermelho-sangue e o amarelo- } \\
\text { verde da mesa de bilhar, por } \\
\text { exemplo, contrasta com o pouco de } \\
\text { verde delicado Louis XV do balcão, } \\
\text { onde há um buquê rosa. } \\
\text { A roupa branca do proprietário, } \\
\text { vigiando as coisas a partir de um } \\
\text { canto deste forno, torna-se amarelo- } \\
\text { limão, verde luminoso pálido. }\end{array}$ & $\begin{array}{l}\text { O homem parado no centro da sala } \\
\text { do Café Lamartine, ao lado da mesa } \\
\text { de bilhar está olhando diretamente } \\
\text { para alguém que não se encontra } \\
\text { representado na cena. Este olhar } \\
\text { sugere uma ação vetorial, como em } \\
\text { uma oração com sujeito, processo, } \\
\text { mas sem uma meta. Encontramos a } \\
\text { ocorrência da representação escrita } \\
\text { dessa ação do homem parado } \\
\text { próximo à mesa de bilhar do Café da } \\
\text { Noite que olha diretamente para } \\
\text { alguém ou para algo. }\end{array}$ \\
\hline
\end{tabular}




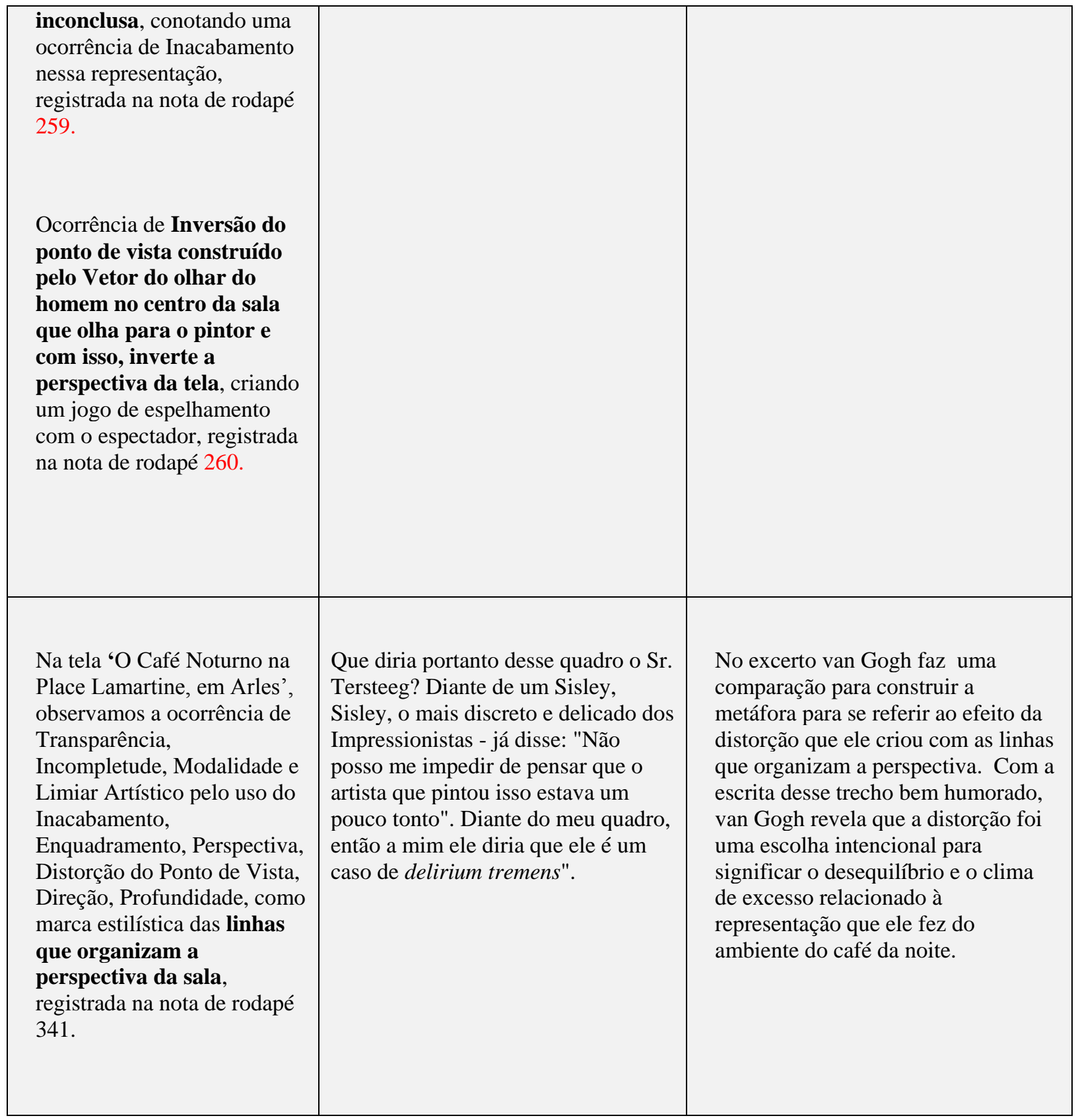

Fonte: Triangulação para Direção ou Vetor dos dados dos corpora visual e textual, com os extratos das cartas.

\subsection{TRIANGULAÇÃO DO ENQUADRAMENTO}

Quadro 70: Triangulação do Enquadramento

\begin{tabular}{|c|c|c|}
\hline Ocorrência nas telas & Orações & Comentário \\
\hline $\begin{array}{l}\text { Na tela 'Por de Sol: Campo } \\
\text { de trigo perto de Arles', } \\
\text { observamos o } \\
\text { Enquadramento aberto na } \\
\text { construção da composição, } \\
\text { como registrado nas notas de }\end{array}$ & $\begin{array}{l}\text { "Eu tenho um terceiro estudo, agora, } \\
\text { de uma paisagem com fábrica, e um } \\
\text { enorme sol em um céu vermelho, } \\
\underline{\text { acima de telhados vermelhos, em }} \\
\text { que a natureza parece estar em um } \\
\text { acesso de raiva, em um dia de }\end{array}$ & $\begin{array}{l}\text { O enquadramento aparece em } \\
\text { diferentes níveis. No nível da tela o } \\
\text { enquadramento se dá em relação à } \\
\text { paisagem. No do relato ele se dá na } \\
\text { relação do artista com a tela, que no } \\
\text { caso, van Gogh se refere à um estudo. }\end{array}$ \\
\hline
\end{tabular}




\begin{tabular}{|c|c|c|}
\hline $\begin{array}{l}\text { rodapé } 50 \text { e } 88 \text { na qual } \\
\text { observamos que o } \\
\text { Enquadramento produz um } \\
\text { sentido de Associação } \\
\text { Metafórica. A escolha do } \\
\text { enquadramento, no qual o } \\
\text { sol está se pondo para o } \\
\text { campo é uma escolha que } \\
\text { produz um sentido } \\
\text { metafórico relacionado ao } \\
\text { final de uma era do qual } \\
\text { van Gogh foi uma } \\
\text { testemunha ocular. }\end{array}$ & mistral desagradável." & $\begin{array}{l}\text { Em um exercício comparativo, } \\
\text { poderíamos imaginar o que o artista } \\
\text { tem quando ele olha para a paisagem? } \\
\text { E o que um olhar de fora um } \\
\text { observador tem ao ver o artista com a } \\
\text { obra. Van Gogh parece fazer um } \\
\text { esforço de se colocar no lugar do } \\
\text { irmão e descrever o que o irmão veria } \\
\text { se estivesse observando ele. Então van } \\
\text { Gogh descreve a paisagem na tela com } \\
\text { um duplo enquadramento: o } \\
\text { enquadramento do olhar do outro, no } \\
\text { caso Theo, em relação ao } \\
\text { enquadramento feito por ele, van } \\
\text { Gogh, sobre a paisagem. }\end{array}$ \\
\hline $\begin{array}{l}\text { Na tela 'Por de Sol: } \\
\text { Campo de trigo perto de } \\
\text { Arles', observamos a } \\
\text { ocorrência de } \\
\text { Enquadramento e } \\
\text { Associação Metafórica no } \\
\text { posicionamento do } \\
\text { homem, que constrói um } \\
\text { elemento de transição e } \\
\text { sugere a metáfora de que } \\
\text { este homem está vivendo } \\
\text { em um mundo em } \\
\text { transição, registrado na } \\
\text { nota de rodapé } 89 .\end{array}$ & & \\
\hline $\begin{array}{l}\text { Na tela 'Por de Sol: Campo } \\
\text { de trigo perto de Arles', } \\
\text { observamos que a ocorrência } \\
\text { de Enquadramento que } \\
\text { representa o homem em } \\
\text { plano aberto produz um } \\
\text { distanciamento do } \\
\text { espectador para observá-lo } \\
\text { de forma abstraída e } \\
\text { conceptual, registrado na } \\
\text { nota de rodapé } 91 .\end{array}$ & & \\
\hline $\begin{array}{l}\text { Observamos também que o } \\
\text { Enquadramento distancia } \\
\text { o homem e a cidade } \\
\text { tornando essa visão mais } \\
\text { reflexiva, e aproxima o } \\
\text { campo tornando essa } \\
\text { relação de proximidade e } \\
\text { envolvimento, registrado na }\end{array}$ & & \\
\hline
\end{tabular}




\begin{tabular}{|c|c|c|}
\hline nota de rodapé 108. & & \\
\hline $\begin{array}{l}\text { Na tela 'Por de Sol: Campo } \\
\text { de trigo perto de Arles', } \\
\text { observamos a ocorrência de } \\
\text { Enquadramento, pela } \\
\text { escolha do ponto de vista } \\
\text { que privilegia a } \\
\text { representação do campo } \\
\text { sobre a cidade e com isso, } \\
\text { constrói uma relação que } \\
\text { realça o valor do campo. } \\
\text { Observamos também a } \\
\text { ocorrência de Saliência e } \\
\text { Associação metafórica por } \\
\text { meio do enquadramento que } \\
\text { aproxima o campo e } \\
\text { distancia a cidade, registrado } \\
\text { na nota de rodapé } 107 \text { e } 114 \text {. }\end{array}$ & $\begin{array}{l}\text { Aqui está um esboço de um } \\
\text { semeador, um grande campo lavrado } \\
\text { com torrões de terra, na sua maioria } \\
\text { fracamente cor de violeta. }\end{array}$ & \\
\hline $\begin{array}{l}\text { Na tela 'Por de Sol: Campo } \\
\text { de trigo perto de Arles', } \\
\text { observamos a ocorrência de } \\
\text { Enquadramento, pelo uso do } \\
\text { ângulo vertical plongee para } \\
\text { representar a cena. Esta } \\
\text { escolha mostra a intenção de } \\
\text { construir um efeito de } \\
\text { sentido no espectador e } \\
\text { uma interação deste com o } \\
\text { posicionamento adotado } \\
\text { pelo pintor para retratar a } \\
\text { cena, registrado na nota de } \\
\text { rodapé } 57,110 \text { e } 112 \text {. }\end{array}$ & & $\begin{array}{l}\text { O ângulo vertical adotado pelo } \\
\text { plongee é predominantemente igual, } \\
\text { estabelecendo uma relação de } \\
\text { cumplicidade e igualdade com o } \\
\text { leitor, e não de distanciamento. } \\
\text { Talvez este distanciamento seja } \\
\text { configurado por outros recursos } \\
\text { semióticos, como por exemplo, o } \\
\text { fato de o imenso campo de trigo } \\
\text { estar em primeiro plano, saliente, } \\
\text { ocupando a maior parte da tela, e os } \\
\text { participantes representados estarem } \\
\text { em segundo plano, distanciados do } \\
\text { observador. }\end{array}$ \\
\hline $\begin{array}{l}\text { Na tela 'Por de Sol: Campo } \\
\text { de trigo perto de Arles', } \\
\text { observamos a ocorrência de } \\
\text { Enquadramento, pelo uso } \\
\text { do plano aberto para } \\
\text { representar a cena. }\end{array}$ & $\begin{array}{l}\text { Aqui está outra paisagem. Sol } \\
\text { poente? Lua nascendo? Noite de } \\
\text { verão, de qualquer modo. Cidade } \\
\text { violeta, estrela amarela, céu azul- } \\
\text { esverdeado; os campos de trigo têm } \\
\text { todos os tons: ouro velho, cobre, } \\
\text { ouro verde, ouro vermelho, ouro } \\
\text { amarelo, verde, vermelho e amarelo } \\
\text { bronze. Tela quadrada número } 30 .\end{array}$ & $\begin{array}{l}\text { Van Gogh escolhe um enquadramento } \\
\text { que valoriza o campo de trigo, o por de } \\
\text { sol, mas que apresenta em detalhes } \\
\text { outros elementos. Assim, podemos } \\
\text { perceber na descrição a proeminência } \\
\text { das cores. Os elementos visuais } \\
\text { (cidade, pessoas) parecem pretextos } \\
\text { para composição das cores em } \\
\text { contraste com o sol e o campo de trigo. } \\
\text { Não há dos elementos em si, tanto que } \\
\text { não importa se o astro representado é o } \\
\text { sol ou a lua, o que importa é seu } \\
\text { colorido na noite de verão. Todos eles } \\
\text { ganham um tom característico. O } \\
\text { enquadramento, tanto na tela quanto na } \\
\text { descrição da tela, parece ser das cores } \\
\text { e não de seus elementos individuais. } \\
\text { Tela e orações se complementam na }\end{array}$ \\
\hline
\end{tabular}




\begin{tabular}{|c|c|c|}
\hline & & $\begin{array}{l}\text { construção dos contrastes enquadrados } \\
\text { pelo artista. }\end{array}$ \\
\hline & $\begin{array}{l}\text { Tenho sete estudos de trigais, } \\
\text { infelizmente todos eles nada além de } \\
\text { paisagens, muito contra a minha } \\
\text { vontade. }\end{array}$ & \\
\hline & $\begin{array}{l}\text { Aqui está um esboço de um } \\
\text { semeador, um grande campo lavrado } \\
\text { com torrões de terra, na sua maioria } \\
\text { fracamente cor de violeta. }\end{array}$ & \\
\hline & $\begin{array}{l}\text { Um campo de trigo maduro, de tom } \\
\text { amarelo-ocre com um pouco de } \\
\text { carmim. }\end{array}$ & \\
\hline & $\underline{\text { Tamanho da tela }-25 \text {, quadrada. }}$ & \\
\hline & $\begin{array}{l}\text { Mas quando eu farei o céu estrelado, } \\
\text { então, essa pintura que está sempre } \\
\text { na minha mente? } \\
\text { Ai, ai, é como nosso excelente amigo } \\
\text { Cyprien diz, em 'En ménage' por JK } \\
\text { Huysmans: as mais belas pinturas } \\
\text { são aquelas que um sonha enquanto } \\
\text { fuma um cachimbo em sua cama, } \\
\text { mas a qual ele não pinta. }\end{array}$ & \\
\hline & $\begin{array}{l}\text { Aqui está o que eu queria dizer sobre } \\
\text { o branco e o preto. Vamos tomar o } \\
\text { Semeador. A pintura é dividida em } \\
\text { dois; metade é amarelo, o topo; a } \\
\text { base é violeta. Bem, as calças } \\
\text { brancas descansam os olhos e os } \\
\text { distraem exatamente quando o } \\
\text { contraste simultâneo excessivo de } \\
\text { amarelo e violeta iriam irritá-lo. Isso } \\
\text { é o que eu queria dizer. }\end{array}$ & \\
\hline & $\begin{array}{l}\text { Eu tive uma semana de concentrado } \\
\text { trabalho duro nos campos de trigo } \\
\text { debaixo do sol, o resultado foi de } \\
\text { alguns estudos de campos de trigo, } \\
\text { paisagens e - um esboço de um } \\
\text { semeador. }\end{array}$ & \\
\hline Na tela 'O Semeador', & & \\
\hline
\end{tabular}




\begin{tabular}{|c|c|c|}
\hline $\begin{array}{l}\text { observamos a ocorrência de } \\
\text { Perspectiva pelo uso de } \\
\text { vários recursos tais como } \\
\text { planos com ângulos de } \\
\text { Enquadramento } \\
\text { diferenciados, em forma de } \\
\text { cunhas que são sugeridas } \\
\text { pela Modulação Cromática } \\
\text { dos torrões de terra, } \\
\text { registrado na nota de rodapé } \\
122 .\end{array}$ & $\begin{array}{l}\text { E o esboço como tal - uma tela } \\
\text { número } 25 \text { - também me preocupa } \\
\text { muito, no sentido de que eu me } \\
\text { pergunto se eu não deveria levar a } \\
\text { sério e fazer uma pintura tremenda } \\
\text { disso. Meu Deus, como eu adoraria } \\
\text { fazer isso. Mas eu só me pergunto se } \\
\text { eu vou ter o poder necessário de } \\
\text { execução. }\end{array}$ & $\begin{array}{l}\text { O enquadramento da tela valoriza o } \\
\text { campo, o horizonte e o semeador. Qual } \\
\text { é o enquadramento feito por van } \\
\text { Gogh? Nesta tela van Gogh parece ter } \\
\text { enquadrado não o semeador, mas a } \\
\text { semeadura, a terra arada pronta para } \\
\text { ser semeada, o ato do semeador sobre } \\
\text { a terra, e o resultado da semeadura no } \\
\text { campo maduro no horizonte. O } \\
\text { processo é enquadrado, a valorização } \\
\text { da luz do sol sobre o campo de trigo, } \\
\text { sobre a terra e o semeador, este como } \\
\text { mais um elemento no processo do que } \\
\text { tendo proeminência em relação aos } \\
\text { demais elementos. }\end{array}$ \\
\hline & $\begin{array}{l}\text { Então, eu estou quase com medo } \\
\text { deles. E, no entanto, depois de Millet } \\
\text { e Lhermitte o que resta a ser feito é } \\
\text { ‥ o semeador, com cor e em um } \\
\text { grande formato. }\end{array}$ & \\
\hline $\begin{array}{l}\text { Na tela 'A Esplanada do } \\
\text { Café na Place du Forum, } \\
\text { Arles, à Noite', observamos } \\
\text { a ocorrência de } \\
\text { Enquadramento, Perspectiva } \\
\text { e Profundidade construída } \\
\text { por linhas diagonais que } \\
\text { convergem no centro e } \\
\text { dividem a tela em quatro } \\
\text { seções. As quatro linhas } \\
\text { diagonais que conduzem o } \\
\text { olhar para dentro da tela, } \\
\text { registrado na nota de rodapé } \\
177 \text {. }\end{array}$ & $\begin{array}{l}\text { Essa é a primeira pintura esta } \\
\text { semana. A segunda mostra o exterior } \\
\text { de um café, iluminado no terraço } \\
\text { externo por uma grande lâmpada de } \\
\text { gás dentro da noite azul, com um } \\
\text { retalho de céu azul estrelado. }\end{array}$ & $\begin{array}{l}\text { O café, o terraço, a lâmpada e o céu } \\
\text { estão dentro da noite. Todos os } \\
\text { elementos convergem para representar } \\
\text { um sentido único, a noite sem preto. O } \\
\text { enquadramento valoriza a } \\
\text { luminosidade da lâmpada a gás e do } \\
\text { céu estrelado. Ambos trabalhando para } \\
\text { gerar os contrastes que darão unidade } \\
\text { entre luz e sombra. O enquadramento } \\
\text { cerca diferentes elementos desta noite, } \\
\text { valorizando como cada um se } \\
\text { comporta diante da luz da lâmpada e } \\
\text { do céu azul estrelado. }\end{array}$ \\
\hline & $\begin{array}{l}\text { Agora há uma pintura de noite sem } \\
\text { preto. Com nada mais do que um } \\
\text { belo azul e violeta e verde e nestes } \\
\text { arredores da praça iluminada é } \\
\text { colorido por enxofre pálido, amarelo } \\
\text { limão. Eu gosto enormemente de } \\
\text { pintar no local à noite. No passado, } \\
\text { eles costumavam desenhar e pintar a } \\
\text { tela do desenho durante o dia. Mas } \\
\text { acho que me convém pintar a coisa } \\
\text { no momento. }\end{array}$ & \\
\hline
\end{tabular}




\begin{tabular}{|c|c|c|}
\hline & $\begin{array}{l}\text { Eu também fiz um novo retrato de } \\
\text { mim mesmo, como um estudo, no } \\
\text { qual eu pareço um Japonês. Você } \\
\text { nunca me disse se você tinha lido } \\
\text { Bel-ami de Guy de Maupassant, e o } \\
\text { que você pensa agora do talento dele } \\
\text { em geral. Digo isto porque o início } \\
\text { de Bel- Ami é precisamente a } \\
\text { descrição de uma noite estrelada em } \\
\text { Paris, com os cafés iluminados da } \\
\text { avenida, e isso é algo como o mesmo } \\
\text { tema que eu pintei bem agora. }\end{array}$ & \\
\hline \multicolumn{3}{|l|}{$\begin{array}{l}\text { Na tela 'A Esplanada do } \\
\text { Café na Place du Forum, } \\
\text { Arles, à Noite', observamos } \\
\text { a ocorrência de } \\
\text { Transparência e } \\
\text { Enquadramento, por meio de } \\
\text { Vetor e Perspectiva } \\
\text { invertida, que é observada } \\
\text { na composição de outras } \\
\text { telas, registradas na nota de } \\
\text { rodapé } 210 .\end{array}$} \\
\hline \multirow[t]{3}{*}{$\begin{array}{l}\text { Na tela 'A Esplanada do } \\
\text { Café na Place du Forum, } \\
\text { Arles, à Noite', observamos } \\
\text { a ocorrência de } \\
\text { Enquadramento construída } \\
\text { pela representação da } \\
\text { árvore pela metade está em } \\
\text { contraposição com uma } \\
\text { representação muito } \\
\text { detalhada para um } \\
\text { membro que está no } \\
\text { segundo plano, registrada na } \\
\text { nota de rodapé } 202 .\end{array}$} & & \\
\hline & $\begin{array}{l}\text { Muitas vezes parece-me que a noite } \\
\text { é muito mais viva e ricamente } \\
\text { colorida do que o dia. Agora como } \\
\text { para recuperar o dinheiro pago ao } \\
\text { senhorio através da minha pintura, } \\
\text { eu não estou fazendo questão disto, } \\
\text { porque a pintura é uma das mais } \\
\text { feias que eu já fiz. É o equivalente, } \\
\text { embora diferente, dos comedores de } \\
\text { batata. }\end{array}$ & \\
\hline & $\begin{array}{l}\text { Eu tentei expressar as terríveis } \\
\text { paixões humanas com o vermelho e } \\
\text { o verde. }\end{array}$ & \\
\hline
\end{tabular}




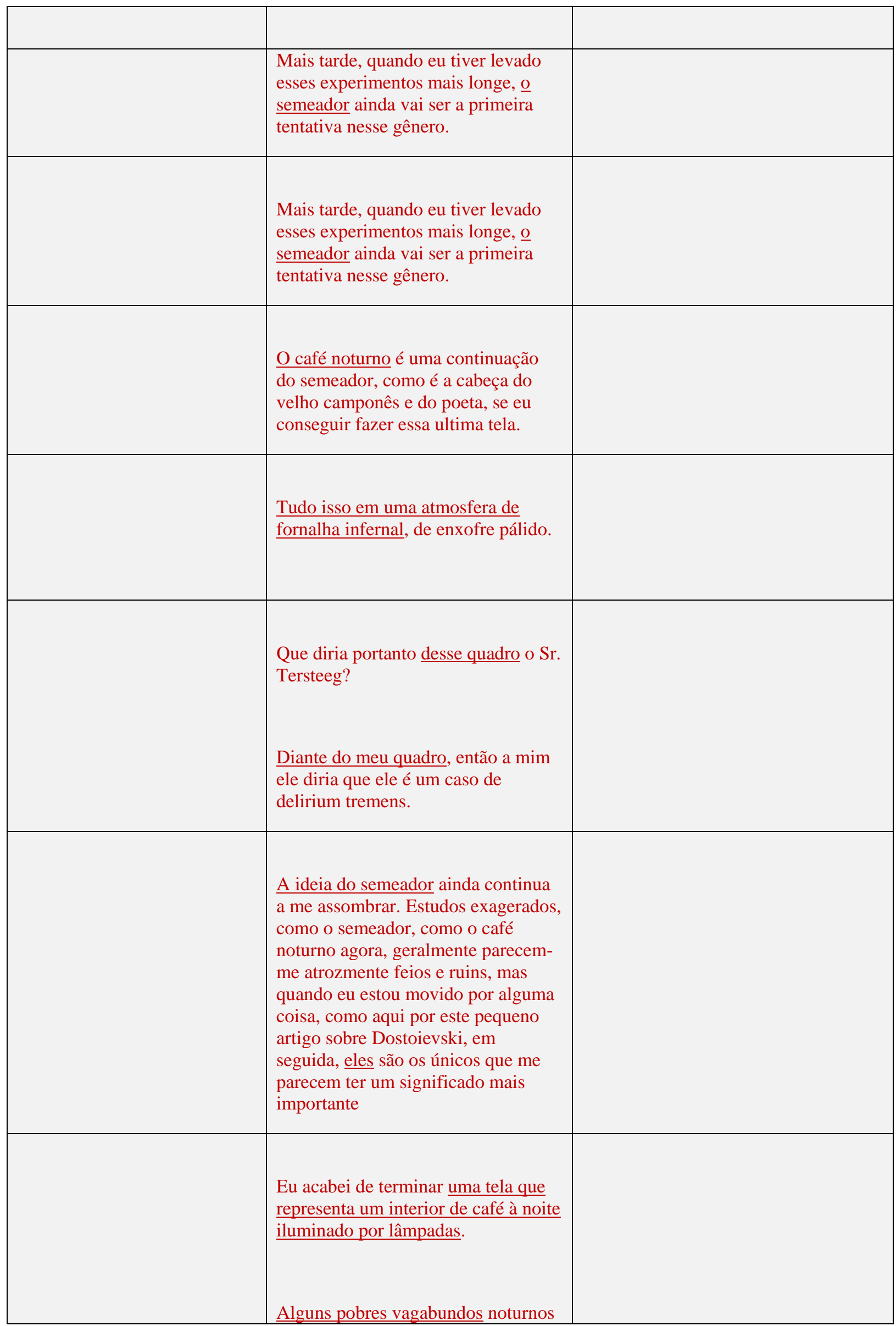




\begin{tabular}{|c|c|c|}
\hline & $\begin{array}{l}\text { estão dormindo em um canto. A sala } \\
\text { está pintada de vermelho, e no } \\
\text { interior, na luz a gás, a mesa de } \\
\text { bilhar verde, a qual lança uma } \\
\text { imensa sombra sobre o chão. Nesta } \\
\text { tela, há } 6 \text { ou } 7 \text { vermelhos diferentes, } \\
\text { desde vermelho-sangue até rosa } \\
\text { delicado, fazendo oposição com o } \\
\text { mesmo número de verdes pálidos ou } \\
\text { escuros. }\end{array}$ & \\
\hline $\begin{array}{l}\text { Na tela ‘O Café Noturno na } \\
\text { Place Lamartine, em Arles', } \\
\text { observamos que van Gogh } \\
\text { usou no ângulo aberto para } \\
\text { representar o interior do } \\
\text { café. } \\
\text { Ocorrência de } \\
\text { Enquadramento que } \\
\text { interagem com a Perspectiva } \\
\text { e a Profundidade presentes } \\
\text { na divisão dos planos no } \\
\text { espaço composicional, } \\
\text { registrada na nota de rodapé } \\
\text { 214. }\end{array}$ & $\begin{array}{l}\text { Ângulo aberto: } \\
\text { A sala é vermelho-sangue e amarelo } \\
\text { sem graça, uma mesa de bilhar verde } \\
\text { no centro, } 4 \text { lâmpadas de amarelo } \\
\text { limão com um brilho laranja e } \\
\text { verde. } \\
\text { Em todos os lugares é uma batalha e } \\
\text { uma antítese dos mais diferentes } \\
\text { verdes e vermelhos; nas personagens } \\
\text { dos rufiões adormecidos, pequenos } \\
\text { na alta sala vazia, algum roxo e azul. }\end{array}$ & $\begin{array}{l}\text { A descrição valoriza o ângulo aberto } \\
\text { usado na produção da tela do interior } \\
\text { de um 'Café Noturno'. A sala e a mesa } \\
\text { de bilhar são contrastantes, o } \\
\text { enquadramento é feito na antítese das } \\
\text { cores em uma grande sala vazia. } \\
\text { Vazia? Van Gogh pincela pequenos } \\
\text { personagens, insignificantes diante da } \\
\text { amplidão de uma sala cuja lâmpada } \\
\text { projeta uma luz incapacitante, } \\
\text { devastadora sobre as pequenas } \\
\text { personagens paralisadas. } \\
\text { Ou seja, as cores e sua relação de } \\
\text { contraposição e tensão delimitam o } \\
\text { espaço do recinto e condicionam } \\
\text { tudo nela à essa percepção de } \\
\text { intensidade, de densidade não } \\
\text { apenas de seu cromatismo individual } \\
\text { que por si só já é intenso, mas } \\
\text { também pela relação de tensão e de } \\
\text { contraposição causada pelo seu } \\
\text { contraste mútuo. O contraste } \\
\text { cromático na tela Café da Noite } \\
\text { cumpre com o papel de desconectar } \\
\text { dois mundos ou sentimentos } \\
\text { opostos, exprimindo esta dicotomia } \\
\text { tensa e conflituosa dos sentidos que } \\
\text { ele quis comunicar. }\end{array}$ \\
\hline $\begin{array}{l}\text { Na tela 'O Café Noturno na } \\
\text { Place Lamartine, em Arles', } \\
\text { observamos a ocorrência de } \\
\text { Distorção do Ponto de } \\
\text { Vista, criada com a interação } \\
\text { do uso de Enquadramento, } \\
\text { Perspectiva e Profundidade, } \\
\text { registrado na nota de rodapé } \\
215 .\end{array}$ & & \\
\hline $\begin{array}{l}\text { Na tela 'O Café Noturno na } \\
\text { Place Lamartine, em Arles', } \\
\text { observamos a ocorrência de }\end{array}$ & & \\
\hline
\end{tabular}




\begin{tabular}{|c|c|c|}
\hline $\begin{array}{l}\text { ocorrência de Distorção do } \\
\text { Ponto de Vista, } \\
\text { Inacabamento e } \\
\text { Incompletude, construídas } \\
\text { com ajuda da perspectiva, } \\
\text { profundidade e } \\
\text { enquadramento na } \\
\text { representação das linhas de } \\
\text { perspectiva distorcidas, } \\
\text { registrada na nota de rodapé } \\
227 .\end{array}$ & & \\
\hline $\begin{array}{l}\text { Na tela 'O Café Noturno na } \\
\text { Place Lamartine, em Arles', } \\
\text { observamos a ocorrência de } \\
\text { Enquadramento, } \\
\text { Inacabamento, Perspectiva e } \\
\text { Distorção do Ponto de vista. } \\
\text { As cadeiras no primeiro } \\
\text { plano foram representadas } \\
\text { parcialmente e não tem uma } \\
\text { proporção e um alinhamento } \\
\text { compatível com as } \\
\text { perspectiva das tábuas no } \\
\text { chão, registrada na nota de } \\
\text { rodapé } 216 .\end{array}$ & & $\begin{array}{l}\text { Foi observado um sentido de } \\
\text { movimentação conferida aos objetos } \\
\text { inanimados em contraposição à } \\
\text { paralisia das figuras humanas na tela } \\
\text { que endossa a disposição } \\
\text { desorganizada e oblíqua das cadeiras, } \\
\text { transmitindo a sensação de que a } \\
\text { presença, o fulgor e a movimentação } \\
\text { de pessoas ali naquele espaço ainda } \\
\text { estivessem presentes, quentes, embora } \\
\text { elas já tenham ido embora daquele } \\
\text { local que é reforçado pela ocorrência } \\
\text { de vetores projetados pelas cadeiras. }\end{array}$ \\
\hline & 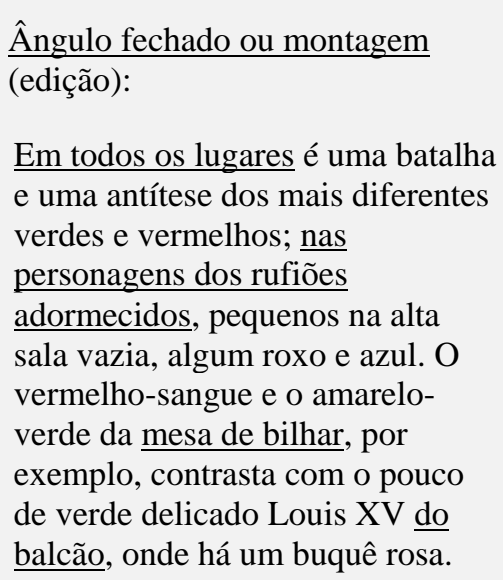 & $\begin{array}{l}\text { Sequência de pequenos close-ups } \\
\text { compatível com a edição } \\
\text { cinematográfica, ou montagem } \\
\text { sequencial de imagens para construir a } \\
\text { narrativa visual por meio da descrição } \\
\text { seccionada de diferentes ângulos de } \\
\text { tomada da cena para apresentar os } \\
\text { detalhes da tela. }\end{array}$ \\
\hline $\begin{array}{l}\text { Na tela 'O Café Noturno } \\
\text { na Place Lamartine, em } \\
\text { Arles', Ocorrência de } \\
\text { Inversão do Ponto de } \\
\text { vista, construída pelo } \\
\text { Vetor, dado pelo homem } \\
\text { no centro da sala que }\end{array}$ & & \\
\hline
\end{tabular}




\begin{tabular}{|c|c|c|}
\hline $\begin{array}{l}\text { olha para o espectador. } \\
\text { A seta, criada pela } \\
\text { sombra da mesa se } \\
\text { encarrega de levar a } \\
\text { atenção do espectador } \\
\text { para aquele ponto desde } \\
\text { o qual se olha a cena. } \\
\text { Esse sentido constrói uma } \\
\text { inversão e um } \\
\text { deslocamento no } \\
\text { Enquadramento e na } \\
\text { Perspectiva que vai desde } \\
\text { o envolvimento até o } \\
\text { distanciamento para se } \\
\text { olhar a cena, registrados } \\
\text { na nota de rodapé } 242 \text {. }\end{array}$ & & \\
\hline $\begin{array}{l}\text { Na tela 'O Café Noturno na } \\
\text { Place Lamartine, em Arles', } \\
\text { observamos a ocorrência de } \\
\text { Associação metafórica, } \\
\text { Enquadramento, Perspectiva } \\
\text { e Incompletude por meio do } \\
\text { sentido de Contraposição } \\
\text { entre centro/periferia, } \\
\text { olhar/não olhar, } \\
\text { ativo/apático construído } \\
\text { pela posição relativa das } \\
\text { figuras, registrada na nota } \\
\text { de rodapé } 302 \text {. }\end{array}$ & & \\
\hline $\begin{array}{l}\text { Na tela 'O Café Noturno na } \\
\text { Place Lamartine, em Arles', } \\
\text { observamos a ocorrência de } \\
\text { Enquadramento, Perspectiva, } \\
\text { Ritmo, Movimento por meio } \\
\text { de Contraposições e de } \\
\text { Inversão de sentido ao } \\
\text { colocar movimento em } \\
\text { objetos inanimados e } \\
\text { paralisia em figuras } \\
\text { humanas, registrada na nota } \\
\text { de rodapé } 310 \text {. }\end{array}$ & & $\begin{array}{l}\text { Observamos também essa ocorrência } \\
\text { no discurso escrito, por exemplo, } \\
\text { procuramos por 'o que é vazio está no } \\
\text { centro e tem destaque', }\end{array}$ \\
\hline $\begin{array}{l}\text { Na tela 'O Café Noturno na } \\
\text { Place Lamartine, em Arles', } \\
\text { observamos a ocorrência de } \\
\text { Enquadramento e } \\
\text { Perspectiva para construir } \\
\text { um distanciamento das } \\
\text { figuras representadas, }\end{array}$ & $\begin{array}{l}\text { Na minha pintura do café à noite eu } \\
\text { procurei exprimir que o café é um } \\
\text { lugar onde você pode arruinar-se, } \\
\text { enlouquecer, cometer crimes. }\end{array}$ & $\begin{array}{l}\text { O enquadramento é da força da sala, } \\
\text { da força da luz e da fraqueza dos } \\
\text { demais elementos diante dessa } \\
\text { condição inefável do café. O ângulo } \\
\text { aberto que valoriza a amplitude da sala } \\
\text { e a incidência da luz parece minimizar } \\
\text { a ação das personagens. Na oração fica }\end{array}$ \\
\hline
\end{tabular}




\begin{tabular}{|c|c|}
\hline $\begin{array}{l}\text { como que para diminuir } \\
\text { sua importância na cena, } \\
\text { registrada na nota de rodapé } \\
333 \text {. }\end{array}$ & $\begin{array}{l}\text { ainda mais evidente a construção do } \\
\text { café como um lugar opressivo, } \\
\text { sufocante, capaz de evidenciar } \\
\text { aspectos sombrios da natureza } \\
\text { humana. }\end{array}$ \\
\hline $\begin{array}{l}\text { Na tela 'O Café Noturno na } \\
\text { Place Lamartine, em Arles', } \\
\text { observamos a ocorrência de } \\
\text { Associação metafórica } \\
\text { construída pelo } \\
\text { Enquadramento e posição } \\
\text { relativa das figuras no } \\
\text { espaço compositivo. O } \\
\text { proprietário tem a posição } \\
\text { central, os vagabundos da } \\
\text { noite têm uma posição } \\
\text { periférica na tela, registrada } \\
\text { na nota de rodapé } 336 .\end{array}$ & \\
\hline $\begin{array}{l}\text { Na tela 'O Café Noturno na } \\
\text { Place Lamartine, em Arles', } \\
\text { observamos a ocorrência de } \\
\text { Associações metafóricas, } \\
\text { Saliência, Incompletude } \\
\text { construída pelo } \\
\text { Enquadramento das } \\
\text { cadeiras vazias no primeiro } \\
\text { plano que instanciam uma } \\
\text { representação simbólica } \\
\text { para a transitoriedade e a } \\
\text { impermanência das pessoas } \\
\text { no café, registrada na nota } \\
\text { de rodapé } 338 \text {. }\end{array}$ & $\begin{array}{l}\text { Foi observado um sentido de } \\
\text { movimentação conferida aos objetos } \\
\text { inanimados em contraposição à } \\
\text { paralisia das figuras humanas na tela } \\
\text { que endossa a disposição } \\
\text { desorganizada e oblíqua das cadeiras, } \\
\text { transmitindo a sensação de que a } \\
\text { presença, o fulgor e a movimentação } \\
\text { de pessoas ali naquele espaço ainda } \\
\text { estivessem presentes, quentes, embora } \\
\text { elas já tenham ido embora daquele } \\
\text { local que é reforçado pela ocorrência } \\
\text { de vetores projetados pelas cadeiras. }\end{array}$ \\
\hline $\begin{array}{l}\text { Na tela ‘O Café Noturno na } \\
\text { Place Lamartine, em Arles', } \\
\text { observamos a ocorrência de } \\
\text { Distorção do Ponto de } \\
\text { Vista construída com } \\
\text { Enquadramento, Perspectiva } \\
\text { e Profundidade em um } \\
\text { ângulo de enquadramento } \\
\text { levemente plongee, como se } \\
\text { van Gogh estivesse pairando } \\
\text { acima do nível do chão, } \\
\text { registrada na nota de rodapé } \\
339 \text {. }\end{array}$ & \\
\hline
\end{tabular}


Na tela 'O Café Noturno na Place Lamartine, em Arles', observamos a ocorrência de Associação metafórica,

Transparência, Incompletude e Limiar Artístico, com o uso do Enquadramento,

Perspectiva, Profundidade, Distorção do Ponto de Vista, levemente plongee para 0 sentido do lugar social com o qual van Gogh se

identifica, registrada na nota de rodapé 340.

Na tela 'O Café Noturno na Place Lamartine, em Arles', observamos a ocorrência de Transparência,

Incompletude, Modalidade e Limiar Artístico pelo uso do Inacabamento,

Enquadramento, Perspectiva, Distorção do Ponto de Vista, Direção, Profundidade, como marca estilística das linhas que organizam a perspectiva da sala, registrada na nota de rodapé 341.

Na tela 'O Café Noturno na Place Lamartine, em Arles', observamos a ocorrência de Associação metafórica com a ajuda de Vetor, Perspectiva, Enquadramento e Saliência na representação do casal no fundo da sala, registrada na nota de rodapé 342 .

Fonte: Triangulação para Enquadramento dos dados dos corpora visual e textual, com os extratos das cartas 


\subsection{TRIANGULAÇÃO DA PERSPECTIVA}

Quadro 71: Triangulação da Perspectiva

\begin{tabular}{|c|c|c|}
\hline Ocorrência nas telas & Orações & Comentário \\
\hline $\begin{array}{l}\text { Na tela 'Por de Sol: Campo de } \\
\text { trigo perto de Arles', } \\
\text { observamos o uso de } \\
\text { perspectiva registrado na nota } \\
\text { de rodapé } 45.51,52,54 \text {. }\end{array}$ & $\begin{array}{l}\text { "Aqui está outra paisagem. Sol } \\
\text { poente? Lua nascendo? Noite de } \\
\text { verão, de qualquer modo. Cidade } \\
\text { violeta, estrela amarela, céu azul- } \\
\text { esverdeado; os campos de trigo têm } \\
\text { todos os tons: ouro velho, cobre, } \\
\text { ouro verde, ouro vermelho, ouro } \\
\text { amarelo, verde, vermelho e amarelo } \\
\text { bronze. Tela quadrada número } 30 \text {. }\end{array}$ & $\begin{array}{l}\text { A perspectiva no texto é criada por } \\
\text { meio de um processo existencial que } \\
\text { abre a sequência e coloca à uma certa } \\
\text { distância da cena. Em seguida, há um } \\
\text { grupo de orações sem o agente da } \\
\text { ação, seguidos por um novo processo } \\
\text { relacional atributivo que é empregado } \\
\text { para descrever, qualificar e envolver o } \\
\text { leitor na cena descrita. O leitor, agora, } \\
\text { está “dentro da cena". Inferimos que o } \\
\text { uso da perspectiva está fortemente } \\
\text { relacionado com a função Modal. }\end{array}$ \\
\hline $\begin{array}{l}\text { A perspectiva nesta tela é } \\
\text { construída por uma } \\
\text { combinação de recursos } \\
\text { semióticos tais como: as } \\
\text { cunhas, a gradação nas } \\
\text { tonalidades de amarelo, a } \\
\text { profundidade obtida pela } \\
\text { gradação de contrastes de } \\
\text { claro e escuro no céu, os } \\
\text { pontos de fuga na distância, } \\
\text { o enquadramento } \\
\text { levemente plongee que } \\
\text { além de contribuir para a } \\
\text { construção da } \\
\text { profundidade e da } \\
\text { perspectiva, também } \\
\text { contribui para a distorção } \\
\text { do ponto de vista. }\end{array}$ & $\begin{array}{l}\text { Eu tenho um terceiro estudo, } \\
\text { agora, de uma paisagem com } \\
\text { fábrica, e um enorme sol em um } \\
\text { céu vermelho, acima de telhados } \\
\text { vermelhos, em que a natureza } \\
\text { parece estar em um acesso de } \\
\text { raiva, em um dia de mistral } \\
\text { desagradável. }\end{array}$ & $\begin{array}{l}\text { Inferimos que o uso do ângulo } \\
\text { vertical plongee tem a função de } \\
\text { criar um distanciamento do } \\
\text { espectador. } \\
\text { Na nota de rodapé 64, observamos } \\
\text { que há um deslocamento na } \\
\text { construção do ponto de vista da } \\
\text { oração, que causa um } \\
\text { distanciamento do ponto de vista do } \\
\text { leitor, pode ser compatível com o } \\
\text { uso do ângulo plongee no texto } \\
\text { visual, também usado com a função } \\
\text { de causar um distanciamento no } \\
\text { espectador. Aqui vemos um tipo de } \\
\text { compatibilidade de função, não de } \\
\text { forma ou de sentido. }\end{array}$ \\
\hline $\begin{array}{l}\text { Na tela 'Por de Sol: } \\
\text { Campo de trigo perto de }\end{array}$ & & $\begin{array}{l}\text { Observamos também na análise dos } \\
\text { excertos das cartas uma alternância }\end{array}$ \\
\hline
\end{tabular}




\begin{tabular}{|c|c|c|}
\hline $\begin{array}{l}\text { Arles', observamos a } \\
\text { ocorrência de um uso } \\
\text { original semiótico: a } \\
\text { inversão do ponto de } \\
\text { fuga, trazendo para o } \\
\text { plano do espectador, o } \\
\text { foco com que olhar a } \\
\text { perspectiva e levando-o a } \\
\text { se identificar } \\
\text { inevitavelmente com o } \\
\text { lugar do experienciador } \\
\text { da tela, o artista. Este é } \\
\text { um uso original de } \\
\text { perspectiva para construir } \\
\text { a distorção do ponto de } \\
\text { vista que caracteriza o } \\
\text { sistema semiótico de van } \\
\text { Gogh. Esta ocorrência está } \\
\text { registrada na nota de } \\
\text { rodapé } 55 \text {. }\end{array}$ & & $\begin{array}{l}\text { na representação de si próprio dentro } \\
\text { da oração. Assim como na tela, ele } \\
\text { se faz presente indiretamente por } \\
\text { meio de recursos semióticos } \\
\text { indexadores de sua presença, nas } \\
\text { orações ele procurou muitas vezes } \\
\text { o apagamento de sua presença } \\
\text { para representar na oração } \\
\text { apenas os assuntos da tela, dando } \\
\text { a voz ativa para a tela e seus } \\
\text { elementos representados, } \\
\text { enquanto em outras orações ele se } \\
\text { representou como o agente da } \\
\text { ação. Esta ocorrência de distorção } \\
\text { da perspectiva pela alternância do } \\
\text { apagamento do agente ou } \\
\text { participante principal dentro da } \\
\text { oração está documentada na nota de } \\
\text { rodapé } 56 \text { e também documentado } \\
\text { na análise do corpus textual. }\end{array}$ \\
\hline $\begin{array}{l}\text { Na tela 'O Semeador', } \\
\text { observamos a ocorrência de } \\
\text { Enquadramento, Saliência, } \\
\text { Vetor para construir a } \\
\text { centralidade do campo na } \\
\text { narrativa, e o sentido } \\
\text { principal do enunciado que é } \\
\text { o de receber a semeadura } \\
\text { do semeador. Observamos } \\
\text { um deslocamento da } \\
\text { agência da ação que é } \\
\text { compatível com as } \\
\text { ocorrências de } \\
\text { deslocamento da agência } \\
\text { da ação nas orações escritas } \\
\text { por van Gogh, registrado na } \\
\text { nota de rodapé } 163 \text {. }\end{array}$ & $\begin{array}{l}\text { Em um campo arado, um grande } \\
\text { campo de torrões de terra roxa - } \\
\text { levantados em direção ao horizonte - } \\
\text { um semeador em azul e branco. No } \\
\text { horizonte um campo de trigo curto, } \\
\text { maduro. } \\
\text { Acima de tudo isso um céu amarelo } \\
\text { com um sol amarelo. }\end{array}$ & $\begin{array}{l}\text { Van Gogh parece antecipar que o } \\
\text { observador ficará surpreendido com } \\
\text { o fato de que dois terços da tela são } \\
\text { ocupados pelo campo arado assim } \\
\text { como a evidente direção do olhar } \\
\text { para o horizonte. Nessa perspectiva } \\
\text { há um distanciamento em relação ao } \\
\text { campo de trigo maduro. Como se } \\
\text { não bastasse, no espaço ocupado } \\
\text { pelo campo, acima e distante deles } \\
\text { talvez em um sentido concreto } \\
\text { material da tela, mas também num } \\
\text { sentido metafórico, estão o sol e o } \\
\text { céu. }\end{array}$ \\
\hline $\begin{array}{l}\text { Na tela 'O Semeador', a } \\
\text { profundidade visual é } \\
\text { construída pela divisão do } \\
\text { espaço em planos, e pela } \\
\text { gradação cromática das } \\
\text { tonalidades de azuis do } \\
\text { campo. Ela também é } \\
\text { construída com a ajuda da } \\
\text { perspectiva, dada pelos } \\
\text { caminhos visuais no campo } \\
\text { arado, como registrado na } \\
\text { nota de rodapé } 121 .\end{array}$ & & \\
\hline A Perspectiva e & & \\
\hline
\end{tabular}




\begin{tabular}{|c|c|c|}
\hline $\begin{array}{l}\text { Profundidade também são } \\
\text { construídas por caminhos } \\
\text { visuais conferidos pelo } \\
\text { agrupamento de membros } \\
\text { como o caminho de terra, } \\
\text { os corvos e a casa, } \\
\text { registradas na nota de rodapé } \\
123 .\end{array}$ & & \\
\hline $\begin{array}{l}\text { Na tela 'O semeador' a } \\
\text { perspectiva faz com que } \\
\text { nos desloquemos para a } \\
\text { distância da tela, deste } \\
\text { um ponto muito próximo } \\
\text { onde se encontram os } \\
\text { torrões arados até o } \\
\text { campo maduro e a casa, } \\
\text { bem ao longe. O uso do } \\
\text { plongee, registrado na nota } \\
\text { de rodapé } 71, \text { faz a função } \\
\text { contrária de } \\
\text { distanciamento do } \\
\text { espectador, enquanto } \\
\text { outros recursos de } \\
\text { profundidade, } \\
\text { enquadramento e } \\
\text { perspectiva, trabalham } \\
\text { para colocá-lo dentro da } \\
\text { cena representada. }\end{array}$ & $\begin{array}{l}\text { A pintura é dividida em dois; } \\
\text { metade é amarelo, o topo; a base é } \\
\text { violeta. Bem, as calças brancas } \\
\text { descansam os olhos e os distraem } \\
\text { exatamente quando o contraste } \\
\underline{\text { simultâneo excessivo de amarelo e }} \\
\text { violeta iriam irritá-lo. Isso é o que } \\
\text { eu queria dizer. }\end{array}$ & $\begin{array}{l}\text { Deslocamento da perspectiva: dentro e } \\
\text { fora da tela. Nessa sequência de } \\
\text { orações evidenciamos novamente um } \\
\text { deslocamento na perspectiva que } \\
\text { inicia 'dentro' da tela por meio de } \\
\text { processos relacionais para construir a } \\
\text { descrição das cores. Em seguida, ele } \\
\text { descreve a relação do branco da calça } \\
\text { que distrai os olhos e da irritação } \\
\text { causada pelo efeito do contraste } \\
\text { complementar violeta amarelo. Na } \\
\text { próxima oração, ele 'tira' o leitor de } \\
\text { dentro do universo representado } \\
\text { iniciando uma oração na qual ele traz } \\
\text { a atenção para si e para a sua intenção } \\
\text { ao narrar a cena. }\end{array}$ \\
\hline $\begin{array}{l}\text { Na tela 'O Semeador', } \\
\text { observamos a ocorrência de } \\
\text { Perspectiva pelo uso de } \\
\text { vários recursos tais como } \\
\text { planos com ângulos de } \\
\text { enquadramento } \\
\text { diferenciados, em forma de } \\
\text { cunhas que são sugeridas } \\
\text { pela modulação cromática } \\
\text { dos torrões de terra, } \\
\text { registrado na nota de rodapé } \\
122 .\end{array}$ & 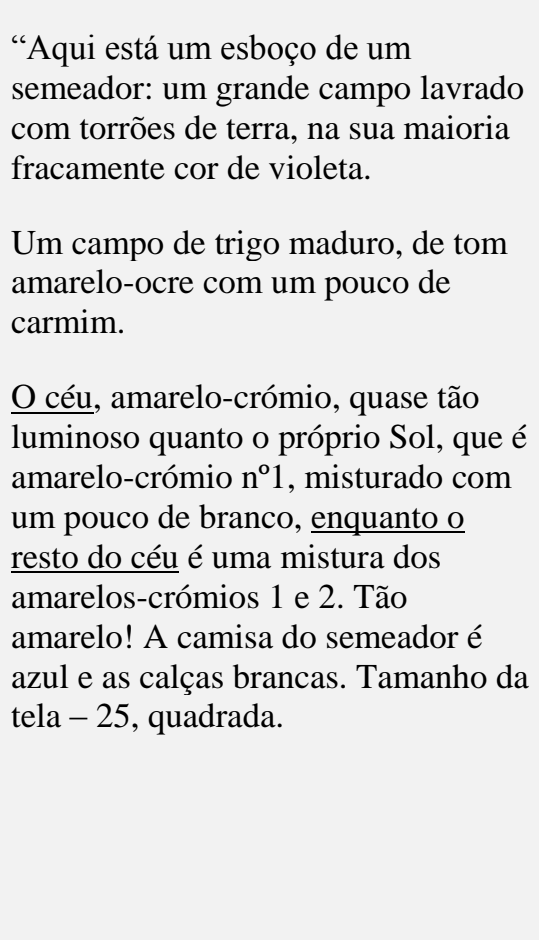 & $\begin{array}{l}\text { Deslocamento da perspectiva: dentro e } \\
\text { fora da tela. A carta é um gênero } \\
\text { narrativo. No primeiro momento ele } \\
\text { narra o quadro: 'Aqui está um } \\
\text { esboço..' por meio de processos } \\
\text { relacionais atributivos. O atributo está } \\
\text { em relação ao que está na tela. } \\
\text { No segundo momento ele está } \\
\text { comentando sobre a tela: 'Há } \\
\text { sugestões (...) Preferia muito mais } \\
\text { fazer', ele começa a explicar a tela, o } \\
\text { que ele fez, o que ele sente em relação } \\
\text { a tela. Ele passa a falar de si mesmo. } \\
\text { Observamos pela mudança na estrutura } \\
\text { léxico-gramatical, já com complexos } \\
\text { oracionais. Quando ele usa o processo } \\
\text { relacional atributivo, ele está falando } \\
\text { da tela que são diferentes dos } \\
\text { processos usados quando fala de si } \\
\text { mesmo. A perspectiva com que ele } \\
\text { narra a tela no primeiro parágrafo, } \\
\text { muda no segundo parágrafo. No }\end{array}$ \\
\hline
\end{tabular}




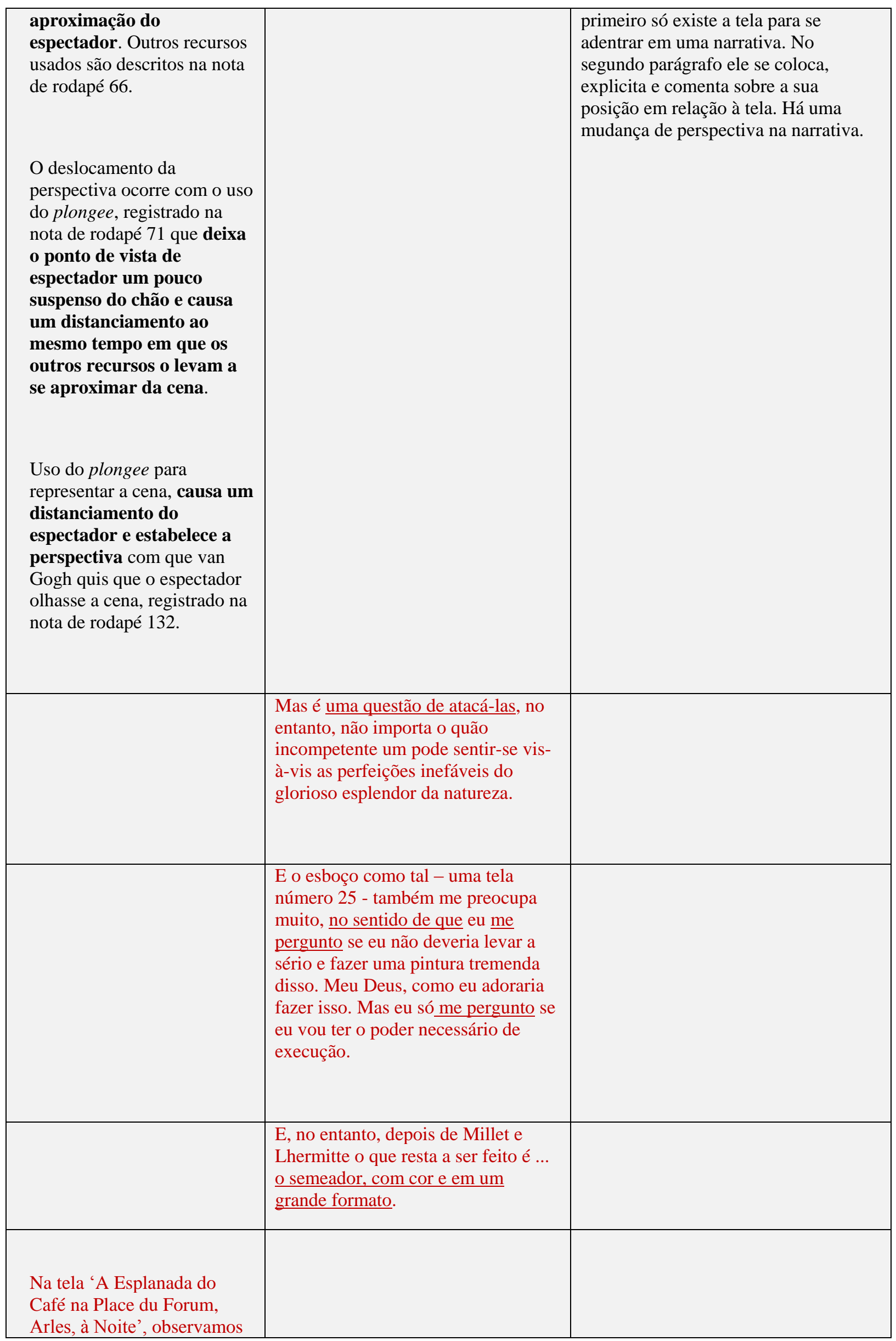




\begin{tabular}{|c|c|c|}
\hline $\begin{array}{l}\text { a ocorrência de } \\
\text { Enquadramento, Perspectiva } \\
\text { e Profundidade construída } \\
\text { por linhas diagonais que } \\
\text { convergem no centro e } \\
\text { dividem a tela em quatro } \\
\text { seções. As quatro linhas } \\
\text { diagonais que conduzem o } \\
\text { olhar para dentro da tela, } \\
\text { registrado na nota de rodapé } \\
177 .\end{array}$ & & \\
\hline $\begin{array}{l}\text { Na tela 'A Esplanada do } \\
\text { Café na Place du Forum, } \\
\text { Arles, à Noite', observamos } \\
\text { a ocorrência de } \\
\text { Transparência e } \\
\text { Enquadramento, por meio } \\
\text { de Vetor e Perspectiva } \\
\text { invertida, que é observada } \\
\text { na composição de outras } \\
\text { telas, registradas na nota de } \\
\text { rodapé } 210 .\end{array}$ & & \\
\hline $\begin{array}{l}\text { Na tela 'A Esplanada do } \\
\text { Café na Place du Forum, } \\
\text { Arles, à Noite', observamos } \\
\text { um ângulo plongee com o } \\
\text { qual van Gogh representou } \\
\text { a cena, um pouco acima do } \\
\text { nível do chão e que produz } \\
\text { um efeito de } \\
\text { distanciamento provoca } \\
\text { um distanciamento do } \\
\text { espectador, enquanto outros } \\
\text { recursos semióticos (cores, } \\
\text { perspectiva, ponto de fuga) } \\
\text { trabalham para conduzir o } \\
\text { espectador para dentro da } \\
\text { cena. Esta ocorrência está } \\
\text { registrada na nota de rodapé } \\
\text { 169. }\end{array}$ & $\begin{array}{l}\text { A segunda mostra o exterior de um } \\
\text { café, iluminado no terraço externo } \\
\text { por uma grande lâmpada de gás } \\
\text { dentro da noite azul, com um retalho } \\
\text { de céu azul estrelado. }\end{array}$ & $\begin{array}{l}\text { Neste complexo oracional, observamos } \\
\text { um deslocamento não apenas de } \\
\text { planos, mas de pontos de vista. Na } \\
\text { oração alfa, van Gogh se refere à tela } \\
\text { enquanto que na oração beta, ele está } \\
\text { se referindo à cena que está } \\
\text { representada na tela. Dessa forma ele } \\
\text { desliza de um ponto de vista externo à } \\
\text { cena, para um ponto de vista que está } \\
\text { dentro da cena. Esta ocorrência está } \\
\text { registrada na nota de rodapé } 83 \text {. }\end{array}$ \\
\hline $\begin{array}{l}\text { Observamos também a } \\
\text { ocorrência de } \\
\text { Enquadramento que interage } \\
\text { com a Perspectiva e a } \\
\text { Profundidade, presentes na } \\
\text { divisão dos planos no }\end{array}$ & $\begin{array}{l}\text { Fui interrompido precisamente pelo } \\
\text { trabalho que uma nova pintura da } \\
\text { parte externa de um café à noite tem } \\
\text { me dado nos últimos dias. }\end{array}$ & \\
\hline
\end{tabular}




\begin{tabular}{|c|c|}
\hline \multirow[t]{2}{*}{$\begin{array}{l}\text { espaço composicional, } \\
\text { registrada na nota de rodapé } \\
214 .\end{array}$} & $\begin{array}{l}\text { As frentes das casas em uma rua que } \\
\text { segue sob o céu azul salpicado de } \\
\text { estrelas são azul escuro ou violeta, } \\
\text { com uma árvore verde. }\end{array}$ \\
\hline & $\begin{array}{l}\text { Agora há uma pintura de noite sem } \\
\text { preto. Com nada mais do que um } \\
\text { belo azul e violeta e verde e nestes } \\
\text { arredores da praça iluminada é } \\
\text { colorido por enxofre pálido, amarelo } \\
\text { limão. }\end{array}$ \\
\hline & $\begin{array}{l}\text { No passado, eles costumavam } \\
\text { desenhar e pintar a tela do desenho } \\
\text { durante o dia. Mas acho que me } \\
\text { convém pintar a coisa no momento. }\end{array}$ \\
\hline & $\begin{array}{l}\text { Eu também fiz um novo retrato de } \\
\text { mim mesmo, como um estudo, no } \\
\text { qual eu pareço um Japonês }\end{array}$ \\
\hline & $\begin{array}{l}\text { A roupa branca do proprietário, } \\
\text { vigiando as coisas a partir de um } \\
\text { canto deste forno, torna-se amarelo- } \\
\text { limão, verde luminoso pálido. }\end{array}$ \\
\hline & $\begin{array}{l}\text { Mais tarde, quando eu tiver levado } \\
\text { esses experimentos mais longe, o } \\
\text { semeador ainda vai ser a primeira } \\
\text { tentativa nesse gênero }\end{array}$ \\
\hline & $\begin{array}{l}\text { É uma cor, então, que não é } \\
\text { localmente verdadeira do ponto de } \\
\text { vista realista do trompe l'oeil, mas } \\
\text { uma cor que sugere alguma emoção, } \\
\text { um temperamento ardente. }\end{array}$ \\
\hline & $\begin{array}{l}\text { Na minha pintura do café à noite eu } \\
\text { procurei exprimir que o café é um } \\
\text { lugar onde você pode arruinar-se, } \\
\text { enlouquecer, cometer crimes. }\end{array}$ \\
\hline & $\begin{array}{l}\text { Alguns pobres vagabundos noturnos } \\
\text { estão dormindo em um canto. }\end{array}$ \\
\hline & $\begin{array}{l}\text { A sala está pintada de vermelho, e no } \\
\text { interior, na luz a gás, a mesa de } \\
\text { bilhar verde, a qual lança uma } \\
\text { imensa sombra sobre o chão. }\end{array}$ \\
\hline $\begin{array}{l}\text { Na tela 'O Café Noturno na } \\
\text { Place Lamartine, em Arles', } \\
\text { observamos a ocorrência de }\end{array}$ & \\
\hline
\end{tabular}




\begin{tabular}{|c|c|c|}
\hline $\begin{array}{l}\text { Distorção do Ponto de Vista } \\
\text { nas linhas da perspectiva, } \\
\text { criada com a interação do } \\
\text { uso de Enquadramento, } \\
\text { Perspectiva e } \\
\text { Profundidade, registrado na } \\
\text { nota de rodapé } 211 \text {. } \\
\text { Na tela 'O Café Noturno na } \\
\text { Place Lamartine, em Arles', } \\
\text { observamos a ocorrência de } \\
\text { Distorção do Ponto de Vista, } \\
\text { Inacabamento e } \\
\text { Incompletude, construídas } \\
\text { com ajuda da perspectiva, } \\
\text { profundidade e } \\
\text { enquadramento na } \\
\text { representação das linhas de } \\
\text { perspectiva distorcidas, } \\
\text { registrada na nota de rodapé } \\
227 .\end{array}$ & & \\
\hline $\begin{array}{l}\text { Na tela 'O Café Noturno na } \\
\text { Place Lamartine, em Arles', } \\
\text { observamos a ocorrência de } \\
\text { Enquadramento, } \\
\text { Inacabamento, Perspectiva e } \\
\text { Distorção do Ponto de vista. } \\
\text { As cadeiras no primeiro } \\
\text { plano foram representadas } \\
\text { parcialmente e não tem } \\
\text { uma proporção e um } \\
\text { alinhamento compatível } \\
\text { com as perspectiva das } \\
\text { tábuas no chão, registrada } \\
\text { na nota de rodapé } 216 .\end{array}$ & & $\begin{array}{l}\text { Foi observado um sentido de } \\
\text { movimentação conferida aos objetos } \\
\text { inanimados em contraposição à } \\
\text { paralisia das figuras humanas na tela } \\
\text { que endossa a disposição } \\
\text { desorganizada e oblíqua das cadeiras, } \\
\text { transmitindo a sensação de que a } \\
\text { presença, o fulgor e a movimentação } \\
\text { de pessoas ali naquele espaço ainda } \\
\text { estivessem presentes, quentes, embora } \\
\text { elas já tenham ido embora daquele } \\
\text { local que é reforçado pela ocorrência } \\
\text { de vetores projetados pelas cadeiras. }\end{array}$ \\
\hline $\begin{array}{l}\text { Na tela 'O Café da Noite', } \\
\text { além do ângulo aberto } \\
\text { para representar o } \\
\text { interior do café, van } \\
\text { Gogh usou um segundo } \\
\text { ângulo, o plongee } \\
\text { explicado na nota de } \\
\text { rodapé } 95 \text {. }\end{array}$ & $\begin{array}{l}\text { Mudança de enfoque: } \\
\text { Ele desliza da narração das telas } \\
\text { para a narração do artigo e volta } \\
\text { para as telas. } \\
\text { "Estudos exagerados, como o } \\
\text { semeador, como o café noturno } \\
\text { agora, geralmente parecem-me } \\
\text { atrozmente feios e ruins, mas } \\
\text { quando eu estou movido por alguma } \\
\text { coisa, como aqui por este pequeno } \\
\text { artigo sobre Dostoievski, em } \\
\text { seguida, eles são os únicos que me }\end{array}$ & $\begin{array}{l}\text { O ângulo plongee, dentro da } \\
\text { semiose construída por van Gogh, } \\
\text { tem a função de causar um } \\
\text { estranhamento e um distanciamento } \\
\text { no espectador. Esse estranhamento } \\
\text { ocorre ao mesmo tempo em que a } \\
\text { perspectiva o leva para dentro da } \\
\text { cena o ângulo plongee o leva a } \\
\text { pensar no pintor, de onde ele teria } \\
\text { pintado esta cena, pois pelo ponto } \\
\text { de vista de quem olha não parece } \\
\text { que ele estava no nível do chão. } \\
\text { Com isso, temos uma mudança de } \\
\text { enfoque, um deslizamento do ponto } \\
\text { de vista de quem faz a narração, e } \\
\text { que leva o espectador a deslizar }\end{array}$ \\
\hline
\end{tabular}




\begin{tabular}{|c|c|c|}
\hline & $\begin{array}{l}\text { parecem ter um significado mais } \\
\text { importante." }\end{array}$ & $\begin{array}{l}\text { também, entre se aproximar e se } \\
\text { distanciar da cena. }\end{array}$ \\
\hline $\begin{array}{l}\text { Na tela ‘O Café Noturno na } \\
\text { Place Lamartine, em Arles', } \\
\text { observamos a ocorrência de } \\
\text { Associação Metafórica } \\
\text { construída com o uso de } \\
\text { Profundidade e Perspectiva } \\
\text { na representação das } \\
\text { figuras no fundo, registrada } \\
\text { na nota de rodapé } 225 \text {. }\end{array}$ & & \\
\hline $\begin{array}{l}\text { Na tela 'O Café Noturno } \\
\text { na Place Lamartine, em } \\
\text { Arles', Ocorrência de } \\
\text { Inversão do Ponto de } \\
\text { vista, construída pelo } \\
\text { Vetor, dado pelo homem } \\
\text { no centro da sala que } \\
\text { olha para o espectador. A } \\
\text { seta, criada pela sombra da } \\
\text { mesa se encarrega de levar } \\
\text { a atenção do espectador } \\
\text { para aquele ponto desde o } \\
\text { qual se olha a cena. Esse } \\
\text { sentido constrói uma } \\
\text { inversão e um } \\
\text { deslocamento no } \\
\text { Enquadramento e na } \\
\text { Perspectiva que vai desde } \\
\text { o envolvimento até o } \\
\text { distanciamento para se } \\
\text { olhar a cena, registrados } \\
\text { na nota de rodapé } 242 .\end{array}$ & & \\
\hline $\begin{array}{l}\text { Na tela 'O Café Noturno na } \\
\text { Place Lamartine, em Arles’, } \\
\text { observamos a ocorrência de } \\
\text { Associação metafórica, } \\
\text { Enquadramento, Perspectiva } \\
\text { e Incompletude por meio do } \\
\text { sentido de Contraposição } \\
\text { entre centro/periferia, } \\
\text { olhar/não olhar, } \\
\text { ativo/apático construído } \\
\text { pela posição relativa das } \\
\text { figuras, registrada na nota } \\
\text { de rodapé } 302 \text {. }\end{array}$ & & \\
\hline
\end{tabular}




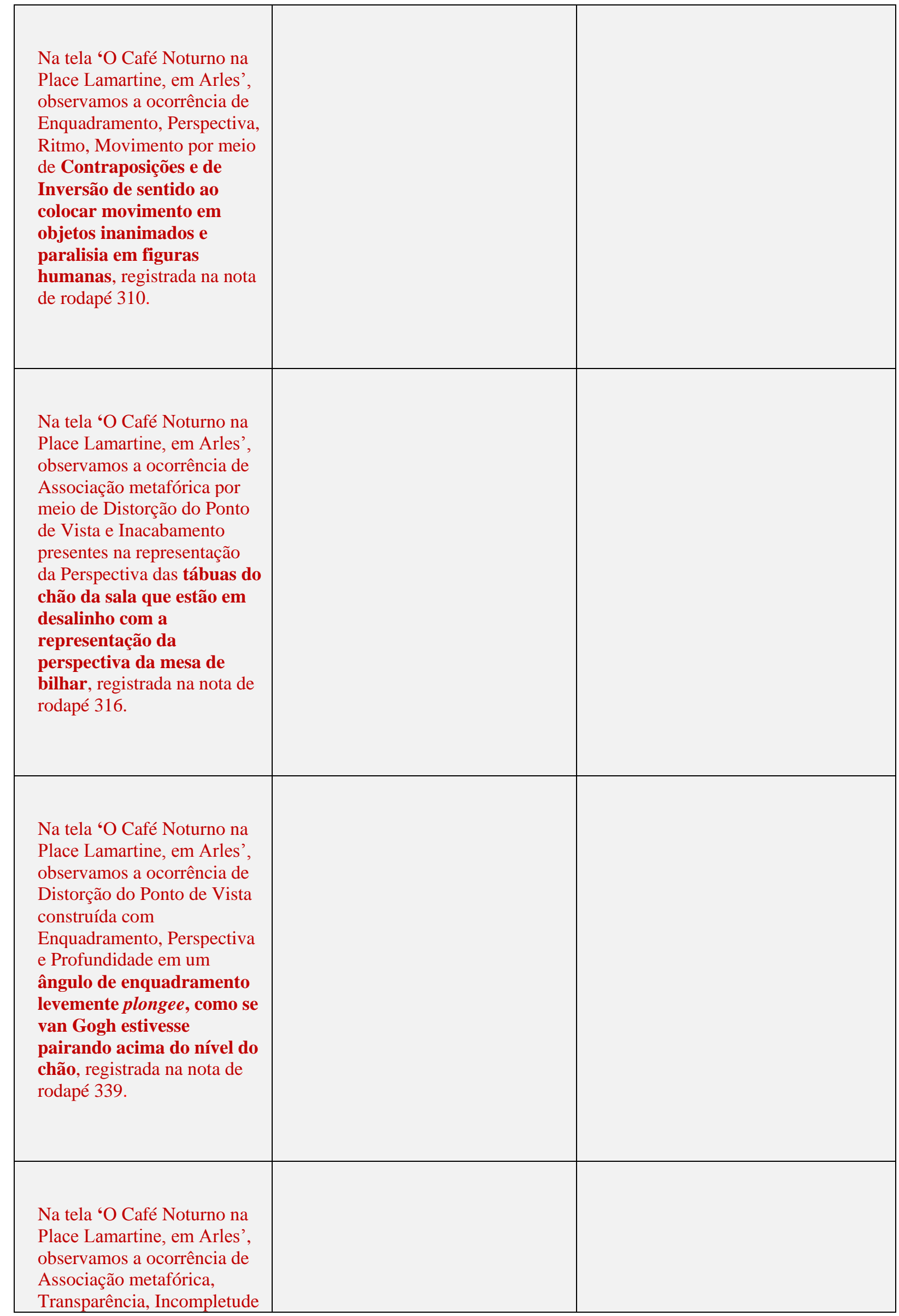




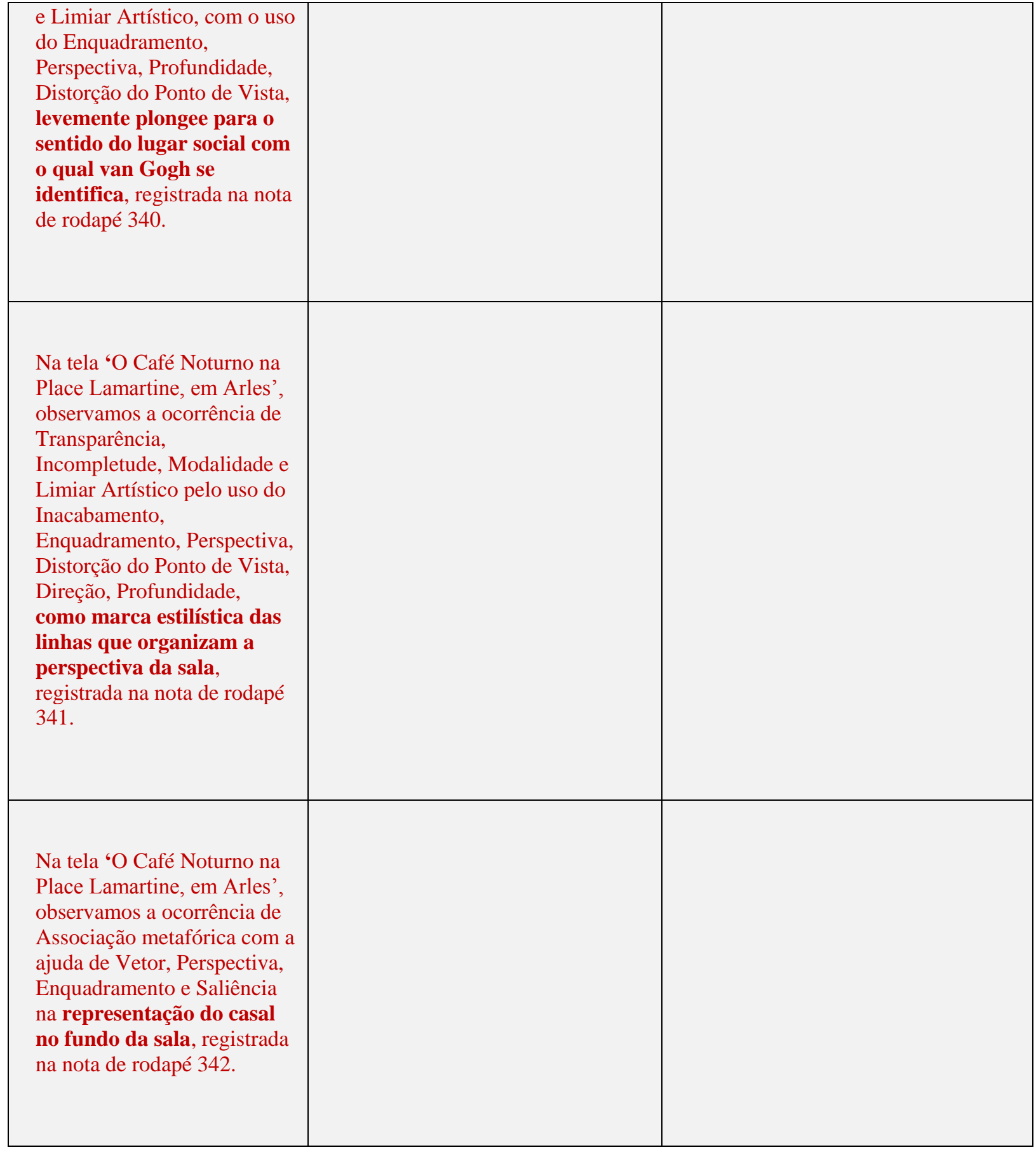

Fonte: Triangulação para Perspectiva dos dados dos corpora visual e textual, com os extratos das cartas.

\subsection{TRIANGULAÇÃO DA PROFUNDIDADE}

Quadro 72: Triangulação da Profundidade

\begin{tabular}{|l|l|l|}
\hline Ocorrência nas telas & Orações & Comentário \\
\hline & & \\
$\begin{array}{l}\text { Na tela 'Por de Sol: Campo } \\
\text { de trigo perto de Arles', } \\
\text { observamos a ocorrência de }\end{array}$ & & \\
\hline
\end{tabular}




\begin{tabular}{|c|c|c|}
\hline $\begin{array}{l}\text { profundidade produzida } \\
\text { pelo uso da modulação } \\
\text { cromática, bem como pela } \\
\text { divisão dos planos com } \\
\text { ajuda de contrastes de } \\
\text { saturação, como comentado } \\
\text { na nota de rodapé } 51 .\end{array}$ & & \\
\hline $\begin{array}{l}\text { Na tela 'Por de Sol: Campo } \\
\text { de trigo perto de Arles', } \\
\text { observamos a ocorrência de } \\
\text { profundidade, obtida pelo } \\
\text { uso da iluminação do céu } \\
\text { que funciona como uma } \\
\text { tonalidade saturada que } \\
\text { confere a percepção de } \\
\text { distância, registrada na nota } \\
\text { de rodapé } 73 \text {. }\end{array}$ & & \\
\hline $\begin{array}{l}\text { Na tela 'O Semeador', a } \\
\text { profundidade visual é } \\
\text { construída pela divisão do } \\
\text { espaço em planos, e pela } \\
\text { gradação cromática das } \\
\text { tonalidades de azuis do } \\
\text { campo. } \\
\text { Ela também é construída } \\
\text { com a ajuda da perspectiva, } \\
\text { dada pelos caminhos } \\
\text { visuais no campo arado, } \\
\text { como registrado na nota de } \\
\text { rodapé } 121 \text {. }\end{array}$ & $\begin{array}{l}\text { Há várias sugestões de amarelo no } \\
\text { solo, tons neutros resultantes da } \\
\text { mistura de violeta e amarelo; mas } \\
\text { tenho travado uma luta diabólica } \\
\text { para atingir a verdade das cores. }\end{array}$ & $\begin{array}{l}\text { O sentido principal deste complexo } \\
\text { está na oração hipotáxica, sugerindo } \\
\text { um deslocamento de 'planos' } \\
\text { causando um efeito de 'profundidade' } \\
\text { no enunciado, registrado na nota de } \\
\text { rodapé } 78 .\end{array}$ \\
\hline $\begin{array}{l}\text { A Perspectiva e } \\
\text { Profundidade são construídas } \\
\text { por caminhos visuais } \\
\text { conferidos pelo } \\
\text { agrupamento de membros } \\
\text { como o caminho de terra, } \\
\text { os corvos e a casa, } \\
\text { registradas na nota de rodapé } \\
123 \text {. }\end{array}$ & & \\
\hline $\begin{array}{l}\text { Na tela 'A Esplanada do } \\
\text { Café na Place du Forum, } \\
\text { Arles, à Noite', observamos } \\
\text { a ocorrência de } \\
\text { Enquadramento, Perspectiva } \\
\text { e Profundidade construída }\end{array}$ & & \\
\hline
\end{tabular}




\begin{tabular}{|c|c|c|}
\hline $\begin{array}{l}\text { por linhas diagonais que } \\
\text { convergem no centro e } \\
\text { dividem a tela em quatro } \\
\text { seções. As quatro linhas } \\
\text { diagonais que conduzem o } \\
\text { olhar para dentro da tela, } \\
\text { registrado na nota de rodapé } \\
177 \text {. }\end{array}$ & & \\
\hline $\begin{array}{l}\text { Na tela 'A Esplanada do Café } \\
\text { na Place du Forum, Arles, à } \\
\text { Noite', o segundo plano está } \\
\text { representado tão ricamente ou } \\
\text { mais do que o primeiro plano, } \\
\text { registrado na nota de rodapé } \\
165 .\end{array}$ & $\begin{array}{l}\text { A segunda mostra o exterior de um } \\
\text { café, iluminado no terraço externo } \\
\text { por uma grande lâmpada de gás } \\
\text { dentro da noite azul, com um retalho } \\
\text { de céu azul estrelado. }\end{array}$ & $\begin{array}{l}\text { Neste complexo oracional, } \\
\text { observamos um deslocamento não } \\
\text { apenas de planos, mas de pontos de } \\
\text { vista. A oração Alfa é um preâmbulo } \\
\text { para o sentido principal que está na } \\
\text { oração Beta, que está ricamente } \\
\text { detalhado, muito mais do que na } \\
\text { oração Alfa. Esta ocorrência de } \\
\text { 'planos' na oração é compatível com a } \\
\text { ênfase que é dada no segundo plano } \\
\text { da tela. A ocorrência está registrada na } \\
\text { nota de rodapé } 82 \text {. }\end{array}$ \\
\hline $\begin{array}{l}\text { Na tela 'O Café Noturno na } \\
\text { Place Lamartine, em Arles', } \\
\text { observamos a ocorrência de } \\
\text { Enquadramento que interage } \\
\text { com a Perspectiva e a } \\
\text { Profundidade, presentes na } \\
\text { divisão dos planos no } \\
\text { espaço composicional, } \\
\text { registrada na nota de rodapé } \\
214 .\end{array}$ & & \\
\hline $\begin{array}{l}\text { Na tela 'O Café Noturno na } \\
\text { Place Lamartine, em Arles', } \\
\text { observamos a ocorrência de } \\
\text { Distorção do Ponto de Vista } \\
\text { nas linhas da perspectiva, } \\
\text { criada com a interação do } \\
\text { uso de Enquadramento, } \\
\text { Perspectiva e Profundidade, } \\
\text { registrado na nota de rodapé } \\
211 .\end{array}$ & & \\
\hline $\begin{array}{l}\text { Na tela 'O Café Noturno na } \\
\text { Place Lamartine, em Arles', } \\
\text { observamos a ocorrência de } \\
\text { Distorção do Ponto de Vista, }\end{array}$ & & \\
\hline
\end{tabular}




\begin{tabular}{|c|c|c|}
\hline $\begin{array}{l}\text { Inacabamento e } \\
\text { Incompletude, construídas } \\
\text { com ajuda da perspectiva, } \\
\text { profundidade e } \\
\text { enquadramento na } \\
\text { representação das linhas de } \\
\text { perspectiva distorcidas, } \\
\text { registrada na nota de rodapé } \\
227 .\end{array}$ & & \\
\hline & $\begin{array}{l}\text { Agora como para recuperar o } \\
\text { dinheiro pago ao senhorio através da } \\
\text { minha pintura, eu não estou fazendo } \\
\text { questão disto, porque a pintura é } \\
\text { uma das mais feias que eu já fiz. } \\
\text { x BETA (oração não-finita - } \\
\text { intensificação de finalidade) - Agora } \\
\text { como para recuperar o dinheiro pago } \\
\text { ao senhorio através da minha } \\
\text { pintura, } \\
\text { ALFA (dominante) - eu não estou } \\
\text { fazendo questão disto, } \\
\text { = BETA (intensificação razão) - } \\
\text { porque a pintura é uma das mais } \\
\text { feias que eu já fiz. }\end{array}$ & $\begin{array}{l}\text { No complexo oracional, observamos } \\
\text { que o sentido secundário está na } \\
\text { primeira oração xBeta 'Agora como } \\
\text { para recuperar o dinheiro pago ao } \\
\text { senhorio através da minha pintura', e } \\
\text { também na oração alfa, 'eu não estou } \\
\text { fazendo questão disto', enquanto que } \\
\text { o sentido principal foi colocado na } \\
\text { segunda oração =Beta ' porque a } \\
\text { pintura é uma das mais feias que eu já } \\
\text { fiz.'. Isso sugere um deslocamento do } \\
\text { enquadramento, bem como uma } \\
\text { distorção do ponto de vista. }\end{array}$ \\
\hline $\begin{array}{l}\text { Na tela 'O Café Noturno na } \\
\text { Place Lamartine, em Arles', } \\
\text { observamos uma ocorrência } \\
\text { visual que é compatível com } \\
\text { a ocorrência textual, na qual } \\
\text { o elemento central está no } \\
\text { segundo plano e não no } \\
\text { primeiro. Apesar de estar } \\
\text { no segundo plano que seria } \\
\text { de menor importância do } \\
\text { que o primeiro, a mesa de } \\
\text { bilhar está ricamente } \\
\text { detalhada, denotando que } \\
\text { ela é o elemento principal } \\
\text { da composição, registrada } \\
\text { na nota de rodapé } 79 .\end{array}$ & $\begin{array}{l}\text { Na minha pintura do café à noite eu } \\
\text { procurei exprimir que o café é um } \\
\text { lugar onde você pode arruinar-se, } \\
\text { enlouquecer, cometer crimes. }\end{array}$ & $\begin{array}{l}\text { A nota de rodapé } 122 \text { indexa para a } \\
\text { análise sobre o fato de que o assunto } \\
\text { principal está na oração beta, deixando } \\
\text { a oração alfa apenas com um } \\
\text { preâmbulo para introduzir o assunto } \\
\text { mais importante. Essa ocorrência é } \\
\text { compatível com o deslocamento do } \\
\text { maior ênfase no segundo plano, como } \\
\text { é o caso da mesa de bilhar que está } \\
\text { representada no segundo plano da } \\
\text { pintura. Observamos que tanto a } \\
\text { ocorrência visual quanto a textual é de } \\
\text { caráter formal, não na função ou no } \\
\text { sentido. }\end{array}$ \\
\hline $\begin{array}{l}\text { Na tela 'O Café Noturno na } \\
\text { Place Lamartine, em Arles', }\end{array}$ & & \\
\hline
\end{tabular}




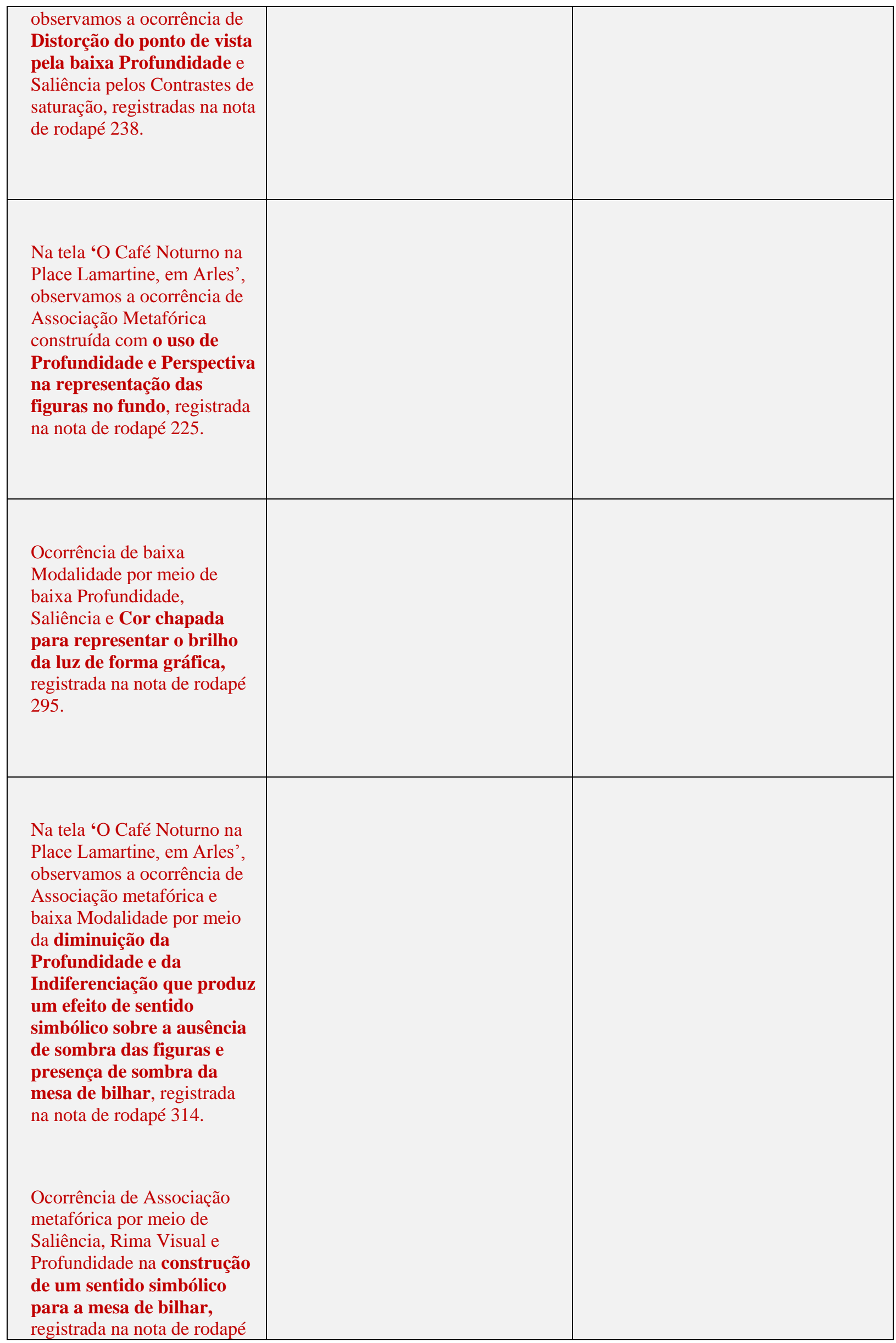




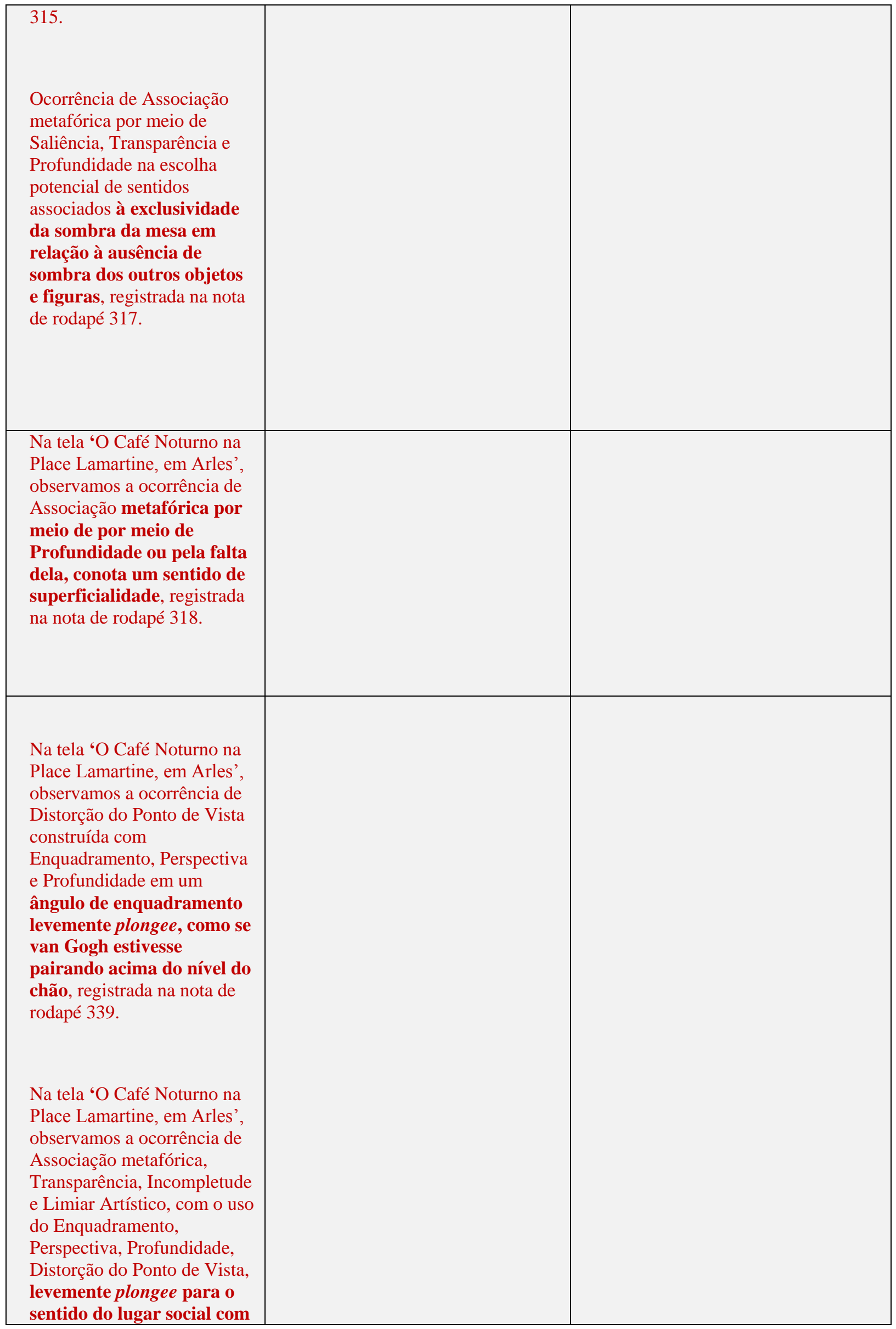




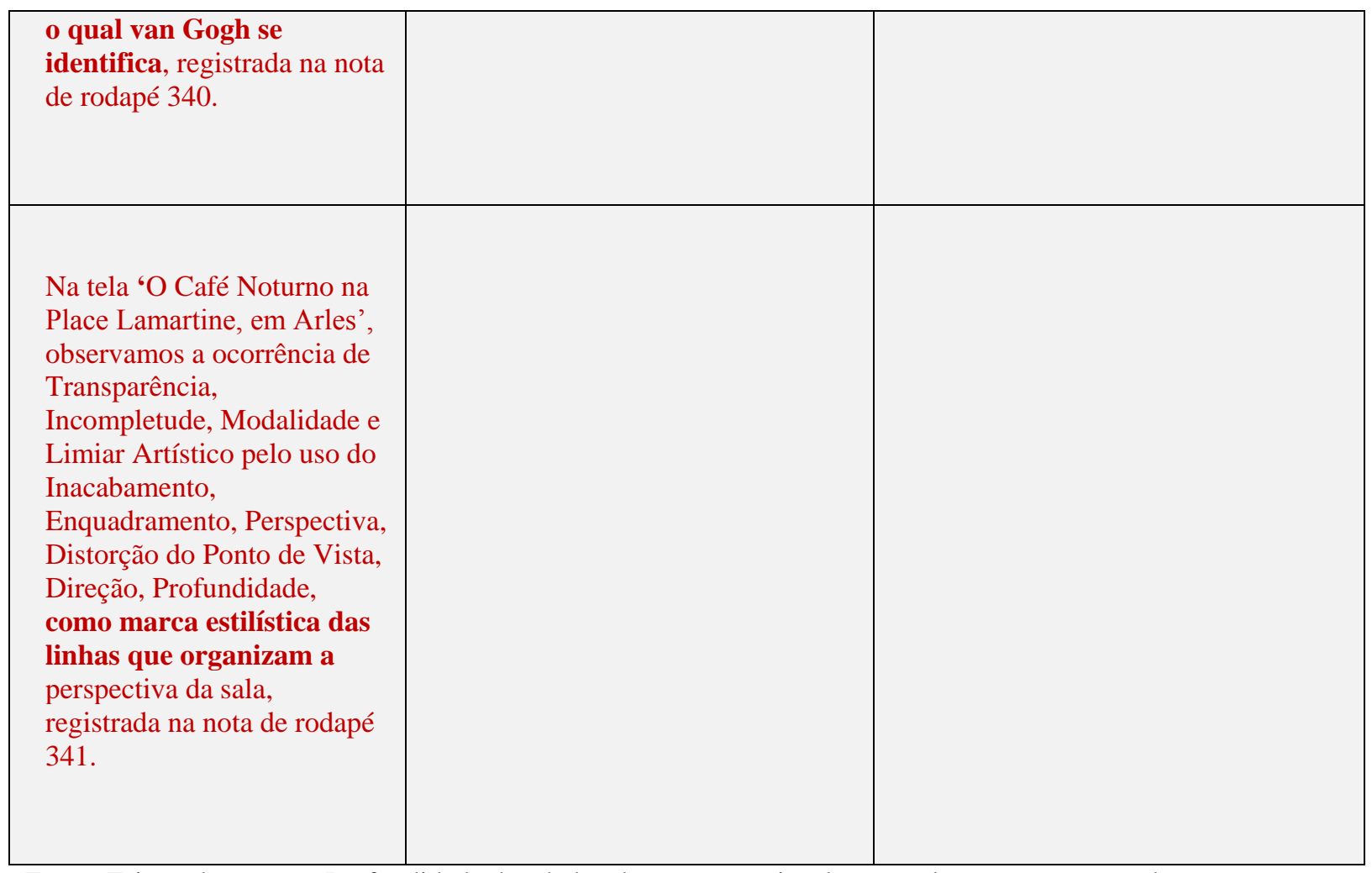

Fonte: Triangulação para Profundidade dos dados dos corpora visual e textual, com os extratos das cartas.

\subsection{TRIANGULAÇÃO DA DISTORÇÃO DO PONTO DE VISTA}

\begin{tabular}{|c|c|c|}
\hline Ocorrência nas telas & Orações & Comentário \\
\hline $\begin{array}{l}\text { Na tela 'Por de Sol: Campo } \\
\text { de trigo perto de Arles', } \\
\text { observamos a ocorrência de } \\
\text { um uso original semiótico: } \\
\text { a inversão do ponto de } \\
\text { fuga, trazendo para o } \\
\text { plano do espectador, o } \\
\text { foco com que olhar a } \\
\text { perspectiva e levando-o a } \\
\text { se identificar } \\
\text { inevitavelmente com o } \\
\text { lugar do experienciador } \\
\text { da tela, o artista. Este é } \\
\text { um uso original de } \\
\text { perspectiva para construir a } \\
\text { distorção do ponto de vista } \\
\text { que caracteriza o sistema } \\
\text { semiótico de van Gogh. } \\
\text { Esta ocorrência está } \\
\text { registrada na nota de } \\
\text { rodapé } 55 .\end{array}$ & $\begin{array}{l}\text { Aqui está outra paisagem. Sol } \\
\text { poente? Lua nascendo? Noite de } \\
\text { verão, de qualquer modo. Cidade } \\
\text { violeta, estrela amarela, céu azul- } \\
\text { esverdeado; os campos de trigo têm } \\
\text { todos os tons: ouro velho, cobre, ouro } \\
\text { verde, ouro vermelho, ouro amarelo, } \\
\text { verde, vermelho e amarelo bronze. } \\
\text { Tela quadrada número } 30 . \\
\underline{\text { Eu pintei-a ao ar livre no mistral. }} \\
\underline{\text { Meu cavalete foi fixado no chão com }} \\
\underline{\text { estacas de ferro, um método que eu }} \\
\underline{\text { recomendo a você. }}\end{array}$ & $\begin{array}{l}\text { Inversão de ponto de vista na tela e na } \\
\text { oração: } \\
\text { Van Gogh descreve a paisagem com } \\
\text { orações sem o participante principal, ou } \\
\text { sem processo, ocultando ou } \\
\text { modalizando o protagonismo da ação. } \\
\text { Logo em seguida desloca o ponto de } \\
\text { vista de dentro da tela para fora da tela } \\
\text { e coloca o foco nele, o protagonista da } \\
\text { ação: 'Eu pintei-a ao ar livre no } \\
\text { mistral.' Irá dedicar as próximas } 3 \\
\text { orações nesse enfoque no qual há uma } \\
\text { inversão do ponto de vista da paisagem } \\
\text { para o trabalho, a ação realizada por } \\
\text { ele, fora da tela. Ele leva a atenção de } \\
\text { Theo para dentro da paisagem para } \\
\text { logo voltá-la para fora da tela que passa } \\
\text { a ser o principal ponto de vista. }\end{array}$ \\
\hline
\end{tabular}




\begin{tabular}{|c|c|c|}
\hline & pode trabalhar com o vento. & \\
\hline $\begin{array}{l}\text { Na tela 'Por de Sol: Campo } \\
\text { de trigo perto de Arles', } \\
\text { observamos a ocorrência da } \\
\text { distorção do ponto de vista, } \\
\text { criada pelo uso do plongee } \\
\text { para causar um efeito de } \\
\text { sentido de estranhamento } \\
\text { no espectador, registrada } \\
\text { na nota de rodapé } 59 . \\
\\
\text { Na tela 'Por de Sol: Campo } \\
\text { de trigo perto de Arles', } \\
\text { observamos a ocorrência do } \\
\text { uso do ângulo plongee no } \\
\text { enquadramento que além } \\
\text { de contribuir para a } \\
\text { construção da } \\
\text { profundidade e da } \\
\text { perspectiva, também } \\
\text { contribui para a distorção } \\
\text { do ponto de vista. Esta } \\
\text { ocorrência está registrada } \\
\text { nas notas de rodapé } 57,110 \\
\text { e } 112 \text {. Observamos com } \\
\text { esse uso o efeito de } \\
\text { distorção do ponto de vista. } \\
\text { Esta escolha mostra a } \\
\text { intenção de construir um } \\
\text { efeito de sentido no } \\
\text { espectador e uma } \\
\text { interação deste com o } \\
\text { posicionamento adotado } \\
\text { pelo pintor para retratar } \\
\text { a cena. }\end{array}$ & $\begin{array}{l}\text { Eu pintei-a ao ar livre no mistral. } \\
\text { Meu cavalete foi fixado no chão com } \\
\text { estacas de ferro, um método que eu } \\
\text { recomendo a você. } \\
\\
\text { Você enterra os pés do cavalete e, em } \\
\text { seguida, você empurra a } 50 \\
\text { centímetros de comprimento um peso } \\
\text { de ferro ao lado deles. Você amarra } \\
\text { tudo com cordas; dessa forma, você } \\
\text { pode trabalhar com o vento. }\end{array}$ & $\begin{array}{l}\text { O plongee sugere que van Gogh estaria } \\
\text { sendo levantado e sendo levado pelo } \\
\text { vento, assim como os diversos objetos } \\
\text { que viu alçar uma certa altura e } \\
\text { trajetória devido à força da ventania. } \\
\text { Ele representou vivamente esta } \\
\text { experiência de sua relação física com a } \\
\text { força da ventania, não apenas pelo } \\
\text { ritmo, textura, movimento e gesto } \\
\text { pictórico, mas também pelo ângulo } \\
\text { plongee usado no enquadramento da } \\
\text { paisagem. }\end{array}$ \\
\hline & $\begin{array}{l}\text { Não te vou ocultar que não desgosto } \\
\text { da região, pois fui criado lá - ainda } \\
\text { me encanta a magia das recordações } \\
\text { do passado, de um desejo do infinito, } \\
\text { do qual o semeador e o enfeixador } \\
\text { são símbolos -, tanto quanto antes } \\
\text { gostava. }\end{array}$ & $\begin{array}{l}\text { Não vou te ocultar = vou te revelar } \\
\text { Que não desgosto = que gosto } \\
\text { Para dizer 'vou te revelar que gosto', } \\
\text { ele utiliza quatro negativas, recurso } \\
\text { que deixa qualquer leitor com a vista } \\
\text { embaralhada. Este é um estranhamento } \\
\text { usado para construir não apenas ênfase, } \\
\text { mas um efeito de sentido maior do que } \\
\text { a ênfase, é uma distorção na forma } \\
\text { como ele constrói a oração e que nos } \\
\text { leva a prestar uma maior atenção aos } \\
\text { sentidos ali contidos, causando um } \\
\text { aguçamento. }\end{array}$ \\
\hline & & \\
\hline
\end{tabular}




\begin{tabular}{|c|c|c|}
\hline $\begin{array}{l}\text { Na tela 'A Esplanada do } \\
\text { Café na Place du Forum, } \\
\text { Arles, à Noite', observamos } \\
\text { a ocorrência de Distorção } \\
\text { do Ponto de Vista e } \\
\text { Inacabamento, construída } \\
\text { pela representação } \\
\text { distorcida das linhas de } \\
\text { perspectiva da edificação } \\
\text { do café, registrado na nota } \\
\text { de rodapé } 170 .\end{array}$ & $\begin{array}{l}\text { Agora há uma pintura de noite sem } \\
\text { preto. Com nada mais do que um } \\
\text { belo azul e violeta e verde e nestes } \\
\text { arredores da praça iluminada é } \\
\text { colorido por enxofre pálido, } \\
\text { amarelo limão. }\end{array}$ & $\begin{array}{l}\text { Não é uma distorção do ponto de vista, } \\
\text { mas há uma licença poética para mudar } \\
\text { as regras de pontuação. }\end{array}$ \\
\hline $\begin{array}{l}\text { Na tela 'O Café Noturno na } \\
\text { Place Lamartine, em } \\
\text { Arles', Ocorrência de } \\
\text { Distorção do Ponto de } \\
\text { Vista, criada com a } \\
\text { interação do uso de } \\
\text { Enquadramento, } \\
\text { Perspectiva e } \\
\text { Profundidade, registrados } \\
\text { na nota de rodapé } 215 .\end{array}$ & & \\
\hline $\begin{array}{l}\text { Na tela 'O Café Noturno na } \\
\text { Place Lamartine, em } \\
\text { Arles', observamos a } \\
\text { ocorrência de } \\
\text { Enquadramento, } \\
\text { Inacabamento, Perspectiva } \\
\text { e Distorção do Ponto de } \\
\text { vista. As cadeiras no } \\
\text { primeiro plano foram } \\
\text { representadas } \\
\text { parcialmente e não tem } \\
\text { uma proporção e um } \\
\text { alinhamento compatível } \\
\text { com as perspectiva das } \\
\text { tábuas no chão, registrada } \\
\text { na nota de rodapé } 216 .\end{array}$ & & $\begin{array}{l}\text { Foi observado um sentido de } \\
\text { movimentação conferida aos objetos } \\
\text { inanimados em contraposição à } \\
\text { paralisia das figuras humanas na tela } \\
\text { que endossa a disposição desorganizada } \\
\text { e oblíqua das cadeiras, transmitindo a } \\
\text { sensação de que a presença, o fulgor e a } \\
\text { movimentação de pessoas ali naquele } \\
\text { espaço ainda estivessem presentes, } \\
\text { quentes, embora elas já tenham ido } \\
\text { embora daquele local que é reforçado } \\
\text { pela ocorrência de vetores projetados } \\
\text { pelas cadeiras. }\end{array}$ \\
\hline $\begin{array}{l}\text { Observamos também a } \\
\text { ocorrência de Distorção do } \\
\text { Ponto de Vista, construída } \\
\text { pela representação das } \\
\text { cadeiras em desalinho } \\
\text { com as linhas de } \\
\text { perspectiva das tábuas do } \\
\text { chão, registrada na nota de } \\
\text { rodapé } 218 \text {. }\end{array}$ & & \\
\hline & & \\
\hline
\end{tabular}




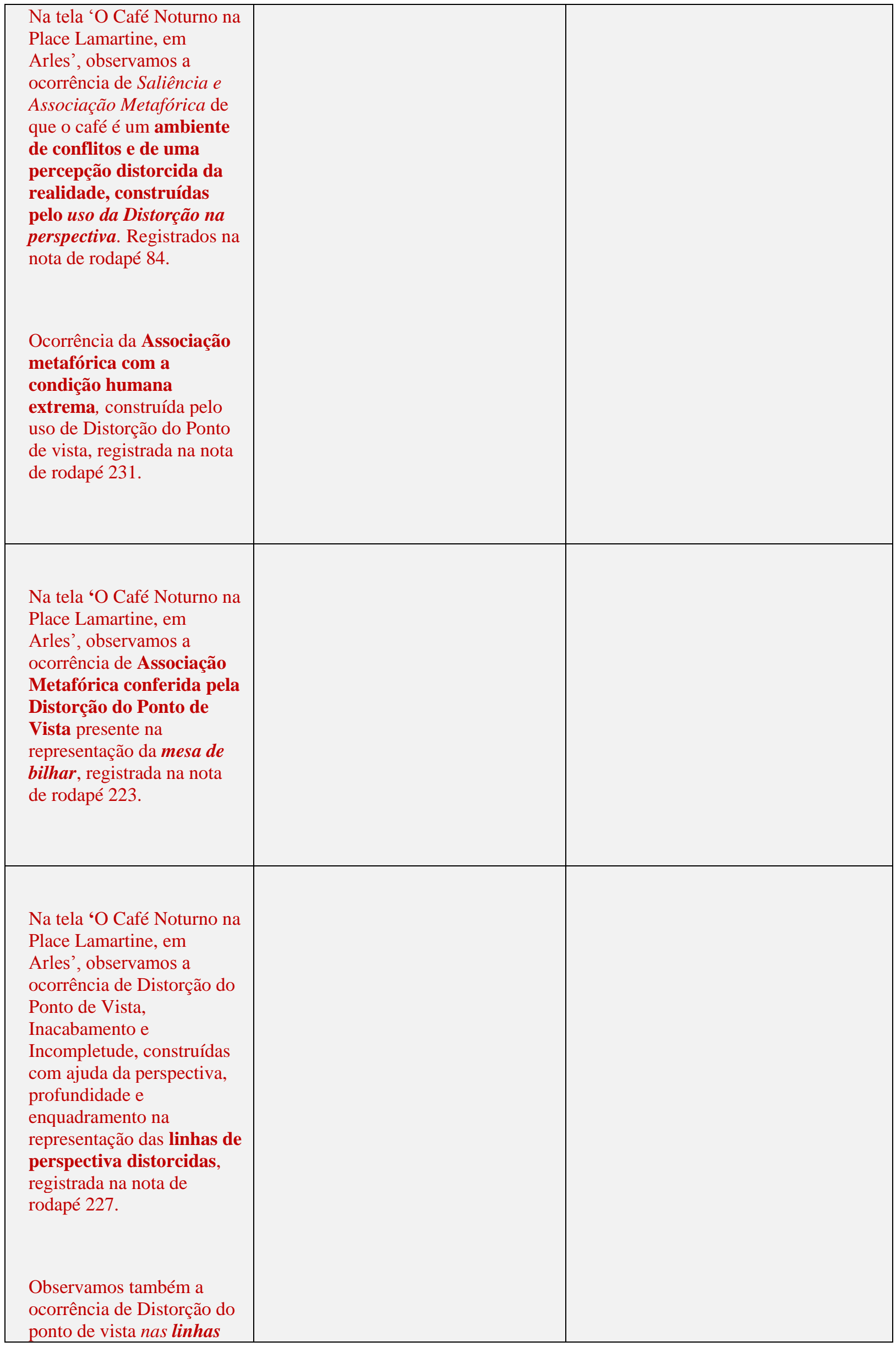




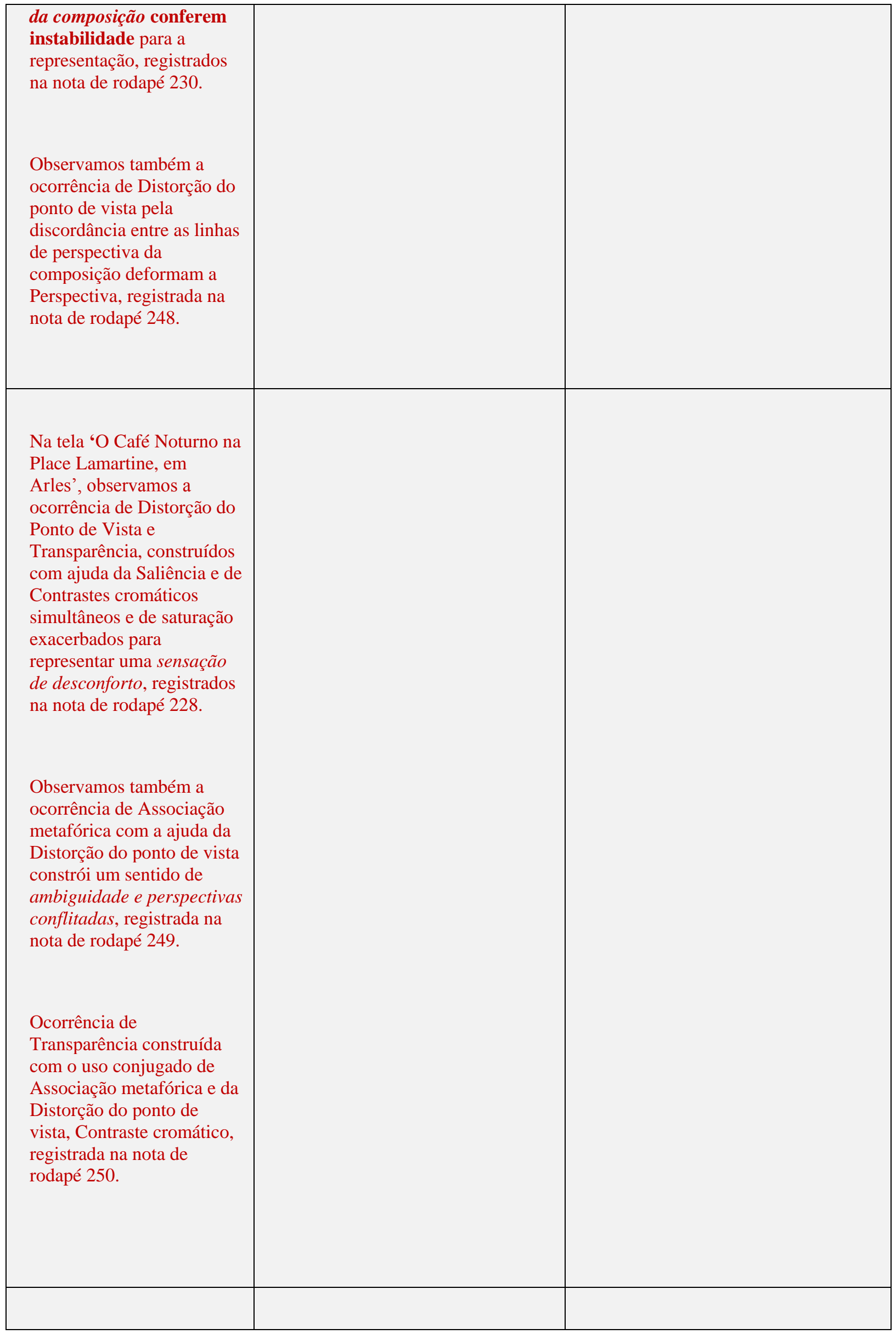




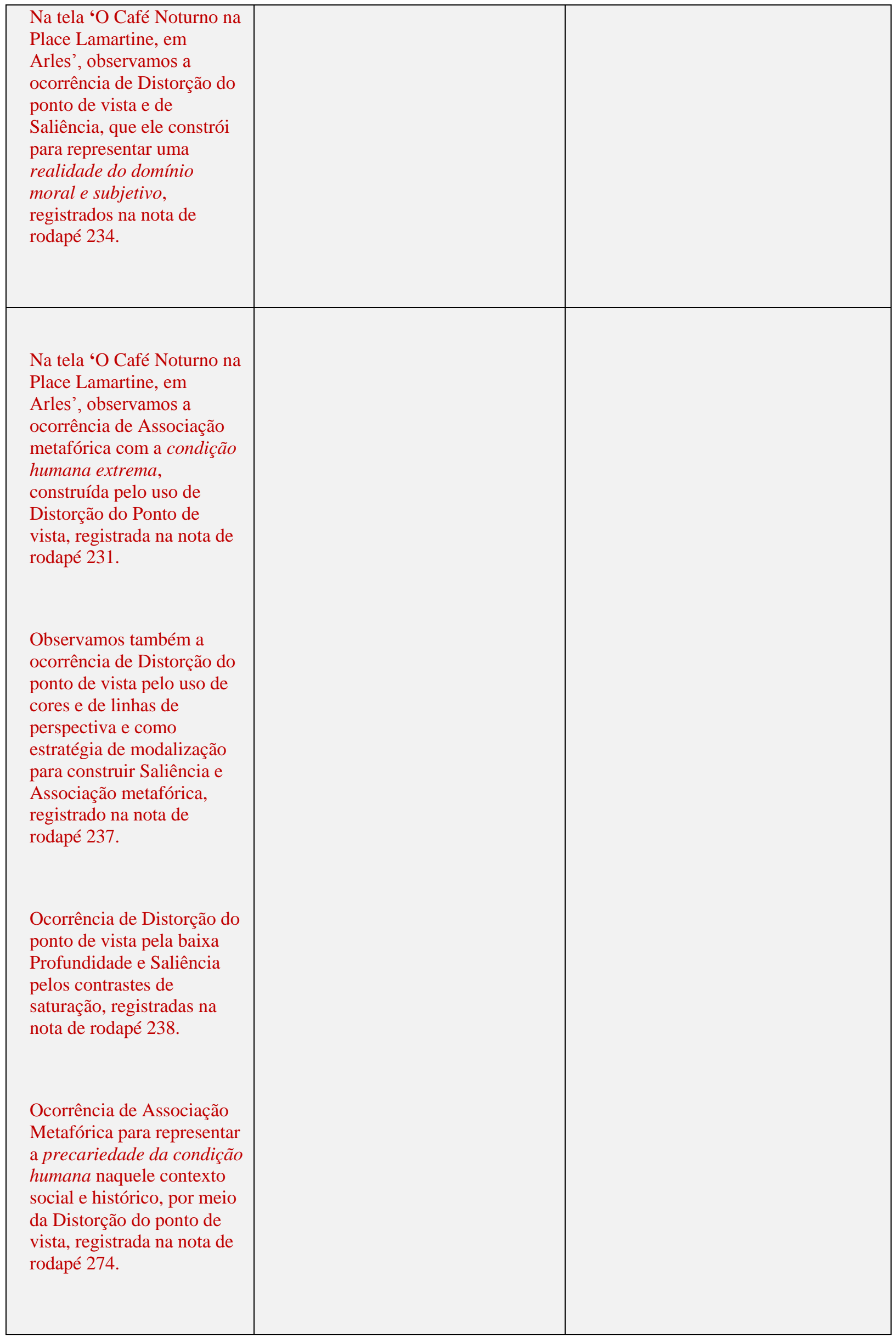




\begin{tabular}{|c|c|}
\hline $\begin{array}{l}\text { Na tela 'O Café Noturno na } \\
\text { Place Lamartine, em } \\
\text { Arles', observamos a } \\
\text { ocorrência de Distorção do } \\
\text { ponto de vista produzida } \\
\text { pela baixa Modalidade na } \\
\text { representação do ambiente } \\
\text { do café. De acordo com } \\
\text { Kress e van Leeuwen } \\
\text { (1996), a ambiguidade é } \\
\text { um traço de ocorrência de } \\
\text { modalidade, registradas na } \\
\text { nota de rodapé } 239 \text {. }\end{array}$ & \\
\hline $\begin{array}{l}\text { Na tela 'O Café Noturno na } \\
\text { Place Lamartine, em } \\
\text { Arles', observamos a } \\
\text { ocorrência de Metáfora } \\
\text { Visual com o uso da } \\
\text { Distorção na perspectiva } \\
\text { para a construção de uma } \\
\text { saliência de que } o \text { café é um } \\
\text { ambiente de conflitos e de } \\
\text { uma percepção distorcida } \\
\text { da realidade, registradas na } \\
\text { nota de rodapé } 243 \text {. }\end{array}$ & \\
\hline $\begin{array}{l}\text { Na tela 'O Café Noturno na } \\
\text { Place Lamartine, em } \\
\text { Arles', Ocorrência de } \\
\text { Inversão do Ponto de vista, } \\
\text { construída pelo Vetor, dado } \\
\text { pelo homem no centro da } \\
\text { sala que olha para o } \\
\text { espectador. A seta, criada } \\
\text { pela sombra da mesa se } \\
\text { encarrega de levar a } \\
\text { atenção do espectador para } \\
\text { aquele ponto desde o qual } \\
\text { se olha a cena. Esse sentido } \\
\text { constrói uma inversão e um } \\
\text { deslocamento no } \\
\text { Enquadramento e na } \\
\text { Perspectiva que vai desde o } \\
\text { envolvimento até o } \\
\text { distanciamento para se } \\
\text { olhar a cena, registrados na } \\
\text { nota de rodapé } 242 \text {. }\end{array}$ & \\
\hline
\end{tabular}




\begin{tabular}{|c|c|c|}
\hline $\begin{array}{l}\text { Na tela 'O Café Noturno na } \\
\text { Place Lamartine, em } \\
\text { Arles', observamos a } \\
\text { ocorrência de Inversão do } \\
\text { ponto de vista, devolve o } \\
\text { Enquadramento e } \\
\text { Perspectiva para o lugar do } \\
\text { espectador da cena, } \\
\text { registrada na nota de } \\
\text { rodapé } 244 \text {. }\end{array}$ & & \\
\hline $\begin{array}{l}\text { Ocorrência de Inversão do } \\
\text { ponto de vista construído } \\
\text { pelo Vetor do olhar do } \\
\text { homem no centro da sala } \\
\text { que olha para o pintor e } \\
\text { com isso, inverte a } \\
\text { perspectiva da tela, criando } \\
\text { um jogo de espelhamento } \\
\text { com o espectador, } \\
\text { registrada na nota de } \\
\text { rodapé } 260 \text {. }\end{array}$ & & \\
\hline $\begin{array}{l}\text { Na tela 'O Café Noturno na } \\
\text { Place Lamartine, em } \\
\text { Arles', observamos a } \\
\text { ocorrência de } \\
\text { Intertextualidade no uso da } \\
\text { Distorção para construir um } \\
\text { sentido semântico na tela } \\
\text { que ele representou } \\
\text { semanticamente na carta: a } \\
\text { precariedade da condição } \\
\text { humana no interior de um } \\
\text { café da noite. O sentido } \\
\text { que, semanticamente, ele } \\
\text { constrói na carta, é aqui } \\
\text { representado por outros } \\
\text { recursos pictóricos tais } \\
\text { como os contrastes } \\
\text { cromáticos, o excesso de } \\
\text { iluminação e a distorção da } \\
\text { perspectiva, registrada na } \\
\text { nota de rodapé } 275 \text {. }\end{array}$ & & \\
\hline $\begin{array}{l}\text { Na tela 'O Café Noturno na } \\
\text { Place Lamartine, em } \\
\text { Arles', observamos a } \\
\text { ocorrência de Associação } \\
\text { metafórica por meio de }\end{array}$ & & \\
\hline
\end{tabular}




\begin{tabular}{|c|c|c|}
\hline $\begin{array}{l}\text { Saliência, Contradição e } \\
\text { Distorção do Ponto de } \\
\text { Vista para representar a } \\
\text { sombra da mesa em } \\
\text { contraste com a ausência } \\
\text { de sombras nos outros } \\
\text { objetos e figuras, registrada } \\
\text { na nota de rodapé } 296 \text {. }\end{array}$ & & \\
\hline $\begin{array}{l}\text { Na tela ‘O Café Noturno } \\
\text { na Place Lamartine, em } \\
\text { Arles', observamos a } \\
\text { ocorrência de Distorção do } \\
\text { Ponto de Vista, } \\
\text { Incompletude e } \\
\text { Associação metafórica por } \\
\text { meio da distorção da forma } \\
\text { e do tamanho da sombra } \\
\text { da mesa de bilhar que se } \\
\text { impõe pela exclusão de } \\
\text { outras sombras, registrada } \\
\text { na nota de rodapé } 308 \text {. }\end{array}$ & & 更 \\
\hline $\begin{array}{l}\text { Na tela 'O Café Noturno } \\
\text { na Place Lamartine, em } \\
\text { Arles', observamos a } \\
\text { ocorrência de Associação } \\
\text { metafórica pela Inversão } \\
\text { de sentidos pela escolha de } \\
\text { uma mesa de bilhar para } \\
\text { simbolizar a solidão e o } \\
\text { isolamento humano, } \\
\text { registrada na nota de } \\
\text { rodapé } 309 \text {. }\end{array}$ & & 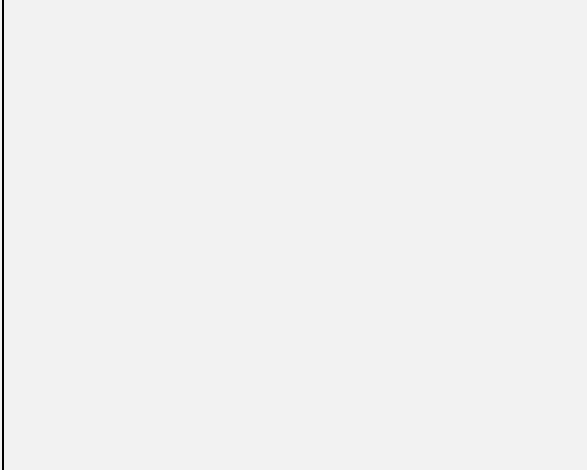 \\
\hline $\begin{array}{l}\text { Na tela 'O Café Noturno } \\
\text { na Place Lamartine, em } \\
\text { Arles', observamos a } \\
\text { ocorrência de Distorção do } \\
\text { Ponto de Vista, } \\
\text { Inacabamento, Associação } \\
\text { metafórica por meio da } \\
\text { distorção da baixa } \\
\text { Modalidade com que o } \\
\text { volume é representado, } \\
\text { devido à ausência de } \\
\text { sombras e a } \\
\text { homogienização das } \\
\text { superfícies, registrada na } \\
\text { nota de rodapé } 312 .\end{array}$ & & 更 \\
\hline Na tela 'O Café Noturno na & & \\
\hline
\end{tabular}




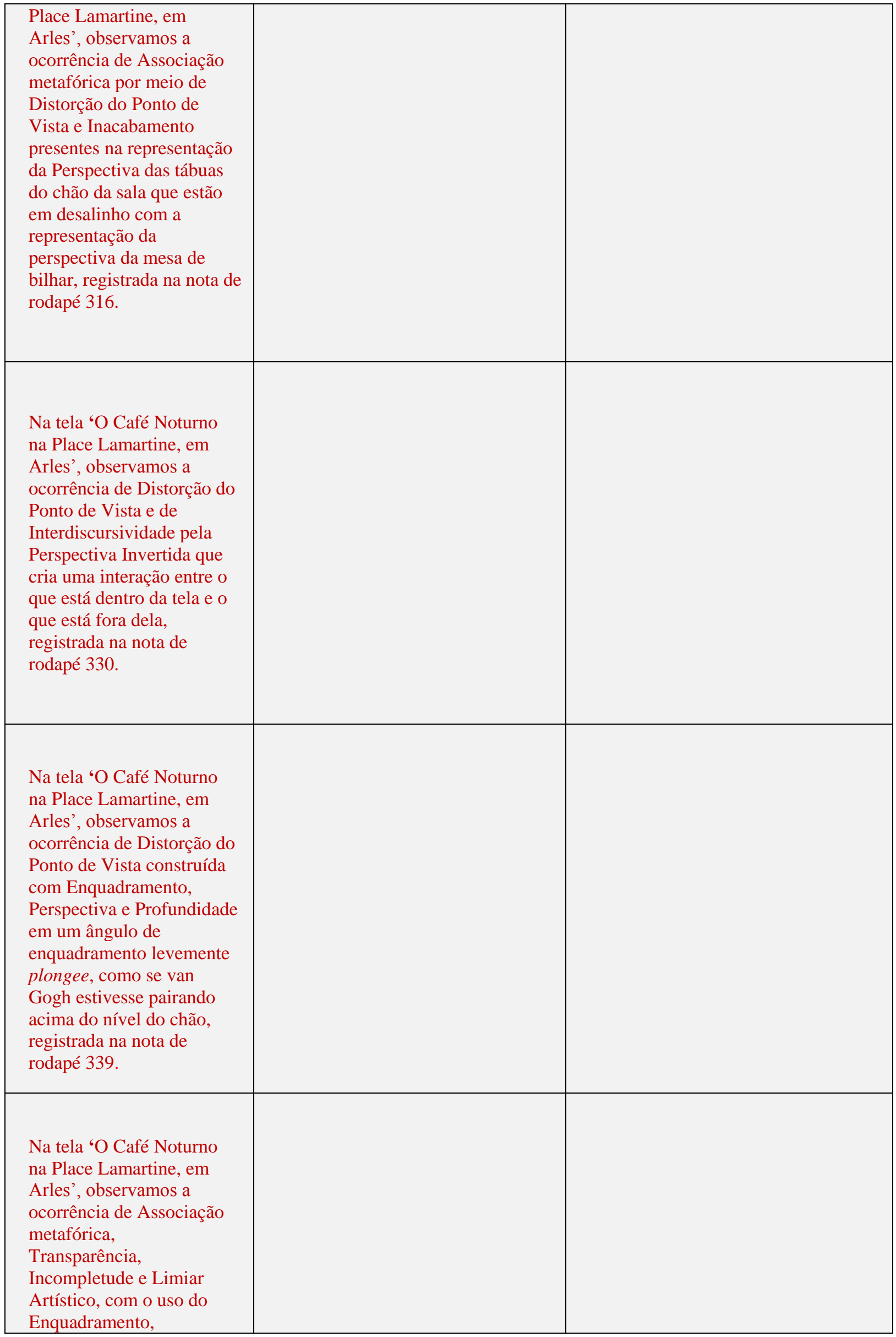




\begin{tabular}{|l|l|l|}
\hline Perspectiva, & \\
Profundidade, Distorção & & \\
do Ponto de Vista, & & \\
levemente plongee para o & & \\
sentido do lugar social & & \\
com o qual van Gogh se & & \\
identifica, registrada na & & \\
nota de rodapé 340. & & \\
& & \\
& & \\
Na tela 'O Café Noturno na & & \\
Place Lamartine, em & & \\
Arles', observamos a & & \\
ocorrência de & & \\
Transparência, & \\
Incompletude, Modalidade & & \\
e Limiar Artístico pelo uso & & \\
do Inacabamento, & & \\
Enquadramento, & & \\
Perspectiva, Distorção do & & \\
Ponto de Vista, Direção, & & \\
Profundidade, como marca & & \\
estilística das linhas que & & \\
organizam a perspectiva da & & \\
sala, registrada na nota de & & \\
rodapé 341. & & \\
& & \\
\hline
\end{tabular}

Fonte: Triangulação para Profundidade dos dados dos corpora visual e textual, com os extratos das cartas.

\subsection{TRIANGULAÇÃO DA COR}

Quadro 74: Triangulação da Cor

\begin{tabular}{|c|c|c|}
\hline Ocorrência nas telas & Orações & Comentário \\
\hline $\begin{array}{l}\text { Na tela 'Por de Sol: Campo de } \\
\text { trigo perto de Arles', } \\
\text { observamos o uso de } \\
\text { modulação cromática no } \\
\text { campo de trigo para produzir o } \\
\text { efeito de profundidade, } \\
\text { registrado nas notas de rodapé } \\
49 \text { e na } 85 \text {, observamos a } \\
\text { ocorrência de modulação e do } \\
\text { uso simbólico da cor, para } \\
\text { organizar os espaços } \\
\text { composicionais, a perspectiva } \\
\text { e para criar caminhos visuais. } \\
\text { Observamos a ocorrência de } \\
\text { cor e saliência conferida pelos } \\
\text { contrastes quente-frio entre }\end{array}$ & $\begin{array}{l}\text { Noite de verão, de qualquer modo. } \\
\text { Cidade violeta, estrela amarela, céu } \\
\text { azul-esverdeado; os campos de } \\
\text { trigo têm todos os tons: ouro velho, } \\
\text { cobre, ouro verde, ouro vermelho, } \\
\text { ouro amarelo, verde, vermelho } e \\
\text { amarelo bronze. }\end{array}$ & $\begin{array}{l}\text { O contraste de cor é detalhadamente } \\
\text { descrito nesse trecho da carta } \\
\text { revelando que a intencionalidade dessa } \\
\text { variedade de cores tem relevância } \\
\text { significativa na forma como van Gogh } \\
\text { busca representar a riqueza natural e } \\
\text { simbólica do campo de trigo. }\end{array}$ \\
\hline
\end{tabular}




\begin{tabular}{|c|c|c|}
\hline $\begin{array}{l}\text { azuis e amarelos registrado na } \\
\text { nota de rodapé } 83 \text {. }\end{array}$ & & $\begin{array}{l}\text { como quem está se permitindo } \\
\text { experimentar os efeitos que um tom } \\
\text { causa no outro. A descrição dele revela } \\
\text { essa liberdade poética no uso dos } \\
\text { efeitos das cores na tela. }\end{array}$ \\
\hline $\begin{array}{l}\text { Na tela 'Por de Sol: Campo } \\
\text { de trigo perto de Arles', } \\
\text { observamos o uso de } \\
\text { modulação cromática no } \\
\text { céu para misturar a } \\
\text { fumaça aos tons de azul do } \\
\text { céu, registrado na nota de } \\
\text { rodapé } 60\end{array}$ & & \\
\hline $\begin{array}{l}\text { Ocorrência do uso da cor } \\
\text { com a função modal, para } \\
\text { criar o envolvimento do } \\
\text { espectador com a cena } \\
\text { registrada na nota de rodapé } \\
84 .\end{array}$ & & \\
\hline $\begin{array}{l}\text { Na tela 'Por de Sol: Campo } \\
\text { de trigo perto de Arles', } \\
\text { observamos também a } \\
\text { ocorrência de saliência pelo } \\
\text { uso cromático de um tom de } \\
\text { amarelo mais claro na área } \\
\text { onde o homem se encontra } \\
\text { registrado na nota de rodapé } \\
89 .\end{array}$ & & \\
\hline $\begin{array}{l}\text { Na tela 'O Semeador', } \\
\text { observamos também a } \\
\text { ocorrência de Associação } \\
\text { Metafórica, construída pelo } \\
\text { contrates simultâneo sugere } \\
\text { contraposição metafórica de } \\
\text { significados do céu e da } \\
\text { terra, registrado na nota de } \\
\text { rodapé } 151 .\end{array}$ & $\begin{array}{l}\text { Noite de verão, de qualquer modo. } \\
\text { Cidade violeta, estrela amarela, céu } \\
\text { azul-esverdeado; os campos de } \\
\text { trigo têm todos os tons: ouro velho, } \\
\text { cobre, ouro verde, ouro vermelho, } \\
\text { ouro amarelo, verde, vermelho e } \\
\text { amarelo bronze. }\end{array}$ & $\begin{array}{l}\text { Na tela e nas cartas o contraste entre o } \\
\text { violeta, o amarelo e o azul aparece } \\
\text { evidenciado e as cores se } \\
\text { complementam para construir um todo } \\
\text { que é a noite de verão. }\end{array}$ \\
\hline $\begin{array}{l}\text { Na tela 'O Semeador', } \\
\text { observamos a ocorrência de } \\
\text { Associação Metafórica é } \\
\text { construída pela associação } \\
\text { dos sentidos do trigo maduro } \\
\text { e os sentidos do céu e do sol: } \\
\text { calor, vida, força e } \\
\text { crescimento, confirmada }\end{array}$ & & \\
\hline
\end{tabular}




\begin{tabular}{|c|c|c|}
\hline $\begin{array}{l}\text { pela divisão do espaço } \\
\text { composicional e pela divisão } \\
\text { cromática da tela na qual o } \\
\text { campo maduro tem tons } \\
\text { quentes e o campo arado tem } \\
\text { tons frios registrado na nota } \\
\text { de rodapé } 119 \text {. }\end{array}$ & & \\
\hline $\begin{array}{l}\text { Na tela 'O Semeador', } \\
\text { observamos a ocorrência } \\
\text { conjugada de Contrastes de } \\
\text { Saturação, Saliência, } \\
\text { Associação Metafórica e } \\
\text { Incompletude na } \\
\text { representação do céu e do } \\
\text { sol, em amarelo sobre } \\
\text { amarelo, registrado na nota } \\
\text { de rodapé } 137 .\end{array}$ & $\begin{array}{l}\text { Um campo de trigo maduro, de tom } \\
\text { amarelo-ocre com um pouco de } \\
\text { carmim. } \\
\text { O céu, amarelo-crómio, quase tão } \\
\text { luminoso quanto o próprio Sol, que é } \\
\text { amarelo-crómio no } 1 \text {, misturado com } \\
\text { um pouco de branco, enquanto o } \\
\text { resto do céu é uma mistura dos } \\
\text { amarelos-crómios } 1 \text { e } 2 \text {. Tão } \\
\text { amarelo! A camisa do semeador é } \\
\text { azul e as calças brancas. Tamanho da } \\
\text { tela - } 25 \text {, quadrada. }\end{array}$ & $\begin{array}{l}\text { Observamos a ocorrência de } \\
\text { modulação textual no construto. No } \\
\text { uso lexical ele vai intensificando a } \\
\text { ênfase no amarelo, pela repetição e } \\
\text { pela exclamação, a fim de descrever o } \\
\text { amarelo. }\end{array}$ \\
\hline $\begin{array}{l}\text { Na tela 'O Semeador', a } \\
\text { profundidade visual é } \\
\text { construída pela divisão do } \\
\text { espaço em planos, e pela } \\
\text { gradação cromática das } \\
\text { tonalidades de azuis do } \\
\text { campo. Ela também é } \\
\text { construída com a ajuda da } \\
\text { perspectiva, dada pelos } \\
\text { caminhos visuais no campo } \\
\text { arado, como registrado na } \\
\text { nota de rodapé } 121 .\end{array}$ & $\begin{array}{l}\text { Há várias sugestões de amarelo no } \\
\text { solo, tons neutros resultantes da } \\
\text { mistura de violeta e amarelo; mas } \\
\text { tenho travado uma luta diabólica } \\
\text { para atingir a verdade das cores. }\end{array}$ & $\begin{array}{l}\text { Tanto a gradação cromática } \\
\text { perceptível na tela quanto a descrição } \\
\text { da oração dos diferentes tons sugerem } \\
\text { que van Gogh construiu } \\
\text { intencionalmente a diferenciação entre } \\
\text { tons na terra e no horizonte com } \\
\text { intuito de ser fiel à percepção de cada } \\
\text { detalhe. Assim ele revela que a } \\
\text { natureza proporciona uma diversidade } \\
\text { de cores que os olhos menos atentos } \\
\text { homogeneízam a fim de apreender } \\
\text { somente o todo. E neste esforço ele } \\
\text { relata que tem "travado uma luta } \\
\text { diabólica para atingir a verdade das } \\
\text { cores". }\end{array}$ \\
\hline $\begin{array}{l}\text { Na tela 'O Semeador', } \\
\text { observamos a ocorrência de } \\
\text { Perspectiva pelo uso de } \\
\text { vários recursos tais como } \\
\text { planos com ângulos de } \\
\text { enquadramento } \\
\text { diferenciados, em forma de } \\
\text { cunhas que são sugeridas } \\
\text { pela modulação cromática } \\
\text { dos torrões de terra, } \\
\text { registrado na nota de rodapé } \\
122 .\end{array}$ & $\begin{array}{l}\text { Há várias sugestões de amarelo no } \\
\text { solo, tons neutros resultantes da } \\
\text { mistura de violeta e amarelo; mas } \\
\text { tenho travado uma luta diabólica } \\
\text { para atingir a verdade das cores. }\end{array}$ & $\begin{array}{l}\text { Aqui, observa-se o uso da modulação } \\
\text { cromática: 'tons neutros resultantes da } \\
\text { mistura de violeta e amarelo'. O uso da } \\
\text { modulação é observada na construção } \\
\text { léxico-gramatical pela escolha da } \\
\text { sequência lexical e pelo uso de } \\
\text { 'sugestão de amarelo', 'tons neutros', } \\
\text { 'mistura de violeta e amarelo' que } \\
\text { constroem uma gradação de cores. }\end{array}$ \\
\hline
\end{tabular}




\begin{tabular}{|c|c|c|}
\hline $\begin{array}{l}\text { Na tela 'O Semeador', há } \\
\text { uma inter-relação entre } \\
\text { Textura, Contrastes } \\
\text { Simultâneos, Saliência, } \\
\text { Sinestesia que criam } \\
\text { Associações Metafóricas da } \\
\text { materialidade da tinta com a } \\
\text { nossa memória sensorial e } \\
\text { tátil da plasticidade da terra, } \\
\text { registrado na nota de rodapé } \\
136 .\end{array}$ & $\begin{array}{l}\text { Não te vou ocultar que não desgosto } \\
\text { da região, pois fui criado lá - ainda } \\
\text { me encanta a magia das recordações } \\
\text { do passado, de um desejo do infinito, } \\
\text { do qual o semeador e o enfeixador } \\
\text { são símbolos -, tanto quanto antes } \\
\text { gostava. }\end{array}$ & $\begin{array}{l}\text { Modulação na linguagem = } \\
\text { Modalização. Neste complexo } \\
\text { oracional foi construído um intrincado } \\
\text { construto léxico-gramatical que } \\
\text { empresta colorido à oração pelas } \\
\text { oposições e contrastes, de sentidos } \\
\text { empregados. A escolha do construto } \\
\text { 'não vou te ocultar que não desgosto' } \\
\text { contém } 4 \text { negativas para construir } 2 \\
\text { afirmações (como já demonstrado } \\
\text { antes) e cria com isso uma trama de } \\
\text { oposições e contrastes que dá um } \\
\text { efeito de sentido colorido para a } \\
\text { linguagem. O segundo contraste se } \\
\text { encontra no deslocamento dentro do } \\
\text { tempo da ação. Ele inicia o período no } \\
\text { presente e esclarece que gosta da } \\
\text { região, abre um travessão e se desloca } \\
\text { para o passado, descrevendo, } \\
\text { detalhando, esmiuçando a natureza } \\
\text { desse gostar; é como se ele estivesse a } \\
\text { viver lá. Em seguida ele fecha o } \\
\text { travessão retornando para o presente, } \\
\text { fazendo a comparação com o tempo } \\
\text { atual e integrando estes dois tempos. }\end{array}$ \\
\hline $\begin{array}{l}\text { Na tela 'O Semeador', } \\
\text { observamos o uso de } \\
\text { modulação cromática de } \\
\text { tons de amarelos que estão } \\
\text { superpostos e que } \\
\text { conjugados, atingem um } \\
\text { aguçamento dos sentidos } \\
\text { compatíveis com experiência } \\
\text { extática que van Gogh } \\
\text { parece querer comunicar. }\end{array}$ & $\begin{array}{l}\text { O céu, amarelo-crómio, quase tão } \\
\underline{\text { luminoso quanto o próprio Sol, que é }} \\
\underline{\text { amarelo-crómio } \mathrm{n}^{\circ} 1}, \underline{\text { misturado com }} \\
\underline{\text { um pouco de branco, enquanto } \underline{\mathrm{o}}} \\
\underline{\text { resto do céu é uma mistura dos }} \\
\underline{\text { amarelos-crómios } 1 \text { e } 2} \text {. Tão } \\
\text { amarelo! }\end{array}$ & $\begin{array}{l}\text { Obsermos no discurso textual a } \\
\text { ocorrência semântica de modulação na } \\
\text { oração que descreve diferentes } \\
\text { tonalidades de amarelos, e a ocorrência } \\
\text { gramatical com a oração: 'Tão } \\
\text { amarelo! que culmina o crescendo das } \\
\text { tonalidades de amarelos descritos na } \\
\text { oração que a antecede. É como um } \\
\text { clímax de um crescendo que explode } \\
\text { com o construto: 'Tão amarelo!'. }\end{array}$ \\
\hline $\begin{array}{l}\text { Na tela 'O Semeador' } \\
\text { observamos a ocorrência de } \\
\text { Associação Metafórica } \\
\text { construída pelo uso } \\
\text { simbólico da cor para } \\
\text { construir o significado } \\
\text { cíclico do plantar e do } \\
\text { colher, e outras associações } \\
\text { de sentidos potenciais são } \\
\text { sugeridas como vida e morte, } \\
\text { registrada na nota de rodapé } \\
156 .\end{array}$ & $\begin{array}{l}\text { Aqui está um esboço de um } \\
\text { semeador, um grande campo lavrado } \\
\text { com torrões de terra, na sua maioria } \\
\text { fracamente cor de violeta. } \\
\text { Um campo de trigo maduro, de tom } \\
\text { amarelo-ocre com um pouco de } \\
\text { carmim. }\end{array}$ & $\begin{array}{l}\text { O campo amarelo que tem um pouco } \\
\text { de carmim, o campo arado de terra } \\
\text { roxa que tem um pouco de amarelo. } \\
\text { Vida e morte se entrelaçam, uma } \\
\text { dentro da outra, parecer construir } \\
\text { metaforicamente nas orações e na tela } \\
\text { um movimento cíclico com as cores } \\
\text { fazendo a transição entre os diferentes } \\
\text { momentos da semeadura. O valor } \\
\text { simbólico da cor potencializado pelo } \\
\text { valor simbólico da semeadura. Van } \\
\text { Gogh valoriza a transição das cores, a } \\
\text { sua heterogeneidade e seu sentido } \\
\text { simbólico na produção da tela }\end{array}$ \\
\hline
\end{tabular}




\begin{tabular}{|c|c|c|}
\hline $\begin{array}{l}\text { Observamos também a } \\
\text { ocorrência de Uso Simbólico } \\
\text { da Cor para conferir } \\
\text { Associação Metafórica para } \\
\text { os sentidos simbólicos do } \\
\text { campo maduro e do campo } \\
\text { arado e da parábola do } \\
\text { Semeador, registrada na nota } \\
\text { de rodapé } 160 \text {. } \\
\\
\text { Observamos também a } \\
\text { ocorrência de Uso Simbólico } \\
\text { da Cor para conferir } \\
\text { Saliência e Associação } \\
\text { Metafórica para os sentidos } \\
\text { simbólicos do campo arado } \\
\text { registrada na nota de rodapé } \\
161 \text {. }\end{array}$ & & $\begin{array}{l}\text { denominada "o Semeador", na qual a } \\
\text { cor ganha grande proeminência, mais } \\
\text { do que a figura em si do semeador. }\end{array}$ \\
\hline \multirow{2}{*}{$\begin{array}{l}\text { Observamos também a } \\
\text { ocorrência de Uso Simbólico } \\
\text { da Cor para conferir } \\
\text { Saliência e Associação } \\
\text { Metafórica para os sentidos } \\
\text { simbólicos do campo arado } \\
\text { registrada na nota de rodapé } \\
161 .\end{array}$} & $\begin{array}{l}\text { Mas quando eu farei o céu estrelado, } \\
\text { então, essa pintura que está sempre } \\
\text { na minha mente? }\end{array}$ & \\
\hline & $\begin{array}{l}\text { Ai, ai, é como nosso excelente amigo } \\
\text { Cyprien diz, em 'En ménage' por JK } \\
\text { Huysmans: as mais belas pinturas } \\
\text { são aquelas que um sonha enquanto } \\
\text { fuma um cachimbo em sua cama, } \\
\text { mas a qual ele não pinta. }\end{array}$ & \\
\hline \multirow[t]{2}{*}{$\begin{array}{l}\text { Observamos a ocorrência de } \\
\text { contraste simultâneo entre o } \\
\text { violeta e o amarelo que } \\
\text { potencializam mutuamente o } \\
\text { seu efeito e que é aguçado o } \\
\text { efeito da textura tátil e da } \\
\text { textura visual, registrado na } \\
\text { nota de rodapé } 141 \text {. }\end{array}$} & $\begin{array}{l}\text { Aqui está o que eu queria dizer sobre } \\
\text { o branco e o preto. A pintura é } \\
\text { dividida em dois; metade é amarelo, } \\
\text { o topo; a base é violeta. Bem, as } \\
\text { calças brancas descansam os olhos e } \\
\text { os distraem exatamente quando o } \\
\text { contraste simultâneo excessivo de } \\
\text { amarelo e violeta iriam irritá-lo. Isso } \\
\text { é o que eu queria dizer. }\end{array}$ & $\begin{array}{l}\text { Ocorrência do uso de saliência na } \\
\text { oração 'Isso é o que eu queria dizer' } \\
\text { que retoma e reforça o sentido da } \\
\text { oração 'Aqui está o que eu queria dizer } \\
\text { sobre o branco e o preto.' que abre o } \\
\text { parágrafo que fala sobre a função do } \\
\text { branco para amenizar o conflito entre o } \\
\text { violeta e o amarelo que preenchem os } \\
\text { dois campos da tela, registrado na nota } \\
\text { de rodapé } 165 \text {. }\end{array}$ \\
\hline & $\begin{array}{l}\text { Em um campo arado, um grande } \\
\text { campo de torrões de terra roxa - } \\
\text { levantados em direção ao horizonte - } \\
\text { um semeador em azul e branco. No } \\
\text { horizonte um campo de trigo curto, } \\
\text { maduro. }\end{array}$ & \\
\hline
\end{tabular}




\begin{tabular}{|c|c|c|}
\hline $\begin{array}{l}\text { Na tela 'O Semeador', } \\
\text { observamos a ocorrência de } \\
\text { Contrastes Cromáticos } \\
\text { Complementares de azuis e } \\
\text { lilazes em contraposição } \\
\text { com laranjas e amarelos, } \\
\text { causa uma ambiência de } \\
\text { vibração e intensidade para } \\
\text { representar a luz do ocaso, e } \\
\text { são compatíveis com a } \\
\text { ocorrência de uma Distorção } \\
\text { do Ponto de vista, registrado } \\
\text { na nota de rodapé } 158 \text {. }\end{array}$ & $\begin{array}{l}\text { Há várias sugestões de amarelo no } \\
\text { solo, tons neutros resultantes da } \\
\text { mistura de violeta e amarelo; mas } \\
\text { tenho travado uma luta diabólica } \\
\text { para atingir a verdade das cores. }\end{array}$ & \\
\hline $\begin{array}{l}\text { Na tela ‘O Semeador', } \\
\text { observamos a ocorrência de } \\
\text { Uso Simbólico da Cor para } \\
\text { conferir Associação } \\
\text { Metafórica para os episódios, } \\
\text { participantes e membros da } \\
\text { pintura, registrado na nota de } \\
\text { rodapé } 159 .\end{array}$ & $\begin{array}{l}\text { Mas é uma questão de atacá-las, no } \\
\text { entanto, não importa o quão } \\
\text { incompetente um pode sentir-se vis- } \\
\text { à-vis as perfeições inefáveis do } \\
\text { glorioso esplendor da natureza. }\end{array}$ & \\
\hline $\begin{array}{l}\text { Na tela 'A Esplanada do } \\
\text { Café na Place du Forum, } \\
\text { Arles, à Noite', observamos } \\
\text { a ocorrência de Modulação } \\
\text { Cromática e Inacabamento } \\
\text { para construir uma gradação } \\
\text { de tons de azuis que são mais } \\
\text { escuros e profundos no fim } \\
\text { da rua e ficam gradualmente } \\
\text { mais claros quando se } \\
\text { aproximam do café criando } \\
\text { uma zona de transição } \\
\text { cromática, registrado na nota } \\
\text { de rodapé } 173 \text {. }\end{array}$ & $\begin{array}{l}\text { Agora há uma pintura de noite sem } \\
\text { preto. Com nada mais do que um } \\
\text { belo azul e violeta e verde e nestes } \\
\text { arredores da praça iluminada é } \\
\text { colorido por enxofre pálido, } \\
\text { amarelo limão. }\end{array}$ & $\begin{array}{l}\text { Nesta oração observamos uma } \\
\text { modulação de intensidade. Ele inicia } \\
\text { descrevendo a tela com apenas uma } \\
\text { cor 'sem preto'. Depois há uma } \\
\text { ênfase 'nada mais' e utiliza três cores. } \\
\text { Depois há uma ênfase mais intensa 'é } \\
\text { colorido e utiliza cores que à noite } \\
\text { não são tão intensas, mas na oração } \\
\text { elas são representadas como intensas } \\
\text { porque são o agente da ação de colorir } \\
\text { a praça iluminada. }\end{array}$ \\
\hline $\begin{array}{l}\text { Na tela 'A Esplanada do } \\
\text { Café na Place du Forum, } \\
\text { Arles, à Noite', observamos } \\
\text { a ocorrência de Saliência } \\
\text { dada pelos Contrastes } \\
\text { Cromáticos do tipo } \\
\text { Simultâneo, Quente/Frio, e } \\
\text { de Saturação para construir } \\
\text { caminhos visuais e saliência } \\
\text { na área do café e conduzir o } \\
\text { olhar para dentro da tela, } \\
\text { registrados na nota de rodapé } \\
\text { 178. }\end{array}$ & $\begin{array}{l}\text { Uma enorme lanterna amarela } \\
\text { ilumina o terraço, a fachada, a } \\
\text { calçada, e até mesmo projeta luz } \\
\text { sobre os paralelepípedos da rua, que } \\
\text { adquirem uma coloração violeta- } \\
\text { rosa. As frentes das casas em uma } \\
\text { rua que segue sob o céu azul } \\
\text { salpicado de estrelas são azul escuro } \\
\text { ou violeta, com uma árvore verde. } \\
\text { Agora há uma pintura de noite sem } \\
\text { preto. Com nada mais do que um } \\
\text { belo azul e violeta e verde e nestes } \\
\text { arredores da praça iluminada é } \\
\underline{\text { colorido por enxofre pálido, }} \\
\underline{\text { amarelo limão. }}\end{array}$ & $\begin{array}{l}\text { A cor da lanterna é projetada para } \\
\text { além dela mesma, incidindo sobre } \\
\text { todos os elementos da tela. A } \\
\text { incidência pode ser direta ou indireta, } \\
\text { proporcionando a produção de uma } \\
\text { noite sem preto. Nesta tela fica ainda } \\
\text { mais evidente o papel das cores na } \\
\text { composição do sentido da obra, ela } \\
\text { aqui ganha não só um sentido } \\
\text { metafórico mas também histórico. Até } \\
\text { então só havia uma forma de } \\
\text { representar a noite, utilizando a cor } \\
\text { preta na composição. Graças à } \\
\text { combinação dos diferentes matizes } \\
\text { em uma noite iluminada é possível } \\
\text { utilizar a luz para construir a ideia de }\end{array}$ \\
\hline
\end{tabular}




\begin{tabular}{|c|c|c|}
\hline $\begin{array}{l}\text { simultâneos para construir } \\
\text { uma ênfase mútua entre as } \\
\text { áreas que ele quis representar } \\
\text { com maior destaque: } o \text { café e } \\
\text { o céu estrelado, registrado } \\
\text { na nota de rodapé } 190 .\end{array}$ & & $\begin{array}{l}\text { uma noite iluminada. } \mathrm{O} \text { uso } \\
\text { combinado das cores aqui é } \\
\text { fundamental nessa construção } \\
\text { intencional de van Gogh, de produzir } \\
\text { uma noite sem utilizar a cor preta para } \\
\text { representá-la. }\end{array}$ \\
\hline $\begin{array}{l}\text { observamos a ocorrência de } \\
\text { Inovação Pictórica com a } \\
\text { representação das cores à } \\
\text { noite, à luz do lampião a } \\
\text { gás, registrada na nota de } \\
\text { rodapé } 180 .\end{array}$ & $\begin{array}{l}\text { Muitas vezes parece-me que a noite } \\
\text { é muito mais viva e ricamente } \\
\text { colorida do que o dia. }\end{array}$ & $\begin{array}{l}\text { Com essa asserção, tanto na carta } \\
\text { quanto na tela, ele está explicitando } \\
\text { um tipo de experiência que é ousada } \\
\text { e inovadora, ao explorar as } \\
\text { possibilidades de representar as } \\
\text { cores com a luminosidade noturna, } \\
\text { como também o fez tanto na tela do } \\
\text { Café Terrace quanto nas cartas a ela } \\
\text { referidas. }\end{array}$ \\
\hline $\begin{array}{l}\text { Na tela 'A Esplanada do } \\
\text { Café na Place du Forum, } \\
\text { Arles, à Noite', observamos } \\
\text { também a ocorrência de } \\
\text { Modulação Cromática na } \\
\text { representação da cor à noite, } \\
\text { iluminada pela lâmpada a } \\
\text { gás, registrada na nota de } \\
\text { rodapé } 181 \text {. }\end{array}$ & $\begin{array}{l}\text { É bem verdade que eu possa tomar } \\
\text { um azul por um verde no escuro, } \\
\text { um azul lilás por um rosa lilás, uma } \\
\text { vez que você não pode perceber a } \\
\text { natureza do tom claramente. Mas é } \\
\text { a única maneira de se livrar da noite } \\
\text { negra convencional com uma luz } \\
\text { pobre, pálida e esbranquiçada, } \\
\text { quando na verdade uma mera vela } \\
\text { por si só nos dá os mais ricos } \\
\text { amarelos e laranjas. }\end{array}$ & $\begin{array}{l}\text { Nesta oração van Gogh procura } \\
\text { explicar que o objetivo na } \\
\text { composição não foi representar a cor } \\
\text { que os objetos assumiriam durante o } \\
\text { dia, mas tomar a cor pela forma como } \\
\text { ela se manifesta à noite. Uma luz que } \\
\text { incide sobre um objeto à noite } \\
\text { proporciona cores que não seriam } \\
\text { possível visualizar durante o dia. O } \\
\text { que importa na composição é ser fiel } \\
\text { à interação entre a luz e os outros } \\
\text { elementos para valorizar cada matiz e } \\
\text { valorizar cada aspecto da cor em uma } \\
\text { noite iluminada pela lâmpada a gás e } \\
\text { pelo céu estrelado. Duas luzes } \\
\text { diferentes, uma amarelada e outra } \\
\text { esbranquiçada. Cada uma interagindo } \\
\text { e produzindo matizes diferentes na } \\
\text { calçada, na frente nos prédios e sobre } \\
\text { as pessoas. }\end{array}$ \\
\hline & $\begin{array}{l}\text { É o equivalente, embora diferente, } \\
\text { dos comedores de batata. }\end{array}$ & \\
\hline & $\begin{array}{l}\text { A sala é vermelho-sangue e amarelo } \\
\text { sem graça, uma mesa de bilhar verde } \\
\text { no centro, } 4 \text { lâmpadas de amarelo } \\
\text { limão com um brilho laranja e verde. }\end{array}$ & \\
\hline
\end{tabular}




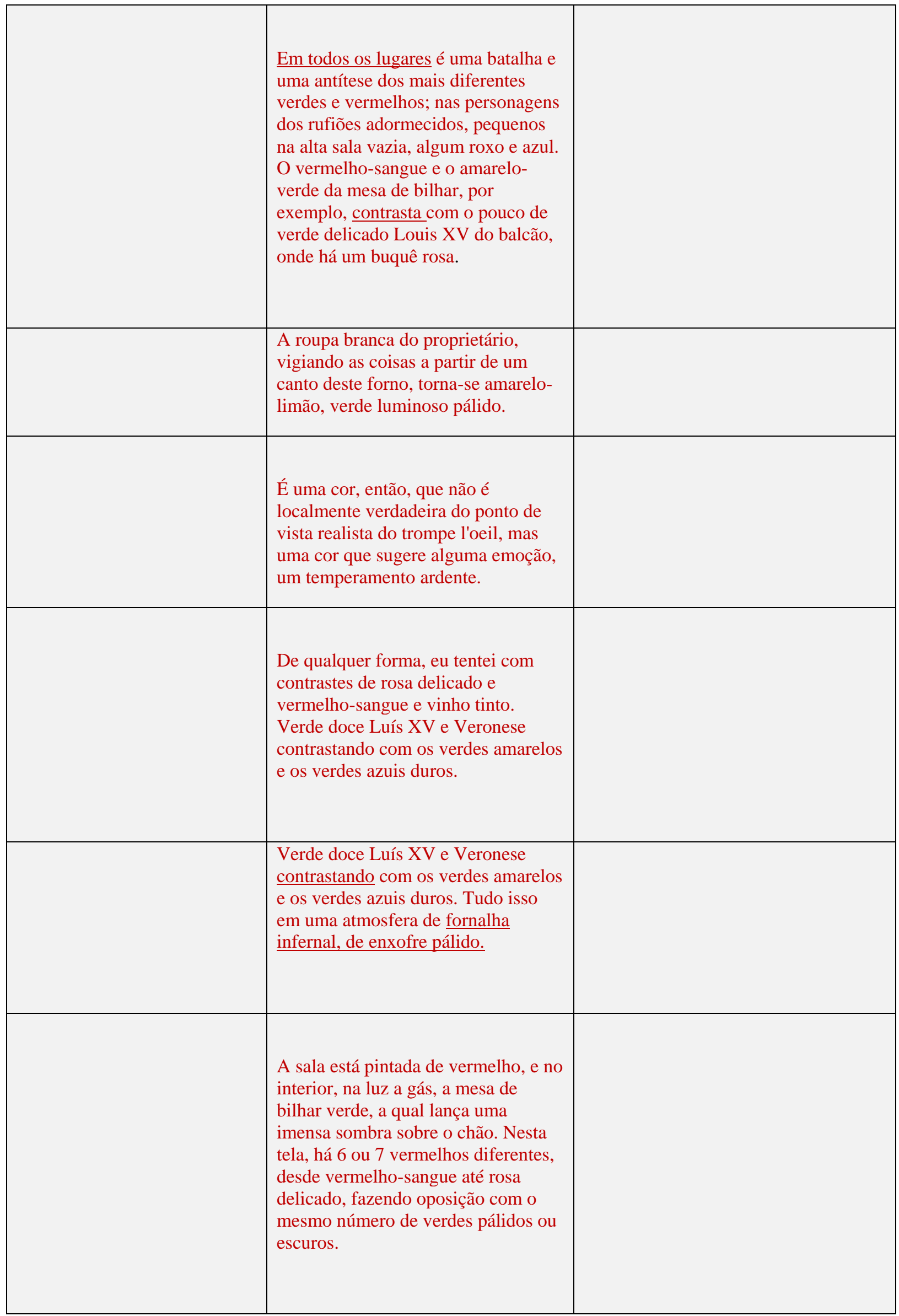




\begin{tabular}{|c|c|c|}
\hline $\begin{array}{l}\text { Na tela A Esplanada do Café } \\
\text { na Place du Forum, Arles, à } \\
\text { Noite observamos a } \\
\text { ocorrência de Modalidade } \\
\text { pela construção da } \\
\text { Modulação de cores como } \\
\text { van Gogh as percebia. A sua } \\
\text { fidedignidade para captar e } \\
\text { representar as cores noite } \\
\text { confere modalidade para a } \\
\text { noite representada na tela, } \\
\text { registrada na nota de rodapé } \\
\text { 204. }\end{array}$ & $\begin{array}{l}\text { Agora há uma pintura de noite sem } \\
\text { preto. Com nada mais do que um } \\
\text { belo azul e violeta e verde e nestes } \\
\text { arredores da praça iluminada é } \\
\text { colorido por enxofre pálido, amarelo } \\
\text { limão. }\end{array}$ & $\begin{array}{l}\text { Observamos a ocorrência de contraste } \\
\text { na escolha lexical 'noite' cujo sentido } \\
\text { está implicitamente relacionado com a } \\
\text { não escolha de 'dia'. O tema da noite, } \\
\text { em contraposição com o dia, seus } \\
\text { desafios e mistérios em contraposição } \\
\text { com as certezas e facilidades da } \\
\text { experiência de representar as cores do } \\
\text { dia, estão de certa forma imbricados } \\
\text { na representação textual da tela Café } \\
\text { da Noite e da tela do Café Terrace na } \\
\text { experiência de pintá-las. }\end{array}$ \\
\hline & $\begin{array}{l}\text { É bem verdade que eu possa tomar } \\
\text { um azul por um verde no escuro, um } \\
\text { azul lilás por um rosa lilás, desde } \\
\text { que você não pode perceber a } \\
\text { natureza do tom claramente. }\end{array}$ & $\begin{array}{l}\text { Observamos quando ele modula na } \\
\text { linguagem, quando ele modula as } \\
\text { cores da rua iluminada pelo lampião } \\
\text { há uma ambiguidade pois ele } \\
\text { descreve uma cor que está entre } \\
\text { uma cor e outra, porque há uma } \\
\text { transição. Quando ele escreve } \\
\text { 'pareço um japonês' há um tipo de } \\
\text { transição. 'tomar um azul por um } \\
\text { verde', 'um azul-lilás por um rosa } \\
\text { lilás.' Além da modulação este } \\
\text { trecho constrói semanticamente uma } \\
\text { paleta, a mesma que encontramos } \\
\text { ocorrência na tela. Há uma } \\
\text { ocorrência de ordem semântica. }\end{array}$ \\
\hline $\begin{array}{l}\text { Na tela 'A Esplanada do } \\
\text { Café na Place du Forum, } \\
\text { Arles, à Noite', observamos } \\
\text { a ocorrência de Saliência e } \\
\text { Cor, construída pelo } \\
\text { detalhamento e pela } \\
\text { intensidade cromática com } \\
\text { que a árvore, mesmo estando } \\
\text { no segundo plano, é } \\
\text { representada, registrada na } \\
\text { nota de rodapé } 199 \text {. }\end{array}$ & & \\
\hline $\begin{array}{l}\text { Na tela 'O Café Noturno na } \\
\text { Place Lamartine, em Arles', } \\
\text { observamos a ocorrência dos } \\
\text { Contrastes simultâneos entre } \\
\text { o verde e o vermelho escuro } \\
\text { no interior do café, } \\
\text { registrado na nota de rodapé } \\
214 \text {. }\end{array}$ & $\begin{array}{l}\text { 'Procuro com o verde e o } \\
\text { vermelho pintar as terríveis } \\
\text { paixões humanas.' }\end{array}$ & $\begin{array}{l}\text { O uso dos contrastes cromáticos } \\
\text { está presente, semanticamente, } \\
\text { tanto na tela quanto nas cartas, e } \\
\text { tornou-se um indicador para } \\
\text { verificar construtos dentro das } \\
\text { orações que explicitassem } \\
\text { contrastes e contraposições. }\end{array}$ \\
\hline
\end{tabular}




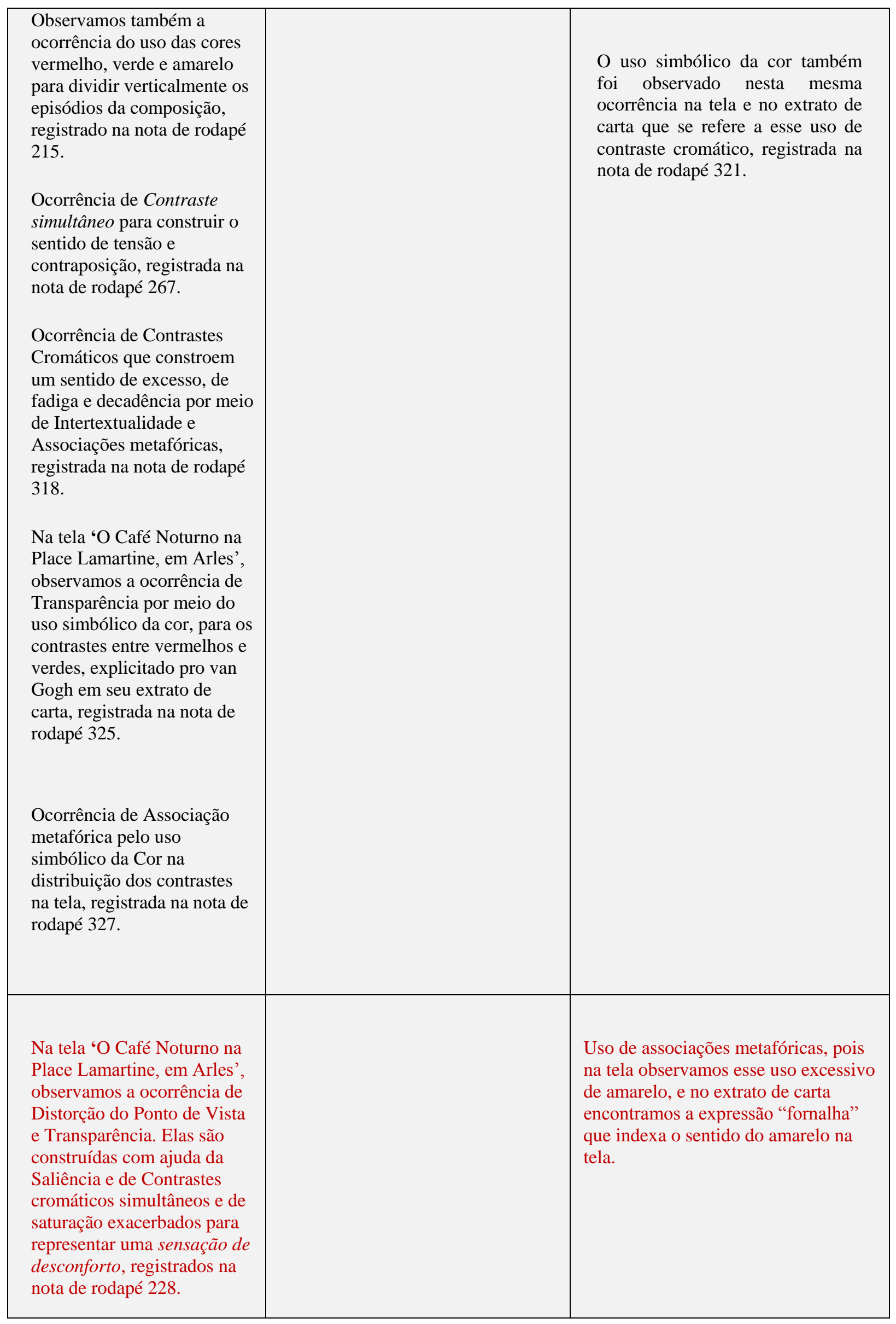




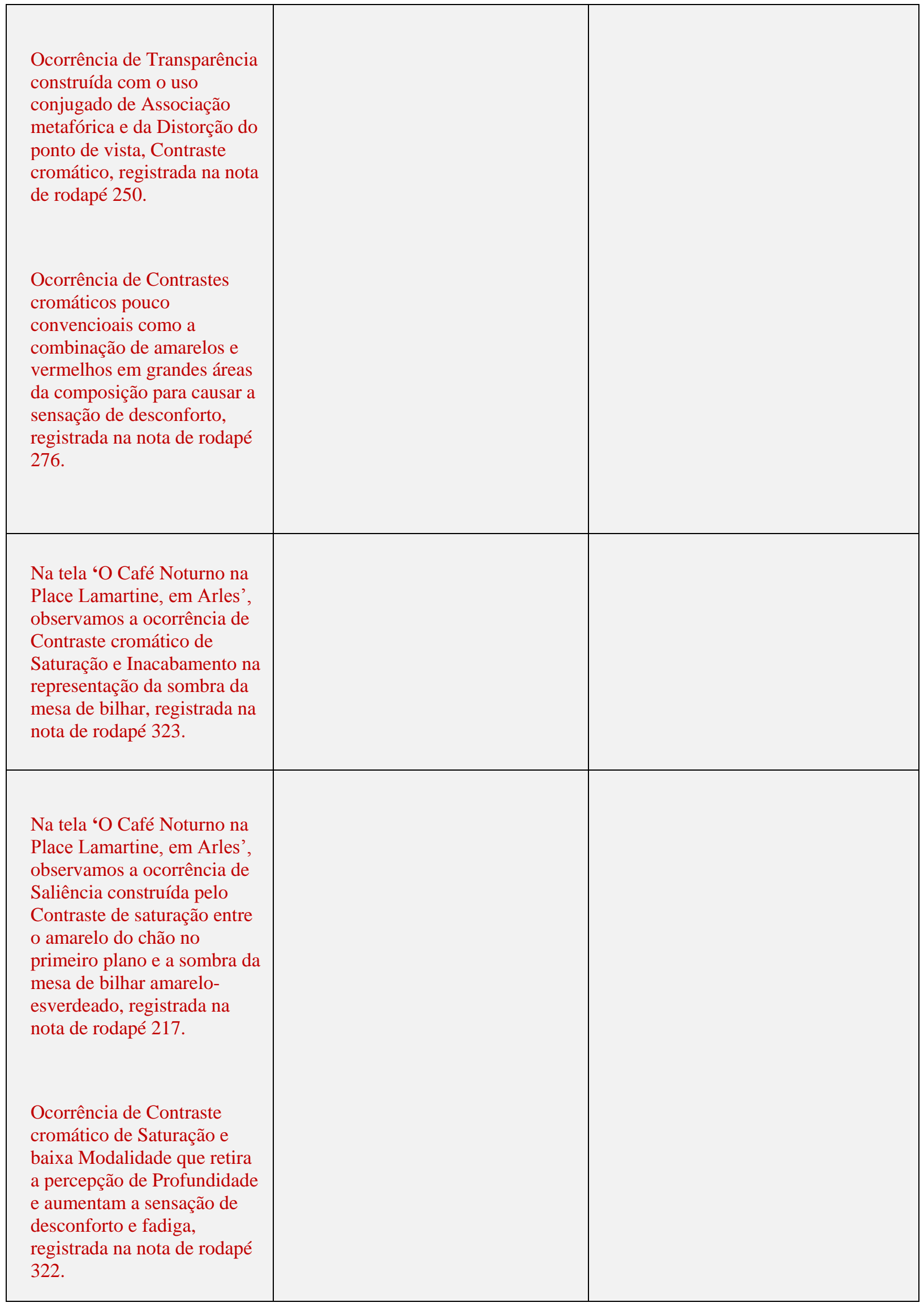




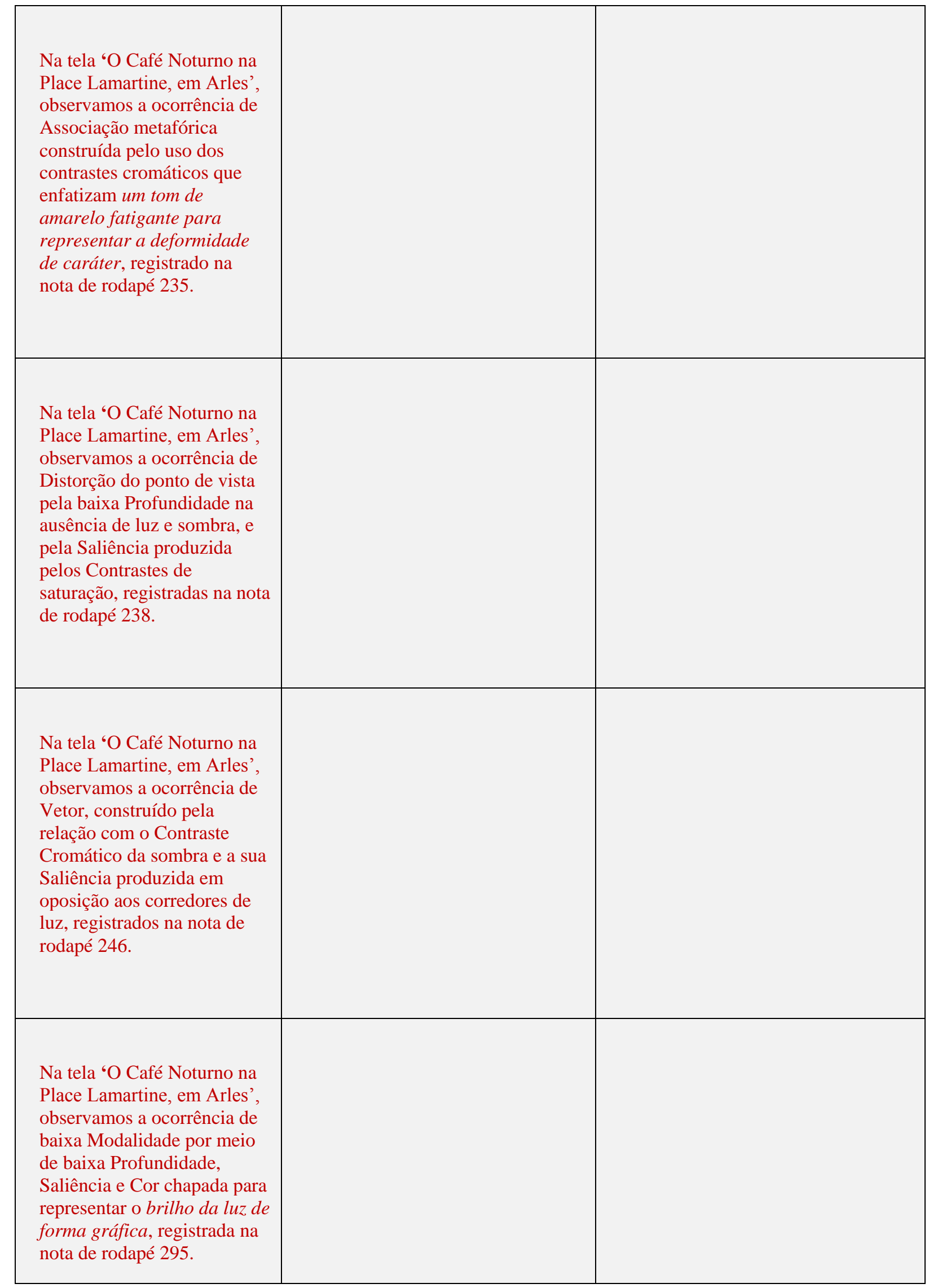




\begin{tabular}{|c|c|c|}
\hline $\begin{array}{l}\text { Na tela 'O Café Noturno na } \\
\text { Place Lamartine, em Arles', } \\
\text { observamos a ocorrência de } \\
\text { Saliência, Inacabamento, } \\
\text { Modalidade por meio dos } \\
\text { Contrastes Cromáticos e do } \\
\text { Gesto Pictórico no uso dos } \\
\text { recursos semióticos do } \\
\text { delineamento do contorno } \\
\text { dos móveis e objetos, como } \\
\text { as cadeiras e a mesa de } \\
\text { bilhar, registrada na nota de } \\
\text { rodapé } 307 \text {. }\end{array}$ & & \\
\hline $\begin{array}{l}\text { Na tela 'O Café Noturno na } \\
\text { Place Lamartine, em Arles', } \\
\text { observamos a ocorrência de } \\
\text { Associação metafórica pelo } \\
\text { uso do Contraste Simultâneo } \\
\text { entre vermelhos e verdes } \\
\text { para construir uma metáfora } \\
\text { visual, registrada na nota de } \\
\text { rodapé } 324 \text {. }\end{array}$ & $\begin{array}{l}\text { A ideia do semeador ainda continua } \\
\text { a me assombrar. Estudos exagerados, } \\
\text { como o semeador, como o café } \\
\text { noturno agora, geralmente parecem- } \\
\text { me atrozmente feios e ruins, mas } \\
\text { quando eu estou movido por alguma } \\
\text { coisa, como aqui por este pequeno } \\
\text { artigo sobre Dostoievski, em } \\
\text { seguida, eles são os únicos que me } \\
\text { parecem ter um significado mais } \\
\text { importante. }\end{array}$ & $\begin{array}{l}\text { Ao comparar o 'Café da Noite' com a } \\
\text { tela 'O Semeador', inferimos que ele } \\
\text { está se referindo ao uso do contraste } \\
\text { simultâneo em ambas. A oração } \\
\text { 'quando eu estou movido por alguma } \\
\text { coisa, como aqui por este pequeno } \\
\text { artigo sobre Dostoievski,' denota que } \\
\text { ambas as telas possuem uma camada } \\
\text { de significação que não se encontra na } \\
\text { própria cena em si, mas em uma ideia, } \\
\text { externa à cena representada e que o } \\
\text { move a comunicá-la por meio de uma } \\
\text { metáfora cromática. }\end{array}$ \\
\hline
\end{tabular}

Fonte: Triangulação para Contrastes Cromáticos dos dados dos corpora visual e textual, com os extratos das cartas.

\subsection{TRIANGULAÇÃO DO GESTO PICTÓRICO}

Quadro 75: Gesto Pictórico

\begin{tabular}{|c|c|c|}
\hline Ocorrência nas telas & Orações & Comentário \\
\hline $\begin{array}{l}\text { Na tela 'Por de Sol: Campo } \\
\text { de trigo perto de Arles', } \\
\text { observamos a ocorrência de } \\
\text { pinceladas direcionais, } \\
\text { ritmadas para representar o } \\
\text { vento ventando no trigal por } \\
\text { meio da combinação do uso } \\
\text { do ritmo, contraste cromático } \\
\text { de saturação, movimento } \\
\text { direcional, para construir a } \\
\text { rima visual registrada na nota } \\
\text { de rodapé } 80 \text { e } 81 \text {. } \\
\text { Ocorrência de Gesto }\end{array}$ & $\begin{array}{l}\text { Paisagens amarelo ouro velho - feito } \\
\text { rápido rápido rápido e com pressa, } \\
\text { como o ceifeiro que está em silêncio } \\
\text { sob o sol escaldante, concentrando-se } \\
\text { em ter o trabalho terminado. }\end{array}$ & $\begin{array}{l}\text { Observamos que van Gogh escreve } \\
\text { do mesmo modo como pinta, ou para, } \\
\text { desse modo, expressar como é a } \\
\text { pintura, ou porque ao escrever sobre } \\
\text { como pintou, ele está de fato } \\
\text { vivenciando a experiência dessa ação } \\
\text { e a escrita reflete isso. }\end{array}$ \\
\hline
\end{tabular}




\begin{tabular}{|c|c|c|}
\hline $\begin{array}{l}\text { pictórico e ritmo, observada } \\
\text { pelo modo como ele distribui } \\
\text { as pinceladas, com repetições } \\
\text { regulares e irregulares para } \\
\text { representar o campo de trigo, } \\
\text { também observada na nota de } \\
\text { rodapé } 87 \text {. }\end{array}$ & & \\
\hline $\begin{array}{l}\text { Na tela 'Por de Sol: Campo } \\
\text { de trigo perto de Arles', } \\
\text { observamos a ocorrência do } \\
\text { Gesto Pictórico na forma da } \\
\text { integração de recursos } \\
\text { gráficos com a plasticidade } \\
\text { do pincel para construir o } \\
\text { campo de trigo, registrado na } \\
\text { nota de rodapé } 68 \text {. }\end{array}$ & $\begin{array}{l}\text { Cidade violeta, estrela amarela, céu } \\
\text { azul-esverdeado; os campos de trigo } \\
\text { têm todos os tons: ouro velho, cobre, } \\
\text { ouro verde, ouro vermelho, ouro } \\
\text { amarelo, verde, vermelho e amarelo } \\
\text { bronze. }\end{array}$ & $\begin{array}{l}\text { Em sua fisicalidade, o Gesto pictórico } \\
\text { integra, visualmente, vários recursos } \\
\text { semióticos como ritmo, textura, } \\
\text { movimento, vetor. Na escrita } \\
\text { observamos uma fisicalidade também } \\
\text { nas vírgulas, no ritmo e no } \\
\text { encadeamento da escolha lexical das } \\
\text { cores. Cada palavra é como se fosse } \\
\text { uma pincelada de uma dessas cores } \\
\text { sobre o papel, reproduzindo a ação do } \\
\text { pincel para aproximar o leitor da } \\
\text { carta ao lugar de observador da tela } \\
\text { sem que esse tenha acesso à pintura. }\end{array}$ \\
\hline $\begin{array}{l}\text { Na tela 'Por de Sol: Campo } \\
\text { de trigo perto de Arles', } \\
\text { observamos a ocorrência do } \\
\text { gesto pictórico, caracterizado } \\
\text { pelo uso do grafismo, do } \\
\text { desenho-pintura, para dar } \\
\text { ênfase ao contorno das } \\
\text { edificações no horizonte e } \\
\text { contra a luz, registrada na } \\
\text { nota de rodapé } 72 \text {. }\end{array}$ & & \\
\hline $\begin{array}{l}\text { Na tela 'O Semeador' } \\
\text { observamos a ocorrência de } \\
\text { Ritmo, Textura, Direção e } \\
\text { Movimento construídos pelo } \\
\text { Gesto Pictórico de van Gogh } \\
\text { para representar } \text { o campo } \\
\text { arado, registrados na nota de } \\
\text { rodapé } 133 \text {. } \\
\text { Observamos a ocorrência do } \\
\text { uso conjugado de Textura, } \\
\text { ritmo, movimento, direção, } \\
\text { gesto pictórico e saliência na } \\
\text { representação dos torrões de } \\
\text { terra revolvida no campo } \\
\text { arado, registrado na nota de } \\
\text { rodapé } 135 \text {. }\end{array}$ & $\begin{array}{l}\text { Há várias sugestões de amarelo no } \\
\text { solo, tons neutros resultantes da } \\
\text { mistura de violeta e amarelo; mas } \\
\text { tenho travado uma luta diabólica para } \\
\text { atingir a verdade das cores. }\end{array}$ & $\begin{array}{l}\text { O momento da produção da tela criou } \\
\text { uma tensão para reprodução das } \\
\text { cores, em sua textura e na } \\
\text { materialidade dos torrões de terra. } \\
\text { Essa tensão que ele relata como uma } \\
\text { luta diabólica fica marcada no } \\
\text { movimento da produção da tela. A } \\
\text { luta é dele com a cor, mas o resultado } \\
\text { da tela parece que a luta se dá na } \\
\text { terra. Ela está pulsando, ela está em } \\
\text { movimento. Há uma tensão dentro } \\
\text { dele, um movimento que ele buscava } \\
\text { e que ficou representado na tela. O } \\
\text { gesto nasce nesse movimento interno, } \\
\text { que vai para o ato de pintar, que vai } \\
\text { para a tela, e que vai para a oração. }\end{array}$ \\
\hline
\end{tabular}




\begin{tabular}{|c|c|c|}
\hline $\begin{array}{l}\text { Na tela 'O Semeador', há } \\
\text { uma inter-relação entre } \\
\text { Textura, Contrastes } \\
\text { Simultâneos, Saliência, } \\
\text { Sinestesia que criam } \\
\text { Associações Metafóricas da } \\
\text { materialidade da tinta com a } \\
\text { nossa memória sensorial e } \\
\text { tátil da plasticidade da terra, } \\
\text { registrado na nota de rodapé } \\
136 .\end{array}$ & & \\
\hline $\begin{array}{l}\text { Na tela 'O Semeador', } \\
\text { observamos a ocorrência de } \\
\text { Movimento, Gesto Pictórico } \\
\text { e Vetor } 1 \text {, sugerido pelo } \\
\text { andar do Semeador, } \\
\text { registrado na nota de rodapé } \\
138 .\end{array}$ & $\begin{array}{l}\text { Em um campo arado, um grande } \\
\text { campo de torrões de terra roxa - } \\
\text { levantados em direção ao horizonte - } \\
\text { um semeador em azul e branco. }\end{array}$ & \\
\hline $\begin{array}{l}\text { Na tela 'O Semeador', } \\
\text { observamos a ocorrência de } \\
\text { Movimento, Gesto Pictórico, } \\
\text { Vetor } 2 \text {, Rima Visual e } \\
\text { Incompletude, sugerido pelos } \\
\text { raios do sol em toda a } \\
\text { pintura, registrado na nota de } \\
\text { rodapé } 139 . \\
\text { Observamos também a } \\
\text { ocorrência de Saliência e } \\
\text { Associação Metafórica para } \\
\text { o céu e o sol, construída pelo } \\
\text { uso de ritmo, textura, } \\
\text { movimento e direção } \\
\text { articulados pelo gesto } \\
\text { pictórico, registrado na nota } \\
\text { de rodapé } 151 .\end{array}$ & 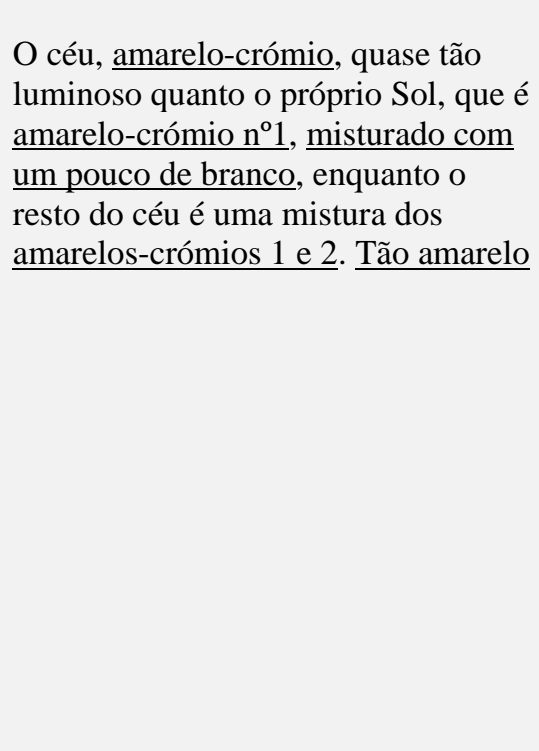 & $\begin{array}{l}\text { Textura } \\
\text { Não é a palavra 'amarelo' em si, mas } \\
\text { o encadeamento de amarelos no uso } \\
\text { da cor na linguagem reproduz essa } \\
\text { simultaneidade e sobreposição de } \\
\text { amarelos que são usados em } \\
\text { sequência e de forma saturada. Na } \\
\text { escolha lexical que van Gogh faz } \\
\text { parece estar presente à mesma } \\
\text { intensidade luminosa que foi } \\
\text { intencionalmente representada no } \\
\text { quadro. Então há uma preocupação } \\
\text { nele não só de descrever o quadro, } \\
\text { mas de reproduzir de forma quase } \\
\text { táctil, vivencial, experiencial, o que o } \\
\text { observador sente quando observa o } \\
\text { quadro. }\end{array}$ \\
\hline $\begin{array}{l}\text { Na tela 'O Semeador', } \\
\text { observamos a ocorrência de } \\
\text { Associação Metafórica e } \\
\text { Incompletude construída pela } \\
\text { Rima Visual e pelo Gesto } \\
\text { pictórico para representar a } \\
\text { unidade entre o Homem e a } \\
\text { Natureza, registrados na nota } \\
\text { de rodapé } 164 \text {. }\end{array}$ & & \\
\hline
\end{tabular}




\begin{tabular}{|c|c|c|}
\hline $\begin{array}{l}\text { Na tela 'A Esplanada do Café } \\
\text { na Place du Forum, Arles, à } \\
\text { Noite', observamos a } \\
\text { ocorrência e Inter-relação } \\
\text { entre Ritmo, Movimento, } \\
\text { Textura, Gesto Pictórico, } \\
\text { Desenho-Pintura para } \\
\text { construir a Perspectiva do } \\
\text { calçamento, registrados na } \\
\text { nota de rodapé } 171 .\end{array}$ & $\begin{array}{l}\text { No terraço, há pequenas figuras de } \\
\text { pessoas que bebem. Uma enorme } \\
\text { lanterna amarela ilumina o terraço, a } \\
\text { fachada, a calçada, e até mesmo } \\
\text { projeta luz sobre os paralelepípedos } \\
\text { da rua, que adquirem uma coloração } \\
\underline{\text { violeta-rosa. As frentes das casas em }} \\
\underline{\text { uma rua que segue sob o céu azul }} \\
\text { salpicado de estrelas são azul escuro } \\
\text { ou violeta, com uma árvore verde. } \\
\text { Agora há uma pintura de noite sem } \\
\text { preto. Com nada mais do que um } \\
\text { belo azul e violeta e verde e nestes } \\
\text { arredores da praça iluminada é } \\
\text { colorido por enxofre pálido, amarelo } \\
\text { limão. }\end{array}$ & $\begin{array}{l}\text { Na oração van Gogh utiliza processos } \\
\text { materiais que explicitam o gesto } \\
\text { pictórico utilizado na produção da } \\
\text { tela: projeta luz, rua que segue, céu } \\
\text { azul salpicado. } \\
\text { A ação dada por diferentes pinceladas } \\
\text { conferem ao resultado um sentido } \\
\text { também diferenciado. Por exemplo, a } \\
\text { descrição do céu como salpicado de } \\
\text { estrela dá à ação do artista um } \\
\text { movimento diferente. Há uma } \\
\text { complementaridade entre o efeito das } \\
\text { estrelas que saltitam no céu e a } \\
\text { descrição de que elas realmente } \\
\text { foram salpicadas pelas pinceladas. }\end{array}$ \\
\hline $\begin{array}{l}\text { Na tela 'O Café Noturno na } \\
\text { Place Lamartine, em Arles', } \\
\text { observamos a ocorrência do } \\
\text { uso de Saliência e Vetor } \\
\text { inter-relacionados com a } \\
\text { ocorrência de Textura e } \\
\text { Gesto Pictórico para construir } \\
\text { a luz das lâmpadas a gás, } \\
\text { registrado na nota de rodapé } \\
\text { 216. O vetor ocorre em } \\
\text { direção radial. }\end{array}$ & $\begin{array}{l}\text { Agora há uma pintura de noite sem } \\
\text { preto. Com nada mais do que um } \\
\text { belo azul e violeta e verde e nestes } \\
\text { arredores da praça iluminada é } \\
\text { colorido por enxofre pálido, amarelo } \\
\text { limão. Eu gosto enormemente de } \\
\text { pintar no local à noite. No passado, } \\
\text { eles costumavam desenhar e pintar a } \\
\text { tela do desenho durante o dia. Mas } \\
\text { acho que me convém pintar a coisa } \\
\text { no momento. É bem verdade que eu } \\
\text { possa tomar um azul por um verde } \\
\text { no escuro, um azul lilás por um rosa } \\
\text { lilás, uma vez que você não pode } \\
\text { perceber a natureza do tom } \\
\text { claramente. Mas é a única maneira } \\
\text { de se livrar da noite negra } \\
\text { convencional com uma luz pobre, } \\
\text { pálida e esbranquiçada, quando na } \\
\text { verdade uma mera vela por si só nos } \\
\text { dá os mais ricos amarelos e laranjas. }\end{array}$ & $\begin{array}{l}\text { Van Gogh enfatiza que a ele convém } \\
\text { pintar a tela no momento, sem esboço } \\
\text { prévio. A descrição na oração } \\
\text { valoriza os diferentes usos das cores } \\
\text { com intuito de apresentar a interação } \\
\text { entre cor e sombra, este movimento } \\
\text { de interação aparece quando em uma } \\
\text { pincelada temos a sombra e ao seu } \\
\text { lado uma pincelada que representa a } \\
\text { projeção da luz no objeto que se } \\
\text { encontra entre a noite e a luz do café. } \\
\text { Ele sofre a ação da noite e da luz, esta } \\
\text { interação exige de van Gogh uma } \\
\text { pincelada que possibilite transmutar o } \\
\text { jogo de sombra e luz para a tela. }\end{array}$ \\
\hline $\begin{array}{l}\text { Ocorrência de Ritmo, } \\
\text { Textura, Movimento, Vetor e } \\
\text { Rima Visual pelo Gesto } \\
\text { Pictórico para expressar o } \\
\text { fluxo e a intensidade da } \\
\text { iluminação na sala, } \\
\text { registrados na nota de rodapé } \\
280 \text {. }\end{array}$ & & \\
\hline $\begin{array}{l}\text { Ocorrência de Saliência, por } \\
\text { meio do uso de Ritmo, }\end{array}$ & & \\
\hline
\end{tabular}




\begin{tabular}{|c|c|c|}
\hline $\begin{array}{l}\text { Movimento, Textura, Vetor e } \\
\text { Gesto Pictórico que são } \\
\text { usados para representar o } \\
\text { brilho intermitente das } \\
\text { lâmpadas, pintado com } \\
\text { riqueza de detalhes, textura e } \\
\text { movimento direcional, } \\
\text { registrados na nota de rodapé } \\
281 \text {. }\end{array}$ & & \\
\hline $\begin{array}{l}\text { Ocorrência de Associação } \\
\text { metafórica por meio do uso } \\
\text { de Ritmo, Movimento, } \\
\text { Textura, Vetor, Gesto } \\
\text { Pictórico e Rima Visual que } \\
\text { juntos constroem uma } \\
\text { metáfora visual para a luz } \\
\text { que interliga todos os } \\
\text { processos na narrativa, } \\
\text { registrados na nota de rodapé } \\
\text { 282. }\end{array}$ & & \\
\hline $\begin{array}{l}\text { Ocorrência de Rima Visual e } \\
\text { Gesto Pictórico na } \\
\text { representação da luz como } \\
\text { uma metáfora visual que } \\
\text { interliga todos os elementos } \\
\text { da tela; o Ritmo é o recurso } \\
\text { que expressa essa metáfora e } \\
\text { que constrói a coesão visual, } \\
\text { registrados na nota de rodapé } \\
283 \text {. }\end{array}$ & & \\
\hline $\begin{array}{l}\text { Uso de Associação } \\
\text { metafórica por meio de } \\
\text { Saliência, Ritmo, } \\
\text { Movimento, Textura e Gesto } \\
\text { Pictórico para dar } \\
\text { centralidade para luz, } \\
\text { registrada na nota de rodapé } \\
292 \text {. }\end{array}$ & & \\
\hline $\begin{array}{l}\text { Na tela 'O Café Noturno na } \\
\text { Place Lamartine, em Arles', } \\
\text { observamos a ocorrência de } \\
\text { Saliência construída com o } \\
\text { uso de Textura, Ritmo, } \\
\text { Movimento e Gesto Pictórico } \\
\text { para representar o brilho da } \\
\text { lâmpada em contraste com os } \\
\text { tons de vermelho e verde } \\
\text { escuro registrada na nota de } \\
\text { rodapé } 224 \text {. }\end{array}$ & $\begin{array}{l}\text { A sala é vermelho-sangue e amarelo } \\
\text { sem graça, uma mesa de bilhar verde } \\
\text { no centro, } 4 \text { lâmpadas de amarelo } \\
\text { limão com um brilho laranja e verde. } \\
\text { Em todos os lugares é uma batalha e } \\
\text { uma antítese dos mais diferentes } \\
\text { verdes e vermelhos; nas personagens } \\
\text { dos rufiões adormecidos, pequenos } \\
\text { na alta sala vazia, algum roxo e azul. } \\
\text { O vermelho-sangue e o amarelo- } \\
\text { verde da mesa de bilhar, por }\end{array}$ & $\begin{array}{l}\text { O brilho laranja e verde não é dado } \\
\text { somente pela cor mas pelo formato } \\
\text { arredondado que o gesto pictórico } \\
\text { confere à luz que emana da lâmpada. } \\
\text { O gesto é crucial para conferir } \\
\text { movimento e ritmo à luz que incide } \\
\text { sobre a sala vazia, para que ela } \\
\text { ganhasse movimento foi necessário } \\
\text { imprimir na tela este movimento, um } \\
\text { gesto contínuo, porém desigual, ora } \\
\text { mais forte, ora mais fraco, mas }\end{array}$ \\
\hline
\end{tabular}




\begin{tabular}{|c|c|c|}
\hline & $\begin{array}{l}\text { exemplo, contrasta com o pouco de } \\
\text { verde delicado Louis XV do balcão, } \\
\text { onde há um buquê rosa. }\end{array}$ & incessante. \\
\hline $\begin{array}{l}\text { Na tela 'O Café Noturno na } \\
\text { Place Lamartine, em Arles', } \\
\text { observamos a ocorrência de } \\
\text { Saliência, por meio de } \\
\text { Textura e Gesto Pictórico no } \\
\text { uso do Desenho-Pintura para } \\
\text { detalhar a representação dos } \\
\text { contornos da mesa de bilhar, } \\
\text { registrada na nota de rodapé } \\
305 . \\
\text { Ocorrência de Saliência, } \\
\text { Inacabamento, Modalidade } \\
\text { por meio dos Contrastes } \\
\text { Cromáticos e do Gesto } \\
\text { Pictórico no uso dos recursos } \\
\text { semióticos do delineamento } \\
\text { do contorno dos móveis } e \\
\text { objetos, como as cadeiras e a } \\
\text { mesa de bilhar, registrada na } \\
\text { nota de rodapé } 307 \text {. }\end{array}$ & $\begin{array}{l}\text { A sala está pintada de vermelho, e no } \\
\text { interior, na luz a gás, a mesa de bilhar } \\
\text { verde, a qual lança uma imensa } \\
\text { sombra sobre o chão. Nesta tela, há } 6 \\
\text { ou } 7 \text { vermelhos diferentes, desde } \\
\text { vermelho-sangue até rosa delicado, } \\
\text { fazendo oposição com o mesmo } \\
\text { número de verdes pálidos ou escuros. }\end{array}$ & $\begin{array}{l}\text { O gesto pictórico que produz a } \\
\text { imensa sombra confere especial } \\
\text { destaque ao contorno da sombra da } \\
\text { mesa de bilhar no chão do café. O } \\
\text { gesto fica registrado no contorno da } \\
\text { mesa, marcado, acentuado, com } \\
\text { objetivo claro de destacar a diferença } \\
\text { de luz e sombra. Na oração van Gogh } \\
\text { enfatiza os contrastes de luz e } \\
\text { sombra, de claro e escuro, } \\
\text { descrevendo a multiplicidade de } \\
\text { tonalidades usadas para construir essa } \\
\text { batalha entre as cores. }\end{array}$ \\
\hline
\end{tabular}

Fonte: Triangulação para Gesto Pictórico dos dados dos corpora visual e textual, com os extratos das cartas.

\subsection{TRIANGULAÇÃO DA SALIÊNCIA}

Quadro 76: Triangulação da Saliência

\begin{tabular}{|c|c|c|}
\hline Ocorrência nas telas & Orações & Comentário \\
\hline $\begin{array}{l}\text { Na tela 'Por de Sol: Campo } \\
\text { de trigo perto de Arles', } \\
\text { observamos a ocorrência de } \\
\text { Saliência e Sinestesia, } \\
\text { construída pelo uso } \\
\text { combinado de Textura, } \\
\text { Ritmo, Movimento, Direção } \\
\text { e Volume para representar o } \\
\text { trigal, registrada nas notas de } \\
\text { rodapé } 77,83,113 \text { e } 114 \text {. } \\
\text { Observamos também a } \\
\text { ocorrência de Cor e }\end{array}$ & $\begin{array}{l}\text { Eu tenho um terceiro estudo, agora, } \\
\text { de uma paisagem com fábrica, e um } \\
\text { enorme sol em um céu vermelho, } \\
\text { acima de telhados vermelhos, em } \\
\text { que a natureza parece estar em um } \\
\text { acesso de raiva, em um dia de } \\
\text { mistral desagradável. }\end{array}$ & $\begin{array}{l}\text { Em ambos, tanto no quadro quanto na } \\
\text { oração, ele está salientando um } \\
\text { momento que é no quadro um por do } \\
\text { sol com vento no trigo. Desse } \\
\text { momento resulta uma experiência na } \\
\text { qual agora possui um estudo. } \\
\text { Inferimos que, tanto na tela quanto na } \\
\text { carta ele expressa o momento da } \\
\text { experiência. Isso sugere que ele } \\
\text { percebe a vida dele como momentos } \\
\text { que são relatados e expressados para }\end{array}$ \\
\hline
\end{tabular}




\begin{tabular}{|c|c|c|}
\hline $\begin{array}{l}\text { Saliência conferida pelos } \\
\text { contrastes quente/frio entre } \\
\text { azuis e amarelos. }\end{array}$ & & $\begin{array}{l}\text { Theo: em um deles o momento de } \\
\text { experiência dele com a natureza (no } \\
\text { quadro) e em outro o momento dele } \\
\text { em relação à tela (na carta). }\end{array}$ \\
\hline $\begin{array}{l}\text { Na tela 'Por de Sol: Campo } \\
\text { de trigo perto de Arles', } \\
\text { observamos a ocorrência de } \\
\text { Saliência no fino halo branco } \\
\text { em torno do sol que pode } \\
\text { enfatizar seu brilho e } \\
\text { também produzir uma } \\
\text { associação com o sentido de } \\
\text { espiritualidade e de } \\
\text { santidade, registrada na nota } \\
\text { de rodapé } 58 .\end{array}$ & $\begin{array}{l}\text { Aqui está outra paisagem. Sol } \\
\text { poente? Lua nascendo? Noite de } \\
\text { verão, de qualquer modo. }\end{array}$ & $\begin{array}{l}\text { A saliência que van Gogh está dando } \\
\text { com a escolha lexical 'Aqui' para a } \\
\text { paisagem deixa ambígua a definição } \\
\text { de que corpo celeste ele representa no } \\
\text { céu. É como se ele dissesse: 'estamos } \\
\text { em uma noite de verão e nesse } \\
\text { espetáculo da natureza, pouco importa } \\
\text { se é a lua ou se é o sol, o que importa } \\
\text { é que nós estamos em uma noite de } \\
\text { verão na qual é possível contemplar a } \\
\text { natureza'. É como se ele dissesse } \\
\text { assim, 'não vamos nos apegar às } \\
\text { coisas em si, mas àquilo que elas nos } \\
\text { proporcionam. }\end{array}$ \\
\hline $\begin{array}{l}\text { Na tela 'Por de Sol: Campo } \\
\text { de trigo perto de Arles', } \\
\text { observamos a ocorrência de } \\
\text { Saliência nos tons de verde } \\
\text { que aparecem no céu para } \\
\text { dar ênfase para as colunas } \\
\text { de fumaça, registrado na } \\
\text { nota de rodapé } 62 \text {. }\end{array}$ & $\begin{array}{l}\text { Cidade violeta, estrela amarela, céu } \\
\text { azul-esverdeado; os campos de trigo } \\
\text { têm todos os tons: ouro velho, cobre, } \\
\text { ouro verde, ouro vermelho, ouro } \\
\text { amarelo, verde, vermelho e amarelo } \\
\text { bronze. }\end{array}$ & $\begin{array}{l}\text { A saliência está nos detalhes, no uso } \\
\text { de recursos pictóricos para enfatizar } \\
\text { cada aspecto. O azul do céu se } \\
\text { mistura à fumaça esverdeada. São } \\
\text { muitas colunas, cerca de } 8 \text { no total, } \\
\text { todas com fumaça que contrasta com } \\
\text { o amarelo do astro e que está } \\
\text { separado do restante por um halo } \\
\text { branco. Toda a composição serve para } \\
\text { enfatizar o contraste, provavelmente } \\
\text { metafórico, entre a natureza e a } \\
\text { indústria nascente no século XIX. }\end{array}$ \\
\hline $\begin{array}{l}\text { Na tela 'Por de Sol: Campo } \\
\text { de trigo perto de Arles', } \\
\text { observamos também a } \\
\text { ocorrência de Saliência pelo } \\
\text { uso cromático de um tom de } \\
\text { amarelo mais claro na área } \\
\text { onde o homem se encontra } \\
\text { registrado nas notas de } \\
\text { rodapé } 89 \text { e } 105\end{array}$ & $\begin{array}{l}\text { Paisagens amarelo ouro velho - feito } \\
\text { rápido rápido rápido e com pressa, } \\
\text { como o ceifeiro que está em silêncio } \\
\text { sob o sol escaldante, concentrando- } \\
\text { se em ter o trabalho terminado. }\end{array}$ & $\begin{array}{l}\text { É interessante que ele se refere ao } \\
\text { ceifeiro concentrado a ter o trabalho } \\
\text { terminado que é semelhante ao sol } \\
\text { que está se pondo tendo o seu } \\
\text { trabalho terminado. Nesse momento } \\
\text { de auge quando ele está se pondo, ele } \\
\text { tem um halo de luz diferente e o } \\
\text { ceifeiro no momento em que está } \\
\text { terminando o trabalho dele, também } \\
\text { tem uma luminosidade diferente, mais } \\
\text { intensa, naquele espaço. }\end{array}$ \\
\hline $\begin{array}{l}\text { Na tela 'Por de Sol: Campo } \\
\text { de trigo perto de Arles', } \\
\text { observamos a ocorrência de }\end{array}$ & $\begin{array}{l}\text { Eu tenho um terceiro estudo, agora, } \\
\text { de uma paisagem com fábrica, e um } \\
\text { enorme sol em um céu vermelho, }\end{array}$ & $\begin{array}{l}\text { É interessante que van Gogh } \\
\text { representa a fábrica de uma maneira } \\
\text { pouco evidente no quadro, mas ao }\end{array}$ \\
\hline
\end{tabular}




\begin{tabular}{|c|c|c|}
\hline $\begin{array}{l}\text { Saliência muito sutil e de } \\
\text { Associação Metafórica. O } \\
\text { uso da saliência, pelo } \\
\text { posicionamento do moinho } \\
\text { junto à chaminé da fábrica, } \\
\text { ambos em um dos pontos de } \\
\text { fuga da composição, sugere } \\
\text { uma metáfora de que o } \\
\text { moinho está em } \\
\text { contraposição com a } \\
\text { fábrica e todos os } \\
\text { significados que isso } \\
\text { implica, registrados na nota } \\
\text { de rodapé } 94 .\end{array}$ & acima de telhados vermelhos, & $\begin{array}{l}\text { descrevê-la na oração, ele se refere à } \\
\text { tela como uma paisagem com fábrica. } \\
\text { Quer dizer a fábrica é salientada na } \\
\text { oração como um diferencial desta tela } \\
\text { em relação a muitas outras nas quais } \\
\text { ele não pintou a fábrica, justamente } \\
\text { porque não é um tema recorrente nas } \\
\text { telas dele pintar o espaço urbano e sim } \\
\text { a Natureza. Mesmo quando ele pinta } \\
\text { como um detalhe longínquo difícil de } \\
\text { id ao descrever ele fala um aspecto que } \\
\text { a diferencia das demais, o fato de que } \\
\text { ali tem uma fábrica. }\end{array}$ \\
\hline $\begin{array}{l}\text { Na tela 'Por de Sol: Campo } \\
\text { de trigo perto de Arles', } \\
\text { observamos a ocorrência de } \\
\text { Enquadramento, pela } \\
\text { escolha do ponto de vista } \\
\text { que privilegia a } \\
\text { representação do campo } \\
\text { sobre a cidade e com isso, } \\
\text { constrói uma relação que } \\
\text { realça o valor do campo. } \\
\text { Observamos também a } \\
\text { ocorrência de Saliência e } \\
\text { Associação metafórica por } \\
\text { meio do enquadramento que } \\
\text { aproxima o campo e } \\
\text { distancia a cidade, } \\
\text { registrado na nota de rodapé } \\
107 .\end{array}$ & $\begin{array}{l}\text { Aqui está outra paisagem. Sol } \\
\text { poente? Lua nascendo? Noite de } \\
\text { verão, de qualquer modo. Cidade } \\
\text { violeta, estrela amarela, céu azul- } \\
\text { esverdeado; os campos de trigo têm } \\
\text { todos os tons: ouro velho, cobre, } \\
\underline{\text { ouro verde, ouro vermelho, ouro }} \\
\underline{\text { amarelo, verde, vermelho e amarelo }} \\
\underline{\text { bronze. Tela quadrada número } 30 .} \\
\text { Eu pintei-a ao ar livre no mistral. } \\
\text { Meu cavalete foi fixado no chão com } \\
\text { estacas de ferro, um método que eu } \\
\text { recomendo a você. }\end{array}$ & $\begin{array}{l}\text { Os telhados laranjas salientam ainda } \\
\text { mais a separação entre cidade e } \\
\text { campo de trigo. Há um esverdeado no } \\
\text { campo, assim como há amarelo no } \\
\text { por de sol. Mas essa comunicação } \\
\text { parece salientar ainda mais a } \\
\text { diferença e a distância entre o campo } \\
\text { e a cidade, a horizontalidade do trigo } \\
\text { e a verticalidade da cidade, o amarelo } \\
\text { e o violeta, o movimento do vento no } \\
\text { trigo e o movimento da fumaça. São } \\
\text { ênfases que trabalham na construção } \\
\text { metafórica sobre a relação entre a } \\
\text { vida do campo e da natureza e a vida } \\
\text { urbana e da indústria. }\end{array}$ \\
\hline $\begin{array}{l}\text { Há uma inter-relação entre } \\
\text { Textura, Contrastes } \\
\text { Simultâneos, Sinestesia que } \\
\text { criam Associações } \\
\text { Metafóricas da } \\
\text { materialidade da tinta com } \\
\text { a nossa memória sensorial } \\
\text { e tátil da plasticidade da } \\
\text { terra, registrado na nota de } \\
\text { rodapé } 136 .\end{array}$ & $\begin{array}{l}\text { Aqui está um esboço de um } \\
\text { semeador, um grande campo lavrado } \\
\text { com torrões de terra, na sua maioria } \\
\text { fracamente cor de violeta. } \\
\text { Um campo de trigo maduro, de tom } \\
\text { amarelo-ocre com um pouco de } \\
\text { carmim. } \\
\text { O céu, amarelo-crómio, quase tão } \\
\text { luminoso quanto o próprio Sol, que } \\
\text { é amarelo-crómio no } 1 \text {, misturado } \\
\text { com um pouco de branco, enquanto } \\
\text { o resto do céu é uma mistura dos } \\
\text { amarelos-crómios } 1 \text { e } 2 . \text { Tão } \\
\text { amarelo! A camisa do semeador é } \\
\text { azul e as calças brancas. Tamanho } \\
\text { da tela - } 25 \text {, quadrada. } \\
\text { Há várias sugestões de amarelo no } \\
\underline{\text { solo, tons neutros resultantes da }} \\
\text { mistura de violeta e amarelo; mas } \\
\text { tenho travado uma luta diabólica }\end{array}$ & $\begin{array}{l}\text { Para dar a idéia de um campo lavrado, } \\
\text { na qual os torrões de terra estão } \\
\text { revolvidos para o plantio, van Gogh } \\
\text { preciso salientar o movimento usado } \\
\text { para cavar a terra e neste movimento } \\
\text { salientou o gesto pictórico que daria } \\
\text { movimento aos torrões. Para isto } \\
\text { utilizou uma variedade de cores e } \\
\text { contrastes que ajudaram a salientar a } \\
\text { conformação dos torrões de terra } \\
\text { sobre o solo. Em contraste com este } \\
\text { movimento no solo está o céu amarelo } \\
\text { com o sol amarelo que ganha } \\
\text { destaque pela homogeneidade do sol } \\
\text { pintado com um tom de amarelo e o } \\
\text { restante do céu pintado com misturas } \\
\text { de tonalidades. }\end{array}$ \\
\hline
\end{tabular}




\begin{tabular}{|c|c|c|}
\hline $\begin{array}{l}\text { ocorrência de Saliência e } \\
\text { Rima Visual, construída } \\
\text { pelo uso conjugado de } \\
\text { vários recursos, registrado } \\
\text { na nota de rodapé } 144 . \\
\text { Observamos também a } \\
\text { ocorrência de Uso Simbólico } \\
\text { da Cor para conferir } \\
\text { Saliência e Associação } \\
\text { Metafórica para os } \\
\text { sentidos simbólicos do } \\
\text { campo arado registrada na } \\
\text { nota de rodapé } 161 .\end{array}$ & para atingir a verdade das cores. & \\
\hline $\begin{array}{l}\text { Na tela 'O Semeador', } \\
\text { observamos a ocorrência } \\
\text { conjugada de Contrastes de } \\
\text { Saturação, Saliência, } \\
\text { Associação Metafórica e } \\
\text { Incompletude na } \\
\text { representação do céu e do } \\
\text { sol, em amarelo sobre } \\
\text { amarelo, registrado na nota } \\
\text { de rodapé } 137 .\end{array}$ & 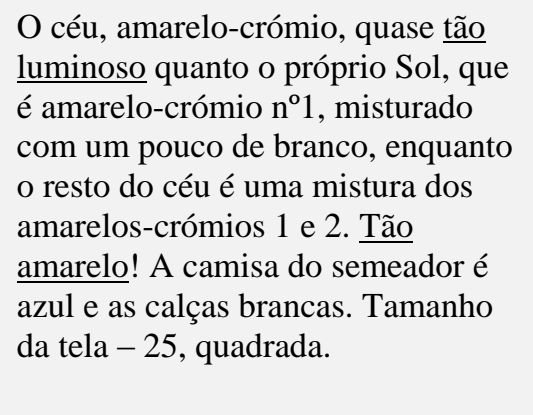 & $\begin{array}{l}\text { O uso de superlativos enfatiza } \\
\text { qualidades na oração equivalentes ao } \\
\text { uso das cores sobrepostas com intuito } \\
\text { salientar seu papel na composição. Ao } \\
\text { descrever o quadro van Gogh salienta } \\
\text { o uso cromático do amarelo com } \\
\text { construtos que parecem saturar na } \\
\text { linguagem o que foi anteriormente } \\
\text { saturado na tela. }\end{array}$ \\
\hline $\begin{array}{l}\text { Observamos também a } \\
\text { ocorrência de Saliência e } \\
\text { Associação Metafórica } \\
\text { para o céu e o sol, } \\
\text { construída pelo uso de ritmo, } \\
\text { textura, movimento e direção } \\
\text { articulados pelo gesto } \\
\text { pictórico, registrado na nota } \\
\text { de rodapé } 151 .\end{array}$ & $\begin{array}{l}\text { Não te vou ocultar que não desgosto } \\
\text { da região, pois fui criado lá - ainda } \\
\text { me encanta a magia das recordações } \\
\text { do passado, de um desejo do infinito, } \\
\text { do qual o semeador e o enfeixador } \\
\text { são símbolos -, tanto quanto antes } \\
\text { gostava. Mas quando eu farei o céu } \\
\text { estrelado, então, essa pintura que } \\
\text { está sempre na minha mente? (...) } \\
\text { Por um longo tempo ele foi meu } \\
\text { grande desejo de fazer um semeador, } \\
\text { mas os desejos que tive por um } \\
\text { longo tempo nem sempre são } \\
\text { alcançados. } \\
\text { (...) } \\
\text { Mas é uma questão de atacá-las, no } \\
\text { entanto, não importa o quão } \\
\text { incompetente um pode sentir-se vis- } \\
\text { à-vis as perfeições inefáveis do } \\
\text { glorioso esplendor da natureza. }\end{array}$ & $\begin{array}{l}\text { Observamos como saliência a escolha } \\
\text { lexical 'ainda' e 'tanto quanto antes' } \\
\text { reforçam a continuidade de uma } \\
\text { condição que mobiliza van Gogh a } \\
\text { criar (ou recriar) um desejo de infinito } \\
\text { que só se aproximou de ser revelado } \\
\text { no uso metafórico da luz, seja no céu } \\
\text { estrelado, no campo de trigo ou na } \\
\text { figura do Semeador. }\end{array}$ \\
\hline $\begin{array}{l}\text { Observamos a ocorrência de } \\
\text { contraste simultâneo entre o }\end{array}$ & $\begin{array}{l}\text { Aqui está o que eu queria dizer } \\
\text { sobre o branco e o preto. Vamos }\end{array}$ & $\begin{array}{l}\text { Ocorrência do uso de saliência na } \\
\text { oração 'Isso é o que eu queria dizer' }\end{array}$ \\
\hline
\end{tabular}




\begin{tabular}{|c|c|c|}
\hline $\begin{array}{l}\text { violeta e o amarelo que } \\
\text { potencializam mutuamente o } \\
\text { seu efeito e que é aguçado o } \\
\text { efeito da textura tátil e da } \\
\text { textura visual, registrado na } \\
\text { nota de rodapé } 141 .\end{array}$ & $\begin{array}{l}\text { tomar o Semeador. A pintura é } \\
\text { dividida em dois; metade é amarelo, } \\
\text { o topo; a base é violeta. Bem, as } \\
\text { calças brancas descansam os olhos e } \\
\text { os distraem exatamente quando o } \\
\text { contraste simultâneo excessivo de } \\
\text { amarelo e violeta iriam irritá-lo. Isso } \\
\text { é o que eu queria dizer. }\end{array}$ & $\begin{array}{l}\text { que retoma e reforça o sentido da } \\
\text { oração ‘Aqui está o que eu queria } \\
\text { dizer sobre o branco e o preto.' que } \\
\text { abre o parágrafo que fala sobre a } \\
\text { função do branco para amenizar o } \\
\text { conflito entre o violeta e o amarelo } \\
\text { que preenchem os dois campos da } \\
\text { tela, registrado na nota de rodapé } 165 \text {. }\end{array}$ \\
\hline $\begin{array}{l}\text { Na tela 'O Semeador', } \\
\text { observamos a ocorrência de } \\
\text { Enquadramento, Saliência, } \\
\text { Vetor para construir a } \\
\text { centralidade do campo na } \\
\text { narrativa, e o sentido } \\
\text { principal do enunciado que é } \\
\text { o de receber a semeadura do } \\
\text { semeador. Observamos na } \\
\text { tela um deslocamento da } \\
\text { agência da ação que é } \\
\text { compatível com as } \\
\text { ocorrências de } \\
\text { deslocamento da agência } \\
\text { da ação nas orações escritas } \\
\text { por van Gogh, registrado na } \\
\text { nota de rodapé } 163 \text {. }\end{array}$ & $\begin{array}{l}\text { Eu tive uma semana de concentrado } \\
\text { trabalho duro nos campos de trigo } \\
\text { debaixo do sol, o resultado foi de } \\
\text { alguns estudos de campos de trigo, } \\
\text { paisagens e - um esboço de um } \\
\text { semeador. (...) } \\
\text { Em um campo arado, um grande } \\
\text { campo de torrões de terra roxa - } \\
\text { levantados em direção ao horizonte - } \\
\text { um semeador em azul e branco. }\end{array}$ & $\begin{array}{l}\text { A saliência é dada no campo de trigo } \\
\text { e no horizonte, a ação da semeadura } \\
\text { perde centralidade diante da imensa } \\
\text { porção ocupada pelo campo arado e o } \\
\text { campo de trigo maduro. As saliências } \\
\text { estão no campo arado e no campo de } \\
\text { trigo que compõe uma paisagem na } \\
\text { qual o semador é apenas mais um } \\
\text { elemento. }\end{array}$ \\
\hline & $\begin{array}{l}\text { E o esboço como tal - uma tela } \\
\text { número } 25 \text { - também me preocupa } \\
\text { muito, no sentido de que eu me } \\
\text { pergunto se eu não deveria levar a } \\
\text { sério e fazer uma pintura tremenda } \\
\text { disso. Meu Deus, como eu adoraria } \\
\text { fazer isso. Mas eu só me pergunto se } \\
\text { eu vou ter o poder necessário de } \\
\text { execução. } \\
\text { Eu estou colocando o esboço de lado } \\
\text { assim como é, mal ousando pensar } \\
\text { nisso. } \\
\underline{\text { Por um longo tempo ele foi meu }} \\
\text { grande desejo de fazer um } \\
\underline{\text { semeador, mas os desejos que tive }} \\
\text { por um longo tempo nem sempre } \\
\text { são alcançados. Então, eu estou } \\
\text { quase com medo deles. E, no } \\
\text { entanto, depois de Millet e } \\
\text { Lhermitte o que resta a ser feito é ... } \\
\text { o semeador, com cor e em um } \\
\text { grande formato. }\end{array}$ & \\
\hline
\end{tabular}




\begin{tabular}{|c|c|c|}
\hline $\begin{array}{l}\text { Na tela 'A Esplanada do } \\
\text { Café na Place du Forum, } \\
\text { Arles, à Noite, observamos a } \\
\text { ocorrência de Saliência, } \\
\text { dada para a lâmpada a gás } \\
\text { que concentra a atenção na } \\
\text { cena, registrada na nota de } \\
\text { rodapé } 175 .\end{array}$ & $\begin{array}{l}\text { Essa é a primeira pintura esta } \\
\text { semana. A segunda mostra o } \\
\underline{\text { exterior de um café, iluminado no }} \\
\text { terraço externo por uma grande } \\
\text { lâmpada de gás dentro da noite azul, } \\
\text { com um retalho de céu azul } \\
\text { estrelado }\end{array}$ & $\begin{array}{l}\text { A saliência é dada na tela pela } \\
\text { proeminência da lâmpada a gás e na } \\
\text { oração pela ênfase 'grande' ao } \\
\text { qualificar a lâmpada. A cena está } \\
\text { concentrada na luz que emana dela, } \\
\text { cuja luz é projetada nos outros } \\
\text { elementos da tela. }\end{array}$ \\
\hline $\begin{array}{l}\text { Na tela 'A Esplanada do } \\
\text { Café na Place du Forum, } \\
\text { Arles, à Noite', observamos } \\
\text { a ocorrência de Saliência } \\
\text { dada pelos Contrastes } \\
\text { Cromáticos do tipo } \\
\text { Simultâneo, Quente/Frio, e } \\
\text { de Saturação para construir } \\
\text { caminhos visuais e saliência } \\
\text { na área do café e conduzir o } \\
\text { olhar para dentro da tela, } \\
\text { registrados na nota de rodapé } \\
\text { 178. }\end{array}$ & $\begin{array}{l}\text { Fui interrompido precisamente pelo } \\
\text { trabalho que uma nova pintura da } \\
\text { parte externa de um café à noite tem } \\
\text { me dado nos últimos dias. No } \\
\text { terraço, há pequenas figuras de } \\
\text { pessoas que bebem. Uma enorme } \\
\underline{\text { lanterna amarela ilumina o terraço, a }} \\
\text { fachada, a calçada, e até mesmo } \\
\text { projeta luz sobre os paralelepípedos } \\
\text { da rua, que adquirem uma coloração } \\
\text { violeta-rosa. }\end{array}$ & $\begin{array}{l}\text { Os caminhos visuais são construídos } \\
\text { para mostrar que a luz que é projetada } \\
\text { na calçada é proveniente da lâmpada a } \\
\text { gás, na oração este caminho á } \\
\text { facilmente construído quando van } \\
\text { Gogh explicita a lâmpada a gás como } \\
\text { agente na ação de projetar a luz nos } \\
\text { paralelepípedos. }\end{array}$ \\
\hline $\begin{array}{l}\text { Na tela 'A Esplanada do } \\
\text { Café na Place du Forum, } \\
\text { Arles, à Noite', observamos } \\
\text { a ocorrência de Saliência na } \\
\text { representação detalhada das } \\
\text { estrelas que, apesar de não } \\
\text { estarem no primeiro plano } \\
\text { ganham destaque e } \\
\text { evidenciam seu grau de } \\
\text { importância semiótica na } \\
\text { narrativa, registrada na nota } \\
\text { de rodapé } 186 .\end{array}$ & $\begin{array}{l}\text { Agora há uma pintura de noite sem } \\
\text { preto. Com nada mais do que um } \\
\text { belo azul e violeta e verde e nestes } \\
\text { arredores da praça iluminada é } \\
\text { colorido por enxofre pálido, amarelo } \\
\text { limão. Eu gosto enormemente de } \\
\text { pintar no local à noite. No passado, } \\
\text { eles costumavam desenhar e pintar a } \\
\text { tela do desenho durante o dia. Mas } \\
\text { acho que me convém pintar a coisa } \\
\text { no momento. É bem verdade que eu } \\
\text { possa tomar um azul por um verde } \\
\text { no escuro, um azul lilás por um rosa } \\
\text { lilás, uma vez que você não pode } \\
\text { perceber a natureza do tom } \\
\text { claramente. Mas é a única maneira } \\
\text { de se livrar da noite negra } \\
\underline{\text { convencional com uma luz pobre, }} \\
\text { pálida e esbranquiçada, quando na } \\
\underline{\text { verdade uma mera vela por si só nos }} \\
\text { dá os mais ricos amarelos e laranjas. }\end{array}$ & $\begin{array}{l}\text { Embora não estejam ocupando um } \\
\text { grande espaço na tela, este retalho do } \\
\text { céu ganha destaque por estar no alto } \\
\text { da composição. Assim, o céu } \\
\text { salpicado de estrelas adquire } \\
\text { importância semiótica por seu sentido } \\
\text { metafórico mas também por seu } \\
\text { sentido histórico no modo de pintar a } \\
\text { noite, que van Gogh inovou, ao } \\
\text { representá-la sem o uso da cor preta. }\end{array}$ \\
\hline & $\begin{array}{l}\text { Você nunca me disse se você tinha } \\
\text { lido Bel-ami de Guy de Maupassant, }\end{array}$ & \\
\hline
\end{tabular}




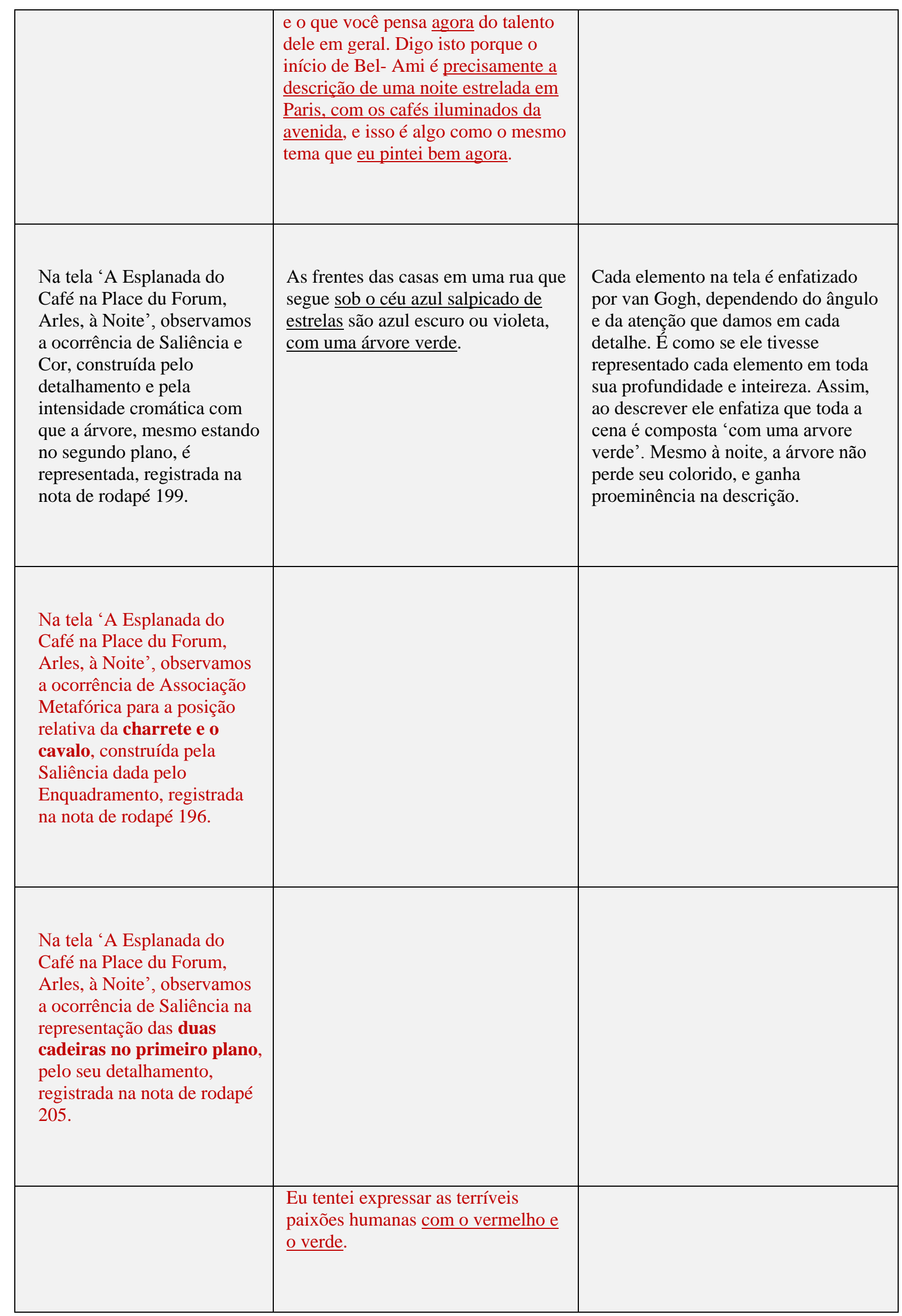




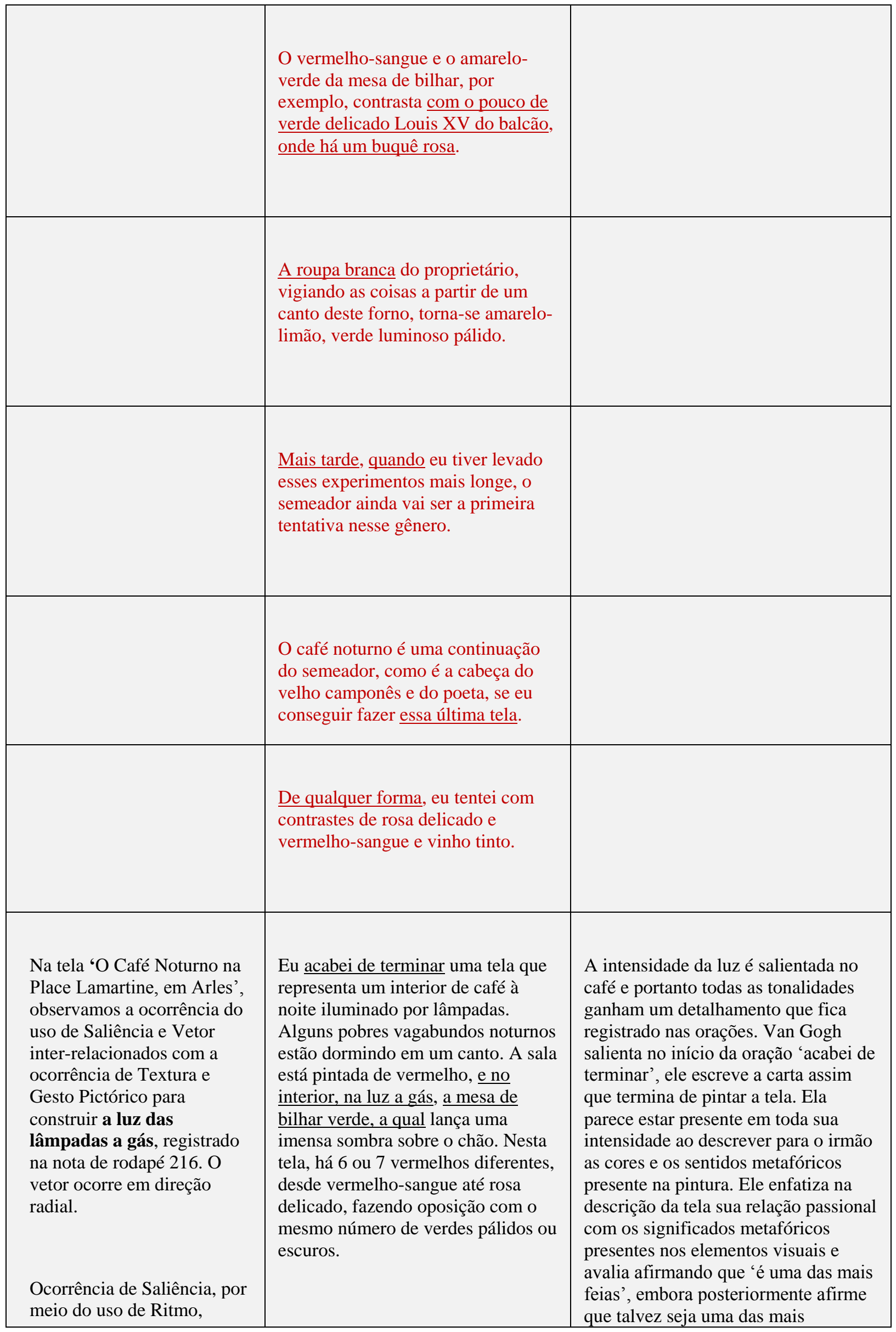




\begin{tabular}{|c|c|c|}
\hline $\begin{array}{l}\text { Movimento, Textura, Vetor e } \\
\text { Gesto Pictórico que são } \\
\text { usados para representar o } \\
\text { brilho intermitente das } \\
\text { lâmpadas, pintado com } \\
\text { riqueza de detalhes, textura e } \\
\text { movimento direcional, } \\
\text { registrados na nota de rodapé } \\
281 . \\
\text { Uso de associação } \\
\text { metafórica por meio de } \\
\text { Saliência, Ritmo, } \\
\text { Movimento, Textura e } \\
\text { Gesto Pictórico para dar } \\
\text { centralidade para luz, } \\
\text { registrada na nota de rodapé } \\
\text { 292 } \\
\text { Ocorrência de baixa } \\
\text { Modalidade por meio de } \\
\text { baixa Profundidade, } \\
\text { Saliência e Cor chapada } \\
\text { para representar o brilho da } \\
\text { luz de forma gráfica, } \\
\text { registrada na nota de rodapé } \\
295 . \\
\text { Na tela 'O Café Noturno na } \\
\text { Place Lamartine, em Arles', } \\
\text { observamos a ocorrência de } \\
\text { Saliência construída pelo } \\
\text { Contraste de saturação } \\
\text { entre o amarelo do chão no } \\
\text { primeiro plano e a sombra } \\
\text { da mesa de bilhar amarelo- } \\
\text { esverdeado, registrada na } \\
\text { nota de rodapé } 217 .\end{array}$ & $\begin{array}{l}\text { Muitas vezes parece-me que a noite } \\
\text { é muito mais viva e ricamente } \\
\text { colorida do que o dia. Agora como } \\
\text { para recuperar o dinheiro pago ao } \\
\text { senhorio através da minha pintura, } \\
\text { eu não estou fazendo questão disto, } \\
\text { porque a pintura é uma das mais } \\
\text { feias que eu já fiz. É o equivalente, } \\
\text { embora diferente, dos comedores de } \\
\text { batata. }\end{array}$ & $\begin{array}{l}\text { significativas. } \\
\text {. Assim como ele enfatiza os sentidos } \\
\text { metafóricos presentes da composição, } \\
\text { ele também enfatiza o sentido } \\
\text { metafórico da tela em si mesma em } \\
\text { relação às demais telas, comparando-a } \\
\text { aos comedores de batata, e aos artigos } \\
\text { de Dostoievski. Ou seja, há uma } \\
\text { semiose na tela em relação à sua obra } \\
\text { em geral. E van Gogh enfatiza essa } \\
\text { analogia entre telas aparentemente } \\
\text { distintas, mas que contém uma } \\
\text { similaridade na construção do próprio } \\
\text { discurso artístico. }\end{array}$ \\
\hline $\begin{array}{l}\text { Na tela 'O Café Noturno na } \\
\text { Place Lamartine, em Arles', } \\
\text { observamos a ocorrência de } \\
\text { Saliência, construída pelo } \\
\text { detalhamento da mesa de } \\
\text { bilhar, feita pelo desenho- } \\
\text { pintura, registrada na nota de } \\
\text { rodapé } 221 \text {. }\end{array}$ & $\begin{array}{l}\text { Eu acabei de terminar uma tela que } \\
\text { representa um interior de café à } \\
\text { noite iluminado por lâmpadas. } \\
\text { Alguns pobres vagabundos noturnos } \\
\text { estão dormindo em um canto. A sala } \\
\text { está pintada de vermelho, e no } \\
\text { interior, na luz a gás, a mesa de } \\
\text { bilhar verde, a qual lança uma } \\
\text { imensa sombra sobre o chão. Nesta } \\
\text { tela, há } 6 \text { ou } 7 \text { vermelhos diferentes, } \\
\text { desde vermelho-sangue até rosa } \\
\text { delicado, fazendo oposição com o } \\
\text { mesmo número de verdes pálidos ou } \\
\text { escuros. }\end{array}$ & $\begin{array}{l}\text { A mesa de bilhar ganha uma saliência } \\
\text { na tela do café, porém na descrição } \\
\text { van Gogh enfatiza sua sombra, ou seja, } \\
\text { revela que seu sentido na composição } \\
\text { se deve mais pela enorme sombra que } \\
\text { projeta do que pelo seu significado em } \\
\text { si mesma. A saliência em relação à } \\
\text { mesa de bilhar é sua sombra, que } \\
\text { inclusive aparece detalhadamente } \\
\text { representada na composição, com } \\
\text { ênfases de luz a sua volta e traços } \\
\text { enegrecidos que a diferenciam do } \\
\text { ambiente, dando um aspecto } \\
\text { monstruoso na composição geral da } \\
\text { tela, como se fosse muito mais do que } \\
\text { originalmente seria. }\end{array}$ \\
\hline
\end{tabular}




\begin{tabular}{|c|c|c|}
\hline $\begin{array}{l}\text { Na tela 'O Café Noturno na } \\
\text { Place Lamartine, em Arles', } \\
\text { observamos a ocorrência de } \\
\text { Saliência construída com o } \\
\text { uso de Textura, Ritmo, } \\
\text { Movimento e Gesto } \\
\text { Pictórico para representar o } \\
\text { brilho da lâmpada na } \\
\text { representação das figuras no } \\
\text { fundo da sala, registrada na } \\
\text { nota de rodapé } 224 \text {. }\end{array}$ & $\begin{array}{l}\text { Alguns pobres vagabundos noturnos } \\
\text { estão dormindo em um canto. }\end{array}$ & $\begin{array}{l}\text { Van Gogh utiliza três adjetivos para } \\
\text { descrever as personagens que se } \\
\text { encontram no café. A ênfase que ele dấ } \\
\text { a estas personagens justifica estarem } \\
\text { dormindo em um café a noite. São } \\
\text { pobres, estão vagando a noite, portanto } \\
\text { são vagabundos e noturnos. Há uma } \\
\text { crítica social à esta condição de vida. } \\
\text { Enquanto os comedores de batatas } \\
\text { comem no escuro, estes vagabundos } \\
\text { dormem embaixo de uma luz insidiosa }\end{array}$ \\
\hline $\begin{array}{l}\text { Na tela 'O Café Noturno na } \\
\text { Place Lamartine, em Arles', } \\
\text { observamos a ocorrência de } \\
\text { Distorção do ponto de vista e } \\
\text { de Saliência, que ele } \\
\text { constrói para representar } \\
\text { uma realidade que é do } \\
\text { domínio moral e subjetivo, } \\
\text { registrados na nota de rodapé } \\
234 \text {. }\end{array}$ & & \\
\hline $\begin{array}{l}\text { Na tela ‘O Café Noturno na } \\
\text { Place Lamartine, em Arles', } \\
\text { observamos a ocorrência de } \\
\text { Distorção do ponto de vista } \\
\text { pela baixa Profundidade na } \\
\text { ausência de luz e sombra, e } \\
\text { pela Saliência produzida } \\
\text { pelos Contrastes de } \\
\text { saturação, registradas na nota } \\
\text { de rodapé } 238 \text {. }\end{array}$ & $\begin{array}{l}\text { As sombras e sombras projetadas } \\
\text { estão removidas; foi colorido em } \\
\text { tons chapados como as gravuras } \\
\text { japonesas Isso vai contrastar, com a } \\
\text { diligência Tarascon e o café à noite. } \\
\text { A idéia do semeador ainda continua } \\
\text { a me assombrar. Estudos } \\
\underline{\text { exagerados, como o semeador, como }} \\
\underline{\text { o café noturno agora, geralmente }} \\
\text { parecem-me atrozmente feios e } \\
\underline{\text { ruins, }} \underline{\text { mas quando eu estou movido }} \\
\text { por alguma coisa, como aqui por } \\
\underline{\text { este pequeno artigo sobre }} \\
\underline{\text { Dostoievski, em seguida, eles são os }} \\
\underline{\text { únicos que me parecem ter um }} \\
\underline{\text { significado mais importante. }}\end{array}$ & $\begin{array}{l}\text { A ausência de sombra nos outros } \\
\text { elementos da cena enfatiza ainda mais } \\
\text { a sombra da mesa de bilhar. A } \\
\text { ausência de sombra chama a atenção } \\
\text { para o efeito chapado das imagens. } \\
\text { Como em uma crítica pela passividade } \\
\text { das personagens, uma passividade } \\
\text { inclusive diante da luz intensa. Não } \\
\text { reagem, não respondem a nada. Van } \\
\text { Gogh parece enfatizar este aspecto } \\
\text { anulando a sombra como forma de dar } \\
\text { ênfase à ausência de ação das } \\
\text { personagens. Que, ao contrário, estão } \\
\text { sujeitas à luz doentia do café. }\end{array}$ \\
\hline $\begin{array}{l}\text { Na tela 'O Café Noturno na } \\
\text { Place Lamartine, em Arles', } \\
\text { observamos a ocorrência de }\end{array}$ & & \\
\hline
\end{tabular}




\begin{tabular}{|c|c|c|}
\hline $\begin{array}{l}\text { Associação metafórica por } \\
\text { meio de Saliência, } \\
\text { Contradição e Distorção do } \\
\text { Ponto de Vista para } \\
\text { representar a sombra da } \\
\text { mesa em contraste com a } \\
\text { ausência de sombras nos } \\
\text { outros objetos e figuras, } \\
\text { registrada na nota de rodapé } \\
296 . \\
\text { Na tela 'O Café Noturno na } \\
\text { Place Lamartine, em Arles', } \\
\text { observamos a ocorrência de } \\
\text { Associação metafórica por } \\
\text { meio de Saliência, } \\
\text { Transparência e } \\
\text { Profundidade na escolha } \\
\text { potencial de sentidos } \\
\text { associados à exclusividade } \\
\text { da sombra da mesa em } \\
\text { relação à ausência de } \\
\text { sombra dos outros objetos } \\
\text { e figuras, registrada na nota } \\
\text { de rodapé } 317 \text {. }\end{array}$ & & \\
\hline $\begin{array}{l}\text { Na tela 'O Café Noturno na } \\
\text { Place Lamartine, em Arles', } \\
\text { observamos a ocorrência de } \\
\text { Saliência construída pela } \\
\text { distorção do ponto de vista } \\
\text { e pelo exagero no uso de } \\
\text { todos os elementos, que } \\
\text { muitas vezes estão } \\
\text { trabalhando na composição } \\
\text { de forma redundante para } \\
\text { obter um efeito de sentido, } \\
\text { registrada na nota de rodapé } \\
241 .\end{array}$ & $\begin{array}{l}\text { Tudo isso em uma atmosfera de } \\
\text { fornalha infernal, de enxofre pálido. } \\
\text { Exprimir como a potência dos cantos } \\
\text { escuros de uma taberna. } \\
\text { Contudo sob uma aparência da } \\
\text { alegria japonesa e da boa natureza de } \\
\text { Tartarin. } \\
\text { Que diria, portanto desse quadro o } \\
\text { Sr. Tersteeg? Diante de um Sisley, } \\
\text { Sisley, o mais discreto e delicado } \\
\text { dos Impressionistas - já disse: "Não } \\
\text { posso me impedir de pensar que o } \\
\text { artista que pintou isso estava um } \\
\text { pouco tonto". Diante do meu } \\
\text { quadro, então a mim ele diria que } \\
\text { ele é um caso de delirium tremens. }\end{array}$ & \\
\hline $\begin{array}{l}\text { Na tela 'O Café Noturno na } \\
\text { Place Lamartine, em Arles', } \\
\text { observamos a ocorrência de } \\
\text { Vetor, construído pela } \\
\text { relação com o Contraste } \\
\text { Cromático da sombra e a } \\
\text { sua Saliência produzida em }\end{array}$ & & \\
\hline
\end{tabular}




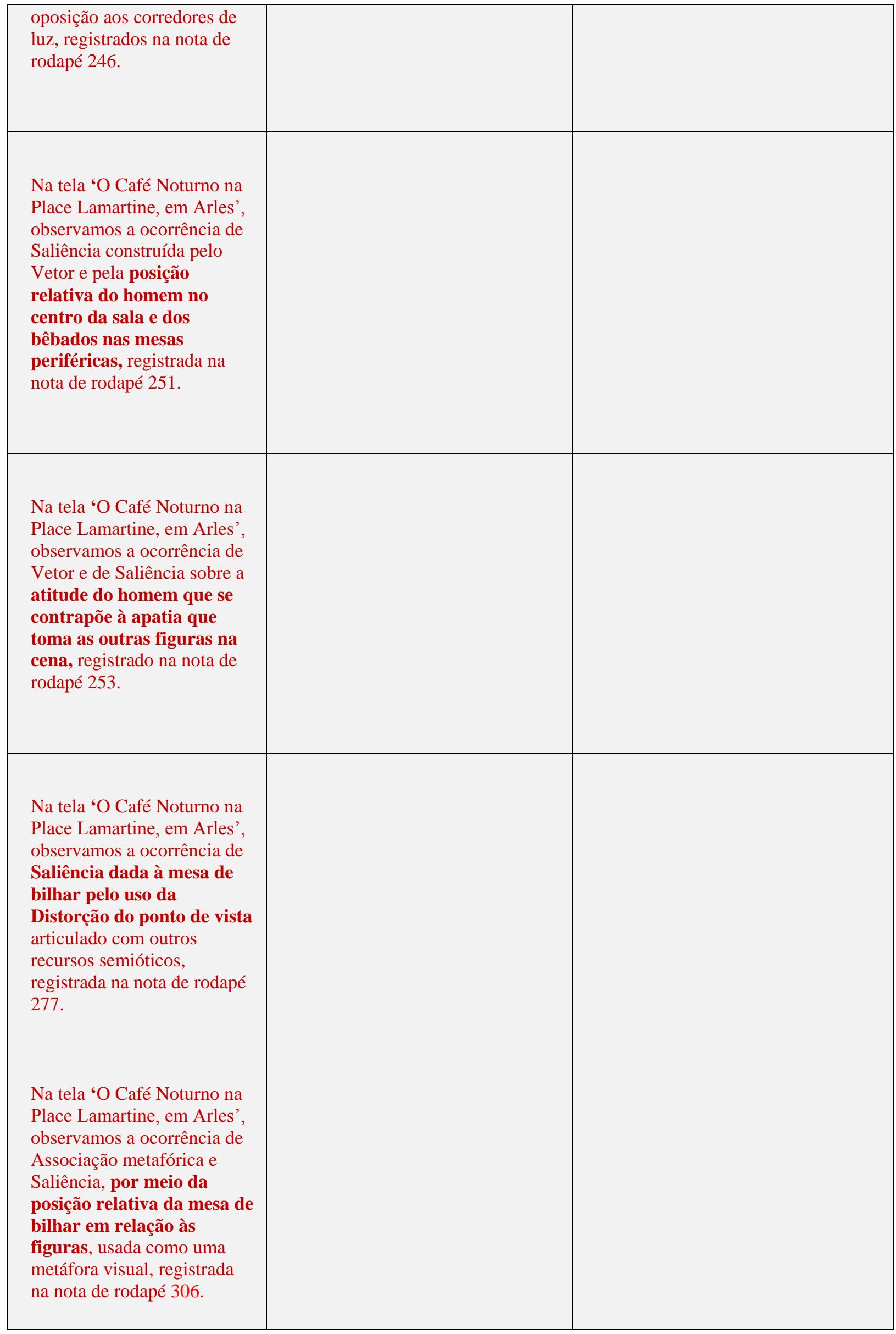




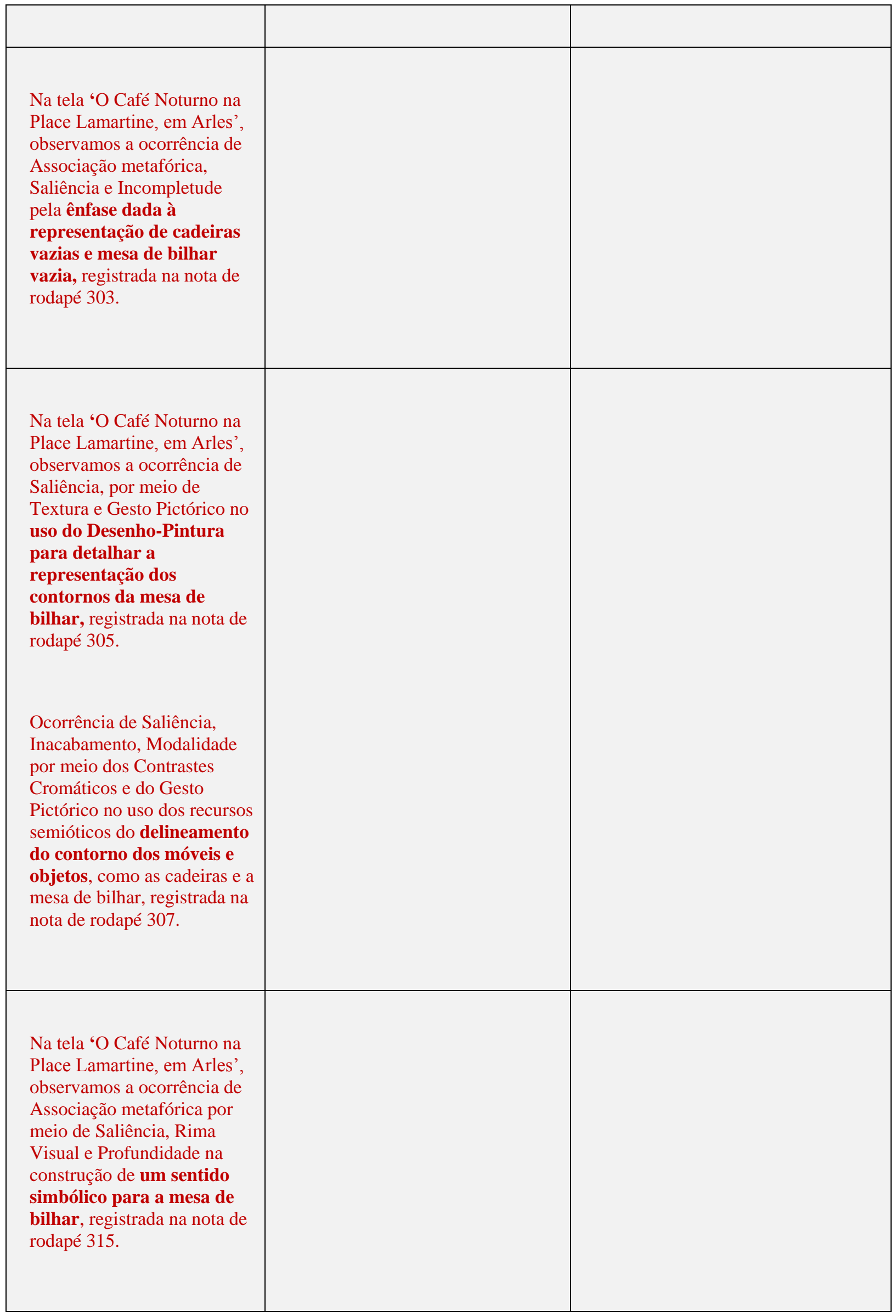




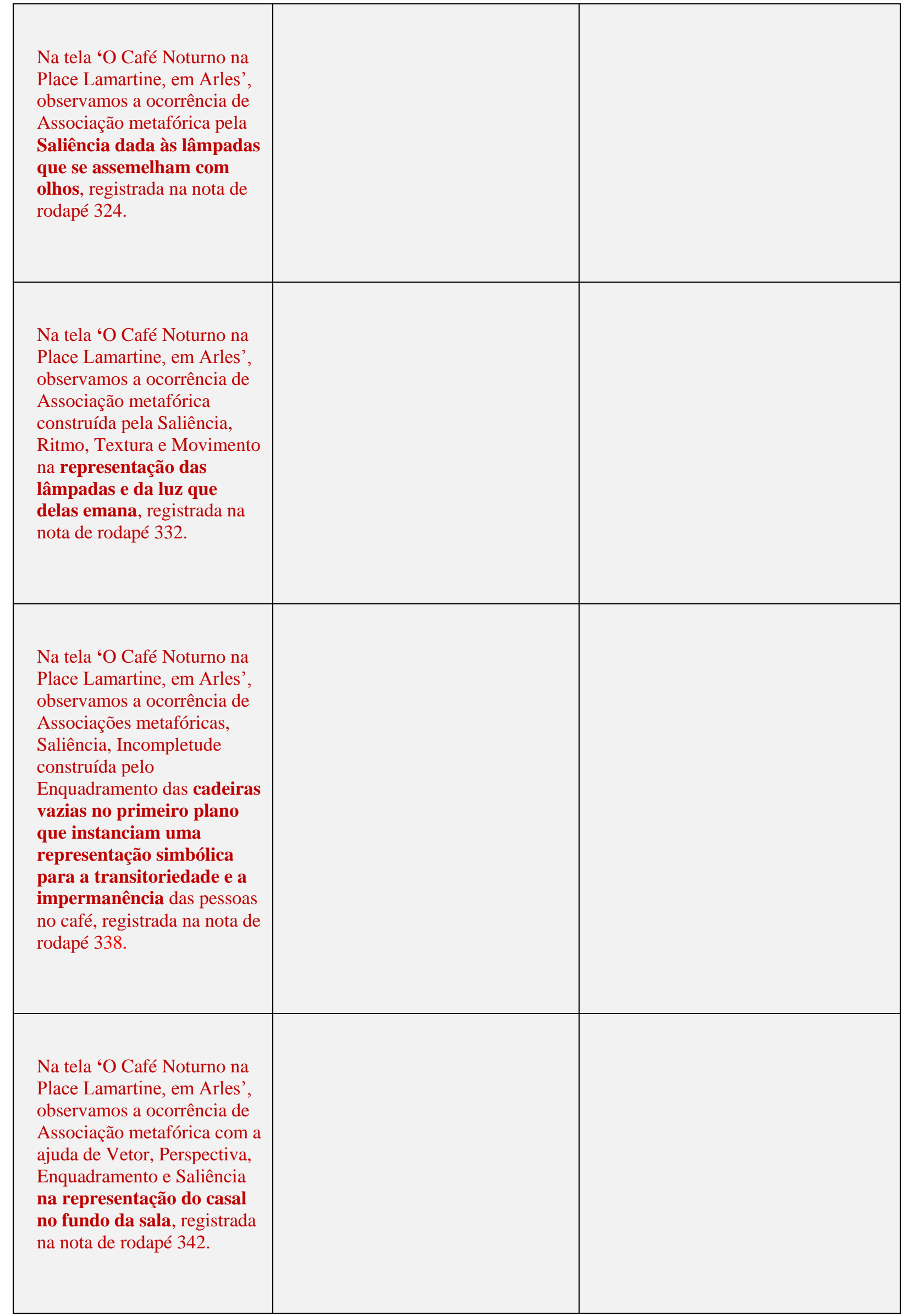

Fonte: Triangulação para Saliência dos dados dos corpora visual e textual, com os extratos das cartas. 


\subsection{TRIANGULAÇÃO DA MODALIDADE}

Quadro 77: Triangulação da Modalidade

\begin{tabular}{|c|c|c|}
\hline Ocorrência nas telas & Orações & Comentário \\
\hline & $\begin{array}{l}\text { Aqui está o que eu queria dizer sobre } \\
\text { o branco e o preto. Vamos tomar o } \\
\text { Semeador. A pintura é dividida em } \\
\text { dois; metade é amarelo, o topo; a } \\
\text { base é violeta. Bem, as calças } \\
\text { brancas descansam os olhos e os } \\
\text { distraem exatamente quando o } \\
\text { contraste simultâneo excessivo de } \\
\text { amarelo e violeta iriam irritá-lo. Isso } \\
\text { é o que eu queria dizer. }\end{array}$ & \\
\hline $\begin{array}{l}\text { Na tela A Esplanada do Café } \\
\text { na Place du Forum, Arles, à } \\
\text { Noite observamos a } \\
\text { ocorrência de Modalidade } \\
\text { pois van Gogh quis retratar a } \\
\text { sutileza da cor sob a } \\
\text { iluminação natural das } \\
\text { estrelas e a diferença entre } \\
\text { esta e a cor e sob a } \\
\text { iluminação artificial da } \\
\text { lâmpada a gás, registrada na } \\
\text { nota de rodapé } 183 \text {. }\end{array}$ & & \\
\hline $\begin{array}{l}\text { Observamos também a } \\
\text { ocorrência de Modalidade, } \\
\text { ou de baixa modalidade e } \\
\text { Inacabamento, Van Gogh } \\
\text { representou o azul da noite } \\
\text { mais claro do que ele é na } \\
\text { realidade, para dessa forma, } \\
\text { poder representar os tons de } \\
\text { lilases e verdes que ele } \\
\text { identificava ocularmente, } \\
\text { mas que não seriam } \\
\text { aparentes na pintura. No } \\
\text { entanto, a busca de } \\
\text { representar a variada } \\
\text { coloração que ele via é uma } \\
\text { forma de dar modalidade } \\
\text { para a representação, } \\
\text { registrada na nota de rodapé } \\
\text { 191. }\end{array}$ & & \\
\hline $\begin{array}{l}\text { Na tela A Esplanada do Café } \\
\text { na Place du Forum, Arles, à } \\
\text { Noite observamos a } \\
\text { ocorrência de Modalidade na }\end{array}$ & & \\
\hline
\end{tabular}




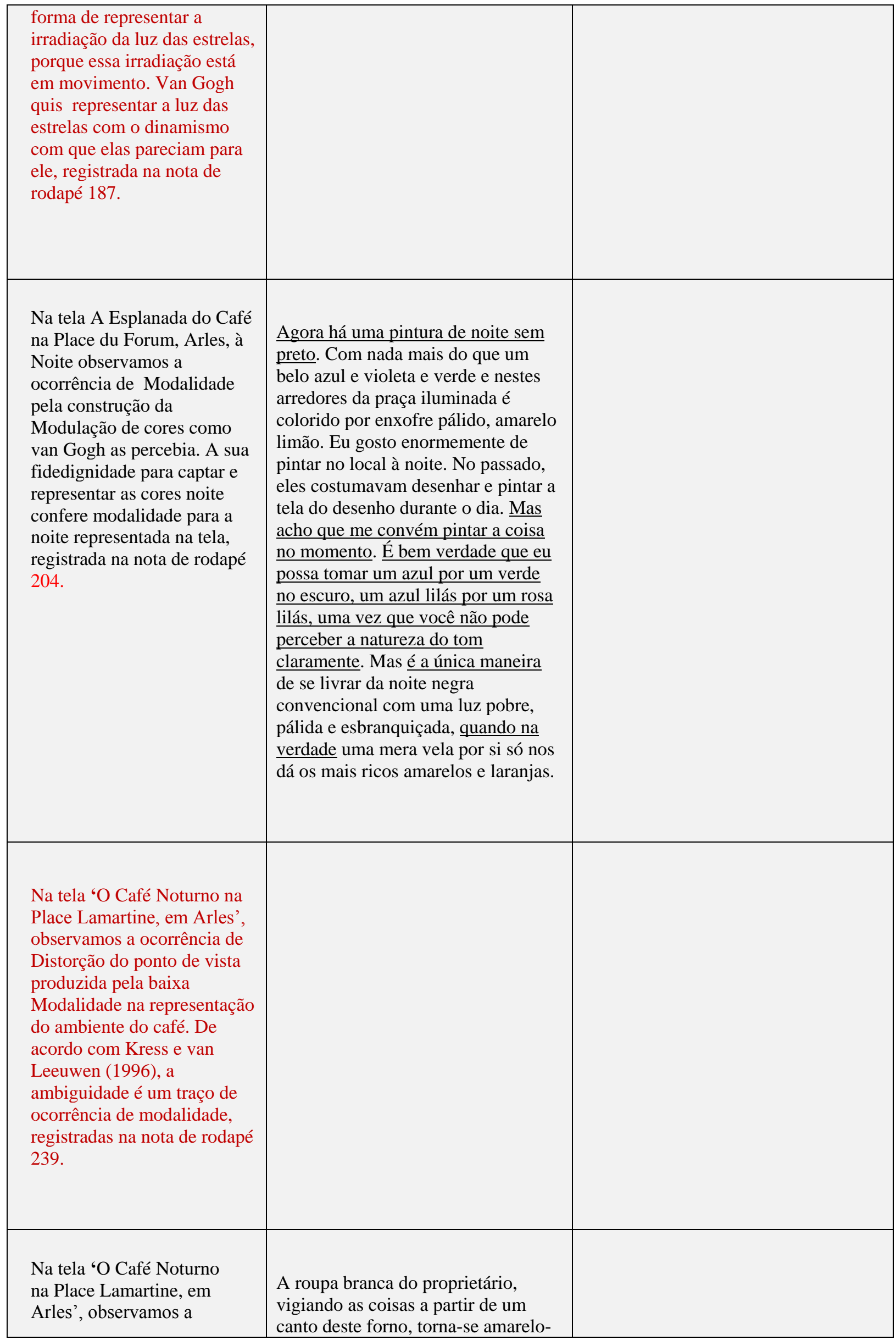




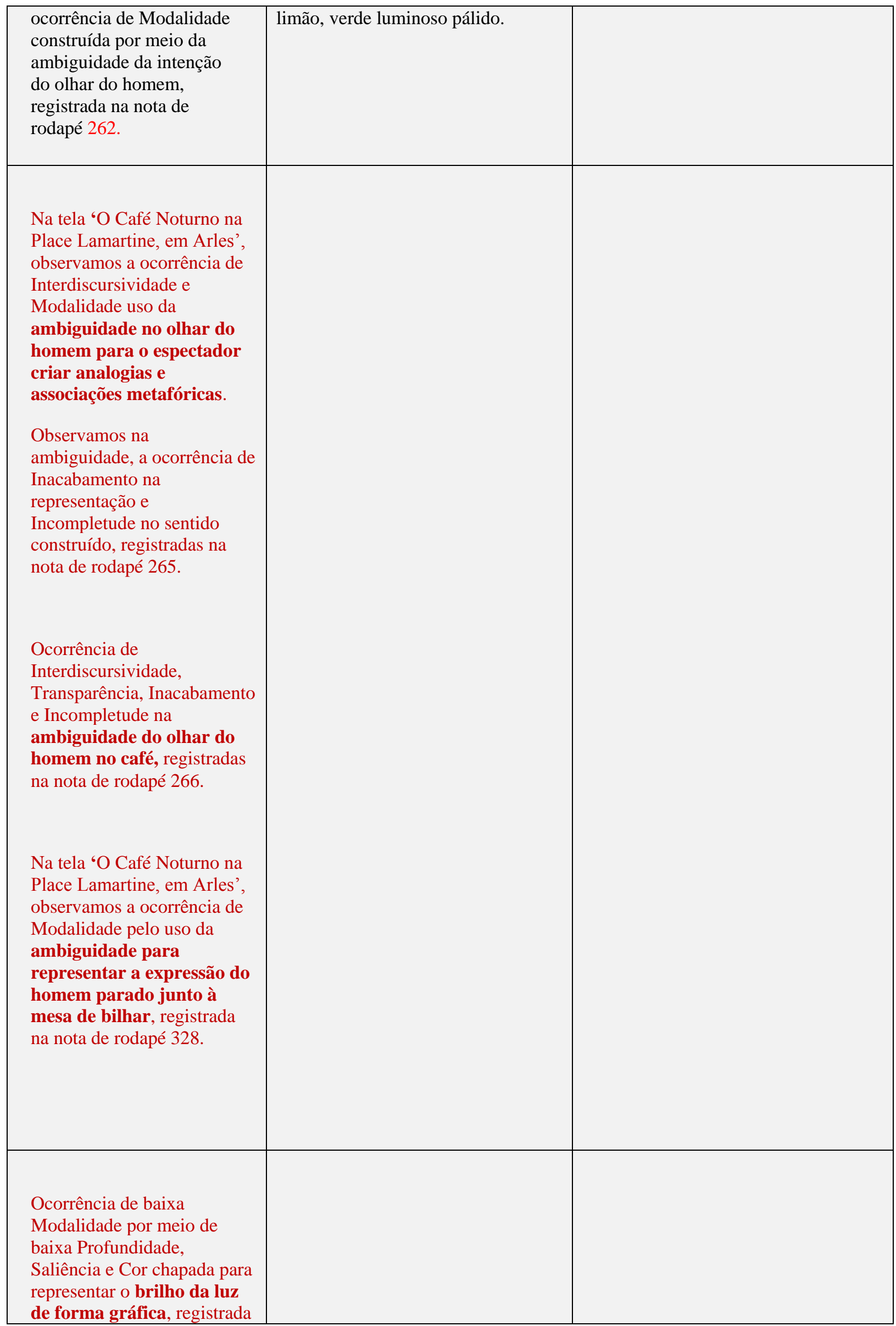




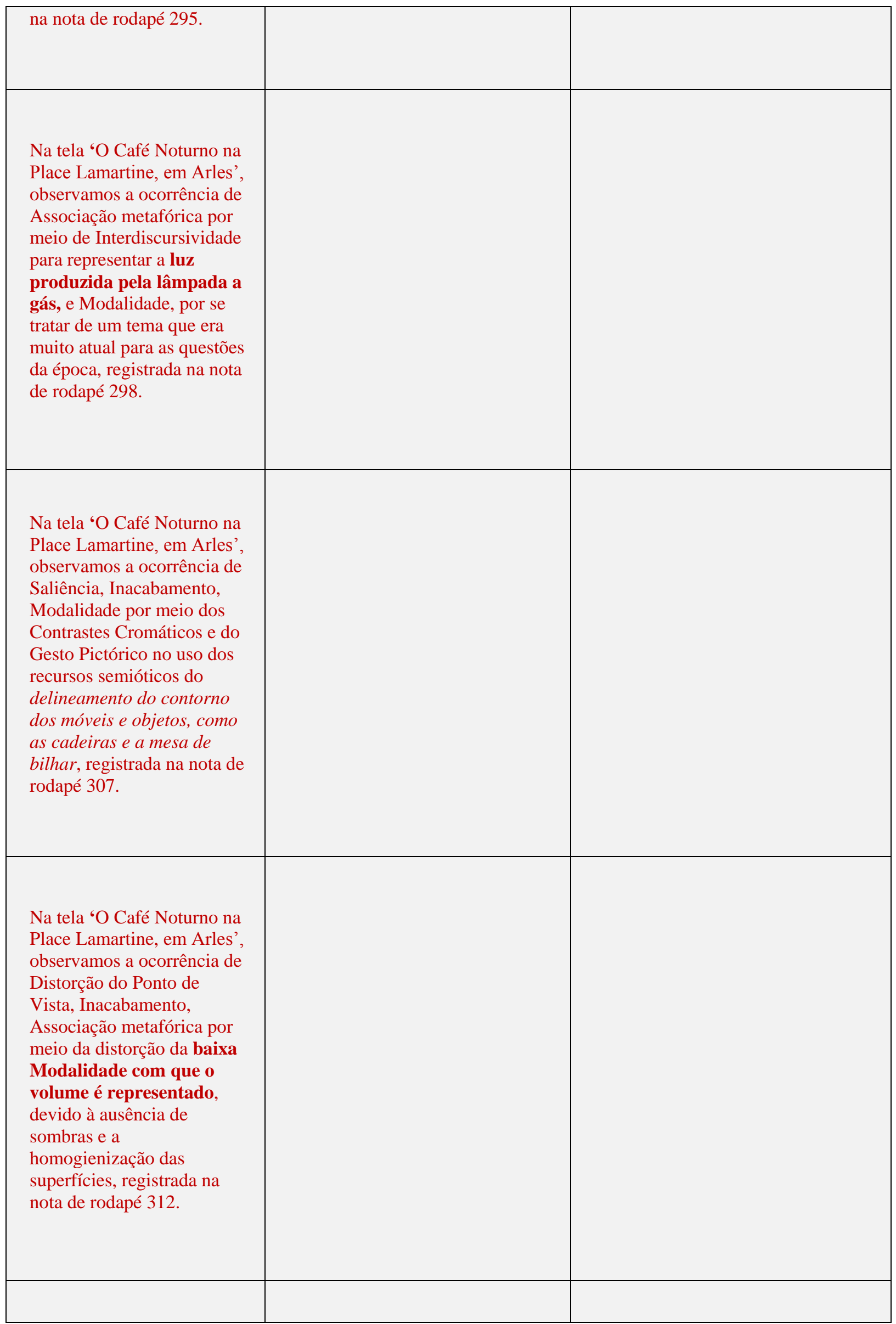




\begin{tabular}{|c|c|}
\hline $\begin{array}{l}\text { Na tela ‘O Café Noturno na } \\
\text { Place Lamartine, em Arles', } \\
\text { observamos a ocorrência de } \\
\text { Associação metafórica e } \\
\text { baixa Modalidade por meio } \\
\text { da diminuição da } \\
\text { Profundidade e da } \\
\text { Indiferenciação que produz } \\
\text { um efeito de sentido } \\
\text { simbólico sobre a ausência } \\
\text { de sombra das figuras e } \\
\text { presença de sombra da } \\
\text { mesa de bilhar, registrada } \\
\text { na nota de rodapé } 314 \text {. }\end{array}$ & $\begin{array}{l}\text { Mais tarde, quando eu tiver levado } \\
\text { esses experimentos mais longe, o } \\
\text { semeador ainda vai ser a primeira } \\
\text { tentativa nesse gênero. } \\
\\
\text { O café noturno é uma continuação } \\
\text { do semeador, como é a cabeça do } \\
\text { velho camponês e do poeta, se eu } \\
\text { conseguir fazer essa ultima tela. É } \\
\text { uma cor, então, que não é localmente } \\
\text { verdadeira do ponto de vista realista } \\
\text { do trompe l'oeil, mas uma cor que } \\
\text { sugere alguma emoção, um } \\
\text { temperamento ardente. }\end{array}$ \\
\hline $\begin{array}{l}\text { Na tela 'O Café Noturno na } \\
\text { Place Lamartine, em Arles', } \\
\text { observamos a ocorrência de } \\
\text { Transparência, } \\
\text { Incompletude, baixa } \\
\text { Modalidade e Limiar } \\
\text { Artístico pelo uso do } \\
\text { Inacabamento, } \\
\text { Enquadramento, Perspectiva, } \\
\text { Distorção do Ponto de Vista, } \\
\text { Direçâo, Profundidade, como } \\
\text { marca estilística das linhas } \\
\text { que organizam a perspectiva } \\
\text { da sala, registrada na nota de } \\
\text { rodapé } 341 \text {. }\end{array}$ & \\
\hline
\end{tabular}

Fonte: Triangulação para Modalidade dos dados dos corpora visual e textual, com os extratos das cartas.

\subsection{TRIANGULAÇÃO DA INTERTEXTUALIDADE E INTERDISCURSIVIDADE NA RECEPÇÃO DA OBRA}

Quadro 78: Intertextualidade e Interdiscursividade

\begin{tabular}{|l|l|l|}
\hline Ocorrência nas telas & Orações & Comentário \\
\hline & & \\
Na tela 'Por de Sol: Campo & Eu também sou totalmente incapaz \\
de trigo perto de Arles', & de julgar o meu próprio trabalho. Eu \\
observamos a ocorrência de & não posso ver se os estudos são bons & \\
interdiscursividade e & ou ruins. Tenho sete estudos de \\
Associação metafórica, & trigais, infelizmente todos eles nada \\
registrado na nota de rodapé & além de paisagens, muito contra a & \\
115. & minha vontade. & \\
& & \\
& & \\
\end{tabular}




\begin{tabular}{|c|c|c|}
\hline $\begin{array}{l}\text { Na tela 'O Semeador', } \\
\text { observamos a ocorrência de } \\
\text { Interdiscursividade e } \\
\text { Intertextualidade. Foi } \\
\text { identificada a superposição } \\
\text { do discurso religioso e do } \\
\text { discurso social e político da } \\
\text { época, bem como elementos } \\
\text { de outros textos visuais e } \\
\text { escritos, registrado na nota } \\
\text { de rodapé } 149 \text {. }\end{array}$ & $\begin{array}{l}\text { Por um longo tempo ele foi meu } \\
\text { grande desejo de fazer um } \\
\text { semeador, mas os desejos que } \\
\text { tive por um longo tempo nem } \\
\text { sempre são alcançados. Então, } \\
\text { eu estou quase com medo deles. } \\
\text { E, no entanto, depois de Millet e } \\
\text { Lhermitte o que resta a ser feito } \\
\underline{\text { é ... o semeador, com cor e em }} \\
\text { um grande formato. }\end{array}$ & $\begin{array}{l}\text { Van Gogh parece querer dizer que o } \\
\text { desejo dele não é o mesmo de Millet e } \\
\text { Lhermittee que a representação do } \\
\text { Semeador não foi alcançada segundo o } \\
\text { seu desejo pelos artistas que } \\
\text { representaram o trabalhador do campo. } \\
\text { Para van Gogh não resta outra coisa } \\
\text { além de ir atrás desse ideal de } \\
\text { representação, até porque algo } \\
\text { parecido já foi feito, mas o Semeador, } \\
\text { tal como ele o idealiza ainda é um } \\
\text { desejo e um estudo. Ele quer alcançar } \\
\text { um sentido espiritual que está presente } \\
\text { junto com esses outros sentidos que } \\
\text { foram retratados por esses artistas } \\
\text { anteriores. }\end{array}$ \\
\hline & $\begin{array}{l}\text { Preferia muito mais fazer quadros } \\
\text { naifs tirados de velhos almanaques, } \\
\text { aqueles velhos "almanaques dos } \\
\text { lavradores" nos quais o granizo, a } \\
\text { neve, a chuva e o bom tempo são } \\
\text { retratados de modo primitivo, como } \\
\text { o Anquetin atingiu tão bem no seu } A \\
\text { Colheita. }\end{array}$ & \\
\hline & $\begin{array}{l}\text { Mas quando eu farei o céu estrelado, } \\
\text { então, essa pintura que está sempre } \\
\text { na minha mente? Ai, ai, é como } \\
\text { nosso excelente amigo Cyprien diz, } \\
\text { em 'En ménage' por JK Huysmans: } \\
\text { as mais belas pinturas são aquelas } \\
\text { que um sonha enquanto fuma um } \\
\text { cachimbo em sua cama, mas a qual } \\
\text { ele não pinta. }\end{array}$ & \\
\hline $\begin{array}{l}\text { A noite e as estrelas foi um } \\
\text { tema iniciado por van Gogh. } \\
\text { Walther e Metzger (2012, p. } \\
\text { 383) argumentam que "ele } \\
\text { criou um novo gênero } \\
\text { artístico: a cena noturna ao } \\
\text { ar livre". }\end{array}$ & $\begin{array}{l}\text { Você nunca me disse se você tinha } \\
\text { lido Bel-ami de Guy de Maupassant, } \\
\text { e o que você pensa agora do talento } \\
\text { dele em geral. Digo isto porque o } \\
\text { início de Bel- Ami é precisamente a } \\
\underline{\text { descrição de uma noite estrelada em }} \\
\underline{\text { Paris, com os cafés iluminados da }} \\
\underline{\text { avenida, e isso é algo como o }} \\
\text { mesmo tema que eu pintei bem } \\
\text { agora. }\end{array}$ & \\
\hline
\end{tabular}




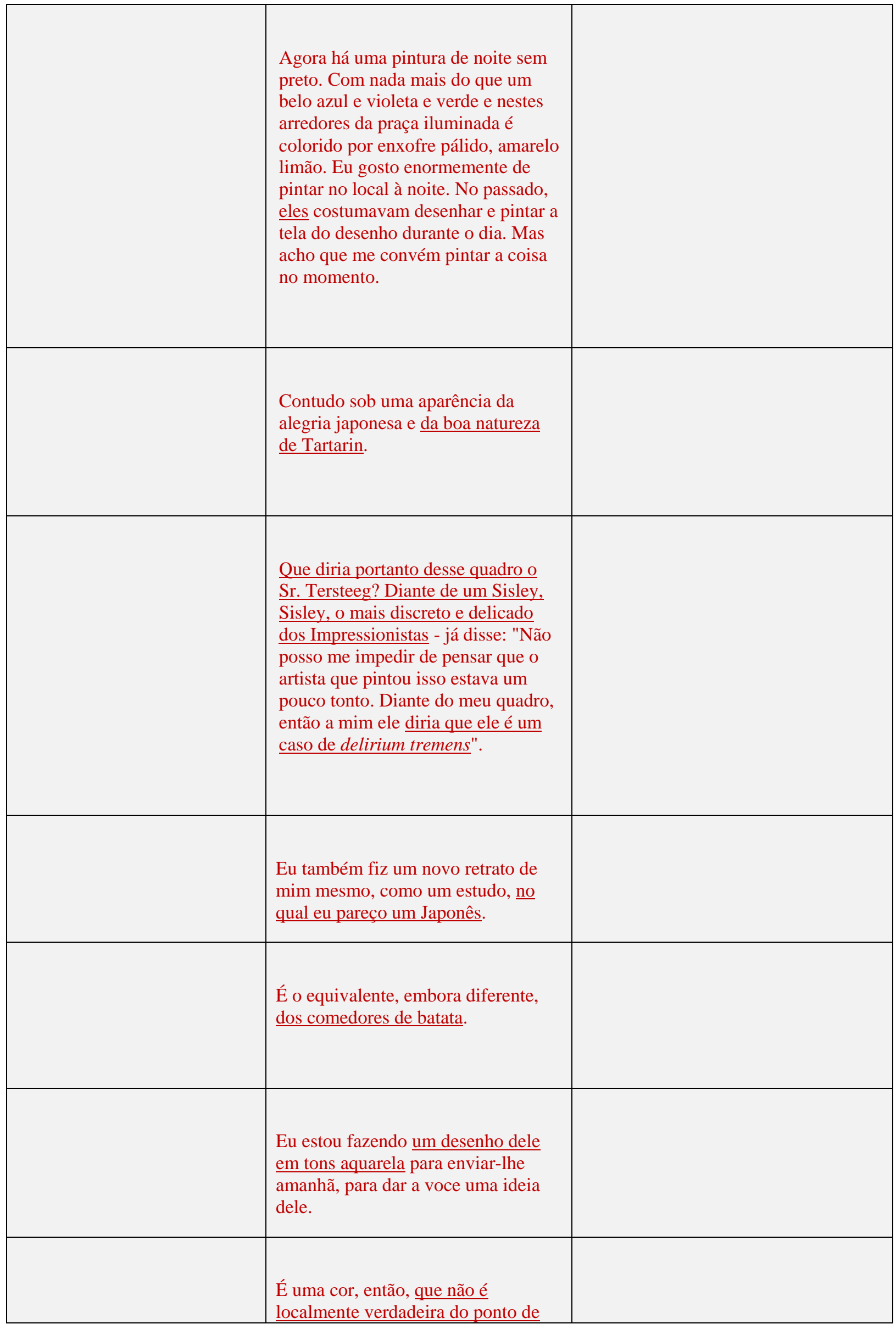




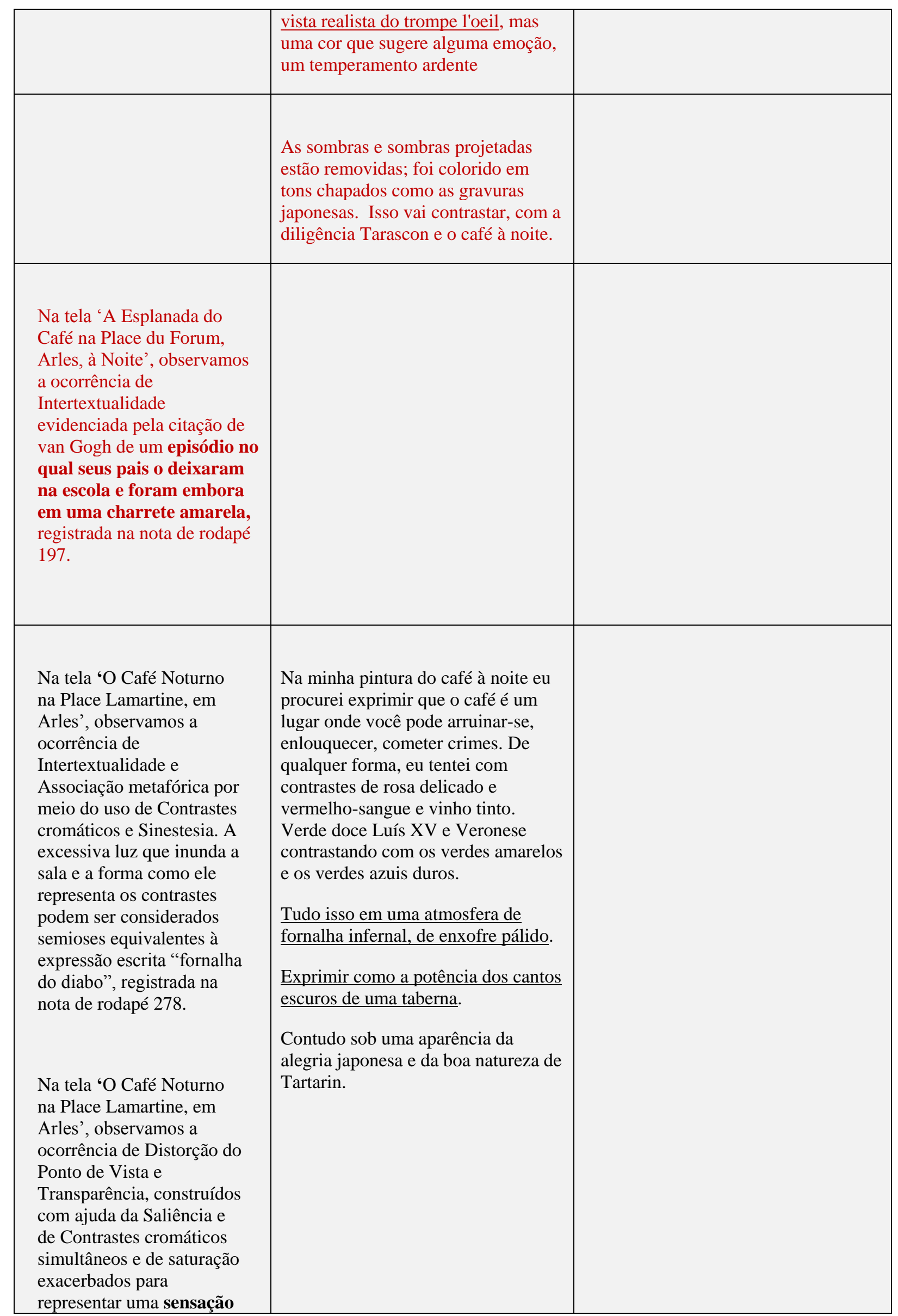




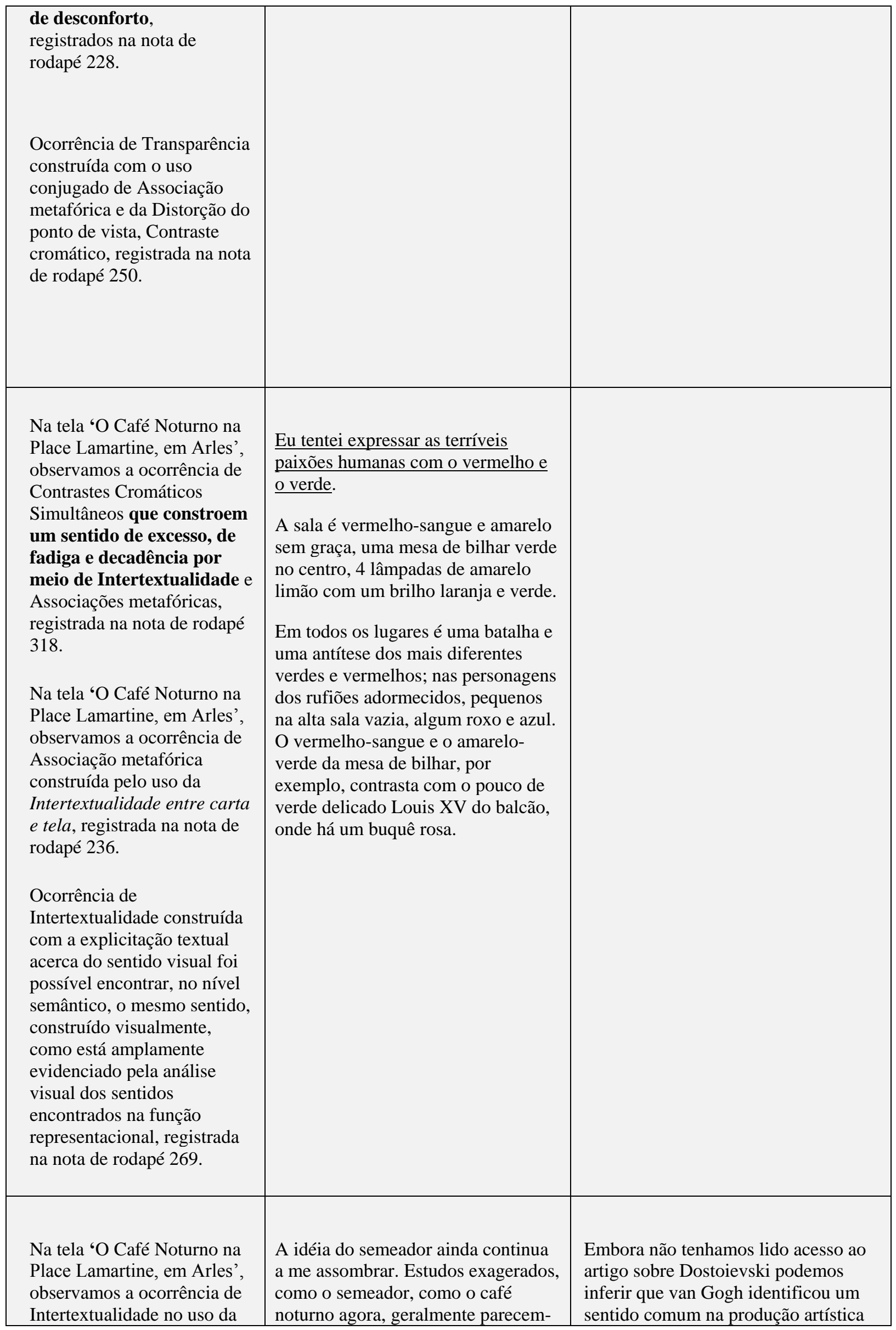




\begin{tabular}{|c|c|c|}
\hline $\begin{array}{l}\text { Distorção para construir } \\
\text { um sentido semântico na } \\
\text { tela que ele representou } \\
\text { semanticamente na carta: a } \\
\text { precariedade da condição } \\
\text { humana no interior de um } \\
\text { café da noite. O sentido que, } \\
\text { semanticamente, ele constrói } \\
\text { na carta, é aqui representado } \\
\text { por outros recursos } \\
\text { pictóricos tais como os } \\
\text { contrastes cromáticos, o } \\
\text { excesso de iluminação e a } \\
\text { distorção da perspectiva, } \\
\text { registrada na nota de rodapé } \\
275 \text {. }\end{array}$ & $\begin{array}{l}\text { me atrozmente feios e ruins, mas } \\
\text { quando eu estou movido por alguma } \\
\text { coisa, como aqui por este pequeno } \\
\text { artigo sobre Dostoievski, em } \\
\text { seguida, eles são os únicos que me } \\
\text { parecem ter um significado mais } \\
\text { importante. }\end{array}$ & $\begin{array}{l}\text { e que ao comparar a sua tela com } \\
\text { produções artísticas comuns na sua } \\
\text { época ela seja julgada como feia e } \\
\text { como ruim. Mas se for avaliada a } \\
\text { partir de um sentido mais profundo, } \\
\text { vai ser possível reconhecer o seu } \\
\text { valor. Para dar legitimidade para a sua } \\
\text { insistência nesse objetivo van Gogh } \\
\text { se apoia em autores, entre os quais } \\
\text { Dostoievski, que o inspiram e com os } \\
\text { quais se identifica. }\end{array}$ \\
\hline $\begin{array}{l}\text { Ocorrência de } \\
\text { Interdiscursividade e de } \\
\text { Transparência com a } \\
\text { inversão do ponto de vista } \\
\text { que trás van Gogh para } \\
\text { dentro da tela por meio do } \\
\text { olhar do homem que } \\
\text { parece nos fitar, registradas } \\
\text { na nota de rodapé } 261 \text {. }\end{array}$ & & \\
\hline $\begin{array}{l}\text { Na tela 'O Café Noturno na } \\
\text { Place Lamartine, em Arles', } \\
\text { observamos a ocorrência de } \\
\text { Interdiscursividade e } \\
\text { Modalidade no uso da } \\
\text { ambiguidade no olhar do } \\
\text { homem para o espectador } \\
\text { cria analogias e } \\
\text { Associações metafóricas. } \\
\text { Observamos na } \\
\text { ambiguidade, a ocorrência de } \\
\text { Inacabamento na } \\
\text { representação e } \\
\text { Incompletude no sentido } \\
\text { construído, registradas na } \\
\text { nota de rodapé } 265 . \\
\\
\text { Ocorrência de } \\
\text { Interdiscursividade, } \\
\text { Transparência, Inacabamento } \\
\text { e Incompletude na } \\
\text { ambiguidade do olhar do } \\
\text { homem no café, registrados } \\
\text { na nota de rodapé } 266 .\end{array}$ & & \\
\hline
\end{tabular}




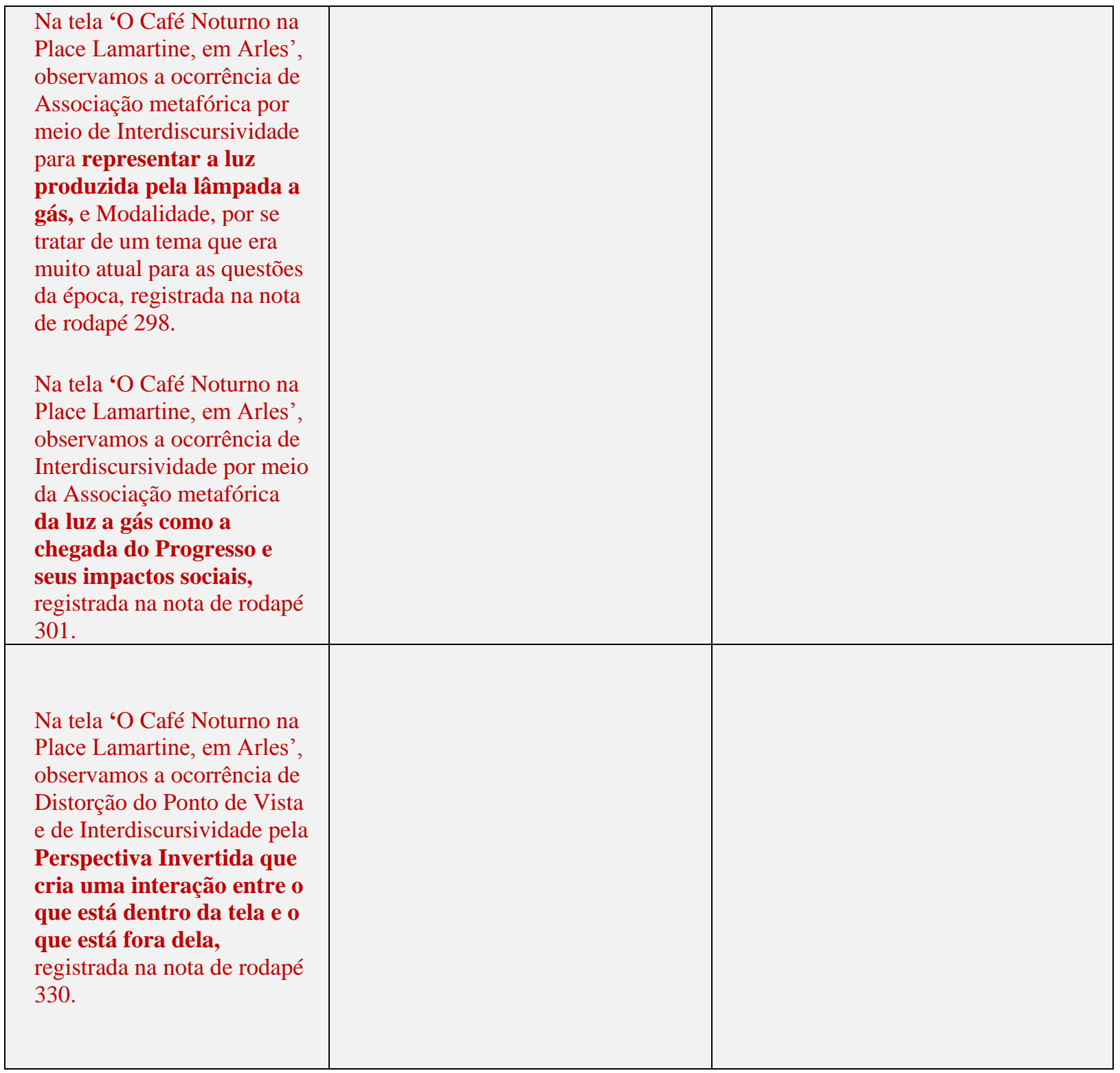

Fonte: Triangulação para Intertextualidade e Interdiscursividade dos dados dos corpora visual e textual, com os extratos das cartas.

\subsection{TRIANGULAÇÃO DO USO DE ASSOCIAÇÕES METAFÓRICAS E SIMBOLISMO}

Quadro 79: Triangulação do uso de Associações metafóricas e simbolismo

\begin{tabular}{|l|l|l|}
\hline Ocorrência nas telas & Orações & Comentário \\
\hline & & \\
Na tela 'Por de Sol: Campo & Cidade violeta, estrela amarela, céu \\
de trigo perto de Arles', & azul-esverdeado; os campos de trigo \\
observamos a ocorrência de & têm todos os tons: ouro velho, cobre, \\
associação metafórica do & ouro verde, ouro vermelho, ouro \\
amarelo com os sentidos & amarelo, verde, vermelho e amarelo \\
associados à força da & bronze. & \\
natureza e da vida, & & \\
\hline
\end{tabular}




\begin{tabular}{|c|c|c|}
\hline $\begin{array}{l}\text { registrado na nota de rodapé } \\
86 .\end{array}$ & & \\
\hline $\begin{array}{l}\text { Na tela 'Por de Sol: Campo } \\
\text { de trigo perto de Arles', } \\
\text { observamos a ocorrência de } \\
\text { ritmo e textura para conferir } \\
\text { saliência para o campo de } \\
\text { trigo. Observamos que a } \\
\text { Saliência é usada para } \\
\text { produzir o efeito de } \\
\text { associação metafórica do } \\
\text { valor do campo sobre a } \\
\text { cidade, registrado nas notas } \\
\text { de rodapé } 113 \text { e } 114 \text {. }\end{array}$ & & \\
\hline $\begin{array}{l}\text { Na tela 'Por de Sol: Campo } \\
\text { de trigo perto de Arles', } \\
\text { observamos que a ocorrência } \\
\text { de Enquadramento produz } \\
\text { um sentido de associação } \\
\text { metafórica. A escolha do } \\
\text { enquadramento, no qual o } \\
\text { sol está se pondo para o } \\
\text { campo é uma escolha que } \\
\text { produz um sentido } \\
\text { metafórico relacionado ao } \\
\text { final de uma era ou o } \\
\text { começo de outra, registrado } \\
\text { na nota de rodapé } 88 \text {. }\end{array}$ & $\begin{array}{l}\text { Aqui está outra paisagem. Sol } \\
\text { poente? Lua nascendo? }\end{array}$ & $\begin{array}{l}\text { Há uma ambiguidade em relação ao } \\
\text { elemento da tela, Sol ou Lua, começo } \\
\text { ou fim, essa ambiguidade simbólica } \\
\text { revela uma metáfora da experiência de } \\
\text { van Gogh em relação às mudanças que } \\
\text { ocorrem em sua época. }\end{array}$ \\
\hline $\begin{array}{l}\text { Na tela 'Por de Sol: Campo } \\
\text { de trigo perto de Arles', } \\
\text { observamos que a ocorrência } \\
\text { de Associação Metafórica } \\
\text { conferida pelo } \\
\text { enquadramento em plano } \\
\text { aberto do homem que } \\
\text { sugerem que van Gogh fala } \\
\text { de uma categoria humana e } \\
\text { não de um homem } \\
\text { específico, registrado nas } \\
\text { notas de rodapé } 92 \text { e } 106 . \\
\text { Observamos a ocorrência de } \\
\text { Associação Metafórica pela } \\
\text { caracterização anônima do } \\
\text { homem, construída com a } \\
\text { ausência de detalhamento, e } \\
\text { por estar contra o sol, } \\
\text { mostrando apenas sua } \\
\text { silhueta. }\end{array}$ & $\begin{array}{l}\text { Paisagens amarelo ouro velho - feito } \\
\text { rápido rápido rápido e com pressa, } \\
\text { como o ceifeiro que está em silêncio } \\
\text { sob o sol escaldante, concentrando- } \\
\text { se em ter o trabalho terminado. }\end{array}$ & $\begin{array}{l}\text { Observamos a ocorrência de } \\
\text { associação metafórica no nível } \\
\text { semântico da oração, com o } \\
\text { construto: 'como o ceifeiro que está } \\
\text { em silêncio sob o sol escaldante, } \\
\text { concentrando-se em ter o trabalho } \\
\text { terminado.' Ele está comparando a } \\
\text { forma como ele trabalha pintando, } \\
\text { com a forma como o ceifeiro } \\
\text { trabalha ceifando, 'feito rápido } \\
\text { rápido rápido e com pressa', e 'em } \\
\text { silêncio sob o sol escaldante, } \\
\text { concentrando-se em ter o trabalho } \\
\text { terminado.' Apesar de ser uma } \\
\text { comparação, ele une duas coisas } \\
\text { aparentemente díspares, pois uma se } \\
\text { caracteriza pela rapidez e a outra, } \\
\text { pelo silêncio. } \\
\text { Ao mesmo tempo ele faz uma } \\
\text { metáfora em que ele iguala o } \\
\text { movimento do ceifeiro sobre o trigo } \\
\text { e o movimento da pincelada sobre a }\end{array}$ \\
\hline
\end{tabular}




\begin{tabular}{|c|c|c|}
\hline & & $\begin{array}{l}\text { tela. Então em um nível talvez } \\
\text { metafórico o vento sobre o trigo tem } \\
\text { um efeito sobre ele como que de } \\
\text { corte e por isso, ele é representado } \\
\text { na tela como o resultado do trabalho } \\
\text { do ceifeiro no trigo. A metáfora } \\
\text { também sugere que o trabalho do } \\
\text { artista também é uma colheita. }\end{array}$ \\
\hline $\begin{array}{l}\text { Na tela 'Por de Sol: Campo } \\
\text { de trigo perto de Arles', } \\
\text { observamos a ocorrência de } \\
\text { associação metafórica do } \\
\text { tom da fumaça das fábricas } \\
\text { em contraposição com o tom } \\
\text { da luminosidade do céu para } \\
\text { conotar um conflito entre o } \\
\text { progresso econômico e a } \\
\text { natureza, registrada na nota } \\
\text { de rodapé } 63 \text {. }\end{array}$ & $\begin{array}{l}\text { Eu tenho um terceiro estudo, agora, } \\
\text { de uma paisagem com fábrica, e um } \\
\text { enorme sol em um céu vermelho, } \\
\text { acima de telhados vermelhos, em } \\
\text { que a natureza parece estar em um } \\
\text { acesso de raiva, em um dia de } \\
\text { mistral desagradável. }\end{array}$ & $\begin{array}{l}\text { Van Gogh intui que existe nesse } \\
\text { movimento de pincelada sobre a tela } \\
\text { uma energia transformadora e } \\
\text { criadora, mas que também tem uma } \\
\text { nuance descontrolada que carrega uma } \\
\text { emoção semelhante à da raiva. Ele } \\
\text { compara esse movimento que } \\
\text { representa o vento na tela ao } \\
\text { movimento da natureza na qual o } \\
\text { vento age sobre o trigo de maneira } \\
\text { desordenada, incontrolável e incisiva. } \\
\text { O ímpeto do artista no momento de } \\
\text { representação do vento da tela o } \\
\text { aproxima da natureza e o aproxima de } \\
\text { sua natureza e da natureza daquilo que } \\
\text { faz a tela ser o que ela é. A } \\
\text { representação de um limiar entre } \\
\text { aquilo que o artista vê e aquilo que ele } \\
\text { não vê quando ele representa o que ele } \\
\text { vê. (Também Transparência, } \\
\text { Incompletude e Limiar Artístico). }\end{array}$ \\
\hline $\begin{array}{l}\text { Na tela 'Por de Sol: Campo } \\
\text { de trigo perto de Arles', } \\
\text { observamos a ocorrência de } \\
\text { enquadramento e associação } \\
\text { metafórica no } \\
\text { posicionamento do homem, } \\
\text { que constrói um elemento de } \\
\text { transição e sugere a metáfora } \\
\text { de que este homem está } \\
\text { vivendo em um mundo em } \\
\text { transição, registrado na nota } \\
\text { de rodapé } 89 \text {. }\end{array}$ & $\begin{array}{l}\text { Paisagens amarelo ouro velho - feito } \\
\text { rápido rápido rápido e com pressa, } \\
\text { como o ceifeiro que está em silêncio } \\
\text { sob o sol escaldante, concentrando- } \\
\text { se em ter o trabalho terminado. }\end{array}$ & \\
\hline $\begin{array}{l}\text { Na tela 'Por de Sol: Campo } \\
\text { de trigo perto de Arles', } \\
\text { observamos a ocorrência de } \\
\text { Associação Metafórica } \\
\text { conferida pelo uso da cor }\end{array}$ & & \\
\hline
\end{tabular}




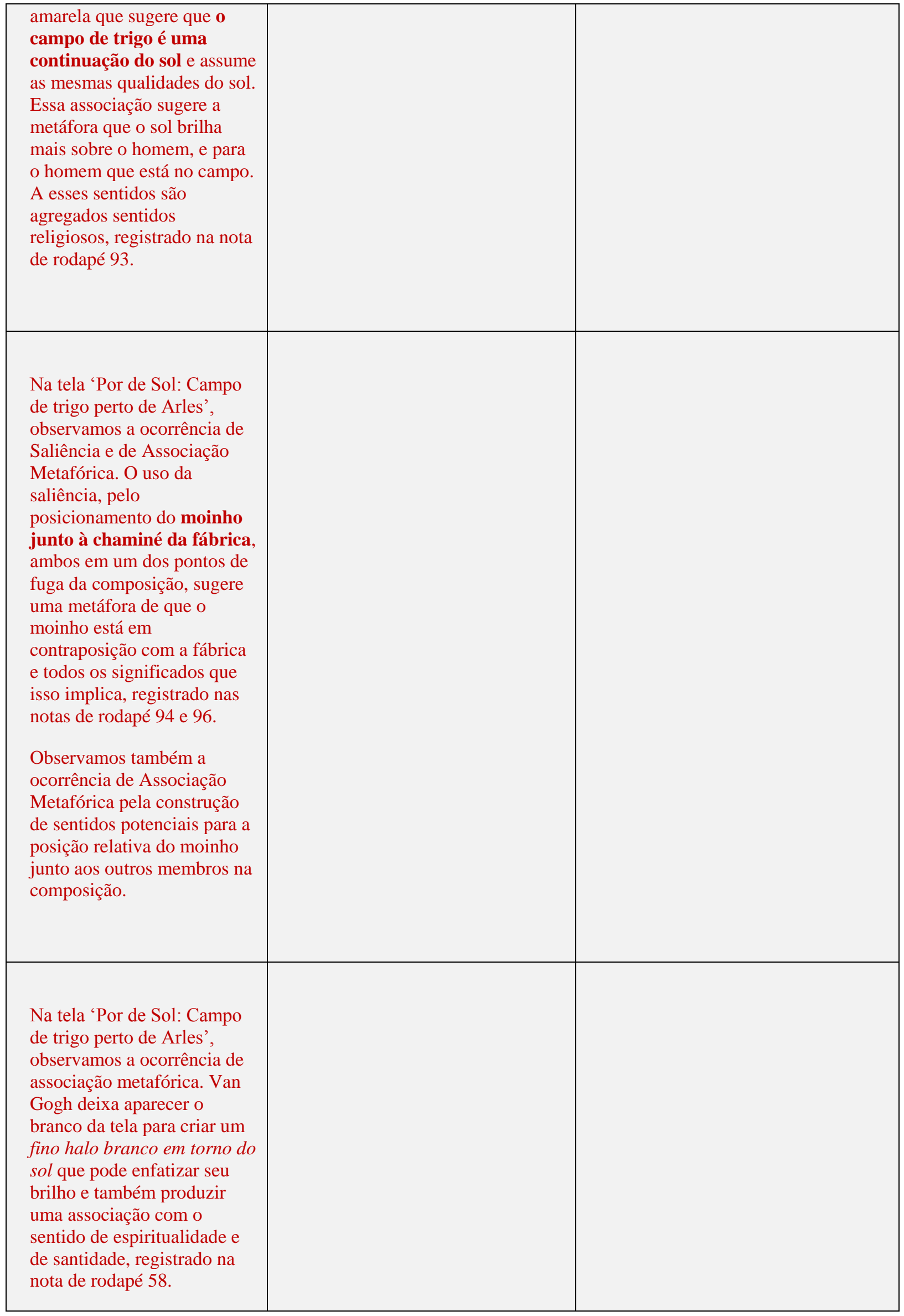




\begin{tabular}{|c|c|c|}
\hline $\begin{array}{l}\text { Observamos a ocorrência de } \\
\text { Associação Metafórica pela } \\
\text { ausência de sombras na tela, } \\
\text { que corrobora com a } \\
\text { metáfora de luz divina para } \\
\text { o sol, construída pelo halo de } \\
\text { luz que remete ao sentido da } \\
\text { divindade, registrado nas } \\
\text { notas de rodapé } 103 \text { e } 104 \text {. }\end{array}$ & & \\
\hline $\begin{array}{l}\text { Observamos também a } \\
\text { ocorrência de Rima visual } \\
\text { que, por meio do uso da cor } \\
\text { para representar a luz do sol } \\
\text { sobre a cidade e o campo, } \\
\text { constroem uma associação } \\
\text { metafórica da luz divina que } \\
\text { tudo interliga. }\end{array}$ & & \\
\hline $\begin{array}{l}\text { Na tela 'Por de Sol: Campo } \\
\text { de trigo perto de Arles', } \\
\text { observamos a ocorrência de } \\
\text { Enquadramento, pela } \\
\text { escolha do ponto de vista } \\
\text { que privilegia a } \\
\text { representação do campo } \\
\text { sobre a cidade e com isso, } \\
\text { constrói uma relação que } \\
\text { realça o valor do campo. } \\
\text { Observamos também a } \\
\text { ocorrência de Saliência e } \\
\text { Associação metafórica por } \\
\text { meio do enquadramento que } \\
\text { aproxima o campo e } \\
\text { distancia a cidade, registrado } \\
\text { na nota de rodapé } 107 .\end{array}$ & $\begin{array}{l}\text { Aqui está outra paisagem. Sol } \\
\text { poente? Lua nascendo? Noite de } \\
\text { verão, de qualquer modo. Cidade } \\
\text { violeta, estrela amarela, céu azul- } \\
\text { esverdeado; os campos de trigo tem } \\
\text { todos os tons: ouro velho, cobre, } \\
\text { ouro verde, ouro vermelho, ouro } \\
\text { amarelo, verde, vermelho e amarelo } \\
\text { bronze. Tela quadrada número } 30 \text {. }\end{array}$ & $\begin{array}{l}\text { No excerto, ele privilegia a } \\
\text { representação do campo sobre a } \\
\text { cidade, pois ao descrever a tela que } \\
\text { retrata uma cidade ao fundo, ele nem } \\
\text { sequer menciona a existência da } \\
\text { cidade, mas descreve o campo } \\
\text { detalhadamente por meio de uma } \\
\text { sequência de tonalidades. }\end{array}$ \\
\hline $\begin{array}{l}\text { Na tela 'O Semeador', } \\
\text { observamos que a ocorrência } \\
\text { de Associação Metafórica é } \\
\text { construída pela associação } \\
\text { dos sentidos do trigo maduro } \\
\text { e os sentidos do céu e do sol: } \\
\text { calor, vida, força e } \\
\text { crescimento, confirmada } \\
\text { pela divisão do espaço } \\
\text { composicional e pela divisão } \\
\text { cromática da tela na qual o } \\
\text { campo maduro tem tons } \\
\text { quentes e o campo arado tem } \\
\text { tons frios, registrada na nota }\end{array}$ & $\begin{array}{l}\text { Há várias sugestões de amarelo no } \\
\text { solo, tons neutros resultantes da } \\
\text { mistura de violeta e amarelo; mas } \\
\text { tenho travado uma luta diabólica } \\
\text { para atingir a verdade das cores. }\end{array}$ & $\begin{array}{l}\text { MODALIDADE } \\
\text { Van Gogh parece expressar que ele } \\
\text { tem uma espécie de lealdade com a } \\
\text { natureza que exige uma entrega no } \\
\text { momento de percepção das cores } \\
\text { porque nós tendemos a homogeneizar } \\
\text { e ver no campo de trigo só o amarelo } \\
\text { e ver na terra só o roxo, ou o marrom, } \\
\text { ou o cinza indifuso, e vê na produção } \\
\text { do Semeador no campo, esse desafio } \\
\text { de identificar a heterogeneidade nos } \\
\text { seus mínimos detalhes e por outro } \\
\text { lado, o movimento das pinceladas }\end{array}$ \\
\hline
\end{tabular}




\begin{tabular}{|c|c|c|}
\hline $\begin{array}{l}\text { de rodapé } 119 . \\
\text { Observamos também a } \\
\text { ocorrência de Associação } \\
\text { Metafórica construída pelo } \\
\text { uso simbólico da cor para } \\
\text { construir o significado } \\
\text { cíclico do plantar e do } \\
\text { colher, e outras associações } \\
\text { de sentidos potenciais são } \\
\text { sugeridas como vida e morte, } \\
\text { registrada na nota de rodapé } \\
156 .\end{array}$ & & $\begin{array}{l}\text { exige um ritmo para ser fiel à textura } \\
\text { e à composição como um todo, mas } \\
\text { nesse estudo especialmente ele }\end{array}$ \\
\hline $\begin{array}{l}\text { Observamos também a } \\
\text { ocorrência de Uso Simbólico } \\
\text { da Cor para conferir } \\
\text { Associação Metafórica para } \\
\text { os sentidos simbólicos do } \\
\text { campo maduro e do campo } \\
\text { arado e da parábola do } \\
\text { Semeador, registrada na nota } \\
\text { de rodapé } 160 \text {. }\end{array}$ & & \\
\hline $\begin{array}{l}\text { Observamos também a } \\
\text { ocorrência de Uso Simbólico } \\
\text { da Cor para conferir } \\
\text { Saliência e Associação } \\
\text { Metafórica para os sentidos } \\
\text { simbólicos do campo arado } \\
\text { registrada na nota de rodapé } \\
161 .\end{array}$ & & \\
\hline $\begin{array}{l}\text { Na tela 'O Semeador', } \\
\text { observamos a ocorrência de } \\
\text { Associação Metafórica, } \\
\text { construída pelo contrates } \\
\text { simultâneo sugere } \\
\text { contraposição metafórica } \\
\text { de significados do céu e da } \\
\text { terra, registrada na nota de } \\
\text { rodapé } 152 \text {. }\end{array}$ & $\begin{array}{l}\text { Aqui está o que eu queria dizer } \\
\text { sobre o branco e o preto. Vamos } \\
\text { tomar o Semeador. A pintura é } \\
\text { dividida em dois; metade é amarelo, } \\
\text { o topo; a base é violeta. Bem, as } \\
\text { calças brancas descansam os olhos e } \\
\text { os distraem exatamente quando o } \\
\text { contraste simultâneo excessivo de } \\
\text { amarelo e violeta iriam irritá-lo. } \\
\text { Isso é o que eu queria dizer. }\end{array}$ & $\begin{array}{l}\text { Ele usa a pintura do Semeador como } \\
\text { metáfora para explicar o que ele pensa } \\
\text { sobre o branco e o preto, que são tão } \\
\text { opostos, tão contrastantes que 'o } \\
\text { contraste excessivo iria irritá-lo', } \\
\text { então ele usa um elemento de } \\
\text { transição para distrair os olhos do } \\
\text { impasse causado pelo contraste } \\
\text { excessivo. Ao mesmo tempo ele usa o } \\
\text { contraste excessivo para simbolizar } \\
\text { sentidos opostos entre o céu e a terra. }\end{array}$ \\
\hline $\begin{array}{l}\text { Na tela 'O Semeador', } \\
\text { observamos a ocorrência } \\
\text { conjugada de Contrastes de }\end{array}$ & $\begin{array}{l}\text { O céu, amarelo-crómio, quase tão } \\
\text { luminoso quanto o próprio Sol, que } \\
\text { é amarelo-crómio } \mathrm{n}^{\circ} 1 \text {, misturado }\end{array}$ & \\
\hline
\end{tabular}




\begin{tabular}{|c|c|c|}
\hline $\begin{array}{l}\text { Saturação, Saliência, } \\
\text { Associação Metafórica e } \\
\text { Incompletude na } \\
\text { representação do céu e do } \\
\text { sol, em amarelo sobre } \\
\text { amarelo, registrado na nota } \\
\text { de rodapé } 137 .\end{array}$ & $\begin{array}{l}\text { com um pouco de branco, enquanto } \\
\text { o resto do céu é uma mistura dos } \\
\text { amarelos-crómios } 1 \text { e } 2 \text {. Tão } \\
\text { amarelo! }\end{array}$ & \\
\hline $\begin{array}{l}\text { Observamos também a } \\
\text { ocorrência de Saliência e } \\
\text { Associação Metafórica para } \\
\text { o céu e o sol, construída pelo } \\
\text { uso de ritmo, textura, } \\
\text { movimento e direção } \\
\text { articulados pelo gesto } \\
\text { pictórico, registrado na nota } \\
\text { de rodapé } 151 \text {. }\end{array}$ & & \\
\hline $\begin{array}{l}\text { Observamos também a } \\
\text { ocorrência de Saliência e } \\
\text { Associação Metafórica pelo } \\
\text { posicionamento relativo do } \\
\text { Sol na composição, } \\
\text { ocupando o centro e a parte } \\
\text { superior da tela, registrado } \\
\text { na nota de rodapé } 152 \text {. }\end{array}$ & & \\
\hline $\begin{array}{l}\text { Na tela 'O Semeador', } \\
\text { observamos a ocorrência de } \\
\text { Vetor e Associação } \\
\text { metafórica por meio de um } \\
\text { caminho visual que constrói } \\
\text { um movimento direcional do } \\
\text { primeiro plano para o } \\
\text { último plano e as metáforas } \\
\text { de uma narrativa visual, } \\
\text { registrada na nota de rodapé } \\
124 .\end{array}$ & & \\
\hline $\begin{array}{l}\text { Na tela 'O Semeador', } \\
\text { observamos a ocorrência de } \\
\text { Vetor 2, construída pelo } \\
\text { Semeador que anda e olha } \\
\text { para a direita da tela. O } \\
\text { Vetor } 2 \text { constrói a } \\
\text { Associação metafórica que o } \\
\text { Semeador se desloca do } \\
\text { passado para o futuro. Há } \\
\text { também uma metáfora de } \\
\text { conflito entre o significado } \\
\text { simbólico dos corvos e o do } \\
\text { semear, registrada na nota de }\end{array}$ & $\begin{array}{l}\text { Preferia muito mais fazer quadros } \\
\text { naifs tirados de velhos almanaques, } \\
\text { aqueles velhos "almanaques dos } \\
\text { lavradores" nos quais o granizo, a } \\
\text { neve, a chuva e o bom tempo são } \\
\text { retratados de modo primitivo, como } \\
\text { o Anquetin atingiu tão bem no seu } \\
\text { A Colheita. } \\
\text { Não te vou ocultar que não desgosto } \\
\text { da região, pois fui criado lá - ainda } \\
\text { me encanta a magia das recordações } \\
\text { do passado, de um desejo do }\end{array}$ & \\
\hline
\end{tabular}




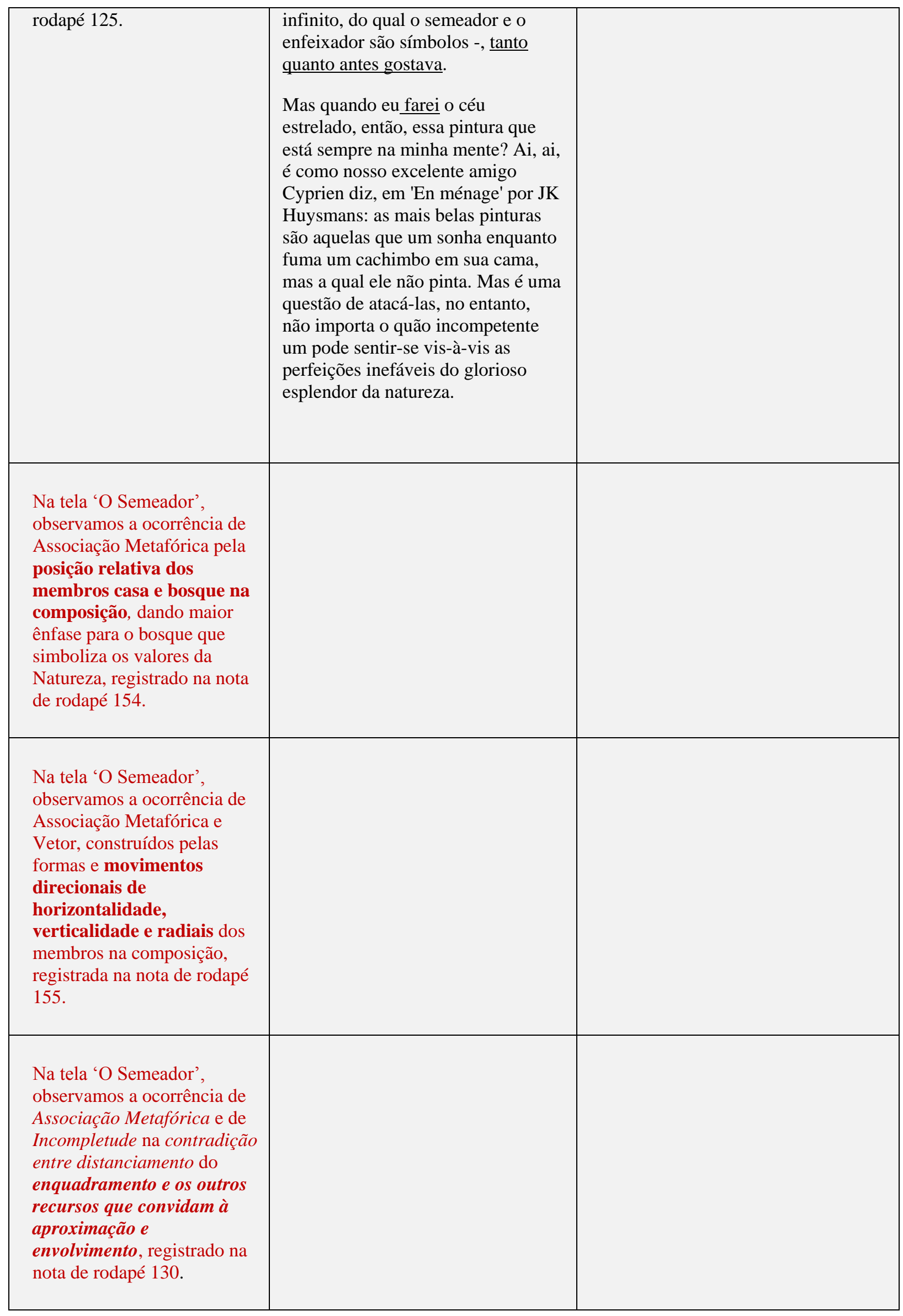




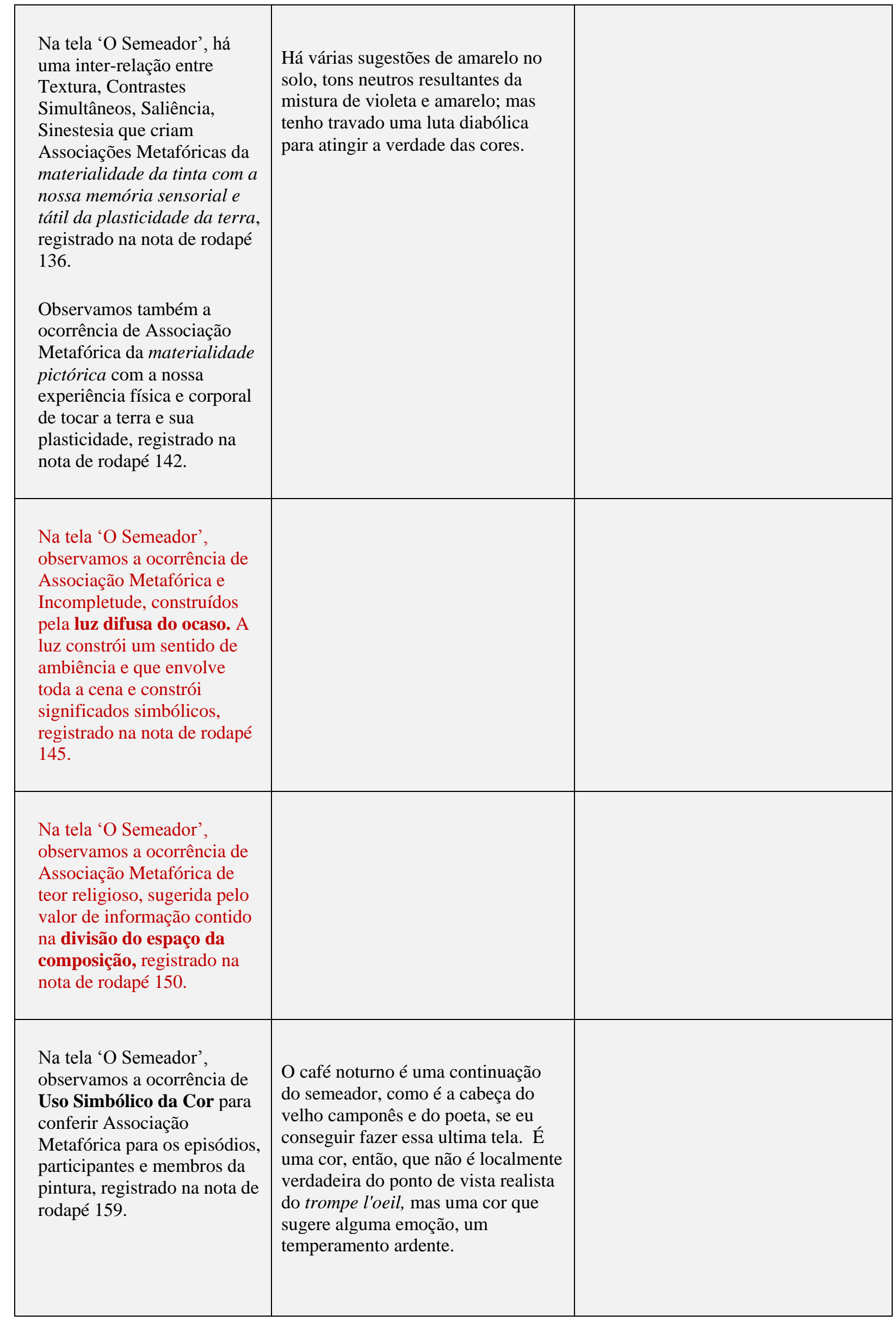




\begin{tabular}{|c|c|}
\hline $\begin{array}{l}\text { Na tela 'O Semeador', } \\
\text { observamos a ocorrência de } \\
\text { Associação Metafórica e } \\
\text { Incompletude construída } \\
\text { pela Rima Visual e pelo } \\
\text { Gesto pictórico para } \\
\text { representar a unidade entre o } \\
\text { Homem e a Natureza, } \\
\text { registrados na nota de rodapé } \\
\text { 164. }\end{array}$ & $\begin{array}{l}\text { Preferia muito mais fazer quadros } \\
\text { naifs tirados de velhos almanaques, } \\
\text { aqueles velhos "almanaques dos } \\
\text { lavradores" nos quais o granizo, a } \\
\text { neve, a chuva e o bom tempo são } \\
\text { retratados de modo primitivo, como } \\
\text { o Anquetin atingiu tão bem no seu } \\
\text { A Colheita. } \\
\text { Não te vou ocultar que não desgosto } \\
\text { da região, pois fui criado lá - ainda } \\
\text { me encanta a magia das recordações } \\
\text { do passado, de um desejo do infinito, } \\
\text { do qual o semeador e o enfeixador } \\
\text { são símbolos -, tanto quanto antes } \\
\text { gostava. }\end{array}$ \\
\hline $\begin{array}{l}\text { Na tela 'A Esplanada do } \\
\text { Café na Place du Forum, } \\
\text { Arles, à Noite', observamos } \\
\text { a ocorrência de } \\
\text { contraposição entre a luz } \\
\text { natural e a luz artificial, } \\
\text { sugerem uma associação } \\
\text { metafórica, registrada na } \\
\text { nota de rodapé } 179 .\end{array}$ & \\
\hline $\begin{array}{l}\text { Observamos também a } \\
\text { ocorrência de Associação } \\
\text { Metafórica pela } \\
\text { contraposição entre a cor } \\
\text { sob a luz natural e a cor sob } \\
\text { a luz artificial, que sugere } \\
\text { sentidos potenciais acerca da } \\
\text { contraposição Progresso x } \\
\text { Natureza, registrada na nota } \\
\text { de rodapé } 182 \text {. }\end{array}$ & \\
\hline $\begin{array}{l}\text { Observamos também a } \\
\text { ocorrência de Associações } \\
\text { Metafóricas e } \\
\text { Intertextualidade para as } \\
\text { escolhas de sentidos que } \\
\text { van Gogh empresta à noite, } \\
\text { à luz noturna, evidenciado } \\
\text { no excerto da carta } 543 \\
\text { citada na análise, registrada } \\
\text { na nota de rodapé } 194 .\end{array}$ & $\begin{array}{l}\text { Você nunca me disse se você tinha } \\
\text { lido Bel-ami de Guy de } \\
\text { Maupassant, e o que você pensa } \\
\text { agora do talento dele em geral. Digo } \\
\text { isto porque o início de Bel- Ami é } \\
\text { precisamente a descrição de uma } \\
\text { noite estrelada em Paris, com os } \\
\text { cafés iluminados da avenida, e isso } \\
\text { é algo como o mesmo tema que eu } \\
\text { pintei bem agora. }\end{array}$ \\
\hline
\end{tabular}




\begin{tabular}{|c|c|}
\hline $\begin{array}{l}\text { Na tela 'A Esplanada do } \\
\text { Café na Place du Forum, } \\
\text { Arles, à Noite', observamos } \\
\text { a ocorrência de } \\
\text { Incompletude e Associação } \\
\text { Metafórica construída pela } \\
\text { representação das estrelas, } \\
\text { seu brilho e seu halo, que } \\
\text { suscita escolhas de sentidos } \\
\text { potenciais metafóricos, como } \\
\text { o halo de santidade, } \\
\text { registradas na nota de rodapé } \\
189 .\end{array}$ & $\begin{array}{l}\text { Mas quando eu farei o céu } \\
\text { estrelado, então, essa pintura que } \\
\text { está sempre na minha mente? Ai, ai, } \\
\text { é como nosso excelente amigo } \\
\text { Cyprien diz, em 'En ménage' por JK } \\
\text { Huysmans: as mais belas pinturas } \\
\text { são aquelas que um sonha enquanto } \\
\text { fuma um cachimbo em sua cama, } \\
\text { mas a qual ele não pinta. Mas é uma } \\
\text { questão de atacá-las, no entanto, } \\
\text { não importa o quão incompetente } \\
\text { um pode sentir-se vis-à-vis as } \\
\text { perfeições inefáveis do glorioso } \\
\text { esplendor da natureza. }\end{array}$ \\
\hline $\begin{array}{l}\text { Na tela 'A Esplanada do } \\
\text { Café na Place du Forum, } \\
\text { Arles, à Noite', observamos } \\
\text { a ocorrência de Associação } \\
\text { Metafórica e Transparencia } \\
\text { para a posição relativa da } \\
\text { charrete e o cavalo, } \\
\text { construída pela Saliência } \\
\text { dada pelo Enquadramento, } \\
\text { registrada na nota de rodapé } \\
196 .\end{array}$ & \\
\hline $\begin{array}{l}\text { Na tela 'A Esplanada do } \\
\text { Café na Place du Forum, } \\
\text { Arles, à Noite', observamos } \\
\text { a ocorrência de Associação } \\
\text { Metafórica construída pelo } \\
\text { tamanho desproporcional da } \\
\text { árvore, em comparação com } \\
\text { o tamanho dos outros } \\
\text { membros representados na } \\
\text { tela, sugerindo que van Gogh } \\
\text { está atribuindo a árvore um } \\
\text { estatuto simbólico mais } \\
\text { amplo, ele se refere à } \\
\text { categoria da Natureza, } \\
\text { registrada na nota de rodapé } \\
201 .\end{array}$ & \\
\hline Na tela 'A Esplanada do & \\
\hline
\end{tabular}




\begin{tabular}{|c|c|c|}
\hline $\begin{array}{l}\text { Café na Place du Forum, } \\
\text { Arles, à Noite', observamos } \\
\text { a ocorrência de Associação } \\
\text { Metafórica construída pela } \\
\text { representação da árvore pela } \\
\text { metade que sugere um } \\
\text { sentido potencial de } \\
\text { contraposição entre o } \\
\text { Progresso a Natureza, ou } \\
\text { que, diante do Progresso } \\
\text { trazido pela luz a gás, a } \\
\text { nossa Natureza ficou 'pela } \\
\text { metade', registrada na nota } \\
\text { de rodapé } 203 \text {. }\end{array}$ & & \\
\hline $\begin{array}{l}\text { Na tela 'A Esplanada do } \\
\text { Café na Place du Forum, } \\
\text { Arles, à Noite', observamos } \\
\text { a ocorrência de Associação } \\
\text { Metafórica e Transparência } \\
\text { construídos pelos sentidos } \\
\text { potenciais que sugerem a } \\
\text { solidão, o isolamento e a } \\
\text { ausência experienciada por } \\
\text { van Gogh, registrada na nota } \\
\text { de rodapé } 209 \text {. }\end{array}$ & $\begin{array}{l}\text { Mas quando eu farei o céu } \\
\text { estrelado, então, essa pintura que } \\
\text { está sempre na minha mente? Ai, ai, } \\
\text { é como nosso excelente amigo } \\
\text { Cyprien diz, em 'En ménage' por JK } \\
\text { Huysmans: as mais belas pinturas } \\
\text { são aquelas que um sonha enquanto } \\
\text { fuma um cachimbo em sua cama, } \\
\text { mas a qual ele não pinta. }\end{array}$ & \\
\hline $\begin{array}{l}\text { Na tela 'O Café Noturno na } \\
\text { Place Lamartine, em Arles', } \\
\text { observamos a ocorrência de } \\
\text { Associação Metafórica } \\
\text { conferida pela Distorção do } \\
\text { Ponto de Vista presente na } \\
\text { representação da mesa de } \\
\text { bilhar, registrada na nota de } \\
\text { rodapé } 223 \text {. }\end{array}$ & $\begin{array}{l}\text { A sala está pintada de vermelho, e no } \\
\text { interior, na luz a gás, a mesa de } \\
\text { bilhar verde, a qual lança uma } \\
\text { imensa sombra sobre o chão. }\end{array}$ & \\
\hline $\begin{array}{l}\text { Na tela ‘O Café Noturno na } \\
\text { Place Lamartine, em Arles', } \\
\text { observamos a ocorrência de } \\
\text { Distorção do Ponto de Vista } \\
\text { e Transparência, construídos } \\
\text { com ajuda da Saliência e de } \\
\text { Contrastes cromáticos } \\
\text { simultâneos e de saturação } \\
\text { exacerbados para representar } \\
\text { uma sensação de } \\
\text { desconforto, registrados na }\end{array}$ & $\begin{array}{l}\text { Que diria portanto desse quadro o Sr. } \\
\text { Tersteeg? Diante de um Sisley, } \\
\text { Sisley, o mais discreto e delicado dos } \\
\text { Impressionistas - já disse: "Não } \\
\text { posso me impedir de pensar que o } \\
\text { artista que pintou isso estava um } \\
\text { pouco tonto". Diante do meu quadro, } \\
\text { então a mim ele diria que ele é um } \\
\text { caso de delirium tremens". }\end{array}$ & \\
\hline
\end{tabular}




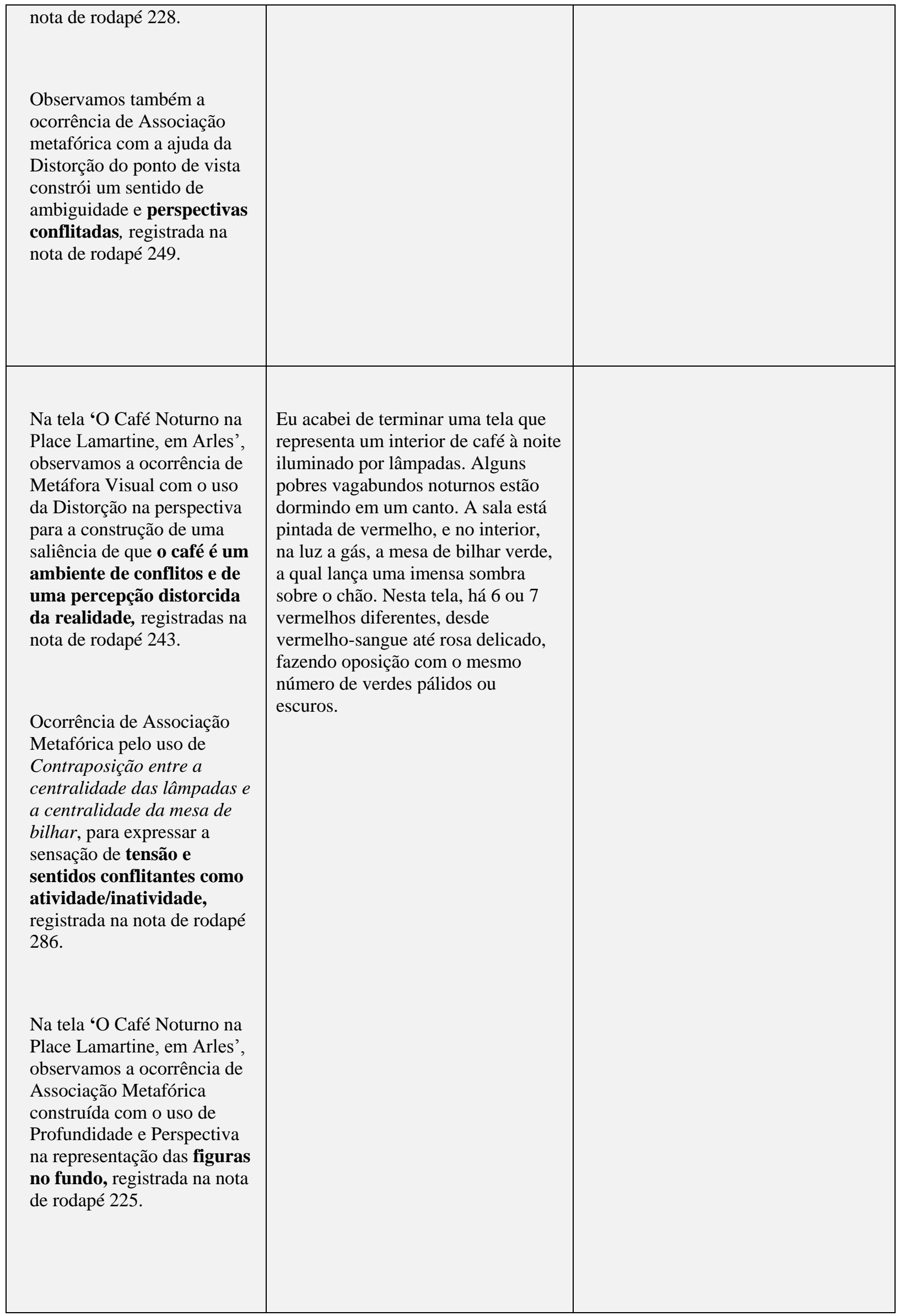




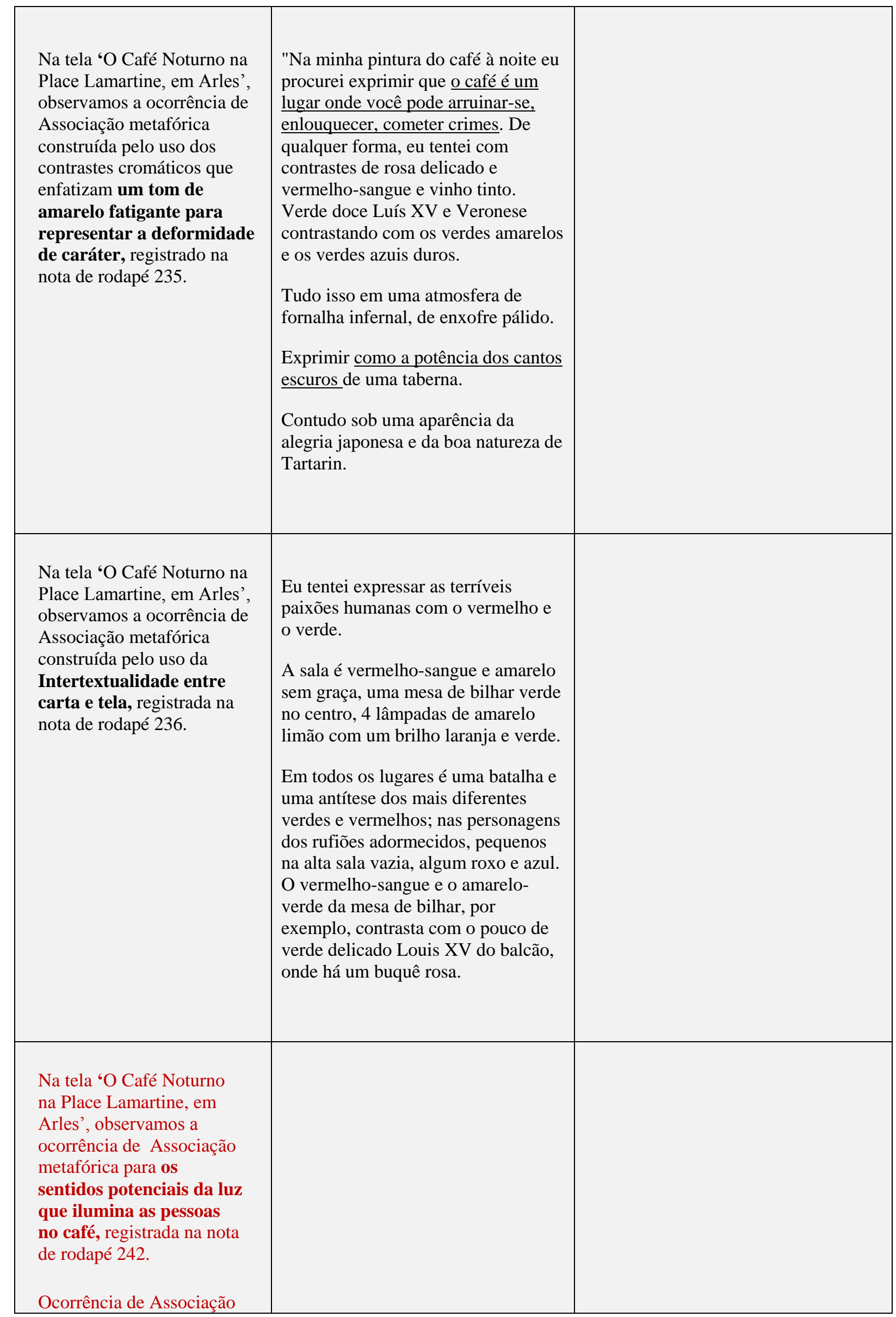




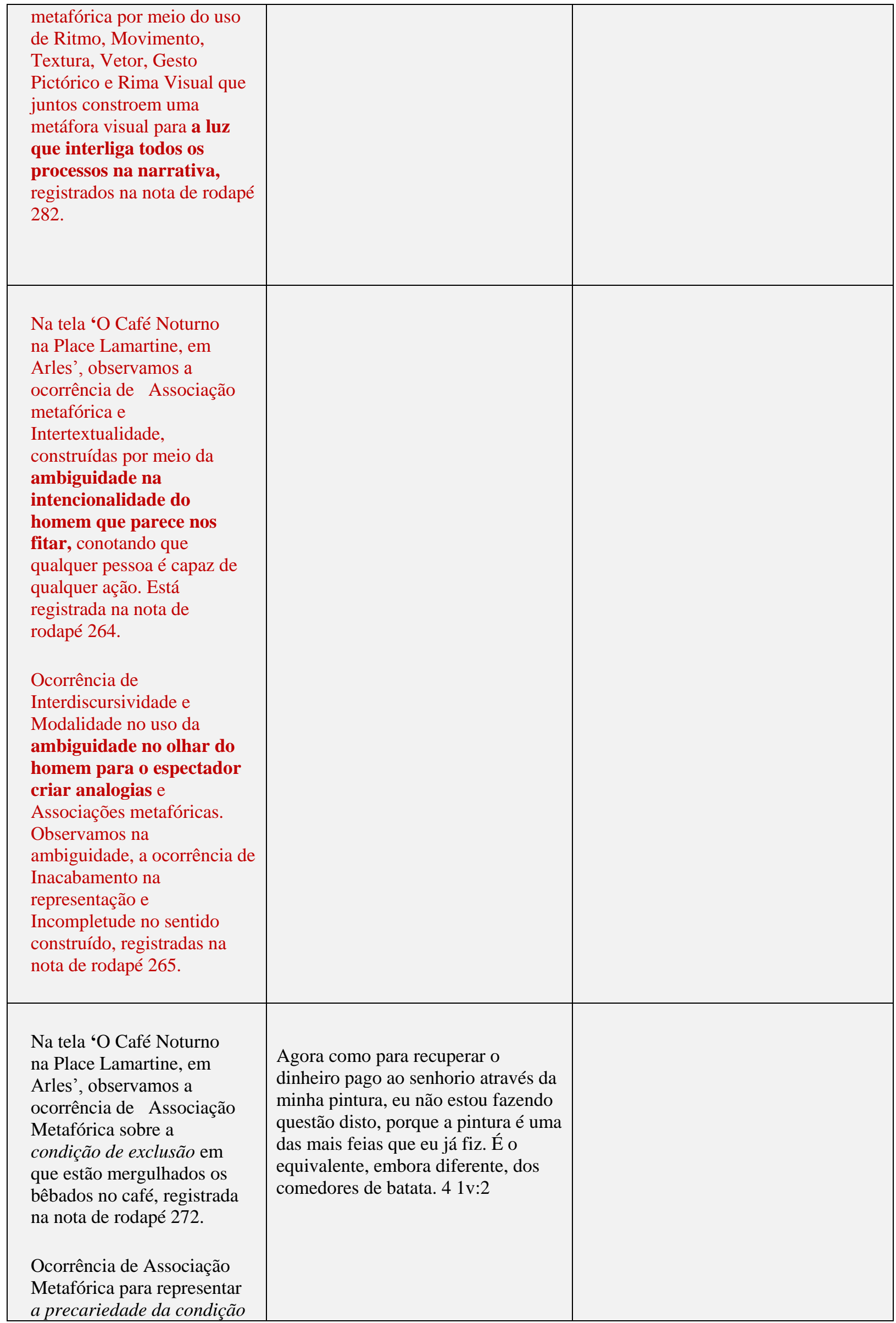




\begin{tabular}{|c|c|c|}
\hline $\begin{array}{l}\text { humana naquele contexto } \\
\text { social e histórico, por meio } \\
\text { da Distorção do ponto de } \\
\text { vista, registrada na nota de } \\
\text { rodapé } 274 \text {. }\end{array}$ & & \\
\hline $\begin{array}{l}\text { Na tela ‘O Café Noturno na } \\
\text { Place Lamartine, em Arles', } \\
\text { observamos a ocorrência de } \\
\text { Intertextualidade e } \\
\text { Associação metafórica por } \\
\text { meio do uso de Contrastes } \\
\text { cromáticos e Sinestesia. A } \\
\text { excessiva luz que inunda a } \\
\text { sala e a forma como ele } \\
\text { representa os contrastes } \\
\text { podem ser considerados } \\
\text { semioses equivalentes à } \\
\text { expressão escrita “fornalha } \\
\text { do diabo", registrada na } \\
\text { nota de rodapé } 278 \text {. }\end{array}$ & $\begin{array}{l}\text { Na minha pintura do café à noite eu } \\
\text { procurei exprimir que o café é um } \\
\text { lugar onde você pode arruinar-se, } \\
\text { enlouquecer, cometer crimes. De } \\
\text { qualquer forma, eu tentei com } \\
\text { contrastes de rosa delicado e } \\
\text { vermelho-sangue e vinho tinto. } \\
\text { Verde doce Luís XV e Veronese } \\
\text { contrastando com os verdes amarelos } \\
\text { e os verdes azuis duros. } \\
\text { Tudo isso em uma atmosfera de } \\
\text { fornalha infernal, de enxofre pálido. } \\
\text { Exprimir como a potência dos cantos } \\
\text { escuros de uma taberna. } \\
\text { Contudo sob uma aparência da } \\
\text { alegria japonesa e da boa natureza de } \\
\text { Tartarin. }\end{array}$ & \\
\hline $\begin{array}{l}\text { Na tela 'O Café Noturno na } \\
\text { Place Lamartine, em Arles', } \\
\text { observamos a ocorrência de } \\
\text { Associações metafóricas por } \\
\text { meio de Contraposições e } \\
\text { contrastes para representar } \\
\text { processos dicotômicos tais } \\
\text { como: centralidade } x \\
\text { periferia; } \text { olhar } x \text { negação } \\
\text { do olhar; presença x } \\
\text { ausência; mundano x } \\
\text { espiritual, registrada na nota } \\
\text { de rodapé } 279 \text {. }\end{array}$ & $\begin{array}{l}\text { A idéia do semeador ainda continua } \\
\text { a me assombrar. Estudos exagerados, } \\
\text { como o semeador, como o café } \\
\text { noturno agora, geralmente parecem- } \\
\text { me atrozmente feios e ruins, mas } \\
\text { quando eu estou movido por alguma } \\
\text { coisa, como aqui por este pequeno } \\
\text { artigo sobre Dostoievski, em } \\
\text { seguida, eles são os únicos que me } \\
\text { parecem ter um significado mais } \\
\text { importante." }\end{array}$ & Inversão de valores \\
\hline
\end{tabular}


Na tela 'O Café Noturno na Place Lamartine, em Arles', observamos a ocorrência de Associação metafórica pela representação da ausência de iluminação nas figuras, estando o ambiente tão excessivamente iluminado, registrada na nota de rodapé 287.

Ocorrência de Associação metafórica dos conflitos e contradições humanas por meio dos contrastes de luz e sombra, de cor, e de posicionamento das figuras e objetos, registrada na nota de rodapé 289.

Ocorrência de Associação metafórica de sentidos potenciais apoiada no discurso religioso que faz $a$ analogia da luz com a luz espiritual e da sombra com a ausência de luz espiritual, registrada na nota de rodapé 289.

Ocorrência de Associação metafórica nas escolhas de sentidos potenciais para a relação entre a luz e a natureza humana, registrada na nota de rodapé 289 .

Ocorrência de Associação metafórica corrobora com o sentido da luz estar em relação ao ser humano, pela disposição das lâmpadas sempre acima das cabeças das figuras, nunca acima de cadeiras vazias, registrada na nota de rodapé 290.

Uso de associação metafórica por meio de Saliência, Ritmo, Movimento, Textura e Gesto Pictórico para dar centralidade para luz, registrada na nota de rodapé 292

Ocorrência de Associação
Eu acabei de terminar uma tela que representa um interior de café à noite iluminado por lâmpadas. Alguns pobres vagabundos noturnos estão dormindo em um canto. A sala está pintada de vermelho, e no interior, na luz a gás, a mesa de bilhar verde, a qual lança uma imensa sombra sobre o chão. Nesta tela, há 6 ou 7 vermelhos diferentes, desde vermelho-sangue até rosa delicado, fazendo oposição com o mesmo número de verdes pálidos ou escuros.

A idéia do semeador ainda continua a me assombrar. Estudos exagerados, como o semeador, como o café noturno agora, geralmente parecemme atrozmente feios e ruins, mas quando eu estou movido por alguma coisa, como aqui por este pequeno artigo sobre Dostoievski, em seguida, eles são os únicos que me parecem ter um significado mais importante 


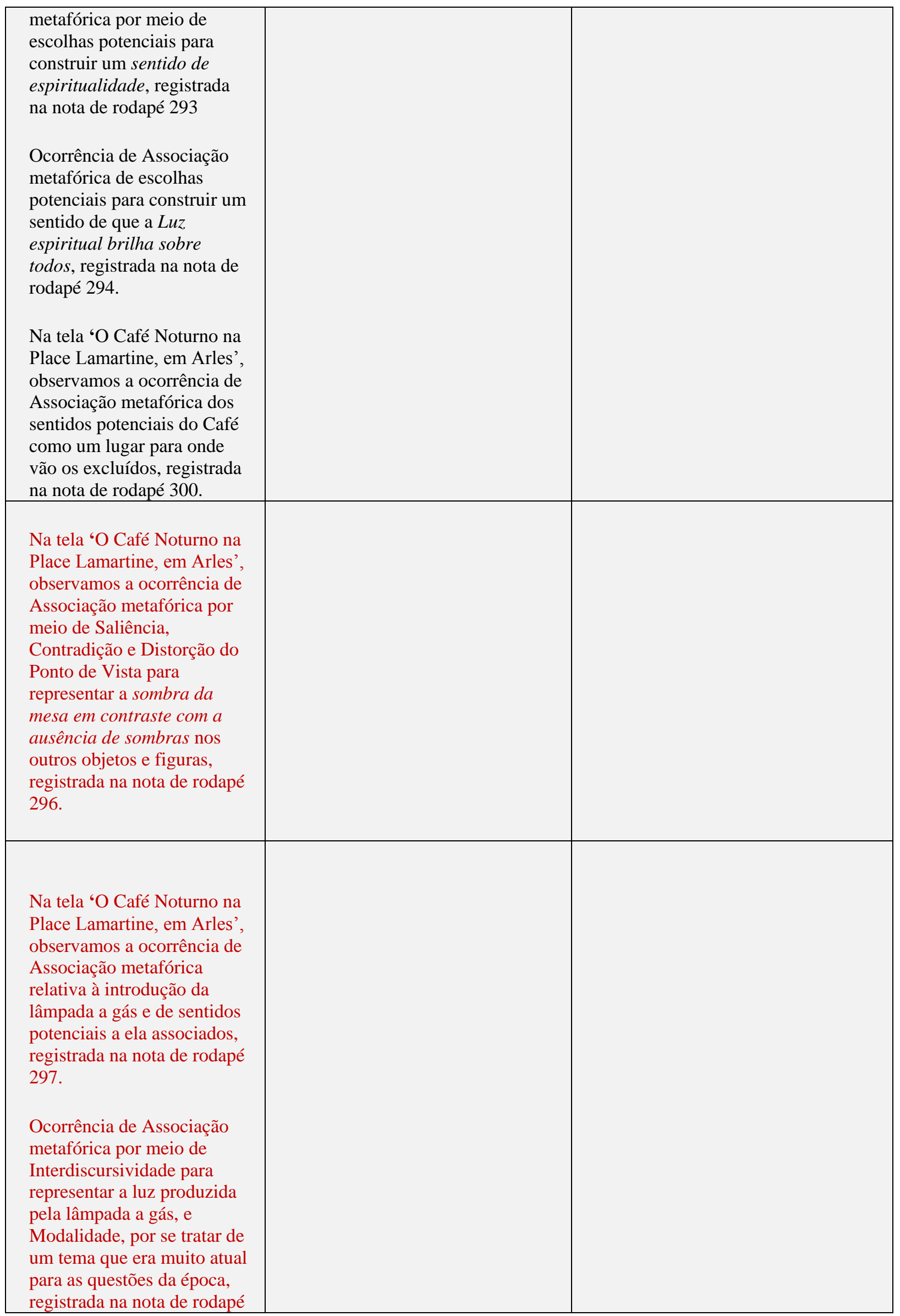




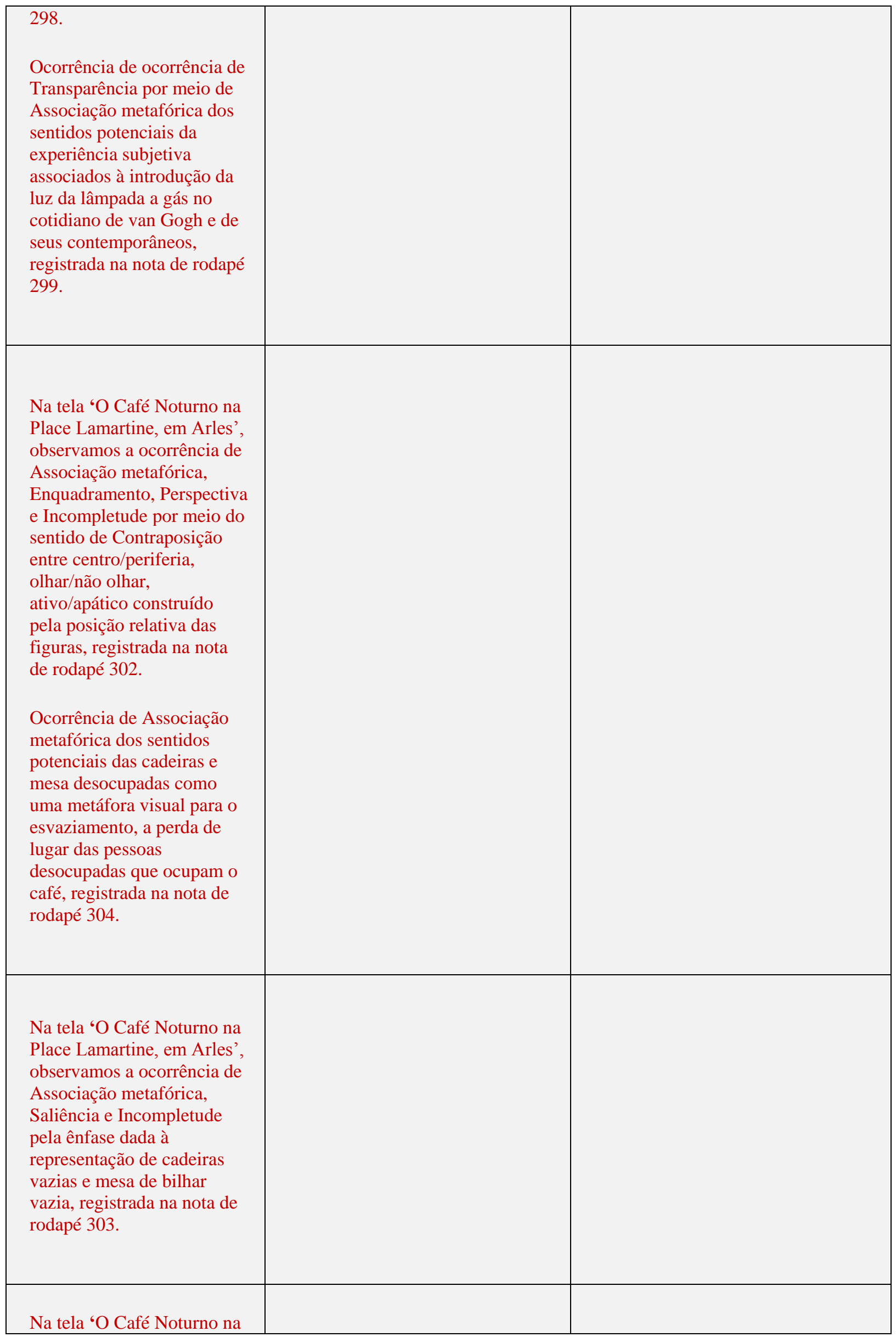




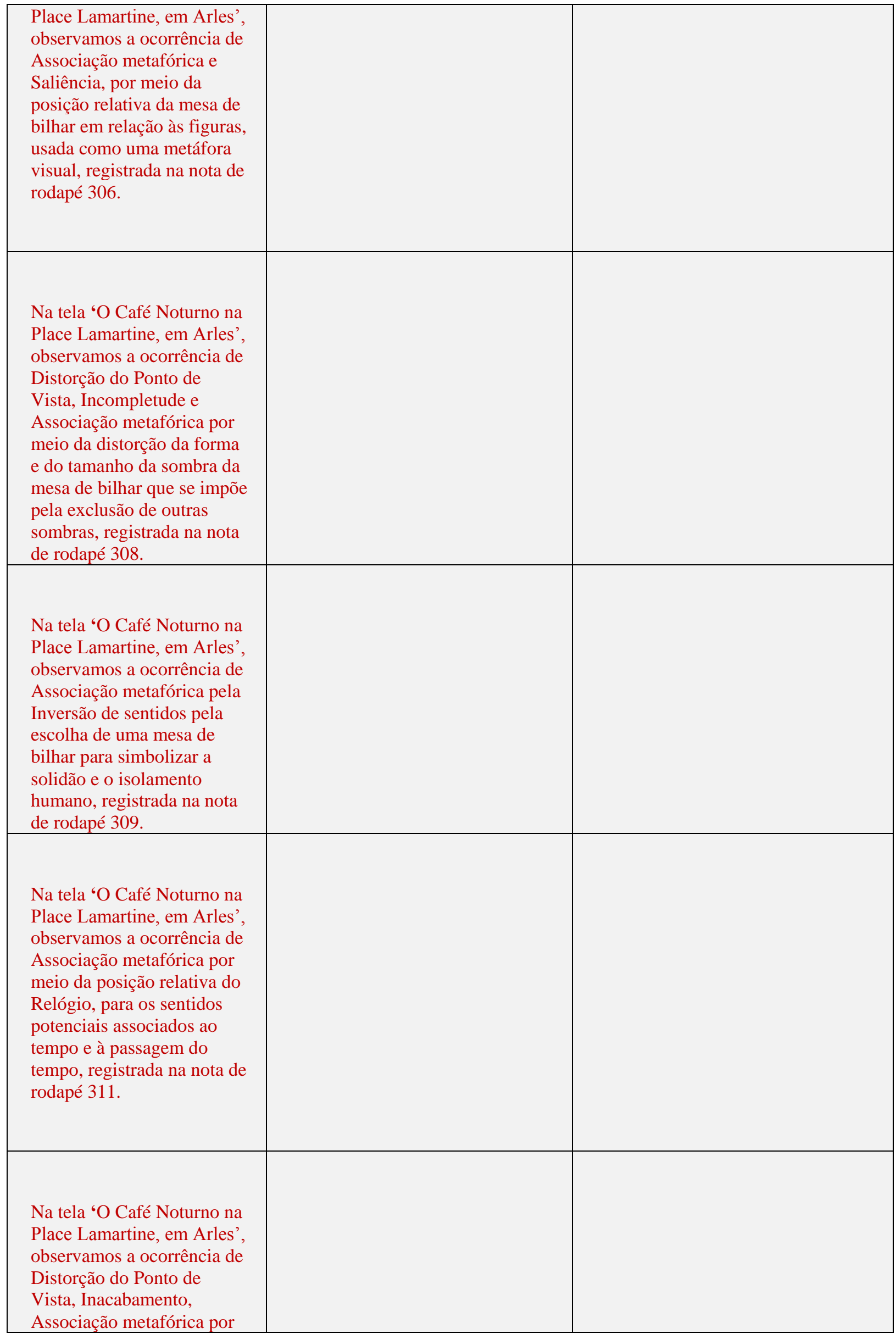




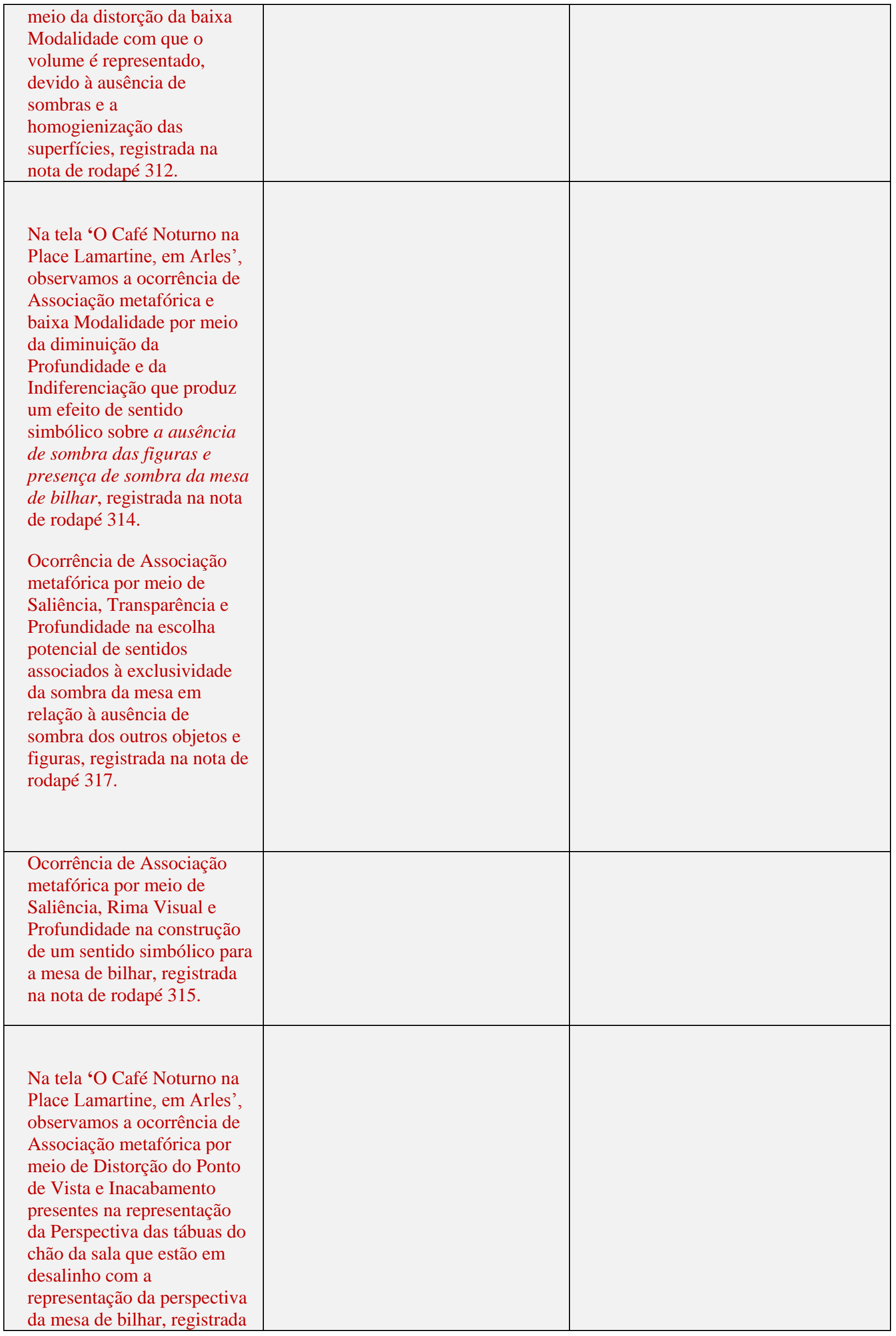




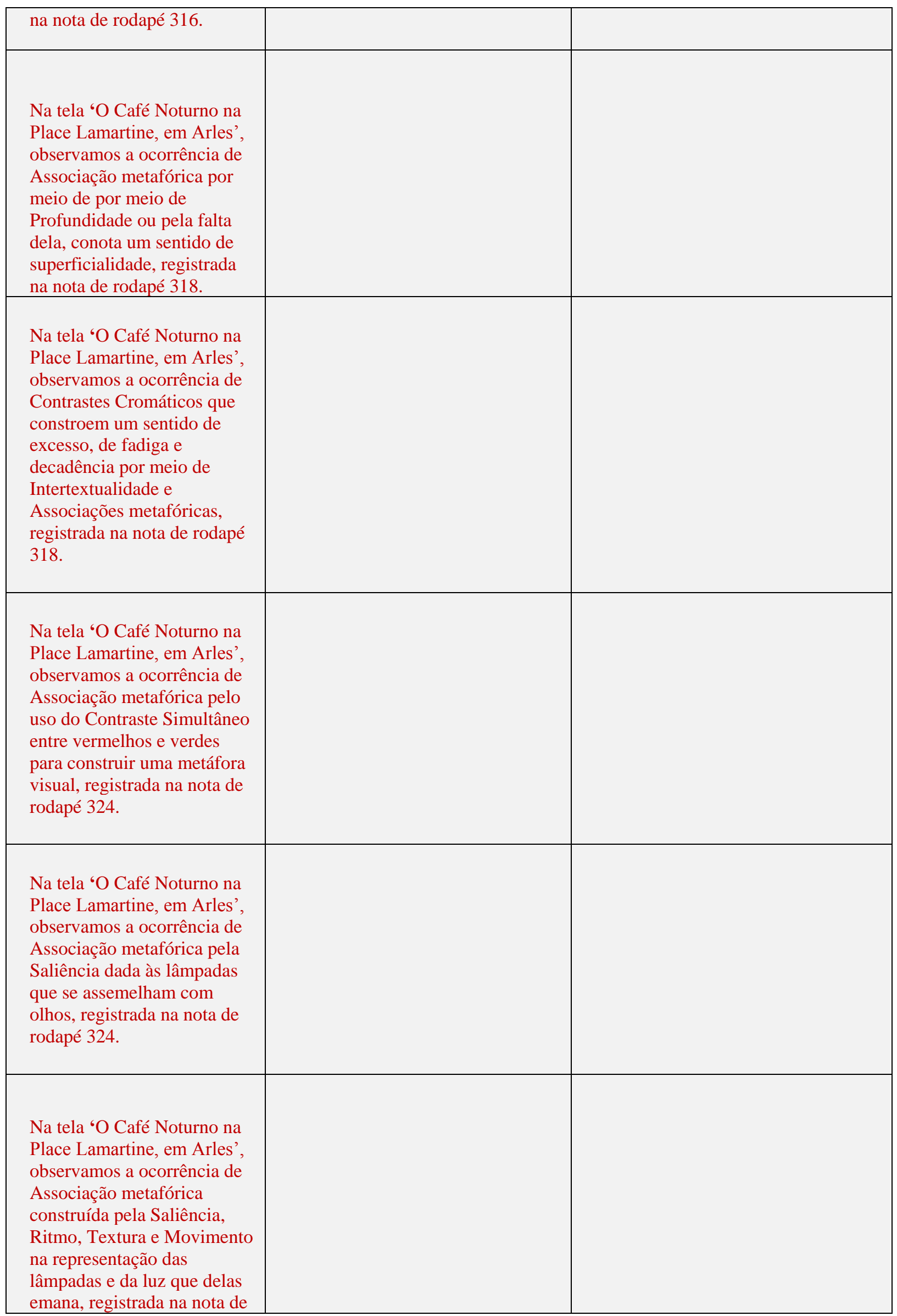




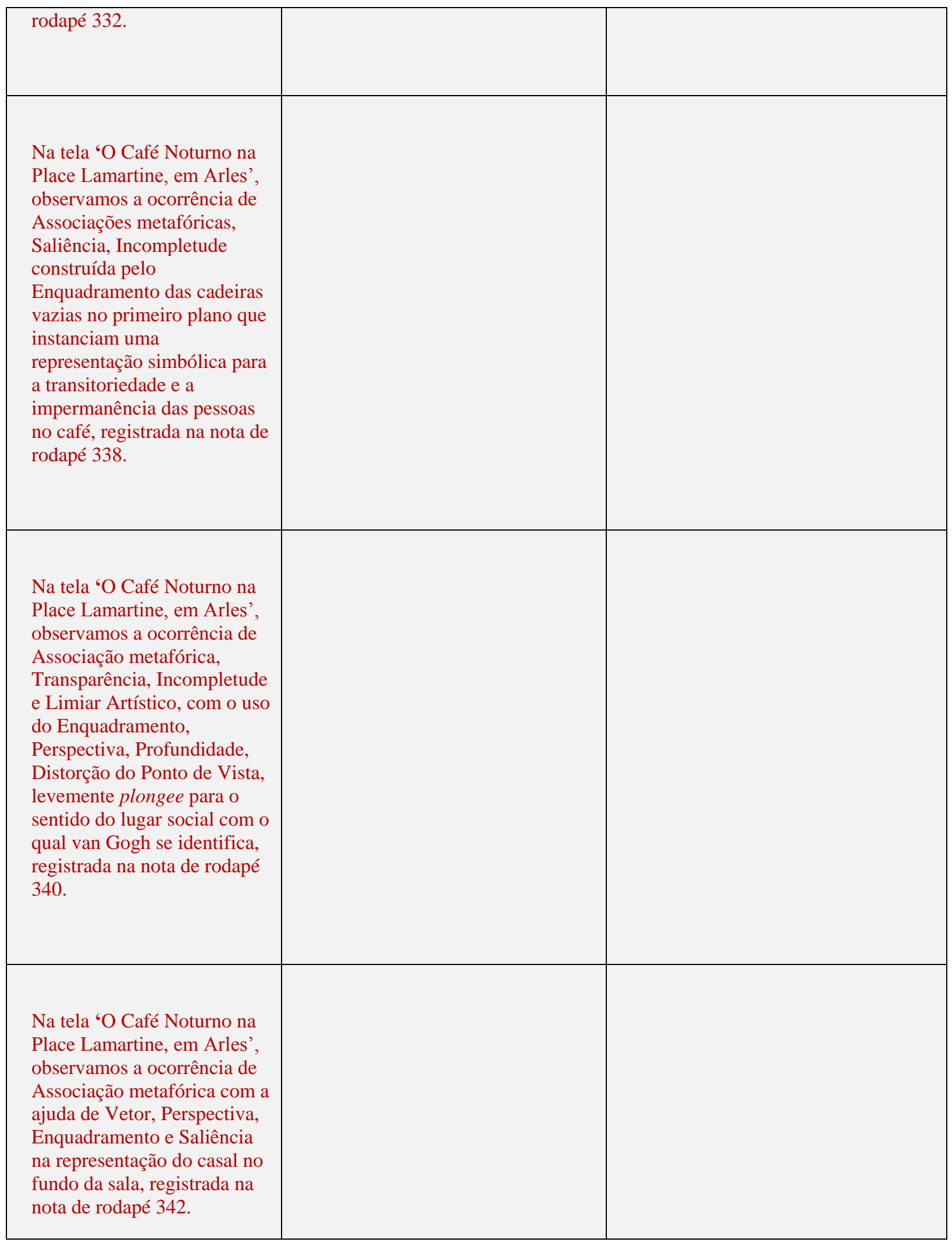

Fonte: Triangulação para Associações Metafóricas e Simbolismo dos dados dos corpora visual e textual, com os extratos das cartas. 


\subsection{TRIANGULAÇÃO DA RIMA VISUAL}

Quadro 80: Triangulação da Rima Visual

\begin{tabular}{|c|c|c|}
\hline Ocorrência nas telas & Orações & Comentário \\
\hline $\begin{array}{l}\text { Na tela 'Por de Sol: Campo de } \\
\text { trigo perto de Arles', a } \\
\text { ocorrência de Rima Visual } \\
\text { conferida pelo uso } \\
\text { concomitante de textura, } \\
\text { ritmo, movimento, direção, } \\
\text { volume e gesto pictórico para } \\
\text { representar o trigal, registrada } \\
\text { nas notas de rodapé } 78 \text { e } 82 \text {. } \\
\text { Observamos também que a } \\
\text { ocorrência de movimento } \\
\text { direcional e rima visual são } \\
\text { conferidos pelo uso do gesto } \\
\text { pictórico, do ritmo, da textura } \\
\text { e do movimento no trigal. }\end{array}$ & $\begin{array}{l}\text { Aqui está outra paisagem. Sol } \\
\text { poente? Lua nascendo? Noite de } \\
\text { verão, de qualquer modo. Cidade } \\
\text { violeta, estrela amarela, céu azul- } \\
\text { esverdeado; os campos de trigo têm } \\
\text { todos os tons: ouro velho, cobre, } \\
\text { ouro verde, ouro vermelho, ouro } \\
\text { amarelo, verde, vermelho e amarelo } \\
\text { bronze. Tela quadrada número } 30 \text {. }\end{array}$ & $\begin{array}{l}\text { Ritmo, cadência, movimento uso de } \\
\text { contrastes cromáticos. } \\
\text { O fato de ele escrever essas orações } \\
\text { sem verbo mostra o uso não } \\
\text { convencional da linguagem em um } \\
\text { texto descritivo na carta. Esse } \\
\text { elemento não convencional de uma } \\
\text { narrativa sem processo mostra um } \\
\text { recurso discursivo que pode condensar } \\
\text { outras semioses tais como uma ênfase, } \\
\text { um tom, um colorido para o discurso, e } \\
\text { além do que, é um tom que é poético e } \\
\text { empresta para esse período ritmo, } \\
\text { movimento, cadência e colorido, pois } \\
\text { matiza o discurso com o seu } \\
\text { temperamento livre e que nos deixa } \\
\text { liberdade de interpretação. Essas três } \\
\text { orações, aparentemente sem } \\
\text { importância para a análise da LSF por } \\
\text { não terem processos, carregam uma } \\
\text { camada semiótica que deu ao período } \\
\text { o que na análise das telas chamamos } \\
\text { de Rima Visual, ou seja, emprestou } \\
\text { harmonia e unidade para o período por } \\
\text { meio de um 'gesto textual' comparável } \\
\text { com suas pinceladas. }\end{array}$ \\
\hline $\begin{array}{l}\text { Na tela 'Por de Sol: Campo } \\
\text { de trigo perto de Arles', } \\
\text { observamos a ocorrência de } \\
\text { Rima visual, construída por } \\
\text { meio das gradações } \\
\text { cromáticas no céu e que se } \\
\text { espelham no campo de } \\
\text { trigo integrando os dois } \\
\text { campos da tela, registrada } \\
\text { na nota de rodapé } 61 .\end{array}$ & & \\
\hline $\begin{array}{l}\text { Na tela 'Por de Sol: Campo } \\
\text { de trigo perto de Arles', } \\
\text { observamos a ocorrência de } \\
\text { Rima visual que, por meio do }\end{array}$ & & \\
\hline
\end{tabular}




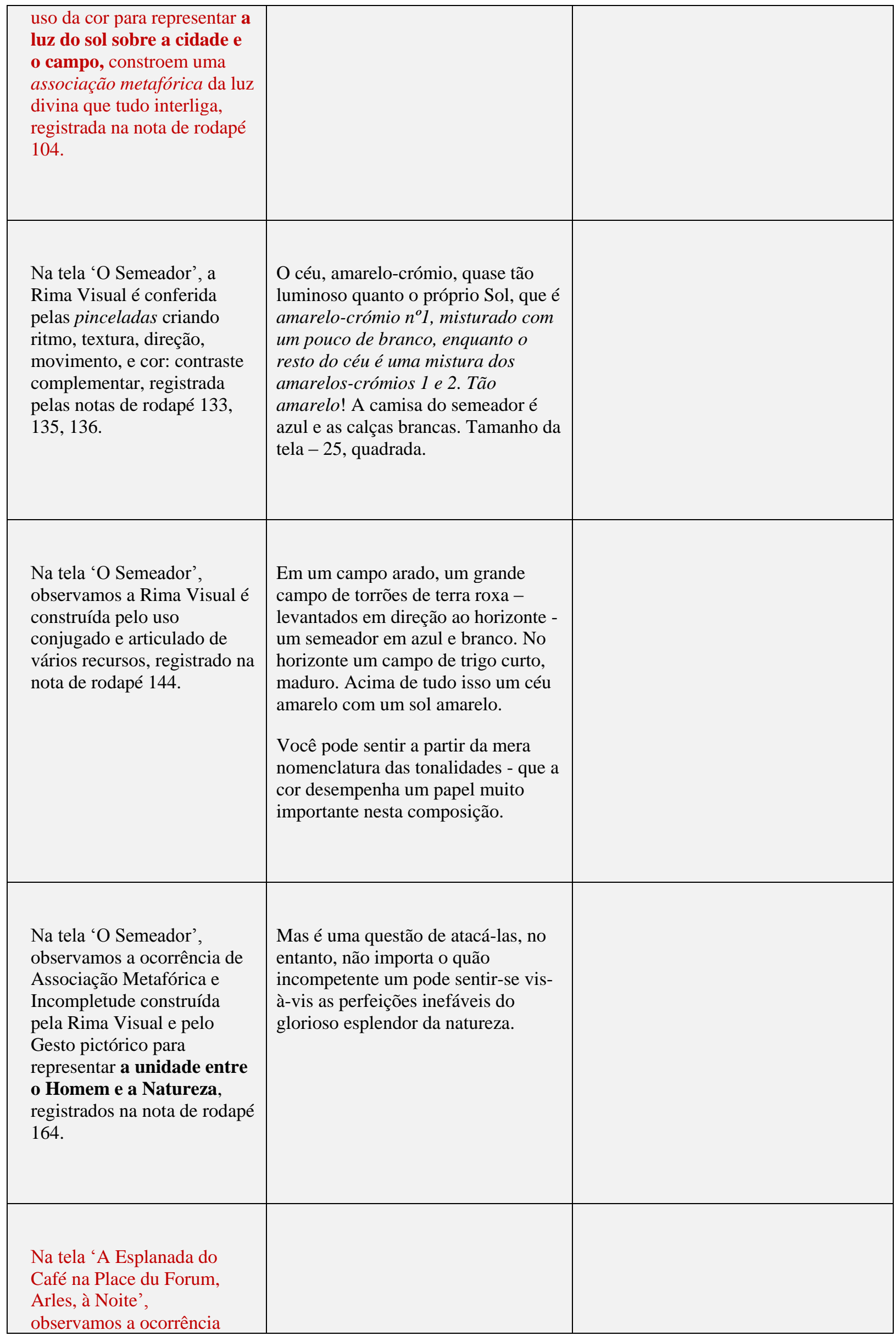




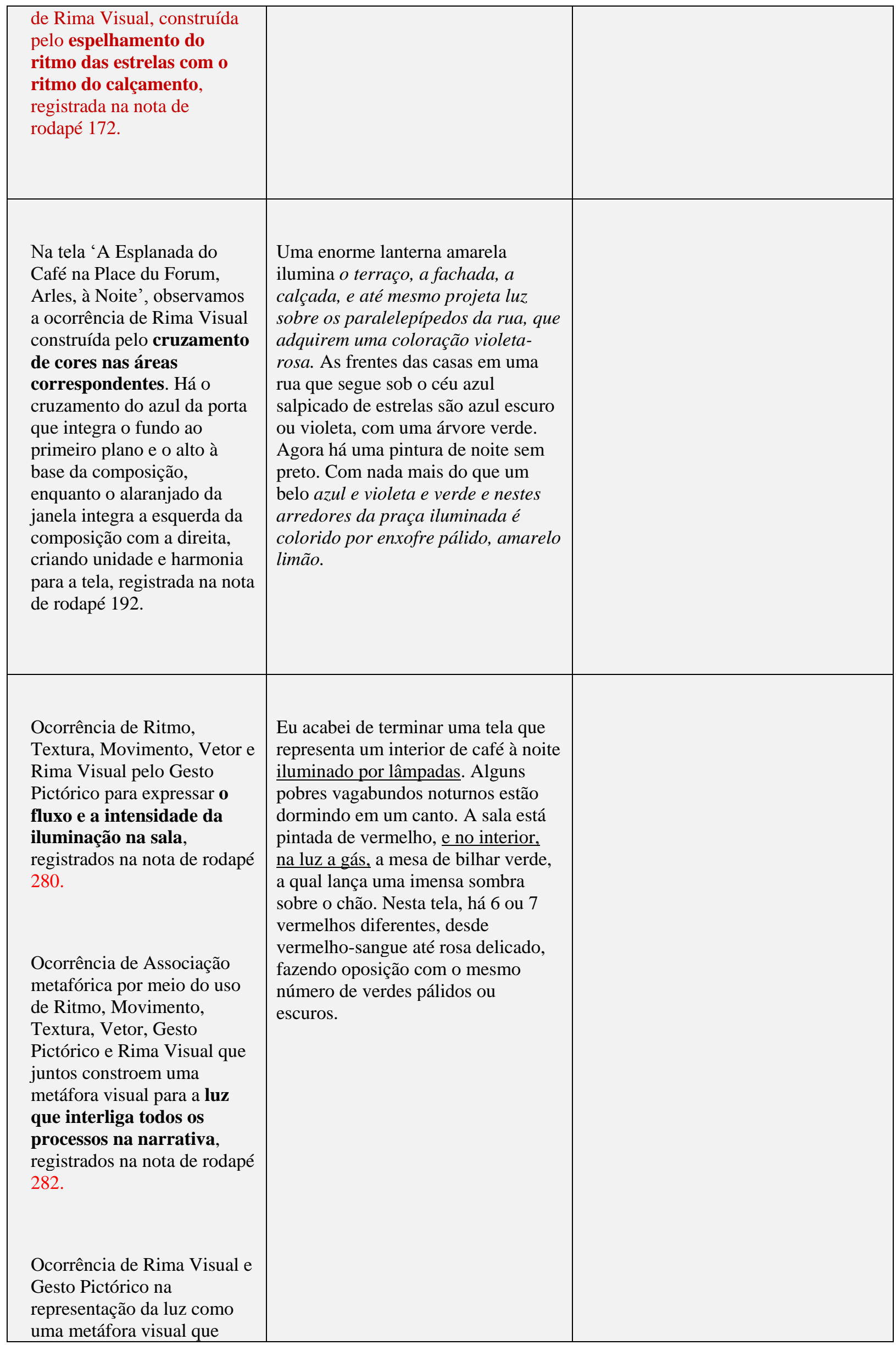




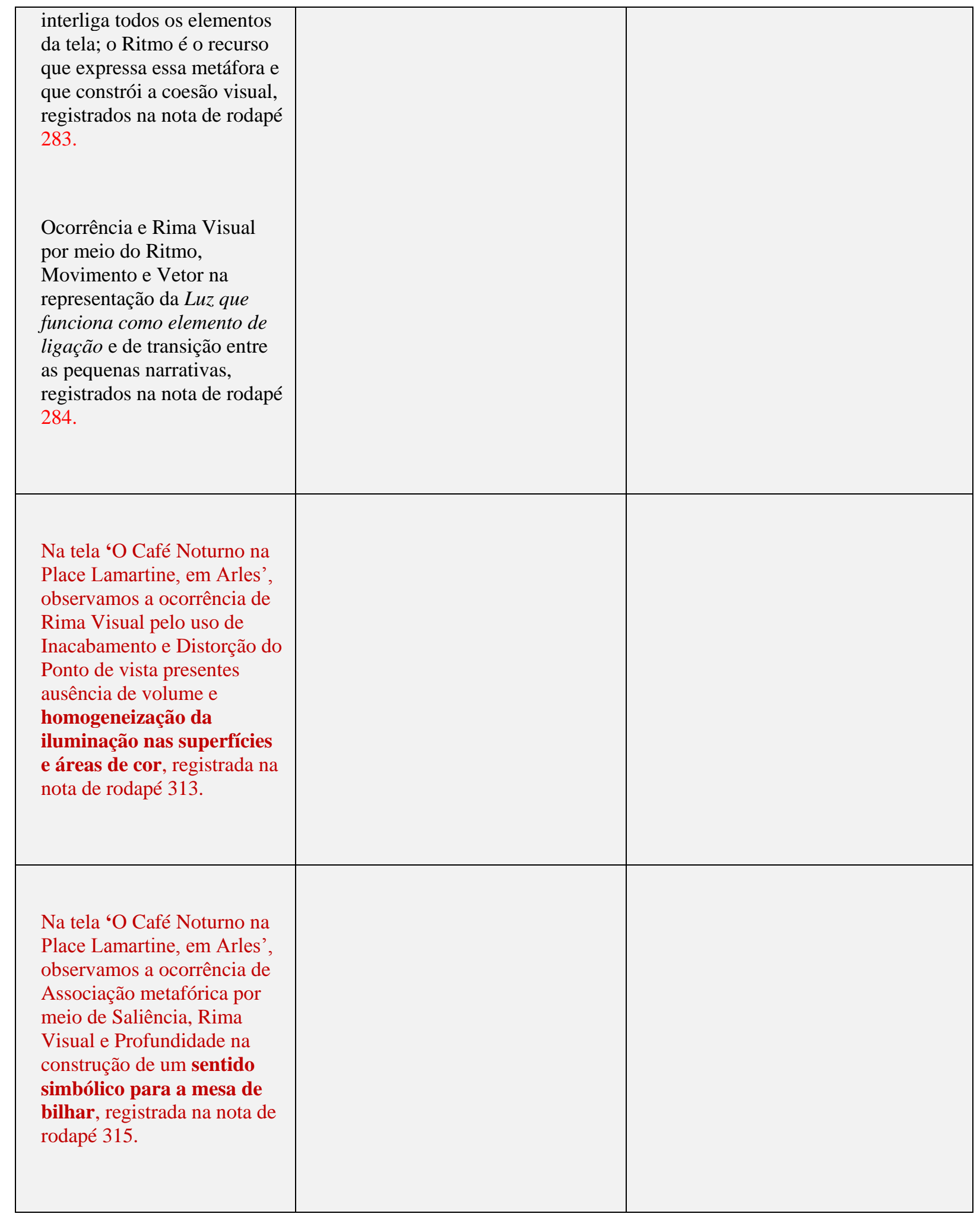

Fonte: Triangulação para Rima Visual dos dados dos corpora visual e textual, com os extratos das cartas. 


\subsection{TRIANGULAÇÃO DA TRANSPARÊNCIA}

Quadro 81: Triangulação da Transparência

\begin{tabular}{|c|c|c|}
\hline Ocorrência nas telas & Orações & Comentário \\
\hline $\begin{array}{l}\text { Na tela 'Por de Sol: Campo de } \\
\text { trigo perto de Arles', } \\
\text { observamos a ocorrência de } \\
\text { transparência na forma como } \\
\text { ele representou o campo de } \\
\text { trigo, integrando ao gesto de } \\
\text { pintar, a sua experiência de } \\
\text { lutar contra a ventania e nas } \\
\text { pinceladas rápidas e ritmadas, } \\
\text { transportar essa experiência } \\
\text { física e subjetiva do contato } \\
\text { com a força do vento, } \\
\text { registrada na nota de rodapé } \\
75 .\end{array}$ & $\begin{array}{l}\text { Eu tenho um terceiro estudo, agora, } \\
\text { de uma paisagem com fábrica, e um } \\
\text { enorme sol em um céu vermelho, } \\
\text { acima de telhados vermelhos, em } \\
\text { que a natureza parece estar em um } \\
\text { acesso de raiva, em um dia de } \\
\text { mistral desagradável." }\end{array}$ & \\
\hline & $\begin{array}{l}\text { Há várias sugestões de amarelo no } \\
\text { solo, tons neutros resultantes da } \\
\text { mistura de violeta e amarelo; mas } \\
\text { tenho travado uma luta diabólica } \\
\text { para atingir a verdade das cores. }\end{array}$ & \\
\hline & $\begin{array}{l}\text { Preferia muito mais fazer quadros } \\
\text { naifs tirados de velhos almanaques, } \\
\text { aqueles velhos "almanaques dos } \\
\text { lavradores" nos quais o granizo, a } \\
\text { neve, a chuva e o bom tempo são } \\
\text { retratados de modo primitivo, como } \\
\text { o Anquetin atingiu tão bem no seu } A \\
\text { Colheita. }\end{array}$ & \\
\hline & $\begin{array}{l}\text { Não te vou ocultar que não desgosto } \\
\underline{\text { da região, pois fui criado lá - } \text { ainda }} \\
\text { me encanta a magia das recordações } \\
\text { do passado, de um desejo do infinito, } \\
\text { do qual o semeador e o enfeixador } \\
\text { são símbolos -, tanto quanto antes } \\
\text { gostava. }\end{array}$ & \\
\hline & $\begin{array}{l}\text { Mas quando eu farei o céu estrelado, } \\
\text { então, essa pintura que está sempre } \\
\text { na minha mente? }\end{array}$ & \\
\hline
\end{tabular}




\begin{tabular}{|c|c|c|}
\hline & $\begin{array}{l}\text { Mas é uma questão de atacá-las, no } \\
\text { entanto, não importa o quão } \\
\text { incompetente um pode sentir-se vis- } \\
\text { à-vis as perfeições inefáveis do } \\
\text { glorioso esplendor da natureza. }\end{array}$ & \\
\hline & $\begin{array}{l}\text { Aqui está o que eu queria dizer sobre } \\
\text { o branco e o preto. Vamos tomar o } \\
\text { Semeador. A pintura é dividida em } \\
\text { dois; metade é amarelo, o topo; a } \\
\text { base é violeta. Bem, as calças } \\
\text { brancas descansam os olhos e os } \\
\text { distraem exatamente quando o } \\
\text { contraste simultâneo excessivo de } \\
\text { amarelo e violeta iriam irritá-lo. Isso } \\
\text { é o que eu queria dizer. }\end{array}$ & \\
\hline & $\begin{array}{l}\text { E o esboço como tal - uma tela } \\
\text { número } 25 \text { - também me preocupa } \\
\text { muito, no sentido de que eu me } \\
\text { pergunto se eu não deveria levar a } \\
\text { sério e fazer uma pintura tremenda } \\
\text { disso. Meu Deus, como eu adoraria } \\
\text { fazer isso. Mas eu só me pergunto se } \\
\text { eu vou ter o poder necessário de } \\
\text { execução. } \\
\text { Eu estou colocando o esboço de lado } \\
\text { assim como é, mal ousando pensar } \\
\text { nisso. }\end{array}$ & \\
\hline & $\begin{array}{l}\text { Por um longo tempo ele foi meu } \\
\text { grande desejo de fazer um semeador, } \\
5, \text { mas os desejos que tive por um } \\
\text { longo tempo nem sempre são } \\
\text { alcançados. Então, eu estou quase } \\
\text { com medo deles. E, no entanto, } \\
\text { depois de Millet e Lhermitte o que } \\
\text { resta a ser feito é ... o semeador, com } \\
\text { cor e em um grande formato. }\end{array}$ & \\
\hline $\begin{array}{l}\text { Na tela ‘A Esplanada do Café } \\
\text { na Place du Forum, Arles, à } \\
\text { Noite', observamos a } \\
\text { ocorrência de Incompletude, } \\
\text { Transparência e Limiar } \\
\text { Artístico, construídos pela } \\
\text { forma de representar as } \\
\text { estrelas e a luz noturna que } \\
\text { para van Gogh simbolizavam }\end{array}$ & $\begin{array}{l}\text { Mas quando eu farei o céu estrelado, } \\
\text { então, essa pintura que está sempre } \\
\text { na minha mente? }\end{array}$ & $\begin{array}{l}\text { Embora escrevendo par o irmão van } \\
\text { Gogh pergunta para si próprio, como } \\
\text { se estivesse falando consigo ou } \\
\text { pensando em voz alta. }\end{array}$ \\
\hline
\end{tabular}




\begin{tabular}{|c|c|c|}
\hline $\begin{array}{l}\text { o infinito, registrada nas notas } \\
\text { de rodapé } 184 \text { e } 185 \text {. } \\
\text { Ocorrência de transparência na } \\
\text { forma como ele representa o } \\
\text { ambiente noturno e a luz das } \\
\text { estrelas, registrada na nota de } \\
\text { rodapé } 195 \text {. }\end{array}$ & & \\
\hline $\begin{array}{l}\text { Na tela 'A Esplanada do } \\
\text { Café na Place du Forum, } \\
\text { Arles, à Noite', observamos } \\
\text { a ocorrência de Associação } \\
\text { Metafórica e Transparência } \\
\text { para a posição relativa da } \\
\text { charrete e o cavalo, } \\
\text { construída pela Saliência } \\
\text { dada pelo Enquadramento, } \\
\text { registradas na nota de rodapé } \\
196 .\end{array}$ & & \\
\hline $\begin{array}{l}\text { Na tela 'A Esplanada do } \\
\text { Café na Place du Forum, } \\
\text { Arles, à Noite', observamos } \\
\text { a ocorrência de Associação } \\
\text { Metafórica e Transparência } \\
\text { construídos pelos sentidos } \\
\text { potenciais que sugerem a } \\
\text { solidão, o isolamento e a } \\
\text { ausência experienciada por } \\
\text { van Gogh, registrada na nota } \\
\text { de rodapé } 209 \text {. }\end{array}$ & & \\
\hline $\begin{array}{l}\text { Observamos também a } \\
\text { ocorrência de Transparência } \\
\text { e Enquadramento, por meio } \\
\text { de Vetor e Perspectiva } \\
\text { invertida, que é observada na } \\
\text { composição de outras telas, } \\
\text { registradas na nota de rodapé } \\
210 .\end{array}$ & $\begin{array}{l}\text { Fui interrompido precisamente pelo } \\
\text { trabalho que uma nova pintura da } \\
\text { parte externa de um café à noite tem } \\
\text { me dado nos últimos dias. No } \\
\text { terraço, há pequenas figuras de } \\
\text { pessoas que bebem. Uma enorme } \\
\text { lanterna amarela ilumina o terraço, } \\
\text { a fachada, a calçada, e até mesmo } \\
\text { projeta luz sobre os paralelepípedos } \\
\text { da rua, que adquirem uma coloração } \\
\text { violeta-rosa. As frentes das casas } \\
\text { em uma rua que segue sob o céu } \\
\text { azul salpicado de estrelas são azul } \\
\text { escuro ou violeta, com uma árvore } \\
\text { verde. Agora há uma pintura de } \\
\text { noite sem preto. Com nada mais do } \\
\text { que um belo azul e violeta e verde e } \\
\text { nestes arredores da praça iluminada } \\
\text { é colorido por enxofre pálido, } \\
\text { amarelo limão. Eu gosto }\end{array}$ & $\begin{array}{l}\text { Transparência na Inversão de Ponto } \\
\text { de Vista na oração. } \\
\text { Van Gogh inicia o excerto dando voz } \\
\text { ativa para o trabalho que a nova } \\
\text { pintura lhe dá. Depois ele desliza para } \\
\text { 'dentro' da paisagem e a descreve em } \\
\text { detalhes. Depois ele inverte o ponto } \\
\text { de vista e volta para o 'lado de fora' } \\
\text { da tela e começa a falar da } \\
\text { experiência subjetiva dele em pintar a } \\
\text { noite. Observamos que a ocorrência } \\
\text { de Inversão do ponto de vista está } \\
\text { conectada com a necessidade que ele } \\
\text { mostra em dar visibilidade a sua } \\
\text { experiência subjetiva em pintar a tela, } \\
\text { que ele quer ver incluída no texto, } \\
\text { seja visualmente por sistema } \\
\text { semiótico de Inversão de Ponto de } \\
\text { vista, seja na escrita, como acabamos }\end{array}$ \\
\hline
\end{tabular}




\begin{tabular}{|c|c|c|}
\hline de rodapé 261. & $\begin{array}{l}\text { enormemente de pintar no local à } \\
\text { noite. No passado, eles costumavam } \\
\text { desenhar e pintar a tela do desenho } \\
\text { durante o dia. Mas acho que me } \\
\text { convém pintar a coisa no momento. } \\
\text { É bem verdade que eu possa tomar } \\
\text { um azul por um verde no escuro, } \\
\text { um azul lilás por um rosa lilás, uma } \\
\text { vez que você não pode perceber a } \\
\text { natureza do tom claramente. Mas é } \\
\text { a única maneira de se livrar da noite } \\
\text { negra convencional com uma luz } \\
\text { pobre, pálida e esbranquiçada, } \\
\text { quando na verdade uma mera vela } \\
\text { por si só nos dá os mais ricos } \\
\text { amarelos e laranjas.. }\end{array}$ & $\begin{array}{l}\text { de observar na estratégia retórica do } \\
\text { excerto. }\end{array}$ \\
\hline & $\begin{array}{l}\text { Eu também fiz um novo retrato de } \\
\text { mim mesmo, como um estudo, no } \\
\text { qual eu pareço um Japonês. }\end{array}$ & \\
\hline & $\begin{array}{l}\text { Você nunca me disse se você tinha } \\
\text { lido Bel-ami de Guy de } \\
\text { Maupassant, e o que você pensa } \\
\text { agora do talento dele em geral. }\end{array}$ & \\
\hline \multicolumn{3}{|l|}{$\begin{array}{l}\text { Na tela 'O Café Noturno na } \\
\text { Place Lamartine, em Arles', } \\
\text { observamos a ocorrência de } \\
\text { Distorção do Ponto de Vista } \\
\text { e Transparência, construídos } \\
\text { com ajuda da Saliência e de } \\
\text { Contrastes cromáticos } \\
\text { simultâneos e de saturação } \\
\text { exacerbados para representar } \\
\text { uma sensação de } \\
\text { desconforto, registrados na } \\
\text { nota de rodapé } 228 \text {. }\end{array}$} \\
\hline $\begin{array}{l}\text { Ocorrência de Transparência } \\
\text { construída com o uso } \\
\text { conjugado de Associação } \\
\text { metafórica e da Distorção do } \\
\text { ponto de vista, Contraste } \\
\text { cromático, registrada na nota } \\
\text { de rodapé } 250 \text {. }\end{array}$ & & \\
\hline Na tela 'O Café Noturno na & Muitas vezes parece-me que a noite & \\
\hline
\end{tabular}




\begin{tabular}{|c|c|c|}
\hline $\begin{array}{l}\text { Place Lamartine, em Arles', } \\
\text { observamos a ocorrência de } \\
\text { baixa Modalidade } \\
\text { naturalística, mas alta } \\
\text { Modalidade Subjetiva e } \\
\text { Transparência, conferida } \\
\text { pela distorção do ponto de } \\
\text { vista, registrada na nota de } \\
\text { rodapé } 231 .\end{array}$ & $\begin{array}{l}\text { é muito mais viva e ricamente } \\
\text { colorida do que o dia. } \\
\text { (...) } \\
\text { É uma cor, então, que não é } \\
\text { localmente verdadeira do ponto de } \\
\text { vista realista do trompe l'oeil, mas } \\
\text { uma cor que sugere alguma emoção, } \\
\text { um temperamento ardente. }\end{array}$ & \\
\hline $\begin{array}{l}\text { Ocorrência de } \\
\text { Interdiscursividade, } \\
\text { Transparência, Inacabamento } \\
\text { e Incompletude na } \\
\text { ambiguidade do olhar do } \\
\text { homem no café, registrados } \\
\text { na nota de rodapé } 266 \text {. }\end{array}$ & & \\
\hline $\begin{array}{l}\text { Na tela 'O Café Noturno na } \\
\text { Place Lamartine, em Arles', } \\
\text { observamos a ocorrência de } \\
\text { Transparência e } \\
\text { Incompletude para } \\
\text { representar a sua } \\
\text { experiência com o } \\
\text { ambiente de um café } \\
\text { noturno, registrada na nota } \\
\text { de rodapé } 256 \text {. }\end{array}$ & $\begin{array}{l}\text { Na minha pintura do café à noite eu } \\
\text { procurei exprimir que o café é um } \\
\text { lugar onde você pode arruinar-se, } \\
\text { enlouquecer, cometer crimes. De } \\
\text { qualquer forma, eu tentei com } \\
\text { contrastes de rosa delicado e } \\
\text { vermelho-sangue e vinho tinto. } \\
\text { Verde doce Luís XV e Veronese } \\
\text { contrastando com os verdes } \\
\text { amarelos e os verdes azuis duros. } \\
\text { Tudo isso em uma atmosfera de } \\
\text { fornalha infernal, de enxofre pálido. } \\
\text { Exprimir como a potência dos } \\
\text { cantos escuros de uma taberna. } \\
\text { Contudo sob uma aparência da } \\
\text { alegria japonesa e da boa natureza } \\
\text { de Tartarin. }\end{array}$ & $\begin{array}{l}\text { Nesta oração van Gogh explicita a } \\
\text { busca de fazer transparecer nas cores } \\
\text { e na forma do café o sentimento } \\
\text { interno que era experienciado por ele } \\
\text { neste lugar. } \\
\text { O exagero, a intensidade colocada } \\
\text { para trazer a tona esse sentimento } \\
\text { coloca-o perto da loucura, da ruína } \\
\text { (parecem-me atrozmente feios e ruis) } \\
\text { e perto do seu objetivo em representar } \\
\text { a ideia que o assombra e que para ele } \\
\text { tem o significado mais importante. } \\
\text { Talvez por isso ele cite Dostoievski, } \\
\text { pela necessidade de encontrar a } \\
\text { beleza, que ele deva se aproximar do } \\
\text { crime. Ou seja, pela necessidade de } \\
\text { fazer representar a ideia que o } \\
\text { assombra, justifica produzir uma tela } \\
\text { que possa parecer aos olhos de um } \\
\text { observador, feia e ruim. Para observar } \\
\text { essa tela é preciso estar em busca } \\
\text { desse mesmo sentido oculto que está } \\
\text { presente no artigo de Dostoievski, que } \\
\text { é espiritual. }\end{array}$ \\
\hline
\end{tabular}




\begin{tabular}{|c|c|c|}
\hline $\begin{array}{l}\text { Na tela 'O Café Noturno na } \\
\text { Place Lamartine, em Arles', } \\
\text { observamos a ocorrência de } \\
\text { ocorrência de Transparência } \\
\text { por meio de Associação } \\
\text { metafórica dos sentidos } \\
\text { potenciais da experiência } \\
\text { subjetiva associados à } \\
\text { introdução da luz da } \\
\text { lâmpada a gás no cotidiano } \\
\text { de van Gogh e de seus } \\
\text { contemporâneos, registrada } \\
\text { na nota de rodapé } 299 \text {. }\end{array}$ & & \\
\hline $\begin{array}{l}\text { Na tela 'O Café Noturno na } \\
\text { Place Lamartine, em Arles', } \\
\text { observamos a ocorrência de } \\
\text { Associação metafórica por } \\
\text { meio de Saliência, } \\
\text { Transparência e } \\
\text { Profundidade na escolha } \\
\text { potencial de sentidos } \\
\text { associados à exclusividade } \\
\text { da sombra da mesa em } \\
\text { relação à ausência de } \\
\text { sombra dos outros objetos } \\
\text { e figuras, registrada na nota } \\
\text { de rodapé } 317 \text {. }\end{array}$ & & \\
\hline $\begin{array}{l}\text { Na tela 'O Café Noturno na } \\
\text { Place Lamartine, em Arles', } \\
\text { observamos a ocorrência de } \\
\text { Transparência por meio do } \\
\text { uso simbólico da cor, para } \\
\text { os contrastes entre } \\
\text { vermelhos e verdes, } \\
\text { explicitado pro van Gogh em } \\
\text { seu extrato de carta, } \\
\text { registrada na nota de rodapé } \\
325 \text {. }\end{array}$ & $\begin{array}{l}\text { Na minha pintura do café à noite eu } \\
\text { procurei exprimir que o café é um } \\
\text { lugar onde você pode arruinar-se, } \\
\text { enlouquecer, cometer crimes. De } \\
\text { qualquer forma, eu tentei com } \\
\text { contrastes de rosa delicado e } \\
\text { vermelho-sangue e vinho tinto. } \\
\text { Verde doce Luís XV e Veronese } \\
\text { contrastando com os verdes amarelos } \\
\text { e os verdes azuis duros. }\end{array}$ & $\begin{array}{l}\text { Van Gogh criou um sistema semiótico } \\
\text { para indexar um sentido subjetivo das } \\
\text { 'paixões humanas' no uso que deu aos } \\
\text { contrastes entre vermelhos e verdes. } \\
\text { Ele usou diferentes tonalidades de } \\
\text { vermelho e verde, para criar uma } \\
\text { atmosfera de náusea, fadiga, excesso. } \\
\text { Embora van Gogh busque uma } \\
\text { experiência espiritual profunda ele se } \\
\text { percebe envolvido por sentimentos e } \\
\text { paixões que não são uma escolha para } \\
\text { ele e esses sentimentos e essas } \\
\text { paixões transparecem em ambientes } \\
\text { mais propícios à sua manifestação, } \\
\text { como é o caso do café. Assim o } \\
\text { ambiente ideal para representar esse } \\
\text { estado de espírito é o mesmo } \\
\text { ambiente no qual van Gogh pode } \\
\text { acessa-los de uma maneira mais crua }\end{array}$ \\
\hline
\end{tabular}




\begin{tabular}{|c|c|}
\hline & $\begin{array}{l}\text { e talvez até descontrolada. Isso mostra } \\
\text { como além de ver na sua obra a busca } \\
\text { de uma beleza e de um simbolismo } \\
\text { espiritualmente elevado, ele procurou } \\
\text { ser fiel àqueles sentimentos que nos } \\
\text { tornam mais humanos e que nos } \\
\text { aproximam uns dos outros, mesmo } \\
\text { nas condições mais desumanas. }\end{array}$ \\
\hline $\begin{array}{l}\text { Na tela 'O Café Noturno na } \\
\text { Place Lamartine, em Arles', } \\
\text { observamos a ocorrência de } \\
\text { Associação metafórica, } \\
\text { Transparência, Incompletude } \\
\text { e Limiar Artístico, com o uso } \\
\text { do Enquadramento, } \\
\text { Perspectiva, Profundidade, } \\
\text { Distorção do Ponto de Vista, } \\
\text { levemente plongee para o } \\
\text { sentido do lugar social com o } \\
\text { qual van Gogh se identifica, } \\
\text { registrada na nota de rodapé } \\
340 \text {. }\end{array}$ & \\
\hline $\begin{array}{l}\text { Na tela 'O Café Noturno na } \\
\text { Place Lamartine, em Arles', } \\
\text { observamos a ocorrência de } \\
\text { Transparência, } \\
\text { Incompletude, Modalidade e } \\
\text { Limiar Artístico pelo uso do } \\
\text { Inacabamento, } \\
\text { Enquadramento, } \\
\text { Perspectiva, Distorção do } \\
\text { Ponto de Vista, Direção, } \\
\text { Profundidade, como marca } \\
\text { estilística das linhas que } \\
\text { organizam a perspectiva da } \\
\text { sala, registrada na nota de } \\
\text { rodapé } 341 .\end{array}$ & \\
\hline
\end{tabular}

Fonte: Triangulação para Transparência dos dados dos corpora visual e textual, com os extratos das cartas. 


\subsection{TRIANGULAÇÃO DO INACABAMENTO}

Quadro 82: Triangulação do Inacabamento

\begin{tabular}{|c|c|c|}
\hline Ocorrência nas telas & Orações & Comentário \\
\hline \multirow[t]{2}{*}{$\begin{array}{l}\text { Na tela 'Por de Sol: Campo de } \\
\text { trigo perto de Arles, } \\
\text { observamos a ocorrência de } \\
\text { Inacabamento na forma como } \\
\text { ele mistura as cores direto na } \\
\text { tela, registrado na nota de } \\
\text { rodapé } 65 .\end{array}$} & $\begin{array}{l}\text { Aqui está outra paisagem. Sol } \\
\text { poente? Lua nascendo? Noite de } \\
\text { verão, de qualquer modo. Cidade } \\
\text { violeta, estrela amarela, céu azul- } \\
\text { esverdeado; os campos de trigo têm } \\
\text { todos os tons: ouro velho, cobre, } \\
\text { ouro verde, ouro vermelho, ouro } \\
\text { amarelo, verde, vermelho e amarelo } \\
\text { bronze. Tela quadrada número } 30 \text {. }\end{array}$ & $\begin{array}{l}\text { Ocorrência observada no uso da voz } \\
\text { passiva, que também dá uma } \\
\text { impressão de processualidade e } \\
\text { imprecisão que combina com a } \\
\text { mensagem pictórica que van Gogh } \\
\text { busca descrever ao irmão, que não é } \\
\text { direta, assertiva, objetiva, mas que é } \\
\text { sensorial, intuitiva e interpretativa. } \\
\text { Essa intenção de inacabamento na } \\
\text { significação fica evidenciada na } \\
\text { oração: 'sol poente? Lua nascendo? } \\
\text { Noite de verão...' possibilitando ao } \\
\text { espectador uma liberdade } \\
\text { interpretativa. Essa atitude de } \\
\text { inacabamento é como uma } \\
\text { declaração: não queira vir aqui } \\
\text { encontrar uma certeza para si; nem } \\
\text { eu tenho uma certeza. Se nem o } \\
\text { artista tem o controle do alcance de } \\
\text { significação que a obra tem, isso } \\
\text { oferece uma liberdade enorme para } \\
\text { o espectador interpretar o } \\
\text { significado que ele quiser com a } \\
\text { obra. O inacabamento é livre e } \\
\text { liberta. }\end{array}$ \\
\hline & $\begin{array}{l}\text { Eu tenho um terceiro estudo, agora, } \\
\text { de uma paisagem com fábrica, }(. . .)\end{array}$ & \\
\hline \multirow[t]{3}{*}{$\begin{array}{l}\text { Na tela, 'Por de Sol: Campo de } \\
\text { trigo perto de Arles' } \\
\text { observamos a ocorrência de } \\
\text { Inacabamento construída por } \\
\text { meio do ritmo, da textura e do } \\
\text { movimento que articulam o } \\
\text { gesto pictórico nas pinceladas } \\
\text { que representam o campo de } \\
\text { trigo, registrado na nota de } \\
\text { rodapé } 65 .\end{array}$} & $\begin{array}{l}\text { Paisagens amarelo ouro velho - } \\
\text { feito rápido rápido rápido e com } \\
\text { pressa, como o ceifeiro que está em } \\
\text { silêncio sob o sol escaldante, } \\
\text { concentrando-se em ter o trabalho } \\
\text { terminado. }\end{array}$ & $\begin{array}{l}\text { O inacabamento aparece nas orações } \\
\text { em forma de imprecisões na } \\
\text { construção gramatical que privilegiam } \\
\text { o movimento, o ritmo, o gesto } \\
\text { semântico, por exemplo, o construto } \\
\text { 'rápido rápido rápido e com pressa.' } \\
\text { que expressa e é análoga semântica e } \\
\text { formalmente, ao o gesto pictórico } \\
\text { desse movimento na tela. }\end{array}$ \\
\hline & $\begin{array}{l}\text { Eu não posso ver se os estudos são } \\
\text { bons ou ruins. }\end{array}$ & \\
\hline & $\begin{array}{l}\text { Tenho sete estudos de trigais, } \\
\text { infelizmente todos eles nada além de } \\
\text { paisagens, muito contra a minha }\end{array}$ & \\
\hline
\end{tabular}




\begin{tabular}{|c|c|c|}
\hline & vontade. & \\
\hline & $\begin{array}{l}\text { Mas quando eu farei o céu estrelado, } \\
\text { então, essa pintura que está sempre } \\
\text { na minha mente? }\end{array}$ & \\
\hline & $\begin{array}{l}\text { (...) as mais belas pinturas são } \\
\text { aquelas que alguém sonha enquanto } \\
\text { fuma um cachimbo em sua cama, } \\
\text { mas a qual ele não pinta. }\end{array}$ & \\
\hline \multirow[t]{2}{*}{$\begin{array}{l}\text { Na tela 'O Semeador', } \\
\text { observamos a ocorrência de } \\
\text { Inacabamento na } \\
\text { representação do campo } \\
\text { arado. Observamos também } \\
\text { que, devido à técnica de } \\
\text { pintar aprendida com os } \\
\text { pontilhistas e aperfeiçoada } \\
\text { para um sistema semiótico } \\
\text { próprio, o Inacabamento } \\
\text { pode ser observado como } \\
\text { uma parte integrante do } \\
\text { Gesto Pictórico, registrado } \\
\text { na nota de rodapé } 140 .\end{array}$} & 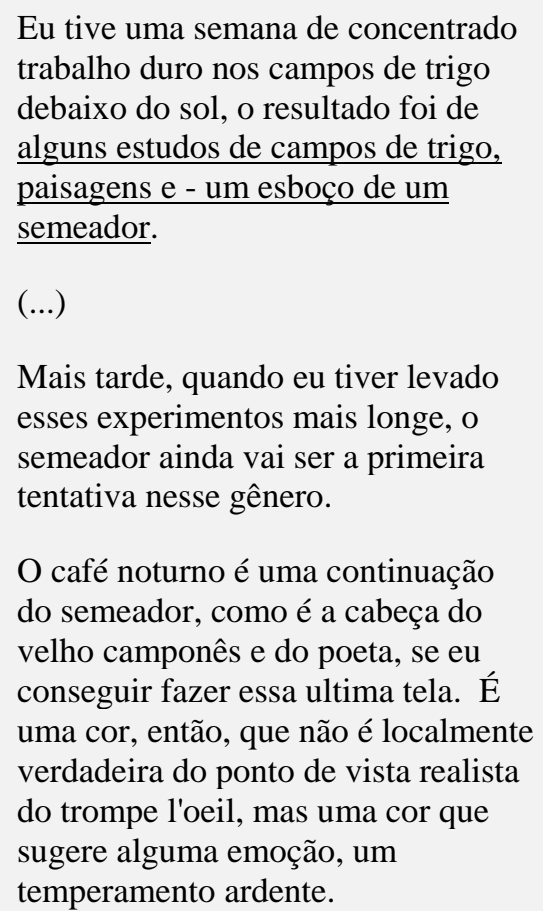 & $\begin{array}{l}\text { A escolha lexical de ‘estudos' para se } \\
\text { referir às suas telas sugere que van } \\
\text { Gogh se relacionava com o seu } \\
\text { processo de produção artística como } \\
\text { uma pesquisa. Esta concepção de } \\
\text { 'estudo' fica evidenciada no excerto } \\
\text { no qual ele se refere ao semeador } \\
\text { como uma 'tentativa' que será a } \\
\text { primeira nesse gênero o qual é um } \\
\text { estudo que inicia no Semeador e } \\
\text { continua no Café da Noite e na } \\
\text { Cabeça do poeta. }\end{array}$ \\
\hline & $\begin{array}{l}\text { E o esboço como tal - uma tela } \\
\text { número } 25 \text { - também me preocupa } \\
\text { muito, no sentido de que eu me } \\
\text { pergunto se eu não deveria levar a } \\
\text { sério e fazer uma pintura tremenda } \\
\text { disso. Meu Deus, como eu adoraria } \\
\text { fazer isso. Mas eu só me pergunto se } \\
\text { eu vou ter o poder necessário de } \\
\text { execução. } \\
\text { Eu estou colocando o esboço de lado } \\
\text { assim como é, mal ousando pensar } \\
\text { nisso. } \\
\text { Por um longo tempo ele foi meu } \\
\text { grande desejo de fazer um semeador, } \\
\text { mas os desejos que tive por um } \\
\text { longo tempo nem sempre são } \\
\text { alcançados. Então, eu estou quase } \\
\text { com medo deles. E, no entanto, } \\
\text { depois de Millet e Lhermitte o que } \\
\text { resta a ser feito é ... o semeador, com }\end{array}$ & \\
\hline
\end{tabular}




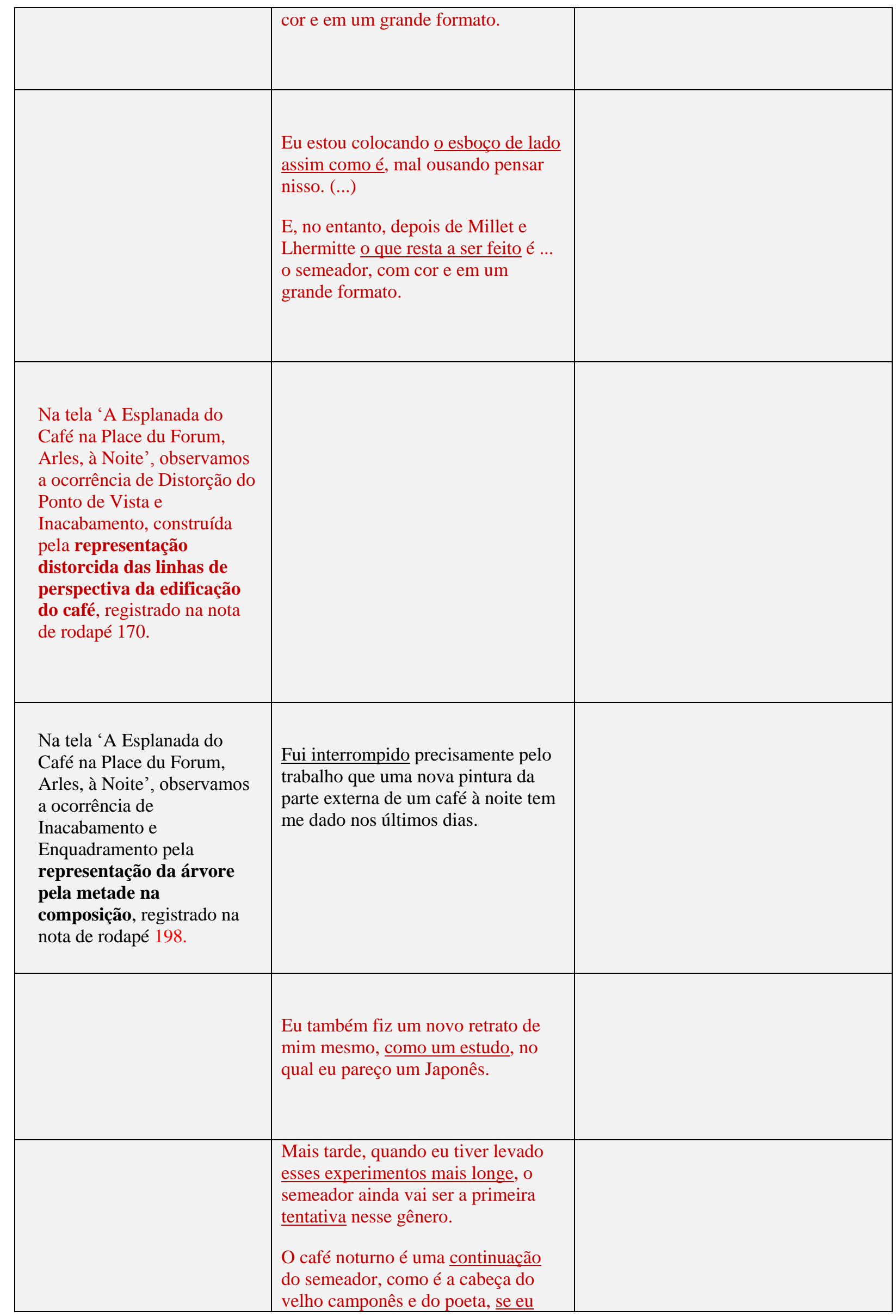




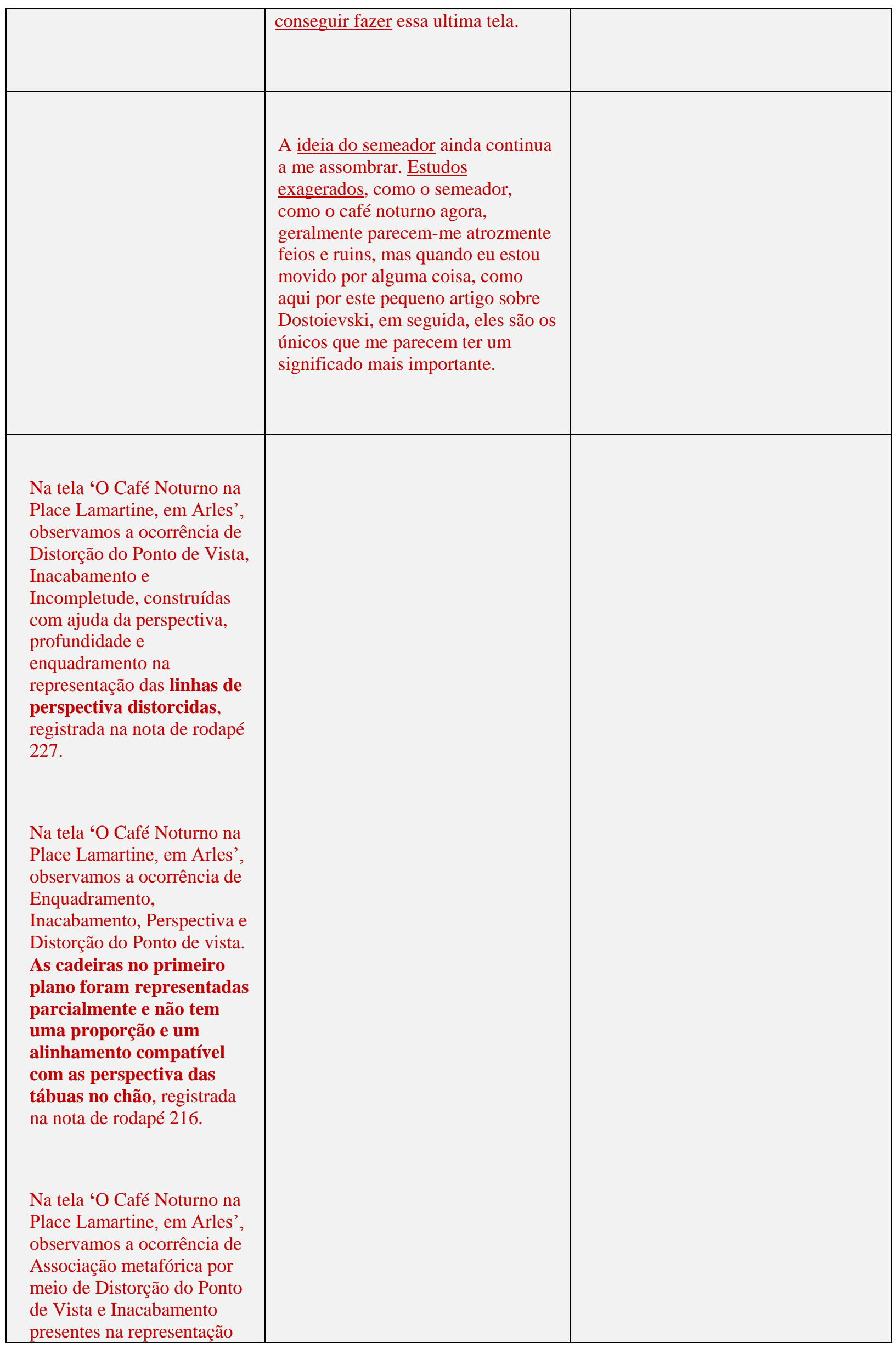




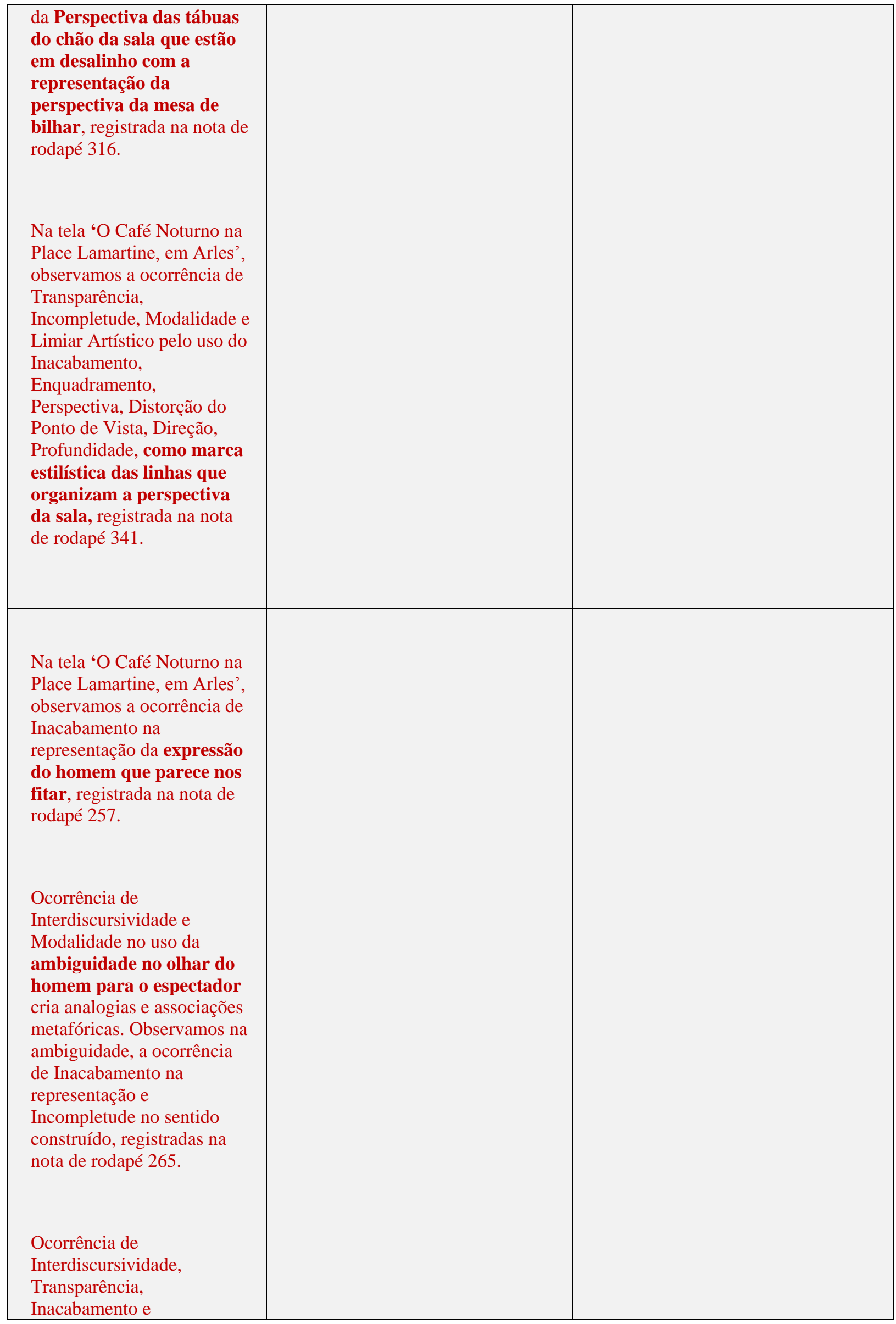




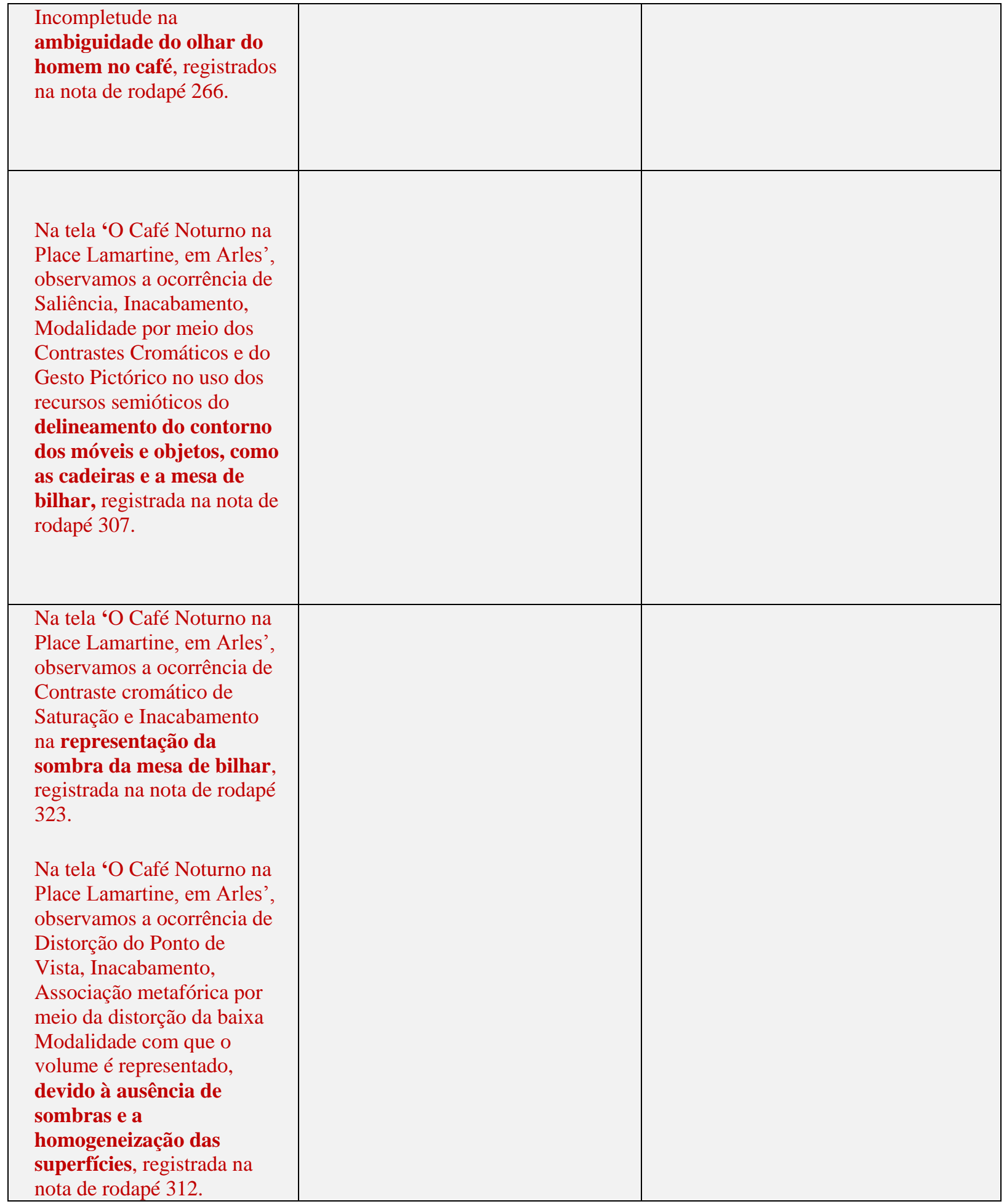

Fonte: Triangulação para Inacabamento dos dados dos corpora visual e textual, com os extratos das cartas. 


\subsection{TRIANGULAÇÃO DA INCOMPLETUDE}

Quadro 83: Triangulação da Incompletude

\begin{tabular}{|c|c|c|}
\hline Ocorrência nas telas & Orações & Comentário \\
\hline $\begin{array}{l}\text { Na tela 'Por de Sol: Campo } \\
\text { de trigo perto de Arles', o } \\
\text { ponto de vista de onde van } \\
\text { Gogh pinta parece estar } \\
\text { acima do chão, como se } \\
\text { olhasse de um nível de quem } \\
\text { está alçado no ar e vê } \\
\text { ligeiramente do alto a cena. } \\
\text { Ele consegue isso com o } \\
\text { enquadramento plongee e } \\
\text { tem a função de conferir uma } \\
\text { sensação de infinidade } \\
\text { registrada na nota de rodapé } \\
58 \text { e } 111 .\end{array}$ & & $\begin{array}{l}\text { Para Muhlberger (2002, p. 22), o } \\
\text { uso do plongee é em van Gogh a } \\
\text { tentativa de estender o alcance da } \\
\text { vista e dar ao espectador uma } \\
\text { sensação de infinidade para o campo } \\
\text { de trigo. Esta semiose é compatível } \\
\text { com a sua busca de representar o } \\
\text { sentimento de incompletude } \\
\text { também presente em semioses como } \\
\text { o movimento do vento no campo, a } \\
\text { luz das estrelas, a coloração da } \\
\text { noite. }\end{array}$ \\
\hline $\begin{array}{l}\text { Na tela 'O Semeador' } \\
\text { observamos a ocorrência de } \\
\text { Contrastes de Saturação, } \\
\text { Saliência, Associação } \\
\text { Metafórica e Incompletude } \\
\text { na representação do céu e do } \\
\text { sol, em amarelo sobre } \\
\text { amarelo, registrado na nota } \\
\text { de rodapé } 137 . \\
\text { Observamos também a } \\
\text { ocorrência de Movimento, } \\
\text { Gesto Pictórico, Vetor } 2, \\
\text { Rima Visual e Incompletude, } \\
\text { sugerido pelos raios do sol } \\
\text { em toda a pintura, registrado } \\
\text { na nota de rodapé } 139 \text {. }\end{array}$ & $\begin{array}{l}\text { O céu, amarelo-crómio, quase tão } \\
\text { luminoso quanto o próprio Sol, } \\
\text { que é amarelo-crómio } \mathrm{n}^{\circ} 1 \text {, } \\
\text { misturado com um pouco de } \\
\text { branco, enquanto o resto do céu é } \\
\text { uma mistura dos amarelos- } \\
\text { crómios } 1 \text { e } 2 \text {. Tão amarelo! }\end{array}$ & $\begin{array}{l}\text { No discurso textual, observamos a } \\
\text { ocorrência semântica de } \\
\text { incompletude na superposição de } \\
\text { amarelos: 'amarelo-crómio n'1, } \\
\text { misturado com um pouco de } \\
\text { branco', e 'uma mistura dos } \\
\text { amarelos-crómios } 1 \text { e } 2 \text {.' e como se } \\
\text { essa descrição não basta para o } \\
\text { artista, ele busca uma nova oração: } \\
\text { 'Tão amarelo!' para tentar expressar } \\
\text { essa incompletude que ele sente na } \\
\text { descrição detalhada dos amarelos. } \\
\text { 'Tão amarelo!' é uma tentativa de } \\
\text { alcançar a incompletude desse } \\
\text { sentimento, dessa experiência que } \\
\text { ele tem com o céu na tela 'O } \\
\text { Semeador'. }\end{array}$ \\
\hline $\begin{array}{l}\text { Na tela 'O Semeador', } \\
\text { observamos a ocorrência } \\
\text { de Associação Metafórica } \\
\text { e Incompletude, } \\
\text { construídos pela luz difusa } \\
\text { do ocaso. A luz constrói } \\
\text { um sentido de ambiência e } \\
\text { que envolve toda a cena e } \\
\text { constrói significados } \\
\text { simbólicos, registrado na } \\
\text { nota de rodapé } 145 \text {. }\end{array}$ & & \\
\hline
\end{tabular}




\begin{tabular}{|c|c|c|}
\hline & $\begin{array}{l}\text { 'Eu também sou totalmente } \\
\text { incapaz de julgar o meu próprio } \\
\text { trabalho. Eu não posso ver se os } \\
\text { estudos são bons ou ruins. }\end{array}$ & $\begin{array}{l}\text { O acabamento escapa do julgamento } \\
\text { incompleto do artista. A tela está acima } \\
\text { do artista e para além da sua } \\
\text { compreensão. }\end{array}$ \\
\hline $\begin{array}{l}\text { Na tela 'O Semeador', } \\
\text { observamos a ocorrência de } \\
\text { Associação Metafórica e de } \\
\text { Incompletude na contradição } \\
\text { entre distanciamento do } \\
\text { enquadramento e os outros } \\
\text { recursos que são convidam à } \\
\text { aproximação e } \\
\text { envolvimento, registrado na } \\
\text { nota de rodapé } 130 .\end{array}$ & $\begin{array}{l}\text { 'Tenho sete estudos de trigais, } \\
\text { infelizmente todos eles nada além } \\
\text { de paisagens, muito contra a minha } \\
\text { vontade.' } \\
\text { Aqui está um esboço de um } \\
\text { semeador, um grande campo } \\
\text { lavrado com torrões de terra, na } \\
\text { sua maioria fracamente cor de } \\
\text { violeta. }\end{array}$ & $\begin{array}{l}\text { Não são em todas as telas que van } \\
\text { Gogh avança no sentido de se } \\
\text { aproximar da ideia que ele persegue } \\
\text { através da pintura, mas ele intui que } \\
\text { essa possibilidade compreende alguns } \\
\text { elementos pictóricos, embora ele } \\
\text { considere que esses elementos em si } \\
\text { não completam a ideia. Embora nos } \\
\text { estudos haja paisagem, a terra, o } \\
\text { semeador, há algo que está faltando, } \\
\text { que tornaria essas telas completas. Isso } \\
\text { dá uma ideia do quanto o processo de } \\
\text { criação artística de van Gogh era } \\
\text { penoso para ele, e a constância de lidar } \\
\text { com a incompletude possibilitou a } \\
\text { reprodução dessa experiência que } \\
\text { persegue todos nós na tela e que nós } \\
\text { como observadores identificamos } \\
\text { porque a incompletude está lá. Ele se } \\
\text { preocupava tanto com ela que ela } \\
\text { estava lá presente na tela. }\end{array}$ \\
\hline $\begin{array}{l}\text { Na tela 'O Semeador', } \\
\text { observamos a ocorrência de } \\
\text { Associação Metafórica e } \\
\text { Incompletude construída } \\
\text { pela Rima Visual e pelo } \\
\text { Gesto pictórico para } \\
\text { representar a unidade entre } \\
\text { o Homem e a Natureza, } \\
\text { registrados na nota de rodapé } \\
164 .\end{array}$ & $\begin{array}{l}\text { E o esboço como tal - uma tela } \\
\text { número } 25 \text { - também me preocupa } \\
\text { muito, no sentido de que eu me } \\
\text { pergunto se eu não deveria levar a } \\
\text { sério e fazer uma pintura } \\
\text { tremenda disso. Meu Deus, como } \\
\text { eu adoraria fazer isso. Mas eu só } \\
\text { me pergunto se eu vou ter o poder } \\
\text { necessário de execução. } \\
\text { Eu estou colocando o esboço de } \\
\text { lado assim como é, mal ousando } \\
\text { pensar nisso. } \\
\text { Por um longo tempo ele foi meu } \\
\text { grande desejo de fazer um } \\
\text { semeador, mas os desejos que tive } \\
\text { por um longo tempo nem sempre } \\
\text { são alcançados. Então, eu estou }\end{array}$ & $\begin{array}{l}\text { A incompletude refere-se ao } \\
\text { reconhecimento da impossibilidade } \\
\text { de manifestação da perfeição da } \\
\text { natureza por meio da arte. É quando } \\
\text { ele fala que não importa o quão } \\
\text { incompetente ele se sinta diante da } \\
\text { perfeição da natureza, ele tem que } \\
\text { fazer mesmo que ele 'não tenha o } \\
\text { poder de execução'. É como se ele } \\
\text { falasse: Eu vou fazer, mesmo que } \\
\text { incompleto. Depois de produzida a } \\
\text { tela mesmo que incompleta, então } \\
\text { ele se refere a ela como uma tela em } \\
\text { processo para chegar na tela ideal. }\end{array}$ \\
\hline
\end{tabular}




\begin{tabular}{|c|c|c|}
\hline & $\begin{array}{l}\text { quase com medo deles. E, no } \\
\text { entanto, depois de Millet e } \\
\text { Lhermitte o que resta a ser feito é } \\
\text {... o semeador, com cor e em um } \\
\text { grande formato. } \\
\text { (...) } \\
\text { Mas é uma questão de atacá-las, no } \\
\text { entanto, não importa o quão } \\
\text { incompetente um pode sentir-se } \\
\text { vis-à-vis as perfeições inefáveis do } \\
\text { glorioso esplendor da natureza. }\end{array}$ & \\
\hline & $\begin{array}{l}\text { Há várias sugestões de amarelo no } \\
\text { solo, tons neutros resultantes da } \\
\text { mistura de violeta e amarelo; mas } \\
\text { tenho travado uma luta diabólica } \\
\text { para atingir a verdade das cores. }\end{array}$ & \\
\hline & $\begin{array}{l}\text { Preferia muito mais fazer quadros } \\
\text { naifs tirados de velhos } \\
\text { almanaques, aqueles velhos } \\
\text { "almanaques dos lavradores" nos } \\
\text { quais o granizo, a neve, a chuva e } \\
\text { o bom tempo são retratados de } \\
\text { modo primitivo, como o Anquetin } \\
\text { atingiu tão bem no seu } A \text { Colheita. }\end{array}$ & \\
\hline & $\begin{array}{l}\text { Ai, ai, é como nosso excelente } \\
\text { amigo Cyprien diz, em 'En } \\
\text { ménage' por JK Huysmans: as } \\
\text { mais belas pinturas são aquelas } \\
\underline{\text { que um sonha enquanto fuma um }} \\
\underline{\text { cachimbo em sua cama, mas a }} \\
\text { qual ele não pinta. }\end{array}$ & \\
\hline $\begin{array}{l}\text { Na tela A Esplanada do Café } \\
\text { na Place du Forum, Arles, à } \\
\text { Noite observamos a } \\
\text { ocorrência de Incompletude, } \\
\text { Transparência e Limiar } \\
\text { Artístico, construídos pela } \\
\text { forma de representar as } \\
\text { estrelas e a luz noturna que } \\
\text { para van Gogh simbolizavam } \\
\text { o infinito. registradas na nota } \\
\text { de rodapé } 184 \text {. }\end{array}$ & $\begin{array}{l}\text { Mas quando eu farei o céu } \\
\text { estrelado, então, essa pintura que } \\
\text { está sempre na minha mente? Ai, } \\
\text { ai, é como nosso excelente amigo } \\
\text { Cyprien diz, em 'En ménage' por } \\
\text { JK Huysmans: as mais belas } \\
\text { pinturas são aquelas que alguém } \\
\text { sonha enquanto fuma um } \\
\text { cachimbo em sua cama, mas a } \\
\text { qual ele não pinta. Mas é uma } \\
\text { questão de atacá-las, no entanto, } \\
\text { não importa o quão incompetente }\end{array}$ & $\begin{array}{l}\text { É quando, por exemplo, ele reconhece } \\
\text { que não é possível produzir essa } \\
\text { completude. Enquanto o } \\
\text { inacabamento é uma tentativa de } \\
\text { alcançar a completude, ou seja, é o } \\
\text { não reconhecimento da incompletude, } \\
\text { é como se ele falasse que a tela é um } \\
\text { esboço, um estudo, que é parcial e que } \\
\text { poderia ser completo, que e esse } \\
\text { estudo pode se tornar uma tremenda } \\
\text { tela, a incompletude é o } \\
\text { reconhecimento dessa }\end{array}$ \\
\hline
\end{tabular}




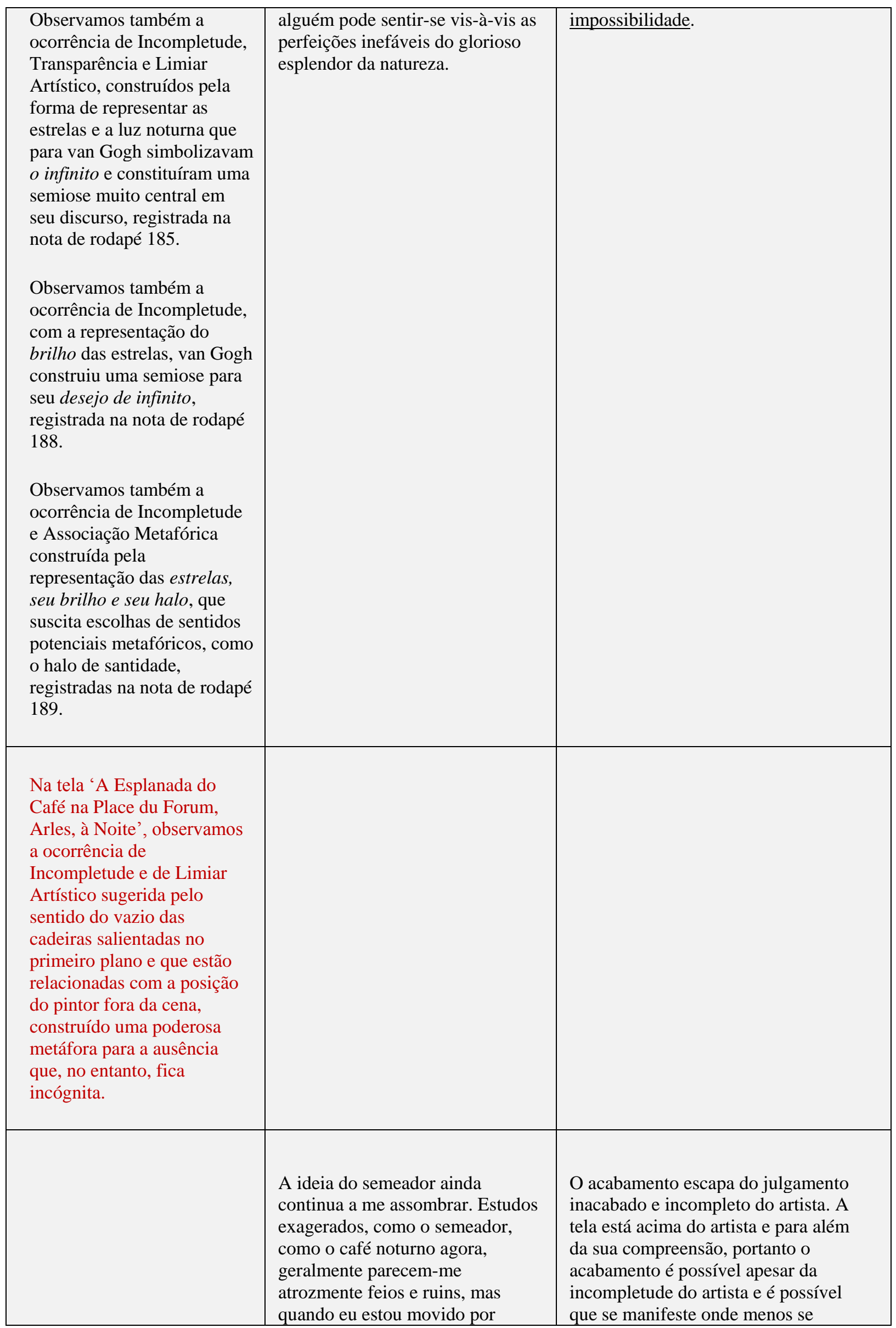




\begin{tabular}{|c|c|c|}
\hline & $\begin{array}{l}\text { alguma coisa, como aqui por este } \\
\text { pequeno artigo sobre Dostoievski, } \\
\text { em seguida, eles são os únicos que } \\
\text { me parecem ter um significado } \\
\text { mais importante. }\end{array}$ & $\begin{array}{l}\text { espera. Quando van Gogh fala do } \\
\text { artigo do Dostoievsky 'se não é essa a } \\
\text { tela mais feia' que traz o sentido mais } \\
\text { completo. }\end{array}$ \\
\hline $\begin{array}{l}\text { Na tela 'O Café Noturno na } \\
\text { Place Lamartine, em Arles', } \\
\text { observamos a ocorrência de } \\
\text { Incompletude, pela } \\
\text { associação de sentidos } \\
\text { potenciais do vazio que as } \\
\text { cadeiras sugerem, registrada } \\
\text { na nota de rodapé } 213 \text {. }\end{array}$ & & \\
\hline $\begin{array}{l}\text { Na tela 'O Café Noturno na } \\
\text { Place Lamartine, em Arles', } \\
\text { observamos a ocorrência de } \\
\text { Distorção do Ponto de Vista, } \\
\text { Inacabamento e } \\
\text { Incompletude, construídas } \\
\text { com ajuda da perspectiva, } \\
\text { profundidade e } \\
\text { enquadramento na } \\
\text { representação das linhas de } \\
\text { perspectiva distorcidas, } \\
\text { registrada na nota de rodapé } \\
227 \text {. }\end{array}$ & & \\
\hline $\begin{array}{l}\text { Na tela ‘O Café Noturno na } \\
\text { Place Lamartine, em Arles', } \\
\text { observamos a ocorrência de } \\
\text { Transparência e } \\
\text { Incompletude para } \\
\text { representar a sua experiência } \\
\text { com o ambiente de um café } \\
\text { noturno, registrada na nota } \\
\text { de rodapé } 256 \text {. }\end{array}$ & & \\
\hline $\begin{array}{l}\text { Na tela 'O Café Noturno na } \\
\text { Place Lamartine, em Arles', } \\
\text { observamos a ocorrência de } \\
\text { Interdiscursividade e } \\
\text { Modalidade uso da } \\
\text { ambiguidade no olhar do } \\
\text { homem para o espectador } \\
\text { criar analogias e associacões }\end{array}$ & & \\
\hline
\end{tabular}




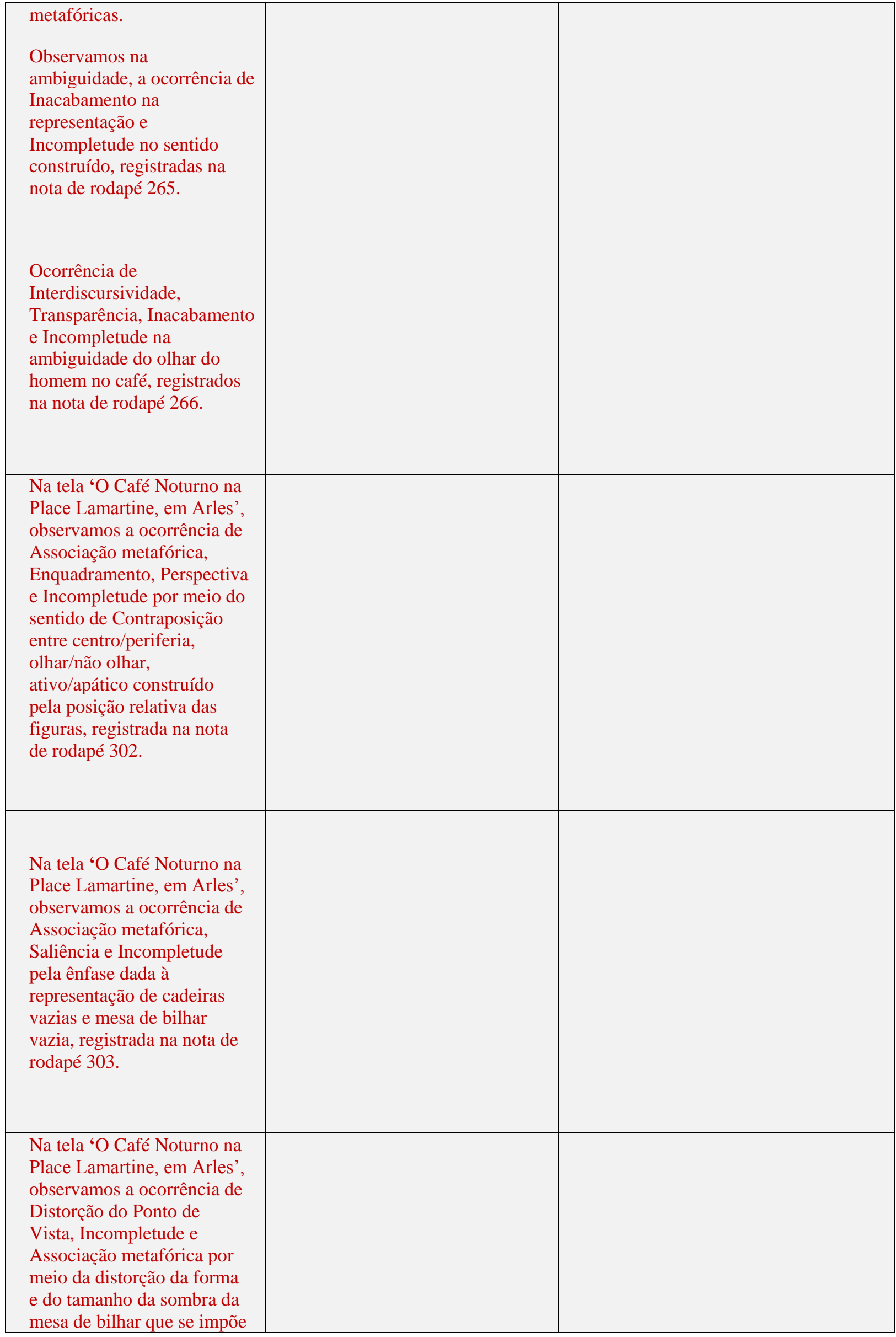




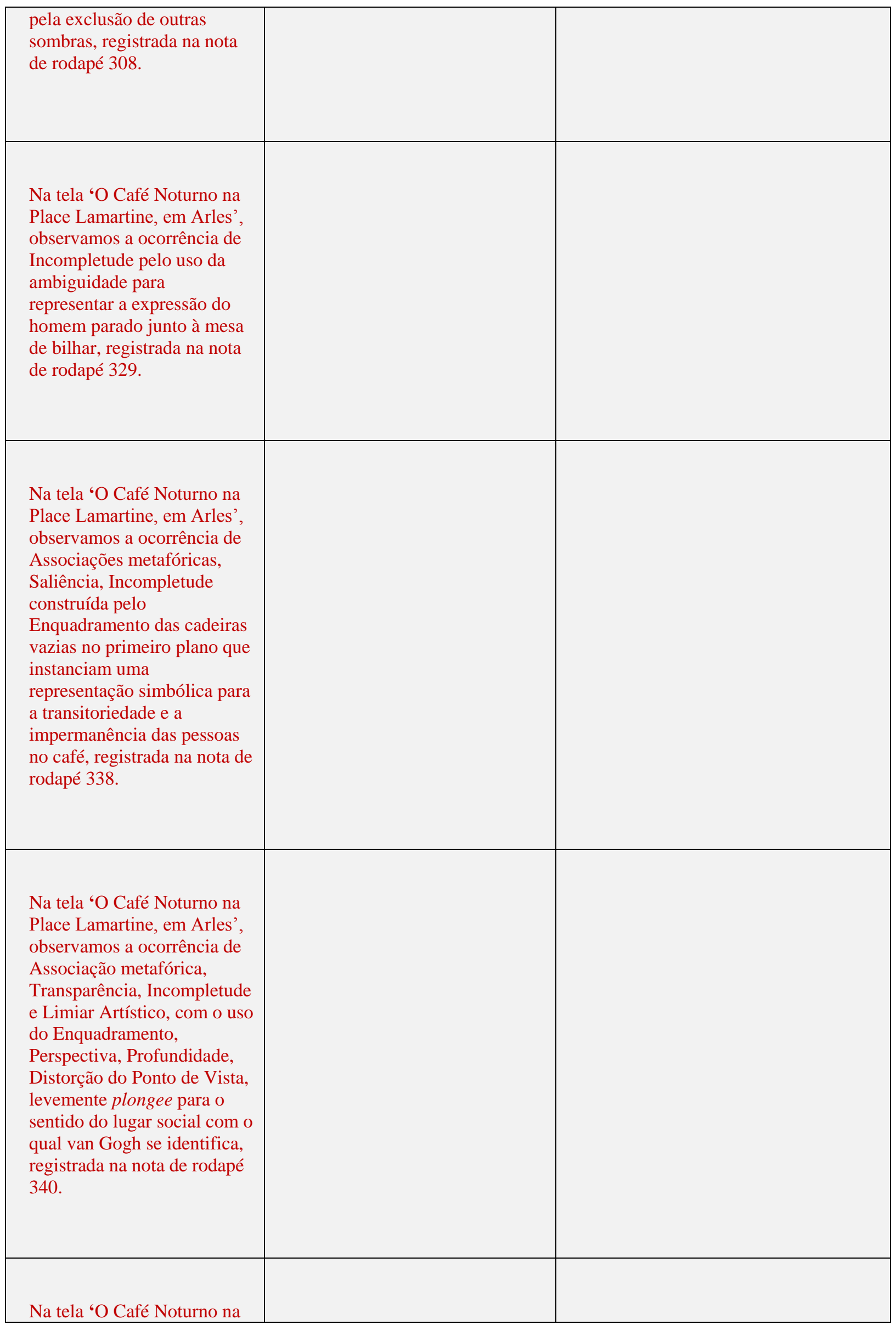




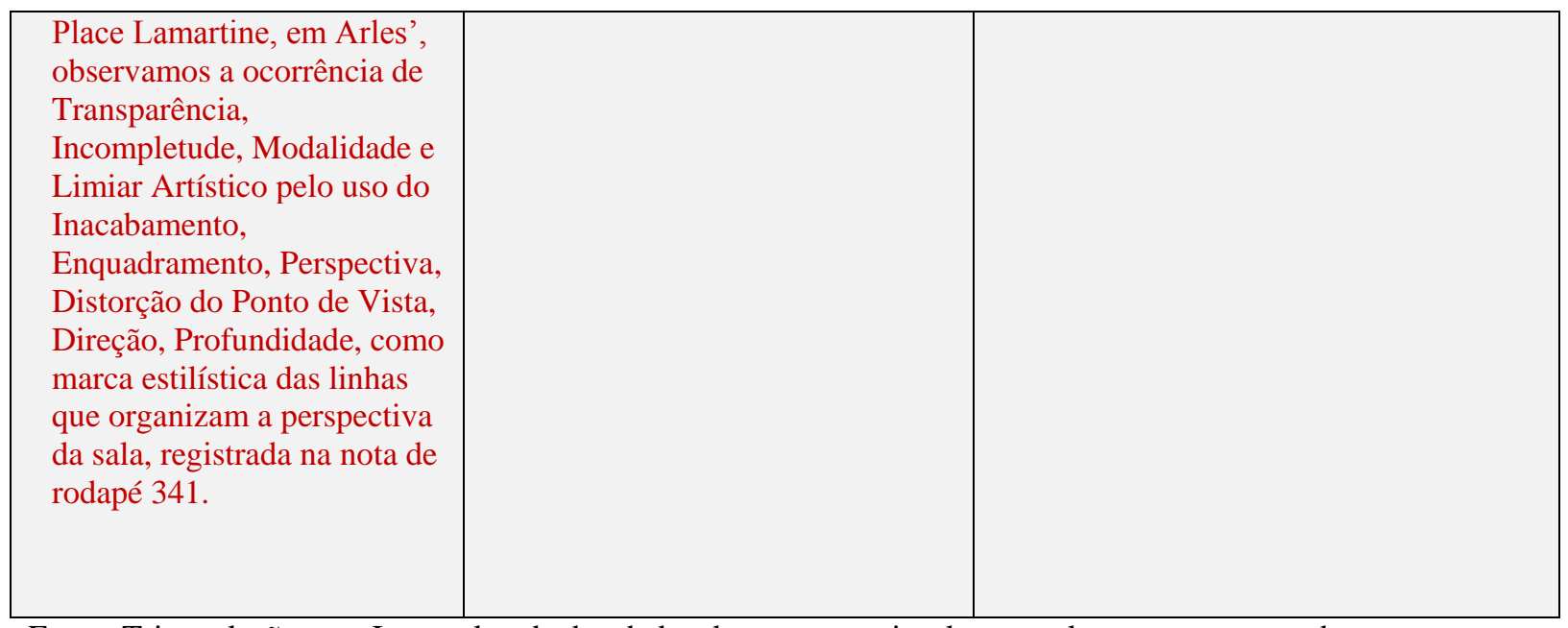

Fonte: Triangulação para Incompletude dos dados dos corpora visual e textual, com os extratos das cartas.

\subsection{TRIANGULAÇÃO DO LIMIAR ARTÍSTICO}

Quadro 84: Limiar Artístico

\begin{tabular}{|c|c|c|}
\hline Ocorrência nas telas & Orações & Comentário \\
\hline & $\begin{array}{l}\text { "Eu também sou totalmente incapaz } \\
\text { de julgar o meu próprio trabalho. Eu } \\
\text { não posso ver se os estudos são bons } \\
\text { ou ruins" }\end{array}$ & $\begin{array}{l}\text { Van Gogh (2009d) declara para o } \\
\text { irmão sua incapacidade de avaliar seu } \\
\text { próprio trabalho. O sentido dessa } \\
\text { oração endossa completamente a } \\
\text { hipótese de que o artista cria seu } \\
\text { discurso artístico a partir de um limiar } \\
\text { artístico }^{483} \text { no qual ele não tem total } \\
\text { apreensão de seus sentidos e precisa } \\
\text { continuar a elaborar sua compreensão } \\
\text { desse processo por meio de uma } \\
\text { cadeia de textos que ele produz para } \\
\text { explorar os sentidos relacionados com } \\
\text { a sua produção artística. Esta } \\
\text { ocorrência está registrada na nota de } \\
\text { rodapé } 67 .\end{array}$ \\
\hline & $\begin{array}{l}\text { "Eu não posso ver se os estudos são } \\
\text { bons ou ruins" }\end{array}$ & $\begin{array}{l}\text { Na primeira oração, ele usa o } \\
\text { processo relacional atributivo: "Eu } \\
\text { também sou totalmente incapaz de } \\
\text { julgar o meu próprio trabalho" e na } \\
\text { segunda o processo mental cognitivo: } \\
\text { "Eu não posso ver se os estudos são } \\
\text { bons ou ruins" (VAN GOGH, 2009d, } \\
\text { p. 1), sinalizando que ele fala de um }\end{array}$ \\
\hline
\end{tabular}

483 'Limiar artístico' é um conceito produzido nesta pesquisa para designar uma instância discursiva que se situa entre o imanente e o manifesto no processo de produção de sentido. O limiar artístico será discutido no capítulo 6 na discussão dos achados. 


\begin{tabular}{|c|c|c|}
\hline & & $\begin{array}{l}\text { lugar no qual ele está dentro do } \\
\text { processo e relaciona a qualidade de se } \\
\text { ver incapaz de julgar seu próprio } \\
\text { trabalho. Esta ocorrência está } \\
\text { registrada na nota de rodapé } 67 .\end{array}$ \\
\hline $\begin{array}{l}\text { Na tela 'O Semeador', } \\
\text { observamos a ocorrência de } \\
\text { Enquadramento na } \\
\text { representação do Semeador } \\
\text { no segundo plano, em pé, o } \\
\text { que denota um certo } \\
\text { distanciamento entre o } \\
\text { espectador e a tela, } \\
\text { registrado na nota de rodapé } \\
129 .\end{array}$ & $\begin{array}{l}\text { Não te vou ocultar que não desgosto } \\
\text { da região, pois fui criado lá - ainda } \\
\text { me encanta a magia das recordações } \\
\text { do passado, de um desejo do } \\
\text { infinito, do qual o semeador e o } \\
\text { enfeixador são símbolos -, tanto } \\
\text { quanto antes gostava. }\end{array}$ & $\begin{array}{l}\text { Van Gogh está se referindo a uma } \\
\text { condição que não é escolhida como } \\
\text { uma expressão da liberdade do } \\
\text { indivíduo. Ele é um meio para que } \\
\text { algo maior aconteça. Então é como se } \\
\text { o Semeador e o Enfeixador não } \\
\text { escolheram ser Semeador e } \\
\text { Enfeixador. Van Gogh fez uma } \\
\text { escolha que não foi a de ser o meio, } \\
\text { ele rejeitou, não se adaptou para ser o } \\
\text { evangelizador que o pai esperava. } \\
\text { Então quando ele representa o } \\
\text { Semeador é como se ele estivesse } \\
\text { representando o desejo que o motivou } \\
\text { a ser um meio dessa semeadura, mas } \\
\text { sem ocupar esse lugar do Semeador. } \\
\text { Ser o Semeador sem ser o Semeador, } \\
\text { porque ele tenta apreender é uma } \\
\text { essência talvez com um conteúdo } \\
\text { espiritual que estava presente nele } \\
\text { desde aquelas lembranças que } \\
\text { conectavam ele com o mundo das } \\
\text { metáforas bíblicas do pai. } \\
\text { Van Gogh estava atrás de uma } \\
\text { essência, uma verdade primeira que se } \\
\text { esmerava em romper com ideias } \\
\text { preconcebidas, com qualquer valor } \\
\text { social, formal, que corrompesse com o } \\
\text { sentido existencial da ética mais } \\
\text { próxima da espiritualidade, de Deus e } \\
\text { do qual o Semeador é um símbolo, } \\
\text { porque van Gogh entra em contato } \\
\text { com esse sentimento, essa } \\
\text { necessidade, essa condição no } \\
\text { momento em que ele é colocado no } \\
\text { lugar do Semeador que não se } \\
\text { identificasse com a centralidade que é } \\
\text { dada para essa ação, mas que buscava } \\
\text { um sentido mais profundo da ação do } \\
\text { Semeador que é o de ser um agente } \\
\text { passivo. Por isso que van Gogh } \\
\text { assume o lugar de artista como uma } \\
\text { condição imposta por uma missão que } \\
\text { é dada a ele então nesse lugar ele se vê } \\
\text { como meio e para ele se ver como } \\
\text { meio ele precisa transcender a obra } \\
\text { dele. Para ele é muito difícil } \\
\text { transcender a obra justamente porque } \\
\text { ele está preso a ela. Ele precisa dela } \\
\text { para sobreviver, assim como o } \\
\text { Semeador precisa do resultado da } \\
\text { semeadura e se vê preso na ação, se vê }\end{array}$ \\
\hline
\end{tabular}




\begin{tabular}{|c|c|}
\hline & $\begin{array}{l}\text { preso à terra, mas com o desejo do } \\
\text { infinito. Van Gogh se vê preso à tela, } \\
\text { mas com desejo de infinito. No final } \\
\text { van Gogh repete o lugar que o pai o } \\
\text { destinou, de ser um Semeador preso à } \\
\text { sua palavra. }\end{array}$ \\
\hline $\begin{array}{l}\text { Na tela A Esplanada do Café } \\
\text { na Place du Forum, Arles, à } \\
\text { Noite observamos a } \\
\text { ocorrência de Incompletude, } \\
\text { Transparência e Limiar } \\
\text { Artístico, construídos pela } \\
\text { forma de representar as } \\
\text { estrelas e a luz noturna que } \\
\text { para van Gogh simbolizavam } \\
\text { o infinito. registradas na nota } \\
\text { de rodapé } 184 \text {. }\end{array}$ & \\
\hline $\begin{array}{l}\text { Observamos também a } \\
\text { ocorrência de Incompletude, } \\
\text { Transparência e Limiar } \\
\text { Artístico, construídos pela } \\
\text { forma de representar as } \\
\text { estrelas e a luz noturna que } \\
\text { para van Gogh simbolizavam } \\
\text { o infinito e constituíram uma } \\
\text { semiose muito central em } \\
\text { seu discurso, registrada na } \\
\text { nota de rodapé } 185 .\end{array}$ & \\
\hline $\begin{array}{l}\text { Na tela 'A Esplanada do } \\
\text { Café na Place du Forum, } \\
\text { Arles, à Noite', observamos } \\
\text { a ocorrência de } \\
\text { Incompletude e de Limiar } \\
\text { Artístico sugerida pelo } \\
\text { sentido do vazio das cadeiras } \\
\text { salientadas no primeiro } \\
\text { plano e que estão } \\
\text { relacionadas com a posição } \\
\text { do pintor fora da cena, } \\
\text { construído uma poderosa } \\
\text { metáfora para a ausência } \\
\text { que, no entanto, fica } \\
\text { incógnita. }\end{array}$ & \\
\hline $\begin{array}{l}\text { Na tela 'O Café Noturno na } \\
\text { Place Lamartine, em Arles', } \\
\text { observamos a ocorrência de } \\
\text { Associação metafórica, } \\
\text { Transparência, Incompletude } \\
\text { e Limiar Artístico, com o uso } \\
\end{array}$ & \\
\hline
\end{tabular}




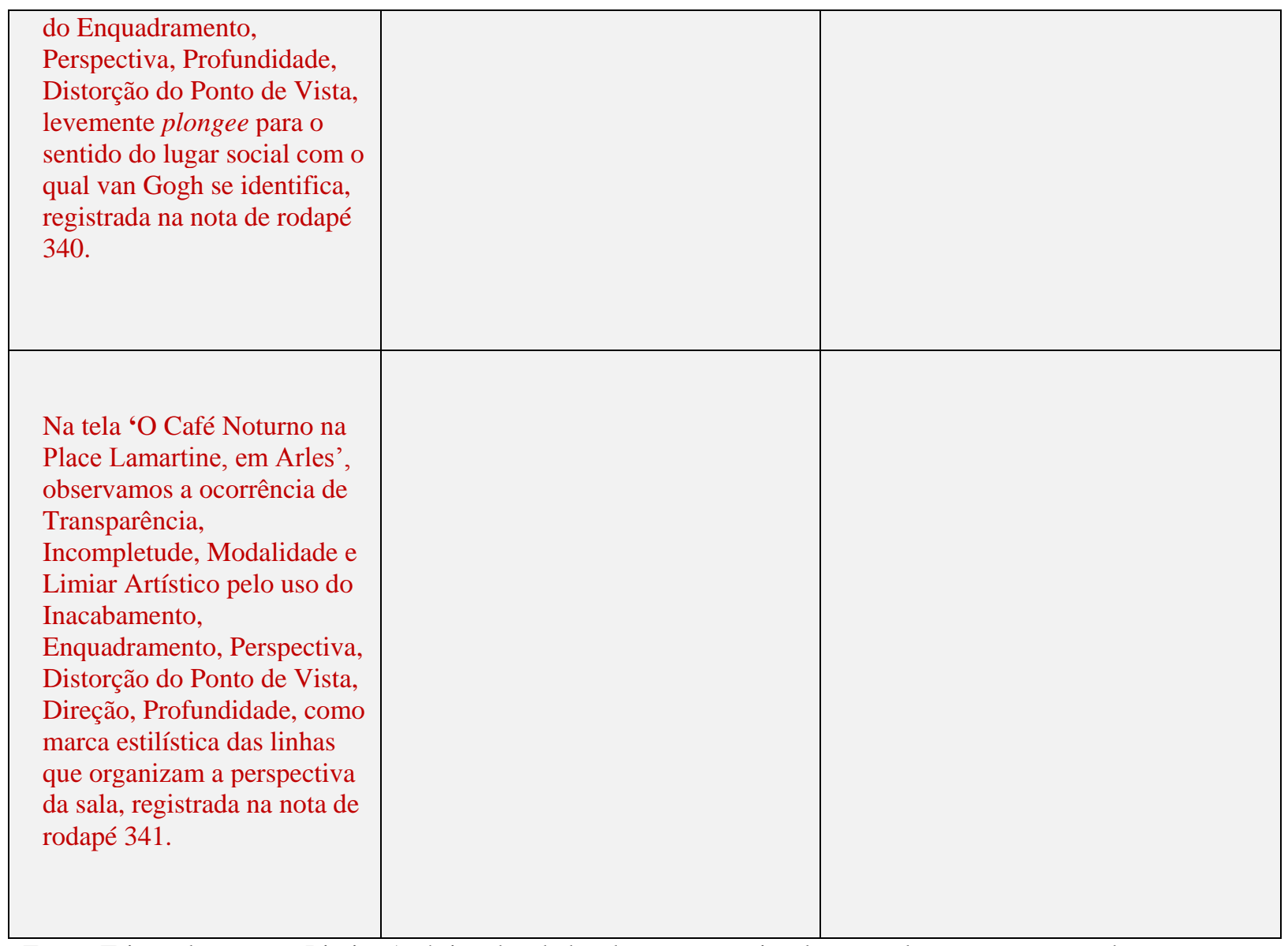

Fonte: Triangulação para Limiar Artístico dos dados dos corpora visual e textual, com os extratos das cartas. 


\section{CONSIDERAÇÕES FINAIS}

Ocorrências das categorias nas orações

Ocorrências das categorias nas orações

Neste item, buscamos descrever a recorrência e relação entre categorias e processos, considerando as 139 orações analisadas.

Quadro 85: Processo Relacional Atributivo (41 ocorrências)

\begin{tabular}{|l|l|}
\hline Categoria & Recorrência \\
\hline Enquadramento & 10 ocorrências \\
\hline Vetor & 9 ocorrências \\
\hline Perspectiva & 7 ocorrências \\
\hline Transparência, distorção & 3 ocorrências \\
\hline Simbolismo & 2 ocorrências \\
\hline Saliência, contraste, incompletude, movimento, ritmo & 1 ocorrência \\
\hline
\end{tabular}

Quadro 86: Em relação ao Atributo (42 ocorrências)

\begin{tabular}{|l|l|}
\hline Categoria & Recorrência \\
\hline Contraste, simbolismo & 11 ocorrências \\
\hline Enquadramento, inacabamento & 5 ocorrências \\
\hline saliência & 4 ocorrências \\
\hline distorção, ritmo & 3 ocorrências \\
\hline Profundidade, incompletude, transparência & 2 ocorrências \\
\hline $\begin{array}{l}\text { Vetor, perspectiva, intertextualidade, movimento, rima } \\
\text { visual, gesto visual }\end{array}$ & 1 ocorrência \\
\hline
\end{tabular}

Quadro 87: Em relação à Circunstância (de todos os processos - 71 ocorrências)

\begin{tabular}{|l|l|}
\hline Categoria & Recorrência \\
\hline saliência & 26 ocorrências \\
\hline Enquadramento, perspectiva & 9 ocorrências \\
\hline Contraste & 10 ocorrências \\
\hline distorção & 6 ocorrências \\
\hline
\end{tabular}




\begin{tabular}{|l|l|}
\hline Simbolismo, intertextualidade & 5 ocorrências \\
\hline Incompletude, inacabamento & 4 ocorrências \\
\hline Profundidade, rima visual & 2 ocorrências \\
\hline Transparência, textura, movimento, ritmo, gesto visual & 1 ocorrência \\
\hline vetor & Nenhuma ocorrência \\
\hline
\end{tabular}

Quadro 88: Em relação ao Processo Mental (33 ocorrências)

\begin{tabular}{|l|l|}
\hline Categoria & Recorrência \\
\hline Transparência & 11 ocorrências \\
\hline Incompletude & 5 ocorrências \\
\hline Simbolismo & 4 ocorrências \\
\hline Saliência, profundidade & 2 ocorrências \\
\hline Vetor, rima, virtual & 1 ocorrência \\
\hline
\end{tabular}

Quadro 89: Em relação ao Experienciador (20 ocorrências)

\begin{tabular}{|l|l|}
\hline Categoria & Recorrência \\
Saliência & 2 ocorrências \\
\hline $\begin{array}{l}\text { Vetor, contraste, Perspectiva, incompletude, } \\
\text { inacabamento }\end{array}$ & 1 ocorrência \\
\hline
\end{tabular}

Quadro 90: Em relação ao Processo Verbal (14 ocorrências)

\begin{tabular}{|l|l|}
\hline Categoria & Recorrência \\
\hline Vetor & 7 ocorrências \\
\hline Transparência & 4 ocorrências \\
\hline Saliência & 3 ocorrências \\
\hline Perspectiva, intertextualidade & 2 ocorrências \\
\hline Simbolismo, incompletude, distorção, movimento & 1 ocorrência \\
\hline
\end{tabular}

Quadro 91: Em relação ao Dizente (13 ocorrências)

\begin{tabular}{|l|l|}
\hline Categoria & Recorrência \\
\hline Intertextualidade, saliência & 3 Ocorrências \\
\hline $\begin{array}{l}\text { Enquadramento, contraste, simbolismo, transparência, } \\
\text { distorção }\end{array}$ & 1 Ocorrência \\
\hline
\end{tabular}


Quadro 92: Em relação à Verbiagem (11 ocorrências)

\begin{tabular}{|l|l|}
\hline Categoria & Recorrência \\
\hline Distorção & 4 Ocorrências \\
\hline Perspectiva & 3 Ocorrências \\
\hline Enquadramento & 2 Ocorrências \\
\hline $\begin{array}{l}\text { Simbolismo, incompletude, intertextualidade, } \\
\text { profundidade }\end{array}$ & 1 ocorrência \\
\hline
\end{tabular}

Quadro 93: Em relação ao Processo Existencial (11 ocorrências)

\begin{tabular}{|l|l|}
\hline Categoria & Recorrência \\
\hline Vetor & 11 ocorrências \\
\hline Perspectiva & 2 ocorrências \\
\hline Enquadramento, simbolismo, movimento e ritmo & 1 ocorrências \\
\hline
\end{tabular}

Quadro 94: Em relação ao Existente (12 ocorrências)

\begin{tabular}{|l|l|}
\hline Categoria & Recorrência \\
\hline Enquadramento, perspectiva & 3 \\
\hline Saliência, contraste & 2 \\
\hline Simbolismo, textura, movimento, ritmo & 1 \\
\hline
\end{tabular}

Quadro 95: Em relação ao Processo Material (35 ocorrências)

\begin{tabular}{|l|l|}
\hline Categoria & Recorrência \\
\hline Vetor & 26 ocorrências \\
\hline Transparência, distorção & 3 ocorrências \\
\hline Contraste e inacabamento & 2 ocorrências \\
\hline
\end{tabular}

Quadro 96: Em relação ao Ator (35 ocorrências)

\begin{tabular}{|l|l|}
\hline Categoria & Recorrência \\
\hline Saliência & 6 ocorrências \\
\hline Enquadramento e contraste & 3 ocorrências \\
\hline Incompletude e profundidade & 2 ocorrências \\
\hline Perspectiva, Transparência, Distorção, Inacabamento. & 1 ocorrências \\
\hline
\end{tabular}


Quadro 97: Intercorrências entre as categorias

\begin{tabular}{|c|c|c|}
\hline Categorias & $\begin{array}{l}\frac{\pi}{0} \\
\text { : } \\
\stackrel{0}{0} \\
0 \\
0\end{array}$ & 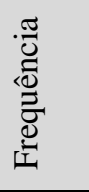 \\
\hline Saliência & 86 & $62 \%$ \\
\hline Enquadramento & 63 & $45 \%$ \\
\hline Direção ou vetor & 61 & $44 \%$ \\
\hline Contraste & 53 & $38 \%$ \\
\hline Perspectiva & 46 & $33 \%$ \\
\hline Simbolismo & 41 & $29 \%$ \\
\hline Incompletude & 35 & $25 \%$ \\
\hline Transparência & 34 & $24 \%$ \\
\hline Distorção & 32 & $23 \%$ \\
\hline Inacabamento & 22 & $16 \%$ \\
\hline Intertextualidade & 22 & $16 \%$ \\
\hline Profundidade & 20 & $14 \%$ \\
\hline Textura & 12 & $9 \%$ \\
\hline Movimento & 11 & $8 \%$ \\
\hline Ritmo & 10 & $7 \%$ \\
\hline Rima visual & 5 & $4 \%$ \\
\hline Gesto Visual & 2 & $1 \%$ \\
\hline
\end{tabular}

\subsection{RECORRÊNCIA ENTRE AS CATEGORIAS CONSIDERANDO A FREQUÊNCIA TOTAL}

Nesta seção listamos alguns achados da triangulação como uma consideração mais conclusiva da pesquisa. Das 139 orações analisadas, podemos perceber que algumas categorias se destacaram pela alta ocorrência no momento da análise. Abaixo apresentamos um quadro síntese considerando a frequência das categorias nas orações: 
Quadro 98: Porcentagem entre as categorias considerando a frequência total

\begin{tabular}{|c|c|c|c|c|c|c|c|c|c|c|c|c|c|c|}
\hline & 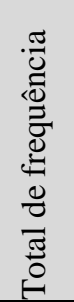 & 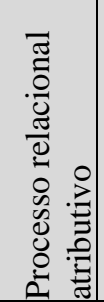 & 䓂 & 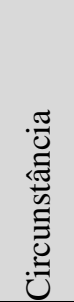 & 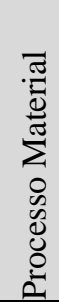 & $\frac{0}{2}$ & $\begin{array}{l}\bar{\pi} \\
\sum_{0}^{0} \\
\sum_{0}^{0} \\
0 \\
0 \\
0 \\
0 \\
0 \\
0\end{array}$ & 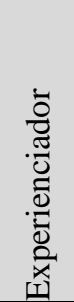 & 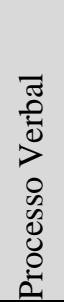 & $\begin{array}{l}\stackrel{0}{\bar{D}} \\
\text { Dี }\end{array}$ & 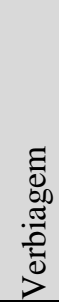 & 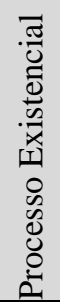 & 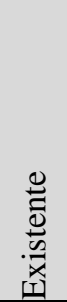 & $\stackrel{\circ}{0}$ \\
\hline $\begin{array}{l}\text { Total - } \\
\text { frequência }\end{array}$ & & 41 & 42 & 71 & 35 & 35 & 33 & 20 & 14 & 13 & 11 & 11 & 12 & \\
\hline Saliência & 86 & 1 & 4 & 26 & 0 & 6 & 2 & 2 & 3 & 3 & 0 & 0 & 2 & 37 \\
\hline $\begin{array}{l}\text { Enquadrame } \\
\text { nto }\end{array}$ & 63 & 10 & 5 & 9 & $\mathbf{0}$ & 3 & $\mathbf{0}$ & $\mathbf{0}$ & $\mathbf{0}$ & 1 & 2 & 1 & 3 & 29 \\
\hline $\begin{array}{ll}\text { Direção } & \text { ou } \\
\text { vetor } & \end{array}$ & 61 & 9 & 1 & 0 & 26 & & 1 & 1 & 7 & 0 & 0 & 11 & 0 & 5 \\
\hline Contraste & 53 & 1 & 11 & 10 & 2 & 3 & & 1 & & 1 & & & 2 & 22 \\
\hline Perspectiva & 46 & 7 & 1 & 9 & & 1 & & 1 & 2 & & 3 & 2 & 3 & 17 \\
\hline Simbolismo & 41 & 2 & 11 & 5 & & & 4 & & 1 & 1 & 1 & 1 & 1 & 14 \\
\hline $\begin{array}{l}\text { Incompletud } \\
\mathrm{e}\end{array}$ & 35 & 1 & 2 & 4 & & 2 & 5 & 1 & 1 & & 1 & & & 18 \\
\hline $\begin{array}{l}\text { Transparênci } \\
\text { a }\end{array}$ & 34 & 3 & 2 & 1 & 3 & 1 & 11 & & 4 & 1 & & & & 8 \\
\hline Distorção & 32 & 3 & 3 & 6 & 3 & 1 & & & 1 & 1 & 4 & & & 10 \\
\hline $\begin{array}{l}\text { Inacabament } \\
0\end{array}$ & 22 & & 5 & 4 & 2 & 1 & & 1 & & & & & & 9 \\
\hline $\begin{array}{l}\text { Intertextualid } \\
\text { ade }\end{array}$ & 22 & & 1 & 5 & & & & & 2 & 3 & 1 & & & 10 \\
\hline Profundidade & 20 & & 2 & 2 & & 2 & 2 & & & & 1 & & & 11 \\
\hline Textura & 12 & & & 1 & & & & & & & & & 1 & 10 \\
\hline Movimento & 11 & 1 & 1 & 1 & & & & & 1 & & & 1 & 1 & 5 \\
\hline Ritmo & 10 & 1 & 3 & 1 & & & & & & & & 1 & 1 & 3 \\
\hline Rima visual & 5 & & 1 & 2 & & & 1 & & & & & & & 1 \\
\hline Gesto Visual & 2 & & 1 & 1 & & & & & & & & & & $\mathbf{0}$ \\
\hline
\end{tabular}

